


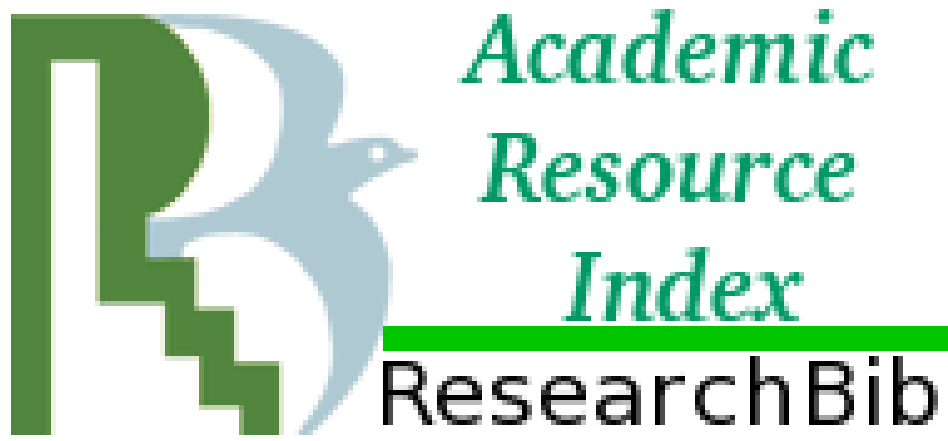

http://journalseeker.researchbib.com/view/issn/2717-8293 IF (Impact Factor) 1.012 / 2020

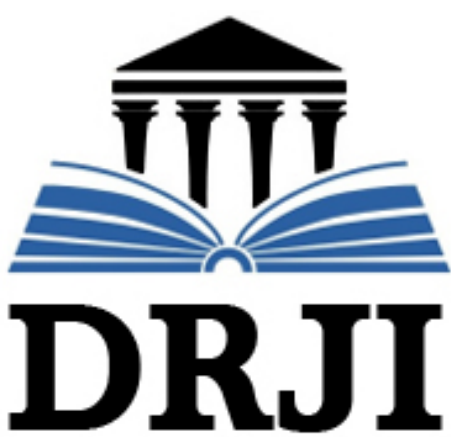

http://olddrji.lbp.world/JournalProfile.aspx?jid=2717-8293

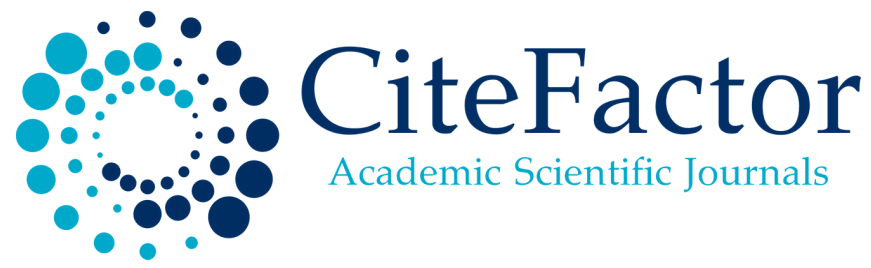

https://www.citefactor.org/journal/index/26200\#.X0Ec3Mhva3A
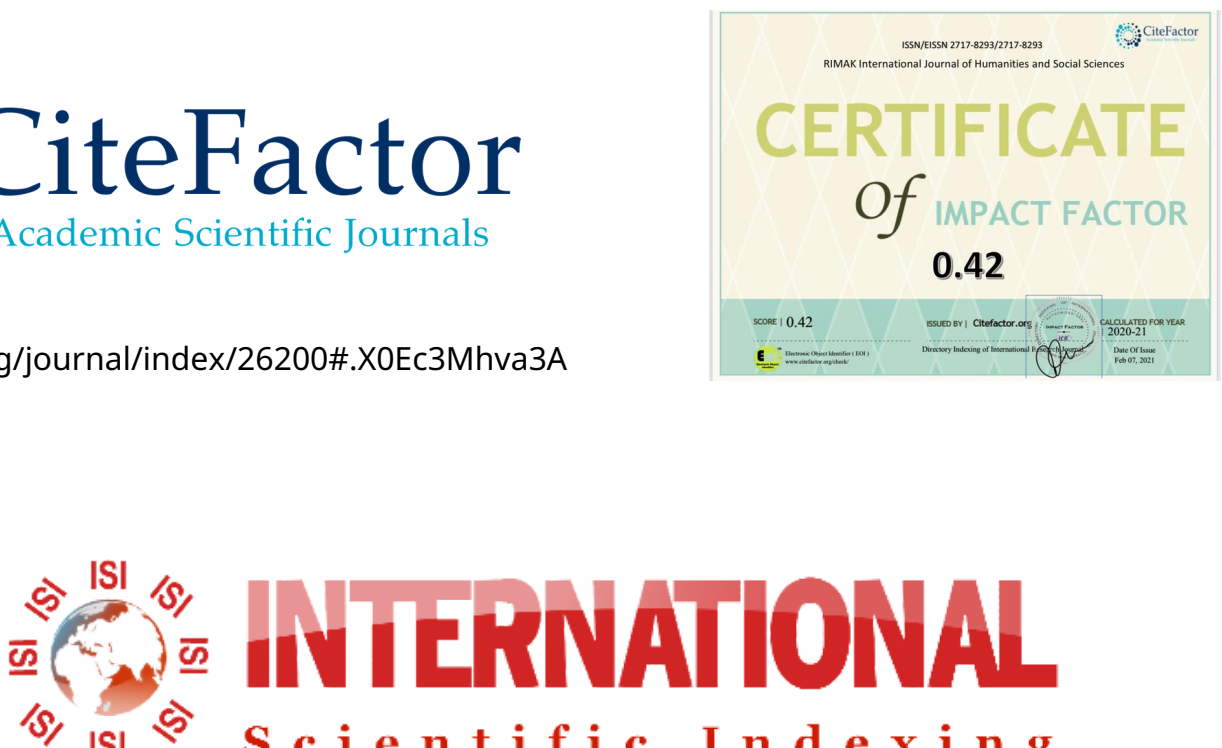

SI c i e n t i f i c I n d e $x$ i n g https://isindexing.com/isi/journaldetails.php?id=14574

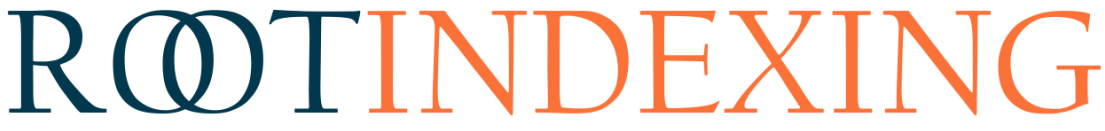

JOURNAL ABSTRACTING AND INDEXING SERVICF

https://www.rootindexing.com/journal/rimak-international-journal-ofhumanities-and-social-sciences-RIMAK\%20Journal/ 


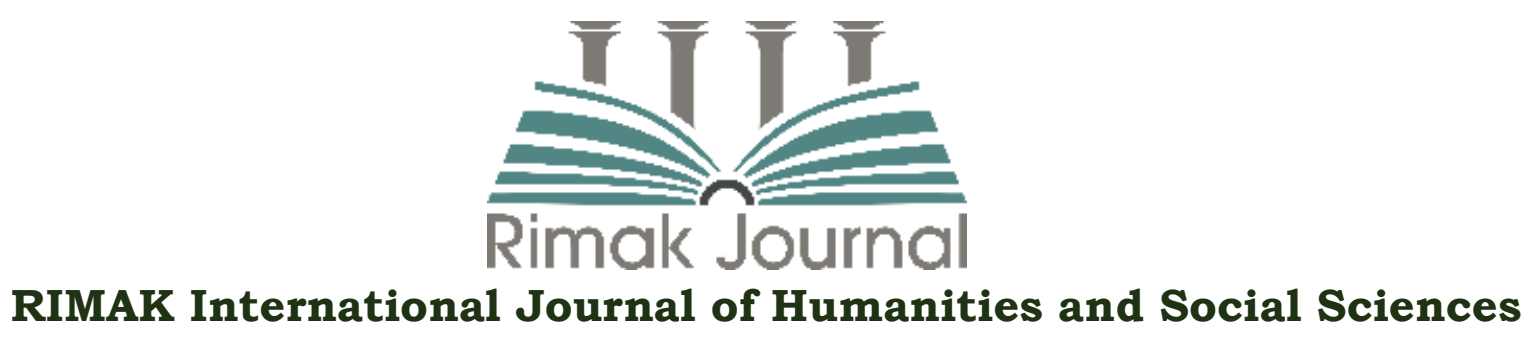

ISSN: 2717-8293

\section{About RIMAK}

RIMAK International Journal of Humanities and Social Sciences is an international scientific journal published by Rimar Academy in Istanbul, Turkey. RIMAK Journal publishes research, studies and revisions written in English, Arabic, and Turkish which are judged by a committee of arbitrators and experts to be handed over to the editorial board to determine its suitability for publication

The board of referees and editors is a collective body of international and Turkish expert scholars who consider the liability of research projects to be published according to the parameters and regulations of RIMAK. Being open access and online available, it is able to offer excellent visibility and a fast processing time from submission to publication. RIMAK aims to provide an inter-disciplinary forum to showcase state-of-the-art research challenges on human and social sciences.

\section{Vision}

Rimak Journal is looking forward to reaching the site of local and global leadership in the field of social studies to build parallel, happy, fair-based, equal and respectful human communities. It also looks forward to establishing a bridge of scientific, human and modern communication among researchers from all over the world firstly, and among societies secondly, to strengthen human, scientific, research-based, dialogue, respect and other ways away from dissonance, exclusion, and nervousness of all kinds.

\section{Mission}

The Journal seeks to connect human societies with each other on the basis of values, and the basic humanitarian principles that are aimed at upholding man and preserveing his dignity. It seeks to develop scientific research in this field, and to provide opportunities for researchers around the world to contribute to solving human problems, whatever the need to reach High-class human communities away from war, destruction, tyranny, enslavement, poverty, hunger, ignorance, spiritual, ethnic, and moral.... 


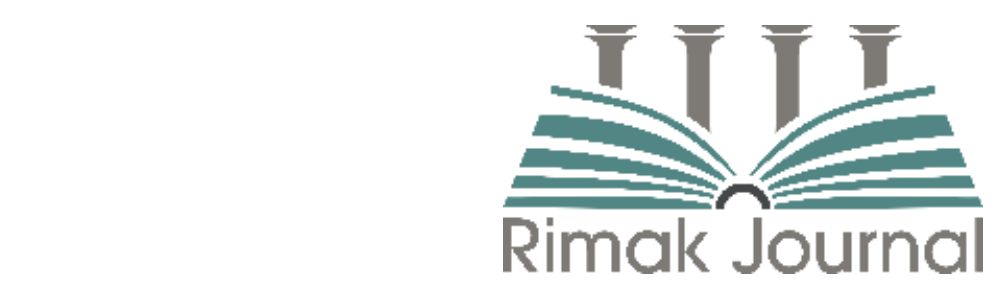

RIMAK International Journal of Humanities and Social Sciences

ISSN: 2717-8293

\section{JOURNAL ID}

- Full name

: RIMAK International Journal of Humanities and Social Sciences

- Short name

: RIMAK Journal

- Area of concentration

: Humanities and Social Sciences

- Frequency of publishing : six Issues a year

- Language of publication : English, Arabic, Turkish

- Reviewing

: Double Blinded Review Process

- Publisher

: Rimar Academy

- Country

: Turkey

- City

: Istanbul

\section{Why Rimak}

Humanities and social sciences are of a wide range of political, religious, spiritual, literary, philosophical, and artistic, and all sciences that sought to address the issues of society. And it is the group of people that make up this society, so the study of social sciences is very important. It tackles the human life, his issues for understanding the life, and others, for developing it, and living with them in the style of a happy human life in its religious, moral, linguistic, literary and historical aspects... It is important, because it helps man to understand himself firstly, and understand his society secondly. Then, he could understand his religion, language, manners, his values, customs, traditions, history, and society, added to his understanding of the languages and traditions of others. If a man who is the core of society and life relies on previous giving's, he will live a balanced happy life, and seek to build civilization, serve humanity instead of corrupting and destroying it. Consequently, the study of the social sciences and their research are important, because the social sciences are based on the true civilization of humanity, which respects the human being whom God has honored by giving him the mind as a guide, and made him above all other creatures. 


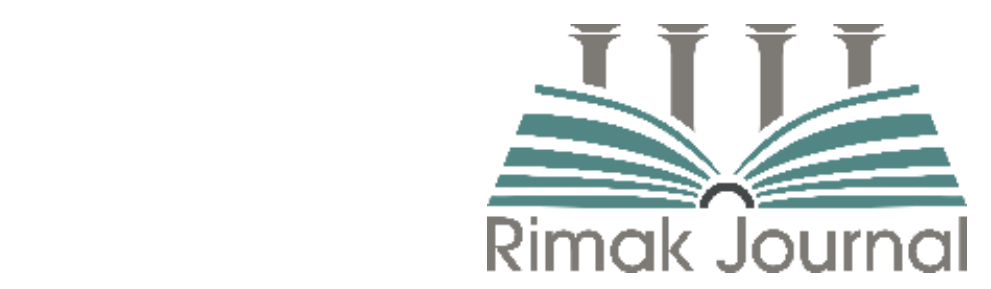

RIMAK International Journal of Humanities and Social Sciences

ISSN: 2717-8293

\section{Commitments}

Rimak Journal is committed to shoulder the following responsibilties:

- Developing scientific research and encouraging it in the field of social and human studies.

- Establishing scientific communicational bridges among researchers in this field throughout the world.

- Providing an equall opportunity for researchers to contribute to the service of humanity and to build its own civilization.

- Holding scientific conferences specialized in social sciences and humanities to find out the latest scientific research in this field, and to find appropriate solutions concerning the serious human problems.

\section{Copyright}

Articles published in RIMAK International Journal of Humanities and Social Sciences will be Open-Access articles distributed under the terms and conditions of the Creative Commons Attribution License. RIMAK Journal will insert the following note at the first page of the published text:

Copyright (C) Published by Rimak Journal www.rimakjournal.com, Rimar Academy, Istanbul, Turkey.

All rights reserved.

\section{Publication Ethics}

RIMAK International Journal of Humanities and Social Sciences emphasizes the importance of strict adhering to ethical policies and standards to ensure to add high quality research articles to the field of scholarly publication. Unfortunately, cases of plagiarism, data falsification, inappropriate authorship credit, and the like, do arise. To verify the originality of content submitted to our journals, we use iThenticate to check submissions. 


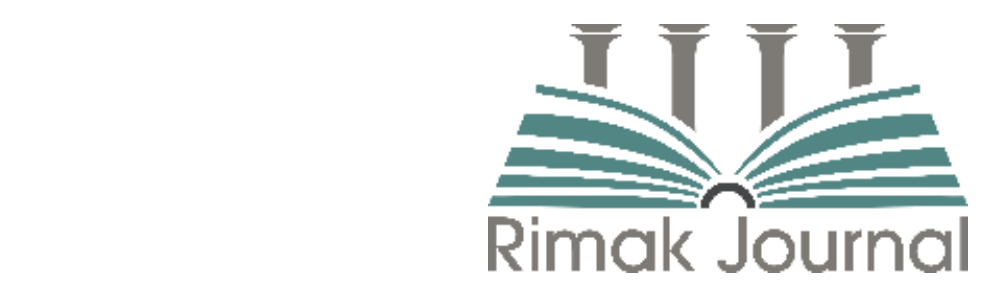

RIMAK International Journal of Humanities and Social Sciences

ISSN: 2717-8293

\section{Publication Principles}

For the submission of research studies the following regulations should be followed:

- The material sent for publication must be authentic, has never been published and has not been sent for publication elsewhere.

- The first page should contain the complete research title, the researcher's name, his/her academic rank, the institution's name and the researcher's email.

- The research article should contain English abstract with key words.

- The research article should not exceed a number of 20 and not less than 7 Microsoft Word document, with 2 centemetres margins and single spaces lines, pages including the bibliography, tables and charts.

- Arabic research article should be written in 13 fonts Simplified Arabic in the body of the research, 20 bold fonts (Gras) for the main title and 16 bold fonts for the subtitles. 12 fonts Times New Roman for the Latin inscript in the body of the research, and 14 fonts bold type (Majusclue) for the main title.

- 7 APA documentation system is the recommended style in writing https://apastyle.apa.org/instructional-aids/reference-guide.pdf

- The research projects will be submitted to a blind peer reviews.

- The researchers will be automatically notified through emails upon the reception of their research projects. They will also be notified about all the procedures of reviewing, and they should submit the amendments if required. 


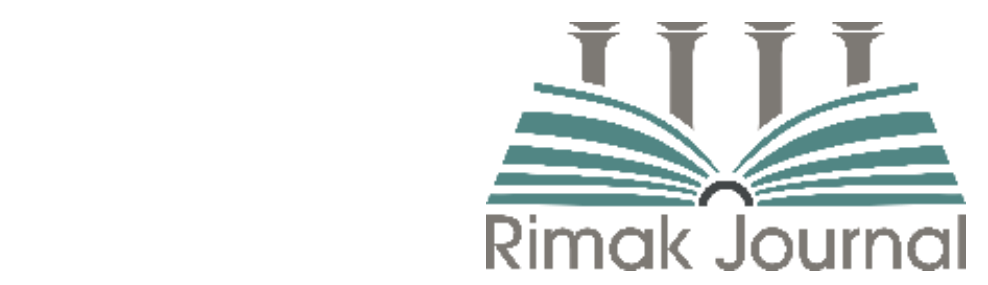

RIMAK International Journal of Humanities and Social Sciences

ISSN: 2717-8293

\section{Boards}

Editor

\begin{tabular}{|l|l|l|}
\hline Prof. Dr. Hani Alyas KHADHER & Rimar Academy & Türkiye \\
\hline
\end{tabular}

\begin{tabular}{|l|c|c|}
\hline Co-Editors \\
\hline Dr. Mahmood Fawzi ABDULLAH & Aliraqia University & Iraq \\
\hline Dr. Ibrahim ALHAMMADI & Rimar Academy & Türkiye \\
\hline Dr. Mais ODEH & Al-Istiqlal University & Palestine \\
\hline
\end{tabular}

\begin{tabular}{|c|c|c|}
\hline \multicolumn{3}{|l|}{ Advisory Board } \\
\hline Prof. Dr. Muhtar KAZIMOĞLU (IMANOV) & $\begin{array}{l}\text { Director of National Academy of } \\
\text { Sciences Institute of Folklore }\end{array}$ & Azerbaijan \\
\hline Prof. Dr. Allawi Sadir Jazea ALDARRAJI & Baghdad University & Iraq \\
\hline Prof. Dr. Husain Dakhil Z. AL-BAHADLY & $\begin{array}{c}\text { Dean of Faculty of Arts, Aliraqia } \\
\text { University }\end{array}$ & Iraq \\
\hline Prof. Dr. Khalil ODEH & Alnajah University & Palastine \\
\hline Prof. Dr. Ghadir GÜLKARIAN & Yakın Doğu University & Cyprus \\
\hline Prof. Dr. Hussein F. KASASBEH & Mutah University & Jordan \\
\hline Prof. Dr. Mehdi Flayih Nasir Al-SAFI & Thi Qar University & Iraq \\
\hline Prof. Dr. Assia CHERIF & $\begin{array}{l}\text { Higher National School of } \\
\text { Statistic and Applied Economy }\end{array}$ & Algeria \\
\hline Dr. Osman TÜRK & Harran University & Türkiye \\
\hline Dr. Abdoulaye Aboubakari NOUROU & Kandi University & Benin \\
\hline Dr. Bekir Mehmetali & Kilis 7 Aralık University & Türkiye \\
\hline Dr. Mohamad TURKEY & Ankara University & Türkiye \\
\hline
\end{tabular}




\section{IIII \\ Rimak Journal \\ RIMAK International Journal of Humanities and Social Sciences}

ISSN: 2717-8293

\begin{tabular}{|c|c|c|}
\hline \multicolumn{3}{|l|}{ Editorial Review Committee (Board of Referees) } \\
\hline Prof. Dr. Zakaria ZALLAM & Gaziantep University & Türkiye \\
\hline Prof. Dr. Khalil ODEH & Alnajah University & Palastine \\
\hline Prof. Dr. Ibrahim Saeed ALBAIDHANI & $\begin{array}{l}\text { Director of International Historians } \\
\text { Association for Cultures Development } \\
\text { and Social Sciences }\end{array}$ & Iraq \\
\hline Prof. Dr. Bahar Burtan DOĞAN & Dicle University & Türkiye \\
\hline Prof. Dr. Omar mohammed AL- KHARABSHEH & Al-Balqa Applied University & Jordan \\
\hline Prof. Dr. Abdurrazak HABBANI & Fes University & Morocco \\
\hline Prof. Dr. Mundher mubdir ABDULKAREEM & Diyala University & Iraq \\
\hline Prof. Dr. Thani Hussein KHACHI & Rimar Academy & Türkiye \\
\hline Prof. Dr. Assia CHERIF & $\begin{array}{l}\text { Higher National School of Statistic and } \\
\text { Applied Economy }\end{array}$ & Algeria \\
\hline Prof. Dr. Maha Ismael Ali AL-SHAIKHLI & Al-Mustansirah University & Iraq \\
\hline Prof. Dr. Bülent YORULMAZ & Yedi Tepe University & Türkiye \\
\hline Prof. Dr. Luma Ibrahim Al-BARZENJI & Diyala University & Iraq \\
\hline Prof. Dr. Samia IBRIAM & Uom El- Bouaghı University & Algeria \\
\hline Prof. Dr. Huda Hsahem Mohammed ALRUBAI & Babylon University & Iraq \\
\hline Prof. Dr. Maher. KHUDAIR & Diwan Sharia Courts & Palastine \\
\hline Prof. Dr. Randa ELKHERBAWY & King Khalid University & Saudi Arabia \\
\hline Prof. Dr. Abddulrazaq Ayda ALUHAIBY & Bilad Alrafdain College & Iraq \\
\hline Prof. Dr. Riyadh Farag Mabrook BIN ABADAT & Seiyun University & Yemen \\
\hline Prof. Dr. Esra SiVEREKLi & Harran University & Türkiye \\
\hline Prof. Dr. Jamal Hamid RASHID & Baghdad University & Iraq \\
\hline Prof. Dr. Hussein F. KASASBEH & Mutah University & Jordan \\
\hline Prof. Dr. Mahmood Fawzi ABDULLAH & Aliraqia University & Iraq \\
\hline Prof. Dr. Wejdan Abdulrhman ALOUDAH & $\begin{array}{c}\text { Princess Nourah Bint Abdulrahman } \\
\text { University }\end{array}$ & Saudi Arabia \\
\hline Prof. Dr. Salah Yarka MELEK & Al Qadisiya University & Iraq \\
\hline Prof. Dr. Mohsen Mohammed AWAWDEH & King Faisal University & Saudi Arabia \\
\hline Prof. Dr. Faeza Abdulameer Nayyef ALHUDEEB & Baghdad University & Iraq \\
\hline Dr. Mohamed Ali Mohamed OFEIN & Dean of Faculty of Arts, Mosul University & Iraq \\
\hline Dr. Wisam Abdullah JASIM & Baghdad University & Iraq \\
\hline Dr. Mohamed KALOU & Adıyaman University & Türkiye \\
\hline
\end{tabular}

RIMAK International Journal of Humanities and Social Sciences www.rimalkjournal.com 


\section{IIII \\ पir \\ Rimak Journal \\ RIMAK International Journal of Humanities and Social Sciences}

ISSN: 2717-8293

\begin{tabular}{|c|c|c|}
\hline Dr. Ghrieb DJAMILA & Badji Mokhtar University & Algeria \\
\hline Dr. Suhad Ali Osman ABDALLAH & King Khalid University & Saudi Arabia \\
\hline Dr. Deniz aşkın & Bitlis Eren University & Türkiye \\
\hline Dr. Sönmez ABBASLI & $\begin{array}{c}\text { National Academy of Sciences Institute } \\
\text { of Folklore }\end{array}$ & Azerbaijan \\
\hline Dr. Yakup GÖÇEMEN & Kilis 7 Aralık University & Türkiye \\
\hline Dr. Maheer M. ABDULKAREEM & Diyala University & Iraq \\
\hline Dr. Ilhem Shahrazed ROUABAH & Blida 2 University & Algeria \\
\hline Dr. Salim Nasser Said AL KAHALI & Rimar Academy & Türkiye \\
\hline Dr. Fatima ALFAQEEH & Palestine Technical University & Palestine \\
\hline Dr. Hind GHEDHAIFI & Hama lakhdhar el oued University & Algeria \\
\hline Dr. Fatma KOÇ & Ministry of Education & Türkiye \\
\hline Dr. Mohamed Abdel Jelil Cheikh El GHADI & $\begin{array}{c}\text { Director of Nouakchott Center for Legal } \\
\text { and Social Studies }\end{array}$ & Mauritania \\
\hline Dr. Khalid ALJABRI & Ministry of Education & $\begin{array}{l}\text { Saltant of } \\
\text { Oman }\end{array}$ \\
\hline Dr. Payman Jalal AHMED & Baghdad University & Iraq \\
\hline Dr. Ahmet ISMAILOĞLU & Ankara Hacı Bayram Veli University & Türkiye \\
\hline Dr. Rashid H R H ALAZIMI & Kuwait University & Kuwait \\
\hline Dr. Muazzez HARUNOĞULLARI & Kilis 7 Aralık University & Türkiye \\
\hline Dr. Bushra Saadoon AL-NOORI & Baghdad University & Iraq \\
\hline Dr. Ibrahim ALHAMMADI & Rimar Academy & Türkiye \\
\hline Dr. Messaouda TALHA & University of Mohamed Khider Biskra & Algeria \\
\hline Dr. Nahidh Falih SULAIMAN & Diyala University & Iraq \\
\hline Dr. Samar KHAMLICHI & International Relations Academy & Morocco \\
\hline Dr. Turgay GÖKGÖZ & Kilis 7 Aralık University & Türkiye \\
\hline Dr. Aouadi MOSTEFA & Hama lakhdhar el oued University & Algeria \\
\hline Dr. Hakim Musa Abed Khudhaier ALHASANAWY & Ministry of Education & Iraq \\
\hline Dr. Rachid CHIKHOU & Mardin Artuklu University & Türkiye \\
\hline Dr. Abdoulaye Aboubakari NOUROU & Kandi University & Benin \\
\hline Dr. Nadjoua HABBA & Mohamed Khidher- Biskra University & Algeria \\
\hline Dr. Soad HABBANI & $\begin{array}{c}\text { Sidi Mohamed Ben Abdellah - Fes } \\
\text { University }\end{array}$ & Morocco \\
\hline Dr. Mohammad Ahmad Nayef ALAKASH & Jadara University & Jordan \\
\hline
\end{tabular}

RIMAK International Journal of Humanities and Social Sciences

www.rimalkjournal.com 


\section{IIII \\ ir \\ Rimak Journal \\ RIMAK International Journal of Humanities and Social Sciences}

ISSN: 2717-8293

\begin{tabular}{|c|c|c|}
\hline Dr. Rabia GHITE & Mohammed V University & Morocco \\
\hline Dr. Mohammad JUMAA & Al-maarif University College & Iraq \\
\hline Dr. Ahmet Derviş MÜEZZIN & Ondokuz Mayıs University & Türkiye \\
\hline Dr. Eyad Nathim JASSEM & Anbar University & Iraq \\
\hline Dr. Ahmed Saleh Ali BAFADHL & Quran And Islamic Sciences & Yemen \\
\hline Dr. Sundus Azeez Faris AL-FARIS & Rimar Academy & Iraq \\
\hline Dr. Alem MALIKA & Khemis Miliana University & Algeria \\
\hline Dr. Saleh Flayeh Za'al ALMATHHAN & Islamic University of Minnesota & USA \\
\hline Dr. İpek Ağcadağ Çelik & Kilis 7 Aralık University & Türkiye \\
\hline Dr. Khalid ELHAMDOUNI & Faculte of Law Rachidia & Morocco \\
\hline Dr. Thabet ZOHRA & $\begin{array}{c}\text { Arts and Humanities Raccada Kairouan } \\
\text { University }\end{array}$ & Tunisia \\
\hline Dr. Salwa Jarjees SALMAN & Kirkuk University & Iraq \\
\hline Dr. İsmet KALKAN & Adıyaman University & Türkiye \\
\hline Dr. Hayder Sahib SAHKIR & Samarra University & Iraq \\
\hline Dr. Dalila BEDRANE & Amar Tlidji Laghouat University & Algeria \\
\hline Dr. Ibrahem ALSHBLI & Mardin Artuklu University & Türkiye \\
\hline Dr.Bashir Sabhan AHMED & Tikrit University & Iraq \\
\hline Dr. Könül MAMMADOVA & Azerbaijan University & Azerbaijan \\
\hline Dr. Muna Hussein Obaid AL-SHEMALI & Baghdad University & Iraq \\
\hline Dr. Ahmet KAYA & Harran University & Türkiye \\
\hline Dr. Bushra Nima Rashid AL- EQABI & Baghdad University & Iraq \\
\hline Dr. Rza HALILOV & $\begin{array}{c}\text { National Academy of Sciences Institute } \\
\text { of Folklore }\end{array}$ & Azerbaijan \\
\hline Dr. Mosaddaq Ameen Ateah AL_DOORI & Ministry of Education & Iraq \\
\hline Dr. Mahmud KADDUM & Bartın University & Türkiye \\
\hline Dr. Alzarga HSIN & Sirte University & Libya \\
\hline Dr. Khawlah Arazzag Abdul WAHHAB & Ministry of Education & Iraq \\
\hline Dr. Yurdal CIHANGIR & Uluslararası Kıbrıs University & Cyprus \\
\hline Dr. Ibrahim Guero Mohamadoul KAIROU & University Entente International & Niger \\
\hline Dr. Muhammed Murtaza ÇAVUŞ & Doku Eylül University & Türkiye \\
\hline Dr. Amira Abdelhaiy Hassan DRAR & International University & Sudan \\
\hline Dr. Mohammad Odeh Enad ALHMMAD & Islamic University & JORDAN \\
\hline Dr. Fatma Saad AL-NAIMI & Qatar University & Qatar \\
\hline Dr. Walaa Ahmed ABDELFATAH & Prince Sattam Bin Abdulaziz University & Saudi Arabia \\
\hline
\end{tabular}




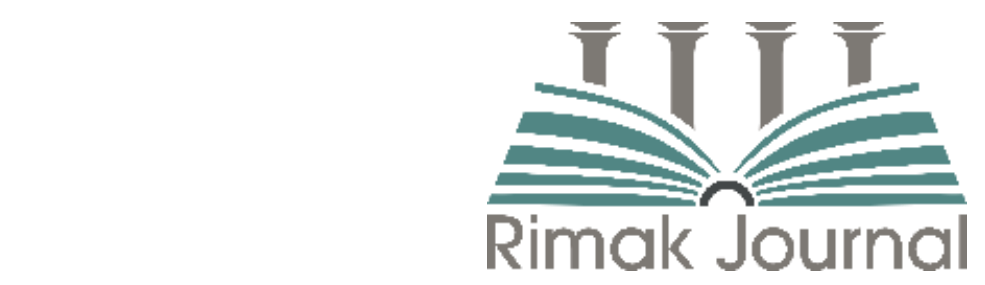

RIMAK International Journal of Humanities and Social Sciences

ISSN: 2717-8293

\begin{tabular}{|c|c|c|}
\hline Dr. Mais ODEH & Al-Istiqlal University & Palestine \\
\hline Dr. Hunida Gindil ABUBACKER & Abu Dhabi University & U.A.E \\
\hline Dr. Awan Abdullah Mhmood ALFAIDHI & Mosul University & Iraq \\
\hline Dr. Khalid Ahmed Hassan AHMED & Omdurman Islamic University & Sudan \\
\hline Dr. Yusuf KÖŞELi & Kilis 7 Aralık University & Türkiye \\
\hline Dr. Fatima AL NAWAYSEH & Mutah University & Jordan \\
\hline Dr. Boune Oueld BAHE & Nouakchoot University & Mauritania \\
\hline Dr. Mohammad Maher JESRY & Ondokuz Mayıs University & Türkiye \\
\hline Dr. Suhad AL KRAWAI & Al Mustansiriyah & IRAQ \\
\hline Dr. Sabrina TEBBOUCHE & Constantine University 2 & Algeria \\
\hline Dr. Daelm Kazum SUHEL & Baghdad University & Iraq \\
\hline Dr. Eman Mohamed Abdal Kader ATAWY & Imam Abdulrahman Bın Faisal University & Saudi Arabia \\
\hline Dr. Ahmet ADIGÜZEL & Iğdır University & Türkiye \\
\hline Dr. Fatma ALNAIMI & Ministry of Education & $\begin{array}{l}\text { Saltant of } \\
\text { Oman }\end{array}$ \\
\hline Dr. Amani Mukhtar Awadalla MOHAMED & Alzaiem Alazhary University & Sudan \\
\hline Dr. Ethar Abdul Mohesen Qasim AL-MAYYAHI & Kufa University & Iraq \\
\hline Dr. youess es SALHI & Fes University & Morocco \\
\hline Dr. Amal Taha Hussien Al ABBDI & Geriatric's Society & Saudi Arabia \\
\hline Dr. Ayad Al_HACHAMi & Ministry of Education & IRAQ \\
\hline Dr. Şentaç ARI & Girne Amerikan University & Cyprus \\
\hline Dr. Rougaya Abedrahman OUMAR & Minsteral of Hig Education & Chad \\
\hline Dr. Rafid Sabah ALdulradha AL-TAMEEMI & Baghdad University & Iraq \\
\hline Dr. Mohamad TURKEY & Ankara University & Türkiye \\
\hline Dr. Suheir Ibrahim HACHIM & Almustafa University College & Iraq \\
\hline
\end{tabular}




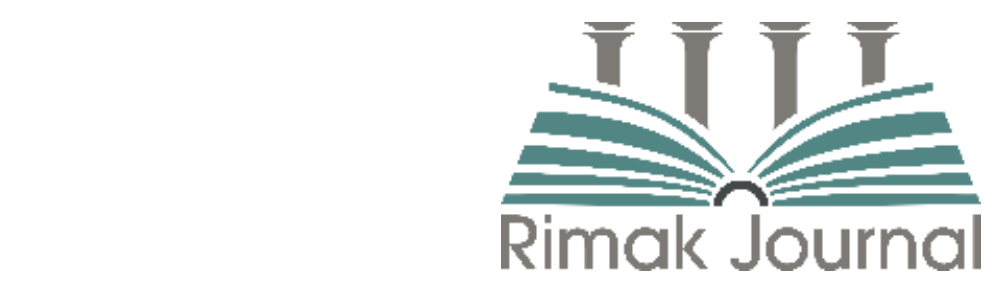

RIMAK International Journal of Humanities and Social Sciences

ISSN: 2717-8293

\begin{tabular}{|l|c|c|}
\hline Dr. Abdullah YILDIRIM & Ministry of Education & Türkiye \\
\hline Dr. Ferhat ÇETINKAYA & Dicle University & Türkiye \\
\hline Dr. Linda ABDELLAOUI & Abou Bekr Belkaid Tlemcen University & Algeria \\
\hline Dr. Sara Mohsin QADER & Salahaddin Universtiy-Erbil & Iraq \\
\hline Dr. Serdal IŞIKTAŞ & Sağlık Bilimleri University & Cyprus \\
\hline Dr. Mohamad ALAHMAD & Gumushane University & Türkiye \\
\hline Dr. Siham GOUASMIA & Mohammed Sherif Mesaadia University & Algeria \\
\hline Dr. Athraa Ismael ZADIN & Baghdad University & Iraq \\
\hline Dr. Tijani BOULAOUALI & KU Leuven University & Belgium \\
\hline Dr. Huda Abed Ali HATTAB & Baghdad University & Iraq \\
\hline Dr. Jihane FAKIH & Lebanese University & Lebanon \\
\hline Dr. Saedah ALBEERISH & Benghazi University & Libya \\
\hline
\end{tabular}


January 2022, Volume 4, Issue 1

\section{From Editor:}

We are pleased to announce the launch of the Fifteenth issue of RIMAK International Journal specifically dedicated to humanities and social sciences, and release this issue. We hope that readers will find the published articles as informative as we found it to be.

Our journal is committed to shoulder the responsibility to encourage humanities and social sciences research, not only by building a Worldwide bridges and bonds among researchers, but also by granting social sciences researchers equal opportunities for serving humanity and finding solutions for its problems.

One of the objectives of this journal is to encourage publication from various contexts addressing different issues dealing with an applied perspective to the field of humanities and social sciences. We therefore would like to welcome submissions to discuss the latest developments in the field of humanities and social sciences for the future issues of RIMAK.

Prof. Dr. Hani Alyas KHADHER

Rimar Academy 
RIMAK International Journal of Humanities and Social Sciences

ISSN: 2717-8293

January 2022, Volume 4, Issue 1

İçindekile / Table of contents/الـفهـرس

ARCHAEOLOGICAL DOCUMENTATION OF HISTORICAL EVENTS IN THE HOLY QURAN STORIES OF THE PROPHETS AS A MODEL-

Chiheb NEGADI :

ARGENTINE WAR OF INDEPENDENCE $1812-1850$

Maher Mubdir AL-ABBASI:.

PUBLIC BANQUET IN THE ABBASID ERA

Moayad Ibrahim Mohamed HASSAN:

NOBUSUKE KISHI AND HIS ROLE IN JAPANESE POLITICS (1957- 1960)

Suha Adel OTHMAN:

THE POSITION OF THE SOVIET UNION ON THE INDEPENDENCE OF KUWAIT IN 1961

Howra Abdul SATTAR:

THE ROLE OF SCHOOL ADMINISTRATION IN INCREASING THE EFFECTIVENESS OF ASSISTIVE TECHNOLOGY FOR STUDENTS WITH SPECIAL NEEDS

Naaila Jeries HADDAD:

NATURAL FACTORS AFFECTING ECO-ARCHITECTURE (DADES OASIS MODEL)

Farida OUZDI: 90

EXERCISES WITH INCREASING AND DECREASING MUTUAL DISTANCE BETWEEN THE TWO COURTYARDS IN DEVELOPING THE ACCURACY OF THE SERVE IN TENNIS

Hasan Ch Sabar AL-DULAIMI, Abduljalil Mouloud Abduljalil ALBAYATI

\& Mohammed Saloom ALRAW: 106

DIGITIZATION AND EDUCATIONAL PROCESS ... A CONCEPTUAL APPROACH

Sumaiah Eid ALZABOOT

THE STRUCTURE OF SYMBOLIZING IN THE NOVEL "TESTIMONY OF WARTIME" IN THE LIGHT OF CHARLES SANDERS PIERCE'S THEORY

Khalid Sulaiman Muhanna ALKINDI 136

TIME MANAGEMENT STRATEGY AND ITS RELATIONSHIP WITH THE ACADEMIC ACHIEVEMENT OF STUDENT'S OF AL ZAIEM A L AZHARI UNIVERSITY, FACULTY OF EDUCATION, MODEL

Amani AWADALL: 


\section{RIMAK International Journal of Humanities and Social Sciences}

ISSN: 2717-8293

January 2022, Volume 4, Issue 1

THE INVESTIGATION OF "DiĞENIS AND AZRAIL" AND "DUHA KOCA OĞLU DELI DUMRUL" IN CONTEXT OF INTERCULTURAL INTERACTION

Şentaç ARI:

CULTURAL HEGEMONY IN CHINUA ACHEBE'S THINGS FALL APART: A POSTCOLONIAL ANALYSIS

Shaymaa Neamah Mohammed ALMKHELIF :

IMAGINATION IN ORHAN PAMUK'S NOVEL THE WHITE CASTLE

Sevsen Aziz HILAYIF:

THE CONTROVERSY OF ROOTING AND CONTRASTING ONE-LETTER FORMATIONS

Kifah Jumaah Hafth SABER

THE VERB IN CONTEMPORARY ARABIC

Majeed Khairallah RAHI:

A CONTRASTIVE ANALYSIS OF RELATIVE CLAUSE GRAMMAR IN BOTH ARABIC AND ENGLISH

Rana Abid THYAB:

ARCHITECTURAL HERITAGE IN THE CITY OF NAZNRETH DURING THE OTTOMAN ERA 1517-1918

Hussein MANSOUR:

DISCOURSE ANALYSIS THEORY AND ITS ROLE IN DEFINING POLITICAL INTENT THE SPEECH OF HIS MAJESTY SULTAN QABOOS BIN SAID, MAY GOD REST HIS SOUL, AT THE OPENING OF THE SIXTH SESSION OF THE COUNCIL OF OMAN AS A MODEL

Zahir Bin Marhoon Bin Khaseef AL-DAOUDI:

THE DEGREE OF EFFECTIVENESS OF DISTANCE LEARNING IN LIGHT OF THE OUTBREAK OF THE CORONA VIRUS FROM THE POINT OF VIEW OF STUDENTS IN HIGHER EDUCATION INSTITUTIONS IN BEERSHEBA

Hatem AZBARG:

CARTOGRAPHY AMONG MUSLIM ARABS IN THE MIDDLE AGES

Dhilal Jawad Kadhim YASSIN:

THE CONCEPT OF EXPATRIATION IN THE POEMS OF FAROUK NAFEZ JAMLIBEL

Hazim Mohammed HUSSEYIN \& Widaad Jasim MOHAMMED:.

LEXICON REFERENCING AND TEXT/PRAGMATIC ANALYSIS CONCEPTS AND APPLICATIONS

Majeed Khairallah RAHI \& Abdelmale BELKHEIR:

DEATH AND POST-DEATH IN THE POETRY OF AHMED ARIF

Ihsan Hadi Ahmed ALDULAIMI: 
RIMAK International Journal of Humanities and Social Sciences

ISSN: 2717-8293

January 2022, Volume 4, Issue 1

THE OTTOMAN POSITION ON THE RUSSO JAPANESE WAR IN THE FAR EAST 1896-1905

Ekrem AKMAN \& Rachid CHIKHOU :

OBSTACLES OF APPLYING SCIENCE AND MATHEMATICS TEACHERS' OF FUTURE SKILLS IN BASIC EDUCATION SCHOOLS IN THE SULTANATE OF OMAN FROM THE POINT OF VIEW OF TEACHERS AND EDUCATIONAL SUPERVISORS

Humaid Muslem ALSAIDI \& Khalid Juma ALSHIDI : 346

DEGREE OF AVAILABILITY OF ACTION RESEARCH STANDARDS FOR SENIOR TEACHERS IN BASIC EDUCATION SCHOOLS IN OMAN

Humaid Muslem ALSAIDI \& Amal Abdallah ALHARMALI:

VISIOCONFERENSING TECHNOLOGY AND THE RIGHT TO A FAIR TRIAL

Lynda MABROUK:

PSYCHOSO CIOLOGICAL CONSTRUCTION OF THE CONCEPT OF MADNESS

Hanane EL GHOUAT.

GRAPHIC DESIGN IN THE AGE OF DIGITAL TRANSFORMATION

Nsiyf Jassem MOHAMMED:

THE WOMEN IN THE NOVELS OF SAAD MOHAMMED RAHEEM

Ihsan Hussain ZUBAID:

A POSSIBLE CORRELATION BETWEEN MYOSTATIN AND TESTOSTERONE AIDED BY GENETIC FACTORS ENHANCING ATHLETIC PERFORMANCE AND MUSCLE RECOVERY

Abdul Razzaq Jabr AL MAJIDI, Rafia S. FATHI \& Rehab S. RAMADHAN:

GENERAL LINGUISTIC DICTIONARY DESCRIPTIVE STUDY

Omar Hassan RASHID \& Waqas Saadi GHARKAN :

CHILD CUSTODY: A RIGHT OR A DUTY (A STUDY OF AN APPROACH TO AMEND ARTICLE 57

OF THE IRAQI PERSONAL STATUS LAW)

Um Kalthum Sabeeh MOHAMME \& Saja Hazim MAHMOOD:

THE POSITION OF THE OTTOMAN EMPIRE ON THE ISSUE OF THE MORISCOS AND ITS STRATEGY TOWARDS IT

Metin ŞERIFOĞLU:.

SYCLE ONE SCHOOL PRINCIPLES'TEACHER JOB SATISFACTION IN NORTH AL BATINAH IN THE SULTANATE OF OMAN

Mohammed Saleh ALAJMI \& Naima Salim Said AL RISI:. 


\section{RIMAK International Journal of Humanities and Social Sciences}

ISSN: 2717-8293

January 2022, Volume 4, Issue 1

THE INFLUENCE OF GREEK PHILOSOPHY ON ISLAMIC CULTUREAL-TAWHIDI IS A MODEL

Nada Mousa ABBAS.

THE ROLE OF THE DIVAN CLERKS AND POLITICAL LETTERS IN THE DEVELOPMENT OF THE I. ABBASID PERIOD LITERATURE PROSE. AHMED BIN YOUSSEF'S ALHAMIS RESSALA AS AN EXAMPLE

Muhammet ABAZOĞLU:

OTTOMAN NAVAL WARS (1454-1918): (HISTORICAL STUDY)

Sahira Hussein MAHMOUD:

A LITERARY READING IN THE LINGUISTIC EFFORTS OF IBN QUTAYBA IN HIS BOOK ADAB AL-KĀTIB "THE WRITER'S LITERATURE"

Saleh ABBOUD:.

THE DISTRIBUTIONALISED (AL) IN THE BOOK (RAWDHAT AL-HADA'IQ IN EXPLAINING THE LAMA MESSAGE ) BY ABDULRAZZAK IBN MUSTAFA AL-ANTAKI (ق 11 A.H.)A STUDY AND AN INVESTIGATION

Zena Kamil SHAKIR:

THE REALITY OF THE EVALUATION OF EDUCATIONAL PERFORMANCE IN THE LIGHT OF THE COMPETENCY-BASED APPROACH

Brahim TAMETELT \& Asma Ben YAHIA:

605

THE POSITION OF THE UNITED STATES OF AMERICA ON IRAQ'S ENTRY INTO

THE LEAGUE OF NATIONS IN 1932

Ilham Mahmoud JADER \& Rawaa Sabahh GANNAWI:

THE AESTHETIC DISCOURSE OF DECORATIVE ART (ISLAMIC CIVILIZATION AS A MODEL)

Jolan Hussien ALWAN

STRUCTURAL PATTERNS IN THE CONSTRUCTION OF THE QURANIC SCENE, A READING IN THE PURPOSES OF SHARIA

Basim Rashid ZOBAA \& Osama Hamdan Abdullah RAHIM:

ELEGIES FOR THE PROPHET'S FAMILY BY CONTEMPORARY LEBANESE CHRISTIAN POETS

Khalid Ahmad SINDAWI:

SPECIAL DATA ACCORDING TO THE BRAIN-BASED LEARNING STRATEGY IN LEARNING SOME BASIC VOLLEYBALL SKILLS FOR FEMALE STUDENTS

Nidal Fadel ABBAS, Esraa Fadel ABBAS \& Magda Hamid KAMBASH 
RIMAK International Journal of Humanities and Social Sciences

ISSN: 2717-8293

January 2022, Volume 4, Issue 1

SCIENTIFIC RESEARCH AND ITS ROLE IN DEVELOPING THE SKILLS OF FACULTY MEMBERS IN THE LIGHT OF QUALITY STANDARDS AND PERFORMANCE EVALUATION AT THE UNIVERSITY OF TRIPOLI

Abdegadir Emhammed Salih MANSOUR:

THE EFFECT OF COMBINING TEACHING GAMES ON ACADEMIC ACHIEVEMENT

Kamilia RADI:

718

THE DESIGN SYSTEM AND ITS FORMAL INFERENCE IN LOGO DESIGN

Fouad Ahmed Shallal AL-SAMARRAEE: 


\title{
ARCHAEOLOGICAL DOCUMENTATION OF HISTORICAL EVENTS IN THE HOLY QURAN - STORIES OF THE PROPHETS AS A MODEL-
}

\author{
Chiheb NEGADI ${ }^{1}$
}

\section{Istanbul / Türkiye}

p. 1-17

Received: 05/11/2021

Accepted: 05/12/2021

Published: 01/01/2022

This article has been scanned I iThenticat No plagiarism detected

\begin{abstract}
:
The modern scientific revolution has imposed on the researcher to broaden his view by referring to more than one science in addressing his research issues, and in the light of the contemporary ideological debate that the unspoken and the accepted are recognized to without the slightest prestige, it is necessary to discuss what these debates erupt with objectivity and impartiality. The issue of the historical existence of the Qur'anic events, which was taken - according to Arab modernists - from the school of archaeological criticism of the Bible as an example, and since the prevailing belief among Muslims is the infallibility of the Holy Qur'an from distortion and falsification through recurrent and because it contained - equivalent to a third - on Historical events, including stories, and previous facts, it is not possible "beliefly" and "realistically" that the divine news contradict the achieved historical reality, and since the main purpose of the Holy Qur'an - including the verses of the stories is guidance, the Qur'an has transmitted history To achieve this purpose without being a book of history that delves into the details and identifies the dates and respects the chronologies with precision and detail, it is not possible "methodologically" and "realistically" to require the archaeological evidence for each Qur'anic event, especially since the nature of the archaeological research itself He suffers from technical and epistemological gaps that make his discoveries and reading of him between the hypothesis of the results of the auxiliary sciences and the selfinterpretation of the archaeologist, and the process of archaeological documentation of historical events in Holy Qur'an remains - if it is achieved - as a matter of concerted evidence despite its suspicion - that raises the believer's faith - and faith in degrees. - It also obliges the non-believer in the Qur'an as a divine source to conform to the material evidence of the divine revelation or what is termed in Islamic thought with the "scientific miracles of the Holy Qur'an ".
\end{abstract}

Key words: Quranic Studies, Historical Miracles, Archeology, Documentation, Stories of The Prophets.

http://dx.doi.org/10.47832/2717-8293.15.1

1 iD Researcher, Ahmed Ben blla university, Oran, Algeria, negadi_chiheb@outlook.fr, https://orcid.org/0000-0003-3544$\underline{3154}$

Copyright (C) Published by Rimak Journal, www.rimakjournal.com Rimar Academy, Fatih, Istanbul, 34093 Turkey 


\section{التوثيق الأركيولوجي للأحداث التاريخية في القرآن الكريم

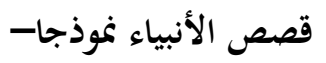

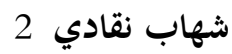

الملمص:

أصبحت الثورة العلمية الحديثة تفرِض على الباحث التوسيع من نظره بالرجوع إلى أكثر من فنّ في معالجة القضية

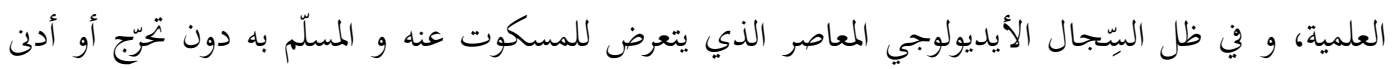

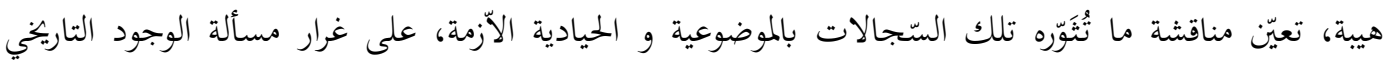
للأحداث القرآنية و التي أخذ حداثيو العرب من مدرسة النقد الأركيولوجي للكتاب المقدس مثلا يُجتدى به، و وبما

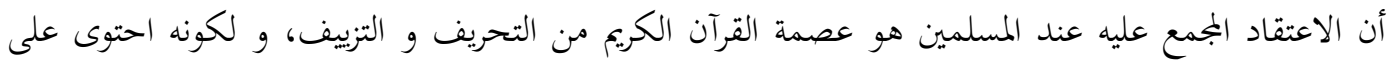
أحداث تاريخية من قصصٍ و أخبارٍ بما يوازي الثلث، فلا يمكن "واقعيا" أن يخالف الخبر الإلهي الواقع التاريخي

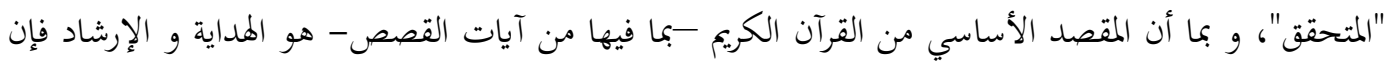

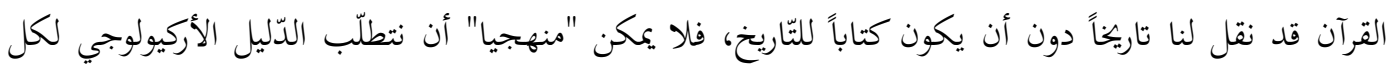

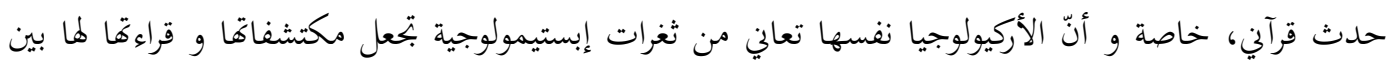

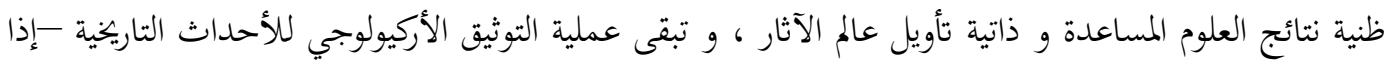

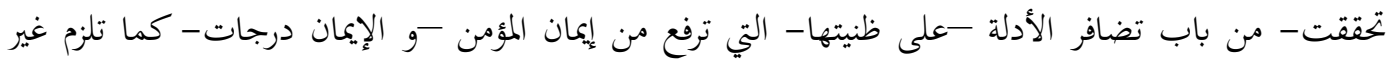

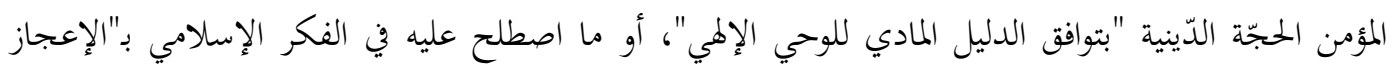

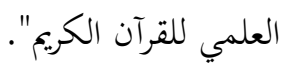
الكلمات المفتاحية: دراسات قرآنية، الإعجاز التاريخي، الأركيولوجيا، التوثيق، قصص الأنبياء.

إنّ تَبيت الحَدَث دَعْوى مَرْونة بتوثيقه، كذا في البحث التاريخي، و يُعتبر توثيق الوقائع التاريخية بالآثار و المخلّفات المادية

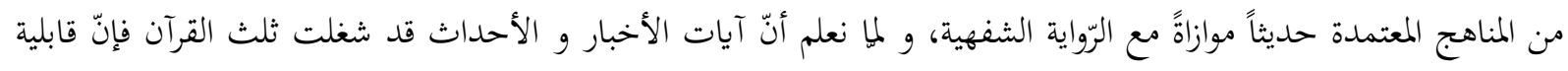

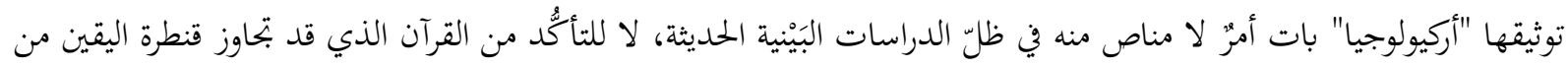

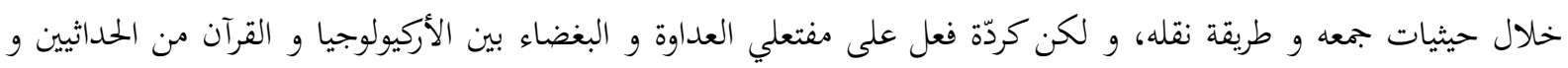

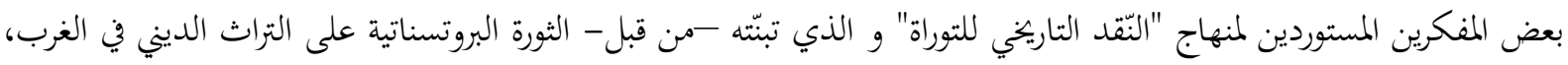

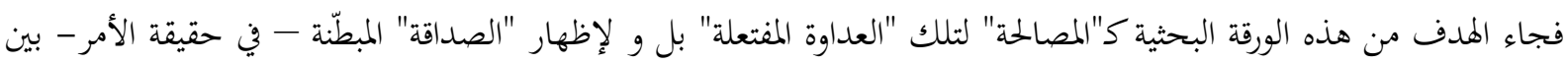

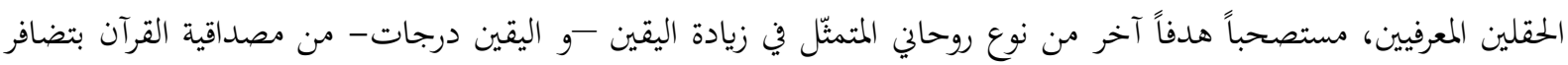
الأدلّة و تصديق بعضها البعض.

و عليه فإنّ بلوغ هذه الأهداف يتوقّف أساساً - و بعيداً عن عاطفة الانتماء و الاعتزاز بالدّين- على محاولة حلّ

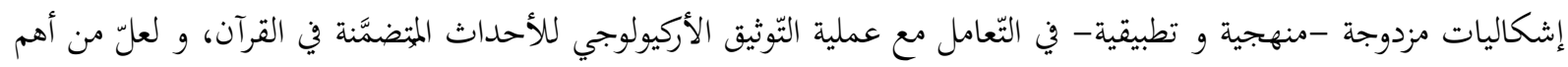

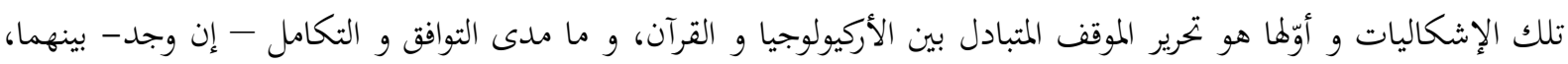


مع محاولةِ نمذجة النتائج المحتملة لتلك الإشكاليات من خلال وقائع تاريخية قرآنية اخترت أن تكون في مجال قَصص الأنبياء -

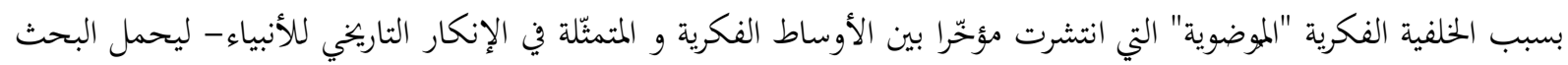

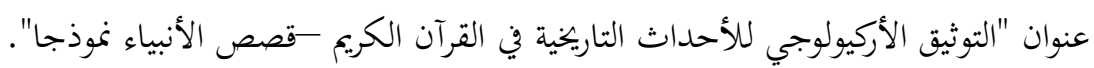
يمكن معالجة الموضوع و إشكالياته بطرق متعددة، و لكني قدّرت أن تكون الطريقة المناسبة بعقد "المقابلة" بين طرفي

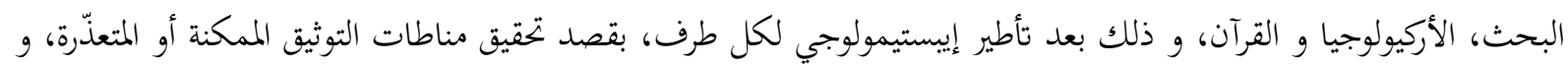

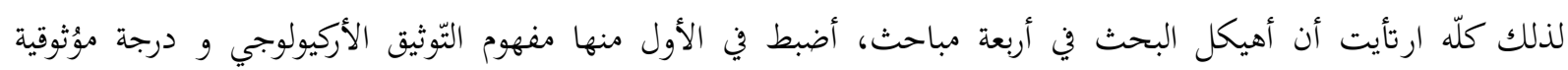

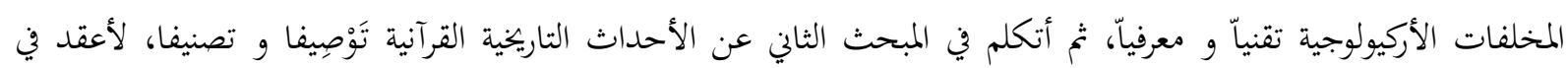

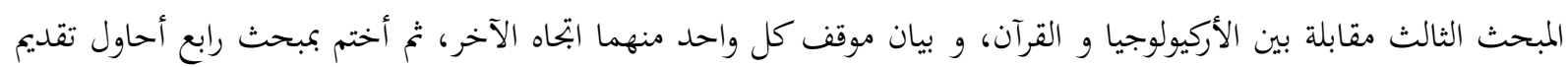
نماذج من التّوثيق الأركيولوجي لبعض الوقائع التاريخية في قصص الأنبياء و النظر في مدى نجاعة ونياعة هذه المقاربة. 


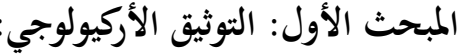

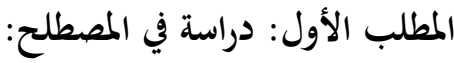

صحح ابن فارس أصل مادة "و ث ق" و أرجعها إلى دلالة العقد و الإحكام، و الميثاق عنده بمعنى العهد المئكم ثم

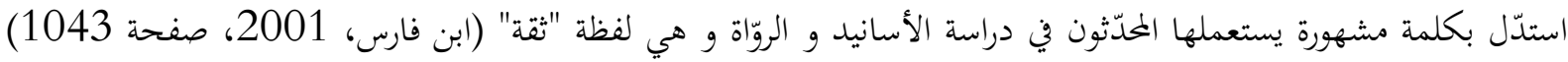

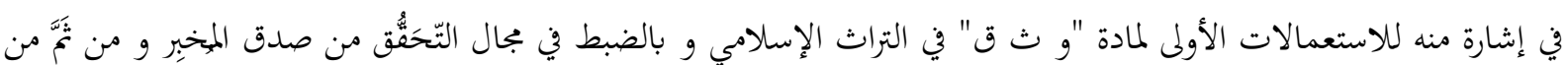
صدق الخحبَر، و تُسمّى هذه العملية بالتّوثيقيق.

بتطوّر العلوم و تشعبّها أخذت كلمة "التوثيق" ثُخصّص أو تُعمّم من مدلولها تبعاً لتطور مدلول كلمة "الوثيقة" بما يوافق

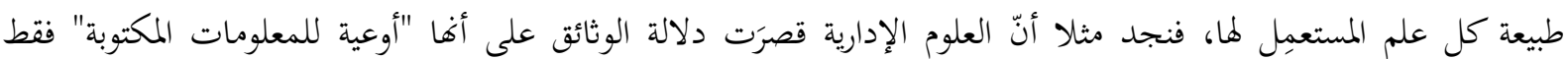

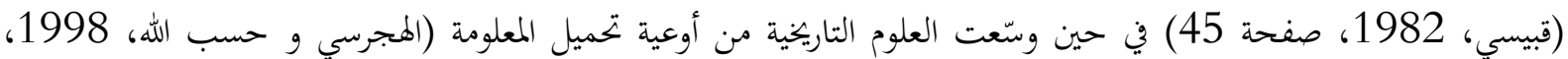

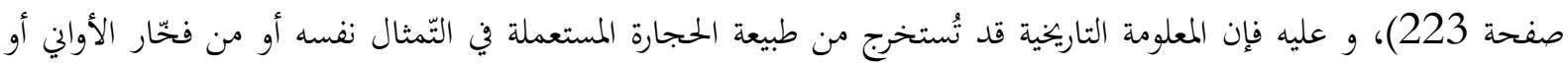

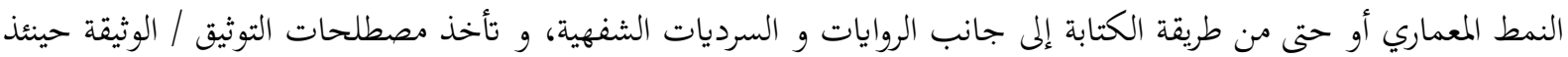
معناها الأعم.

أما مصطلح الأركيولوجياً Archeologie، فرغم تركيبه المزجي بين مصطلحين إغريقيين "أركيوس arkhaios" أي

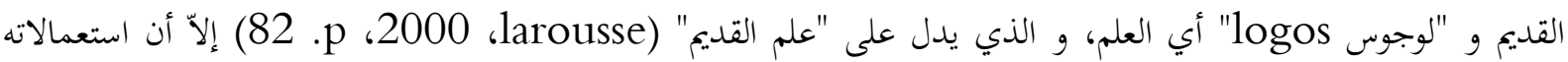

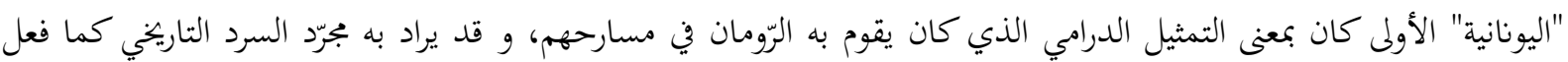

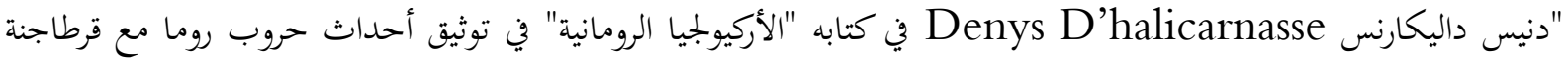
في القرن الأول الميلادي، ثم كان من الأوائل الذين استعملوا كلمة أركيولوجيا بمعناها المعهود الفرنسي "جان سبون"، لكنه كان

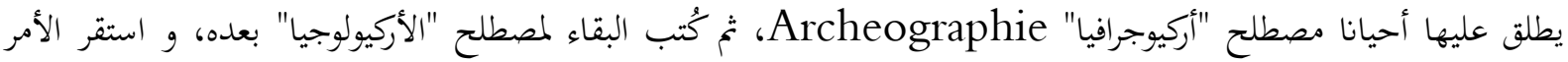
عليه إلى العصر الحديث (حسن ع.، 1993، الصفحات 12-13)، و الذي يدل على "علم التحري عن الأصول المادية

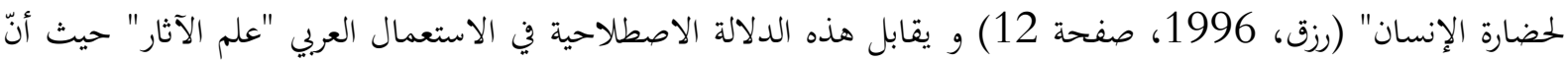

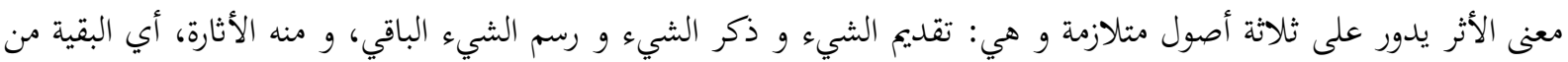

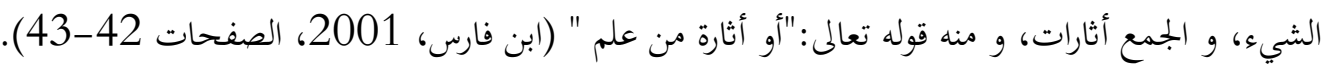
يحدد المصطلحان -سواء اللاتيني "archeologie" أو العربي "الآثار"- موضوع الدراسة الذي هو الإنسان بثقافته و فكره و فنّه، كما يحدد موضِع الدراسة و هي كل مُخلّفٍ أو بقايا تُشكّل وعاء لموضوع تلك الدراسة. بعد تأصيل اصطلاحي ل"التوثيق الأركيولوجي" يمكن اقتراح التعريف التالي و هو "عملية التَّقُقُق من الخبر التاريخي "الشفهي" من خلال البقايا "المادية" لذلك الخبر" حيث تُصبح الرواية التاريخية موضُوع التوثيق، و المخلّفات المادية موضعِع التوثيق، و الأركيولوجيا منهج التوثيق من ل

المطلب الثاني: موثوقية الأركيولوجيا

في أي عملية توثيقية يُشترط فيها تحديد درجة موثوقية الوعاء المعلوماتي الموثق به، بغض النّر عن مصداقية المحتوى الذي

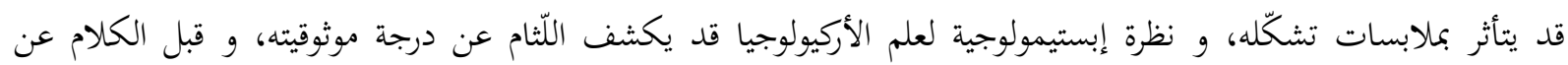

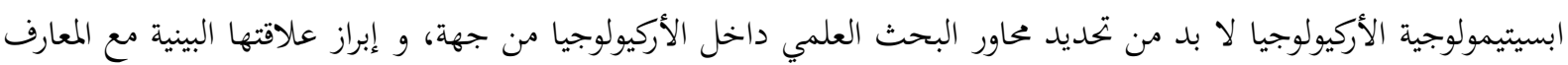
المختلفة من جهة أخرى. 
أما من جهة محاور البحث الداخلية فإن ثمة بجالين أساسين يتلخص فيهما البحث الأركيولوجي، الأول المتمثّل في عملية

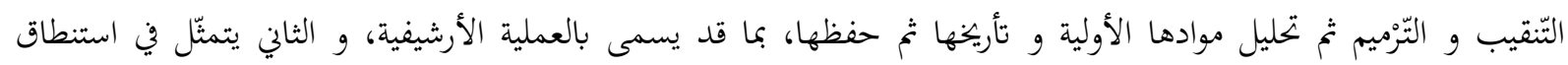

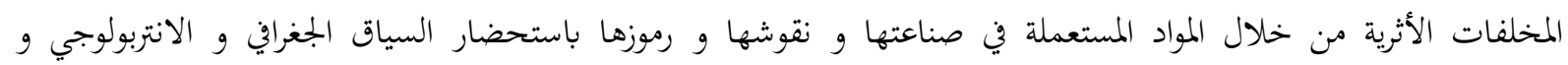

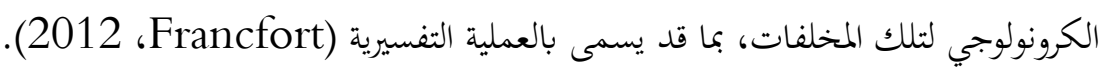
بناء على تحديد محاور الدراسة الأركيولوجية، فإن علاقتها البينية بالحقول المعرفية الأخرى باتت ظاهرة، حيث أن عملية

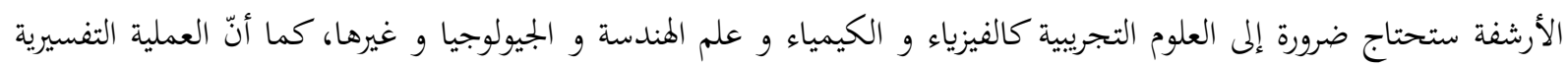

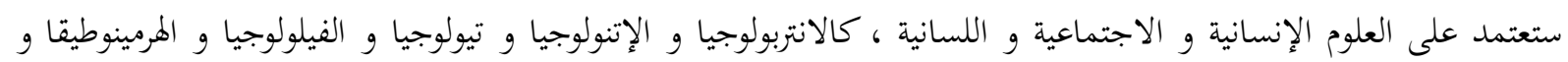

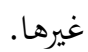
يظهر أن علم الأركيولوجيا هو أكثر العلوم التي يتقاطع فيه الحقول المعرفية على الإطلاق (yoffee \& severin،

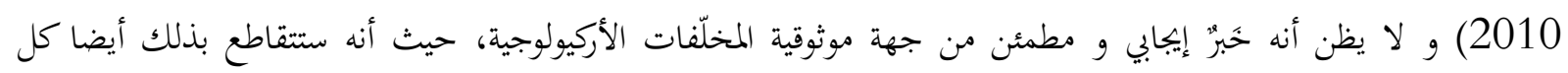

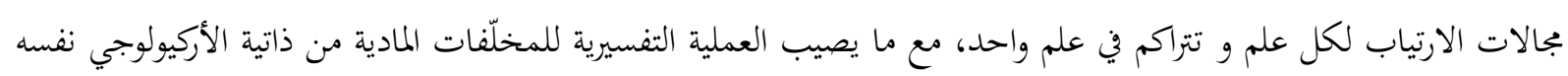

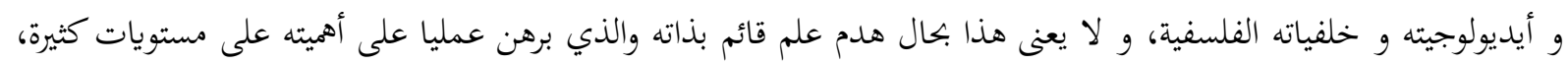

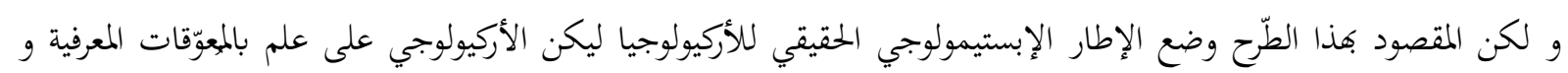
التقنية و يتعامل معها بأكبر قدر ممكن من الحيادية و الموضوعية مستحضرا أثناء بحثه بأن المعلومة الأركيولوجية تتميّز بأها:

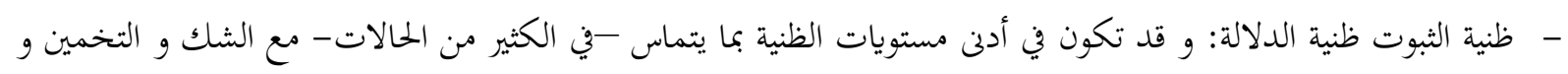

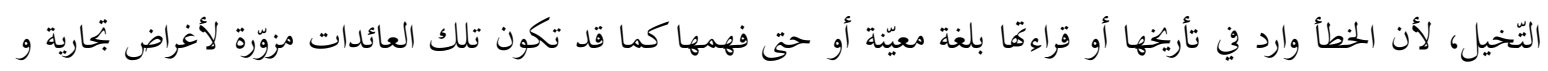
سياحية و حتى إيديولوجية فلا يتعجّل في الجزم بالحقائق.

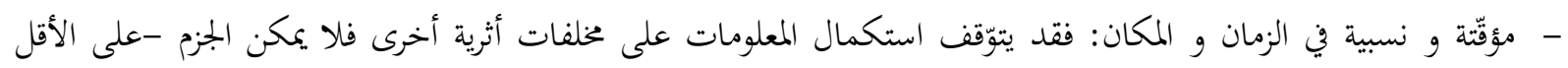

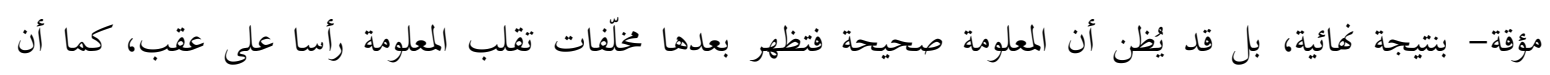

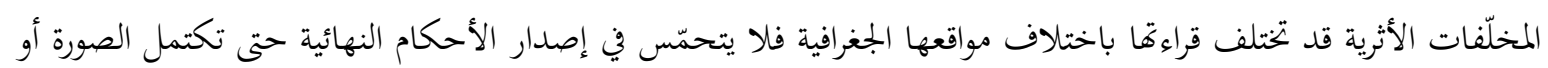

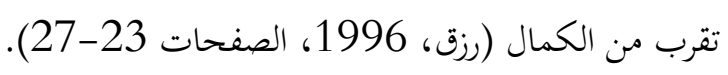
- تحتمل الأدلجة من مستنطقيها: و من ذلك توجيه بعض التفسيرات بما يتوافق و إيديلوجيات معينة كالعِلموية الإلحادية المنكرة

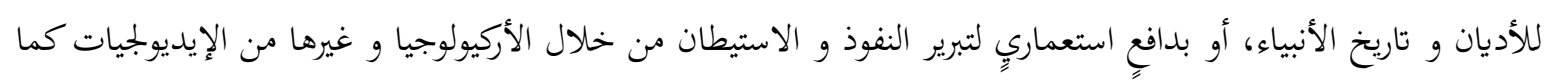

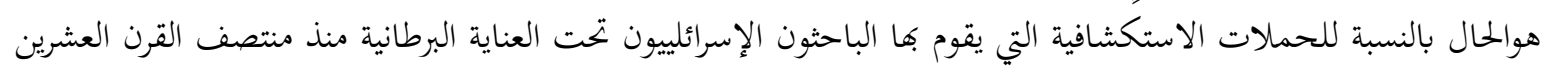

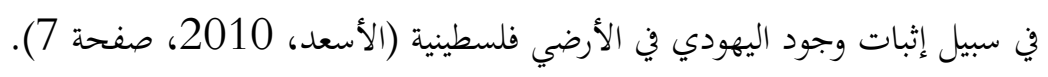

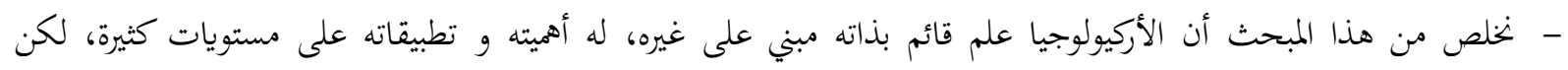

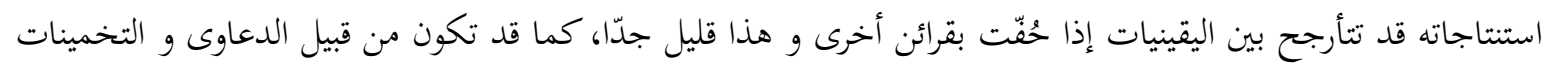

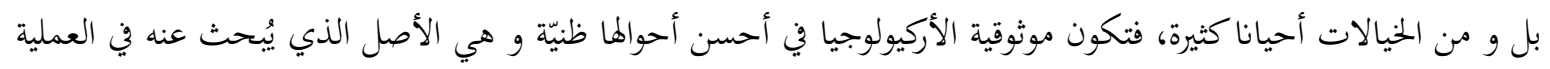
التوثيقية (علي، 2019). 


\section{المبحث الثاني: التاريخ في القرآن الكريم \\ المطلب الأول: توصيف و تصنيف}

من منطلقٍ إحصائي احتوى القرآن الكريم على مادّة تاريخية بنسبة الثُّث، مما يرشحه أن يكون أحدَ مصادر الرواية التاريخية

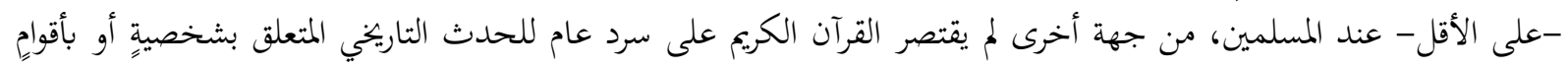

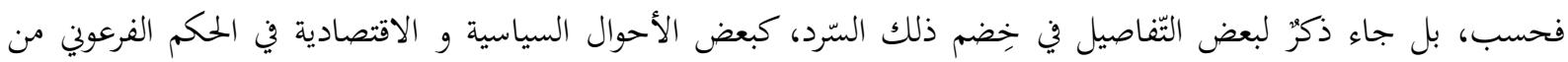

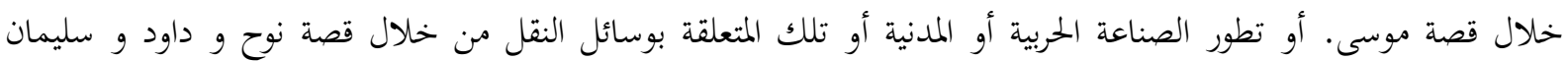

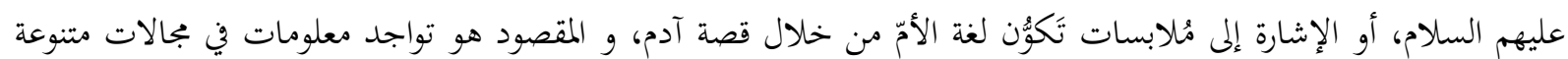

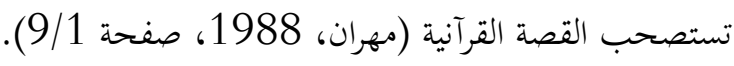
و مما يجب التأكيد عليه إبستيمولوجيا هو أن القرآن الكريم يعتبر مصدراً تاريخياً من غير أن يكون كتابا للتّريخ، و هذا

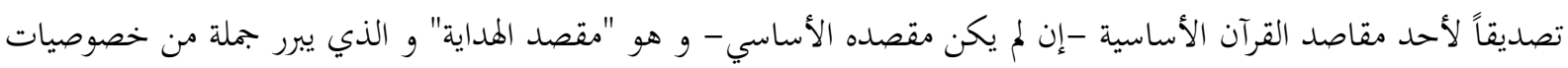

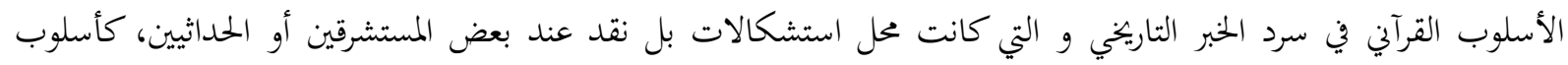

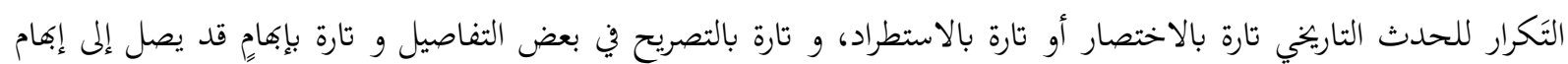

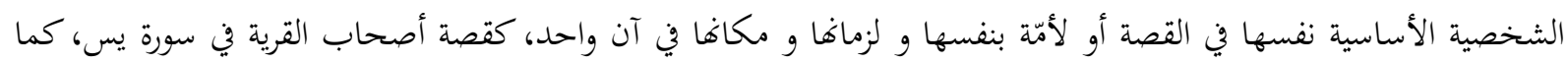

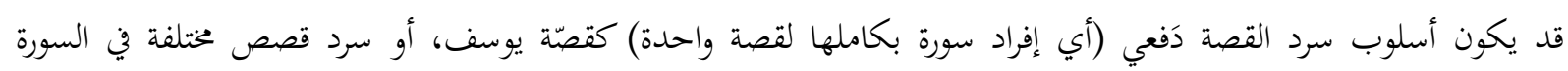
الواحدة تارة بترتيبها الكرونولوجي كما في سورة الأعراف وهود و القمر، و تارة بغير تريتب كما في سورة مريم و الأنبياء و الشعراء

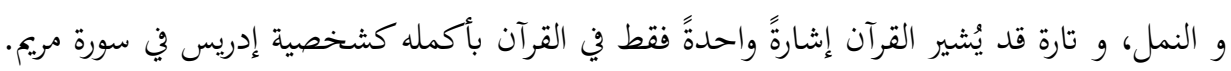

كل هذا التنوع في الأسلوب السردي التاريخي في القرآن جاء ليحقق مقصد الإرشاد و الوعظ و تثبيت القلوب فلا يُتعامل

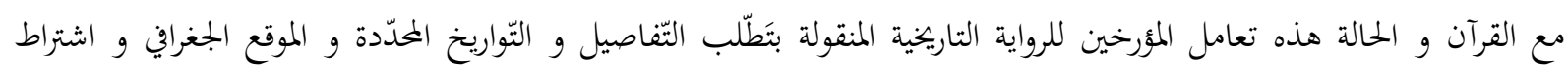

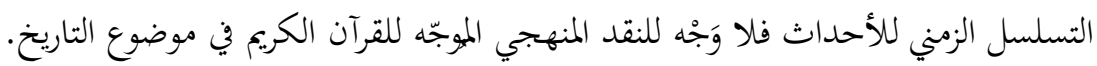
و بعقد مقارنة بين المضمون التاريخي في القرآن الكريم و السّرديات التاريخية الأخرى، سواء ذات مصدر بشري أو إلهي

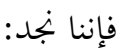
1- توافقاً كبيراً مع بعض الأساطير و الأحداث و الأخبار الشعبية الموروثة، مما يقيم أصلا للحَدَث أو ما يسمى بـ"نواة الحدث"

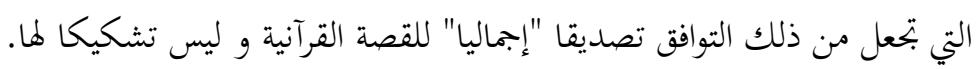

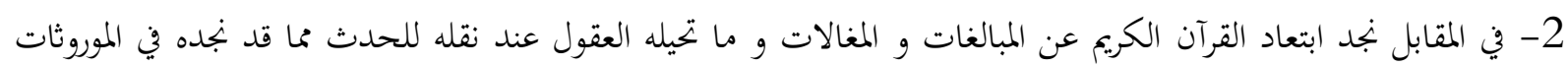

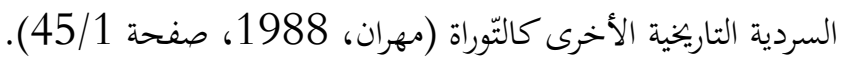
3- انفرادات القرآن بأحداث لم ترد إلا فيه، بل و مخالفات لبعض التفاصيل التاريخية جاء القرآن كالمرصحّح لها و الممعقّب للمعهود

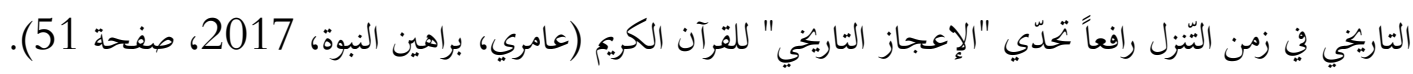

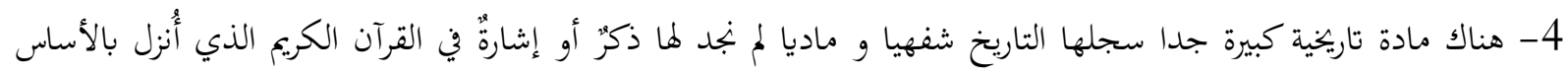

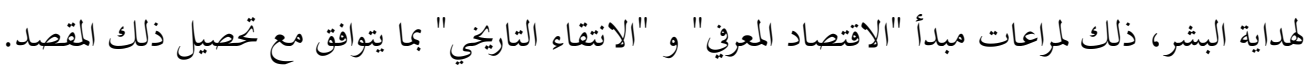




\section{المطلب الثاني: موثوقية الأحداث القرآنية}

يقابل هذا المطلبُ المطلب الثاني من المبحث الأول و الذي جاء تحت عنوان "موثوقية الأركيولوجيا"، للوقوف على

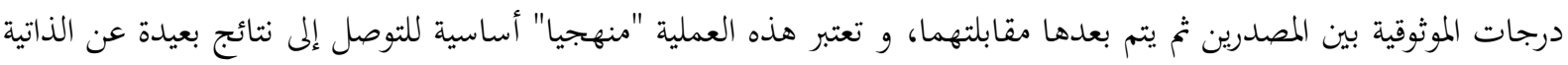
و عاطفة الانتماء الديني، و كذلك لتحقيق الدقة في عملية التوثيق بعد ترتيب درجة الموثوقية لكل مصدر.

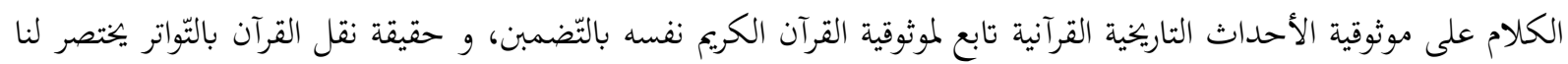
طريق تثبيت موثوقيته (و ليس مصداقيته التي يتعلق موضوعها بفلسفة العلوم الدينية و مقارنة الأديان) . التّواتر هو ما رواه جمعُ عن جمع عن جمع تحيل العادة اتفاقهم على الكذب (عبدالمنعم، 1999، صفحة 212/3) و هو

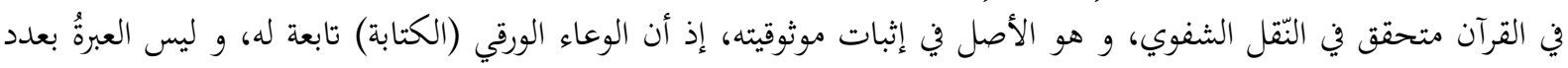

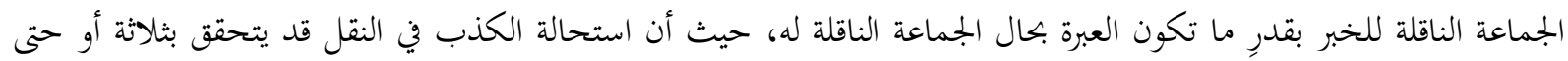

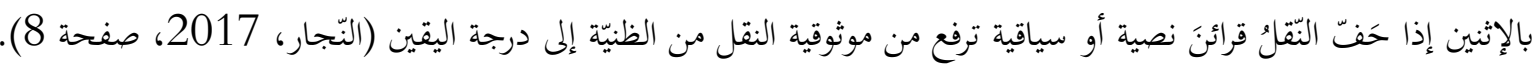

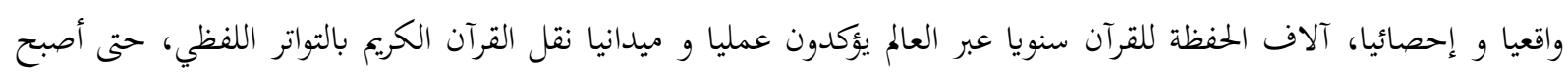

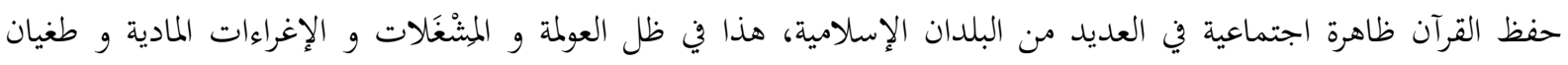

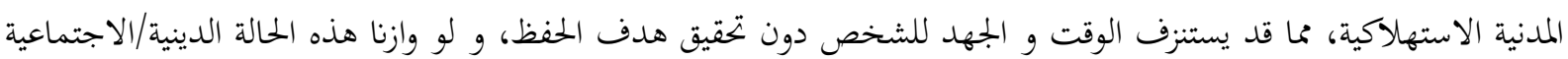

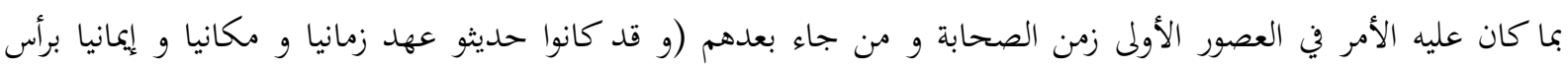

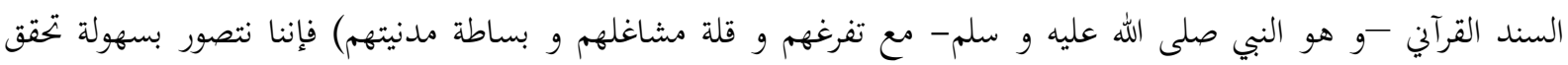

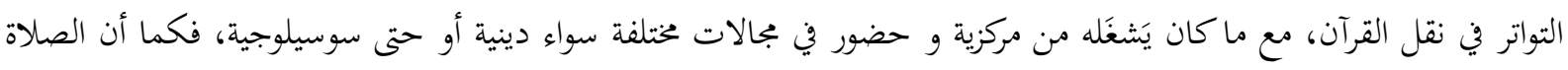

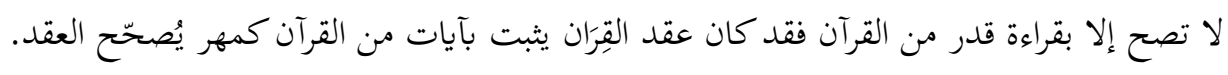
أما من ناحية الأنتروبولوجية فقد كانت القدرة على الحفظ عالية "كما و كيفا" في الأزمنة القديمة و هي ملكة كاد الإنسان

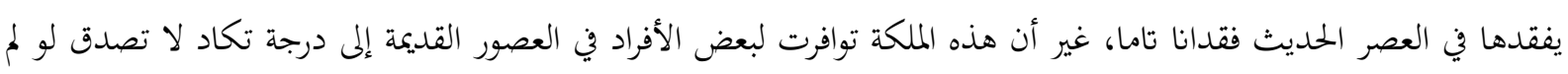

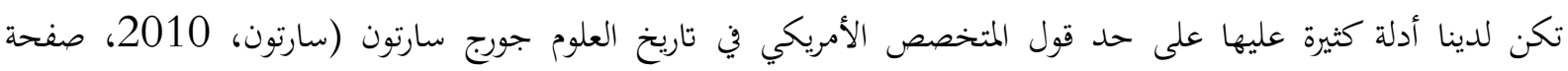

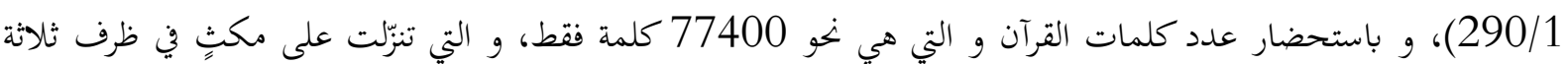
عشر سنة كاملة، لا يُتصوّر أبدا ضياع القرآن الكريم من جهة حفظ كلمات كلماته.

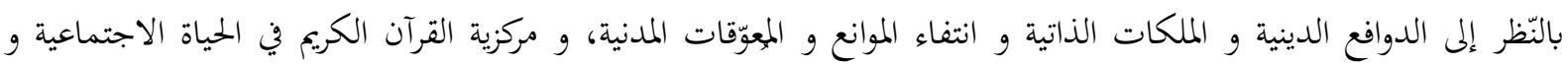

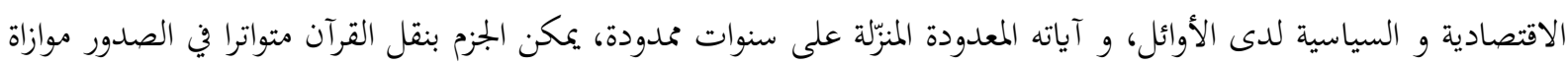

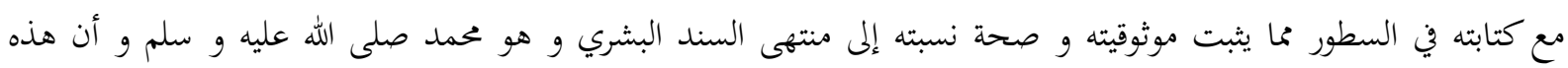
الموثوقية ترقى إلى درجة اليقين بلا شك.

يقول أحد أشهر و أشرس المستشرقين الناقدين للقرآن و هو مارجليوث حول نظرية الإسناد:"إن قيمة نظرية الإسناد في

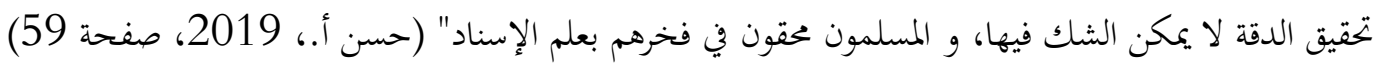




\section{المبحث الثالث: الأركيولوجيا و القرآن، المقابلة \\ المطلب الأول: موقف القرآن من الأركيولوجيا}

بمقاربةٍ موضوعية للآيات القرآنية سأسرد بعض الآيات الدّالة -بالمقتضى أو باللاّزم- على موقف القرآن من الأركيولوجيا كعلم قائم

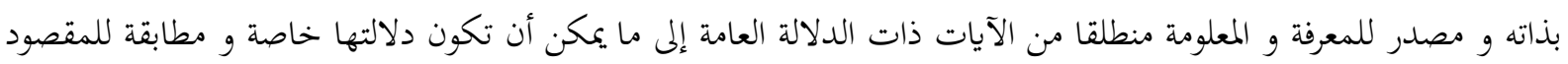
محيلا إلى التفاسير المعتمدة طلبا للاختصار:

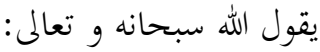

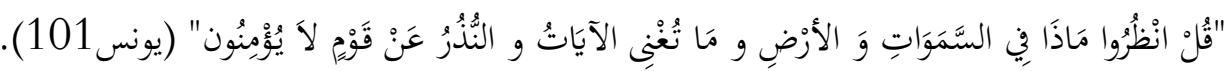

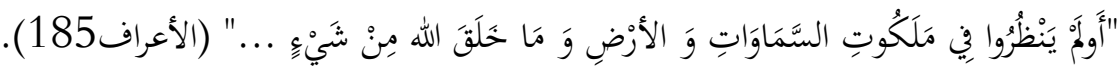

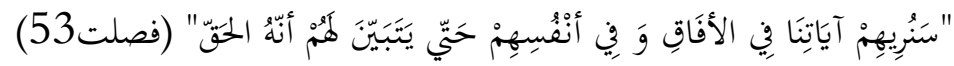

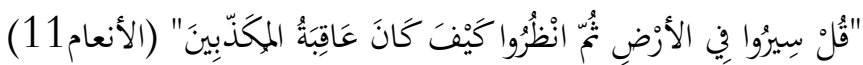

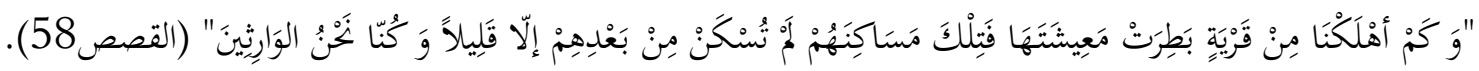

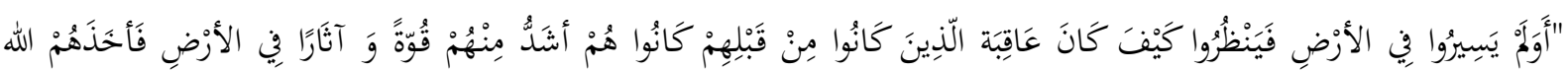

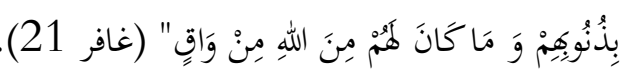

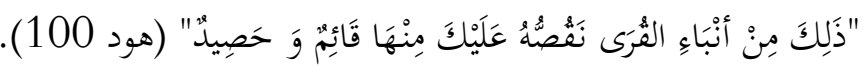

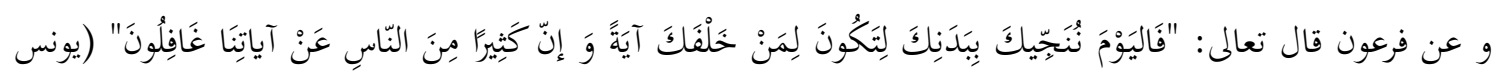

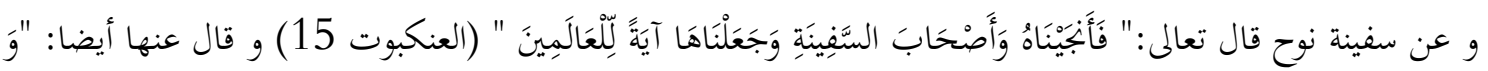

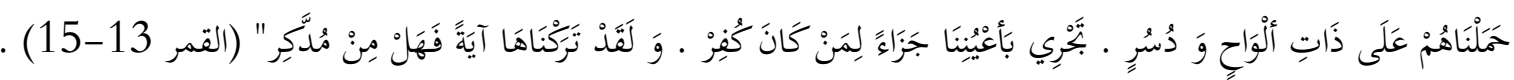

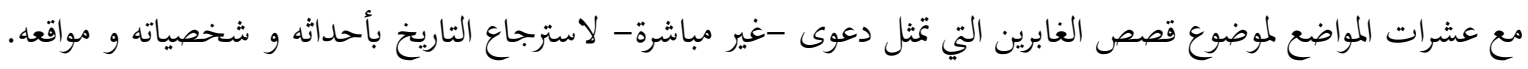

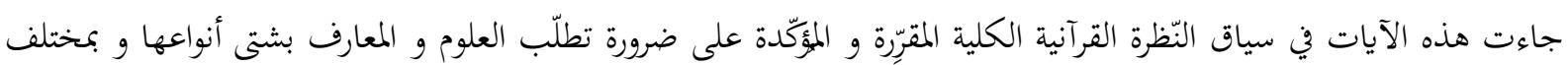

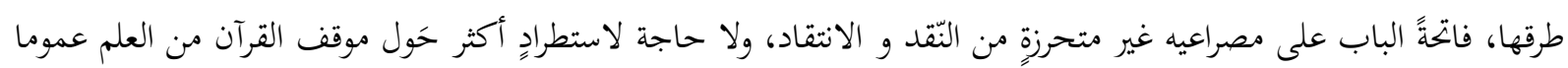

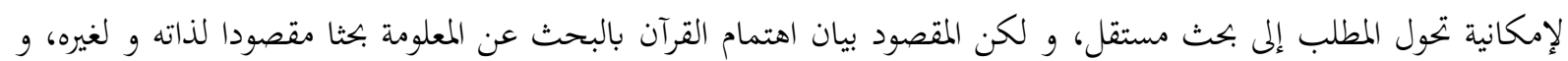

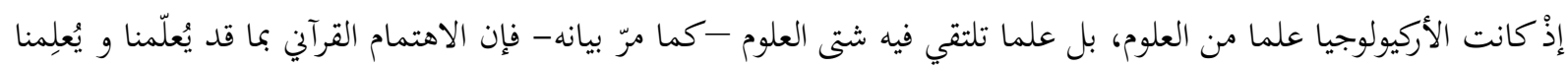

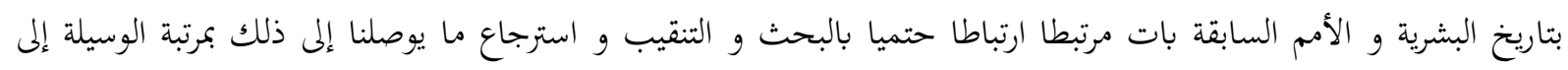
مقصَد و الطريق إلى منفَد.

زد على ذلك، أن الموضُوع و المؤضع بين آيات الأحداث و الأخبار و القصص من جهة و الاسترجاع التاريخي في

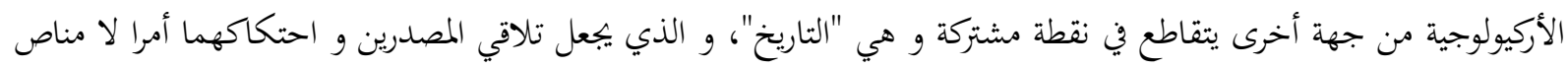

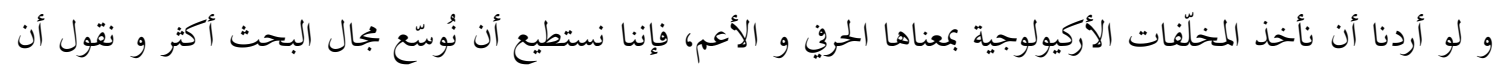

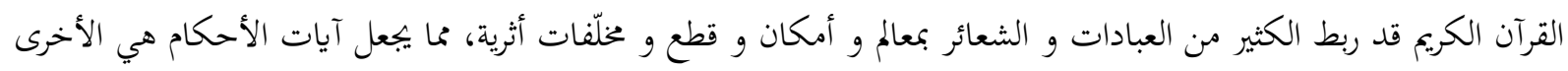

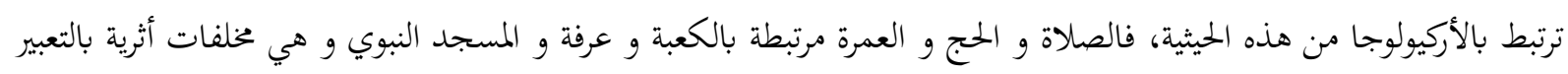

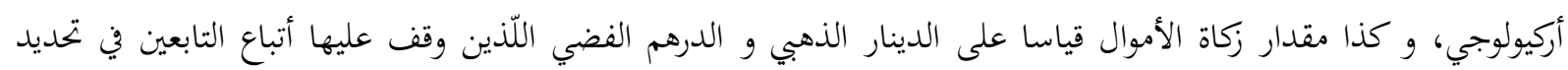

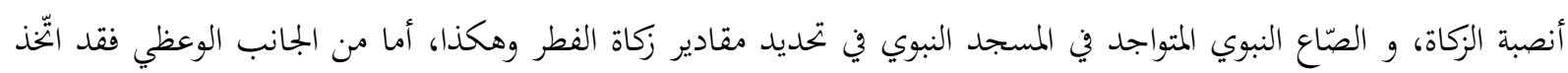


القرآن الكريم من النظر في الأمم السابقة و ديارهم و ما بقي من آثارهم منهجا وعظيا يعتمد على قياس الحاضر بالمستقبل، و نفوذ

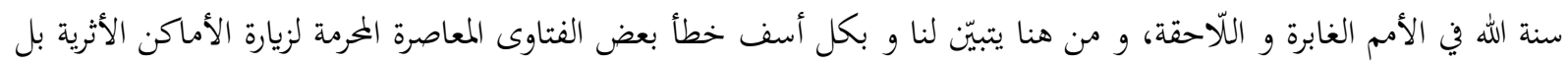

$$
\begin{aligned}
& \text { و تحريم -أو كراهة- علم الأركيولوجيا من أساسه !! } \\
& \text { المطلب الثاني: موقف الأركيولوجيا من القرآن }
\end{aligned}
$$

تقف الأركيولوجيا أمام القرآن و تتعامل معه كوثيقةٍ و كمرويةٍ، أما كالوثيقة فإن الأركيولوجيا تعتمدُ علمَ الإبيغرافيا

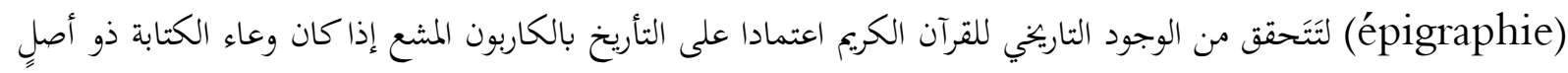

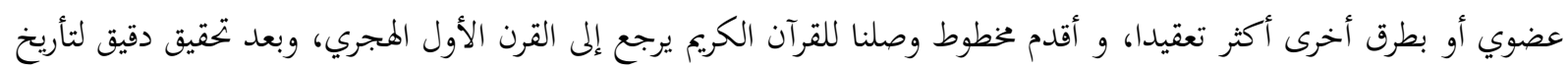

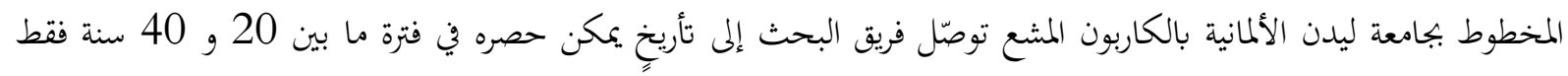

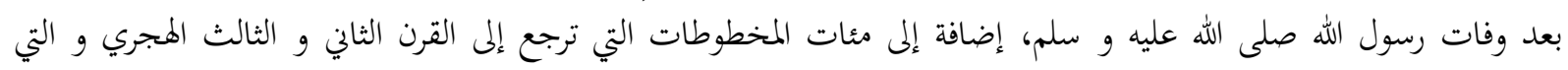
تبرهن على وجود القرآن التاريخيا كما تبرهن على حفظ مضمونه إذ لم يسجلوا -بعد المقارنة بينها و بين القرآن المطبوع بين أيدينا-

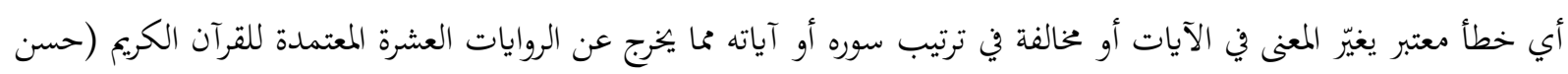
أ.، 2019، الصفحات 183-211).

إنّ إثبات الوجود التاريخي للقرآن إبيغرافياً هو دليل أركيولوجي مستقل عن مجرّد وجود القرآن كوثيقة، لأن نقل القرآن في

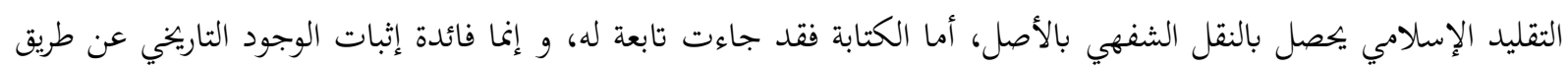

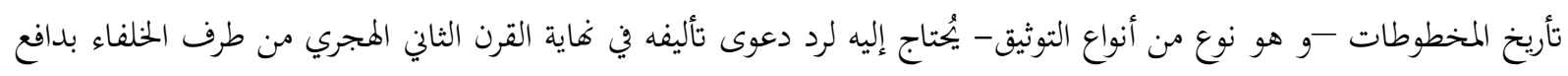

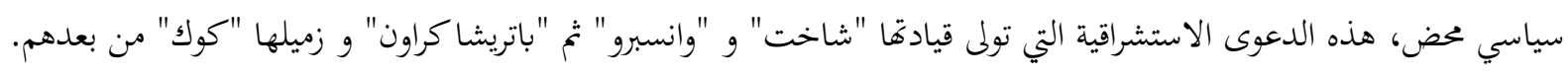

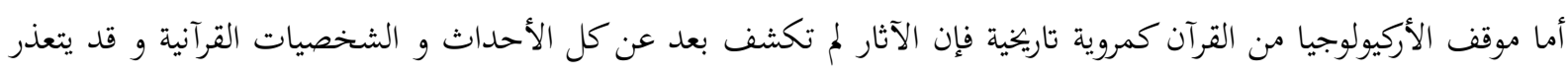

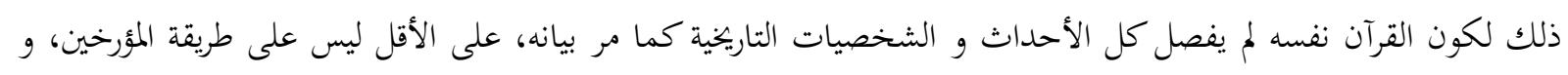

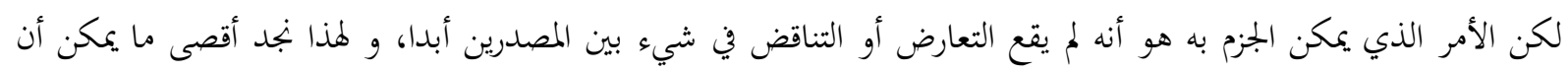

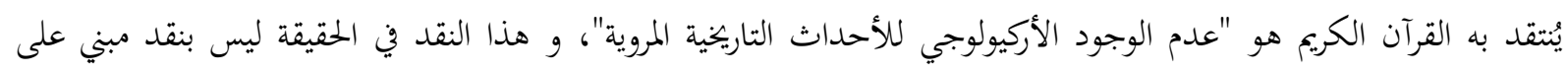

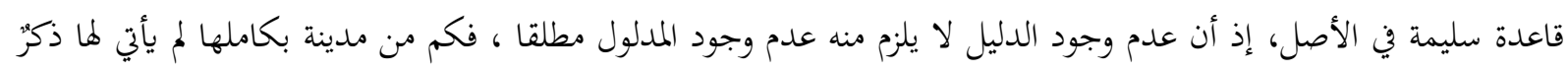

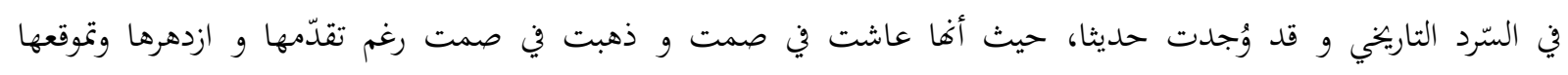

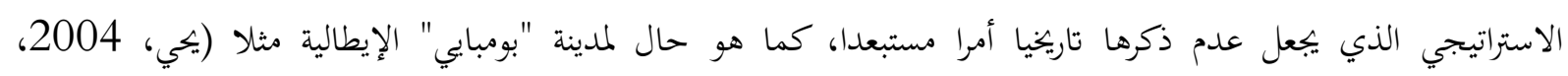
الصفحات 63-69).

لا بأس بعَقد مقارنة بين القرآن و الكتاب المقدس و موقف الأركيولوجية منهما كي يظهر حقيقة التصادم المزعوم بين

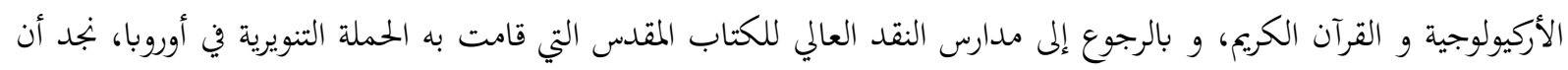

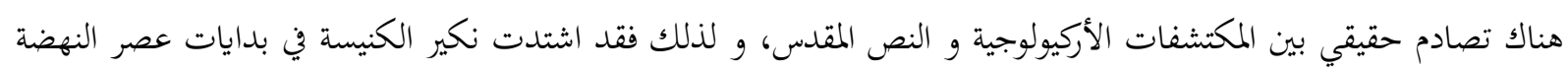

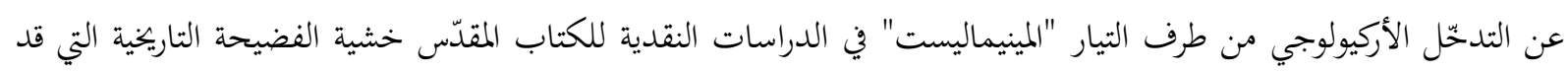

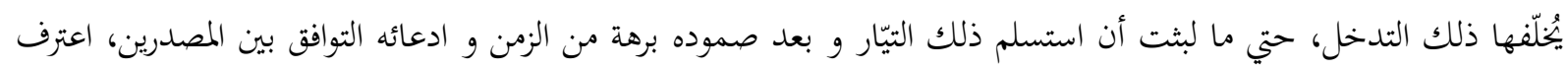

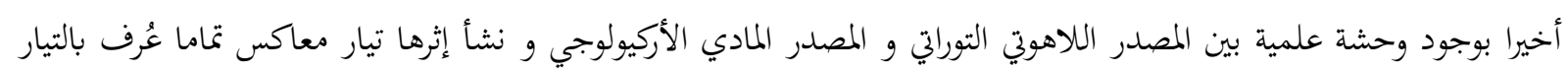

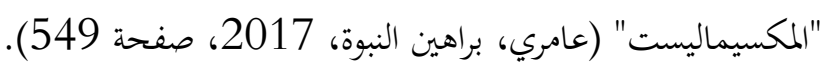

أما من الجانب القرآني فإنه لم يفصل الأحداث التاريخية و لم يهتم بجزيئات الحدث و إنما كان السرد التاريخي في القرآن

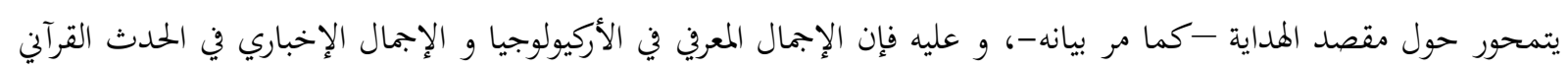


لا يضع المصدرين في موقف التعارض لاحتمالية التأويل في المصدرين على السواء، عكس الكتاب المقدس الذي ورط نفسه بذكر التفصيلات و الإغراق فيها و التي جاء التعارض من جهتها، و لا يعنى هذا بحال غياب بعض التعالئ الإشارات في التفصيلات القليلة

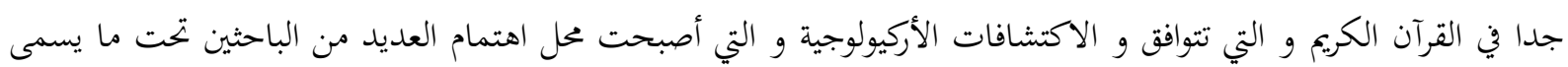

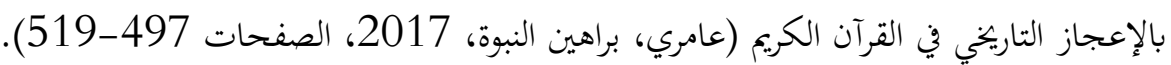
أما من الجانب الأركيولوجي فلا يمكنه بحال رفض الأحداث التاريخية في القرآن بحجة عدم وجود ما يثبتها آركيولوجيا، كون

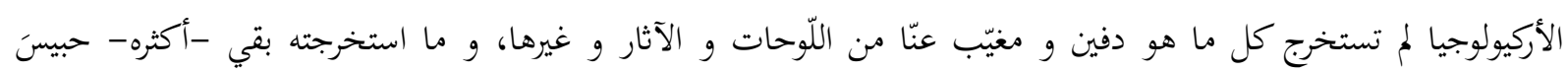

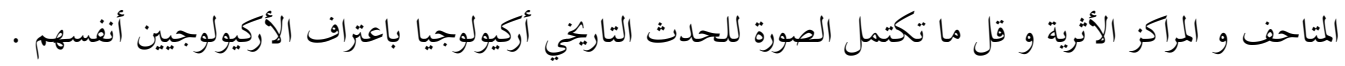




\section{المبحث الرابع: قصص الأنبياء، بين القرآن الكريع و الأركيولوجيا}

كخلاصة للمباحث السابقة النظرية و كتأصيل لهذا المبحث التطبيقي، يتقابل القرآن الكريم و الآثار الأركيولوجية باعتبار

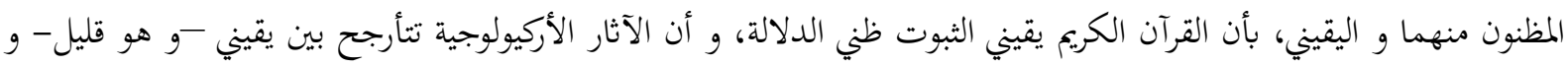

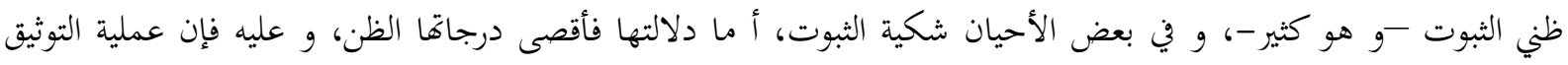

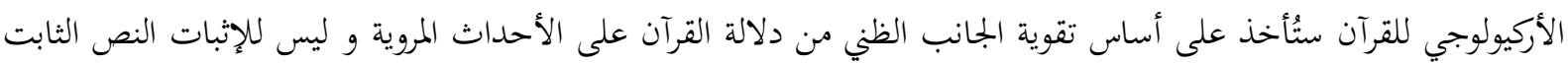
يقينا بالأصل، نظيرها تصحيح معنى الحديث النبوي بالشواهد في علم "مصطلح الحديث"، على أن غياب هذا التوثيق يُبقى دلالة النص القرآي في دائرة الاحتجاج.

ثم إن الفائدة الأخرى من هذا التوثيق هو دفع موهم التعارض و افتعال الخصومة بين القرآن الكريم و الأركيولوجيا فجاء

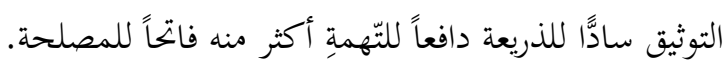
و بناء على ذلك سأقدّم موضوع قصص الأنبياء كنموذج تطبيقي للأحداث التاريخية التي يمكن توثيقها أركيولوجيا مع بيان المنهجية المتّبعة والتي تتناسب مع إبيسنيمولوجية الحقلين (القرآي و الأركيولوجي).

المطلب الأول: أسماء الأنبياء في النقوش و الألواح القديمة

ذكر القرآن الكريم خمسة و عشرون نبياً بأسمائهم، و لم يذكر كل الأنبياء المبعوثين من الله لقوله تعالى:"و منهم من لم

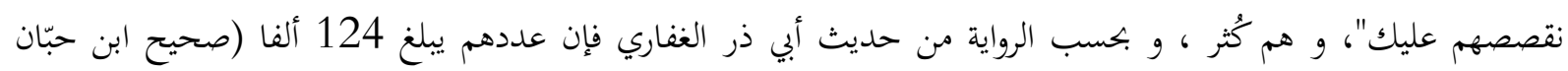

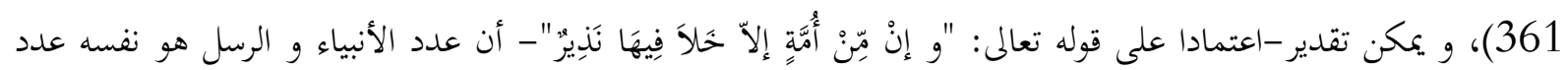

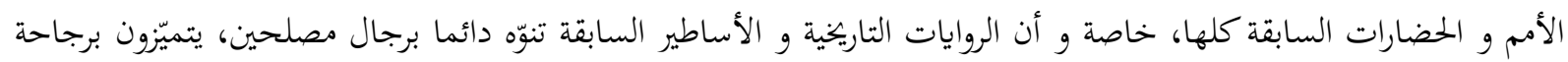

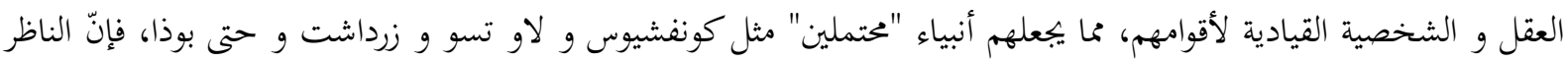

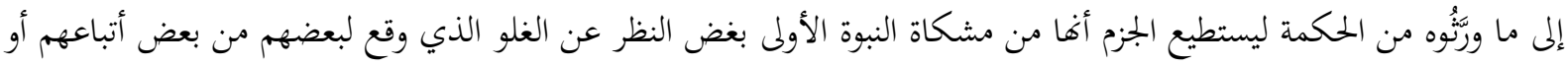
تحريف لبعض مقولاعم كما حصل مع أنبياء الملل السابقة. من جهة أخرى جرت عادة الطغاة على إخماد ذكر الثائرين المنتفضين ضد طغياهم و ضلالهم، فلا يُنتظر -و الحالة هذه-

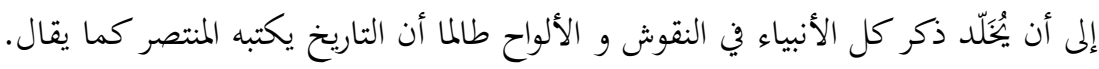
نخلص مما سبق أن: - - هناك أنبياء جاء ذكرهم في النقوش و الألواح على أثّم مصلحون صالحون و لم يُنذكروا في القرآن و قد تكون أسمائهم

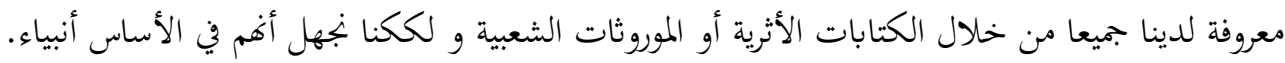

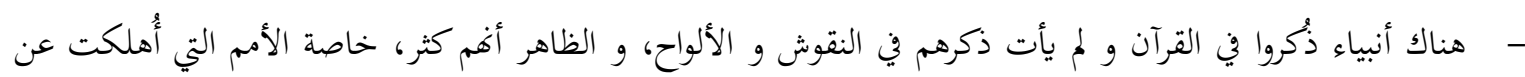

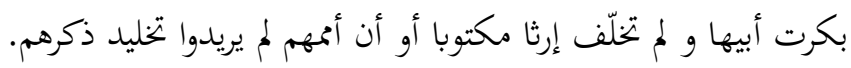
- - هناك أنبياء ذكروا في القرآن و ذكروا في النقوش و الألواح و هم قلة (عامري، الوجود التاريخي للأنبياء، 2021،

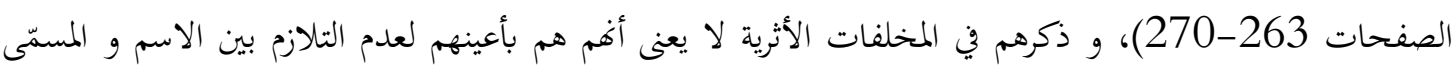
بالضرورة، لكن الاحتمال قائم مادام هناك قرائن أخرى قد تؤيد هذا التوثيق، مع استحضار حقيقية فيلولوجية مهمّة للأسماء المنقولة عبر الكتابات، و هي احتمالية تعرّض تلك الأسماء عند نقلها من لغة لأخرى إلى شيء من من التحريف

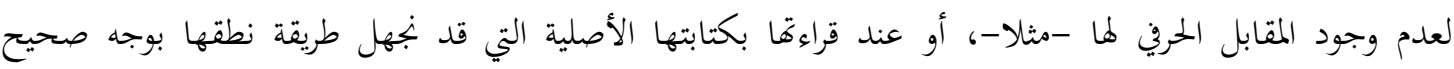
كالهيوغليفية (حمّاد، 1991، صفحة 81)، و هذا كله يجعل منهج البحث عن الأسماء في النقوش لإثبات تاريخية 
الأنبياء منهجا غير دقيق، و هو منهج سبق استعماله من طرف مدرسة "الماكسيماليزم" التوراتية عند تنقيبها للأدلة الأركيولوجية لإثبات صحة التوراة، و هذا ما يجعل الباحث أكثر حذرا و ودئ دقة إذا ما أراد الأخذ بهذه الطريقة.

\section{المطلب الثاني: قصص الأنبياء في المذكرة الإنسانية}

كثيرا ما يستند بعض الحداثيين و اللاّدينين على الموروث الفولكلوري للإنسان في إثبات أسطورية القصص الدينية عموماً و

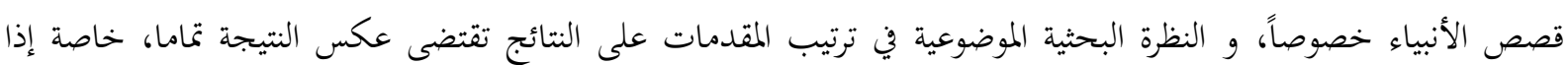

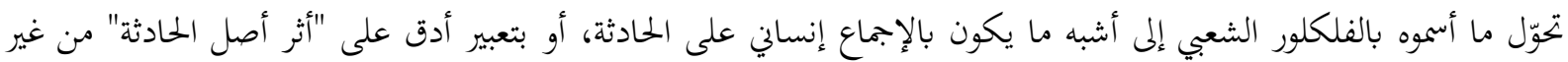
الالتفات لتفاصيلها و جزئيّاتا و التي تعتبر عادة محل الأسطرة في المخيال الجماعي. فورود حادثة خلق آدم من قوة متعالية و مفارقة عليه و على الطبيعة، و أنه خُلق من طين أو تراب مع الماء ثم خُلق منه

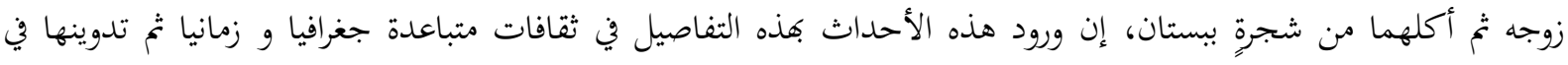
لوحات و نقوش طينية مختلفة (الكيلاني، 2001، الصفحات 28-30) يدل كل ذلك على صحة أصل القصة رغم وجود

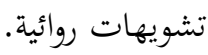

نفس الملحظ لقصة طوفان نوح عليه السلام الواردة في الذاكرة الإنسانية و قد ذكرت أكثر من 500 قصة أسطورية تحاكي أحداث طوفان نوح، و من بين أقدم الروايات ملحمة جيلجاميش المنحوتة في أحد اللوحات السومرية (الكيلاني، الصفحات 155-160).

قد يكون التطابق بين صفات شخصية نبيّ و ما تتميّز به قصته مع شخصية تاريخية نقلتها الذاكرة البشرية -مؤيّدة

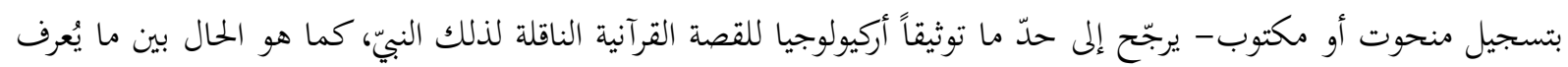

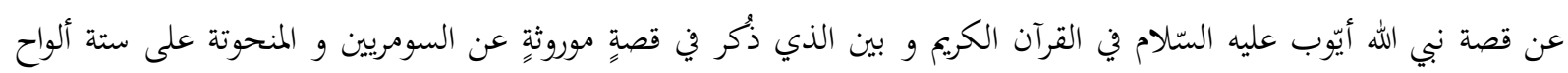

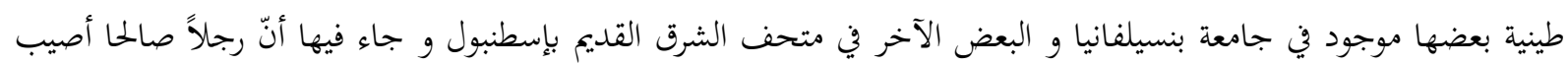

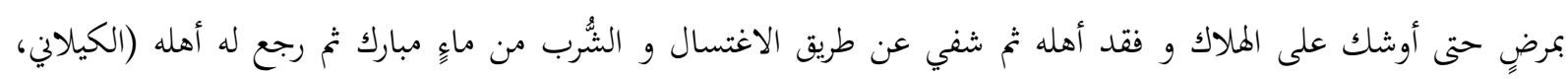
2001

و هكذا يمكن الاستفادة من القصص المنقولة من خلال اللوحات و البرديات و غيرها في عملية التوثيق الأركيولوجي إذا ما

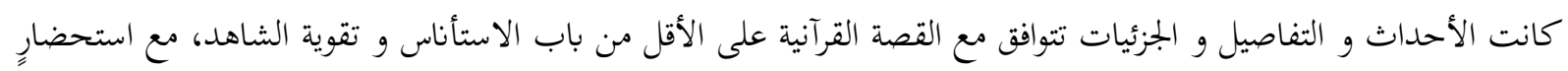
دائمِ لِما يمكن أن يصيب القصة من أسطرة أو إهمال أو زيادة تفرضها طبيعة التفكير البدائي لدى الإنسان، و لعل أهم مؤلّف

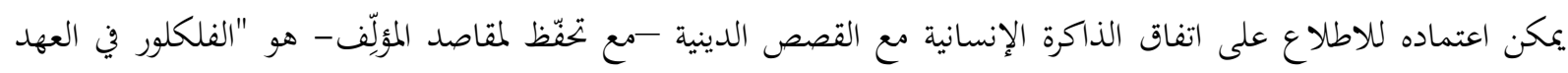
القديم" لجيمس فريزر (فريزر، 1972).

\section{المطلب الثالث: الأنبياء من خلال مخلفات أمهرم الأثرية}

إن مبدأ حرمة توريث آثار الأنبياء الخاصة بأجسادهم كصورهم و تماثيلهم في الديانات التوحيدية الثلاثة، يجعل مهمة البحث عن

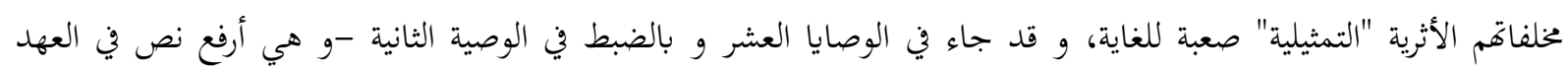

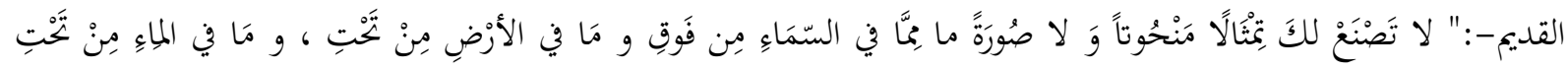
الأزضضِ" (سفر الخروج20) كما جاء في العهد الجديد ما يؤكد ذلك حيث قال المسيح عليه السلام كما ورد في إنجيل مَتِّي رقم

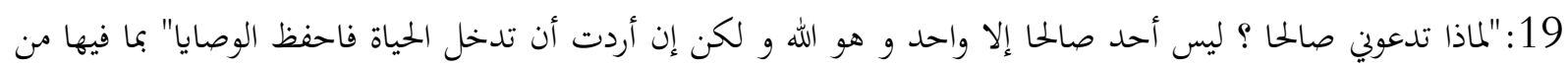


نجد نفس المبدأ في التراث الإسلامي، حيث جاء عن حنش ابن المعتمر قال: "قال لي علي ابن أبي طالب رضي الله عنه:

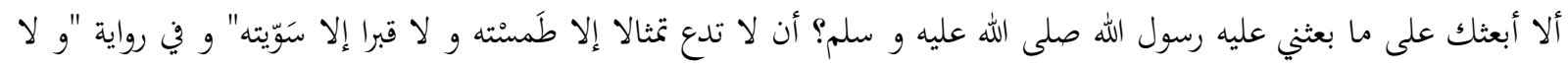

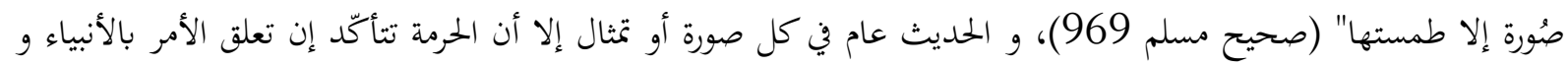

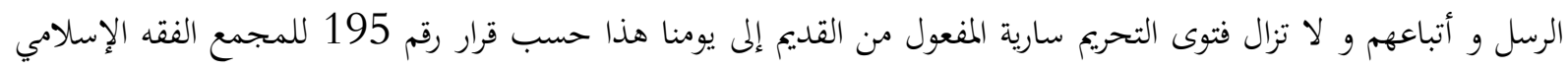

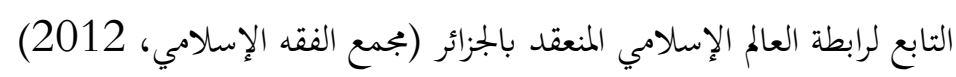

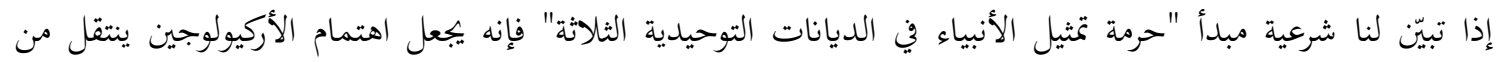
المخلفات الأثرية الخاص بأجساد الأنبياء و ذواقم إلى المخلّفاقم السكنية و المعمارية و المكانية لهم و لأقوامهم و هذا هذا المجال

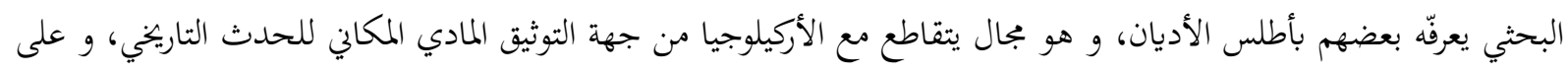

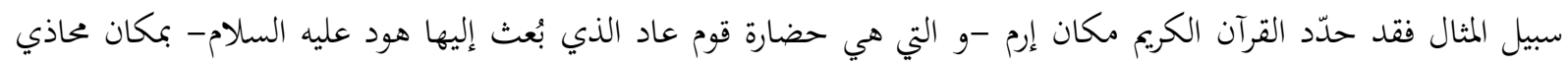

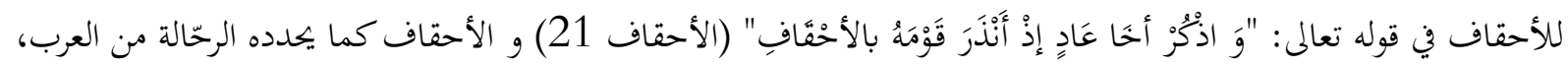

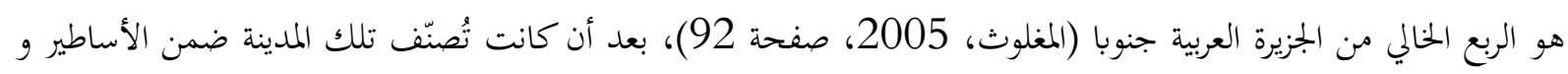

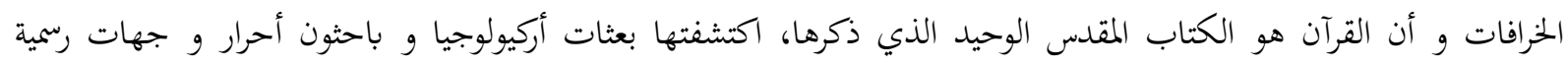

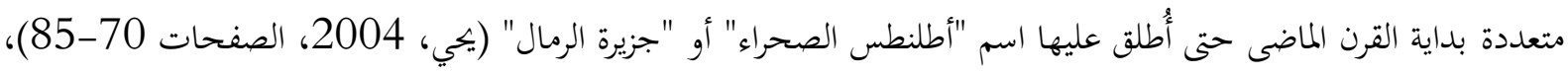

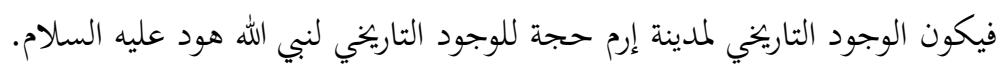
إن التنقيب عن آثار المادية للأمم و الحضارات التي بُعث إليهم الأنبياء -خاصة تلك التي تفرّد بها القرآن روايةً- هو إثباتُ للوجود الأركيولوجي للأنبياء بطريقة غير مباشرة، ذلك بأن الأسلوب القرآني يتّجه تارة في تسمية الأمم السابقة بأسمائهم و

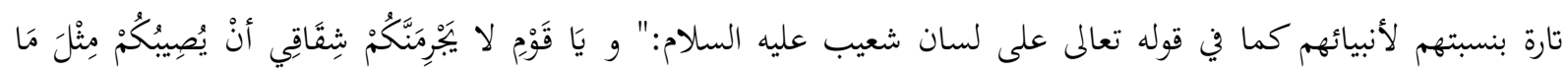

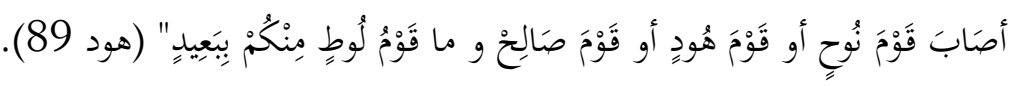
المطلب الرابع: معجزات الأنبياء بين الآثار و الرواية عرّف العلماء المعجزة بأها: "أمر خارف للعادة مقرون بالتّحدي، سالم من المعارضة" (مصي، 1980، صفحة 9)، مما

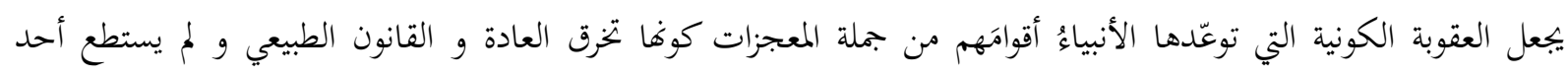

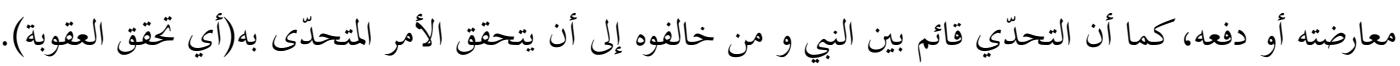
و بناء على ما مضى فإن مجال البحث الأركيولوجي في باب المعجزات لا يقتصر على مجرد البحث عن عصى موسى أو

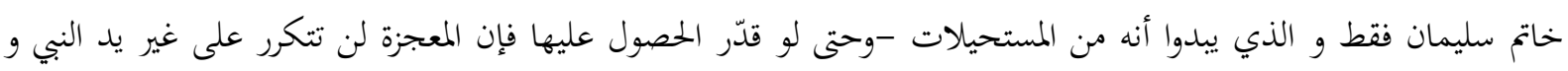

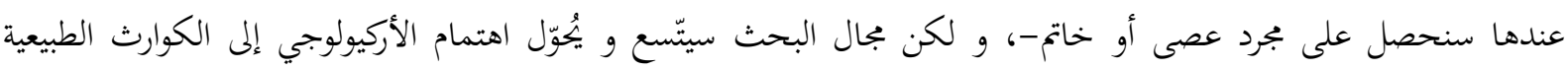

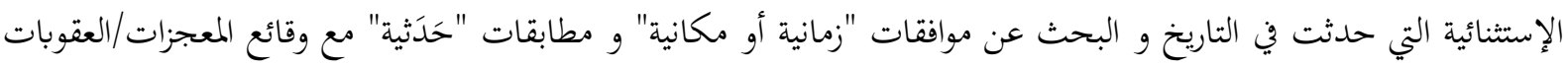
التي وردت في القصة حسب الرواية القرآنية.

إن الالنفات إلى المعجزات المتعلقة بالعقوبات الكونية / الطبعية التي توعّد بها الأنبياء أقوامهم و وقعت حقيقة، لهي أحد

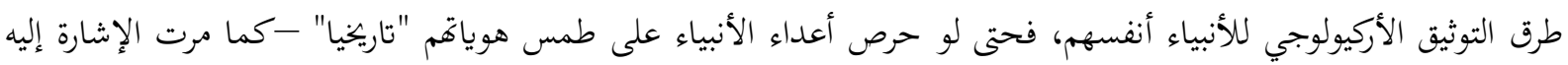

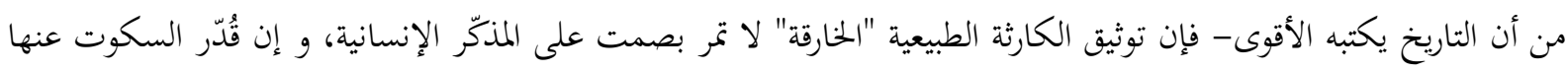
فإنها تترك ندوباً في الأرض يمكن استنطاقها "جيولويجا". فمثلا لو أخذنا حادثة طوفان نوح عليه السلام و قلنا - كما يدل عليه ظاهر القرآن بخلاف ما ورد في التوراة- أنه لم يعم جميع الأرض، بل كان مُتَموققعا في بلاد الرافدين (يحي، 2004، صفحة 21 21) فإن السّجلات التاريخية السومرية و الإغريقية و 
غيرها تنص على كارثة طبيعية جعلت منطقة العراق تحت عشرات الأمتار من الماء، كما صدقتها أعمال التي قام بها كل من الأركيولوجي البريطاني "ليونارد وولي" (تحت إشراف المتحف البريطاني و جامعة بانسيلفانيا)، و الأركيولوجي الألماني "إيريك فريديرك التيك

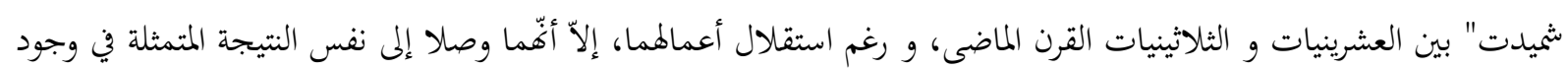

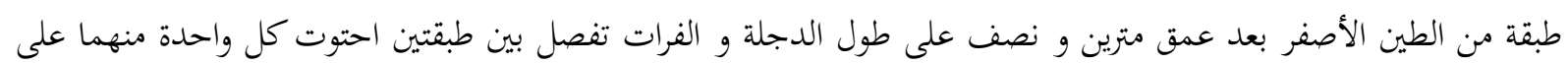

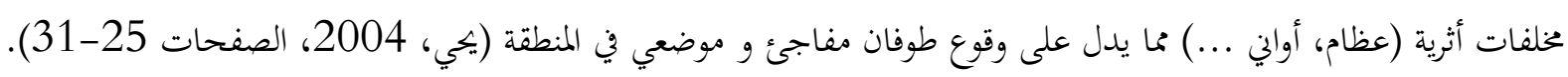

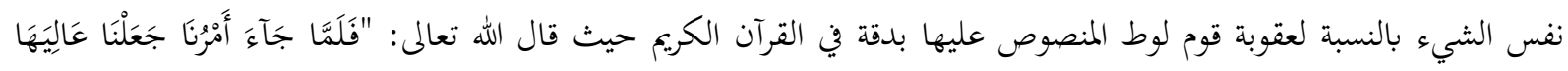

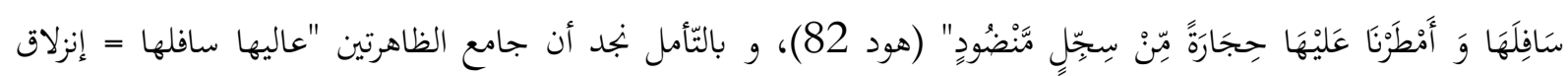

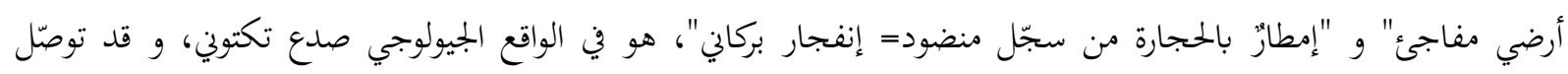

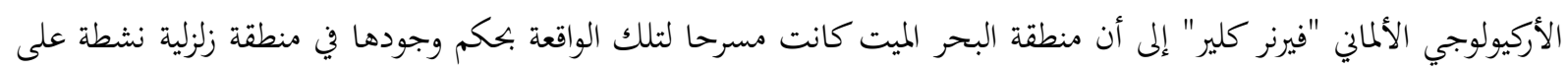

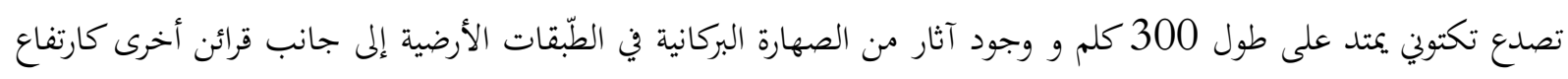

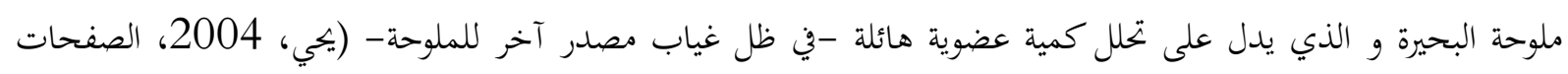

نجد أيضا في نصّ بردية إيبوير ipuwer papyrus -التي ترجع لـ 1300 سنة ق.م (أي بعد خروج بني إسرائيل بـ 200 سنة فقط) و المتواجدة بمتحف ليندن بهولاندا- موافقة كبيرة بين مضموها و المصائب و الكوارث (عقوبات كونية/معجزات

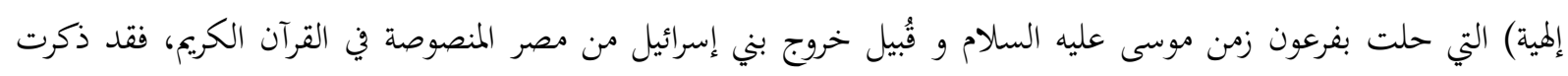

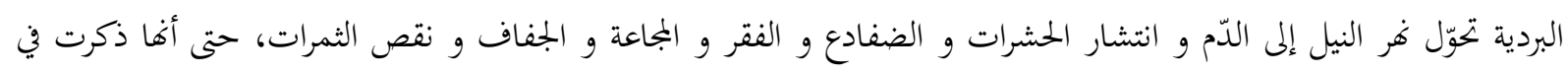
الورقة (1: 7-2) أن فرعون "قد فُقد في ظروف لم يحدث مثلها من قبل"، و وكل ذلك ملك موافق بالتصريح (تحول النهر إلى دم) أو

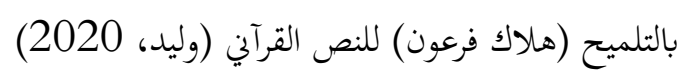

و الملاحظ من خلال هذا المطلب أن هذا المجال من التوثيق، أي توثيق العقوبات/المعجزات، أركيولوجياً/جيولوجياً هو أكثر

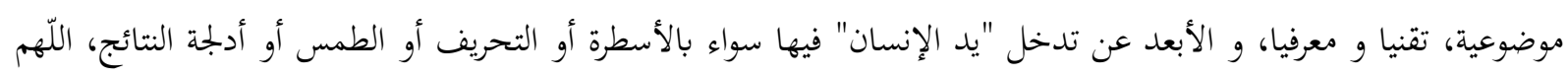
إلا ما كان من تعمية إعلامية لتلك الاكتشافات تقودها خلفية إيديولجية ما.

\section{نتائج البحث:}

بناءً على شِقَّيّ البحث، النظري و التطبيقي، يمكن استخلاص النتائج التالية:

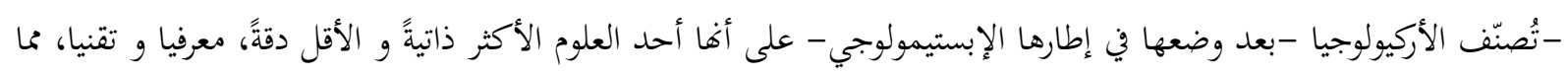

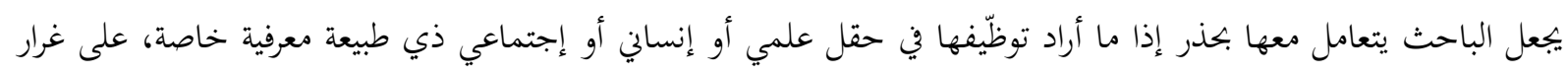
العلوم المتعلّقة بالوحي كتفسير القرآن الكريم مثلا.

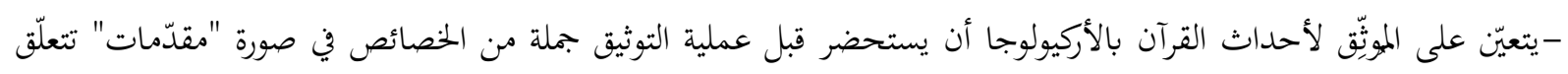
بطبيعة القرآن كمصدر وحي قبل أن يكون وثيقة تاريخية هي كالتّلي:

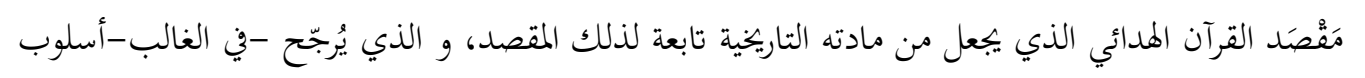

$$
\text { الاختصار و الإبهام في سرد القصة. }
$$

القرآن كتاب احتوى على التاريخ و ليس بكتاب في التاريخ، فلا ينبغى أن يُتعامل معه بالصّرامة المنهجية التي

$$
\text { تُسلّط على المؤلفات التاريخية الحديثة. }
$$

نَقل القرآن بما فيه من مضامين تاريخية بالتواتر يجعل منه كتابا مُوَثقّا بذاته. 


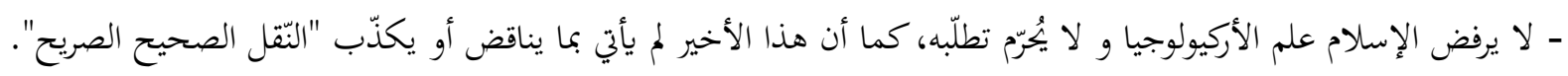

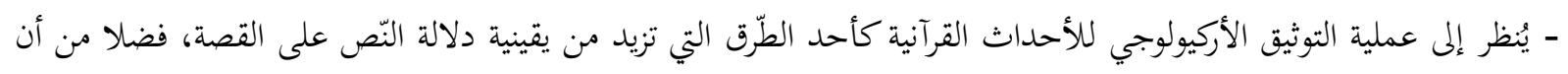

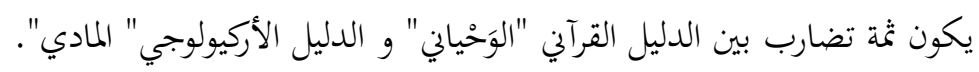

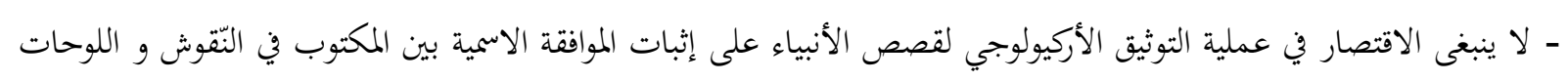

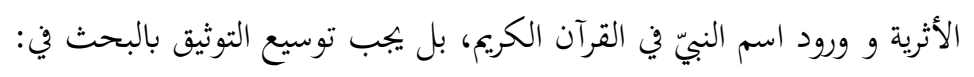

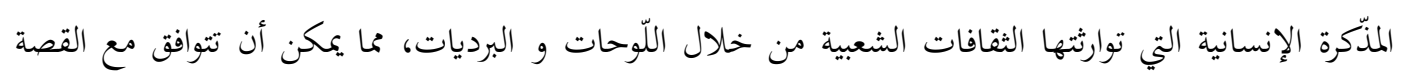

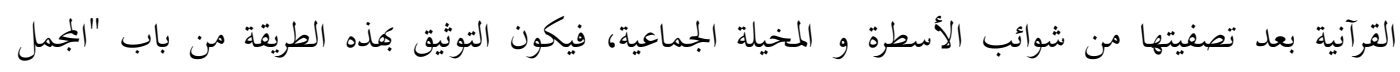
بالجممل". • التنقيب عن المدن و المخلفات السكنية للأقوام الذين أُرسل إليهم الأنبياء، فإن وجودهم التاريخي تابع لوجود

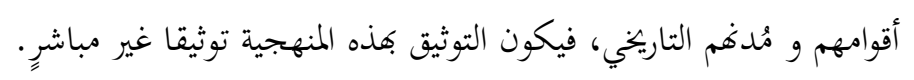

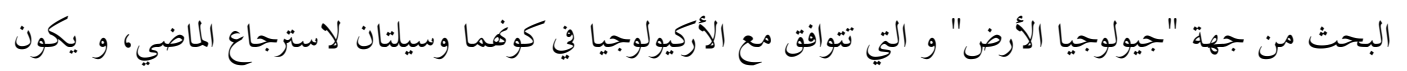

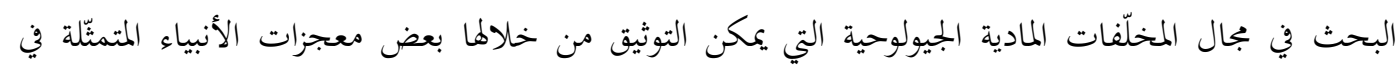

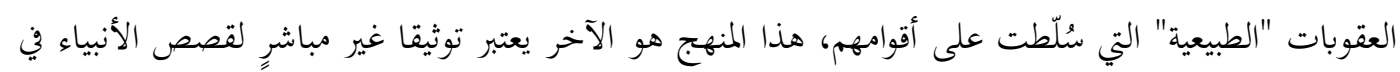
القرآن الكريم. 
أبي الحسن أحمد ابن فارس. (2001). معجم مقاييس اللغة. بيروت - لبنان: دار إحياء التراث العربي. أحمد حسن. (2019). أركيولوجيا الإسلام. الرياض: مركز دلائل.

جورج سارتون. (2010). تاريخ العلم، العلم القديم في العصر الذهبي لليونان. ('براهيم بيومي مدكور، محمد كامل حسين، قسطنطين رزيق، و محمد مصطفى زيادة، المترجمون) القاهرة: المركز القومي للترجمة. جيمس فريزر. (1972). الفلكلور في العهد القديم. القاهرة: الميئة المصرية العامة للكتاب. حمال مصطفى عبد الحميد النّجار. (2017). تواتر القرآن الكريم. القاهرة: الجمعية المصرية للقراءة و المعرفة. رعد شمس الدين الكيالي. (2001). الأنبياء في العراق، دراسة مقارنة بين القرآن و التوراة و الإنجيل. بغداد: دار الشؤون الثقافية العامة.

سامي بن عبد الله المغلوث. (2005). أطلس تاريخ الأنبياء و الرسل صلوات الله عليهم. الرياض: مكتبة العبيكان. سامي عامري. (2017). براهين النبوة و الرد على اعتراضات المسترقين و المنصّرين. لندن: تكوين للدراسات و البحاث. سامي عامري. (2021). الوجود التاريخي للأنبياء و جدل البحث الأركيولوجي. الكويت: رواسخ. سعد محمد الهجرسي، و سيد حسب الله. (1998). المكتبات و المعلومات و التوثيق. الإسكندرية: دار الثقافة العلمية. عاصم محمد رزق. (1996). علم الآثار بين النظرية و التطبيق. القاهرة: مكتبة مدبولي. علي حسن. (1993). موجز في علم الآثار. مصر : الهيئة المصرية العامة للكتاب. (2012). مجمع الفقه الإسلامي. الجزائر: رابطة العالم الإسلامي. محمد الأسعد. (2010). مستشرقون في علم الآثار، كيف قرؤوا الألواح و كتبوا التاريخ. بيروت: الدرا العبية للعلوم ناشرون. محمد بيومي مهران. (1988). دراسات تاريخية من القرآن الكريم. بيروت: دار النهضة العربية. محمد حمّاد. (1991). تعلّم الهيروغليفية، لغة مصر القديمة و أصل الخطوط العالمية. القاهرة: الهيئة المصرية للكتاب. محمد قبيسي. (1982). علم التوثيق و التقنيات الحديثة. بيروت: منشورات دار الآفاق الجديدة. محمود عبد الرحمن عبدالمنعم. (1999). معجم المصطلحات و الألفاظ الفقهية. القاهرة: دار الفضيلة. نعيم حصي. (1980). فكرة إعجاز القرآن، من البعثة النبوية إلى عصرنا الحاضر. لبنان: مؤسسة الرسالة. هارون يجي. (2004). الأمم البائدة. بيروت: مؤسسة الرسالة ناشرون.

المراجع باللغة الأجنبية:

Francfort، H.-P. (2012). la postion épistimologique de l'archéolgie. archéologie à decouvrir ، 269-277.

larousse، 1. p. (2000). le petit larousse. france: HER.

yoffee، n.، \& severin، f. (2010). L'archéologie dans les sciences humaines. Diogène (229)، 51-77.

مراجع الشبكة العنكبوتية:

نيبيل علي. (14 06، 2019). فلسفة الأركيولوجيا. تاريخ الاسترداد 12 07، 2021، من قناة الفينق - اليوتيوب: $\mathrm{t}=1$ s\&https://www.youtube.com/watch?v=-RKiYG3Scww

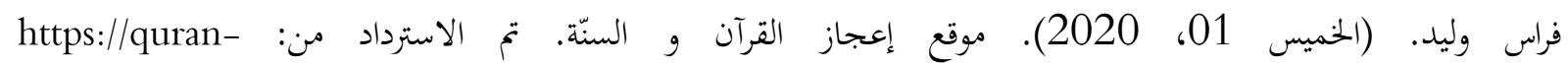
m.com/\%D9\%85\%D8\%AE\%D8\%B7\%D9\%88\%D8\%B7\%D9\%87- 
\%D8\%A7\%D9\%8A\%D8\%A8\%D9\%88\%D8\%B1\%D8\%AA\%D8\%AD\%D8\%AF\%D8\%AB\%D9\%86\%D8\%A7-\%D8\%B9\%D9\%86\%D9\%85\%D8\%A7-\%D8\%AD\%D9\%84\%D8\%A8\%D9\%81\%D8\%B1\%D8\%B9\%D9\%88\%D9\%86/\%D9\%88\%D9\%82\%D9\%88 


\section{ARGENTINE WAR OF INDEPENDENCE 1812-1850}

\section{Istanbul / Türkiye \\ p. $18-27$}

Received: $12 / 11 / 2021$

Accepted: 08/12/2021

Published: 01/01/2022

This article has been scanned $\mathrm{l}$ iThenticat No plagiarism detected

\author{
Maher Mubdir AL-ABBASI ${ }^{1}$
}

\begin{abstract}
:
Argentina is located in the continent of South America and it is considered the eighth largest country in the world in terms of an area of 2780,400 square kilometers. The city of Buenos Aires is the official capital of the country. The first European explorers reached it in 1516 were the Spanish who occupied most of South America. In opposition to them, Simon Bolivar and Jose San de Martin appeared, who imagined that the homeland would one day be born, free of Spanish intervention. The personality of Jose San Martin represented the pillar of independence in Latin America because he led the independence movement for three countries: Argentina, Peru, and Chile, in which he proved that he had the greatest role in the independence of these countries. The research dealt with three sections. The first topic included the naming of Argentina and its indigenous people, geographical explorations and the Spanish colonization of Argentina. The second topic focused on the personality of Jose San Martin because of its paramount importance in supporting the liberation movements in Argentina, his birth and his military upbringing. As for the progress of liberation movements and the emergence of the Argentine Republic was Among the third topic.

The researcher concluded that the country of Argentina, which was called in Latin the country of silver, is inhabited by many ancient civilizations, including the Indians, the Mayan peoples and the people of Diaguita.San Martín benefited from his military and leadership experience, which he had accumulated in the leadership of the Andean Army to liberate Chile and then Peru.

San Martin's victory in Chile was not to push him to invade, but he ceded to his friend Ohanes to lead Chile and harnessed all his energy to complete the liberation of Peru, the last stronghold of the Spaniards. San Martin cooperated with his friend Simon Bolivar to complete the liberation of Peru and offered him to be a soldier under his command. Martin's liberation of all the lands occupied by the Spaniards.

After the liberation of Peru, San Martin did not cling to power, although he described himself as the protector of Peru, so after he sensed that there was opposition among the patriots to him, he quickly resigned, and left for Argentina, then to Chile, and after the death of his wife in 1823, he took his only daughter to France to spend the rest of his life In, He died in August 17, 1850.
\end{abstract}

Key words: Argentina, War of Independence.

http://dx.doi.org/10.47832/2717-8293.15.2

1 iD Dr. , Diyala University, Iraq, maher_mubder@yahoo.com 


\section{حرب الاستقلال الأرجنتينية ( 1812-1850)}

\section{ماهر مبدر عبدالكريم العباسي 2}

الملخص:

تقع الأرجنتين في قارة أمريكا الجنوبية وتعد ثامن أكبر دولة على مستوى العالم من حيث المساحة، إذ تبلغ

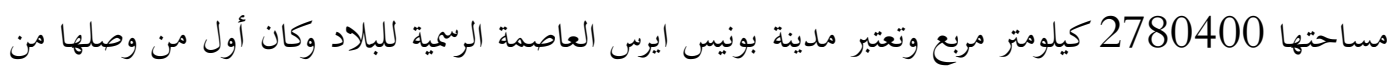

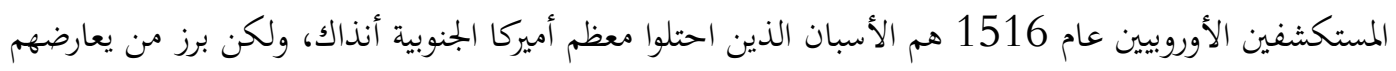

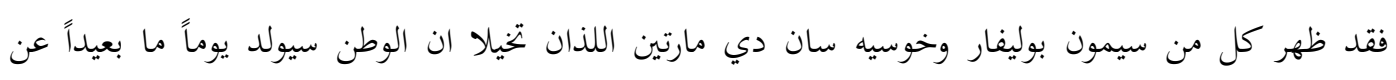
التدخل الأسباني. مثلت شخصية خوسيه سان مارتين عمود الاستقلال في أمريكا اللاتينية لأنه قاد حركة الاستقلال لثلاث دول وهي: الأرجنتين، البيرو، وتشيلي وأثبت فيها انه صاحب الدور الأكبر في الاستقلال لهذه الدول.

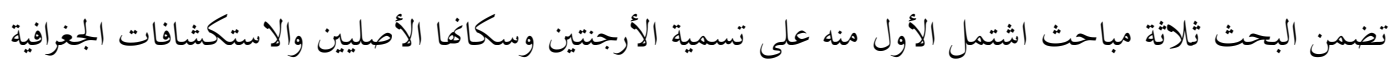
والاستعمار الأسباني لها، أما الثاني فركز على شخصية خوسيه سان مارتين لمان لمان لها من أهمية قصوى في دعم حركات

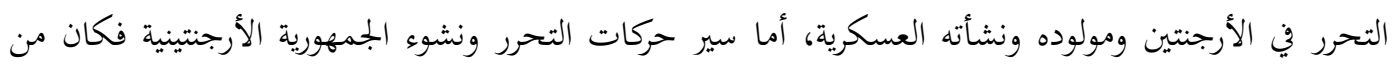
ضمن المبحث الثالث. الكلمات المفتاحية: الأرجنتين، حرب الاستقلال. 


\section{المبحث الأول}

\section{استكشاف الأرجنتين وسكاغا الأصليين}

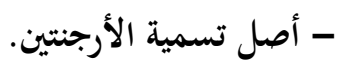

اشتق اسم الأرجنتين من التعبير اللاتيني أرجنتينو (Argentine) وتعني الفضة كما يستخدمها الشعراء الأسبان في عصر

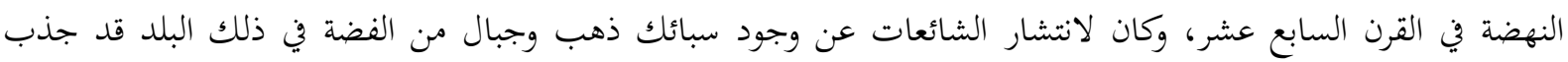
المستكشفون الأسبان للبحث عنه، ولكنهم في حقيقة الأمر لم يعثروا على أي منها، من ثم فأن الأرجنتين لا تنطبق عليه التسمية

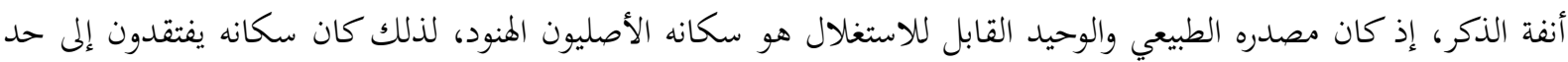

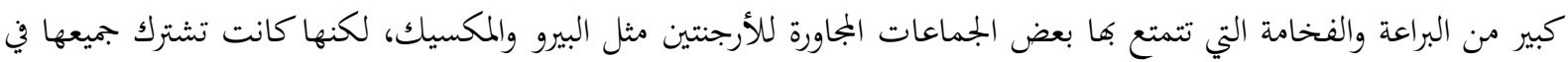
العديد من السمات، وهي طرائق الري والزراعة (1).

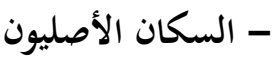

ينسب سكان الأرجنتين إلى شعب دياجويتا (Diaguita) ويتركز سكانا في مقاطعات سالتا (Salta) وتوكمان وسان خوان، وكانوا يفتقرون إلى نظام سياسي مركزي، إذ لم يكونوا شعب موحد، وكانت قراهم مشتتة، ويسكنون في ملاجئ مانس مصنوعة

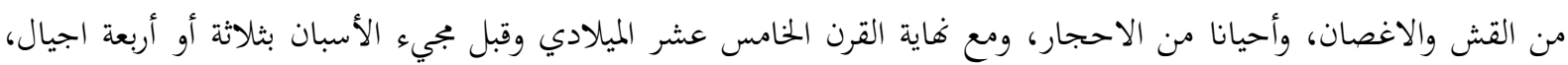

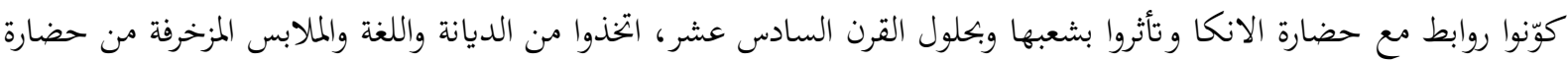

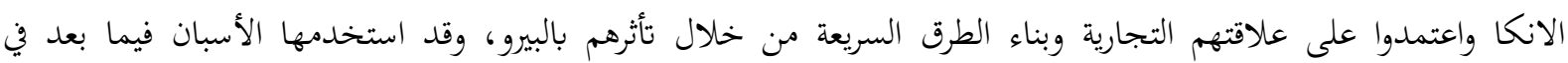

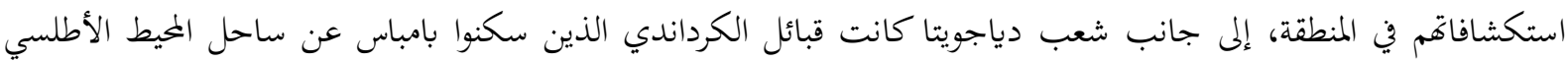

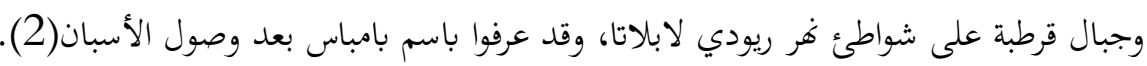

\section{- الاستكشاف الأسباني والاستعمار حتى عام 1850}

أدرك ملوك أسبانيا ان الاراضي الامريكية كانت جزء من منطقة جديدة وغير معروفة، وتباينت الدوافع في إرسال بعثات

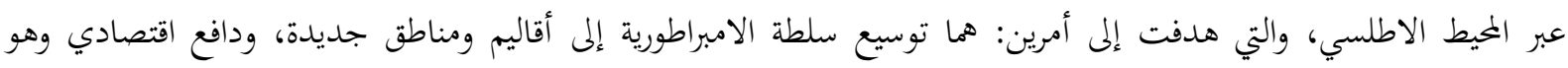
استغلال موارد جديدة وثمينة مثل (معادن الفضة والذهب، المحاصيل الزراعية، اليد العاملة)، كما هنالك دافع ديني، فإنها كانت مهتمة بنشر ديانتها وثقافتها في العالم(3).

جاءت أول رحلة أسبانيا استكشافية إلى الأرجنتين تحت قيادة (خوان دياز دي سوليس)(4)، إذ غادرت الرحلة عام

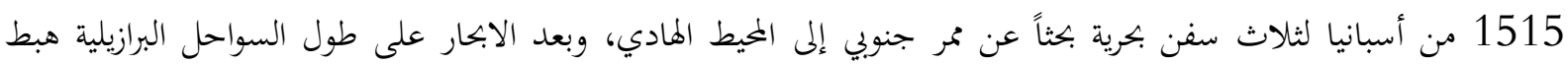

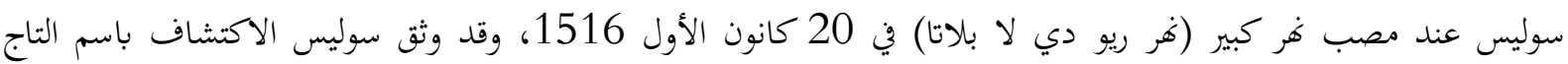
الأسباني، لكن سوليس اسر وقتل مع طاقمه من قبل السكان المحليين(5). في عام 1520 استكشف فرديناند ماجلان(6)، في رحلته التاريخية حول العالم، مصب فر لابلاتا وبعد سبع سنوات من

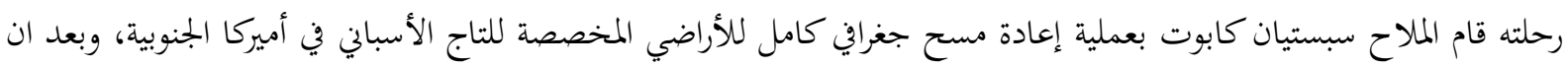

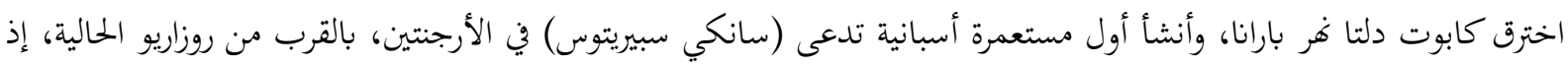

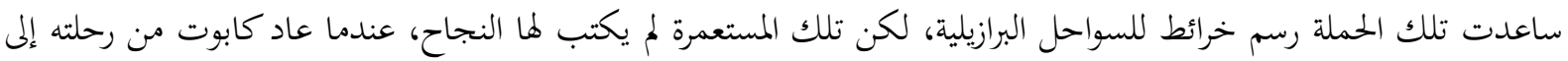
أسبانيا جلب معه بعض الحلي من الفضة العائدة للهنود بارانا، كما عادة مع بعض القصص المغرية للأسبان الذين صادفهم هناك، ركاك

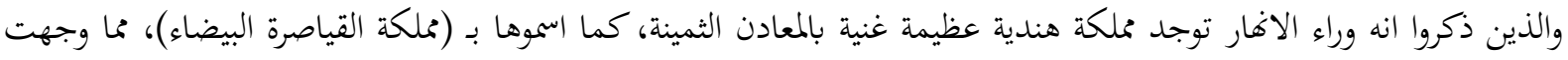


الأسبان مرة اخرى إلى غر لاللاتا (هر الفضة)، واثار تصميمهم الشروع في الغزو، وقد وصلت الشائعات نفسها إلى البرتغال،

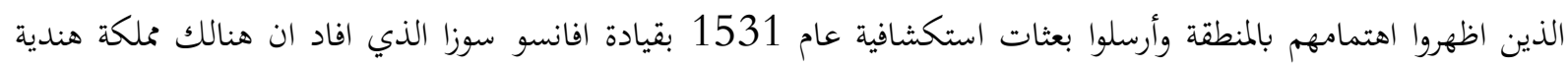
عظيمة ومناجم الذهب والفضة (7). في عام 1536 وخوفاً من التوسع البرتغالي في المنطقة قام التاج البريطاني بإرسال رحلة استكشافية في الأرجنتين قادها

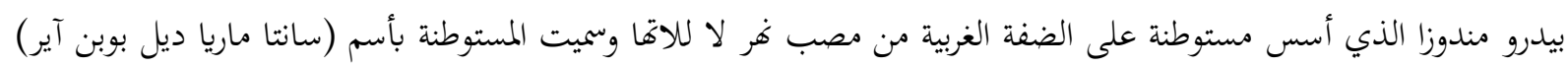

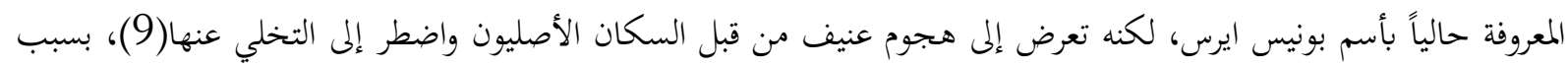

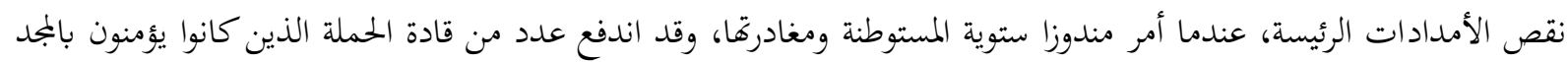

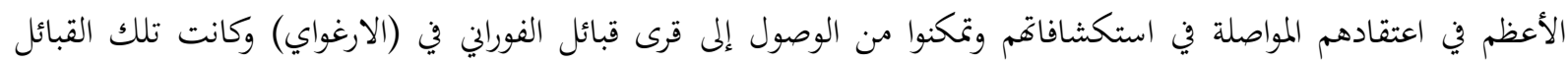

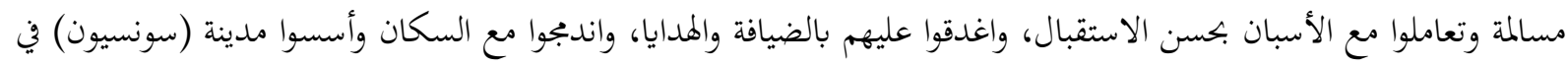
الارغواي(10).

ومع ازدياد معرفة الأسبان بالأمريكيين فأن مناطق غر ريو دي لا بلاتا لم تحظى الا بالقليل من اهتمام السلطات الأسبانية،

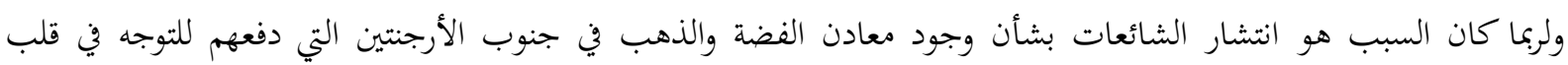

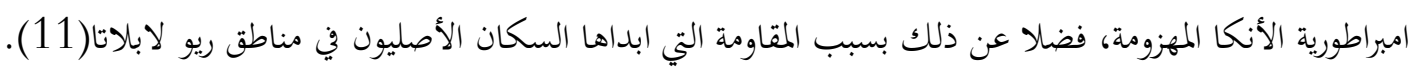

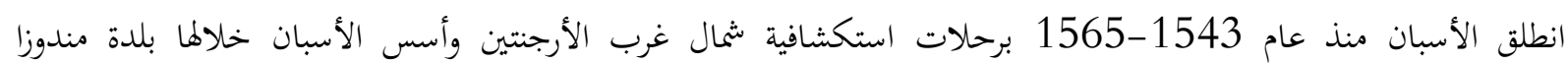
1561، وسان خوان 1562، واستيرو 1553، وسان ميفل توكمان 1565، وقرطبة 1573 1573، وسالتا 1582 1582، وايوخا 1591، سان لويس 1596، وسان

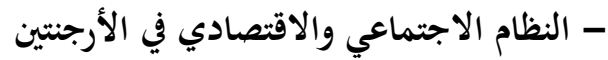

استطاعت الامبراطورية الأسبانية بعد احكام سيطرتا على مناطق واسعة من القارة الأمريكية وبعد بناء مستوطنة في

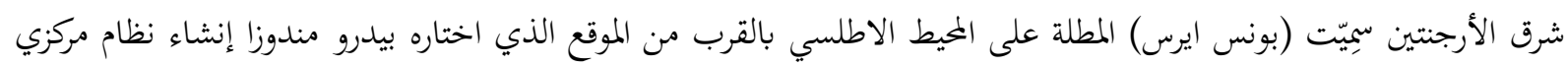

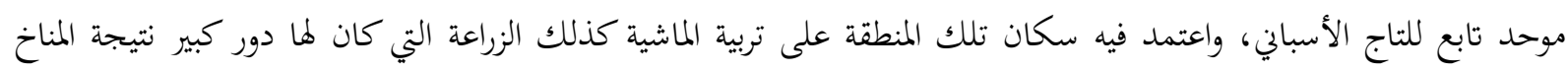
الجيد فيها.

منذ منتصف القرن السادس عشر قسمت أسبانيا أمريكا اللاتينية على ولايتين كبيرتين الأولى المكسيك عام 1535 وعرفت باسم أسبانيا الجديدة، والثانية: شملت ما تبقى من المناطق وسميت بها عام 1545 وكانت الأرجنتين تابعة إلى ولاية

ساد استخدام نظام الإقطاع في الأرجنتين أو الامتياز الذي يمنح فيه الأراضي إلى أفراد أسبان يعمل تحت حكم السكان

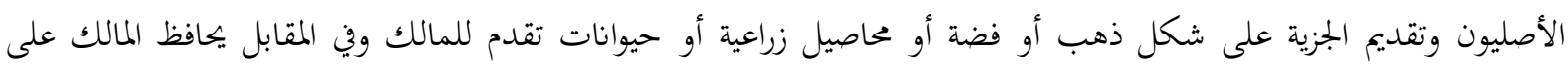

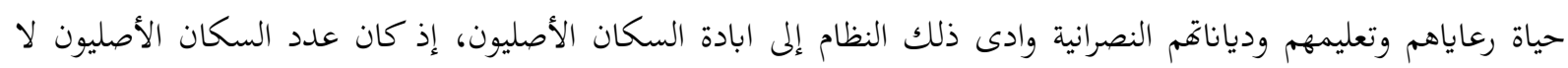

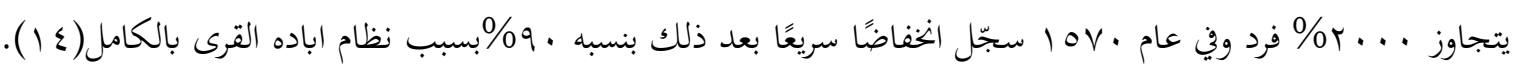
ونتيجة انخفاض اليد العاملة للسكان الأصليين أسس المستعمرون بتطبيق نظام عمل يتطلب من السكان القيام بأشغال تتراوح بين

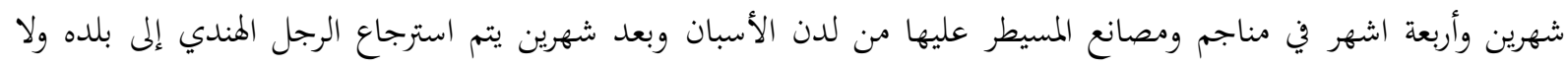

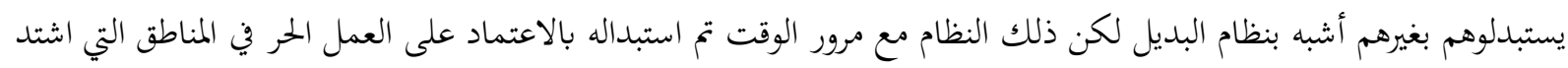

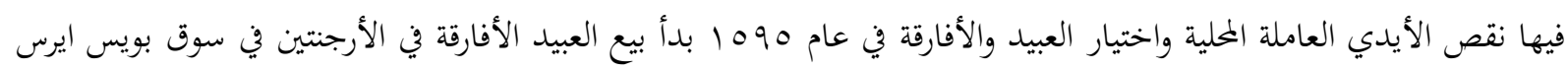


وفي عام بr آ انشأت أسبانيا مكتب كمارك يشرف على التجارة الداخلية والسفر اليسوعيين الكاثوليك التي أدت دورًا مهما في

$$
\text { تثقيف نخبة من سكان الأرجنتين(10) }
$$

وفي العام VVY اقدمت حكومة التاج الأسباني على خطوة مهمة في تاريخ الأرجنتين وهي إنشاء وحدة إدارية جديده في

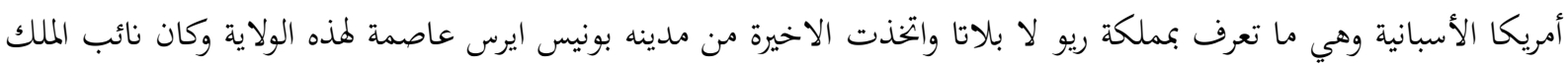

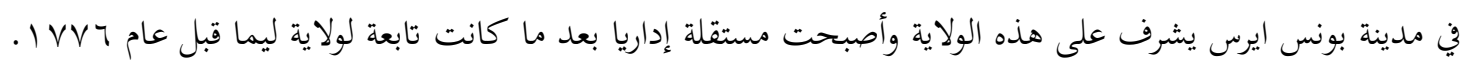

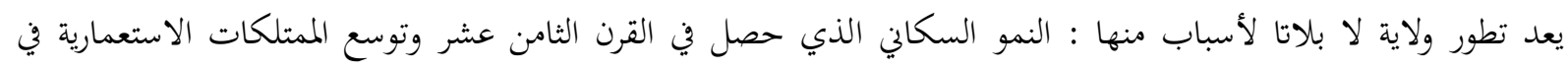

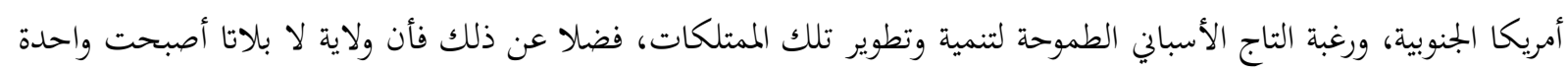

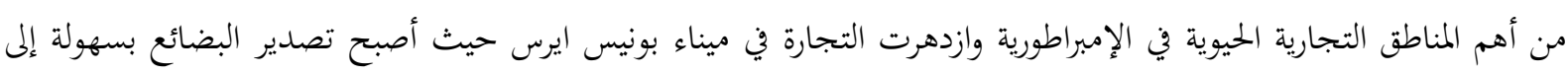

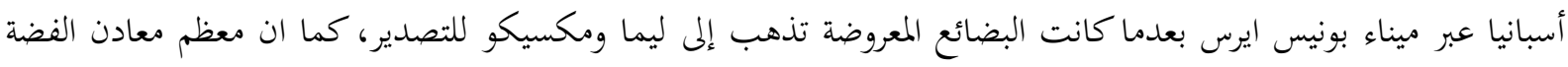
بدأت تتدفق من اعالي البيرو إلى بوينس ايرس، فضلا عن وصول أعداد متزايدة من العبيد إلى المدينة فارتفع بذلك التعداد السكاني في مناطق لا بلاتا وأخذت التجارة الناجمة عن تربية الماشية تتوسع بالاعتماد على الأساليب الأكثر كفاءة وارتفاع حجم التهم الصادرات

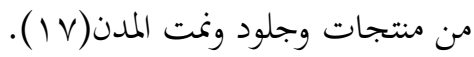


المبحث الثاني

\section{دور خوسيه دي سان مارتين في حرب الاستقلال الأرجنتينية 1812-1850}

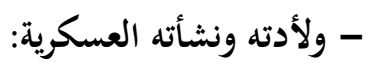

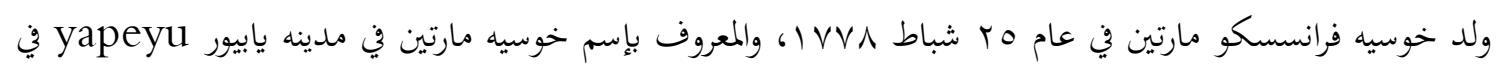

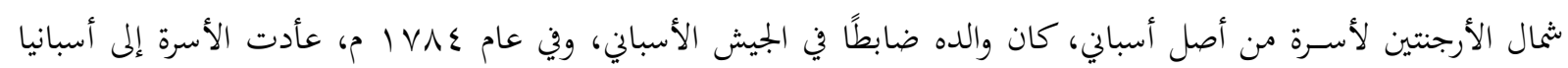

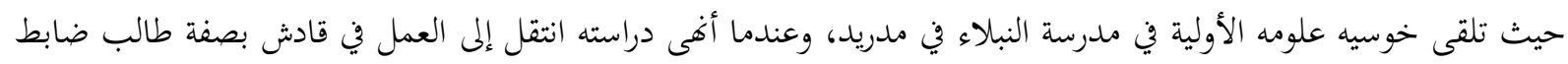

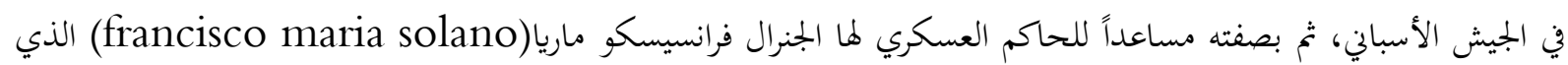

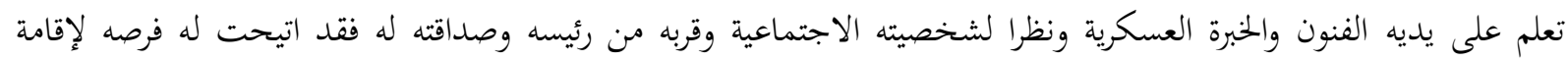

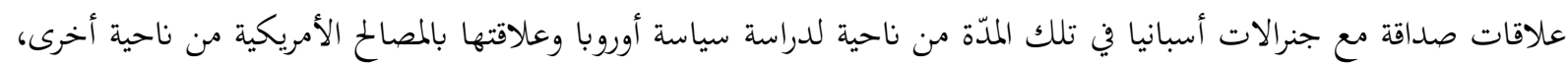
وكانت ظروف تلك المدة في أسبانيا مواتية لتنمية ذكاء وقدرات سان مارتين، إذ توفرت له فرصة المشاركة كمفكر ليبرالي في

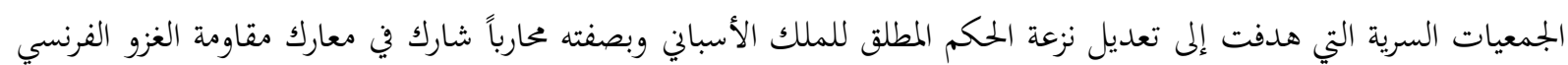
لأسبانيا(IV).

صدرت الأوامر إلى الجنرال سولانو solan بتشكيل فصيل قوامه ... . بـ للتحرك إلى البرتغال، فيتقاسم مسؤولية تلك

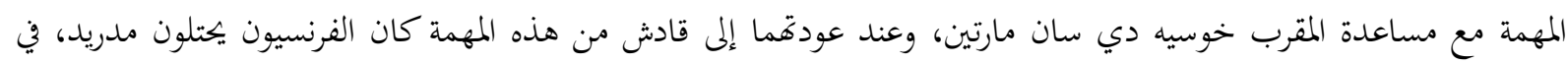

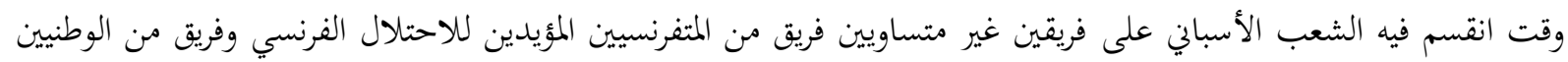

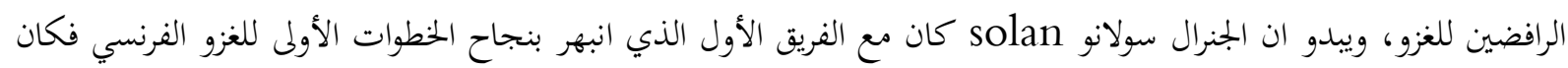

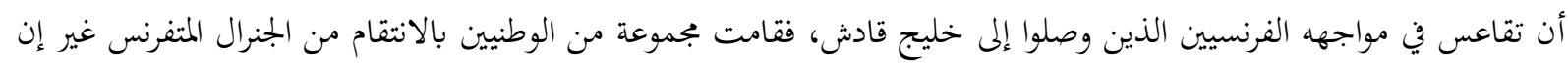

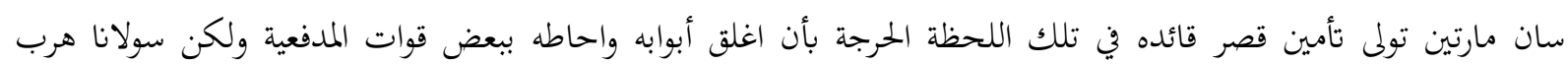

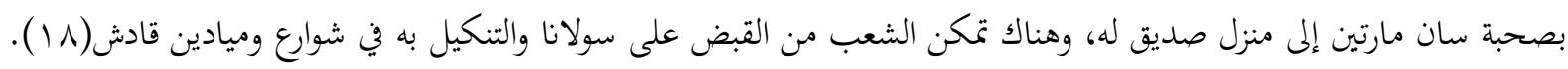

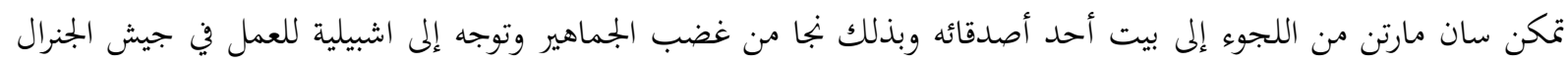

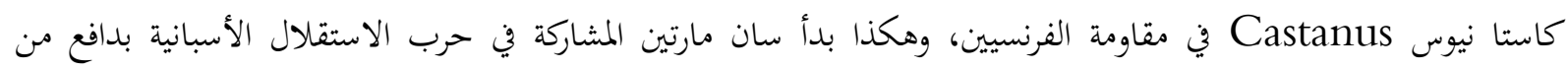

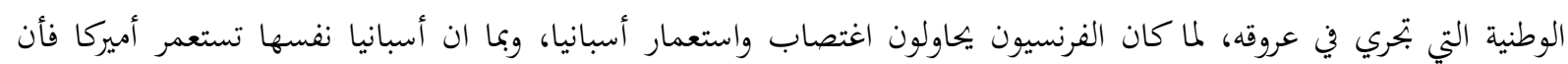

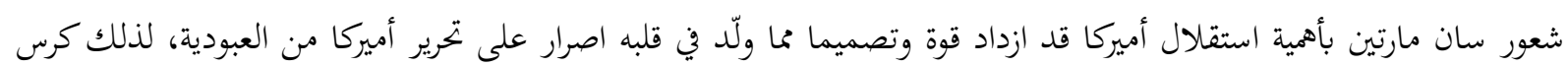

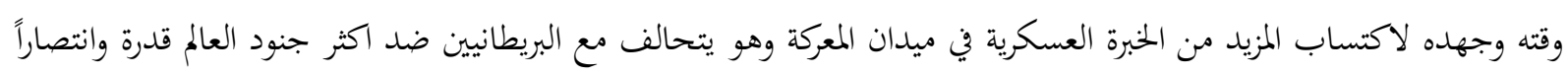

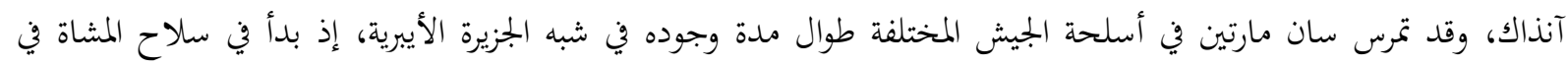

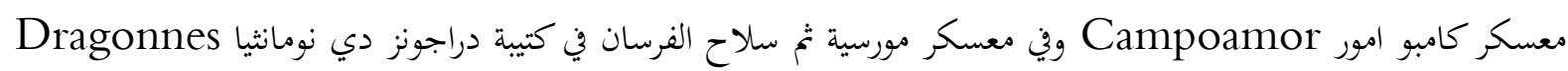
Denuman Cia

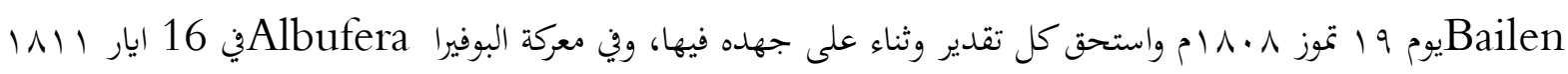

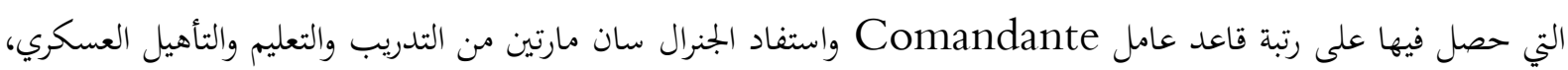

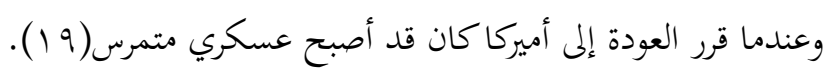

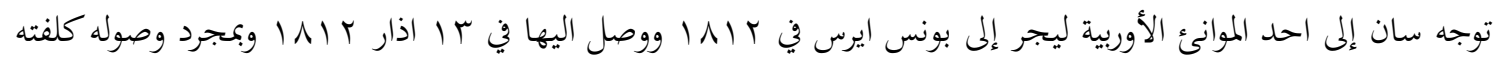

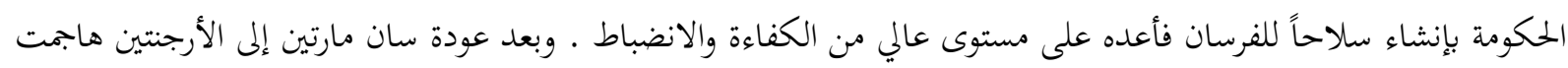

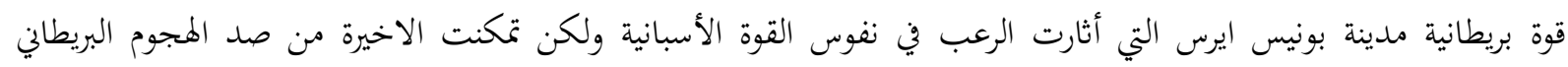


وطردهم من المدينة بعد اشهر من القتال وكان لتلك الاحداث تأثيراً عميقا في نفوس سكان بونس ايرس وعززت الثقة بإمكانياتم

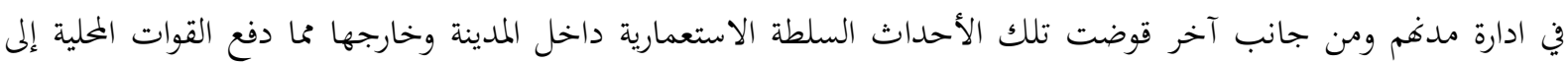
تجريد نائب الملك من سلطته.

انضم سان مرتين إلى محفل لونارو Lautaro وهي جمعية سرية ذات طابع سياسي انشأت في بونيس ايرس وكان لها تأثير

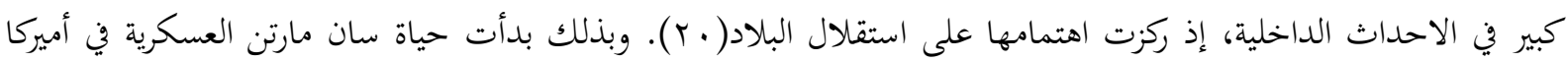
الجنوبية عام ז | 1 | على ضفاف غر البارنا عندما كان البحارة الأسبان يقومون بالهجوم المفاجئ من حين إلى آخر على المناطق

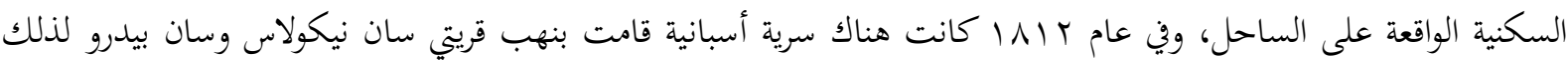
توجهت كتيبة من الفرسان بقيادة العقيد سان مارتين إلى تلك القرية لتخليص المنطقة من المستعمرين. وعندما علم سان مارتين بان

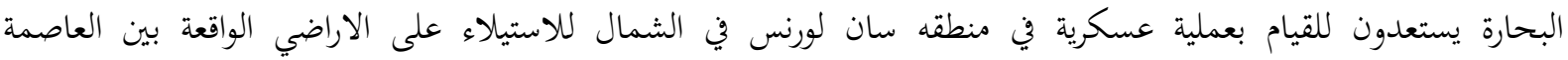

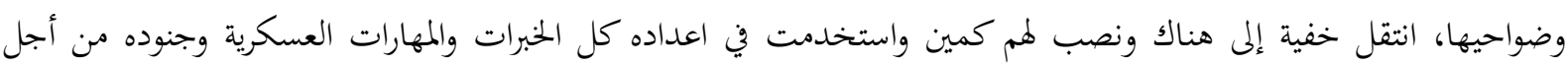

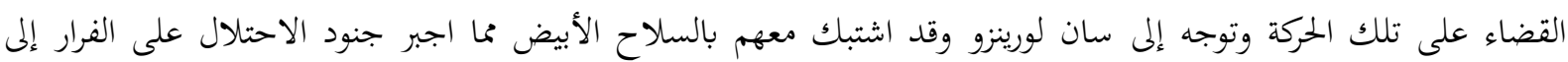

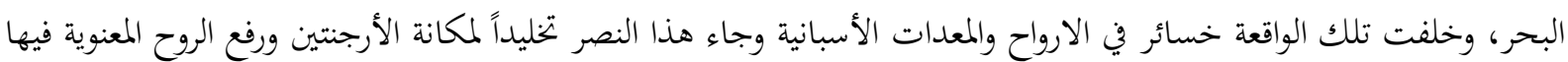
بعد ان أثبتت تلك المعركة التفوق المادي الأرجنتيني على العدو ورفع الروح المعنوية (ابك). أصبح سان مارتين على استعداد لتنفيذ حلمه الذي راوده كثيرا وتحرك بجيش يضم ....

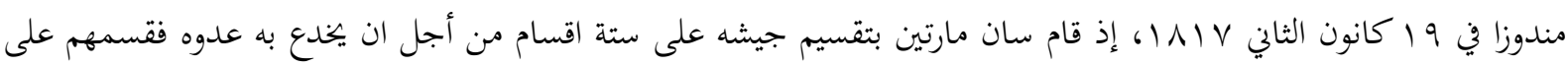
اقسام متساوية في العدد حتى يستطيعون عبور جبال الانديز مستخدمين خمسة بمرات جبلية مختلفة وذلك بهدف أشغال العدو وإرباكه فقاموا بتسلق ممرات قاحله بلغ ارتفاعها . .. با ا قدم عن مستوى سطح البحر مستخدمين حركات سريعة، ولكي يحقق

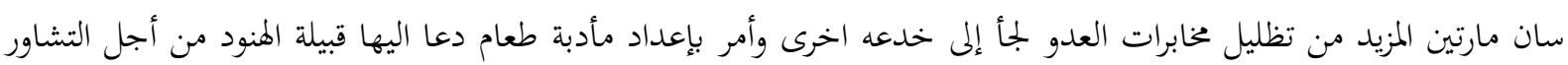

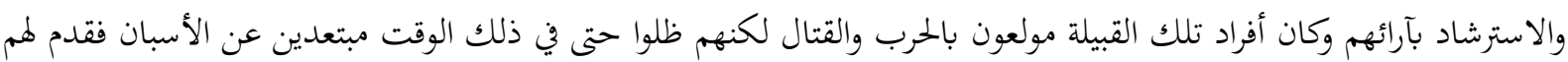

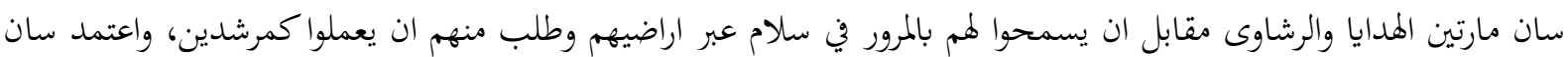
مارتين على اولئك الهنود الذين يقدمون المعلومات عن الأسبان له مقابل حصولهم على المزيد من الهدايا والهبات ونقل للأسبان المعلومات الزائفة عن جيش سان مارتين وبتلك الوسيلة أصبح الطريق الذي تسلكه قوات مارتين في مأمن من اكتشاف الأسبان

في 12 شباط 1817 انتصر جيش سان مارتين على القوات التشيلية في معركة تشا كابكو ودخلت القوات المنتصرة مدينة سانتياغو عاصمة تشيلي وانتشر الخبر بسرعة البرق في جميع انحاء تشيلي فقرر سان مارتين إقامة حكومة تشيلية باختيار

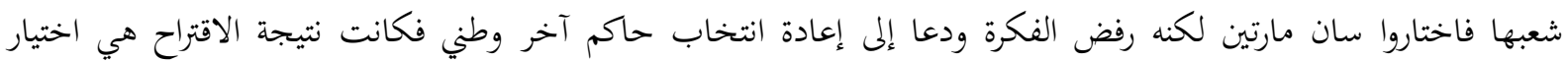

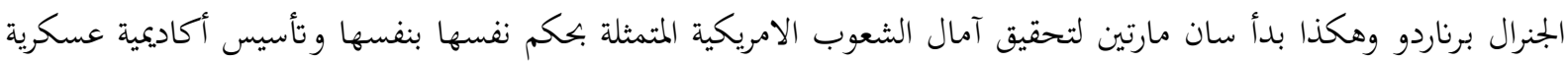

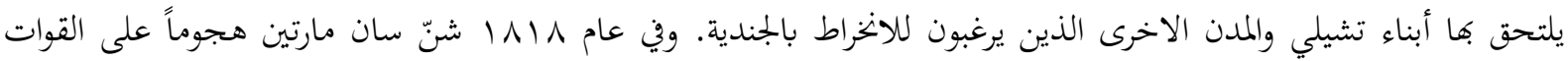

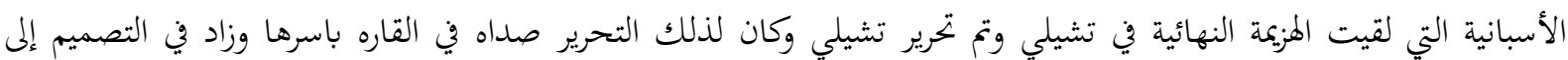
تنفيذ مشروع تحرير البيرو وهكذا تمت المرحلة الأولى من خطة سان مارتين، وبعد تأكيد استقلال تشيلي امر سان مارتين قواته

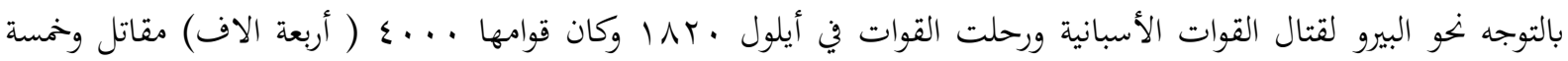

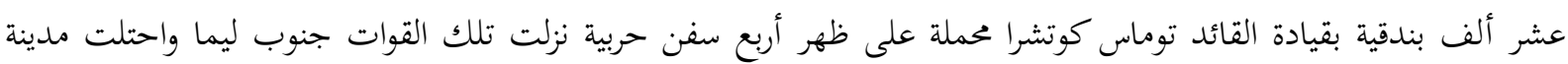

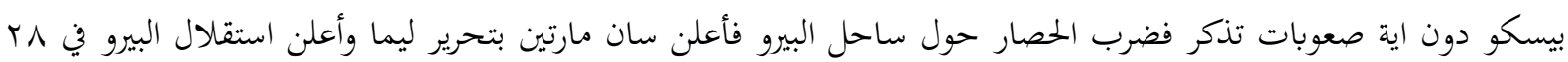


تموز الم ا بكلماته الشهيرة قائلاً: " لقد أصبحت البيرو منذ هذه اللحظة حرة مستقلة بفضل ارادة شعبها وعدالة قضيتها التي يدافع عنها الله "(r) (r).

أسس سان مارتين جمعية الاخاء العسكري تحت اسم (جماعة شمس)، إذ هدفت إلى مكافأة الضباط الذين يحاربون من

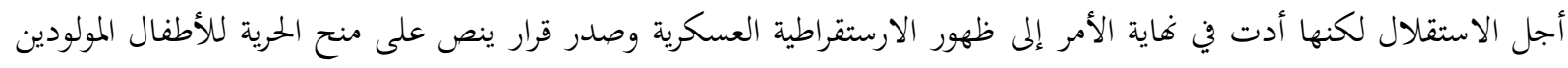

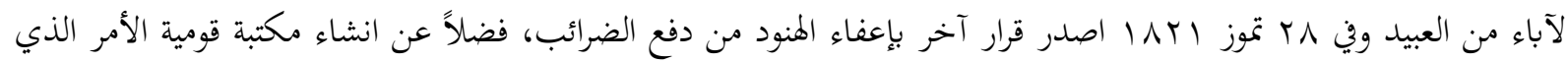
ادى إلى ترك آثار عظيمة بعيدة المدى في نفس شعب البيرو لان حاكمها القديم اتصف بشيء من الطغيان والعنف وسان مارتين واتصف بملامح الخير والعطف وكان موضع حسد بعض انصاره ومنافسيه ومنهم كان سيمون بوليفار . وفي الخامس والعشرين من تموز YKY Y جرت مقابلة بين سان مارتين وسيمون بوليفار، إذ عرض سان مارتين على بوليفار

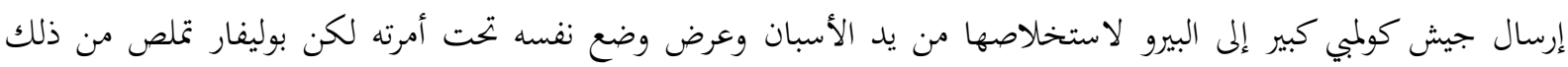

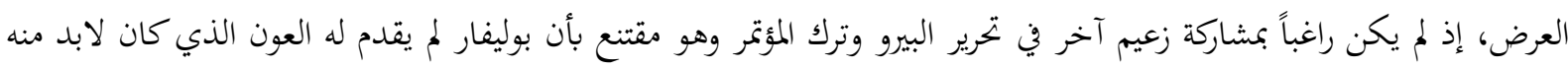

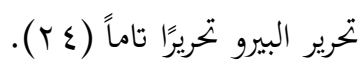

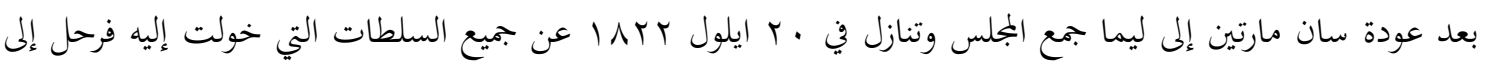

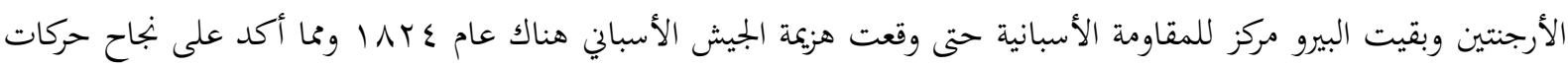

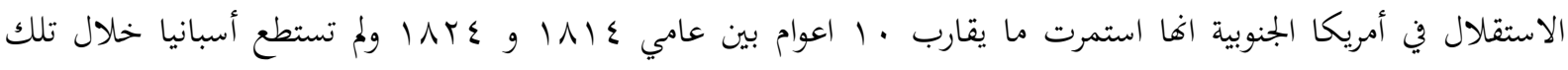

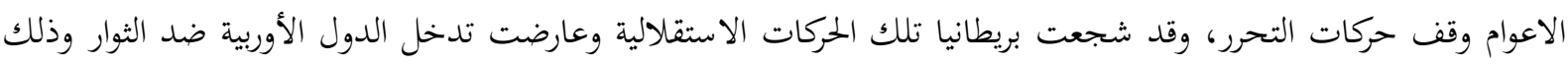

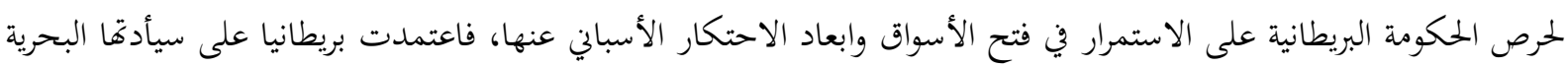

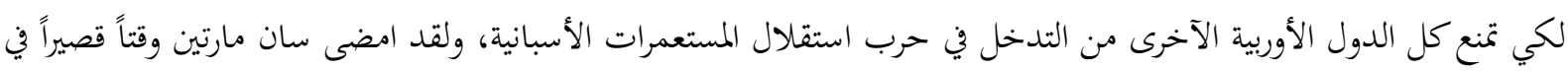

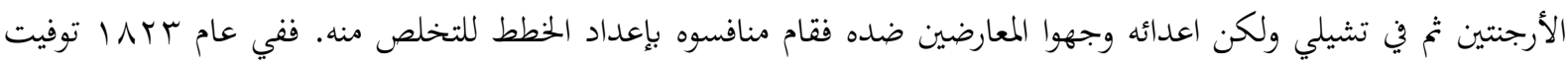
زوجة خوسيه دي مارتين في بونيس ايرس بعد نشوب الحرب الاهلية في مقاطعات الانديز وتوجه إلى فرنسا مع ابنه الصغير بعد

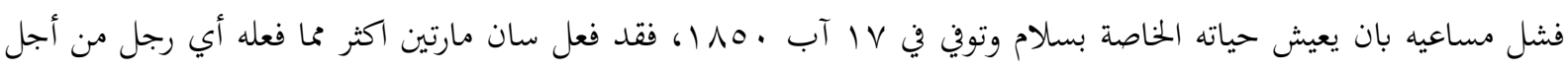

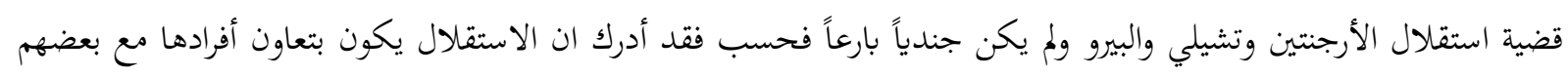

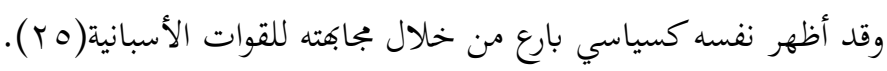

\section{الجمهورية الأرجنتينية}

أصدر في عام سم11ا دستور للأرجنتين نص على ضرورة إجراء مجلس تمثيلي جمهوري لحكومتها وفقاً للدستور كذلك

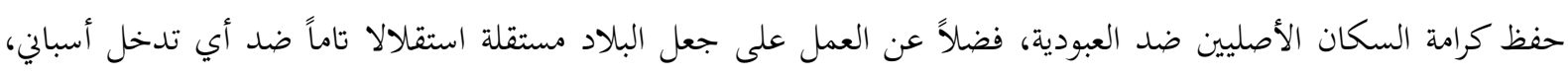

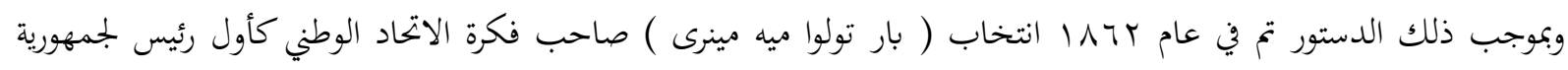

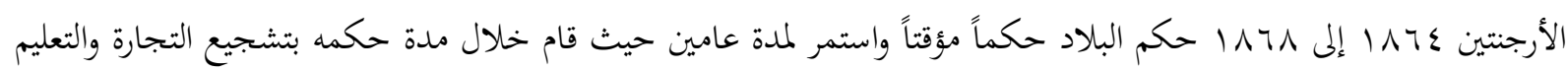

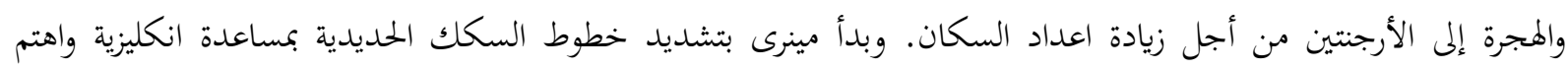

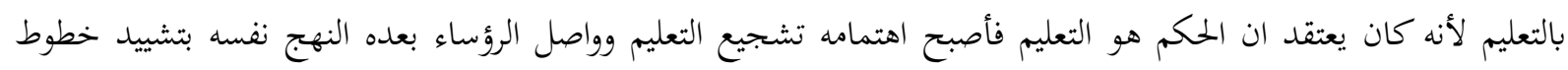

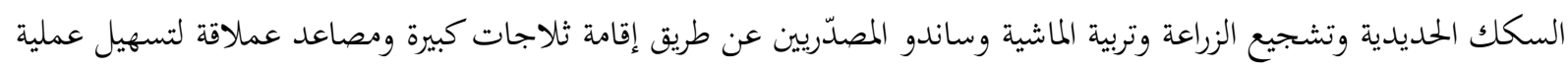

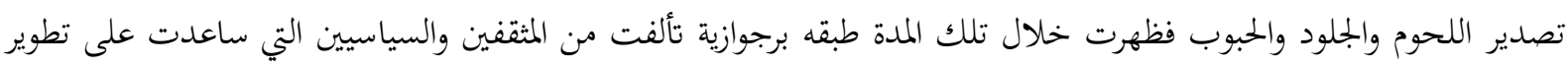
الدولة اقتصادياً) (ب ب). 
تعرضت الأرجنتين على غرار هذا التحول الكبير إلى نمو سكاني بسبب الهجرة المتوالية من الأسبان والايطاليين حتى زأدت

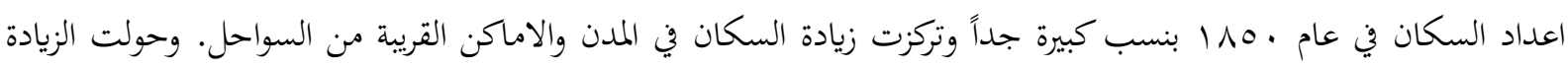

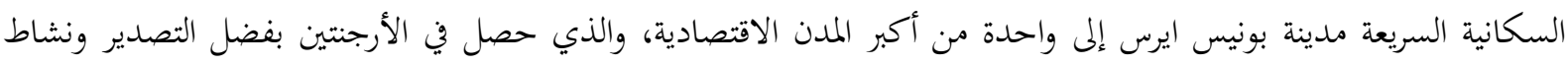

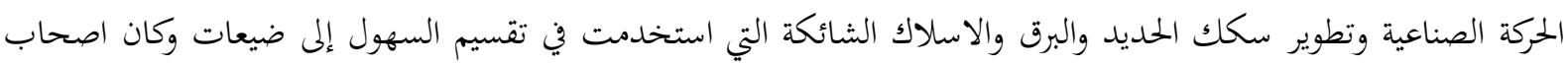

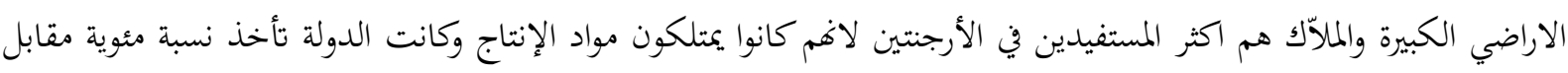

$$
\text { التنازل عن حقوق التصدير للشركات الاجنبية(27). }
$$

كانت بلاد الأرجنتين التي اطلق عليها باللغة اللاتينية بلاد الفضة يسكنها العديد من الحضارات القديمة منهم الهنود

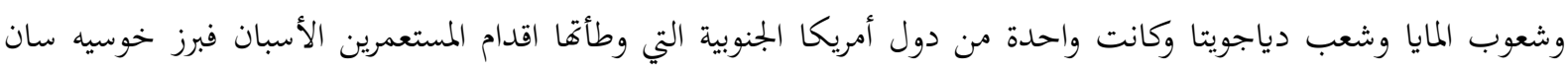

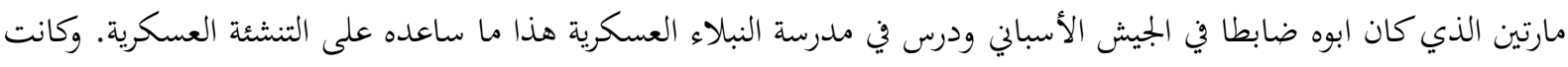

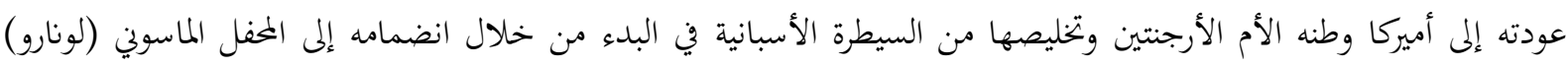

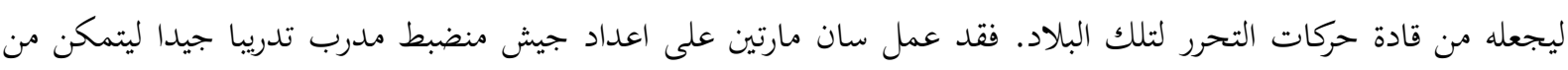

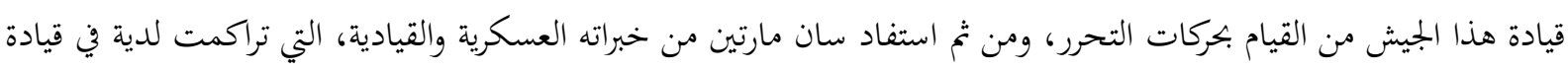
جيش الانديز لتحرير تشلي ثم بعدها البيرو.

لم يكن النصر الذي حققه سان مارتين في تشيلي ليدفعه للغزو بل تنازل إلى صديقه اوهحينز لقيادة تشلي وسخر كل

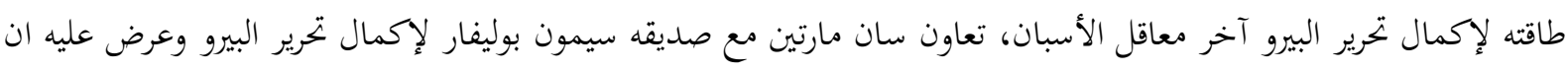
يكون جنديا تحت قيأدته وهذا يعكس الشعور الوطني الكبير لسان مارتين في تحرير كل الاراضي التي يحتلها الأسبان.

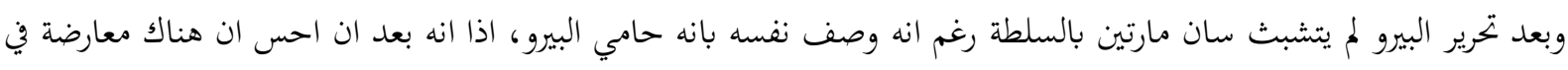

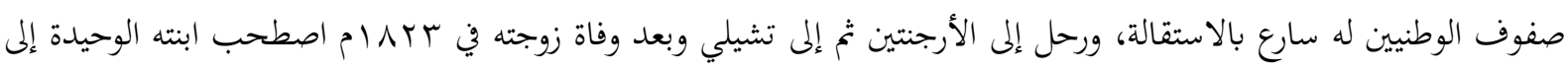

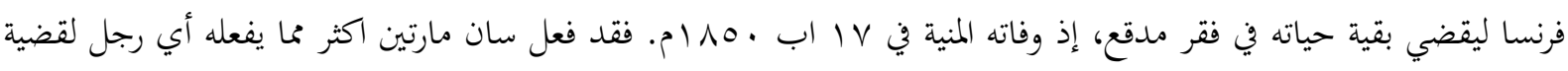
استقلال الأرجنتين وتشيلي والبيرو. 


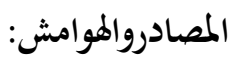

David Rock, Argentane, 1316 -1987, USA, 1985, PP.6-7. .1 The New Encyelopeolia, Britannica,Vol.27, London, 1974, P.19. .2 Danial k.Liwis, The History of Argntine, Greenwood preess, London, 2001, P. $19 . \quad 3$

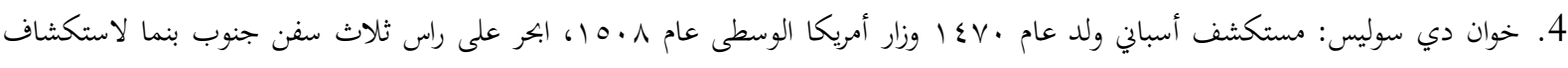

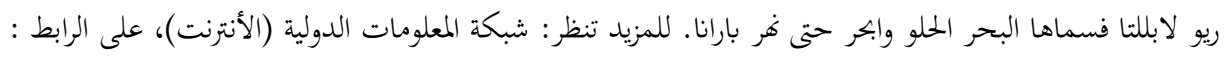

.ar.m.wikipedia.org .1

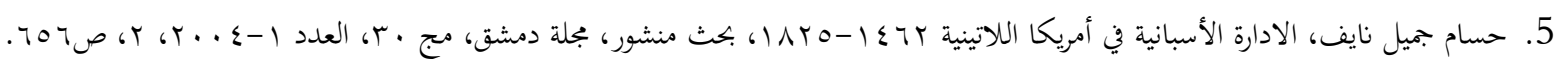

Op.Cit, P.25. Daniel k.Lewis, .6

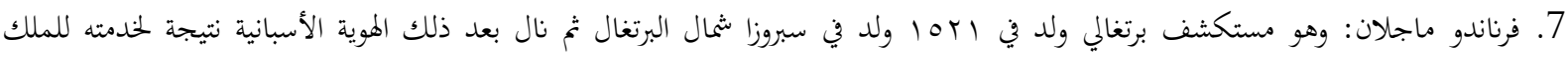

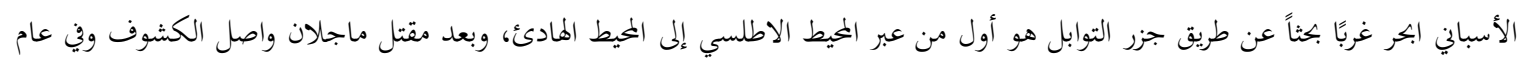

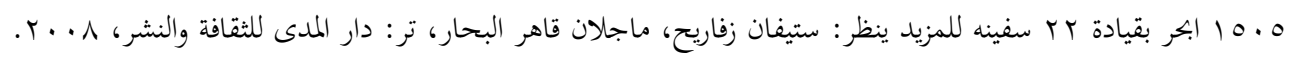

Lilian del easkillo. laborde, the Rio de Lapta and its, Maritime fourt Legel Regime, Boston, .8

2008, P.22.

Jontah c . Brown, Abrief historyof Argentine, lexing ton, 2003, PP.51-32. .9

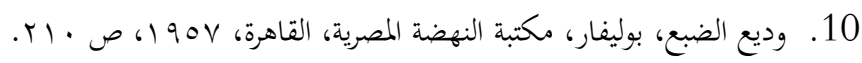

Todd L. Edewads, Op, Cit, P.38. . .11

Jose Desan, Elsolarnativo- Enrique Mario Mayochi Martin- El Libertacor, Instituttosanm . .12

Martiniano, P.12.

Jose' lgnacio Garcis Hamilton, Don Jose' Lavida san Marthin, P.323. .13

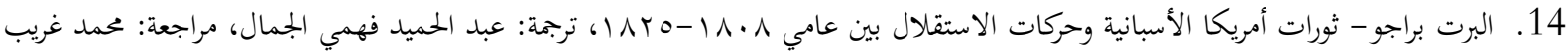

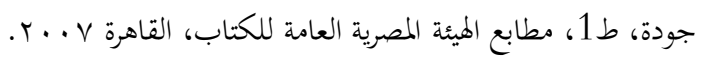

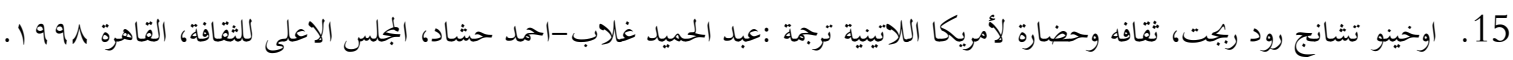

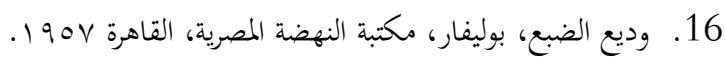

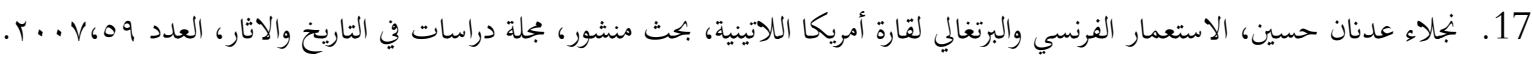

The cokkege of saint rose, Benjamin keen, keitn haynes, A history of latin America, .18

Op, P.60, poston, Newrork,

19. حسام جميل النايف، المصدر السابق، ص7010.

Daniel k . Lewis, Op.Cit, P.25. .20

Daniel k . Lewis, Op.Cit, P.90. .21

Woodbine parish, Buenos-Ayres and he provinces of the Rio de laplata, London, 1832, .22

P.76.

Daniel k lewis, Op.Cit, P.35. .23

24. حسام جميل النايف، المصدر السابق، ص 709.

Todd L. Edewads, Op,Cit, P.128. .25

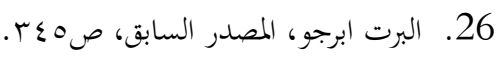

Daniel k lewis, Op.Cit, P.36. . 27 


\title{
PUBLIC BANQUET IN THE ABBASID ERA
}

\author{
Moayad Ibrahim Mohamed HASSAN ${ }^{1}$
}

\section{Istanbul / Türkiye \\ p. $28-40$}

Received: $15 / 11 / 2021$

Accepted: 06/12/2021

Published: 01/01/2022

This article has been scanned $l$ iThenticat No plagiarism detected

\section{Abstract:}

Some unfortunate brothers were baptized to feasts and banquets for the public, and during season times Historical sources ndicate that the cults of the Abbasid Caliphs, including the Abbasid aliphate Al-Mahdi, the Mamoun and the Mu 'taad, ranged between six thousand and a thousand dinars a day, while the expenses of the Al-Mutakil kitchen amounted to one thousand dirhams, which is a fairly large budget.

He was also known to identify the Abbasids with public and rivate tables, including the Caliph al-Mansur Al-Rasheed al-Mamoun with a stature favourable to the general public in addition to the state of development that Arab and Islamic society witnessed during the Arab era, in terms of the literature of the gourmet and the pious tools related to the Arab cuisine Result for Tth.

Key words: Public Banab, Abbasid Era. 


\section{المأدب العامة في العصر العباسي}

\section{مؤيد إبراهيم محمد حسن 2}

الملخص:

اعتمد بعض الخلفاء العباسيين إلى اقامة الولائم والمأدب للعامة، وفي أوقات المواسم والاعياد والاحتفالات الرسمية، وخصصوا من أجل ذلك الميزانيات الكبيرة من الأموال والتي تصرف على مثل تلك الولائم، إذ اشارت المصادر

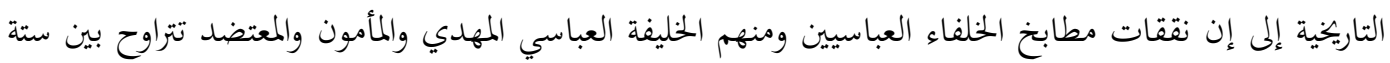

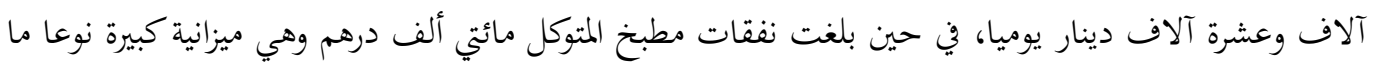

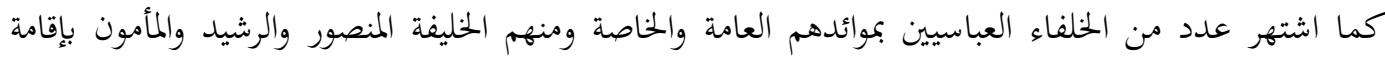
موائد للعامة الخاصة إضافة إلى حالة التطور الذي شهدها المجتمع العربي والإسلامي في العصر العباسي من حيث آداب المائدة والأدوات والأواني المتعلقة بالمطبخ العربي نتيجة للتاثر بالثقافات الغير عربية. الكلمات المفتاحية: المأدب العامة، العصر العباسي.

تعد الماكل والمأدب العامة والتي كان يقيمها الخلفاء والأمراء العباسيين من أهم الظواهر الاجتماعية التي اشتهر بها البعض

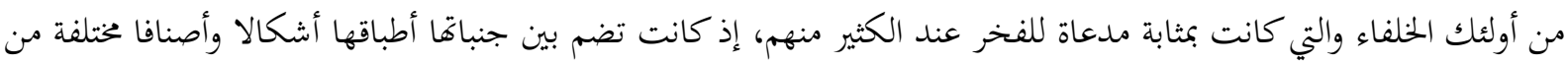
الأطعمة والفواكة منها ما هو معروف ومشهور بين الناس ومنها ما هو غريب جديد لم يكن معروفا ومشتهرا بينهم بل جاءت وصفاته من أماكن بعيدة وثقافات مناطق جديدة افتتحها العرب والمسلمون في ذلك الزمان. كما كان يدعى إلى تلك الماكل والمأدب فئات متعددة من الناس منهم ما هو مقرب إلى الخلفاء كالوزراء والولاة والقادة

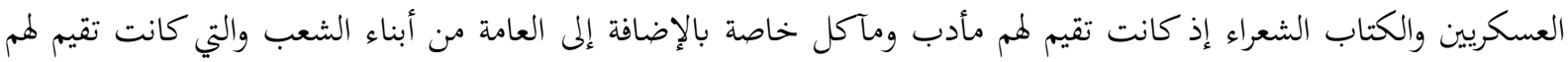
الوجبات المأكل العامة وفي أوقات ومناسبات مختلفة.

وستناول في هذا البحث جميع ما يتعلق بتلك المأدب والموائد التي كان يقيمها أولئك الخلفاء لخاصة الناس ولعامتهم بالإضافة إلى أهم الأواني التي كانت تستعمل في الطبخ وانواع المطابخ المشهورة في تلك الفترة وذلك الزمن.

المائدة لغة واصطلاحا

المأدب جمع مآدبة، وهي مشتقة من (أدب)، ويبدوا ان لهذا الاشتقاق أهمية كبيرة، فقد أطلق النبي محمد (صلى الله عليه اله وسلم) على القران الكريم لفظة (مآدبة) فقال عليه الصلاة والسلام (إن هذا القران مآدبة الله في الأرض فتعلما من مآدبته ما استطعتم)(1)، فهذه اللفظة توحي إلى النرفع عن كل ما يجافي الآداب والأخلاق والذوق العام عند حضور الطعام. أما لغة فان الأدب: هو الذي يتأدب به الأديب من الناس سمي به لانه يؤدب الناس إلى المحامد وينهاهم عن المقابح،

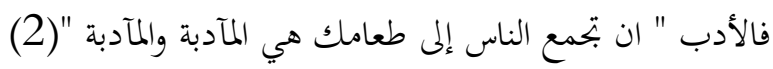


أما اصطلاحا فللمآدبة عدة معاني عدة تعاريف تعطي جميعها معنى واحد، فقد عرفت على اها " الصنيع الذي يصنعه

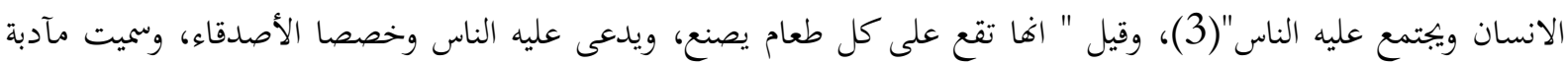

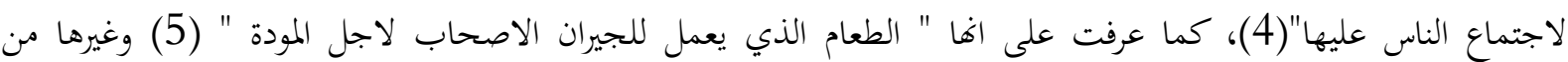

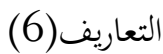

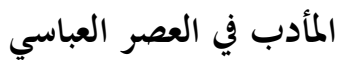

لم يكن الطعام في الجاهلية وصدر الإسلام غنيا ومنوعا إذ أنه كثيرا ما ما كان يتكون من اللبن أو مشتقاته، أو من التمر

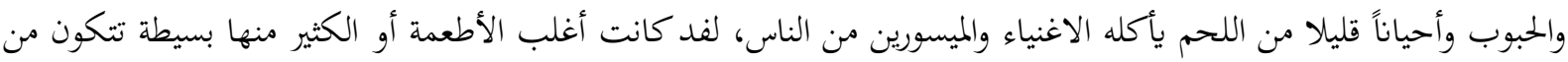
الثريد الذي كان يصنع من اللحم والخبز واللبن، أما الحلوى فلم تكن أكثر من الرغيدة والرهيدة اللتان تصنعان من اللبن والبن والدقيق، والعصيدة من السمن والدقيق والضيعة من الدقيق والعسل.

ويبدوا ان جميع هذه الأصناف من الطعام والوجبات قد طرا عليها الكثير من التطور والتحسن والتحديث مع ازدياد حركة الفتوحات الإسلامية ودخول لكثير من البلدان والمناطق كالشام وفارس ومصر والعراق إلى حاضرة الإسلام ودخلت معهم وجباتم مرهم

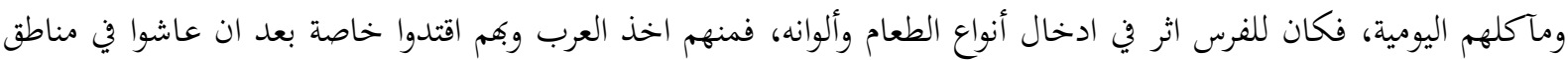
واسعة ذات ثروات طبيعية ومراع دائمة الخضرة.

لعل الملوك والخلفاء كانوا من اشد الناس على انتقاء ما لذ من الطعام وطاب، فهم يتخيرون اللذيذ من كل شيء، وما عليهم ان اتعبوا غيرهم أو أنفقوا الأموال الطائلة في سبيل ذلك، فكان الحنلفاء العباسيون يعنون هذذا الأمر كل العناية، ويحرصون على ان لا يفوقم من لذائذ المأكل والثمار شيء، فكانت هذه اللذائذ تحمل من الأقطار إلى قصورهم في بغداد ليتمتعوا بها، وكانوا

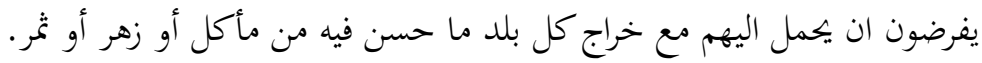
فعلى سبيل المثال لا الحصر كان الرمان والخوخ المقدد يحمل مع خراج الري، وكان العسل والشمع يأتي مع خراج الموصل

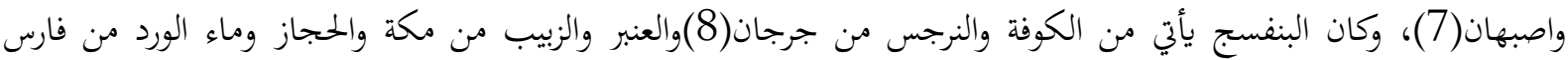
وغيرها.

كان الخلفاء والأمراء والوزراء يعدون السخاء على العامة والخواص من الفروض التي يجب تأديتها أما العامة فكانوا يسترضوغم بأبسط أساليب السخاء وهو الدعوة إلى الموائد، فكان العامة يجتمعون على مائدة الأمير أو الخليفة يأكلون منها

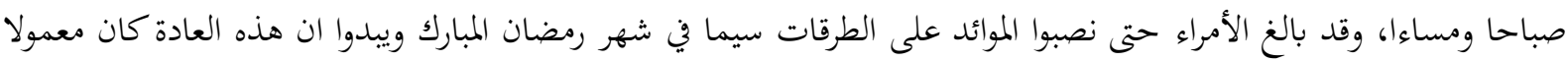
بها عند الأمم القديمة وبالخصوص من قبل بعض ملوك الفرس، إذ ان الخلفاء العباسيين قلدوا الفرس واقتدوا بهم في كثير من آدابهم (9) الاجتماعية

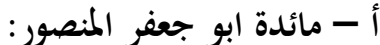

كان الخليفة المنصور العباسي من أوائل الخلفاء العباسيين الذين اهتموا بالموائد والطعام على الرغم مما اشتهر به من حرص

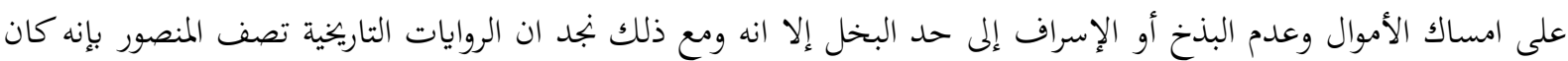

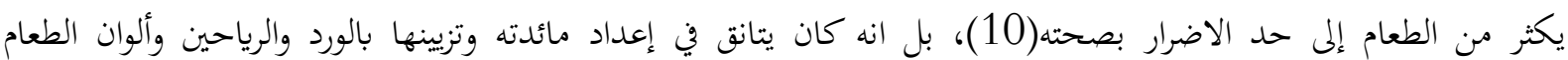
والشراب ويبالغ في ذلك فقد روى المسعودي(11) نقلا عن عبد الرحمن القمي(12) قوله: " دخلت عليه في بعض الأيام وهو جالس في موضع في آخر داره وقد رفعه على بركة ويف صدره صفة ويشرف منها على البستان وعلى حير الغزلان وحظيرة 
القمارى(13) واشباهه فقلت له: يا أبا جعفر انت والله جالس في الجنة، قال: أليس لك ان تخرج من الجنة حتى تصطبح فيها فما

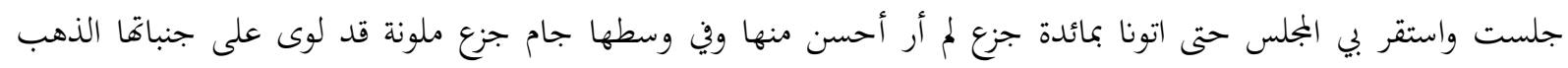

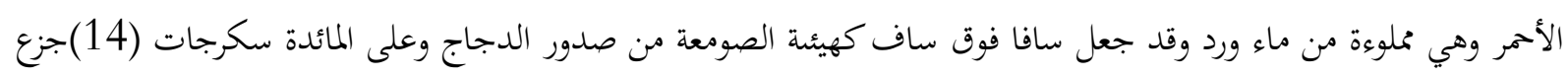

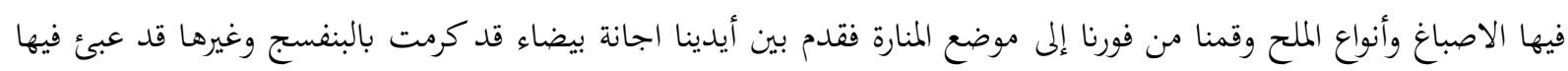

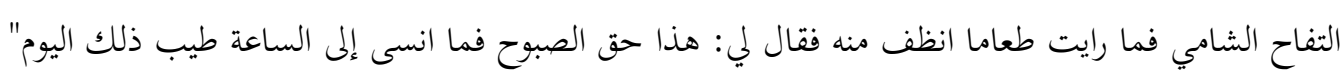

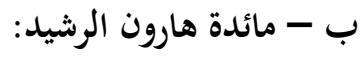

أشارت أحدى الروايات التاريخية إلى ان الرشيد كانت له مائدة عامرة بافخر أنواع الأطعمة وينفق عليها الأموال الطائلة

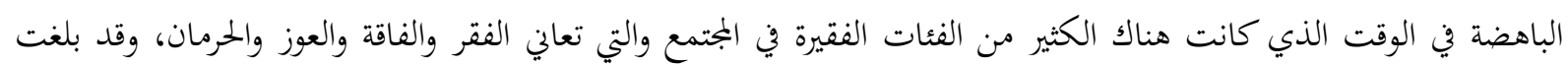

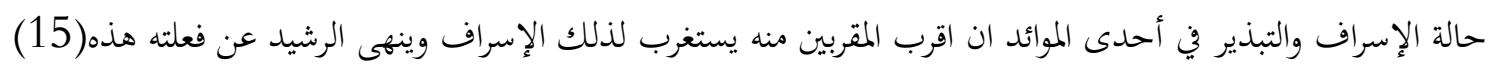
وقد تحدث المؤرخين عن الرشيد وشدة حبه وشغفه بالأكل والطعام حتى قالو ان الطباخين اتخذوا له أكثر من ثلاثين لونا

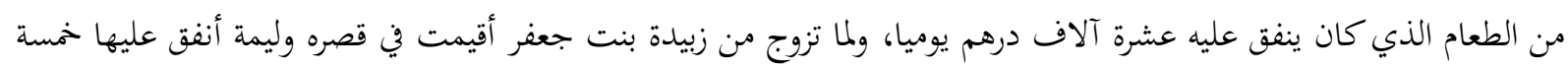

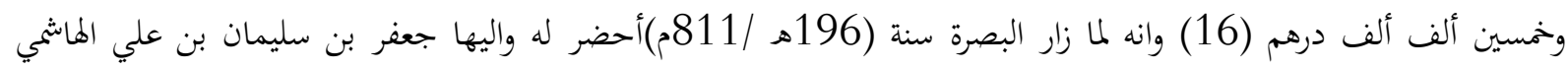

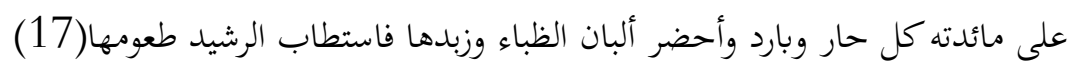

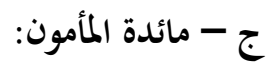

لم يختلف المأمون العباسي عن ابيه الرشيد أو عن جده المنصور من حيث إقامة الموائد العامة أو الخاصة أو من حيث

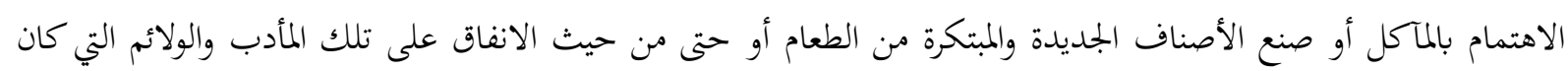
يقيمها بين الحين واللآخر وبمختلف انواع المناسبات حتى وان لم تكن ذات الهن أهمية أو قيمة. وقد أوردت لنا المصادر التاريخية الكثير من الإشارات والروايات التي تدلل على ذلك منها ما رواه أحدهم بقوله: "كنت

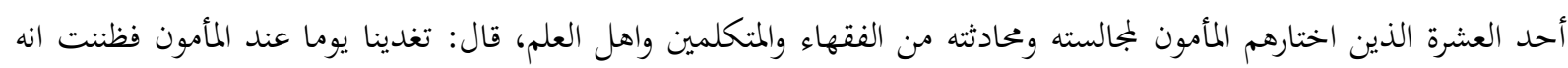

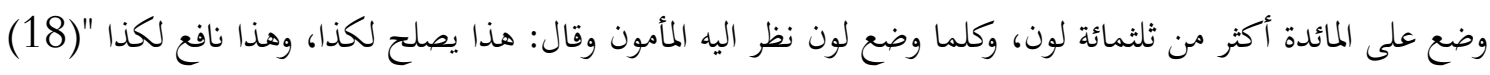
كما كان المأمون شانه شان ملوك بني العباس أكثر ميلا إلى اللحوم وخاصة لحوم الدجاج حتى ان الجاحظ يشير إلى ذلك

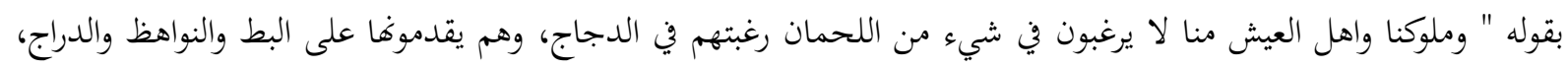

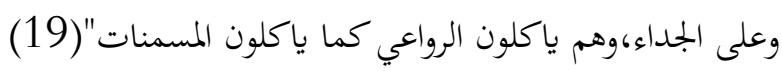
كما كان المأمون يميل أيضا إلى لحم الغنم، فقد قال للحسن بن سهل يوما: " نظرت في اللذات فوجدةقا كلها مملولة سوى

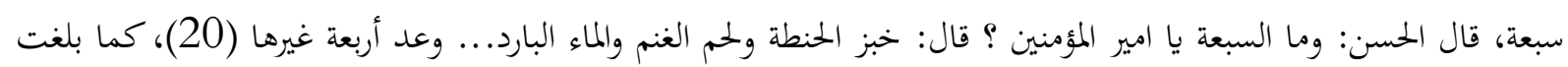
نفقته في اليوم الواحد ستة آلاف دينار، كان الكثير منها يخصص لمطبخه (21) وهذا دليل على حسئل حرصه المبالغ فيه في تقديم الطعام وحالة الإسراف التي تمتع بها فيما يخص بالمآدب. وكان المغني المشهور زرياب(22) ذا حظوة كبيرة عند الخليفة المأمون وهو المعروف بكونه صاحب اللياقة في الملبس والمطعم

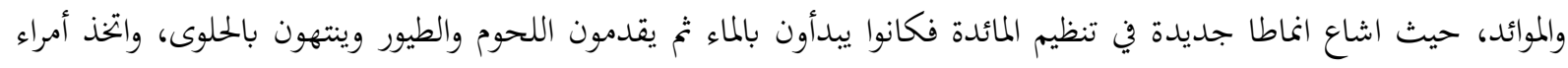

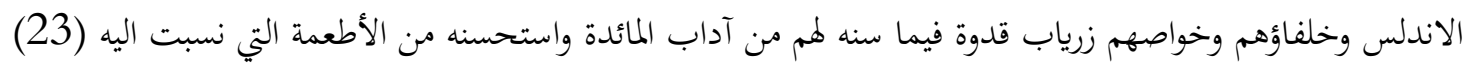


بالإضافة إلى ما ذكرنا فقد عرف عن بعض الخلفاء العباسيين المتاخرين اشتهارهم بنصب الموائد نذكر منهم الخليفة المعتضد

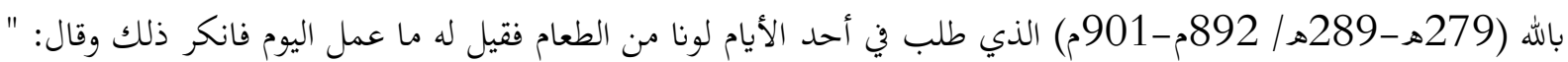
يجب ان لا يخلوا المطبخ من كل شيء حتى إذا طلب لم يتعذر، ووقع إلى ديوان النفقات بإقامة ذلك اللون إلى ان يرد التوقيع بقطعه، فكان يعمل وينفق عليه دراهم كثيرة ولا يهظر المائدة توقعا ان يطلبه فيقدم عند الطالب كما رسم فمضى على ذلك سنة

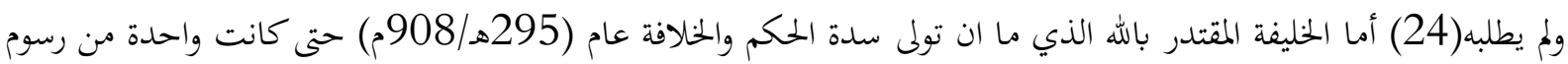
الخلافة التي امر بها التوسع في الطعام والوظائف، ففرق على بني هاشم الأموال والارزاق والابل والبقر(25)، كما اتبع الخليفة

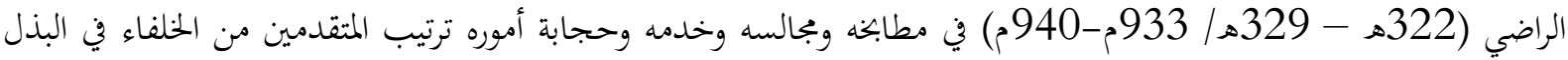

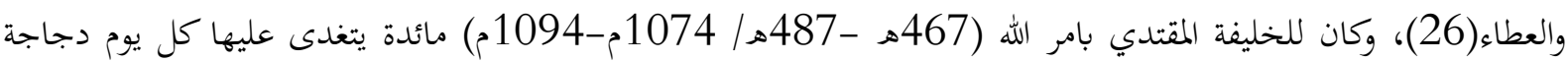
مشوية وفي أحدى المرات استلقى على ظهره فوجدوه ميتا قبل ان يغسل يديه (27)

تعد الموائد سواء العامة منها أو الخاصة من الظواهر الاجتماعية في العصر العباسي والتي يدعى اليها مختلف فئات المجتمع

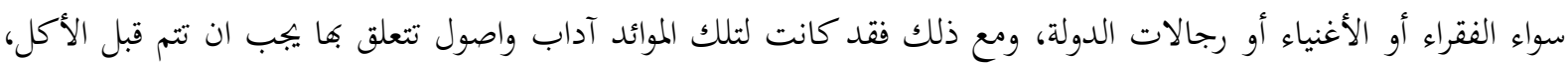
فعلى سبيل المثال لا الحصر ما الذي يجب عمله في المائدة وما هو الشيء الذي يجب تحاشيه من الضيوف رئ والمضيف، وكيف يتم تقديم الأطعمة ومتى تقدم الفواكه والحلوى، وماذا يفعل المدعوون بعد الطعام إلى غيرها من الامور الأخرى تعتبر مسالة تزيين المائدة بالورود والأزهار من المقدمات المهمة والمستحسنة بل والمستلطفة والتي يجب القيام بها، كما ان اول عمل يقدم عليه المدعوون قبل تناولمم الطعام غسل الايدي من وعاء واحد ثم يبدا رب البيت بالتقدم للطعام لئلا يحتشم

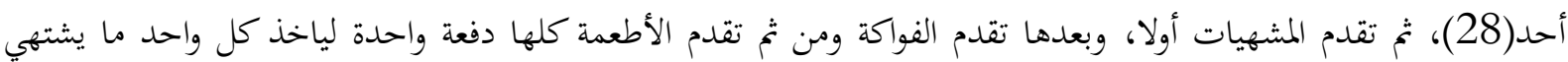

أما لجهة افراد كل ضيف بصحنه وطبقه، فإن الطعام كان يوضع على الموائد في أطباق مشتركة للجميع، فيتناول كل أكل حاجته، أما البسملة فكانت من اللوازم الإسلامية المستحسنة في بدء الطعام، كما ان قراءة سورة الحمد كانت من الأمور المكروهة

خلال الطعام خصوصا من جانب صاحب المنزل كوفا تدفع الضيوف إلى ترك المائدة قبل الشبع، حتى ان أحدهم انشد قائلا: وحمد الله يحسن كل وقت ولكن ليس في وقت الطعام

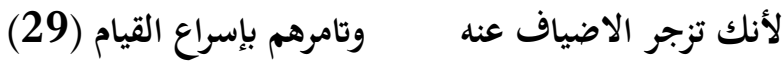

أما الحديث على الطعام وبحاذب الأراء فقد استحسنه قوم وكرهه آخرون، وفضل بعضطم ان يكون الحديث من قبل صاحب المنزل، كي لا يضيع وقت الأكل على الضيف، والهدف من راء المحادثة التي يقوم بها المضيف تامين المتعة للاكل وتشجيعا

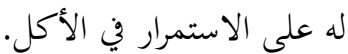
ويبدوا ان أراء الكثير من المفكرين والعلماء المسلمين قد تنوعت حول مسالة قواعد آداب المائدة وأهميتها التي يجب الالتزام والتمسك هما، فقال ابن حمدون(30): " النديم من أكل مع الملوك والأمراء والسادة، فليكن اظفاره مقلومة، وطرف كمه نظيف،

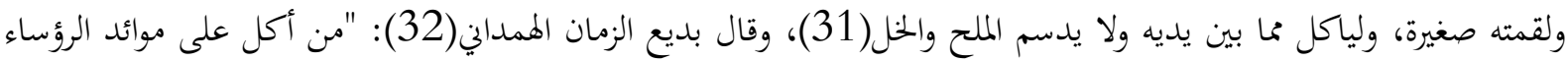

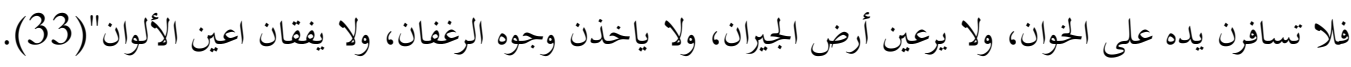


كما ان ابن كشاجم(34) الشاعر وضع كتابا في أدب النديم يتطرق إلى أصول الأكل على الموائد، وجاء في كتاب الموشى في الظرف والظرفاء لمؤلفه ابن يجيى الوشاء مجموعة نصائح للاكلين من الظرفاء تتعلق بتصغير اللقم، والتجلل عن الشره والنهم،

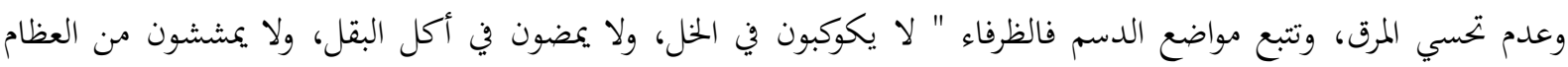

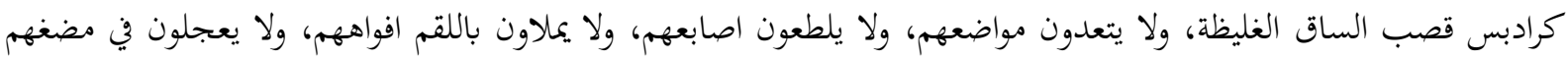
ولا ياكلون بجانبي الشدقين" (35) ومن العادات المتعلقة بالمائدة أيضا تعتبر من آدابها انه إذا ما انتهى الطعام، فان الجميع يبادر إلى الغسل، ويعمد رب البيت أو المضيف إلى غسل يديه بعد ضيوفه، وكان يفضل ان يغسل كل انسان بمفرده لما يحتاج اليه من استقصاء الغسل، والمبالغة

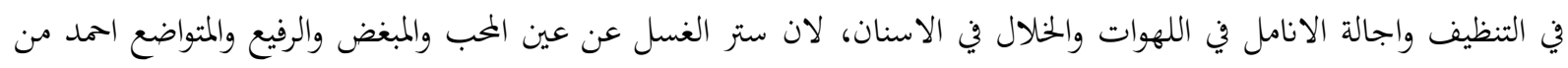
اطلاعه عليه(36) ويبدوا ان الأدب العربي قد تاثر إلى حد ما بآداب المائدة صياغة وموضوعا، فكانت الدعوات الخطية لحضور المأدب

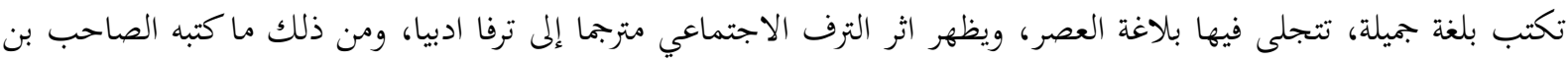

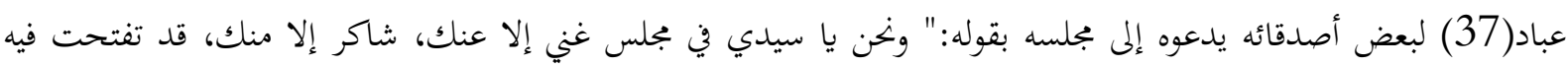
عيون النرجس، وتوردت فيه خدود البنفسج، وفاحت مجامر الاترج، وفتقت فارات النارنج، ونطقت السنة العيدان، وقام خطباء

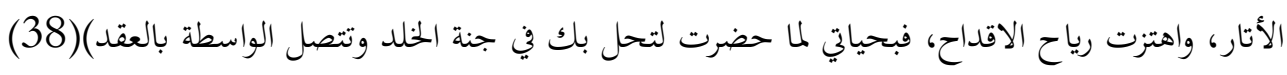

\section{أدوات المطبخ وأواني المائدة:}

تميزت أواني الطعام التي استخدمت على الموائد بأها تتناسب مع إعداد المدعويين ونوع الدعوة، إذ ظهر استخدام أنواع

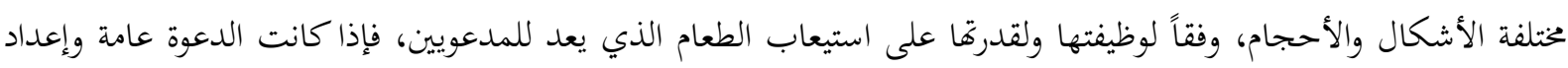

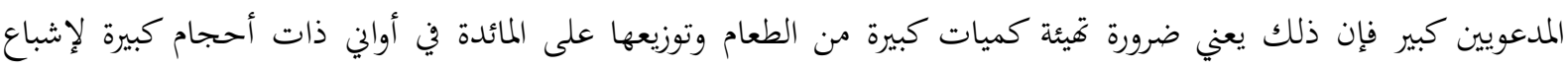

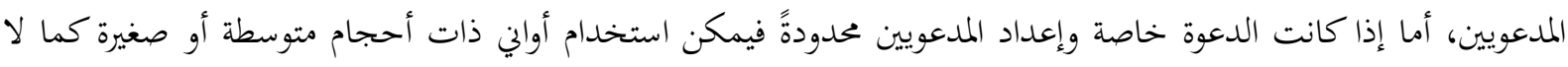
يككن إغفال المستوى المعاشي في استخدام أنواع الأواني سواء كان ذلك من حيث الحجم أو الشكل أو مادة الصنع، فهناك أواني فاخرة وأخرى رخيصة.

والواقع ان المطبخ ذكان يضم عددا من القدور تصنع من النحاس أو من الفخار اللامع، وكانت اسماؤها تختلف حسب

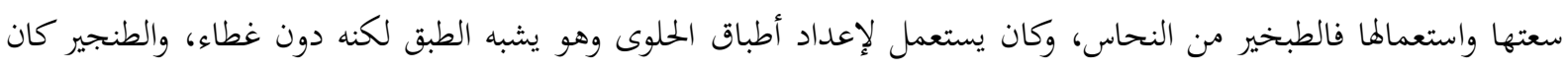

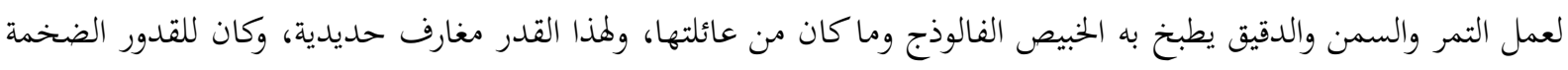

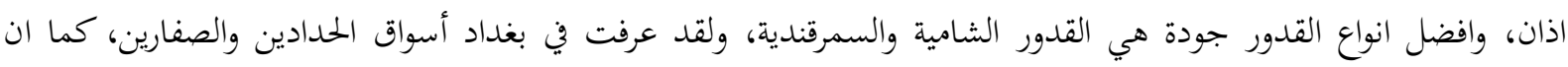

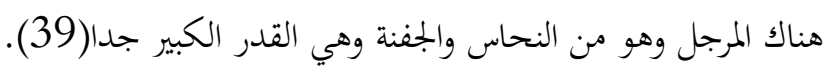

ومن القدور الأخرى التي تستخدم في عملية الطبخ قدر المقلى وهو من الفولاذ أو من الحجر،وطبق الصاج وهو من المعدن

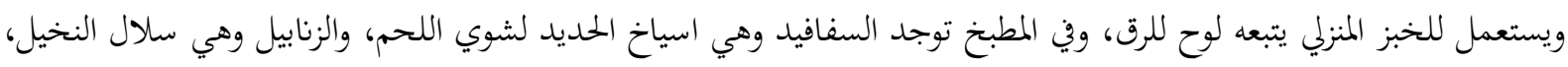

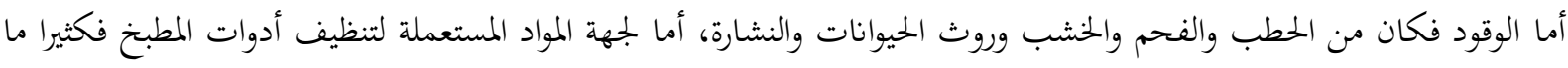

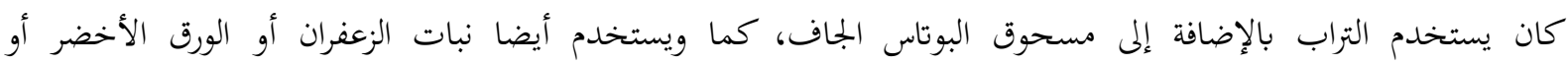

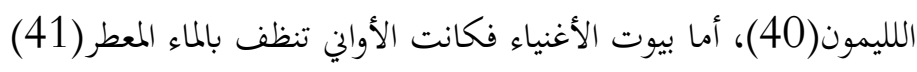


وفي عالم المائدة فان الأواني كثيرة تختلف بالشكل وبالسعة وطريفة الاستعمال من الفرد أو من بجموعة الأكلين، فلأطباق

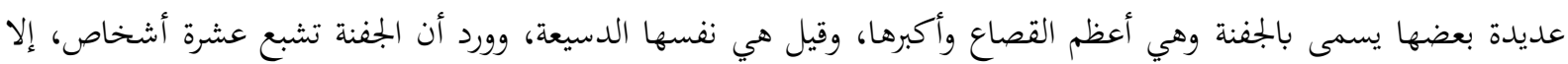

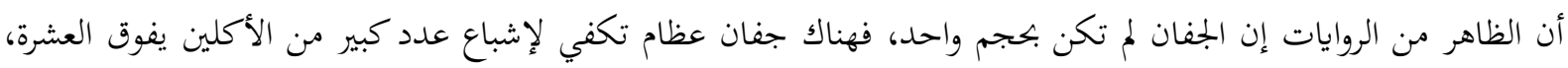

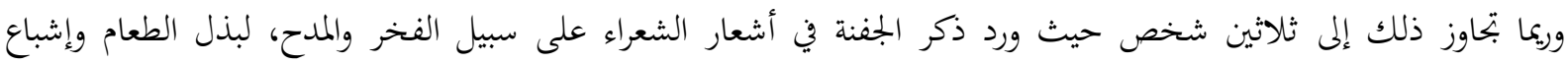
الضيوف والفقراء، وكانت العرب تمدح عظم الجفان وسعة الآنية فيقال (فلان عظيم الجفنة) إذا كان مطعماً (42) كما ان هناك القصعة وهي تلي الجفنة في الحجم، إذ قيل إنها تشبع عشرة أشخاص فقط، وقيل أيضاً بأها تكفي لأربع أو

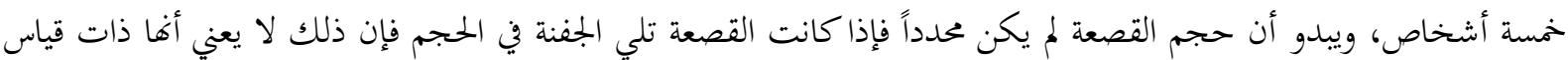

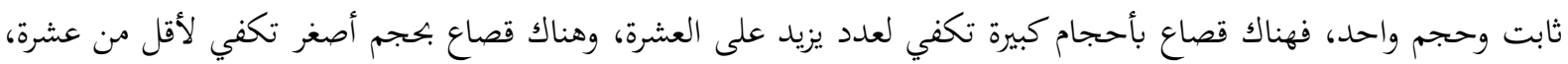

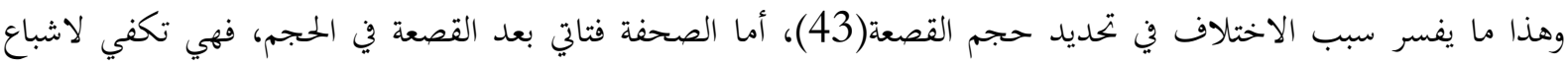

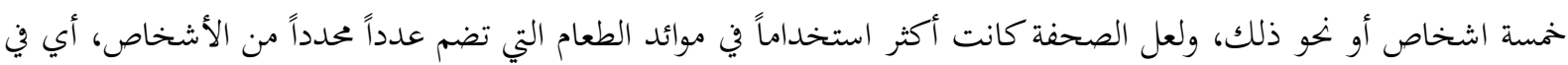
الدعوات الخاصة وليست في الدعوات العامة.

ومن الأواني الأخرى المكتلة، وقيل المأكلة، وهي تكفي لشخصين أو ثلاثة، لذا فإن استخدامها يكون على الموائد الخاصة،

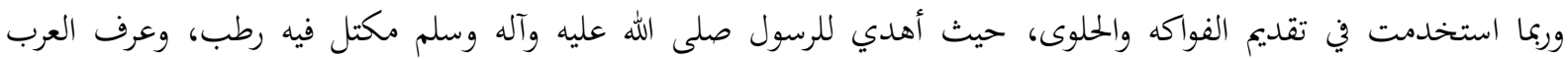

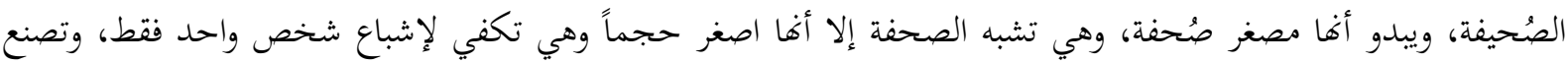
الصحيفة من خشب الخلنج وتنقش بأشكال مختلفة، وكانت السكرجة مستخدمة عند العرب وهي من آنية الفرس التي انتقلت إلى لى العرب، أما الغضارة فهي الإناء من الفخار الأخضر بحجم القصعة، وقد تصنع الغضارة من الخشب، وهناك الطيفورية وجمعها

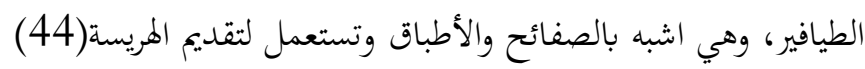
ويضاف إلى أواني المائدة الابريق المصنوع من الزجاج، والصينية وهي طبق معدني كبير مستدير جوانبه مرتفعة، وكان يطلق

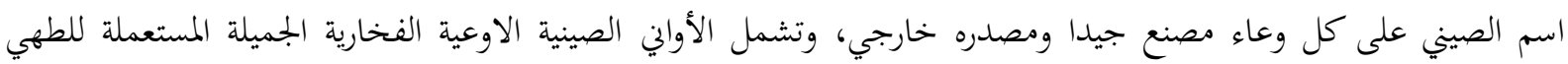
والسلق والقلي(45)

ومن توابع المطبخ والمائدة الماء والثلج، وكان الماء يوضع في جرار فخارية بعضها مفتوح من أعلاه الذي هو أوسع من قعره

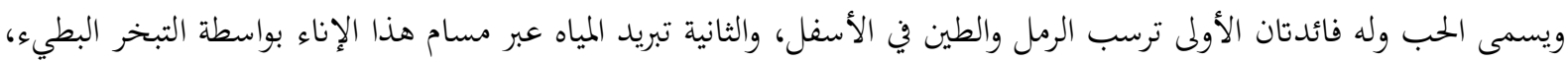

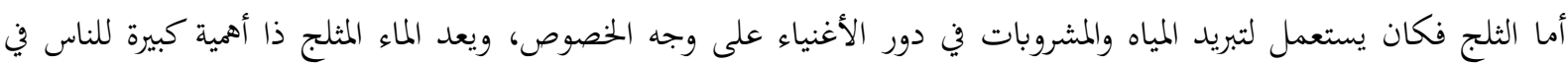

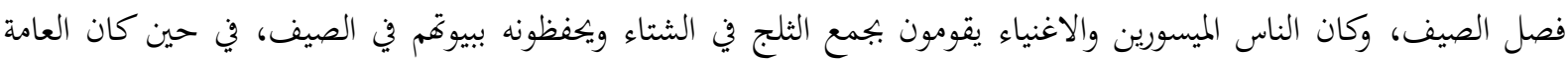
يجمعون الماء البارد ويضعونه في اكواز إلى زمن الصيف ليشربوا الماء البارد مقام الثلج وسموا الاكواز بالثلجيات، أما الجرار التي كانت توضع فيها المياه فتسمى بالمزملات(46)، كما كان الثلج يباع في الأسواق شتاءا وصيفا ويستعمل لتبريد الخضروات في في أوان فخارية خزفية، في حين كانت الفواكه والوصفات الطبية والأدوية توضع لحفظها في قوالب معباة بالثلج.

الخاتمة:

من خلال دراستنا للمأدب العامة في العصر العباسي نجد ان هنالك مجموعة من الأمور تتضح لنا بصورة جلية، فبعد ان عرفنا معنى المآدبة و المائدة لغة واصطلاحا لاحظنا ان تلك المأدب التي كانت تقام في العصر العباسي كانت تختلف بصورة جلية وواضحة عن الفترات التي سبقتها من حيث النوع والكم ولعل السبب يرجع في ذلك إلى تاثير الثقافات الأجنبية من فارسية تركية 
وغيرها على مختلف جوانب الحياة ولا شك ولا ريب كانت الموائد أحد أهم الأمور التي تاثرت بتلك الثقافات ويتضح ذلك أكثر

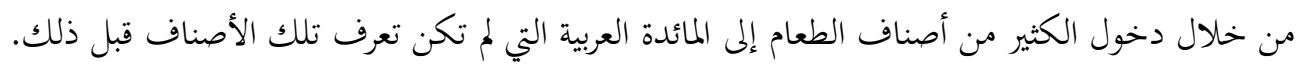

كما يبدو واضحا تاثر الخلفاء العباسيين بتلك الثقافات ولا سيما الفارسية منها في بادئ الأمر ثم التركية والذي انعكس بدوره على طريقة تناولم للطعام والآداب التي دخلت والتي لم تكن معروفة أصلا على المائدة العربية.

كذلك اشتهر عدد من الخنفاء العباسيين بموائدهم التي كانوا ينصبوها للعامة من الناس أو للخاصة والمقربين منهم من شعراء وأدباء وندماء أو وزراء وأمراء كما هو الحال مع المنصور مرورا بالرشيد والمأمون وغيرهم من الخلفاء العباسيين المتاخرين.

ونرى ايضا حالة الإسراف والبذخ والمبالغ الضخمة التي خصصت من خزينة الدولة والذي يرافق نصب تلك الموائد فهناك آلاف الاف الدنانير والدراهم تنفق على وجبات للطعام ثم يرمى ذلك الطعام دون الاستفادة منه لمجرد الانتهاء منه.

وأخيرا نرى تعدد الأواني التي تستخدم في الطعام في هذا العصر فمن تلك الأواني ما كان أصلا موجود ومنه من جيء به من مناطق ودول بعيدة كما ان المطبخ العباسي قد شهد تطور اختلف عما كان موجود قبله. 


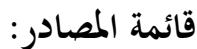

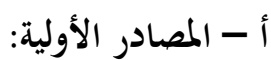

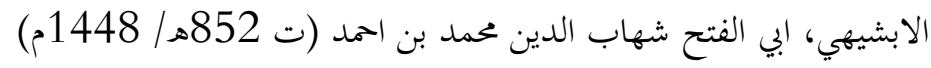

المستطرف في كل فن مستظرف (شرح: مفيد محمد قميحة، دار الكتب العلمية - بيروت/د.ت)

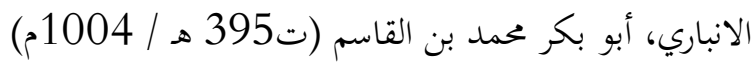

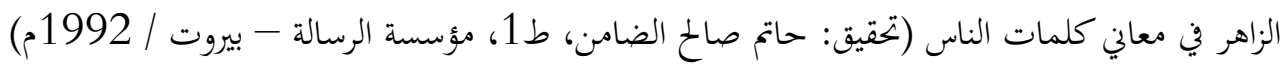

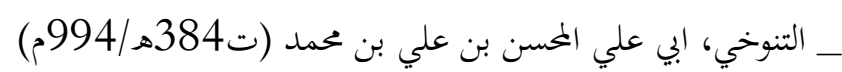

نشوار المحاضرة واخبار المذاكرة (تحقيق: مصطفى حسين عبد الهادي، دار الكتب العلمية - بيروت (د.ت)

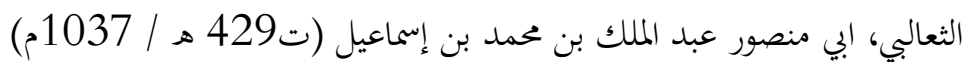

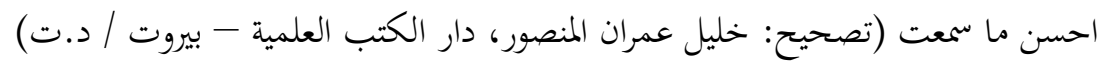

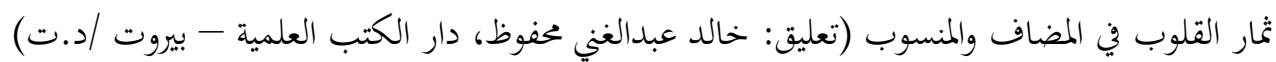

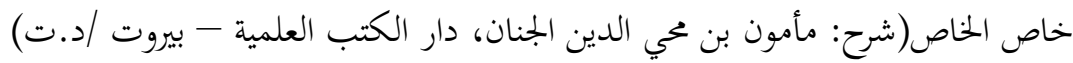

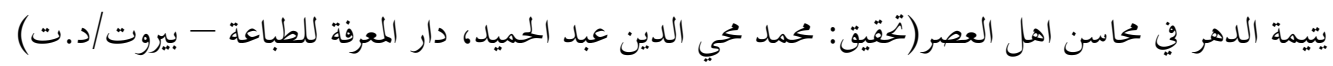

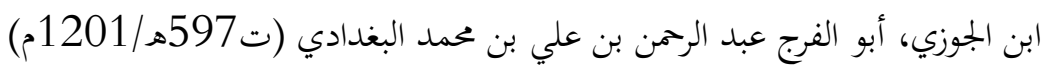

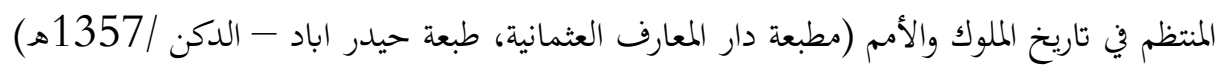

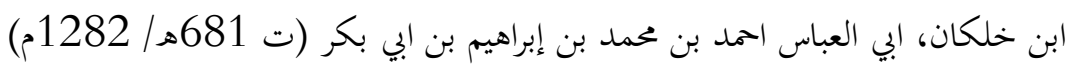

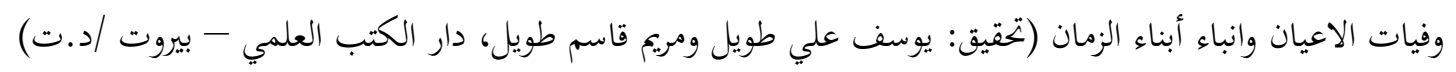

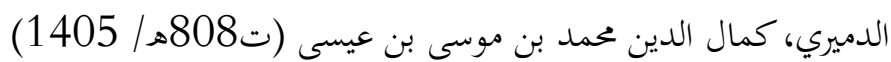

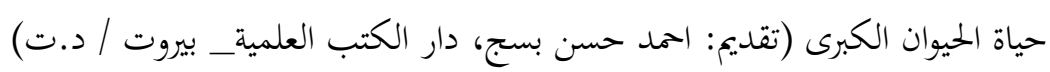

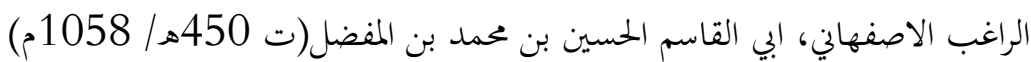

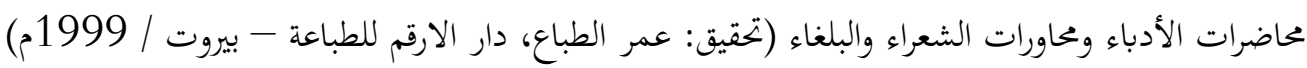

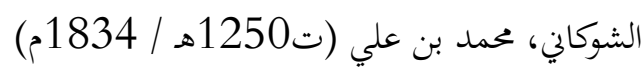

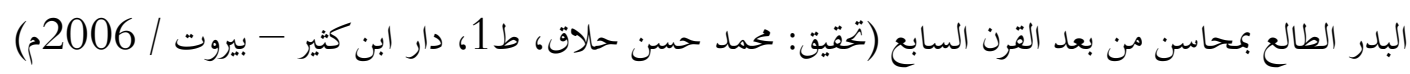
الصابي، أبو الحسن الهلال بن الخسن (ت 448هـ / 1056م)

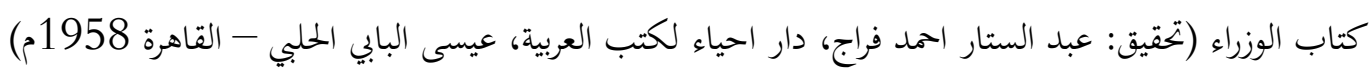

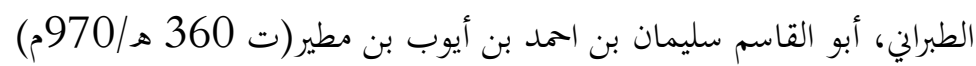

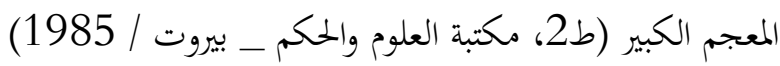

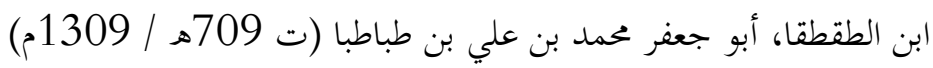

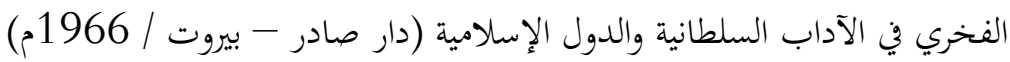

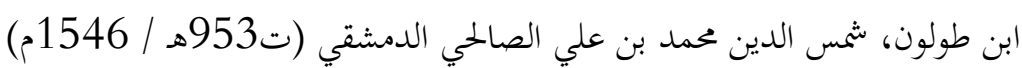

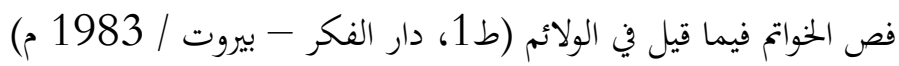




$$
\begin{aligned}
& \text { ابن عساكر، ابي القاسم علي بن الحسن بن هبة الله (ت 571هـ / 1175م) }
\end{aligned}
$$

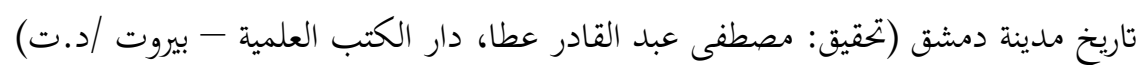

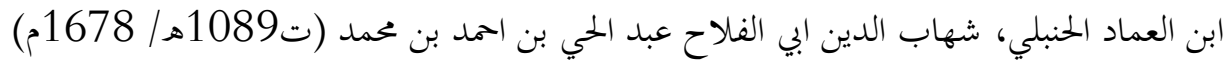

$$
\begin{aligned}
& \text { شذرات الذهب في اخبار من ذهب(تحقيق: مصطفى عبد القادر عطا، دار الكتب العلمية - بيروت/د.ت) } \\
& \text { الغزولي، علاء الدين علي بن عبد الله البهائي الدمشقي (ت 815هـ/ 1412م) } \\
& \text { مطالع البدور في منازل السرور (تحقيق: التجاني سعيد محمود، دار الكتب العلمية - بيروت / د. ت) }
\end{aligned}
$$

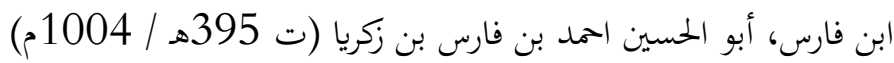

$$
\begin{aligned}
& \text { معجم مقاييس اللغة (تحقيق: عبد السلام محمد هارون، ط2، دار الجيل - بيروت / 1999م) }
\end{aligned}
$$

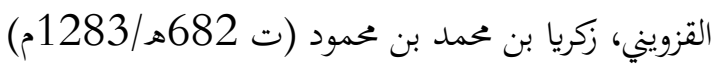

$$
\begin{aligned}
& \text { اثار البلاد واخبار العباد (دار صادر - بيروت / د. ت) }
\end{aligned}
$$

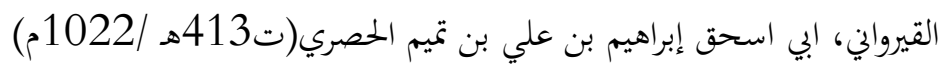

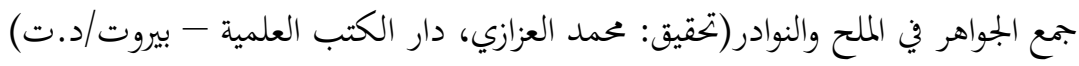

$$
\begin{aligned}
& \text { زهر الآداب وثمر الالباب (شرحه: صلاح الدين المواري، ط1، المكتبة العصرية - بيروت / 2001م) } \\
& \text { ابن الكردبوس، ابي مروان عبد الملك التوزري(من اعلام القرن السادس الهجري) }
\end{aligned}
$$

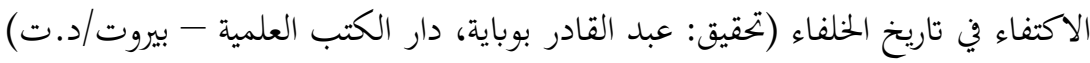

$$
\begin{aligned}
& \text { المسعودي، ابي الحسن علي بن الحسين بن علي (ت346هـ / 957م) } \\
& \text { مروج الذهب ومعادن الجوهر (طبعة ليدن / د. ت) }
\end{aligned}
$$

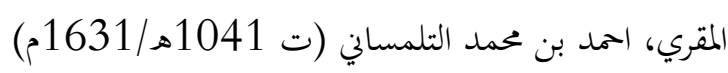

$$
\begin{aligned}
& \text { نفح الطيب من غصن الاندلس الرطيب (تققيق: احسان عباس، دار صادر - بيروت /1988م) } \\
& \text { النابلسي، عبد الغني بن إسماعيل (ت143 114هـ / 1730م) } \\
& \text { علم الملاحة في علم الفلاحة (تعليق: يجيى مراد، دار الكتب العلمية - بيروت / د.ت التمبيل }
\end{aligned}
$$

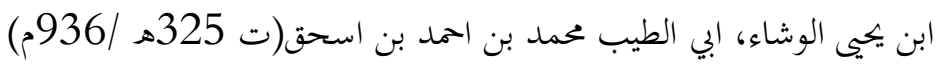

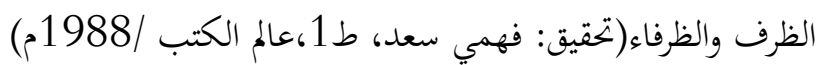

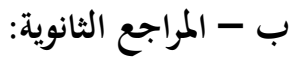

$$
\begin{aligned}
& \text { امين، حسين احمد } \\
& \text { المائة الأعظم في تاريخ الإسلام (بيروت /د.ت } \\
& \text { السامرائي، إبراهيم } \\
& \text { الشادياق، فارس بن يوسف } \\
& \text { الساق على الساق فيما هو الفارياق (باريس /1855م) } \\
& \text { العاني، ناصر } \\
& \text { في الحضارة العربية صور عباسية (بغداد /د.ت) }
\end{aligned}
$$




$$
\text { ألمبد الحافظ، احمد الرشيد قصة العصر الذهبي للخلافة الإسلامية (دار البشير للثقافة والعلوم - القاهرة / د.ت) }
$$

المائدة أنواعها ورسومها وأهميتها في صدر الإسلام والعصر الاموي (رسالة ماجستير غير منشورة، كلية الآداب،جامعة البصرة $($ 2002/

$$
\text { مكي، محمد كاظم }
$$$$
\text { المدخل إلى حضارة العصر العباسي (ط2، دار الزهراء للطباعة والنشر - بيروت /1999م) }
$$$$
\text { المنجد، صلاح الدين }
$$$$
\text { بين الخلفاء والخلعاء في العصر العباسي (دار الحياة - بيروت / 1957م) مانين }
$$

الموسوعة الفقهية الكويتية، وزارة الأوقاف والشؤون الإسلامية (ط2، دار السلاسل - الكويت / 1997م) 
1

2 - ابن فارس: معجم مقاييس اللغة، 3 - $14 / 1$ - 14

3 - ينظر: الانباري: الزاهر في معاني كلمات الناس،276/1 اللعايس

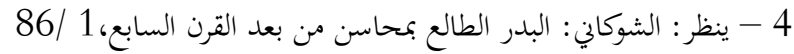

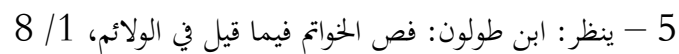

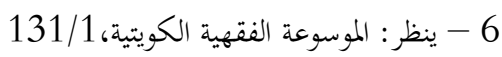

7 - 7 -ينظر: الثعالبي: ثمار القلوب في المضاف والمنسوب، 183/2

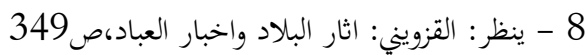

9 - القيرواني: زهر الآداب وثمر الالباب، 10

10 - مكي، محمد كاظم: المدخل إلى حضارة العصر العباسي، ص161 الإباب 161

11 - المسعودي، مروج الذهب معادن الجوهر، 229/2

12 - 13

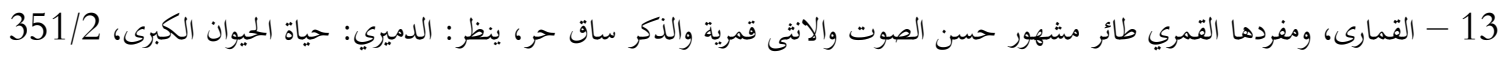

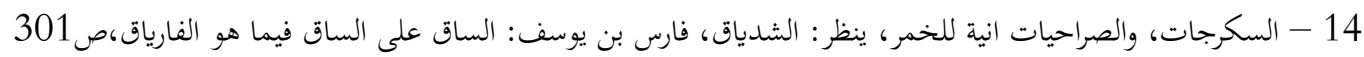

15 - 1ينظر : ابن عساكر، تاريخ مدينة دمشق،

16 - عبد الحافظ، احمد: أيام الرشيد قصة العصر الذهبي للخلافة الإسلامية، ص188

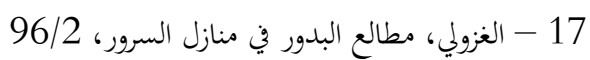

18- الراغب الاصفهاني: محاضرات الأدباء، 1/ 373

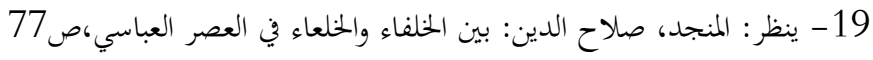

20 - الابشيهي: المستطرف في كل فن مستظرف، 11 1/ 130

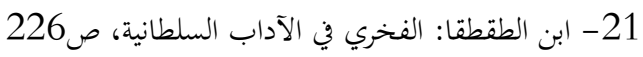

22 - زرياب، من اركان الغناء العربي بالاندلس و صاحب اكبر تاثير في فنون الحياة، لقب بزرياب لسواد لونه نشا ببغداد ودرس الغناء على يد إبراهيم

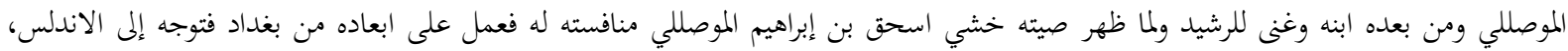

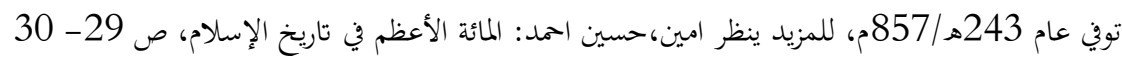

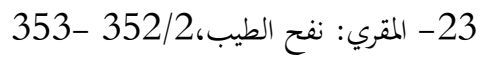

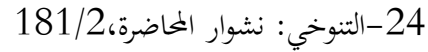

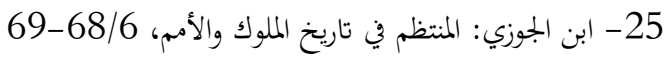

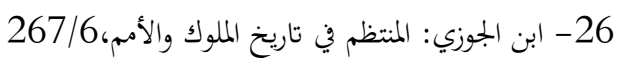

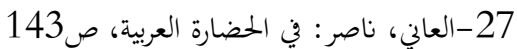

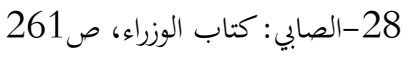

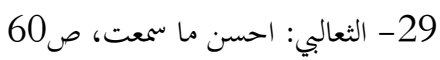

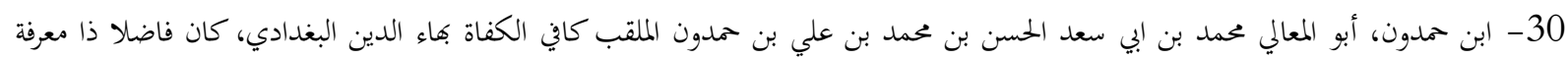

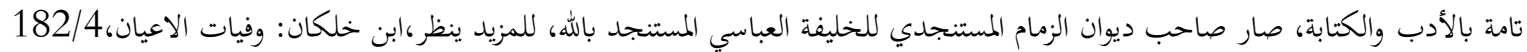

$$
\text { 31 - 32 - } 31
$$

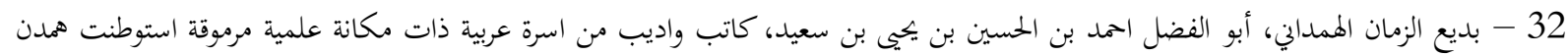

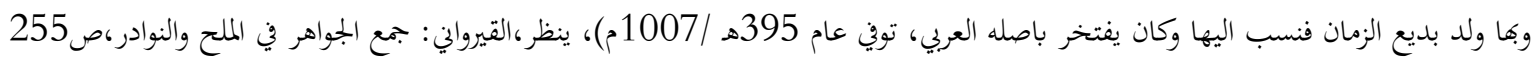

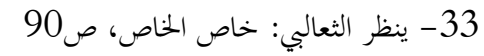


34- كشاجم، أبو الحسين أو أبو الفتح بن السندي الكاتب، من اهل الرملة من نواحي فلسطين، كا رئيا في الكتابة ومقدما في الخطابة والفصاحة،

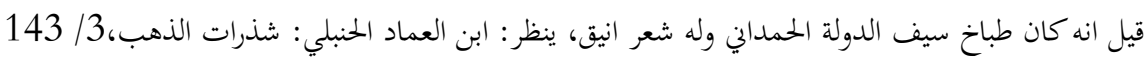

$$
\text { 35 }
$$

36- محمد كاظم مكي: المدخل إلى حضارة العصر العباسي،صنمر

37- الصاحب بن عباد، أبو القاسم إسماعيل بن عباد بن العباس بن عباد بن احمد بن ادريس الطالقاني، الملقب بكافي الكفاة وزير لمؤيد الدولة بن ركن

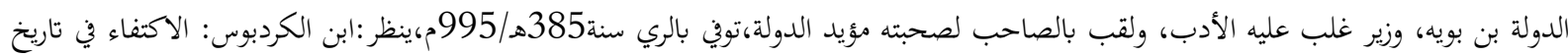

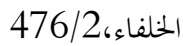

81/3، الثعالبي: يتيمة الدهر، 38

39 - ينظر: محمد كاظم مكي: مدخل إلى الحضارة العباسية،ص166 160

40

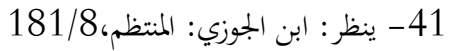

42- ينظر : المكصوصي، ماجد عبد الحميد عبد الرزاق: المائدة أنواعها ورسومها وأهميتها، 158

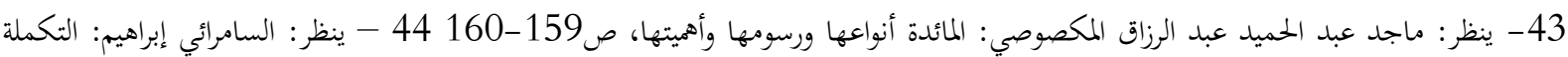

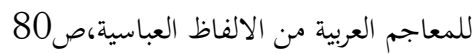

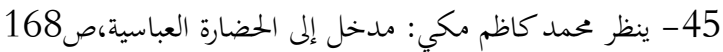

46- الصابي: كتاب الوزراء،ص216 


\title{
NOBUSUKE KISHI AND HIS ROLE IN JAPANESE POLITICS (1957- 1960)
}

\author{
Suha Adel OTHMAN ${ }^{1}$
}

\section{Istanbul / Türkiye \\ p. 41-59}

Received: $16 / 11 / 2021$

Accepted: 08/12/2021

Published: 01/01/2022

This article has been scanned $\mathrm{l}$ iThenticat No plagiarism detected

\begin{abstract}
:
The study touched on an important topic in Japan, which is (Prime Minister of Japan Nobusuke Kishi from 1957-1960) and he also had an "important political role because of his great importance to Japan, where in this year (1957) he became the Prime Minister of Japan and had a great role in his proximity It was also characterized by a policy of establishing good relations with European countries for joint cooperation in order to establish friendly relations and establish security agreements, especially with the United States of America.

Nobusuke Kishi was the great statesman, especially in the field of economy, and he was loved by the United States of America because of its strong and reassuring relations with him.

The study was divided into an introduction, a conclusion, and three sections. The first topic dealt with Nobusuke Kishi, his life and political role until 1957. While the second topic spoke to Nobusuke Kishi's internal policy in Japan, as well as regarding the third topic, it shed light on it, dealing with Nobusuke Kishi's foreign policy.

Finally, it should be noted that Nobusuke Kishi's political role still needs more studies and research, especially since this modest effort touched on one aspect of the political aspect. We hope that later studies will address the economic, social and cultural aspects that had an important impact on Japan's policy and in In conclusion.
\end{abstract}

Key words: Nobusuke Kishi, Japan, Political, United States of America, Foreign Policy.

\section{http://dx.doi.org/10.47832/2717-8293.15.4}

\footnotetext{
1 ID Researcher, Ministry of Education- Al-Karkh Second Directorate of Education, Iraq, hum.salah.khalaf@uobabylon.edu.iq, https://orcid.org/0000-0002-3260-0014
} 


\section{نوبوسوكه كيشي ودوره في السياسة اليابانية}

1960-1957

\section{سها عادل عثمان2}

الملتخص: تطرقت الدراسة إلى موضوع مهم في اليابان ألا وهو (رئيس وزراء اليابان نوبوسوكه كيشي من 1957-1960)

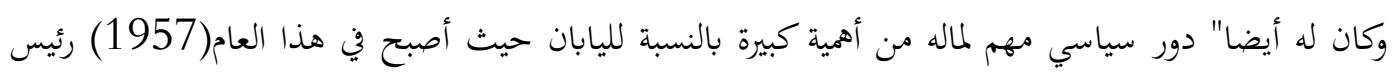

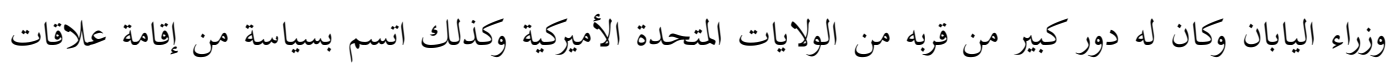

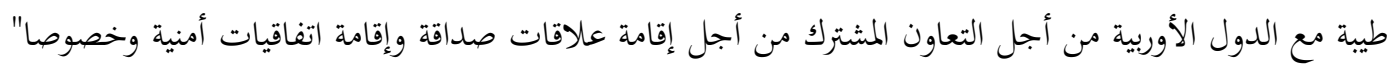
مع الولايات المتحدة الأميركية. وأخيراً لابد من الإشارة إلى دور نوبوسوكه كيشي السياسي لا زال بحاجة إلى المزيد من الدراسات والبحوث، سيما

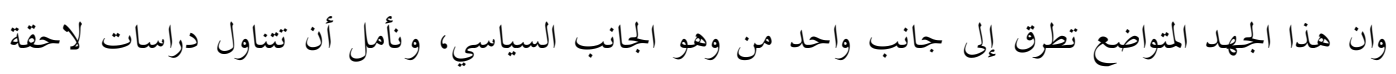

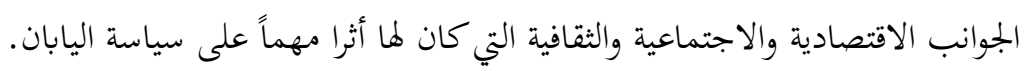
الكلمات المفتاحية: نوبوسوكه كيشي، اليابان، السياسة، الولايات المتحدة الأميركية.

إن دراسة الشخصيات السياسية تفتح الباب للتعرف على تاريخ الدول لاسيما تلك الشخصيات التي يكون تأثيرها مهم

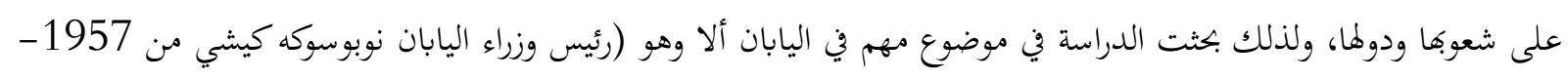

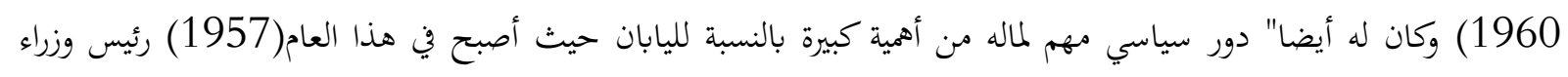

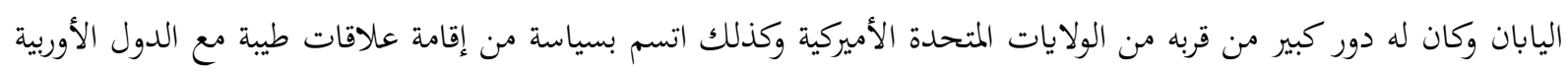
من أجل التعاون المشترك من أجل إقامة علاقات صداقة وإقامة اتفاقيات أمنية وخصوصا" مع وديه الولايات المتحدة الأميركية. كان نوبوسوكه كيشي رجل الدولة الكبير وخصوصا" في بجال الاقتصاد إضافة كان محبوبا" من قبل الولايات المتحدة الأميركية لما لها معه من علاقات قوية ومطمئنه منه. قسمت الدراسة إلى مقدمة وخاتمة وثلاث مباحث فقد تطرق المبحث الأول إلى نوبوسوكي كيشي وحياته ودوره السياسي حتى عام

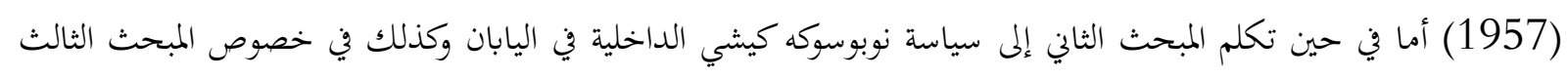
فقد سلط الضوء عليه فتناول سياسة نوبوسوكه كيشي الخارجية. اعتمدت الدراسة إلى العديد من المصادر كان من أهمها رساله الماجستير مهند سلمان صالح الغلاقات الأميركية اليابانية

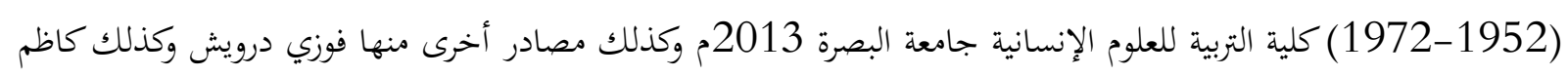
هيلان وظاهر مسعود والخ من المصادر في متن البحث. hum.salah.khalaf@uobabylon.edu.iq الباحثة، وزارة التربية -مديرية تربية الكرخ الثانية، العراقي 
وأخيراً لابد من الإشارة إلى دور نوبوسوكه كيشي السياسي لا زال بحاجة إلى المزيد من الدراسات والبحوث، سيما وأن هذا الججهد

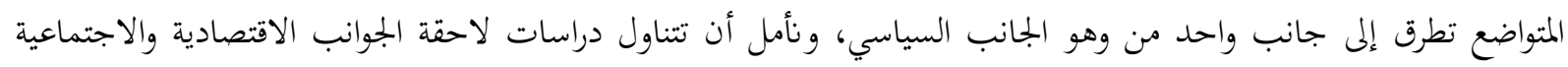
والثقافية التي كان لما أثرا مهماً على سياسة اليابان.

مشكلة الدراسة: The Problem of Study من خلال هذه الدراسة يمكن التعرف على إجابات الأسئلة الآنية: 1. ماهو الدور الذي اداه رئيس الوزراء الياباني نوبوسوكه كيشي في السياسة اليابانية. 2. مل تاثر نوبوسوكه كيشي بالسياسة اليابانية.

\section{فرضية الدراسة: Hypothesis of Study}

كان لنوبوسوكه كيشي دور مهم في استقرار الوضع الداخلي في اليابان وكذلك دوره المهم في تجديد معاهدة الأمن والتعاون المشترك مع الولايات المتحدة الأمريكية.

\section{منهجية الدراسة: Approach of Study:}

اعتمدت الدراسة على المنهج الوصفي و التحليلي للاحداث من خلال إبراز دور نوبوسوكه كيشي في تاريخ اليابان بعد الحرب العالمية الثانية.

\section{أهمية الدراسة: Importance of Study:}

تبرز أهمية الدراسة كون اليابان خرجت بعد الحرب العالمية الثانية خاسرة وقامت بتوقيع معاهدة استسلام مع الدول الأوربية وكذلك

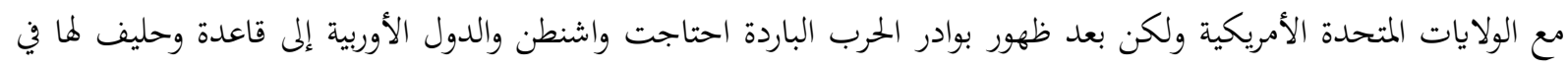
منطقة الشرق الأقصى لذلك وقعت على معاهدة أمن وسلام عام 1952 وبدأت اليابان تؤدي دوراً مهماً في السياسة الدولية.

\section{هدف الدراسة: Objective of the Study}

هدفت الدراسة إلى التعرف إلى الدور الذي ادته اليابان في منطقة اسيا وكيف تعاملت مع حليفتها واشنطن وهل كان لمعاهدة السلام مع الولايات المتحدة الأمريكية دور في تنشيط اليابان سياسياً.

$$
\text { الإطار الزمني للدراسة: }
$$

حددت مدة الدراسة بالاعوام 1957-1960 وهي المدة التي أصبح فيها نوبوسوكه كيشي رئيسا للوزراء في اليابان. 


\section{المبحث الأول: (نوبوسوكه كيشي -حياته ودوره السياسي حتى عام 1957م)}

ولد كيشي Nobusuke ساتو في Tabuse في محافظة ياماغوتشي وعند نشوءه ترك عائلنه في سن مبكر ثم

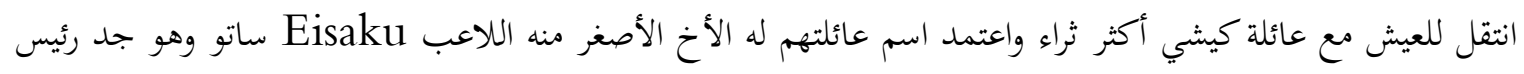
الوزراء الحالي في اليابان (شينزو أبي)، درس كيشي في جامعة طوكيو الامبراطوري وفي شبابه كان كيشي من اتباع اليابانية

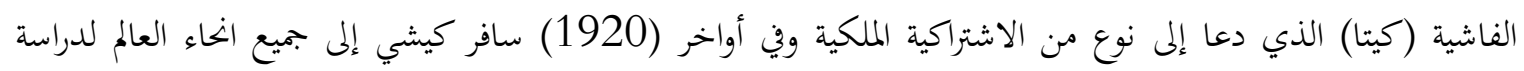

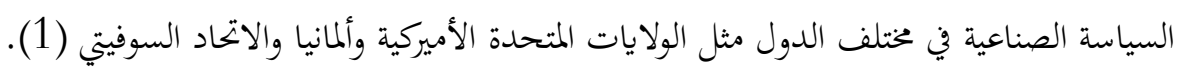
وفي عام (1929) كان كيشي معجب في الصناعات الغربية وكذلك الخطط السياسية والاقتصادية وخصوصاً الاتحاد

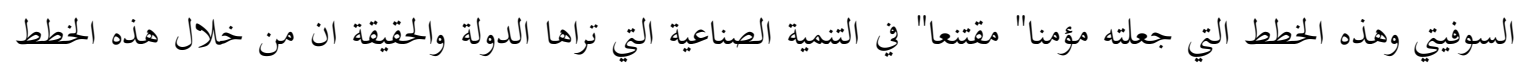

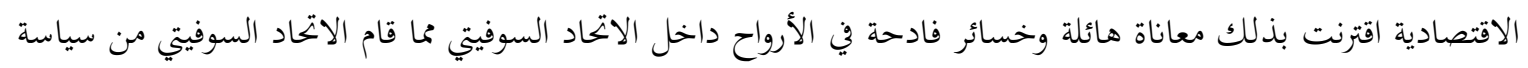

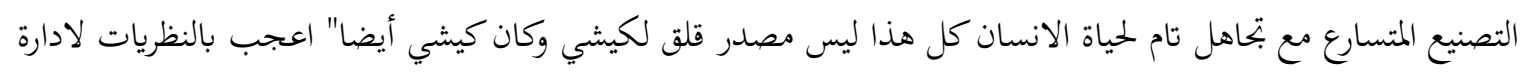

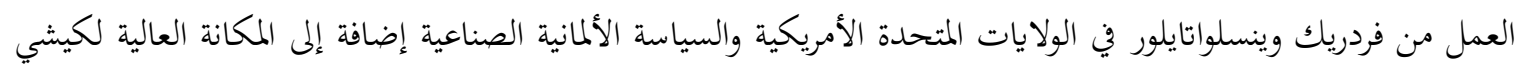

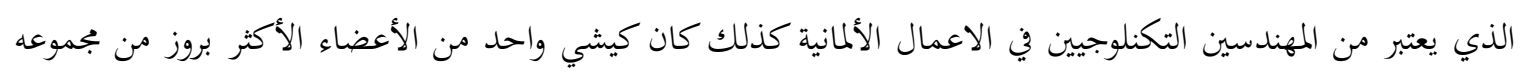
البيروقراطيين لإصلاح الحكومة اليابانية (2). فضل كيشي نموذج التنمية الاقتصادية مع ارشاد الدولة وتوجية الاقتصاد وفي عام (1933) فصاعداً بداً كيشي يغير

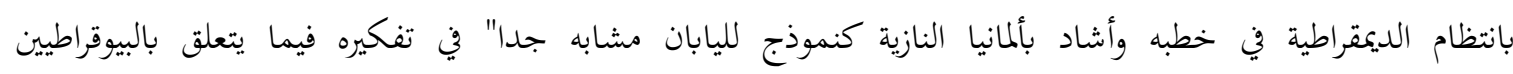

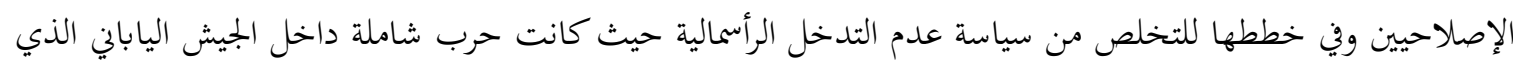

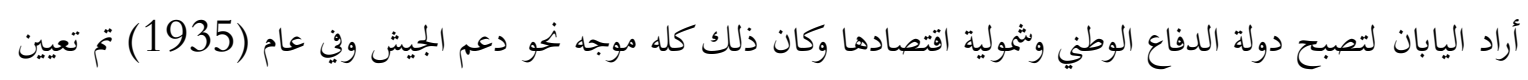
كيشي نائب وزير(مانشوكو)للتنمية الصناعية (3).

بين كيشي التخطيط الاقتصادي لمانشوكو عن طريق اختيار بعض الصناعات الغربية لبلاده والذي من شأنه ان يخلق

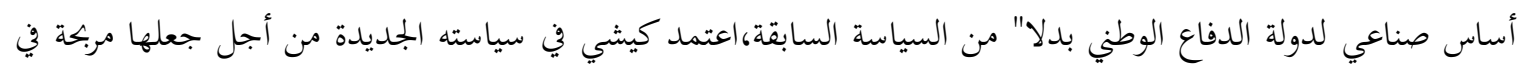

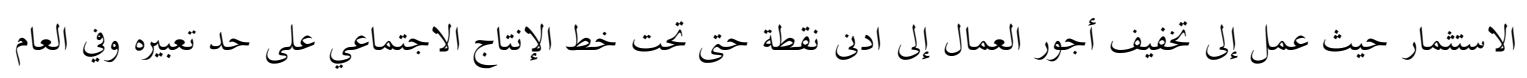

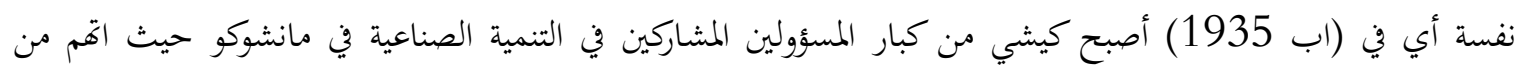
استغلال السخرة للصينيين وفي نفس العام أيضا" قدم كيشي خطط اقتصادية للمانشوكو مع التركيز على الصناعات الثقيلة

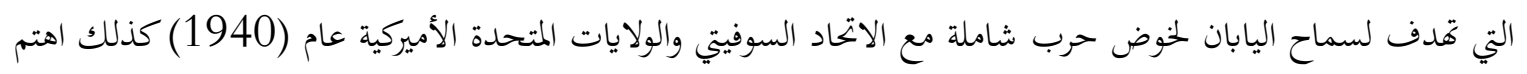

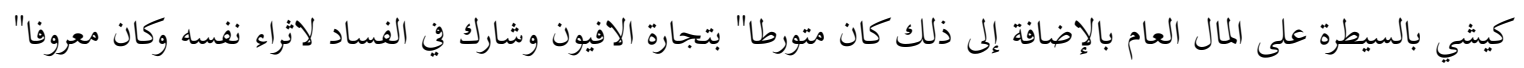

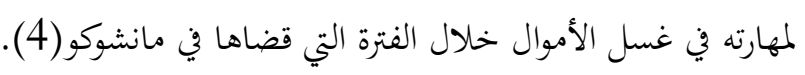

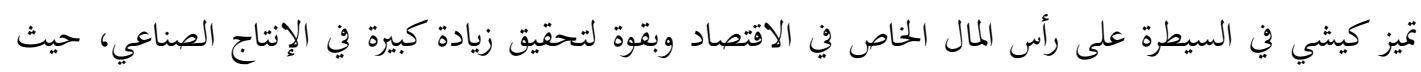

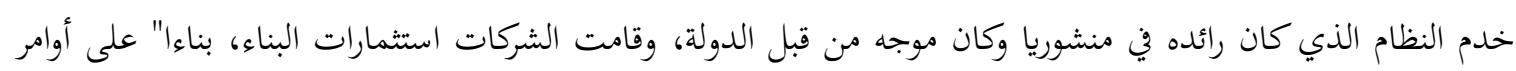

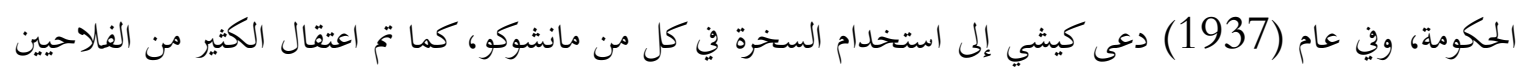
الصينيين واتخذهم كعبيد لمانشوكو وكان أسلوب كيشي هو الاحتقار للصينيين كشعب الذي ألشار الشار به إلى وجود العصابات

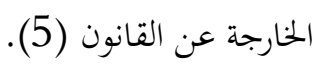


وفي عام (1940) أصبح كيشي وزيرا" في حكومة (فوميماروكونويه) وفي عام (1941) عين كيشي وزيرا" للذخائر

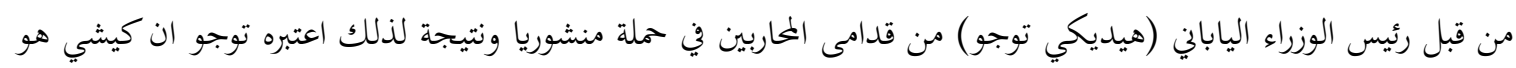

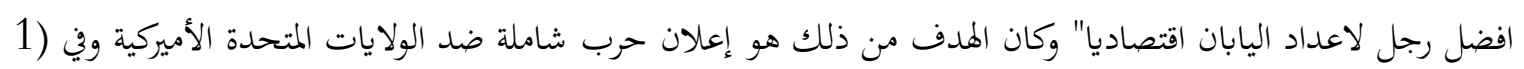

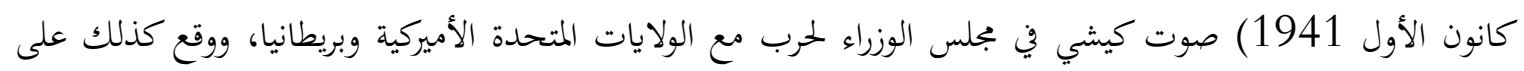
إعلان الحرب الصادر (7 كانون الأول 1941)،انتخب كيشي في بحلس النواب الياباني كعضو في جمعية المساعدة في

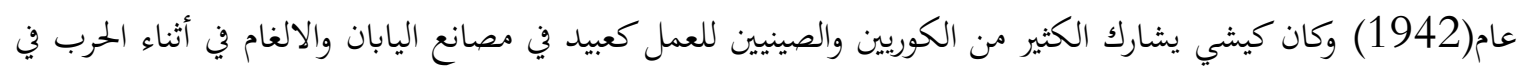

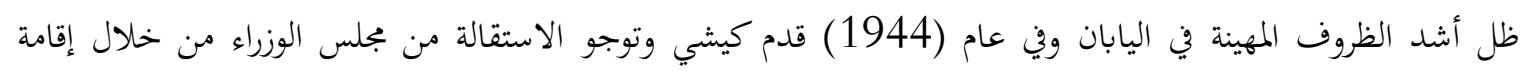

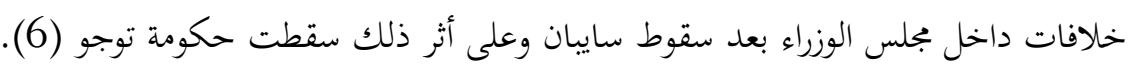
مما غادر كيشي من جمعية المساعدة وأسس حزبا" سياسيا" جديدا" مع (32) من أعضاء البرمان وبمرور الوقت

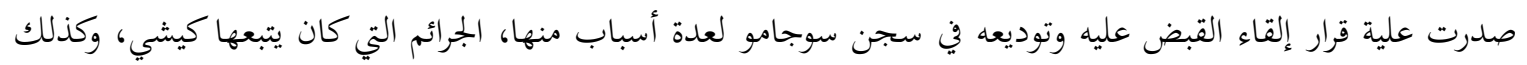

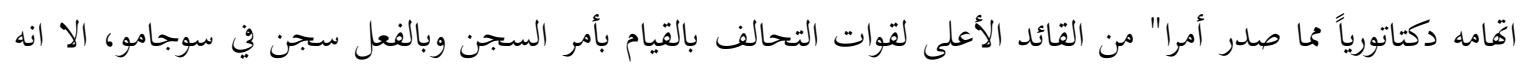

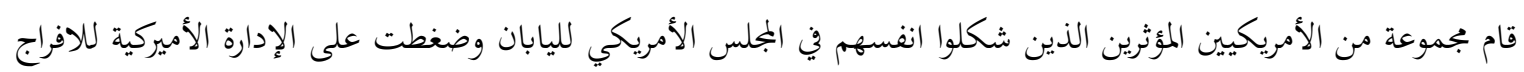

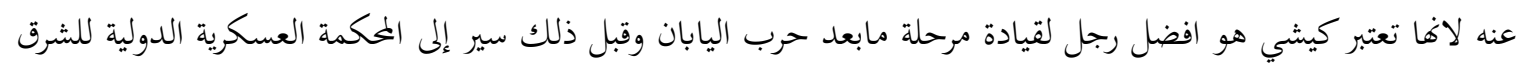

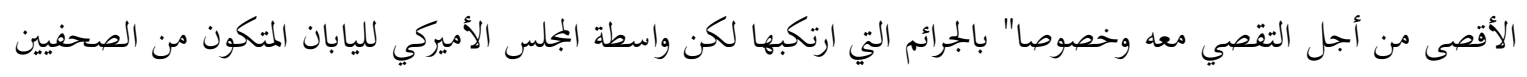

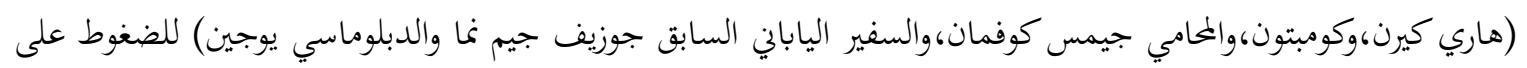
الإدارة الأميركية (7). (هيرن).

وبالفعل تم الافراج عنه واطلاق سراحه من سجن سوجامو في (24 كانون الأول 1948) بداً كيشي يفكر بالفعل

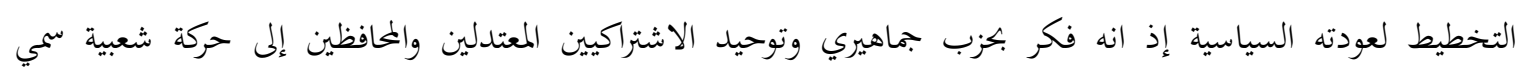
(الخلاص الوطني) وهو حزب شعبوي والذي من شأنه استخدام أساليب لتشجيع النمو الاقتصادي وكذلك دعم سياسة الامة في سياستها القومية (8). أما عن سياسته بعد الحرب العالمية الثانية فقد كان كيشي يسعى إلى خلق اتحاد أعادة أعمار اليابان بالإضافة طمح

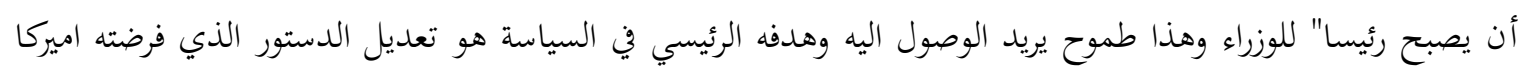

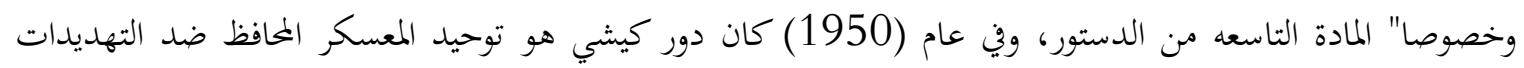
المصورة من الحزب الاشتراكي الياباني وفي عام (1952) فشل كيشي في مسعاه لينتخب عضوا" في البرلمان وبعد هذه الهزيمة

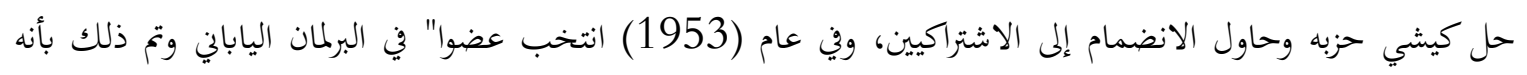

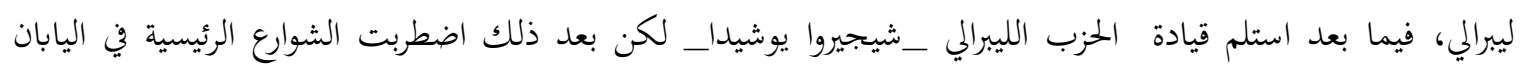
بالمظاهرات على ان يوشيدا كان قريبا" للاميركيين وكذلك الحاجة من التخلص من المادة التاسعه (9). وفي عام (1954) حدث نزاع بين شيجيروا يوشيدا ونوبوسوكي كيشي مما تم تنحية كيشي وذلك لماولاته من أجل

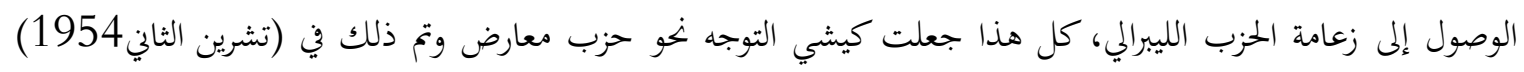

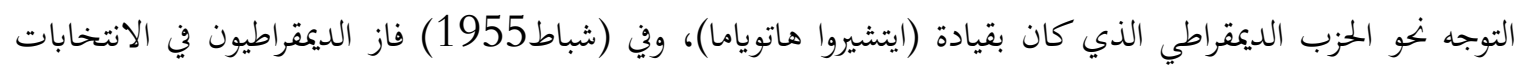

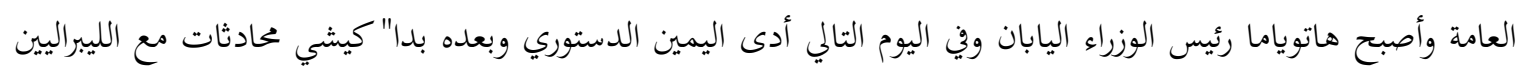




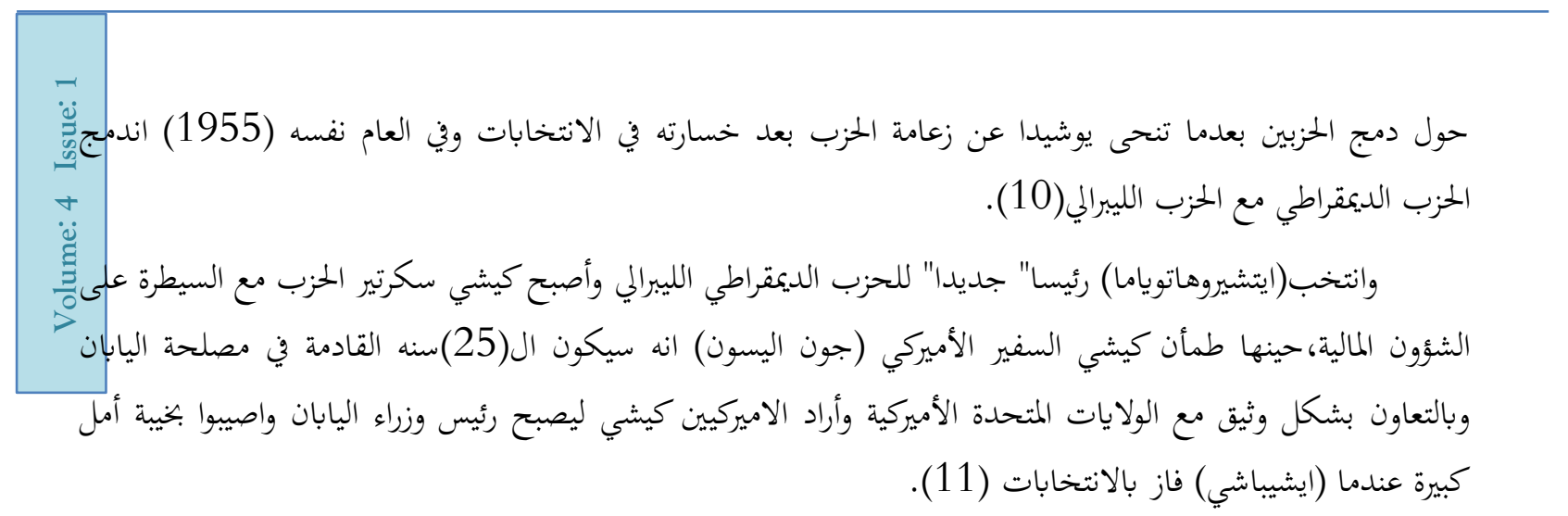




\section{المبحث الثاني:- (سياسة نوبوسوكه كيشي الداخلية)}

وعندما انتخب (ايشباشي تانزان)رئيساً للوزراء خلفاً لهاتوياما الذي كان متحمساً لتعديل المعاهدة الأمنية وإعادة العلاقات

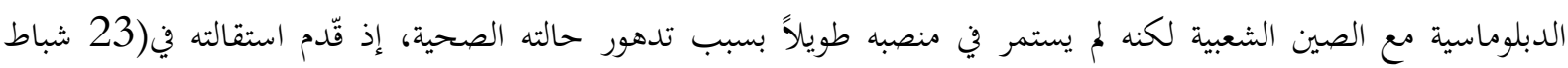
1957) الأمر الذي مهد الطريق لوصول(نوبوسوكه كيشي)إلى رئاسة الوزراء في 25 شباط من العام نفسه وين اليوم التهبية التالي صرح كيشي في مؤتمر صحفي قائلاً: "من وجهة نظر الشعور الوطني فإن الشعب الياباني يرغب بإلغاء المعاهدة الأمنية والاتفاقية الإدارية بين اليابان والولايات المتحدة(xii).

شهدت اليابان بخصوص الوضع الداخلي انقساماً حاداً في المواقف تجاه معاهدة الأمن والتعاون المشترك فكان كيشي وحكومته من أشد المدافعين عن المعاهدة، ووجه انتقادات لمواقف السوفييت والصين الشعبية، وعّد هذه التصريحات تدخلاً مباشراً

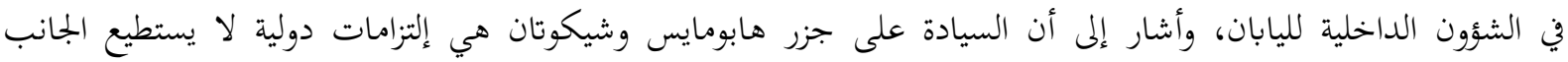

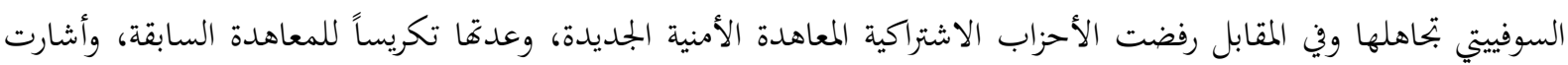

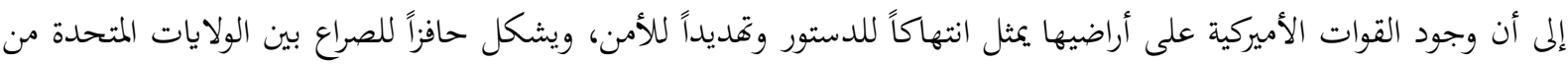

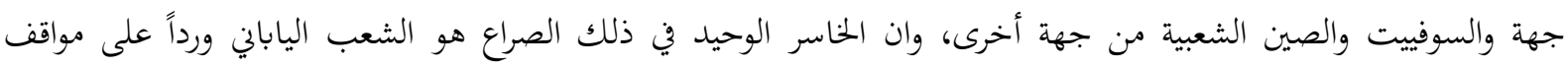

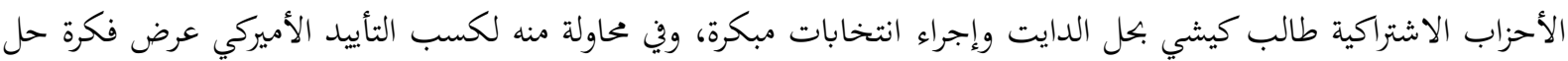

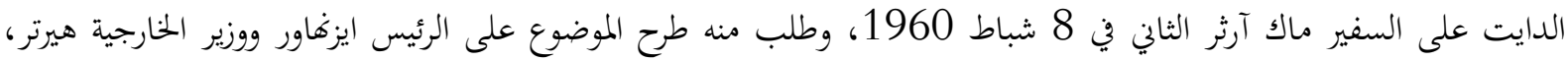

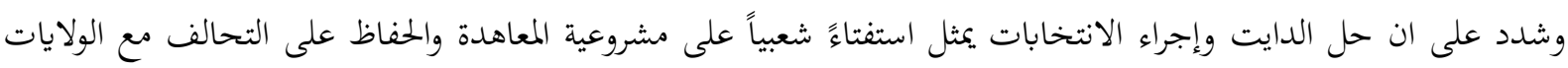

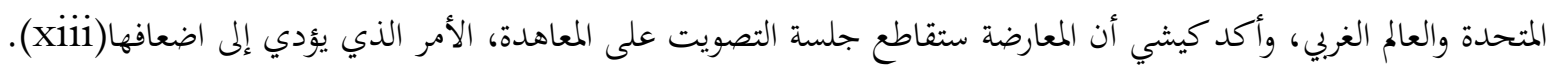

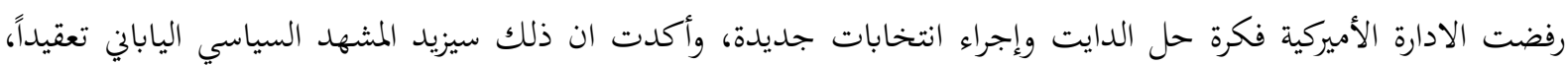
وأمام الرفض الأميركي اضطر كيشي التخلي عن مطالبه، وبدأ العمل على تدعيم موقفه داخل حزب الأحردية فحرة الحرار الديمقراطي، إذ كانت

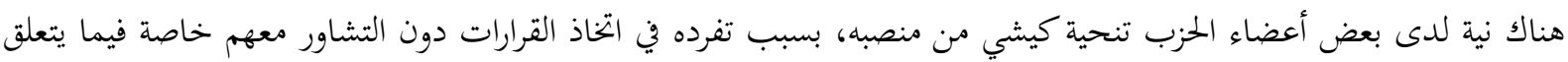
بمعاهدة الأمن وكان في مقدمتهم يوشيدا، ونتيجة لذلك التقى كيشي في 6 نيسان بالسفير ماك آرثر الثاني وطلب مناء منه التدخل

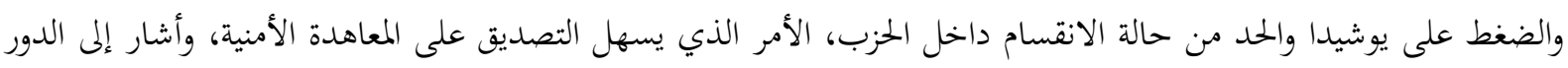

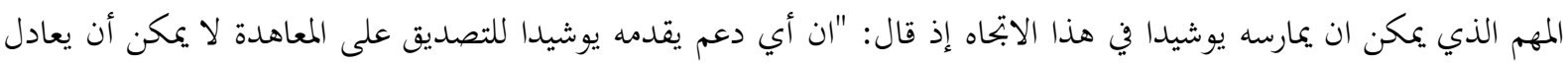
بأي ثمن(xiv).

عدت الأحزاب الاشتراكية الطريقة التي تم من خلالها التصويت على المعاهدة بغير الديمقراطية، وهددت بالاستقالة الجماعية ومقاطعة جلسات الدايت، وطالبت بتنحي كيشي خلال ثلاثين يوماً، الأمر الذي يهول دون الذابن نفاذ المعاهدة، وإجراء انتخابات مبكرة بينما وجهت الصحف اليابانية الكبرى حملة انتقادات شديدة طالت الحكومة وحزب الأحرار الديمقراطي على يلى حد سواء، إذ وصفت استخدام الأجهزة الأمنية ضد نواب الأمة بـعنف الأغلبية، والعمل غير الديمقراطي"، ووصفت كيشي بـ"الشخص المتملق لسيده الأجنبي"، الذي كان حرياً به تعزيز مكانته بين أبناء شعبه بدل من الاعتماد على الأميركيين، وان حيلة

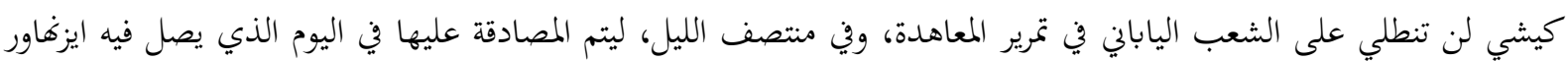

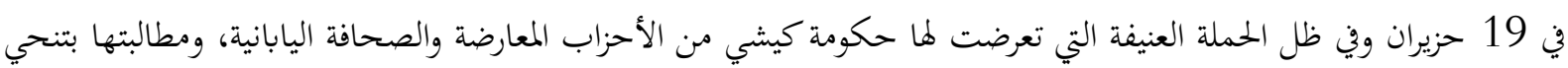

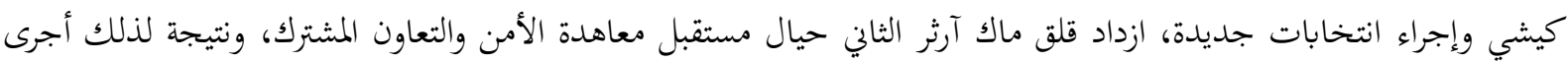

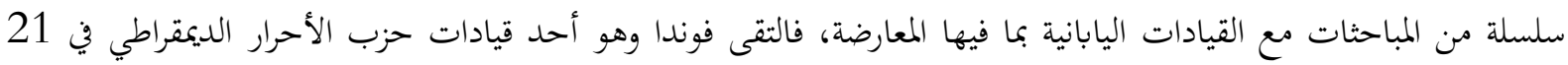

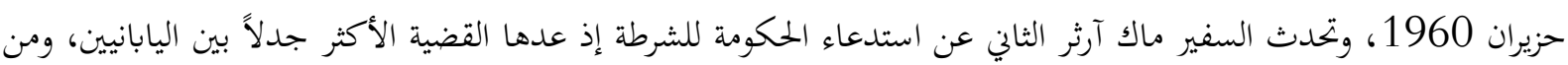

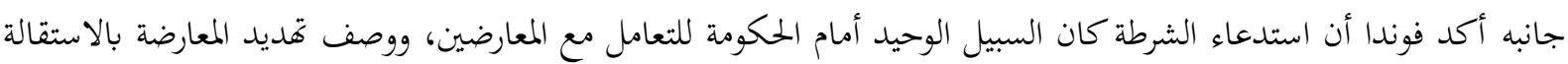


الجماعية بالأمر السخيف لأفم سيتعرضون إلى هزائم أقسى، ونبه فوندا إلى ان المعارضة لكيشي بين أعضاء حزب الأحرار

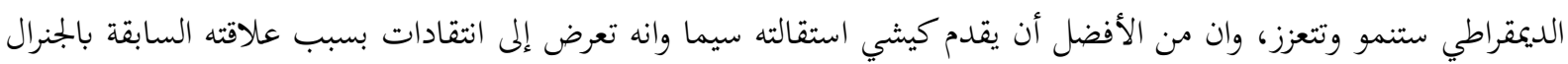

هيديكي توجو ودوره في الحرب العالمية الثانية(XV).

طلب ماك آرثر في اليوم نفسه من حكومته الاتصال بيوشيدا الذي كان موجوداً في الولايات المتحدة للمشاركة في احتفالات الذكرى المئوية لانطلاق العلاقات الدبلوماسية بين اليابان والولايات المتحدة وحثه على دفع القيادات المحافظة لمبندة لمساندة

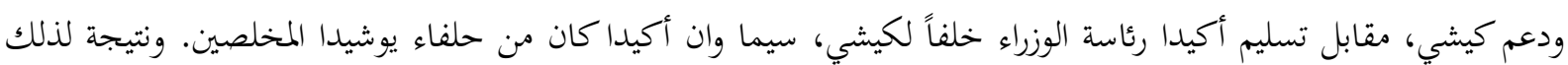

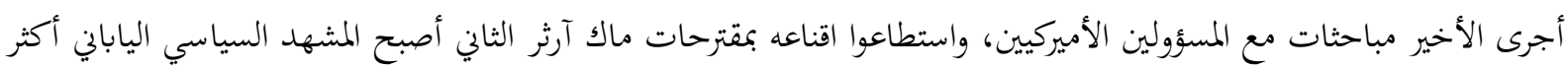

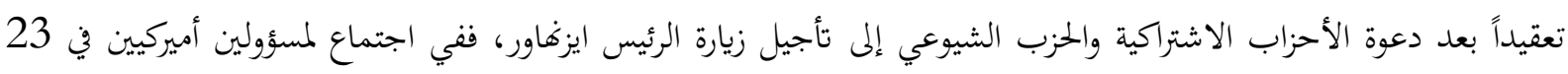

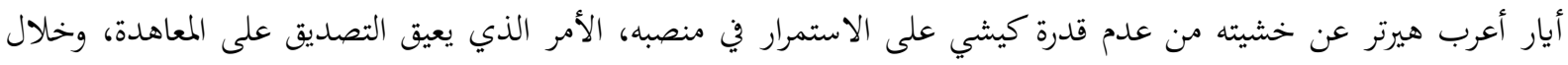

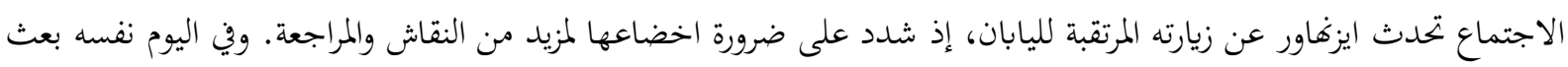

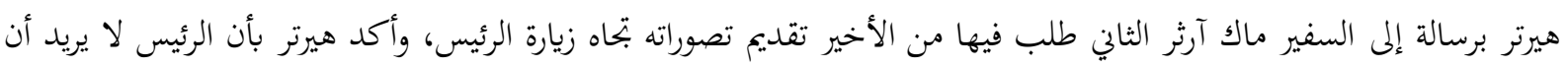

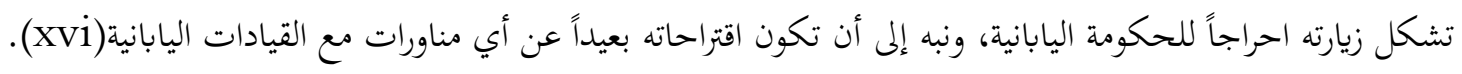

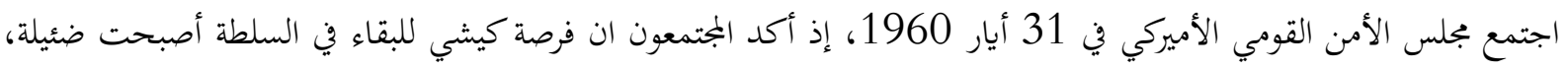

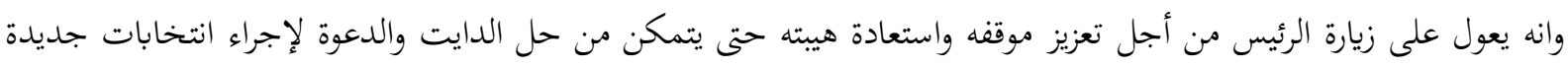

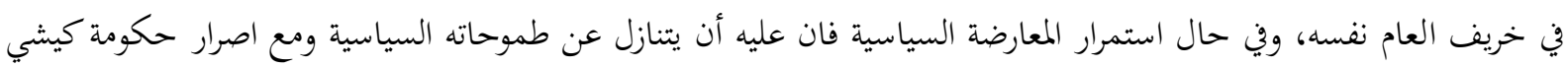

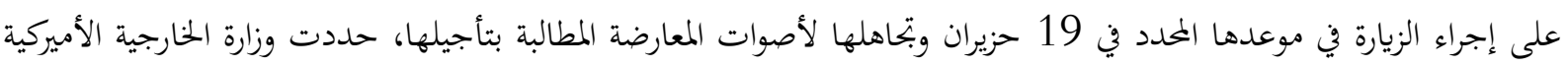

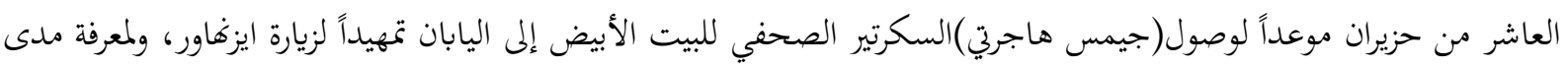

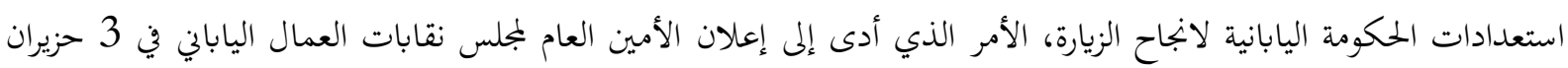

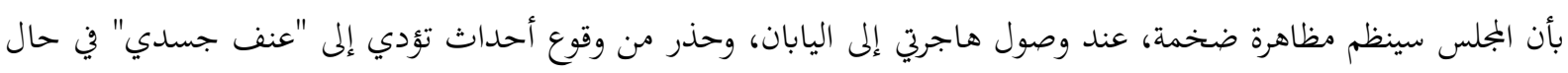
(xvii) (xتخدمت الحكومة القمع ضد المتظاهرين وفي الوقت الذي كانت فيه الأوضاع في اليابان تتجه نهو التصعيد، كان هيرتر يدلى بشهادته أمام لجنة العلاقات الخارجية في الكونغرس الأميركي في 7 حزيران من العام نفسه، وتساءلت اللجنة عن مدى استخدام كيشي لزيارة الرئيس من أجل تدعيم فئه

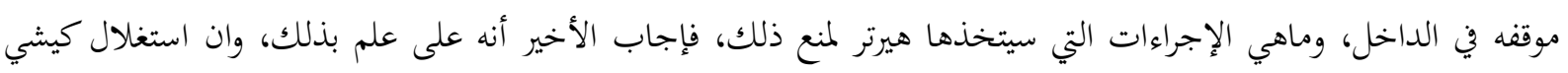

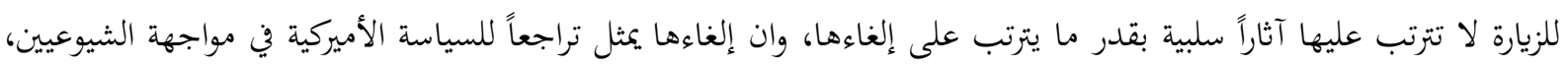

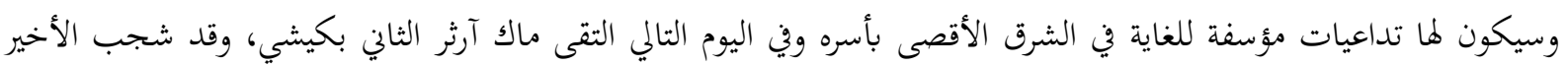

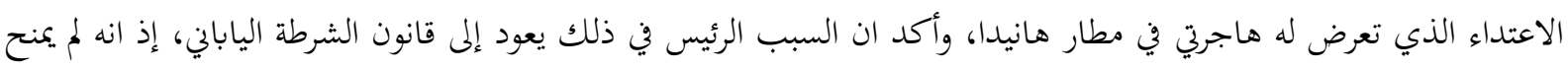

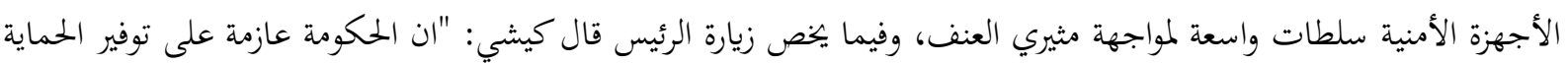

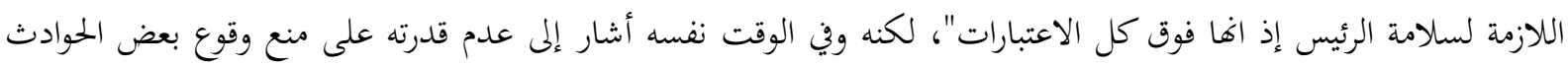

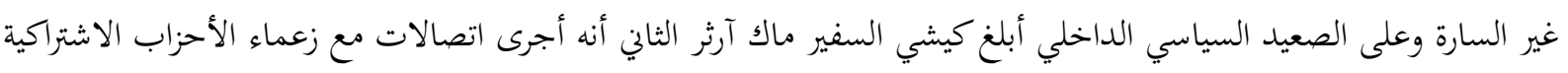

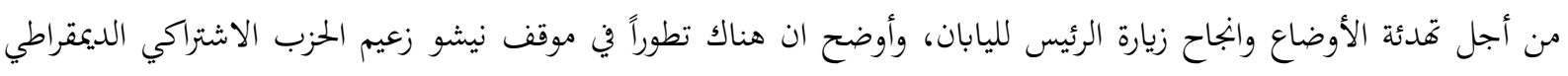

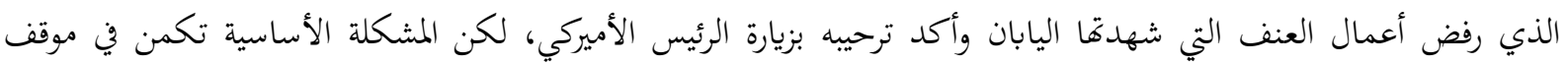
أنشيرو ايسنامي زعيم الحزب الاجتماعي الديمقراطي الذي أصر على استقالة الحكومة والغاء المعاهدة الأمنية وارجاء زيارة الرئيس.

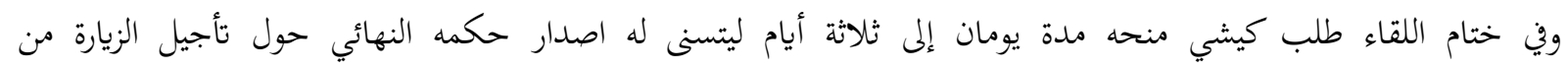

عدمه(Xiii). 
قبل أن تتسلم وزارة الخارجية الأميركية توصيات ماك آرثر الثاني شهدت اليابان توترات أمنية خطيرة، ففي يوم 15 حزيران 1960

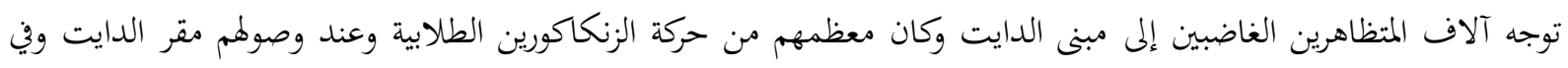

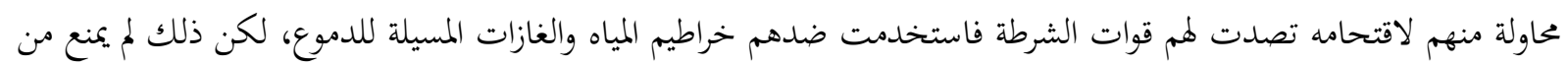

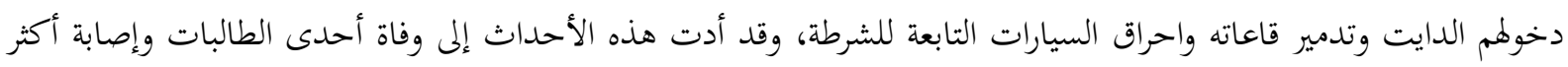

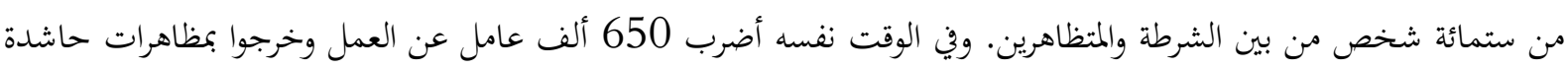
طالبو من خلالها عدم مصادقة مجلس المستشارين على المعاهدة الأمنية، وقد أدت المظاهرات إلى توقف حركة الشحن في السكك ونك

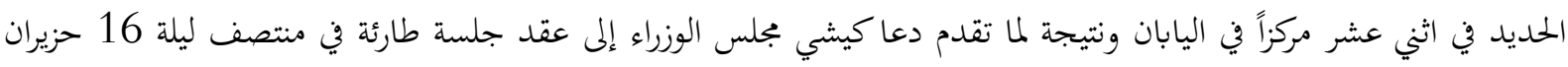

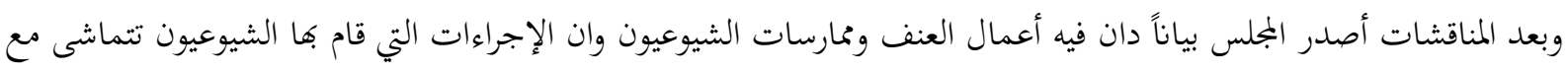
أهداف الشيوعية العالمية من أجل الهيمنة على العالم (xix).

وهكذا دخلت معاهدة الأمن والتعاون المشترك حيز التنفيذ في 20 حزيران 1960 دون عرضها على بجلس المستشارين للتصديق عليها وفي اليوم نفسه التقى ماك آرثر الثاني مع يوشيدا وأبلغه عن نية كيشي تقديم استقالته قريباً، واقترح عليه ادارة البلاد

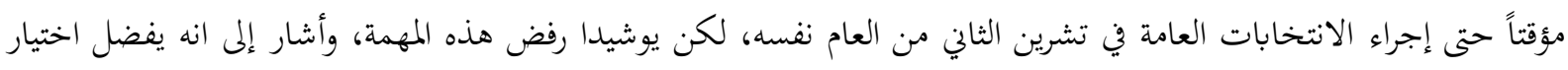

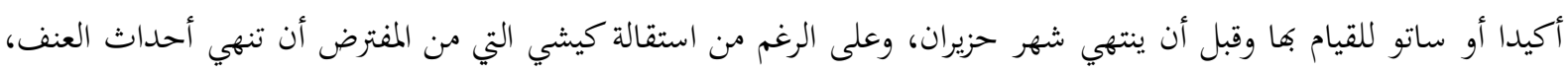

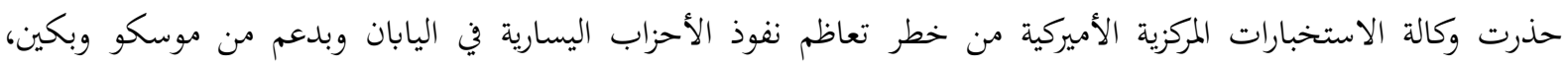

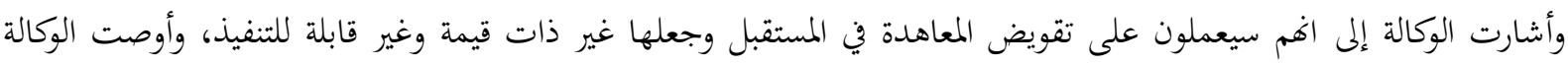

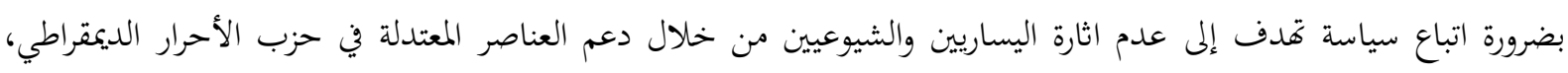

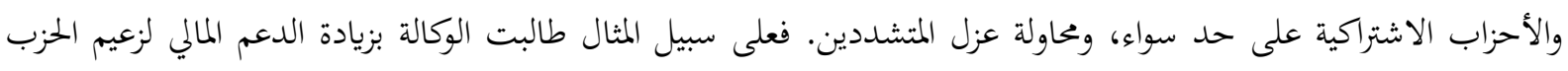
الاشتراكي الديمقراطي نيشو، وذلك لضمان مساندته لمرشح حزب الأحرار الديمقراطي في الانتخابات القادمة(Xx). 


\section{المبحث الثالث: (سياسة نوبوسوكه كيشي الخارجية)}

وصل كيشي إلى الولايات المتحدة في(19 حزيران 1957) وفور وصوله عقد اجتماعا مع ايزهاور، تناول فيه عدد من

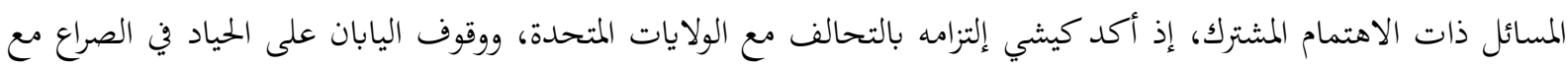
الشيوعيين، لكنه أشار إلى ضرورة تصحيح بعض السياسات الخاطئة التي تؤثر سلباً على العلاقات بين البلدين، مؤكداً على ان

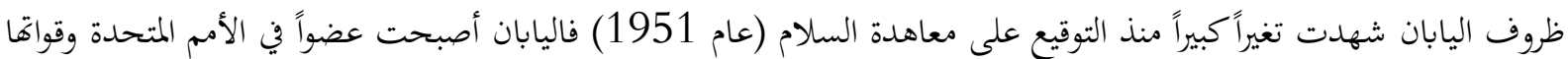
الدفاعية بدأت تنمو باطراد، الأمر الذي أدى إلى تنامي رغبة الشعب الياباني لإعادة النظر في المعاهدة الأمنية، ومن المشكلات الأخرى التي أثارها كيشي مسألة تخفيف القيود على التجارة اليابانية مع الصين الشعبية، ومشكلة إعادة اليابانيين إلى مناطقهم

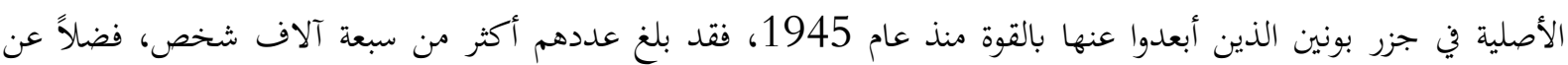

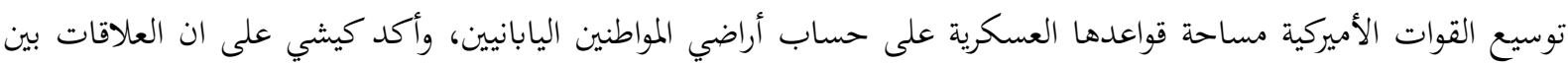

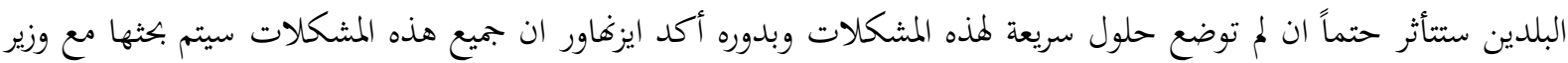

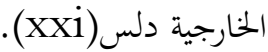

وفي اليوم التالي عقد كيشي اجتماعه الأول مع دلس وكان محور الحديث حول المعاهدة الأمنية واستهل كيشي حديثه بالتأكيد على الإلتزام بالمعاهدة الأمنية، لكنه وفي الوقت نفسه شدد على أهمية إجراء تحسينات على بعض بنودها بشكل يطمئن

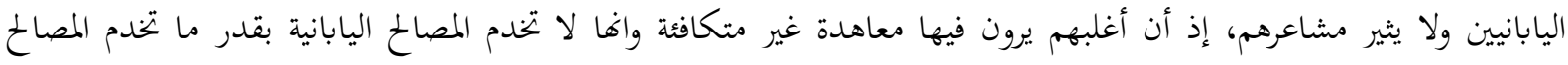

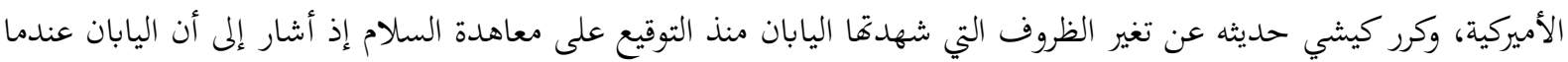
وقّعت عليها لم يكن أمامها خيارات أخرى واها كانت تعاني من آثار الهزيمة ومن أهم البنود التي طالب كيشي بإجراء تغيير عليها

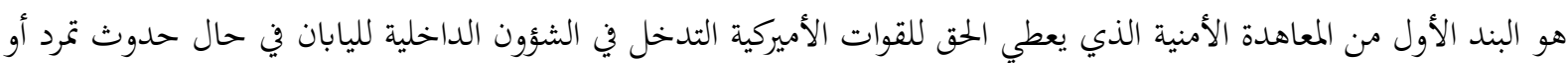

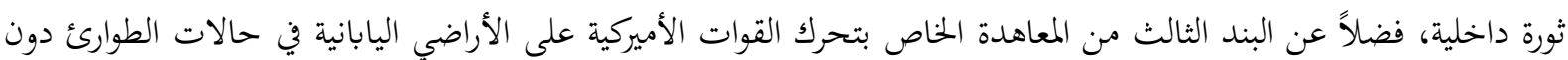
التشاور مع الحكومة اليابانية، واقترح كيشي تحديد مدة المعاهدة بخمس سنوات بدلا من عشرة سنوات رفض دلس المطالب التي

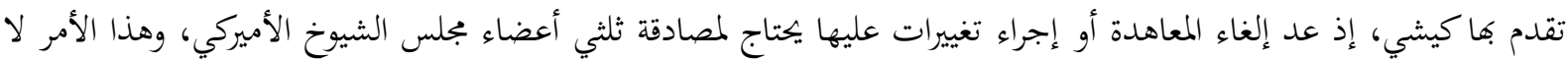

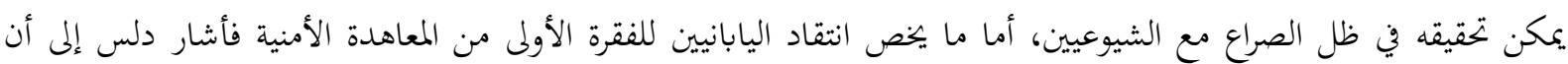

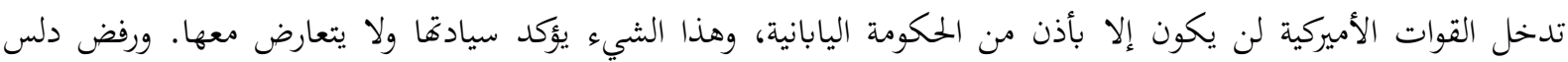
التشاور مع الحكومة اليابانية في حالات الطوارئ كحدوث عدوان لمدئ مفاجئ على اليابان ووصفه بغير العملي، وانه يفقد القوات

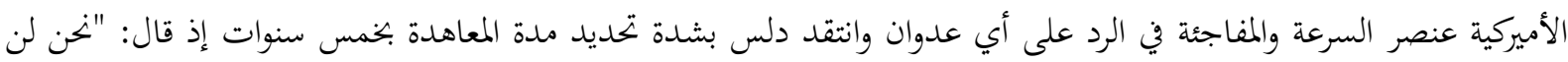
نعارض رغبات الحكومة اليابانية إذ طلبت إفاء التعاون معنا ولن نفرض أنفسنا على حليف متردد ونحن مستعدون لتطوير استراليا

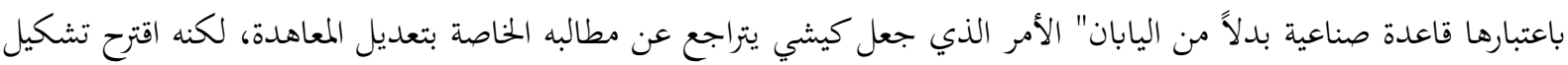

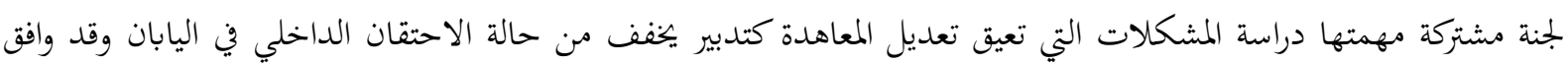

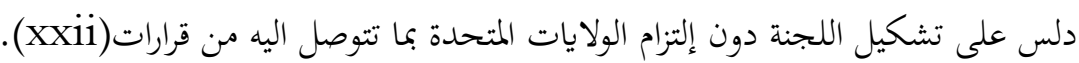

أفىى كيشي زيارته إلى الولايات المتحدة في 21 حزيران من العام نفسه وان أهم ما حققه في مباحثاته مع المسؤولين الأميركيين هو انتزاعه لاعتراف علني من دلس بتحاه المعاهدة الأمنية إذ أكد دلس على على إنى انه ليس لدئ لديه الرغبة في الاستمرار في المعاهدة

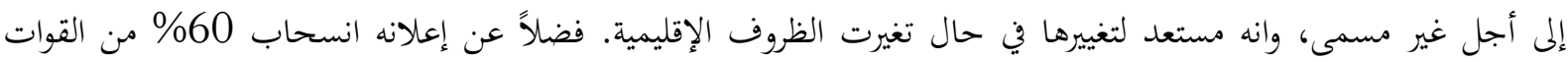
العسكرية الأميركية في اليابان بعد فهاية عام واحد، ومن جهة أخرى، فشل كيشي في حل المشكلات العالقة بين البلدين فلم تحل مشكلة توسيع القوات العسكرية الأميركية لقواعدها على حساب أراضي المواطنين اليابانيين، ولم يعاد المهجرين اليابانيين إلى 
مناطقهم الأصلية في جزر بونين، فضلاً عن رفض دلس تخفيف القيود المفروض على التجارة اليابانية مع الصين الشعبية وبناء على

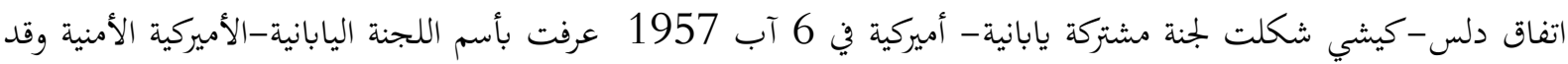

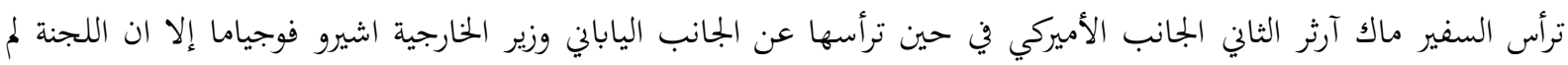

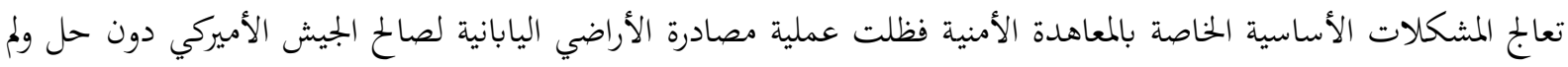
تسهم اللجنة بعودة المهجرين إلى موطنهم الأصلي بل على العكس من ذلك أرادت الولايات المتحدة أن بتعل من هذه اللجنة أداة

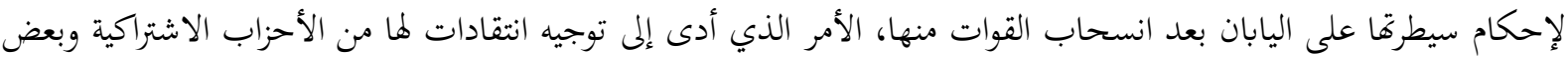

الشخصيات المحافظة وطالبوا بإلغائها(xxiii).

أدت هذه الأحداث والتطورات الأنفة الذكر إلى تولد قناعة لدى السفير ماك آرثر الثاني بضرورة تعديل المعاهدة الأمنية ففي مطلع عام 1958 كان السفير ماك آرثر الثاني هو أول من أثار موضوع المعاهدة الأمنية داخل مراكز صنع القرار السياسي

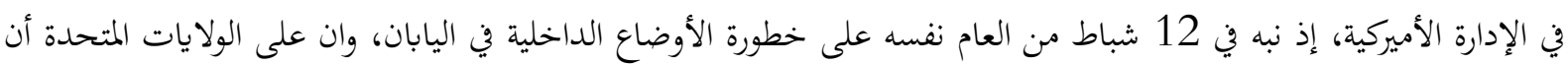

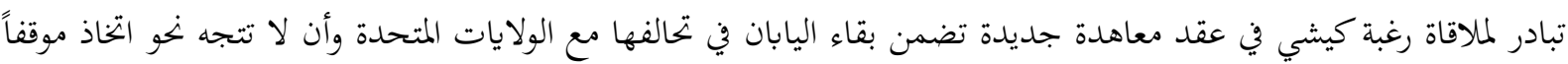

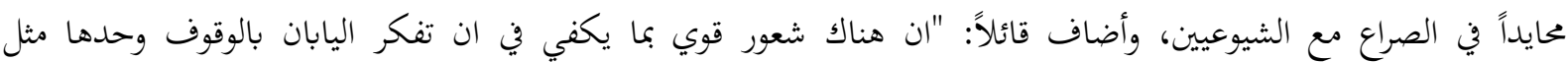

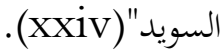

وفي السياق نفسه أرسل ماك آرثر الثاني مذكرة إلى وزارة الخارجية تضمنت أفكاراً ومقترحات في كيفية التعامل مع اليابان،

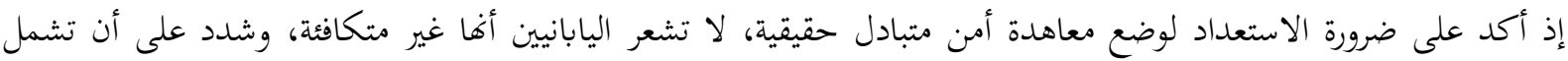
المعاهدة جميع منطقة الخحيط الهادئ بمعنى ان تكون المعاهدة إقليمية وليس ثنائية، وهذا يعني توسيع مسؤولية اليابان الدفاعية إلى لي لئي خارج نطاق جزرها الأربع الرئيسة، والتوصل إلى ترتيبات قضائية مرضية للجانب الياباني. واقترح السفير ماك آرثر الثاني أن يكون

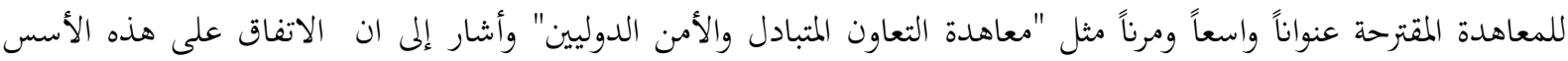

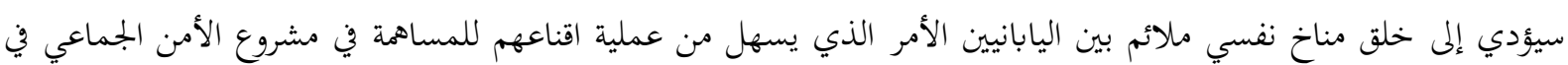
منطقة المحيط الهادئ ومن المسائل المهمة التي أثارها ماك آرثر الثاني هي المنطقة التي ستشملها المعاهدة، إذ عدها المشكلة الأساسية التي تعيق التوصل إلى معاهدة أمنية جديدة بين اليابان والولايات المتحدة إذ كتب للخارجية الأميركية في 18 شباط من العام نفسه، "ان أغلبية الشعب الأميركي يريد أن يكون لليابان دوراً مهماً في الدفاع عن أراضي الولايات المتحدة القارية" في حال

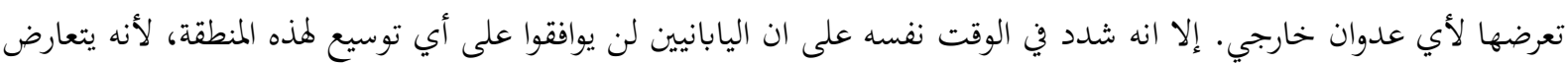

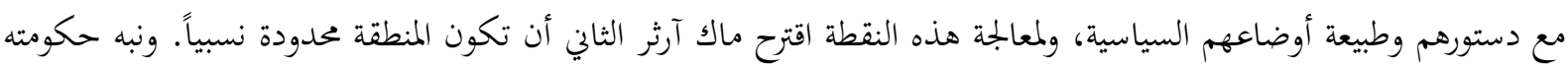

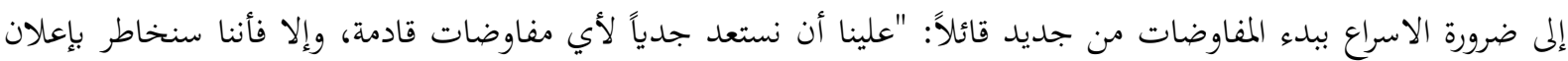
اليابان إهاء المعاهدة الحالية من جانب واحد(XXV).

رفضت وزارة الخارجية الأميركية الأفكار والمقترحات التي تقدم بها سفيرها في اليابان، وجاء ذلك الرفض في 22 آذار

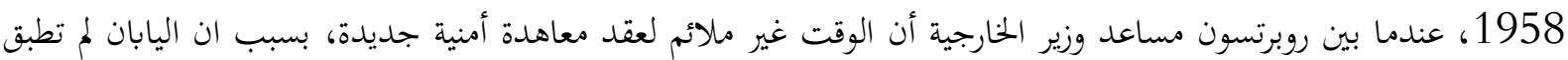
بنود المعاهدة الأمنية بشكل صحيح، فقواتها العسكرية لا تزال غير مكتملة وغير قادرة للدفاع عن أراضيها. وطرح روبرتسون

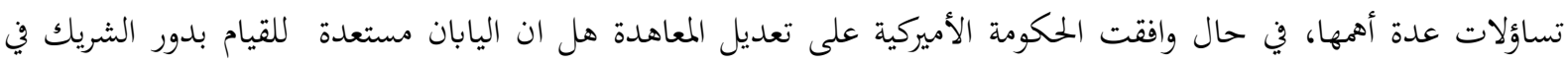

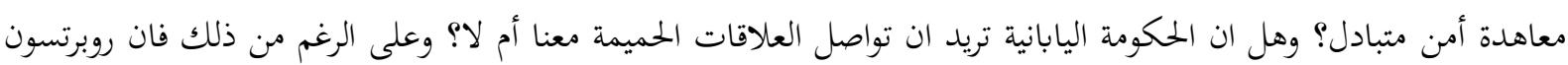

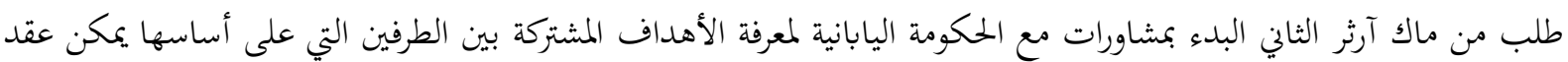

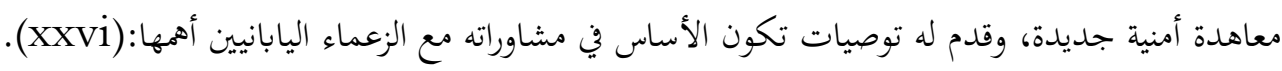


1. أن تكون في اليابان قوة عسكرية قادرة على الدفاع عن نفسها، وتساهم في الدفاع عن دول (العالم الحر) خارج أراضيها.

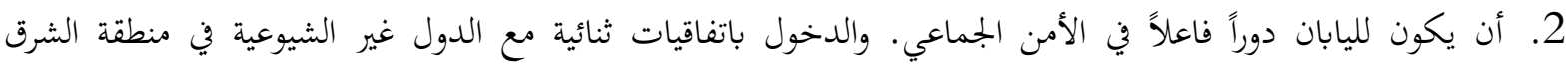
الأقصى. 3. استمرار وجود القوات الأميركية في اليابان وفقاً لما تقتضيه الأوضاع الدولية. 4. موافقة اليابان على دخول الأسلحة النووية إلى أراضيها. 5. أن تعمل اليابان على تقوية اقتصادها بما يضمن قدرتها على التهلى التسلح. 6. أن توجه اليابان اقتصادها على أساس المنفعة المتبادلة مع دول (العالم الحر). من الواضح ان توصيات روبرتسون كانت ذات سقف مرتفع ولا تتناسب مع الواقع السياسي لليابان، وكان الهدف منها

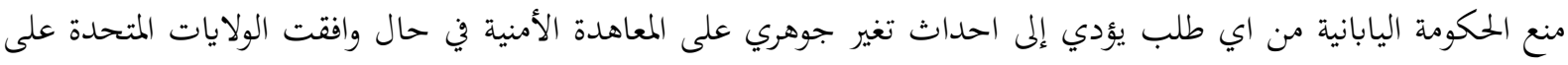
إجراء مفاوضات حولها وعلى الرغم من رفض وزارة الخارجية الأميركية مقترحات ماك آرثر الثاني لكنها كانت حريصة على على ملى معرفة

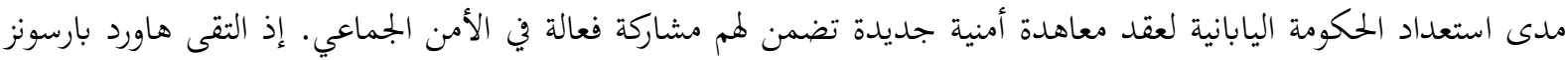
مدير مكتب شؤون شمال شرق آسيا مع السفير الياباني في واشنطن في 9 نيسان 1958 وتساءل بارسونز عن المشكلة الرئيسة في العلاقات الأميركية-اليابانية فإجاب السفير أها الادارة المستمرة من جانب الولايات المتحدة لجزير اوكيناوا وبونين، وذلك لأن اليابانيين يعدون هذه الجزر جزءً من أراضيهم قبل اندلاع الحرب العالمية الثانية، وان اليابان تنازلت عن فرموزا وكوريا ومنشوريا لأهنا

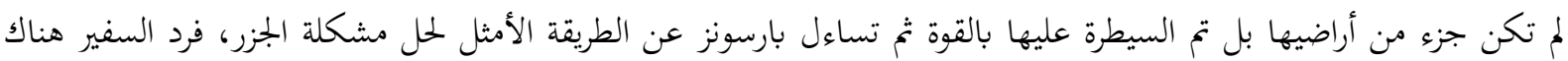

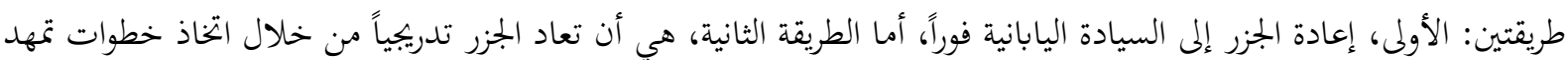
لإعادقا للسيادة اليابانية، كاعتماد المناهج الدراسية اليابانية في المدارس، ورفع العلم الياباني فوق أسطح المؤسسات بدلاً من العلم

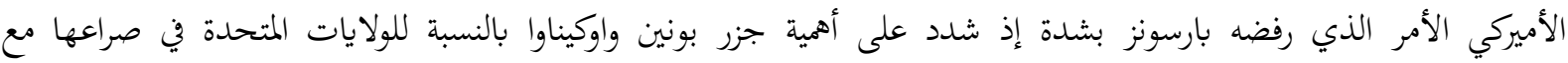
الشيوعيين وان على الشعب الياباني أن يفهم ان عودة الجزر لن يكون بدون ثمن وان الثمن هو عدم تقييد حركة القوات الأميركية على هذه الجزر وبدوره أكد السفير أن الحكومة اليابانية ستطالب بعودة الجزر بعد الانتهاء من الانتخابات العامة والمقررة في 18 آيار (xxvii)(x)

من جانبها عارضت وزارة الدفاع الأميركية أية مفاوضات لعقد معاهدة أمنية جديدة تنص على عودة جزر اوكيناوا وبونين للسيادة اليابانية، إذ عدها نقطة الارتكاز في الصراع مع الشيوعيين على منطقة الشرق الأقصى. غير ان ماك آرثر الثاني كان له له

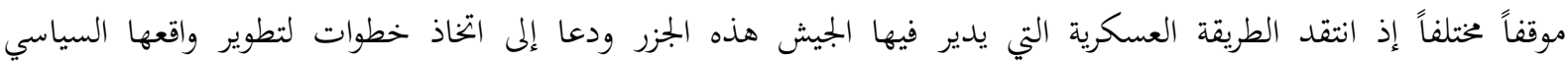
والاقتصادي كتقديم مساعدات مالية للسكان، وإعطائهم مزيداً من الحرية لادارة شؤوغم المحلية، وأكد ماك آرثر الثاني على امكانية تسليم الادارة في هذه الجزر لليابانيين مع الحفاظ على المصالح الإستراتيجية للولايات المتحدة فيها، الأمر الذي ينعكس ايجاباً على

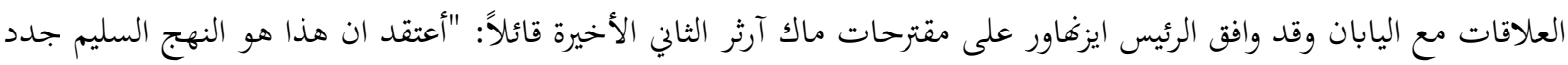

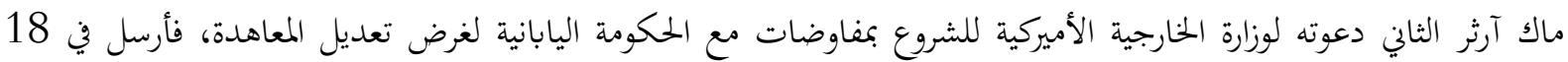

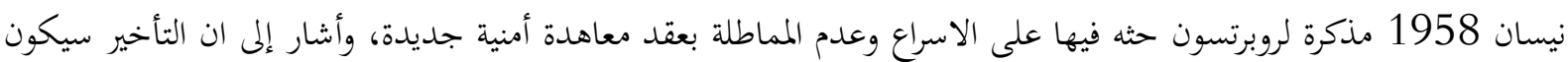
له نتائج سلبية على الوضع الداخلي في اليابان، إذ ان الشيوعيين يعملون على اثارة الرأي العام الياباني ضد الثدان السياسة الأميركية، متهمين إياها برفض تعديل المعاهدة، وأكد ماك آرثر الثاني على ان أي حكومة يابانية ستفرزها الانتخابات القادمة والمقرر اجرائها في 22 أيار القادم ستكون من أهم أولوياتها التفاوض مع الأميركيين على تعديل المعاهدة، وتطرق ماك آرثر الثاني إلى المنطقة التي

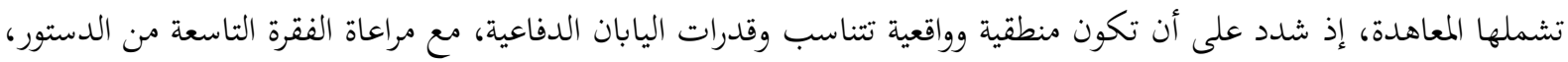


وأضاف قائلاً: "اسمحوا لي أن أقول مرة أخرى وبصراحة ان ليس لدينا خيار سوى التحرك بسرعة بعد الانتخابات اليابانية والبدء بمحادثات هادئة مع كيشي على مشروع معاهدة جديدة وفقاً لما قدمته من اقتراحات (XXviii). ومع اقتراب موعد الانتخابات حاول كيشي الحصول على دعم مالي من الولايات المتحدة لتمويل مملته الانتخابية

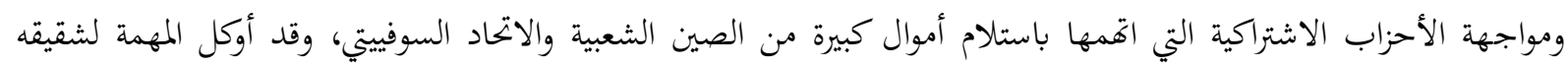

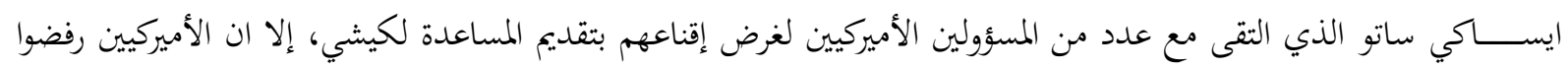

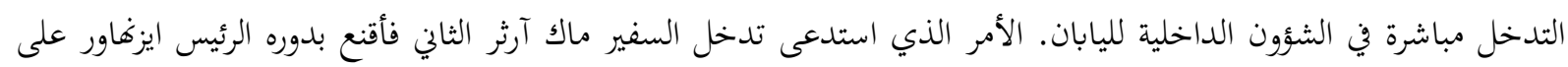

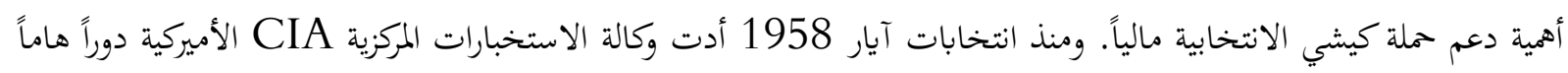

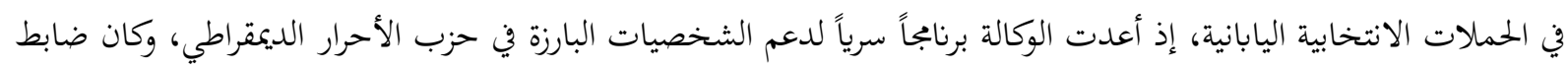
المخابرات الفريد أولمر (xxix).

المسؤول الأول عن البرنامج وفي ظل رفض وزارة الدفاع الأميركية بحث المعاهدة الأمنية، شهدت اليابان نشاطاً سياسياً، سيما بعد تشكيل الحكومة برئاسة كيشي، إذ التقى فوجياما مع ماك آرثر الثاني في 31 تموز

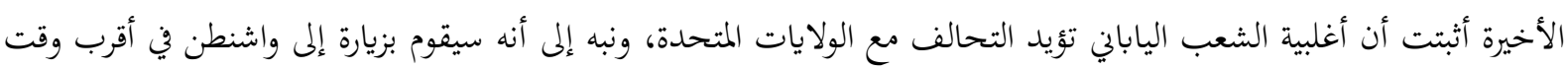

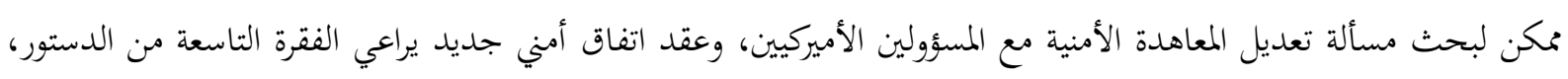

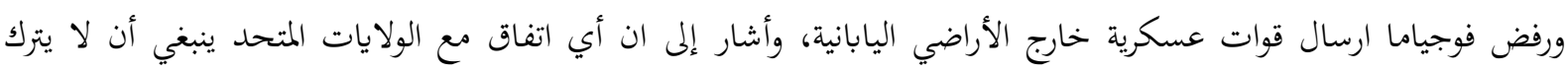

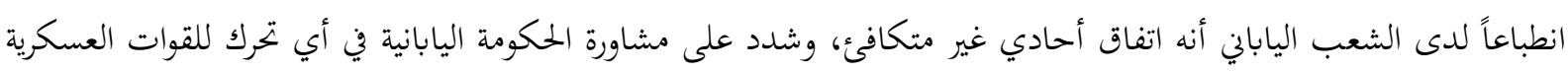
الأميركية انطلاقاً من أراضيها وقال: "أعتقد ان ذلك سيكون مفيداً لواشنطن(XXx). غادر ماك آرثر الثاني إلى واشنطن في 8 أيلول 1958، وذلك تحضيراً لزيارة فوجياما المقررة في 11 من الشهر نفسه،

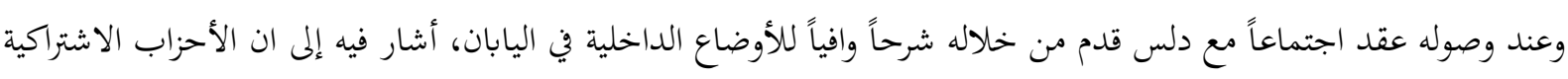

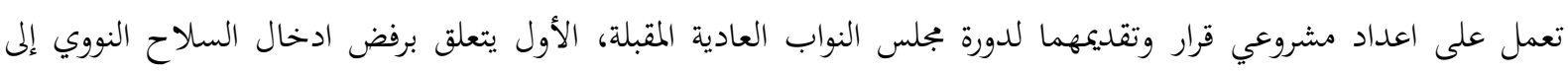

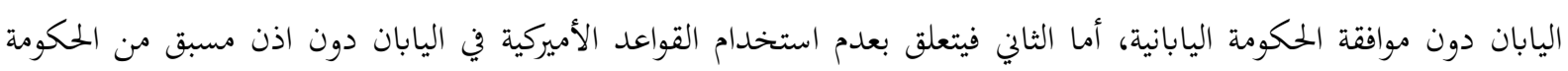

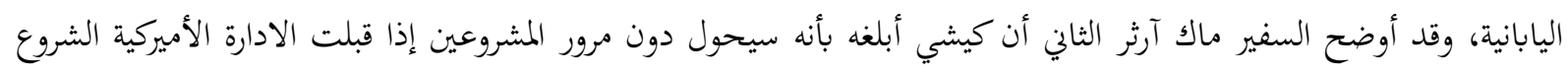

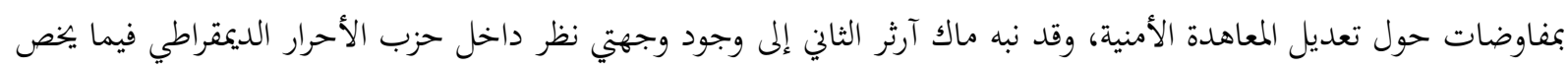

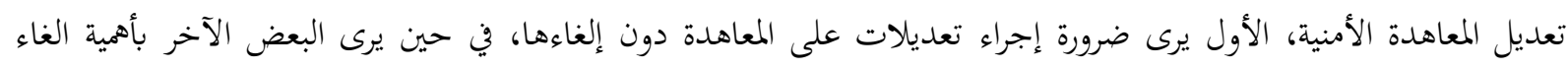

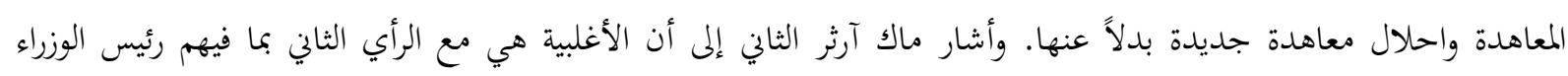

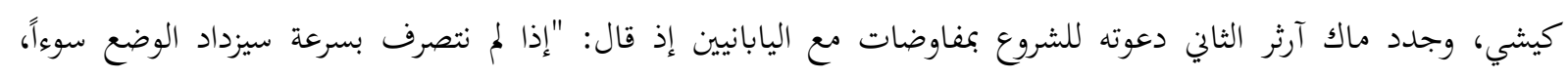

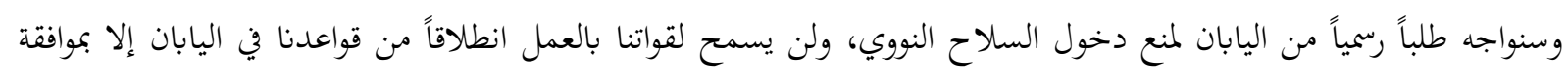

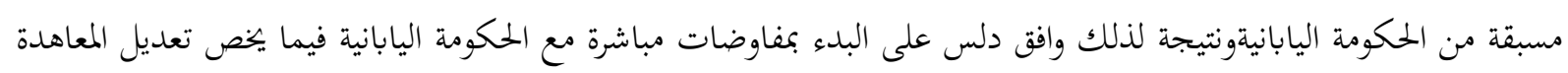

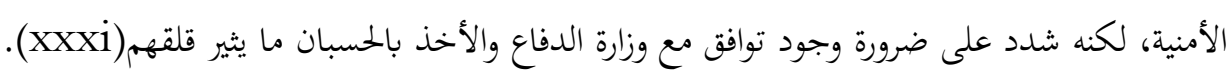
وفي اليوم التالي عقد اجتماع ضم مثثلين عن وزارتي الخارجية والدفاع من أجل التوصل إلى صيغة مشتركة بتحاه المفاوضات

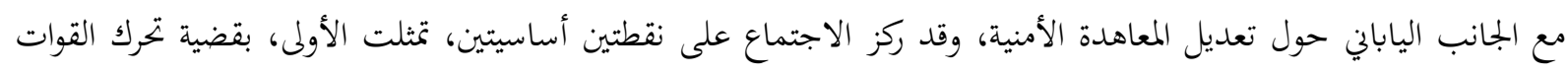

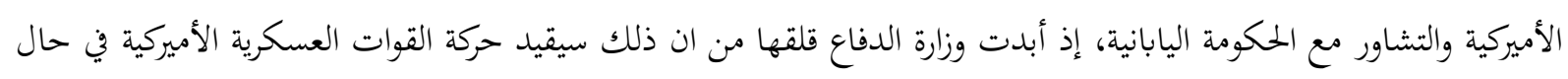

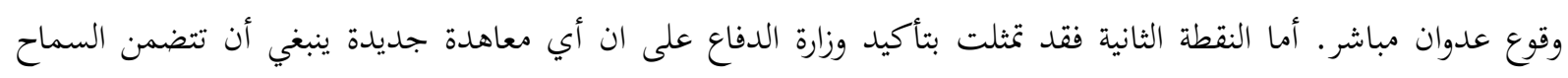

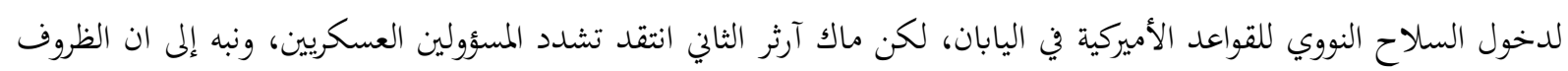


التي وقعت فيها معاهدة 1951 تختلف بشكل كبير عن الظروف الحالية، وينبغي أن يكون هدف المعاهدة الأساسي هو المحافظة

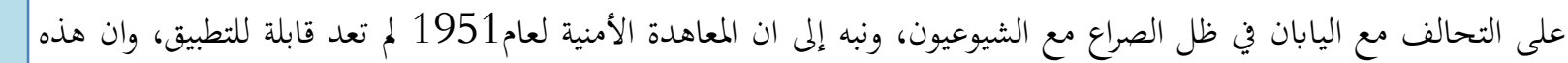

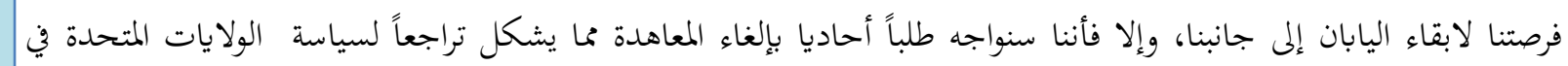

المنطقة)(Xxxii).

وصل فوجياما إلى واشنطن في 11 أيلول 1958 لإجراء مفاوضات تمهيدية حول القضايا الأمنية(Xxxiii)، وفي اليوم

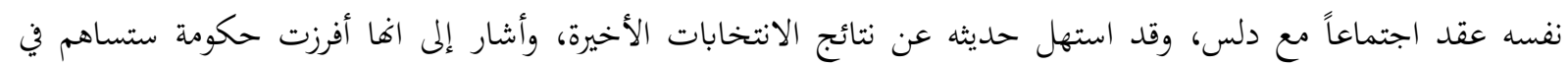

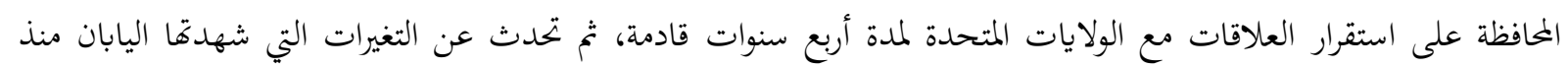

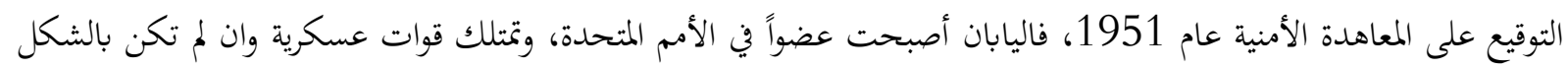

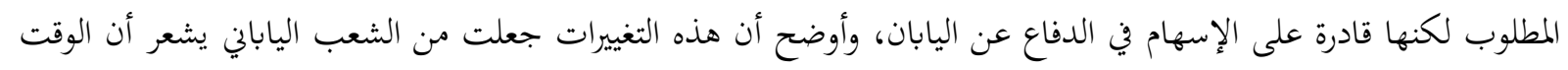

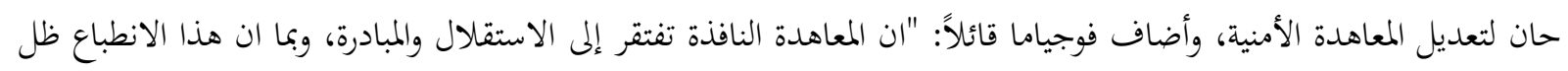

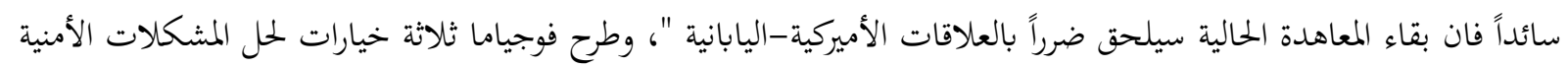
وهي عقد معاهدة جديدة، أو إجراء تعديلات على المعاهدة الحالية، او توقيع اتفاق سري بين الحكومتين الأميركية واليابانية، لكنه

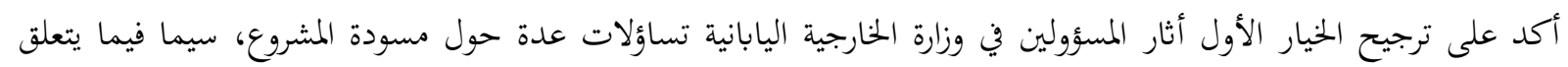

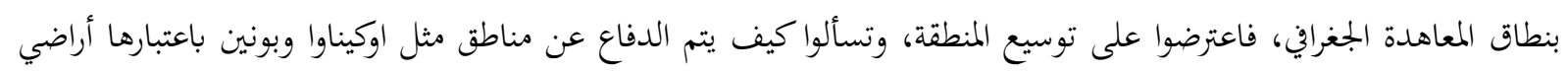

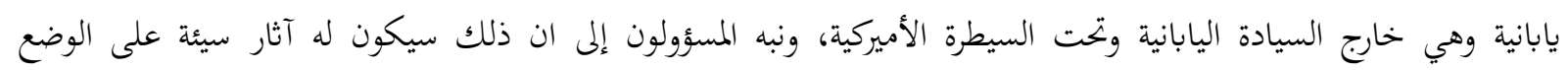

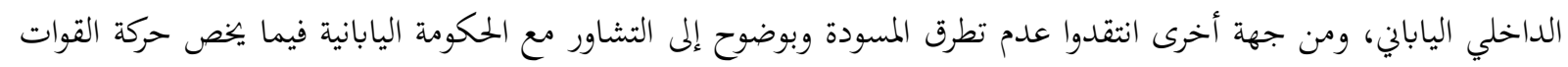

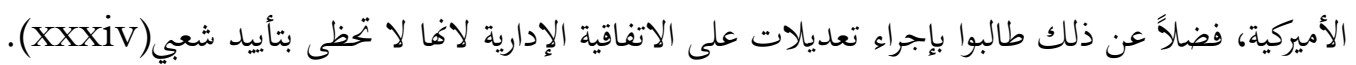
وفي ظل حالة الانقسام بين السياسيين اليابانيين، التقى ماك آرثر الثاني مع فوجياما في 28 تشرين الثاني من العام نفسه،

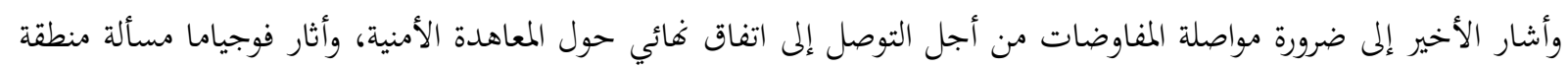

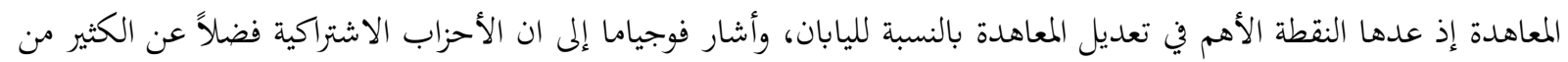

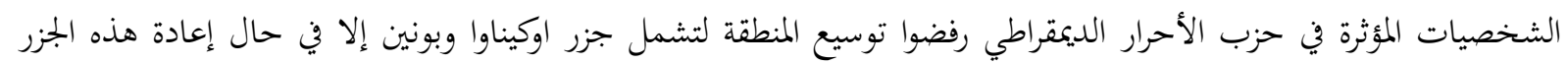

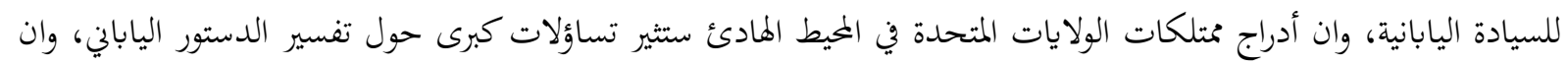

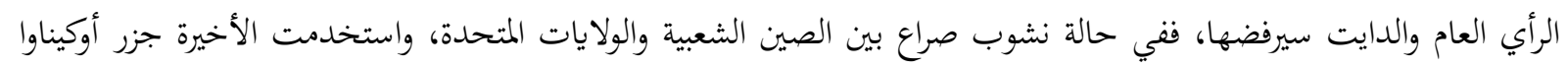

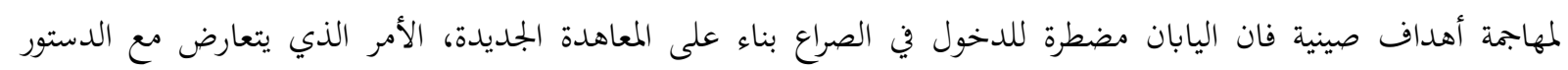
الياباني. وفي اليوم نفسه نقل ماك آرثر الثاني تحفظات الحكومة اليابانية على منطقة المعاهدة إلى كل من وزاريت الدفاع الداع والخارجية الأميركيتين(xXXv).

استمرت المناقشات بين المسؤولين الأميركيين واليابانيين حتى شهر أيلول عام 1959، إذ توصل الطرفان إلى اتفاق حول

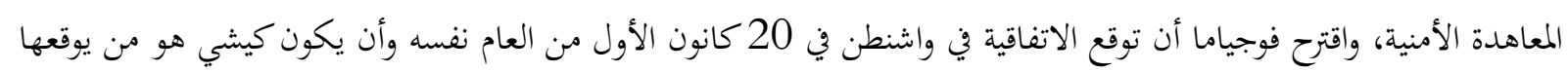

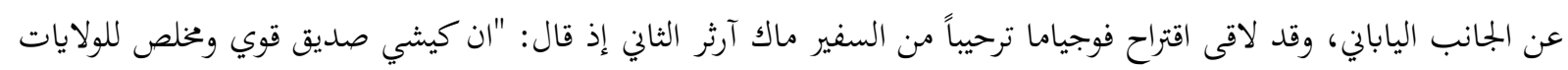

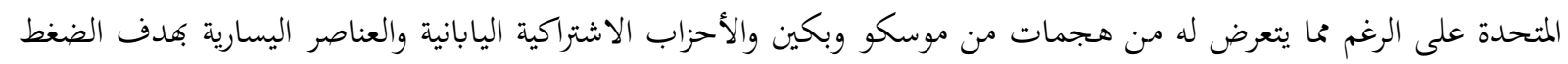

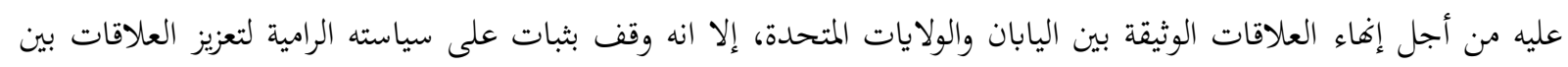

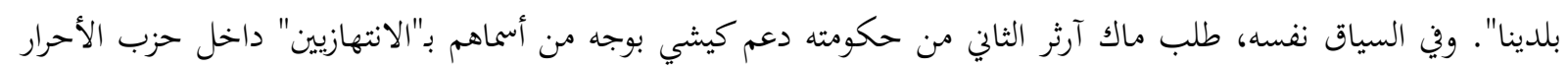

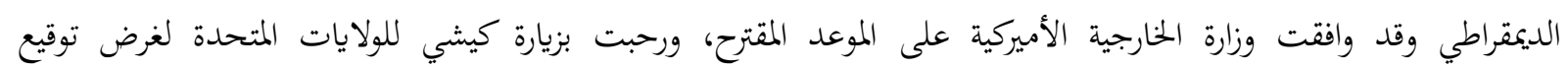
المعاهدة(xxxvi). 
وفي مطلع عام 1960 بدأت الحكومة اليابانية تحضر لزيارة كيشي إلى الولايات المتحدة والمقرر إجراءها في 19 كانون الثاني من العام نفسه، لغرض التوقيع على المعاهدة الأمنية، وقد رافق هذه التحضيرات خروج مظاهرات كبيرة عمت المدن اليابانية،

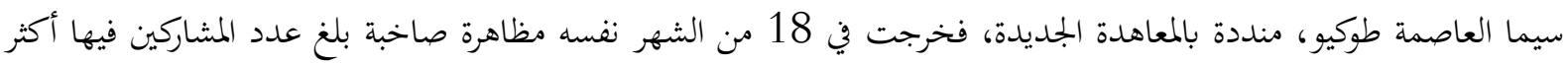

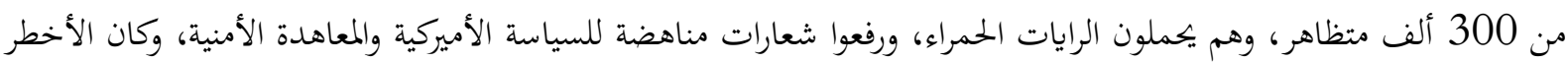
في هذه المظاهرات مشاركة 2000 عنصر من حركة زنكاكورين الطلابية المتطرفة، التي طالبت بإنهاء العلاقات مع الولايات المتحدة حتى وان تطلب ذلك استخدام العنف وفي اليوم التالي توجهت المظاهرة نحو مطار هانيدا لمنع كيشي من السفر إلى لئل الولايات المتحدة، الأمر الذي استدعى دخول قوات مكافحة الشغب فاعتقلت أكثر من ألف متظاهر، وفسحت الطريق لكيشي للسفر إلى الولايات المتحدة(xxxvii).

وصل كيشي إلى الولايات المتحدة في 19 كانون الثاني 1960، وفور وصوله عقد اجتماعاً مع الرئيس ايزهاور استعرضا

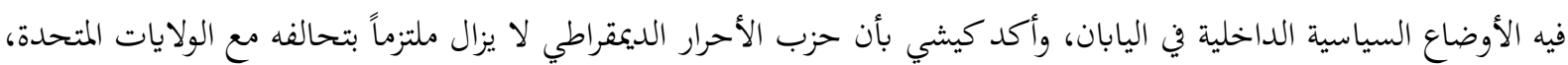

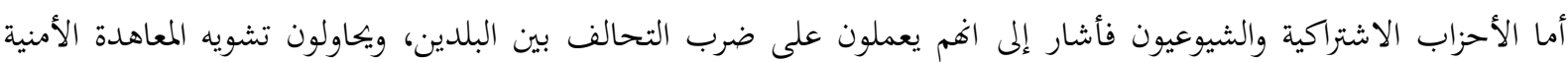
وأوضح كيشي أن الاتحاد السوفييتي والصين الشعبية متورطين بدعم المعارضة من أجل تقويض التئر التحالف الأميركي الياباني. وبدوره

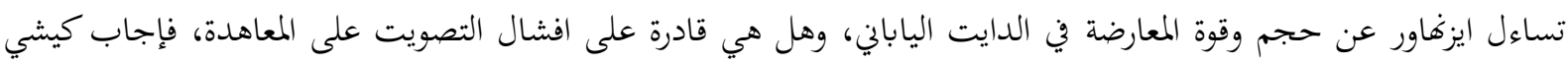

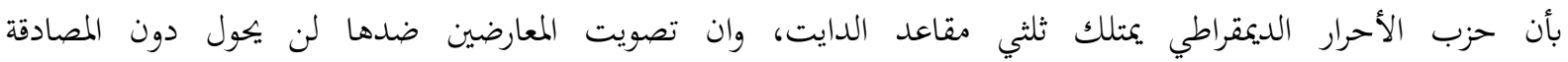
عليها(Xxxviii).

وقّع كيشي في اليوم نفسه مع وزير الخارجية الأميركي هيرتر على المعاهدة الأمنية التي أطلق عليها اسم معاهدة الأمن

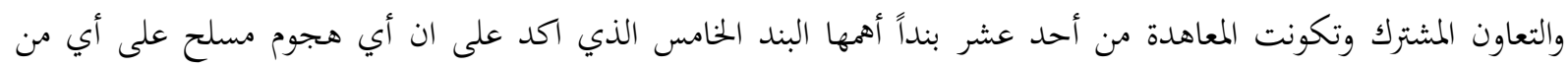
الطرفين في المنطقة التابعة للسيطرة اليابانية يعد تمديداً لأمن وسلامة كل منهما ويجب مواجهته وفقاً للإلتزامات الدستورية والعملية

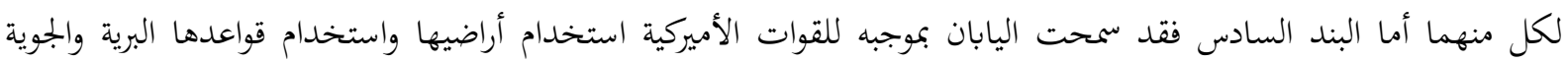
والبحرية في اليابان، وبموجب هذه المعاهدة الغي البند الذي يسمح للولايات المتحدة التدخل العسكري في حال وقوع اضطرابات داخلية، فضلاً عن إلغاء البند الذي يمنع اليابان منح قواعد لقوة ثالثة بدون موافقة مسبقة من الولايات المتحدة، وحدّدت المعاهدة

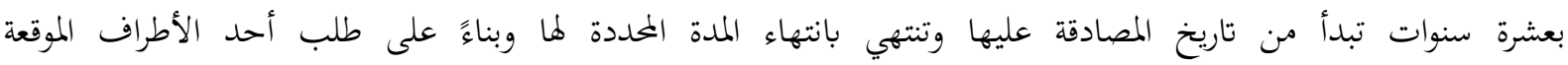

عليها(Xxix).

وفي الوقت نفسه تم التوقيع على اتفاقية(سوفا)وهي اختصار للاسم الكامل اتفاقية وضع القوات الأميركية وهي اتفاقية

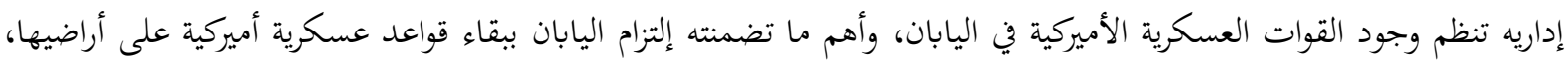

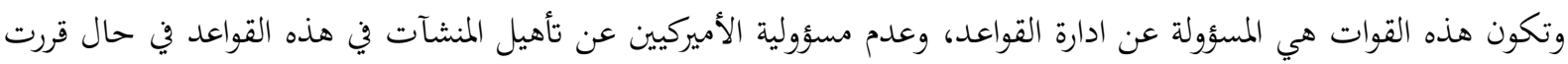

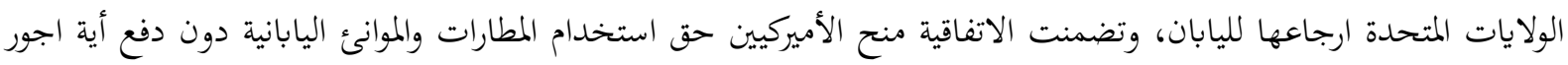

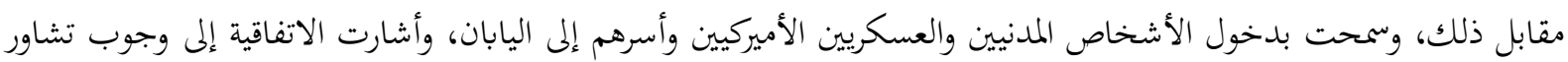

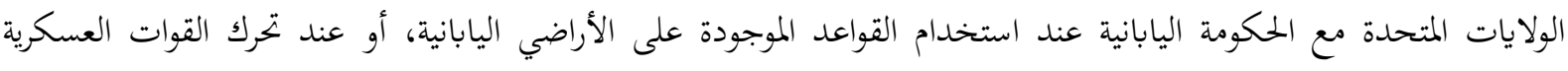
الأميركية عند حدوث أية عمليات قتالية، واها غير ملزمة بالتشاور مع اليابان في حالة وقوع عدوان مباشر على اليابان(xl).

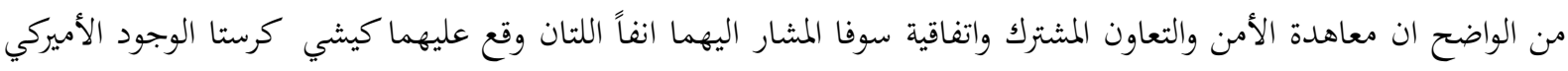

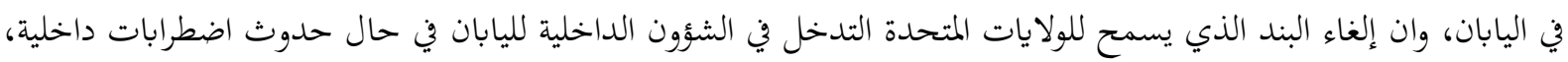

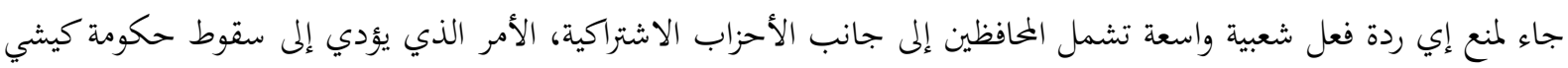

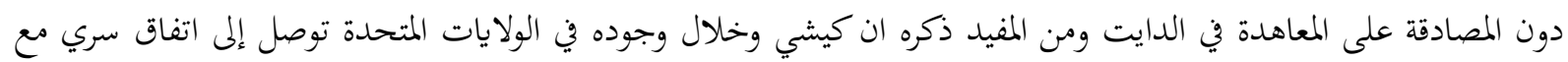


بارسونز مساعد وزير الخارجية الأميركية تضمن السماح للقوات الأميركية المتواجدة في اليابان برد فعل فوري ودون العودة والتشاور

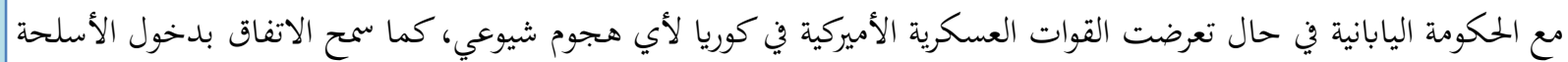
النووية إلى القواعد الأميركية في اليابان(xli).

تفاوتت ردود الفعل الداخلية والخارجية بحاه التوقيع على معاهدة الأمن والتعاون المشترك، فعلى المستوى الأميركي، رحبت

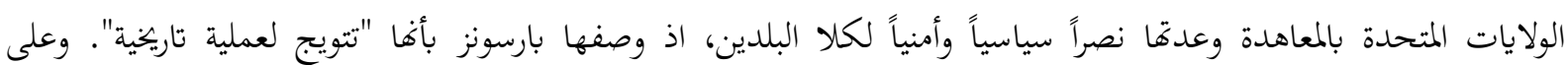
الصعيد الدولي رفض كل من الاتحاد السوفييتي والصين الشعبية معاهدة الأمن والتعاون المشترك، فبعد ثلاثة أيام من التوقيع عليها

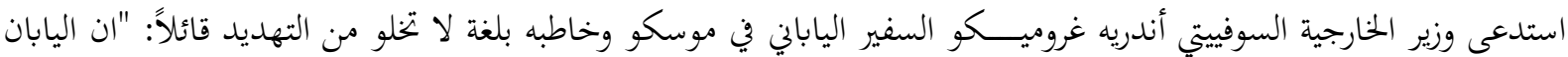
لن تكون بمنأى عن صواريخنا الحديثة في ظل وجود القواعد الأميركية على أراضيها، وعليكم أن تتذكروا المصير المأساوي لهيروشيما وناكازاكي، وان توقيع اليابان على معاهدة الأمن والتعاون المشترك مع الولايات المتحدة يمثل استفزازاً للشعوب السوفييتية والصينية، وان هناك أعضاء في الكرملين يطالبون بالانسحاب من الإعلان المشترك وإعادة جزيرتي هابومايس وشيكوتان. أما حكومة الصين الشعبية فوجهت انتقادات لاذعة إلى الحكومة اليابانية ووصفت اعضائها بـ(بجرمي الحروب)(xlii).

إن الانعطافة التي تمثلت طبيعة السياسة بين الولايات المتحدة واليابان، ورسمت حدود هذه العلاقة ومقتضياتا الأمنية وإبعادها الإستراتيجية، ويمكن وصفها ب(الصفقة طويلة الأمد) بين طرفين كان لكل منهما مصلحة خختلفة، التقت في هدف واحدة،

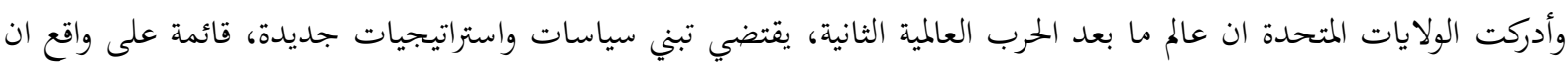

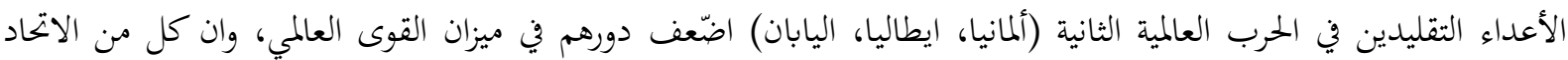
السوفيتي والولايات المتحدة، حلفاء الحرب العالمية الثانية، والمنتصران القويان، متجهان إلى حالة من التنافس والصراع بسبب

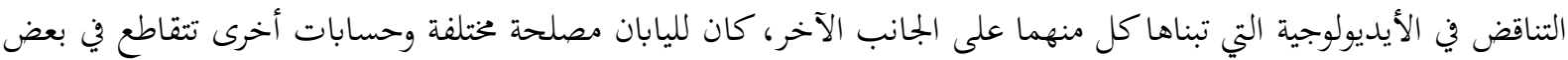

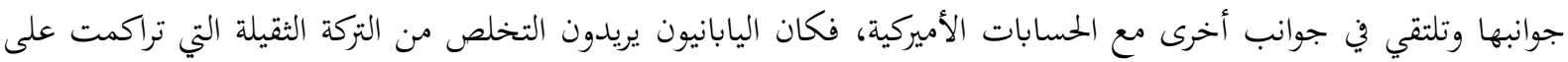

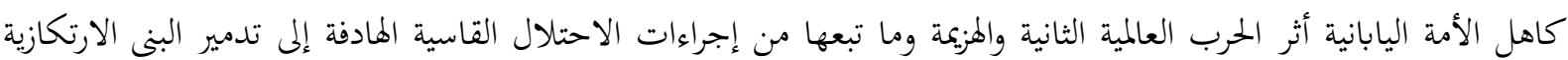

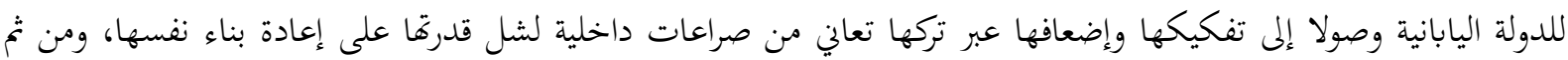
كانت اليابان متحمسة بقوة لأية تحولات في سياسة الاحتلال ترمي لرفع وتخفيف هذه العقبات، وذلك حتى تأخذ اليابان المسار الذي اختارته وهو البناء الاقتصادي والتخلي عن التوجهات العسكرية والنأي بنفسها عن الصراعات الدولية، ولان كل ذلك كان

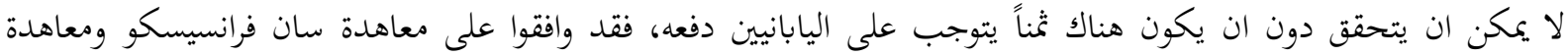
الأمن عام 1951، ليكونوا تحت ما يمكن ان نطلق عليه (المظلة الأميركية)، وأفرزت طبيعة السياسة الأميركية اليابانية إنتاج نظام

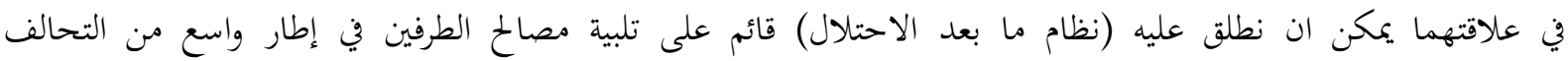

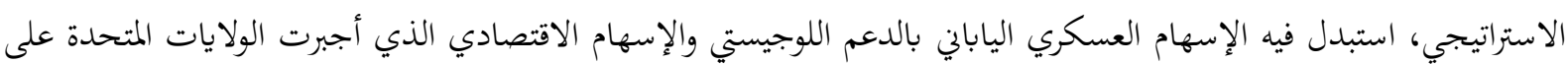

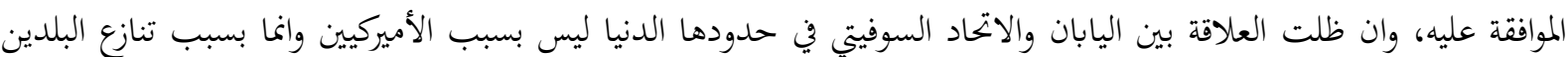
على جزر الكوريل وفشلهما في إيجاد تسوية مرضية للطرفين. 
قائمة المصادر

أولا:الكتب العربية:

كاظم هيلان محسن، سياسة الاحتلال الأميركي في اليابان 1945-1952: دراسة في التاريخ السياسي، دار الفراهيدي للنشر

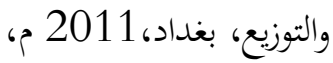

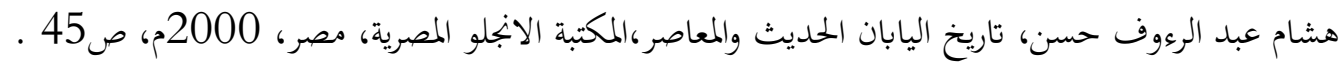

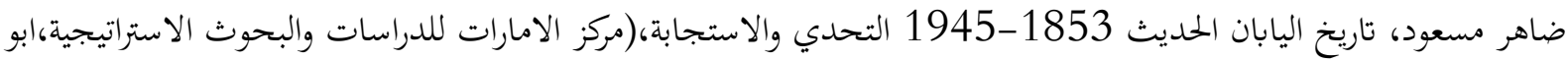
ظبي، 2009م.

درويش، فوزي، الشرق الاقصى الصين واليابان (1853-1972)،مطابع غيباشي، القاهرة ,1994م

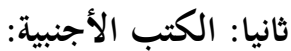

Akira Iriye and Warren I. Cohen(eds.), The United States and Japan in the postwar world, 1989, University of Kentucky Press, United States, P.67

Roger Buckley, The United States in the Asia-Pacific Since 1945, University of Cambridge Press, New York, .110،p.2002

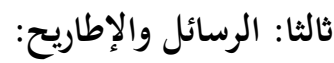

مهند سلمان،صالح، العلاقات الامريكية اليابانية 1952-1972، رسالة ماجستير، كلية التربية للعلوم الانسانية، جامعة البصرة، 2013

عباس فنجان صدام الإمارة، أوضاع اليابان الاقتصادية في عهد الاحتلال الاميركي 1945-1952، رسالة ماجستير غير منشورة، كلية التربية، جامعة البصرة، 2009م .

رابعا: المقالات والبحوث العربية: ت

كاظم هيلان، معاهدة الأمن والتعاون المشترك بين الولايات المتحدة واليابان دراسة تاريخية في ضوء وثائق الخارجية الأميركية

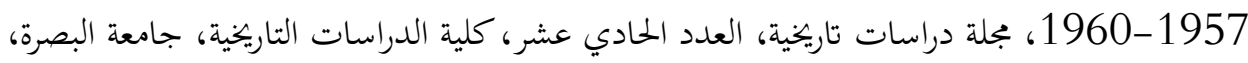

2010

عبد اللطيف شهاب زكري، النموذج الياباني وازمته الاقتصادية، المجلة العراقية للعلوم الاقتصادية، العدد(30)، السنة (2011م).

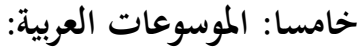
ربيع، محمد محمود واخرون، موسوعة العلوم السياسية، دار الوطن،الكويت، 1993م.

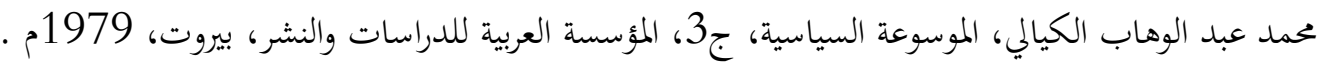
سادسا: الموقع الالكتروني شبكة المعلومات الدولية: https:/en.wikipedia.org-wiki-Nobusuke-kishi www.wikipedia.org https:/en.wikipedia.org-wiki-Nobusuke-kishi 
https:/en.wikipedia.org-wiki-Nobusuke-kishi (1) https:/en.wikipedia.org-wiki-Nobusuke-kishi (2) (3) كاظم هيلان محسن، سياسة الاحتلال الأميركي في اليابان 1945-1952: دراسة في التاريخ السياسي، دار الفراهيدي للنشر والتوزيع، بغداد، 2011 م،

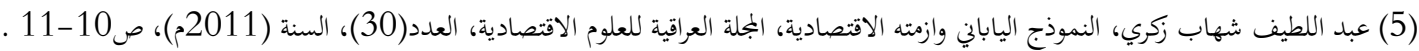

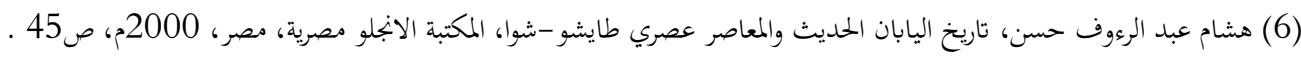

$$
\text { (7) محمد عبد الوهاب الكيالي، الموسوعة السياسية، ج3، المؤسسة العربية للدراسات والنشر، بيروت، 1979م، ص243 . }
$$$$
\text { . }
$$

(9) عباس فنجان صدام الإمارة، أوضاع اليابان الاقتصادية في عهد الاحتلال الاميركي 1945-1952، رسالة ماجستير غير منشورة، كلية التربية، جامعة البصرة،

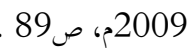

ضiv) (xiv)

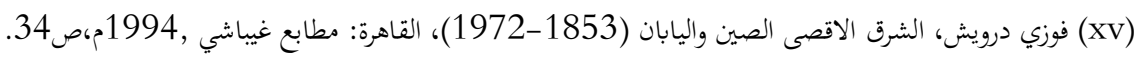
(Xvi)

(Xvii)

(Xviii)

(xix)

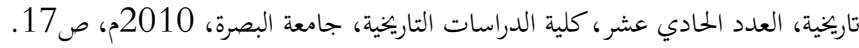

مهند سلمان، المصدر السابق، ص114 (xx)

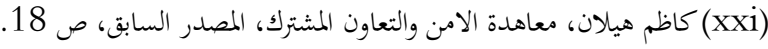

(xxii)

كاظم هيلان محسن، معاهدة الأمن والتعاون المشترك، المصدر السابق، صندxiii)

المصدرنفسة، ص (xxiv)

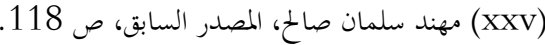

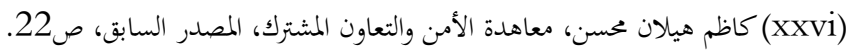

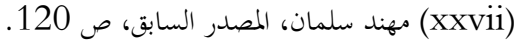

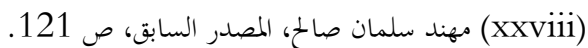

Www.wikipedia.org للتوسع ينظر (xxix)

كاظم هيلان محسن، معاهدة الأمن والتعاون المشترك، المصدر السابق، ص25xx)

(xxxi) Akira Iriye and Warren I. Cohen(eds.), The United States and Japan in the postwar world, 1989,

University of Kentucky Press, United States, P.67.

(xxxii)

(xxxiii) Roger Buckley, The United States in the Asia-Pacific Since 1945, University of Cambridge

Press, New York, 2002, P. 110

مهند سلمان، المصدر السابق، ص 124. 
(xxxv)

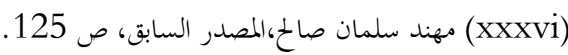

(xxxvii)

(xxxviii)

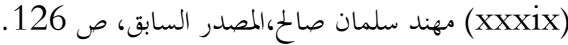

كاظم هيلان محسن، معاهدة الأمن والتعاون المشترك ن المصدر السابق، ص ص 28 (xl)

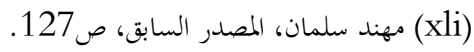

(xlii) 


\title{
THE POSITION OF THE SOVIET UNION ON THE INDEPENDENCE OF KUWAIT IN 1961
}

\author{
Howra Abdul SATTAR ${ }^{1}$
}

\section{Istanbul / Türkiye \\ p. $60-68$}

Received: $17 / 11 / 2021$

Accepted: 01/12/2021

Published: 01/01/2022

This article has been scanned $l$ iThenticat No plagiarism detected

\begin{abstract}
:
Since the end of World War II, the Soviet Union has sought to find a foothold in the Middle East, as it was waiting for the opportunity to penetrate the Middle East, especially the Arab Gulf, which is of international strategic importance. The British were in the region, and at the same time, it did not want to disturb his relations with the United Arab Republic, which supported the independence of Kuwait and rejected Abdul Karim Qasim's position on Kuwait's annexation of Iraq. This research attempts to study the Soviet policy towards the independence of Kuwait and how the Soviet Union reconciled its good relationship with Iraq and Egypt, and its rejection of Kuwait's distinguished relations with Britain.
\end{abstract}

Key words: Kuwait, The Soviet Union, Kuwait and Iraq, The Independence of Kuwait. 


\section{موقف الإتحاد السوفيتي من استقلال الكويت عام الج9 ام}

\section{حوراء عبد الستار 2}

الملخص:

سعى الإتحاد السوفيتي منذ غاية الحرب العالمية الثانية للبحث عن موطئ قدم له في الشرق الأوسط، حيث كان

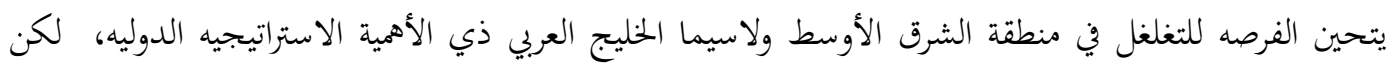
أزمة استقلال الكويت جعلت الإتحاد السوفيتي في موقف صعب فهو يرغب في التخلص من الوجود البريطاني في المنطقه وفي نفس الوقت لم يكن يرغب في تعكير علاقاته مع الجمهوريه العربيه المتحده التي إيدت استقلال

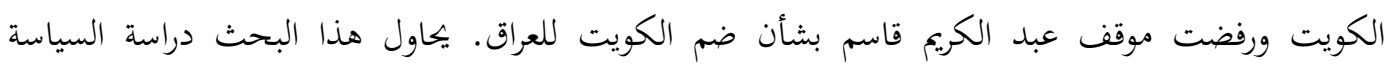

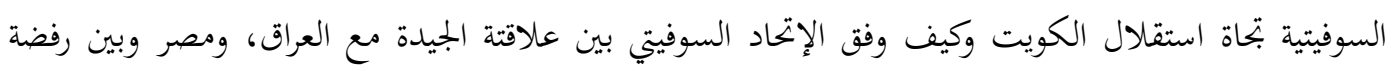
لعلاقات الكويت المميزة مع بريطانيا. الكلمات المفتاحية: الكويت، الإتحاد السوفيتي، استقلال الكويت. لكاتيا.

ظهر الإتحاد السوفيتي كقوه عظمى بعد الحرب العالميه الثانيه (1939-1945) وبدء بعد تعافيه من أثار تلك الحرب توسيع علاقاته الدوليه ومحاولة التغلغل في المناطق التي كانت تيمن عليها بريطانيا , ومنها منطقة الخليج العربي التي اهتمت بها بها

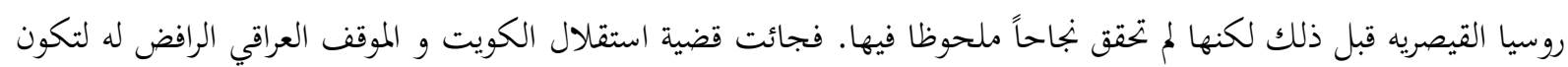

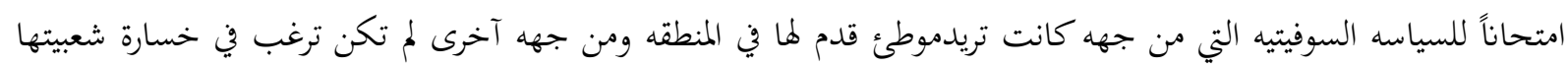

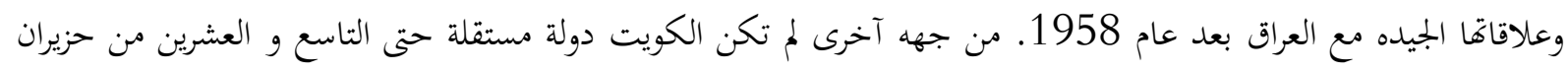

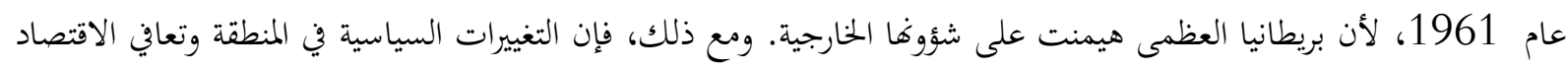

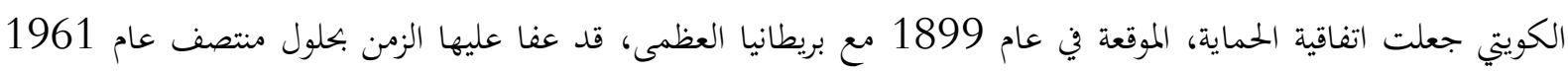
تقريباً ، مما جعل تأسيس السيادة الكاملة أمرًا مككنًا للكويت.

أدى سماح بريطانا باستقلال الكويت إلى نشوب صراع مع العراق، مما أثر على التقييم الدولي للدولة الجديدة في الشرق

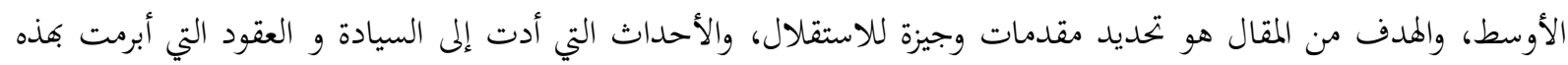

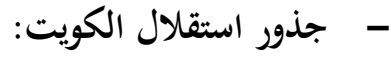

تم توقيع اتفاقية الحماية بين بريطانيا والكويت في عام 1899. ووقع المعاهدة في الثالث و العشرين من كانون الثاني

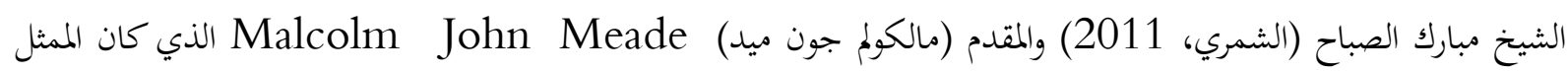

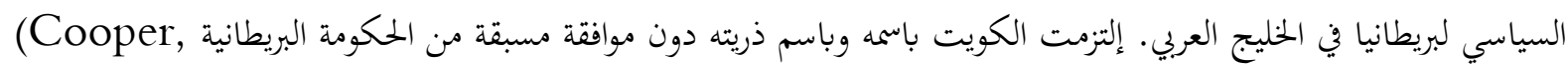


1. عدم استقبال وكيل أو مثثل لأي سلطة أو حكومة في الكويت أو في أي مكان آخر ضمن حدود أراضيها 2. عدم التنازل أو بيع أو الإيجار أو رهن أو منح أي جزء من أو أراضيه لحكومة أو رعايا أي سلطة آخرى.

ومن الجدير بالذكر انه حتى منتصف الأربعينيات من القرن الماضي، كانت الكويت منطقة متخلفة اقتصاديًا حيث عاش

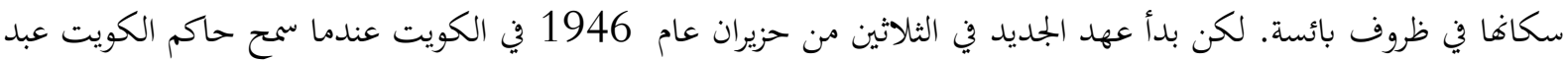

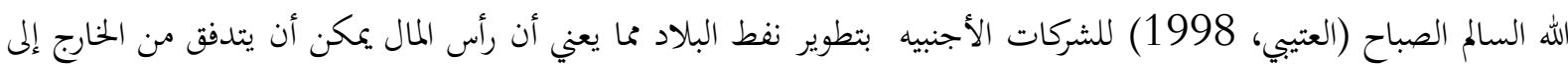

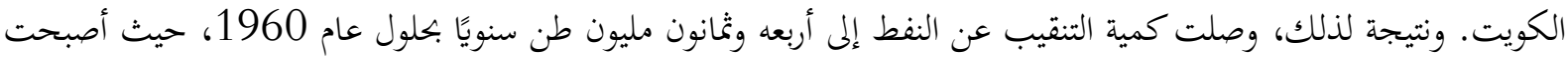
الكويت وفقاً لذلك رابع أكبر دولة في العالم في مجال التنقيب عن النفط بعد الولايات المتحدة الأمريكية وفنزويلا والإتحاد (Slight, 1990).السوفيتي

أفسحت الكويت الطريق أمام القيادة المستقلة للشؤون السياسية. فمن ناحية، حاولت دول جامعة الدول العبية عدة مرات قبل الستينيات تحقيق انضمام الكويت إلى المنظمة دون أي نجاح. من ناحية آخرى، جعلت طموحات الدول العربية من الواضح لحكومة بريطانيا العظمى أن بعض فقرات عقد المحمية قد فقدت صلاحيتها في الوضع المعين ولهذه فيجب الغائها.ففي

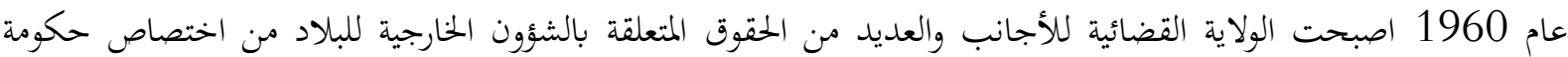
(Bernard \& Salles, 1999). الأمير

\section{- الموقف العراقي - ماقي}

W. H. في التاسع عشر من حزيران 1961 حصلت الكويت على استقلالها رسميًا. وشكلت مذكرة (دبليو إتش لوس) التهان Luce

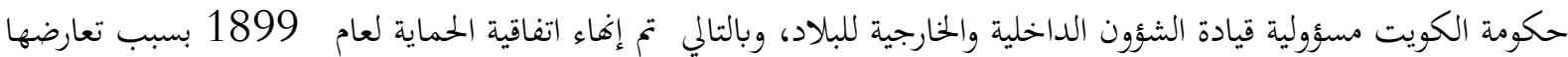
مع سيادة الكويت واستقلالها. وتوجب أن تحكم العلاقات بين البلدين بروح الصداقة الوثيقة في المستقبل أيضًا، فضلاً عن ذلك الك

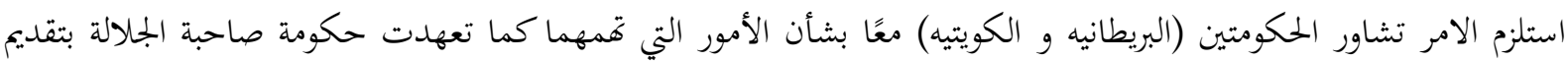

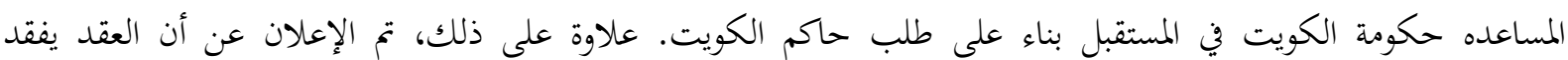
صلاحيته بعد ثلاث سنوات من مطالبة أحد الأطراف المتعاقدة بإلغائه (الشواف، قاسم، و و عراقيون آخرون، 2004). قبل الأمير الشروط المذكورة أعلاه في مذكرة الرد الخاصة به، والتي أعادها في نفس اليوم. ومع ذلك، واجهت الكويت موقفاً عراقياً رافضه للاجراءات السالفه.ففي الرابع و العشرين من حزيران عام 1961، 196ر، أعلن رئيس الوزراء العراقي عبد الكريم

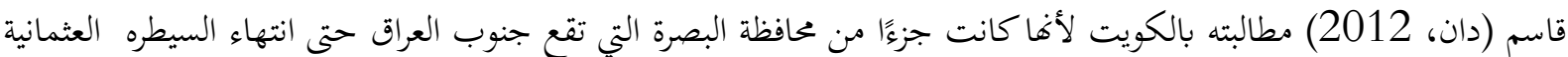
على العراق خلال الحرب العالميه الاولى (1914-1918). وزعم عبد الكريم قاسم أن اتفاقية عام 1899 التي أبرمها الحاكم

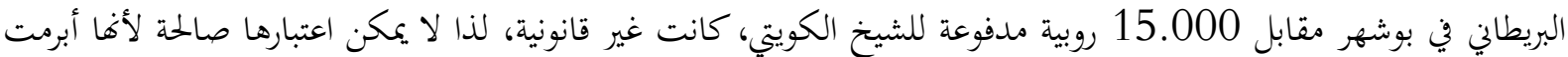
دون علم السلطان العثماني. وبسبب ذلك " قررت جمهورية العراق حماية الشعب العراقي في الكويت والمطالبة بالأرض التي تعود

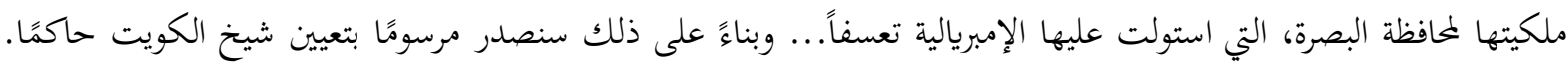
قائمقام الكويت، الذي سيخضع لسلطة محافظة البصرة... " (الزبيدي، 1981) تم طرح مطالبة الحكومة في شكل مذكرة إعلامية وأرسلت إلى جميع الوفود الأجنبية المقيمين في العراق. وأكدت عبد الكريم قاسم أن"حكومة العراق تعلن إفشاء هذه الحقائق للرأي العام العربي والدولي بأن الكويت ملك للعراق". علاوة على ذلك تؤكد الحكومة قرارها بشأن النضال ضد الإمبريالية، وبذلك تعرب عن قناعتها بأن الإمبريالية ستقضي على الكويت وفي البلدان العربية الآخرى. علاوة على ذلك، تعلن الحكومة قرارها المؤكد 
بالإصرار باستمرار على تأسيس وحدة الشعبين الكويتي والعراقي، ولن تتخلى الحكومة عن ذلك حتى تقيق هدفها يرى البعض

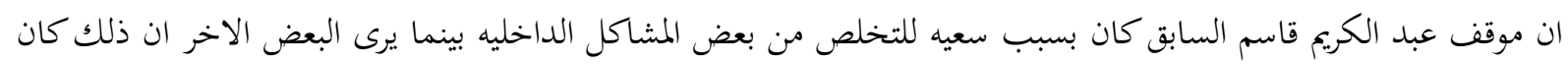

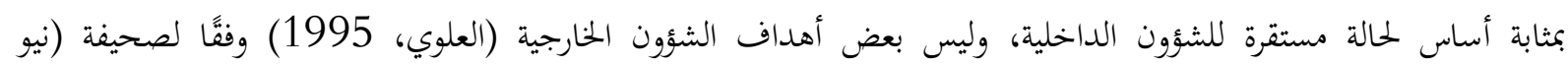

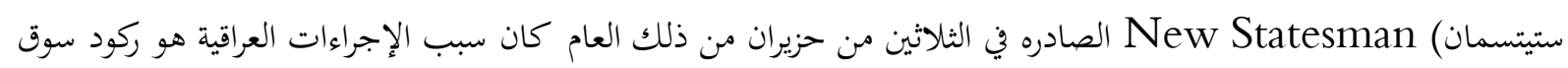

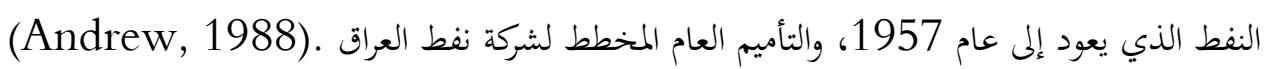
لم يئس رئيس الوزراء العراقي عبد الكريم قاسم من طموحه في أن يصبح زعيما للعالم العربي كله أو على الأقل جزء منه.

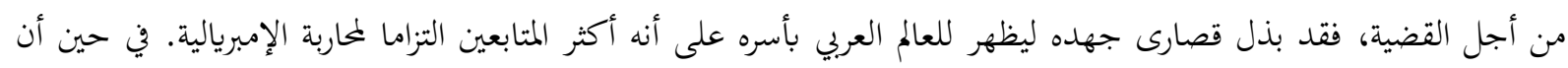

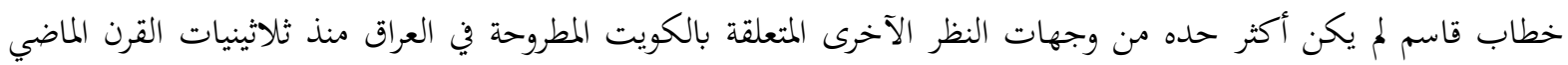

(Phyllis, 1990).

من جهته أصدر أمير الكويت مرسومًا استثنائيًا وتعبيًا. في الثلاثين من حزيران عام 1961م طلب فيه مساعدة عسكرية

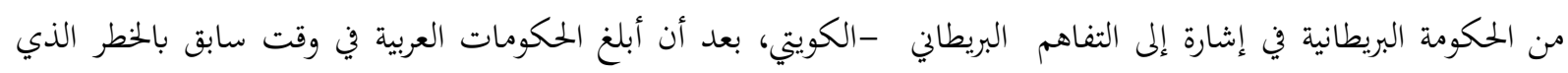

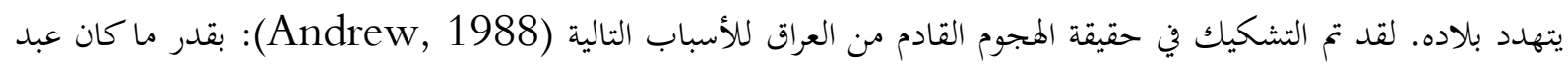

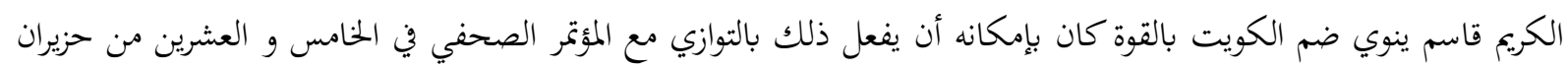

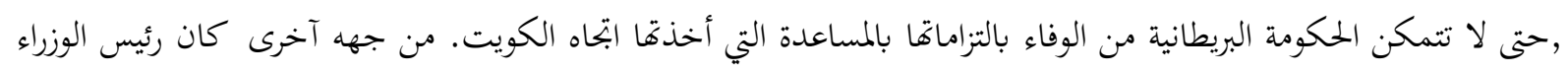

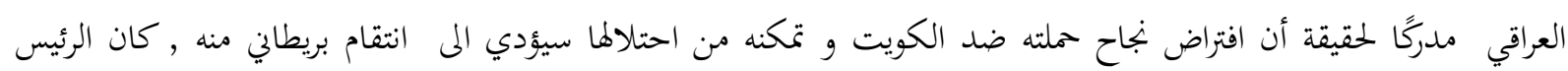

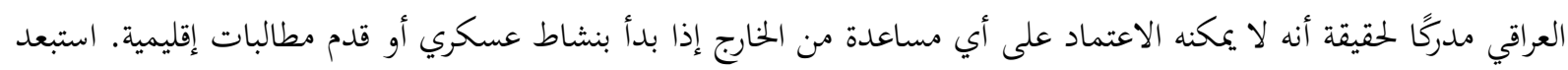

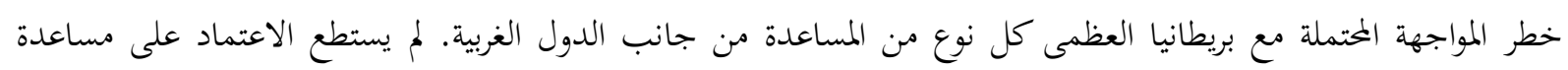

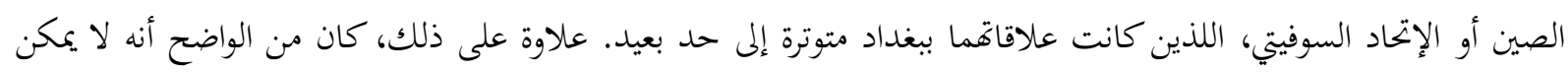

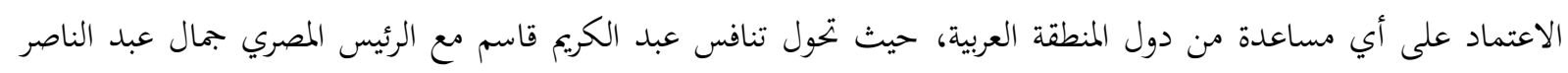

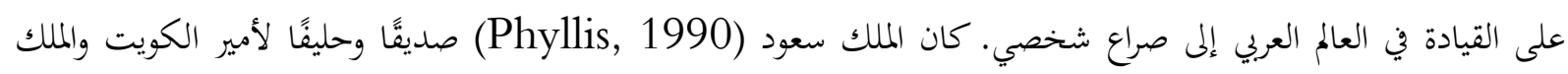

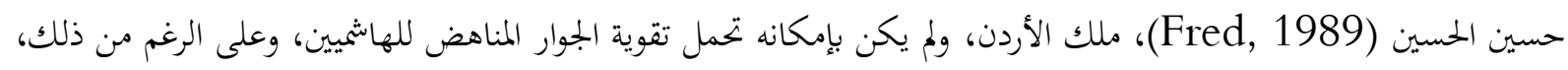

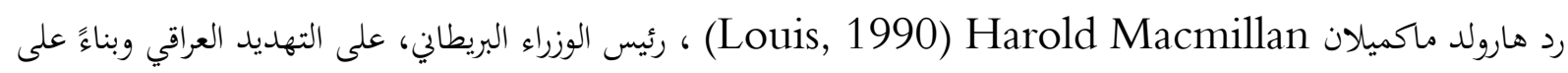

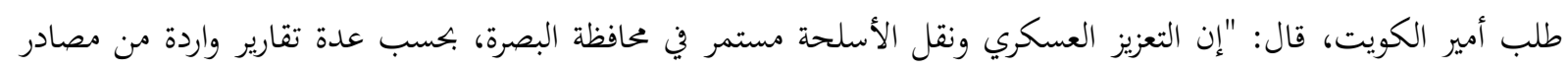

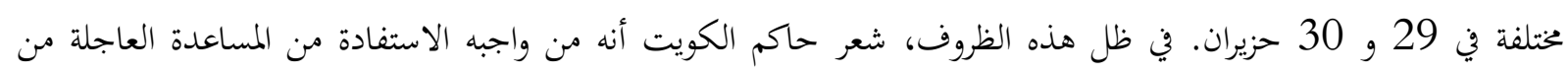

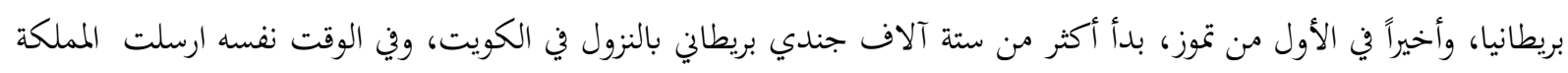

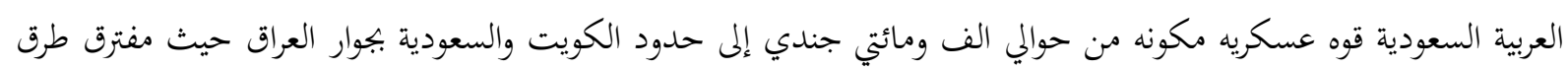

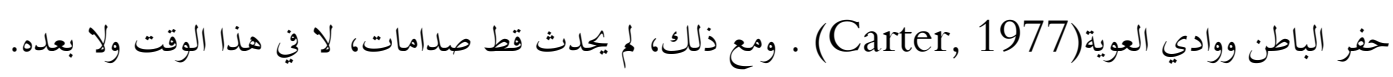

\section{موقف الإتحاد السوفيتي:}

لم يكن لإعلان استقلال الكويت في حزيران عام 1961 أي تأثير على الشؤون الخارجية السوفيتية. اذ رأت الحكومه السوفيتيه ان أمير الكويت ليس حاكماً لبلد محتل أو ملكًا يعتزم الحصول على الاستقلال لبلده (Philip, 2001) . وقد تأكد هذا الرأي حول الإتحاد السوفيتي من خلال وجود الاتفاق بين بريطانيا والكويت، والذي كان يعتبر إشارة إلى الاستعمار الجديد. ونتيجة لذلك، لم ترسل الحكومة السوفيتية برقية تُنئه إلى حاكم الكويت بمناسبة إعلان استقلال بلإد بلاده، ولم يتم 
ذكر الحدث إلا لفترة وجيزة في إحدى الصحف المحليه السوفيتيه التي ذكرت أن بريطانيا تمكنت من الاحتفاظ بموقعها في البلاد

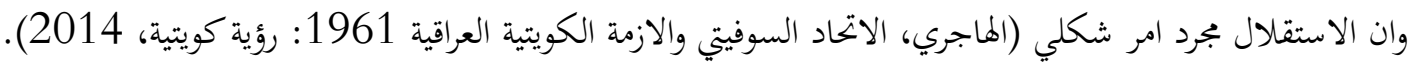
خلال الفترة القصيرة بين إعلان عبد الكريم قاسم رفضه لاستقلال الكويت والتدخل البريطاني انتقدت الصحف السوفيتية سياسة عبد الكريم قاسم، لكن لم يتم اتخاذ موقف دقيق، فقد تغير بعد انضمام القوات البريطانية بطلب من الأمير. عند

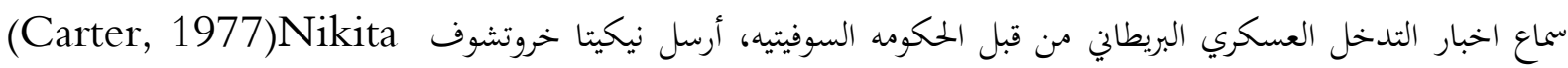
Sergeyevich Khrushchev موسكو Moscow، الذي أبلغه أن التدخل حدث وفقًا لتعهد سابق لالتزامات بريطانيا العظمى. وأعرب عن افتراضه أن الإتحاد السوفياتي فعل الشيء نفسه في هذا الوضع. وأضاف أن بريطانيا ستعتزم سحب قواتا عندما يتم ضمان سلامة الكويت. أكد خروتشوف للسفير البريطاني أنه استفسر للتو وتأكد من أنه حتى لو لم يفعل ذلك دون أي أي سبب، فلن يتخذ هو ولا دولته خطوات في هذا الشأن. إلا أن التدخل البريطاني وإعلان عبد الكريم قاسم كرد فعل على ذلك، والذي كشف عن عن رغبته في في الاستمرار في معركته من أجل عودة الأراضي الكويتية إلى العراق، بالوسائل السلمية، جعل من الممكن للإتحاد السوفيتي و - لفترة معينة من الزمن - لمصر لشن هجوم أيديولوجي، معلنة أن الصراع بين الشعوب العربية هو معركة ضد الإمبرياليين والمستعمرين (Philip, 2001)

وبهذا المعنى، كان تغيير الاتفاقيه في عام 1961 بمثابة مناورة بسيطة، وطموح جماعي لبريطانيا والكويت لتأكيد حكمهما الاستعماري والاحتفاظ بمكانتهما في الشرق الأوسط من أجل التغلب على الدول العبية التقدمية - مثل العراق والجمهورية العربية المتحدة - وحركات التحرر الوطني. لقد بتاهلوا ادعاء العراق، الذي يستند إلى حقوق تاريخية مشكوك فيها، وركزوا فقط على إنى الإنزال البريطاني الذي اعتبروه غير قانوين. والتي جعلت احتلال الكويت ممكنًا مرة آخرى. من ناحية آخرى، يمكن بهذه الطريقة ممارسة الضغط على الحكومة العراقية لسحب قانون كانون الأول 1960 الذي صدر بعد المفاوضات البريطانية العراقية بشأن النفط والتي حرمت شركة نفط العراق من امتيازاها. لم يكن الإتحاد السوفيتي والدول الاشتراكية الآخرى، على غراره، في نية قبول

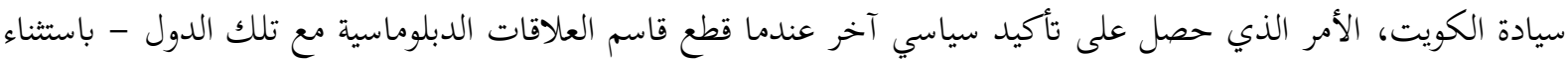
الصين - التي اتخذت موقفا بشأن الاستقلال الكويت بعد خطابه (Carter, 1977).

\section{مناقشة القضية الكويتية في مجلس الأمن:}

في نفس اليوم الذي نزلت فيه القوات البريطانية في الكويت، اجتمع بجلس الأمن التابع للأمم المتحدة لبحث الوضع. في

اليوم التالي، طالب ممثل العراق لدى الأمم المتحدة، عدنان الباجه جي (الهاجري، الاتحاد السوفيتي والازمة الكويتية العراقية

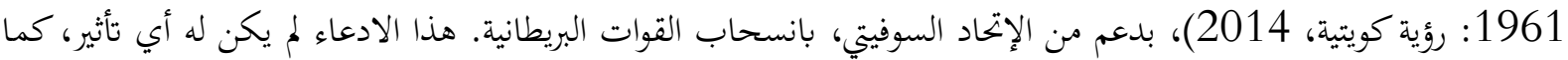

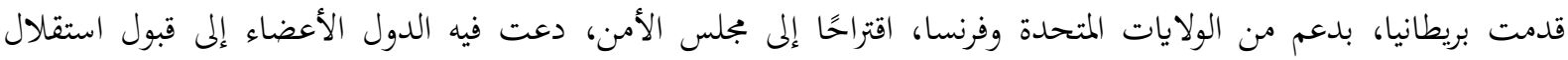

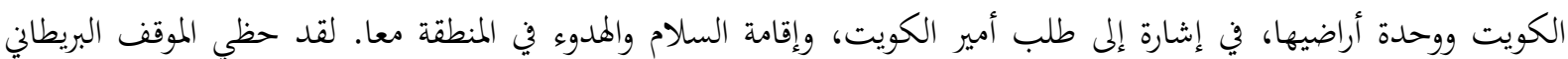
بدعم كامل من الحكومة الكويتية التي أعلن مثثلها: أن بلاده ساهمت في انسحاب القوات البريطانية بشرط أن تضمن الأمم المتحدة أها ستقدم يد العون في حالة حدوث أي نوع من العدوان من جانب العراق. وطالب بقبول الكويت في الأمم المتحدة

(Trevor, 1990)

فيما أعرب مثثل الإتحاد السوفيتي في مجلس الامن الدولي زورين Valerian Zorin عن احتجاجه بمناسبة اجتماع مجلس الأمن على المشاركة الوفد الكويتي في الاجتماع، لانه عد الكويت بلد محتل اذ تيمن السلطة البريطانية على الإدارة المحلية 
فيه. في هذه الحالة، لا يمكن اعتبار البلاد دولة مستقلة. وبسبب هذا، فقد استخدم حق النقض ضد الاقتراح الذي قدمته

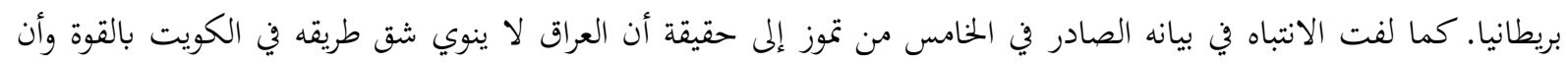

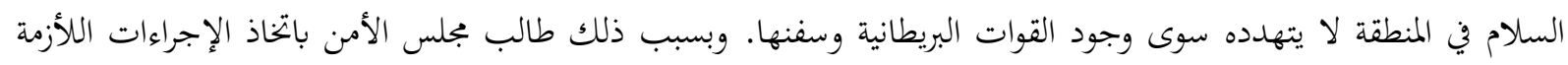

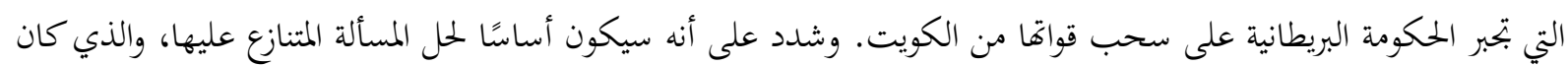

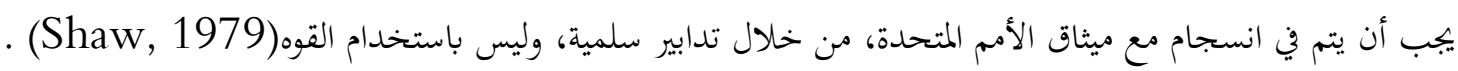
لم تعترف الجمهورية العربية المتحدة بسيادة الكويت بعد، بينما رفضت المطالب العراقيه بضم الكويت , تم تحديد وجهة

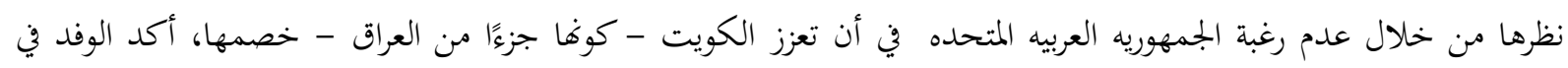

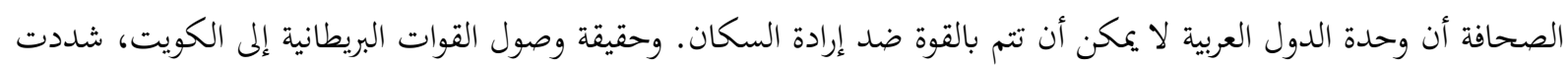
الدعاية المصرية على الشك في استقلال الكويت. فقد اعتبرت الدعاية أن دولة عربية تستخدم مساعدة دولة إمبريالية مثل بريطانيا

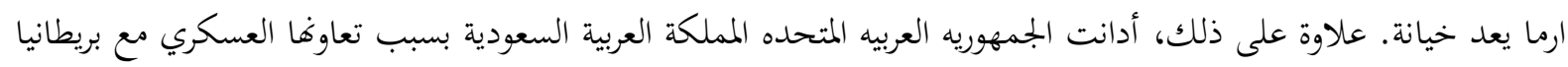

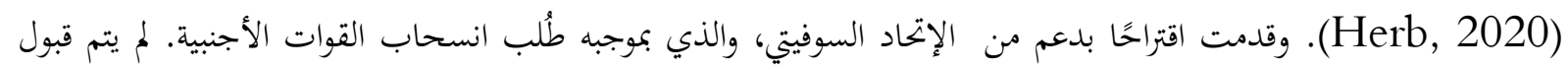

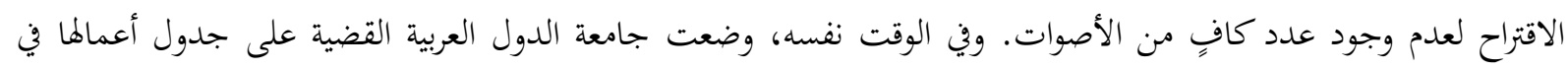

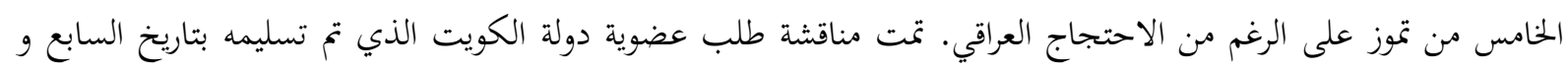

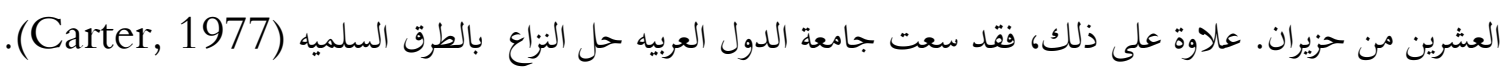

في فماية المفاوضات - في التاسع عشر من تموز عام 1961 تم اتخاذ القرارات التالية (Philip, 2001): 1. تتعهد حكومة الكويت بطلب انسحاب القوات البريطانية من الأراضي الكويتية في أقرب وقت مكمات عكن. 2. تتعهد العراق حكومة جمهورية العراق. بعدم استخدام القوة لضم الكويت للعراق.

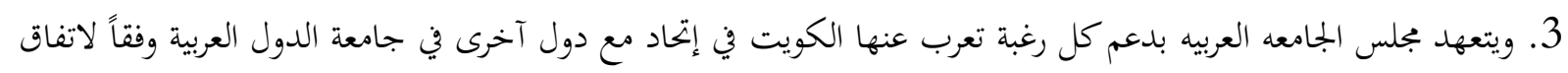
الجامعة. ويقرر المجلس الترحيب بدولة الكويت كعضو في جامعة الدول العربية. 4. ترحب الجامعة بتقديم المساعدة للكويت في الانضمام إلى الأمم المتحدة. 5. تتعهد الدول العربية بتقديم المساعدة الفعالة للمحافظة على استقلال الكويت. بناء على طلبها، ويمنح المجلس الأمين العام سلطة اتخاذ التدابير اللأزمة للتنفيذ العاجل لهذا القرار. كما اتفق امير الكويت ومحمد علي حسونة الأمين العام لجامعة الدول العربية على مسألة تكوين القوات العربية، و في

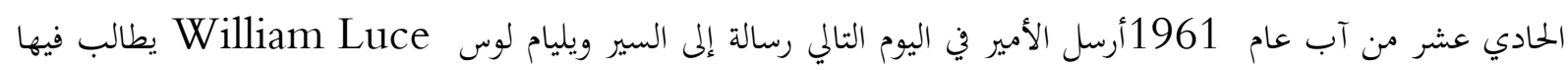

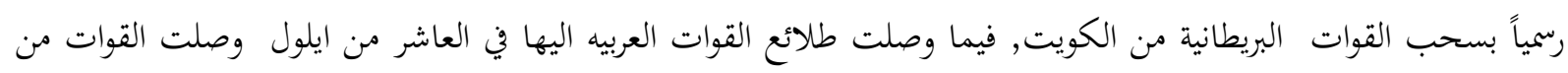

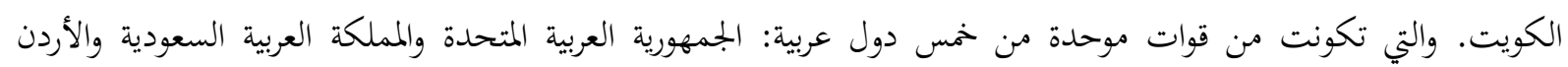

والسودان وتونس (Carter, 1977).

في منتصف تموز، بدا أن الإتحاد السوفيتي بمعزل عن الموضوع، وترك الدول العربية تحل الخلاف مع الأمل في أن الدعم

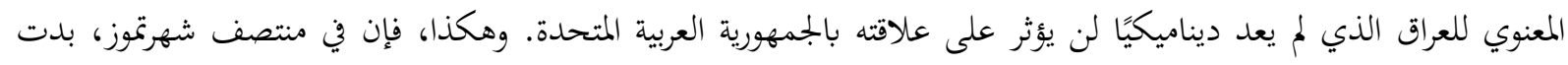

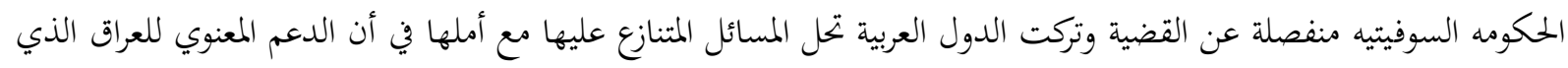

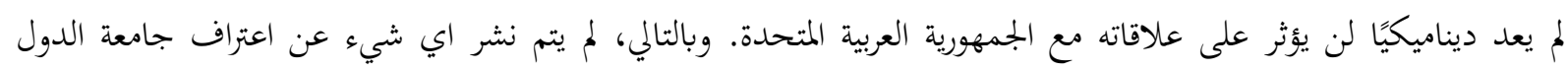

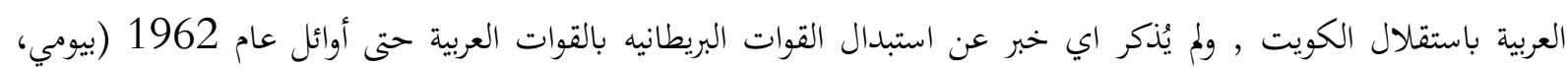


وقد تعززت وجهة النظر السوفيتية الثابتة في هذه القضية من خلال حقيقة أنه في الثلاثين من تشرين الثاني عام 1961 اقترحت الجمهورية العربية المتحدة الاعتراف بالكويت كعضو في الأمم المتحدة. واتخذ الإتحاد السوفياتي موقفا من تأجيل القضية،

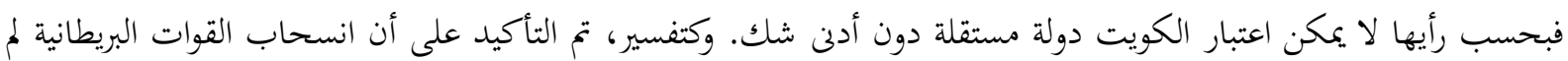
يؤسس لسيادة الكويت، لذا فإن الإتحاد السوفيتي لن يعترف بسيادة الكويت طالما كان الاتفاق مع معنى بريطانيا ساري المفعول

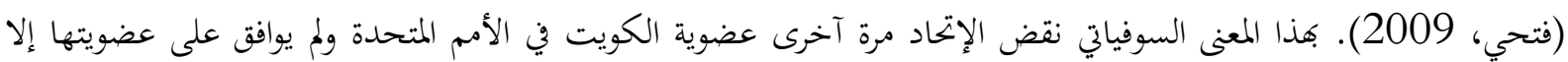
بعد سقوط حكومة عبد الكريم قاسم (بيومي، 2002).

أن انقلاب الثامن من شباط عام 1963 في العراق و الإطاحة بعبد الكريم قاسم احدث تغييرات جذرية في قضية الكويت. على الرغم من أن إدارة الجمهورية الجديدة بقيادة عبد السلام عارف (Trevor, 1990) لم تقدم إعلانا محددًا بشأن

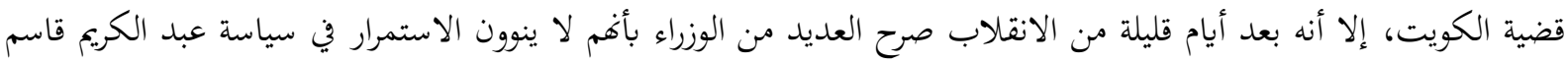

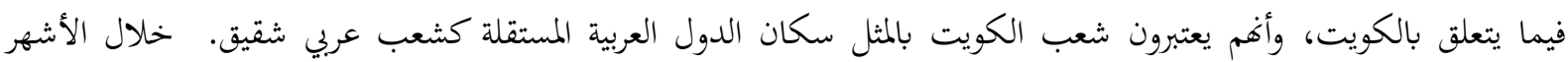

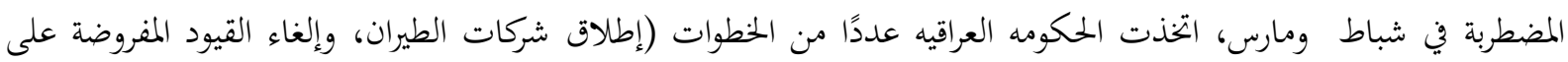
متطلبات التأشيرة، إعادة العلاقات الاقتصادية، واستقبال وفد حكومي كويتي غير رسمي في الفترة ما بين 21 و 24 مارس، إلخ.)

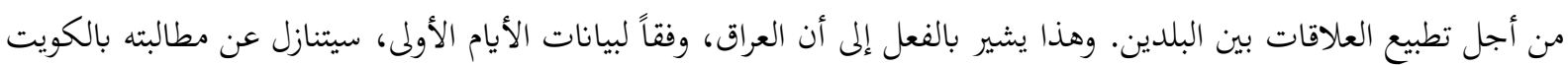

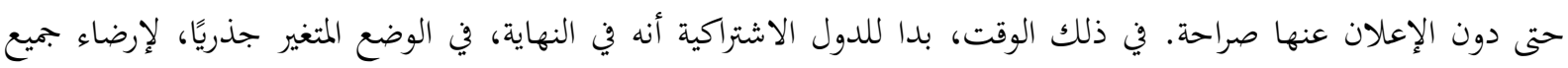

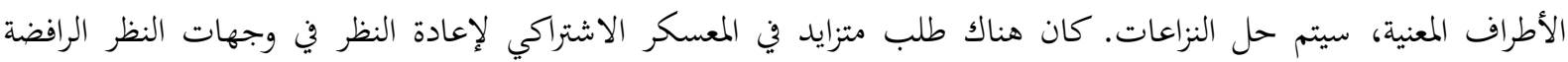
السابقة. لقد اعتبروا أن إقامة اتصالات مهمة في المقام الأول من وجهة نظر اقتصادية، ويف هذا الصدد، حكموات على الاعتراف

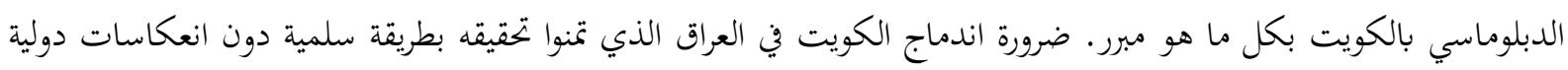
خاصة. ومع ذلك، فشلت الجهود ليس فقط بسبب إعادة تقييم وجهة النظر الاشتركية في شباط , ولكن أيضًا بسبب السياسات

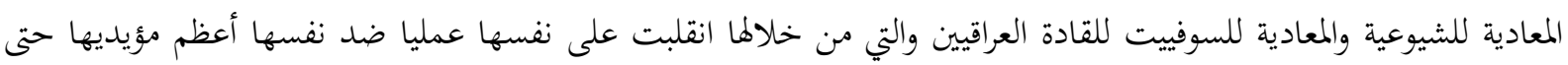
تلك النقطة. كواحدة من نتائج تدهور العلاقات العراقية السوفيتية، بعد أنسحاب قوات الجامعة الدول العربية من الكويت في في لئي

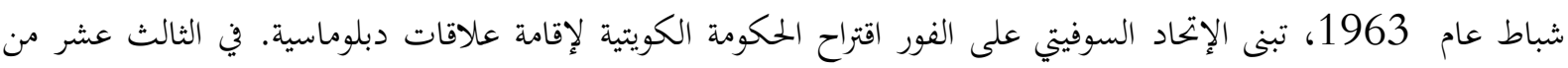
آذار اعترف الإتحاد السوفيتي رسميًا بالحكومة الكويتية بهدف إجبار العراق على إعادة النظر في سياساته حتى تلك النقطة

.(Shaw, 1979)

في نيسان عام 1963م قامت المغرب يبذل جهودًا للاعتراف بالكويت كعضو في الأمم المتحدة، ونتيجة لذلك، استدعوا

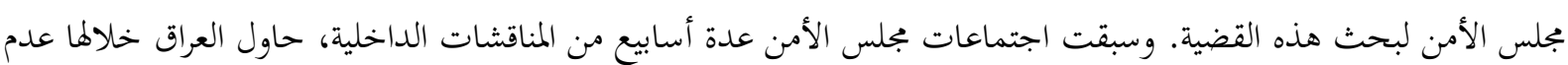

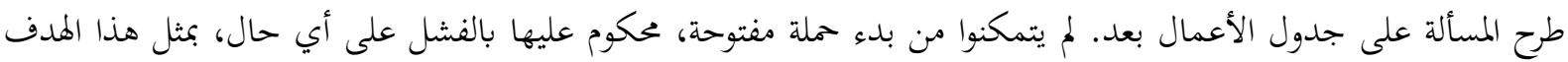
بعد تصريحات الثامن من شباط. وهكذا في بداية شهر أيار، أثناء محادثاتم مع السفراء الأجانب المنتدبين لدى العراق، أرأه أراد الوزراء

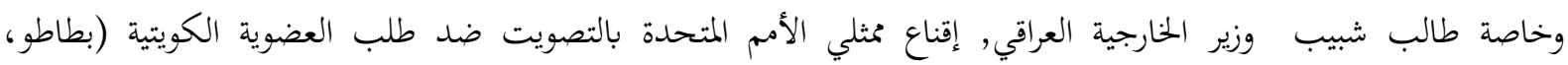

بحلول ذلك الوقت تغيرت بالفعل وجهة نظر الإتحاد السوفيتي بشأن الكويت، وكان يدعو بشدة إلى قبول الكويت في

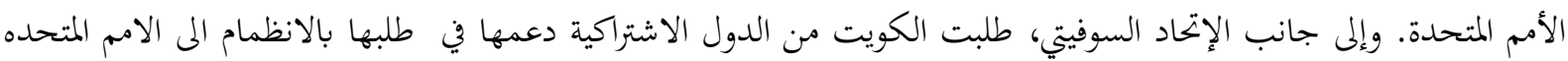

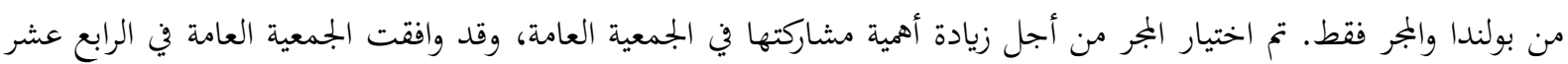

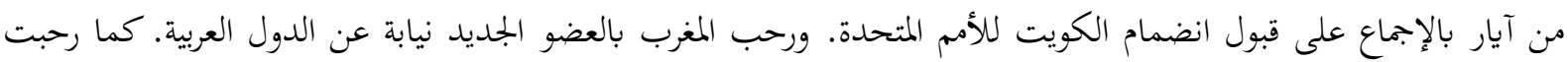


الجزائر بالامر وذكرت بالمساعدات التي قدمتها الكويت للجزائرين ابان الثوره ضد الاستعمار الفرنسي وبذلك أصبحت الكويت العضو رقم مئه واحد عشر في الأمم المتحدة (Trevor, 1990). إلى جانب فشل السياسة الخارجية، فقد شكل التدهور الاقتصادي أيضًا مشكلة خطيرة في العراق. رفضت الدول الغربية تقديم القروض له واقترحت بدلاً من ذلك أن يتحول العراق إلى الكويت التي تمتلك كمية كبيرة من الأموال الاحتياطية. لم

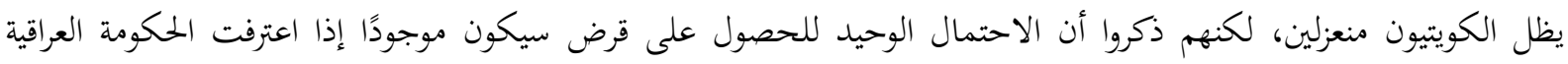

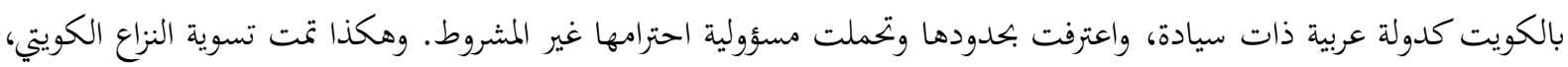

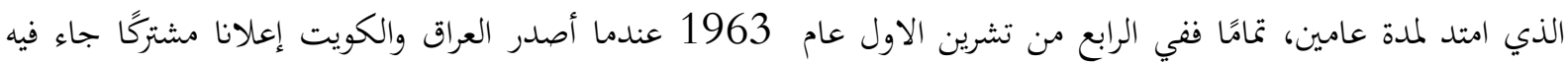
:(Trevor, 1990) 1. اعترفت جمهورية العراق باستقلال دولة الكويت وسيادتما الكاملة مع حدودها على النحو المحدد في رسالة رئيس وزراء العراق

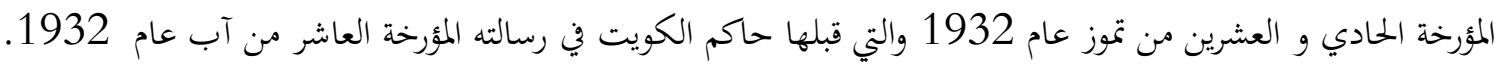

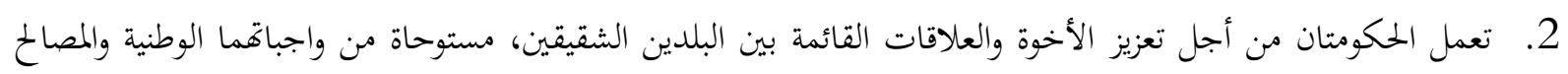
المشتركة والتطلع إلى وحدة عربية كاملة. 3. تعمل الحكومتان على إقامة تعاون ثقافي وبتاري واقتصادي بين البلدين وتبادل العلاقات بين البلدين. "من أجل تحقيق جميع

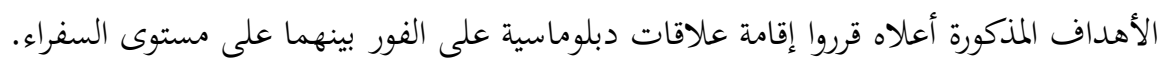
وبالتالي أكد عبد الله سالم الصباح أمير الكويت في خطابه في كانون الثاني عام 1963 في الدورة الأولى لمجلس الأمة

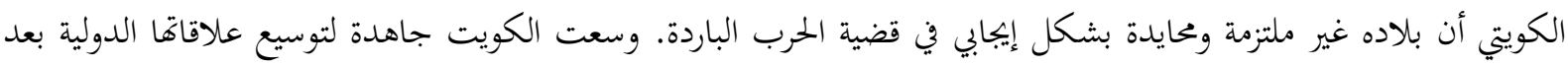

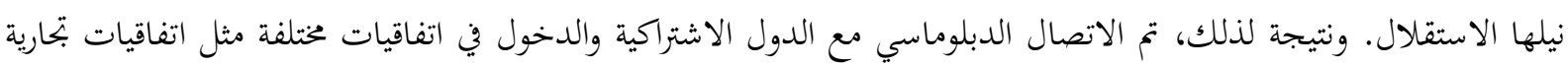
واتفاقيات لتنظيم حركة الطيران فضلاً عن الاتنفاقيات الثقافية (Shaw, 1979).

كان الإتحاد السوفيتي يتحين الفرصه للتغلغل في منطقة الشرق الأوسط ولاسيما الخليج العربي ذي الأهمية الاستراتيجيه الدوليه , لكن أزمة استقلال الكويت جعلت الإتحاد السوفيتي في موقف صعب فهو يرغب في التخلص من الوجود البريطاني في

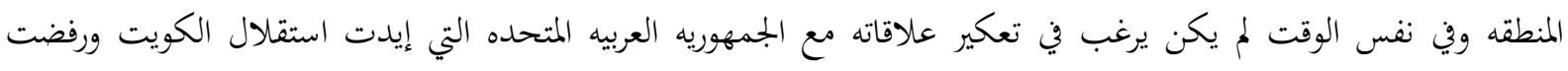

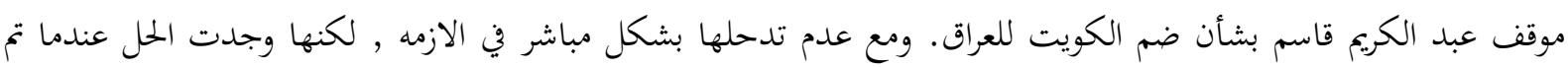

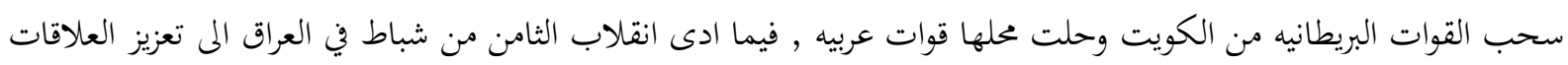
الكويتيه السوفيتيه لان حكومة الانقلاب العراقيه اعترفت باستقلال الكويت. 
Andrew, B. (1988). Iraq and world. London.

Bernard, V., \& Salles, J. F. (1999). Britain and Arab states. New York.

Carter, R. (1977). Kuwait. Washington.

Cooper, B. B. (1967). Britann and the Persian Gulf. Los Angeles.

Fred, H. (1989). Iraq and Arab states. London.

Herb, M. (2020). Iraq After Saddam. London.

Louis, B. (1990). Britain Modern History. London.

Philip, M. (2001). Kuwait Modern History. Washington.

Phyllis, B. (1990). Iraq under Qasim regime. New York.

Shaw, R. (1979). Soviet and Middle east States. London.

Slight, J. (1990). Kuwait and Britain until 1990. London.

Trevor, B. (1990). Soviet and Arab world. London.

$$
\begin{aligned}
& \text { أوريل دان. (2012). العراق في عهد عبدالكريم قاسم (المجلد 1). (جرجيس فتح الله، المترجمون) دار اراس للطباعة والنشر. } \\
& \text { حسن العلوي. (1995). اسوار الطين: في عقدة الكويت وايديولوجية الضم (المجلد 1). بيروت: دار الكنوز الادبية. } \\
& \text { حنا بطاطو. (1992). الشيوعيون والبعثيون والضباط الاحرار (المجلد 1). بيروت: مؤسسة الابحاث العربية. }
\end{aligned}
$$

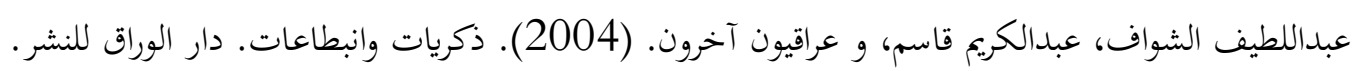

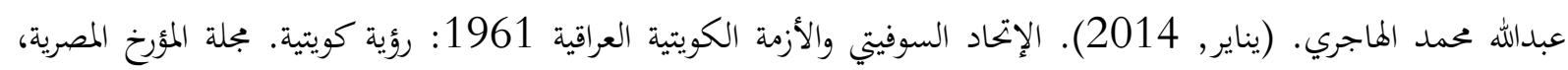

$$
\begin{aligned}
& \text { جامعة القاهرة، صفحة } 272 . \\
& \text { عبدالله محمد الهاجري. (يناير, 2014). الإتحاد السوفيتي والأزمة الكويتية العراقية 1961: رؤية كويتية. مجلة المؤرخ المصري، } \\
& \text { صفحة } 272 . \\
& \text { كامل ممدوح فتحي. (2009). تاريخ الانقسام العربي. بيروت. } \\
& \text { ليث عبدالحسين الزبيدي. (1981). ثورة } 14 \text { تموز } 1958 \text { في العراق (المجلد 2). بغداد، العراق: منشورات مكتبة اليقضة } \\
& \text { العربية. } \\
& \text { محمد الشمري. (2011). تاريخ الكويت الحديث. الكويت: مطبعة خيطان. } \\
& \text { محمد طلعت بيومي. (2002). الجامعة العربية وقضايا العرب. القاهرة. } \\
& \text { منصور جاسم العتبي. (1998). تاريخ الكويت السياسي الحديث (الجملد 3). الكويت. }
\end{aligned}
$$




\title{
THE ROLE OF SCHOOL ADMINISTRATION IN INCREASING THE EFFECTIVENESS OF ASSISTIVE TECHNOLOGY FOR STUDENTS WITH SPECIAL NEEDS
}

\author{
Naaila Jeries HADDAD ${ }^{1}$
}

\section{Istanbul / Türkiye \\ p. 69-89}

Received: $28 / 11 / 2021$

Accepted: $11 / 12 / 2021$

Published: 01/01/2022

This article has been scanned $t$ iThenticat No plagiarism detected

\begin{abstract}
:
The current study aimed to identify the role of school administration in increasing the effectiveness of assistive technology for students with special needs. To achieve the goal of the study, the descriptive approach was used, as the study tool was developed, which consisted of six areas, which were distributed to male and female teachers in Arab schools in Israel, which consisted of (312) teachers, and the results showed a medium degree for the role of school administration in increasing the effectiveness of assistive technology for students with special needs. The results also showed that there were no statistically significant differences for the role of school administration in increasing the effectiveness of assistive technology for students with special needs, attributed to the main study variables.
\end{abstract}

Key words: School Administration, Assistive Technology, People With Special Needs.

http://dx.doi.org/10.47832/2717-8293.15.6 


\section{دور الإدارة المدرسية في زيادة فعالية التكنولوجيا المساندة لطلاب ذوي الاحتياجات الحخاصة}

\section{نائلة جريس حداد 2}

\section{الملخص:}

هدفت الدراسة الحالية التعرف إلى دور الإدارة المدرسية في زيادة فعالية التكنولوجيا المساندة لطلاب ذوي الاحتياجات الخاصة، ولتحقيق هدف الدراسة، تم استخدام المنهج الوصفي، حيث تم تطوير اداة الدراسة والمكون من ستة بجالات، تم توزيعها على المعلمين والمعلمات في المدارس العربية في الداخل الفلسطيني في لواء الشمال والتي تكونت من (312) معلمًا ومعلمة، وقد أظهرت النتائج وجود درجة متوسطة لدور الإدارة المدرسية في زيادة

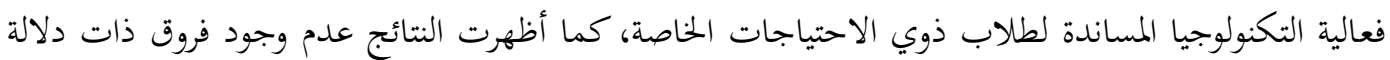
احصائية لدور الإدارة المدرسية في زيادة فعالية التكنولوجيا المساندة لطلاب ذوي الاحتياجات الخاصة، تعزى إلى متغيرات الدراسة الرئيسة. الكلمات المفتاحية: الإدارة المدرسية، التكنولوجيا المساندة، ذوي الاحتياجات الخاصة.

تحتاج عملية التعلم والتعليم إلى تطوير وتحسين في ضوء التقدم العلمي والتكنولوجي الهائل في مختلف مناحي الحياة؛ من

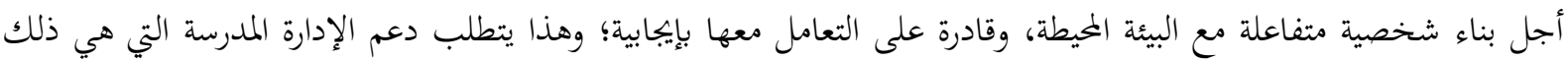

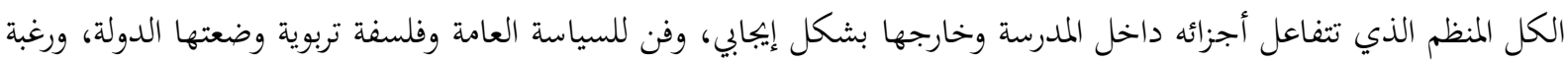

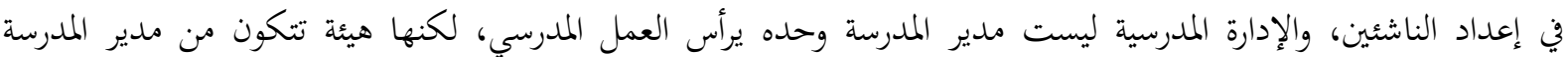
ومساعديه من وكلاء ومعلمين إداريين وفنيين كل حسب مسؤولياته ومهامه ومتطلبات عمله، حيث يعمل الجميع في قسمه بروح

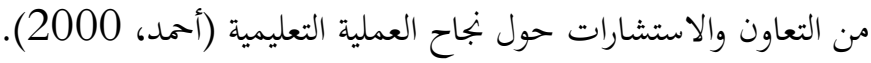

من هنا نرى أن الإدارة المدرسية من خلالها تحقق أهداف لمجتمع وآماله وتطلعاته، حيث تقوم ببناء الشخصية السليمة في كافة الجوانب العقلية، والجسمية، والاجتماعية، والانفعالية، وإعداد القوى البشرية القادرة على الإنتاج. فلم تعد وظيفة الإدارة

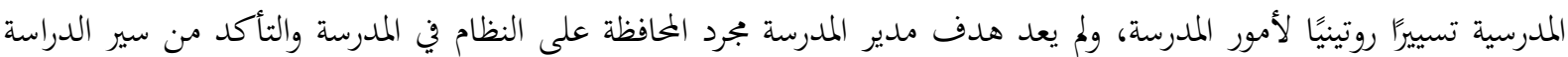

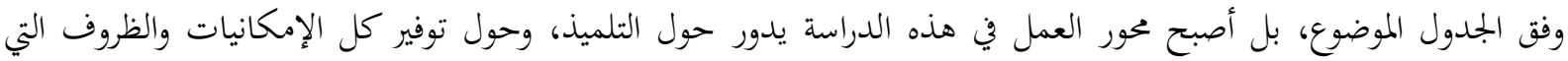

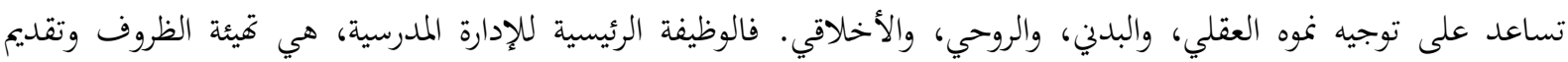
الخدمات التي تساعد على تربية التلاميذ وتعليمهم رغبة في تحقيق النمو المتكامل لهم، وذلك لنفع أنفسهم وبجتمعاقم (أحمد،

فللإدارة المدرسية وظائف ذات جانبين (إداري، وفني) ويخدم كل منهما الآخر بما يحقق أهداف المدرسة، إلا أن المدارس

$$
\text { العربية تعطي كل الاهتمام للجوانب الإدارية وتغفل الجوانب الفنية على الرغم من أهميتها وضرورةتان. }
$$

إن الدور الذي تقوم به الإدارة المدرسية يعد دورًا ضروريًّ؛ في بجال تقديم الدعم فيما يتعلق بالتكنولوجيا المساندة للطلبة ذوي الاحتياجات الخاصة. أصبح الأشخاص الذين يعانون من إعاقات سمعية وبصرية وفكرية وحركية واضطرابات وطيف التوحد 
قادرين الآن على التخلص من إعاقتهم أو التخفيف من آثارها السلبية، والتواصل مباشرة مع المجتمع والاندماج والمشاركة فيه. بشكل عام، مع هذه التكنولوجيا المتقدمة، يمكن للأشخاص ذوي الاحتياجات الخاصة أداء جميع الأعمال التي يقوم بها الآخرون. مثل: القراءة والكتابة والرسم والترجمة والتواصل مع العالم والحصول على المعلومات التي يحتاجوفها. وفي هذا الإطار تمثل التكنولوجيا أهميةً بالغةً لذوي الإعاقات بما أحدثثه من تغير في حياة الفرد والمجتمعات، كما أن

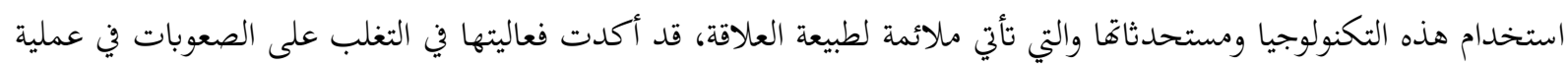
التعليم وسد الفجوة نتيجة الإعاقة بغض النظر عن نوعها فيما توفره من فوائد تعود على ذوي الإعاقات من الناحية النفسية، والأكاديمية، والاجتماعية، والاقتصادية (مرزوق، 2010).

تعتبر تكنولوجيا التعليم المساندة من الوسائل الفعالة في التعليم، حيث تعتمد على الأساليب العلمية الحديثة في التعليم بدلًا

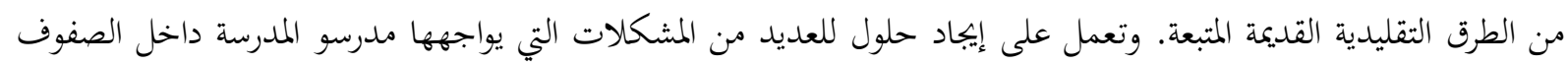

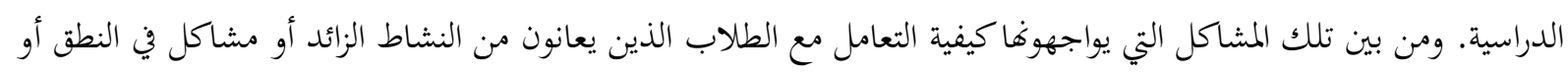
مشاكل في السمع وغيرها في المرحلة الابتدائية. يواجه المعلمون صعوبة كبيرة في كيفية التعامل مع هؤلاء الطلاب بلئية بطريقة حضارية.

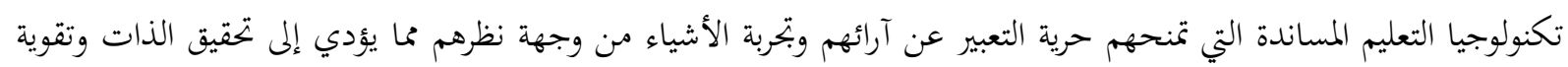

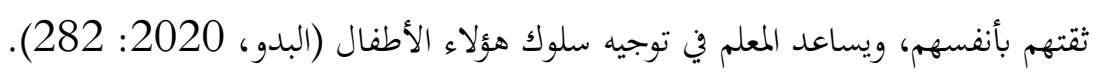
تتطلب خصائص الطلاب ذوي الاحتياجات الخاصة التعليمية والمعرفية واللغوية والعاطفية الاجتماعية إجراء تغييرات

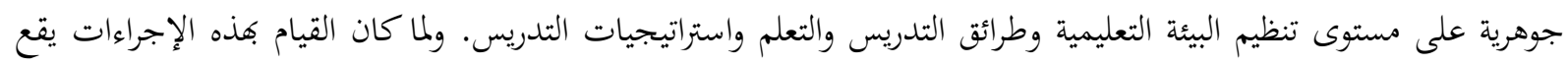

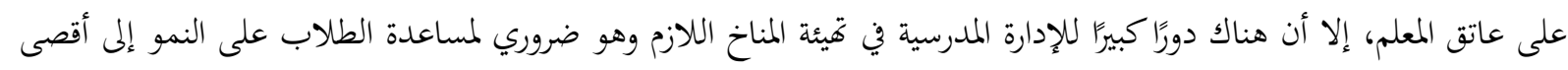

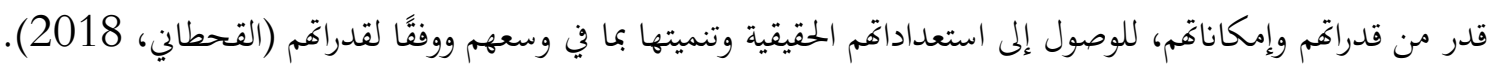

\section{متطلبات ذوي الاحتياجات الخاصة من تكنولوجيا التعليم، وفيما يلي شرح مبسط لهذه المنطلبات:}

1- الدراسة والتحليل: قبل اتخاذ قرار بشأن تكنولوجيا التعليم لذوي الاحتياجات الخاصة، يجب إجراء دراسات تمدف إلى تحليل مشاكل ذوي الاحتياجات الخاصة، تقييم احتياجاهم التعليمية وتحليل خصائص كل فئة والمقررات الدراسية الموجهة إليهم. وتحليل الموارد والمعوقات البيئية والتعليمية. 2- التصميم والتطوير: وهذا يتطلب وضع مواصفات ومعايير علمية محددة ودقيقة لتصميم كل مصدر تعليمي لكل فئة منها، وتصميم الموارد وتطويرها بطريقة منهجية سليمة، وإنشاء مركز تكنولوجيا تعليم مركزي متخصص وفي في إنتاج الموارد والأنظمة التعليمية.

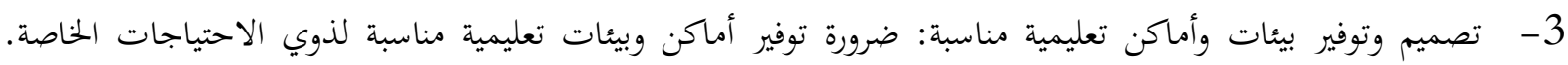
تشمل هذه البيئات: المباني المدرسية ومراكز مصادر التعلم والمكتبات المدرسية الشاملة.

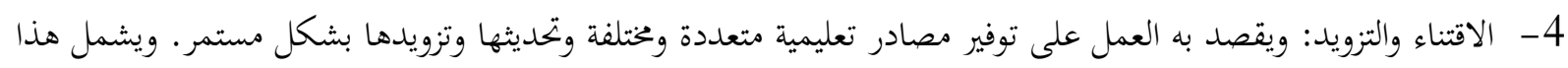

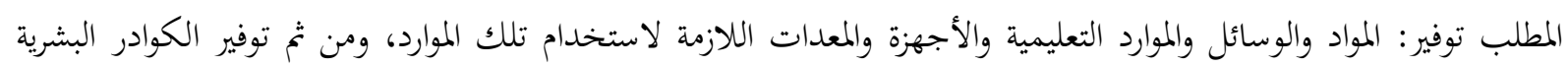
المؤهلة والمدربة لتوظيف تلك الموارد. 5- المتابعة والتقويم: يجب إنشاء إدارة متخصصة للمتابعة والتقويم وتشمل مهامها: متابعة وتقييم الموارد البشرية وغير البشرية،

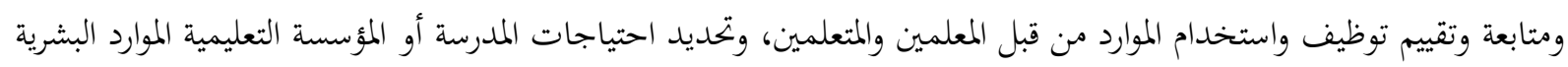
وغير البشرية، تم كتابة التقارير ورفعها إلى المسئولين لتوفيرها. 
6- التدريب: التدريب مطلب ملح لنجاح أي برامج تطويرية، ويشمل التدريب تدريب المجموعات التالية: معلمو الأشخاص

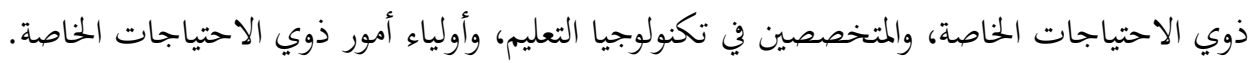

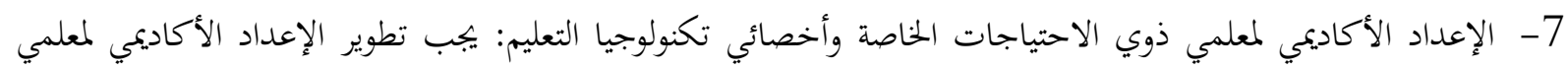
ذوي الاحتياجات الخاصة وأخصائي تكنولوجيا التعليم لتلك الفئة بكليات التربية. 8- التوعية والإعلام: وهو مطلب أساسي لتوعية المعلمين والمتخصصين في تكنولوجيا التعليم وأولياء أمور ذوي الاحتياجات الخاصة في تلك الفئة، ويتطلب ذلك ما يلي: عقد محاضرات وندوات ومؤتمرات وورش عمل، وإنشاء مركز تعليمي، وقناة تلفزيونية لذوي الاحتياجات الخاصة وتصميم مواقع على شبكة الإنترنت. 9- النشر والتوظيف والتبني: يجب ألا تتوقف تكنولوجيا التعليم عند تصميم وتطوير المنتجات والابتكارات التكنولوجية لذوي

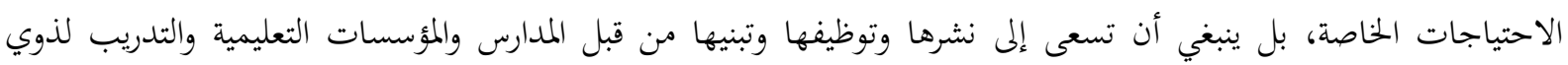
الاحتياجات الخاصة (عبد العاطي، 2014).

وقد أدى التعليم الخاص لذوي الاحتياجات الخاصة دورًا رائدًا في استخدام أجهزة الحاسوب والتقنيات التكنولوجية الأخرى

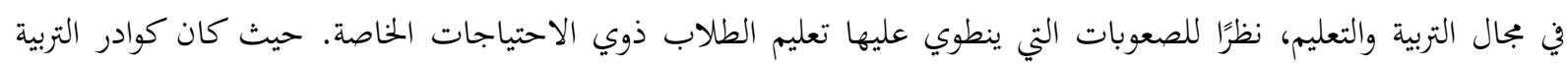

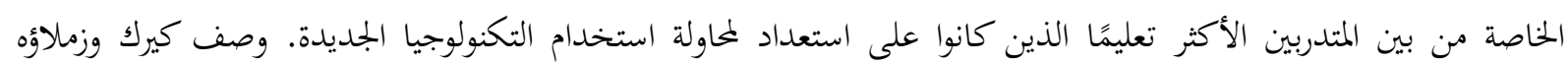

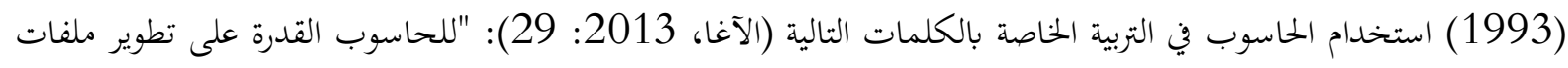
تخزين المعلومات وتنظيم وعرض النصوص والفيديو والمعلومات الرقمية وتوفير وصول سهل للمعلومات والبرامج، وتتيح للطفل التعلم

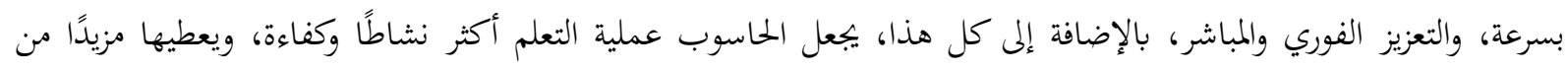

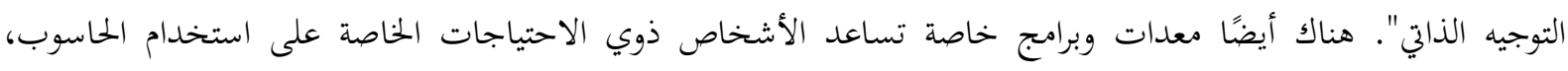

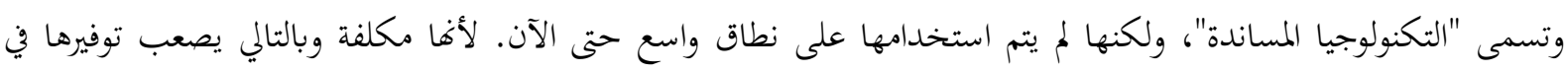

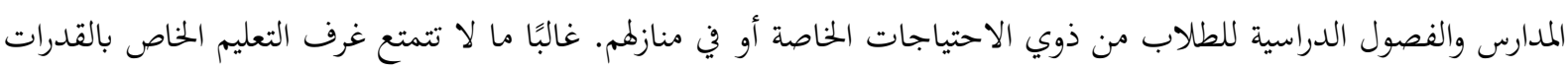

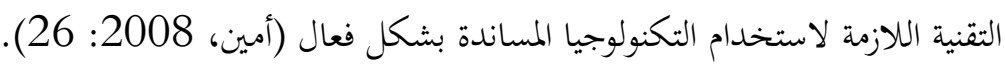

يتحمل معلمو التربية الخاصة المسؤولية الرئيسية في توفير المداخل المناسبة لتقديم المناهج للطلاب ذوي الاحتياجات

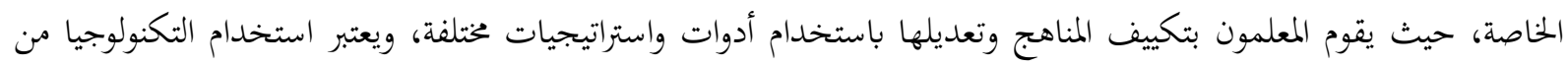

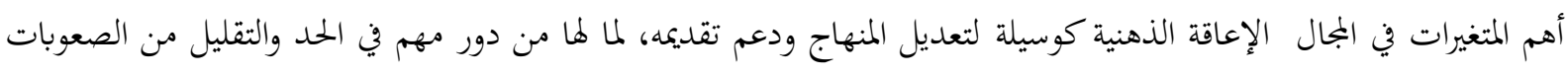

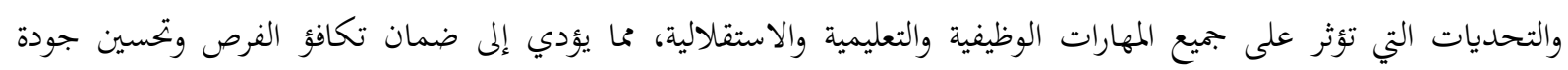

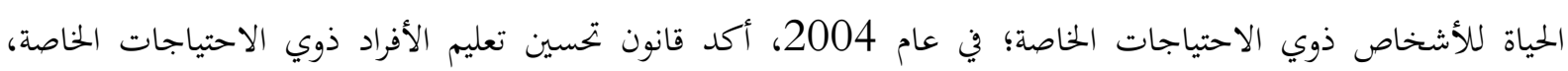

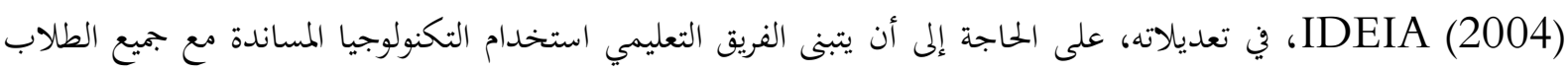
ذوي الاحتياجات الخاصة.

وهذا الاعتماد يتطلب تحديد الوسائل التكنولوجية المناسبة لإدراجها ضمن الخطة التربوية الفردية للطالب، وبالتالي،

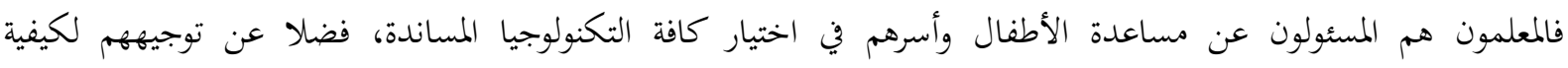

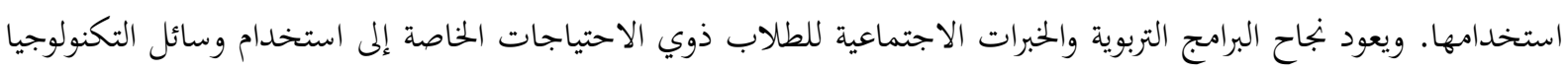

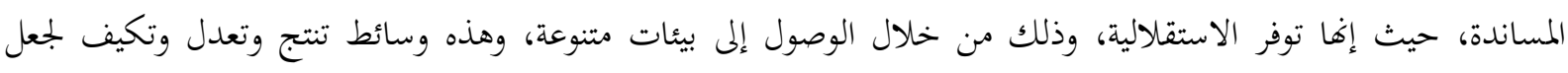

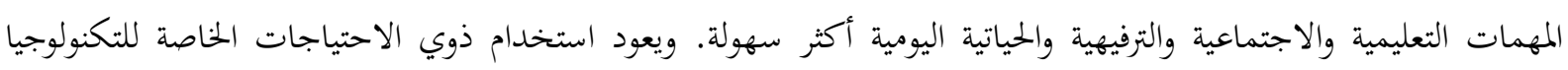

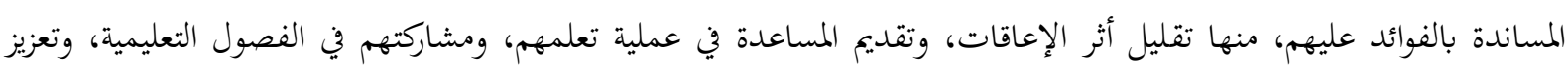

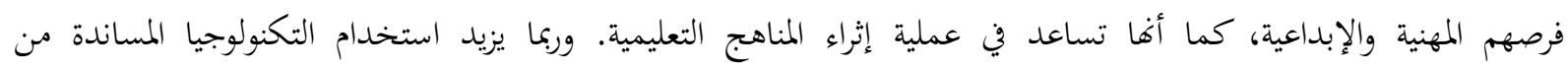


الاستقلالية، وتدعيم التقدير الذاتي والثقة بالنفس لكل طالب، وتشجيع التعاون بين الطلبة، ولا سيما ذوي الاحتياجات الخاصة،

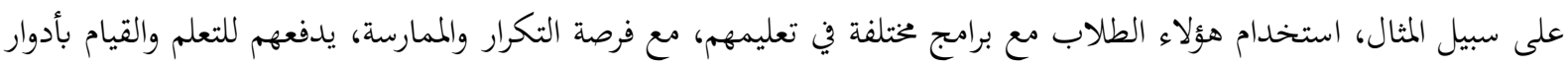
نشطة في جميع مجالات حياتم. وقد تقلل التكنولوجيا المساندة من الاعتماد على الآخرين، وتحكمهم في بيئتهم، كما أهنا

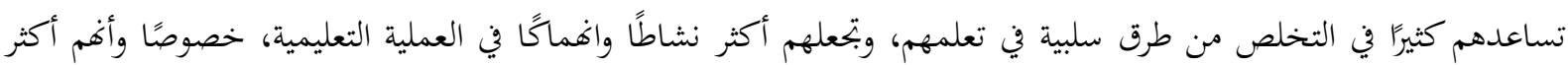

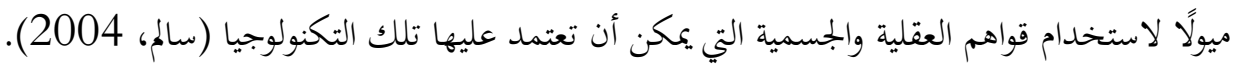

\section{لكل إنسان الحق في العيش بمساواة، كرامة، راحة واستقلاليّة.}

هذا الحق أيضا يشمل الأشخاص مع إعاقة، إذ يحق لهم كذلك العيش حياةً طبيعيّة مثل الآخرين. من أجل تحقيق هذا الهدف مطلوب وجود الاتفاقيات والنصوص بهذا الشأن لتمكين الأشخاص مع إعاقة من الوصول إلى كلّ مكان، والمشاركة التهاه والاندماج بالمجتمع بتساوٍ، واحترام واستقلاليّة قصوى.

والسبب في توفّر الإتاحة هو الأشخاص مع إعاقة حيث إن ما يقارب الـ 18\% من المجتمع في الداخل الفلسطيني هم أشخاص مع إعاقة منها: الإعاقات الجسدية، إعاقات حسية (البصر والسمع)، إعاقات عقليّة ونفسيّة. وفقا لبيانات لدائرة الإحصاء المركزيّة، يعيش في الداخل الفلسطيني ما يقارب الـ 1,440,000 إنسان مع إعاقة، مما يعني أنه تقريبا في كل عائلة من بين ستّ عائلات في الداخل الفلسطيني يوجد شخص مع إعاقة، وذلك بغضّ النظر عن ديانته، عرقه،

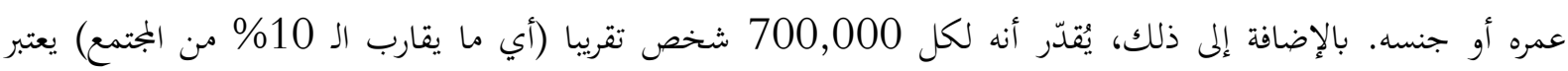
موضوع الإتاحة مسألة حاسمة وبالغة الأهميّة. إن الشخص مع إعاقة يتمّ تعريفه وفقا لقانون المساواة في الحقوق للأشخاص مع إعاقة والذي سنّ عام 1998، إذ ينصّ القانون على أن "إنسان مع إعاقة جسدية، نفسيّة أو عقليّة، ثابتة أو مؤقتة، والتي بسببها يكون الإنسان محدود إلى لئل حدّ كبير بأدائه في مجال واحد أو أكثر من بجالات حياته الأساسيّة".

\section{تعريف "الإناحة" وفقا لقانون المساواة بالحقوق للأشخاص مع إعاقات 1988:}

"التمكن من الوصول إلى كل مكان، التحرّك به ومعرفته، استخدامه والاستمتاع من الخحدمات التي يقدّمها، الخصول على

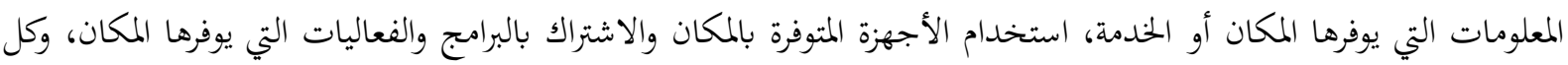
هذا يجري بمساواة، واحترام، واستقلالية وأمان".

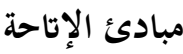

يوجد مبدأين أساسيين في موضوع الإتاحة وهما "مبدأ الاندماج" و "مبدأ التسلسل"

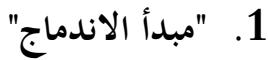
الأشخاص مع إعاقة هم جزء لا يتجزأ من المجتمع والجمهور الواسع، بالتالي هم متساوي الحقوق مع الآخرين، إذ يحق لمم العيش، والاندماج من دون تمييزهم أو إقصائهم من الآخرين. 


\section{2. - 2}

وفقا لهذا المبدأ، على أي إنسان مع إعاقة أن يصل لأي مكان يقصده وأن يحل على نفس الخدمات المتوفرة تماما مثل أي

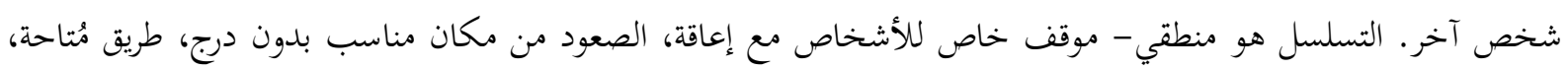

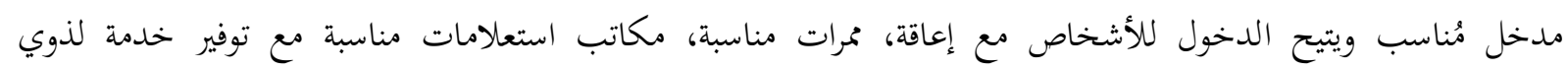

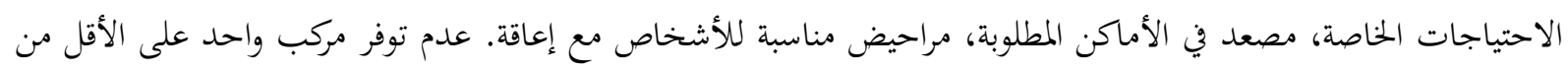

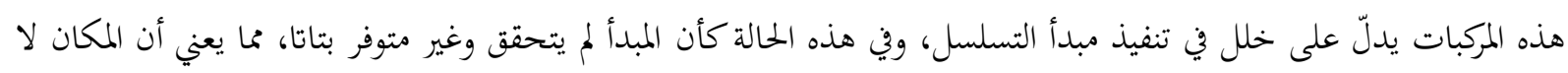
يوفر الإتاحة المطلوبة.

شُرّع فصل "الإتاحة" عام 2005، وذلك في إطار قانون المساواة في الحقوق للأشخاص مع إعاقة (منذ عام 1998).

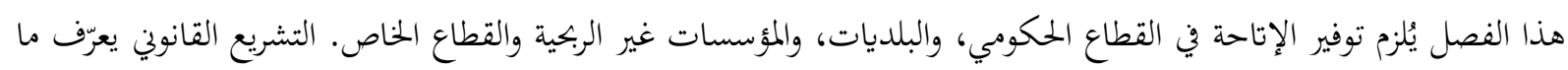

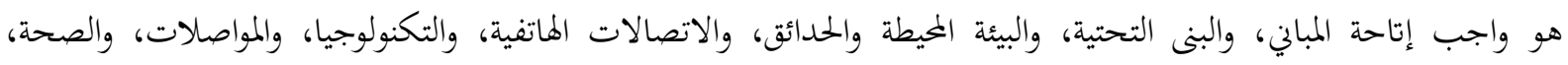

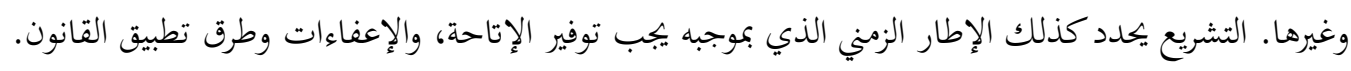

إتاحة الخدمات

القوانين الثانوية الخاصة هذه تتطرّق لكل ما يُطلب عمله بالإضافة لإتاحة المباني، وكذلك تتطرّق القوانين إلى سؤال

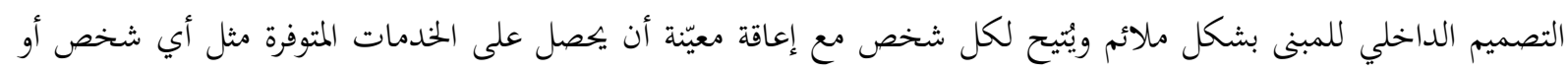

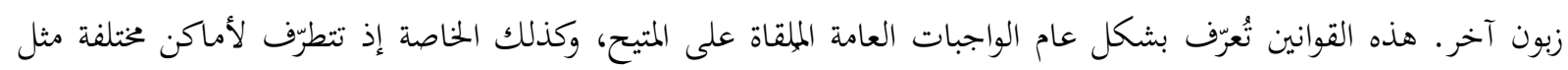

المطاعم، الفنادق، المكتبات وغيرها.

$$
\begin{aligned}
& \text { في إطار هذه القوانين الثانوية، مطلوب الأخذ بالحسبان والاهتمام بالجمالات التالية: } \\
& \text { 1. تصميم داخلي يوفّر الإتاحة }
\end{aligned}
$$

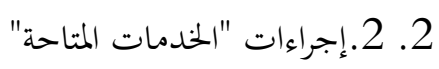

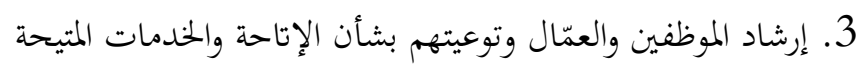

$$
\begin{aligned}
& \text { 4. إتاحة الإنترنت } \\
& \text { 5. إتاحة مركز الاتصالات وأجهزة توجيه المحادثات } \\
& \text { 6. إتاحة الإعلانات } \\
& \text { 7. إتاحة المعلومات }
\end{aligned}
$$

8. إتاحة وسائل التكنولوجيا كجزء من الخدمات، الاستعانة أيضا بأجهزة مثل الصراف الآلي، آلات دفع النقود لموقف

$$
\begin{aligned}
& \text { السيارات وغيرها. } \\
& \text { 9. أجهزة تكنولوجية مُساعدة } \\
& \text { 10. إتاحة مركز خدمات الجمهور تكوجية مُعدة } \\
& \text { 11. إتاحة المناسبات والمعارض والمؤتمرات (دليل المتيح، } \\
& \text {.(https://www.aisrael.org/?CategoryID=3171 }
\end{aligned}
$$

يتمثل أحد أهداف التعليم المنصوص عليها في قانون التعليم في الداخل الفلسطيني في "توفير فرص متكافئة لكل فتى وفتاة،

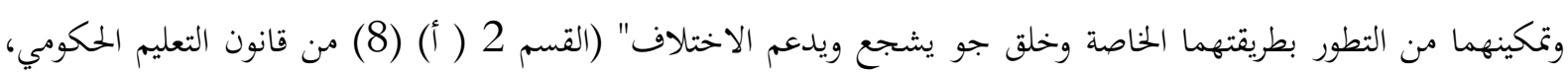


1953). حوار مهم بين الطلاب والمعلمين والموظفين وأولياء الأمور والمجتمع، وتصميم بيئة تعليمية وتوفير استجابة مثالية لجميع الطلاب، وهذا الحوار يمكّن الطلاب والموظفين من أن يكونوا أشخاصًا شاملين.

وفقًا للجزء ب من المادة 7 من قانون المساواة في الحقوق للأشخاص ذوي الإعاقة، 5758-1998 (المشار إليه فيما

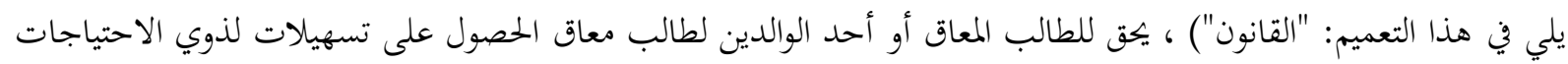
الخاصة سيسمح له ذلك بالوصول إلى قدراته والتعلم والقيام بدور نشط في جميع أنشطة المؤسسة التعليمية وكذلك الطلاب وأولياء الأمور الآخرين بطريقة متساوية، ومحترمة، ومستقلة، وآمنة.

بموجب هذا القانون، وضع وزير التعليم اللوائح التي تتناول التعديلات المطلوبة لإمكانية الوصول الفردي - اللوائح رقم

يشترط القانون واللوائح ملكية المؤسسة التعليمية لإتاحة الوصول إلى كل من المؤسسات التعليمية والخدمات التعليمية التي

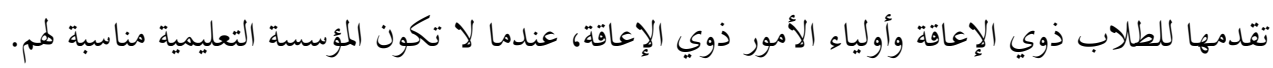
تتضمن اللوائح تفاصيل حول الأنواع الممكنة لإمكانية الوصول المقدمة للطالب الذي يدرس في نظام التعليم وللوالد المعاق الذي يأتي إلى المؤسسة التعليمية (عندما قد تكون هناك وسائل راحة إضافية غير مدرجة هناك). نوضح أن إمكانية الوصول في نظام التعليم هي إمكانية وصول فردية للطالب فيما يتعلق باحتياجاته الشخصية ويتم

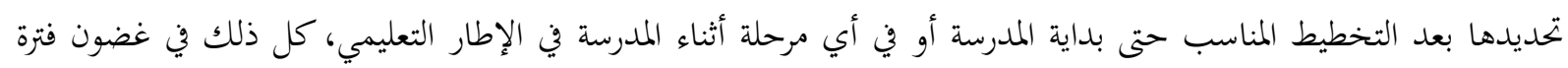
زمنية معقولة وبسرعة.

يجب أن بحري ملكية مؤسسة تعليمية (سلطة محلية أو ملكية) على الفور تعديلات إمكانية الوصول التي يمكن إجراؤها بالوسائل الموجودة في حوزتما.

ستكون ملكية مؤسسة تعليمية، أي سلطة محلية أو شركة مُنحت ترخيصًا لتشغيل مؤسسة تعليمية، والتي ينطبق عليها الالتزام بإمكانية الوصول، مسؤولة عن ضمان أن تكون تعديلات إمكانية الوصول مناسبة ومتاحة. نؤكد أن مالك مؤسسة تعليمية أو أي شخص آخر لن يفرض رسومًا على شخص من ذوي الإعاقة بسبب تقديم طلب وبسبب إجراء تعديلات إمكانية الوصول اللازمة لجعل الخدمة في متناوله بموجب لوائح إمكانية الوصول.

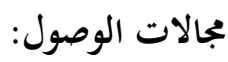
- تسهيلات الوصول الجسماني: الطلاب ذوو الإعاقة، على سبيل المثال: الإعاقات الجسدية وضعف السمع وضعاف البصر،

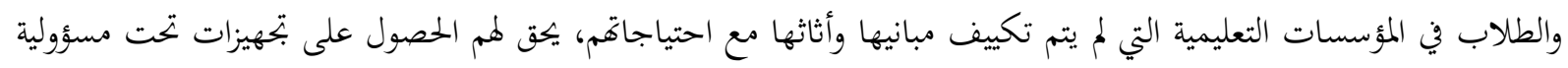
المؤسسة التعليمية أو من خلالها المساواة إذا رغب المالك في الحصول على مشاركة من وزارة التربية والتعليم، فعليه الاتصال بالوزارة لهذا الغرض والعمل وفقًا للإجراءات. - تسهيلات الوصول في الجمال التبوي: الطلاب ذوو الإعاقة الذين كانوا مؤهلين للحصول على خدمات التعليم الخاص والذين

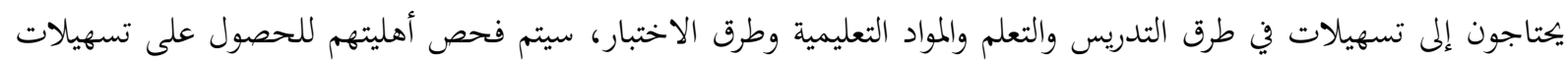
من قبل طاقم المدرسة التعليمي والعلاجي الملائم. 
- بخصوص التسهيلات في امتحانات البجروت للطلاب غير المؤهلين لحدمات التربية الحاصة: يجب على المدرسة اتباع

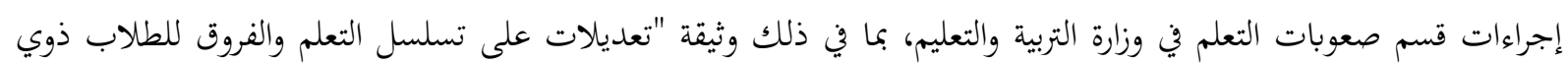
صعوبات التعلم و ADHD - للطلاب المؤهلين للحصول على خدمات التربية الخاصة: يجب اتباع الدليل الإلكتروني "تلام في التربية الخاصة" وكتيب "إنشاء قاعدة التقارير".

- تسهيلات الوصول في الجال التربوي-التكنولوجي: الطلاب ذوو الإعاقة الذين يحتاجون إلى بحهيزات تقنية مساعدة سيحصلون على أهليتهم للحصول على مساعدات تم فحصها من قبل الهيئات المهنية ذات الصلة وفقًا للإعاقة (خبراء ميدانيون

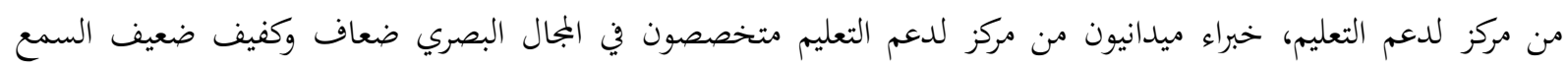

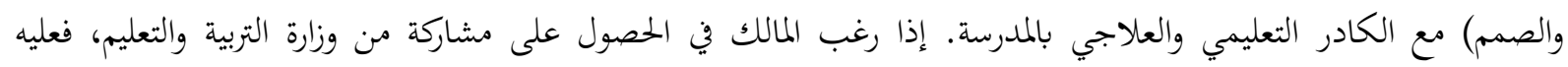
الاتصال بالوزارة لهذا الغرض والعمل وفقًا للإجراءات. - الرحلات والأنشطة المدرسية الداخلية والحخارجية: يجب أن تضمن ملكية المؤسسة التعليمية أن الأنشطة التعليمية التي تتم

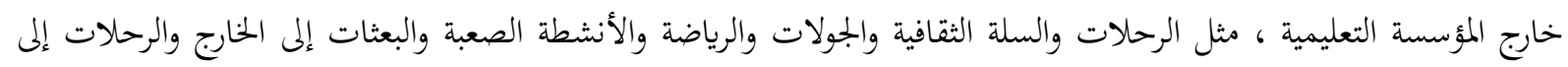
بولندا، ستكون يمكن الوصول إليها بموجب القانون واللوائح.

عند التخطيط للنشاط، ستعطى الأولوية للنشاط العام الذي يمكن الوصول إليه، ولكن في حالات خاصة، يمكن إجراء

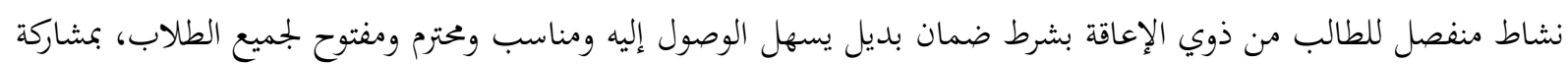
الطلاب المعاقين والطلاب غير المعوقين.

إلى الحد الذي تطلب فيه ملكية المؤسسة التعليمية من وزارة التربية والتعليم المشاركة في تمويل إمكانية الوصول الفردي، فإن تحديد التعديلات سيكون بناءً على الحكم المهني للخبراء الميدانيين في وزارة التربية والتعليم ووفقًا لسياسة الوزارة.

\section{إمكانية الوصول الفردي لولي الأمر الطالب}

الوالد ذو الإعاقة، الذي يحتاج إلى تعديلات في إمكانية الوصول لغرض المشاركة في الأنشطة المتعلقة بأطفاله في المؤسسة

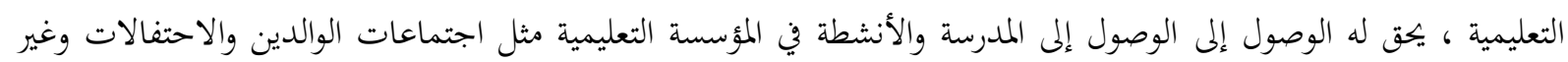
ذلك، مع مراعاة اللوائح والإجراءات.

هدفت دراسة البدو (2020) إلى التعرف على وجهة نظر المعلمات بمدارس دولة الامارات العربية المتحدة (مدرسة الرفاع الثانوية للبنات) نخو فاعلية استخدام تكنولوجيا التعليم المساندة في الدمج التربوي لذوي الاحتياجات الخاصة بالمدارس. تكونت عينة الدراسة من (70) معلمة. استخدمت الباحثة المنهج الوصفي التحليلي لمناسبته لأهداف الدراسة؛ حيث قامت ببناء استبانة علمية لقياس الهدف من الدراسة. إنّ معوقات استخدام تكنولوجيا التعليم المساندة في الدمج التبوي في المدارس هي: قلة المبلة المتخصصات المالية، ضعف تأهيل وتدريب المعلم على استخدام الحاسب الآلي، قلة توافر أجهزة الحاسب الآلي في مدارس وبرامج الدمج، قلة البرامج الالكترونية المتخصصة لكل حالة من الحالات ولكل إعاقة. قلة البرامج التعليمية المرتبطة بالمناهج الدراسية، أيضًا قلة الوقت للحصول على التدريب وتدريب الطلبة لاستخدام التكنولوجيا، نقص الوقت اللازم لإعداد وتطوير الاستراتيجيات التعليمية الجديدة التي تدمج التقنية في المناهج الدراسية، الافتقار إلى أدوات موثوق فيها في بعض المدارس، نقص في استقلالية الطالب. وأخيرًا مستوى راحة المدرس ونقص في سهولة الوصول. 
هدفت دراسة الحطاب (2016) بالكشف عن درجة استخدام التكنولوجيا المساندة من جانب المكفوفين، وذلك من خلال اختيار عينة مكونة من 60 طالبًا وطالبة من المكفوفين في الفئة العمرية 9-11 سنة في مؤسسات التعليم الخاصة بالمكفوفين في عمان ومأدبا في العام الدراسي 2013- 2014، والعمل على تقسيم العينة إلى مجموعتين (مستخدمي التكنولوجيا، وغير مستخدمي التكنولوجيا)، وإجراء المقابلة مع المكفوفين مستخدمي التكنولوجيا البالغ عددهم 30 طالبا وطالبة. كما تمدف الدراسة إلى مقارنة الفروق في الدافعية للتعلم لدى المجموعتين من خلال تطبيق مقياس الدافعية للتعلم على جميع أفراد

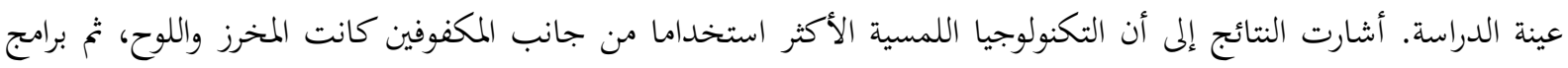
الحاسوب ومعداته التي تستخدم تطبيقات بريل، ثم آلة بيركنز، وأما أقلها استخداما فهو جهاز الأوبتكون. أما بالنسبة للتكنولوجيا

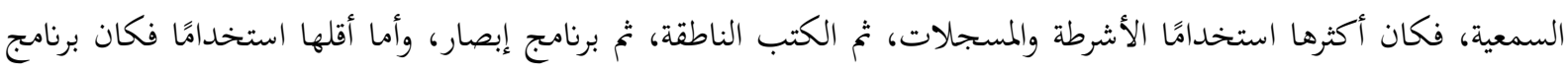

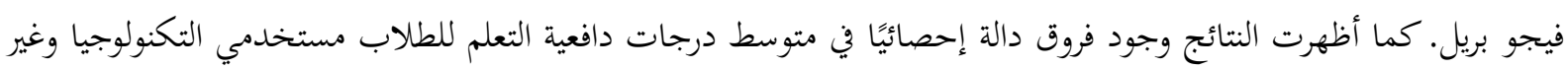
مستخدمي التكنولوجيا، وجاءت الفروق لصالح المكفوفين مستخدمي التكنولوجيا. وخلصت الدراسة إلى مجموعة توصيات، منها:

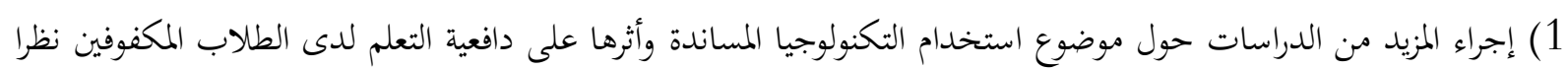

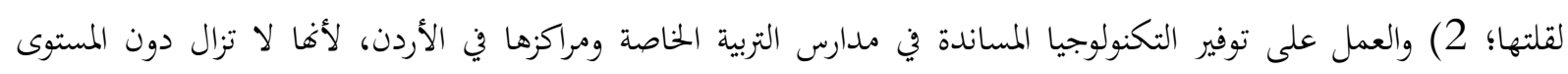
المطلوب؛ 3) العمل على تأهيل المعلمين والمعلمات في مدارس التربية الخاصة ومراكزها لمساعدةتم في كيفية التعامل مع التكنولوجيا

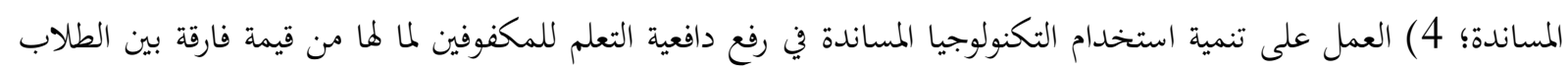
المكفوفين مستخدمي التكنولوجيا وغير مستخدمي التكنولوجيا.

هدفت دراسة الدوايدة (2014) إلى تحديد درجة أهمية وامتلاك معلمي التربية الخاصة للكفايات المهنية المتعلقة

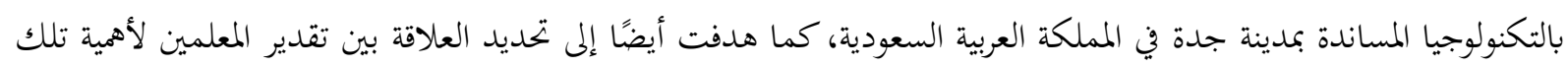

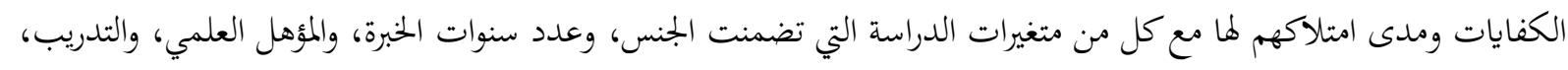
وتخصص المعلم الدقيق. ولتحقيق ذلك أستخدم المنهج الوصفي بالأسلوب المسحي من خلال استبانة تضمنت (21) كفاية. وقد الفدات

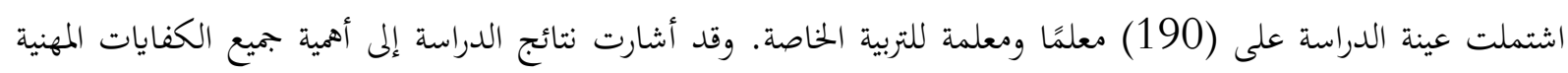

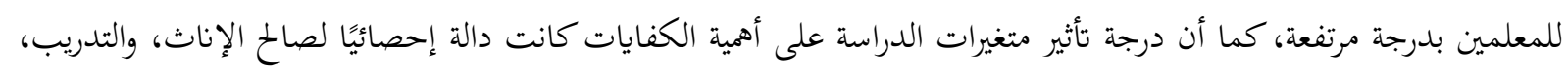

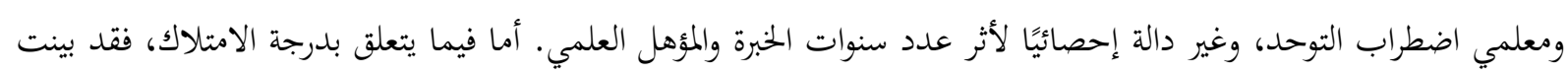

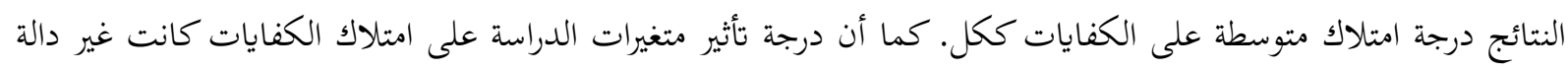
إحصائيًا لأثر الجنس، وعدد سنوات الخبرة، والمؤهل العلمي، وتخصص المعلم الدقيق. ودالة إحصائيًا لأثر التدريب. قام هاريس (Harris, 2011) في الولايات المتحدة الأمريكية بدراسة هدفت إلى معرفة مدى توظيف التكنولوجيا الحديثة من قبل المعلمين في العملية التعليمية وتحديد العوامل التي تؤثر على توظيفها، كما هدفت إلى الكشف عن عن امتلاك مهات مهارات

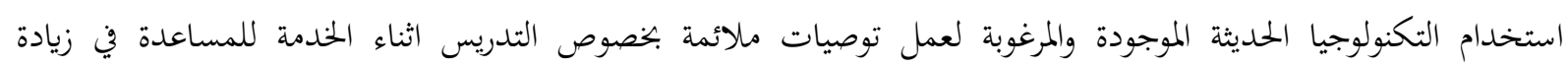

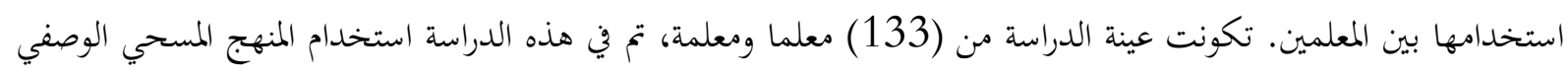

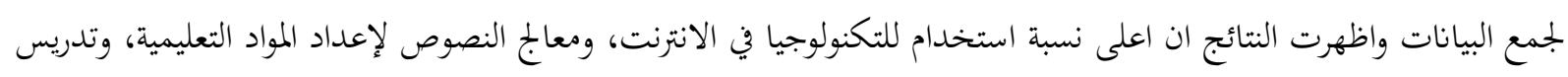

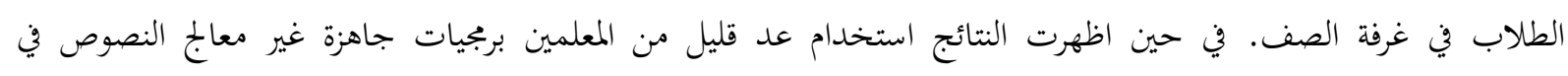

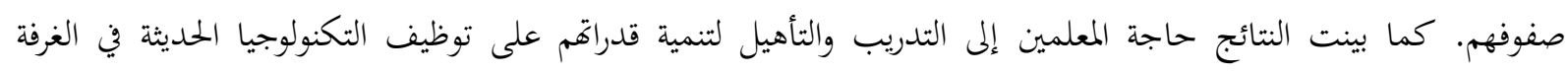
الصفية، وأشارت النتائج إلى ان استخدام التكنولوجيا الحديثة بدرجة منخفضة، نتيجة لعدم توافر الإمكانات التي تسهم في 
من خلال اطلاع الباحثة على الدراسات السابقة التي تناولت تكنولوجيا التعليم المساندة ودور الادارة المدرسية وفعاليتها على العملية التعليمية التعلمية، لاحظت الباحثة قلة الدراسات التي طبقت على واقع دور الإدارة المدرسية في زيادة فعالية التكنولوجيا المساندة لطلاب ذوي الاحتياجات الخاصة في الداخل الفلسطيني في منطقة الشمال، وأن غالبية الدراسات تناولت التكنولوجيا المساندة لدى العادين ولكن تندر لدى فئات ذوي الاحتياجات الخناصة بالرغم من الحاجة الماسة إليها، لذا جاءت المات

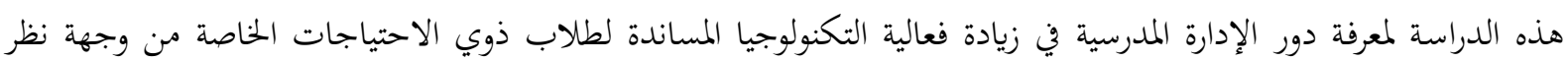
المعلمين في منطقة الشمال في الداخل الفلسطيني. وبالتالي تكمن مشكلة الدراسة الحالية في الإجابة عن الآتي:

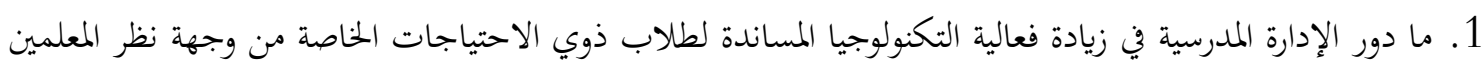

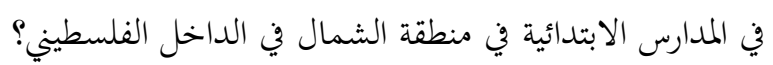

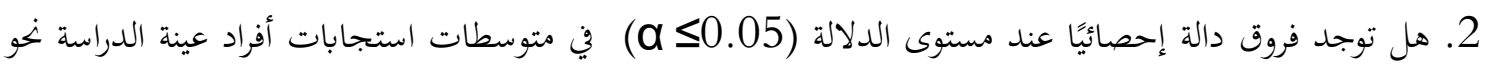

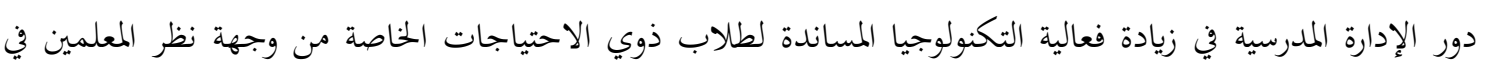
المدارس الابتدائية في منطقة الشمال في الداخل الفلسطيني باختلاف الجنس، المؤهل العلمي، سنوات الخديات

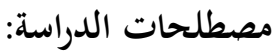

تعرف الإدارة المدرسية بأها الجهود المنسقة التي يبذها فريق من العاملين في المجال التربوي مديرو وفنيو المدارس، ههدف

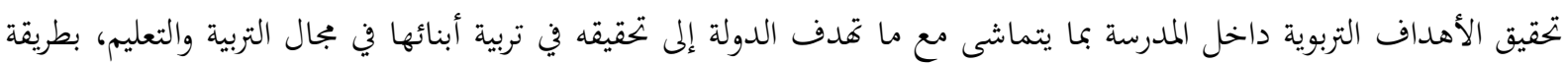
صحيحة وعلى أسس سليمة.

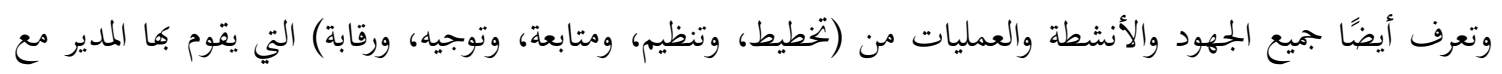

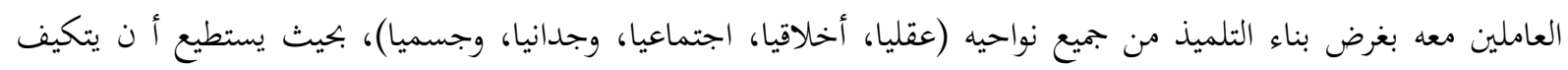

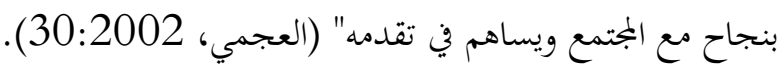

ومن خلال التعريفات السابقة تعرف الباحثة الإدارة المدرسية إجرائيا بما يلي: هي مجموعة العمليات التي يقوم كل العاملين

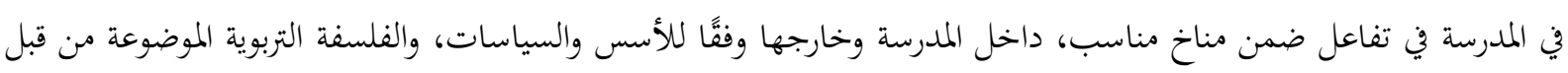
الدولة، رغبة في إعداد النشء بما يتوافق مع المجتمع، ورفع الكفاية الإنتاجية للمدرسة، والارتقاء بمستوى العاملين فيها. يعرف الخطيب والحديدي (2010: 163) الأداة التكنولوجية المساعدة بأها أي جهاز أو جزء من جهاز، أو نظام يتم شراؤه جاهزًا من الأسواق، أو يتم تعديله وتكييفه ليستخدم من أجل زيادة أو تحسين القدرات الوظيفية للطفل المعاق، وأما

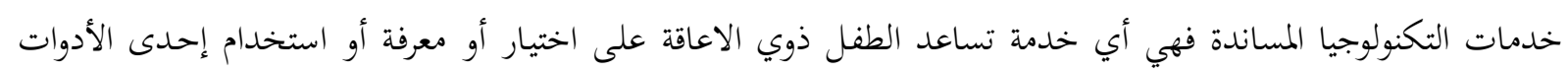

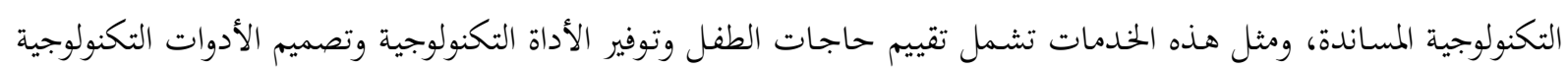
أو تكييفها أو صيانتها أو استخدامها، وتدريب الطفل وأسرته والمعلمين على استخدامها. وتعرف سعيد (2010: 22) التكنولوجيا المساعدة بأها: مجموعة المبادئ والأساليب والاختراعات التي تساعد ذوي الإعاقات في التأهيل والتدريب للوصول إلى الاستقلالية والالتحاق بالعمل والاستقرار من خلال الانتاج وعوائده. كما يذكر الخطيب (2012 : 32) أن مصطلح التكنولوجيا المساعدة يستخدم للإشارة إلى الأدوات التكنولوجية التي

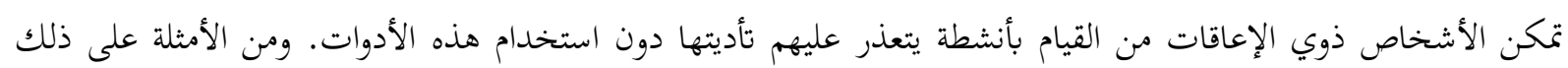


الكتب الناطقة، وبرامج الحاسوب الناطقة، وأشرطة التسجيل والمعينات السمعية والبصرية، ومعينات الحركة والتنقل، ومعينات القراءة والكتابة، ومعينات التواصل.

كما يعرف الشرمان (2015: 56) التكنولوجيا المساعدة بأها الأدوات والخدمات واستخدامها من أجل التغلب على

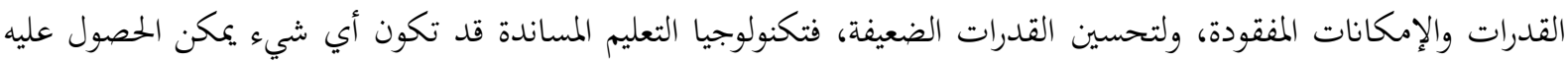
وتوفيره للطلبة من ذوي الإعاقات من أجل زيادة أو استدامة أو تحسين القدرات الوظيفية للطلبة ذوي الإعاقات.

ومن خلال التعريفات السابقة تعرف الباحثة التكنولوجيا المساندة بما يلي: كل ما أنتجه العلم الحديث من أجهزة وأدوات وبرجيات مصممة بناء على نظريات وأسس علمية لتساعد ذوي الاحتياجات الخاصة في التأهيل والتدريب للوصول للاستقلالية. يعرف القريطي (2012) ذوي الاحتياجات الخاصة بأفم: "أولئك الأفراد الذين ينحرفون عن المستوى العادي أو المتوسط

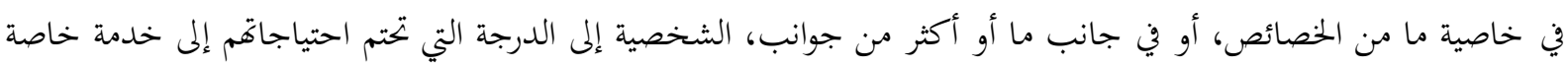

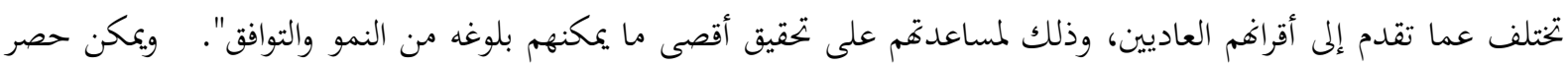
فئات ذوي الاحتياجات الخاصة الشائعة فيما يلي: الإعاقة البصرية، الإعاقة السمعية، الإعاقة الجسدية أو الصحية، الإعاقة

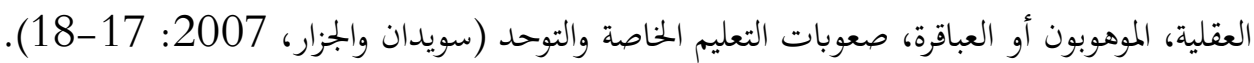

أهمية الدّراسة

الأهميّة النّريّة: تتمثل الأهميّة النّرية للدّراسة في الجوانب التّالية: 1. تتناول موضوعا تربويا مهما وهو الكشف عن دور الإدارة في زيادة فعالية التكنولوجيا المساندة للطلاب ذوي الاحتياجات الخاصة، حيث إن هذا الموضوع يشغل اهتمام كل من له علاقة بالمدرسة من التربويين والطّلبة وأولياء أمورهم

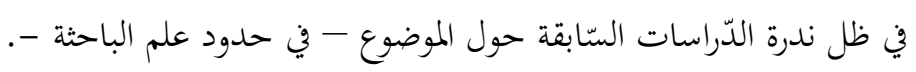
2. إضافتها لأدب تربوي ينطوي على معرفة تربويّة جديدة حول دور الإدارة في زيادة فعالية التكنولوجيا المساندة للطلاب ذوي الاحتياجات الخاصة في المؤسسات التعليمية في الداخل الفلسطيني في لواء الشمال من وجهة نظر المعلمين، مما

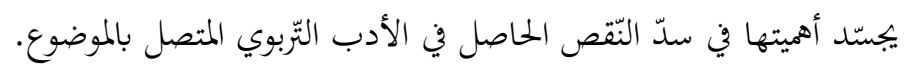
الأهميّة التّطبيقيّة: تتمثل الأهميّة التّطبيقيّة لمذه الدّراسة فيما يلي: 1. الاستفادة من نتائج الدّراسة الحاليّة في خدمة جميع الأطراف المتصلة بالدّراسة من المسئولين في وزارة التّربية والتّعليم

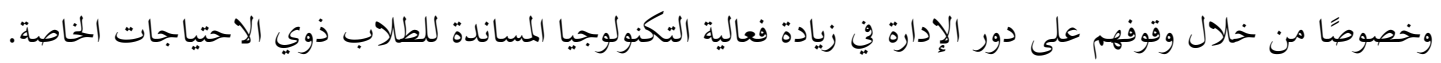

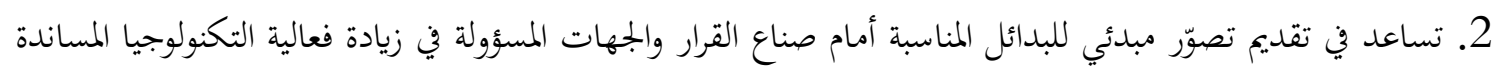
لطاب ذوي الاحتياجات الخاصة.

\section{حدود الدراسة: تشتمل حدود الدراسة على الآتي:} - الحدود الموضوعية: ينحصر موضوع الدّراسة في عنواها الذي يركز على دور الإدارة المدرسية في زيادة فعالية التكنولوجيا المساندة لطلاب ذوي الاحتياجات الخناصة. - ـ الحدود البشريّة: يتم تطبيق هذه الدّراسة على عينة تم اختيارها من المعلمين في المدارس الابتدائية في الداخل الفلسطيني في لواء الشمال. ــ ـ الحدود الزّمانيّة: أجريت هذه الدّراسة في الفصل الدّراسي الأول من العام الدّراسي 2022/2021. 
- - ملحدود المكانية: أجريت هذه الدّراسة في المدارس الابتدائية في الداخل الفلسطيني في لواء الشمال.

منهج الدراسة: لتحقيق أهداف الدراسة ولإججابة عن أسئلتها تم استخدام المنهج الوصفي الذي يصف الظاهرة المراد دراستها، وتحليل بياناتا وبيان العلاقات بين مكوناها.

مجتمع الدراسة: تكون بجتمع الدراسة من جميع معلمي المرحلة الابتدائية في لواء الشمال وعددهم (4691) معلمًا ومعلمة،

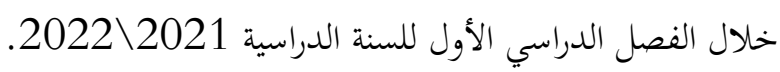

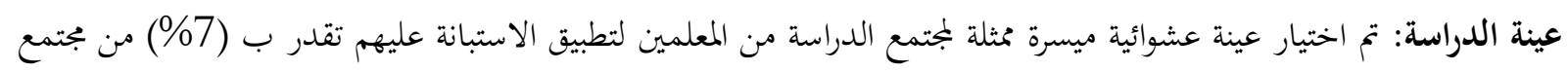

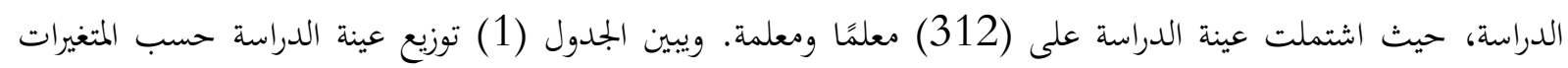

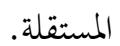

الجدول (1): توزيع أفراد عينة الدراسة حسب مستويات متغيراتما

\begin{tabular}{|c|c|c|c|}
\hline النسبة المئوية\%\% & العدد & المستوى/الفئة & المتغير \\
\hline $37.2 \%$ & 116 & ذكر & الجنس \\
\hline $62.8 \%$ & 196 & انثىى & \\
\hline$\% 100$ & 312 & المجموع & \\
\hline $69.9 \%$ & 218 & بكالوريوس فما دون & المؤهل العلمي \\
\hline $30.1 \%$ & 94 & در اسات عليا & \\
\hline$\% 100$ & 312 & المجموع & \\
\hline $64.1 \%$ & 200 & اقل من 10 سنو ات & سنوات الخبرة \\
\hline $35.9 \%$ & 112 & 10سنوات فأكثر & \\
\hline$\% 100$ & 312 & المجموع & \\
\hline
\end{tabular}

أداة الدراسة: من أجل تحقيق أهداف الدراسة وبعد الرجوع إلى الأدب التربوي السابق المتعلق بموضوع دور الإدارة المدرسية في

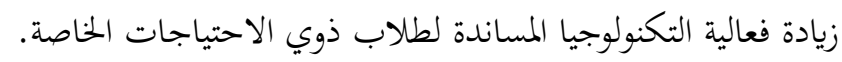

صدق أداة الدراسة: تم تطبيق الاستبانة على عينة استطلاعية قوامها (30) مستجيبًا من مجتمع الدراسة، وتم استبعادهم من عينة

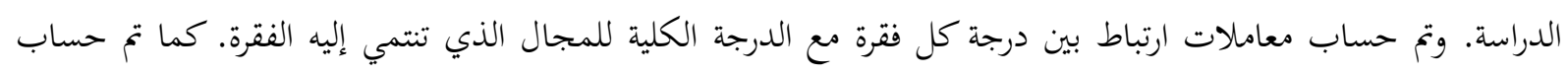

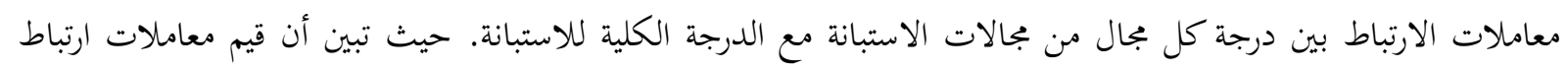

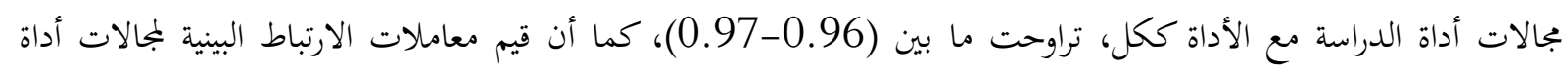
الدراسة تراوحت ما بين (30.88-96.01). كذلك تم التحقق من مؤشرات صدق البناء، من خلال تطبيق أداة الدراسة على عينة

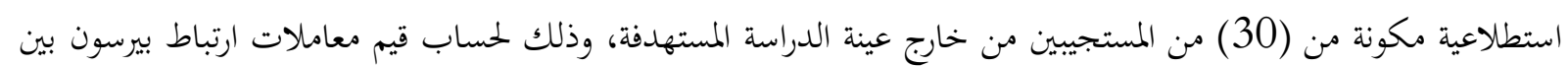

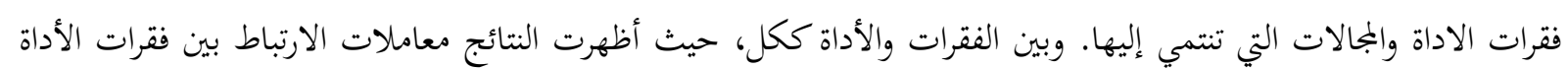

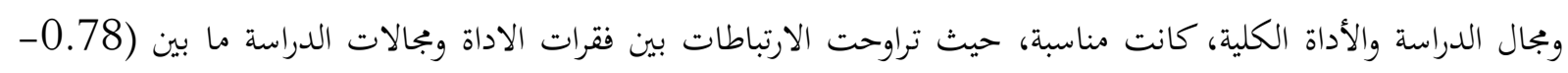
0.94)، وبين فقرات المجالات والأداة الكلية ما بين (0.76-0.88)، وهي ملائمة لأغراض لتحقيق أهداف الدراسة الحالية. 
ثبات أداة الدراسة: تمّ استخدام طريقتين للتحقق من ثبات أداة الدراسة، الطريقة الأولى هي الاختبار وإعادة الاختبار والطريقة الثانية هي حساب معامل كرونباخ لفقرات الاستبانة. حيث تم في الأولى تطبيق الاستبانة على العينة الاستطلاعية (30 مستجيبا) مرتين بفارق زمني مدته أسبوعين وتم حساب معامل الارتباط بيرسون (معامل ثبات الاستقرار) بين التطبيقين. كما تم في الطريقة الثانية حساب معامل ثبات الاتساق الداخلي من خلال معامل كرونباخ ألفا.

الجدول (2): معامل ثبات الإعادة والاتساق الداخلي كرونباخ ألفا للأداة ككل ومجالاتما

\begin{tabular}{|c|c|c|}
\hline ثبات الإعادة & ثبات الاتساق الداخلي & المقياس ومجالاته \\
\hline 0.83 & 0.87 & المجال الأول توفير التكنولوجيا المساندة \\
\hline 0.84 & 0.86 & المجال الثاني تتظيح عملية التعليم \\
\hline 0.85 & 0.89 & الهجال الثالث التفاعل الذاتي لتعليم الطلبة باستخدام التكنولوجيا الدساندة \\
\hline 0.89 & 0.90 & المجال الر ابع الإبداع في تعليم الطلبة \\
\hline 0.87 & 0.90 & المجال الخامس الخطة النظويرية للمدرسة \\
\hline 0.88 & 0.84 & المجال السادس التسهيلات والإتاحة \\
\hline 0.93 & 0.92 & الاداة الكلية \\
\hline
\end{tabular}

أظهرت النتائج في الجدول (2) أن معامل ارتباط بيرسون بين درجات المفحوصين على الأداة في مرتي التطبيق بلغ معامل الثبات

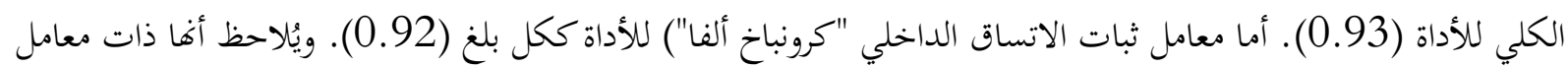
ثبات مرتفع. وعليه اعتبرت هذه القيم ملائمة لغايات هذه الدراسة وتحقيق غرضها والوثوق بنتائجها.

\section{تصحيح أداة الدراسة}

لأجل احتساب الدرجة الكلية للأداة، تم وضع خمسة بدائل يختار المستجيب أحد هذه البدائل التي تعبر عن رأيه، وأعطيت الدرجات (5، 4، 3، 2، 1) للبدائل الخمسة على التوالي للفقرات، إذ أعطيت الدرجة (5) على البديل كبيرة جدًا، البدا، والدرجة (4) للبديل كبيرة، وأعطيت الدرجة (3) على البديل متوسطة، وأعطيت الدرجة (2) على البديل متدنية، وأعطيت الدرجة (1) على البديل متدنية جدًا. وللحكم على مستوى المتوسطات الحسابية للفقرات والمجالات والأداة ككل، اعتمد المعيار

الإحصائي باستخدام المعادلة الآتية:

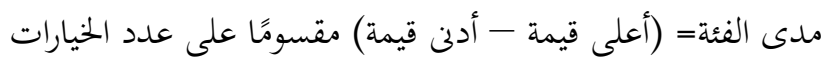

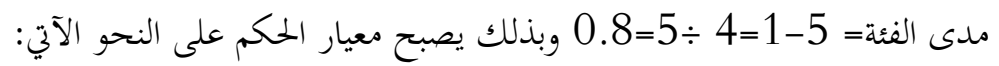

الجدول (3): المعيار الإحصائي لتحديد درجة المتوسطات الحسابية

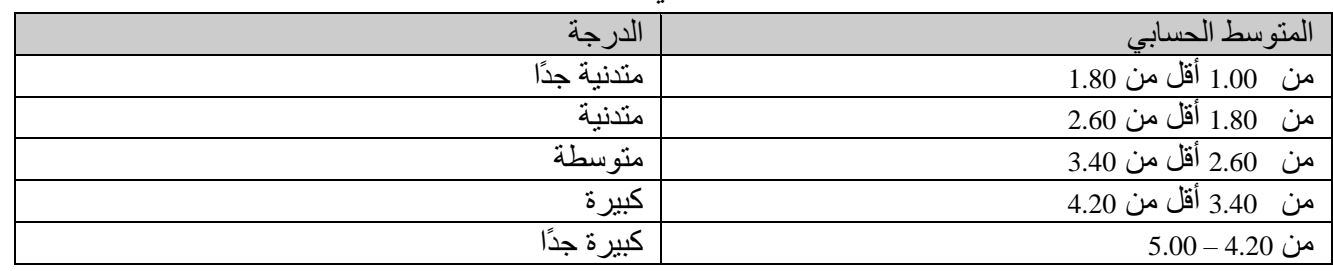

- المتغيرات الئيسية: دور الإدارة المدرسية في زيادة فعالية التكنولوجيا المساندة لطلاب ذوي الاحتياجات الخاصة. - المتغيرات الوسيطة وتشمل: الجنس: وله فئتان (ذكر وأنثى)، المؤهل العلمي: وله ثلاثة مستويات (بكالوريوس فما دون، دراسات عليا)، الخبرة: ولها ثلاث مستويات (أقل من 10 سنوات)، (10 سنوات فأكثر). 


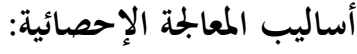

- للإجابة على السؤال الأول من أسئلة الدراسة تم استخدام المتوسطات الحسابية والانحرافات المعيارية . - للإججابة عن السؤال الثاني تم استخدام المتوسطات الحسابية والاخرافات المعابيات المارية، وتحليل التباين الثلاثي المتعدد لمعرفة الدلالة الإحصائية للفروق الظاهرية بين المتوسطات الحسابية لتقديرات أفراد عينة الدراسة على فقرات.

(ائن

نتائج السؤال الأول الذي نص على: ما دور الإدارة المدرسية في زيادة فعالية التكنولوجيا المساندة لطلاب ذوي

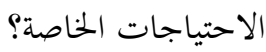

\begin{tabular}{|c|c|c|c|c|c|}
\hline 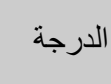 & 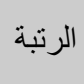 & 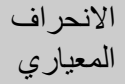 & 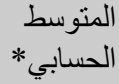 & 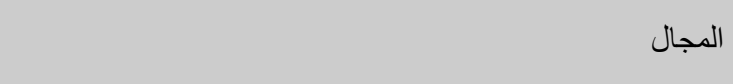 & المجال \\
\hline متوسطة & 1 & .837 & 3.08 & المجال الأول توفير التكنولوجيا المساندة & 1 \\
\hline متوسطة & 2 & .921 & 3.08 & المجال الثاني تنظيم عملية التعليم & 2 \\
\hline متوسطة & 3 & .906 & 2.99 & المجال السادس التسهيلات والإتاحة & 6 \\
\hline متوسطة & 4 & .940 & 2.95 & المجاندة الثالث التفاعل الذاتي لتعليم الطلبة باستخدام التكنولوجيا & 3 \\
\hline متوسطة & 5 & .916 & 2.95 & المجال الخامس الخطة التطويرية للمدرسة & 5 \\
\hline متوسطة & 6 & .842 & 2.87 & المجال الر ابع الإبداع في تعليم الطلبة & 4 \\
\hline متوسطة & & .815 & 2.99 & الاداة الكلية & \\
\hline
\end{tabular}

جدول (4): المتوسطات الحسابية والانخرافات المعيارية لتقديرات أفراد عينة الدراسة على مجالات دور الإدارة المدرسية في زيادة فعالية التكنولوجيا المساندة لطلاب ذوي الاحتياجات الخاصة، مرتبة تنازليًا وفق المتوسطات الحسابية

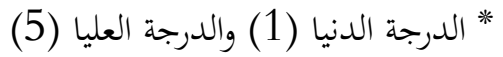
يلاحظ من جدول (4) أن دور الإدارة المدرسية في زيادة فعالية التكنولوجيا المساندة لطلاب ذوي الاحتياجات الخاصة جاءت بدرجة متوسطة بمتوسط حسابي (2.99)، حيث تعزو الباحثة هذه النتيجة المتوسطة إلى وجود العديد من التحديات التي تواجه المديرين في زيادة فعالية التكنولوجيا المساندة، حيث ينصب تركيز المديرين في المدارس على التكنولوجيا المحوسبة والتي تعنى بعملية التعليم والتعلم بشكل عام، بينما لا يركزون بشكل كبير على التكنولوجيا المساندة التي تساعد الطلبة ذوي الاحتي لماحتياجات 


\section{تم حساب المتوسطات الحسابية والانحرافات المعيارية:}

المجال الأول توفير التكنولوجيا الممساندة الجدول (5): المتوسطات الحسابية والانحرافات المعيارية لتقديرات أفراد عينة الدراسة

على فقرات المجال مرتبة تنازليا وفق المتوسطات الحسابية

\begin{tabular}{|c|c|c|c|c|c|}
\hline الدرجة & الرتبة & 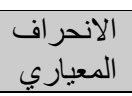 & | الحسابيط & الفقرة & 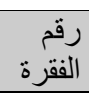 \\
\hline كبيرة & 1 & 1.084 & 3.60 & توفر الإدارة الددرسية طرق التواصل مع أولياء الأمور بسهولة. & 6 \\
\hline متوسطة & 2 & .975 & 3.27 & 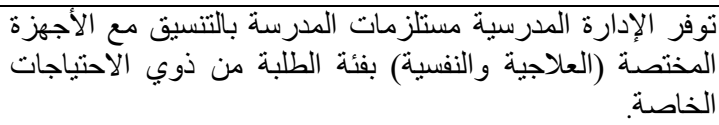 & 7 \\
\hline متوسطة & 3 & 1.092 & 3.17 & 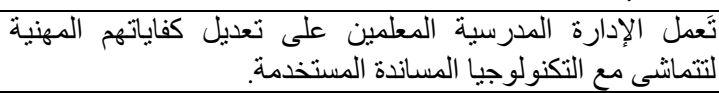 & 9 \\
\hline متوسطة & 4 & .952 & 3.08 & تونية على الإدارة التكنولوجيا المساندة. المعين للمساهمة في إعداد خطة فردية & 3 \\
\hline 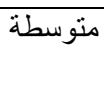 & 5 & 1.062 & 3.00 & الاحتياجات الخاصدة. المدرسية وسائل تعليمية مساندة مناسبة للطلبة ذوي & 1 \\
\hline 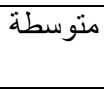 & 6 & 1.207 & 3.00 & 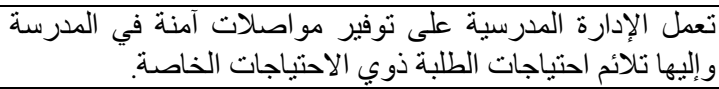 & 5 \\
\hline 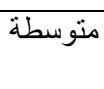 & 7 & 1.092 & 3.00 & المساندي الإدارة المدرسية الثقييم المستمر لفاعلية التكنولوجيا & 10 \\
\hline متوسطة & 8 & 1.045 & 2.96 & 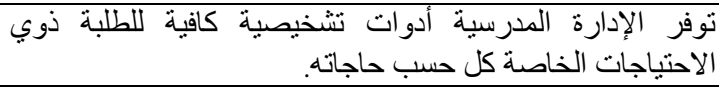 & 4 \\
\hline 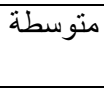 & 9 & 1.159 & 2.91 & وندوات ذالإدارة علاقة بالتكنية علوجيا المساندة. المعلمين في مؤتمرات & 8 \\
\hline 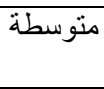 & 10 & 1.042 & 2.85 & الخاصفة. الإدارة المدرسية بنية تحتية مناسبة للطلبة ذوي الاحتياجات & 2 \\
\hline متوسطة & & .837 & 3.08 & المجال الأول توفير التكنولوجيا المساندة & \\
\hline
\end{tabular}

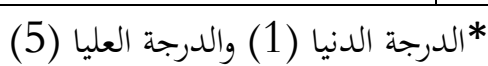

يلاحظ من جدول (5) أن المتوسطات الحسابية لفقرات المجال جاءت بدرجة متوسطة، حيث يمكن عزو هذه النتيجة المتوسطة إلى أن المديرين يتعاملون مع التكنولوجيا المساندة في المدرسة في ضوء الامكانيات المتاحة في المدرسة، حيث إن إن درجة المباء توافر مثل هذه التكنولوجيا ليس بالأمر السهل في المدارس، حيث إن الحاجات المختلفة للتكنولوجيا المساندة يصعب الحصول عليها واستخدامها في المدارس.

المجال الثاني تنظيم عملية التعليم الجدول (6): المتوسطات الحسابية والانحرافات المعيارية لتقديرات أفراد عينة الدراسة على

فقرات المجال مرتبة تنازليا وفق المتوسطات الحسابية

\begin{tabular}{|c|c|c|c|c|c|}
\hline الدرجة & الرتبة & 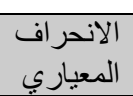 & | الحسابيط & الفقرة & 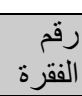 \\
\hline متوسطة & 1 & 1.021 & 3.28 & التعساندة مع الإدارة الطلبة. & 2 \\
\hline متوسطة & 2 & 948. & 3.20 & تُحكرص الإدارة المدرسية على التطور الذاتي للمعلمين فيما يخص & 1 \\
\hline متوسطة & 3 & 1.004 & 3.09 & المعاندة. الإدارة المدرسية تواصل المعلمين مع الطلبة باستخدام التكنولوجيا & 4 \\
\hline متوسطة & 4 & 1.068 & 3.06 & تشجع الإدارة المدرسية على إرسال الدروس عبر التكنولوجيا المساندة. & 3 \\
\hline متوسطة & 5 & 1.135 & 3.01 & تقدم الإدارة المدرسية نشر ات إرشادية لاستخدامات التكنولوجيا المساندة. & 5 \\
\hline متوسطة & 6 & 1.072 & 2.96 & التعليم والتصعلم. المدرسية ثقافة دور التكنولوجيا المساندة في تعزيز عملية & 6 \\
\hline متوسطة & 7 & 1.047 & 2.95 & المساندة. الإدارة المدرسية عناصر المنهج التي تناسب تطبيقات التكنولوجيا & 7 \\
\hline متوسطة & & 921. & 3.08 & المجال الثاني تنظيم عملية التعليح & \\
\hline
\end{tabular}


يلاحظ من جدول (6) أن المتوسطات الحسابية لفقرات المجال جاءت بدرجة متوسطة، حيث يمكن عزو هذه النتيجة إلى

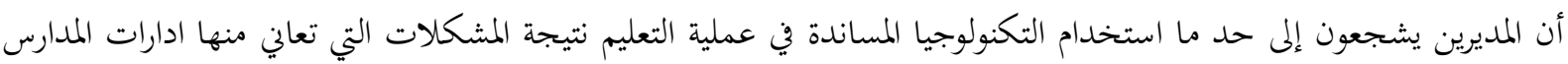
في توفير متطلبات التكنولوجيا المساندة للطلبة.

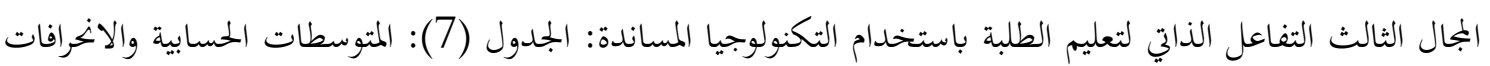
المعيارية لتقديرات أفراد عينة الدراسة على فقرات المجال مرتبة تنازليًا

\begin{tabular}{|c|c|c|c|c|c|}
\hline الدرجة & الرتبة & 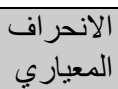 & 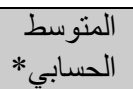 & الفقرة & 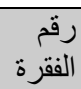 \\
\hline متوسطة & 1 & 1.024 & 3.01 & تزلى التكنولوجيا المدساندة. المعلمين ببرامج تعليمية تتعلق بالتعلم الذاتي تعتمد & 1 \\
\hline متوسطة & 2 & 1.043 & 3.00 & تلتزنوز الإدارة المدارسية التفاعل الذاتي للتعليم بين الطلبة أنفسهم من خلال & 2 \\
\hline متوسطة & 3 & 991. & 2.95 & 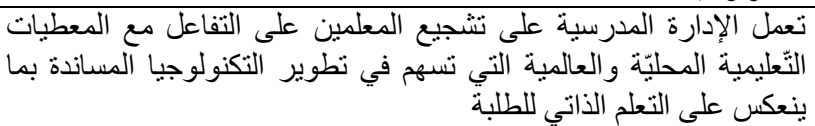 & 4 \\
\hline متوسطة & 4 & 995. & 2.83 & 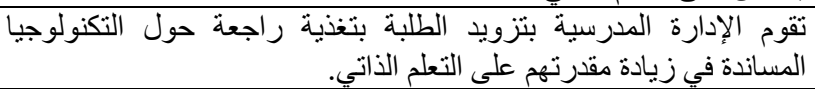 & 3 \\
\hline 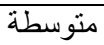 & & 940. & 2.95 & المجال الثالث التفاعل الذاتي لتعليم الطلبة بآستخدام التكنولوجيا المساندة & 5 \\
\hline
\end{tabular}

يلاحظ من جدول (7) أن المتوسطات الحسابية لفقرات المجال جاءت بلداءل بلدرجة متوسطة، حيث إن ما يتوفر لدى الطلبة من

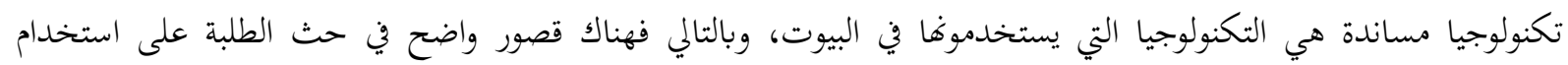
التكنولوجيا المساندة حتى تساعدهم على التعليم.

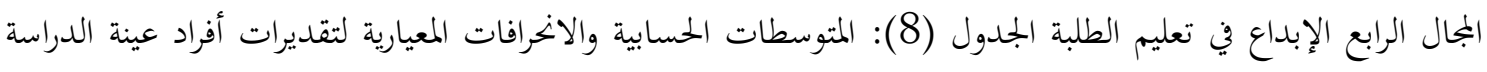

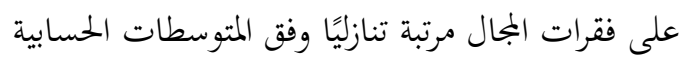

\begin{tabular}{|c|c|c|c|c|c|}
\hline 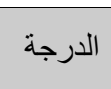 & الرتبة & 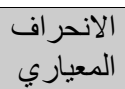 & 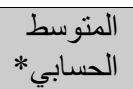 & 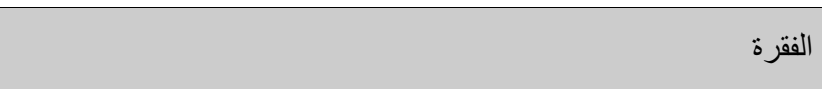 & 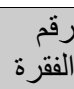 \\
\hline متوسطة & 1 & 1.076 & 3.21 & ليتمكن الطلبة من اكتشاف المعترفة المدرسة إنتاجها. على توظيف التكنولوجيا المساندة & 1 \\
\hline متوسطة & 2 & 1.108 & 2.94 & 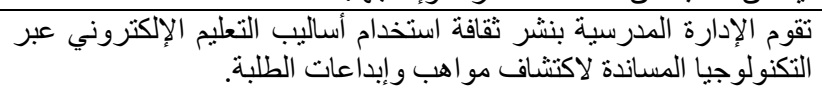 & 2 \\
\hline منوسطة & 3 & 1.011 & 2.92 & رئُبسًا للأنشطة الإدبّعلمية. & 3 \\
\hline متوسطة & 4 & 969. & 2.88 & الطلبة. الإدارة المدرسية من فعالية التكنولوجيا المساندة في تلبية احتياجات & 5 \\
\hline متوسطة & 5 & 980. & 2.76 & تثتجع الإدارة المدرسية المعلمين على التعاون في تثغيل أجهزة وأدوات & 7 \\
\hline 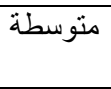 & 6 & 969. & 2.75 & 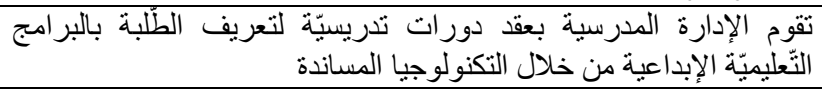 & 4 \\
\hline منوسطة & 7 & 1.080 & 2.60 & تلتضخيم، الإدارة المزة السمع، و التكنولوجيات السمعية. المساندة مثل آلة برايل، واجهزة & 6 \\
\hline متوسطة & & 842. & 2.87 & المجال الر ابع الإبداع في تعليم الطلبة & \\
\hline
\end{tabular}

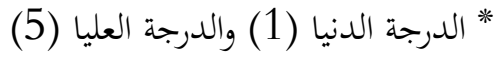

يلاحظ من جدول (8) أن المتوسطات الحسابية لفقرات المجال جاءت بدرجة متوسطة، حيث تعزو الباحثة هذه النتيجة المتوسطة إلى المحددات والمعوقات التي تساهم بشكل واضح في تنظيم عملية التعليم والتعلم، والتركيز على الجوانب الابداعية للطلبة

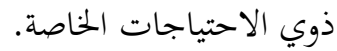
المجال الخامس الخطة التطويرية للمدرسة الجدول (9): المتوسطات الحسابية والانحرافات المعيارية لتقديرات أفراد عينة الدراسة على فقرات المجال مرتبة تنازليًا وفق المتوسطات الحسابية 


\begin{tabular}{|c|c|c|c|c|c|}
\hline 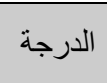 & 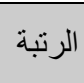 & 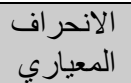 & | الصسابيط & 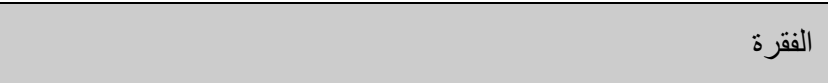 & الفقرة \\
\hline متوسطة & 1 & 1.011 & 3.10 & تُدرب الإدارة المدرسية المعلمين على استخدام التكنولوجيا المساندة. & 7 \\
\hline 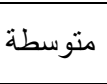 & 2 & 1.137 & 3.03 & 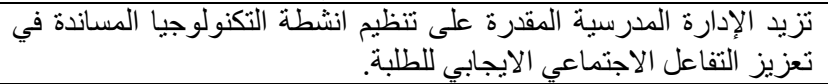 & 5 \\
\hline 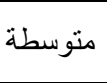 & 3 & 1.048 & 3.00 & تضكع الإدارة المدرسية برنامج تحفيز الطلبة المبدعين من خلال استخدام & 3 \\
\hline 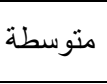 & 4 & 1.017 & 2.97 & تاستخذ الإدارة الفاعل للتكنولوجية منحى العساندة. & 4 \\
\hline متوسطة & 5 & 1.053 & 2.90 & تضع الإدارة المدرسية لَو ائح مدرسية لاستخدام التكنولوجيا المساندة. & 1 \\
\hline 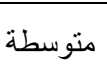 & 6 & 1.040 & 2.83 & تحسدد الإدارة المدرسية مصادر التمويل لشر اء أجهزة ومعدات التكنولوجيا & 6 \\
\hline 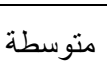 & 7 & 1.067 & 2.81 & تخاطب الإدارة المدرسية أولياء الأمور رسميًّا لتوعية أبنائهم لاستخدامات & 2 \\
\hline متوسطة & & 916. & 2.95 & المجال الخامس الخطة التطويرية للمدرسة & \\
\hline
\end{tabular}

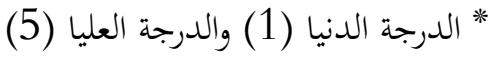

يلاحظ من جدول (9) أن المتوسطات الحسابية لفقرات المجال جاءت بدرجة متوسطة، حيث تعزو الباحثة هذه النتيجة المتوسطة إلى أن المديرين يضعون الخطط التطويرية في المدرسة في ضوء الامكانات المتاحة. المجال السادس التسهيلات والإتاحة الجدول (10): المتوسطات الحسابية والانحرافات المعيارية لتقديرات أفراد عينة الدراسة على فقرات المجال مرتبة تنازليا وفق المتوسطات الحسابية

\begin{tabular}{|c|c|c|c|c|c|}
\hline الدرجة & 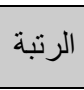 & الانحرباري & الحسابي & 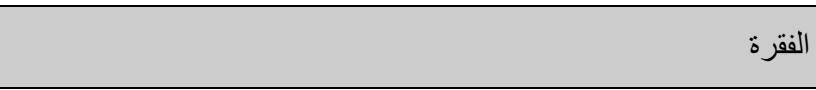 & 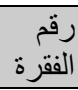 \\
\hline متوسطة & 1 & 1.029 & 3.11 & تحقيق التعليم اللطارة المدة ذوسية الاحتياجات الخلطة المحلية لتقديم الخدمات التي تسهل & 3 \\
\hline متوسطة & 2 & 998. & 3.07 & 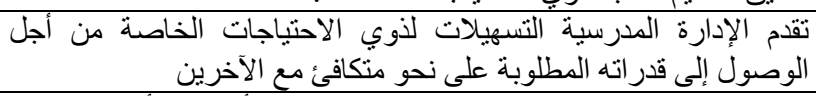 & 4 \\
\hline متوسطة & 3 & 1.079 & 3.03 & 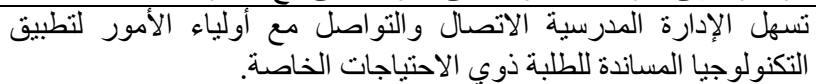 & 1 \\
\hline متوسطة & 4 & 1.070 & 3.00 & و التحديث توفير خبر اءهر في التكنا. لولوجيا المساندة من أجل إجر اء الإرشاد والصيانة & 7 \\
\hline متوسطة & 5 & 1.080 & 2.98 & تُطُبِّقَ الإدارة المدرسية الإنسانية القوانين المتعلقة بذوي الاحتياجات الخاصة على & 5 \\
\hline متوسطة & 6 & 1.039 & 2.91 & 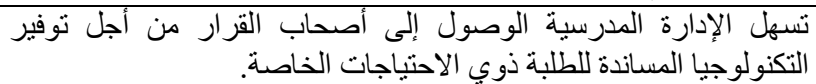 & 2 \\
\hline متوسطة & 7 & 1.001 & 2.81 & الاحتياجات الخاع الدليل الالكتروني للحصول على كافة الخدمات للطلبة ذوي & 6 \\
\hline متوسطة & & 906. & 2.99 & المجال السادس التسهيلات والإتاحة & \\
\hline
\end{tabular}

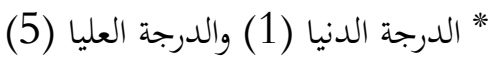

يلاحظ من جدول (10) أن المتوسطات الحسابية لفقرات المجال جاءت بدرجة متوسطة، حيث تعزو الباحثة هذه النتيجة المتوسطة إلى وجود مشكلات في تطبيق الانظمة والقوانين المتعلقة بتعلم الطلبة ذوي الاحتياجات الخاصة في ضوء التكنولوجيا المساندة.

نتائج السؤال الثاني الذي نص على: هل توجد فروق ذات دلالة إحصائية عند مستوى الدلالة (a 0.05$)$ بين متوسطات تقديرات أفراد عينة الدراسة لدور الإدارة المدرسية في زيادة فعالية التكنولوجيا المساندة لطلاب ذوي الاحتياجات

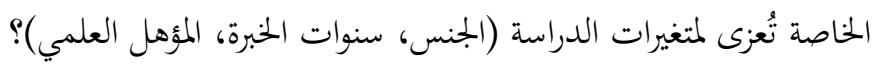
للإجابة عن هذا السؤال؛ يبين جدول (11) المتوسطات الحسابية والانحرافات المعيارية لتقديرات أفراد عينة الدراسة على

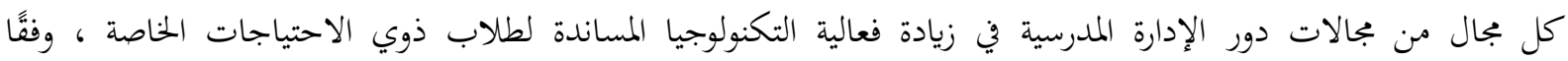
لمتغير (الجنس، سنوات الخبرة، المؤهل العلمي) 
Rimak International Journal of Humanities and Social Sciences

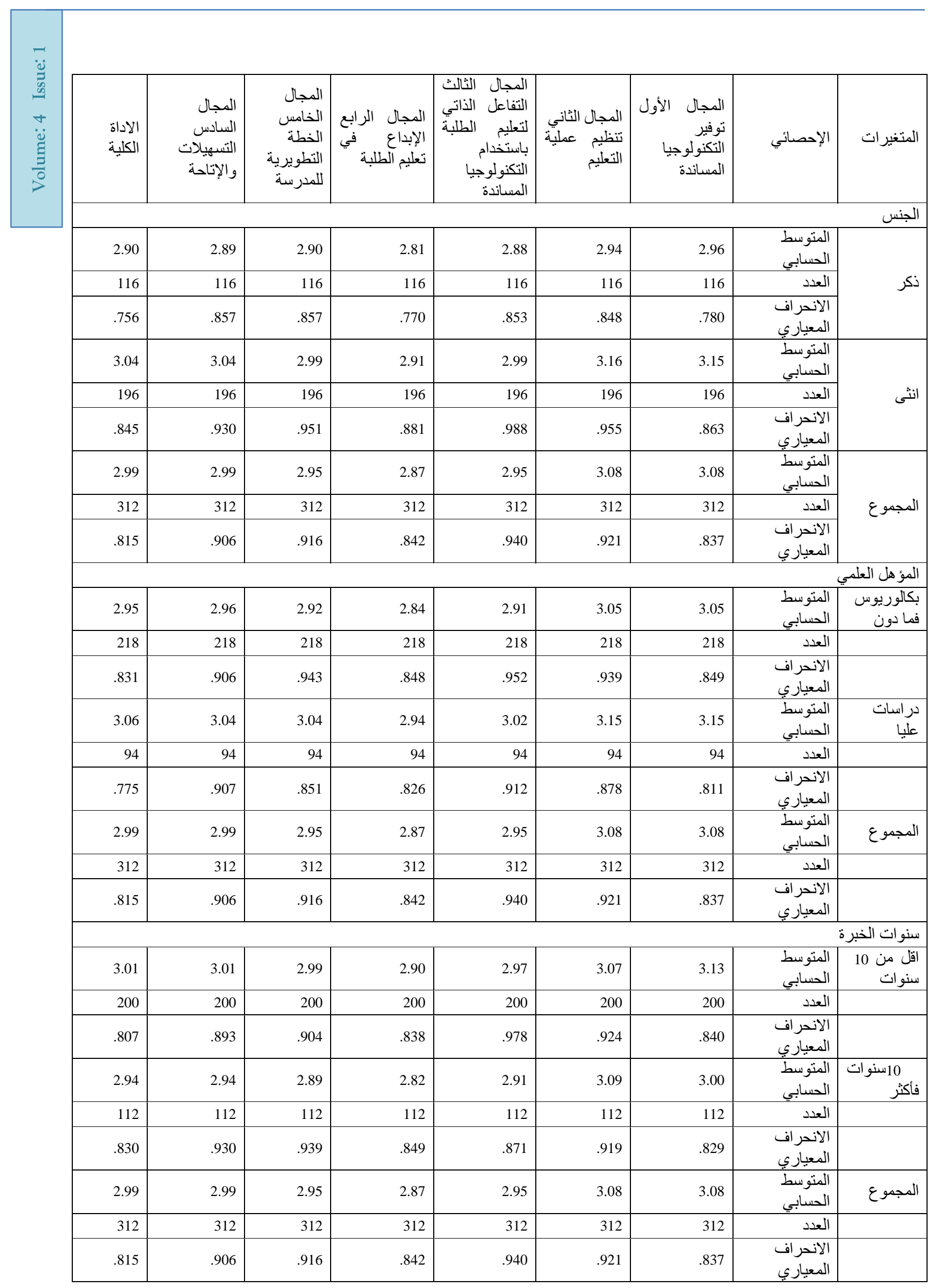


يُّاحظ من جدول (11) وجود فروق ظاهرية بين المتوسطات الحسابية لتقديرات أفراد عينة الدراسة على كل بجال من

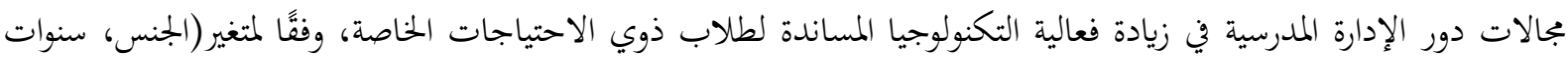
الخبرة، المؤهل العلمي) ولتحديد الدلالة الإحصائية لمذه الفروق الظاهرية، تم تطبيق تحليل التباين المتعدد، ويبين جدول: جدول (12) تحليل التباين المتعد للمتوسطات الحسابية لتقديرات أفراد عينة الدراسة على كل مجال من مجالات دور الإدارة المدرسية في زيادة فعالية التكنولوجيا المساندة لطلاب ذوي الاحتياجات الخاصة، وفقًا لمتغير(الجنس، سنوات الخبرة، المؤهل

\begin{tabular}{|c|c|c|c|c|c|c|}
\hline الإحصائية & 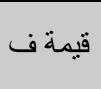 & متوسط المربعات & الحرية & المربعوع & 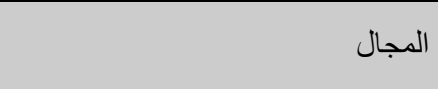 & مصدر التباين \\
\hline .100 & 2.722 & 1.811 & 1 & 1.811 & المساندة الأول توفير التكنولوجيا & 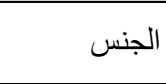 \\
\hline .028 & 4.864 & 3.959 & 1 & 3.959 & المجال الثاني تتظيم عملية التعليم & \\
\hline .422 & .645 & .562 & 1 & .562 & الطلبة باستخدام التكنولو التفاعل الذاتي لتعليا الثساندة & \\
\hline .450 & .573 & .398 & 1 & .398 & المجال الر ابع الإبداع في تعليم الطلبة & \\
\hline .608 & .264 & .217 & 1 & .217 & اللمدرسة الخامس الخطة التطويرية & \\
\hline .149 & 2.089 & 1.693 & 1 & 1.693 & المجال السادس التسهيلات و الإتاحة & \\
\hline .179 & 1.810 & 1.167 & 1 & 1.167 & الاداة الكلية & \\
\hline .408 & .686 & .456 & 1 & .456 & المساندة الأول توفير التكنولوجيا & 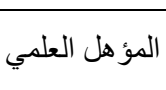 \\
\hline .206 & 1.609 & 1.309 & 1 & 1.309 & المجال الثاني تنظيم عملية التعليم & \\
\hline .783 & .076 & .066 & 1 & .066 & 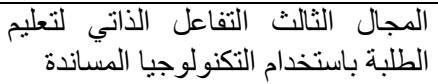 & \\
\hline .506 & .444 & .309 & 1 & .309 & المجال الر ابع الإبداع في تعليم الطلبة & \\
\hline .278 & 1.181 & .970 & 1 & .970 & اللمدرسة الخامس الخطة التطويرية & \\
\hline .706 & .143 & .116 & 1 & .116 & المجال السادس التسهيلات والإتاحة & \\
\hline .729 & .120 & .077 & 1 & .077 & الاداة الكلية & \\
\hline .037 & 4.388 & 2.919 & 1 & 2.919 & المساندة & سنوات الخبرة ل \\
\hline .417 & .660 & .537 & 1 & .537 & المجال الثاني تتظيم عملية التعليم & \\
\hline .473 & .516 & .449 & 1 & .449 & 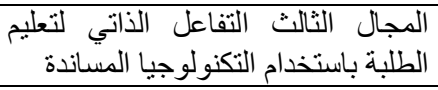 & \\
\hline .203 & 1.625 & 1.130 & 1 & 1.130 & المجال الر ابع الإبداع في تعليم الطلبة & \\
\hline .105 & 2.651 & 2.177 & 1 & 2.177 & اللمدرسة الخامس الخطة التطويرية & \\
\hline .233 & 1.426 & 1.156 & 1 & 1.156 & المجال السادس التسهيلات والإتاحة & \\
\hline \multirow[t]{11}{*}{.276} & 1.191 & .768 & 1 & .768 & الاداة الكلية & \\
\hline & & .665 & 305 & 202.926 & المساندة & 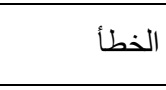 \\
\hline & & .814 & 305 & 248.245 & المجال الثاني تتظيم عملية التعليم & \\
\hline & & .871 & 305 & 265.708 & 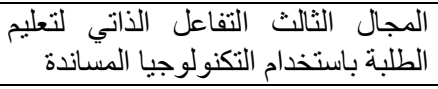 & \\
\hline & & .695 & 305 & 212.024 & المجال الر ابع الإبداع في تعليم الطلبة & \\
\hline & & .821 & 305 & 250.447 & المدرسة الخامس الخطة التطويرية & \\
\hline & & .810 & 305 & 247.122 & المجال السادس التسهيلات والإتاحة & \\
\hline & & .645 & 305 & 196.713 & الاداة الكلية & \\
\hline & & & 312 & 3182.565 & المساندة & 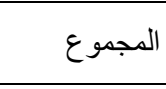 \\
\hline & & & 312 & 3216.796 & المجال الثاني تتظيم عملية التعليم & \\
\hline & & & 312 & 2983.313 & المجال الثالث التفاعل الذاتي لتعليم & \\
\hline
\end{tabular}




\begin{tabular}{|c|c|c|c|c|c|c|}
\hline \multirow[t]{13}{*}{ الإلإلة } & 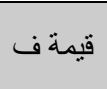 & متوسط & 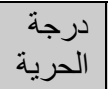 & المربعات & 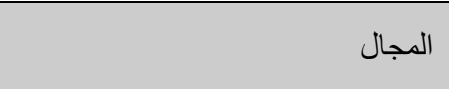 & 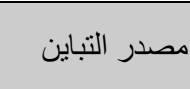 \\
\hline & & & & & الطلبة باستخدام التكنولوجيا المساندة & \\
\hline & & & 312 & 2786.939 & المجال الرابع الإبداع في تعليم الطلبة & \\
\hline & & & 312 & 2983.875 & اللمدرسال الخامس الخطة التطويرية & \\
\hline & & & 312 & 3037.388 & المجال السادس التسهيلات و الإتاحة & \\
\hline & & & 312 & 2987.542 & الاداة الكلية & \\
\hline & & & 311 & 218.111 & المساندة الأول توفير التكنولوجيا & المجموع المعدل \\
\hline & & & 311 & 263.829 & المجال الثاني تنظيم عملية التعليم & \\
\hline & & & 311 & 274.913 & الطلبة باستخدام التكنولو التفاعل الذاتي التعانليم & \\
\hline & & & 311 & 220.370 & المجال الر ابع الإبداع في تعليم الطلبة & \\
\hline & & & 311 & 261.217 & للمدرسة المجال الخامس الخطة التطويرية & \\
\hline & & & 311 & 255.043 & المجال السادس التسهيلات و الإتاحة & \\
\hline & & & 311 & 206.410 & الاداة الكلية & \\
\hline
\end{tabular}

* ذو دلالة إحصائية عند مستوى الدلالة الإحصائية (م = 0.05)

يُلاحظ من جدول (12) عدم وجود فرق ذي دلالة إحصائية عند مستوى الدلالة الإحصائية (م = 05.05) استجابات

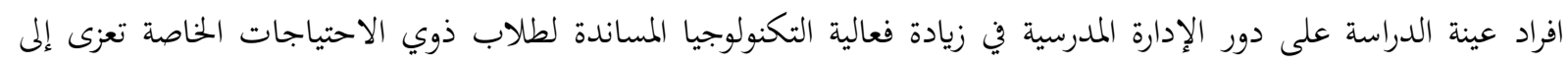

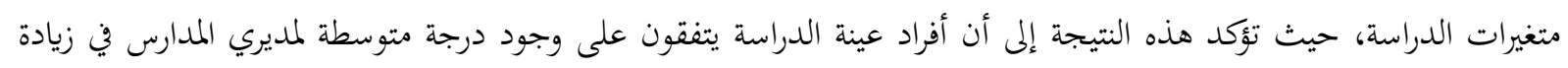
فعالية التكنولوجيا المساندة للطلبة ذوي الاحتياجات الخاصة.

التوصيات: وفي ضوء نتائج الدراسة، فقد أوصت الدراسة بالآتي: - الحوار والتوعية المستمرة للجميع حول توفير التكنولوجيا المساندة بصورة كبيرة. - إقامة ورشات عمل وتدريب مستمر فيما يتعلق باستخدام التكنولوجيا المساندة - تجسير الهوة المعرفية بين المعلمين والطلاب في استخدام التكنولوجيا المساندة. - تجهيز المدارس بالأجهزة التكنولوجية المساندة. 
أحمد، إبراهيم أحمد. (2000). القصور الإداري في المدارس: الواقع والعلاج. دراسة منشورة. دار الفكر العربي: القاهرة.

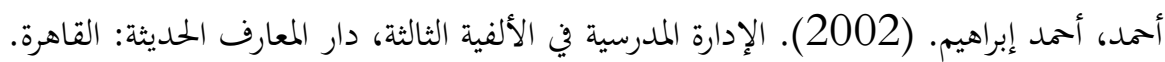

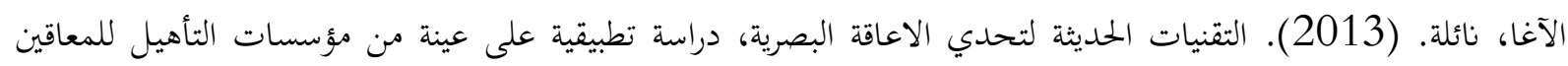
بصريا بقطاع غزة، مقدمة لليوم البحثي بعنوان: استخدام تكنولوجيا المعلومات والاتصالات في التعليم والتعلم

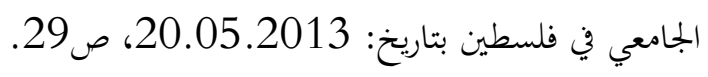

أمين، زينب. (2008). تكنولوجيا التعليم لذوي الاحتياجات الخاصة، ط 2، المنبأ، دار التسيير للطباعة والنشر.

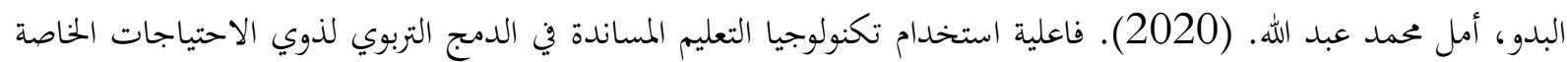

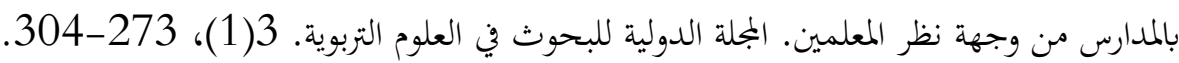

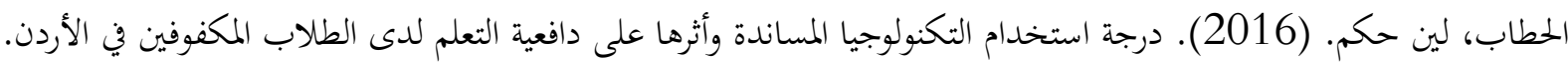
مجلة جامعة الطيبة للعلوم التربوية. 12(2011).

الخطيب، جمال حممد. (2012). استخدامات التكنولوجيا في التربية الخاصة، الطبعة الثانية. دار وائل للنشر والتوزيع: عمان.

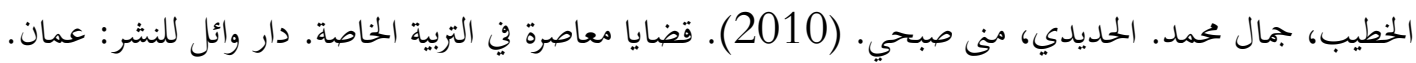

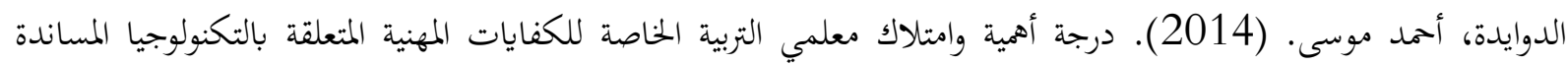

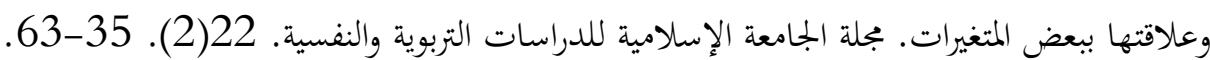

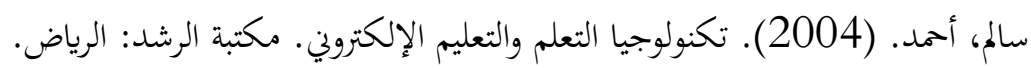

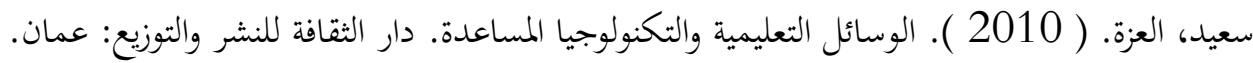

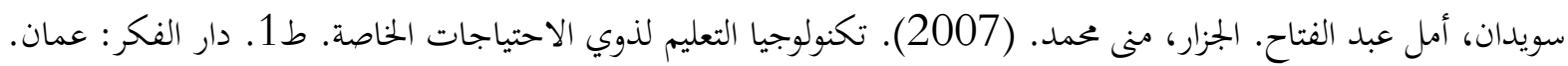

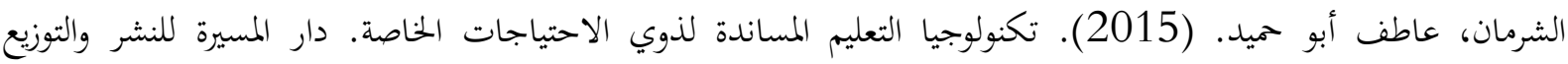
والطباعة: عمان.

عبد العاطي، حسن الباتع. (2014). تكنولوجيا تعليم ذوي الاحتياجات الخاصة والوسائل المساعدة. دار الجامعة الجديدة: الإسكندرية.

العجمي، عمد حسنين. (2002). الإدارة المدرسية، دار الفكر العربي: القاهرة.

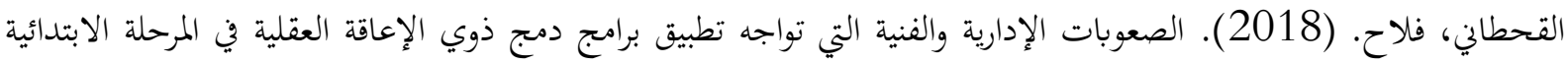

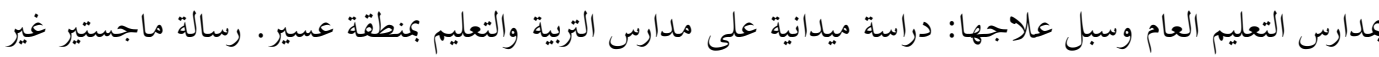
منشورة، جامعة الملك خالد، المملكة العربية السعودية.

القريطي، عبد المطلب أمين. (2021). سيكولوجية ذوي الاحتياجات الخاصة وتربيتهم، مكتبة الأنجلو المصرية: القاهرة.

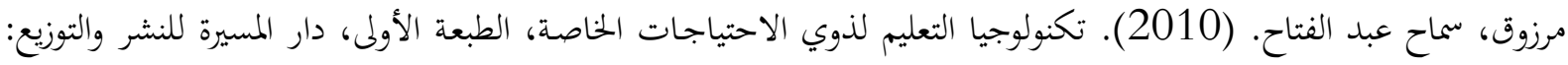
عمان.

Harris, J. (2011). Utilization of computer technology by teacher at carl Schurz High school, a Chicago public school. Dissertation Abstract International, A61/06, 2268. 


\title{
NATURAL FACTORS AFFECTING ECO-ARCHITECTURE (DADES OASIS MODEL)
}

\author{
Farida OUZDI ${ }^{1}$
}

\section{Istanbul / Türkiye \\ p. $90-105$}

Received: $29 / 11 / 2021$

Accepted: 08/12/2021

Published: 01/01/2022

This article has been scanned $t$ iThenticat No plagiarism detected

\begin{abstract}
:
Some unfortunate brothers were baptized to feasts and banquets for the public, and during season times Historical sources ndicate that the cults of the Abbasid Caliphs, including the Abbasid aliphate Al-Mahdi, the Mamoun and the Mu 'taad, ranged between six thousand and a thousand dinars a day, while the expenses of the Al-Mutakil kitchen amounted to one thousand dirhams, which is a fairly large budget.

He was also known to identify the Abbasids with public and rivate tables, including the Caliph al-Mansur Al-Rasheed al-Mamoun with a stature favourable to the general public in addition to the state of development that Arab and Islamic society witnessed during the Arab era, in terms of the literature of the gourmet and the pious tools related to the Arab cuisine Result for Tth.
\end{abstract}

Key words: Dades Oasis, Eco-Architecture.

http://dx.doi.org/10.47832/2717-8293.15.7 


\title{
العوامل الطبيعية المؤثرة في العمارة البيئية \\ (واحة دادس أنموذجا)
}

\section{فريدة أزدي 2}

\begin{abstract}
الملخص: ارتبط استقرار الإنسان بالمجالات الواحية، بمدى إمكانية العيش التي يمكن أن يوفره له هذا المجال. فكان الماء هو العامل الأول الذي جذب الإنسان. قام هذا الأخير بتكييف العناصر الأخرى المكونة للطبيعة لصالحه بما يوافقها،

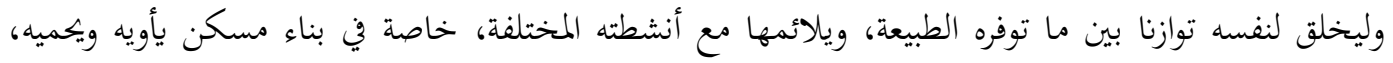

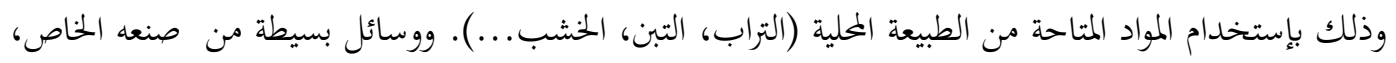
وتقنيات محلية معروفة بالتابوت أو الطابية. هذه العمار المشيدة من طرف الإنسان الواحي تعتبر صديقة للبيئة

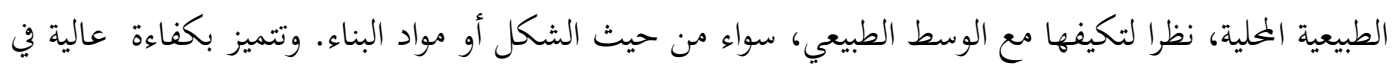

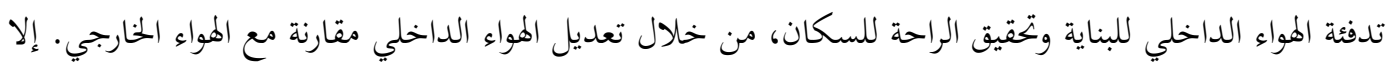

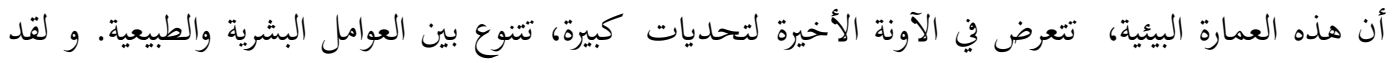

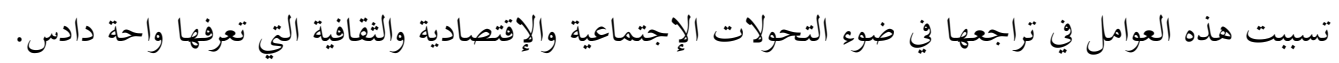
الكلمات المفتاحية: العمارة البيئية، الواحة، العوامل الطبيعية.
\end{abstract}

تعتبر العمارة البيئية من أهم مظاهر تفاعل الإنسان مع البيئة الطبيعية داخل المجال الواحي، وتحدي كل ظروف الحياة

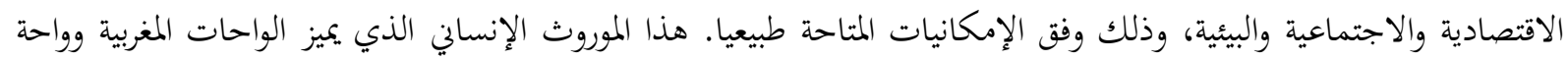

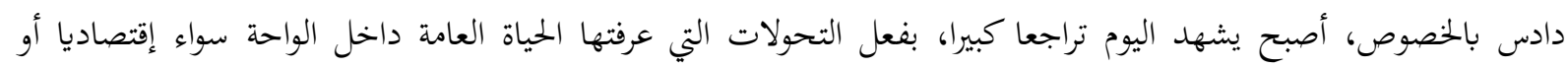
إجتماعيا وثقافيا.

شكلت كل هذه التحولات تحديا أمام استمرارية العمارة البيئية، خاصة بعد الإهمال والتهميش الذي لحقها من طرف الإنسان. ما جعلها عرضة لكل أسباب التدهور الطبيعية والبشرية. وستركز هذه الدراسة على العوامل الطبيعية المؤثرة على العمارة

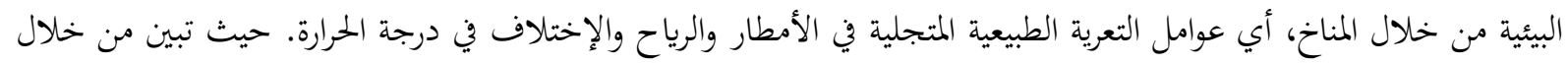
المسح الميداني الدمار الكبير الذي تخلفه هذه الأخيرة على المباني الواحية التقليدية.

تشكل العمارة البيئية أحد أهم المعالم الحضارية بواحة دادس. كما أها الشاهد الأساسي على تاريخ المجتمعات، وثقافتها

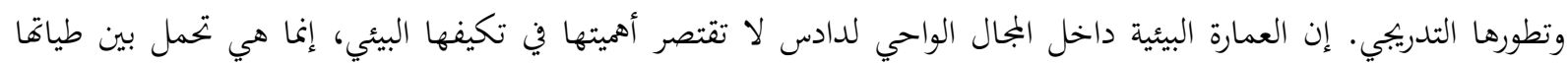

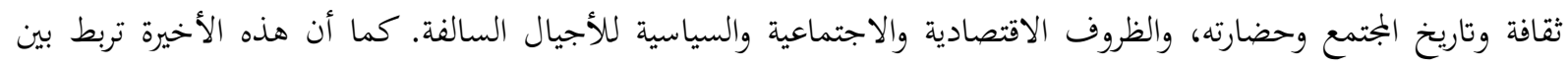

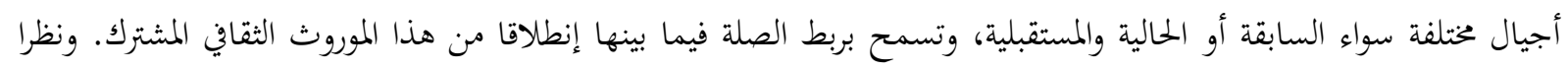


لتطور التحديات الطبيعية والبشرية وعمق تأثيرها على العمارة البيئية بالمجال الواحي مع مرور الزمن، كان من الأهمية بمكان إثارة

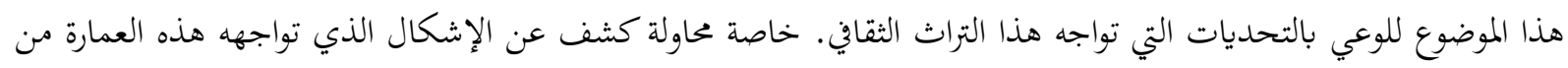

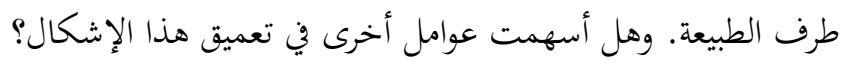

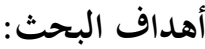

تحدف هذه الدراسة إلى كشف بعض العوامل الطبيعية المؤثرة في العمارة البيئية بواحة دادس الواقعة بالجنوب الشرقي المغربي،

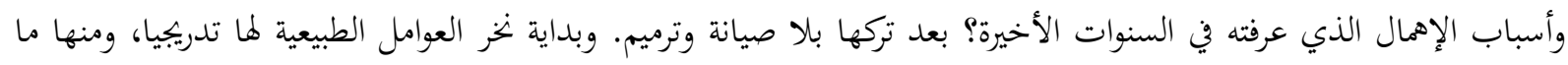

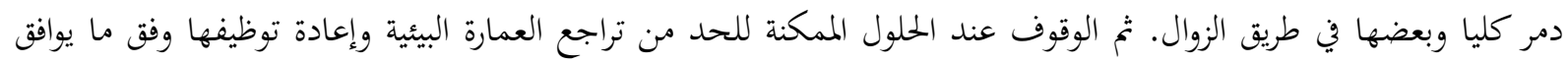
العصر الحديث، وذلك باقتراح بعض التدابير اللممكنة للنهوض بهذا الموروث الحضاري والعمل على استدامتهن.

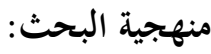

اعتمد في هذه الدراسة على المنهج الوصفي التحليلي، لجمع المعلومات والبيانات المتعلقة بالعمارة البيئية، والوقوف على الملى

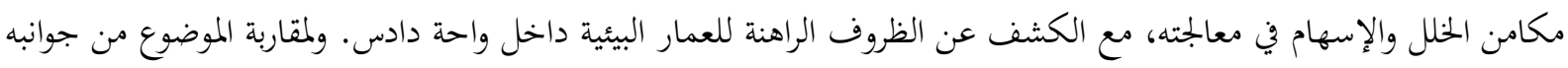

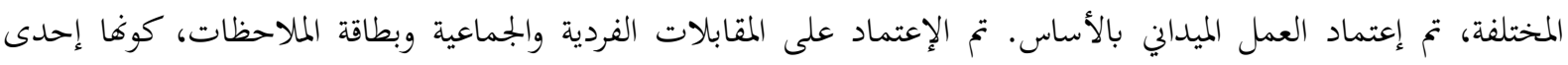

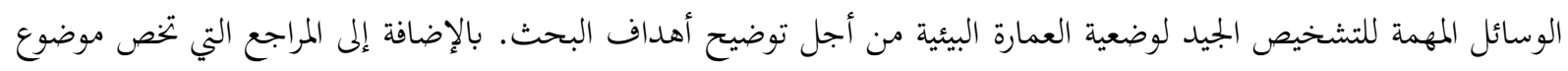

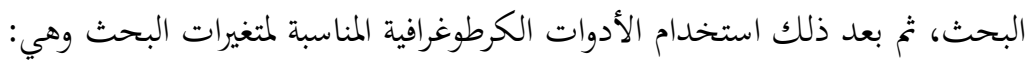

\section{Arc GIS برنامج -}

Google Earth صور -

- الصور الرقمية لمجال الدراسة -

\section{1. - 1 العمارة البيئية بواحة دادس}

يقصد بالعمار البيئية، المباني المتكيفة مع الوسط البيئي الطبيعي. لأها تعتمد على الموارد الطبيعية. فهي لا تأثر على البيئة

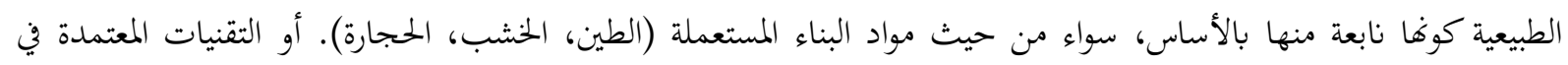

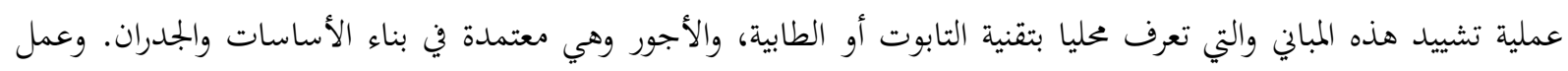

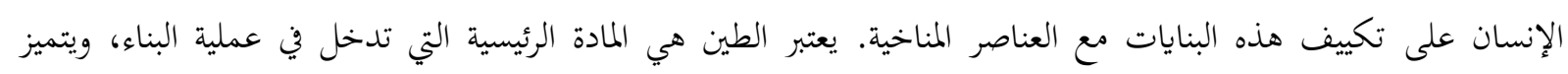

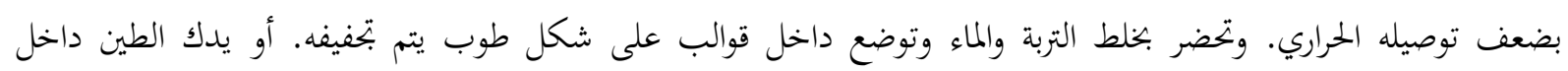

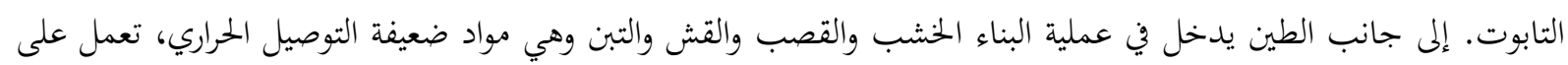
نقل الحرارة بالتباطؤ التدييجي إلى داخل المبنى. وتمثل القصبات والقصور والدور التقليدية هذه العمارة البيئية داخل الواحة.

1.1 موقع واحة دادس

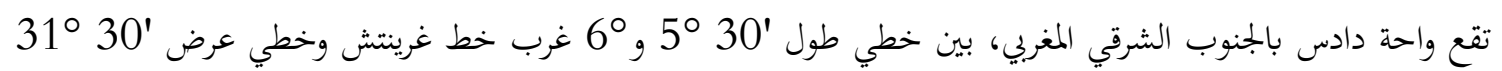

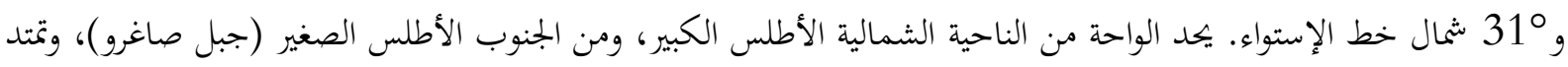
على طول وادي دادس (خريطة رقم 1). 
أسهم الموقع الجغرافي للواحة بخصائصه المناخية، في تبني الإنسان بهذا المجال سلوكات معينة نابعة من العمل الجماعي الذي

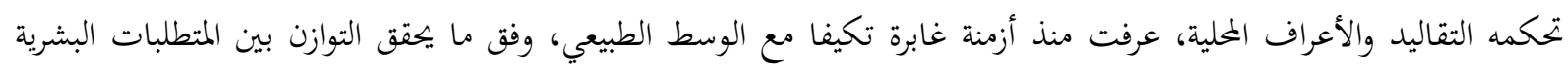

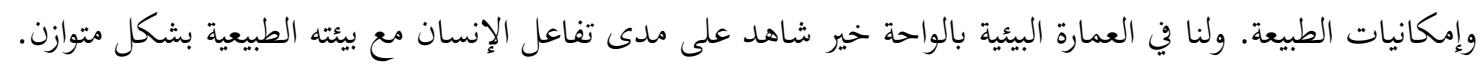

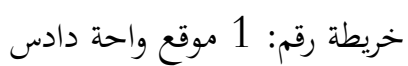

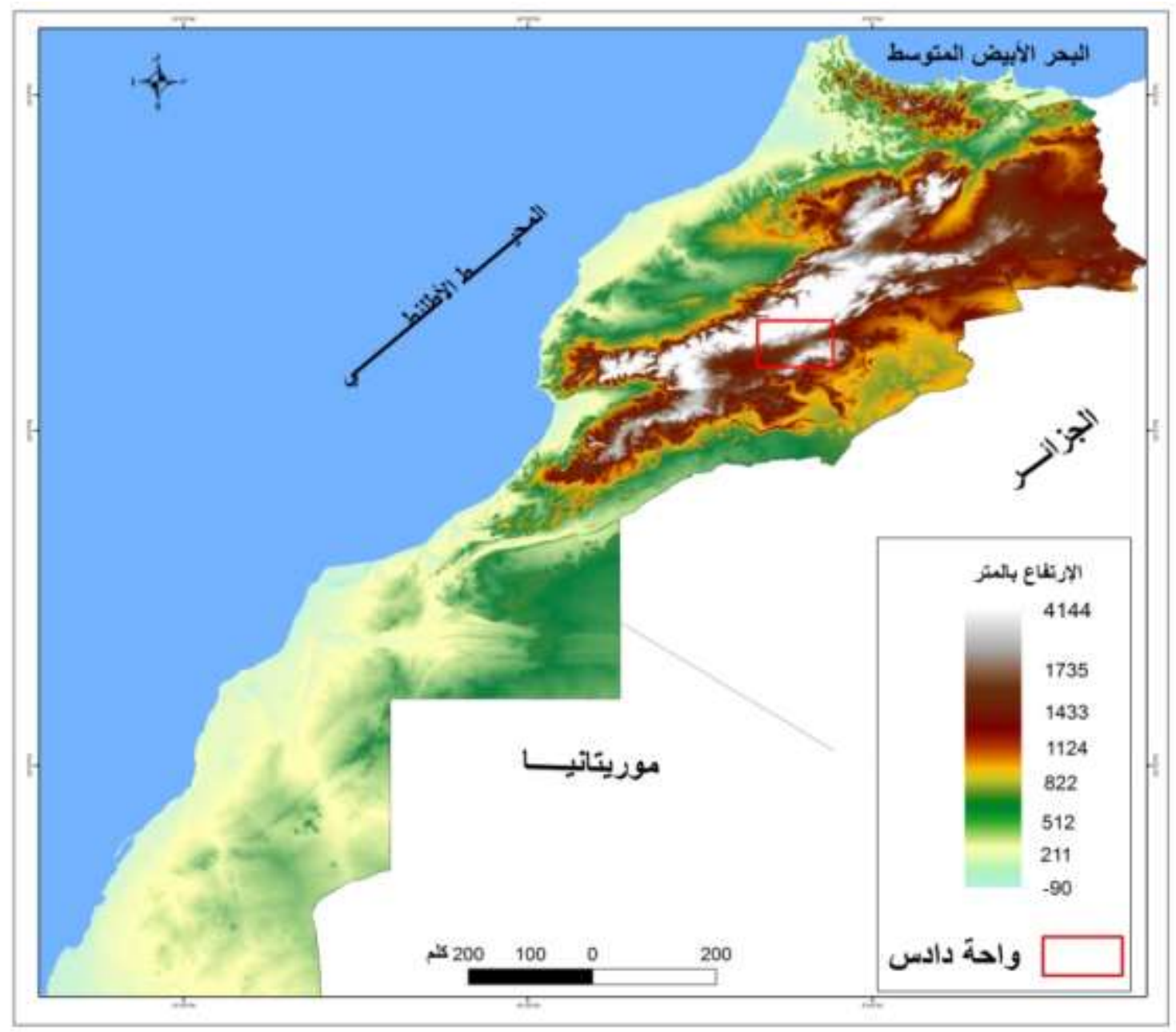

المصدر: الصور الرقمية لواحة دادس

نظرا للموقع الجغرافي للواحة، وانفتاحها في الجنوب على المؤثرات الصحراوية الجافة. ما أضفى عليه المناخ شبه جاف.

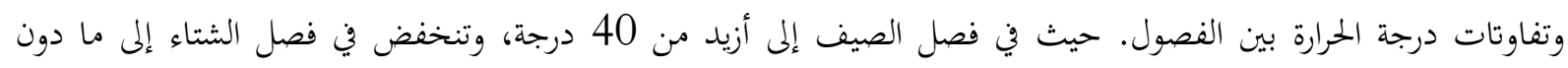

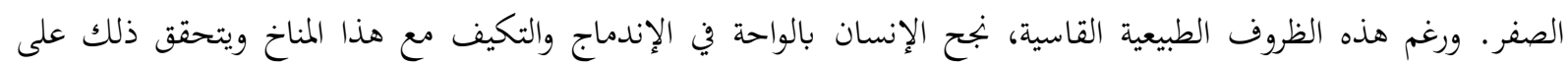
مستوى العمارة البيئة. أنماط العمارة البيئية بالواحة

تشكل المباني التقليدية مركز الإنتماء المشترك لكل الفئات الإجتماعية المشكلة للمجال. وتعتبر هذه المباني من أهم مظاهر

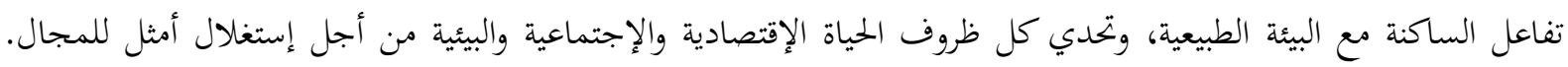
وتتنوع هذه المباني بين القصور؛ كوحدات سكنية أولى جمعت فئات إجتماعية مختلفة والقصبات التي بنيت بعد الإستقلال التدريجي عن القصر ثم الدور التقليدية. 
القصور: تتعدد تعاريف الباحثين لهذا النوع من العمارة البيئية كل من زاويته، فهناك من يعطي القصر أو كم يسمى محليا

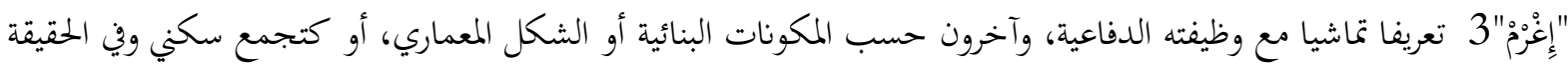

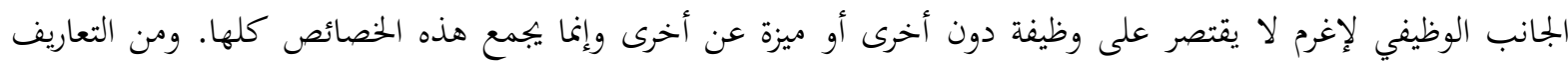

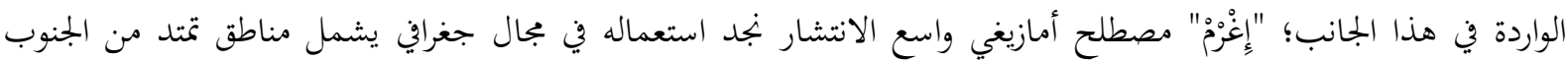
الأطلس الكبير والجنوب الشرقي، إلى الريف، واذا كان استعماله عند بعض القبائل يتخد صيغة المؤنث تغرمت ويطلق حينئذ على لئى

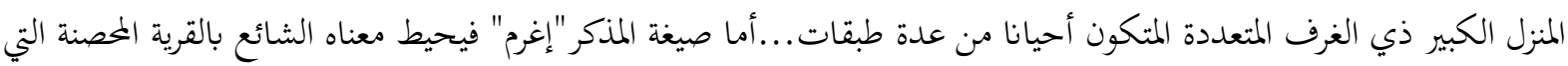

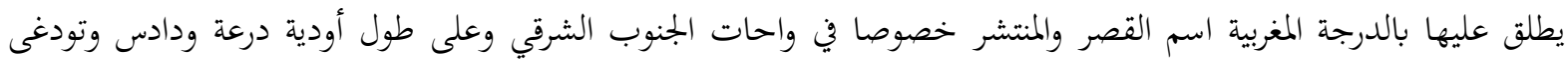

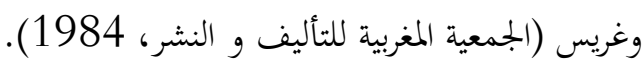

القصر أو "إغْرْم" حسب تعبير الباحث محمد لمراني علوي(كلية الآداب مكناس) هو خلية سكنية تضم العديد من المنازل

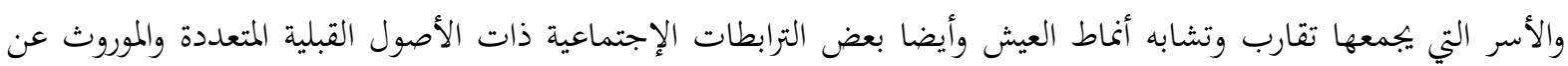

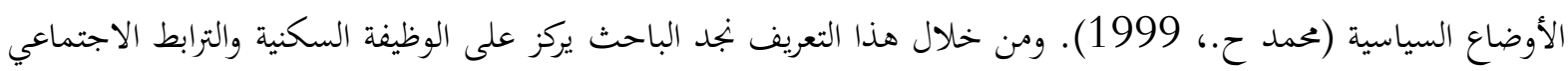
للقصور.

ما يمكن أن نخلص اليه في الأخير أن المعمار الطيني عبارة عن بنايات تقليدية أنتجتها الظروف التاريخية،المناخية و الأمنية؛

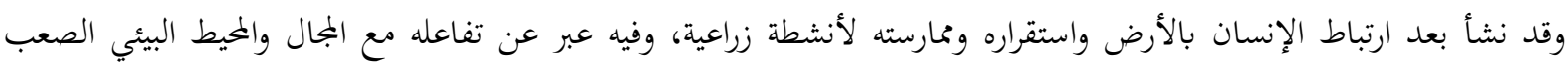

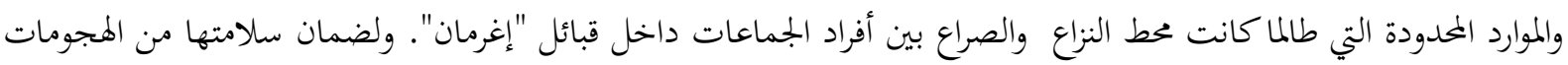

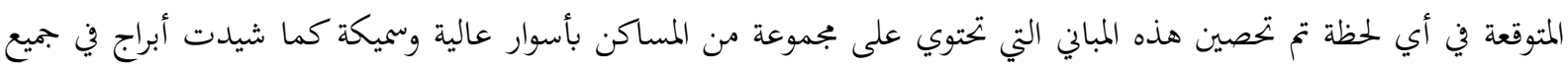

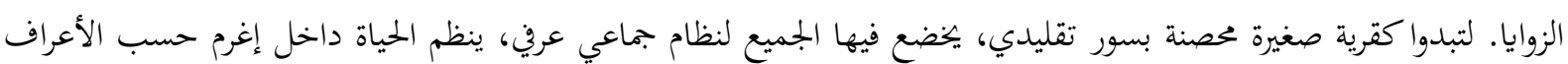
المتفق حولها.

القصبات: ويطلق عليها باللغة المحلية إسم "تِغْْْمَتِنْ". لمُ يأتي بناء" تغرماتين "بشكل اعتباطي، انما أسهم في ذلك ظروف

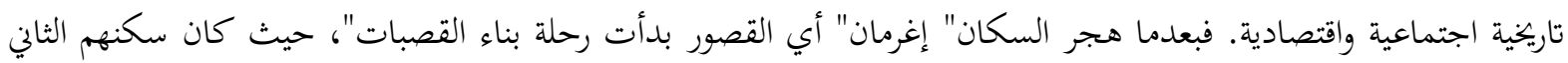

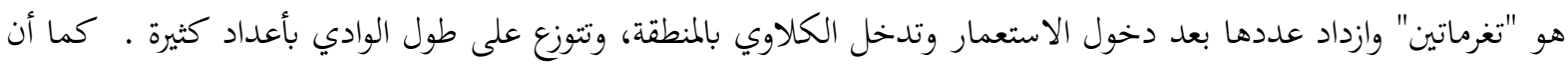

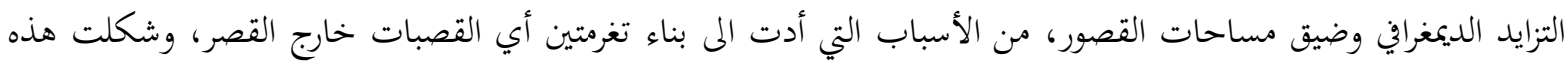
المرحلة أولى البوادر والإشارات

لاحتضار إغرمان بعد اهمالها بالكامل. و تِغْرْمْتُ أو القصبة لا تختلف كثيرا عن المباني التي نجدها داخل القصور. وانما ما

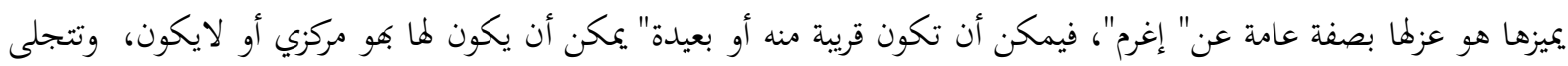

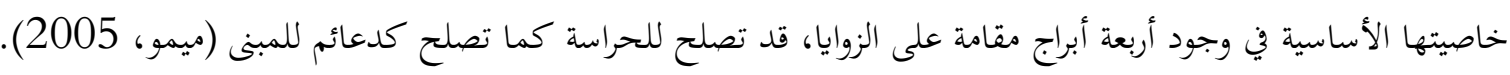

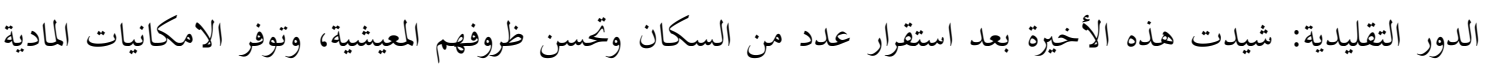

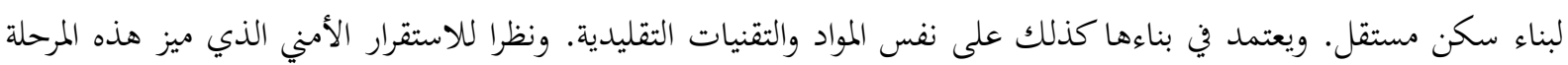
التي شيدت فيها إنعكس ذلك على شكل البناية، حيث يلاحظ غياب الأبراج التي كانت تستعمل للمراقبة وذلك لإستباب

3 بتحهل الكثير من الباحثين التسمية الأصلية والفعلية لهذا المعمار حيث يقدمه الكثيرين على تسمية القصر بمعنى" إغرم "والقصبة بمعنى"تغرمت" والأجدى هو

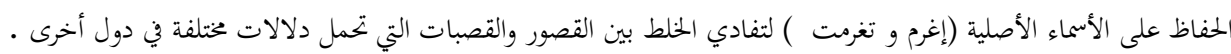


تطورت هذه المباني على مر التاريخ من إغرمان الى تغرمتين الى دور تقليدية، وتتميز بخصائص مناخية متميزة حيث تلطف

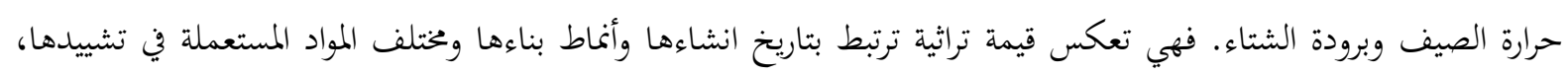
وعلاقتها بشخصيات وأحداث تاريخية.

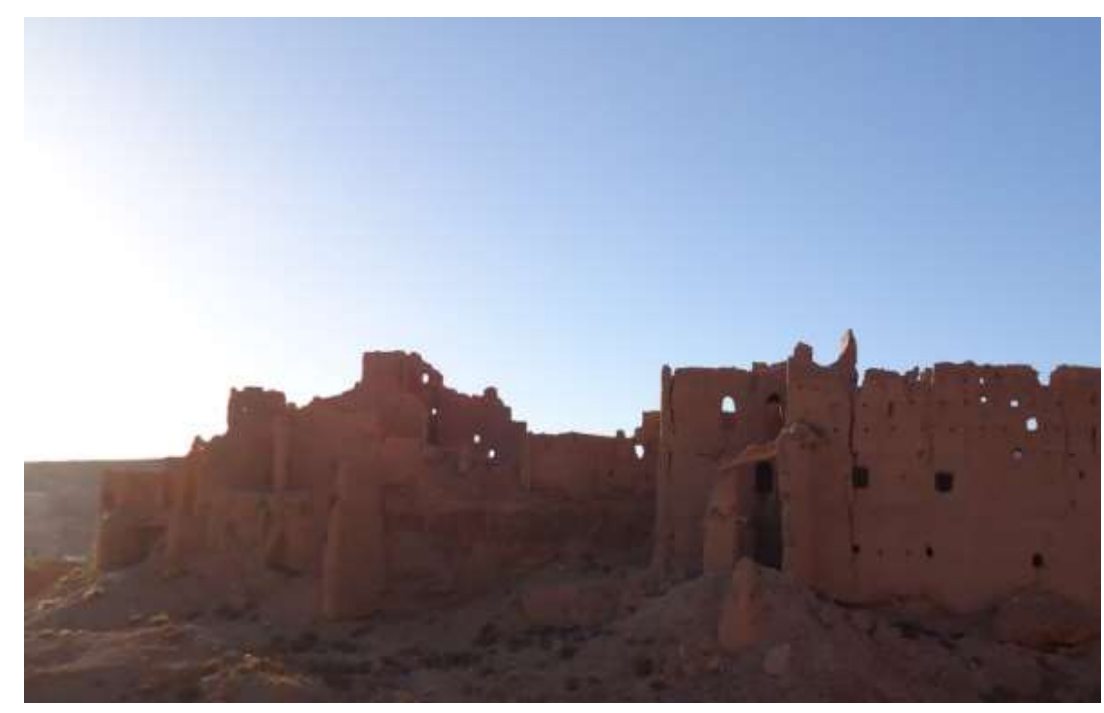

صورة رقم 1: نموذج للقصر بدوار أقبوب

المصدر: تصوير شخصي، 2014

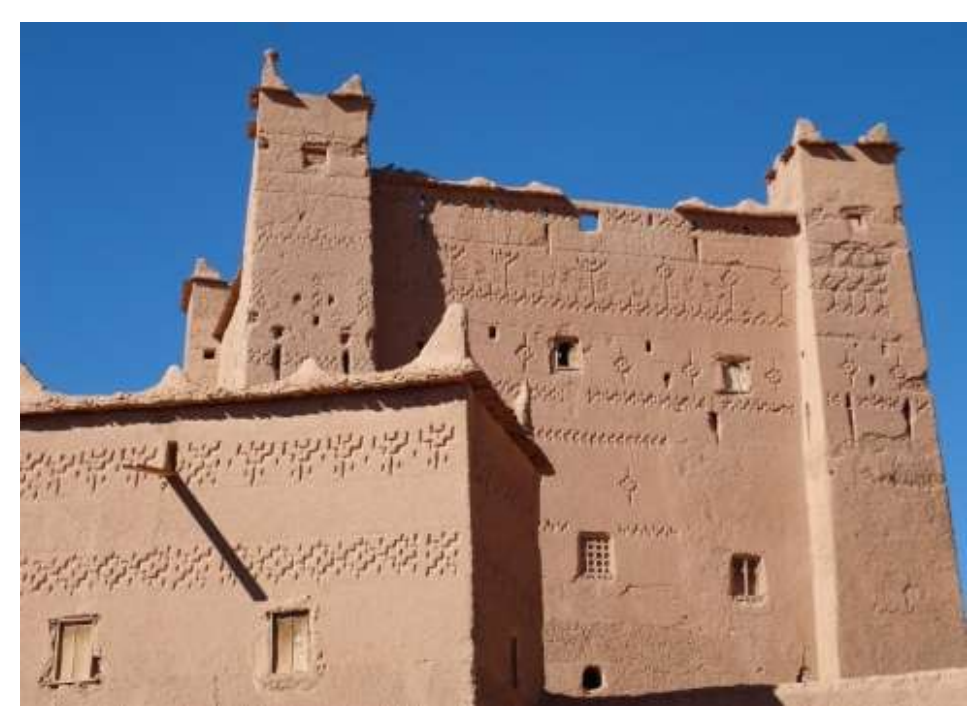

صورة رقم 2: نموذج للقصر بدوار أيت بومان

المصدر: تصوير شخصي، 2014 فوذج للفر بلور ابت بومان 


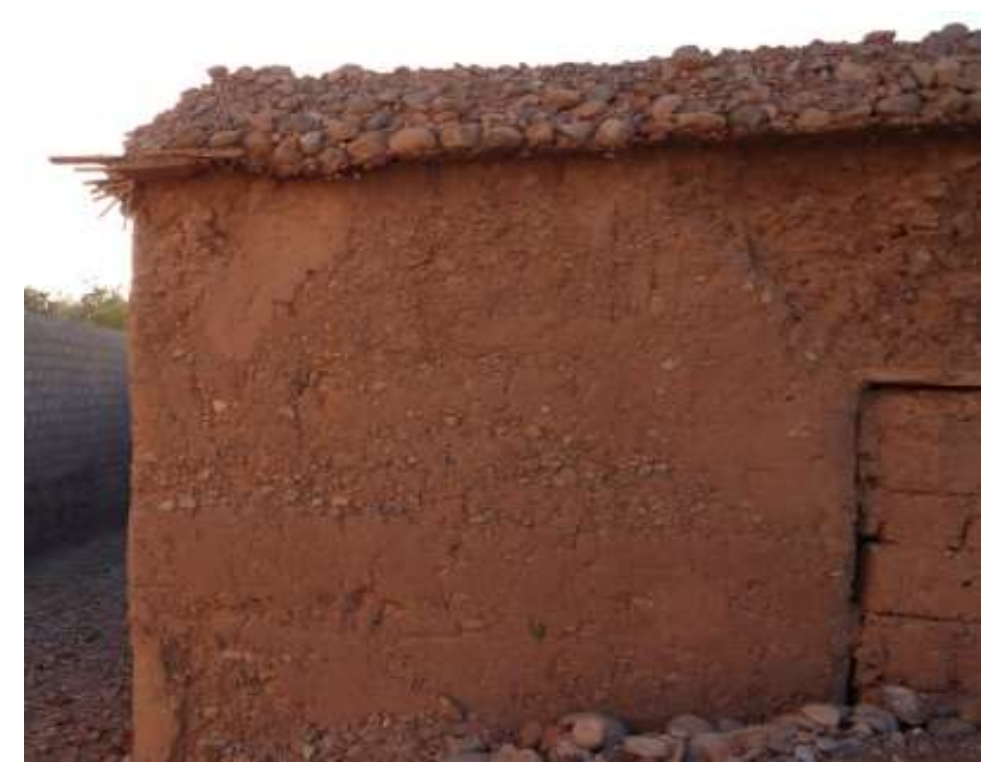

صورة رقم 3: نموذج للقصر بدوار أيت عبدون المصدر: تصوير شخصي، 2014

توضح الصور التالية، مجموعة مختلفة من المباني الواحية التقليدية. شيدت في مراحل تاريخية مختلفة، بناء على الأوضاع الاقتصادية والاجتماعية والسياسية التي تميز كل مرحلة.

2. المزايا البيئية للعمارة الواحية التقليدية

تتضح المزايا البيئية داخل مباني الواحة التقليدية في جوانب مختلفة. تنطلق من الكفاءة العالية في تدفئة الهواء الداخي للبناية

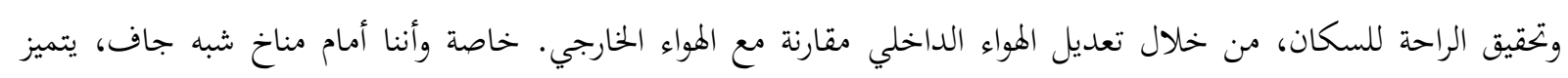

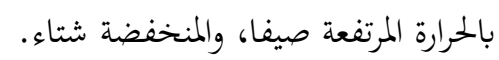

نجد الملائمة البيئية في العمارة الواحية على مستوى مواد البناء المستعملة وكذا على مستوى التقنيات. هذا الشكل العمراني المتوارث عبر الأجيال تم تشييده تلقائيا مع مراعاة الظروف المحيطة بالسكان أنذلك منها؛ الأمنية، والاقتصادية والطبيعية.

1.2

اعتمد الإنسان بواحة دادس على ما توفره البيئة الطبيعية من مواد أولية لتشييد المباني، واستعمل التربة والخشب والتبن وجذوع الأشجار المحلية والقصب. حيث لم يتطلب البناء منه السفر البعيد والبحث عن الجلديد انما، يستخدم ما توفره له بيئته

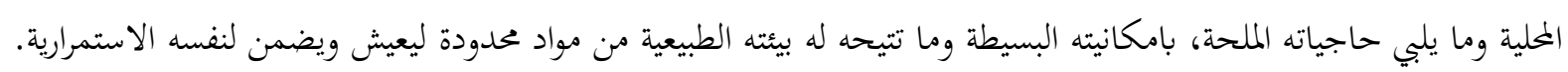

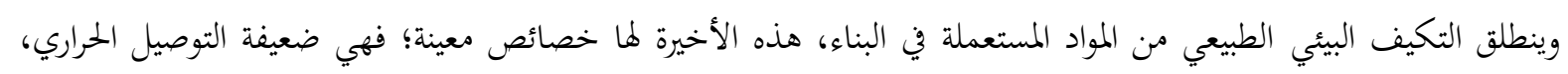

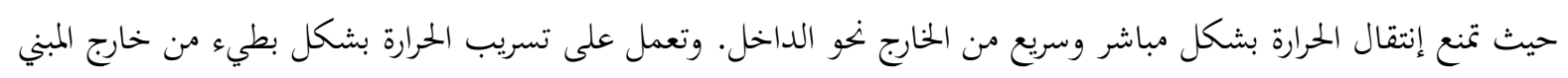

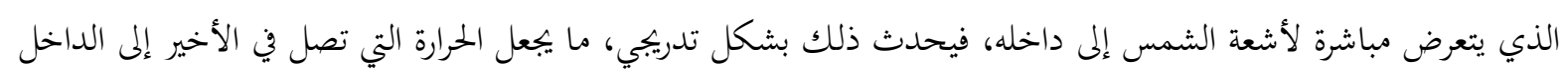




\section{2 التكيف البيئي بين تقنيات البناء وشكل البناية}

يتناسب هذا النوع من العمارة في مواجهة الظروف المناخية القاسية، إنطلاقا من التقنية المستعملة في البناء وشكل البناية.

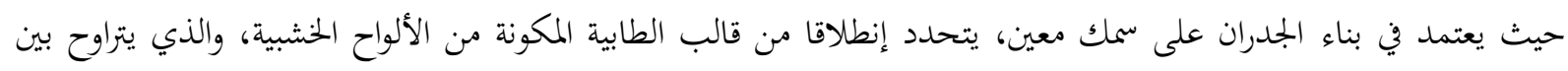

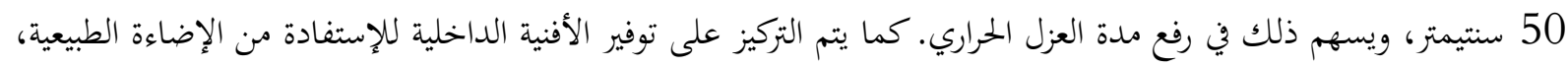
وبتحيد الهواء داخل البناية للحفاظ على مناخ معتدل في الداخل.

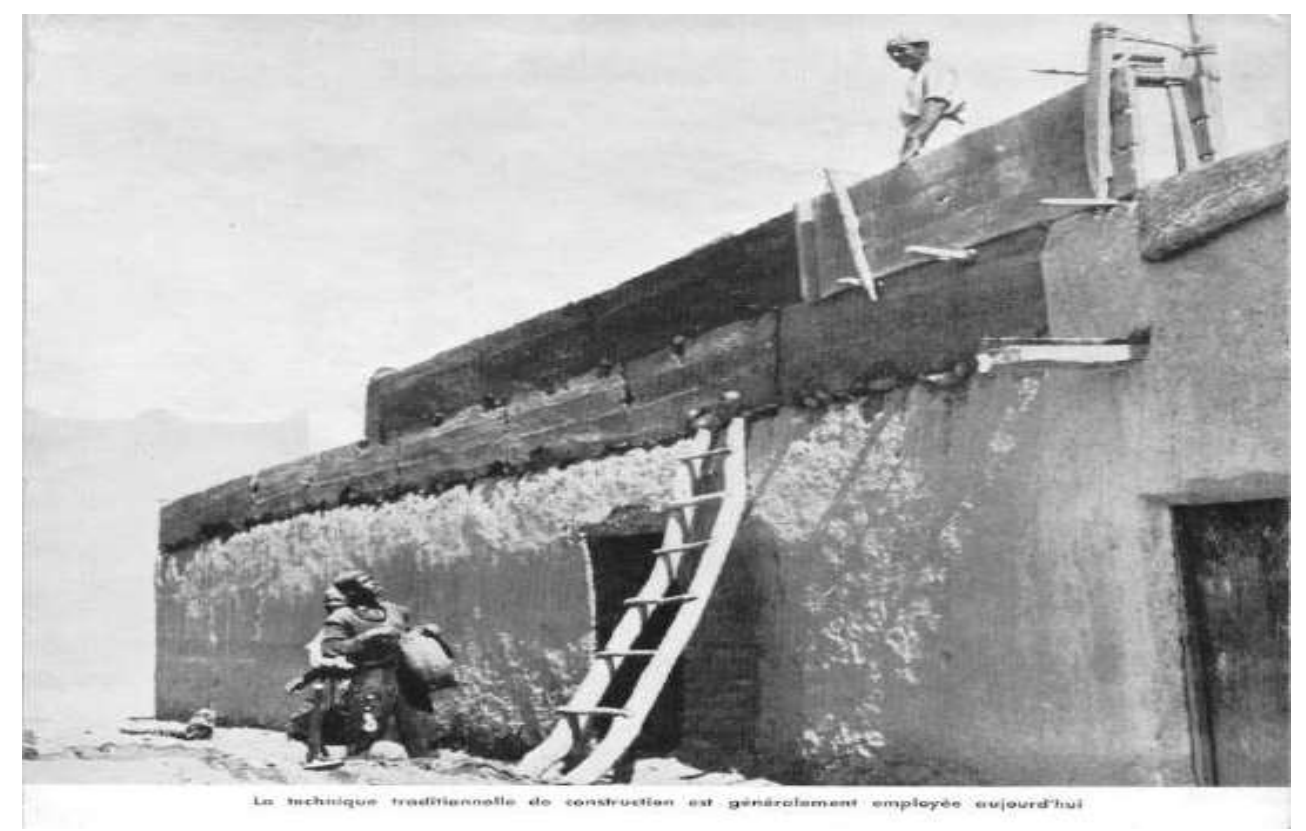

صورة رقم 4: تقنية الطابية أو التابوت المعتمدة في بناء العمارة البيئية

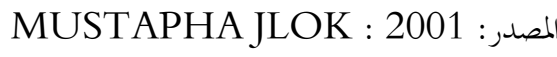

إن هذه البنايات بمزاياها المتعددة وخصوصياتا المحلية، تعرضت للإهمال، بعد التحولات المجالية التوسع العمراني الحديث

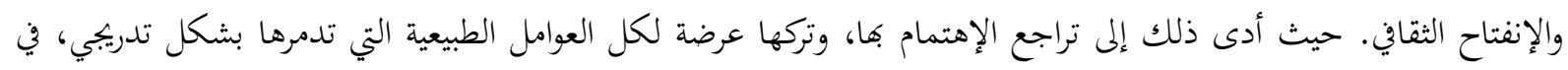
ظل غياب عملية الترميم.

\section{3. تأثير العوامل الطبيعية على العمارة البيئية}

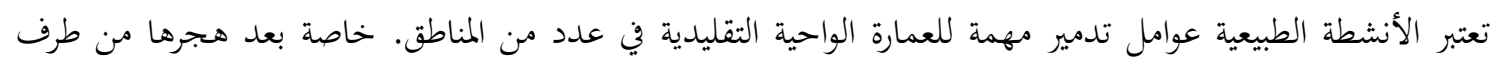

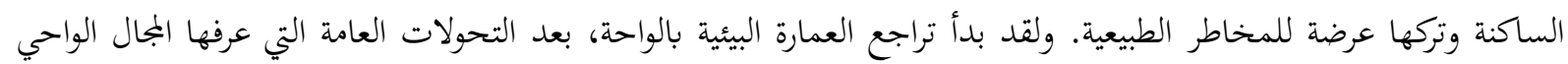

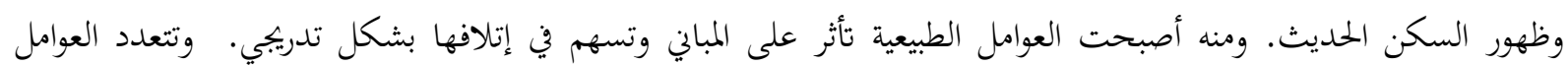
الطبيعية المؤثرة على العمارة البيئة؛منها ماهو ميكانيكي وفيزئيائي.

1.3.

تأتي أهمية الإشارة إلى الوضعية المناخية داخل الواحة إلى أهمية الخروج بمعطيات موضحة للسمات الأساسية المميزة للمناخ الواحي،

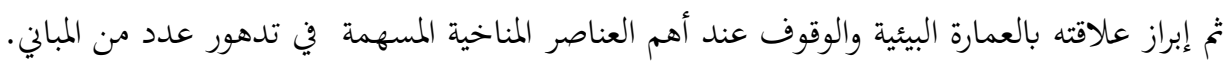

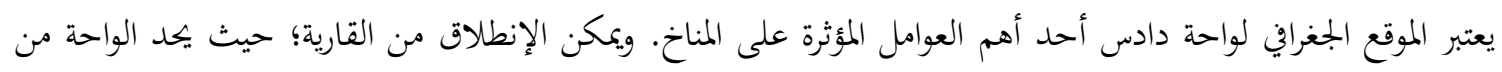

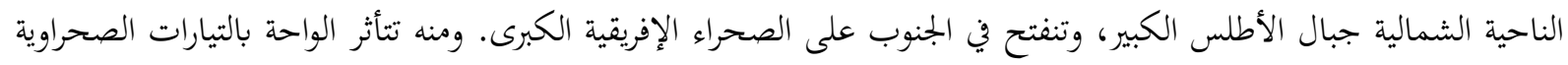

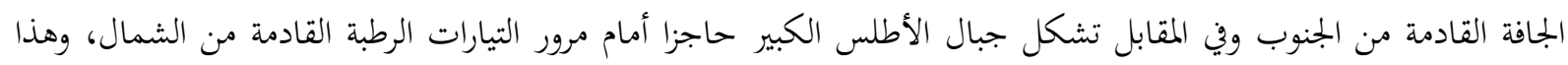


"يجعل مناخ الواحة يتميز بالقساوة. ويتضح ذلك من خلال التفاوت الكبير في درجة الحرارة، وشح الأمطار المتساقطة وتباينها.

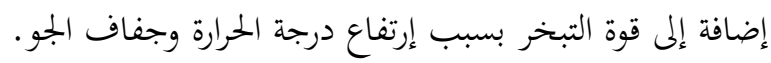

$$
\text { تأثير التساقطات المطرية }
$$

على الرغم من قلة الأمطار لسيادة المناخ شبه الجاف، إلا أنه تشهد أحيانا بعض السنوات المطيرة، ذات أمطار غزيرة

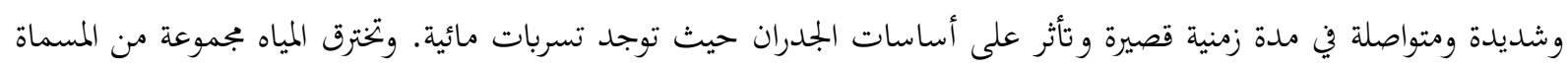

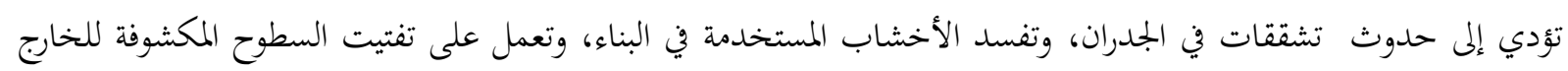
خاصة إذا تراكمت المياه بعد إنسداد قنوات التصريف. إن التساقطات المطرية من ضمن الأسباب الرئيسية التي أدت إلى تدهور

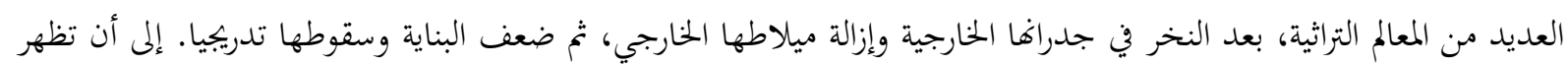
معالمها الداخلية التي لا تسلم هي الأخرى من مجمل هذه التأثيرات.

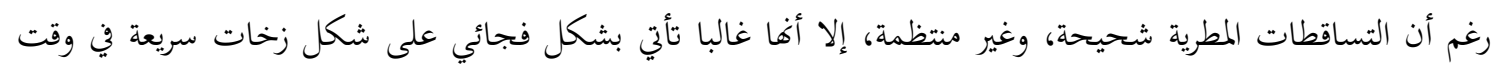

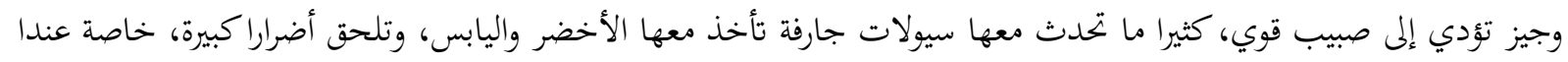

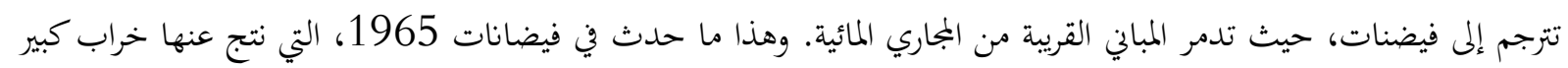
للعمارة البيئية وزوال عدد مع هذه المباني. صورة رقم 6: نموذج للقصر بدوار أيت عبدون صورة رقم 5: نموذج للقصر بدوار إمزيلن

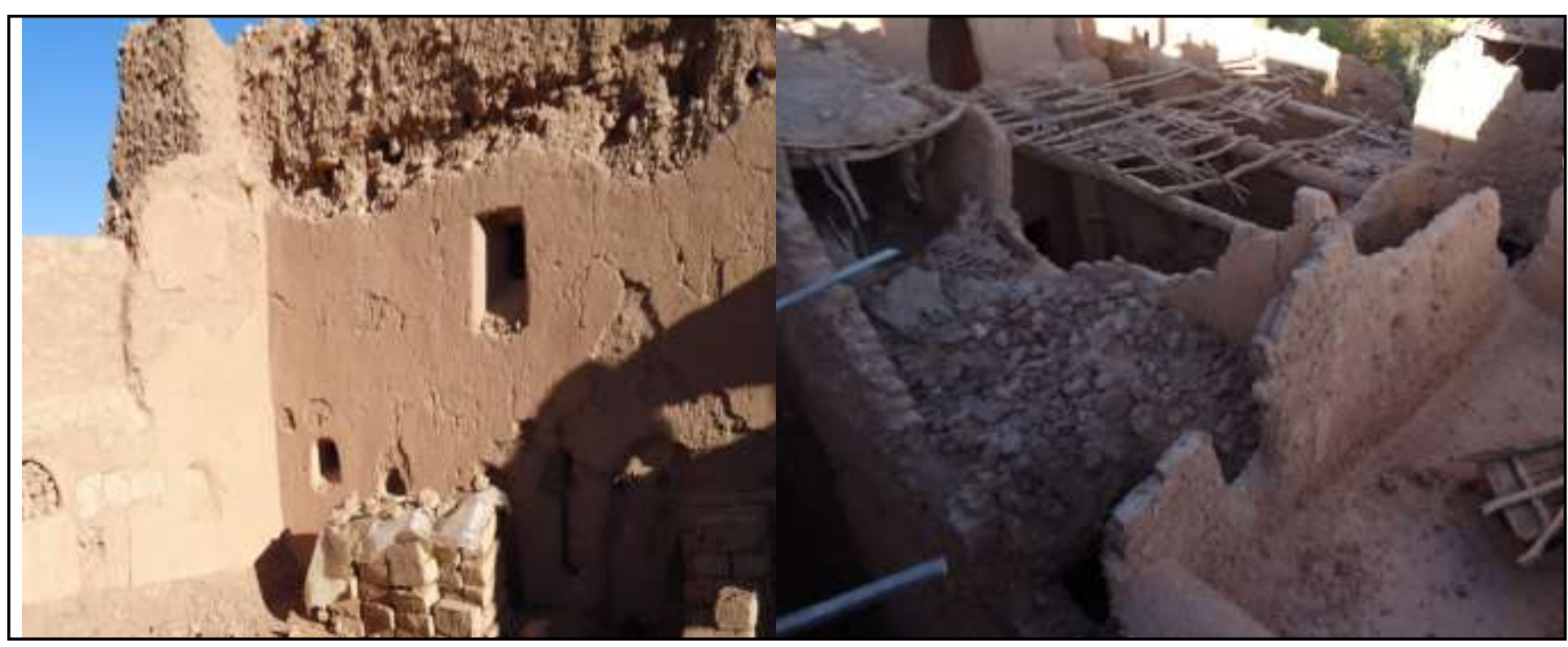

المصدر: تصوير شخصي، 2014

المصدر: تصوير شخصي، 2014

رغم أن التساقطات المطرية شحيحة، وغير منتظمة، إلا أغا غالبا تأتي على شكل زخات مطرية سريعة في وقت وجيز.

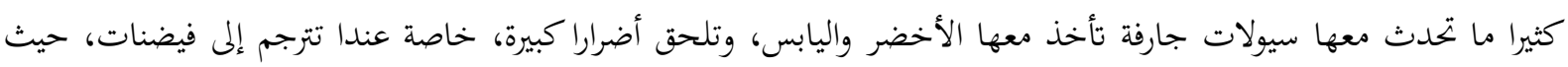

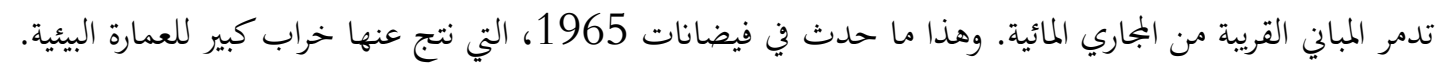


صور جوية: توزيع العمارة البيئية بواحة دادس

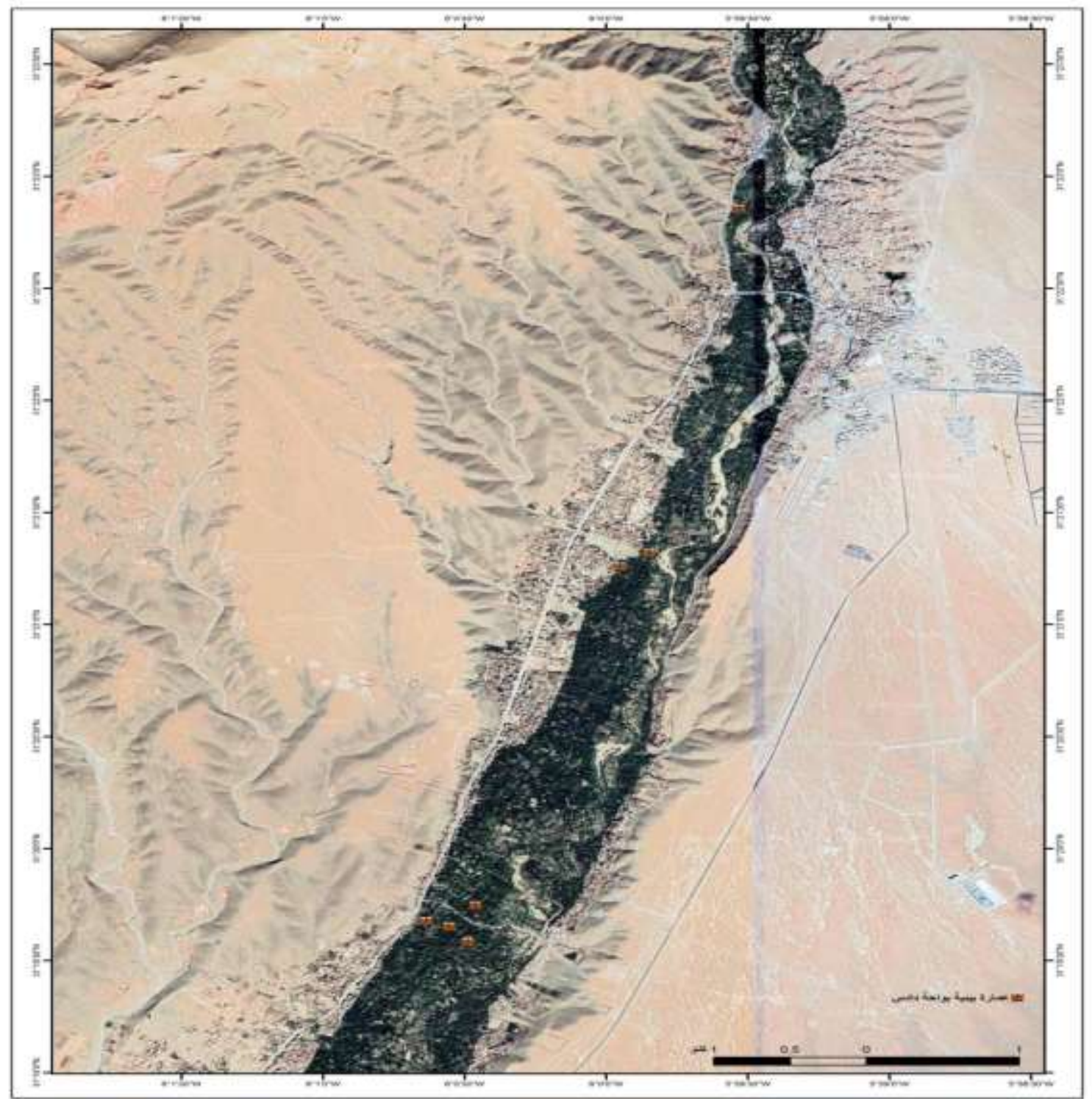

Google Earth المصدر: برنامج

3.3 تدخل عامل الرطوبة في إضعاف العمارة البيئية

تتعرض العمارة البيئية لمشكل الرطوبة بشكل كبير. وتظهر هذه الخطورة عند البنايات التي تتوسط الحقول الزراعية، وقريبة من المجاري المائية. تتسرب المياه إلى الجدران عن طريق المسامات وتؤثر على البناية إنطالاقا من:

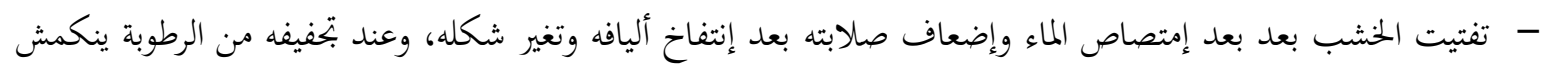

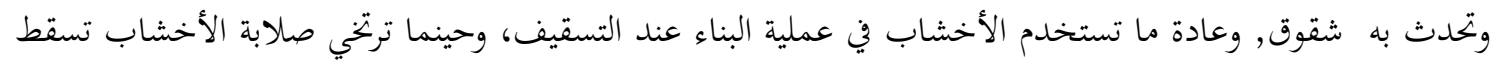
الأسقف؛

- نمو بعض النباتات ولو بشكل ضعيف، بحكم أن الواحة تعرف مناخا جافا تغيب في الرطوبة. إلا أن الرطوبة التي تؤدي إلى نمو النباتات ناتحة عن الأمطار المتساقطة والضايات النابتحة عنها بسبب تراكم المياه في الأجزاء السفلية من الجدران.

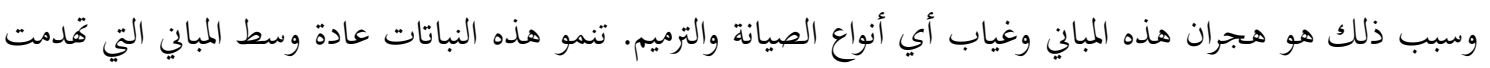

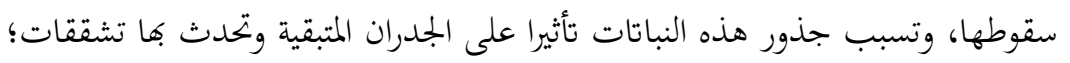


- - إمهان مواجهة الطبقة الخارجية وسقوطها، بعد تعرضها لعمليات تدهور ميكانيكية وفيزيائية. - فقدان أساسات البنايات للصلابة بعد بتع المياه بالقرب من الأساسات واختراق المياه للمسامات، كما يصبح اللحام

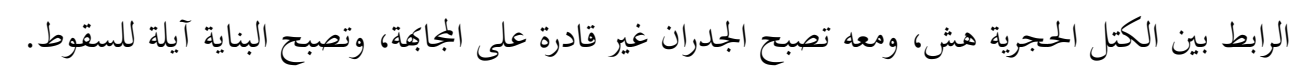

مصدر الرطوبة بالنسبة للعمارة الواحية نابع بالأساس من القرب من المصادر المائية. حيث أن أغلبها يتموقع بالقرب من وادي دادس.

ثم مياه الأمطار المؤثرة بشكل وتأثر الرطوبة على المبنى إنطلاقا من؛ تفتيت الخشب المستخدم في البناء تدريجيا، وتكاثر الفطريات والبكتيريا في المبنى، وتساقط ميلاط الجدران. وتتعرض المباني المجاورة لوادي دادس لرطوبة كبيرة تأثر على أساس البناية. حيث تأثر على أساس البناية. تتسرب المياه إلى

الجدران عن طريق المسمات.

\section{3 فعالية الرياح الجنوبية والجنوبية الشرقية}

تدخل الرياح ضمن العوامل الميكانيكية المؤثرة في العمارة البيئية، وهذه الأخيرة بكل كبير في تدهور عدد من المباني.

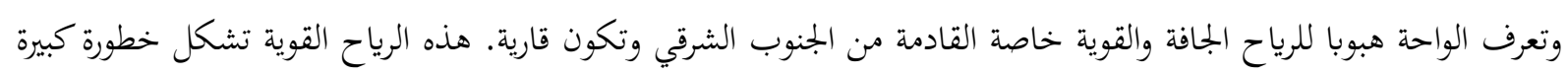

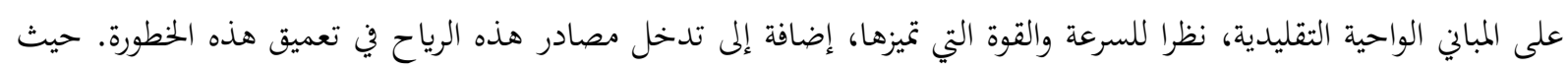
الواحة تستقبل الواحة في الغالب الرياح القادمة المناطق الصحراوية الجافة.

عادة ما تكون هذه الرياح محملة بالحبات الرملية الخشنة والصلبة. وبعد إصطدام الرياح المحملة بالرمال بالجدران الخارجية

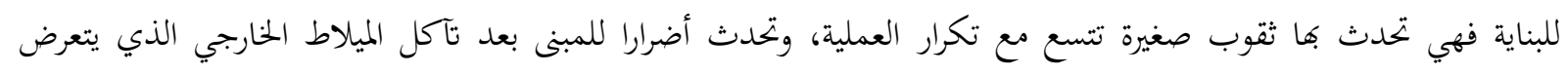

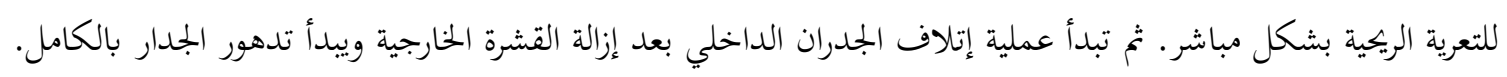

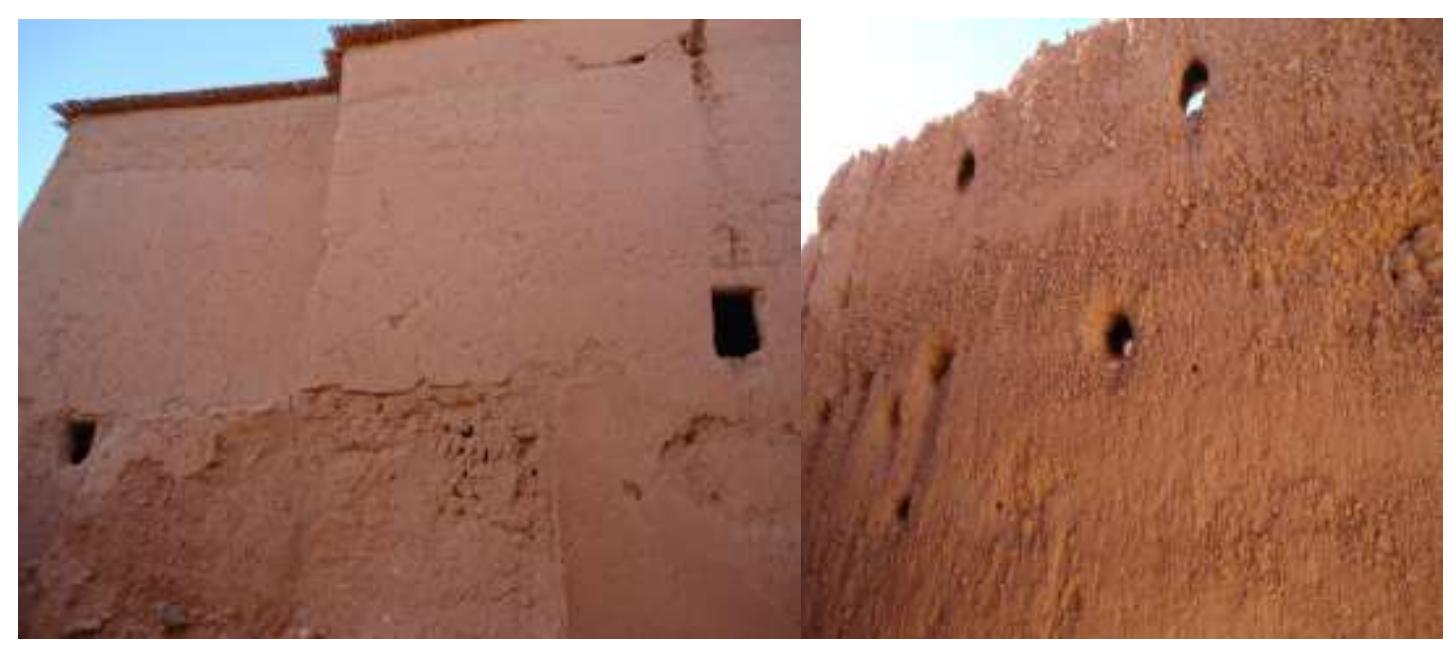

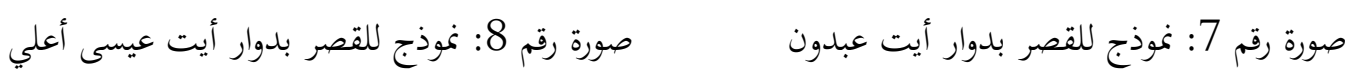

$$
\begin{aligned}
& \text { المصدر: تصوير شخصي، } 2014 \\
& \text { المصدر: تصوير شخصي، } 2014
\end{aligned}
$$




\section{3}

تدخل الحرارة ضمن العوامل الفيزيائية المؤثرة في العمارة البيئية، نتيجة التفاوت الكبير في درجة الحرارة بين السنوات، وبين

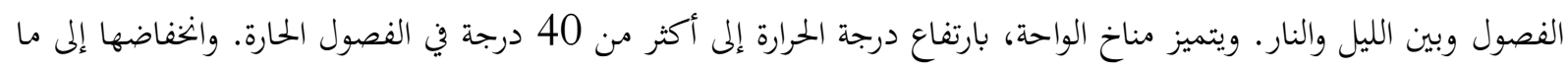
دون الصفر في الفصول الباردة. حيث قد يصل أدنى معدل مسجل إلى (9-) درجات. والعوامل المتحكمة في حرارة المنطقة متنوعة، تتلخص في القارية والإرتفاع والعرض، وهي عوامل حاسمة يضاف إليها التوجيه، و تأثيره محلي مادام التوجيه السائد هنا

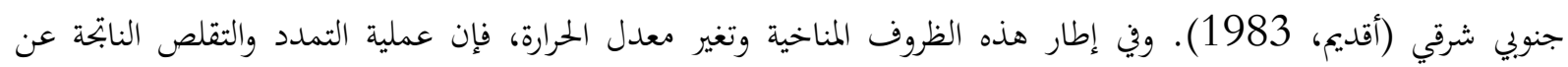
الإختلاف في درجة الحرارة تتردد باستمرار سواء بين السنوات أو الفصول أو بين الليل والنهار.

الحرارة المرتفعة: تتأثر المواد المشكلة للبناية بارتفاع درجة الحرارة. وتؤدي إلى تمددها بعد زيادة حجمها. لأن هذه المواد بعد تعرضها للتسخين بفعل أشعة الشمس تتمدد عند كل الاتحاهات وتتغير حالتها. رغم أن التمدد يبقى نسبي، إلا أنه يظهر تأثيره

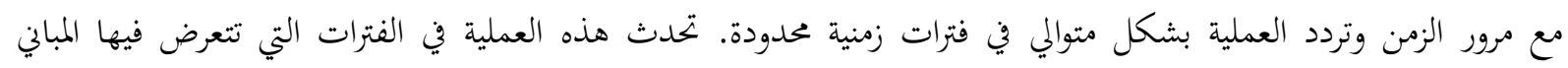

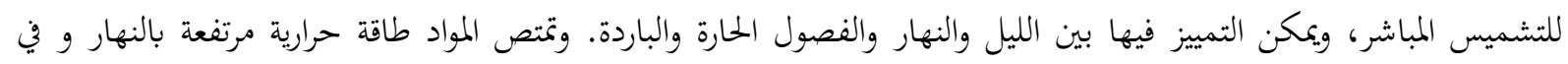

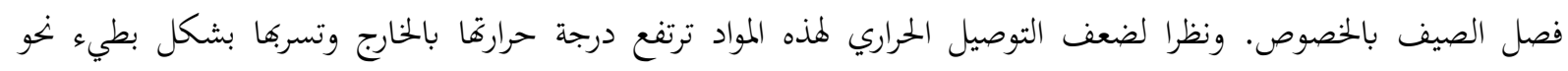

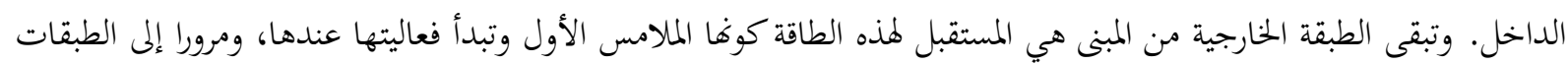

الحرارة المنخفضة: تتعرض مواد البناء إلى تغير في حالتها من جديد بعد انخفاض درجة الحرارة، وتصبح باردة إستجابة

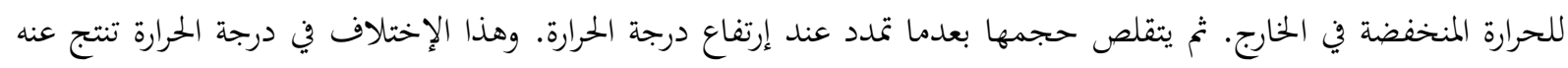

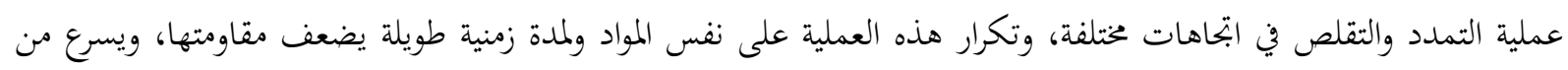

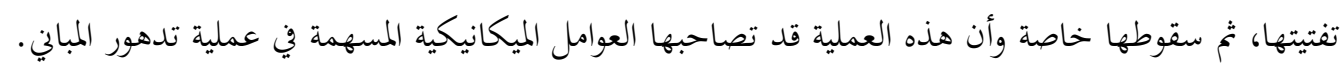
تتأثر الجدران الخارجية للعمارة البيئية بشكل كبير من هذه العملية، خاصة الميلاط الخارجي للبناية. كون هذا الأخير هو هوليه

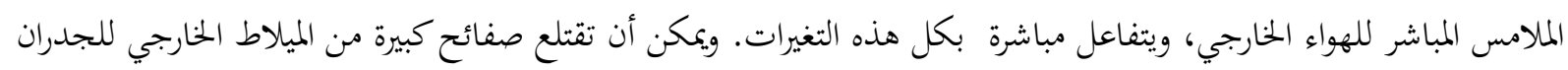
بعد إزالة الحماية ويتسبب ذلك في إتلافه بسرعة. يتدخل الماء المتسرب إلى الجدران عبر المسامات في إحداث أضرار على مستوى العمارة البيئية، بعد تغير حالته الفيزيائية

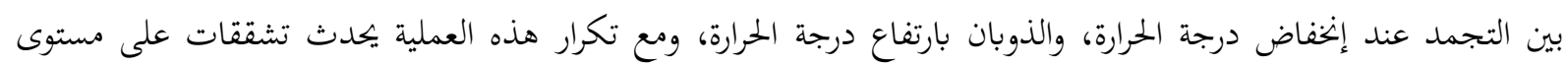

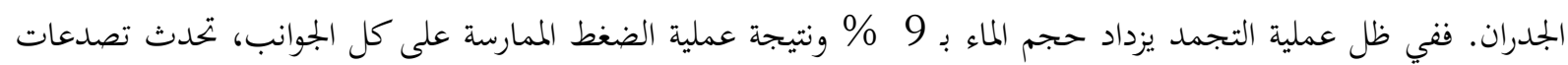
تتسع مع تكرار هذه العملية، كما تتفتت المواد المشكلة للبناية ثم سقوطها تدريجيا. 


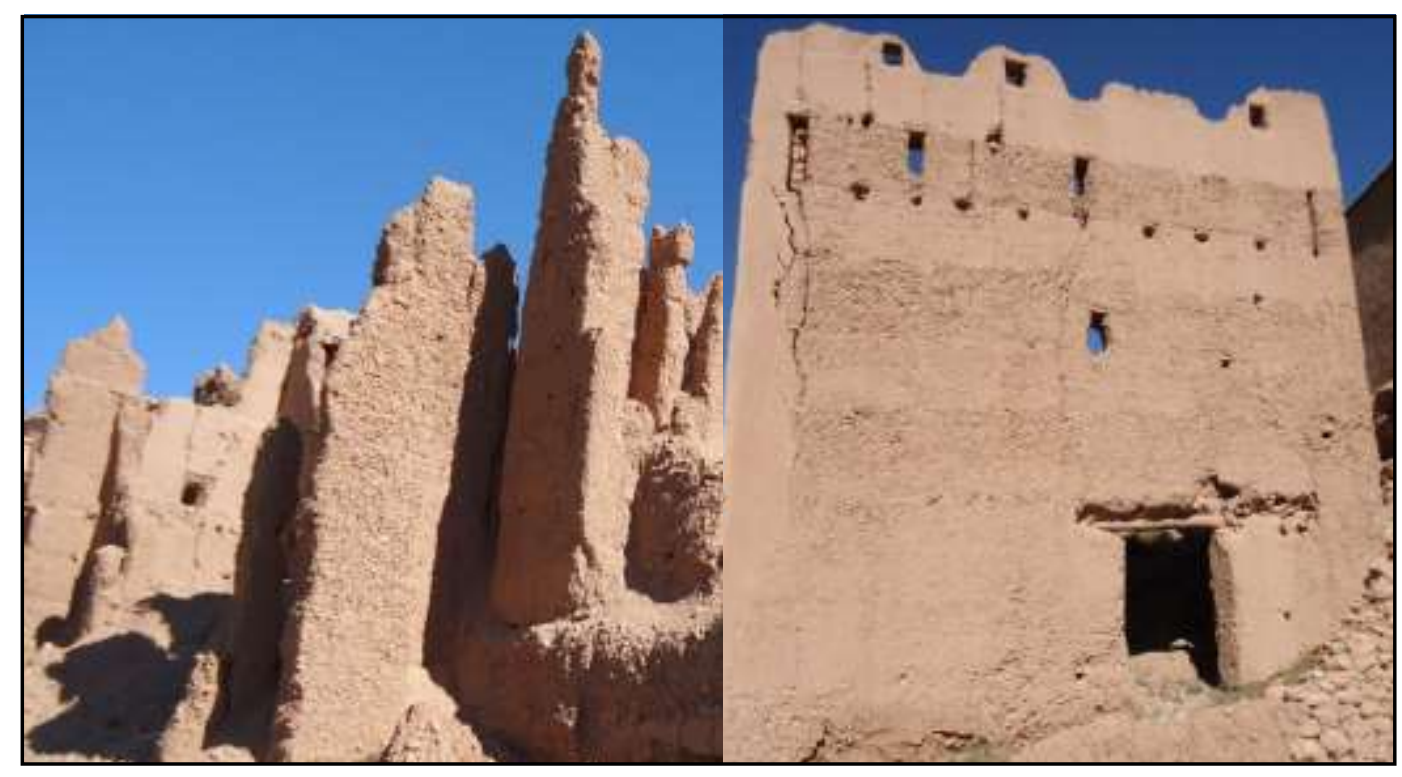

$$
\begin{aligned}
& \text { صورة رقم 7: نموذج للقصر بدوار أيت عبدون صورة رقم 7: نموذج للقصر بدوار أيت عبدون } \\
& \text { المصدر: تصوير شخصي، } 2014 \text { م } 2014
\end{aligned}
$$

إن هذه الأخطار الطبيعية تبدوا تأثيراتا بشكل جلي، ويمكننا توقع الأسوأ مسقبلا، ما لم نعي هذذه الأخطار وأثارها

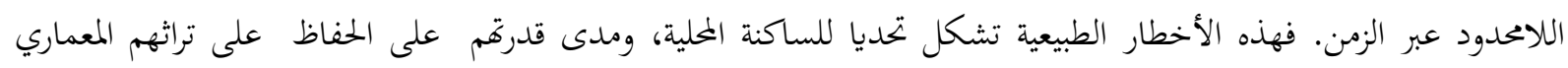

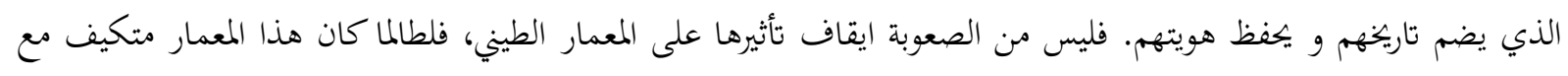

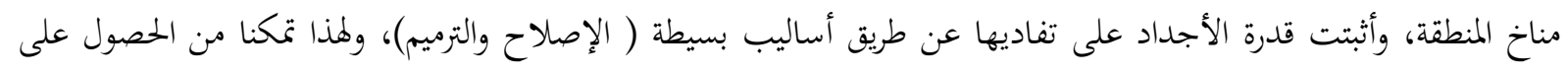
معمار طيني متكيف مع الظروف المناخية.

مع فقدان الأفكار المسايرة للاستمرارية، بدأنا نفقد هذه المعالم بشكل تدريبي. لذلك لابد من الوعي بأهمية البنايات

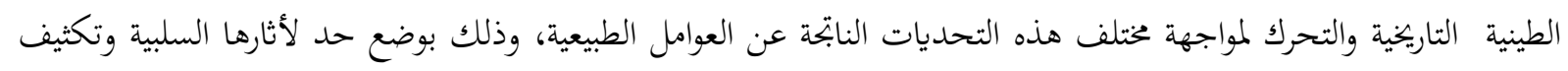

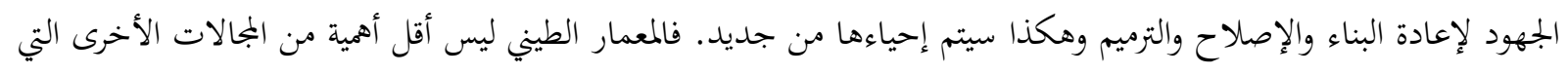

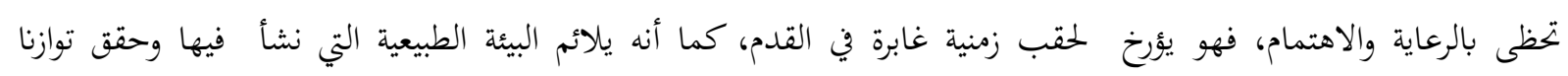

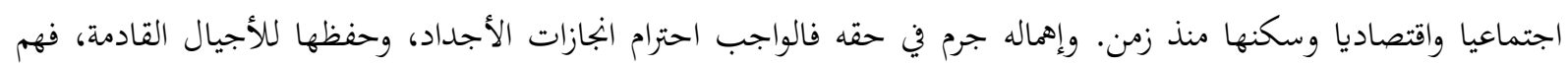

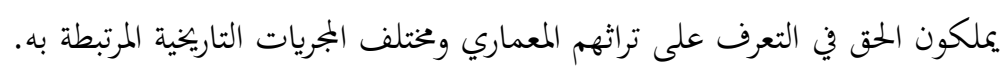


إن مواجهة التحديات الطلبيعية، ورد الإعتبار للعمارة البيئة والحفاظ عليها من الإندثار، أصبح أمرا ضروريا و ملحا،

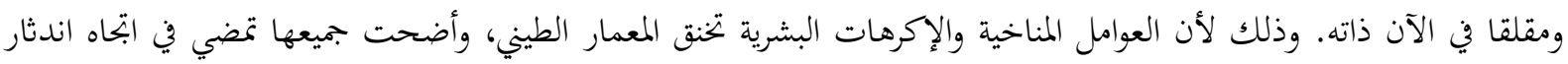
هذا الأخير الذي يشكل موروثا إنسانيا يميز واحة دادس محليا، وسيكون محط جذب مستب مستقبل إذا تم إحياءه وتوظيفه بشكل مستدام. كما أنه يمكن أن يصبح منطلقا لإحياء بجموعة من الفنون الثقافية والأنشطة الحرفية داخل الواحة.

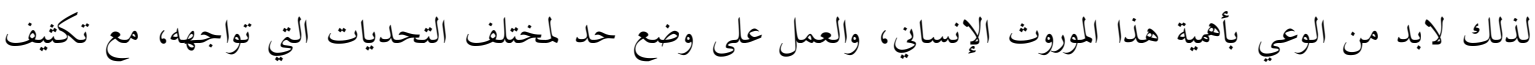
الجهود لإعادة البناء والترميم، و هكذا سيتم احياءه من جديد و و إعادة توظيفه.

\section{من خلال الدراسة تم استخلاص مجموعة من النتائج والتوصيات:}

- أثرت الظروف الاجتماعية التي عرفتها الواحة؛ من تزايد ديمغرافي، الهجرة الخارجية، ظهور خدمات جديدة والإنفتاح على

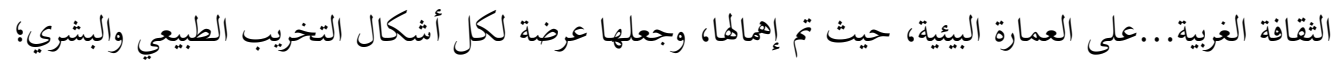
- -

- - هدم مجموعة من المباني التقليدية رغبة في تشييد سكن بموصفات عصرية؛ - - تعدد العوائق على أي تدخل تنموي يخص المعمار الطيني خاصة وأن الوضعية العقارية لهذا الأخير معقدة، إضافة إلى وضعه المتدهور؛ - - غياب المعمار الطيني في مخططات وتصاميم التهيئة العمرانية؛ - - - استمرارية الضغط على العمارة البيئية، أمام التزايد الديمغرافي وحاجة الساكنة لتشييد بنايات اسمنتية حديثة. - - مشكل الملكية الخاصة للمعالم التراثية، ما يصعب كل التدخلات الممكنة.

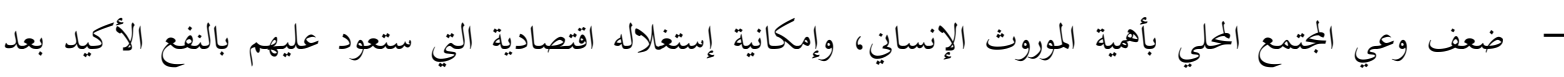
الإسهام في عملية تطويره؛

\section{التوصيات:}

إن طبيعة التحديات التي تواجهها العمارة البيئية بواحة دادس تفرض تكثيف الجهود والمشاركة من أجل رفع مختلف

$$
\text { التحديات الطبيعية، التي تسهم في تدهورها من خلال: }
$$

- - جمع المعلومات والمعطيات الكافية عن العمارة البيئية بالمنطقة لتسهيل عمليات التدخل التنموي وذلك للقيام بدراسات و أبحاث عميقة؛

- - التنسيق بين المتدخلين من؛ الملاكك والدولة ةالقطاع الخاص والمجتمع المدني لرفع قيمة المعالم التراثية وإعادة احياء زمنها المنسي؛

- الحفاظ على العمارة البيئية وإحيائها من جديد، وضمان إستدامتها على المدى البعيد، فهي موروث إنساني لن يكررها

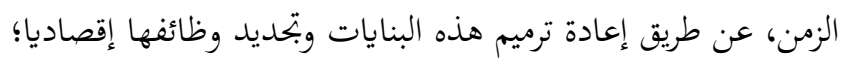


- - إدماج العمارة البيئية في خخططات و تصاميم التهيئة لتأخذ صبغة قانونية وتكون عملية التنمية أمر ملح وضروري؛ - - نشر التوعية بالأهمية البيئية والتاريخية والاجتماعية والاقتصادية للعمارة البيئية وإمكانية إعادة إستغلالها بشكل يضمن إستدامتها؛

$$
\text { - - تصنيف العمارة البيئية كتراث وطني. }
$$

أسهمت هذه الدراسة في تبيان بعض من التحديات الطبيعية التي تواجهها العمارة البيئية داخل المجال الواحي لدادس. في حين أن جوانب أخرى من العوامل المدمرة لا تزال خفية، تحتاج إلى دراسات أخرى تنفض الغبار عنها وتكشفها للواقع، لتسهيل عمليات التدخل لإعادة إحياء هذا الموروث الإنساني الذي هجر لسنوات وترك عرضة للضياع. وذلك لتسهيل كل عملية تدخل تروم إعادة الإحياء من جديد، بطرق تضمن إستدامته على المدى البعيد. 
ابراهيم أقديم. (1983). إسهام في الدراسة الهيدرولوجية والمرفلوجية لحوضي دادس وتودغة، بحث لنيل شهادة

$$
\text { الدراسات العليا. الرباط: جامعة محمد الخامس كلية الآداب والعلوم الإنسانية. }
$$

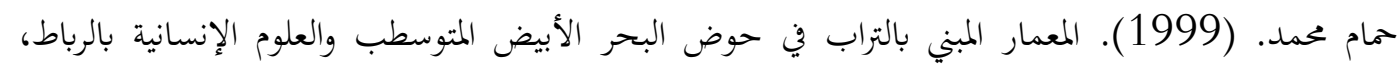

سلسلة ندوات ومناظرات، جامعة محمد الخامس، ص101. 101. (المجلد الأولى). الرباط: كلية الآداب والعلوم الإنسانية.

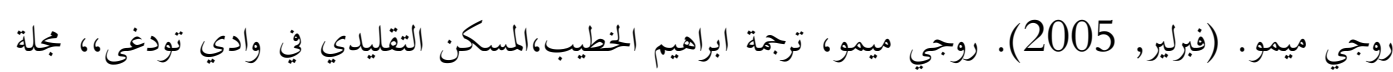

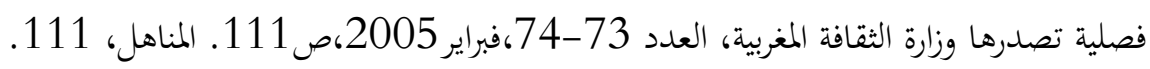

DE FOUCAULD C., 1888, Reconnaissance au Maroc, Société d'Edition

Géographique, Maritimes et Coloniales, Paris, 493.

JACQUES MEUNIE., 1963, Architectures et Habitats du Dadès, Journal de la société des Africanistes.

MUSTAPHA JLOK., 2001, Habitat et Patrimoine au Maroc Présaharien, Etat des lieux, Evolution et Perspectives de Développements, cas D’IGHREM N IGOULMIMN, Mémoire de Fin d'Etudes, Université internationale en langue Français au service du développement Africain Département Gestion du patrimoine culturel.

https://srtm.csi.cgiar.org/index.asp 


\section{EXERCISES WITH INCREASING AND DECREASING MUTUAL DISTANCE BETWEEN THE TWO COURTYARDS IN DEVELOPING THE ACCURACY OF THE SERVE IN TENNIS}

\section{Istanbul / Türkiye \\ p. 106-115}

Received: $30 / 11 / 2021$

Accepted: $10 / 12 / 2021$

Published: 01/01/2022

This article has been scanned $t$ iThenticat No plagiarism detected

\author{
Hasan Ch Sabar AL-DULAIMI ${ }^{1}$ \\ Abduljalil Mouloud Abduljalil ALBAYATI ${ }^{2}$ \\ Mohammed Madallah Saloom ALRAWI ${ }^{3}$
}

\begin{abstract}
:
The research aims to identify the importance of the exercises used in the research using exercises with increasing and decreasing distance on both sides of the court, the aim of which is to develop the accuracy of the transmission in ground tennis, which is one of the most important skills of the game of tennis, as the experimental method was used for its suitability and the nature of the research, the research sample included the team of the University of Anbar In tennis for the academic year (2020-2021), they were chosen deliberately, and the following statistical methods were used: arithmetic mean, standard deviation, t-test for linked samples, t-test for unrelated samples and percentage The researchers reached the following conclusion The development of the accuracy of the serve skill in tennis.
\end{abstract}

Key words: Tennis, Exercises, The Team of The University of Anbar In Tennis.

http://dx.doi.org/10.47832/2717-8293.15.8

(iD) Researcher, Anbar University, Iraq, ssanchsabar@gmail.com, https://orcid.org/0000-0003-1637-371X 
تمرينات بتزايد الممسافة وتناقصها المتبادلين بين ساحتي الملعب في تطوير دقة الإرسال بالتنس الأرضي

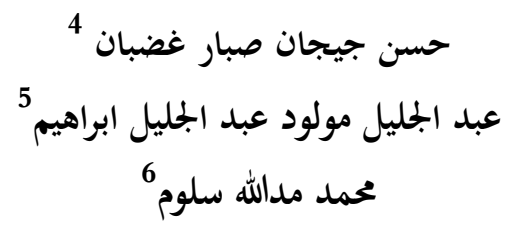

الملخص:

يههف البحث في التعرف على أهمية التمرينات المستخدمة في البحث باستخدام تمرينات بتزايد المسافة وتناقصها

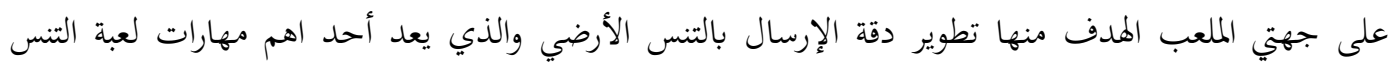

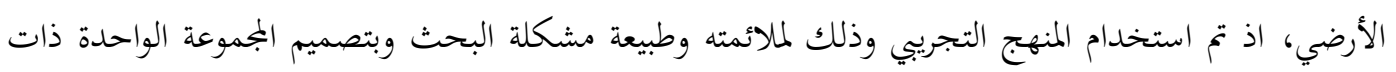

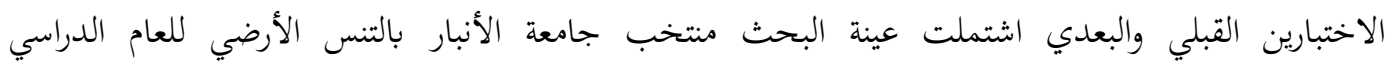
(2020-2021) وتم اختيارهم بصورة عمدية، وتم استخدام الوسائل الإحصائية الآتية: المتوسط الحسابي لإبياري والانحراف المعياري واختبار(ت) للعينات المرتبطة وقد توصل الباحثان إلى الاستنتاجات الآتية: - تطور دقة مهارة الإرسال بالتنس الأرضي.

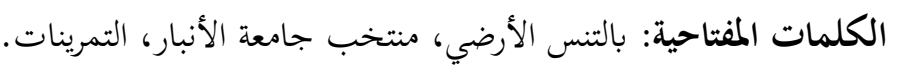




\section{الفصل الأول}

1

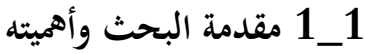

إن ما يشهده العالم من تقدم كبير في جميع بجالات الحياة لا يأتي من فراغ وانما يأتي نتاج دراسات وبكوث يقوم بها الباحثين

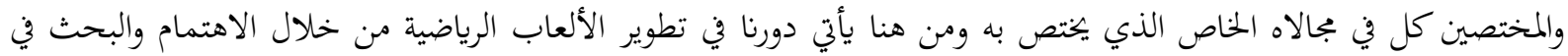

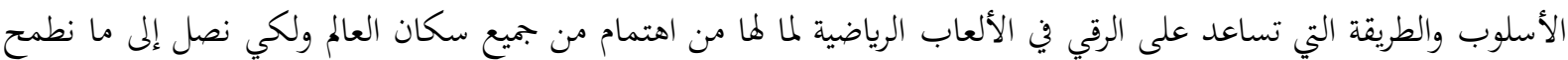
به كمختصين في المجال الرياضي يجب التفكير بشكل خاص بكل لعبة لا وبكل مهارة على حده ولكل مهارة من مهارات الألعاب حيث يذكر (ماهر محمد العامري 2014)" ان المدربين يسعون دائما إلى تطبيق افضل الطرائق التعليمية والتدريبية التي من خلالها يستطيع المدرب أو المدرس الوصول باللاعب أو المتعلم المبتدئ الأفضل مستوى ممكن في الأداء المهاري من خلال المال

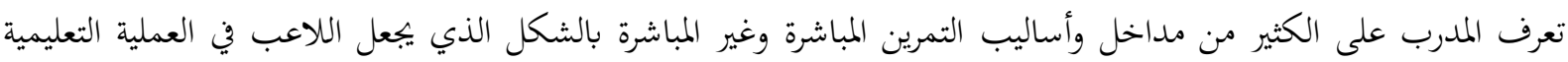

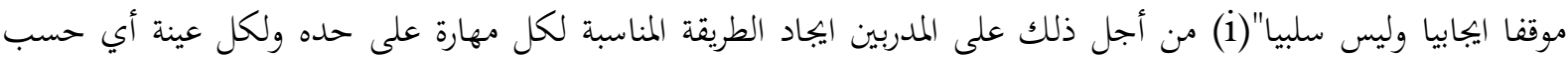
مستوى وعمر العينة المستهلفة من أجل الاختصار في الجهد المبذول والوقت لان ذلك يساعد على الاستفادة من المدة الزمنية التي يبدأ فيها المنافسة وخاصة في الألعاب الفردية وهي ما سوف يتم استهدافه في هذا البحث لان الألعاب الفردية تحتاج إلى اهتمام أكبر من الألعاب الجماعية لان اللاعب يحتاج إلى تدريب خاص يستهدف نقاط الضعف ويعالجها ويقوي نقاط القوة لدى اللاعب ومن هنا جات أهمية البحث الحالية وذلك باستخدام تمرينات بتزايد المسافة وتناقصها المتبادلين بين ساحتي الملعب في تطوير دقة الإرسال عند اللاعب باعتبار الإرسال من المهارات المغلقة التي تكون ادائها متوقف على اللاعب ومدى تركيزه وارتفاع

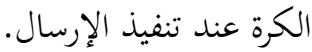

\section{2}

إن لعبة التنس الأرضي تحتاج إلى تركيز كبير من اللاعب لأفها يجب ان تؤدى بسرعة ودقة متناهية أي انه هناك ترابط كبير

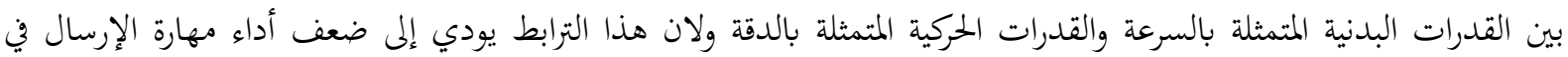

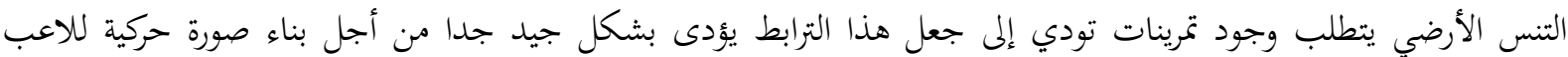
تحاكي الإرسال، ومن هنا جاءت مشكلة البحث، لذى ارتأى الباحثان إلى وضع تمرينات بتزايد المسافة وتناقصها المتبادلين بين ساحتي الملعب في تطوير دقة الإرسال بالتنس الأرضي.

\section{1}

التعرف على تأثير التمرينات بتزايد المسافة وتناقصها المتبادلين بين ساحتي الملعب في تطوير دقة الإرسال بالتنس الأرضي.

هناك فروق ذات دالة احصائية بين الاختبارات القبلية والبعدية لمجموعة البحث التجريبية في تطوير دقة الإرسال بالتنس 
1 1_5 مجالات البحث.

1 1_5_1 البجال البشري: منتخب جامعة الأنبار للتنس الأرضي.

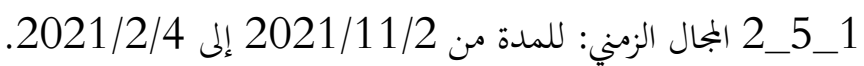

1 3_5_5 المجال المكاني: ملعب الأنشطة الطلابية في جامعة الأنبار.

الفصل الثاني

2- 2 - منهجية البحث وإجراءاته الميدانية:

2-2 1-2 1 nنهج البحث:

استخدام الباحث المنهج التجريبي وذلك لملائمته وطبيعة مشكلة البحث وبتصميم المجموعة الواحدة ذات الاختبارين القبلي

والبعدي.

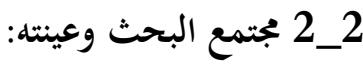

تم تحديد مجتمع البحث والتي تمثل بلاعبي منتخب جامعة الأنبار والبالغ عددهم (6) لاعبين،اما العينة فقد تم اختيارها

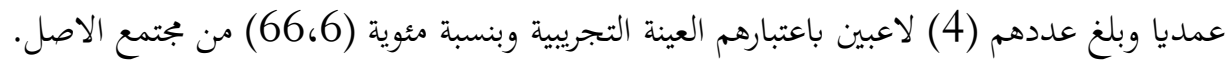

2_3 الأجهزة والأدوات ووسائل جمع المعلومات

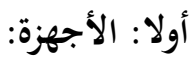

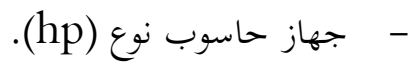

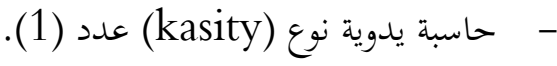

- ماعة توقيت نوع بابانية.

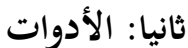

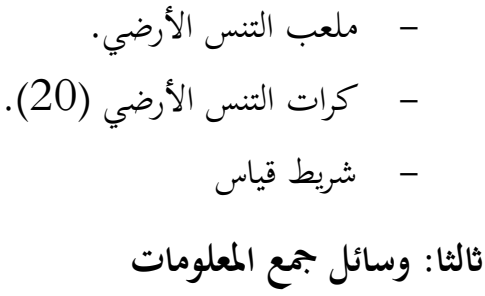

- - المصادر العربية والأجنبية.

- م الاختبارات والقياس.

2_4 تحديد متغير البحث واختباره

استهدف الباحث متغير الإرسال في لعبة التنس الأرضي لأنه يعتبر بداية لكل نقطة وتعتمد عليها اللعبة بشكل اساسي لا

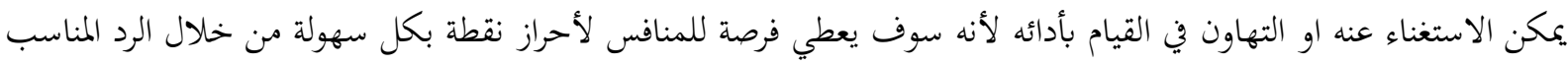




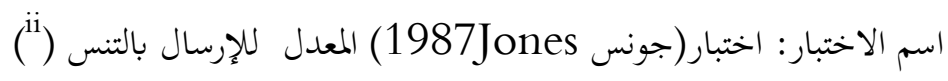 الغرض من الاختبار: لقياس القدرة المهارية والدقة لمهارة ضربة الإرسال.

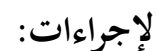

- - يتم تخطيط منطقة الإرسال كما هو موضح في شكل (2_1).

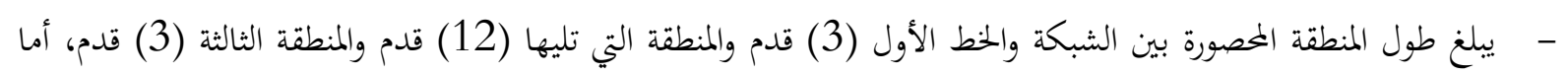

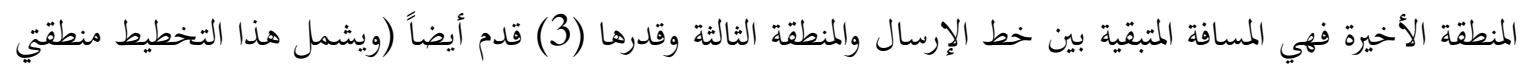

$$
\text { الإرسال اليمين واليسار). }
$$

- - البدء بالاختبار وذلك بان يقف المختبرين على شكل أزواج (كل زميلين) أحدهما يرسل والآخر يسترجع الكرات، ويعطى

$$
\text { لكل طالب (5) محاولات من كل جانب. }
$$

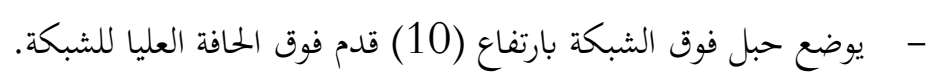

- - إذا عبرت الكرة من فوق الحبل تعطى نصف درجة التقييم المحددة على أرض الملعب الذي تسقط فيه الكرة.

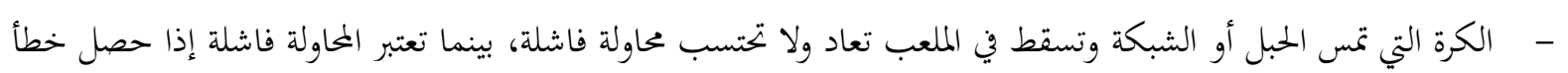

$$
\text { في الإرسال. }
$$

- - ميعى لكل طالب محاولتين للتمرين.

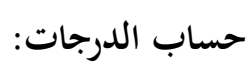

يتم اختيار أفضل محاولة من اليمين وأفضل محاولة من اليسار وبحمع الاثنان ويستخرج الوسط الحسابي لما.

\section{كيفية تسجيل الدرجات:}

- عند سقوط الكرة في المنطقة الأولى يحصل اللاعب على (2) درجة، أما سقوطها في المنطقة الثانية فيحصل على (4) درجة والمنطقة الثالثة (5) درجات أما المنطقة الأخيرة فيحصل على (6) لفئل (6) درجات. 


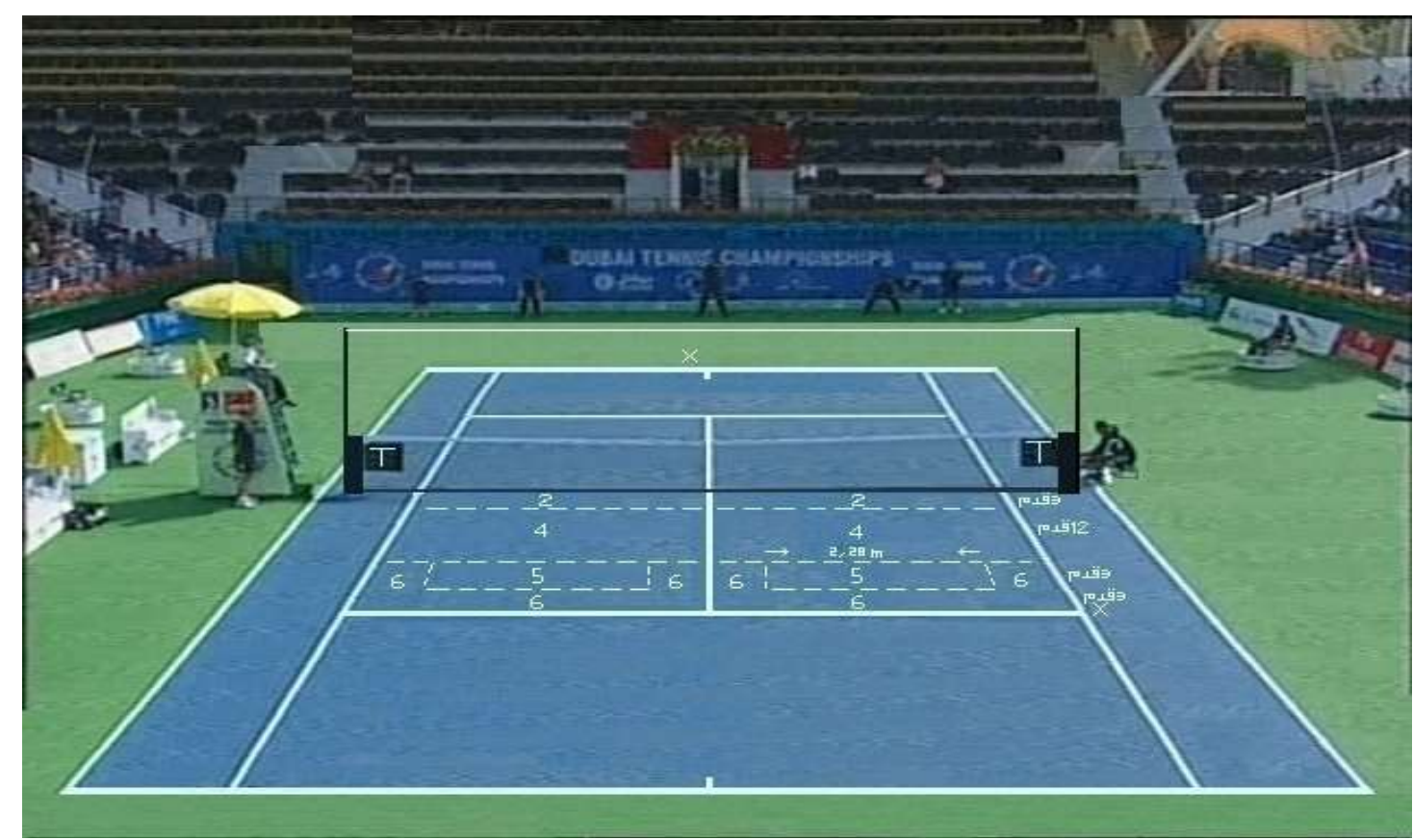

شكل رقم (1_1)

توضح الدرجات التقويمية ومناطق الدقة لاختبار (جونس)

لقياس أداء مهارة الإرسال

بعد اطلاع الباحث بتصميم تمرينات بتزايد المسافة وتناقصها المتبادلين بين ساحتي الملعب في تطوير دقة الإرسال بالتنس الأرضي، حيث قام الباحث بتقسيم المنطقة الخلفية إلى ثلاث مناطق متساوية بقياس 82، 1 طول

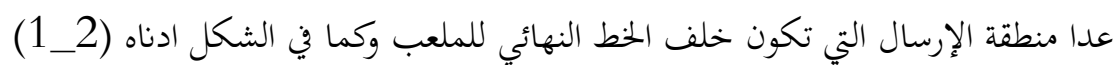

$\mathrm{d}$ g

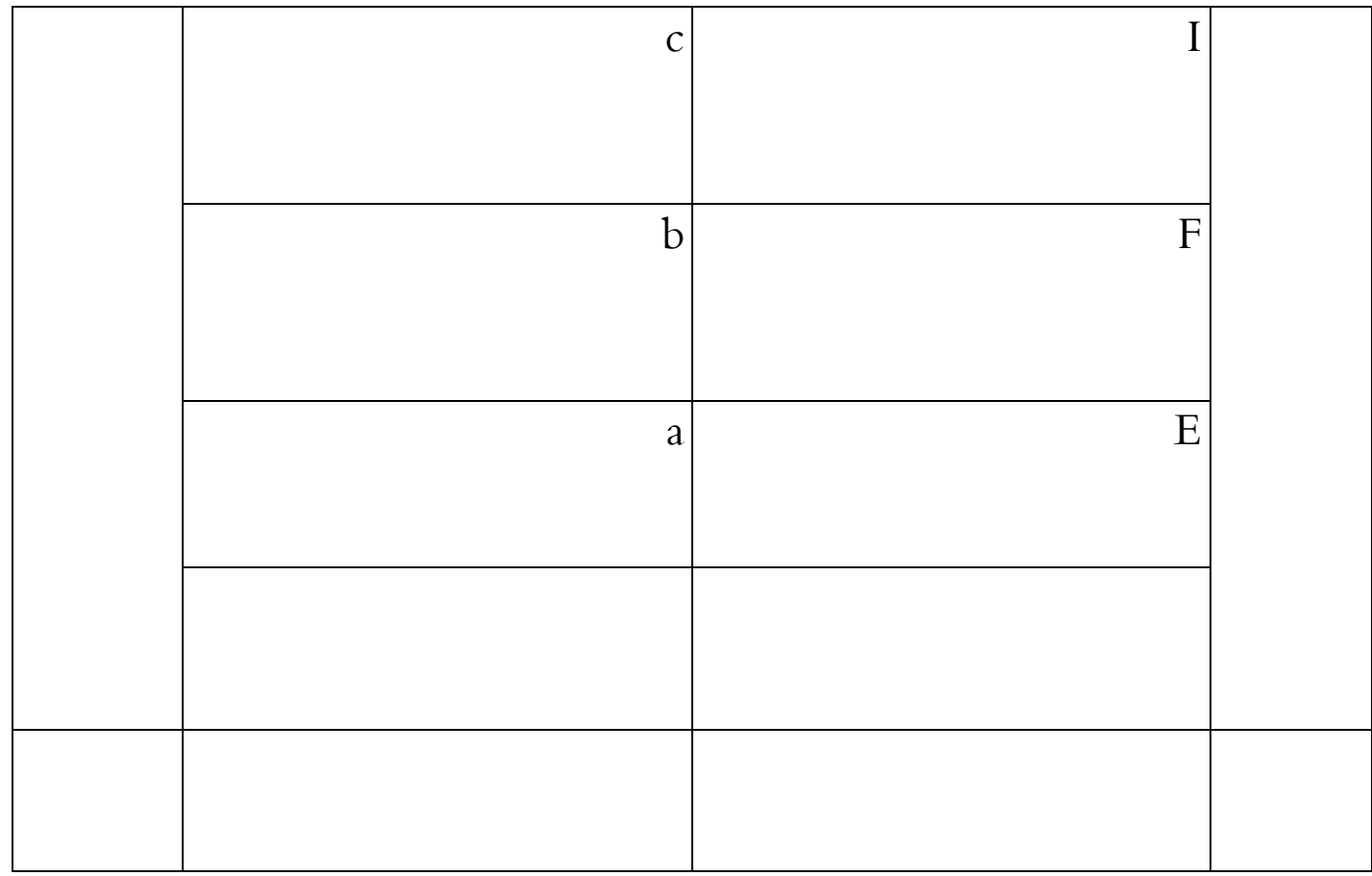




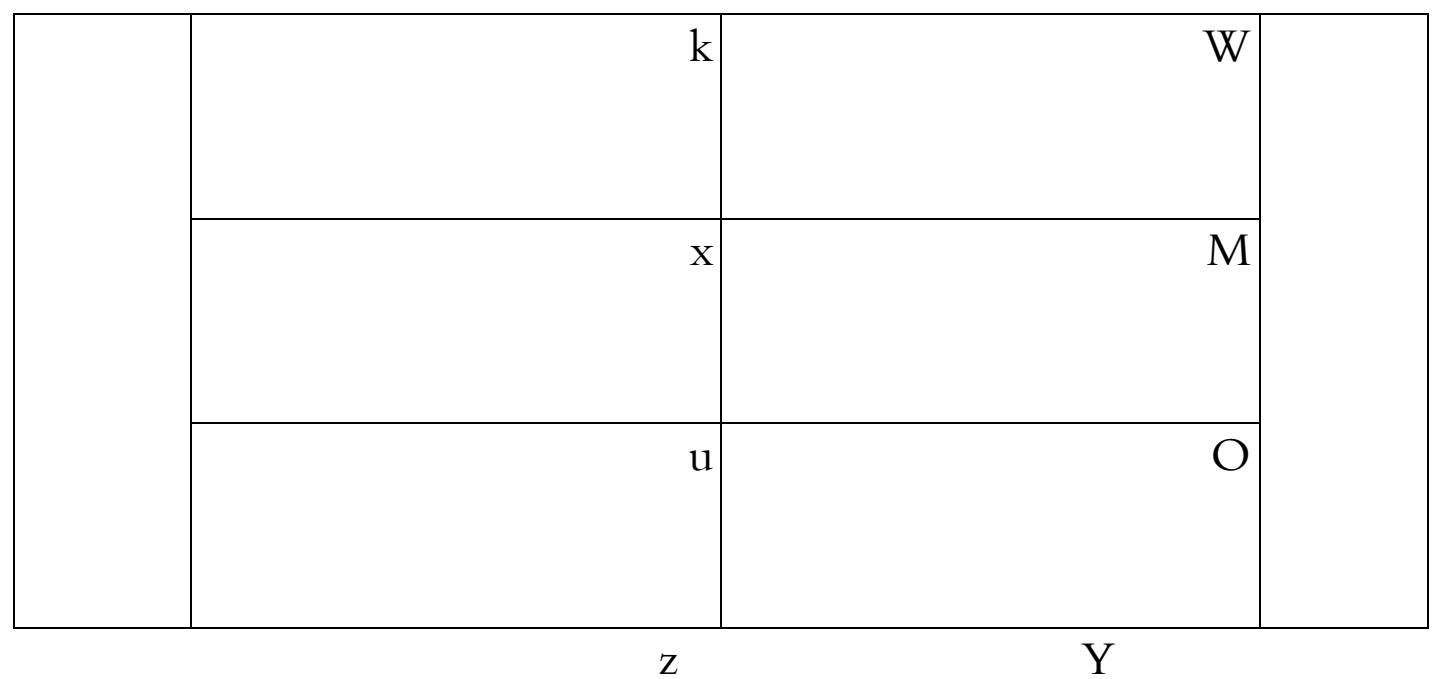

يرسل اللاعب من منطقة a إلى الملعب المقابل إلى منطقة O مرة إلى منطقة W مرة إلى منطقة W مرة وإلى منطقة الإرسال المخصصة حسب القانون.

يرسل اللاعب من منطقة b إلى منطقة O مرة إلى منطقة W مرة إلى منطقة W مرة وإلى منطقة الإرسال المخصصة حسب القانون. يرسل من منطقة C إلى O مرة وإلى W مرة إلى W مرة وإلى منطقة الإرسال المخصصة حسب القانون. يرسل من منطقة d إلى منطقة O مرة إلى W مرة إلى W مرة وإلى منطقة المخصصة للإرسال حسب القانون. ومن جميع المناطق المحددة في الملعب بالترتيب.

2_6 2

قام الباحث بأجراء الدراسة التجريبة الأولية على عينة قبل الدخول في الدخول في البرنامج المعد من قبل الباحث من أجل

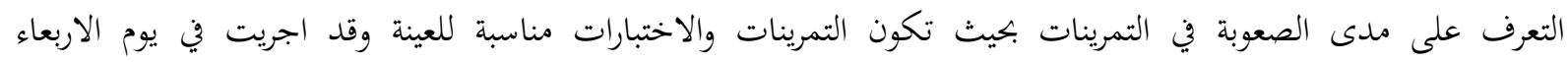
2020/11/4 على للاعبين من منتخب الجامعة. هـ2

2_1_2 قام الباحث باجراء الاختبارات القبلية لمجموعة البحث التجريبية يوم الخميس 5 / 11/ 2020 لمتغير الإرسال في لعبة التنس الأرضي.

\section{2_2_2}

بدأ الباحث باجراء تجربة البحث الرئيسية في يوم الأحد الموافق 8/ 11/ 2020 وذلك بتطبيق تمرينات بتزايد المسافة

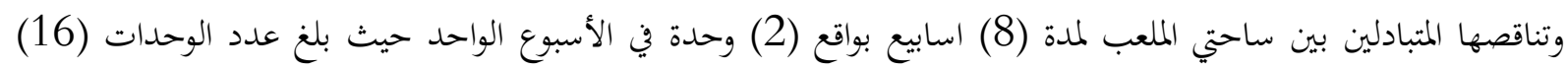
وحدة وقد تم الانتهاء من تجربة البحث الرئيسية يوم الاثنين الموافق (2021/1/4).

3_7_2

أجريت الاختبارات البعدية يوم الاربعاء الموافق 2021/1/6 لمهارة الإرسال في التنس الأرضي وقد أتبع الباحث نفس طريقة أداء الاختبارات القبلية والشروط ذاتحا. 
8_2

3-

3 1_1 عرض نتائج الاختبارات القبلية والبعدية وتحليلها ومناقشتها

جدول (1_3)

يبين الاوساط الحسابية للاختبارات القبلية والبعدية والوسط الحسابي للفروق وانخرافتها المعيارية وقيم (ت) المحسوبة والدلالة لمهارة الإرسال لمجموعة

البحث

\begin{tabular}{|c|c|c|c|c|c|c|c|c|c|}
\hline \multirow[t]{2}{*}{ الدلالة } & \multirow[t]{2}{*}{ ت المحسوبة } & \multirow[t]{2}{*}{ ع ف } & \multirow[t]{2}{*}{ س ف } & \multicolumn{2}{|c|}{ الاختبار البعدي } & \multicolumn{2}{|c|}{ الاختبار القبلي } & \multirow{2}{*}{ وحدة } & \multirow[t]{2}{*}{ المتغير } \\
\hline & & & & $\varepsilon$ & س & $\varepsilon$ & س & & \\
\hline دال & 16.24 & $1 ، 49$ & $9 ، 91$ & $1 ، 83$ & 20.58 & $1 ، 21$ & 10.66 & نقطة & الإرسال \\
\hline
\end{tabular}

(ت) الجدولية (2،57) درجة الحرية (5) ومستوى دلالة (0605)

يبن الجدول (3_1) الخاص بالفروق بين الاختبارات القبلية والبعدية في مهارة الإرسال للتنس الأرضي لمجموعة البحث التجريبية وان قيمة (ت) المسوبة لمهارة الإرسال (16،24) وبما ان قيمة (ت) المحسوبة لمهارة الإرسال بالتنس الأرضي كانت أكبر

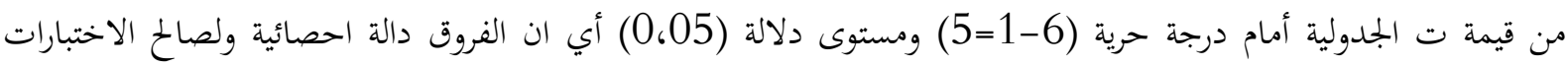
البعدية والذي يعزوه الباحث إلى التمرينات بتزايد المسافة وتناقصها المتبادلين بين ساحتي الملعب والتي ساعدت على المه تطوير دقة أداء الإرسال بالتنس الأرضي لما للتمرينات التي أعدت من قبل الباحث التي كانت قريبة من أداء المهارة او ساعدت علئ على أداء المهارة بشكل فعال بكيث كانت التمرينات بشكل متدرج ومختلف يحاكي واقع المهارة المراد تطويرها حيث تذكر (رشا طالب 2007) نقلا عن ابراهيم عصمت "ان التمارين اذا احسن انتقاؤها ووضع برابجها واستخدامها وتقويمها تستطيع ان تشوق اللاعب وتثير همته وتوسع خبراته وتساعده في الفهم فهي تشحذ الفكرة وتساعد في تعليم المهارات وفي تنمية الاتحاهات "(iii)

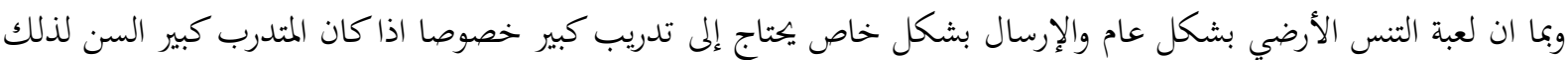

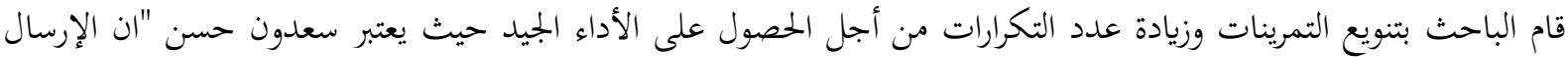
أكثر ضربة مركبة ومعقدة ومهمة في لعبة التنس وتحتاج لتدريب طويل لاتقاها ليعتاد الجسم على تحقيق التوافقات بين الاستناد جانبا على القدم الأمامية اليسرى للاعب اليد اليمنى ورمي الكرة باليد الآخرى في الهواء وحركة المضرب الصحيحة باليد الحاملة للمضرب وحركة القدم الآخرى في التقدم ودوران الجسم بقوس من دائرة والقفز في بعض الأحيان عند التسديد (iv) ومن ذلك

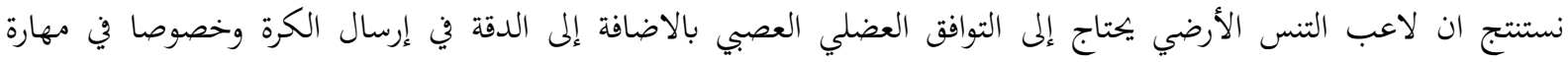
الإرسال والتي لا تاتي الا من خلال تمرينات تناسب مهارة الإرسال لاهما تعتبر من المهارات الهجومية للعبة حيث يعتبر رافد مهدي ان الإرسال "من مفاتيح اللعب الهجومي والقوة الضاربة في اللعب الحديث للتنس، واللاعب الذي يتميز بالقوة والدقة في الإرسال تكون فرصته كبير في كسب المبارة "(v) وعلى ذلك فان الإرسال يعتبر المهارة الاصعب في لعبة التنس الأرضي لان اللاعب عليه ان يشرك كل اعضاء جسمه في الإرسال من أجل جعل الإرسال بشكل يصعب مهمة استلام اللاعب المنافس للإرسال بالتالي يعطي اللاعب المرسل امكانية الحصول على نقطة بسبب الاستقبال الخاطئ للمنافس او الحصول على نقطة من خلال الإرسال

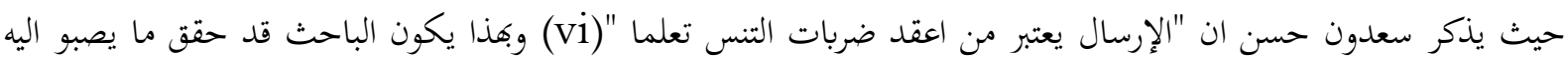
من هدف البحث وفرضيته. 


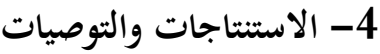

1-4 1-4 (لاستنتاجات

1- التمارين بتزايد المسافة وتناقصها المتبادلين بين ساحتي الملعب حققت تاثير اييابيا في تطوير الإرسال في التنس الأرضي. 4 4

1 ضــرورة اعتماد التمرينات بتزايد المسافة وتناقصها المتبادلين بين ساحتي الملعب في تعلم وتطوير الإرسال في التنس الأرضي. 2_ اجراء بحوث ودراسات آخرى في تعلم وتدريب في مهارات اللعبة وألعاب آخرى مشاهمة. 3_ ضرورة اجراء دراسات آخرى على فئات عمرية أكبر ولكلا الجنسين. 
ماهر محمد عواد العامري:فسيلوجيا التعلم الحركي، ط1، النبراس للطباعة والتصميم، 2014. P 62،os Angles 1987، 1، A. Measure of Tennis Serving Ability، S. K،2_Jones رشا طالب ذياب: استخدام تمارين مقترحة في نقل اثر التعلم لليد المفضلة وغير المفضلة لمهارة التصويب في كرة السلة، رسالة

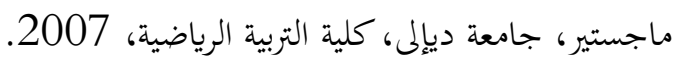

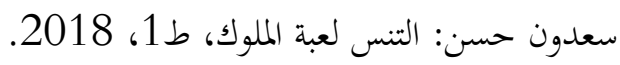
رافد مهدي قدوري: جوهر التنس الأرضي، ديإلى مطبعة جامعة ديإلى، 2013.

i - ماهر حمد عواد العامري :فسيلوجيا التعلم الحركي , ط1 , النبراس للطباعة والتصميم, 2014 ,ص214 .

P 62 ،os Angles 1987 ، 1، A . Measure of Tennis Serving Ability ، S . K ، (1) Jones-ii

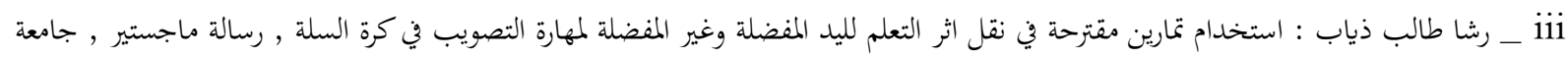

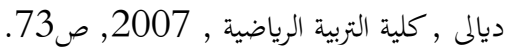

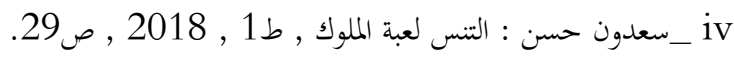

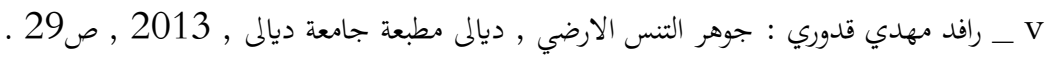

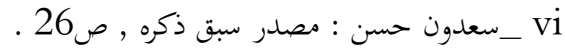




\title{
DIGITIZATION AND EDUCATIONAL PROCESS ... A CONCEPTUAL APPROACH
}

\author{
Sumaiah Eid ALZABOOT ${ }^{1}$
}

\section{Istanbul / Türkiye}

p. $116-135$

Received: $29 / 11 / 2021$

Accepted: 09/12/2021

Published: 01/01/2022

This article has been scanned $k$

iThenticat No plagiarism detected

\section{Abstract:}

The research aimed to reveal the role of the digitization literature, and the theories that explain it, in associating digitization and educational process, by adopting the qualitative approach, and grounded theory method.

The research findings show that the aspects of approach between digitization and the educational process include five elements: teacher and learner, curriculum, educational tools, learning environment, and educational strategies.

The most prominent recommendation is that officials should understand the importance of planning in the use of digitization technology, with the involvement active stakeholders in the field of education. Experts and researchers should be interested in conducting more researches about digitization and educational process.

Key words: Approach, Digitization, Educational Process, Digital Education, Digital Transformation.

http://dx.doi.org/10.47832/2717-8293.15.9

(iD) Prof.Dr. , Rimar Academy, Jordan, alusool2013@gmail.com, https://orcid.org/0000-0002-4012-1259 


\section{الرقمنة والعملية التعليمية .... مقاربة مفاهيمية}

\section{2 سمية عيد زعبوط}

الملتخص:

هدف البحث إلى الكشف عن دور أدبيات الرقمنة، والنظريات المفسرة لها، في المقاربة بين الرقمنة والعملية

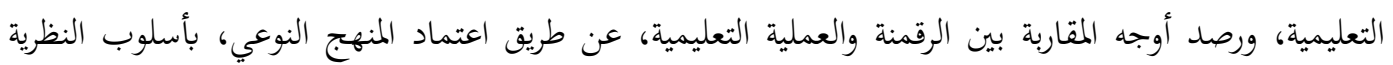
المجذرة. وأظهرت أبرز النتائج أن أوجه المقاربة بين الرقمنة والعملية التعليمية وُّجدَت في خمسة محاور هي: المعلم والمتعلم، المنهاج، والوسائل التعليمية، والبيئة التعليمة، والاستراتيجيات التعليمية.

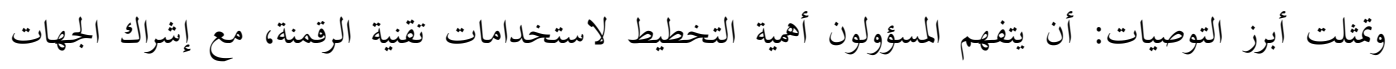

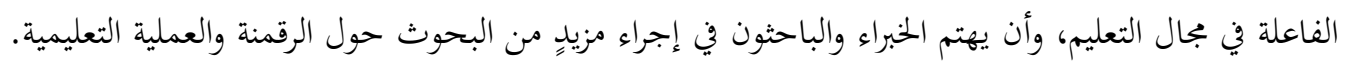

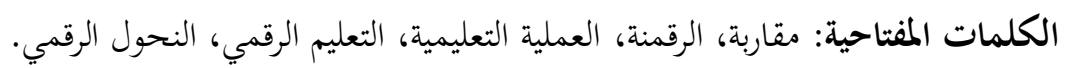

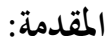

لم أجد أفضل من التوجه إلى يوميات إحدى الأسر كي تكون مدخلاً فيه شيء من الواقعية، فبينما كان الأب ينجزُ بعض كأل

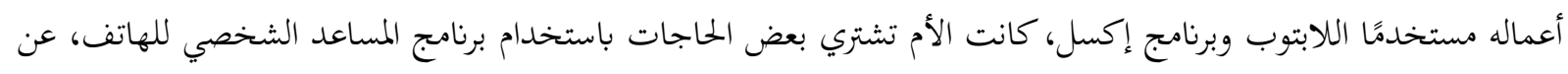
طريق السوق الإلكتروني، ويشارك الابن الأكبر في إحدى الدورات التدريبية عبر إحدى المنصات، أما الابن الأصغر فإنه يتلقى

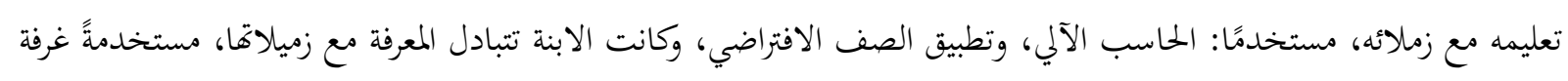

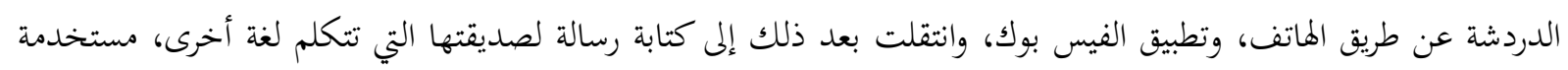
الجهاز اللوحي للترجمة.

يُمكن القول أن هذا الجزء من حياة هذه الأسرة، أصبح مألوفًا لدى كثيرين، إذ أصبح التعلمُ، والعملُ، و واللعبُ، وتبادل

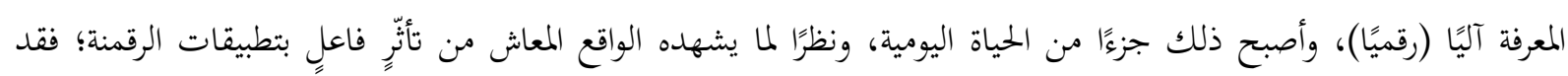

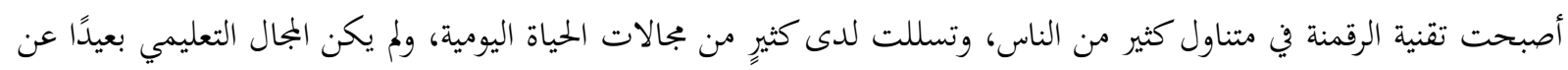
ذلك؛ بل أسهمت الرقمنة في تحقيق مزيدٍ من التحولات الرقمية، وفي تحقيق مزيدٍ من المعرفة العلمية التعلّمية. وقد يُحدثُ هذا المزيد من التحولات الرقمية، والتسارع الذي يُلازمها، خلطًا في المفاهيم المنبثقة عن الرقمنة؛ ما يُوثنر سلبًا في العملية التعليمية في ظل الرقمنة، الأمر الذي يُؤكد الحاجة إلى المقاربة المفاهيمية بين الرقمنة والعملية التعليمية.

مشكلة البحث:

تكمن مشكلة البحث فيما يُلاحظ عن طريق الاطلاع، والبحث في بعض الأدبيات، والنظريات التي تم رصدها، إذ لوحظ

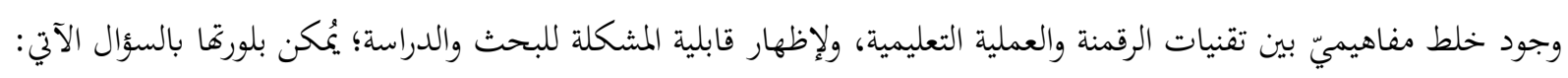

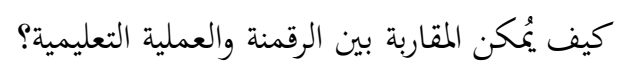


أسئلة البحث: يُمكن توضيح مشكلة البحث بالإجابة عن الأسئلة الآتية: السؤال الرئيس: ما إمكانية المقاربة بين الرقمنة والعملية التعليمية؟ وتتبلور إمكانية المقاربة بالإجابة عن الأسئلة الفرعية الآتية: 1. ما دور أدبيات الرقمنة في المقاربة بين الرقمنة والعملية التعليمية؟

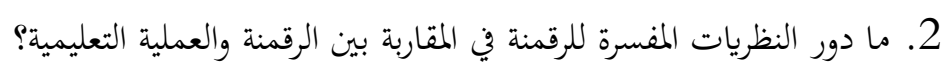

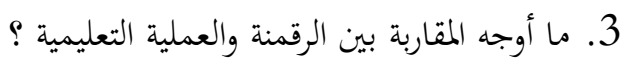

$$
\begin{aligned}
& \text { أهداف البحث: يُمكن الإجابة عن أسئلة البحث بتحقيق الأهداف الآتية: } \\
& \text { 1. الكشف عن دور أدبيات الرقمنة في المقاربة بين الرقمنة والعملية التعليمية . } \\
& \text { 2. الكشف عن دور النظريات المفسرة للرقمنة في المقاربة بين الرقمنة والعملية التعليمية. } \\
& \text { 3. رصد أوجه المقاربة بين الرقمنة والعملية التعليمية. }
\end{aligned}
$$

\section{أهمية البحث: تمثلت أهمية البحث بالآتي:}

تلبية البحث لأحد محاور المؤتمر العلمي الدولي للدراسات المعاصرة في العلوم الاجتماعية، ألا وهو: محور التربية والتعليم.

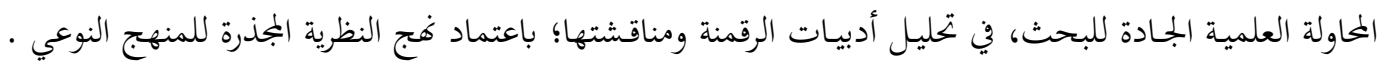
انتهاج البحث فه المقاربة بين الرقمنة، والعملية التعليمية؛ عن طريق استقراء بعض الأدبيات والبحوث التي تتعلق بالرقمنة والحياة الرقمية؛ الأمر الذي يُضفي تنوعاً مهماً في الطرح.

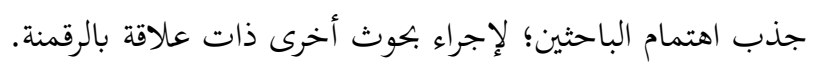

منهجية البحث: تم اعتماد النظرية المجذرة بوصفها إحدى أساليب البحث النوعي، للمقاربة بين الرقمنة، والعملية التعليمية،

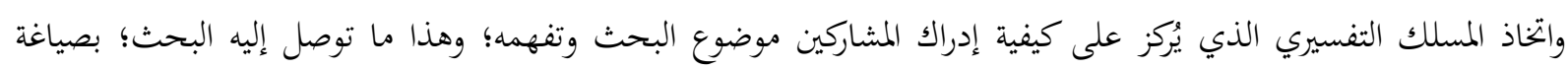

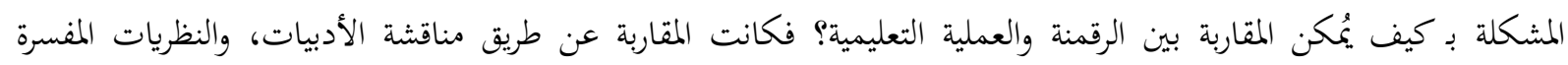

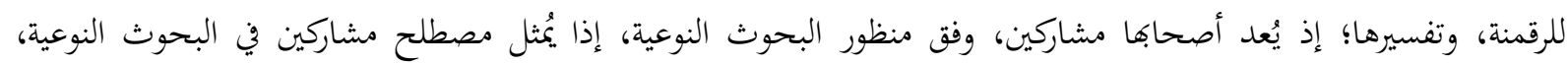

$$
\text { مصطلح العينة في البحوث الكمية. }
$$

ولتوضيح عملية المقاربة، اعتُمَدَ النموذج المطور من قبل ماكسويل (Maxwell) عام (1998م)، بمكوناته الخمسة: أسئلة البحث، أهداف البحث، الإطار المفاهيمي، المنهج، النتائج، على النحو الآتي: 


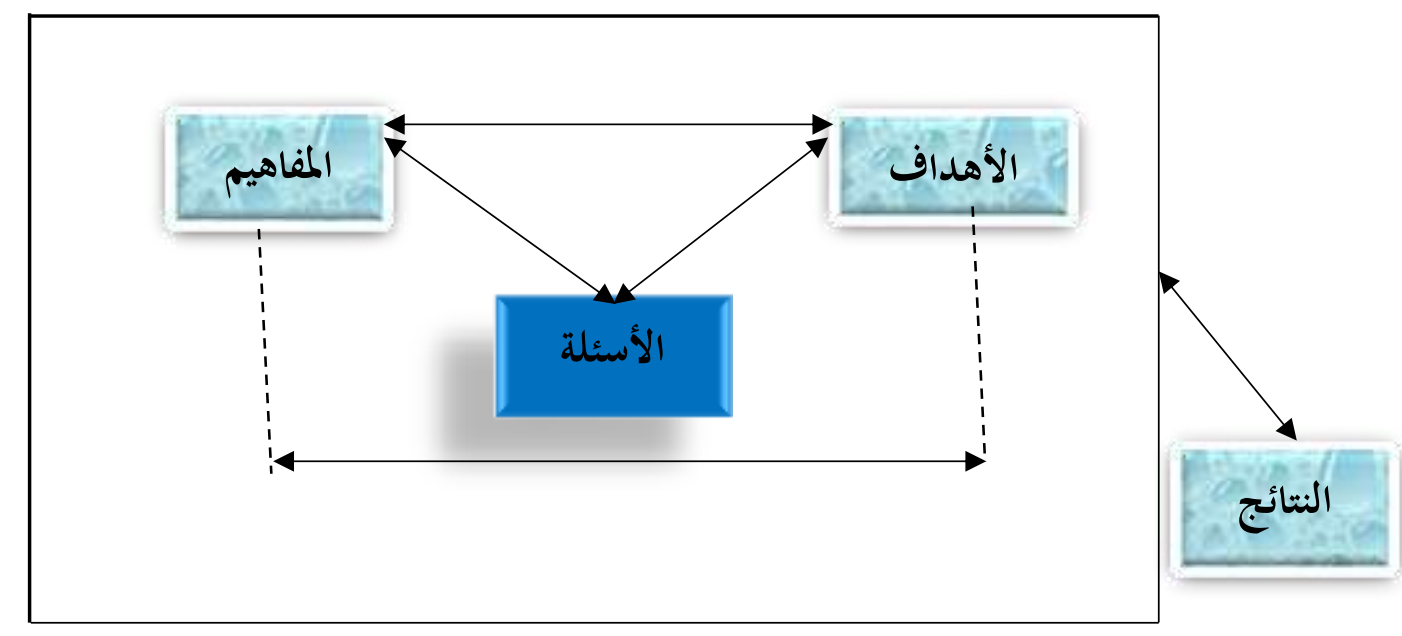

الشكل (1): نموذج ماكسويل

يُلاحظ من الشكل (1) أن أسئلة البحث هي نقطة الانطلاق بالنسبة للبحث النوعي؛ ويتبين من السهم الموصول(ب)

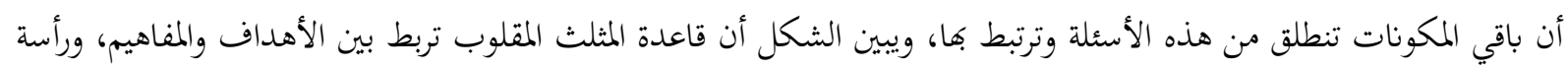
مرتبط بأسئلة البحث؛ ما يُوكد أن أسئلة البحث تستدعي صياغة الأهداف، وتُشَّل الإطار المفاهيمي؛ لتحقيق الأهداف. أما المثلث في أسفل الشكل فهو يربط بين المنهج، والنتائج، ورأسه في الأعلى مرتبط بالأسئلة ما يُوكد أن أسئلة البحث

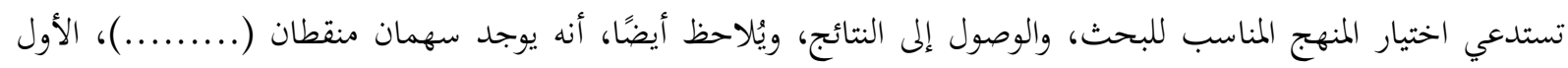

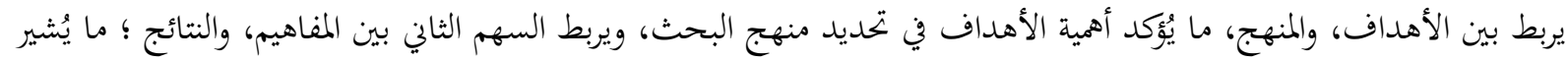
إلى أن مناقشة النتائج وتفسيرها، ينبغي أن تكون في ضوء المفاهيم المعتمدة في البحث؛ لتحقيق الأهداف.

المواد المشاركة في البحث:

يُطلق على عينة البحث النوعي مسمى المواد المشاركة أو المشاركين؛ سواء أكانوا أفرادًا أم غير ذلك، نظرًا للتفاعل المشترك

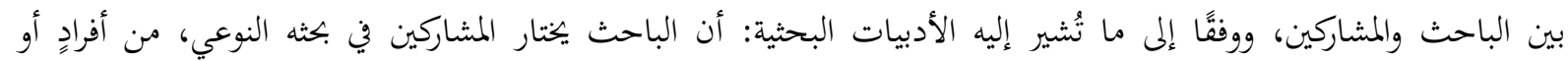
أدبيات، أو وثائق بطريقة مقصودة، بناءً على تقديره وتصوره أن ذلك يُسهم في تحقيق أهداف البحث، ويُجيب عن أسئية أسئله. (الفقيه، 2017) . لذا اختيرت خمس أدبيات ونظريتان بطريقة العينة القصدية؛ لتمثل المواد المشاركة للبحث الحالي.

\section{المصطلحات العلمية للبحث:}

مقاربة: هي أساس نظري يتكون من مجموعة من المبادي؛ وهي الطريقة التي يعتمدها الدارس، أو الباحث؛ من أجل

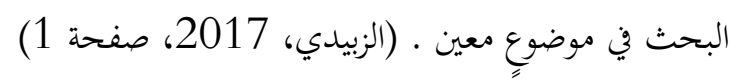

المقاربة إجرائيًا هي: الأسس والمفاهيم التي تحتوى على سمات مشتركة، ويتم التوصل إليها بعد مناقشة المعلومات وتحليلها. الرقمنة: هي عملية تحويل الإجراءات والأنشطة من أنشطة تقليدية، إلى أنشطة رقمية، باستخدام الأجهزة الآلية، والبرمجيات، والتطبيقات الرقمية ـ (الحوسي، 2021، صفية صفحة 1) 
الرقمنة إجرائيًا هي: المهمة التي تتعلق بالحاسب الآلي، والتطبيقات المنبثقة عنه، وتُشير هذه المهمة إلى تحويل المعلومات،

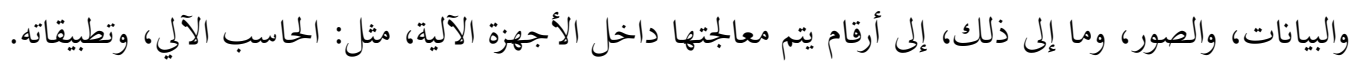

العملية التعليمية: هي بجموعة منظمة من الأنشطة والإجراءات، تحدف إلى تلبية الحاجات التعليمية وتتضمن العملية

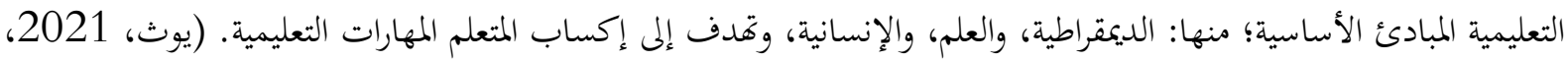

صفحة 1)

التعليمية إجرائيًا هي: أنشطة علمية مدروسة، تمدف إلى إكساب المتعلم المعرفة في مراحلٍ مختلفة؛ باعتماد الأساليب المناسبة لكل مرحلة، ومن أهم عناصرها المعلم، والمتعلم، والمنهاج.

التعليم الرقمي: هو تقديم محتوى تعليمي إلكتروني عبر الوسائط المعتمدة الموجودة على الحاسب الآلي، وشبكاته، إلى

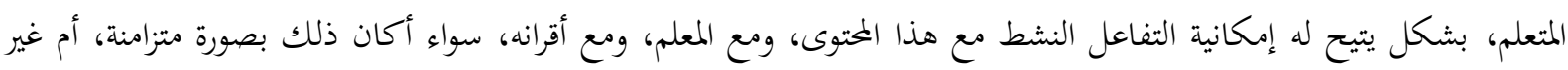

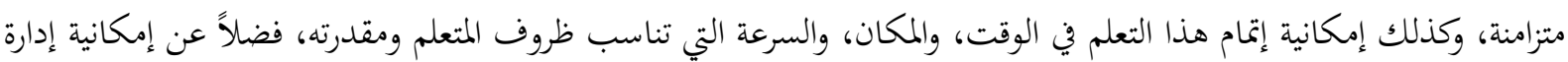

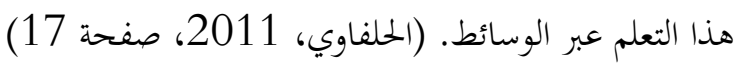

التعليم الرقمي إجرائيًا هو: التعليم الذي يعتمد استخدام جهاز الحاسب الآلي، وبرجياته، أو اللابتوب، أو الشبكة الإلكترونية، وتطبيقاةا، ويشمل التعليم الافتراضي، والتعليم الشبكي، والتعليم الإلكتروني، والجانب الإلكتروني من التعليم عن بعد. التحول الرقمي هو: الاستثمار في الفكر وتغيير السلوك؛ لإحداث تحول جذري في طريقة العمل، عن طريق الاستفادة من

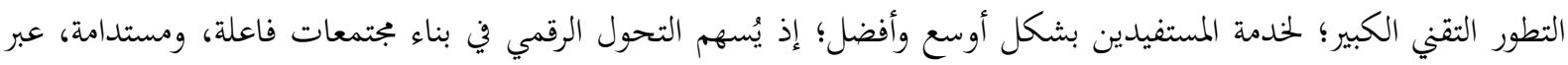
تحقيق تغيير جذري في خدمات مختلفة الأطراف من مستهلكين، وموظفين، ومستفيدين، مع تحسين بتحاركم وتطويرها، عبر سلسلة من العمليات، وإعادة صياغة الإجراءات اللازمة للتفعيل والتنفيذ. (المفضي، 2021، معني، صفينة التحول الرقمي إجرائيًا هو: عملية استبدال الأساليب والوسائل، والخدمات المستخدمة، والسلوكات الممارسة في التعليم، والعمل، في الواقع الحالي، إلى أساليب العالم الرقمي، ووسائله وخدماته، ومن أمثلة ذلك: الحوسبة السحابية، بوصفها تحول رقمي،

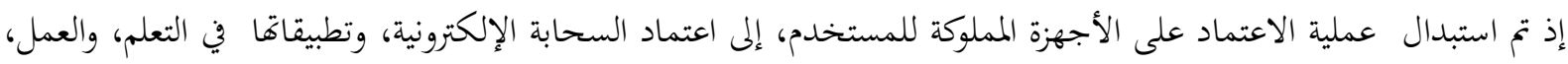
والتسوق، وغير ذلك.

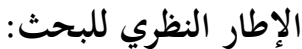

تضمن الإطار النظري للبحث أربعة محاور هي: الرقمنة، وأدبيات الرقمنة، والنظريات المفسرة للرقمنة، ومناقشة المحاور وتفسيرها، على النحو الآتي:

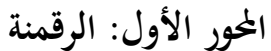

تُشير الرقمنة لغويًا في المعجم الوسيط، إلى أها من الرَّم، بمعنى الخط العريض، ويُقال جاء بالرقم أي الكثير وفي علم

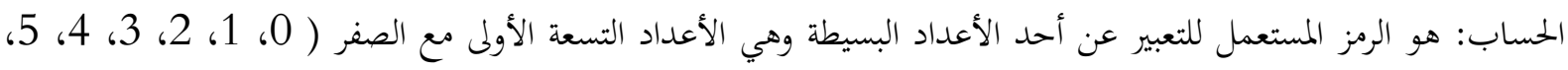

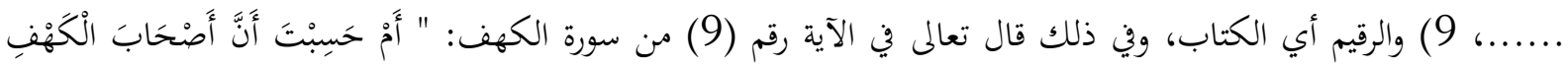

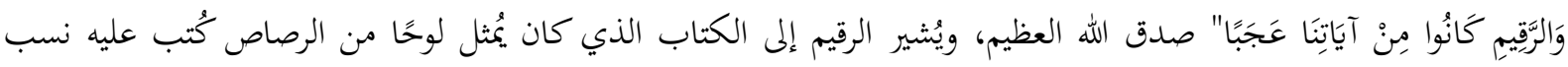

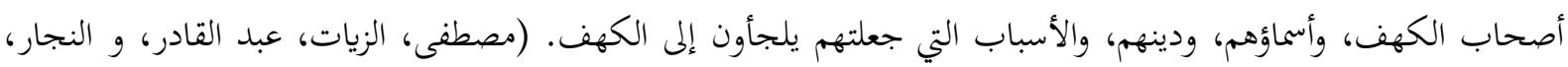
بدون تاريخ، صفحة 367) 
بناءً على مفهوم الرقمة ؛ فإن تقنياتا دخلت في مجالات الحياة كافة، منها: الاجتماعية، والاقتصادية، والزراعية، والتربوية،

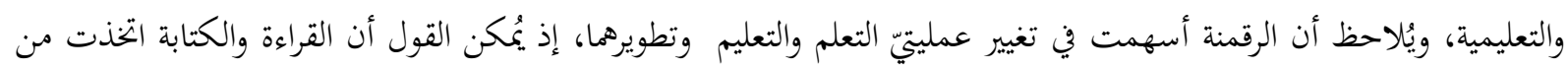

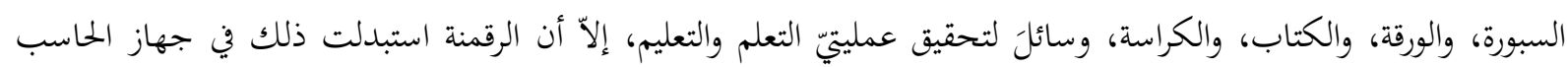
الآلي، وبربجياته، وفي تطبيقات السحابة الإلكترونية، والشبكة الإلكترونية. (الزعبوط، وابك، 2021) ومن منطلق أن الحاسب الآلي اعتمد في البداية على الأرقام فيما يُسمى بالخوارزميات، التي يعود أصلها إلى عالم الرياضيات

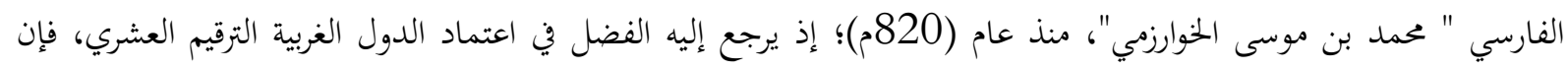

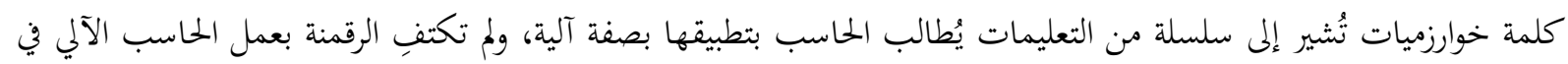

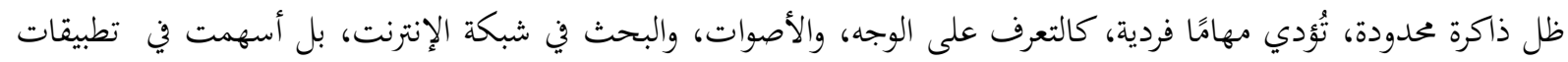

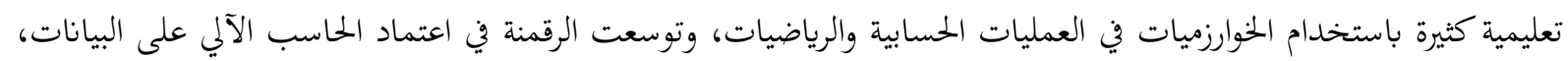

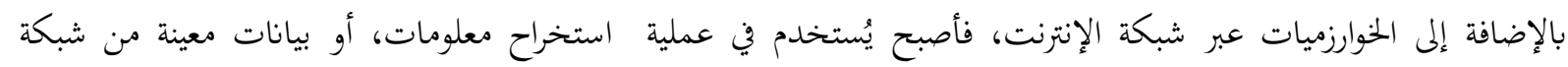

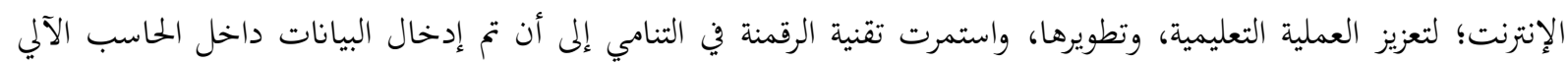

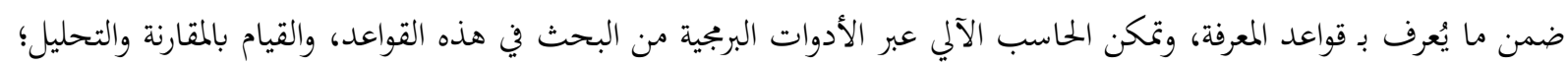

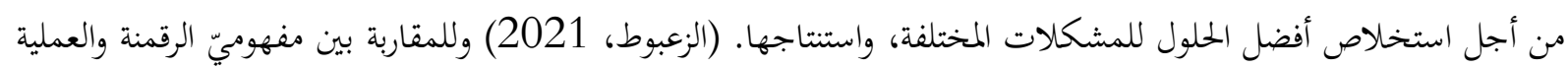
التعليمية، ينبغي البحث في أدبيات الرقمنة والنظريات المفسرة لها، عبر محاور البحث.

الخور الثاني: أدبيات الرقمنة

ركزت خطة عمل المفوضية الأوروبية على العملية التعليمية الرقمية عبر إعادة التعليم والتدريب للعصر الرقمي، وأظهرت

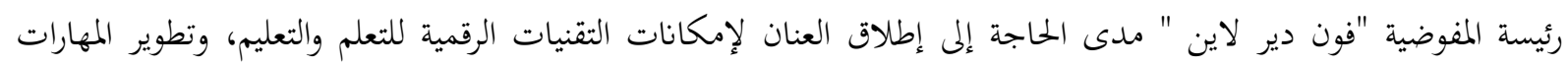

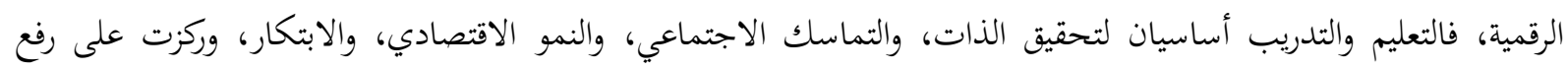

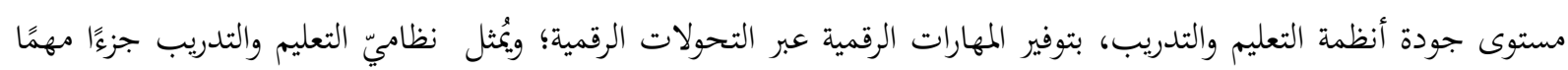

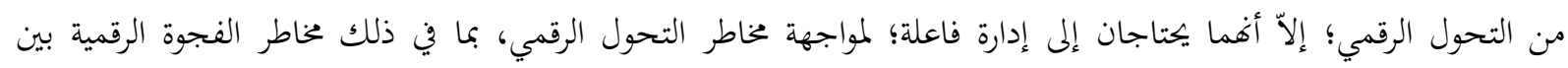

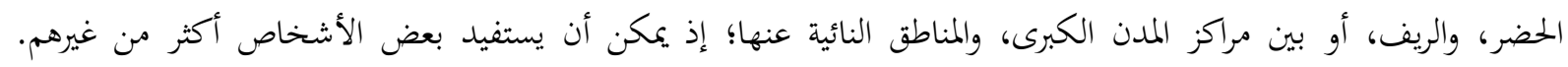

(Commission, 2021)

وركزت الخطة أيضًا على جانبين مترابطينْ للعملية التعليمية الرقمية هما: (Commission, 2021)

الأول: نشر مجموعة واسعة من التقنيات الرقمية (التطبيقات والمنصات والبرجيات)؛ لتحسين نطاق التعليم والتدريب وتوسيعه، إذ إن التعليم عبر الإنترنت، والتعليم عن بعد، والتعليم المدمج أمثلة محددة لكيفية استخدام

$$
\text { تقنية الرقمنة لدعم عملتيّ التعليم والتعلم. }
$$

الثاني: تزويد المتعلمين كافة، بالكفاءات الرقمية (المعرفة والمهارات والمواقف)؛ للعيش، والعمل، والتعلم، والازدهار في عالم تتوسطه التقنيات الرقمية بشكل متزايد.

وركزت خطة العمل الأوروبية على التغيير الرقمي طويل المدى في التعليم والتدريب، الذي يشمل تحسين مهارات القراءة

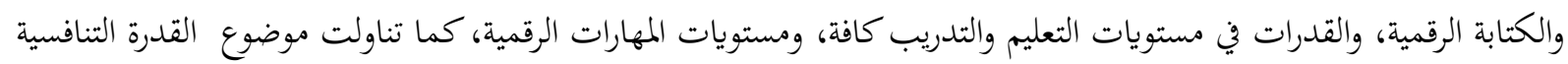

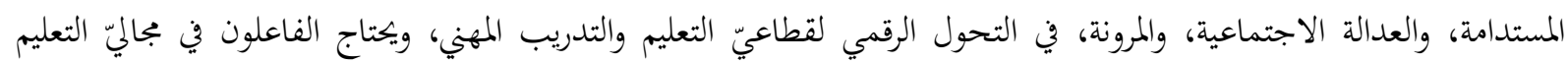


والتدريب إلى التفكير بشكل استراتيجي في كيفية دمج التقنيات الرقمية في التعليم والتدريب، ويُشير التفكير بشكل استراتيجي إلى كيفية دمج التقنيات الرقمية في التعليم والتدريب إلى الآتي: (Commission, 2021)

التحول الرقمي: إن تحويل التعليم للعصر الرقمي مهمة تشمل أفراد المجتمع كافة: بحيث يشترك التربويون، والقطاع العام،

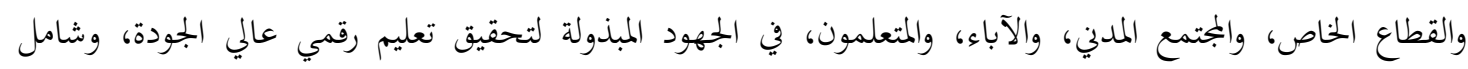

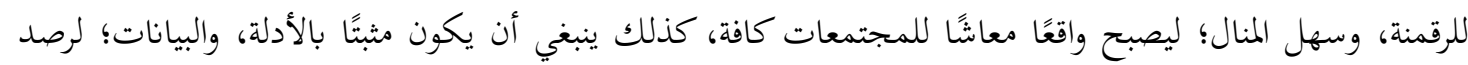

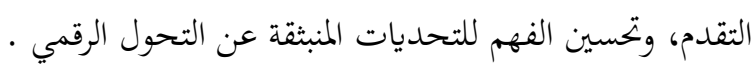

الاستثمار المناسب: ينبغي أن يكون الاستثمار في الاتصالات، والتجهيزات، والقدرات، والمهارات التهات التنظيمية، لتتمكن

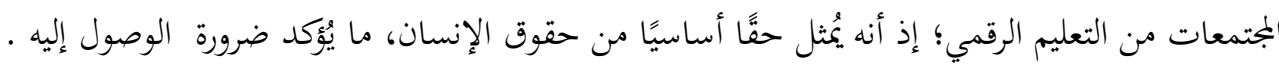

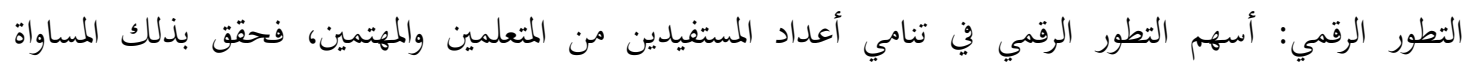
والشمولية، وتناميًا في المهارات الرقمية، ونشر أنظمة شاملة يمكن الوصول إليها رقمياً؛ إذ إن الافتقار إلى المهارات

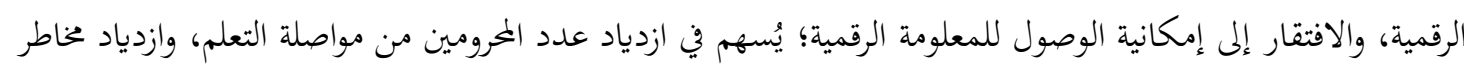
الفقر والحرمان، كذلك يُسهم في تنامي الأمية الرقمية.

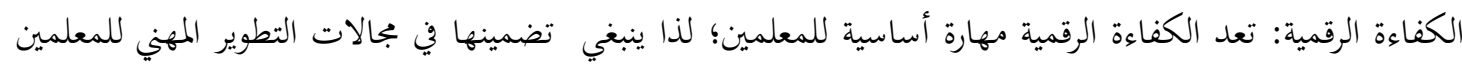

كافة. محو الأمية الرقمية: يُعد محو الأمية الرقمية من ضروريات الرقمنة؛ إذ تدخل الحاسبات والخوارزميات في الأنشطة اليومية

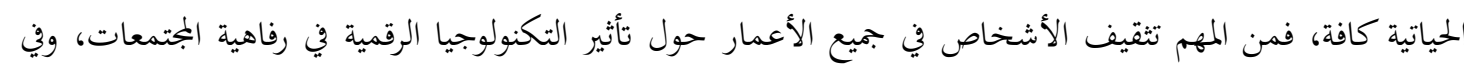

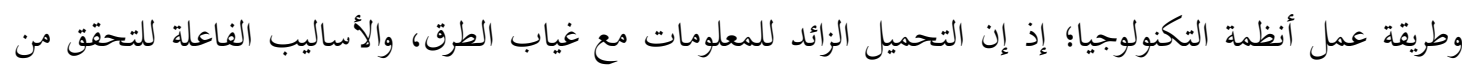

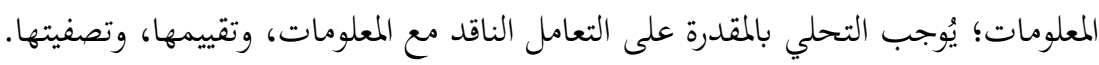
وأظهرت إحدى الأدبيات تصورات طلبة المرحلة الجامعية حول التعليم الإلكتروني، إذ اتخذ الباحثون عينة تكونت من

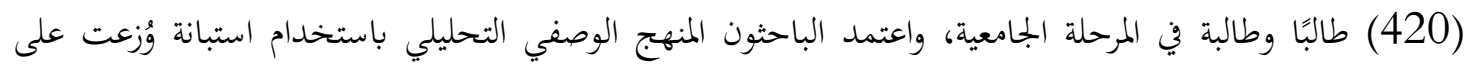

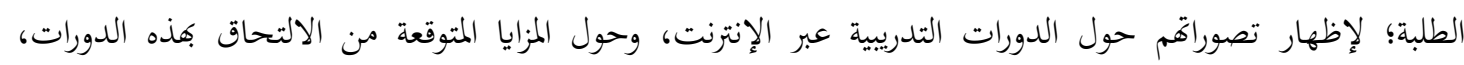

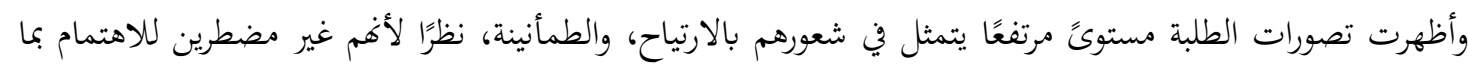

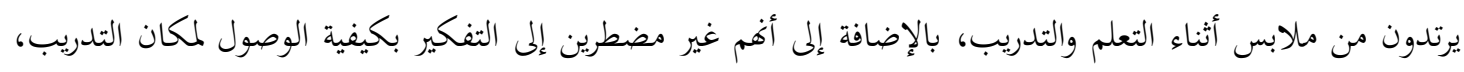

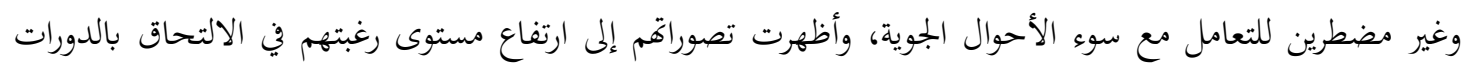

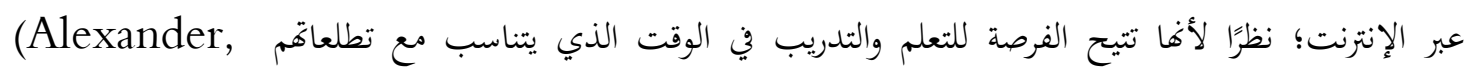
.Truell, \& Zhao, 2012)

كما أظهرت تصورات الطلبة بعض العيوب الملازمة للدورات التدريبية الرقمية، التي تتعلق باحتمال المماطلة، وقلة فهم

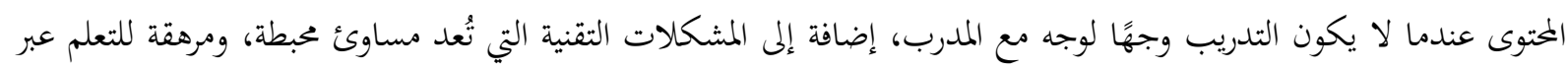

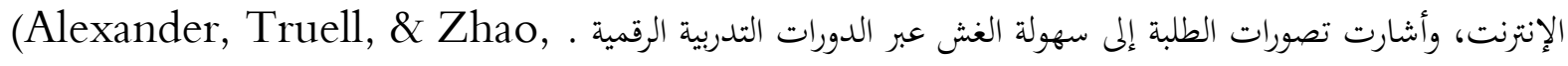

وأوردت إحدى دراسات معهد تونغ فانغ للتصميم في تايوان أن التعلم الرقمي جاء في البداية ليحمل مسمى التعليم

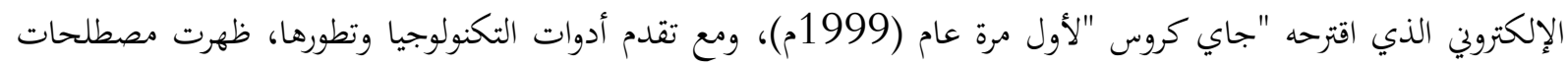

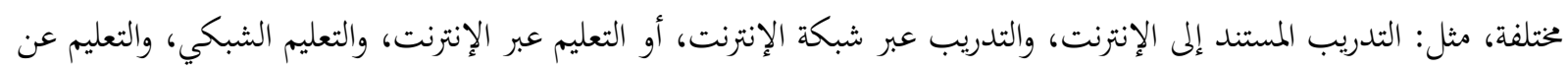


بعد، ويُعد التعليم الرقمي شاملاً لمذه الأنواع، وفي العصر الذي تتدفق فيه المعرفة والمعلومات بسرعة؛ يغطي تطبيق التعليم الرقمي مجالات الحياة كافة. (Ming, Huang, \& Kuang, 2017) بناءً على ذلك، فقد اقترحت الجمعية الأمريكية للتدريب والتعليم (ASTD) أن التعليم الرقمي يُشير إلى أنه عملية

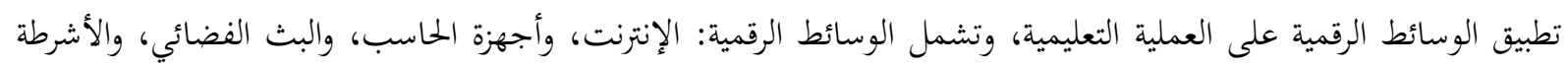

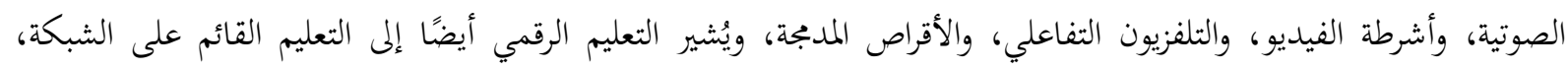

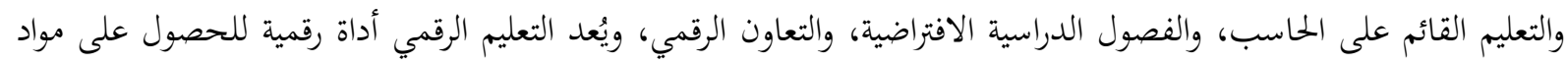

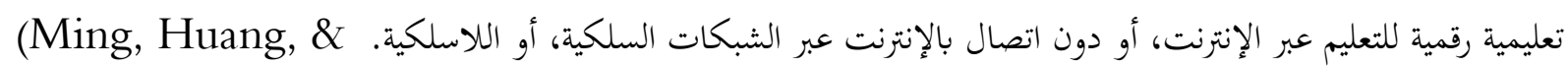

Kuang, 2017)

وأظهرت الدراسة: أن التعلم الرقمي يُسهم في تعزيز ممارسات إيمابية تُحفز على التعلم بشكلٍ أفضل، مقارنة بما يقدمه

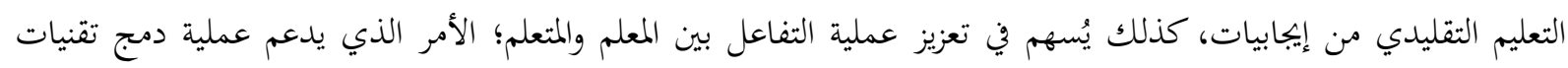

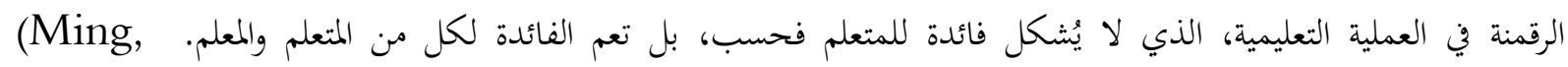

Huang, \& Kuang, 2017)

وأظهرت إحدى أدبيات اليونسيف عام (2021) أن المجتمعات منخفضة الدخل، وذات الدخل المتوسط تواجه عددًا لا

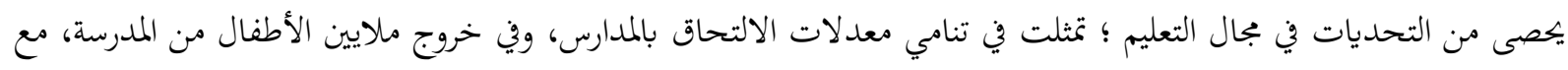

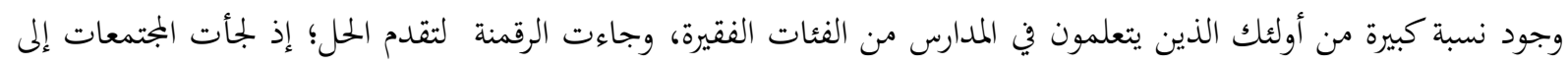

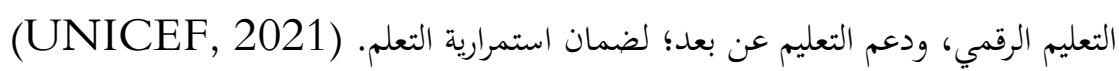

وحول تطبيق حلول التعليم الرقمي في البلدان المنخفضة الدخل، والبلدان مرتفعة الدخل، أظهر هذا التطبيق وعدًا كبيرًا في تحسين نتائج التعلم، عندما يتم دججه في عمليات التعليم؛ إذ يؤدي دمجه في التعليم إلى تسهيل المرونة في التعليم، وإلى تزويد المتعلمين عملية التحكم في تعلمهم، وتشجيع تنمية الكفاءات المعرفية. (UNICEF, 2021) وقد ثبت أن حلول التعلم الرقمي تجذب المتعلمين عاطفياً، إذ يتضح أن مواقف المتعلمين، ومتعتهم واهتماماتم تزداد بتحاه

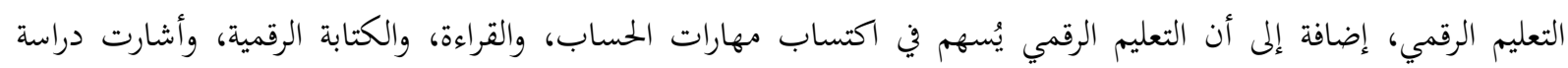

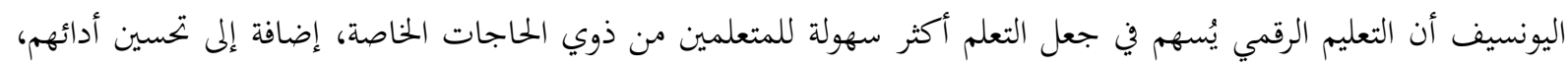
وتحسين مهارات القراءة لدى الذين يعانون من عسر القراءة، وتعزيز مهارات الرياضيات للصم، وضعئ وضعاف السمع، والمكلكوفين.

(UNICEF, 2021)

واهتمت إحدى الأدبيات بموضوع منصات التعليم الرقمي، وذلك عبر دراسة نقدية لهذه المنصات، إذ أوردت أن التعليم

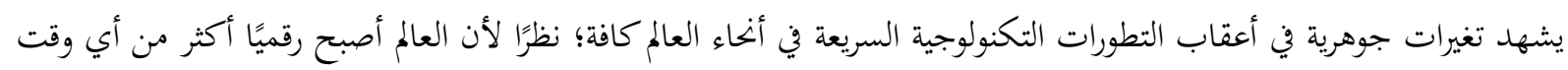

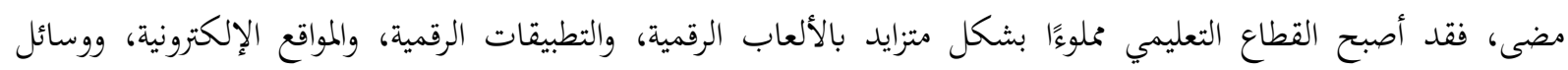

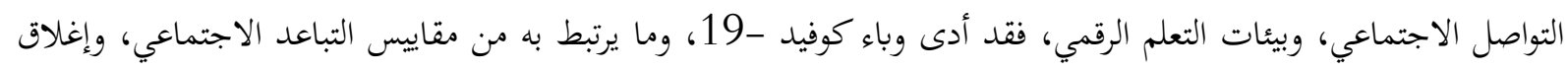

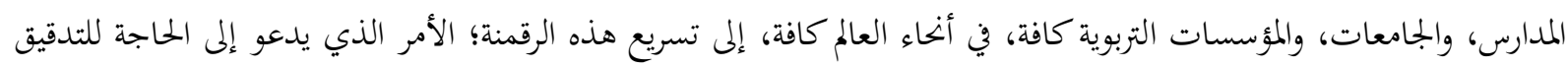
الدقيق حول كيفية إعادة تشكيل هذه الرقمنة ودبجها في البيئات التعليمية. (Decuypere, Landri, \& Grimaldi,

كذلك، انتشرت المنصات، وتنوعت أشكالها، وأصبحت شركات التكنولوجيا العالمية، والمحلية على حد سواء، من البيئات

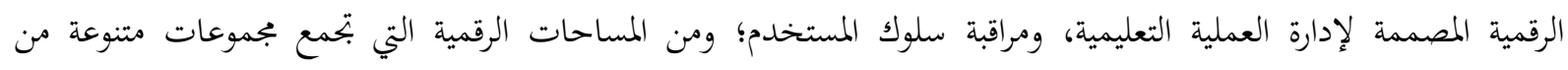


الوظائف إلى واجهات أكثر تفردًا، وأشارت الدراسة إلى منصات رقمية متخصصة لكل مجال من بجالات الحياة، مثل: المجال

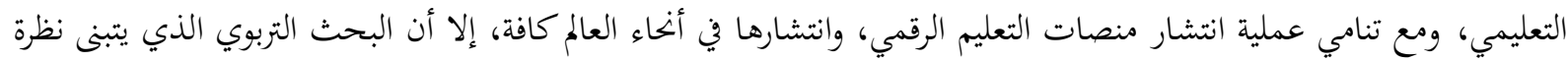
نقدية لمثل هذه المنصات لا يزال محدودًا. (Decuypere, Landri, \& Grimaldi, 2021) وأشارت الدراسة إلى توافر النظام الأساسي لهذه المنصات عبر الإنترنت، فهو يمُثل بنية رقمية قابلة للبرمجة، ومصممة لتنظيم التفاعلات بين المستخدمين، والشركات، والهيئات، وما إلى ذلك، كذلك هو موجه بأسلوب منهجي؛ ليقوم بالمعالجة الحسابية، وتداول البيانات، وتبادل المعلومات، وتحقيق الدخل من بيانات المستخدم؛ لذا فالحاجة ماسة إلى المنصات الرقمية، لأهما أصبحت راسخة في الحياة الاجتماعية بشكل عام، وفي المجال التعليمي بشكل خاص، ما أدى إلى تبنّ المؤسسات التعليمية بجموعة متنوعة من المنصات العالمية التي تتعلق بالتعليم. (Decuypere, Landri, \& Grimaldi, 2021) وتُعد المنصات الرقمية معماريات رقمية؛ فهي تعمل كأبراج زمانية، ومكانية، وتُمكّن المستخدم من عرض أنشطته، وتتكون المنصات الرقمية من نوعين مختلفين من الواجهات: واجهات المستخدم الرسومية، وواجهات بربجة التطبيقات، وتشتهر المنصات

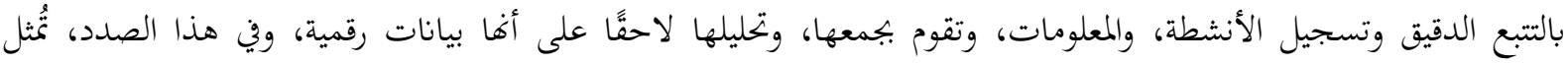

المنصات الرقمية نوعًا جديدًا من البيئات التعليمية. (Decuypere, Landri, \& Grimaldi, 2021) وتعتمد المنصات الرقمية وسائل جديدة لإنتاج قيمة، ما يعني أها تقيس أنشطة المستخدم، ومعلوماته بوصفها بيانات، وتقدم تلك الأنشطة عبر المنصات الرقمية على أفها سلوك يمكن ملاحظته وقياسه، وبذلك فهي تعمل بوصفها قناةً؛ لتسهيل تبادل المحتوى والأنشطة التعليمية، مثل: مجموعة (منصات أمازون)، ومنصة (كلاس رووم)، وكثير من أنظمة إدارة التعلم الشائعة

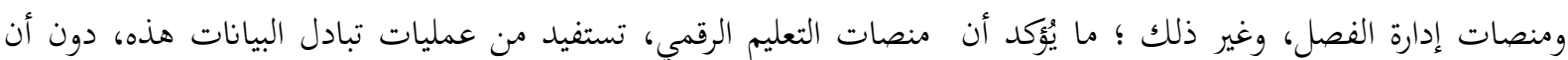

تشارك بالضرورة في إنتاج المحتوى التعليمي بنفسها. (Decuypere, Landri, \& Grimaldi, 2021) ومن المنصات ما يتسم بالكفاءة في تقديم المحتوى التعليمي، ما يعني أها تعد مزودًا للمحتوى المنتج ذاتيًا، مثل: منصة(

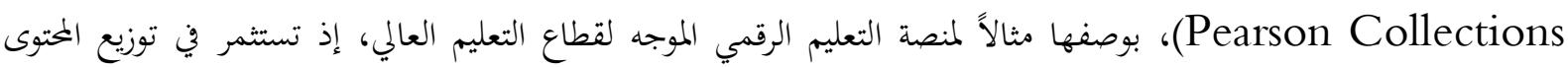

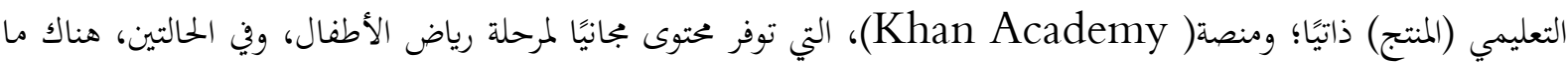

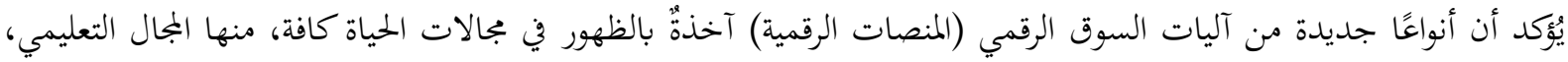

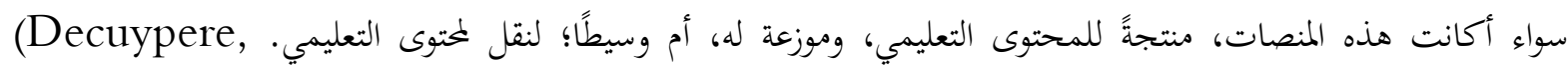
Landri, \& Grimaldi, 2021)

المحور الثالث: النظريات المفسرة للرقمنة إن تبني نظريات تعلم حديثة، يُسهم في تصميم الأنظمة المعرفية والتقنية وتنظيمها؛ ويُمْكّن من صناعة المستقبل القائم على

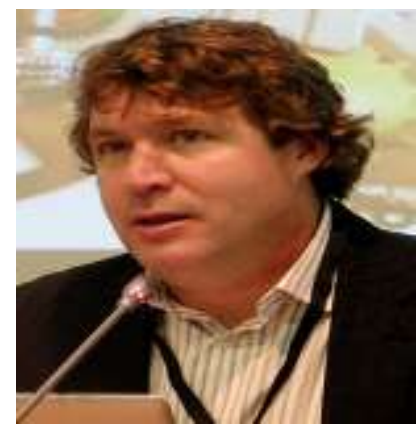

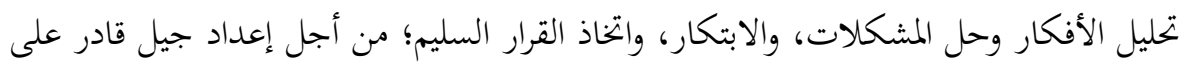

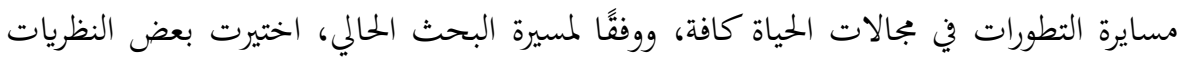
المفسرة للرقمنة. نظرية الاتصال الشبكي لـ جورج سيمنز

وُلََِِ جورج سيمنز عام (1970م) وهو كندي الأصل، وحصل على درجة الدكتوراه في علم النفس من جامعة أبردين عام (2011م)، وطورت أطروحته كنموذج للمعلومات في بمال 
السلوك الفردي في الشبكات الاجتماعية، وانضم سيمنز إلى هيئة التدريس في جامعة تكساس في( أرلينغتون )، بوصفه أستاذًا في

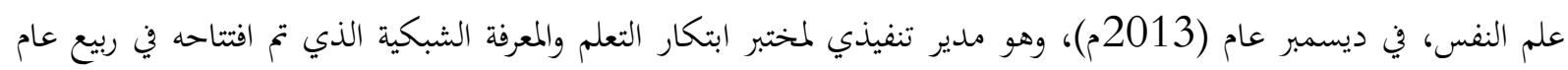
(2014م)، وهو مؤلف لكتاب " معرفة المعرفة" الذي ترجم إلى عدة دمات لغات منها: الإسبانية، والفارسية، والهنغارية.

(Siemens, wikipedia., 2020)

تسعى النظرية الاتصالية إلى توضيح كيفية حدوث التعلم في البيئات الإلكترونية المركبة، وكيفية تأثر التعلم عبر

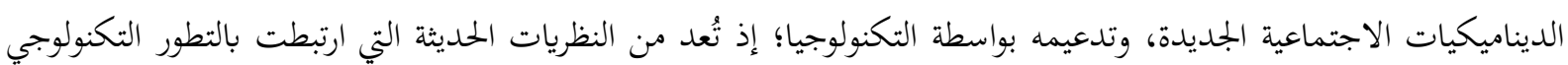

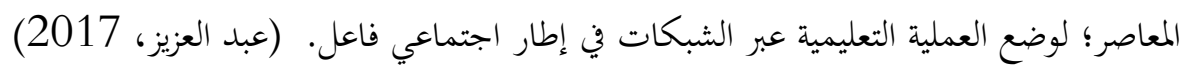
وترتكز النظرية الاتصالية على مقولة أن العصر الحالي، هو عصر قائم على المعرفة في مجالات الحياة كافة؛ ولهذا فالإنسان

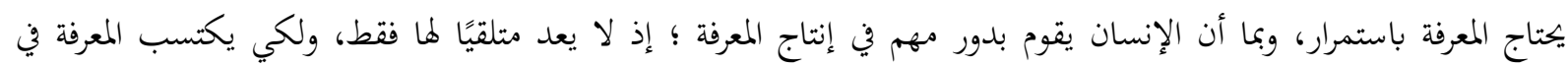

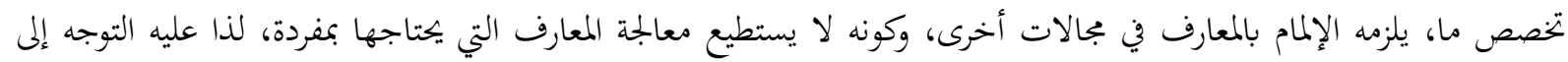

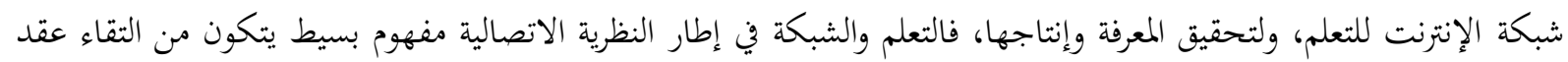

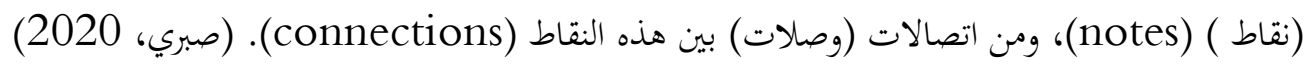
وتُشير نقاط الالتقاء إلى مكونات بشرية، ومكونات غير بشرية، وتتضمن المكونات البشرية المتعلمين، أو الخبراء في مجالات

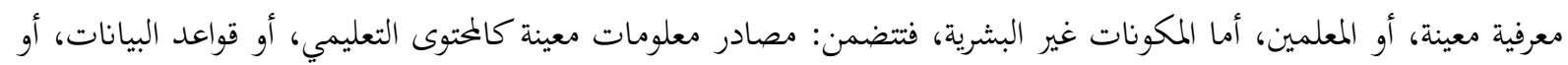

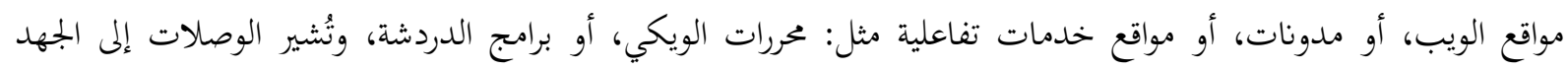
المبذول في عملية التعليم، إذ يربط هذا الجهد التعليمي (الوصلات) بين النقاط المتمثلة بالمكونات البشرية، والمكونات غير البشرية. (صبري، 2020)

ومن مميزات النظرية الاتصالية أها تُسهم في تشجيع الاتصال بين المتعلم والمؤسسة التعليمية، كما أن لها دور في تنمية التبادل والتعاون بين المتعلمين عبر التعلم النشط، وتركز دائماً على إعطاء تغذية راجعة؛ للتأكيد على أهمية الوقت في إنجاز المهمة، لتهات

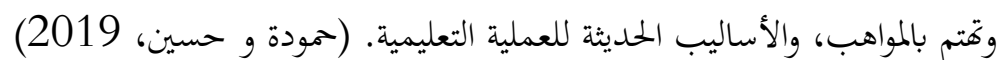

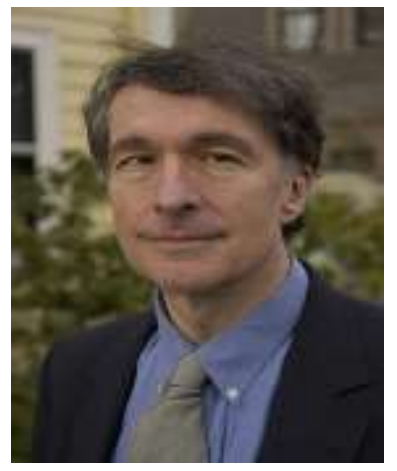

نظرية العقول الخمسة لموارد جاردنر

ولد هوارد جاردنر في 11 يوليو عام (1943م) في سكرانتون بولاية بنسلفانيا، وحصل على درجة الدكتوراة في جامعة هارفارد عام (1971م)، وهو عالم في علم النفس التنموي، واشتهر بنظرية الذكاءات المتعددة؛ إذ كان يعتقد أن المفهوم التقليدي للذكاء يتسم

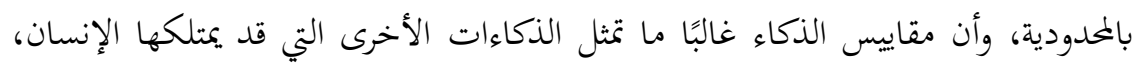

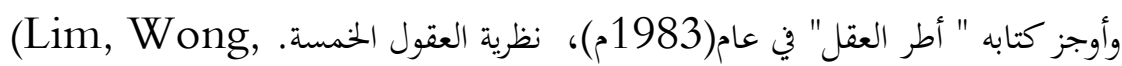
Boon, \& Tan, 2009)

وتُعد نظرية العقول الخمسة من النظريات التربوية الحديثة لهوارد جاردنر الذي أشار عبرها إلى مجموعة القدرات العقلية التي ينبغي أن يتصف بها إنسان القرن الحادي والعشرين، وهي العقل المتخصص، والعقل التركيبي، والعقل المبدع، والعقل المحترم، والعقل

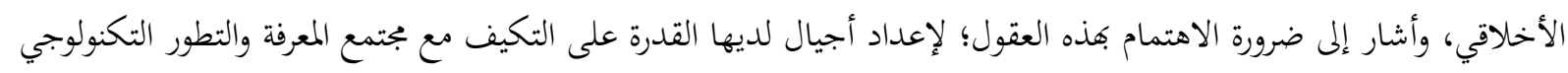
في العصر الرقمي. (Kimberly, 2014) 


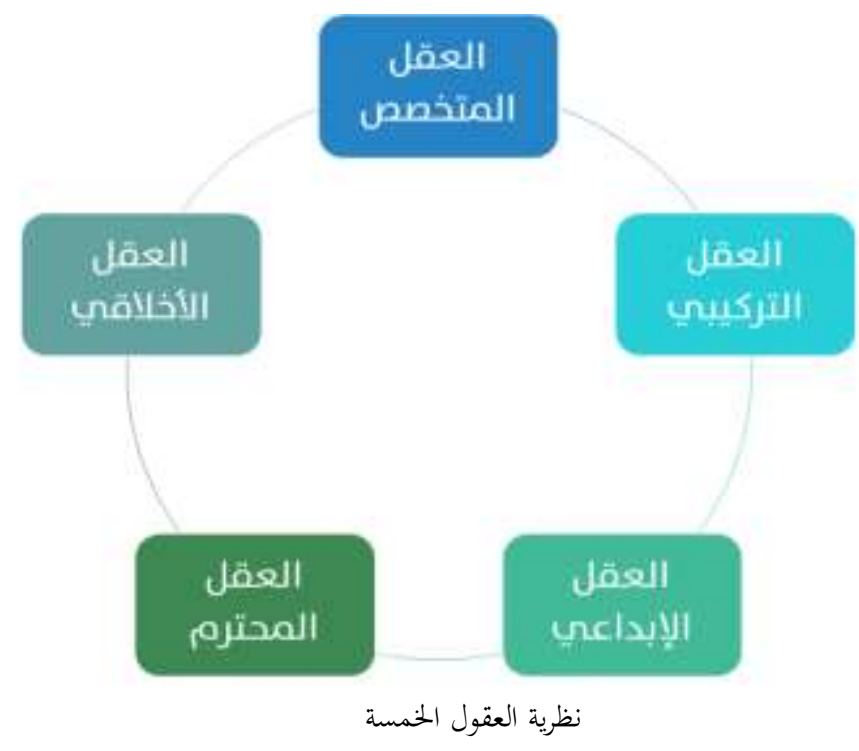

https://shaghf.net/ar/resources/read/khmsh-aqwl-mn-ajl-almstqbl:المصدر

وفي ذات السياق، يُشير العقل المتخصص، أو التخصصي إلى مقدرة المتعلم على تحديد المعارف المهمة، والمعارف غير

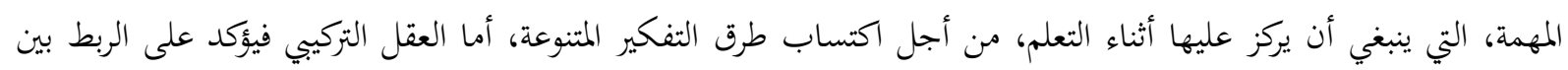

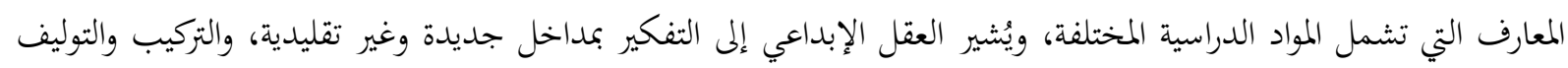

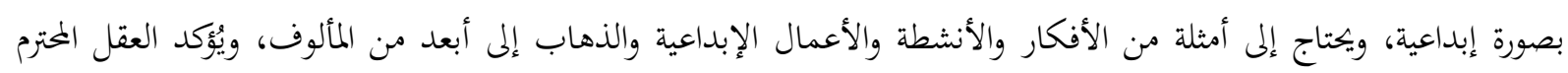

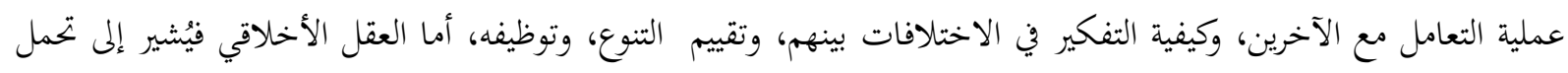

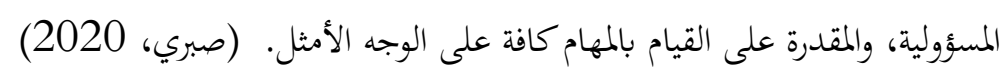

بناءً على ذلك، ينبغي أن تسعى المؤسسات التعليمية إلى تنمية العقول الخمسة لجاردنر للمراحل التعليمية كافة؛ نظرًا لما

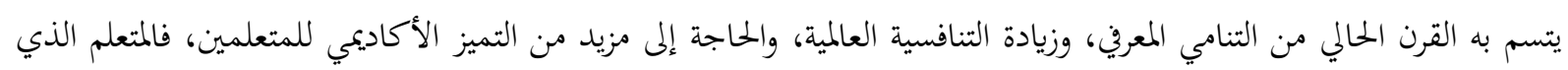

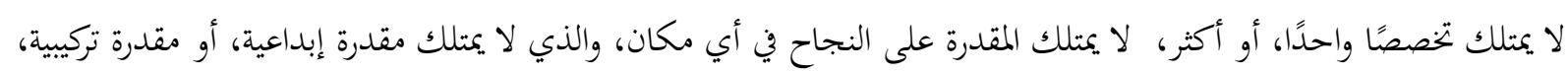

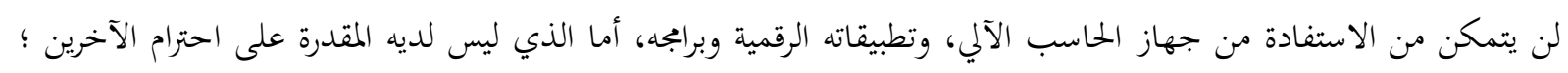

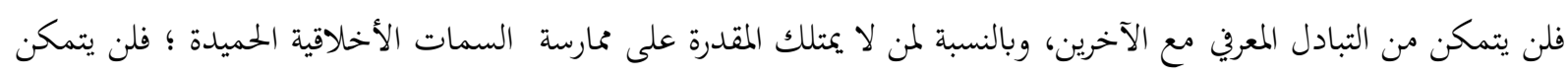

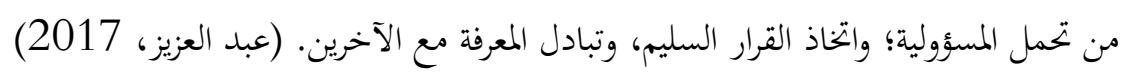

الخور الرابع: مناقشة المحاور

الإجابة عن السؤال الأول: ما دور أدبيات الرقمنة في المقاربة بين الرقمنة والعملية التعليمية؟

يُلاحظ أن خطة عمل المفوضية الأوروبية ركزت على جانبين للتعلم الرقمي، هما التقنيات الرقمية، والكفاءات الرقمية، وهذا

يتطلب سياسات تتناول محاور التعليم الرقمي كافة، وتتطلب إجراءات عملية، بحيث تشمل البنية التأسيسية (التحتية)، والاستراتيجيات التعليمية، وإدارة القيادات، ومهارات المعلم، ومهارات المتعلم والمحتوى التعليمي، والتقييم، والأطر القانونية الوطنية. كذلك ركزت خطة عمل المفوضية على أهمية التفكير الاستراتيجي في دمج التقنيات الرقمية في التعليم والتدريب، الأمر

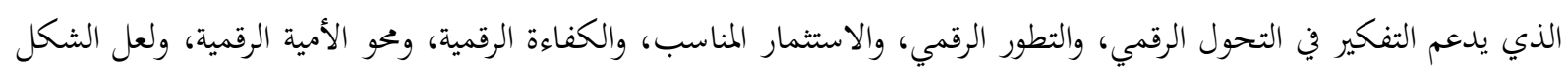
الآي يُوضح ذلك: 


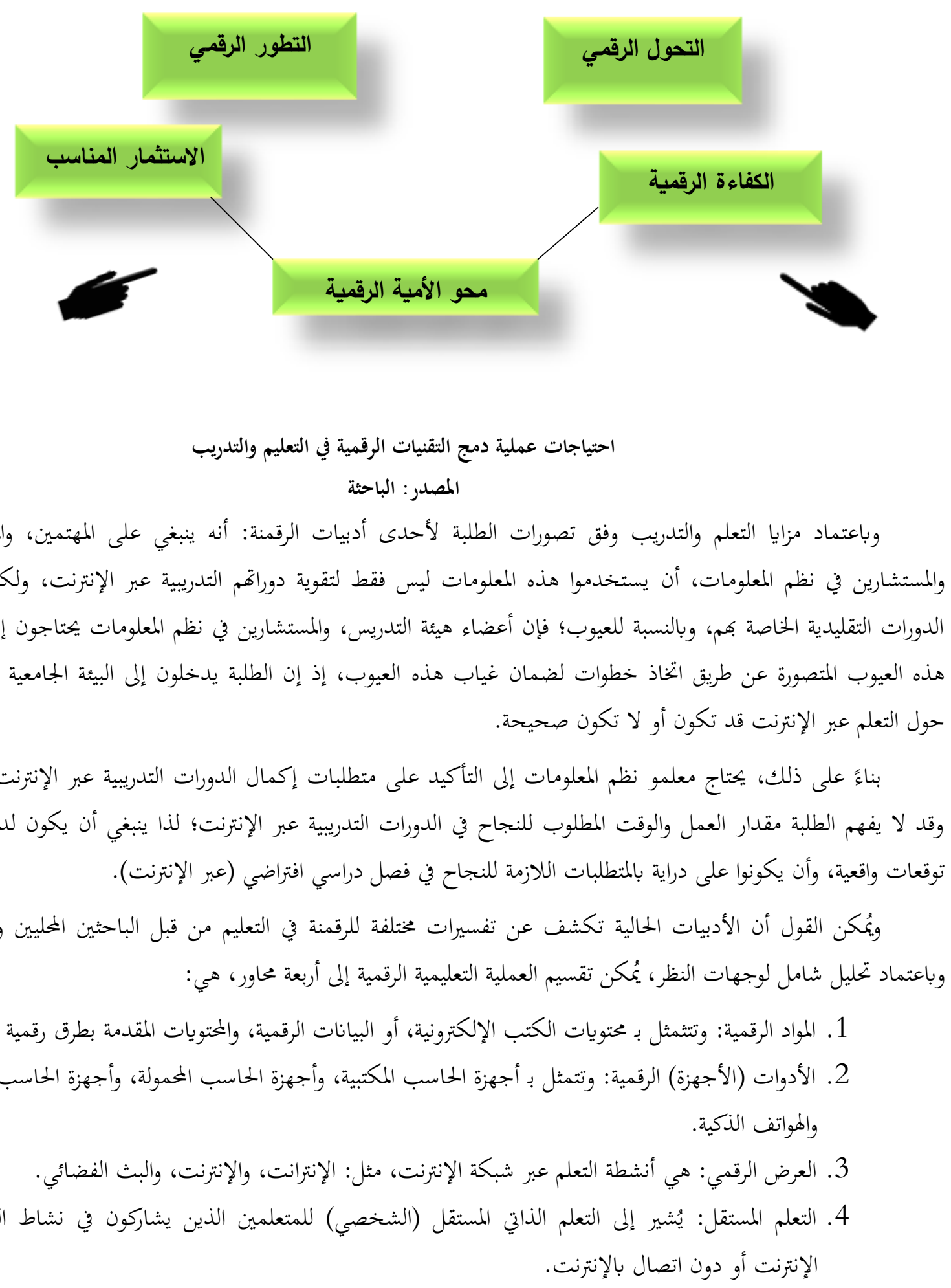



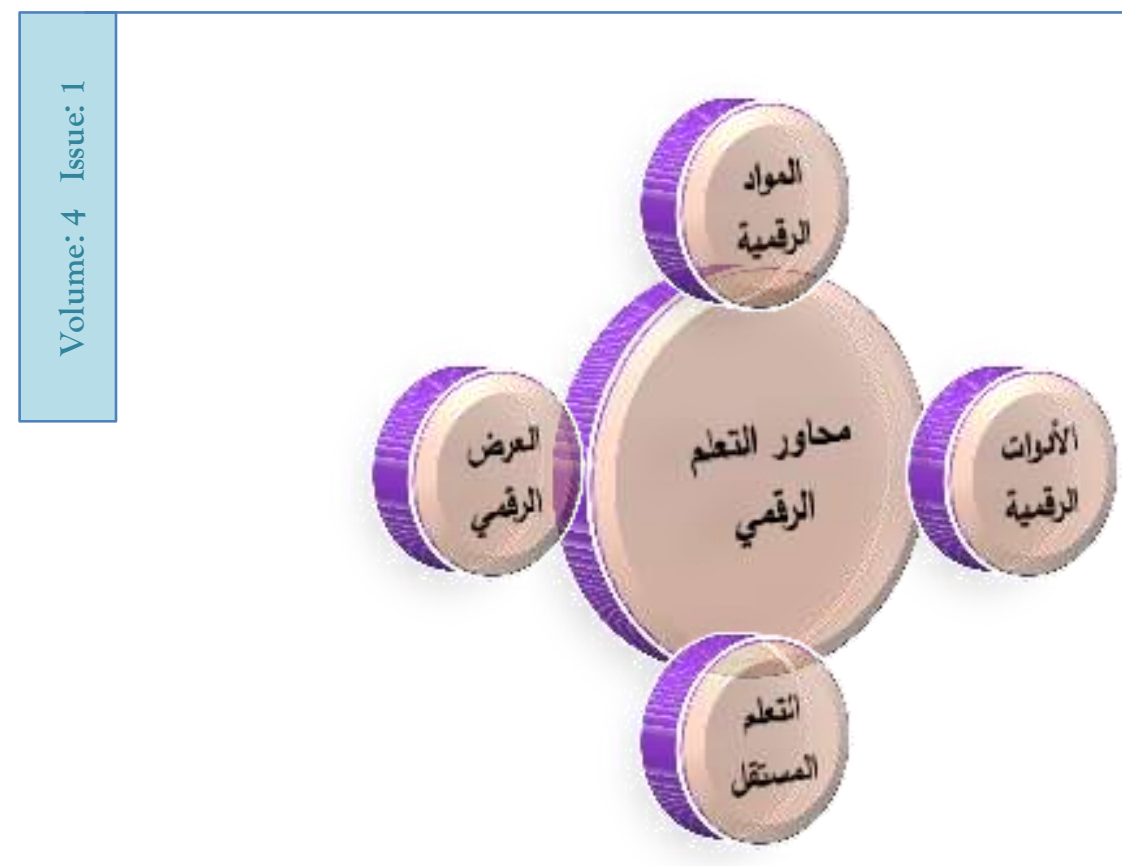

\section{محاور العملية التعليمية الرقمية}

المصدر: الباحثة

وفي ذات السياق، يُمكن استنتاج أن تعزيز فاعلية التعليم تتحقق، عندما تكون وظائف المنظومة التعليمية غنية، ومتنوعة لتكون قريبة من إدراك المتعلم، وبتذب المتعلم الذي يسجل عبر النظام الرقمي للتعليم، وفيما يتعلق بالمشكلات التي تواجه التعليم

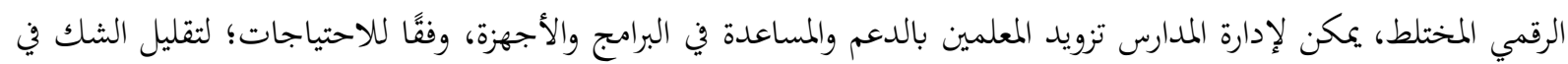
التعليم الرقمي، ويُمكنهم دمج المعلمين ذوي الاهتمامات لجمع الموارد ذات الصلة من الإنترنت وتطوير البرامج ذاتيًا، أو إنشاء صفحات الويب؛ لتعزيز عملية التعليم الرقمي .

فالمعلم هو مفتاح تطوير فاعلية التعليم الرقمي، فعندما يتبادل المعلمون خبرات التعليم مع أقراغم، أو مع الخبراء، أو المشاركة

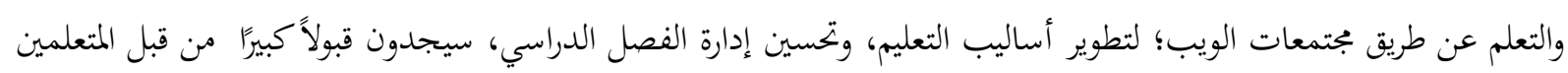

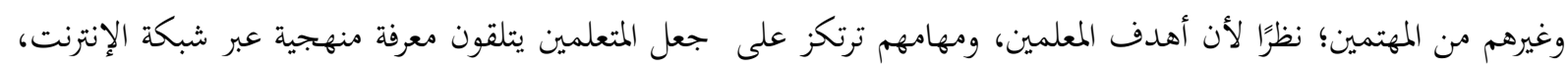

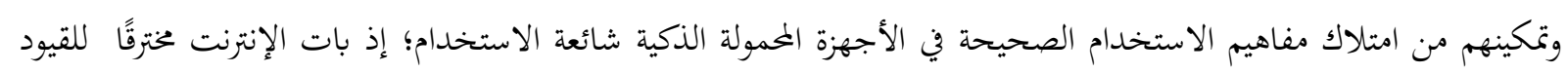

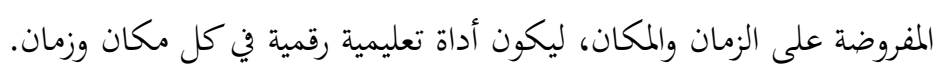
بناءً على ذلك، فإن تكلفة حلول التعليم الرقمي، واستدامتها، من الأسئلة الحاسمة التي لها نتائج قد تختلف كثيرًا لدى الباحثين حولما؛ إذ تعد الاستدامة وقابلية التوسع من الاهتمامات الكبيرة لواضعي السياسات والمهتمين في مجال التعليم، لا سيما

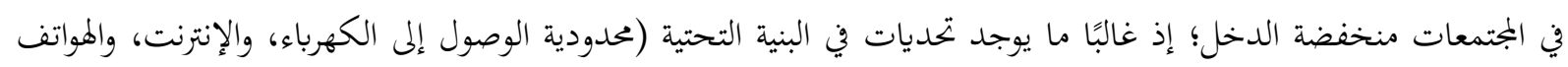
المحمولة) لأجزاء كبيرة من البلدان.

وبنظرة نقدية إلى إحدى الأدبيات التي ركزت على التعلم الرقمي باستخدام المنصات، يُمكن القول أن هذه المنصات

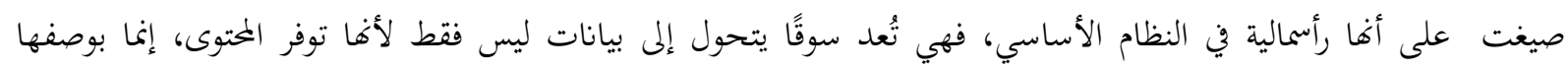

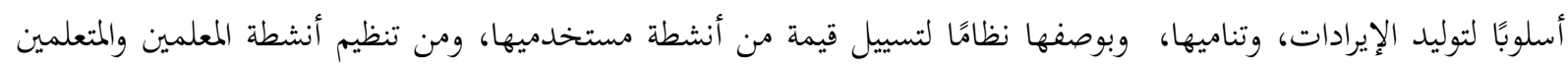

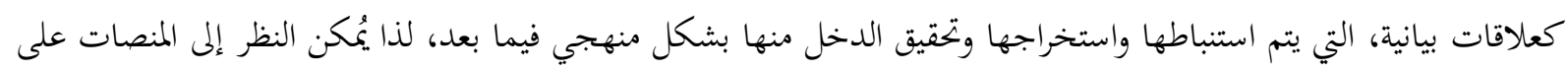

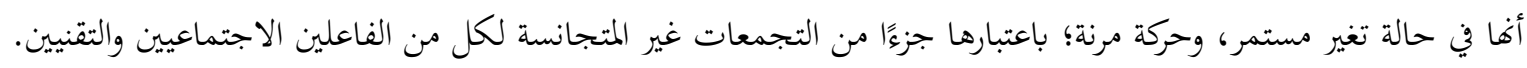


وفي مدى تأثير المنصات الرقمية في عملية التعليم وإعدادها؛ فهي تتدخل بقوة في عمليات الإعداد التعليمي، مع وجود

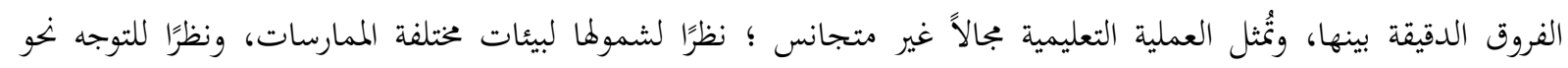

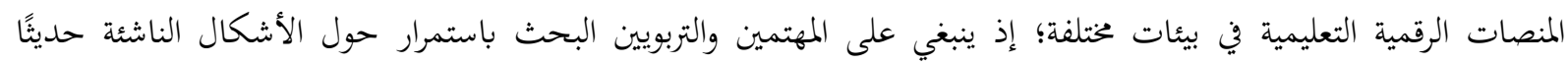
لمنصات التعليم الرقمي، وينبغي الاهتمام الحثيث في طبيعة المنصات الرقمية بوصفها أجهزة تعليمية رئيسة في إدارة العملية التعليمية،

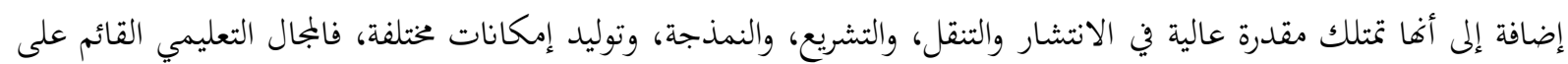

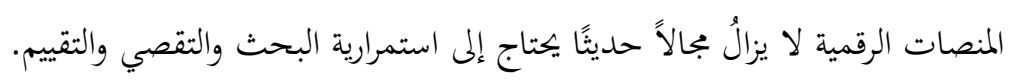

الإجابة عن السؤال الثاني: ما دور النظريات المفسرة للرقمنة في المقاربة بين الرقمنة والعملية التعليمية؟ يُككن القول أن نظرية جورج سيمنز عُرِفَت بمسميات كثيرة منها: الاتصالية، والشبكية، ونظرية التواصل الشبكي، ولعل

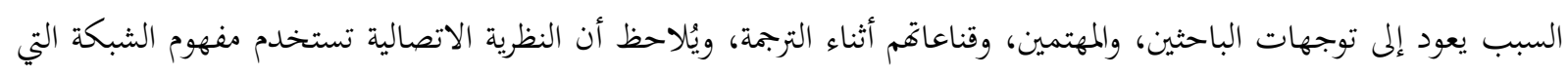

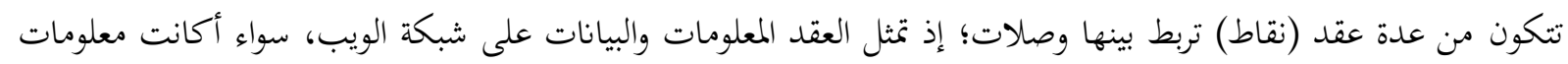

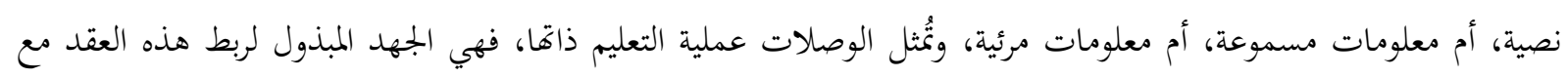
بعضها لتشكيل شبكة من المعارف الشخصية.

ويُمكن إبراز أهمية النظرية الاتصالية في التعليم الرقمي؛ إذ يحتل التعليم الرقمي أهمية كبيرة لدى النظرية الاتصالية عبر تطويع

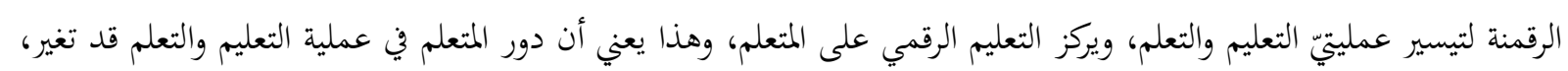

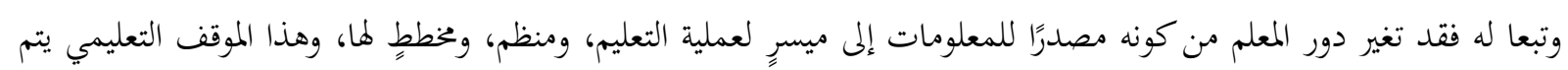

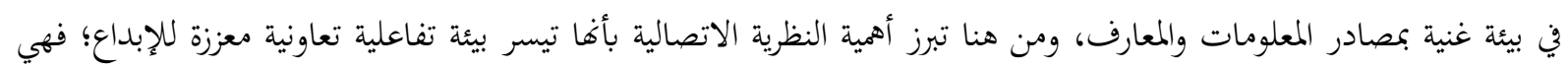

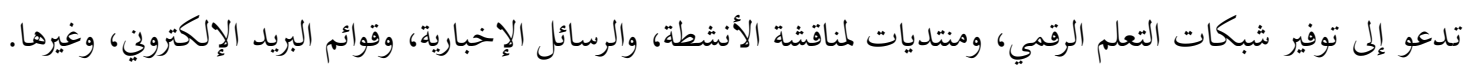
ويتضح أن التعليم في ضوء النظرية الاتصالية يتسم بالاستمرارية، والتعاونية، والتواصل، فهو ليس بثًا لمحتوى يتضمن مجموعة

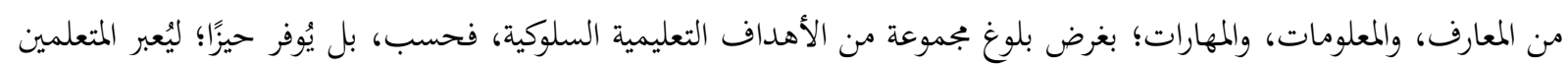

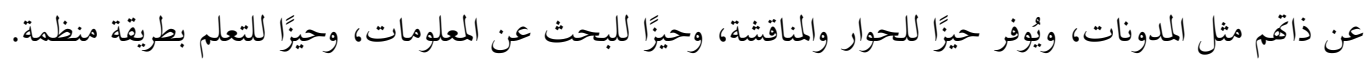
كما يتضح أن العملية التعليمية وفق نظرية العقول الخمسة تُمثل المقدرة على المشاركة لبناء المعرفة؛ لتكون العملية التعليمية

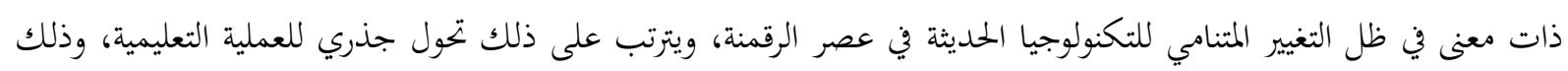

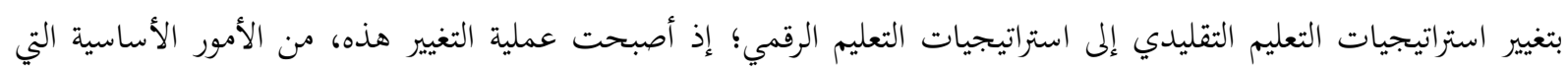
ينبغي اتخاذها في العصر الحالي ألا وهو العصر الرقمي.

بناءً على ما تقدم، فإن التعليم وفق نظرية العقول الخمسة يتطلب إعادة بناء المفاهيم العلمية بطريقة علمية في ذهن المتعلم،

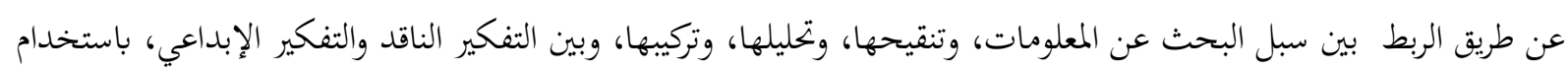

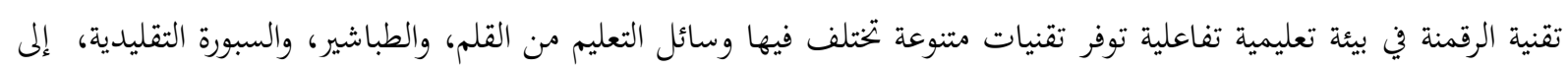
اللوح الذكي، والأجهزة المحمولة، والنقل الإلكتروين للوظائف التعليمية، والكتاب الإلكتروني (الرقمي). وفي ذات السياق، فقد تََّّل التغيير في استراتيجيات التعليم التقليدية، إلى استراتيجيات التعليم الرقمي مثل: استراتيجية

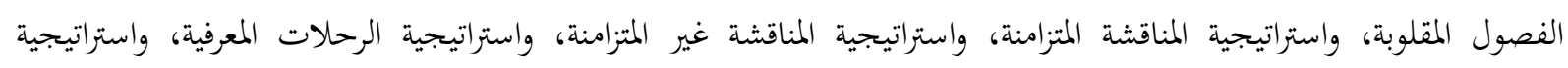

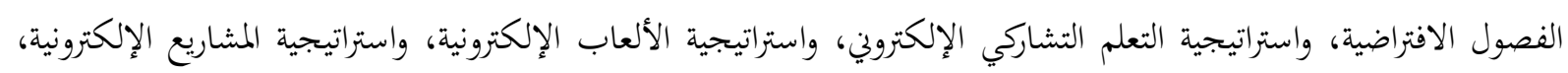

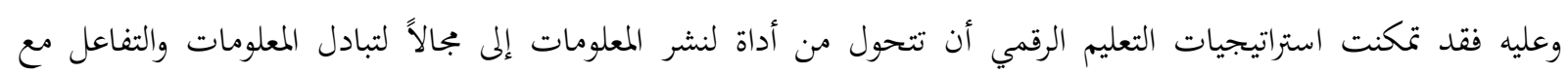


الآخرين، فلم يعد المتعلمين مستهلكين للإنترنت؛ عن طريق اكتساب المعلومات، بل أصبحوا مشاركين فاعلين فيها؛ نظرًا لدوررهم

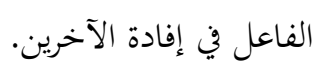

بناءً على ذلك، يُكن القول أن استخدام برنامج البلاك بورد) (Blackboard) يُسهم في تفاعل المعلم والمتعلم في

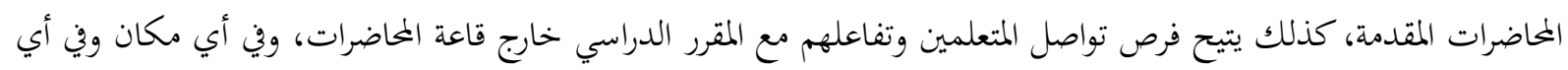

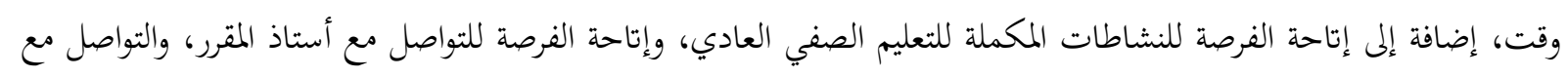

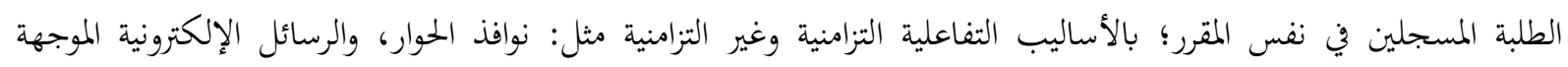

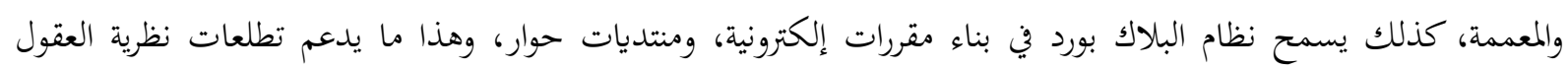

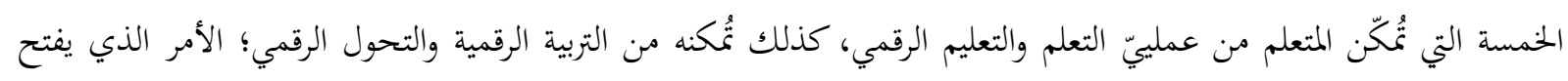

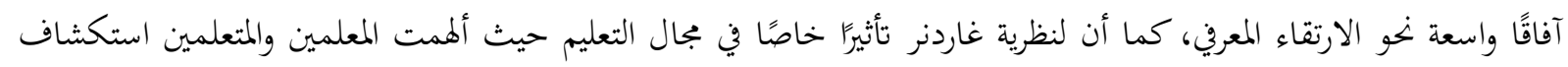

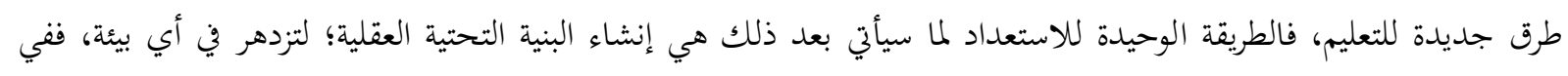

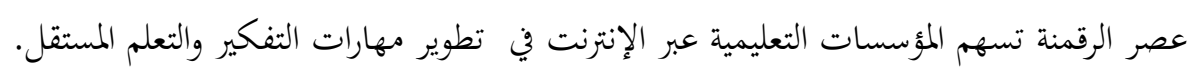

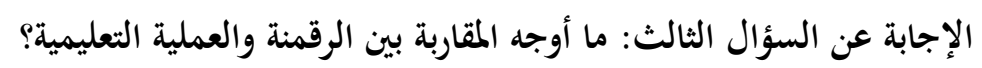

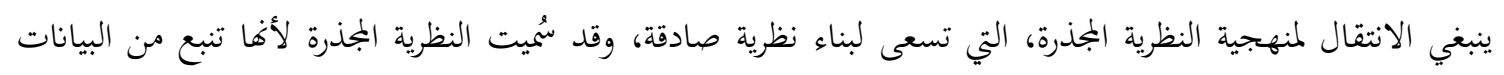

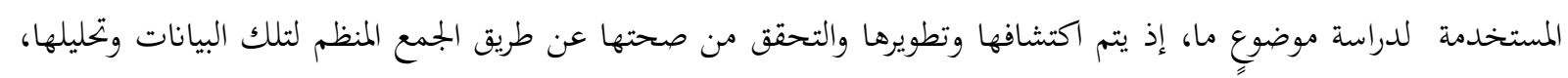

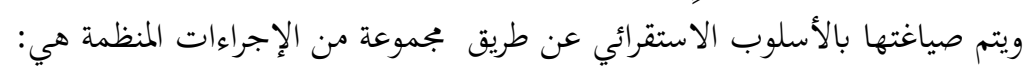

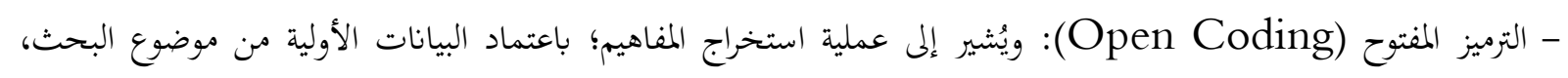

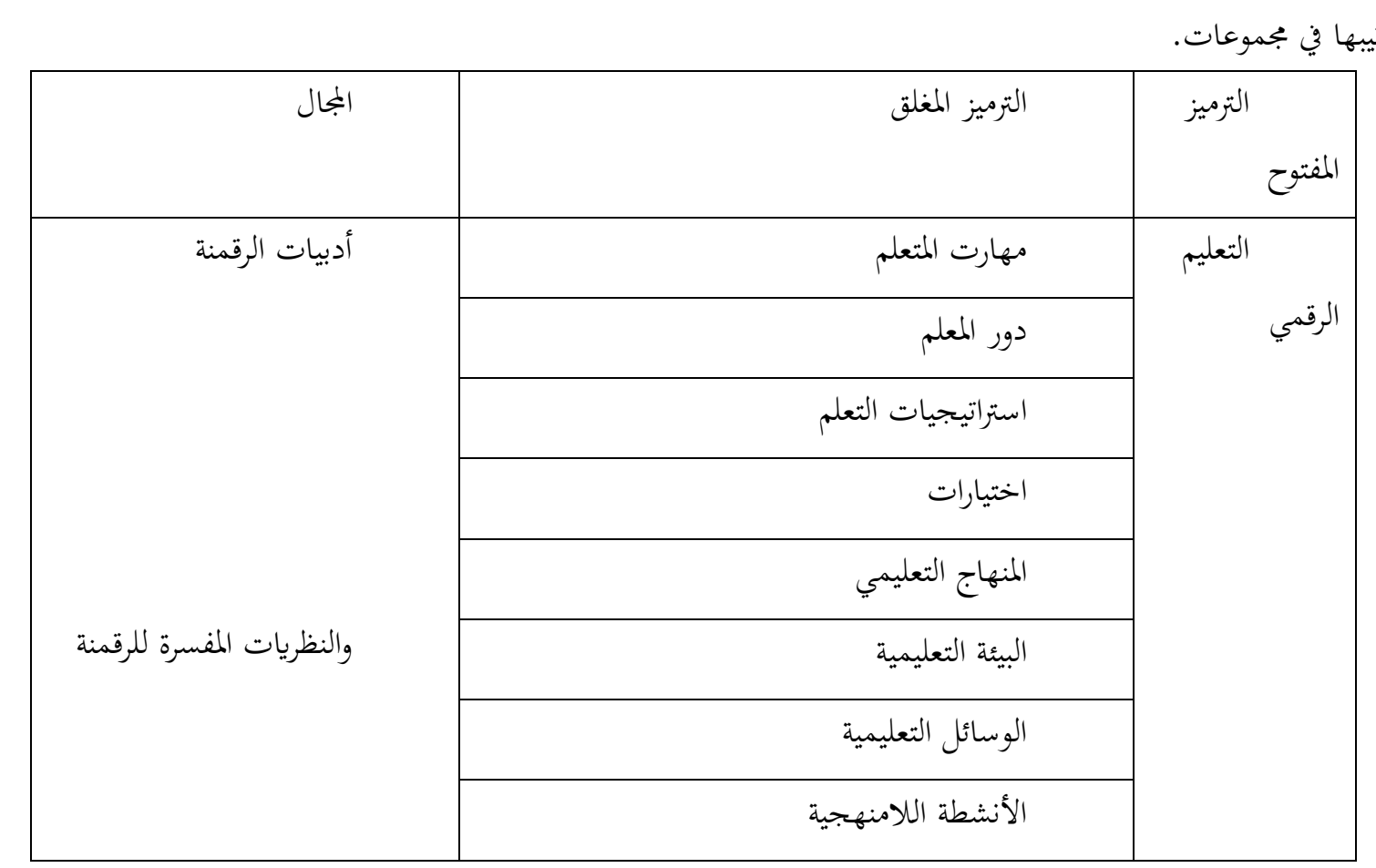

- الترميز المحوري (Axial Coding): يُشير إلى ترتيب البيانات بعضها مع بعض مرة أخرى؛ ليتم وضعها في مجموعات

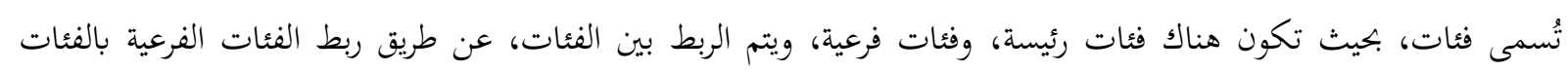




\begin{tabular}{|c|c|c|}
\hline الفئات الفر عية & الفئة الرئيسة & الترميز المحوري \\
\hline 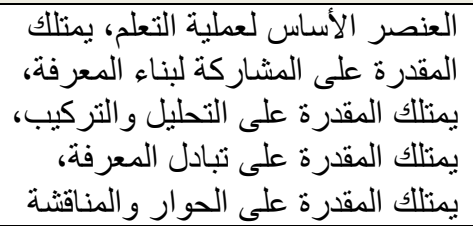 & المتعلم & تعليمية الرقمنة .... مقاربة \\
\hline 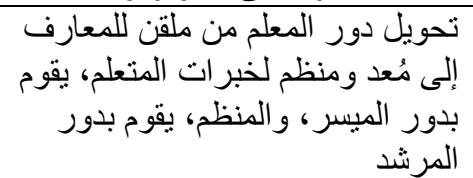 & المعلم & \\
\hline مقرر (رقمي)، مكتبة رقمية، نظتاب إلكترونية البلاكي & المنهاج & \\
\hline 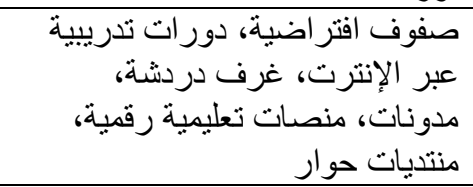 & بيئة تعليمية، صفي & \\
\hline ألواح ذكية، فيديو تعليمي، صفحة & وسائل تعليمية & \\
\hline 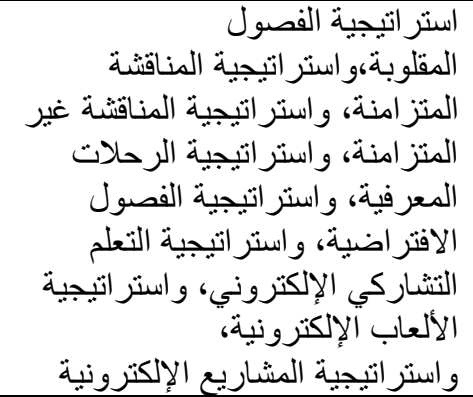 & استر اتيجيات التدريس & \\
\hline
\end{tabular}

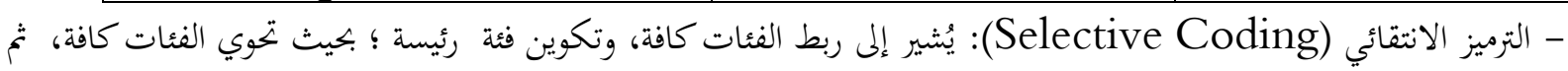

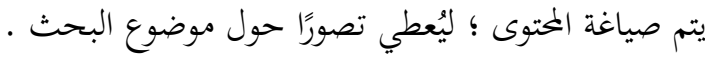

\begin{tabular}{|c|c|c|}
\hline المكونات & الفئة الرئيسة & الترميز الانتقائي \\
\hline المعلم و المتعلم & الرقمنة و العملية التعليمية & 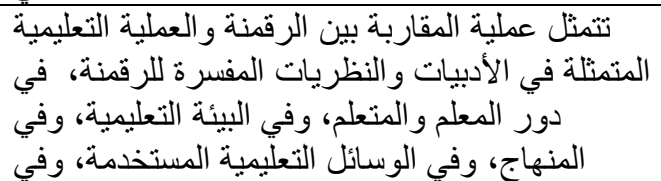 \\
\hline البيئة التعليمية & & 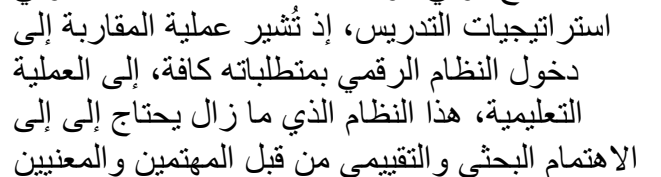 \\
\hline المنهاج & & 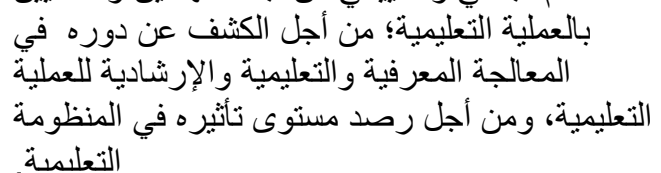 \\
\hline و استراتيجيات التندريسية، & & \\
\hline
\end{tabular}




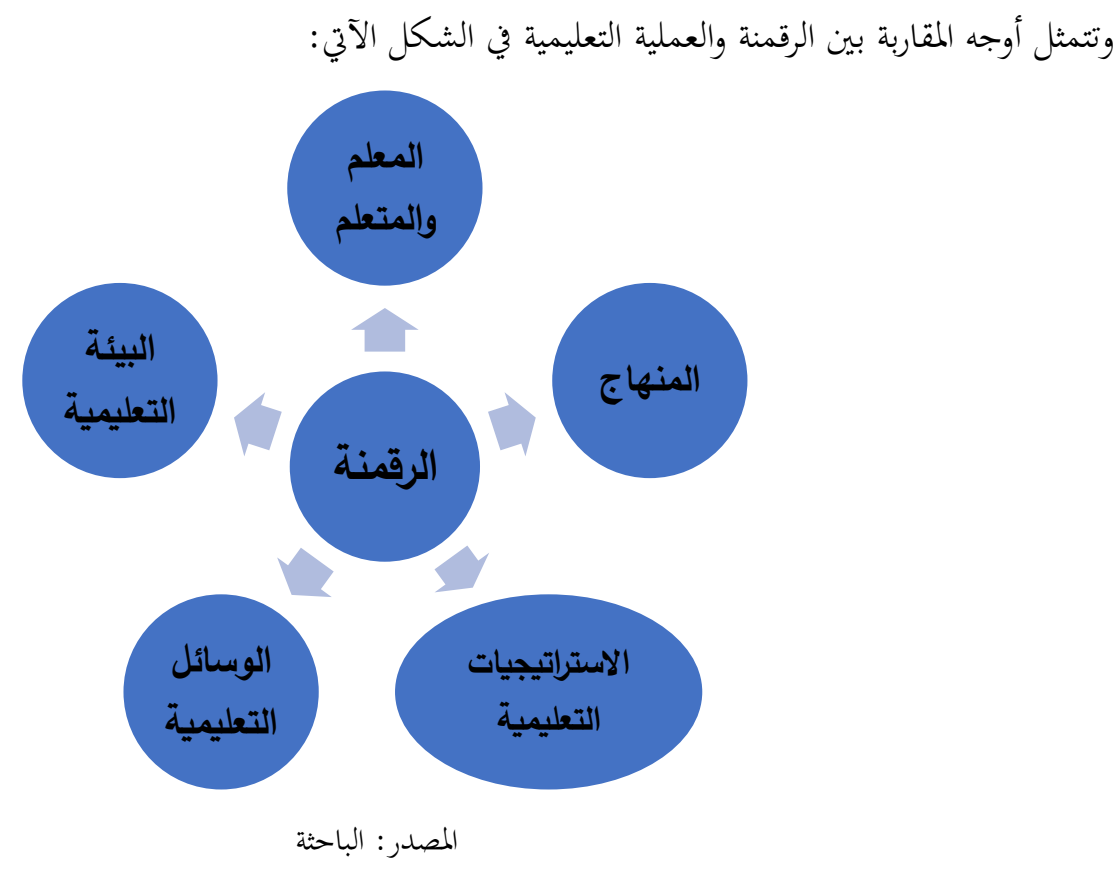

مؤشرات النتائج: تمثلت أوجه المقاربة بين الرقمنة والعملية التعليمية في المحاور الآتية: محور المعلم والمتعلم: أظهرت مؤشرات النتائج مقدرة الأجهزة الرقمية على تغيير دور المعلم والمتعلم في العملية التعليمية، فقد

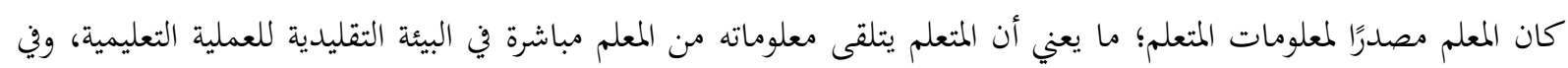

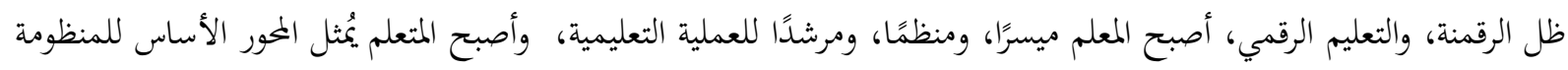

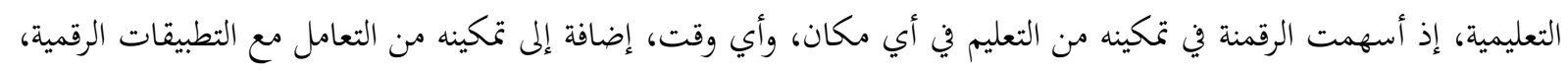
والتعلم عبرها. محور المنهاج: أظهرت مؤشرات النتائج مقدرة الرقمنة والتعلم الرقمي على استبدال الكتاب (المنهاج)، والمساقات التدريسية،

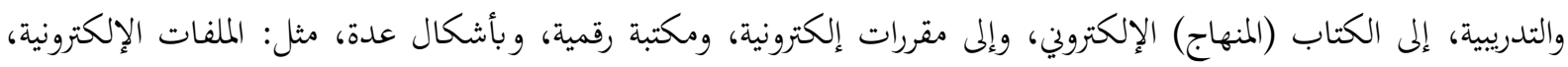

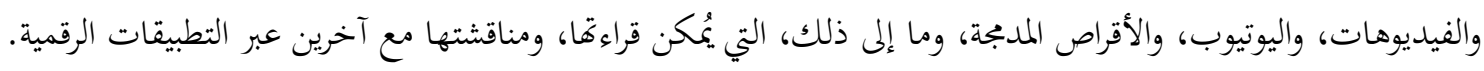
محور الوسائل التعليمية: أظهرت مؤشرات النتائج أن المقاربة بين الرقمنة والعملية التعليمية تكمن في استبدال الوسائل التعليمية التقليدية، مثل: السبورة، والقلم، والطباشير، وما شابه ذلك من الوسائل التعليمية التقليدية، إلى وسائل تعليمية رقمية ؛ مثل: نظام البلاك بورد، والألواح الذكية، والحاسب الآلي، وبرامجة المتنوعة، وتطبيقات الشبكة الإلكترونية. محور البيئة التعليمية: أظهرت مؤشرات النتائج أن المقاربة بين الرقمنة والعملية التعليمية تكمن في استبدال البيئة التعليمية

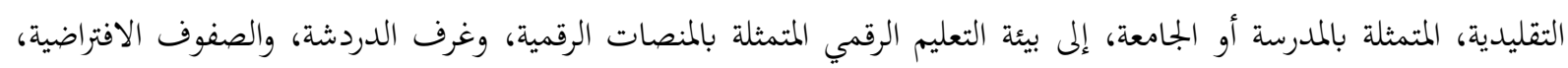
وتطبيقات الشبكة الإلكترونية المتنوعة.

محور الاستراتيجيات التعليمية: أظهرت مؤشرات النتائج أن المقاربة بين الرقمنة والعملية التعليمية تكمن في استبدال الاستراتيجيات التعليمية التقليدية، إلى استراتيجية الفصول المقلوبة، واستراتيجية المناقشة المتزامنة، واستراتيجية المناقشة غير المتزامنة، واستراتيجية الرحلات المعرفية عبر تطبيقات الشبكة، واستراتيجية الفصول الافتراضية، واستراتيجية التعلم التشاركي الإلكتروني،

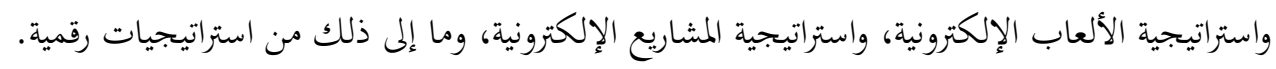




\section{التوصيات: يُمكن أن يُوصى بالآتي:}

1. أن يتفهم المسؤولون أهمية التخطيط لاستخدامات تقنية الرقمنة، مع إشراك الجهات الفاعلة في مجال التعليم، نظرًا لدخول الرقمنة في مجالات الحياة كافة، منها المجال التعليمي. 2. أن يتفهم المسؤولون أهمية تطوير البرامج التعليمية؛ لتحسين استجابتها للتغييرات التي تُحدثها الرقمنة في العملية التعليمية؛

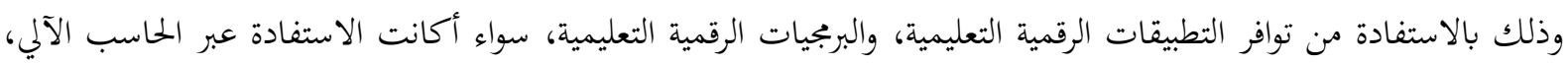
أم عبر الشبكة الإلكترونية. 3. أن يتفهم المعلمون أهمية التحاقهم بالبرامج التدريبية الخاصة بالرقمنة والعملية التعليمية؛ إذ يُسهم ذلك في الحدة من الممارسات السلبية جراء استخدام الأجهزة الرقمية ؛ الأمر الذي يدعم الدور الحقيقي للرقمنة في نجاح المسيرة التعليمية. 4. أن يتفهم المسؤولون أهمية التعاون، والمشاركة، للقطاعات كافة، في تجهيز البهاء البنية التأسيسية (التحتية) للتعليم الرقمي؛ نظرًا لانتشاره عبر التطبيقات الرقمية كافة، واعتماده لدى الدول المتقدمة . 5. أن يهتم الخبراء والباحثون في إجراء مزيدٍ من البحوث حول الرقمنة والعملية التعليمية، ويُمكن اقتراح بعض المسميات للبحوث المقترحة كالآتي: - - دور الرقمنة في تعزير العملية التعليمية من وجهة نظر المعلمين. - الرقمنة وأثرها في العملية التعليمية من وجهة نظر الخبراء. - الآثار الإيجابية والسلبية الناجمة عن استخدام تقنية الرقمنة في العملية التعليمية من وجهة نظر الطلبة.

يُمكن صياغة النظرية المجذرة لنهج هذا البحث، بالتأكيد على وجود علاقة ترابطية وثيقة بين الرقمنة والعملية التعليمية، إذ

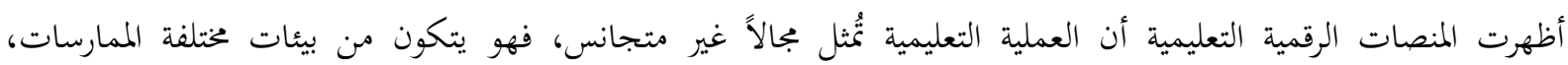

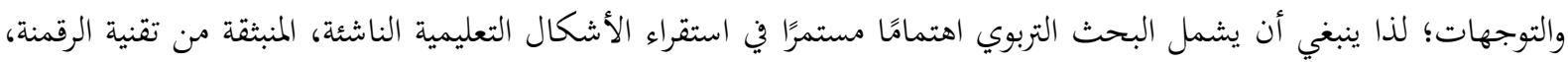
وما يتصل بذلك حول الكشف عن الإمكانيات التعليمية، ورصدها. وفي ذات السياق، يُمكن القول أن التقنية الرقمية، وما تحمله من سمات مستجدات العصر ومتطلباته، قد بتحد مسيرتا عائقًا لدى بعض المجتمعات التي ترفض التغيير، وتُثقله بالسلبيات، ومن منظور الأدبيات والنظريات المفسرة للرقمنة في التعليم؛ فإنه ومنه

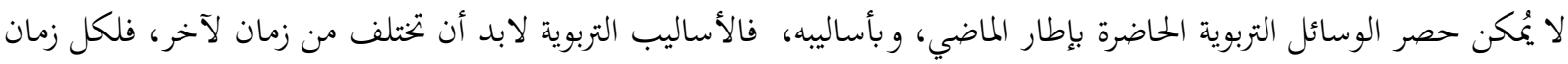

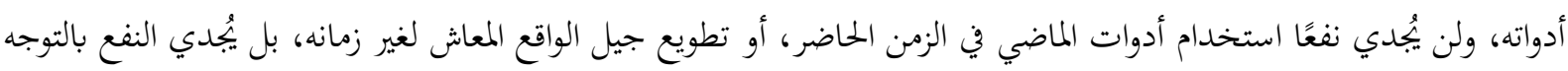
إلى الاستثمار في العقول البشرية، عن طريق استخدام ما يناسب زمافم من أساليب وأدوات؛ لتحقيق أهداف العملية التعليمية. 


$$
\begin{aligned}
& \text { مصطفى، إبراهيم ـ الزيات، أحمد حسن. عبد القثادر، حامد . والنجار، محمد علي. (بدون تاريخ). المعجم الوسيط. اسطنبول: } \\
& \text { المكتبة الإسلامية للطباعة والنشر والتوزيع. } \\
& \text { الفقيه،أحمد حسن (2017). تصميم البحث النوعي في البمال التربوي مع التركيز على بحوث تعليم اللغة العربية. المجلة الدولية }
\end{aligned}
$$

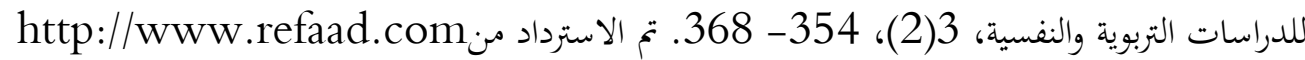

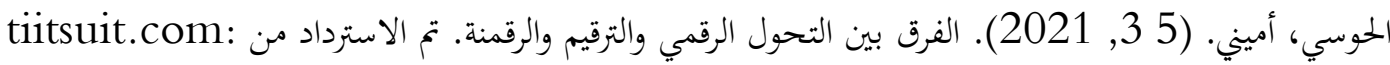

$$
\begin{aligned}
& \text { https://www.tiiitsuit.com/ } \\
& \text { الودية، رانية طه. (8 8, 2018). التربية الرقمية. تم الاسترداد من }
\end{aligned}
$$

http://www.lahaonline.com/articles/view/56031.htm.

$$
\text { صبري، رشا السيد. (2020). برنامج مقترح قائم علي نظريتي تعلم لعصر الثورة الصناعية الرابعة. المجلة التربوية/ جامعة عين } 440 \text { - 540. }
$$

https://webinar.attaa.sa/files/webinars: المفضي، سارة محمد. (2021). التحول الرقمي. تم الاسترداد من https://webinar.attaa.sa/files/webinars

$$
\text { الزعبوط، سمية عيد. (2021). تقنية الذكاء الاصطناعي: مقاربة تعليمية. المؤتمر العلمي الدولي الثاني عشر، بعنوان (بحوث }
$$

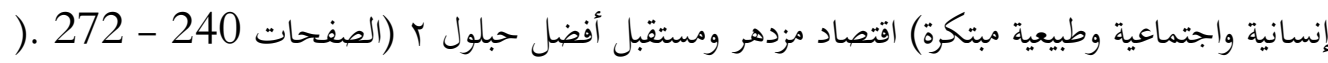

$$
\text { شn Line: }
$$

https://azimyouth.org/: يوث، عزام. ( 2021). مفهوم العملية التعليمية. تم الاسترداد من مورات العبية

https://azimyouth.org/

حمودة،علي · وحسين، محمد. (2019). فاعلية بنية محتوى البوابات إللكترونية في. بجلة البحوث الإلعالمية، 33 - 76. الزبيدي، كمال. (6 12, 2017) 2017). المقاربة . عبد العزيز، منى طه. (2017). الجودة في التعليم الإلكتروني: الخبرات العالمية. بجلة المعرفة التربوية، 80 - 100.

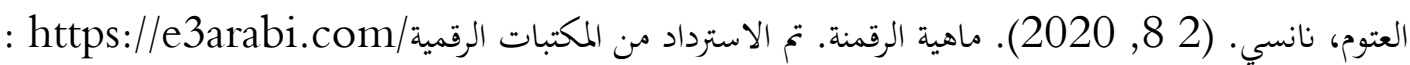
الحلفاوي، وليد سالم. (2011). التعلم الإلكتروني: تطبيقات مستحدثة. القاهرة: دار الفكر العربي للنشر والتوزيع.

\section{References}

Alexander, M. W., Truell, A. D., \& Zhao, J. J. (2012). “ EXPECTED ADVANTAGES AND DISADVANTAGES OF ONLINE LEARNING: PERCEPTIONS FROM COLLEGE STUDENTS WHO HAVE NOT TAKEN ONLINE COURSES”. Issues in Information Systems, 13(2), 193- 200.

Commission, E. (2021). Digital Education. Retrieved from Action Plan about Resetting Education and Training for Digital Age: https://ec.europa.eu/education/education-in-theeu/digital-education-action-plan_en

Decuypere, M., Landri, P., \& Grimaldi, E. (2021). Critical studies of digital education platforms. Critical Studies in Education Journal, 62(1), 1 -16.

Erickson, F. (1986). Qualitative methods in research on teaching. In M. Wittrock (Ed.), Handbook of research on teaching (3.ed ed.). New York: New York Macmillan. 
Kimberly, S. (2014). Five Minds for the Future: Shaping the Future through Education. Athletic Training Education Journal, , 9(1.(

Lim, A., Wong, S., Boon, L., \& Tan, A. (2009). Developing The Five Minds of the future, Villach: Conference I.C.L, Austria. Conference I.C.L, Austria. Austria: http://www.iclconference.org/di/proceedings/2009/program/pdf/Contribution_133.pdf.

Ming, L. H., Huang, C. C., \& Kuang, L. S. (2017). A Study of the Effects of Digital Learning on Learning Motivation and Learning Outcome. EURASIA Journal of Mathematics Science and Technology Education., 13(7), 3554 - 3564.

Siemens, G. (2020). wikipedia. Retrieved from https://en.wikipedia.org/wiki/George_Siemens. UNICEF. (2021). Effectiveness of Digital Learning Solutions Improve Educational Outcomes: A Review of the Evidence. Retrieved from https:/www.unicef.org/media/103246/.pdf: https://www.unicef.org/media/103246/.pdf 


\title{
THE STRUCTURE OF SYMBOLIZING IN THE NOVEL "TESTIMONY OF WARTIME" IN THE LIGHT OF CHARLES SANDERS PIERCE'S THEORY
}

\author{
Khalid Sulaiman Muhanna ALKINDI ${ }^{1}$
}

\section{Istanbul / Türkiye}

p. $136-151$

Received: 05/11/2021

Accepted: $15 / 12 / 2021$

Published: 01/01/2022

This article has been scanned ! iThenticat No plagiarism detected

\begin{abstract}
:
Symbolizing means the transition from the significance of the phonetic, morphological and syntactic units to the implicated meaning arising from the relations and common knowledge between the interlocutors and the circumstances surrounding them at the moment of the speech. The study seeks to present the symbolizing mechanism presented by Charles Sanders Peirce in the theory of signs, test the value of this mechanism and search for the linguistic structures responsible for symbolizing in the novel "Testimony from Wartime.
\end{abstract}

Key words: Symbolizing, Bitcoin, Charles Sanders Pierce's Theory, Testimony of Wartime.

http://dx.doi.org/10.47832/2717-8293.15.10

1 (iD) Dr. , Sultan Qaboos University, Sultanate of Oman, abuqasimkindi@ gmail.com, https://orcid.org/0000-0003-1349$\underline{4460}$ 


\section{بُنَى الترميز في رواية "شهادة من زمن الحرب" في ضوء نظرية تشارلز ساندرس بيرس}

\section{خالد بن سليمان بن مهنا الكندي 2}

الملخص:

يعني الترميز الانتقال من دلالة الوحدات الصوتية والصرفية والتركيبة إلى المعنى الاقتضائي الناشئ من العلاقات والمعرفة المشتركة بين المتخاطبين والظروف المحيطة بهم لحظة الخطاب. وتسعى الدراسة إلى تقديم آلية الترميز التي قدّمها تشارلز ساندرس بيرس في نظرية العلامات، واختبار قيمة هذه الآلية والبحث عن البنى اللغوية المسؤولة الترميز في رواية "شاهد من زمن الحرب".

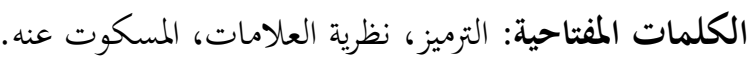

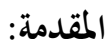

يفرق الناقد والمفكر الفرنسي تزفيتان تودوروف بين العلامة والرمز، فيجعل العلامة دالَّا لغويَّ يَفْهَمُ منه المتلقي الدلالة

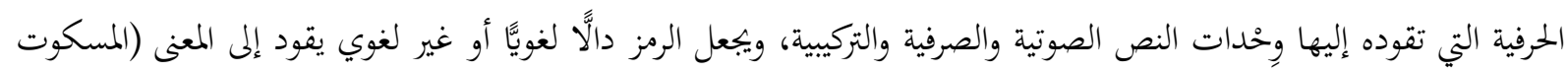

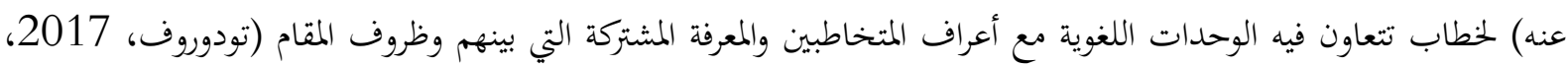

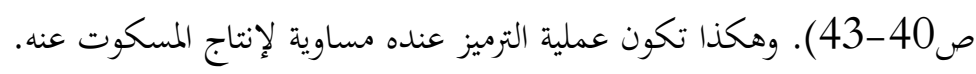
وقد اجتهد مؤسس الفلسفة الذرائعية الفيلسوف الأمريكي تشارلز ساندر بيرس (1839-1914م) في الدعوة إلى علم

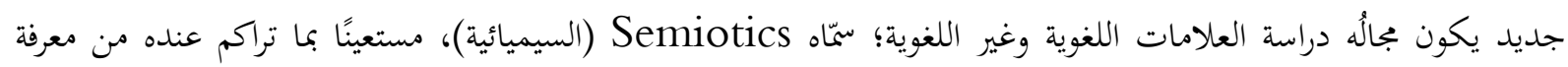

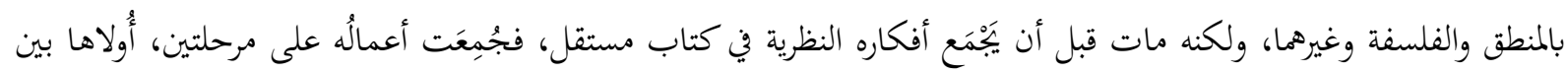
عامَي 1931-1935م، وأُخْراها عام 1958.

وغايتنا في هذه الدراسة البحث في نظرية بيرس عن البنى المسؤولة عن صناعة الترميز بمفهومه الذي قدّمه تزفيتان تودوروف،

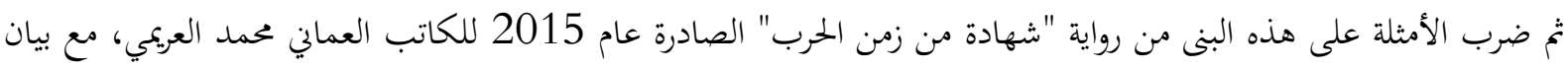
القيمة الفنية لهذه البنى الرمزية. 


\section{المبحث الأول: مضمون رواية "شهادة من زمن الحرب":}

أُخِخَ محتوى الرواية من اعترافات شاب عُماني اسمه ماجد عاش أحداث سقوط كابل على يد حلف الناتو، وأدلى بشهادته

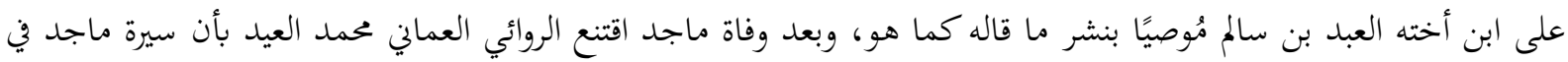

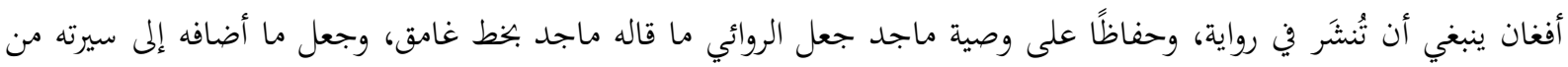
تفصيلات حقيقية أخذها من العبد بن سالم أو تصوّرها بخياله بخط مائل.

ماجد من أسرة مَشْيْة في ولاية صُور في عُمان، هاجر إلى لندن ليدرس في إحدى جامعاما؛ لكنه انغمس في مراقص

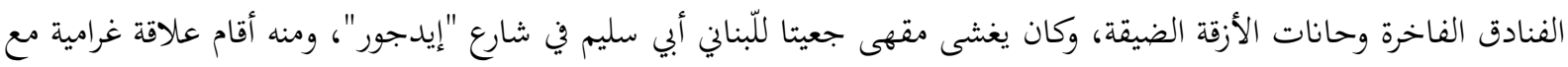

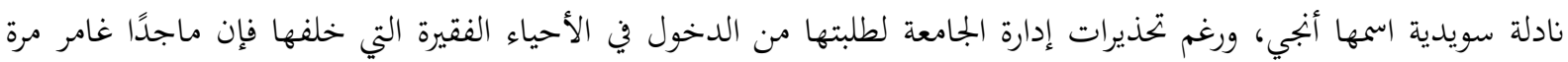

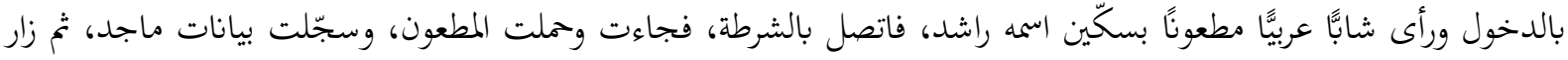

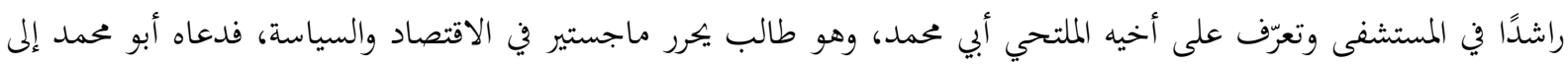

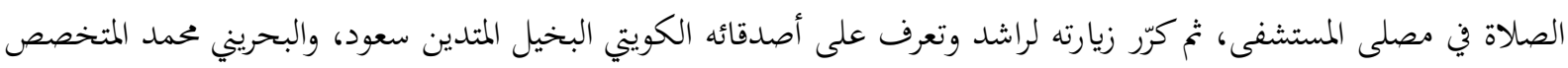
في الإنجليزية، والفلسسطيني ياسين المتخصص في الترجمة، ثم صار يزورهم في الشقة وأدرك تشدّد سعود ودماثة ياسين.

ياسين يعرف لغة الأوردو لأن أمه باكستانية وُلِيدت في بريطانيا، وبحكم تعامله مع الهيئات الدبلوماسية عمل في وكالة

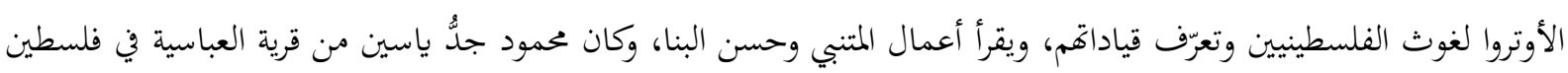
- التي سمّاها الاحتلال يهودا، ثم هرب من عصابة الهاغانة الصهيونية إلى جنوب لبنان، وحصل طه بن محمود على منحة دراسية

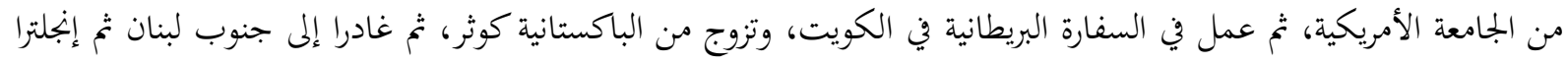

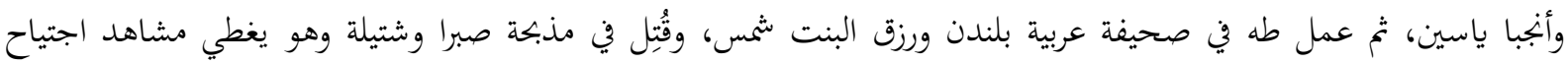

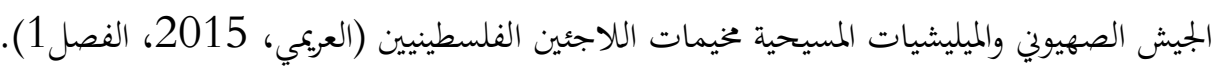
بعد اهيار البرجين في 11 سبتمبر 2001حرّضت أمريكا على الهجوم على العرب والمسلمين، وقررت غزو أفغانستان،

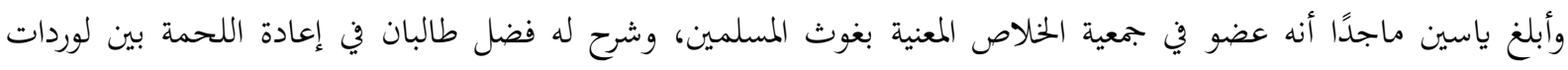
الحرب الأفغان بعد خروج الاتحاد السوفييتي، وبفضل ياسين ترك ماجد حياة الفحش، وشجّع ياسين بقية زملائه على دعم الجمعية، فوافق راشد على الإسهام بماله، واختار سعود أن يتصرف وحده، وتابع ماجد أخبار أفغانستان، وقرأ في إصدارات جمعية لئية الخلاص وقد أحضرها له ياسين؛ حتى اقتنع بالانضمام إلى الجمعية، وعادت به الذاكرة إلى بندقية "أم عشر" المعلقة في مجلس والدهاه الملقب بالشيخين؛ لأنه حصل على مشيخة القبيلة بعد وفاة والده وعلى مشيخة العلم من المدرسة الصولتية في مكة. وفي مطار

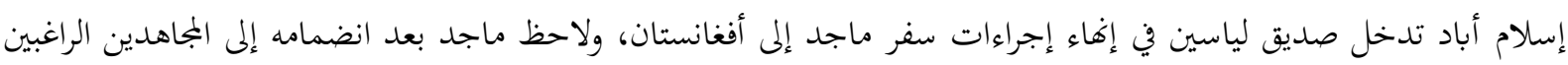

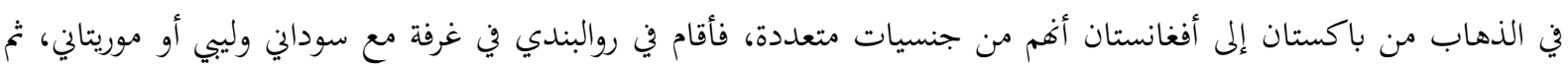

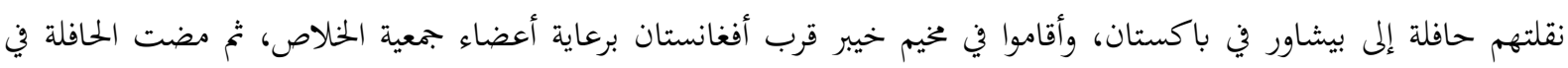
طرق وعرة شاهقة بين هندوكوش، وكان جوارَ ماجد صحفي بريطاني اسمه توم آشلاند، له معرفة واسعة بالإسلام لأنه درس في الأزهر، وغطّى انتفاضة الأقصى الثانية ضد شارون (السابق، الفصل 2هند).

في أفغانستان أصبح ماجد في جيش الخلاص لا في جمعية الخلاص، واختار له اسمًا جهاديًّ هو سعد العشيرة، وعلموا أنه

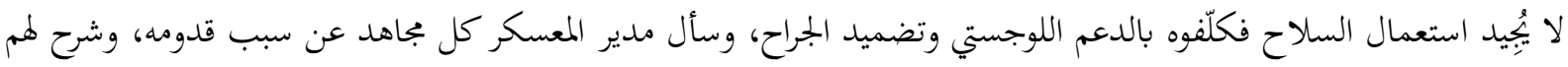
أن مهمة جيش الخلاص حماية قوافل الإمداد الباكستانية إلى طالبان من لوردات الحرب، وعلم ماجد أن الأفغان في الشمال

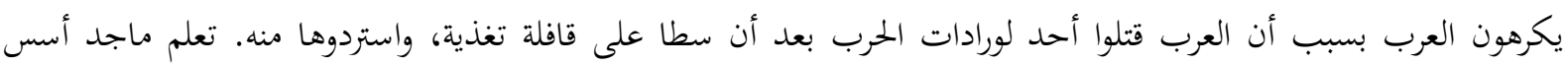


الإسعاف الأولي على يد الطبيب البوشناقي يوسف (أو كاظم الأسى في رمزه الجهادي)، وحدّثه عما فعله الصربيون بالتعاون مع

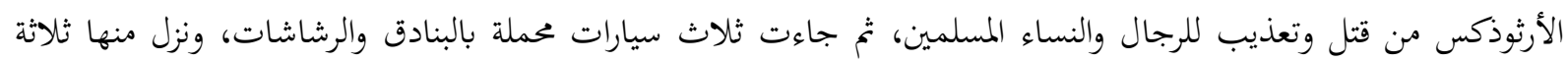

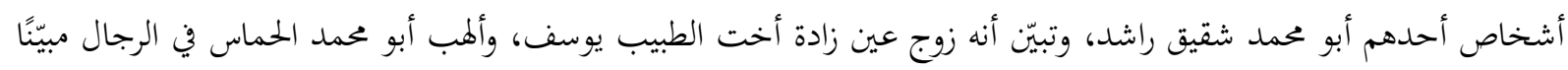

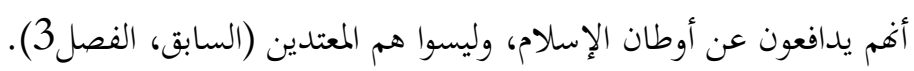
أبو محمد قائد كتيبة استطاعت تحرير نساء بوشناقيات منهن عين زادة أخت يوسف، ثم أسس جمعية لمساعدة الأسر المهجرة، وتزوج عين زادة بعد أن قتل الصربيون زوجها أمام عينيها لما ثار عليهم حين لمسوا بطنها الحامل، وأنجبت عين زئه زادة ابنها

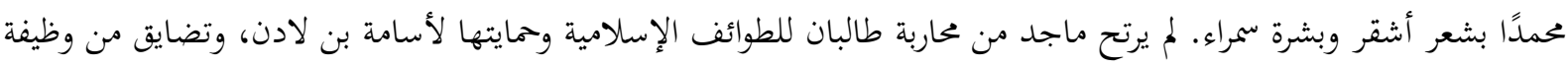

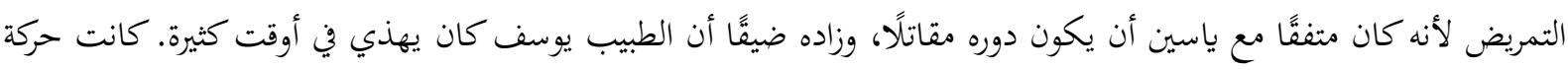

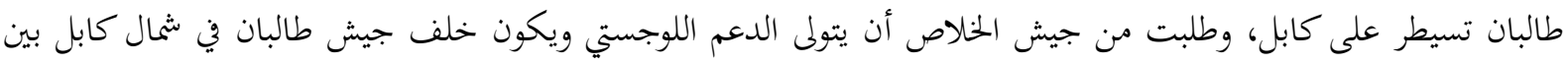

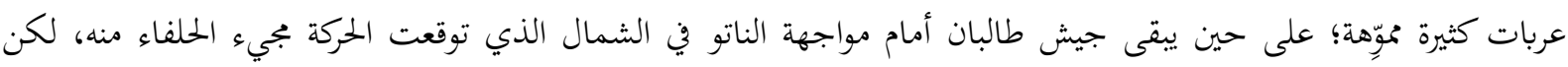

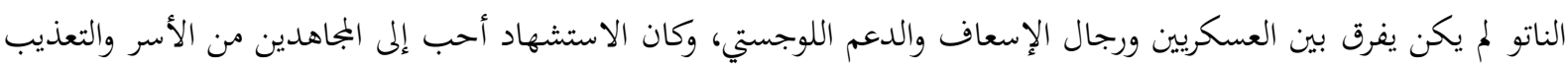

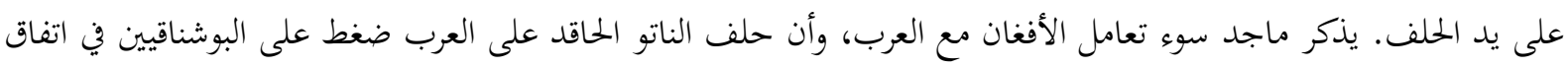
السلام مع صربيا على سحب جنسيات المجاهدين العرب، ما جعل هؤلاء العرب معلقين غير قادرين على البقاء في البوسنة

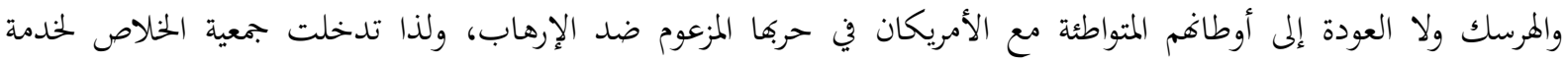

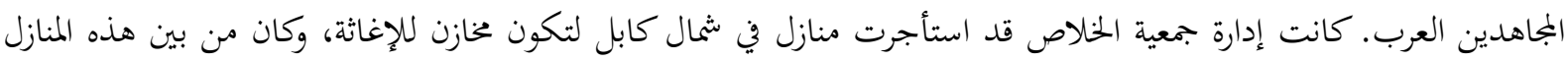

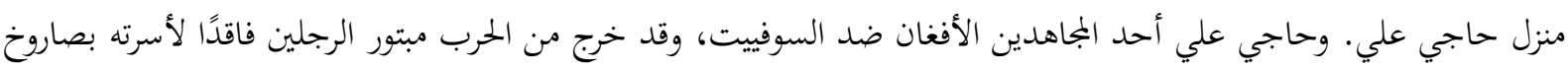

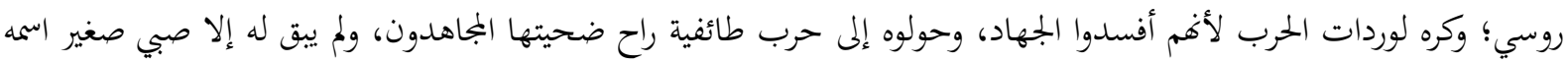

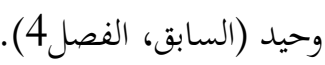

شنّت أمريكا هجومًا عنيفًا على مواقع طالبان والمدنيين، ودلّ وحيد ماجدًا وأصحابه على سرداب للهرب من القصف،

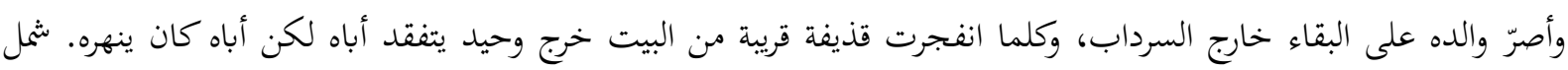

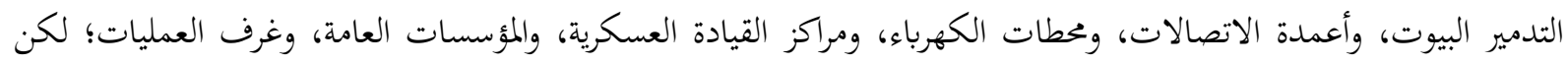

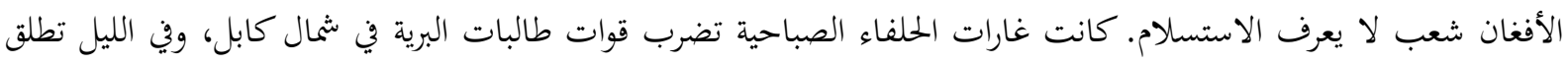

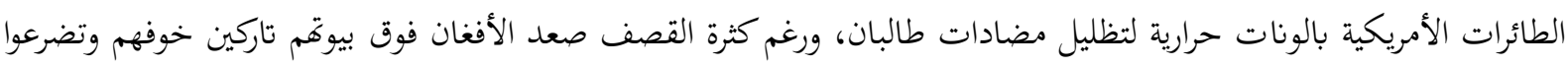

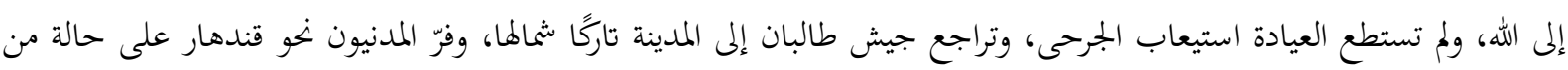

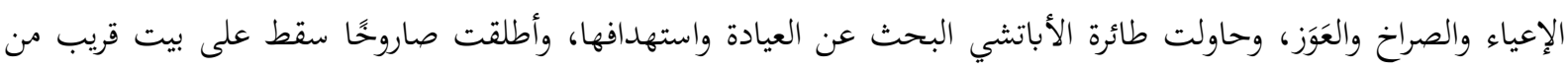

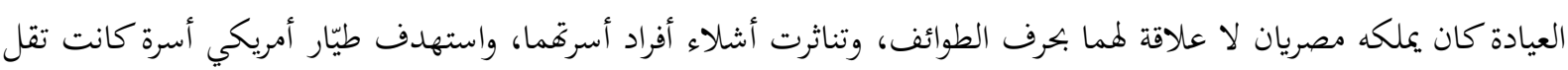

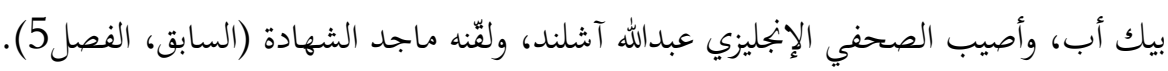
سقطت كابل في يد الحلفاء، وفقدت قيادات طالبان تواصلها، وفقد أعضاء جيش الخلاص تواصلهم أيضًا؛ لكن بقي

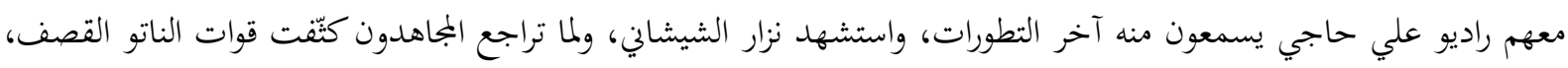

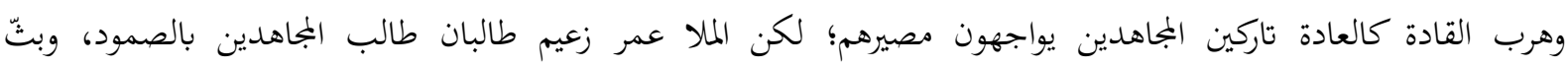

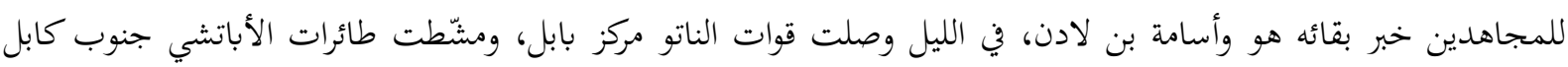

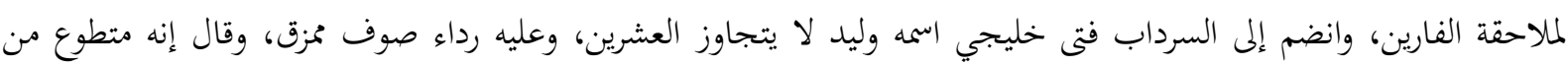

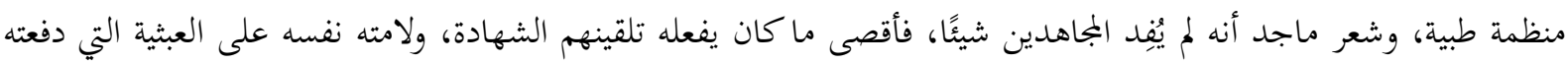

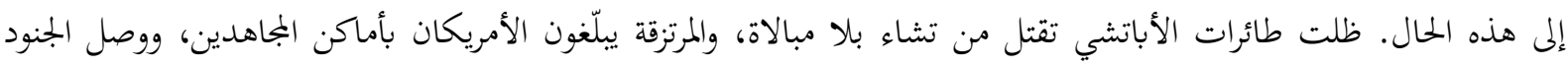


عيادة علي حاجي، لكن عليَّا حاجيَّا لم يدُلمّم على شيء، وخَشي المندسون في السرداب من أن يفتك الجنود بعلي فخرجوا، وكان

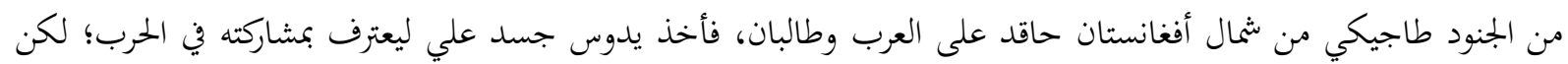

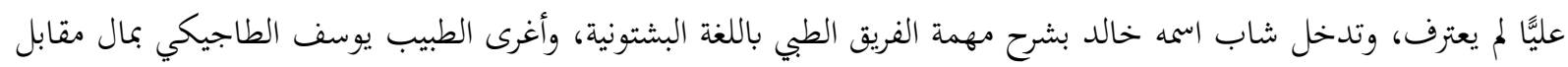

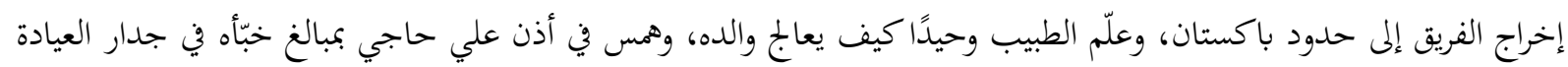

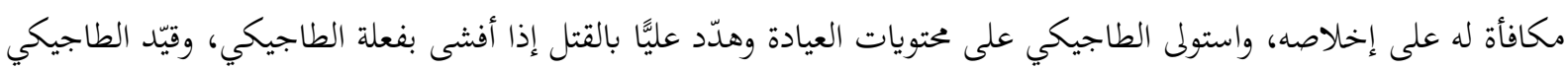

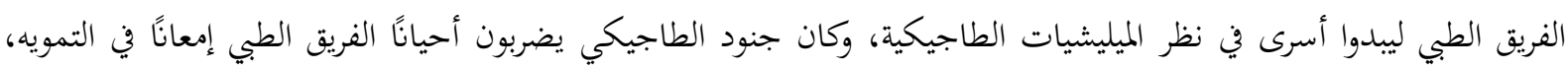

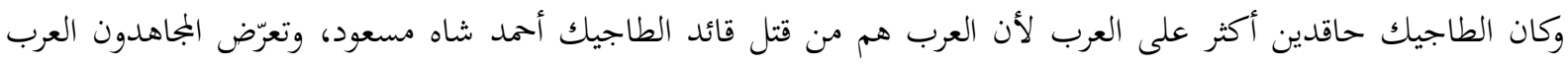

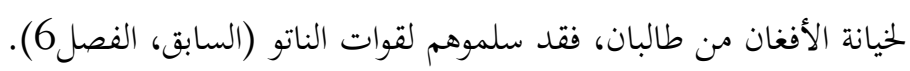
صرّح الفتى الخليجي وليد أن اسمه الحقيقي خالد، وأنه جاء للبحث عن والده المجاهد في أفغانستان بعد أن بلغهم خبر

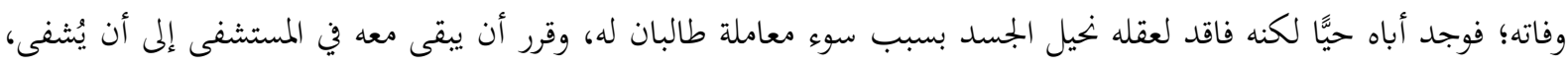

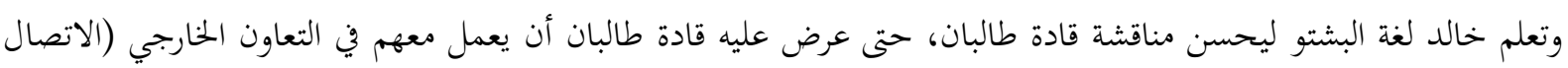

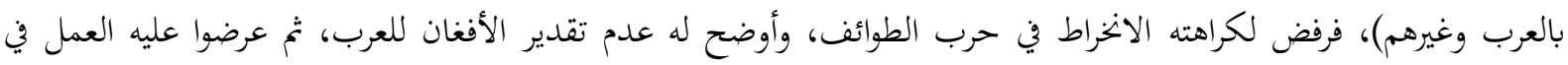

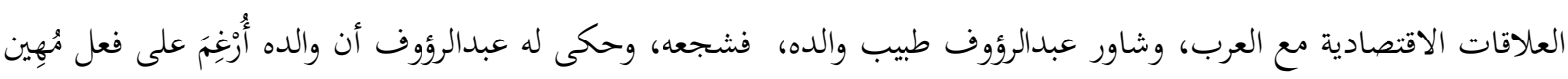

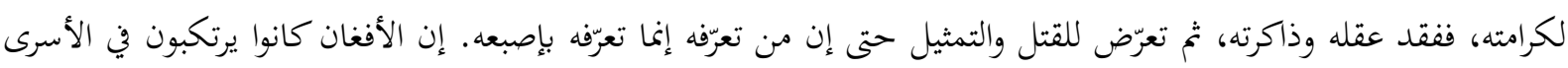

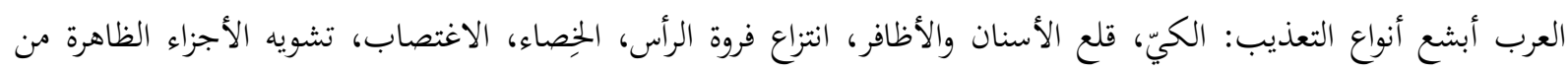

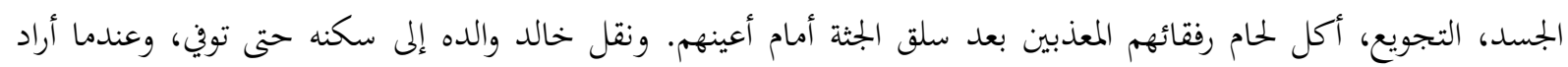
البحث عمن يساعده في غسله ودفنه قصفت قوات الناتو السكن فتحول إلى مقبرة لجثة والده (السابق، الفصل

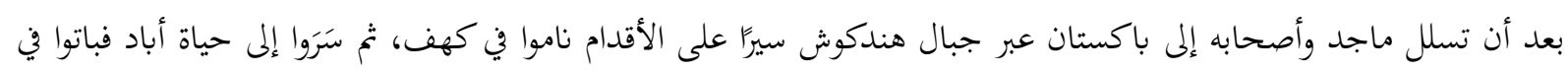

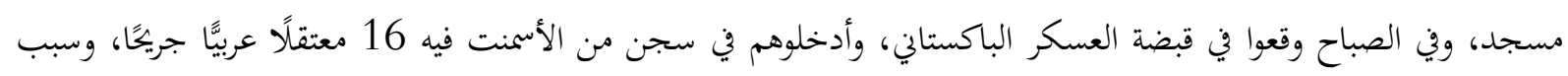

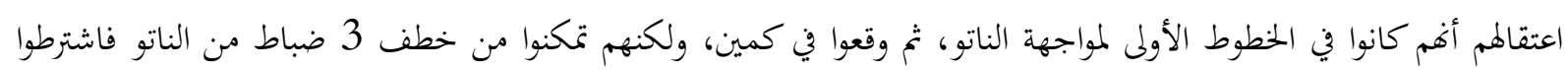

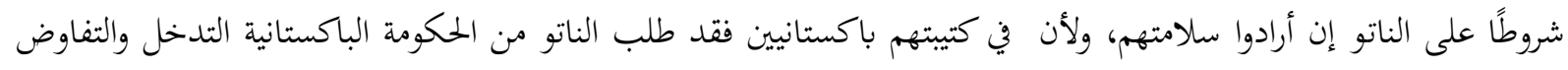

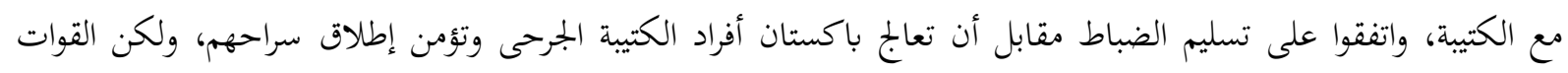

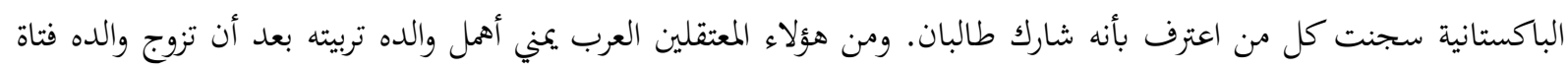

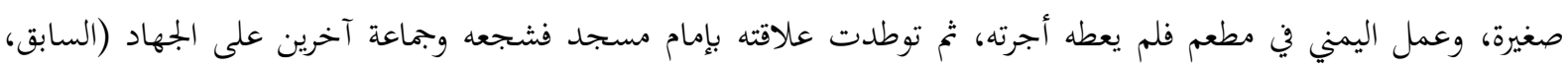

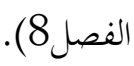

كان ياسين الفلسطيني قد لقّن ماجدًا ماذا يقول لو وقع في الأسر، فلما حقق مع الباكستانيين أخبرهم ما وصّاه به ياسين

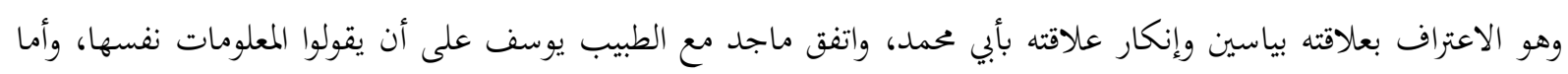

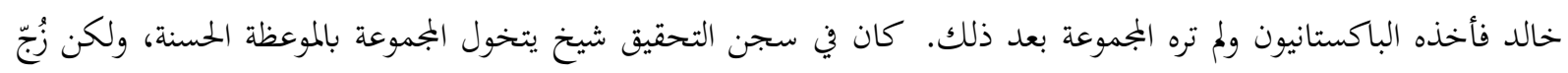

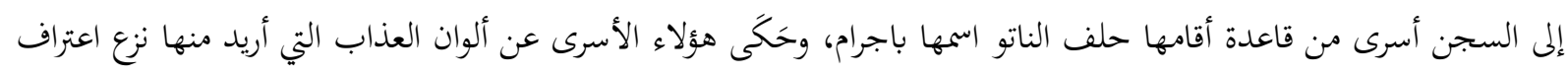

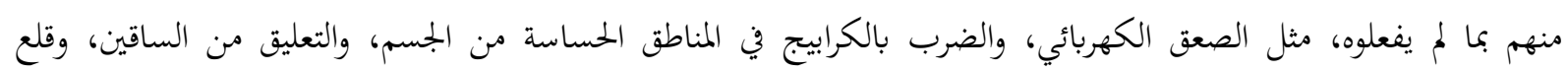

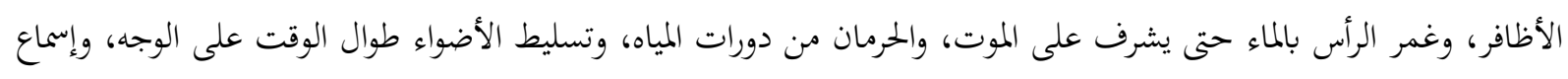

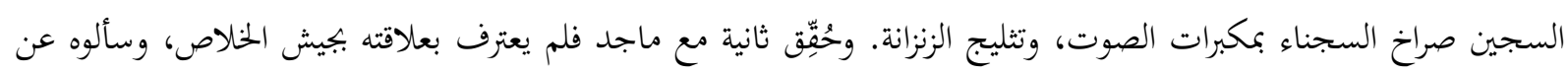

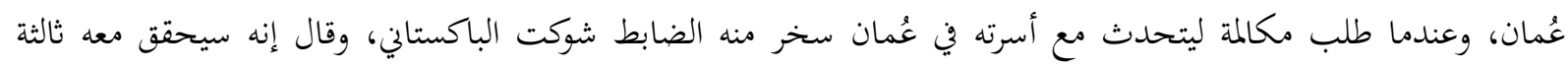

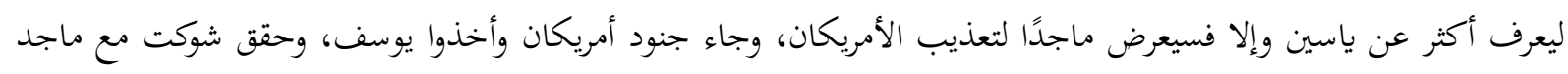


مرة ثالثة، وهدّده بأنه سيسلّمه للأمريكان بتهمة علاقته بابن لادن أو للطاجيك بتهمة أنه عربي؛ لكن ماجدًا لم يعترف بشيء جديد، وفي التحقيق الرابع حقق معه أمريكي يرتدي زي رعاة البقر اسمه سام في ردهة فيها مختلف الجنسيات، وسأله إن كان إنسان

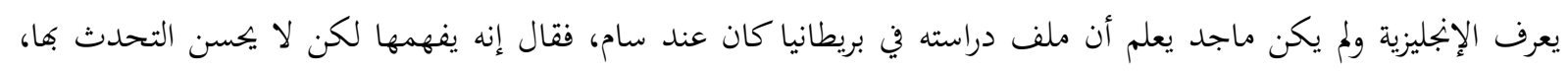

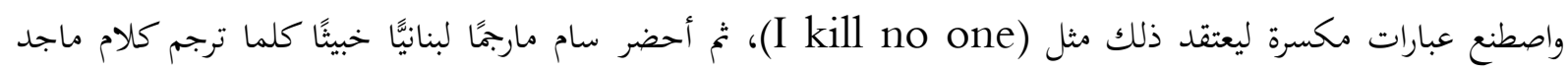
أضاف أمورًا لم يقلها ماجد، حتى تعارك معه ماجد وضحك الأمريكي، وأصر ماجد على عدم وجود ما يدينه (السابق،

أُخْرجِ ماجد من السجن، ووضع في غرفة نوم مريحة، فاغتسل، وقضى صلواته، ثم أدخل غرفة تحقيق، وظل غافيًا فيها حتى

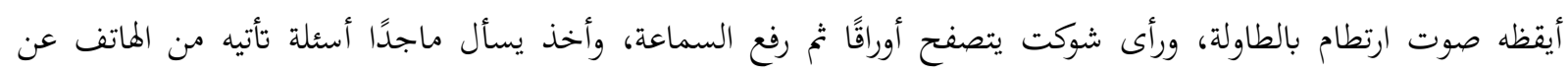

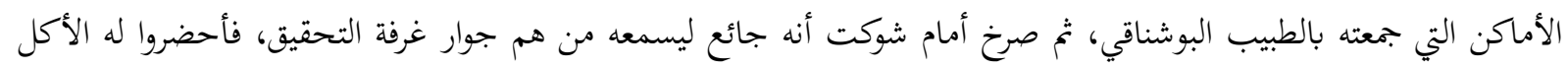

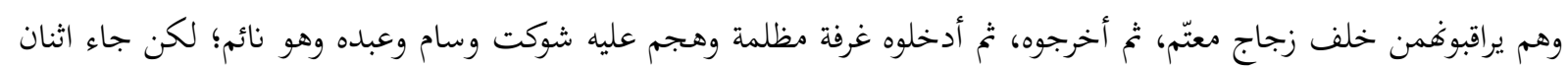

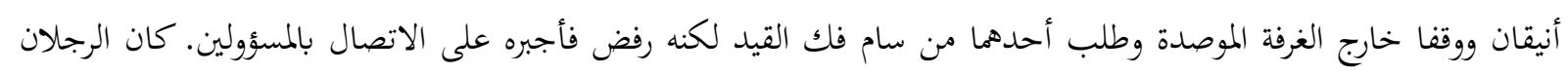

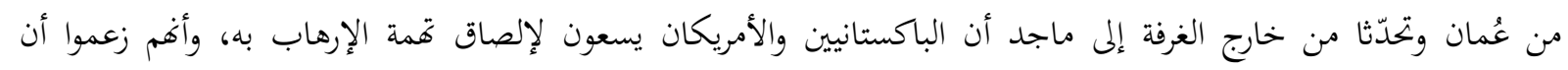

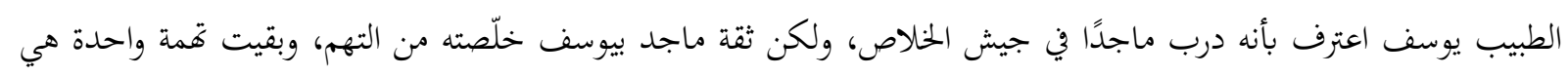

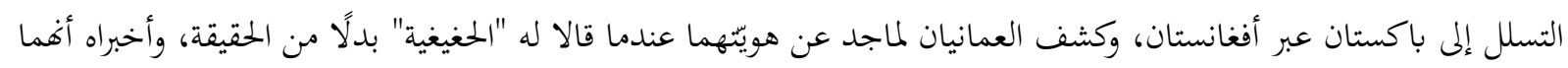

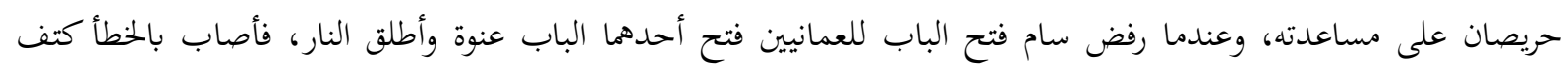

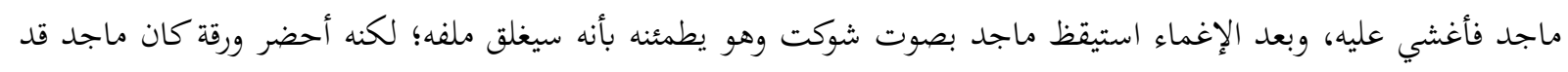

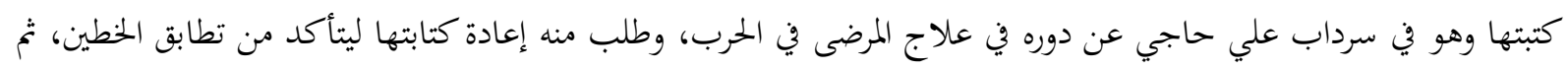

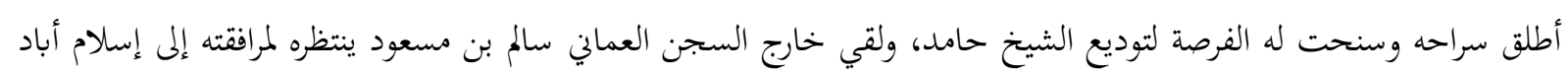

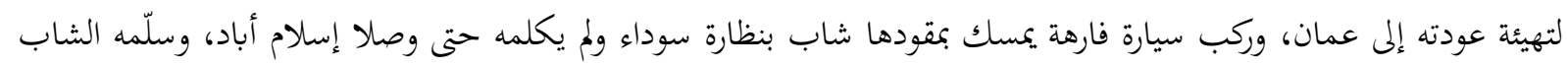

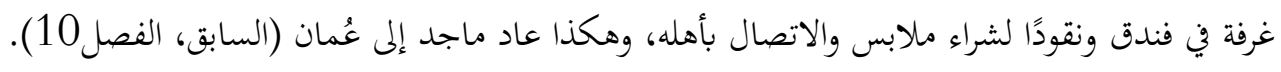




\section{المبحث الثاني: العلامات عند تشارلز بيرس وعلاقتها بالترميز:}

إن أيسر تعريف قدّمه بيرس للعلامة sign هو قوله: إفها "أيُّ شيء يُمثِّل موضوعًا [أي ينوب عنه] بأية طريقة"

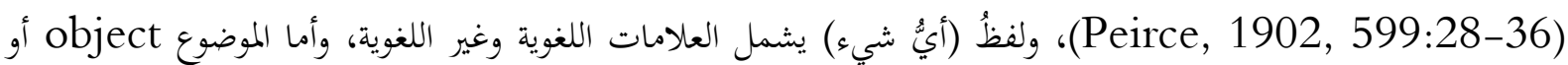
المحال إليه the denoted thing فهو ينطبق على أي شيء يمكن الحديث عنه أو التفكير فيه، سواء كان له وجود في العالم

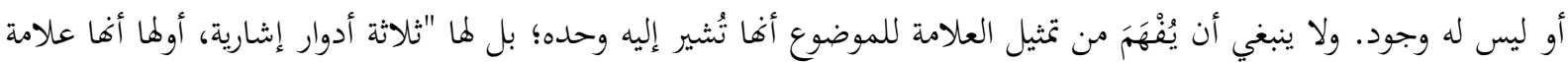

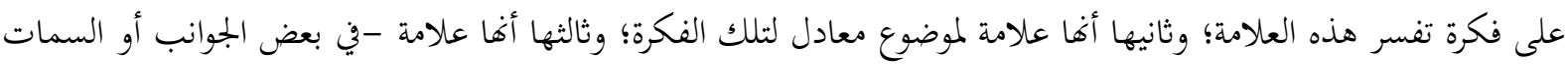
المميّزّة qualities- بحعل الفكرة على اتصال مع موضوعها" (Peirce,1868, W 2:223). Peirce,1873, W 3:66- ويُمكِننا أن نستخلص جُلّ السمات التي لا تنفك عن أية علامة من حديث بيرس

2) العلامة شيء مادِّي سواء كانت صوتَّا مسموعًا، أو كلمة مكتوبة، أو أي شيء محسوس، وتُسمَّى هذه السمة المادية بالمصطلح المنطقي "الفصل" موصوفًا بوصف "المادي: material quality. 3) أن يكون لها صلة بالموضوع الذي تشير إليه؛ حتى يتمكن الذهن من ربطها بموضوعها.

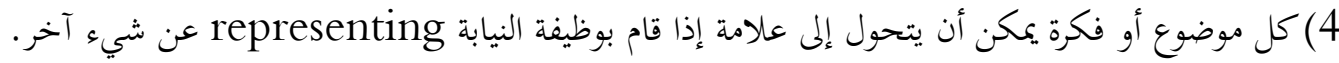

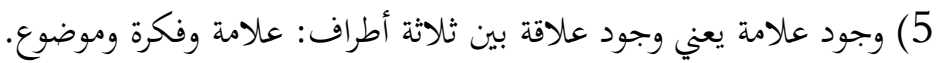

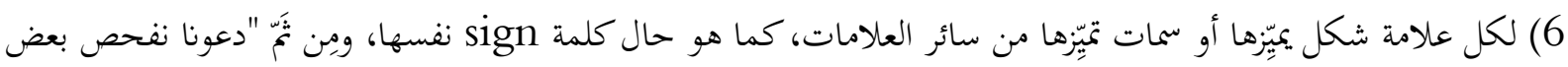
الرموز اللغوية للعلامات على العموم. يجب أن يكون للعلامة فصول [سمات] في نفسها تعمل على تمييزها، ويجب أن يكون

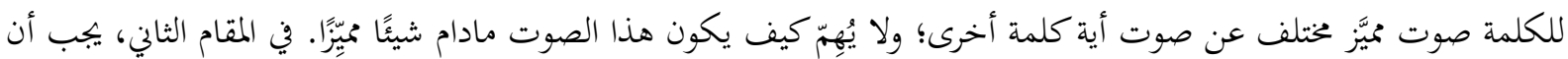

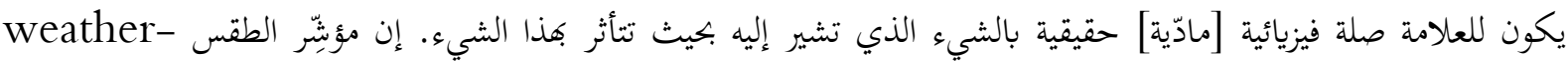

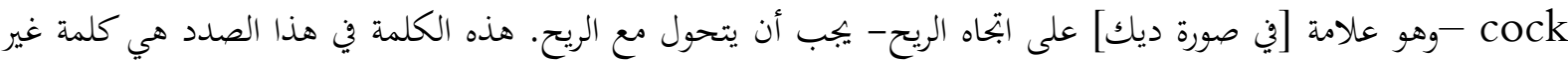

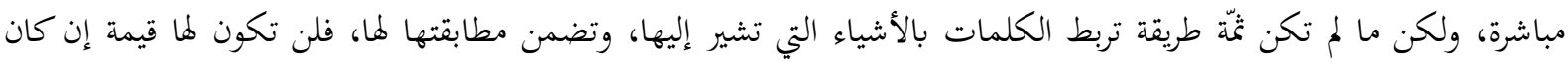

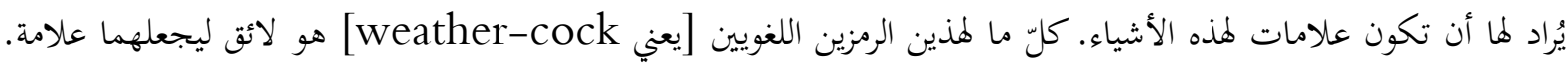

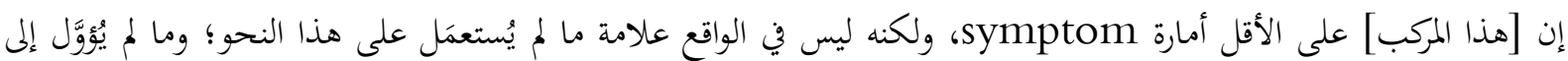
فكرة، ويعرض نفسه للمعالجة الذهنية" (Peirce,1873, W 3:76; CP 7.355). 7) العلامة تنتج الفكرة في الذهن.

\section{وثمة سمات أخرى للعلامة وردت في مواضع أخرى من أعمال بيرس، وهي:} 1) العلامة وسيط representamen لأنها تنقل المعرفة من مُبِلِّغ العلامة إلى مؤوِّها: "تستلزم العلامة أو الوسيط علاقة

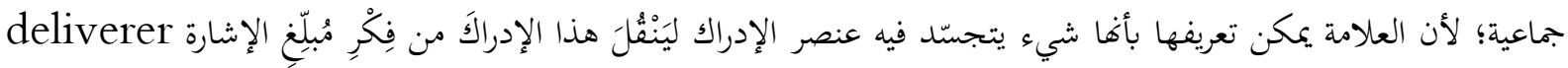

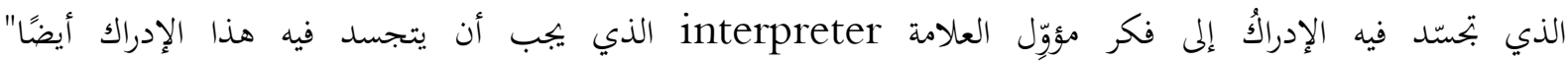
(Peirce,1895, MS [R] 16:12; PM 52) فكرة عن الموضوع: ((قد تكون لدينا مصلحة وسيطة في شيء مادام هذا الشيء ينقل إلى الذهن فكرة عن شيء آخر، ومادام يفعل ذلك فهو علامة أو وسيط" (Peirce,1894, EP 2:5; MS [R] 1009). 
2) العلامة تنوب عن الموضوع فتثير فكرته في الذهن ثم تصبح الفكرة علامة للموضوع نفسه: "العلامة شيء يعمل على نقل

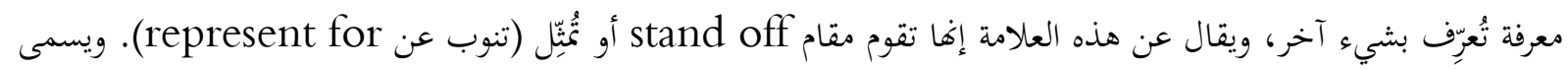
هذا الشيء الذي تنوب عنه العلامة: موضوع العلامة، أو الفكرةً التي تثيرها العلامة في الذهن، وتُعَدّ الفكرة أيضًا علامة ذهنية

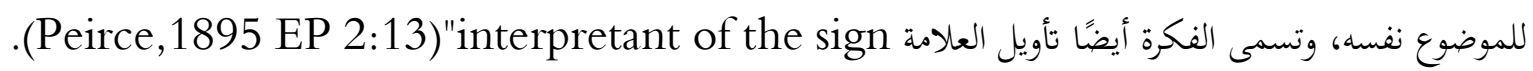

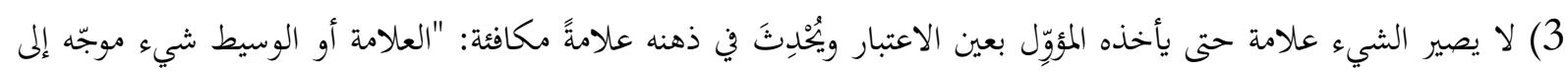

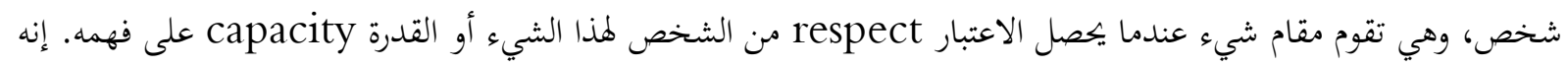

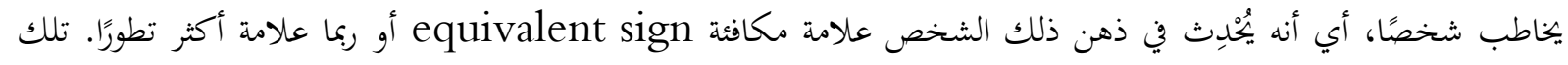

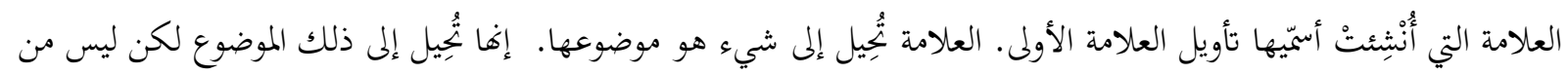

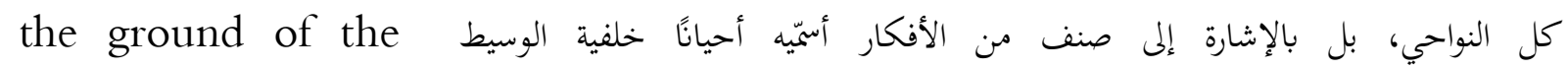
representamen

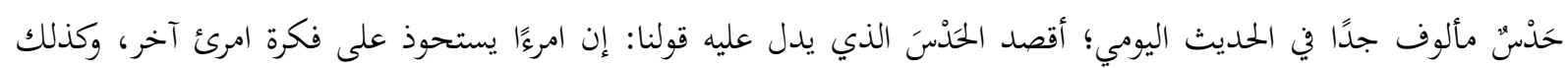

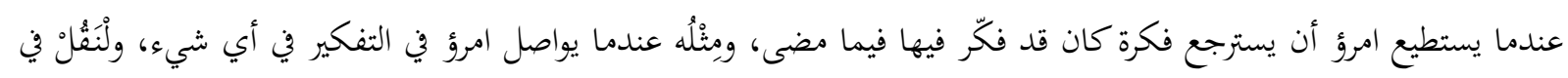

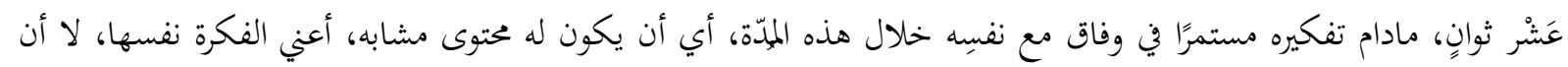
تتغير فكرته في كل لحظة زمنية فاصلة" (Peirce,1897 CP 2.228).

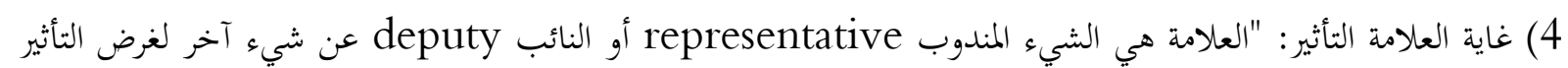
في الذهن" (Peirce,1899-1900 MS [R] 142:3).

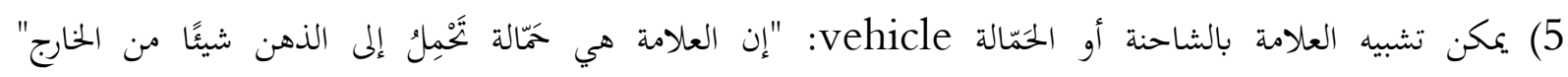
.(Peirce,1893 NEM 4:309-10; CP 1.339) 6) يمكننا أن نعبر عن وظيفة العلامة بقولنا (تُجِيل إلى موضوع)، أو (تحمل معنى)، أو (تؤدي إلى تأويل): "ذلك الذي تقوم

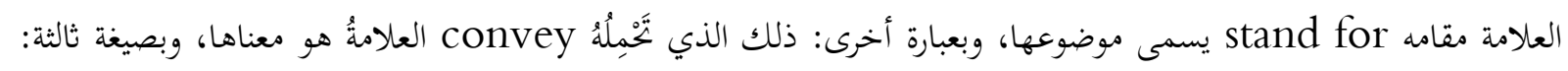
إن الفكرة التي تؤدي إليها give rise العلامةُ هي تأويلُها" (ibid). وحسب تلك السمات يمكن تيسير تعريف العلامة عند بيرس بأفا: شيء محسوس ينوب عن موضوع، ويثير في الذهن

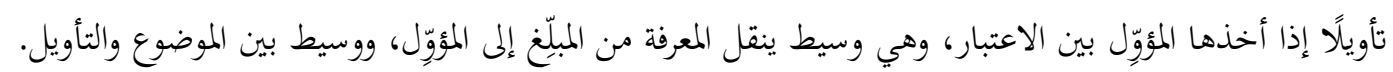

\section{الأنواع الرئيسية للعلامة بحسب أنواع الوجود:} تأتي هذه الأنواع الرئيسية نتيجة لرؤية بيرس إلى الوجود على أنى أنه ثلاثة أنواع:

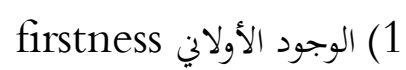
2) الوجود الثانياني (1) الوجود الالي Secondness 3) الوجود الثالثاني (لوجود النيان Thirdness

إن كل الحقائق الممكن تحقُقها قبل أن تُوجَد في الكون هي الوجود الأولاني، فإذا ظهر منها شيء في الكونِ وعالم الحقيقة

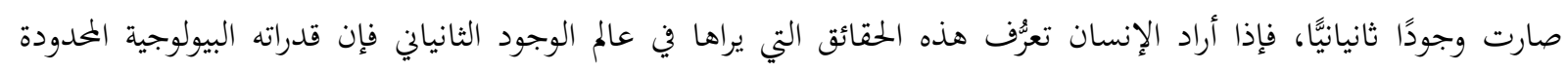

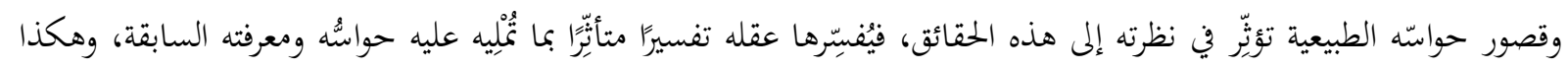

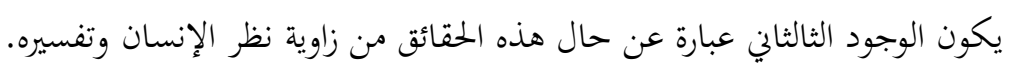


فلنأخذ مثالًا على ذلك- الألوانَ، فالألوان حقيقة كونية، فإذا استقرّ لون أحمر في كرسي أنيق صار في الوجود الثانياني، فإذا أوّله الإنسان على أنه لون ملكيّ صار في الوجود الثالثاني.

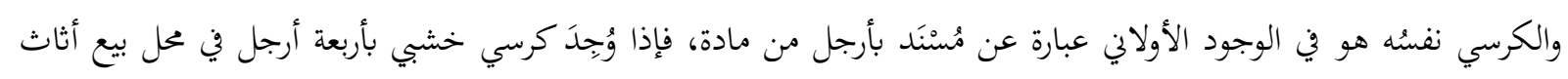

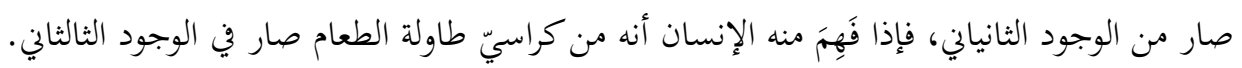

إن الإنسان في الوجود الثالثاني يجعل كل الأشياء علامات يفهم منها أمورًا أخرى، وهذا ما يسمّيه بيرس التمثيل أو النيابة

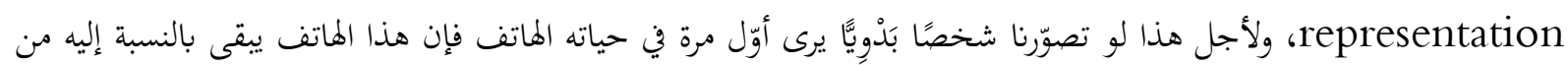

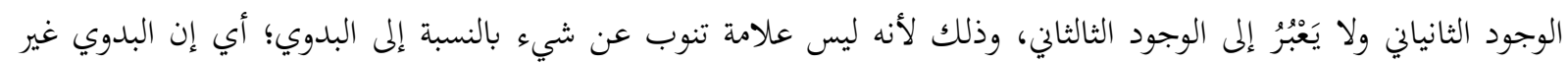
قادر على أن يفهم من هذا الهاتف شيئًا.

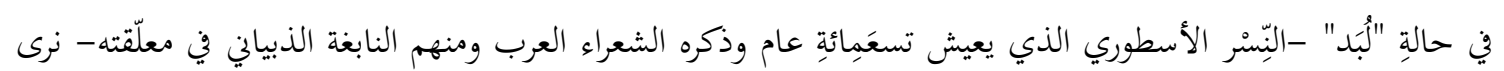

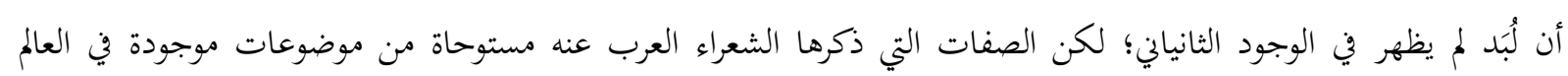

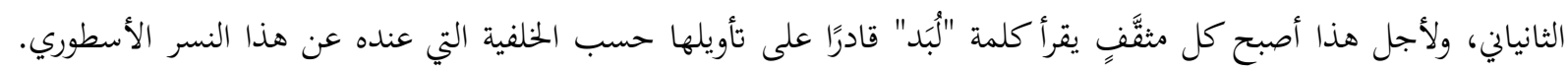

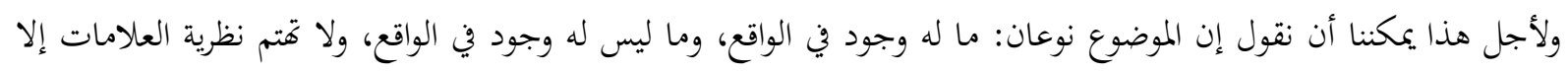

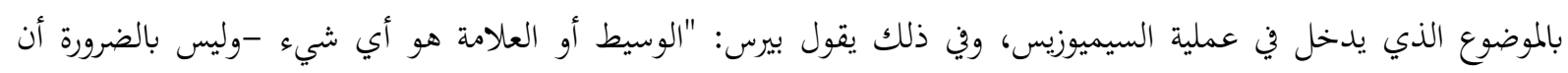

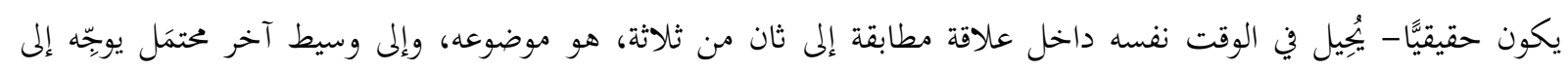

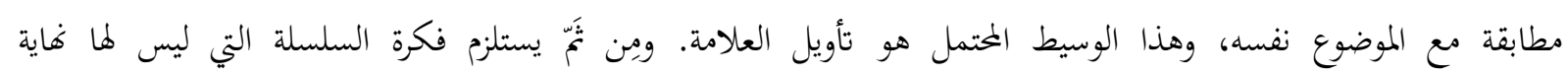
مكنة"(Peirce, 1902 MS [R] 1147).

يقول بيرس عن الأنواع الثلاثة الرئيسية للعلامات النابتحة عن أنواع الوجود: "ثمّة ثالوث مهم للغاية هو أن هناك ثلاثة أنواع

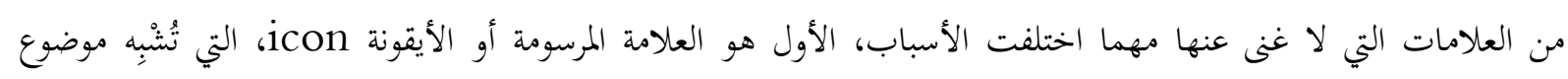

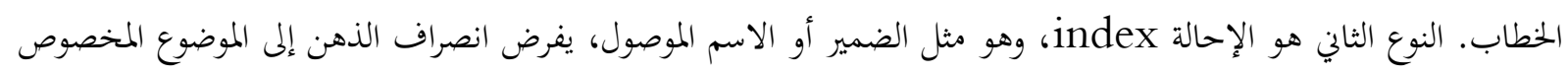

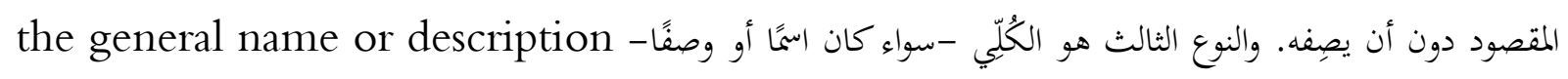

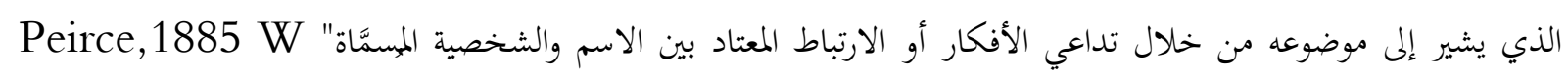

إن الأيقونة icon أو العلامة المرسومة the diagrammatic sign هي العلامة التي تماثل أو تشابه المشار إليه نخو

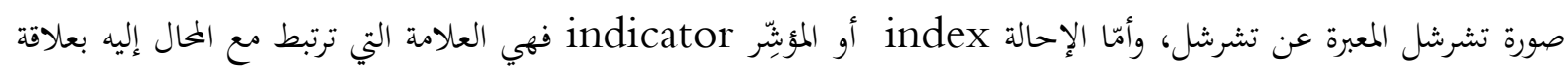

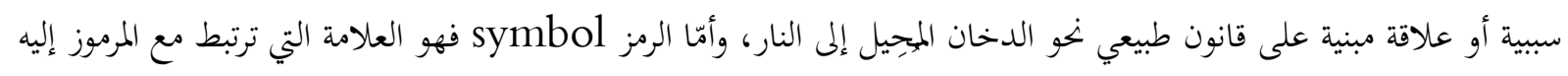

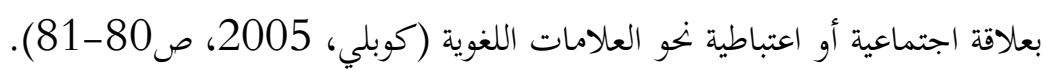
وتتفاوت أنواع العلامة الثلاثة الرئيسية في درجة قدرتا على الاستغناء عن العنصرين الآخرَيِِْ اللذين يشكِّلان مع العلامة

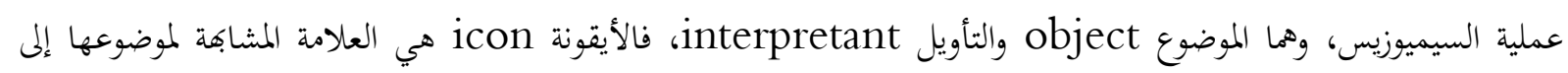

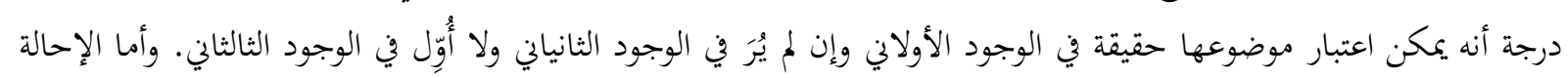
index

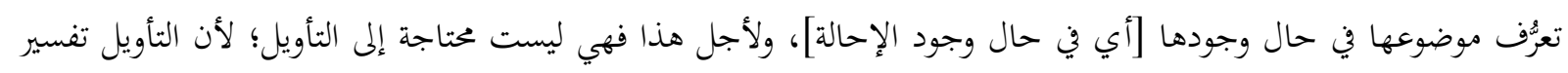

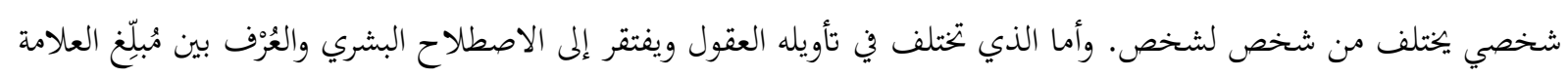
interpreter فهو النوع الأخير من العلامات Symbol deliverer 
ثلاثة أنواع، الأول هو الأيقونة، وهي تمثل موضوعها تمثيلًا مُغنِيًا بهكم خِصِيصة virtue تمتلكها حتى لو كان الموضوع وعملية

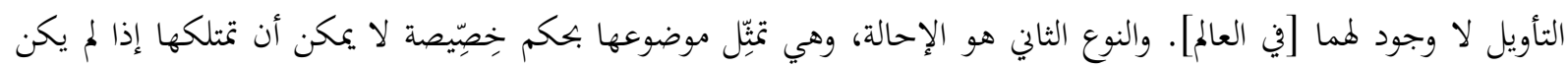

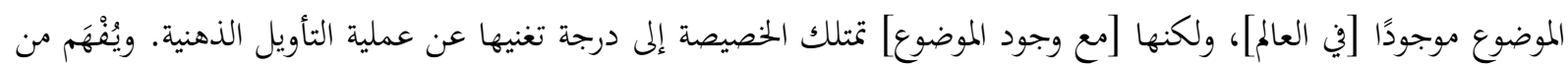

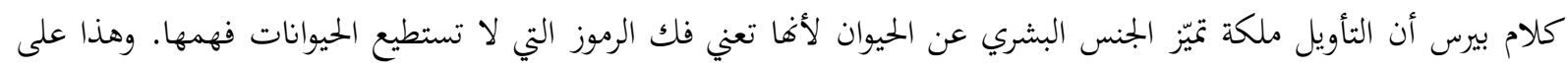

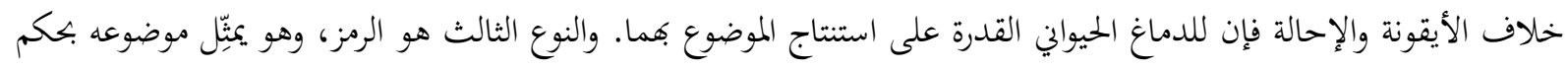

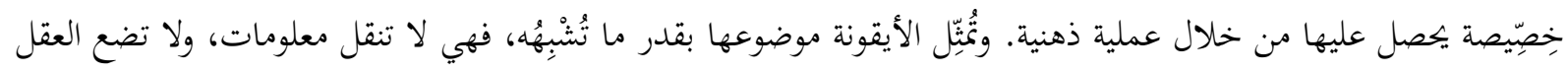

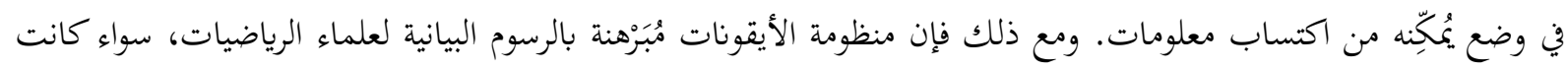

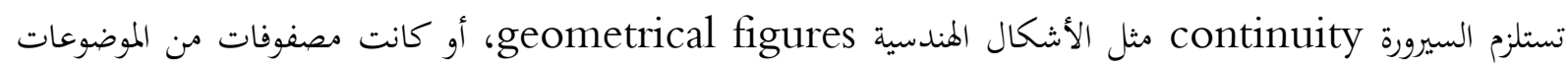
المنفصلة arrays of discrete objects مثل مجموعة من الصيغ الجبرية algebraical formulae، فكلها أيقونات. إن الأيقونات لابد أن تُستعمل في أية عملية تفكير)(Peirce,1900 MS [R] 142:3-4). من الواضح تأثير المفاهيم المنطقية والفلسفية في تقسيم العلامات وفق أنواع الوجود، فقد ربطها بيرس بفكرة الأجناس

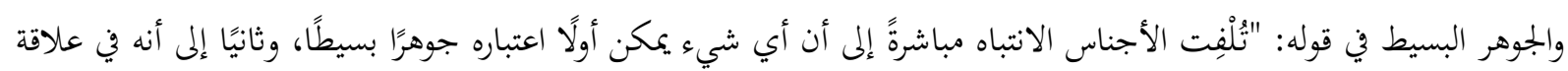

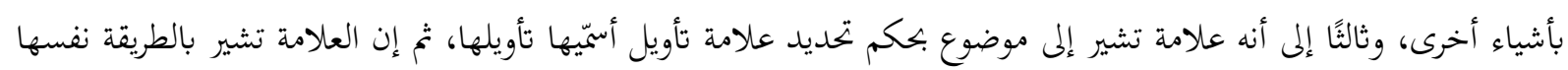

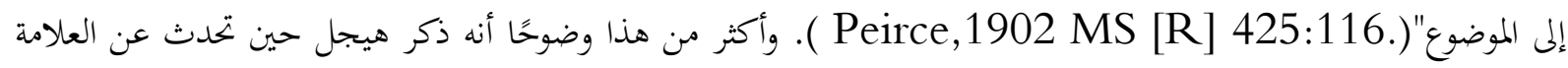

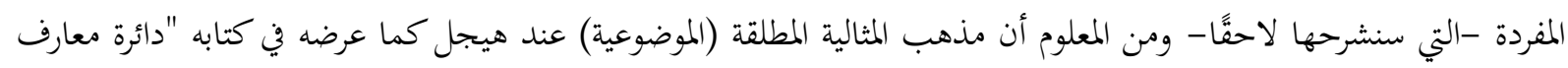
العلوم الفلسفية" يرى أن كل الظواهر الطبيعية والاجتماعية تقوم على أساس المطلق (الروح والعقل أو الفكرة المطلقة أو عقل العالم

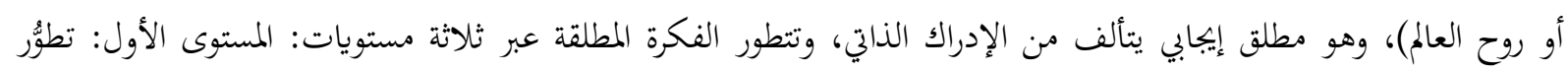

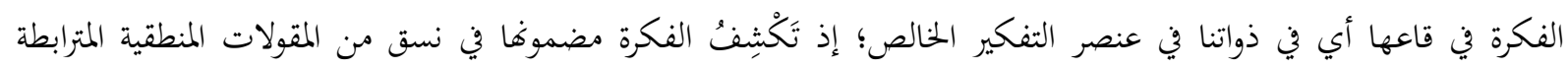

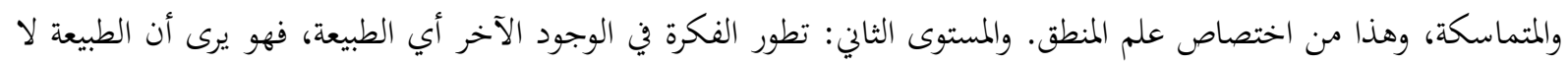

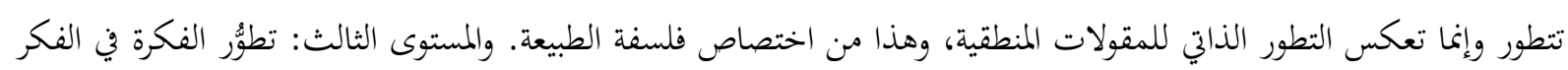

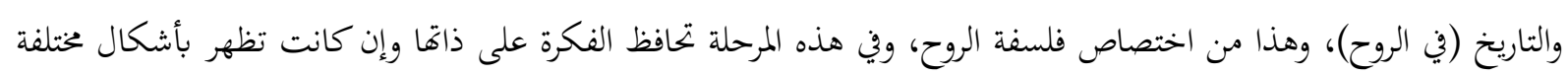

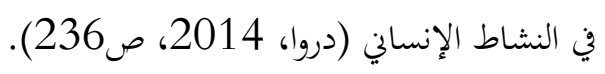

نفهم من الأقسام الرئيسية للعلامة -التي ذكرناها سابقًا - أها أقسام لا تخلو منها أية علامة، فكل علامة لابد أن تكون

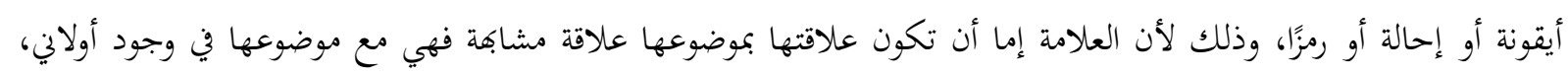

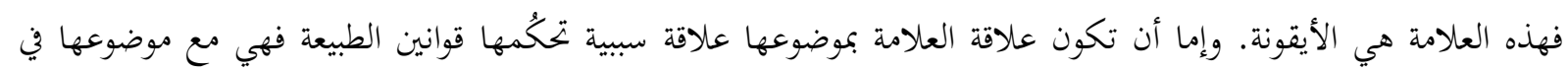

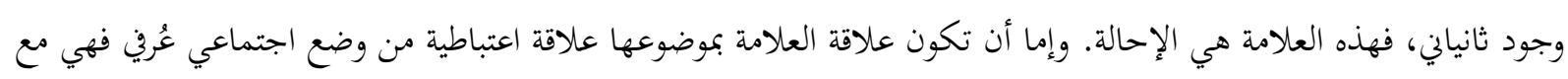
موضوعها في وجود ثالثاني، فهذه العلامة هي الرمز .

قسّم بيرس الموضوع إلى موضوع مباشر Immediate Object (الموضوع الذي ثُتِيل إليه العلامة قبل أن تُعيَّد بتأويل

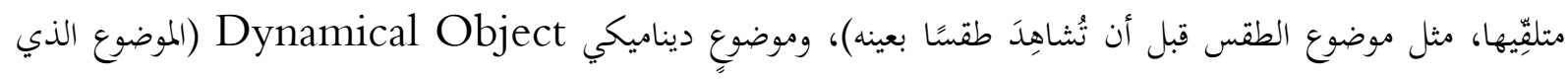

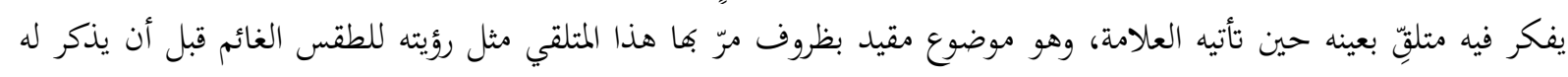

أحد كلمة الطقس) (Peirce, 1909, a site).

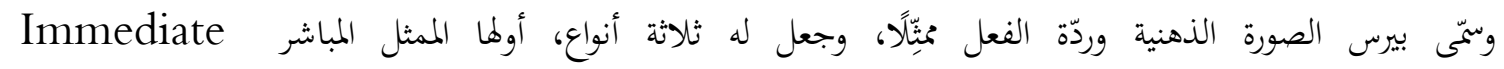

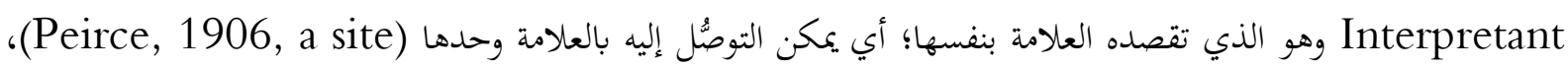




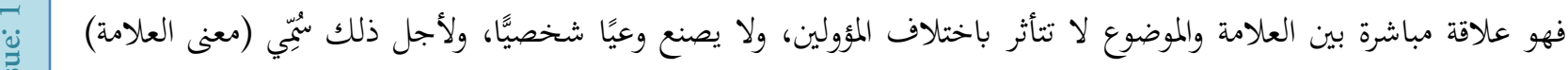

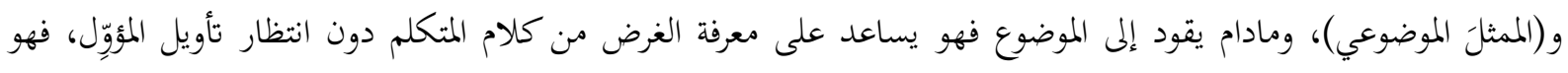

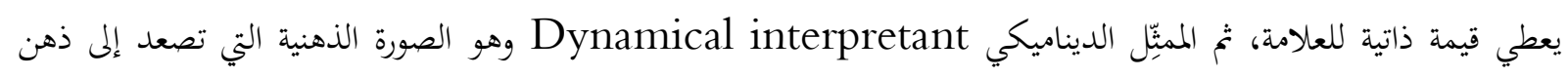

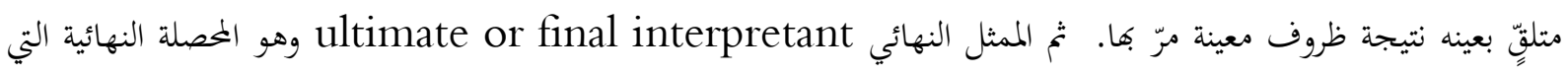

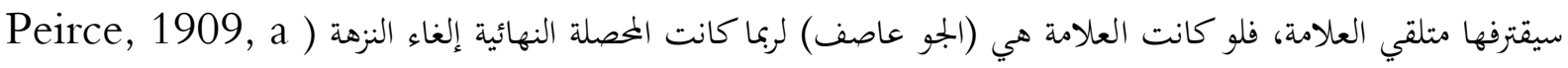
(site 


\section{المبحث الثالث: سمات الترميز وبُنَاها في رواية شهادة من زمن الحرب: السمة الأولى: الترميز عبر العلامات اللغوية والعلامات غير اللغوية:}

من خلال المبحث السابق عرفنا أن العلامة عند بيرس (شيء ينوب عن موضوع، ويثير في الذهن تأويلاً إذا أخذها المؤوِّل

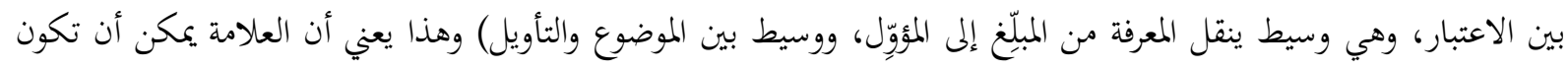

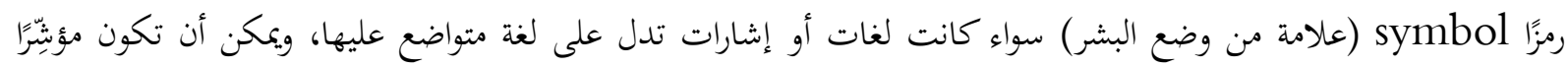

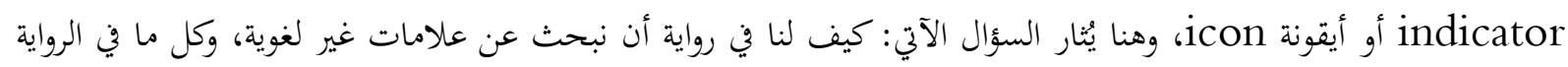

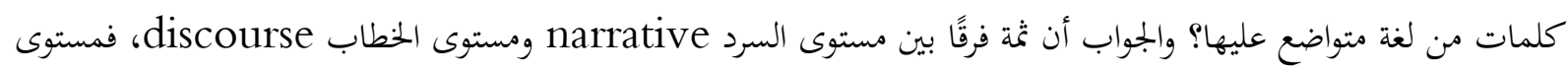

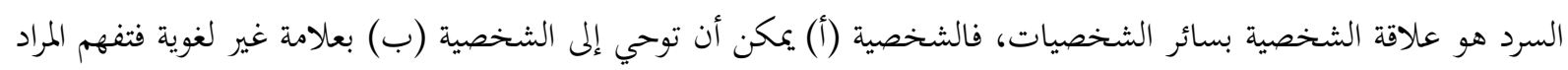

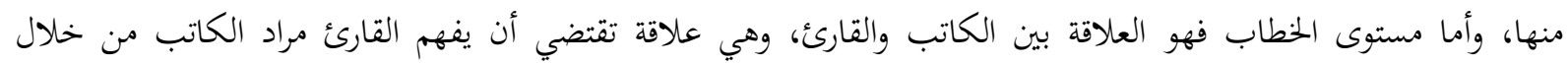
علامات لغوية فقط هي الكلمات والجمل المسطرّة في روايته.

فمن أمثلة العلامات اللغوية التي جرت بين الشخصيات ما سمعه ماجد من "قفشات أبو سليم اللبناني (صاحب المقهى)

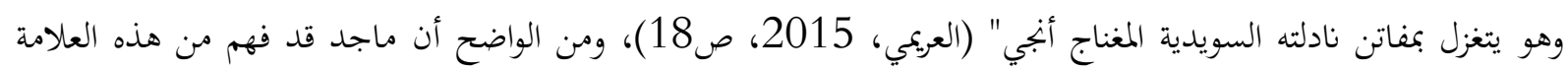

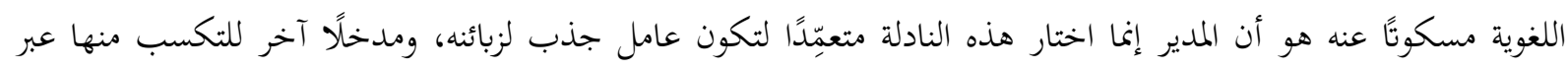

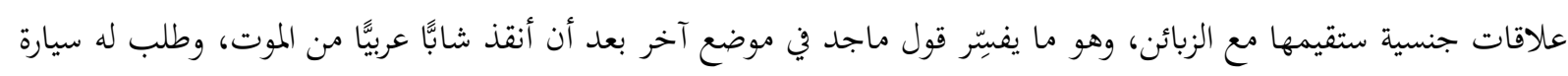

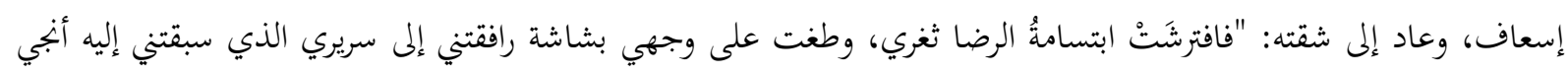

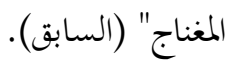

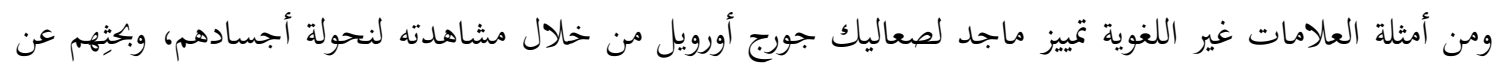

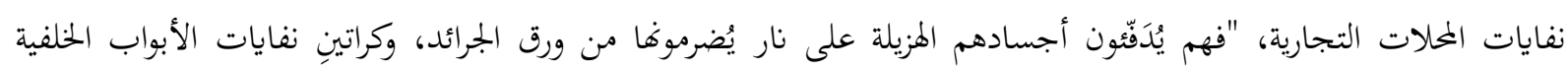
للمحلات التجارية" (السابق)، فهذا السلوك منهم غير اللغوي كان علامة غير لغوية قادته إلى معنى اقتضائي هو اعتبارهم صعاليك.

إن التبئير الداخلي الذي أسنده محمد العريكي إلى شخصية ماجد جعل تأويل العلامات اللغوية وغير اللغوية في روايته إنما

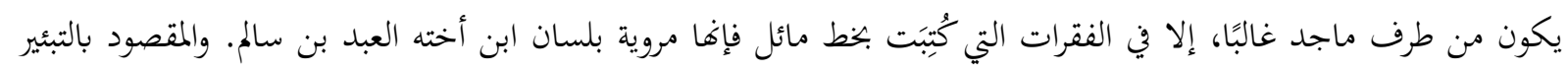

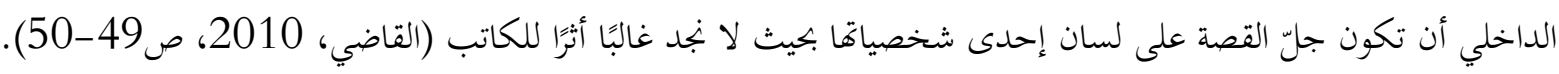
السمة الثانية: تحوّل الأفكار إلى علامات تؤدي وظيفة الترميز: الأصل أن العلامة - كما يذكر بيرس- شيء مادي سواء كانت صوتًا مسموعًا، أو كلمة مكتوبة، أو أي شيء محسوس،

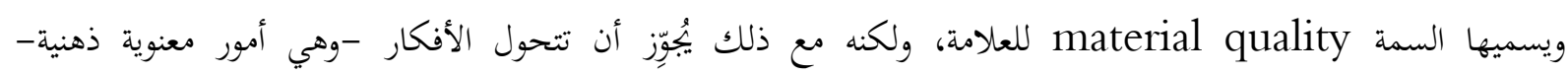

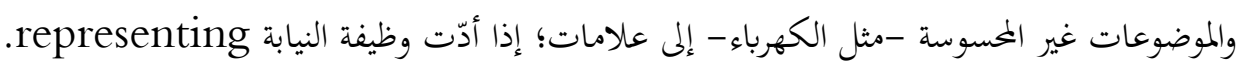
بعد إعلان الرئيس الأمريكي بوش الابن الحرب على الإرهاب وأفغانستان صارح ياسين ماجدًا بأنه ينتمي إلى جمعية خيرية

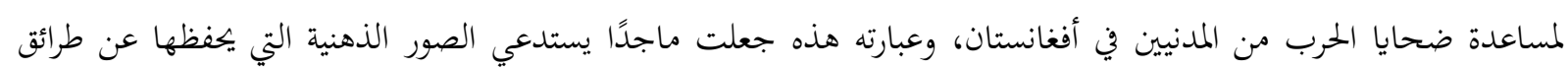

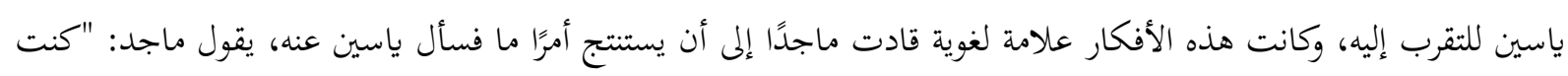

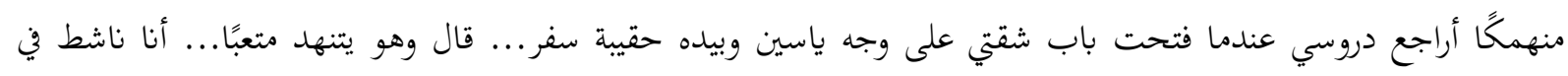

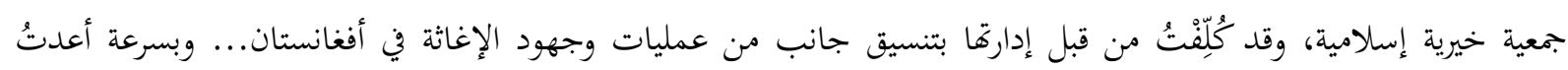


شريط علاقتي بياسين منذ بداية تعريف عليه، وسعيه للتقرب مني أكثر دون أصدقائه الثلاثة، فسألته: هل مهمتك المكلف بها لدعوة

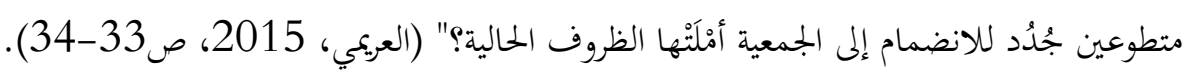
وكاد ماجد أن يرفض الانجراف خلف دعوة ياسين لولا أن الأفكار مرت أخرى دفعته إلى استنتاج إيجابي نحو نوايا ياسين:

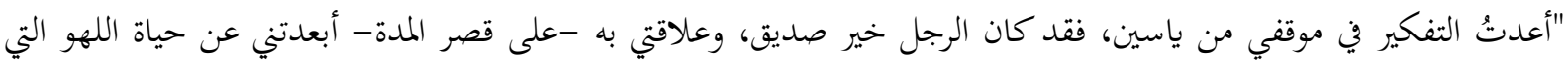

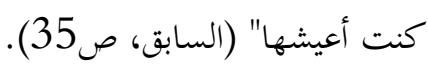

والواضح من هذه الأمثلة أن تحوّل الفكرة إلى علامة في الرواية ترمز إلى معنى اقتضائي إنما يجصل في مواضع المونولوج النفسي حين تخلو الشخصية بنفسها أو ينتقل صوتا من مخاطبة العالم الخارجي إلى محاورة ذاتما.

\section{السمة الثالثة: تأويل العلامة مرهون بالمعرفة المشتركة بين المبلِّغ والمؤوِّل:}

يذكر بيرس أن العلامة وسيط depresentamen ينقل إدراكًا من مُبلِِّغِها deliverer ئلى مؤٍِّ

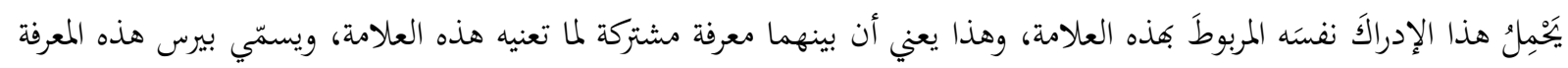

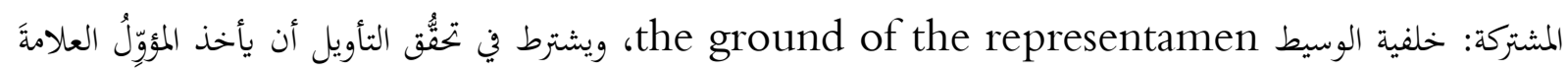

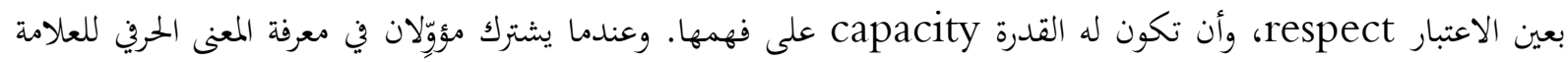
لكن أحدهما هو القادر على فهم معناها الاقتضائي بسبب الخلفية المعرفية التي بينه وبين المبلِّغ - تتولد عملية الترميز. إن الطبيعة العسكرية لهذه الرواية، ومشاهدها الحربية، وطرائقها الاستخباراتية- جعلها أرضًا خصبة للرموز التي لا يفهمها

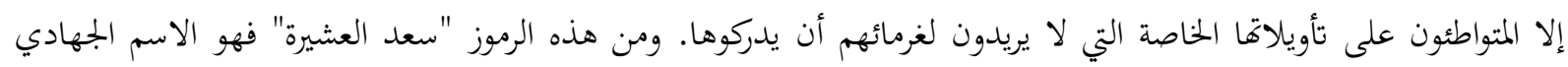

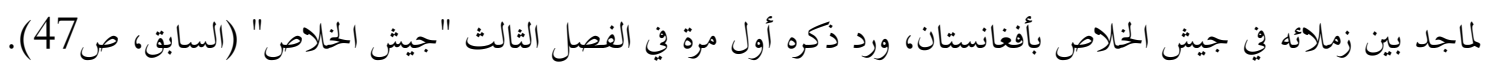
بعدما قِيدَ ماجد مكبّاً بأغلال اليدين والقدمين بوساطة سام الأمريكي وشوكت الباكستاني وعبده اللبناني أدخلوه على

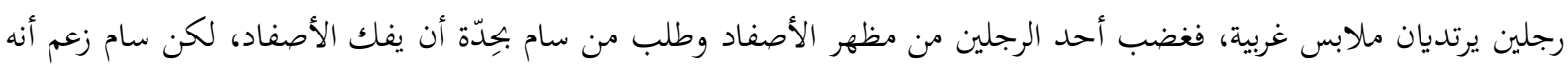

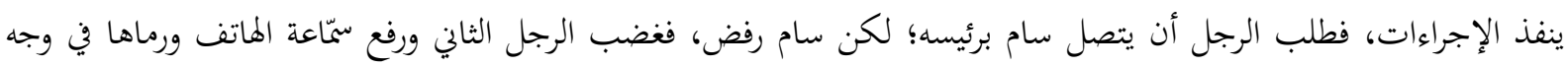

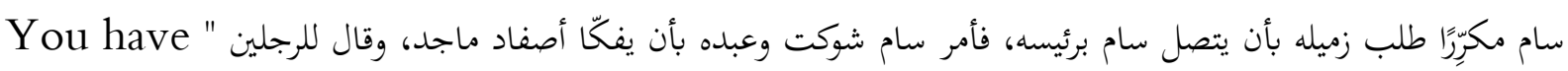

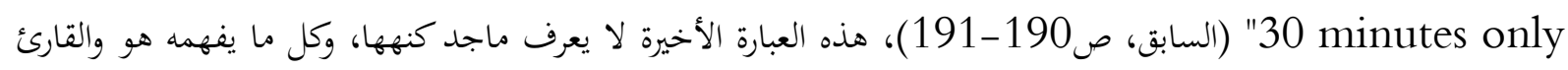

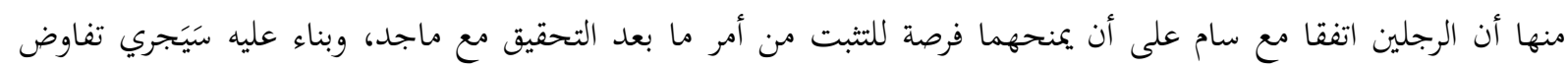

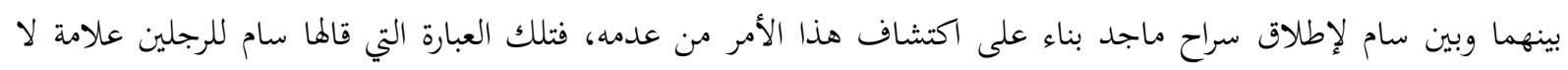

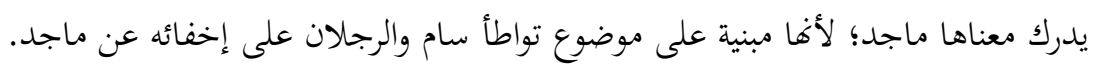

\section{السمة الرابعة: تفاوت الأنواع الرئيسية للعلامة في قدراتما الترميزية:}

حسب تقسيم بيرس للعلامة من حيث أنواع الوجود إلى أيقونة ومؤشر ورمز يتضح أن كل الناس قادرون على فهم الأيقونة لأهما

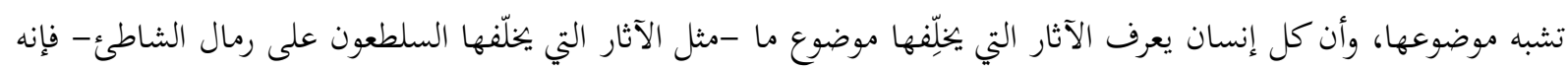

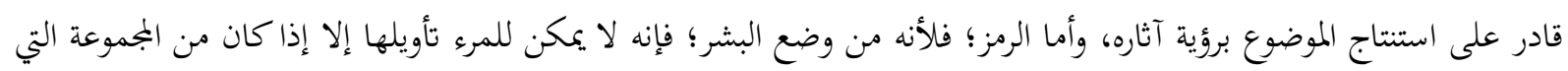
تواطأت على دلالة الرمز على مفهوم معين. والسؤال المهم المتعلق بالترميز: هل يمكن أن نجد من كل نوع من أنواع العلامات الرئيسية ما يؤدي دور الترميز أي الإحالة

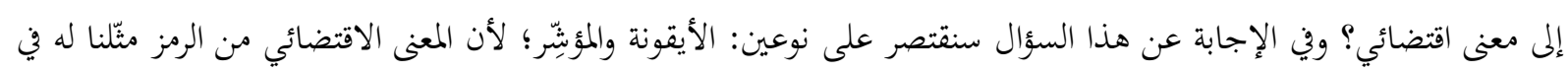


ومن المؤشِّرات الترميزية الواردة في الرواية الشقة الفاخرة التي كان يسكنها ماجد في أحد المجامع السكنية، فقد استتتجت

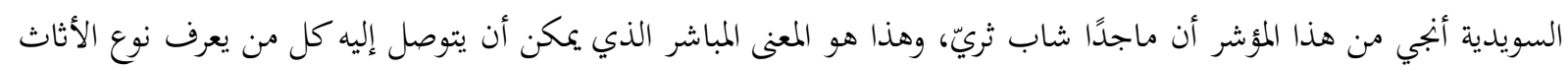

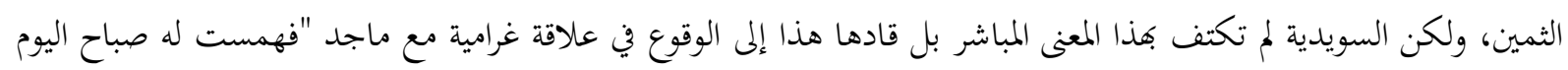

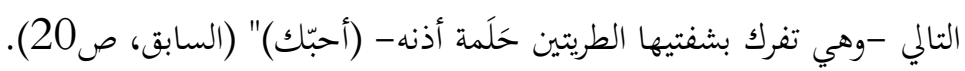

ومن الأيقونات الترميزية العربات المموِهة التي وضعها جيش الخلاص في شمال كابل، وخارطة كابل التي رُبسم فيها خط أحمر

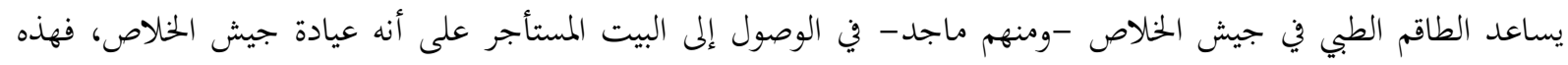

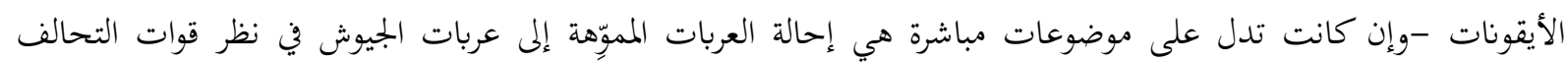

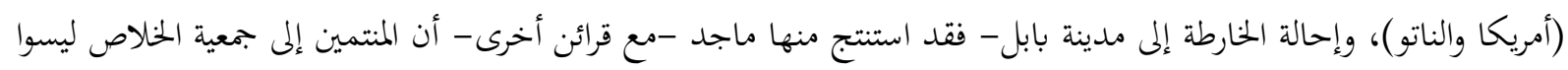

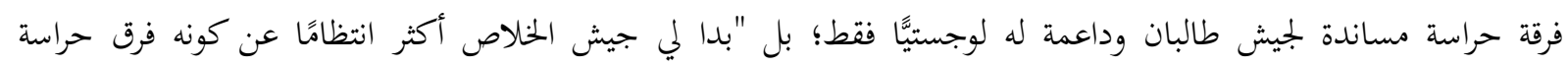

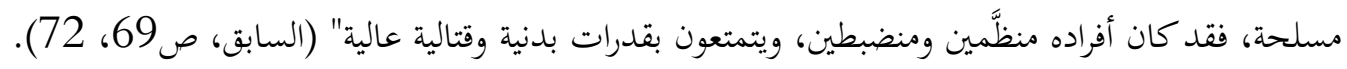

\section{السمة الخامسة: المباشر والديناميكي والنهائي:}

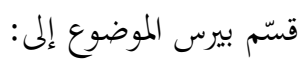

1. موضوع مباشر Immediate Object هو الموضوع قبل ربطه بموقف معين رآه مؤوِل معين، وموضوعٍ ديناميكي Dynamical Object

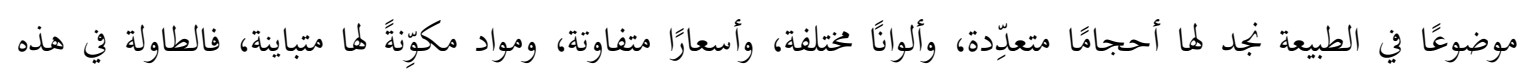

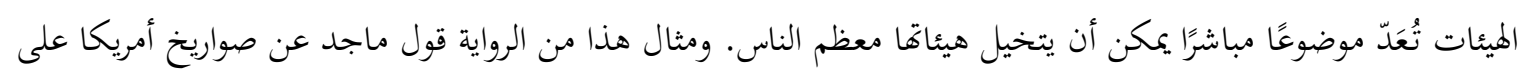

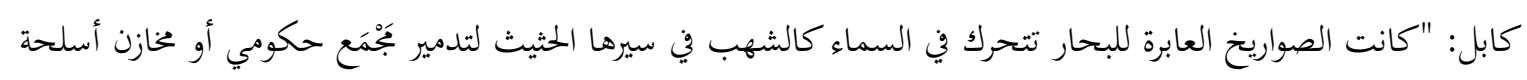

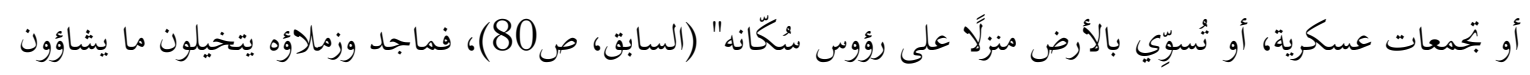

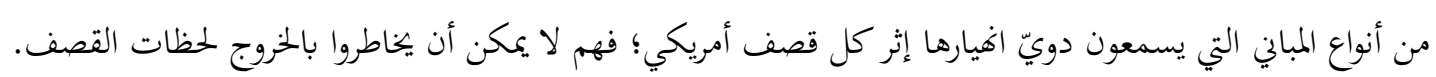

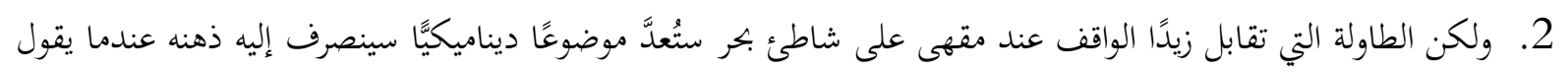

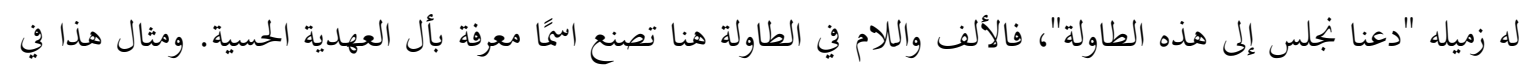

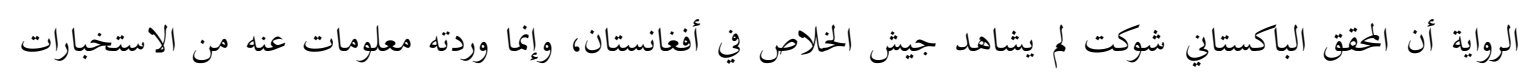

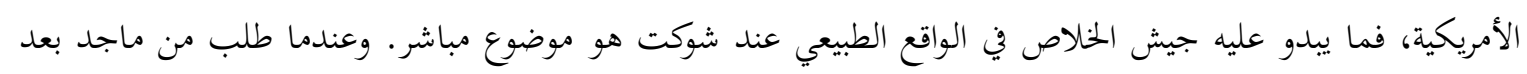

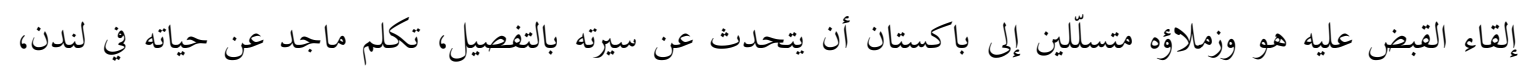

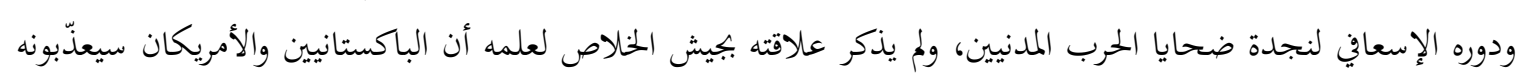

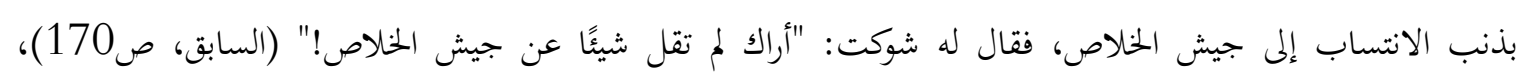

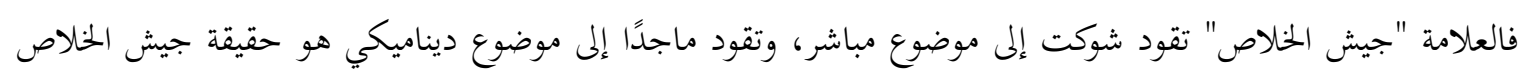
في أرض الواقع.

\section{وقسّم بيرس التأويل من حيث علاقته بالمعنيين الحرفي والاقتضائي إلى:}

1. تأويل مباشر هو الصورة الذهنية لجنس الشيء قبل رؤيته على أرض الواقع.

2. وتأويل ديناميكي هو الصورة الذهنية عن الشيء بعد رؤيته في أرض الواقع، فالمؤوِل بعيد عن هذا الشع الشيء الشئ الآن لكن

$$
\text { صورته الذهنية تحتفظ بتفصيلاته. }
$$

$$
\text { 3. و تأويل فائي، هو ردة فعل المخاطب بعد أن يستمع أو يرى علامة الشيء. بندئه }
$$


ويمكن التمثيل لهذه الأنواع بأن صورة جيش الخلاص في ذهن شوكت هي تأويل مباشر، وصورة الجيش في ذهن ماجد تأويل ديناميكي، وردة فعل ماجد -وهي إنكار علاقته بجيش الخلاص - بعد أن سأله شوكت عن جيش الخلاص هي تأويل فائي.

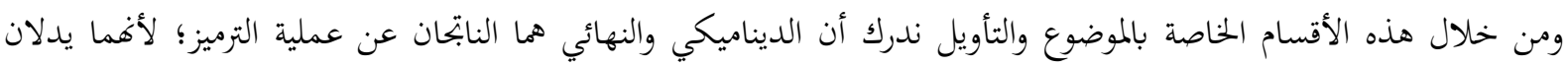

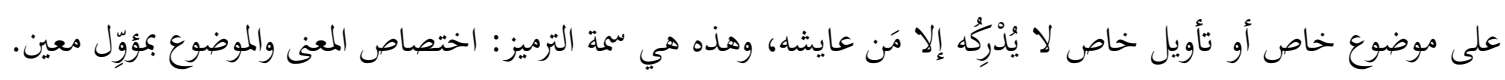




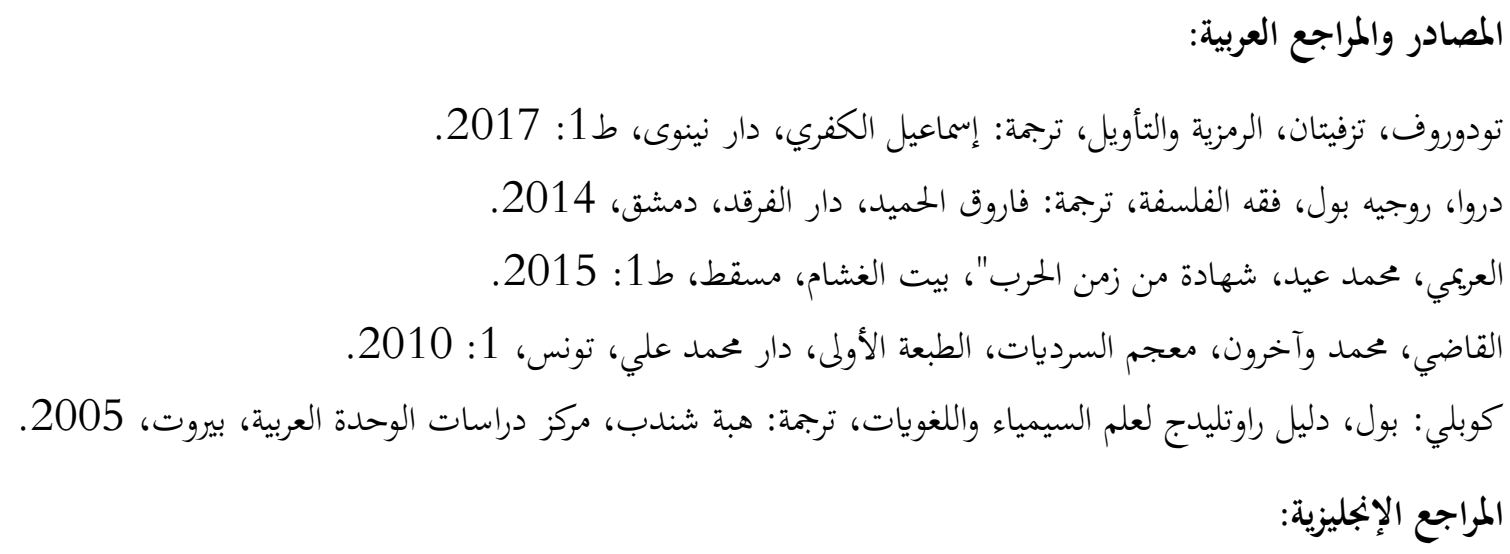

First: Charles Sanders Peirce researches within the site "Stanford Encyclopedia of philosophy Peirce's theory of signs":

1868 | Some Consequences of Four Incapacities | W 2:223.

1873 | On the nature of signs | W 3:66-8.

1873 | Logic. Chap. 5th | W 3:76; CP 7.355-6.

1885 | One, Two, Three: Fundamental Categories of Thought and of Nature | W 5:243.

1894 | The Art of Reasoning. Chapter II. What is a Sign? | EP 2:5; MS [R] 1009.

1895 [c.] | On the Logic of Quantity, and especially of Infinity | MS [R] 16:12; PM 52.

1895 | Short Logic: Chapter I. Of Reasoning in General | EP 2:13.

1897 [c.] | On Signs [R] | CP 2.228.

1893-5 [c.] | Chapter II: The Categories | NEM 4:309-10; CP 1.339

1899-1900 [c.] | Notes on Topical Geometry | MS [R] 142:3.

1901-1902 [c.] | Definitions for Baldwin's Dictionary [R] | MS [R] 1147

1902 [c.] | Reason's Rules | MS [R] 599:28-36, within the site.

1902 | Minute Logic: Chapter I. Intended Characters of this Treatise | MS [R] 425:116.

Second: Charles Sanders Peirce researches within the site "iass-ais.org/the-commensdictionary-of-peirces-terms":

Letters to William James, 1909.

On the system of existential graphs considered as instrument for the investigation of logic, 1906. 


\section{TIME MANAGEMENT STRATEGY AND ITS RELATIONSHIP WITH THE ACADEMIC ACHIEVEMENT OF STUDENT'S OF AL ZAIEM A L AZHARI UNIVERSITY,FACULTY OF EDUCATION, MODEL}

\section{Istanbul / Türkiye}

p. $152-173$

Received: $15 / 11 / 2021$

Accepted: 06/12/2021

Published: 01/01/2022

This article has been scanned I iThenticat No plagiarism detected

\author{
Amani AWADALLA ${ }^{1}$
}

\begin{abstract}
:
The study addressed the field of educational management, it aimed to know the relationship between management strategy and academic achievement of science class students of the Faculty of Education at Al Zaeim Al Azhari university.The researcher followed the descriptive method, the sample was (94) of the students, the questionnaire was used as a tool of data collection, the data was analyzed by the statistical package of the social sciences (SPSS), (T) test, the one way analysis of variance( ANOVA), Person correlation, chi-squared test and ( MAN-WHITENY)

The researcher came to many results, the most important:

There was no statistically significant differences attributable to the gender, housing and major variables, there is appositive statistical correlation between dimensions of time management and Grande Point Average (GPA), there was an inverse negative correlation between time management waster and the Grade Point Average(GPA) of the students.

Through what the researcher's came to as results, she recommended:

The necessity of holding training workshops on the importance of time in the student's academic and social life at Al Zaeim Al Azhari university, introducing courses on all levels of education on time management and its strategy.
\end{abstract}

Key words: Al Zaeim Al Azhari University Management Strategy, Academic Achievement.

http://dx.doi.org/10.47832/2717-8293.15.11

1 iD Dr. , AL Zaiem A L Azhari University, Sudan, amaniawadalla888@ gmail.com, https://orcid.org/0000-0002-7306-2814 


\section{استراتيجية إدارة الوقت وعلاقتها بالتحصيل الدراسي لدى طلاب جامعة الزعيم الأزهري، كلية التربية أنموذجا}

\section{أماني مختار عوض الله محمد 2}

تناول البحث مجال الإدارة التربوية وهدف لمعرفة العلاقة بين استراتيجية إدارة الوقت والتحصيل الدراسي لدى

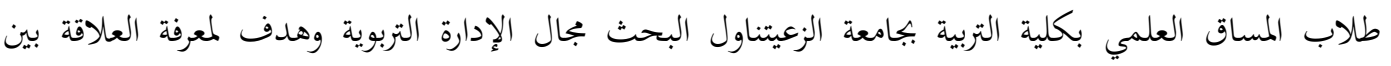
استراتيجية إدارة الوقت والتحصيل الدراسي لدى طلاب المساق العلمي بكلية التربية بجامعة الزعيم الأزهري.

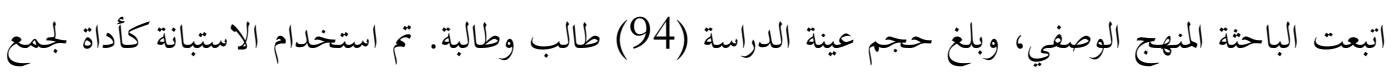

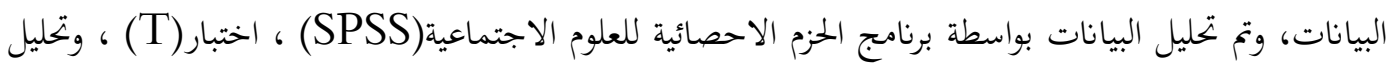

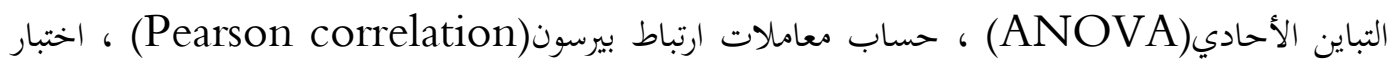
كاي تربيع، مان -وتني. (MAN-WHITNEY) ومن ثم توصلت الباحثة للعديد من النتائج من أهمها: لا توجد فروق ذات دلالة احصائية تعزي لمتغير الجنس، السكن او التخصص، توجد علاقينة ارتباطية طردية موجبة

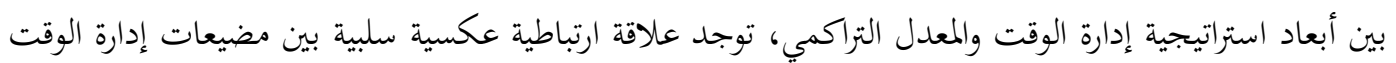
والمعدل التراكمي لدي الطلاب. من خلال ما توصلت إليه الباحثة من نتائج قد أوصت بالعديد من من التوصيات من أهمها: ضرورة عقد ورش تدريبية حول أهمية الوقت في حياة الطالب الأكاديمية والاجتماعية بجامعة الزعيم الأزهري.، إدخال مقرر دراسي بجميع مراحل التعليم يختص بإدارة الوقت واستراتيجياته.

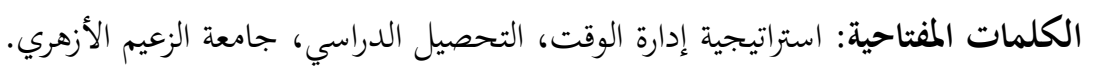

إن العصر الحديث يسمى بعصر السرعة، مما أدي إلى وجود صراع دائم في عملية اللحاق بالزمن لتحقيق الاهداف من قبل الأفراد والجماعات. ونجد ان المشكلة الحقيقية تكمن في إدارة الوقت وليست في الوقت نفسه، فهناك من يحسن إدارة وقته بفاعلية ويستطيع ان ينجز الكثير من الاعمال بينما نجد هنالك من يهدر وقته دون فائدة، لذا يعد الوقت مورد مهم يجب الاستفادة منه والمحافظة عليه.

وتعتبر استراتيجية إدارة الوقت من أهم العوامل التي تؤدى إلى تحسين مستوي التحصيل الدراسي لدي الطلاب الجامعيين

من خلال تقسيم الوقت بين حياتم الأكاديمية والاجتماعية ولا يتأتى ذلك إلا من خلال إدراكهم لأهمية الوقت وحسن وإدئ وإدارته. ومن ناحية اخرى يعد الطالب من أهم العناصر التي تعتمد عليها العملية التعليمية في تحقيق أهدافها، وخاصة الطالب

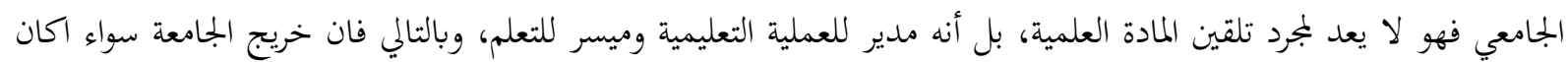


في العمل المهني بأنواعه المختلفة بشكل عام، أم في الحقل التربوي عند ممارسته لمهنة التدريس، فلا ينبغي أن يمارسها إلا بعد ان يعد

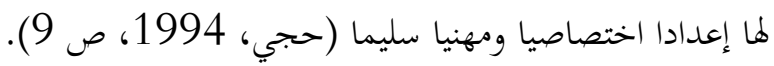
ويتضح من كل ما ذكر ان الوقت يعتبر أحد فنون الحياة، إذ أن إدارته وتنظيمه وحسن استغلاله أهم فن يجب أن يتعلمه

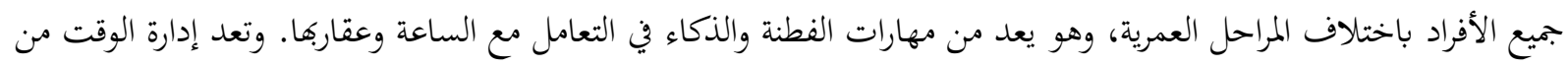

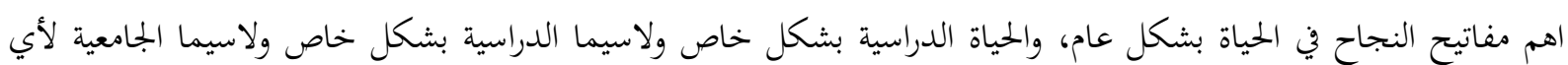
نشاط يقوم به الطالب الجامعي فلابد من تعلم بعض المهارات لتنظيم الوقت التي تمدف إلى تزويد الطالب ببعض الاستراتيجيات

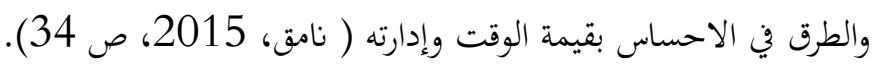

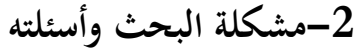

من خلال عمل الباحثة في بجال التدريس الجامعي لاحظت قلة اهتمام الطلاب بأهمية إدارة الوقت بفاعلية وما يترتب على ذلك من مشكلات تصاحب تحصيلهم الأكاديمي ومن هنا انبثت مشكلة البحث الحالية في الكشف عن عن استراتيجية إدارة الوقت

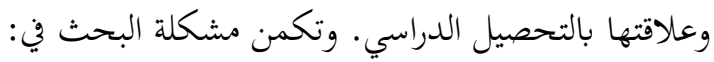

$$
\text { السؤال الرئيس التالي: - n }
$$

هل توجد علاقة ارتباطية بين استراتيجية إدارة الوقت والتحصيل الدراسي لدي طلاب المساق العلمي بكلية التربية بجامعة

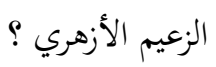

وتتفرع من السؤال الرئيس الاسئلة الفرعية التالية: 1- هل توجد فروق ذات دلالة إحصائية في أبعاد استراتيجية إدارة الوقت لدى طلاب المساق العلمي بكلية التربية جامعة الزعيم الأزهري تعزى لمتغير الجنس ؟ 2- هل توجد فروق ذات دلالة إحصائية في أبعاد استراتيجية إدارة الوقت لدى طلاب المساق العلمي بكلية التربية جامعة الزعيم الأزهري تعزى لمتغير التخصص ؟ هون دات 3-هل توجد فروق ذات دلالة إحصائية في أبعاد استراتيجية إدارة الوقت لدى طلاب المساق العلمي بكلية التربية جامعة الزعيم الأزهري تعزى لمتغير السكن؟ 4-هل توجد علاقة ارتباطية طردية موجبة بين أبعاد استراتيجية إدارة الوقت والمعدل التراكمي لدى طلبة المساق العلمي بكلية التربية جامعة الزعيم الأزهري؟ 5-هل توجد علاقة ارتباطية عكسية سلبية بين مضيعات إدارة الوقت لدى طلبة المساق العلمي بكلية التربية جامعة الزعيم

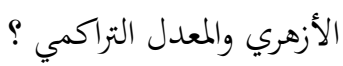
6-هل توجد فروق ذات دلالة إحصائية في المعدل التراكمي لدى طلبة المساق العلمي بكلية التربية جامعة الزعيم الزهري تعزى

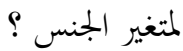

$$
\text { تكمن أهمية هذا البحث في الآتي: }
$$

1-قلة الدراسات التي تتم بموضوع استراتيجية إدارة الوقت لدى طلبة الجامعات الحكومية وغير الحكومية 1- لفت انتباه طلاب جامعة الزعيم الأزهري لأهمية إدارة الوقت وكيفية استثماره. 
3-لفت الانتباه لإدارة الذات من خلال إدارة الوقت بفاعلية لدى طلاب كلية التربية بجامعة الزعيم الأزهري. 3- لفت انتباه الطلاب لمضيعات الوقت بكلية التربية بجامعة الزعيم الأزهري. 4-الخروج بنتائج وتوصيات قد يستفيد منها المسؤولين في توجيه برامج تنمية استراتيجيات إدارة الوقت. لترئ.

\section{4-أهداف البحث:}

1__معرفة الفروق ذات دلالة إحصائية في أبعاد استراتيجية إدارة الوقت لدى طلاب المساق العلمي بكلية التربية جامعة الزعيم الأزهري تعزى لمتغير الجنس. 2 ـ معرفة الفروق ذات دلالة إحصائية في أبعاد استراتيجية إدارة الوقت لدى طلاب المساق العلمي بكلية التربية جامعة الزعيم الأزهري تعزى لمتغير التخصص. 3_ معرفة الفروق ذات دلالة إحصائية في أبعاد استراتيجية إدارة الوقت لدى طلاب المساق العلمي بكلية التربية جامعة الزعيم الأزهري تعزى لمتغير السكن. 4- الكشف عن وجود علاقة ارتباطية طردية موجبة بين أبعاد استراتيجية إدارة الوقت والمعدل التراكمي لدى طلبة المساق العلمي بكلية التربية جامعة الزعيم الأزهري. 5_ الكشف عن وجود علاقة ارتباطية عكسية سلبية بين مضيعات إدارة الوقت والمعدل التراكمي لدى طلبة المساق العلمي بكلية التربية جامعة الزعيم الأزهري. 6- معرفة الفروق ذات الدلالة الإحصائية في المعدل التراكمي لدى طلبة المساق العلمي بكلية التربية جامعة الزعيم الزهري يعزى

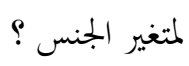

\section{5-منهج البحث:}

اتبعت الباحثة في هذا البحث المنهج الوصفي التحليلي.

\section{6-حدود البحث:}

الحدود الموضوعية: تتمثل في عنوان البحث استراتيجية إدارة الوقت لدي طلاب كلية التربية بجامعة الزعيم الأزهري

$$
\begin{aligned}
& \text { الحمدود المكانية: تتمثل في كلية التربية جامعة الزعيم الأزهري } \\
& \text { الحدود الزمانية: للعام 2020-2021م }
\end{aligned}
$$

\section{7-مصطلحات البحث:}

1-الوقت: هو العامل المشترك بين جميع الناس ويختلفون في كيفية استغلاله ويعود ذلك إلى طبيعة ثقافتهم ومهمتهم واهدافهم

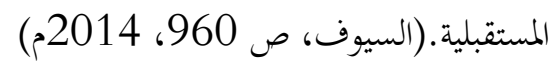

2-2إدارة الوقت:العملية التي توزع الوقت بفعالية بين المهام المختلفة، وذلك بهدف انجازها في الوقت الملائم والمحدد، وبذلك يتكون

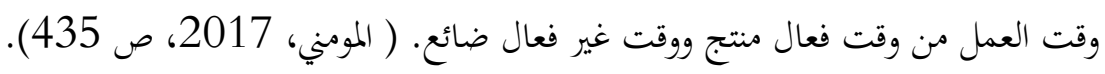


3-استراتيجية إدارة الوقت: بمفهومها الواسع تعرف بأغا:الإدراك الواعي بفن استخدام الوقت، والمعرفة العملية بكيفية استغلاله

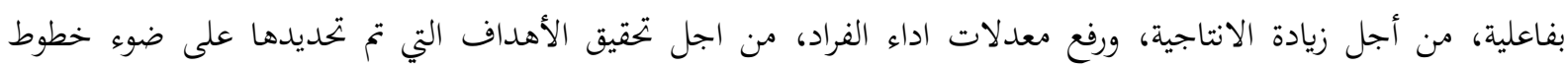

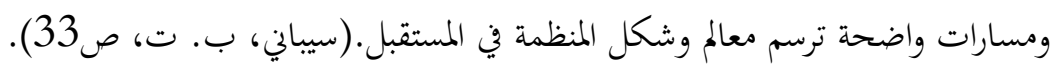

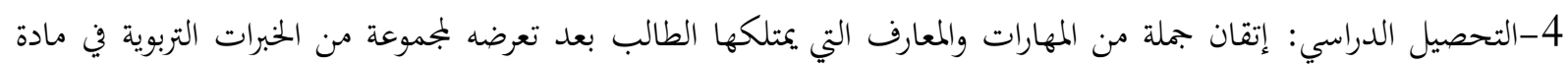

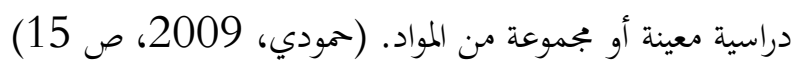
5-التحصيل الدراسي: المعدل التراكمي للطالب الذي يتم احتسابه من خلال الوسط الحسابي لجميع المقررات التي درسها الطالب مقسوما على عددها (اماني مختار، تعريف اجرائي) 6-طلاب جامعة الزعيم الأزهري. هم الطلاب المنتسبون إلى كلية التربية بجامعة الزعيم الأزهري ويدرسون بها حسب النسائي الظمة الجامعة ولوائح التعليم العالي. ( أماني مختار، تعريف اجرائي) 7- جامعة الزعيم الأزهري:احدى الجامعات السودانية الحكومية. ( اماني مختار، تعريف اجرائي الجياتي) 
الفصل الثاني

1- 1 الإطار النظري والدراسات السابقة

- تمهيد:

في هذا الفصل تقوم الباحثة بعرض الإطار النظري الذي يتكون اولا من ثلاث مباحث، المبحث الأول إدارة الوقت أما المبحث

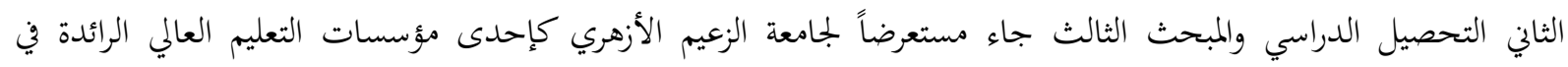
السودان ثم ثانياً الدراسات السابقة.

\section{المبحث الأول}

مدخل:

يتسم هذا العصر بسرعة الايقاع ويعتبر عنصر الوقت واستراتيجية إدارته هي الفيصل في كيفية الاستفادة من الوقت دون

هدo.

وأشارت خلفان ( خلفان،، ص48) بأنه لكي نحصل على معنى واضح لاستراتيجية إدارة الوقت فهي عكس معنى التشويش والاضطراب، وحياة الفوضى وانعدام الرقابة والاستغراق في الحاضر والتصرف وفق الافعال وردود الافعال وغياب الرؤية

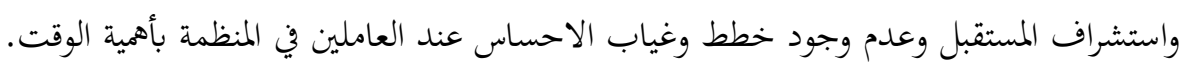

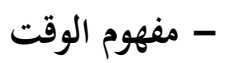

لغة:هو مقدار من الزمان، وكل شيء قدرت له حينا، وأقدرت غايته فهو مؤقت، والوقت من الدهر المعروف (الأنصاري،

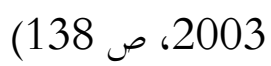

و الوقت اصطلاحا عرفه سلامة (1988، ص16) بأنه وحدة قياس لدوران الارض حول محورها وحول الارض، بحيث

$$
\text { يمثل اليوم 24ساعة والشهر } 30 \text { يوما والسنة 12شهرا. }
$$

بينما يرى الصرفي( 2003، ص12) أن مفهوم الوقت يطلق على عملية تخطيط وتنظيم ورقابة الوقت بما يمكنا من

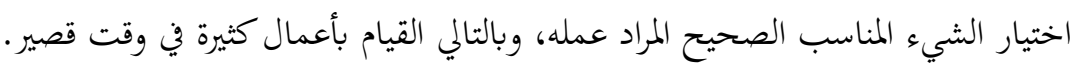

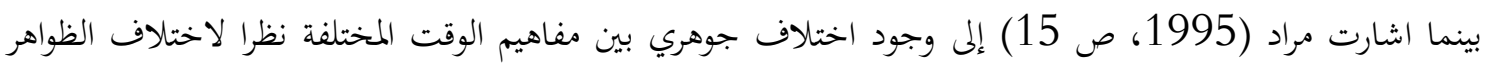
التي تشير اليها هذه المفاهيم وفقا لتصنيف الظواهر الكونية الموجودة، وبناء على هذا الاختلاف استعرض سلاد سلامة ( ص16) خمسة مفاهيم مختلفة للوقت وهي كما اوردها على النحو التالي:

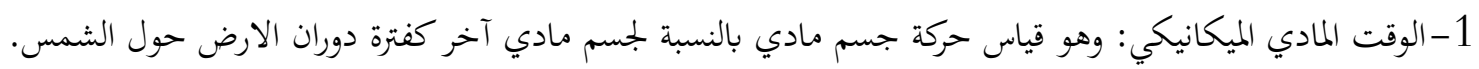

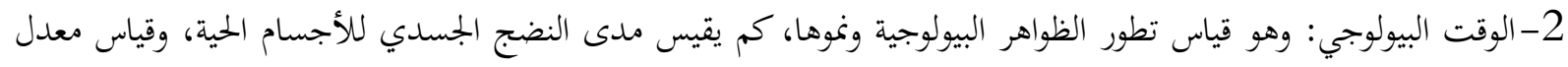
نمو الجسم بيولوجيا.

3-الوقت النفسي: وهو شعور داخلي يعتمد على طبيعة الظرف او الحدث الذي يعيشه الفرد وحالته النفسية.

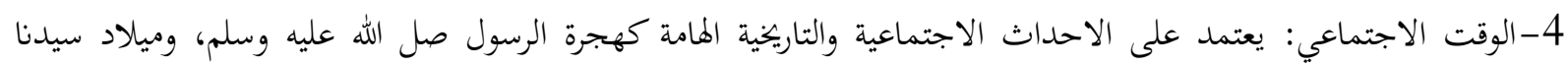

$$
\text { المسيح عليه السلام. }
$$

5- الوقت الميتافيزيقي: او عالم ما وراء الطبيعة ولا نعلم عنه سوى ما ورد في الكتب السماوية عن الحساب والخلود والأزل وغيرها. 


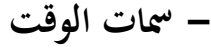

$$
\text { كما اوردةما فضيلة(2008، ص 30) كما يلي: }
$$

ا - رأس مال ينفد وليس دخلا يتجدد، ويتناقص بالسحب الحتمي الذى لا مفر منه، ولا توجد و سيلة لإيقافه او زيادته او

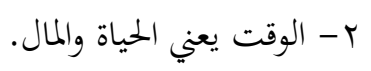

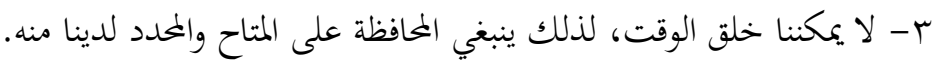

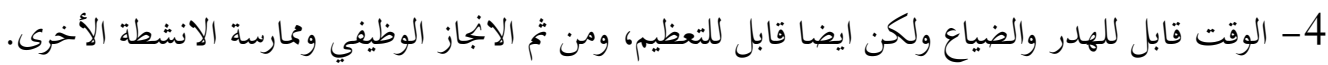
5-الوقت غير مرن ولا يمكن اعادته لكن فقط يمكن قضاؤه بحكمة.

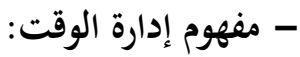

يرتبط مفهوم إدارة الوقت بالزمن الخاص المتاح للفرد بعد انتهاء مدة العمل الرسمي الذى يستطيع الفرد من خلاله ممارسة

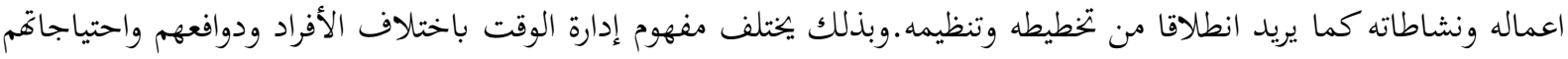

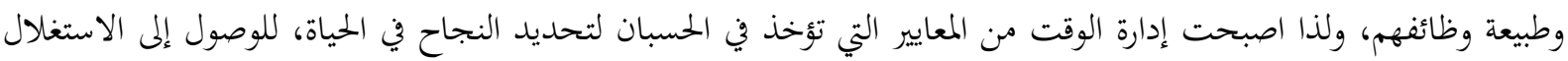

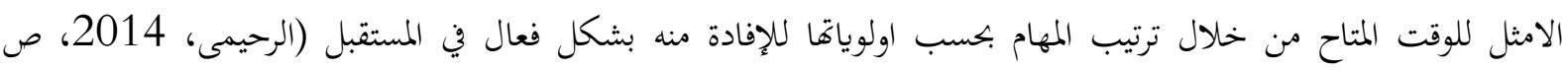

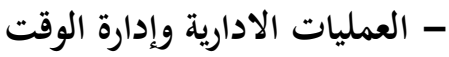

تتكون العمليات الإدارية من اربع وظائف وهي: التخطيط، والتنظيم، والتوجيه والرقابة. وفيما يلي توضيح لكل منها كما

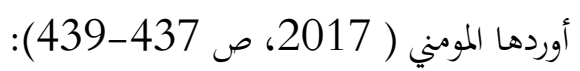

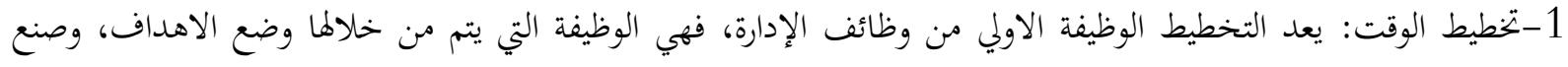

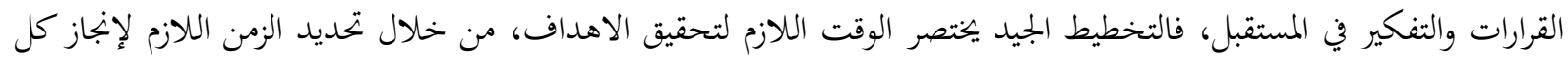

2- تنظيم الوقت: يعثل تنظيم الوقت الوسيلة التي عن طريقها يتم انجاز الأهداف، فالتنظيم ضرورة لابد منها لترتيب الجهود البشرية، وتصنيفها نت أجل الوصول إلى الغايات.

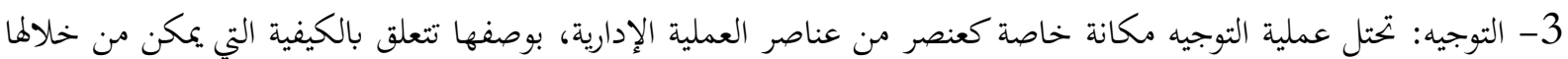

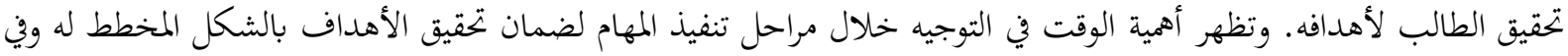

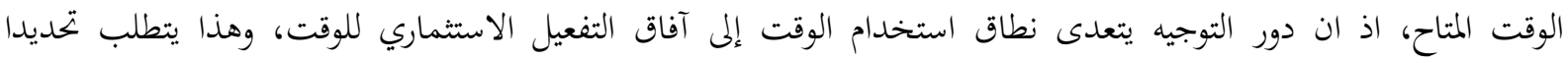

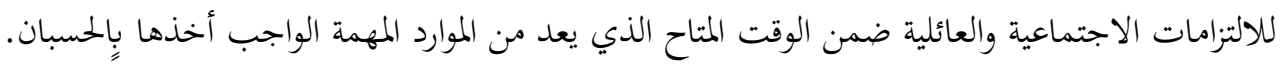

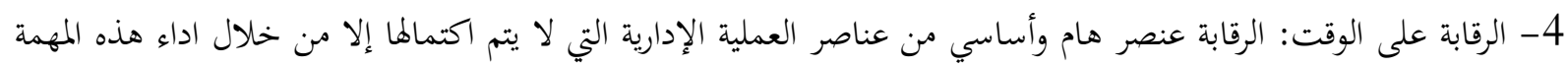
بشكل علمي وعملي، يؤدي إلى تحقيق مستوي كفؤ من الأداء.

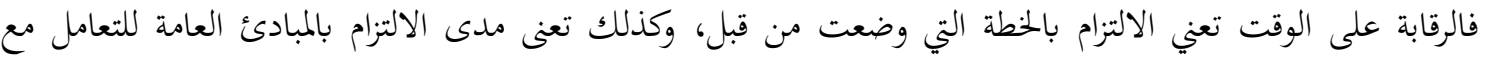

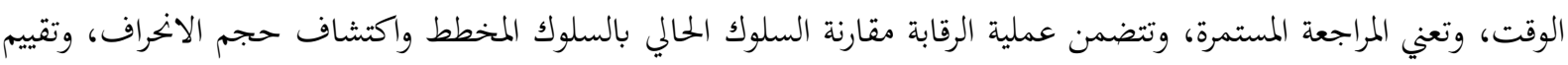

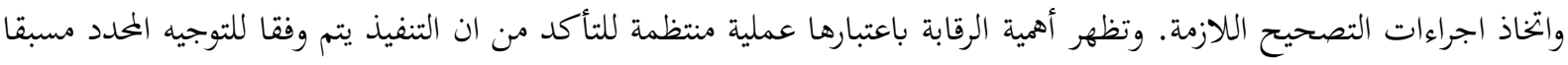

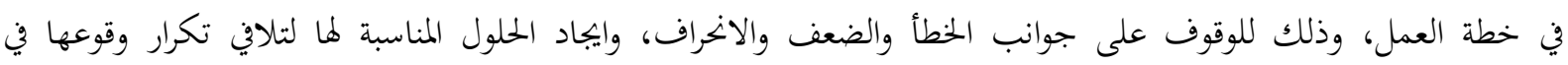


- معوقات تنظيم الوقت: تعرف معوقات تنظيم الوقت بأها نشاط غير ضروري يستغرق وقتا بطريقة غير ملائمة ولا يظهر منه

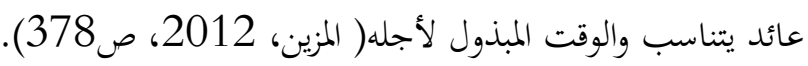

$$
\begin{aligned}
& \text { ومن أشكال هدر الوقت كما أوردها المزين ( 2012، ص378) كما يلي: }
\end{aligned}
$$

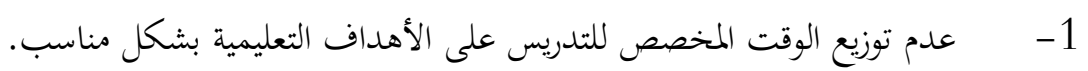

$$
\begin{aligned}
& \text { 2- - الوقت الضائع نتيجة كثافة الطلبة في تصحيح الكراسات وغيرها. } \\
& \text { 3- - الوقت الانتقالي بين القاعات الدراسية وايضا عند التحول من نشاط تعليم إلى نشاط تعليمي آخر. }
\end{aligned}
$$

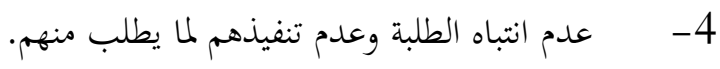

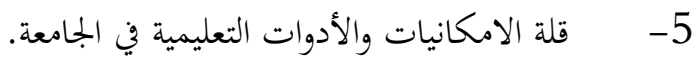

المبحث الثاني: التحصيل الدراسي

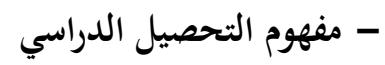

هو إتقان جملة من المهارات والمعارف التي يمكن أن يمتلكها الطالب بعد تعرضه لمجموعة من الخبرات التربوية في مادة

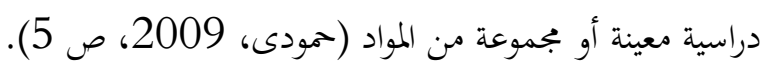

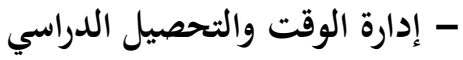

أشارت خلفان (2011، ص62) ان اختلاف الطلاب في تنظيمهم للزمن المتاح على المواد الدراسية والأنشطة الإدارية والفنية المختلفة، سوف يترتب عليه تفاوت التحصيل العلمي للطلاب واختلافهم في خبراتم بالمنهج التعليمي. وأوضحت بأنه من

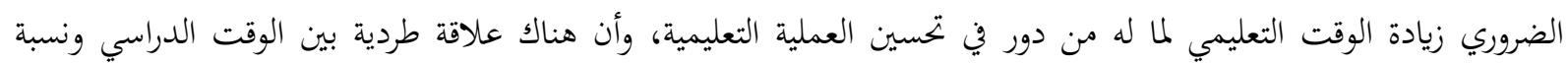
الحضور، وأن هناك علاقة عكسية بين الوقت المدرسي ونسبة التسرب.

\section{المبحث الثالث: امعة الزعيم الأزهري \\ - نبذة تاريخية:}

التعليم الأساسي:يقصد بالتعليم الأساسي القدر الضروري للتعليم والمعارف والقدرات الذهنية والقيم والمهارات الأساسية

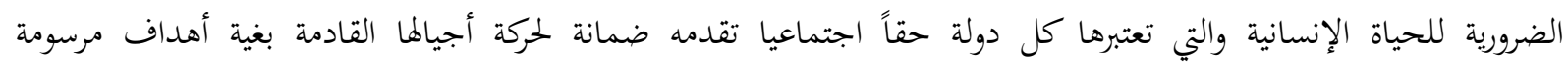

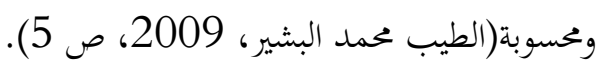

ويتبلور الطموح للنهضة في الوطن العربي في بجال بناء رأس المال البشري راقي النوعية، في غايات ثلاث (المؤتمر العالمي بجنيف، 2008، ص 36-37) وهي:

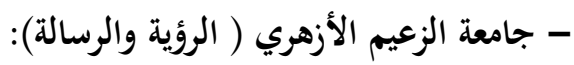
إن جامعة الزعيم الأزهري برؤيتها التي تتمثل في الريادة العلمية تميزا وانتماء ا لدعم مقومات النهضة القومية والانفتاح عالميا

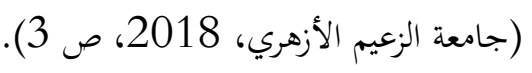

وأما رسالة جامعة الزعيم الأزهري تتمثل في تعزيز التحول لمجتمع المعرفة وقيم التعاون والتعاضد العلمي بكادي مادر مبدع وخريج

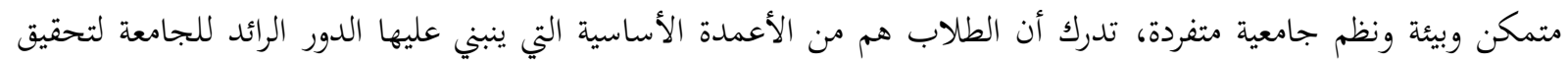

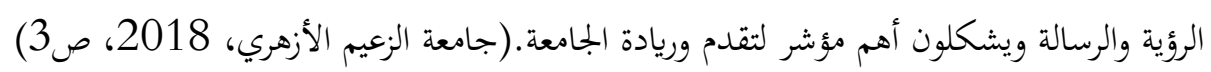




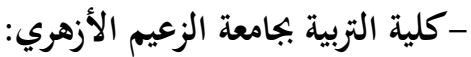

هي واحدة من كليات جامعة الزعيم الأزهري، انشئت عام 1993، وبدأت في استقبال أول دفعة من الطلاب عام

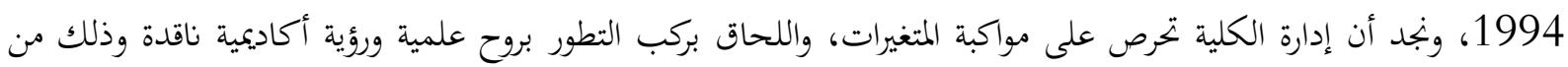

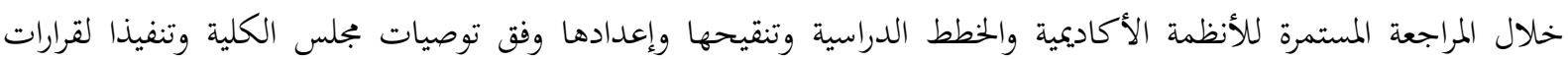

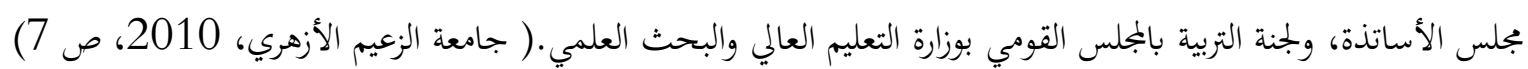
- الدراسات السابقة فيما يتعلق بالدراسات السابقة، لم بحد الباحثة الكثير من الدراسات المحلية، لذلك سوف نستعرض الدراسات العربية

عنوان الدراسة:إدارة الوقت وعلاقته بالدافعية للإنجاز والتحصيل لدى طلاب كلية الاقتصاد المنزلي، حيث بينت النتائج تفوق الطلاب على الطالبات في إدارة الوقت، كما بينت الدراسة تفوق طلاب السنة الثانية على طلاب السنة الأولى الذين درسوا

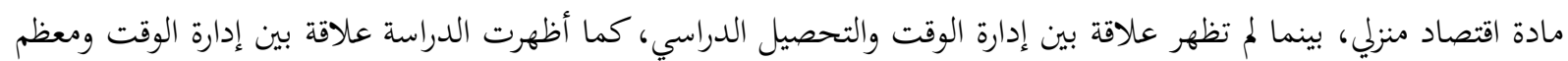
أبعاد دافعية الانجاز وهي: المثابرة، قلق التحصيل، المنافسة، التحكم في البيئة، احترام الذات والتوجه نهو المهيل المستقبل. 2-2005 2005):

بعنوان: مستويات إدارة الوقت لدى طالبات جامعة قطر وتخصهن الجامعي في علاقتها بالتحصيل الأكاديمي والرضا عن الحياة، حيث تكونت عينة الدراسة من (759) طالبة من كليات (التربية، الانسانيات، العلوم، الشريعة والاقتصاد) وقد بينت الدراسة عدم وجود فروق دالة احصائيا بين التخصص الأكاديمي ومستويات إدارة الوقت، كما بينت وجود فروق دالة الة احصائيا بين

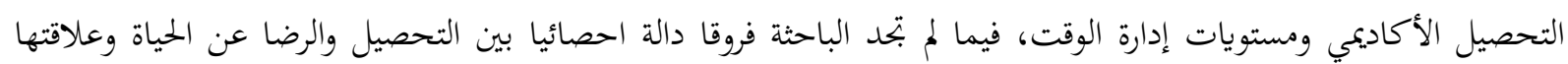
بمستويات إدارة الوقت. 3- 3 دراسة عبد العال (2009):

عنوان الدراسة:فاعلية إدارة الوقت لدى طلاب كلية المعلمين بحائل بالمملكة العربية السعودية وعلاقته بالتحصيل، هدفت

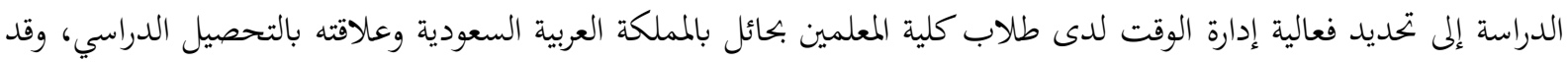

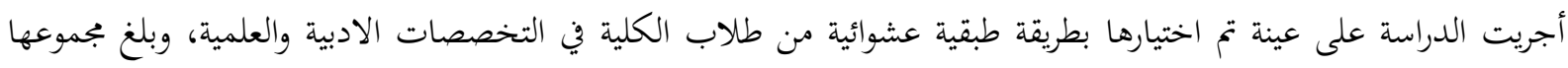

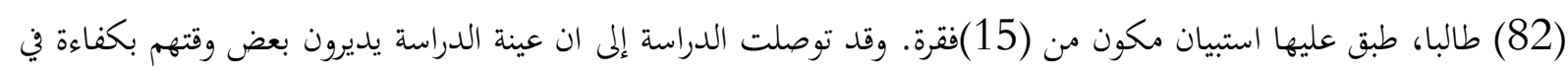

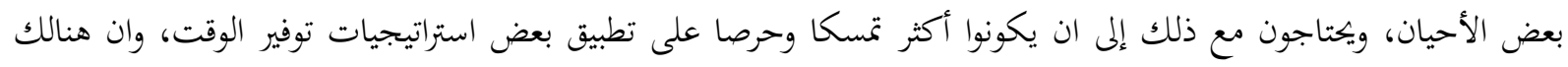
علاقة ارتباطية بين إدارة الوقت وبين التحصيل الدراسي، فكلما ارتفعت فعالية إدارة الوقت ارتفع معها التحصيل الدراسي. بعضي.

ثانيا: الدراسات الأجنبية

1- 1 دراسة اوغلو وفيلز (2008)

عنوان الدراسة:العلاقة بين إدارة الوقت والتحصيل الأكاديمي للطلبة الذين يدرسون في كليات التربية في جامعة غازي تركيا. بينت الدراسة ان سلوك الطالب في مجال تخطيط الوقت كان على مستوي عال، وفي مجال مضيعات الوقت كان في ادني 
مستوياته، كما ان نجاح الطلبة كان فوق المعدل، كما أظهرت الدراسة ان هناك علاقة ايجابية ذات دلالة بين تخطيط الوقت ومضيعات الوقت بين التحصيل الأكاديمي للطلبة، وهناك علاقة متوسطة ذات معنى بين إدارة الوقت والتحصيل الأكاديمي. كما

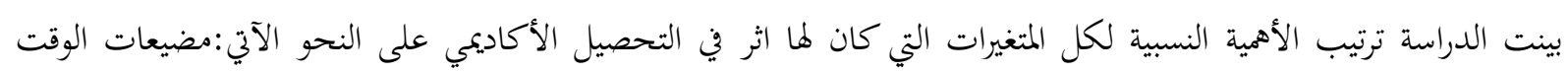
وتخطيط الوقت، والابحاه نحو الوقت.

2-2012 دراسة دانلنجر (2012)

عنوان الدراسة: اثر إدارة الوقت في التحصيل لدي الطلاب الجامعيين -الولايات المتحدة الامريكية، هدفت الدراسة

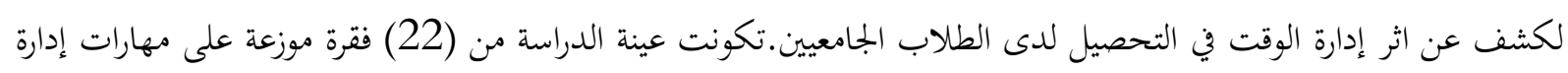
الوقت، وتنظيم الذات، وتم الحصول على علامات الطلاب من سجلاتم والحصول على تقارير اشراكهم في النشاطات

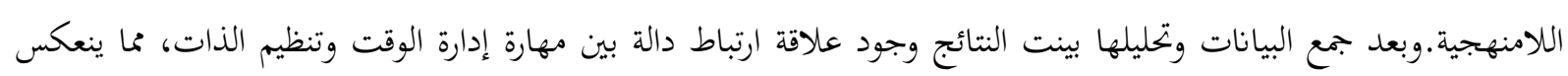

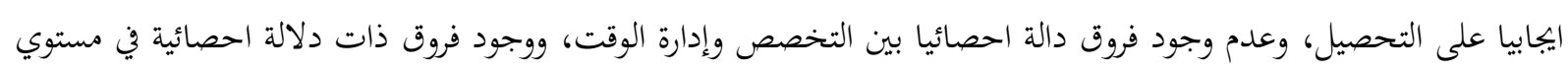

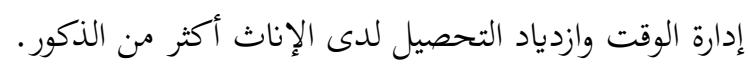

$$
\text { 3- دراسة دالي (2014) - دولة تركيا }
$$

عنوان الدراسة: مهارات إدارة الوقت لدى الطلبة الجامعيين على مستوى تحصيلهم الأكاديمي ورضاهم عن الحياة، هدفت

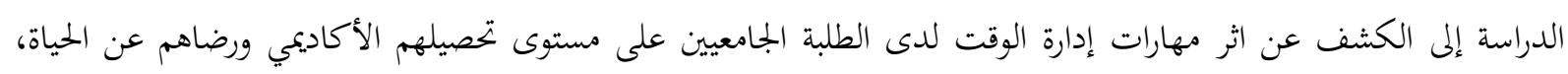

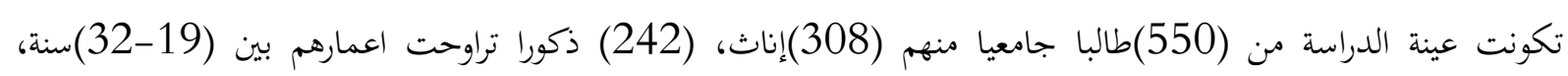

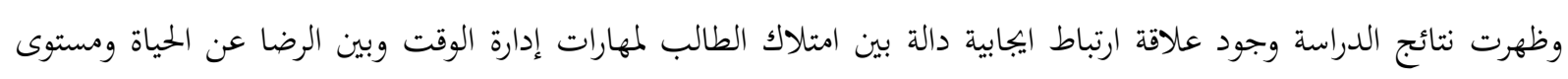

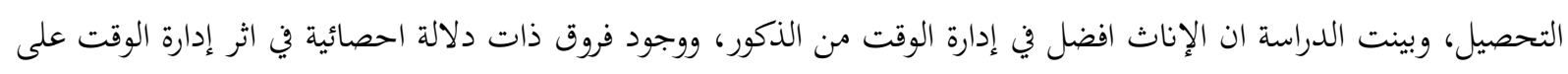
التحصيل والرضا عن الحياة لمن تزيد اعمارهم عن (26) سنة.

\section{التعليق على الدراسات السابقة:}

من خلال الدراسات السابقة لاحظت الباحثة أن معظم الدراسات تمثلت أهدافها في الكشف عن العلاقة بين إدارة

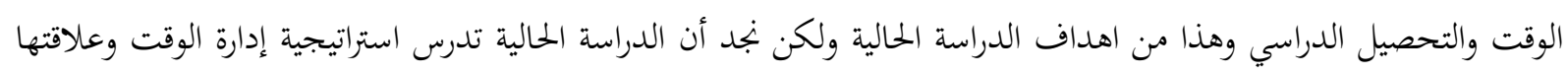

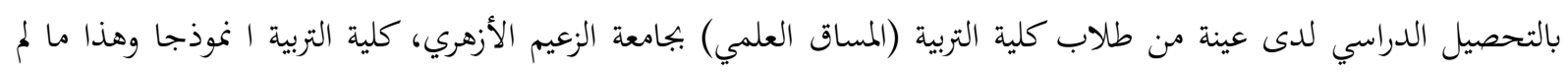

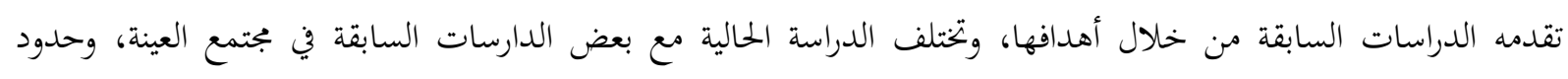
الدارسة والمنهج المستخدم، وقد استفادت الباحثة من الدارسات السابقة في إعداد الخطة، والاستبانة وفي كتابة الإطار النظري. 


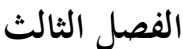

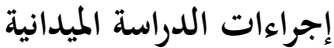

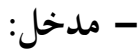

يشتمل هذا الفصل إجراءات الدراسة الميدانية التي أتبعتها الباحثة حيث تتناول المنهج وبجتمع الدراسة وعينتها وأداة

الدراسة و المعالجات الإحصائية.

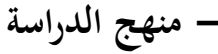

أتبعت الباحثة المنهج الوصفي التحليلي الذي يناسب هذا النوع من الدراسات، حيث قدف البحوث الوصفية إلى وصف ظواهر أو أحداث أو أشياء معينة وجمع الحقائق والمعلومات والملاحظات عنها ووصف الظروف الخاصة بها وتقرير حالتها كما

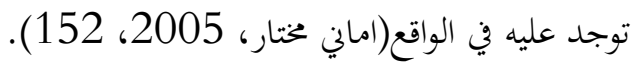

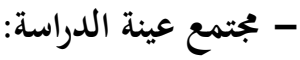

يتكون مجتمع الدراسة من طلاب المساق العلمي بكلية التربية بجامعة الزعيم الأزهري البالغ عددهم (572) طالب وطالبة، اما عينة الدراسة بلغ عددها (94) من طلاب المساق العلمي بكلية التربية بجامعة الزعيم الأزهري.

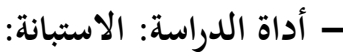

القسم الأول البيانات الشخصية للمفحوصين وقد كانت ( الجنس، التخصص، المعدل التراكمي، السكن)

$$
\text { القسم الثاني: محاور الاستبانة. }
$$

اختارت الباحثة الاستبانة المقيدة كوسيلة لجمع المعلومات من عينة الدراسة وهو نوع يسمح باختيار الإجابات المناسبة من

$$
\text { بين بدائل، مقياس لكرت الثلاثي. }
$$

\section{- - الخصائص السيكو مترية للمقياس:}

صدق الاتساق الداخلي مع الدرجة الكلية:: (Internal Validity):

قامت الباحثة بحساب معاملات ارتباط (بيرسون) Pearson correlation بين درجات كل بند من بنود الاستبانة والدرجة الكلية لمجموع الاستبانة الكلية، واتضح من هذا الإجراء أن جميع بنود الاستبانة لها معامل ارتباط موجب غير صفري بالدرجة الكلية، ما عدا البند رقم (8)والجدول التالي يوضح ذلك.

\begin{tabular}{|c|c|c|c|c|c|}
\hline معامل الارتباط & رقم & معامل الارتباط & رقم & معامل الارتباط & رقم \\
\hline 0.448 & 25 & 0.214 & 13 & 0.450 & 1 \\
\hline 0.525 & 26 & 0.471 & 14 & 0.402 & 2 \\
\hline 0.413 & 27 & 0.411 & 15 & 0.400 & 3 \\
\hline 0.273 & 28 & 0.256 & 16 & 0.573 & 4 \\
\hline 0.546 & 29 & 0.206 & 17 & 0.576 & 5 \\
\hline 0.353 & 30 & 0.344 & 18 & 0.125 & 6 \\
\hline 0.335 & 31 & 0.325 & 19 & 0.536 & 7 \\
\hline
\end{tabular}

جدول رقم (1) يوضح معامل ارتباط بيرسون بين درجة كل عبارة والدرجة الكلية لمحاور الاستبانة 


\begin{tabular}{|r|r|r|r|r|r|}
\hline 0.485 & 32 & 0.107 & 20 & 0.087 & 8 \\
\hline 0.223 & 33 & 0.257 & 21 & 0.235 & 9 \\
\hline 0.301 & 34 & 0.252 & 22 & 0456 & 10 \\
\hline 0.331 & 35 & 0.192 & 23 & 0.368 & 11 \\
\cline { 3 - 6 } & & 0.319 & 24 & 0.271 & 12 \\
\hline
\end{tabular}

يتضح من الجلدول السابق ان جميع بنود استبانة استراتيجية إدارة الوقت لدى طلاب كلية التربية بجامعة الزعيم الأزهري موجبة غير

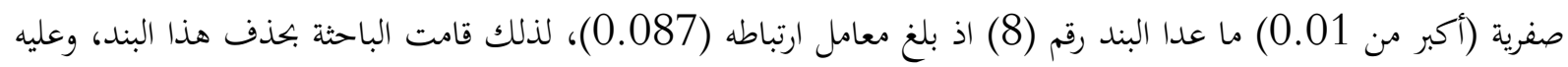

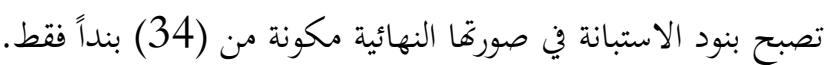
معامل الثبات:جدول رقم (2) يوضح معامل الثبات بطريقة الفاكروبناك والتجزئة النصفية لكل محور من محاور الاستبانة والاستبانة

\begin{tabular}{|c|c|c|c|c|}
\hline \multicolumn{2}{|r|}{ التجزئة النصفية } & معامل & عدد البنود & لمحور \\
\hline سبيرمان- & الارتباط بين & الفاكروبناك & & \\
\hline 0.612 & 0.441 & 0.707 & 9 & لتخطيط \\
\hline 0.510 & 0.342 & 0.623 & 10 & لتنظيم \\
\hline 0.618 & 0.447 & 0.510 & 5 & لتوجيه \\
\hline 0.633 & 0.463 & 0.660 & 5 & لتقويم \\
\hline 0502 & 0.329 & 0.566 & 5 & مضيعات الوقت \\
\hline 0.648 & 0.479 & 0.747 & 34 & لاستبانة الكلية \\
\hline
\end{tabular}

توصيف عينة الدراسة:

\begin{tabular}{|c|c|c|}
\hline النسبة المئوية ( \%) & التكرار & | الجنس \\
\hline$\% 28$ & 26 & ذكر \\
\hline$\% 72$ & 67 & أنثى \\
\hline$\% 100$ & 93 & المجموع \\
\hline
\end{tabular}

يتضح من الجدول أعلاه بأن عدد الإناث أكثر من الذكور حوالي 72 \% بينما الذكور يبلغ عددهم حوإلى 28\% من النسبة

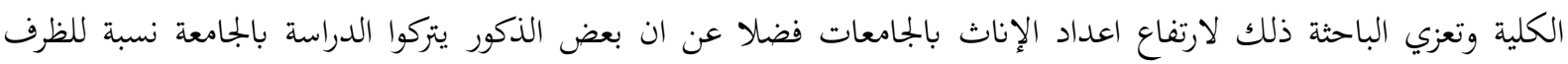
الاقتصادية والاجتماعية الضاغطة. 
جدول رقم ( 4) يوضح توزيع أفراد عينة الدراسة وفقا للتخصص الأكاديمي

\begin{tabular}{|c|c|c|}
\hline النسبة المئوية ( \%) & التكرار & المؤهل الأكاديمي \\
\hline$\% 15.1$ & 14 & فيزياء \\
\hline$\% 32.2$ & 30 & رياضيات \\
\hline$\% 23.7$ & 22 & كيمياء \\
\hline$\% 29$ & 27 & احياء \\
\hline$\% 100$ & 93 & المجموع \\
\hline
\end{tabular}

يتضح من الجدول أعلاه بأن طلاب قسم الرياضيات هم يشكلون اعلى نسبة حوالي 32.2\% من جملة طلاب أفراد عينة الدراسة

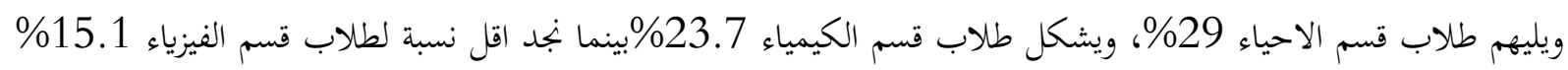
ويعزى ضعف هذه النسبة لرغبة الطلاب في تخصص في المواد التي يحتاجها سوق وقلئ العمل. جدول رقم (5) يوضح توزيع أفراد عينة الدراسة وفقا للمعدل التراكمي.

\begin{tabular}{|c|c|c|}
\hline النسبة المئوية ( \%) & التكرار & المعدل التراكمي \\
\hline$\% 9.7$ & 9 & من 22إلى اقل من 2.5 \\
\hline$\% 47.3$ & 44 & من 2.5إلى اقل من 3 \\
\hline$\% 43$ & 40 & 3 فأكثر \\
\hline$\% 100$ & 93 & المجموع \\
\hline
\end{tabular}

يتضح من الجدول اعلاه بأن حوالي 90.3\% من الطلاب معدلمم التراكمي يتراوح بين 2.5\%- وأكثر من 3\%ة \% بينما بلغت

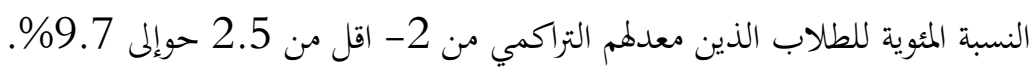
جدول رقم (6) يوضح توزيع أفراد عينة الدراسة وفقا للسكن

\begin{tabular}{|c|c|c|}
\hline النسبة المئوية ( \%) & التكرار & السكن \\
\hline$\% 35.5$ & 33 & دخلي \\
\hline$\% 64.5$ & 60 & خارجي \\
\hline$\% 100$ & 93 & المجموع \\
\hline
\end{tabular}

من الجدول أعلاه يتضح بأن معظم أفراد العينة 64.5 يسكنون سكنا خارجيا ويعزى ذلك لعدم توفر اماكن شاغرة بالنسبة ومعظمهم يأتي من خارج ولاية الخرطوم فيضطر بعضهم للسكن مع اقاركمم في أغلب الأحيان. 
الفصل الرابع (تحليل البيانات ومناقشة النتائج)

عرض ومناقشة نتيجة الفرض الأول: عرض نتيجة الفرض الأول:

للتحقق من صحة نتيجة الفرض الأول والذي ينص على انه ( توجد فروق ذات دلالة إحصائية في أبعاد استراتيجية إدارة

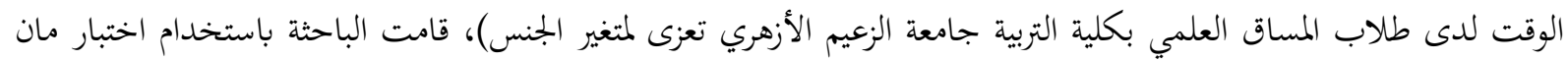
- وتني ( Mann- Whitney)، وأظهرت نتائج التحليل الاحصائي الجدول التالي.

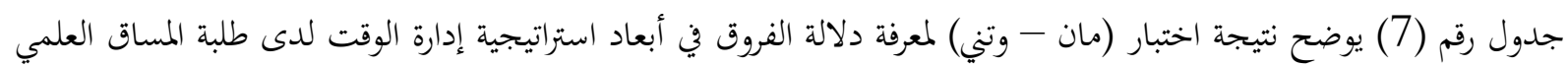
بكلية التربية جامعة الزعيم الأزهري والتي تعزى لمتغير الجنس.

\begin{tabular}{|c|c|c|c|c|c|c|c|}
\hline الاحتمالية & قلميمة (z) & قيمة المعلمة (u) & مجموع الرتب & متوسط & $\tau^{2}$ & المقارنة & أبعاد إستبانة إستبة الوقتية \\
\hline \multirow[t]{2}{*}{0.777} & \multirow[t]{2}{*}{0.284} & \multirow[t]{2}{*}{838.000} & 3182.00 & 47.49 & 67 & الإناث & \multirow[t]{2}{*}{ التخطيط } \\
\hline & & & 1189.00 & 45.73 & 26 & الذكور & \\
\hline \multirow[t]{2}{*}{0.012} & \multirow[t]{2}{*}{2.508} & \multirow[t]{2}{*}{579.500} & 3440.50 & 51.35 & 67 & الإناث & \multirow[t]{2}{*}{ التنظيم } \\
\hline & & & 930.50 & 35.79 & 26 & الذكور & \\
\hline \multirow[t]{2}{*}{0.009} & \multirow{2}{*}{2.598} & \multirow{2}{*}{571.000} & 3449.00 & 51.48 & 67 & الإناث & \multirow[t]{2}{*}{ التوجيه } \\
\hline & & & 922.00 & 35.46 & 26 & الذكور & \\
\hline \multirow[t]{2}{*}{0.204} & \multirow[t]{2}{*}{1.271} & \multirow[t]{2}{*}{724.500} & 3295.50 & 49.19 & 67 & الإناث & \multirow[t]{2}{*}{ التقويم } \\
\hline & & & 1075.50 & 41.37 & 26 & الذكور & \\
\hline \multirow[t]{2}{*}{0.005} & \multirow[t]{2}{*}{2.785} & \multirow[t]{2}{*}{550.000} & 2828.00 & 42.21 & 67 & الإناث & \multirow{2}{*}{ مضيعات } \\
\hline & & & 1543.00 & 59.35 & 26 & الذكور & \\
\hline \multirow[t]{2}{*}{0.108} & \multirow[t]{2}{*}{1.607} & \multirow[t]{2}{*}{683.500} & 3336.50 & 49.80 & 67 & الإناث & \multirow{2}{*}{ اللارجة اللية } \\
\hline & & & 1034.50 & 39.79 & 26 & الذكور & \\
\hline
\end{tabular}

من الجدول اعلاه يلاحظ في أبعاد استراتيجية إدارة الوقت لدى طلبة المساق العلمي بكلية التربية جامعة الزعيم الأزهري والتي تعزى لمتغير الجنس، كانت النتائج كالتالي: 1

بالنظر إلى الجدول أعلاه يلاحظ ان قيمة المعلمة (u) بلغت

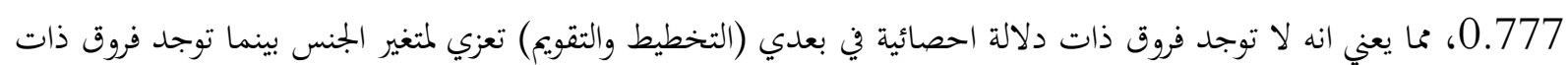
دلالة احصائية لبقية الأبعاد (التنظي، التوجيه، مضيعات الوقت) تعزى لمتغير الجنس. 2- 2حور التنظيم

بالنظر إلى الجدول أعلاه يلاحظ ان قيمة المعلمة (u) بلغت 0.012، مما يعني انه لا توجد فروق ذات دلالة احصائية في بعد التنظيم تعزي لمتغير الجنس. بينما توجد فروق ذات دلالة

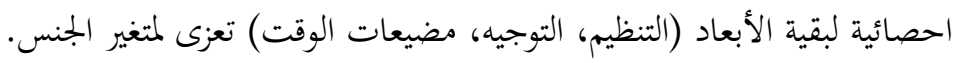




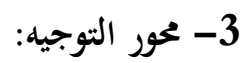

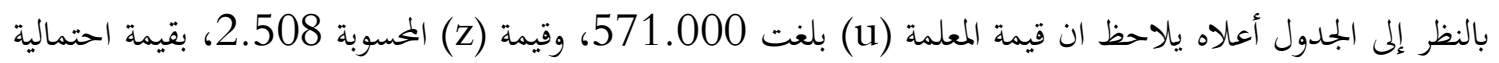
0.009، مما يعني انه توجد فروق ذات دلالة احصائية في بعد التنظيم تعزي لمتغير الجنس. 4- محور التقويم:

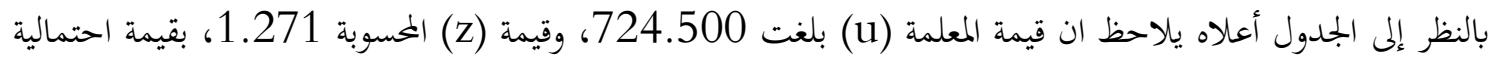
0.204، مما يعني انه لا توجد فروق ذات دلالة احصائية في بعد التقويم تعزي لمتغير الجنس.

5-مضيعات الوقت:

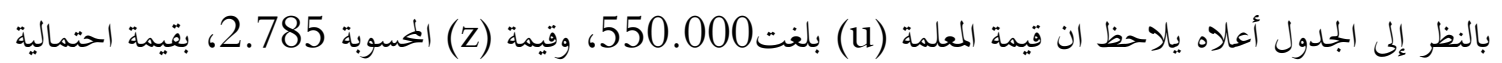

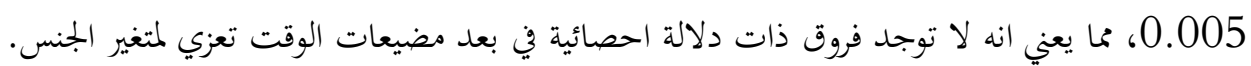

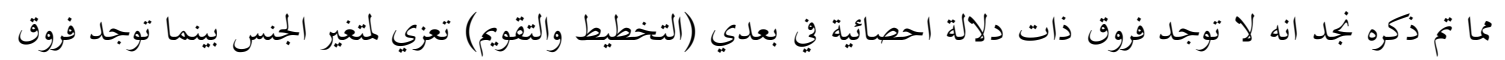
ذات دلالة احصائية لبقية الأبعاد (التنظيم، التوجيه، مضيعات الوقت) تعزى لمتغير الجنس، إلا أن الدرجة الكلية(السمة العامة)

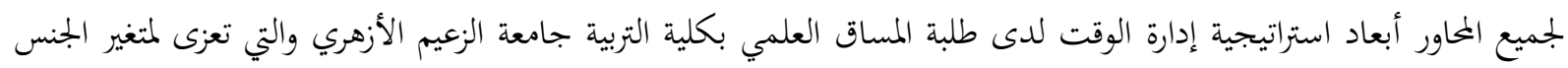

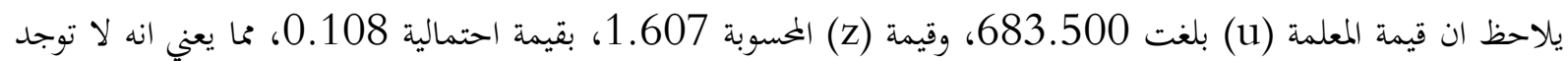
فروق ذات دلالة احصائية في تعزي لمتغير الجنس. عرض نتيجة الفرض الثاني: للتحقق من صحة نتيجة الفرض الثاني والذي ينص على انه ( توجد فروق ذات دلالة إحصائية في أبعاد استراتيجية إدارة

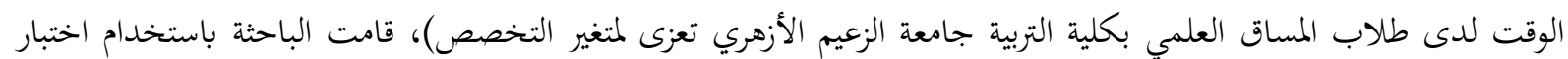
تحليل التباين الأحادي (ANOVA)، وأظهرت نتائج التحليل الاحصائي الجدول التالي. جدول رقم (8) يوضح نتيجة اختبار تحليل التباين الأحادي (ANOVA) لمعرفة دلالة الفروق في أبعاد استراتيجية إدارة الوقت لدى طلبة المساق العلمي بكلية التربية جامعة الزعيم الأزهري والتي تعزى لمتغير التخصص. جدول رقم (8) يوضح نتيجة اختبار تحليل التباين الأحادي (ANOVA) لمعرفة دلالة الفروق في أبعاد استراتيجية إدارة

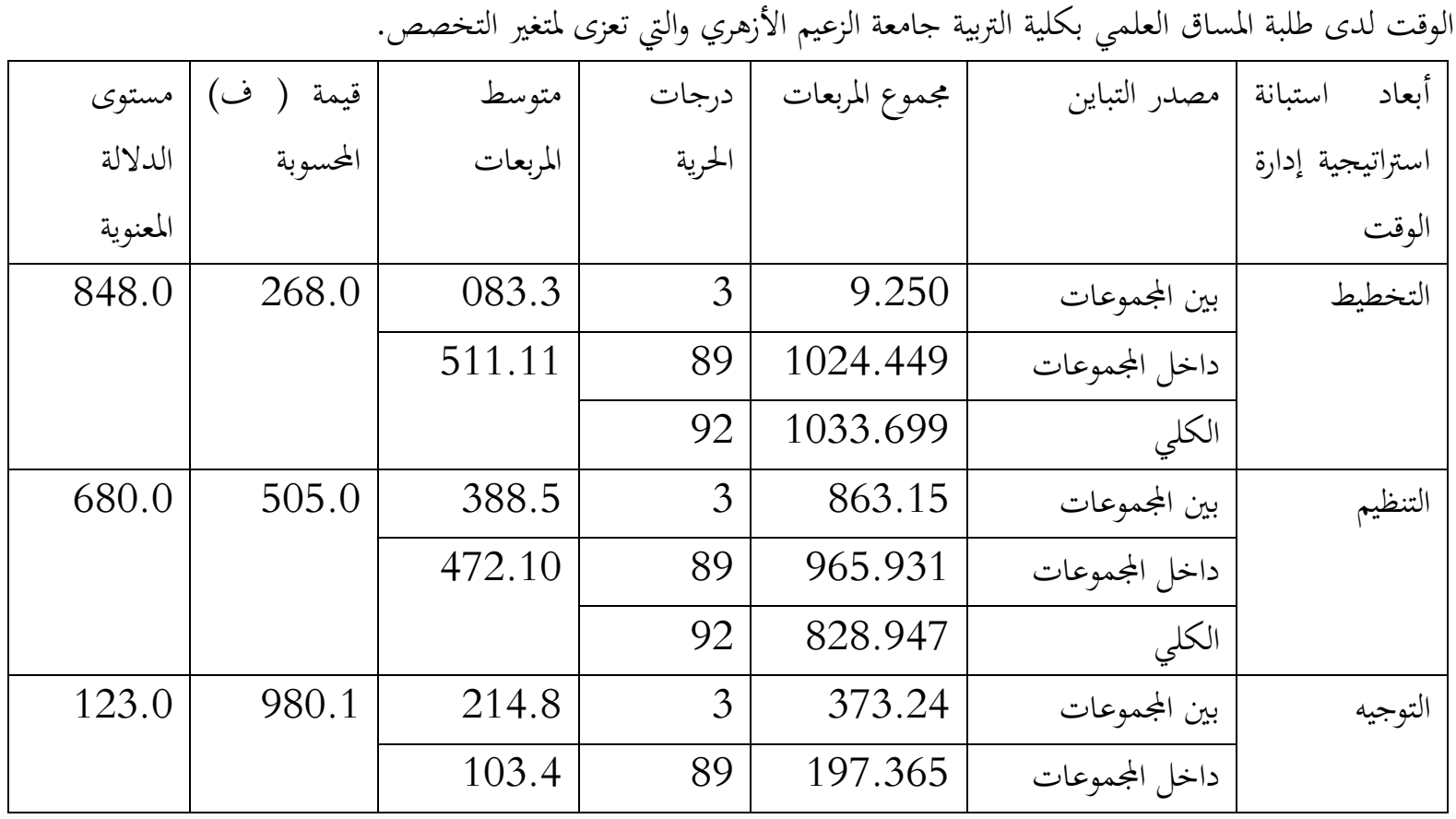




\begin{tabular}{|c|c|c|c|c|c|c|}
\hline & & & 92 & 570.389 & الكلي & \\
\hline \multirow[t]{3}{*}{434.0} & \multirow[t]{3}{*}{922.0} & 368.4 & 3 & 104.13 & بين المجموعات & \multirow{3}{*}{ التقويم } \\
\hline & & \multirow[t]{2}{*}{737.4} & 89 & 563.421 & داخل المجموعات & \\
\hline & & & 92 & 667.443 & الكلي & \\
\hline \multirow[t]{3}{*}{052.0} & \multirow{3}{*}{2678.0} & 678.10 & 3 & 034.32 & بين المجموعات & \multirow{3}{*}{ مضيعات } \\
\hline & & \multirow[t]{2}{*}{988.3} & 89 & 891.354 & داخل المجموعات & \\
\hline & & & 92 & 925.386 & الملي & \\
\hline \multirow[t]{3}{*}{369.0} & \multirow[t]{3}{*}{063.1} & 936.62 & 3 & 010.188 & بين المجموعات & \multirow{3}{*}{ للاستبانة الدرجة الكلية } \\
\hline & & \multirow[t]{2}{*}{936.58} & 89 & 034.5345 & داخل المجموعات & \\
\hline & & & 92 & 034.5433 & الكلي & \\
\hline
\end{tabular}

في أبعاد استراتيجية إدارة الوقت لدى طلبة المساق العلمي بكلية التربية جامعة الزعيم الأزهري والتي تعزى لمتغير التخصص،

كانت النتائج كالتالي:

1

بالنظر إلى الجدول أعلاه يلاحظ أن قيمة (ف) المحسوبة بلغت 268.0، بقيمة احتمالية، 848.0 مالما يعني عدم وجود فروق دالة احصائيا عند مستوى دلالة معنوية 0.05، في محور التخطيط لدى تعزى لمتغير التخصص.

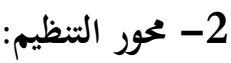

بالنظر إلى الجدول أعلاه يلاحظ أن قيمة (ف) المحسوبة بلغت 505.0، بقيمة احتمالية، 680.0 مالما يعني عدم وجود فروق دالة احصائيا عند مستوى دلالة معنوية 0.05، في محور التنظيم لدى تعزى لمتغير التخصص. 3- محور التوجيه: بالنظر إلى الجدول أعلاه يلاحظ أن قيمة (ف) المحسوبة بلغت 980.1، بقيمة احتمالية، 123.0 مما يعني عدم وجود فروق دالة احصائيا عند مستوى دلالة معنوية 0.05، في محور التوجيه لدى تعزى لمتغير التخصص.

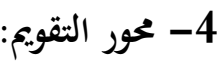

بالنظر إلى الجدول أعلاه يلاحظ أن قيمة (ف) المحسوبة بلغت 922.0، بقيمة احتمالية، 434.0 مما يعني عدم وجود

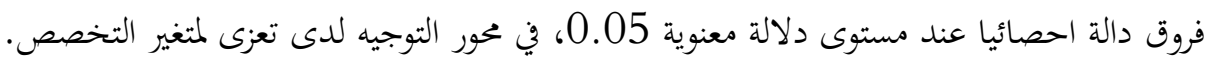
5 - 5حور مضيعات الوقت:

بالنظر إلى الجدول أعلاه يلاحظ أن قيمة (ف) المحسوبة بلغت 2678.0، بقيمة احتمالية،

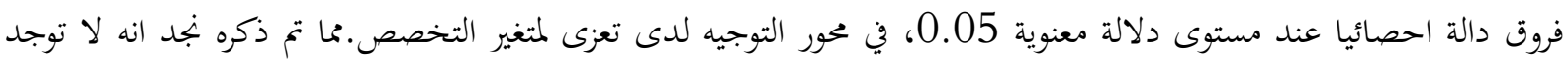
فروق ذات دلالة احصائية تعزي لمتغير التخصص، إلا أن الدرجة الكلية(لجميع المحاور) أبعاد استراتيجية إدارة الوقت لدى طلبية المساق العلمي بكلية التربية جامعة الزعيم الأزهري والتي تعزى لمتغير التخصص يلاحظ ان قيمة(ف)الخسوبة بلغت

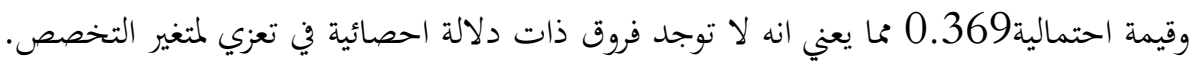




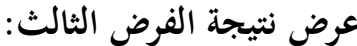

للتحقق من صحة نتيجة الفرض الثالث والذي ينص على انه ( توجد فروق ذات دلالة إحصائية في أبعاد استراتيجية

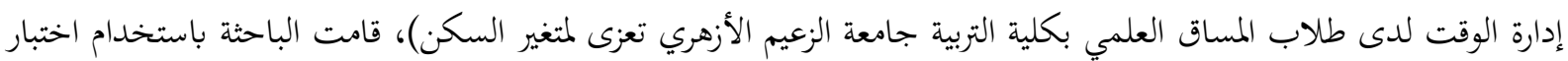
(ت) لمتوسط مجموعتين مستقلتين (، وأظهرت نتائج التحليل الاحصائي الجدول التالي.

جدول رقم (9) يوضح نتيجة اختبار (ت) لمتوسط مجموعتين مستقلتين لمعرفة دلالة الفروق في أبعاد استراتيجية إدارة الوقت لدى

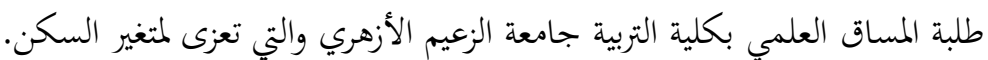

\begin{tabular}{|c|c|c|c|c|c|c|}
\hline مستوى الدلالة & المحسوبة $\quad$ (ت) & درجات الحرية & الانحراف & |الوسطابي & مجموعتا المقارنة & أبعاد إستراتيجة البتبانة \\
\hline \multirow[t]{2}{*}{0.277} & \multirow[t]{2}{*}{1.094} & \multirow[t]{2}{*}{91} & 3.23335 & 20.2727 & داخلي & \multirow[t]{2}{*}{ التخطيط } \\
\hline & & & 3.40919 & 21.0667 & خارجي & \\
\hline \multirow[t]{2}{*}{0.708} & \multirow[t]{2}{*}{0.375} & \multirow[t]{2}{*}{91} & 3.51566 & 23.2121 & داخلي & \multirow[t]{2}{*}{ التنظيم } \\
\hline & & & 3.0556 & 22.9500 & خارجي & \\
\hline \multirow[t]{2}{*}{0.759} & \multirow[t]{2}{*}{0.308} & \multirow[t]{2}{*}{91} & 2.01697 & 11.5455 & داخلي & \multirow[t]{2}{*}{ التوجيه } \\
\hline & & & 2.09512 & 11.6833 & خارجي & \\
\hline \multirow[t]{2}{*}{0.767} & \multirow[t]{2}{*}{0.298} & \multirow[t]{2}{*}{91} & 2.00047 & 11.2424 & داخلي & \multirow{2}{*}{ التقويم } \\
\hline & & & 2.27806 & 11.3833 & خارجي & \\
\hline \multirow[t]{2}{*}{0.879} & \multirow[t]{2}{*}{0.153} & \multirow[t]{2}{*}{91} & 2.06339 & 7.5152 & داخلي & \multirow{2}{*}{ مضيعات } \\
\hline & & & 2.06087 & 7.5833 & خارجي & \\
\hline \multirow[t]{2}{*}{0.600} & \multirow[t]{2}{*}{0.526} & \multirow[t]{2}{*}{91} & 7.70048 & 73.7879 & داخلي & \multirow{2}{*}{ للاستبانة الدرجة الكلية } \\
\hline & & & 7.72332 & 74.667 & خارجي & \\
\hline
\end{tabular}

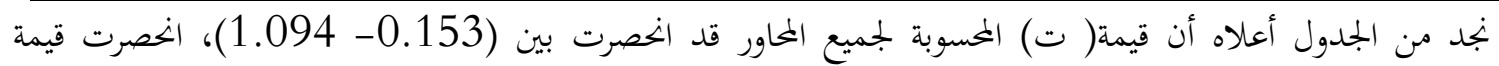

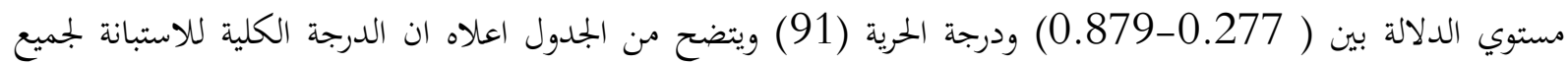
محاورها قيمة ت المحسوبة(0.526) وقيمة مستوى دلالة (0.600) مما يعني عدم وجود فروق دالة احصائيا عند مستوى دلالة معنوية 0.05، في محاور استبانة استراتيجية إدارة الوقت بأبعادها المختلفة ( التخطيط، التنظيم، التوجيه، التقويم ومضيعات الوقت) تعزى لمتغير السكن. عرض ننيجة الفرض الرابع:

للتحقق من صحة نتيجة الفرض الرابع والذي ينص على أنه ( توجد علاقة ارتباطية طردية " موجبة) بين أبعاد استراتيجية

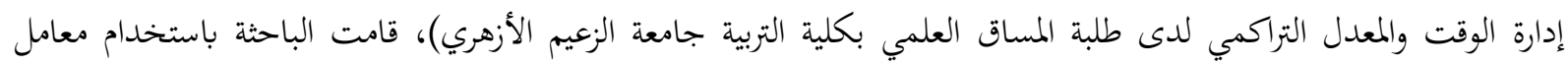
ارتباط بيرسون، وأظهرت نتائج التحليل الإحصائي جدول رقم (10) ما يأتي:

\begin{tabular}{|c|c|c|c|}
\hline مستوى الدلالة & درجات الحرية & قالتراكمة معامل ارتباط بيرسون مع المعدل & 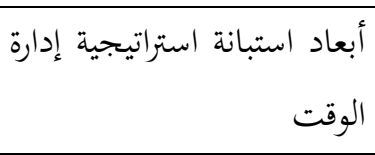 \\
\hline 0.01 & 93 & $0.418^{* * *}$ & التخطيط \\
\hline
\end{tabular}




\begin{tabular}{|c|c|c|c|}
\hline 0.05 & 93 & $0.209^{*}$ & التنظيم \\
\hline 0.05 & 93 & $0.248^{*}$ & التوجيه \\
\hline 0.05 & 93 & $0.265^{*}$ & التقويم \\
\hline
\end{tabular}

يتضح من الجدول اعلاه لا بعاد استراتيجية إدارة الوقت في بعد التخطيط قيمة معامل ارتباط بيرسون والمعدل التراكمي (01)

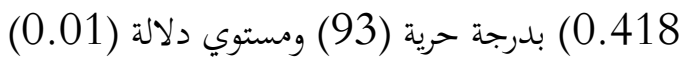

أما في بعد التنظيم قيمة معامل ارتباط بيرسون والمعدل التراكمي ( 0.209) بدرجة حرية (93) ومستوي دلالة (0.05))، وفي بعد التوجيه قيمة معامل ارتباط بيرسون والمعدل التراكمي (

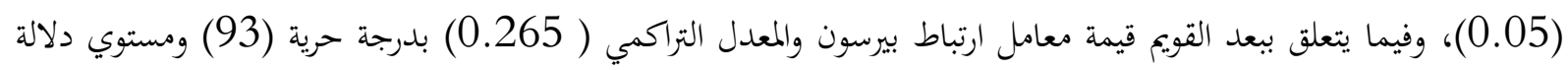

ومما سبق ذكره يتضح ان هنالك علاقة ارتباطية طردية موجبة بين أبعاد استراتيجية إدارة الوقت (التخطيط، التنظيم، التوجيه، التقويم) لدى طلبة المساق العلمي بكلية التربية بجامعة الزعيم الأزهري والمعدل التراكمي.

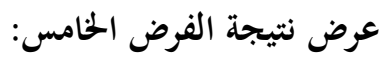

للتحقق من صحة نتيجة الفرض الخامس والذي ينص على أنه ( توجد علاقة ارتباطية عكسية " سلبية) بين مضيعات

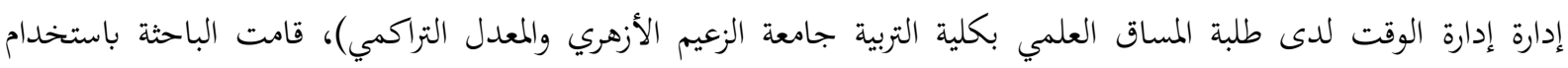
معامل ارتباط بيرسون، وأظهرت نتائج التحليل الإحصائي الجدول التالي. جدول رقم (11) يوضح نتيجة معامل الارتباط العزمي لبيرسون لمعرفة دلالة العلاقة الارتباطية بين مضيعات إدارة الوقت لدى

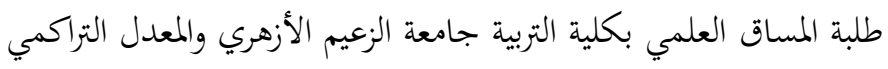

\begin{tabular}{|c|c|c|c|}
\hline مستوى الدلالة & درجات الحرية & قيمة معامل ارتباط بيرسون مع المعدل & 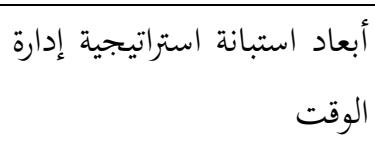 \\
\hline 0.01 & 93 & 0.499 ***_ & مضيعات إدارة الوقت \\
\hline
\end{tabular}

أظهر معامل ارتباط بيرسون وجود علاقة ارتباطية فيما بين المعدل التراكمي و مضيعات الوقت حيث بلغت قيمة معامل معامل

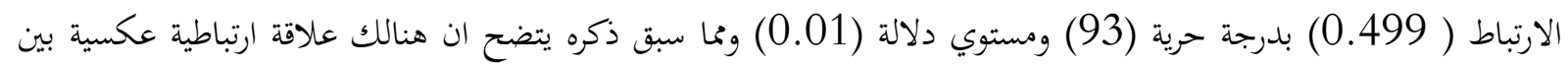

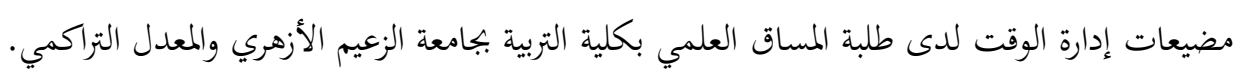
عرض نتيجة الفرض السادس: للتحقق من صحة نتيجة الرفض السادس والذي ينص على أنه ( توجد فروق ذات دلالة إحصائية في المعدل التراكمي لدى طلبة

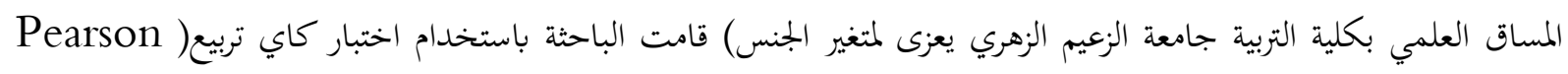
Chi- Square جدول رقم (12) يوضح نتيجة اختبار مربع كاي لمعرفة دلالة الفروق في المعدل التراكمي لدى طلبة المساق العلمي بكلية التربية جامعة الزعيم يعزى لمتغير الجنس.

\begin{tabular}{|c|c|c|c|c|c|c|}
\hline \multirow[t]{2}{*}{ مستوى الدلالة } & \multirow[t]{2}{*}{ درجة الحرية } & \multirow{2}{*}{ كاي } & \multicolumn{3}{|c|}{ الجنس } & \multirow[t]{2}{*}{ المعدل التراكمي } \\
\hline & & & المجموع & انتى & ذكر & \\
\hline 0.043 & 93 & 4.208 & 9 & 5 & 4 & 2 وأقل من 2.5 \\
\hline
\end{tabular}


Rimak International Journal of Humanities and Social Sciences

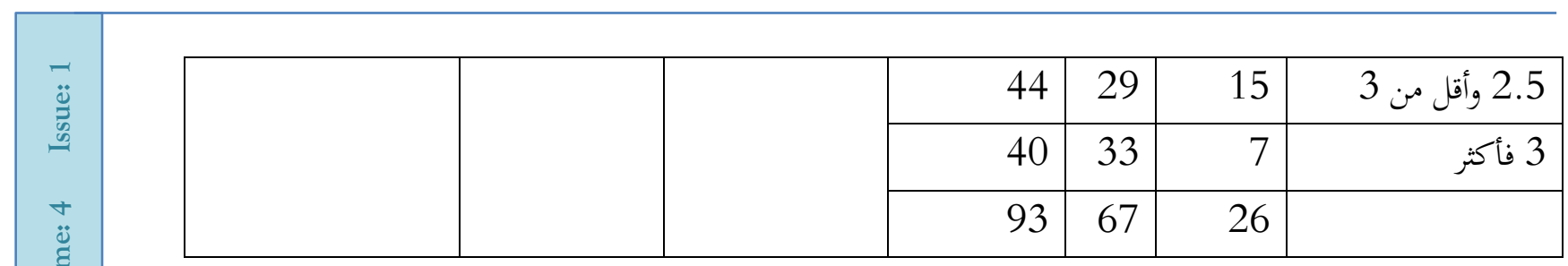

نلاحظ من الجدول أعلاه ان قيمة كا2 المحسوبة المقدرة (4.208)، بدرجة حرية (93)عند مستوى دلالة (0.043)

توضح بان هنالك فروق ذات دلالة احصائية في المعدل التراكمي لدي طلبة المساق العلمي بكلية التربية تعزى لمتغير الجنس. 


\section{الفصل الخامس \\ النتائج والثوصيات}

استناداً على نتائج تحليل البيانات في الفصل السابق تعرض الباحثة أهم النتائج التي توصلت إليها الدراسة، والتي على

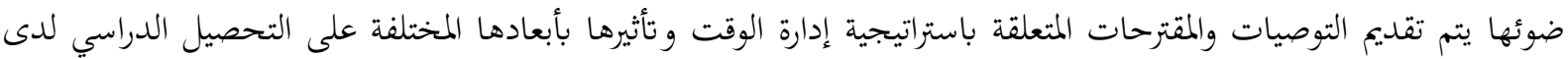
طلاب كلية التربية بجامعة الزعيم الأزهري. وتتلخص أهم النتائج في هذه الدراسة فيما يلي: 1- لا توجد فروق ذات دلالة احصائية لدى طلاب بكلية التربية تعزي لمتغير الجنس. 2- لا توجد فروق ذات دلالة احصائية لدى طلاب كلية التربية تعزى لمتغير السكن.

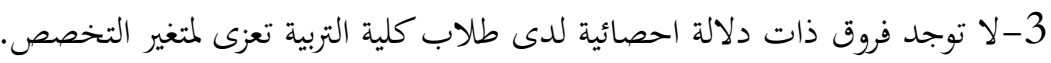

4- توجدعلاقة ارتباطية طردية موجبة بين أبعاد استراتيجية إدارة الوقت (التخطيط، التنظيم، التوجيه، التقويم) والمعدل التراكمي لتولئي

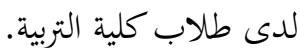

5- توجد علاقة ارتباطية عكسية سلبية بين مضيعات إدارة الوقت لدى طلاب المساق العلمي بكلية التربية والمعدل التراكمي. 6- فروق ذات دلالة احصائية في المعدل التراكمي لدي طلبة المساق العلمي بكلية التربية تعزى لمتغير الجنس. من خلال ما توصلت إليه الباحثة من نتائج قد أوصت بما يأتي: 1-ضرورة عقد ورش تدريبية للطلاب حول أهمية الوقت في حياة الطالب الأكاديمية والاجتماعية بجامعة الزعيم الأزهري. 2-ادخال مقرر دراسي بجميع مراحل التعليم العام والعالي يختص بإدارة الوقت واستراتيجياته.

3- تطوير مهارات استثمار الوقت، لزيادة التحصيل الدراسي لدى طلاب المساق العلمي بكلية التربية بجامعة الزعيم الأزهري.

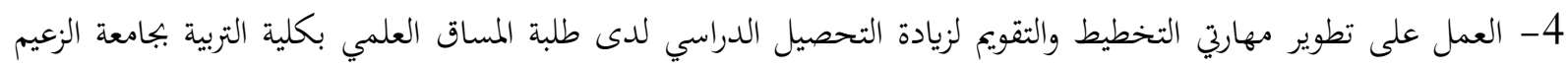
الأزهري. 


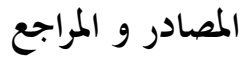 \\ أولاً: المراجع العربية}

أبو دنيا، نادية (2003)، أثر كل من التحصيل الأكاديمي وبعض خصائص الشخصية على تنظيم الوقت ودقة تقدير الأداء

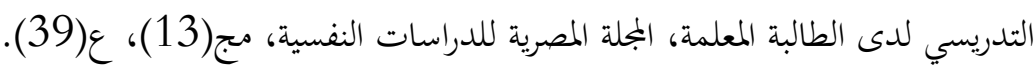

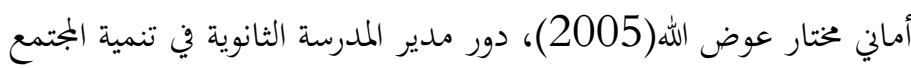

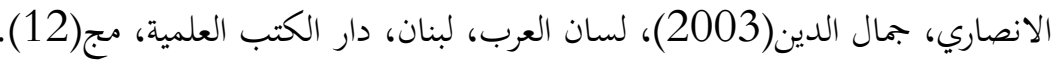

جامعة الزعيم الأزهري(2010)، منهج كلية التربية:خطة كلية التربية بكالوريوس الشرف، السودان، شركة مطابع السودان للعملة

$$
\text { المحدودة. }
$$

جامعة الزعيم الأزهري(2019)، أمانة الشؤون العلمية:دليل الطالب، السودان، دار جامعة الزعيم الأزهري للنشر.

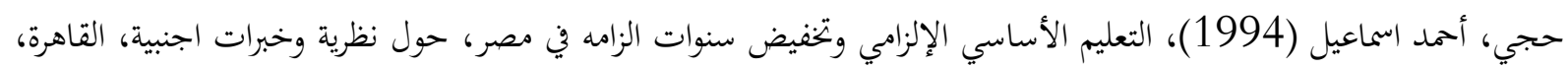

$$
\text { النهضة المصرية. }
$$

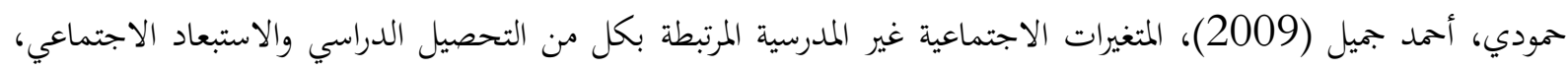

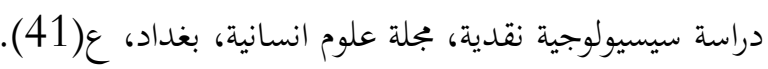

خلفان، فوزية(2011)، فاعلية برنامج ارشادي جمعي في تحسين مهارة تنظيم الوقت ورفع مستوى التحصيل لدى طلبة كلية العلوم

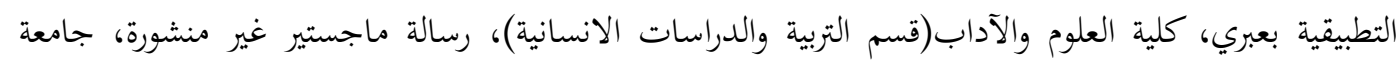

نزوى، سلطنة عمان.

خليل، نبيل سعد (1996)، فعالية إدارة الوقت من وجهة نظر مديري/ نظار مدارس التعليم العام: دراسة تحليلية ميدانية بمحافظة

$$
\text { سوهاج، كلية التربية بسوهاج، مصر. }
$$

الرحيمي، سالم و الماردينى، توفيق(2014)، أثر إدارة الوقت في التحصيل الأكاديمي للطلبة بجامعة إربد الأهلية (دراسة ميدانية

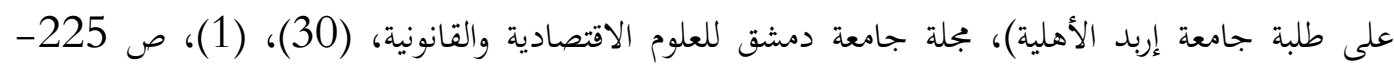

ص255.

سلامة، سهيل فهد (1988)، إدارة الوقت (منهج متطور للنجاح)، المنظمة العربية للعلوم والادارية، عمان، الأردن.

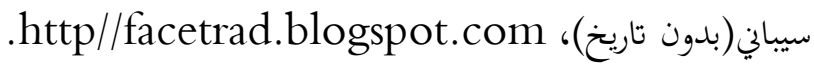
السيوف، أحمد علي (2014)، استراتيجيات إدارة الوقت لدى طلبة كلية العلوم التربوية في الجامعة الاردنية، مجلة دراسات العلوم

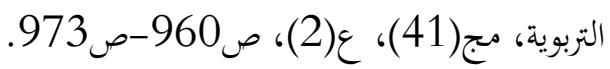

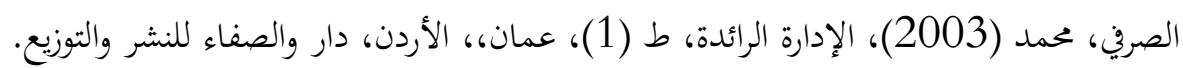

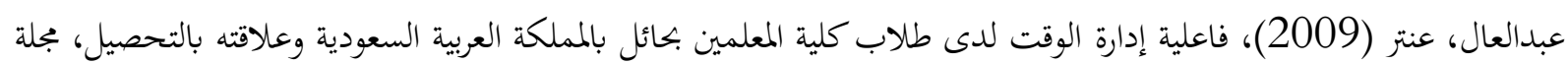

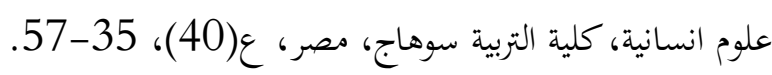

فخرو، حصة عبدالرحمن (2005)، مستويات إدارة الوقت لدى طالبات جامعة قطر وتخصصهن الجامعي في علاقتهما بالتحصيل

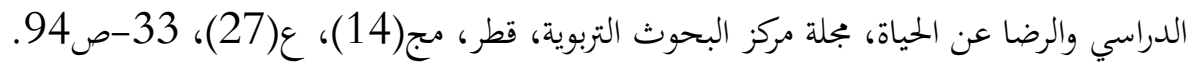

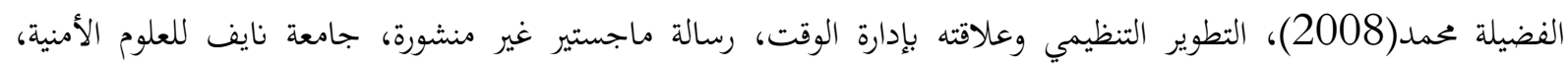

المحلي من وجهة نظر المعلمين وأولياء الأمور،، رسالة دكتوراه غير منشورة، كلية التربية، جامعة الزعيم الأزهري، الخرطوم. 
مراد، فاطمة(1995)، العوامل المؤثرة في إدارة الوقت لدى الادارات الوسطى في القطاع الاردني، رسالة ماجستير غير منشورة، جامعة اليرموك، اربد، الأردن.

المزين، سليمان حسن (2012)، فاعلية إدارة الوقت لدى طلبة الجامعة الإسلامية وعلاقتها بالتحصيل في ضوء بعض المتغيرات،

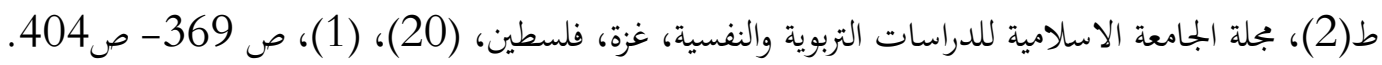

المومني، خالد (2017)، فاعلية إدارة الوقت لدى طلبة كلية العلوم في الجامعة الهاشمية وعلاقتها بالتحصيل الأكاديمي، مجلة المنار،

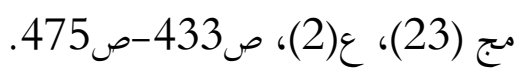

نامق، صابر نيان، (2015)، إدارة الوقت لدى طلبة الجامعة وعلاقته ببعض المتغيرات، مجلة أما راباك، مج(6)، ع(17)،

$$
\begin{aligned}
& \text { ص33- صاك } 50 . \\
& \text { ثانياً: المراجع الإنجليزية: }
\end{aligned}
$$

Cemaloglu ،Necati \& Filiz.(1996). The Relation Between Time management Skills and Academic Achievement Of Potential Teachers ،G a z I University ،Educational research Quarterly ،Vo 1(33)، (4) 3-23.

D alli ،M.(20014). The University students time management skills in terms of their academic satisfaction and academic achievement Levels. Education Review Journal ، ، 1090-1096.

D enlinger J.(2012). The Effects of management on college students academic Performance.PHD Dissertation ،Ball University ،USA. 


\title{
THE INVESTIGATION OF "DİĞENIS AND AZRAIL" AND "DUHA KOCA OĞLU DELI DUMRUL” IN CONTEXT OF INTERCULTURAL INTERACTION
}

\author{
Şentaç ARI ${ }^{1}$
}

\section{Istanbul / Türkiye \\ p. $174-183$}

Received: 02/12/2021

Accepted: 09/12/2021

Published: 01/01/2022

This article has been scanned k iThenticat No plagiarism detected

\begin{abstract}
:
Epics are the oldest products in the world. They are passed down from generation to generation. They allow us to detect cultural exchanges. In the study, the works of "Digenis and Azrael" and "Duha Kocaoğlu Deli Dumrul" were compared. The work focused on common cultural elements. Anonymous epic called "Digenis and Azrael" was translated from Dimotiki Greek into Turkish. Both works were analyzed in a holistic way with content analysis method.

There are religious elements in both works. Belief in the existence and oneness of God is emphasized. In both works, the protagonists are famous for their beatings. They both fought with the Azrael who came to take their lives. In the end, they accepted God's will and accepted death. In both works, there is a grandfather who is defined as a wise person and he comments on the hero.

The differences in the works are as follows: Azrâil wants to take Digenis' life because the time has come. He wants to take Deli Dumrul's life because he is suspicious of God's unity and power. Azrâil, who is a strong character in Deli Dumrul, bows to the power of Digenis in Digenis. Deli Dumrul's mother does not want to give her life for her son. Azrael's mother advises Azrael not to take anyone's life. In both works, the inability to accept death in the universal human thought and the desire to change the result are handled.
\end{abstract}

Key words: Dede Korkut Stories, Duha Kocaoğlu Deli Dumrul, Digenis and Azrael. 


\section{DİĞENİS İLE AZRAIIL” VE “DUHA KOCA OĞLU DELİ DUMRUL” UN" KÜLTÜRLERARASI ETKILLEŞIM BAĞLAMINDA İNCELENMESİ}

\section{ÖZET}

Destanlar, bütün dünyanın en eski ürünleri olarak kabul edilmektedir. Anlatıcıların dilinde, halkın gözüyle yorumlanırlar ve farklı kültürlerin iç içe geçmiş yapı taşlarını birbirine ularlar. Bu nedenle destanlar, bir milleti millet yapan unsurları barındırırken kültür alışverişlerini de tespit etmemize olanak sağlarlar. Çalışmada, MS 8. yüzyılda yaşadığı düşünülen Diğenis'in yaşantısından bir kesiti anlatan Kıbrıs destanı "Diğenis ile Azrail" ve İ.S.15. yüzyılda yazıya geçirildiği tahmin edilen Dede Korkut hikâyelerinden "Duha Koca Oğlu Deli Dumrul" arasındaki benzerlikler ve farklılıklar ele alınmıştır. "Diğenis ile Azrail" adlı anonim destan Dimotiki Rumcasından Türkçeye aslına uygun olarak çevrilmiştir. Her iki eser de içerik analizi yöntemiyle bütünlüklü olarak incelenmiştir. İçerik analizi, birbirine benzeyen verileri belirli kavramlar ve temalar çerçevesinde bir araya getirmeyi ve bunları okuyucunun anlayabileceği şekilde düzenleyerek yorumlamayı amaçlar. Eserlerin içeriği, olayların kurgulanış1, olayların gelişiminde etken olan unsurlar olarak iki ana başlik altında sınıflandırılarak analiz edilmiştir.

Eserlerin ikisinde de dinî unsurlar yer almakta; Tanrının varlığına ve birliğine yönelik inanç vurgulanmaktadır. Her iki eserde de olay kahramanları dayak atışları ile ünlenmişlerdir. Her ikisi de canlarını almaya gelen Azrail ile dövüşmüşler; ancak Tanrı'nın isteğine razı gelerek ölümü kabullenmişlerdir. Her iki eserde de bilge kişi diye tanımlanan bir dede vardır ve kahramanla ilgili yorum yapmaktadır. Eserdeki belirgin farklıl1klardan biri, Tanrı'nın olay kahramanlarının ölümlerine yönelik verdiği emrin içeriğinde görülmektedir. Azrail, Diğenis’in canını zamanı geldiği için almakla görevlendirilirken; Deli Dumrul'un canının alınması Tanrı'nın birliğine ve gücüne şüpheyle bakmasından kaynaklı cezalandırmak amaçlıdır.

İkinci farklılık Azrail'in olaylar karşısındaki tutumunda görülmektedir. Deli Dumrul'da güçlü karakter olan Azrail, Diğenis'te Diğenis'in gücüne boyun eğmektedir. Diğer bir fark anne karakterindedir. Deli Dumrul'da anne kahramanın annesi iken, Diğenis'te Azrail'in annesidir. Deli Dumrul'un annesi oğlunun yerine canını vermek istemez. Azrail'in annesi ise Azrail'e kimsenin canını almaması yönünde nasihat eder. Destanlar, tüm sözlü anlatılarda olduğu gibi, onları anlatan kişinin hafızasında yer ettiği nispette aktarılmaktadır. Bazen bu anlatılar, ortak konuların işlendiği diğer anlatılarla beslenir ve farklı olayların benzer parçaları birbirine eklenir. Bu nedenle farklı kültürlere ait olsalar da ortak motifleri taşıyan sözlü geleneğin ürünleri anlatıcıların hayal gücünde yeniden şekillenerek anlatılır. Çalışmada da görüleceği üzere iki eserde de evrensel insan düşüncesinde yer alan ölümü kabullenemeyiş ve sonucu değiştirme arzusu işlenmektedir. Kıbrıs, tarihinde binlerce yıllık kültür mirasını barındırmaktadır. Gün itibarıyla bu kültür alışverişini eldeki metinlere göre kesin çizgilerle açıklamak elbette ki mümkün değildir. Amaçlanan, çalışmanın sonraki çalışmalar için bir temel oluşturmasıdır.

Anahtar Sözcükler: "Dede Korkut Hikâyeleri", "Duha Koca Oğlu Deli Dumrul", "Diğenis ile Azrail". 


\section{Giriş}

Dil, toplumun hizmetinde canlı bir varlık olduğuna göre, zamana ve toplumda beliren yeni ihtiyaçlara göre değişir. Bu değişim politik sebepler, doğa olayları, coğrafi şartlar, geçim kaynakları vb. nedenlerle insanların kavram ve nesneleri adlandırmalarını sağlamıştır (Tuğluk, 2021: 154-155). Yaşamla edebiyat arasındaki yapıya eşdeğer olarak, çağın yaşayışını, felsefesini, dünya görüşünü ve zevkini takip eder. Bir toplumun zihin yapısını gösteren, milleti millet yapan, insan ile toplum arasındaki bağı sağlayan en güçlü kültür öğesidir. $\mathrm{Bu}$ bağlamda bakıldığında kültürel bağların nesilden nesile aktarımının sağlanabildiğini ve toplum yapısının anlaşılırlığını kolaylaştıran asıl unsurdur. İnsanların yaşadığı toplum yapısıyla bağlantılı olarak bir yaşayıs şekli ve dil yapısı vardır (Türk, 2017: 786; 2021:137). Dil, yaşamın her alanında varlığını gösteren, dilin etkide bulunma gücü yaşamın bütün alanlarına yayılır. Dilin kendine mahsus gereksinimleri ve koşulları ile kendi çevresini ve yönünü belirler (Türk, 2020: 323).

Edebî eserler, sosyal ve kültürel yaşamı en etkileyici biçimde tanımlayan, nesilden nesile köprü oluşturan yapı taşlarıdır. Yüzyıllar içerisinde oluşturulan kimlik unsurları, edebî eserler sayesinde varlığını sürdürür. Özellikle destanlar, yaratıldığı ve yaşatıldığı çevrenin kültürel unsurlarını ortaya çıkarmaları yönüyle oldukça önemli veriler olarak kabul edilirler.

Günay (2000: s.194), bütün dünya edebiyatlarının başlangıcı olarak destanları gösterir. Ona göre destanlar; çeşitli konularda yaradılış hikâyeleri yanında, milletlerin hayatında büyük yankılar uyandırmış bir kahramanın veya tarih olayının millet muhayyilesinde ortak sembol ve ifadelerle zenginleştirilmiş uzun manzum hikâyelerdir. Her kültür olgusu kültürlerin tümünde de görüleceği gibi doğar, gelişir ve kaybolur veya yeni fonksiyonlarla yenilenir ve gençleşir. Güzel (2003: s.212) destanların öneminin anlatılan olayların ve şahsiyetlerin gerçeğe uyup uymadığından ziyade, söylendiği dile ve o dili konuşan millete ait pek çok özelliği bünyesinde bulundurmasından kaynaklandığına dikkat çeker.

Destan anlatıcıları duydukları veya dinledikleri olayları dinleyici kitlelerine göre yeniden üretirler. Kahramanlar, olaylar, zaman ve mekân olgusu onların dilinde yeni anlamlar kazanır. Turan (2006:s. 95), destanların yalnız tarihin eksikliklerini doldurmakla kalmadığını; içtimai ruhun akislerini, düşünce ve inançlarını meydana koymak bakımından da çok mühim bir yer işgal ettiklerini söyler.

Dede Korkut Hikâyeleri, bu yönüyle, Türk kültürünün zenginliklerini, renkli Türk folklorunun sayısız değerlerini Türk milletinin yüksek insanî vasıflarını, duygularını, faziletlerini ve meziyetlerini dile getirmektedir. Muharrem Ergin, Dede Korkut Hikâyelerinin önemini vurgulamak için 1971 yılında yayınlanan Dede Korkut Kitabı" adlı eserin önsözünde Fuat Köprülü'nün derslerinde söylediği sözlerine dikkat çeker. "Bütün Türk edebiyatını terazinin bir gözüne, Dede Korkut’u öbür gözüne koysanız, yine Dede Korkut ağır basar"(Ergin: 1971: s. 1).

Bugün için Dede Korkut kitabının iki yazma nüshası bulunduğu bilinmektedir. İlk bilinen yazması, Dresden Krallık Kütüphanesi'nde; ikinci yazma nüshası ise Vatikan Kütüphanesi'ndedir. Gökyay (1973:IV) yazmaların üzerinde yazıya geçirildikleri tarihin belli olmadığını; ancak eserlerin paleografik özellikleri dikkate alındığında XVI. yüzyıl olabileceği yönünde bir çıkarımda bulunur.

Ergin (1971:XIII) eserlerin, destan devri bittikten ve destanlar halk hikâyesine dönmeğe başladıktan sonra 15.asrın sonu ile 16. asrın başlarında meçhul bir sanatkâr tarafından yazıya geçirildiğini söyler. Hikâyelerde nazım ve nesir iç içedir. Olayların anlatımında nesir; karşılıklı konuşmalar, soylama ve dua bölümlerinde nazım kullanılmıştır

Araștırmacıların ortak görüşü; Dede Korkut Hikâyeleri'nin devre bakımından Eski Anadolu Türkçesi, saha bakımından Doğu Anadolu ve Azerbaycan sahasının eseri ve hikâyelerde anlatılanların da büyük bir Türk boyu olan Oğuzlarla ilgili olduğudur. Eski Anadolu Türkçesi döneminde yazı dilil oluşumu yeni olduğu için batıya göç eden Oğuz boyları kendi ağız özelliklerini eserlere yansıtmışlardır (Koç, 2020: 56).

Boratav (1939, Aktr. Gökyay, 1973:LVII), hikâyelerdeki destanî unsurların, bu destanların doğuşuna yol açan tarihî olaylardan ibaret olmadığını söyler. Bu örgünün içinde Türklerle Oğuzlarda ve başka milletlerde bu destanların dışında yaşamış ve gelişmiş olan türlü folklor temlerinin ve motiflerinin görüldüğüne vurgu yaparak Oğuzların Azerbaycan'a 
olsun, Aandolu'ya olsun, büyük Selçuklu akınından önce türlü şekilde sızmalarından kalma tarihî kalıntıların karışmış olabileceğine işaret eder.

Köprülü (2003:277), Anadolu serhatlerindeki daimî Türk-Bizans mücadelelerinin doğurduğu destan ürünlerine dikkat çekerek; "Bizans edebiyatında Akritas destanını doğuran bu devamlı cenk, aynı şartlar altında Türkler arasında da "Battal Gazi" ve Dânişmend Gazi" menkıbeleri gibi birtakım destanî mahsuller vücuda getirmiştir. Her manası ile "Darü'1 - Cihad" olan uçlardaki bu "Alpler Devri"nde, Bizans hudutlarında yaşayan "Akrit: Hudut muhafızları" ve "Apelet" : akıncılara karşı Müslüman Türklerin de "alp"leri ve "Gâzi"leri vard1." demektedir. Ona göre; "Akritas", onların hayat ve mefkûrelerini, "Battalnâme" ve "Dânşmendnâme" ise Türklerin hayat ve mefkûrelerini göstermektedir."der.

Dede Korkut Hikâyeleri içinde Duha Koca Oğlu Deli Dumrul, bu bağlamda üzerinde en çok araştırma yapılan hikâyelerdendir. "Duha Koca Oğlu Deli Dumrul hikâyesi dejenere olmaya yüz tutmuş alp tipinin, İslâmiyet'in getirdiği manevî kuvvet karşısında mağlubiyetini gösteren en güzel hikâyelerden birisidir" (Kaplan, 1991, s. 60).

Deli Dumrul, Dede Korkut Kitabı'nın Vatikan nüshasında yoktur. On iki hikâyelik Dresden nüshasında ise beşinci hikâye olarak yer almaktadır. Deli Dumrul'da ana tema ölümle mücadeledir. Bu tema etrafında şekillenen olay örgüsü içerisinde derin yapıda yeni bir inanç sistemine adapte olmaya çalışan bir toplumun ikilemleri sembolik bir üslupla kahraman üzerinden dile getirilmiştir (Ergin, 1994).

Duha Koca Oğlu Deli Dumrul, Bizans destanı olarak kabul gören Digenis Akritas ile benzerliği ve ortak motifler taşıması yönüyle de araştırmacıların oldukça ilgisini çekmektedir. Sevim ( 2002: 1-5 ), Türklerin hem Bizans, hem de bölgede yaşayan Ermenilerle yüzyıllarca süren savaşlarından bahseder.

Digenis Akrites Destanı'nın bilinen altı versiyonu vardır. Kimin tarafından yazıya geçirildiği bilinmemektedir. Araștırmacılar tarafından en güvenilir versiyon olarak "Grotaferrata" gösterilmektedir. (Aktr: Yılmaz:2011) Destan, VIII. yüzyıldan XI. yüzyıla kadar neredeyse üç yüz yıl süren Arap- Bizans savaşlarını anlatmaktadır.

Destan kahramanı Digenis, bu savaşlarda sınır muhafızlığı yapmaktadır. Yani bir "Akrites"tir Basileios adı, Digenes lakabıdır. Çift soylu anlamına gelen bu lakab ona Annesi Yunanlı babası Suriyeli olduğu için verilmiştir. Diğenis bu özelliği nedeniyle hem Hristiyanlar hem de Müslümanlar arasında bilinen bir karakterdir (Baysal, 2009). Bizans tarihinde iki Basileios'tan söz edilir; ancak Baysal çalışmasında buna yönelik herhangi bir bilgi aktarmamıștır. Ozansoy (2009), "Digenis Akrites" kitabında, Digenisi, kahramanlığ1 ülkeden ülkeye geçerek dillere destan olmuş; yakışıklı, güçlü, savaşçı bir yiğit olarak tanimlar.

Baştav 1988'de Uluslararası Türk Dili Kongresi'nde Bizans'ın Türk kavimleri ile olan temaslarının IV. yüzyılda başladığını söyler. Byzantinoturcica Moravcsik'ten yaptığı aktarmaya dayanarak; bu uzun temaslar sonunda Bizansliların Türk kavimlerinden birçoğunun adını veya unvanlarını, Yunan diline uydurarak kaydettiklerine vurgu yapar. Ayrıca bu yolla bu kavimlerin teşkilâtı, hayat tarzı, maddî veya manevi kültürü ile ilgili birçok kelimenin de muhafaza edildiğinden bahseder.

Kıbrıs'in İslâm diniyle olan tanışıklığının 7. yüzyılda Arap Hilafet ordusunun Müslümanlığı yaymak amacıyla Kıbrıs'a seferler düzenlemesiyle başladığı bilinmektedir. 647-649 yıllarında Larnaka'yı ele geçiren muaviye ordusuyla adaya çıkan Hz. Muhammed’in halası ve sütannesi Ümmü Haram ( Hala Sultan), attan düşüp ölünce öldüğü yer olan Tuz gölü kenarında onun için bir türbe yapılmıştır. Hala Sultan'in üzerinde havada asılı durduğu söylenen kutsal taşlar bu şekilde korumaya alınmıştır. Cami ve türbe mermerlerinde Şemi, Müftü Raci Efendi gibi Kıbrıslı Türk divan şairlerinin şiirleri yer almaktadır. (Yaşın:s41). 1974 Kıbrıs Barıș Harekâtı'ndan sonra Güney Kıbrıs'ta kalmıș olan bu kutsal türbe, Müslümanların izin almak kaydıyla gidebildikleri İslâm dünyası için önemli bir ziyaret ve ibadet yeridir.

Osmanlının 1571 yılında Kıbrıs'ı fethetmesi, adada büyük bir Türk nüfusunun oluşmasında önemli bir etkendir. Bu durum, Türk- İslâm kültürüyle tanışan ve tarih boyunca farklı kültürlerin nüfuzu altında yaşamak zorunda kalan adadaki Müslüman Türklerin de kendi kimliklerinin farkına varmaları yönünde bir uyanış hareketi olmuştur. 
Bilindiği üzere Kıbrıs 1571 ile 1878 yılları arasında Osmanlı İmparatorluğu sınırları içerisindeydi. 1878 yılında ada İngilizlere devredildi. Bu bağlamdan bakıldığında dönem itibarıyla Ada'ya hâkim olan düşüncenin izleri görmek mümkündür (Türk, 2019; 282).

Bugün ada, iki bölgeli devlet olma sürecinde Kuzey ve Güney olarak ikiye ayrılsa da, ada halkı kendini Rum ya da Türk olarak tanımlasa da, Hristiyanlığı ya da Müslümanlığ1 benimsese de reddedemeyeceği ortak bir kültürü vardır. Yüzyıllarca Mısırlılar, Hititler, Fenikeliler, Asurlular, Persler, Makedonlar, Romalılar, Bizanslılar, Lüzinyanlar, Venedikliler, Osmanlılar ve İngilizler gerek ticari gerekse stratejik sebeplerle bu adaya kendi kültürlerini taşımışlardır.

Bu nedenle Kıbrıs Türk edebiyatını Türk kültürüne paralel bir şekilde ele almak ve Osmanlıdan önceki edebî ürünlerin Kıbrıs Türk edebiyatı üzerindeki etkisini görmezden gelmek adada bin yıllardır birikmiş kültür zenginliğini yok saymakla eşdeğerdir. Üstelik bu durum siyasi nedenlerle adanın tüm kültürünün Elen mitolojisine dayandığını, adada yaşayanların Elenlerden (Yunanlı) ibaret olduğunu savunan yanlı görüşlere de ideolojik malzeme sunmak anlamina gelecektir.

Adada yaşayan Türk halk, farklı kültürleri kendi kültürel kotasında asimile etmemiş olsa bile, tarihe dayalı her kurgunun, dilden dile dolaşan her anlatının buralardaki yaşanmışlı̆̆ın gerçekliğine dayandığını bilmektedir. Özellikle toplumsal etki yaratmış olayların anlatıldığ destanlar, hemen her dönemde, her kültürde, konuşulan her dilde söylenmiş ya da yazıya aktarılmıştır.

Çalışmada ele alınan eserin aslı Dimotiki Rumcasıyla yazıya geçirilmiştir. Yaşın ( 2005) çalışmasında eserin yazıya geçirildiği dönem ile ilgili herhangi bir bilgi vermemiştir. Eser yazarın deyimiyle; Dimotiki Rumcasından Türkçeye, Türkçenin söyleyiş esprileriyle çevrilerek aslına sadık kalınarak yapılmıştır. Çalışmada üzerinde durulan nokta metnin asl1 yani olay kurgusudur. Eserin Türkçe anlatım özelliklerinin gözetilerek çevrilmesi çalışma konusu oluşturulmasında önemli bir etken olmuştur.

\section{Eserlerin Olay Kurgusu Bağlamında İncelenmesi Duha Koca Oğlu Deli Dumrul' un Olay Kurgusu}

Hikâyede olayın kahramanı Deli Dumrul, insanları kuru çay üzerine yaptırdığı bir köprüden zorla geçirmektedir. Bunun için onlardan otuz üç akçe almakta; dahası geçmek istemeyen olursa döverek kırk akçe alarak geçmeye zorlamaktadır. Hikâyede Deli Dumrul'un bunu yapma amac1 "Bunu niçin böyle ederdi? Onun için ki benden deli, benden güçlü er var mıdır ki çıssın benimle savaşsın der idi, benim erliğim, benim bahadırlığım, kahramanlığım, yiğitliğim Ruma, Şama gitsin, ün salsın der idi.” sözleriyle kendi ağzından konuşturularak veriliyor.

Hikâyenin devamında Deli Dumrul, köprünün yanına konaklayan obadan gelen ağlama seslerini duyarak sebebini öğrenmek için onların yanlarına gider. Orada Allah Taâla'nın buyruğuyla al kanatlı Azrâil'in gelerek yiğidin canını aldığını öğrenir. Deli Dumrul, "Bre, Azrâil dediğiniz ne kişidir ki adamin canını alıyor, yâ kadir Allah, birliğin varlığın hakkı için Azrâil'i benim gözüme göster, savaşayım, çekişeyim mücadele edeyim, güzel yiğidin canını almasın."der.

Bu sözler, Hak Taâla tarafından hoş karşılanmaz. "Bak bak, bre deli kavat benim birliğimi tanımıyor, birliğime şükür kılmıyor, benim ulu dergâhımda ( eşiğimde, huzurumda) gezsin benlik eylesin. Azrâil, var ve o deli kavatın gözüne görün, benzini sarart, canını hırıldat al." sözleriyle kızgınlığını dile getirerek Azrâil'i Deli Dumrul'un canını alması için gönderir.

Azrâil, Deli Dumrul'un canını almak için kırk yiğitle yeyip içtiği yere gelir. Azrâil’i karşısında gören Deli Dumrul, Azâil'in ne çavuşa ne kapıcıya yakalanmadan içeriye girmesine çok şaşırır. "Bre ne heybetli ihtiyarsin söyle bana, Kazam belâm dokunur bugün sana" diyerek meydan okur. Azrâil, "Gözü güzel kızların gelinlerin canını çok almışım, Sakalımın ağardığını ne beğenmiyorsun, Ak sakallı kara sakallı yiğitlerin canını çok almışım, Sakalımın ağarmasının mânası budur.” diyerek Deli Dumrul'u kendisiyle dövüşmeye (cenk etmeye) çağırır.

Deli Dumrul kara kılıcı ile Azrâil'e saldırınca Azrâil güvercin olur ve pencereden kaçar. Deli Dumrul bunu bir zafer olarak algılasa da hikâyenin devamında yanılgısı ortaya çıkar. Etrafındaki güvercinleri Azrâil adderek elindeki doğanıyla avlayarak evine dönerken Azrâil, 
atının gözüne görünür ve atını ürkütür. At ürktüğünden Deli Dumrul'u üzerinden atar, yere vurur. Azrâil'in gücünü hisseden Deli Dumrul Azrâil'e yalvararak canını bağışlaması için yalvarır. Azrâil, "Bre deli kavat bana ne yalvarıorsun, Allah Taâla'ya yalvar, benim elimde ne var, ben de emir kuluyum."der.

Hikâyenin devaminda Deli Dumrul, Azrâil'in aradan çekilmesini Allah Taâla ile kendisinin konuşmak istediğini söyler. "Yücelerden yücesin, Kimse bilmez nicesin,Güzel Tanr, Nice cahiller seni gökte arar yerde ister, Sen bizzat müminlerin gönlündesin, Dâim duran cebbar Tanrı, Baki kalan settar Tanrı, Benim canımı alacaksan sen al, Azrâil'e almağa bırakma." sözleriyle Allah’ın birliğini inandığını ve birliğine şükür kıldığını söyler.

Deli Dumrul'un bu sözleri Tanrı'nın hoşuna gider. Azrâil'den Deli Dumrul' a canının yerine can bulursa canını bağışlayacağını iletmesini ister. Deli Dumrul bunun üzerine babasından ve annesinden kendi canı yerine can vermelerini ister. İkisi de kabul etmez. Azrâil canını almak için gelir. Bunun üzerine Azrâil'den canını almadan önce eşiyle helâlleşmek için zaman ister. Eşi, Deli Dumrul yerine canını vermeyi gönüllü olarak kabul eder. Azrâil eşinin canını almaya gelince Deli Dumrul eşine kıyamaz. "Alırsan ikimizin canını beraber al, Bırakırsan ikimizin canını beraber bırak, Keremi çok kadir Tanrı" sözleriyle Tanrı'ya yalvarır.

Bunun üzerine Tanr1, Azrail'e Deli Dumrul'un anne ve babasının canını almasinı emreder. Deli Dumrul ile eşine yüz kırk yıl daha ömür verir. Hikâyenin sonunda Dedem Korkut gelerek "Bu destan Deli Dumrul'un olsun, benden sonra alp ozanlar söylesin alnı açık cömert erenler dinlesin." der ve iyi dileklerde bulunarak hikâyeyi bitirir.

\section{Diğenis ile Azrail'in Olay Kurgusu}

Eser, Azrail'in panayıra giderken annesi ile yol üstünde karşılaşması ile başlar. Anne, Azrail'e insanların canını almaması için nasihat etmektedir: "Evlâdım ne güzellerin canını al, ne kocakarıların küçük çocuklarınkini de alma, analar ağlamasın.”

Azrail bu sözlere karş1l1k annesine: "Güzelleri almazsam, kocakarlar almazsam, Çocukları almazsam bana Azrail mi denir?” sözleriyle karşılık verir.

Olayın devamında Siyahlar giyinmiş, siyah ata binmiş, altın kılınç kuşanmış olan Azrail, içinde bir sürü beyin yeyip içtiği bir bahçeye gider. Beyler Azrail’i görünce onu da yeyip içmeye davet ederler.

"Hoş gelmişsin Azrail bizimle yeyip içmeye,Tavşan eti yemeye, firnda ördek yemeye,Erkekler için pek makbul yaban balından yemeye, Dermansız hastalara hemenden şifa veren Nam salmışlara layık tatlı şaraptan içmeye."

Ancak Azrail onlara, "“Ben Azrail, yeyip içmeye gelmiş değilim sizinle, Tek muradım Diğenis'i almaktır."diye cevap verir. Diğenis Azrail'in canını almaya geldiğini anlayınca sinirlenir ve Azrail'i dövüşmeye çağırır.

"Bunu duyunca fes başından atar Diğenis'in,

O öfkeyle bir tekme savurur masaya, iskemlelere,

Sürahisini kaldırdığ gibi finda eder havaya,

Sonra Azrail'in karşısina geçer, şöyle der:

"Beni hafif tutasin ki ben de seni hafif tutayım."

Aralarındaki dövüş üç gün üç gece sürer. Üç gecenin sonunda Diğenis galip gelir. Azrail, Diğenis'ten dövüşe ara vermelerini ister. Sonra ellerini açıp Tanrıya şükreder ve Diğenis’in yenemeyeceği kadar güçlü olduğunu söyler.

"Ve Azrail ellerini açıp şükreder Tanrısına:

"Şükürler olsun iyi Tanrim, sen yukarda olana,

Bilenleri de bilmeyenleri de bilene,

Bana gönderdiğin varlık yiğit bir varlık çıtt.

Ona öylesine bir insanca güç vermişsin ki

Bu dövüşte onu yenip de sana nasil getirebilirdim ki."

\section{Bunun üzerine Azrail'e Tanrıdan ve baş meleklerinden ses gelir:}

"Seni dövüş yapmaya göndermediydim ki ey Azrail, onun ruhunu söküp getiresin diye yolladıydım." 


\section{Bunun üzerine Azrail kara kartala döner ve pençeleriyle Diğenis'in canını almaya başlar.}

"Ve Azrail kara kartala döner Diğenis'in başında

Başlar pençesiyle can içinden ruhunu kazımaya."

\section{Destanın bu bölümünde Diğenis'in ölüm döşeğindeki hali anlatılır.}

"Can çekişir Diğenis, demir saraylara girse olmaz,

Demir yataklara, demir yorganlara girse olmaz."

Diğenis’in ölmek üzere olduğunu duyan üç yüz yiğit onu görmek için dışarıda beklerler; ama Diğenis’in bu halinden korkarlar. Diğenis korkacak bir şey olmadığını içeri gelebileceklerini söyler.

"Dışarıda ise üç yüz yiğit bekleşir

görmek isterler Diğenis'i ama korkarlar halinden.

Aralarindan ufak tefek birisi çıkar

uzun dizlikli gençten biri, içeri dalar ve selam verir:

"Selam Diğenis, sen ki bir vakitler sevdalıyken

ayın gölgesinde yürür de hiç korkmazdın,

şimdi dişarıda üç yüz yiğit bekler seni,

hem girip görelim derler, hem de korkarlar halinden."

Diğenis cevap verir, şöyle der:

"Söyle de korkmasinlar, geleceklerise gelsinler."

Yiğitleri içeri alan Diğenis onlara izaz ikramda bulunmak ister; ama yiğitlerin isteği ondan eski savaşları dinlemektir. Diğenis onların bu isteğini yerine getirir.

"Diğenis cevap verir ve aynen şöyle der:

"Siz orada ekmeğinizi yeyedurun

ben burada eski savaşları naklederim.

Uzak mi uzak diyarlarda, ötelerde bir sazlıkta,

tam dokuz torba doldurmuştum diller ve burunlarla

burunlar ejderha burnu, diller arslan diliydi.

Ortalığ zehir gibi keskin bir koku alıp götürmekteydi,

Bu koku beni susuzluktan kurutmak üzereydi, toprağı da.

Duraksadim atıma su verecek yer arandım

Firat nehrini gördüm, koşup suyunda durdum

Nehirde bir Arap varıdl, durmuş da nöbet tutar.

Duraksadım ona münasip bir selam aradım.

Gül ağacı desem dikenleri var,

Karanfil diyecek olsam, boğumları var,

Ey ince dal, diyesim geldi, bükülür diye korktum.

İyisi mi ona layığını vereyim dedim:

"Selam sana ey yiğit Arap, yiğitlere nur olsun..."

Burada sözü anlatıcı alır ve Diğenis’in iyi niyetle verdiği selama karşılık Arab'in Diğenis'e vurduğunu anlatır.

Ama Diğenis selam verirken, Arap vurmaya başlar.

Anlatıcı burada sözü Diğenis'e bırakır ve ardından Arab’ı nasıl dövdüğünü anlatmak için yine kendisi devreye girer.

"Seni gidi Arap seni, şimdi sana gösteririm!"

Bir tane, güm, kafasına, öyle bir okkalı indirir ki

ama taş değil çatlasın, köprü değil yıkılsın,

eski kale değil altı üstüne gelsin.

Arabin burun deliklerine kisraklar dolup taştı,

koltukaltlarinda ördekler ötüşe başladi.

Diğenis’in Araba attığı dayak o civarlardaki bir memleketin her köşesinde duyulur. Bu memlekette yaşayanlar, duydukları sesi, Tanrı'nın memleketin birini yok ettiği şeklinde yorumlarlar.

"O civarlarda bir memleket varld ki

Diğenis'in attığ dayak her köşesinde nam saldı.

Bir yerlerde gök gürülder, bir yerlerde şimşek çakar,

bir yerlere dolu düşer, dolu düşer, dolu, dolu... 
Bir yerlerde Tanr memleketin birini yok eder."

Destanın bu bölümünde ortaya yaşlı bir dede çıkar ve duydukları sesin Diğenis’in dayağı olduğunu anlatır.

"Yaşlı bir dede ise, o eski bilge insanlardan biri

ahalinin bu sözlerine karşıllk şöyle der:

"Ne gök gürülder ne ne de şimşek çakar,

ne bir yerlere dolu, dolu, dolu düşer,

ne de Tanr memleketin birini yok eder,

Diğenis'in dayağıdır bu, vay yiyenin haline!"

Destan bilge kişinin sözlerinden sonra bitmez. Anlatıcı Diğenis'in dayağının ne kadar etkili olduğunu anlatmak için dayak yiyen Arab'ın hikâyesine geçer.

"Sözüm ya bitti ya bitmediydi, Arap ovadan gitti,

SSehre inince sağa sola hoşça bir selam verdi:

"Bre beyler ey, geliniz de yaremi görünüz,

Bir köpek, kudurmuş bir köpek, pek fena vurdu beni,

Dokuz kaburgamı kırdl, üçünün işini bitirdi..."

İnsanlar, elini kaldırırlar yarayı görsünler diye ,"

Saçı başı yolunmuş yerlerde debelenir Arap.

Eserin devamı varsa bile bugün elde olan ve Türkçeye çevrilmiş metni burada bitmektedir.

\section{Olayların Gelişiminde Etken Olan Unsurlar}

\section{Duha Koca Oğlu Deli Dumrul'da Olayların Gelişiminde Etken Olan Unsurlar}

Olayların başlangıcı, Deli Dumrul'un, kuru bir çayın üstüne köprü yapması ve hiç gerek yokken insanları oradan geçirmeye zorlaması, geçmeyenleri döverek onlara meydan okuması kendi deyimiyle; erliğinin, bahadırlığının, kahramanlığının, yiğitliğinin Ruma, Şama gitmesi ve ününün yayılması içindir. Ağlama seslerinin geldiği oba, hikâyede olayların başlamasında tetikleyici unsurdur. Obadakiler, yiğitlerinin canını alan Allah Taâla'nın buyruğuna boyun eğmiş, inançlı kişilerdir. Deli Dumrul onların bu kanaatkâr tutumlarını algılayamaz ve Azrâil'e dolayısıyla Tanrı'ya meydan okur.

Hak Taâla, Deli Dumrul'un kendisine meydan okumasına çok kızdığından Azrâil'i onun canının alması için görevlendirir. Amacı Deli Dumrul'u kendi birliğine inanmadığı ve şükretmediği için cezalandırmaktır. Azrâil,, dört büyük melekten biridir ve canlıların canın almakla görevlidir. Azrâil, kimseye görünmeden istediği mekâna girebilmekte; ortama göre görüntü değiștirebilmektedir. Obadaki yiğidin canını alırken al kanatlı; Deli Dumrul ile dövüşürken güvercin olabilmektedir.

Deli Dumrul'un beraber yiyip içtiği kırk yiğit, onun çevresi tarafından ne kadar sevildiği aynı zamanda ne kadar güçlü olduğunu göstermesi şeklinde yorumlanabilir.

Hikâyede Deli Dumrul'a canlarını vermeyi istemeyen ve sonunda bu nedenle Tanrı tarafından canlarının alınarak cezalandırıldığı kişiler onun annesi ve babasıdır. Anne ve babanın canını vermemesi Deli Dumrul'un eşini ön plana çıkarması nedeniyle dikkat çekici bir ayrıntıdır.

Dede Korkut, Deli Dumrul'un okuyucu tarafindan olumlu bir karakter olarak algılanmasinda önemli bir etkendir.

\section{Diğenis ile Azrail'de Olayların Gelişiminde Etken Olan Unsurlar}

Olayların başlangıcı Diğenis'i öldürmekle görevli Azrâil’in panayıra giderken annesi ile karşılaşması ile başlar. Anne Azrâil'in insanların canlarını almak için görevlendirildiğini bildiğinden ona can almaması yönünde nasihat eder.

Azrâil için annesinin nasihatlerinin bir anlamı yoktur; çünkü ona bu görevi Tanrı ve Baş Melekler vermiştir. Diğenis'in canını alması için bir gerekçeye ihtiyacı yoktur. Diğenis'in canını almak için onunla üç gün üç gece savaşır; ama gücü karşısında geri çekilir. Tanrıya Diğenis'in çok güçlü olduğu için canını alamadığını söylese de Tanrı ve Baş Melekler görevini tamamlaması gerektiğini bildiriler. 
Azrail verilen görevi tamamlamak için geri döner.

Destanın bu bölümünde Diğenis’in ölmek üzere olduğu anlatılır. Diğenis ölümden korkmaktadır. Dışarıda toplanan üç yüz yiğit yanına girmek ister; ama Diğenis'in ölümden korkması onları şaşırtmıştır. Bu nedenle yanına girmeye korkarlar. Onlara cesaret veren ve korkmadan Diğenis'in yanına giden uzun dizlikli, ufak tefek bir gençtir. Diğenis ziyaretine gelen yiğitlere eski kahramanlıklarını anlatarak ölüm korkusunu atmaya çalışır.

Destanda geçen Arap karakteri Diğenis'ten dayak yiyen ve Diğenis’in dayağının komşu memleketlerde duyulmasinda etken olan kişidir.

Destanda yer alan Bilge kişi dayak sesini duyup da Tanrının bir memleketi yok ettiği şeklinde yorumlayanlara Diğenis’in dayağının gücünü anlatır.

\section{Sonuç}

Çalışma konusu olan destanları bütünlüklü olarak karşılaştığında aşağıdaki çıkarımlarda bulunur.

İki destanda benzer unsurlar;

1. Eserlerin ikisinde de dinî unsurlar yer almakta; Tanrının varlığına ve birliğine yönelik inanç vurgulanmaktadır.

2. Her iki eserde de olay kahramanları dayak atışları ile ünlenmişlerdir.

3. Her ikisi de canlarını almaya gelen Azrail ile dövüşmüşler; ancak Tanrı'nın isteğine razı gelerek ölümü kabullenmişlerdir.

4. Her iki eserde de bilge kissi diye tanımlanan bir dede vardır ve kahramanla ilgili yorum yapmaktadir.

İki destanda yer alan farkl1liklar;

1. Azrâil, Diğenis'in canını zamanı geldiği için almakla görevlendirilirken; Deli Dumrul'un canının alınması Tanrı'nın birliğine ve gücüne şüpheyle bakmasından kaynaklı cezalandırmak amaçlıdır.

2. Deli Dumrul'da güçlü karakter olan Azrâil, Diğenis'te Diğenis'in gücüne boyun eğmektedir.

3. Deli Dumrul'da anne kahramanın annesi iken, Diğenis'te Azrail'in annesidir. Deli Dumrul'un annesi oğlunun yerine canını vermek istemez. Azrail'in annesi ise Azrail'e kimsenin canını almaması yönünde nasihat eder.

Genel itibarıyla ortaya çıkan sonuç; anlatıcının farklı kültürlerin kahramanlarını ortak bir paydada buluşturarak anlattığı yönünde yorumlanabilir. Kıbrıs edebiyatına yönelik kurumsallaşmış çalışmaların 19. yüzyılda başladığı ve bu çalışmaların daha çok Kıbrıs Türk edebiyatına yönelik olduğu bilinmektedir. Bunun yanında sözlü gelenek içinde yer alan ve kaynağını eski anonim halk anlatılarından alan ortak kültüre ait birçok ürünün olduğu da bir gerçektir. Ne yazık ki bu ürünler tarih içinde farklı sebeplerle yazıya geçirilememiştir veya farklı dillerde geçirildiği için gereği gibi değerlendirilememiştir. "Diğenis İle Azrâil" de bu bağlamda üzerinde durulması gereken ortak kültüre ait bir Kıbrıs destanıdır. Kimin tarafından yazıya geçirildiği veya anlatıcısının kim olduğuna yönelik bir bilgiye bugün itibarıyla sahip değiliz. Bazen anlatıcıların farklı ortamlarda, değişik kişilerden dinlediklerini kendi yorumlarıyla yeniden şekillendirebildikleri de bilinmektedir. Nitekim "Diğenis ve Azrâil" ile "Duha Koca Oğlu Deli Dumrul" arasındaki benzerlikler ve farklılıklar bizi bu yönde düşündürmeye yöneliktir. 


\section{Kaynakça}

Baştav, Şerif. ( 2000). "Osmanlı İmparatorluğunun Kuruluşunda Bizans ve Avrupa", XIII. T.T.Kongresi, C.III., Ankara: T.T.K. Yay.

Ergin, M. (1971). "Dede Korkut Kitabı". İstanbul: Millî Eğitim Basımevi.

Ergin, M. (1989). Dede Korkut Kitabı I. Giriş-Metin-Faksimile. Atatürk Kültür Dil ve Tarih Yüksek Kurumu. Ankara: TDK Yay.

Günay, U. (2000). Dede Korkut Kitabı ve Toplumsal Değerlerin Tahlili. Uluslararası Dede Korkut Bilgi Şöleni. Ankara: Atatürk Kültür Merkezi Başkanlığı Yay.

Gökyay, O. Ş. (2006). Dedem Korkutun Kitabı. İstanbul: Millî Eğitim Basımevi.

Güzel, A.; Torun, A. (2003). Türk Halk Edebiyatı El Kitabı. Ankara: Akçağ Yayınları .

Kaplan, M. (1991).Türk Edebiyatı Üzerine Araștırmalar 1 Tip Tahlilleri. İstanbul: Dergâh Yay Koç, F. (2020). Karışık Dilli Eserlerin Fonetik Özellikleri Üzerine Bir Değerlendirme. Milli Kültür Araştırmaları Dergisi, 4 (1), 55-68.

Köprülü, Fuad, M. (2003). "Türk Edebiyat Tarihi” 5. Baskı, Ankara: Akçağ Yayınları.

Tuğluk, M. E. (2021). "îlyas Köyündeki (Diyarbakır-Çüngüş) Tarım ve Hayvancılık ile İlgili Söz Varlığı" Uluslararası Dil, Edebiyat ve Kültür Araştırmaları Dergisi. (UDEKAD). 4 (1): 153-169

Turan, O. (2006). Türk Cihan Hâkimiyeti Mefkûresi Tarihi. İstanbul: Ötüken Yayınları.

Türk, O. (2017). Türkçe Öğretmenlerinin Konuşma İlgileri Ve Sınıf İçinde Kullandıkları Konuşma Dili Üzerine Bir Araştırma. Turkish Studies, 12(6), 783-798.

Türk, O. (2019). Osmanll Döneminde Kıbrıs'ta Basın. Dicle Üniversitesi Sosyal Bilimler Enstitüsü Dergisi, (DÜSBED), 11/22, 281-294.

Türk, O. (2020). Kültürel Miras Olarak Hayvanların Atasözlerimize Kattıkları Anlam Üzerine Bir Değerlendirme. Karadeniz Uluslararası Bilimsel Dergi, 11 (44), (320-334).

Türk, O. (2021). Hamzaname'nin 72. Cildinde Yer Alan Arkaik Kelimeler. Akademik Dil ve Edebiyat Dergisi Journal of Academic Language and Literature (Hikmet). 7/15, 135-148. 


\title{
CULTURAL HEGEMONY IN CHINUA ACHEBE'S THINGS FALL APART: A POSTCOLONIAL ANALYSIS
}

\author{
Shaymaa Neamah Mohammed ALMKHELIF ${ }^{1}$
}

\section{Istanbul / Türkiye \\ p. 184-191}

Received: $10 / 12 / 2021$

Accepted: $21 / 12 / 2021$

Published: 01/01/2022

This article has been scanned $l$ iThenticat No plagiarism detected

\begin{abstract}
:
The current research paper considers theory of cultural hegemony as reflected in the Nigerian novelist Chinua Achebe's 1958 novel Things Fall Apart. The study aims to examine Achebe's novel as a profound example of cultural hegemony during the colonial era. The novelist exhibits his mother land Nigeria as a culturally hegemonized territory by the English colonizer at that time. The study also presents Antonio Gramsci's theory of cultural hegemony as the main subject in the development of both fields Cultural Studies and Postcolonialism. The research paper is divided into three main sections and a conclusion. The first section shows the development of cultural hegemony as a new theory at the hand of the Italian theorist Antonio Gramsci, who is known for his own perspective of hegemony as a cultural component. Based on Gramsci's theory, the second section examines the significance of cultural hegemony in the fields of Cultural Studies and Postcolonialism. As for the third section, it tackles the theory of cultural hegemony through a selective analysis of Achebe's novel. As far as Things Fall Apart is concerned, the analysis traces the novelist's attempt to expose colonialism as a hegemonic power through an overt portrayal of the cultural struggle between the colonizer and the colonized in Nigeria. Finally, the study ends with a conclusion that sums up the ultimate findings of the research..
\end{abstract}

Key words: Cultural Hegemony, Postcolonialism, Marxism, Cultural Studies, Coercion, Consent.

http://dx.doi.org/10.47832/2717-8293.15.13

1 iD Researcher, Kerbalaa University, Iraq, msc.shaiman@gmail.com, $\underline{\text { https://orcid.org/0000-0002-4900-4016 }}$ 


\section{Antonio Gramsci's Theory of Cultural Hegemony}

Cultural hegemony, in general, refers to the domination of a powerful class over weaker classes through ideological and cultural means. It is usually achieved by social institutions which allow the powerful class to highly influence the values, norms, ideas, beliefs and behavior of the rest of society. In order to understand the concept of cultural hegemony, which has first been developed by the Italian theorist Antonio Gramsci, it is necessary to start with hegemony itself.

Hegemony is often based on the use of political and economic powers by the superior over the inferior. Hegemony has traditionally been defined as a political power, which exists between two or more states. However, Karl Marx extends the traditional view of hegemony to the relations between social classes within the state. Marx maintains that the power of the ruling class is based on economic content in which the class struggle ultimately influences the economic and political systems of the state. While the ruling class is securing its power by the formulation of dominant ideas, the working class may react against the dissemination of hegemonic ideas. As a result, the state becomes unstable economically and politically (Williams, 1977, p.108). However, the Italian theorist Antonio Gramsci modifies Marx's view of hegemony. For Gramsci, hegemony is not only economic and political, but also cultural. He looks at culture as a tool by which the dominating class controls the lower class.

While in prison, Gramsci is writing a series of essays that is known as Prison Notebooks in 1926. In Prison Notebooks Volume 1, Gramsci focuses on how the social, political, economic and cultural conditions contributed to the rise of Fascism as a political force in Italy. He wonders how that political force is entrenched as a dictatorship. By referring to the working people's consent as hegemony, Gramsci examines their consent to the Fascist dictatorship as a new phenomenon in society. Although he mentions the term "hegemony" only once in his essay "Some Aspects of the Southern Question", Gramsci highlights hegemony interestingly (Buttigieg, 1992, p.21). According to Gramsci, it is not only coercion that functions in hegemony, but also consent does (Gramsci,1971, p.156). Accordingly, Gramsci raises "The Southern Question" of why the Italian working class adapted to Benito Mussolini's Fascism. Gramsci seems to be puzzled by the consent of people to Mussolini's tyranny. Mussolini's tyranny extends from the North to the South. Mussolini controls labor and factory owners. He also suppresses the uprising of unions. As such, Prison Notebooks is designed to solve the problem of "The Southern Question". The question centers on bringing the laborers of the Italian North with the peasants of the South to produce a new form of cultural hegemony (Srivastava and Bhattacharya, 2012, p.24). Here, comes the role of ideology in producing the new form of cultural hegemony which is based on consent.

From a Gramscian point of view, ideology is a terrain of principles, practices and dogmas, where the individuals are assigned as social agents. This terrain produces the social agents in order to play economic roles in the level of production as well as in the overall structure of society. For Gramsci, ideology has a Marxist materialistic and constitutional nature since its products, represented by the social agents, are directly influenced by economic and institutional motives. In addition, Gramsci perceives ideology as a battle field where persistent struggles exist when two hegemonic principles confront each other (Mouffe, 1979, pp.185-186). According to Gramsci, the practice of ideology has its own representatives and intellectuals. Intellectuals are responsible for spreading ideology and realizing its moral and intellectual reform. Their role centers on persuading people of their ideological project. They, therefore, employ institutional structures so that they would be able to accomplish their mission. Churches, schools, media and even architecture are all instruments that can be used for the function of ideology. The setting, where these tools are found to produce ideology, is called civil society. For Gramsci, civil society achieves stability when hegemony functions within two types of institutions. The first type uses coercion to preserve people's subordination through the police and military institutions. As for the second type, it preserves people's consent by religious institutions, schools, and media. It is here where ideology manages to produce hegemony, that can be exercised by a certain social group over another (Mouffe, 1979, p.187). Mussolini's ideology is the best example of what Gramsci presents.

Mussolini's ideology plays a central role in the development of people's consent to Fascism. As a matter of fact, Fascism has not precisely been defined, but it is generally 
characterized by the absolute power of the state and rule by a dictator. It is a doctrine of action and thought. Before being a political force, Fascism has first been shaped by ideological thought. Gramsci and Mussolini agree that ideology is a battle field of continuous struggles. This stresses the idea that man should be active. He must conceive life of struggle where permanent peace has no place. Accordingly, Fascist ideology is a system of education where people learn how to run a battle (Mussolini, 1935, p.237). However, Mussolini disagrees with Gramsci's understanding of the nature of ideology. Ideology, from a Gramscian perspective, has a Marxist materialistic and constitutional nature. Yet, Mussolini develops an ideology that embodies a rather spiritual thought than materialistic one. $\mathrm{He}$ states that the Italians should grasp Fascism as a new way of life. Culture, as known, is usually referred to as a new way of life. So, Mussolini's description of Fascism as a new way of life suggests the establishment of a new culture in Italy. In order to make this new culture or way of life survive, Mussolini, thereby, refuses the materialistic body of Marxism and substitutes it by religious spirituality. He, therefore, embraces "holiness" and "heroism" as reliable bases for his ideology. Mussolini, finally, clarifies that his Fascist state is completely spiritual and moral by nature. As a result, his ideology makes the state a good guarantor of security on both internal and external levels (Mussolini, 1935, pp.238-242). Compared to the Marxist ideology, Mussolini's ideology seems to be triumphant as it brilliantly touches the ethos of the Italian nation in the 1920s.

\section{Importance of Cultural Hegemony to Cultural Studies}

In the 1970s, cultural hegemony has been introduced to the field of cultural studies by Raymond Williams and others. They play an important role in understanding Gramsci's question. Cultural Studies aims to complete what Gramsci has already proposed. In this sense, Cultural Studies gives Gramsci's theory of cultural hegemony a final shape and applies it to other fields. According to Williams' view of Gramsci's work, the answer lies in the fact that hegemony is a concept which goes beyond two vigorous concepts. Williams identifies the two concepts as culture and ideology. Culture is the social process in which people shape their lives. This culture submits to a system of values and meanings that is set to serve the interests of a particular social class (Williams, 1977, p.108).

The theory of hegemony, in general, and cultural hegemony in particular, is of central importance to the development of Cultural Studies. Stuart Hall sheds light on this by saying: "I have said enough to indicate that, in my view, the line in Cultural Studies which attempted to think forward from the best elements in the structuralist and culturalist enterprises, by way of some of the concepts elaborated in Gramsci's work, comes closest to meeting the requirements of the field of study" (Hall, 2018, p.72).

Although Hall believes that Gramsci's contribution is significant in the field of Cultural Studies, he indicates that Gramsci has not offered absolute responses to "the conundrums of theory". Nevertheless, Gramsci at least addresses many of them. Hall refers to the issues which Marxist theory did not resolve. Cultural hegemony is one of them. Hall also confirms that having a "detour through Gramsci" remains inevitable. He specifies the degree of importance of Gramsci's work to Cultural Studies by arguing that British Cultural Studies has learned from Gramsci a thorough record of information about the nature of culture itself and about the importance of questions of class relations to the development of the theory of cultural hegemony. However, while Gramsci still belongs to Marxism, the importance of his work lies in the radical displacement of some Marxist legacies in British Cultural Studies (During, 1999, p.102).

It seems that Gramsci's theory works to the advantage of practice in Cultural Studies. The theory helps the field understand how cultural forms function in any society; either to develop social domination or to provide people with the power of resistance against such domination. From the perspective of Cultural Studies, society is analyzed as a hierarchical and counter set of social relations where the oppression of subordinate classes prevails (Ritzer, and Smart, 2000, p.396). Hence, taking Gramsci's theory of hegemony, and "counter-hegemony" which means resistance, as a base, Cultural Studies seeks to analyze cultural hegemony through the analysis of ruling or hegemonic social and cultural domination. At the same time, the field aims to find "counterhegemonic" forces to struggle and resist the domination of the ruling social and cultural forces (Durham, and Kellner, 2009 , p. xxiv). It is also worthy noting that Williams emphasizes the importance of counter hegemony to the practice of Cultural Studies: "We have then to add to the concept of 
hegemony the concepts of counter-hegemony and alternative hegemony, which are real and persistent elements of practice" (Williams, 1977, p.112).

Moreover, one of the theories that Cultural Studies pays attention to is Postcolonial theory. The major concern of Cultural Studies and Postcolonialism is culture. Postcolonial theory primarily depends on the analysis of literary texts in relation to the historical contexts of Colonialism. Simultaneously, text analysis is pivotal to Cultural Studies. Yet, texts that Cultural Studies deals with include films, music, mass media, fashion, and even photographs.

The interdisciplinarity of Cultural Studies urges the field to deal with the colonial discourse. Cultural Studies admits the British colonial rule throughout the world. Williams confirms that British colonialism achieved a powerful dominance through the penetration of societies and cultures (Williams, 1973, p.280). In postcolonial studies, the concept of dominance and Gramsci's theory of cultural hegemony really matter. Although most of colonial regimes are originally established through military dominance, the colonizer eventually develops a hegemonic regime. Edward Said, for instance, reveals the fact that European colonial power in the East prevails through dominance and consent. Gramsci's theory is vital to Said's study of Orientalism since European powers dominate the East through the manipulation of the Orientals' culture. In Said's opinion, Orientalism itself, as an influential academic field, is a cultural instrument by which the consent of the Oriental colonized can be achieved. Said indicates that Orientalism has been established as an ideology in order to make both the East and the West believe in the importance of civilizing the Oriental people

(Said, 1978, p.42).

Furthermore, Postcolonial theory takes advantage of Gramsci's reflections on the Indian struggle against British Imperialism and his theory of Italian colonialism. Srivastava and Bhattacharya indicate that Gramsci tackles the Indian nationalist struggle against the British colonization under the leadership of Gandhi. He focuses on the relationship between the political struggle and military war, and the influence of this relationship on the design of the state and the civil society respectively. He also argues that Italy can be taken as an example of the colonial relationship on the national level and the international level as well. Italy, as Gramsci sees, is a representative for a national colonization through the domination of the North over the South. He refutes the idea of the "supporting" North and describes the South as a "semi-colonial market" to the North. As for the international level, Gramsci refers to Italy as being both colonized and colonizing. Italy has been divided by external European powers into fragmented territories, such as, the Bourborn Kingdom of the Two Sicilies and the Catholic Church. In addition, he turns the attention to Italy as an imperialistic power.

In this respect, he refers to the Lybian struggle against Italian colonization (Gramsci, 1971, pp.3-4).

\section{Analysis of Things Fall Apart}

Things Fall Apart is written by the Nigerian novelist Chinua Achebe and published in 1958. The novel is meant to show the Igbo culture before and after colonization. The pretext of colonization is the civilizing mission which is supposed to civilize the primitives and modify their culture. The novel summons the focal points of Gramsci's theory of cultural hegemony. As it has been observed earlier, Gramsci theorizes that any regime does not necessarily relies on dominance by force but uses hegemony as a system of control. According to Gramsci, a hegemonic system is established through the willing consent of people. That consent is obtained by the dominant regime through cultural hegemony. Achebe's novel, hence, presents the hegemonic model of consent and coercion that can be found in the relationship between the colonizer and the colonized.

The Igbo society is known for its distinctive social structure which is composed of the Igbo Council of Chiefs. The Council of Chiefs comprises the Igbo Clan Heads of many villages. Each clan consists of families and each family has a leader. Each clan also has its own political and economic system. Nevertheless, the Igbos, as a whole, are unified by their beliefs and traditions. They all believe in ancestors, gods, and goddesses. These beliefs are the main source of their religious and human activities (Ogbaa, 1995, p.21). As soon as the colonizer enters this society, the Igbo culture starts changing. 
As far as the novel is concerned, language and religion are the cultural components that have been penetrated by the British colonizer. Throughout the novel, the colonial regime uses ideological means to convince the colonized that it is at their best interest to believe in the current regime. The colonizer does not force them into following orders. But, it convinces the colonized through religion. As a result, People of Umuofia are divided into two opposite sides. Some of them show consent to the new religion, while others resist it by all means. The British colonizer employs the church as an ideological institution where he teaches the natives Christianity. Looking at the people of Umuofia as primitives, the colonizer deploys the Christian beliefs as a part of their civilizing mission.

The church focuses on those who suffer because of Igbo customs. It wins such outcasts as Nwoye and Nneka. Okonkwo's son Nwoye abandons the Igbo beliefs that caused his brother Ikemefuna to be slaughtered by Okonkwo. As for Nneka, she escapes from her ancestors' beliefs as her twins have been thrown in the forest of evil by the elders: "[She] had had four previous pregnancies and child-births. But each time she had born twins, and they had been immediately thrown away" (Achebe, 1959, p.138). Nneka seems to be content with the new religion that authorizes her to be a mother of twins.

The colonizer establishes cultural hegemony through language as well. Language plays a huge role in stabilizing the colonial power. The colonizer introduces his educational system to the colonized through English. The colonized is ultimately required to learn the new language in order to establish himself in the new emerging society. Ngugi wa Thiong'o, for instance, conveys a personal experience of being a Kenyan who speaks Gikuyu language. His culture is transmitted by the oral stories of ancestors that have been told in the Gikuyu language. But, things suddenly change as he goes to a colonial school where the language of his education is no longer the language of his culture. He describes English as the official vehicle and the magic formula to colonial elitedom. Ngugi Thiong'o explains three roles of language in a living culture. The first role is that language is a code of understanding social roles that introduce people to the modes of production in a given society. The second role is that language is a mode of communication through which people communicate with each other. The third role is that language is a carrier of culture. Language, as a culture, is the collective memory container of people's experience in history (Thiong'o, 1986, pp.11-14).

In Things Falls Apart, Achebe gives voice to the voiceless Africans as he introduces Igbo language as a cultural carrier of Igbo culture. Igbo culture is conveyed in an oral form of proverbs and songs. Proverbs, as Achebe shows, are the core of the Igbo language: "Among the Igbo the art of conversation is regarded very highly and proverbs are the palmoil with which words are eaten" (Achebe,1959, p.11). When Obierika condemns the colonizer's rule, he recalls an Igbo proverb to describe the rapid spread of the colonizer's culture: "As the elders said, if one finger brought oil it soiled the others" (Achebe,1959, p.116). However, the colonizer imposes his own language on the natives. According to the colonizer's mindset, the language of the superior must prevail. The Igbos, for the colonizer, have no language because they are only savages who communicate through an awkward babble of uncouth sounds. As English language manages to penetrate the natives' culture, it profoundly gains the consent of Okonkwo's son Nwoye. He seems to be heavenly overwhelmed by the hymn of Christianity: "It was not the mad logic of the Trinity that captivated him. He did not understand it. It was the poetry of the new religion, something felt in the marrow" (Achebe,1959, p.135). This sort of poetry touches Nwoye's heart because it reminds him of Ikemefuna, who has been sacrificed for the survival of the tribe: "The hymn about brothers who sat in darkness and in fear seemed to answer a vague and persistent question that haunted his young soul" (Achebe,1959, p.135).

In spite of the fact that the colonizer's language wins many natives, a mutual misunderstanding of each other's culture takes place. In the discussion between Okonkwo and Obierika, the latter suggests the impossibility of understanding the customs of Umuofia by the colonizer, who speaks a completely different language: "How can he when he does not even speak our tongue?" (Achebe,1959, p.160). The encounter of English and the Igbo language, therefore, ends with what Homi Bhabha refers to as mimicry. Bhabha points out mockery as an outcome of the natives' attempts to mimic the colonizer's culture. It turns the colonized to be a jester-like performer. Mimicry is usually directed towards undermining the colonizer's cultural superiority (Homi Bhabha, 1994, p.8591). Ajofia's mockery of Mr. Smith is a salient example. The spokesman of the nine ancestors of Umuofia, Ajofia, makes fun of Mr. Smith as the latter shows lack of understanding to Ajofia's salutation. But, the spokesman's attempt to salute in English goes in vain: "Ajofia laughed in his guttural 
voice...'They are strangers...and they are ignorant' " (Achebe,1959, p.171). Obviously, the linguistic difference furthers the cultural gap. A clash of two cultures may also occur due to the lack of communication between the colonizer and the colonized. As Mr. Smith asks the interpreter to tell Okonkwo and his fellows to leave the church, their answer is: "We cannot leave the matter in his hands because he does not understand our customs, just as we do not understand his. We say he is foolish because he does not know our ways, and perhaps he says we are foolish because we do not know his" (Achebe,1959, p.172). So, the ultimate clash between the two cultures stems from the lack of knowledge about the other culture including language.

At the end, the colonizer's system of education succeeds in accomplishing the civilizing mission, for the church teaches the new ideology in a very intelligent way: "The white man is very clever. He came quietly and peaceably with his religion. We are amused at his religion. We were amused at his foolishness and allowed him to stay. Now he has own our brothers, and our clan can no longer act like one. He has put a knife on the things that held us together and we have fallen apart", Obierika said (Achebe,1959, p.160). The ideology of the church becomes the only means through which more outcasts are won in Umuofia: "Before God...there is no slave or free. We are all children of God and we must receive these our brothers" (Achebe,1959, p.144). Yet, the church threateningly stimulates the converters to give up their native religion: "Unless you shave off the mark of your heathen belief I will not admit you in the church", the white missionary said (Achebe,1959, p.145). The Igbo natives start giving up their cultural identity in favor of the new religion. Consequently, they must be excluded from the clan: "the adherents of the new faith were thenceforth excluded from the life and privileges of the clan" (Achebe,1959, p.146). This provokes the spirit of resistance in Umuofia that is represented by Okonkwo.

For Okonkwo, it is an unbearable situation to witness the eradication of ancestors' heritage by the Igbos themselves. The "Roaring Flame" Okonkwo is an emblem of cultural preservation against cultural hegemony. He aggressively reacts against the persistent endeavor to spread Christianity: " 'Answer me,' roared Okonkwo, 'before I kill you!' ... He seized a heavy stick that lay on the dwarf wall and hit him two or three savage blows" (Achebe,1959, p.139). While the colonizer regards the colonized as savages who need to be civilized, Okonkwo views the colonizer's culture as filth: "Let us not reason like cowards...These people are daily pouring filth over us" (Achebe,1959, p.146). Likewise, he deeply mourns his people's contribution to the downfall of their culture: "What is it that has happened to our people? Why have they lost the power to fight?" (Achebe,1959, p.159). Being unconquerable warriors is an essential part of Igbo cultural identity. The Igbo man must cultivate his skills in war and fighting. It is an urgent need for their survival. However, the fearless people of Umuofia ultimately bow to the power of the colonizing ideology.

It is noted that the colonizer achieves control through consent. Nevertheless, coercion is also used only when consent fails. For Gramsci, physical force is used against those who never show consent. He says: "The apparatus of state coercive power which 'legally' enforces discipline on those groups who do not 'consent' either actively or passively. This apparatus is, however, constituted for the whole society in anticipation of moments of crisis of command and direction when spontaneous consent has failed" (Gramsci, 1971, p.12). As the novel tells, the colonizer's use of force contributes to the subordination of the natives. Obierika informs Okonkwo of the military force that has been used against those who refuse to accept the colonial regime willingly in Abame: "Have you not heard how the white man wiped out Abame?" (Achebe,1959, p.159). Now, it is too late for Okonkwo and his fellows to restore their culture again. Similar to his culture, the great Okonkwo falls apart too. By committing suicide, Okonkwo, eventually, becomes a man who deserves to be remembered in one paragraph only: "The story of this man who had killed a messenger and hanged himself would make interesting reading. Perhaps not a whole chapter but a reasonable paragraph, at any rate", the Commissioner said (Achebe,1959, p.187).

\section{Conclusion}

In conclusion, cultural hegemony is the product of an enormous collaboration between ideology and culture. A certain power turns to be culturally hegemonic once ideology manages to penetrate the culture of a specific society. As it has been observed, cultural hegemony occupies a wide range of interest in the field of Cultural Studies and Postcolonial studies as well. Cultural Studies tackles the theory of cultural hegemony according to Antonio Gramsci's perception of hegemony within the Fascist regime of Mussolini. Gramsci's 
theory also functions in Postcolonial theory as colonialism results in cultural hegemony. Most, if not all, of the colonized countries inevitably experience hegemonic domination. Hegemonic powers attack the culture of the colonized in favor of the colonizer's interests. A case in point is Achebe's Things Fall Apart that exposes the British cultural hegemony in Nigeria where Igbo society is subject to be culturally penetrated by the colonizer. At the end, the Igbos collapse and their culture finally falls apart due to cultural hegemony. 


\section{References}

Achebe, Chinua (1959). Things Fall Apart. A Division of Random House, Inc.

Bhabha, K. Homi (1994). The Location of Culture. Routledge.

Buttigieg, Joseph A., ed. (1992). Antonio Gramsci: Prison Notebooks Volume 1. Columbia University Press.

Durham, Meenakshi Gigi and Douglas M. Kellner, ed. (2009). Media and Cultural Studies Key Words. John Wiley and Sons.

During, Simon (1999). The Cultural Studies Reader. Psychology Press.

Gramsci, Antonio (1971). Selections from the Prison Notebooks. Quintin Hoare and Geoffrey Nowell Smith. Eds. and Trans. International Publishers.

Hall, Stuart (2018). "Cultural Studies: Two Paradigms". Essential Essays Vol. 1: Foundations of Cultural Studies, ed. David Morley. Duke University Press.

Mouffe, Chantal, ed. (1979). Gramsci and Marxist Theory. Routledge and Kegan Paul.

Mussolini, Benito (1935). The Doctrine of Fascism. Ardita.

Ogbaa, Kalu (1995). Igbo: Nigeria. The Rosen Publishing Group, Inc..

Ritzer, George, and Barry Smart (2000). Handbook of Social Theory. Sage.

Said, Edward W. (1978). Orientalism. Vintage Books.

Srivastava, Neelam Francesca Rashmi and Baidik Bhattacharya (2012). The Postcolonial Gramsci. Routledge.

Thiong'o, Ngugi wa (1986). Decolonizing the Mind.: The Politics of Language in African Literature. East African Publishers Ltd..

Williams, Raymond (1977). Marxism and Literature. OUP Oxford. (1973). The Country and the City. Oxford University Press. 


\title{
IMAGINATION IN ORHAN PAMUK'S NOVEL THE WHITE CASTLE
}

\author{
Sevsen Aziz HILAYIF ${ }^{1}$
}

\section{Istanbul / Türkiye \\ p. $192-200$}

Received: 02/12/2021

Accepted: 09/12/2021

Published: 01/01/2022

This article has been scanned $l$ iThenticat No plagiarism detected

\begin{abstract}
:
Orhan Pamuk is considered one of the most important novelists and short story writers in Turkish Literature. The full name is Ferit Orhan Pamuk. He was born in Istanbul in 1952. He is now 69 year old and still alive. He is considered the first Turkish writer who wins Noble Prize for literature for the year 2006. He won several other prizes, one of which is Noble Prize because he has several short stories and novels.

The White Castle is one of the most important novels for the author Orhan Pamuk who won the Noble Prize. It is considered a historical novel that belongs to the Ottoman Empire era in the 17 th century. The novel revolves on one of the passengers who travels to Napoli through the sea. The Ottoman pirates captivate him and sell him to one of the Turkish people as slave. Both the master and the slave almost share the same features although they are from different geographic areas. The novel deals with the similarities and differences among the people of the and the people of the west in an accurate way.

The concept of dream is to wish something favorable in the future. There were several types and ways of daydreams. This concept is different from one person to another. This term cannot be clearly defined because of its subjective nature. It appears in a very wide area, from the ability to maintain the thing dreamt to achieve to the world of dreams of the dreamer. Hence, the reality of daydreams is a wonderful art that is different from one person to another.

We start the research by giving inclusive summary. In the Introduction, there is short summary for the life and literary personality of the Turkish author Orhan Pamuk as well as his works. The research introduces information about the novel which is the subject of the research paper. It introduces, through detailed study for the novel The White Castle, a detailed explanation about the art of dreams.
\end{abstract}

Key words: Orhan Pamuk, White Castle, Dreaming, Thought, Time.

http://dx.doi.org/10.47832/2717-8293.15.14

1 iD Researcher, Baghdad University, Iraq, sawsanaziz1984@gmail.com 


\section{ORHAN PAMUK'UN BEYAZ KALE ROMANINDA“ \\ HAYAL KURMA SANATI}

\section{ÖZET}

Orhan PAMUK, Türk Edebiyatının en önemli hikaye ve roman yazarlarındandır. Tam adı Ferit Orhan PAMUK olan yazar, 1952 tarihinde İstanbul'da dünyaya gelmiştir. Halen hayatta olan 69 yassındaki PAMUK, 2006 Nobel Edebiyat Ödülünü alan ilk Türk yazarıdır. Nobel başta olmak üzere, daha birçok ödüle layık görülen yazar, hikaye ve roman türünde çok sayıda eseri, Türk Edebiyatına armağan etmiştir.

Beyaz Kale, Nobel Edebiyat Ödüllü yazar Orhan PAMUK'un en önemli romanlarından biridir. 17. asır Osmanlı İmparatorluğu zamanından bahseden, tarihi bir romandır. Napoli isimli şehre deniz seferiyle giden bir yolcunun, Osmanlı korsanları tarafından alıkonulması ve köle olarak bir Türke satılmasın konu edinir. Esasında hem efendi hem de köle, hemen hemen aynı özelliklerdedir ve iki farklı coğrafyanın insanıdırlar. Doğu ve Batı insanının aralarındaki benzerlik ve farklılıkların yoğun olarak konu edildiği roman, psikolojik ve sarsıcı özelliktedir.

Hayal kurmak, geleceğe yönelik çok arzu edilen bir şeyi, istemek ve onu arzulamaktır. Hayal kurmanın birçok çeşidi ve metodu vardır. İnsandan insana farkl1lik arz eden bu kavramın, öznel olmasından kaynaklı olarak net bir tarifi mümkün değildir. Hayali kurulan şeyin gerçekleşme olasılığından, hayal kuranın Düş dünyasına kadar oldukça geniş bir alanda karşımıza çıkar. Dolayısıyla hayal kurmanın kişiden kişiye değişen muhteşem bir sanat olduğu gerçeği ortaya çıkmış olur.

Çalışmamıza, bu kapsamlı özetle başlıyoruz. Giriş kısmında, büyük Türk yazarı Orhan PAMUK'un kısaca hayatı, edebi kişiliği ve eserleri tanıtıldıktan sonra, çalışma romanı ve çalışma konusu hakkında bilgiler verilecektir. Ardından Orhan PAMUK'un Beyaz Kale isimli romanından hareketle, hayal kurma sanat hakkında geniss izahat verilecektir.

Anahtar Sözcükler: Orhan Pamuk, Beyaz Kale, Hayal Kurmak, Düşünce, Zaman.

\section{Giriş}

(Ferit) Orhan PAMUK, hayatı, edebi kişiliği ve eserleri:

Nobel Edebiyat Ödüllü büyük Türk yazarı Orhan PAMUK, 1952 tarihinde Türkiye'nin en büyük şehri olan İstanbul'da dünyaya geldi. Çocukluğu, Nişantaşı isimli semtte geçti. 1970 yılında Robert Kolejinden dereceyle mezun oldu. Ortaöğrenimini burada tamamlayan Orhan PAMUK, İstanbul Üniversitesi Gazetecilik Bölümüne kaydını yaptırdı. Bu fakülteden 1977 yılında mezun oldu. Aynı zamanda, bu fakültede yüksek lisansını tamamladı. Henüz 23 yaşındayken, tüm ömrünü yazarlığa adayacağına dair kendisine söz verdi ve yazarlık hususunda çalışmalara başladı. İlk çalışmaları şiir üzerine idi. Yeditepe isimli meşhur İstanbul dergisinde, şiirlerini yayınladı. Çok geçmeden öykü ve roman türüne ağırlık verdi ve şiiri neredeyse biraktı (BOZDEMİR, 2011: 73).

Yazdığı hikaye ve romanlar, daha ilk yıllarda çok rağbet gördü. Edebiyat camiasında ismi yavaş yavaş anılmaya başladı. İlk başarısı, yazdığı Hançer adındaki hikaye ile geldi. Antalya ilinde düzenlenen festivalde, bu hikaye ile üçüncülük kazandı. Ardından, yazdığ bir roman sayesinde birincilik duygusunu tattı. Bu romanın adı Karanlık ve Işık idi. Karanlık ve Issik adlı bu roman, Orhan PAMUK'a Milliyet Gazetesi roman yarışmasında birincilik getirdi bununla birlikte, artık iyice tanınmaya ve keşfedilmeye başlandı (DEMİR, 2011: 128).

Ödüllerin ardı arkası kesilmedi. Her yazdığı eser, oldukça popüler oldu. Bizim de çalışma kitabımız olan Beyaz Kale isimli 1985 basımlı romanıyla, tüm dünyada tanınır oldu. Ünü yurtdışına giden yazar, yazma faaliyetlerine hız kesmeden devam etti. 
Orhan PAMUK, her ne kadar edebiyatın çeşitli alanlarından eserler verse de, romancılığ ile ön plana çıkmaktadır. Orhan PAMUK'un roman anlayışı, postmodern diye tabir edilen çağdaş roman anlayışıdır. Eserlerinde takip ettiği metod, öncesinde yazacağ1 konu hakkında derin bir araştırma yapmasıdır. Bu araștırmalar neticesinde yazacağı eserin tarihine gider, orada yaşıyormuş gibi içten ve samimi bir üslupla anlatır (KILIÇ, 2000: 11). Bu samimiyetten kaynaklı olarak okuyucu kitlesi oldukça fazladır. Yalnızca Türkiye'de değil, tüm dünyada eserleri okunmaktadır. Hatrı sayılır pek çok dile çevrilen kitapları, yalnızca Türkiye'de değil, dünyanın pek çok ülkesinde ödüllere layık görülmüştür.

Eserlerinin başlıca konularından biri, doğu insanı ile batı insanı arasında köprüler kurmasıdır. Bu iki insan türünün psikolojik ve sosyolojik derinliklerine iner, yer yer onları kavga ettirir, ve bazen de onları bir araya getirir. Bu metod, Ahmet Hamdi TANPINAR gibi usta yazarların metodudur. Bu halde TANPINAR'dan etkilendiği söylenebilir.

Dünyanın 32 farklı diline çevrilen eserleri, yalnızca Türkiye'nin değil, dünyanın yetiştirdiği en önemli yazarlardan biri olduğunu kanıtlar niteliktedir (DEMİRALP, 2018: 14).

Orhan PAMUK, bir söyleşisinde, Türklerin tarihte katliam yaptığına dair imada bulunmuş, bundan dolayı hapis istemiyle hakkında dava açılmıştır. Davası görülen yazar, beraat ermiştir. Bu olaydan sonra yazım hayatında yavaşlama olmuştur. Fakat 2006 yılında dünyanın en önemli ödülleri olan Nobel Edebiyat Ödülüne layık görülmüştür. Nobel'in herhangi bir dalından daha önce bir Türk, herhangi bir ödül alamamıştır. Bu zinciri kıran Orhan PAMUK, Nobel Ödülünü almış olan ilk Türk ünvanının da sahibi olmuştur.

$\mathrm{Bu}$ en önemli ödül dahil, dünya genelinde 20 civarında ödüle layık görüldü. Ayrıca, çeşitli dünya üniversiteleri tarafından kendisine fahri doktoralık verildi. Şu an dünyanın 12 üniversitesinde fahri doktor kabul edilmektedir.

İyi derecede İngilizce bilen yazar, halen yaşamaktadır ve 69 yaşındadır.

Eserleri (ECEVIT, 2004: 80)

ROMAN:

Cevdet Bey ve Oğulları (1982), Sessiz Ev (1983), Beyaz Kale (1985), Kara Kitap (1990), Yeni Hayat (1994), Benim Adım Kırmızı (1998), Kar (2002), Masumiyet Müzesi (2008), Kafamda Bir Tuhaflık (2014), Kara Kitap 25 Yaşında (Numaralı Özel Baskı, 2015), Kırmızı Saçlı Kadın (2016).

\section{ANI:}

İstanbul: Hatıralar ve Şehir (2003), Babamın Bavulu (2007), Resimli İstanbul Hatıralar ve Şehir (2015).

\section{SENARYO:}

\section{DİĞER:}

Gizli Yüz (senaryo 1992).

Öteki Renkler (denemelerinden ve söyleşilerinden seçmeler, 1999), Manzaradan Parçalar (denemelerinden ve söyleşilerinden seçmeler, 2010), Saf ve Düşünceli Romanc1 (Harvard Üniversitesi'nde verdiği Norton dersleri, 2011), Ben Bir Ağacım (2013, Öykü), Hatıraların Masumiyeti (2016, anlatı).

\section{ALDIĞI ÖDÜLLER: (SIRASIYLA) (DOĞAN, 2014: 55)}

1- 1979 Milliyet Roman Yarışması Ödülü - Karanlık ve Işık kitabıyla

2- 1983 Orhan Kemal Roman Ödülü - Cevdet Bey ve Oğulları kitabıyla

3- 1984 Madaralı Roman Ödülü - Sessiz Ev kitabıyla

4- 1990 Independent Yabanc1 Roman Ödülü - (İngiltere) Beyaz Kale kitabıyla

5- 1991 Prix de la Découverte Européene - (Fransa) Sessiz Ev kitabiyla

6- 1991 Antalya Altın Portakal film festivali en iyi senaryo ödülü - Gizli Yüz kitabıyla

7- 2002 Prix du Meilleur Livre Etranger - (Fransa) Benim Adım Kırmızı kitabıyla

8- 2003 Premio rinzane Cavour - (İtalya) Benim Adım Kırmızı kitabıyla

9- 2003 International Impac-Dublin Literary Award - (İrlanda) edebi kişiliğinden dolayı

10-2005 Prix Médicis Étranger - (Fransa) Kar kitabiyla

11-2005 Alman Yayıncılar Birliği'nin Barıș Ödülü - (Almanya) edebi kişiliğinden dolayı 
12-2005 Richarda Huch Ödülü - (Almanya) edebi kişiliğinden dolayı

13-2006 Le Prix Méditerranée étranger Ödülü - (Fransa) Kar kitabiyla

14- 2006 Nobel Edebiyat Ödülü - edebi kişiliğinden dolayı

15-2008 Ovid Ödülü - (Romanya) edebi kişiliğinden dolayı

16-2010 Norman Mailer Yaşam Boyu Başarı Ödülü - (ABD) edebi kişiliğinden dolayı

17-2012 Sonning Ödülü - edebi kişiliğinden dolayı

\section{Beyaz Kale Romanı Hakkında:}

Beyaz Kale, Türk Edebiyatının en önemli romanlarından biridir. Orhan PAMUK'a ait olan eser, 1985 yılında yayınlanmıştır. 1990 yılında yabancı dillere çevirisi yapılan eser, Orhan PAMUK'un ilk çevirisi yapilan eseridir (ESEN, 1996: 66). Küçük hacimlidir ve en önemli özelliği, ilk postmodernist eser olmasıdır.

Eserin şahıs kadrosunda önemli olarak iki kişi göze çarpar. Bir İtalyalı köle ve bir Osmanlı hocası, eserin başrol kadrosundadır. Beyaz Kale'nin kısaca özeti şu şekildedir:

Venedikli bir alim, deniz yolculuğu esnasında, Osmanlı korsanları tarafından esir alınır. Kendisi İtalyandır ve Osmanlı topraklarında pek çok zorluk ve tehlike ile karşı karşıya kalır. Esir pazarında satılır. Zaman geçtikçe, Venedikli alimin ünü artar. Engin tecrübesi ve muhteşem zekası sebebiyle padişahın dikkatini üzerine çeker. Padişah, paşasına bu esiri satın almasını emreder. İtalyan yani Venedikli bilgin, artık Osmanlı sarayında ilim ve tecrübesiyle yaşamaya başlar. Günler sonra, padişahın paşası, Venedikli alimi biriyle tanıştırır. Bu kişi, tıpkı kendisi gibi ilim seviyesi çok yüksek bir Osmanlı alimidir. Bu alimin lakabı Hoca'dır. Hoca ile Venedikli alim, zaman geçtikçe arkadaş olurlar. Saray eşrafının sorunlarını çözerler. Osmanlı'ya çok faydası dokunan bu iki bilgin, dönemin coğrafyasında meydana gelen veba isimli salgın karşı tüm ilim ve tecrübeleri ile çözüm bulurlar. Bu süre zarfında arkadaşlıkları günden güne artar. Hoca, çok önemli bir mevkii olan müneccimbaş1ık görevine terfi alır. Padişah ile birebir görüşme ve konuşma imkanını elde eden hoca, yıllardır hayalini kurduğu bir icadı padişah ile paylaşır. Yapmak istediği şey büyük bir silahtır ve yapar. Padişahın sonsuz desteği sayesinde kısa sürede silah icad edilir. Kısa zaman sonra, Beyaz Kale isimli bir sefere çıkma kararı alan padişah, bu silahın savaşta kullanılmasını ister. Silahın ağır olmasından kaynaklı olarak çamura gömülmesi, savaşın kaybedilmesine yol açar. Bu başarısızlığın sebebi Hoca olarak görülür. Hoca ise, padişah emriyle öldürüleceğini anlar. Her noktada kendisiyle birebir benzeyiş gösteren Venedikli Alim'e ricada bulunur. Her ikisi yer değiştirir. Hoca, batıya yani Avrupa'ya kaçar. Yıllardır hayali olan silahı geliştirir.

\section{Hayal kurmak nedir? Neden sanattir?}

Hayal kurmak, geleceğe yönelik olarak bir olgunun meydana gelmesini düşünmek manasındadır. (GÜNCEL TÜRKÇE SÖZLÜK VE YAZIM KILAVUZU, Hayal Kurmak Maddesi) Daha geniş bir ifadeyle, kişinin gelecekte olmasını temenni ettiği şeyi, zihninde büyük bir heyecanla canlandirmasidir. Hayal kurmak, her insanın fitratında var olan bir olgudur. Dolayısıyla, hayal kurmayan bir insan düşünülemez.

Hayal kurmanın en önemli özelliği, geleceğe yönelik olmasıdır. Geçmişe dair "keşke şöyle yapsaydım" veya "şöyle yapsam nasıl olurdu acaba?" gibi cümleler de esasında birer hayal kurma eylemidir. Fakat geçmişe yönelik kurulan hayaller, pişmanlık kavramıyla ifade edilir. Çünkü geçmiş, geçmişte kalmıştır ve şekillendirilemez. Hayal kurmak ise, şekil verilebilir bir kavramdır. Dolayısıyla hayal kurmak eyleminin çalışma alanı, gelecektir.

Hayal kurmanın pek çok çeşidi vardır. Genel olarak 2 kısma ayırabiliriz. Bunlar, olması muhtemel olan hayaller ve olması mümkün olmayan hayaller olarak karşımıza çıkar. Kişinin çok çalışıp gelecekte öğretmen olmayı istemesi, olması muhtemel ve dolayısıyla çabaya bağlı hayal kurmaktır. Fakat örneğin kişinin ölümsüz olmayı hayal etmesi, imkansız hayallerdendir. Her ne dense insan, çabaya bağlı olmayan ve zihni zorlayan bu imkansız hayalleri çokça kurar. İnsana cazip gelen, inşirah veren bir düşü düşlemesi, psikolojik olarak kişiyi daha iyi hissettiren bir eylemdir. Zorluklardan kaçışın en kolay yolu, kolaylıklar dünyasında hayal kurmaktır.

Peki neden hayal kurmak bir sanattır? Öncesinde, sanat kavramını açıklayalım. Sanat, Arapça kökenli bir kelimedir. "Yapmak", "meydana çıkarmak" manalarına gelir. Fakat, bu dar manası ile bu kavramı açıklamamız mümkün değildir. Çünkü her yapılan veya meydana çıkarılan şey, sanat değildir. Bir şeyin sanat olması için, estetik kaygısı ile yapılmış olması lazımdır. Örneğin, tahtadan bir kaşık yapmak, sanat değildir. Beceri ve 
zanaattir. Fakat bu kaşığa süslemeler, bezgiler ve geometrik oymalar yapıldığı takdirde, sanat ve estetik kaygısı ile yapıldığı için sanat olur. O halde bir şeyin sanat olması için, işlevsellikten ziyade, estetik bir düşünce ile yapılması lazımdır.

Kişi hayal kurarken, istediği her şeyi düşünebilir. Başta da belirttiğimiz gibi, hayal kurmanın sınırı yoktur. Dikkat edildiği takdirde, kişi hayal kurarken asla basit, sıradan ve öylesine hayal kurmaz. Aksine, kişi hayaline birçok estetik güzellik katar. Bir televizyonun hayalini kurarken, ister istemez altında isslemeli bir televizyon sehpası hayal eder. Ya da bir arabanın hayalini kurarken hayalinde yalnızca bir araba değil, etrafında yeşillikler, yanında kıvrılarak akan bir dere ve cıvil cıvıl kuşları da hayal eder. İşte hayal kurmanın bu estetik yönü, hayal kurma eylemini bir sanata dönüştürür. Bu yüzden hayal kurmak, yalnızca düşlemek değildir. Hayal kurmak, aynı zamanda bir sanattır.

Hayal kurmak ve hayal kurma eyleminin neden sanat olduğu, tarafımızca açıklandıktan sonra, şimdi de Orhan PAMUK'un Beyaz Kale isimli muhteşem romanından hareketle, hayal kurma sanatına bakalım:

\section{Orhan PAMUK'un Beyaz Kale Romanında Hayal Kurma Sanat1:}

Beyaz Kale romanının daha ilk sayfasında, konumuzla ilgili olarak muhteşem bir detay göze çarpmaktadır. Venedikli Bilgin, Türk korsanları gemilerini ele geçirmeye başladıklarında kurduğu hayali şöyle anlatmaktadır:

"Şimdi sisin içinde hayalet gibi dolanan Türk gemilerinin renklerini düşleyip, eski bir masanın üzerinde kitabımı yazmaya çalışırken, öyle bir dönemin, bir hikayeye başlayıp onu bitirmek için en uygun zaman olduğunu düşünüyorum" (PAMUK, 2021: 11).

Görüldüğü üzere Venedikli Bilgin'in, tüm bu seyehat ve problemlerden kurtulduktan sonra, tecrübelerini aktarmak için yazmak istediği bir kitap var. Bu kitap, Venedikli'nin hayalidir. Düşlediği şey, tüm bu olumsuzlukların meyvesi olarak ortaya çıkacak olan bir kitaptır. Bu kitabın yazım aşamasına tekabül eden bu muhteşem hayalin en dikkat çekici noktas1, şüphesiz, gemilerin renklerini hayal etmesidir. Yani gelecekte bir kitap yazacak ve bu kitabı yazarken aklına, kendilerini istila etmek için gelen Türk gemilerinin renklerini getirecektir. Dolayısıyla bu hayal, basit bir hayalden çok daha ötede, stratejik olarak düşünülmüş ve her bir ayrıntısı önceden tahayyül edilmiş bir hayaldir.

Hayallerin sanat ile bütün olduğundan bahsetmiştik. Söz konusu bahsin en güzel örneklerinden birini, bu alıntıda görmekteyiz. Kurulacak olan hayalde, gemilerin rengini düşünüyor olmak, estetik duygusuyla hayal kurmak manasına gelir. Yoksa tam tersi, "gemiler bize saldırdı" demek, sanatı bir hayal değildir. Fakat gemilerin rengine değin düşünülmüss, estetik ve güzel noktaları ön plana çıkarılmış bir hayalden bahsedildiği görülmektedir. Bu hayal, hayal kurma sanatına 1şık tutmaktadır.

Kitabın ilerleyen kısımlarında, Venedikli'nin bir başka hayali göze çarpmaktadır. Bu hayalin en önemli özelliği, anında kurulmuş olmasıdır. Acele edilmiş, hızlıca kurulmuş olan bu hayale bakalım:

"Sisin içinde, kargacık burgacık dar sokaklarda yürürken birden evimize gelivereceğimizi, ya da onları (akrabalar), bir rüyadan uyanır gibi karşımda buluvereceğimi sanıyordum." (PAMUK, 2021: 14)

Burada konumuza dair dikkat edilmesi gereken en önemli ayrıntı, telaş içinde iken kurulan hayallerin ne özellikte olduğudur. Zindanda iken bir Osmanlı paşası tarafindan alınıp götürülen Venedikli Bilgin, bu aciliyet içerisinde hayal kurmaktadır. Hayali, imkansız olan hayaller kategorisindedir. Çünkü Venedikli de bilir ki, bulundukları yer, Osmanlı topraklarıdır. Dolayısıyla İtalya'daki evine gelmiş olmaları, imkansızdır. Kişi tüm imkansız hayallerini, en çaresiz zamanlarında kurar. Çünkü hayal kurmak, gerçek acı içerisinde kişiye az da olsa keyif verir. İlerleyen kısımlarda, rüyadan uyanır gibi kendisini evinde hayal etmesi, durumun vehametini gözler önüne sermektedir. Öyle kötü kabuslar vardır ki, kişi uykusundan uyanınca şükreder. Mutlu olur. Çünkü az önce gördükleri yalnızca kötü birer rüyadır. Dolayısıyla kötü rüyadan yani kabustan uyanmak, o kabustan kurtulmaktır. Venedikli Bilgin, tutsak edildiği günden beri sanki büyük bir kabusun içerisindedir. Bu kabustan uyanmak ister, fakat kendisi de bilir ki yaşadıkları rüya veya kabus değildir. Tüm bu çaresizlik ve telaş içerisinde kurulan hayallerin estetik ve ince bir ruhla kuruluyor olmas1, her ne olursa olsun kissinin hayal kurabileceğini gösterir. Hayal kurmak, engel tanımaz. Acı büyüdükçe, hayalin şiddeti de büyür. Dolayısıyla daha sanatlı, daha estetik ve 
daha zarif hayaller, en çaresiz zamanlarda kurulur. Estetik kaygis1, hayalleri süsleyen bir olgudur.

Orhan PAMUK'un eşsiz eseri Beyaz Kale'nin ilerleyen kısımlarında, çalışmamızı ilgilendiren oldukça önemli bir kısım geçmektedir. Venedikli Bilgin, şunları söylemektedir:

"Bir ay süren bu yazı işinin sonunda, bir gece, pişmanlığa kapılıp bütün yazdıklarını yırttı. Bu yüzden o yazdıklarını ve kendi geçmişimi, şimdi, hayal gücüme dayanarak yeniden kurarken sevdiğim ayrıntılara kapılmaktan korkmuyorum hiç." (PAMUK, 2021: 51).

Hoca lakaplı Osmanlı Bilgin, bir ay boyunca yazım hayatına adım atmıs, anılarını kaleme almıştır. Fakat bir ayın sonunda, tüm yazdıklarını pişmanlık duygusuna kapılıp yırtmıştır. Venedikli Bilgin, tüm bu olup bitenleri zihninin bir köşesine yazmıştır. Çünkü tüm bu seyahatten ve tutsaklıktan kurtulup memleketine döndüğünde, anılarını yazmak istemektedir. Tüm kitap boyunca Venedikli Bilgin'in en büyük hayali, yaşadıklarını yazmaktır. Geçmişi geleceğe taşımak ve ölümsüz kılmak, Venedikli'nin kurduğu hayaldir.

İşte bu hayalinin önemli bir parçası, Hoca ile biriktirdiği anılardır. Hocanın anılarını bir çırpıda yırtması, Venedikli'nin hayaline konu olmuştur. Tüm bu olup bitenleri, tahayyül ettiği kitabına almak için sabırsızlanıyordur.

Burada belki de en önemli ayrıntı, Venedikli'nin "hayal gücüme dayanarak" sözüdür. Hayal kurmanın sınırı olmadığından bahsettik. Herkes istediği hayali zihninde canlandırabilir. Fakat kimi insanların hayal dünyası oldukça geniştir. Hayal gücü denilen şey, bu geniş düşünce kabiliyetidir. Venedikli, hayal gücüne çok güvenmektedir. Çünkü yaşadığı olayları aktarmak istemektedir. Bu sebeple, yaşadığı her bir olayı, farklı gözle analiz etmektedir.

"Sevdiğim ayrıntılara kapılmaktan korkmuyorum hiç" söylemi ise, temel konu dururken, ayrıntılarda boğulmaktan korkmadığı anlamındadır. Kişi günlük hayatta, ayrıntılara kapılmaktan korkar. Çünkü onlar, kişiyi asıl meseleden uzaklaştırır. Fakat hayali kurulan şeyin ayrıntıları, kişiye zevk verir. Bu yüzden, günlük hayattaki olgular, hayaldeki olgular gibi değildir. Hayal kurarken zihne gelen ayrıntılar, hayali daha sanatlı bir mevkiye taşır. Çünkü sanat, ayrıntılarda gizlidir.

Çalışmamızın bu kısmında, kurulacak bir hikayenin ayrıntıları göze çarpıyor. Hikayeler, hayal ürünü anlatılardır. Bir hikayenin şekillenme süreci, Beyaz Kale isimli romanda şu şekilde izah edilir:

"Sonra, iyi bir hikayenin başı masal gibi çocuksu olmall, diye düşündük, ortası korkulu rüya gibi korkutucu, sonu da ayrllkla biten bir aşk hikayesi gibi acıklı olmalıydı." (PAMUK, 2021: 74)

Hikayeler, birer hayal ürünüdür. Hikaye yazarları ise, hayal kurma sanatının sanatçılarıdır. İyi bir hikaye, iyi bir hayal demektir. Kişinin hayal gücü ve düşünce perspektifi ne kadar büyük ise, ortaya o kadar önemli bir hikaye çıkacaktır. Her hikaye mutlu sonla bitmez veya her hikaye baştan sona kadar mutluluk barındırmaz. İyi bir hayal gücü, iyilik ve kötülüğü savaştırır. Bir örnekle izah edelim:

Zulüm gören mazlum bir kişi, hayalinde zulüm görmediği bir ortamı canlandırır. O kişi, artık mazlum değildir. Fakat aynı hayalinde, zalim olan ve kendisine zulmeden kişiyi cezalandırır. Kötü olanı hayalinin bir parçası yapar. Bu sayede, çok daha mutlu olacaktır. Madem ki hayal kurmak, kissiye mutluluk veren bir sanattır, o halde kötü ile iyinin savaşında iyinin galip gelmesi de mutluluktur.

Romanın alıntıladığımız bu kısmında, Hoca ve Venedikli, bir hikayenin temelini oluşturmaktadır. Giriş kısmı çocuksu ve güzel, gelişme kısmı korkunç, sonuç kısmı ise acıklı ve kötü bir şekilde bitmektedir. Hayal kurmanın öznel olduğunu, yani kişiden kişiye farklılık arz ettiğinden bahsetmiştik. Hayal ürünü olan bu hikayenin içeriği, elbette Hoca ve Venedikli'ye göre bu şekildedir. Bir başkası, bambaşka bir hikaye hayal edebilir. Fakat burada konumuzla ilgili temel nokta, hayallerin bir düzen içerisinde kurulduğudur. Birbirini takip eden konular, bir düzenin parçalarıdır. Sanat ise, intizam üzerine kuruludur. O halde diyebiliriz ki, hayal kurmak, zihnin düzenli bir şekilde yaptığ bir eylemdir. Sanat ise, baştan sona düzen üzerine kuruludur. O halde bu alıntıdan yola çıkarak diyebiliriz ki, intizamın yani düzenin olduğu yerde sanat vardır. Hayal kurmak, bu bakımdan bir sanattır. 
"O bana her şeyi anlatmiş; ben de ona anlatırsam Evliya da karşılliğında bana eğlenceli şeyler anlatırmış: hayatın en hoş yanı, hoş hikayeler uydurup, hoş hikayeler dinlemek değil miymiş?" (PAMUK, 2021: 119).

Evliya adındaki bir şahıs, kendisini sakin bir hayata adayan Venedikli Bilgin'in evine gelir. Venedikli'ye alıntıladığımız kısmı söyler. Kendisi de, tıpkı Venedikli gibi anı ve hikaye yazarı olan Evliya, kurmuş olduğu bu cümle ile Venedikli'nin dikkatini çekmeyi başarmıştır. Burada temel nokta, tüm zevklerin en üst merhalesinin hayal kurmak olduğudur. Hikayelerin, sanatlı birer hayal ürünü olduğundan bahsetmiştik. Tüm insani zevklerin en üstünü, en güzel hayali kurmak ile mümkündür.

Kişi, mutluluk kaynağı olarak, elde ettiği şeylerin varlığını düşünür. Elde edilmemiş şeyler, mutluluğun kaynağı olamaz. Örneğin bir başkasının arabası, bizim için mutluluk vermez. Çünkü o arabanın sahibi değilizdir. Madem kişi, elinde olanlar kadar mutluluk duyuyorsa, elinde olmayanlar kadar da acı ve keder hissini duymalıdır. Bir başkasının arabası için mutlu olmayız, bununla beraber kendi arabamız yok diye üzüntü duyabiliriz. Gelecekte bir arabamız olabilir. Arabamızın olduğu bir geleceği hayal etmek, bize zevk verecektir. O halde, elde olmayan şeylere karşı duyulan hüznün ilac1, hayal kurmaktır.

Hayal kurmak, parayla alınıp satılmaz. Ücretsizdir ve sınırı yoktur. Ücretsiz ve sınırsız bir dünya, cennet gibi bir yerdir. İşte bu adeta cennetten bir parça olan yer, kişinin hayal dünyasıdır. Belki de Türkçede kullanılan "hayal dünyası" kavramının sebebi budur. Çünkü hayal kurmak, bambaşka bir dünyaya adım atmaktır. Tamamen kişiye özgü bu dünyada dolaşmak, manevi anlamda kişiye mutluluk ve huzur verir. Buna binaen Evliya'nın da dediği gibi: hayatın en hoş yant, hoş hikayeler uydurup, hoş hikayeler dinlemek değil miymiş?

Hayal kurmak, muhteşem bir sanattır. Sanatkarları ise insanlardır. Her insan, hayal dünyasında sürekli olarak bir şeyler inşa eder. Estetik ve zarafet, bu yapiların başat faktörüdür. Estetiğin olduğu yerde sanat vardır. Güzeli görmek, mutluluk için çabalamak, derin ve eşsiz bir sanatın tezahürüdür.

\section{Bunlar:}

1- Hayal kurmak, estetik ve zarafet yönünden dolayı, bir sanattır

2- Kişi, en telaşlı anında bile hayal kurabilir. En sanatı hayaller, en zor zamanlarda kurulur.

3- Hayal kurmanın sanat oluşunun temelinde, ayrıntılar ve hayal gücü vardır.

4- Hikayeler, en sanatı hayal ürünüdür. Çünkü her açısı önceden detaylıca düşünülür.

5- Dünyanın en güzel hissi, bir hayalin ürünü olan uydurma hikayeler anlatmak ve dinlemektir. Çünkü hayal kurmak, sonu olmayan bir sanattır. Sonsuzluk, insana mutluluk ve huzur verir.

\section{Sonuç}

Orhan PAMUK, Türk Edebiyatının en önemli hikaye ve roman yazarlarındandır. Halen hayatta olan 69 yaşındaki PAMUK, 2006 Nobel Edebiyat Ödülünü alan ilk Türk yazarıdır. Nobel başta olmak üzere, daha birçok ödüle layık görülen yazar, hikaye ve roman türünde çok sayıda eseri, Türk Edebiyatına armağan etmiştir.

Beyaz Kale, Nobel Edebiyat Ödüllü yazar Orhan PAMUK'un en önemli romanlarından biridir. 17. asır Osmanlı İmparatorluğu zamanından bahseden, tarihi bir romandır. Napoli isimli şehre deniz seferiyle giden bir yolcunun, Osmanlı korsanları tarafından alıkonulması ve köle olarak bir Türke satılmasını konu edinir. Esasında hem efendi hem de köle, hemen hemen aynı özelliklerdedir ve iki farklı coğrafyanın insanıdırlar. Doğu ve Batı insanının aralarındaki benzerlik ve farklılıkların yoğun olarak konu edildiği roman, psikolojik ve sarsıc1 özelliktedir.

Hayal kurmak, geleceğe yönelik çok arzu edilen bir şeyi, istemek ve onu arzulamaktır. Hayal kurmanın birçok çeşidi ve metodu vardır. İnsandan insana farklılık arz eden bu kavramın, öznel olmasından kaynaklı olarak net bir tarifi mümkün değildir. Hayali kurulan şeyin gerçekleşme olasılığından, hayal kuranın Düş dünyasına kadar oldukça geniş bir alanda karşımıza çıkar. Dolayısıyla hayal kurmanın kişiden kişiye değişen muhteşem bir sanat olduğu gerçeği ortaya çıkmış olur.

Çalışmamızda, hayal kurma sanatına dair, Orhan PAMUK'un Beyaz Kale isimli romanından hareketle 5 noktaya temas ettik. 5 önemli açıdan, hayal kurma sanatının inceliklerini ortaya koymaya çalıştık. Hayal kurmak, olmayanı düşlemek, geleceğe dair umut 
dolu olmak, bir şeylerin çok daha farklı olmasını ummak, maddi ve manevi arzuları, sanki varmış gibi yapmak... bunların hepsi birer hayal kurma ürünüdür. Tüm hayaller estetik kaygı ile kurulur. Estetik ve zarafet, sanatın birer parçasıdır. 


\section{Kaynakça:}

BOZDEMİ, Orhan. (2011). Kimlik Arayışı ve Orhan Pamuk, İstanbul: Berikan Yayınevi. DEMİRALP, Oğuz. (2018) Orhan Bey ve Romanları, İstanbul: Kırmızı Kedi Yayınları.

DEMİR, Fethi. (2011). Orhan Pamuk'un Romanları Üzerine Bir Araştırma, (Yayımlanmamış Doktora Tezi) Yüzüncü Yıl Üniversitesi.

DOĞAN, Zafer. (2014). Orhan Pamuk Edebiyatında Tarih ve Kimlik Söylemi, İstanbul: İthaki Yayınları.

ECEVİT, Yıldız. (2004). Orhan Pamuk'u Okumak, İstanbul: İletişim Yayınları.

ESEN, Nüket (1996). Kara Kitap Üzerine Yazılar, İstanbul: İletişim Yayınları.

Güncel Türkçe Sözlük ve Yazım Kılavuzu. (2001). hayal kurmak maddesi, Türk Dil Kurumu Yayınları.

KILIÇ, Engin. (2000). Orhan Pamuk'u Anlamak, İstanbul: İletişim Yayınları.

PAMUK, Orhan. (2021). Beyaz Kale, İstanbul: Yapı Kredi Yayınları. 


\title{
THE CONTROVERSY OF ROOTING AND CONTRASTING ONE-LETTER FORMATIONS
}

\author{
Kifah Jumaah Hafth SABER ${ }^{1}$
}

\section{Istanbul / Türkiye \\ p. 201-216}

Received: $29 / 11 / 2021$

Accepted: 08/12/2021

Published: 01/01/2022

This article has been scanned $t$

iThenticat No plagiarism detected

\begin{abstract}
:
The concept of rooting and renewal in Arabic calligraphy is linked to the calligrapher's need to show new aesthetic methods, through formations and calligraphic structures based on a single letter. The perceptual vision of the calligrapher, so this research was concerned with studying the rooting and renewal of the rule of the single letter in the formations of Arabic calligraphy in particular, which included four chapters, the first chapter included the research problem, its importance, objectives, limits and definition of its terms.

As for the second chapter, it deals with tracing the concept of rooting and renewal and its connection with the artist and the possession of the idea and the ability to technical aesthetic expression, through the one-letter linear formations made by calligraphers, relying on the spatial organization and choosing the appropriate letter for the composition.

The analysis concluded with a number of results that were devoted to the fourth chapter, which showed rooting, renewal, acceptance of decorative and different aesthetic formations in structural structures, and investing some characteristics of letters to arrange and divide the linear structure into creative forms and structures.
\end{abstract}

Key words: Contrasting, Formations, Renewal. 


\section{جدل التأصيل والمغايرة في تكوينات الحرف الواحد}

\section{كفاح جمعة حافظ صبر 2}

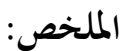

أرتبط مفهوم التأصيل والتجديد في الخط العربي بحاجة الفنان الخطاط إلى إظهار أساليب جمالية جديدة، من خلال التكوينات والتراكيب الخطية المبتكرة المعتمدة على الحرف الواحد، وقد ساعدتها بعض الخصائص الفنية

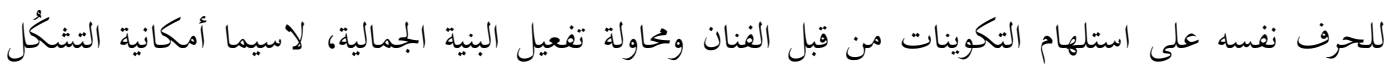
والتحكم بالحروف وتوسع الرؤية الإدراكية للخطاط، لذا عني هذا البحث بدراسة التأصيل والتجديد لسيادة

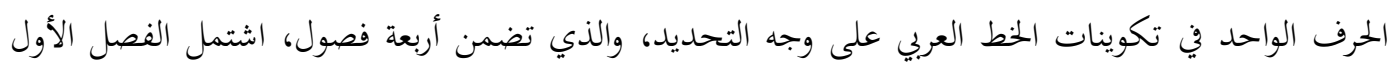

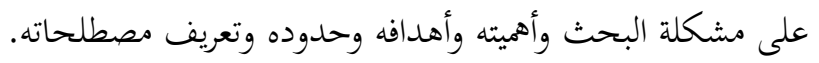

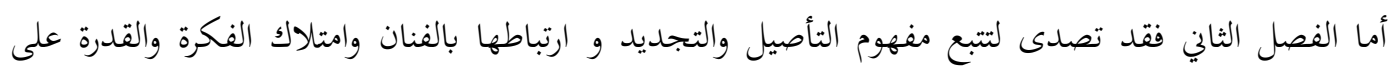
التعبير الجمالي التقني، من خلال التكوينات الخطية ذات الحرف الواحد التي قام بها الخطاطين، باعتماده على التنظيم المكاني واختيار الحرف المناسب للتكوين. أما الفصل الثالث فقد مثل إجراءات البحث وبجتمعه الذي بلغ (20) تكويناً معتمداً على الحرف الواحدا، اختير منها (2) نموذجاً لتمثيل المجتمع والتي اعتمد فيها الباحث على المنهج الوصفي التحليلي على وفق المنهج العلمي.

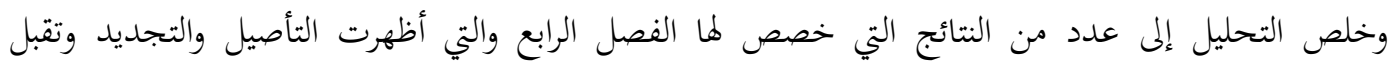
التكوينات الجمالية الزخرفية والمغايرة في البنى التركيبة واستثمار بعض خصائص الحروف لترتيب وتقسيم التركيب

$$
\text { الخطي إلى أشكال وبنى إبداعية. }
$$

الكلمات المفتاحية: جدل التأصيل، المغايرة، تكوينات الحرف الواحدي، إندال

المغايرة والتأصيل في التقليد والمحاكاة مفهومان متناقضان كلياً، فالتقيد عُد قاعدة سار عليها طلاب الخط العربي على

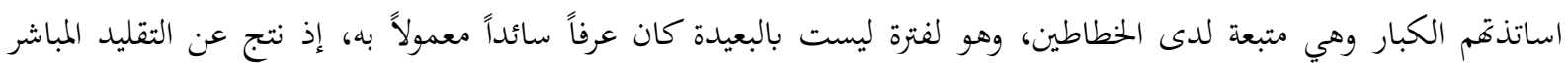

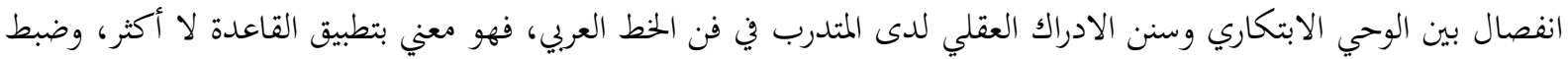
حروفها بشكل تطابقي مع الاستاذ أو المدرب، وهي صفة ليست ذميمة، بالعكس كان كبار الخطاطين المجودين يتبارون في تقليد

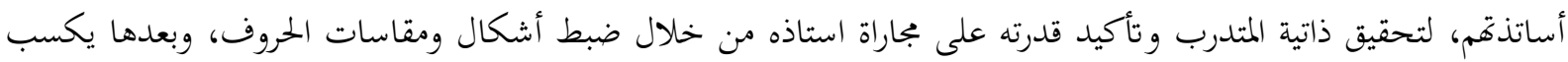

$$
\text { رضا استاذه فيجيزه ضمن العرف المعمول به تقليدياً. }
$$

والتجديد والتأصيل يبدوان مصطلحان متضادان في المعنى بشكل كامل، إلا ان الوقت الحاضر وبعد كل هذه النتاجات

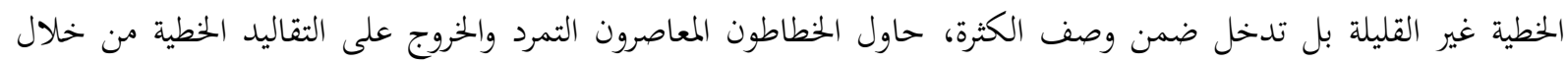

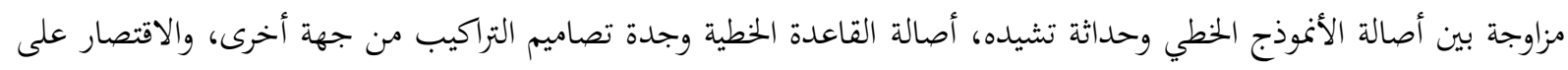

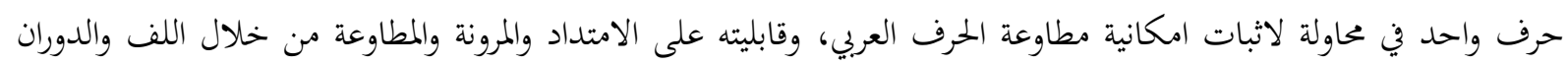


والصعود والنزول والاستطالة والمد وغيرها من الصفات التي يتمتع بها دون الخروج عن الأصالة في القاعدة الجمالية والهندسية،

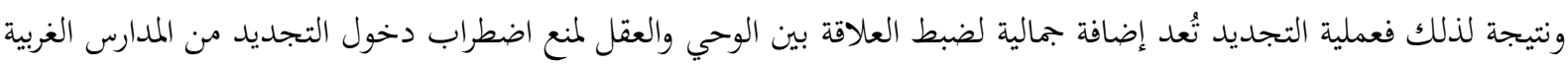

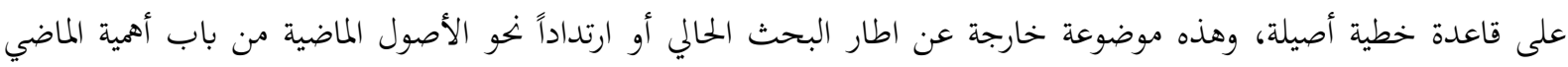

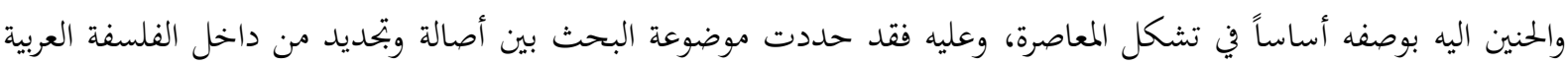
الاسلامية والعرف الخطي المتأصل مع التحرر ضمن معطيات المرحلة. 


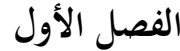

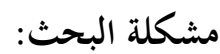

يُعد الخط العربي أحد الانجازات الجمالية التي تحتضن فاعلية الإبداع ومفصلاً مهماً من خلال المنجزات الخطية المتقنة، فهو

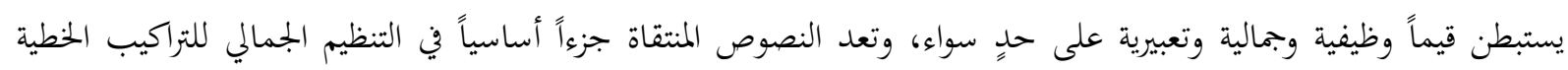

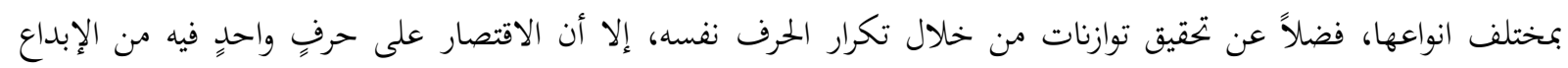

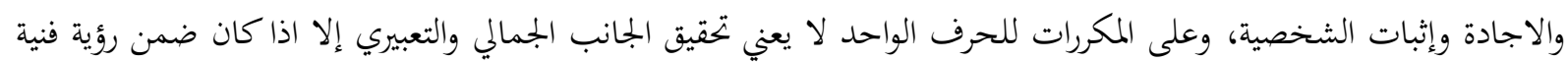

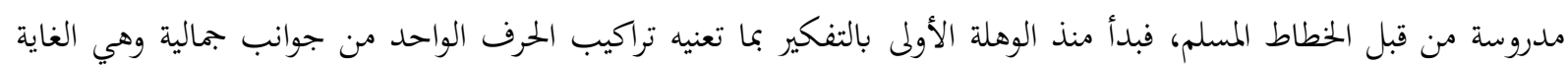
الأساسية وتعبيرية ان وجدت فئل الخطات

فظهر الجانب الجمالي والتعبيري للخط العربي من خلال تكرار رسم الحرف الواحد و معالجة الفضاءات البينية داخل البناء

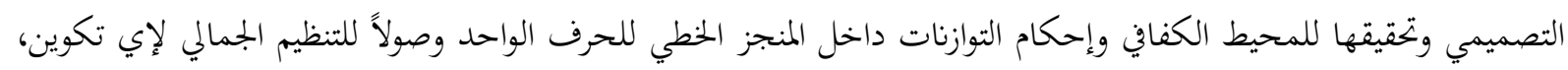

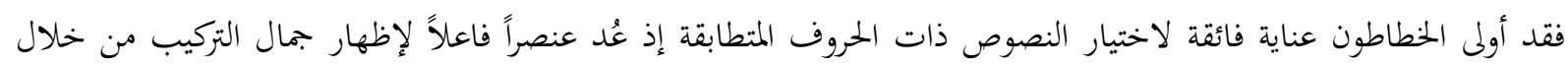

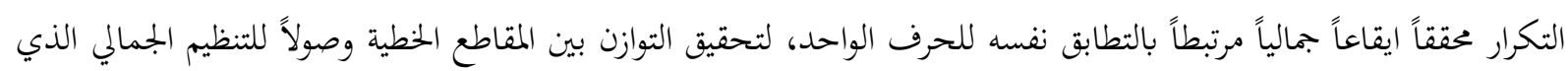

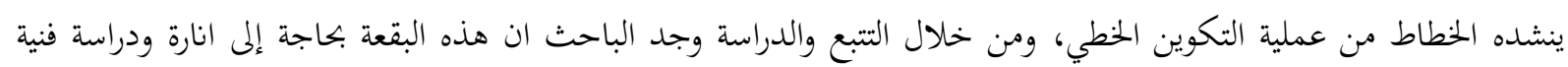
أكاديمية وعليه صاغ مشكلة بحثه بالتساؤل الاتي:

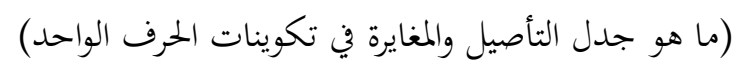

\section{أهمية البحث والحاجة اليه:}

1- يسهم البحث الحالي في تحديد جماليات التأصيل والمغايرة في ايقاع الحرف المتطابق الواحد وأسباب التطابق الشكلي له في تكوينات الخط العربي وصولاً للتنظيم الجمالي والتعبيري. 2- يسلط البحث الضوء على موضوعة مهمة مرتبطة بين الخط العربي قاعدياً وجمالية المنجز البصري المتمثل بالتكوينات الخطية، فضلاً عن إمكانية الإفادة من نتائج البحث في تعزيز الجوانب الفكرية والتطبيقية لدى المعنيين بميدان الخط العربي عموماً. 3- مرونة وطلاقة الحرف العربي وقابليته على التجدد والانتشار ضمن قاعدة تناسبية جمالية.

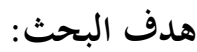

كشف التأصيل المغايرة للتكوينات المعتمدة على الحرف الواحد في الخط العربي، وأسسها التنظيمية المتبعة وصولاً للتنظيم

$$
\text { الجمالي داخل التراكيب الخطية وارتباطها بمعانيها. }
$$

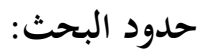

1.الحد الموضوعي: التكوينات الجمالية المتقنة المعتمدة على الحرف الواحد في خط الثلث الجلي على خامة الورق.

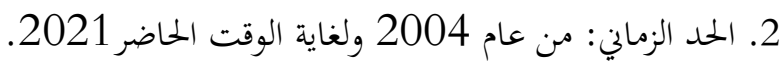

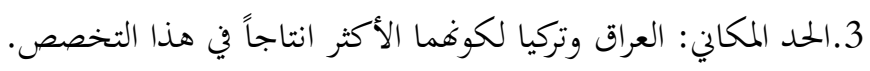


1. (عرف الباحث المطلح لأنه جديد ويخص موضوعة البحث اجرائياً)

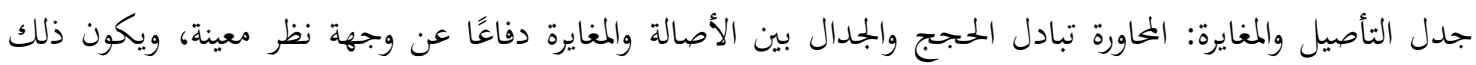

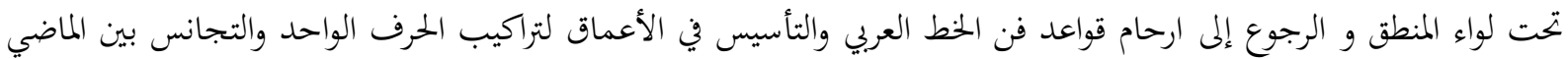
والحاضر فكل بتديد بلا أساس يكون غير مستقر فنياً، لتجنب الازدواجية بين أنصار الأصالة وأنصار التجديد في فن الخط العربي، وبهذا المغايرة تكون شرط الأصالة.

2. المغايرة: وجود اختلاف في البجال المرئي (جيلام،1980،ص15)

هو نوع من المقارنة بين الاختلافات التي تظهر في هيأتين أو أكثر ومختلفة فينة في جوانب أخرى

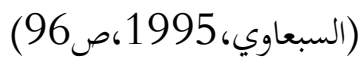

المغايرة إجرائياً: المزج بين القديم والجديد في هيأة بصرية تحتكم إلى معايير وقواعد جمالية أصيلة، مرتبطة بالتجديد ضمن رؤى فلسفية. 3. تكوينات الحرف الواحد: التراكيب المعتمدة في بِنيتها الشكلية على تطابق وتكرار حرفاً واحداً، لتحقيق التجديد ضمن رؤية فنية حديثة، مستعيناً بخصائص الحروف التصميمية لتحقيق ذلك. 


\section{تأصيل القاعدة في تكوينات الحرف الواحد}

التأصيل في الخط العربي هو بيان الأصل من قواعده و إتباع طريقة الاساتذة من المجودين القداما، والذين ساروا على هذا

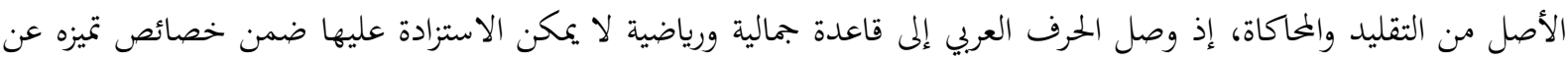
غيره وهو ما ينفرد به الثكل (الحرف أو الكلمة) من صفات بارزة تحدد كينونته وتدل عليه محددة معالمه بما تفرقه عن غيره وبتعل

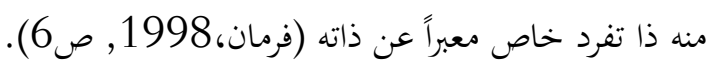

فبينما يصر بعض الخطاطين على ضرورة المحافظة عليها واستبعاد اي ممارسة بتحيدية قد تضر بشكل الحرف العربي، إلا ان ان

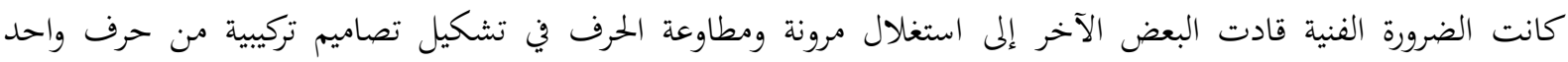

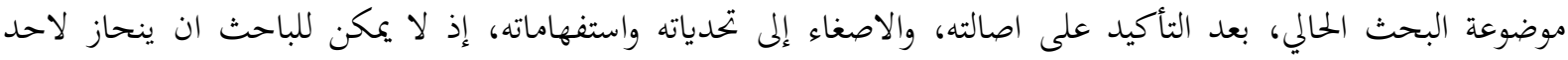
الموقفين ويسبغ عليه المشروعية، ومن الاجدر ان نبحث وبدقة متناهية عن بواعث كل موقف وتداعياته ومنطلقاته، وهنا تبرز

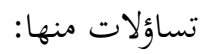
1. للتجديد دوراً جمالياً في اغناء التأصيل ضمن فلسفة جمالية مختلفة تتواكب ومعطيات العصر في تكوينات الحرف الواحد دون نصاً محدداً ام خلاف ذلك. 2. هناك تقاطع سلبي بينهما، اي اضافة المغايرة تضر بالأصالة التناسبية لقاعدة الحرف الواحد أو تفيده جمالياً، وما سبب غزارة الانتاج فيه.

3. القواعد والمعايير تنطبق عليهما في اي زمن، ام تتحدد بالرؤى الفلسفية المتجددة.

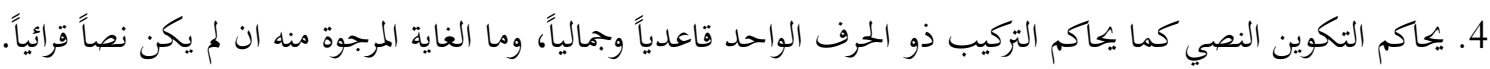

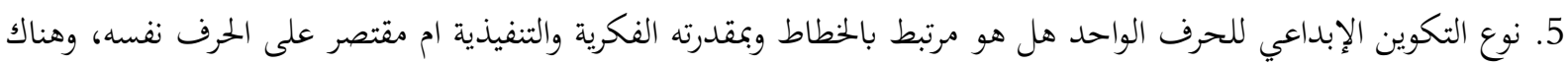
تباين في تجارب الفنانين في الخط العربي. فمنهم من يفهم التجديد بالاغتراب الفكري بعد اتصال الفنان بالغرب، وتأثر أغلب الفنون التشكلية بذلك، وتشبع

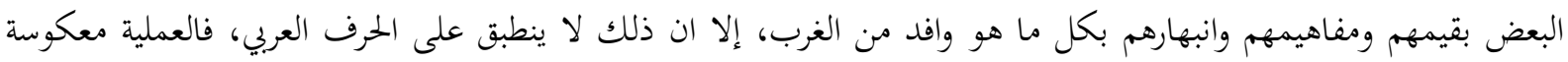

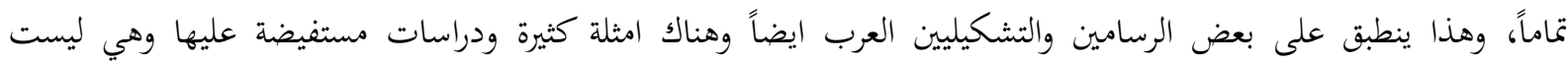

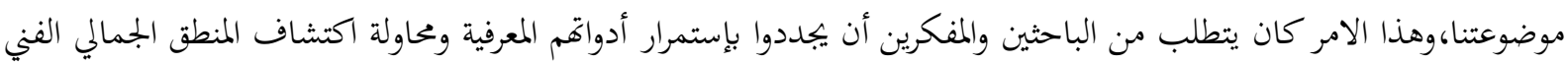

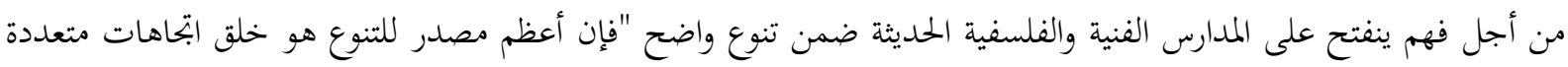

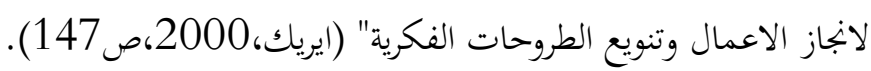

ويواكب تطورها المستمر والتفاعل مع عناصرها الايجابية وإعادة صياغتها في أطر خلفيتهم الفكرية وثوابتها الفنية والجمالية على حدٍ سواء، على عكسه عندما يتوقف ويتعطل الفكر عن التجديد وأدواته المعرفية في الخط العربي وتنشط الذاكرة والتقليد الصارم، والتأكيد على الوقوف عند قاعدة الحروف والسير على فج الاقدمين دون الخروج عن عباءقم المعتادة اعتزازاً بتراثهم الفني

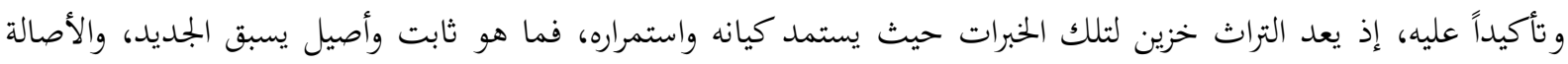
أساس المعاصرة والوسيلة تؤدي إلى الغاية (حنفي، 1987، صنائس 11) فهو يؤدي إلى السكون وفقدان الثقة بالذات والتبعية الصارمة للاساتذة على طلابهم من خلال التقليد والمحاكاة. 
ثََمة حقيقة ان بجموعة من الأقدمين تقاطعت أرائهم مع المغايرة وأخفت الوجه المشرق له حتى صار يشار له بدلالات غير

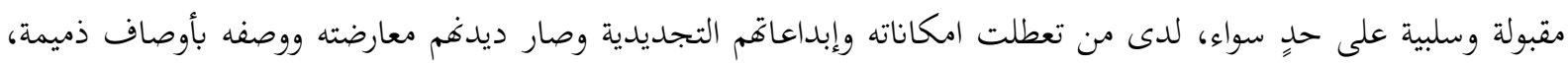

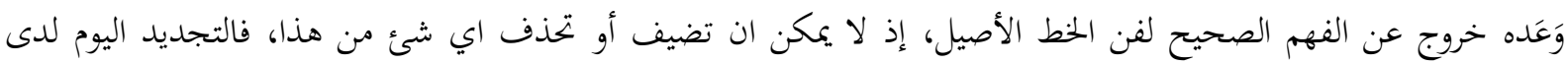

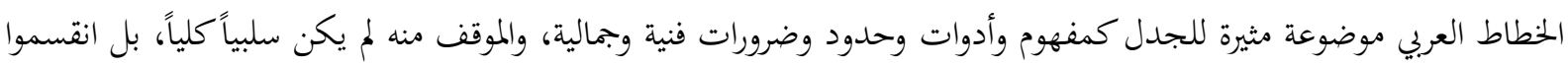

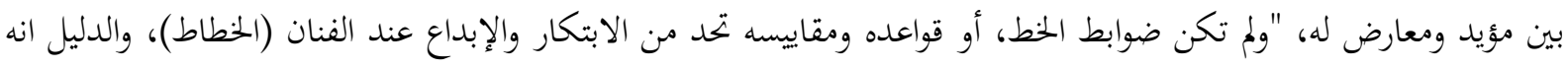

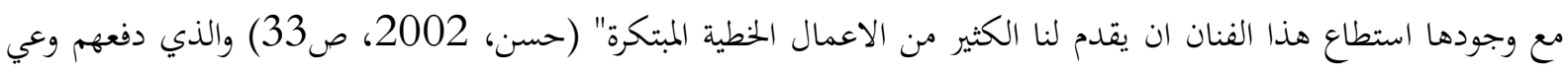

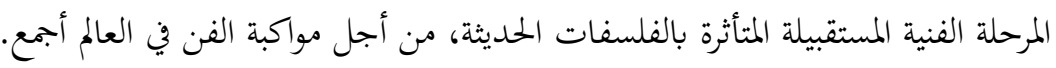

فالقيم الخطية الفنية تتحقق من خلال ترتيب العناصر والمفردات المتمثلة بالحرف العربي الواحد، في البنية الخطية دوراً جمالياً

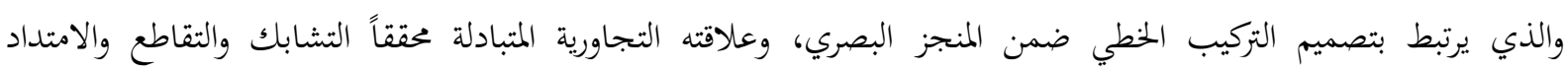
والاستطالة والتقصير ان لزم الامر، وهي تمثل الهدف الجمالي والوظيفي بعد تصميمه الذي يمتوي ذاتية وفردية الخطاط المجود، فلكل

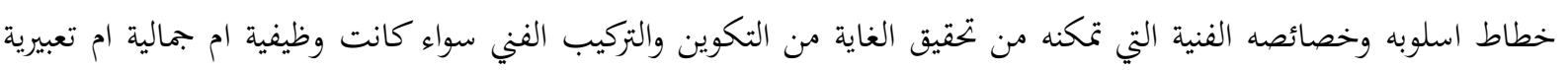
فالاسلوب "إنه طريقة صياغة الشكل وعملية تنظيم هذه القوالب التي يصب فيها الشكل، وطريقة صياغة تراكيب الأشكال التي

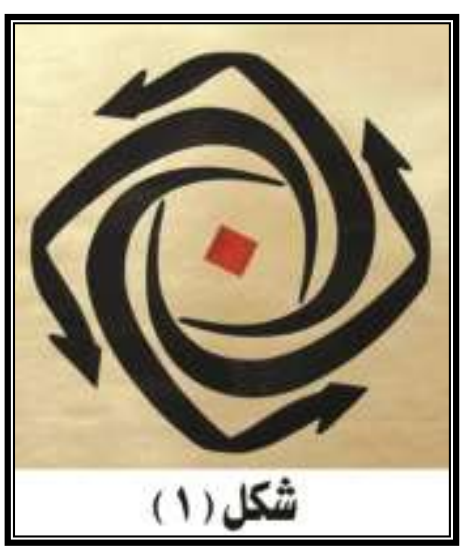

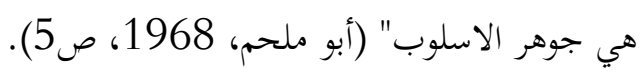

وهذا قد يجبر الخطاطين الذين يسيرون في تدريباتم على كبار الخطاطين في تطبيق النسبة الفاضلة دون ان يشعر لانه مدرب بشكل صارم وبشكل فطري وتلقائي، إذ لا يوجد تعارض بينهما أو بين الإحساس والذوق الفطري بالجمال والتفكير التناسبي

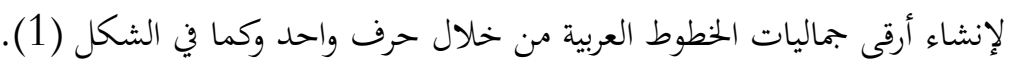
وهنا ظهر مجموعة من الخطاطين المبدعين الذين توغلوا في الممنوع والمحذر منه ألمانه

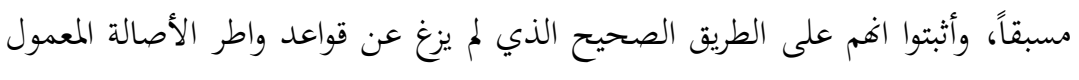
كها لدى المجودين الاقدمين.

وفي ضوء ذلك نرى أن أغلب فلاسفة العصر قد اشاروا إلى أهمية ما هو ثابت ومستقر في الحياة، كون المستقبل ليس

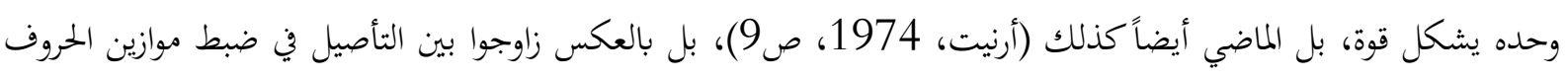
وقياساتما وجمالها الشكلي المتمثل بالمحاكاة والتقليد للحرف الواحد، وبين إبداعهم في الابتكار والتصميم من خلال خلال خلق تراكيب

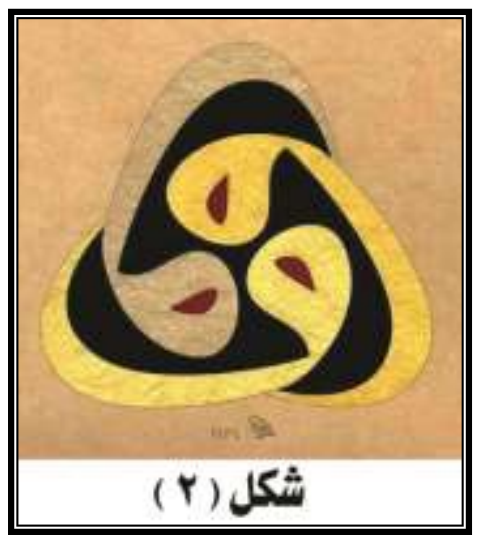
تصميمية جديدة تدخل ضمن أطر الحداثة والتجديد. وبهذا فقد باغتوا الواقع المقفل وفتحوا أبواب الإبداع ومزجوا بين الأصيل والحديث،

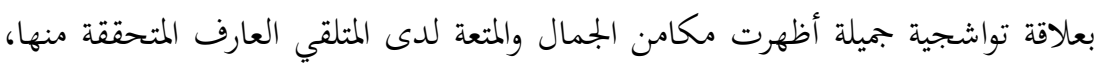
وكما في الشكل (2)

غير أن هناك بعض التكوينات لم تحقق ذلك نتيجة التشابك والتعقيد في اختيار التراكيب الفنية أو لضعف امكانية الخطاط الفنية نفسه، وعدم درايته لأصول وقواعد الخط العربي من جهة، وضعف معرفته بالتصميم والتركيب من جهة أخرى، وهذا لا يدخل

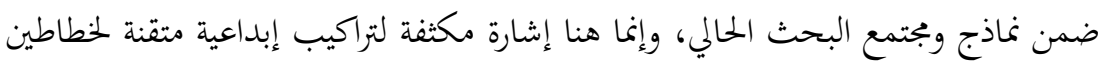
معاصرين محترفين وبجودين استغلوا حرفٍ واحٍِ وأسسوا عليه تركيبهم. 
فقد ظهر الإيقاع الخطي بشكل واضح نتيجة التكرار، لان التركيب اصلاً مبني على حرفاً واحداً وهذه من أكثر صفاة

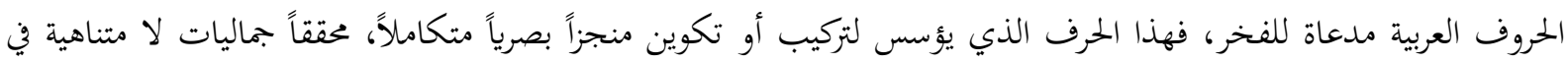
حركة تصميمية بتحيدية مبتكرة.

فعندما نراجع وندقق في التراكيب الخطية المتقنة بحثاً عن عوامل نجاحها، سيتمثل أمامنا دور الوعي الفني لدى الخطاط في

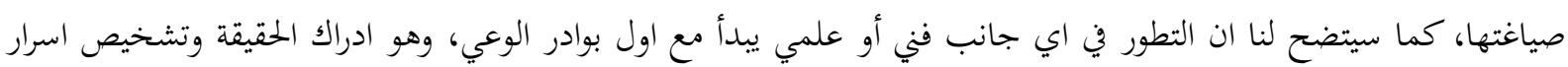
النجاح الفنية،

فالفنان الواعي مستبصر ومكتشف يقض بعيداً عن الجمود والمحدودية والتقليد الاعمى، اضافة إلى تضخيم الذات والشعور بالفوقية نتيجة ضبطه لقواعد الحروف وامكانية الخط بشكل متقن تقليدي، والانعزال والانغلاق والتقوقع ضناً منه وصوله إلى قمة ولئ الهرم والنجاح. فالفنان الواعي لا يتهيب المحذور والممنوع في الفن، ضمن تخصصه الفني، انما يتوغل في الشك والتساؤل حتى يصل لغايته ويفهم الحقائق، فهو مرهف الحس قلق متوثب يصغي دائماً ليدرك ويناقش ليفهم ولا يشتغل إلاعن قناعة ورؤية واضحة.

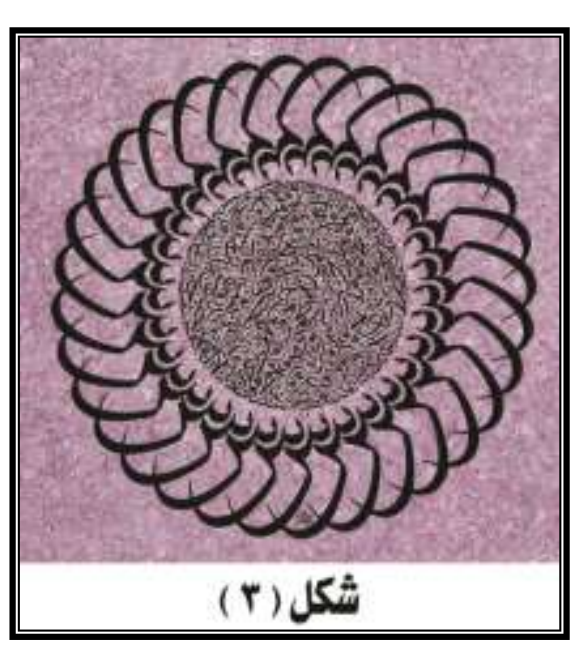

وقد بتسدت من خلال اعماله الفنية في تراكيب إبداعية متقنة بين

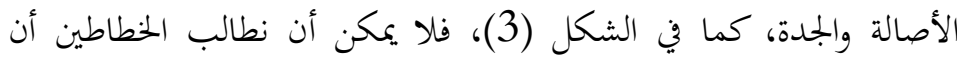
يسيروا على فه معين بالاكراه، لان المنهج نتاج الثقافة الفنية اياً كان البحاهها،

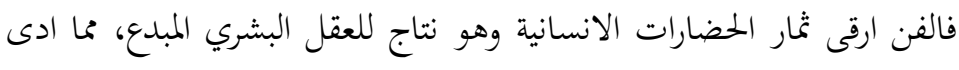
إلى ظهور مدارس ومناهج متعددة قاطعت وخالفت سابقتها وازاحتها نتيجة

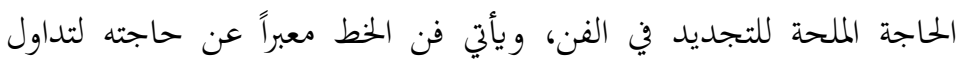

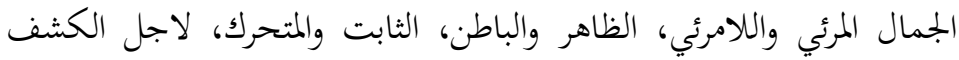
عن اهم المعايير التي يمكن الركون اليها في فن الخط العربي والتي عرفت

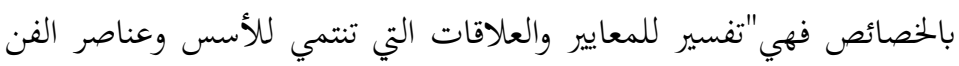

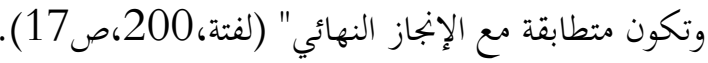
فكان منها ما اتفق مع فكرة التجديد والانفتاح واختلف البعض الاخر، وبهذا فأن فن الخط العربي يؤشر خصوصيته الفنية وفقاً إلى عملية الاستقراء الفلسفي والنظري ضمن المعطيات التي تحيط به، كما ينبغي قراءة التراث الخطي بعد توافر أدواته وفهمه وهنه وهضمه، لاجل استقراء التجديد دون انقطاع عن جذره" فما هو ثابت وأصيل يسبق الجديد، والأصالة أساس المعاصرة والوسيلة

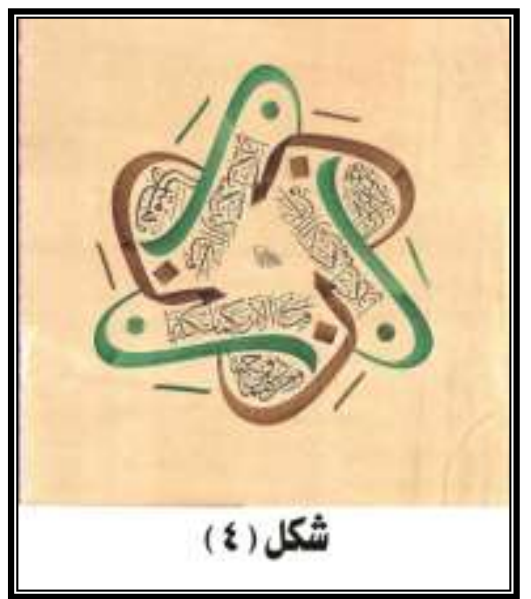

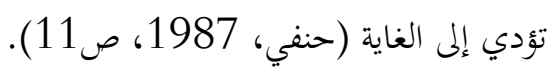

وهذا تحقق بضبط كتابة الحرف العربي جمالياً ضمن رؤية تصميمية جديدة

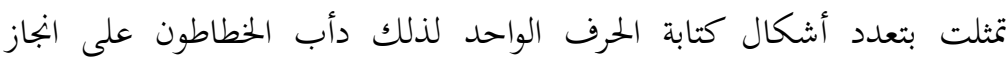

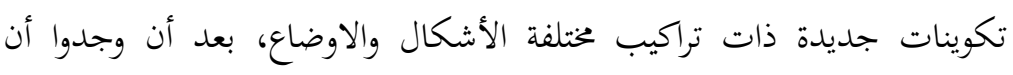
الصفات الفنية لهذه الحروف تساعد على امكانية تشكيلها، لرشاقتها وتعدد أشكالها، وتتميز بالمرونة والمطاوعة، وتتقبل المد والاستطالة والقصر بسهولة، اذهاذ

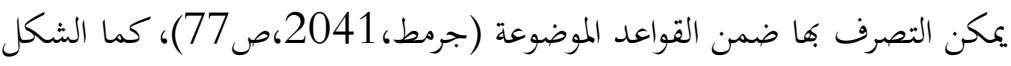


فالفنان المبدع مبادر إلى قراءة الفن قراءة معاصرة، تنسجم مع الواقع وتستجيب لحاجاته ومتطلباته، وأن يهذر التراجع

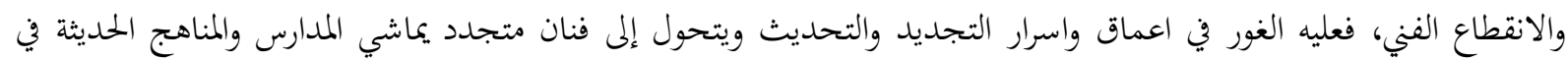

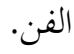

كما هو الحال في باقي الفنون الأخرى، فالخط العربي جزءً لا ينفصل عنها مع المحافظة على التأصيل، فهو بذلك يتحول

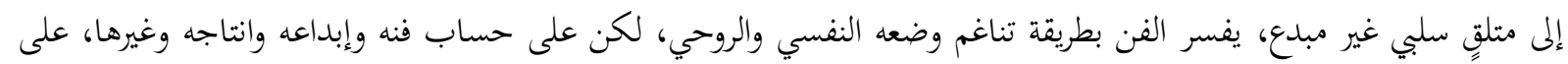

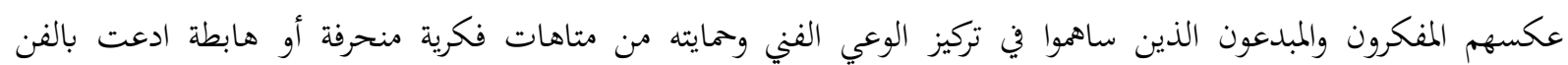
والتجديد لكنها فشلت نتيجة عدم معرفتهم لقواعد واصول الخط العربي والتي هي جزءاً لا يتجزأ من التجديد. فكل بتحيد يبنى على تأصيل وهو حاله متميزة من النشاط الانساني يترتب عليها إنتاج جديد يتميز بالجدة والأصالة، وهو

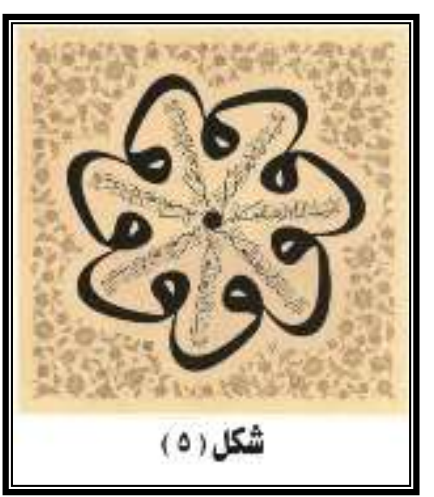

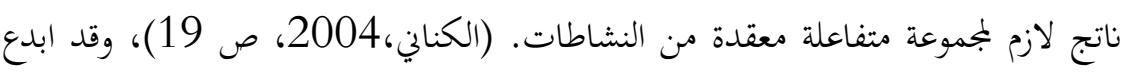
الفنان العربي في ابتكار تراكيباً خطية متنوعة متقنة ولدت بحرفٍ واحدٍ منطلقة في فضاءها

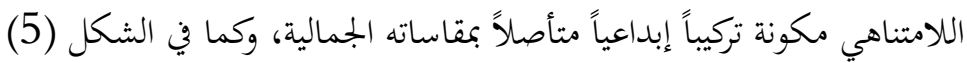
وهنا يتجسد دور الوعي الفني في تشخيص المنهج الصحيح، فالفنان الواعي المبدع لا تؤثر فيه اي بتحارب غير صحيحة، ولا المناخات الفنية السلبية، ولا يتشوه بصره في الانجازات البصرية الهابطة، وغير المتقنة والتي هي بعيدة عن الأصالة وضبط القاعدة الجمالية والهندسية

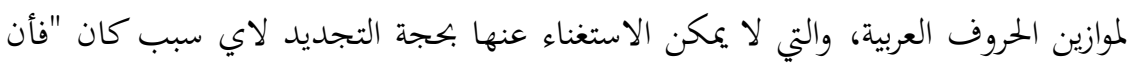

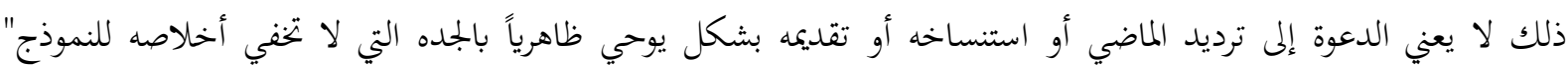

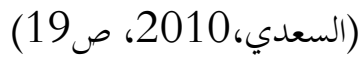

فالفنان يحتاج إلى خطاب ثقافي فني يطور وعيه إلى مستوى القبول بالرأي الاخر، والسماح بمراجعة الافكار والمفاهيم الفنية لاها قد تشيخ وتستوجب استبدالها، فالأصيل من القديم يحتاج إلى رؤية جديدة تنهض به ليواكب التطور ويتماشى مع طروحات

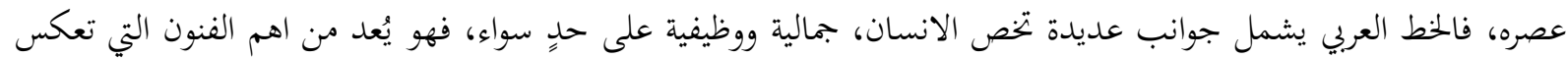

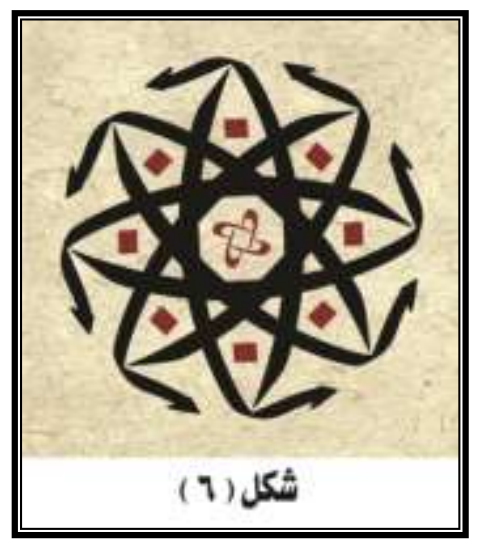
رؤيا وفكر الانسان في دراسات متعددة حديثة، لغوية وتأريخية ومنطقية وتشكلية ودراسة

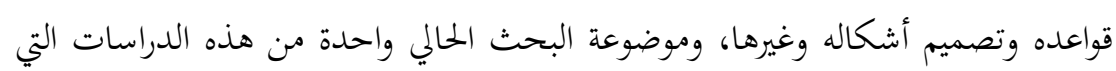

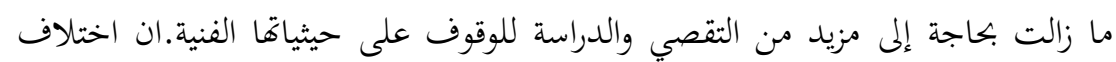
الرؤيا الجمالية للخط العربي بين دعاة الأصالة ودعاة التجديد، تتعدد معايير القياس بينهما.

فلا يمكن قياس المعايير الجمالية لديهم بنفس المقياس، ولكن يمكن الدعوة إلى المزاوجة بينهما وهذا ما هو حاصل في نماذج البحث المنتقاة بشكل قصدي، وكما في

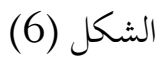

ان من اهم المفاهيم التي يبنى عليها الخط العربي هي موضوعة التأصيل، فهي موضوعة متوارثة، وهي امتداد الماضي إلى المستقبل مروراً بالحاضر، وهذه الطريقة التي يحافظ بها الخطاط المجود على قواعد واصول الخط العربي، وهذه لا تتحقق إلا بالمثابرة والاخلاص لتحقيق الاتقان في المحافظة على جمالية الخط العربي، وهي غاية كبرى للفنان أو الخطاط. 


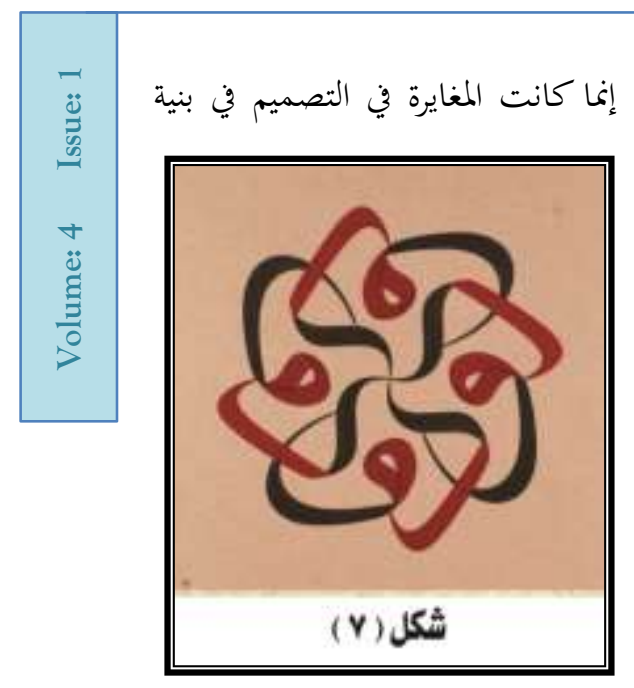

ولكن لا يمكن له حذف أو اضافة خطوط جديدة، وفق رؤية حديثة بتحيدية، التراكيب وأشكاله المتباينة، هي الميدان الاوسع لإظهار أمكانياته ضمن رؤية بتحيدية

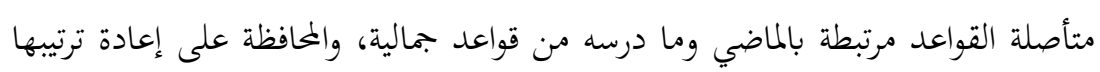

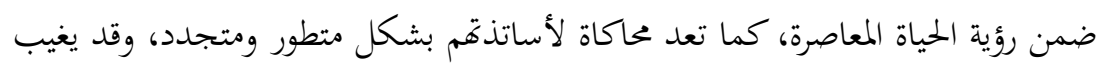
الموضوع في التركيب للحرف الواحد، ويكتفي المصمم الخطاط بتحقيق الجانب الجمالي

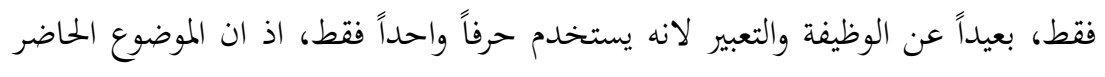

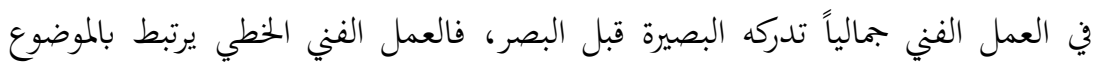

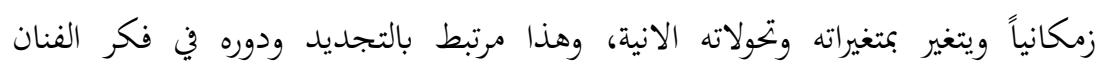

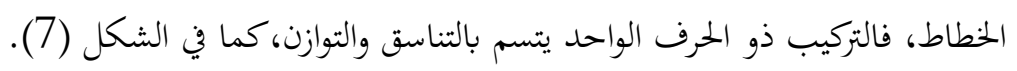
جذاب المنظر يسر الرؤيا لدى المتلقي لما يمتلكة من انتظام وترديد في شكل الحرف الواحد، متناغم ومتوافق وتكون الوحدة

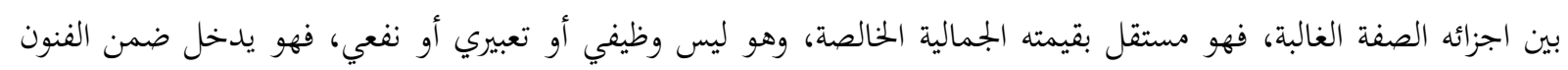

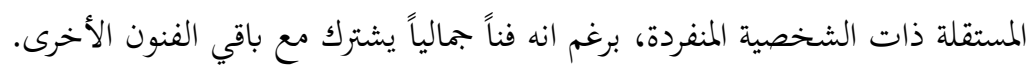
وهنا يجب الإشارة إلى ان نقاط الخلاف بين دعاة التأصيل ودعاة التجديد المتعددة، تشكل قيوداً ومعرقلاً على عملية

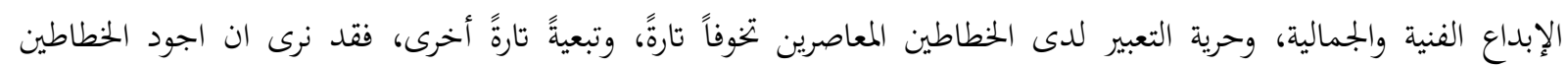

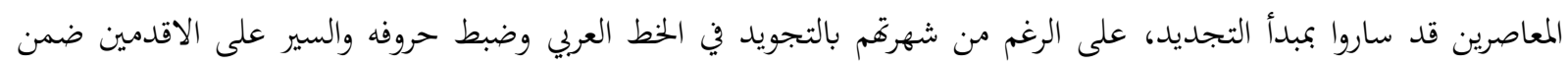

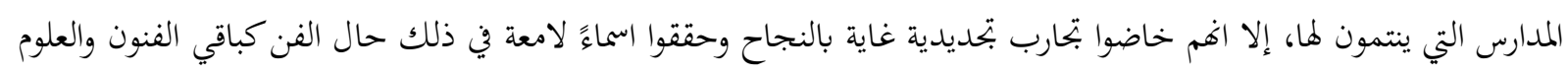
الأخرى.

المبحث الثاني

\section{مسارات التحديث في تكوينات الحرف الواحد}

إتخذت مسارات تحديث التكوينات الخطية المعاصرة شكلاً جديداً في تصيرها تبعاً للمتغيرات الخارجية التي جاء بها الرؤى

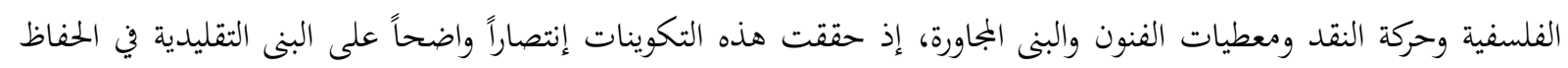

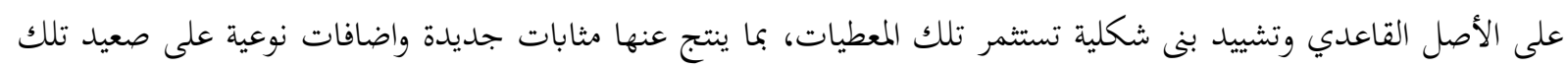

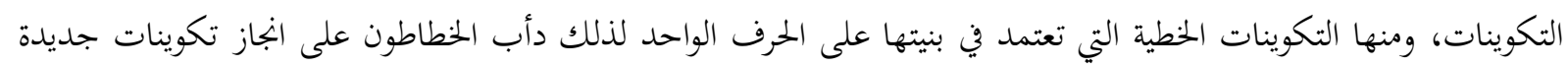

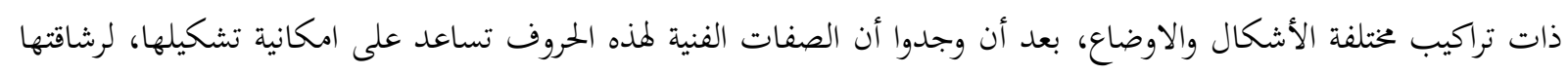

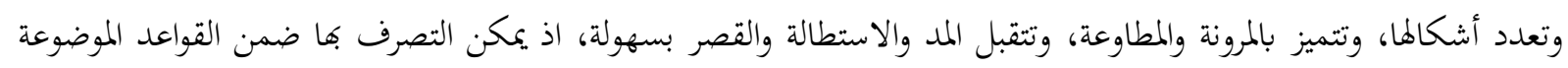

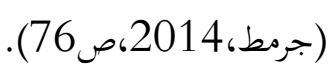

فنرى اللوحات الخطية والتراكيب متجددة ومتنوعة كلاً وامكانية الخطاط الفنية والتنفيذية، ضمن القواعد الخطية الثابتة

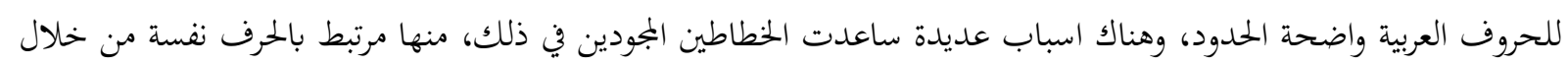

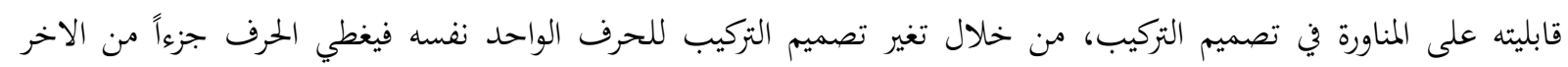

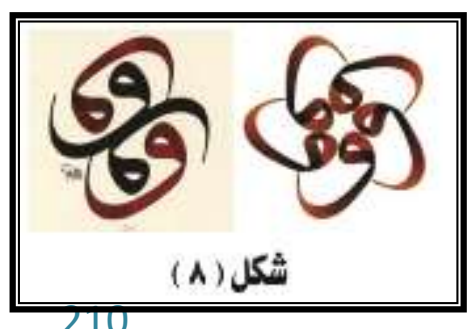

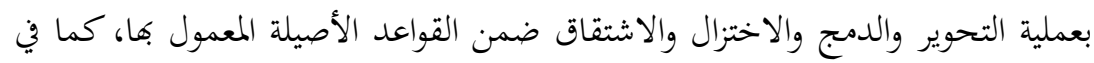
الشكل (8) 
وامتلاكه أكثر من صورة لرسم الحرف الواحد من خلال التداخل والتراكب ضمن قواعد التأصيل، محققاً الزخرفية الحروفية

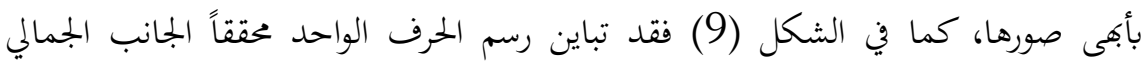

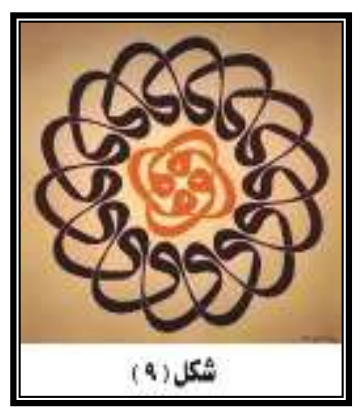

$$
\text { والزخريف في نفس التكوين. }
$$

وغيرها من المواصفات التي ساعدت على تطور تصاميم التراكيب الخطية على مر

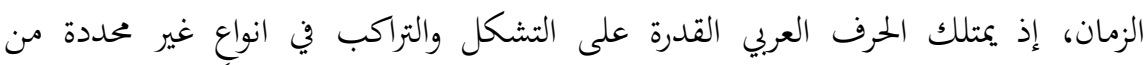

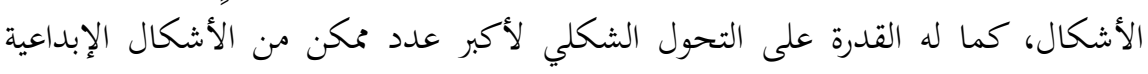

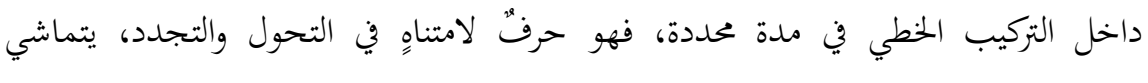
ومختلف التراكيب الفنية في الخط العربي.

وقد شهدت الساحة الفنية تكوينات خطية ذات ميول ابتكارية افرزت لنا قيماً جماليةً مضافة تتسم بالحركة والجدة والأصالة ولا تخضع للتقنين الذي يعتمد القواعد الثابتة، عكست مرونة وطلاقة واسعة في القدرة على التشكل والثنوع والإبداع لتنظيم

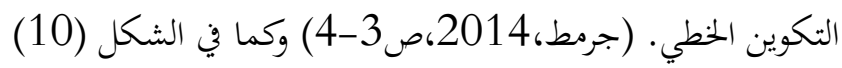

وهناك ما هو مرتبط بالخطاط المجود نفسه الذي يمتلك صفات الإبداع التي ساعدته على التجديد وهو الميدان الاوسع في ذلك، فالمبدع يمتلك صفات الإبداع وهي الأصالة والطلاقة والمرونة "وما اظهره الخطاط من قدرات إبداعية وطاقات فنية متميزة في

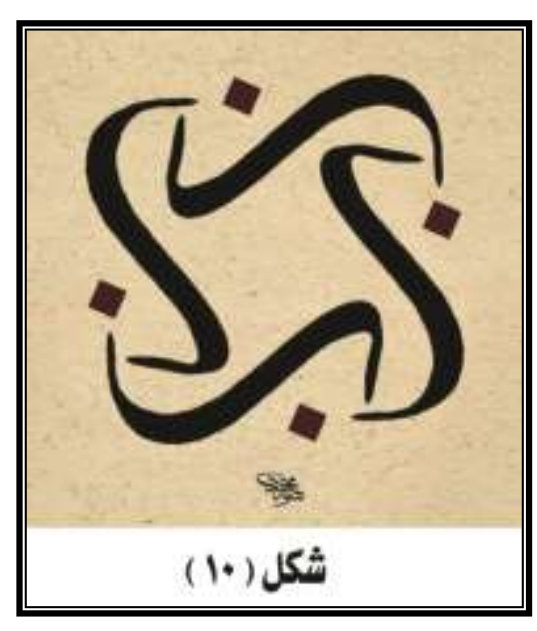
صياغة الحرف العربي وإظهاره بالمستوى اللائق الذي ميز الحرف العربي عن سواه

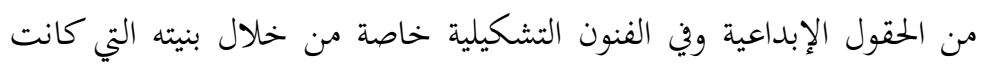

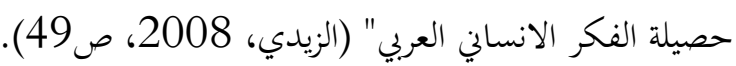
فهو ينظر إلى فن الخط العربي نظرة تشكيلية فنية مرنة غير جامدة من

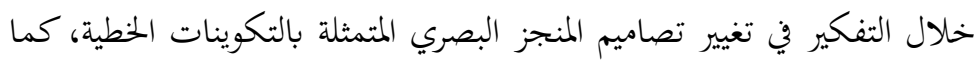

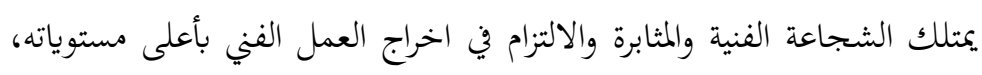

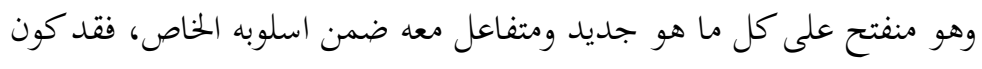

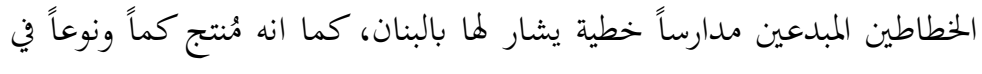
مجال اختصاصه ضمن أطر التجديد ومواكبته.

الدراسات السابقة

بعد الإطلاع على أدبيات التخصص واستقراء ومتابعة الرسائل والأطاريح الجامعية خلال الدراسة الاستطلاعية للمكتبة

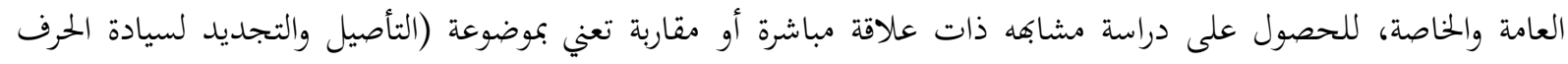

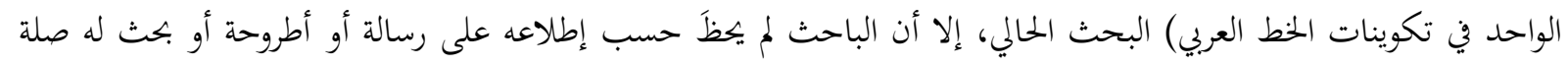
مباشرة بالموضوعة الحالية.

مؤشرات الإطار النظري 1. إن التكوينات الخطية ذات الحرف الواحد، تراكيب جمالية تخلو على الأغلب من الجانب القرائي الوظيفي وعليه اتسمت بالليونة. 2. ساعدت مطاوعة الحرف العربي في تنوع أشكال التكوينات ومتغيراتما البنيوية ضمن رؤية الخطاط جمالية. 


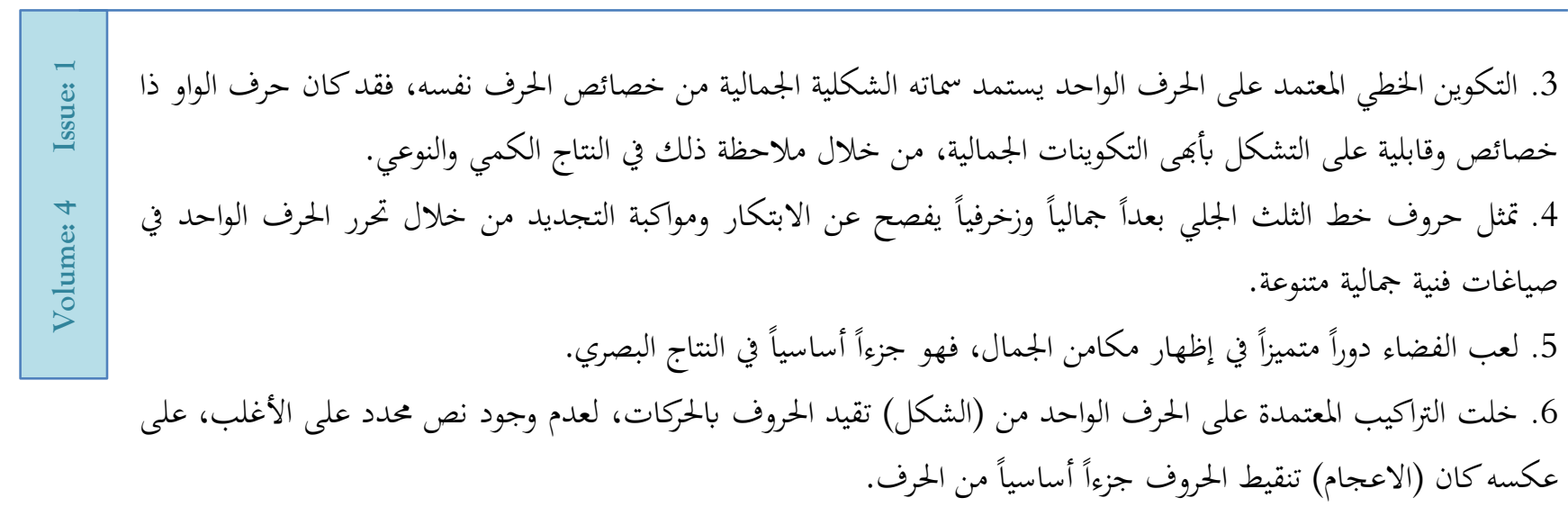


(الفصل الثالث)

\section{مجتمع البحث:}

شمل مجتمع البحث النماذج الخطية المنفذة بتكوينات ذات سيادة لحرفٍ واحٍٍ وبلغ مجموع النماذج غير المتكرة (20)

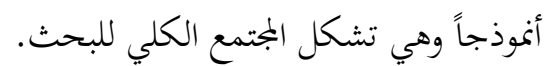

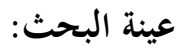
إعتمد الباحث في إختيار عينته على الانتقاء القصدي، وفقا للتشابه في تنفيذ بعض أشكال تكوينات الحرف الواحد، وطريقة توزيعها ضمن المجتمع الكلي للبحث، إذ بلغ عدد العيينات المنتقاة (2) عيينات وهي النسبة العلمية للبحث مستثني المتشابه منها.

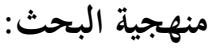

أتبع الباحث المنهج الوصفي للعينة كونه الأنسب مع هدف البحث الحالي.

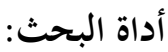

لغرض تحقيق هدف البحث الحالي، قام الباحث بتحديد المرتكزات الأساسية لتكوينات الحرف الواحد في استمارة ضمن

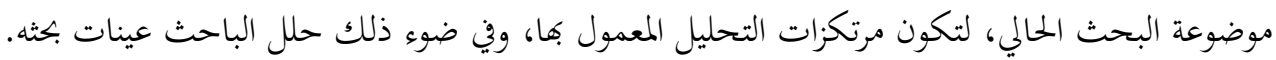

تحليل العينة

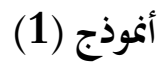

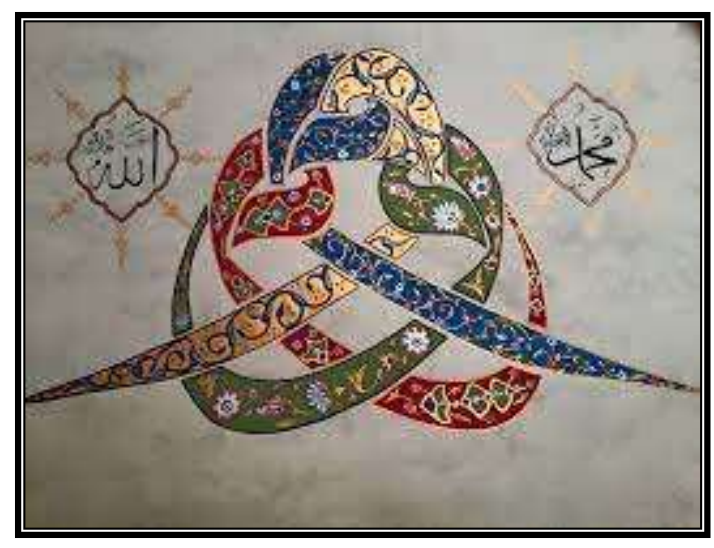

الوصف العام: تكوين خطي كتب بخط الثلث الجلي، ذو تنظيم

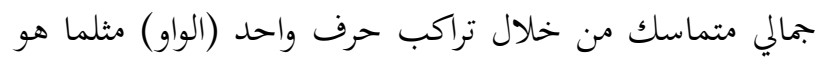

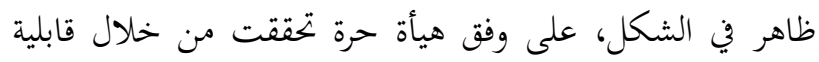
حرف الواو على التنوع،وفق تصور إبداعي دون نص قائي معين.

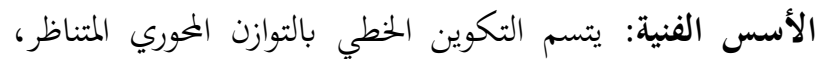

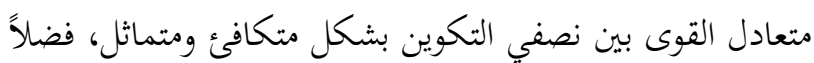

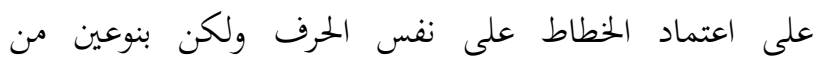

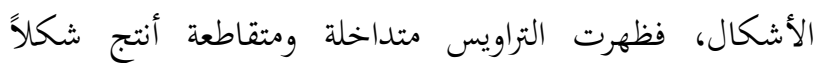

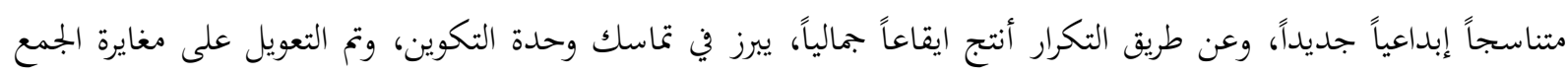

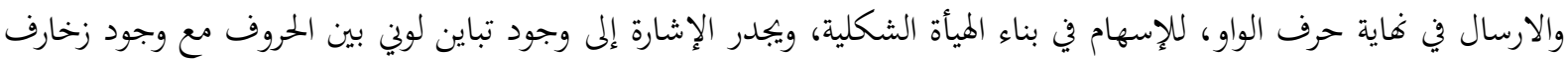

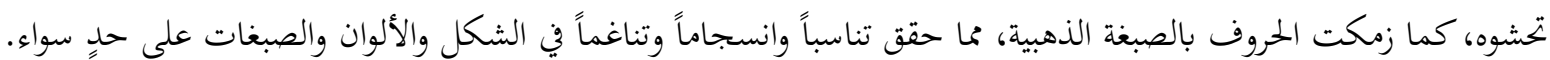
خصائص التكوين: لقد اظهر الخطاط مقدرته في المعالجات التصميمية في التجديد ضمن قواعد الأصالة، في توزيع حرف الواو

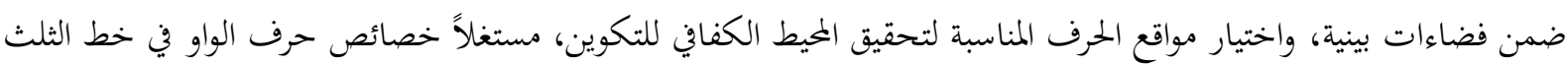


الجلي، في المرونة والمطاوعة وتنوع رسم شكل الحرف الواحد، إضافة إلى اعتماده التعاكس المرآي، مما اكسب التكوين شكلاً

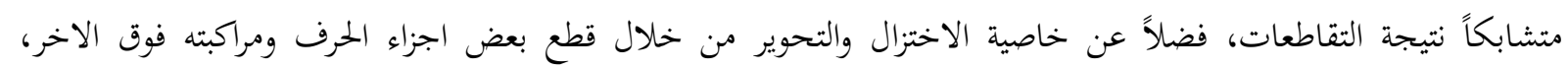
واستغلال تنوع الألوان لابراز ذلك.

دور الأصالة في خط الحرف: عمد الخطاط الالتزام بالقاعدة الخطية المعمول بها ومراعاة الاصول الخطية الصحيحة.

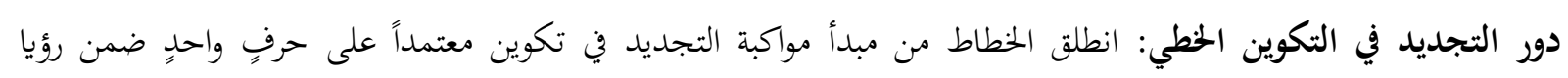
تصميمية منفتحة على الحاضر، ضمن مرجعيات فنية أصيلة.

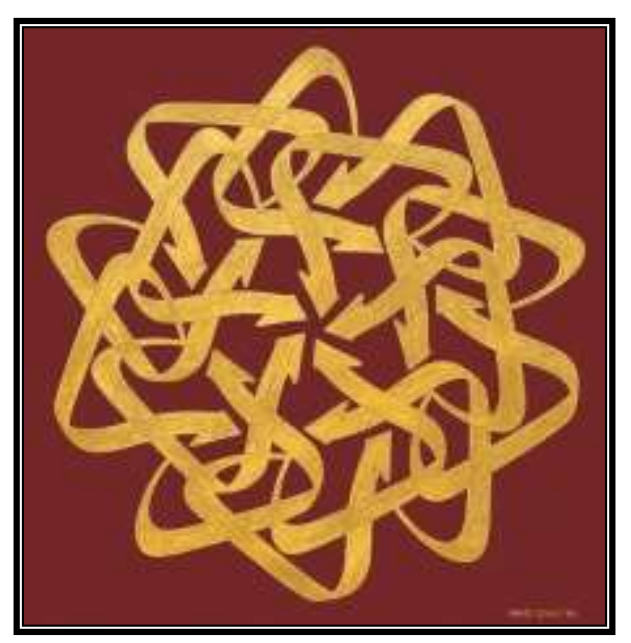

(2) (2) (2) (2)

- الوصف العام: تكوين خطي كتب بخط الثلث الجلي، ذو تنظيم جمالي متماسك من خلال تراكب حرف واحد (الدال) خلا من الاضافات الأخرى، على وفق هيأة دائرية غير منتظمة تحققت من خلال حنال قابلية حرف الدال على التشابك، محقاً شكلاً جمالياً خالي من الوظيفة القرائية.

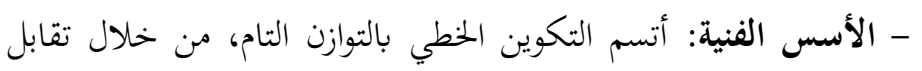

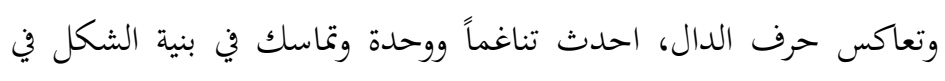
التكوين، مستغلاً شكل حرف الدال في خط الثلث الجلي، وقابليته على ونى

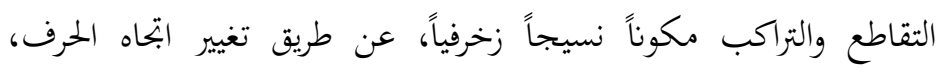

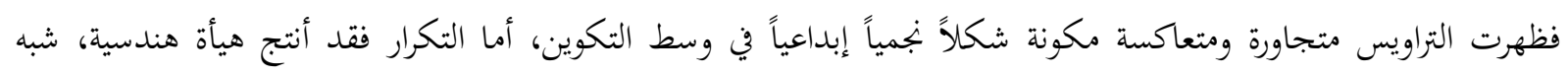
دائرية، كما عزز تكرار رسم الحرف الواحد نفسه احداث الترابط والانسجام من خلال التشابه في رسم الحرف المكرر واشغاله مساحياً ومعالجة التكوين تصميمياً.

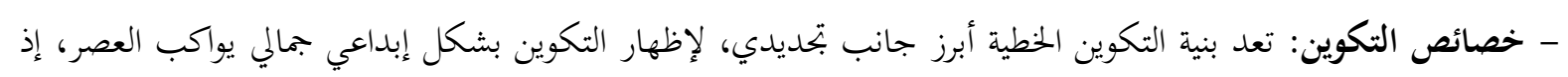

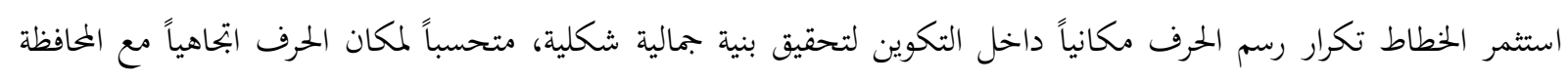
على الخميط الكفافي للتكوين، مستغلاً الفضاءات الضمنية للحرف بطريقة فنية مدروسة تدل على المهارة في معالجة التكوين.

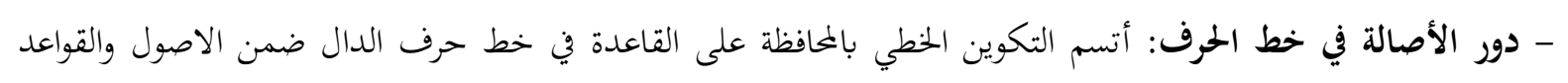
المعمول بها.

- دور التجديد في التكوين الخطي: ظهر التكوين الخطي بشكل تجديدي معاصر معتمداً على حرف الدال ضمن التوجه التصميمي ذو التجديد والابتكار. 
1. الاستمار الواعي لمفاهيم التركيب والتصميم في تراكيب الحرف الواحد الذي حقق الجانب الجمالي والإبداعي وكما في العينتين

2. المغايرة للسياق النمطي التقليدي واحدة من مظاهر التراكيب المعتمدة على حرفاً واحداً في الخطط العربي وكما في العينة (2).

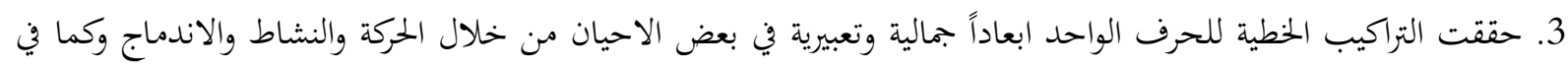

4. ظهر التوازن الجمالي والرتابة في أغلب التكوينات المعتمدة على الحرف الواحد وكما في العينة (1).

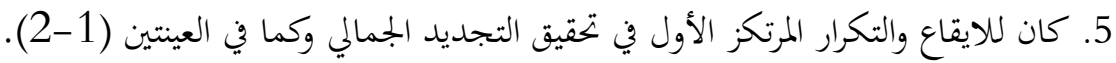

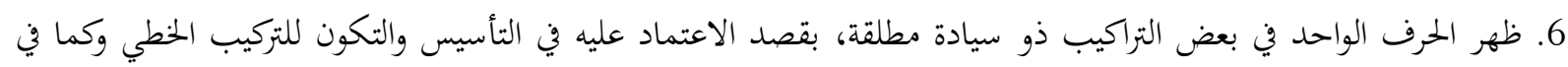

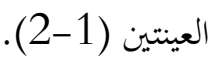
7. التناظر والتقابل له الحصة الاكبر في تكوينات الحرف الواحد في الخط العربي زكما في العينتين (1-2).

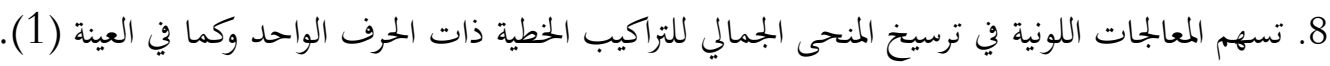

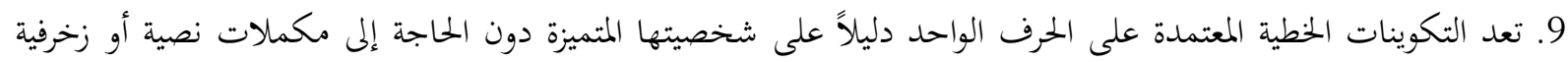
وكما العينتين (1-2) 10. حقق الحرف الواحد شكلاً زخرفياً نتيجة الايقاع المتحقق من التكرار، وعليه اكتفى ذاتياً عن الزخارف النباتية أو الهندسية أو غيرها وكما في العينة (2). الاستنتاجات

1. يككن لمفاهيم التركيب والتصميم ان تكون المرتكز الذي يعول عليه في تراكيب الحرف الواحد.

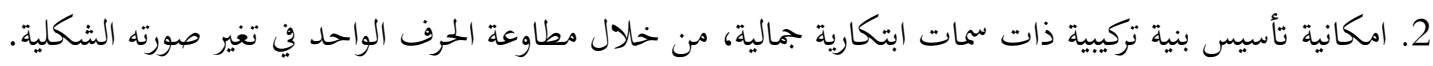

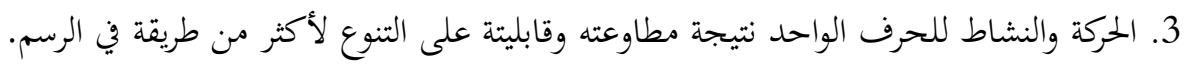

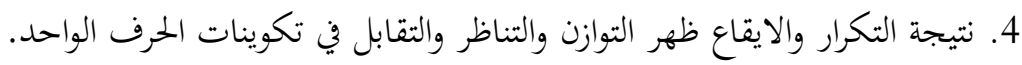

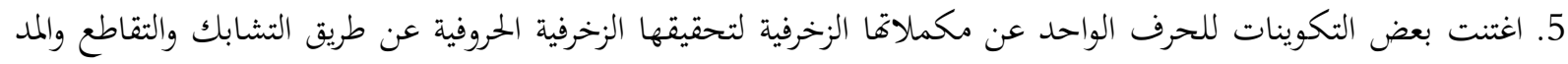
وغيرها.

1. الافادة من المغايرة في تراكيب الخط العربي لمواكبة المدراس الفنية الحديثة، بوصفه مرتكز لتطوير فن الخط العربي والمزاوجة بين الأصالة والتجديد. 2. التركيز على التأصيل في رسم الحرف ضمن القواعد الخطية، ومعرفة المرتكزات الفنية والتصمية للتجديد ضمن رؤى مدروسة. 2- المرتكزات الفنية للتجديد في تكوينات الخط العربي ضمن رؤية حداثوية. 


\section{المصادر}

(ابو ملحم،علي،1990)، نحو رؤية جديدة إلى فلسفة الفن،ط1، المؤسسة الجامعية للدراسات والنشر والتوزيع،بيروت،لبنان.

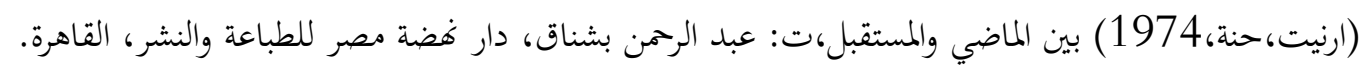

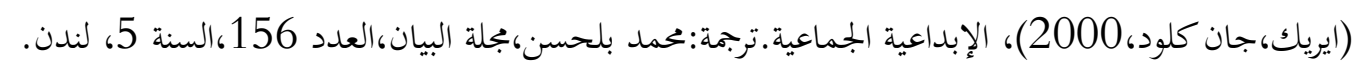
(جرمط،حسين علي،)2014، التحول من الثبات التقليدي إلى المفاهيمي في بنية تكوينات الخط العربي، كلية الفنون الجميلة،

$$
\text { جامعة بغداد، (اطروحة دكتوراه منشورة) }
$$

(حسن،حسن طه حسن،2002)،التحوير كخاصية فنية في الخط العربي وكمدخل لإثراء التصاميم الزخرفية،، كلية التربية، جامعة

$$
\text { طنطا، ( رسالة ماجستير غير منشورة) }
$$

(حنفي،حسن، (حن)، 1987، حنفي، حسن، التراث والتجديد (موقفنا من التراث القديم)، القاهرة، مكتبة الانجلو المصرية.

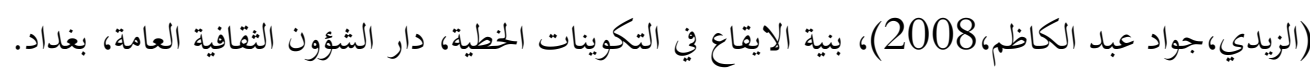

(روبرت،سكوت جيلام،1980)، 1. أسس التصميم. ترجمة محمد محمود يوسف , دار غضة مصر للطبع والنشر ,القاهرة.

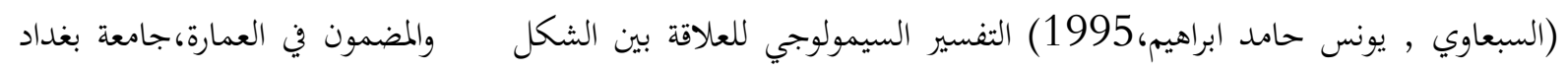

$$
\text { (رسالة ماجستير غير منشورة). }
$$

(السعدي،علي عطية موسى، 2010)،الثابت والمتحول في الفن المصري القديم، كلية الفنون الجميلة، جامعة بابل، (اطروحة

$$
\text { دكتوراه غير منشورة). }
$$

(الكناني , محمد جلوب جبر،2004)،حدس الانجاز في البنية الإبداعية بين العلم والفن. قسم الفنون التشكيلية , كلية الفنون

$$
\text { الجميلة , جامعة بغداد، (أطروحة دكتوراه غير منشورة). }
$$

(لفتة،حمد سعدي،2000)،أنموذج تدريس لإستقصاء خصائص المدرسة الفنية الحديثة. قسم التربية الفنية , كلية الفنون الجميلة

$$
\text { , جامعة بغداد، (أطروحة دكتوراه غير منشورة). }
$$

(فرمان،عدي ناظم،2004)، الخصائص الفنية في خط الثلث في المدرسة البغدادية الخطاط هاشم البغدادي أنموذجا. قسم الخطاد العربي والزخرفة , كلية الفنون الجميلة , جامعة بغداد , (رسالة ماجستير غير منشورة). 


\section{Istanbul / Türkiye \\ p. $217-230$}

Received: $23 / 11 / 2021$

Accepted: 19/12/2021

Published: 01/01/2022

This article has been scanned $t$ iThenticat No plagiarism detected

\section{THE VERB IN CONTEMPORARY ARABIC}

\author{
Majeed Khairallah RAHI ${ }^{1}$
}

\begin{abstract}
:
We have inherited an Arabic language with a long history that was rich in a great wealth of words, words, structures and different styles, and many materials were prepared for it from the reasons for sophistication that were used to keep pace with the ages. From colloquial expressions, wrong words and styles such as verbs, nouns, derivatives and plurals.

The structures of verbs in linguistic blogs have received great care and clear attention, because verb is a fertile material that has enriched the language with countless words through derivation and addition. That is why scholars called them buildings, and most of the knowledge of the Qur'an and Sunnah is inferred by their knowledge.

The verb in contemporary Arabic has proceeded in many directions, some of which is correct and acceptable, because it came in accordance with the rules of the language, and did not violate its analogy, and some of them were not acceptable, because they violate the rules of the language and its origins, and it is necessary to warn about the places of error in it, and to respond to pens and tongues. To the correct eloquent one of its buildings, we thought that we present in this research the trends of the development of the verb in contemporary Arabic, so we dealt with its formulation, its significance, its transgression and its necessity, and its conjugation with prepositions, and we have clarified the error in the uses of writers, orators and writers of these verbs in their different conjugations.
\end{abstract}

Key words: Verb, Contemporary Arabic, Formulation, Semantics, Transgression And Necessity.

http: //dx.doi.org/10.47832/2717-8293.15.16

1 (iD) Dr. , Wasit University, Iraq, Drmajeed40@ yahoo.com 


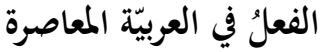

\section{2 جيد خير الله راهي}

الملخص:

لقد ورِثنا لغةً عربيّة ذات تأريخ طويل حفلت بثروة كبيرة من الكلمات والألفاظ والتراكيب والأساليب المختلفة، وهيّأ لها من أسباب الرّقيّ موادّ كثيرة استعانت بها على مسايرة العصور ، فكانت الفكر النيّ والحضارة الخالدة،

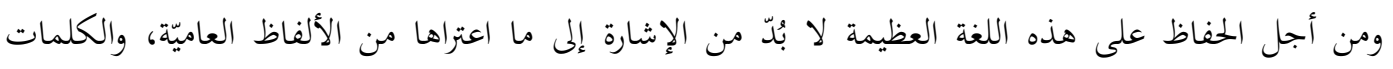

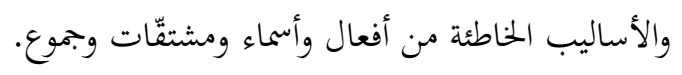

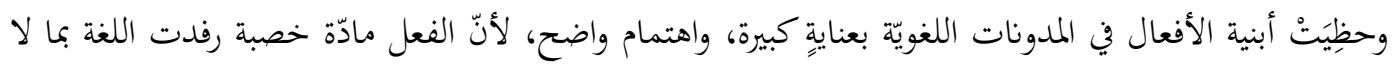

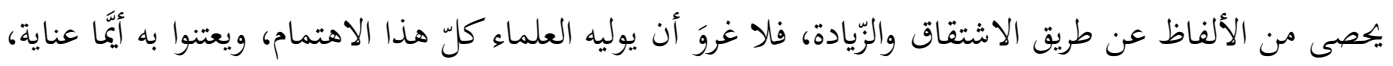

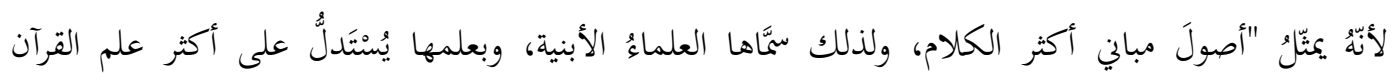
والسنّة". وقد سار الفعلُ في العربيّة المعاصرة في ابّحاهاتٍ متعدّدة، فكانَ منها ما هو صحيح مقبول، لأنبّهُ جاء على وفق

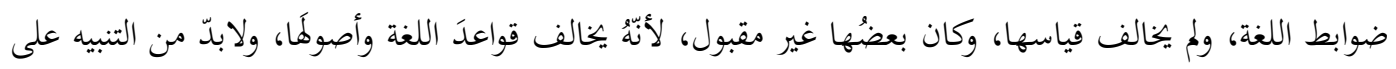

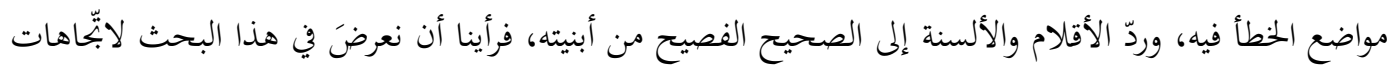

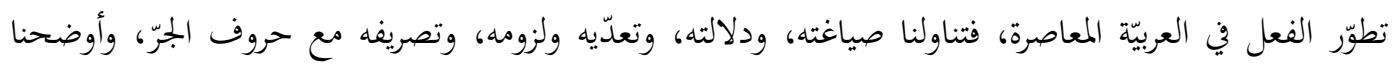

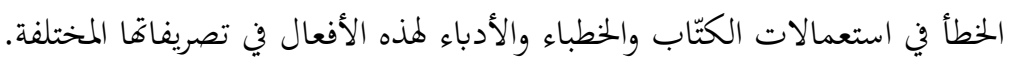
الكلمات المفتاحية: الفعل، العربية المعاصرة، الصياغة، الدلالة، التعدي واللزوم.

حظِيَتْ أبنية الأفعال في المدونات اللغويّة بعنايةٍ كبيرة، واهتمام واضح، لأنّ الفعل مادّة خصبة رفدت اللغة بما لا يحصى

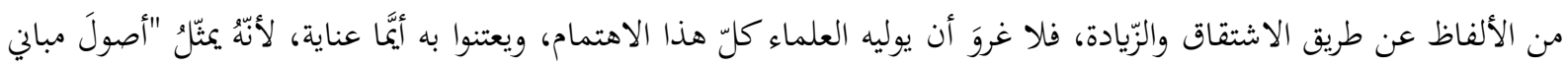

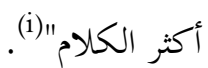

وقد سار الفعلُ في العربيّة المعاصرة في ابتّاهاتٍ متعدّدة، فكانَ منها ما هو صحيح مقبول، لأنبّهُ جاء على وفق ضوابط فيط

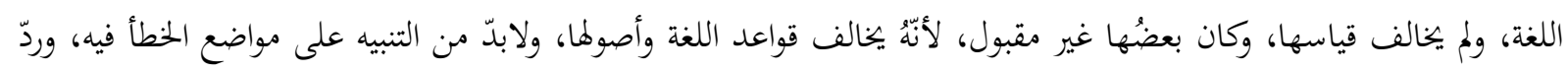

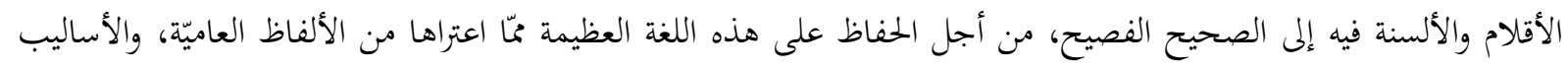

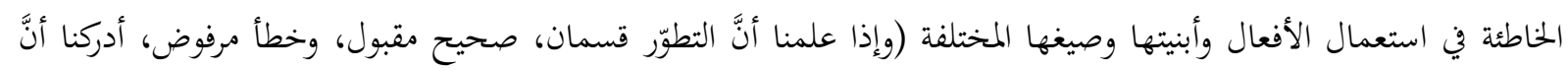

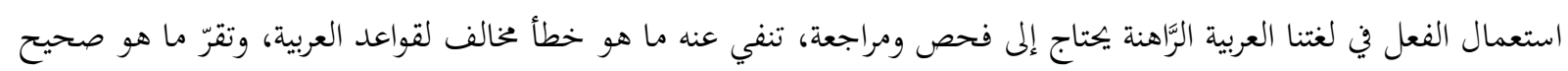

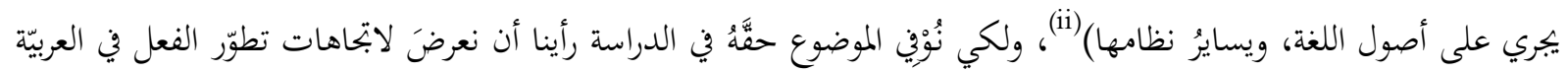

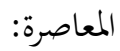


إنّ التطوّر الذي طرأ على صياغة بعض الأفعال والمشتقات منها في العربيّة المعاصرة ناجم عن الجهل بصياغتها الصحيحة،

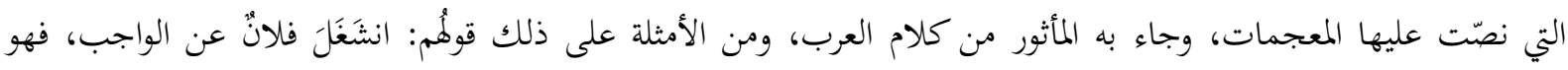

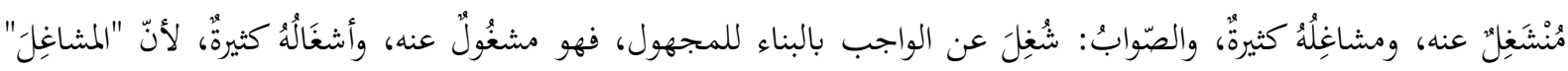

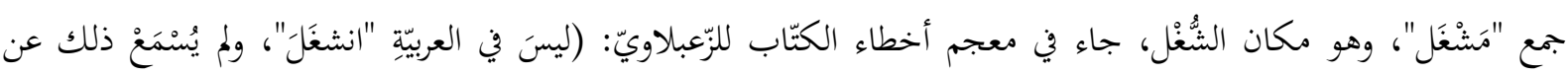

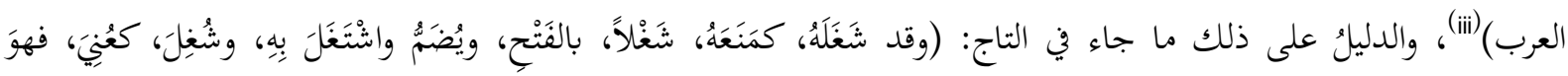

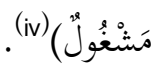

ومن أمثلة تطوّر صياغة الفعل في العربية المعاصرة قولُم: تأكَل الجدارُ، على وزن "تفاعل"، فيوقعون الفعل من واحد، في

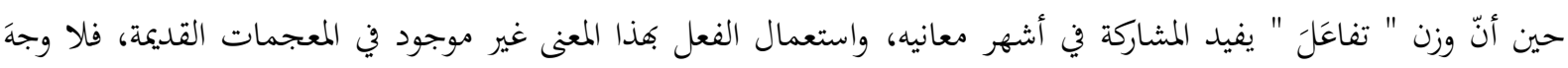

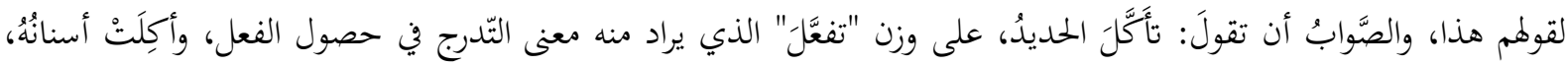

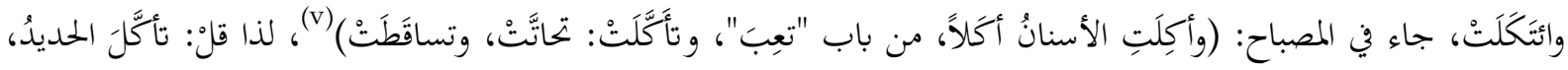
ولا تقلْ: تآكَلَ الحديذُ، إذ لا وجةَ لقولهم هذا.

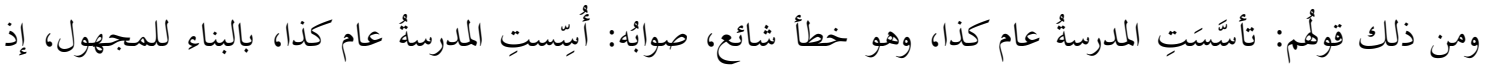

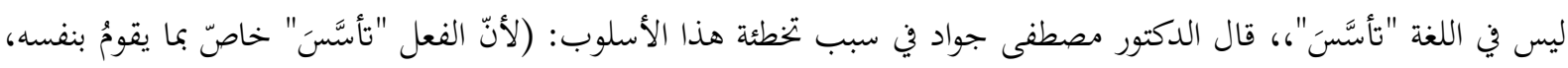

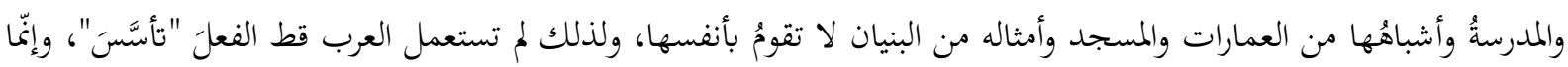

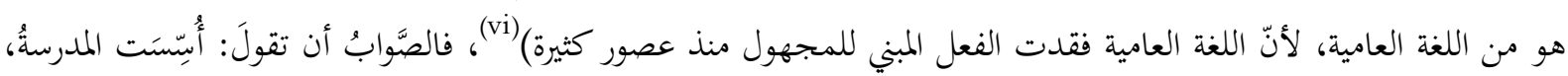

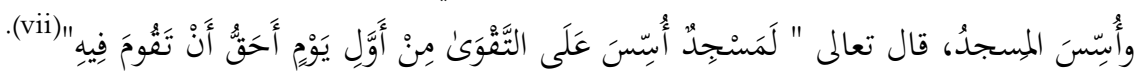

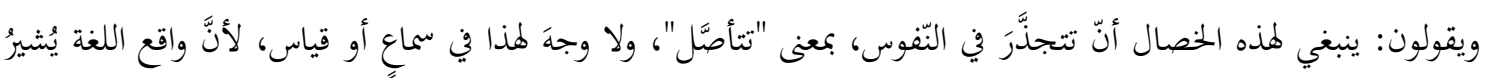

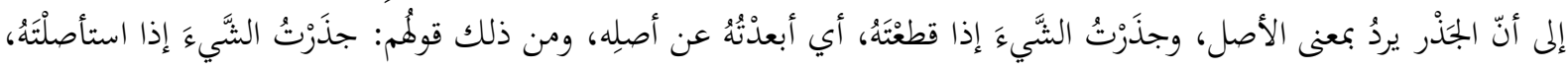

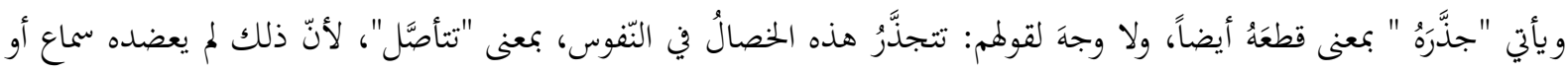

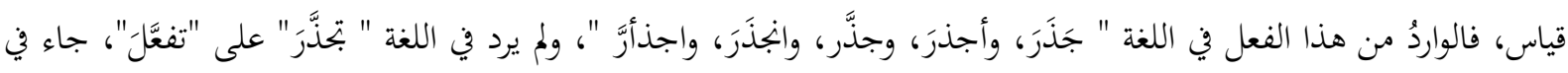

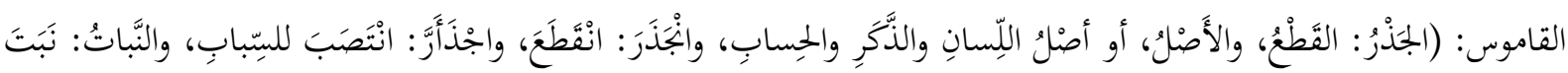

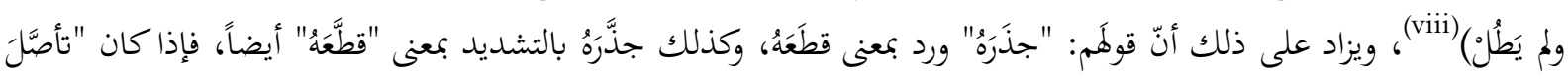

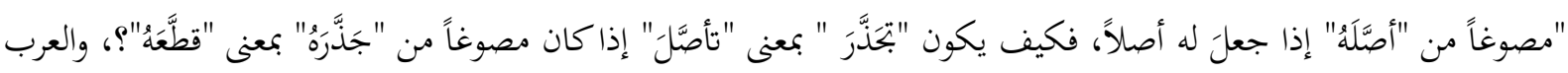

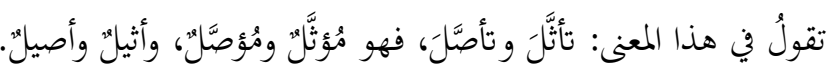

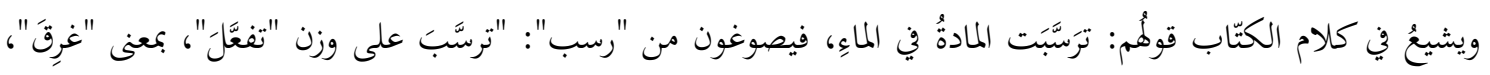

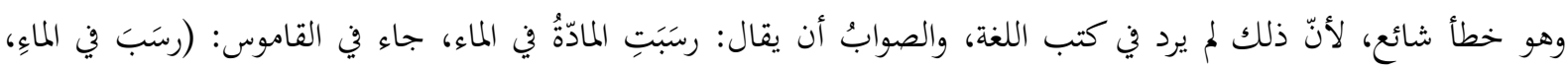

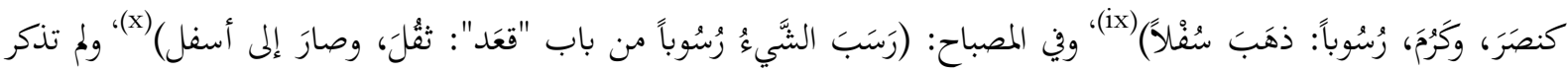

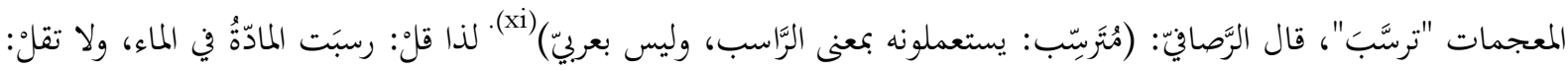
ترسَّبَت المادّةُ في الماء.

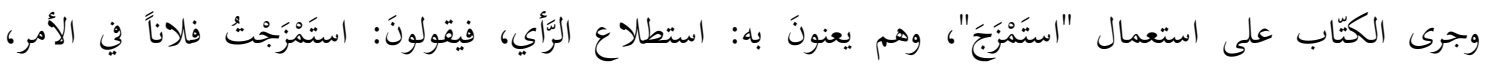

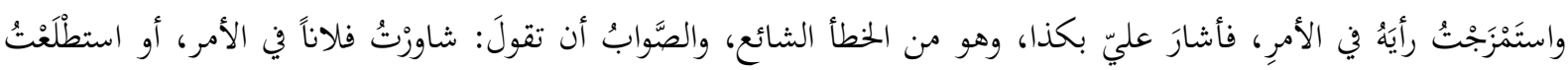

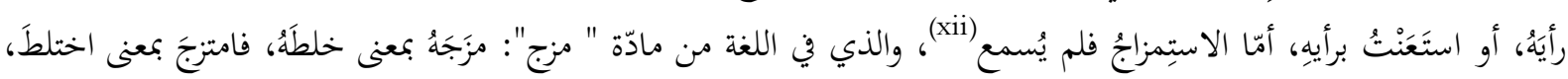




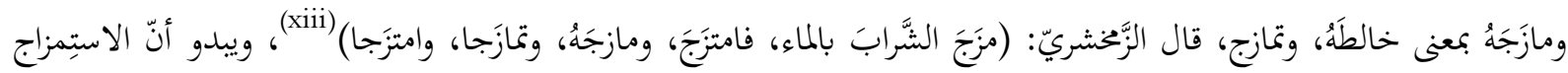

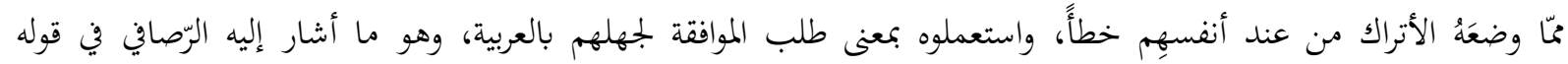

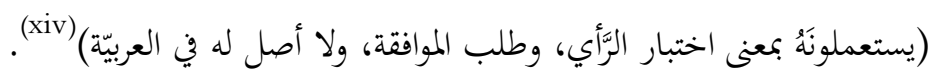

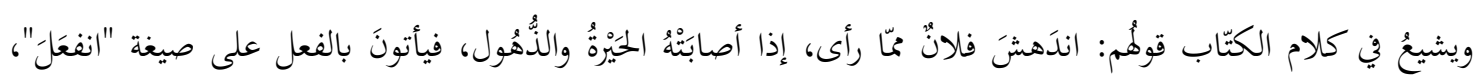

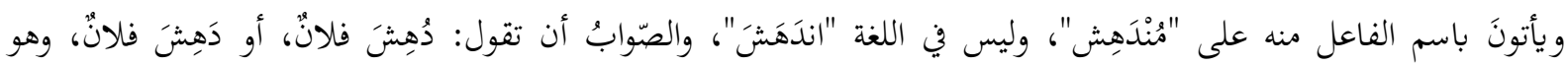

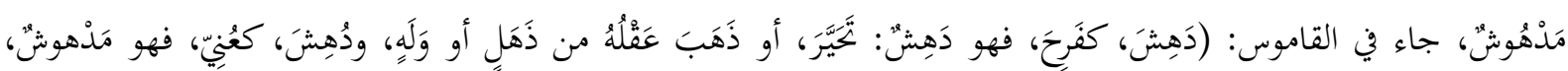

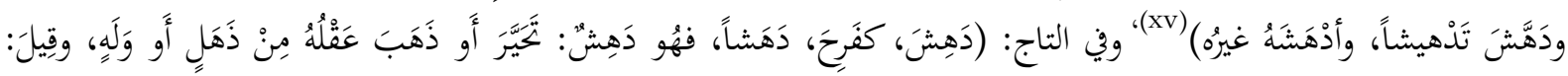

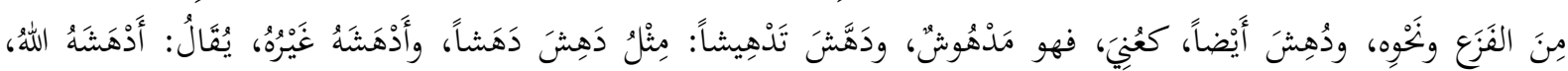

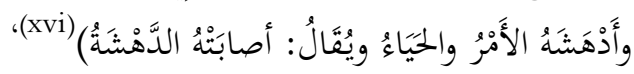

جاء في لغة الجرائد للشّيخ إبراهيم اليازجي: (ويقولونَ: عرضَ له كذا، فاندهشَ وانذهلَ، ولمُ يُحْكَ مثال "انفعلَ" من هذين

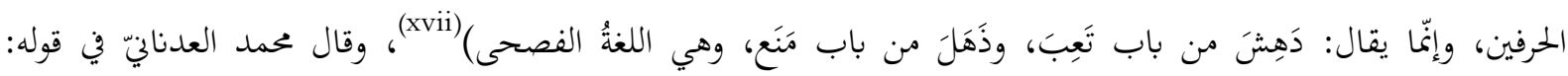

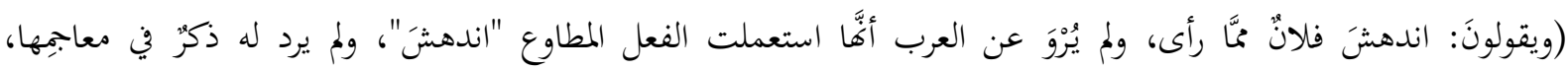

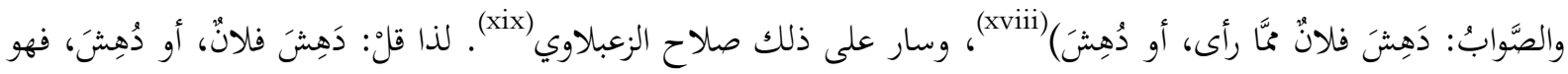

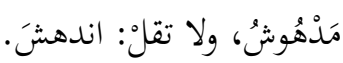
وإذا أراد الكتّابُ أن يُشيروا إلى فعل أو عمل تناوَلَهُ القانونُ بالوصف، ورتَّبَ عليه حكماً من الأحكام، قالوا: هذا فعلٌ

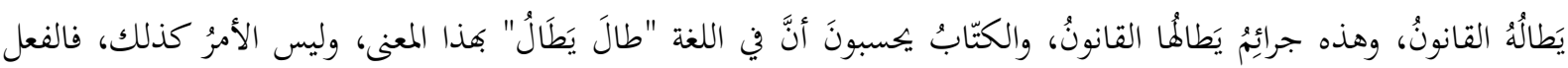

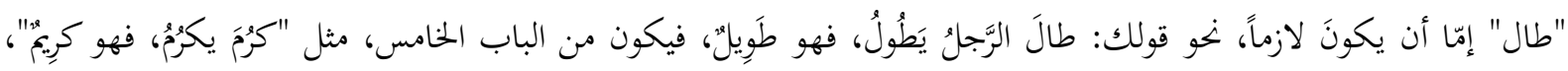

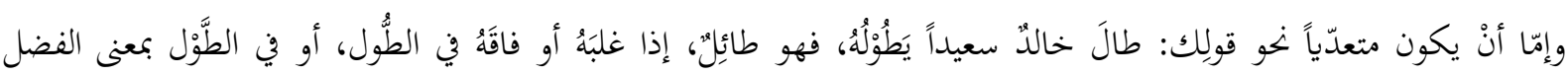

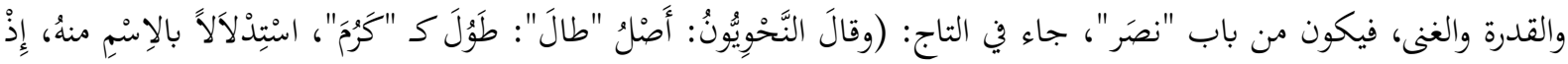

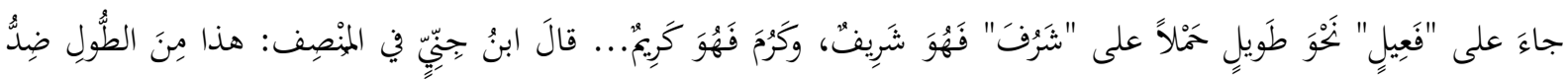

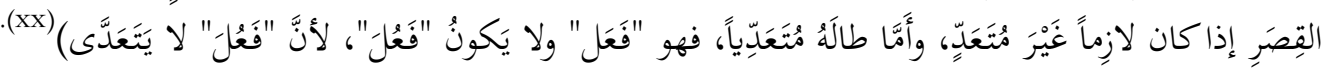

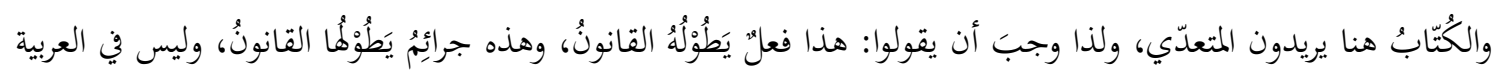
"يُطَال" ( - 20 وَيَرِدُ في التَّعبير الحديث استعمال الفعل "أسَّرَ" للدَّلالة على معنى أخذ الأسير، فيقولون: أسَّرَ العُدوُّ خمسةَ مقاتلينَ، وأسََّر

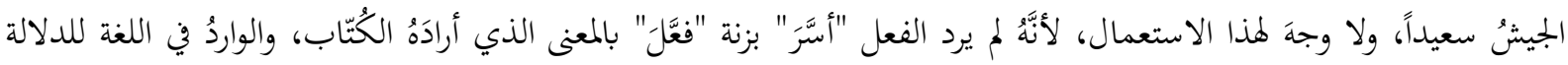

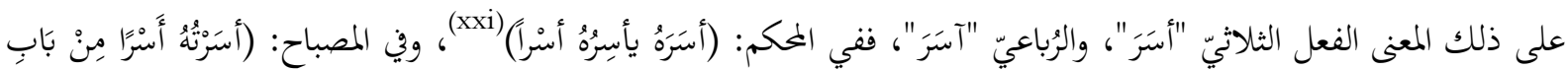

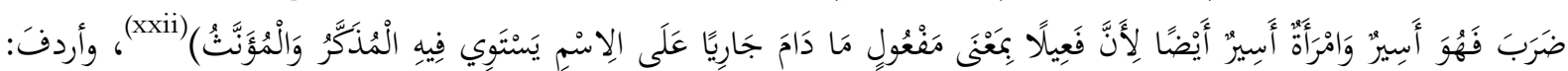

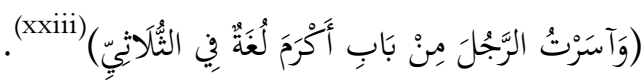

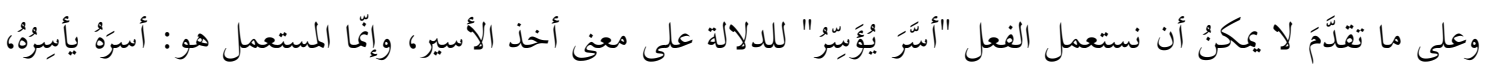
وآسرهُ يُوِْْسِرُهُ.

وَيَرِدُ في الاستعمال الحديث قولُم: تآلفَ القومُ، للسَّلالة على معنى التَّعاون، وليس كذلك، إذلم لمُ ترد صيغة "تفاعَل" من

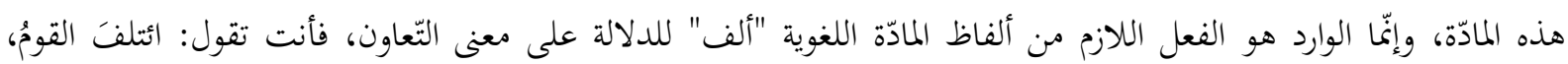




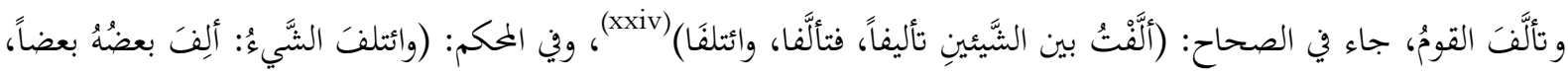

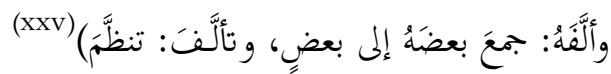

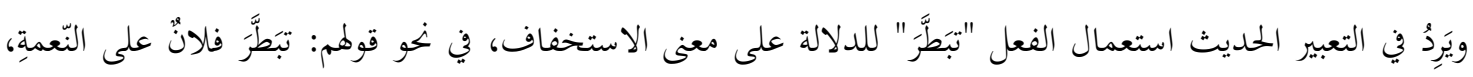

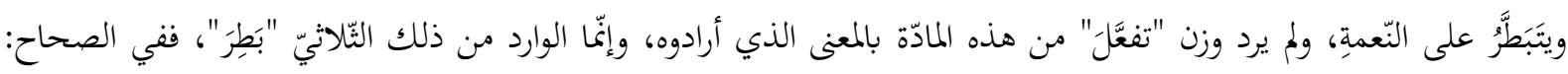

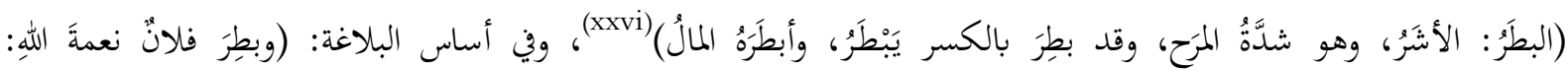

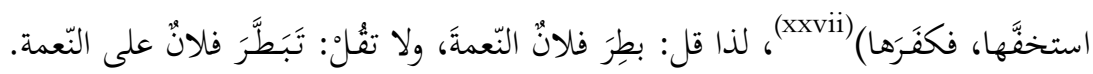

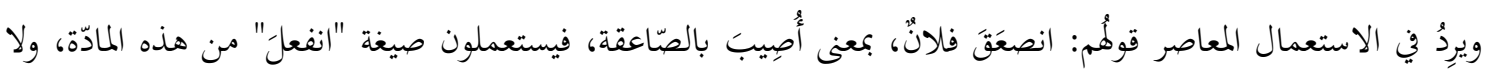

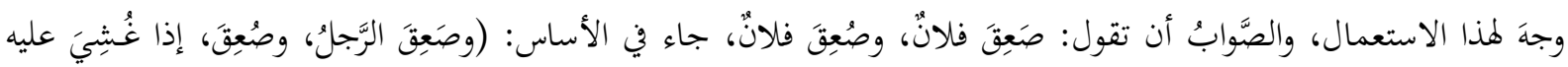

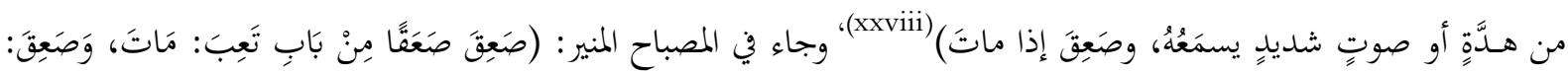

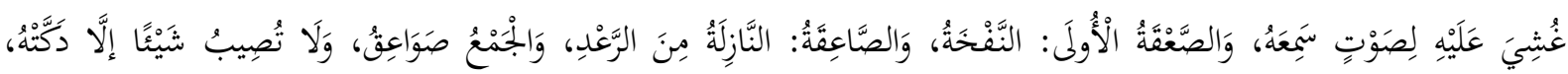
(xxix)

ولذا لا يستعمل الفعل "انصعق" للدلالة على الإصابة بالصاعقة، لأنَّ ذلك لم يرد في مصنفات اللغة وأسفار القوم، فلا

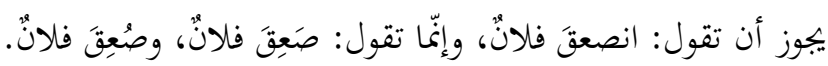

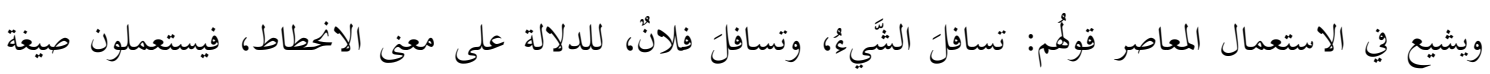

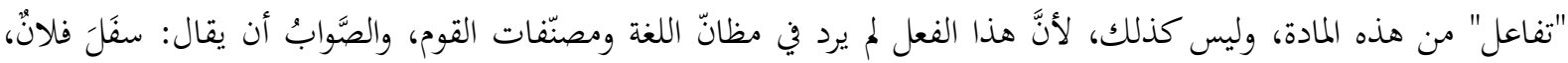

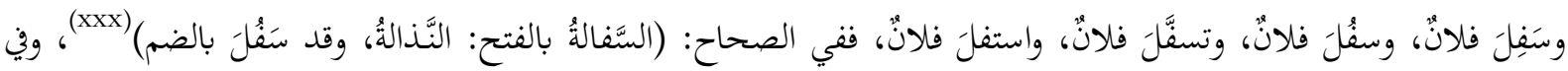

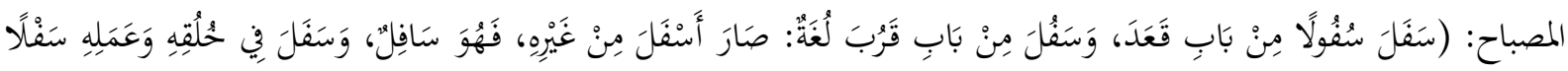

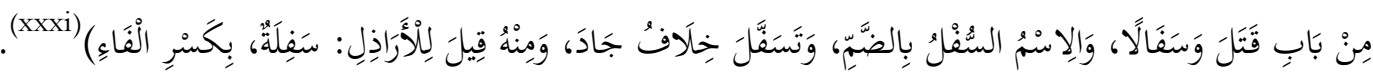

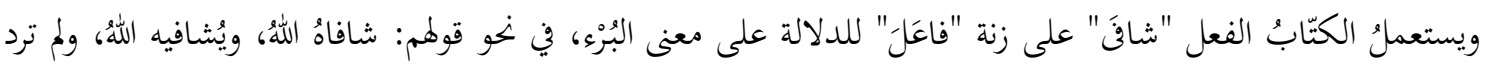

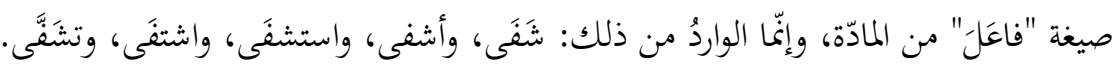

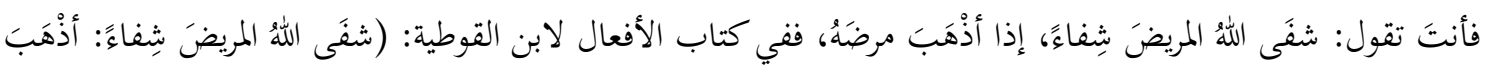

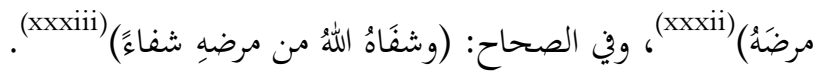

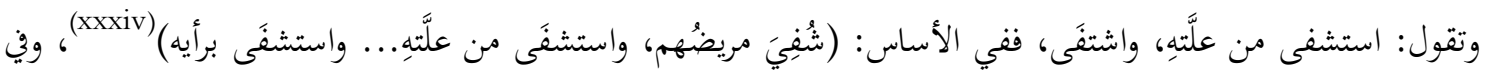

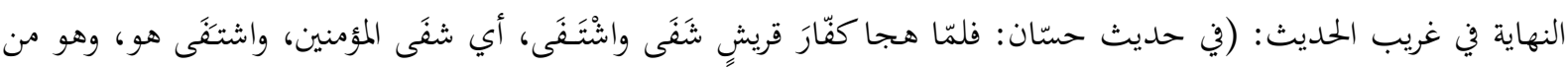

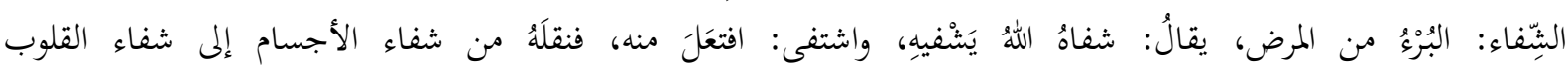

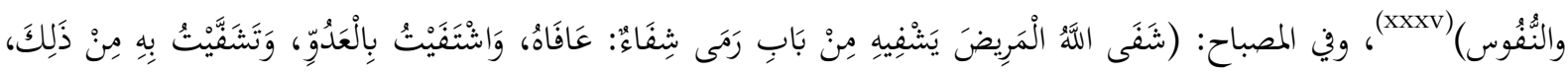

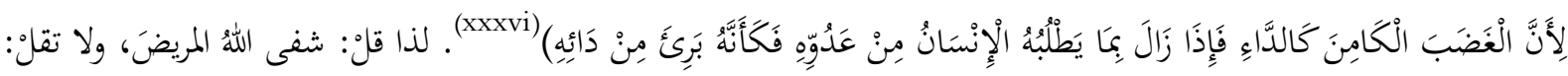
شافاه.

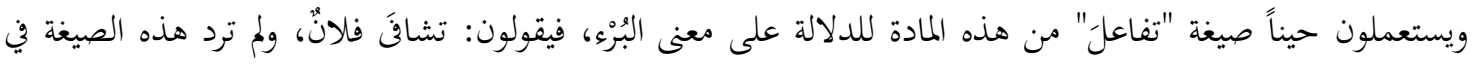

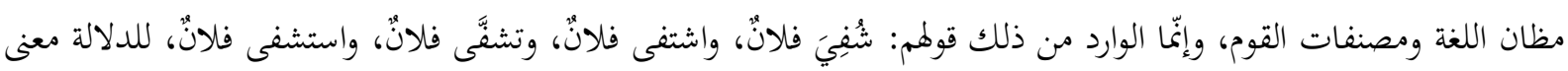

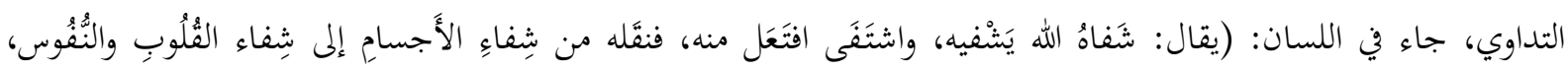

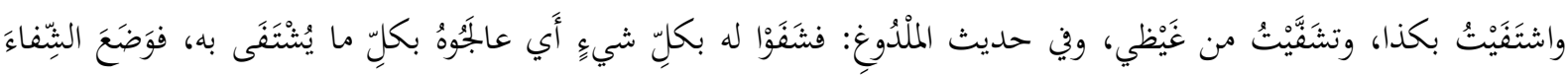

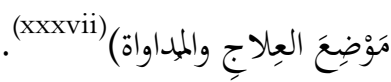


ويقولُ بعضُ الكتّاب حيناً: تضامَنَ الشَّعبُ، والأمّةُ بتضامُنِها تبلغُ الآمالَ، فيوردونَ الفعل "تضامَنَ" على "تفاعَل" بمعنى

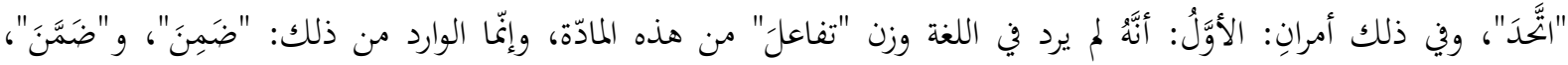

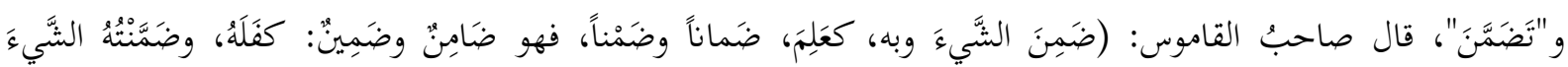

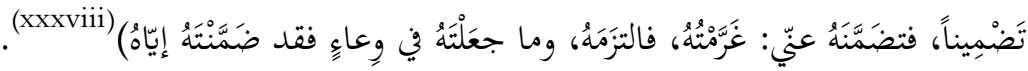

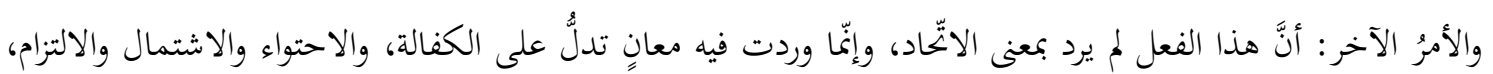

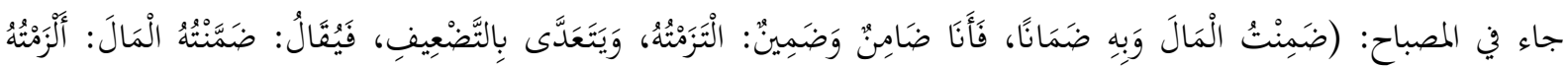

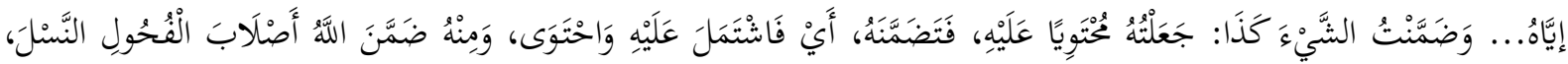

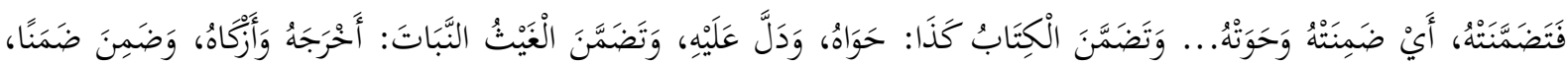

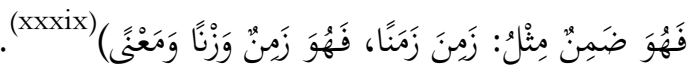

ويرى د.إبراهيم السامرائي أنَّ مجيء "التَّضامُن" بمعنى الاتّحاد شيء من المولّد الجديد الذي جاءت به لغة العصر، يقول:

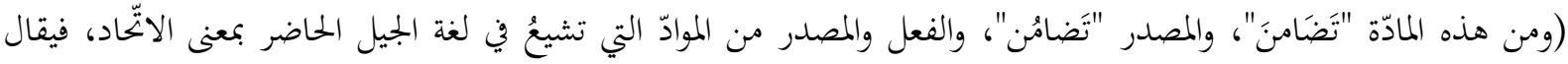

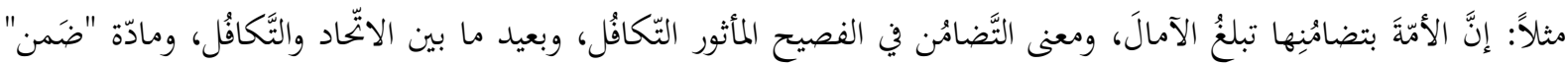

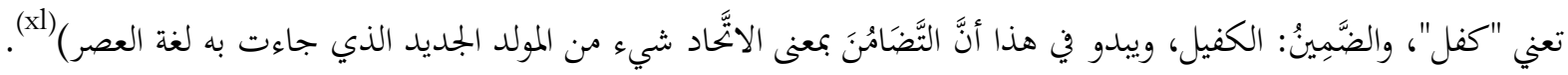

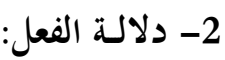

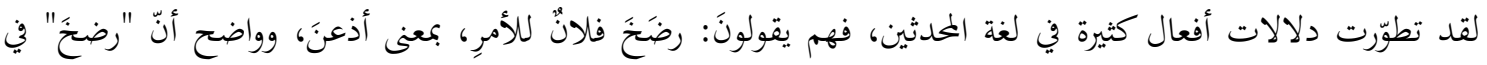

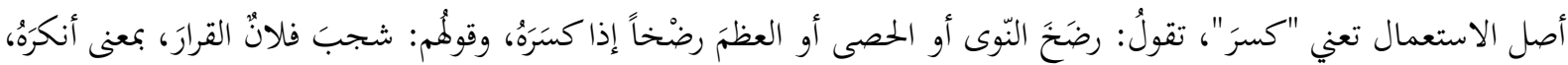
والأصلُ في " شجبَ " أنبّهُ يعني أهلكَ.

تقولُ العربُ: شجبَهُ إذا أهلكَهُ، وأحُزنَهُ، ونخُُ نقبلُ التّطوّر إذا كان لا يخالف ضوابط اللّغة، ولا يخرج عن أقيستها، بحيث

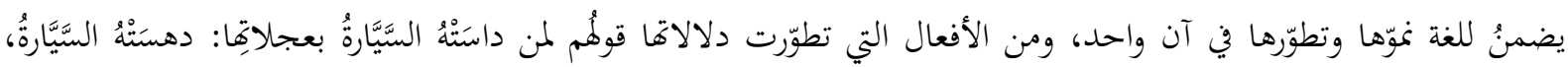

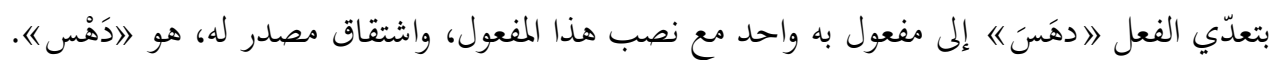
وقد مرّت عشرات السّنين على هذا الفعل الغريب ومصدره، ودخلا في سجلّات الحوادث في دواوين الشّرطة ودواوين

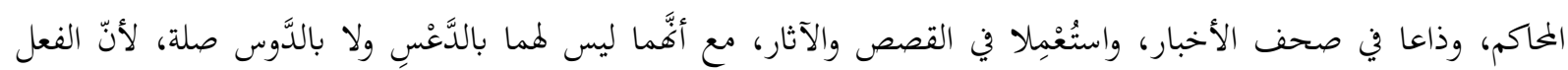

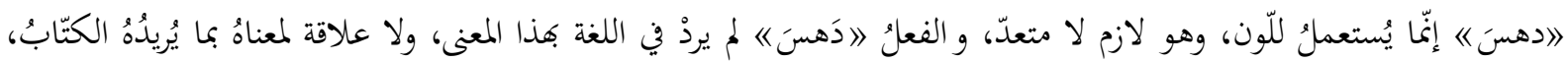

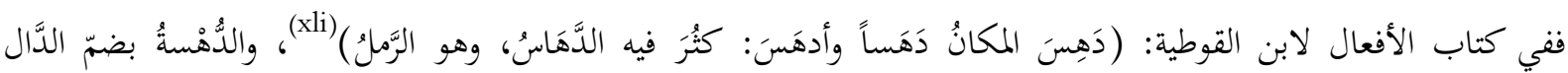

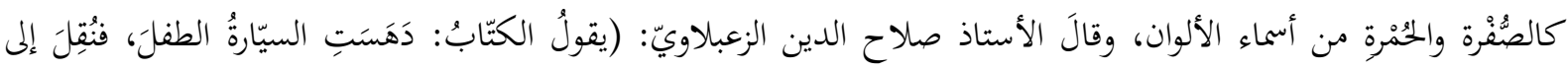

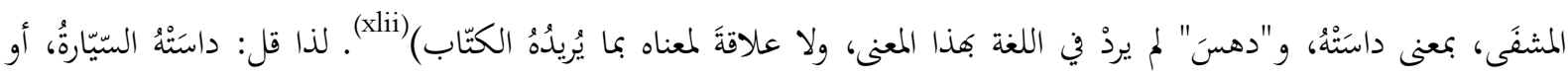
دعسَتْهُ، ولا تقل: دهسَُْْه.

ومن ذلك قولُم: تنازلَ فلانْ عن حقّه، إذا تركَهُ ونَزَلَ عنه، وهو خطأ شائع، لا يكادونَ يُعبّرونَ عن هذا المعنى إلّاّ بمثل هذا

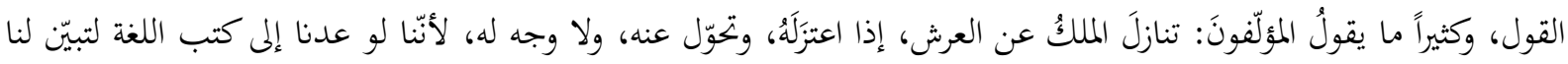

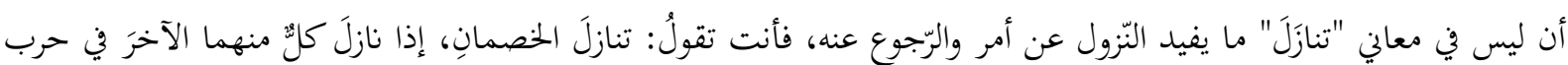

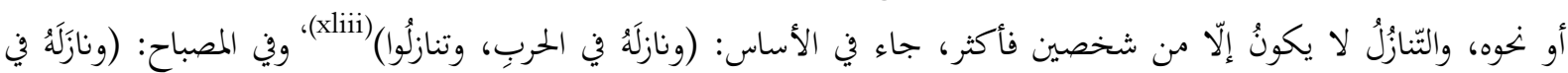

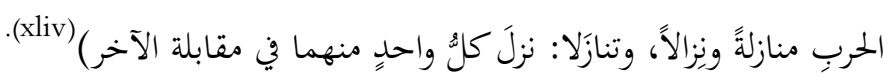


واستناداً إلى ذلك منع بعضُ النقّاد العبارة المذكورة، قال محمد العدنائّ: (يقولونَ: تنازلَ فلانٌ عن حقِّهِ لجاره، والصَّوابُ: نزلَ له عن حقِّه.

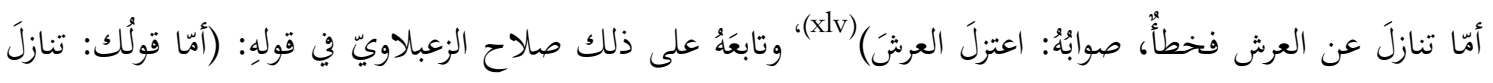

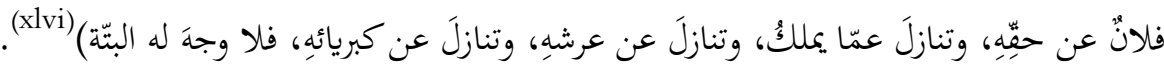

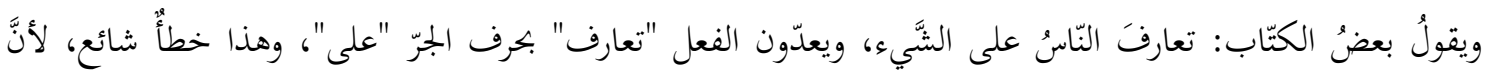

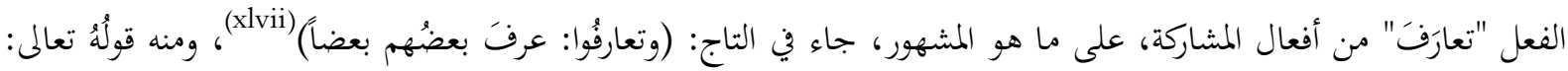

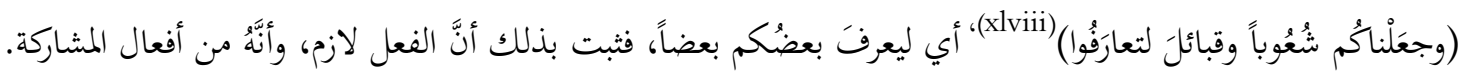
ولكن جاء في كلام الفصحاء "تعارَفوا الشَّيءَ" إذا عرَفُوه، قال الجوهريّ: (أمَّا اليوم فيما يتعارَفُها النّاسُ، ويقدر عليه

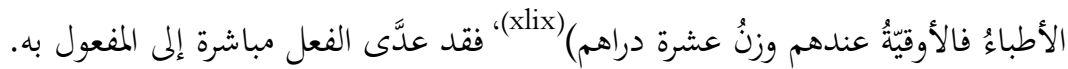

ونرى أنّ الفعل "تعارفَ" يكون لازماً إذا جاء بمعنى المشاركة، ويكون متعدّياً بنفسهِ إذا جاء لغير معنى المشاركة، وكان

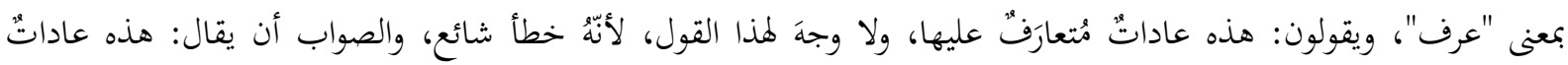

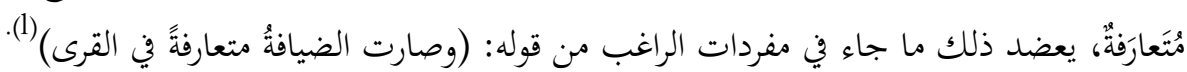
وقد ورد في كلام بعض الكتاب قولُم: تساءَل فلانٌ عن الأمر، وأرادوا به "سألَ فلانٌ عن الأمر"، في حين أنّ الاستعمال

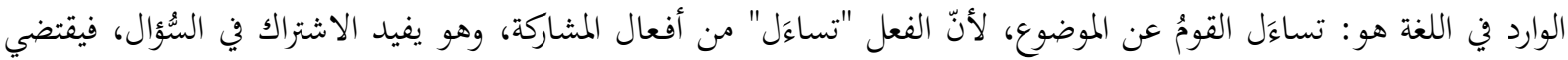

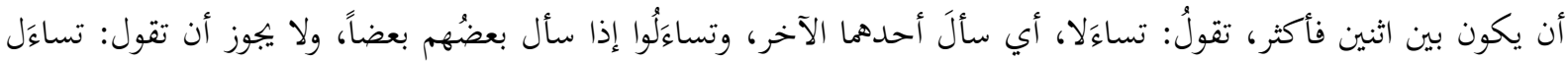

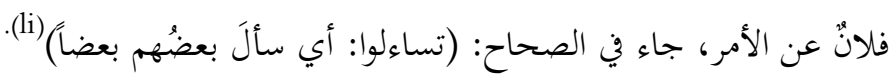
واستند إلى ذلك بعضُ النقّاد، فأنكروا ورود الفعل "تَساءل" لغير المشاركة، قال الناقدُ أسعد داغر: (ويقولونَ: فتساءَلْتُ:

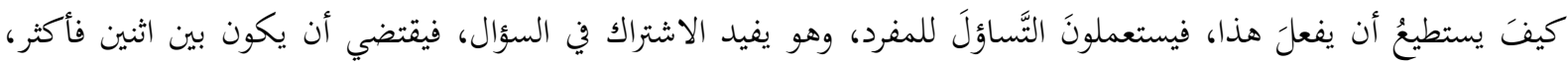

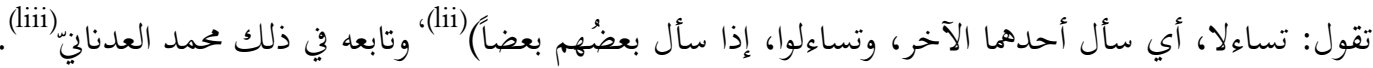

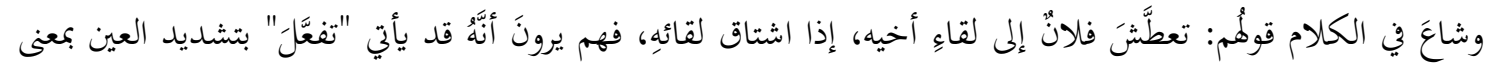

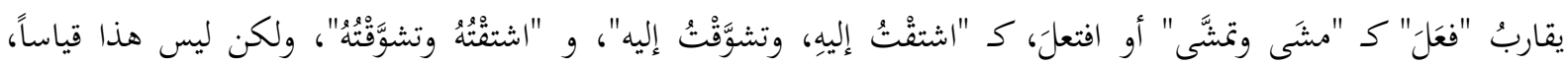

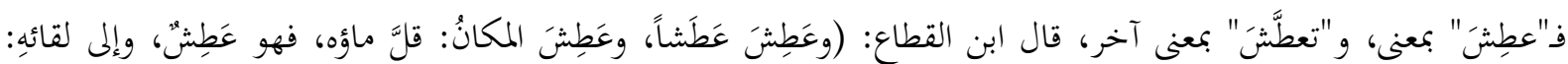

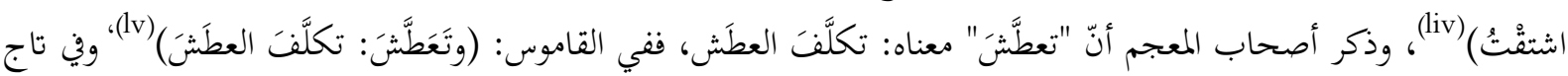

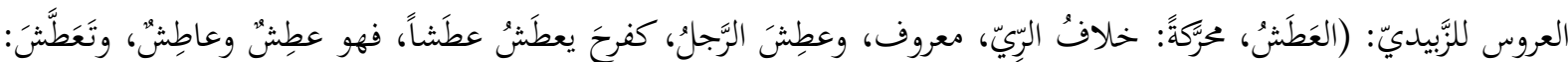

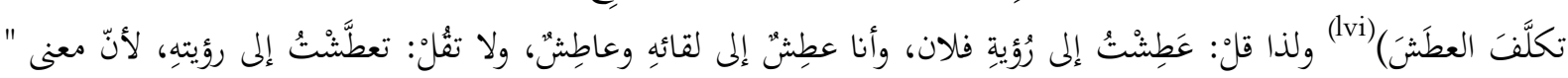

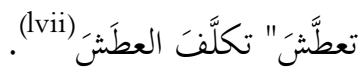

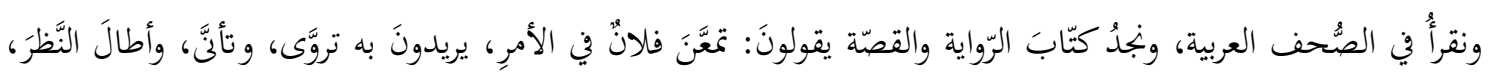

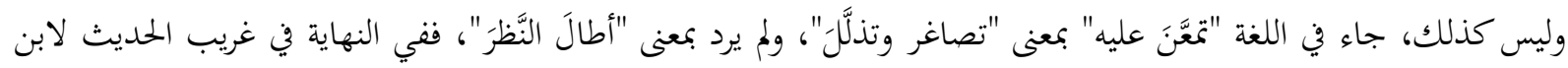

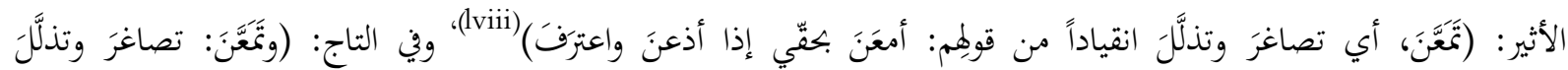

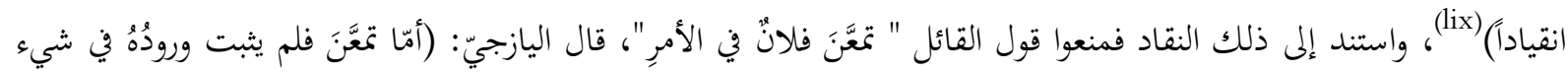

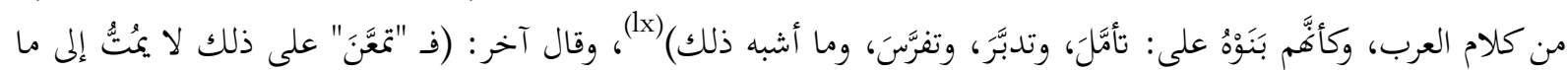

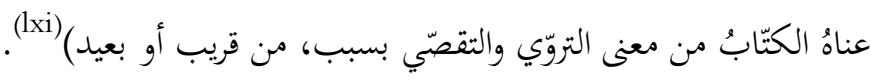


وشاع في العربيّة المعاصرة قولُم: هذا العملُ لا يتماشَى مع القانون، و يقصدونَ أنَّ العمل لا يساير القانون، ولا يطابقُهُ،

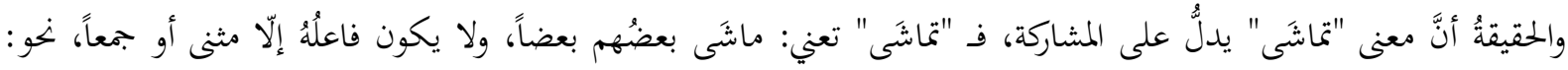

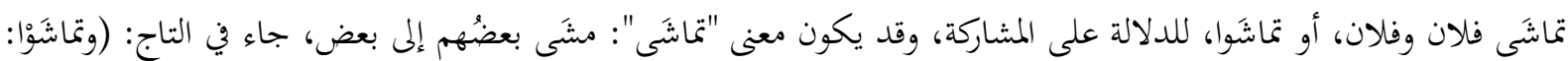

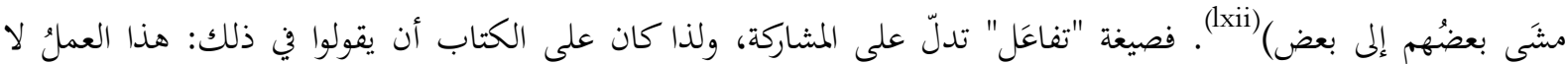

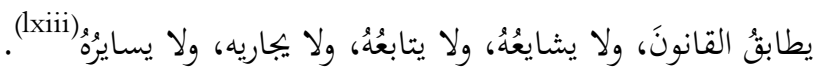

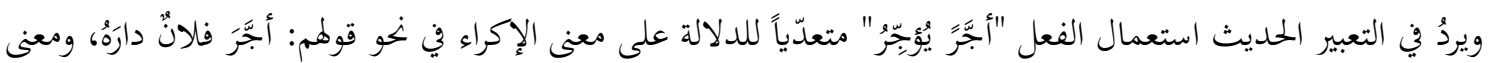

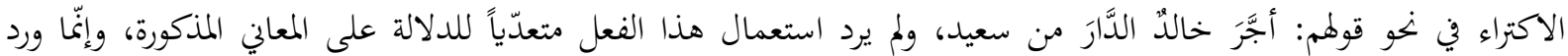

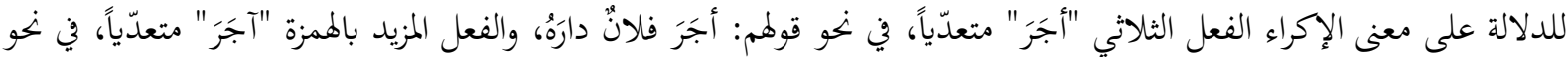

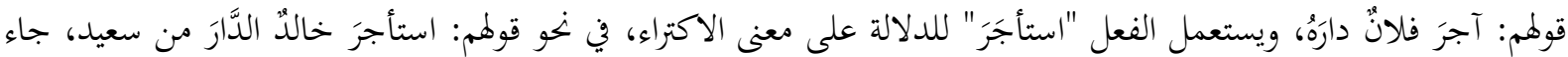

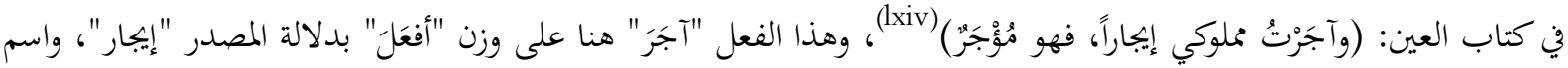

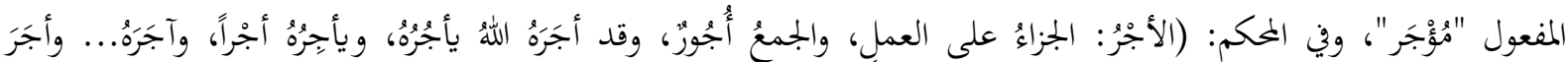

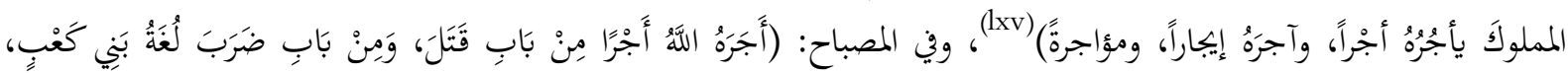

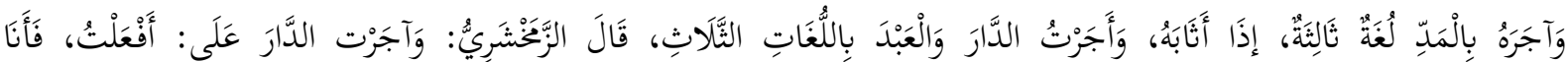

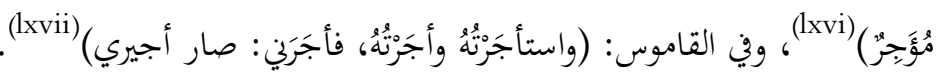

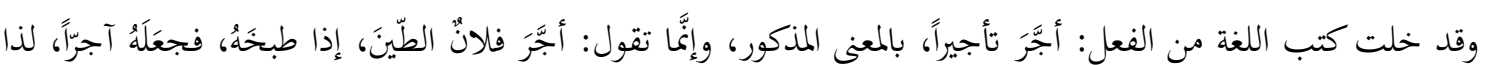

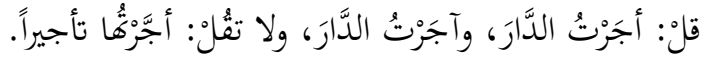
ويرد في التعبير المعاصر استعمال الفعل "تبضَّعَ" متعدياً للدلالة على أخذ البضاعة، في نحو قولمم: تبضَّعَ زيدٌ حاجاتِِهِ من

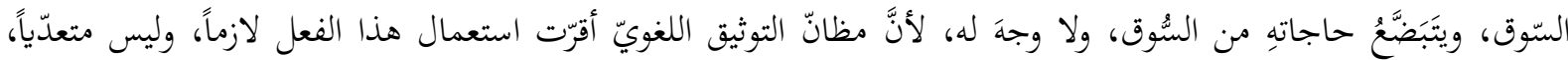

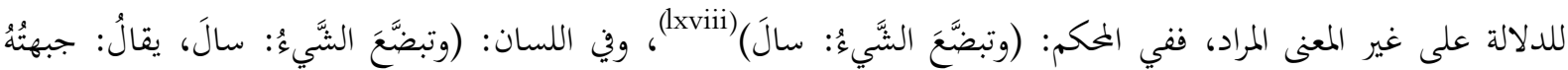

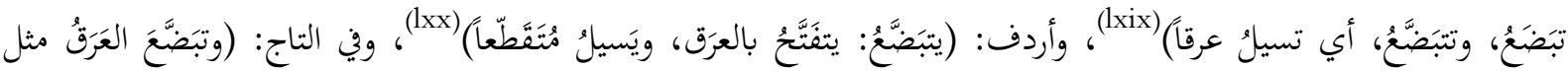

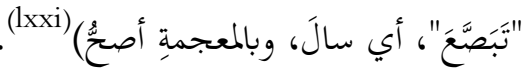

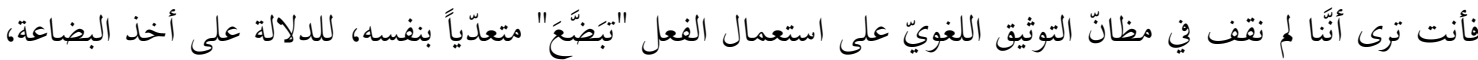

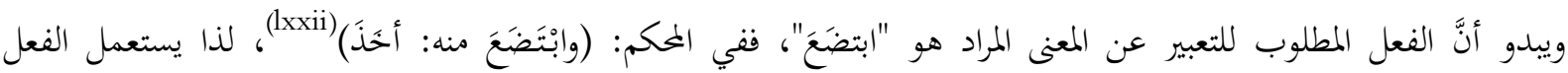

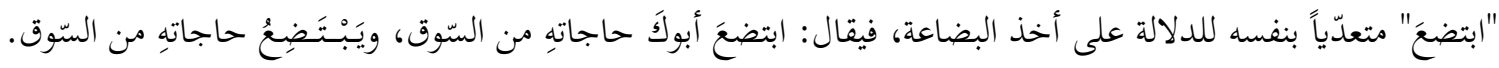
ويرد في التعبير المعاصر استعمال الفعل "تاجَرَ" لازماً للدلالة على معنى التجارة من دون المشاركة، في نحو قولهم: تاجرَ

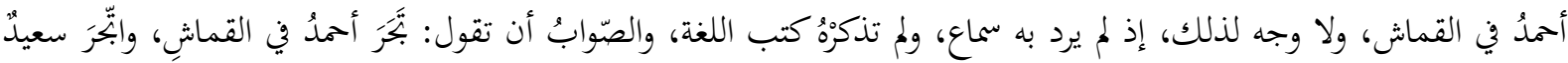

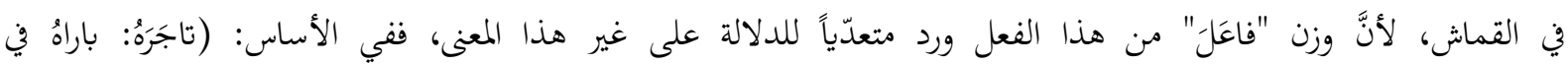

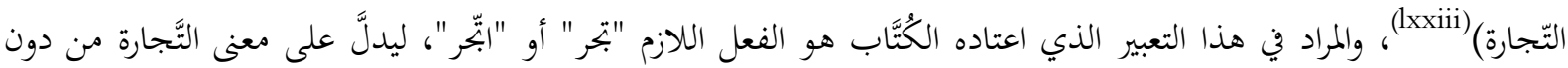

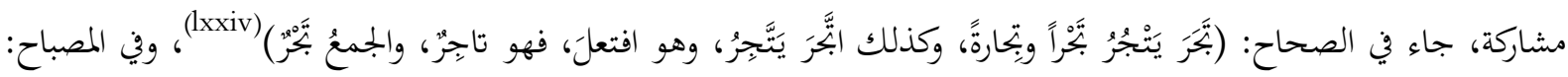

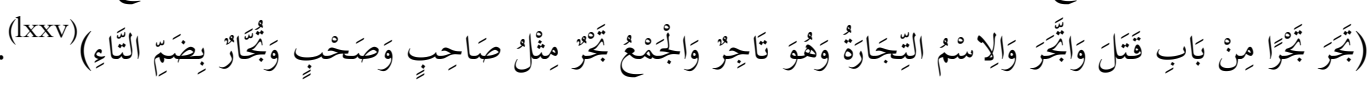
ويشيع في الاستعمال المعاصر قولُم: تجاهَرَ فلانٌ بالقولِ، فيستعملون صيغة "تفاعل" من الجهر للدلالة على معلى معنى

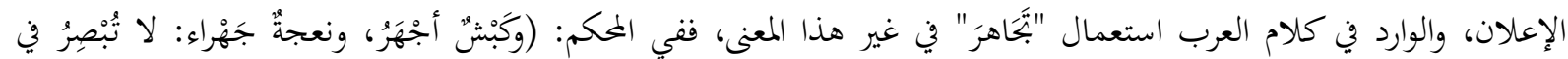




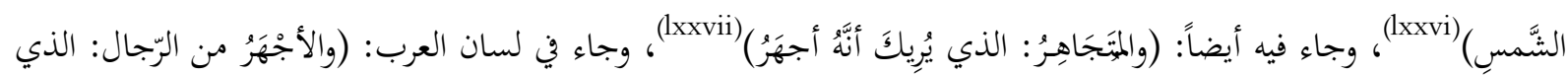

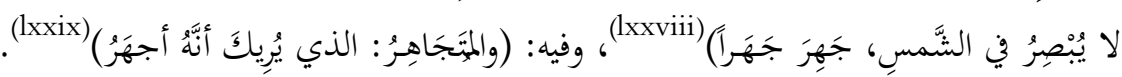

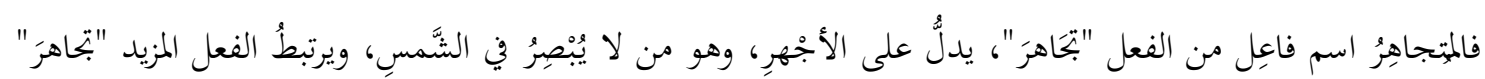

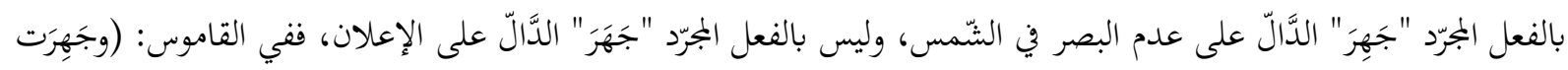

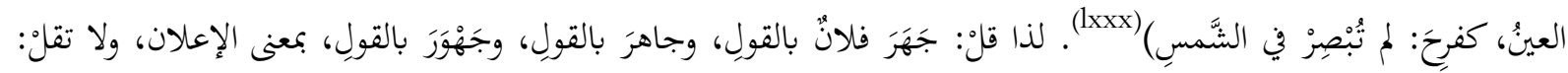

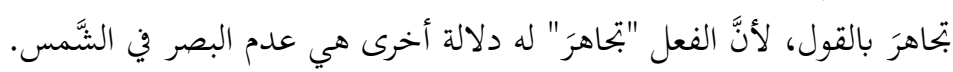

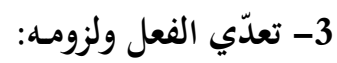

هذه ظاهرةٌ أخرى من ظواهر تطوّر الفعل في العربيّة المعاصرة، فقد يكون الفعل لازماً، والمحدثونَ يُعَدَّونهُ، وقد يكونُ متعدّيّاً

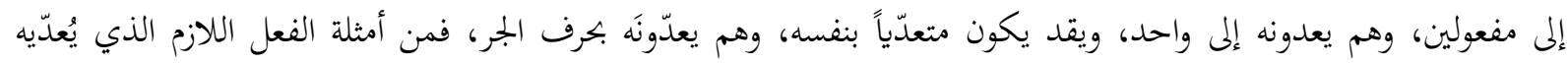

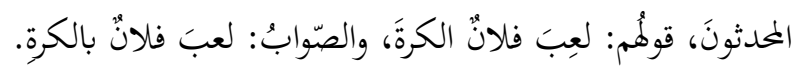

ومن الأمثلة على الفعل المتعدّي الذي يستعملُهُ المحدثونَ لازماً قولُم: تداوَلُوا في الأمر، والصّوابُ: تداولوا الأمرَ، وقولُمم:

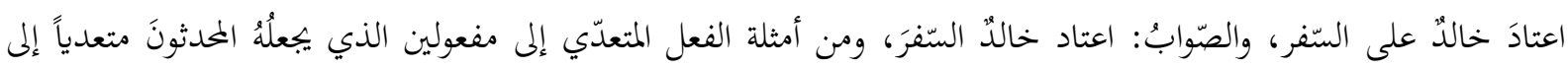

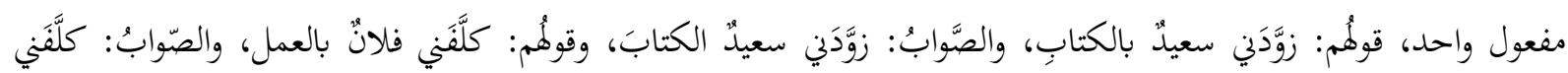

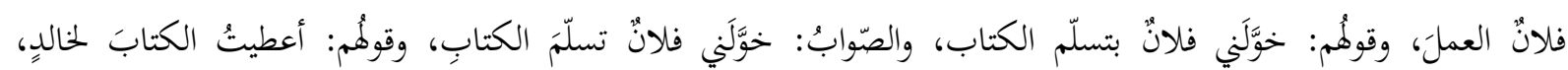
والصَّوابُ: أعطيتُ خالداً الكتابَ.

ومن ذلك قولُ الكتّابُ: حازَ فلانٌ على الثَّهادةِ، وأنا حائزٌّ على شهاداتٍ عاليةٍ، وهو من الأخطاء الشّائعة، فـ الحازَ

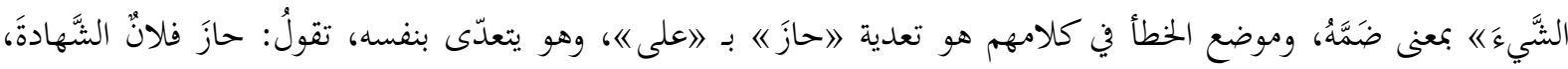

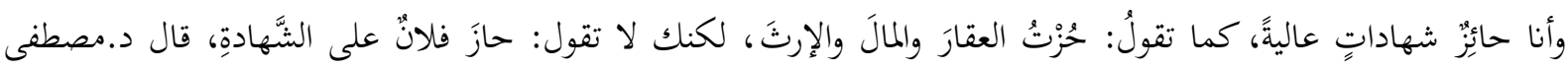

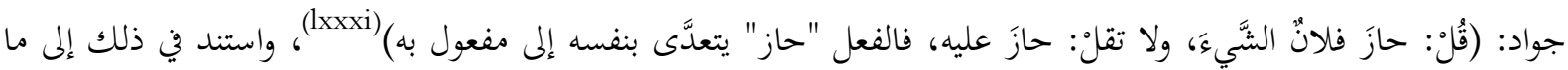

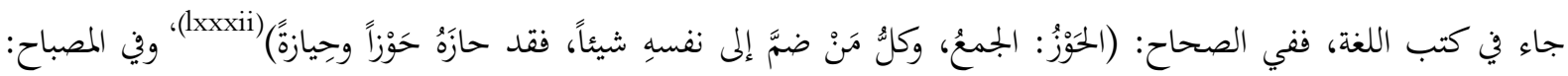

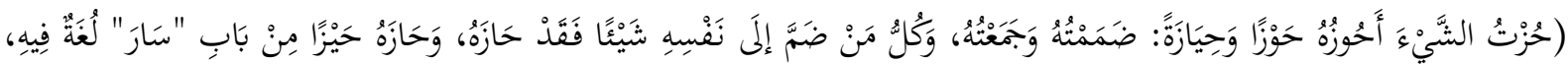

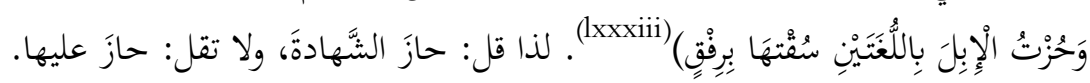

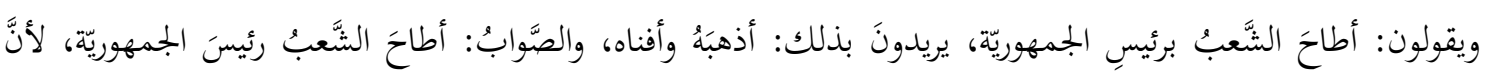

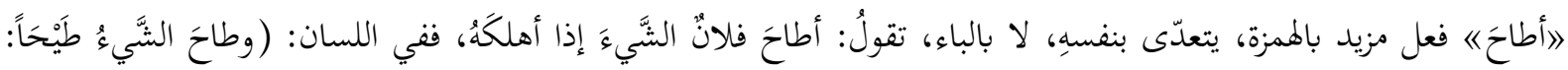

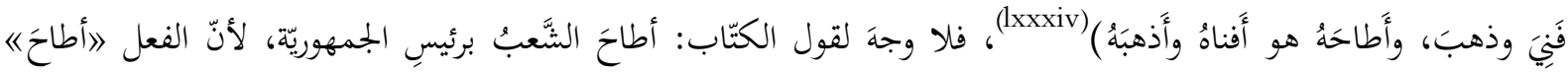

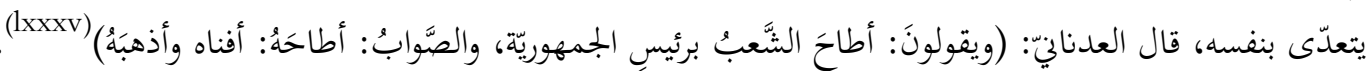

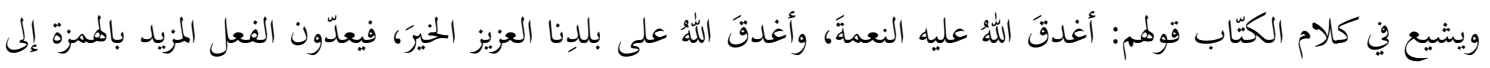

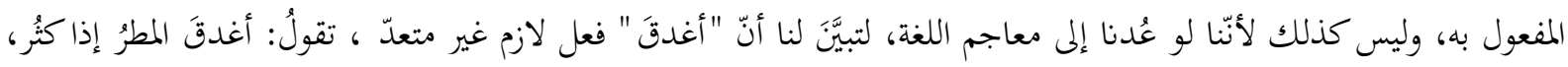

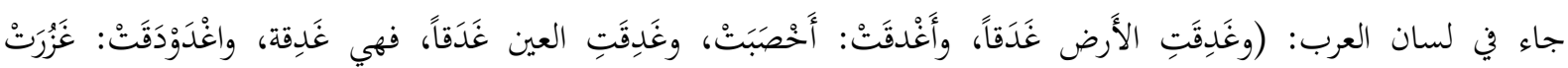

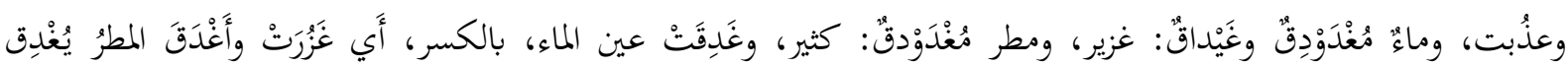

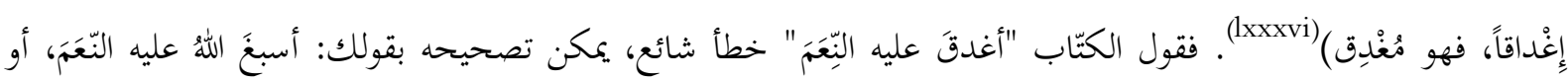
أفاضَ عليه النّعَم، أو أجزلَها. 
وكثُرُ في كلام المعاصرين قولُم: باشَرَ فلانُ بعملهِ، وباشَرَتُ في العمل، بتعدية الفعل بحرف الجرّ، وهذا خطأ شائع،

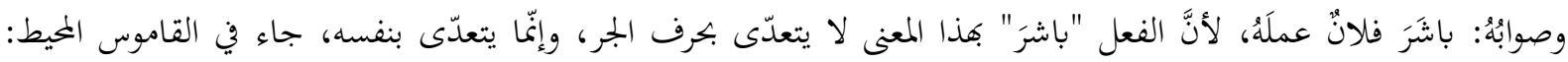

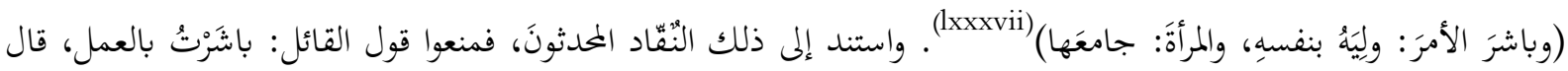

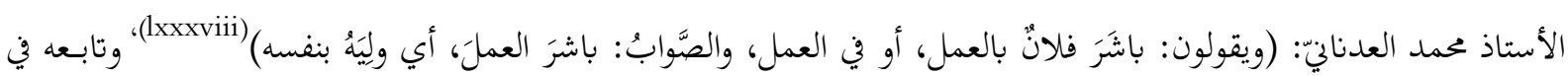

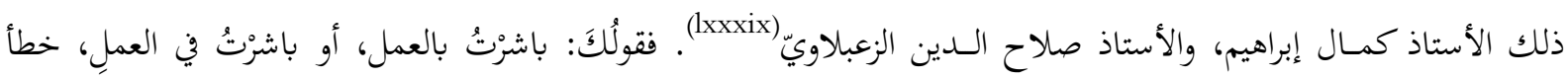
شائع، صوابُه: باشرْتُ العملَ.

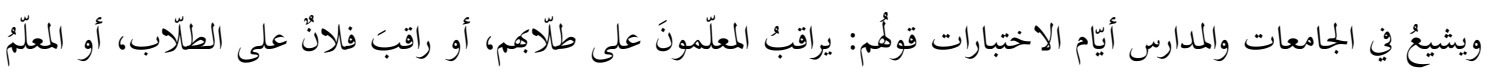

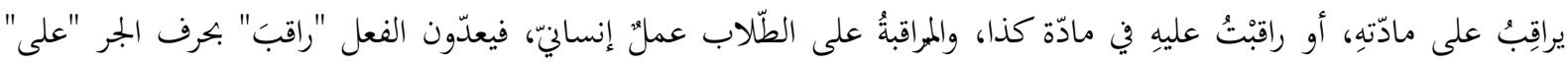

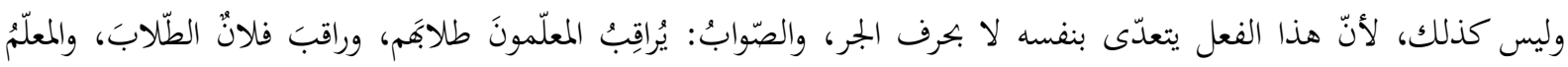

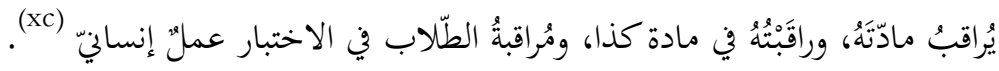

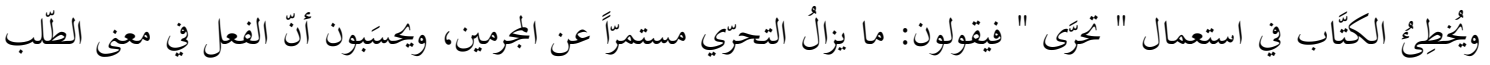

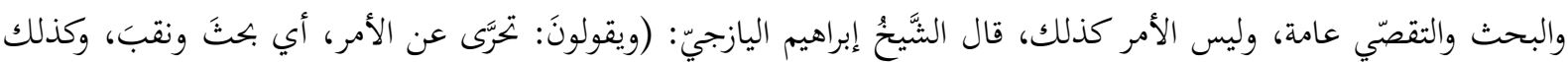

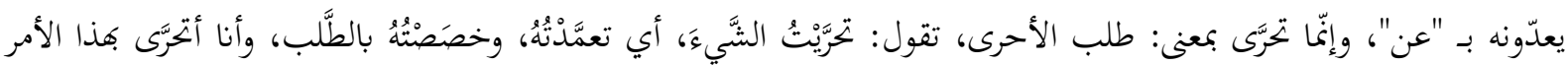

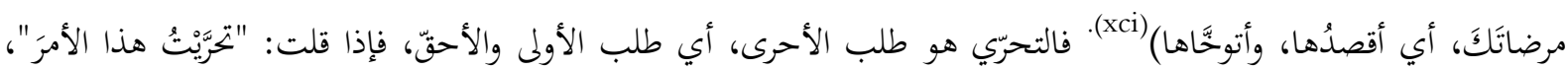

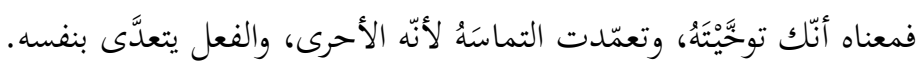

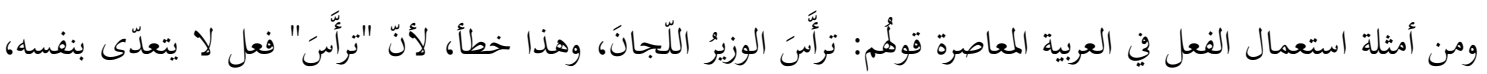

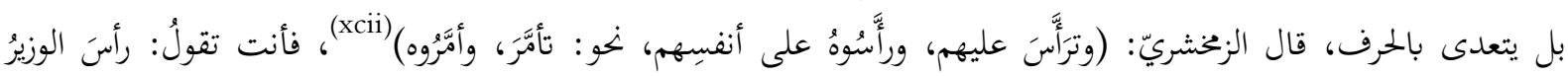

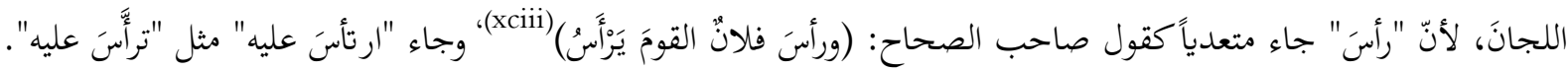

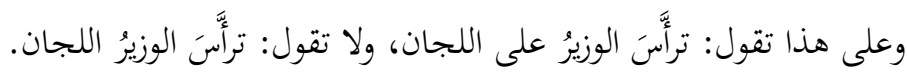

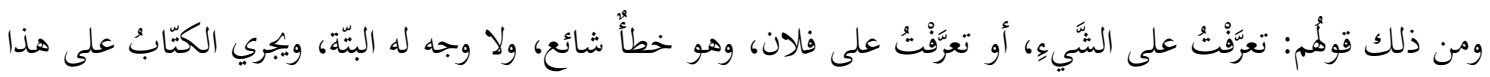

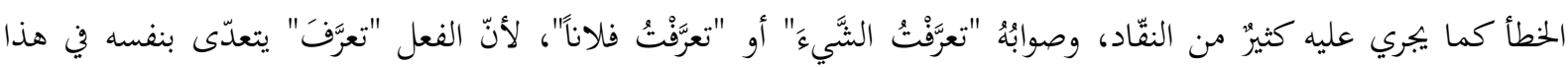

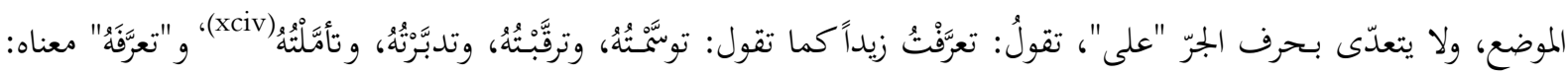

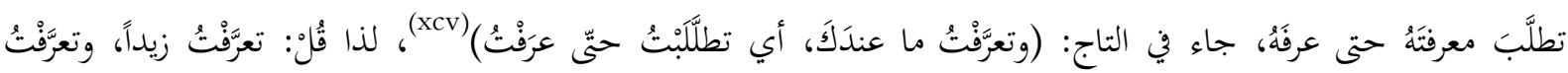

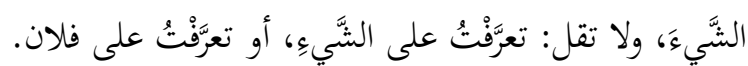
4- استعمال الفعل مع حروف الجر: استُعمِلَ الفعلُ في العربيّة المعاصرة في غير مواضعه الصحيحة في أحيان كثيرة، فمن ذلك قولُمْم: أثنّر الحزنُ على فلان،

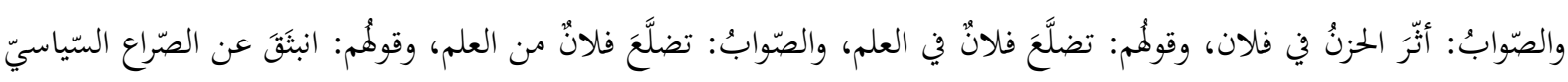

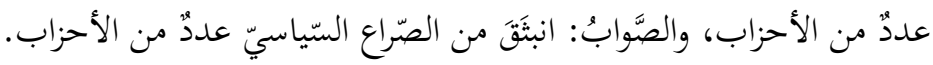

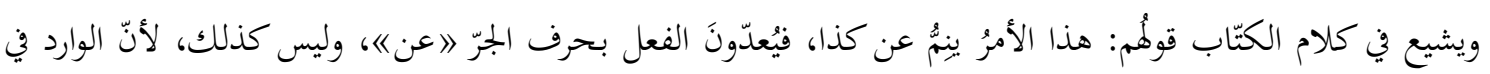

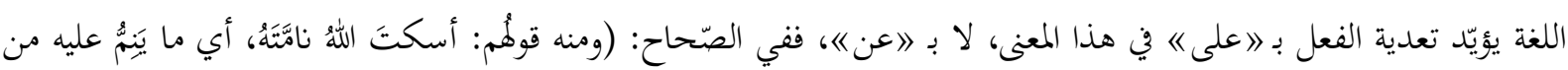

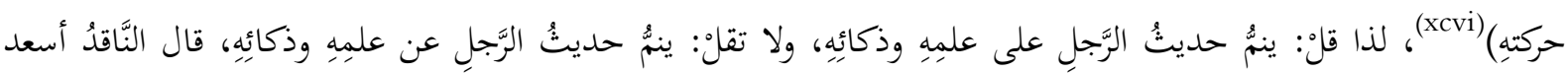

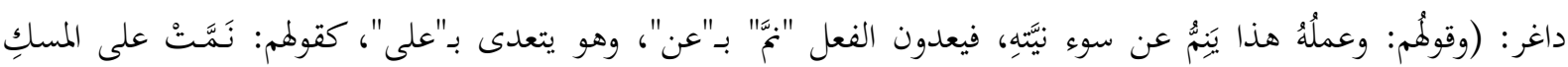

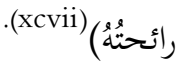




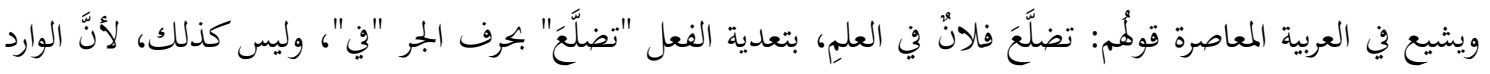

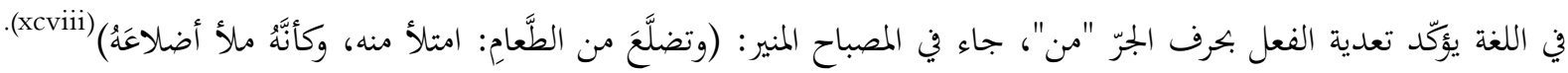

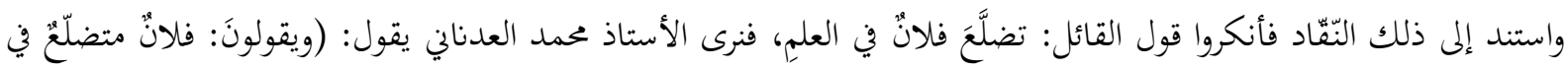

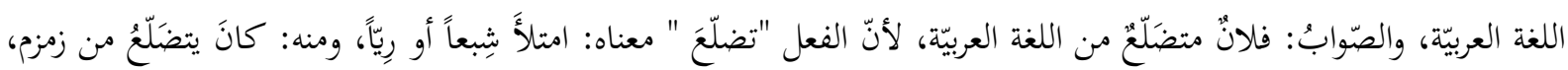
وهو لا يتعدّى إلّا بحرف الجر "من")(

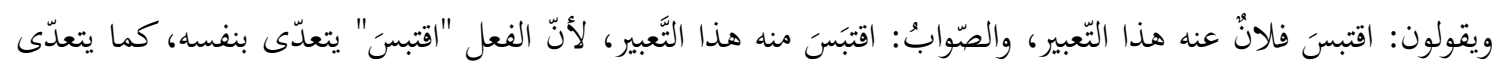

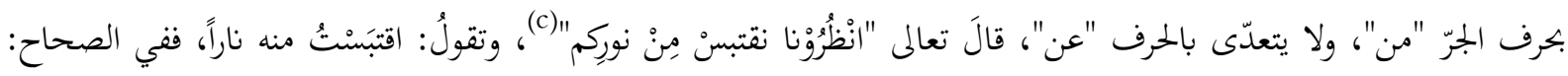

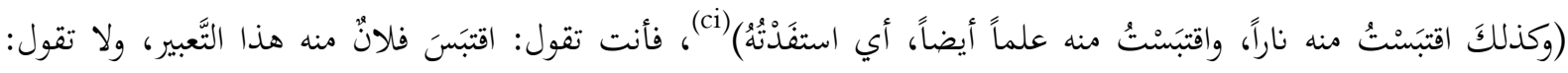
اقتَسَنَ عنه هذا التُّبير.

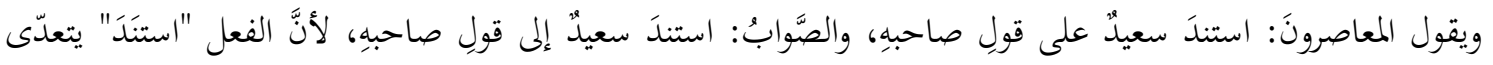

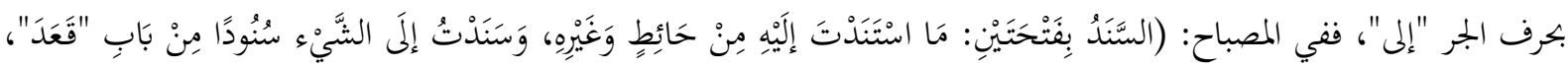

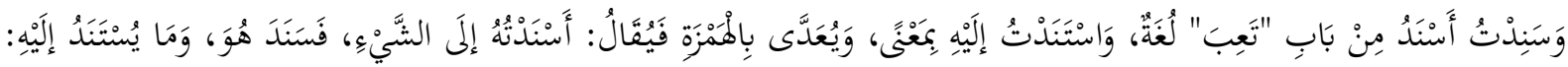

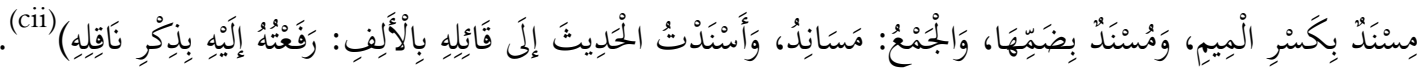

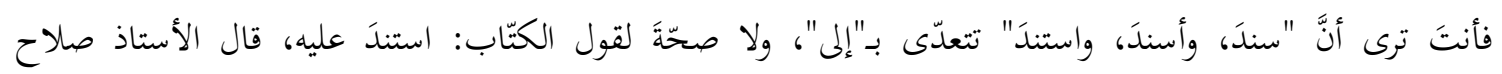

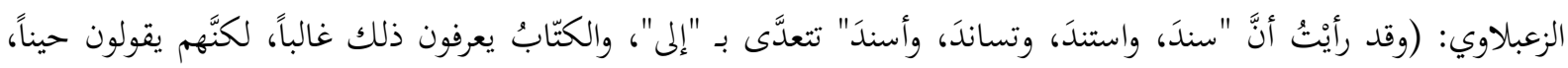

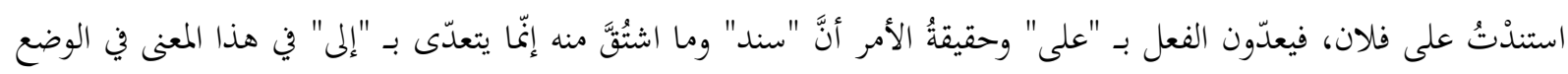

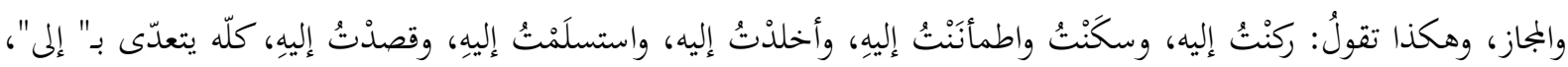

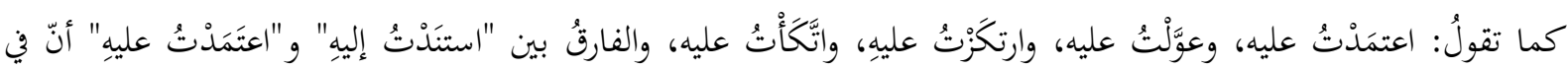

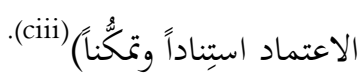

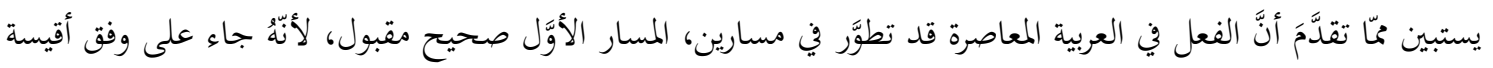

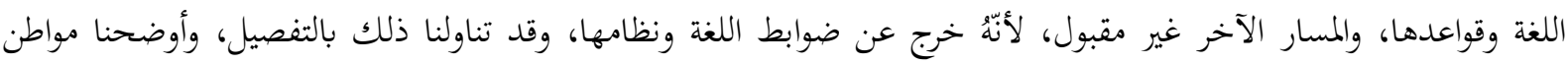

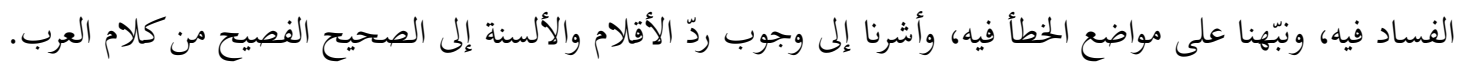




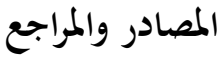

أساس البلاغة، جار الله الزخشريّ 538هـ، تحقيق محمد باسل عيون السود، دار الكتب العلمية، بيروت، ط1، 1998م.

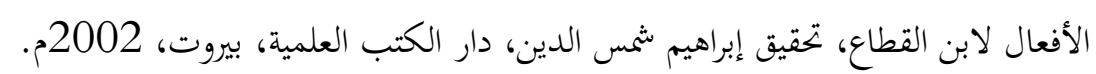

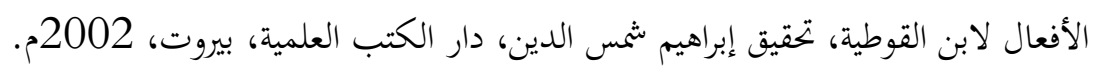
تاج العروس من جواهر القاموس لمحمد مرتضى الزبيدي، تحقيق مجموعة كبيرة من العلماء، طبعة الكويت. تذكرة الكاتب، أسعد خليل داغر، كلمات عربية للطباعة والنشر، القاهرة. الصحاح (تاج اللغة وصحاح العربية): إسماعيل بن حماد الجوهريّ (ت في حدود 400هـ)، دار إحية إسياء التراث العربي، بيروت، 2009

فصول في اللغة والنقد، د. نعمة رحيم العزاوي، المكتبة العصرية، بغداد، 2004م. القاموس المحيط للفيروز آبادي (ته17هـ) تحقيق محمد عبد الرحمن المرعشلي، دار إحياء التراث العربي، بيروت، 2003 2003م.

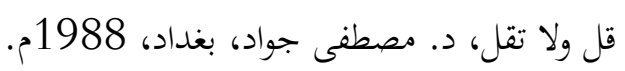

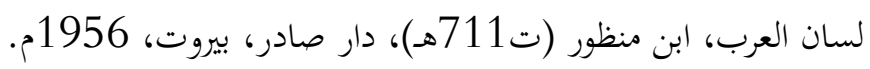

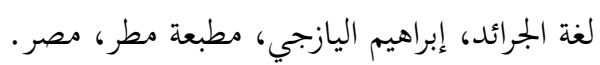

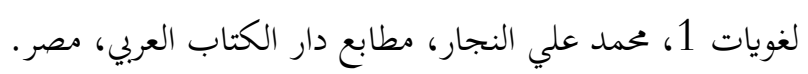

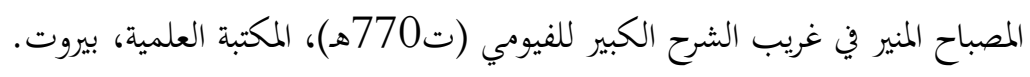

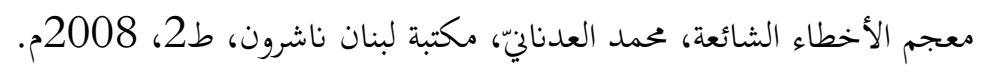

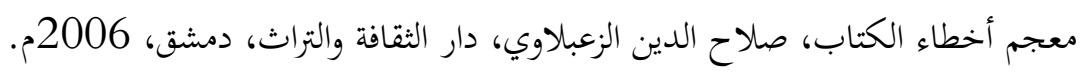

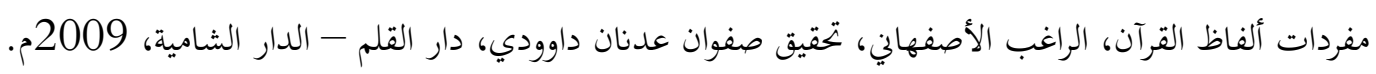

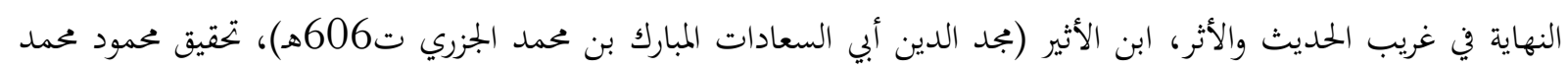

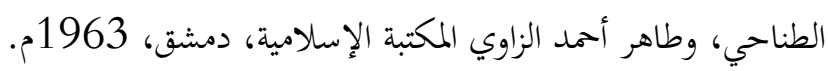




$$
\begin{aligned}
& \text { (i) الأفعال لابن القطاع: } 17 . \\
& \text { (ii) } \\
& \text { نفسه: (iii) } \\
& \text { (iv) التاج (شغل). (iv) }
\end{aligned}
$$

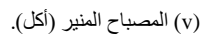

$$
\begin{aligned}
& \text { (القو لو لا تقل: } 87 \text { (vi) } \\
& \text { (التوبة: } 108 \text { (vii) } \\
& \text { (القاموس المحيط: (جذر). (viii) }
\end{aligned}
$$

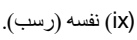

$$
\begin{aligned}
& \text { (x) المصباح المنير (رسب). (X) (X) (x) } \\
& \text { (الهُ (xi) }
\end{aligned}
$$

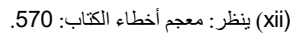

$$
\begin{aligned}
& \text { (xiii) } \\
& \text { (xiv) } \\
& \text { (XV) } \\
& \text { (XVi) } \\
& \text { لغة الجر اند: 23vii) } \\
& \text { (xviii) } \\
& \text { (xix) }
\end{aligned}
$$

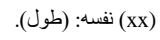

$$
\begin{aligned}
& \text { (xxi) } \\
& \text { (xxii) }
\end{aligned}
$$

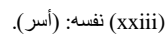

$$
\begin{aligned}
& \text { (الصحاح: (ألف). (xxiv) } \\
& \text { 67/12 المحكم: (xxv) } \\
& \text { (xxvi) } \\
& \text { (xxvii) } \\
& \text { (xxviii) } \\
& \text { (xxix) }
\end{aligned}
$$

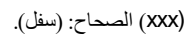

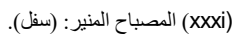

$$
\begin{aligned}
& \text { (xxxii) } \\
& \text { (xxxiii) } \\
& \text { (xxxiv) } \\
& \text { النهاية: (xxxv) } \\
& \text { (xxxvi) } \\
& \text { (xxxvii) } \\
& \text { (xxxviii) } \\
& \text { (المباح المنير: (xxxix) } \\
& \text { (العربية تاريخ وتطور: } 248 \text { (xl) } \\
& \text { (الأفعال: (xli) } 149 .
\end{aligned}
$$

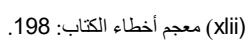

$$
\begin{aligned}
& \text { (أساس البلاغة: (نزل). (Xliii) } \\
& \text { (نxliv) } \\
& \text { (Xlv) } \\
& \text { (Xlvi) } \\
& \text { (xlvii) } \\
& \text { (xlviii) } \\
& \text { (الصحاح: (وقى). (xlix) }
\end{aligned}
$$

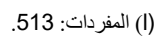

$$
\begin{aligned}
& \text { (li) } \\
& \text { تنكرة الكاتب: } 111 . \\
& \text { (liii) } \\
& \text { (الأفعال: (liv) } \\
& \text { (IV) } \\
& \text { (IVi) }
\end{aligned}
$$


Rimak International Journal of Humanities and Social Sciences

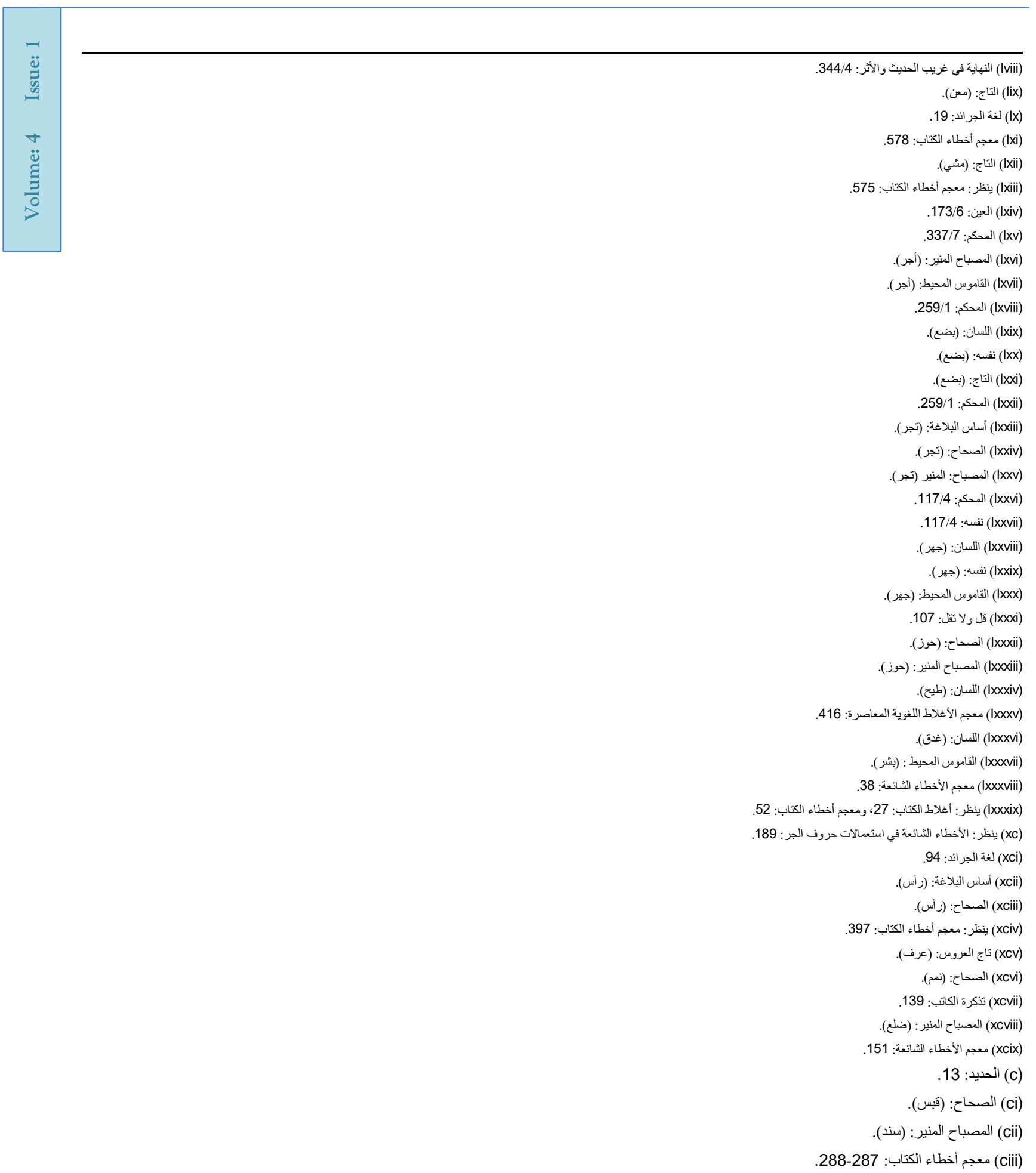




\title{
A CONTRASTIVE ANALYSIS OF RELATIVE CLAUSE GRAMMAR IN BOTH ARABIC AND ENGLISH
}

\author{
Rana Abid THYAB ${ }^{1}$
}

\section{Istanbul / Türkiye \\ p. 231-237}

Received: $02 / 12 / 2021$

Accepted: $18 / 12 / 2021$

Published: 01/01/2022

This article has been scanned $l$ iThenticat No plagiarism detected

\begin{abstract}
:
As with any language learning process, learning English relative clauses is not an easy task for a number of reasons. Moreover, learning relative clauses by English language learners whose mother-tongue is Arabic is faced with difficulty for many. Learners of English relative clauses, with an Arabic first language, come across areas of similarity and difference regarding rule formation in both English and Arabic. These similarities and differences could be a major source of positive and negative transfer. Also, known within contrastive studies and error analysis. This paper supports and highlights such limited findings. Arabic mothertongue learners of English encounter difficulties in their use of the English relative clauses because of negative transfer. The Arabic language has relative clause formation rules that function both similarly to English, in parts, and differently, in other parts. Thus, notions which are encoded differently than in that of the English language is found to cause noticeable mistakes and errors by learners. Given the fact that relative clauses are one of the most frequent grammatical structures used in the English language, as well as in Arabic, this paper has aimed to pin down such an important issue. The aim of this paper is to pinpoint limited findings and limited studies regarding English relative clauses' use by Arabic native speakers. This is done by illustrating how the differences between the Arabic and English languages in concern to relative clauses' formation rules cause learners of English with an Arabic mother-tongue to make repeatable mistakes and errors in their English learning process, specifically with regard to relative clause grammar and formation rules.
\end{abstract}

Key words: Relative Clauses, Transfer, Mother-Tongue. 


\section{Introduction}

Language has an interactive function because it is used to communicate. Language allows us to perform speech acts and to have an expressive effect. This study aims to discuss two different languages: English and Arabic. Within this study the focus is on English and Arabic relative clauses. (Diagne, S. \& Faye, J. C., 2021)

Within the English language, a relative pronoun is considered as a group of words which replace nouns or other pronouns which are derived from (Wh-) such as: who, which, whose, whom, and whose. A relative pronoun in English introduces a clause or a part of a sentence which describes a noun. (Ibid)

Relative clauses' formation in both the English and the Arabic language are somewhat similar in many constructions. Nonetheless, there are certain distinct aspects which cause mother-tongue interference and a place for error and mistakes. (Hamdallah R.W. \& Tusheyeh H. Y., 2019)

within this paper a contrastive study will be implemented to investigate areas of comparison and contrast between English and Standard Arabic relative clauses to also investigate areas of mother-tongue interference.

The treatment, here in this paper, of the relative clauses is an analysis in the generation of English relative clauses and an examination of how the rules of derivation of these clauses in Standard Arabic interact with the application of English relative clauses. Analysis, here, is of surface structure similarities and differences between the two languages. This, hopefully is attempted to be done, in the aim of identifying areas which pose problems for Arabic speakers in learning to produce English relative clauses.

\section{Literature Review}

English language learners encounter a number of difficulties when it comes to learning English. Moreover, when it comes to forming relative clauses, problematic issues arise due to differences between languages, as well as the nature of the English language regarding relitivization. Mother-tongue interference with concern to relitivization is also a source of difficulty, mistakes and error. Before moving more deeply, mother-tongue interference means the effect of the learner's native language on second/foreign language learning.

Mother-tongue is one's native language, first language or parent language. (The Free Dictionary, 2015)

Mother-tongue interference refers to the effect of the learner's first language (L1) on her/his acquisition of the target language. The target language, in turn, is the language the learner is aiming to learn (L2). (Contrastive Analysis, 2015)

Problems of mother-tongue interference come about when learning a new language whether English or otherwise. One of these problems is mother-tongue interference in the acquisition of the English relative clauses.

Contrastive Analysis examines different languages with the aim of discovering their structural similarities and differences. Contrastive Analysis is a method that was greatly used in the 1960s and 1970s to explain reasons behind new language learning difficulties and reasons why some features of a target language were more difficult to learn than others. (Mozlan, 2015)

The basis within this method is that the more difference between the learners' mothertongue and the target language, the more difficulty the learner will come across when learning the target language structures and features. (Contrastive Analysis, 2015)

It was suggested in (Cantrative Analysis Hypothesis (CAH)) that difficulties faced with learning a new language could be predicted depending on the degree of difference between the learner's first language and second/foreign language. Nevertheless, there are certain problems with this hypothesis, for instance, this hypothesis does not predict many of the errors and mistakes that the learner makes in second language learning. Another problem is that this hypothesis predicts interference errors and mistakes where they, in fact, do not ascend. (Eric, 2008)

It was asserted by Lado that those items of a target language that are similar to the learner's native language would be easy for her/him to learn. Whereas, those features of a 
target language that are different from the learner's native language would be difficult for the learner to learn. This is the basis of what the Contrastive Analysis Hypothesis suggests. (Lado, 1957)

The Contrastive Analysis Hypothesis (CAH) has two versions. One is known as the strong version and the other as the weak version. The strong version claims that the number of errors a learner of a target language will come upon could be equated to the degree of difference between the learner's native and target language. The weak version asserts that errors a leaner of a target language encounters depends on the degree of mother-tongue interference a learner face. (Contrastive Analysis Hypothesis (CAH))

Arabic speaking learners of English tend to make errors when they try to form relative clauses in English as a Second/ Foreign Language (ESL/EFL). Some of these errors are attributed to the difference between relitivization in both Arabic and English. I.e., these errors are made due to the interference of the learner's mother-tongue (Arabic) on the learner's target language (English). Interference of the mother-tongue is also known as "Transfer". Transfer defined as the effect of the learner's first language upon the learner's target language. It is important to mention, though, that there are two types of transfer, in language learning. (Sabbah, 2015)

According to Sabbah, nevertheless, transfer is of two types. There is both positive transfer and negative transfer. Positive transfer refers to the process of using rules from the learner's mother-tongue which facilitates or has a positive influence on learning the target language. This transfer is mostly due to similarities between the learner's first language and target language. In contrast, negative transfer is the transfer of rules from the learner's mother-tongue which impedes or has harmful influence on the command of rules of target language This is due to differences between the first and second/foreign language. (Ibid)

Errors in language learning can be explained by referring to language learning theories. Among these theories are the Contrastive Analysis Theory and the Error Analysis Theory. The Contrastive Analysis Theory is used to explain a language learner's errors. Contrastive Analysis studies the similarities and differences between two languages or more asserting to the claim that learners will tend to refer back to their native language when they encounter target language items that greatly differ from their native language. The second theory of language learning is "Error Analysis", which studies learners' errors in the target language with the aim of recognizing the reasons behind such errors and their causes.

\section{Definition of Relative Clauses}

A relative clause, according to transformational grammar, is a surface structure of an embedded sentence that's is formed following a definite or an indefinite head noun phrase named the antecedent. (Hamdallah R.W. \& Tusheyeh H. Y., 2019)

The antecedent is who or what a sentence is talking about and relative clauses either help to clarify the antecedent or give extra information about it. (Diagne, S. \& Faye, J. C., 2021)

Relative clauses could be adnominal clauses which are considered central types of relative clauses. The antecedent of adnominal relative clauses form part of the main clause. Nonetheless, nominal relative clauses have its antecedent. Sentential and nominal relative clauses are also adnominal clauses but are briefly discussed. In the sentential relative clause, the antecedent is the complete clause. Whereas restrictive relative clauses are connected with the antecedent and as they give essential information for the identification of the antecedent which they modify, non-restrictive relative clauses have a weak relation with the antecedent they modify. Non-restrictive relative clauses are also known as parenthetic or descriptive relative clauses and they give additional and non-essential information about the antecedent which they modify. (Ibid)

When forming the relative clause, the rule asserts the deletion of the second identical noun phrase. That is, the noun phrase of the embedded sentence. The rule acquires the replacement of the second identical noun phrase by the appropriate relative pronoun. Here, the relative clause formation rule is similar to its rule in Standard Arabic. That is, the relative clause is always placed after the antecedent. Yet, there is a small difference between both languages concerning the relative pronoun. Within the English language, the relative 
pronoun may come after either a definite antecedent or an indefinite antecedent. For example:

1. The girl who was swimming fast stopped.

2. A girl who was swimming fast stopped

In Standard Arabic, however, relative pronouns do not follow an idefinte antecedent. Thus, while example (3) in Arabic is correct, example (4) is not.

3. I saw the man who lost.

رأيت الرجل الذي خسر

4. I saw a man who lost.

رأيت رجلا الذي خسر

\section{Relative Pronouns in both Arabic and English}

In English, there are five forms of the relative pronoun which are: who, whom, whose, which, and that. Relative pronouns, in Standard Arabic, have the same base but with phonological differences in masculine and feminine and different endings for case and number. That is, in Standard Arabic, the relative pronoun is determined by gender, number, and case. In Standard Arab, these forms are not distinct as they are in English. Therefore, there are eight various relative pronouns in Standard Arabic. These forms are: الذي، التي، اللذان، (Hamdallah R.W. \& Tusheyeh H. Y., 2019)

However, in Standard Arabic, unlike in English, the relative pronoun does not take the place of a subject or object. Instead, it acts as an adjective and agrees with the antecedent in gender, number, and case. (Ibid)

Moreover, a basic difference between Standard Arabic and English in relativization is that in Standard Arabic there is an appearance of a personal pronoun in the relativized site called (الضميرالعائد) which agrees with the relativized noun phrase in number, gender, and case. In English, nonetheless, there is no such pronoun. (Hamdallah R.W. \& Tusheyeh H. Y., 2019)

For example: "الفتاة التي سافر أبوها اسمها هبة" أو "الرجل الذي أحمد أطول منه فاز"

As well, there are restrictive and non-restrictive relative clauses in both English and Arabic. In both English and Standard Arabic, non-restrictive relative clauses are surface structure realizations of a conjoined sentence immediately preceded by a noun phrase. This noun phrase has a reference that is unique to both speaker and hearer and contains a noun phrase that is referential with a specified antecedent. Similar to non-restrictive relative clauses in English, non- restrictive relative clauses in Standard Arabic are derived from conjoined sentences. (Ibid)

Furthermore, both in English and Arabic, there are nominal and verbal relative clauses. In nominal sentences, the predicate is either an adjective or a prepositional phrase. Also, both in English and Arabic, there are two types of relativization: object and subject. Object relativization is the relativization of the direct object, the indirect object or the object of a preposition. As, for example: "الكتاب الذي قرأت" meaning "The book which I read".

In English, as in Standard Arabic, there are free or headless relative clauses as in the example: "من يدرس ينجح" which is translated into "He who studies succeeds"

As stated above, relative clauses in English and Standard Arabic are formed in similar ways in many constructions. Nevertheless, there are distinct aspect between both languages. Relative clauses' formation process is basically the same in English and Standard Arabic. English has, for instance, five different forms of relative pronouns.

Standard Arabic, on the other hand, has eight different relative pronouns. The relative pronoun in Standard Arabic, unlike in English, agrees with the antecedent in number, gender, and case.as well, in Standard Arabic, the relative pronoun appears with definite antecedents only. Furthermore, there is a basic difference between relative clauses, in both English and Arabic. This basic difference is appearance of a personal pronoun in the relativized site. This pronoun, known in Standard Arabic as (الضمير العائد) agrees with the antecedent in gender, number and case. English relative clauses and Arabic relative clauses could be formed as both restrictive and non-restrictive clauses, nominal and verbal relatives, subject and object relatives and free or headless relative clauses. That is, English 
and Standard Arabic relative clauses are similar in many forms, however, there are slight differences between English and Standard Arabic in this respect. (Hamdallah R.W. \& Tusheyeh H. Y., 2019)

From the above rules regarding relative clauses, it is found that there are areas where the process of relativization in both English and Standard Arabic are similar. For instance, in both English and Standard Arabic relative clauses are identical in function and in distribution. In both languages relative clauses are derived by embedding a sentence in a noun phrase as a modifier if the embedded sentence contains a noun phrase and only if this noun phrase be identical with the noun phrase it serves as modifier. Nevertheless, there are differences between the two languages despite the similarities. For instance, despite the apparent similarities, differences between the two systems regarding relativization appear even within this correspondence. (Hadra, 1978)

In English, for instance, the shared noun phrase which is in the embedded sentence (whether subject or object) is replaced by an acceptable relative pronoun which is itself governed by certain restrictions. In Standard Arabic, unlike English, the shared noun in the embedded sentence is deleted and left with no pronoun in its place when the noun in the relative clause is subject of the clause. For example, "الرجل الذي قابلني "translated into " The man the met me", instead of "The man who me" which is correct English. Also, for instance, the example "رجل قابلني translated as "Man met me" instead of the correct English relative clause "A man who met me". In such sentences, it is found that mother-tongue interference and first language negative transfer appears obvious and clear. This is because the rule in Standard Arabic suggests that when the relativized noun phrase is subject of the relative clause, the duplicate embedded noun is deleted. The rule in Standard Arabic, unlike English, also leaves a zero pronoun when it is non-subject of the relative clause. In Standard Arabic, the relativization rule states the deletion of the identical embedded noun in the relative clause. As in, for example, in Arabic, it is correct to say "الرجل الذي قابلته البارحة" which is translated as "The man that I met him yesterday" instead of the correct English sentence "The man (whom) I met yesterday". Another example includes the Arabic sentence "رجل قابلته البارحة" which could be incorrectly translated as "Man I met him yesterday" instead of a correct English relative clause sentence "A man whom I met yesterday". This is a further illustration of mother-tongue interference and error or mistake due to first language negative transfer despite similarities between English and Arabic relative clauses. These errors or mistakes occur if an English language learner of an Arabic native language attempted to rely on her/his mother-tongue to solve difficulties she/he might face when dealing with relative clause formation. (Ibid)

\section{Results}

Learning English Relative clauses, by students whose mother-tongue is Arabic can also be asserted to the significance of the Contrastive Analysis Hypothesis, similar to other grammatical structures in English. This paper backs and highlights such findings. Due to similarities and differences between the rules of Arabic relative clause formation and English relative clause formation rules we find that Contrastive Analysis has a role to play in such structures. Many Arabic first language learners of English may encounter difficulties while trying to learn the correct use of relative clauses in English language and may commit many repeated mistakes and errors influenced by their mother-tongue and due to first language interference. The difficulty in learning English relative clauses faced by L2 English learners whose native language has both similar and dissimilar relative clause formation rules can cause English learners' confusion. According to Error Analysis and Contrastive studies, Arabic mother-tongue learners of English may refer back to their native language when dealing with relative clauses. Similarities between the two languages could be a helpful tool in grammatical rules which are similar but are a source of repeatable mistakes in parts which are different. That is because the Arabic language encodes the notion of relitivization in a similar way to English could be a source of equivalent error because learners of English may assume that dissimilar rules are in fact identical and be a source for implementing the Arabic rule formation of relative clauses in rules that apply different ways than that of the English language. Because of the uniqueness of the English relative clause formation rule system, Arabic L1 learners of the English language face significant difficulties in learning English relative clauses. Given the fact that relative clauses are one of the most frequent structures used in the English language, this paper has aimed to discuss such an important matter. 
The aim of this paper is to pinpoint Contrastive Analysis findings regarding English relative clauses, clarifying how the similarities and differences between the Arabic and English languages in concern to relative clause formation rules could lead Arabic native learners of English to make repeatable errors in their English learning process. These mistakes or errors are unconsciously or involuntarily made by Arabic native learners of English due to the differences between the relative clause rules in the two languages. These errors are made because of ignorance of the correct rule or structure, are made repeatedly and cannot be recognized by the learner of the target language. These errors are problems in the learner's knowledge of the target language. Such contrastive errors are considered gaps in the learner's competence or knowledge.

\section{Discussion}

Errors and mistakes due to first language interference is made in relative clauses when students of an Arabic mother-tongue aim to translate relative pronouns from Arabic into English. Due to similarities between both English and Arabic relative clauses, English language learners may attempt to refer back to their native language in order to support English second/foreign performance regarding relative clauses.

Making mistakes and errors during the journey of new language learning is something inevitable, nevertheless, errors should lead to improvement, progress and not lead to frustration. As well, teachers should learn how and when to correct these errors. The suggestion, here, to teachers of second/ foreign language classrooms is to show respect to the learners' native language and that teachers highlight areas where the native language would be a source of error, if the teacher was knowledgeable of the learners' native language. This, in turn, should help learners of the English language to overcome such problems and lead to better target language acquisition.

\section{Methods}

A qualitative approach has been followed in this paper through the study of previous case studies, and accomplished researches. Within this paper analysis has depended on the study and analysis of pre-existing data as well as through the comparison between Arabic and English relative clause formation rules. Certain cases, within this paper, are observed and based according to Contrastive studies and Contrastive Analysis theories and thus a thorough analysis of data has been reached.

\section{Conclusion}

This paper concludes that learning English relative clauses by learners whose mothertongue is Arabic emphasizes the importance of Contrastive Analysis. This is due to the fact that Arabic native speakers encounter noticeable difficulty while attempting to use English relative clauses. The source of such difficulty is based on the degree of similarity and difference between relative clause formation rules in Arabic and the English.

The difficulty in learning English relative clauses by Arabic natives is because their native language has relative clause formation rules that functions both similarly and differently. Areas of similarity is found to lead to positive transfer from the mother-tongue into English. Similarity; however, can be a huge source of error, because learners of English tend to refer back to their mother-tongue in most relative clause formation rules. Furthermore, formation rules, which learners find difficulty in learning could be a major source of error. Similarity between both English and Arabic relative clauses is found to mislead learners of English to overgeneralize Arabic relative clause rules. Learners, thus, apply and mistranslate these Arabic relative clause rules into English in aim to solve difficulties in English relative clause formation rules. 


\section{References}

Al-Lami, M. (2006) "Assessing EFL Students' Cultural Awareness of the English Language," Dissertation Univ. of Baghdad, 1-25.

Contrastive Analysis. (June 17, 2015). Wikipedia. Retrieved from https://en.wikipedia.org/wiki/Contrastive_analysis

Contrastive Analysis Hypothesis (CAH). Retrieved from csuni.edu website https://www.csun.edu/ ghagopian/Documents/CAHContrastiveAnalysisHypot heses.pdf

Diagne, S. \& Faye, J.C. (2021). A Contrastive Study of Relative Pronouns: The Case of WhConstructions in English and U-Constructions in Wolof. Himalayan Journal of Humanities and Cultural Studies, 2 (2).

https://himjournals.com/articles/141_A_Contrastive_Study_of_Relative_Pronouns_The_Cas e_of_WH_Constructions_in_English_and_U_Constructions_in_Wolof

Eric. (April 23, 2008). Contrastive Analysis Hypothesis. [Web log comment]. Retrieved from

http:/ / embruner.blogspot.com/2008/04/contrastive-analysis-hypothesis.html

Fromkin, V., Rodman, R. \& Hyms, N. (2003). An Introduction to Language. United States: Heinle Thomson Corporation.

Hadra, T. O. (1978). The Relative Clause in English and Sudanese Spoken Arabic: A Contrastive Analysis, 59, 24-46.

https: / /www.jstor.org/stable/44947532

Hamdallah, R.W. \& Tushyeh, H.Y. (2019). A Contrastive Analysis of English and Arabic in Relativization. Papers and Studies in Contrastive Linguistics 34, 141-152.

https:/ / sharifling.files.wordpress.com/2019/02/1.-a-contrastive-analysis-of-english-andarabic-in-relativization.pdf

Hassan, M. (2011). Acquisition of English Articles by L1 Arabic Speakers. Universiti Putra Malaysia, 1-214

http://psasir.upm.edu.my/20076/1/FBMK_2011_24_ir.pdf

Hudson, R.A. (1556). Sociolinguistics. Great Britain: Cambridge University Press.

Lado, R. (1957). Linguistics Across Cultures. Michigan: University of Michigan Press.

Mazlan, A. (2015). Contrastive Analysis Theory. Sribd.com. Retrieved from http: / / ar.scribd.com/doc/129396815/Contrastive-Analysis-Theory\#

Mother Tongue. (2015). The Free Dictionary. Retrieved from http:/ /www.thefreedictionary.com/mother+tongue

Sabbah, S. (2015). Negative Transfer: Arabic Language Interference to English Learning. Arab World English Journal, 4, 269-288 http://www.academia.edu/12680728/Negative_Transfer_Arabic_Language_Inter ference_to_Learning_English 


\title{
ARCHITECTURAL HERITAGE IN THE CITY OF NAZNRETH DURING THE OTTOMAN ERA 1517-1918
}

\author{
Hussein MANSOUR $^{1}$
}

\section{Istanbul / Türkiye \\ p. 238-255}

Received: $20 / 11 / 2021$

Accepted: $12 / 12 / 2021$

Published: 01/01/2022

This article has been scanned $l$ iThenticat No plagiarism detected

\begin{abstract}
:
This study aims to show the urban aspects of the Nazareth during the Ottoman era 1517 - 1918 in the light of the Ottoman documents and the drawings and pictures of European travelers and its role in its transformation from a small village to an urban city and then a district center. And learn about the interest that the city of Nazareth purified from the Ottoman government in this field. And that is through studying the urban monuments in the city, such as: the houses, Islamic and Christian religious places, the Saraiya, the markets, the khans, Mary's well.

It began with a discussion of historical geography, and I presented the descriptions of Arab and European travelers to Nazareth, then the study touched on the presentation of the architectural style in the city of Nazareth, the presentation of the survey and reconciliation process for some historical monuments in Nazareth, and finally the conclusion.
\end{abstract}

Key words: Architectural Heritage, The City Of Nazareth, The Ottoman Era. 


\section{الموروث المعماري في مدينة الناصرة إبان العهد العثماني}

\section{8-1517}

\section{حسين منصور 2}

الملخص:

همدف هذه الدراسة إلى إظهار الجوانب العمرانية لمدينة الناصرة إبان العهد العثماني 1517-1918 في ضوء

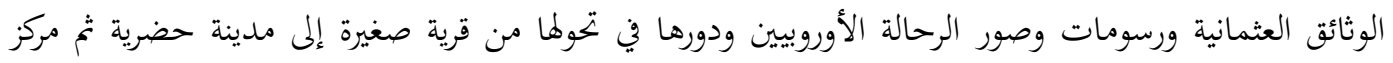

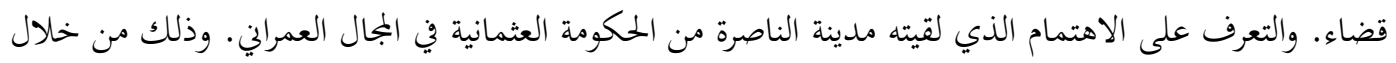

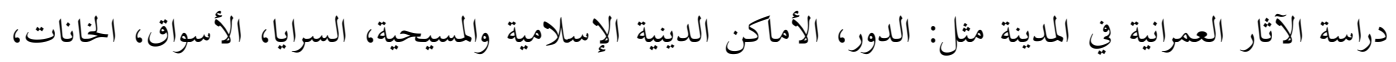

$$
\text { عين العذراء. }
$$

وقد بدأت بمناقشة الجغرافيا التاريخية، وعرض أوصاف الرحالة العرب والأوروبيين للناصرة، ثم تطرقت الدراسة عرض المراء الطراز المعماري في مدينة الناصرة، وعرض عملية المسح والتوثيق لبعض المعالم التاريخية في الناصرة، وأخيراً الخاتمة. اعتمدت الدراسة في الأساس على سجلات محكمة الناصرة الشرعية ودفاتر الطابو العثمانية والسالنامات وكتابات ورسومات الرحالة الأوروبيين والجرائد والصحف التي صدرت في فترة الدراسة. كما أفادت الدراسة من مجموعة المصادر والمراجع التاريخية ذات العلاقة. الكلمات المفتاحية: الموروث المعماري، مدينة الناصرة، العهد العثماني.

تعالج هذه الدراسة الموروث المعماري في مدينة الناصرة إبان العهد العثماني 1517-1918 وانعكاسها على الحياة الاقتصادية والاجتماعية ولإظهار عمق الروابط والتغييرات المعمارية التي مرت بها المدينة خلال فترة الدراسة. وذلك من خلال دراسة الاثار العمرانية في المدينة. تسعى هذه الدراسة إلى إظهار الجوانب العمرانية لمدينة الناصرة، وأثرها في نمو وتطور المدينة وحياة سكاها من خلال

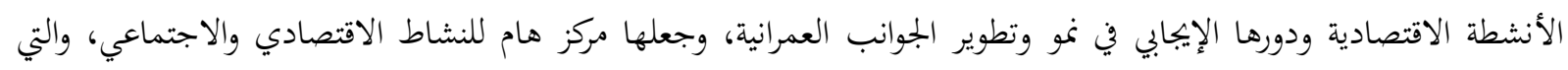

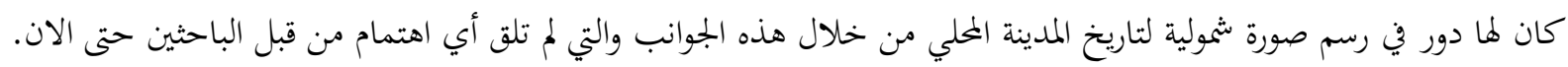
كما تسعى هذه الدراسة إلى قراءة للتاريخ المحلي إبان العهد العثماني بعد أن شهدت أوروبا تحولات عمرانية، اقتصادية واجتماعية مهمة أثنَّت بشكل واضح على جوانب كثيرة من الأوضاع في الدولة العثمانية خلال فترة الدراسة. وقد اهتم الباحثون في الآونة الأخيرة من القرن العشرين بإبراز هذا التاريخ على مستوى مناطق فلسطين كافة كابة. 
مشكلة الدراسة: The Problem of Study

لعبت الظروف التاريخية الصعبة التي مرت بها مدينة الناصرة إبان العهد العثماني، دوراً كبيراً في تطور الأوضاع الاقتصادية

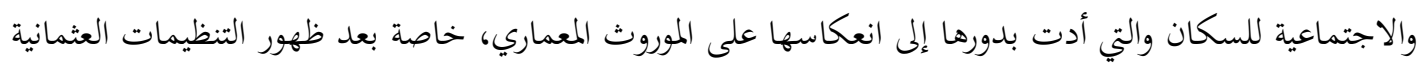

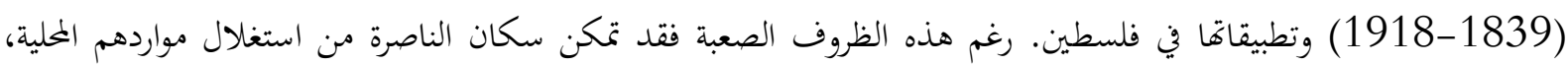

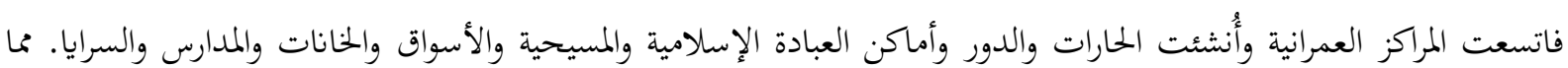
زاد من إظهار الحركات السكانية وازدياد حركة الحجاج المسيحيين من مناطق خختلفة إلى مدينة الناصرة.

أهمية الدراسة: Importance of Study

تسعى هذه الدراسة إلى سد النقص الحاصل في الدراسات التاريخية عن الموروث المعماري لمدينة الناصرة والتي تم استخدام وثائق عثمانية تتيح وفرة من التفصيلات عن الحياة الاقتصادية والاجتماعية، وعن العلاقات بين المدينة والقرى المخيطة بها.

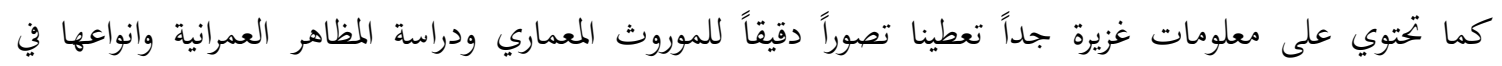

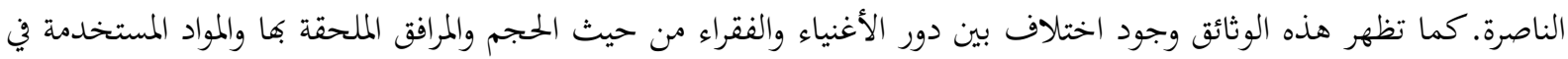
البناء، وذلك حسب المكانة الإدارية والاقتصادية والاجتماعية لأصحاهما.

\section{منهجية الدراسة: Approach of Study}

اعتمدت الدراسة على المنهج التحليلي معتمداً التسلسل التاريخي للأحداث والتوازن بين الذات والموضوع وجمع الحقائق والمعلومات من خلال تحليل الرسومات والوثائق لمعرفة كيفية استخراج المعلومات والتأكد من صحتها.

حدود الدراسة: Boundaries of Study تتمثل منطقة الدراسة بمدينة الناصرة التي تقع في وسط الجليل الجنوبي شمال فلسطين، والتي تقع جغرافياً في الجزء الغربي من

الناصرة أكثر المدن قداسة في الديانة المسيحية على وجه الأرض لأنه فيها جرت بشارة مريم العذراء بالحبَّلْ من الملاكك جبريل بولادة السيد عيسى ابن مريم عليه السلام. إن مدينة الناصرة عُرفت عند اليهود باسم المدينة البيضاء على الجبل أو المدينة المختبئة أسفل جبل ساعير (النبي ساعين).

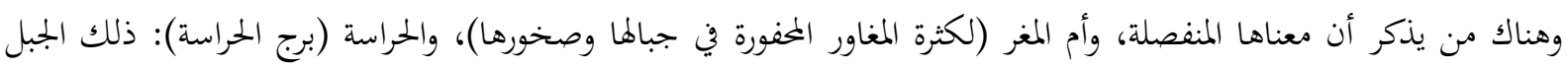

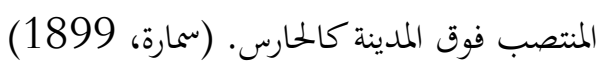

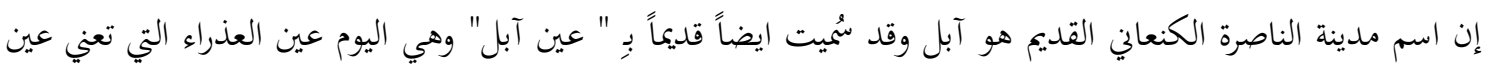

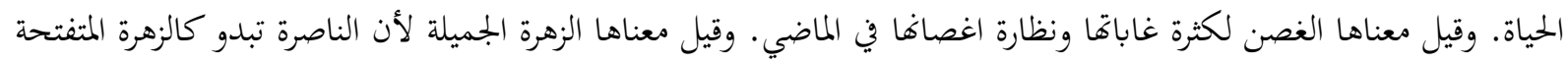

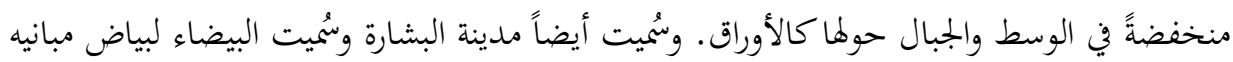


تقع مدينة الناصرة في وسط الجليل الجنوبي، في منتصف الطريق تقريباً بين البحر الأبيض المتوسط وهر الأردن على خط الطول (35,15 درجة) وعلى دائرة عرض (32 و44 درجة) (عبيد، 2010) في جنوب جبال الجليل الى الجهة الجنوبية الغربية من بحيرة طبريا والى الشمال من جبل طابور بالقرب من قرية كفركنا والى الجنوب الشرقي من حيفا وأسفل جبل النبي ساعين. وتمتد

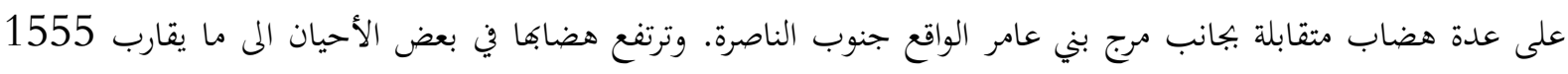

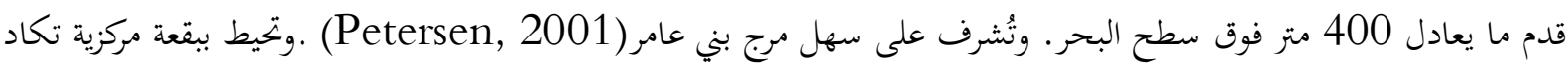

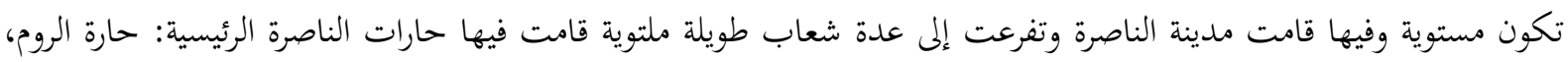
وحارة الإسلام، وحارة اللاتين. أشار(Tobler) ، إلى أن معظم سكان الناصرة تركزوا في حاراتما الثلاث: حارة الإسلام ما بين

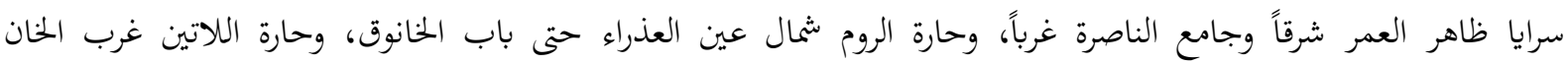
التحتاني(Tobler, 1868)

من المفيد ان نذكر، كان لموقعها الجغرافي أهمية منذ القدم فكانت بالقرب منها الطريق التجاري الرئيسي البري دمشق-

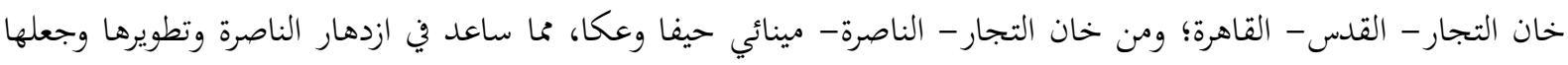

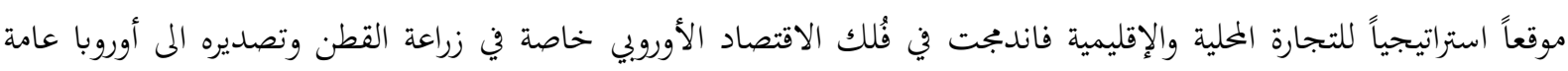
وفرنسا خاصة.

يُدد الناصرة من الغرب التلال الغربية للجليل الأسفل ومن الجنوب مرج بني عامر وجبل الدحي ومن الشرق جبل طابور

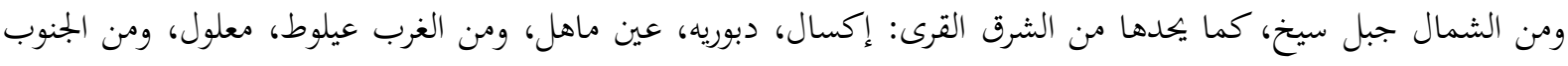

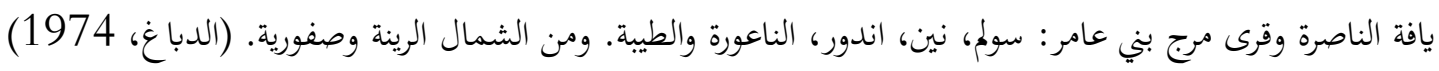

نبذة تاريخية:

مدينة الناصرة هي من المدن الفلسطينية القديمة، ترجع في نشأتما إلى عصور ما قبل التاريخ. وقد أظهرت الحفريات التي

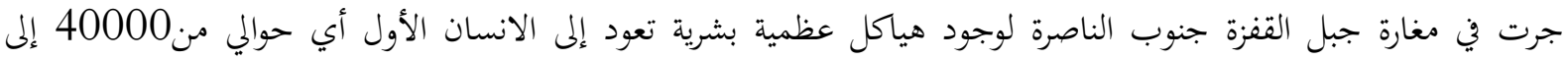
100000 عام. كما دلت الحفريات الأثرية على أن الناصرة كانت مسكونة في العصر البرونزي والعصر الحديدي. (حاكمة،

تم ذكر الناصرة في العهد الجلديد باعتبارها المكان الذي نشأ فيه المسيح. أخذت الناصرة تنمو وتزدهر بعد ميلاد السيد

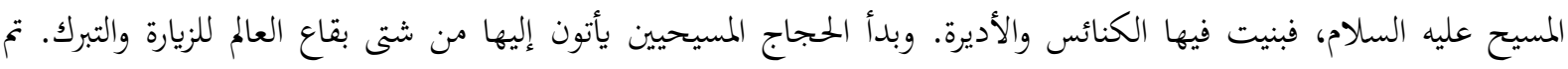
إنشاء أول كنيسة هناك في القرن الرابع الميلادي، وفي القرن الثامن الميلادي كانت هناك كنيستان في المدينة (Peterson) .

دخلت الناصرة ضمن الدولة الإسلامية على يد شرحبيل بن حسنة سنة 635م، فكانت من جند الأردن وكان فيها

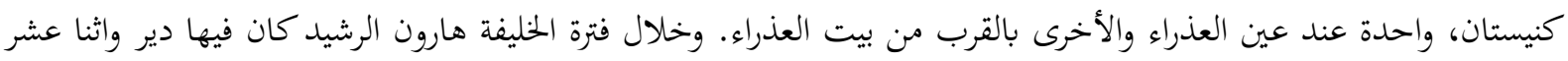
راهباً بالإضافة إلى دير وكنيسة في جبل القفزة فيه 8 رهبان. وكانت الناصرة في هذا العهد مدينة صغيرة وغير هامة، ومعظم سكاناها من المسيحيين. (الدباغ، 1974) بالإفافة وكنيسة

استولى الصليبيون على الناصرة سنة 1100م، وقام تنكرد في إعادة بناء المدينة، فبنى الكنائس ونقل مقر الأسقفية من

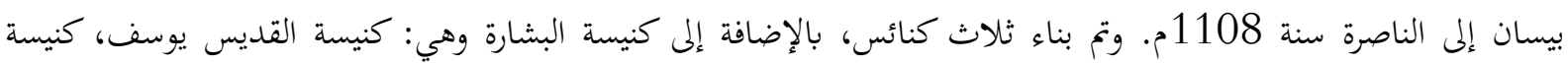

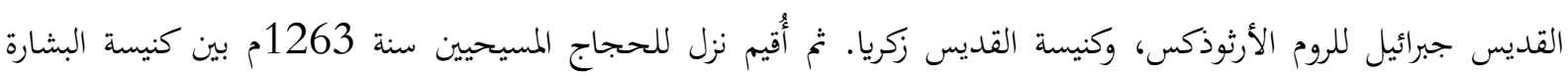


وكنيسة الملاكك جبرائيل. كانت الناصرة خراباً خلال الحروب الصليبية التي دامت 194 عاماً (1097- 1290م)، بعد أن دمرها

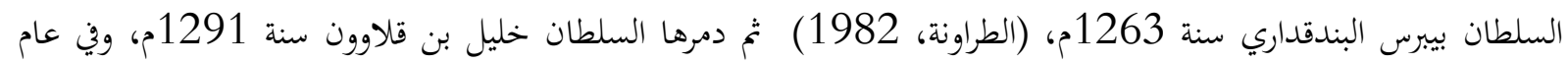

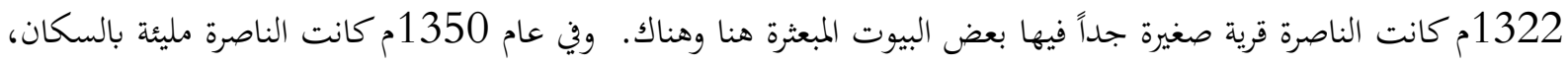

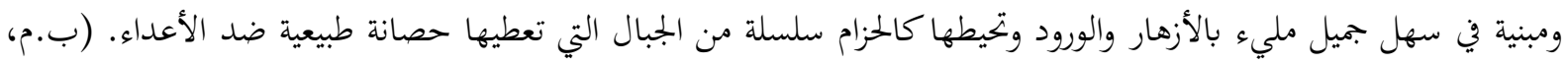

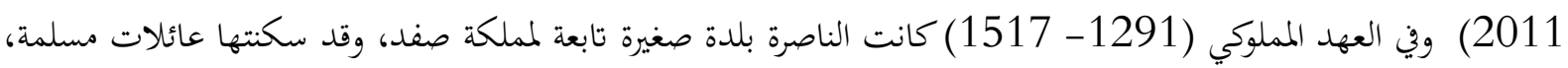
وكانت جميع كنائسها خربة.

اهتم العثمانيون بالناصرة كثيراً، فلم يسكنها في أوائل العهد العثماني إلا المسلمون، منهم حمولة كبيرة اسمها بيت حجير التي

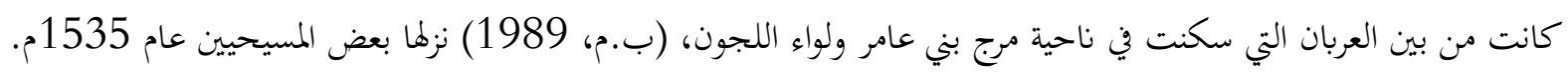
تشير معطيات دفاتر الطابو العثمانية لسنة 1525م، كان يوجد في الناصرة 43 بيت، ارتفع العدد إلى 95 بيت سنة

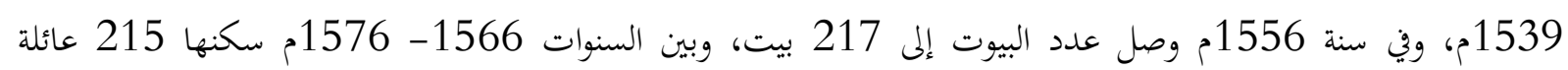
مسلمة، و17 عائلة مسيحية، (Lewis, 1976)تدل المعطيات التي وردت في هذه الدفاتر أن الناصرة منذ بداية العهد العثماني كانت مأهولة بالسكان، وبذلك يكون عدد السكان المسلمين 1075 نسمة، وعدد السكان المسيحيين 85 نسمة، وبجموع عدد سكان الناصرة في تلك الفترة 1160 نسمة. وفي منتصف القرن السادس عشر رحل إلى الناصرة رجلان من بني المعلوف وسكنا في الجهة الشمالية من المدينة واستأذنوا

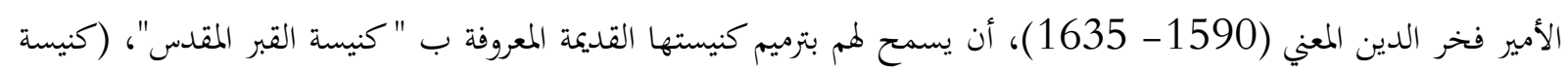

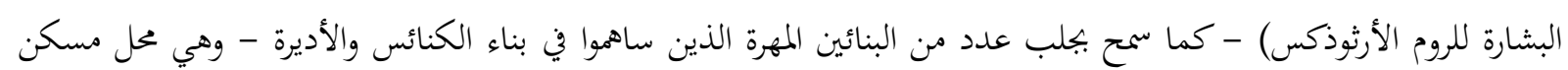

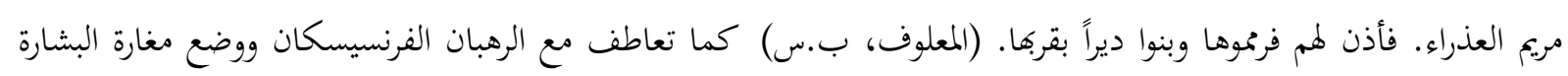

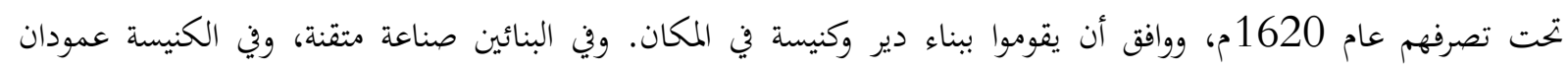

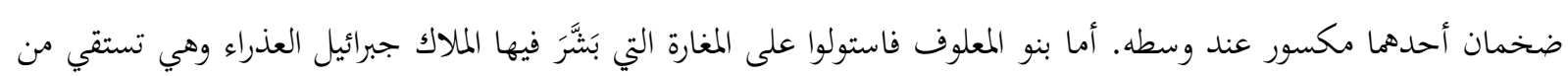
العين، وبنوا لها درجاً .

بدأ النشاط العمراني ينمو في الناصرة في عهد الامير فخر الدين، فأقام علاقات تجارية مع تجار ايطاليا وفرنسا والبندقية،

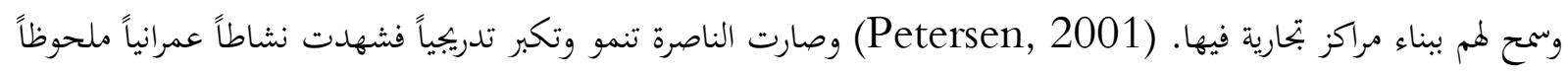

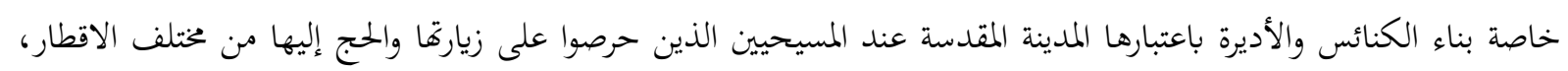
مما أدى إلى انتعاشها اقتصادياً وعمرانياً.

\section{النهضة العمرانية خلال فترة ظاهر العمر الزيدالي (1730- 1775م) (الدباغ، 1986)}

بعد القضاء على الأمير فخر الدين سنة 1635م، حدث فراغ سياسي في مناطق حكمه أدى إلى ظهور قوى محلية منها

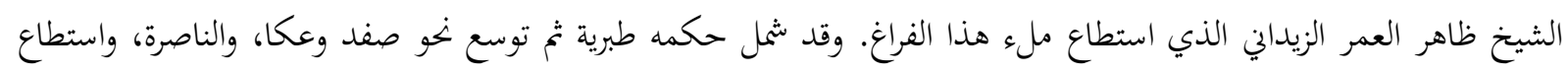

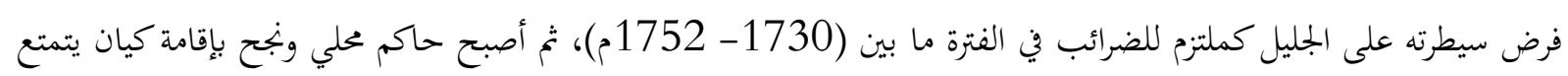

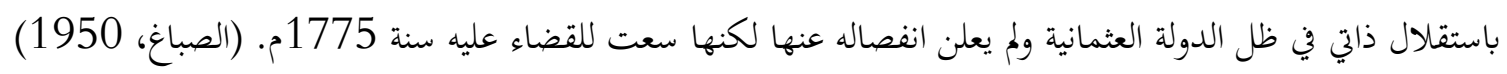
تمتع سكان الناصرة بالأمن والاستقرار في عهد ظاهر العمر، ساهم ذلك في هجرة الكثير من السكان إلى الناصرة قادمين

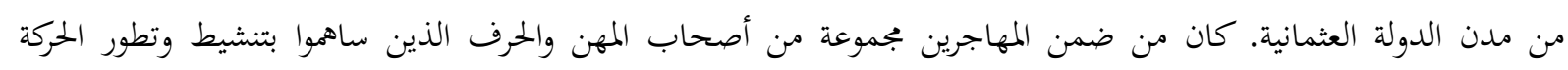

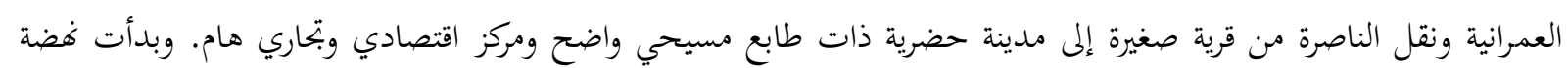

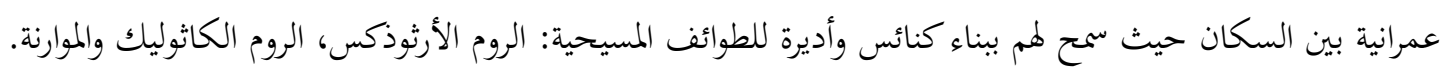




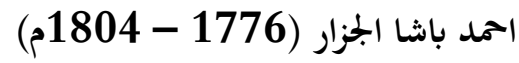

تسلم احمد باشا الجزار ولاية صيدا سنة 1776م، بعد مقتل ظاهر العمر الزيداني. وقد عانت الناصرة من ركود اقتصادي

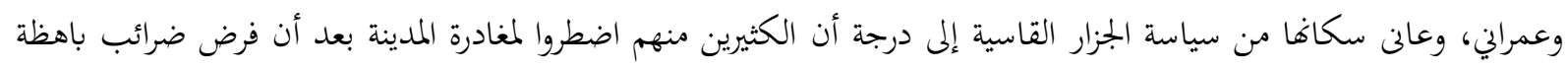

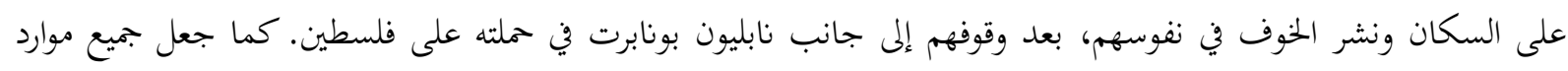
الولاية تحت تصرفه بما فيها أملاك رهبان دير الناصرة.

بعد وفاة الجزار سنة 1804م، انتقل الحكم إلى سليمان باشا العادل (1804 - 1819م). تميزت فترته بالهدوء والامن والرفاهية، وشهدت الناصرة نمواً اقتصادياً وعمرانياً نسبياً حيث شجع الناس على العودة إلى المدينة. وازداد عدد الحجاج المسيحيين القادمين واستقرار قسم منهم في الناصرة.

صارت الناصرة خلال القرن التاسع عشر مدينة عصرية، ازداد عدد سكاها وتوسعت عمراها وحيزها العام لتشمل مناطق تجاوزت منطقة كنيسة البشارة.

\section{هناك العديد من العوامل التي ساهمت في التوسع العمراين:}

- التحسن في الظروف الأمنية، التحولات الاقتصادية، التكاثر الطبيعي، الهجرة، نشاط المؤسسات الدينية المسيحية وازدياد نشاط الدول الأوروبية في البلاد. - أقيمت في الناصرة خلال القرن التاسع عشر الباد 12 كنيسة وعدد من الأديرة. - وأقيمت 7 مدارس جديدة ومستشفيان وثلاث دور ايتام. وأقيمت فنادق ونزل للحجاج المسيحيين. - وصارت المدينة مركز قضاء مهم لبلاد الشام.

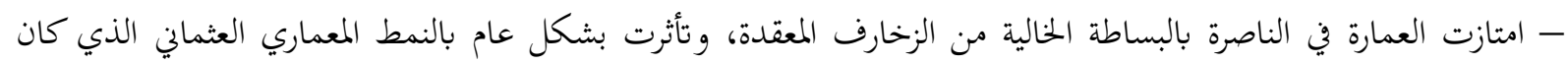
منتشراً في أرجاء الدولة العثمانية. - واستخدام المواد الأولية اللازمة، الحجارة والاخشاب المتوفرة في المنطقة، فقد وجد الحجر الأبيض في جبل القفزة الذي يقع جنوب الناصرة. (سمارة، 1899) - وكانت سطوح المنازل مغطاة بالقرميد الأحمر المرسيلي، مما كان يضفي على بيوت الناصرة جمالاً ورونقاً، فكانت تظهر للناظر

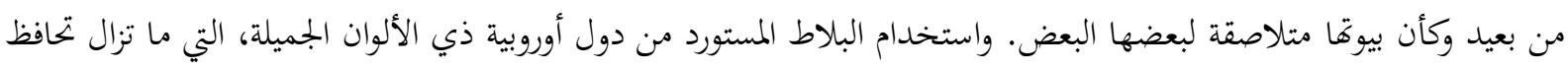
على جمالها حتى يومنا هذا.

\section{ثانياً: أوصاف الرحالة العرب والأوروبيين للناصرة:}

قدم إلى الناصرة إبان العهد العثماني (1517 - 1918) عدد من الرحالة العرب والأوروبيين الذين جاؤوا للتعرف على

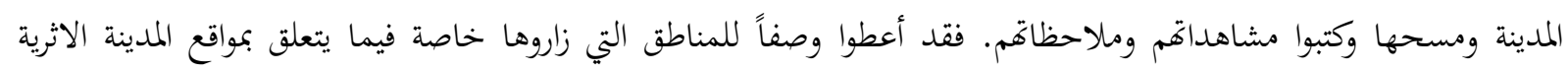
والمقدسة والسكان وأعدادهم وعاداقم وتقاليدهم وظروفهم الاقتصادية والاجتماعية.

أظهرت رحلات الرحالة الموروث المعماري للناصرة إلى حيز الوجود، حيث لم تكن للناصرة أهمية في الأزمنة القديمة ولم يرد

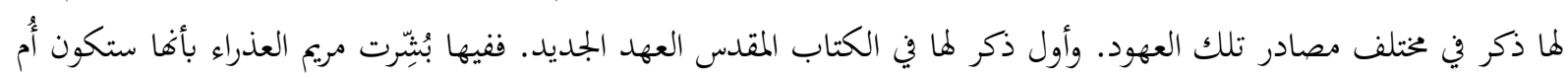
المسيح، وهي مقدسة عند المسيحيين فيها نشأ وقضى معظم حياته. 
أخذت الناصرة تنمو وتتقدم بعد تنصير الملك قسطنطين (306 - 337م)، فبنيت فيها الكنائس والأديرة وأَمَّها الكثيرون

للزيارة والتبرك ببقاعها. (الدباغ، 1974)

زار الرحالة العرب والمسلمين الناصرة ووصفوها بأهما قرية من بلاد اللجون من أعمال جند الأردن، وعدها شيخ الربوة

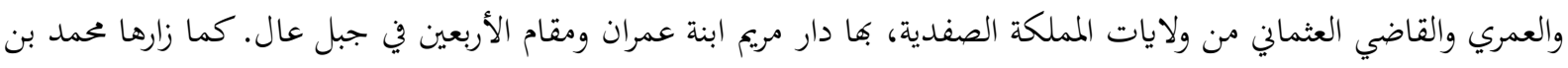

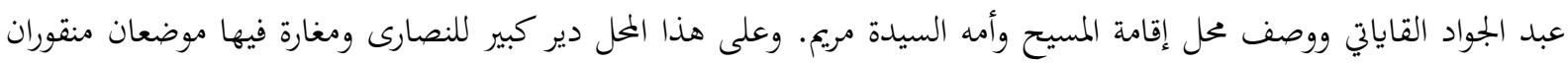

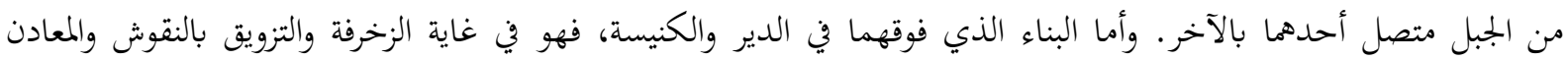

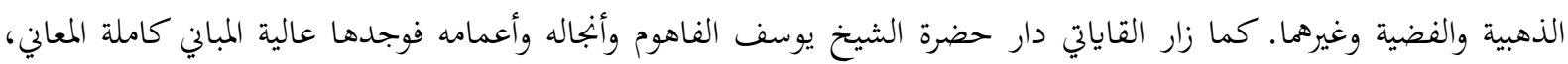

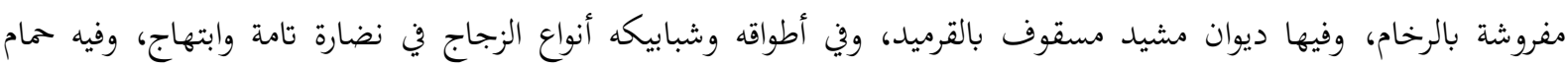

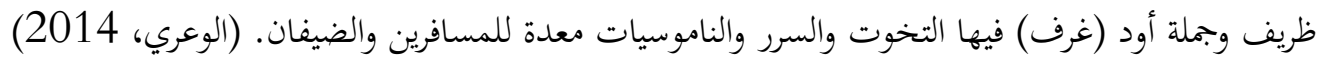

ظهرت الناصرة في العديد من كتب الرحالة الأوروبيين خلال الفترة الإسلامية التي وصفت المدينة وأظهرت آثارها، حيث

قاموا بأعمال البحث والتنقيب في الكنائس والأديرة وأرفقوا وصوفاقم برسومات تقريبية لمخطط المدينة، منهم: (ب.م، 2011) سي وولف Caewulf، الذي زارها سنة 1102م وقال: أن في المدينة دير جميل يدل على مكان البشارة، ويوجد

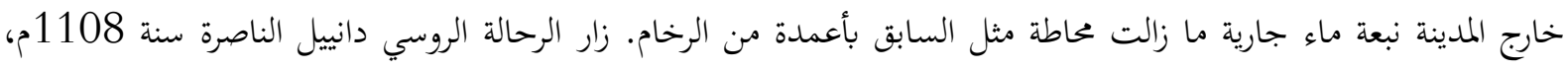

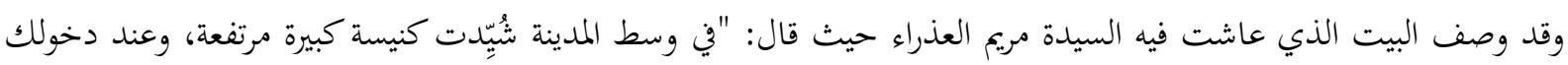

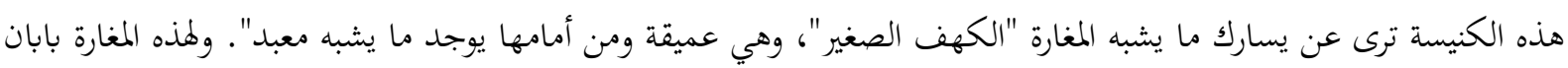
واحد عن جهة الغرب وآخر عن جهة الشرق وإذا "ما نزلت"، بعض الدرجات فسترى في جهة الباب الغربي عن اليمين صومعة.

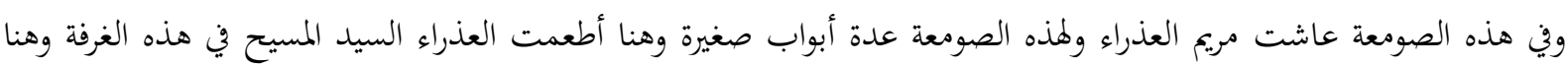

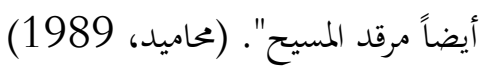

جوناس فوكاس Joannes Phocas، زار الناصرة سنة 1185م وقال: أفا غير مأهولة بالسكان، وبعد أن تدخل القرية الكبيرة من بوابتها الأولى بتح كنيسة الملاكك جبرائيل، والتي تشاهد فيها مغارة صغيرة موجودة على الجانب الأيسر من مذبح

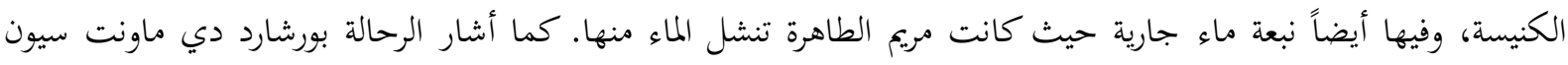
Burchard De Mount Sion

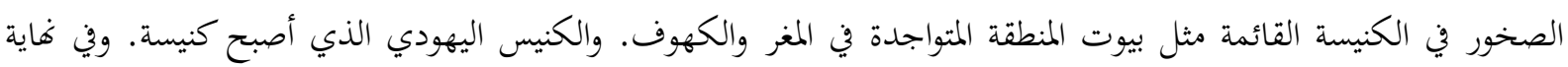

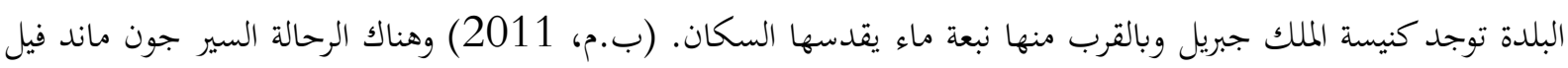

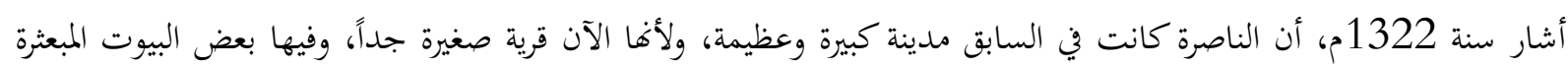
هنا وهناك. (ب.م.م، 2011)

أما الرحالة ريتشارد جاي لفور دي Sir Richard Guylforde، وصف الناصرة سنة 1506م، بأنه كانت فيها كنيسة جميلة اهدمت ولم يبق منها إلا مصلى صغير يقف على كهف البشارة. كان هذا المصلى جزء من الكنيسة التي هي الآن

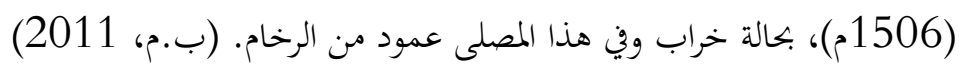

وصف أحد الرحالة الناصرة سنة 1621م، بأغما قرية في سفح جبل في مكان قبيح المنظر في وادٍ ضيق تحيط به الجبال.

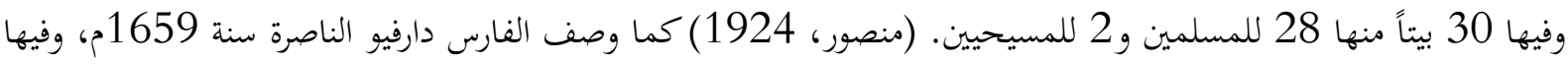
دير رهبان الأرض المقدسة، وبقايا الكنيس الذي يُدَّعى أن المسيح وعظ فيه. (الصباغ ل.، 1996) وفئن وفئ أواخر القرن الثامن عشر 
زارها الرحالة فولني وقال عنها: "الناصرة ذات الشهرة العالمية، سكاها ثلثهم مسلمون والثلثان مسيحيون. ولآباء الفرنسيسكان فيها نزل ومعبد".

كما وصف الناصرة الرحالة بيركهارت سنة 1812م، عندما زارها ونزل في دير إرساليات الأرض المقدسة، ودير الفرير (الأخوية اللاتينية)، وهو عبارة عن بناية واسعة، رمتت عام 1730م بكاملها ووسعت إلى حد كبير، وفي داخلها كنيسة البشارة

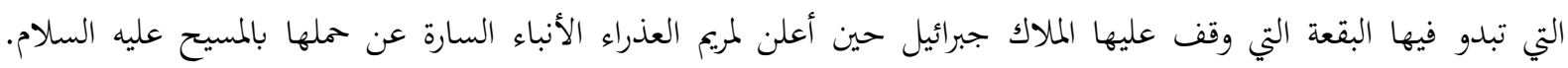

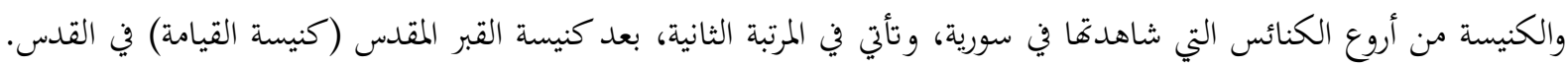

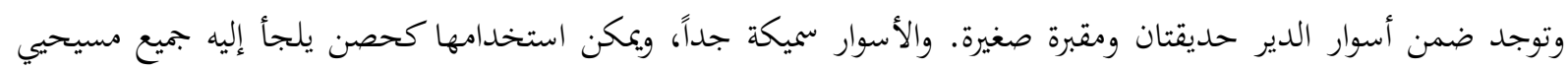

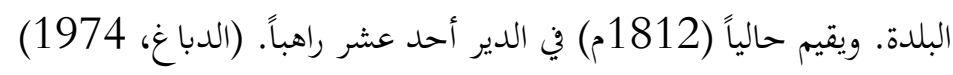
وصف باكنغهام J.S. Buckingham الناصرة سنة 1816م، أهم المباني الرئيسية العامة في الناصرة هو المسجد

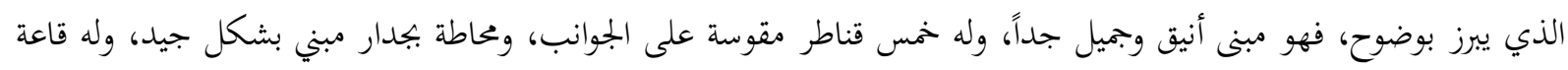

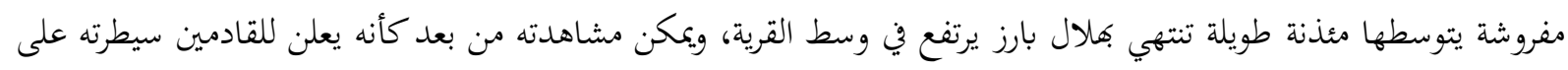

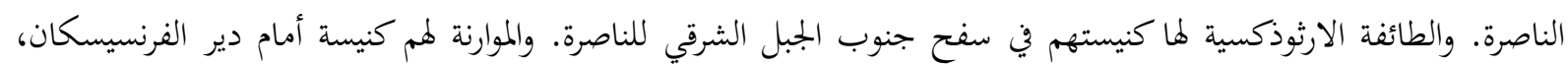

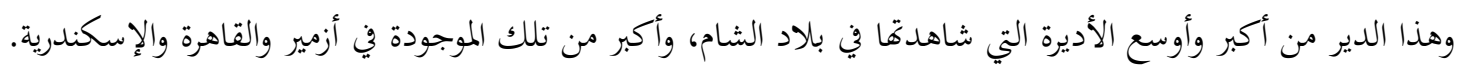

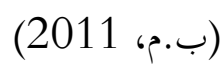

وصفت ماري إليزا روجرز الناصرة عندما زارتا سنة 1855م، كان هذا السطح عالياً ويطل على مشهد ساحر للبلدة،

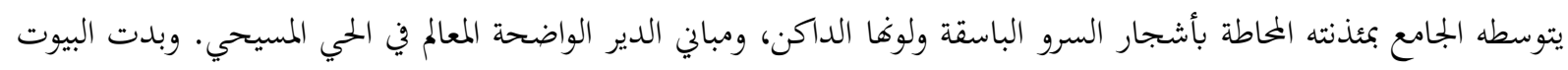

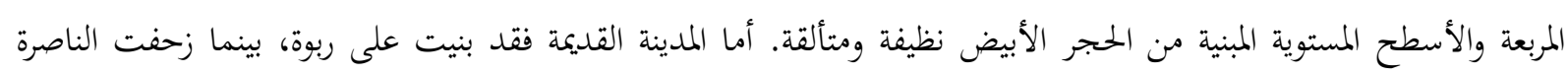

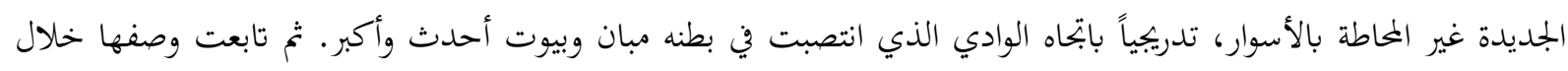

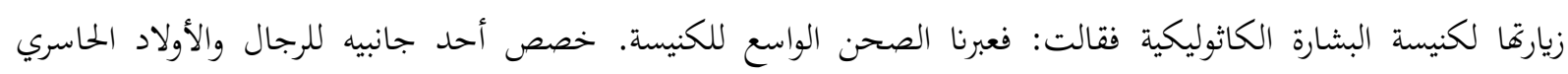

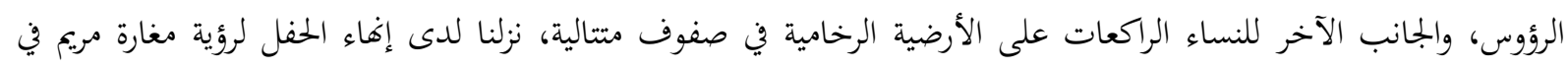

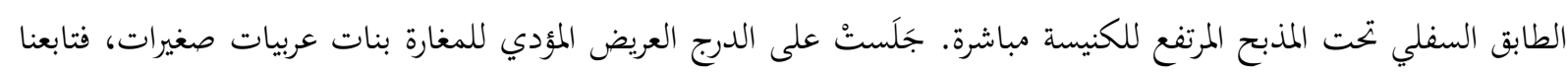

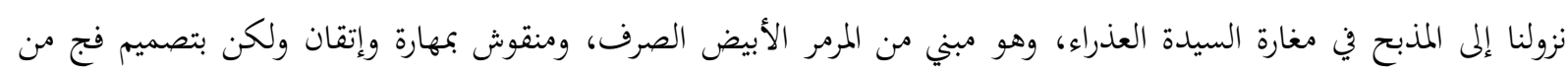

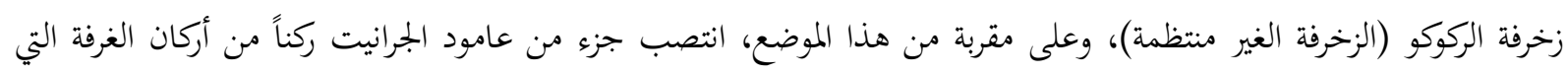

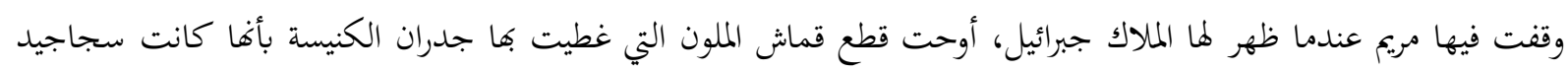
حائطية مزخرفة، يوجد في ساحة الدير أجزاء وشظايا من الحجر المنحوت لعمود قديم تستخدم في الجمدران الأحدث عهاث عهداً. (روجرز، 2013)

وصف محمد رفيق بك ومحمد بهجت بك الناصرة أواخر العهد العثماني، هي مبنية على السطح المائل الجنوبي من جبل

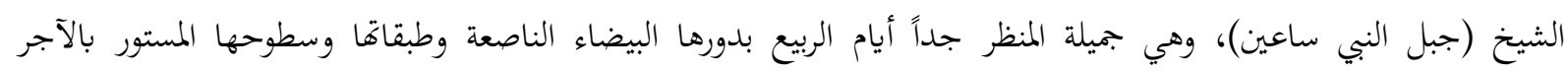

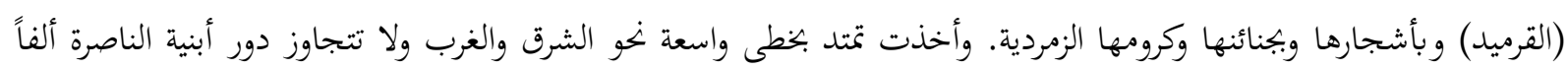

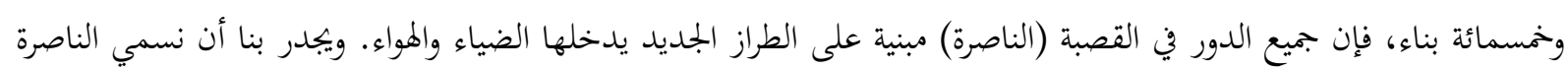

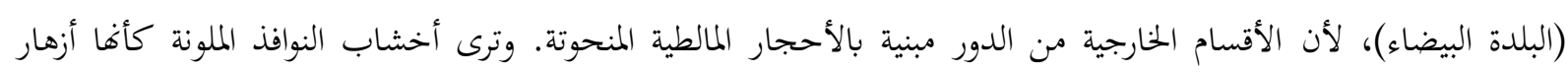

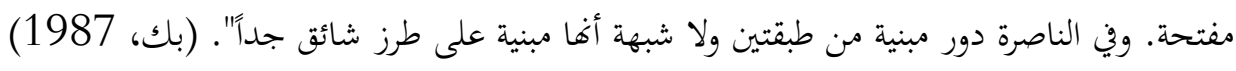




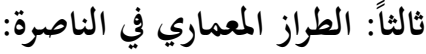

كان العصر الذهبي للعمارة في الناصرة قد بدأ في عهد ظاهر العمر الزيداني، حيث تم تنفيذ عدد من المشاريع العمرانية

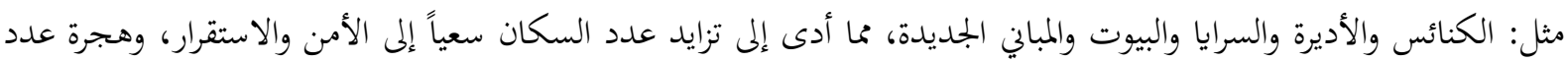

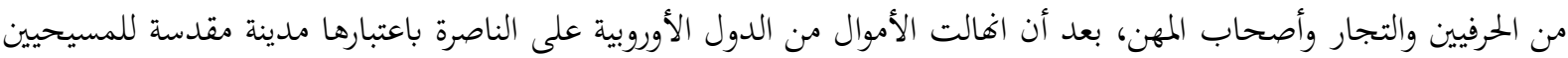
التي ساهمت في بناء مؤسسات مسيحية وإقامة أبنية متعددة بنماذج عمرانية أوروبية وإسلامية.

تلعب الطبيعة الجغرافية دوراً كبيراً في تحديد طراز النمط المعماري للمشاريع العمرانية في الناصرة وتتأثر هذه المشاريع لطبيعة النشاط الاقتصادي الممارس. وكانت هذه المشاريع مبنية من الحجارة البيضاء والكلس (الجير) وسقوفها مغطاة بقرميد أحمر مستورد من مرسيليا الذي بدأ استعماله عام 1831م، وما واكب ذلك من تغريب بعض العناصر المعمارية والزخرفية. وهذا يشير إلى مئل التطور المعماري والاقتصادي والاجتماعي. واستخدم سكان الناصرة مواد البناء التي وفرتما لهم الطبيعة وكانت تتكون من الحجر

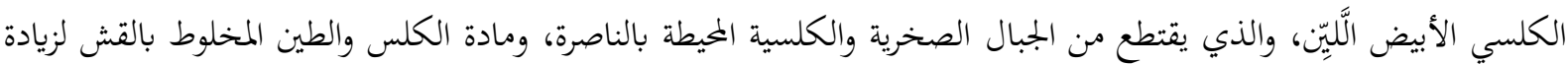
صلابة البناء وتماسكه.(Cunningham, 1824) كما أظهرت السجلات الشرعية أن مكونات الدور والبيوت لحارات

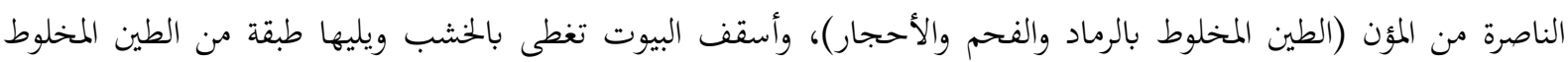
بالتبن للربط بين الحجارة، ثم تقصر هذه الجدران بطبقة من الشيد الأبيض. (سجل محكمة الناصرة الشرعية، 1293هـ

بدأ النشاط العمراني بالنمو في الناصرة نظراً لأهميتها الدينية وحركة الحجاج المسيحيين الوافدين إليها واستقرار عائلات عديدة فيها، منهم المسلمين والمسيحيين. وطريقة تخطيطها وتوزيع معالمها العمرانية مثل: الحارات، الأسواق، الأماكن الدينية، الخانات، المستشفيات والمدارس.

\section{رابعاً: أهم المعالم العمرانية في مدينة الناصرة:}

\section{كنيسة الجممع (الروم الملكيين الكاثوليك) "The Synagogue":}

تقع كنيسة المجمع في مركز الناصرة وسط أسواقها (سوق الخواجات)، وهي عبارة عن هيكل قاعة واحدة صغيرة وبسيطة، وهو المكان الذي دخله السيد المسيح ليعلن فيه لأهل وطنه أنه المسيح ورفضوه فيه، وأن السيد المسيح تعلم وصلى فيه. عند مدخل الكنيسة بتحد بوابة كبيرة على جانبيها قطعتي عمود من الجرانيت الأسمر، وإذا دخلت منها بحد درجاً عن يمينك يصعد إلى الأمطوش مسكن خوري الطائفة. ويقابلك باب الكنيسة الجلديدة وعن شمالك باب المجمع المذكور، تنزل إليه ببضع درجات فتجد نفسك في عقد من نوع العقد المعروف بالأنبوب طوله 30 قدماً وعرضه 26 قدماً. ويقابلك أبواب ثلاثة هياكل حسب نظام الكنائس الشرقية، وله باب آخر إلى الشرق وبجوار هذه الكنيسة دكاكين وَقْها وخان الكاثوليك. (منصور، 1924) داخل الكنيسة قاعة واحدة، وبها مذبح مصنوع من الرخام، ومن وراء المذبح صليب. وهناك أقبية تؤدي إلى فناء، وأحد

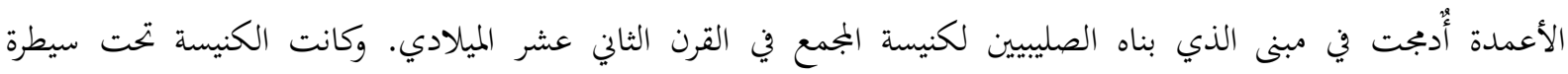

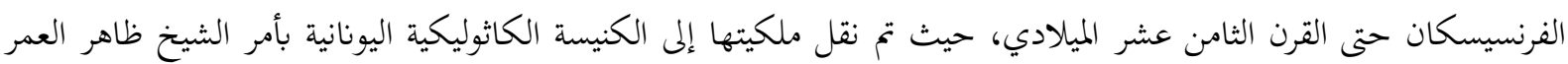
الزيداني.

كما تم تجديد وتوسيع الكنيسة بعد إضافة قطعة أرض تم شراوها، ليكون طوها 25 ذراعاً وعرضها 20 ذراعاً وارتفاعها

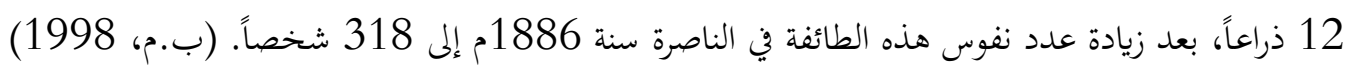




\section{كنيسة البشارة للروم الأرثوذكس (كنيسة الملاك جبرائيل):}

سكن الناصرة المسيحيون زمن الملك قسطنطين في القرن الرابع الميلادي. وشيدت فيها زوجته الملكة هيلانة كنيستين

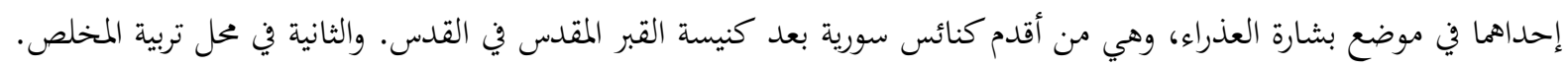
وفي سنة 1109م صارت الناصرة كرسي أسقف، وفي سنة 1140م التأم فيها مجمع لإقامة البابا إسكندر الثالث في

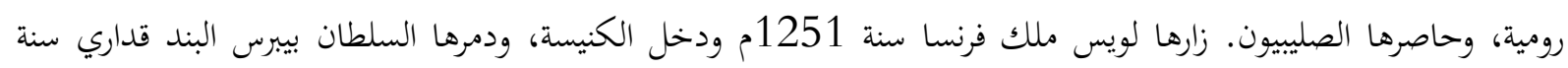

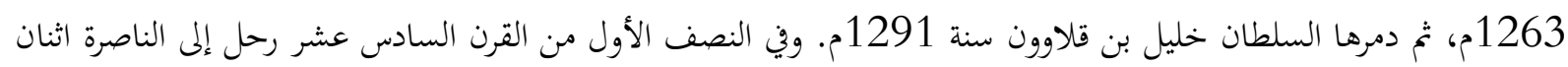

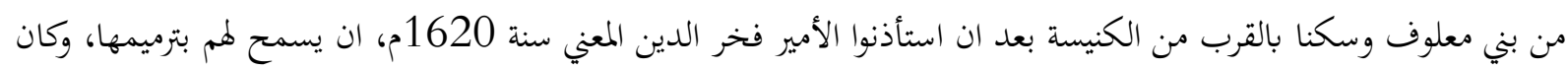

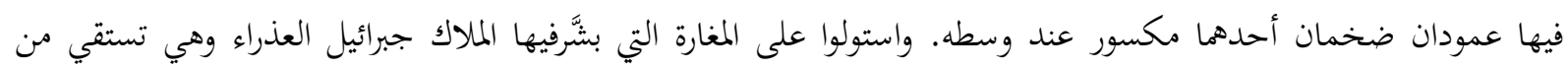

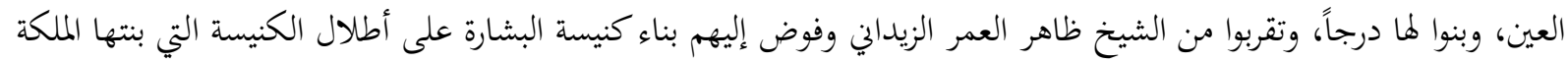

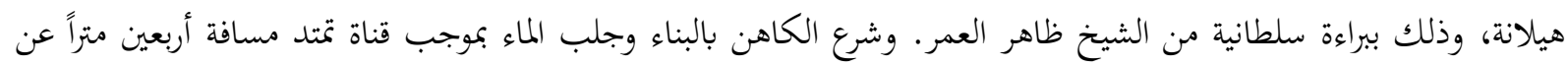

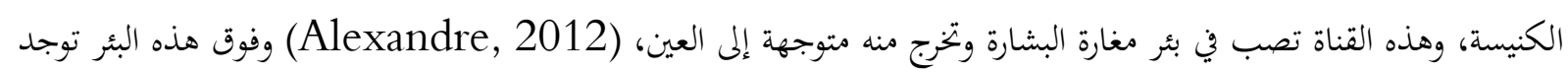

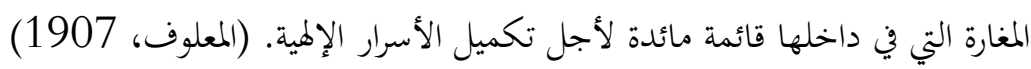
جرى توسيع الكنيسة بإضافة ثمانية أمتار على العرض ليصبح 23 متراً والطول 29 متراً والارتفاع 12 متراً، بعد الزيادة في

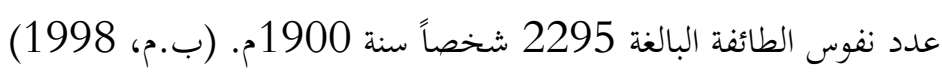
كنيسة البشارة للاتين: بُنيت في الموضع الذي يَعتقد اللاتين أنه بيت العذراء وهو بيت صغير مسقوف بالخشب ومطين بالطين مسند إلى صخر فيه باب مغارة منقورة في ذلك الصخر وهو الآن كنيسة. (منصور، 1924) حيث ظهر لها الملاك جبر جبائيل مبشراً إياها بالحبل

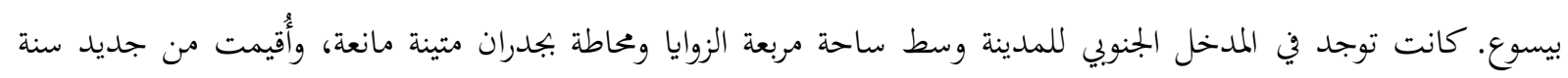

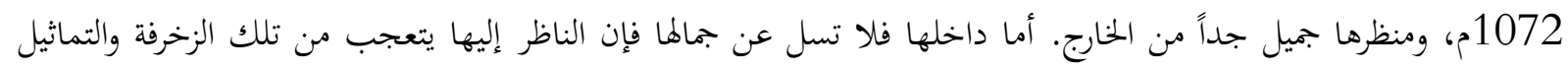

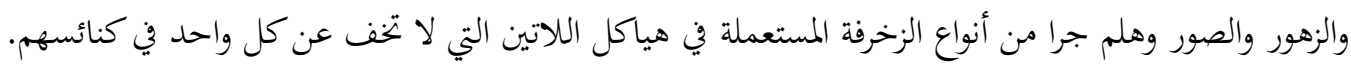
أشهر موضع مقدس في دير اللاتين هو المغارة التي كانت ساكنة فيها والدة الإله الموجودة تحت وسط نفس الهيكل

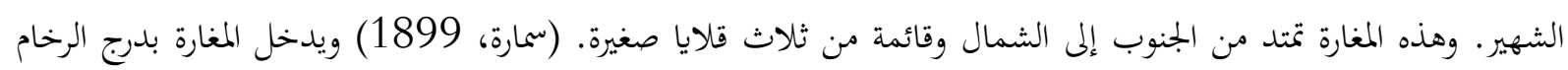

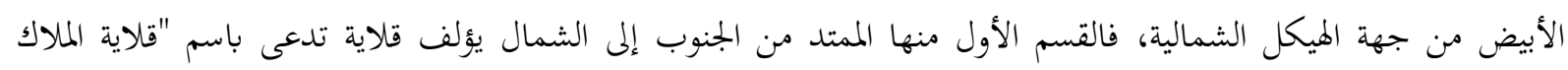

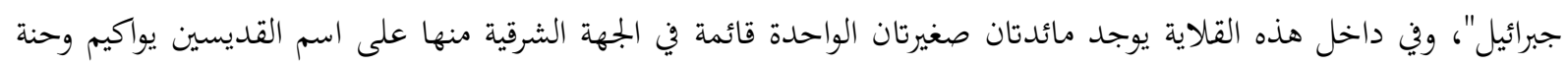

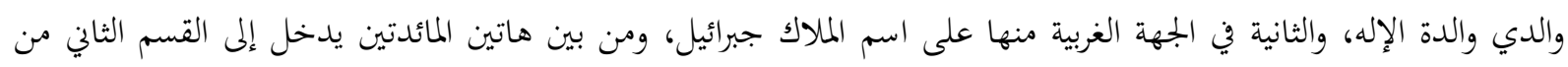

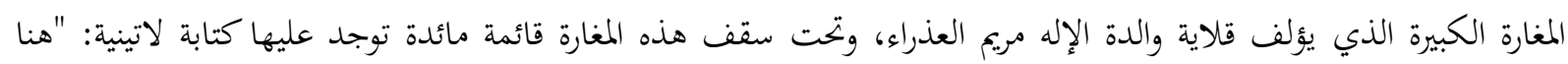

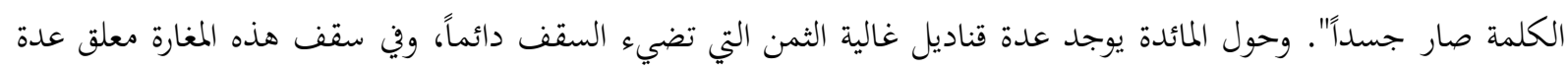
ثريات من بلور. وفوق المائدة يوجد تمثال جميل جداً كتمثال الهيكل من الداخل. 


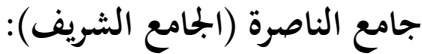

يعتبر جامع الناصرة (المعروف بالجامع الأبيض)، (سجل محكمة الناصرة الشرعية، 1302هـ/1885م) من المرافق الدينية المهمة في مدينة الناصرة، ومن أهم المظاهر العمرانية التي تعتبر روح وجوهر العقيدة الإسلاميةَ لأهل المدينة. وكان الجامع من أبراه ميزات المدينة التي تجلت فيها المعالم الأثرية والمظاهر العمرانية العثمانية باعتبارها مكاناً للعبادة والتعلم والثقافة الدينية.

يتكون الجامع من مبنى بسيط يحيط بساحة مفتوحة مستطيلة الشكل، مع ترتيب داخلي من الأعمدة، حيث تقام فيه الصلوات اليومية لله تعالى وتلقى فيه الجِطبة يوم الجمععة، وفي وسطه الفناء أو صحن الجامع يتوسطه ينبوع ماء للوضوه ومئذنة

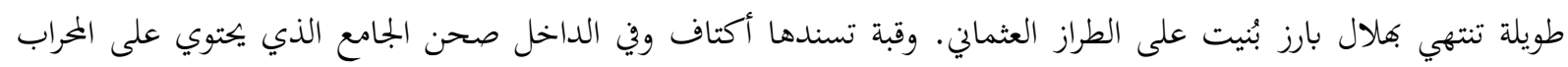

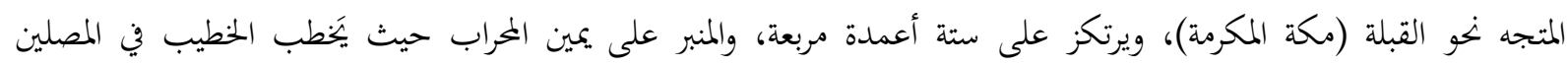

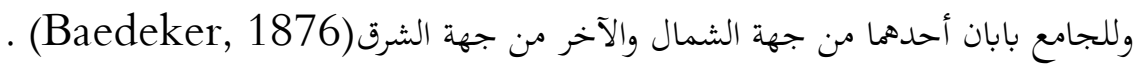
أظهرت الرسومات المنقولة للناصرة منذ بداية العهد العثماني (1517م)، للرحالة الأوروبيين على وجود جامع وسط البلدة. كما أظهرت المعطيات التي وردت في دفاتر الطابو العثمانية خلال القرن السادس عشر لقرية الناصرة، وجود 43 خانة

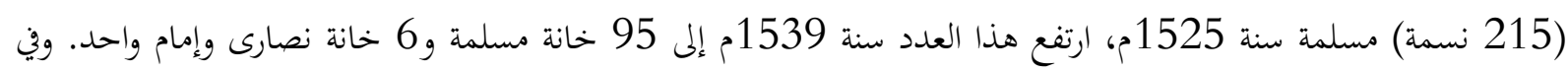

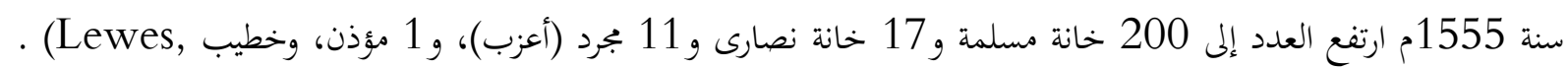

مما يلفت النظر في هذه المعطيات، وجود وظائف دينية: مؤذن، إمام وخطيب. وهذا يدل على وجود جامع في الناصرة،

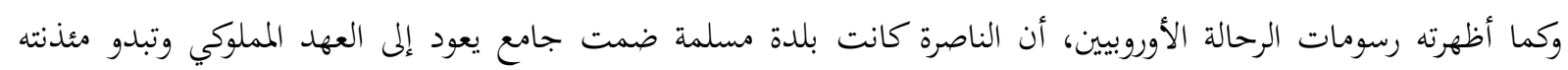

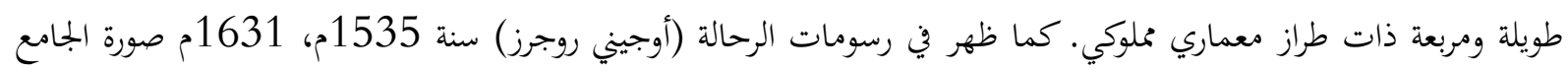

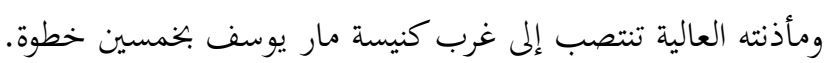
تجدر الإشارة أن وجود جامع الناصرة يرجع إلى بداية العهد العثماني، ومر بمراحل متعددة من حيث إعادة البناء أو الترميم

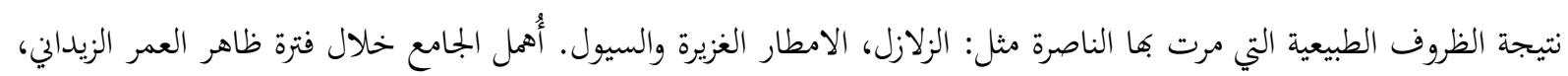

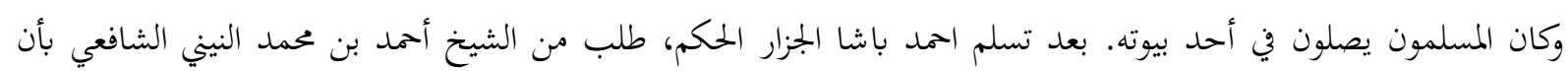

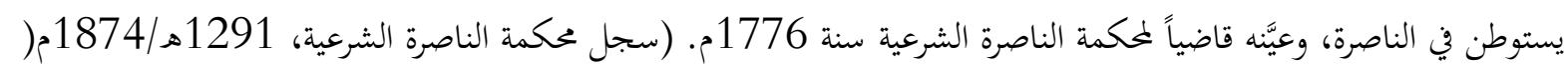
ما قام به احمد باشا الجزار وخلفائه من بعده واهتمامهم برفع مكانة الناصرة عمرانياً واقتصادياً ودينياً، ساهم في ترميم

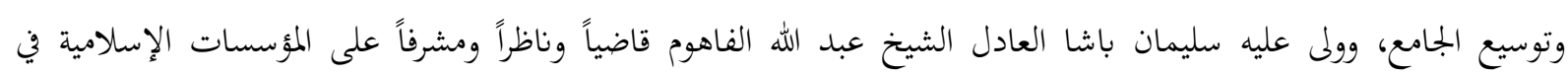
الناصرة. (رستم، 1987) وشهدت الناصرة زمن سليمان باشا العادل نمو وتطور عمراني وزيادة عدد سكافاها.

أشار اسعد منصور في كتابه "تاريخ الناصرة" (منصور، 1924) وبناءاً على قراءاته أن الجامع بُني سنة 1805-

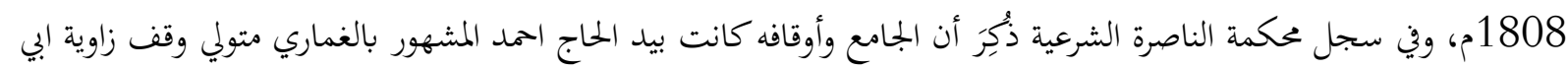

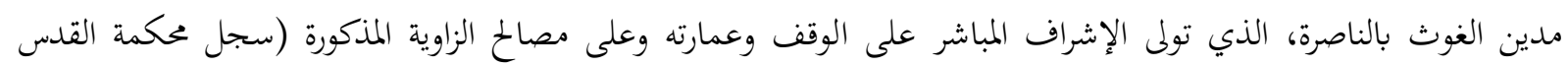

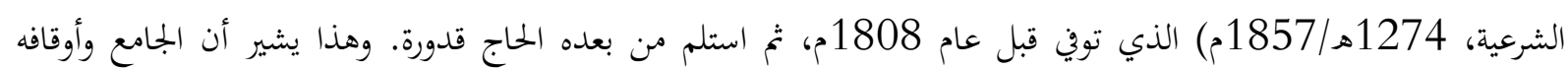

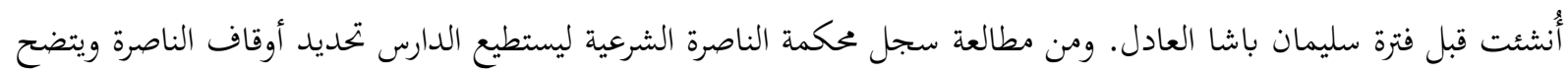
أفها اشتملت على بيوت ودور ودكاكين وأراضي وخان. 


\section{سرايا ظاهر العمر الزيدالي:}

بنى الشيخ ظاهر العمر الزيداني سرايا عظيمة في الطرف الشرقي من الناصرة سنة 1730م، مؤلفة من عدة بيوت على

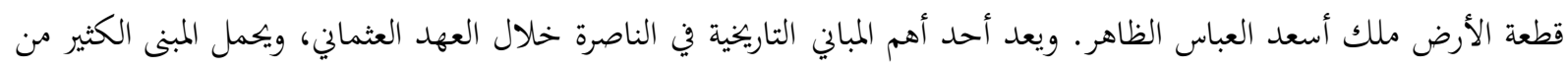
القيم التاريخية وانماط معمارية مختلفة. تشرف السرايا على سهول مرج بني عامر ولمراقبة تخركات أهالي جبل نابلس، والعشائر البدوية ليسيطر ظاهر العمر على طرق المواصلات والنقل والتجارة، التي مرت من منطقة المرج. كما استخدم ظاهر العمر سرايا الناصرة

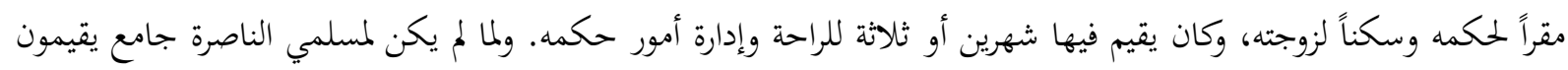

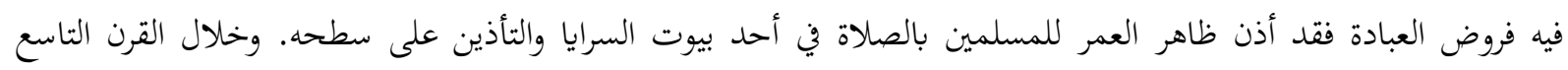

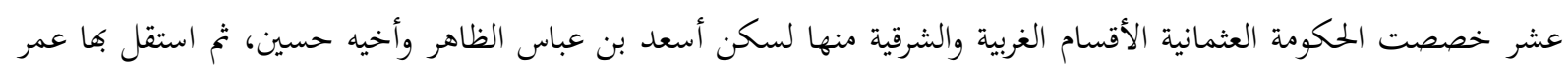

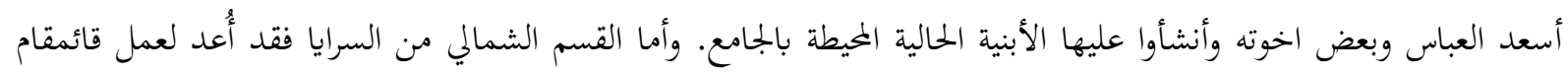

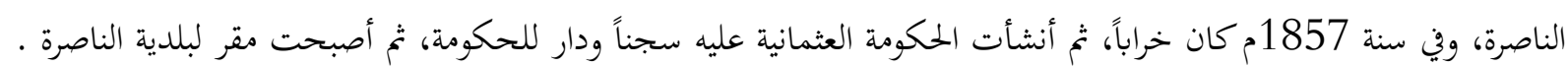

(Mariti, 1792)

يتكون مبنى السرايا من طابقين تربط بينهما أدراج حجرية. القسم السفلي يتكون من عدة عقود مصلبة، والقسم العلوي

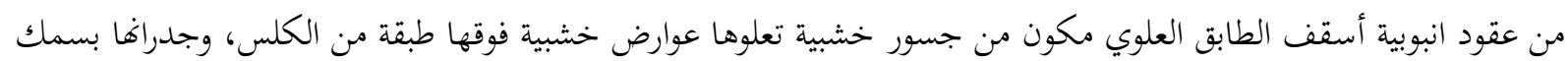
1.5 متر وذلك لأسباب أمنية. وقد بُني سنة 1870م، خلال فترة القائمقام محمد الصلاح، (منصور، 1924 1924) والرواق عقوده ذات أقواس نصف دائرية. وأمام السرايا ساحة مبلطة بالحجر. وقدام وقام عباس الظاهر بإجراء إضافات على السرايا في القسم الجنوبي.

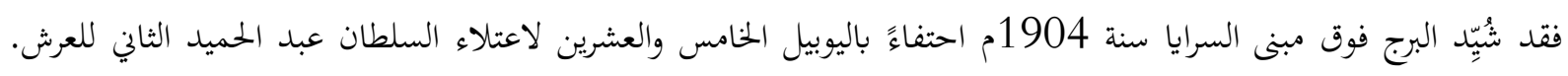
وكان برجاً متواضعاً مقارنة بباقي الأبراج في القدس، يافا، نابلس، حيفا وصفد، ولم تثبت فيه ساعة. البرج مبني بالطراز الاكلكتي لئي

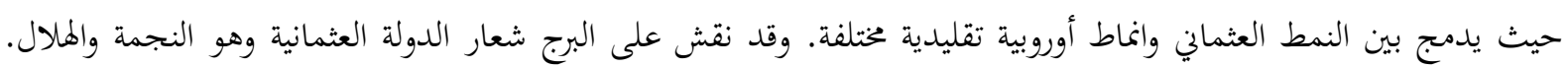

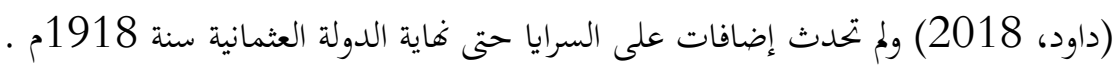

عُرف خان الناصرة التحتاني (سجل محكمة الناصرة الشرعية، 1244هـ/1828م) كمركز تجاري، وهو المكان لإيواء

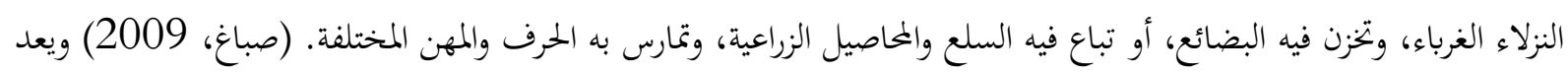

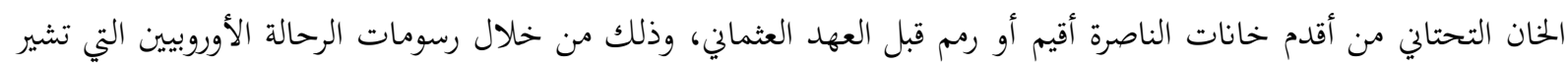

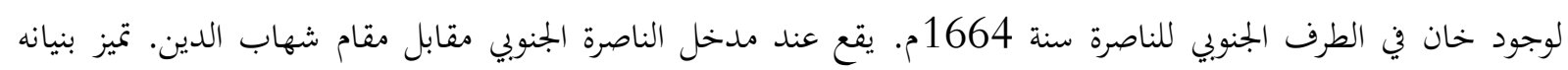

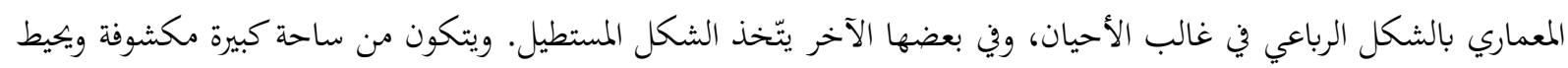

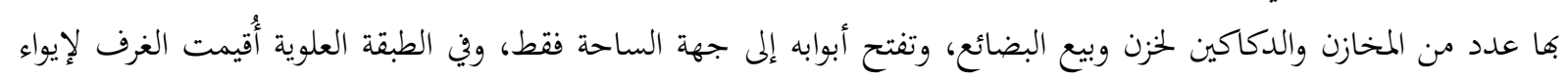

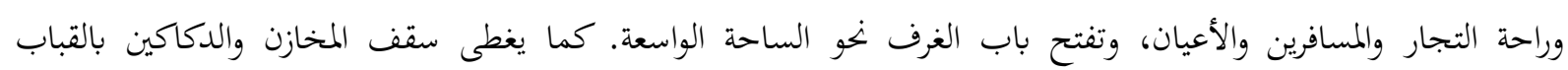

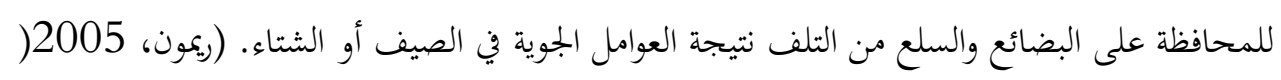
جاء تصميم الخان المعماري على نسق تخطيطي كالتالي: مخازن تقع على محيط ساحة مربعة ذات طابق أو طابقين تحت

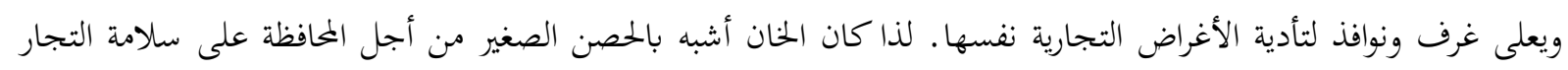
والنزلاء وبضائعهم من الاعتداء وبتعلهم في مأمن فيكون الخان قد حاز على الدور الدافية الأهم في المجال الاقتصادي والتجاري في المدينة.

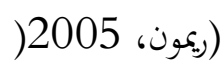

استخدم الخان التحتاني أواخر العهد العثماني "سجن الديوان العرين" وكان على بابه لوحة كتب عليها بالألمانية "الآخور

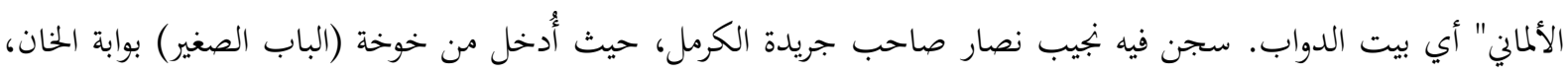


ومشى تحت عقد إلى فناء. وكان الخان عبارة عن غرف أرضية كانت تستعمل أواخير لخيول وحيوانات المسافرين وغرف علوية كان

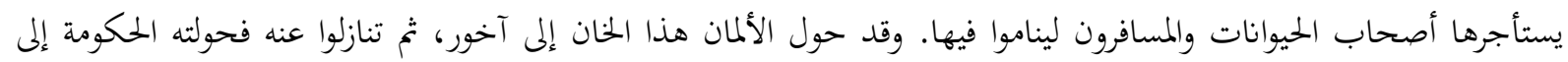

$$
\text { سجن. (نصار، 1981) }
$$

\section{الاستنتاجات: Conclusion (المات}

اهتمت الدولة العثمانية بالموروث المعماري للناصرة خلال العهد العثماني (1517 - 1918)، وكان لها دور واضح في تحديد المعالم التاريخية في المدينة، ويجب المحافظة عليه كتاريخ عربي عريق للناصرة. فالدولة العثمانية تركت موروثاً معمارياً متمثلة في المباني والمنشآت والأماكن الدينية الإسلامية والمسيحية التي تم عرضها.

يتضح من ذلك أن مدينة الناصرة مليئة بالآثار الإسلامية والمسيحية التي تشهد على عروبة هذه المدينة، وأن نشاطها العمراني بدأ بالنمو نظراً لأهميتها الدينية وحركة الحجاج المسيحيين الوافدين إليها واستقرار عائلات فيها، منهم المسلمين المينه والمسيحيين. عاشوا في حالة استقرار وانتعاش اقتصادي، انعكس ذلك على الموروث المعماري وتطور حضارة الناصرة من حيث مظهرها العمرائ العام وطريقة تخطيطها وتوزيع معالمها العمرانية مثل: الحارات، البيوت، الأسواق، الدكاكين، المدارس، أماكن العبادة، الخانات، السرايا، الأديرة والمستشفيات.

يلاحظ من خلال ذلك أن عدد سكان الناصرة تضاعفوا خلال العهد العثماني عدة مرات، وزاد عدد المسيحيين عن المسلمين نتيجة الزيادة الطبيعية والهجرة المتواصلة من مدن بلاد الشام وباقي أنحاء الدولة العثمانية لأسباب اقتصادية ودينية. تشكل

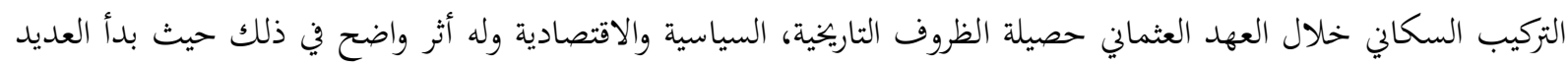

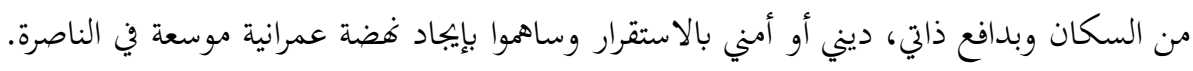

\section{التوصيات: Suggestion}

- العمل على مساعدة أصحاب الأملاك العقارية في مدينة الناصرة والمهددة بالبيع أو الهدم نتيجة الإهمال بإجراء ترميمات لمعالم

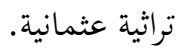
- إعادة الدور الإداري الذي كانت تتمتع به الناصرة خلال العهد العثماني كمركز قضاء.

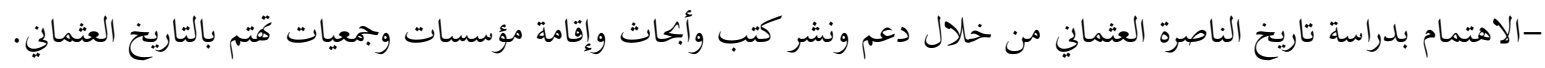

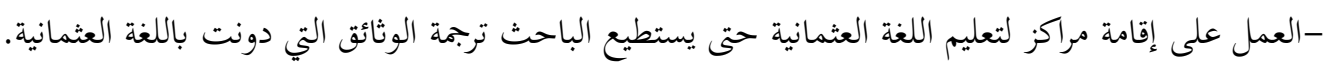

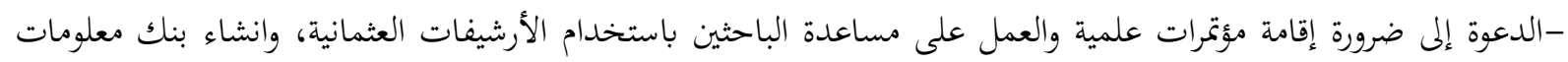
لمواضيع التاريخ العثماني وتقديمها خدمة للباحثين والدارسين. 


$$
\begin{aligned}
& \text { المصادر: } \\
& \text { سجل محكمة الناصرة الشرعية، مجلد (1)، 1291هـ / 1874م. }
\end{aligned}
$$

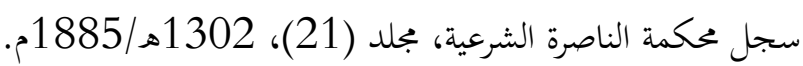

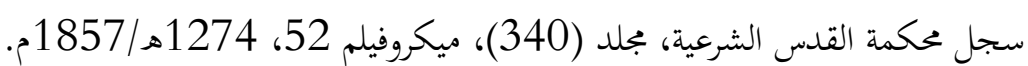

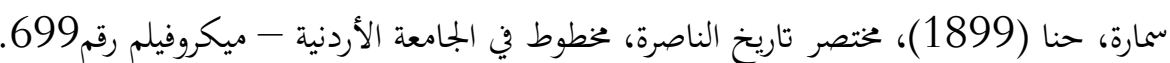

Peterson, Andrew (2001), A Gazetteer of Building in Muslim Palestine, British, Oxford University Press.

الدباغ، مصطفى (1974)، بلادنا فلسطين، عمان، الشركة الدولية للطباعة والنشر.

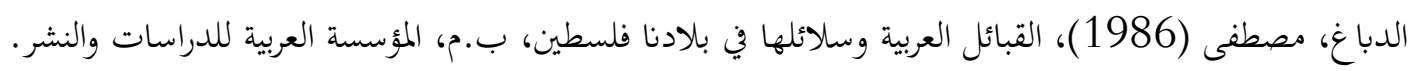
الطراونة، طه ثلجي (1982)، مملكة صفد في عهد المماليك، بيروت، منشورات دار الآفاق الجديدة. البخيت، محمد عدنان والحمود، نوفان رجا (1989)، دفتر مفصل ناحية مرج بني عامر وتوابعها ولواحقها التي كانت في تصرف لهرف

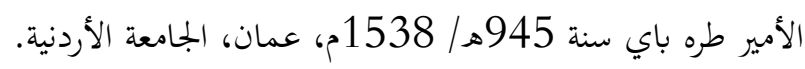

Lewis, Bernard (1976), " Nazareth in Sixteenth Century According to Ottoman Tapu Registers", London,

المعلوف، عيسى إسكندر (بلا سنة)، تاريخ الأمير فخر الدين المعني الثاني، بيروت، المكتبة الكاثوليكية.

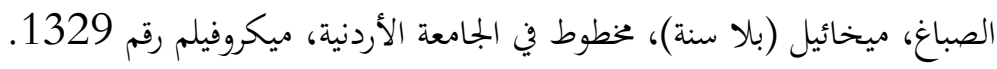

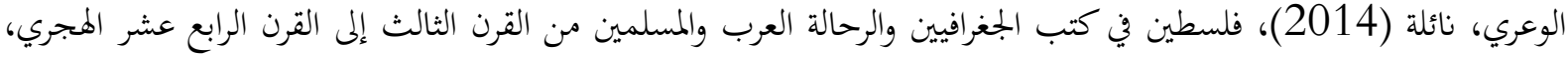

$$
\text { عمان، دار ورد الأردنية للنشر والتوزيع. }
$$

بلا مؤلف (2011)، الناصرة العثمانية في عيون غربية، ترجمة وتحرير هزاع أبو ربيع، الناصرة، الحكيم للطباعة والنشر.

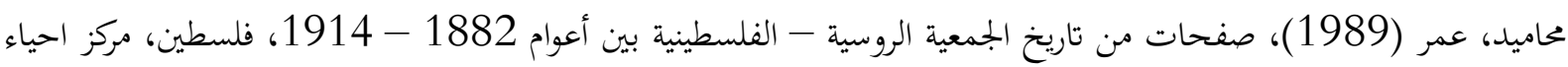

$$
\text { التراث العربي. }
$$

$$
\text { الصباغ، ليلى (1996)، فلسطين في مذكرات الفارس دارفيو، بيروت، المصادر. }
$$
روجرز، ماري إليزا (2013)، الحياة في بيوت فلسطين 1855 - 1859، ترجمة جمال أبو غيدا، عمان، دار الفارس للنشر دربر

$$
\text { والتوزيع. }
$$

$$
\text { رفيق بك، محمد وبهجت بك، محمد (1987)، ولاية بيروت القسم الجنوبي، بيروت، دار لحد خاطر. }
$$

Cunningham, Geikie (1824), Holy Land and the Bible, London, James Clark.

$$
\begin{aligned}
& \text { بدون مؤلف (1998)، الكنائس العربية في السجل الكنسي العثماني } 1869 \text { - 1922، جمع وترجمة وتحقيق عبد الرحيم أبو } \\
& \text { حسين وصالح سعداوي، عمان، المعهد الملكي للدراسات الدينية. } \\
& \text { رستم، اسد (1987)، الأصول العربية لتاريخ سورية في عهد محمد علي باشا، بيروت، منشورات المكتبة البوليسية. }
\end{aligned}
$$

Mariti, Abbe (1792), Travels Through Cyprus, Syria and Palestine with a General History of the Levant, Dublin.

بلان، مها وداود، اسعد (2018)، " سرايا الناصرة"، حجر الزاوية بجلة تعنى بالمواقع الأثرية والتراثية، العدد الأول. 
Rimak International Journal of Humanities and Social Sciences

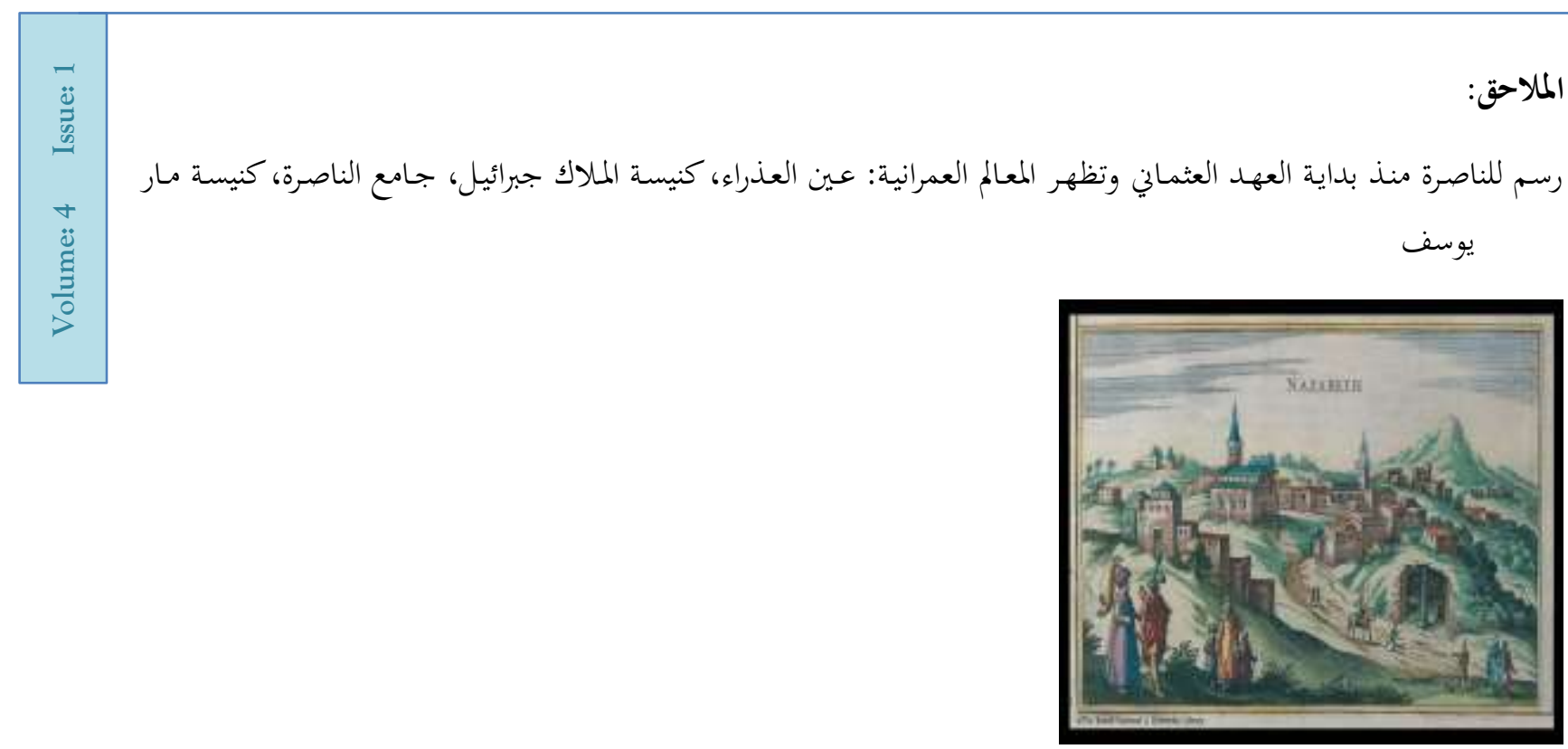

خريطة تظهر موقع قضاء الناصرة

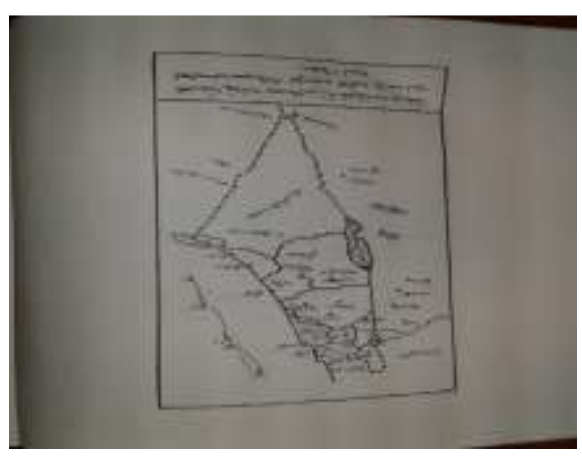

رسم للناصرة عام 1677م، وتظهر فيه جامع الناصرة، عين العذراء، كنيسة الملاك جبرائيل، الخان.

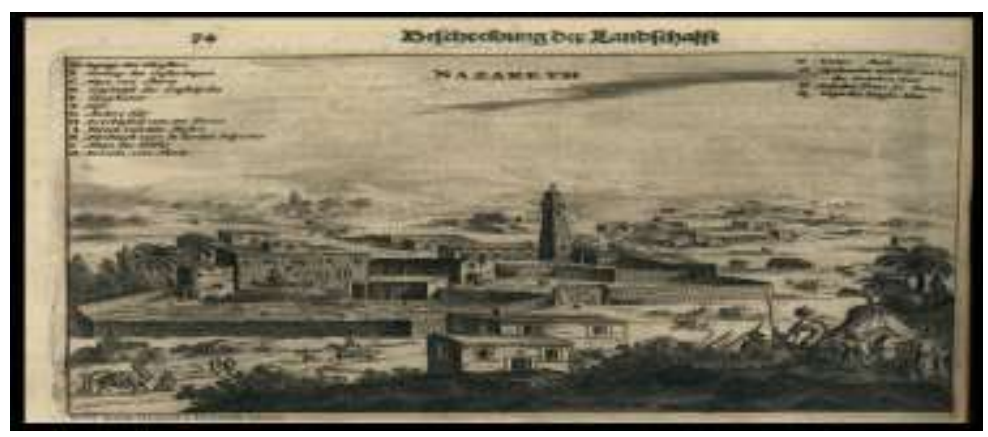

رسم للشيخ ظاهر العمر الزيداني بريشة المرحوم المهندس زياد أبو السعود الزيداني

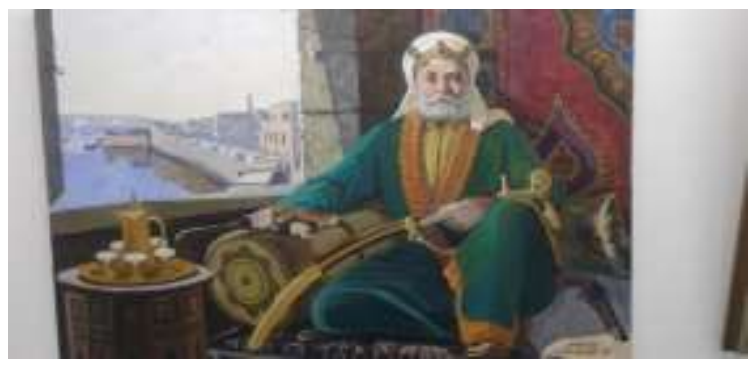


نموذج لطراز معماري في بناء الأقواس

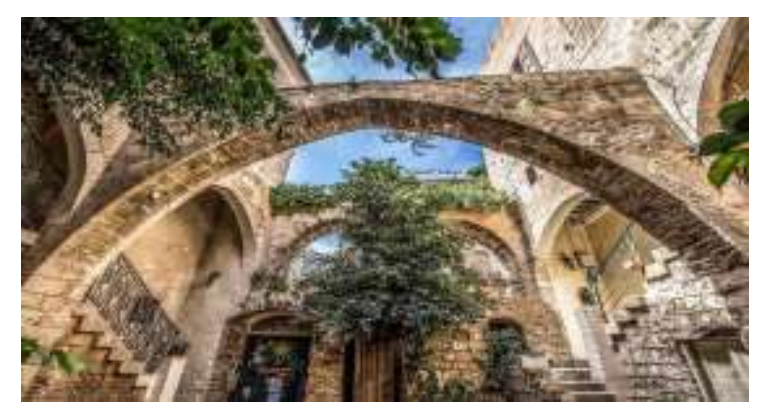

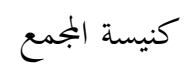
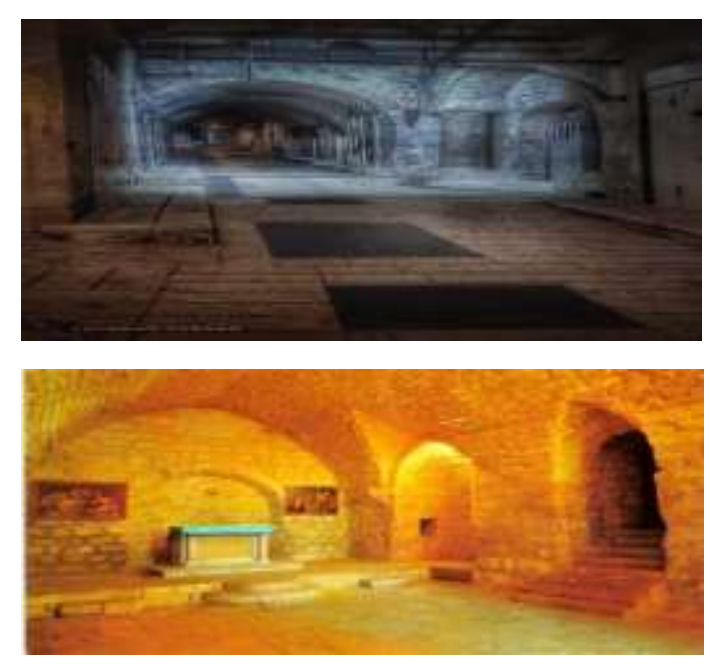

كنيسة البشارة لروم الارثوذكس

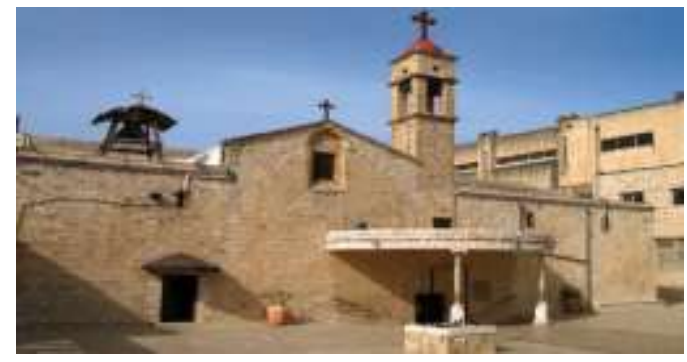

كنيسة البشارة للاتين

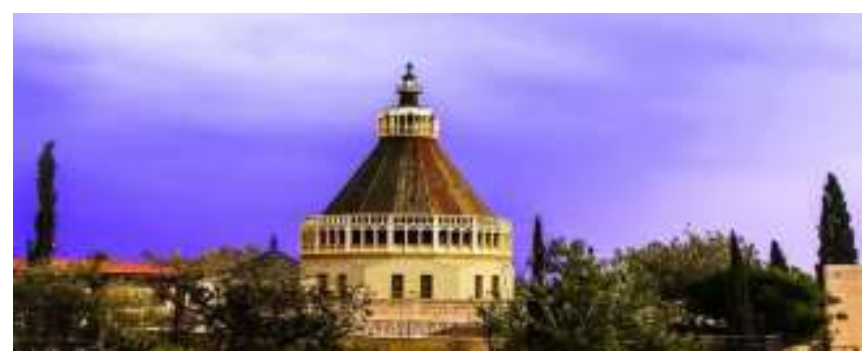




$$
\text { جامع الناصرة (جامع شريف) }
$$
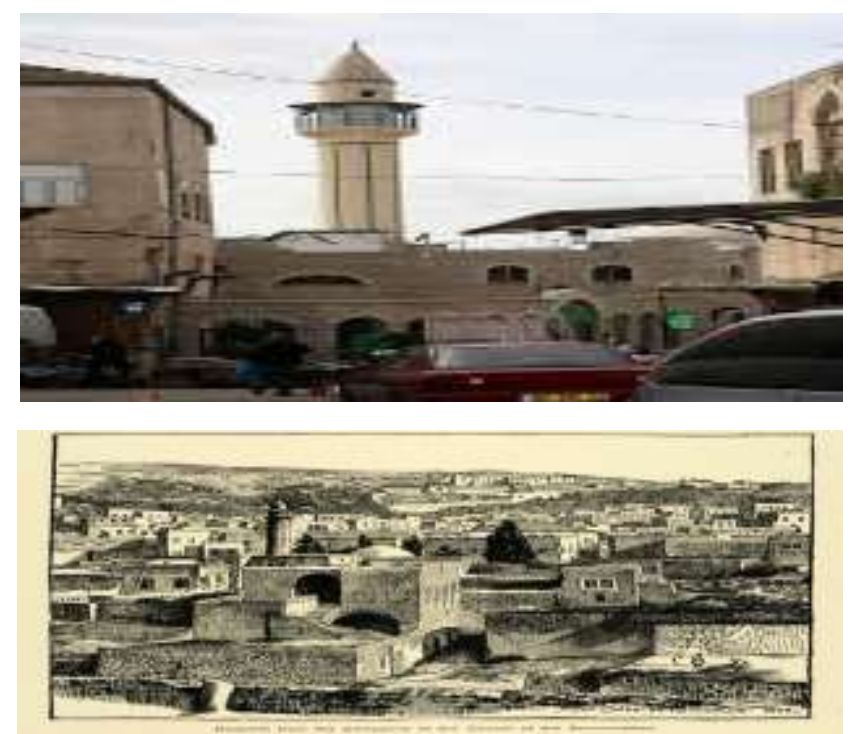

سرايا ظاهر العمر الزيداني - (- - س
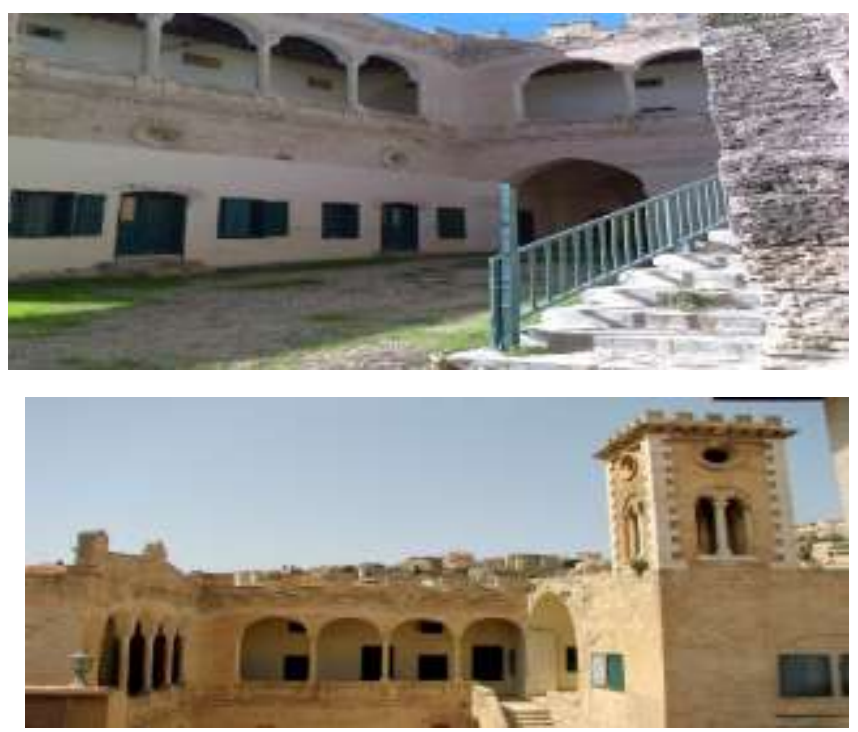

خان الناصرة التحتاني (المعروف بخان الباشا)
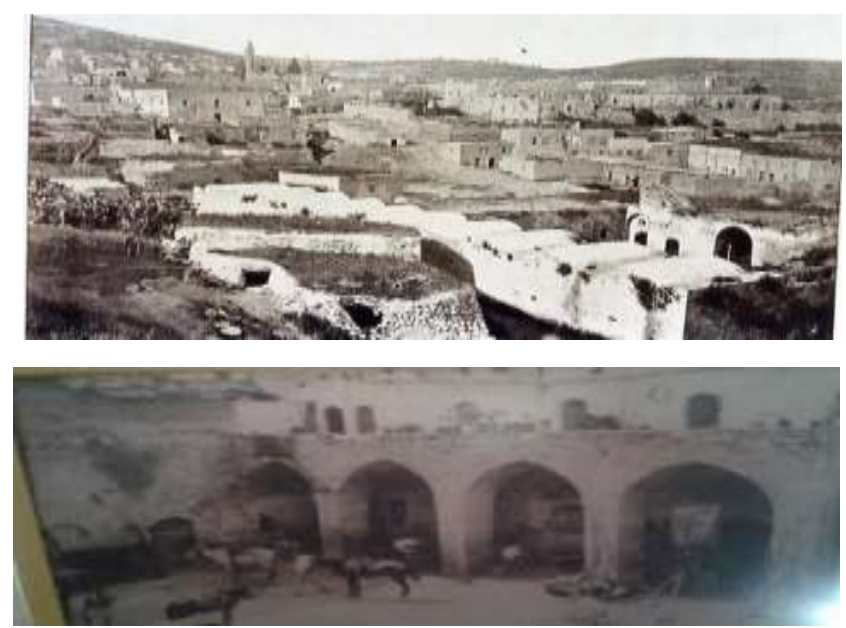
بوابة الخان (الآخور الألماني)

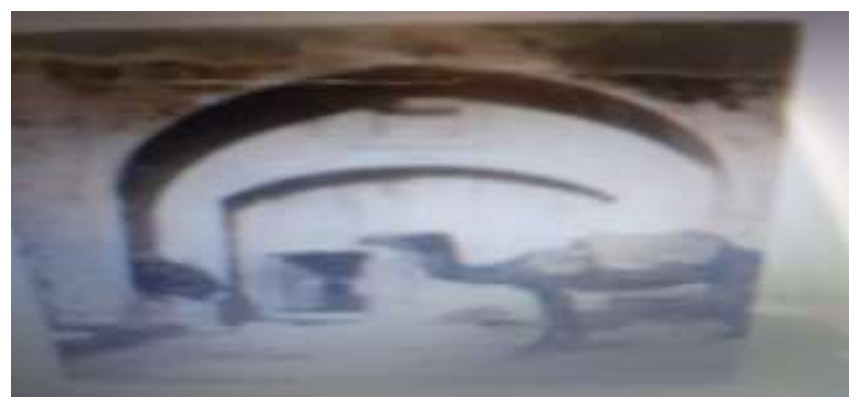

الناصرة عام 1918

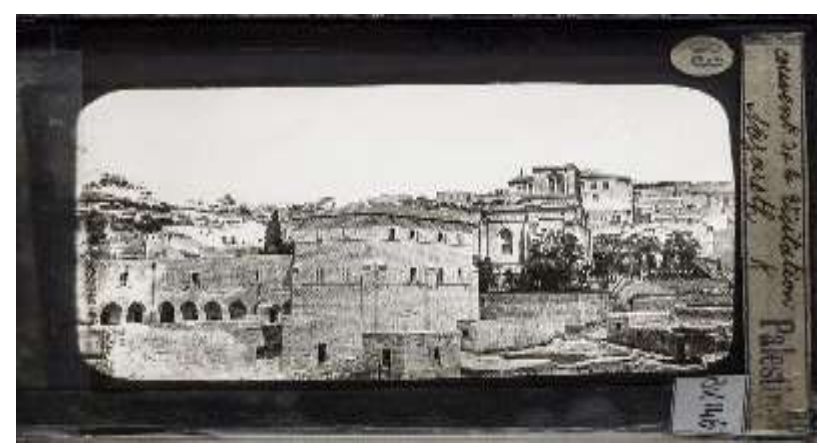




\section{DISCOURSE ANALYSIS THEORY AND ITS ROLE IN DEFINING POLITICAL INTENT THE SPEECH OF HIS MAJESTY SULTAN QABOOS BIN SAID, MAY GOD REST HIS SOUL, AT THE OPENING OF THE SIXTH SESSION OF THE COUNCIL OF OMAN AS A MODEL}

\section{Zahir Bin Marhoon Bin Khaseef AL-DAOUDI ${ }^{1}$}

\section{Istanbul / Türkiye \\ p. 256-267}

Received: $27 / 11 / 2021$

Accepted: $14 / 12 / 2021$

Published: 01/01/2022

This article has been scanned I iThenticat No plagiarism detected

\begin{abstract}
:
This research seeks to analyze the speech of His Majesty Sultan Qaboos bin Said, may his soul rest in peace, based on the theory of discourse analysis; This is because the text is the internal structure of discourse that consists of vocabulary, structures, and sentences, which helps to know the various rhetorical methods that His Majesty, may God have mercy on him, relied on to convince the recipient, and to clarify the linguistic effects that indicate the political and social functions that the discourse on democracy accomplishes for the actors; Because language reveals the depths of politics and its purposes, it is the first language of communication with citizens and the masses, and it has strength and ability to realize the common and speed of understanding, and the ability to influence the recipients and convince them.

Discourse analysis in this study, like the rest of the studies, depends on the vocabulary, structures, and sentences that make up the text. major.
\end{abstract}

Key words: Discourse Analysis, His Majesty Sultan Qaboos, May God Rest His Soul, Council Of Oman, Producer Of The Text, Recipient, Intentionality.

http://dx.doi.org/10.47832/2717-8293.15.19

1 (iD) Dr. , Sultan Qaboos University, Sultanate of Oman, zaher@ squ.edu.om, https://orcid.org/0000-0002-4597-4963 
نظرية تحليل الخطاب ودورها في بيان المقاصد السياسية خطاب حضرة صاحب الجلالة السلطان قابوس بن سعيد طيب الله ثراه في افتتاح الدورة السادسة لجلس عُمان أنموذجا

\section{زاهر بن مرهون بن خصيف الداودي2}

\section{الملخص:}

يسعى هذا البحث إلى تحليل خطاب صاحب الجلالة السلطان قابوس بن سعيد طيب الله ثراه، معتمدا على

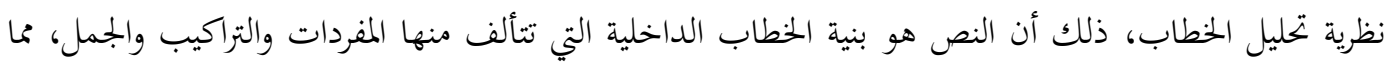
يعين على معرفة الأساليب الخطابية المتنوعة التي اعتمد عليها صاحب الجلالة طيب الله ثراه في إقناع المتلقي، وبيان الآثار اللغوية الدالة على الوظائف السياسية والاجتماعية التي ينجزها الخطاب عن الديمقراطية للفاعلين، ذلك أن

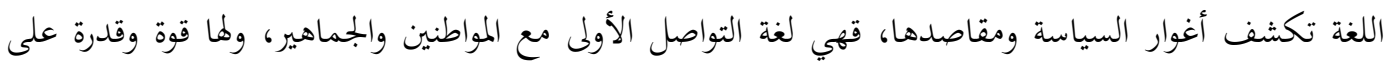
إدارك المشترك وسرعة الفهم، والقدرة على التأثير على المتلقين وإقناعهم.

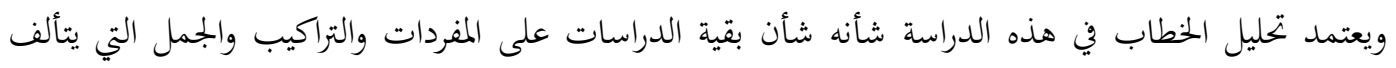
منها النص، كما يعتمد على السياق اللغوي والسياق غير اللغوي الذي يعنى بدراسة الخطاب في ضوء ظروف إنتاجه، ويشمل خصائصه الإدراكية والاجتماعية والثقافية، وارتباطه بالزمان والمكان، مما يشكل بنية نصية كبرى. الكلمات المفتاحية: تحليل الخطاب، جلالة السلطان قابوس طيب الله ثراه، بجلس عمان، منتج النص، المتلقي، القصدية.

النص هو بنية الخطاب الداخلية التي تتألف منها المفردات والتراكيب والجمل، بغية معرفة الأساليب الخطابية المتنوعة التي

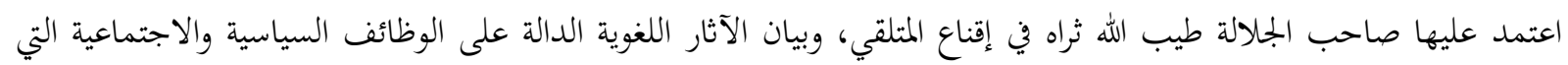
ينجزها الخطاب عن الديمقراطية للفاعلين، ذلك أن اللغة تكشف أغوار السياسة ومقاصدها، قهي لغة التواصل الأولى مع المواطنين والجماهير، ولها قوة وقدرة على إدارك المشترك وسرعة الفهم، والقدرة على التأثير على المتلقين وإقناعهم. ويعتمد تحليل الخطاب في هذه الدراسة شأنه شأن بقية الدراسات على المفردات والتراكيب والجمل التي يتألف منها النص، كما يعتمد على السياق اللغوي والسياق غير اللغوي الذي يعنى بدراسة الخطاب في ضوء ظروف إنتاجه، ويشمل خصائصه

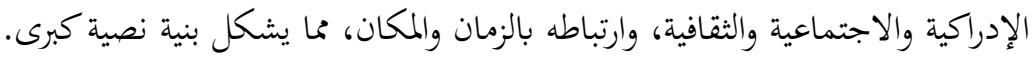

ونظرا لعزوف كثير من الباحثين عن دراسة الخطابات السياسية في عمان، وخطابات صاحب الجلالة خاصة، دفعني إلى اختيار هذا الموضوع خاصة أن هذا الخطاب (خطاب صاحب الجلالة في افتتاح مجلس عمان) أن استطاع منتجه في أن يحمل كلماته وبمله القصيرة معان سامية عظيمة، لن يتمكن من الوصول إلى كنهها إلا بدراستها والوقوف عند سياقاتحا المختلفة. ولا أزعم أن هذه الدراسة هي الدراسة الأولى لخطب صاحب الجلالة، إنما هناك دراسات سبقت هذهة هذه الدراسة، مع قلتها، أهمها:

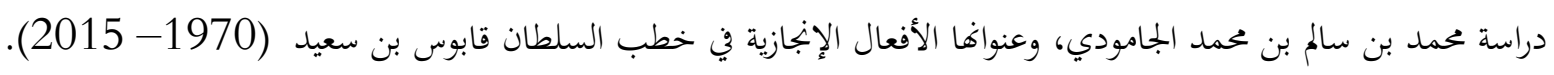


وقد كان هدف هذه الدراسة تحليل الأفعال الإنجازية في خطب السلطان الراحل السلطان قابوس بن سعيد طيب الله ثراه،

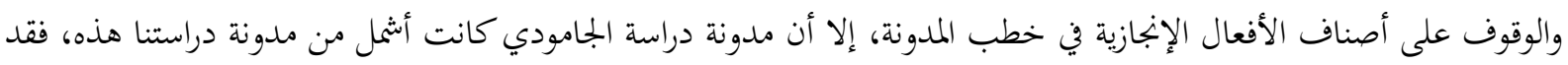
اعتنت دراستنا على خطابه طيب الله ثراه في افتتاح الدورة السادسة لمجلس عمان. كما أن هدف دراستنا ليس تتبع الأفعال الإنجازية، وإنما هدفنا الوقوف على المستويات اللغوية، والعلاقات اللغوية، التي وظفها السلطان الراحل حضرة صاحب الجلالة السلطان قابوس بن سعيد طيب الله ثراه في خطاباته السياسية، وقد اعتمد البحث البحث

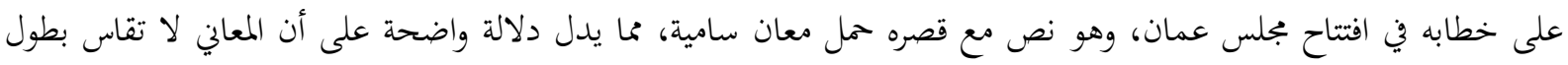
النصوص أو قصرها، وإنما تقاس بمضموها، ولن يتحقق هذا المضمون إلا بامتلاك الأدوات الصحيحة السليمة، وتوظيف القرائن المختلفة توظيفا يخدم معاني الخطاب ومضامينه السامية. وستعتمد الدراسة نظرية الاتصال في علم اللغة النصي، ذلك أن الاتصال نشاط اجتماعي حيوي، يتناقل الأفراد أو

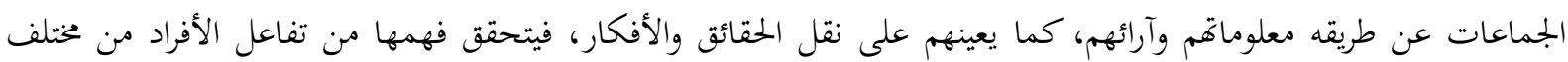
الثقافات والاتحاهات الفكرية للوصل إلى المعنى المنشود من هذه الرسائل.

وستقسم الدراسة إلى قسمين رئيسين هما القسم النظري وفيه سيبين البحث تعريف الخطاب السياسي نظريا، ثم القسم

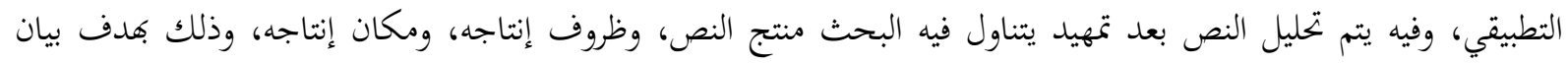

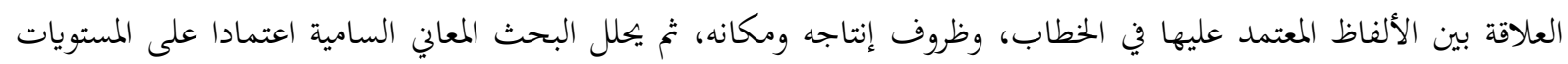

المختلفة.

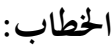

يعد أفلاطون أول من نظر إلى الخطاب، فقد ضبط المفهوم الفلسفي للخطاب استنادا إلى قواعد عقلية محددة، وهو أول من كشف المعنى الفلسفي للخطاب اليوناني.وبما أن الخطب تعبر عن حقائق واقعية بألفاظ واضحة مباشرة بعيدة عن الصنعة

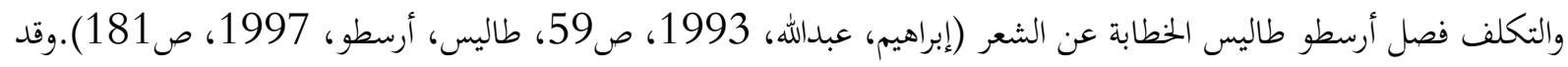

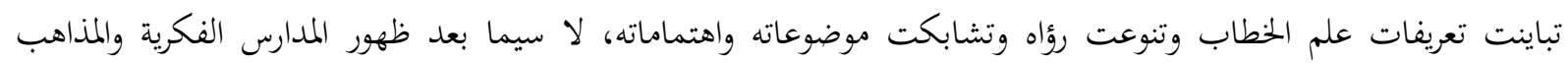

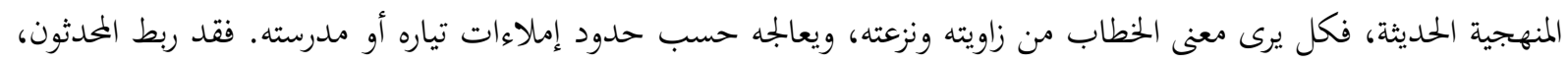

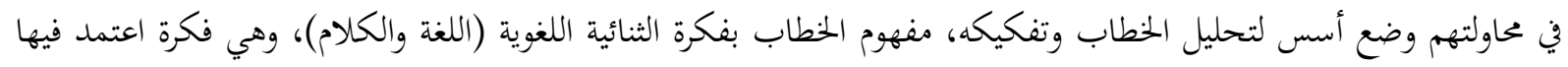

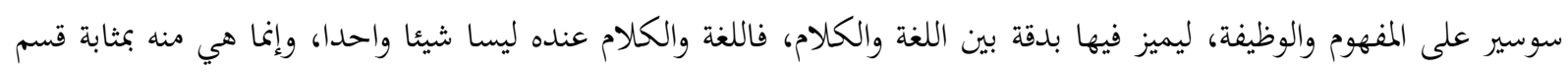

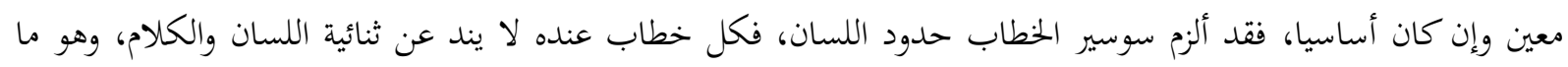

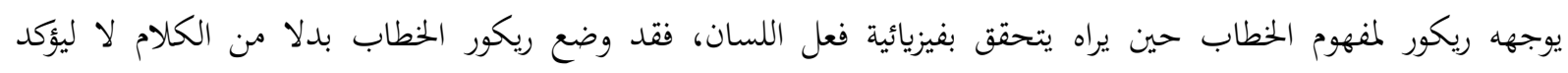

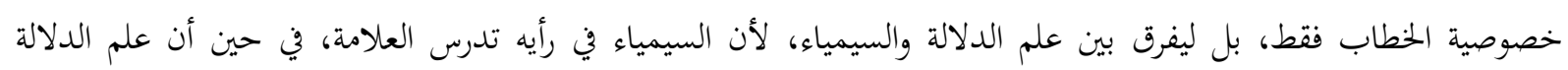

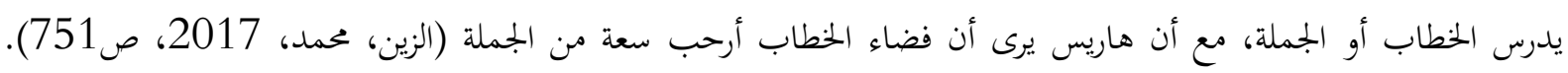

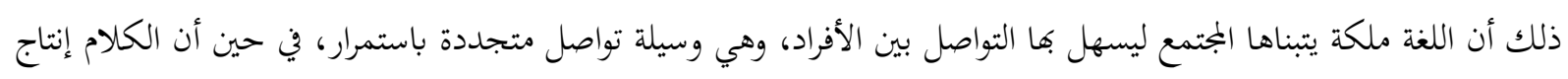

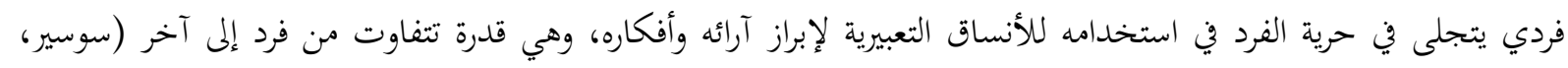

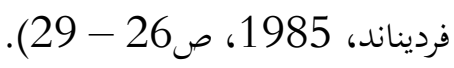

وقد اهتم إميل بنفينست بالتلفظ حين رأى أن الخطاب كل لفظ يفترض متكلما يهدف إلى التأثير في المستمع، فجعل

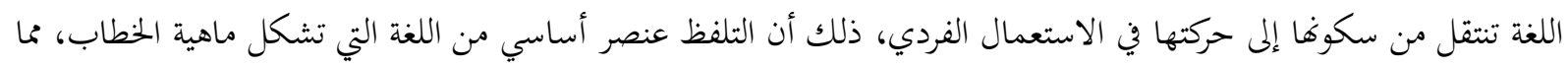


يتيح لنا بناء علاقة تفاعلية بين المخاطب والمتلقين، اللغة وسيلة للتعبير وأداة للتفكير وحقل للتأويل والتفسير، ولا يمكن بأي حال

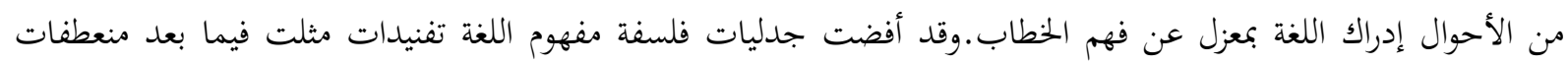
متداخلة، منها مفهوم الكلام، ومفهوم الجمملة، وصولا إلى مفهوم النص الذي استندت على إثره نظريات عنيت بتفسيره، وتفتيت

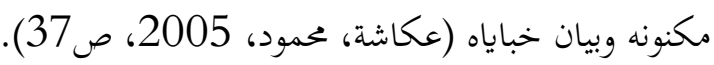
والخطاب كما يراه ميشيل فوكو مصطلح لساني وشكل أدبي يتميز عن غيره من الأشكال الأدبية بطريقة نظمه، وكونه نابتا

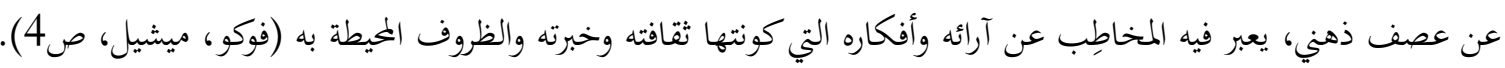
والخطاب السياسي هو خطاب السلطة يوجه عن قصد نحو المتلقي للتأثير فيه، وإقناعه بمضمون خطاب يتضمن أفكارا

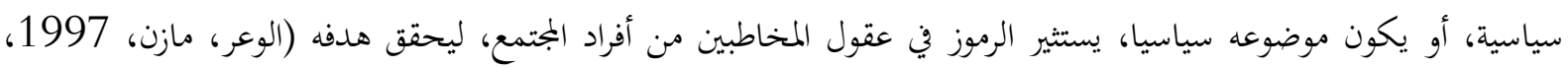

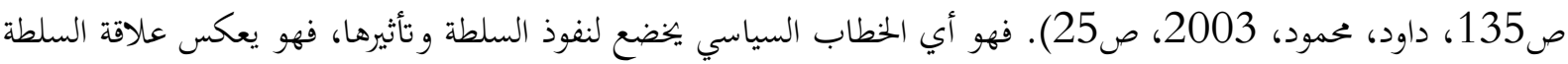

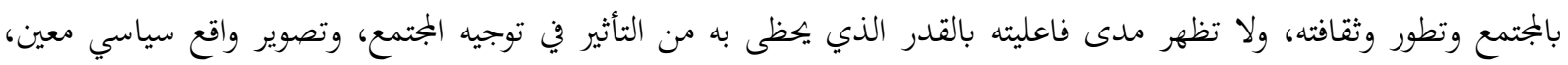
ومفاهيم سياسية يفهمها المتلقين في محيط اجتماعي معين، وهو يشكل وحدة لغوية خاضعة للتأمل، لدمج المتلقي بالأفكار والآراء

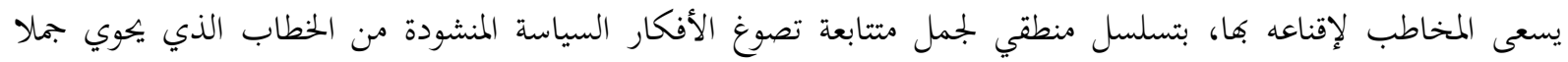
مصوغة بأسلوب يثير مشاعر المتلقي ويحرك فهمه، ليدرك مضمون الرسالة التي يتضمنها الخطاب، ويدرك القصد الذي أراده

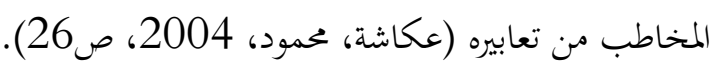
والخطاب السياسي شأنه شأن بقية الخطابات فإنه يعتمد اللغة أداة من أدواته، فيحقق السياسي براعة في انتقاء ألفاظه وتعابيره وصياغتها صياغة صحيحة سليمة ليؤثر في الرأي العام، وقد ربط ديل هايمز الكفاية الاتصالية بقدرة المتكلم على إنتاج منطوقات مناسبة لأنماط المواقف الاتصالية المختلفة، وعدم الاقتصار على تحقيق التواصل في نمط الجمل النحوية فقط، وإنما يتم

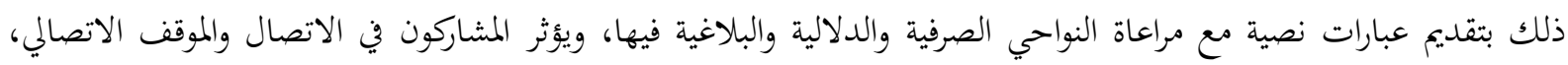

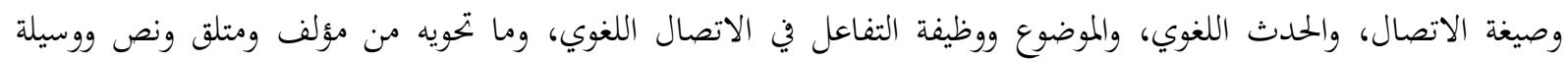

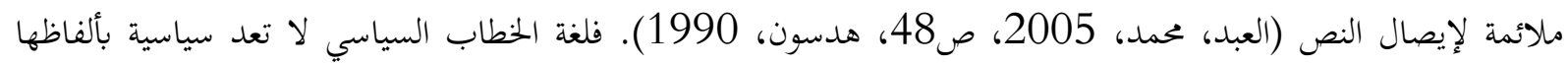
وعباراتا، وإنما بمعلوماتها المهمة التي تنقلها، ذلك أن الخطاب السياسي محفز للمثيرات الاجتماعية والسياسية التي تنعكس عليه،

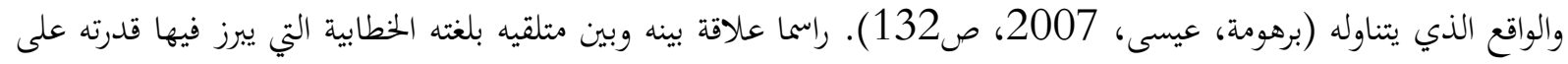

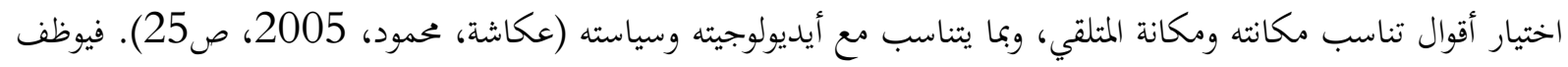

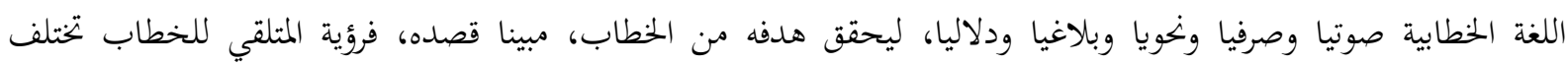
ومستوى فهمه وتحليله بناء على ما يمتلكه من خبرة وثقافة، ومع ما يتناسب هذه الخطابات ومعيات مع طبيعة المتلقي بتنوعها (الجابري،

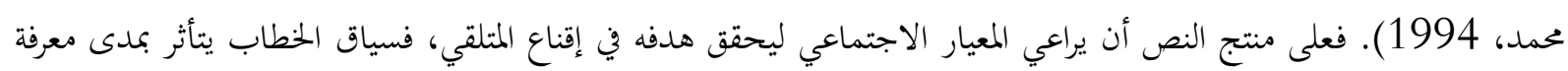

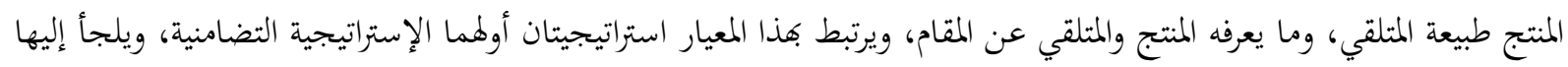

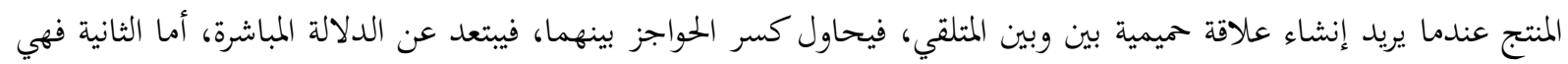

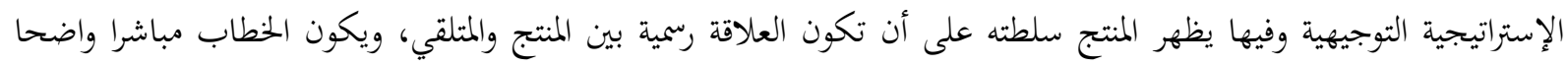

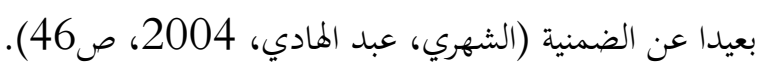


اعتمدت الدراسة على النص المسموع وهو خطاب صاحب الجلالة السلطان قابوس بن سعيد طيب الله ثراه، وهو نص

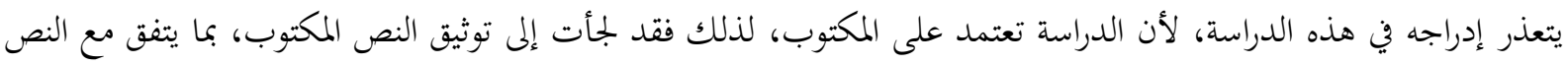

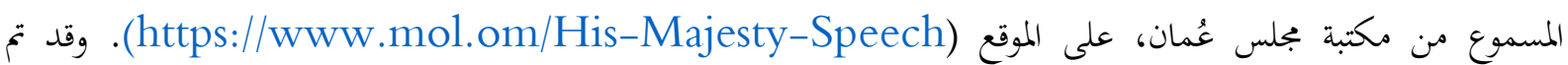

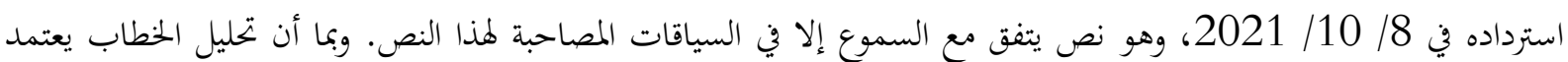
على المعطيات اللغوية، وغير اللغوية، ومنها السياق المصاحب للخطاب، فقد عاد الباحث إلى النص المسموع. ويمكن العودة إليه

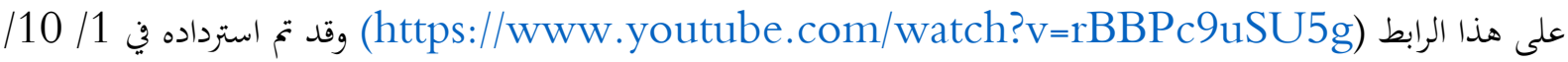
2021م، وهو تسجيل كامل لخطاب صاحب الجلالة السلطان قابوس في افتتاح الفترة السادسة لمجلس عمان الأحد 3 صفر 1437هـ، 15 نوفمبر 2015م، ونسج، خطاب ألقاه في حصن الشموخ، في ولاية منح.

\section{والنص المكتوب للخطاب، هو:}

$$
\text { بسم الله الرحمن الرحيم }
$$

الحمدُ له على ما أفاء به علينا من نِعم، وأسبغه من آلاء، والصلاةُ والسلامُ على من أُرسل رحمة للعالمين.

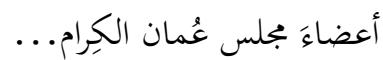
إنه ليسُرنا أن نلتقي بكم في هذا اليوم المهارك، لنفتتح أعمال الفترة السادسة لمجلس عُمان، متمنين أن تُكلل أعماله

$$
\text { بالتوفيقِ والسدادِ لحدمة هذا الوطن العزيز. }
$$

إن ما تحقق على أرض عُمان من مُنجزات في مختلف المجالات، لهي مبعث فخرِ ومصدر اعتزاز، وإننا نتطلعُ إلى مواصلة

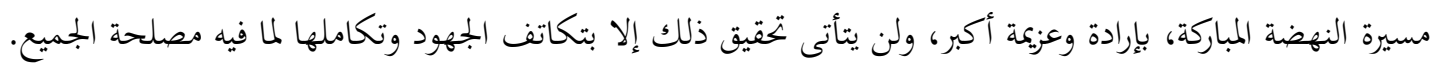

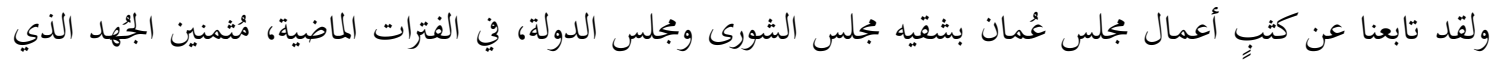
بذله المجلس خلالها، مما كان له الأثر الملموس للإسهام في دفع مسيرة التنمية الشاملة قُدماً نحو مزيلٍ من التطور والنماء.

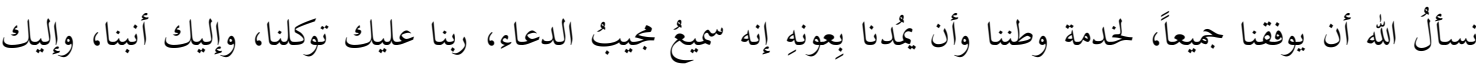
المصير، وُكل عام وبلادنا العزيزةُ وأبناؤها الأوفياء في خير ومسرة، وطنال والسلام عليكم ورمة الله وبركاته.

\section{تحليل خطاب حضرة صاحب الجلالة السلطان قابوس بن سعيد طيب الله ثراه في افتتاح بجلس عُمان:

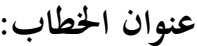

اهتم علم السيمياء اهتماما واسعا بالعنوان في النصوص الأدبية كونه "نظاما سيميائيا ذا أبعاد دلالية وأخرى رمزية تغري الباحث بتتبع دلالاته ومحاولة فك شفرته الرامزة"، فقد أصبح العنوان موازيا للنص لا يمكن بتحاوزه، فقراءة العنوان إنتاج الدلالة لتؤدي إلى التشخيص المطلوب أو المرسوم في ذهن المتلقي بل في تأويله ويف نموه باكتشاف الدلالات المخبوءة في نسيج العنوان،

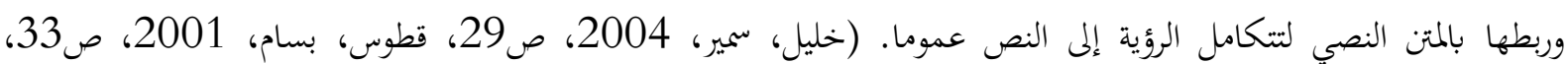

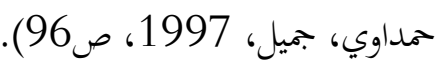
والعنوان هو العلامة الجوهرية والعنصر الأهم من عناصر النص الموازي، حتى كاد يستقل بعلم خاص هو علم العنونة أو

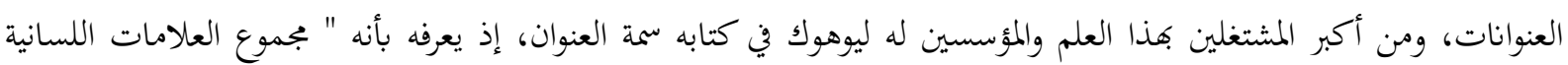
كلمات مفردة، أو جمل أو نص يمكن أن تدرج على رأس نصه لتحدده وتدل على محتواه العام وتعرف الجمهور بقراءته" (رضا، 
عامر، 2014، ص125). وقد حدد جرار جينيت أربع وظائف للعنوان هي: الوظيفة التعينية، أو التحديدية، والوظيفة الوصفية،

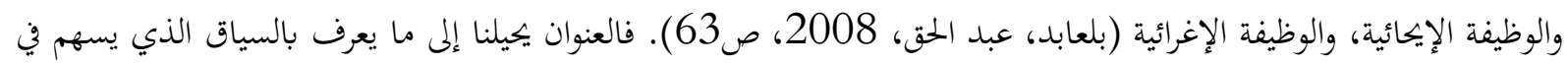

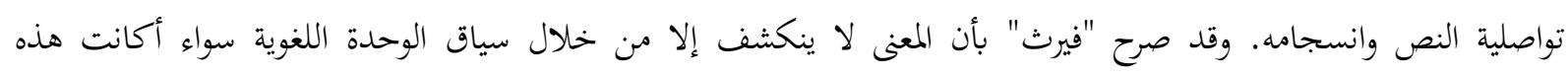

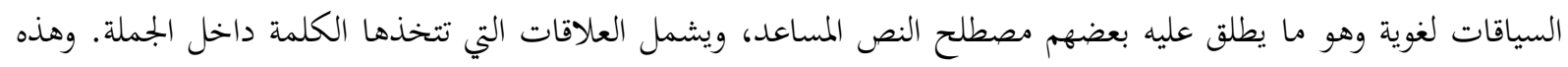

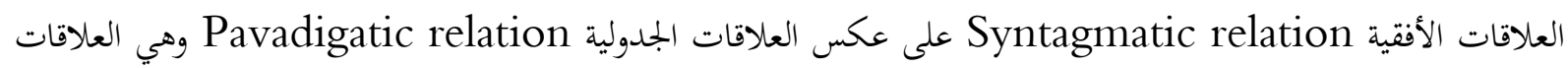

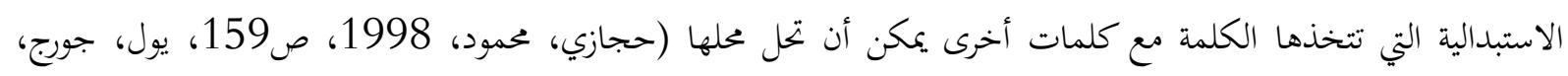

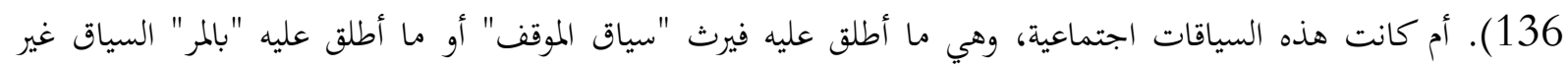

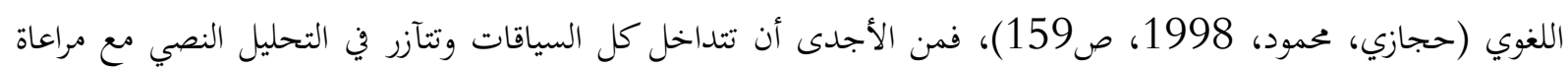

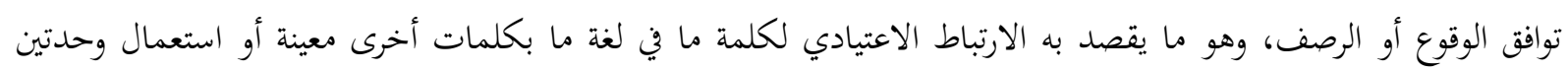

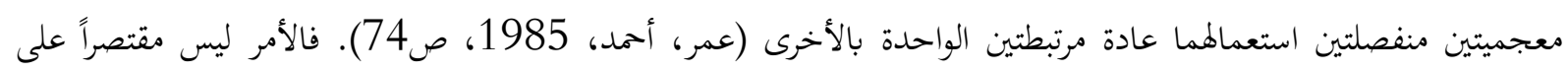

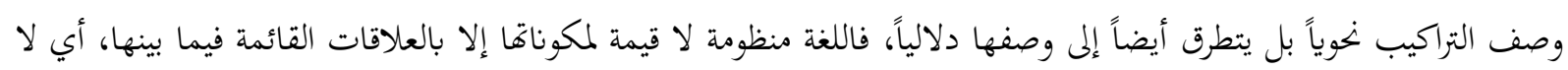

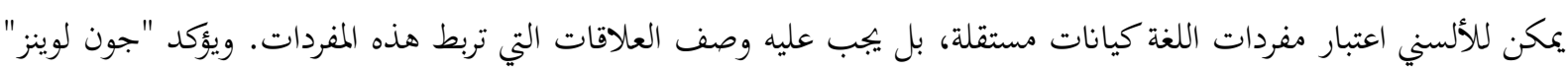

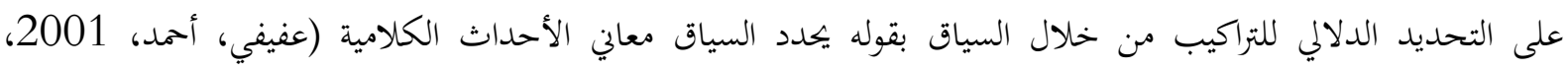

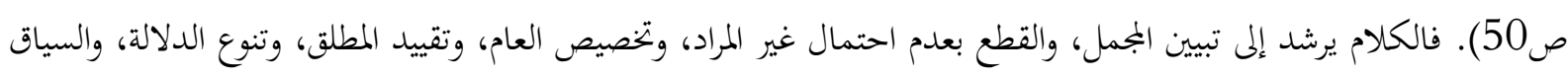

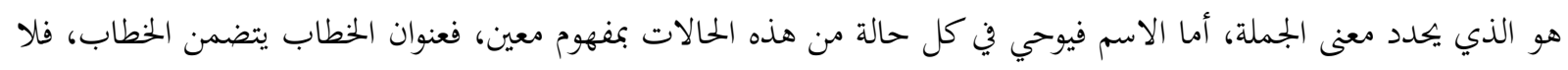

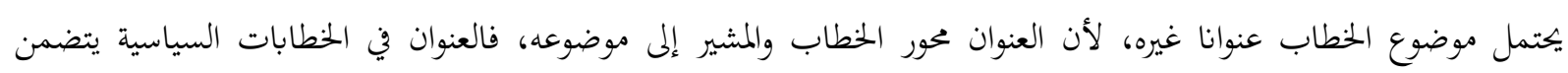
الموضوع الأساسي في الخطاب. مع تتبع خطابات السلطان الراحل حضرة صاحب الجلالة السلطان قابوس بن سعيد طيب الله ثراه يتضح أن هذه

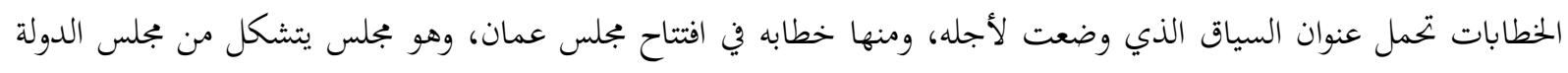

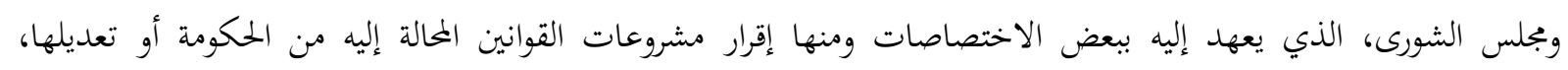

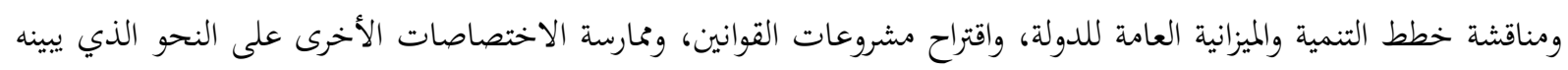
القانون.

وقد صدر قانون بجلس عمان بموجب المرسوم السلطاني رقم (2021/7) مبيناً الفئات التي يتم من بينها الاختيار لعضوية

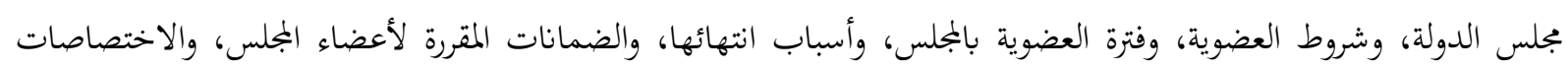

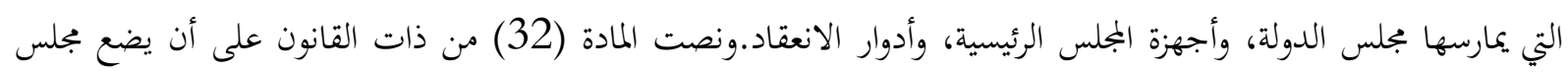

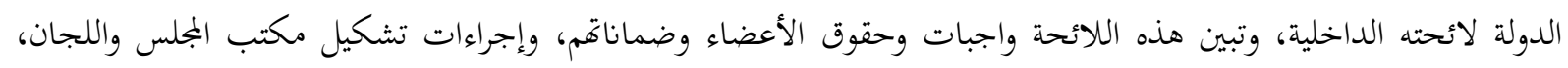

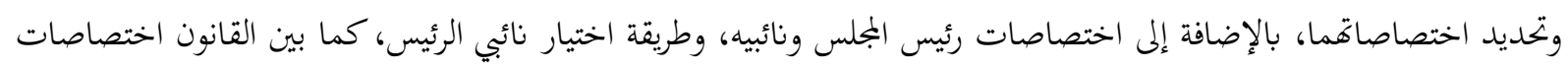
الأمانة العامة بالمجلس.

بنية الخطاب:

يتكون الخطاب من بنى مترابطة، ومنسجمة في مقاصدها، فتنضبط بالمقصدية التي ينشدها منتج النص، فعند استماعنا

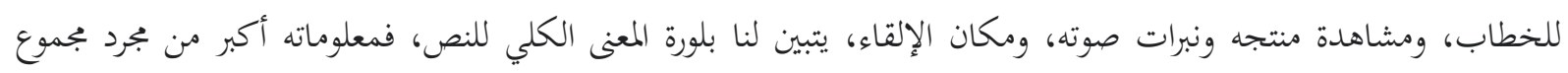

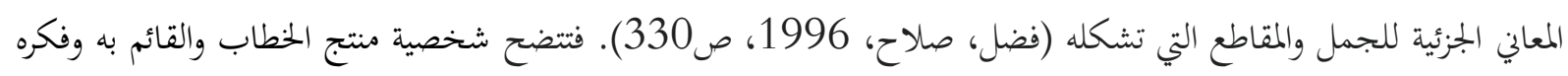
في خطابه، فمنتج الخطاب السلطان الراحل حضرة صاحب الجلابة السلطان قابوس بن سعيد طيب الله ثراه، وهو 
السلطان التاسع لسلطنة عُمان ورئيس مجلس الوزراء، ووزير الدفاع، والخارجية، والمالية، وحاكم البنك المركزي، والقائد الأعلى للقوات المسلحة، والحاكم الثاني عشر لأسرة آل بو سعيد، عُدَّ صاحب أطول فترة حكم من بين الحكام العرب والثالث في العالم

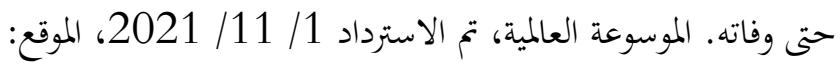
(https://ar.wikipedia.org/wiki/\%D9\%82\%D8\%A7\%D8\%A8\%D9\%88\%D8\%B3_\% D8\%A8\%D 9\%86_\%D8\%B3\%D8\%B9\%D9\%8A\%D8\%AF)

عرف بحنكته السياسية داخليا وخارجيا، فقد استطاع أن يؤمن سياسته الخارجية ويقيم علاقات ودية مع كل أقطار العالم،

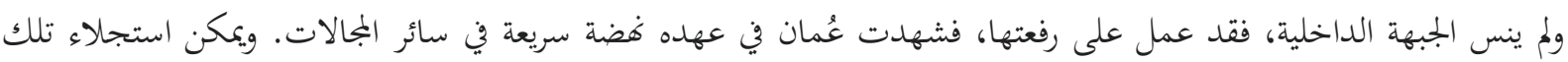

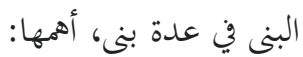

1- البنية الأولى: وتتمثل هذه البنية في مستهل الخطاب تحديدا، وهي جملة تتضمن معنى الحمد، وهذا دأب صاحب الجلالة السلطان قابوس طيب الله ثراه، في كل خطاباته، فقد كان يبدأ خطابه بالبسملة، ثم الحمدلة، رابطا الحمد بمضمون خطابه، وهذا فهذه طيب الله ثراه، ففي افتتاح الدورة الثانية لمجلس عمان ربط الحمدلة بالشورى بقوله الحمد لله الذي جعل الشورى منهجا من

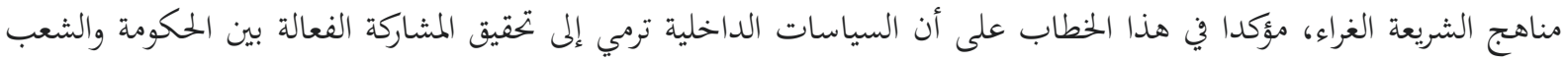

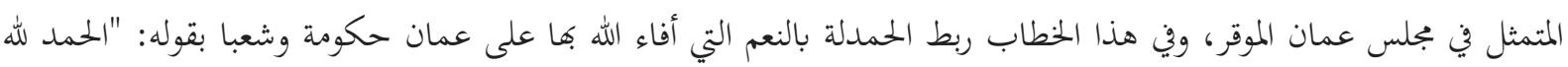

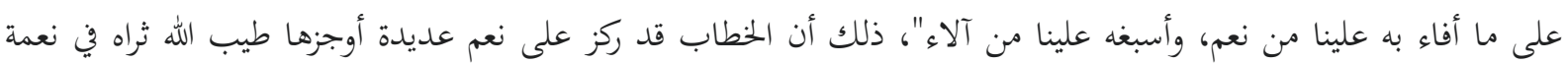

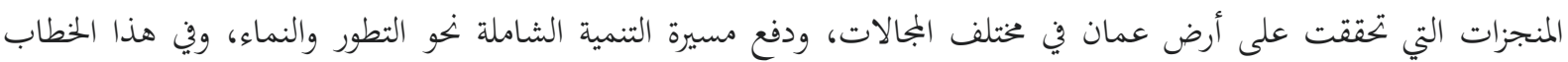

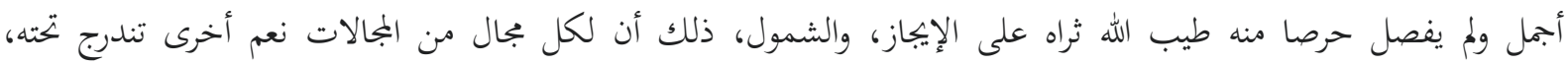
وتتضمنه، ولعل أهم نعمة تمتعت بها عمان نعمة الأمن والأمان.

2- البنية الثانية: متن الخطاب، ولا يمكننا أن نعدها بنية مستقلة في اللسانيات النصية، لأن النص بنية واحدة تتضافر معه مجموعة من البنى لتشكل بنيته الكلية، وقد تضمن المتن مجموعة من البنى التي تخدم مقصد منتج الخطاب، ولعل أهم هذه البنى، هو

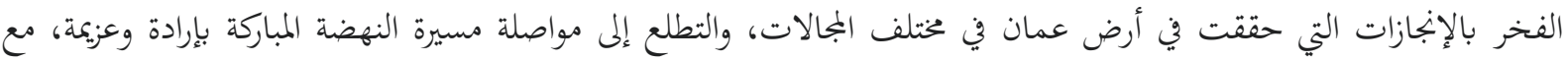
ضرورة تكاتف الجهود وتكاملها. 3- البنية الثالثة: الخاتمة، وفيها الدعاء الذي فجه صاحب الجلالة السلطان قابوس بن سعيد طيب الله ثراه، في كل خطاباته، مؤكدا على ربط الدعاء (الخاتمة) بموضوع الخطاب، وبما أن موضوع الخطاب هنا هو السعي إلى مواصلة مسيرة النهضة المباركة،

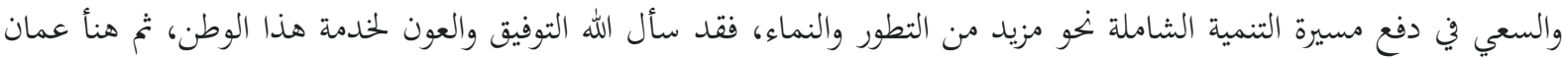
(بلادنا العزيزة) وأبناؤها الأوفياء في خير ومسرة، وهذه التهئة حملها صاحب الجلالة السلطان قابوس بن سعيد طيب الله ثراه

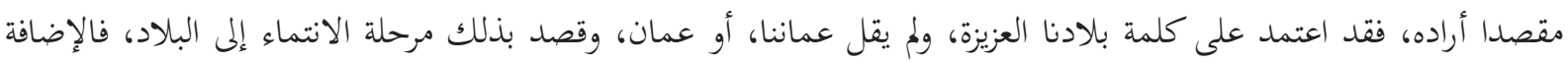

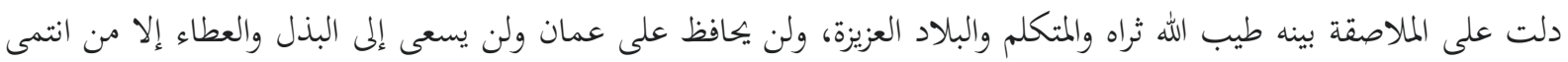

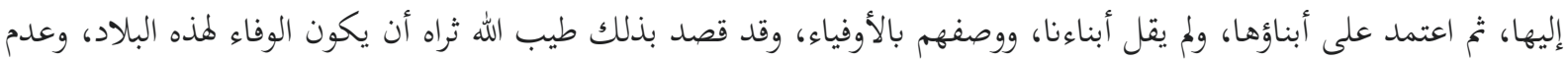

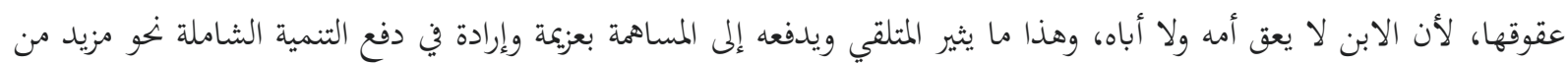
التطور والنماء.

4- السياق ودوره في الحطاب: وندرك من الخطاب السامي لخضرة صاحب الجلالة السلطان الراحل السلطان قابوس بن سعيد طيب الله ثراه، أنه راعى منزلة متلقي الخطاب ومستقبله، فالمتلقي فردا كان أم جماعة، أم شعبا، فهو يسعى لإقناع المتلقين، فقد 
استخدم الوسائل الثقافية والدينية، واللغوية، فقد وظف منتج الخطاب الثقافة الدينية، فقد سبق الخطاب تلاوة آيات من الذكر الحكيم تلاها القارئ طالب بن سعيد القنوبي، وهي آيات اختارها منتج الخطاب.

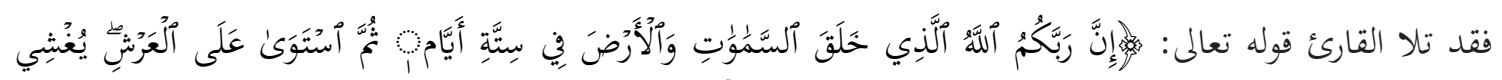

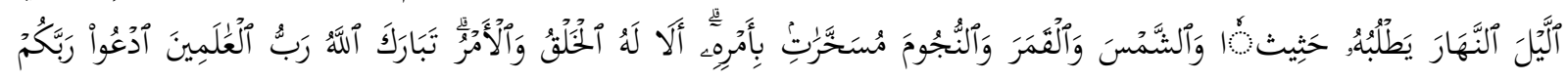

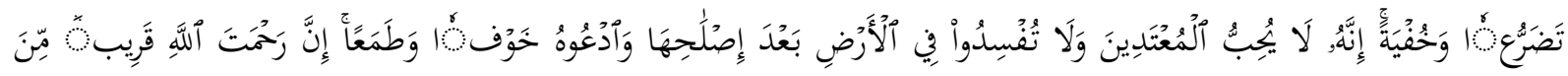

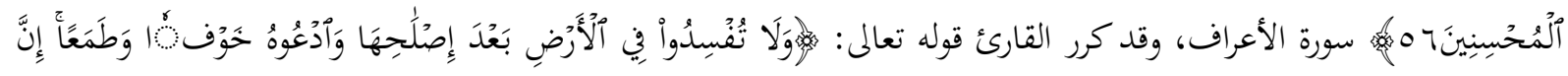

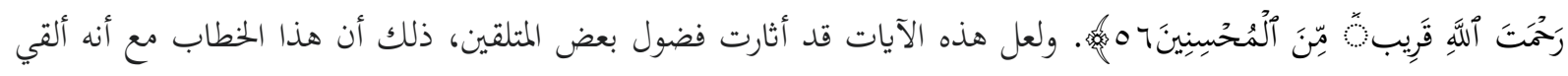

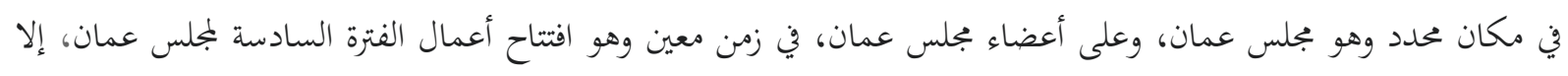

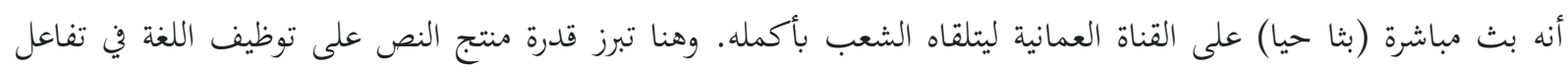

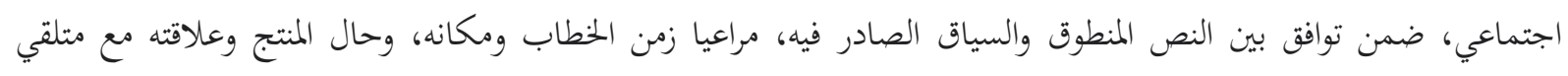

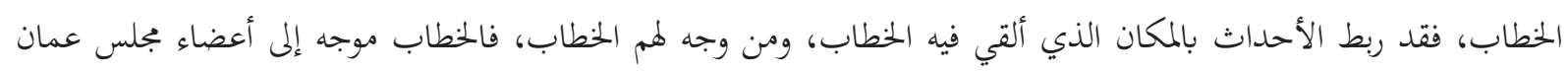

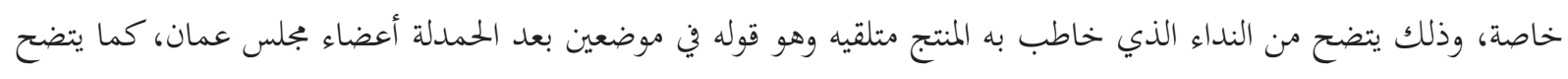

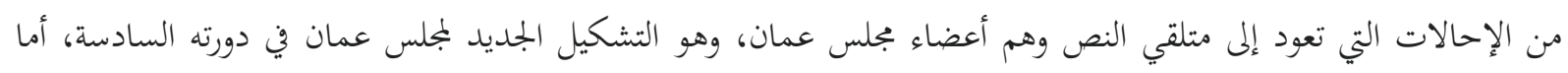

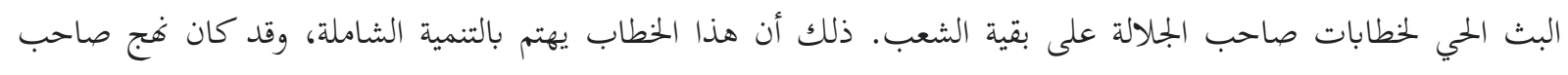
الجلالة السلطان قابوس بن سعيد المعظم طيب الله ثراه إنما يلقي خطاباته مباشرة على شعبه ويبين لهم الخطط التنموية الشاملة،

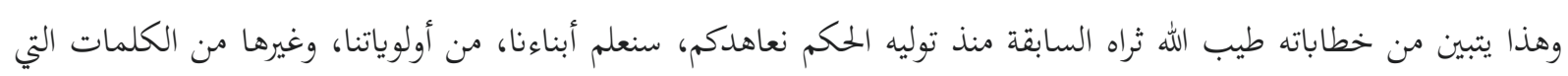
تبين اهتمامه طيب الله ثراه بالتنمية الشاملة، وحرصه على أن يدرك الشعب الخطوات التي ستبنى عليها التنمية الشاملة.

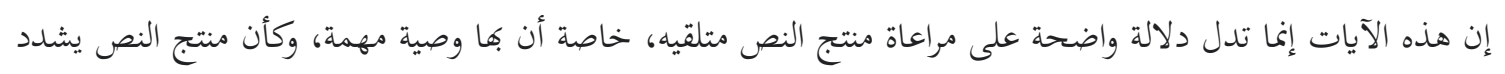

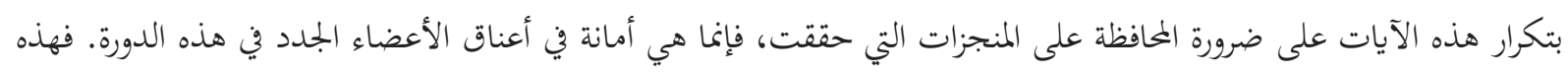

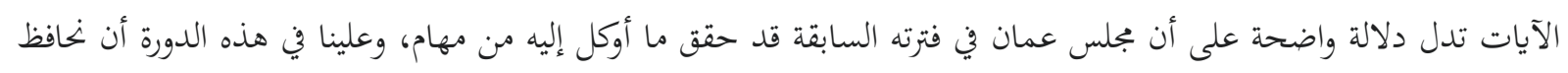

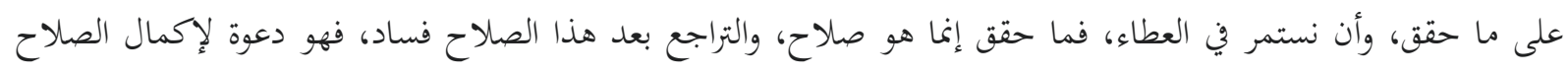

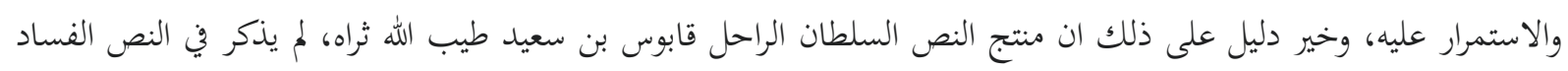

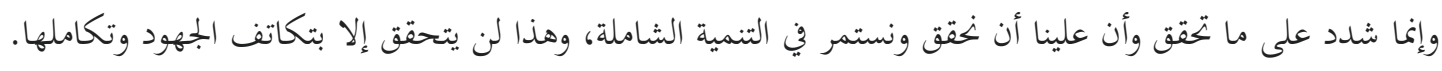
لعل متلقي الخطاب لم يتبين الإنجازات التي حققت على أرض عمان، مع أن صاحب الجلالة طيب الله ثراه قد أجمل هذه

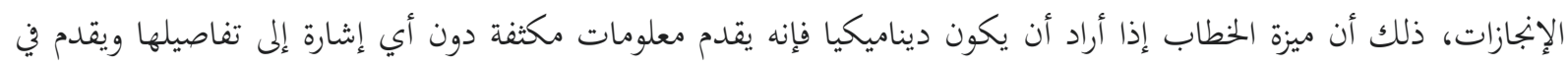

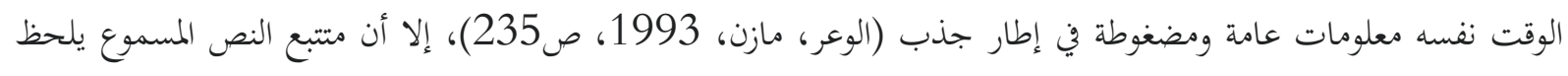
أن السياق المصاحب للنص، قبل بداية الخطاب قد عدد الإنجازات التي حققتها السلطنة في كافة المجالات.

\section{المستويات التحليلية في الخطاب:}

ارتكز خطاب صاحب الجلالة طيب الله ثراه في افتتاح الفترة السادسة لمجلس عمان، على المستويات اللغوية المختلفة، وهي

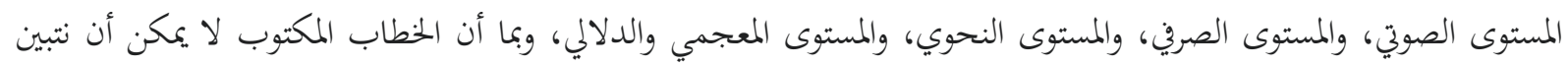

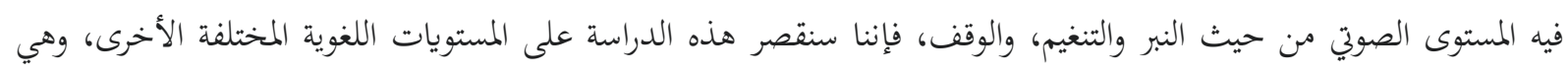

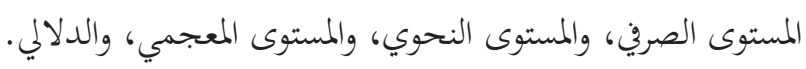


وردت الأفعال في خطاب صاحب الجلالة السلطان قابوس طيب الله ثراه ستة عشر مرة، وقد اعتمد في تسع مرات على

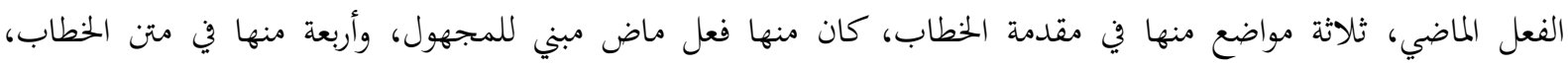

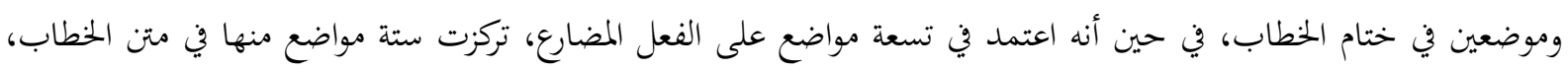

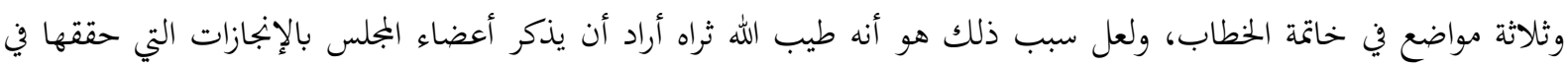
الماضي، ليحث الأعضاء الجلدد على العمل بعزيمة لمواصلة مسيرة النهضة المباركة، والفعل الماضي يدل دلالة واضحة على على الإنجازات التي تمت، فخطبه طيب الله ثراه تخظى باهتمام الجهات السياسية والمؤسسات الإعلامية، فقد كان يطلع شعبه على بعلى بحريات مسيرة التنمية والنهضة التي قادها، وسياسات حكومته داخليا وخارجيا، لذلك يذكر الإنجازات التي تمت في الفترة السابقة، وهي إنجازات قد وضعت في خطط مجلس عمان، ونوقشت، وحققت ثناء من لدن صاحب الجلالة السلطان قابوس طيب الله ثراه.

المستوى النحوي:

إن الجمل النواة الأساسية تصاغ على حد تعبير تشومسكي في جملة تحويلية مشتقة واحدة، عن طريق استخدام أدوات

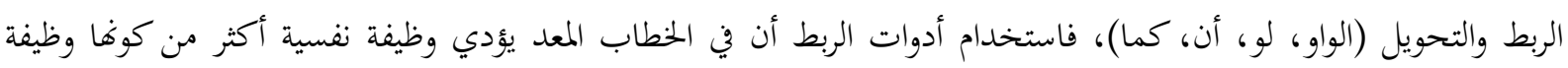

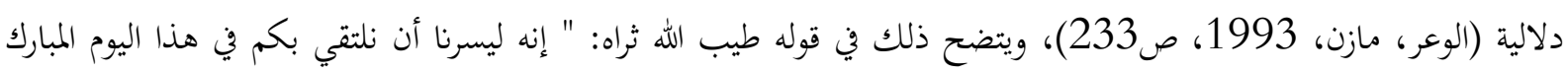

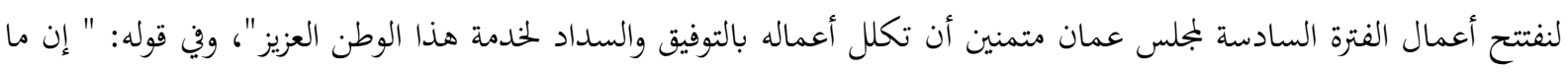

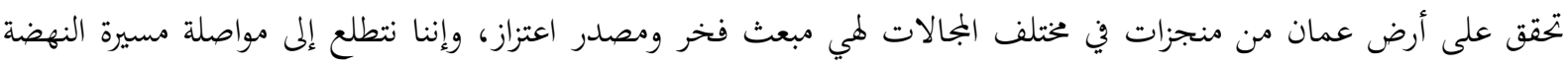

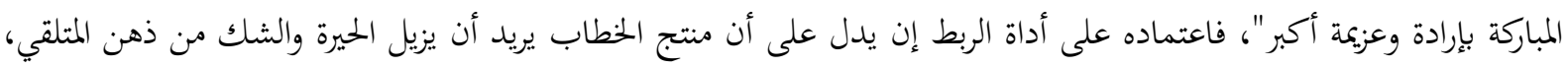

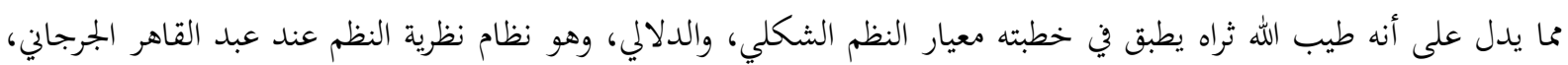
وقد اعتمد في ذلك على مجموعة من الإستراتيجيات اللغوية، أهمها:

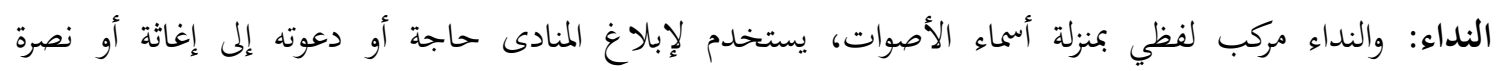

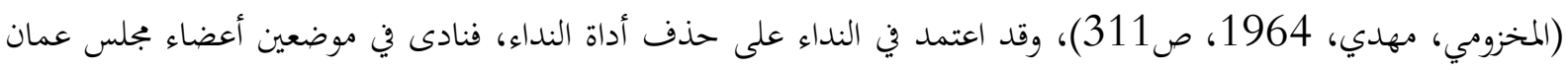

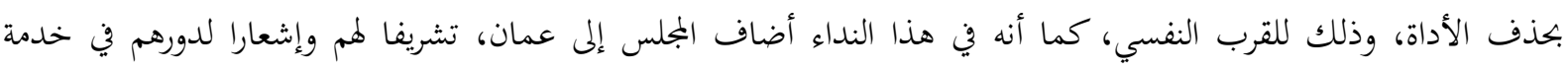

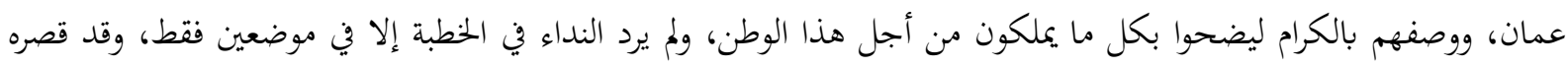

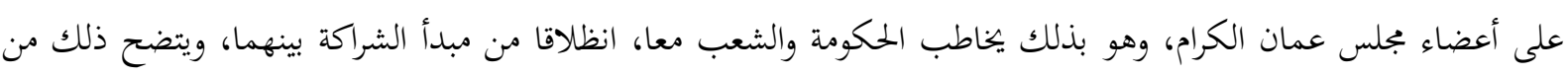

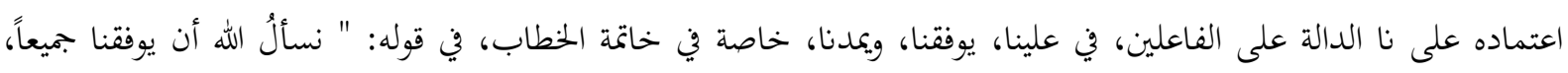

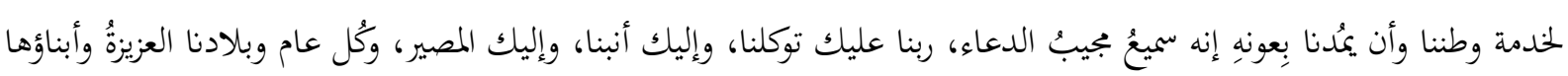
الأوفياء في خير ومسرة".

فقد شارك منتج النص المتلقي في طلب التوفيق من الله، وذلك ليقينه بأن مسيرة التنمية إنما هي شراكة بين الحكومة

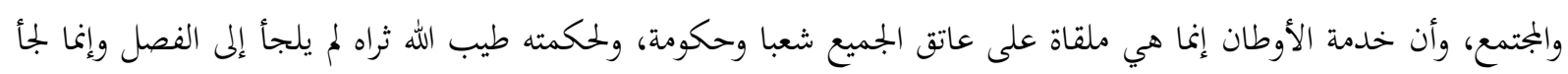

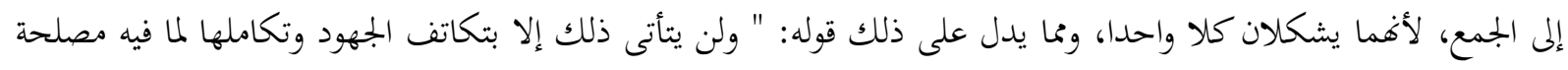

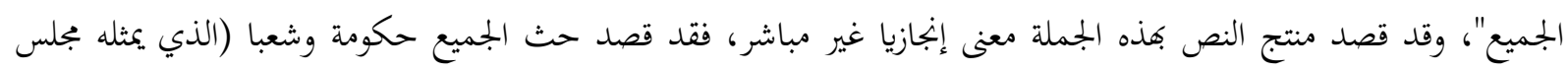

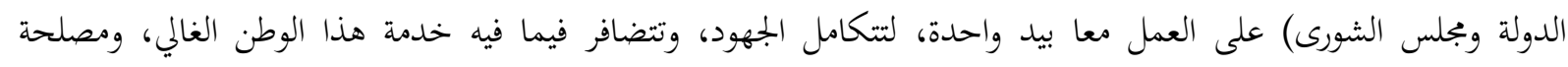

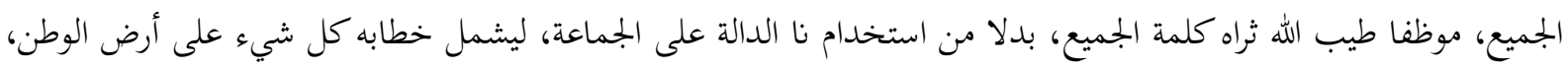
يمكنه الاستفادة من هذه النهضة المباركة. 
ويمكن أن يتضمن هذا الفعل الإنجازي غير المباشر النهي، وهو في عن التشتت والتفرقة، وقد اعتمد في ذلك على أداة

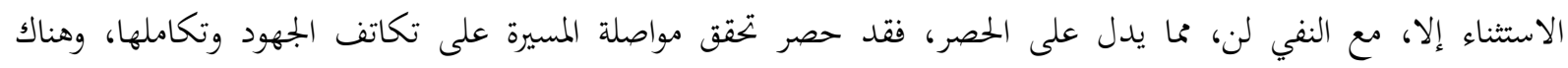

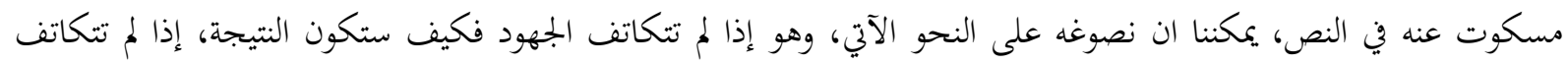
فإن النتيجة ستكون فتفشلوا وتذهب ريكهم.

ولن تتحقق المسيرة كما هو مرسوم لها، لذلك حث على التكاتف مراعيا مصلحة الجميع، ولذلك فقد اعتمد على

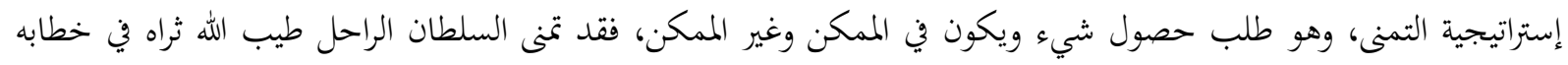

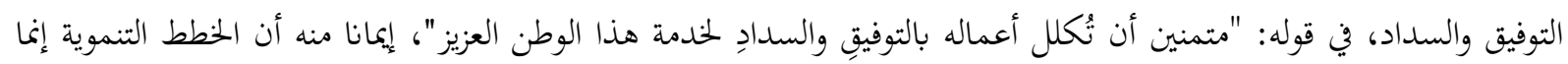
هي خطط مدروسة تحقيق إلى عزيمة المجلس، وتوفيق الحق تبارك وتعالى لتحقيقها، ومما يدل على ذلك: قوله طيب الله ثراه: "وإننا نتطلعُ إلى مواصلة مسيرة النهضة المباركة، بإرادة وعزيمة أكبر".

لعل أهم عنصر نقف عنده في هذا المستوى عنصر الاستبدال، ذلك أن الاستبدال عنصر من عناصر ترابط النص واتساقه،

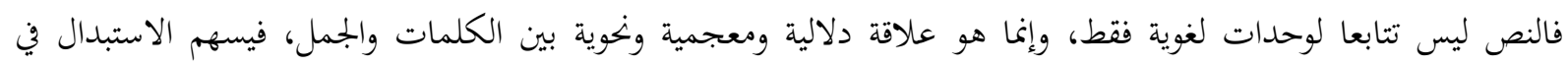

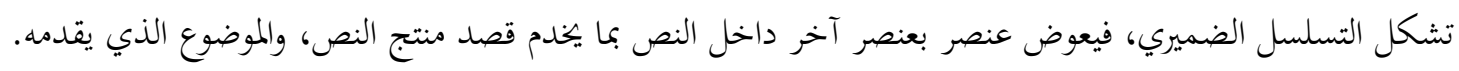
ونلمس ذلك في خطب صاحب الجلالة السلطان قابوس بن سعيد طيب الله ثراه، فكان ينتقي الكلمات التي تخدم موضوعه، وقصده في خطابه، ويتبين ذلك في مواضع عدة في مقدمة خطابه في متن خطابه ويف خاتمة خطابه، من ذلك:

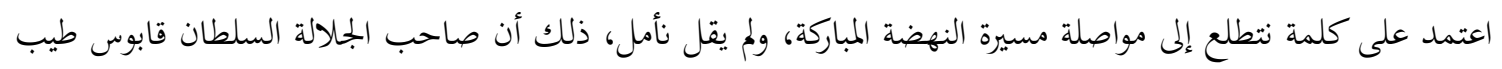

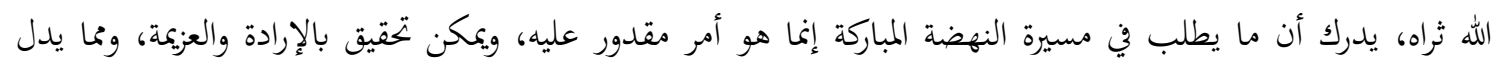

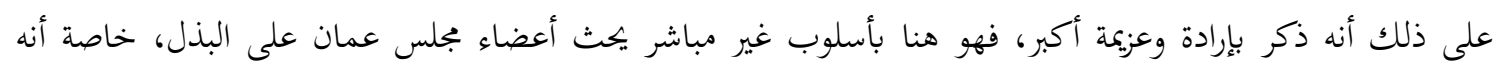

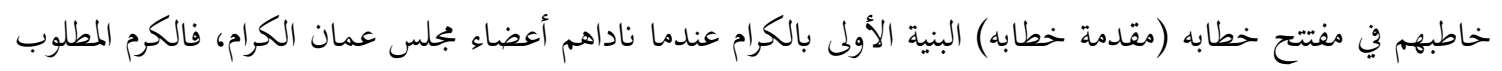
في مجلس عمان هو البذل في سبيل تحقيق الإنجازات المختلفة، وقد أدرك طيب الله ثراه أنه لو اعتمد على على كلمة نأنساء تأمل وكأنه

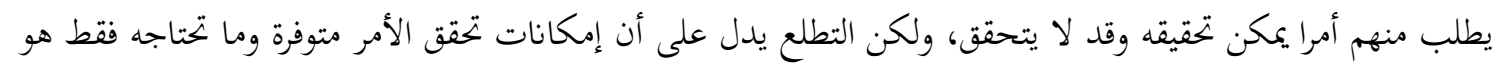
البذل والتضحية. اعتمد على كلمة "تابعنا" في قوله ولقد تابعنا عن كثب أعمال مجلس عمان بشقيه مجلس الشورى وبجلس الدولة، ولم

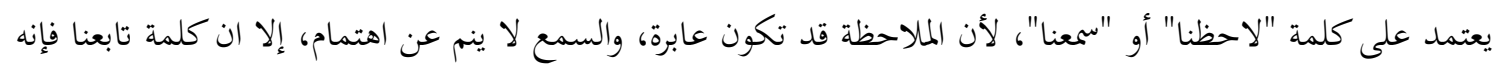
يدل على حرص واهتمام، وهو يدل بصورة غير مباشرة على اهتمام صاحب الجلالة السلطان قابوس طيب الله ثراه، وحرصه على ما يقدم في هذا المجلس الذي يحمل اسم عمان، واهتمامه بالنهضة بلمه المباركة وأنه يتابعها بنفسه.

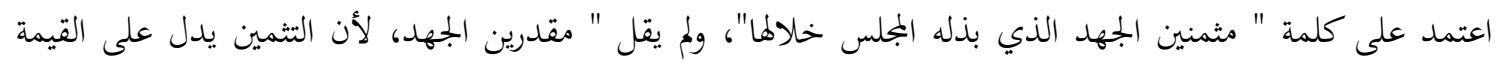

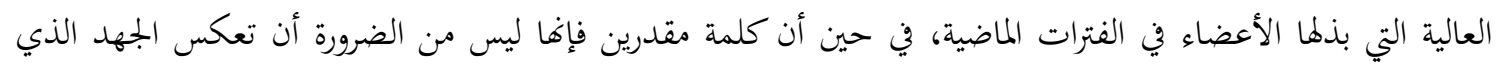

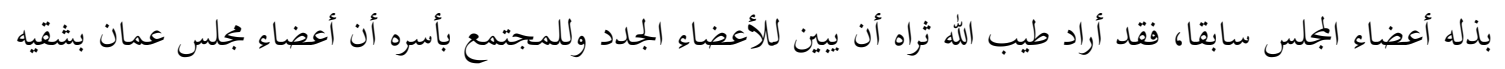

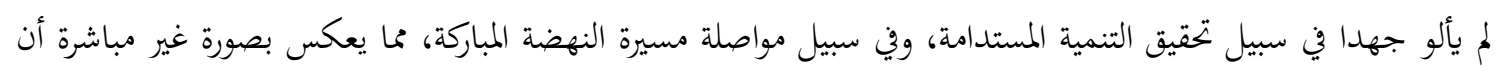

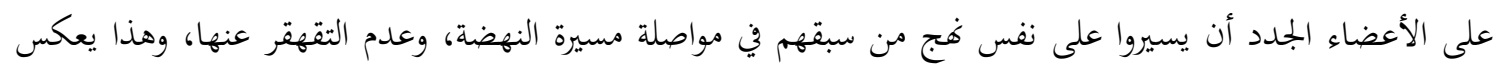

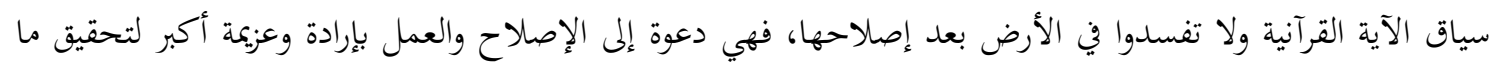
يرجوه طيب الله ثراه، وما يرجوه المجتمع من هذا المجلس. 
بينت هذه الدراسة أن الخطاب السياسي للمقام السامي لحضرة صاحب الجلالة السلطان قابوس بن سعيد طيب الله ثراه

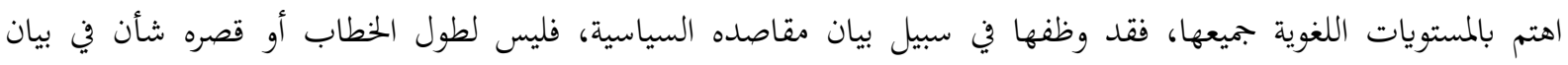

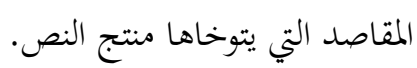

كما بينت هذه الدراسة أن خطاب السلطان الراحل طيب الله ثراه تكون من بنى مترابطة، ومنسجمة في مقاصدها، فراعى في تشكيله المتلقي، والمقام، فكان للسياق اللغوي وغير اللغوي دور في بيان قصد المخاطِب.من إستراتيجيات الخطاب التنموي

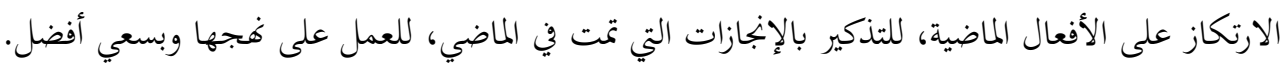




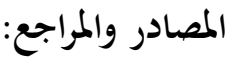

إبراهيه، عبدالله (1993م)، إنكالية المصطلح النقدي (الخطاب والنص) مجلة آفاق العربية.

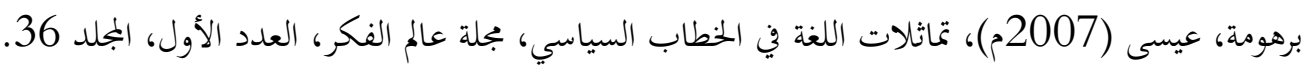

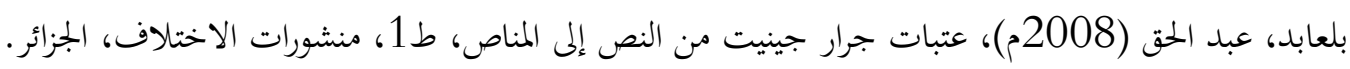

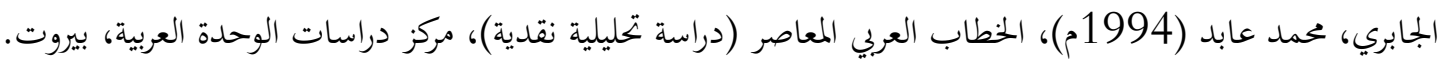
حجازي، محمود فهمي (1998م)، مدخل إلى علم اللغة، دار قباء للطباعة، القاهرة.

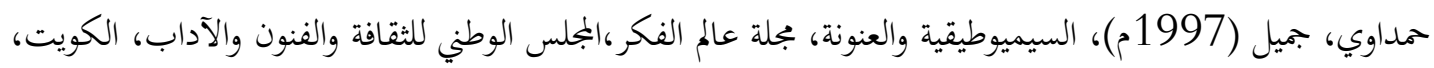
م25، عدد 3.

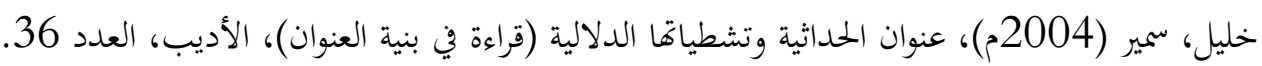

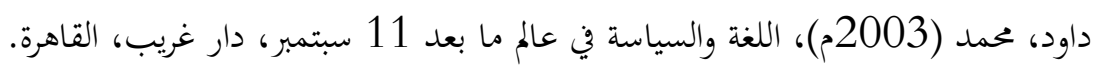

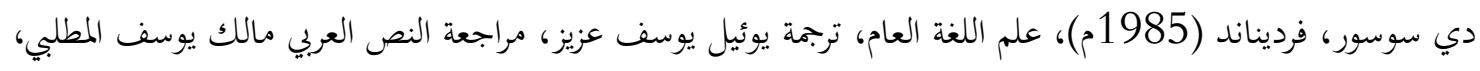
دار آفاق عربية، العراق.

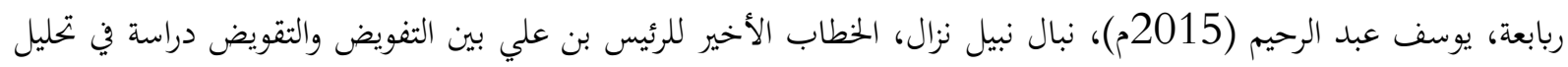

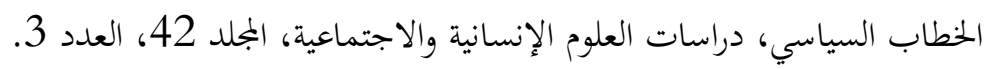

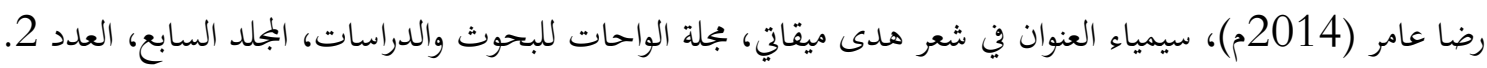
الزين، محمد (2017م)، الحجاج في الخطاب السياسي.

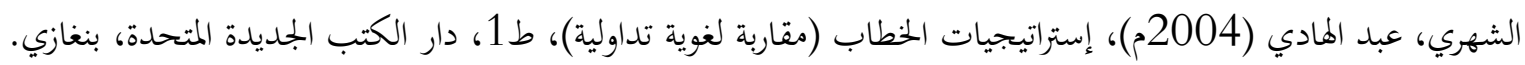

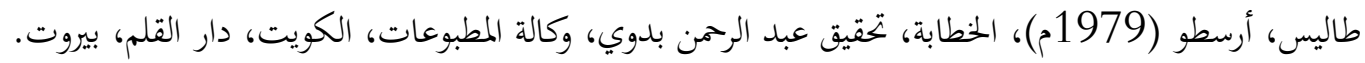

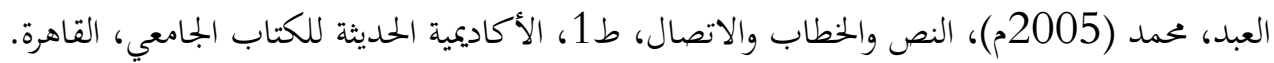

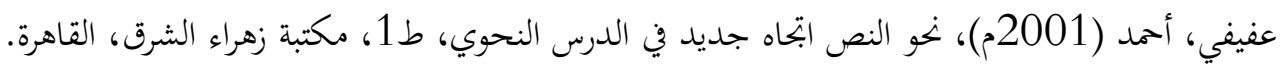

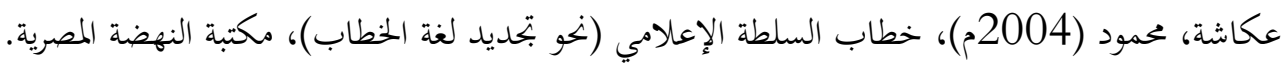

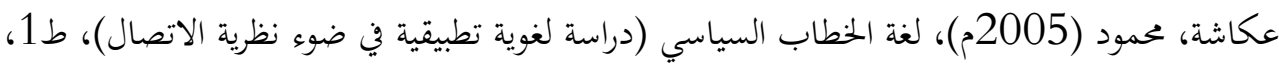
دار النشر للجامعات، مصر.

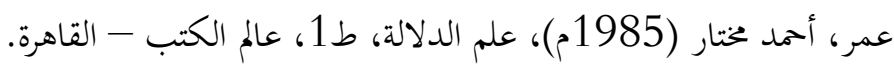

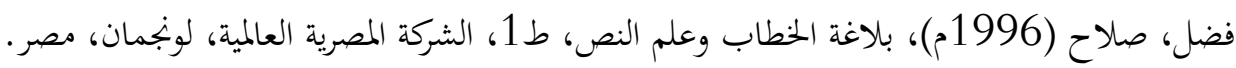
فوكو، ميشيل، نظام الخطاب، ترجمة حممد سبيلا، مطبعة التنوير.

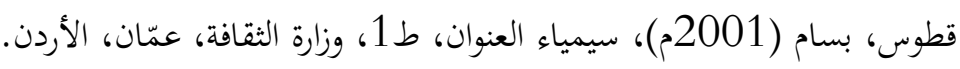

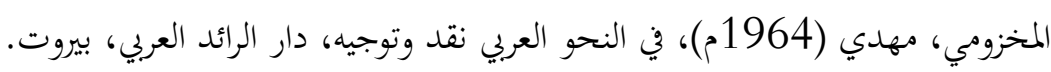

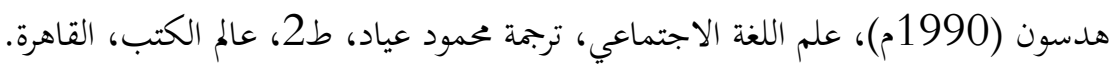

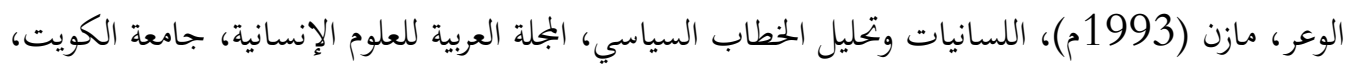

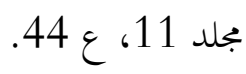
يول، جورج، معرفة اللغة، ترجمة عمود فراج عبد الحافظ، دار الوفاء لدنيا الطباعة والنشر، الإسكندرية. https://www.mol.om/His-Majesty-Speech

https://www.youtube.com/watch?v=rBBPc9uSU5g 


\title{
THE DEGREE OF EFFECTIVENESS OF DISTANCE LEARNING IN LIGHT OF THE OUTBREAK OF THE CORONA VIRUS FROM THE POINT OF VIEW OF STUDENTS IN HIGHER EDUCATION INSTITUTIONS IN BEERSHEBA
}

\author{
Hatem AZBARGA ${ }^{1}$
}

\section{Istanbul / Türkiye \\ p. $268-285$}

Received: $26 / 11 / 2021$

Accepted: $13 / 12 / 2021$

Published: 01/01/2022

This article has been scanned k iThenticat No plagiarism detected

\begin{abstract}
:
The study aims to identify the degree of effectiveness of distance learning in light of Covid-19 outbreak from the point of view of students in higher education institutions in Beersheba. In this study, the researcher used the descriptive approach through a questionnaire that was given to (150) students in higher education institutions in Beersheba. The students were chosen randomly, and the validity of the study tool was verified by presenting it to a group of arbitrators, and its stability was verified, as the value of Cronbach's alpha was (94.4\%), which has a high degree of stability, and appropriate statistical methods were used for: Reaching the results The results were as follows:

1. The degree of effectiveness of distance learning in light of the outbreak of the Corona virus from the point of view of students in higher education institutions in Beersheba region came to a medium degree.

2. The degree of continuity of distance learning in light of the outbreak of the Corona virus from the point of view of students in higher education institutions in Beersheba region came to a medium degree.

3. The degree of e-learning obstacles from the point of view of students in higher education institutions in Beersheba region came to a medium degree.

4. The degree of interaction of faculty members with distance education in light of the Corona crisis from the point of view of students in higher education institutions in Beersheba region came to a medium degree.

5. The degree of students' interaction with distance learning in light of e-learning from the point of view of students in higher education institutions in Beersheba region came to a high degree.

6. There are statistically significant differences in the responses of the study sample members towards the degree of effectiveness of distance learning in light of the outbreak of the Corona virus from the point of view of students in higher education institutions in Beersheba region due to the gender variable, and the differences were in favor of females versus males.

7. There are differences in the average responses of the sample members about the degree of effectiveness of distance learning in
\end{abstract}

http: //dx.doi.org/10.47832/2717-8293.15.20

1 iD) Dr. , Palestine, hatemm10@gmail.com, https://orcid.org/0000-0003-3520-4380 
light of the outbreak of the Corona virus from the point of view of students in higher education institutions in Beersheba region due to the variable of the teaching stage in the college in favor of those studying a teaching certificate versus those studying a first and a second title.

8. There are no differences in the average responses of the sample members about the degree of effectiveness of distance learning in light of the outbreak of the Corona virus from the point of view of students in higher education institutions in Beersheba region due to the variable of the year of study in the college.

Key words: The Effectiveness of Distance Learning, The Corona Virus, Higher Education Institutions.

\section{درجة فاعلية التعلم عن بعد في ظل تفشّي فيروس الكورونا من وجهة نظر طلبة

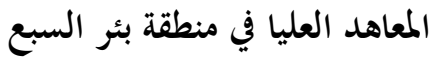

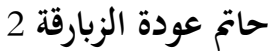

\section{الملخص:}

هدفت لدراسة إلى التعرف على درجة فاعلية التعلم عن بعد في ظل تفشّي فيروس الكورونا من وجهة نظر طلبة

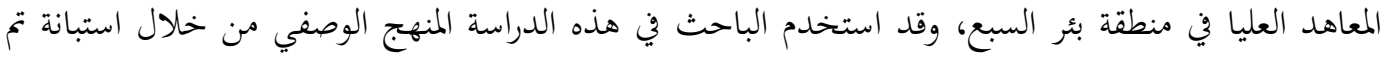

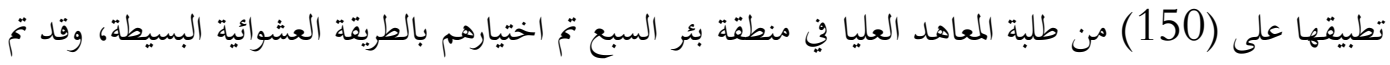

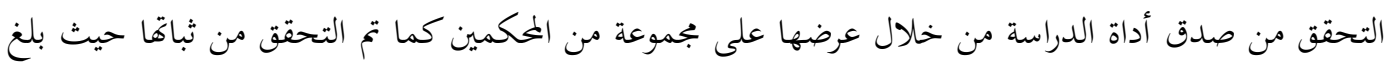

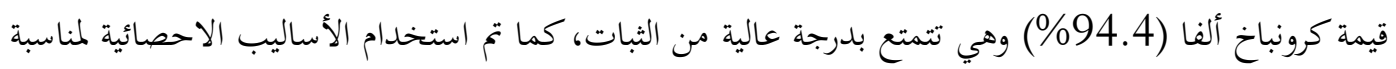
من أجل التوصل إلى النتائج وكانت النتائج على النحو الآتي:

1. أن درجة فاعلية التعلم عن بعد في ظل تفشّي فيروس الكورونا من وجهة نظر طلبة المعاهد العليا في منطقة بئر

$$
\text { السبع جاءت بدرجة متوسطة }
$$

2. أن درجة استمرارية التعلم عن بعد في ظل تفشّي فيروس كورونا من وجهة نظر طلبة المعاهد العليا في منطقة

$$
\text { بئر السبع جاءت بدرجة متوسطة }
$$

3. أن درجة معيقات التعليم الإلكتروني من وجهة نظر طلبة المعاهد العليا في منطقة بئر السبع جاءت بدرجة بلدة

4. أن درجة تفاعل أعضاء هيئة التدريس مع التعليم عن بعد في ظل ازمة كورونا من وجهة نظر طلبة المعاهد

$$
\text { العليا في منطقة بئر السبع جاءت بدرجة متوسطة }
$$

5. أن درجة تفاعل الطلبة مع التعلم عن بعد في ظل التعليم الإلكتروين من وجهة نظر طلبة المعاهد العليا في

$$
\text { منطقة بئر السبع جاءت بدرجة مرتفعة }
$$


6. توجد فروق ذات دلالة إحصائيّة في استجابات أفراد عيّنة الدّراسة نحو درجة فاعلية التعلم عن بعد في ظل

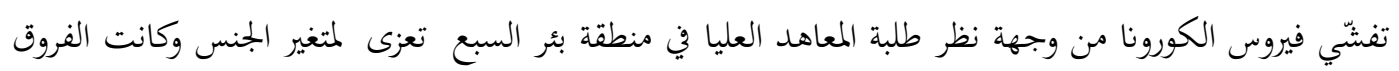
لصالح الإناث مقابل الذكور 7. توجد فروق في متوسطات استجابات أفراد العينة حول درجة فاعلية التعلم عن بعد في ظل تفشّي فيروس

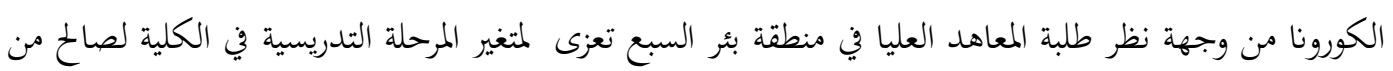
يدرسون شهادة التدريس مقابل من يدرسون لقب أول ولقب ثاني

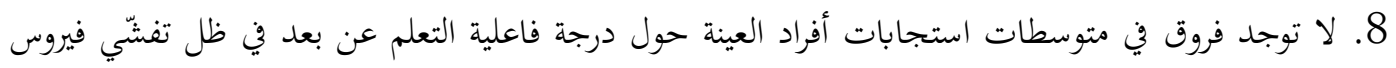
الكورونا من وجهة نظر طلبة المعاهد العليا في منطقة بئر السبع تعزى لمتغير السنة الدراسة في الكلية. الكلمات المفتاحية: فاعلية التعلم عن بعد، فيروس الكورونا، المعاهد العليا. 
ما درجة فاعلية التعلم عن بعد في ظل تفشّي فيروس الكورونا من وجهة نظر طلبة المعاهد العليا في منطقة بئر السبع؟

أهمية البحث:

تظهر أهمية الدراسة من خلال إظهار أهمية التعليم عن بعد في ظل أزمة كورنا، كما أن التعليم عن بعد من أهم الوسائل

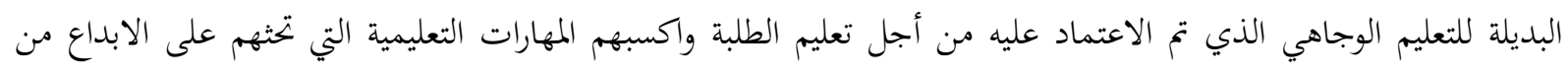

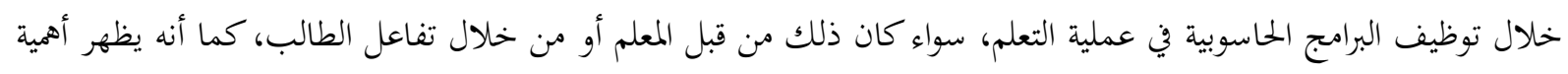

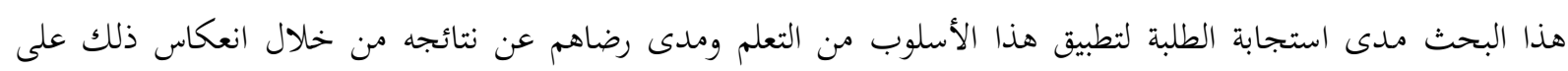

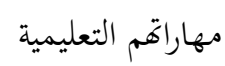

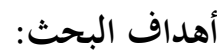

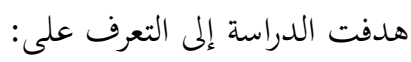

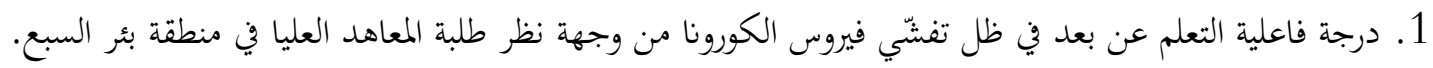

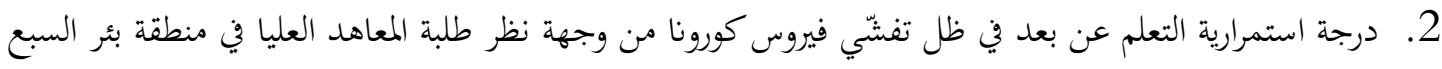

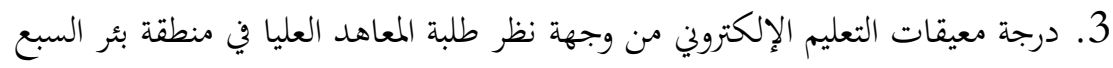
4. درجة تفاعل أعضاء هيئة التدريس مع التعليم عن بعد في ظل ازمة كورونا من وجهة نظر طلبة المبات المعاهد العليا في منطقة بئر

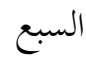

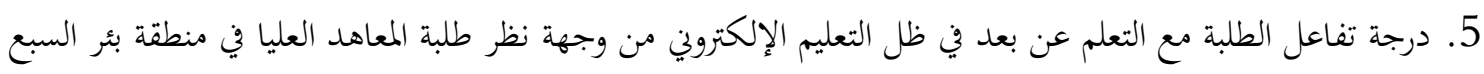

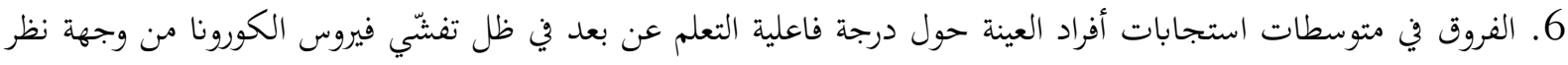

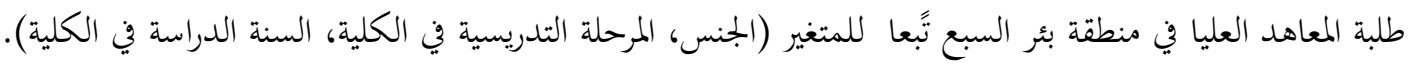

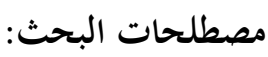
- التعليم عن بعد: هو ذلك النوع من التعليم الذي يعتمد على استخدام الوسائط الإلكترونية في تحقيق الأهداف التعليمية

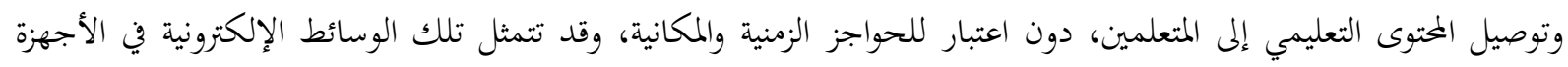

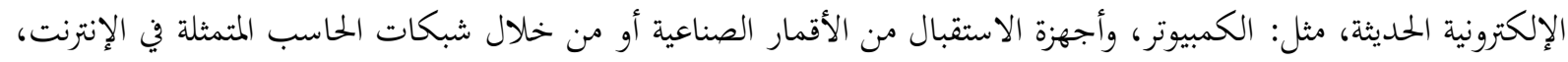

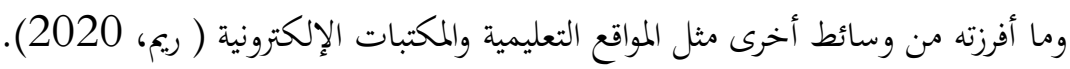

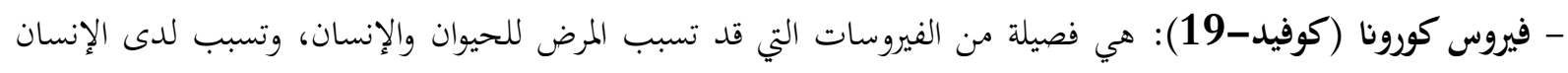

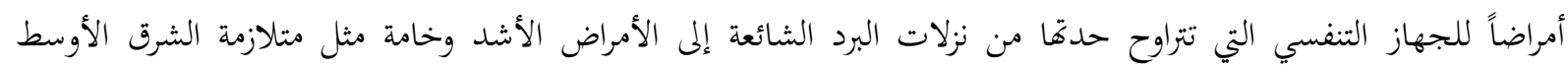

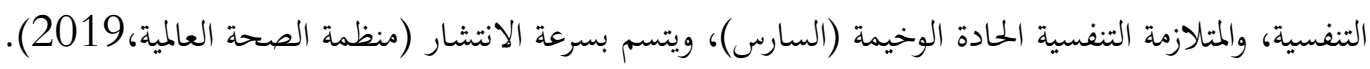

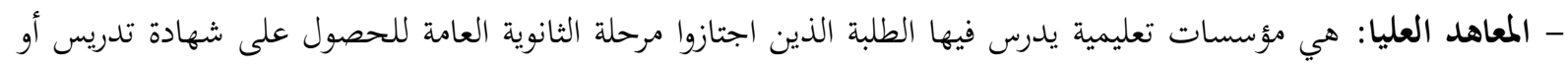
لقب أول أو لقب ثاني. 


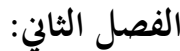

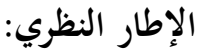

المبحث الأول: التعليم عن بعد

وقد يرى بعض المعلمين أن التعليم عن بعد سيعمل على إلغاء دور المعلم في العملية التعليمية، والحقيقة أن التعليم عن بعد زاد من أهمية التعليم، وجعل دوره أكثر أهمية وأكثر صعوبة، فالمعلم في التعليم عن بعد هو شخص مبدع ذبع ذو كفاءة عالية، ويدير

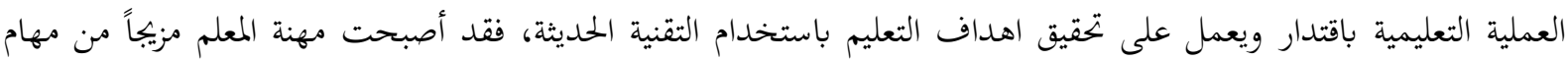

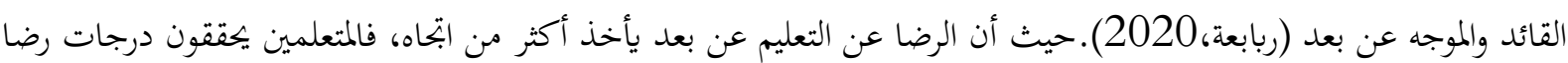

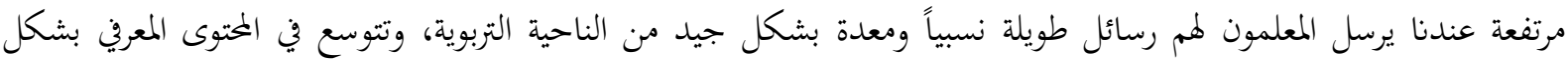

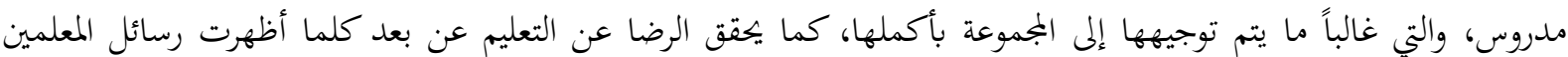

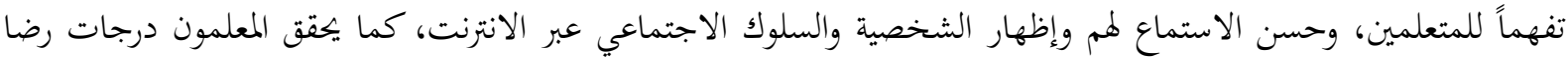

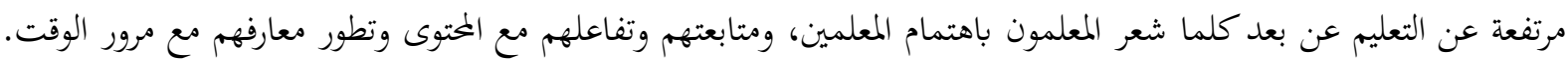
( قرعان، 2021).

ويرى (2020،Yulia) أن التعليم عن بعد سيكون نمط التعليم في المستقبل لأنه يسجم مع طبية الطلبة في هذا العصر،

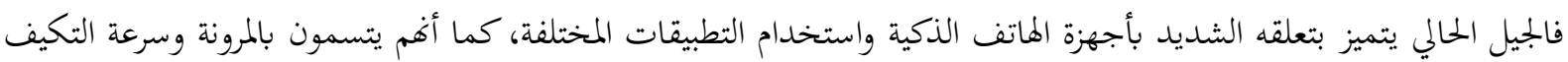

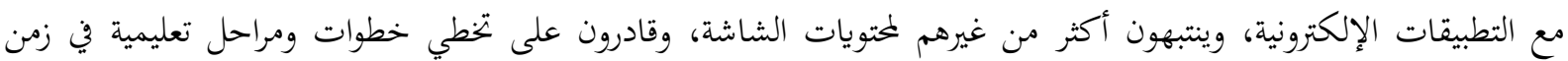
قياسي، ويستطيعون تداول معارف مكثفة خلال تفاعلهم مع التطبيقات الإلكترونية. وعرفه (العتببي، 2019) بأنه توظيف تكنولوجيا الاتصال بواسطة الانترنت في التعاليم، فهو نظام تعليمي يساعد على توصيل المعلومات إلى مكان تواجد المتعلم. ويعرف (2018،Berg \& Simonson ) بأهما منظومة تفاعلية ترتبط بالعملية التعليمية التعلمية، وتقوم هذه المنظومة بالاعتماد على وجود بيئة إلكترونية رقمية تعرض للطالب المقررات والأنشطة بواسطة الشبكات الالكترونية والأجهزة الذكية.

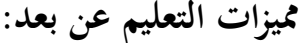

- عدم حصر الطلاب باختيار جامعة في منطقة جغرافية معينة، وبذلك تزداد اختيارات البرامج الدراسية أمام الطالب. - زيادة إمكانية الاتصال بين الطلبة فيما بينهم وبين المعلمين والمدرسة، من خلال بجالس النقاش وغرف الحوار على سبيل المثال.

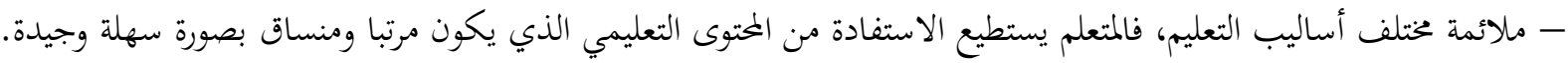
- توفير فرصة أكبر للطلاب غير القادرين كذوي الاحتياجات الخاصة من التعلم في جامعات مرموقة.

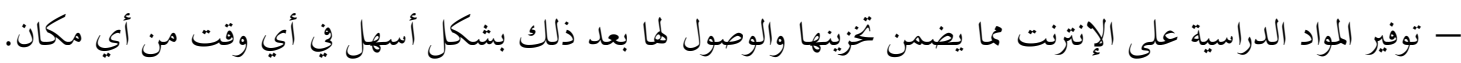
- توفير فرصة أكبر للطلاب للعمل بالسرعة التي يفضلوها.

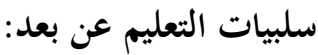

1. عياب القدوة والتأثر بالمعلم في هذا النوع من التعليم. 2. لا يمكن هذا النوع من التعليم من اكتشاف المواهب والقدرات لدى لئ المتعلمين. 3. لا ينمي القدرة اللفظية لدى المتعلم. 


$$
\begin{aligned}
& \text { 4. قد يتسرب للمتعلم الملل من طول الجلوس أمام الأجهزة. } \\
& \text { 5. التعلم عن بعد يضعف العلاقات الاجتماعية لدى المتعلم. } \\
& \text { 6. غياب الجانب الانساني في العملية التعليمية لغيابه في الآلة. } \\
& \text { 7. يؤثر التعليم عن بعد على الناحية الصحية لدى المتعلم. }
\end{aligned}
$$

8. تتطلب هذا النمط من التعليم من الطالب الدراية الكافية باستخدام التكنولوجيا وكيفية الاستفادة من المادة التعليمية. 9. غياب فرصة التواصل الجيد مع الاساتذة للإجابة عن استفساراتم حول ما يدرسوه ( محمد، 2020).

معيقات التعليم عن بعد:

أثبت التجربة أن بعض المعلمين والأهالي والطلبة غير مهيئين لتعليم عن بعد، وأبرزت المتابعة بشأن الحصص عبر برامج

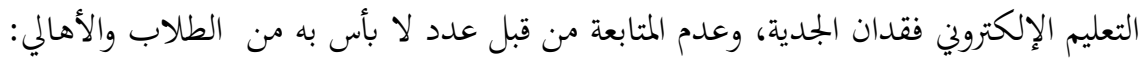
الطلبة: شعر الطلاب بعدم كفاءة التعلم عن بعد، فقد تفاوتت درجة جديتهم من طالب إلى آخر، ويرون أن العبء الدراسي قد تضاعف، وأفم يعانون من ضغط نفسي كبير لأفم لا يعرفون ماذا يفعلون، وكيف يدرسون، بالإضافة إلى الضغط

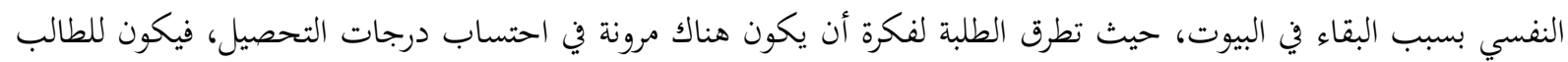

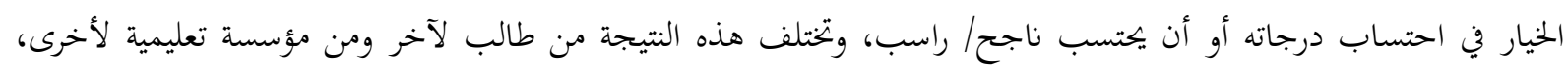

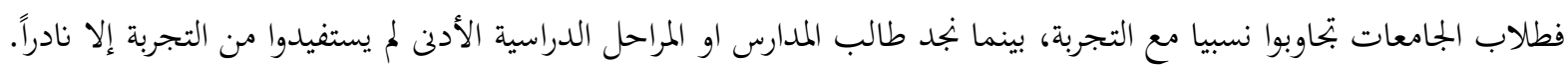
الأهالي: لم يعتادوا هذا الكم أو النوع من التعلم الذاتي داخل البيت، مع صفوف ومراحل تعليمية مختلفة، وتقع على عاتق والوالدين عبئ التعليم والمراقبة والمواكبة لتعلم الأبناء، خاصة في الصفوف الأولى، بالإضافة لشبكات الإنترنت التي لا تستوعب هذا

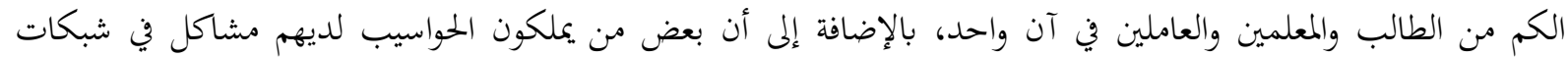

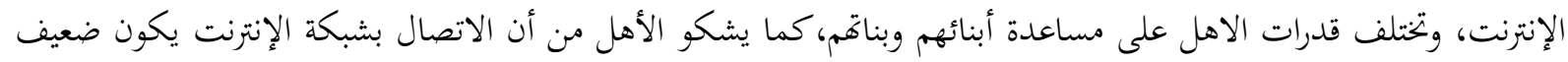

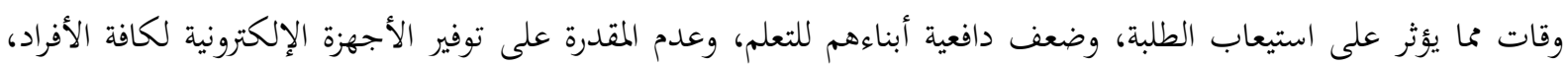

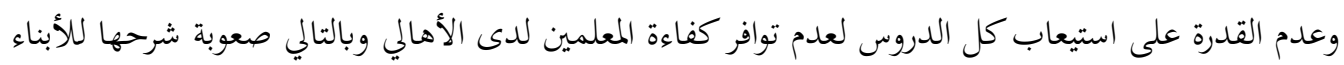
المعلمين: يختلف دور المعلم في التعليم التقليدي عن دوره بالتعليم الإلكتروني، فيتطلب منه التعامل مع الوسائل التكنولوجية الحديثة ليتمكن من توظيفها بشكل جيد في العملية التعليمية، ويتطلب منه اتباع استراتيجيات تعليمية تناسب بيئة التعليم الإلكتروني منها: التعلم التعاوني، والنقاش، والتعلم التشاركي، والمحاضرة الإلكترونية، والعروض العلمية لبرجيات الوسائط المتعددة،

$$
\text { التعلم بمحاكاة لعب الأدوار بالويب (جريد، 2020) }
$$

مبررات التعليم عن بعد:

إن تعالي الأصوات التي تطالب بالتعليم عن بعد له مبررات منها أورده الشرهان (2014) كما يلي: - التوجيهات العالمية وتوصيات المنظمات المختصة بالتعليم: فقد طالبت الكثير من المنظمات العالمية المختصة بالتعلم على

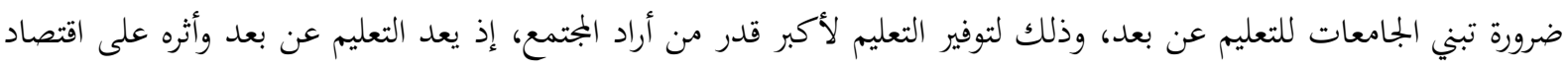

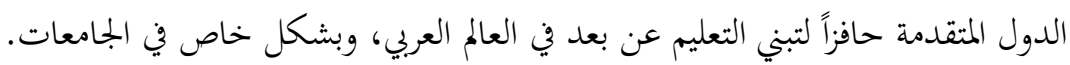
- مبررات اجتماعية وثقافية: إن التعليم عن بعد يتيح فرصة التعليم لمن لم يحالفهم الحظ في الالتحاق بالجامعة نتيجة لبعض التقاليد والظروف الاجتماعية، ففي التعليم عن بعد يستطيع العامل والأم الحامل وربة البيت والسجين من مواصلة التعليم. 
- مبررات بشرية وجغرافية: يتيح التعليم عن بعد التحاق طالب في قرية فقيرة في البادية من الالتحاق بجامعة في الولايات المتحدة

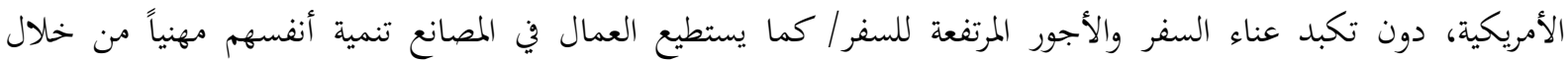
الالتحاق بدورات تدريبية عن بعد.

- مبررات إنسانية ونفسية: إن التعليم عن بعد يحقق غاية سامية، إذ يوفر فرصة التعليم لمن حرم منها، ويحقق التعليم للجميع، وهو مرن يستطيع تحقيق رغبات المتعلمين المتنوعة، ويمكن أن يسترجعه المتعلم ويحفظه بسهولة. - مبررات اقتصادية: فالتعليم عن بعد اقتصادي وغير مكلف، فالتكاليف التواصل مجانية في بعض الدول، كما أنه لا يتطلب شراء مواد دراسية، ويمكن حفظه واسترجاعه بسهولة ويسر. - مبررات سياسية: ويمكن الاحساس بهذا المبرر خلال جائحة كورونا، فالتعليم عن بعد قد يكون الخيار الوحيد لاستمرار التعلم في الحروب والصراعات، والظروف الطارئة مثل انتشار الأوبئة والكوارث الطبيعية.

\section{الحلول التي يمكن استخدامها للتغلب على المعيقات التي يمكن أن توجه التعليم ما بعد كورونا} 1. التوسع في التعليم عن بعد وتكنولوجيا المعلومات، والتوسع في استخدام المنصات التي يمكن تقديم الدروس من خلالها، والتوسع في مكينة الامتحانات من خلال التوسع في انشاء بنوك للأسئلة وتطبيق التصحيح الآلي والعمل على ربط المؤسسات التعليمية المدارس والجامعات بشبكة اتصالات موحدة.

2. تطوير البنية التحتية والتكنولوجية وهو ما يطلب ضرورة تحديث البنية التحتية بالمؤسسات خاصة في المناطق الفقيرة حتى يمكنهم الحصول على الحخدمات المقدمة عن طريق التعليم عن بعد، وتوفير اللازم لاستكمال تغطية المحافظات بكابلات الالياف الضوئية

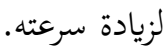

3. توفير مزيد من الاجراءات الاحتزازية الصحية وتوعية الافراد بأهمية وضرورة الالتزام بها، ولعل ذلك يتطلب ان تقوم الاجهزة

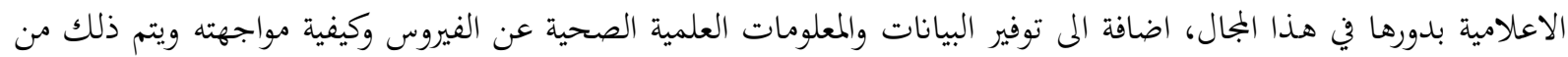
خلال تضمين تلك المعلومات في المقررات والانشطة في المراحل التعليمية المختلفة. 4. سرعة عقد الدورات التدريبية لأعضاء هيئة التدريس بالمدارس والجامعات لإدارة المناهج الدراسية وفقا للصيغة التي سوف تتبناها كل دولة سواء كانت تعليم عن بعد أو تعليم نختلط، والتوجه نهو تدريب المعلمين على استخدام التكنولوجيا الحديثة في التعليم.

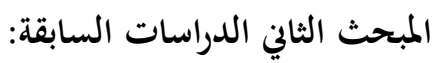

هدفت دراسة قنبي وآخرون (2020) إلى التعرف على واقع التعليم الإلكتروني في فلسطين خال جائحة كورونا (COVID 19)

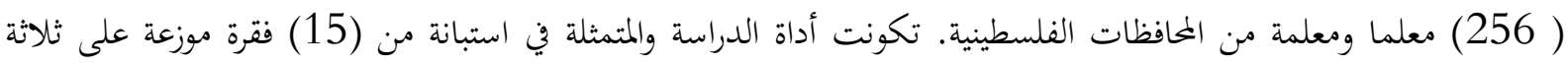
مجالات هي: مجال "المنهاج الفلسطيني"، وبجال "المعلم الفلسطيني والتدريب الإلكتروني"، وبجال "البنية التقنية الفلسطينية والعلاقة

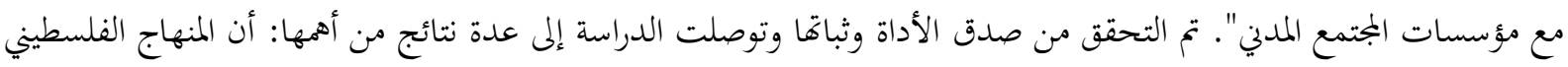

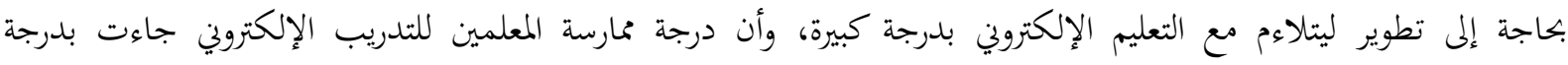

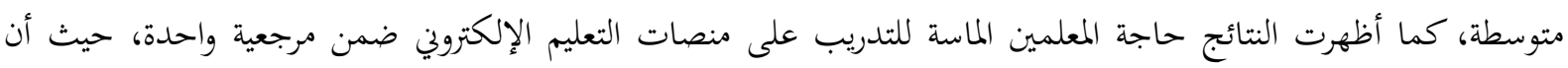

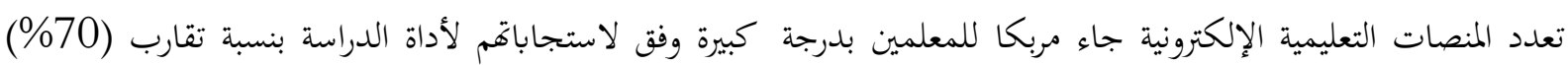

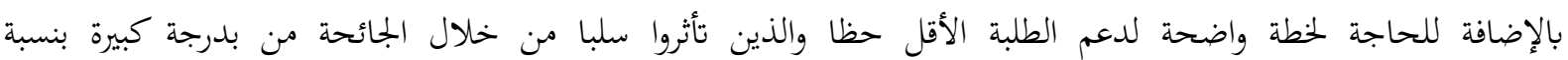


(69.5\%) من المستجيبين لأداة الدراسة. كما أشارت النسب المئوية لنتائج الدراسة أن جهوزية البنية التقنية الفلسطينية تراوحت بين القليلة والمتوسطة ـوفي ضوء هذه النتائج توصي الدراسة بضرورة تطوير المنهاج الفلسطيني من خلال تصميم المحتوى التعليمي

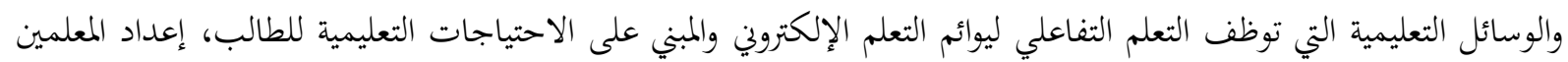

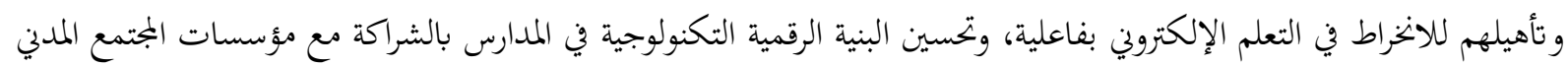
وكافة أطراف الدعم والتمويل المجتمعي والوطني .

وهدفت دراسة ريم (2020) إلى الكشف عن التحديات التي واجهت الأسر السعودية في تعليم أبنائها، واستخلاص

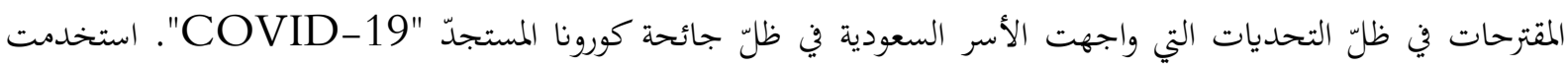
الباحثة المنهج الوصفي المسحي لمناسبته لأهداف الدراسة، وتضمَّن مجتمع البحث الحالي جميع الآباء والأمهات الذين لديهم طلاب أو طالبات بمراحل التعليم العام خلال العام الدراسي. أمّا عينة البحث فقد التهن التملت على (412) فردًا تم اختيارهم

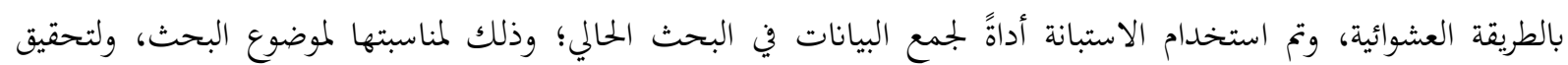

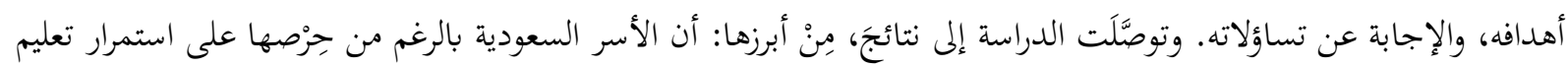

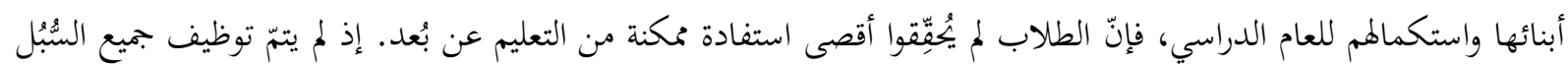

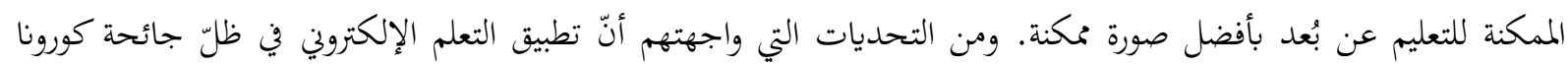

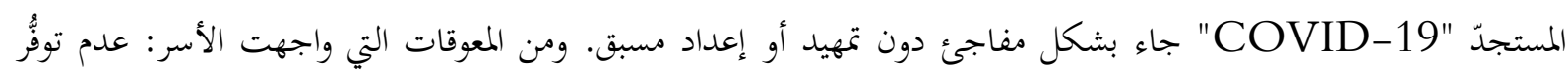

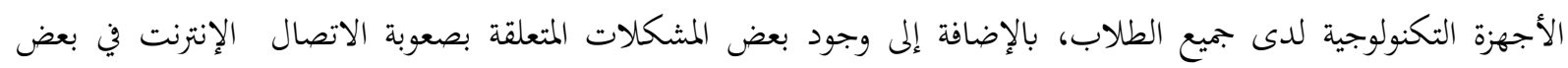
المناطق، وكذلك وجود بعض العوامل المتعلقة بقصور توظيف المعلمين لمهارات استخدام التقنيات الحديثة في التعليم، وأيضًا التكلفة

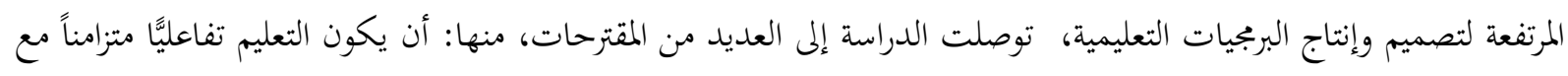

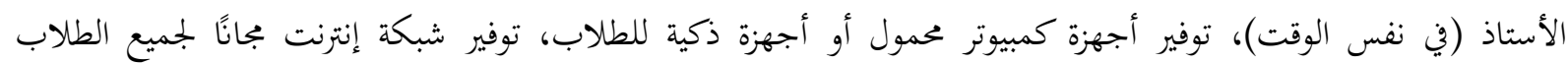

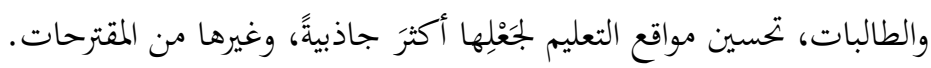
وأجرى ربابعة (2020) دراسة هدفت إلى الكشف عن الدور الذي يؤديه التعليم عن بعد في تنمية التعلم الذاتي لدى طلبة جامعة الزرقاء الخاصة في ظل انتشار فيروس كورونا من وجهة نظرهم، وتكونت عينة الدراسة من (138) طالباً من طلبة

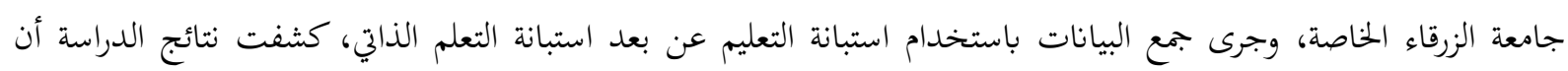

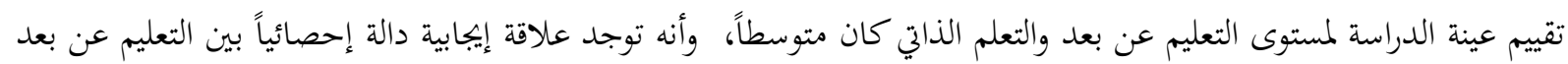

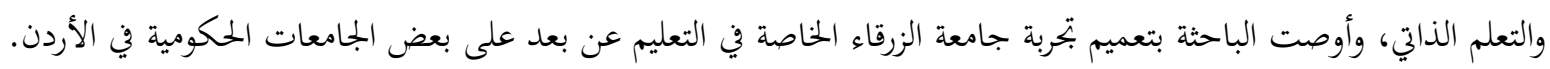

\section{دراسة العتبي (2019): معايير الجودة في أنظمة التعليم الإلكتروبي}

ومن خلال بحث أجراه العتبي (2019) سعى إلى التعرف على مفهوم الجودة ومبادئها، وتسليط الضوء على أهمية

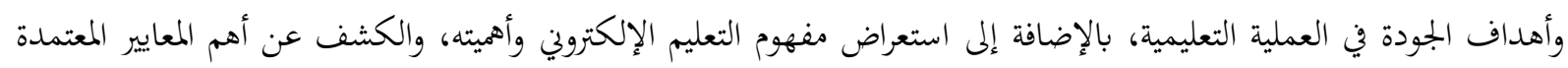

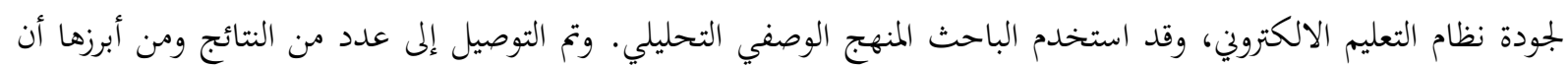

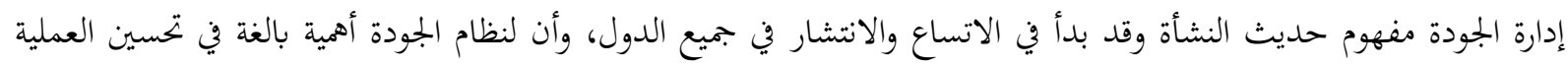

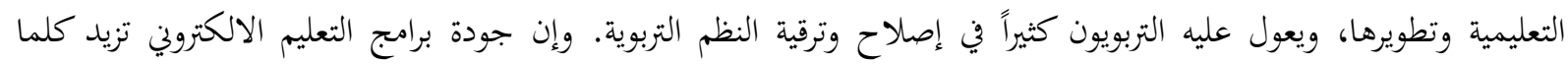

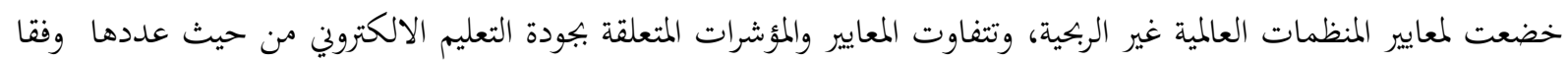
لتنوع الدراسات والمؤسسات التي تناولت هذه المعايير. 
دراسة (19)،Basilaia \& Kvavadze، 2020، ) الانتقال إلى التعليم عبر الإنترنت في المدارس أثناء جائحة فيروس كورونا COVID-19 في جورجيا.

هدفت إلى دراسة بحربة الانتقال من التعليم في المدراس إلى التعليم عن بعد خلال انتار وباء فيروس كورونا في جورجيا، فقد

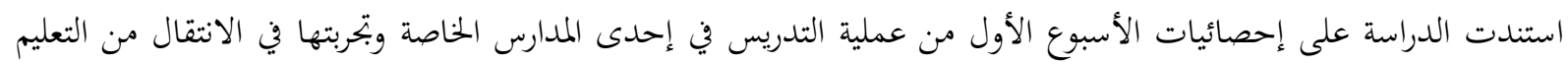

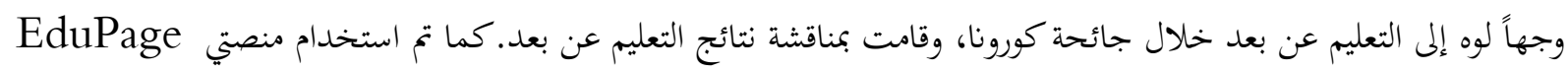

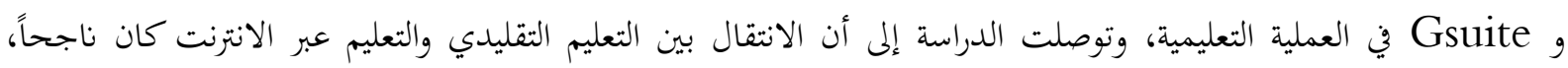

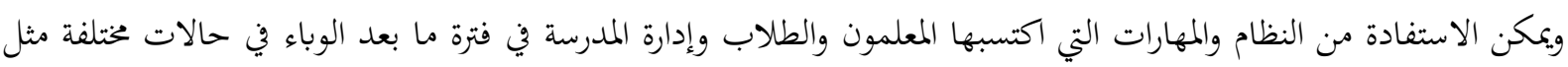

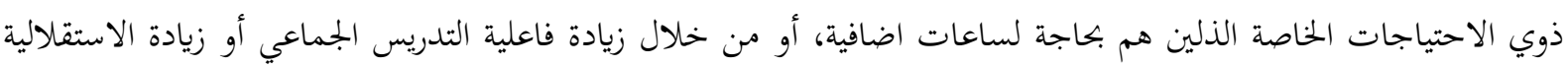

$$
\text { لدى الطالب والحصول على مهارات جديدة. }
$$

دراسة (COVID-19) (2020،Draissi \& Yong) خطة الاستجابة لتفشي مرض الجامعات المغربية وتنفيذ

التعليم عن بعد

وهدفت إلى التعرف إلى خطة الاستجابة لتفشي مرض (COVID-19) في الجامعات المغربية وتنفيذ التعليم عن بعدا،

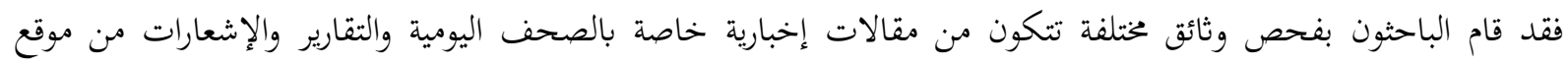

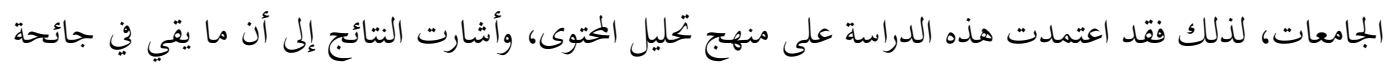

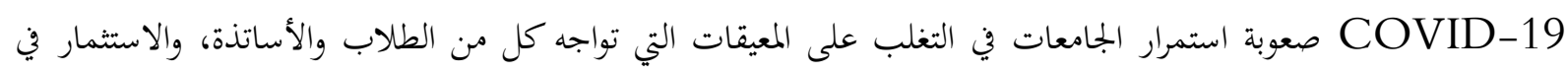

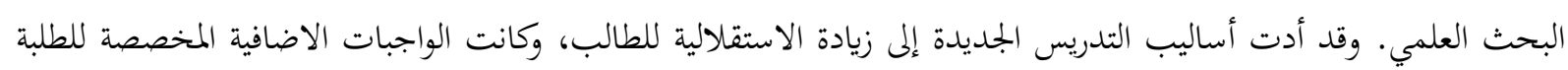

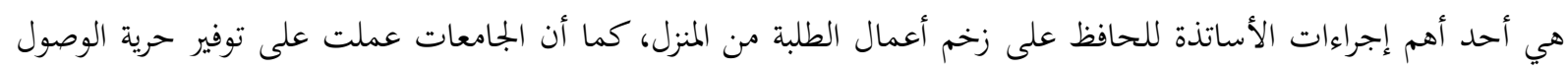

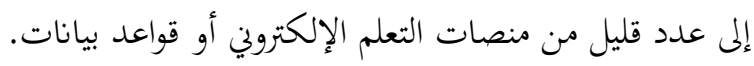




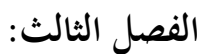

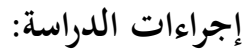

منهجية البحث: استخدم الباحث في هذه الدراسة المنهج الوصفي الذي يعتمد على دراسة الظاهرة في الوقت الحاضر وكما هي في الواقع، وهو المنهج المناسب والأفضل لمثل هذه الدراسات. مجتمع البحث: يتكون مجتمع الدراسة من طلبة المعاهد العليا في منطقة بئر السبع. عينة البحث: تتكون العينة من 150 من طلبة المعاهد العليا في منطقة بئر السبع، وقد تم اختيارهم بالطريقة العشوائية، والجدول رقم (1) يبين خصائص العينة الديموغرافية: جدول (1): خصائص العينة الديموغرافية

\begin{tabular}{|c|c|c|c|}
\hline النسبة & العدد & مستويات المتغير & المتغير \\
\hline 15.3 & 23 & ذكر & \multirow{2}{*}{ الجنس } \\
\hline 84.7 & 127 & انثى & \\
\hline 61.3 & 92 & لقب أول & \multirow{3}{*}{ المرحلة التدريسية في } \\
\hline 8.0 & 12 & لقب ثاني & \\
\hline 30.7 & 46 & شهادة تدريس & \\
\hline 58.0 & 87 & أولى & \multirow{4}{*}{ السنة الدراسية في } \\
\hline 6.0 & 9 & ثانية & \\
\hline 16.7 & 25 & ثالثة & \\
\hline 19.3 & 29 & رابعة & \\
\hline
\end{tabular}

أداة البحث: تم بناء أداة الدراسة على شكل استبانة من خلال الاستفادة من الدراسات السابقة، وقد كانت الاستبانة مكونة من (37) فقرة تشترك جميعها في قياس درجة فاعلية التعلم عن بعد في ظل تفشّي فيروس الكورونا من وجهة نظر طلبة المعاهد العليا في منطقة بئر السبع.

وقد تم تقسيمها إلى أربعة محاور: وهي: استمرارية التعلم عن بعد في ظل تفشّي فيروس كورونا، ومعيقات التعليم الإلكتروين من وجهة نظر الطلبة، وتفاعل أعضاء هيئة التدريس مع التعليم عن بعد في ظل ازمة كورونا من وجهة نظر الطلبة، وتفاعل الطلبة مع التعلم عن بعد في ظل التعليم الإلكتروني وبعد عرضها وإجراء التعديلات اللازمة من إضافة وحذف تم اعته اعتمادها بصيغتها النهائية بناء على طلب المحكمين.

صدق أداة البحث (صدق البناء): تم التحقق من صدق أداة الدراسة بعرضها على مجموعة من المحكمين من ذوي الاختصاص،

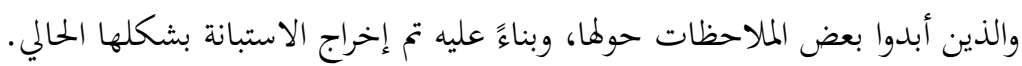
ثبات أداة البحث: تم حساب الثبات بطريقة الاتساق الداخلي وبحساب معادلة الثبات كرونباخ ألفا، حيث بلغت قيمة الثبات (0.944) وبذلك تتمتع الاستبانة بدرجة جيد جداً من الثبات. 


\begin{tabular}{|c|c|}
\hline الدرجة & المتوسط الحسابي \\
\hline منخفضة & $2.33-1.00$ \\
\hline متوسطة & $3.67-2.34$ \\
\hline مرتفعة & $5.00-3.68$ \\
\hline
\end{tabular}

متغيرات البحث:

المتغير التابع: درجة فاعلية التعلم عن بعد في ظل تفشّي فيروس الكورونا من وجهة نظر طلبة المعاهد العليا في منطقة بئر السبع. المتغيرات التصنيفية: الجنس، المرحلة التدريسية في الكلية، السنة الدراسة في الكلية.

الفصل الرابع: النتائج والاستنتاجات والتوصيات نتائج السؤال الرئيس: ما درجة فاعلية التعلم عن بعد في ظل تفشّي فيروس الكورونا من وجهة نظر طلبة المعاهد العليا في منطقة بئر السبع؟ للإجابة عن السؤال السابق تم استخراج المتوسطات الحسابية والانحرافات المعيارية لقياس درجة فاعلية التعلم عن بعد في

ظل تفشّي فيروس الكورونا من وجهة نظر طلبة المعاهد العليا في منطقة بئر السبع، وذلك كما هو موضح في الجدول رقم (2). جدول (2): المتوسطات الحسابية الاخرافات المعيارية لدرجة فاعلية التعلم عن بعد في ظل تفشّي فيروس الكورونا من وجهة نظر طلبة المعاهد العليا في منطقة بئر السبع

\begin{tabular}{|c|c|c|c|}
\hline 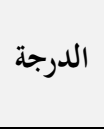 & 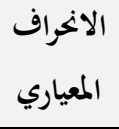 & المتوسط & 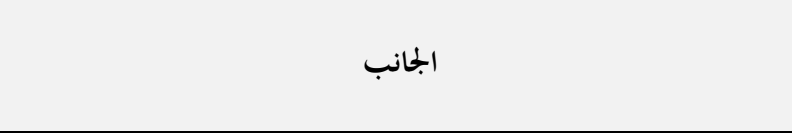 \\
\hline 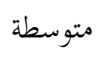 & 0.87 & 3.56 & المجال الأول: استمرارية التعلم عن بعد في ظل تفشّي فيروس كورونا. \\
\hline 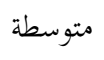 & 0.52 & 3.23 & المجال الثاني: معيقات التعليم الإلكتروني من وجهة نظر الطلبة . \\
\hline 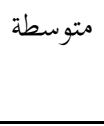 & 0.78 & 3.53 & المجال الثالث: تفاعل أعضاء هيئة التدريس مع التعليم عن بعد في ظل ازمة \\
\hline 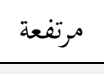 & 0.93 & 3.74 & المجال الرابع: تفاعل الطلبة مع التعلم عن بعد في ظل التعليم الإلكتروين \\
\hline 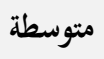 & 0.64 & 3.52 & 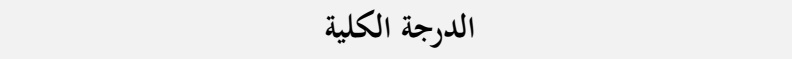 \\
\hline
\end{tabular}

نلاحظ من الجدول السابق ومن خلال المعطيات الواردة في الجدول أن درجة فاعلية التعلم عن بعد في ظل تفشّي فيروس

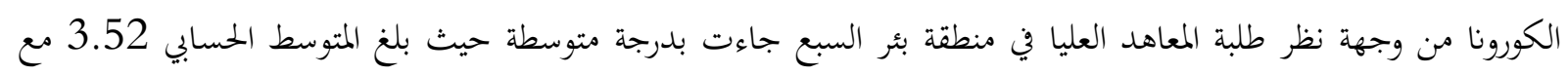
انخراف معياري 0.64 وقد كانت أهم الأبعاد (تفاعل الطلبة مع التعلم عن بعد في ظل التعليم الإلكتروني) بمتوسط حسابي 3.74 مع انحراف

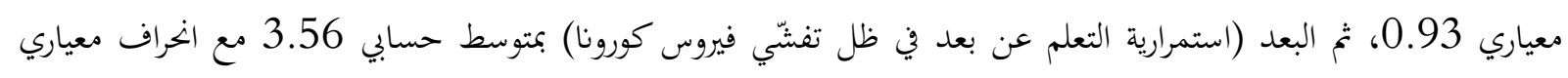

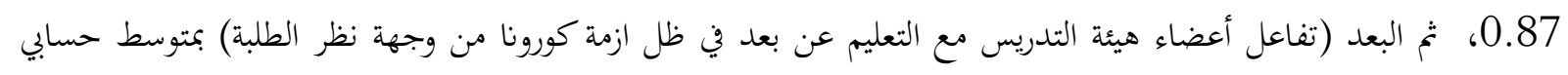

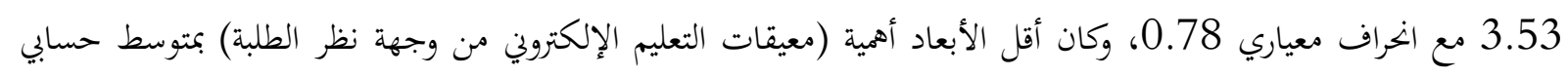

$$
\text { 3.23 مع انخراف معياري } 0.52 .
$$


نتائج السؤال الأول: ما درجة استمرارية التعلم عن بعد في ظل تفثّي فيروس كورونا من وجهة نظر طلبة المعاهد العليا في منطقة بئر السبع؟ للإجابة عن السؤال السابق تم استخراج المتوسطات الحسابية والانحرافات المعيارية لدرجة استمرارية التعلم عن بعد في ظل تفشّي فيروس كورونا من وجهة نظر طلبة المعاهد العليا في منطقة بئر السبع، وذلك كما هو موضح في الجدول رقم (3) (3). جدول (3): المتوسطات الحسابية الانحرافات المعيارية لدرجة استمرارية التعلم عن بعد في ظل تفشّي فيروس كورونا من وجهة نظر طلبة المعاهد العليا في منطقة بئر السبع مرتبة حسب الأهمية

\begin{tabular}{|c|c|c|c|}
\hline الدرجة & 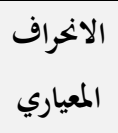 & المتوسط & 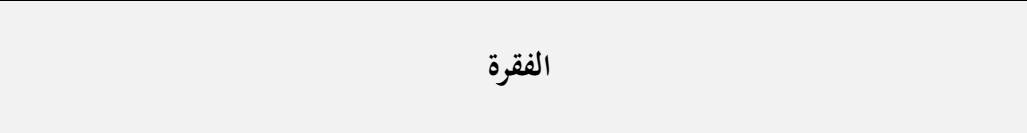 \\
\hline مرتفعة & 1.18 & 3.84 & تم توفير دليل لاستخدام الموقع الخاص بالمادة التعليمية للطلبة \\
\hline 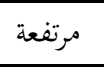 & 0.93 & 3.76 & يمتلك المحاضرون مهارات كافية لتصميم وإنتاج محتوى الكتروني فعّال \\
\hline 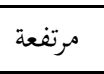 & 1.05 & 3.71 & يسهل تصميم الموقع الذي وفرته الكلية للتعليم الإلكتروني عرض المادة بطريقة شيقة \\
\hline 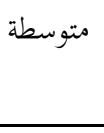 & 1.49 & 3.65 & أشعر بالرضا عن استخدام نظام التعلم عن بعد كبديل عن نظام التعلم الوجاهي في ظل وباء \\
\hline متوسطة & 1.08 & 3.65 & تسهم تقنية التعلم عن بعد بفاعلية في استمرارية ونجاح العملية التعليمية في ظل أزمة كورونا \\
\hline 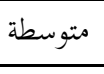 & 1.09 & 3.62 & تتم عملية تبادل المواد التعليمية دون عوائق فنية \\
\hline 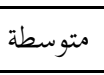 & 1.18 & 3.56 & توفر الكلية الدعم الفني الملائم لتسهيل توظيف التكنولوجيا في المادة التعليمية \\
\hline 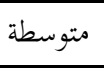 & 1.27 & 3.54 & هناك سلاسة في الانتقال من التعليم التقليدي إلى التعليم عن بعد في ظل أزمة كورونا \\
\hline متوسطة & 1.21 & 3.53 & تم تدريب الطلبة من قبل الكليات على استخدام التعلم عن بعد من خلال اعطائهم بعض المساقل التهيلية خلاءل الوباء \\
\hline 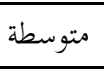 & 1.11 & 3.51 & تقوم إدارة الكلية بتقييم مستمر لآلية التدريس عن بعد \\
\hline 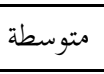 & 1.33 & 3.44 & نظام التعلم عن بعد يوفر تواصلا بين الطلبة والمحاضرين \\
\hline 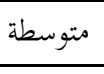 & 0.99 & 3.38 & التقنيات المتبعة في التعلم عن بعد فعالة تغطي كافة جوانب الخطة الدراسية للمساقات \\
\hline متوسطة & 1.28 & 2.84 & يتم تدريب الطلبة على التعلم الالكتروني من خلال دورات أو مساقات تأهيلية أو ورشات عمل \\
\hline متوسطة & 0.87 & 3.56 & 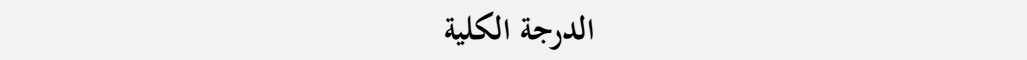 \\
\hline
\end{tabular}

نلاحظ من الجدول السابق ومن خلال المعطيات الواردة في الجدول أن درجة استمرارية التعلم عن بعد في ظل تفشيّي

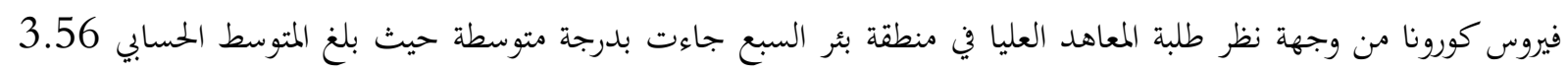
مع انخراف معياري 0.87

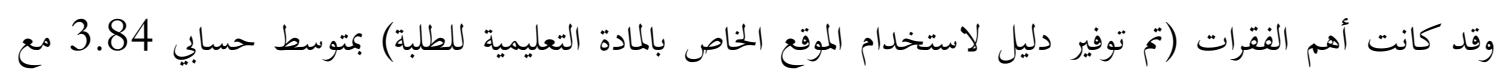

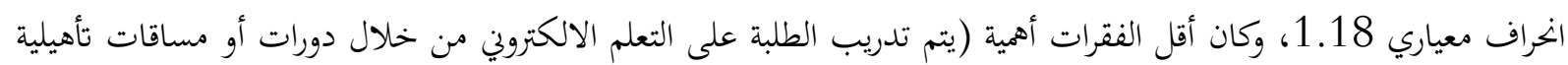

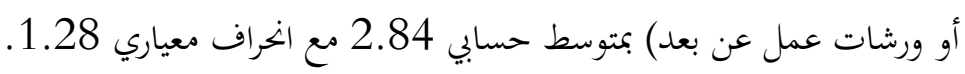

نتائج السؤال الثاني: ما درجة معيقات التعليم الإلكتروبي من وجهة نظر طلبة المعاهد العليا في منطقة بئر السبع؟ للإجابة عن السؤال السابق تم استخراج المتوسطات الحسابية والانحرافات المعيارية لدرجة معيقات التعليم الإلكتروني من

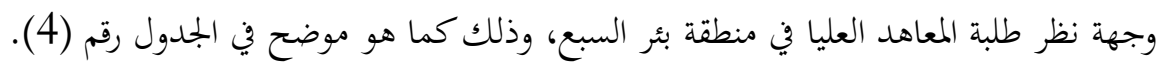


جدول (4): المتوسطات الحسابية الانحرافات المعيارية لدرجة معيقات التعليم الإلكتروني من وجهة نظر طلبة المعاهد العليا في منطقة بئر السبع مرتبة حسب الأهمية

\begin{tabular}{|c|c|c|c|}
\hline الدرجة & الإنراف & المتوسط & الفقرة \\
\hline مرتفعة & 1.29 & 3.72 & تم عقد مساقات تدريبية وإعداد الطلاب قبل أزمة الكورونا لآلية استخدام التعليم الإلكتروي من قِبل \\
\hline مرتفعة & 1.04 & 3.62 & جميع المحاضرين لديهم الخبرة والمهارات الكافية والمناسبة لاستخدام الحاسوب، الانترنت والادوات \\
\hline 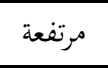 & 1.09 & 3.55 & يتناسب نظام التعلم عن بعد مع نوع المواد بشقيها النظري والعملي \\
\hline متوسطة & 1.11 & 3.43 & تأثر تفاعل الطلبة مع التعليم الإلكتروبي والمحاضرات بسبب ظروف معيشية صعبة او خاصة عند \\
\hline 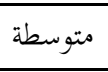 & 1.22 & 3.29 & سرعة الانترنت مناسبة في بيتي وأستطيع حضور أي محاضرة دون أي انقطاع \\
\hline 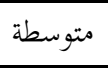 & 1.28 & 3.16 & تواجه المحاضرين مشاكل في التعليم عبر برنامج الزوم من وجهة نظرك \\
\hline متوسطة & 1.02 & 3.08 & 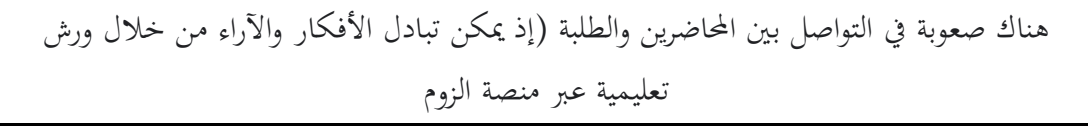 \\
\hline متوسطة & 1.18 & 3.01 & هناك صعوبة لدى المحاضرين في متابعة الأعداد الكبيرة للطلبة خلال المساق عبر أدوات التعليم عن \\
\hline متوسطة & 0.52 & 3.23 & الدرجة الكلية \\
\hline
\end{tabular}

نلاحظ من الجدول السابق ومن خلال المعطيات الواردة في الجدول أن درجة معيقات التعليم الإلكتروني من وجهة نظر

طلبة المعاهد العليا في منطقة بئر السبع جاءت بدرجة متوسطة حيث بلغ المتوسط الحسابي 3.23 مع الخراف معياري 0.52 وقد كانت أهم الفقرات (تم عقد مساقات تدريبية وإعداد الطلاب قبل أزمة الكورونا لآلية استخدام التعليم الإلكتروني من

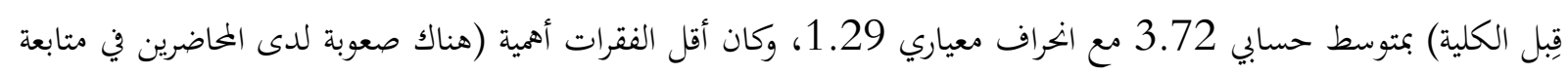

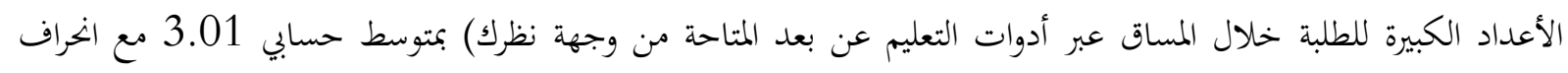
معياري 1.18.

نتائج السؤال الثالث: ما درجة تفاعل أعضاء هيئة التدريس مع التعليم عن بعد في ظل ازمة كورونا من وجهة نظر طلبة

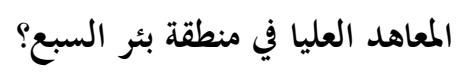

للإجابة عن السؤال السابق تم استخراج المتوسطات الحسابية والانخرافات المعيارية لدرجة تفاعل أعضاء هيئة التدريس مع

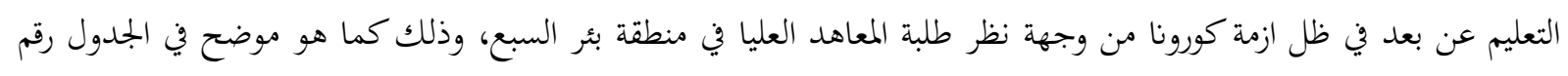

جدول (5): المتوسطات الحسابية الانحرافات المعيارية لدرجة تفاعل أعضاء هيئة التدريس مع التعليم عن بعد في ظل ازمة

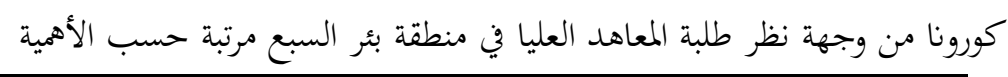

\begin{tabular}{|c|c|c|c|}
\hline 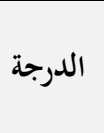 & الالانحراف & المتوسط & 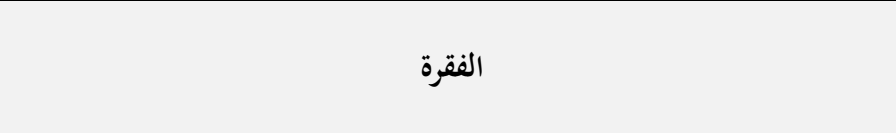 \\
\hline 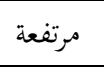 & 0.99 & 4.11 & يجيب المحاضر عن استفسارات الطلبة عن المادة العلمية المرفقة في موقع المساق \\
\hline 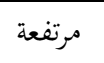 & 0.91 & 3.88 & يشتمل المتوى التعليمي على اضافة تمارين وواجبات تساعد على التعلم بشكل عا \\
\hline
\end{tabular}




\begin{tabular}{|c|c|c|c|}
\hline 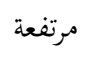 & 0.99 & 3.84 & يتم إرفاق المادة التعليمية للطلبة بسهولة ويسر في موقع الكلية \\
\hline متوسطة & 1.02 & 3.66 & تتوافق خطة المساق عن بعد مع التعلم الوجاهي \\
\hline 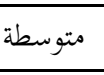 & 1.11 & 3.39 & يقوم المحاضرون بتنويع أساليب التقييم \\
\hline 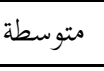 & 1.03 & 3.39 & يتم تقييم الطالب بشكل مستمر اثناء عملية التعلم عن بعد من وجهة نظرك \\
\hline 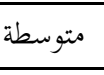 & 1.12 & 3.36 & يعتقد الطلبة أن الاختبارات عن بعد وسيلة مناسبة لتقييم التحصيل العلمي \\
\hline 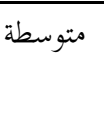 & 1.32 & 3.34 & التعلم عن بعد أكثر فاعلية من حيث استغلال الوقت أكثر من التعليم التقليدي من وجهة \\
\hline 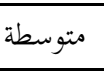 & 1.25 & 3.23 & هناك مصداقية عالية في تقييم الطلبة من وجهة نظرهم من خلال نظام التعلم عن بعد \\
\hline 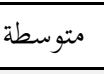 & 1.23 & 3.16 & يبدي المحاضرون رضاهم عن نظام التعلم الإلكتروني من وجهة نظرك \\
\hline 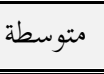 & 0.78 & 3.53 & 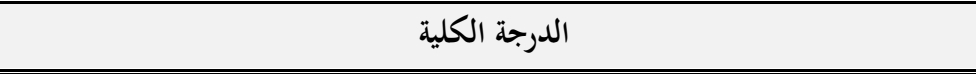 \\
\hline
\end{tabular}

نلاحظ من الجمدول السابق ومن خلال المعطيات الواردة في الجدول أن درجة تفاعل أعضاء هيئة التدريس مع التعليم عن بعد في ظل ازمة كورونا من وجهة نظر طلبة المعاهد العليا في منطقة بئر السبع جاءت بدرجة متوسطة حيث إند بلغ بلغ المتوسط الحسابي

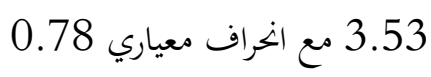
وقد كانت أهم الفقرات (يجيب المحاضر عن استفسارات الطلبة عن المادة العلمية المرفقة في موقع المساق) بمتوسط حسابي

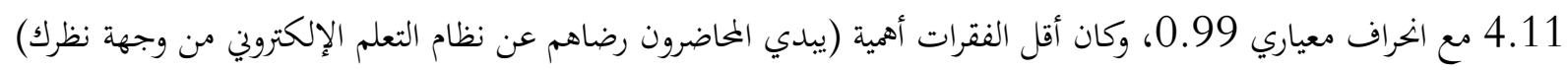
بمتوسط حسابي 3.16 مع انحراف معياري 1.23.

نتائج السؤال الرابع: ما درجة تفاعل الطلبة مع التعلم عن بعد في ظل التعليم الإلكتروبي من وجهة نظر طلبة المعاهد العليا في منطقة بئر السبع؟ للإجابة عن السؤال السابق تم استخراج المتوسطات الحسابية والانحرافات المعيارية لدرجة تفاعل الطلبة مع التعلم عن بعد

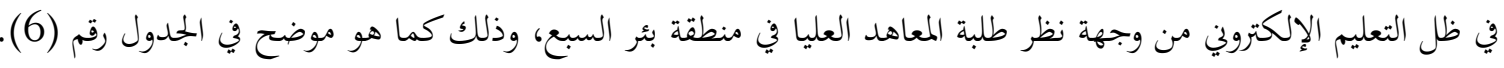

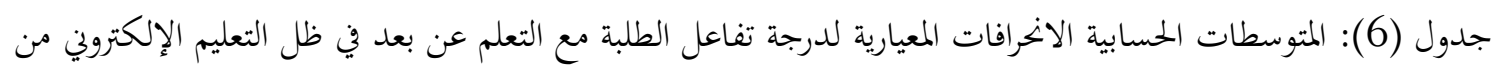
وجهة نظر طلبة المعاهد العليا في منطقة بئر السبع مرتبة حسب الأهمية

\begin{tabular}{|c|c|c|c|}
\hline 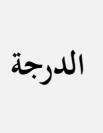 & الالمعراف & المستوسط & 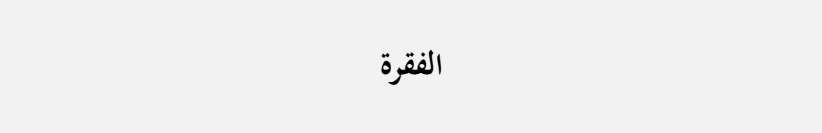 \\
\hline مرتفعة & 0.92 & 4.11 & يتيح نظام التعلم عن بعد للطالب الوصول للمادة التعليمية في أي وقت \\
\hline 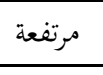 & 1.12 & 3.78 & يستطيع الطالب طرح أي تساؤلات واستفسارات من خلال التعلم عن بعد \\
\hline مرتفعة & 1.11 & 3.77 & أتفاعل مع نظام التعلم عن بعد بشكل مستمر \\
\hline 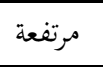 & 1.16 & 3.71 & عرض المادة الكترونيا يزود الطالب بمهارات اضافية \\
\hline 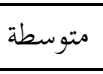 & 1.18 & 3.58 & أشعر بالرضا عن مدى الاستفادة من التعلم عن بعد \\
\hline 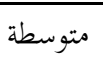 & 1.16 & 3.51 & يساعد أسلوب التعلم الإلكتروني في فهم المادة العلمية بشكل واضح ومفهوم \\
\hline 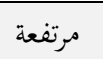 & 0.93 & 3.74 & الدرجة الكلية \\
\hline
\end{tabular}

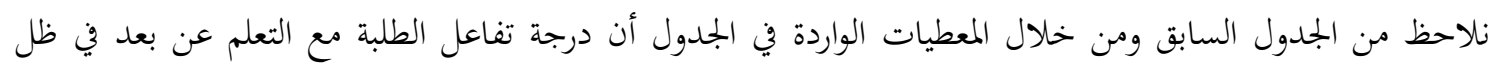

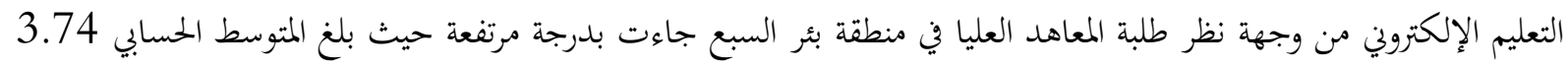
مع انحراف معياري 0.93 
وقد كانت أهم الفقرات (يتيح نظام التعلم عن بعد للطالب الوصول للمادة التعليمية في أي وقت) بمتوسط حسابي 4.11 مع انحراف معياري 0.92، وكان أقل الفقرات أهمية (يساعد أسلوب التعلم الإلكتروني في فهم المادة العلمية بشكل واضح

$$
\text { ومفهوم) بمتوسط حسابي } 3.51 \text { مع انحراف معياري } 1.16 .
$$

نتائج الفرضية الأولى: لا توجد فروق ذات دلالة إحصائية عند مستوى الدلالة (150.05) في متوسطات استجابات أفراد العينة حول درجة فاعلية التعلم عن بعد في ظل تفشّي فيروس الكورونا من وجهة نظر طلبة المعاهد العليا في منطقة بئر السبع

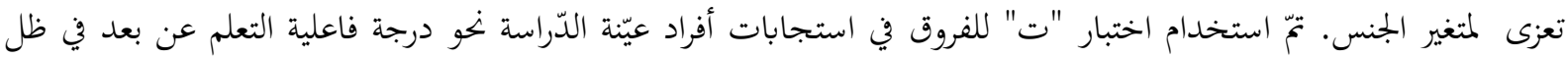
تفشّي فيروس الكورونا من وجهة نظر طلبة المعاهد العليا في منطقة بئر السبع لمتغير الجنس، وقد حصل الباحث على النّائج كما

هي موضّحة في جدول (7).

جدول (7): نتائج اختبار "ت" للفروق في استجابات أفراد عيّنة الدّراسة نحو درجة فاعلية التعلم عن بعد في ظل تفشّي

فيروس الكورونا من وجهة نظر طلبة المعاهد العليا في منطقة بئر السبع تعزى لمتغير الجنس

\begin{tabular}{|c|c|c|c|c|c|c|}
\hline مستوى الدّلالة & قيمة"t" & درجة الحريّة & الانحراف المعياريّ & المتوسّط الحسابيّ & العدد & الجنس \\
\hline \multirow{2}{*}{0.017} & \multirow{2}{*}{-2.408} & \multirow{2}{*}{148} & 0.58 & 3.22 & 23 & ذكر \\
\hline & & & 0.64 & 3.57 & 127 & أنثى \\
\hline
\end{tabular}

تشير المعطيات الواردة في الجدول السّابق أنه توجد فروق ذات دلالة إحصائيّة عند مستوى الدّلالة (0.05 ك م) في

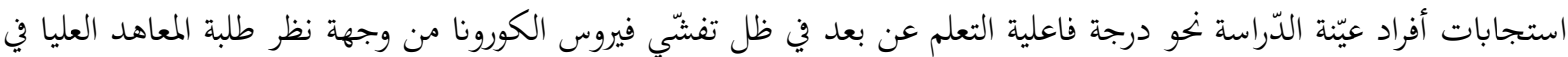

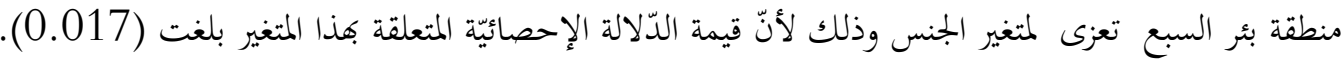
أي أن هذه القيمة أقل من قيمة ألفا (0.05)، وكانت الفروق لصالح الإناث بمتوسط حسابي (3.57) مقابل الذكور

$$
\text { بمتوسط حسابي (3.22). }
$$

الفرضية الثانية: لا توجد فروق ذات دلالة إحصائية عند مستوى الدلالة (20.05) في متوسطات استجابات أفراد العينة حول درجة فاعلية التعلم عن بعد في ظل تفشّي فيروس الكورونا من وجهة نظر طلبة المعاهد العليا في منطقة بئر السبع تعزى لمتغير المرحلة التدريسية في الكلية تمّ استخدام اختبار تحليل التباين الأحادي (One Way ANOVA) للفروق في متوسطات استجابات أفراد

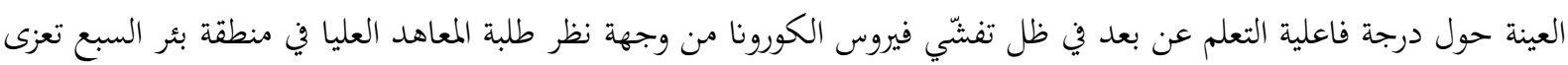

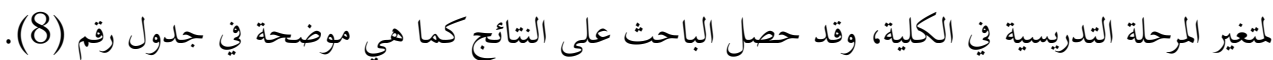
جدول (8): نتائج اختبار تحليل التباين الأحادي للفروق في متوسطات استجابات أفراد العينة حول درجة فاعلية التعلم عن بعد في ظل تفشّي فيروس الكورونا من وجهة نظر طلبة المعاهد العليا في منطقة بئر السبع تعزى لمتغير المرحلة التدريسية في

\begin{tabular}{|c|c|c|c|c|c|}
\hline الإحصائية & قيمة ف & متوسط المربعات & درجات & مجموع المربعات & \\
\hline \multirow{3}{*}{0.000} & \multirow{3}{*}{14.820} & 5.206 & 2 & 10.412 & بين الججموعات \\
\hline & & \multirow[t]{2}{*}{0.651} & 147 & 51.638 & الجموعات \\
\hline & & & 149 & 62.050 & الجمموع \\
\hline
\end{tabular}
الكلية 


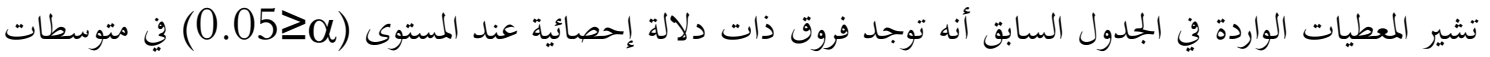
استجابات أفراد العينة حول درجة فاعلية التعلم عن بعد في ظل تفشّي فيروس الكورونا من وجهة نظر طلبة المعاهد العليا في

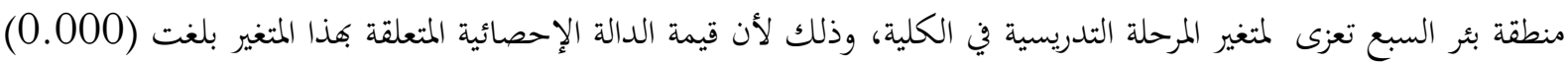
أي أن هذه القيمة أقل من قيمة ألفا (0.05)، وبذلك نرفض الفيع الفرضية الصفرية. ومن أجل دراسة الفروق حول درجة فاعلية التعلم عن بعد في ظل تفشّي فيروس الكورونا من وجهة نظر طلبة المعاهد العليا في منطقة بئر السبع تعزى لمتغير المرحلة التدريسية في الكلية، تم استخدام اختبار توكي (Tukey) للمقارنات الثنائية البعدية، حيث تمثل الأرقام في الجلدول الفروق في الأوساط الحسابية، والجدول التالي يوضح نتائج هذا الاختبار: الجدول رقم (9): نتائج اختبار توكي (Tukey) للمقارنات الثنائية البعدية حول درجة فاعلية التعلم عن بعد في ظل تفشّي فيروس الكورونا من وجهة نظر طلبة المعاهد العليا في منطقة بئر السبع تعزى لمتغير المرحلة التدريسية في الكلية.

\begin{tabular}{|r|r|r|r|}
\hline & لقب & & لقب \\
\hline & & & \\
\hline & & & \\
\hline & & & \\
\hline
\end{tabular}

الفروق دالة إحصائيا عند مستوى 0.05.

من خلال الجدول السابق كانت الفروق بين من يدرسون شهادة التدريس وبين كل من يدرسون (لقب أول، لقب ثاني)

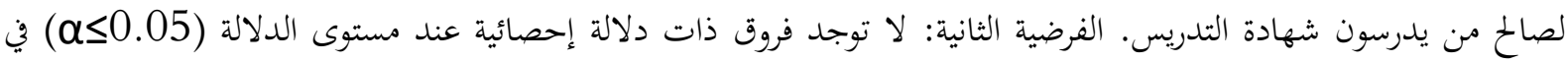

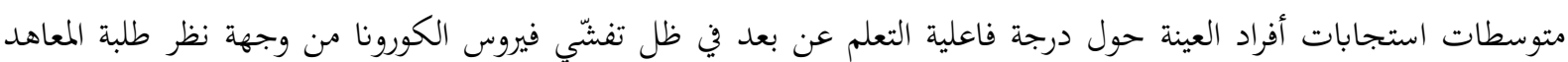
العليا في منطقة بئر السبع تعزى لمتغير السنة الدراسة في الكلية تمّ استخدام اختبار تحليل التباين الأحادي (One Way ANOVA) للفروق في متوسطات استجابات أفراد العينة حول درجة فاعلية التعلم عن بعد في ظل تفشّي فيروس الكورونا من وجهة نظر طلبة المعاهد العليا في منطقة بئر السبع تعزى مئى

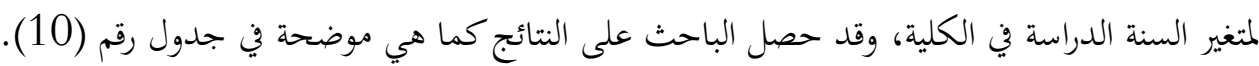
جدول (10): نتائج اختبار تحليل التباين الأحادي للفروق في متوسطات استجابات أفراد العينة حول درجة فاعلية التعلم عن بعد في ظل تفشّي فيروس الكورونا من وجهة نظر طلبة المعاهد العليا في منطقة بئر السبع تعزى لمتغير السنة الدراسة في الكلية

\begin{tabular}{|c|c|c|c|c|c|}
\hline الإحصائية & قيمة ف & متوسط المربعات & درجات الحرية & المجبعات & \\
\hline \multirow{3}{*}{0.128} & \multirow{3}{*}{1.926} & 0.787 & 3 & 2.362 & بين الجموعات \\
\hline & & \multirow{2}{*}{0.409} & 146 & 59.688 & داخل الجموعات \\
\hline & & & 149 & 62.050 & الجموع \\
\hline
\end{tabular}

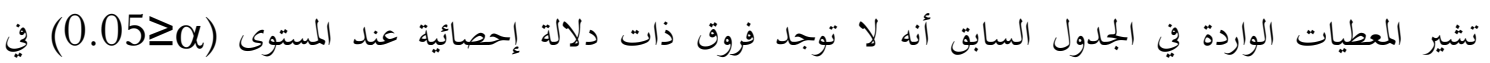
متوسطات استجابات أفراد العينة حول درجة فاعلية التعلم عن بعد في ظل تفشّي فيروس الكورونا من وجهة نظر طلبة المعاهد العليا في منطقة بئر السبع تعزى لمتغير السنة الدراسة في الكلية، وذلك لأن قيمة الدالة الإحصائية المتعلقة بهذا المتغير بلغت (0.128) أي أن هذه القيمة أكبر من قيمة ألفا (0.05)، وبذلك نقبل الفرضية الصفرية. 


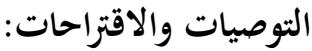

1. أن تعمل المعاهد على اختيار الأنسب من أدوات التكنولوجيا استناداً إلى الإمكانات المتوافرة

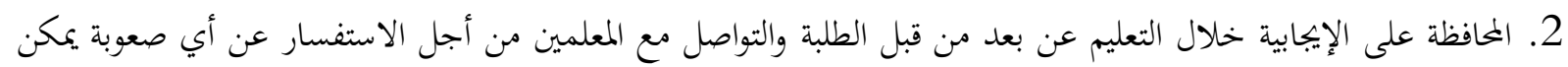
أن تواجه الطلبة 3. علاقة التعليم عن بعد بدافعية الطلبة نخو التعليم. 4. أساليب التقويم من خلال التعليم عن بعد في ظل انتشار جائحة كورونا. 
جريد، أريج، (2020)، معيقات التعليم الالكتروني في فلسطين في ظل أزمة كورونا، ضمن أنشطة مشروع منتدى الشباب للسياسة والتنمية، (أوراق بحثية شبابية)، تنفيذ مؤسسة بال ثينك للدراسات الاستراتيجية.

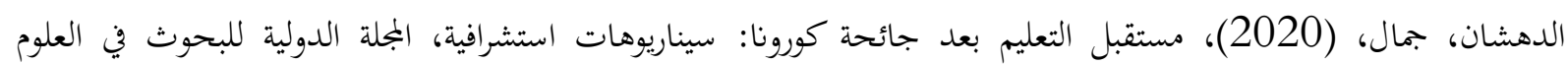

$$
\text { التربوية، المجلد 3، العدد } 4 .
$$

ربابعة، أماني، (2020)، دور التعليم عن بعد في تعزيز التعلم الذاتي لدى طلبة جامعة الزرقاء الخاصة، مجلة جامعة فلسطين للأبحاث والدراسات، العدد 3، الجزء الثاني.

ريم، العتبي، (2020)، التحديات التي واجهت الاسر السعودية في تعليم أبنائها في ظل جائحة كورونا المستجد، المجلة العربية

$$
\text { للنشر العلمي، العدد الثاني والعشرون. }
$$

الشديفات، منيرة، (2020)، واقع توظيف التعليم عن بعد بسبب مرض الكورونا في مداري قصبة المفرق من وجهة نظر مديري

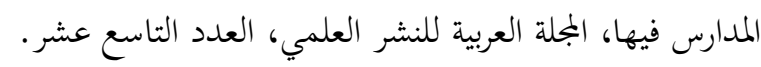

الشرهان، صلاح (2014)، التعليم المفتوح والتعليم عن بعد في الوطن العربي: نهو التطوير والابداع، ورقة مقدمة في المؤتمر الرابع

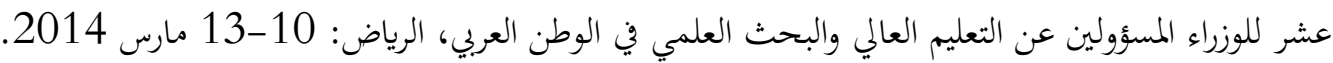

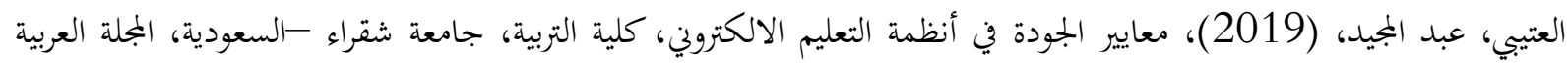

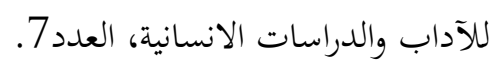

قرعان، محمد، (2021)، مستوى رضا معلمي اللغة العربية في مدينة الزرقاء عن التعليم عن بعد، مجلة افاق العلوم، المجلد 6،

$$
\text { العدد2. }
$$

محمد، زايد، (2020)، أهمية التعليم عن بعد في ظل تفشي فيروس كورونا، المركز الجامعي نور البشير، مجلة الاجتهاد للدراسات

$$
\text { القانونية والاقتصادية، المجلد9، العدد } 4 .
$$

قنبي، عبير وآخرون، (2020): جائحة "كوفيد -19": واقع التعليم الالكتروني في السياق الفلسطيني من وجهة نظر المعلمين، https: //inee.org/system/files/resources/\%3F\%3F\%3F\%3F\%20\%3F\%3.pdf

$$
\text { سناء أحمد فتوح، التعليم عن بعد: نظام تعليمي له مزاياه وعيوبه، منشور على الموقع }
$$

education- https: //www.arageek.com/edu/onl .

$$
\text { موقع منظمة الصحة العالمية. (2019م). فيروس كورونا (كوفيد-19). }
$$

https: //www.who.int/ar/emergencies/diseases/novel-coronavirus-2019

Basilaia، G.، \&Kvavadze، D. (2020). Transition to Online Education in Schools during a SARS-CoV-2 Coronavirus (COVID-19) Pandemic in Georgia. Pedagogical Research، 5 (4)، em0060

Berg، G.، Simonson، M. (2018). Distance learning. Britannica. Retrieve in 2/4/2012 at: https: //www.britannica.com/topic/distance-learning

Draissi، Z. Yong، Q، Z. (2020). COVID-19 Outbreak Response Plan: Implementing Distance Education in Moroccan Universities. School of Education، Shaanxi Normal University، retrieve in 5/4/2020 at: https: //papers.ssrn.com/sol3/papers.cfm?abstract_id=3586783

Yulia، H. (2020). Online Learning to Prevent the Spread of Pandemic Corona Virus in Indonesia. ETERNAL (English Teaching Journal). 11 (1). 


\title{
CARTOGRAPHY AMONG MUSLIM ARABS IN THE MIDDLE AGES
}

\author{
Dhilal Jawad Kadhim YASSIN ${ }^{1}$
}

\section{Istanbul / Türkiye \\ p. 286-299}

Received: $23 / 11 / 2021$

Accepted: $11 / 12 / 2021$

Published: 01/01/2022

This article has been scanned I iThenticat No plagiarism detected

\section{Abstract:}

Arab geographers played an important role in laying the first chapter on the foundations of cartography through their original traces that they immortalized throughout the history of their ancient civilizations. Later, I moved to the countries of the Arab world for their knowledge of the foundations of the rules and principles of cartography. Their books also made an effective contribution to making the Arab map from their knowledge of the concept of the map, the foundations of its mathematical and artistic construction, and its developmental stages, which reached its climax in the tenth century AH Therefore, the Arab maps represented the life of the Arabs in its various fields and manifestations with simple and few symbols such as the square, the rectangle and the circles. Its effects were reflected in the emergence of the most prominent cartographic schools that were characterized by scientific ideas and original and contemporary curricula at the same time, which were represented by their geographical maps on which they represented the various geographical phenomena (natural and human) of many countries of the world that they visited and toured, and they reflected this in their maps, which later became the basis for the manufacture of Arabic map.

Key words: Maps, Muslim Arabs, Middle Ages.

http://dx.doi.org/10.47832/2717-8293.15.21 


\section{علم خرائط عند العرب المسلمين في العصور الوسطى}

\section{ظلال جواد كاظم 2}

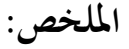

للجغرافيين العرب دور مهم في وضع الباب الأولى لأسس علم الخرائط عن طريق تتبعاتم الأصلية التي خلدوها عبر

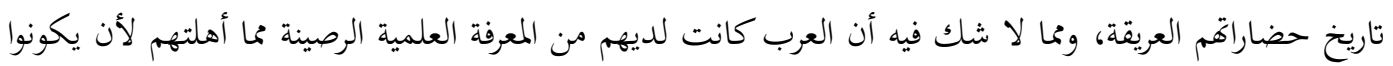

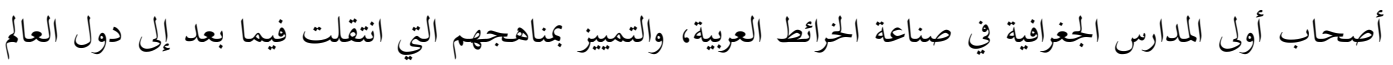
العربي لمعرفتهم اصول القواعد ومبادئ علم الخرائط. كما ساهمت مؤلفاتم مساهمة فعالة في صنع الخريطة العربية من معرفتهم لمفهوم الخريطة وأسس بناءها الرياضية والفنية ومراحلها التطورية التي وصلت ذروما في القرن العاشر الهجري، لذلك مثلت الخرائط العربية حياة العرب بمختلف مجالاتما ومظاهرها برموز بسيطة وقليلة كالمربع

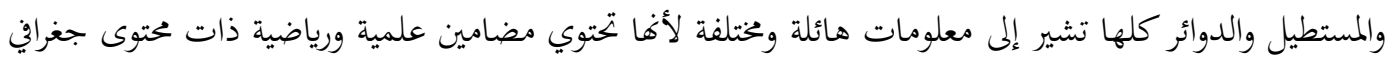

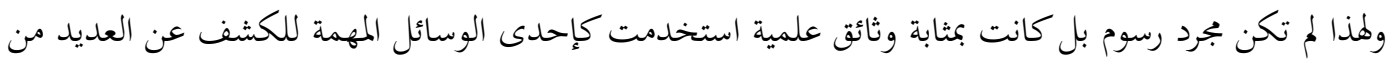

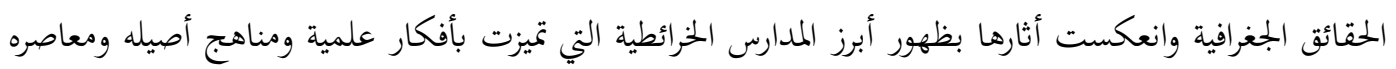
في آن واحد والتي تمثلت بخرائطهم الجغرافية التي مثلوا عليها مختلف الظواهر الجغرافية (الطبيعية والبشرية) للعديد من بلدان العالم التي زاروها وتجولوا فيها فنكسوا ذلك في خرائطهم التي أصبحت فيما بعد القاعدة الاساس في صناعة

يرتبط تاريخ صناعة الخرائط بتاريخ وتطور الإنسان على سطح الأرض فقد وجدت الخرائط بوجوده وتطورت بتطوره

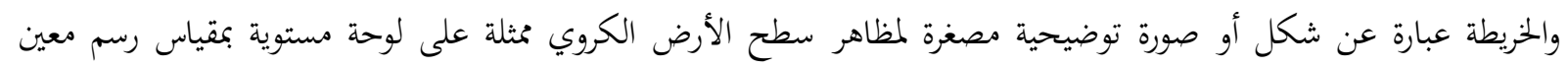
وتشمل الظواهر الطبيعية والبشرية ولقد ساهم العرب طوال القرون مساهمة كبيرة في تطوير علم الخرائط وفنون صناعتها متأثرين لترهين بالإغريق الذين ساهموا في هذا لميدان.

وأول خريطة التي عرفها العرب كانت الخريطة التي أمر بصنعها الحجاج بن يوسف الثقفي عندما أمر القائد قتيبة بن مسلم

$$
\text { الباهلي فاتح بلاد ما بين النهرين ان يرسل صورة للمنطقة التي طال حصارها. }
$$

بدأ اهتمام في جداول الموقع التي تسمى الزيجات وأول من أهتموا بها كان العالم الفلكي الغزاوي وجاء بعد الخوارزمي وهنا بدت مرحلة صنع الخرائط على أساس خطوط الطول ودوائر العرض، ازداد الاهتمام في الموضوعات الجغرافية وتركز في وصف بلى بلاد

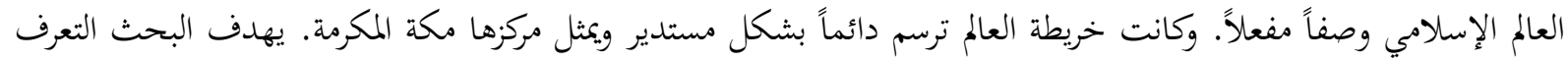
على مستويات المعرفة والوسائل المستخدمة في إنجاز الخريطه في العصور القديمة والوسطى مقارنه مع الحالية ليتسنى لنا معرفه دقه الهاته تلك الخرائط وأنواع المستخدمة في إنجازها والمناطق التي مثلها. 
مشكلة البحث: دراسة لمساهمات العرب المسلمين في علم الجغرافية ولاسيما في علم الخرائط في العصور الوسطى والتي تعد أهم

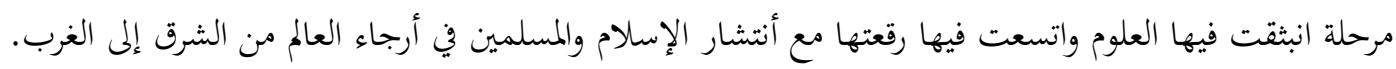
تفترض الدراسة: معرفة دور العرب المسلمين ومساهمتهم في علم الخرائط وأطلس العالم اذ يعد العرب على مر العصور هم الواضعين

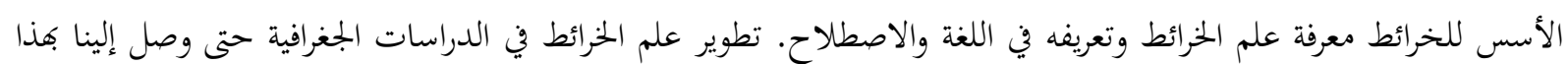
الكيفية العلمية الرصينة وبصورة مدروسة ودقيقة. بيان أهم رواد علم الخرائط المسلمين وأهيتهم في هذا العلم.

يعد تتبع الخريطة في المصطلح لاتيني يعني قطعة قماش في حجم منديل اليد تقريباً فان كلمة الخريطة لم تعجب الرومان

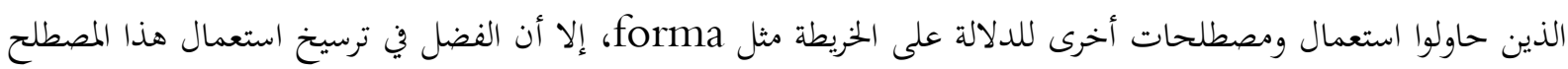
mappamundi

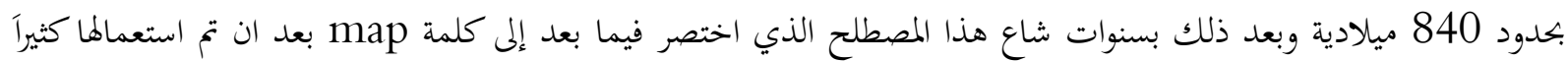
ووجدت قبولاً عالمياً وفي اللغة العامة يمكن الخريطة ما اهما تمثيل اصطلاحي أو صغير المقياس للأرض أو جزء منها. علم الخرائط أو فن علم الخرائط هو دراسة أو ممارسة رسم الخرائط استخدم لرسم الخرائط تقليدياً القلم والورق ولكن انتشار الحواسيب الآلية طور هذا الفن اغلب الخرائط التجارية ذات الجودة العالية ترسم بواسطة برامج كمبيوترية ويعرف على على

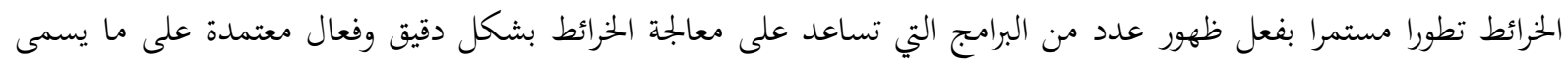

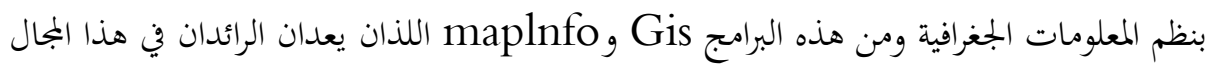

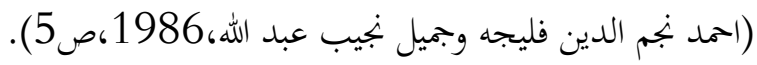
تعد تعريف الأجيال العربية الجديدة بالإنجازات الجغرافية التي حققها الجغرافيون العرب والمسلمين في عصر ازدهار الدولة

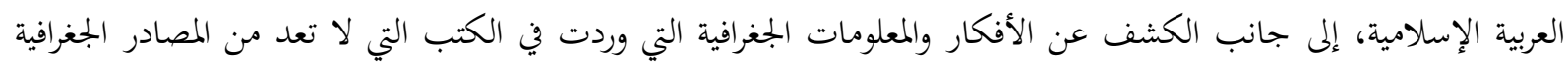
البحتة كالمعلومات التي وردت في ثنايا النصوص القرآنية.

وفي النصوص الشعرية وإهمال الدارسين لما ورد في كتب المغازي والتاريخ والأخبار وما ذكر من معلومات جغرافية مهمة في مدونات الأموال والخراج بهدف بيان المساهمة الهامة التي قدمها الجغرافيون المسلمون، وأثرت في الفكر الجغرافي الأوربي في القرون الوسطى. ولعل المفارقة التي يشير إليها والمتمثلة في إهمال الجغرافيين العرب المعاصرين لتلك المنجزات ظنا منهم أن الجغرافيين القدماء لم يقدموا مساهمة جادة في تطوير الفكر الجغرافي، في حين أن اهتمام المستشرقين بتلك الإنجازات كان كبيرا بتحلت في قيامهم بتحقيق ونشر ودراسة أمهات الكتب الجغرافية العربية الإسلامية التي عملوا على التنقيب عنها.

2- أهمية الخريطة الجغرافية:

تعد الخريطة وسيلة بصرية فان دورها يعتبر مركزياً في تثبيت الحقائق والمفاهيم في الاذهان، ذلك كون حاسة البصر اقوى

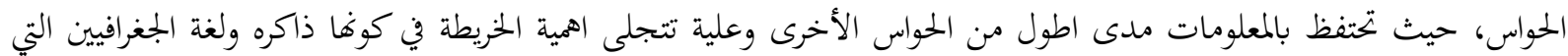
تسمح بتحديد التوزيع المجاني للظاهرة ويمكن حصر الاهمية في الاتي: 
1- تساعد على تسجيل المعلومات وبمعها بكيفية مركزة في مكان واحد امام بدل تقديم المعلومات بكيفية بجردة سرعان ما تحمي

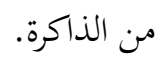

2- تسهيل فهم العديد من العلاقات التي لا يمكن إدارقا باستعمال وسائل أخرى وتسهم في فهم البيئة الجغرافية.

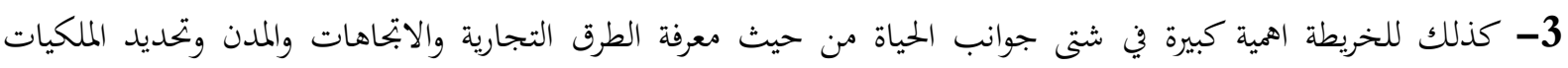

الزراعية والصناعية والتجمعات السكانية. 
الحورالثالي:

تطور الخرائط في العصور الوسطى عند المسلمين.

كانت الجغرافيا علم وصف الأرض وتعني من خلال هذا الوصف إبراز البيئة الطبيعية التي تحيط بالإنسان. ثم بالبيئة البشرية وما مدى تأثير كل من البيئتين بالأخرى وهي على ضوء ذلك علم ديناميكي يتطور بالمشاهدة الدقيقة والثفكير المنطقي،

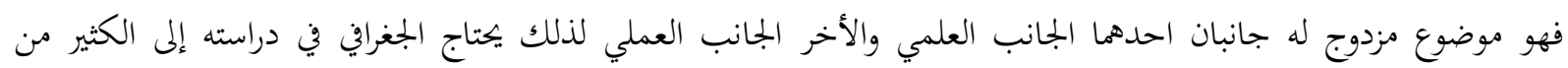
الوسائل العلمية له سواء تلك التي تعيينه على الملاحظة والرصد والتسجيل ويدخل في هذا البمال العملي للدراسة الجغرافية

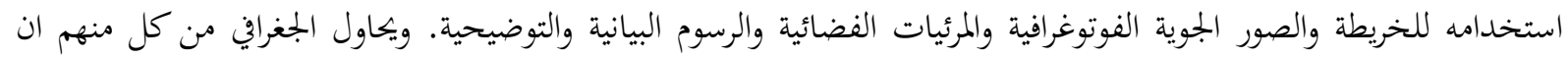

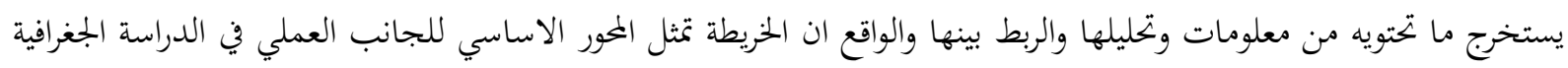

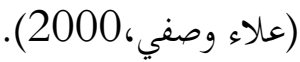

فالجغرافي بدون خريطة يكاد يكون لا يرى طريقة الصحيح فهي اداة ضرورية لأها تقدم الصورة المرئية التي تساعد في تغيير

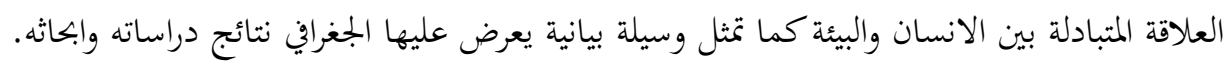
الخرائط التي وضعها الجغرافيون للعالم فضلا عن المجسمات للكرة الأرضية التي كان الجغرافيون العرب والمسلمون قد

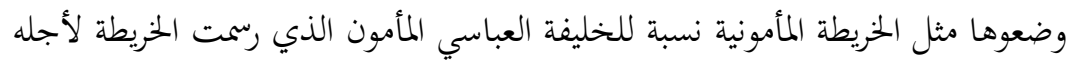
(عبد الرحمن صالح مزوري، وضعوها، 2009،صند250).

\section{مراحل تطور خرائط المسلمين:}

قد قسم علماء الجغرافية أدوار خرائط المسلمين إلى ست مراحل هي:

1- المرحلة التي سبقت الخرائط المأمونية:

وردت إشارات عن رسم الخرائط في زمني الحجاج والمنصور، دون العثور علي هذه الخرائط، واهتم حكام المسلمين برسم

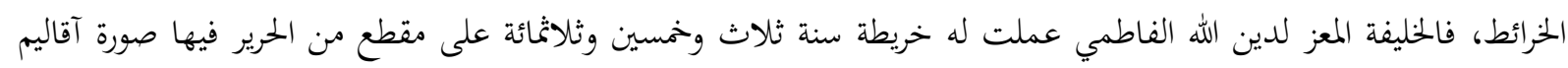
الأرض وجبالها ونجادها ومدها وأهارها ومسالكها وفيها صورة مكة لمعة والمدينة.

وكتب على كل مدينة وجبل وبلد وغر وبحر وطريق اسمه بالذهب أو الفضة أو الحرير وأنفق عليها اثنين وعشرين ألف دينار

\section{2 - 2 - مرحلة الخريطة المأمونية:}

وهي أول صورة للأرض رُسمت في زمن المأمون، وقام على صنعها بجموعة من علماء الفلك والرياضيات وأغم جعلوا لكل

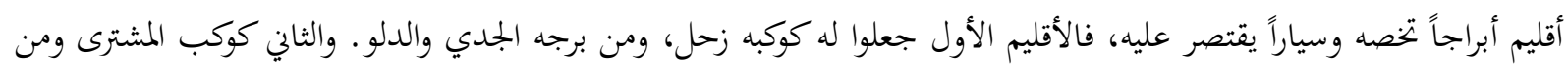

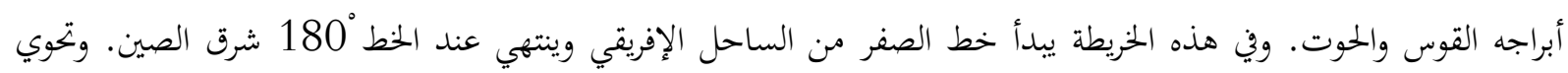

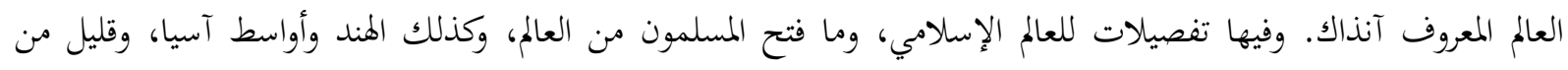

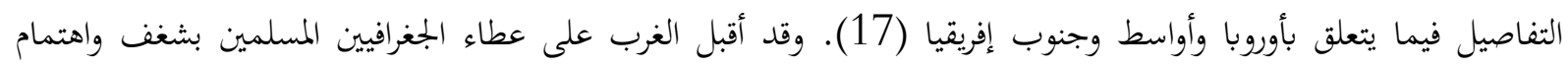

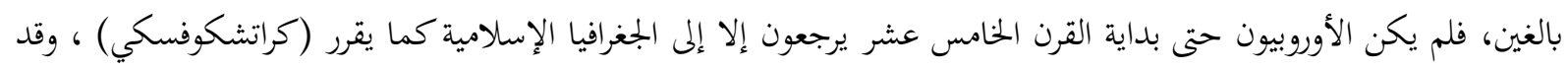

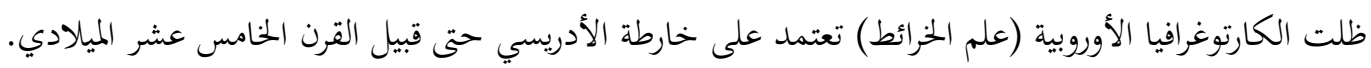


خريطة الأدريسي: وإجمالاً فإنه منذ وقت الأدريسي 1150م إلى حوالي 1450م، استمدت الجغرافيا الأوروبية رأسًا من

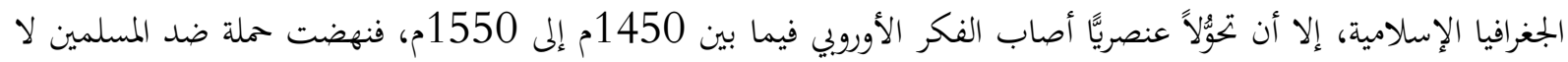

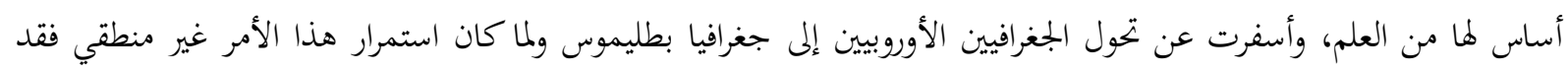

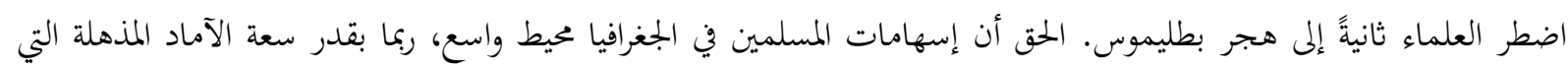

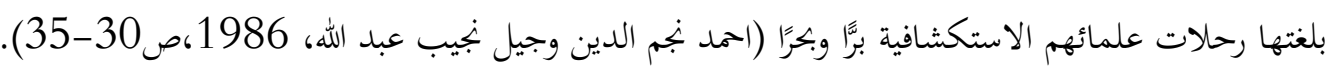

3- مرحلة الحرائط الفلكية:

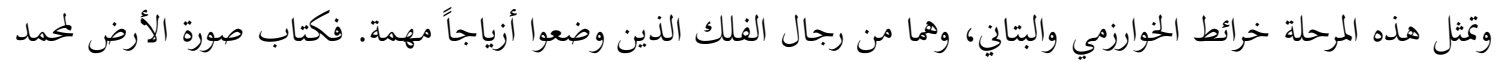

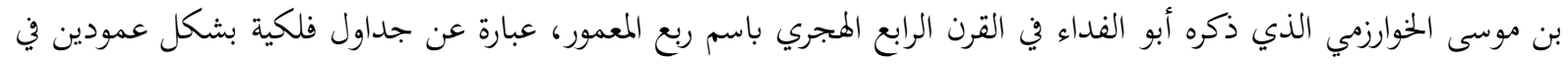

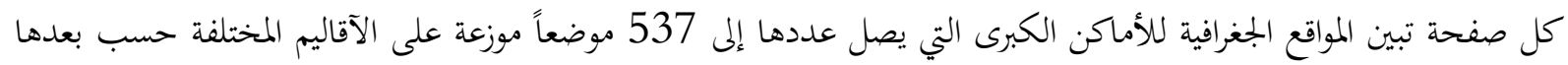

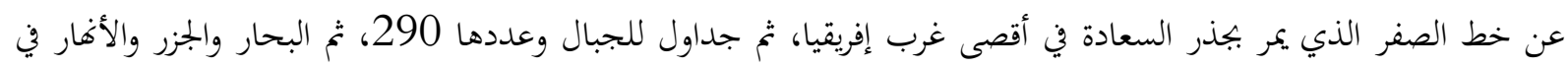
كل أقليم (18).

\section{4- 2 - مرحلة الحرائط الأقليمية:}

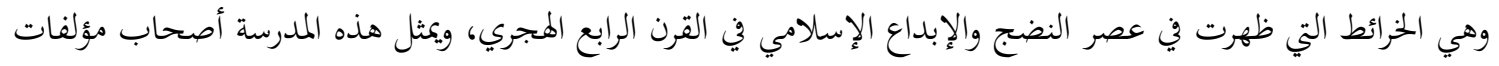

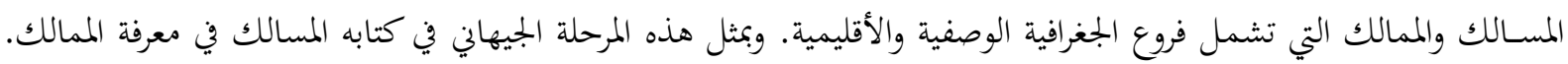

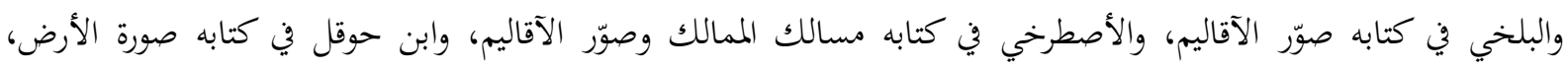

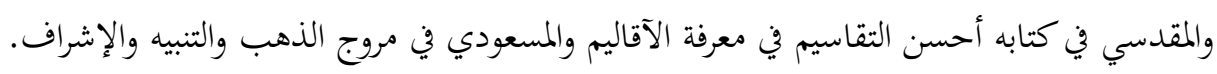

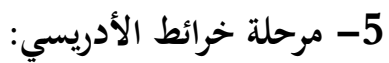

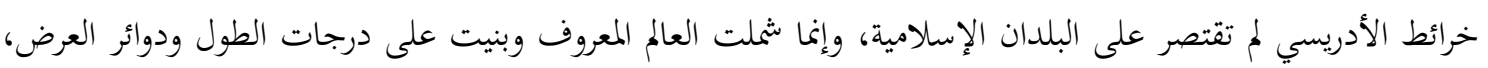

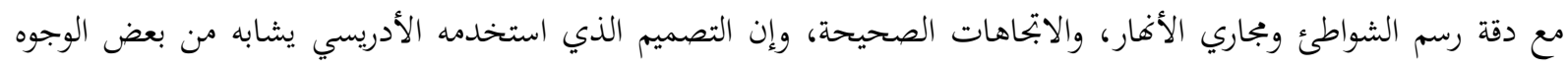

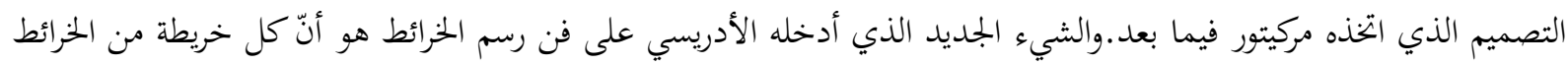

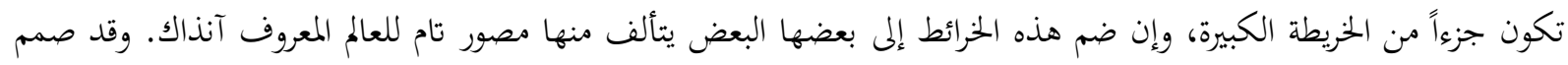

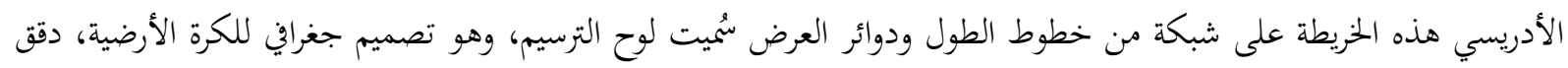

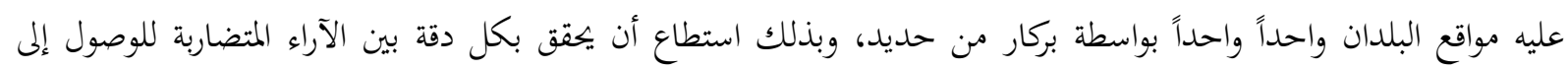

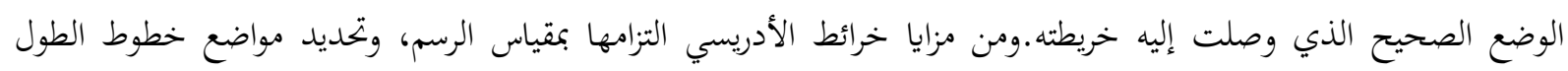

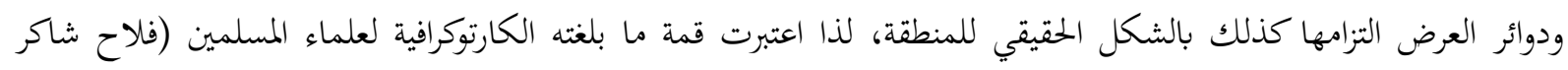

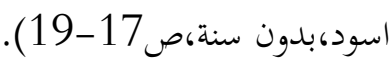

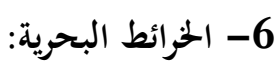

عرف العرب المسلمون هذا اللون من الخرائط بحكم نشاطهم التجاري بين الجزيرة العربية وساحل الهند، أو مع الساحل

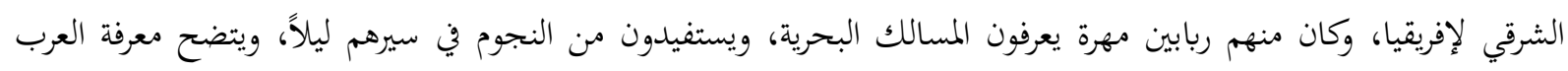

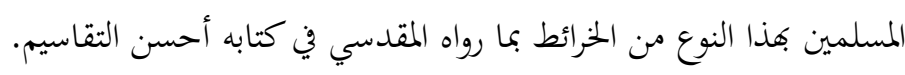

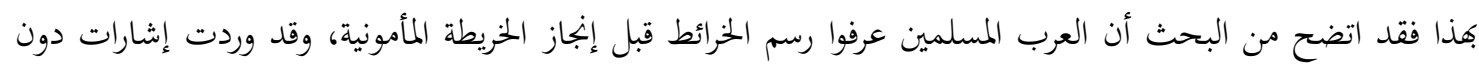

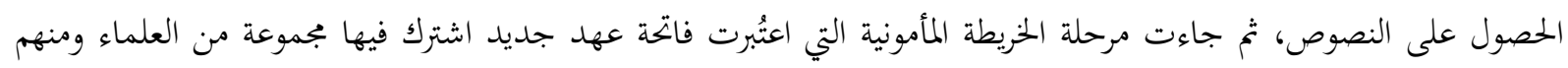
الخوارزمي. 
وقد أنجزت هذه الخريطة بعد اطلاع المسلمين على ما تُرجم من الحضارات التي سبقتهم، ورغم ذلك لم يكونوا ناسخين

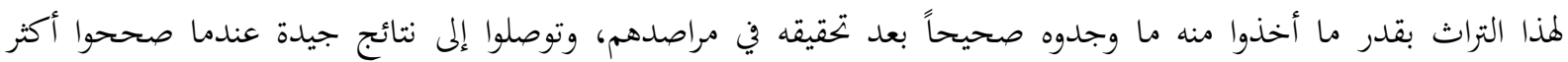
الأخطاء، ويبدو أنّ الخريطة المأمونية ابتكار إسلامي خالص الحتوه اعتمد على جهود مستقلة كل الاستقلال عن التأثيرات اليونانية. أما خرائط الخوارزمي والبتاني، فإنّ الأزياج التي وضعوها توضح جهودهم القِّمة في هذا المجال، وأن الخريطة التي وضعوها

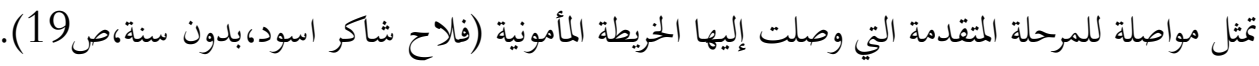

أهم النتائج الجغرافية الطبيعية والبشرية والفلك والرياضيات:

الجغرافيا الطبيعية:

تعرف باللغة الانكليزية بمصطلح physiography وتعرف ايضا باسم الفيزيوجغرافيا وهي علم من العلوم الجغرافية المتخصصة بدراسة تأثير الظواهر الطبيعية على التضاريس الجغرافية في الكره الأرضية ويهتم بمعرفة نسبة وجود المسطحات المبهرية المائية والسلاسل الجبلية والمناطق السهلية.

تعرف الجغرافية الطبيعية ايضا بانما العلم الذي يتحلل ويدرس دور العوامل الطبيعية والمناخية في التغيير من طبيعة الكره الأرضية. والتي لا يوجد أي دور مباشر للإنسان والكائنات الحية التي تعيش على سطح الأرض في التأثير على هذه التغيرات

خصائص الجغرافية الطبيعية: تتميز الجغرافيا الطبيعية بمجموعة من الخصائص (بجد خضر،2016) ، ومنها: 1- تعد علما من العلوم التي تساعد في دراسة العديد من التغيرات الجغرافية التي تحدث في الكئية الكرة الأرضية. 2- تساهم في تزويد الباحثين والطلاب بمجموعة من المعلومات المهمة حول التضاريس الجغرافية في الطبيعة.

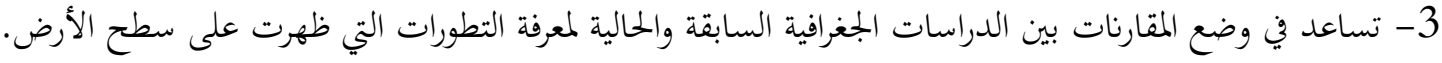
فروع الجغرافيا الطبيعية: تقسم الجغرافية الطبيعة إلى بجموعة من الفروع، اهمها: 1- علم الأرض: يعرف علميا بمصطلح جيومورفولوجيا، وهو العلم الجغرافي الطبيعي الذي يهتم بدارسة التضاريس الأرضية التي توجد على سطح الأرض كالجبال والسهول والهضاب والبحار والمخيطات وغيرها. ويحرص هذا الفرع من علم الجغرافيا الطبيعة على متابعة التطورات التي ظهرت على التضاريس الأرضية بالاعتماد على الى

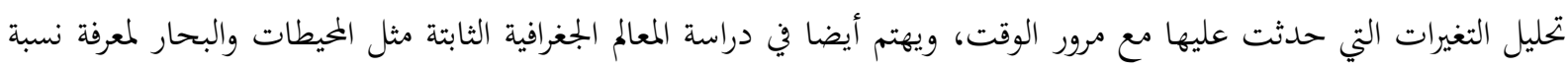
المياه والكائنات الحية التي تعيش فيها. 2- علم الماء: يعرف علميا بمصطلح هيدرولوجيا وهو العلم الجغرافي الطبيعي الذي يدرس الماء بصفته مكوناً من مكونات

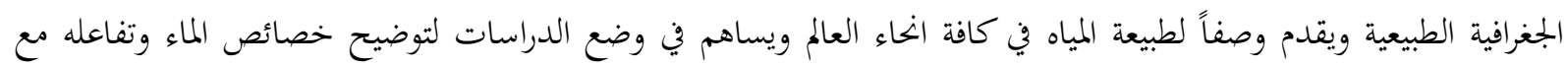
البيئة المخيطة به و تأثير الكائنات حية والانسان على المياه في الأرض. 3- علم المناخ: هو العلم الجغرافي الطبيعي المرتبط بدراسة المناخ وتأثيره على الكرة الأرضية عن طريق ربط الغلاف الجوي والعناصر المكونة له كالطقس ودرجة الحرارة وحركة الرياح والضغط الجوي كما انه يهتم بدراسة تأثير طبيعة التقلبات الجوية في

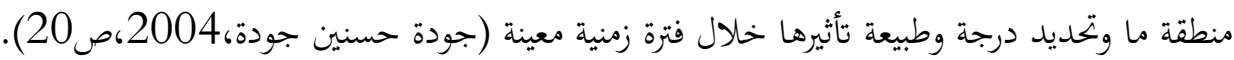


4- علم التربة: يعرف علميا بمصطلح بيدولوجيا وهو العلم الذي يهتم بدراسة التربة بصفتها من المكونات الاساسية في الجغرافيا

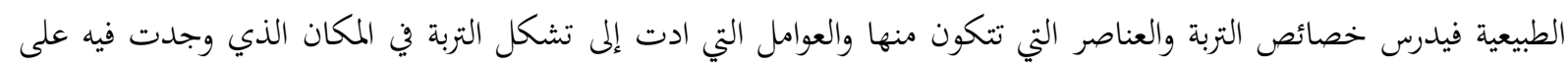
سطح الأرض. - مبع.

5- علم الصخور: هو احد فروع علم الجغرافيا الطبيعية والذي يهتم بدراسة طبيعة وانواع وخصائص وصفات واشكال الصخور التي توجد في الكره الأرضية سواءً على سطحها أو ضمن طبقاتما الداخلية.

6- الجغرافية البشرية: هو فرع من فروع الجغرافيا يدرس النماذج والعمليات التي تصوغ تعامل البشر مع البيئة مع تركيز على

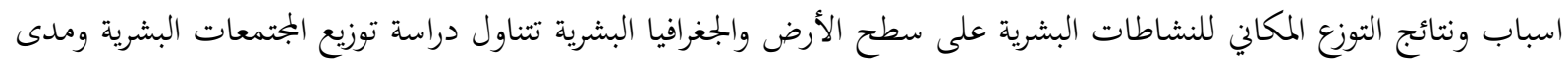

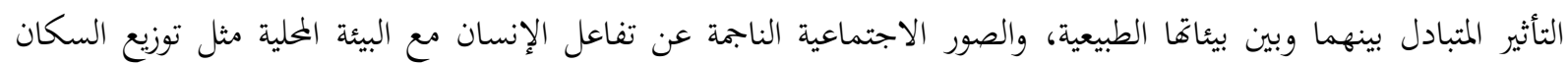

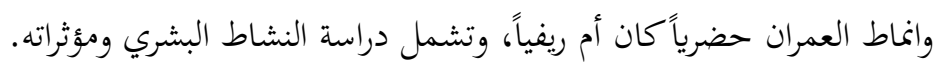
التركيب السياسي بوصفة ظاهرة جغرافية تمثل رقعاً من سطح الأرض لها حدودها الاصطناعية وامكانياتما الاقتصادية والبشرية وما يترتب على ذلك مشكلات يوجهها ويؤثر فيها بالضرورة والظروف الجغرافية السائدة على المستويين الأقليمي والعالمي

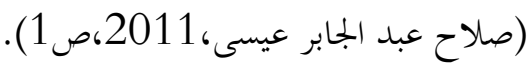

الجغرافية البشرية تتحدد بدراستها لملامح التفاعل، واوجه التباين والتشابه بين الآقاليم المختلفة في البيئات بعناصرها الطبيعية

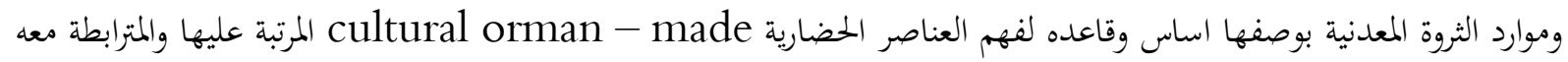
داخل إطار بيئي محدد.

Cause - Effect الذي يثمر في فهم العلاقات التأثيرية والتأثرية correlation وهئ تؤكد مبدأ الارتباط Relationships

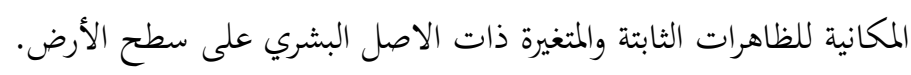
وتنقسم الجغرافيا البشرية إلى ثلاثة فروع رئيسية: 1- الجغرافيا الاجتماعية: تتصل الجغرافيا الاجتماعية اتصالاً وثيقاً بعلم الاجتماع كما يفهم من اسمها وكل فرع من فروعها يرتبط هو الأخر ارتباطاً وثيقاً ببعض العلوم الأخرى. 2- جغرافيا السكان: ذات صلة وثيقة بعلم السكان أو الديموجرافيا. 3- جغرافيا العمران الحضري والريفي: ذات صلة وثيقة بعلم تخطيط المدن والريف country planning and town وتعتمد جغرافية الخدمات على كل هذه العلوم السابقة في توزيع وتصنيف المراكز الخحدمية.

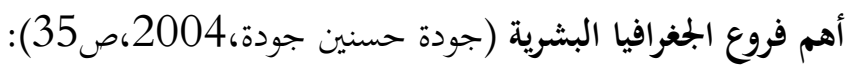

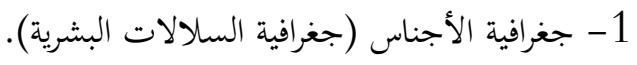
2- 2 - جغرافية السكان.

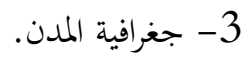
4- الجغرافية السياسية. 5- الجغرافية الأقليمية. 
الفلك: هو الدراسة العلمية للكون وكل الاجرام الموجودة في الفضاء كالشمس والكواكب والنجوم والأقمار

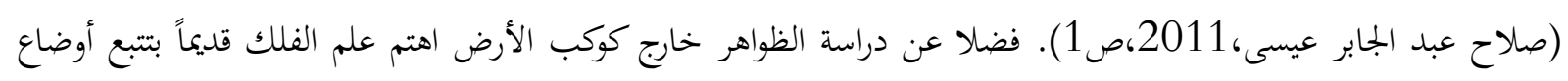

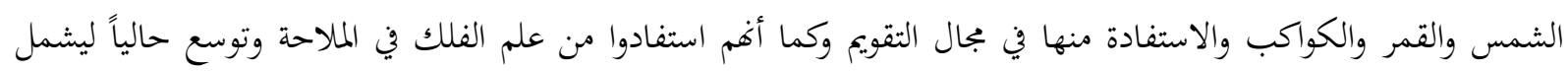

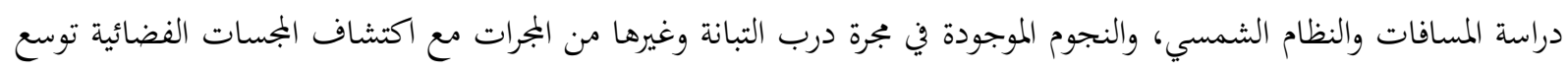

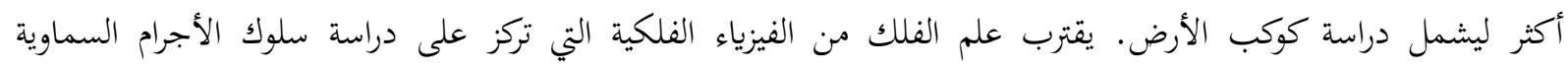

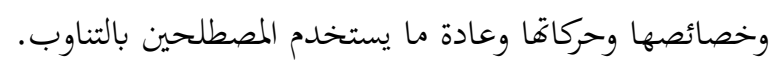

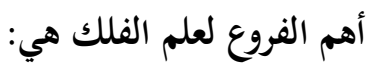

$$
\text { 1 - 2- علم الفلك البصري. }
$$$$
\text { 2- 2 - 2 - ملم الفلك غير البصري. }
$$

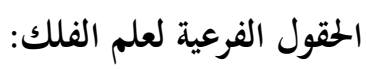

$$
\begin{aligned}
& \text { 1- علماء الكواكب. } \\
& \text { 2- } \\
& \text { 3- 2- علماء الشمس. علماء الجزم. } \\
& \text { 4- علماء الجزة. } \\
& \text { 5- علماء الكون. }
\end{aligned}
$$

وفي مجالات فلكية أخرى بما فيها موقع الأرض بين الكواكب وشكلها وحركتها وميطها وقطرها. وميدان الجغرافيا الوصفية

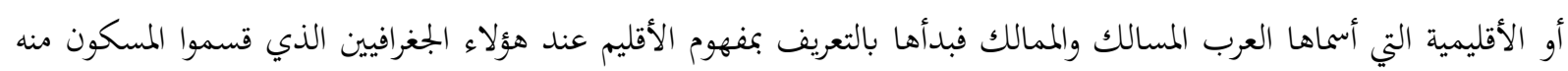

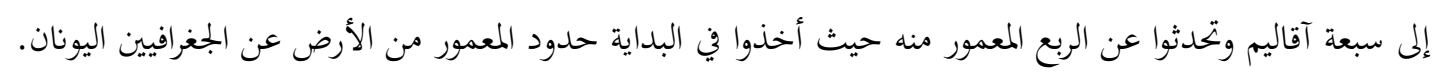

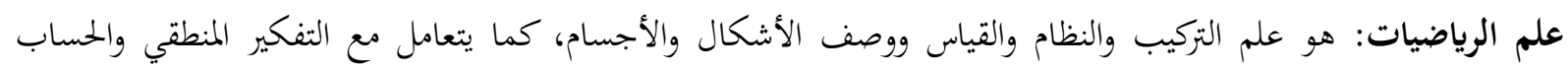

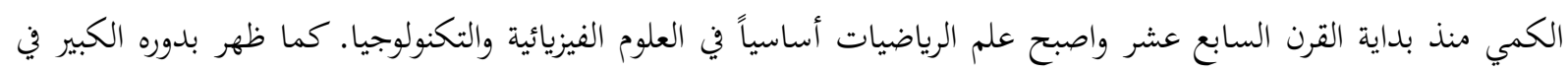

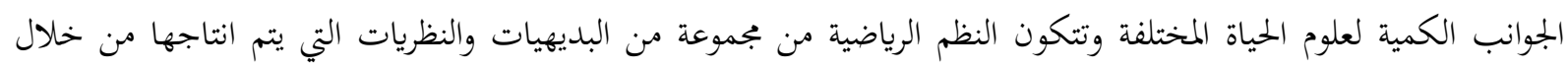

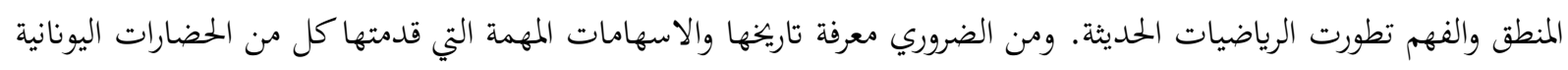

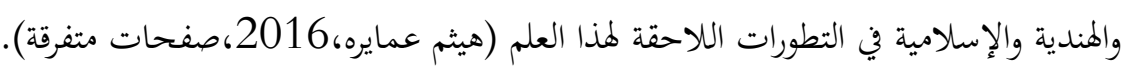

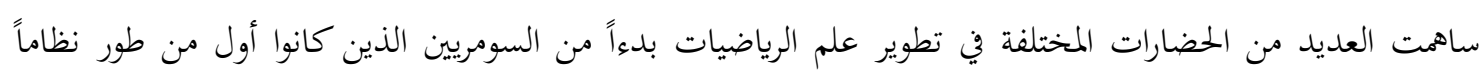

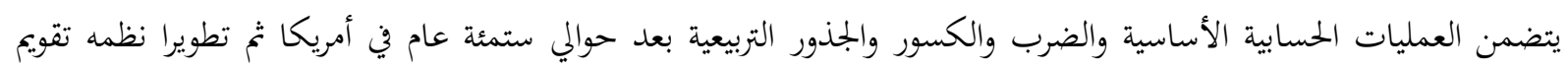

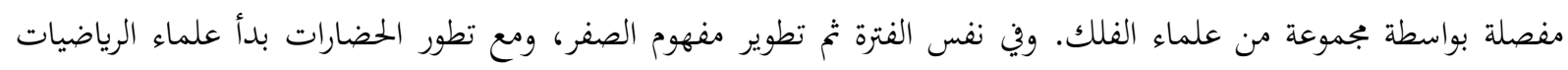

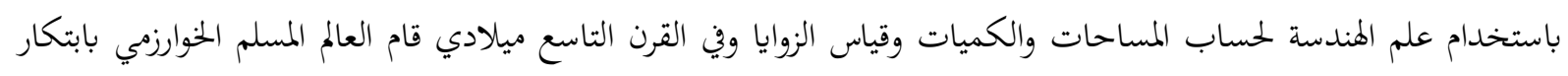
علم الجبر وطور نظام الخوارزميات الذي نسبه إليه.

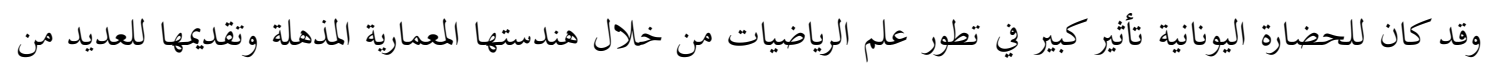

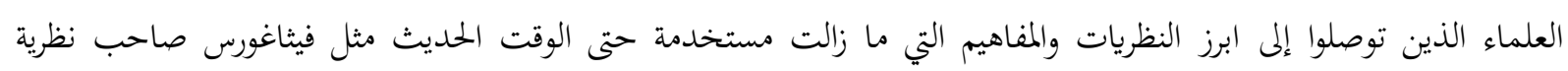

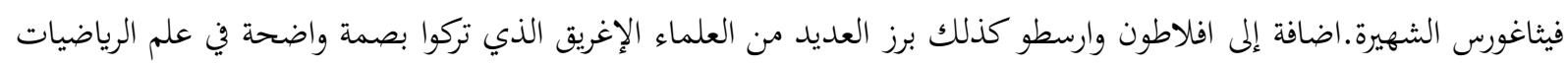

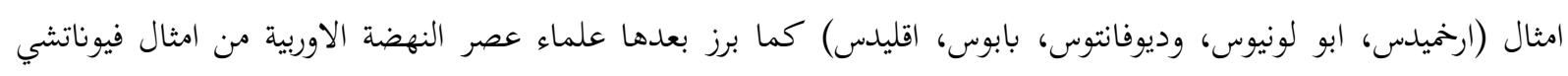


الذي اشتهر بنظرياته حول الحساب والجبر والهندسة وفي ذات الفترة برزت تطورات عدة شملت الكسور العشرية واللوغارتيمات والهندسة الاسقاطية والتي بشرت بعهد جديد من الرياضيات.

فروع علم الرياضيات:

$$
\begin{aligned}
& \text { 1- الحساب } \\
& \text { 2- الجبر } \\
& \text { 3- الهندسة } \\
& \text { 4- علم المثلثات } \\
& \text { 5- علم الاحصاء }
\end{aligned}
$$




\section{المسلمون ودورهم في تقدم علم الخخائط.}

لم يكن للعرب قبل إسلامهم اهتمام هذا العلم ولذلك استخدموا الشعر في وصف بعض المناطق داخل جزيرقم وخارجها وعندما جاء المسلمون وانطلقوا ينشرون الإسلام اهتموا بالخرائط البرية والبحرية على حد سواء، واعتمدوا القياسات الفلكية والرياضية فأتت خرائطهم على اسس صحيحة واعطوا هذا العلم دفعة جديدة. ومن العوامل التي ساهمت في تقديم هذا العلم عند المسلمين (فلاح شاكر اسود، 1982،صنيم:198): 1 - 1 الفتوحات الإسلامية.

2- أتساع رقعة العالم الإسلامي وخاصة العصر الذهبي وتولد الحاجة لجهاز البريد الذي يتطلب معرفة الطرف والاتحاهات كان مبرراً لظهور الخرائط والكتب التي تعالج ذلك. 3- نشاط حركة التجارة البرية والبحرية بين مختلف البلدان.

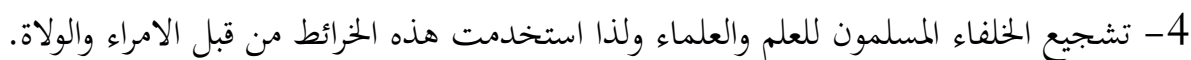
ولقد تمثل دور علماء المسلمين في تقديم هذا العلم بأمور عدة من بينها:

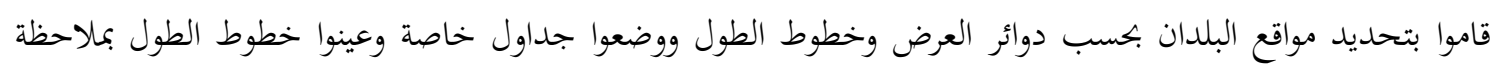

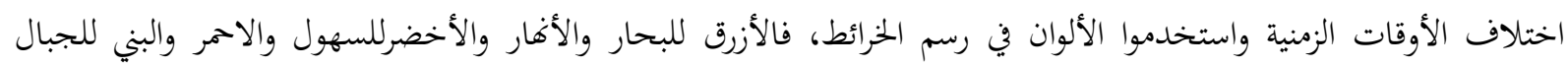
ورسموا المدن على دوائر مذهبة.

\section{1 - خطوط الطول وخطوط العرض:}

يعدُّ المسلمون أول من وضع خطوط الطول وخطوط العرض على خريطة الكرة الأرضية وضعها العالم أبو علي المراكشي (ت 660هـ - 1262م) وذلك لكي يستدل المسلمون على الساعات المتساوية في بقاع الأرض المختلفة للصلاة. كما وضع البيروني قاعدة حسابية لتسطيح الكرة أي نقل الخطوط والخرائط من الكرة إلى سطح مسطح وبالعكس.. وبهذا سهل رسم الخرائط الجغرافية.

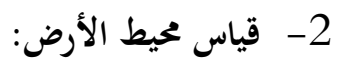

كان أول من قام بمحاولة قياس أبعاد الكرة الأرضية الخليفة العباسي العالم المأمون (ت: 218هـ- 833م) ، فقد جاء بفريقين من علماء الفلك والجغرافيا فريق برئاسة: سند بن علي، وفريق بقيادة: علي بن عيسى الإسطرلابي. ويقال إن رئاسة أحد

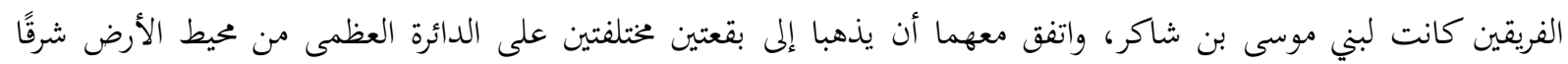

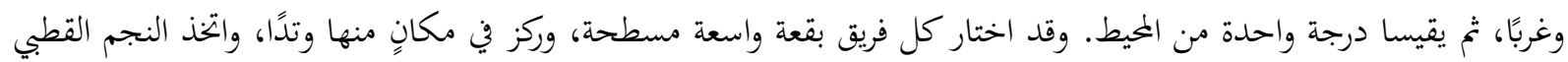

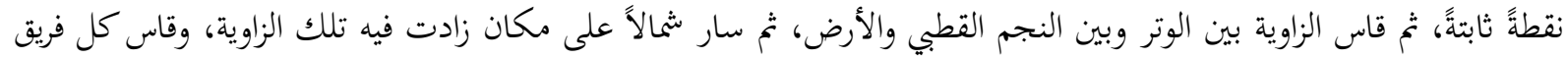

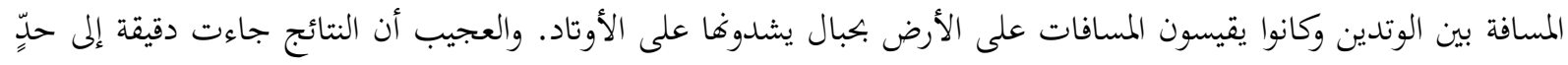

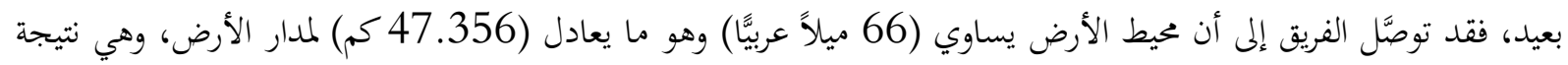

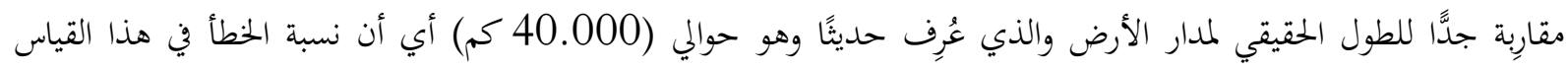

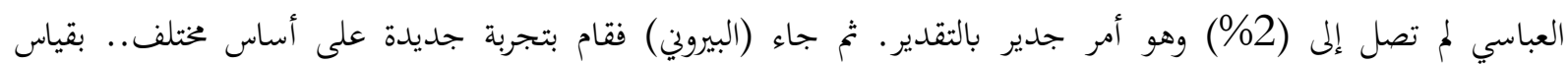

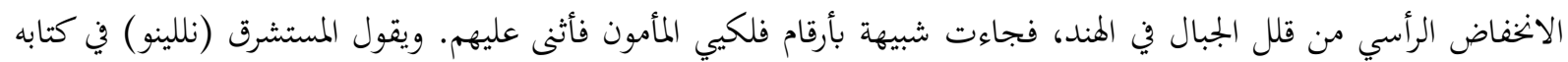


(علم الفلك عند العرب): إن قياس العرب للكرة الأرضية هو أول قياس حقيقي أُجري كله مباشرة مع كل ما تقتضيه تلك المسافة الطويلة وهذا الفريق الكبير من العلماء والمساحين العرب فهو يعد من أعمال العرب المأثورة وأبجادهم العلمية.

\section{3- دوران الأرض حول نفسها:}

في الوقت الذي كان العالم لا يتخيل فيه أن الأرض كرة لم يكن هناك من يناقش مسألة دوران الكرة حول نفسها، ولكن

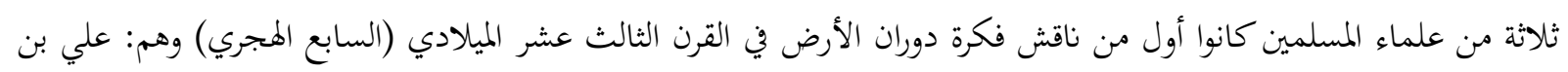

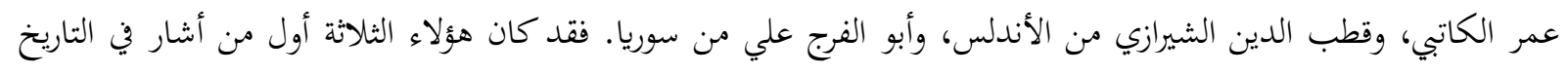
الإنساني إلى احتمال دوران الأرض حول نفسها أمام الشمس مرة كل يوم وليلة، ويقول سارتون في كتابه (مقدمة في تاريخ العلم):

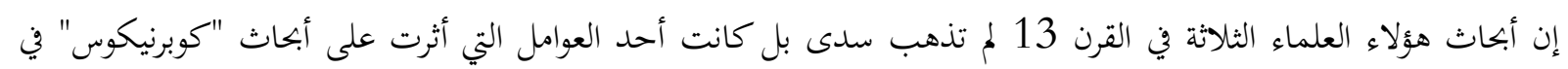
نظريته التي أعلنها سنة 1543م.

لا يُنكِر أحد أن الغرب قد استفاد من مجهودات المسلمين في علم الجغرافيا عامة إلا أن (أطلس الإسلام) أو الخرائط

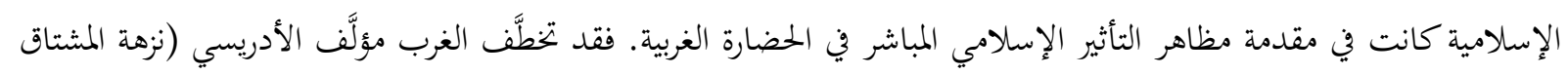

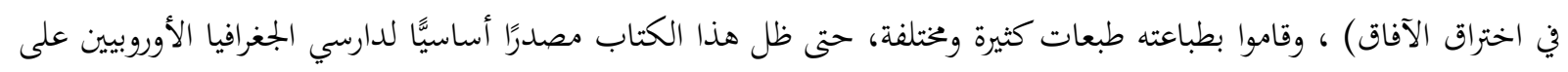

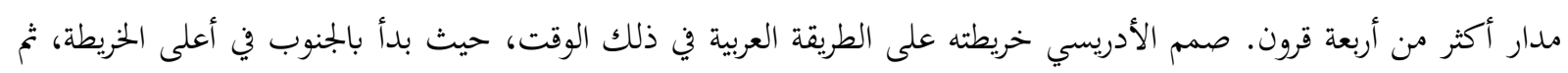

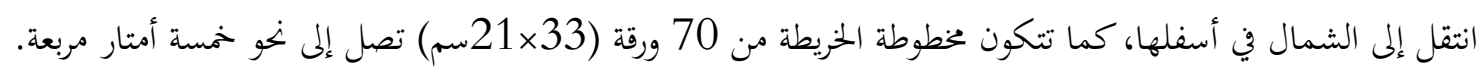

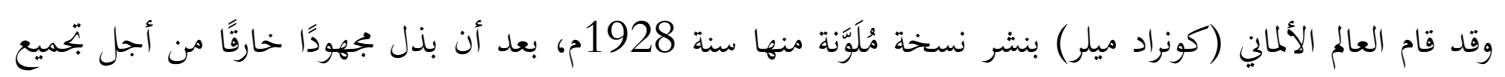

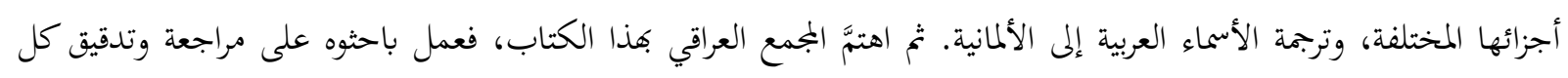
النسخ الموجودة في العالم، وأخرجوا خريطة الأدريسي وطبعوها سنة 1951م وهي بطول مترين وعرض متر واحد المباء (فلاح شاكر اسود،،1982، 198، 198).

\section{من أهم العلماء المسلمين في مجال علم الخرائط:} 1- الأدريسي: الذي قسم أرض كما تصورها إلى سبعة آقاليم وقسم كل أقليم إلى عشره اقسام متساوية، ورسم لكل قسم خريطة (70) 2- المقدسي: الذي يعد أول من استخدم الألوان في الخرائط. 3- ابن حوقل: وقد ألف كتابا اسماه صوره الأرض، ورسم خرائطه بطريقة هندسية تخطيطية.

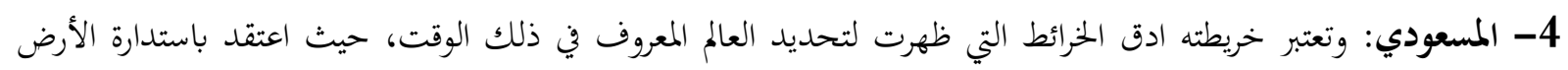

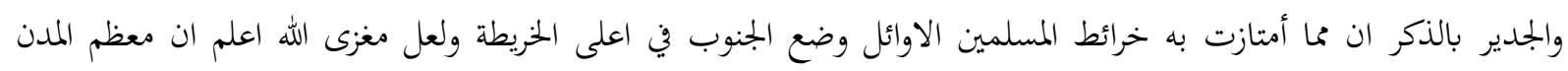

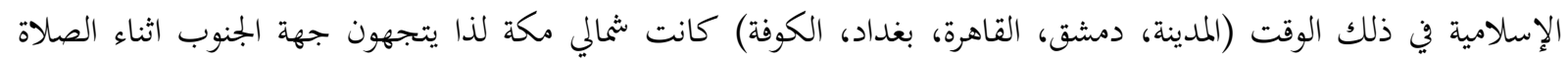
ويعتبوونه يشير إلى اشرف بقع المسلمين ومن هنا كان لابد من وضع الجنوب في اعلى الخريطة (الموسوعة ويكيبيديا).

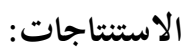

1- تعد الخرائط إحدى وسائل المستخدمة في ايصال المعلومات فهي كتابة وسيلة ايضاح لمختلف الظواهر الممثلة عليها سواء

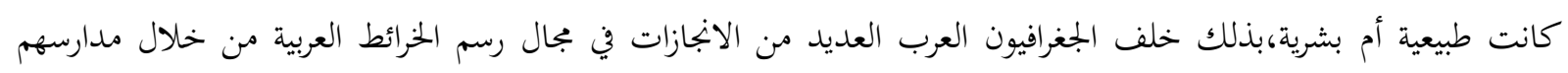

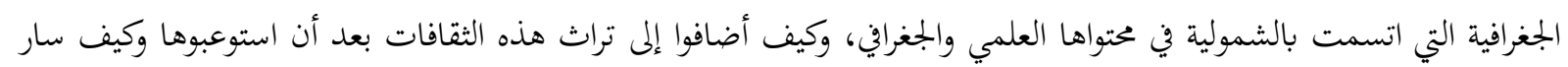


المسلمون من الرحلة إلى الكشف إلى الوصف والتحليل، ومن الفلك إلى الكارتو جغرافيا، وكيف ارتبطت الجغرافيا بالخرائط في عصر ازدهارها.

2- أدرك العرب بان علم الخرائط هو علم يؤثر بشكل مباشر على جميع المجالات للأغراض الفكرية والادارية وغيرها، اتضح كيف

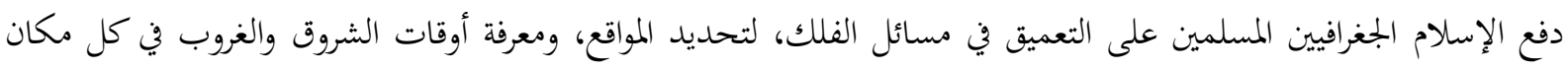

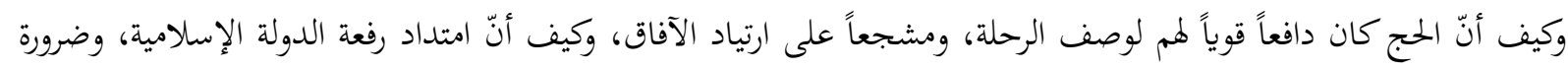

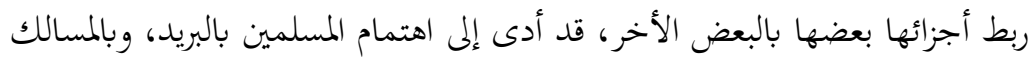

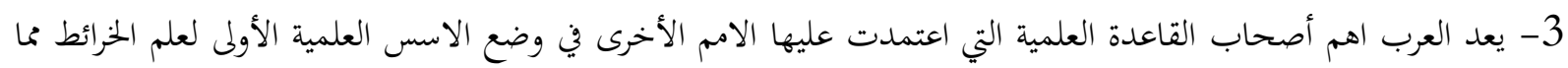

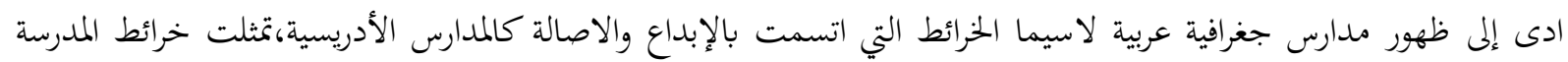

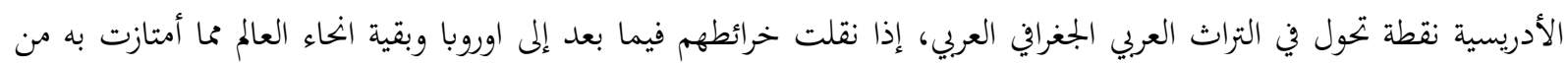

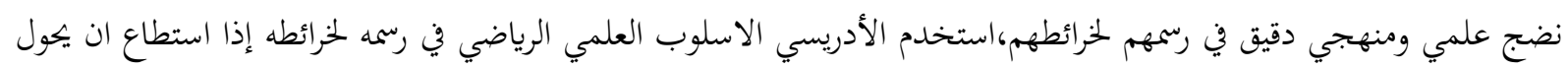

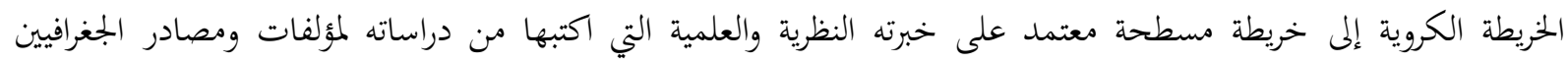

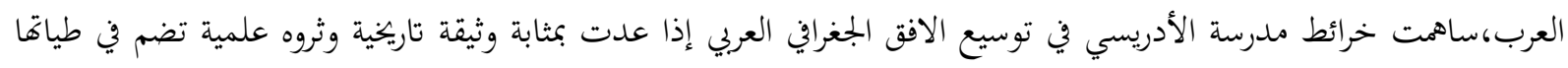

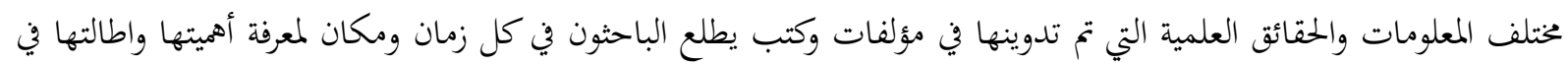
مجال رسم الخزائط. 4- 8-تعد الخرائط عند العرب المسلمون تمثل مرحلة متطورة في استخدام الأساليب الكمية التي لا تختلف عما يجري في رسم الخرائط في العصر الحديث والمعاصر.

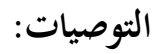

1- الاهتمام بالتراث الجغرافي الإسلامي لاسيما في بجال رسم الخرائط.

2- اعتماد بعض المساقط العربية الإسلامية لأهميتها في التمثيل الخرائطي. 3- ضرورة الكشف عن الخرائط العربية الإسلامية المفقودة. 


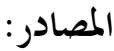

احمد نجم الديم فليجه وجميل نجيب عبد الله (1986) ،علم الخرائط والدراسة الميدانية،جامعة بغداد، بغداد. جودة،حسين جودة (2004) اسس الجغرافيا العامة، منشاة المعارف الإسكندرية. صلاح عبد الجابر عيسى (2011) مناهج وأساليب البحث في الجغرافيا، مطابع جامعة المنوفية، شبين الكوم.

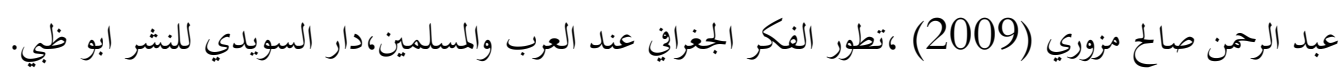

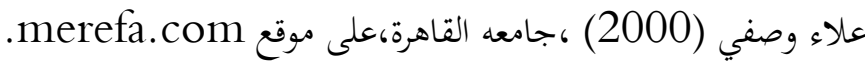
فلاح شاكر أسود (2 198) ،دور العرب والمسلمين في رسم الخرائط، بحوث المؤتمر الجغرافي الأول، المجلد الثالث،الرياض. فلاح شاكر اسود (بدون سنة) ،الخرائط العملي، بغداد.

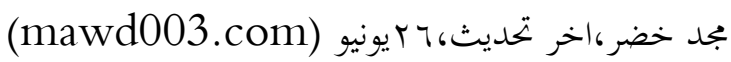

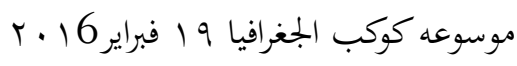
موسوعه ويكيبيديا (ar.m.wikipeddia.org)

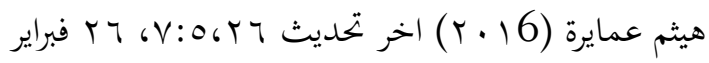




\section{THE CONCEPT OF EXPATRIATION IN THE POEMS OF FAROUK NAFEZ JAMLIBEL}

\section{Istanbul / Türkiye \\ p. $300-308$}

Received: $27 / 11 / 2021$

Accepted: $17 / 12 / 2021$

Published: 01/01/2022

This article has been scanned I iThenticat No plagiarism detected

\author{
Hazim Mohammed HUSSEYIN ${ }^{1}$ \\ Widaad Jasim MOHAMMED ${ }^{2}$
}

\begin{abstract}
:
Faruk Nafez Jamlibel is one of the greatest poets of the twentieth century. He was born in Istanbul in 1898 and died in 1973 at the age of 75 . Farouk Naviz Jamlibel wrote a part of the literary collection "Five Parts" with Anis Bahish, Youssef Zia, Khaled Fakhri and Orhan Seif. He wrote many outstanding poetic and theatrical works. In his poems, the writer used mostly syllabic meters. The main feature of five-syllabic groups, which he already used within his poems, is that they depend on syllabic meters. He used the syllabary very effectively in his poems. Because of his contributions to Turkish literature, he has preserved his reputation even decades after his death. Faruk Nafez Jamlibel has dealt with various topics in his poems such as death, longing, pain, trouble, distress, anguish, anxiety, and homeland intensely and effectively. It also dealt with the issue of homelessness, which is not without (devoid of) pain and hope. Through our research, we have seen that one of the most important concepts used in Farouk Nafez Jamlibel's poems is displacement (homelessness). Since there is no study in this field, we have identified the subject of our study under this name, which expresses alienation, i.e. moving away from the homeland. The research paper deals with a person who migrates to different and foreign cities and often faces financial difficulties and bemoans deeply his original hometown. The subject of our research is distinguished by the name of the concept of "expatriation in the poems of Farouk Nafez Jamlibel". Therefore, it is natural for him to use the concept of homelessness in his poems. At the beginning of the research, we worked to provide a comprehensive summary of the research topic. Then, we briefly introduce Faruk Nafez Jamlibel's life, literary personality and works. Then, after a comprehensive definition of the displaced person, we will try to give details about this topic in Faruk Nafez Jamlibel's poems.
\end{abstract}

Key words: Faruk Nafiz Çamlıbel, Literature, Hometown, Poetry, Han Duvarları, Anatolia.

http://dx.doi.org/10.47832/2717-8293.15.22

Dr. , Baghdad University, Iraq, hazimm2001@yahoo.com, https://orcid.org/0000-0002-8104-2389

Dr. , Baghdad University, Iraq, Widaad.j@ colang.uobaghdad.edu.iq 


\section{FARUK NAFIZ ÇAMLIBEL'İN ŞIIIRLERINNDE GURBET ANLAYIŞI}

\section{Özet:}

Faruk Nafiz ÇAMLIBEL, 20. yüzyılda yetişmiş en büyük şairlerdendir. 1898 İstanbul doğumlu olan şair, 1973’te hayata gözlerini yumdu. Enis Behiç, Yusuf Ziya, Halit Fahri ve Orhan Seyfi ile birlikte "Beş Hececiler" adındaki edebiyat grubunun parçası olan Faruk Nafiz Çamlıbel, çok sayıda güzide şiir ve tiyatro eseri kaleme almıştır.

Şiirlerinde daha çok hece ölçüsünü tercih etmiştir. Zaten içinde bulunduğu beş hececiler grubunun temel özelliği, şiirleri hece ölçüsüyle yazmaktır. Türk milli nazım birimi olan hece ölçüsünü oldukça etkili kullanmıştır. Türk Edebiyatına yaptığı katkılar sebebiyle, ölümünün üzerinden onlarca y1l geçmesine rağmen şöhretini korumaktadır.

Faruk Nafiz ÇAMLIBEL, şiirlerinde ölüm, hasret, sanc1, dert, sıkınt1, 1zdırap, tasa, memleket gibi temaları oldukça yoğun ve etkili bir şekilde işlemiştir. Buna bağlı olarak, acının ve umudun hiç eksik olmadığı gurbet temasını ele almıştır. Yaptığımız araştırmalar neticesinde, Faruk Nafiz Çamlıbel'in, şiirlerinde en çok kullandığ kavramlardan birinin Gurbet olduğunu gördük. Bu alanda yapılmış bir çalışmanın olmaması dolayısıyla, çalışma konumuzu bu isim altında belirledik.

Gurbet, kişinin öz vatanından uzak kalmasıdır. Daha çok geçim sıkıntısından dolayı, farklı ve yabancı şehirlere göç eden kişi, asıl memleketine oldukça yoğun bir şekilde özlem duyar. Bu tarifi zor özlem, Gurbet adıyla nitelendirilir. Faruk Nafiz ÇAMLIBEL, esasında bir memleket şairidir. Dolayısıyla şiirlerinde, Gurbet kavramını kullanması oldukça doğaldır.

Çalışmamızın başında, konuya dair kapsamlı bir özet sunuyoruz. Ardından Faruk Nafiz ÇAMLIBEL'in kısaca hayat1, edebi kişiliği ve eserlerine değineceğiz. Ardından kapsamlı bir Gurbet tanımından sonra, Faruk Nafiz ÇAMLIBEL'in şiirlerinde, bu temayı etraflıca incelemeye gayret edeceğiz.

Anahtar Kelimeler: Faruk Nafiz Çamlıbel, Edebiyat, Şiir, Han Duvarları, Gurbet, Anadolu.

\section{GİRİŞ:}

\section{Hayatı, edebi kişiliği ve eserleri:}

18 Mayıs 1898 tarihinde İstanbul'da dünyaya geldi. İlk ve orta öğrenimini Bakırköy Rüşdiyesi ile Hadîka-i Meşveret İdâdîsi'nde tamamladı. Tip fakültesinde 4 sene okudu, fakat bitiremeden ayrild1. O sırada bir gazetenin, yazar kadrosundan kendisine is buldu. İki yıl süreyle aynı gazetenin mümessili oldu. Bu gazetenin adı "İleri" gazetesi idi. İlk iş deneyimini bu şekilde yaptıktan sonra, tarihi Kayseri Lisesi'ne, edebiyat öğretmeni olarak girdi. Bu dönem 1922 ve 1924 yılları arasındadır. Burada çok başarılı ve çok verimli iki senelik bir öğretmenlik döneminden sonra mesleği çok sevdi. Ankara'da çeşitli okullarda edebiyat ve Türkçe öğretmenliği yapmaya başladı. Bu süreç 1946 senesine kadar devam etti. Sirayla öğretmenlik yaptığı kurumlar ise şu şekildedir:

Kayseri lisesi edebiyat öğretmenliği, (1922-1924)

Ankara Muallim Mektebi, (1924)

Ankara Kız lisesi/ Ankara Erkek Lisesi, (1924-1932)

İstanbul Vefa Lisesi, Kabataş Lisesi, Arnavutköy Amerikan Kız Koleji, (1932-1946) (ORTAÇ, 1937: 44)

Öğretmenlik yaptığı dönemin sonunda, siyasete önem vermeye başladı. Türk siyasetinde aktif olarak çalışmak ve memleket meseleleriyle bizzat ilgilenmek istiyordu. Çünkü Faruk Nafiz ÇAMLIBEL, bir memleket şairiydi. Bu duygu ve düşüncelerle 1946 y1lında siyasete girdi. Merhûm başbakan Adnan Menderes'in kurduğu Demokrat Parti'den milletvekili seçildi. Siyasete girdiği ilk yıl milletvekili olarak göreve başladı. 1960 yılında gerçekleşen darbe girişimi neticesinde, diğer tüm parti üyeleriyle birlikte hapse mahkum 
edildi. 1 sene 3 ay boyunca, Yassiada denilen cezaevinde tutuklu kaldıktan sonra, 1961 yılında özgürlügüne kavuştu. Bundan sonra asla siyasetle uğraşmadı. Artık direnci kırılmıştı. Yorulmuştu. Ömrünün geri kalanını sakin ve huzurlu bir şekilde geçirmeye karar verdi. Evi İstanbul'daydi. İstanbul'un Arnavutköy semtinde bulunan bu evinde ikamet etti. 1973 yılında, bir deniz gezisinde yere yığıldı. Vücudu yorulmuştu. Bir sonbahar günü, hayata gözlerini yumdu. Kabri, İstanbul'un en meşhur kabristanı olan Karacaahmet Mezarlığındadır.

Faruk Nafiz ÇAMLIBEL, küçük denilebilecek yaşlarda edebiyatın en önemli parçalarından olan siire merak saldı ve çok kaliteli şiirler yazmaya başladı. Onun bu konuda yol göstericileri, büyük türk şairleri olan Tevfik Fikret, Ahmed Hâşim ve Cenap Şahabettin gibi ustalardır. Faruk Nafiz CCAMLIBEL'in şiirinin gelişmesinde, saydığımız bu şairlerin rolü ve etkisi büyüktür. Şiirlerinin konusu genel olarak aşk ve kederdir. Şiirlerine çok bağlıdır. Çok önemli olayları göz ardı edebilir, fakat çok küçük detaylara şiir yazabilirdi. Şiirde özgür ruhlu bir yapısı vardır. Hürriyet kavramnı savunan ve özgürlüğü her alanda olmasını savaunan yazarlardandır. Kısaca canı ne istiyorsa, onu şiirine konu edinmiştir.

Özgür ve bağımsızlığını koruyamayan milletlerin, ahlakının da kaybolduğu görülür. Bağımsız olmayan bir milletin kültür hayatını devam ettirmesi, dinini, dilini yaşaması da mümkün değildir (Türk, 2016: 449).

1918'de Şarkın Sultanları adıyla ilk kitabını yayınlamıştır. Bu, onun ilk şiir kitabıdır aynı zamanda. Yeni Mecmua, Fağfûr, Şâir gibi edebî dergilerde de şiirleri yayımlanmaya başlamıştır. 1918 yılı, Faruk Nafiz ÇAMLIBEL'in şiirde arayışının başladığı yıldır. Aynı zamanda ilk ürünlerini edebiyata kazandırdığı yıl olacaktır. Artık aruz veznini çok iyi derecede kullanıyordur. Faruk Nafiz ÇAMLIBEL'in edebiyatçı yönü, yavaş yavaş kendini belli etmeye başlar. Orijinal bir üslupla yazdığı şiirler, yavaş yavaş meşhur olmaya ve dilden dile dolaşmaya başlar (Yücebaş, 1974: 75). Cumhuriyet dönemi Türk şiirinde hecenin ve bilhassa aruzun gevşemesinin tesiriyle muhtelif yapıların kullanması hayli yaygındır (Türk, 2020: 163).

1919'da Edebî Mecmua isimli derginin müdürlüğünü yapmıştır. Bu sıralarda yazdığ1 şiirlerin teması, genel olarak aşk ve sevgidir. Daha sonraki dönemlerinde acı ve 1stırap gibi kederli şiirlerine rastlamaktayız. Faruk Nafiz ÇAMLIBEL, özenle sürdürdüğü sanat anlayışını, 1922 yılında değiştirmiştir. 1922 yılından sonra, memleket meselelerine yönelir. Artık eskisi kadar aşk ve sevgi üzerine yazmamaya başlar. Onun için önemli olan şey, memlekettir. Ayrica bu vakte kadar aruz vezniyle yazıyorken, artık yalnızca hece veznini kullanır. Çünkü hece ölçüsü, Türk milli nazım birimidir. Milliyetçi bir tavır içinde olmasından kaynaklı olarak hece veznini, aruz veznine tercih etmiştir. Bu yeni tavrının nişanı ise, 1926 yılında 10 kıta halinde yazdığı "Sanat" şiiridir. Şiir, baştan sona milliyetçilik üzerine yazılmış, doğu-batı yorumudur. Batı edebiyatı ve batı, ayaklar altına alınmış, Türk milliyetçiliği yüceltilmiştir. Anadolu insanı, Anadolu kültürü, ön plana çıkmaktadır. Dolayısıyla Faruk Nafiz ÇAMLIBEL, artık bir Anadolu şairidir (Kaplan, 1965:16).

Meşhur olan birçok şiiri vardır. Bunlardan en meşhur olanı, hiç şüphesiz "Han Duvarları" şiiridir. Şiirde Anadolu ve millet tasvirleri göze çarpar. Çok uzun bu şiir, bir solukta okunacak şekilde sade ve akıcı bir üslupla yazılmıştır. Bu şiirle birlikte artık Faruk Nafiz ÇAMLIBEL, memleket edebiyatının önde gelen isimlerinden biri olmayı başarır. Çünkü Anadolu denilen nazlı gelini çok iyi tanımaktadır ve çok sevmektedir. Anadolu coğrafyasını karış karış şiirlerine ekleme ve yorumlama gayreti içerisinde, halkın diliyle sayısız şiirler yazmaya devam eder. Anadolu'nun sevgisini, kavgasını, örf ve adetini şiirlerinde anlatır ve artık $\mathrm{O}$, büyük bir Anadolu şairidir.

Hecenin Beş Şairi'nin öncüsü olarak adlandırılsa da Türk şiirinin köklü kaynaklarına eğilmekten geri durmayan Faruk Nafiz, modern Türk şiirini besleyen kaynaklar arasında yer alan divan şiirinin şekillendirdiği geleneğin imkânlarından yararlanmayı tercih etmiştir (Karataş, 2013: 212).

Aruz ve hece ölçüsünü oldukça etkili kullanmıştır. Her ne kadar son dönemini hece ölçüsünü kullanarak geçirse de, Aruzu tamamen terk etmemiştir. Aruz vezni noktasında, Türk Edebiyatının baş şairi Yahya Kemal BEYATLI'yı üstad kabul eder. Daha sonra kendisi de en az Yahya Kemal kadar usta olacaktır.

Faruk Nafiz Çamlıbel, tüm bu ustalık süresince, kendisine has özellikler ortaya koyar. Anadolu'yu, okulla birleştirme hayali, onun orijinalitesini ortaya koyan eşsiz bir duruştur. Anadolu'da çeşitli yerlerde öğretmenlik yaptığından bahsetmiştik. Bu öğretmenlik yılları, gönüllülük esasına dayanmaktadır. Yani kısaca öğretmenlik mesleğinin karşılığ 
olarak maaş istemez. Çünkü kendisi bizzat Anadolu'dan beslenmektedir. Anadolu insanını tanımak ve iyice onlarla hemhal olmak için çıktığ bu yolda, onların geleneklerini ve göreneklerini, acısıyla tatlısıyla şiirlerine muhteşem bir üslupla yansıtmayı başarır. Onun için samimiyet ön plandadır. Bu yüzden yüksek zümre edebiyat1 yerine, samimi Anadolu edebiyatını tercih etmiştir (Koşar, 2009: 61).

Faruk Nafiz ÇAMLIBEL'in belki de en dikkat çekici yönü, aynı zamanda bir mizah ustası olmasıdır. Mizahî bir üslupla kaleme aldığı eserlerinde, Faruk Nafiz Çamlıbel adı yerine, farklı isimler kullanır. Bunlardan bazıları Çamlıviran, Çamdeviren, Deli Ozan, Çamlıbel ve Akıllı Ozan'dır. Bu takma isimlere "mahlas" adı verilir ve Türk Edebiyatının olmazsa olmazı bir gelenektir. Bu takma isimlerle yazdığı espri yüklü şiirlerin sayısı neredeyse 1000 'i bulur. Bu tarz şiirlerini, mizahî edebiyat dergilerinde yayınlamısstır. Bunlardan bazıları Akbaba Dergisi (1934), Karikatür Dergisi (1936), Mizah Dergisi'dir (1946).

20. yüzyılda yetişmiş en büyük şairlerden biri olan Faruk Nafiz ÇAMLIBEL, 1973 tarihinde hayata gözlerini yuman şairin mezarı, Memleketi İstanbul'da, Karacaahmet Mezarlığındadır.

Eserleri: (Türkiye Diyanet Vakfi İslam Ansiklopedisi: cilt 8, 196)

Şiirler: Şarkın Sultanları (İstanbul 1918); Dinle Neyden (İstanbul 1335); Gönülden Gönüle (İstanbul 1919); Çoban Çeşmesi (İstanbul 1926); Suda Halkalar (İstanbul 1928); Bir Ömür Böyle Geçti (İstanbul 1932); Elimle Seçtiklerim (İstanbul 1934); Boğaziçi Şarkısı (İstanbul 1936); Tatlı Sert (mizahî şiirler, İstanbul 1938); Akıncı Türküleri (İstanbul 1938); Akarsu (İstanbul 1940); Heyecan ve Sükûn (İstanbul 1959); Zindan Duvarları (1960'lardan sonra yazmaya başladığı kıta tarzında şiirleri, İstanbul 1967); Han Duvarları (İstanbul 1969).

Tiyatrolar: İlk Göz Ağrısı (İstanbul 1922); Sevk-i Tabîî (İstanbul 1925); Canavar (İstanbul 1926); Akın (İstanbul 1932); Özyurt (İstanbul 1932); Kahraman (İstanbul 1933); Ateş (İstanbul 1939); Dev Aynas1 (İstanbul 1945); Yayla Kartalı (İstanbul 1945). Mektep Temsilleri. Numaralar (İstanbul 1928); Bir Demette Beş Çiçek (İstanbul 1933); Yangın (İstanbul 1931); Hanım Şiir Yazacak, Yeni Usûl, Mektublar (İstanbul 1933); Kanbur (İstanbul 1922).

Tüm eserleri bunlarla sınırlı değildir. Her ne kadar çok bilinmese de, Faruk Nafiz ÇAMLIBEL'in bir romanı vardır. Bu roman, 1936 yılında İstanbul'da yayınladığı "Yıldız Yağmuru" isimli küçük hacimli bir eserdir. Ayrıca çeşitli dergi ve gazetelerde hâtıra, sohbet, makale ve denemeleri yayımlanmıștır.

\section{Gurbet nedir?}

isim, "Doğup yaşanılmış olan yerden uzak yer, gurbetlik:

Örneğin, "Ben gurbette değilim / Gurbet benim içimde." -Kemalettin Kamu (Güncel Türkçe Sözlük ve Yazım Kılavuzu, Gurbet maddesi)

Güncel Türkçe Sözlük ve Yazım Kılavuzu, Gurbet tanımını kısaca bu şekilde izah etmiştir. Böylesine derin ve kapsamlı bir kavramın açıklaması, tam anlamıla mümkün değildir. Çünkü Gurbet kavramı, oldukça karışık ve bir o kadar hassas bir konudur. Gurbet, yalnızca doğup büyüdüğümüz yerden uzak kalmak manasına gelmez. Beklemek, özlem duymak, kavuşma hasretiyle yanıp tutuşmak gibi duyguları da içinde barındırır. Dolayısıyla Gurbet, birçok açıdan ele alınabilir bir kavramdır. Çeşitleri oldukça fazladır. Örneğin kişinin ülkesinden ayrı kalması, yurtdışında çalışıyor olması, ülkesinin hasretini doğurur. Dolayısıyla il, ilçe, köy fark etmeksizin, kişi vatanını özler. Dolayısıyla başta belirttiğimiz üzere Gurbet, yalnızca doğup büyüdüğün yerden uzak kalmak değildir. Az önce verdiğimiz örnekte kişi, ülkesinden ayrı düşmüş, ve geniş kapsamlı bir Gurbet hissi yaşamaktadır.

Gurbet kavramının birçok çeşidi olduğundan bahsetmiştik. Faruk Nafiz ÇAMLIBEL'in şiirlerinde bu kavramı sıkça görmekteyiz. Bunun temel sebebi ise, kendisinin bizzat memleket şairi olmasından kaynaklıdır. Birçok açıdan Gurbet kavramını şiirlerinde işleyen şairin, konuya dair kapsamlı bir yaklaşımı söz konusudur. Öncesinde belirtmek isteriz ki Gurbet, yalnızca toprak-yer-yurt ile alakalı değildir. Kişinin psikolojik olarak kendisini Gurbette hissettiği anlar olabilir. Örneğin sevilmediği ya da sevgisine karşılık bulamadığ yerde insan, gurbette gibidir. İsterse kişi bizzat doğup büyüdüğü vatan 
toprağında yaşıyor olsun. Buna rağmen kişi, ilgili psikolojik buhranlar ve bunalımlar yaşadığı zamanlarda, tanınmamaktan, anlaşılmamaktan, sevgisine karşıllk bulamamaktan kaynaklı olarak, kendi topraklarında yabancılık hissedebilir. İşte belirttiğimiz husus budur. Gurbet, tanımı kısaca yapılacak ve hemen anlaşılacak bir olgu değildir. Yapısında birçok duygu, Düşünce ve yaklaşımı barındırır.

Gurbet tanımının, bu denli karışık ve oldukça psikolojik yönünün olduğunu bilen şairler, bu kavramı sıkça kullanmışlardır. Çünkü şiir, Dil ötesi bir üslupla yazılmaktadır. Konusu daha çok komplike yani karışık temalardır. Sıradan, basit ve hemen anlatılıp anlaşılacak kavramlar, şiire çok az konu olur. Şiirin merak uyandırmasının temel sebebi, içimden çıkılmaz hususlara getirilen süslü ve pratik yaklaşımlardır. Örneğin Faruk Nafiz ÇAMLIBEL'in meşhur şiiri olan Han Duvarları'nda, bir satır göze çarpmaktadır:

Bu gurbetten gurbete giden yolun üstünde

Ben üç mevsim değişmiş görüyordum üç günde

(BANARLI, 1949: 29)

Bir gurbetten diğerine gitmek, Gurbet üstüne gurbet yaşamak konu edinilmiştir. Zamanın tesirinin, Gurbet söz konusu olunca çok daha uzun olduğu anlatılmaktadır. İşte bahsettiğimiz psikolojik hadiselere şiirsel yaklaşımın bir örneği bu şekildedir.

Faruk Nafiz ÇAMLIBEL'in şiirlerinde Gurbet anlayışına geçmeden önce, Gurbet kavramı ancak bir şairin dilinden çok daha iyi anlaşılır. Matematiksel veya bilimsel kavramlar, daha normatiftir. Etrafı sınırlıdır. Örneğin yerçekimi kanunu değișmez. Fakat insani bir psikolojik olgu, pek çok açıdan incelenebilir. Söz konusu Gurbet olunca ve söz konusu şair Faruk Nafiz ÇAMLIBEL olunca, ortaya çok farklı yaklaşımlar çıkacaktır. O halde şimdi, Faruk Nafiz ÇAMLIBEL'in şiirlerinde Gurbet anlayışını etraflıca inceleyelim.

\section{Faruk Nafiz ÇAMLIBEL'in şiirlerinde gurbet anlayışı:}

Faruk Nafiz ÇAMLIBEL, başta belirttiğimiz üzere, gurbeti doya doya yaşayan bir şairdir. Esasında İstanbullu olan şair, öğretmenlik yaptığı yıllarda Ankara ve Kayseri gibi, Türkiye'nin iç kesimlerinde bulunan şehirlere gitmiştir (TANSEL, 1974: 39). Eğitimini tamamlayana kadar hiç Gurbete çıkmamış olan Faruk Nafiz ÇAMLIBEL, gurbetle tanıştığında daha henüz 30'lu yaşlarındadır. Bu yaşına kadar memleket şiirleri yazmış, Anadolu'ya bağlanmıştır. $\mathrm{Bu}$ memleketi sevmekte, Türk toprağına aşırı bağlılık duymaktadır. Tüm bu duygu ve düşüncelerle beraber, doğup büyüdüğü İstanbul'da ayrılık vakti gelmiştir. Aslında gurbete ilk defa çıkacağı zaman çok mutludur. Üzüntü veya herhangi bir burukluk hissetmez. Çünkü Faruk Nafiz ÇAMLIBEL için vatan toprağının her bir yanı, onun memleketidir. Başta böyle düşünür, çünkü o, bir memleket şairidir ve her yer onun için asli vatandır. Her ne kadar bu duygu ve düşüncelerle yola çıksa da, yol esnasında tüm duygu ve düşünceleri değişir. Gurbetin aslında o kadar da kolay olmadığını anlar. Tüm bu yolculuk, onun zindanı olur. Memleketi İstanbul'dan ayrıldığı her saniye, Gurbet onun içinde büyür. Gurbet yangınıyla dolup taşan Faruk Nafiz ÇAMLIBEL, HAN DUVARLARI isimli uzun şiirini yazarak tüm bu yaşadığı Gurbet duygusunu çarpıcı bir biçimde anlatmaya başlar:

\section{Gidiyordum, gurbeti gönlümde duya duya, Ulukışla yolundan Orta Anadolu'y. (Çamlıbel, 2015: 15).}

Burada dikkat çeken en önemli detay, Gurbet hissini duymaktır. İnsan, bir şeyi duyduğu zaman ona kayıtsız kalamaz. Duyduğu sese yönelir. Anlamaya çalışır. Şiirin bu şekilde başliyor olması çok önemlidir. Çünkü şair, çok derin bir duygu olan Gurbeti, önce duymuştur. Yani bu durum, Gurbetin başlangıcıdır. Hissetmek ise daha sonra ortaya çıkar. Ulukışla şehri üzerinden bir yolculuk yaptığ ve bu yolculuğun Anadolu'ya yapıldığ1 anlaşılmaktadır. Orta Anadolu söyleminden kasıt ise, Anadolu'nun tam ortası olan Kayseri şehrini tarif etmektedir. İlerleyen, çalışmamız açısından oldukça önemli bir durum söz konusudur:

Ilk sevgiye benzeyen ilk act, ilk ayrilık! Yüreğimin yaktığı ateşle hava ılık (Çamlıbel, 2015: 15).

Belirtmiş olduğumuz üzere, Faruk Nafiz ÇAMLIBEL, daha önce hiç gurbete çıkmamıştır. Bu itirafı bizzat görmekteyiz." İlk acı, ilk ayrılık" diyerek, bu ayrılığın ilk kez olduğunu söylemektedir. Daha da önemlisi, bu ilk Gurbet duygusunu, ilk sevgi duygusuna benzemektedir. İnsan, ilk defa sevgiyle ve aşkla tanıştığında ne yapacağını bilemez. Hatta ve hatta içini korku kaplar. Bilinmezlik ya da bir duyguyu ilk defa hissediyor olmak, kişiyi 
bunalıma sürükler. Neticesinde ortaya panik, acı veya korku gibi duygular çıkar. Faruk Nafiz ÇAMLIBEL ise bu ilk Gurbet duygusunu, ilk sevgi duygusuna benzetmiştir. Ne yapacağını veya ne hissedeceğini şaşıran şair, bu panikle yüreğinin yandığını söyler. Yürek, kalp demektir. Kalbin yanması mecazi bir anlatımdır. Aşırı duygu yüklenmesinde kişinin kalbi daha hızlı çarpar ve terleme gibi belirtiler gösterir. Burada şu tespiti yapmaktayız. Kişi, çok sicak olunca terler. Buradaki sicaklıkla, kişinin heyecandan terlemesi birbirine bağdaştırılır. Neticesinde kişi, heyecandan terleyince, kalbinde bir yanık olduğunu söyler. Faruk Nafiz ÇAMLIBEL ise, alıntıladığımız bu kısmın ikinci dizesiyle bunun bize anlatmaktadır. Ve hatta şair, daha ileri giderek, havanın 1lik olmasının sebebinin, yüreğindeki yangın olduğunu söylemektedir. Bu durumda, duyulan heyecanın çok şiddetli olduğunu söylemek ister. Yüreği bir ateş yakar, ve bu ateş, havayı 1sıtır. Havayı 1sıtacak bir ateş ise, oldukça büyük bir ateş olması gerekir. Demek ki Faruk Nafiz ÇAMLIBEL, yüreğinde yanan Gurbet ateşinin çok büyük olduğunu söylemektedir. İlerleyen kısımlarda şu iki dize, dikkat çekicidir:

\title{
Gurbet beni muttasıl çekiyordu kendine. \\ Yol, hep yol, daima yol... Bitmiyor düzlük yine (Çamlıbel, 2015: 16)
}

Gurbet, Faruk Nafiz ÇAMLIBEL'in muttasıl olarak kendine çekmektedir. Buradaki muttasıl kelimesi, Arapça'dır. Türkçesi ise" süreklidir". Yani fasıla olmadan, ara vermeden manalarına gelmektedir. Dolayısıyla şairin hissettiği gurbetin, arada bir hissedilen değil; sürekli olarak hissedilen bir duygu olduğu anlaşıllyor. Bu sürekliliği meydana çıkaran şey ise yollardır. Dönemin şartlarında bir at ve at arabası ile yaptığı yolculuk hem çok zahmetli ve hem de çok uzun sürmektedir. Bu zahmetli yolculukta, yollar bitmeyecek gibidir. Belki de Faruk Nafiz ÇAMLIBEL, gittiği yere alışacak ve Gurbetlik çekmeyecek. Fakat yol esnasında, yolların da uzayıp gitmesiyle Gurbet aklından bir türlü çıkmamaktadır. Gurbetin muttasıl olması, yolların uzun ve zahmetli olmasıyla ortaya çıkmaktadır. Başka bir kısımda Faruk Nafiz ÇAMLIBEL, şunları söylüyor:

Bir noktada birleşmiş vatanin dört bucağl,

Gurbet çeken gönüller kuşatmıştı ocağ. (Çamlıbel, 2015: 16).

Kayseri yolculuğunda, Niğde isimli bir Türk şehrinde mola vermektedir. Kervansaraylar, ya da diğer adıyla "Han"lar, yolcuların dinlenmesi için yol kenarlarına kurulmuş konaklama yerleridir ve oldukça mühimdir. Niğde'de bulunan Kervansaraya girdiğinde, ülkenin dört bir yanından gelen misafirler göze çarpar. Bu yüzden şair, vatanın dört bucağının, bu Kervansarayda birleştiğini, mecazi bir yolla söylemektedir. Türkiye'nin her tarafından, bu Kervansarayı ziyaret eden insanlar, tıpkı Faruk Nafiz ÇAMLIBEL gibi gurbettedir. Söz konusu Gurbet olunca, yolculuk akla gelir. Yolcuların durağ ise Kervansaraylardır. Dolayısıyla Kervansaraylara toplanan insanlar, bu ocağı gurbetle doldurur. Gönüller Gurbet yüklüdür, ve Gurbet yüklü gönüllerin toplanma ocağı ise bu Kervansaraylardir.

Belki de çalışmamızın en dikkat çekici yeri, Faruk Nafiz ÇAMLIBEL'in bu Kervansarayda, duvara kazınmış bir şiiri keşfetmesidir. Üç kıtadan oluşan ve Maraşlı Şeyhoğlu Satılmış isimli bir şaire ait olan bu şiirin her bir kıtasını, Faruk Nafiz ÇAMLIBEL'in Han Duvarları isimli meşhur şiirinde görebiliriz. Buna iktibas denir. Yani bir metni olduğu gibi kendi yazdığı metnin içine almak işidir iktibas. Han Duvarları başlı başına bir Gurbet şiiri olduğuna göre, duvardaki şiir de bir Gurbet şiiri olmalıdır. Üç kıtanın üçünü de konu edineceğiz. Maraşlı'nın Han Duvarına kazınmış üç kıtalık şiirinin ilk kıtası şöyledir:

\author{
"On yıl var ayrıyım Kınadağı'ndan \\ Baba ocağından yar kucağından \\ Bir çiçek dermeden sevgi bağından \\ Huduttan hududa atılmışım ben" (Çamlıbel, 2015: 16).
}

Şimdiye kadar Gurbet temasını, Faruk Nafiz ÇAMLIBEL'in ağzından işledik. Burada artık başka bir şairin bakış açısı ele alınacak. Hemen ardından Çamlıbel'e geri döneceğiz. Faruk Nafiz ÇAMLIBEL neden şiirinin içine, bir başka şairin şiirini konu edindi? Bunun cevabını yine kendisi verir. Bu Şiir o kadar dikkatini çeker ki, olduğu gibi üç kıtayı da Han Duvarları isimli şiirine ekler. Burada Maraşlı'nın şiirinin ilk kıtasını görmekteyiz. Anlaşılan Maraşlı Şeyhoğlu Satılmış Kınadağı isimli bir şehirde yaşamaktadır ve bu memleketten 10 yıldır ayrı kalmıştır. Baba ocağı şeklinde tarif etmesi, Memleketi olduğunu gösterir. Ayrıca Gurbete yalnız başına çıkmıştır. Karısı da Kınadağı'nda kalmıştır. Memleket hasreti bir 
yana, yarinin hasreti de üstüne gelince iyice dolmuş taşmıştır. Huduttan hududa atılmış olduğunu, yani bir o Gurbetten bir başka Gurbete sürekli olarak gittiğini, Acı bir haykırışla dile getirmektedir. Belki de bu Kayseri yolculuğu, Faruk Nafiz ÇAMLIBEL'in ilk Gurbetidir. Fakat burada Maraşlı'nın şiirini görüp irkilmiştir. Çünkü kendisi daha bir Gurbete dayanamazken, Maraşlı Huduttan hududa, Gurbetten gurbete gitmiştir. Hal böyle olunca, bu orijinal Anadolu şairinin Duvarda kazınmış şiirini, Han Duvarları' na konu etmiştir. Bizler de çalışmamızda konu edinerek, Maraşlı'yı anmış olalım:

Biz bu sonsuz yollarda variyoruz, gitgide,

İki dağ ortasinda boğulan bir geçide (Çamlıbel, 2015: 17).

Burada şair, yolların çok uzun olmasından şikayet etmektedir. O kadar uzun, yorucu ve sıkıcı bir yoldur ki bu, Faruk Nafiz ÇAMLIBEL'in göre sonsuz olarak nitelendirilir.

Tanr yardimci olsun gayri yolda kalana

Biz menzile vararak atları çektik hana (Çamlıbel, 2015: 18).

Burada ise, yolun bittiğini ve artık bu eziyeti çekmeyeceğini dile getirmektedir. Her yol biter. Her ne kadar karamsarlık ve yorgunluktan ötürü, sonsuz gibi gözükse de, aslında her yol biter. Şiirin bu kısmında ise, artık menzile, yani ulaşılması gereken yere ulaştıklarını dile getirir ve tanrıdan, yolda olanlara yardım ister. Çünkü çok yorulmuştur ve o anda yolda olan gurbetçilerin halinden anladığı için dua eder. Sıra tekrar Maraşlı Şeyhoğlu Satılmış'ın şiirine gelir. Şiirin ikinci kıtası şu şekildedir:

\section{"Gönlümü çekse de yârin hayali \\ Aşmaya kudretim yetmez cibali \\ Yolcuyum bir kuru yaprak misali \\ Rüzgârın önüne katılmışım ben" (Çamlıbel, 2015: 18).}

Faruk Nafiz ÇAMLIBEL, gurbete ilk defa çıktığı için, Gurbet duygusunu tam olarak tarif edememekten korkmaktadır. Dolayısıyla, gurbeti çok ağır bir şekilde hisseden Maraşlı'nın şiirini iktibas etmiştir. Bu alıntı, bir acziyetin göstergesi ve Maraşlı'ya duyduğu derin saygının tezahürüdür. Burada Maraşl1, gönlünün sürekli memleketinde ve karısında olduğunu söylemektedir. Fakat gücü memleketine gitmeye yetmez. Bu durumu "aşmaya kudretim yetmez cibali" dizesiyle tarif eder. Cibal, dağlar demektir. Gurbet onun için bir dağdır ve aşılması imkansızdır. Bu çaresizliği, kendisini rüzgarın önündeki kuru bir yaprağa benzeterek açıklamaktadır. Kuru yaprağın, rüzgar önünde hiçbir iradesi yoktur. Tıpkı bu örnekte olduğu gibi şairin de Gurbet önünde hiçbir iradesi yoktur. Bu Gurbet rüzgarının önüne katılan şair, Huduttan hududa, Gurbetten gurbete sürüklenir. Bu çarpıcı örnek, çalışmamızla ilgili birçok noktayı aydınlatmaktadır:

\section{Bu gurbetten gurbete giden yolun üstünde \\ Ben üç mevsim değişmiş görüyordum üç günde (Çamlıbel, 2015: 18).}

Burada çok önemli bir husus vardır. O da, Gurbet söz konusu olunca, zaman algısının değişiyor olmasıdır. Yalnızca üç gün, Söz konusu Gurbet olunca üç mevsim gibi gelmektedir. Yabancı bir yerin meşakkati, yolculuğun zorluğu ve memleket özlemi gibi etkenlerden dolayı şair, üç gün gibi kısa bir süreyi, sanki üç mevsim geçmiş kadar uzun hissetmiştir. Başlarda belirttiğimiz üzere Gurbet, psikolojik bir olgudur. Hissedilen duygunun şiddeti, kişiden kişiye değişir. Birçok çeşit ve yönü vardır. Bu çalışmanın gayesine uygun olarak alıntılandığımız bu kısımda, Gurbette geçen vaktin, göreceli olduğu anlaşılmaktadır. İlerleyen kısımlarda, Maraşlı Şeyhoğlu Satılmış'ın şiirinin son kıtası göze çarpmaktadır:

\section{"Garibim namıma Kerem diyorlar Asli'mı el almiş haram diyorlar \\ Hastayım derdime verem diyorlar}

\section{Maraşlı Şeyhoğlu Satılmış'ım ben" (Çamlıbel, 2015: 19).}

Maraşl1, bu son kıtada çok çaresiz olduğunu dile getirmektedir. Türk halk destanlarında Kerem ile Aslı'nın hikayesinde, kendisini Kerem' e benzetmiştir. Çünkü Kerem, Aslı'sına kavuşamadan ölmüştür. Kendisi de, kendi karısına kavuşamamaktadır. Bu yüzden kendisini Kerem'e benzetmiştir. İkinci dizede, Aslı'yı, yani karısını başkasıyla evlendirmişler. Bu durumda karısı, artık Onun helali değildir. Hal böyle olunca, çok üzücü bir tablo karşımıza çıkmaktadır. Şiirin son kıtasının son dizesinde ise, kendi ismini söyleyip bitirdiği şiirini incelemiş bulunmaktayız. 
$\mathrm{Bu}$ tarif edilemez duyguların içinde, Faruk Nafiz Çamlıbel, şiirini şu iki dizeyle bitirmektedir:

Ey garip çizgilerle dolu han duvarlar,

Ey hanların gönlümü sızlatan duvarlar!! (Çamlıbel, 2015: 19).

Niğde şehrinde, bir hanın duvarında rastladığı üç kıtalık Gurbet şiiri, Faruk Nafiz ÇAMLIBEL'i oldukça etkilemiştir. Kendisi de ilk kez Gurbet hissini yaşamıştır. Dolayısıyla tarif edilemez duygularına tercüman olan bu Duvarda yazılı şiiri, kendi şiirine almıştır. Şiiri ise bu iki dizeyle bitirmektedir. Han Duvarlarına ne zaman baksa, artık gönlü sızlamaktadır. Yani duygu patlaması yaşamaktadır. Bu aşırı yoğun duygular içerisinde olmasına rağmen şair, anlatmak istediği mesajı oldukça etkili ve başarılı bir şekilde bizlere sunmuştur.

\section{SONUÇ}

Faruk Nafiz ÇAMLIBEL, 20. Yüzyılda yetişmiş en büyük şairlerdendir. Her ne kadar tiyatro ve deneme gibi edebiyatın çeşitli sahalarında eserler verse de, biz onu daha çok şair vasfiyla tanıoruz. Türkçenin en önemli ediplerinden, en önemli temsilcilerinden. Onu bu denli önemli kılan husus, şüphesiz Türk Edebiyatına yaptığı katkılar, verdiği eserlerdir.

Faruk Nafiz ÇAMLIBEL, başlarda aşk ve sevgi üzerine şiirler kaleme almıştır. Bu şiirleri destansı ve çok önemlidir. Fakat yayın hayatının ilerleyen zamanlarında, Memleket meselelerine yönelmiştir. $\mathrm{Bu}$ onu, daha çok vatan-memleket üzerine eserler vermeye yöneltmiştir. Artık tanınmış ve ciddi bir okuyucu kitlesine ulaşmıştır. Onun bu şöhretinin asıl sebebi, şüphesiz, Anadolu insanının acı ve kederlerini çok iyi tanıyıp aynı zamanda tanıtmasıdır. Gurbet ise, özellikle Türk insanının, asla kaçamadığı duygulardan biridir.

Gurbet, Acı ve keder demektir. Kişinin doğup büyüdüğ̈̈ topraklardan ayrı kalması neticesinde memleketine duyduğu özlemdir. Faruk Nafiz ÇAMLIBEL ise, hayatının otuzlu yaşlandıran itibaren gurbette büyümüş bir şairdir. Başlarda tarif edemediği bu gurbet duygusu, daha sonraları Gurbet hakkında yazılmış en güzel şiirlerin şairi yapacaktır onu. Biz de çalışmamızda bu konuyu seçmemizin temel sebebini buna dayandırıyoruz. Bir memleket ve Gurbet şairinin şiirlerinde işlediği Gurbet teması, değerli bir çalışma kaynağ oluşturmaktadır. Maraşlı Şeyhoğlu Satılmış'ın bir şiirini de içinde barındıran bu uzun ve eşsiz şiir, Gurbet teması altında etraflıca incelenmiştir. Çalışmamızın ilerleyen kısımlarında bu sonuç cümlesi ve ardından son olarak bir kaynakça, çalışmamıza eklenmiştir. Calıșmamıza konu ettiğimiz tüm șirleri, Faruk Nafiz CAMLIBEL'in "Han Duvarlar - Toplu Şiirler" isimli 2005 Yap1 Kredi Yayınlarından çıkmış olan kitaptan aldığımızı belirtmek isteriz. 


\section{Kaynakça:}

BANARLI, Nihad Sâmi (1949). Faruk Nafiz ve Seçilmiș Şiirleri, İstanbul.

ÇAMLIBEL, Faruk Nafiz. (2005). Han Duvarları - Toplu Şiirler: İstanbul: Yapı Kredi Yayınları.

Güncel Türkçe Sözlük ve Yazım Kılavuzu. (2001). Gurbet maddesi. Ankara: Türk Dil Kurumu Yayınları.

KAPLAN, Mehmet. (1965). Şiir Tahlilleri. İstanbul.

KARATAŞ, Ömer Faruk. (2013). Faruk Nafiz ÇAMLIBEL'in Şiirlerinde Geleneğin Tesiri, Atatürk Üniversitesi Sosyal Bilimler Dergisi.

KOŞAR, Emel (2009). Faruk Nafiz ÇAMLIBEL'in Şiirlerinde "Yol" Motifiyle İlgili Unsurlar, The Journal of Academic Social Science Studies.

ORTAÇ, Yusuf Ziya Faruk Nafiz: Hayat1 ve Eserleri, İstanbul 1937.

TANSEL Fevziye Abdullah, "Faruk Nâfiz Çamlıbel", İstanbul, 1974.

Türk, Osman. (2016). Mehmet Akif Ersoy'un "Safahat" Adli Eserinde Sosyal Eğitim Unsurlari. Akademik Sosyal Araștırmalar Dergisi (Asos Journal), 4, (26), 443457.

Türk, Osman. (2020). Sabri Esat Siyavuşgil’in Şiirlerinde Geçen Kelime Gruplari Resimler Ve Biblolar SSiirinin Tahlili. Dicle Üniversitesi Sosyal Bilimler Enstitüsü Dergisi (DÜSBED), 12 (2 4), 161-172.

Türkiye Diyanet Vakfi İslam Ansiklopedisi, ÇAMLIBEL Faruk Nafiz maddesi, İstanbul 1993.

YÜCEBAŞ, Hilmi. (1974). Bütün Cepheleriyle Faruk Nafiz: Hayatı, Hatıraları, Şiirleri, İstanbul. 


\title{
LEXICON REFERENCING AND TEXT/PRAGMATIC ANALYSIS CONCEPTS AND APPLICATIONS
}

\author{
Majeed Khairallah RAHI ${ }^{1}$ \\ Abdelmalek BELKHEIRY ${ }^{2}$
}

\section{Istanbul/Türkiye \\ p. 309-319}

Received: $17 / 11 / 2021$

Accepted: 03/12/2021

Published: 01/01/2022

This article has been scanned $l$ iThenticat No plagiarism detected

http://dx.doi.org/10.47832/2717-8293.15.23

1 (iD) Dr. , Wasit University, Iraq, Drmajeed40@yahoo.com

2 (D) Dr. , Algeria, abdelmalekbelkhiri@gmail.com 
dictionaries and their expressive efficiency achieved in the context.

Key words: Lexicon, Analysis, Text, Concepts.

\author{
الإحالة بالمعجم وإجراء التحليل النصي التداولي \\ مفاهيم وتطبيقات \\ 3 \\ مجيد خير الله راهي 3 \\ عبد المالك بلخيري 4
}

\begin{abstract}
الملخص:
يسعى هذا البحث لدراسة العلاقة الوظيفية بين الوحدات المعجمية وما تطرحه فرضيات لسانيات النص والتداولية،

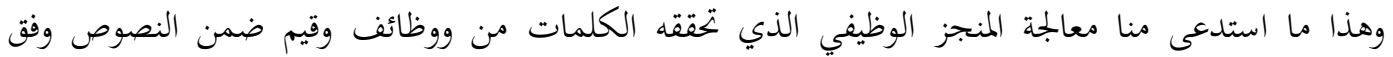
علاقات أساسها المعنى والإحالة والقصد الوصول إلى كفاءة تفسيرية فعلية تضمن المعرفة الدقيقة بكيفية اشتغال المعجم، يستدعي ذلك البحث في علاقات التساند الوظيفي بين مستويات، النـحو، والــلالة، والتداول في بناء وتفسير قواعد تكوين النصوص والخطابات على المستوين اللساني والتداولي، وهذا على اعتبار أن الخواص التركيبية والدلالية، شكلت صلب البحث النصي، وعليه فإن البحث النصي ينجز على مستويات هي: النحو، والدلالة

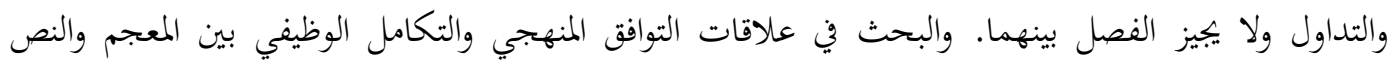

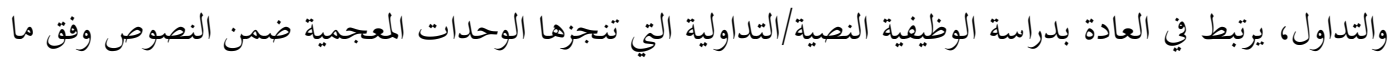
تضفيه من عمليات الربط والتماسك بين الوحدات المكونة للنص وعمليات التخاطب المنجزة بين متخاطبين في ظروف سياقية معينة، وعليه تبقى معالجة العلاقة المؤسسة بين المعجم والنص والتداول، تتحدد في الأساس بتبيين

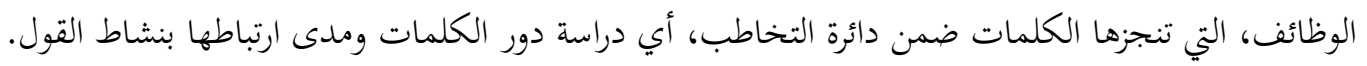

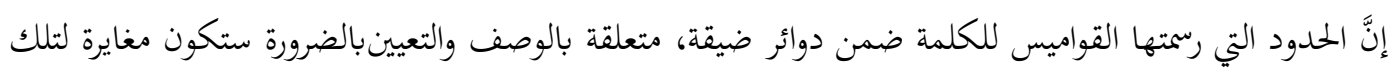

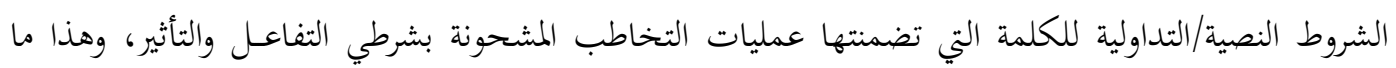
يدفعنا نحو التمييز بين الكلمات المودعـة في ذاكرة القواميس ومردوديتها التعبيرية المنجزةفي السياق. الكلمات المفتاحية: المعجم، التحليل، النص، مفاهيم.
\end{abstract}

البحث في علاقات التوافق المنهجي والتكامل الوظيفي بين المعجم والنص والتداول، يرتبط في العادة بدراسة الوظيفية

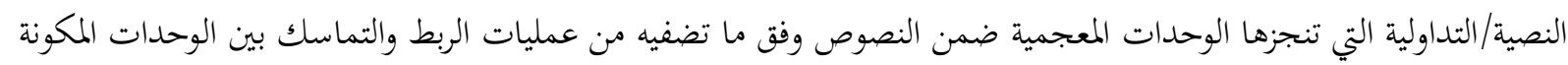

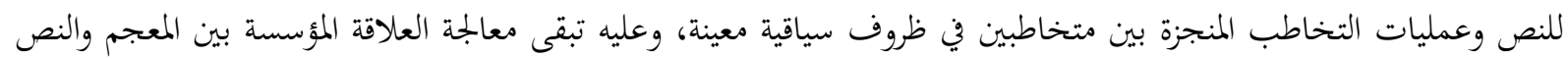


والتداول، تتحدد في الأساس بتبيين الوظائف، التي تنجزها الكلمات ضمن دائرة التخاطب، أي دراسة دور الكلمات ومدى (i) ارتباطها بنشاط القول.

عملية دراسة الحدود النصية/التداولية للمعجم، تستدعي في المرحلة الأولى التمييز المنهجي، بين المقتضى المعجمي للكلمة،

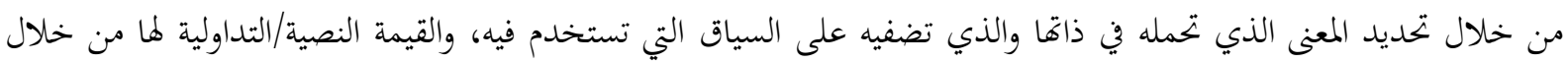
التعابير التي تستخدم فيها. (ii) وفي مرحلة ثانية، يستدعي ذلك أيضا التمييز بين وظيفة المعجم في تحديد تسمية الأشياء والوقائع

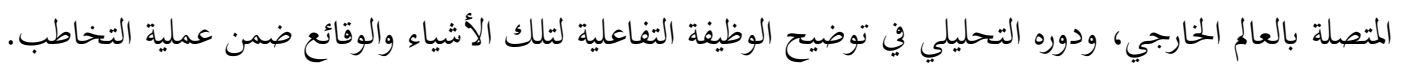
إن الحدود التي رسمتها القواميس للكلمة ضمن دوائر ضيقة، متعلقة بالوصف والتعيينبالضرورة ستكون مغايرة لتلك الشروط

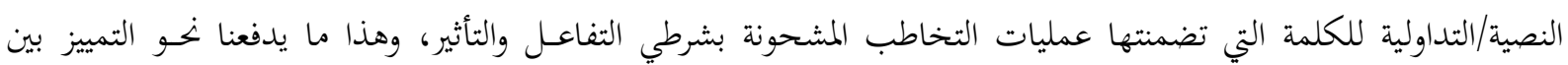

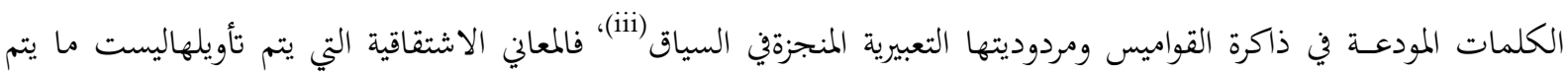
ترتيبه ضمن القاموس ولكنها مستمدة من استدلال سياقي وفق ما يلزمنا به الخطاب من تعابير مضمرة ومقاصد واستعمالات

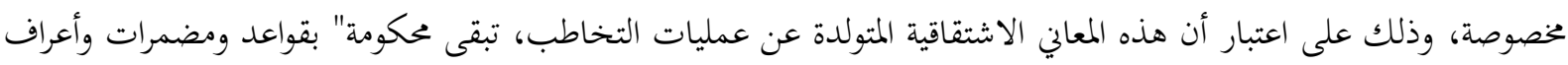
واستعمالات خخصوصة، هي العناصر التداولية التي تفصل المبني في النص حقا، عن المعطى الدلالي الخام " (iv). إن الفرضية النصية/التداولية وما قدمته من حلول وإمكانات لكيفية تحليل المعجم، سمح للسانين والتداوليين، نحو التمييز

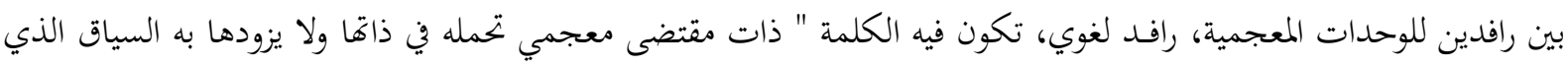
تستخدم فيه " (v) بل " الأمر على العكس من ذلك فهي التي من شأها، بفضل ذلك رافلك المقتضى الذي تحمله، أن بتعل للسياق

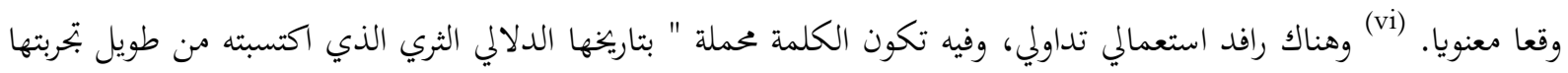
القولية بدخولها سياقات استعمال كثيرة مختلفة، أو خروجها منها. يبقى البحث في علاقة الإحالة بالمعجم بما تطرحه فرضيات إجراء التحليل النصي/التداولي، يستدعي من الوجهة العملية،

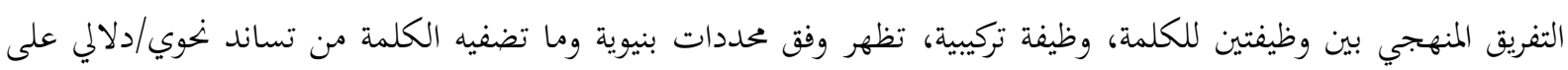

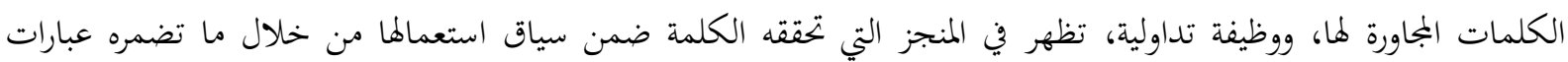
المتكلم من معان ومقاصد.

قصد الوصول إلى كفاءة تفسيرية فعلية تضمن المعرفة الدقيقة بكيفية اشتغال المعجم، يستدعي ذلك البحث في علاقات التسانـد الوظيفي بين مستويات، النـحو، والـدلالة، والتداول في بناء وتفسير قواعد تكوين النصوص والخطابات على المستوين

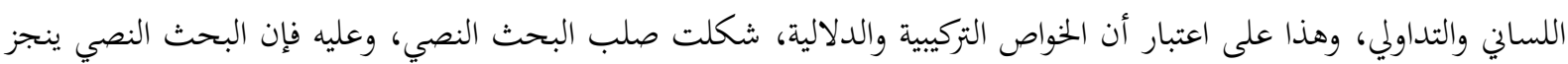
على مستويات هي: النحو، والدلالة والتداول ولا يجيز الفصل بينهما . (viii)

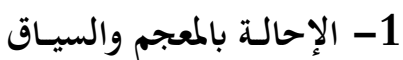

إذا اعتبرنا أن السياق " إطار عامتتظم فيه عناصر النص ووحداته اللغوية، ومقياس تتصل بوساطته الجمل فيما بينها

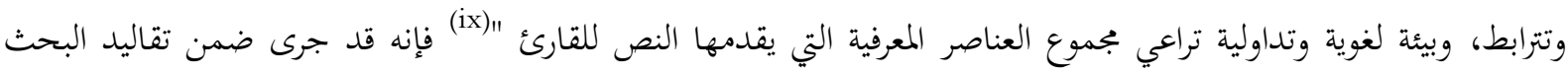

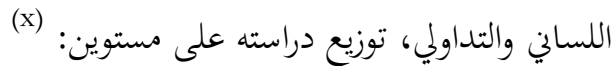
أ) مستوى أول: يتعلق بدراسة مستوى العلاقات الداخلية للنص أي يتعلق بدراسة العلاقات الوظيفية والتركيبية للكلمات المكونة

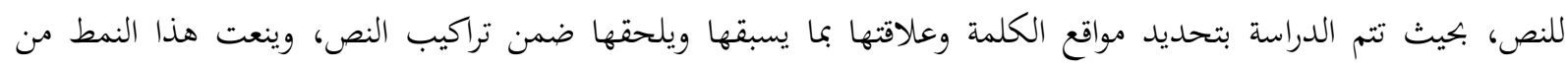
السياق، بالسياق اللغوي (xi) (x). 
ب) مستوى ثاني: يتعلق بدراسة والبحث في الظروف المنشئة للنص أو ظروف المحيطة به، والتي تتحدد عادةفي الجوانب الاجتماعية، والتاريخية، والثقافية.. الخ، وينعت هذا النمط بسياق الاجتماعي والتاريخي والثقافي للنص، كما ينعت كذلك بلكئل بالسياق التداولي، أي ظروف إلقاء الخطاب. (xii)

لقد كانت عناية الدراسات اللسانية في شقها التداولي بالسياق جد متقدمة، حيث أقبلت على تبيين سمات التمايز

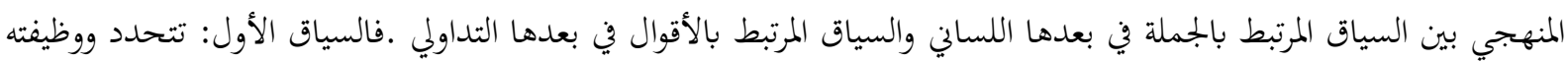

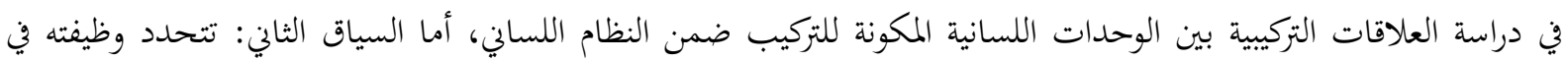
تتبع جوانب الانجاز التي تحققها الأقوال ضمن ظروف إلقاء الخطاب في بعده التداولي، ومنه فالسياق الأول يحتكم في بنائه إلى قواعد التكوين اللساني بينما السياق الثاني يجتكم إلى قواعد التكوين التداولي. لتعني. تبقى وظيفة السياق المركزية ومنجزه في نظر التداوليين، تظهر في إزالة اللبس في الأقوال وإسناد المراجع ضمن دائرة

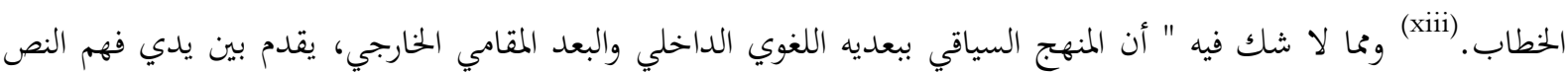

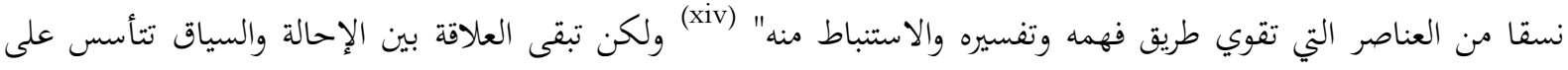

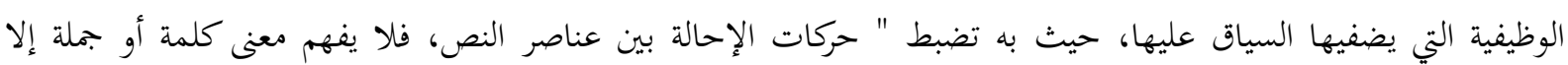

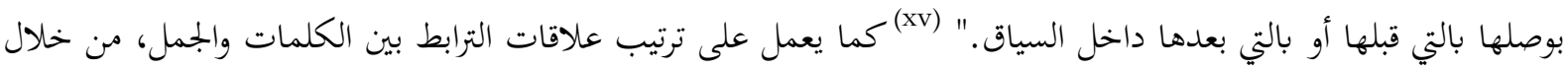
الكشف حدود الاتساق والانسجام المؤسس بين وحدات التركيب ضمن النص وفق ما تطرحه الشروط النحوية والدلالية في بعدها النصي، ومسالة التأويل والفهم والتفسير في بعدها التداولي. إن مركزية الإحالة ضمن السياق يمكن تحديدها بدقة وذلك من خلال " أن العناصر المحيلة كيفما كان نوعها لا تكتفي

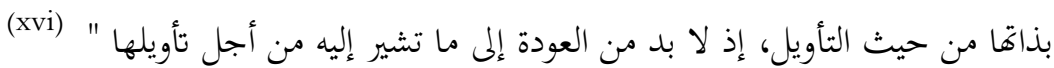
مسالة معالجة وظيفة الإحالة ضمن السياق، تتعلق في الأساس في البحث عن الروابط التي تحقق الاتساق، الذي يعتبر شرطا ضروريا للانسجام، (xvii) كما تتعلق بالبحث عن العناصر التي تحقق نظرية العائد (anaphore) وضمن هذا السياق، يحدد G. VINGER وظيفة العائد، حيث يعتبره " نظاما يحوي ذاكرة داخلية تمكن القارئ من اقتصاد بجهود الاحتفاظ بالعناصر اللسانية كلها وتمكن هذه العناصر من الاتساق" (xviii) وفق هذا الدور الوظيفي للإحالة فقد تم دراسة وظيفتها الخطية والتداولية، من خلال تحديد وظائف الربط النحوي/الدلالي والتأويل التداولي التي تحققها ضمن النصوص، وعليه فقد تم تقسيمها إلنوعين: (xix)

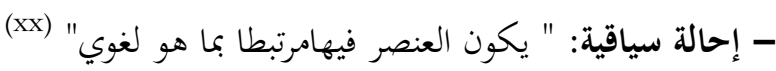

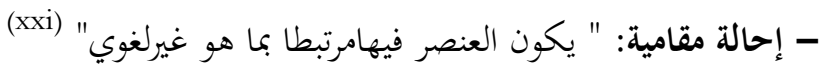
هذا التفريق المنهجي بين ما هوإحالة سياقية وإحالة مقامية، يحيلنا نحو التمييز بين مفهوم السياق والمقام، فالسياق في

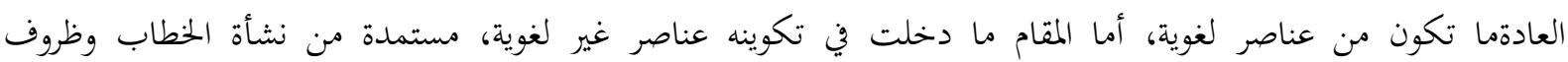
إلقائه. (xxii)

يمكن تقسيم الوحدات المكونة للإحالة من الوجهة البنوية إلى نمطين: (xxiii) - حالة معجمية: تتم بوحدات معجمية المالأسماء والأفعال، وهي عادة تعرف على أنها كلمات مملوءة les mots pleins. 
-إحالة نحوية: تتم بوحدات نهوية les Unités grammaticaux كأسماء الإشارة، وأسماء الموصول، والضمائر، وهي عادة تعرف على أفا كلمات فارغة اهذه الوحدات هي التي تتشكل منها نظرية العائد anaphos mots vides.

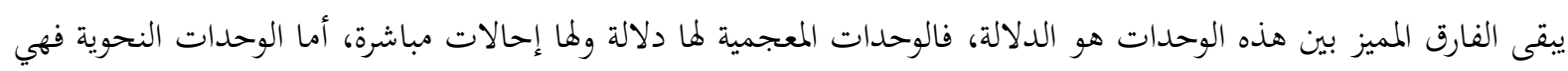
وحدات فارغة من الدلالة وإحالتها تتحدد ضمن الوظيفة التركيبية. (xxiv)

في المقابل من هذا التقسيم البنوي الذي أخذته الوحدات اللغوية ضمن النظام اللساني، بينوحدات معجمية

les Unitéslexicaux فإن جان كلود ميلنر JeanClaude Milner اقترح " نظريـة لسانية في الإحالة، ولهذه النظرية مزية، من جملة مزايا

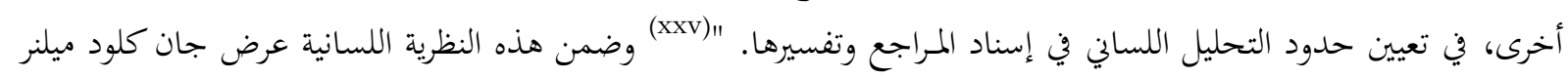
نوعين من الإحالة: (xxvi)

أ) إحالة حاصلة: فهي مرتبطة بتعيين مرجع العبارة. ب) إحالة محتملة: فهي مرتبطة بتعيين دلالته المعجمية، أي دلالة مرجع العبارة. ولهذاعتبر أن الضمائر مفتقرة إلى الإحالة

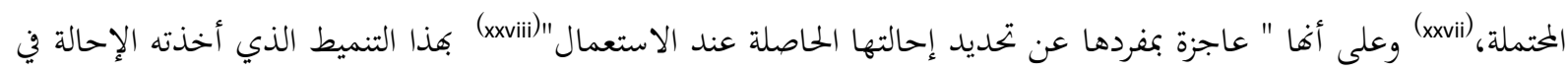
تصنيف جان كلود ميلنر، نجدهيميز بين نوعين من التعابير الإحالية: (xxix) أ) النوع الأول: تعابير ذات إحالة محتملة واستقلالية إحالية.

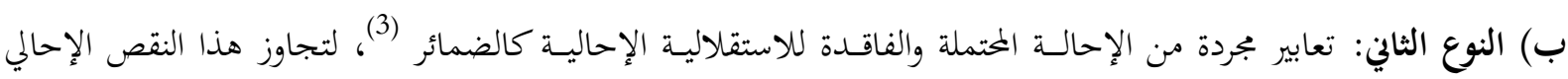

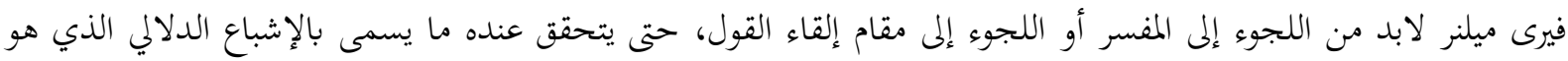

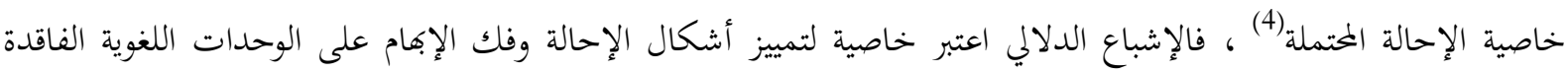
للاستقلالية الاحالية.

في المقابل من الطرح البنوي لمفهوم الإحالة وتصنيفاهما ضمن تيارات البنوية اللسانية، فإن تيار الدلالة الصورية ضمن ما

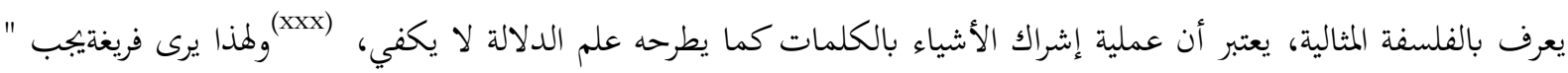

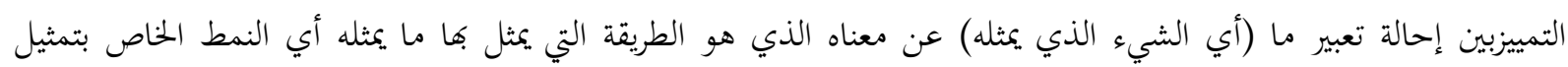
(الإحالة " (xxxi)

ولهذا يرى أنصار الدلالة الصورية، أن تحديد المعنى يتوقف على مفهوم الإحالة، وأنه ليس سوى الطريقة التي تقدم أو تحدد

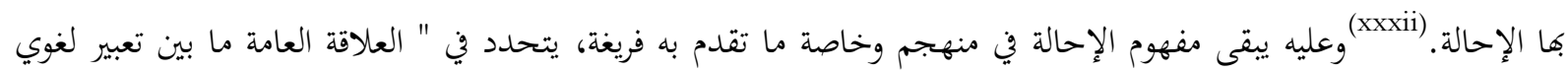
ومظهر الواقع الذي يحيل إليه هذا التعبير " (xxxiii) يبدو أن أنصار التيار التداولي لم يقتنعوا بهذه الأطروحات السابقة، حيث وجهوا تصوراقم نحو دراسة العلاقة الوظيفية مابين الإحالة والمعنى، التي تتجاوز في عمومها ما جاء به علم الدلالة الاحالي الذي يشرك مع الكلمات أشياء أشياء وعلم الدلالة المعريف الذي

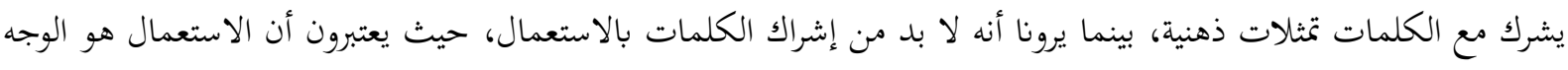
الحقيقي الذي تظهر فيه الوظيفة. (xxxiv) وبهذا فإنهم يقدمون الوظيفة على المتوى التمثيلي ويعتبرون وجوده يتوقف عليها. (xxxv) إن الاهتمام بالاستعمال في إظهار الوظيفة التداولية للتعابير اللغوية، كان من المقدمات المنهجية التي توسل بها التيار

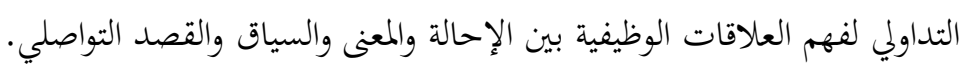




\section{2- الإحالة بالمعجم والاتساق والانسجام المؤسس في الحدود بين الجملل(xxxv):}

نقصد بالإحالة بالمعجم وفق فرضيات الاتساق والانسجام، تعني البحث عن الوظائف الدلالية والتداولية التي تنجزها

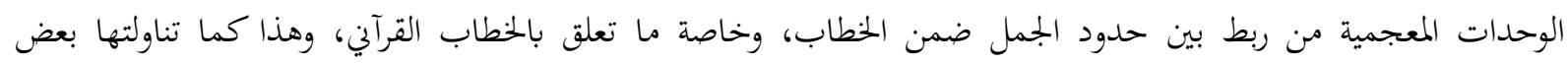
مدونات النحو وفسرتا وتأولتها بعض التفاسير.

\section{الثـــاهد القـرآي الأول: يقول الله تعـالى: (وأسـروا النجوى الذذين ظلمـوا هل هـذا إلا بشر مثلكم)}

إن عملية تأويل العلاقة الوظيفية بين الجملتين وفق محددات الاتساق والانسجام المؤسس في الحدود بينهما ضمن هذا

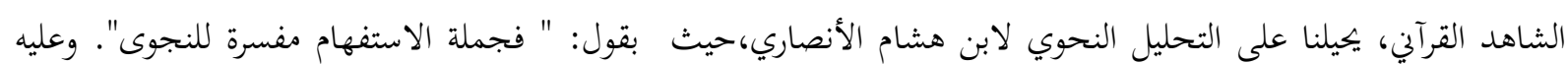

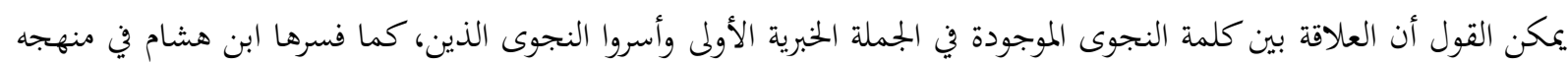

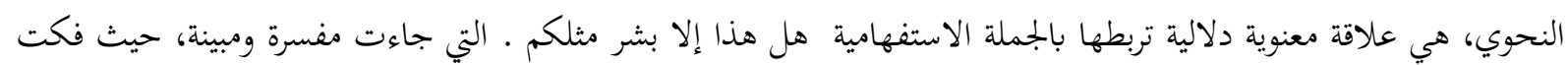
الإبهام كلمة النجوى الموجود في الجملة الخبرية وأسروا النجوى الذين ظلموا.

هذا التخريج النحوي لدراسة الحدود الدلالية بين الجملتين ضمن هذا الشاهد القرآي، يرجعه محمد الطاهر بن عاشور،

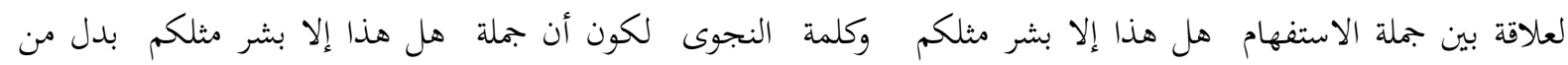

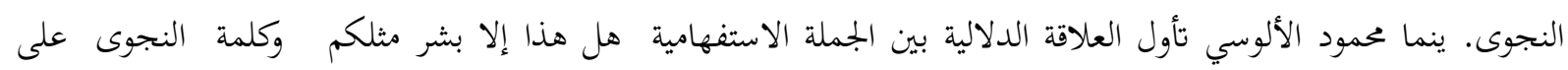

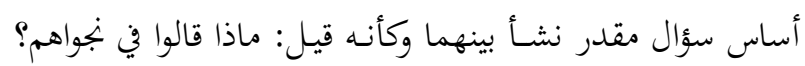
يمكننا أن نستخلص من خلال هذا التخريج النحوي لابن هشام وتفسير محمد الطاهر بن عاشور ومحمود الألوسي لهذا

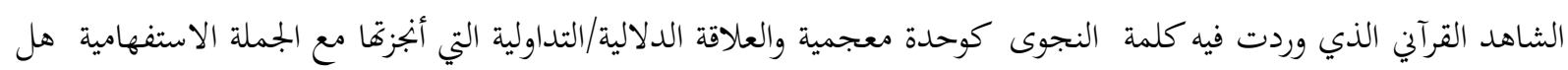

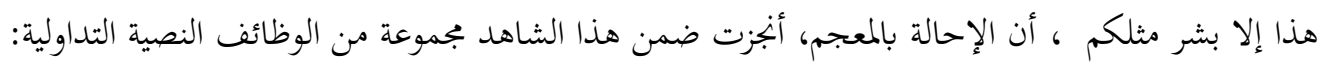

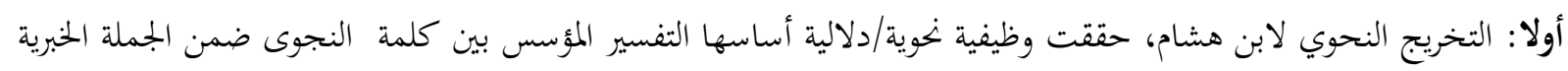

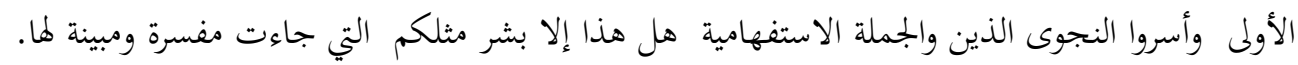

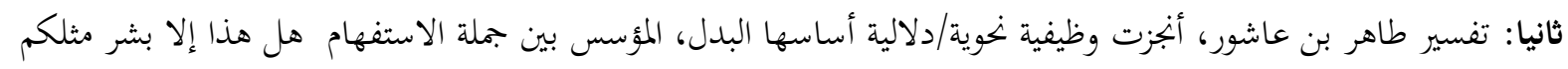

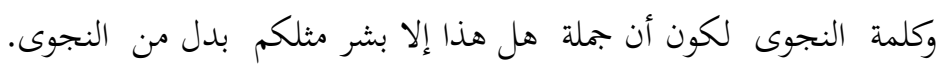

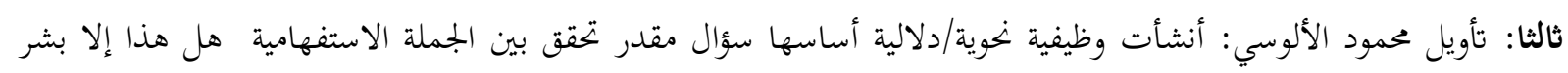
مثلكم وكلمة النجوى وكأنه قيل: ماذا قالوا في نجواهم؟ تكودئ

الشاهد القرآي الثاني: يقول الله تعالى: هل أدلكم على تجارة تنجيكم من عذاب اليم تؤمنون بالله ورسوله. يمكن تبين العلاقة النحوية/الدلالية بين كلمة التجارة الموجودة في الجملة الاستفهامية الأولى هل أدلكم على بحارة

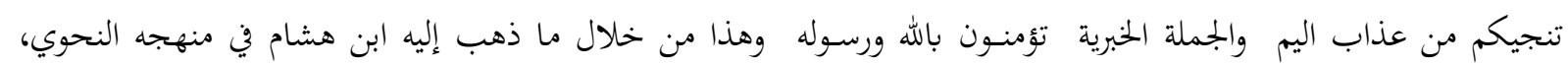
حيث اعتبر "جملة تؤمنون تفسير للتجارة." وهذا على اعتبار أن كلمة التجارة الموجودة في الجملة الاستفهامية الأولى هل هل أدلكم

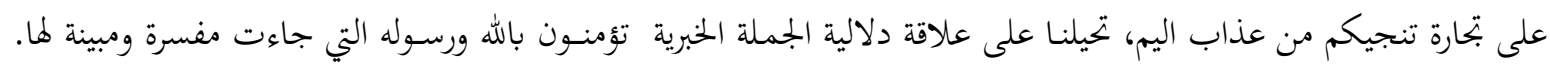
في مقابل من هذا التخريج النحوي لدراسة الحدود الدلالية بين الجملتين ضمن هذا الشاهد القرآي، يرجع محمد الطاهر بن عاشور العلاقة بين جملة الخبرية تؤمنون بالله ورسوله وكلمة التجارة لكون أن جملة تؤمنون بالله ورسوله" مستأنفة استئنافا بيانيا

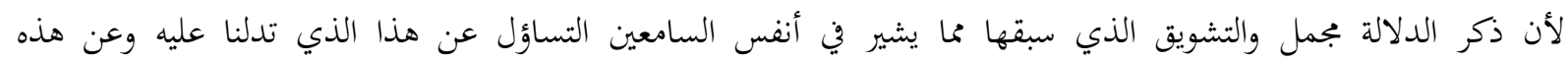


التجارة."بينما محمود الألوسي تأول العلاقة الدلالية بين الجملة الخبرية تؤمنون بالله ورسوله وكلمة التجارة على أساس سؤال مقدر

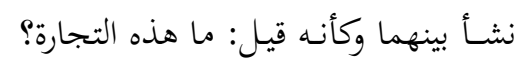

يمكننا أن نستخلص من خلال هذا التخريج النحوي لابن هشام وتفسير محمد الطاهر بن عاشور ومحمود الألوسي لهذا

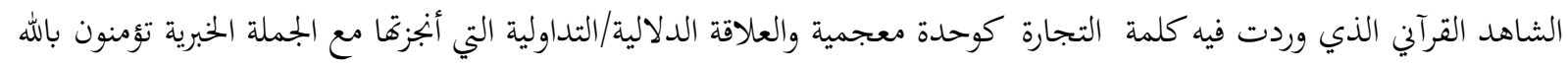

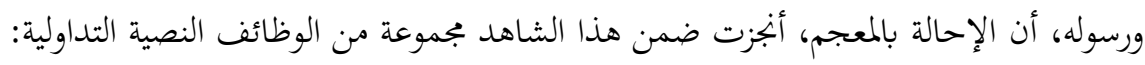

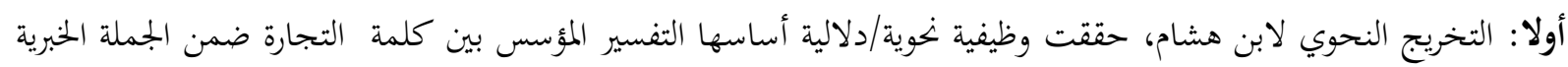

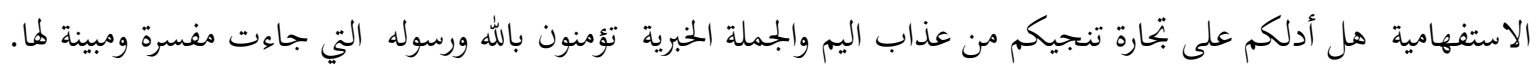

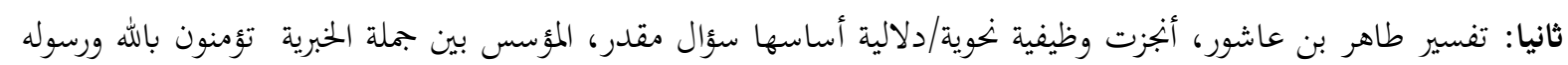
وكلمة التجارة لكون أن جملة تؤمنون بالله ورسله مستأنفة استئنافا بيانيا.

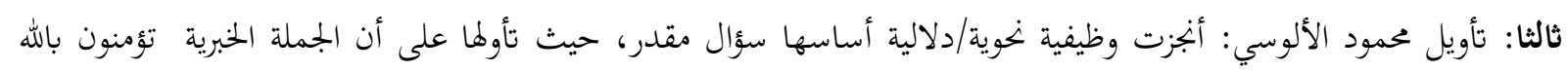

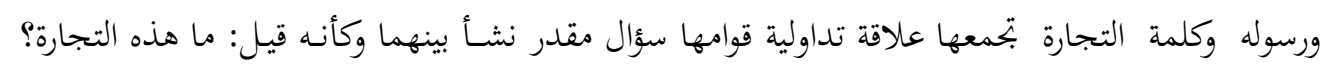

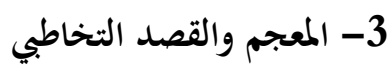

جرى ضمن مباحث الدرس التداولي، التفريق المنهجي بين فرضيتي المعنى والقصد في تحليل الخطاب، وذلك على اعتبار "

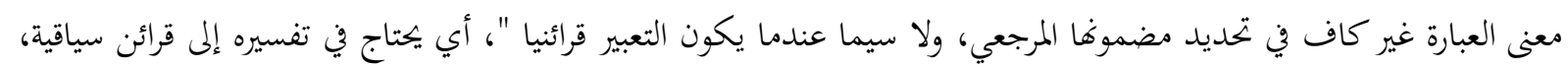

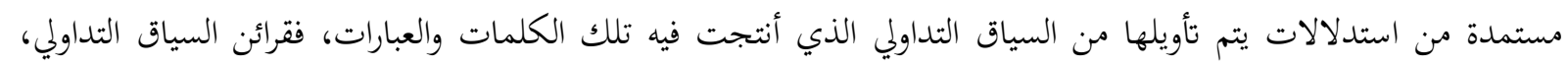

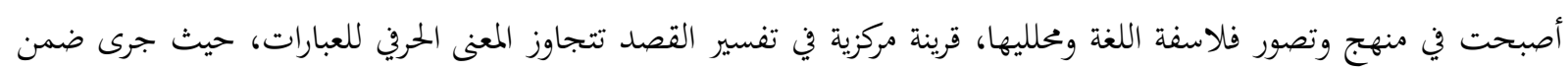
نظرية قصد المتكلم كما يطرحها غرايس GRICE في نظرية الاستلزام الحواري، البحث في قصد المتكلم الذي يتأسس في العادة على خلفية معرفية مشتركة أو قصد يتجاوز

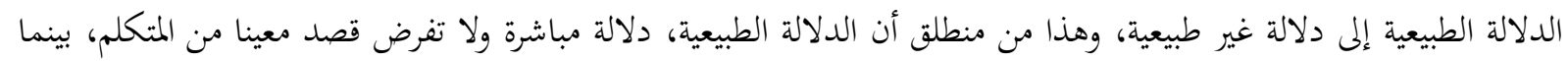

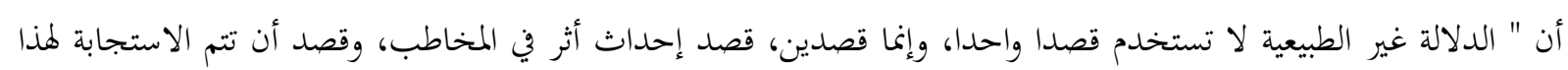

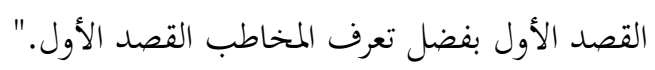

تبقى مسالة البحث في علاقة المعجم بالقصد ضمن هذا البحث، تتعلق في الأساس بدراسة وظيفة المعجم وما يضفيه من

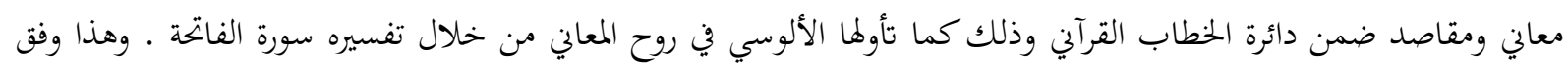

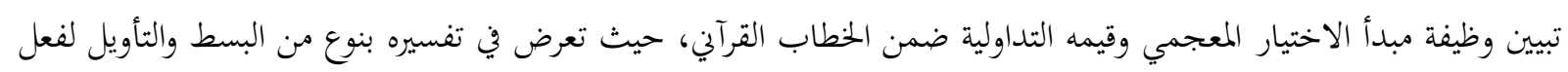

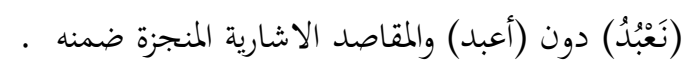

يقول الألوسي: " في سر قوله (نَعْبُدُ) دون (أعبد) فقد قيل:هو الإشارة إلى حال العبد كأنه يقول: إلهي ما بلغت عبادتي

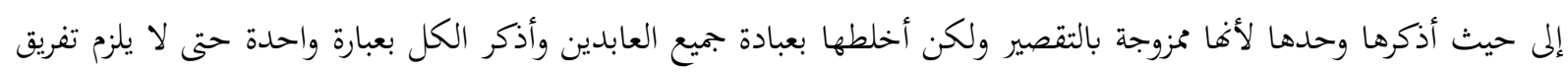

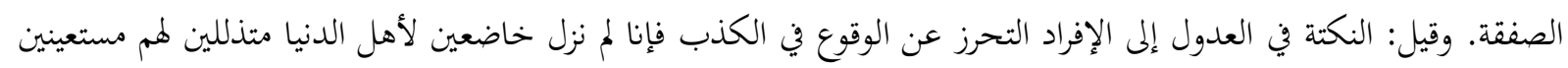

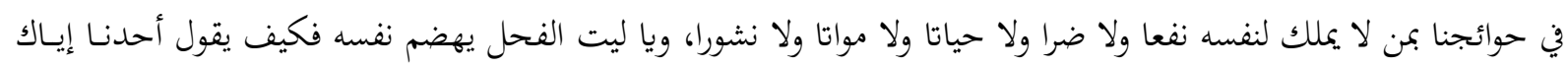

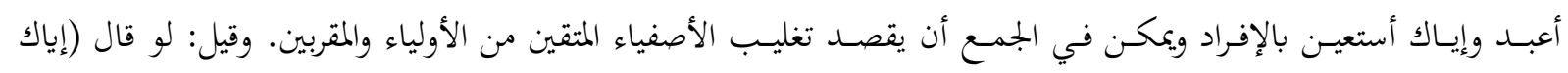

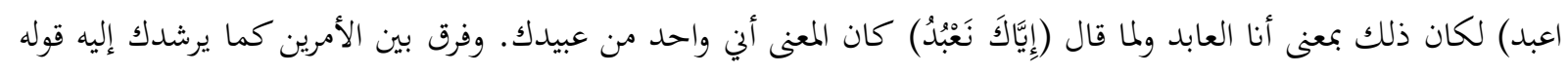

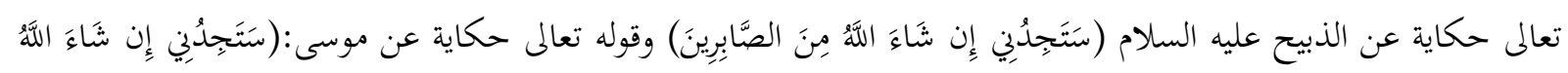


صَابِرًا) فصبر الذبيح لتواضعه بعد نفسه واحدا من جمَع ولم يصبر الكليم لإفراده نفسـه مع أن كـلا منهما عليهما السلام قال إِن شَاءَ الَّهُ

إن العدول عن صيغة المضارع المفرد (أعبد) إلى صيغة المضارع بالجمع في (نَعْبُدُ) في سورة الفاتحة، تأولها الألوسي من أوجه

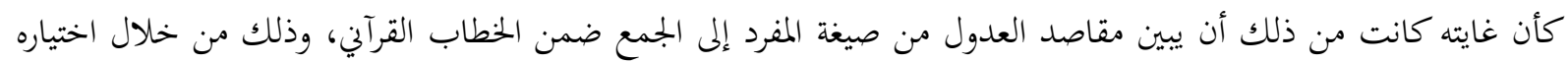

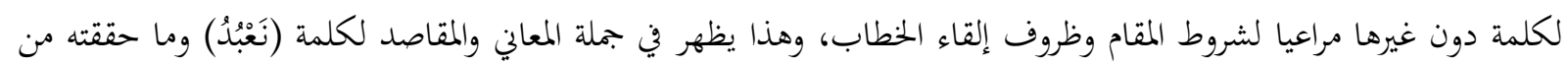

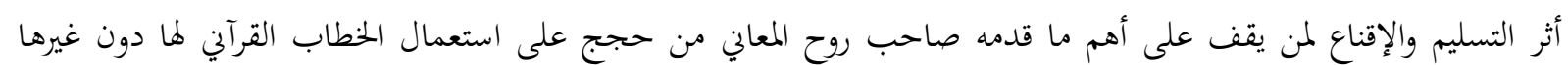
وهذه الحجج تظهر في المقاصد الآتية: أ- أولا: حين يقول: " هـو الإشـارة إلى حسال العبــ كأنه يقول: إلهي ما بلغت عبادتي إلى حيث أذكرها وحدها لأهما ممزوجة

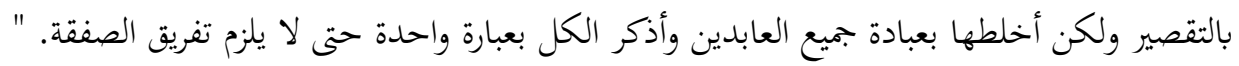

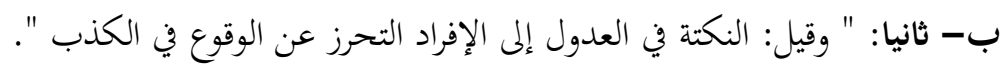
ج- ثالثا: " ويمكن في الجمع أن يقصد تغليب الأصفياء المتقين من الأولياء والمقربين، وقيل: لو قال (إياك اعبد) لكان ذلك ذلك بمعنى

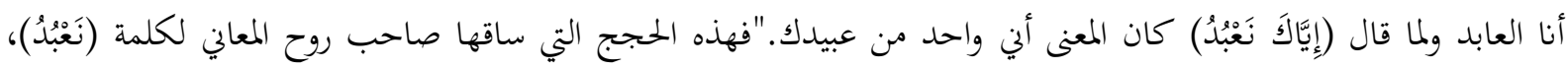

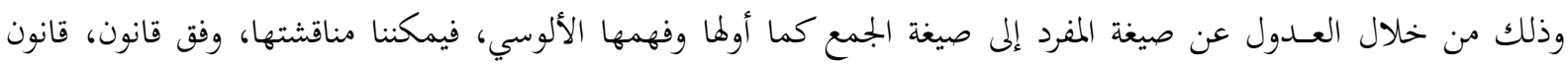

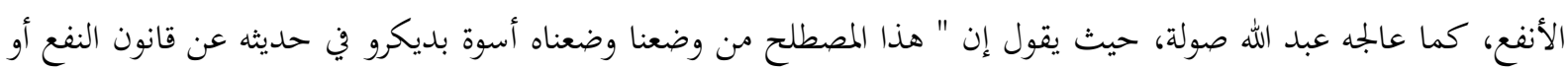

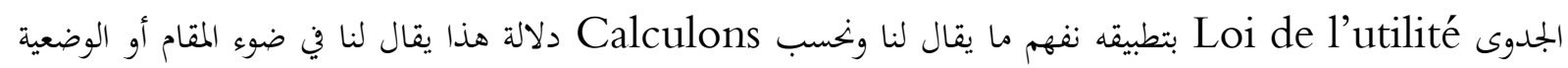

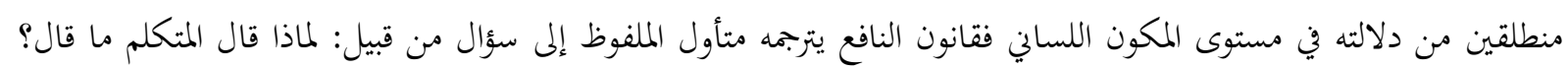

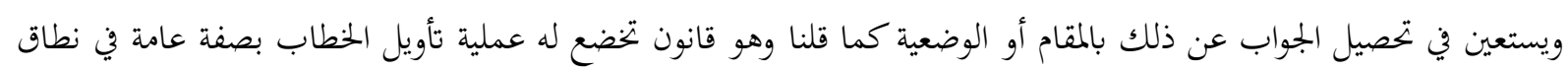

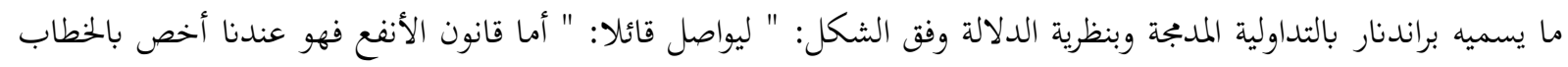

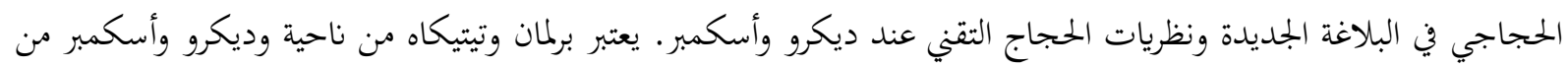
ناحية أخرى، كل على طريقته، أن بين وحدات اللغة تفاوتا في درجة التعبير عن فكرة ما بحيث يعتمد التعبئ التعبير بالعنصر (أ) دون

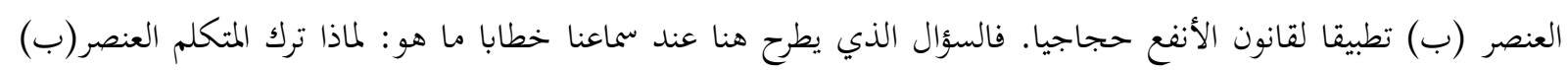

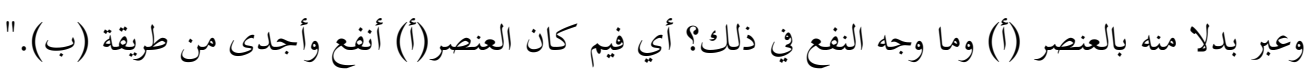
هذا الشكل الذي أخذه قانون الأجدى والأنفـع عند عبد الله صولة في اختيـار الكلمـات ضمـن الخطاب الحجاجي.

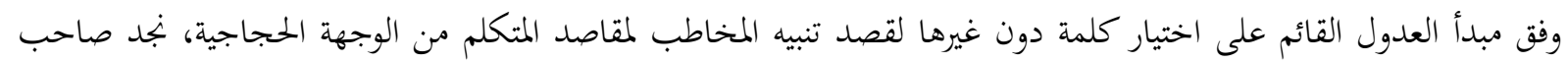

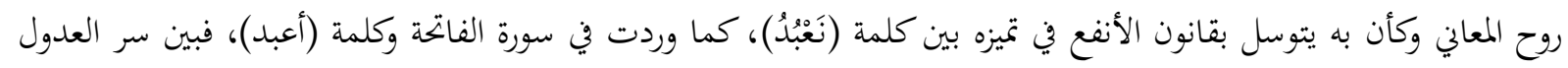

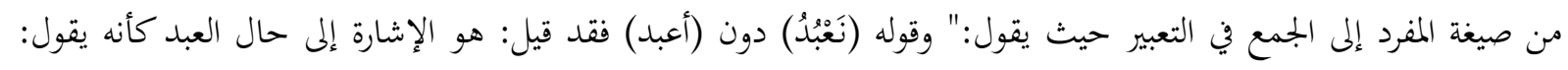

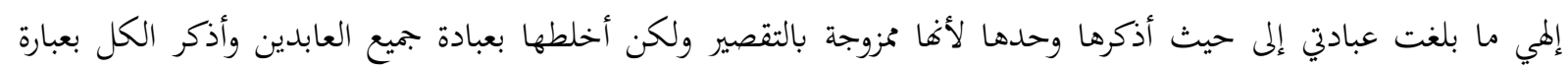

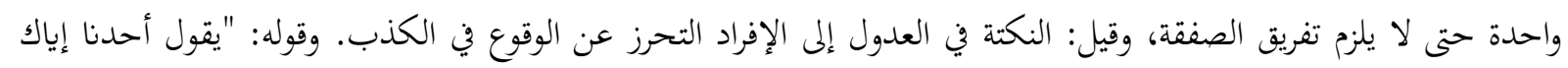

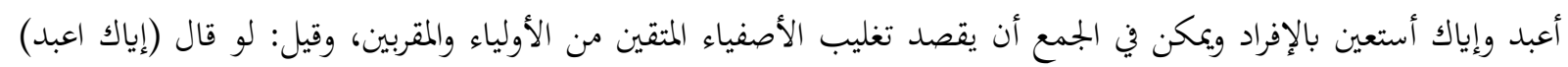

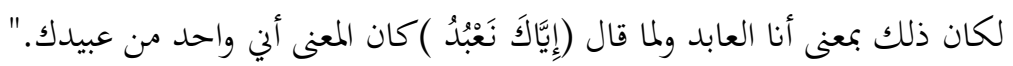




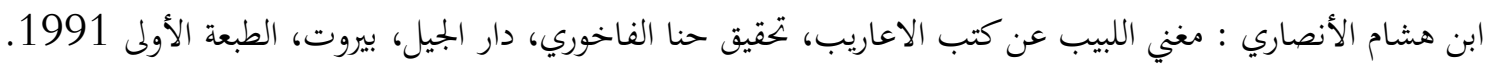

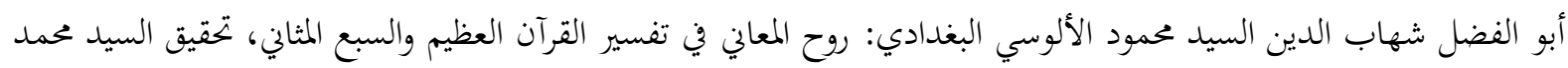

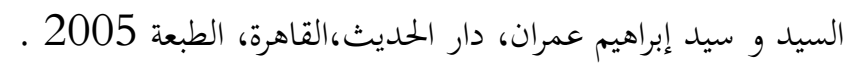

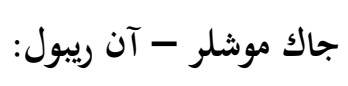

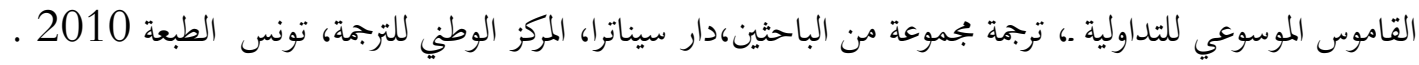

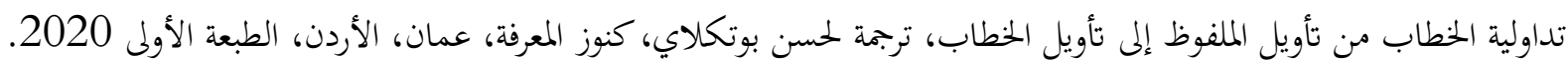

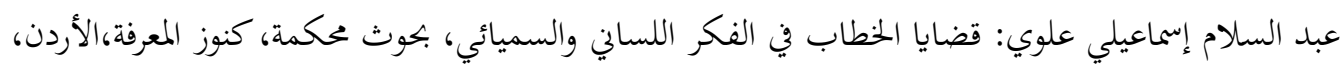
الطبعة الأولى 2019

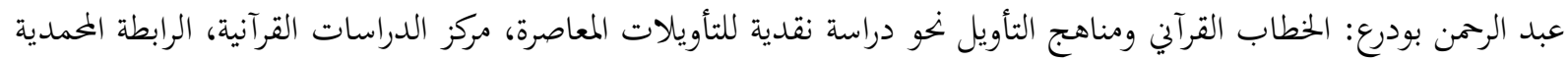

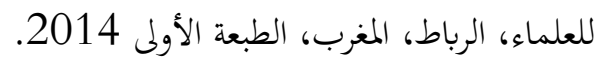

عبد الله صولة: - م آل الحجاج في القرآن من خلال خصائصه الأسلوبية، دار الفارابي، بيروت، لبنان، الطبعة الثانية 2007.

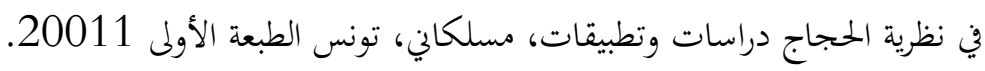

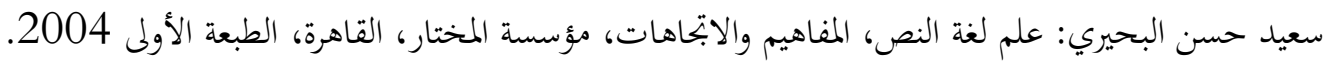

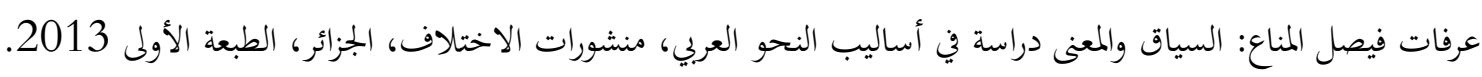
فرنسوا ريكاناتي:

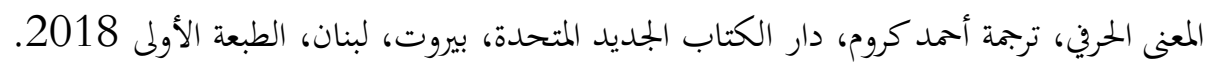

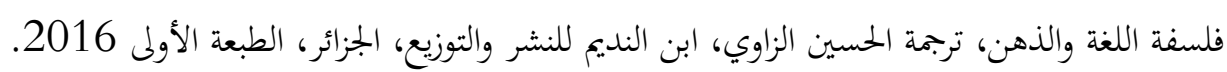

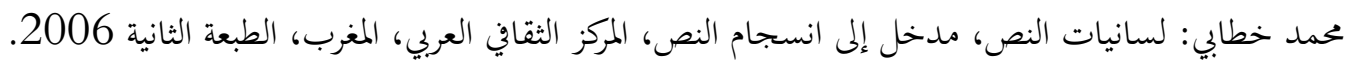
محمد الطاهر بن عاشور: التحرير والتنوير ، دار سحنون للنشر والتوزيع، تونس، بدون طبعة .

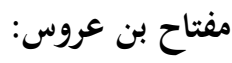

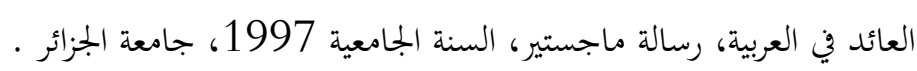

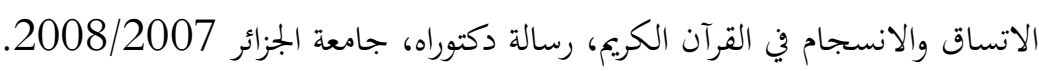
ELEMENT DE SYNTAXE STRUCTRALE..Pari1959. LUCIEN TUSNIER

Jean/Michel ADAM Lalinguistique textuelle introduction a l'analyse textuelle des discours. ARMAND.Paris2005. 


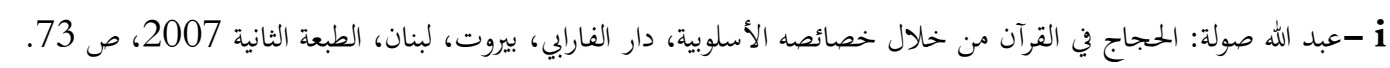

$$
\text { - ii }
$$



$$
\text { بحث: النص صناعة للمعنى، سعيد بنكراد، ص } 10 .
$$

iv

- v $\mathbf{v}$

vi

- vii

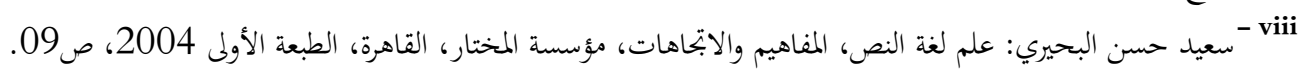

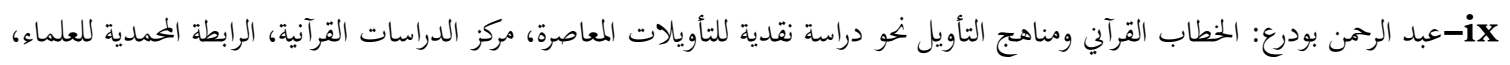

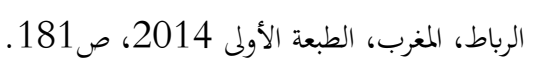

xi

- xii ـ _iii - جاك موشلر - آن ريبول: القاموس الموسوعي للتداولية .، ترجمة مجموعة من الباحثين، دار سيناترا، المركز الوطني للترجمة، تونس الطبعة 2010، ص 133.00 عiv - xبد الرحمن بودرع: الخطاب القرآين ومناهج التأويل، ص 180.

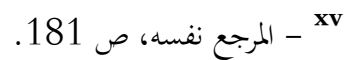

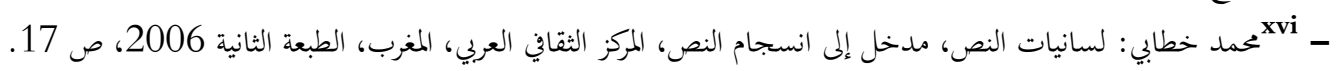

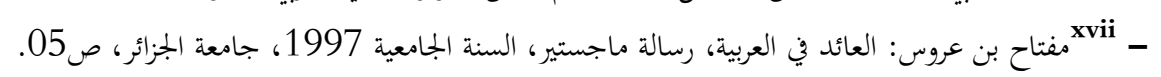
xviii xix - xx xxi xxii xxiii ELEMENT DE SYNTAXE STRUCTRALE..Pari1959.P06. LUCIEN TUSNIER -6 ${ }^{x x i v}$ - Jean - Michel ADAM.Lalinguistique textuelle introduction a l'analyse textuelle des discours. ARMAND.Paris2005.P86/87

$$
\begin{aligned}
& \text { - } \\
& \text { xxvi } \\
& \text { xxvii - المرجع نفسه، صنxvili }
\end{aligned}
$$

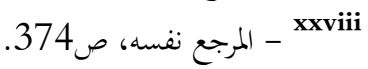

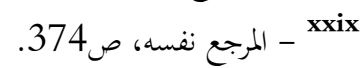

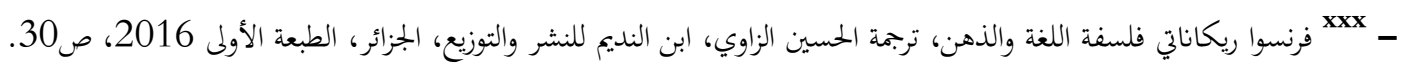

$$
\begin{aligned}
& \text { xxxi } \\
& \text { - المرجع نفسه، ص30xii }
\end{aligned}
$$




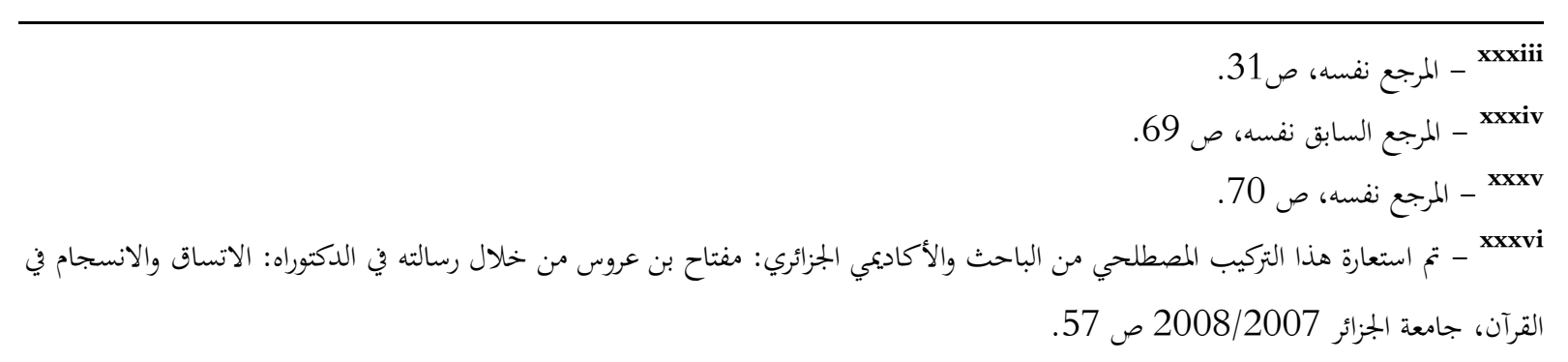




\title{
DEATH AND POST-DEATH IN THE POETRY OF AHMED ARIF
}

\section{Istanbul / Türkiye}

p. $320-328$

Received: $28 / 11 / 2021$

Accepted: $10 / 12 / 2021$

Published: 01/01/2022

This article has been scanned $l$ iThenticat No plagiarism detected

\author{
Ihsan Hadi Ahmed ALDULAIMI ${ }^{1}$
}

\begin{abstract}
:
The great Turkish poet Ahmed Arif is considered one of the important poets in Turkish literature in the 20th century. He was born in Diyar Bakr on 23rd of April 1923 and died on 2nd of June 1991 in Ankara. Through his life that lasted for 68 years, he published one book about poetry. It was considered the best book to be published in Turkey which makes him different from any other poet.

Death as a fact and part of our nature is considered the end of life. The separation of the soul from the body is inevitable. It is impossible that a man can be born again after his death. Hence, there was a great discussion about the nature of our life and the existence of death throughout the whole history of human beings. Specifically, the scientists, philosophers, and thinkers, made scientific activities over humanity and death and what would happen after it. The poets are among the groups who express their opinion concerning this subject arousing different new point of views in their comments and thoughts. The nature of the poem is to think differently and explain it differently too resorting to symbolic language. Hence, the exposition of the beliefs difficult to be understood through poetry and literature create a genuine overflow of thoughts. Ahmed Arif is one of the well-known poets by his valuable thoughts in this subject.

I decide to introduce a detailed explanation about life of the great Turkish poet Ahmed Arif as well as his literary orientation and poem. Among his poems, we introduce some information about death and life after death through which I browse all the poems by Ahmed Arif who is considered one of the important poets in Turkish literature in the 20th century.
\end{abstract}

Key words: Ahmed Arif, Turkish Literature, Death, Death and Beyond.

http://dx.doi.org/10.47832/2717-8293.15.24

1 Dr. , Ministry of Education, Iraq, ihsaneldeleymi@gmail.com, https://orcid.org/0000-0001-5529-9722 


\section{AHMED ARIF'İN ŞIIIRLERINDE ÖLÜM VE ÖTESI}

Özet:

Büyük Türk Şairi Ahmed Arif, 20. yüzyıl Türk Edebiyatının en önemli şairlerindendir. 23 Nisan 1923 tarihinde Diyarbakır'da doğan şair, 2 Haziran 1991 tarihinde Ankara'da vefat etmiştir. 68 y1llık ömrüne çok az sayıda eser sığdıran Ahmed Arif, bu yönüyle diğer şairlerden ayrılmaktadır. Kendisi hayattayken yalnızca 1 şiir kitabı yayınlanan Ahmed Arif'in bu kitabı, Türkiye'de en çok baskı yapan şiir kitapları arasına girmiştir. Ölüm, yaşamın sona ermesi, ruhun bedenden ayrılmasıdır. Esasında ölümden sonra tekrar dünyaya gelmek, insanlar için olanaksızdır. Dolayısıyla ölümden sonraki hayatın varlığı ve mahiyeti, insanlık tarihi boyunca tartışılmıştır. Bilim insanları, mütefekkirler ve filozoflar başta olmak üzere tüm insanlık, ölüm ve ötesi hakkında ilmi faaliyetlerde bulunmuşlardır. Bu hususta fikir belirten, yorum ve düşünceleriyle yeni bakış açıları getiren gruplardan biri de şairlerdir. Şiirin doğasında farklı düşünmek, farklı yorumlamak ve sembolik anlatımlara başvurmak vardır. Dolayısıyla anlassılması zor kavramları, şiir ve edebiyat metoduyla ortaya koymak, orijinal bir fikir akımı meydana getirir. Bu hususta oldukça kıymetli fikirleriyle tanınan şairlerden biri, Ahmed Ariftir.

Çalışmamıza, bu kapsamlı özet ile başlıyoruz. Ardından Büyük Türk Şairi Ahmed Arif in yaşamı, edebi yönü ve yapıtları tanıtılacaktır. Ardından ölüm ve ölüm ötesi hakkında bilgiler sunulduktan sonra, 20. yüzyıl Türk Edebiyatının en önemli şairlerinden biri olan Ahmed Arif'in tüm şiirlerinde, konuya ilişkin incelemeler yapılacaktır. Sonuç bölümü ve kaynakça eklentisi ile, çalıșmamız tamamlanacaktır.

Anahtar Kelimeler: Ahmed Arif, Türk Edebiyatı, Ölüm, Ölüm ve Ötesi.

\section{GİRİŞ:}

Ahmed Arif, 23 Nisan 1923'te Türkiye'nin doğusunda yer alan Diyarbakır ilinin Hançepek semtinde dünyaya geldi. Babası, devlet memuru olan Arif Hikmet Bey'dir. Annesi ise kanaat önderi Abdulkadir Cibrali'nin kızı Sare Hamım'dır. 8 çocukları olan çiftin, en küçük oğlu, Ahmed Ariftir. Kendi ismi Ahmed Hamdi Önal'dır. Fakat yapılarında Ahmed Arif ismiyle yayın yaptığı için, bu isimle tanınmış ve meşhur olmuştur.

Babası Arif Hikmet Bey, memuriyeti dolayısıyla Siverek ve Harran ilçelerinde bulundu. $\mathrm{Bu}$ sebeple Ahmed Arif'in çocukluğu, bu ilçelerde geçti. Bu ilçelerde Türkçeden ziyade Zazaca adındaki bir dil konuşuluyordu. Henüz çocukken Zazaca dilini öğrendi. Harran ilçesinde Arapça konuşulduğu için Arapça'yı öğrendi. Ayrıca kendisi bizatihi Kürt olduğu için Kürtçe'yi öğrendi (Durbaş, 2009: 29). Henüz çocuk yaşta pek çok dil ve kültürle tanışmış oldu. 1929 yılında, henüz 9 yaşındayken, annesi vefat etti. Babası, Arif Hanım'la evlendi. Üvey annesi Arif Hanım, Ahmed Arife annelik yaptı (Durbaş, 2009: 35).

Ahmed Arif, artık okul çağına geldi. Babasının görev yaptığı Siverek'te, ilkokula başladı. Türkiye'nin Şanlıurfa ilinde, ablasının yanında ortaokulu bitirdi. Lise eğitimini, Afyon Lisesinde bitirdi. Burada parasız yatılı olarak okudu. Burada edebî yönü şekillenmeye başladı. Lise yıllarında edebiyata merak saldı. Henüz küçük yaşlarda, şiir yazmaya başladı. İlk şiirinin ismi yoktur. Tasspınar isimli bir dergide 1942 yılında yayınlanan bu şiiri, oldukça sevildi (Şeker, 1997: 39). 1943 yılında, Lise eğitimini aldığ Afyon Lisesinden mezun oldu.

Liseden sonra, büyük abisi Muhammed Necati Bey'in Uşak ilindeki evinde kaldı. Bu süre zarfında babası, emekli oldu ve memleketi Diyarbakır'a yerleşti. Ahmed Arifi de yanına çağırdı. Ardından çok geçmeden vatani görevini yapması için askere gitti. Riva ilçesinde yedek subay rütbesi ile askerliğini bitirdi. 1947 yılında terhis oldu. Üniversite okumak için Türkiye'nin başkenti olan Ankara'ya gitti. Ankara Üniversitesi Dil ve Tarih-Coğrafya Fakültesinin felsefe bölümüne kayıt yaptırdı. Fakat mezun olmadan kaydını sildirdi.

Bir müddet kendini şiire verdi. Behçet NECATIGIIL, Faruk Nafiz ÇAMLIBEL gibi usta şairlerden etkilendi ve şiirlerini buna göre yazdı. Vakit geçtikçe, kendi şiir algısı oturmaya 
başladı. Pek çok dergide şiir yazsa da, asıl adını duyurduğu ve kendisine şöhret getiren dergiler, İnkılapçı Gençlik Dergisi ve Meydan Dergisi oldu. Bu dergilerde yazdığı şiirler neticesinde artık daha çok tanınmaya başladı. 1948 yıllarında, yayın hayatına kesin olarak başladı ve sürekli edebi metin üretti.

1948 yılında, Dışişleri Bakanlığı, personel alımı için sınav yaptı. Bu sınavı kazanan Ahmed Arif, tam yurtdışına gönderileceği sırada, Palmiro ismini verdiği bir şiiri nedeniyle tutukland1 (Odabaş1, 2014: 22). Bu tutukluluk hali çok uzun sürmedi. Komünizm savunucusu olmakla suçlanmış, fakat hakkındaki dava, delil yetersizliğinden dolayı düşmüştür. Bu tutukluluk hali nedeniyle, Dışişleri Bakanlığı'ndaki işe kabul edilmedi. Aynı yı1, Danıştay'a iş başvurusu yaptı ve Merkez Bankasında memur olarak çalışmaya başladı. Aynı zamanda yarım bıraktığı üniversite eğitimine devam etme firsatı buldu (Paşaoğlu, 2019: 7).

1950 yılında, Türk kanunlarına aykırı olduğu gerekçesiyle, ve 1952 yılında hükümet karşıtı örgüt oluşturma suçlamaları nedeniyle 2 kez tutuklandı. İstanbul'a götürülen şair, burada toplam 38 ay cezaevinde kald1. 2 yıl hapis cezası ald1 ve 8 ay gözetim altında tutulma cezasına çarptırıldı. 1954 senesinde, cezaevinden tahliye edildi. 8 aylık gözetim cezası için memleketi Diyarbakır'a gitti ve burada bir fabrikada katip vasfiyla çalışmaya başladı. Cezası bittikten sonra Ankara'ya geri dönüş yaptı. 1954-1959 yıllarında, Leyla Erbil adındaki hanımefendiye asskından dolayı, aşk temalı şiirler ve mektuplar kaleme aldı.

Benzersiz bir ozan (Akın, 2004: 58) namıla bilinen Ahmed Arif, üniversite eğitimini tamamlayamadı. 1956 yılında, redaktör olarak bazı gazetelerde çalışmaya başladı. Bu gazetelerin başlıcaları, Medeniyet, halkçı ve öncü ismindeki dönemin popüler gazeteleridir. Ahmed Arifin şair kimliğinin yanısıra gazeteci kimliği ile de tanınıyor olmasının sebebi budur. 1967 yllında, Aynur Hanım ile tanısstı ve aynı y1l onunla evlendi. Filinta isminde bir oğlan çocuğu oldu. Bu süre zarfında, Türkiye Kominist Partisi'nin Ankara İl Temsilciliğinde görev yapt1.

Fikret OTYAM ismindeki Türk Edebiyatçıs1, verdiği bir röportajda, Ahmed Arifin şiirlerinden bahsetti. Bu bahis, Ahmed Arif'in şöhretini zirveye taşıdı. Türkiye'de herkes, artık Ahmed Arifi tanıyordu. Sene 1968 'de, tüm şiirlerini bir araya topladi. Hasretinden Prangalar Eskittim adını verdiği bu şiir kitabı, Ahmed Arif'in tek şiir kitabıdır. Şiirlerinde yerel ve modern motifler iç içedir (Oktay, 1990: 44). Döneminde o kadar popüler oldu ki, henüz basımı yapıldığı yılda bile onlarca baskı yaptı. Tüm Türkiye'de okundu, araştırıldı. Bir şairin tek bir şiir kitabı ile meşhur olması oldukça zordur. Fakat Ahmed Arif, kendine has üslubu ve kalitesiyle, imkansızı başardı. Türkiye'nin en çok baskısı yapılan şiir kitapları arasındadır. Aynı zamanda birçok şiiri bestelendi. Ahmet Kaya ve Cem Karaca gibi Türk müziğinin öncü şahsiyetleri, onun birçok şiirini besteledi. Şiirlerinde yoğun bir müzik kültürü göze çarpmaktadır (Belge, 2018: 4).

Şiirlerinden genel olarak memleketi olan Doğu illerinin derdini, sıkıntısını ve kültürünü anlattı. Doğu başta olmak üzere, Türkiye'nin her yerinde okuyucu kitlesine sahip oldu. İlk ve son şiir kitabı olan Hasretinden Prangalar Eskittim'den sonra, başka bir şiir kitabı yayınlamadı. Artık şiir yazmamaya başladı.

1977 senesinde, gazetecilik mesleğinden emekliye ayrıldı. Emeklilik hayatını, Ankara'daki evinde sürdürdü. Birkaç dostu ve ailesi dışında kimseyle konuşmak istemiyordu. Kimseye röportaj vermedi. Kimseyi kabul etmedi. Sessiz ve sakin bir emeklilik dönemi yaşadı. 1989 yılında, Refik Durbaş ismindeki bir gazeteciye röportaj verdi. Bu oldukça önemli röportajdan, çalışmamıza kaynaklık edecek pek çok bilgiyi almış bulunuyoruz. Öncesinde bir gazetede yayınlanan bu önemli röportaj, daha sonra kitap halinde basıldı. 2 Haziran 1991 senesinde, Ankara'daki evinde, geçirdiği kalp krizi sonucu hayatını kaybetti.

\section{Eserleri:}

Hasretinden Prangalar Eskittim (1968 - şiir)

Yurdum Benim Şahdamarım (2003 - ölümünden sonra, yayınlanmamış şiirleri)

Leylim Leylim (2013 - Leyla Erbil'e yazdığı aşk mektupları)

\section{Ölüm Hakkında:}

"isim. 1. Bir insan, bir hayvan veya bitkide hayatın tam ve kesin olarak sona ermesi, ahiret yolculuğu, emrihak, irtihal, memat, mevt, vefat: "Çenesinde babamin ölüm günü 
gördüğüm asabi buruşmalar var." -Yusuf Ziya Ortaç. 2. Ölme biçimi: Yanarak ölümü, feciydi. 3. İdam cezası: Ölüme mahkûm oldu. 4. ünlem. Ölmesi istenen canlı için kullanılan bir söz: Zalimlere ölüm! 5. mecaz, Sona erme, yok olma, ortadan kalkma: Küçük sanayinin ölümü. 6. mecaz, Çok büyük sıkınt1, üzüntü: "Sürgün benim için ölüm gibi bir şey olmuştu." -Reşat Nuri Güntekin" (Güncel Türkçe Sözlük Ve Yazim Kilavuzu, 2001: Ölüm Maddesi)

Güncel Türkçe Sözlük ve Yazım Kılavuzu, ölüm kavramını bu şekilde izah etmiştir. Ölüm, canlılığın sona ermesi, kişinin yaşamının son bulmasıdır. Yalnızca insanlar için değil, hayvanlar ve bitkiler gibi tüm canlı organizmalar için mutlak bir gerçektir. Bu gerçeklik, tüm hayat çizgisinin bozulmasıla ve ruhun bedenden ayrılmasıyla ortaya çıkar. Bu büyük hakikatin, tarih içerisinde pek çok tanımı yapılmıştır. Birçok açıdan ele alınmış ve alınmaya devam etmektedir. Esasında oldukça basit bir olay olmasına rağmen, İnsan psikolojisine olan etkileri ve sonrasında herhangi bir yaşamın var olup olmaması gibi tezahürleri dolayısıyla ölüm, oldukça karmaşık bir yapıya bürünür.

Tarihte var olmuş tüm dini inançların merkezinde, ölüm ve ötesi vardır. Muhakkak her din, ölüme ve ötesine kendi yorumunu getirmiștir. İslam dini de, diğer dinler gibi bir ölüm anlayışına sahiptir. Ahiret olarak adlandırılan öte dünya tasvirleri ve tanımları, İslam diniyle zirveye ulaşmıştır. Tüm ölüm ve ötesine ait kavramları, sistematik bir şekilde ele almış ve inanç sistemine oturtmuştur. Bununla beraber örneğin Yahudi inancında, ölüm sonrası için çok az bilgiler verilir veya neredeyse hiç üstünde durulmaz. Bu hadisenin dini boyutunu ele almamızın sebebi, bu husus hakkında bilgi veren ve bilgi anlayışı içerisine giren en önemli yapı olmasından dolayıdır. Örneğin bilim, var olanla ilgilenir. Veya örneğin felsefe, hakikat arayışıdır. Dolayısıyla ölüm ve ötesi, bu her iki ilim dalı için de pek önemli değildir. Fakat dini yapılanmalar, ölüm ve ötesi hakkında oldukça yoğun bir araştırma içerisindedirler. Bu yüzden ölüm ve ötesinin dini boyutuna kısaca değinmiş olduk.

Ölüm ve ötesi, daha çok psikolojik yönleriyle ele alınır. Bu sebeple psikolojik unsurları içinde barındıran alanların konusudur. Edebiyatın en kuvvetli dalı olan şiir, psikolojik unsurları ele alır. Farklı bakış açılarıyla, farklı yönleri ele alır. Ölüm gibi psikolojik bir olgunun, şiirin konusu olması, bu bakıma oldukça doğaldır. Bu sürecin işleyişi, bir annenin bebeğine olan ilgisi gibidir. Nasıl anne bebeğini büyütür ve onu yanından ayırmaz, tıpkı bunun gibi şiir de, ölüm kavramından ayrı kalamaz. Tüm şairler, ölüm ve ötesine dair muhakkak şiirler yazmıştır. Kapsamı bu kadar geniş olan kavramın, şiirlerde yer alması, doğal bir sürecin ürünüdür. Bu süreci şiirlerinde oldukça yoğun bir şekilde işleyen şairlerin başında, Ahmed Arif gelmektedir. Onun ölüme bakışı oldukça farklı ve orijinaldir. Bu durumu şiirlerinde sıklıkla görmekteyiz. Ahmed Arif'in şiirleri, pek çok açıdan incelenmiştir. Fakat ölüm ve ötesine dair düşünceleri, neredeyse hiç dile getirilmemiştir. Çalışmamızın konusu, bu durumun mahsulüdür.

Ölüm ve ötesine dair yaptığımız bu girişten sonra şimdi de, Ahmed Arifin şiirlerinden hareketle ölüm ve ötesini inceleyeceğiz.

\section{Ahmed Arif'in şiirlerinde ölüm ve ötesi:}

Ahmed Arif, şiirlerinde ölüm temasını oldukça sık kullanmıştır. Şiirin doğasında farklı düşünmek, farklı yorumlamak ve sembolik anlatımlara başvurmak vardır. Dolayısıyla anlaşılması zor kavramları, şiir ve edebiyat metoduyla ortaya koymak, orijinal bir fikir akımı meydana getirir. Bu hususta oldukça kıymetli fikirleriyle tanınan şairlerden biri, Ahmed Arif'tir.

Birazdan inceleyeceğimiz üzere, pek çok şiiri ölüm vurgusu yapar. Çeşitli açılardan ele alır ve şiirlerinde titizlikle işler. Konumuz bağlamında ilk olarak, şairin Yalniz Değiliz şiirinin bir kısmina bakalım:

"Çukurovam,

Kundağımız, kefen bezimiz." (ARİF, 2021: 23)

Ahmed Arif, Türkiye'nin doğusunda bulunan illere atıfla, doğunun güzelliklerini anlatır çoğu şiirinde. Bu şiir, onlardan biridir. Çukurova, Adana ilini içine alan çok geniş bir alandır. Tarımla uğraşan çifçilerin çektiği eziyetlerden ve tarım topraklarının öneminden bahseder. Bu sebeple Çukurova için kundak ve kefen bezi benzetmelerini yapar. Bir insan doğduğunda kundağa sarılır. Öldüğünde ise kefen bezine sarılır. Bu durum, hayat döngüsünü bize anlatır. Tarlalarda çalışırken doğum yapan emekçi Türk kadını, aynı şekilde çalışmaya devam eder, ve ömrünün sonuna kadar kendi alın terini döker. Sonunda 
aynı toprağa gömülür. Her ne kadar bu şiirde ölüm ötesine yani ahirete yönelik bir içerik bulunmasa da, ölüme giden bir yol tarifi vardır. Buna göre, kişinin doğup büyüdüğü ve emek verdiği topraklar, o kişinin aynı zamanda mezar yeridir. Dolayısıyla buradan konumuza ilişkin çıkarılacak sonuç, ölümün bize çok yakın olduğudur.

Ahmed Arif'in Hani Kurşun Siksan Geçmez Geceden isimli muhteşem şiirinde, ölüm ve ötesine dair çok önemli bir ayrıntı göze çarpmaktadır:

"Derya dibinde yanginlar,

Kan kesmiş ovalar üstünde Mayıs...

Uçmuş bir kuştüyü hafifliğinde,

Çelik kadavrası, koruganlarin.

Ölünmüş, canım, ölünmüş,

Murad alınmıs..." (ARİF, 2021: 30)

Burada her ne kadar alenen ölümden bahsedilmese de, ölüm tarif edilmektedir. Bir kişinin ölümü, çevre insanları oldukça etkiler. Deryada yangın; ovalarda kan vardır. Bu mecazi anlatım, ölüm haberinden sonra gelen sessizliği ve kederi tarif eder. Kuştüyü hafifliğiyle uçan şey, ruhtur. Geriye sadece insan kadavrası, yani cesedi kalmıștır. Çelik kadavra tabiri, Ölü bedenin kişide bıraktığı sancıdır ve bu sancı oldukça ağırdır. Bu yüzden çelik benzetmesi yapılır. Öldükten sonra, murad alınmış olur şaire göre. Çünkü tüm çaba ve hayat telaşı, ölüme koşmak içindir. Derdin ve kederin bittiği, kişinin ebedi uykuya yattığ1 ölüm, bazıları için murad edilen yani istenilen bir şeydir. Ölüm sonrası için ahiret hazırlığı yapmış bilinçli bir kişi, ölümden korkmaz ve ölümü murad eder.

İnsan ruhunu yücelten derin ve ulvi duyguların ölümü demektir (Türk, 2020: 170).

Ahmed Arif, bir başka şiirinde, kişiyi ölüme yaklaştıran bir sebepten bahseder. Ve bunu öylesine güzel bir dille anlatır ki, kişide hayranlık uyandırır. Bu bağlamda şairin Akşam Erken İner Mahpusaneye isimli şiirinin ilgili kısmına bakalım:

"Hirsla çakarim kibriti

Ilk nefeste yarilanir cigaram,

Bir duman alırim, dolu,

Bir duman, kendimi öldüresiye.

Biliyorum," sen de mi?"diyeceksin,

Ama akşam erken iniyor mahpusaneye.

Ve dişarda delikanlı bir bahar,

Seviyorum seni,

Çıldırasıya..." (ARİF, 2021: 38)

Hayatından kesitler sunduğumuz Ahmed Arifin, ömründe çok defa hapse mahkum edildiğini biliyoruz. Çoğu şiirini, hapishanede yazmıştır (Aydoğdu, 2020: 1306). Sigara alışkanlığı, hapishane yıllarına dayanır. Cigara tabiri, Türk Halk ağzında, sigara kavramının karşılığıdır. Sigaranın daha ilk nefeste yarıya kadar yanması, çok derin bir nefes alındığını gösterir. $\mathrm{Bu}$ ise, daha çok dertli zamanlarda ortaya çıkar. Sigaranın insan vücuduna oldukça zararlı olduğu açıktır. Bu zarar neticesinde kişiyi ölüme yaklaştırır. Bu denli hırsla içilen sigara, kişide ölüm düşüncesini beraberinde getirir. Öfke ve mutluluk duyguları, sigara bağımlısı kişilerde ortaya çıkınca, bir sigara yakmak isterler. Ahmed Arif ise, bu durumda ölüme yaklaştığını ve kendine zarar verdiğini bilmektedir. O halde, kişiyi ölüme yaklaştıran her etmen, kişide ölüm düşüncesini ön plana çıkarır. Örneğin kaza geçirmiş biri, derhal ölümü düşünür. Ölümü düşünmek ise, kendisine yaklaştıran sebeplerle karş1laşmakla daha çok mümkündür.

Ahmed Arifin en güzel şiirlerinden biri olan Suskun adlı şiirinde, sevdiği kişiye hitaben yazdığı şu dizeler, konumuz açısından oldukça önemlidir:

"Seni bulmuşum sonra.

Seni, kaburgamin altın parçası,

Seni, dişlerinde elma kokusu.

Bir daha hangi ana doğurur bizi?" (Arif, 2021: 45). 
Burada ölüm kavramı bizzat geçmese de, ölüme ve sonrasına vurgu vardır. Alıntıladığımız kısmın ilk üç dizesinde, sevgilisine büyük bir aşk duymaktadır. Bu sevgisini şiirsel bir üslupla dile getirir ve oldukça başarılıdır. Son dize, konumuzu ilgilendiren kısımdır. Bir daha hangi ana doğurur bizi, kendilerinin ve sevgilerinin eşsiz olduğunu gösterir. Ayrıca ölüme vurgu vardır. Burada kasıt, biz öldükten sonra manasındadır. Yani, Biz öldükten sonra bir daha bizim gibi sevenler bir daha dünyaya gelmez, hiçbir ana, bizim gibi iki insanı doğurmaz manasındadır. Dolayısıyla ölüm, kişiyle birlikte kişiliği de sonlandırır. Bedeni çürüttügü gibi sevgiyi de yok eder. Seven kalmayınca, sevgi de kalmaz. O halde her insan ve her sevgi kıymetlidir. Bununla beraber, ne kadar kiymetli olunursa olunsun, bu hayatın tekrarı yoktur. Ölümden sonra dönüş olmadığ1 gibi, Ahmed Arif ve k1z arkadaşının yaşadığı aşk gibi bir aşk yoktur. Onlar ölünce, aşkları da mezara girecek ve bir daha kimse bu denli kıymetli bir aşk yaşamayacak. Aşkın kıymetini, ölümle ifade etmesi, Ahmed Arif'in ne kadar büyük bir şair olduğunu göstermektedir.

Ümit, aşk ve şevk, insanlara ilerleme azmi verir (Türk, 2016: 448).

Aynı şiirin devam eden kısmında, ölümün kaçınılmaz oluşuna dair çok önemli bir kısım yer almaktadır:

"Derimizin altında, o ölüm namussuzun...

Ve Ahmed'in işi ilk rasgidiyor.

Ilktir dost elinin hançersizliği...

Ağlıyor yeşil." (Arif, 2021: 46)

Burada, iki husus vardır. Birincisi ölüme kafa tutmak, onu alaya almak vardır. Türkçede namussuz kelimesi, hakaret olarak kullanılır. Bir kişiye veya şeye hakaret etmek, onu hakir görmektir. Dolayısıyla Ahmed Arif'in ölüm hakkında namussuz kavramını kullanması, onu hakir gördüğü anlamına gelir. Bir diğer husus ise, ölümün kaçınılmaz oluşudur. Derimizin altında tabiri, ölümün her an içimizde olduğu anlamina gelmektedir. Dolayısıyla kaçınılmaz olan bir şey, korkulması gereken değil, aksine, cesaretle hakir görülebilir bir şeydir. Bu şey ölümdür, hem kaçınılmaz, hem namussuzdur.

Ahmed Arif, Vay Kurban şiirinde, ilginç bir metodla ölümü tasnif eder. İki tür ölümden bahseder. İlgili kısma bakalım:

"Ölüm bu,

Fukara ölümü.

Geldim, geliyorum demez.

Ya bir kuşluk vakti, ya akşam üstü,

Ya da seher, mahmurlukta,

Bakarsin, olmuş olacak.

Bir hastan vardı umutsuz,

Hasreti uykularda,

Hasreti soğuk sularda.

Gayrı, iki korku çiçeğidir gözleri,

İki mavi, kocaman korku çiçeği,

Açar, derin kuyularda..." (Arif, 2021: 51)

Burada bahsi geçen ölüm türleri ikidir. İlki zengin bir kişinin, ikincisi fakir bir kişinin ölümü. Bu kısımda ise, yalnızca fakirlerin yani fukaranın ölümü anlatılmaktadır. Geldim geliyorum demez söyleminden kasıt, zenginlerin ilaç ve şifa bulurken, fakirlerin bir an önce ölüyor olmasıdır. Bu yüzden her an gelebilir. Bir zengin, en ufak bir acıda doktora başvurur ve şifa arar. Fakat bir fakir, derdine çare, yarasına merhem bulamaz. Bu yüzden ölüm, fukaraya aniden gelir. Bir diğer husus, fakirlerin, ölüm döşeğinde umutsuz olmasıdır. Bu da zenginler ile kiyas edilecek olursa şöyledir. Zengin bir kimse, ücretini ödeyip tuttuğu doktorlar sayesinde, tıbbın tüm imkanlarını kullanır. Ve tüm bu süre zarfında umut hep vardır. Bu durumda fakirin yapabildiği tek şey, umutsuzca beklemektir. Hem ölümü ve hem de sekerat hali denilen ölüm anını görmemiz açısından oldukça önemli olan bu şiir, ölüm kokmaktadır. Aynı zamanda sınıfsal ayrıcalıklara başkaldırıdır, isyandır. Burada bahsi 
geçen derin kuyular kavramı, mezar yerini işaret eder. Korku çiçekleri, derin kuyularda açar ve derin kuyular, mezarlardir.

Ahmed Arif, Unutamadığım adını verdiği șiirinde, ölüm kavramı yerine 3 adet mecazi kavram kullanır. Bunları görmek için, şiirin ilgili kısmına bakalım:

"Asıl iş, anlamak kaçınılmaz't,

\section{Durdurulmaz çı̆̆}

Sonsuz akımı" (Arif, 2021: 59).

Öncelikle, asıl iş olarak tabir edilen şeyin ölüm olduğu unutulmamalıdır. Asıl anlaşılması gereken şey, ölümdür. Ölüm ise, Ahmed Arif in dediği gibi 3 özelliğe sahiptir:

1- Kaçınılmaz

2- Durdurulmaz çığ

3- Sonsuz akım

Ölümün kaçınılmazlığı ile alakalı olarak daha önce bahsetmiştik. Her nereye giderse gitsin, canlılar ölümü tadacaktır. Bu ise, ölümün kaçınılmazlığı demektir. Durdurulmaz çığ benzetmesi ise, önüne geçilemez ve karşı konulamaz manalarına gelir. Hemen hemen kaçınılmaz oluşuyla aynı anlamaları taşır. Sonsuz akım benzetmesi ise, ölen kişinin bir akıma kapılmış gibi ruhunu teslim etmesi, ve bir daha uyanmamak üzere sonsuz bir sessizliğe bürünmesidir. Dolayısıyla bu durum, Ahmed Arifin dilinden, sonsuz akım tabiriyle ifade edilir. Ölümden sonra hayatın var olup olmadığı hakkında bilgi vermez, fakat gittikten sonra bir daha geri dönüșü olmayan bir yola girildiğini söyler şair. Ölümden sonrası ise, Ahmed Arif'e göre tamamen sonsuzluktur. Ölen kişi, sonsuzluğa adım atmış demektir.

Anadolu şiirinin son kısmında, Ahmed Arif, ölüm ve sonrasına ait oldukça derin bir vurgu yapmaktadir:

"Gör, nasıl yeniden yaratılirim,

Namuslu, genç ellerinle.

Kızlarım

Oğullarım var gelecekte

Her biri vazgeçilmez cihan parçası" (Arif, 2021: 82).

Ölüm, kaçınılmazdır. Fakat kişi, babasının varisidir. Dolayısıyla evladı yaşadıkça, babasının aziz hatırasını yaşatır. Yeniden yaratılmak şeklinde tabir edilen şey, kız ve oğlan çocuklarının varlığı ile, kişinin bir çeşit varlığını devam ettiriyor oluşudur. Bu bağlamda ölümsüzlük, hakiki manada olmasa bile, mecaz olarak mümkündür. Bunun yolu da, bahsettiğimiz şekildedir. Şiir, mecaz işidir. Şiirin ve mecazın ustası Ahmed Arif'in şiirlerinde ölüm ve ötesi, bu şekilde izah edilmiştir.

\section{Sonuç}

Büyük Türk Şairi Ahmed Arif, 20. yüzyıl Türk Edebiyatının en önemli şairlerindendir. 23 Nisan 1923 tarihinde Diyarbakır'da doğan şair, 2 Haziran 1991 tarihinde Ankara'da vefat etmiştir. 68 yıllık ömrüne çok az sayıda eser sığdıran Ahmed Arif, bu yönüyle diğer şairlerden ayrılmaktadır. Kendisi hayattayken yalnızca 1 şiir kitabı yayınlanan Ahmed Arif'in bu kitabı, Türkiye'de en çok baskı yapan şiir kitapları arasına girmiştir.

Ölüm, yaşamın sona ermesi, ruhun bedenden ayrılmasıdır. Esasında ölümden sonra tekrar dünyaya gelmek, insanlar için olanaksızdır. Dolayısıyla ölümden sonraki hayatın varlığ ve mahiyeti, insanlık tarihi boyunca tartışılmıştır. Bu tartışmanın en önemli ayağını, şairler oluşturur.

Şiirin doğasında farklı düşünmek, farklı yorumlamak ve sembolik anlatımlara başvurmak vardır. Dolayısıyla anlaşılması zor kavramları, şiir ve edebiyat metoduyla ortaya koymak, orijinal bir fikir akımı meydana getirir. Bu hususta oldukça kıymetli fikirleriyle tanınan şairlerden biri, Ahmed Arif'tir.

Ahmed Arif, şiirlerinde ölüm temasını oldukça fazla işler. Ölümü birçok açıdan ele alır ve muhtemel manalara hamleder. Mecazi anlatımlara başvurur ve zaman zaman ölüme isyan eder. Bu çok yönlü şairin, şiirlerinde ölüm temasını nasıl ele aldığını işledik. Özellikle ölüm kavramının bizzat geçtiği şiirler başta olmak üzere, ölüme vurgu yapan şiirleri de 
incelemeye gayret ettik. Ölümün sonsuzluk olduğu, kaçınılmaz olduğu ve isyana yönlendirdiği gibi pek çok özelliğinin olduğunu, çalışmamızda ifade etmeye çalıştık.

Çalışmamıza, kapsamlı bir özetle başladık. Ardından, 20. Yüzyılda yetişmiş en önemli Türk edebiyatçılarından biri olan Ahmed Arif'in hayatı, edebi kişiliği ve eserleri tanıtıldıktan sonra ölüm ve ölüm ötesi kavramı üzerinde durduk. Konunun iyice anlaș1ması hedefine ulaşıldıktan sonra, Ahmed Arif'in tek şiir kitabı olan Hasretinden Prangalar Eskittim'den hareketle, konu bağlamındaki şiirlerin tahlilini gerçekleştirdir. 


\section{Kaynakça}

Akın, Gülten. (2004). Şiir Üzerine Notlar. İstanbul: Yapı Kredi Yayınları.

Arif, Ahmed. (2021). Hasretinden Prangalar Eskittim. İstanbul: Metis Yayınları.

Aydoğdu, Yusuf. (2020). Ahmed Arifin Şiir Anlayışı ve Gelenekle İlişkisi, Muş Alparslan

Üniversitesi Sosyal Bilimler Dergisi.

Belge, Murat. (2018). Şairaneden Şiirsele. İstanbul: İletişim Yayınları.

Durbaş, Refik. (2009). Kalbim Dinamit Kuyusu. İstanbul: Cumhuriyet Kitapları.

Güncel Türkçe Sözlük ve Yazım Kılavuzu. (2001). Ölüm maddesi. Ankara: TDK.

Odabaşi, Yılmaz. (2014). "Ahmet Arif". İstanbul: Dergah Yayınları.

Oktay, Ahmet. (1990). Karanfil ve Pranga. İstanbul: Metis Yayınları.

Paşaoğlu, Nilda. (2019). "Ahmed Arifi okumak (Hayatı-edebi şahsiyeti-eserleri)", Düzce Üniversitesi / Sosyal Bilimler Enstitüsü yüksek lisans tezi.

Şeker, Ziya. (1997). Ahmed Arif Şiirini Besleyen Kaynaklar: Ankara: Ürün Yayınları.

Türk, Osman. (2016). Mehmet Akif Ersoy'un "Safahat" Adli Eserinde Sosyal Eğitim Unsurlari. Akademik Sosyal Araştırmalar Dergisi (Asos Journal), 4, (26), 443457.

Türk, Osman. (2020). Sabri Esat Siyavuşgil'in Şiirlerinde Geçen Kelime Gruplari Resimler Ve Biblolar Şiirinin Tahlili. Dicle Üniversitesi Sosyal Bilimler Enstitüsü Dergisi (DÜSBED), 12 (2 4), 161-172. 


\section{THE OTTOMAN POSITION ON THE RUSSO JAPANESE WAR IN THE FAR EAST 1896-1905}

\section{Istanbul / Türkiye \\ p. 329-345}

Received: 01/12/2021

Accepted: $20 / 12 / 2021$

Published: 01/01/2022

This article has been scanned I iThenticat No plagiarism detected

\author{
Ekrem AKMAN ${ }^{1}$ \\ Rachid CHIKHOU ${ }^{2}$
}

\begin{abstract}
:
The research aims to shed light on the Ottoman position on the Russo-Japanese war in the Far East 1904-1905; Where the Ottoman Empire took an intriguing stance, there was a discrepancy between the popular stance and the official stance of the Attic State. The Ottoman people took the stance of open hostility to the Russians, and supported Japan in its struggle against Russia, and the people and intellectuals in the Ottoman Empire showed a great desire for Japan's victory and defeat." Petersburg ". While we find the position of Sultan Abdul Hamid and the Ottoman Empire in contradiction to the position of the public towards the people; He adopted the policy of strategic balance in the conflict between the Japanese and the Russians, considering that Russia is the largest neighboring country to the Ottoman Empire, and it still poses a great danger to the property of the Ottoman Empire that must be avoided. Therefore, the Ottoman Sultan followed a completely different plan and policy to the trends of public opinion. He was keen to support Japan, and at the same time avoided angering the European countries that supported the Russians and the possibility of confronting Russia, which is the strongest and most dangerous neighbor to him. Therefore, Sultan Abdul Hamid II adopted many other strategies, and followed a neutral policy towards Russia and Japan, went in the direction of the policy called the policy of balances. We also discussed in this research the development of Ottoman-Japanese relations before the Russo-Japanese war, and focused on the causes of the conflict between the Japanese and Russian states, and its repercussions on the balance of power in the region. And the international position on this conflict, We dealt with the American endeavors to end the war between the two parties under the Port Smouth Agreement, and discussed the effects of the Japanese victory over Russia and its repercussions on the peoples of the East.
\end{abstract}

Key words: Russo, Japanese War, Far East, Abdul Hamid Ii, Ottoman Empire.

http://dx.doi.org/10.47832/2717-8293.15.25

Dr. , Mardin University, Türkiye, ekremakman@artuklu.edu.tr, https://orcid.org/0000-0003-2784-3908

2 (D) Dr. , Mardin University, Türkiye, rashed197588@gmail.com, https://orcid.org/0000-0003-3770-1583 


\section{الموقف العثماني من الحرب الروسية اليابانية في الشرق الأقصى 1896-1905 \\ أكرم أقمان 3 \\ رشيد شيخو}

الملخص:

يهدف البحث إلى تسليط الضوء على الموقف الدولي العثماني من الحرب الروسية اليابانية في منطقة الشرق الأقصى 1904 - 1905، حيث اتخذت الدولة العثمانية موقفاً مثيراً للفضول فقد كان هناك تباين بين الموقف الشعبي، والموقف الرسمي للدولة العلية، فقد اتخذ الشعب العثماني موقف العداء الصريح للروس، وناصر اليابان في

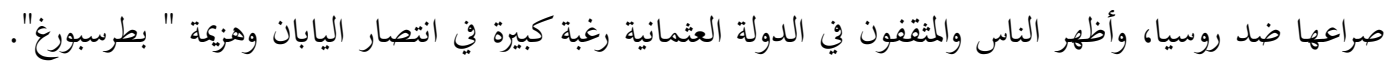

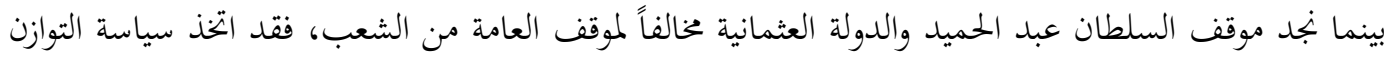
الاستراتيجي في الصراع القائم بين اليابانيين والروس باعتبار أن روسيا أكبر الدول المجاورة للدولة العثمانية، ولاتزال تشكل خطراً كبيراً على أملاك الدولة العثمانية يجب تجنبه، لذلك اتبع السلطان العثماني خطة وسياسة مختلفة تماماً

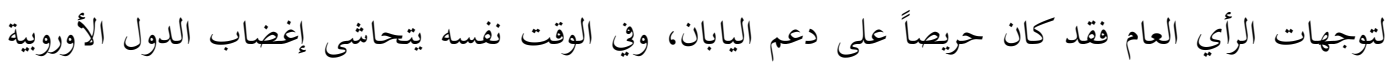

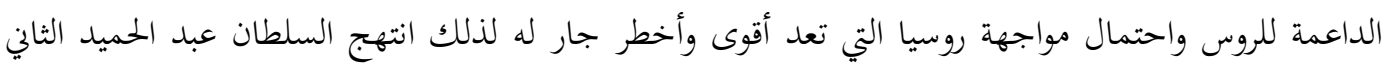

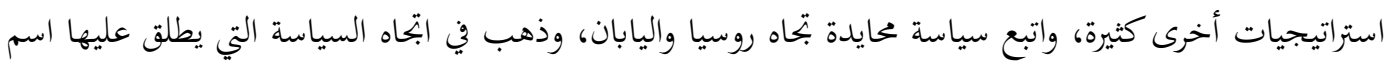
سياسة التوازنات. كما تطرقنا في هذا البحث إلى تطور العلاقات العثمانية اليابانية قبل الحرب الروسية اليابانية، وركزنا على أسباب الصراع بين الدولتين اليابانية والروسية، وانعكاساته على توازن القوى في المنطقة. والموقف الدولي من هذا الصراع، وتناولنا المساعي الأمريكية لإهاء الحرب بين الطرفين بموجب اتفاقية بورت سماوث، وناقشنا آثار الانتصار الياباني

$$
\text { على روسيا وانعكاساته على شعوب الشرق. }
$$

الكلمات المفتاحية: الحرب اليابانية الروسية، الشرق الأقصى، عبد الحميد الثاني، الدولة العثمانية.

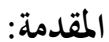

يرى اليابانيون في روسيا جارةً مثيرة للمتاعب، ومصدر تمديد حقيقي في شمال شرق آسيا, باعتبارها أقوى الدول المجاورة لليابان، والقوة الوحيدة في المنطقة "غير الآسيوية ثقافياً وعرقياً. وقد تناولنا في هذه الدراسة مرحلة مهمة من مراحل الصراع العسكري الياباني في الشرق الأقصى من عام 1896 إلى عام

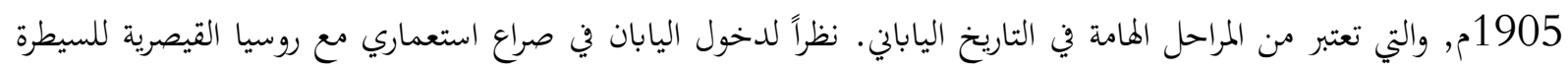
على كوريا وشمال منشوريا في سبيل إقامة إمبراطورية استعمارية على غرار الإمبراطوريات الاستعمارية الغربية.

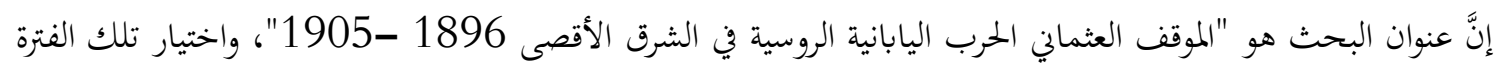

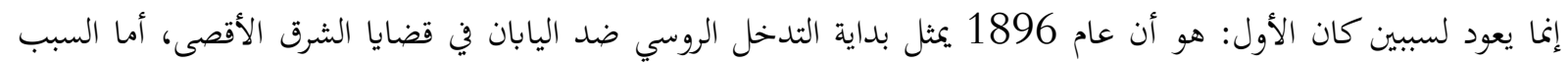


الثاني: فكون أن عام 1905 وضع غاية للحرب التي اندلعت بين الطرفين وحققت فيها اليابان أول نصر في تاريخها على العرق الأبيض.

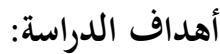

- إبراز العلاقات العثمانية اليابانية قبل الحرب والموقف العثماني من الحرب الروسية اليابانية.

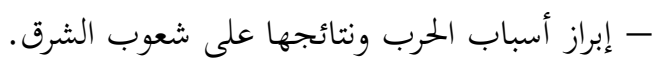
- التعرف على الموقف الدولي من الحرب اليابانية الروسية.

اعتمدت الدراسة على المنهج الوصفي لوصف ظاهرة الصراع الدائر بين اليابان وروسيا وتحليله وتقويمه في ضوء الدراسات

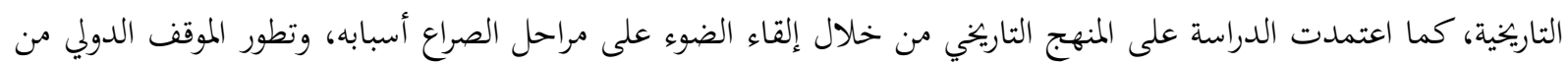
الصراع، ورصد تطورات الحرب بين الطرفين، وصولاً لنتائج الحرب على الطرفين وشعوب المنطقة. وقد اشتمل البحث على مقدمة وخمسة مباحث منها مبحث تمهيدي بالإضافة لخاتمة وقائمة بأهم الملاحق, وكذلك قائمة بالمصادر والمراجع.

تناولنا في البحث النقاط التالية: الجذور التاريخية للصراع الياباني الروسي، ودور المسألة الكورية في اندلاع الحرب الروسية اليابانية، والموقف الدولي من

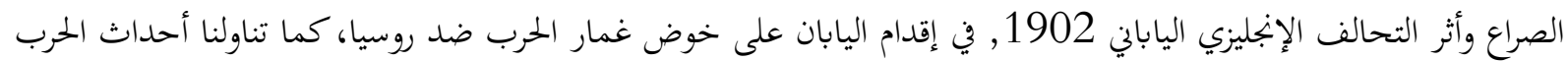
اليابانية-الروسية 1904-1905. والموقف الدولي أثناء الحرب، وخاصة الموقف العثماني، وكذلك تناولنا المساعي السلمية الدولية

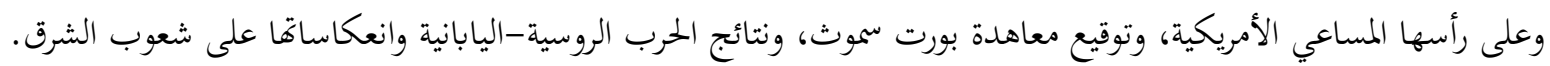
ومن ثم اعتمد الباحث في هذه الدراسة على مصادر ومراجع متنوعة ومنها على سبيل المثال: الوثائق الأمريكية الخاصة

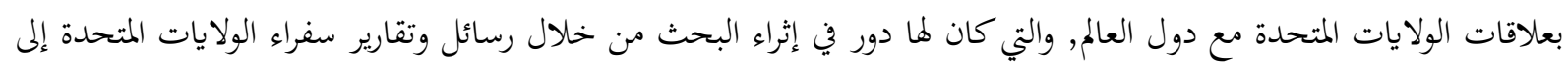

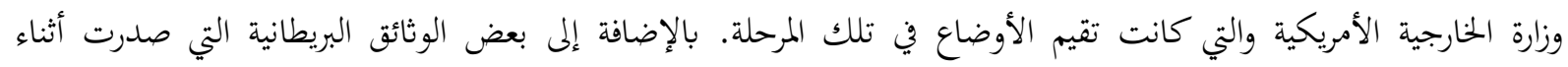

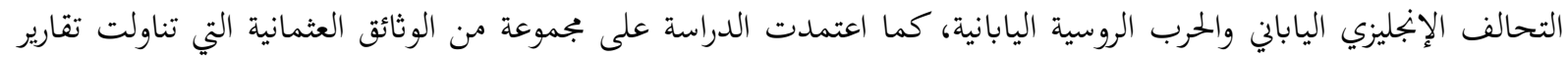
ومراسلات السفراء العثمانيين خلال فترة الصراع ـ كما اعتمد الباحث في هذه الدراسة على عدد من المصادر والمراجع والدوريات العربية والأجنبية الخاصة بفترة بحثه.

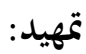

لقد كانت اليابان وعلى امتداد تاريخها الطويل أكثر دول العالم عزلة، إذ لم يحدث أي اتصال بينها وبين أقرب بلدين مجاورين لها إلا مع بداية عصر التجارة عبر المحيطات في القرن السادس عشر. حيث وصلتها عبر كوريا والصين التأثيرات الحضارية

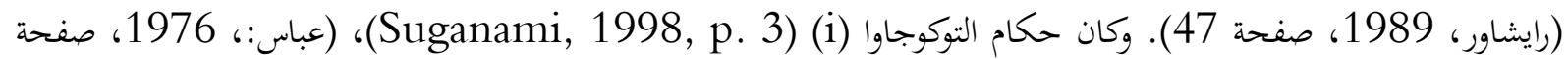
238) اليابانيين قد اتخذوا قراراً عام 1639 بإغلاق أبواب بلادهم في وجه العالم الخارجي (Others, 1976, p. 484)

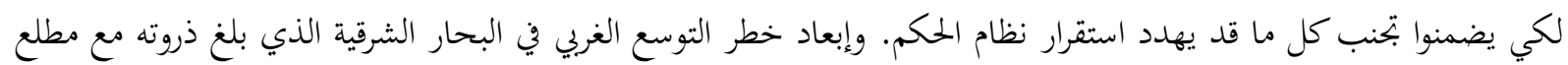

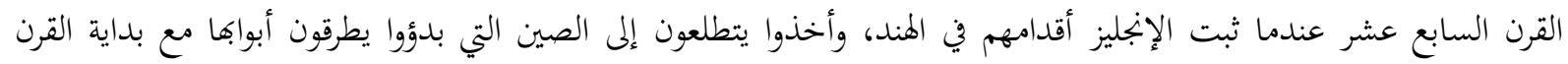

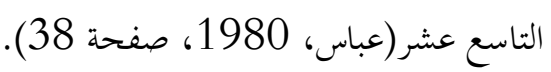


وإذا كانت اليابان قد أدارت ظهرها للعالم الخارجي، فليس معنى ذلك أن القوى الغربية قد تركتها وشأها، خاصةً وأن تطور

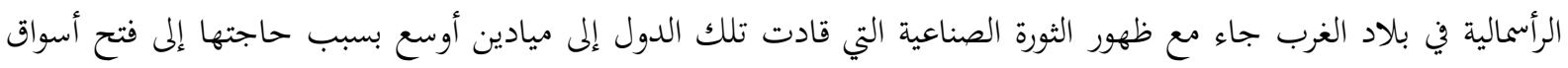

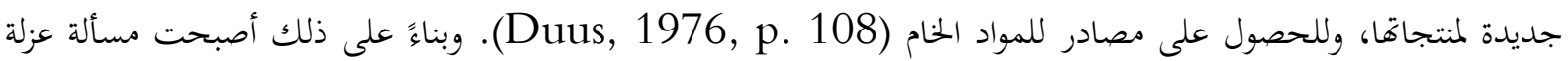

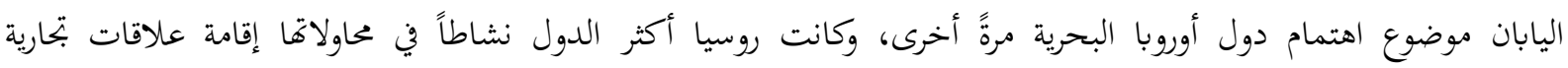

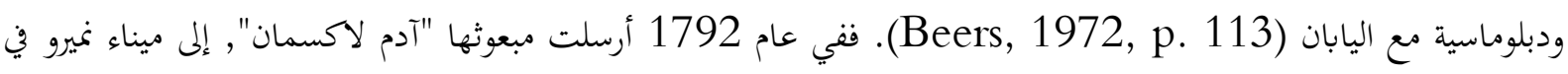
هوكايدو لإعادة البحارة اليابانيين الذين جرفهم التيار إلى الشواطئ الروسية، وأثناء ذلك قدم لاكسمان مذكرة رسمية تطالب بفتح

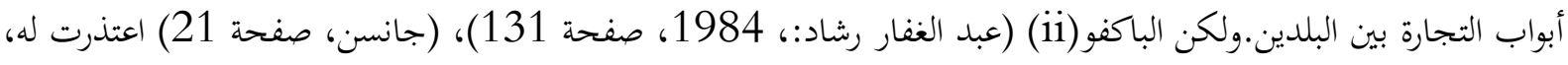

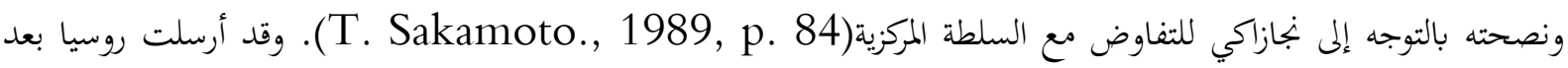
ذلك عدة بعثات إلى اليابان قوبلت جميع مطالبها بالرفض والمقاومة، وذلك لخوف اليابابانيين من مطامع الروس في أراضيهم (Beers, 1972, p. 113). وخاصة في جزر الكوريل التي تقع ما بين شبه جزيرة كامتشاتكا الروسية وجزيرة هوكايدو اليابانية في أقصى شمال شرق آسيا. وهذه الجزر التي تبلغ مساحتها الإجمالية نهو 15.5 ألف كلم مربع ويسكنها أكثر من

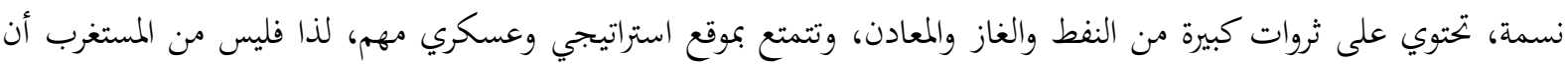

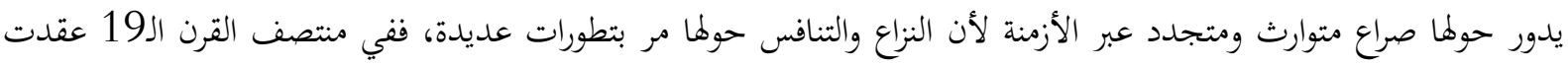

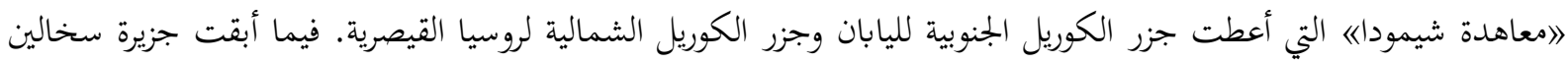
تحت إدارة مشتركة، وبعد ذلك بعقدين من الزمن أبرمت 》امعاهدة سان بطرسبرغن لعام 1875 والتي قبلت روسيا بموجبها التنازل

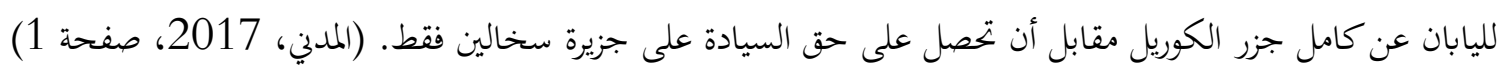
وقعت تطورات كبيرة في نهاية القرن التاسع عشر في منطقة الشرق الأقصى قلبت موازين القوى العالمية، حيث هزمت اليابان الصين في الحرب اليابانية الصينية 1894 - 1895. وسيطرت بموجبها على على كوريا، وبدأت تمهد للسيطرة على منشوريا

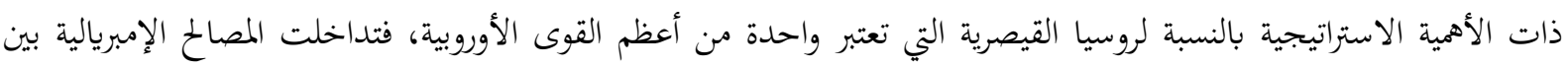

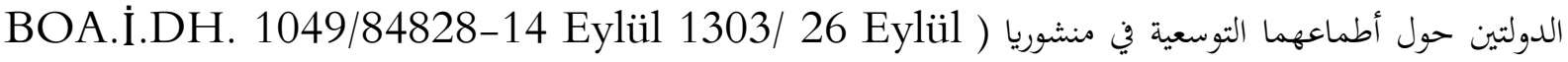

.(1887.

وإذا كانت الحرب اليابانية الصينية 1894 - 1895، قد أدت إلى إهاء النفوذ الصيني في كوريا، فإنها في الوقت نفسه

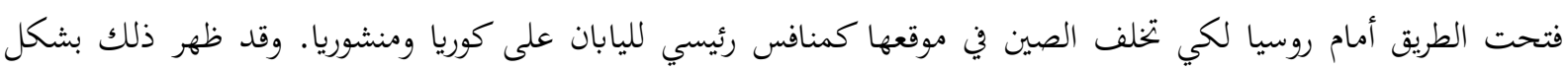

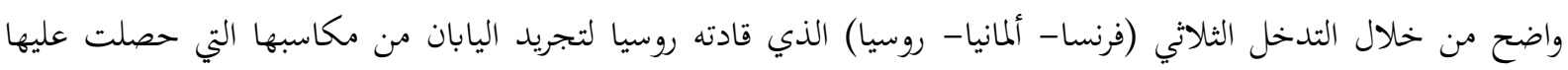

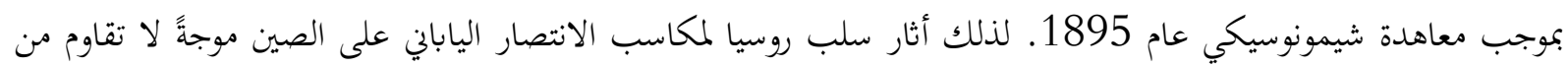

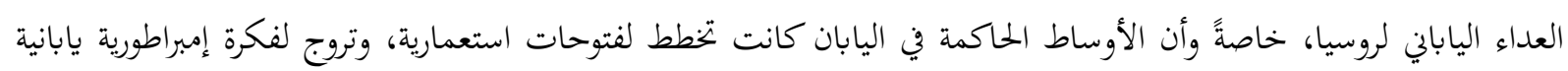

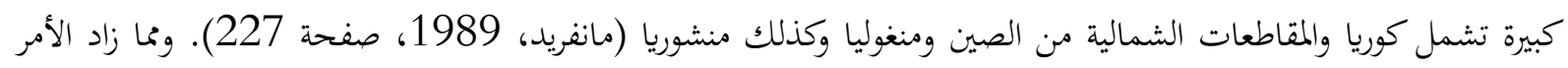

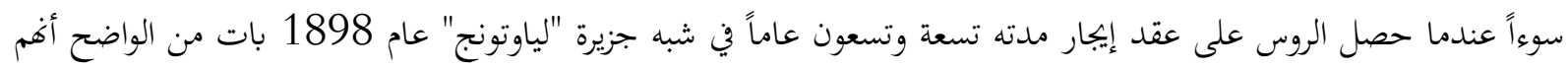

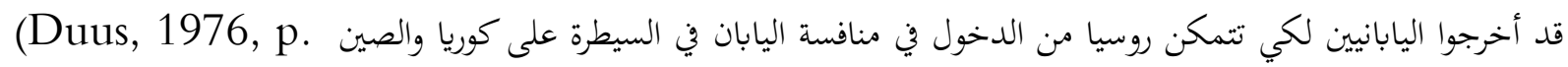

يعود سبب الاهتمام الروسي بتلك المنطقة لكوها ذات أهمية استراتيجية كبيرة بالنسبة لها، فقد أدركت أن الوجود الياباني

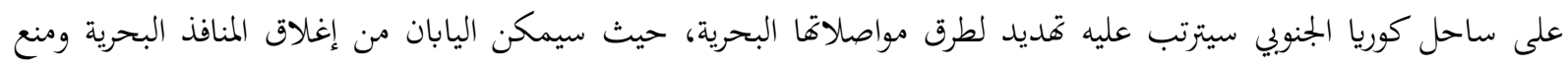

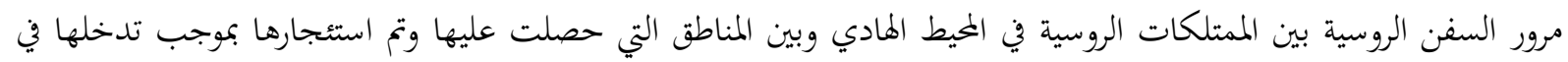
هاية الحرب الصينية- اليابانية، ولذلك سعت لمنافسة اليابان على كوريا لتأمين طرق مواصلاتها البحرية. 


\section{- الصراع الياباني الروسي في كوريا:}

أدت الإصلاحات التي قام بما اليابانيون في كوريا بعد الحرب إلى قيام حركة مضادة لمم بتأييد من الملكة "مين" التي كانت

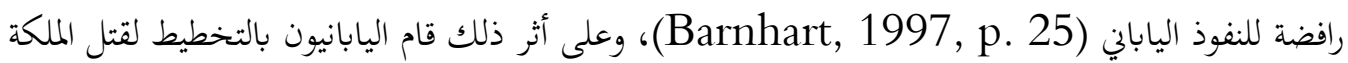

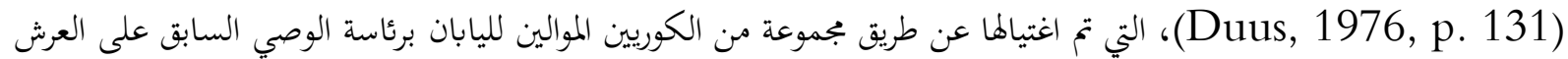
(يهيى، 1985، صفحة 210). وقد أسفرت تلك المذبحة عن سخط الدول الأوروبية على اليابان, وإلى ازدياد الشعور العدائي بين صفوف الشعب الكوري، الذي رد على تلك المذبحة بقتله عدد كبير من اليابانيين، مما جعلهم يضطرون لمغادرة كوريا والعودة لبلادهم (عباس، 1980، صفحة 180).

ومن جانبه استغل الملك الكوري فرصة غياب القوات الملكية عن سيؤول وفرّ مع ولي عهده في فبراير 1896، إلى

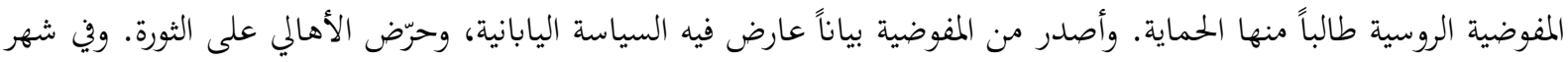

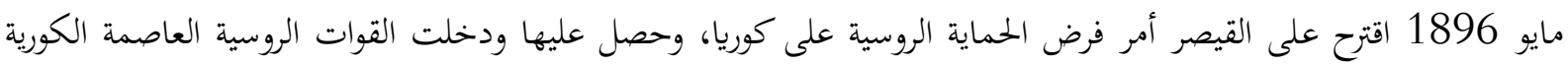

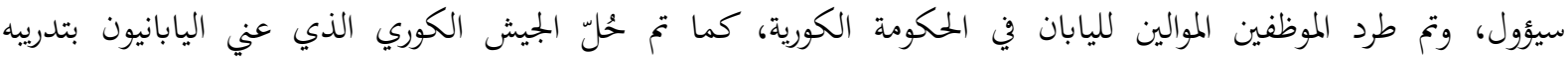
(Barnhart, 1997, p. 25)

ونستنتج مما سبق، أن هروب الملك الكوري والتجائه إلى المفوضية الروسية في سيؤول, وضع بداية النهاية للنفوذ الياباني في كوريا، وأسهم بشكل كبير في ازدياد النفوذ الروسي في كوريا. كما يلاحظ هزيمة اليابان ولممرة الثانية أمام المحافظين الكوريين،

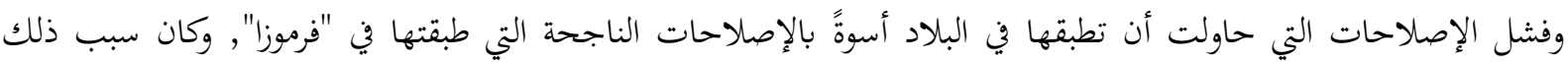
الفشل احتدام الصراع بين أنصار الملكة من ناحية, وأنصار الإصلاح على الطريقة اليابانية من ناحية أخرى.

وبذلك أصبح النفوذ الياباني والنفوذ الروسي يواجهان أحدهما الآخر، ليتكرر سيناريو المواجهة التي حدثت في فترة الصراع الصيني

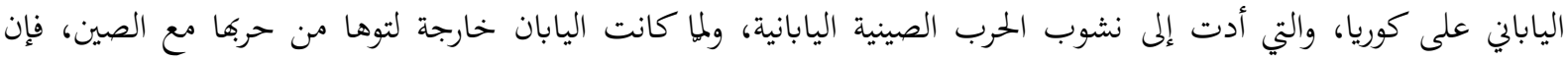

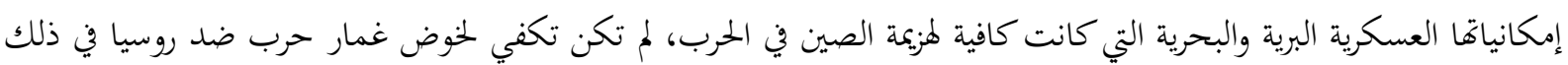

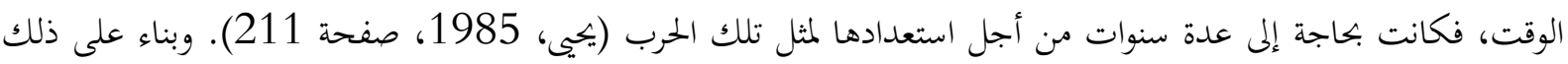

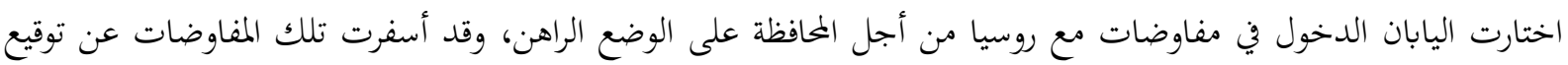

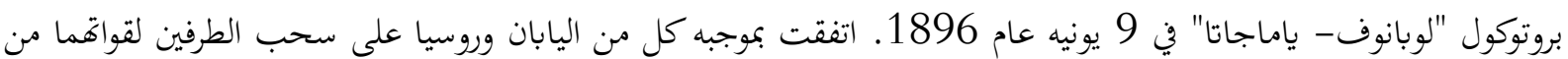

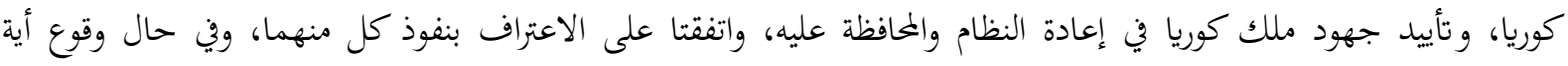

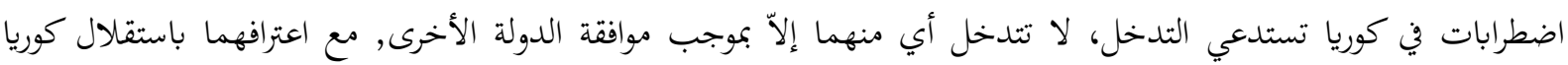

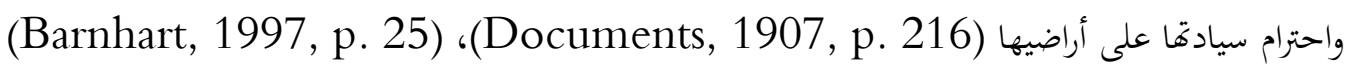
إلا أن روسيا لم تلتزم بتلك الاتفاقية (تيدمان، د. ت ، صفحة 42)، ولم تلتزم أيضاً باتفاقية أبريل 1898، إذ استمر

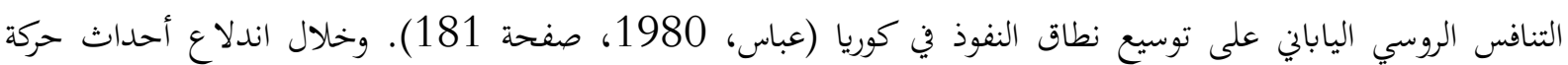

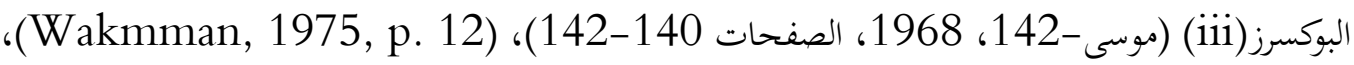
انتهزت روسيا فرصة انشغال الدول بالقضاء على تلك الحركة لتوسيع مخططاتما الإمبريالية (Jinsheng, 1981 , p. 381)

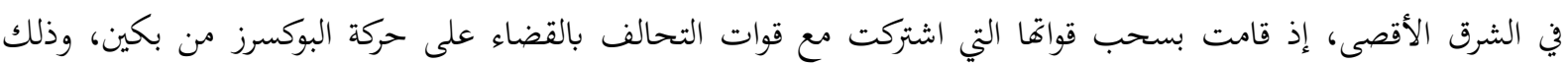

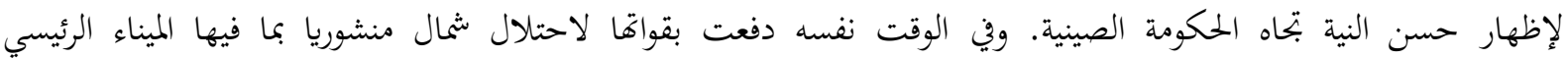
"نيوتشوانج" Niuchauang واستولت على جسور السكك الحديدية في "تيان تسين" وبكين 
(Barnhart, 1997, p. 32)، كما دفعت قواتما نحو الجنوب وسيطرت على "شيهلي" في محاولة منها للتوغل في كوريا عن طريق تحريك قواتما من جنوب منشوريا بابحاه شمال كوريا (Storry, 1960, p. 135). وقد أثار التوسع الروسي ارتياباً عميقاً لدى اليابانيين، الذين بدا لمم أن هدف الروس هو تعزيز حامياقم التي أقاموها في

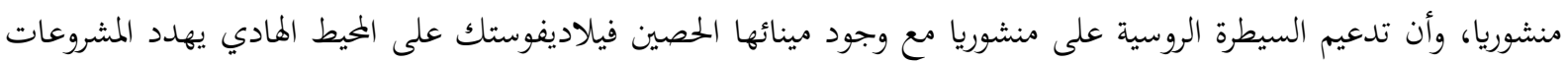

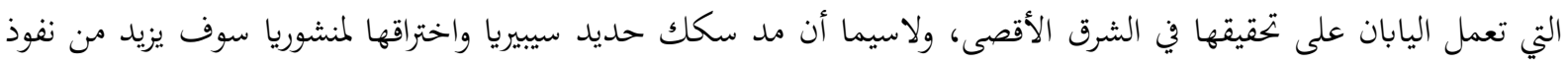

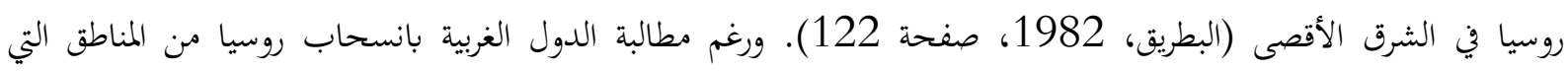
سيطرت عليها، لم تعر روسيا ذلك أي اهتمام، ومضت في إجراء مفاوضاتما السرية مع "تسينج" جنرال المانشو وقائد القوات

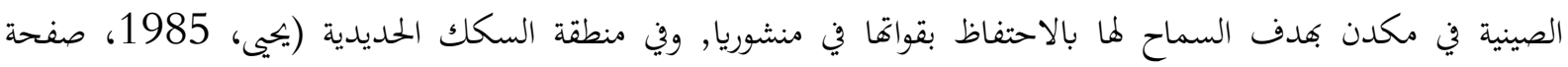

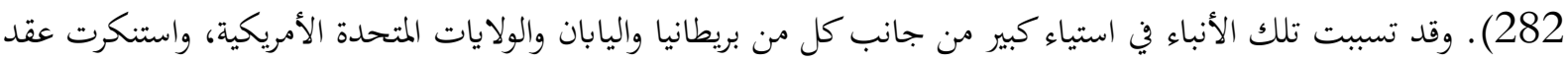

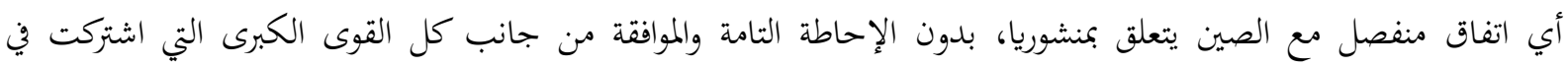
مفاوضات البوكسرز (زكريا، 1999، صفحة 205). فأعلنت روسيا عن عدولها عن اتفاقية "تسينج- الكسييف"، وإنكارها نواياها العدوانية في منشوريا، لكنها بالمقابل عملت على تقوية قبضتها على منشوريا من خلال المحاولة المخفقة في إجبار الصين

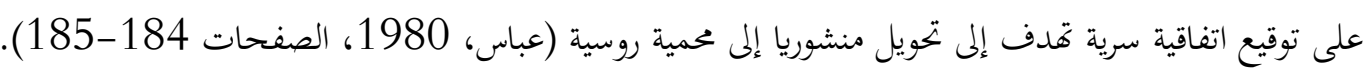

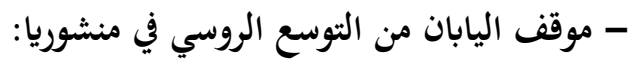

ومن الطبيعي أن يؤدي التوسع الروسي في منشوريا إلى إثارة حفيظة القيادات اليابانية لأنه إذا بقيت منشوريا محمية روسية،

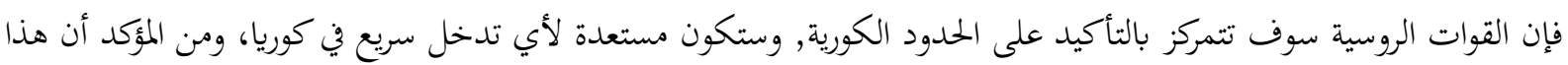

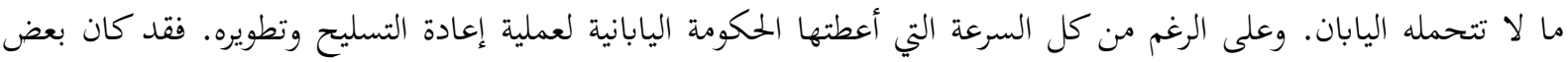

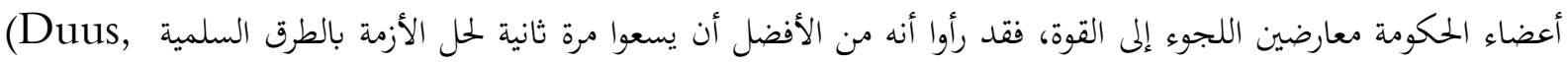
(1976, p. 131. فقد رأى كل من "ايتو هيروبومي" و"أينوي" عقد صفقة مع الروس تقضي باعتراف اليابان بمصالخ روسيا

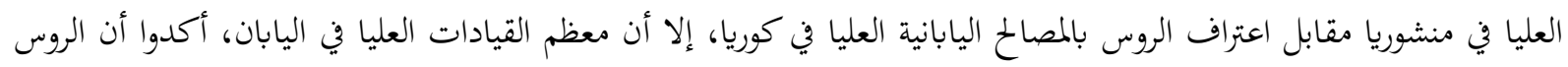

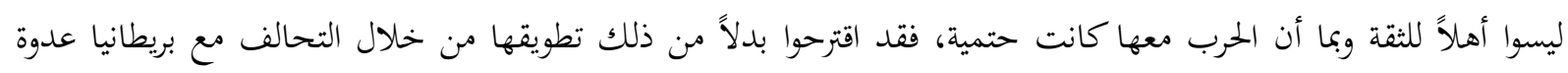
روسيا اللدودة في الشرق الأقصى (Others, 1976, p. 555).

فإذا كانت المنافسة الروسية اليابانية منحصرة في كوريا وشبه جزيرة "لياوتونج"، فإنها الآن امتدت لتشمل منشوريا، وإذا لم

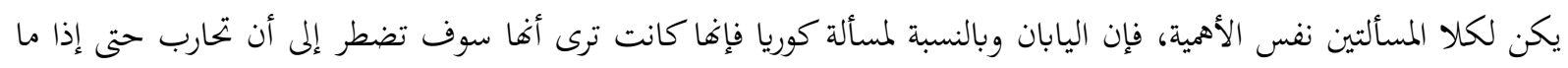
كانت وحدها. بينما لم تكن تنوي أن تحارب بالنسبة لمنشوريا إلا في حالة حصولها على معونة خارجية (يهيى،

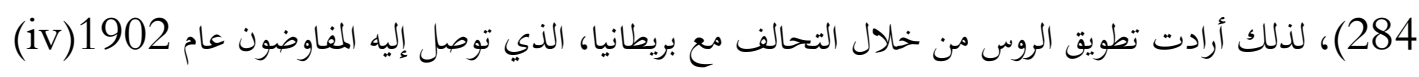

(Marder, W. D, pp. 427-428.) ،(Temperley, 1927, pp. 115-120) وبموجب ذلك التحالف اطمأن قادة اليابان أنه إذا نشبت حرب بينهم وبين الروس أصبح بوسعهم الاعتماد على مساعدة بريطانيا

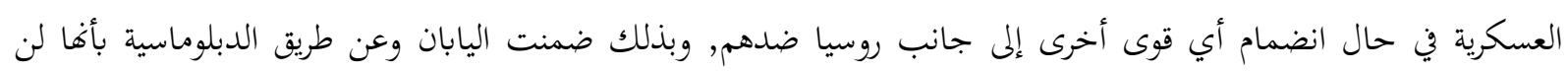

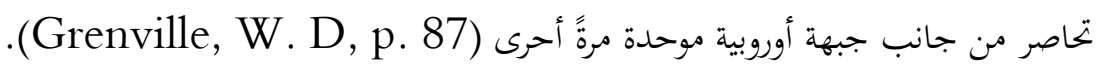

أدى التحالف الأنجلو-ياباني 1902 إلى نتائج سريعة على أطراف النزاع، فقد عرضت روسيا على الصين في 8 أبريل

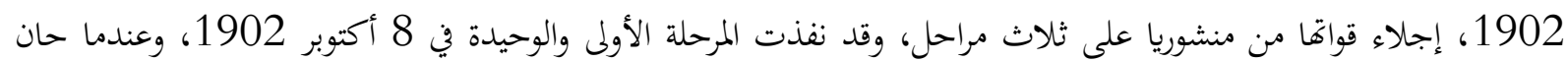


موعد تنفيذ المرحلة الثانية في أبريل 1903 لم تلتزم روسيا بما عاهدت عليه (Barnhart, 1997, p. 35).بل راحت تطالب

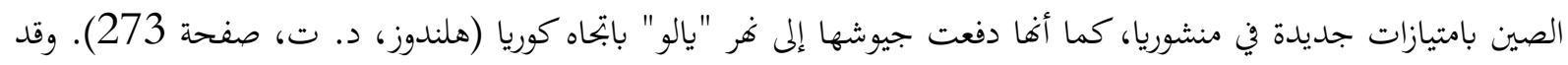

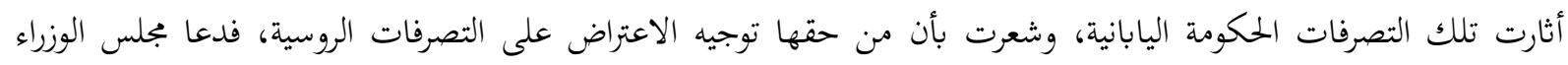

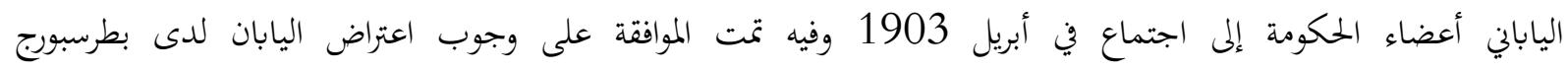

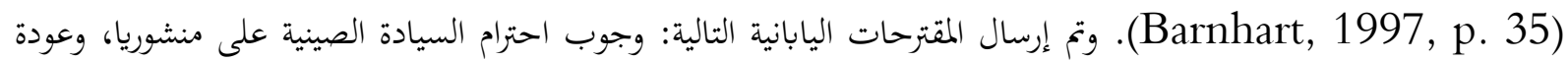
إدارتا للصين، واعتراف اليابان بمصالح روسيا في منشوريا، في مقابل اعتراف روسيا بمصالح اليابان السياسية والتجارية والصناعية في كوريا وفقاً لنص التحالف الأنجلو -ياباني (Beers, 1972, p. 234). وقد رفضت روسيا الاقتراحات التي قدّمتها اليابان، لكنها نوّهت إلى أغما توافق فقط على الاعتراف لليابان بمركزها التجاري

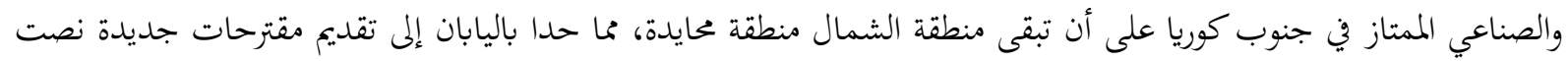
على ما يلي: - حرية الملاحة في بوغاز كوريا. - إنشاء منطقة حياد على طول الحدود بين كوريا ومنشوريا (بحيث يكون غر "يالو" منطقة عازلة بين نفوذ -- روسيا في منشوريا ونفوذ اليابان في كوريا). - ربط سكك حديد كوريا ومنشوريا بعضهما ببعض. في كوريا.

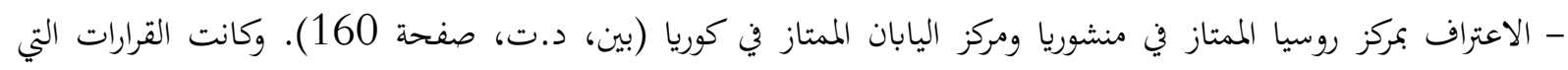

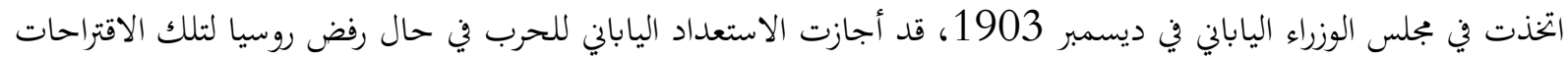
(J. Crowley., 1973, p. 225)

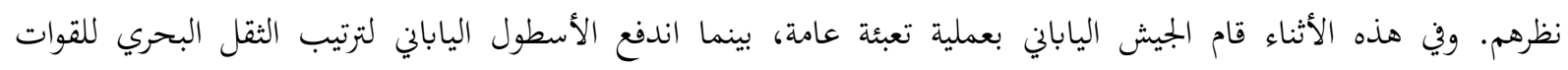
والحصول على سفن حربية إضافية عن طريق الشراء من الترسانات الغربية (Barnhart, 1997, p. 38)

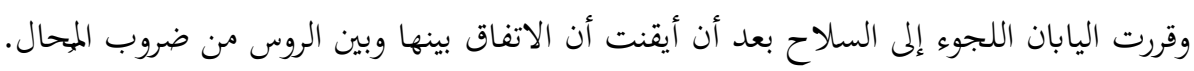

\section{أحداث الحرب اليابانية- الروسية 1904- 1905:}

بدأت اليابان عملياتا العسكرية في 8 فبراير 1904، بهجوم ليلي بقوارب الطوربيد على الأسطول الروسي في بورت آرثر،

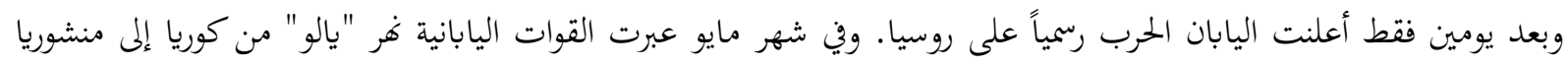

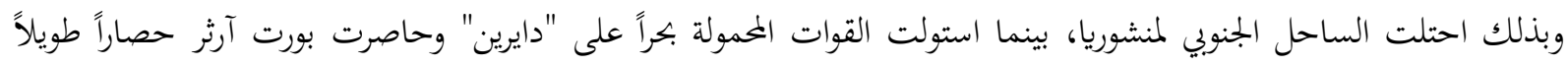
،(Cox., 1992, p. 393)

(Beers, 1972, p. 234)

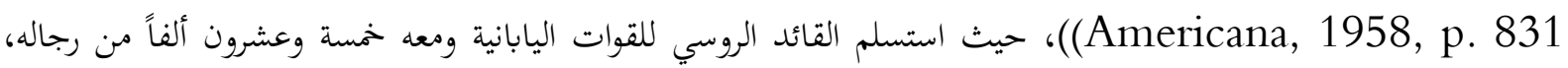
وسلمهم الميناء دون أن يستشير ضباطه، وذلك على الرغم من وجود إمدادات وذخائر كانت تكفيه للمقاومة ثلاثة أشهر أخرى (مرهون، 2002، صفحة 2).

لم يُدهش نبأ سقوط بورت آرثر واستسلام حاميتها أحداً من الناس لتوقعهم قرب سقوطها، وكان استسلام قائد الحامية

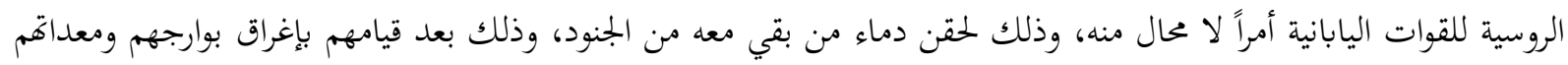


حتى لا تستفيد منها القوات اليابانية (المحرر، 1905، صفحة 1). إلا أن اليابانيين حصلوا على قاعدة بحرية يكاد يكون إخراجهم منها بالقوة محالاً إذا لم يسترد الروس سلطتهم على البحار ثانية.

وكان الروس قد أقاموا بقيادة "كوروباتكين" موقعاً حصيناً في "مكدن" (يحيى، 1985، صفحة 298). التي دارت فيها

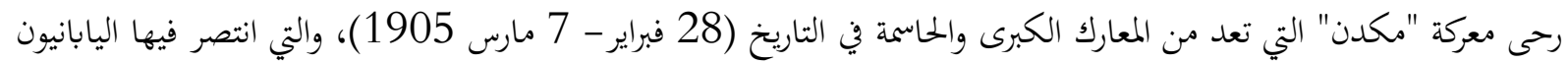

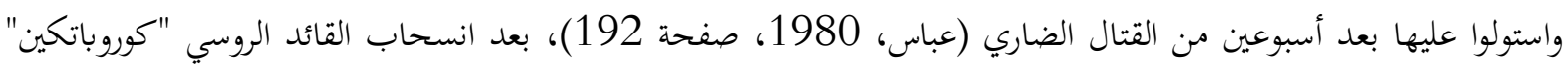

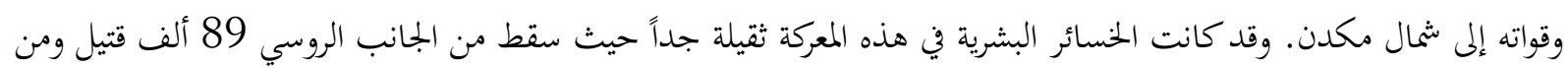

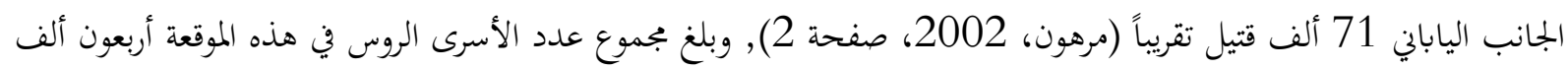
أسيراً (هلندوز، د. ت، صفحة 275)

بعد هذه الهزيمة حاولت روسيا أن تعوّض هزائمها البرية والدمار الذي لحق بأسطول المحيط الهادي، فسارعت إلى استدعاء أسطولها في بحر البلطيق لتعزيز وجودها في فيلاديفوستك (كعدان، 1999، صفحة 200), إلا أن رود ستفينسكي قائد

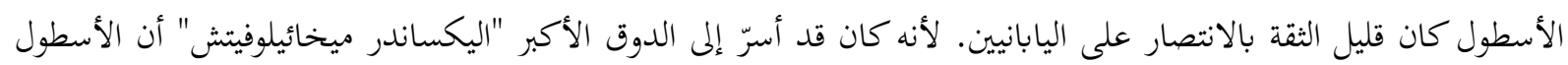

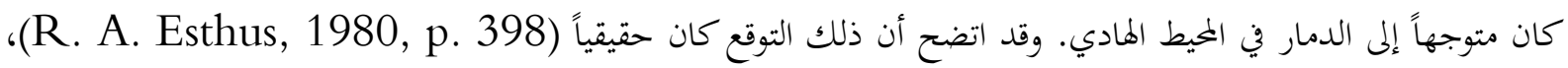

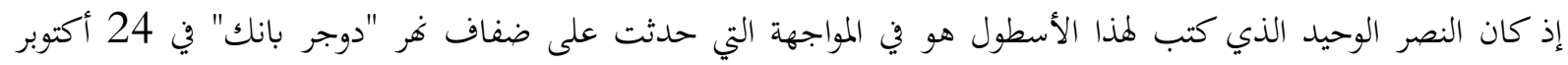

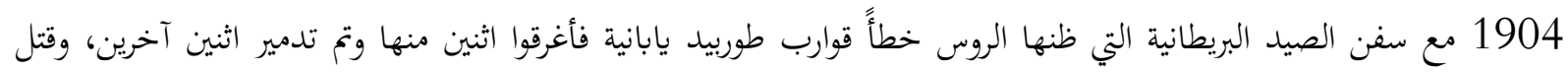

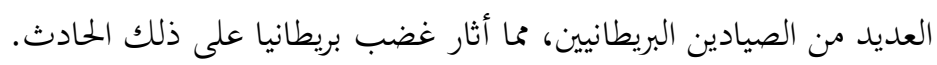
وفي المعركة التي جرت في يوم 27 مايو 1905 (موقعة بحر اليابان)، حقق اليابانيون انتصاراً ساحقاً على الروس، دمروا

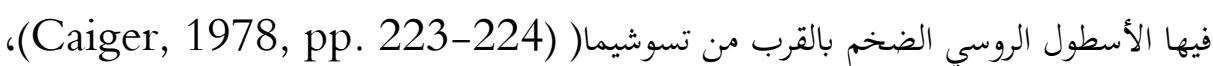
وعانت البحرية الروسية بذلك من هزيمة كبيرة، كان تأثيرها هائلاً على العزة الروسية (T. Sakamoto., 1989, p. 102) (BOA. Y.PRK. EŞA.47/72, 26. R.Evvel 1324/21 Mayıs 1905.) ثلاث سفن حربية فقط من أصل خمس وثلاثين سفينة. كما بلغ عدد ضحايا الحرب من الجانب الروسي بحوالي أربعة آلاف

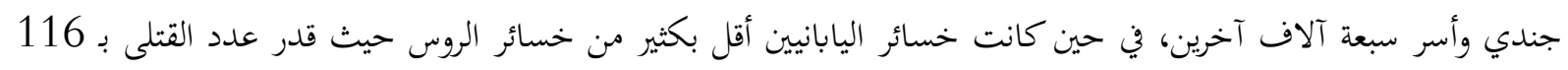

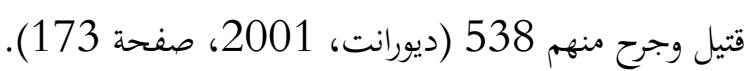
وكان لزيمة الروس في موقعة بحر اليابان أثر كبير في نفوسهم، فقد كانت ضربة شديدة للعزة الروسية، وأدت عملياً إلى إنهاء الحرب بين البلدين في مايو عام 1905 لتبدأ مفاوضات السلام بين الطرفين (R. A. Esthus, 1980, p. 404).

\section{- موقف الدولة العثمانية من الحرب اليابانية الروسية:}

كان موقف الدولة العثمانية التي خسرت حرب ال 93 عاماً (1877-1878) أمام الروس وأصبحت أملاكها في

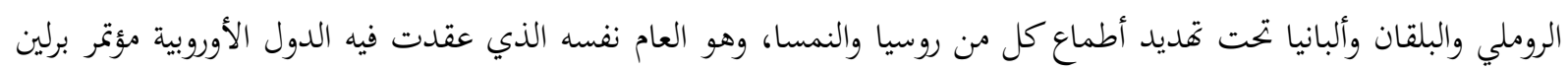

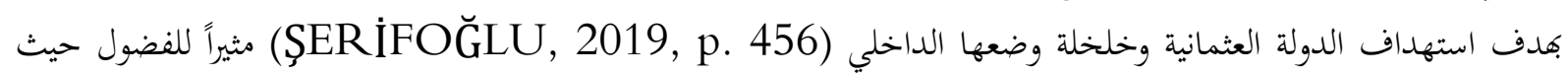

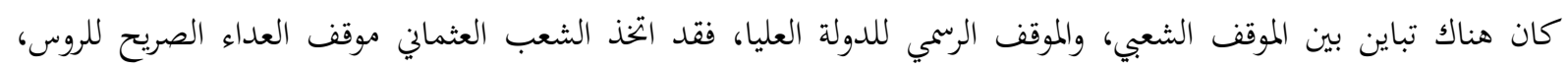

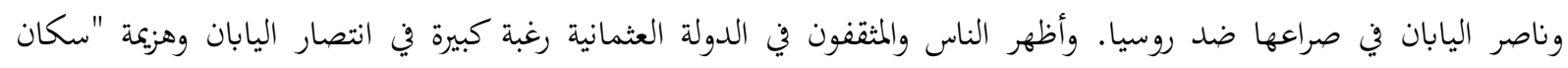

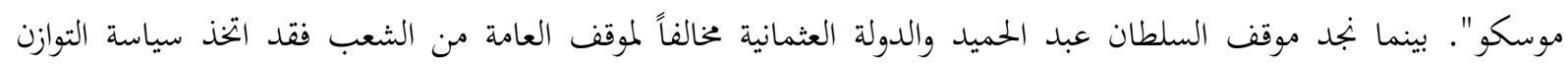

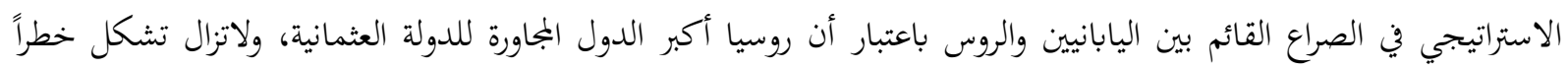


كبيراً على أملاك الدولة العثمانية يجب تجنبه (14 Eylül 1303/ 26 Eylïl.DH. 1049/84828-14 .(1887.

وقد شهدت العلاقات العثمانية اليابانية تحسناً كبيراً قبل الصراع الياباني الروسي، فقد زار الأمراء اليابانيون الإمبراطورية

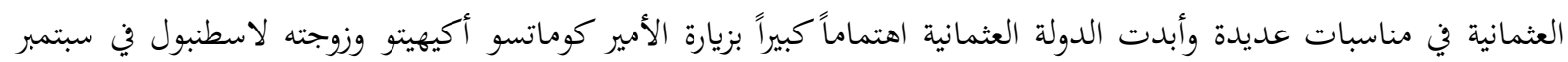
1887 ونظمت احتفالاً كبيراً على شرف زيارةمما للعاصمة العثمانية

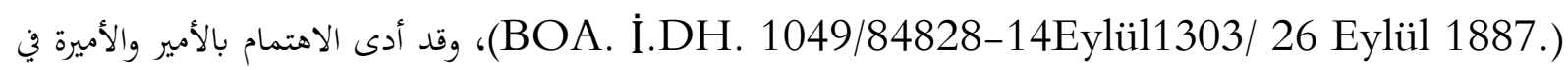
اسطنبول إلى تطور العلاقات العثمانية اليابانية، وأعقب ذلك تبادل الهدايا بين الإمبراطور الياباني والسلطان العثماني. حيث منح الإمبراطور الياباني للسلطان العثماني (وسام الأقحوان) وهو أعظم وسام في اليابان كتعبير عن رضاه بالترحيب الذي

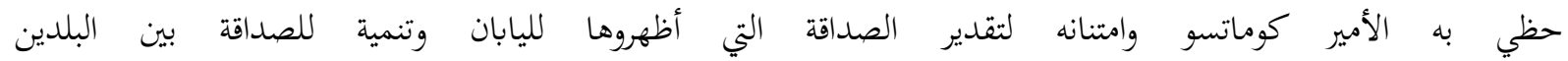

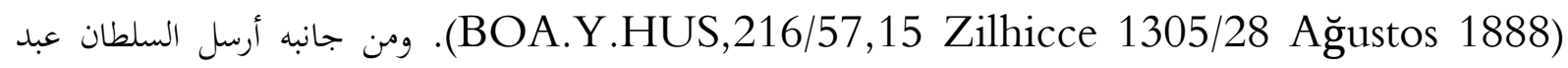
الحميد إلى الإمبراطور الياباني هدايا من أفضل الخيول الموجودة في القصر، وتم تعيين النقيب محمد باي أحد مساعدي السلطان، لنقل هذه الخيول إلى اليابان (BOA.Y.MTV.52/26,7.Zilhicce1308/14Temmuz 1891) ويعد غرق الفرقاطة- Ertuğrul التي انطلقت في 5 رمضان في 1306 في مهمة دبلوماسية إلى اليابان، وفي طريق

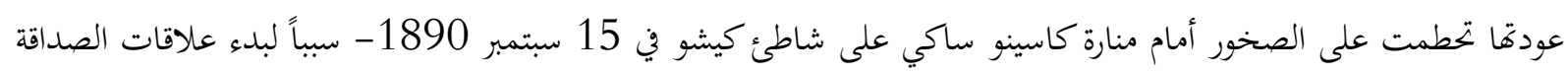

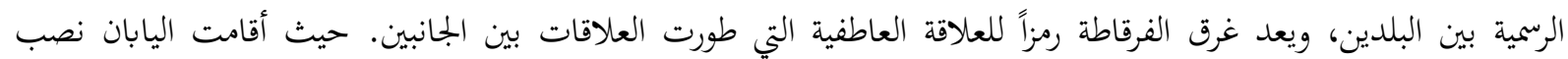

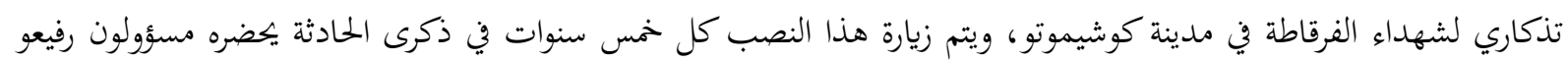

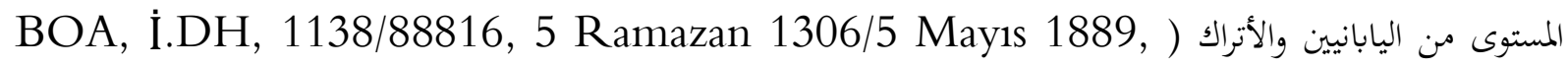
(BOA, Y.A.HUS.239/21, 19 Eylül 1890

\section{- موقف الدولة العثمانية أثناء الحرب:}

أقام السلطان عبد الحميد غرفة عمليات خاصة لمتابعة أخبار الصراع في الشرق الأقصى، حيث كان يتلقى تقارير فورية من رجال الدولة وضباط المخابرات الذين كانوا على اتصال بالعالم الخارجي. وتابع بعناية وبشكل مستمر من خلال سفارات السلطنة

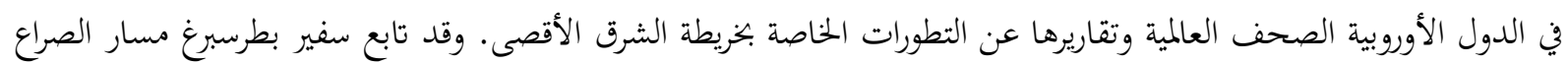

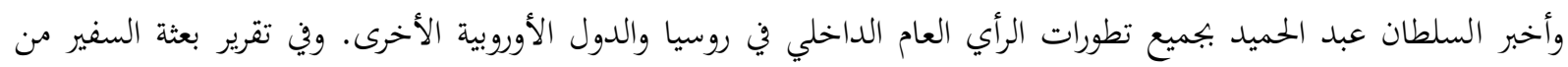

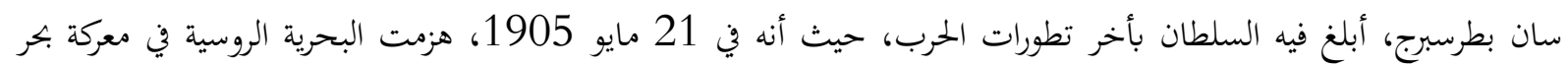

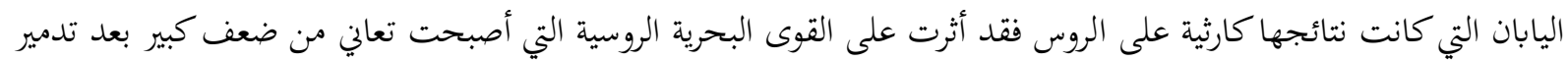

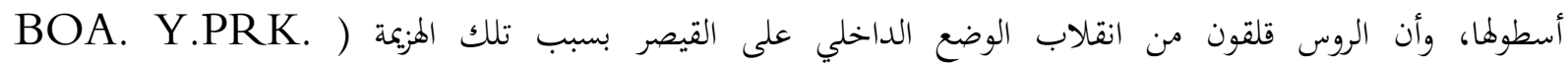
1905.

$$
\text { بعد يوم ويعمل على اختيار الموقف الذي سيتبناه إيزاء الدولتين المتحاربتين والدول القوية الأخرى. }
$$

ومن خلال ما تقدم نرى أنه في الوقت الذي كان فيه الرأي العام العثماني يقف صراحة مع اليابان في الحرب، نجد أن السلطان

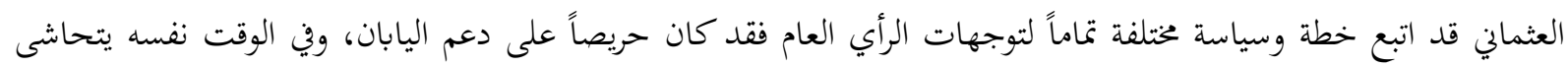

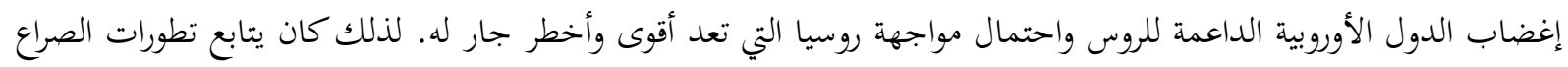

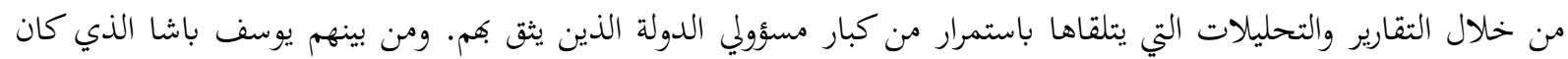


يحاول تحديد الوضع الذي ستخخه الإمبراطورية العثمانية أثناء الحرب وبعدها، من خلال الاعتماد على تقارير حاكم أيدين كامل باشا ومساعديه. وتوضح التقارير المقدمة إلى السلطان عبد الحميد أنه يجب على الدولة العثمانية اتباع سياسة الحياد الاستراتيجي

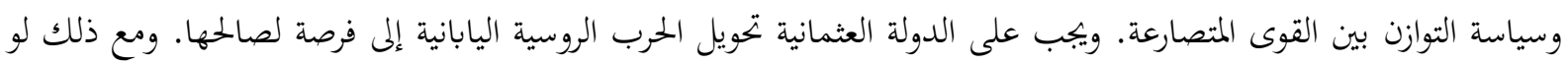

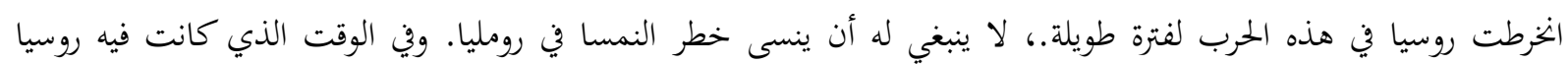

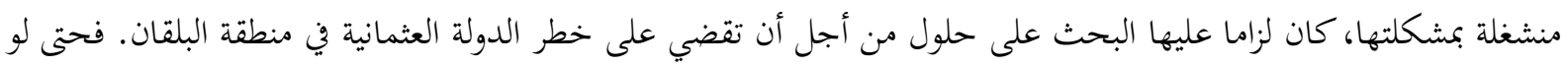

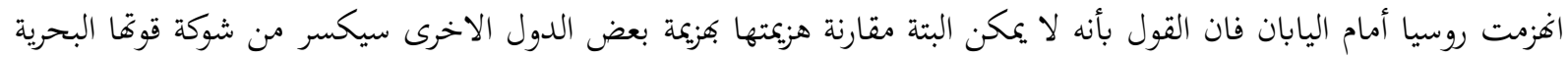

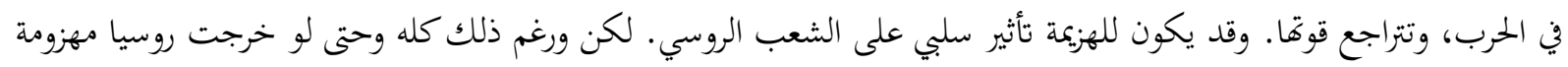

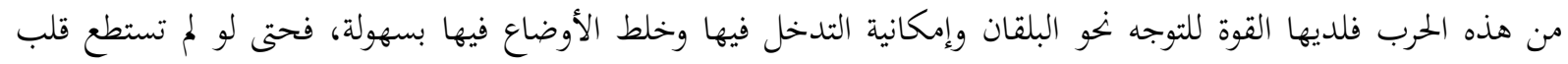

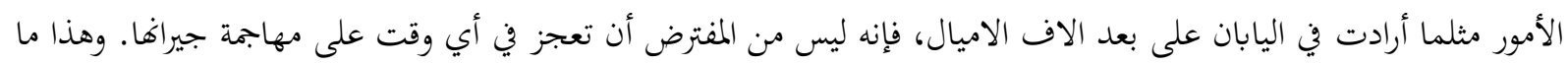

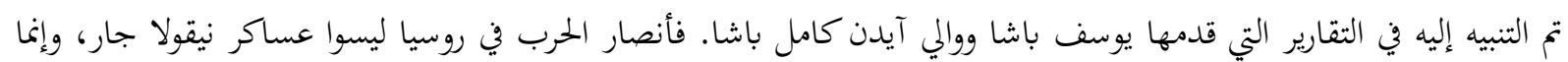

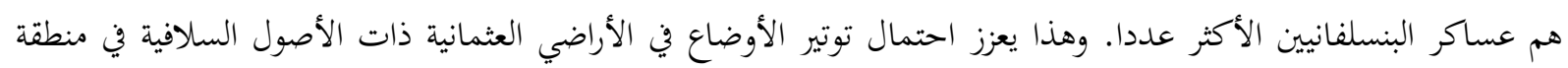

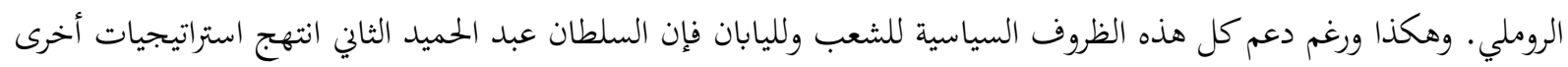

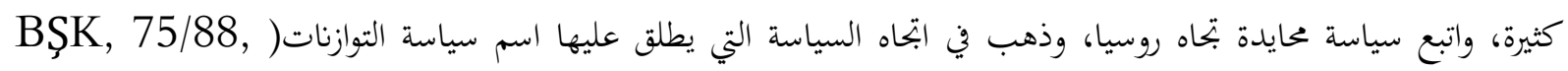

.(Evail-i 1323/ Mart 1905, BOA. .EE.86/29,9.R.Ahir.1324/2Haziran 1906. بحث السلطان عبد الحميد بعد اندلاع الحرب عن طرق لتجنب الظهور بمظهر المؤيد لليابان ومعاد لروسيا، فقد أظهرت

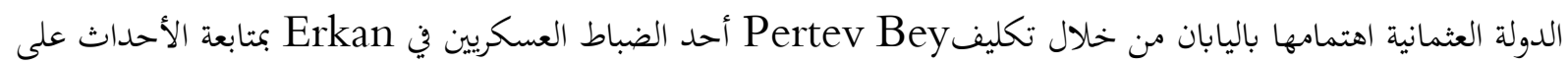

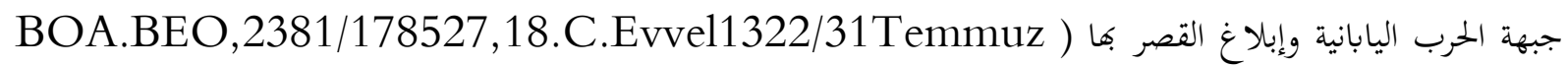

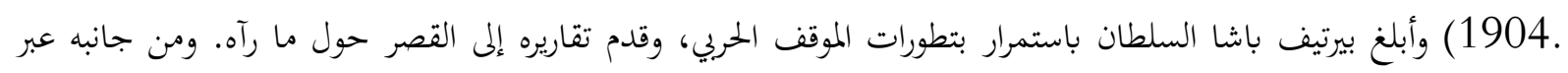

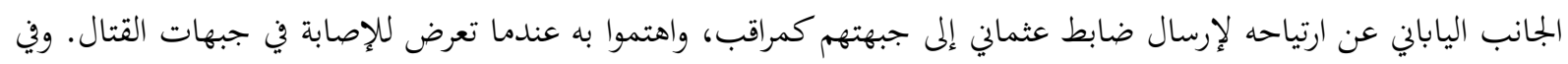

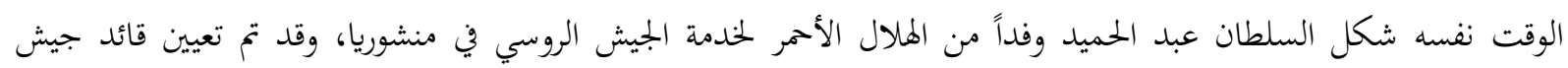

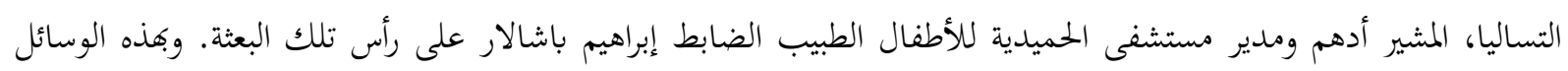

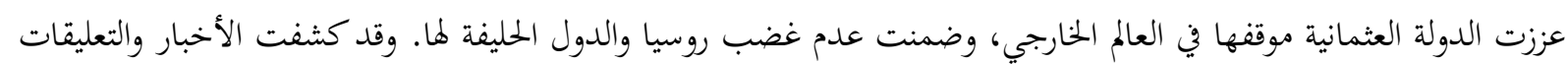

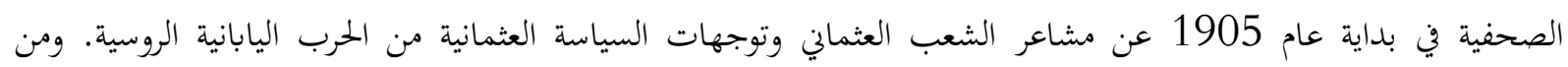

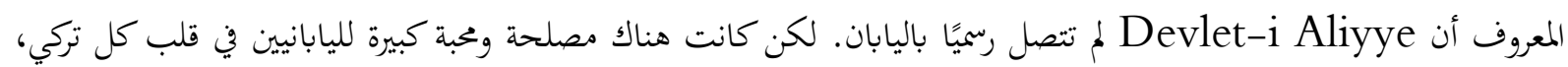

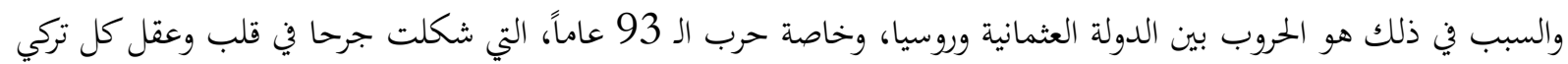

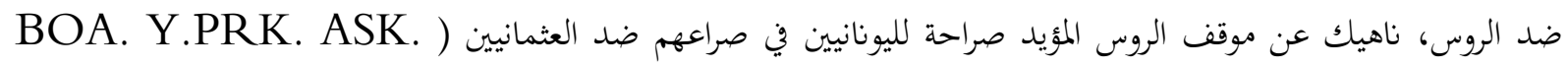

\section{- موقف فرنسا من الحرب اليابانية الروسية:}

في الوقت الذي استولت فيه روسيا على منشوريا وقيامها بتهديد كوريا، كان واضحاً أن الحياد سيكون هو موقف فرنسا

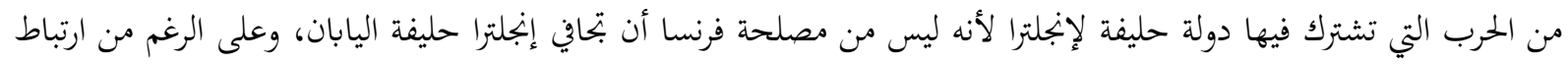

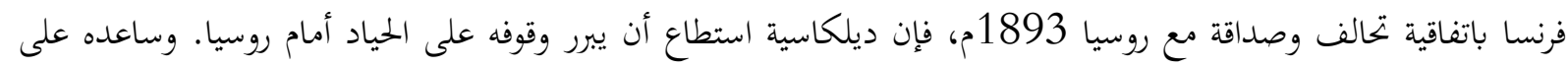

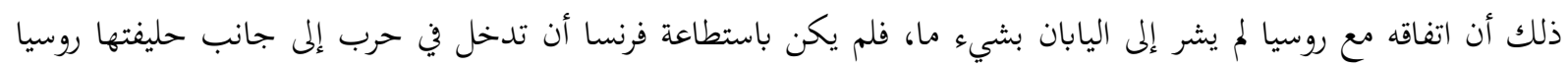

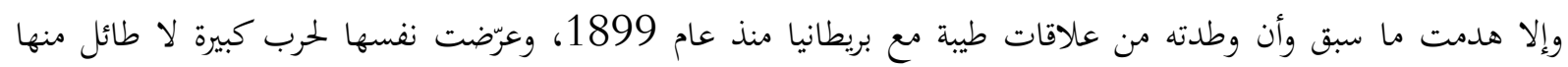


(نوار، 1999، صفحة 347). هذا وقد أثمرت جهود ديلكاسية وموقفه من هذه الأحداث إلى توقيع الاتفاق الودي بين فرنسا

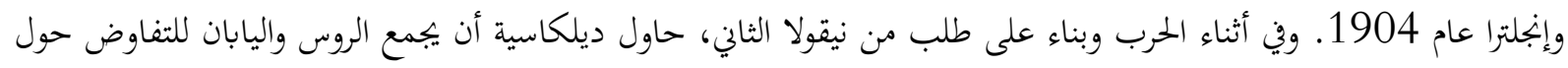
شروط السلام وإنهاء حالة الحرب بين الطرفين، إلا أن جهوده باءت بالفشل (R. A. Esthus, 1980, p. 400).

\section{- موقف الولايات المتحدة من الحرب وتوقيع معاهدة بورتسموث 1905:}

كان الرئيس الأمريكي "تيودور روزفلت" Theodor Roosevelt في بداية الحرب متعاطفاً مع اليابان إذ أنه كان

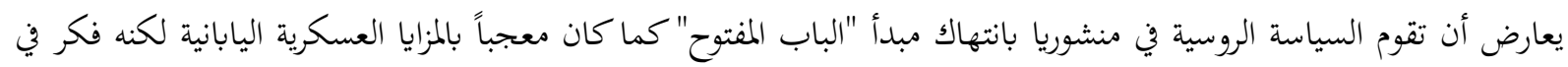

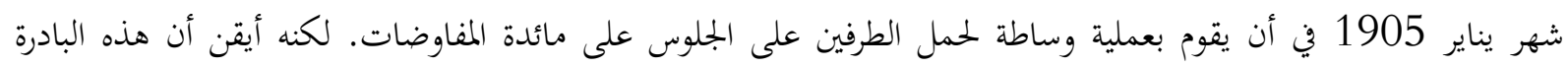

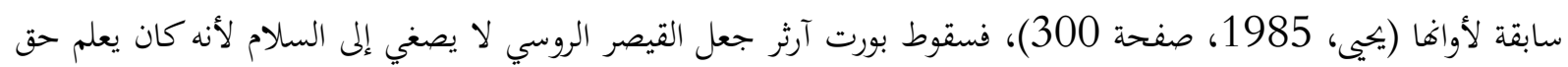

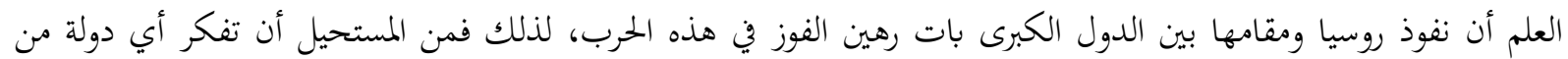

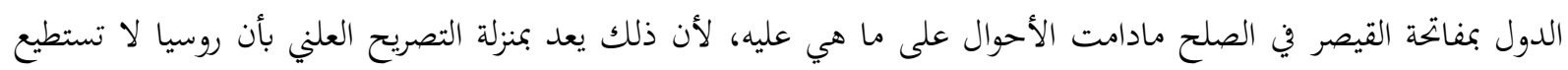
التخلص من هذه الورطة التي وقعت فيها.

وعندما وصلت أخبار مساعي روزفلت للسفير الروسي في واشنطن "كاسيني" Cassin الذي كان مدركاً جيداً لمدى

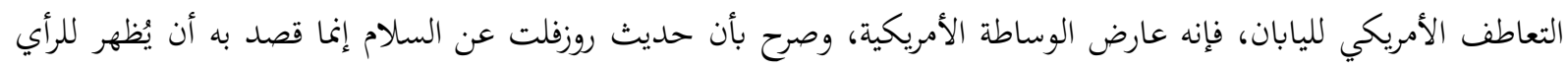

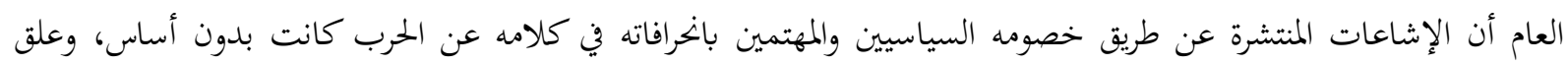

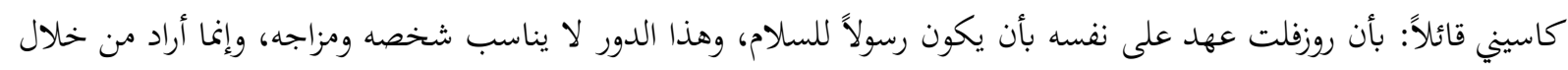

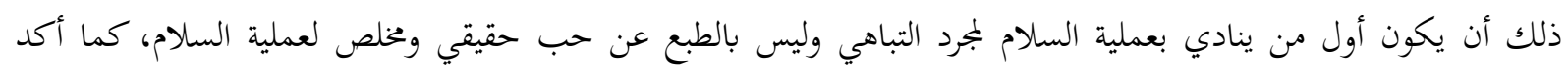

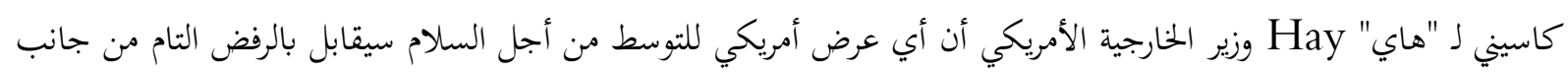
روسيا ( 349 - 348 - May, 1957 , pp.

لكن بعد هزيمة الأسطول الروسي في موقعة بحر اليابان في 27- 28مايو 1905، وقضاء الأسطول الياباني على معظم القوى

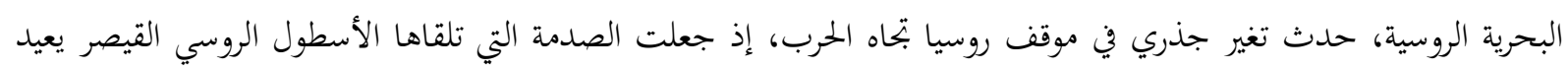

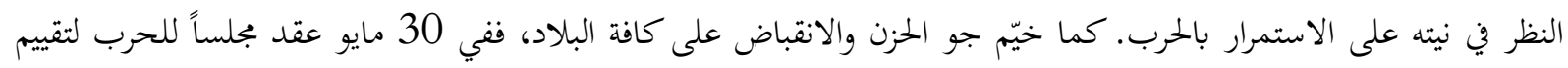
الحاله المأسوف عليها ( Dispatch from Hardinge to Lansdowne, Jun 5, 1905, No. 76, 83

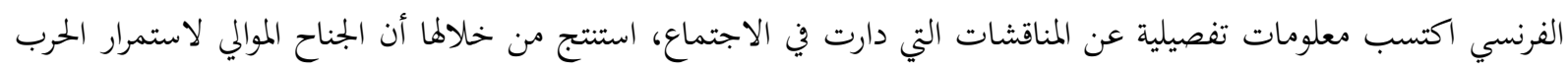

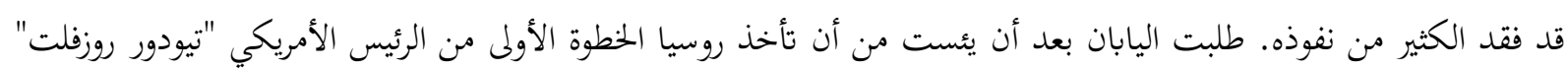

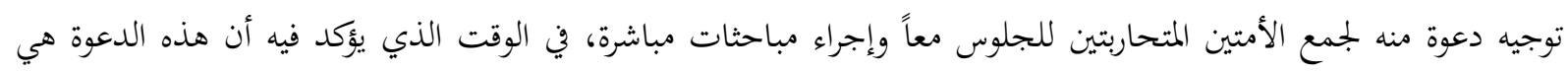

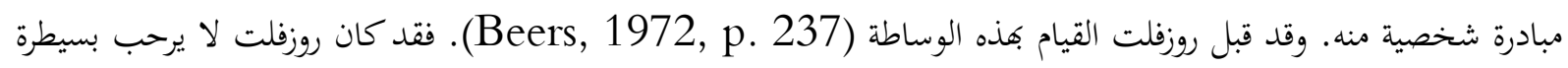

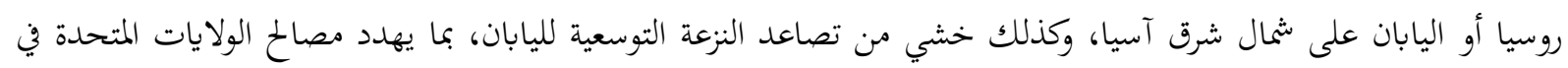

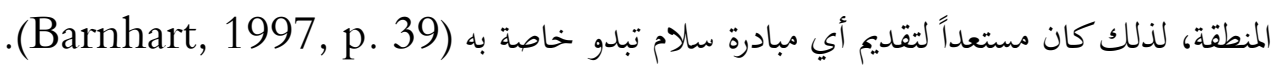

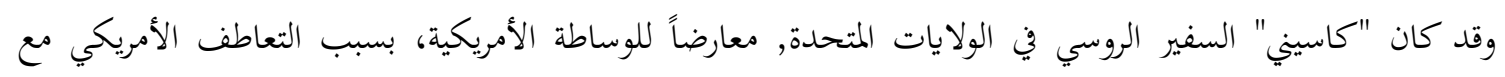

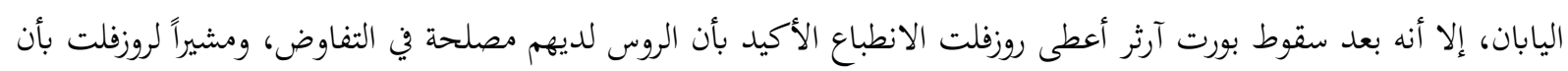

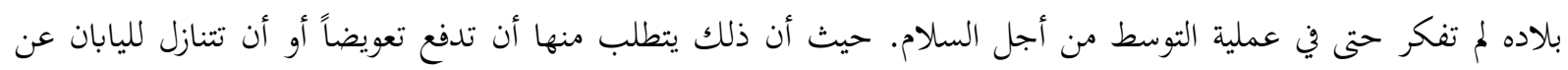




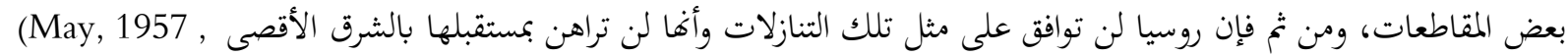

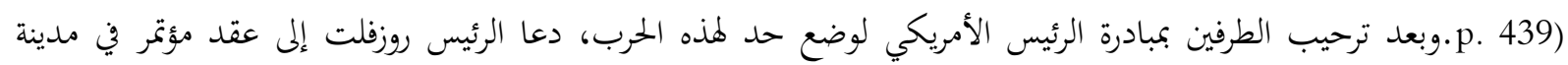
بورتسموث (في ولاية نيوهامبشير) في الولايات المتحدة الأمريكية، وذلك في صيف عام 1905 لمناقشة مقترحات السلام

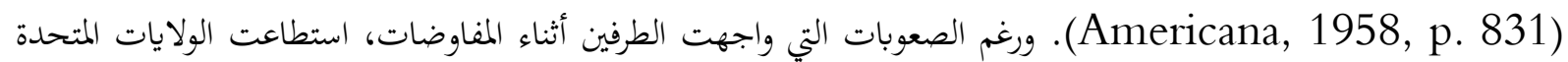

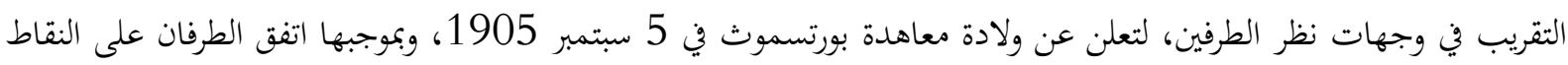

- - إقامة سلام دائم بين الطرفين.

- اعتراف روسيا بالهيمنة السياسية والعسكرية والاقتصادية اليابانية على كوريا. - تعهد روسيا بإخلاء منشوريا وإعادتما للإدارة الصينية.

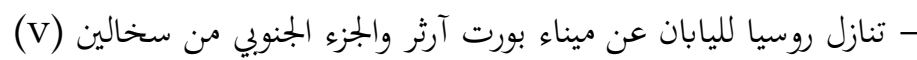

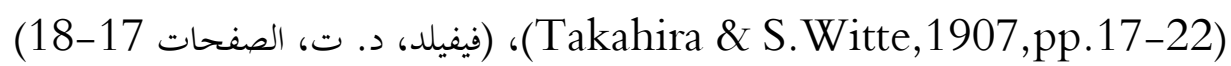

وطبقاً لذلك وضعت معاهدة بورتسموث فاية للتوسع الروسي في الأراضي الصينية. كما أدى إلحاق جنوب جزيرة

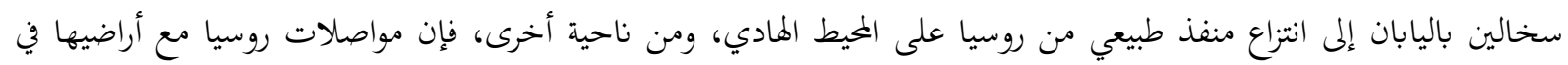

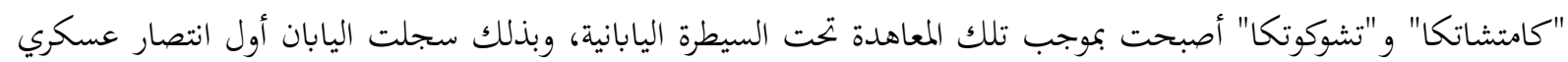
لقوة شرقية على قوة غربية في التاريخ الحديث.

وفي الواقع كان التحالف الأنجلوياباني سبباً مباشراً في الانتصار الياباني على روسيا في الحرب اليابانية الروسية 1904-

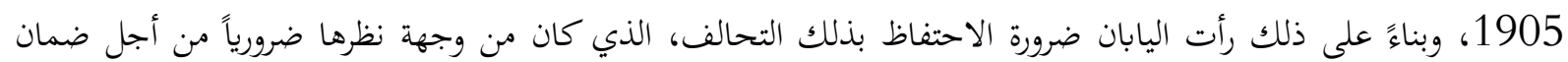

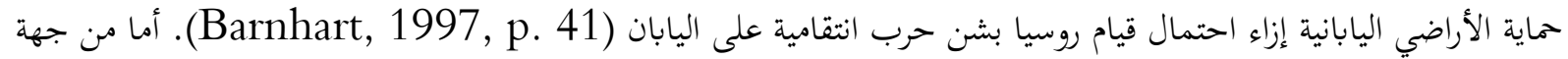
بريطانيا، فقد شعرت هي الأخرى بحاجتها إلى المحافظة على التحالف بشرط توسيع أهدافه، فقد ساد الاعتقاد في الأوساط الدولية

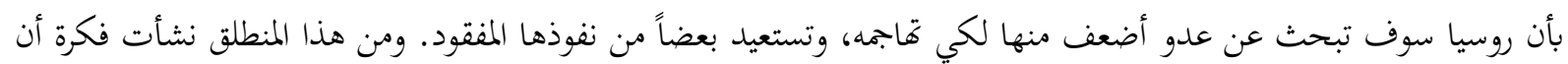

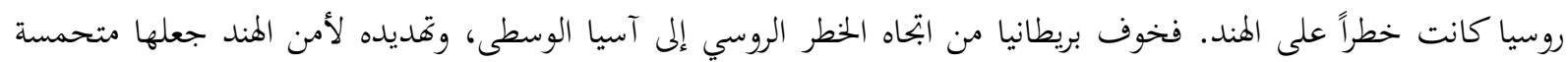
للمحافظة على التحالف الأنجلوياباني (P. Towlc, 1980, p.112)، (Gamble,1993, p.244). لتتفق الدولتان في 12 أغسطس 1905 على تجديد ذلك التحالف لمدة خمس سنوات أخرى، وتوسيع مداه، فقد وافقت بريطانيا على أن تتدخل عسكريا في الحرب التي تكون فيها اليابان طرف مع دولة عظمى واحدة

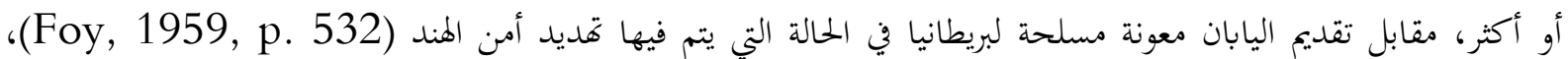
(James, 1951. , p. 155)

يلاحظ مما تقدم أن قلق كل من بريطانيا واليابان من روسيا قد دفعهما إلى تجديدهما للتحالف، كما أن التعديل الذي تم على ذلك التحالف كان في صالح اليابان، وكان بمثابة اعتراف آخر من بريطانيا بقوة اليابان الجلديدة التي أصبحت على قدم المساواة مع باقي الدول العظمى 


\section{نتائج الحوب اليابانية الروسية على شعوب الشرق:}

حققت اليابان بنصرها على روسيا جميع أهدافها التي خططت لها، وكان لنصرها صداه الداوي في آسيا، إذ أصبحت

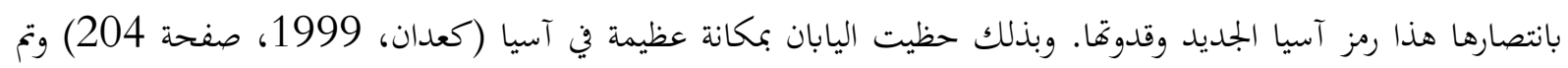

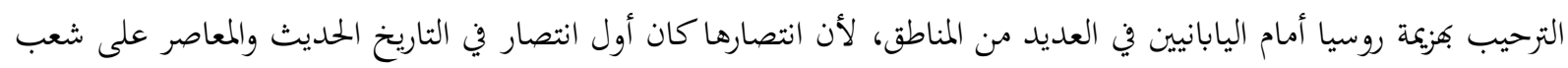

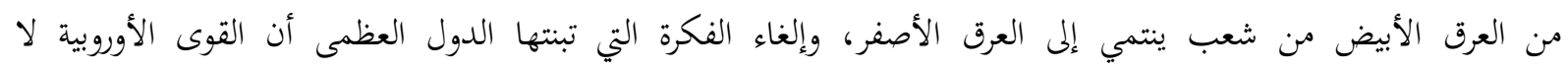

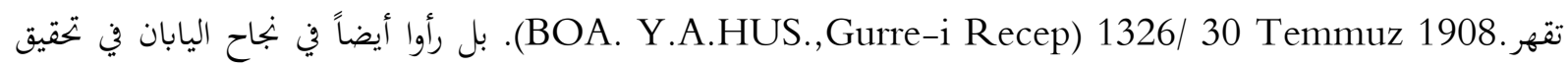
ذلك إثباتاً لمنزلتها الرفيعة على قارة آسيا ومبرراً لها لكي تتولى مسؤولية قيادة الشعوب الآسيوية في صراعها ضد الإمبريالية الغربية (Mendl. W, 1995, p. 22)

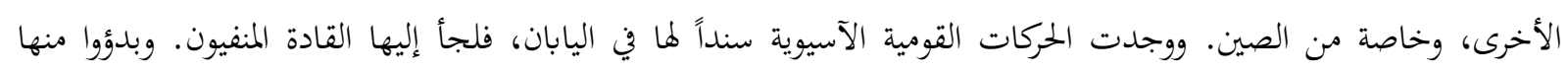
بتوجيه الكتابات النقدية ضد المستعمرين، وبذلك أصبحت طوكيو المركز الثوري للشرق الأقصى من منطلق آسيا للآسيويين (سكالابينو، 1961، صفحة 342).

فقد أدى انتصار اليابان إلى دب الحماس في جميع شعوب آسيا، فها هي الصين تدبر خطة لثورتا وبدأت تحلم بحريتها

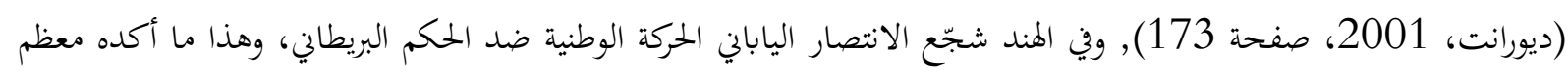

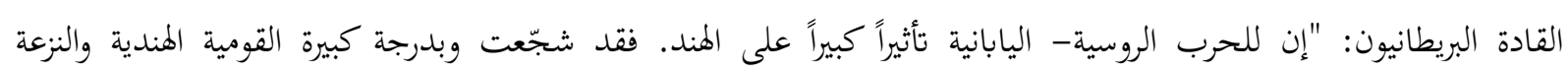

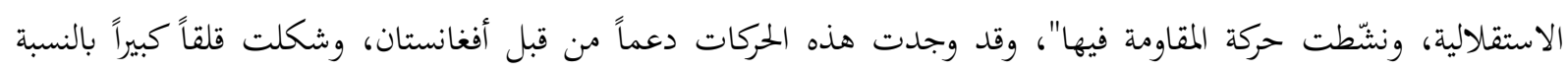

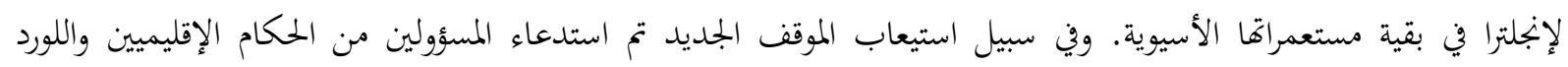

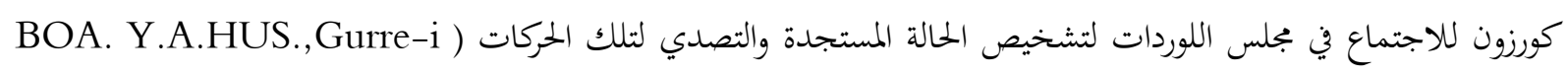
كecep 1326/30 Temmuz 1908. كان للانتصار الياباني صداه الداوي، حيث كانت الحركة الوطنية قد بلغت ذروما بزعامة مصطفى كامل الذي ألضّ كتيباً بعنوان

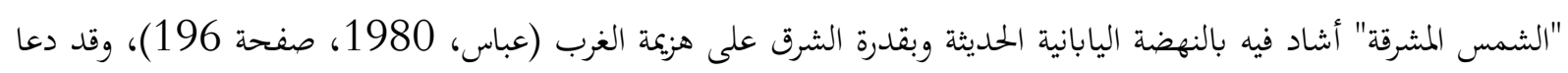

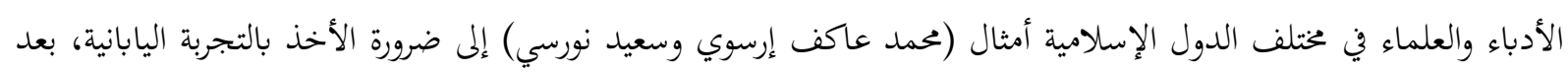
أن أيقنوا أن نموذج التقدم ليس النموذج الغربي وإنما هو النموذج الياباني الإنياء

(M. Akif Ersoy,Safahat, Süleymaniye Kürsüsünden,, Said Nursi, Divan-1 Harbi Örfi,s.79).) وكان من أعظم نتائج الحرب ضياع هيبة روسيا كدولة كبرى لها وزغها السياسي على الساحة الأوروبية والعالمية (العبد،

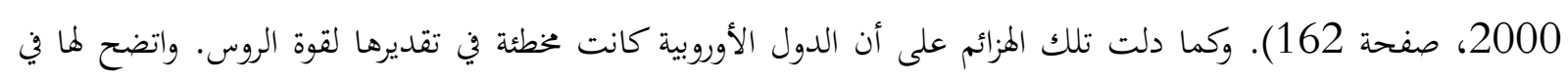

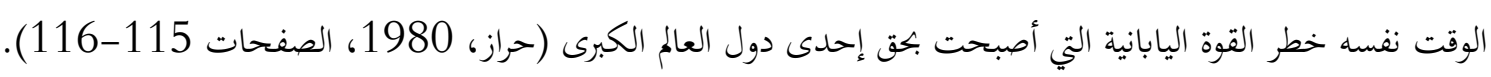

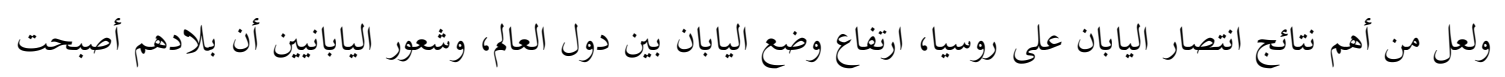

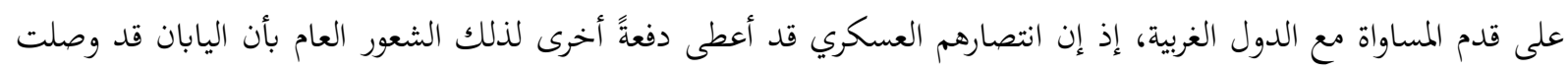

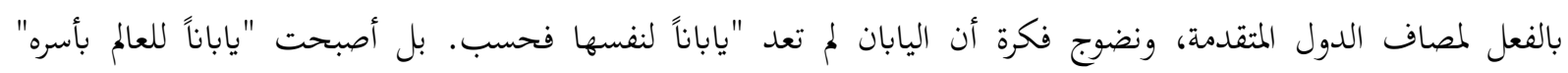

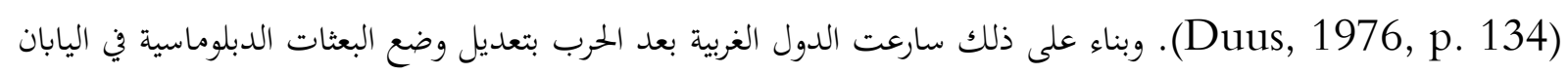

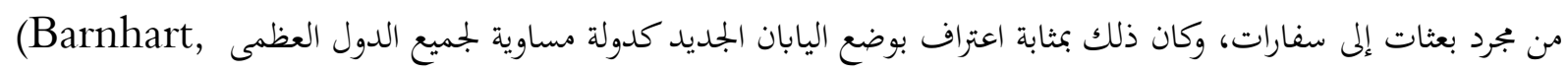
.1997, p. 42) 


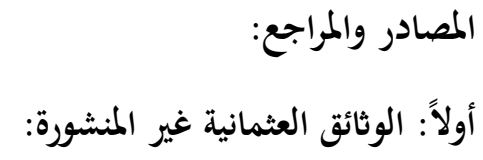

BOA. İ.DH. 1049/84828-14 Eylül 1303/ 26 Eylül 1887.

BOA.Y.HUS,216/57,15 Zilhicce 1305/28 Ağustos 1888

BOA. Y.PRK. EŞA.47/72, 26. R.Evvel 1324/21 Mayıs 1905

BOA. Y.MTV.52/26,7.Zilhicce 1308/14 Temmuz 1891

BOA, İ.DH, 1138/88816, 5 Ramazan 1306/5 Mayıs 1889,

BOA, Y.A.HUS.239/21, 19 Eylül 1890

BOA. PRK. BȘK, 75/88, Evail-i 1323/ Mart 1905,

BOA. Y.EE.86/29, 9.R.Ahir.1324/ 2 Haziran 1906.

BOA. BEO, 2381/178527, 18.C.Evvel 1322/31 Temmuz 1904.

BOA. Y.PRK. ASK. 225/137, 27.11.1322/ 2 Şubat 1905.

BOA. Y.A.HUS.,Gurre-i Recep 1326/ 30 Temmuz 1908.

M. Akif Ersoy, Safahat, Süleymaniye Kürsüsünden,, Said Nursi, Divan-1 Harbi Örfi,s.79).

ثانياً: الوثائق المنشورة:

Department of State, Foreign Relations of the United States, Diplomatic Papers, United States Government Printing Office, Washington: Vols:

FRUS, 1902.

FRUS, 1905.

British Documents on the Origins of the War, 1898-1914, Ed. By: G. P. Gooch \& H. Temperley., Vol. II, London 1927.

British Documents on the Origins of the War (1898 - 1914)، Ed. By: Gooch \& Temperley, Vol. IV, London 1929.

المراجع العربية:

البطريق عبد الحميد: التيارات السياسية المعاصرة 1815 - 1960, المركز العربي للبحث والنشر , القاهرة 1982. بين تشستر: الشرق الأقصى، ترجمة: حسين الحوت، مراجعة: فريد عبد الرحمن، مكتبة مصر، القاهرة د.ت، ص 160.

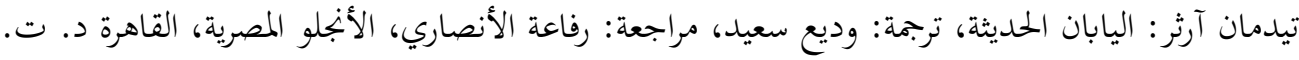

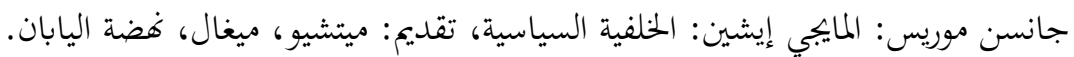
حراز رجب: تاريخ أوروبا المعاصر , دار النهضة العربية, القاهرة 1980. ديورانت ول: قصة الحضارة، (الشرق الأقصى اليابان)، المجلد الثالث, الجزء الخامس، الهيئة المصرية العامة للكتاب، القاهرة رايشاور أدوين: اليابانيون، ترجمة: ليلى الجبالي، مراجعة: شوقي جلال، سلسلة عالم المعرفة، العدد 136، 136، الكويت الكينه 1989. رسل فيفيلد، ج. بيرسي: الجيوبولتيكا، ج2، ت: يوسف مجلي، لويس إسكندر، مراجعة: عبد المنعم الشرقاوي، دار الكرنك، مركاك. القاهرة د. ت

رشاد عبد الغفار: التقليدية والحداثة في التجربة اليابانية, مؤسسة الأبحاث العربية، ط1، بيروت1984. رونوفان بيير: تاريخ العلاقات الدولية، 
زكريا فريد: من الثروة إلى القوة (الجذور الفريدة لدور أمريكا العالمي)، ترجمة: رضا خليفة, الأهرام للترجمة والنشر, ط1, القاهرة .1999

سكالابينو روبرت: السياسة الخارجية لليابان الحديثة, إشراف: روي مكريدس, مناهج السياسة الخارجية في دول العالم, ترجمة: حسن صعب, مراجعة: يوسف إيبش, منشورات المكتبة الأهلية, بيروت 1961.

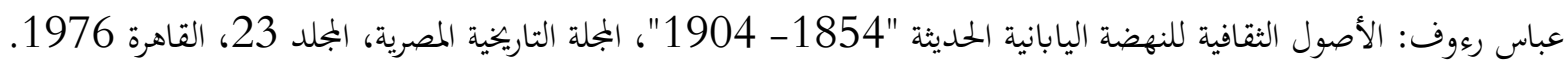
عباس رووف: المجتمع الياباني عصر مايجي 1868- 1912، دار الكتاب الجامعي، القاهرة 1980.

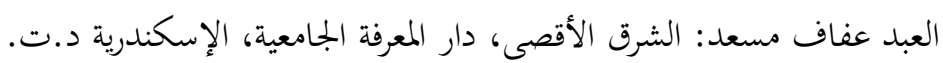

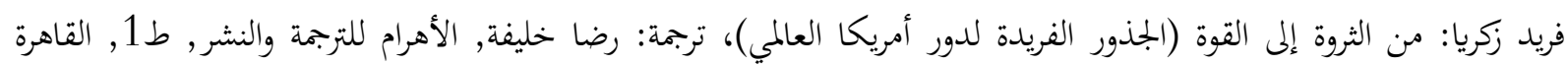
.1999

$$
\begin{aligned}
& \text { كعدان صباح: تاريخ آسيا الحديث والمعاصر، دمشق } 1999 .
\end{aligned}
$$

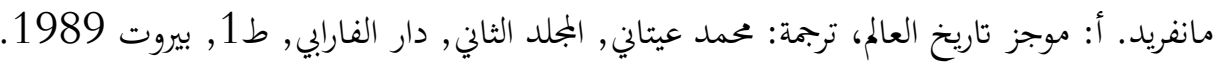

$$
\begin{aligned}
& \text { موسى محمد العزب: حرب الأفيون، دار المعارف، القاهرة } 1968 .
\end{aligned}
$$

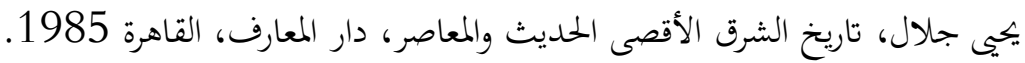

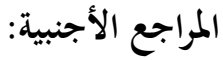

Barnhart. M. A., Japan and The World Since 1868, $3^{\text {rd }}$, Ed, London 1997, P. 25.

Clyde P. H \& Beers. B. F., The Far East: A History of the Western Impact and the Eastern Response (1830-1970)، $5^{\text {th }}$. Ed, New Delhi 1972, P. 113.

Crowley. J., Creation of an Empire (1896-1910)، Ed .By: J. Livingston., The Reader Japan (Imperial Japan 1900-1945)، Random House inc, New York 1973, P. 225.

Duus. P., Feudalism in Japan, $2^{\text {nd }}$. Ed, New York 1976, P. 108.

Fairbank. J \& Others., East Asia: Tradition and Transformation, $1^{\text {st }}$. Ed, Tokyo 1976, P. 484.

Gamble. R. C., Britain and the Washington Naval Conference 1921-1922, University of Massachusetts 1993, P. 244.

Grenville J. A .S., A History of the World in the $20^{\text {th }}$ Century, P.

James D. H., The Rise and Fall of the Japanese Empire, $1^{\text {st }}$. Ed, London 1951, P. 155;

Marder. A. J., British Naval Policy (1880-1905)، London W. D.

Mason. R. H. P \& Gaiger. J. G., A History of Japan, 5th. Ed, Tokyo 1978.

Mendl. W., Japan's Asian Policy, 1 ${ }^{\text {st }}$ Ed, London 1995.

Sakamoto. T., The Japanese Through History, $2^{\text {nd }}$. Ed, Tokyo 1989.

Stinberg., Germany and the Russo- Japanese War, P. 1976.

Storry. R., A History of Modern Japan, $1^{\text {st }}$. Ed, London 1960, P. 135.

Suganami. H., Japan's Entry into International Society, Ed. by: P. Kornicki., Meiji Japan Political, Economic and Social History 1868- 1912, Vol. 1, 1 ${ }^{\text {st }}$ Ed, London 1998.

The Encyclopedia Americana, Vol. 15, $1^{\text {st }}$. Ed, New York 1958, Article Japan, P. 831.

The Encyclopedia of Asian History. 


$$
\begin{aligned}
& \text { المددني عبد الله: العلاقات الروسية اليابانية ورواسب الماضي، صحيفة الاتحاد، } 9 \text { يوليو } 2017 .
\end{aligned}
$$

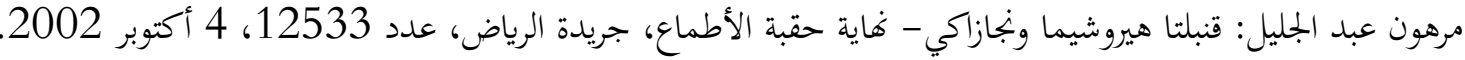

$$
\begin{aligned}
& \text { المقطم (سقوط بورت آرثر)، عدد } 4794 \text { (3 } 473 \text { يناير 1905 1905). } \\
& \text { المقطم: العدد 4803، (13 يناير 1905). }
\end{aligned}
$$

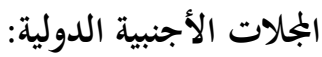

Agreement between Great Britain and Japan, Signed at London, Jan 30, 1902, Foreign Relations of United States, 1902, Vol. I, U. S Government Printing Office Washington 1903, Hereafter cited as FRUS; Agreement between Great Britain and Japan, (A.J.I.L)، Vol. 1, No. 1, Supplement: Official Documents, (Jan.1907)،

Cox. P., of Aphorisms, Lessons, and Paradigms, Comparing The British and German Official Histories of The Russo- Japanese War, The Journal of Military History, Vol. 56, Issue 3 (Jul., 1992).

Esthus. R. A., Nicholas II and the Russo- Japanese War, Russian Review, Vol. 40, Issue 4 (Oct., 1980).

Komura. I \& Takahira K.; S. Witte., The Peace of Portsmouth, 5 Sep, 1905, (A.J.I.L)، Vol. 1, No. 1, Supplement: Official Documents (Jan., 1907)،

Kublin. H., The Evolution of Japanese Colonialism, Comparative Studies in Society and History, Vol. 2, Issue 1, (Oct., 1959).

May. E. R., The Far Eastern Policy of The U.S.A in the Period of The Russo- Japanese War: A Russian View, The American Historical Review, Vol. 62, Issue 2 (Jan. 1957).

Nish. I., Regaining- Japan after the Loss of Empire, Journal of Contemporary History, Vol. 15, Issue 1, Imperial Hangovers (Jan., 980)،

Tate. M. \& Foy. F., More Light on the Abrogation of the Anglo-Japanese Alliance, Political Science Quarterly, Vol. 74, No. 4, (Dec., 1959).

Towlc. P., The Russo-Japanese War and The Defense of India, Military Affairs, Vol. 44, Issue 3, (Oct., 1980)،

Treaty Annexing Korea to Japan, (A.J.I.L)، Vol. 4, No. 4, Supplement: Official Documents, (Oct., 1910)، 


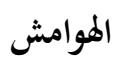

(i) التوكوجاوا: هي الأسرة التي انفردت بحكم اليابان بين عامي 1603-1867، وهم عشيرة من المحاربين استطاعوا إنشاء إدارة مركزية أطلقوا عليها

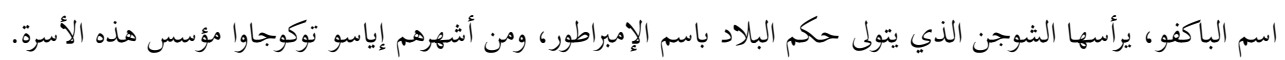

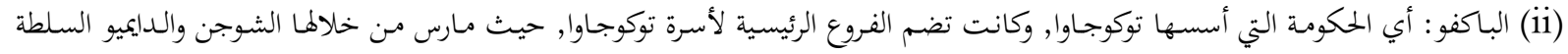
التنفيذية على البلاد.

(iii) البوكسرز: ومعناها القبضات المستقيمة والمتآلفة، وهم جماعات ينبثقون من جماعات مسلحة قتمت بشكل مباشر بممارسة الملاكمة والفنون الحربية،

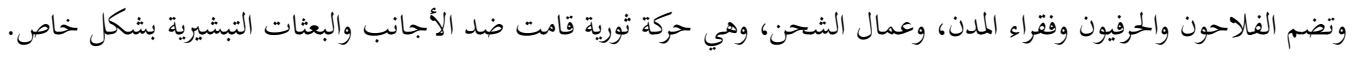
(iv)

Agreement between Great Britain and Japan, Signed at London, Jan 30, 1902, Foreign Relations of United States, 1902, Vol. I, U. S Government Printing Office Washington 1903, PP. 514-515; Hereafter cited as FRUS; Agreement between Great Britain and Japan, (A.J.I.L), Vol. 1, No. 1, Supplement: Official Documents, (Jan.1907), PP. 14-15; G. P. Gooch \& H. Temperley., British Documents on the Origins of the War, 1898-1914, London 1927, Vol. II, PP. 115-120; A. J. Marder., British Naval Policy (1880-1905), London W. D, PP. 427-28.

(v) Ratification of the treaty of peace signed at Portsmouth Sep 5, 1905, between Russia and FRUS, 1905, U. S Government Printing Office Washington 1906, PP. 824-828. 


\title{
OBSTACLES OF APPLYING SCIENCE AND MATHEMATICS TEACHERS' OF FUTURE \\ SKILLS IN BASIC EDUCATION SCHOOLS IN THE SULTANATE OF OMAN FROM THE POINT OF VIEW OF TEACHERS AND EDUCATIONAL SUPERVISORS
}

\author{
Humaid Muslem ALSAIDI ${ }^{1}$ \\ Khalid Juma ALSHIDI ${ }^{2}$
}

\section{Istanbul / Türkiye \\ p. 346-364}

Received: $28 / 11 / 2021$

Accepted: $12 / 12 / 2021$

Published: 01/01/2022

This article has been scanned $l$

iThenticat No plagiarism detected

http://dx.doi.org/10.47832/2717-8293.15.26

1 (iD) Dr. The Ministry of Education, Sultanate of Oman, Hm.alsaidi@gmail.com, https://orcid.org/0000-0001-6251-3571

2 iD Researcher, The Ministry of Education, Sultanate of Oman Khalid.Juma9@ moe.om, https://orcid.org/0000-0002-7619$\underline{1718}$ 


\section{معوقات توظيف معلمي العلوم والرياضيات لمهارات المستقبل بمدارس التعليم الأساسي بسلطنة عمان من وجهة نظر المعلمين والمشرفين التربويين}

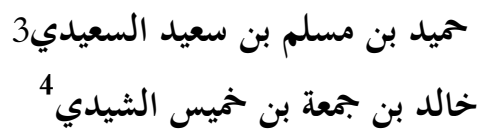

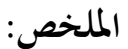

هدفت الدراسة إلى الكشف عن المعوقات التي تحول دون توظيف معلمي العلوم والرياضيات في توظيف مهارات المستقبل في مدارس التعليم الأساسي، ولتحقيق أهداف الدراسة استخدم الباحثان المنهج الوصفي، وذلك بإعداد

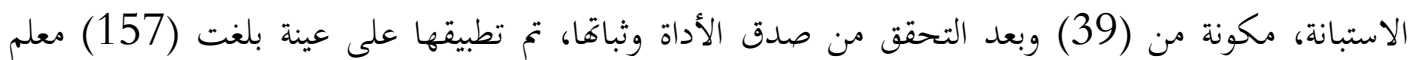
ومعلمة، و(51) مشرفاً ومشرفةً، وقد كشفت نتائج الدراسة أن درجة المعوقات التي يواجهها معلمو العلوم والرياضيات في توظيف مهارات المستقبل بمدارس التعليم الأساسي بسلطنة عمان من وجهة نظر المعلمين والمشرفين

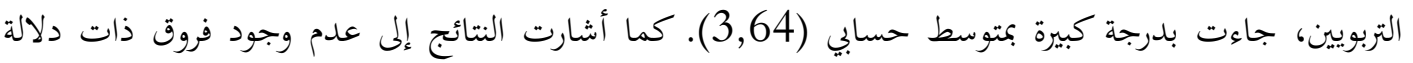
إحصائية عند مستوى دلالة (Q=0,05) بين متوسطات درجة المعوقات تعود إلى متغيرات الوظيفة والجنس، في

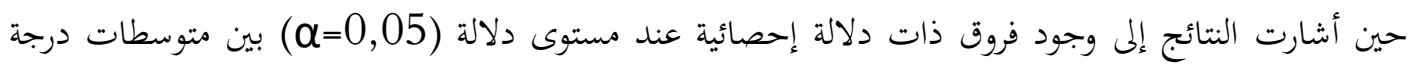

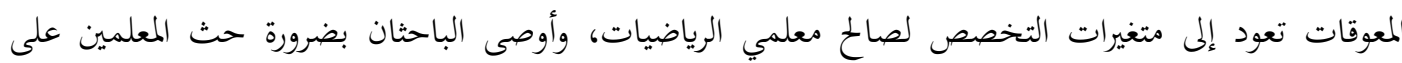
تطبيق الاستراتيجيات التدريسية الحديثة، والأنشطة التقيمية التي تركز على مهارات المستقبل، وضرورة تخفيف الأعباء الإدارية على المعلمين. الكلمات المفتاحية: المعوقات، مهارات المستقبل، معلمي العلوم والرياضات.

يمثل الذكاء الاصطناعي وأنترنت الأشياء أهم مظاهر الثورة الصناعية الرابعة، والتي تمثل مرحلة انتقالية في الحضارة البشرية بما تمثله من انتقال نوعي في أنماط الحياة المختلفة، مما يتطلب أن يمتلك الفرد العديد من المهارات الأساسية التي تتوافق مع متطلبات القرن الحادي والعشرين، لذا أصبح لزاماً على الأنظمة التعليمية العمل على اكساب المخرجات مهارات المستقبل. إذ أنتجت الثورة الصناعية الرابعة فرص عمل كثيرة غير مسبوقة خلافا للثورات السابقة التي اعتمدت العمل اليدوي والآلي المباشر، فقد زادت الثورة الصناعية الرابعة من الطلب النسبي على المهارات بصورة غير متساوية في الوظائف المختلفة، وعلى فرصي الرغم من ذلك فقد خلقت عددا من التحديات المهمة والتي كان من أبرزها المهارات المستقبلية والعمل على تنميتها لدى لمع المتعلمين

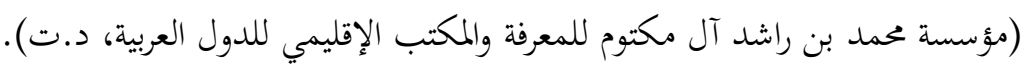

إن إحداث تغيير في مؤسسات التعليم وأنظمتها بجيث تصبح قادرة على استشراف المهارات اللازمة للنجاح في المستقبل

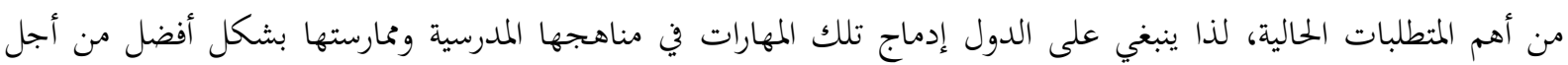
تحسين جودة التعليم، وتعزيز فرص واستمرارية التعلم مدى الحياة وإنشاء روابط وعلاقات أقوى مع الصناعة وسوق العمل واتباع 
طرائق حديثة تستند إلى التكنولوجيا المتطورة، وتعاني بيئة العمل العربية من مشكلات أدت إلى تأخرها في اللحاق بركب الدول المتقدمة (محمد، ومحمد، 2020).

هذا التغيير في الأنظمة التعليمة يتطلب العديد من التغيرات في عناصر العملية التعليمية بدء من المنهاج الدراسي والذي ينبغي أن يتضمن كل ما يتعلق بمهارات المستقبل ومتطلبات القرن الحادي والعشرين إلى جانب الاهتمام بتدريب المعلمين و تأهليهم من أجل تمكينهم من توظيف الأساليب التدريسية الحميثة التي تساعد على اكساب الطلبة هذه المهارات.

لذلك اهتمت سلطنة عمان بوضع إطار وطني للمهارات يرتبط بمجالات التدريس والتدريب، حيث تم اعتماد الإطار الوطني العماني لمهارات المستقبل في العام 2021، وهو إطار شامل، توازن أهدافه بين المتطلبات الوطنية التي تنشدها رؤية عُمان

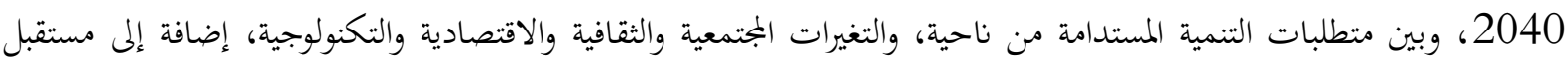

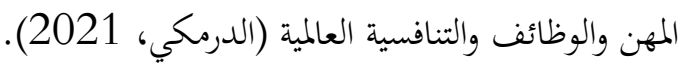
وقد أُعد هذا الإطار الوطني ليكون رُؤية للتربويين والمعنيين بالتعليم في السلطنة تعينهم على تضمين مهارات المستقبل في

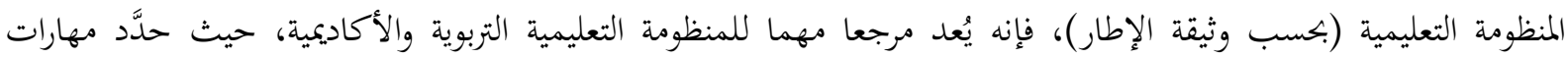
المستقبل في سلطنة عمان وموجهاها، إضافة إلى متطلبات تضمين هذه المهارات في العملية التعليمية، وآليات تطبيقها وفقا للأطر العالمية (بجلس التعليم، 2021).

ومن أجل إدماج مهارات المستقبل في النظام التعليمي، يحتاج المتعلمون إلى بنية متكاملة وشاملة من المهارات حتى يصبحوا من خلالها أكثر فاعلية عند تطبيق مهاراتم في العالم الواقعي، وبما يمكن من تحقيق رؤية سلطنة عمان 2040 والتي يعد فيها

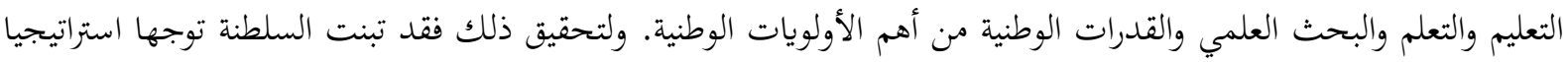
يقوم على تعليم شامل ومستدام وبحث علمي يقود إلى مجتمع المعرفة من خلال التركيز على رفع جودة التعليم وتطوير المناهج

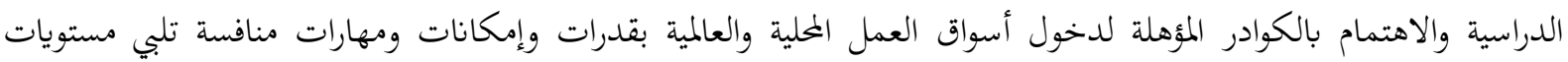

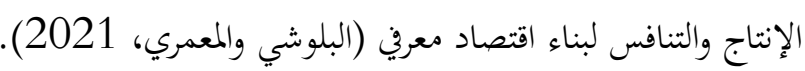
وبما أن المحتوى المعرفي والمهاري في مواد العلوم والرياضيات الذي يقدم في المدارس أمر بالغ الأهمية للنجاح على صعيد

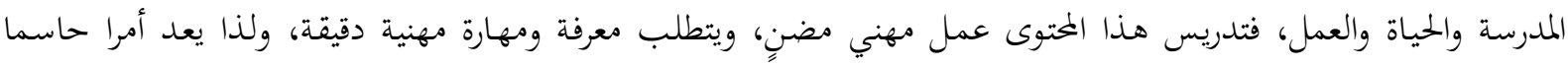
لضمان اكتساب جميع المعلمين المعارف والمهارات اللازمة للتدريس بفعالية. وعلى المعلمين الاستعداد الجيد فيما يتصل بالتعليم والتعلم مستعينين بصور خاصة من الدربة والدراية بموضوع التخصص وبالمهارات المهنية والمعارف المكتسبة عبر الدراسة والممارسة والإلمام بالمختوى وإدراك قضايا المنهج التي يواجها المعلمون في تدريس العلوم والرياضيات (The Economist Intelligence Unit, 2017) وتعد مناهج العلوم والرياضيات من أهم المناهج المرتبطة بتقدم المجتمعات وتطوير المهارات المتنوعة والمرتبطة بالتقدم العلمي،

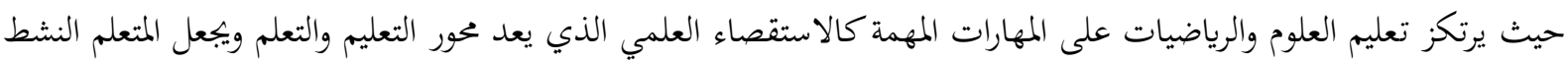

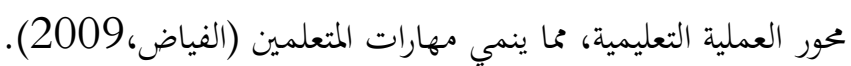

من أجل ذلك كان لا يزال هناك حراك تربوي لتطوير وإصلاح مناهج العلوم على المستوى الدولي والمحلي، وهناك عدد من المعوقات التي تواجه تمكين معلمي العلوم من تدريس المهارات الضرورية واللازمة منها ما يتعلق بالمعلم وتتمثل: في عدم إعداد المعلم

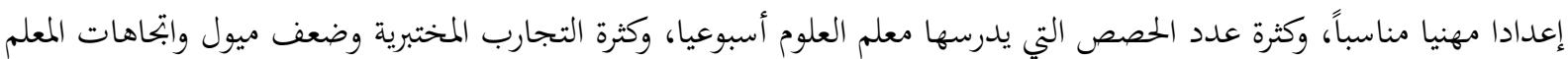
نخو العمل المختبري. ومنها ما يتعلق بالمتعلم المتمثلة في ازدحام الطلبة في الفصول الدراسية، وصعوبة ضبط الطالب في قاعة المختبر 
ومن أجل تنمية مهارات المستقبل سعى عدد من الباحثين إلى تقصي كثير من الجوانب المرتبطة بتنمية تلك المهارات بما

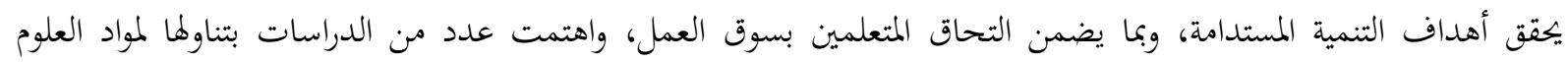
والرياضيات لما لها من قيمة في تنمية مهارات المستقبل. وقد تنوعت تلك الدراسات كما وكيفا، ومنها ما قامت به شهن شبلي (2014) حيث سعت في دراستها إلى تحديد مهارات القرن الحادي والعشرين التي يمكن دمجها في مناهج فئنس العلوم بمرحلة التعليم الأساسي المتوسط بمصر، وتقويم محتوى كتب العلوم في ضوء توافر هذه المهارات. ولتحقيق هذا الهدف اعتمدت الدراسة المنهج الوصفي التحليلي القائم على تحليل محتوى كتب العلوم، وقد أظهرت نتائج الدراسة تدني مستوى تضمين مقررات العلوم لمهارات

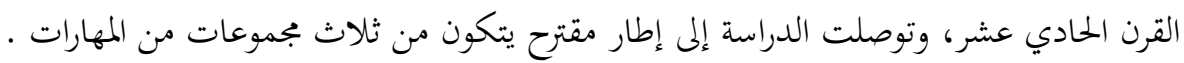
وأجرى البحراوي (2015) دراسة هدفت إلى التعرف على درجة امتلاك الطلاب المعلمين المعايير في ضوء مهارات القرن الحادي والعشرين والمعوقات التي يواجهوها، انتهجت الدراسة المنهج الوصفي التحليلي. واشتملت عينة الدراسة على (179)

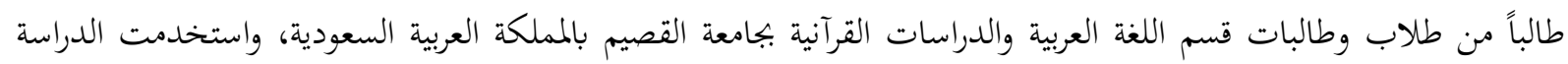

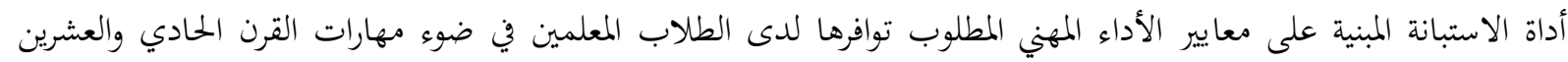

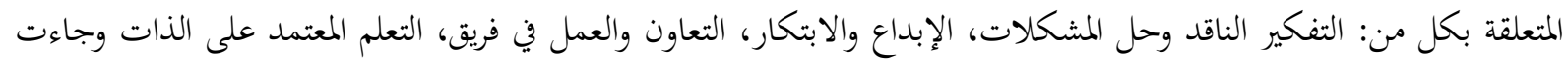
جميعها بدرجة أهمية عالية من وجهة نظر أفراد عينة الدراسة. هدفت دراسة الجهني (2015) إلى التعرف على معوقات تدريس مادة الرياضيات في المرحلة الابتدائية بمحافظة خيبر وسبل تطويرها، وأظهرت نتائج الدراسة وجود عدد من الصعوبات، حيث جاءت في المرتبة الأولى الصعوبات المتعلقة بالمتعلم

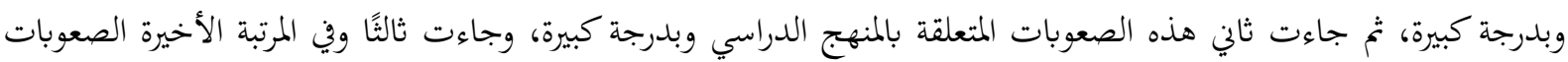

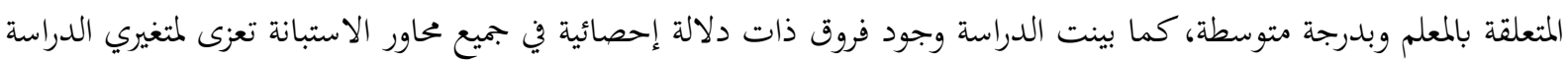

$$
\text { (عدد سنوات الخبرة، صفوف التدريس). }
$$

وأجرت دويكات (2016) دراسة هدفت إلى التعرف على مدى فهم معلمي المرحلة الأساسية الدنيا للمفاهيم الرياضية

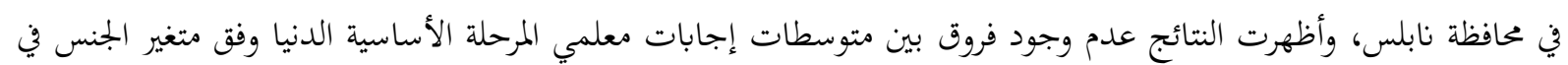

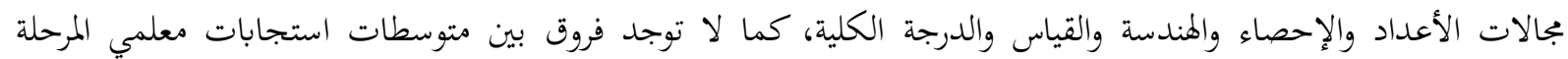
الأساسية وفق متغير عدد سنوات الخبرة في مجال المندسة والقياس، بينما توجد فروق في مجال الأعداد والإحصاء والدرجة الكلية

$$
\text { لصالح المعلمين الأقل خبرة من ه سنوات. }
$$

وأجرى العقالي (2018) دراسة هدفت إلى التعرف على معوقات توظيف تكنولوجيا الواقع الافتراضي في تدريس الرياضيات من وجهة نظر معلمات مادة الرياضيات بجدة في ضوء بعض المتغيرات، استخدمت الدراسة المنهج الوصفي. وكانت

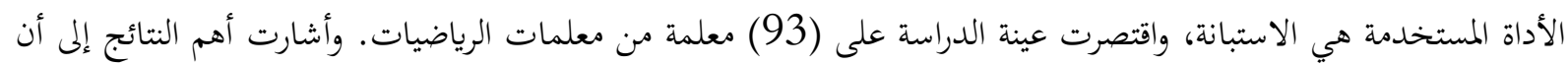

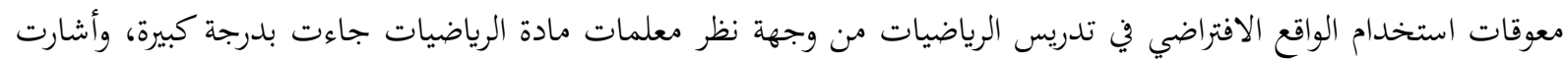

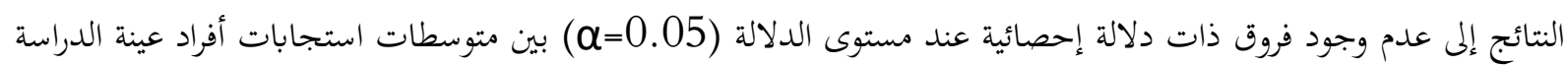
حول معوقات استخدام الواقع الافتراضي في تدريس الرياضيات تُعزى لمتغيري المرحلة التعليمية، وسنوات الخبرة. وهدفت دراسة علامي(2018) إلى التعرُف على درجة تأثير معوقات تدريس المفاهيم الرياضية في الصفوف الأولية من

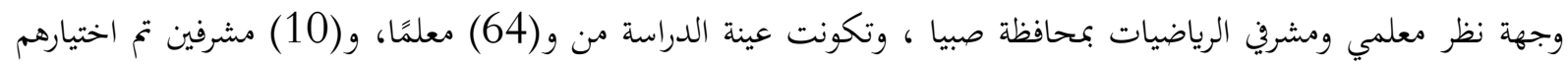

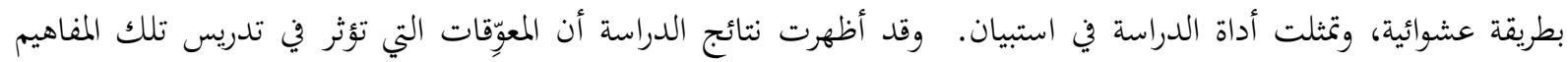


بدرجةٍ عاليةٍ، وجاء في مقدمتها المعوِقات المتعلقة بالبيئة المدرسية بدرجة كبيرة جداً، وجاءت المعوقات المتعلقة بالمعلِّم وبالمتعِلِّم

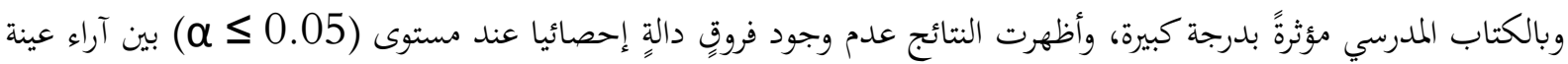
الدراسة تُعزى لمتغيرات: الجنس، وطبيعة العمل، والمؤهل العلمي، وسنوات الخبرة.

وهدفت دراسة الحربي والحسين (2019) إلى التعرف على معوقات تنفيذ الأنشطة التعليمية المضمنة في مقررات العلوم

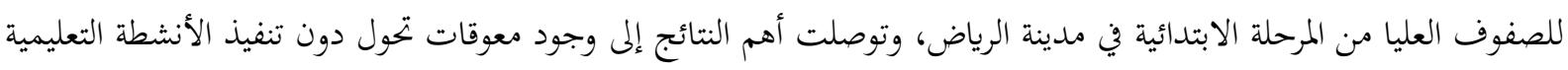

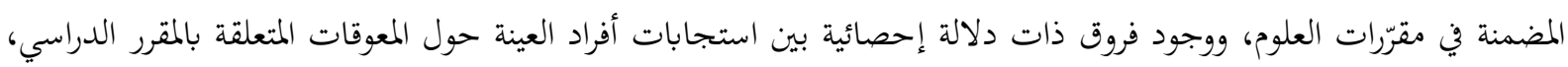

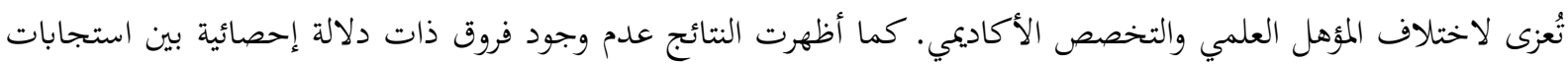
أفراد العينة حول المعوقات المتعلقة بالبيئة المدرسية والطالبات، تعزى لاختلاف المؤهل العلمي والتخصص الأكاديمي، وكذلك حول المول المعوقات المتعلقة بالبيئة المدرسية والمقرر الدراسي والمعلمات، تعزى لعدد سنوات الخبرة لمبنة لأفراد العينة. وهدفت دراسة ملحم (Melhem, 2020) إلى التعرف على مستوى مهارات القرن الحادي والعشرين لدى طلبة قسم

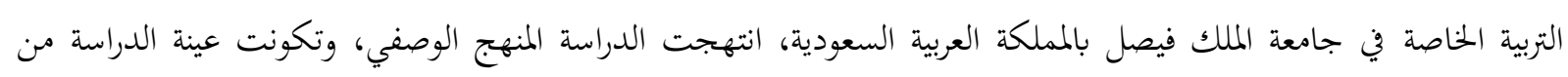
(65) طالبا تم اختيارهم بشكل عشوائي. قام الباحث بتطوير استبيان الدراسة المكون من (80) فقرة حول مهارات القرن الحادي

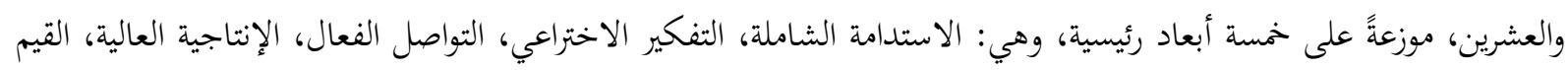
الدينية. وأشارت نتائج الدراسة الى أن مستوى مهارات القرن الحادي والعشرين لدى الطلاب كان ضمن ألمن المستوى المتوسط . وأجرى عليان والمزروعي (2020) دراسة هدفت إلى الكشف عن المعوقات التي تحد من تطبيق منهج STEM المتكامل في تعليم العلوم في سلطنة عمان، والتحقيق في تأثير متغير الجنس في وجود هذه المعوقات. ولتحقيق أهداف الدراس الدراسة تحم

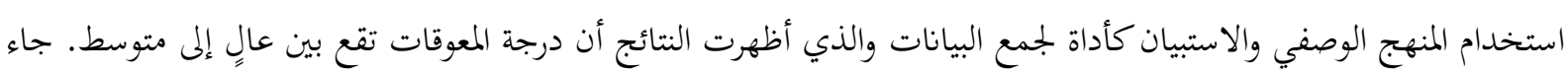
الجزء الثالث (المعوقات المتعلقة بالمحتوى) في المرتبة الأولى بمتوسط (3.51) وبدرجة المانديات عالية، يليه الجزء الثاني (المعوقات المتعلقة ببيئة

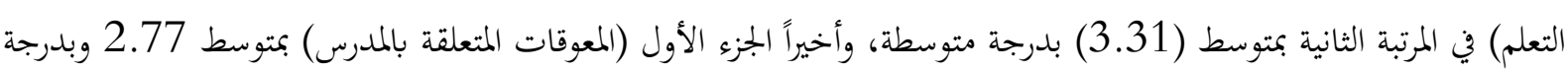

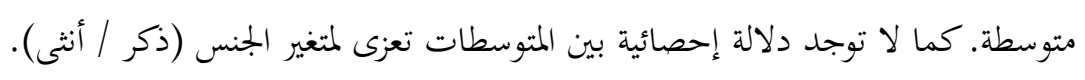
وقد أشارت هذه الدراسات السابقة إلى أهمية توظيف مهارات المستقبل في الموقف التعليمي، كما أكدت على هناك العديد من التحديات التي تواجه المعلمين في توظيف المعلمين للأساليب التدريسية التي تمكنهم من اكساب مهارات المستقبل، كما فئات لاحظ الباحثان قلة الدراسات العمانية التي بحثت في التحديات التي تواجه المعلمين في توظيف مهارات المستقبل لذا تأتي هذه التهات الدراسة للتقصي عن هذه التحديات ومعرفة تأثيرها على أداء المعلمين.

\section{مشكلة الدراسة وأسئلتها:}

أكد مؤتمر القمة العالمي للابتكار في التعليم في قطر ثمة حاجة إلى إجراء بحوث حول المعوقات التي تحول دون تحقيق

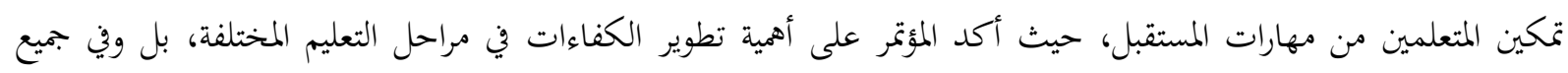

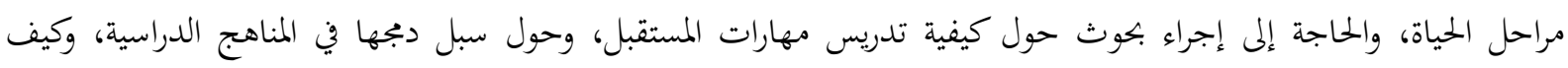

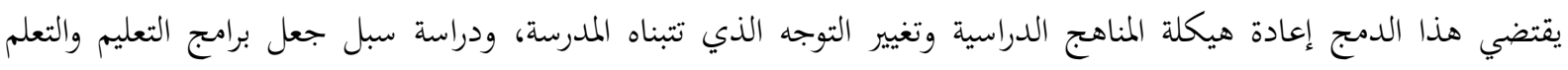

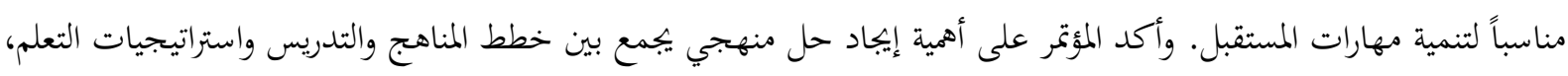

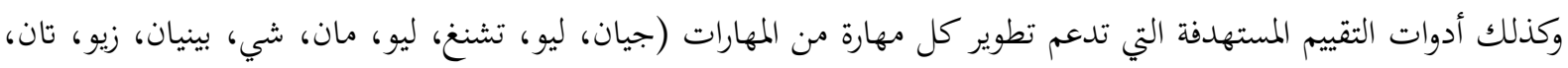
كريس، وخيا، ليو، 2019). 
وأظهر مؤشر جاهزية مهارات المستقبل إلى أن أكثر الدول التي سجلت أعلى نشاط على الانترنت في مجال مهارات

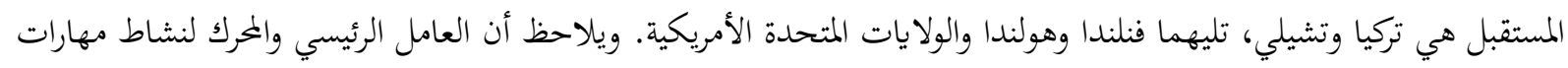

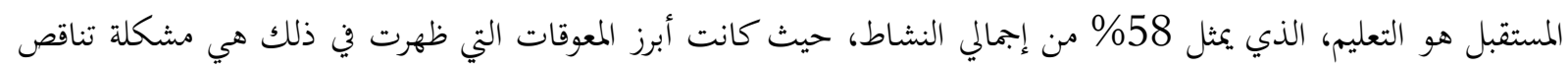

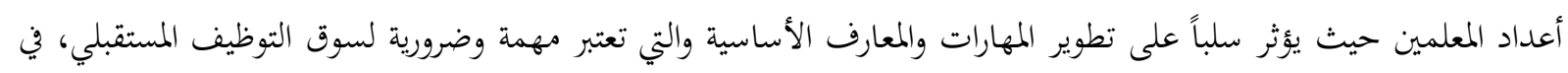

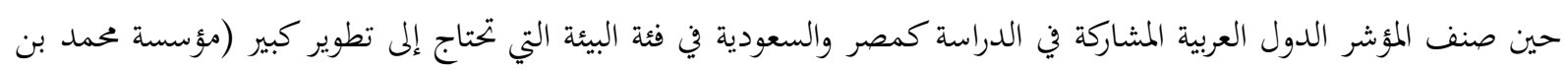
راشد آل مكتوم للمعرفة والمكتب الإقليمي للدول العربية، د.ت).

وأوصت دراسة عبد العال (2018)، باسم وخضير (2020) بأن يكون تنمية مهارات القرن الحادي والعشرين من الأهداف الأساسية لبرامج إعداد المعلمين خصوصا في مواد العلوم والرياضيات، وبالتركيز على إكساب الطلبة مهارات القرن

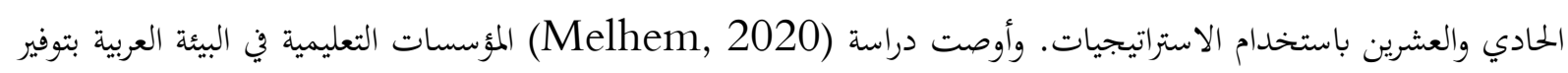
وتعزيز اكتساب مهارات القرن الحادي والعشرين لجميع المتعلمين لتمكينهم من البقاء بقوة في سوق العمل من خلال إعادة العادئ النظر في البرامج والمقررات الجامعية لتتوافق مع متطلبات ومهارات العصر الحالي.

ونبعت هذه الدراسة أيضاً من شعور الباحثان بوجود معوقات يواجها معلمي مادني العلوم والرياضيات في توظيف

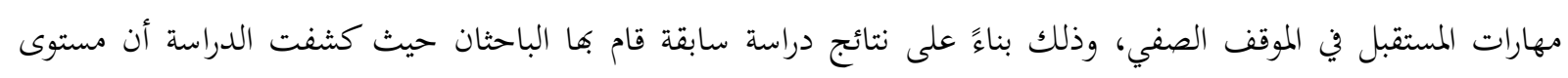

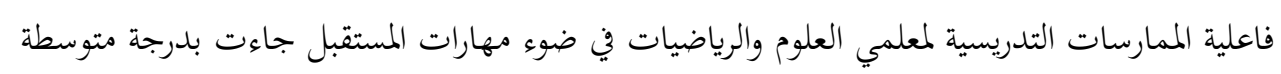
(الشيدي، السعيدي، 2021)، وهذا يتطلب القيام بدراسة علمية للكشف عن المعوقات التي تضعف من توظيف معلمي مادتي العلوم والرياضيات لمهارات المستقبل في الموقف الصفي، وهو ما تمدف الدراسة الحالية إلى تحقيقه.

\section{وتتلخص مشكلة الدراسة في الإجابة عن الأسئلة الآتية:}

1. ما درجة المعوقات التي يواجها معلمو العلوم والرياضيات في توظيف مهارات المستقبل بمدارس التعليم الأساسي بسلطنة عمان من وجهة نظر المعلمين والمشرفين التربويين؟ 2. هل توجد فروق ذات دلالة إحصائية في درجة المعوقات التي يواجها معلمو العلوم والرياضيات في توظيف مهارات المستقبل

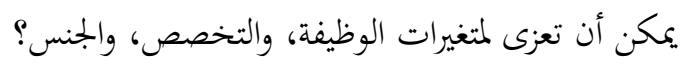

\section{أهداف الدراسة:}

تسعى هذه الدراسة إلى تحقيق الأهداف التالية:

1. تحديد درجة المعوقات التي تحول دون توظيف معلمي العلوم والرياضيات في توظيف مهارات المستقبل في مدارس التعليم الأساسي.

2. الكشف عن أثر متغيرات الوظيفة والجنس والتخصص في تقديرات معلمي العلوم والرياضيات لدرجة المعوقات التي تحول دون توظيفهم مهارات المستقبل في مدارس التعليم الأساسي. 
تكتسب الدراسة أهميتها من المناهج المطورة في العلوم والرياضيات والتي سعت وزارة التربية والتعليم العمانية لربطها بمهارات

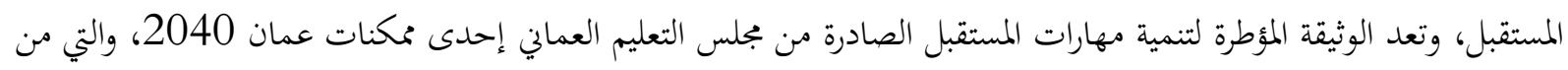

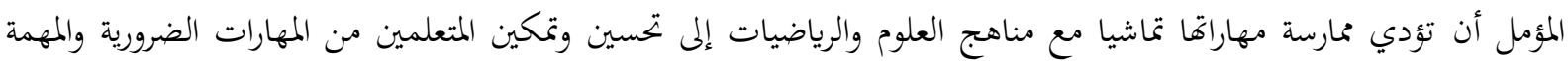

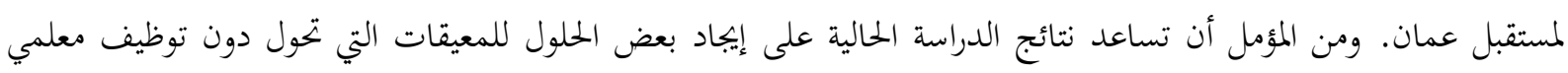

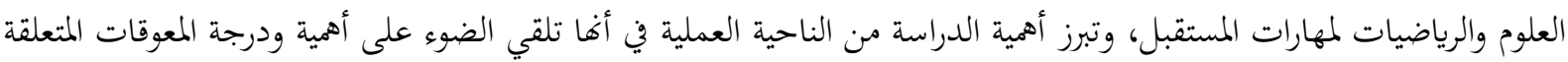
بالمنهج، طرائق التدريس الحديثة، المعلم، والمتعلمين، والتقويم التربوي.

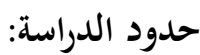

الحدود الموضوعية: اقتصرت الدراسة على تحديد درجة معوقات توظيف مهارات المستقبل في مادتي العلوم الرياضيات. الحدود البشرية: اقتصرت الدراسة على معلمي العلوم والرياضيات والمشرفين التربويين بمرحلة التعليم الأساسي للصفوف بمرحلة التعليم الأساسي.(12-5 (5)

الحدود المكانية: اقتصرت على المدارس الحكومية بمرحلة التعليم الأساسي للصفوف بمرحلة التعليم الأساسي (5-12) في محافظات: مسقط، شمال الباطنة، والبريمي، والداخلية. الحدود الزمانية: أجريت الدراسة في العام الدراسي (2021/ 2022).

مصطلحات الدراسة:

هالمعوقات: أوضاع صعبة يكتنفها شيء من الغموض يحول دون تحقيق الأهداف المرجوة بكفاءة وفاعلية (أبو عابد، 2005).

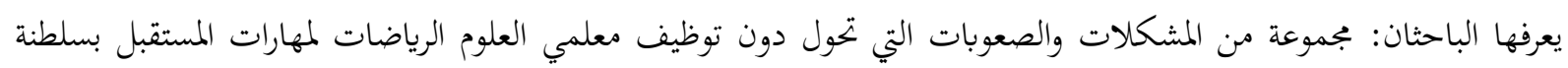
عمان. وهي موزعة على خمسة بحالات هي: المعوقات المتعلقة بمنهج العلوم والرياضات، والمعوقات المتعلقة بطرائق تدريس مهارات المستقبل.والمعوقات التي تتعلق بالمعلم، والمعوقات التي تتعلق بالمتعلم، والمعوقات التي تتعلق بقياس مهارات المستقبل وتقويمها، ومقاسة بمقياس خماسي (كبيرة جداً، كبيرة، متوسطة، قليلة، قليلة جداً). مهارات المستقبل: مجموعة من المهارات الضرورية لضمان استعداد المتعلمين للحياة والعمل وتتضمن الاستخدام الأمثل

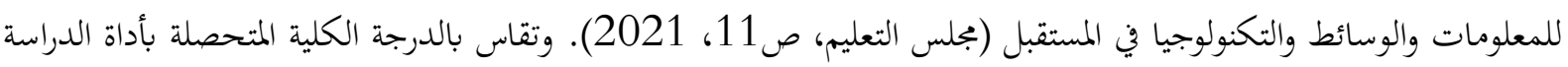
في ضوء مقياس ليكرت الخماسي. ه معوقات مهارات المستقبل: يعرفها الباحثان: هي مجموعة من المشكلات أو الصعوبات التي تحول دون توظيف معلمي العلوم والرياضيات لمهارات المستقبل بسلطنة عمان. وهي ترتبط بخمسة مجالات من المعوقات (المنهج، طرائق التدريس الحديثة، المعلم،

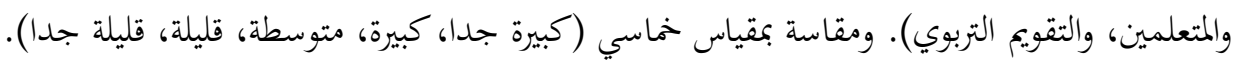
مشرفو العلوم والرياضيات: هم مشرفو العلوم والرياضيات، تخصُصي العلوم والرياضيات، العاملون في المحافظات التعليمية 


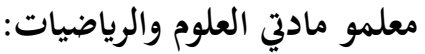

هم معلمو العلوم والرياضيات، العاملون في مدارس الحلقة الثانية من التعليم الأساسي (5-12)، المحافظات التعليمية بسلطنة

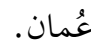

الطريقة والإجراءات مجتمع الدراسة

أ) المعلمون: تألف مجتمع الدراسة من جميع معلمي مادتي العلوم والرياضيات العاملين في مدارس التعليم الأساسي الحلقة الثانية،

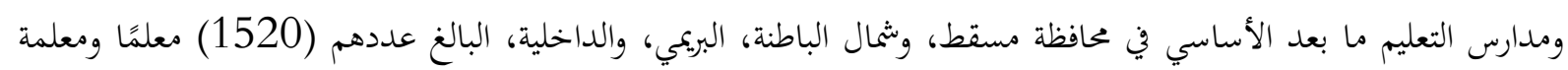

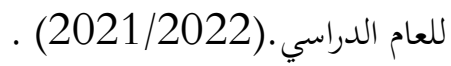

ب) المثرفين التربوين: تألف مجتمع الدراسة من جميع المشرفين التربويين لمادتي العلوم والرياضيات المدارس العاملين في مدارس التعليم الأساسي الحلقة الثانية، ومدارس التعليم ما بعد الأساسي، في محافظة مسقط، وشثمال الباطنة، البريمي، والداخلية البالغ

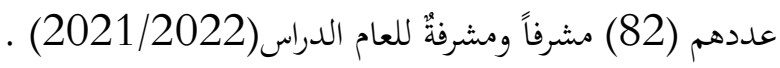

عينة الدراسة (المعلمين): ( تكونت عينة الدراسة من (157) معلمًا ومعلمة، وتم اختيارهم بالطريقة العشوائية البسيطة، وهي الطريقة المناسبة نظرًا

لحجم المجتمع، ويوضح جدول (1) متغيرات الدراسة.

$$
\text { عينة الدراسة (المشرفين): }
$$

وتكونت عينة الدراسة من (51) مشرفاً ومشرفة، وتم اختيارهم بالطريقة العشوائية البسيطة، وهي الطريقة المناسبة نظراً

لحجم المجتمع، ويوضح جدول (1) متغيرات الدراسة. جدول (1) توزيع أفراد عينة الدراسة حسب متغير الجنس للعام الدراسي 2021/2020

\begin{tabular}{|c|c|c|c|}
\hline النسبة المئوية & العدد & \multicolumn{2}{|c|}{ متغيرات الدراسة } \\
\hline $24.5 \%$ & 51 & مشرف تربوي & \multirow[t]{2}{*}{ الوظيفة } \\
\hline $75.5 \%$ & 157 & معلم & \\
\hline $54.8 \%$ & 114 & ذكر & \multirow[t]{2}{*}{ الجنس } \\
\hline $45.2 \%$ & 94 & أنثى & \\
\hline $100 \%$ & 208 & \multicolumn{2}{|c|}{ المجموع } \\
\hline
\end{tabular}

منهج الدراسة:

اعتمد الباحثان في الدراسة المنهج الوصفي، والذي يعتبر مناسباً لهذا النوع من الدراسات، وذلك عن طريق وصف الظاهرة من خلال جمع البيانات الميدانية حولها بواسطة أداة الاستبانة. 
أداة الدراسة (الاستبانة):

لتحقيق أهداف الدراسة قام الباحثان بإعداد استبانة، حيث تكونت أداة الدراسة في صورةا النهائية من (39) عبارة،

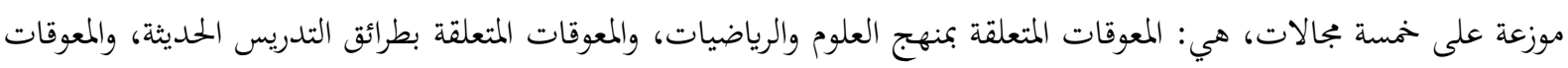
المتعلقة بالمعلم، والمعوقات المتعلقة بالمتعلمين، والمعوقات المتعلقة بالتقويم التربوي.

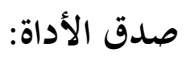

تَّ قياس صدق أداة الدراسة من خلال التحقق من الصدق الظاهري وذلك بعرضها على مجموعة من المحكمين المتخصصين في مجال المناهج وطرق التدريس، والمتخصصين في مهارات المستقبل ثم إجراء التعديلات المقترحة.

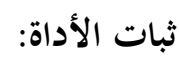

تم التأكد من ثبات الأداة من خلال تطبيقها على عينة تجريبية مكونة من (10) مشرف ومشرفة، (10) معلم ومعلمة،

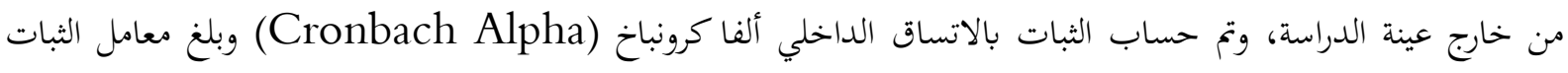
الكلي للأداة (0,869)، بما يفيد ثبات الأداة، وقابليتها للتطبيق من أجل تحقيق أهدات أهداف الدراسة.

\section{تطبيق الدراسة:}

بعد تحديد مشكلة الدراسة، وأسئلتها ومتغيراتا، وبعد الانتهاء من إعداد أداة الدراسة، والتأكد من صدقها وثباها، طبقت على عينة الدراسة في الفصل الدراسي الأول (2022/2021) عن طريق توزيع الرابط في البريد الإلكتروني وبواسطة برنامج "الواتس اب" لعينة الدراسة.

\section{المعالجة الإحصائية:}

لتحقيق أهداف الدراسة استخدم الباحثان برنامج الرزمة الإحصائية (SPSS) في تحليل البيانات التي تم جمعها بعد تطبيق أداة الدراسة وهي: وهي: معامل الثبات ألفاكرونباخ، والمتوسطات الحسابية والانحرافات المعيارية والأهمية النسبية (الرتبية)، وتحليل التباين الأحادي، الموضح في الجدول (2) لتفسير تقديرات أفراد العينة. جدول (2) المعيار الإحصائي لتفسير تقديرات أفراد العينة

\begin{tabular}{|c|c|c|}
\hline درجة المعوقات/ التحديات & مدى الدرجات & الدرجة \\
\hline كبيرة جدا & $4.20-5.00$ & 5 \\
\hline كبيرة & $3.40-4.19$ & 4 \\
\hline متوسطة & $2.60-3.39$ & 3 \\
\hline قليلة & $1.80-2.59$ & 2 \\
\hline قليلة جداً & $0-1.79$ & 1 \\
\hline
\end{tabular}




\section{نتائج الدراسة ومناقشتها}

\section{نتائج السؤال الأول ومناقشتها:}

للإجابة عن هذا السؤال ونصه: ما درجة المعوقات التي يواجهها معلمو العلوم والرياضيات في توظيف مهارات المستقبل

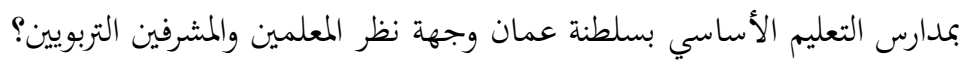

تم استخراج المتوسطات الحسابية والانخرافات المعيارية لجميع بجالات أداة الاستبانة والمجال العام حيث تم ترتيبها ترتيبا

تنازلياً كما هو واضح في الجدول (3)

جدول (3) المتوسطات الحسابية والانخرافات المعيارية لمجالات الاستبانة والمتوسط العام للدراسة

\begin{tabular}{|c|c|c|c|c|}
\hline التحدي & المعياري الانراف & المستوسطي & 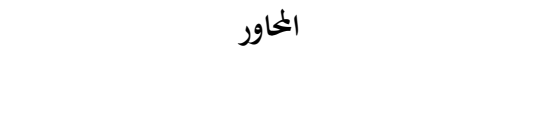 & s \\
\hline كبيرة & 0.73 & 3.81 & المعوقات التي تتعلق بالمعلم. & 1 \\
\hline كبيرة & 0.72 & 3.80 & المعوقات المتعلقة بالمتعلم. & 2 \\
\hline كبيرة & 0.62 & 3.60 & المعوقات المتعلقة بطرائق تدريس مهارات المستقبل. & 3 \\
\hline كبيرة & 0.75 & 3.53 & المعوقات المتعلقة بقياس مهارات المستقبل وتقويكها. & 4 \\
\hline متوسطة & 0.63 & 3.39 & المعوقات المتعلقة بمنهج الرياضيات والعلوم. & 5 \\
\hline كبيرة & 0.62 & 3.64 & المتوسط العام & \\
\hline
\end{tabular}

يتضح من الجدول (3) أنه على المستوى العام فإن درجة المعوقات التي يواجهها معلمو العلوم والرياضيات في توظيف

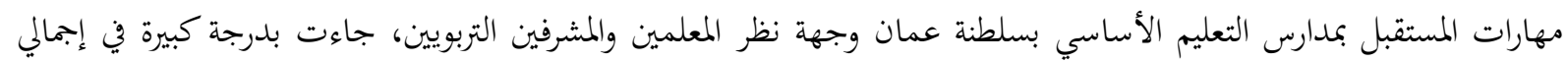

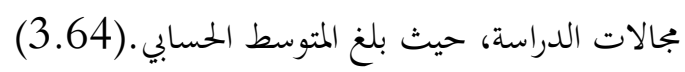

وقد تراوحت المتوسطات الحسابية لكل مجال من مجالات أداة الدراسة بين (3.81-3.39) بين الكبيرة والمتوسطة، حيث جاء بجال "المعوقات المتعلقة بالمعلم" في المرتبة الأولى بمتوسط حسابي (3.81) بدرجة كبيرة، في حين جاء مباء مجال "المعوقات المتعلقة بالمتعلم" في المرتبة الثانية بمتوسط حسابي (3.80) بدرجة كبيرة. وجاء في المرتبة الثالثة مجال " المعوقات المتعلقة بطرائق

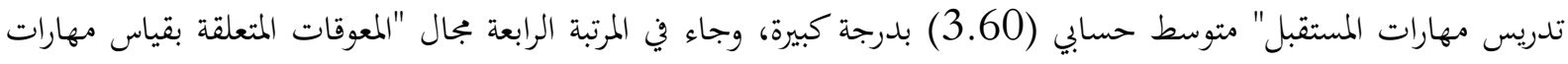
المستقبل وتقويمها" بمتوسط حسابي (3.53) بدرجة كبيرة، في حين جاء في المرتبة الأخير بجال " المعوقات المتعلقة بمنهج الرياضيات والعلوم" بمتوسط حسابي (3.39) بدرجة متوسطة. ويمكن أن تعزى هذه النتيجة إلى كثرة الأعمال الإدارية والفنية التي

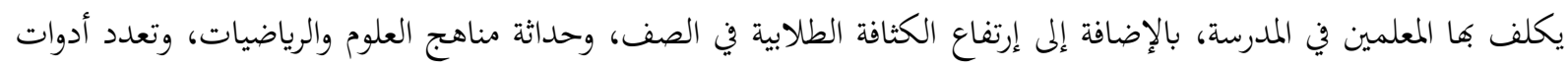
التقويم وتقنياته في ضوء المناهج المطورة، كما يعود ذلك على قلة البرامج التدريبية، وصعوبة المناهج التي تطبق لأول مره في المدارس

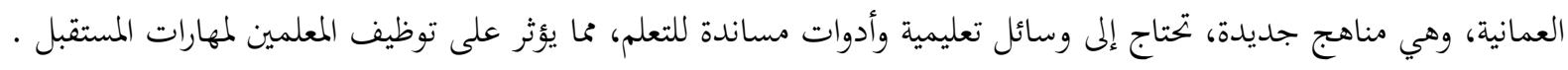
أما عما أظهرته نتائج الدراسة حول كل مجال من مجالات الدراسة فقد جاءت المتوسطات الحسابية والاخرافات المعيارية

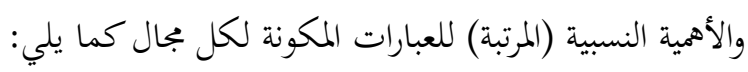

\section{البجال الأول: المعوقات المتعلقة بمنهج الرياضيات والعلوم}

المتوسطات الحسابية والانحرافات المعيارية والأهمية النسبية (المرتبة) للعبارات المكونة للمجال الأول المعوقات المتعلقة بمنهج

الرياضيات والعلوم، ويوضح ذلك الجدول (4) 
جدول (4) المتوسطات الحسابية والانرافات المعيارية لمجال المعوقات المتعلقة بمنهج الرياضيات والعلوم

\begin{tabular}{|c|c|c|c|c|}
\hline 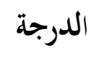 & الانخراف المعياري & المتوسط الحسابي & 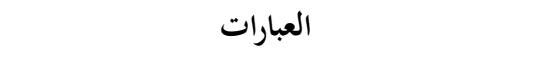 & b \\
\hline كبيرة & 1.04 & 3.58 & ضعف مراعاة المنهج لحاجات المتعلمين وميولم. & 1 \\
\hline كبيرة & 1.09 & 3.47 & ضعف استخدام المنهج للتكنولوجيا التعليمية. & 2 \\
\hline كبيرة & 1.07 & 3.45 & افتهارات المنهج للأنشطة التي تساعد على تطبيق & 3 \\
\hline كبيرة & 1.01 & 3.38 & والمشكلات ارتباط الجانب المعريف بالتطبيقات & 4 \\
\hline كبيرة & 1.10 & 3.38 & عدم مناسبة الأهداف والمحتوى لمهارات المستقبل. & 5 \\
\hline كبيرة & 1.13 & 3.37 & لا لا يهتم المنهج بتدريس المحتوى الذي يساعد على & 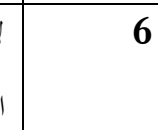 \\
\hline كبيرة & 0.98 & 3.36 & ضعفف تضمين المنهج للمفاهيم التي تشكلت لدى & 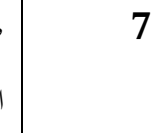 \\
\hline متوسطة & 1.10 & 3.16 & لا يقدم المنهج فرص للمتعلم للتعلم الذاتي. & 8 \\
\hline كبيرة & 0.83 & 3.39 & & المتوسط العام \\
\hline
\end{tabular}

يتضح من الجدول (4) بأنه على المستوى العام فإن درجة المعوقات التي يواجهها معلمو العلوم والرياضيات في توظيف مهارات المستقبل بمدارس التعليم الأساسي بسلطنة عمان وجهة نظر المعلمين والمشرفين التربويين في بجال المعوقات المتعلقة بمنهج الرياضيات والعلوم جاءت بدرجة كبيرة حيث بلغ المتوسط الحسابي (3.39) واحتل بذلك المرتبة الخامسة بالنسبة لمجالات الدراسة

أما المتوسطات الحسابية لكل عبارة من عبارات المجال فقد تراوحت بين (3.58-3.16) بين الكبيرة والمتوسطة، وكانت الأكثر معوقاً عبارة "ضعف مراعاة المنهج لحاجات المتعلمين وميولم" بمتوسط حسابي (3.58) وبدرجة كبيرة. في حين كانت

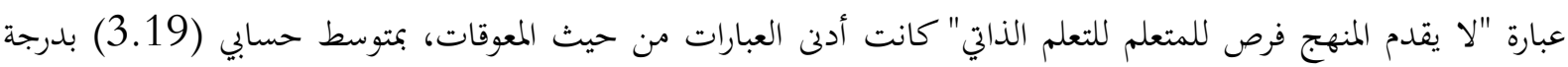

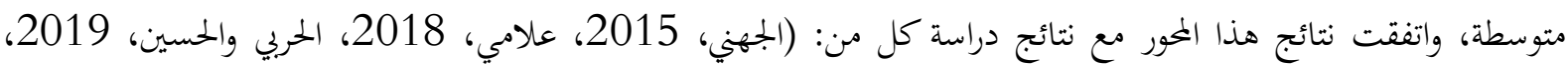
عليان والمزروعي، 2020).

وتعزى هذه النتيجة إلى حداثة المناهج وبعض الأخطاء التي تحتويها، وتعدد محاور وبجالات محتوى المناهج، وزيادة عدد الوحدات الدراسية المضمنة في المنهج حيث بلغت في بعض المراحل إلى ضعف عدد الوحدات التي تضمنتها المناهج السابقة. 


\section{المجال الثاين: المعوقات المتعلقة بطرائق تدريس مهارات المستقبل}

المتوسطات الحسابية والانحرافات المعيارية والأهمية النسبية (المرتبة) للعبارات المكونة للمجال الثاني المتعلقة بطرائق تدريس

$$
\text { مهارات المستقبل، ويوضح ذلك الجدول (5) . }
$$

جدول (5) المتوسطات الحسابية والاخرافات المعيارية لمجال المعوقات المتعلقة بطرائق تدريس مهارات المستقبل.

\begin{tabular}{|c|c|c|c|c|}
\hline الدرجة & الانحراف المعياري & المتوسط المتي & العبارات & b \\
\hline كبيرة & 1.07 & 4.13 & 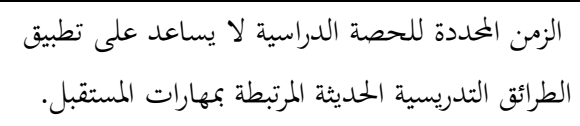 & 1 \\
\hline كبيرة & 0.97 & 4.05 & 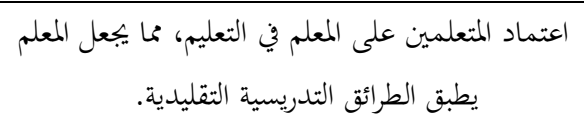 & 2 \\
\hline كبيرة & 0.99 & 3.90 & ضعف البيئة التقنية لتوظيف استراتيجيات التعليم & 3 \\
\hline كبيرة & 1.10 & 3.54 & 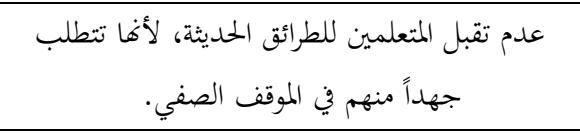 & 4 \\
\hline كبيرة & 0.96 & 3.37 & لا تساعد على توظيف المهارات في المواقف التعليمية & 5 \\
\hline كبيرة & 1.07 & 3.33 & عدم إلمام المعلم بالاستراتيجيات التدريسية الحديثة & 6 \\
\hline كبيرة & 1.06 & 3.30 & 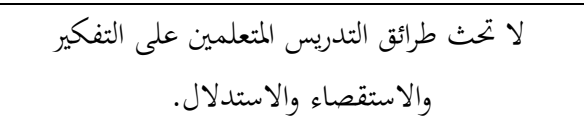 & 7 \\
\hline كبيرة & 1.07 & 3.23 & الطرائق التدريسية لا تساعد على تنمية مهارات & 8 \\
\hline كبيزة & 0.75 & 3.60 & المتوسط العام & \\
\hline
\end{tabular}

يتضح من الجدول (5) بأنه على المستوى العام فإن درجة المعوقات التي يواجهها معلمو العلوم والرياضيات في توظيف مهارات المستقبل بمدارس التعليم الأساسي بسلطنة عمان وجهة نظر المعلمين والمشرفين التربويين في مجال المعوقات المتعلقة بطرائق تدريس مهارات المستقبل، جاءت بدرجة كبيرة حيث بلغ المتوسط الحسابي (3.60) واحتل بذلك المرتبة الثالثة بالنسبة لمجالات الدراسة الخمسة.

أما المتوسطات الحسابية لكل عبارة من عبارات المجال فقد تراوحت بين (4.13-3.23) بدرجة الكبيرة، وكانت الأكثر

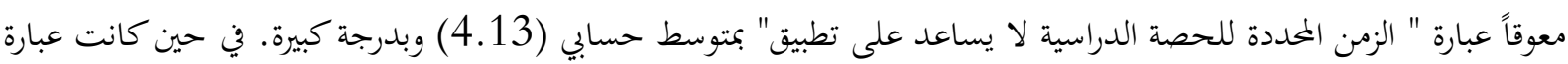

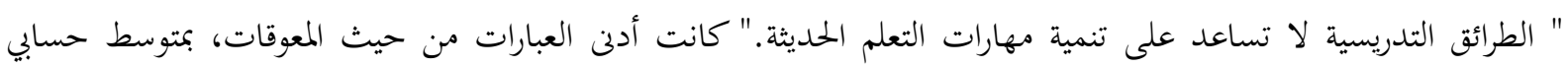

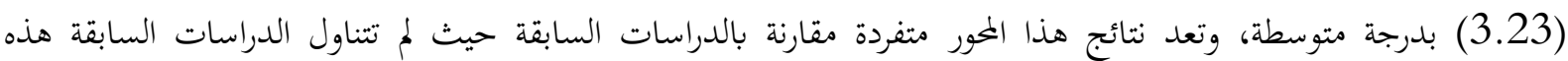
المعوقات في حدود علم الباحثين.

وتعزى هذه النتيجة إلى عدم تمكين المعلمين من تعلم الاستراتيجيات الحديثة، وعدم وضوحها في المنهج حيث جاءت

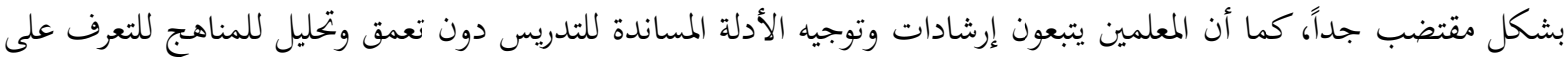
تلك الاستراتيجيات والطرائق المدبجة في كتاب الطالب. 
المجال الثالث: المعوقات التي تتعلق بالمعلم.

المتوسطات الحسابية والانرافات المعيارية والأهية النسبية (المرتبة) للعبارات المكونة للمجال الثالث المعوقات المتعلقة

$$
\text { بالمعلم، ويوضح ذلك الجدول.(6) }
$$

جدول (6)المتوسطات الحسابية والانخرافات المعيارية لمجال المعوقات المتعلقة بالمعلم

\begin{tabular}{|c|c|c|c|c|}
\hline 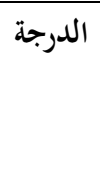 & المعياري & المسابي & 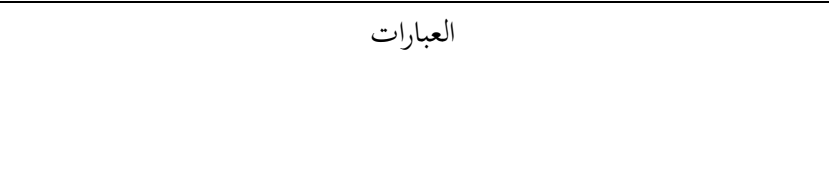 & s \\
\hline كبيرة & 0.85 & 4.42 & كثرة الأعباء الإدارية التي يقوم .ما المعلم. & 1 \\
\hline كبيرة & 1.02 & 4.10 & لا يتيح وقت الحصة فرص للحوار الاجتماعي بين المتعلمين. & 2 \\
\hline كبيرة & 1.04 & 3.90 & صعوبة توجيه الدرس في ضوء تفكير المتعلمين وخبراقم السابقة لأن هذا يمتاج & 3 \\
\hline كبيرة & 1.04 & 3.90 & قلة البرامج التدرييية المتعلقة برفع كفاءة المعلم. & 4 \\
\hline كبيرة & 1.00 & 3.54 & صعوبة استخدام الطرائق التدريسية التي تركز على نشاط المتعلم. & 5 \\
\hline كبيرة & 1.03 & 3.48 & صعوبة توجيه المتعلمين على اكتساب المعرفة نتيجة لتفاعلهم مع العالم الخارجي. & 6 \\
\hline كبيرة & 1.06 & 3.35 & عدم الاقتناع بأهمية توظيف مهارات المستقبل في الموقف الصفي & 7 \\
\hline كبيرة & 0.73 & 3.81 & المتوسط العام & \\
\hline
\end{tabular}

يتضح من الجدول (6) بأنه على المستوى العام فإن درجة المعوقات التي يواجهها معلمو العلوم والرياضيات في توظيف

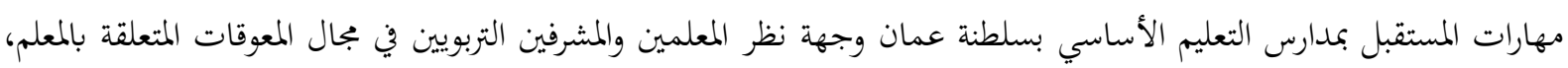

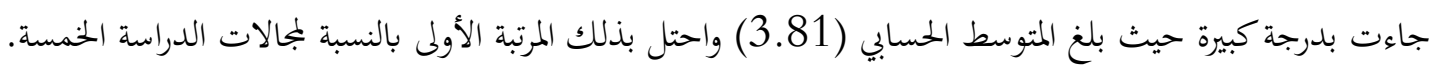

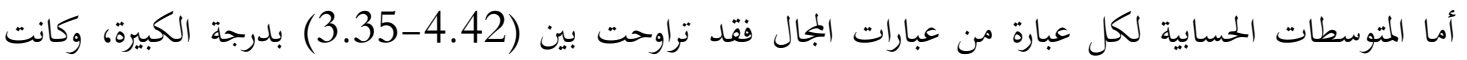

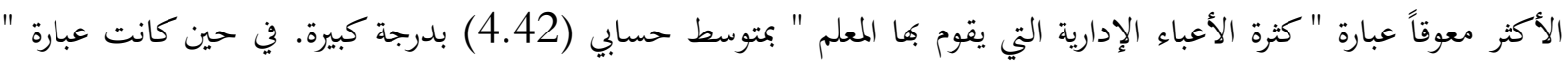

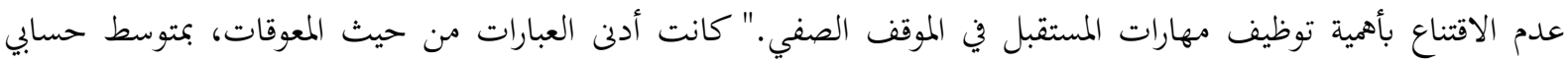
(3.35) بدرجة كبيرة، وجاءت نتائج هذا المحور متفقة مع دراسة كل من: (الجهني، 2015، علامي، 2018). وتعزى هذه النتيجة إلى تعدد المناهج التي يدرسها المعلمون في بعض المدارس، وإرتفاع أنصبتهم، وتغيب البعض منهم

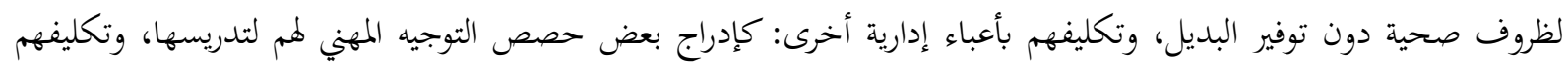
بأنشطة المدرسة مثل الجدول المدرسي. الجمال الرابع: المعوقات المتعلقة بالمتعلم. المتوسطات الحسابية والانحرافات المعيارية والأهمية النسبية (المرتبة) للعبارات المكونة للمجال الثاني المتعلقة بالمتعلم، ويوضح ذلك الجدول.)(7) جدول (7) المتوسطات الحسابية والانخرافات المعيارية لمجال المعوقات المتعلقة بالمتعلم

\begin{tabular}{|c|c|c|c|c|}
\hline الدرجة & الانمراف & المتوسط & 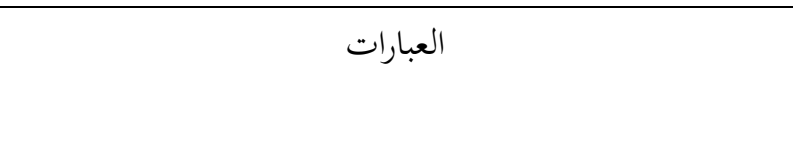 & م \\
\hline 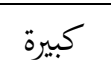 & 0.91 & 4.37 & إرتفاع كثافة المتعلمين في الصف. & 1 \\
\hline 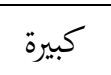 & 0.92 & 4.16 & اعتماد المتعلمين الضعاف على زملائهم المتفوقين في المجموعات. & 2 \\
\hline
\end{tabular}




\begin{tabular}{|c|c|c|c|c|}
\hline 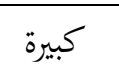 & 0.99 & 4.01 & ضعف مهارات القراءة والكتابة لدى المتعلمين. & 3 \\
\hline كبيرة & 0.95 & 3.86 & عدم قيام المتعلمين بإنجاز المهام المكلفين بها. & 4 \\
\hline كبيرة & 1.07 & 3.75 & لا يسمح وقت الحصة بتعبير المتعلم عن رأيه. & 5 \\
\hline 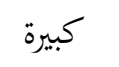 & 0.93 & 3.69 & ضعف الثقة بالنفس لدى بعض المتعلمين. & 6 \\
\hline كبيرة & 1.06 & 3.43 & عدم تقبل المتعلمين للأنشطة التي تتطلب مشاركتهم في الموقف & 7 \\
\hline 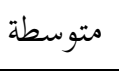 & 1.22 & 3.17 & تكرار غياب المتعلمين بصورة مستمرة طوال العام الدراسي. & 8 \\
\hline كبيرة & 0.75 & 3.60 & المتوسط العام & \\
\hline
\end{tabular}

يتضح من الجدول (7) بأنه على المستوى العام فإن درجة المعوقات التي يواجهها معلمو العلوم والرياضيات في توظيف مهارات المستقبل بمدارس التعليم الأساسي بسلطنة عمان من وجهة نظر المعلمين والمشرفين التربويين في مجال المعوقات المتعلقة بالمتعلم جاءت بدرجة كبيرة حيث بلغ المتوسط الحسابي (3.69) واحتل بذلك المرتبة الثانية بالنسبة لمجالات الدراسة الخمسة فئسة أما المتوسطات الحسابية لكل عبارة من عبارات المجال فقد تراوحت بين (4.37-3.17) بدرجة كبيرة، وكانت الأكثر معوقاً عبارة " إرتفاع كثافة المتعلمين في الصف" بمتوسط حسابي (4.37) وبدرجة كبيرة. في حين كانت عبارة تكرار غياب

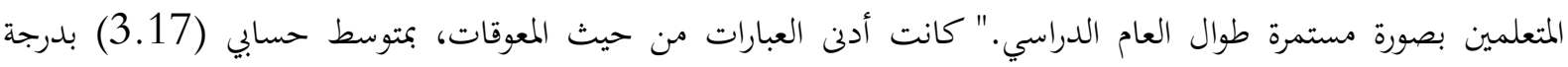
متوسطة، واتفقت نتائج هذا المحور مع دراسات كل من: (الجهني، 2015، عليان والمزروعي، 2020). وتعزى هذه النيجة إلى ضعف الدافعية لدى المتعلمين، وتصوراتم المسبقة حول صعوبة تعلم العلوم والرياضيات، وقلة

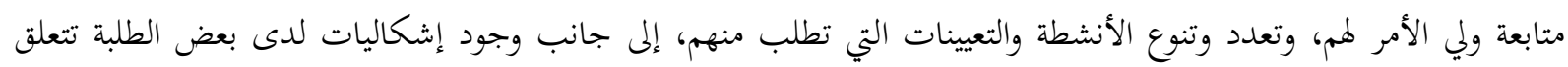
بمهارات القراءة والكتابة.

\section{الجمال الخامس: المعوقات المثعلقة بقياس مهارات المستقبل وتقويمها.}

المتوسطات الحسابية والانحرافات المعيارية والأهمية النسبية (المرتبة) للعبارات المكونة للمجال الخامس المعوقات المتعلقة

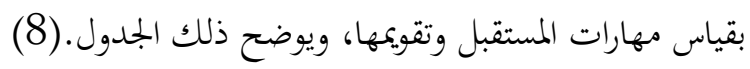
جدول (8) المتوسطات الحسابية والاخرافات المعيارية لمجال المعوقات المتعلقة بقياس مهارات المستقبل ونعبل وتقويمها

\begin{tabular}{|c|c|c|c|c|}
\hline 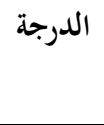 & اللمعياري & المستوسطي & 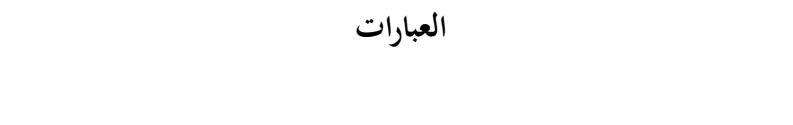 & b \\
\hline كبيرة & 0.88 & 4.04 & تعتمد أساليب التقويم على الكتابة بصورة كبيرة. & 1 \\
\hline كبيرة & 0.81 & 3.65 & يرتبط نظام التقييم للمعايير بلمنهج الدراسي والانماء المهني للكوادر التدرييية & 2 \\
\hline كبيرة & 0.94 & 3.63 & لا تشجع أدوات التقويم المتعلمين على قياس مهارات المستقبل لدى الطلبة. & 3 \\
\hline كبيرة & 0.84 & 3.55 & تركز المؤشرات على قياس مهارات التفكير العليا & 4 \\
\hline كبيرة & 0.92 & 3.53 & عدم إعطاء المتعلمين الفرصة للتقويم الذاتي وتقويم الأقران. & 5 \\
\hline 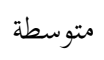 & 1.00 & 3.32 & ضعف العلاقة بين أساليب التقويم والأهداف التعليمية. & 6 \\
\hline 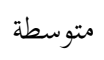 & 0.92 & 3.30 & يستخدم التقويم الالكتروني وبرجياته لمتابعة مدى تطبيق المهارات وتقييمها & 7 \\
\hline 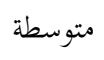 & 0.94 & 3.29 & لا تراعي الأسئلة الفروق الفردية بين المتعلمين. & 8 \\
\hline كبيرة & 0.63 & 3.53 & المتوسط العام & \\
\hline
\end{tabular}


يتضح من الجدول (8) بأنه على المستوى العام فإن درجة المعوقات التي يواجهها معلمو العلوم والرياضيات في توظيف

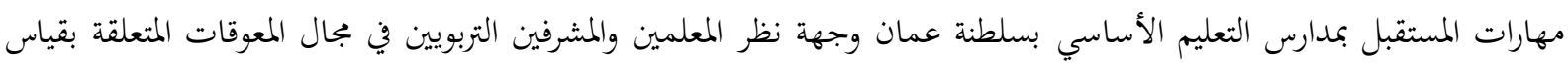
مهارات المستقبل وتقويمها جاءت بدرجة كبيرة حيث بلغ المتوسط الحسابي (3.69) واحتل بذلك المرتبة الرابعة بالنسبة لمجالات

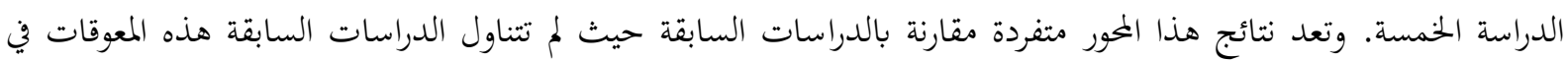
حدود علم الباحثين.

أما المتوسطات الحسابية لكل عبارة من عبارات المجال فقد تراوحت بين (4.04-3.29) بدرجة الكبيرة، وكانت الأكثر

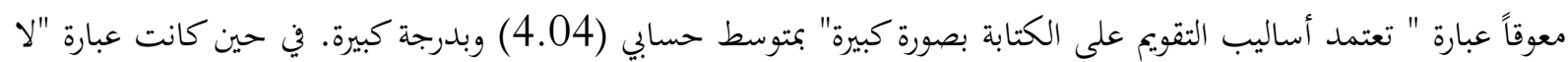
تراعي الأسئلة الفروق الفردية بين المتعلمين" كانت أدنى العبارات من حيث المعوقات، بمتوسط حسابي (3.29) بدرجة متوسطة. وتعزى هذه النتيجة إلى تعدد تقنيات التقويم وأدواته وعدم تمكن المعلمين من ممارستها في المواقف الصفية، وضعف

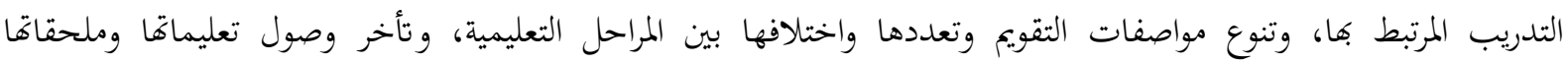
كلمعين.

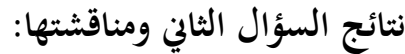

للإجابة عن السؤال الثاني الذي نصه: هل توجد فروق ذات دلالة إحصائية في درجة المعوقات يواجهها معلمو العلوم

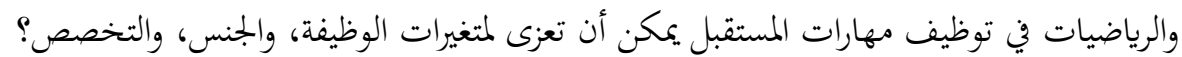

أ) الوظيفة للكشف عن أثر متغير الوظيفة تم استخدام المتوسطات الحسابية والاخرافات المعيارية واختبار (T-Test)، ويوضح ذلك

الجدول (9).

جدول (9) المتوسطات الحسابية والانحرافات المعيارية واختبار(T-Test) تبعاً لمتغير الوظيفة

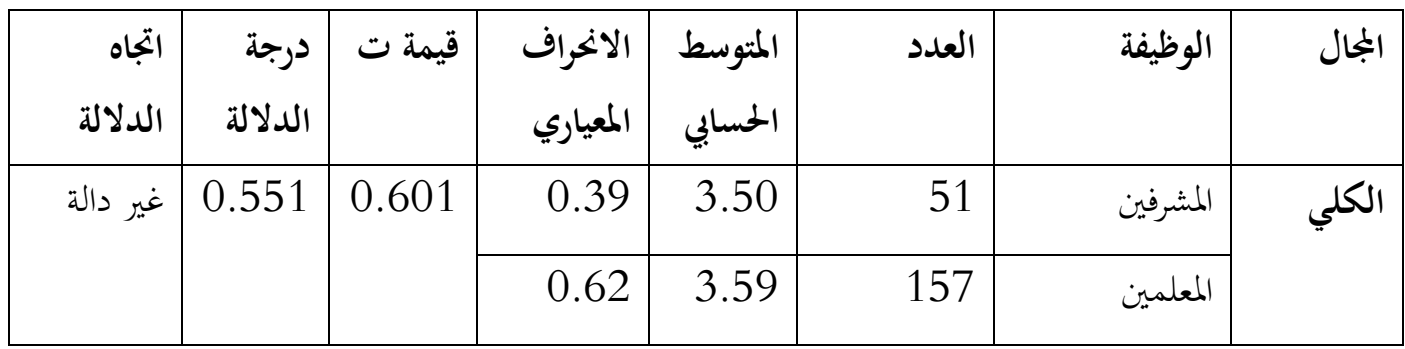

تشير نتائج الجدول (9) إلى عدم وجود فروق ذات دلالة إحصائية عند درجة الدلالة (م=0.05)في درجة المعوقات التي يواجهها معلمو العلوم والرياضيات في توظيف مهارات المستقبل يمكن أن تعزى إلى متغير الوظيفة. واتفقت نتائج هذا السؤال مع نتيجة دراسة (علامي، 2018). ويمكن تفسير هذه النتيجة بأن كل من المشرف والمعلم يشتركون في كثير من المهام المرتبطة

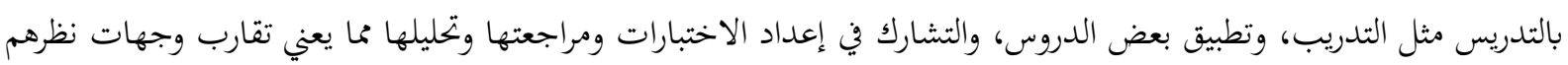
حول كثير من موضوعات التدريس.

للإجابة عن هذا السؤال (متغير التخصص) تم استخدام المتوسطات الحسابية والانخرافات المعيارية واختبار(T-Test)، ويوضح الجدول (10) ذلك. 
جدول (10) المتوسطات الحسابية والانخرافات المعيارية واختبار( T-Test) تبعاً لمتغير التخصص

\begin{tabular}{|c|c|c|c|c|c|c|c|}
\hline الداه & درجة & قيمة ت & الالمعياري & المتوسط المسابي & العدد & الوظيفية & الججال \\
\hline \multirow[t]{2}{*}{ دالة } & \multirow[t]{2}{*}{0.005} & \multirow[t]{2}{*}{2.842} & 0.59 & 3.73 & 139 & الرياضيات & \multirow[t]{2}{*}{ التخصص } \\
\hline & & & 0.64 & 3.47 & 69 & العلوم & \\
\hline
\end{tabular}

تشير نتائج الجدول (10) إلى وجود فروق ذات دلالة إحصائية عند درجة الدلالة (0.05=0)بين درجة المعوقات التي يواجهها معلمو العلوم والرياضيات في توظيف مهارات المستقبل تعزى إلى التخصص ولصالح مادة الرياضيات، وتتفق هذه النتيجة مع ما توصلت إليه دراسة الحربي والحسين(2019). ويعزى ذلك إلى عدة عوامل منها طول منهج الرياضيات مقارنة بالعلوم، وكذلك العبء التدريسي، والتطوير المستمر للمناهج، والتعيينات الجديدة في الرياضيات.

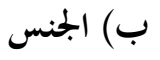

للإجابة عن هذا السؤال (متغير الجنس) تم استخدام المتوسطات الحسابية والانخرافات المعيارية واختبار (T-Test)، ويوضح الجدول (11) ذلك. جدول (11) المتوسطات الحسابية والانحرافات المعيارية واختبار(T-Test) تبعاً لمتغير الجنس

\begin{tabular}{|c|c|c|c|c|c|c|c|}
\hline الدالة الداه & الدلالة & قيمة ت & الالمعراف & المتوسط & العدد & الجنس & البجال \\
\hline \multirow[t]{2}{*}{ غير دالة } & \multirow[t]{2}{*}{0.087} & \multirow[t]{2}{*}{1.719} & 0.59 & 3.71 & 114 & ذكور & \multirow[t]{2}{*}{ لكلي } \\
\hline & & & 0.64 & 3.56 & 94 & إناث & \\
\hline
\end{tabular}

تشير نتائج الجدول (11) إلى عدم وجود فروق ذات دلالة إحصائية عند درجة الدلالة (0.05=0 ه) بين درجة المعوقات يواجهها معلمو العلوم والرياضيات في توظيف مهارات المستقبل، وتختلف هذه النتيجة مع ما توصلت إليه دراسة الحربي والحسين

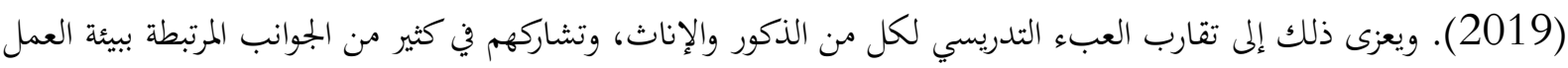
كالتحضير والتدريب من خلال مجتمعات التعلم المهنية المشتركة.

\section{توصيات الدراسة}

في ضوء النتائج التي توصلت إليها الدراسة، يوصي الباحثان بالآتي: 1. تخفيف الأعباء الإدارية عن المعلمين.

2. حث المعلمين على تطبيق الاستراتيجيات التدريسية الحديثة، والأنشطة التقويمية التي تركز على مهارات المستقبل.

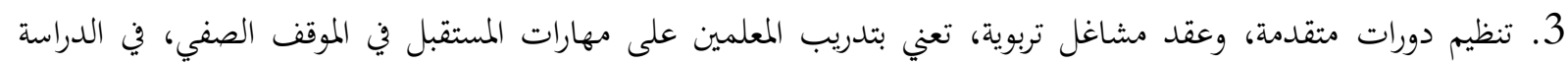
الجامعية، وأثناء الخدمة. 


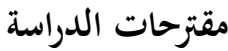

يوصي الباحثان إجراء مجموعة من الدراسات المرتبطة بموضوع الدراسة الحالية، وهي كالآتي: 1. دراسة الاحتياجات التدريبة اللازمة لتوظيف مهارات المستقبل في التدريس من قبل معلمي العلوم والرياضيات بالحلقة الثانية من التعليم الأساسي.

2. دراسة أثر البرامج التدريبية أثناء الخدمة في توظيف معلمو العلوم والرياضيات لمهارات المستقبل على المستوى التحصيلي للطلبة . 


\section{المراجع}

أبوعابد، محمد. (2005). المرجع في الإشراف التربوي والعملية الإشرافية. دار الكتاب الثقافي.

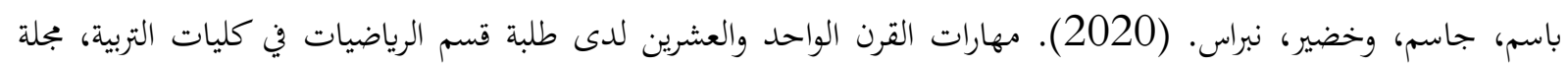

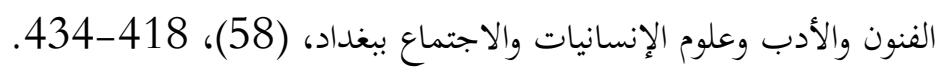

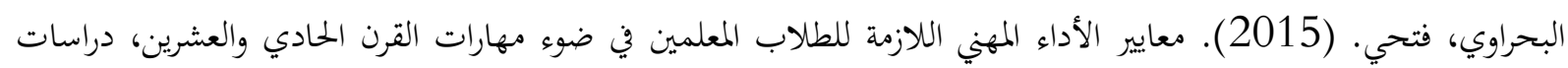

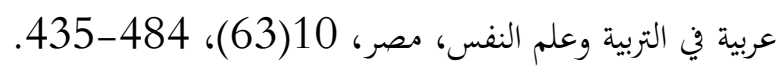

البلوشي، جليلة، والمعمري، سيف. (2021). مهارات المستقبل: دليل لمؤسسات التعليم وقطاع سوق العمل. سلطنة عمان.

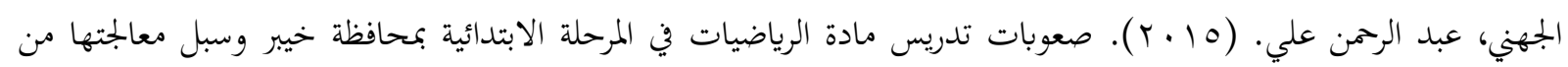
وجهة نظر معلميها، (رسالة ماجستير غير منشورة). الجامعة الإسلامية، المدينة المنورة.

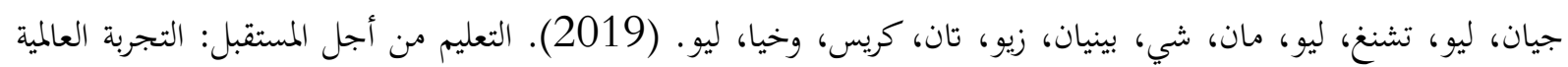

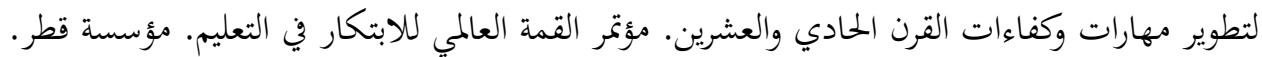
الحسين، أحمد، والحربي، حصة. (2019). معوقات تنفيذ الأنشطة التعليمية في مقررات العلوم للصفوف العليا من المراحل الابتدائية من وجهة نظر المعلمات والمشرفات. رسالة التربية وعلم النفس. (53) (257-285.

الدرمكي، عائشة. (28أغسطس 2021). مهارات المستقبل العاجلة. مقالة بجريدة عمان اليوم مسترجعة بتاريخ https://www.omandaily.om/2021/11/27 دويكات، لؤي نمر. (7 ا • Y). مدى فهم معلمي المرحلة الأساسية الدنيا للمفاهيم الرياضية في محافظة نابلس (رسالة ماجستير غير منشورة). جامعة النجاح الوطنية في نابلس، فلسطين. زيتون. عايش محمود. (2013). أساليب تدريس العلوم. دار الشروق للنشر والتوزيع. شلبي، نوال. (2014). إطار مقترح لدمج مهارات القرن الحادي والعشرين في مناهج العلوم بالتعليم الأساسي في مصرد الثروف المجلة

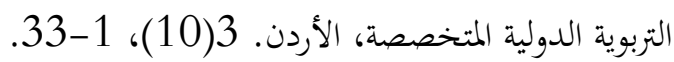

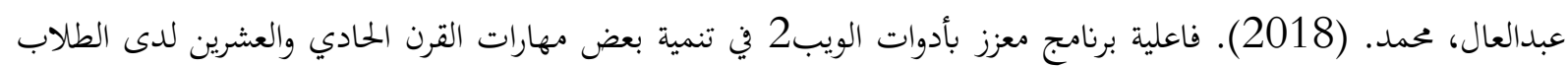

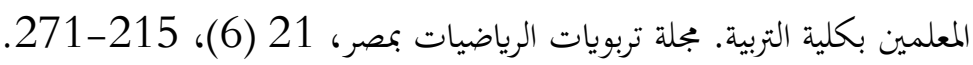

العقالي، محمد أحمد. (2018). معوقات توظيف تكنولوجيا الواقع الافتراضي في تدريس الرياضيات من وجهة نظر المعلمات في ترئي

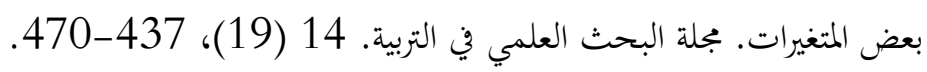

علامي، علي بن حمد. (2018). معوقات تدريس المفاهيم الرياضية من وجهة نظر معلمي ومشريز الرياضيات في محافظة صبيا. مجلة كلية التربية. (18)، 217-248.

عليان، شاهر، والمزروعي، يوسف. (2020). معوقات تطبيق منحى STEM في تدريس العلوم من جهة نظر المعلمين في

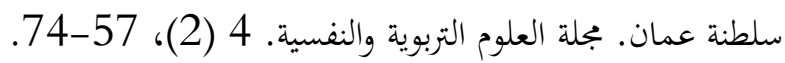

الفياض، راشد (2009). تطوير مناهج العلوم في ضوء الاتحاهات العالمية الحميثة (رؤية مستقبلية). دار عالم الكتب. مجلس التعليم. (2021). الإطار الوطني العُماني لمهارات المستقبل. سلطنة عمان. محمد، أسماء السيد، ومحمد، كريمة محمود. (2020). تطبيقات الذكاء الاصطناعي ومستقبل تكنولوجيا التعليم. المجموعة العربية للتدريب والنشر.

مؤسسة محمد بن راشد آل مكتوم للمعرفة، المكتب الإقليمي للدول العربية. (د.ت). استشراف مستقبل المعرفة. الغرير للطباعة والنشر 
Melhem, Tareq (2020). level of 21st century skills among students of the Special Education Department in the College of Education at King Faisal University, Journal of Scientific Research in Education. King Faisal University (Saudi Arabia) College of Education, 21(3), 272-303.

The Economist Intelligence Unit (2017). Worldwide Educating for the Future Index: A benchmark for the skills of tomorrow. Available from: https://dkf1ato8y5dsg.cloudfront.net/uploads/5/80/eiu-yidan-prize-educating-forthe-future-wp-fi nal.pdf 


\section{DEGREE OF AVAILABILITY OF ACTION RESEARCH STANDARDS FOR SENIOR TEACHERS IN BASIC EDUCATION SCHOOLS IN OMAN}

\section{Istanbul / Türkiye}

p. $365-384$

Received: 02/12/2021

Accepted: $16 / 12 / 2021$

Published: 01/01/2022

This article has been scanned I iThenticat No plagiarism detected

\author{
Humaid Muslem ALSAIDI ${ }^{1}$ \\ Amal Abdallah ALHARMALI ${ }^{2}$
}

\begin{abstract}
:
The study aimed to identify the level of availability of action research standards among senior teachers to improve educational practices in Oman's schools. To achieve the objectives of the study, the researchers used the descriptive curriculum, and after verifying the validity and stability of the tool was applied to a sample of (55) teachers and senior teachers, the results of the study revealed that the degree of availability of action research standards among teachers in basic education schools in Oman came with an average percentage (37.33), and that there were no statistically significant differences at the level of significance (a $=0.05$ ) between average availability of action research criteria attributable to the sex variable.

The researchers recommended that teachers should be trained in how to interpret the results of the study and discuss them, spreading the culture of action research in the field of education.

Key words: Action Research- Criteria Of Action Research.
\end{abstract}

http://dx.doi.org/10.47832/2717-8293.15.27

Dr. , The Ministry of Education, Oman, Hm.alsaidi@gmail.com, https://orcid.org/0000-0001-6251-3571

Dr. , Basra University, Oman, al-ama185@ moe.om, https://orcid.org/0000-0003-2542-3328 


\title{
درجة توافر معايير البحث الإجرائي لدى المعلمين الأوائل في مدارس التعليم الأساسي في سلطنة عمان
}

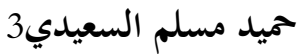 \\ أمل عبدالله الحرملية 4
}

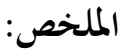

هدفت الدراسة إلى التعرف على مستوى توافر معايير البحث الإجرائي لدى المعلمين الأوائل لتحسين

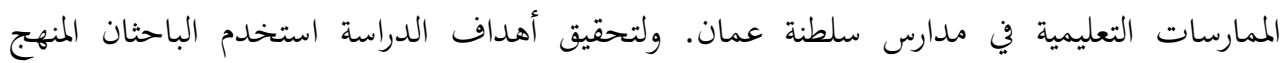

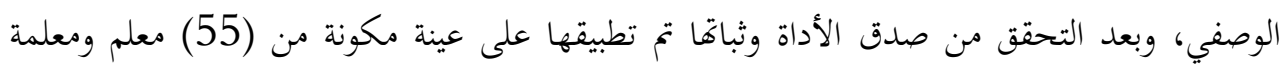
أولى، وقد كشفت نتائج الدراسة إلى أن درجة توافر معايير البحث الإجرائي لدى المعلمين في مدارس

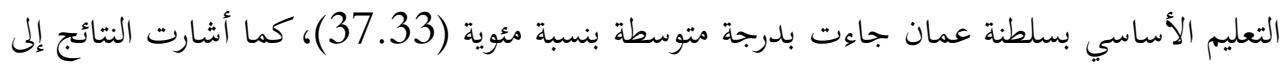
عدم وجود فروق ذات دلالة إحصائية عند مستوى الدلالة (0.05=0 م) بين متوسطات توافر معايير البحث الإجرائي تعزى لمتغير الجنس. وأوصى الباحثان بضرورة تدريب المعلمين على كيفية تفسير نتائج الدراسة مناقشتها، نشر ثنقافة البحت البحث الإجرائي في الحقل التربوي. الكلمات المفتاحية: البحث الإجرائي، معايير البحث الإجرائي.

يواجه المعلم في مهنته العديد من الإشكالات سواء كانت بسيطة أو مركبة، والتي يقف أمامها حائرا فيسعى البعض لإيجاد

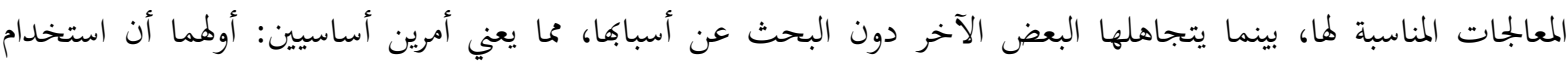

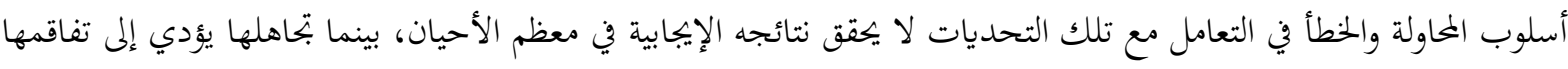
وتراكمها وتشعبها إلى إثكالات جديدة، بتعل المعلم يواجه مشاكلا حقيقية عصية على الحل، وتقف عائقا في سبيل سبيل الارتقاء بمستويات أدائه وأداء طلابه، وبالتالي يؤثر سلبا على مخرجات إندات التعليم الكلية. وتشير التوجهات المعاصرة (فيما يتعلق بالتنمية المهنية) إلى أهمية التركيز على وعي المعلم، وتنمية قدراته على التعرف على

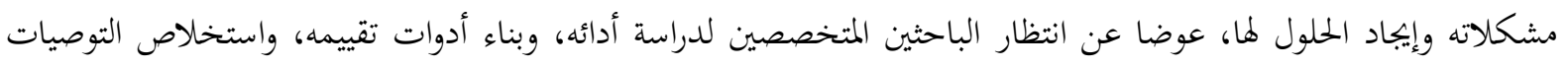

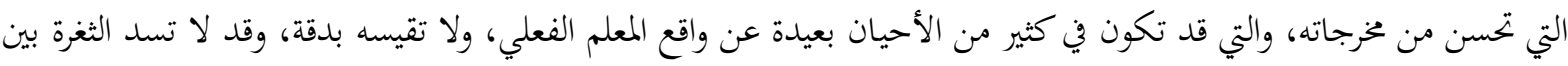
المنهج على المستوى النظري وممارساته الفعلية في الصف الدراسي. إن العصر الحديث يتطلب معلمين ذوي مهارات عالية في تشخيص المشكلات التربوية ومعالجتها، ولديهم القدرة على ملى الاطلاع والبحث، وتطوير الأدوات بما يسهم في تحقيق الأهداف، والعمل على إجراء البحوث التربوية كمنهجية علمية في معالجة المشكلات التي تواجهرم في الموقف الصفي (سرور، وحسين، ومحسن، 2011). 
هذا الأمر يجعل البحوث التربوية ضرورة ملحة بما تتضمنه من ممارسات تحليل وتفكر وتأمل بغية حل المشكلات أو تطوير أداء قائم، وهو ما يتطلب امتلاك المعلم للمعارف والمهارات اللازمة للقيام بالبحث الإجرائي.

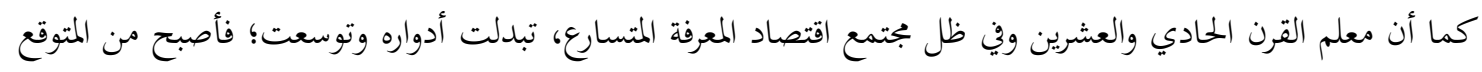

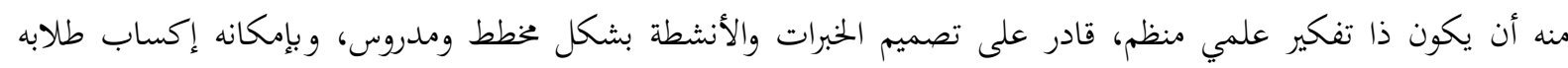

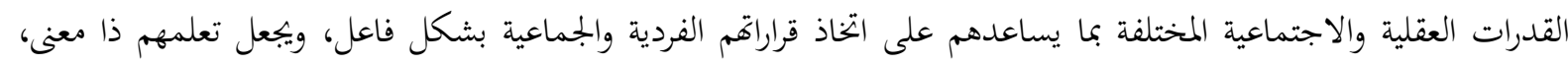

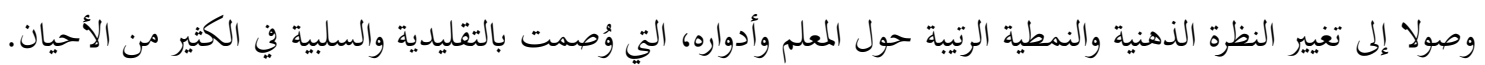

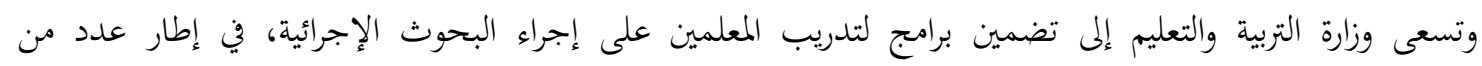

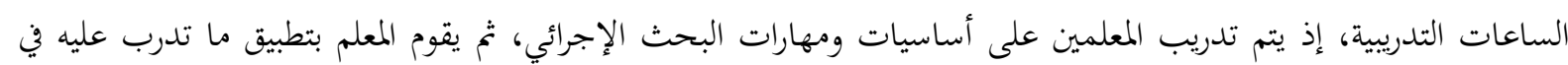

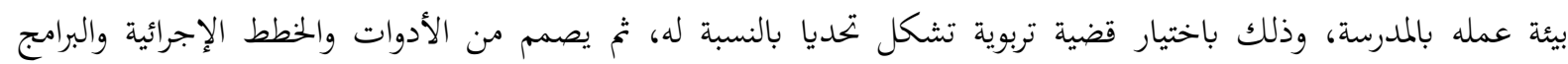

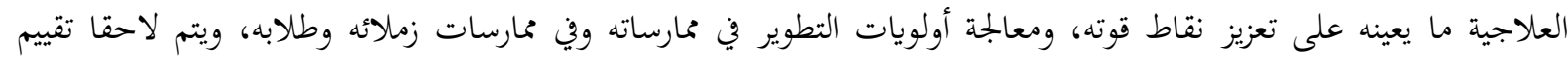

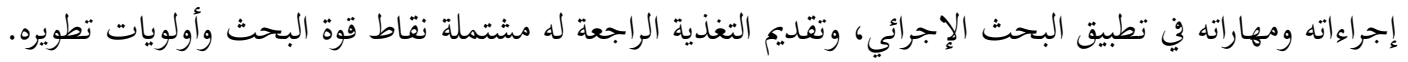

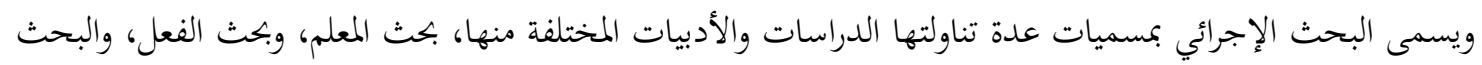

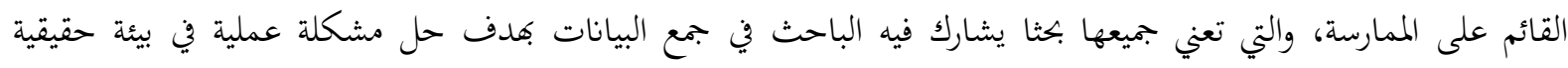
(العمراني، (2020).

كما يرى (2019) Coghlan, Coughlan \& Shani أن مفهوم البحث الإجرائي يمكن تناوله باعتباره دبجا

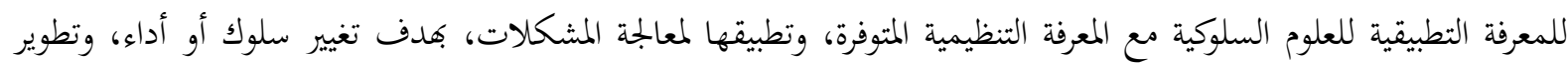
الكفاءات والمعارف العلمية.

ووفق هذا المنظور فإن تطبيق البحث الإجرائي يسهم في تحول المعلمين إلى ممارسين، وهي إحدى توجهات التنمية المهنية

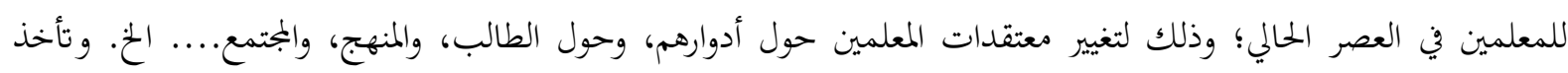

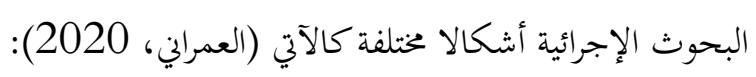

1-البحوث التآزية: حيث يريها مجموعة من الباحثين من مدارس محددة؛ لدراسة المشكلات التربوية، وتأسيس قناة حوار مستدام بينهم.

2 -البحوث الصفية: يقوم هما معلم واحد أو بجموعة معلمين بهدف تحسين أداءاقم وممارساتم في الغرفة الصفية. 3 -البحوث التشاركية: والتي تمدف لدراسة الواقع الحلالي بالمدرسة لتطويره، ومعالجة تحديات العمل التي تحد من الإنتاج. ويتم اختيار النوع المناسب في ضوء بعض الضوابط منها طبيعة البحث، والغرض منه، ونوع الدعم الذي سيحصل عليه

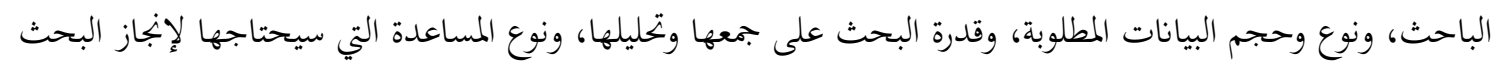
(ضحاوي، 2013).

إن امتلاك المعلم للمهارات البحتية عموما ليس أمرا من الكماليات كما كان في الزمن القريب الماضي، بل إنه اعتمد

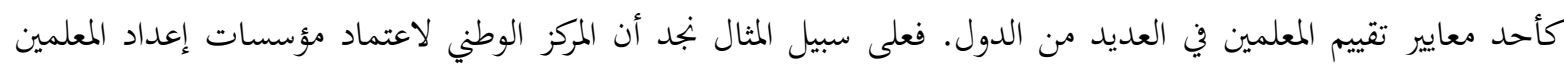
(NCATE) 
ومن هذه المعايير ما يعتبر ذا صلة وثيقة بالمعلم وهي (سليم، 2018):

المعيار 1: اكتساب المعلمين مدى واسع من المعارف والمهارات والاتحاهات، التي تنمي شخصياتم وتؤهلهم في الجوانب المهنية والشخصية.

المعيار 2: ويتمثل في نظام التقويم المتبع لجمع البيانات التي تقيس أداء المعلمين، وتوظيف تلك البيانات في تحسين وتطوير طرائق تدريسه وأساليبه.

المعيار 3: اهتمام المعلم بالتنوع بين طلابه، ووجود الفروقات الفردية بينهم، والتعامل مع ذلك بكياسة من خلال تطبيق الاستراتيجيات التدريسية الملائمة والحديثة.

ونلاحظ أن هذه المعايير تنظر للمعلم بصفته منتجا للمعرفة وليس مستهلكا لما فقط، وهو ما أقرته أيضا الجمعية الدولية للتكنولوجيا في ججال التعليم (ISTE)، التي وضعت ستة معايير رئيسة للمعلمين هي المواطن الرقمي، والمتعاون العالمي، والمفكر الحاسوبي، والمصمم المبتكر، والمتواصل المبدع، وآخرها أن يكون منتجا للمعرفة.

وعليه، فإن تنمية مهارات المعلمين في القيام بالبحوث الإجرائية يعتمد على ما يتلقونه من تدريب و تأهيل في ضوء المعايير

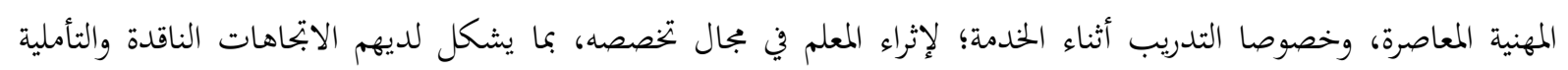
والتحليلية، ويطور القدرات البحثية لديهم.

وانطلاقا من هذا الاهتمام بالإنتاج البحثي كمعيار جودة لأداء المعلمين، نجد أن استمارة المعايير المهنية للمعلم العماني التي أصدرقا وزارة التربية والتعليم، والتي اشتملت ثلاث مجالات رئيسة هي: المعارف، والمهارات، والقيم، قد تضمنت في في المجال المال

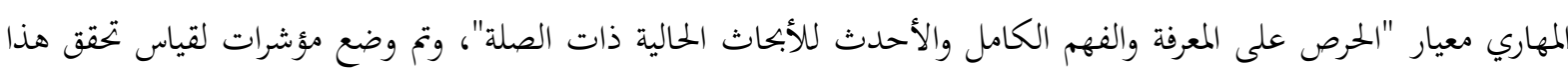
المعيار.

إن هذا التوجه يعكس رغبة المخططين والإدارات العليا في جعل كل معلم باحث، وقادر على ملاحظة تأمل وتقييم

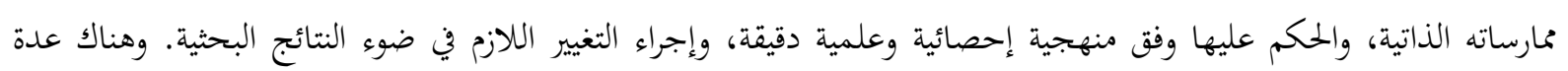
نماذج للبحث الإجرائي والتي أشار إليها(Arora,2017) ، (Ward,2017)، وايمكن إيبازها كالآتي:

\section{Mcniff نموذج}

يرى هذا النموذج أن البحث الإجرائي هو بجموعة من الخطوات التي ترتبط منطقيا، بدءا بالملاحظة، ثم التأمل وانتهاء بالمعالجة التجريبية من قبل المختص. 1. نموذج مركز تكنولوجيا التعليم في جامعة هوبكينز في واشنطن الأمريكية (CTE)، والذي ينظر للبحث الإجرائي بأنه سلسلة

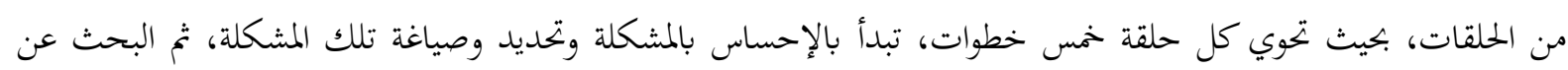

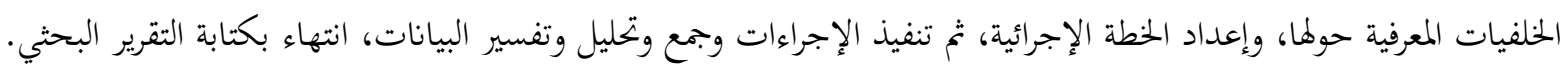
2. نموذج مركز البحث الإجرائي التعاوني في جامعة بيردين الأميركية (CCAR) يرى هذا النموذج أن البحث الإجرائي يبدأ

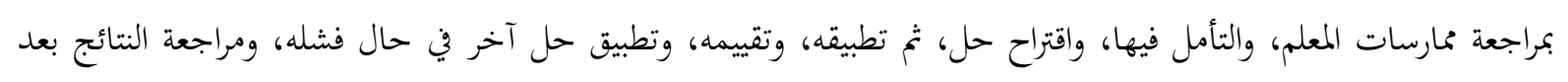
كل حل. 3. نموذج :Stephen Kemmis وفي هذا النموذج فالبحث الإجرائي هو سلسلة خطوات، وتتكون كل دورة من أربع خطوات هي: التخطيط، بعدها الإجراء يليها الملاحظة والتأمل، ثم الممارسة. 
4. نموذج :kurt Lewin والذي يعتبر البحث الإجرائي كسلسلة حلزونية الحلقات، حيث تمثل الحلقة الأولى تحديد المشكلة، ثم الأداء، يليها تقييم النتائج وفق الأداء.

5. نموذج أبو عواد ونوفل: وتتلخص فكرته في مجموعة من الخطوات تتمثل في: التأمل والاحساس بالمشكلة، تحديد المشكلة

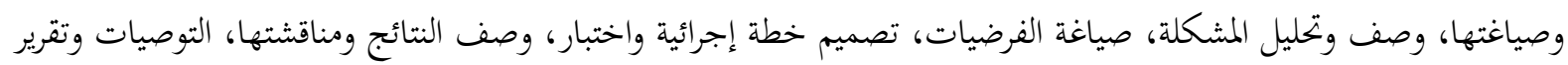
البحث، التأمل لمشكلة جديدة أو التعديل (أبو عواد، نوفل، 2012).

وقد أجريت العديد من الدراسات البحثية لقياس امتلاك المعلمين لمهارات البحث الإجرائي، ومنها دراسة المزيني (2012)، وقد هدفت الدراسة إلى استقصاء فاعلية برنامج تدريبي مقترح في تنمية مهارات الدراسة الإجرائية ومفهوم تعليم العلوم لدى معلمات العلوم أثناء الخدمة. ولتحقيق هذا الهدف استخدم المنهج التجريبي، وقد أسفرت نتائج الدراسة عن وجود فرق دال دال إحصائيا بين متوسط رتب درجات معلمات العلوم في التطبيق القبلي ومتوسط رتب درجاهن في التطبيق البعدي في أبعاد

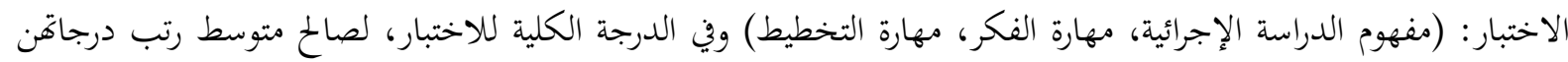

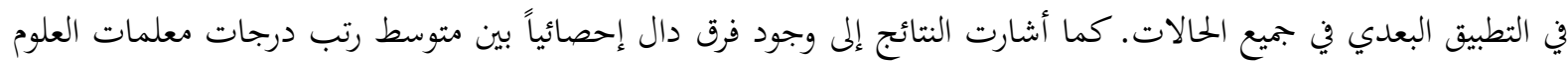

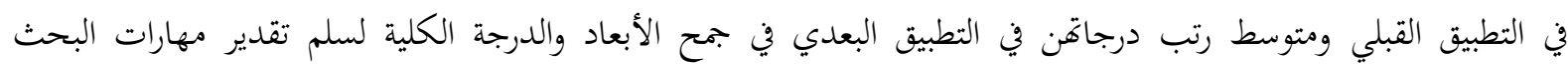
الإجرائي، لصالح متوسط رتب درجاهن في التطبيق البعدي في جميع الحالات. وهدفت دراسة نصر (2014) إلى معرفة أثر البحث الإجرائي كأسلوب إشرافي على النمو المهني للمعلم والمشرف.

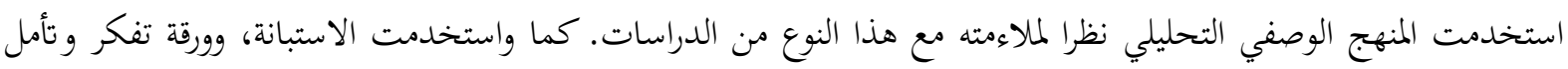

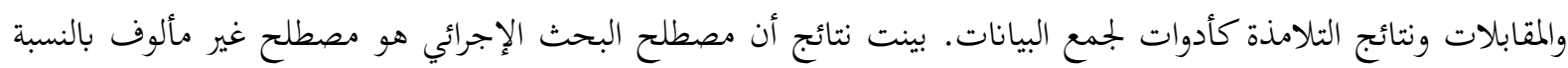

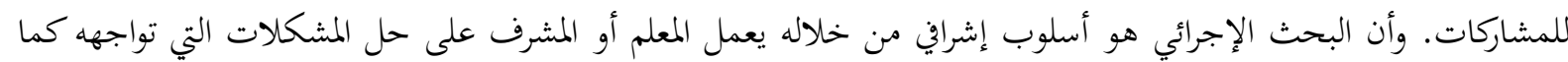

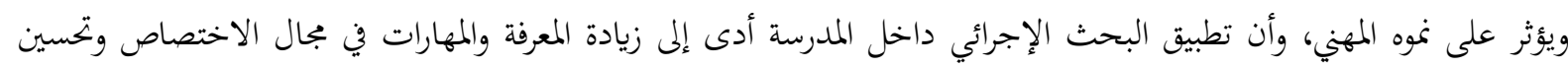

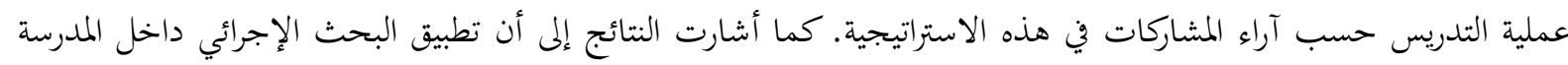

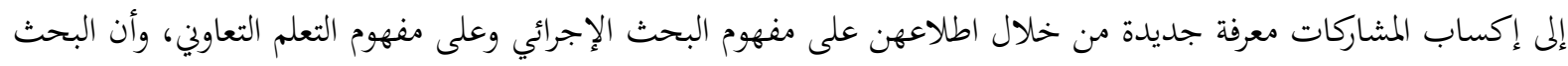

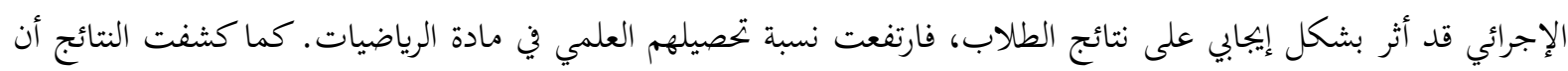

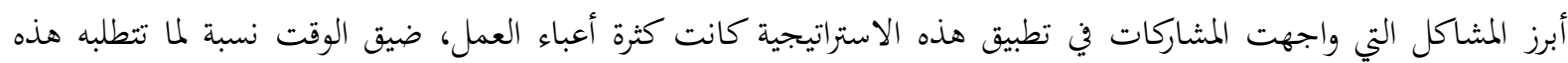

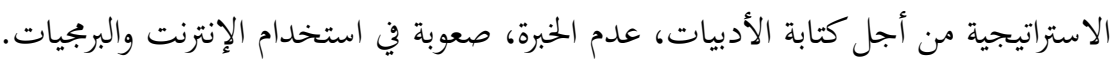

وأجرى الدغمي (2015) دراسة هدفت إلى التعرف إلى درجة تمكن معلمي العلوم من مهارات البحث الإجرائي في

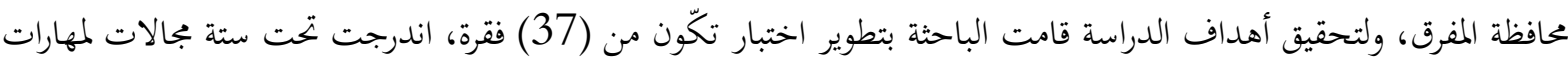
البحث الإجرائي (مهارة معرفة البحث الإجرائي، مهارة تحديد مشكلة البحث الإجرائي، مهارة صياغة فرضيات البحث

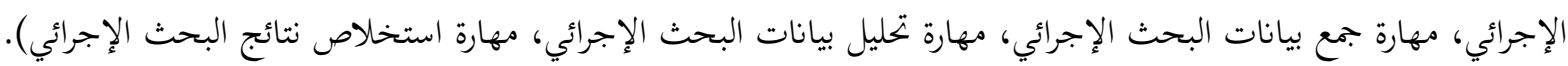

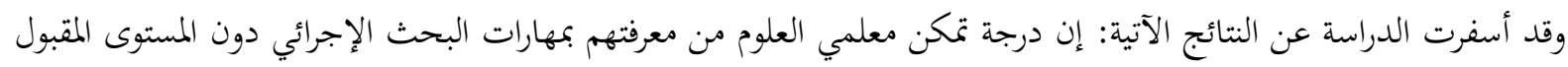

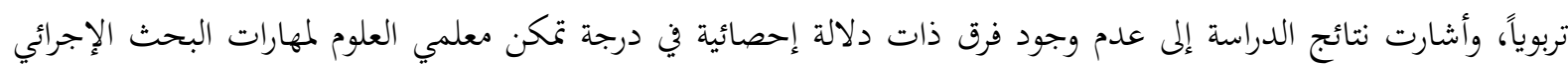

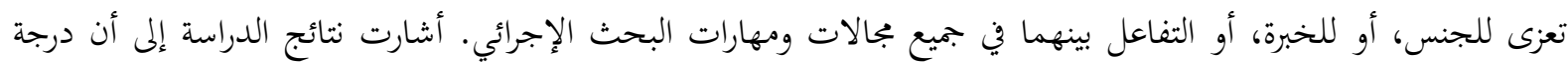

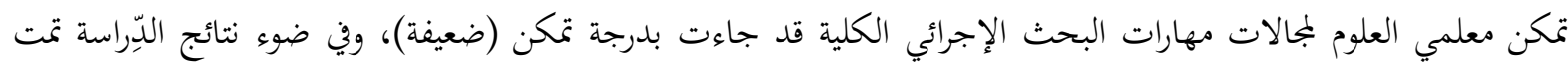
التوصية إلى وزارة التربية والتعليم والمؤسسات الأكاديمية بالتركيز على تمكين المعلمين من مهارات البحثث الإجرائي. 
وسعت دراسة السيد والعمري (2015) إلى تحديد مدى توافر مهارات البحث الإجرائي لدى المعلمات الأوائل بمدارس

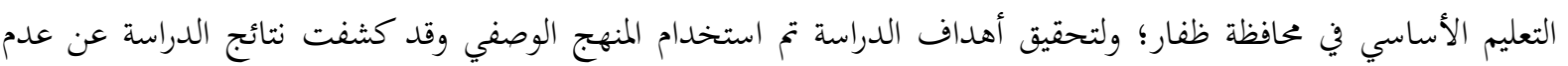
توافر مهارات البحث الإجرائي لدى المعلمات الأوائل

حيث جاءت دون مستوى الإتقان، كذلك عدم وجود فروق ذات دلال إحصائية بين متوسطي درجات المعلمات

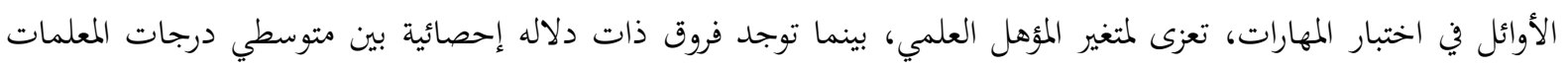

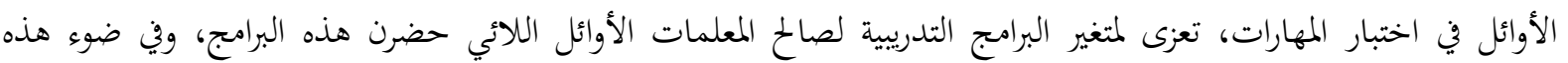
النتائج قدمت الدراسة بعض التوصيات، منها: إثراء خطة الإنماء المهني لوزارة التربية والتعليم ببرامج تدريبية متكاملة حول تنمية مهارات البحث الإجرائي لدى المعلمات الأوائل. كما اقترحت بعض الدراسات، منها: دراسة فاعلية برنامج تدريبي في تنمية بلدية مهارات البحث الإجرائي لدى المعلمات الأوائل.

وهدفت دراسة العتبي (2016) إلى قياس مهارات البحث الإجرائي بين معلمات الصف الابتدائي قبل الحندمة، وعمل برنامج تدريبي لتطوير مهارات البحث الإجرائي لديهن، وقياس فعالية البرنامج في تطوير مهارات البحث الإجرائي لديهن.

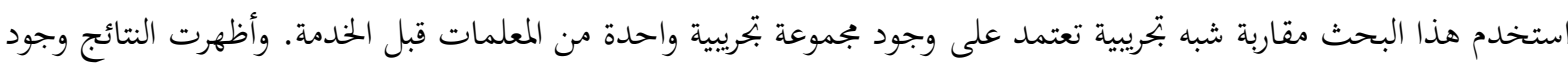
فروق ذات دلالة إحصائية بين متوسطات أفراد الدراسة في القياس القبلي والبعدي للمعرفة والمهارات لمهارات البحته البحث الإجرائي.

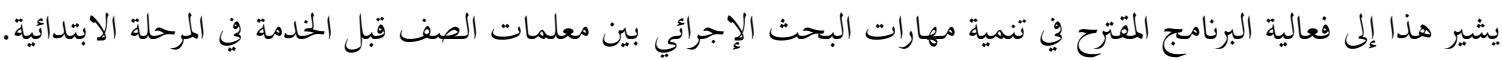
واقترحت الباحثة ضرورة وجود مسار بحث عملي يتم تدريسه في كليات التربية، ويمكن أن يكون مشروع تخرج في هذه الكليات، وتشجيع المعلمين على القيام ببحوث إجرائية لحل المشكلات الميدانية. أما الدوسري (2016) فقد هدفت الدراسة إلى التعرف على العوامل ذات العلاقة بعزوف المعلمين عن إجراء البحوث

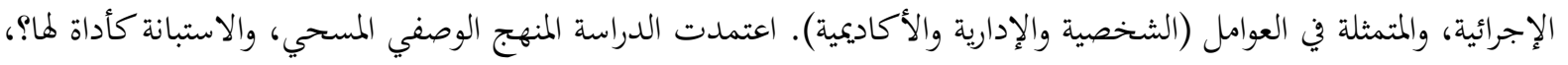

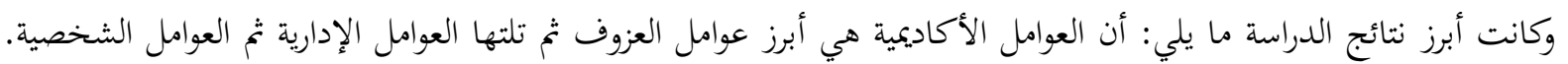

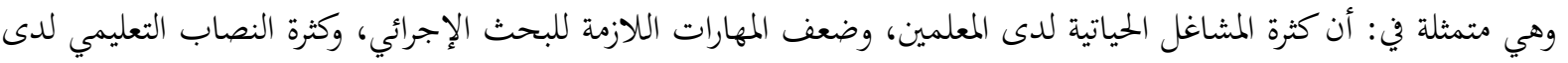

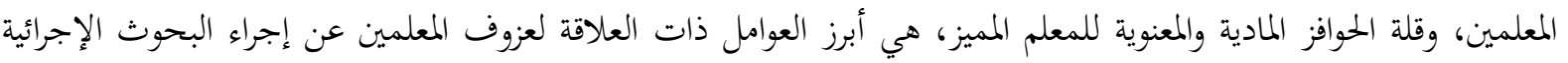

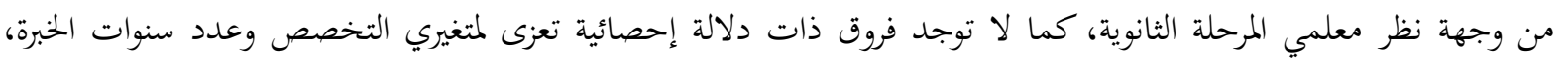
وتوجد فروق ذات دلالة إحصائية تعزى لمتغير نوع التأهيل لصالح المعلمين. وهدفت دراسة عساف (2017) إلى التعرف على آراء المعلمين في محافظة غزة حول أهمية البحث الإجرائي ودرجة

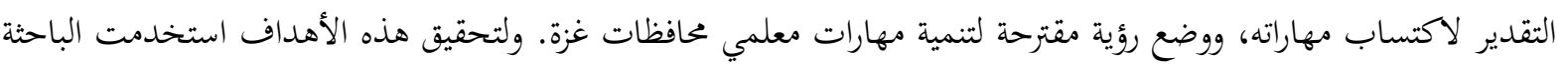

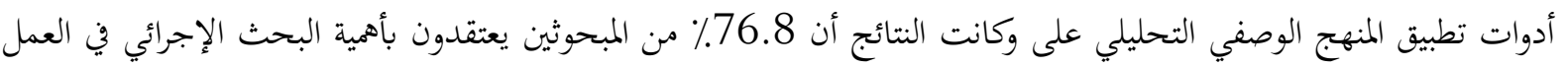

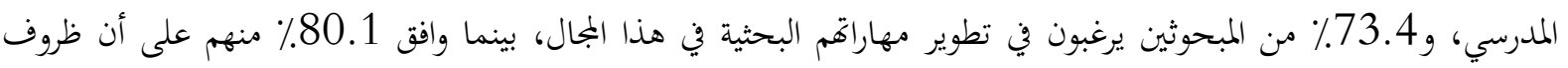

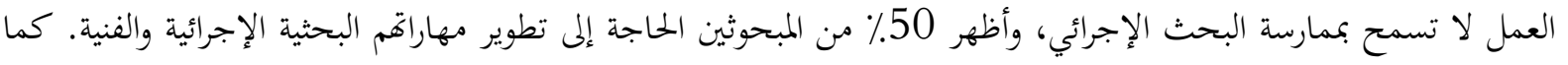

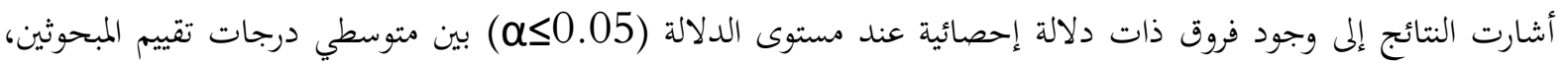

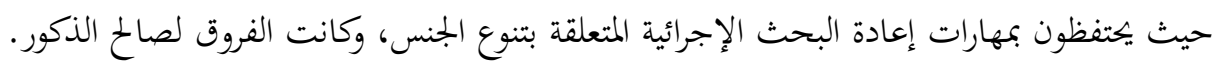
أما دراسة الغتامي (2018) فقد هدفت إلى قياس مدى توافق البحث الذي أجراه معلمو المدارس مع معايير البحث العملي. صمم الباحثون بطاقة تقييم لتحليل عينة من البحوث التي كتبها مدرسو المدارس العاملون في سلطنة عمان. كما تم إجراء

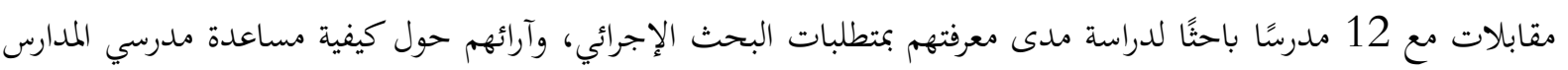


على أن يصبحوا أكثر تأهيلًا لإجراء بحث مدرسي موثوق. وخلصت الدراسة إلى أن البحوث التي تم تحليلها لا تحمل سمات

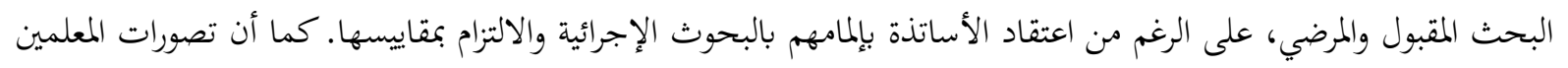
وفهمهم للبحث تتأثر بعدد من العوامل بما في ذلك التعليم الجامعي، والقواعد واللوائح التي تقدمها وزارة التربية والتعليم وآراء

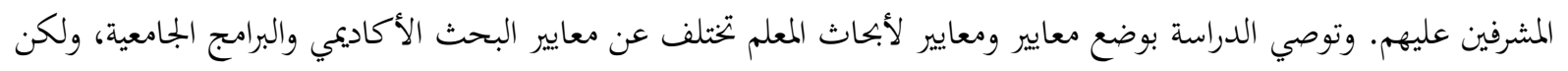
يجب أن تتوافق مع اتفاقيات البحث العملي. وهدفت دراسة الأفندي (2018) إلى التعرف على المعوقات التي تواجه المعلمين لإجراء البحوث الإجرائية في المدارس

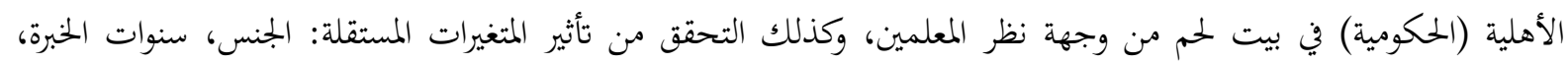

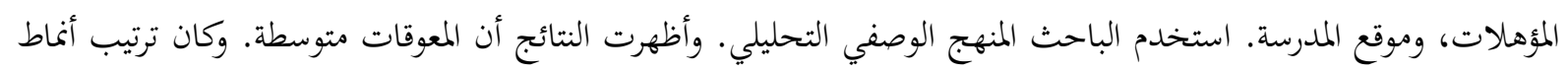

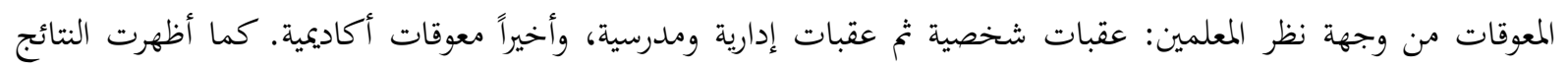

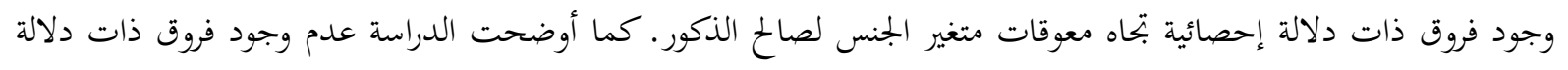
إحصائية تعزى لمتغير المؤهلات، وسنوات الخبرة، ومتغير موقع المدرسة.

وأجرى أبو علي (2020) دراسة هدفت إلى تقصي درجة ممارسة معلمي العلوم في المدارس الأردنية لمهارات البحث

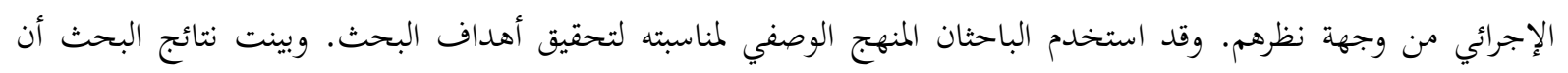

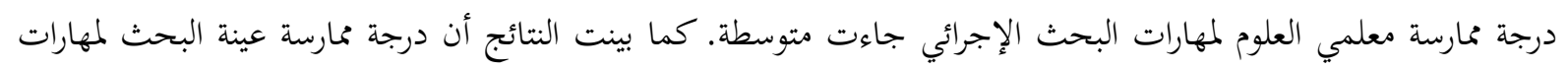

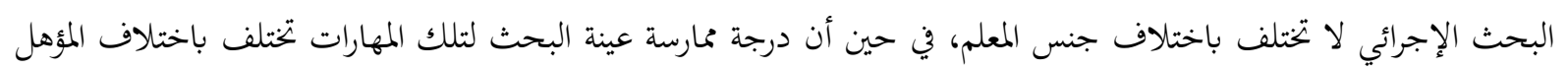

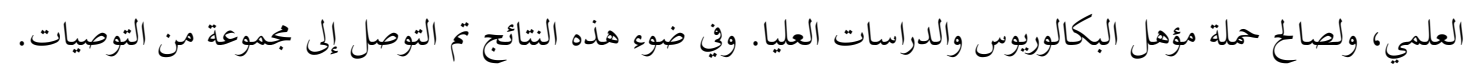
وقد كشف Ronen (2020) أن هناك فجوة واضحة متأصلة بين أفكار ومعتقدات المعلمين من جهة وبين تنفيذهم

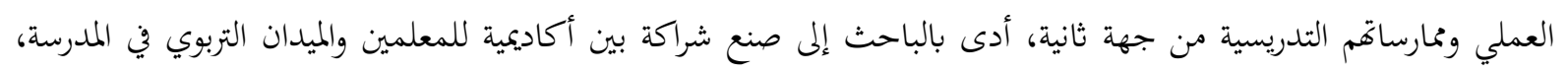

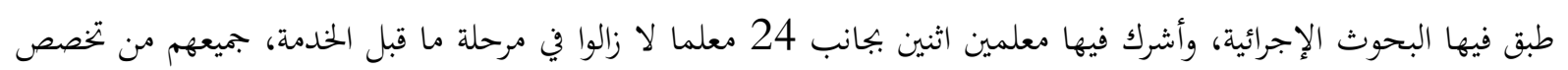

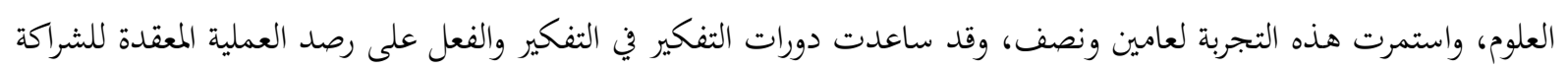
التي تسد الفجوة بين الثقافات الأكاديمية والميدانية لدى المعلمين.

خضعت البيانات التي تم جمعها لثلاث مراحل من تحليل المحتوى التفسيري، تشير إلى دور دورات التفكير في التفكير والتنفيذ، مما أدى إلى تداخل السمات المعرفية والتأثيرية والنظرية والعملية خلال نموذج الممارسة الأكاديمية الميدانية. Hegazy, Ellerton, Campos-Remon, Zaphir, Mazzola, \& Brown (2021) أن البحوث الإجرائية مكنت طلاب السكان الأصليين وسكان جزر مضيق توريس في برنامج التنمية المهنية الخاصة بكم،

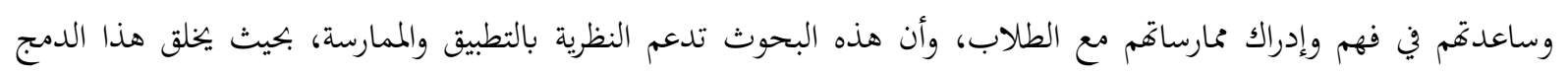

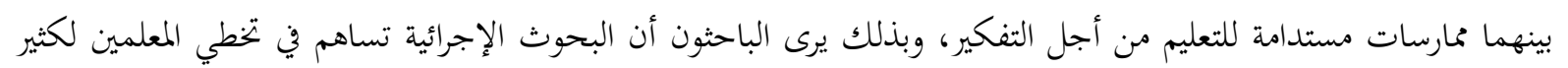

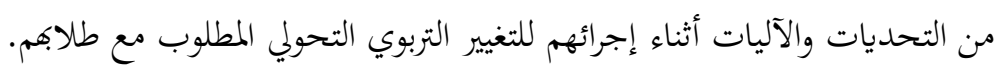

وقد كشفت نتائج الدراسات السابقة ضعف المهارات والمعايير المتعلقة بالبحث الإجرائي لدى المعلمين، بالرغم من تأكيد

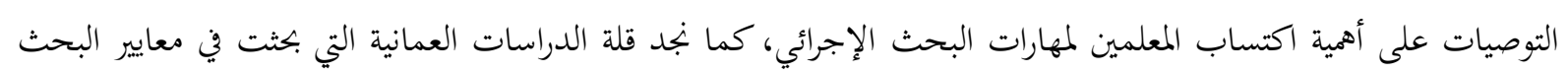
الإجرائي، لذا تسعى هذه الدراسة إلى التقصي عن توافر معايير البحث الإجرائي لدى المعلمين الأوائل. 


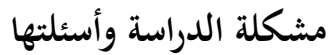

برغم أهمية البحوث الإجرائية (كما سلف) إلا أن تطبيقاته في الحقل التربوي لا زالت تحظى باهتمام محدود، ومن خلال

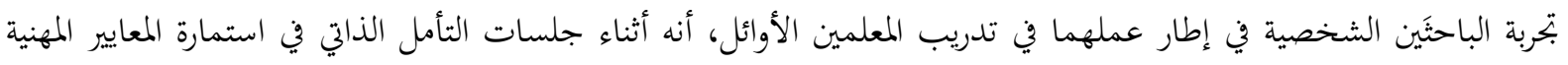

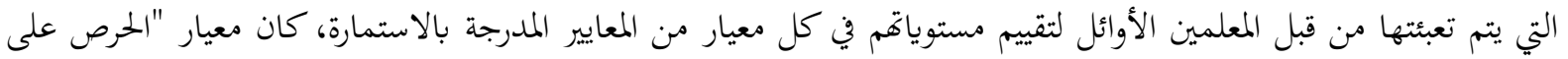

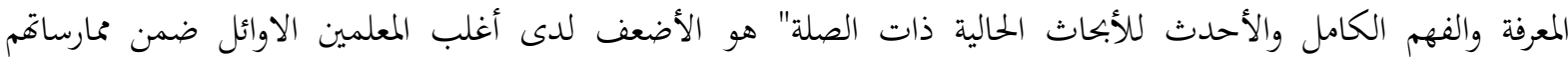
التدريسية، مما يعكس الحاجة الملحة لتدريبهم على إجراء هذه البحوث، وتقييم كل مرحلة من أبحاثهم والوقوف على أوجه القصور العامة المشتركة بينهم؛ للتركيز عليها بشكل مكثف أثناء تطوير المتتوى التدريبي للبحث الإجرائي.

وتكشف العديد من الدراسات عن ضعف توفر مهارات البحث الإجرائي لدى المعلمين، فنجد في دراسة مأوي والمحسن

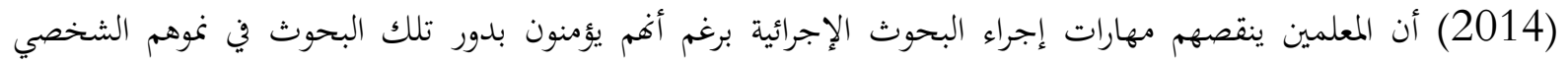

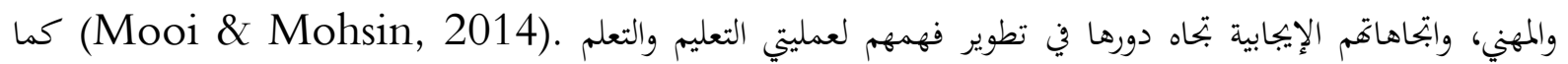
توصلت دراسة عبد القادر والعمري (2015) على عدم توفر مهارات البحث الإجرائي الأساسية لدى عينة الدراسة، وأفم لم ملماهم

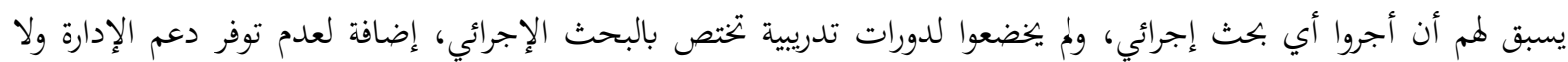

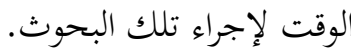

كما وجد عساف (2017) في دراسته أن هناك ضعف في مهارات المعلمين في إجراء البحث الإجرائي تعزى لأعباء التدريس الكثيرة، وانحسار الثقافة البحثية لدى المعلمين، وضعف وجود الحوافز في بيئة العمل. وتتفق أيضا دراسة بخاري (2019) التي رصدت آراء القيادات المدرسية، والتي توصلت إلى أن للبحث الإجرائي أهمية

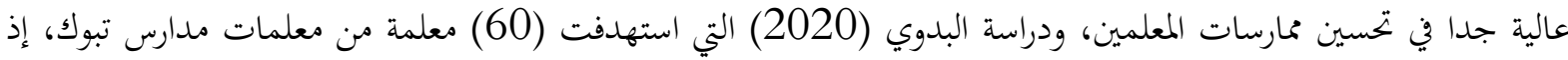
خلصت هذه الدراسة إلى تفاوت معايير البحث الإجرائي لدى أفراد العينة، وأن النسبة الأكبر منهن يمتلكن مهارة تصور وتحليل المشكلة فقط.

وللتصدي لهذه المشكلة، تحاول الدراسة الحالية الكشف عن درجة توافر معايير البحث الإجرائي لدى المعلمين الأوائل، والإسهام في توظف المعلمين لهذه المعايير من خلال الإجابة عن السؤالين: 1. ما مدى توافر معايير البحث الإجرائي لدى المعلمين الأوائل في مدارس التعليم الأساسي بسلطنة عمان؟ 2. هل توجد فروق ذات دلالة إحصائية عند مستوى دلالة (1<0.05) بين متوسطات توافر معايير البحث الإجرائي لدى

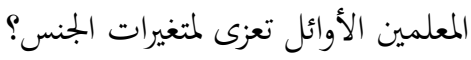

أهداف الدراسة

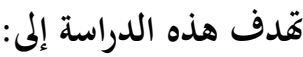

1. تحديد مستوى توافر معايير البحث الإجرائي لدى المعلمين الأوائل لتحسين الممارسات التعليمية في مدارس سلطنة عمان. 2.الكشف عن إمكانية وجود فروق ذات دلالة إحصائية عند مستوى دلالة (0.05 م) بين متوسطات مستويات تقدير أفراد العينة لهذه الممارسة تعزى لمتغيرات الجنس. 


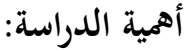

الأهمية النظرية:

تعتبر هذه الدراسة استجابة للتوجهات التربوية المعاصرة في تطوير ممارسات المعلمين وبجموعات التعلم المهنية، عبر إجراء

بحوث إجرائية لتحسين الأداء، وتحقيق التوازن والتكامل بين مهامهم كمعلمين ومهامهم كباحثين، وتطوير قدراتم على تقييم عمليات التعليم والتعلم في صفوفهم الدراسية، وإصدار الأحكام بموضوعية وفق منهجية علمية بعيدا عن التخمين والعشوائية.

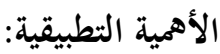

يمكن أن تكون الدراسة مرجعا للمعلمين الأوائل، والمدربين في مراكز التدريب، وعموم الباحثين، لتحسين ممارسات

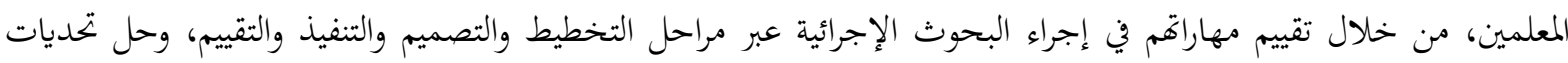
عمليتي التعليم والتعلم بمنهجية علمية قائمة على البحث العلمي، وبالتعاون مع زملائه المعلمين. كما تفيد الدراسة في مراجعة

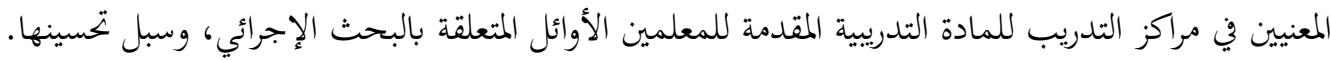

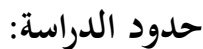
الحدود الموضوعية: اقتصرت الدراسة على تحديد درجة توافر معايير البحث الإجرائي لدى المعلمين الأوائل. الحدود المكانية: مدارس التعليم الأساسي بمحافظة مسقط، وشمال الباطنة، وجنوب الباطنة. الحدود الزمانية: العام الدراسي.(2022) / 2021) الحدود البشرية: المعلمين الأوائل في مدراس التعليم الأساسي بسلطنة عمان.

مصطلحات الدراسة:

يعرف المقبل (2018)، و (2018) Clayton \& Broome البحث الإجرائي بأنه البحث الذي يقوم به المعلمون لأجل تطوير أدائهم وممارساتم في التدريس، ومعالجة المشكلات التي تواجهُم في التدريس؛ للوصول للتغيير المنشود. ويعرفه الباحثان إجرائيا بأنه: أحد بحوث التنمية المهنية والذي يسعى إلى مساعدة المعلم على استقصاء ممارساته من خلال دراسة الظواهر والقضايا التربوية، ومعالجة التحديات التي تواجهه؛ بغية بحويد العملية التعليمية. المعايير: يعرفها هجتون (Houghton, 1996; 42) بأها "جمموعة من المقاييس المعبرة عن المستوى النوعي الذي يجب أن يكون متواجداً في جميع المجالات الأساسية والمكونة لأي برنامج تعليمي." ويعرفها الباحثان معايير البحث الإجرائي إجرائياً بأها: مجموعة من المقاييس تستخدم لتحديد مدى توافر مواصفات

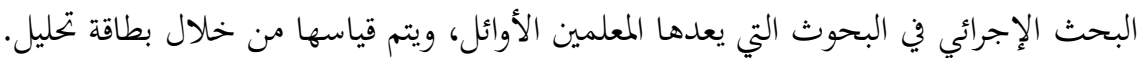




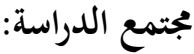

تألف بجتمع الدراسة من جمع المعلمين الأوائل العاملين في مدارس التعليم الأساسي بسلطنة عمان في محافظة مسقط،

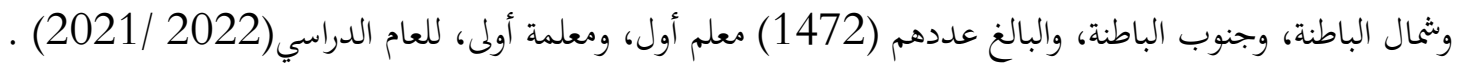

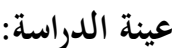

تكونت عينة الدراسة من (55) بحثاً إجرائياً لمعلم أول، ومعلمة أولى، وتم اختيارهم بالطريقة العشوائية البسيطة، وهي

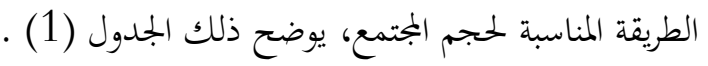
جدول (1) توزيع أفراد عينة الدراسة حسب متغير الجنس للعام الدراسي 2021/ 2022

\begin{tabular}{|c|c|c|c|}
\hline النسبة المئوية & العدد & \multicolumn{2}{|c|}{ متغيرات الدراسة } \\
\hline$\% 43.6$ & 24 & ذكر & النوع \\
\hline$\% 56.4$ & 31 & أنثى & \\
\hline$\% 100$ & 55 & & المجموع \\
\hline
\end{tabular}

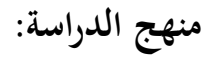

اعتمد الباحثان في الدراسة المنهج الوصفي، وهو المنهج المناسب لهذا النوع من الدراسة التي قدف إلى تعرف مدى توافر معايير البحث الإجرائي لدى المعلمين الأوائل، وقد قام الباحثان بإعداد بطاقة تحليل تضمنت معايير البحث الإجرائي.

أداة الدراسة:

طبقت الدراسة بطاقة تحليل تضمنت معايير البحث الإجرائي، وقد تم تصميمها بعد الرجوع للأدب التربوي، وقد تكونت

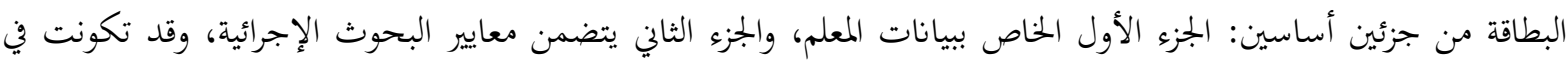
صورتا النهائية بعد تحكيمها ستة محاور موزعة على (45) معيارًا.

المقياس المعتمد في الدراسة:

تم استخدام مقياس التدرج الخماسي حسب نظام ليكرت (Likert) لاستجابات أفراد العينة في لماور الدراسة على

النحو المبين في الجدول (2) 


\begin{tabular}{|c|c|}
\hline 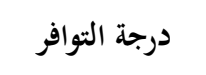 & درجات مقياس ليكرت(Likert) \\
\hline توافر المعيار & 1 \\
\hline عدم توافر المعيار & 0 \\
\hline
\end{tabular}

صدق الأدوات:

للتحقق من صدق بطاقة التحليل استخدم الباحثان صدق المحكمين من خلال عرض الأداة على مجموعة من المحكمين

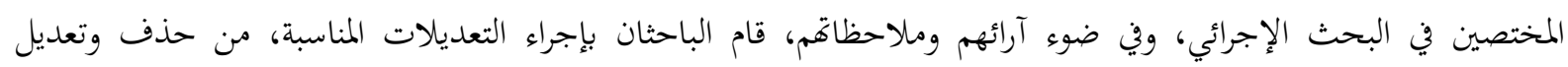
وإضافة، وإخراج الأداة في صورها النهائية.

ثبات الأدوات:

للتأكد من ثبات الأداة، قام الباحثان بتطبيق الاستبانة على عينة بتريبية بلغت (5) معلم ومعلمة، وكانت العينة التجريبية

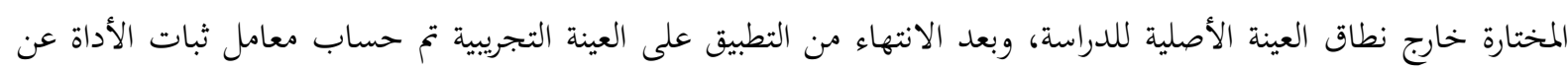

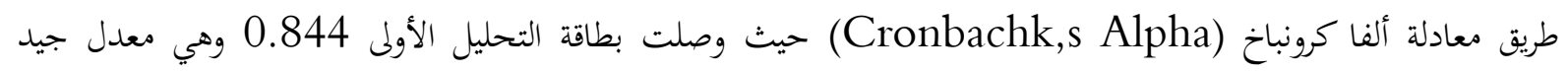
ومناسب للتطبيق معرديق

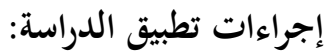

بعد تحديد مشكلة الدراسة، وأسئلتها ومتغيراتما، وبعد الانتهاء من إعداد أداة الدراسة، والتأكد من صدقها وثباتا، طبق الباحثان الأداة على عينة الدراسة في الفصل الدراسي الثاني (2021/2022).

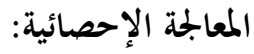

تم معالجة بيانات الدراسة إحصائياً باستخدام برنامج(spss) ، وذلك على النحو التالي: • • لقياس الثبات لأدوات الدراسة: تم استخدام معامل الثبات الفاكرونباخ. • للإجابة عن السؤال الثاني: تم استخدام اختبار (ت) للعينات المستقلة (T-test) للتحقق من دلالة الفروق التي تعزى لمتغير الدراسة. ويوضح الجدول (3) الحدود الفعلية للفئات. 
جدول (3) الحدود الفعلية للفئات بناءً على التدرج المستخدم في أداة الدراسة

\begin{tabular}{|c|c|c|c|}
\hline الممستخدم & النسبة المئوية & النكرارات & الدرجة \\
\hline مرتفع & $100-\% 67$ & $100-67$ & 3 \\
\hline متوسط & $\% 66-\% 33$ & $66-33$ & 2 \\
\hline منخفض & $\% 32-0$ & $32-0$ & 1 \\
\hline
\end{tabular}

\section{نتائج الدراسة ومناقشتها}

نتائج السؤال الأول ومناقشتها

للإججابة عن هذا السؤال ونصه: ما مدى توافر معايير البحث الإجرائي لدى المعلمين الأوائل في مدارس التعليم الأساسي

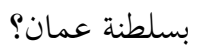

تم استخراج النسبة المئوية، لجميع تكرارات محاور معايير البحث الإجرائي في أداة بطاقة التحليل، حيث تم ترتيبها ترتيبا

تنازلياً كما هو واضح في الجدول (4)

جدول (4) النسبة المئوية لمعايير البحث الإجرائي في أداة بطاقة التحليل، والأهمية النسبية (الرتبة) لجميع محاور الأداة

\begin{tabular}{|c|c|c|c|c|}
\hline 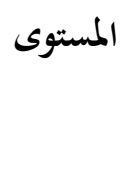 & المئوية & 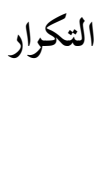 & 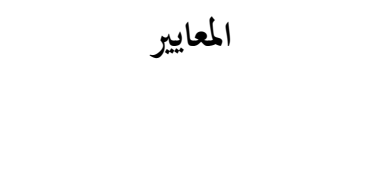 & s \\
\hline متوسط & 42.8 & 214 & أدوات الدراسة & 1 \\
\hline متوسط & 41.8 & 209 & إجراءات الدراسة ومنهجيتها & 2 \\
\hline متوسط & 41.2 & 412 & مشكلة الدراسة وأسئلتها & 3 \\
\hline متوسط & 37.1 & 371 & مناقشة النتائج وتفسيرها & 4 \\
\hline متوسط & 31.2 & 375 & الموضوع ومقدمة الدراسة & 5 \\
\hline منخفض & 29.9 & 89 & المراجع والتوثيق & 6 \\
\hline متوسطة & 37.33 & & النسبة العامة & \\
\hline
\end{tabular}


يتضح من الجدول (4) أنه على المستوى العام فإن درجة توافر معايير البحث الإجرائي لدى المعلمين في مدارس التعليم الأساسي بسلطنة عمان جاءت بدرجة متوسطة في إجمالي محاور الدارسة. كما يتبين من الجدول (4) أن النسبة المئوية للمتوسطات الحسابية لكل معيار من معايير البحث الإجرائي في أداة

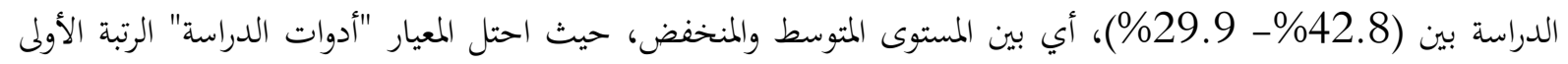

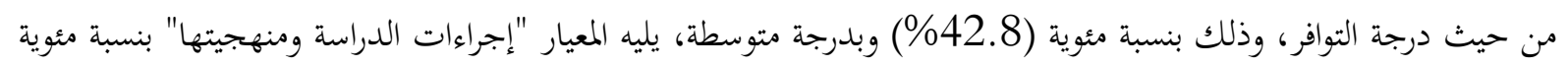

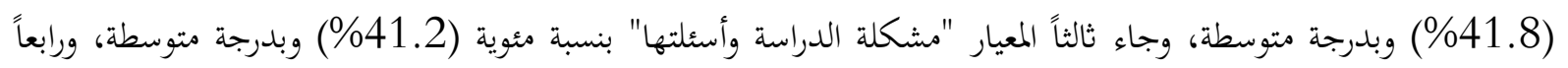

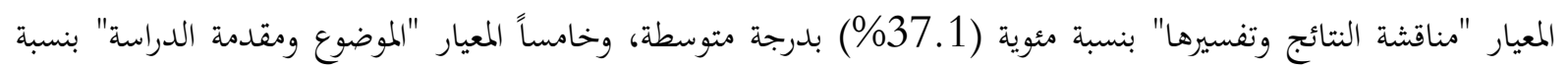

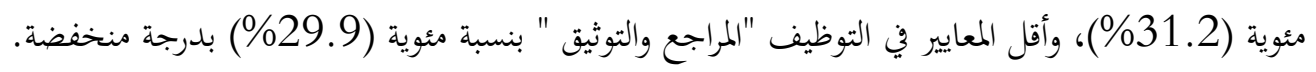
وتعزى هذه النتيجة إلى أن إعداد الأدوات البحثية يعد من المهارات العامة، حيث يعتمد الباحث على الأدب التربوي

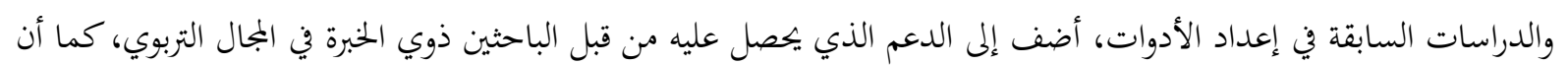
إجراءات الدراسة غالبا تكون جاهزة، إذ يعمل الباحث على تكييف الإجراءات وتطويرها في ضوء الدراسة البحثية التي يقوم

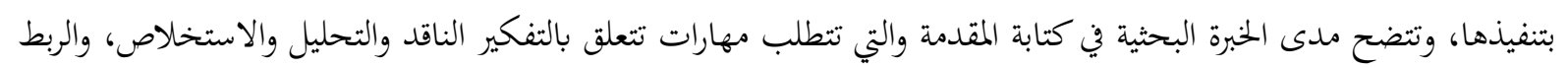
بين أجزاء المقدمة وبيان مشكلة الدراسة بأسلوب علمي، لذا جاء هذاء هذا المعيار في المرتبة قبل الأخيرة، كما أن خبرة المعلمين في فئسي التعامل مع المنهجية العلمية في التوثيق جاء في المرتبة الأخيرة، وهذا يعود على المعايير الخاصة بنظام التوثيق الأمريكي والذي فئي يتطلب أن يكصل الباحث على تدريب كافي حتى يتمكن من التوثيق بطريقة علمية ومتوافق مع معايير التوثيق العلمية. وتتفق هذه النتيجة مع دراسة السيد والعمري (2015)، حيث كشفت عن عدم توافر مهارات البحث الإجرائي لدى المعلمات الأوائل وجاءت دون مستوى الإتقان، ودراسة أبو علي (2020) التي بينت أن درجة محارسة معلمي العلوم لمهارات البحث الإجرائي جاءت متوسطة.

تختلف نتيجة هذه الدراسة مع دراسة الدغمي (2015) التي توصلت إلى أن درجة تمكن معلمي العلوم من معرفتهم

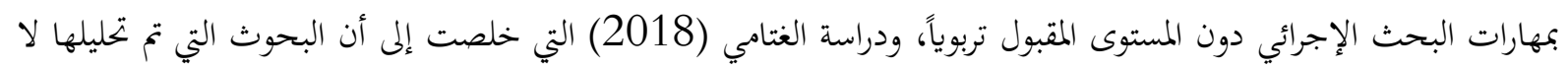
تحمل سمات البحث المقبول والمرضي. أما عما أظهرته نتائج الدراسة حول كل معيار من معايير الدراسة فقد جاءت التكرار والنسبة المئوية والأهمية النسبية

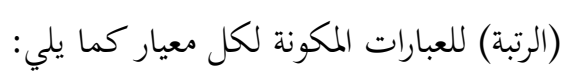
المعيار الأول: الموضوع ومقدمة الدراسة التكرارات للمفردات والنسبة المئوية لجميع المفردات المعيار الأول الموضوع ومقدمة الدراسة في بطاقة التحليل، والنسبة

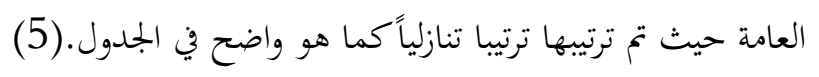
الجدول (5) التكرارات والنسبة المئوية والأهمية النسبية (الرتبة) للمعيار الأول الموضوع مقدمة الدراسة

\begin{tabular}{|c|c|c|c|c|}
\hline ى 1 المستو & المئوية النسبة & 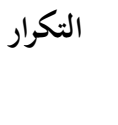 & 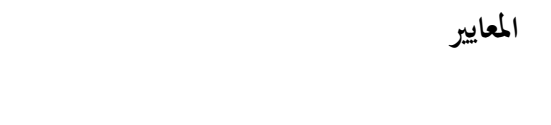 & b \\
\hline | مرتفع & 98.2 & 54 & موضوع البحث له علاقة بالحقل التربوي. & 1 \\
\hline 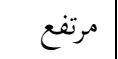 & 83.6 & 46 & تضمين الدراسات السابقة المرتبطة بموضوع الدراسة. & 2 \\
\hline 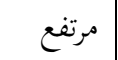 & 80.0 & 44 & يظهر معرفة وفهم (الباحث) بمشكلة الدراسة. & 3 \\
\hline
\end{tabular}




\begin{tabular}{|c|c|c|c|c|}
\hline مرتفع & 76.4 & 42 & عنوان البحث واضح ومحدد ويشمل متغيرات الدراسة. & 4 \\
\hline مرتفع & 70.9 & 39 & الاقتباسات (التصرف) ذات الصلة بمشكلة الدراسة. & 5 \\
\hline متوسط & 65.5 & 36 & ترابط الأفكار والتسلسل في عرض المشكلة. & 6 \\
\hline متوسط & 52.7 & 29 & كتابة المقدمة بأسلوب علمي متضمنا تحليل الأفكار وتمحيصها. & 7 \\
\hline 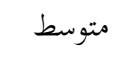 & 50.9 & 28 & الشمولية والدقة في عرض الدراسات السابقة والتعليق عليها. & 8 \\
\hline متوسط & 36.4 & 20 & التحليل التأملي ووضوح الكتابة الاكاديمية للنص. & 9 \\
\hline منخفض & 25.5 & 14 & التحليل المنطقي للنص المقتبس. & 10 \\
\hline منخفض & 23.6 & 13 & الكلمات المفتاحية مناسبة وذات صلة بموضوع البحث & 11 \\
\hline منخفض & 18.2 & 10 & ملخص الدراسة واضح ويتضمن العناصر الرئيسة & 12 \\
\hline متوسط & 31.2 & 375 & & 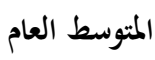 \\
\hline
\end{tabular}

تشير النتائج في الجدول (5) أن درجة توافر معايير البحث الإجرائي لدى المعلمين في معيار الموضوع ومقدمة الدراسة جاء متوسطاً فقد بلغت النسبة المئوية للتكرارات (31.2\%). وجاء أنجاء المعيار في المرتبة الخامسة من إجمالي معايير الدراسة. كما يتبين من الجدول (5) أن النسبة المئوية للتكرارات لكل مفردات المعيار الأول الموضوع ومقدمة الدراسة فقد تراوحت بين (18.1\%- 18.2\%)، أي بين المستوى المرتفع والمنخفض، وكانت الأكثر توافر معيار "موضوع البحث له علاقة بالحقل

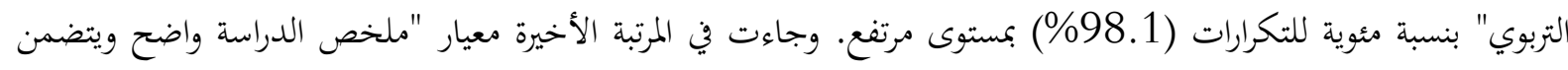
العناصر الرئيسة" بنسبة مئوية للتكرارات (18.2) بمستوى منخفضئ.

وتعزى هذه النتيجة إلى أن الدراسة البحثية تتعلق بمعرفة مدى توافر معايير البحث لدى المعلمين، لذا من المتوقع أن تكون

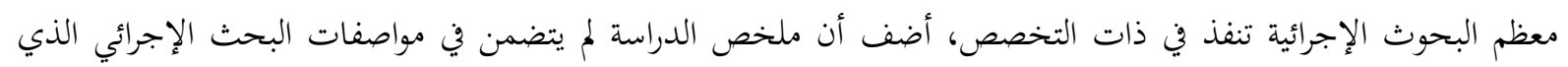

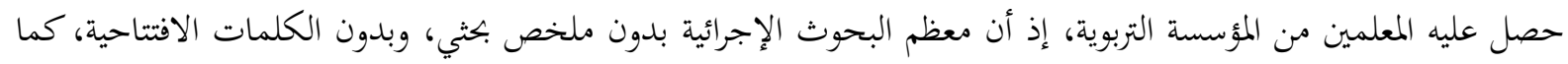

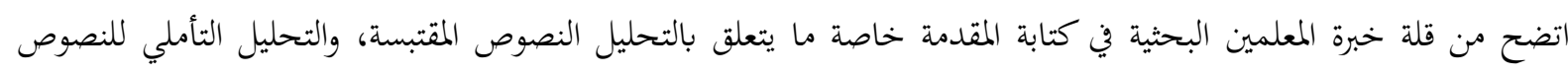
الأكاديمية، وهذا يعزى إلى قلة الساعات التدريبة التي حصل عليها المعلمين في البرامج التدريبية المقدمة لهم من المؤسسة التربوية.

المعيار الثاني: مشكلة الدراسة وأسئلتها

التكرارات للمفردات والنسبة المئوية لجميع المفردات المعيار الثاني مشكلة الدراسة وأسئلتها في بطاقة التحليل، والنسبة

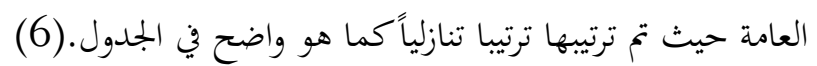
الجدول (6) التكرارات والنسبة المئوية والأهمية النسبية (الرتبة) للمعيار الثاني مشكلة الدراسة وأسئلته

\begin{tabular}{|c|c|c|c|c|}
\hline 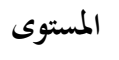 & 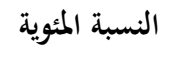 & 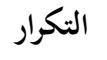 & المحاور & s \\
\hline مرتفع & 96.4 & 53 & تحديد الحدود المكانية والزمانية والموضوعية والبشرية والمادية بدقة. & 1 \\
\hline مرتفع & 94.5 & 52 & ارتباط المصطلحات بعنوان الدراسة. & 2 \\
\hline مرتفع & 94.5 & 52 & صياغة الأسئلة بطريقة علمية. & 3 \\
\hline مرتفع & 94.5 & 52 & ارتباط الأسئلة بمشكلة الدراسة. & 4 \\
\hline 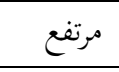 & 90.9 & 50 & استعمال مفردات قابلة للقياس. & 5 \\
\hline مرتفع & 87.3 & 48 & الصياغة العلمية لمشكلة الدراسة وارتباطها بالعنوان. & 6 \\
\hline 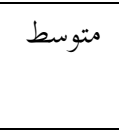 & 61.8 & 34 & البحث فيهمل عرض المشكلة جوانب مقنعة بوجودها ومظاهرها وأسباهما وأهمية & 7 \\
\hline 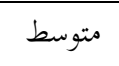 & 52.7 & 26 & تحديد مبررات الدراسة. & 8 \\
\hline
\end{tabular}




\begin{tabular}{|c|c|c|c|c|}
\hline 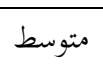 & 45.5 & 25 & صياغة الأهداف بطريقة علمية. & 9 \\
\hline 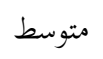 & 36.4 & 20 & بيان أهمية الدراسة وفائدةا وإسهامها في المجال التربوي. & 1 \\
\hline متو س & 41.2 & 412 & العاد & لمته \\
\hline
\end{tabular}

تشير النتائج في الجدول (6) أن درجة توافر معايير البحث الإجرائي لدى المعلمين في معيار مشكلة الدراسة وأسئلتها

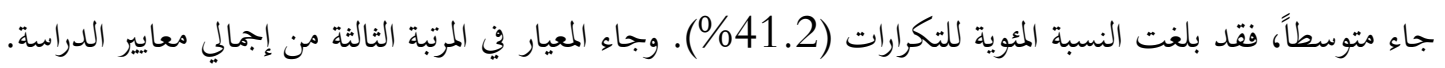
كما يتبين من الجدول (6) أن النسبة المئوية للتكرارات لكل مفردات المعيار الثاني مشكلة الدراسة وأسئلتها، فقد تراوحت بين (96.4\%- 36.4\%)، أي بين المستوى المرتفع والمتوسط، وكان الأكثر توافر معيار "تحديد الحدود المكانية والزمانية والموضوعية والبشرية والمادية بدقة" بنسبة مئوية للتكرارات (96.4\%) بمستوى مرتفع. وجاءت في المرتبة الأخيرة معيار "بيان أهمية

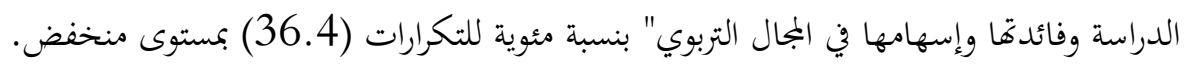
وتعزى هذه النتيجة إلى أن محددات الدراسة من المهارات السطحية التي يستطيع الباحث القيام هما، أضف إلى أن توافر

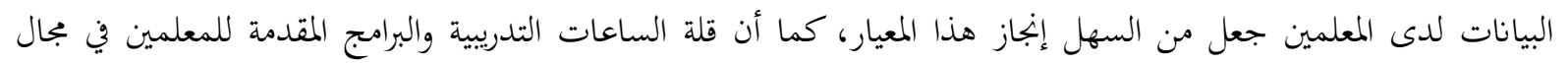
الدراسات البحثية أثرت على بقية المعايير والتي كانت بمستوى متوسط، ما يعطي دلالة على فقدان المعلمين للعديد من المهارات

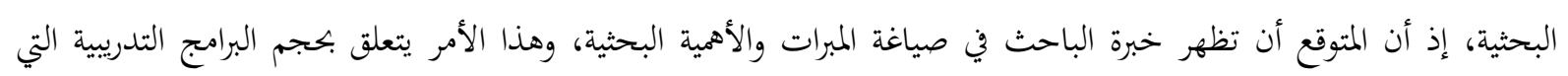
تقدم للمعلمين في البحث الإجرائي.

المعيار الثالث: إجراءات الدراسة ومنهجيتها

التكرارات للمفردات والنسبة المئوية لجميع المفردات في المعيار الثالث الخاص بإجراءات الدراسة ومنهجيتها في بطاقة

التحليل، والنسبة العامة حيث تم ترتيبها ترتيبا تنازلياً كما هو واضح في الجدول. الجدول (7) التكرارات والنسبة المئوية والأهمية النسبية (الرتبة) للمعيار الثالث إجراءات الدراسة ومنهجيتها

\begin{tabular}{|c|c|c|c|c|}
\hline 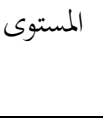 & المئوية & التكرار & المحاور & s \\
\hline 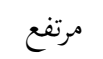 & 94.5 & 52 & وصف بجتمع الدراسة من حيث نوعه وحجمه ومكانه. & 1 \\
\hline 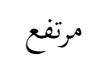 & 90.9 & 50 & تحديد عينة الدراسة وطريقة اختيارها. & 2 \\
\hline 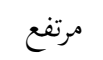 & 90.6 & 50 & تحديد إجراءات الدراسة وبمع البيانات بشكل واضح. & 3 \\
\hline 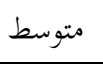 & 56.4 & 31 & تحديد نوع البحث ومنهجيته بوضوح (كمي - نوعي - مزجي) & 4 \\
\hline 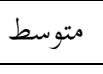 & 47.3 & 26 & توضيح الأساليب الإحصائية المستخدمة في تحليل البيانات. & 5 \\
\hline 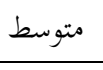 & 41.8 & 209 & \multicolumn{2}{|c|}{ المتوسط العام } \\
\hline
\end{tabular}

تشير النتائج في الجدول (7) أن درجة توافر معايير البحث الإجرائي لدى المعلمين في معيار إجراءات الدراسة ومنهجيتها

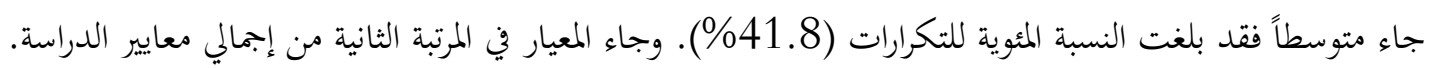
كما يتبين من الجدول (7) أن النسبة المئوية للتكرارات لكل مفردات معيار إجراءات الدراسة ومنهجيتها قد تراوحت بين

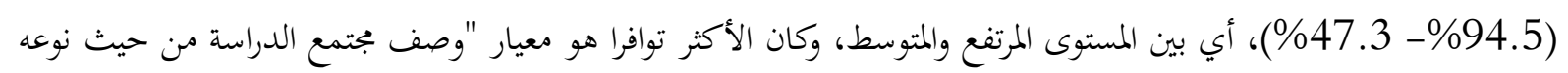
وحجمه ومكانه" بنسبة مئوية للتكرارات (94.5\%) بمستوى مرتفع. وجاء في المرتبة الأخيرة معيار "توضيح الأساليب الإحصائية

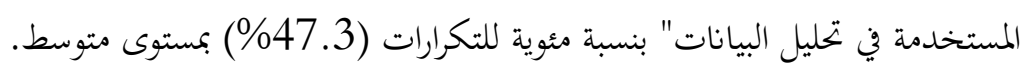


وتعزى هذه النتيجة إلى أن إجراءات الدراسة تعد من المهارات السطحية التي من السهل أن يمتلكها الباحث، وتأتي في

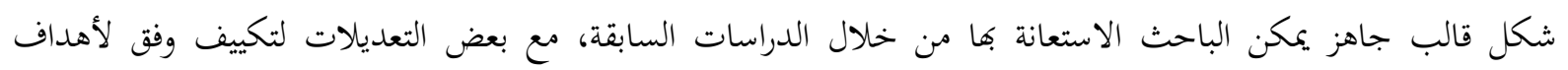

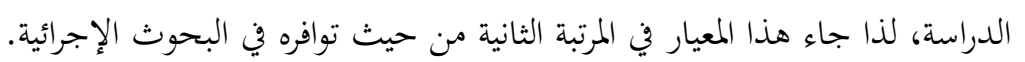

\section{المعيار الرابع: أدوات الدراسة}

التكرارات للمفردات والنسبة المئوية لجميع المفردات المعيار الرابع أدوات الدراسة في بطاقة التحليل، والنسبة العامة حيث

تم ترتيبها ترتيبا تنازلياً كما هو واضح في الجدول(8). الجدول (8) التكرارات والنسبة المئوية والأهمية النسبية (الرتبة) للمعيار الرابع أدوات الدراسة

\begin{tabular}{|c|c|c|c|c|}
\hline 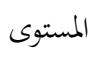 & النسبة المئوية & التكرار & المحاور & s \\
\hline 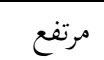 & 92.7 & 51 & ارتباط محتوى الأداة مع موضوع الدراسة. & 1 \\
\hline 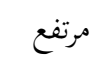 & 92.7 & 51 & السلامة اللغوية لأدوات الدراسة. & 2 \\
\hline 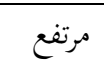 & 83.6 & 46 & وصف شامل ومحدد للأداة وطريقة إعدادها. & 3 \\
\hline مرتفع & 76.4 & 42 & البحثية (وصفي/ المنهجية العلمية المستخدمة وتوافقها مع المشكلة) - (كمي/ نوعي/ مزجي؟) & 4 \\
\hline متوسط & 43.6 & 24 & التأكد من صدق وموثوقية الأدوات. & 5 \\
\hline متوسط & 42.8 & 214 & & \\
\hline
\end{tabular}

تشير النتائج في الجدول (8) أن درجة توافر معايير البحث الإجرائي لدى المعلمين في معيار أدوات الدراسة جاء متوسطاً، فقد بلغت النسبة المئوية للتكرارات (42.8\%). وجاء المعيار في المرتبة الأول من إجمالي معايير الدراسة. كما يتبين من الجدول (8) أن النسبة المئوية للتكرارات لكل مفردات معيار أدوات الدراسة فقد تراوحت بين

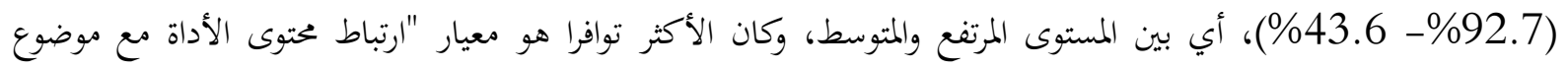

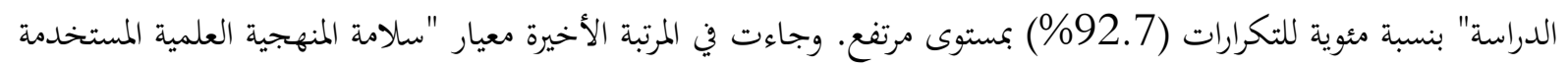

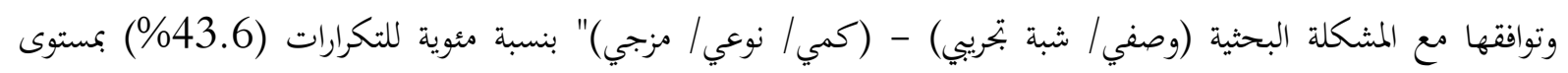
متوسط.

وتعزى هذه النتيجة إلى أن معظم الباحثين يعتمد على الباحثين ذوي الخبرة في تحكيم ومراجعة الأدوات التي يقوم بإعدادها

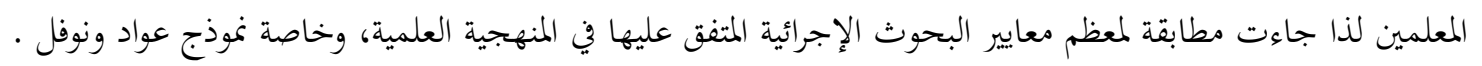
المعيار الخامس: مناقشة النتائج وتفسيرها التكرارات للمفردات والنسبة المئوية لجميع المفردات المعيار الخامس مناقشة النتائج وتفسيرها في بطاقة التحليل، والنسبة

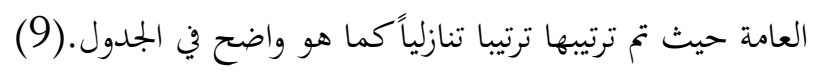
الجدول (9) التكرارات والنسبة المئوية والأهمية النسبية (الرتبة) للمعيار الخامس مناقشة النتائج وتفسيرها

\begin{tabular}{|c|c|c|c|c|}
\hline المستوى & النسبة المئوية & التكرار & المحاور & p \\
\hline 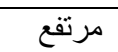 & 100 & 55 & تنظيم البيانات وفقا لأدو ات الدراسة. & 1 \\
\hline مرتفع & 92.7 & 51 & الإجابة على جميع أسئلة الدراسة. & 2 \\
\hline 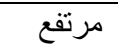 & 89.1 & 49 & ارتباط التوصيات بنتائج الدراسة. & 3 \\
\hline مرتفع & 87.3 & 48 & تصنيف البيانات وتحديد مستو اها. & 4 \\
\hline
\end{tabular}




\begin{tabular}{|c|c|c|c|c|}
\hline 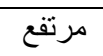 & 74.5 & 41 & الربط بين نتائج الدر اسة و الأدب النظري و الدراسات السابقة. & 5 \\
\hline 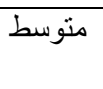 & 54.5 & 30 & والخملاصة التقرير لكافة عناصر ومكونات الدراسة من المقدمة الى الخاتمة & 6 \\
\hline 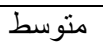 & 47.3 & 26 & التركيز على الدلالة العلمية للصفة المر اد قياسها. & 7 \\
\hline متوسط & 43.6 & 24 & شمولية النتائج وامكانية تعميمها وفقًا لعينة الدراسة التي حددها الباحث & 8 \\
\hline متوسط & 43.6 & 24 & بروز صوت الباحث و هو يته من خلال مناقثة النتائج & 9 \\
\hline متوسط & 41.8 & 23 & تفسير النتائج بطريقة علمية ومنهجية. & 10 \\
\hline 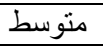 & 37.1 & 371 & بام & المنو \\
\hline
\end{tabular}

تشير النتائج في الجدول (9) أن درجة توافر معايير البحث الإجرائي لدى المعلمين في معيار مناقشة النتائج وتفسيرها جاء

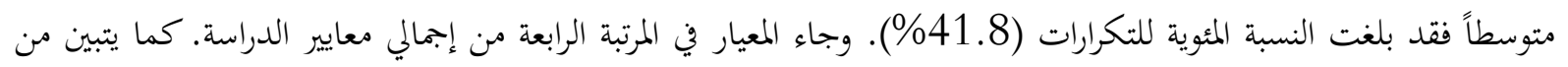

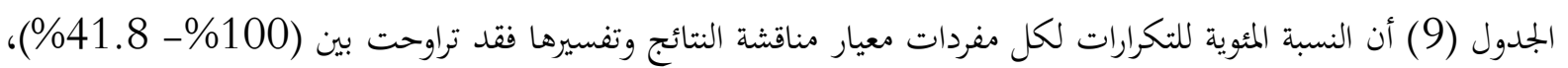
أي بين المستوى المرتفع والمتوسط، وكان الأكثر توافرا معيار " تنظيم البيانات وفقا لأدوات الدراسة" بنسبة مئوية للتكرارات

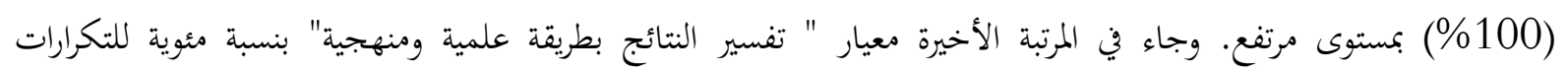
(\%41.8)

وتعطي هذه النتيجة دلالة تربوية إلى أن هناك غياب لخبرة المعلمين في مناقشة النتائج وإظهار التفكير الناقد في تفسير هذه

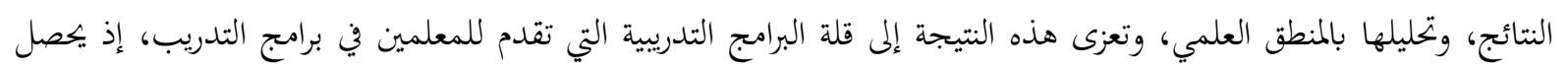
البحث الإجرائي على عدد قليل من الساعات التدريية لا تتجاوز (5) ساعات تدريبية.

\section{الخحور السادس: المراجع والتوثيق}

التكرارات للمفردات والنسبة المئوية لجميع المفردات في المعيار السادس الخناص بالمراجع والتوثيق في بطاقة التحليل، والنسبة

$$
\text { العامة حيث تم ترتيبها ترتيبا تنازلياً كما هو واضح في الجدول. (10) }
$$

الجدول (10) التكرارات والنسبة المئوية والأهمية النسبية (الرتبة) للمعيار السادس المراجع والتوثيق

\begin{tabular}{|c|c|c|c|c|}
\hline المستوى & النسبة المئوية & 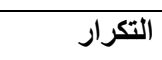 & المحاور & م \\
\hline 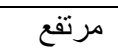 & 83.6 & 46 & التوثيق في المتن بطريقة علمية دقيقة وفقا لنظام APA. & 1 \\
\hline 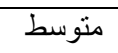 & 52.7 & 29 & تتوع المر اجع وحداثتها. & 2 \\
\hline 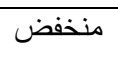 & 25.5 & 14 & التوثيق في قائمة المر اجع بالطريقة العلمية وفقا لنظام APA. & 3 \\
\hline منخفض & 29.9 & 89 & & المتوسط \\
\hline
\end{tabular}

تشير النتائج في الجدول (10) أن درجة توافر معايير البحث الإجرائي لدى المعلمين في معيار المراجع والتوثيق جاء منخفضا، فقد بلغت النسبة المئوية للتكرارات (29.9\%) وجاء المعيار في المرتبة الخامسة من أجمالي معايير الدراسة. كما يتبين من الجدول (10) أن النسبة المئوية للتكرارات لكل مفردات المعيار السادس الخاص بالمراجع والتوثيق قد تراوحت بين (83.6\%- 25.5\%)، أي بين المستوى المرتفع والمنخفض، وكان الأكثر توافرا معيار "التوثيق في المتن بطريقة

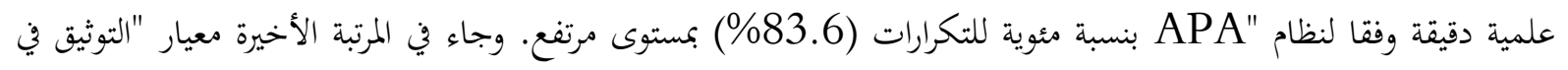

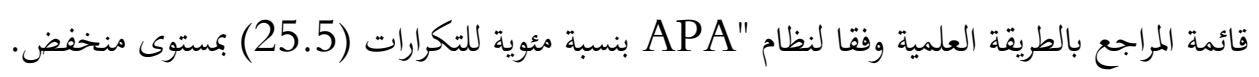
وتعزى هذه النتيجة إلى ضعف مهارات المعلمين في التوثيق العلمي للمراجع، إذ اتضح ذلك من خلال التوثيق في قائمة

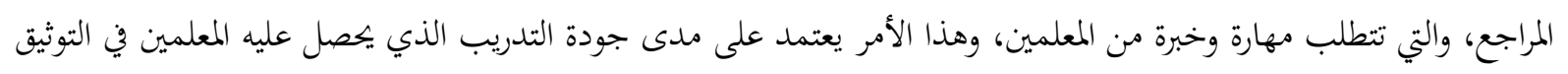

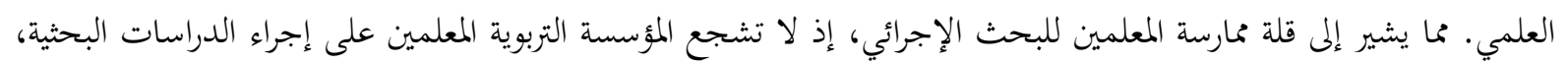


ولا يكصلوا على حوافز مادية أو معنوية على إجرائها مما يقلل من جودتها، إذ يقوم بما المعلمين بين فترة وأخرى كمتطلب ثانوي أو متطلب متعلق بالترقية الوظيفية.

\section{نتائج السؤال الثاني ومناقشتها}

لإججابة على السؤال الثاني: هل توجد فروق ذات دلالة إحصائية عند مستوى دلالة (20.05 م) بين متوسطات توافر

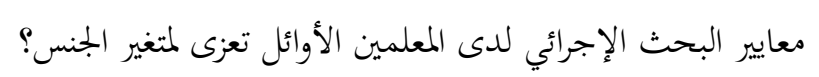

للإجابة عن هذا السؤال (متغير الجنس) تم استخدام المتوسطات الحسابية والاخرافات المعيارية واختبار(T-Test (T-T) ، ويوضح

الجدول (11) ذلك.

جدول (11) المتوسطات الحسابية والانحرافات المعيارية واختبار (T-Test) تبعاً لمتغير الجنس

\begin{tabular}{|c|c|c|c|c|c|c|c|}
\hline اتجاه الدلالة & الدلالة & قيمة ت & الالنعراف & الحسابي & العدد & الجنس & المجال \\
\hline \multirow[t]{2}{*}{ غير دالة } & \multirow[t]{2}{*}{0.756} & \multirow[t]{2}{*}{0.312} & 2.21 & 6.70 & 24 & ذكر & \multirow[t]{2}{*}{ المتوسط العام } \\
\hline & & & 2.35 & 6.90 & 31 & أنثى & \\
\hline
\end{tabular}

تشير نتائج الجدول (11) إلى عدم وجود فروق ذات دلالة إحصائية عند درجة الدلالة (11) (م=05) بين متوسطات

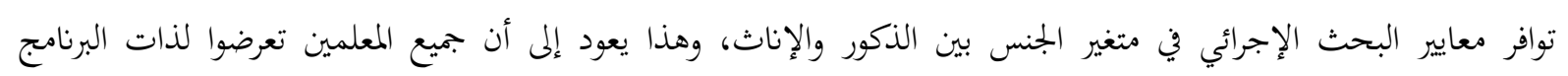

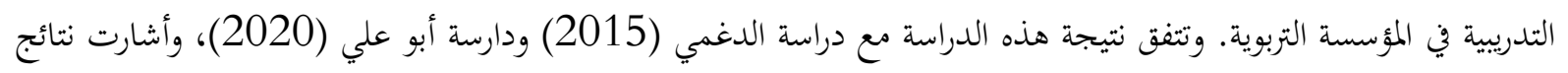
الدراسة إلى عدم وجود فرق ذات دلالة إحصائية في درجة تمكن معلمي العلوم لمهارات البحث الإجرائي تعزى للجنس الجنس.

\section{توصيات الدراسة}

في ضوء النتائج التي توصلت إليها الدراسة، يوصي الباحثان بالآتي: 1. تدريب المعلمين على كيفية تفسير نتائج الدراسة ومناقشتها.

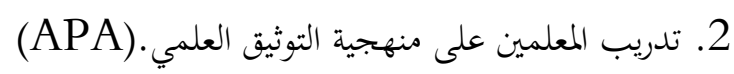
3. نشر ثقافة البحث الإجرائي في الحقل التربوي.

4. تطوير برامج تدريب المعلمين وإضافة ساعات تدريبية أكثر في البحث الإجرائي.

\section{مقترحات الدراسة}

يوصي الباحثان إجراء مجموعة من الدراسات المرتبطة بموضوع الدراسة الحالية، وهي كالآتي: 1. فاعلية برنامج تدربي قائم على البحث الإجرائي في تطوير مهارات المعلمين البحثية. 2. تطبيق معايير البحث الإجرائي على المشرفيين التربويين ومدراء المدراس. 3. قياس فاعلية البحث الإجرائي في معالجة القضايا التربوية. 


\section{المراجع}

أبو علي، محمد زهران. (2020). درجة ممارسة معلمي العلوم لمهارات البحث الإجرائي في المدارس الأردنية من وجهة نظرهم.

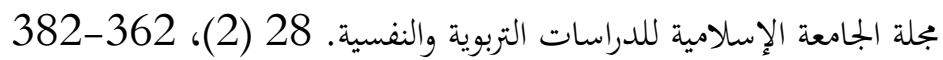

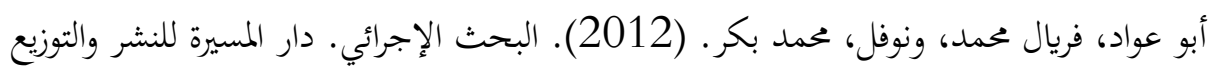

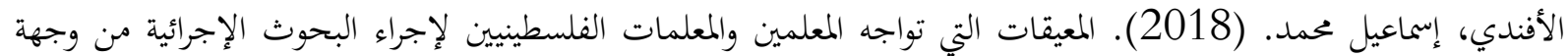
نظرهم: بحث مقدم لمؤتمر التعليم في الوطن العربي نحو نظام تعليمي متميز. بجلة اتحاد الجامعات العربية للتربية وعلم

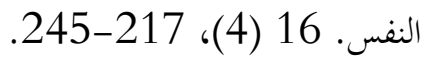

بخاري، خلود أسحاق إبراهيم (2019). دور البح الإجرائي في تحين الممارسات التعليمية من وجهة نظر القيادات المدرسية بمدينة

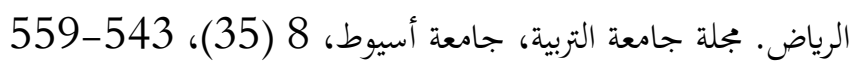

البدوي، عائشة محمد خليفة (2020). مهارات البحث الإجرائي لدى معلمات التعليم العام بمدينة تبوك في المملكة العربية

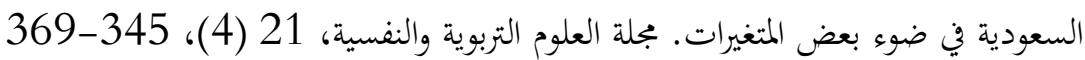

حسين، ابتسام ياسين. (2019). تدريس مقرر البحث الإجرائي ودوره في تحسين التعليم والتعلم ببرامج بكالوريوس رياض

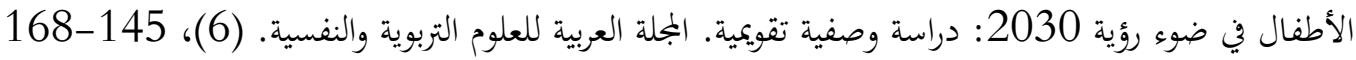
الدغمي، ماجدة محمد ناصر (2015). درجة تمكن معلمي العلوم لمهارات البحث الإجرائي في محافظة المفرق (رسالة ماجستير

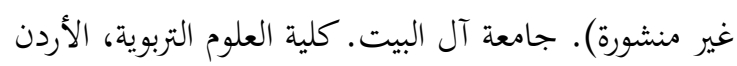
الدوسري، محمد بن سعد بن حويل. (2016). العوامل ذات العلاقة بعزوف المعلمين عن إجراء البحوث الإجرائية من وجهة نظر معلمي المرحلة الثانوية بمدينة الرياض (رسالة ماجستير غير منشورة). جامعة الإمام محمد بن سعود الإسلامية.

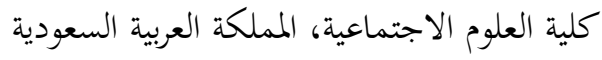

سرور، أميرة اسماعيل حسين، أمل حسين سرور، ورفيق عبد الرحمن محسن. (2011). واقع ومعوقات البحث التربوي وسبل

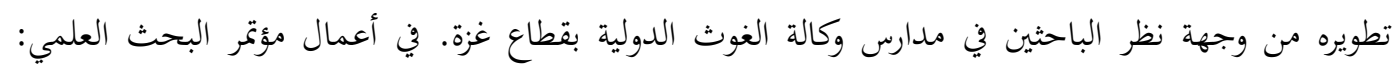

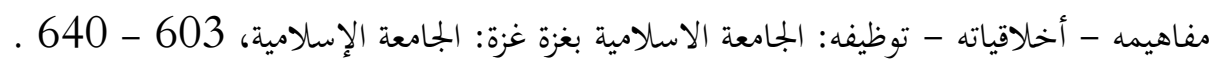
سليم، شيماء عبد السلام (2018). برنامج تدريبي قائم على المعايير المهنية العالمية الحديثة لتنمية مهارات البحث الإجرائي لدى لهري

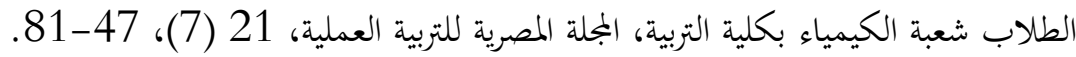

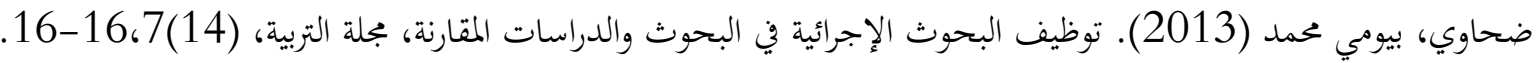

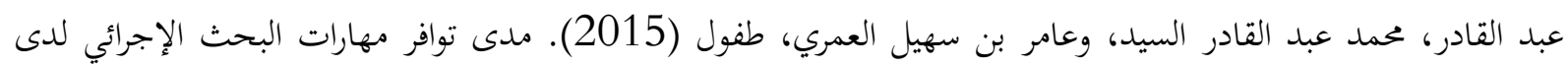
المعلمات الأوائل في مدارس التعليم الأساسي في محافظة ظفار-سلطنة عمان. مجلة كلية التربية، جامعة بنها،

$$
\text { .162-129، (103)26 }
$$

العتبي، ساره بنت بدر محسن.. (2016). فاعلية برنامج تدريبي مقترح في تنمية مهارات البحث الإجرائي لدى معلمات

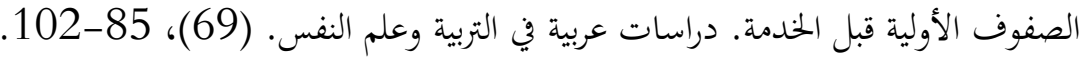

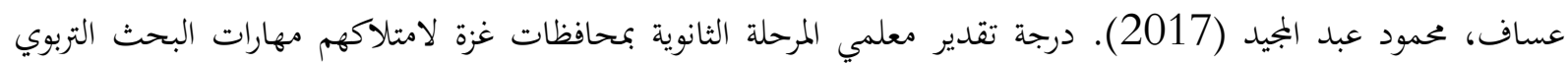

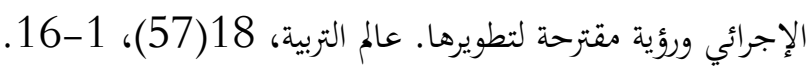

عساف، محمود عبد المجيد.. (2017). درجة تقدير معلمي المرحلة الثانوية بمحافظات غزة لامتلاكهم مهارات البحث التربوي

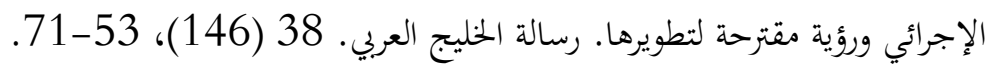




$$
\begin{aligned}
& \text { العمراني، ليلى بنت فلاح سليم (2020). مستوى ممارسة أعضاء هيئة التدريس بجامعة تبوك لمهارات البحث الإجرائي التشاركي }
\end{aligned}
$$

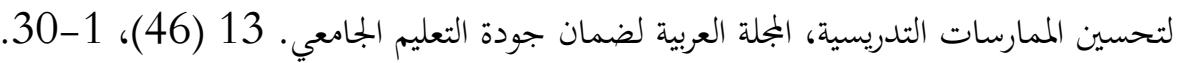

$$
\begin{aligned}
& \text { الغتامي، سليمان بن سيف (2018). مدى تقيّد بحوث المعلمين بمنهجية البحث الإجرائي ومعاييره: دراسة تحليلية نوعية. المجلة } \\
& \text { التربوية الدولية المتخصصة. } 7 \text { (1)، 109-120 (12014. } \\
& \text { محمد، وليد يوسف. (2014). أثر استخدام دعامات التعلم العامة والموجهة في بيئة شبكات الويب الاجتماعية التعليمية في } \\
& \text { تنمية مهارات التخطيط للبحوث الإجرائية لدى طلاب الدراسات العليا وتنمية التحاهاتم نحو البحث العلمي لئه }
\end{aligned}
$$

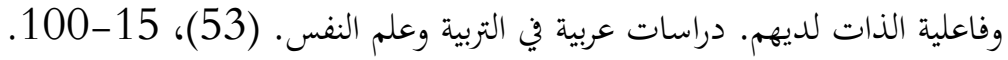

$$
\begin{aligned}
& \text { المزيني، تماني بنت عبد الرحمن بن علي.. (2012). فاعلية برنامج تدريبي مقترح في تنمية مهارات البحث الإجرائي ومفهوم تعليم }
\end{aligned}
$$

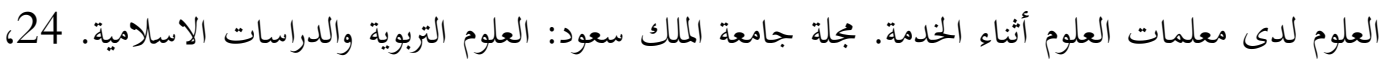

$$
\begin{aligned}
& \text {.618-585، (2) } \\
& \text { المقبل، العنود (2018). البرنامج التدريبي للبحث الإجرائي. وزارة التربية والتعليم: المملكة العربية السعودية } \\
& \text { نصر، ميرا ماريا. (2014). أثر البحث الإجرائي على التنمية المهنية للمعلم والمشرف: مادة الرياضيات في مرحلة التعليم الأساسي } \\
& \text { في مدرسة خاصة في بيروت (رسالة ماجستير غير منشورة). الجامعة اللبنانية كلية التربية - العمادة، لبنان. }
\end{aligned}
$$

Arora, CH.(2017).Action Research in Schools and Utility for Teachers, International Journal of Education\& Multidisciplinary Studies,6(2),163-169.

Clayton, C.\& Broome,J.(2018). Thinking like researchers: action research and its impact on novice teachers'thinking, Educational Action Research, 26(1),59-74.

Coghlan, D., Coughlan, P., \& Shani, A. B. (2019). Exploring Doctorateness inInsider Action Research. International Journal of Action Research, 15(1)

Hegazy, H., Ellerton, P., Campos-Remon, H., Zaphir, L., Mazzola, C., \& Brown, D. (2021). Working from theory: developing the bases of teachers' critical thinking pedagogies through action research. Educational Action Research, 1-16.

Houghton, J. (1996). Academic Accreditation: Who, What, Where, and Why?. National Recreation Park Association. 31 (2). 42-46.

Moi Mooi, L; Mohsin, M. (2012). Developing competency of pre-service teachers in doing action research: outcome and issues. International Journal of Arts

Riel, M. (2017). Understanding Action Research, Center for collaborative Action Research, Retrieved March, 28, 2018, from: http://cadres.pepperdine.edu/ccar/define.html.

Ronen, I. K. (2020). Action research as a methodology for professional development in leading an educational process. Studies in Educational Evaluation, 64, 100826.

Ward, G. (2017). Action Research in Montessori Classrooms, AMS National Conference San Diego, American Montessori Society, California, March,11 


\title{
VISIOCONFERENSING TECHNOLOGY AND THE RIGHT TO A FAIR TRIAL
}

\author{
Lynda MABROUK ${ }^{1}$
}

\section{Istanbul: Türkiye \\ p. $385-401$}

Received: $27 / 11 / 2021$

Accepted: $18 / 12 / 2021$

Published: 01/01/2022

This article has been scanned I iThenticat No plagiarism detected

\section{Abstract:}

The diffusion of communication and information technologies and their great development in recent years have had a great impact on all aspects of life, including the justice sector, through what is called the electronic court or electronic dispute resolution. The intrusion of this technology in the area of justice has had great success, particularly with regard to the speed of dispute settlement, the reduction in the load of cases and their accumulation or the displacement of litigants before the courts. The videoconferencing technology adopted by the courts has led to a number of modifications in the working methods of the judge as well as in the rights of the parties, particularly in criminal matters. This technology has changed the characteristics of the traditional trial and affected the principles and guarantees of a fair trial.

Key words: Traditional Trial, Video Conferencing Technology, Principles of Fair Trial, Rights of Defence, The Presence, The Public, Oral, The Right to Judge, Parties To The Case, Protection of Human Rights, The Justice. 


\section{تقنية التحاضر المئي والحق في محاكمة عادلة}

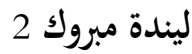

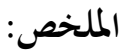

كان لانتشار تكنولوجيا الاتصالات والمعلومات وتطورها الكبير في السنوات الأخيرة أثرها البالغ، فلقد هيمنت

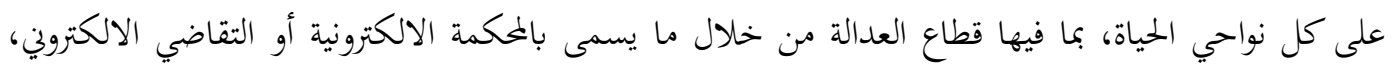

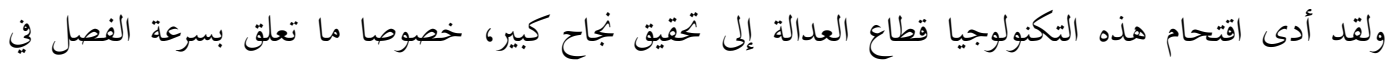
المنازعات وتتفيف عبء تراكم القضايا وتنقل المتقاضين إلى المحاكم لكن في نفس الوقت أفرزت هذه التكنولوجية عدد من التعديلات في أساليب عمل القاضي، وكذلك في حقوق الأطراف خصوصا في الدعوى الجزائية بعد تبني

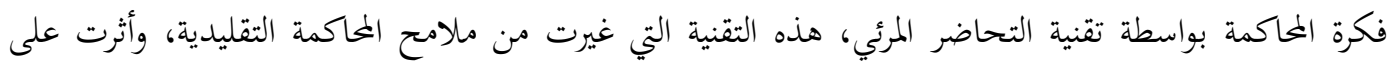

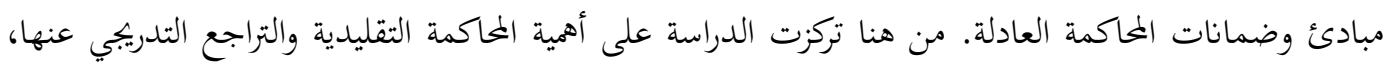

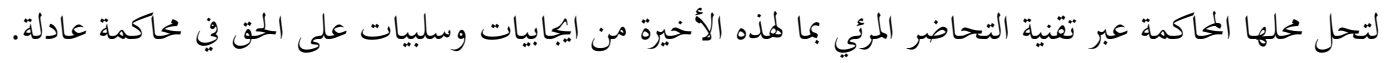

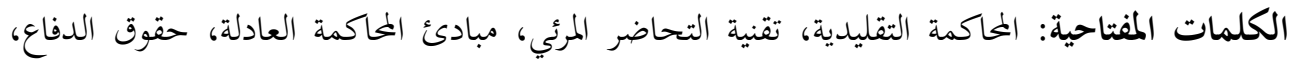
الحضورية، العلنية، الشفوية، الحق في القاضي، أطراف الدعوى، حماية حقوق الإنسان، العدالة.

لقد أفرزت الثورة الرقمية التي يشهدها العالم، تطورا كبيرا على جميع الأصعدة والنواحي دوليا ومحليا. وهيمنت على كل

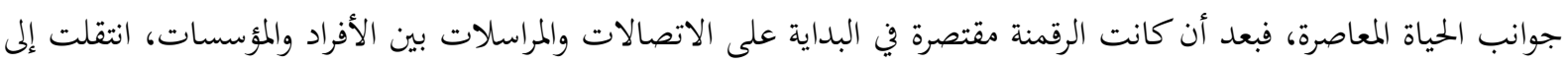

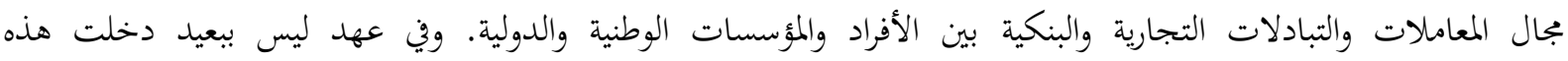

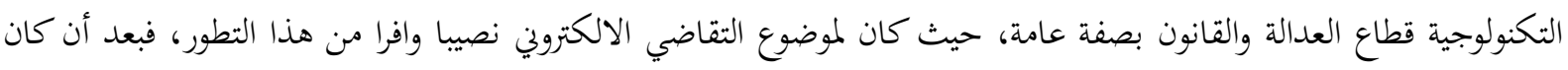

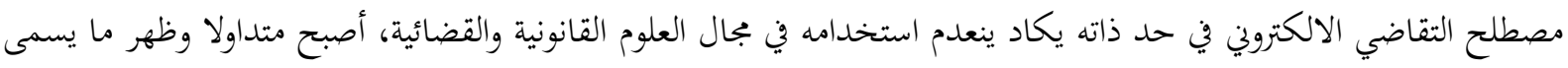
بالمكمة الالكترونية كواحدة من نتائج الحكومة الالكترونية، ليحدث تغييرا كبيرا في إجراءات التقاضي التقليدية، حيث التهت

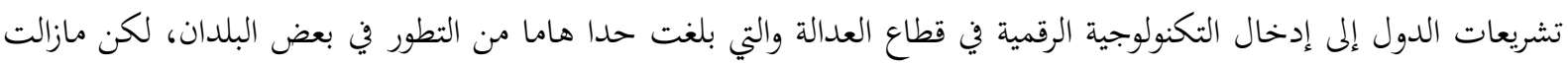

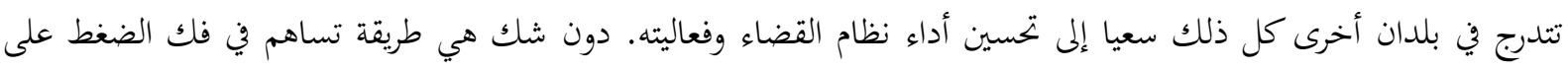

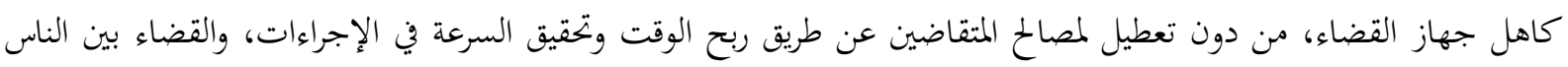

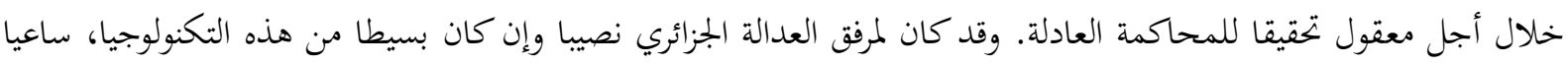
نهو مسايرة التوجه العالمي في هذا المجال، حتى يتسنى لهذا المرفق الحساس من مواجهة التحديات، ومواكبة ما ينجر عن هذه

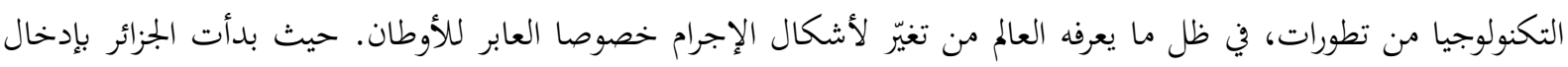

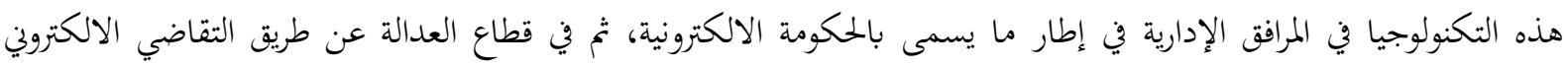
بواسطة ما يسمى بقانون عصرنة العدالة، واستخدام آلية التحاضر المرئي عن بعد، والتي يقابلها باللغة الفرنسية مصطيلح 
"Visio-conférence" جلسات المحاكمة وتوسع استخدامها أكثر في ظل جائحة كوفيد 19. وإذ ندرس المحاكمة عبر تقنية التحاضر المرئي فإننا نسلط الضوء على هذا الأسلوب الجلديد في الإجراءات أمام القضاء

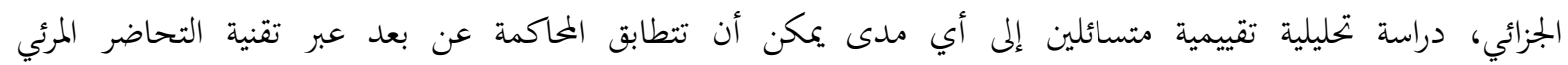
Visioconférence بها من ضمانات، هي محور النظم الرسمية والرمزية والعملية لتحقيق العدالة، ونتساءل أيضا كيف تنجح العدالة البعيدة في ترسيخ نفسها كبديل للعدالة الحضورية؟ وهل تتحقق فعلا الحماية اللازمة والاحترام الكافي للحقوق والحريات في الحالة التي يقدم فيها

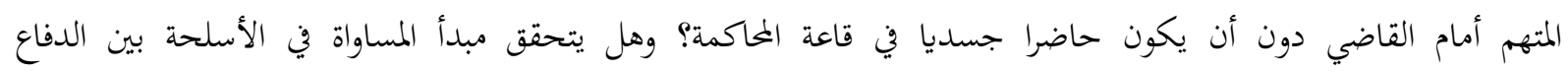

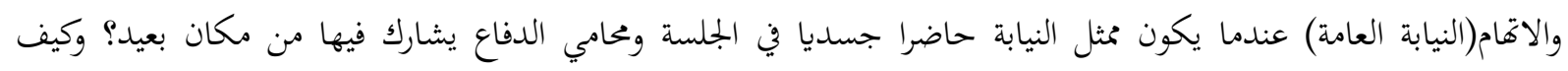
ساهم تقنية التحاضر المرئي عن بعد وأثرت في تحقيق المحاكمة العادلة؟ وما هي أهم التحديات التي تواجه تطبيق هذه التهائ التقنية؟ هذه الأسئلة التي يحددها هذا البحث للإجابة عليها، تكون من خلال تحليل ديناميكيات نشأة هذا الابتكار وتطويره

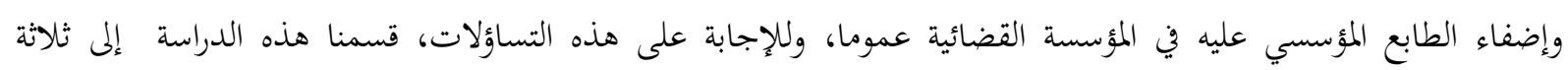
مباحث كما يلي:

- - المبحث الأول: الانتقال من المحاكمة التقليدية إلى المحاكمة الرقمية. - - - المبحث الثاني: تأثير تقنية التحاضر المئي على الحق في محاكمة عادلة. - - ملمبحث الثالث: تطابق تقنية التحاضر المرئي مع الحقى في المحاكمة العادلة. 


\section{المبحث الأول: الانتقال من المحاكمة التقليدية إلى المحاكمة الرقمية}

تعد الدعوى الجنائية إحدى حلقات الشرعية، لما تنطوي عليه من ضمان إجراء محاكمة عادلة للفصل في إدانة الفرد من

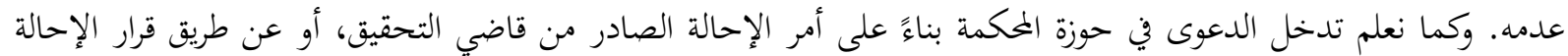

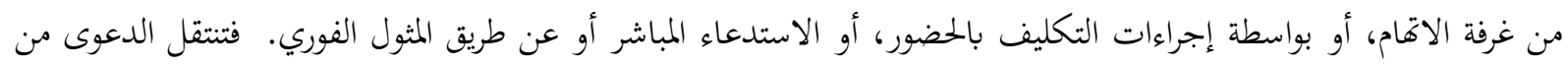

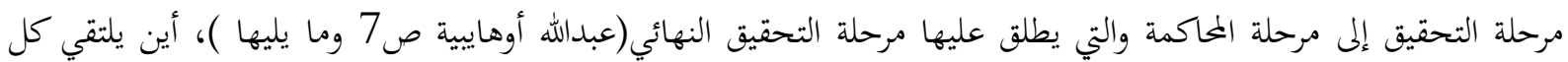
الخصوم في جلسة المحاكمة بمفهومها التقليدي، هذا المفهوم الذي بدأ في الآونة الأخيرة يشهد تغيرّات جذرية، طالته كما طالت قطاع العدالة عموما وجلسة المحاكمة خصوصا، بما تحمله هذه الأخيرة من رمزية وطقوس وهيبة استمرت في الزمن إلى يومنا هذا.

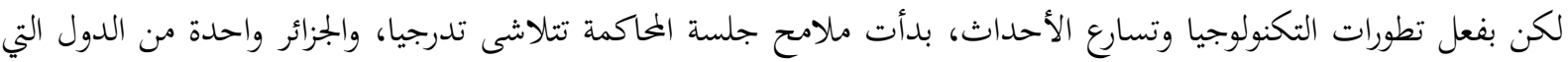

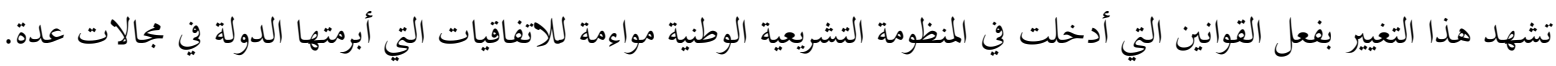

\section{المطلب الأول: بداية التراجع عن المحاكمة التقليدية}

مرت المحاكمة الجنائية أو ما يطلق عليها (بالتحقيق النهائي)، بمحطات أساسية كانت ومازالت تتمحور حول جلسة المحاكمة التقليدية، التي ترتكز على البعد المسرحي وهو الطابع الأصلي والمستمر في التنظيم القضائي المعاصر، رغم القيود المتزايدة

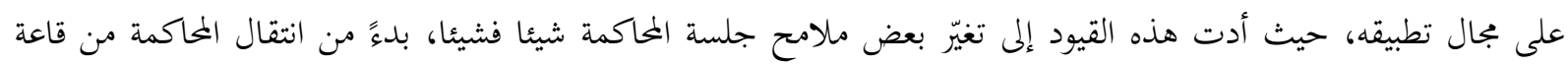
المحكمة إلى مكتب القاضي، إلى غاية الوصول بالمحاكمة خارج أسوار المحكمة عن طريق تكنولوجيات الاتصال والمعلومات.

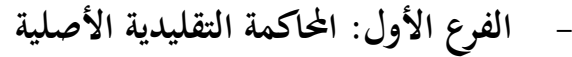

ترتكز المحاكمة التقليدية على طقوس أصبحت اليوم بنظر البعض عتيقة وذات نتائج عكسية، فهناك من يرى ضرورة تجنبها

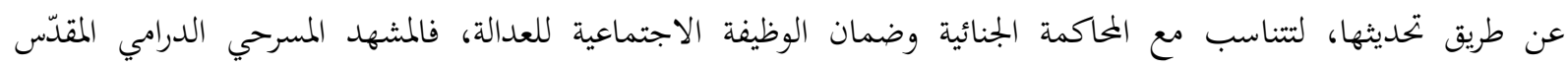

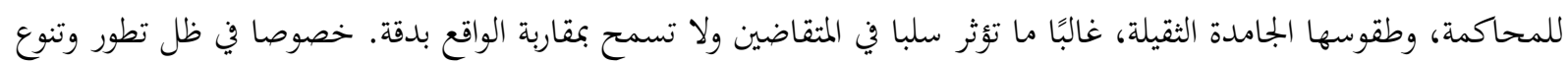
الإجرام واتساع رقعته وعبوره للأوطان، مما يستدعي تنسيقا وتواصلا سريعا بين العديد من الجهات القضائية بما يوفر فعالية ونجاعة

\section{- - الفرع الثاني: الانتقال التدريجي من قاعة الطحكمة إلى مكتب القاضي}

يقول أنطوان غاربون Antoine Garapon: " تدريجياً انتقل مركز الثقل في العدالة من قاعة المحكمة إلى مكتب

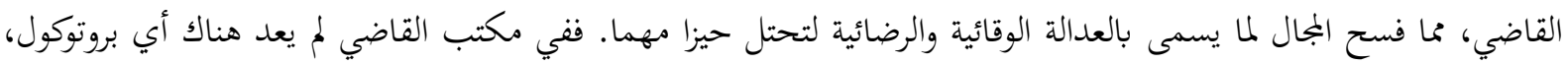

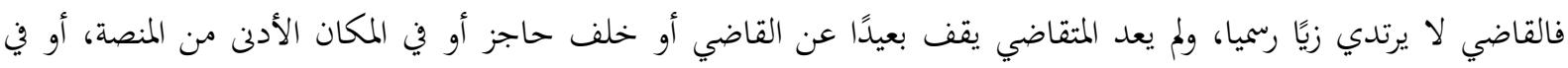

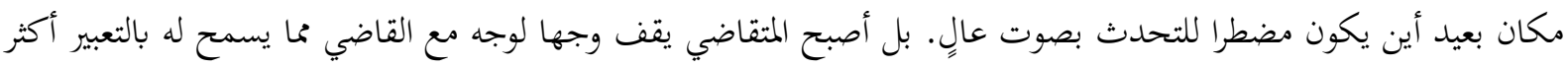

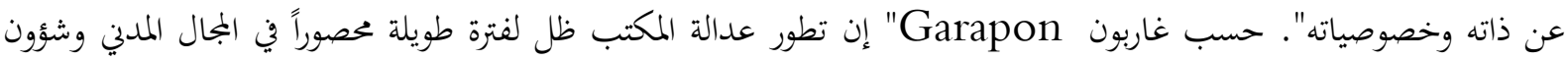

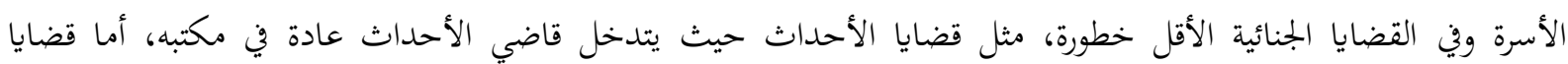

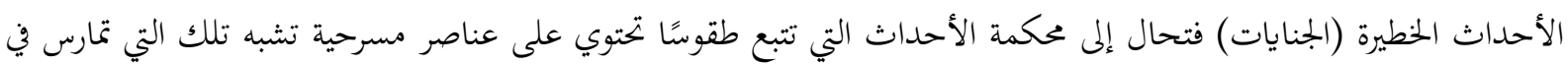
مكمة جنايات البالغين." (Antoine Garapon,1997)

\section{أولا: التحول من العدالة القهرية إلى العدالة الرضائية}

صاحب تطور الدولة وإسرافها في التجريم تضخما تشريعيا في المجال الجنائي، أدى إلى ما يعرف بأزمة العدالة الجنائية،

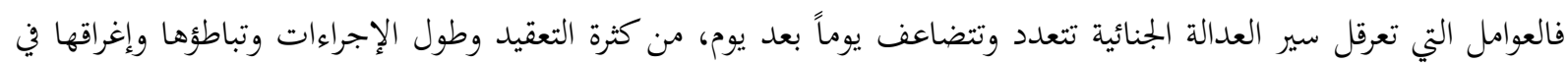


الشكليات، مما أدى بالسياسة الجنائية الحديثة مواجهةً لهذه الأزمة، إلى معاصرة بدائل العقوبة مع بدائل الدعوى الجنائية. وكان

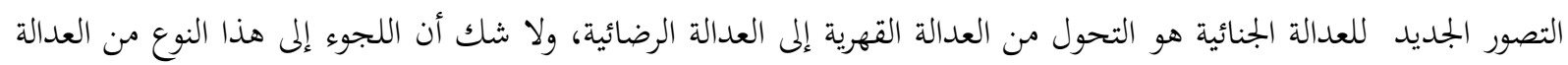

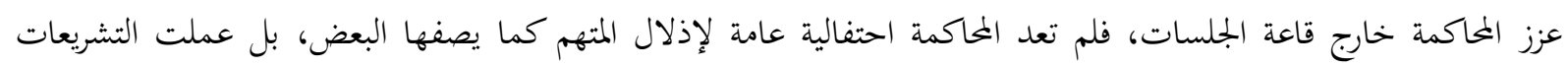

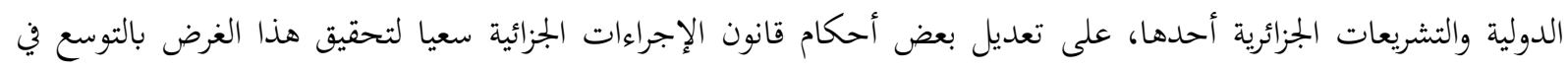

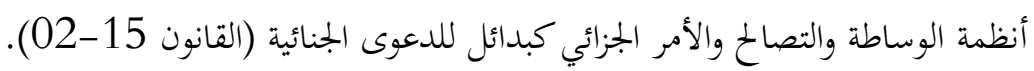

ثانيا: الانتقال إلى المكمة الالكترونية

إن الانتقال إلى المحكمة الالكترونية كان عبر تكنولوجيا المعلومات والاتصالات، بانتقال مرفق العدالة من الشكل التقليدي

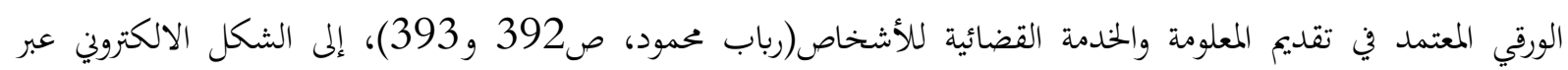
الانترنت، عن طريق ربط المحاكم القضائية كلها ضمن دائرة الكترونية واحدة بعد حوسبة عمل كل محكمة قضائية على حدىى،

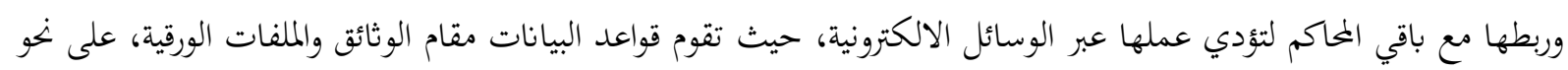

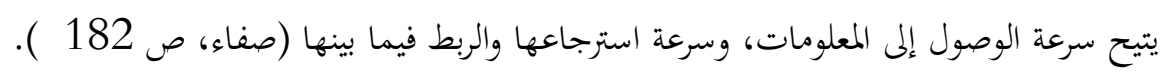
ويمكن أن تتخذ أشكالًا عديدة كالتوقيع الإلكتروني، والاتصال الإلكتروني بين المهنيين القانونيين، وكذلك رسائل البريد

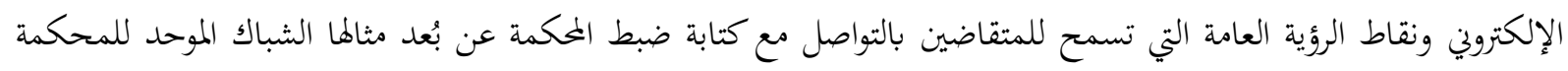

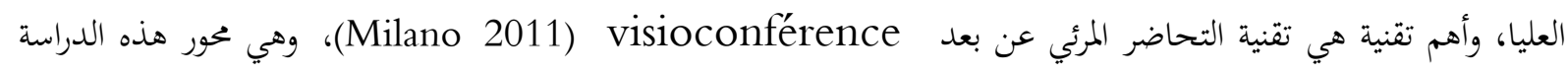

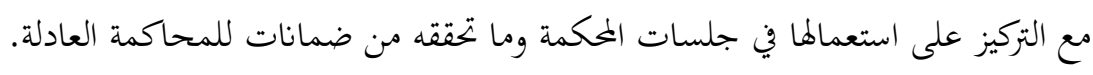
المطلب الثاني: التحاضر المرئي عن بعد تعريفه وأساسه القانوني لقد أصبح استخدام تكنولوجيا المعلومات والاتصالات في المسائل الإجرائية ضرورة حتمية في السنوات الأخيرة باعتراف

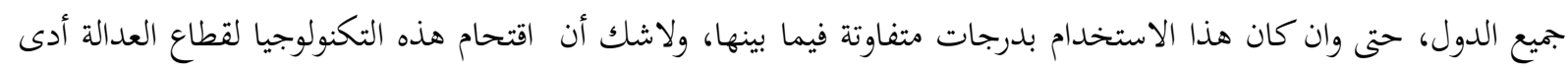
إلى عدد من التعديلات في أساليب عمل القاضي، وكذلك في حقوق أطراف الدعوى، على رأسها الحق في محاكمة عادلة وما يتطلبه من مفترضات.

\section{Visioconférence الفرع الأول: تعريف تقنية التحاضر المرئي -}

تُعرف تقنية التحاضر المرئي بأها عبارة عن: "اتصال سمعي مرئي يجري في وقت واحد، بين أطراف متفاعلة معاً في مواقع

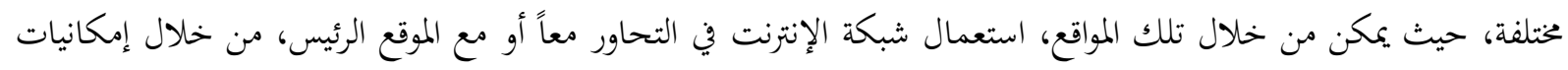

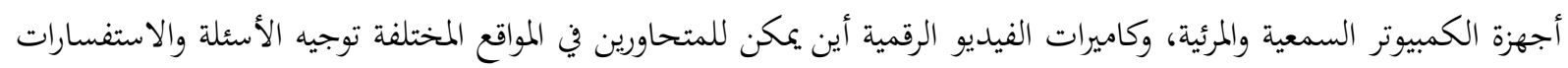

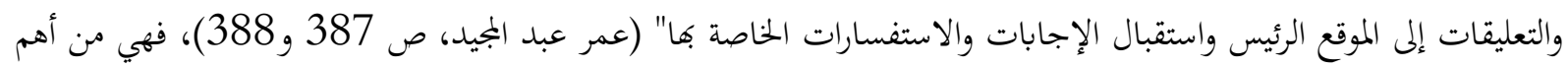

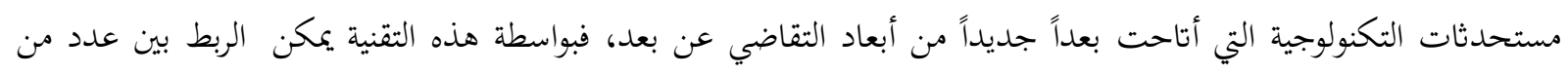
الأشخاص متواجدين في أماكن مختلفة وتفصل بينهم مسافات شاسعة، كأن تكون هيئة الحكم في مقر الجهة القضائية بعلية، فيما يتم

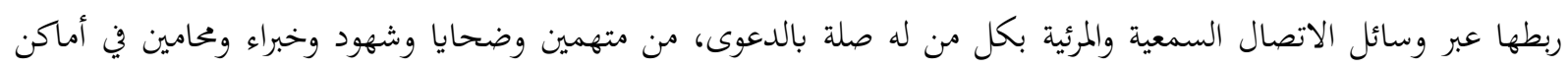

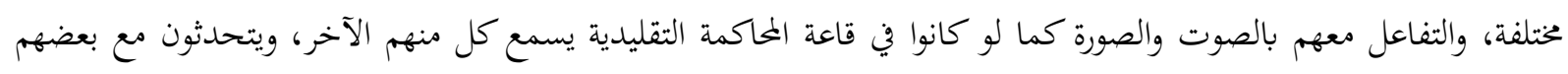

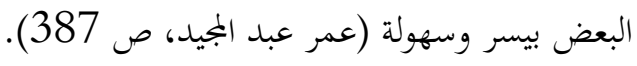




\section{- - الفرع الثاني: الأساس القانوبي لتقنية التحاضر المرئي عن بعد}

ترتبط فكرة التقاضي أو المحاكمة عن بعد عبر تقنية التحاضر المرئي في الجزائر بالتقاضي الالكتروني و التي تحد أساسها

$$
\text { القانوين في الاتفاقيات الدولية، وبعض القوانين الداخلية. }
$$

\section{أولا: تقنية التحاضر المرئي عن بعد في الاتفاقيات الدولية}

نصت المادة 69:2 من نظام روما الأساسي (جويلية 1998) على استخدام التحاضر المرئي عن بعد في قطاع العدالة بقوها:

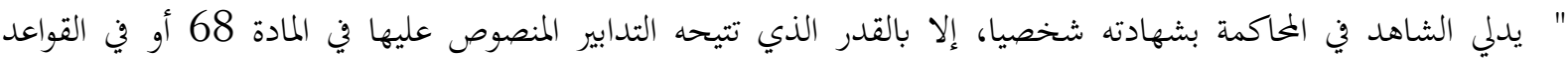

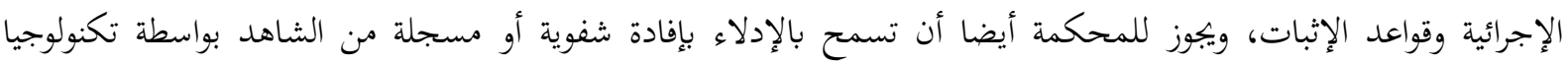

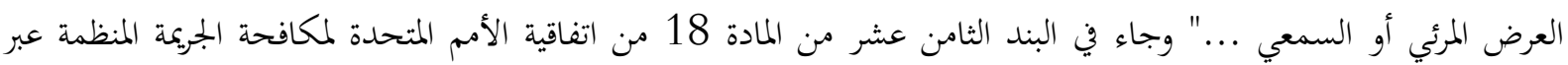

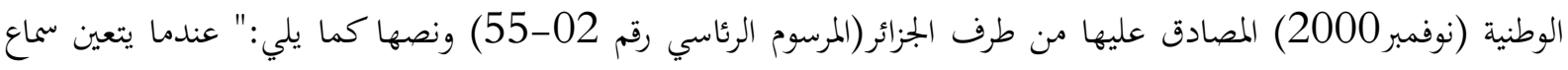
شخص موجود في إقليم دولة طرف، بصفة شاهد أو خبير أمام السلطات القضائية لدولة طرف أخرى، ويكون ذلك ممكنا ومتفقا

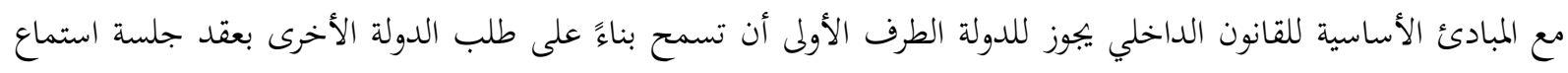

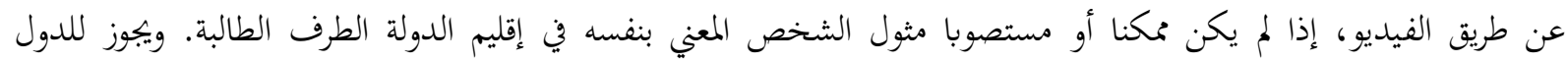

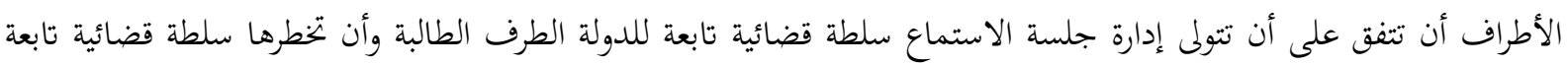
للدولة الطرف متلقية الطلب." أيضا ورد في المادة 36:3: ب من الاتفاقية العربية لمكافحة الجريمة المنظمة عبر الحمدود الوطنية لسنة (2010) النص على: " إتاحة الإدلاء بالشهادة على نخو يكفل سلامة الخبراء والضحايا، ويجوز استخدام التقنيات الحديثة في

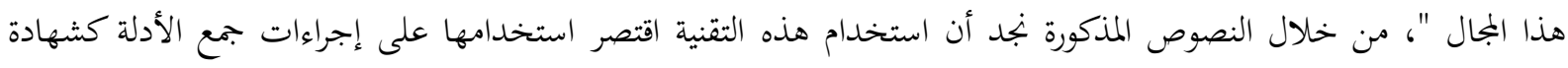
الشهود والخبراء الذين يتعذر حضورهم شخصيا.

\section{ثانيا: تقنية التحاضر المرئي عن بعد في القانون الداخلي}

إن من أهم القوانين التي شرعت استخدام هذه التقنية في الجزائر، القانون رقم 15-03 المتعلق بعصرنة العدالة(عمد

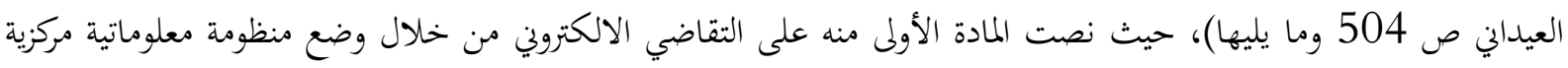
لوزارة العدل، واستخدام تقنية المحادثة المرئية عن بعد في الإجراءات القضائية، وإرسال الوثائق والمحرات القضائية بطريقة الكترونية، حيث نصت المادة 14 على أنه: " إذا استدعى بُعد المسافة أو تَطلب ذلك حسن سير العن العدالة يمكن استجواب وسماع الأطراف

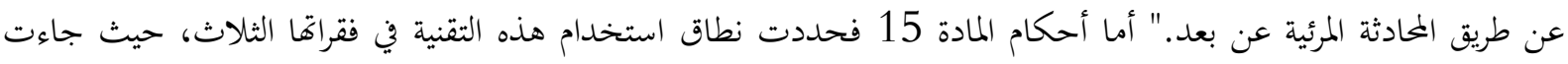

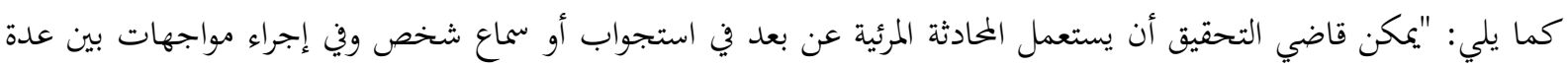

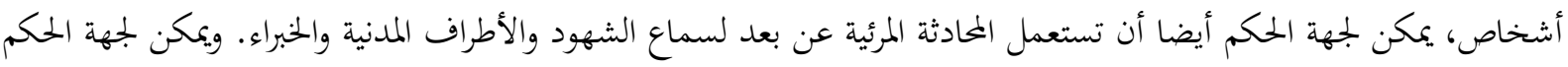

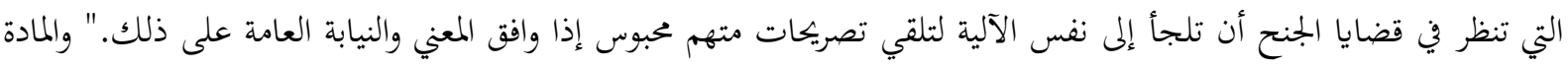
16 التي حددت مكان إجراء التقاضي الالكتروني بنصها: "يتم الاستجواب أو السماع أو المواجهة باستعمال آلية المحادثة المرئية

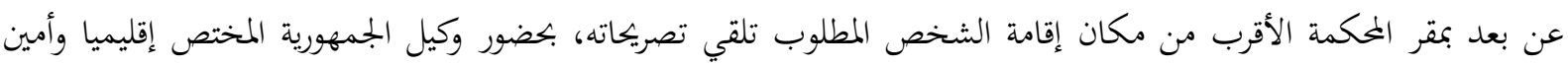

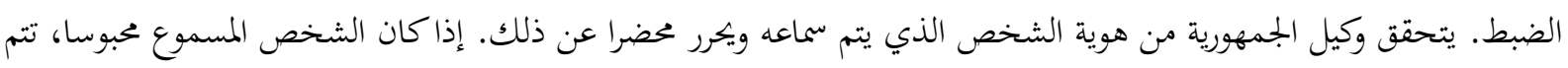

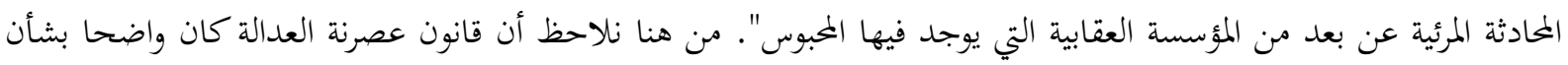
استخدام هذه التقنية في مرحلة المحاكمة.

ونص المشرع لأول مرة في قانون الإجراءات الجزائية على استخدام هذه التقنية بموجب الأمر رقم 15-02، المعدل والمتمم

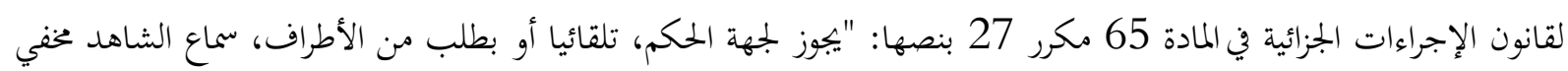


الهوية عن طريق وضع وسائل تقنية تسمح بكتمان هويته، بما في ذلك السماع عن طريق المحادثة المرئية عن بعد واستعمال

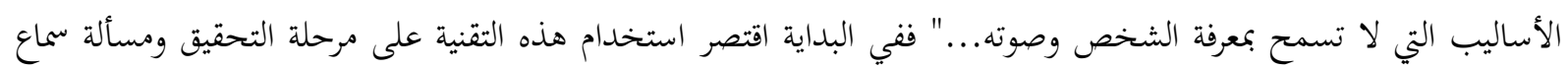

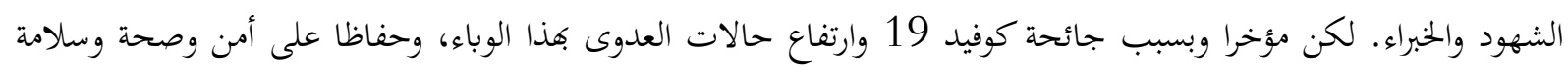

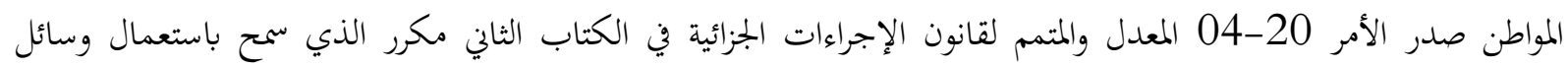

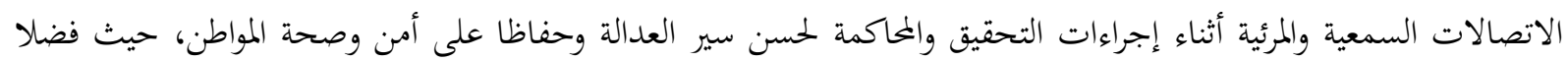

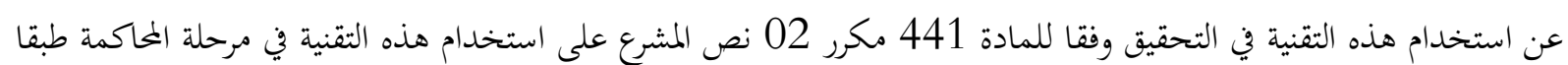

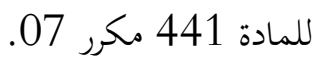
ثالثا: تقنية التحاضر المرئي عن بعد غيرت من ملامح جلسة الحماكمة

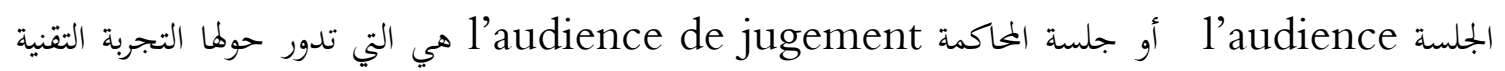

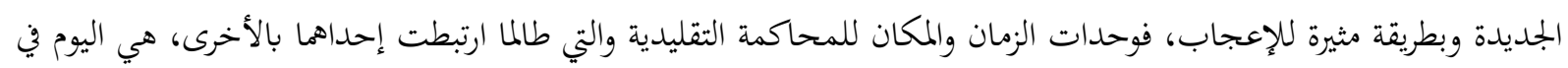

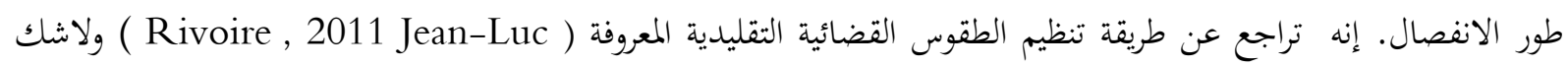

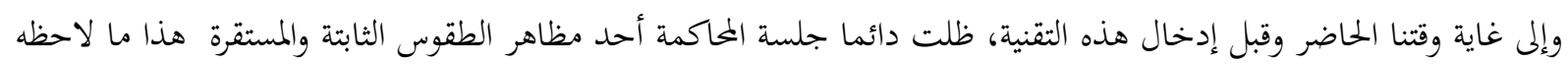

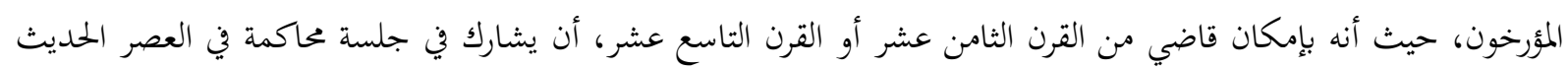

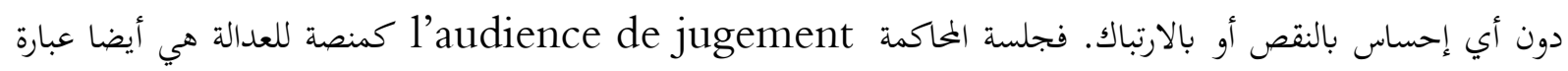

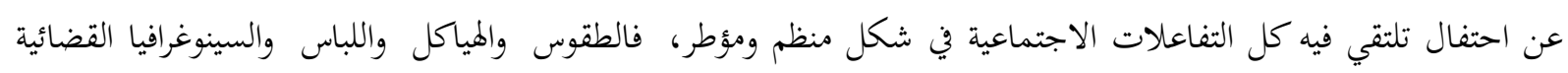

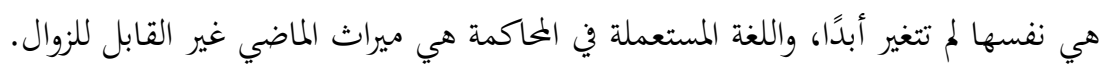

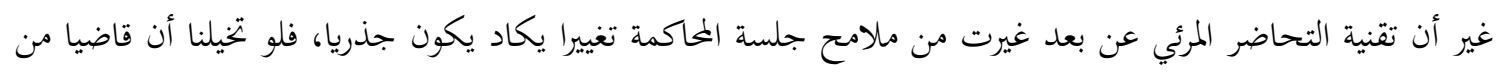

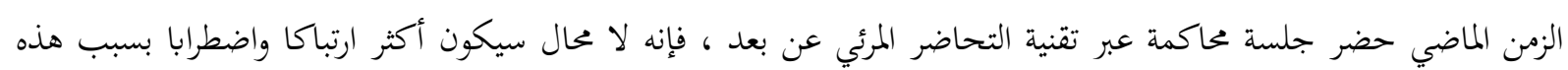

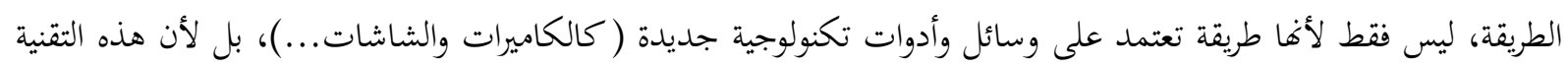

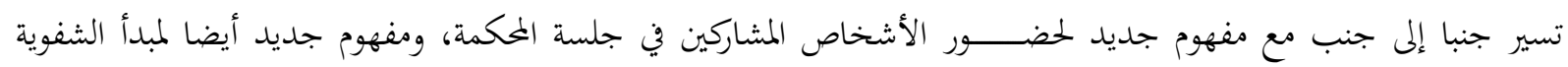
والمواجهــــــــ (Licoppe Dumoulin, p13) باعتبارهما من المبادئ الأساسية للمحاكمة العادلة. 


\section{المبحث الثاني: تأثير تقنية التحاضر المرئي عن بعد على الحق في محاكمة عادلة}

يعتبر الحق في محاكمة عادلة من أهم حقوق الإنسان، بما يوفره من حماية لحقوق الإنسان الأخرى. وحتى تكون المحاكمة

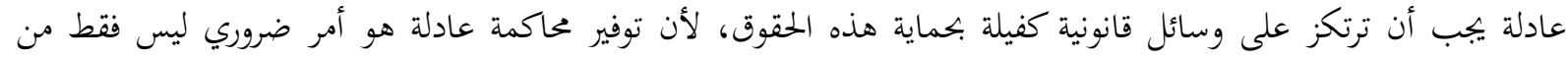
منظور حماية حقوق المتهمين أو الضحايا، لكن لضمان حسن سير العدالة أيضا، وإذا كانت المحاكمة العادلة تتعلق بكافة المراحل الإجرائية للدعوى، فإننا في دراستنا هذه نسلط الضوء على المرحلة النهائية وهي مرحلة المحاكمة وما يرتبط بها من ضمانات إنهات إجرائية كانت أو موضوعية تكفل الحق في محاكمة عادلة.

المطلب الأول: مخاطر التحاضر المرئي عن بعد على مبادئ المحاكمة العادلة إن أهم المبادئ التي نود التركيز عليها هي تلك التي ترتبط ارتباطا مباشرا بمرحلة المحاكمة، مثل مبدأ الحضورية والشفوية

\section{- الفرع الأول: الحق في الحضور الشخصي لجلسة المحاكمة(مبدأ الحضورية)}

تكون إجراءات التحقيق النهائي حضورية بالنسبة لخصوم الدعوى، فالقاضي الجنائي يبني عقيدته بحرية كاملة بناءً على ما

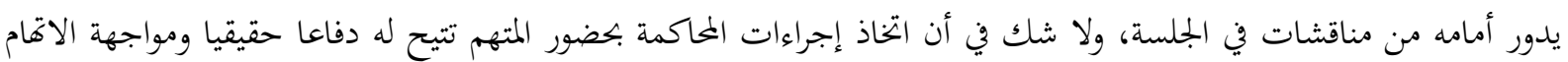

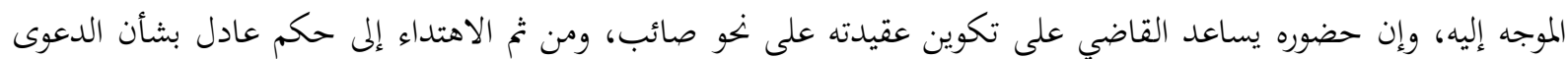

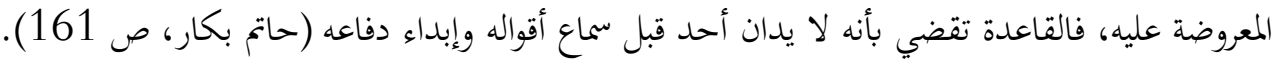
أولا: ضرورة الحضور الشخصي كضمانة في التحقيق النهائي:

إن الحضور الشخصي ضمانة أكيدة وضروري أيضا لمبدأ شفوية المرافعة حيث يُمَكِّنُ جهة الحكم والخصوم من مناقشة الأدلة المقدمة، فلا يكفي صحة الدليل لاقتناع المحكمة به، بل لابد من أن يكون هذا الدليل قد تمت مناقشته في الجلسة المادة

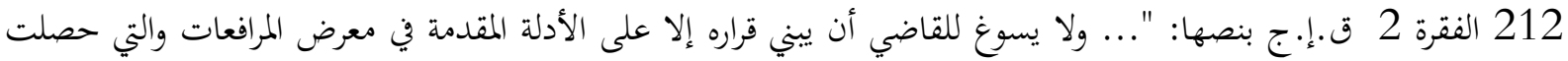
المناقشة فيها حضوريا أمامه "، ويقتضي هذا المبدأ تمكين الخصوم من حضور الجلسة وذلك بإعلامهم بموعدها قبل انعقادها،

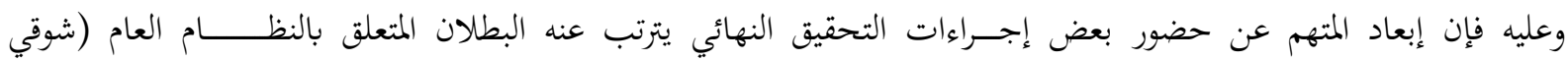

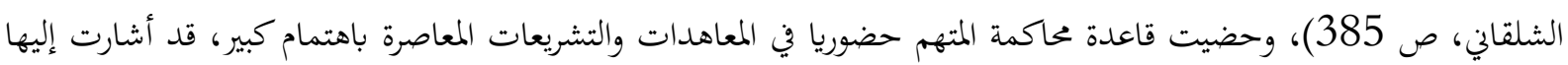

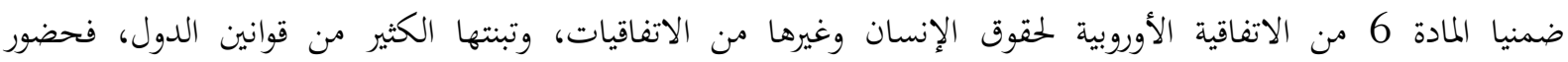

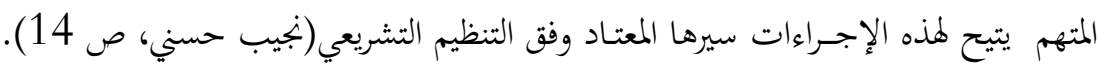
ثانيا: موقف المشرع من مبدأ الحضورية عبر تقنية التحاضر المرئي عن بعد

بعد أن كانت هذه التقنية مقتصرة على مرحلة التحقيق لأجل الاستجواب وسماع الشهود، انتشرت بشكل ملفت للانتباه

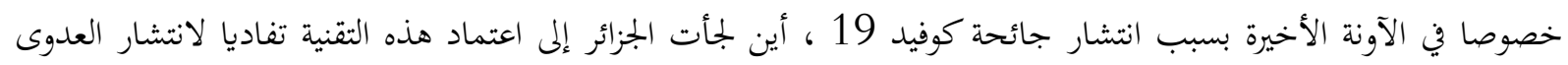
وتسييرا حسنا لمرفق العدالة الذي عرف تدبدبا كبيرا بسبب الحجر الصحي، حيث أدخل المشرع تعديلات على قانون الإجراءات

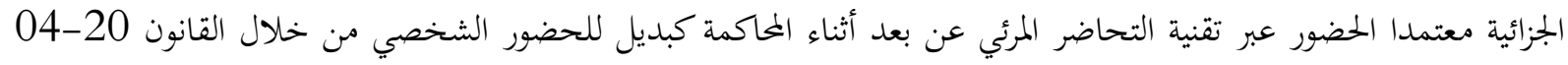

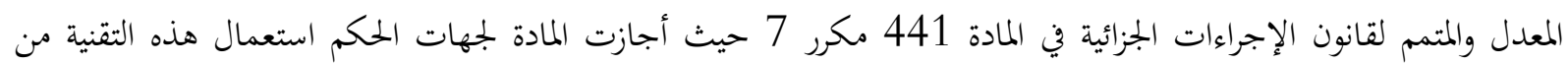

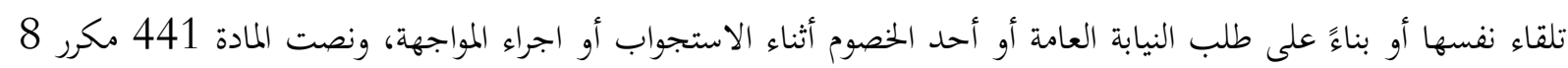

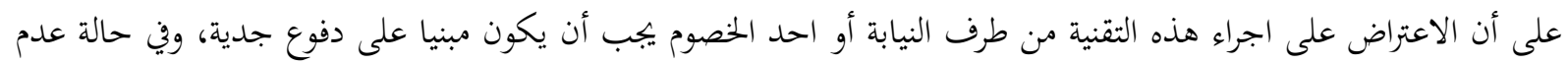

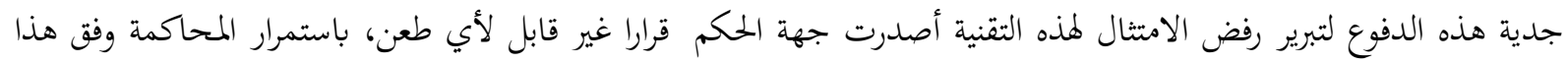


الإجراء وفي هذه الحالة يمق للدفاع الحضور رفقة موكله بككان سماعه أو أمام جهة الحكم المختصة. ونصت المادة 441 مكرر 9 المان

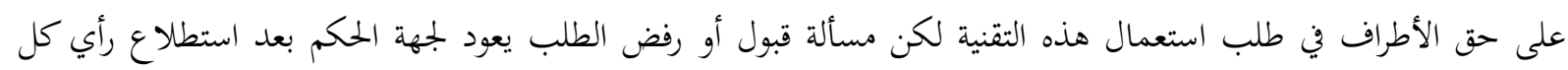

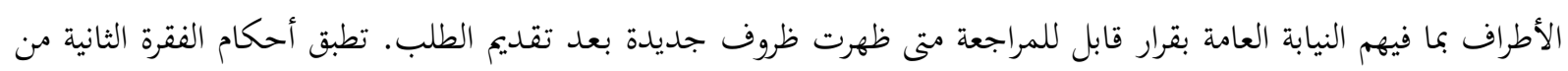

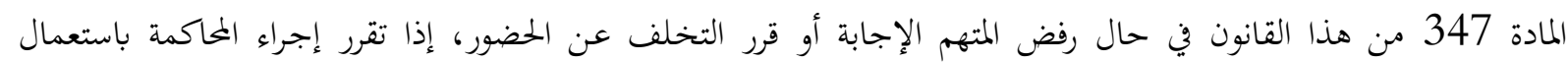

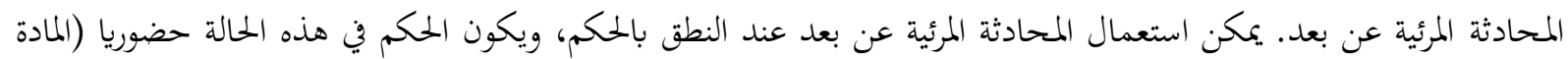

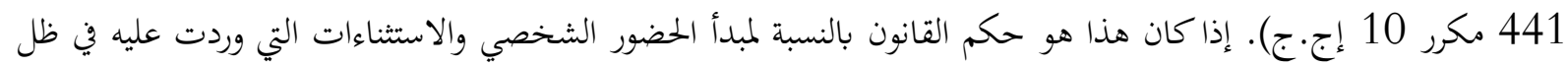

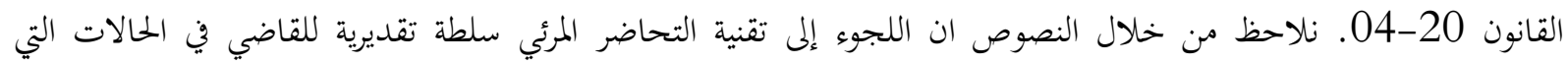

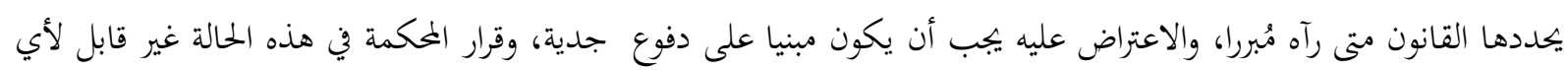

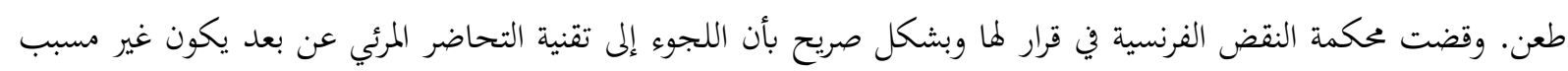

.(cass. Crim., 2 mars 2011)

ثالثا: موقف القضاء من مبدأ الحضورية عبر تقنية التحاضر المرئي عن بعد لقد ثار جدل كبير بخصوص الحضور عبر تقنية التحاضر المرئي عن بعد وأثره على قاعدة الحضور الشخصي كضمانة

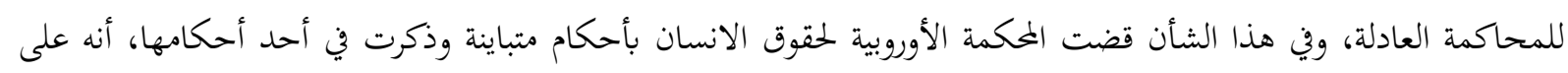

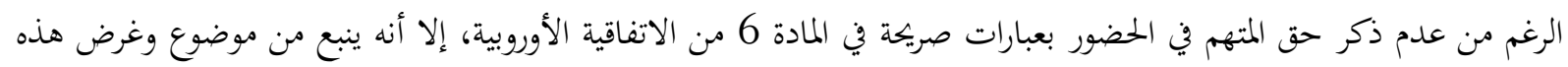

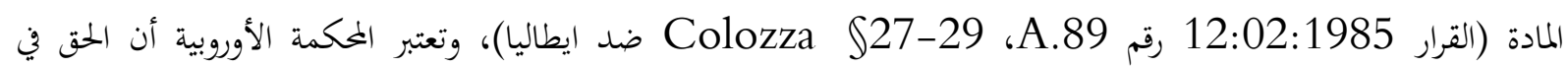

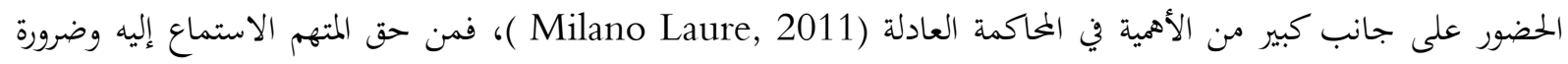

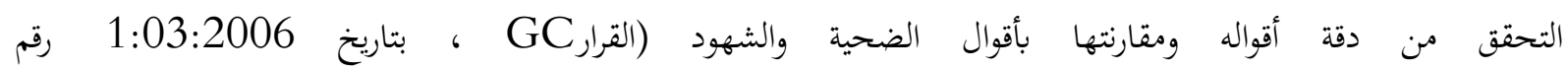

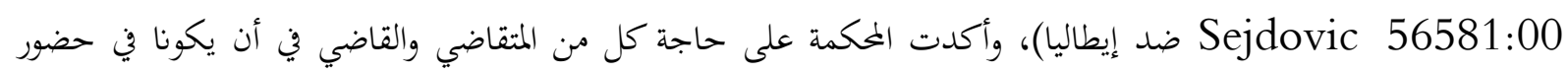

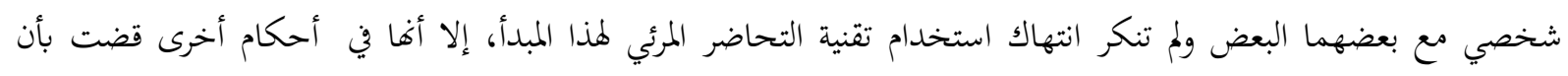

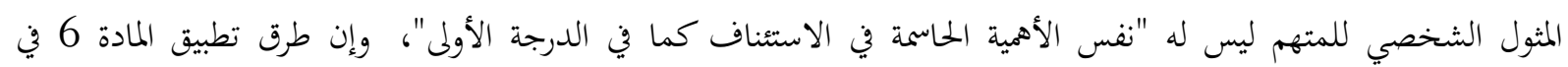

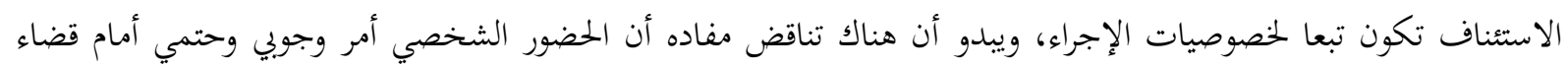

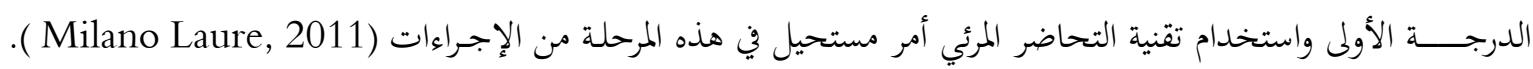

- الفرع الثاني: تأثير تقنية التحاضر المرئي عن بعد على حق الخصوم في تبادل الحوار شفاهة( مبدأ الشفوية)

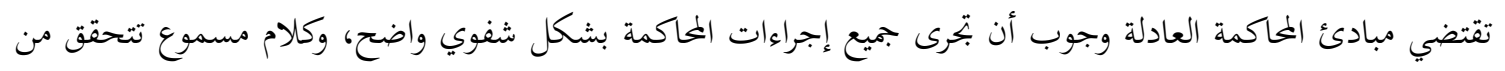

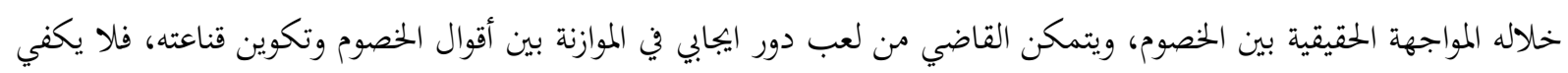

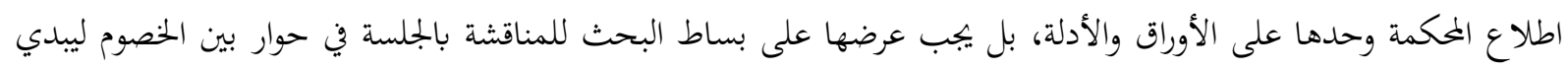

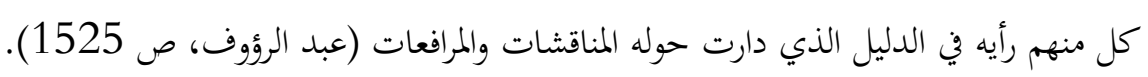

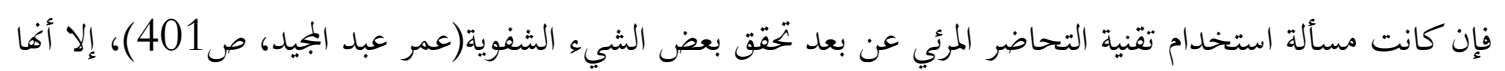

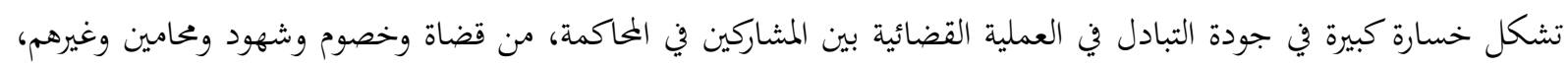

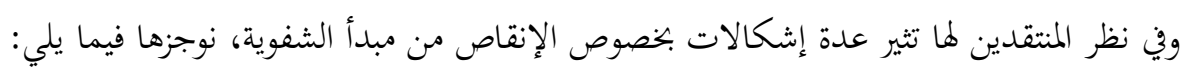

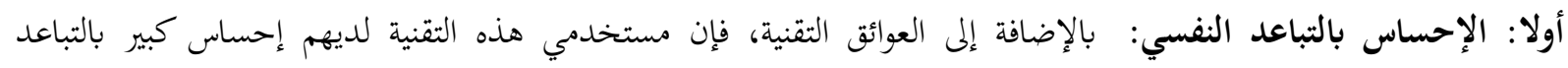

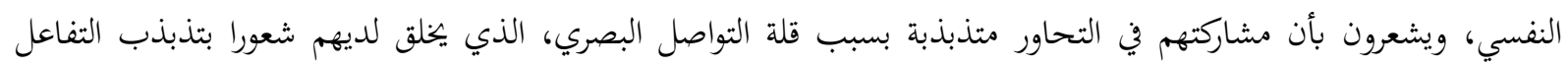

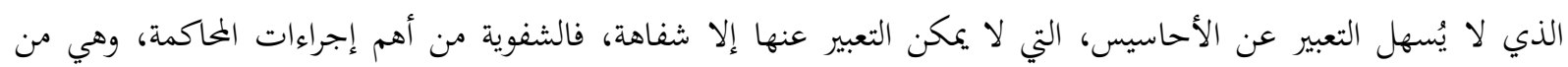


مظاهر المواجهة بين الخصوم، وضمانة أساسية من ضمانات المحاكمة العادلة ( Jean-Luc Rivoire , 2011 ) واستعمال هذه التقنية قد يجعل الحوار لا يتحقق معه مبدأ الشفوية بالمفهوم التقليدي السابق، حيث يجتمع كل الأطراف في مكان واحد هو جلسة المحاكمة، وترتبط الشفوية بالوجاهية التي يجب احترامها من حيث المبدأ في إعطاء الكلمة لجميع الخصوم على قدم المساواة. ثانيا: تقنية التحاضر المرئي عن بعد تقوض جودة الاستماع: لا شك أن استخدام هذه التقنية يقوض عمليًا جودة استماع

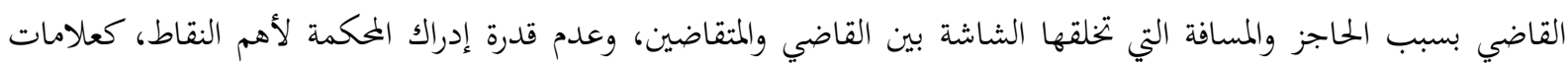

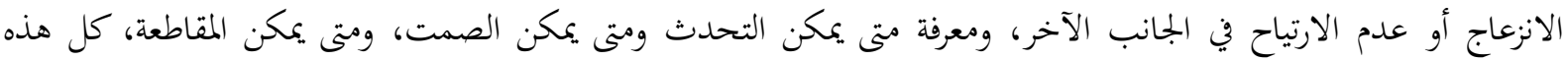
البديهيات الضرورية لممارسة حق الدفاع بشكل كامل تختنفي أثناء المرافعة من خلال تقنية التحاضر المرئي عن بعد، بالإضافة إلى بلى الأعطال الفنية في الاتصال، مثل انقطاع الصورة أو الصوت، حيث يصعب على الخصم والشخص المترافع الإحساس بأن القضية قد نوقشت بطريقة وجاهية. ويزداد الإحساس بالإحباط أكثر لأن النيابة العامة حاضرة في قاعة المحكمة وتستفيد من الاستماع والمعلومة التي لا تتناسب جودةا مع تلك المقدمة إلى المتقاضي في الطرف الآخر، وفي هذا السياق قضت محكمة النقض المصرية بأنه:" في الحالة التي تتعذر فيها المواجهة وفقا للمفهوم التقليدي ويكون سماع الأقوال الشفوية غير ممكنا، فإن تطبيق مبدأ الشفوية عبر تقنية التحاضر المرئي عن بعد من شاشة إلى أخرى تكون ملائمة وعادلة وأكثر قدرة على أداء وظيفتها من التمسك بلك بالمفهوم

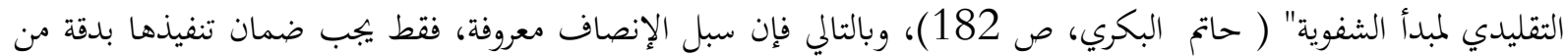
خلال بنية تحتية تقنية ذات جودة عالية وتسيير فعال، بالإضافة إلى اهتمام القضاة المتزايد ووعيهم الدائم بالحفاظ على تكافؤ مبدأ التساوي في الأسلحة liégalité des armes بينة الاتحام والدفاع.

\section{- الفرع الثالث: الحق في علنية المحاكمة عبر تقنية التحاضر المرئي عن بعد (مبدأ العلنية)}

العنية ضمانة هامة لتحقيق المحاكمة العادلة ضد أي عدالة سرية، فهي الرقيب على عدالة الإجراءات، ومن أبرز مظاهرها

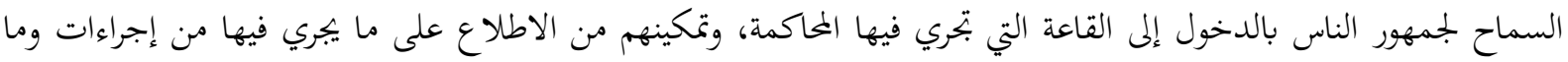

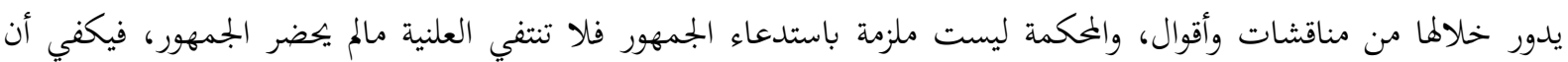
المحكمة أتاحت له ذلك ما دامت أبواب القاعة مفتوحة. أولا: ضرورة اجراء المحاكمة بصفة علنية: وتوصف جلسة المحاكمة العلنية l'audience public بأها أحد النقاط الأساسية

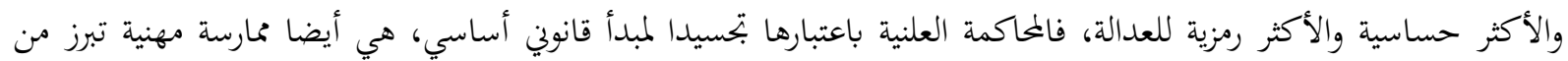
خلالها خبرة وأهلية الفاعلين في الساحة القضائية من محامين وقضاة وكتاب ضبط وخبراء، فهي عبارة عن عرض مسرحي علني للعملية القضائية، وتقليديا جلسة المحاكمة تعتمد على احتفالية شعبية أساسها حضور ومشاركة الأطراف في هذه الاحتفالية و طقوس تكون أساسية في القضايا الجنائية حيث تكون النيابة العامة، المتهمين، الضحايا، القضاة والجمهور مجتمعين شخصيا في في نفس المكان وهو قاعة الجلسات (Antoine Garapon, 2001 ). فالعنية هي النتيجة الطبيعية للمحاكمة العادلة، فعندما تجرى المرافعات على شبكة اتصالات وليس في قاعة الجلسات، فإن مبدأ علنية المرافعات يصبح محل استفهام. ثانيا: العلنية ليست قاعدة مطلقة: نعلم جيدا أن مبدأ علنية جلسة المحاكمة ليس مطلقًا فله عدة استثناءات في حالات معينة معروفة قانونا، ولقد لاحظنا أخيراكيف أصبحت قاعات المحاكم شبه مهجورة بسبب إجراءات الحجر الصحي التي تبعت جائحة

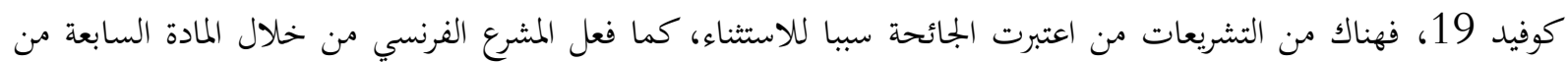

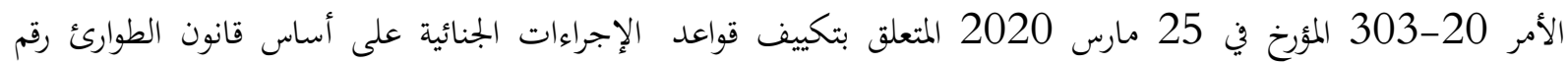

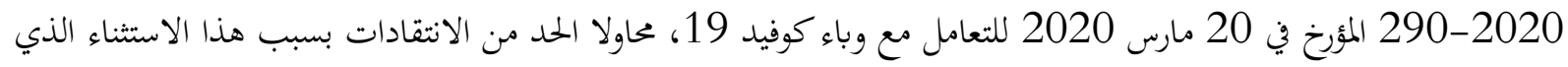


يحد من العلنية وذلك من خلال النص صراحة على إمكانية السماح بحضور الصحفيين الجلسات حتى في الحالة التي يأمر فيها

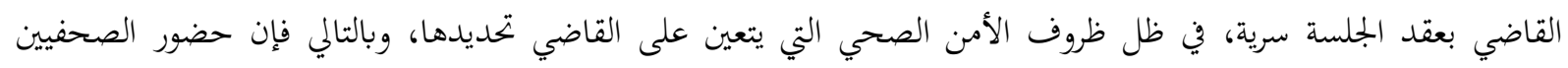

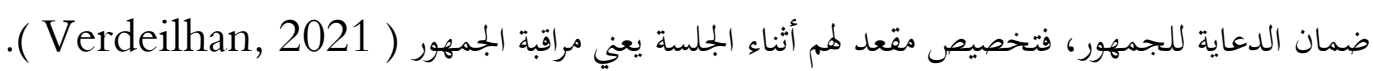
إن علانية المحاكمة وفقاً لتقنية التحاضر المرئي عن بعد لا تحقق الفائدة المرجوة المطلوبة في إجراءات التقاضي كما هو الحال عند

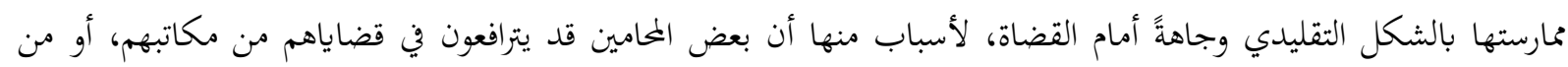

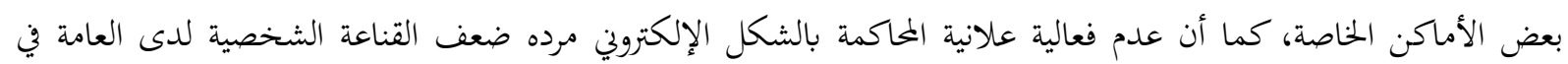
التقاضي الالكتروني.

في الحالة التي لم يكن من الممكن فيها أن تُعقد الجلسة بحضور الجمهور (كفرضية محاكمة متهم موجود في السجن) فمن

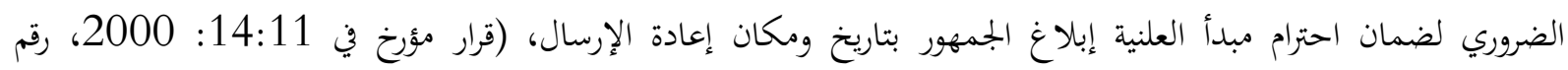
Riepan 35115:97

المطلب الثاني: مخاطر تقنية التحاضر المرئي على بعض الحقوق الأخرى نلخص هذه الحقوق في بعضها والتي لها أهميتها كالحق في الوصول إلى القاضي والحق في المشورة القانونية وإعداد الدفاع. - الفرع الأول: الحق في الوصول إلى القاضي - المي

يطرح المختصون عدة تساؤلات حول المحاكمة عبر تقنية التحاضر المرئي بعد، وما إذاكانت تتيح للمتهم الوصول الملموس والفعال

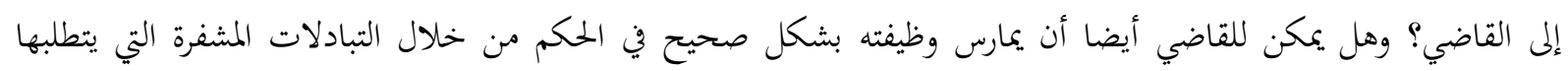

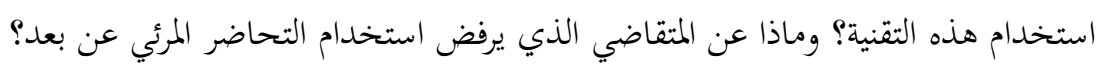

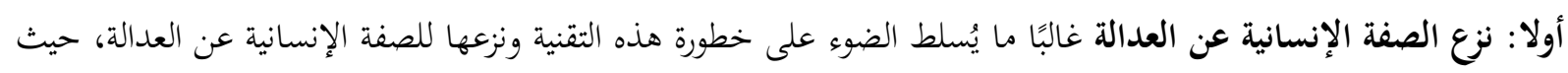

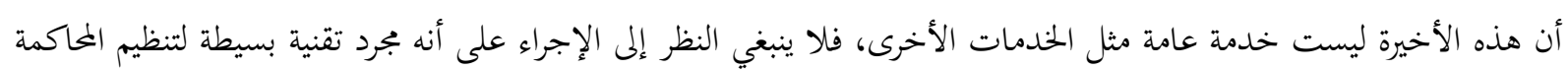

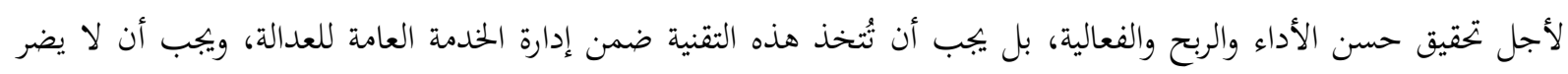

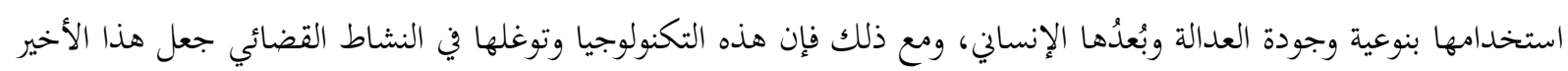

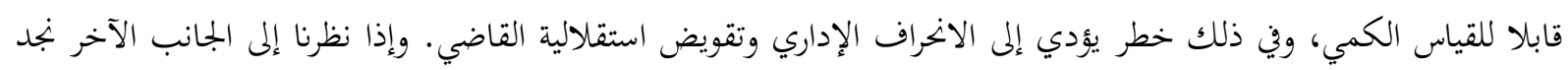

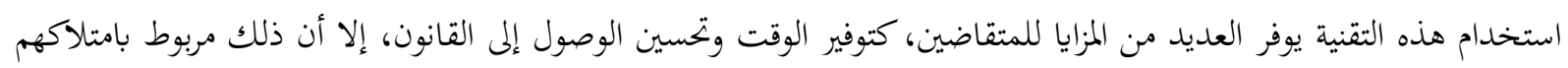

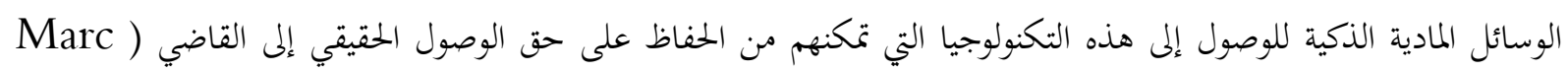

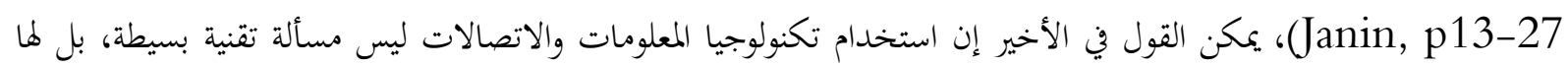
تأثير حقيقي على مهمة القضاء وعلى الحقوق الإجرائية للمتقاضين خصوصا في البلدان التي تفتقد لوسائلها. ولقد أصدرت المحكمة الأوروبية لحقوق الإنسان عددًا من الأحكام المتعلقة بالتحاضر المرئي رصدت من خلالها بعض الانتهاكات

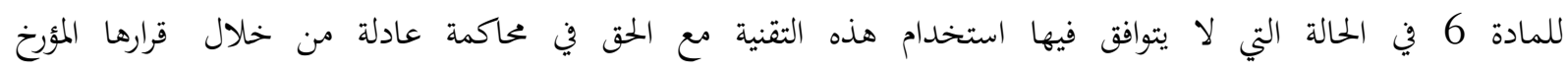
في 21272:03 02:11:2011 رقم ثانيا: رفض المتقاضين للمحاكمة عبر تقنية التحاضر المرئي عن بعد قضى المجلس الدستوري الفرنسي في هذا الشأن في قرارين له بعدم دستورية الفقرة الأولى من المادة 5 من الأمر رقم 303 لسنة

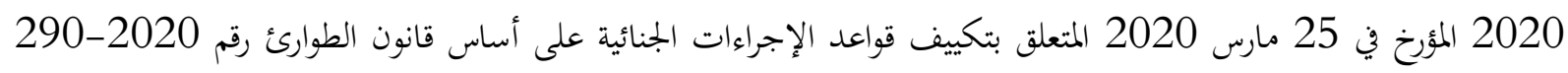

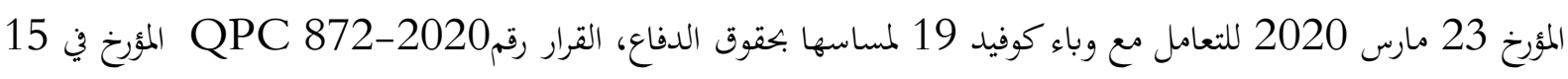


جانفي 2021، والقرار رقم 2021-QPC 919 المؤرخ في 4 جوان 2021، حيث أن المشرع في المادة 5 السالفة الذكر

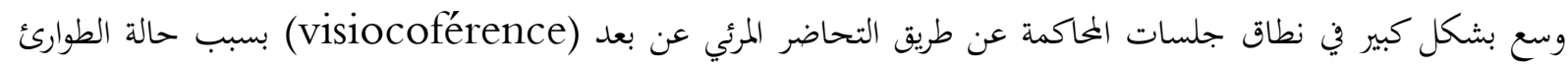

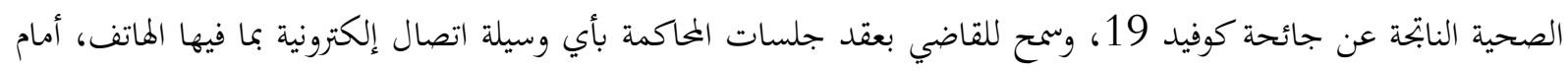

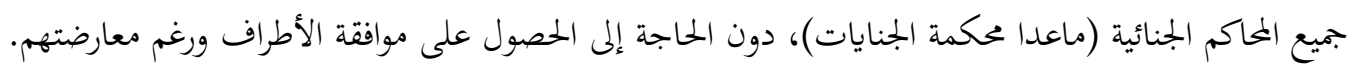
- الفرع الثاني: ضمان الممارسة الفعلية للحق في الاستعانة بمحام

أقر المشرع الجزائري شأنه شأن كل التشريعات حقوق الدفاع بنص الدستور المادة 169 ونصوص القوانين الأخرى، الماني،

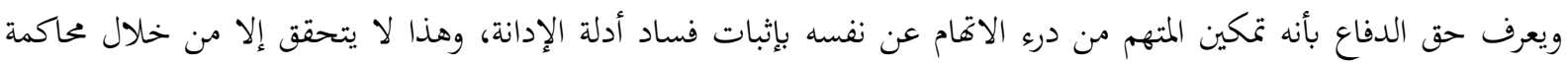

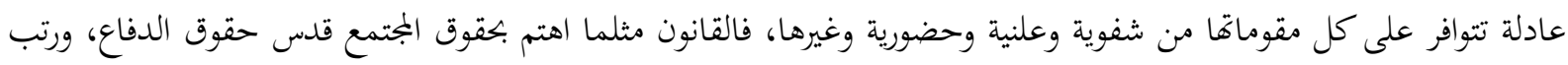

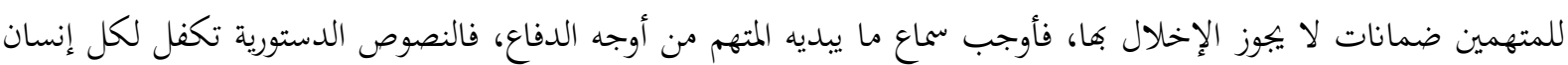

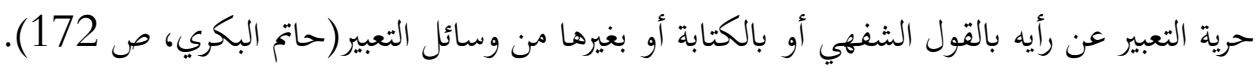

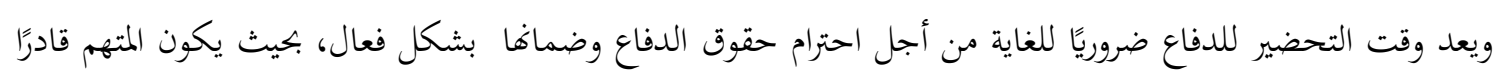

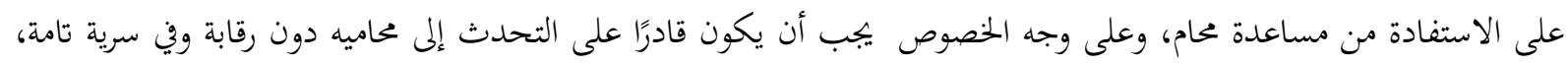

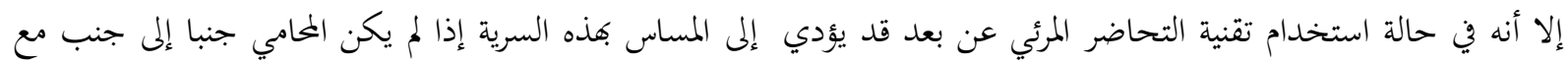

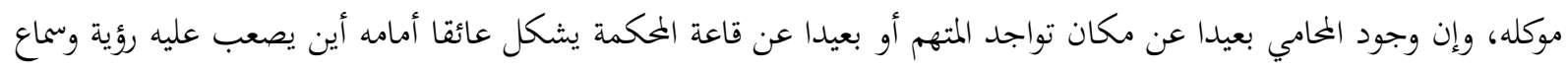

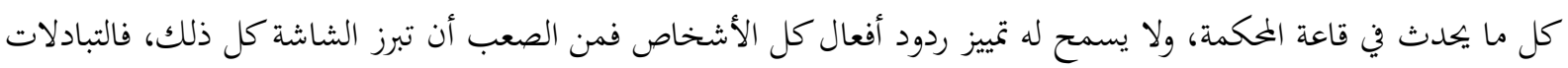

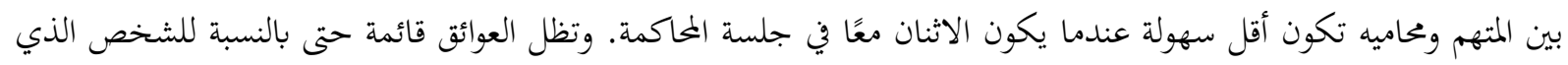

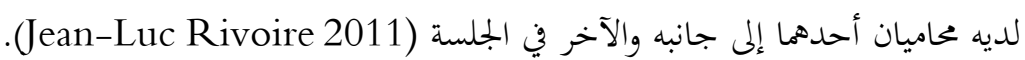

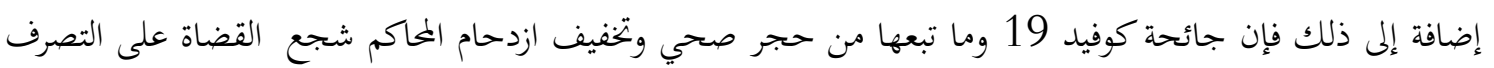

$$
\text { بسرعة، طبعا مع وجوب الاحترام اللازم لوقت التحضير للدفاع. }
$$




\section{المبحث الثالث: تطابق تقنية التحاضر المرئي عن بعد مع الحقى في محاكمة عادلة}

بالنسبة لاستخدام هذه التقنية ومدى تطابقه من عدمه مع الحق في المحاكمة العادلة، فإن المحكمة الأوروبية لحقوق الإنسان قضت في هذا الشأن بعدة أحكام مختلفة نستعرضها ونستعرض رأي المختصين في هذا الشأن فيما يلي: المطلب الأول: التحاضر المرئي يسعى لتحقيق هدف مشروع تعتبر المحكمة الأوروبية لحقوق الإنسان مشاركة المتهم في الإجراءات عن طريق تقنية التحاضر المرئي عن بعد لا يتعارض في

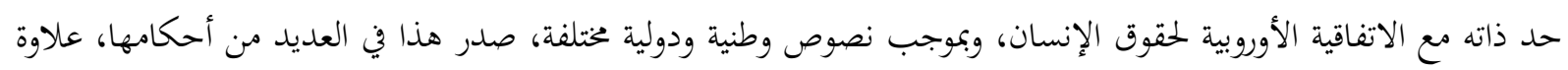

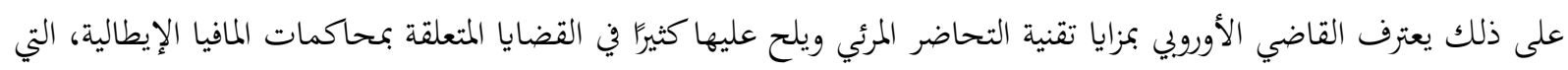

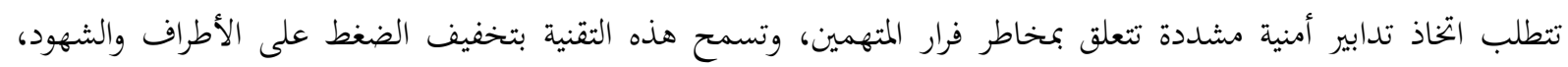

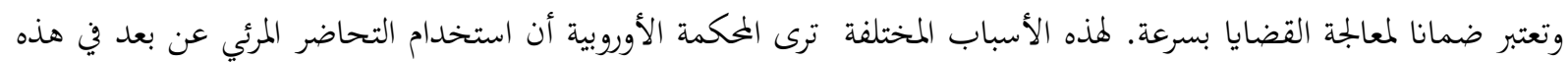

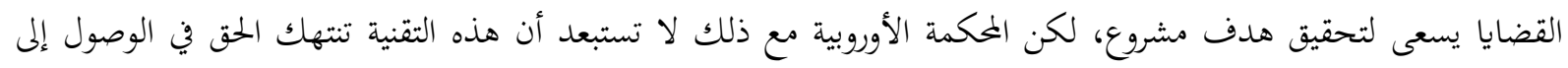

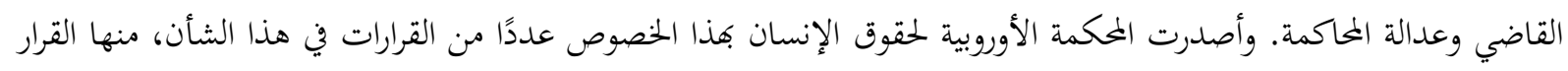

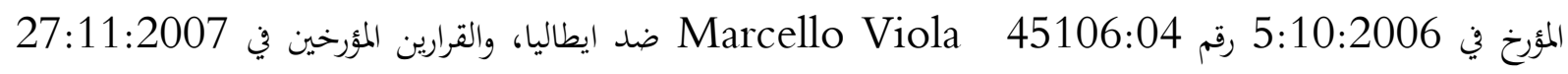

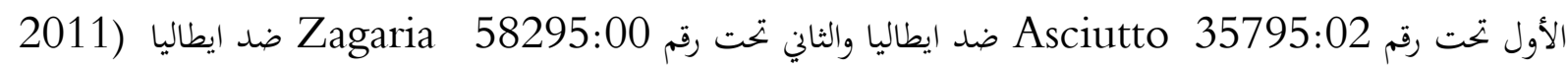

.(Milano Laure

\section{المطلب الثاني: ضرورة الإشراف على التحاضر المرئي عن بعد لضمان الحق في محاكمة عادلة.}

إن مختلف القضايا المرفوعة أمام المحكمة الأوربية، دافعت فيها الدول المدعى عليها جميعًا بأنه لا يوجد فرق جوهري بين الحضور الشخصي للمتهم ومشاركنه في الإجراءات باستخدام تقنية التحاضر المرئي عن بعد، لكن هناك من المختصين من يدعو

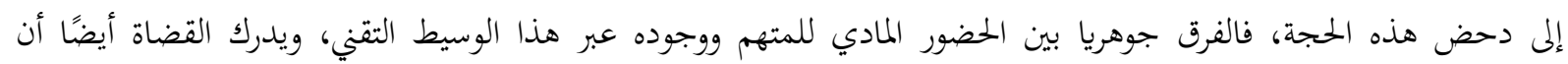

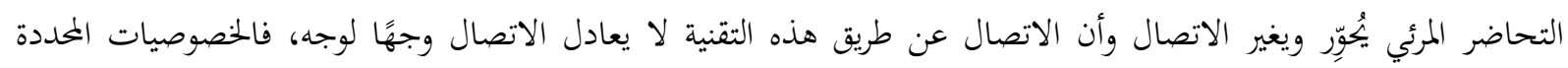

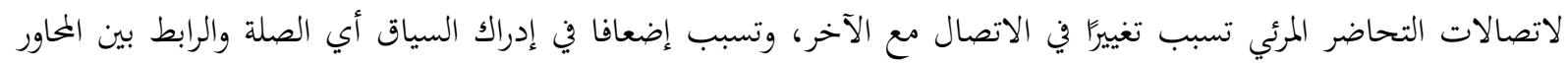

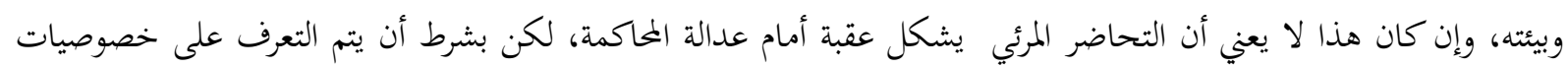

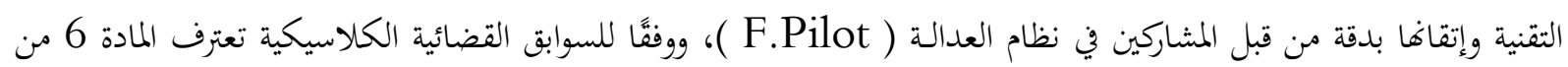

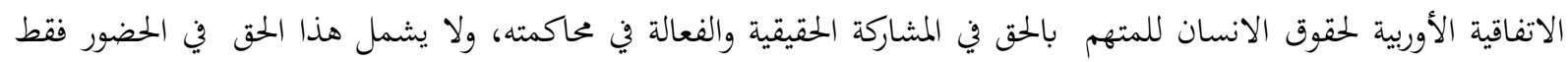

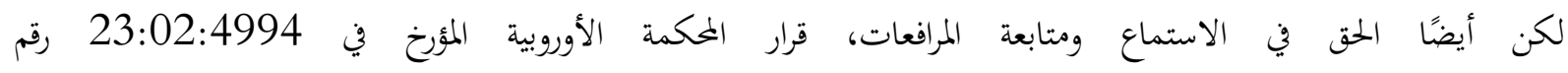
16757:90 ومع ذلك تمارس المحكمة الأوروبية رقابة حقيقية من أجل احترام عدالة المحاكمة عند استخدام التحاضر المرئي. وبحري رقابة

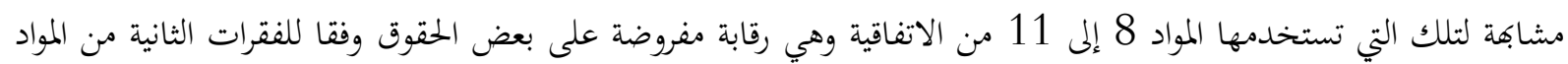
السابقة الذكر، التي تحدد قائمة بالقيود الواردة على التمتع بتلك الحقوق، ولا تحتوي المادة 6 على أسباب مقيدة المباد (باستثناء المتعلقة

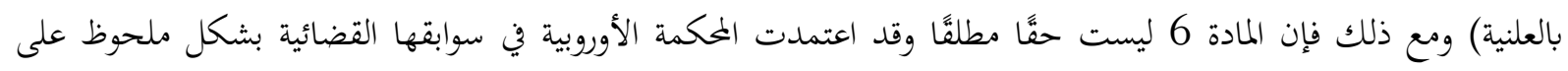
نظرية القيود الضمنية لتنظيم الحق في الوصول إلى المحكمة، من هنا يبرز أنه في قضايا التحاضر المرئي تنظر المحكمة في المادة

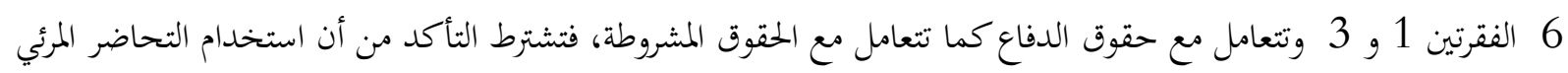
منصوص عليه في القانون وأنه يسعى لتحقيق أهداف مشروعة، حيث أن بعض النزاعات لا تصلح لأن تكون محلا لاستخدام

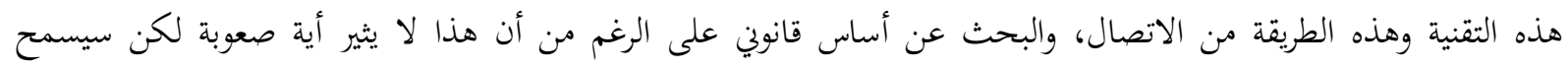


للمحكمة بالتحقق من عدم وجود استخدام مفرط لهذه التقنية، وتبقى الخطوة الأخيرة التحكم بشكل أكثر دقة فيما يتعلق بالمادة

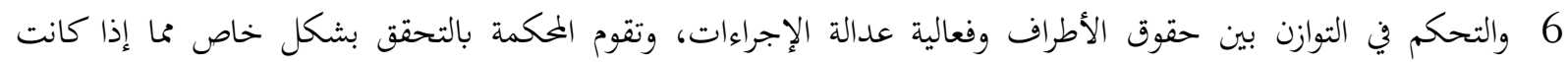

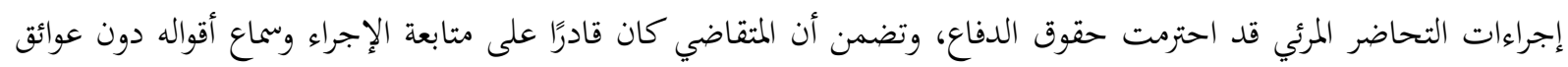

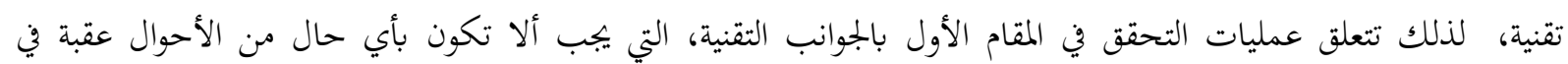
الاتصال بين المتهم والأطراف الأخرى والقاضي.

لذلك يجب على الدول توفير الموارد اللازمة للمحاكم، كما يجب عليها توقع الأعطال الفنية المختملة.

المطلب الثالث: أهمية تقنية التحاضر المرئي بالنسبة للعدالة والمتهم

توفر استخدام تقنية التحاضر المرئي في المسائل القضائية العديد من المزايا، وهذا ما يفسر لجوء العديد من الدول إلى تكثيف

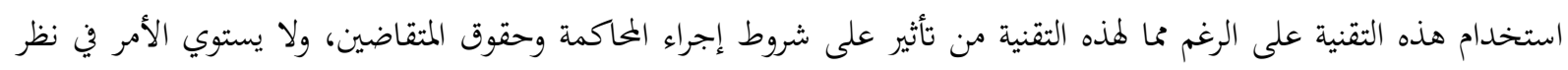

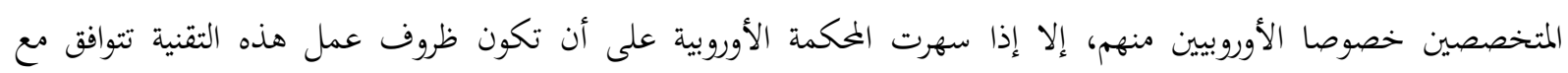
متطلبات المحاكمة العادلة، وذلك من خلال تعزيز وسيطرة مراقبتها في السنوات القادمة (Milano Laure 2011). إن استخدام تقنية التحاضر المرئي في مجال العدالة يميل اليوم ليصبح مؤسسيًا، مما يؤدي إلى ميلاد شكل جديد للإجراءات

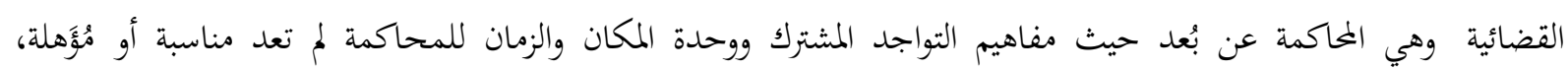

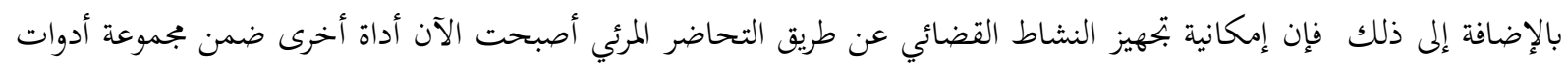
العمل العام وحل ثابت، من المرجح أن يتم استعماله على نطاق واسع لحل المشاكل العامة الجديدة مثل نقل المعتقلين.

\section{- الفرع الأول: مزايا تقنية التحاضر المرئي بالنسبة للعدالة}

تعد تقنية التحاضر المرئيe la visioconférence دون شك واحدة من أكثر الأدوات الرمزية لتكنولوجيا المعلومات

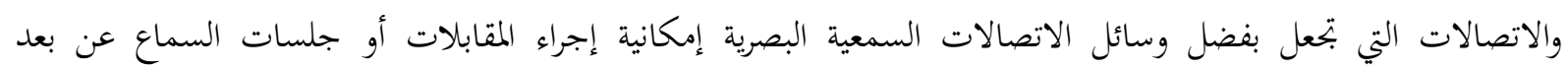
entretiens ou auditions à distance المحامين أو الخبراء، وتقلل من التكاليف (فرج يوسف، ص 41) والمواعيد، وكذلك تنفص من المشاكل الأمنية، هذه المزايا كانت السبب في انتشار استخدام تقنية التحاضر المرئي عن بعد على نطاق واسع في المحاكم الوطنية للدول، وتشجع كل الدول ولئ اليوم

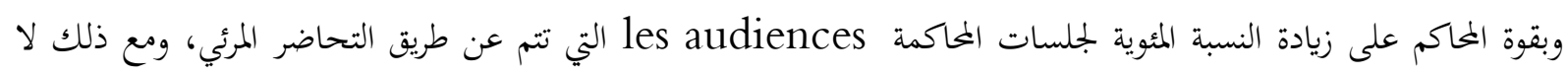

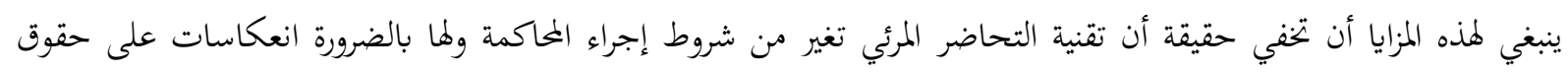

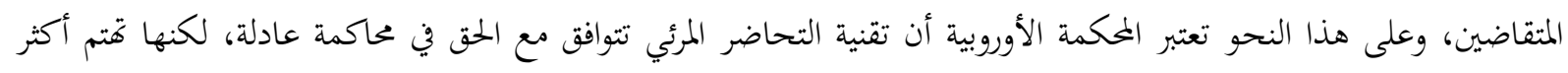

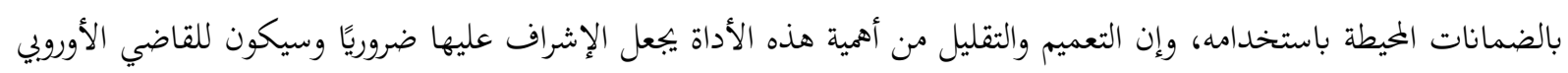

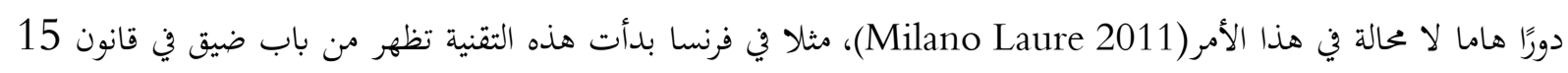

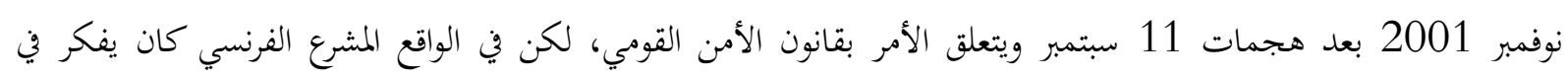

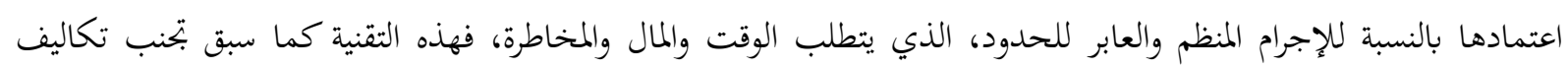

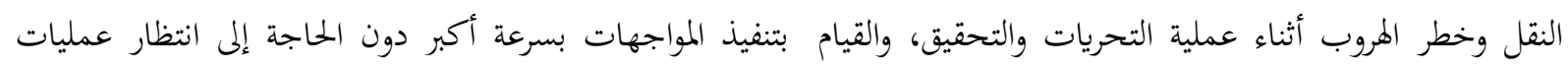

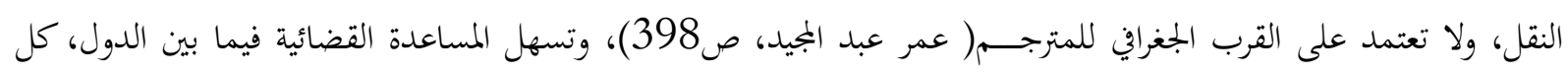

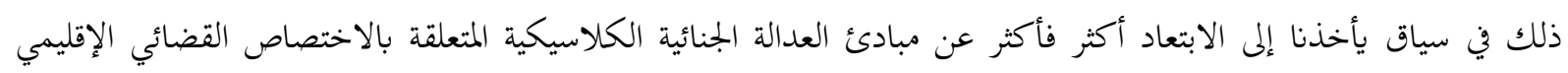

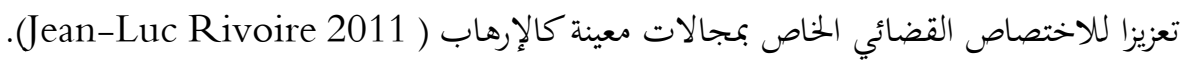


- الفرع الثاني: مزايا التحاضر المرئي عن بعد بالنسبة للمتهم

بصرف النظر عن الجانب النفعي البحت السابق ذكره، قد يتم دفع الأطراف للمطالبة باستخدام تقنية التحاضر المرئي

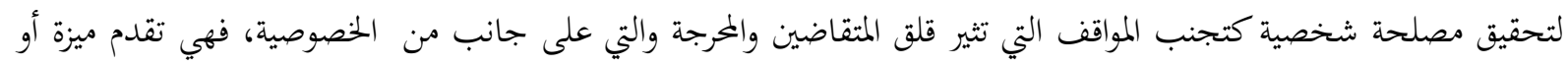

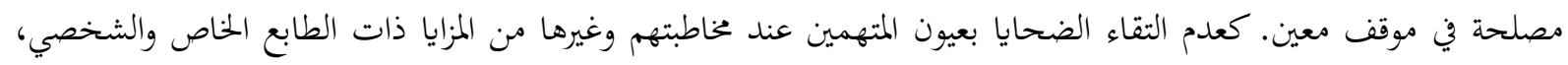

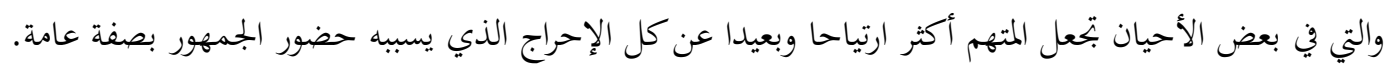

في الأخير ودون إنكار مزايا إجراء المحاكمات الجنائية عبر تقنية التحاضر المرئي عن بعد، وفي ظل التوجه نخو الانتشار

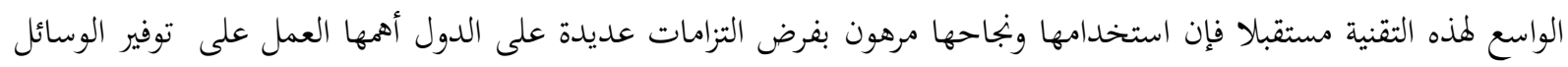

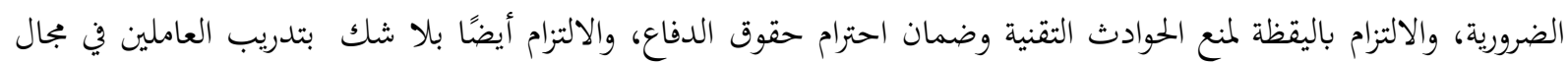
العدالة على هذا النوع من الاتصالات والتقنيات.

وطبعا الأمر دائما متروك للمحكمة من ناحية أن تقتصر استخدام هذه التقنية على قضايا محددة، في حين قد تبقي

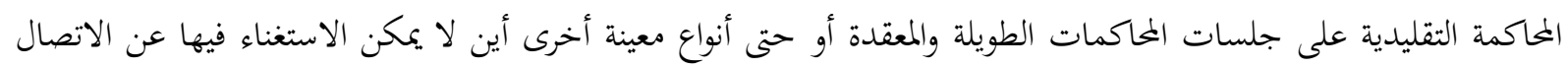

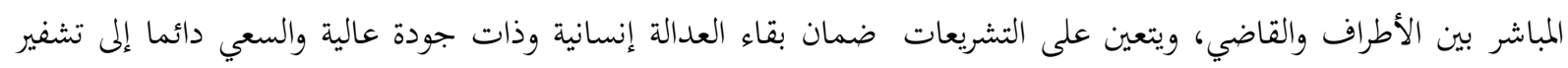
البيانات الشخصية حفاظا على الحق في الخصوصية والسرية.

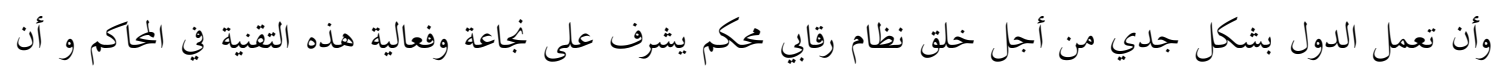
استعمالها يجب أن لا يهدر حقوق الدفاع، حفاظا على المبادئ العامة للمحاكمة العادلة. 


\section{قائمة المراجع باللغة العربية}

- اتفاقيات وقوانين

نظام روما الأساسي للمحكمة الجنائية الدولية المعتمد في روما في 17تموز: يوليه 1998) اتفاقية الأمم المتحدة لمكافحة الجريمة المنظمة عبر الوطنية، اعتمدت بموجب قرار الجمعية العامة للأمم المتحدة الدورة 25 المؤرخ في 15 تشرين

$$
\text { الاتفاقية الأوروبية لحقوق الإنسان، روما في } 04 \text { نوفمبر } 2000 .
$$

الأمر رقم 15-02، المتضمن قانون الإجراءات الجزائية المعدل والمتمم الأمر رقم 66-155، المؤرخ في 08 جوان كوان 1966، 1960، المؤرخ في 23 جويلية

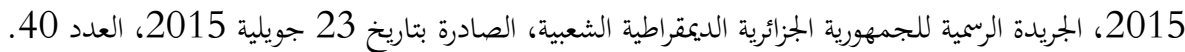

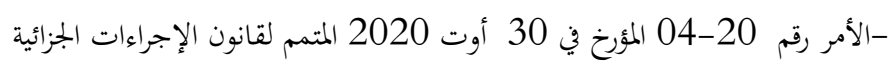

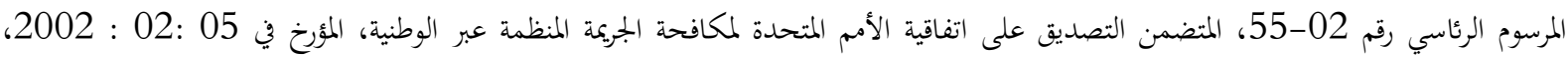

$$
\text { المنشور بتاريخ 10:02: 2002، الجريدة الرسمية للجمهورية الجزائرية، عدد } 09 .
$$

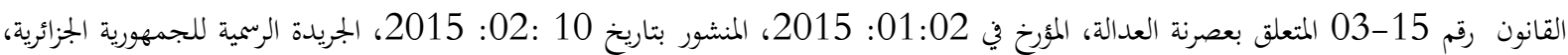
عدد 06.

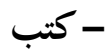

أمير فرج يوسف، المحاكم الالكترونية والتقاضي الالكتروني، المكتب العربي الحديث، القاهرة، 2014.

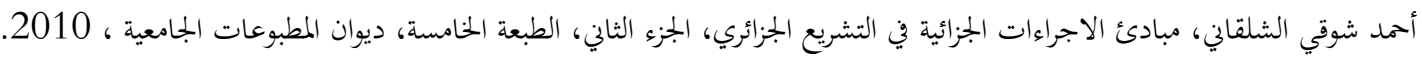

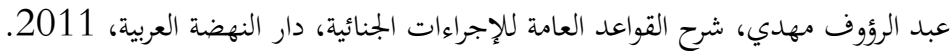

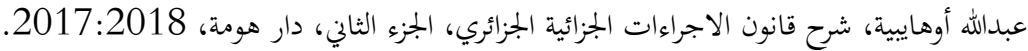
حاتم بكار، حماية حق المتهم في محاكمة عادلة، دراسة تحليلية تأصيلية انتقادية مقارنة في ضوء التشريعات الجنائية (المصرية، الليبية، الفرنسية، الانجليزية، الأمريكية، الشريعة الاسلامية)، منشأة المعارف، الاسكندرية، 1997.

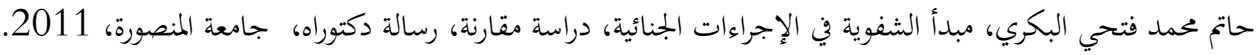
محمد زكي أبو عامر، الإجراءات الجنائية، منشورات الحلبي الحقوقية، الطبعة الأولى، 2010.

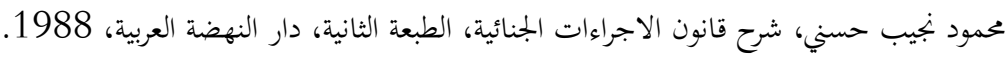

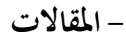

عمر عبد المجيد، ضمانات المحاكمة العادلة على ضوء تقنية الاتصال عن بعد في الاجراءات الجنائية في دولة الامارات، دراسة مقارنة، مجلة القانون الكويتية العالمية، السنة السادسة، العدد4، 2018.

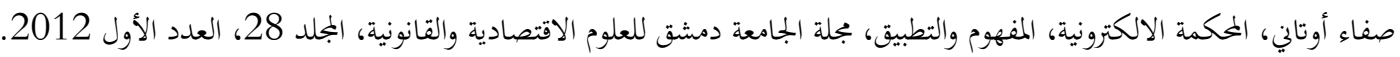

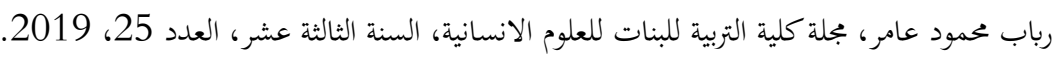
محد العيداني يوسف زروق، رقمنة العدالة في الجزائر على ضوء قانون 15-03، بجلة الباحث للدراسات الاكاديمية، البجلد 07، العدد 01، 2020. 
Antoine Garapon, bien juger, Essais sur le rituel judiciaire,Odile Jacop, Paris,2001.

Dominique Verdeilhan, L'audience est ouverte - Chroniques d'une justice défaillante Éditeur Rocher,2021.

F. Pillot, «La visioconférence. Ethique, modernité, humanité », intervention à la Conférence des Cours d'appel de l'UE).

L. Cadiet, "Le procès civil à l'épreuve des nouvelles technologies », Procédures, avril 2010, Dossier 8).

Laurence Dumoulin et Christian Licoppe, Les audiences à distance, Genèse et institutionnalisation d'une innovation dans la justice, LGDJ-Lextenso édition 2017.

$$
\text { - - عناوين المراجع الالكترونية }
$$

Vers une nouvelle oralité ? Entretien avec internet : voir -, par Jean-Luc RivoireJean Danet

le site internet : https:::www.cairn.info:revue-les-cahiers-de-la-justice-2011-2-page-

73.htm

Visioconférence et droit à un procès équitable, RDLF 2011, chron. $n^{\circ} 08$ Milano Laure,

Marc Janin, http:::www.revuedlf.com:cedh:visioconference-et-droit-a-un-proces-equitable.

La visioconférence à l'épreuve du procès équitable, Les Cahiers de la Justice -

Voir le site : https:::www.cairn.info:revue-les-cahiers-de-la-justice-2011. 


\title{
PSYCHOSO CIOLOGICAL CONSTRUCTION OF THE CONCEPT OF MADNESS
}

\author{
Hanane EL GHOUAT ${ }^{1}$
}

\section{Istanbul Türkiye}

p. $402-416$

Received: 29/11/2021

Accepted: $13 / 12 / 2021$

Published: 01/01/2022

This article has been scanned I iThenticat No plagiarism detected

\begin{abstract}
:
Neurosciences have known a comprehensive renewal and change, especially when they tended to build a relationship between the soul and each of physiology, biology and neuroscience.

$\mathrm{He}$ is treated outside the human system, he is the fool the madman, this problematic question that frames this paper, through which we tried to combine three different directions:

The neurobiologique trend, which attempts to understand the human being mentally and behaviorally, and this trend is clearly linked to the mind, where it attaches great importance.

The psychodynamique trend, which is based on the psychic apparatus, as a basic link in human behavior, because any behavior emanating from the individual is due to this psychological system.

The sociologique trend, in that it is the trend that actually contributed to the birth and emergence of Antipsychiatry and is based on the social environment, linking the behavior of the individual with his social environment, and the individual interactions that exist between individuals. Through these major approaches, we will try to formulate a specific geometry for the concept of madness, starting from its common and colloquial use, with the intention of building a comprehensive connotation, passing through some meanings from within the human sciences such as psychology and sociology.
\end{abstract}

Key words: The Madness, Logic, Mind, Psychological System, Society.

http://dx.doi.org/10.47832/2717-8293.15.29 


\section{هندسة سيكوسوسيولوجية لمفهوم الجنون}

\section{2 حنان الغوات}

الملخص:

عرفت العلوم العصبية المعاصرة بتحيدا وتغييرا شاملا، خاصة حينما اتجهت نحو بناء علاقة بين الروح وكل من

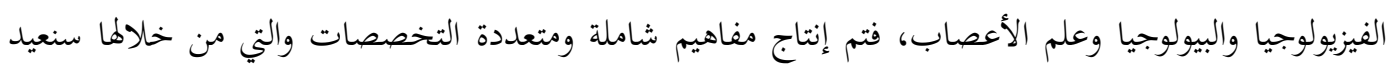

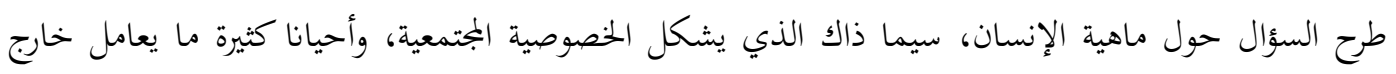

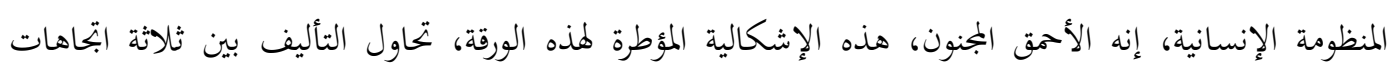

مختلفة:

الاتحاه النوروبيولوجي، الذي يحاول فهم الإنسان عقليا وسلوكيا، ويرتبط هذا الاتحاه بشكل واضح بالعقل حيث

$$
\text { يوليه الأهمية الكبرى. }
$$

الاتحاه السيكودينامي، الذي يرتكز على الجهاز النفسي، كحلقة أساسية في السلوك الإنساني، ذلك أن أي

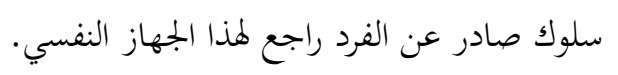

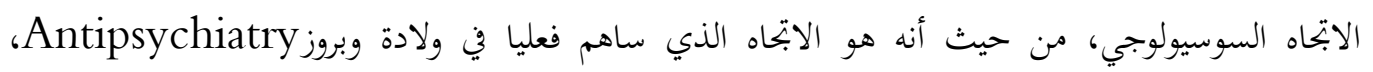

فيرتكز على المحيط الاجتماعي، ويربط سلوك الفرد بمحيطه الاجتماعي، والتفاعلات الفردية القائمة بين الأفراد. فمن خلال هذه المداخل الكبرى، سنحاول صياغة هندسة معينة لمفهوم الجنون، منطلقين من استعماها الشائع والعامي، قاصدين بناء دلالة شاملة، مرورا ببعض المعاني من داخل العلوم الإنسانية كعلم النفس والسوسيولوجيا.

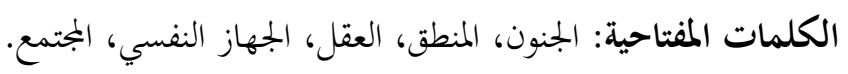

المقدمة:

منذ أن وجد الإنسان، ومع بداياته الأولى في التفكير، شغل موضوع وجوده وقدره، وماهيته أيضا حيزا كبيرا من تفكيره.

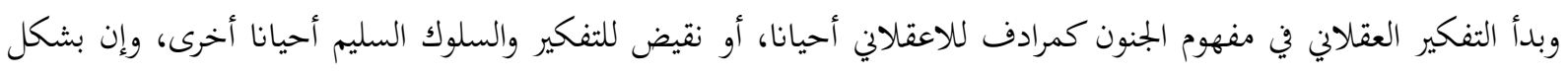

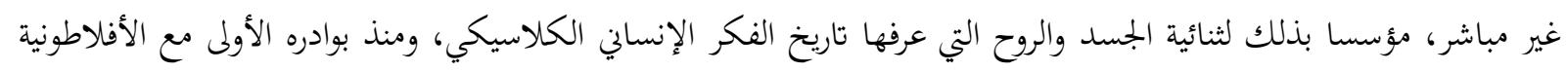

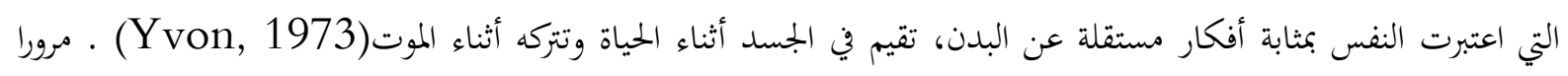

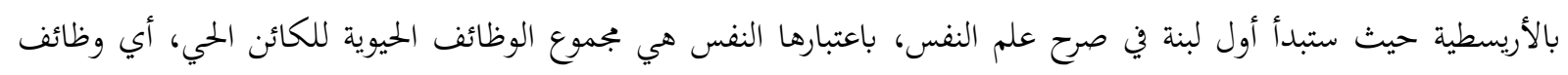

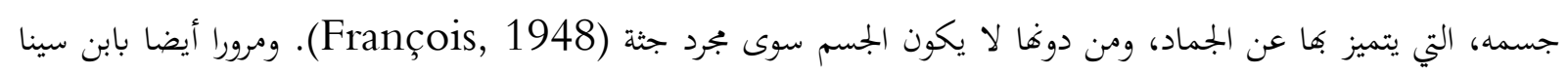

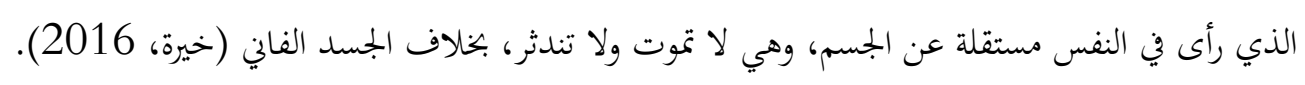
لتكتمل فكرة ثنائية الجسد والروح، في الفترة الحديثة، مع الديكارتية التي عالجت العلاقة الإشكالية بين العقل والجسم

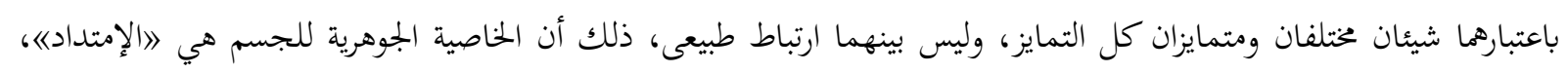

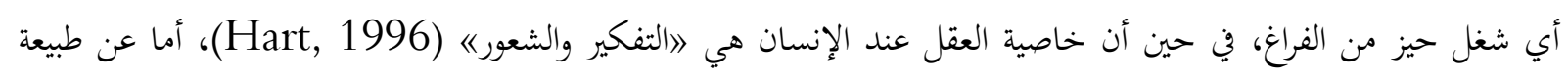

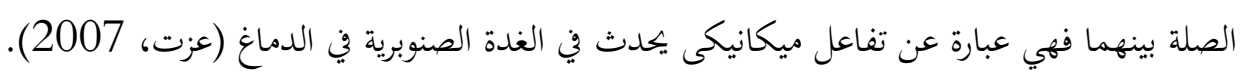


ليتم تعديل هذه الرؤية قليلا مع النظرية الأحادية القائلة بأن العقل والجسد ليسا كيانين وجوديين منفصلين، وإنما جوهر

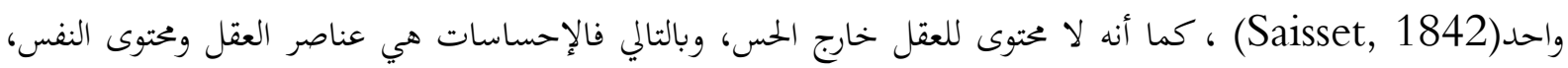

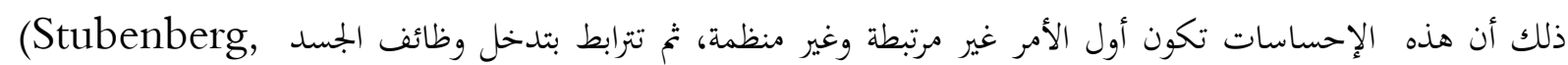
(2016، فينشأ عن هذا الترابط العمليات العقلية ك: التفكير التصور التخيل الإدراك.

عبر هذا التاريخ الفكري حول ماهية الإنسان والنفس، بدأ القضاء على ثنائية الجسد والروح في ابتاه بناء علاقة بين هذه الأخيرة وكل من الفيزيولوجيا والبيولوجيا وعلم الأعصاب كما ستصلنا مع العلوم المعاصرة اليوم، بمفاهيمها الشاملة والمتعددة

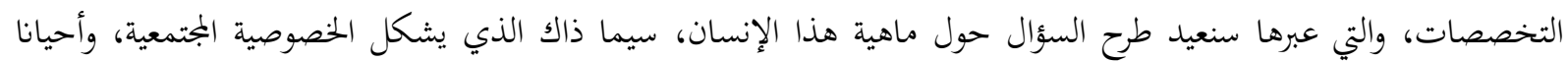

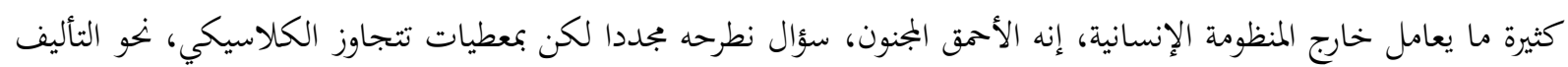
بين ثلاثة ابتحاهات علمية مختلفة:

الاتجاه النوروبيولوجي، الذي يحاول فهم الإنسان عقليا وسلوكيا، ويرتبط هذا الاتحاه بشكل واضح بالعقل حيث يوليه الأهمية

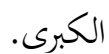
الاتجاه السيكودينامي، الذي يرتكز على الجهاز النفسي، كحلقة أساسية في السلوك الإنساني، ذلك أن أي سلوك صادر عن الفرد راجع لهذا الجهاز.

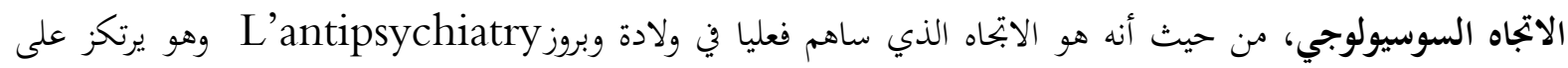
المحيط الاجتماعي، ويربط سلوك الفرد بمحيطه الاجتماعي، والتفاعلات الفردية القائمة بين الأفراد.

1 . مفهوم الجنون من الاستعمال العامي نحو التحديد المفهومي - مفهوم الجنون في السياق العامي التداولي لم تستخدم كلمة الجنون في البداية من طرف أطباء علم النفس، ولا حتى من طرف المرضى أنفسهم، بل يعود أصل هذا

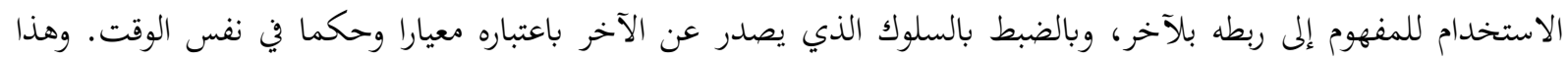

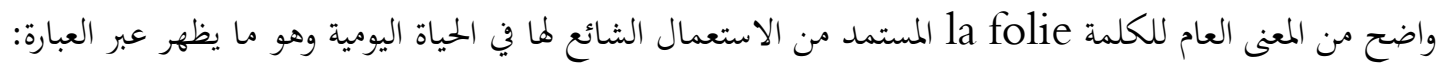
il est complètement fou (Zarifian, 1999) التساؤل حول المشروعية الأخلاقية والقانونية لهذا الاستخدام.

ومن هذا المنطلق يمكن أن نعتبر أن تداول كلمة مجنون مجتمعيا، أمر يخضع للعشوائية والتلقائية. وفي هذا السياق نستحضر تلك الصورة التحقيرية للجنون، ولأمراض العقلية من وجهة نظر مجتمعية، وهي نفس الرؤية التحقيرية كذلك بحاه الأقليات المجتمعية، التي تعتبر ضحية للرفض الاجتماعي، والتي تؤكدها الوقائع المتعلقة ببعض الأمراض السابقة من قبيل مرضى ونى الزهري،

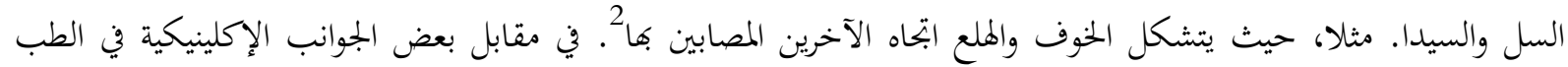

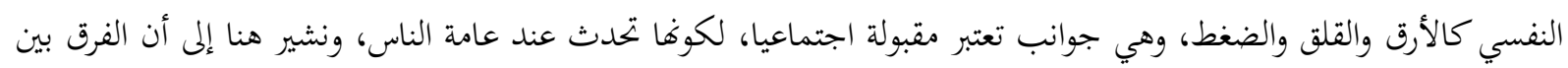

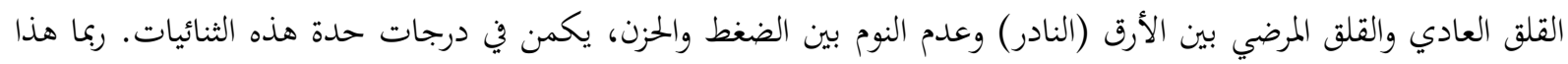
السياق هو الذي أدى إلى غياب لفظة الجنون في الإطار الطبي عموما، وهو ما أدى أيضا إلى ضرورة الاستعانة بمفاهيم متقبلة اجتماعيا عوض أخرى غير متقبلة، كتوظيف مفهوم الضغط عوض الانفصام في الشخصية، والاضطراب العقلي بدل الجنون مثلا 
إن ما قد يثير الانتباه، أن حالة الجنون كما هي متداولة داخل المجتمع، قد تتقاطع مع بعض الحالات الأخرى، من قبيل

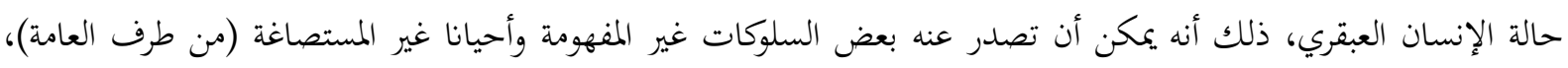

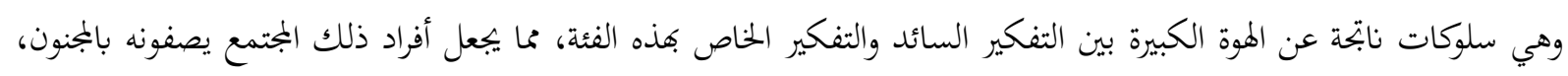
ولعل تاريخ تطور الفكر الإنساني يزخر بأمثلة من هذا القبيل: مثل، شخصية سقراط شخصية الأنبياء في السياق الديني. كما أن طبيعة المجتمع المغربي من وجهة نظر سوسيو أنثروبولوجية تحيلنا في هذا السياق على ما يطلق عليهم اسم البوهالي

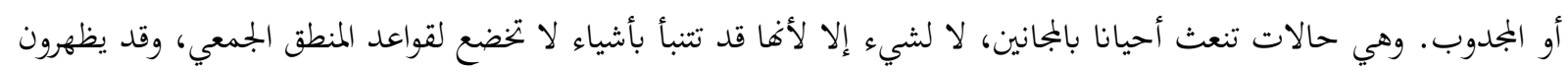

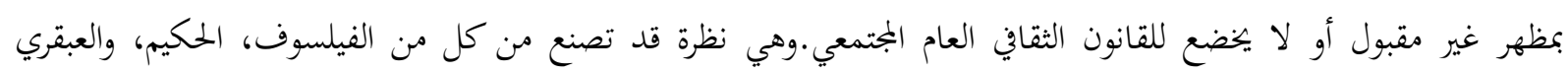
بجانين 3 كما أننا قد نلاحظ من جهة أخرى، أن حالة الجنون في سياقها التداولي، قد تتقاطع أيضا مع حالة الاستهتار المفرط، أو

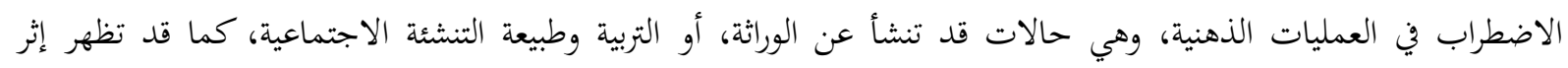

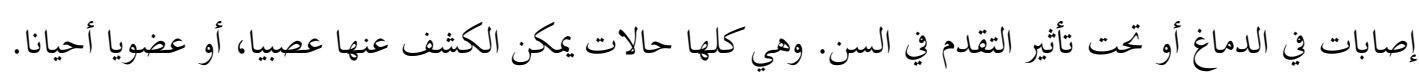
هذه الأمثلة وغيرها قد بتعل من التنبؤ بطبيعة السلوك الناتج عن حالة الجنون كمعيار للحكم أمرا غير مككن، خاصة

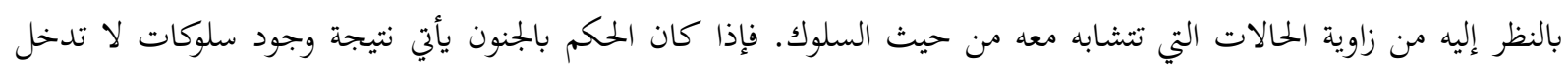

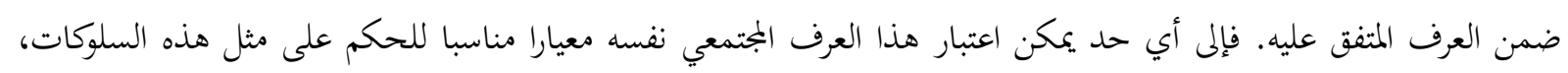

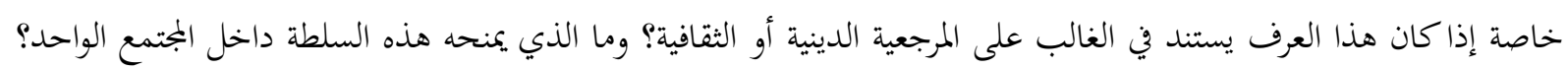
خاصة أن ما هو عادي في ثقافة منطقة معينة قد يكون جنونيا في ثقافة منطقة أخرى. يتبين مما تقدم أنه يصعب تشييد هندسة لماهية الجنون من المنطلق العامي لأفها مرتبطة بالآخر وتقييمه للحالة، وبمرجعياته

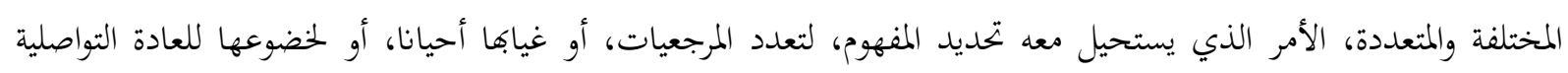

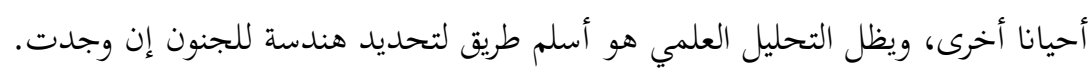

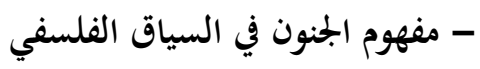
وإذا ما استحضرنا سياق الفكر الفلسفي فسنجده ينطلق مع أفلاطون بتصنيف الجنون كالآتي: هناك نوعان من الجنون:

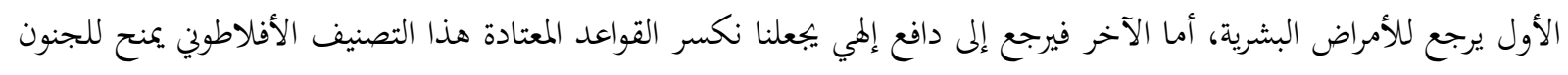

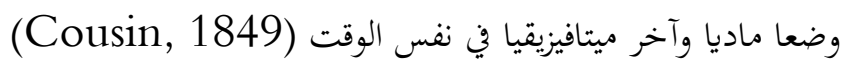
بذلك يكون تاريخ الفكر الإنساني قد وجد نفسه مقيدا في تجسيدات لهذه الحالة الجنون، والتي تقوم على مجموعة من

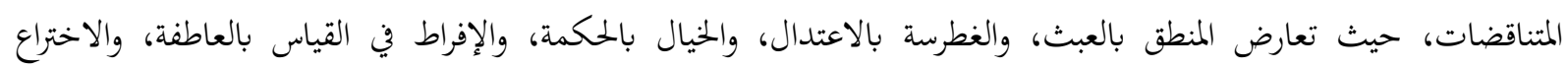

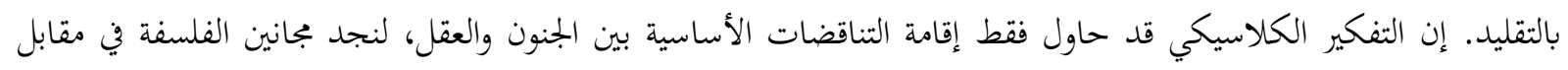

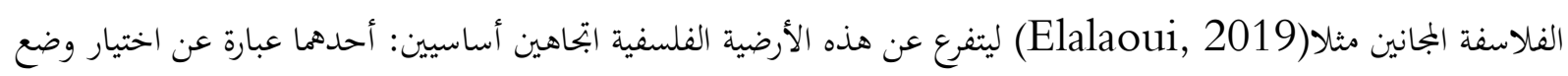
إنساني وجمالي يجتفي بالجنون، فيضع نفسه طوعا بعيدا عن القاعدة، وهنا يصبح الجنون فلسفيا، ومكتملا اجتماعيا ودافعا أخلاقيا

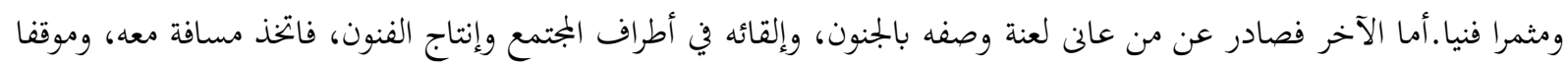

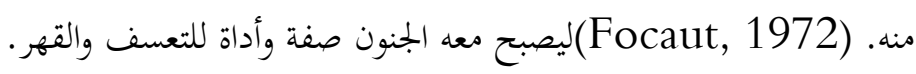
ويؤكد ميشيل فوكو في هذا الإطار بأن الحبس النفسي هو سبب الجنون، هو الحيلة المثالية لإحباط الأفراد الذين يطمحون

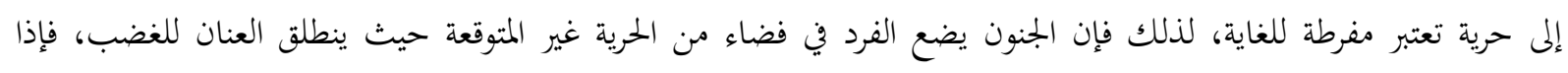

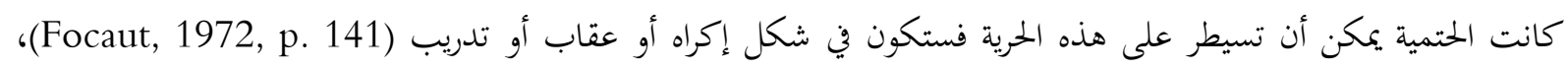


وهو ما قد نجده لدى بعض الأفراد من رفض أو غضب أو انفعال لمزاولتهم لأعمال أو وظائف قد تشكل نوعا من التقيد أو

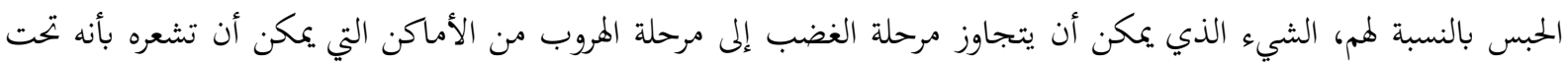
رقابة الآخرين، وأعرافهم.

وفي مواجهة اختبار الواقع، نجد أن جميع اليوتوبيات تقع ضمن فضاءات الجنون، مثل اليوتوبيا الأخلاقية والسياسية (أفلاطون، توماس مور، فورييه، موريلي)، ويوتوبيا الخيال العلمي (العلوم)، ويوتوبيا البيئة والدين، ثم اليوتوبيا الرومانسية (رابليه، فولتير)

(Elalaoui, 2019)

ومن جهة أخرى، فخطاب الجنون، والخطاب حول الجنون (إيغرار، 2009)، هو زخم بتحه الآخرين وترجمة لطبيعة العلاقة

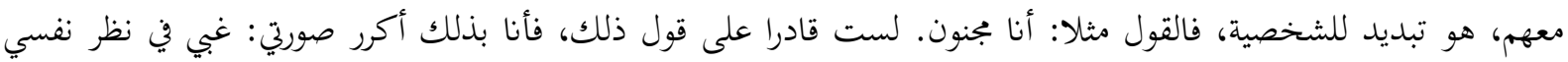
(أعرف هذياني)، ببساطة غير منطقي في عيون الآخرين، الذين أخبرهم بجنوني بحكمة شديدة. يجيل على حالة الوعي بهذا الجنون، فيمنح إمكانية الحديث عنه.وهنا نحيل على الجنون (الأدبي) الذي يعبر عنه بعبارة: أنا شخص آخرين (Focaut, 1972, p. 142) . هكذا يتبين بأن هناك الجنون الواعي الذي نعبر عنه بوعي تام بأسبابه ومآلاته، وهناك جنون لاواعي أو ما تطلق عليه الأفلاطونية

لقد كشف الجنون عن نفسه، عبر مجموعة من الأعراض النابحة عن الحماس النفسي (الاغتراب، جنون العظمة، الكآبة، الخرف، الهوس، الهستيريا)، باعتباره تحد للعقل بغض النظر عن جانبه الطبي (سعيد، 2011). أما من الناحية الدينية، فإن الجنون يقع خارج المكان، وخارج حدود ما هو غير معترف به، حسب ما جاءت به الديانات

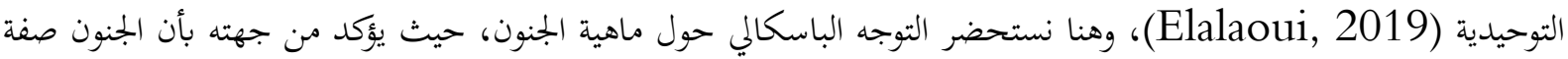

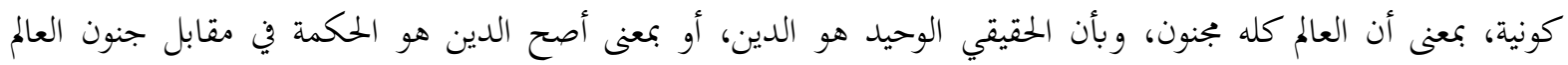
(Icard, 2010) (Pascal, 1979) (Elalaoui, 2019) من خلال طرح باسكال في مقاربته لمفهوم الدين في علاقته بالجنون يتبين بأنه يعيد تقييم الجنون، باعتباره عمق الحكمة. ومن الناحية الاجتماعية يتم إضفاء الطابع المكاني على الجنون من حيث الحبس والتضييق والتهميش، ومع ذلك فقد عالجت العلوم الإنسانية هذا التضييق. وهو ما سنتطرق له لاحقا (سيكولوجيا وسوسيولوجيا). من هذا الإطار الفلسفي لمفهوم الجنون، يتبين بأن هندسة الجنون هنا، قد بتحاوزت ما هو عامي عشوائي ومتعدد، نحو بناء نظرة جديدة حول ماهية الجنون، نظرة تحاول إقامة علاقة إيجابية معه، في ابتحاه المصالحة مع هذه اللفظة بجتمعيا وإنسانيا. وهذا ما يثير حافظة السؤال: أليس الجنون طريقة أخرى لتمثيل نفسك، ولتمثل العالم أيضا؟، فإذا كان الأمر كذلك فإن الجنون سيصبح مثل ما أشار إليه أفلاطون: هو عطية إلهية، فهو ليس شيئا مخيا أو سيئ السمعة (Yvon, 1973, p. 244D)،

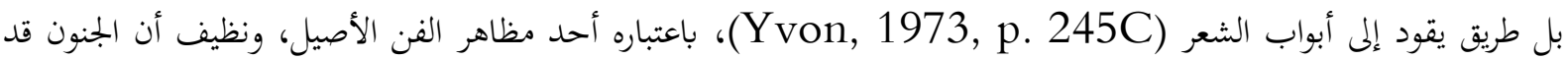
يشكل أحد أبواب الإبداع والفن بكل أنواعه.

هكذا تمت هندسة الجنون داخل الفلسفة، فرغم عدم قدرقا على تحديد الجانب الميتافيزيقي للمفهوم، إلا أها استطاعت إضفاء الطابع الإيجابي عليه، والانفتاح على حدوده وامتداداته وأحيانا رهاناته. الشيء الذي يستدعي منا الانفتاح على طبيعة الجنون من داخل العلوم الإنسانية. 


\section{2. الهندسة السيكولوجية للجنون (نموذج التحليل النفسي)}

\section{- هندسة حالة الجنون بالقياس على حالات نفسية أخرى}

تشكل أرضية التحليل النفسي، مرآة شفافة لبيان ملامح كل الحالات الثاوية خلف السلوكات الإنسانية، بشكل علمي

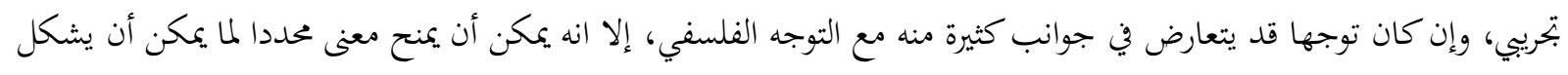

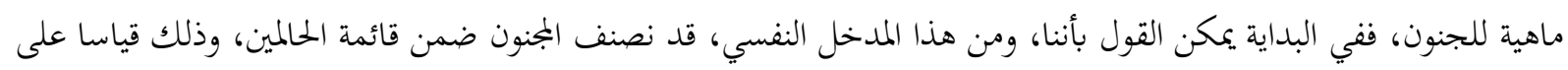

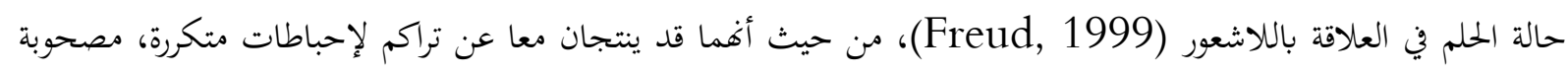

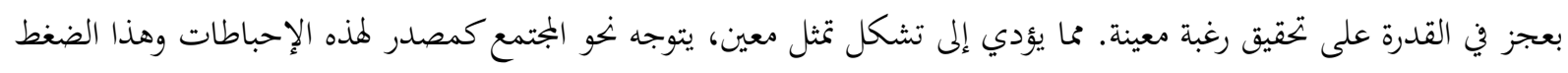

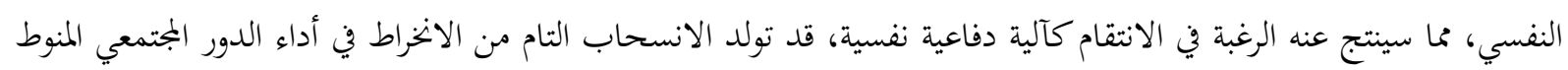
به، وبالتالي التمرد على المجتمع عبر رفض التقيد بأعرافه ونظامه.

فالعدوانية مثلا كأحد مظاهر الجنون، لا تظهر إلا بعد التعرض لمثير معين، ثم إها نتيجة سيرورات ذهنية معينة تعتبر هي

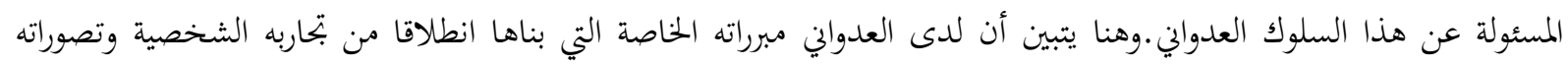
وتمثلاته النابتحة عن تراكم وتوالي الإحباطات، وفي هذه الحالة يكون مغيب الوعي أو مضطربه. إن الوقائع قد بينت أنه لدى بعض الأشخاص، يكون التمثل (المتعلق بالأفعال غير المقبولة داخل المجتمع) تلقائيا، لأنه

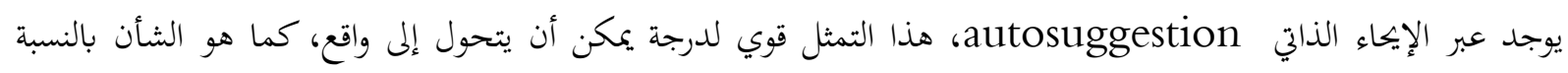
للهلوسة أو الثلل أو أي ظاهرة أخرى من نفس النوع، هذا التحول من إيحاء ذاتي إلى واقع لا يمكن تفسيره دون استحضار اللاوعي، لأنه نتيجة سيرورات نفسية وتمثلات لاواعية4. (Freud, 1999).

وبالقياس على الظواهر النفسية النابحة لمجموعة من الاضطرابات الجسدية والعقلية مثل اضطراب الرؤية، يمكن القول أن

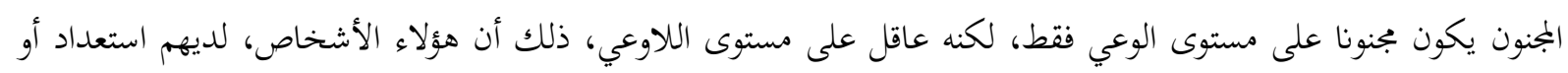

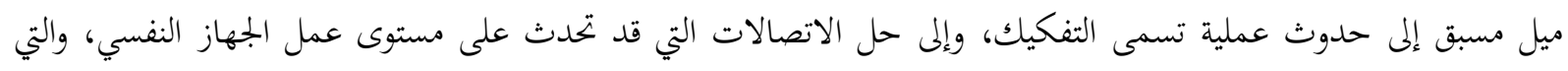

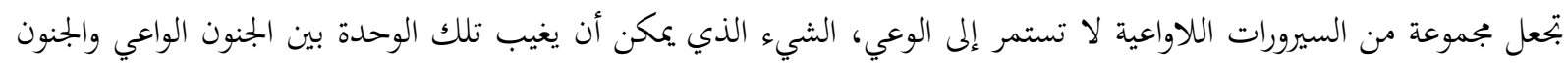

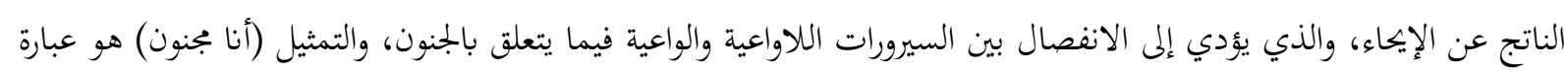
مبررة لحالة الأشياء في النفس وليس سببها. إن التحليل النفسي قد ربط بين الوعي واللاوعي في شكل مفهوم ديناميكي يعيد الحياة النفسية إلى لعبة القوى التي تحابي

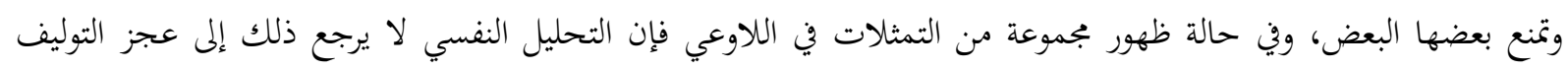

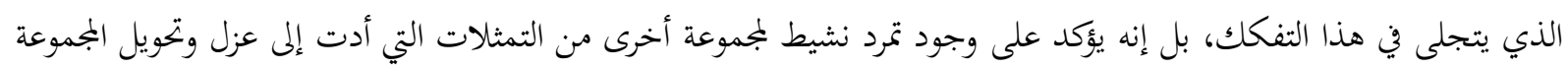

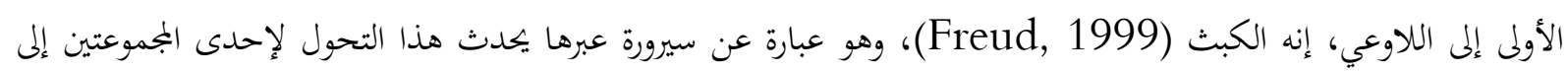

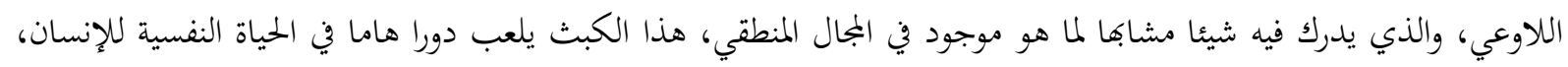
فإذا فشلت سيرورة الكبث فإن ذلك يؤدي إلى ظهور أعراض توحي بوجود أمراض معينة. قد يكون الجنون من بينها. مما سبق يتبين أن الاضطراب النفسي المنتج لحالة الجنون، بالقياس على حالة اضطراب الرؤية أو الشلل. يتم بسبب ارتباط

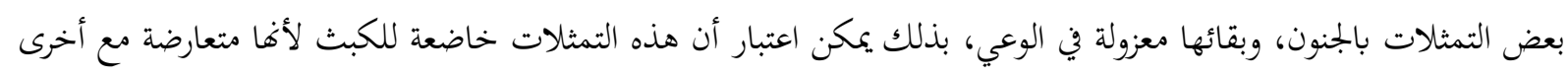

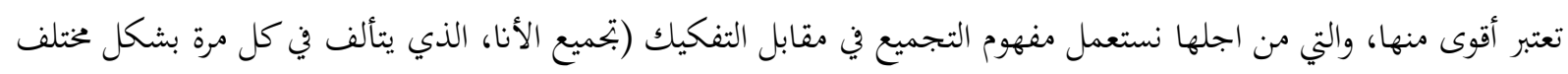

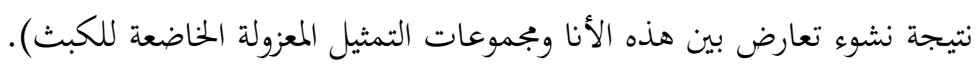


إن الأمراض العقلية عبارة عن حالات أو اضطرابات تميز كل إنسان مهما بلغ من درجة التوازن، وإن بدرجات متفاوتة،

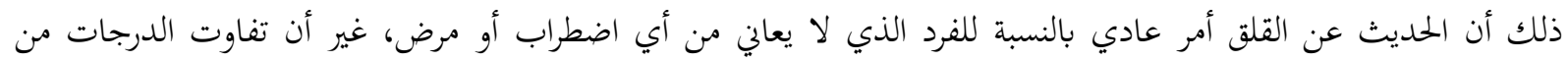

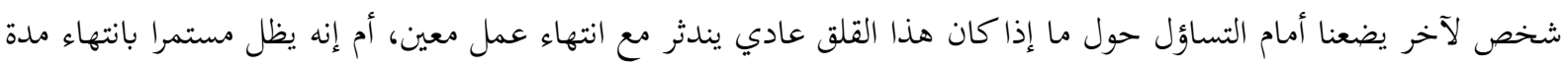

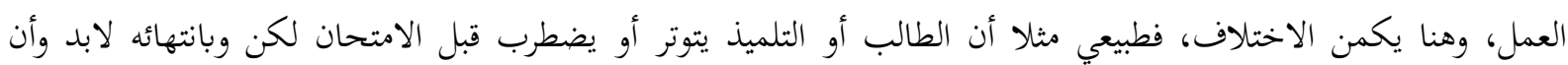

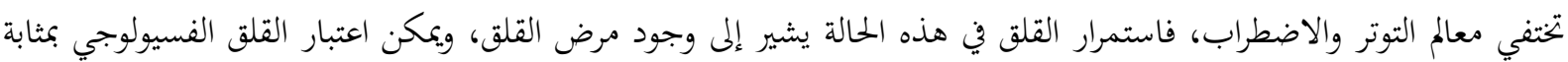

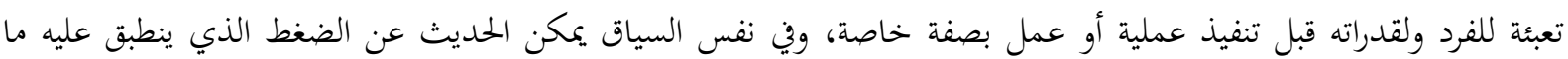

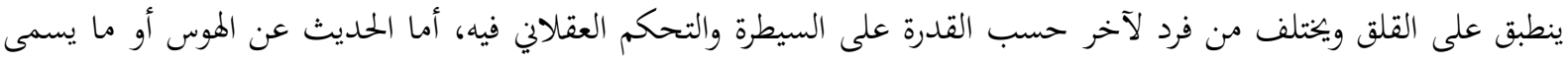
l'état maniaque

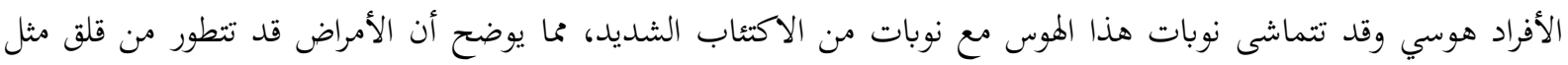

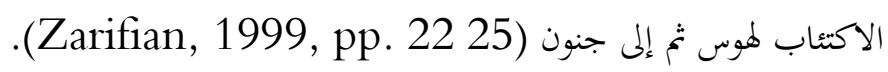

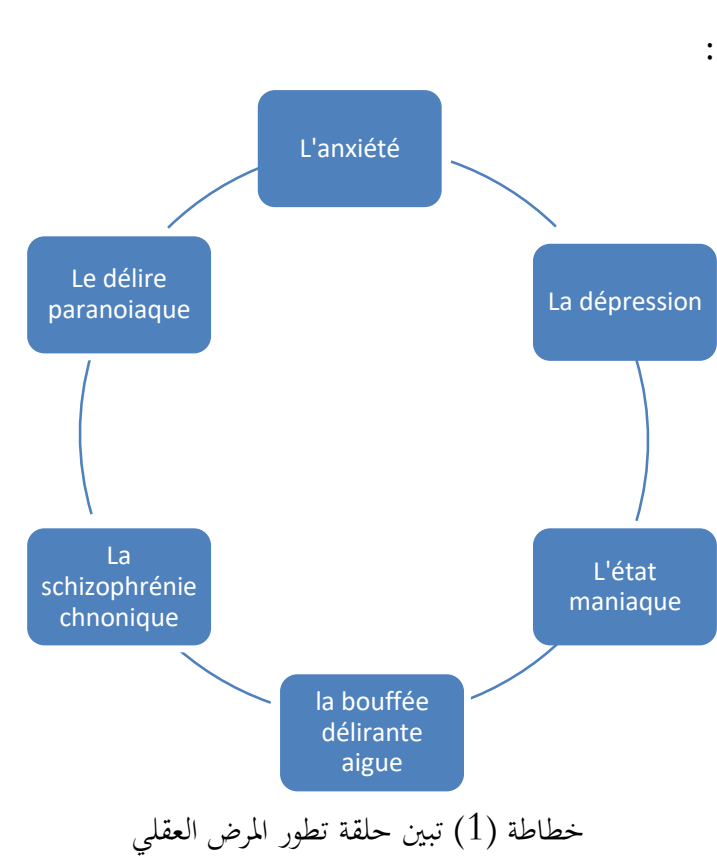

أما عن la bouffée délirante aigue أو ما يعرف بالهذيان، باعتباره مجموعة من الأفكار غير المنطقية، غير

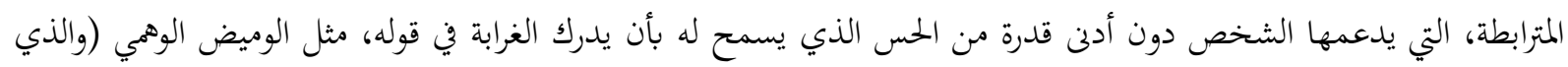

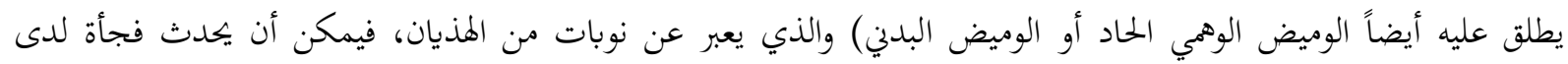

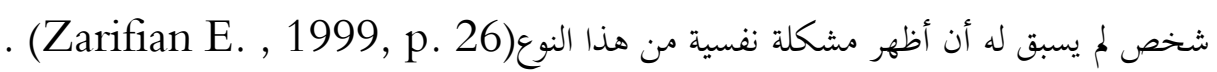
هذذا المعنى يصبح الشخص المضطرب غير مدرك لما يفعله، ولا يظهر أي تراجع عن أفكاره وخطابه. وكما هو الحال في

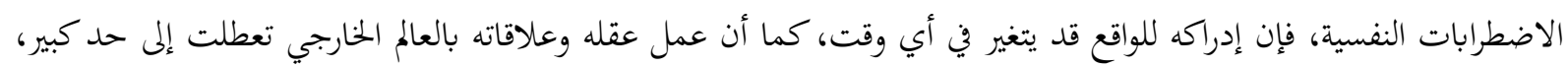
وقد يستمر الوضع لبضع ساعات، أيام أو حتى أسابيع (Fabienne, 2009). وفي جانب آخر من الاضطرابات العقلية، نخص بالذكر هنا الفصام كمرض نفسي معقد، والذي يترجم إلى تصور مضطرب للواقع، والمظاهر النابحة عنه، مثل الأوهام أو الهلوسات، والمظاهر السلبية، باعتبارها عزلة اجتماعية وعلائقية، فمن الناحية العملية، يمكن أن تكون مختلفة جدا من مريض لآخر، اعتمادا على طبيعة وشدة الأعراض المختلفة التي يطرحها المرض ونئه 
وبتحر الإشارة إلى وجود شخصيات قابلة للإصابة بالأمراض دون غيرها، وهي ما يصطلح على تسميتها بالشخصيات

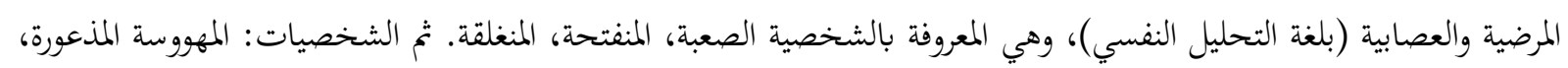
المضطربة العقل، فبهذا نكون انتقلنا من المرض كمرض إلى الشخصية الحاملة للمرض (Zarifian, 1999)، بالإضافة إلى الشخصيات العصابية التي فصلت فيها نظرية التحليل النفسي الفرويدية والتي قسمتها إلى: (Freud, 1999) .hystérique, obsessionnelle et phobique

هكذا تمت هندسة مفهوم الجنون، باعتباره مرض ناتج عن اضطراب سيكولوجي، خاضع لسيرورات سيكولوجية فاشلة

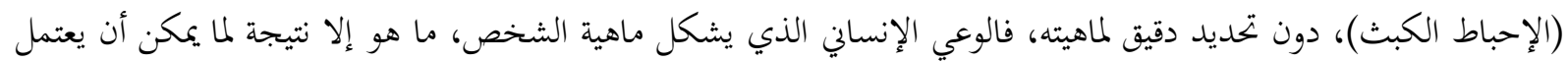

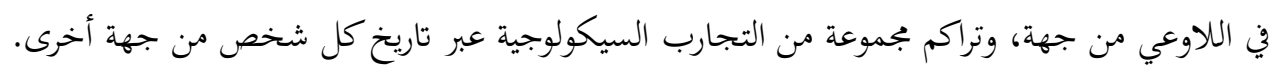
هذه الرؤية السيكولوجية، لا تنفي تأثير الآخر في تشكل هذه الحالة النفسية الجنون، وإن بشكل مضمر، ذلك أن ربط

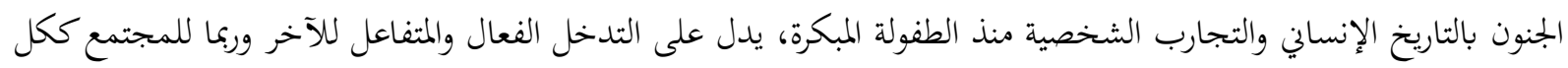

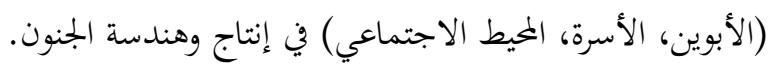

\section{3. الهندسة السوسيولوجية للجنون}

إن تحديد الثنائية طبيعي مرضي، يستدعي رصد دور الأفراد في تقرير مصير السلوك هل هو طبيعي أم مرضي، وهنا يجب

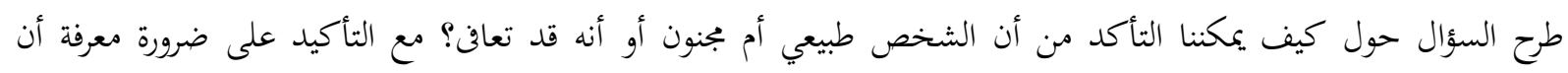

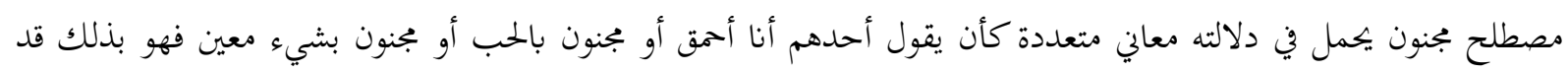

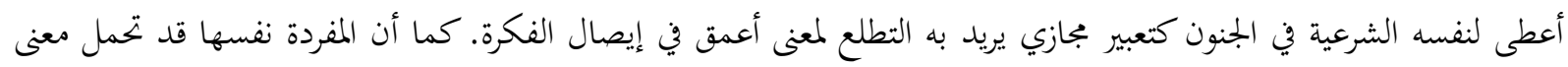

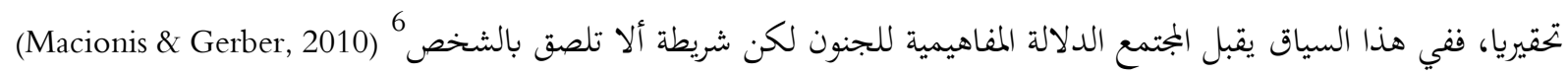
في نفس السياق يمكن الحديث أيضا عن الانفصام السياسي أو الانفصام الاجتماعي. ومن جهة أخرى فإذا كان الفرد مختلفا عن الجماعة فهذه الأخيرة تعتبره ضدها، وإذا كان كذلك فسيدمرها، وبالتالي

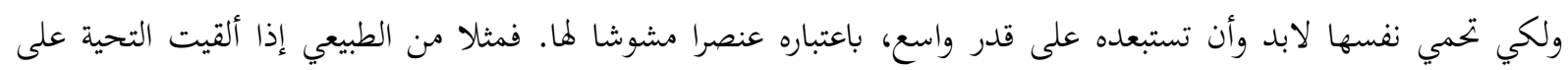

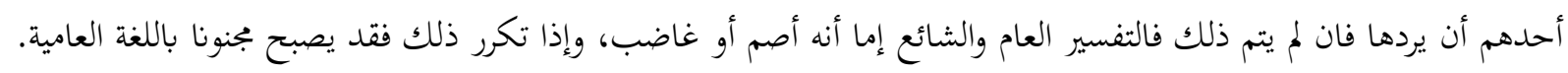

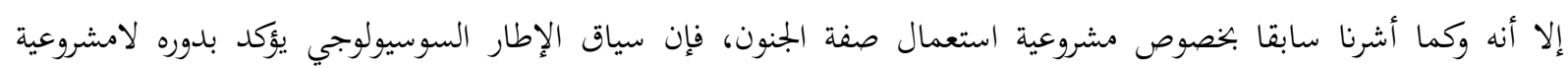
استخدامها بشكل مستمر ولنفس الشخص، مما يحيل على ضرورة استعمال عبارة المرض العقلي بدل مفردة الجنون، هذه الأخيرة نفسها لا يمكن توظيفها خارج التشخيص الطبي.

إن أول ما يمكن التساؤل حوله ونحن نؤسس للهندسة السوسيولوجية للجنون، هو طبيعة وجوده بين جدلية الحقيقة

وهنا نستحضر النظرة التي ترى أن الأمراض هي مجرد أسماء، أو تصنيفات مجردة، والتي تستمر فقط طالما أن المصالح

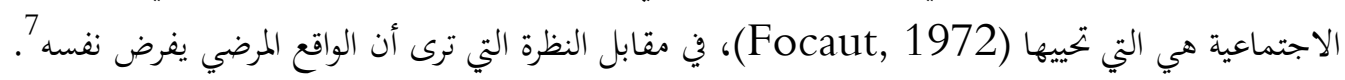

ويؤكد السياق السوسيولوجي على أن المرض بشكل عام لا يصيب الكائن الحي أو الفرد الجسد فحسب، بل يصيب

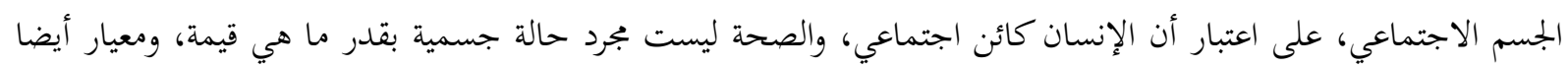

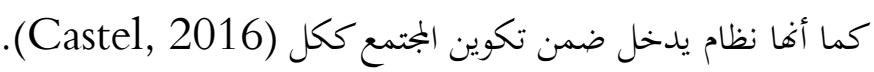


وإذا ما ألقينا نظرة على حياتنا اليومية، فإننا نلاحظ أنه عندما يكون التشخيص شأنا بين الطبيب والمريض، فإن كل شيء

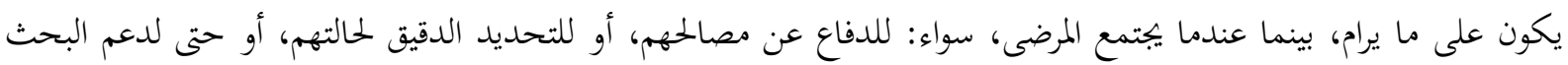

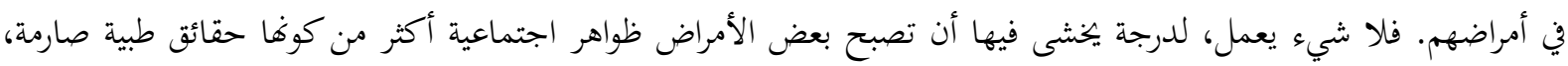

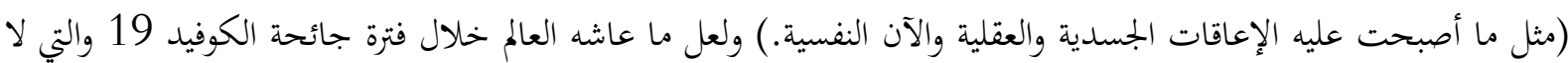
زلنا نعيشها إلى اليوم خير دليل على ذلك، وهنا نتحدث عن إعادة ترميز المرض القديم إلى خسارة اجتماعية: أي الخفاض في

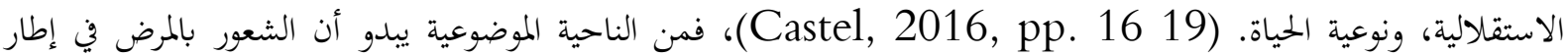
مختلف العلاقات يؤدي إلى إقامة تحديات متعددة داخل المجتمع الواحد، وبذلك يسبب أي مرض مستقل بذاته مشكلة اجتماعية

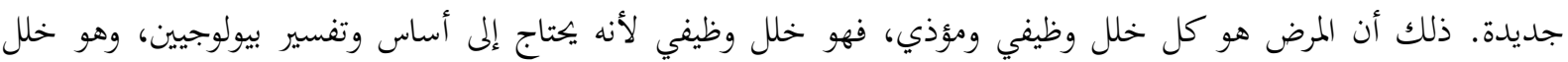

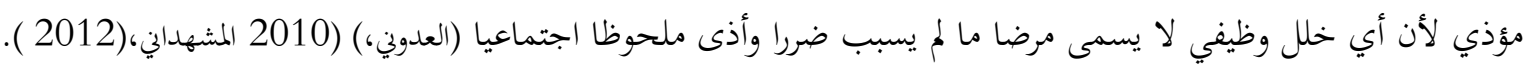
ومن خلال ما تقدم، فإنه لا يمكن الفصل بين وجهة النظر السوسيولوجية هذه، وبين الحدود القانونية الوضعية التي تؤطرها، على اعتبار أهما هي التي تحتوي، تعالج، تؤهل وتدمج المجانين المصابين بمرض عقلي داخل دانل المجتمع. هذا السياق يفتحنا على إعادة طرح مجموعة من الأسئلة من قبيل: كيف يتأسس حضور الجنون داخل المجتمع، وما طبيعة هذه العلاقة، هل الجنون نتاج لاختلالات اجتماعية أكثر منها نفسية (Castel, 2016, p. 21). وتفاعلا مع هذا الطرح، وفي إطار العلاقة مع تعقد وتركيب المشكلات المجتمعية داخل المجتمع الواحد، نستحضر التوجه

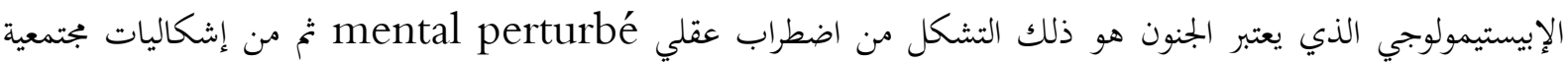

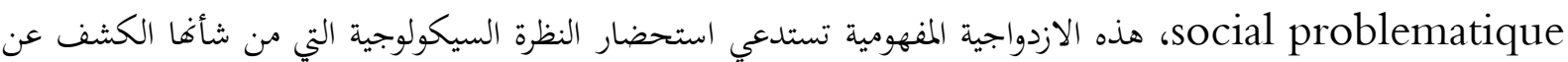

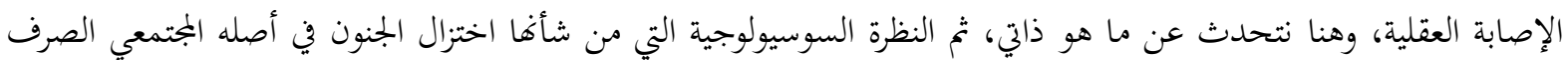

.(Otero, 2015, p. 16)

فمن هذه النظرة الأخيرة (السوسيولوجية) يصبح الجنون هو نتاج دينامية اجتماعية تحت تأثير توترات حادة وعنيفة أصابت العلاقات الاجتماعية ومنظومة القيه، في عمق نسقها بالإعاقة والأعطاب: فالجنون من وجهة نظر سوسيولوجية هو تعبير عن سيرة مجتمع تعرضت فيه الروابط للتحطيم والتفكيك. (الغيلاني 2018)

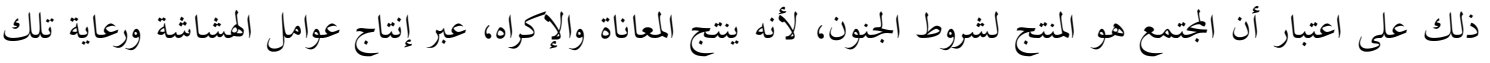

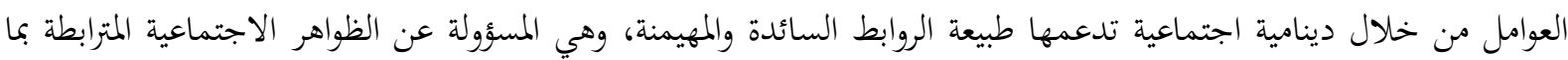
فيها الجنون. هذه الظواهر نفسها هي مادة اجتماعية جوهرية لتطوير المقاربة السوسيولوجية ومناهجها في الاتحاه المعاكس. (الغيلاني، (2018) إن الأبعاد العقلية والاجتماعية للجنون المرض العقلي (بحدودها غير الواضحة وغير المتقبلة) غير قابلة للفصل تحريبا، وغير

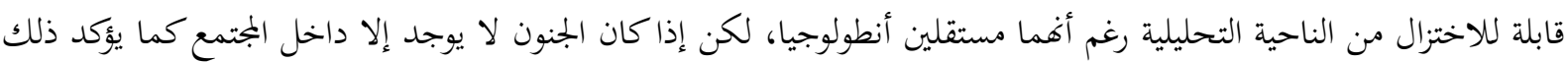

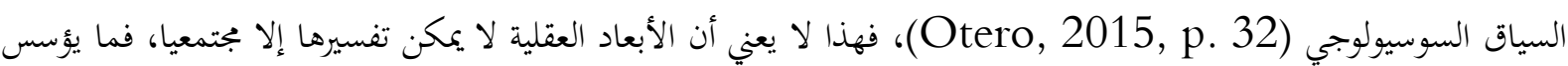

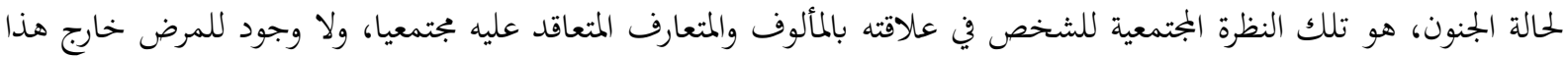
السياق. هذا الحضور للمرض وعلاقته بالجمتمع يجيل على طرح سؤال جديد: ما الذي يجعل من الجنون مشكلا بجتمعيا؟ إن الإجابة عن هذا السؤال بتعلنا نفعل الجنون من خلال إدراك المشاكل التي يحملها، فيؤثر من خلالها على المجتمع، والتي

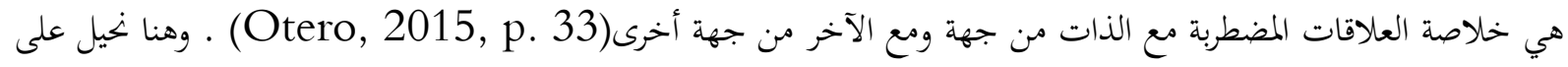
مفهوم الجنون المدني باعتباره مشكلة اجتماعية معقدة، ويرجع تعقدها إلى ضرورة تحديد التقييم النفسي لها، مما ينتج اللاتحانس بين 
المواقف المعقدة والملامح الفردية المرتبطة بالخطورة العقلية، سواء كما يتصورها القانون الوضعي، أو كما تحللها النماذج الإدارية

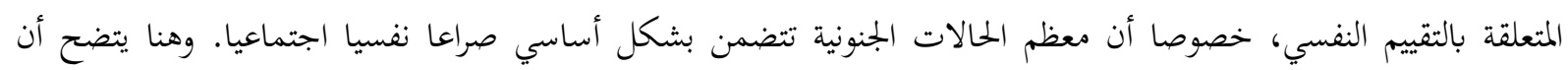

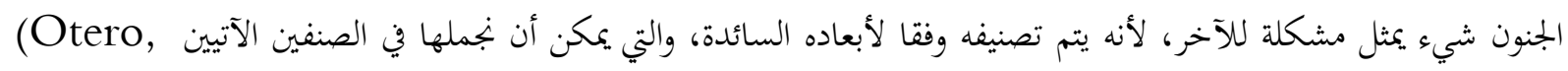
:2015, p. 34) ما ينطوي على خطر على الذات، وهو صنف يتميز بالضعف العام (الفوضى العقلية وخطر الانتحار). ما يتعلق بالصراع مع الآخرين (غرباء، محيط، أقارب) وتمتد من الإزعاج البسيط إلى العنف الفئ الجسدي. لقد حاول هذا الاتحاه السوسيولوجي أن يسلط الضوء أيضا على عالم الجنون المعاصر، طالما أنه لا يبالغ في تفسير ادعاءاته

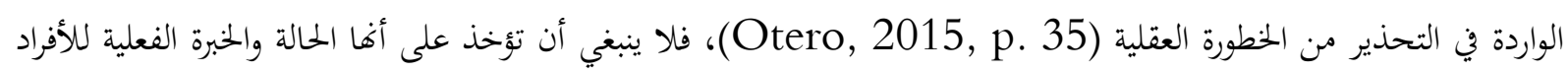
المعنيين فقط، وإنما من طبيعة خطاب هؤلاء الذين يعتبرهم الآخرون إشكاليات.

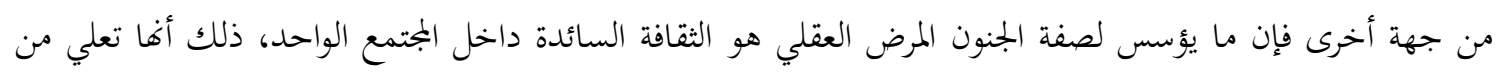

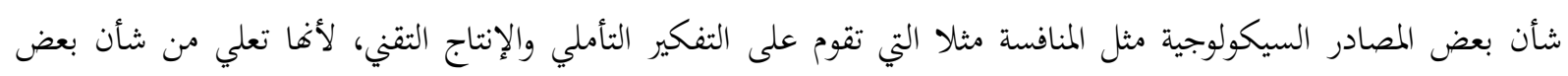

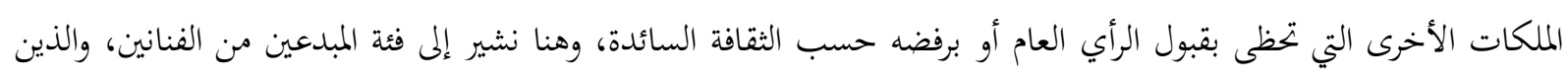

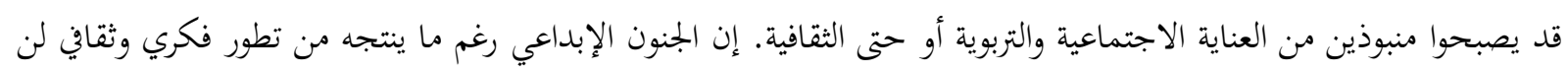

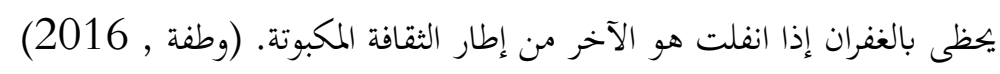
وباستحضار الأدب المكتوب في مجال الطب النفسي، في علاقته بإثيولوجيا الأمراض العقلية (Bhandari, 2020)،

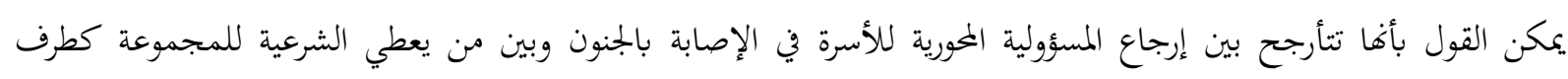

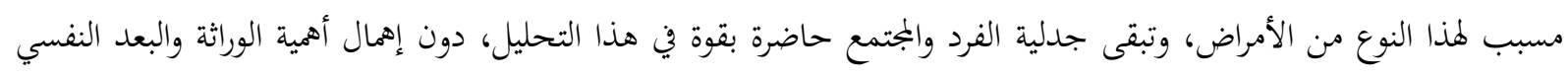
والفيزيولوجي في الموضوع. ومن وجهة نظر اجتماعية قانونية، نشير إلى الخطر الذي يمكن أن ينتج عن حالة الشخص العقلية، سواء على نفسه أو

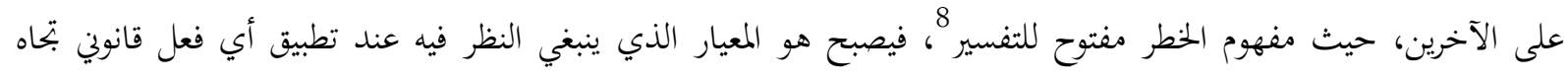
الشخص المجنون المريض عقليا، وهنا يصبح الانفتاح على إشكالات تتعلق بطبيعة العلاقة الجدلية بين الطب النفسي والعدالة أمرا مهما (المملكة المغربية، 1963)

مما تقدم يتبين بأن الجنون المرض العقلي، مفهوم لا يمكنه أن ينشأ إلا في سياقه المجتمعي من جهة، كما أنه ينشأ ويتفاعل

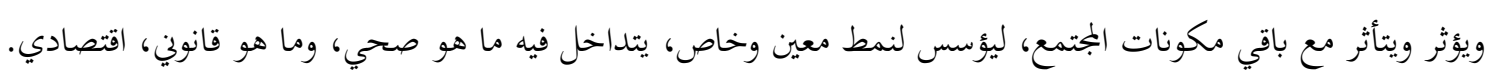

\section{ZARIFIAN الهندسة التركيبية للجنون نموذج}

بعد التحديدات السابقة لكيفية تشكل الجنون، من مدخل كل من الفلسفة، التحليل النفسي والسوسيولوجيا، يتبين بأنه

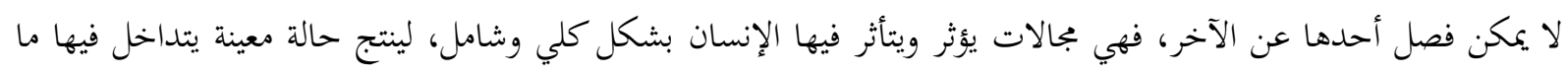

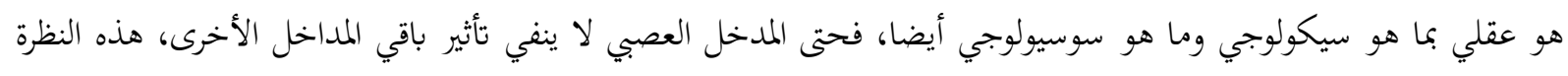

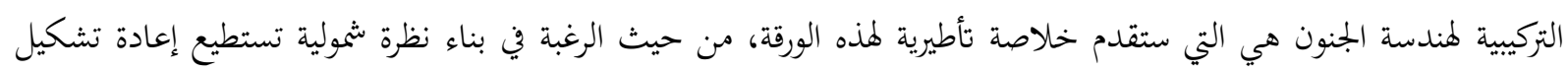

$$
\text { الجنون كمفهوم وكسلوك ووظيفة أيضا. }
$$

وللحديث عن هذه الهندسة التركبية، نستحضر توجه EDOUARD ZARIFIAN من خلال كتابه

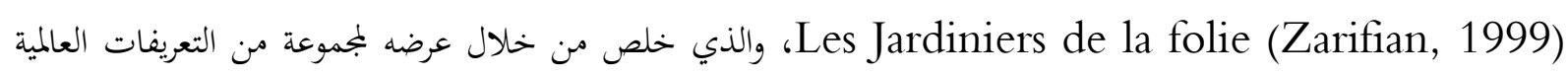


للجنون إلى اعتبار هذا الأخير بمثابة خلل في سلوكيات الفرد أولا، خلل مصدره الآخر، مما يضفي عليه صفة الذاتية، كما يتم

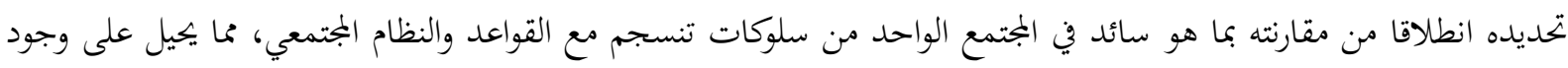

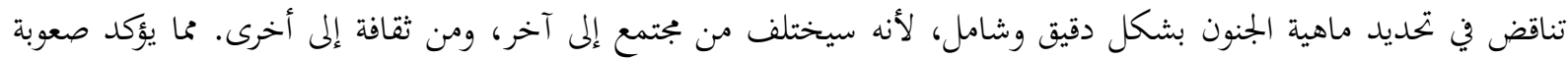
تحديد ماهية الجنون. (Zarifian, 1999)

يتبين عبر هذه الخلفية النظرية، في علاقتها وتقاطعها مع الاتحاهات العصبية أنه ليس من السهل تحديد عتبة محددة للجنون

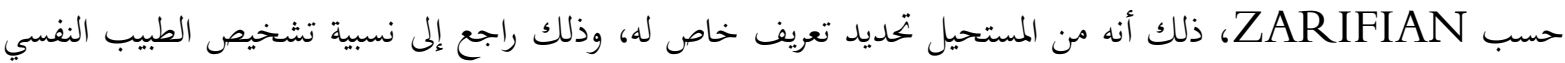

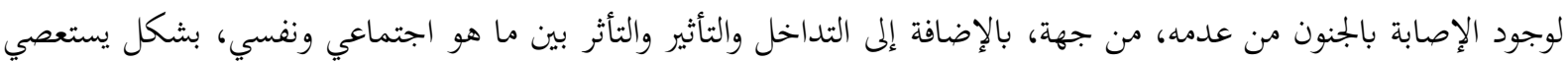
معه الفصل بينهما.ففي غياب النظرة التشخيصية الشمولية لحالة الجنون لا يمكن التحديد والتشخيص المطلق والنهائي لها، ولا يمكن حتى الجزم بوجودها، لأنه وجود يتعلق بالإضافة إلى ما هو ذاتي بطبيعة وشكل ثقافة الفئة الاجتماعية، باعتبارها صاحبة القاعدة التي يتم بموجبها الحكم على أي سلوك وقياسه (Zarifian, 1999). وبهذا المعنى يصبح استخدام كلمة المجنون اقرب إلى الاستعمال العامي المتداول منه إلى الاستخدام العلمي،، وهو تأكيد

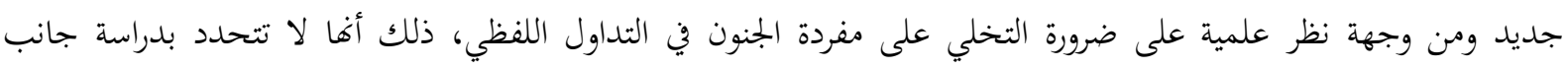

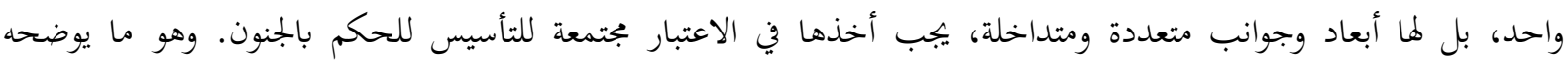
الشكل أسفله: 9 هندسة الجنون

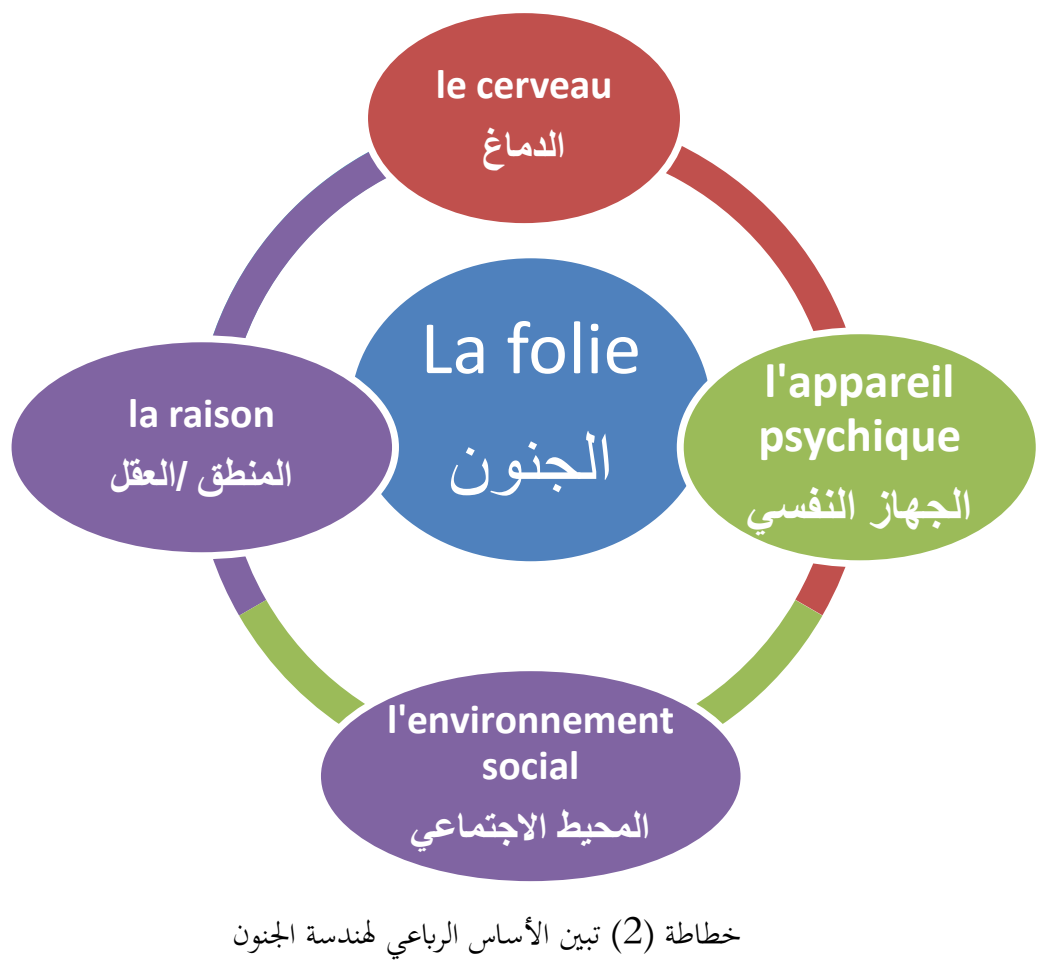

الدماغ: ويحيل في السياق الطبي العصبي، إلى ضرورة سلامة الجهاز العصبي، ذلك أن أي خلل فيه قد يؤدي إلى بجموعة من الاضطرابات من بينها الاضطراب الوظيفي، والذي يتراوح بين فقدان كامل للوعي (في حالته القصوى)، والتوهان، وعدم القدرة إنهان على الانتباه. الهذيان. في الحالات الأقل خطورة، وذلك حسب طبيعة الحنلل العصبي (Shekhar, et al., 2017). 


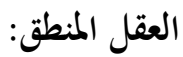

باعتبار الجنون هو نتيجة نمط من التفكير، ومنطق عقلي شخصي، قد يصبح طريقة خاصة لتمثيل النفس، وتمثل العالم

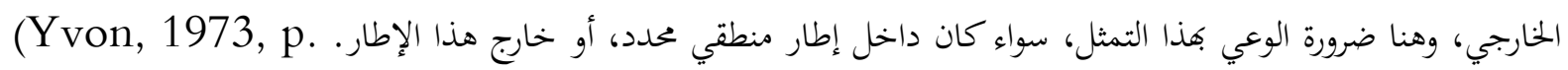

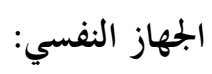

حين يصبح القلق كحالة نفسية مرضية، منتجا أعراضا مستمرة، وتوترا دائما، وهي أعراض تؤثر على المزاج والتفكير

$$
\text { والسلوك أيضا (M.D, 2018). }
$$

\section{الخيط الاجتماعي:}

باعتباره مجال اعتمال جميع الحالات النفسية والعقلية، وباعتباره مصدر الاضطراب ويف نفس الوقت المجال المعياري المحدد لطبيعة هذا الاضطراب، وذلك باعتماد مرجعيات خاصة بالمجتمع نفسه (ثقافية، دينية، إديولوجية، اقتصادية، قانونية).

مما تقدم نؤكد أولا على ضرورة التخلي على لفظة الجنون في التداول العام، ذلك انه لا أساس لها لا من الناحية الإنسانية،

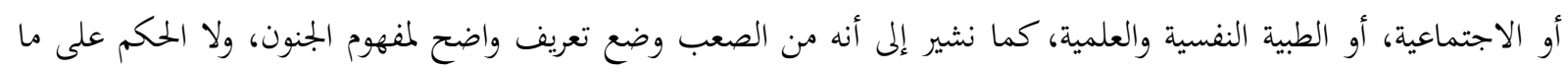

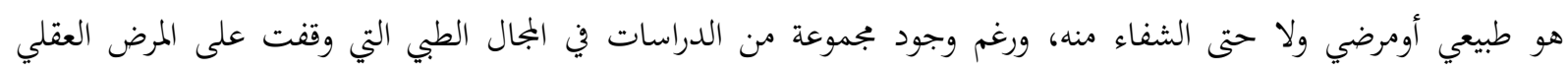

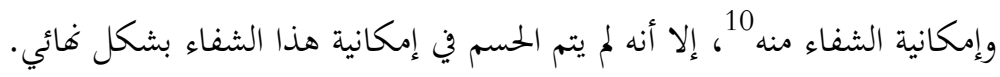

صحيح أن الأدوية قد تساعد على التخفيف من القلق، الضغط والألم، لكن لا يعني ذلك الاختفاء الكلي والتام

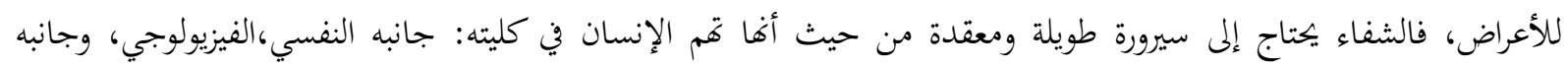

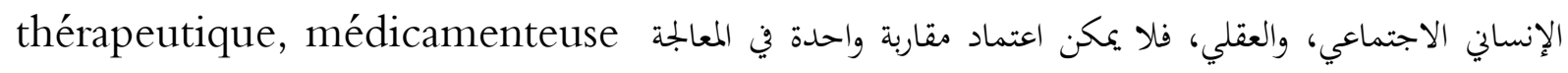

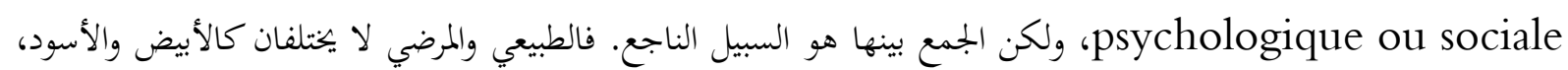
بل إن الأمر على العكس من ذالك، ذلك أن كل فرد يوجد داخل وضع معين من الاستقرار لكن هذا الاستقرار لا يعني توازن تام

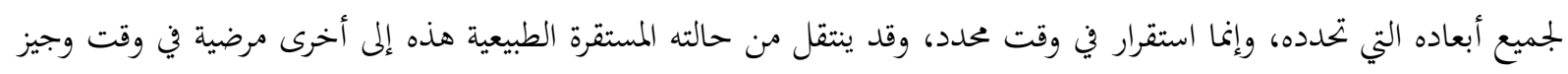
جدا، ومفاجئ.

وعليه فلا يمكن تحديد الجنون، إلا في سياق تركبي يجمع بين المحددات الأربعة (العقلي، العصبي، النفسي والاجتماعي)، وأي تحديد خارج هذه النظرة التركيبية، قد يصبح ناقصا، فيشكل عائقا لهندسة الجنون بمعناها الشامل والكلي.

\section{قائمة المراجع}

Bhandari, S. (2020, février 18). mental illness basics. Consulté le 11 15, 2021, sur MENTAL HEALTH: https: www.webmd.com Mental health mental illness basics\#1

Castel, P. H. (2016, septembre). la folie une condtruction sociale dans troubles mentaux et psychotherapies. (L. g. Dossiers, Éd.) Sciences Humaines(20), pp. 1619. 
Cousin, V. (1849). Oeuvres de platon (éd. p.J. REY; libraire). paris, la France: QUAS Des Augustins.

Elalaoui, A. E. (2019, juin 12). Catégories. Consulté le 11 15, 2021, sur Calenda: https: WWW.fpe.umi.ac.ma

Fabienne, B. (2009). Judith Butler Trouble dans le sujet; trouble dans les normes. presses Universitaire de France, pp. 6988.

Focaut, M. (1972). l'histoire de la folie à l'âge classique. paris: Galimard.

François, N. (1948). l'évolution de la psychologie d'aristote. paris: l'institut supérieur de philosophie.

Freud, S. (1999). névrose, psychose et perversion. (J. Laplanche, Trad.) Paris , France: PUF.

Hart, W. (1996). A Companion to the philosophy of mind. New York: Blackwell Oxford.

Icard, S. (2010). éloge de la folie et désaveu de la raison dans les pensées de Pascal. dix septième siècle(247), pp. 235246.

M.D, S. C. (2018). More about Mayo Clinic Family Health Book (éd. FIFTH EDITION). (M. C. PRESS, Éd.) USA

Macionis, J. J., \& Gerber, L. M. (2010). Sociology. Canada: Pearson Education.

Otero, M. (2015). les fous dans la cité, sociologie de la folie contemporaine. montréa: montréal boréal.

Pascal. (1979). Méthode chez pascal. actes du colloque tenu à clermont ferrand (pp. 279 307). paris: PUF.

Saisset, E. (1842). A Theologico Political Treatise.

Shekhar, S., Wang, S., Gonzalez Fernandez, P. N., Zhang, C., He, X., Liu, C. Y.,. Fan, a. F. (2017). Impaied Cerebral Autoregulation A Common Neurovascular Pathway in diabètes may play a critical role in diabètes related Alzheimer disease. (c. research, Éd.) diabètes obesity jornal, 2(3).

Stubenberg, L. (2016). stanford encyclopedia of philosophy. Consulté le 11 15, 2021, sur Mirror Sites : https: plato.stanford.edu entries neutral monism \#9.4

Yvon, B. (1973). La psychologie de Platon. press universitaire de France, p. 244D.

Zarifian. (1999). Jardiniers de la folie. Paris: Odile Jacob.

العدوني, ع .(2010) .الصحة والمرض رؤية سوسيوانثربولوجية .بجلة اضافات.(9)

مؤمنون بلا حدود غشت، Consulté le 11 15, 2021, sur MOMINONE: https:www.mominoun.com articles $\quad \% D 9 \% 81 \% D 9 \% 8 \mathrm{~A}$ \%D8\%A7\%D9\%84\%D8\%B9\%D9\%88\%D8\%A7\%D9\%85\%D9\%84 \%D8\%A7\%D9\%84\%D9\%85\%D8\%AC\%D8\%AA\%D9\%85\%D8\%B9\%D9\%8A\%D8 \%A9 \%D9\%84\%D8\%B8\%D8\%A7\%D9\%87\%D8\%B1\%D8\%A9 \%D8\%A7\%D9\%84\%D8\%AC\%D9\%86\%D9\%88\%D9\%86 548

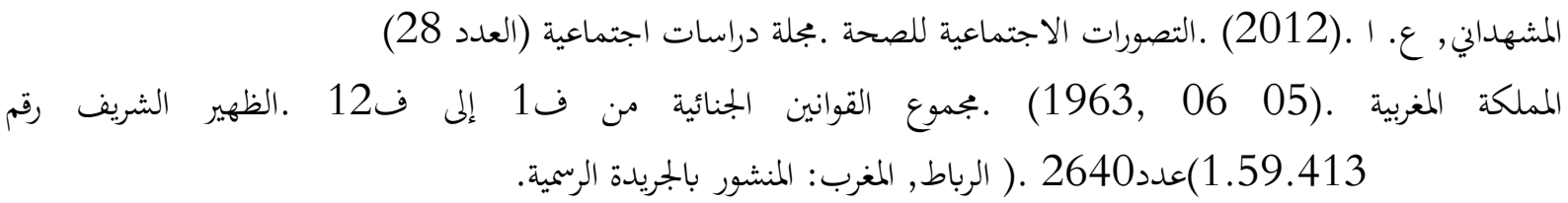


إيغرار, ف .(2009) . رولان بارث مغامرة في مواجهة النص .سوريا: دار الينابيع.

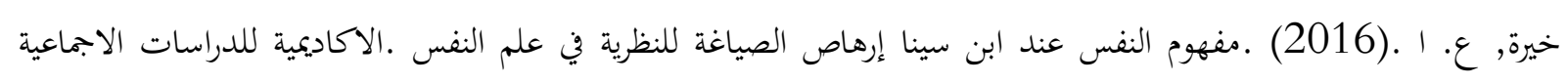

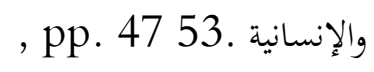

سعيد, أ . (2011) .مديح الحماقة .القاهرة: وكالة سفنكس.

عزت, أ . (2007) .أصول علم النفس .الاسكندرية: دار المعارف. ألمان.

(أبريل Consulté le 11 15, 2021, sur watfa.net: https: watfa.net archives 4369

2 هو ما يكيل عليه مفهوم اللعنة الإلهية، في فلسفة ميشيل فوكو

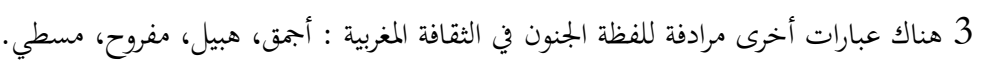

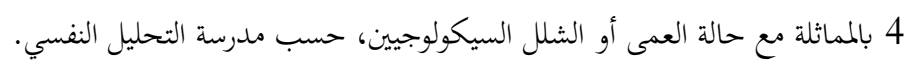

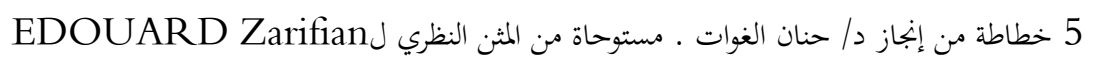


l'étiquetage نظرية 6

7 الحركة الكاملة لتجنيس الأمراض العقلية عن طريق الاختزال إلى الحالات الدماغية

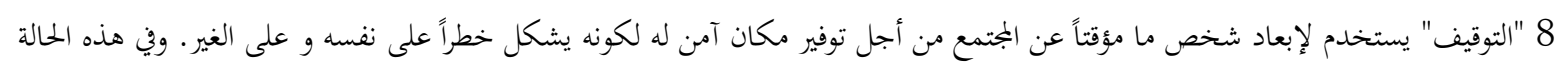

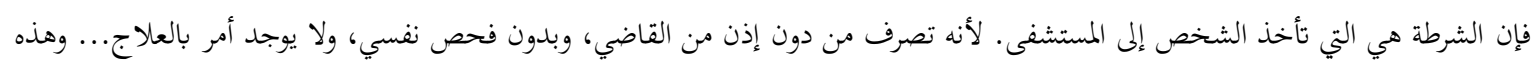

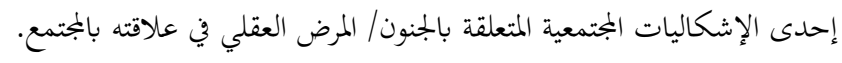

9 خطاطة من إنجاز د/ حنان الغوات ـ وباستثمار المثن النظري ل 10 مثل الدراسة: somatique sur le normale et le pathologique Georges Canguilhem : réflexion 


\title{
GRAPHIC DESIGN IN THE AGE OF DIGITAL TRANSFORMATION
}

\author{
Nsiyf Jassem MOHAMMED ${ }^{1}$
}

\section{Istanbul / Türkiye \\ p. 417-431}

Received: 01/12/2021

Accepted: $13 / 12 / 2021$

Published: 01/01/2022

This article has been scanned I iThenticat No plagiarism detected

\begin{abstract}
:
In the midst of economic and consumer competition between companies and industrial institutions, graphic design emerges as an active actor in the sustainability of the advertising and media cycle alike, a role that would not have been important without the tireless work carried out by designers in various design activities, especially after entering into the digital experience. He benefited from it and kept pace with the new developments of quality, and it is useful to point out that the motives of digital development have reinforced the values that the design worked on, and today it is witnessing many transformations in a digital world that is constantly evolving, transformations related to the core of the designer's work and what he offers in work sites based on Decades of traditional experiences that designers have been working with, and the trend towards traditions and modern digital frameworks that have been reinforced by the increase in related digital applications and software in a remarkable qualitative shift that indicates an important stage in the design process that extends to centuries of work and technical development.

The current research explores some of the turning points of this procession with important articulated transformations, based on the question that:

What is the status of graphic design in the age of digital transformation? The importance of the research lies in the following:

-Theoretical dimension: It can be useful in enhancing the theoretical framework of the graphic design process and the transformations it has witnessed in the digital age.

-Applied dimension: it can benefit those interested and working in the matter of graphic design, and the research aims to: Identify the problems of graphic design in the age of digital transformation.

The theoretical framework includes the following topics:

-What is digital transformation?

-A brief history of graphic design

-Graphic design from traditional to digital

The impact of digital technologies on graphic design.
\end{abstract}

Key words: Transformation, Digital, Graphics, Digital Applications.

http://dx.doi.org/10.47832/2717-8293.15.30

1 iD Dr. , Baghdad University, Iraq, nsiyfjassem@gmail.com, https://orcid.org/0000-0001-7052-6583 


\section{التصميم الكرافيكي في عصر التحول الرقمي}

\section{نصيف جاسم محمد 2}

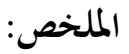

في خضم التنافس الاقتصادي والإستهلاكي بين الشركات والمؤسسات الصناعية يبرز التصميم الكرافيكي بوصفه

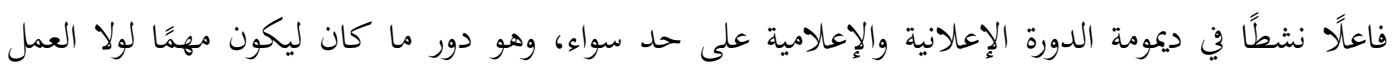

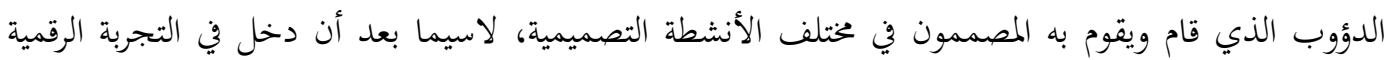
وأفاد منها خير فائدة وليواكب ما يستجد من ابتكارات نوعية، ومن المفيد الإشارة الى أن بواعث التطور الرقمي

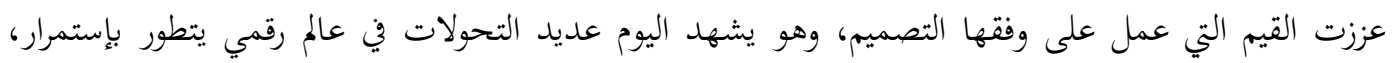
تحولات ترتبط بصميم عمل المصمم وبما يقدمه في مواقع العمل مستندا إلى عقود من التجارب التقليدية التي كان

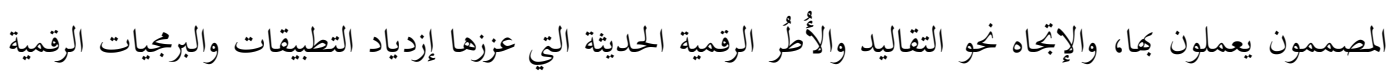
ذات العلاقة في تحول نوعي لافت يؤشر لمرحلة مهمة في مسيرة التصميم التي تمتد إلى قرون من العمل والتطور التقني. البحث الحالي يسبر غور بعضٍ من منعطفات هذه المسيرة ذات التحولات المفصلية المهمة منطلقًا من تساؤل مفاده: - ما حال التصميم الكرافيكي في عصر التحول الرقمي؟

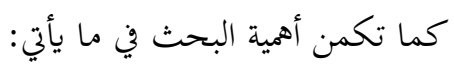

- البعد النظري: يمكن أن يفيد في تعزيز الإطار النظري لمسيرة التصميم الكرافيكي وما شهده من تحولات في العصر الرقمي. - البعد التطبيقي: يمكن أن يفيد المهتمين والمشتغلين في شان التصميم الكرافيكي، كما يهدف البحث إلى: تعرف مُألات التصميم الكرافيكي في عصر التحول الرقمي. الكلمات المفتاحية: تحول، رقمي، كرافيك، تطبيقات رقمية.

من بين أهم ماشهده التطور الكبير في التصميم تحوله من التطبيق التقليدي الذي عرف به الى البيئة الرقمية، وهو المفصل

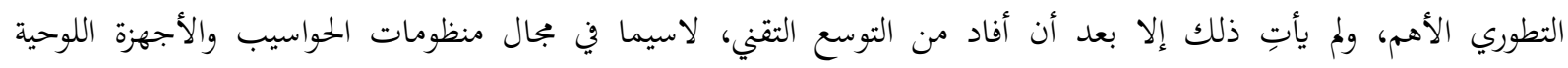

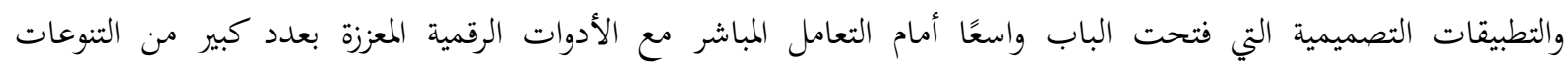

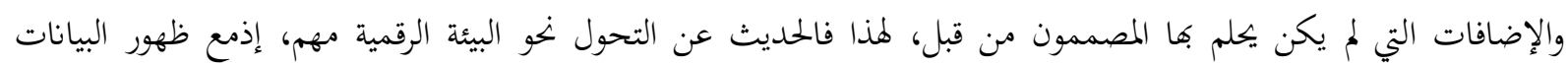

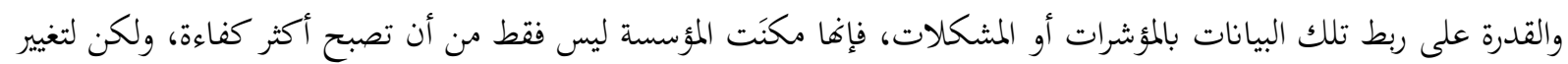


وفي عالم يعتمد على البيانات، أمكن للمؤسسة إعادة التفكير في عديد إفتراضاتما القديمة، وعند إعادة التفكير في تلك الإفتراضات القديمة يمكننا الوصول إلى حيث تظهر القيمة، أو الفرص في أماكن مختلفة عن العالم المحدد بالعملية. وعلى مدى العقد الماضي، ناقش عدد من العلماء بأننا شهدنا تحولات جذرية في إنتاج الثقافة والمعرفة في عالم به منصات

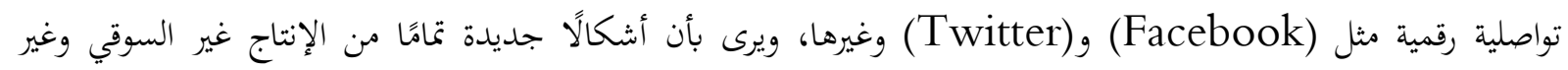
المملوك للمعرفة والثقافة نشأت عن طريق الإمكانات الفريدة للتقنيات الرقمية. وأدى هذا إلى تغيير في آلية من يُمَكْن ليبتكر في المجتمع. (Bendor-Samuel، وإبتكار أنموذج الأعمال الناتج إلى تغيير جذري في توقعات المستهلكين وسلوكياقم، والضغط على الشركات التقليدية، وتعطيل

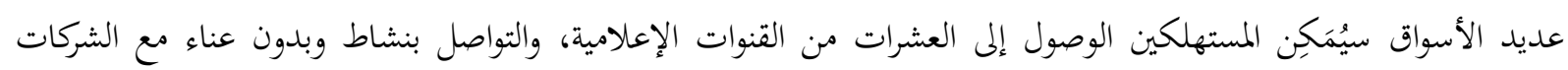

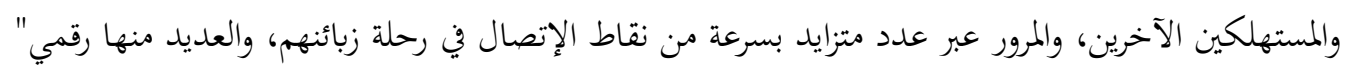
(Lemon)

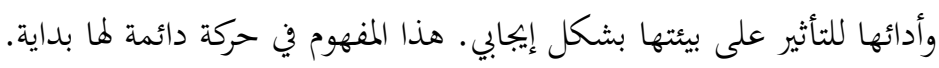
ولكن ليس لها فاية، إذ يمكن أن يكون التحول الرقمي بمثابة إنتقال من الورق إلى الأرشفة الرقمية، وملء النماذج

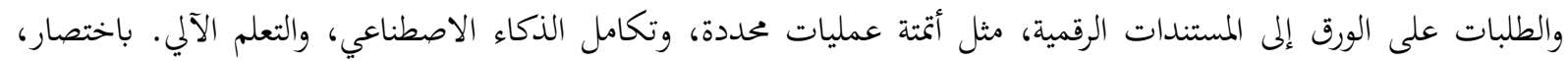

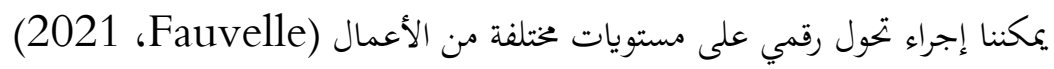
وأفاد التصميم الكرافيكي من هذا التحول وهو مانراه في التطبيقات الرقمية التي تتعزز كل يوم، ويشير الحديث عن التحول

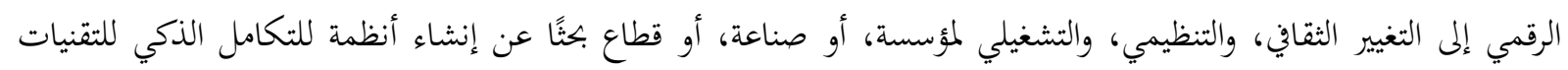

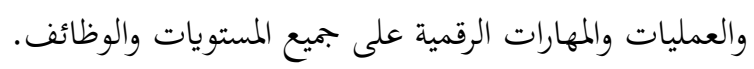
كما يجب أن يتم هذا التكامل بشكل استراتيجي وعلى مراحل بتاوز أدوار المبيعات والتسويق وخدمة الزبائن التقليدية يبدأ

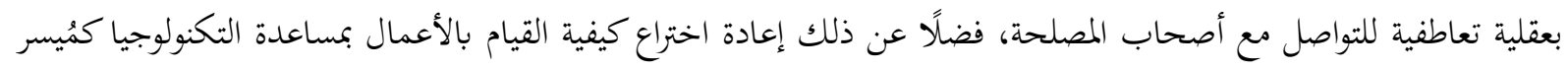
لتحقيق ذلك.

ولا يعتمد التحول الرقمي على التكنولوجيا والتطبيقات فقط، بل يركز على القيمة والأشخاص والتحسين والقدرة على التكيف بسرعة بإستعمال الأدوات المثالية لتسهيل الأمر. (Sayol, 2021) هنا نود الإشارة الى أن هناك بعض الإختلافات بين الرقمنة (Digitization) والرقمنة (digital) والتحول الرقمي (Digital transformation)

الرقمنة (Digitization): هي الإنتقال من التناظرية إلى الرقمية، فمنذ وقت ليس ببعيد، إحتفظت الشركات بسجلات على الورق، سواء أكانت

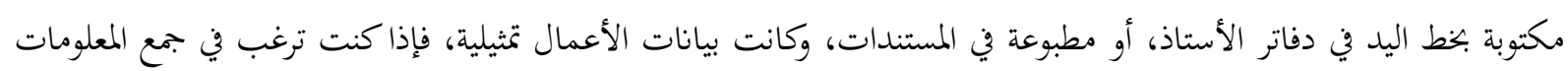

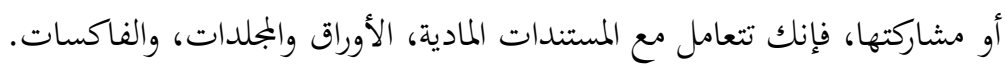
ثم أصبحت أجهزة الكمبيوتر سائدة، وبدأت معظم الشركات في تحويل كل تلك السجلات المطبوعة بالحبر على الورق إلى

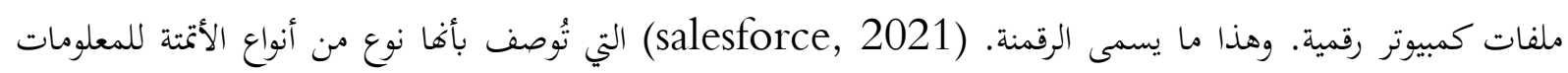
التناظرية (العمليات اليدوية والورقية) إلى تنسيق رقمي. 
كما يستعمل العلماء عبر التخصصات مصطلح الرقمنة للإشارة إلى العملية التقنية لتحويل تدفقات المعلومات التناظرية إلى بِتات رقمية من (1) و (0) مع قيم منفصلة وغير متصلة. (Feldman، 1997).

الرقمنة (digital): (2)

تمثل كيفية إستعمال تكنولوجيا المعلومات، أو التقنيات الرقمية لتغيير العمليات التجارية الحالية، على سبيل المثال، إنشاء قنوات إتصال جديدة عبر الإنترنت، أو عبر الهاتف المحمول تتيح لجميع الزبائن التواصل بسهولة مع الشركات التي تغير التفاعلات التقليدية بين الشركة والزبائن. كما باتت تشير إلى هيكلة عديد بجالات الحياة الاجتماعية حول الإتصالات الرقمية والبنى التحتية لوسائل الإعلام. ويرى لئرى

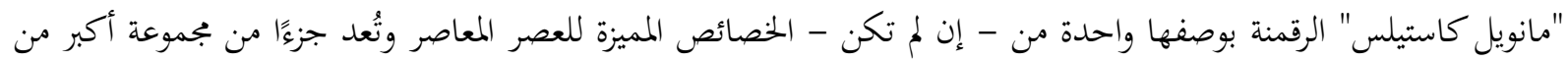
المنح الدراسية التي تشير إلى وسائل الإعلام ونظام الإتصالات الأساس كطريقة لشرح، أو فهم لعديد من جوانب الحسياة الاجتماعية المعاصرة. (Castells)، 2010)

\section{التحول الرقمي (Digital transformation):}

هو الأكثر أتساعًا وانتشارًا، يتعلق المفهوم بالتغيير على مستوى الشركة يؤدي إلى تطوير نماذج أعمال جديدة، إذ تتنافس إنس

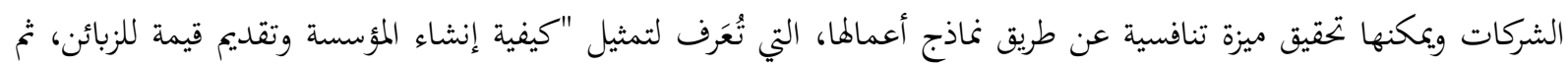
تحويل المدفوعات المستلمة إلى أرباح.

وقدم التحول الرقمي أنموذج عمل جديدًا عن طريق تنفيذ منطق عمل جديد لإنشاء القيمة وإنجازها

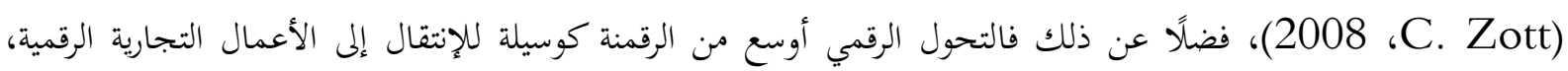
ويتطلب الأمر بناء المزيد من الجسور في استراتيجية شاملة للتحول الرقمي. وإذا بحثنا عن تعريف التحول الرقمي في (Google)، فسوف تقرأ "التحول الرقمي هو التحول العميق والمتسارع لأنشطة

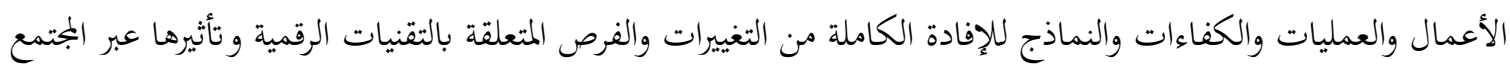
(i-scoop.eu, 2021) من جانب آخر تُعد الرقمية طريقة جديدة للتفاعل مع الزبائن ولا زالت تمثل بالنسبة للآخرين طريقة جديدة لممارسة

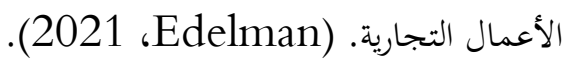
وعلى الرغم من الانتشار الواسع والتأثير المرئي للتحول الرقمي ونماذج الأعمال الرقمية الجلديدة النابتة، إلا أن الأدبيات

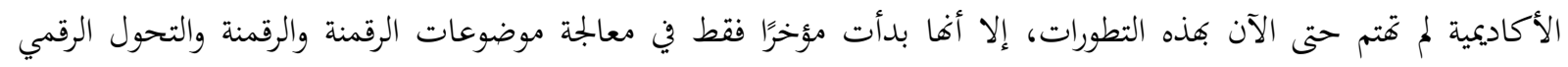

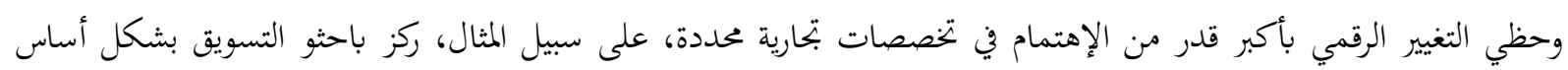

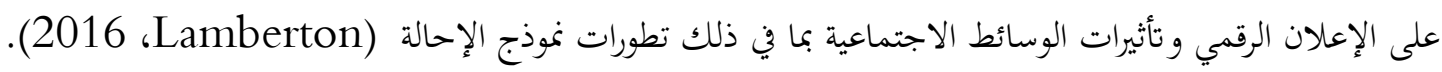
فضلا عن تطبيقات تصميمية، منها العلامات التجارية وتصاميم أغلفة المجلات وتصميم مواقع الويب. ويصور "مات، وهيس، وبينليان" أربعة أبعاد مشتركة بين معظم - إن لم يكن كل - استراتيجيات التحول الرقمي: 
- استعمال التكنولوجيا: موقف الشركة بتحاه التقنيات الجديدة وقدرقا على استعمالها.

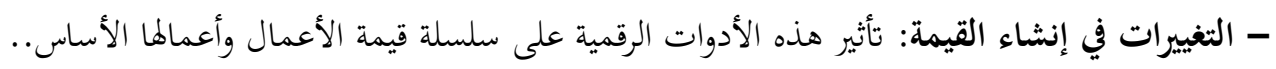

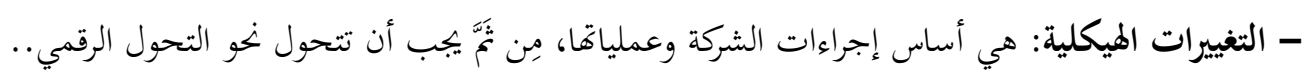

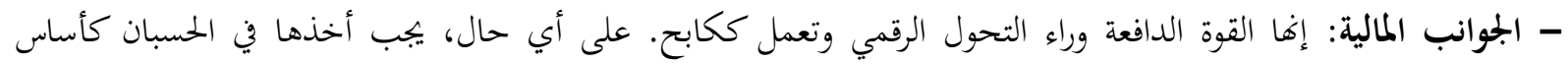

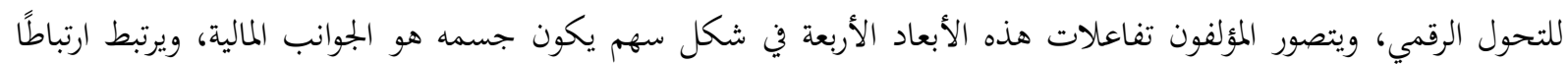
جوهريًا بخلق القيمة وهيكل الأعمال التي يجب أن تتغير للانتقال نخو التحول الرقمي واستخدام التقنيات. Fauvelle)

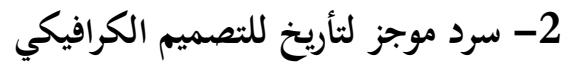

شكل التصميم الكرافيكي لعقود مضت محورًا تفاعليًا مهمًا في سياق التطور الواضح في وسائل التواصل المرئي، وكان

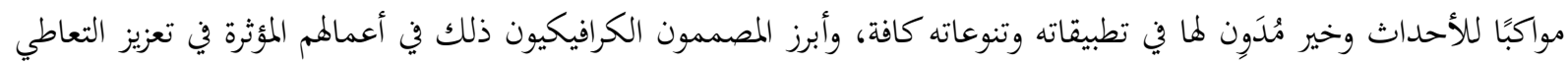

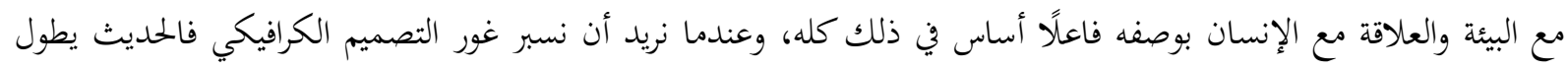

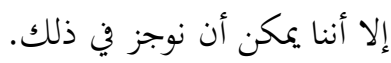

فقد"عُعَّ فنًا لإنشاء الرسومات، أو إنتاج لمرئيات، يمكن القيام بذلك على ورق، أو القماش، أو الحجر، أو الفخار، أو ربما

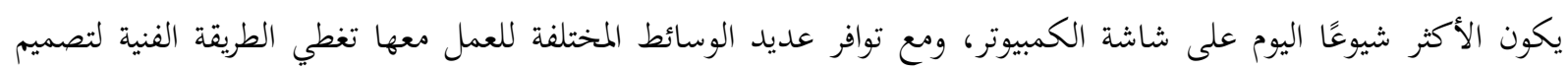

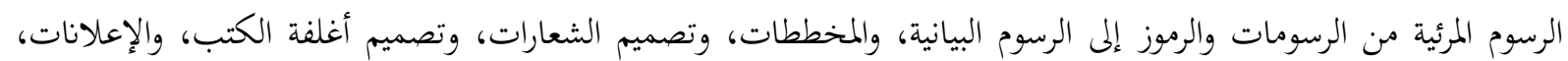

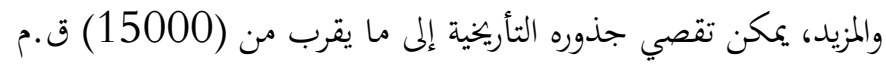

عندما ظهرت أُوَل المظاهر التي يمكن أن نسميها بالإتصال المرئي من رسومات وخطوط على جدرات الكهوف، لكنه

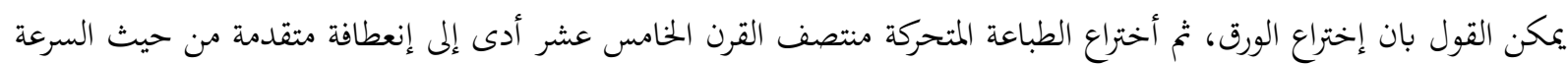
والتكلفة وحداثة الأنظمة (customlogos, 2021).

كما (عُرِفَ مصطلح التصميم الكرافيكي لأول مرة في الطباعة في مقال صدر عام (1922) بعنوان "نوع جديد من

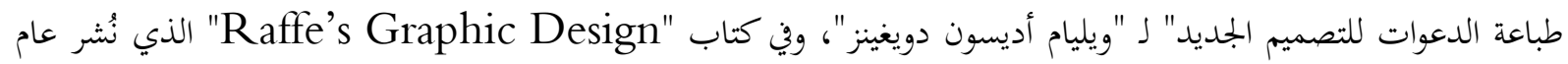
(1927) الذي عُلَّ أول عنوان لكتاب يتضمن كلمات "تصميم رسومي" على غلاف، على الرغم من أنه يُظن أن كتاب "ليون

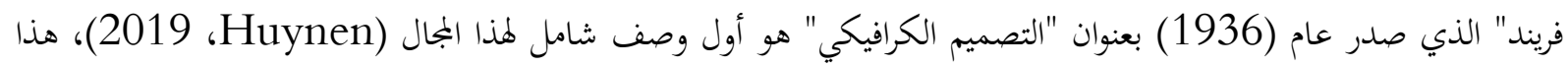
ويُرِع المؤرخون تاريخ التصميم الكرافيكي إلى لوحات الكهوف التي يعود تأريخها إلى حوالى (38000) سنة ق. ق. م. لوحات الكهوف هذه هي الطريقة التي نقل هها الناس الأفكار من جيل إلى آخر، ومعظم الشخصيات المصورة في لوحات

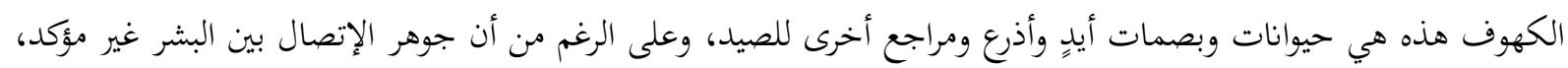

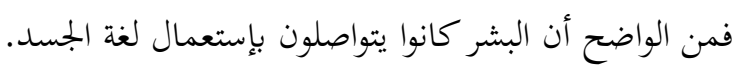
التصميم الكرافيكي المستند إلى اللغة والأبجدية هو الخطوة اللاحقة في تطور الحرفة، ومن المفترض أن السومريين إخترعوا

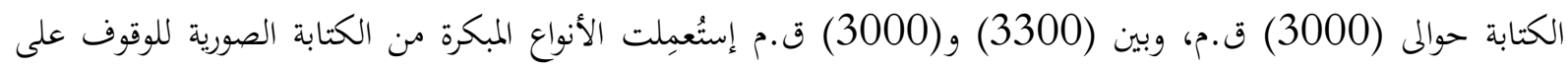

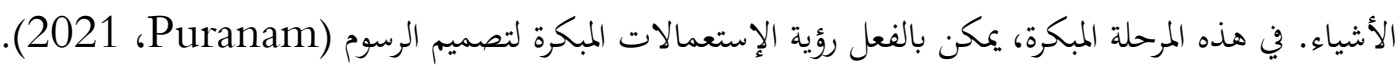


وهنا أبزت فكرة التمثيل المرئي للاحداث البحث الإنساني للوصول إلى آلية للتواصل بينه وبين مكونات المحيط الذي كان

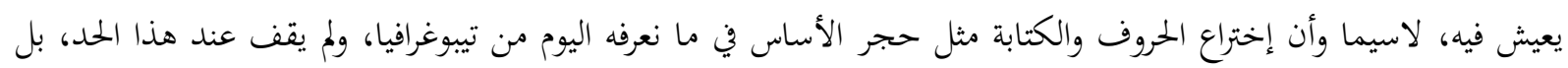
أثبت القرون التالية حقيقة ذلك في التطور المفصلي للتصميم الكرافيكي.

ومَثَل اختراع الطباعة الحجرية من أهم المعطيات التصميمية للثورة الصناعية، هذا الإبتكار أفسح المجال أيضًا للطباعة الحجرية الملونة، التي هي مجرد طباعة حجرية، ولكن مع مطبوعات ملونة. كما أثرت (Art Nouveau) حركة تصميم العالمية بشكل كبير على الهندسة المعمارية والأزياء والتصميم الكرافيكي أواخر القرن التاسع عشر.

ويمكن إرجاع التصميم الكرافيكي الحديث كما نعرفه اليوم إلى مدرسة باوهاوس في ألمانيا، التي أسسها "والتر غروبيوس"

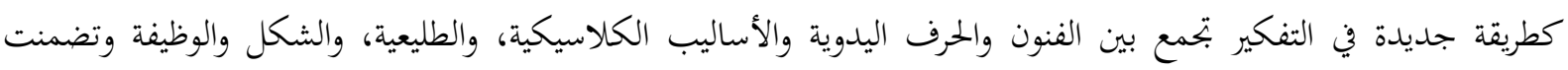

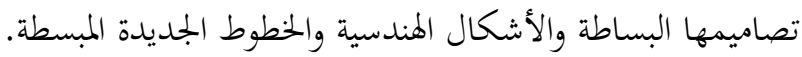
وظهرت ما بعد الحداثة كتطور وتمرد ضد الأفكار الحداثية، وبحكم طبيعتها، لا تؤيد ما بعد الحلداثة بجموعة معينة من المُمُل.

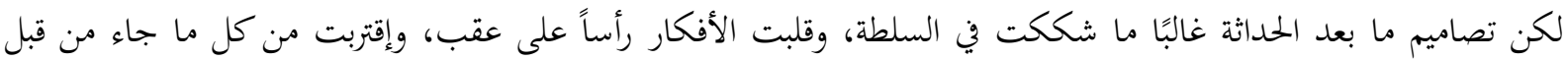
بالشك والسخرية. (Walgrove, 2021). وعلى الرغم من أن المصطلح لمُ يُصَغ بعد، إلا أن بعض التصاميم المبكرة تضمنت طباعة الكتب والصحف، ويمكن للمرء

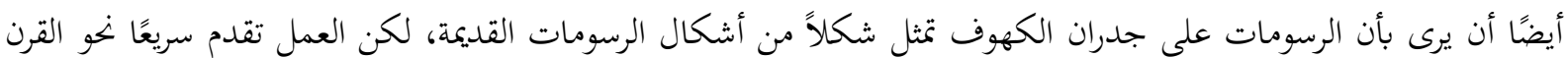

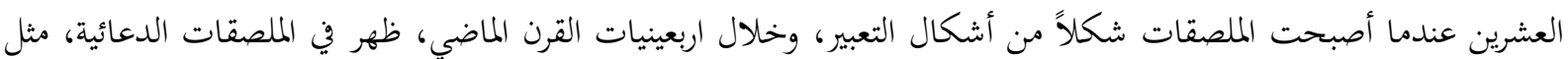
ملصق "We Can Do It"، وكانت الشعارات قصيرة، إلى حد كبير. وعندما بدأت التكنولوجيا في التغيير وأصبحت متاحة لمزيد من الناس، بدأت الصناعة بأكملها التي أصبحت تُعرف باسم التصميم الكرافيكي في الظهور. (Lu)، 2021).

من جانب أخر حُسِنَت الأدوات جنبًا إلى جنب مع الواجهات، مما منح المصممين حرية لم يسبق لهم الحصول عليها من قبل، وبات من السهل تصميم خخططات بالحجم الطبيعي وبحربة الظلال والخطوط والملامس، فضلا عن تصميم تخطيطات معقدة بايماءات بسيطة، ومع التطور التكنولوجي بسرعة. إذ منحت التكنولوجيا المتطورة الواقع الإفتراضي والواقع المعزز المصممين درجة جديدة من الحرية التي بدأوا للتو في

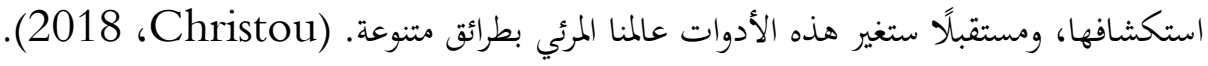
كما برز التصوير الفوتوغرافي بوصفه الخيار الأكثر هيمنة في تصاميم المجلات والإعلانات خلال هذه المدة مع هيمنة تقنية

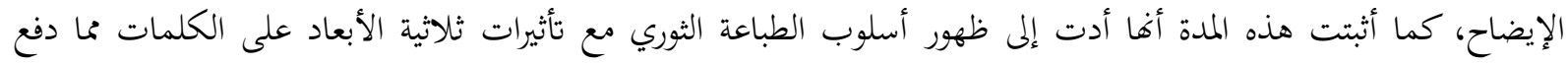

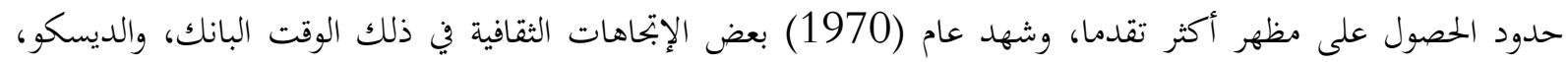
والحركة الهيبيّة. (visualbest, 2021) ومنذ أن اكتشفت الشركات أها تستطيع تمييز نفسها عن طريق التصوير الفوتوغرافي الإحترافي للعلامة التجارية والشعارات

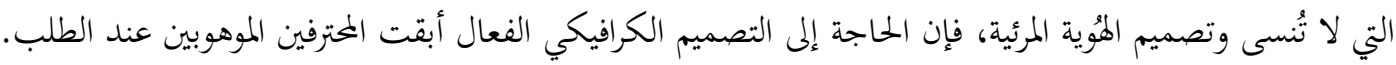


في البداية، كان المصممون فنانين رسموا الأشكال والمفاهيم بناءً على الإتحاهات الحالية مثل حركة التصميم الكرافيكي الحديثة، ونظرًا لأن الصناعة أصبحت أكثر ارتباطًا بشكل أساس بالتكنولوجيا، وبدأت الأدوات المبتكرة في التقدم، بدأ مجال التهال التصميم الكرافيكي في التطور.

واليوم، قطع التصميم الكرافيكي الحديث شوطًا طويلاً في توظيف الصور الرمزية والتقليدية المرسومة يدويًا في العقود

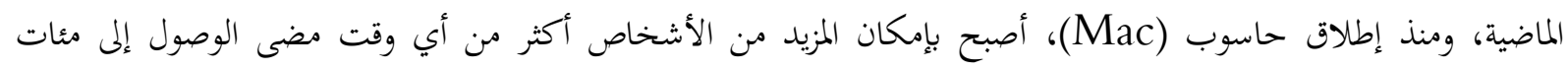

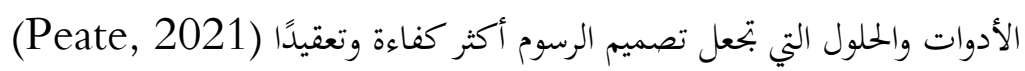
وأخذ الجمع بين التسويق الذكي للمحتوى والتصميم الكرافيكي في بجال التسويق الرقمي بالإزدياد أيضًا. ولعل أفضل مثال على ذلك هو صناعة الفنادق. إذ تأثرت بشدة بهذا الإتجاه، ولم تَعُد مواقع الفنادق على الإنترنت مخصصة للحجز فقط، إذ تعمل الآن كمنصة لعرض

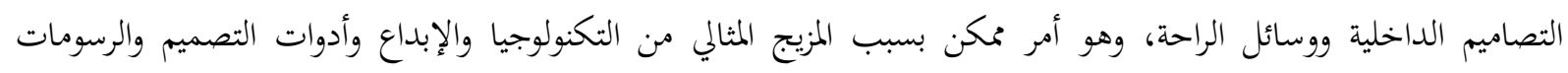
المتميزة. (Monsters، 2020). نشير كذلك إلى حقيقة أن التصميم الكرافيكي أكثر ارتباطًا بالتكنولوجيا وأقل ارتباطًا بالنظرية، إذ تتناسب كل من

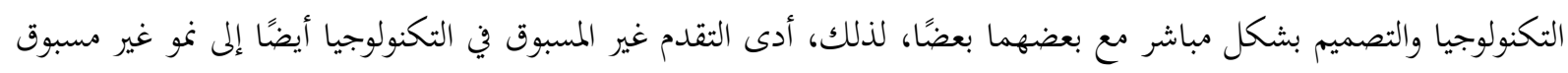
في تصميم الكرافيك.

بادئ ذي بدء، لم تكن أجهزة الكمبيوتر أوائل عام (2010) متقدمة جدًا مقارنة بما هي عليه الآن، ومع محدودية ذاكرة

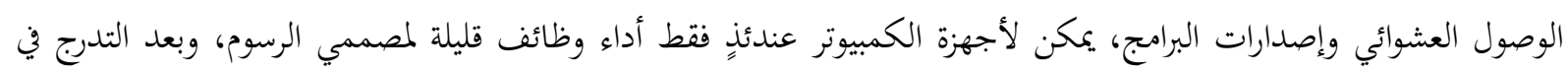

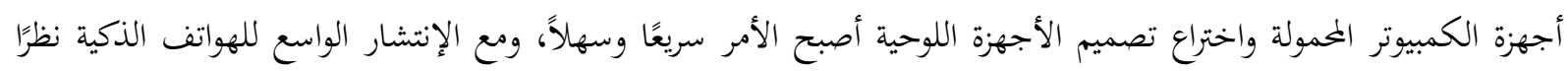

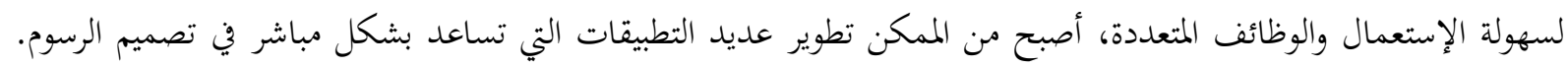
(2020،Kathotia)

\section{3- 2 - التصميم الكرافيكي من التقليدي إلى الرقمي}

لاشك إن الظروف التي مربها التصميم الكرافيكي كانت إلى حد ما معقدة، بسبب التداخلات الكثيرة التي ألقت بظلالها

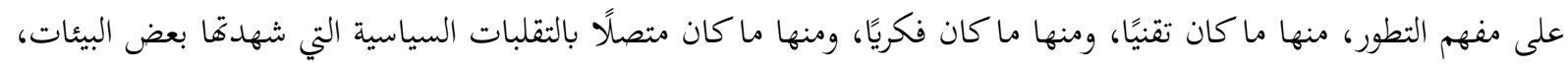

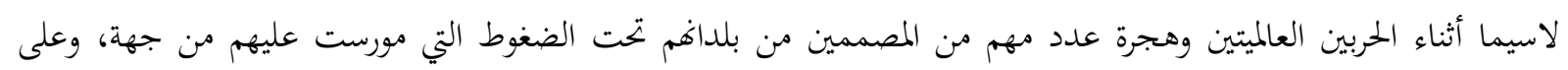
اليات إنتاج التصميم كذلك.

ولو بحثنا في السيرة السردية للتصميم ومؤالات تحوله الى ما نراه اليوم فهو ضارب في عمق التأريخ الرسومي التقليدي الذي

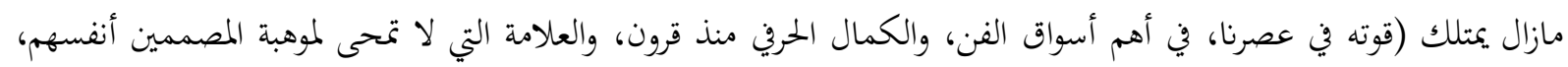

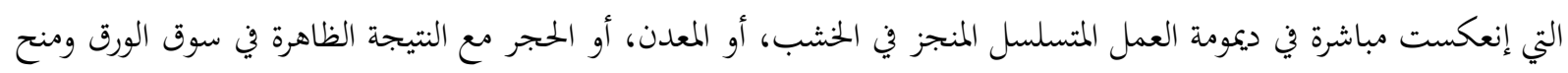

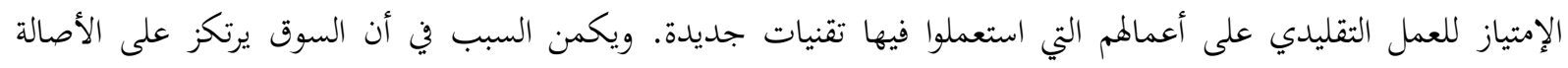

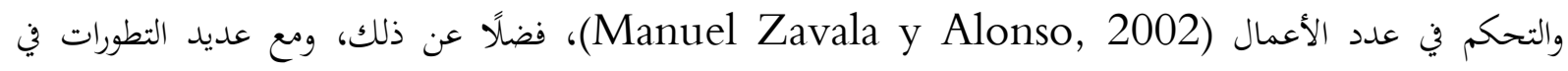
التكنولوجيا، أصبح دور مصمم الكرافيك مختلفًا جدًا اليوم مقارنةً ببضع سنوات مضت حسب" جيني دارمودي" فقد كان

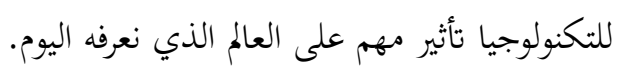


ولم تؤدِ التطورات التكنولوجية إلى توفير وظائف جديدة تمامًا فحسب، بل إها غيرت الأدوار التقليدية، لهذا فالتصميم في

يومنا هذا هو مجرد واحد من عديد المهن التي تغيرت بسبب التقدم التكنولوجي (Darmody, 2018). من جانب أخر شكل الإنتقال الوظيفي إلى التصميم الرقمي أمرًا منطقيًا، لاسيما بعد التحول إلى المنصات عبر الإنترنت لجميع الوسائط التقليدية تقريبًا.

وتلك التي تعتمد إلى حد كبير التصميم الكرافيكي من بجلات، وصحف وقنوات فضائية بات قسم منها يتحرك في الفضاء الرقمي. بهذا المعنى يمثل التصميم الرقمي في يومنا هذا، وضمن التحول من الصيغ التقليدية طليعة الثورة الرقمية. إنه يقود مفاهيم

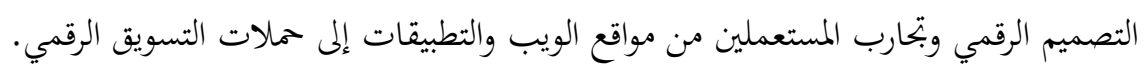
ولكن هذا هو مجرد بداية، إذ سيعمل مصممو الغد الرقميون على تصميم تجاربنا الرقمية المستقبلية من الصور المجسمة إلى

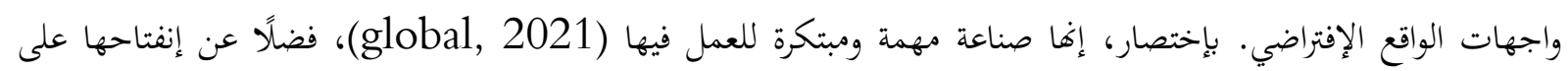
مختلف التقنيات البينية الساندة التي باتت تشكل هي الأخرى ملمحًا في خضم النظرة التحولية الجديدة.

هذا وشهد مجال الفن والتصميم والتخصصات المرتبطة، أو ما تسمى بالعلوم البينية إنتقالة نوعية منذ ظهور ألية تكامل

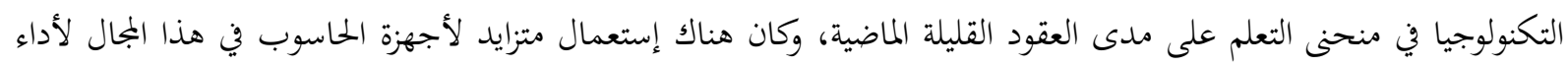
مهام غختلفة تتراوح من الإبتكار إلى التحليل المتقدم للأعمال الفنية. فضلًا عن تنمية العلاقات المتبادلة بين التكنولوجيا والفن (التصميم) التي لم تشكل مفهومًا جديدًا على مر العصور، إذ إذان

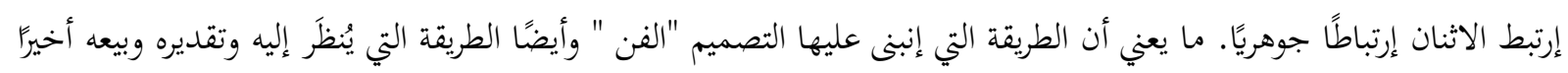
تتطور مع تغير عالم التكنولوجيا (March 201625 Sarah Gamboa) وتبنى الناس هذه التكنولوجيا بحماس، غالبًا كإجابة على أسئلة لم تُطرح في كثير من الحالات، وبضمن هذا السياق يسمع

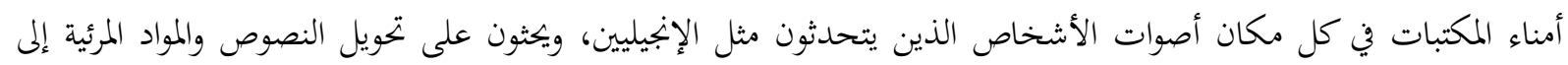

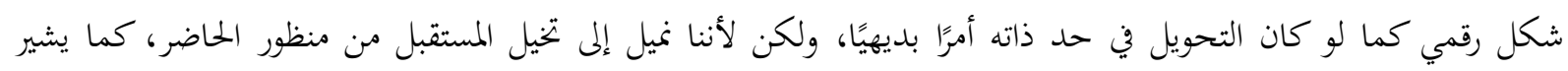
"أودونيل"، فإن مثل هذه الإسقاطات للحاضر على المستقبل قد تكون، في أحسن الأحوال مضللة.

إذا كانت هذه التكنولوجيا الجديدة ثورية بالفعل، فلا يمكننا توقع تأثيرها بالكامل، ويجب أن نكون حذرين بشأن ترك

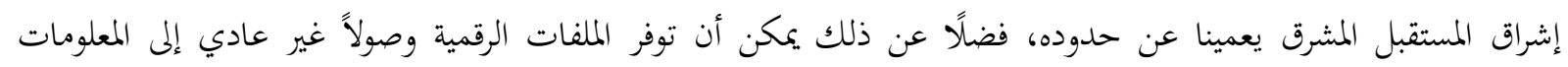

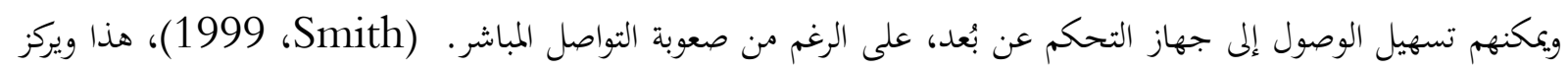
المصممون الرقميون بشكل أكبر على تصميم العناصر الرقمية.

إذ يقومون بجمع بين مهارات التصميم الكرافيكي والتكنولوجيا لتصميم اعلانات وصفحات تفاعلية، وإعلانات ورسوم، متحركة وتمذجة، ورسومات ثنائية وثلاثية الأبعاد. كما لا يستعمل التصميم الرقمي الفنون المرئية فحسب، بل قد يتضمن أيضًا مؤثرات صوتية وصوتية... علاوة على ذلك،

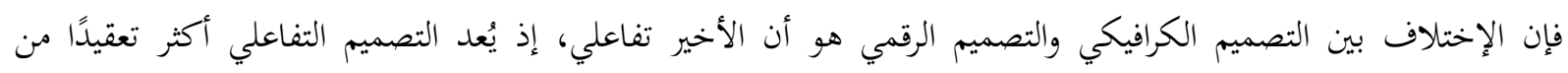

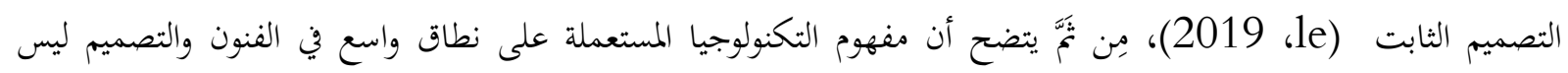

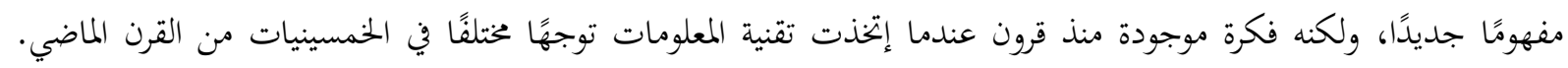
. (2013، KRISTIN THOMSON) 
وبسبب الإستهلاك المستمر للوسائط ذات المصدر الواحد تتوافر اليوم عديد القنوات والمنصات ذات البعد الجماهيري

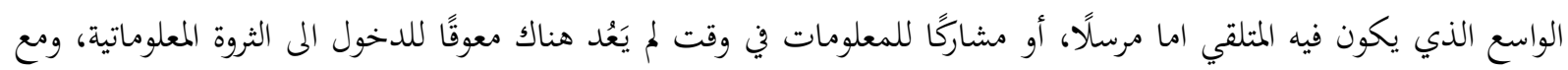
النمو المتزامن في الإتصال يمكن تصميم ملصق ملون ما بما يكفي لإرساله عن طريق الايميل او المنصات الإجتماعية (2003،Bilda, Zafer and Halime Demirkan) ومن المزايا المهمة التي تشكل اليوم مفصلا نوعيًا في سياق التطور هو دمج الروبوتات والذكاء الإصطناعي مع التعلم

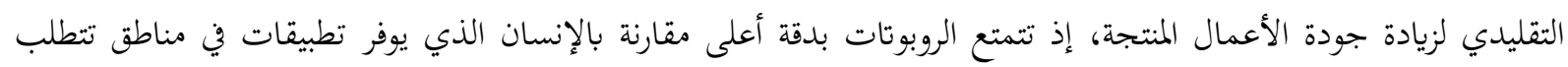

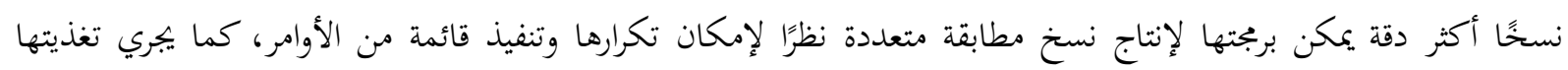
معلوماتيًا، ما يسمح للمشتغلين للجمع بين الحوسبة، والروبوتات، والفنون، والتصميم للتوصل إلى مزيج يؤدي إلى الإنتاج النهائي

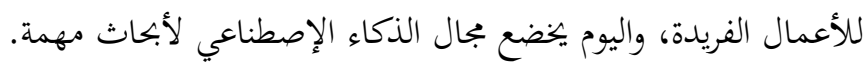
إذ يحاول العلماء إبتكار آلات يمكنها إتخاذ قرارات عقلانية ومستقلة.. (Robo/arch, 2015) ، ويؤدي إستعمال

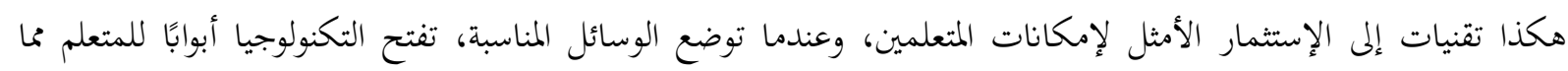

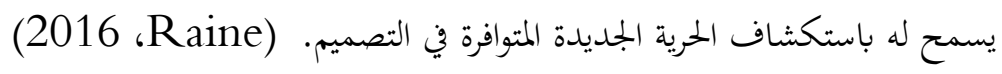

\section{4- - تأثير التقنيات الرقمية على التصميم الكرافيكي}

من نافلة القول بأن التكنولوجيا أثرت على التصميم الكرافيكي مثلما أثرت على شؤون الحياة، والحديث حول مديات هذا

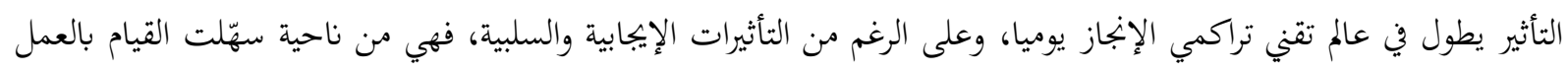

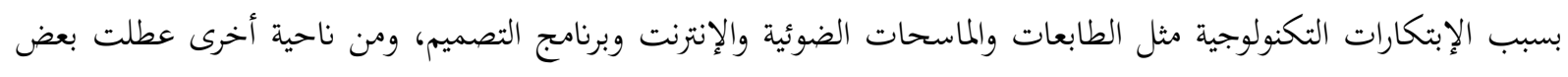
المهارات اليدوية التي كانت تشكل السمة المهارية للمصممين.

إلا أنه مع ذلك أحدثت التكنولوجيا البرجية لتطبيقات مثل Corel PageMaker) انعطافة مهمة في عملية تصميم الرسوم، التي خَلصَت المصمم من العمل التقليدي في تصميم الرسوم والنشر المكتبي. هذا التغيير الجذري في الأدوات المستعملة في تلئي التصميم غير المجال نحو منحى تكنولوجي مهم، إذ جعل اكتشاف أجهزة الكمبيوتر عملية التصميم أكثر سهولة ومرونة واختصارًا للوقت وسرعة في التنفيذ (Jennifer)، 2021).

وهو تطور نوعي لافت إستجاب له المصمم وتفاعل معه بشكل كبير، وإتساقًا مع ذلك فإن التصميم الكرافيكي تأثر

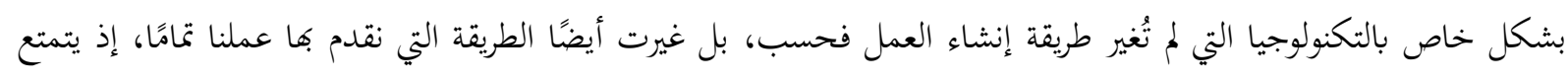

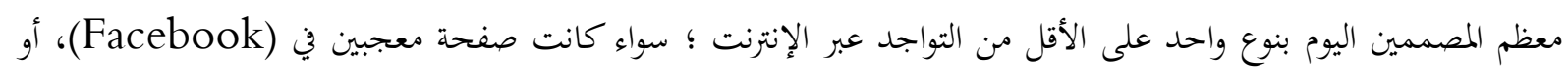
متابعين في (Twitter)، أو في مدونة.

إذ يتشاركون أفكارهم، أو حتى مجرد موقع في محظظة تُعرض فيها أعمالهم، ويستعمل عديد المصممين الإنترنت كمصدر

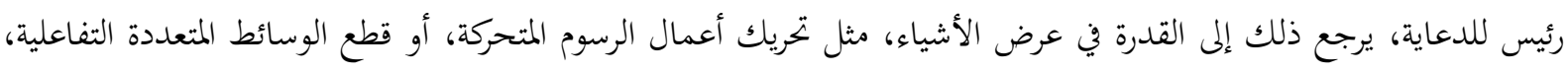

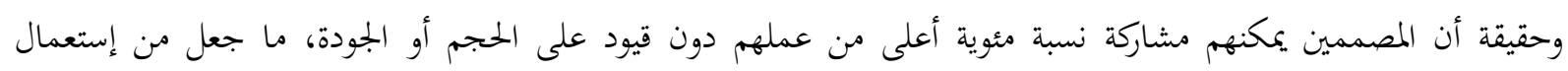

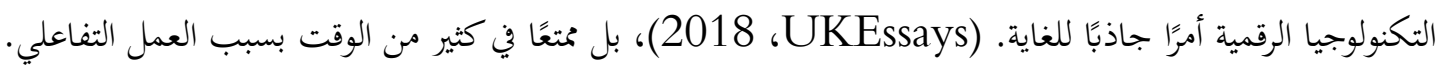
من جانب أخر أثر توافر الدورات والبرامج التعليمية ومقاطع الفيديو التدريبة على المجال بشكل كبير. من قبل، كان

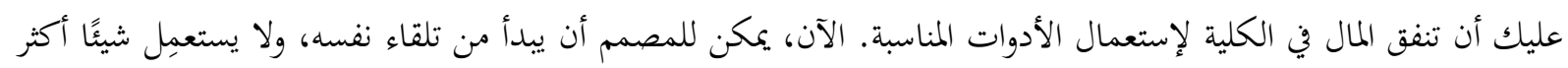

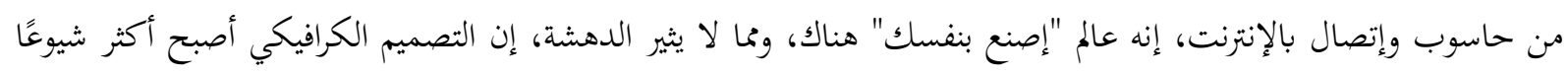


من أي وقت مضى. ووفقًا للإحصاءات التي جمعها (Brandon Gaille) يعمل الآن أكثر من (260.000) عامل في قطاع التصميم الكرافيكي في الولايات المتحدة فقط، وعلى الرغم من عدم توافر أي إحصائيات حول هذه الموضوع، يمكننا أن نفترض أن الرقم أعلى بكثير على المستوى العالمي، بينما تزدهر الصناعة حاليًا في الغالب بفضل الإنترنت

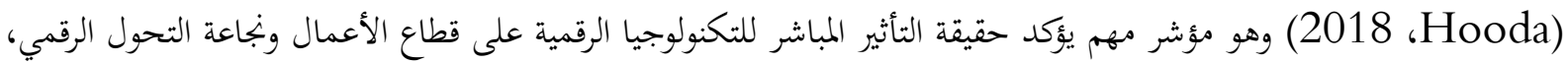
فلقد ولت الأيام التي كان فيها التصميم الكرافيكي يركز فقط على العناصر الرسومية الواضحة لمنتج مثل التعبئة والتغليف ومواد

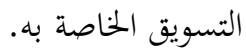

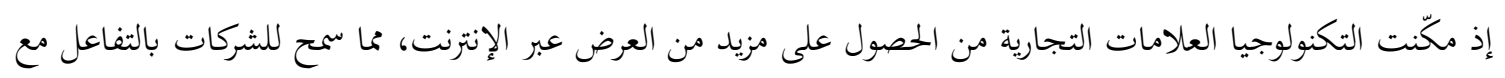

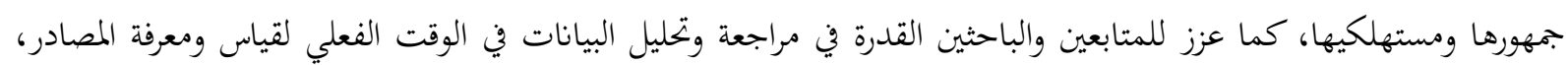

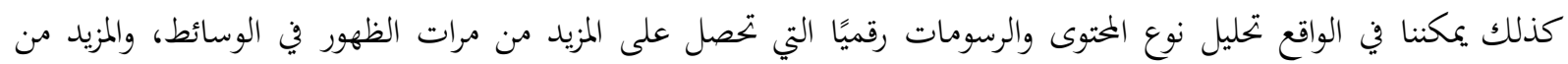

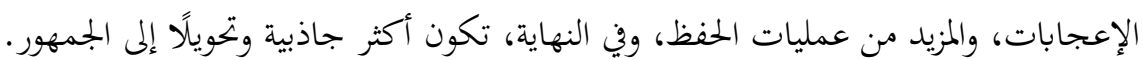

ونظرًا لأن الإنترنت هو المصدر الرئيس للتسويق والعرض، فقد إستثمرت الشركات الكثير في إنشاء محتوى أيوني لتواصل

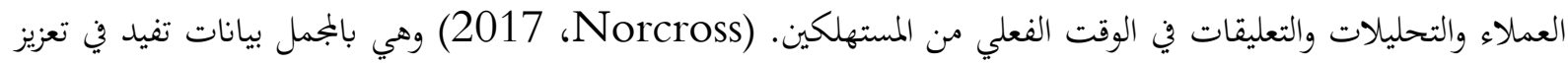

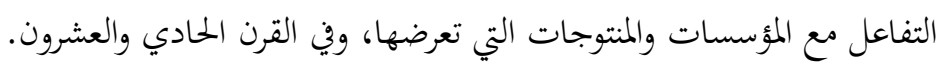

يبدو أن معظم الأشياء تتغير بمعدل ينذر بالخطر، إذ تُعد التكنولوجيا من أصعب الموضوعات التي يجب تحاهلها نظرًا

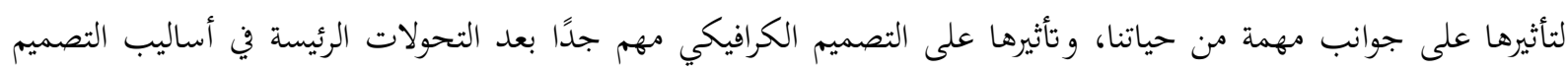

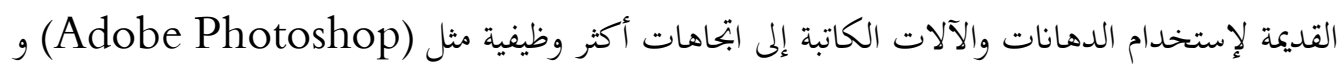

.(Autodesk Maya)

وتمامًا مثل أي تغييرات أخرى، أثارت التغييرات التكنولوجية في تصميم الرسوم ردود فعل متباينة بين معظم المصممين،

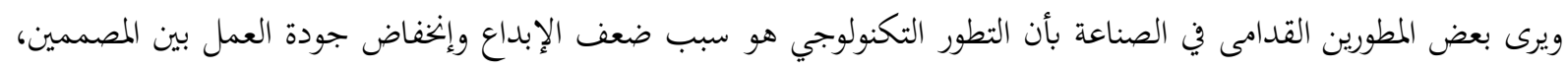

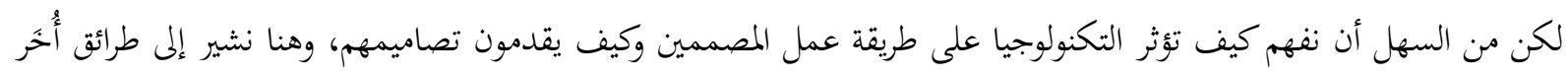

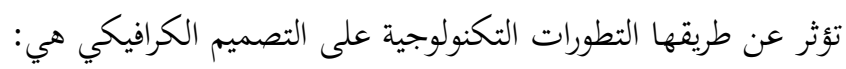
- التأثير على طريقة الاتصال.

$$
\text { - }
$$

- ردود الفعل السريعة (Graphicszoo, 2021)

ومن الناحية التاريخية، كان التصميم الكرافيكي والتكنولوجيا مرتبطين دائمًا ببعض القدرات، ومع تقدم أدوات التصميم،

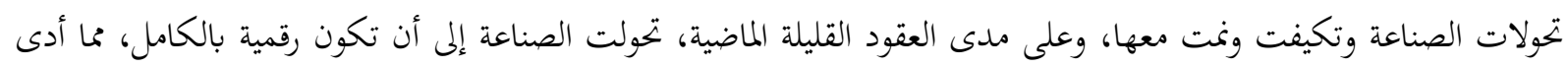

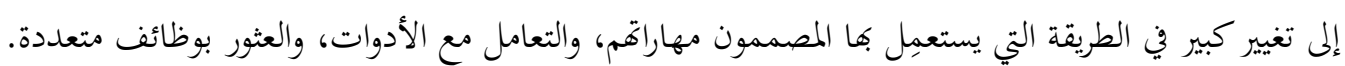
فيما يأتي أهم أربعة طرائق أثرت بها التكنولوجيا على صناعة التصميم الكرافيكي:

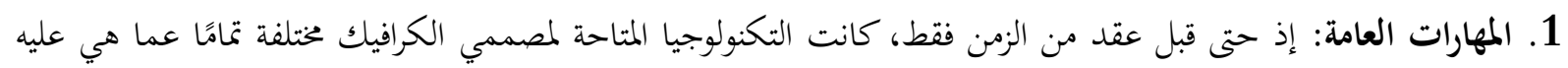

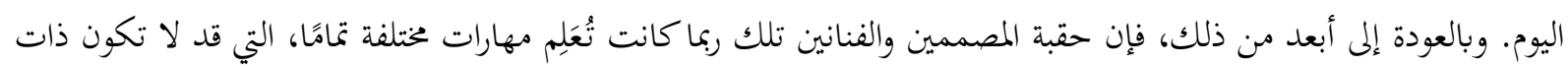
صلة بالعمل هذا اليوم. 
2. البرامج المتاحة: عندما أصبحت عمليات التصميم رقمية، بدأ عدد البرامج المتاحة بالإزدياد. في السابق، كان على المصممين

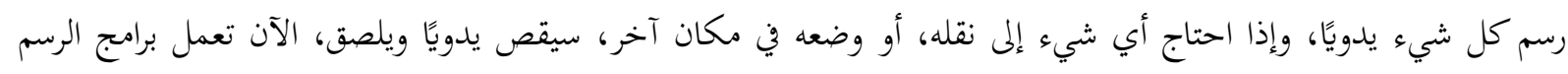
الرقمي وتحرير الصور والتخطيط على التخلص من العملية الشاقة التي كانت متبعة.

3. الوصول إلى التعلم: إن كمية الموارد المتاحة عبر الإنترنت لمصممي الرسوم في عالم اليوم المتصل بالإنترنت مذهلة. نعم، إذ يُعد

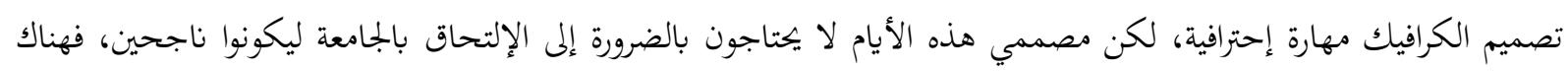
عديد مواقع الويب التي تقدم المعلومات والبرامج التعليمية ودورات الشهادات.

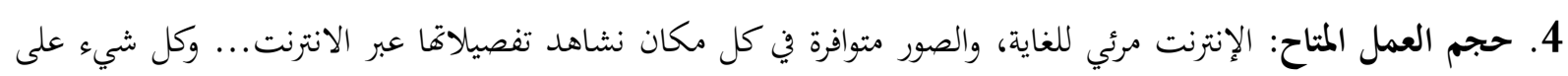

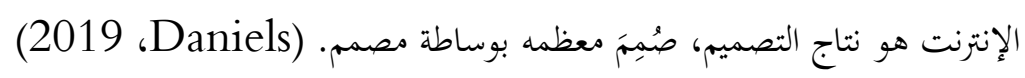

\section{منهجية البحث}

تشير أبحاث الإتصال الثانوية إلى أية بيانات بحمع لغرض واحد من قبل طرف واحد مِن ثَََ وضعها للإستعمال ثانية لأداء

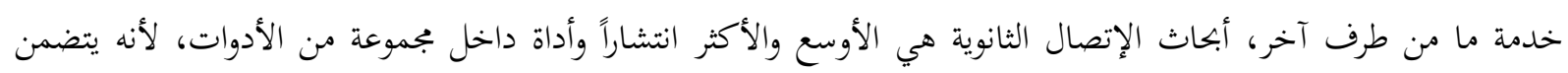

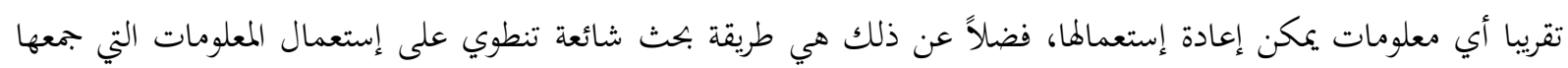
آخرون عن طريق البحوث الأولية.

البحث الحالي يتخذ من الأدبيات ذات الصلة عمقاً مرجعياً ومعرفياً لتتبع مسيرة التصميم الكرافيكي في عصر التحولات الرقمية، والبحث في مُآلاته التقنية النوعية.

\section{النتائج ومناقشتها}

1- شَكَّلَ الخروج من دائرة البحث التقليدي إلى دائرة البحث الرقمي عاملاً نوعيًا في سياق تطور التصميم الكرافيكي، الذي أفاد

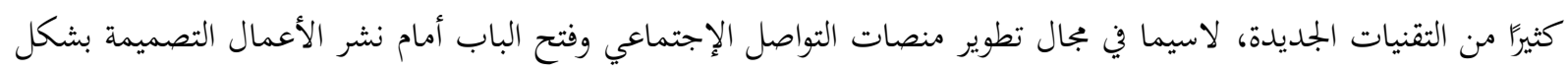
تفاعلي مباشر.

2- أظهرت التجارب التي قام بها المصممون القدرة الواضحة في تغيير الأنماط التي كانت سائدة والتعامل مع المعطيات الجديدة

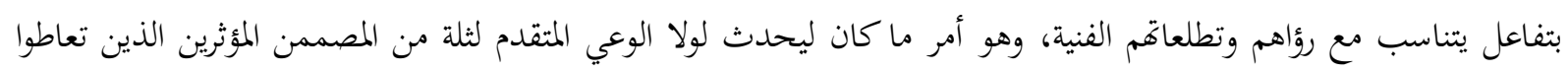
مع المعلومات الرقمية بشكل يتناسب مع ما يفكرون به من جهة، ومع ما يتطلبه حراك السوق والتسويق. 3- إنعكست التقانة الرقمية بشكل مباشر على تطبيقات التصميم الكرافيكي، وظهر الفن الرقمي ليشكل إضافة نوعية لِما كان

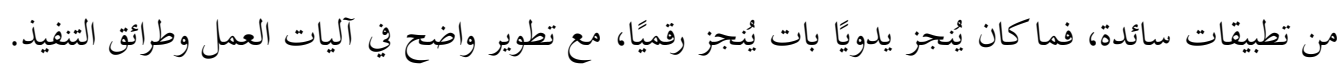
4- لم ياتِ تحول التصميم الكرافيكي الى الفضاء الرقمي، إلا عن طريق الإفادة من العلوم البينية ذات العلاقة بطابعه التطبيقي،

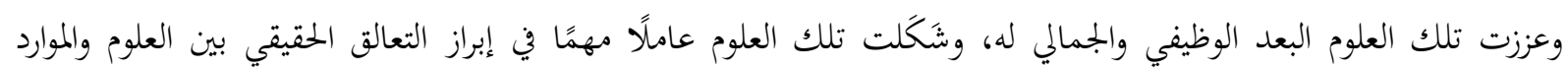
الثقافية والأدبية ذات الأثر.

5- تنوعت التحولات التي مر بها التصميم الكرافيكي، منها ما جاء على شكل منظومات إبتاهية- أسلوبية، ومنها تنفيذية،

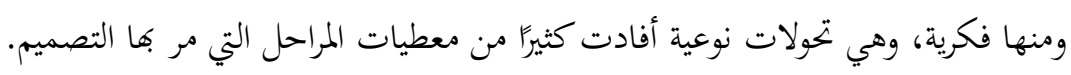


6- إنعكس تطور البرجيات الرقمية بشكل مباشر على أداء المصممين، وأثمر ذلك على جودة التنفيذ وإختزال الوقت، وتطوير

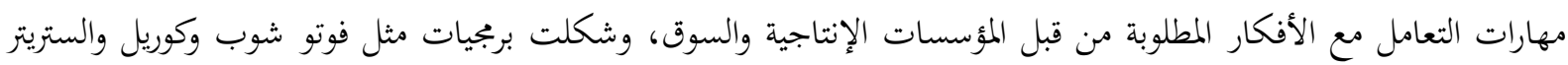
وغيرها تطورا اسهم كثيرا في إبراز قيمة التحولات المفصلية، التي باتت ملمحًا من ملامح العصر الرقمي.

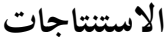

- القيمة الأهم في مسار التحولات التي مر بها التصميم الكرافيكي تكمن في التعاطي التفاعلي مع التطورات التقنية التي كانت معززًا نوعيا في إرتقاءه.

- معنى التحول نحو الفضاء الرقمي جسدته بعض من أفضل التجارب والإتحاهات التصميمية الحديثة التي طبعت العصر التواصلي

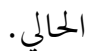
- المصممون المؤثرون كانوا سببًا فاعلاً في ما تشهده التطبيقات الرقمية الحديثة، واليهم يعود الفضل في تطوير البيئة العملياتية

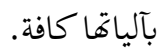

\section{التوصيات}

- تعزيز البحث النوعي في بجال التصميم الرقمي، سيما في كشف تعالقاته مع العلوم البينية.

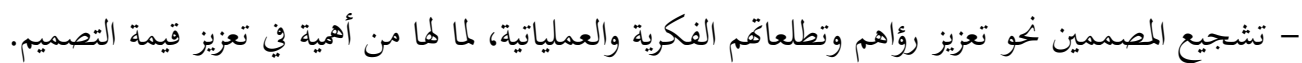

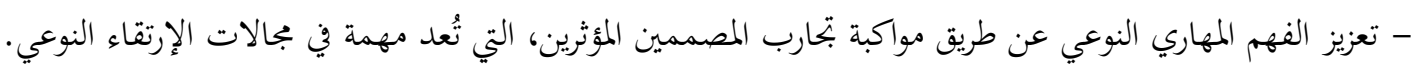




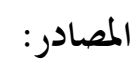

Bendor-Samuel, P. ( 2019, August 27). Why digital transformations fail: 3 exhausting reasons. Retrieved from enterprisersproject.com: https://enterprisersproject.com/article/2019/8/why-digital-transformations-fail-3reasons

Bilda, Zafer and Halime Demirkan. ( 2003, January 24). An Insight on Designers' Sketching Activities in Traditional Versus Digital Media. researchgate.net, pp. 27-50.

C. Zott, R. (2008). AmitThe fit between product market strategy and business model: Implications for firm performance. Strategic Management Journal, 1-26.

Castells, M. (2010). The Rise of the Network Society. Malden: MA: Wiley-Blackwell. Christiaan Huynen. (29 November, 2019). A short hitory of graphic design . blog.designbro: https://blog.designbro.com/a-short-history-of-graphic-design/

Christou, M. ( 2018, April 27). The Evolution of Graphic Design. Retrieved from blog.proto.io: https://blog.proto.io/the-evolution-of-graphic-design customlogos. (2021, May 29). A BRIEF HISTORY OF GRAPHIC DESIGN. Retrieved from customlogos: http://customlogos.com/blog/history-graphic-design/

Daniels, J. ( 2019, June 13). 5 Ways Technology Advancements Have Affected Graphic Design. Retrieved from vectorgraphit.com: https://www.vectorgraphit.com/5-waystechnology-advancements-have-affected-graphic-design/amp

Darmody, J. (2018, APR 3). How has technology changed the career of a graphic designer? Retrieved from siliconrepublic: https://www.siliconrepublic.com/people/graphicdesigner-jonathan-leahy-maharaj-fuzion

Edelman, K. D. (2021, July 20). What 'digital' really means. Retrieved from mckinsey.com: https://www.mckinsey.com/industries/technology-media-andtelecommunications/our-insights/what-digital-really-means\#

Fauvelle, L. ( 2021, Mar 8). intotheminds.com. Retrieved from Digital transformation: concept, models, and examples: https://www.intotheminds.com/blog/en/digitaltransformation/

Fauvelle, L. (2021, Mar 8). Digital transformation: concept, models, and examples. Retrieved from intotheminds.com: https://www.intotheminds.com/blog/en/digitaltransformation/

Feldman, T. (1997). An Introduction to Digital Media. New York: New York: Routledge. global, d. s. (2021, June 7). Why Digital Design is the Best Next Career Step for Graphic Designers. Retrieved from digitalskillsglobal: https://digitalskillsglobal.com/blog/why-digital-design-is-the-best-next-careerstep-for-graphic-designers

Graphicszoo. (2021, May 15). How Advancements in Technology Have Influenced the Graphic Design Industry. Retrieved from graphicszoo.com: 
https://www.graphicszoo.com/article/how-advancements-in-technology-haveinfluenced-the-graphic-design-indu

Hooda, S. ( 2018, July 17). How digital technology is driving a surge in graphic design software in 2018. Retrieved from yourstory.com: https://yourstory.com/2018/07/topgraphic-design-software/amp

i-scoop.eu. (2021, May 31). Digitization, digitalization and digital transformation: the differences. Retrieved from i-scoop.eu: https://www.i-scoop.eu/digitaltransformation/digitization-digitalization-digital-transformation-disruption/

Jennifer, D. (2021, November 6). What Impact Have Digital Technologies Had on the Graphic Design Industry. Retrieved from studymoose.com: https://studymoose.com/whatimpact-have-digital-technologies-had-on-the-graphic-design-industry-essay

Kathotia, A. ( 2020, March 21). Evolution of Graphic Designing from 2010 to 2020. Retrieved from digitalpolo.com: https://www.digitalpolo.com/evolution-of-graphicdesigning-from-2010-to-2020/

KRISTIN THOMSON, K. P. (2013, JANUARY 4). Overall Impact of technology on the arts. Arts and Digital Technologies. Retrieved from pewresearch.org: https://www.pewresearch.org/internet/2013/01/04/section-6-overall-impact-oftechnology-on-the-arts/

Lamberton, C. (2016). A.T. StephenA thematic exploration of digital, social media, and mobile marketing: Research evolution from 2000 to 2015 and an agenda for future inquiry. CrossRefView Record in ScopusGoogle Scholar, 146-172.

le, P. ( 2019, October 15). What is the difference between graphic design and digital design? Retrieved from gostudy.com: https://www.gostudy.com.au/blog/graphic-designvs-digital-design/

Lemon, K. (2017). P.C. VerhoefUnderstanding customer experience throughout the customer journey. CrossRefView Record in ScopusGoogle Scholar, 69-96.

Lu, L. (2021, June 11). The Evolution of Graphic Design. Retrieved from blog.marketo.com: https://blog.marketo.com/2018/06/the-evolution-of-graphic-design.html

Manuel Zavala y Alonso. (2002, February 18). Traditional graphics and Technology. Retrieved from https://www.milpedras.com/en/noticias/40/traditional-graphics-andtechnology/: https://www.milpedras.com/en/noticias/40/traditional-graphics-andtechnology/

Monsters, C. (2020, JUNE 17). UPDATED: The evolution of graphic design. Retrieved from omahamediagroup.com: https://www.omahamediagroup.com/blog/article/theevolution-of-graphic-design

Norcross, N. ( 2017, Oct 9 Oct). How Graphic Design Is Evolving. Retrieved from forbes.com: https://www.forbes.com/sites/forbesagencycouncil/2017/10/09/howgraphic-design-is-evolving/?sh=7be625eb1ff3 
Peate, S. (2021, May 10). From vintage to modern: The future, present, and history of graphic design. Retrieved from fabrikbrands: https://fabrikbrands.com/brand-transparencyand-consumer-trust/

Puranam, H. ( 2021, February 26). The Story of Graphic Design - A Brief History of Graphic Design. Retrieved from harshdesigns.com: https://harshdesigns.com/the-story-ofgraphic-design-a-brief-history-of-graphic-design/

Raine, P. \&. ( 2016, March 27). Overall Impact of technology on the arts. Arts and Digital Technologies. Retrieved from pewinternet.org: http://www.pewinternet.org/2013/01/04/section-6-overall-impact-of-technologyon-the-arts/

Robo/arch. (2015, April 5). Robotiv Fabrication in architecture, art and design. Retrieved from springer: https://www.springer.com/gp/book/9783709114643\#aboutAuthors

salesforce. (2021, April 20). What Is Digital Transformation? Retrieved from salesforce.com: https:/www.salesforce.com/products/platform/what-is-digital-transformation/

Sarah Gamboa. (25 March 2016). The influence of technology in arts appreciation and sales as a factor in the sustainability of the retail art industry. Canadian Public Arts Funders Network: Public Arts Funders Network.

Sayol, I. (2021, may 13). Understanding Digital Transformation: Concepts, facts, and examples.

Retrieved from ignasisayol.com: https://ignasisayol.com/en/understanding-digitaltransformation-concepts-facts-and-examples/

Smith, A. ( 1999, February 10). Why Digitize? Retrieved from clir.org: https://www.clir.org/pubs/reports/pub80-smith/pub80-2/

UKEssays. (2018, November 13). Impact of Technology on Graphic Design. Media, pp. https://www.ukessays.com/essays/media/thesis-technologys-impact-on-graphicdesign-media-essay.php.

visualbest. (2021, june 11). The Evolution Of The Graphic Design. Retrieved from visualbest.com: https://www.visualbest.co/evolution-of-the-graphic-design/

Walgrove, A. (2021, April 10). Your ultimate guide to the history of graphic design. Retrieved from canva: https://www.canva.com/learn/ultimate-guide-history-graphic-design/ 


\title{
THE WOMAN IN THE NOVELS OF SAAD MOHAMMED RAHEEM
}

\author{
Ihsan Hussain ZUBAID ${ }^{1}$
}

\section{Istanbul / Türkiye \\ p. $432-446$}

Received: 03/12/2021

Accepted: $19 / 12 / 2021$

Published: 01/01/2022

This article has been scanned I iThenticat No plagiarism detected

\begin{abstract}
:
Women suffered - and as soon as they were removed - from the sway of the patriarchal society, the domination of men over them and their denial of achieving their independence, and the failure to take their opinion on fateful decisions such as marriage, education, and work, and that the novels of (Saad Muhammad Rahim) shed light on these problems and other inferiority of their role. In public life, in addition to the appearance of women in the society of novels (the research material) in a stereotypical manner, as these novels did not give a good space for women - Arab and Western - thought, literature and culture, while his body recorded the presence of femininity in the presence of a valuable cultural sting, revealing the patriarchal view Towards the woman.
\end{abstract}

Key words: Women, Body, Love, Culture, Gender, Dominance.

http://dx.doi.org/10.47832/2717-8293.15.31 
المرأة في روايات سعد محمد رحيم

\section{إحسان ناصر حسين الزبيدي 2}

الملخص:

عانت المرأة -ولمكا تزل- من سطوة المجتمع الذكوري، وهيمنة الرجل عليها وحرماها من تحقيق استقلاليتها، وعدم

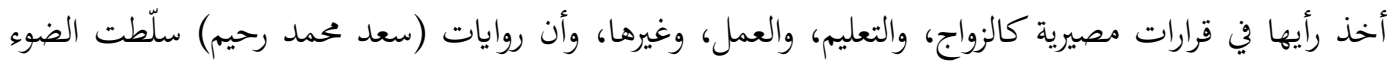

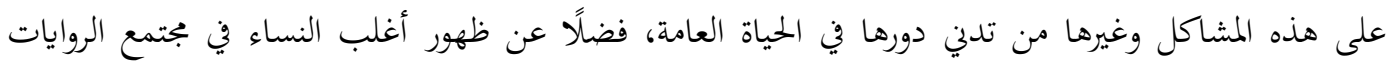
(مادّة البحث) بصورة نمطية، كما لم تمنح هذه الروايات مساحة جيدة لفكر المرأة العربية والغربية وأدها وثقافتها،

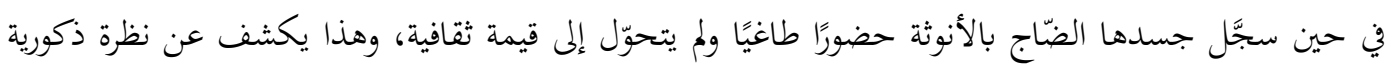
تجاه المرأة، الكلمات المفتاحية: المرأة، الجسد، الحبّ، الثقافة، الجنس، المهيمنة.

قضية المرأة في الأدب عامة قضية في غاية الأهمية، نظرًا للدور الكبير الذي باتت تؤديه في المجتمع، فضلًا عن كوها واحدة

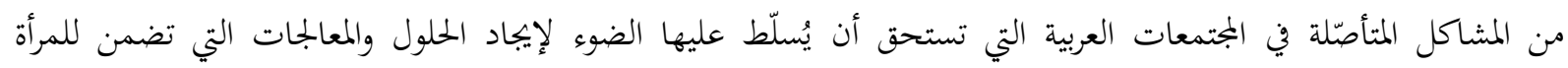

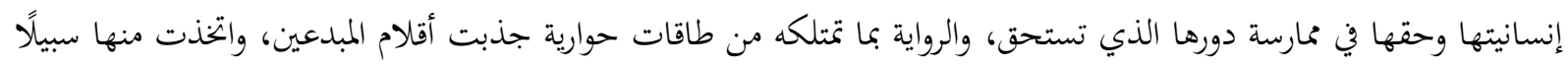
لمعالجة الكثير من قضايا الفرد والمجتمع. ولاسيما تلك التي يصعب التصريح بها، فقد انفتح السرد الروائي على عالم المرأة، وعالج قضايا تمسَّها مثل: الحبِّ، والكره، والزواج، والطلاق، ودور المرأة في المجتمع وعلاقتها بالرجل، فضلاً عن معالجة أوضاعها الجنسية، والثقافية، والنفسية، والاقتصادية.

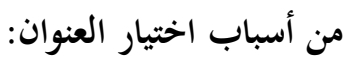

يُعد (سعد محمد رحيم) من الروائين الذين عالجوا قضية المرأة ومنحوها مساحة مهمة في كتاباقم، ولعلّ حضور المرأة في

متون رواياته بات ثيمة وعلامة فارقة تميزّ أعماله الروائية، ومن هنا جاءت هذه الدراسة للكشف عن وضع المرأة العراقية، وغيرها في

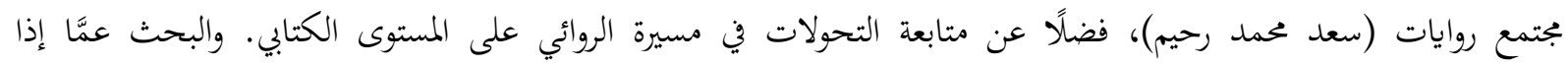

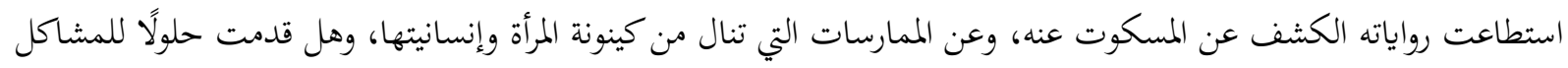

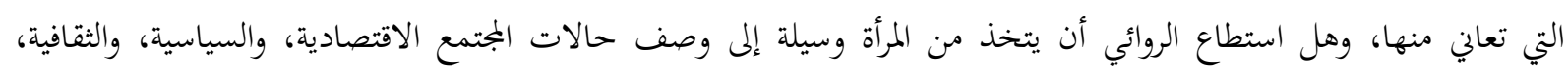
والاجتماعية. 


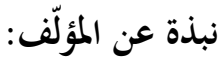

سعد محمد رحيم (1957 - 2018) كاتب عراقي، عمل في الصحافة والتدريس، صدرت له ست مجموعات قصصية،

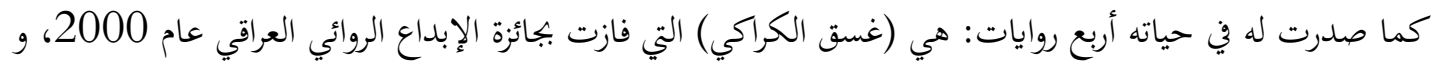

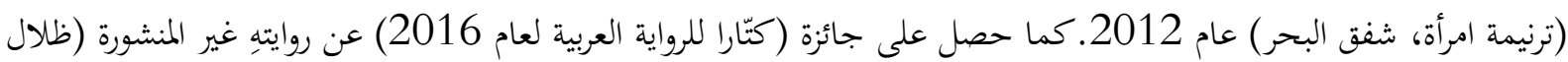
جسد، ضفاف الرغبة)، وصدرت له عام 2017 رواية (مقتل بائع الكتب) التي وصلت إلى القائمة القصيرة لجائزة البوكر العربية،

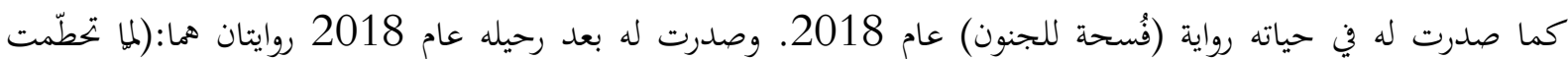

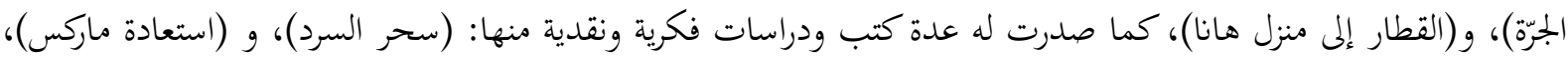
و (المثقف الذي يدس أنفه).

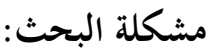

لا جدالَ في أنَّ أيّ بلد لن يستطيع تطوير نفسه ما لم تأخذ المرأة فيه مكانتها، ويُفسح لها المجال لأخذ دورها في عملية

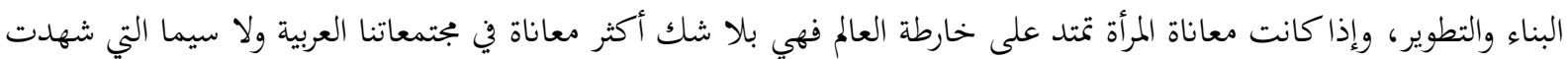
تحولات سياسية وأزمات اقتصادية ومنها المجتمع العراقي. إذ لم تحصل المرأة على أبسط حقوقها التي تضمن لها إنسانيتها وتحقق

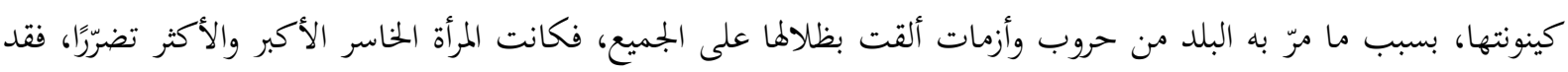

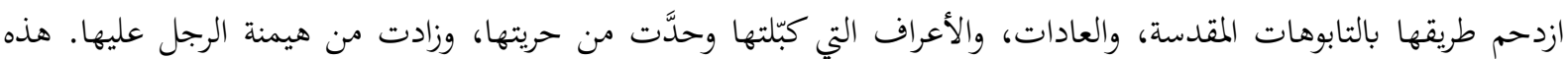
المشكلة تناولما الروائي (سعد محمد رحيم) وسلّط الضوء عليها في رواياته ليكشف حجم الظمات الظلم الذي لحق بالمرأة والمعاناة الكبيرة

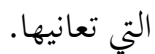

\section{المنهج المتّبع:}

هو المنهج الوصفي التحليلي الذي يسمح للباحث توصيف مشكلات البحث بدقة، والوصول لاستنتاجات علمية على وفق الشواهد التي يتضمّنها البحث بعيدًا عن التحيّز الشخصي.كما يسمح بتسليط الضوء على الأمراض الثقافية، والأنساق

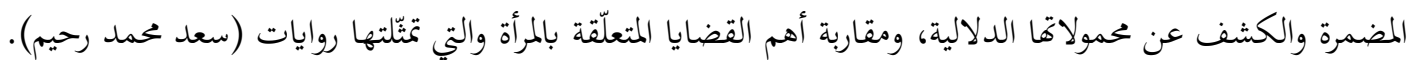

\section{أنماط المرأة وتجلياتما في روايات (سعد محمد رحيم).}

الأم، هي ينبوع المحبة المتدفق، والكوكب الدري الذي يبعث للقلوب أشعة العطف، والإيثار، والعطاء، لذا يُفترض بها أن

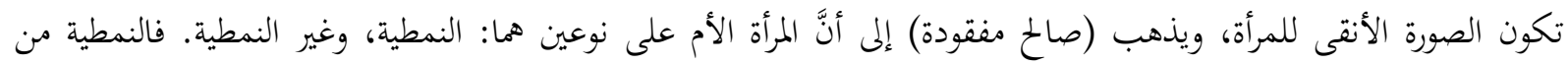

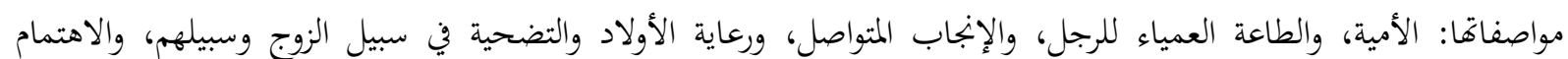
بشؤون المنزل، وعدم الخروج منه إلا بإذن الرجل (مفقوده، 2009). وذهبت (إمان القاضي) إلى توصيف المرأة النمطية بقوها:

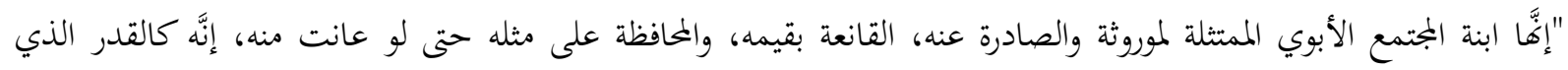

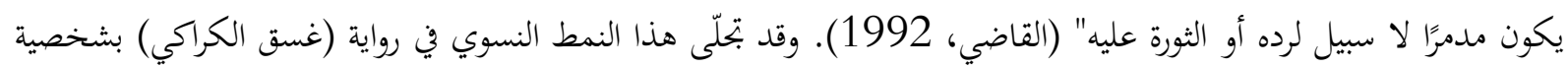

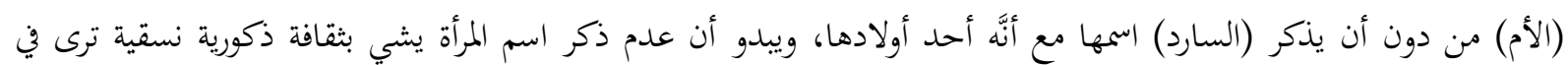


كما أنَّ عدم ذكر الاسم بوجه عام أو مصادرته إنما ينطوي على دلالة بعيدة تكمن في التقليل من قيمة الشخص والنزول بكينونته إلى درك من الدونية (بحراوي، 1990)، فضلًا عن أنّ اخفاء الاسم فيه إشارة إلى عمومية الحالة. هذه الأم امرأة بسيطة تؤمن بالخرافات، وتلبّس الشياطين بالبشر، وتلجأ إلى الغيبيات والقيام ببعض الطقوس البدائية، لطرد الحسد والجن عن أفراء الفراد عائلتها (رحيم، غسق الكراكي، 2017)

ويبدو أنَّ من أسباب تكريس دونيّة المرأة "اعتمادها اقتصاديا على الرجل وحالة الجهل التي كانت تعيشها، إلى جانب

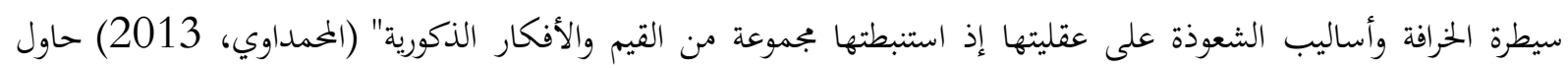
(السارد) أن يظهرها بصورة امرأة زاهدة وقور، وصلدة، وبهية على الرغم من شيخوختها المبكرة، لكنَّها في الوقت ذاته لا بتحيد عملاً

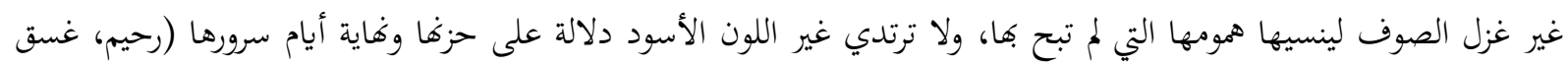

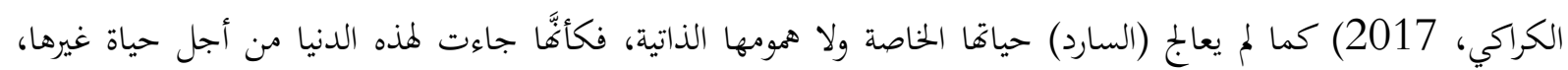

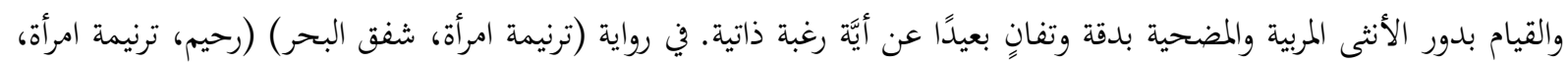

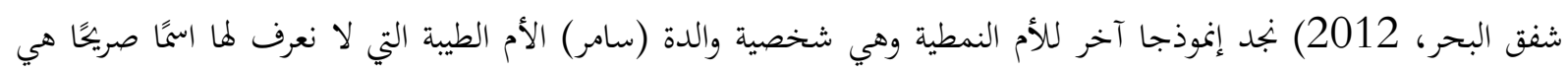

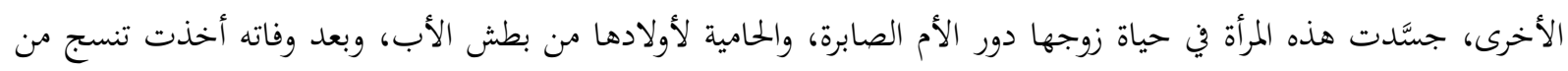

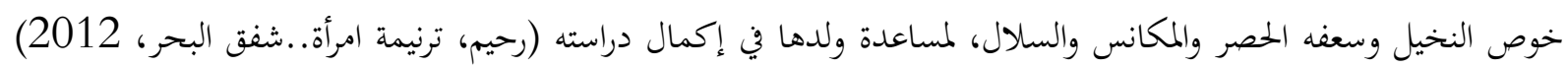

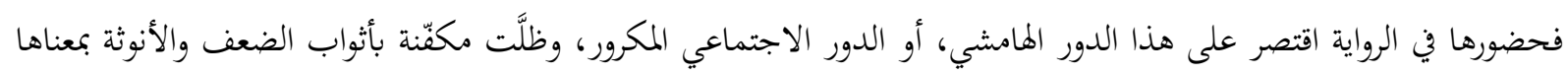

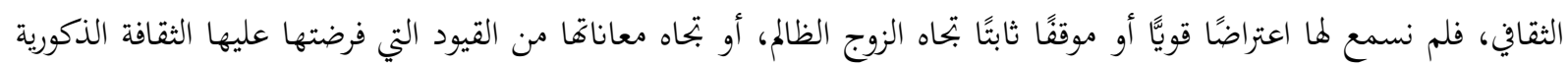

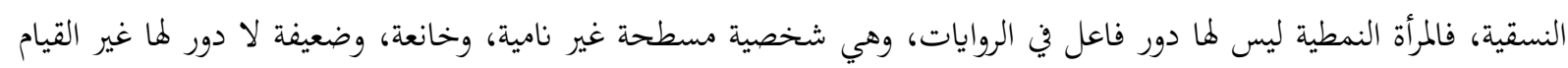

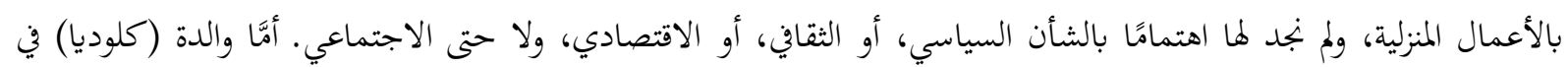
الرواية ذاتما لم تكن

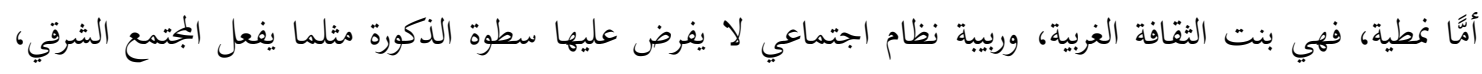

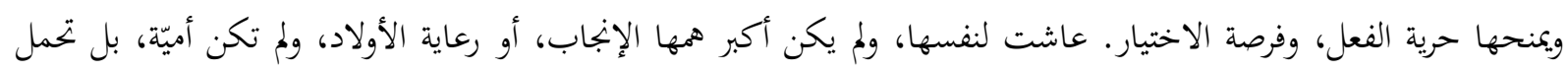

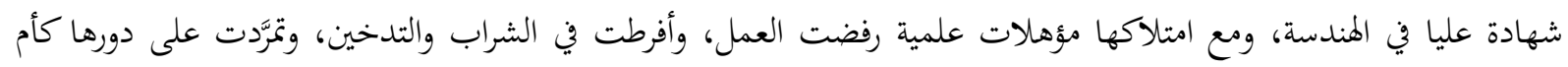
(رحيم، ترنيمة امرأة..شفق البحر، 2012)

من نماذج هذا النمط (سارة) التي لم يُسمح لها أن تستمتع بأيام طفولتها كما ينبغي، فقد منعها أخوها الأكبر -بتوجيه

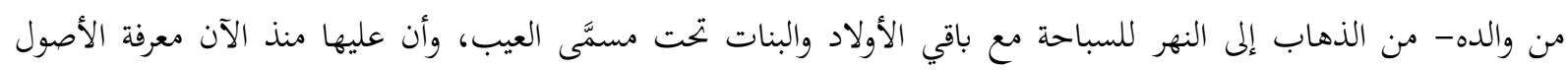
(رحيم، غسق الكراكي، 2017).

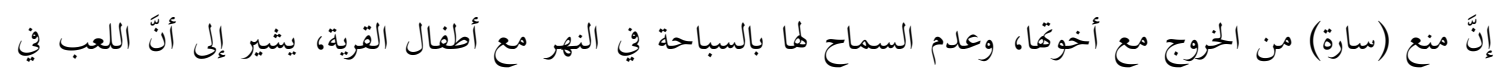

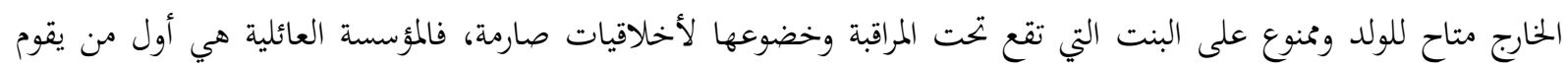

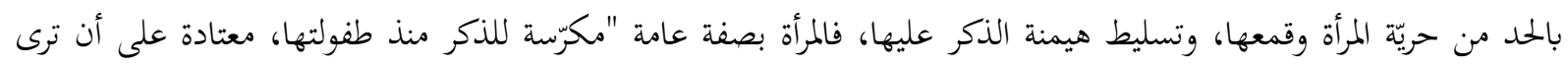

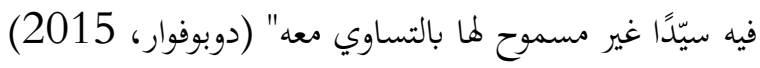
تحصّلت (سارة) على شهادة جامعية ولكنها لم تحصل على فرصة للعمل لإتبات وجودها وتحقيق استقلاليتها وانحسر

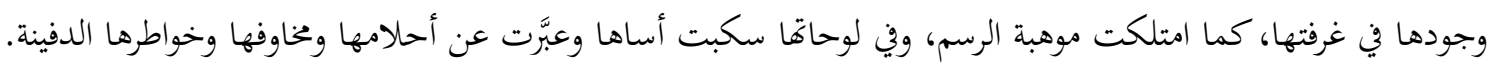


ترك غياها في بغداد خلال سنوات دراستها الجامعية فراغًا كبيرًا في نفوس اخوتها الثلاثة، فقد مثَّت النسغ الحيوي المتصاعد في كيان عائلتها (رحيم، غسق الكراكي، 2017)، وعلى الرغم من كلِّ ذلك وقعت (سارة) الموهوبة والجامعية ضحية أحد زملائها

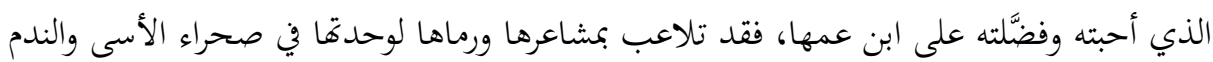
(رحيم، غسق الكراكي، 2017).

ويمكن أن نفهم من قصة (سارة) أنَّ المرأة العربية عمومًا تعيش في أزمة، فحتى المتعلّمة وقعت ضحية لمشاعرها، ولم تحسن

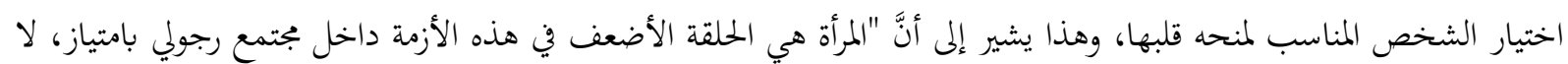

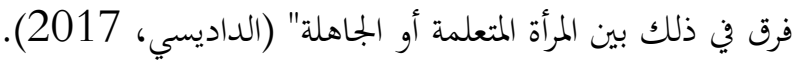

ومن الأمثلة الأخرى على هذا النمط شخصية (شيماء) أخت (سامر) بطل رواية (ترنيمة امرأة، شفق البحر) فقد مثّلت

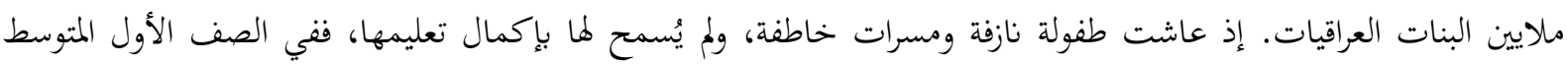

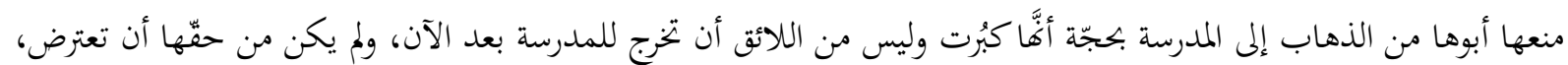

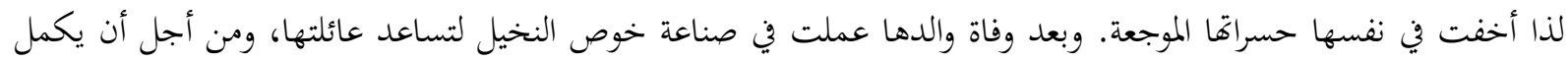

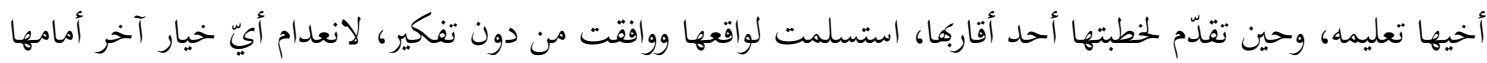
(رحيم، ترنيمة امرأة، شفق البحر، 2012). ولم يختلف حال (علياء) أخت (حكمت/عامر) عن حال سابقاقا، فعلى الرغم من

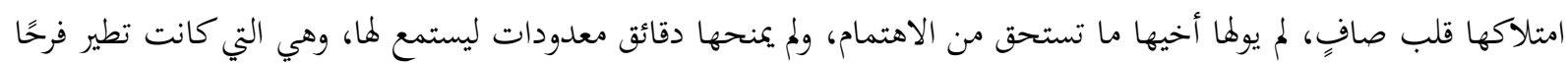

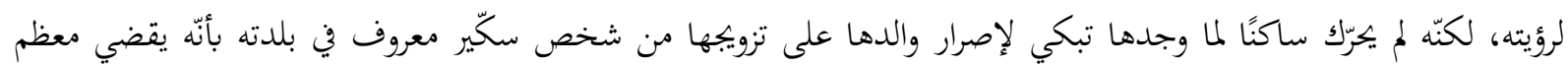

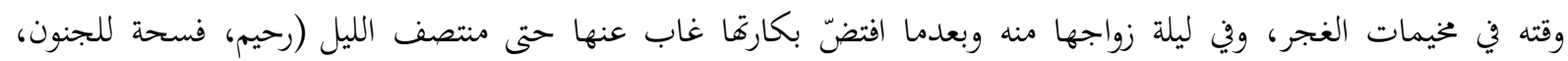

هذه النماذج النسائية بيَّت أن علاقة المرأة بالرجل أقرب ما تكون إلى علاقة السيّد بالعبد أو الجارية، فهي علاقة هيمنة واستسلام، فالرجل هو سيّد الموقف والمرأة تابعة مهمّشة مقموعة، وجاءت في مرتبة دونيّة.

لا شكَّ في أنَّ قضية المرأة بوجه عام من "القضايا القديمة المتجددة أها قضية ملحة ومفتوحة. كثيرا ما تثار بطريقة تصل

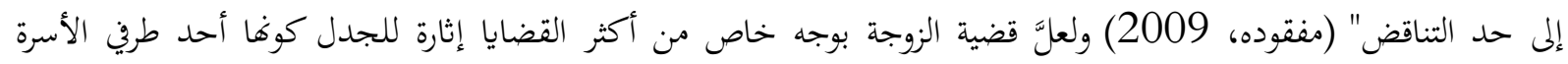

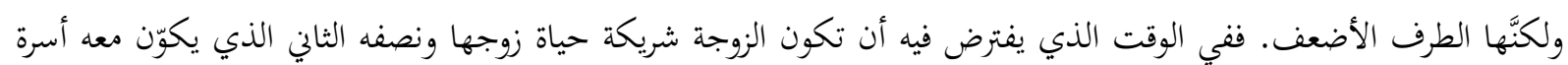

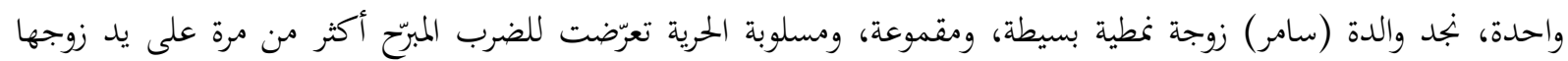

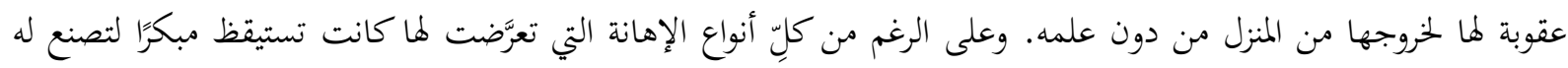

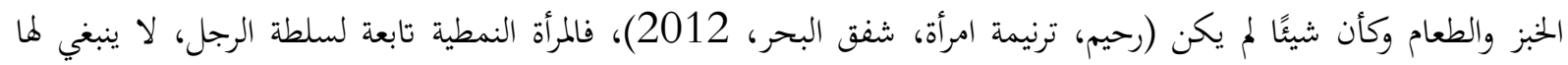

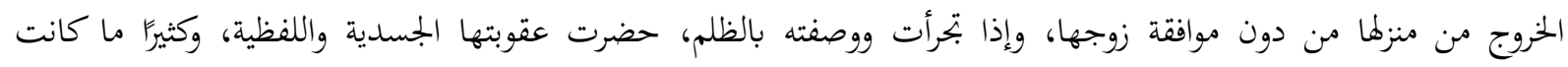
تستقبلها بدموع وصمت. ويبدو أنَّ ضرب الزوجة وسيلة تقليدية لفرض سطوة الزوج وهيمنته، وإحساسه برجولته، وربما يقوم بذلك تنفيسًا عن كبته

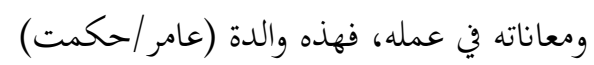
عاملها زوجها العسكري الذي يقضي أيام إجازته سكرانًا معاملة سيئة للغاية وأذاقها الويل على مدى سبع سنين، وكان سببًا غير مباشر لوفاتما في يوم ولادة (عامر/حكمت)، فقد ضرجها بنطاقه العسكري قبل يوم واحد من الولادة (رحيم، فسحة 
للجنون، 2018)، وحين مرضت زوجة الحاج (إبراهيم)، رُميت في غرفتها كخرقة بالية، ولم تكن تتمتّع بأيّة سلطة مادية أو

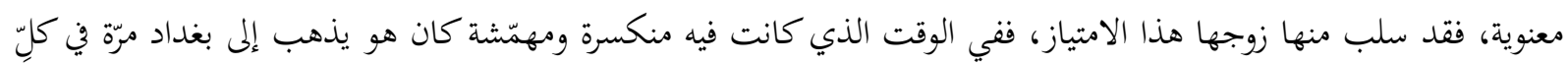

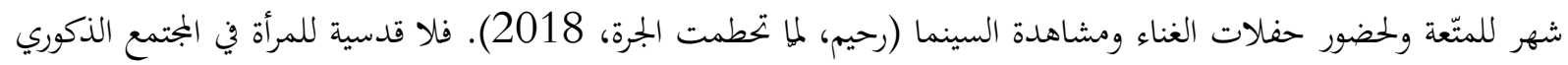

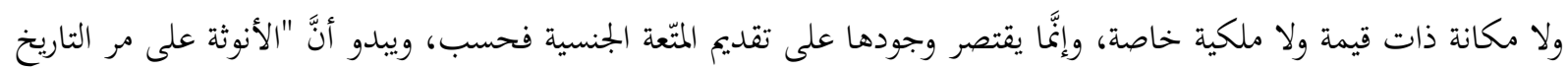

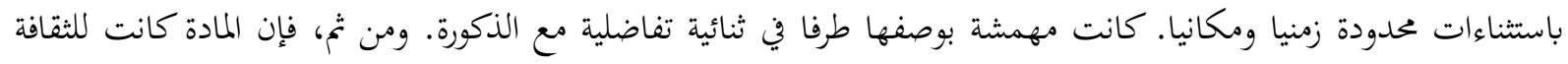
الأبوية على حساب الثقافة الأموية" (عبدالمطلب، 2008)، وفي الرواية ذاتها ظهرت الزوجة غير النمطية أنانية، ومتمرّدة، وغير

أخلاقية، وعلاقتها سيئة بزوجها، ولا تسكت على الإهانة، ولا تنفذ أوامره، ولا تتردد في خيانته، مثالها (عاتكة) هذه الزوجة كانت ترد الشتيمة بالشتيمة، بل وهدّدت زوجها(عادل) بالندم إن بترأ وضربها (رحيم، لما تحطمت الجرة، 2018)، ومع ذلك لم تكن (عاتكة) محل احترام وتقدير من عائلة زوجها، بل كانت تتعرّض للإهانة من أغلب أفراد هذه العائلة،

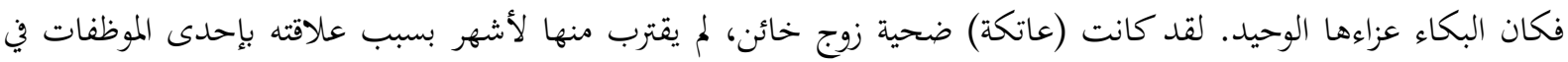

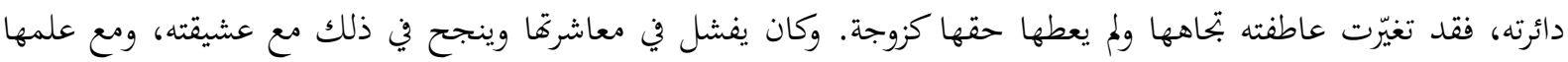

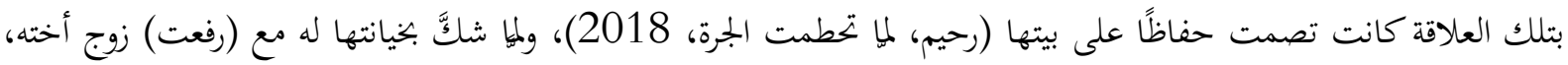

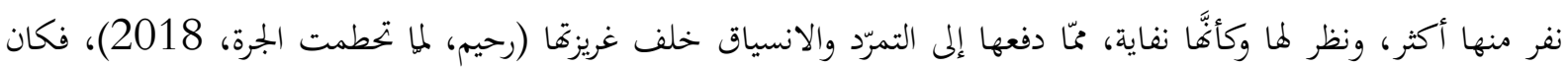

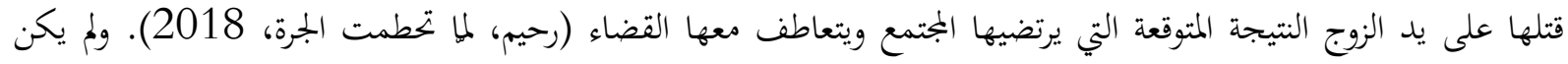

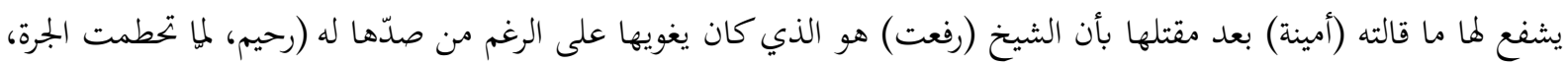

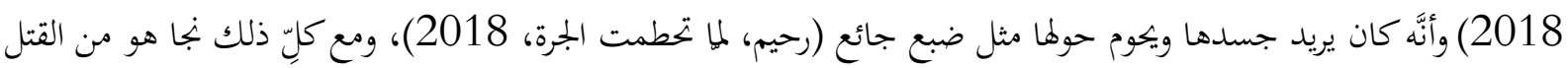

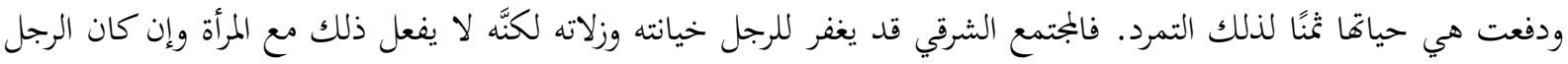

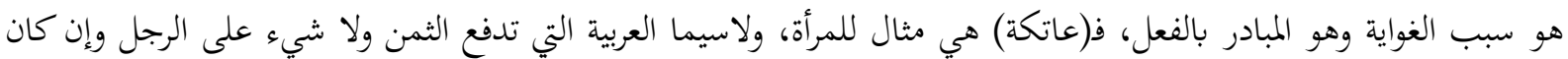
شريكها في الخطيئة.وبحدر الإشارة إلى أنَّ ما قامت به (عاتكة) و(عارف) من خيانة زوجية يشير إلى تحلّ العلاقات الأسرية والاجتماعية وتفسخها وزيفها بعد الغزو الأمريكي للعراق عام 2003، فالرواية بنية أيديولوجية لا يمكنها الانفصال عن التحولات التي يشهدها المجتمع. أَّاّا (نجاة) زوجة الشيخ (رفعت) هي الأخرى ضحية زوجها الخائن المتستر على نزقه وشيطنته بلباس الدين، بعد أن كانت

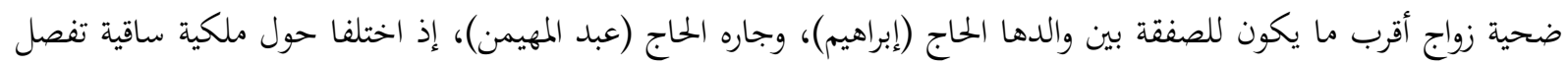

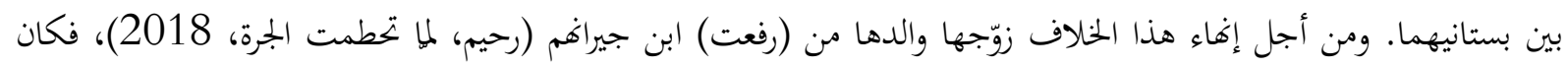

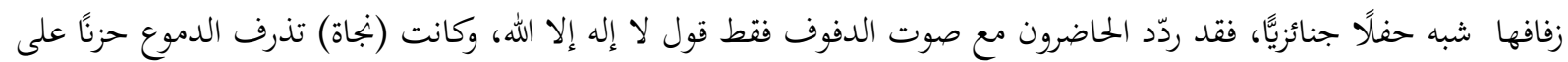

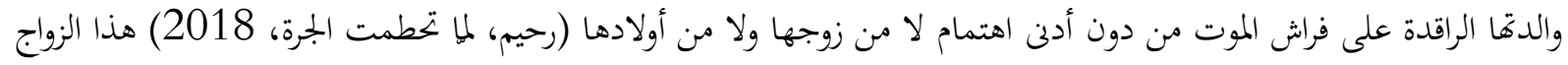
الصفقة الذي يصادر حق المرأة في اختيار شريك حياتا، كانت فايته الخيانة والفشل والضياع، دفع الزوجان ثمنه، ولاسيما (نجاة)

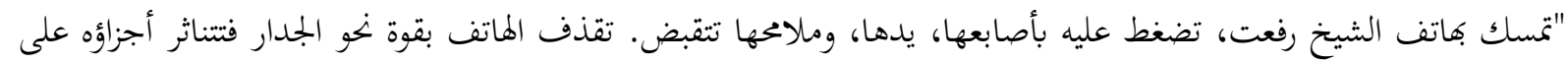

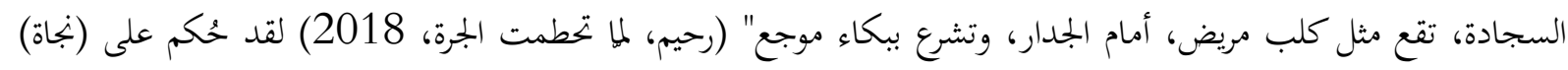

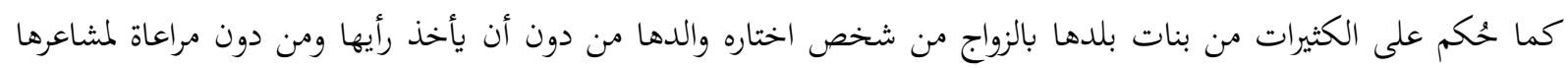
ورغباتما.

أمَّا (أمينة) فقد تزوّجت من الحاج (إبراهيم) وهو الذي يكبرها كثيرًا، لم يُسمعها كلمة (حبيبتي) ولو مرّة واحدة، فهو لا

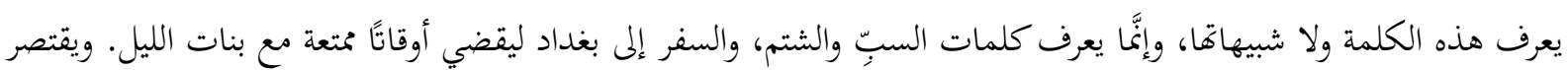

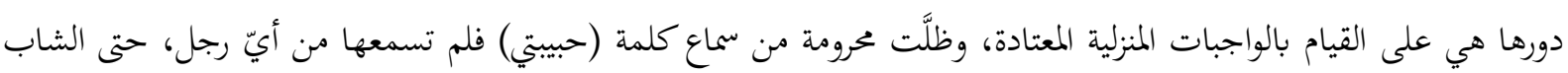


الذي أحبته سابقًا لم يُسمعها عبارات غزل إلّا نادرًا، فقد كان من النوع الذي يكتم مشاعره، ولمها بتركَّأ وأسععها كلاما غزليَّا للمرّة

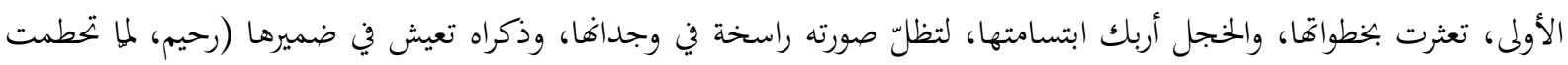

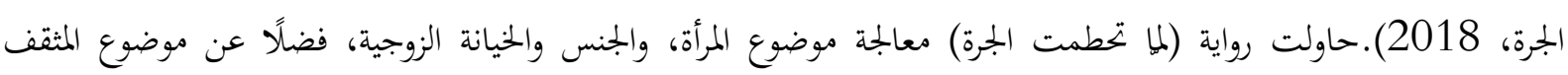

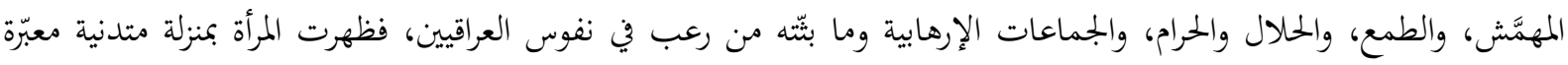
عن واقعها المأزوم، وعن مجتمعها الذكوري الذي يرتضي للرجل ما وال الا يرتضيه لها. يبدو أنَّ الروائي (سعد محمد رحيم) أراد -عبر رواياته- أن يصوّر المرأة، ولاسيما العراقية بمختلف صورها وما تعانيه على يد

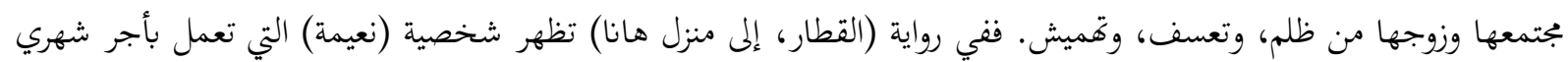

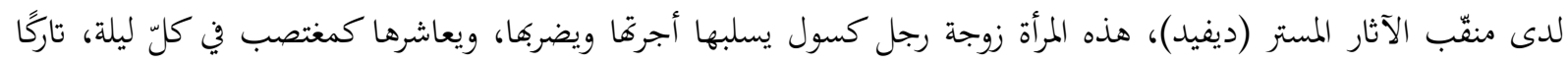

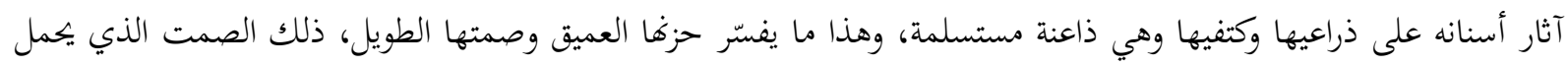

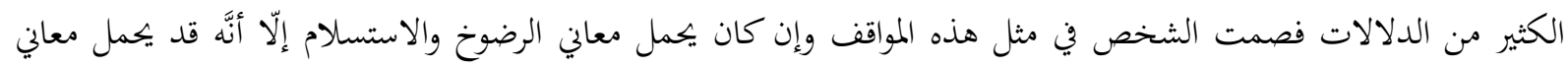

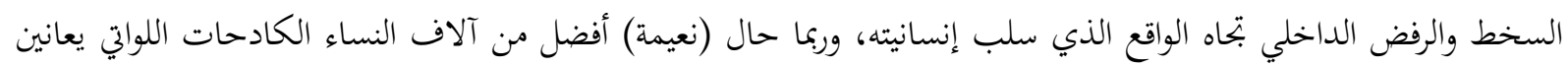
من شتى أنواع الأمراض ويمتن قبل بلوغ الأبعين (رحيم، القطار ..إلى منزل هانا، 2018).

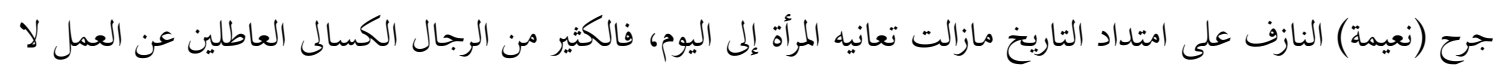

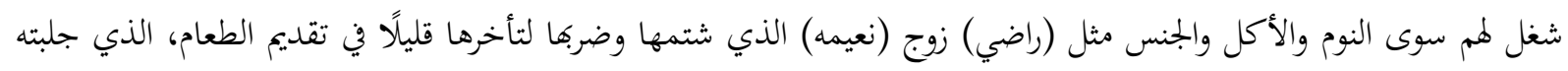

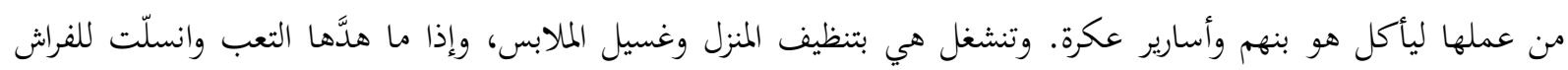

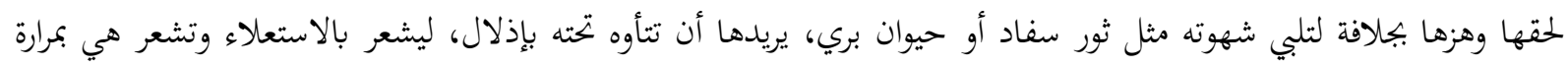

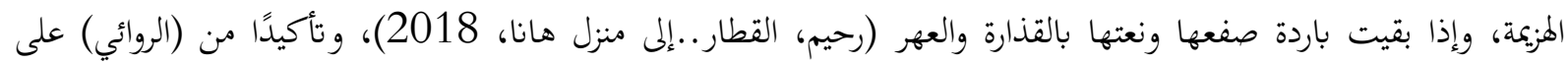

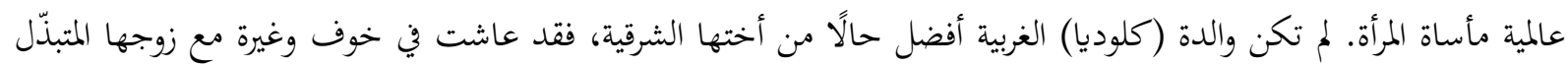

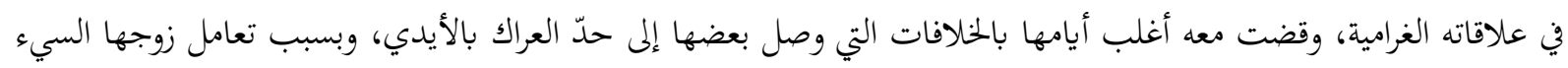
أصاهما المرض، وفقدت رونقها وجمالها. ولم تعد كما كانت ممتازة في فراش الزوجية على حلدِ تعبير زوجها (ألبرتو) (رحيم، ترنيمة

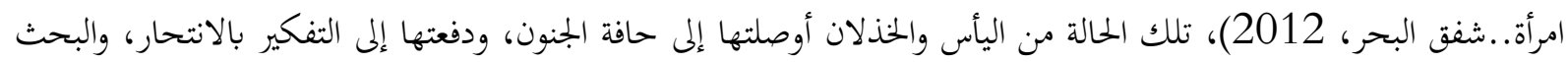

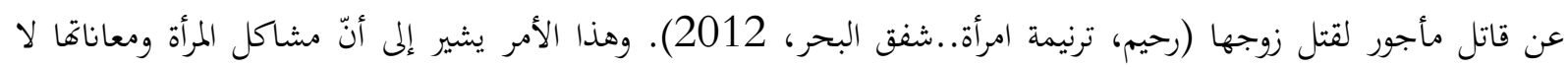

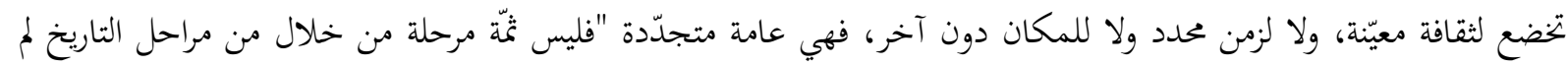

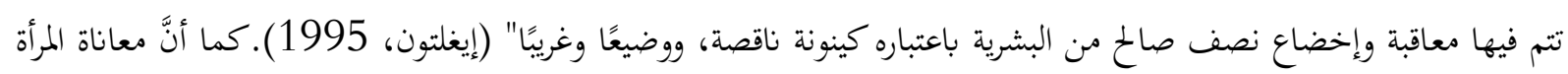

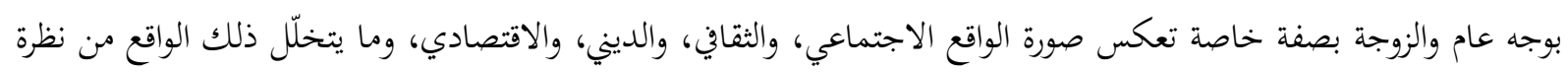

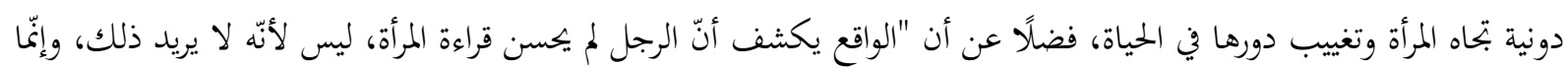

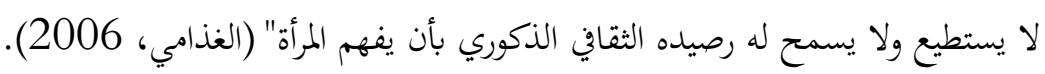

- المرأة الحبيبة قبل الحديث عن المرأة الحبيبة أودُّ أن أشير إلى الفرق الدلالي بين الحبٍّ والجنس "الجنس معطى ملموس مرتبط بالجسد، والحب إحساس هلامي مرتبط بالروح والشعور" (الداديسي، 2017). 


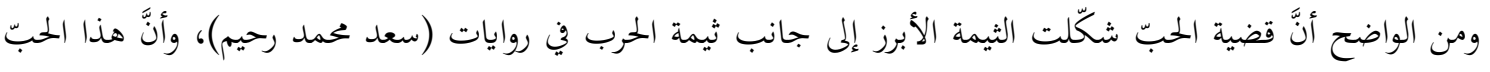

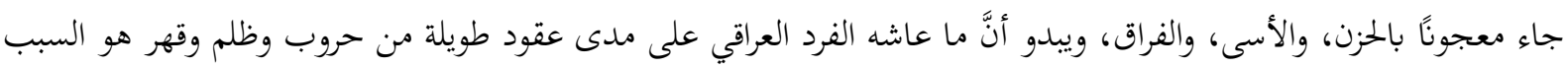

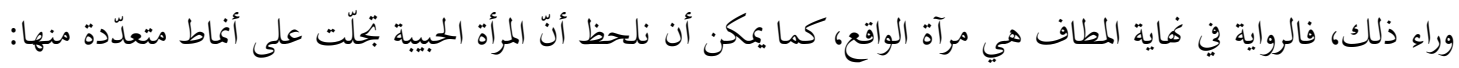

1

من نماذج هذا النمط (كلوديا) وهي فتاة إيطالية، تعرَّف عليها (سامر) على ساحل مدينة (سوسة) التونسية في أثناء تنقّله

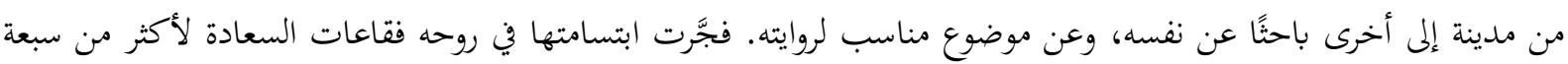

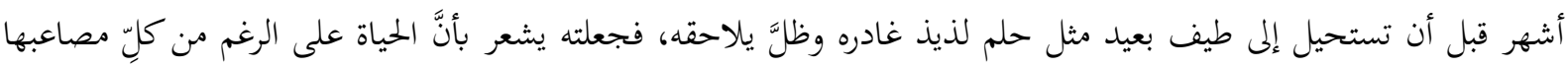

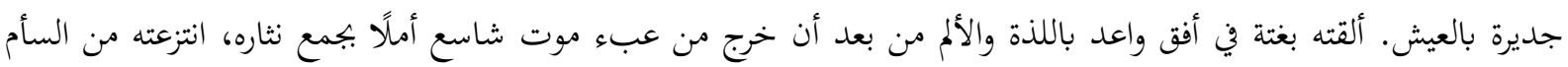
والوحدة واللاجدوى ومنحته ولعًا بالحرية والحياة (رحيم، ترنيمة امرأة..شفق البحر، 2012) هذه ونه المرأة الحبيبة التي منحت (سامر)

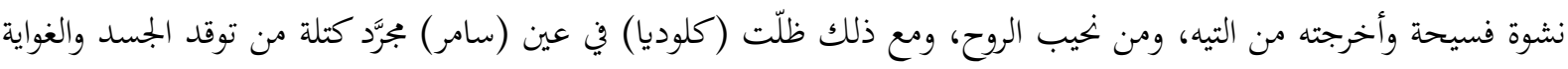

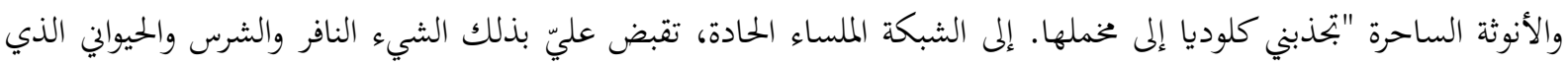

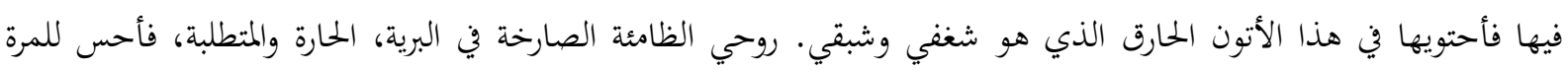

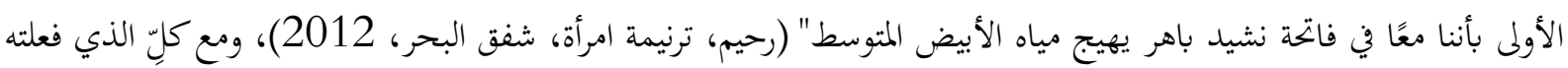

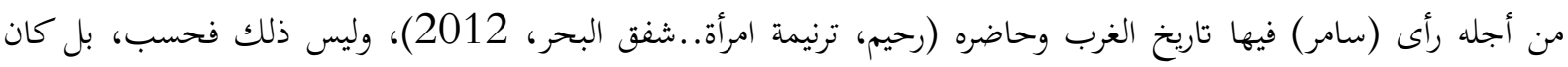

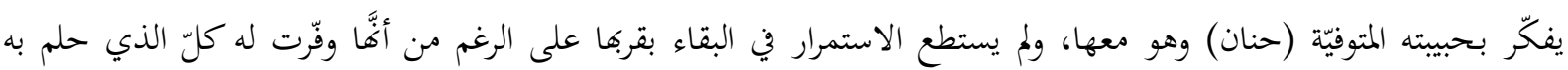

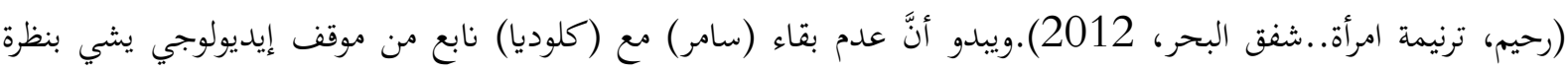

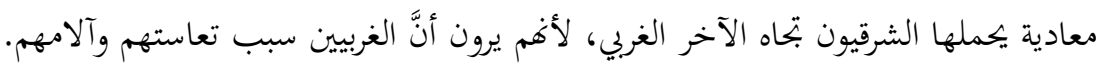

وفي رواية (فسحة للجنون) نلحظ قصة حبّ بين (عامر /حكمت) و(هلة)، لكنّ هذه الحبيبة كانت في نظر حبيبها مجرد موضوع للوحة فنيّة، فهي مجرد موديل وجسد عارٍ جميل يفيض أنوثة وقوة روح، يمكن أن يكون موضوع لوحة تبهر العالم وبتعل

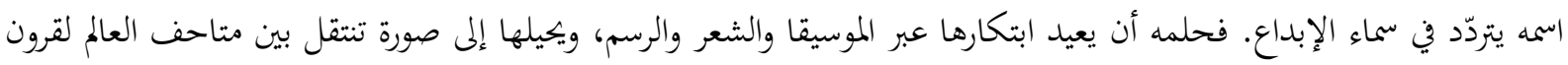

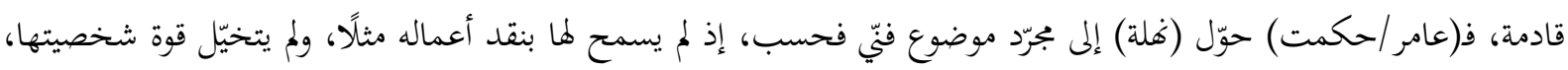

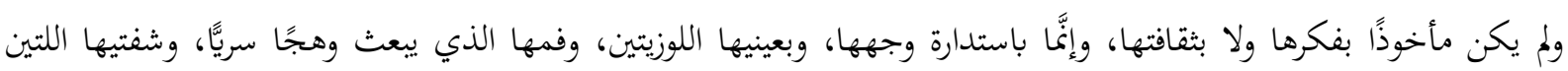

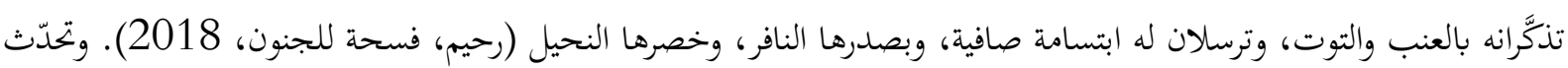

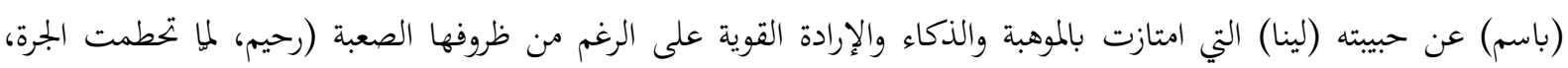

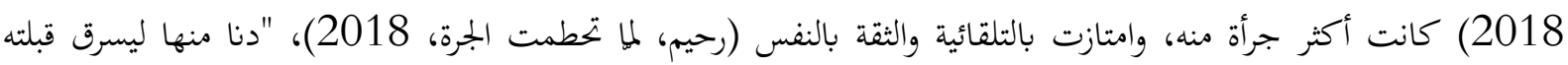

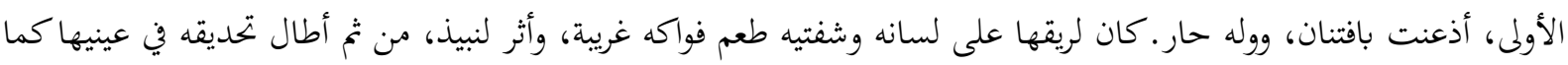
لو أنّ في شرفة يطل على الفردوس، مع ست قبل أخرى بدا أن الحياة تختلج بين ساعديه، تعطيه أبهى ما عندها" (رحيم، لما

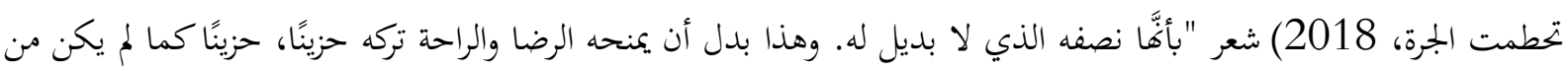

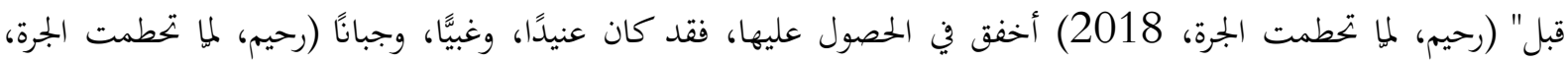

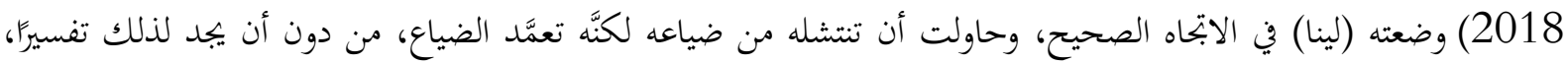

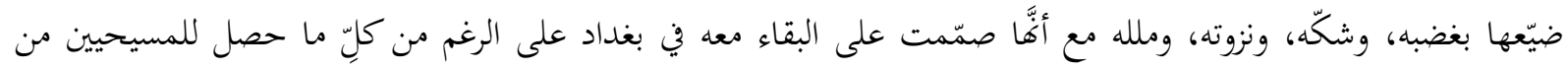

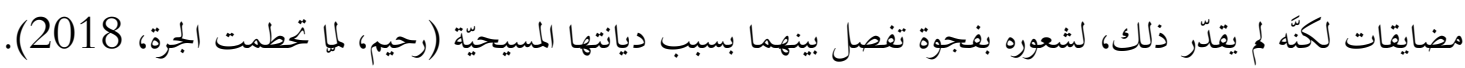


ولم تكن (ناتاشا) بأفضل حالٍ من (لينا)، فقد وقعت ضحية حبّها لـ(محود المرزوق) الذي لوّنت حياته، وانتشلته من

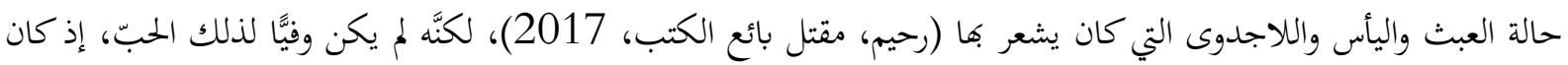

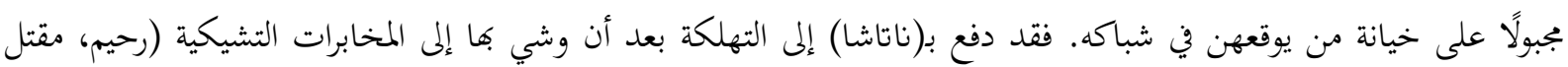

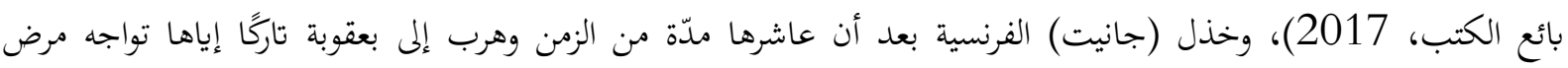
السرطان والعوز (رحيم، مقتل بائع الكتب، 2017)، وقبل ذلك تسبّب بمقتل ابنة الفلاح ذات السبعة عشر ربيعًا، استدرجها

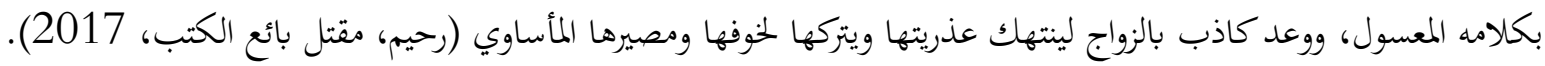

2- 20 - 2 - الحبيبة المعطوبة

أعني هما الحبيبة المعطوبة جسديَّا بسبب المرض، ومن تمظهرات هذا النمط (حنان) وهي فتاة من الديوانية، تعرَّف عليها

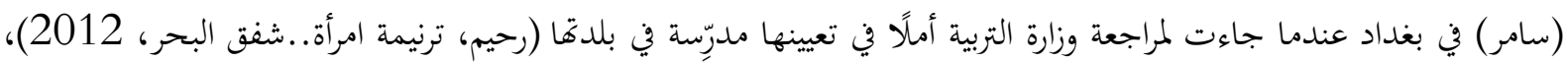

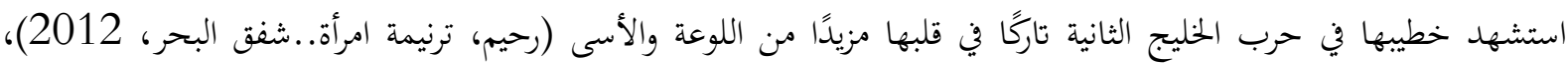

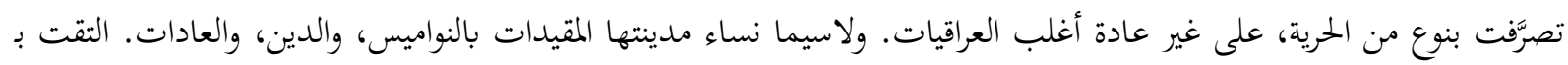

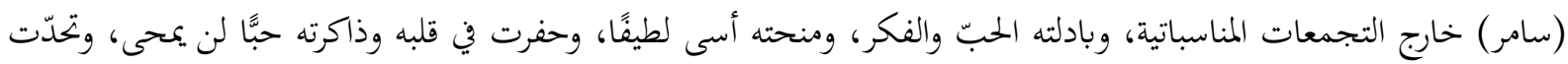

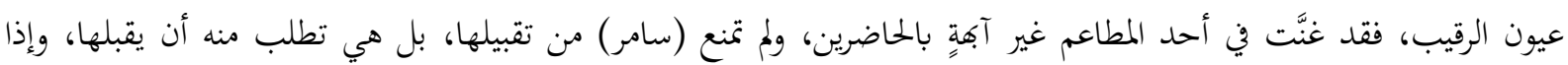

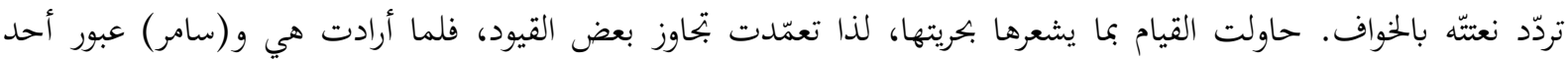

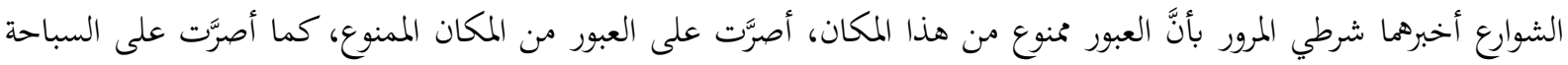

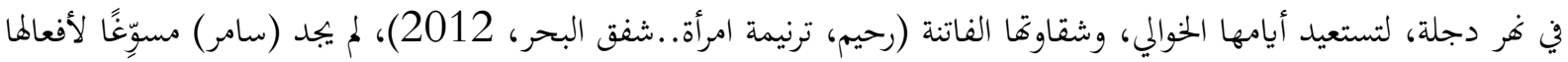

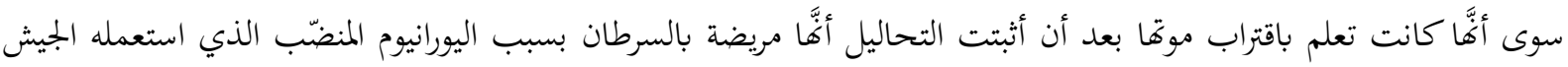

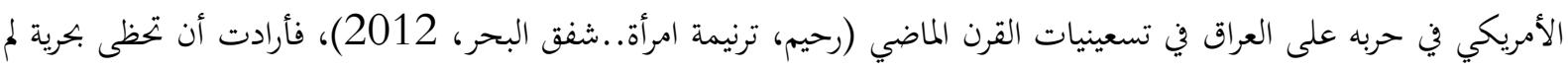

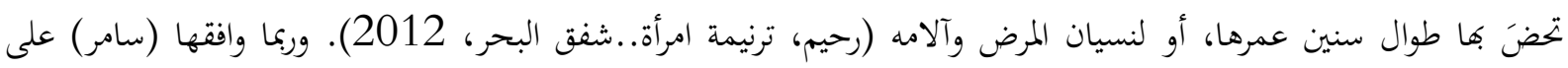

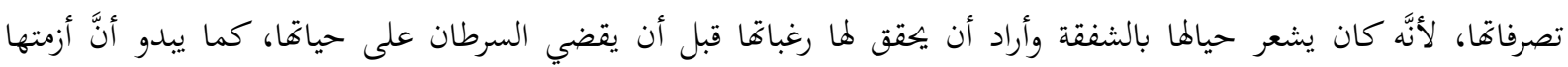

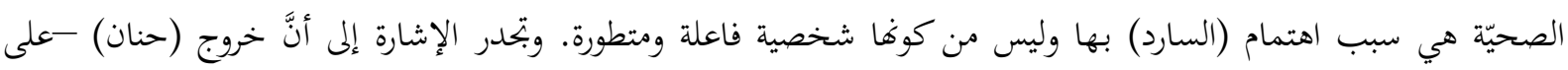
الرغم من انتمائها لبيئة محافظة- للبحث عن عمل هو مؤشر على استجابة المجتمع وتعاطيه الإيجابي مع قضية خروج المرأة وممارستها

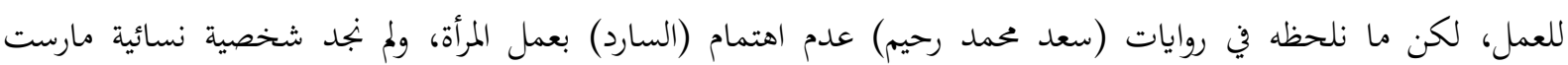
تخصصها بشكل فاعل في هذه الروايات.

لم يكن التقدم في العمر مانعًا (رمزي)، و (هانا) من الذوبان في عوالم الحبّ واقتناص اللحظات السعيدة من بين براثن الزمن

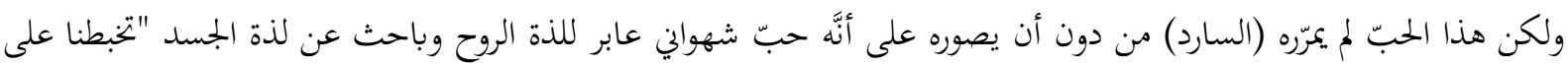

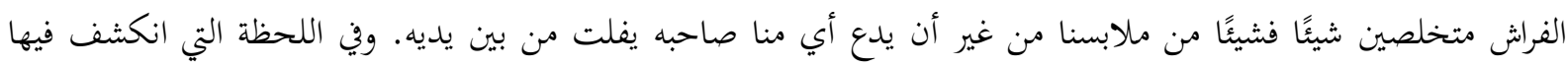

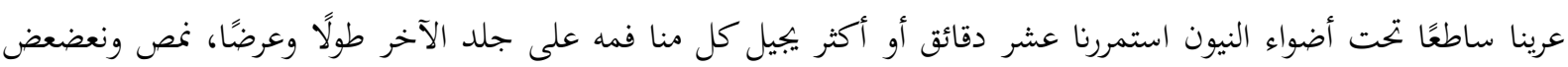

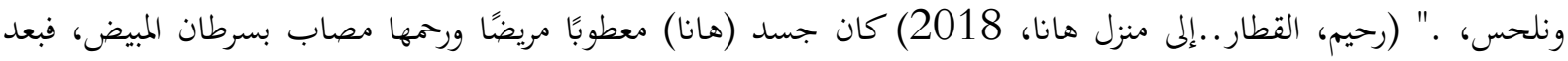

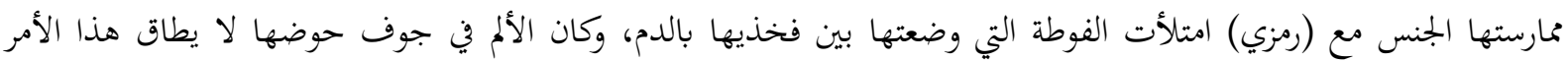

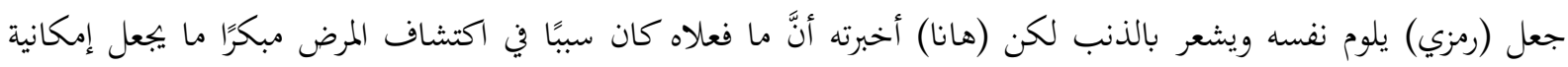

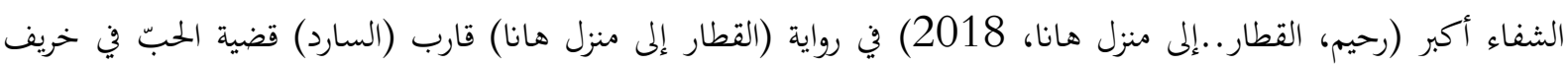

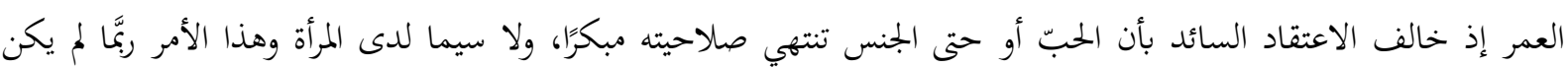


ليحصل لو كان في غير البيئة التي جرت فيها أحداث الرواية، فالبيئة والمجتمع هما من سمح لـ(هانا)، و(رمزي) بهذا التقارب وعيش الحيش تجربة الحبّ في أخريات العمر.

\section{3- 3 الحبيبة اللعوب أو المتقلّبة}

وأقصد بها المرأة التي تتلاعب بمشاعر الرجل وتسعى للتقرب منه حتى إذا ما تمكّنت من قلبه تخلّت عنه وبحثت عن آخر، وبذلك تفقد هويتها ومصداقيتها وتعيش في صراع مع ذاتما، من نماذج هذا النمط (مها) وهي طالبة جامعية، تنتمي لعائلة ثرية إدية

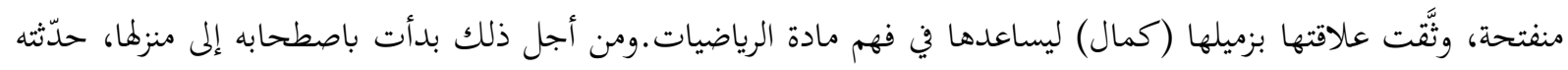

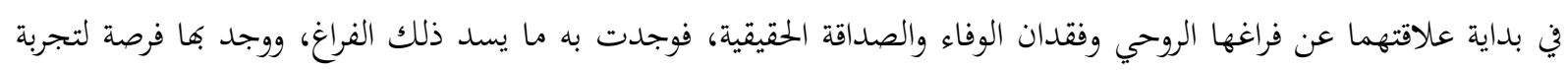

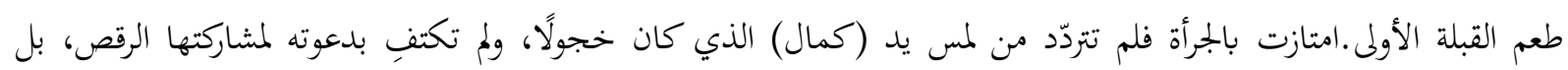

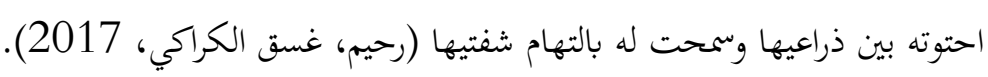
لقد عملت الرواية على إظهار (لينا) قليلة الفهم، فهي بتحيد الرقص ولكنها لا بحيد فهم الرياضيات، كما ظهرت بصورة

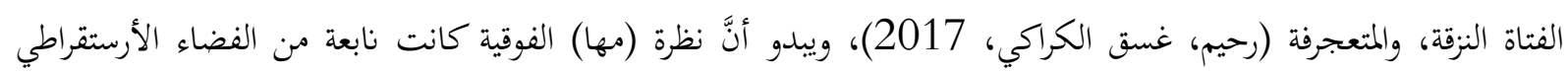

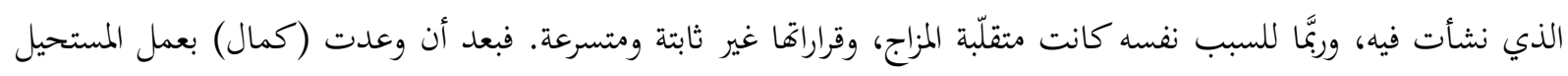

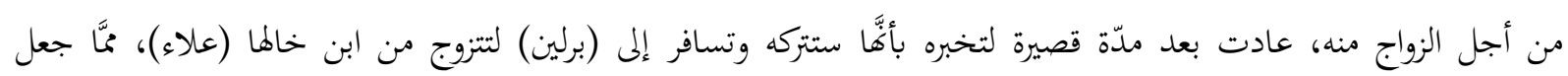

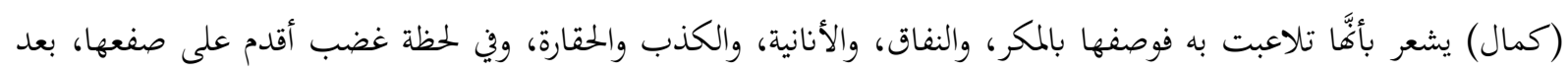

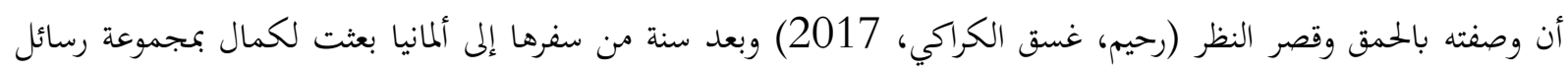

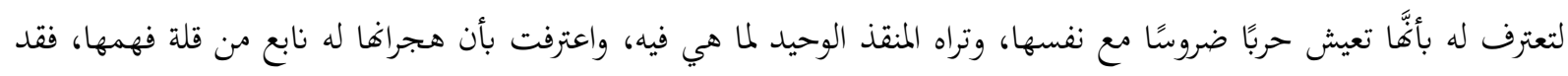

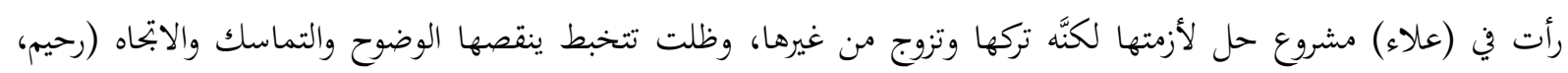

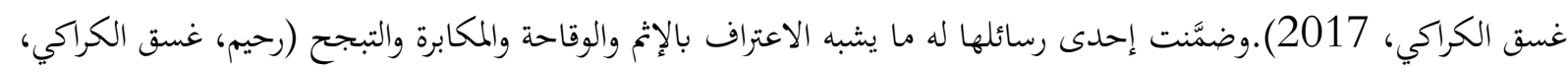

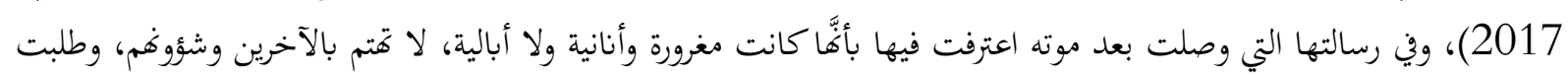

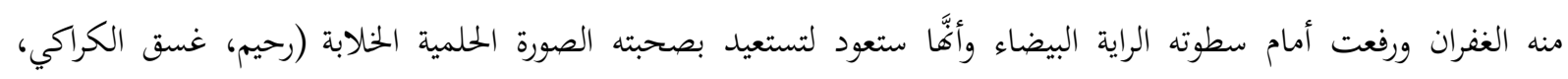

لقد كشفت شخصية (مها) عن سطحيّة المرأة الارستقراطية وتعاليها وشعورها بالضياع والتوهان، وعدم مشاركتها أبناء

مجتمعها معاناتم وقضاياهم.

من الواضح أنَّ معشوقات (كمال) جميعهن متقلبات لا يثبتن على حال، وهذا ما كشفته مذكراته إذ إنَّه تعرَّف مصادفة

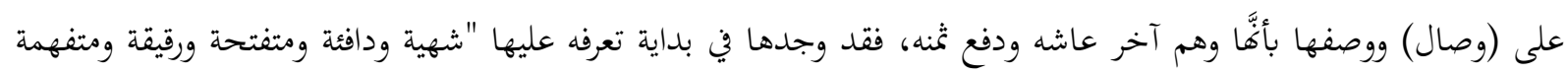

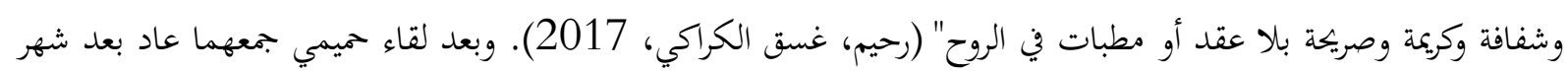

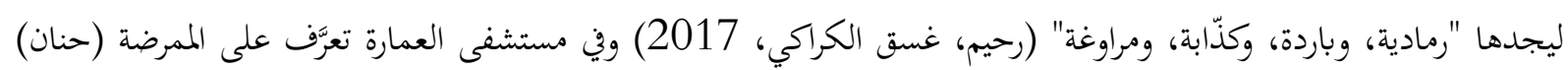

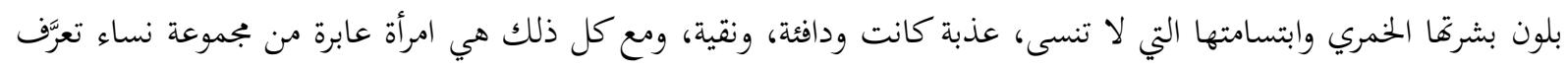

$$
\text { عليهن (رحيم، غسق الكراكي، 2017). }
$$

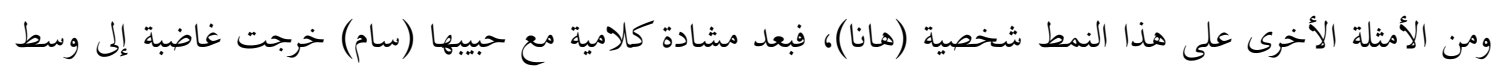

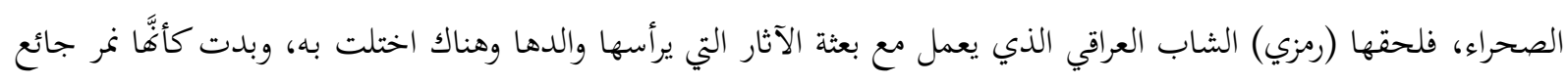

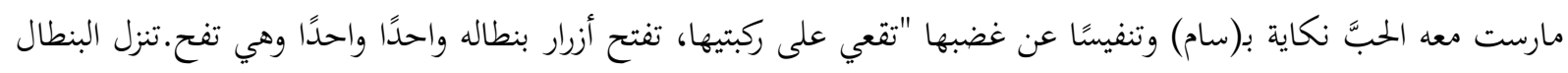

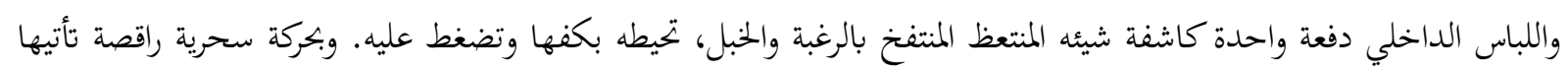


يجد نفسه وقد انزلق فيها. وإذ يروح جذعها يهتز صاعدًا نازلًا عليه كفارسة منطلقة على حصاها في الريح بألف روح والجة في

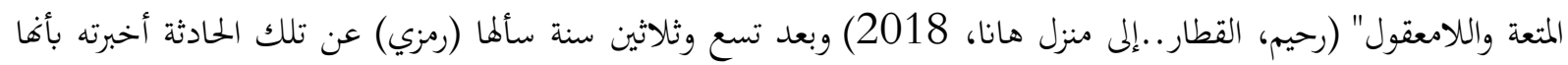

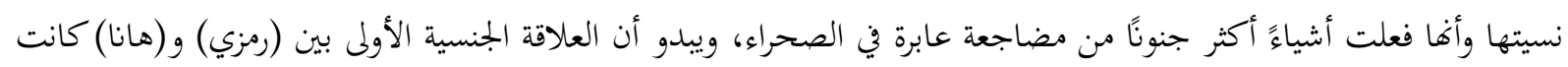

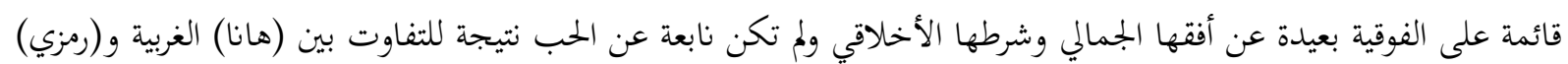

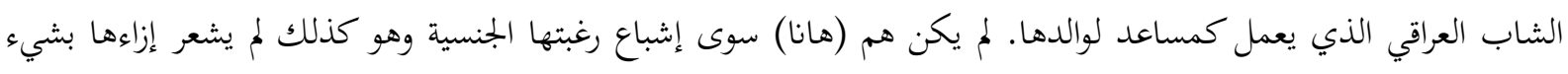

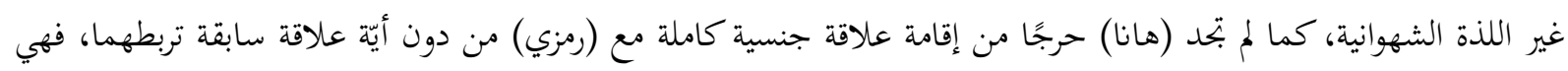

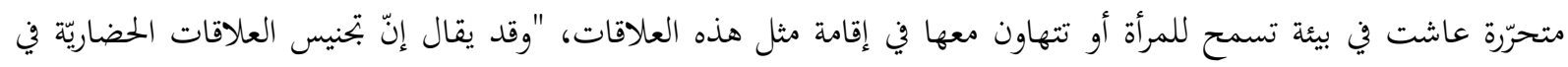

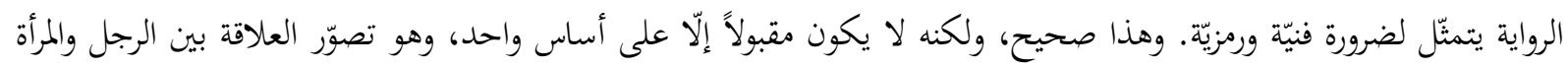

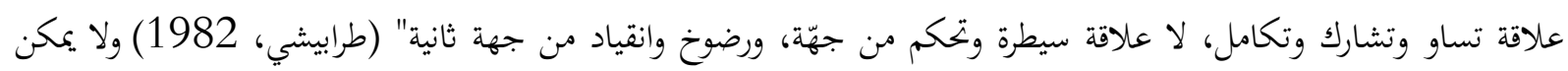

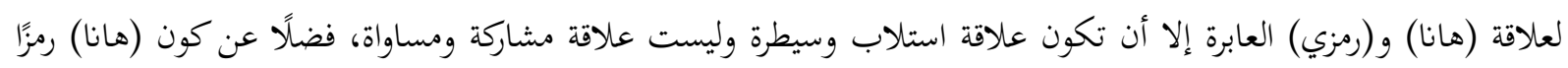

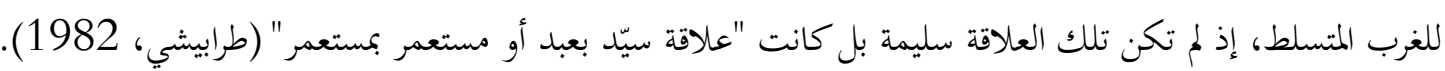

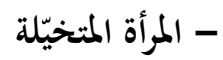

جاء في مذكرات (كمال) أنّه تختيّل وهج النور في الساحة الخلفية للفندق كما لو أنَّه امرأة رآها من نافذة غرفته، "أو ظل

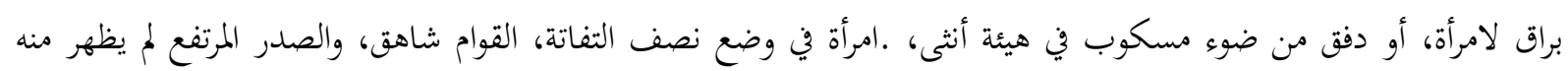

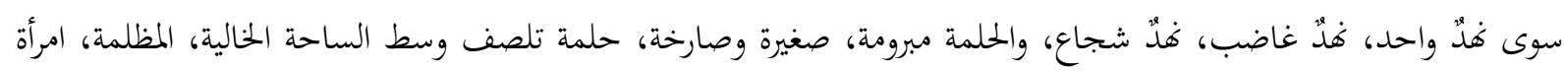

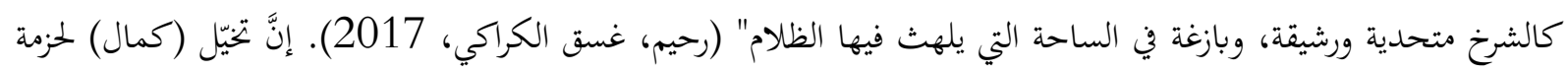

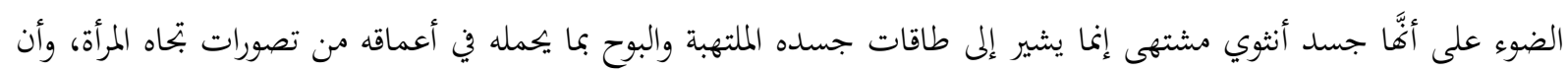

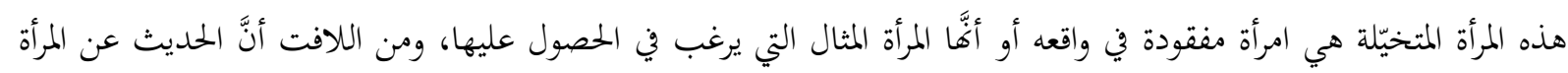

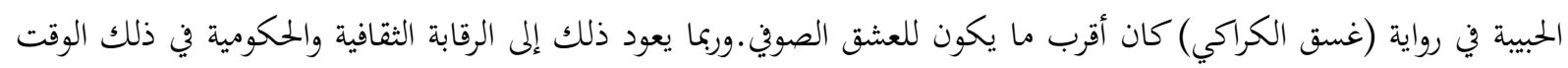

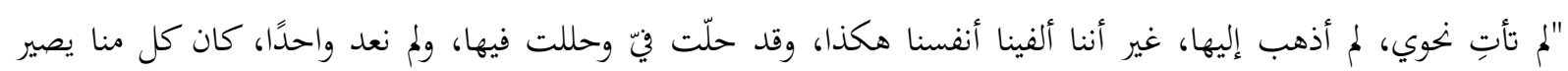

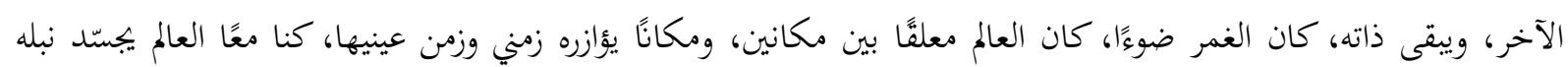

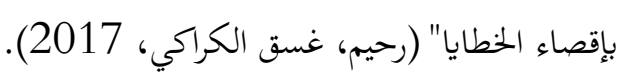

لقد شكّلت المرأة المتخيّلة أو المحلوم بها صورة موازية للمرأة الواقعية ومتنفّسًا للرجل غير القادر على نواها في الواقع -أو

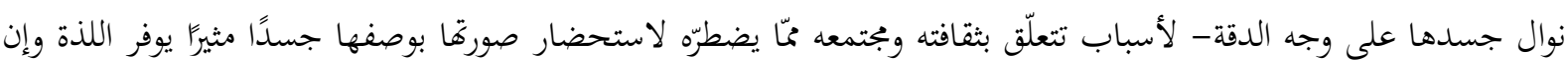

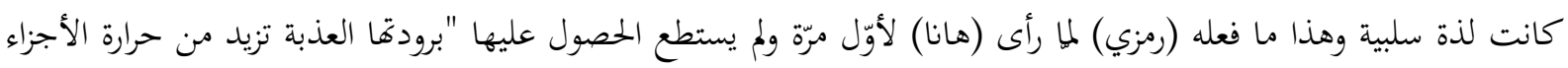

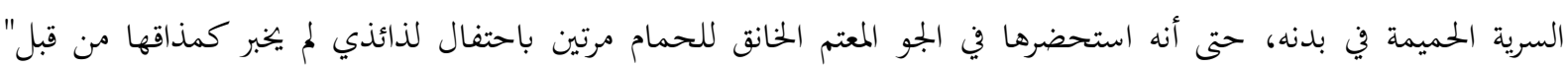
(رحيم، القطار ..إلى منزل هانا، 2018).

لقد عالجت هذه الروايات قضية الحبِّ على نحو يشي بأهمية هذه القضية المرتبطة بعاطفة الإنسان وطبيعة تكوينه ولكن ما

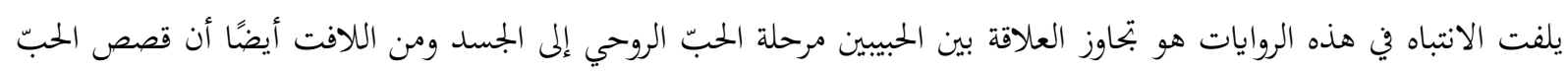

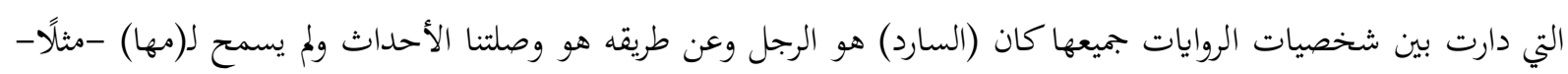

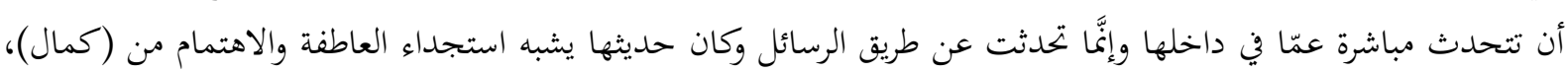

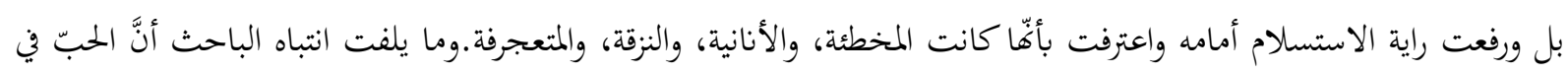


روايات (سعد محمد رحيم) اختلط بالجنس، فبعد قراءة الروايات لم نجد رواية فصلت بين الحبّ والنظرة الشهوانية للجسد، كما

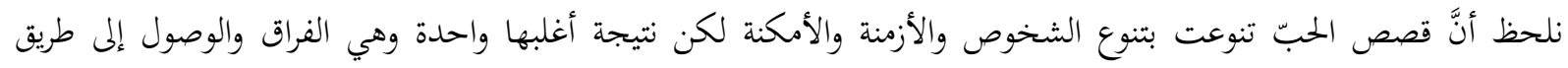

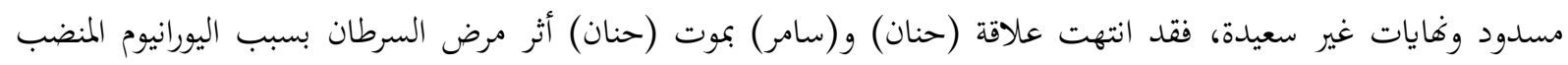

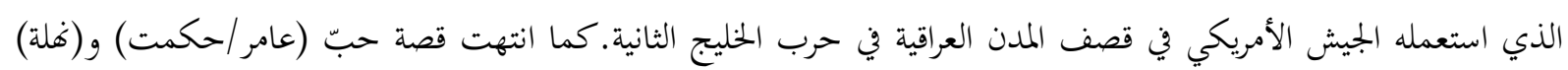

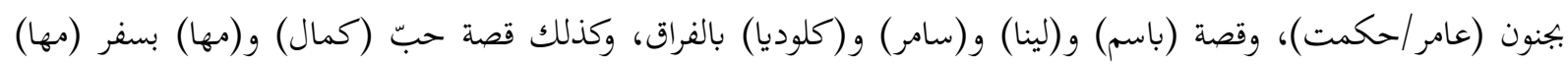

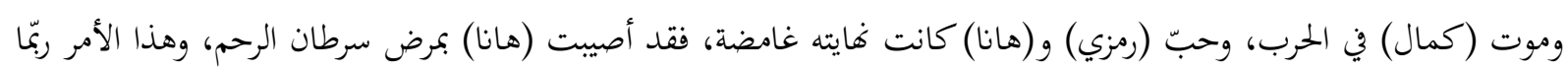
يشير إلى نظرة (السارد) التشاؤمية للمستقبل.

- المرأة الجسسد

للجسد في الرواية علاقة متينة بطرح أسئلة العلاقة بين المرأة والرجل وقد "عمدت كثير من النصوص الروائية العربية إلى

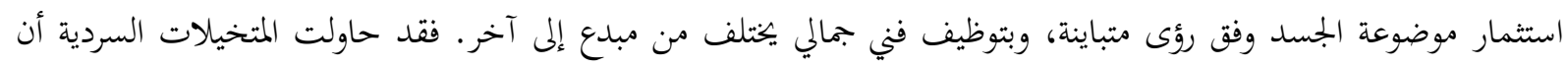

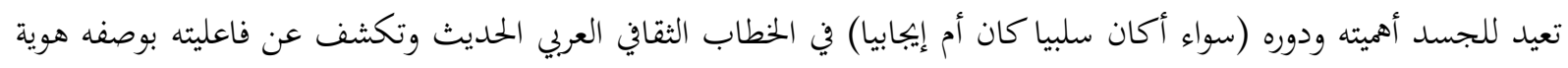
ثقافية ملغزة" (النعيمي، 2007).

لقد طفحت روايات (سعد محمد رحيم) -ماعدا رواية غسق الكراكي- بمشاهد جريئة جلًا صوّرت الجسد بكامل تفصيلاته، ولم يتحرّج (السارد) من وصف العلاقات الجنسية تلك التي تقع ضمن المسكوت عنه سواءً التي حصلت في إطار

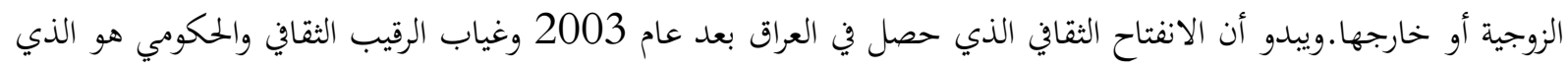

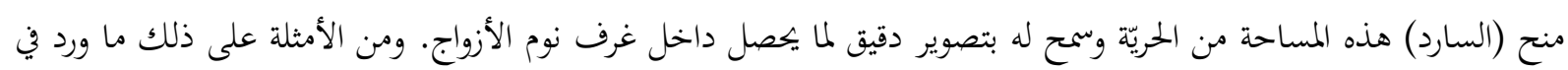

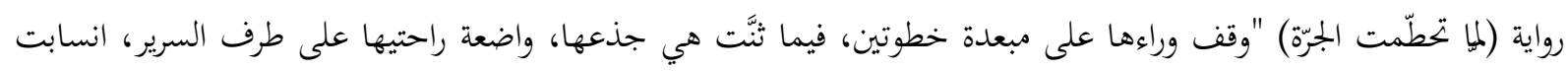

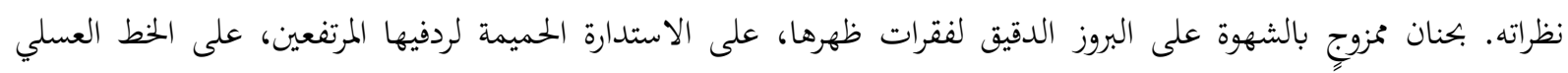

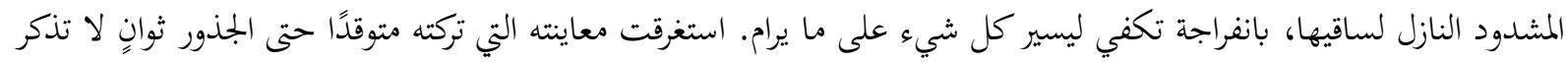

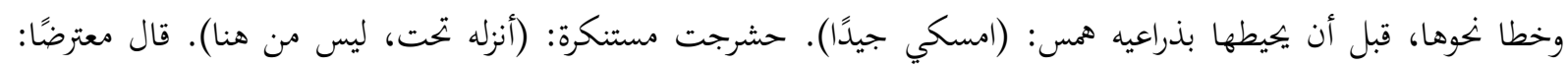

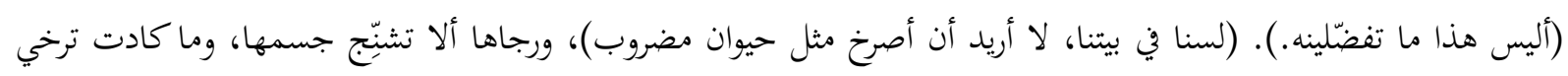

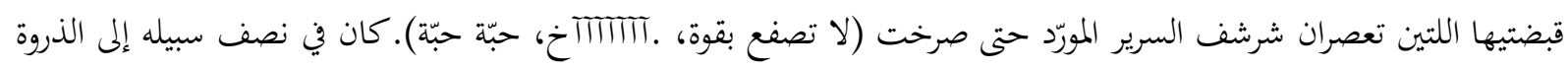

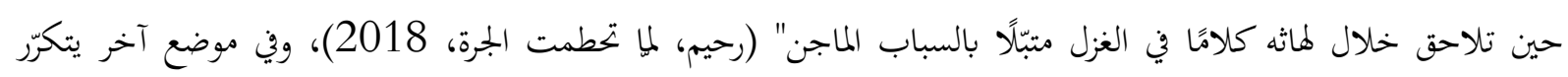

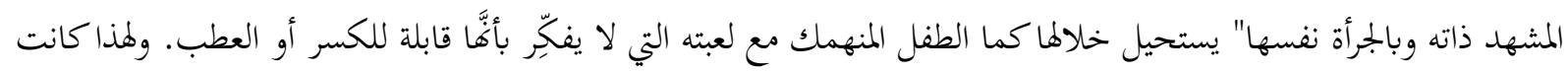

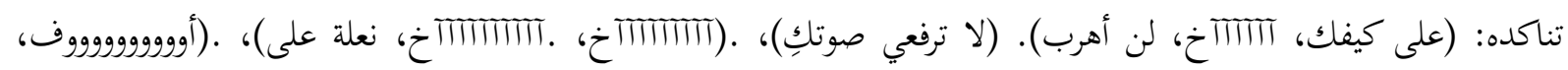

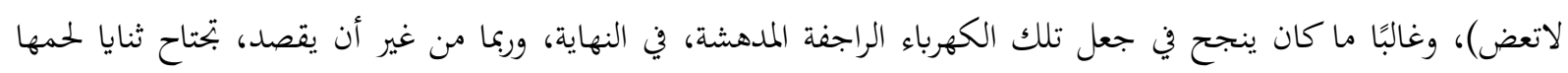

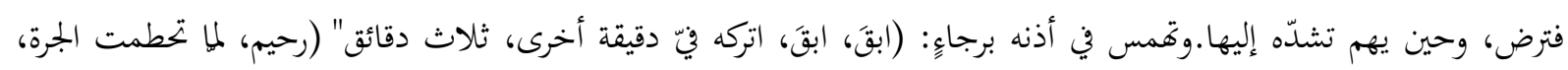

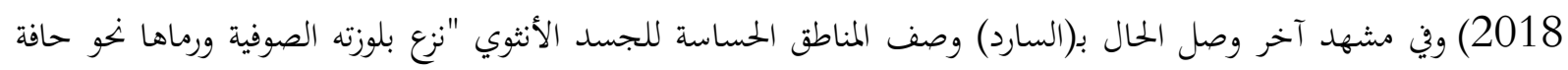

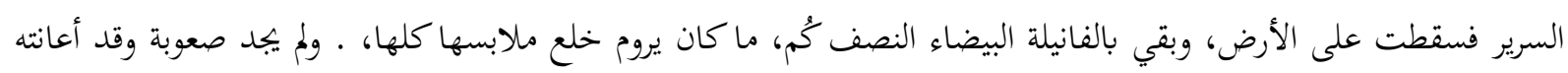

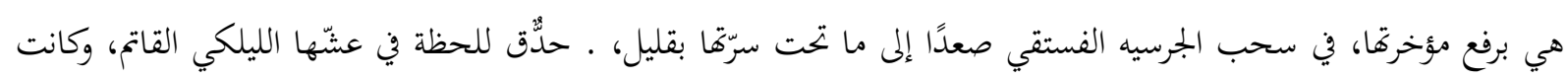
تعرف أنه يفضّل الإبقاء على هذه المتاهة المثيرة من الشعر الخشن الكثيف" (رحيم، لما تحطمت الجرة، 2018) 
إن وصف المشاهد الجنسية بما فيها من حركات وأصوات مثيرة ربمّا يكون المدف من ورائها جذب القارىء، وتسويق الرواية، أو يكون الهدف منها تحطيم القيود والأعراف تماشيًا مع دعوات ما بعد الحداثة، ويبدو أن الجسد بصفة معنة عامة "في الفضاء

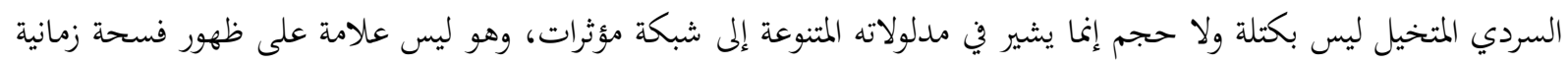

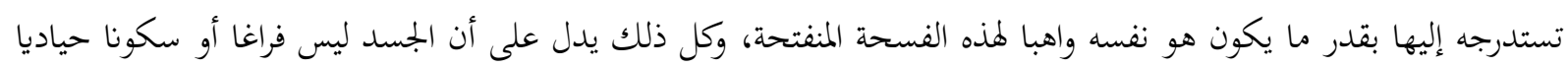

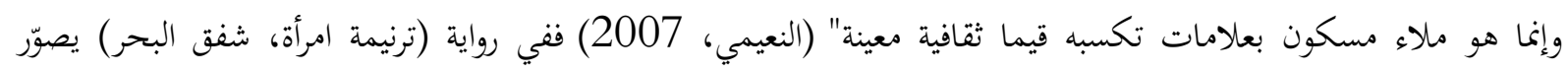

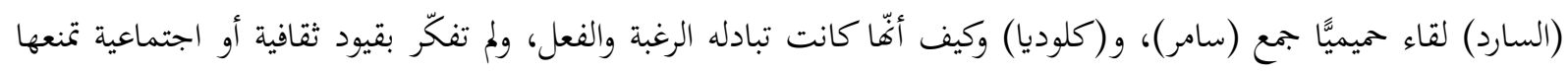

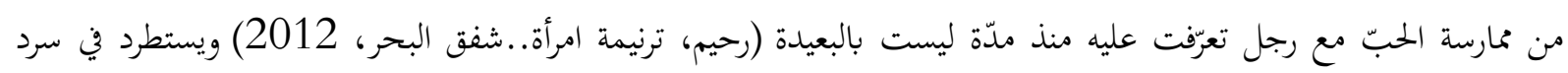

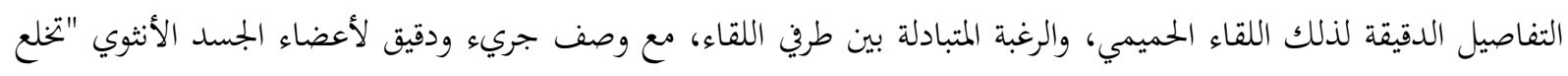

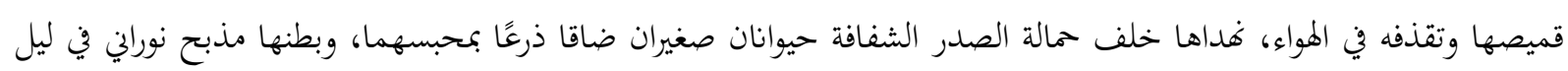

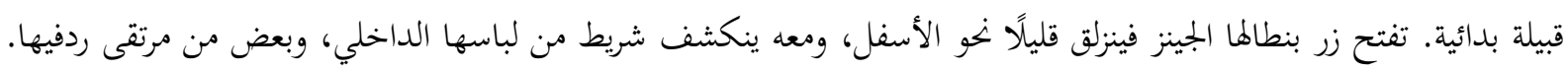

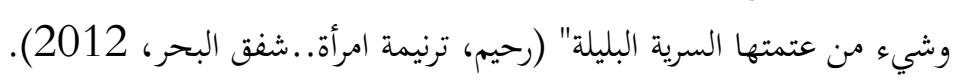

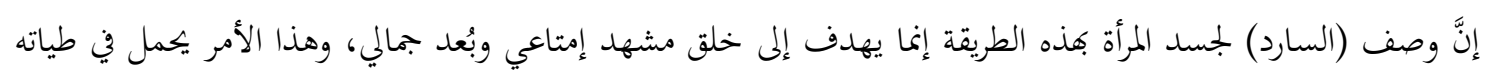

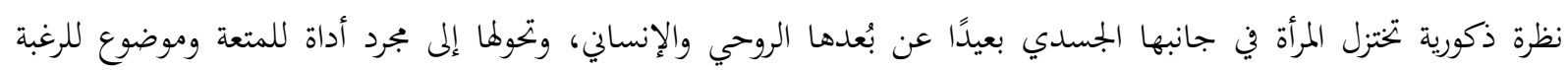
والإثارة.

\section{المرأة المومس}

قد يلجأ (السارد) إلى توظيف شخصية ما ومنها الشخصية المتهتكة، لتحقيق أهداف كتابية فقد "تشكّل الشخصية

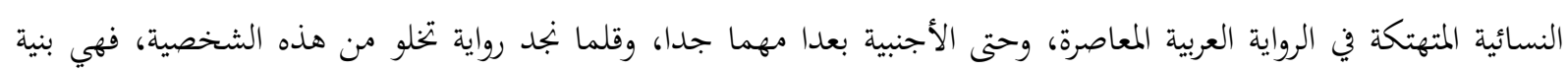

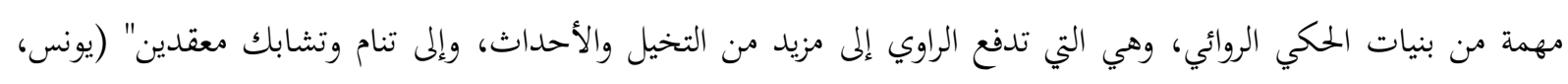

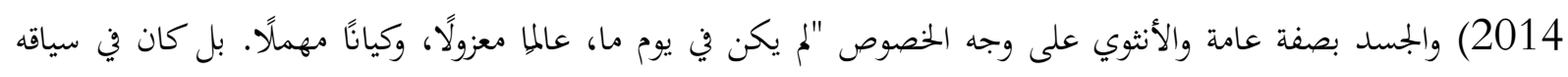

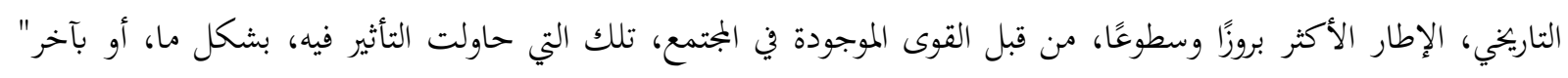

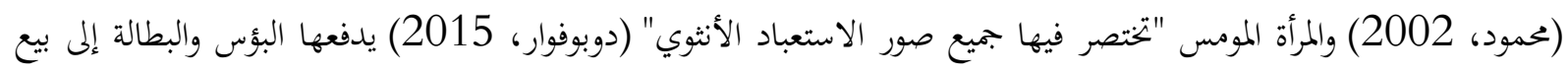

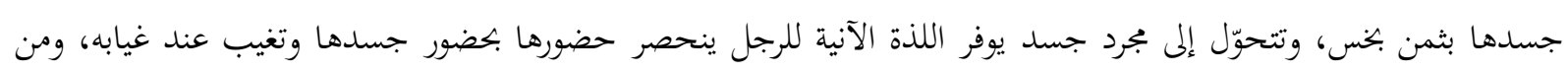

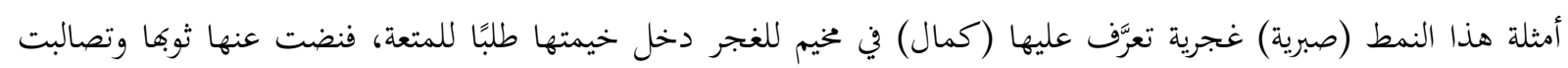

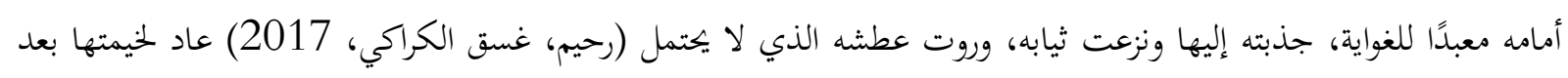

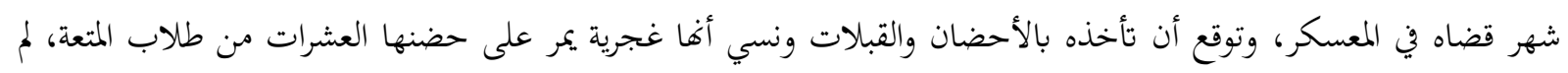

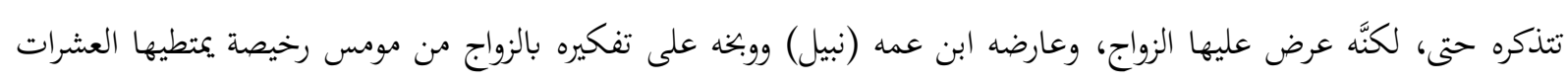

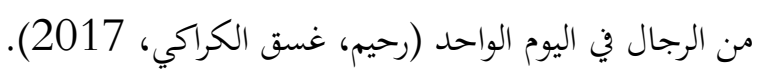

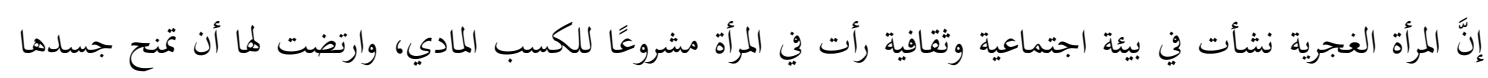

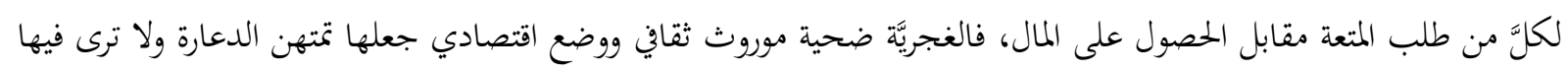

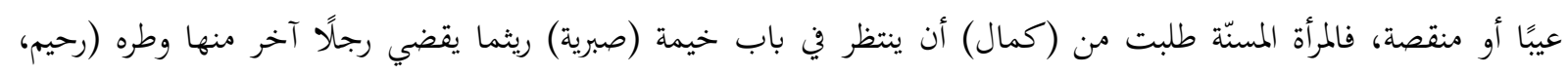
غسق الكراكي، 2017).

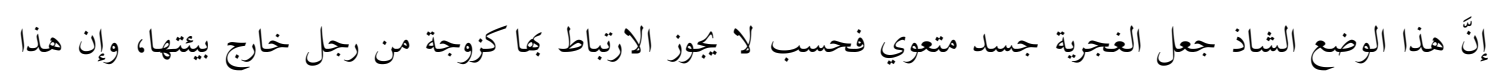

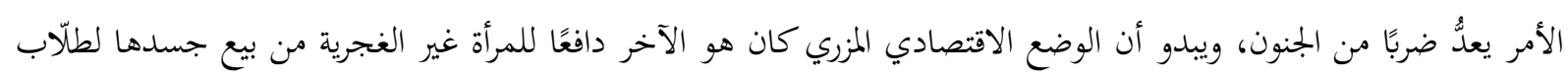

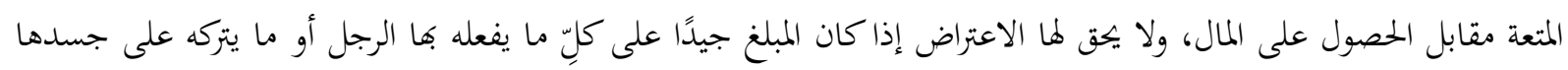


وهو في قمة نشوته الجنسية من آثار وكدمات نتيجة الضرب أو العض، فضلًا عن الشتائم والألفاظ المهينة، ليجعلها باكية تستدر

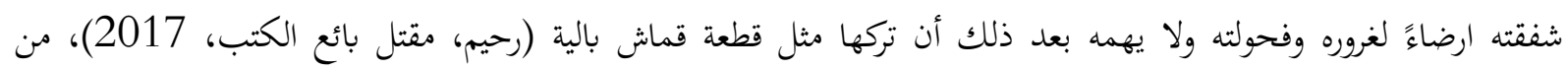

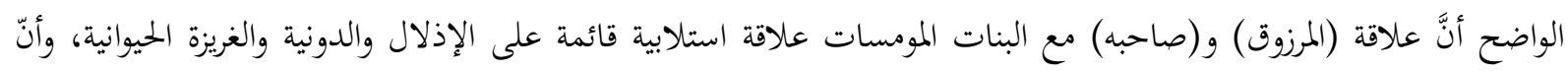

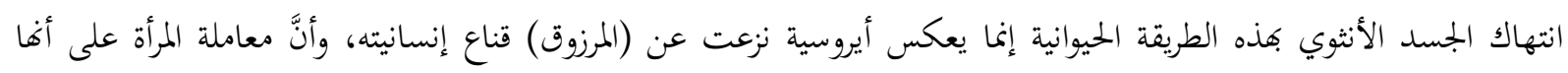

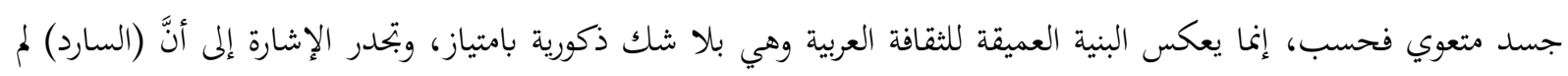

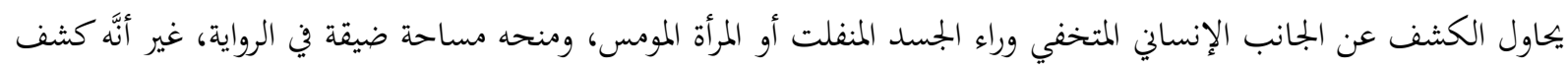

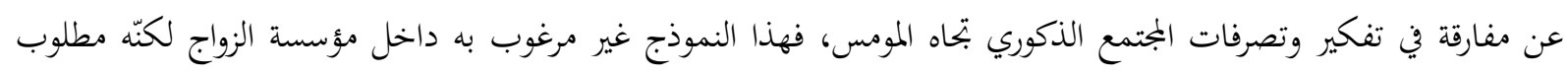
بشدة خارج أسوارها.

\section{الخاتمة ونتائج البحث}

- لم يمنح (السارد) مساحة جيدة لفكر المرأة وأدهما وثقافتها، في حين سجّل جسدها حضورًا طاغيًا في جميع روايات البحث، ولم

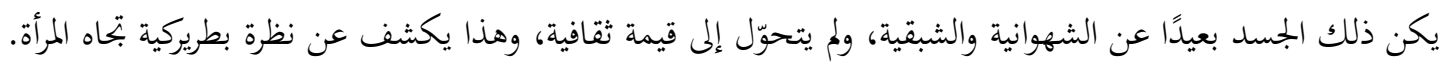

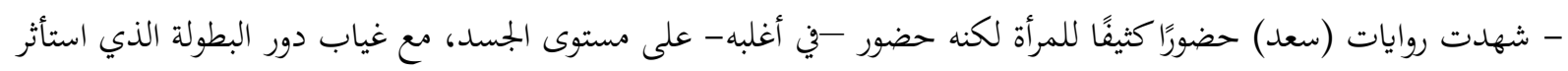
به الرجل فهو الشخصية الرئيسة والمرأة شخصية ثانوية.

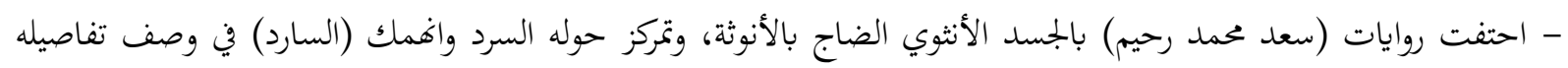
وغالبا ما كان ذلك على حساب الرواية. - حضرت المرأة في أغلب الروايات عاشقة ومعشوقة وإن ظهرت أيضا صبورة مطيعة للزوج وخائنة وأنانية، كما ظهرت أيضا في

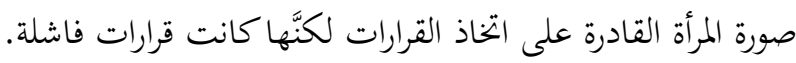
- تنوّع الحبّ في روايات (سعد محمد رحيم) بين حبّ الجسد الأنثوي والحبّ الروحي، ولكن الأول كان طاغيا على جميع الروايات،

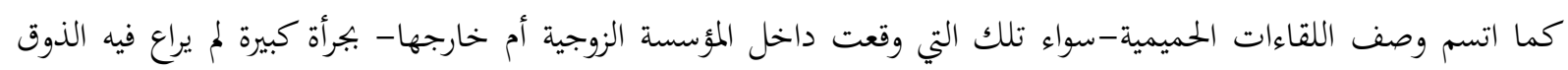

- كل الشخصيات النسائية في روايات البحث لم يكنَّ مؤثرات في محيطهن وغير مهتمات بشأن المجتمع ولا هدف لهنَّ ولا رسالة

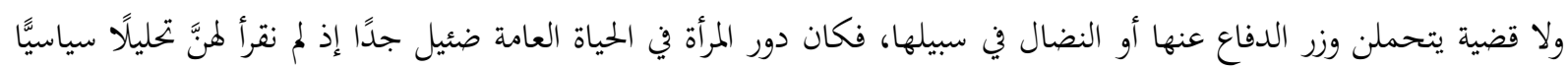

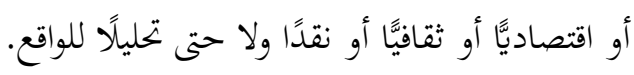
- المرأة عامل مساعد في روايات (سعد) وظل الرجل هو الفاعل وهو السارد يطوّر شخصياته بالطريقة التي يريد، فالنساء في هذه

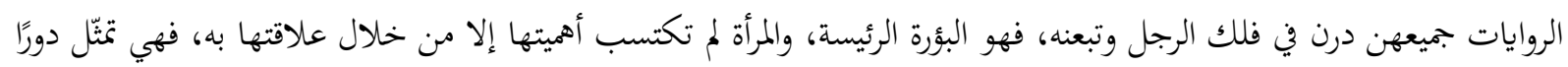

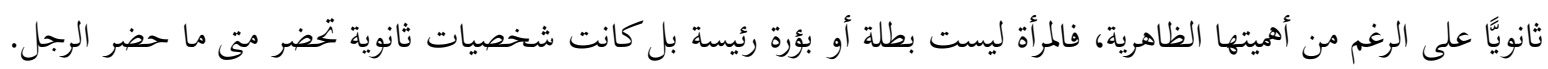
- صورة المرأة في روايات (سعد محمد رحيم) كانت نمطية وهي نتاج معطى ثقافي متجذر ولم تكن صورة جديدة.

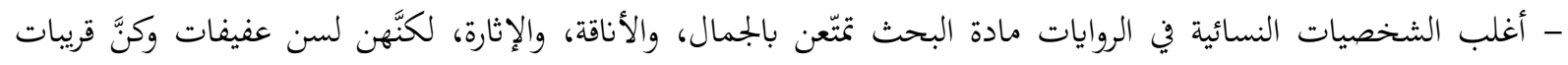
المنال.

- لم يختلف (سعد محمد رحيم) في وصف جسد المرأة عن الشعراء وربما نافسهم في نحت تمثال جسدها وبحميله فقد أبدع في وصفه حسيَّا ولم يترك وصف حتى من مناطقه الحساسة. - تمحورت روايات (سعد محمد رحيم) حول الحرب والحبّ والاحتفال بالجسد من أنوثة وفحولة. 
- في روايات (سعد محمد رحيم) لم تتنوع مهام الشخصيات النسائية ووظائفها التي قامت بها فلا أدوار سياسية ولا دينية ولا اجتماعية مع إشارات تربوية بسيطة اقتصرت على توجيه الأولاد وهذا يدل على سطوة المجتمع الذكوري الأبوي على المجتمع.

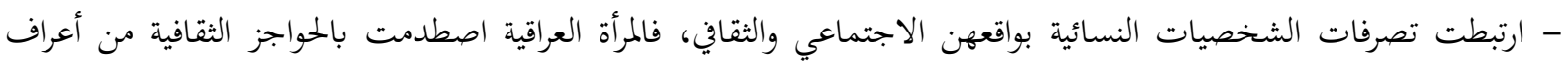

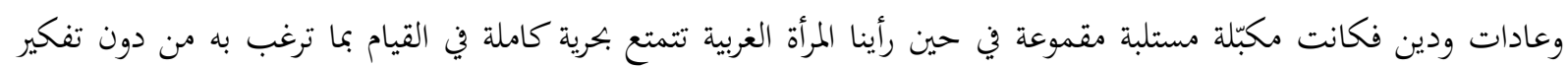
بالقيود والحواجز. - في روايات (غسق الكراكي)، و (فسحة للجنون)، و(ترنيمة امرأة، شفق البحر) نلحظ أنَّ المرأة العراقية في العقود الأخيرة

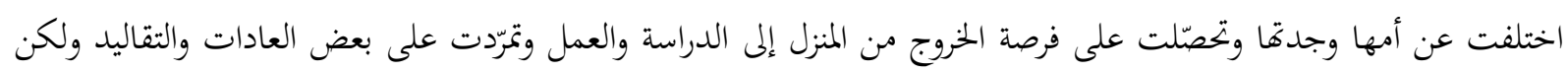

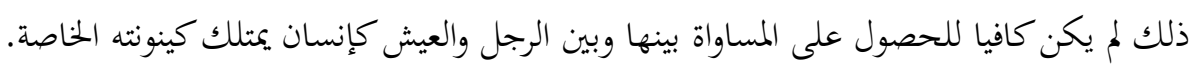

مراجع

إبراهيم محمود. (2002). جماليات الصمت في أصل المخفي والمكبوت (البملد 1). دمشق، سوريا: مركز الإنماء الحضاري. إيمان القاضي. (1992). الرواية النسوية في بلاد الشام (المجلد 1). دمشق: الأهالي للطباعة والنشر والتوزيع.

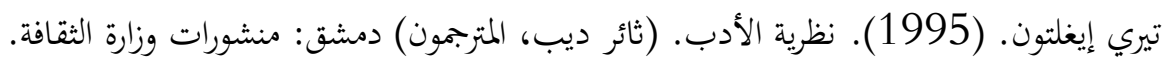

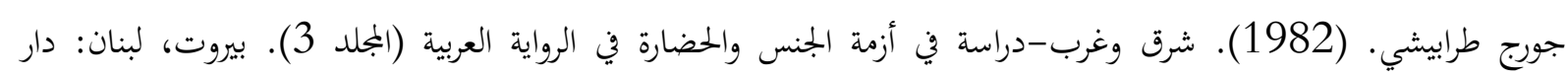
الطليعة.

حسن بحراوي. (1990). بنية الشكل الروائي (المجلد 1). بيروت، لبنان: المركز الثقافي العربي.

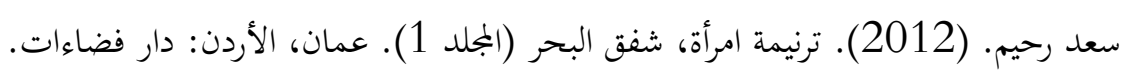

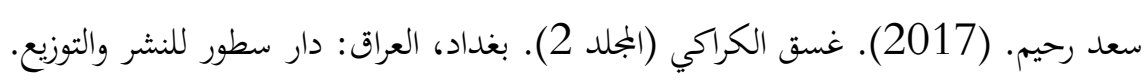

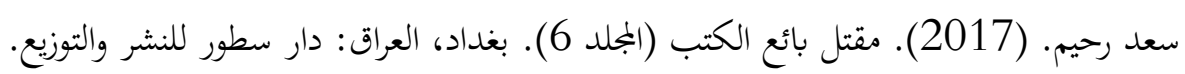

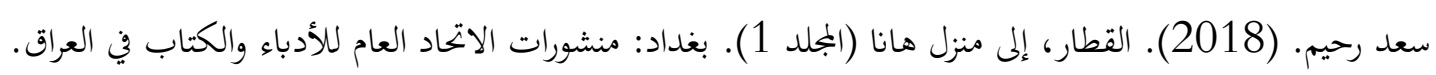
سعد رحيم. (2018). فسحة للجنون (المجلد 1). بغداد، العراق: دار سطور للطباعة والنشر.

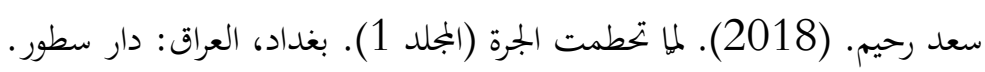

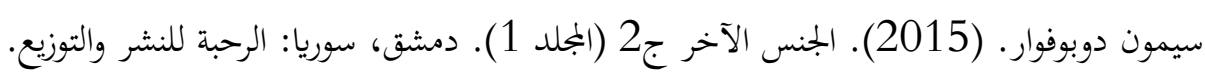

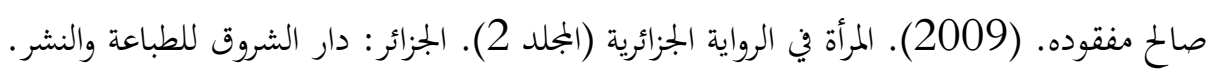

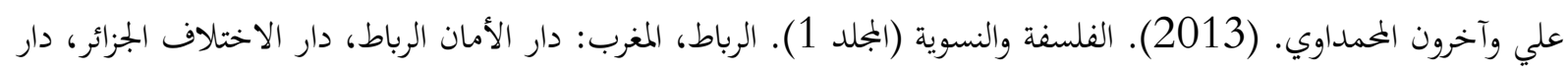

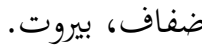

فيصل النعيمي. (23- 24 آيار, 2007). تسويق الجسد بين المتعة والنسق الثقافي مقاربة لرواية: خطوط الطول، خطوط

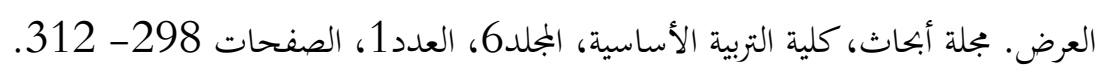

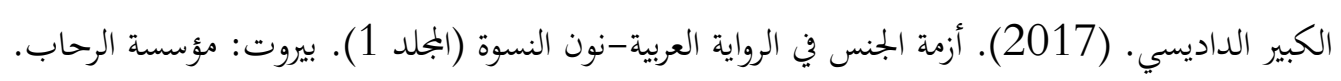
محمد عبدالمطلب. (2008). ذاكرة النقد الأدبي (المجلد 2). القاهرة: المجلس الأعلى للثقافة. محمد الغذامي. (2006). المرأة واللغة (المجلد 3). الدار البيضاء، المغرب: المركز الثقافي العربل العربي.

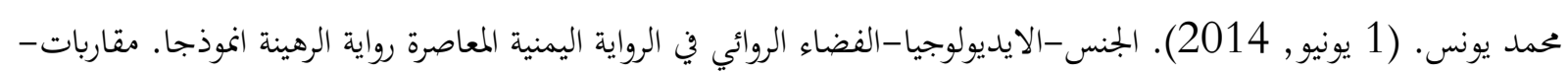
بجلة العلوم الانسانية، الصفحات 5- 36. 


\section{A POSSIBLE CORRELATION BETWEEN MYOSTATIN AND TESTOSTERONE AIDED BY GENETIC FACTORS ENHANCING ATHLETIC PERFORMANCE AND MUSCLE RECOVERY}

\section{Istanbul / Türkiye \\ p. $447-453$}

Received: 03/12/2021

Accepted: $19 / 12 / 2021$

Published: 01/01/2022

This article has been scanned I iThenticat No plagiarism detected

\author{
Abdul Razzaq Jabr AL MAJIDI ${ }^{1}$ \\ Rafia S. FATHI ${ }^{2}$ \\ Rehab S. RAMADHAN ${ }^{3}$
}

\begin{abstract}
:
Background: multiple factors can affect athletic performance including nutrition, environmental, physiological, physical fitness, and genetic factors. Hormonal factors such as testosterone, and myostatin (MSTN) or GDF8 can be named to show significant effect on muscle growth and recovery after intensive training. Illustrating the combined relationship between the latest factors may help in developing efficient program for athletic care and exceled performance.

Methods: participation in this work came from 67 male divided into two groups of 35 endurance and sprinters and 32 power athletes, with 36 females fall into two groups of 20 sprinters and 16 power athletes. Testosterone and MSTN levels were measured in both genders before, and after intensive training program followed by third measurement after 5 hours rest and recovery. The MSTN gene was analyzed for the presence of genetic polymorphism using specific PCR amplification.

Results: data obtained showed the presence of negative relationship between testosterone and MSTN, whereas genetic analysis showed presence of three genotypes with different frequencies each one of them affected MSTN with different rate ranging from normal production levels with normal function to lack of function found in power athletes showing speedup muscle recovery and higher muscle mass.

Conclusions: higher levels of testosterone reduced MSTN levels significantly showing negative correlation between them. Low expression or production of nonfunctional MSTN protein enhanced muscle recovery, higher muscle mass, and improved athletic performance.
\end{abstract}

Key words: MSTN, Testosterone, Athletic Performance, Athletic Genes.

http://dx.doi.org/10.47832/2717-8293.15.32

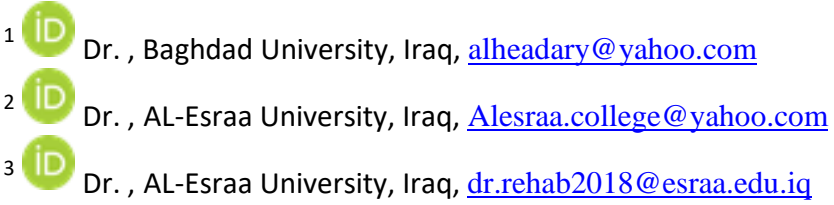




\section{Introduction}

Skeletal muscles is the system for movement, posture, and body functions that influence life and act as protein reservoir, contributing to homeostasis of blood sugar, generation of heat, metabolism regulating and health throughout life $[1,2]$. The endeavor to obtain increased lean body mass is a quest pursued by athletes practicing power sports such as football, rugby, and powerlifting. In addition, high quality and quantity of muscle mass is the critical issue among bodybuilders by which competitors are judged. On the other hand, muscle hypertrophy is also pursued by the many recreational lifters who desire to develop their physiques to the fullest. Therefore, variety of populations associated with sports and health were implicated [3]. High muscle mass is the major components for coping with various sports for the presence of strong correlation between muscle cross-sectional area and muscle strength $[4,5]$ taking in concern that correct ratio of muscle mass is an important factor from a health point of view since decreased muscle mass is associated with increased risks of several diseases such as cardiovascular disease [6,7], cardiometabolic risk in adults [8] and increased incidence of type II diabetes millets in middle aged and elderly people [9].

Myostatin, or can be named as growth-differentiation factor 8 (GDF8), is classified as member of the Transforming Growth Factor Beta (TGF- $\beta$ ) superfamily involved in wound healing, angiogenesis, immunoregulation and cancer that expressed mainly in muscle causing muscle growth inhibition [10,11]. When this factor losses its function due to gene mutations, an enhances muscle growth is initiated causing muscular hypertrophy, higher muscle mass showing no extra-muscular abnormalities, and explosive strength [12]. Few reports have evaluated serum myostatin normal levels and control in the general population associated with age, physiological status, with a drawback that it is made in small and nonrepresentative groups elaborating limited and inconsistent data. However, mechanical loading of skeletal muscle is thought to be the main and critical factors in the regulation of myostatin production $[13,14]$.

Most studies delt with testosterone considered it as one of the main anabolic hormones affecting skeletal muscle synthesis, recovery, and hypertrophy upon supplementation. It influences different physiological functions including sexual capability, systemic metabolism, cognitive function, as well as bone growth, development, and repair [15]. With its vital role in muscle growth, increased evidence that testosterone might involve in development of muscle mass in adults, adaptive growth in response to anabolic signals with increased load, maintenance of muscle mass after injury, and prevention of muscle mass loss due to cessation or lack of movement and aging [16]. However, the in skeletal muscle, testosterone found to be highly anabolic [17].

Elite athletes possess special characteristics appear to emerge from interaction among anatomical, metabolic, functional, or behavioral factors responding to exogenous influences of environmental factors [18] in addition to genetic interactions associated with physical performance. Among the many potential genes influencing athletic performance, low or lack of myostatin gene (MSTN) gene expression enhanced muscle development playing a negative role in this process whereas testosterone considered as positive regulator [19]. Genetic analysis of myostatin 5'-regulatory region, several binding sites for the androgen-receptor complex were found, giving the indication that testosterone may down-regulates the transcription of myostatin causing the reduction of myostatin content [20].

Thus, with our previous study [21], we aim to investigate the possible relationship between MSTN, testosterone, and presence of genetic polymorphism in exceled and elite athletes participated in this study.

\section{Methods}

\section{Study approval}

This study was approved by Scientific and Ethical Committee at Al-Esraa University College, Baghdad-Iraq as a part of selection program for elite athletes at the department of Physical Education.

\section{Participants}

Signed and written consent was obtained from all participants who ranged in age 18$25 \pm 5.6$ years old divided into 67 male stratified into two groups of 35 endurance and sprinters and 32 power athletes, 10 of them are local and regional championships winners, 
and 36 female fall into two groups of 20 sprinters and 16 power athletes, 3 of them with exceled winning history during local and regional tournaments. Control was 50 divided as 20 female and 30 males of the same age.

\section{Sample collection}

Blood samples of $5 \mathrm{ml}$ were collected from participants and kept in sterile tubes. Serum and WBCs were separated to be used for biochemical and genetic analysis. All samples were subjected to testosterone and MSTN measurement at the same day using Testosterone ELISA Kit (ab108666), Abcam, USA, and Human Myostatin (MSTN) ELISA Kit, Abbexa, UK respectively before and after active training session, while WBCs were the source for DNA extracted using Genaid Total DNA extraction kit, Korea as instructed by the company.

\section{MSTN gene amplification}

Four primers designed by [19] were used to cover the same sites constructing MSTN gene. PCR amplicons were resolved by $1.5 \%$ agarose for $90 \mathrm{~min}$. at field strength of $10 \mathrm{v} / \mathrm{cm}$. resulted PCR products were purified and cleaned using Favorgen PCR cleaning kit, Taiwan, then sent for sequencing by Macrogen, Korea.

\section{Data analysis}

Data obtained were subjected to statistical analysis using SPSS for windows version 21.00. $\mathrm{chi}^{2}$ was used to confirm the genotype frequencies were in Hardy-Weinberg equilibrium and comparing alleles and genotype frequencies between athletes and controls, and between athletes from different sports. Student's t-test was used for genotype indexes. Resulting data were represented by mean \pm standard deviation (SD). Differences among groups were considered as statistically significant when $p$-value was below 0.05 .

\section{Results}

Athletes are specific group among society characterized by special features such as height, power, endurance, muscularity, and tolerance to intense training. Response to training programs and intense exercise reflects it effect on body shape, muscles size, bone structure, and quantity of fats. Anthropometric data obtained from athletes studied are listed in table 1.

Table 1. Anthropometric data and phenotypic characteristics of athletes participated in the study.

\begin{tabular}{|l|l|l|l|l|}
\hline $\begin{array}{l}\text { Phenotypic } \\
\text { Characteristics }\end{array}$ & $\begin{array}{l}\text { Sprinters and Endurance } \\
\mathrm{N}=55\end{array}$ & $\begin{array}{l}\text { Power athletes } \\
\mathrm{N}=48\end{array}$ & $\begin{array}{l}\text { Control } \\
\mathrm{N}=50\end{array}$ & $\mathrm{p}$-Value \\
\hline Height, $\mathrm{cm}$ & $180.2 \pm 9.1$ & $177.8 \pm 8.7$ & $177.5 \pm 6.3$ & 0.597 \\
\hline Weight $(\mathrm{kg})$ & $72.5 \pm 10.7^{*}$ & $77.8 \pm 12.6^{*}$ & $82.6 \pm 8^{*}$ & 0.007 \\
\hline BMI $\left(\mathrm{kg} / \mathrm{m}^{2)}\right.$ & $22.2 \pm 1.6^{*}$ & $23.8 \pm 3 *$ & $27.5 \pm 4^{*}$ & 0.000 \\
\hline Body fat mass $(\mathrm{kg})$ & $8 \pm 2.2$ & $7.8 \pm 3.8$ & $10.6 \pm 2^{*}$ & 0.637 \\
\hline Muscular mass $(\mathrm{kg})$ & $39.6 \pm 8.9^{*}$ & $43.1 \pm 8.7^{*}$ & $35.2 \pm 3$ & 0.015 \\
\hline
\end{tabular}

Data recorded and analyzed were average values regardless gender and are specific to sport categories compared to control who showed specific difference to weight, BMI, and fat mass.

\section{Testosterone and MSTN measurement}

Anabolic steroid such as testosterone and muscle growth factor MSTN (GDF8) may play a key role to enhance athletic performance. With such factors available at optimum concentration, athletes may excel during sports and competitions. However, measurement of their concentration is not stable at all time, but varies due to training and need of the body to recover after intense exercise. Table 2 shows measurement of testosterone and GDF8 before and after one day training program in athletes participated in the study. 
Table 2. measurement of testosterone and MSTN (GDF8) in athletes at different periods of training program.

\begin{tabular}{|c|c|c|c|c|c|c|c|c|}
\hline & \multicolumn{4}{|c|}{ Testosterone $\mathrm{ng} / \mathrm{ml}$} & \multicolumn{4}{|c|}{ MSTN ng/ml } \\
\hline $\begin{array}{l}\text { Participants/ } \\
\text { Males } \\
\mathrm{N}=67\end{array}$ & $\begin{array}{l}\text { Before } \\
\text { exercise }\end{array}$ & $\begin{array}{l}\text { After } \\
\text { exercise }\end{array}$ & $\begin{array}{l}\text { After } 5 \\
\text { hours rest }\end{array}$ & Pvalue & $\begin{array}{l}\text { Before } \\
\text { exercise }\end{array}$ & $\begin{array}{l}\text { After } \\
\text { exercise }\end{array}$ & $\begin{array}{l}\text { After } 5 \\
\text { hours rest }\end{array}$ & Pvalue \\
\hline $\begin{array}{l}\text { Control } \\
\mathrm{N}=30\end{array}$ & $4 \pm 0.2$ & $4 \pm 0.21$ & $4 \pm 0.2$ & 0.005 & $6 \pm 0.3$ & $6 \pm 0.25$ & $6 \pm 0.27$ & 0.005 \\
\hline $\begin{array}{ll}\text { Sprinters and } \\
\text { Endurance } \\
\mathrm{N}=35\end{array}$ & $7 \pm 0.23$ & $3 \pm 1.1^{*}$ & $8 \pm 0.2 *$ & 0.005 & $5 \pm 0.7$ & $3 \pm 0.3^{*}$ & $2 \pm 0.78^{*}$ & 0.005 \\
\hline $\begin{array}{l}\text { Power athletes } \\
\mathrm{N}=32\end{array}$ & $8 \pm 0.31$ & $2 \pm 0.88^{*}$ & $9 \pm 0.1 *$ & 0.005 & $4 \pm 0.85$ & $2 \pm 0.25^{*}$ & $2 \pm 0.21 *$ & 0.005 \\
\hline $\begin{array}{l}\text { Participants/ } \\
\text { Females } \\
\mathrm{N}=36\end{array}$ & $\begin{array}{l}\text { Before } \\
\text { exercise }\end{array}$ & $\begin{array}{l}\text { After } \\
\text { exercise }\end{array}$ & $\begin{array}{l}\text { After } 5 \\
\text { hours rest }\end{array}$ & Pvalue & $\begin{array}{l}\text { Before } \\
\text { exercise }\end{array}$ & $\begin{array}{l}\text { After } \\
\text { exercise }\end{array}$ & $\begin{array}{l}\text { After } 5 \\
\text { hours rest }\end{array}$ & $\mathrm{P}$ value \\
\hline $\begin{array}{l}\text { Control } \\
\mathrm{N}=20\end{array}$ & $2 \pm 0.19$ & $2 \pm 0.21$ & $2 \pm 0.2$ & 0.005 & $7 \pm 0.33$ & $7 \pm 0.35$ & $7 \pm 0.37$ & 0.005 \\
\hline $\begin{array}{l}\text { Sprinters and } \\
\text { Endurance } \\
\mathrm{N}=20\end{array}$ & $3 \pm 0.23$ & $1 \pm 1.13 *$ & $4 \pm 0.3^{*}$ & 0.005 & $7 \pm 0.7$ & $4 \pm 0.5^{*}$ & $4 \pm 0.78 *$ & 0.005 \\
\hline $\begin{array}{l}\text { Power athletes } \\
\mathrm{N}=16\end{array}$ & $4 \pm 0.31$ & $2 \pm 0.6^{*}$ & $6 \pm 0.14^{*}$ & 0.005 & $6 \pm 0.85$ & $4 \pm 0.25^{*}$ & $3 \pm 0.98^{*}$ & 0.005 \\
\hline
\end{tabular}

Control in both genders were listed for comparison. None of them performed any exercise causing stress on their body.

\section{Genetic analysis and detection of polymorphism in MSTN gene}

The GDF8 maintains three coding exons responsible for MTCN production. We successfully amplified all three exons with partial sequence of intron 1. Blast results of obtained sequences showed exon 1 without change whereas point mutation at intron 1 at position 88-90 bp referred to as rs 11333758 where c.373+90delA. This SNP varied according to the allele and can be classified as wild type positive homozygous where both DNA strands kept (A) nucleotide, heterozygous where one (A) nucleotide is deleted, and negative homozygous where the (A) nucleotide is missing in both alleles. Functionality of this SNP was not widely reported [22]. Allele distribution and genotype of rs11333758 SNP among participants is illustrated in table 3 .

Table 3. allele distribution and genotype of rs11333758 SNP in athletes and control.

\begin{tabular}{|c|c|c|c|c|c|c|c|c|}
\hline \multirow[t]{2}{*}{ Groups } & \multirow[t]{2}{*}{$\mathrm{N}$} & \multicolumn{2}{|c|}{$\begin{array}{l}\text { Allele Frequency } \\
(\%)\end{array}$} & \multirow[t]{2}{*}{$\begin{array}{l}\text { p-Value Compared with } \\
\text { Control }\end{array}$} & \multicolumn{3}{|c|}{$\begin{array}{lr}\text { Frequency } & \text { percentage of } \\
\text { GDF8 } & \text { c.373+90delA } \\
\text { Genotype } & \end{array}$} & \multirow[t]{2}{*}{$\begin{array}{l}\mathrm{p} \text {-Value } \\
\text { Compared } \\
\text { with Control }\end{array}$} \\
\hline & & $\mathrm{A}$ & - & & AA & $\mathrm{A} /-$ & $(-1-)$ & \\
\hline Control & 50 & 85.5 & 14.5 & - & $\begin{array}{l}88 \\
(69.3)\end{array}$ & $\begin{array}{l}38 \\
(29.9)\end{array}$ & $\begin{array}{l}1 \\
(0.8)\end{array}$ & - \\
\hline $\begin{array}{l}\text { Sprinters and } \\
\text { Endurance }\end{array}$ & 55 & 73.6 & 26.4 & 0.014 & 57.8 & 29.6 & 13.6 & 0.001 \\
\hline Power athletes & 48 & 76.0 & 24.0 & 0.140 & 64.7 & 28.5 & 6.8 & 0.060 \\
\hline
\end{tabular}

Significant differences were also found in genotype frequencies in relation to gender listed in table 4.

Table 4. difference in allele frequency within the same gender.

\begin{tabular}{|l|l|l|l|l|}
\hline & AA (\%) & A/- (\%) & $(-/-)(\%)$ & \\
\hline Male athletes & 65.3 & 25.7 & 9.0 & 0.032 \\
\hline Control & 64.7 & 35.3 & 0 & \\
\hline Female athletes & 54.8 & 34.1 & 11.1 & 0.037 \\
\cline { 1 - 3 } Control & 74.6 & 23.7 & 1.7 & \\
\hline
\end{tabular}

\section{Discussion}


Among genetic factors affecting athletic performance, MSTN (GDF8) drew attention since it represents the negative control over muscles growth and exerts its influence on adipose tissues influencing human physical activity [23]. Among many factors affecting athletic performance such as nutrition, environmental factors, physiological factors, neural and cardiac fitness, anabolic hormones come to play a key role with their direct influence on muscles fiber synthesis and recovery from intensive training. It seems there is a relationship between MSTN and testosterone in enhancing athletic performance. During our study we found there is a significant decrease in testosterone levels and MSTN in athletes after intensive training which can be attributed to the need of body to increase energy levels within cells to cope with stress of exercise. However, data obtained after 5 hours of rest showed high elevation of testosterone in participants with continued lowering of MSTN suggesting negative relationship between them. With such relationship exist, the body can speedup recovery period and produce higher muscle mass as training program continues. This can be considered as crucial factor differentiating elite athletes from the others in future selection programs.

From another point of view, genetic factors have been considered during the research. The main focus on MSTN gene analysis showed a significant difference between athletes and control. Comparing deletion rate between control and athletes, we found it is higher in athletes $29.0 \%$ than control group $14.0 \%$, especially in endurance athletes which was $38.2 \%$ $(\mathrm{p}<0.05)$. The negative homozygous genotype $(-/-)$ was significantly higher in endurance athletes rated $23.5 \%$ and in power athletes measured to be $10 \%$ than in the controls with respect to gender $(\mathrm{p}<0.05)$. Presence of the novel SNP rs 11333758 in athletic group suggest exceled endurance performance status in elite athletes and seems to be more frequent in Iraqi athletes. Previous reports showed that this SNP is associated with production of peak power during muscle contractions [24], thicker biceps [25], and low body fat [23].

\section{Conclusions}

We found during this work the presence of negative relationship between testosterone and MSTN (GDF8). An elevated concentration of testosterone lowered significantly MSTN levels in blood allowing faster muscle recovery and synthesis of more muscle fibers for bigger muscles. With presence of different alleles of MSTN gene, the null genotype was the least percentage among athletes, but associated with increasing muscle size and enhancing athletic performance. This genotype was significantly higher in male athletes than females, and in general higher in athletes compared to control. 


\section{References}

Richter EA, Hargreaves M. Exercise, GLUT4, and Skeletal Muscle Glucose Uptake. Physiol Rev [Internet]. 2013;93(3):993-1017. Available from: http://physrev.physiology.org/cgi/doi/10.1152/physrev.00038.2

Bonaldo P, Sandri M. Cellular and molecular mechanisms of muscle atrophy. Dis Model Mech [Internet]. 2013;6(1):25-39. Available from: http:/ / www.pubmedcentral.nih.gov/articlerender.fcgi?artid=3529336\&tool $=$ pmcentrez\&rendertype $=$ abstract

Maughan, RJ, Watson, JS, and Weir, J. Strength and cross-sectional area of human skeletal muscle. J Physiol 338: 37-49, 1983.

Herman, J.R.; Rana, S.R.; Chleboun, G.S.; Gilders, R.M.; Hageman, F.C.; Hikida, R.S.; Kushnick, M.R.; Ragg, K.E.; Staron, R.S.; Toma, K. Correlation Between Muscle Fiber Cross-Sectional Area and Strength Gain Using Three Different ResistanceTraining Programs In College-Aged Women. J. Strength Cond. Res. 2010, 24, 1.

Jones, E.J.; Bishop, P.A.; Woods, A.K.; Green, J.M. Cross-Sectional Area and Muscular Strength: A Brief Review. Sports Med. 2008, 38, 987-994.

Hackett, D.A.; Johnson, N.A.; Chow, C.M. Training Practices and Ergogenic Aids Used by Male Bodybuilders. J. Strength Cond. Res. 2013, 27, 1609-1617.

Srikanthan, P.; Horwich, T.B.; Tseng, C.H. Relation of Muscle Mass and Fat Mass to Cardiovascular Disease Mortality. Am. J. Cardiol. 2016, 117, 1355-1360.

Burrows, R.; Correa-Burrows, P.; Reyes, M.; Blanco, E.; Albala, C.; Gahagan, S. Low muscle mass is associated with cardiometabolic risk regardless of nutritional status in adolescents: A cross-sectional study in a Chilean birth cohort. Pediatr. Diabetes 2017, 18, 895-902.

Michal Krzysztofik, Michal Wilk, Grzegorz Wojdała and Artur Goła's. Maximizing Muscle Hypertrophy: A Systematic Review of Advanced Resistance Training Techniques and Methods. Int. J. Environ. Res. Public Health 2019, 16, 4897; doi:10.3390/ijerph 16244897.

McPherron AC, Lawler AM, Lee SJ 1997 Regulation of skeletal muscle mass in mice by a new TGF- $\beta$ superfamily member. Nature. 387:83-90.

Rodgers BD, Garikipati DK 2008 Clinical, agricultural, and evolutionary biology of myostatin: a comparative review. Endocr Rev. 29:513-534.

Schuelke M, Wagner KR, Stolz LE, Hu" bner C, Riebel T, Ko" men W, Braun T, Tobin JF, Lee SJ 2004 Myostatin mutation associated with gross muscle hypertrophy in a child. N Engl J Med 350:2682-2688.

Szulc P., Schoppet M., Goettsch C., et al. Endocrine and Clinical Correlates of Myostatin Serum Concentration in Men-the STRAMBO Study. J Clin Endocrinol Metab, 2012, 97(10):3700 -3708.

Kawada S, Tachi C, Ishii N (2001) Content and localization of myostatin in mouse skeletal muscles during aging, mechanical unloading and reloading. J Muscle Res Cell Motil 22: 627-633

Clay C a, Perera S, Wagner JM, Miller ME, Nelson JB, Greenspan SL. Physical function in men with prostate cancer on androgen deprivation therapy. Phys Ther. 2007;87(10):1325-33.

Shin MJ, Jeon YK, Kim IJ. Testosterone and Sarcopenia. World J Mens Health. 2018;36(3):192.

Arik Davidyan, Keith Baar, Sue C. Bodine. The Maintenance of Muscle Mass Is Independent of Testosterone in Adult Male Mice. bioRxiv, 2020: https://doi.org/10.1101/2020.09.24.311266

Filonzi, L.; Franchini, N.; Vaghi, M.; Chiesa, S.; Marzano, F.N. The potential role of myostatin and neurotrans mission genes in elite sport performances. J. Biosci. 2015, 40, 531-537.

Ginevi`cien'e V., Jakaitien'e A., Pranckevi`cien'e E., Milašiusand K. and Utkus A. Variants in the Myostatin Gene and Physical Performance Phenotype of Elite Athletes. Genes 2021, 12, 757.https://doi.org/10.3390/genes12050757.

Kawada S., Okuno M. and Ishii N. Testosterone Causes Decrease in the Content of Skeletal Muscle Myostatin. International Journal of Sport and Health Science Vol.4, 4448, 2006. http://www.soc.nii.ac.jp/jspe3/index.htm.

Abdul Razzaq Jabr Al Majidi, Rafia S. Fathi, Rehab S. Ramadhan. A molecular insight in sport and athletic alpha - actin3 gene in students of Physical Education Faculty 
and bodybuilders. Periodicals of Engineering and Natural Sciences. 2021, Vol. 9, No. 3, pp.699-714.

Karlowatz, R.J.; Scharhag, J.; Rahnenführer, J.; Schneider, U.; Jakob, E.; Kindermann, W.; Zang, K.D. Polymorphisms in the IGF1signalling pathway including the myostatin gene are associated with left ventricular mass in male athletes. Br. J. Sports Med. 2011, 45, 36-41.

Guo T., McPherron A. C., Jou W., Chanturiya T., Portas J., Gavrilova O. Myostatin Inhibition in Muscle, but Not Adipose Tissue, Decreases Fat Mass and Improves Insulin Sensitivity. PLoS ONE, 2009. Volume 4 (3): e4937.

Santiago, C.; Ruiz, J.R.; Rodriguez-Romo, G.; Fiuza-Luces, C.; Yvert, T.; Gonzalez Freire, M.; Gómez-Gallego, F.; Morán, M.; Lucia, A. The K153R polymorphism in the myostatin gene and muscle power phenotypes in young, non-athletic men. PLoS ONE 2011, 6, e16323.

Khanal, P.; He, L.; Herbert, A.J.; Stebbings, G.K.; Onambele-Pearson, G.L.; Degens, H.; Morse, C.I.; Thomis, M.; Williams, A.G. The Association of Multiple Gene Variants with Ageing Skeletal Muscle Phenotypes in Elderly Women. Genes $2020,11,1459$. 


\title{
GENERAL LINGUISTIC DICTIONARY DESCRIPTIVE STUDY
}

\author{
Omar Hassan RASHID ${ }^{1}$ \\ Waqas Saadi GHARKAN ${ }^{2}$
}

\section{Istanbul / Türkiye \\ p. 454-472}

Received: $14 / 12 / 2021$

Accepted: 20/12/2021

Published: 01/01/2022

This article has been scanned I iThenticat No plagiarism detected

\begin{abstract}
:
The first antecedents in the service of the language of the Holy Qur'an were serious about learning, teaching and compilation. They exerted extraordinary efforts that reflected an organized mentality, sincerity and unparalleled dedication which impressed the whole world. These efforts included the linguistic part of the language, its morphology, phonetics and dictionary, and they have in each aspect fruitful studies and precedent and informed opinions.

There are several aspects that have contributed to the admission of linguistics into modern Arab culture. Of these, sending Arab scholarships to western universities; conducting university studies and thesis by Arab students in European and American universities; establishing a special section in linguistics in some Arab universities; the emergence of linguistic writings known as modern linguistics; the emergence of Arabic translations of some linguistic articles; the organization of local and international scientific seminars and meetings in the field of linguistics; and the establishment of self-list specialties in general linguistics.

However, it is no wonder that others add up to the achievements of the antecedents of theories that deal with linguistic studies, and extract meanings from beyond the linguistic text, all of which is related to the renaissance witnessed by other sciences in the modern era, and which linguists have benefited from in the linguistic field.

Some linguists have collected the terms that have emerged from modern linguistic literature, who have varied in their approaches in arranging these terms. I have chosen five of these general linguistic dictionaries and addressed them in description and analysis, indicating the differences amongst them and what distinguishes each from others.
\end{abstract}

Key words: Linguistics, Culture, Phonetics.

http://dx.doi.org/10.47832/2717-8293.15.33

1 Dr. , Baghdad Education Directorate, Iraq

2 iD Dr. , Imam Azam University College, Iraq, w__87s@icloud.com, https://orcid.org/0000-0001-5538-023X 


\section{المعجم اللسالي العام دراسة وصفية}

\section{عمر حسن رشيد 3 \\ وقاص سعدي غركان}

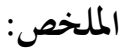

قد جادتُ أقلام الاوائل في خدمة لغة القرآن تعلّما وتعليما وتأليفا، فوردت عنهم جهود متميزة، تنمُّ عن عقلية منظمة، وإخلاص وتفالٍ منقطع النظير أهرت القاصي والداني، وقد شملت هذه الجهود نحو اللغة وصرفها وصوتها ومعجمها، ولمم في كل جانب من هذه الجوانب دراسات مثمرة، وآراء متقدمة وواعية.

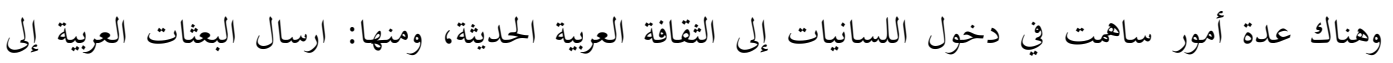
الجامعات الغربية، والقيام بدراسات جامعية واطروحات من قبل طلاب عرب في الجامعات الاوربية والامريكية، وانشاء كرسي خاص بعلم للغة في بعض الجامعات العربية، وظهور كتابات لغوية تعرف بعلم اللغة الحديث، وظهور ترجمة عربية لبعض المقالات اللسانية، وتنظيم ندوات ولقاءات علمية محلية ودولية في بجال اللسانيات، وانشاء تخصصات قائمة الذات في اللسانيات العامة ولكن ليس عجبا أن يزيد الآخرون على ما جاء به الأولون من نظريات تعنى بدراسة اللغة، وتستخرج ما وراء

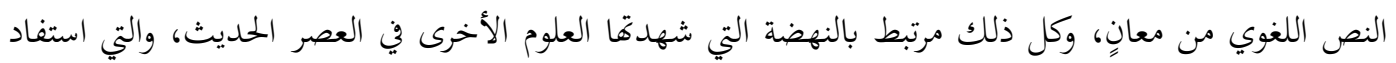
منها المختصون بالمجال اللغوي. وقد هض بعض الباحثين بجمع المصطلحات التي استجدت من المؤلفات اللغوية الحديثة، وهم متباينون في المناهج التي اتبعوها في ترتيب هذه المصطلحات، وقد وقفت على خمسة من هذه المعاجم اللسانية العامة، فتناولتها بالوصف والتحليل مبينًا الفرق بينها وما يميز بعضها على الآخر. الكلمات المفتاحية: اللسانيات، اللغة، المصطلحات.

قد جادتُ أقلام الاوائل في خدمة لغة القرآن تعلّما وتعليما و تأليفا، فوردت عنهم جهود متميزة، تنمُّ عن عقلية منظمة، وإخلاص وتفانٍ منقطع النظير أهرت القاصي والداني، وقد شملت هذه الجهود نحو اللغة وصرفها وصوقا ومعجمها، ولهم في كل جانب من هذه الجوانب دراسات مثمرة، وآراء متقدمة وواعية.

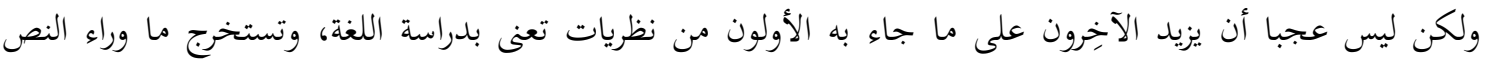
اللغوي من معانٍ، وكل ذلك مرتبط بالنهضة التي شهدما العلوم الأخرى في العصر الحديث، والتي استفاد منها المختصون بالمجال

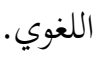


وقد هض بعض الباحثين بجمع المصطلحات التي استجدت من المؤلفات اللغوية الحديثة، وهم متباينون في المناهج التي

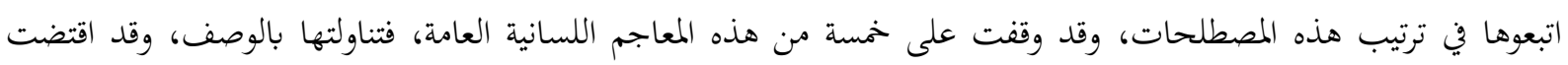
طبيعة المادة أن أسرد المعاجم بشكل متسلسل تسبق الدراسة الوصفية مقدمة وتختمها خاتمة البحث. وجاء المبحث الأول بنظرة تاريخية موجزة في اللسانيات ومعاجمها، واشتمل المبحث الثاني على وصف عامّ للمعاجم، بينما

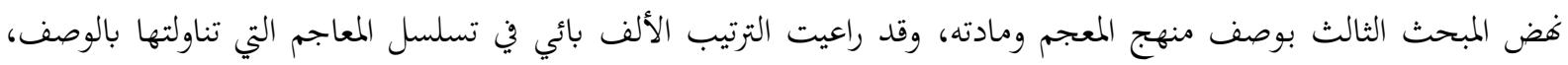
وأعطيت كل معجم رقم، ابتداء برقم (1) وانتهاء بالرقم (5)، وذكرت ما يندرج تحته من تفصيلات عامة، وتفصيلات منهجية. 


\section{المبحث الأول}

\section{نظرة تاريخية في اللسانيات ومعاجمها}

تعدّ اللسانيات من العلوم الحديثة، ويرجع تاريخها إلى القرن التاسع عشر (لأنه شهد ثلاثة منعطفات كبرى في مسيرة هذا

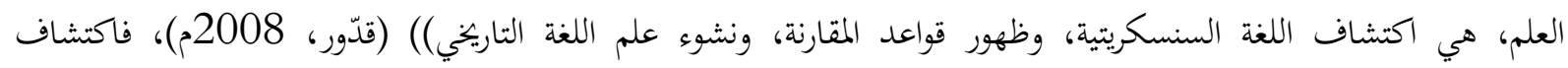

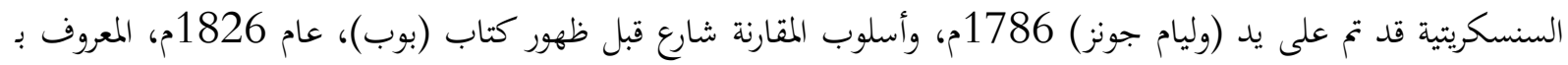
(في نظام تصريف اللغة السنسكريتية ومقارنته بالأنظمة الصرفية المعروفة في اللغات اليونانية واللاتينية والفارسية والجرمانية)، وأبرز مجال عرف أسلوب المقارنة هو علم التشريح وعلم الحياة، واهتم غريم ودييز وشليشر بوضع القواعد التاريخية، ولم يكن الفرق واضحا

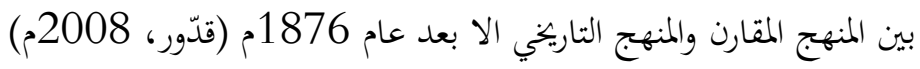

ولم تأخذ اللسانيات في الوطن العربي حقها من العناية في الدرس اللغوي؛ لأن الاعتقاد السائد ((أن مشكل المعطيات

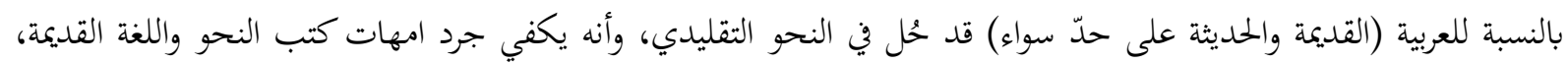

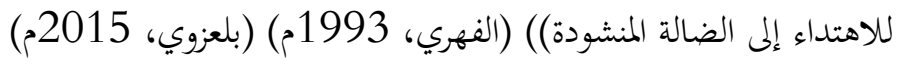

وذهب بعض الدارسين العرب أن اللغة العربية انفردت بخصائص لا توجد في لغات أخرى، وعلى هذا الأساس لا يمكن

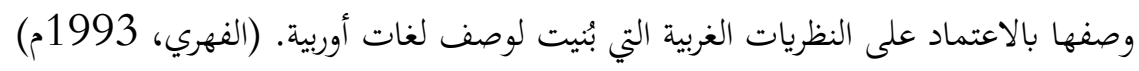
وهناك عدة أمور ساهمت في دخول اللسانيات إلى الثقافة العربية الحديثة، ومنها: ارسال البعثات العربية إلى الجامعات الغربية، والقيام بدراسات جامعية واطروحات من قبل طلاب عرب في الجامعات الاوربية والامريكية، وانشاء كرسي خاص بعلم العاد للغة في بعض الجامعات العربية، وظهور كتابات لغوية تعرف بعلم اللغة الحديث، وظهور ترجمة عربية لبعض المقالات اللسانية، وتنظيم ندوات ولقاءات علمية محلية ودولية في مجال اللسانيات، وانشاء تخصصات قائمة الذات في اللسانيات العامة. (غلفان، $(2006$ ومن أشهر تعريفات المعجم اللساني ما ذكره الدكتور سمير استيتية بقوله: ((هو المصطلح الذي يتداوله اللسانيون، للتعبير عن أفكار ومعاني لسانية، ويمكن أن يكون مظلة بحثية تضم تحت جناحيها أعمالاً علمية تبحث في المصطلحات المبات اللسانية))

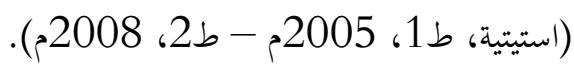

والمقصود بالمعجم العام: هو المعجم الذي يهدف إلى تغطية أكبر عدد ممكن من مفردات اللغة، وهو على العكس من

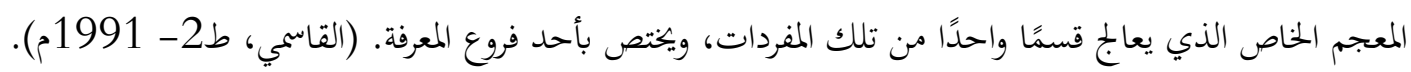
أما أشهر الجهود المعجمية العربية في اللسانيات فقد ذكر سمير ستيتية في بحثه (نو معجم لسان يشامل موحد)، بعضا من هذه الجهود، وهي (ستيتية، 1992م). 1 - نشرت الدكتورة فاطمة محجوب معجما لسانيا في اللغة الانكليزية. بعنوان:(Dictioanry of Linguistics) وقد

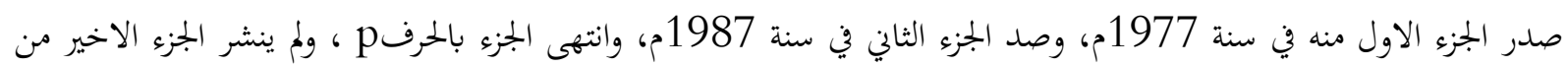

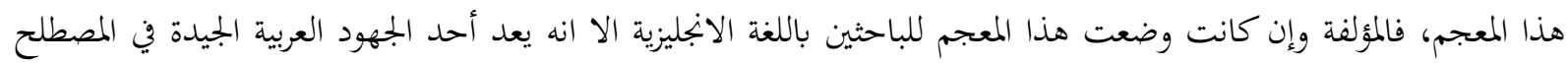
اللساني.

2 - نشر عبد الرسول شاني في الجزء الثاني من المجلد 15، من مجلة اللسان العربي معجما ثنائيا (انكليزي - عربي)، سماه: معجم علوم اللغة، وقد وصل عدد السياقات الاصطلاحية فيه ثمانئة سياق. 
3 - نشر الدكتور محمد علي الخولي في سنة 1982م، معجما من عدة معاجم وضعها، وعنوانه: (معجم علم اللغة النظري)،

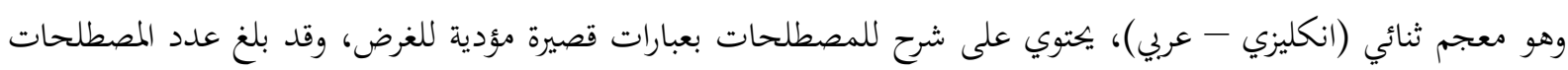
في هذا المعجم زهاء اربعة آلاف وسبعمائة مصطلح.

4 - قام مجموعة من اللغويين العرب بإعداد معجما سمّوه: (معجم مصطلحات علم اللغة الحديث) وقد نشرت دار لبنان في

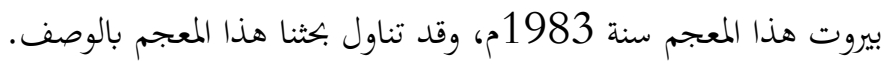
5 - وضع مكتب تنسيق التعريب في الرباط معجما لسانيا ثلاثي اللغة (انجليزي- فرنسي - عربي) في سنة 1984م، وقد جاء هذا المعجم بعنوان: (معجم علم اللسانيات). 6 - نشر الدكتور عبد السلام المسدّي (قاموس اللسانيات) مع مقدمة في علم المصطلح في سنة 1984م، وهو قاموس ثنائي (فرنسي - عربي)، قدم فيه المؤلف أربعة آلاف وثلاثمئة وخمسين مصطلحا فرنسيا، وقدم نظائرها في العربية، دون شرح لمضامينها. 7 - نشر الدكتور بسام بركة في سنة 1985م معجما لسانيا ثنائي اللغة (عربي - فرنسي) سمّاه: (قاموس اللسانية)، وقد ضم هذا المعجم ألفين ومئتي مصطلح. 8 - نشر الدكتور محمد علي الخولي في سنة 1986م، معجمه الثاني، وهو: (معجم علم اللغة التطبيقي)، وهو معجم ثنائي اللغة (انكليزي- عربي)، وهذا المعجم - كما هو واضح من عنوانه- خاص بعلم اللغة التطبيقي. 


\section{المبحث الثاني \\ وصف عام للمعاجم

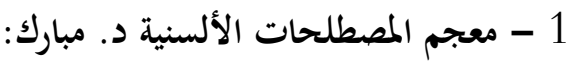 \\ أ. وصف المقدمة:}

لا تتجاوز مقدمة مبارك مبارك صفحة واحدة فقط، شرح فيها الغاية من معجمه، والمنهج الذي اتبعه، وكيفية تعامله مع

بعض العقبات التي اعترضت سبيل ولادة هذا العمل، ولاسيما تلك المترادفات المصطلحية بين العربية ونظائرها (مبارك، ط/1، 1995م)

ب. الغاية والهدف من وضع هذا المعجم:

إن الغاية من هذا العمل تنطلق من الانفتاح للمصطلح العربي على اللغتين الانكليزية والفرنسية، ولا يتوقف هدفه عند

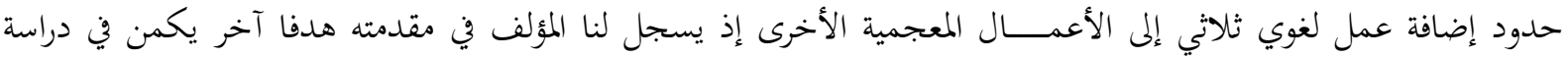
المصطلحات التي تقع تحت تأثير المعطيات الحضارية، فهذه لها أثر في تكوين تعدد للمعنى اللغوي للمصطلح دون أن يكون هناك

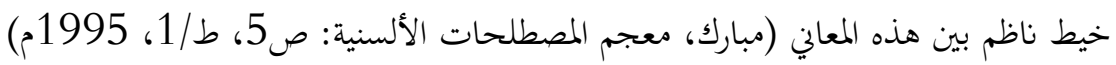

\section{2 - معجم مصطلحات علم اللغة الحديث:}

تأليف نخبة من اللغويين العرب، وهم (د.محمد حسن باكلّا، و د.محيي الدين خليل الرَّّح، و د.جورج نعمة سعد،

ود.محمود اسماعيل صيني، ود.علي القاسمي):

أ. وصف المقدمة:

وقعت مقدمة المعجم في ثمان صفحات، ذُكر فيها الغاية من تأليف المعجم، وجاء في المقدمة الحديث عن طريقة اعداد

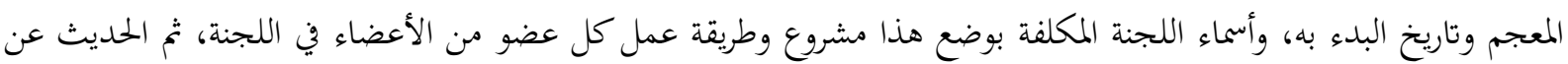

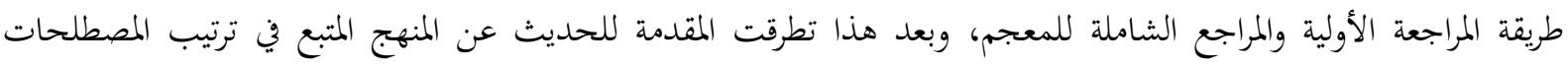

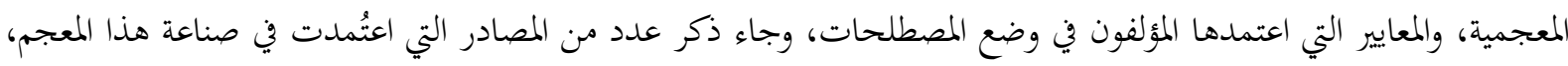

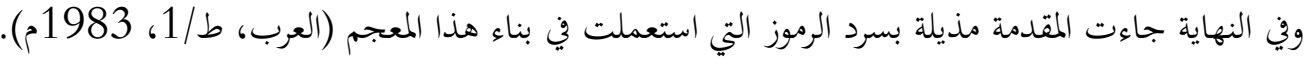

ب. الغاية والمدف من التأليف:

من الملاحظ ان الدراسات اللغوية العربية أصاها الجمود منذ العصور المتأخرة بعد إن ازدهرت في العصور الأولى، وهذا

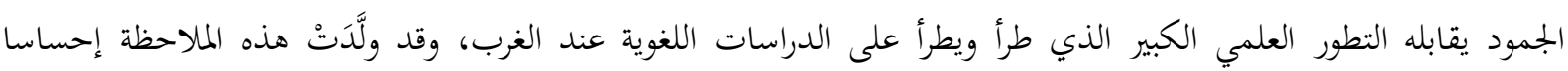

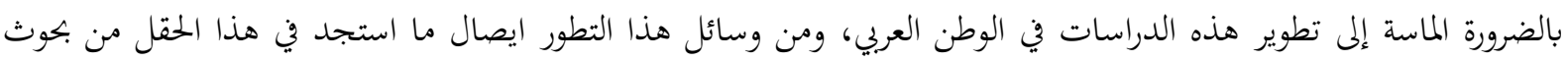

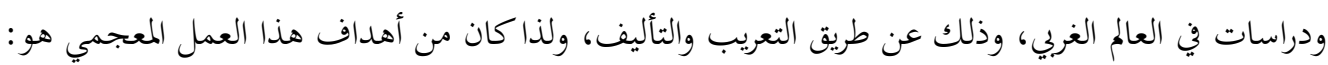
1 - المساهمة في توحيد مصطلحات علم اللغة الحديث على مستوى الوطن العربي.

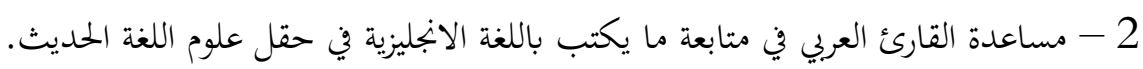
لكن كلا من التعريب والتأليف في حقل الدراسات اللغوية يواجه عقبة كبية وهي مشكلة المصطلحات العلمية لمثل هذا

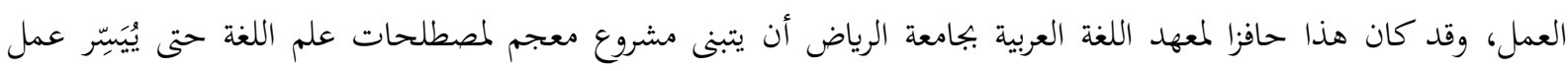

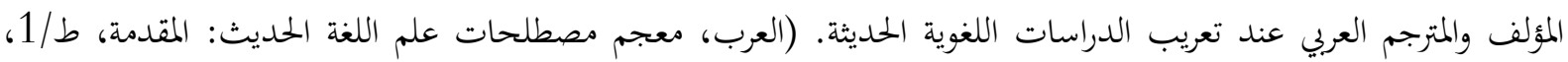




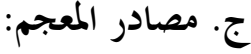

استعان الأعضاء المكلفون بوضع هذا المعجم ببعض المصادر والمسارد في بناء هذا المعجم، ومن هذه المصادر: أ_ مسارد مجمع اللغة العربية بالقاهرة الخاصة بالمصطلحات اللغوية. ب__مسرد معجم علوم اللغة (انجليزي- عربي) للدكتور عبد الرسول شاني، المنشور في مجلة اللسان العربي عام 1977م. جـــ المسارد التي وردت في الكتب الآتية: أولا: دراسة الصوت اللغوي: أحمد مختار عمر. ثانيا: علم اللغة وصناعة المعجم: علي محمد القاسي. ثالثا: علم اللغة: محمود السعران.

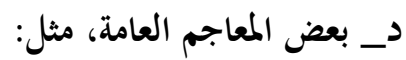
أولا - معجم المصطلحات العلمية والفنية: أحمد شفيق الخطيب. ثانيا - المورد: منير بعلبكي.

3 - معجم المصطلحات اللسانية للدكتور عبد القادر الفاسي الفهري، بمشاركة نادية العمري:

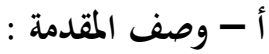

وقعت مقدمة الفاسي في صفحتين، ذكر فيها مصادر معجمه، والمنهج الذي اتبعه في بناء معجمه، وذكر موقفه من المصطلحات العربية القديمة، والمصطلحات الغربية المحيثة، ثم ذكر اسهامات الزملاء من اساتذة وطلبة في ولادة هذا المعجم، ووقف قلمه على الغاية من معجمه تلميحاً لا تصريحاً، وهي جمع المصطلحات التي انتشرت على ألسنة الطلبة والأكاديميين في

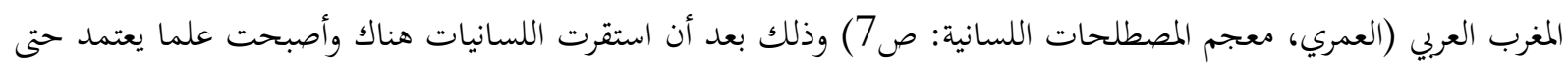

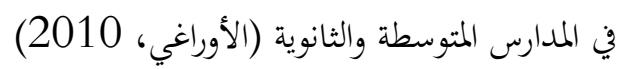
ب - مصادر المعجم: n ذكر المؤلف أن عمله هذا يمثل حصيلة خبرته في البحث والتدريس والتطبيق في الجامعات المغربية، وانه سرت على ألسنة الطلبة مفردات جديدة غالبا ما تكون مضامينها في الأدبيات الغربية، اللاتينية والأنكلوساكسونية والجرمانية، وهذه الروافد التي أمدت العربية ألفاظا ومضامين، أمدت العربية ببناءات تصورية ومعرفية وثقافية مغايرة، وبذلك أعرض المؤلف عن المصادر القديمة،

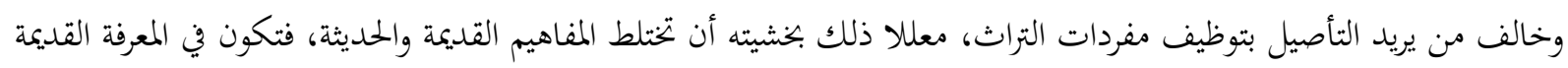
ما لا يوجد فيها، أو تحمّل المعرفة الجديدة تمثُّلات قديمة.

ولميا كانت اللسانيات في المغرب العربي تكلّمت أولا بمفردات المدرسة الوظيفية الفرنسية التي يتزعمها مارتينيه

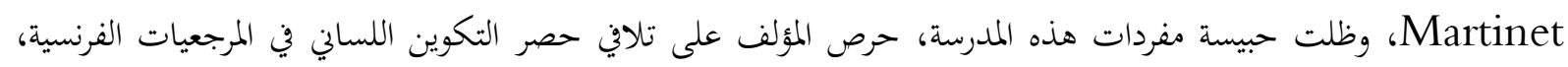
ووسع ذلك من خلال اعتماده ونظره إلى مدارس أخرى من ضمنها النحو التوليدي والتحويلي، والدلالة التصورية أو الصورية،

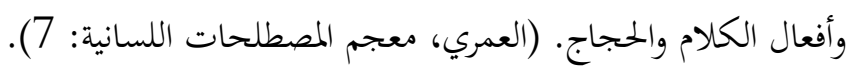




\section{4 - معجم المصطلحات اللغوية الحديثة في اللغة العربية:}

أ - أ - وصف المقدمة:

وقعت مقدمة المعجم في عشر صفحات، ذكر فيها المؤلف الغاية والهدف من هذا المعجم، وموقفه من المصطلحات القديمة، ثم ذكر المصادر التي اعتمدها في معجمه وطريقة اشارته لهذه المصادر، وأهم ما جاء في المقدمة المنهج المتبع في صناعة هذا منها المعجم وطيفية عرض المادة المعجمية (معجم المصطلحات اللغوية الحديثة في اللغة العربية:7 - 16، العدد:4، 1977مهاء 1972م). ب - الغاية والهدف من المعجم:

إن الغاية من هذا المعجم اللساني الحديث هو مواكبة كل جديد في ميادين علم اللغة، ولاسيما في القرن العشرين، فهو كما

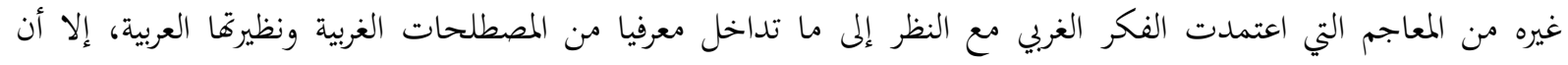
المصطلحات الغربية قد فرضت أصالتها في المجال المعرفي اللغوي مما أرغم العرب على دراستها والتعرف على كنهاتها ؛ كوها مفاتيح

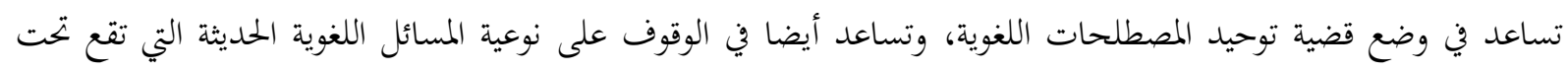

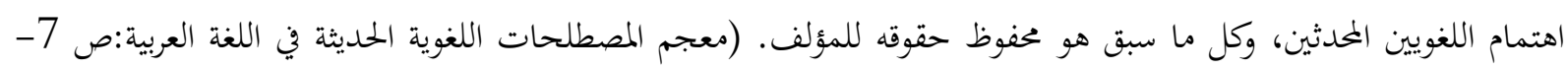

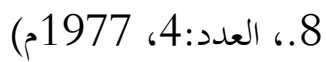
ومما تقدم نجد أن المعجم قد اعتمد على المصادر اللغوية الحديثة التي تناولت بالدرس المسائل اللغوية على ضوء علم اللغة

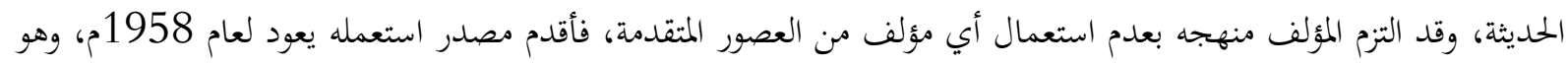

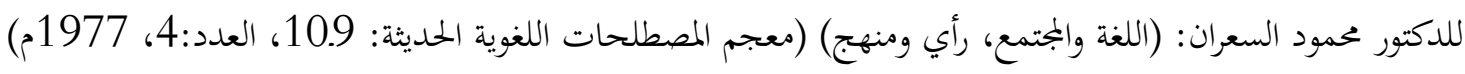
تعامل المعجم مع المصادر في إثباتها نظام الرموز، وهو قائم على ذكر الحرف الأول من اسم المؤلف وأبيه، ومثال ذلك:

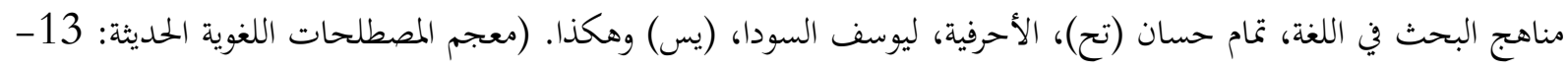

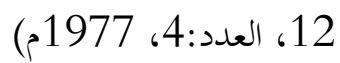

\section{5}

\section{أ - - وصف المقدمة:}

لما كان هذا المعجم موجزا كانت المقدمة موجزة أيضاً، فقد اقتصرها المؤلف في صفحتين، غير أها حوت الأسس والغاية

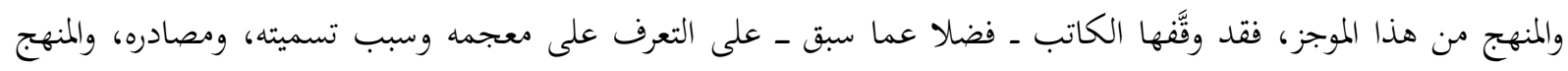
المتبع في بناء عمله. ب - الغاية والمدف من الموجز: قبل الوقوف على الغاية يجب أن نعرف سر تسميته كما يرويها المؤلف: أسميت هذا المسرد موجزا بمصطلح اللغويات،

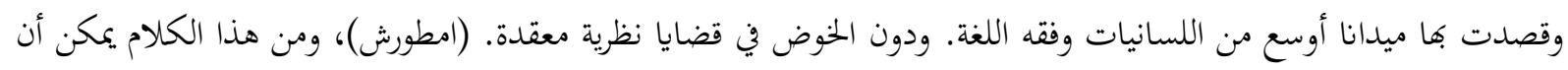

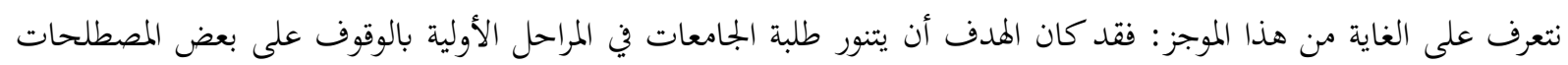

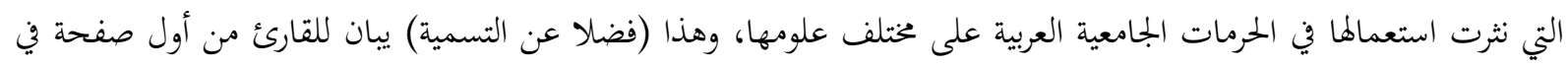

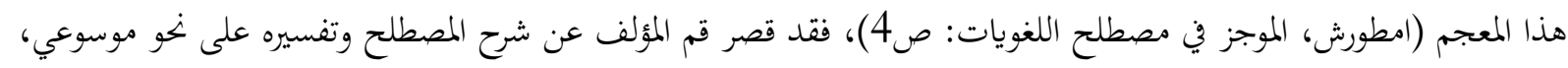
واقتصر على إيراد المصطلح وما يقابله في الانكليزية والفرنسية فقط. 


\section{ج - مصادر الموجز اللساين:}

اعتمد المؤلف في تكوين معجمه على منهج ميداني قائم على التقاط المصطلحات من مجالاتحا المعرفية الموجودة في الكتب

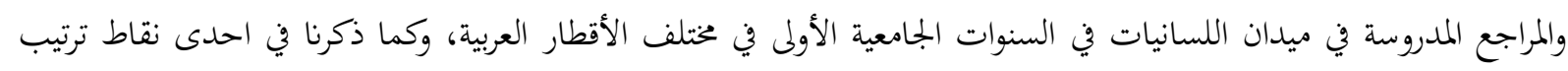

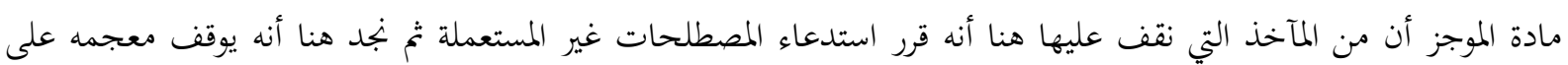

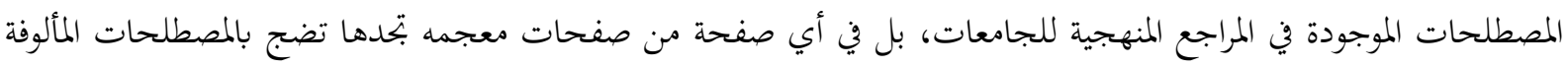
للقارئ، وإن كان لا يعرف كنهها. وكان المصطلح الغربي هو حصيلة الاستعمال الجامعي العربي له، فهذا المصطلح كان منتشرا كذلك في مظان المراجع

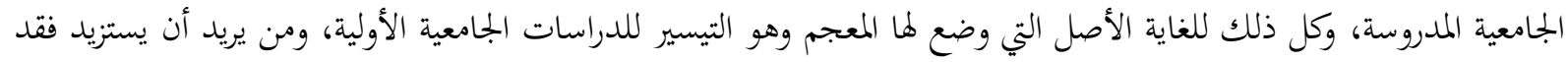

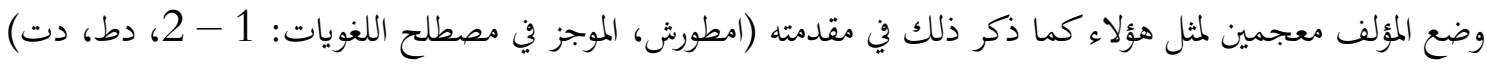


يعد هذا المعجم من المعاجم الثلاثية الوضع ( انكليزي - فرنسي ـ عربي )، لم يعتمد المؤلف أي ترتيب عربي كما هو

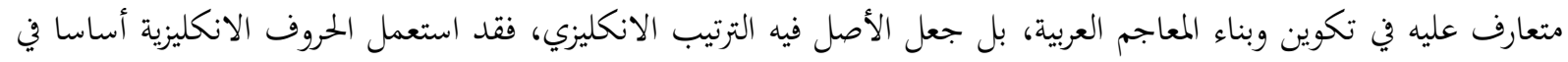

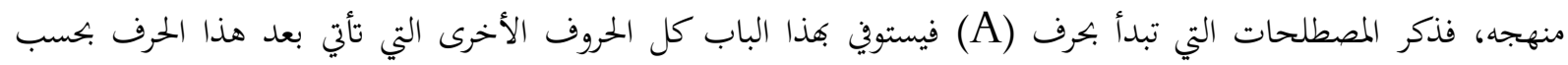

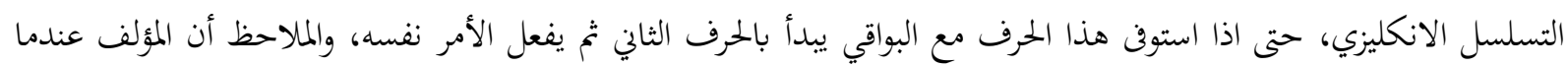
يبدأ بأي حرف فإنه يذكر معه الحروف التي تسبقه في الترتيب الانكليزي.

ب- المادة المعجمية:

الصفة الغالبة على هذا المعجم المصطلح الصوتي وكل ما يحيط به، غير أنه تناول بعض المصطلحات البلاغية واللغوية وغيرها، ولم تقتصر مصطلحاته على بناء مفردي بل تعدى بعض المصطلحات ثلاث كلمات، وبحسب الغاية من ذلك إذ أن الغاية هو زيادة التوضيح لهذه المصطلحات، ومثال ذلك: دراسة الأنظمة الكتابية، التغيير الصائتي الكبير، حركة عالية مصوت عكات عال

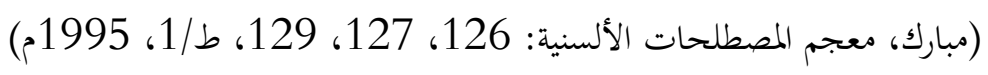

وفي بعض المصطلحات قد يستعمل بعض الروابط الحرفية بينها ولاسيما أحرف العطف، مثال ذلك: مدى ترابطي أو

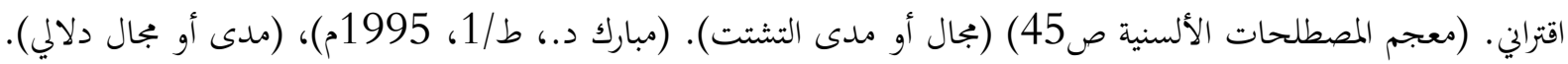

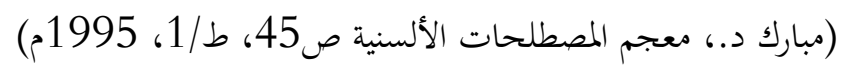

وقد يستعمل الشارحة بين المصطلحات العربية وما يقابلها في الانكليزية، ومن ثوابت العلم أن علامات التنقيط تستعمل بين ثنايا العبارة وليس الكلمة: (المدى الصري - الدلالي) (MORPHO_SEMAN)( (د.مبارك، معجم المصطلحات الألسنية: 46، ط/1، 1995م) استعمل في بعض مداخل المادة المعجمية نظام الإحالة، وقد التزم بأن يحيل السابق للاحق، وقد تكون إحالاته من خاص

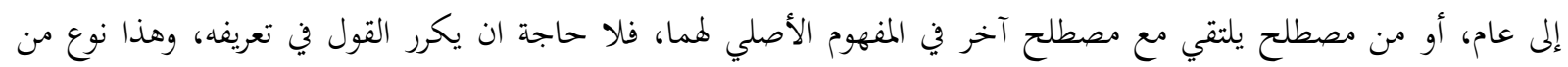

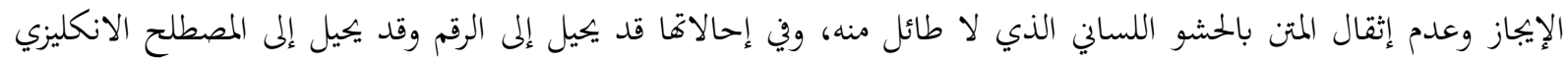
ورقمه، وهذا إن دل على شيء إنما يدل على أصالة المصطلح الغربي عنده، ومثال إحالاته:

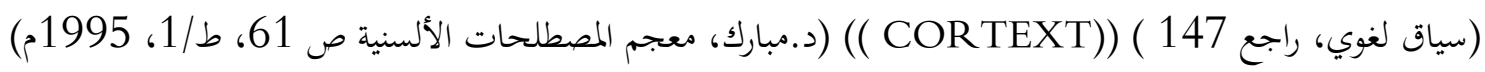
قد يجمع أكثر من مصطلح تحت مفهوم واحد يجمع بينهما ناظم واحد كما ذكر في مقدمته، ومثال ذلك: منسوب إليه،

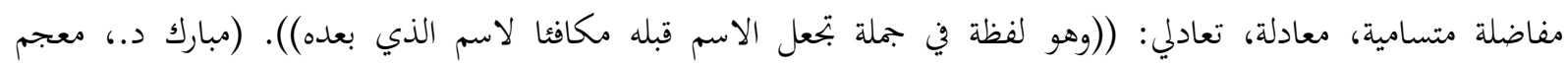
المصطلحات الألسنية ص 99.، ط/1، 1995م) ويلحظ تنوع هذا المصطلح العربي في الانكليزية والفرنسية أيضاً.

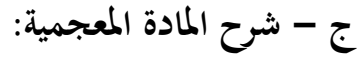

بلغت مداخل هذا المعجم ألفان وتسعمئة وثلاثة وأربعون مدخلا، وعلى عموم هذا العمل لم يثقل المؤلف متن معجمه

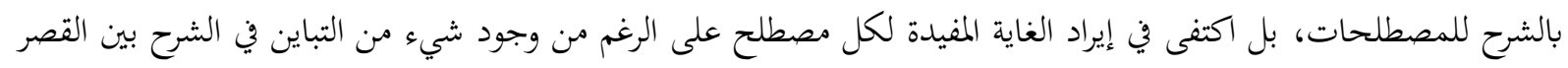


والإطالة إلا أن الفرق بينهما لا يتعدا سطرين أو ثلاثة، وكل ذلك لغاية الفائدة منه، ومثال ذلك: ((وجوب: هو أحد المعاني

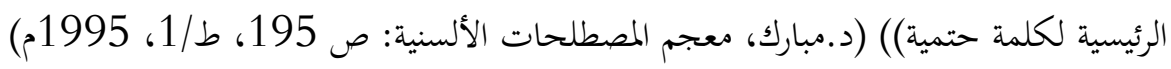

وأما مثال ما أطال في شرحه من مصطلحات: ((أعضاء النطق وهي الاعضاء التي تساهم في عملية النطق، وهي الحنجرة

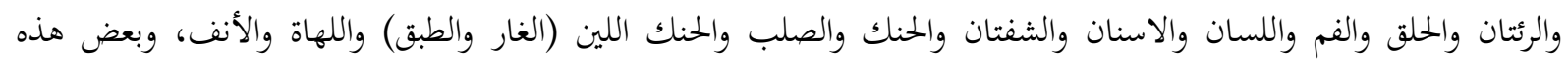

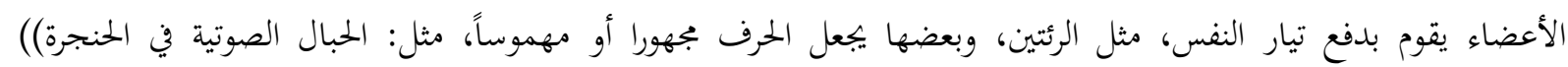

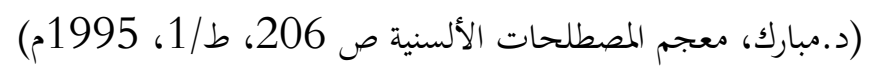

قد يستمل في شرحه للمادة المعجمية بعض الشواهد وإن كان قليلاً في هذا المجال، وهذا ليس مأخذا عليه، وإنما الغاية في

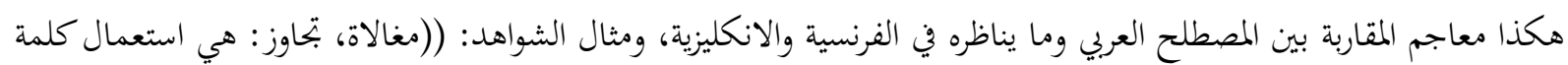

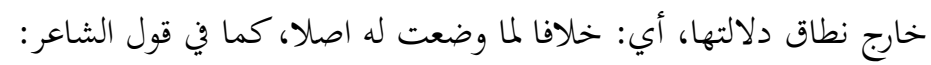

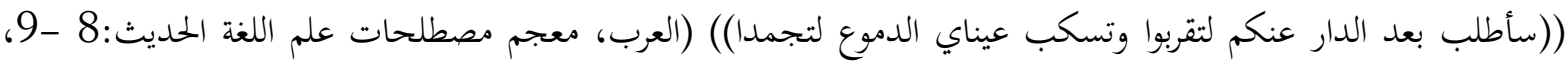
. وقد يكون الشاهد غربيا من أقوال علما الغرب، ((ظرف) أما العالم اللغوي ل. تانيير فقد عرف الظرف بأنه الوحدة أو

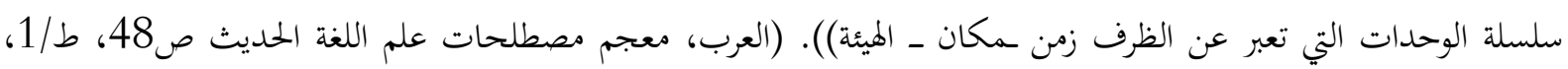

\section{2 - معجم مصطلحات علم اللغة الحديث:} أ - المنهج المعتمد في الترتيب:

يعد معجم مصطلحات علم اللغة الحديث من المعجمات الثنائية (عربي - انكليزي)، سار هذا المعجم في ترتيب مادة

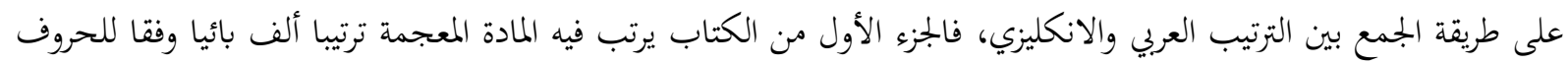

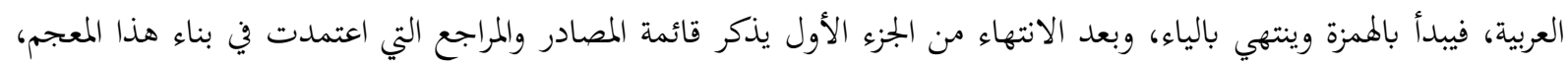

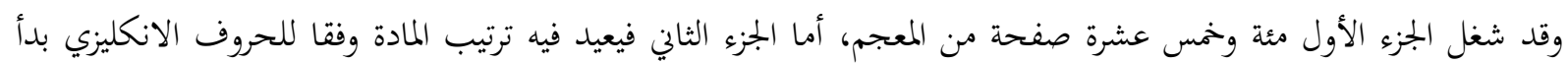

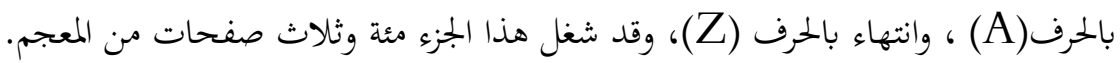
ويلاحظ أن الترتيب الألف بائي لم يأخذ بعين الاعتبار أداة التعريف (ال)، فمثلا (الارتفاع) يأتي قبل (ارتفاع الاسنان)، وعلى هذا يعامل المصطلح المعرّف كمعاملة المصطلح الذي ليس به أداة تعريف. (العرب، معجم مصطلحات علم اللغة الحديث:

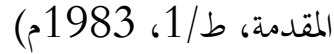

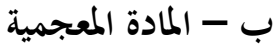
سارت اللجنة المؤلفة لمذا المعجم على عدة معايير في صناعة المادة المعجمية، ومن هذه المعايير (العرب، معجم مصطلحات علم

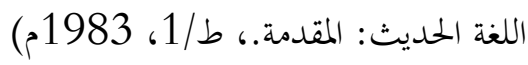
أولا- الاقتصار على مقابلة واحدة لكل معنى من معاني المصطلح الانجليزي ما أمكن ذلك. ثانيا - إعطاء الاولوية للمصطلحات العربية المعروفة قديمها وحديثها، وذلك نحو:

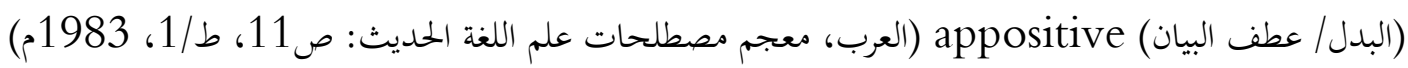
(الخبر في النحو) comment (العرب، معجم مصطلحات علم اللغة الحديث: ص35، ط/1، 1983م) 


$$
\text { ثالثا - صوغ مصطلحات جديدة عند الضرورة، وذلك نحو: }
$$

التبير (accentuation)(العرب، معجم مصطلحات علم اللغة الحديث ص24، ط/1، 1983م) رابعا - تعريب المصطلح الانكليزي في حال غياب مقابل عربي دقيق ومناسب له مع شرح موجز لذلك المصطلح، وذلك نحو: الأكوستي acoustic

(يتعلق بالصوت من حيث موجاته المنتشرة بالهواء) (العرب، معجم مصطلحات علم اللغة الحديث: 7.، ط/1، 1983م) خامسا - استبعاد المصطلحات المهجورة وكذلك اسماء اللغات. سادسا - الاطراد والاتساق في استعمال المصطلحات العربية مع مقابلاتما الانكليزية.

أما علامات الترقيم فِإنه استخدم العلامات الآتية. (العرب، معجم مصطلحات علم اللغة الحديث: المقدمة.، ط/1، (1983

أولا - القوسان الهلاليان: ويشيران إلى ان ما بداخلها هو شرح موجز للمصطلح، أو مرادف له، وذلك نحو: الإبداع ((اللغوي)) creativity العرب، معجم مصطلحات علم اللغة الحديث: ص1، ط/1، 1983م) (الدال على فكرة او شيء)( significant (العرب، معجم مصطلحات علم اللغة الحديث: ص37، ط/1، 1983م) ثانيا - الخط المائل: يشير إلى ان ما بعده بديل للمصطلح الأساسي، وذلك نهو: (الطبق / الحنك اللين) soft palate العرب، معجم مصطلحات علم اللغة الحديث: 57، ط/1، 1983م) (العالمي / العمومي) universal العرب، معجم مصطلحات علم اللغة الحديث: 61، ط/1، 1983م) ثالثا - الأرقام (1 - 2 - 3..(: وتشير إلى المعاني المختلفة للمصطلح الواحد، وذلك نحو: 1 - (بداية المقطع) onset :العرب، معجم مصطلحات علم اللغة الحديث ص11، ط/11، 1983م) 2

\section{3 - معجم المصطلحات اللسانية: أ - المنهج المعتمد في الترتيب :}

يعد هذا المعجم من المعاجم الثلاثية الوضع (انكليزي - فرنسي ـ عربي)، لم يعتمد المؤلف الترتيب عربي كما هو متعارف

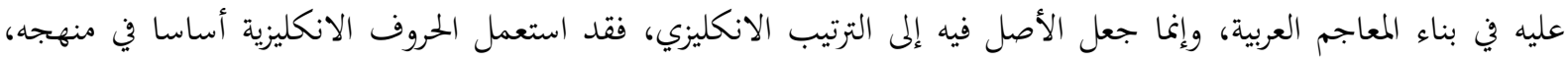

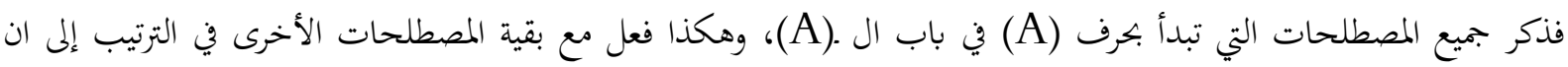
انتهى بالحرف (Z)، وعلل سبب اعتماده الترتيب الانكليزي بأن هذه اللغة نشأت بها في أصل الوضع كثير من المصطلحات بعديه

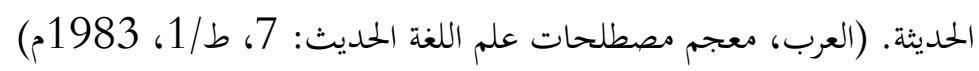
يبدأ ترقيم المعجم من اليسار كما هو معروف في اللغة الانكليزية، وينتهي برقم (406)، ومن جهة اليمين يبدأ ترقيم جديد وينتهي برقم (64)، ويذكر في فاية المعجم من جهة اليمين فهارس بالعربية والانكليزية والفرنسية، ورتب المصطلحات العربية في مهري الفهرس وفق الحروف الالفبائية ويذكر أمام كل مصطلح رقم الصفحة التي وقع فيها، وهكذا فعل مع المصطلحات الانكليزي 
والفرنسية، فرتب الانكليزية وفق الترتيب الانكليزي للحروف، ورتب المصطلحات الفرنسية وفق الترتيب الفرنسي للحروف، وقد

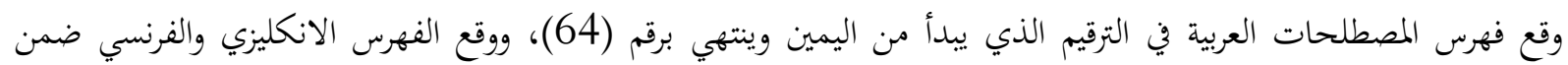

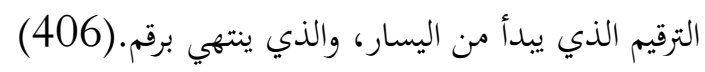

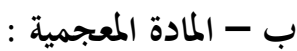

هذا المعجم من المعجمات الثلاثية التي تورد المصطلح الانكليزي كما أسلفنا، وترتب على أساسه، ثم تثبت ما يقابله بالفرنسية والعربية، وذكر المؤلف أن منهجه امتاز بالجرأة في وضع المصطلحات، إذ إنه لم يتبع طرقا مألوفة في ايجاد الألفاظ

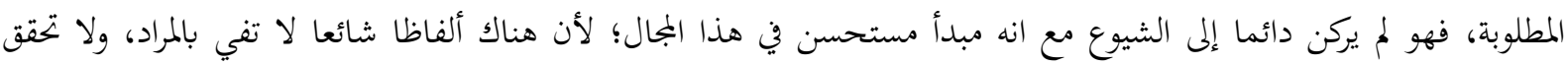
المقصود، وذكر أنه توخى النسقية في وضع المقابلات التي تتعارض مع مبدأ الشيوع، ولجأ إلى كثير من المولدات الجديدة؛ لأن كثيرا من المصطلحات الغربية لم يسبق أن نقلت إلى العربية، وانفرد المؤلف في ذلك في كثير من الاحيان (العمري، معجم المصطلحات

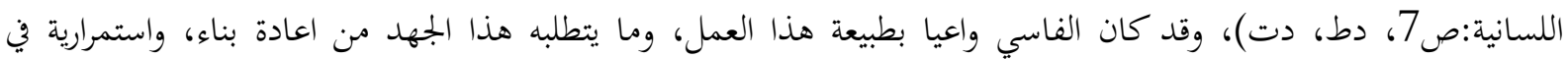

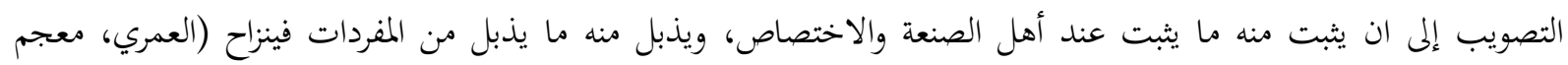
(المصطلحات اللسانية:ص).

ولم يصرح المؤلف في عدد المصطلحات التي ضمها معجمه، ولم يعمد إلى ترقيمها مما يجعل معرفة عدد مصطلحاته امرا عسيرا، وقد تباينت طريقة المؤلف في عرض المصطلح فقد يضع شارحة قبل المصطلح ومرة يستغني عن الشارحة، فمثال ما وضع

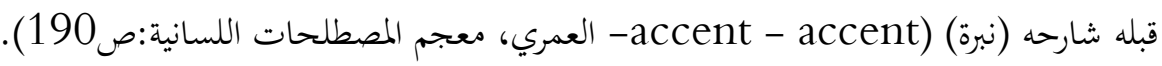
(ومثال ما لم يضع قبله شارحة :حَدْس1intuition intuition (العمري، معجم المصطلحات اللسانية ص 15) وقد يضع شارحة أمام المصطلح الانكليزي دون ما يقابله في العربي والفرنسي، ومثال ذلك: (صوت مقحم. SON)

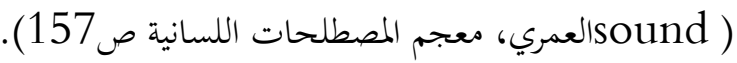

وإذا كان المصطلح الانكليزي يقابله أكثر من مصطلح في العربية، فإنه يذكرها ويفرق بينها بفاصلة، وذلك نحو( :مَزْمَن، فيه زمن) (العمري، معجم المصطلحات اللسانية (334).

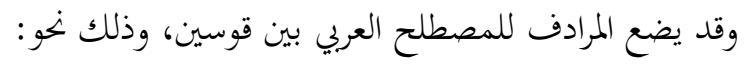
(معجم (قاموس)) (dictionnaire - dictionary) (العمري، معجم المصطلحات اللسانية:327) ويسير المؤلف في معجمه ( كما هو واضح من خلال الامثلة السابق ) على طريقة عرض المصطلح الانكليزي وما يقابله بالفرنسية والعربية، دون أن يشرح المصطلح أو يوضحه.

\section{4 أ- المنهج المعتمد في الترتيب المعجمي:}

اعتمد المؤلف النظام الألف بائي في مداخل المعجم، وهذا بين من ثنايا الفهرست والمادة المعجمية. (معجم المصطلحات

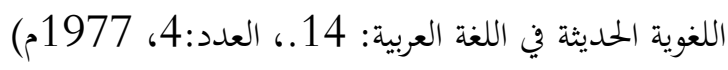

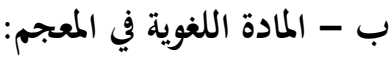

ضم هذا المعجم ألف ومئتين وواحد من المصطلحات، وعلى الرغم من تنوع هذه المصطلحات بين جديدها وقديما إلا أن

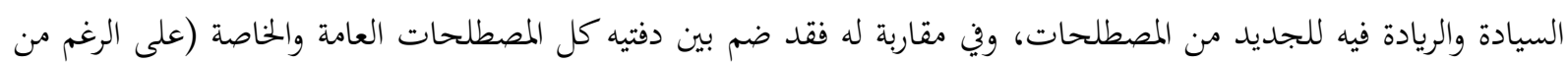


قدم بعضها) التي لم يسبق استعمالها من قبل في العربية، في حين أن القديم منها شرط استعمالها في هذا المعجم أن ترتدي ثوبا

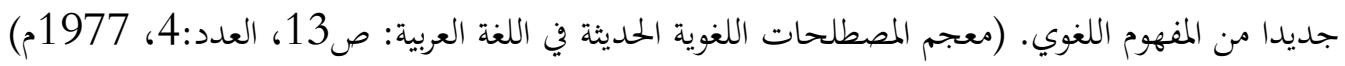
ولم يركز في مادته على المصطلحات التي اشترك العرب في ترجمتها على اعتبار الاتفاق أو المخالفة، بل جمع ما كان مشتركا

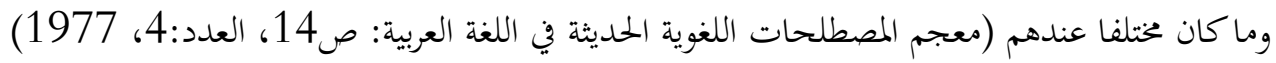
وهذا المعجم ثلاثي التكوين في غالبه، عربي ـ انكليزي ـ فرنسي، غير أنه في بعض الأحايين قد يقدم المؤلف إلى تثبيت

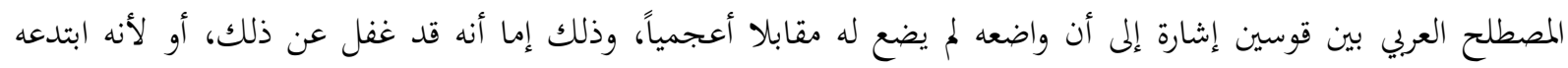

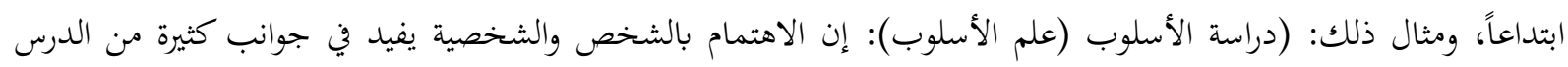

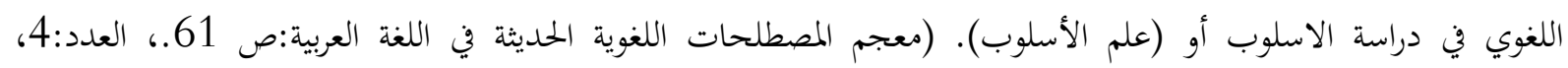
1977م ) وقد يعمد المؤلف بترك فراغ في المكان المقابل الأعجمي خشية اللبس والغموض لإنمان لاسيما إذا كان المصطلح المذكور غير واضح تماماً:

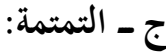

وقد تكون (اللازمة اللغوية) عيباً عضوياً في النطق كاللثغة أو الفأفأة أو التمتمة، وقد تكون أمرا آخر يكفي سماعه أو ذكره

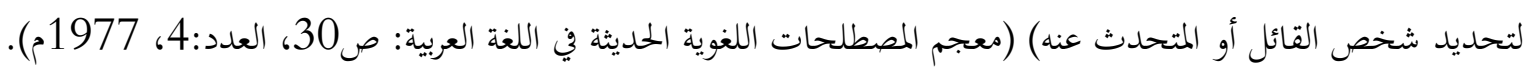
ولم يلتزم المؤلف منهجية واحدة في شرح المادة العلمية فقد يطيل في تبيان مصطلح، وقد يقصر في آخر وكل ذلك بحسب

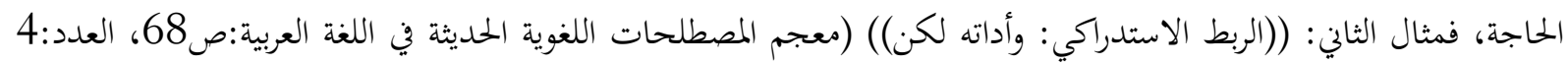

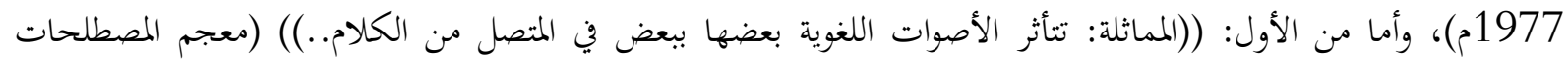

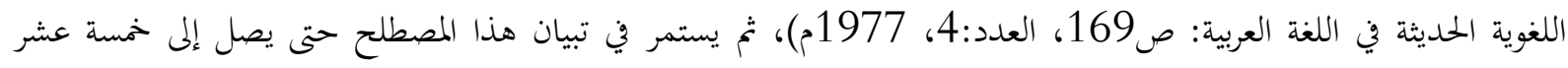
سطرًا.

وقد يعمد في بعض المصطلحات إلى منهج الإحالة عندما تتشابه المصطلحات أو تتقارب على نحو كبير في المعنى، وهو لا

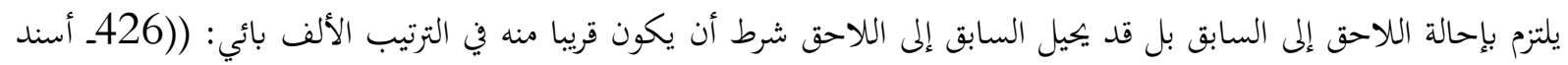

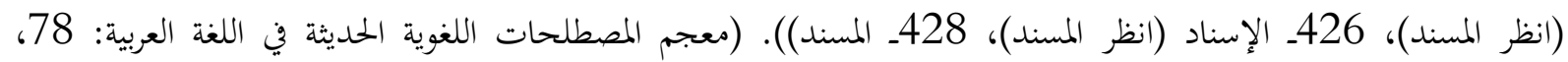
العدد:4، 1977م).

5 - الموجز في مصطلح اللغويات: أ - ترتيب المادة المعجمية:

الموجز من المعجمات الثلاثية البناء (عربي، انكليزي، فرنسي)، لم يزيغ المؤلف عن الأسس التي وضعها في مقدمة معجمه

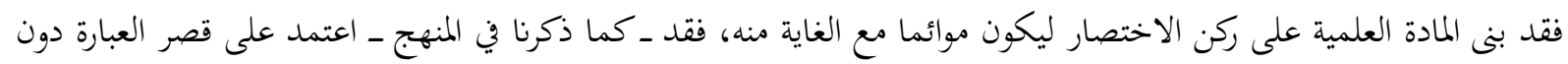

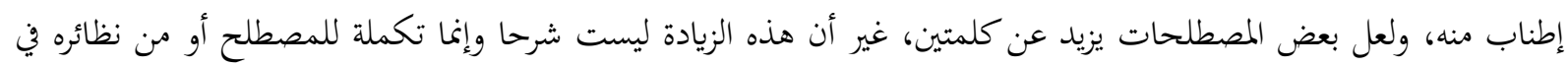

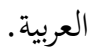

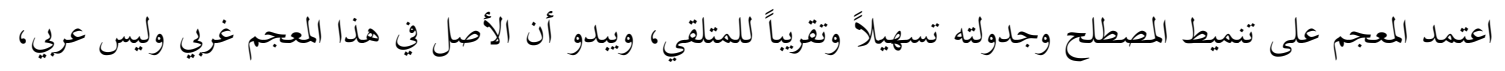

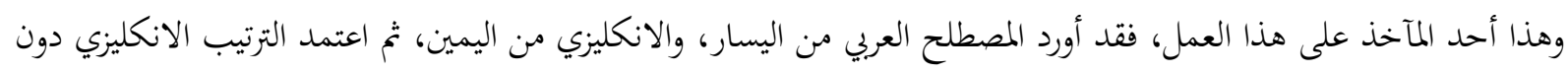


أي مراعاة للعربي، وهذا معجم للنشى العربي، فكيف يمكن أن يقف أحدهم وحتى المتخصص على المصطلح المراد وهو غير مرتب، فصعوبة البحث فيه واضحة للعيان، ولا يبدو سببا مقنعا دفع المؤلف إلى ذلك إلا التشبه والتعبد للموائد اللسانية الغربية. وابتعد عن المصطلح المستعمل ولو كان تراثيا مشهوراً، وهذا أمر غريب يتعارض مع مصادر المعجم كما سنرى. لم يطل الوقوف على إشكاليات المصطلح العربي، فقد خلا من تعدد الاستعمالات، وما يرافقها من ابتكار مصطلحات أخرى، والهدف من ذلك في رأي المؤلف عدم الاستقرار في المصطلح العربي، وابتعاده عن التوحد تحت مظلة المجالات اللغوية. (امطورش، الموجز في مصطلح اللغويات:1 - 1 - 2). ابتعد عن الجمل التفسيرية الكثيرة الاستعمال في الكتابات العربية، فالمصطلح عنده جملة لا تتجاوز ثلاث كلمات في

استدعى بعض الوسائل التوضيحية والتفسيرية التي تمدف أيضا إلى الوقوف على تنويع المجالات التي يستعمل فيها

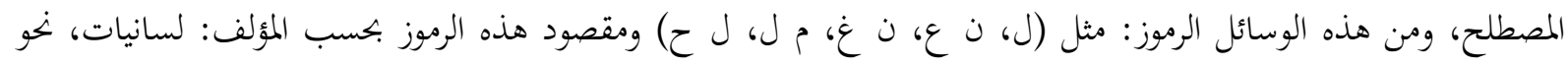

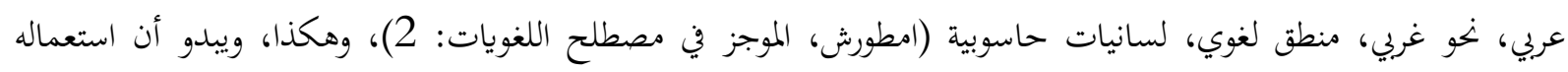

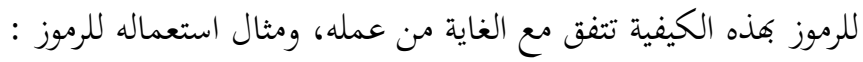

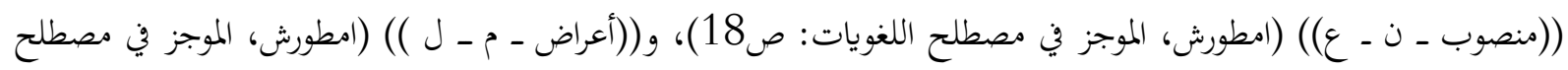

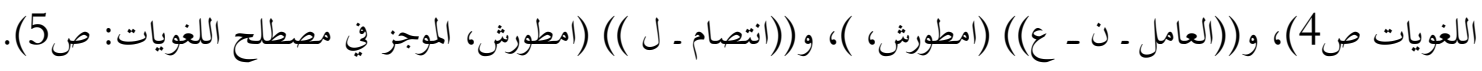
قد يستعمل المؤلف الشارحة في بعض المصطلحات ولاسيما التي ترتبط فيما بينها بخيط تضارعي دقيق، مثال ذلك: ((زائد/ ملحق/ لحاق )) (امطورش، الموجز في مصطلح اللغويات صنات 14)، ((معنى عادي/ إدراج)) (امطورش، الموجز في مصطلح

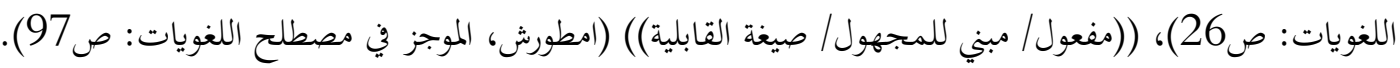

بعد الانتهاء من هذا البحث الوجيز بحمد الله توفيقه آن لي أن أدون اهم ما نتج عنه من نتائج:

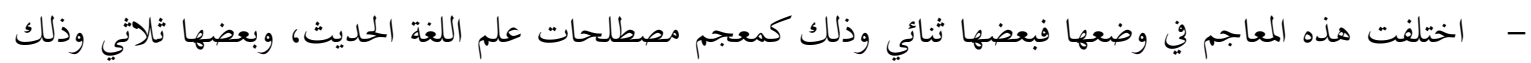

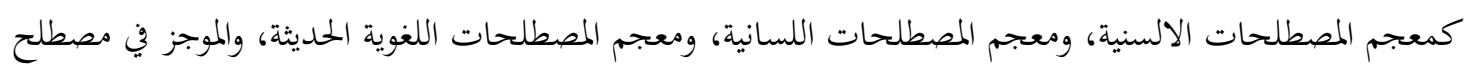
اللغويات. - - بعض المعاجم اللسانية يعتمد الأحرف العربية في ترتيب المادة المعجمية وذلك كمعجم المصطلحات اللغوية الحديثة، وبعضها يرتب المادة وفقا للأحرف الانكليزية وذلك كمعجم المصطلحات الألسنية، ومعجم المصطلحات اللسانية، والموجز في مصطلح اللغويات، وبعضها يجمع بين الطريقتين في الترتيب وذلك كمعجم مصطلحات علم اللغة الحديث.

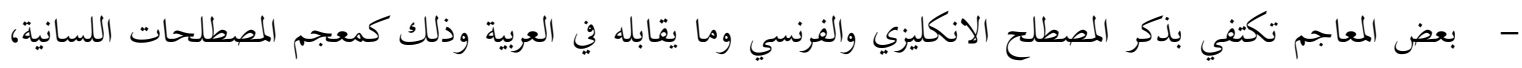

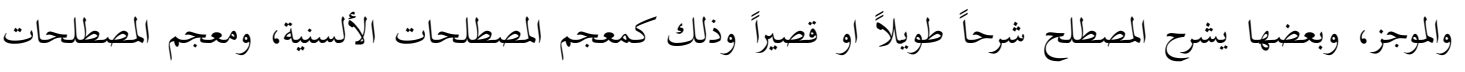

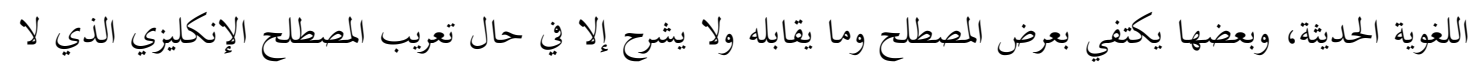
مقابل له في العربية وذلك كمعجم مصطلحات علم اللغة الحديث. - ق قد تمتم بعض المعاجم بإيراد الشواهد في شرح المصطلح اللساني كما جاء ذلك في معجم المصطلحات الألسنية. 
- - أعطت بعض المعاجم الأولوية للمصطلحات العربية قديمها وحديثها؛ وذلك كمعجم مصطلحات علم اللغة الحديث، وذهبت بعض المعاجم إلى تفضيل المصطلحات المولدة كما هو الحال في معجم المصطلحات اللسانية، ومعجم المصطلحات اللغوية الحديثة في اللغة العربية، والموجز. - - استعملت المعاجم اللسانية بعض علامات الترقيم كوسيلة لتنظيم المادة المعجمية. 
د. أممد محمد قدّور. (2008م). مبادئ اللسانيات، ص 17. دمشق: دار الفكر، ط/2008).

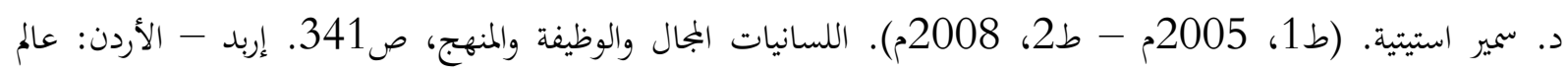

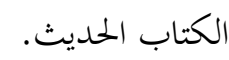

د. عبد القادر الفاسي الفهري. ( 1993م). اللسانيات واللغة العربية نماذج تركيبية ودلالية، ص53-54. المغرب: دار توبقال

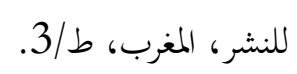

د. عبد القادر الفاسي بمشاركة د. نادية العمري. (بلا تاريخ). معجم المصطلحات اللسانية ص 157. دار الكتاب الجديد المتحدة.

د. عبد القادر الفاسي بمشاركة د. نادية العمري. (بلا تاريخ). معجم المصطلحات اللسانية ص157. دار الكتاب الجديد المتحدة.

د. عبد القادر الفاسي بمشاركة د. نادية العمري. (بلا تاريخ). معجم المصطلحات اللسانية: 7. دار الكتاب الجديد المتحدة.

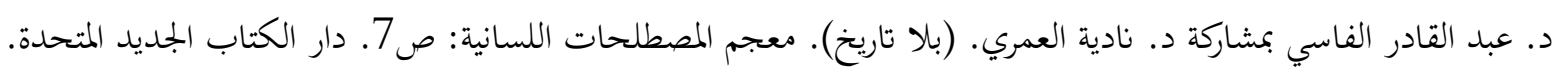

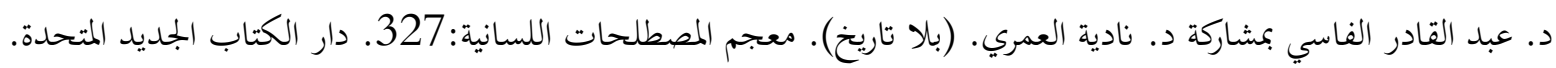

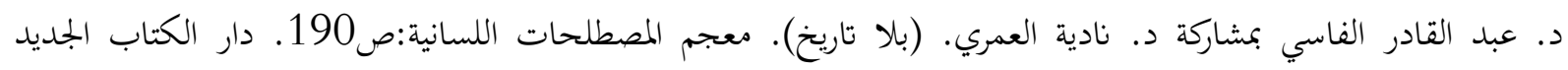
المتحدة.

د. عبد القادر الفاسي بمشاركة د. نادية العمري. (بلا تاريخ). معجم المصطلحات اللسانية:ص7، دط، دت. دار الكتاب الجديد المتحدة.

د. عبد القادر الفاسي بمشاركة د. نادية العمري. (بلا تاريخ). معجم المصطلحات اللسانية:ص8 8. دار الكتاب الجديد المتحدة.

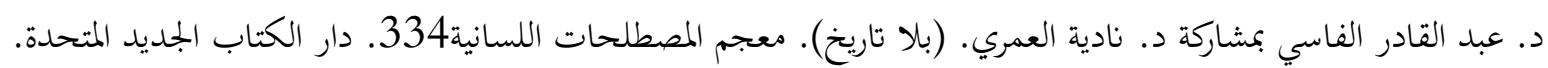

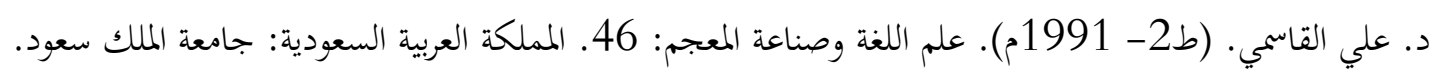

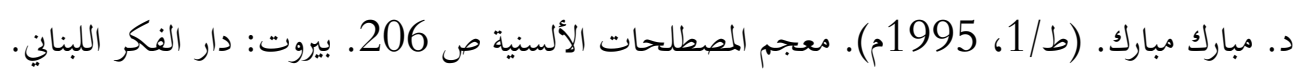

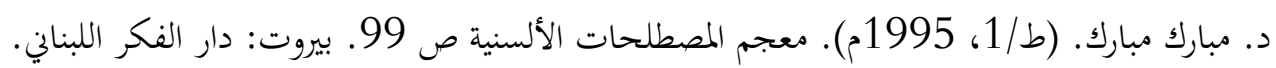

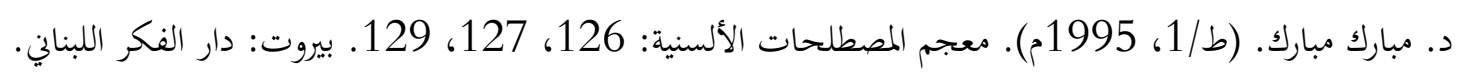

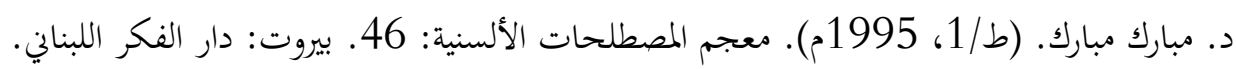

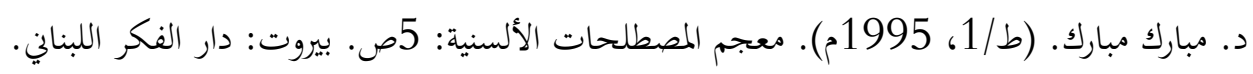

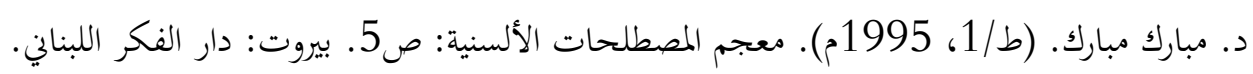

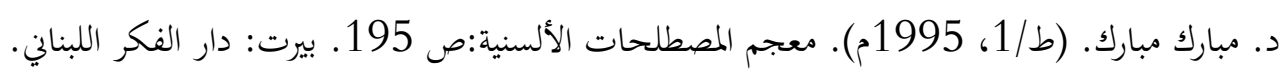

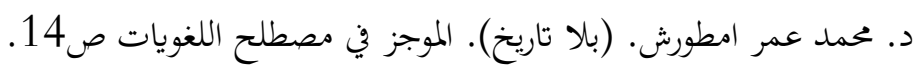

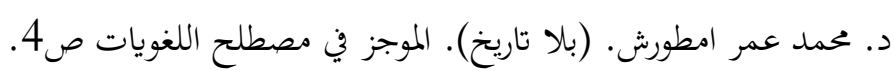

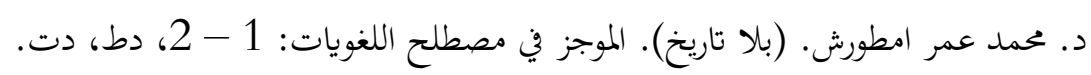

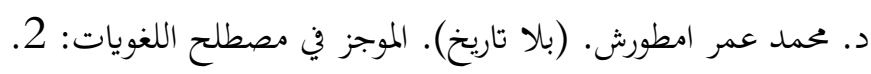

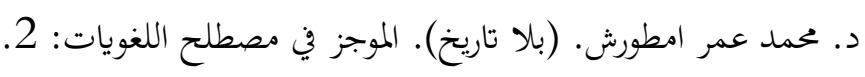

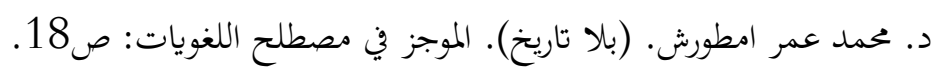

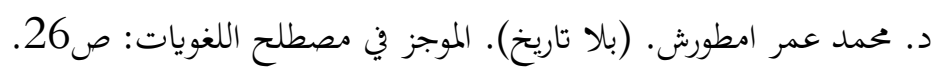


د. محمد عمر امطورش. (بلا تاريخ). الموجز في مصطلح اللغويات: صبات.

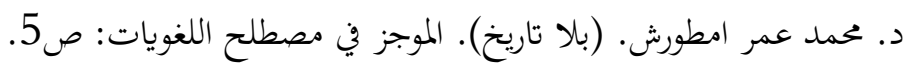

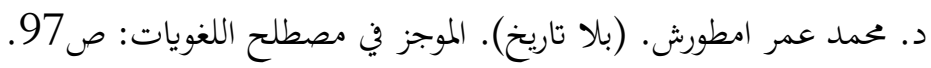

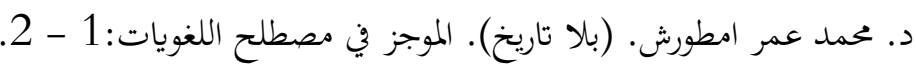

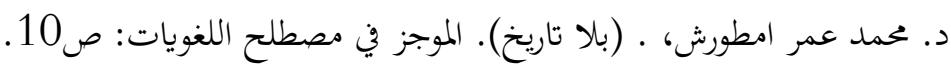

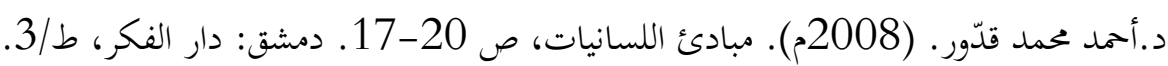

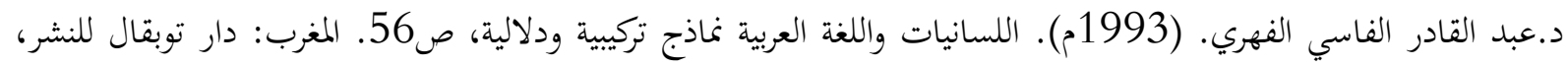
. $3 / 6$

د.مبارك مبارك. (ط/1/3، 1995م). معجم المصطلحات الألسنية ص 6195. بـ بيروت: دار الفكر اللبناني.

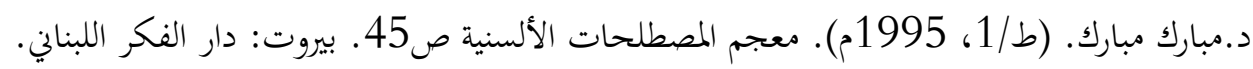

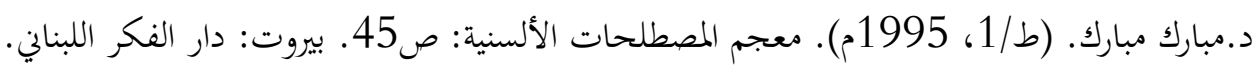

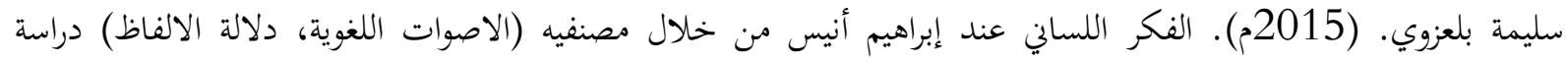

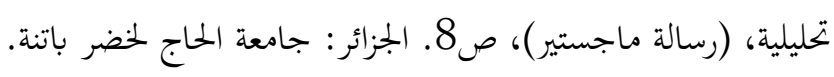

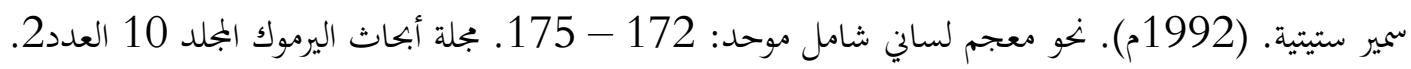

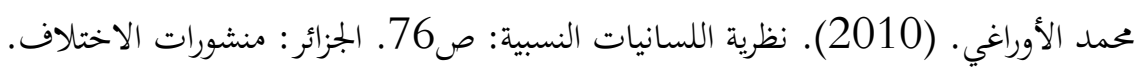

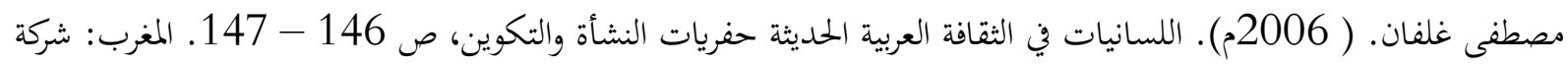

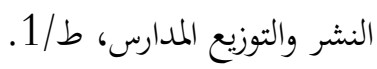

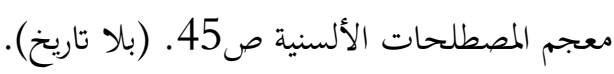

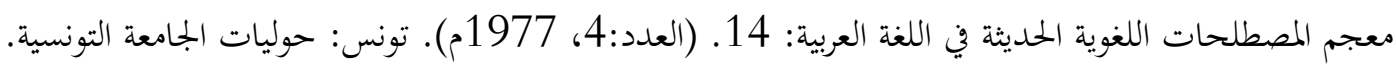

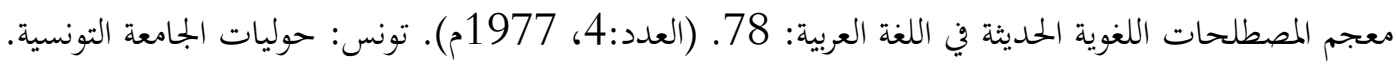

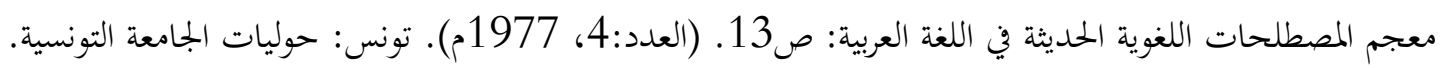

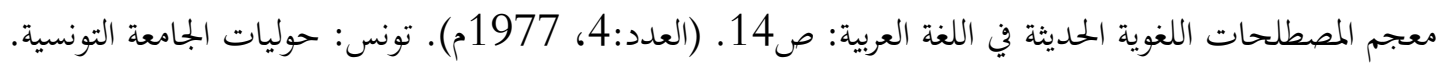

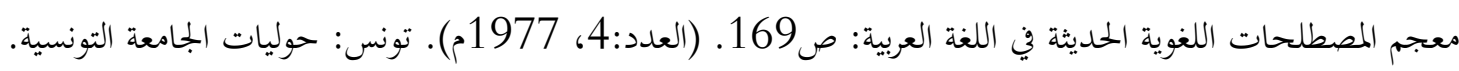

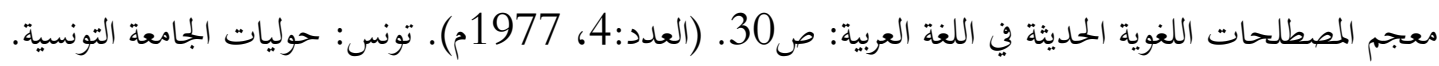

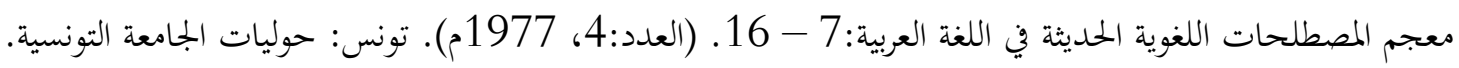

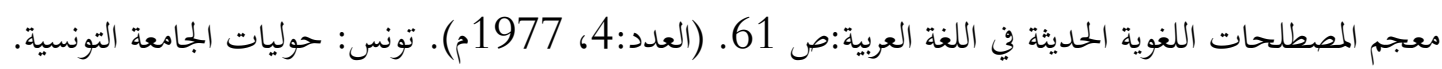

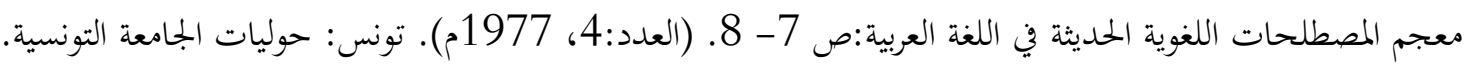

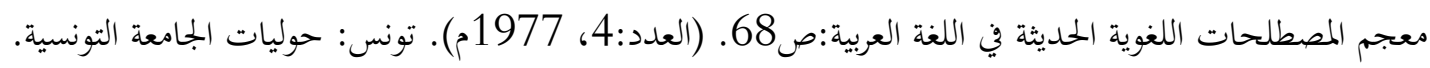

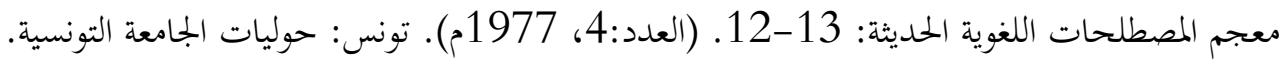

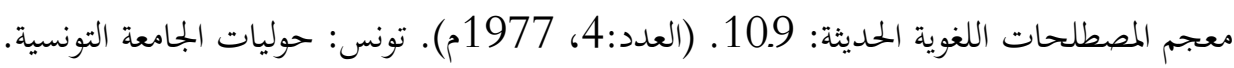

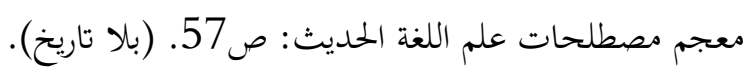
معجم مصطلحات علم اللغة الحديث:. (n.d).

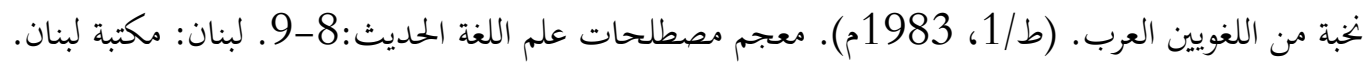

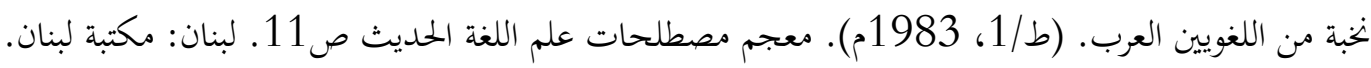


نخبة من اللغويين العرب. (ط/1، 1983م). معجم مصطلحات علم اللغة الحديث ص24. لبنان: مكتبة لبنان.

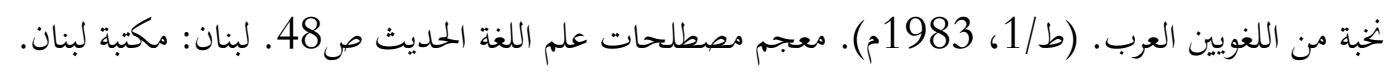
نخبة من اللغويين العرب. (ط/1/، 1983م). معجم مصطلحات علم اللغة الحديث: 57. 57 لبنان: مكتبة لبنان.

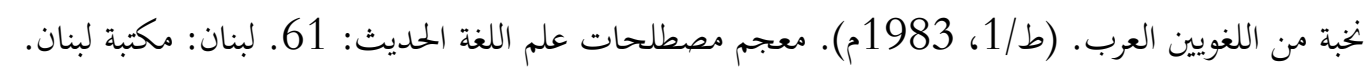
نخبة من اللغويين العرب. (ط/1/، من 1983م). معجم مصطلحات علم اللغة الحديث: 7. 7.

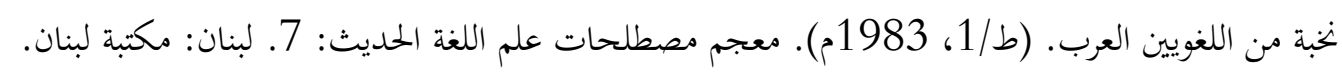

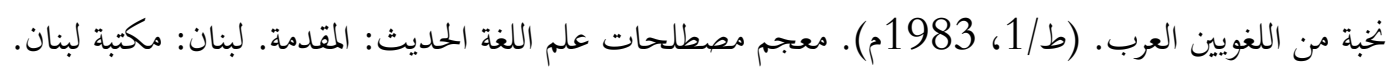
نخبة من اللغويين العرب. (ط/1/، 1983م). معجم مصطلحات علم اللغة الحديث: المقدمة. لبنان: مكتبة لبنان، لبنان. نخبة من اللغويين العرب. (ط/1)، 1983م). معجم مصطلحات علم اللغة الحديث: المقدمة. لبنان: مكتبة لبنان.

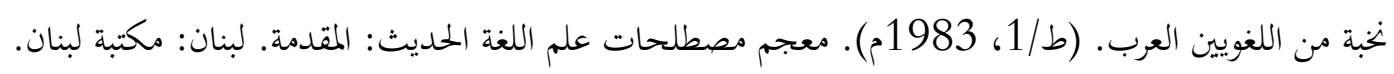
نخبة من اللغويين العرب. (ط/1، 1983م). معجم مصطلحات علم اللغة الحديث: المقدمة. لبنان: مكتبة لبنان.

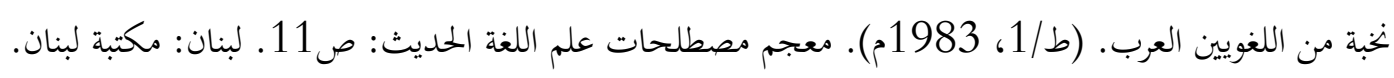

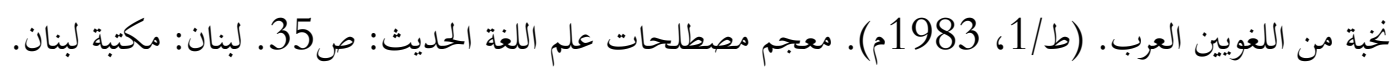

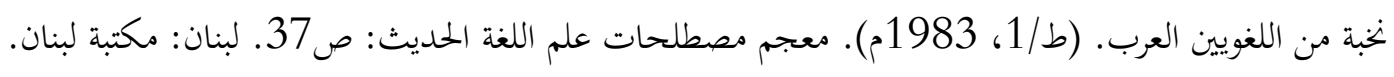

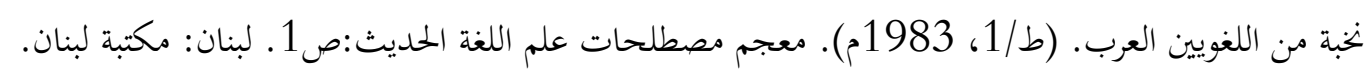




\section{Istanbul / Türkiye p. $473-487$}

Received: $12 / 12 / 2021$

Accepted: $21 / 12 / 2021$

Published: 01/01/2022

This article has been scanned I iThenticat No plagiarism detected

\title{
CHILD CUSTODY: A RIGHT OR A DUTY \\ (A STUDY OF AN APPROACH TO AMEND ARTICLE 57 OF THE IRAQI PERSONAL STATUS LAW)
}

\author{
Um Kalthum Sabeeh MOHAMME $^{1}$ \\ Saja Hazim MAHMOOD ${ }^{2}$
}

\begin{abstract}
:
The current century has witnessed a revolution in different fields which required some legal rules to be reformulated to adapt with the volume of challenges imposed by the contemporary life on marriage life in general, on the children, which are the most important thing that may result from marriage, and on the importance of caring for their needs. As God has divided the parents' duties in caring for their children throughout the stages of their liv.es. He laid upon the mother the responsibility of caring for children starting from pregnancy, delivery, breastfeeding until infancy. While He, especially, assigned the father the responsibility of what comes after. But sometimes a child may lose one or both parents; and here the question arises about who shall take custody and what is the period required to satisfy that right. Article (57) of Personal Status Law No. (188) for the year 1959 has answered this question with its nine clauses and confirmed the necessity of caring for the child's best interest and prioritizing it over the parents' rights. However, the Iraqi Parliament has adopted an amendment of this Article in its latest proposals under the pretext of being in line with changes of everyday life with the assurance of applying the spirit of Islamic Law. It discussed the transmission of the child's custody from the mother to the father after the age of seven in opposition to the current law that grants the mother this right until the child turns fifteen years of age; it also stipulated that the mother shall not get married in order to attain custody over the child which is regarded as a Statutory Offence represented in forcing the mother not to get married during which she holds custody over the child. Meanwhile, it did not stipulate over the father abstinence from marriage in order to attain custody over his children. The amendments have also showcased the entitlement of the grandfather's right in custody rather than the mother in case the father died or didn't fulfill the conditions of custody. By doing so, the rule would deprive the mother from her child upon turning seven years of age without attention being paid to the subsequential feeling of instability such decision causes to the
\end{abstract}

http://dx.doi.org/10.47832/2717-8293.15.34

Prof. Dr. , Mustansiriyah University, Iraq, destructive.98@gmail.com, https:// orcid.org/0000-0002-9453-1157

Researcher, Mustansiriyah University, Iraq, sosohazm95@gmail.com , https:// orcid.org/0000-0003-4833-1784 
child. The parliament should have tried to balance between the child's right of maternal tenderness or paternal security. This is the aim of our research which will shed light on this subject in two scopes, the first of which focuses on educating the people of the right of custody and its period, and the second of which is dedicated to discussion of amendments and making proper recommendation.

Key words: Custody, Custody Period, Mother's Right, Father's Duty, Article 75, Personal Status Law.

\section{مدة حضانة الصغير بين الحق والواجب (دراسة في مقترح تعديل المادة 57 من قانون الأحوال الثخصية العراقي)}

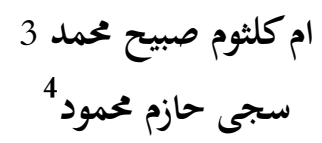

الملخص:

شهد القرن الحالي ثورة في مختلف المجالات مما استوجب إعادة صياغة بعض القواعد القانونية لتتلائم مع حجم التحديات التي فرضتها الحياة المعاصرة على الحياة الزوجية بشكل عام، وعلى أهم ما قد ينتج عنها وهم الأولاد وضرورة رعاية مصالحهم بشكل خاص، فقد قسم الله (جل وعلا) واجبات الوالدين في حفظ الأولاد على مراحل حياقم فخص الأم بمسؤولية الاعتناء بالأطفال بدا من الحمل والولادة والرضاعة والحضانة, بينما خص الأب بتربية الولد بعد ذلك، لكن قد يحدث أحيانا أن يفقد الصغير أحد والديه أو كلاهما، وهنا يثار التساؤل حول من يتولى

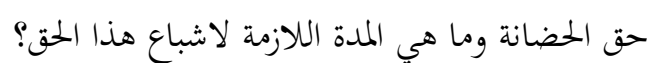

لقد اجابت المادة (57) من قانون الأحوال الشخصية العراقي رقم 188 لسنة 1959 بفقراقا التسع عن هذا السؤال مع التاكيد على وجوب مراعاة مصلحة المضون وتغليبها على حق كل من الأم والاب، إلا أن البرلمان العراقي في طروحاته الاخيرة تبنى تعديلا لنص هذه المادة بحجة الاستجابة لمتغيرات الواقع مع ضمان تطبيق روح

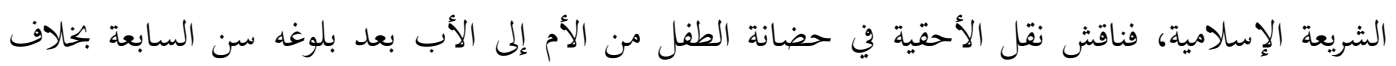
القانون الساري الذي يمنح الأم امكانية بقاء هذا الحق لغاية بلوغ الطفل سن الـ15 عاما كما اشترط عدم زواجها لأخذ الحضانة وهذا يعد مخالفة شرعية تتمثل باجبار الأم على عدم الزواج خلال فترة حضانة الطفل، في حين لم يشترط التعديل في الأب عدم الزواج لنيل حضانة الأبناء، كما نصت التعديلات على أحقية الجد من جهة الأب في الحضانة من الأم، في حال توي الأب أو انتفت لديه شروط الحضانة وبذلك يصبح الأصل حرمان الأم من الأحقية في حضانة أبنائها عندما يتمون السابعة من العمر دون ملاحظة ما يترتب على نفسية الطفل نتيجة عدم

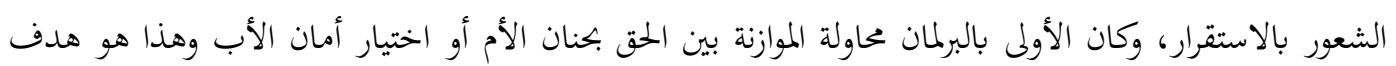
بحثنا الذي سيسلط الضوء على هذا الموضوع في مبحثين نركز الأول على التعريف بكق الحضانة وأحكامها بينما

$$
\text { نخصص الثاني لمناقشة التعديلات وطرح التوصيات الملائمة. }
$$

الكلمات المفتاحية:الحضانة، مدة الحضانة، حق الأم، واجب الاب، المادة 75، قانون الأحوال

الشخصية. 
يعتبر موضوع الحضانة من المواضيع التي نالت حيزاً كبيراً من اهتمام علماء الشريعة والقانون لاها تتعلق بالطفل بالدرجة

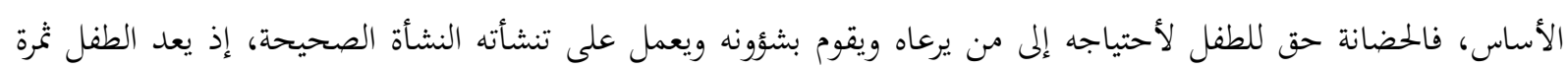

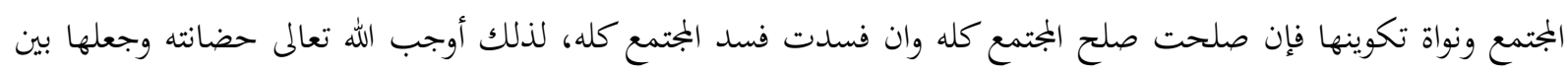

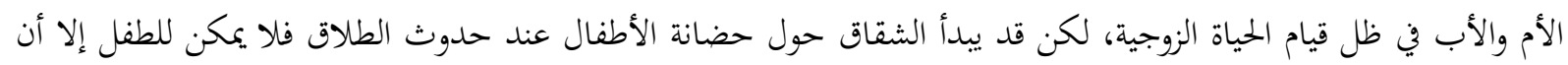

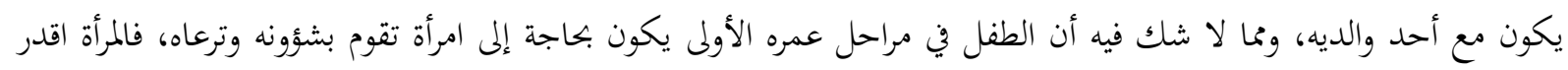

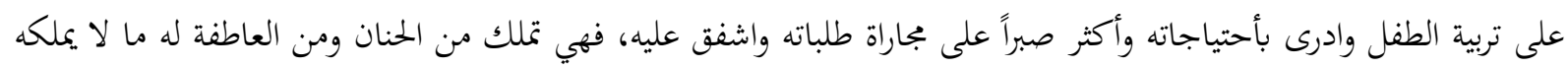

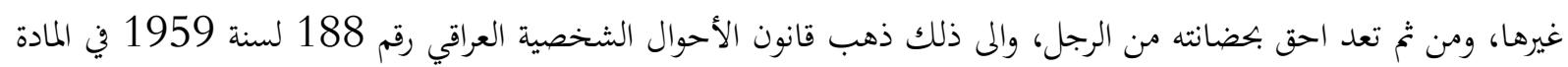

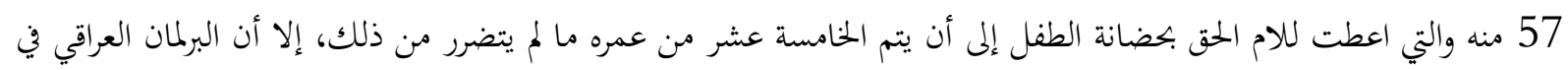

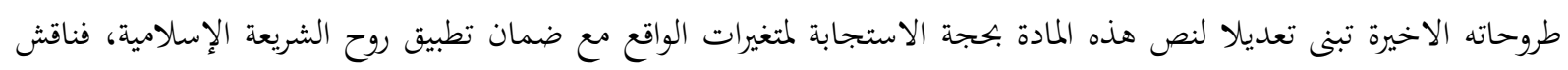

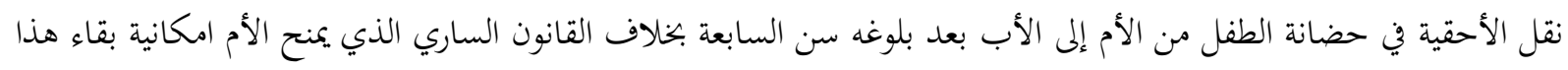

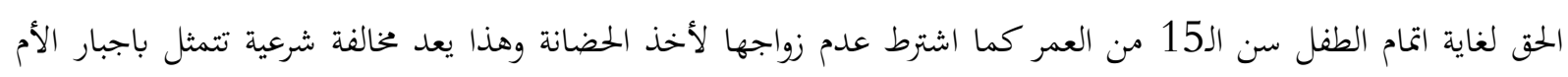

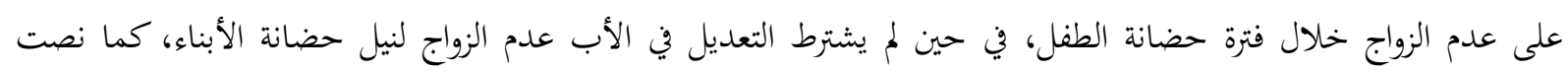

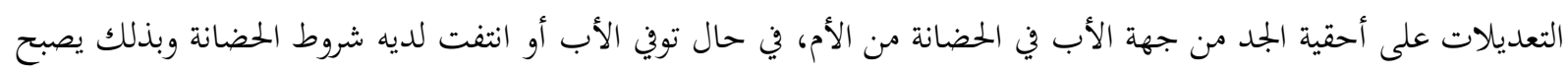

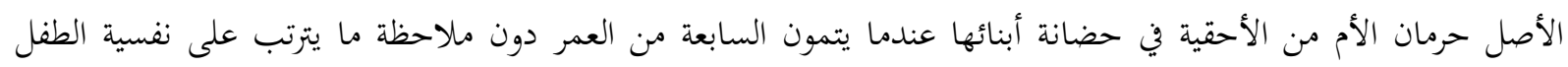

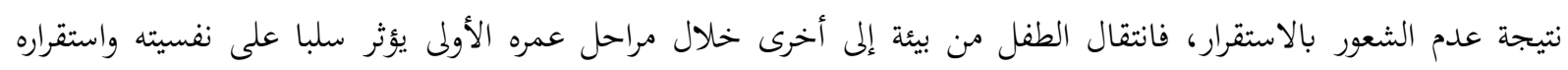

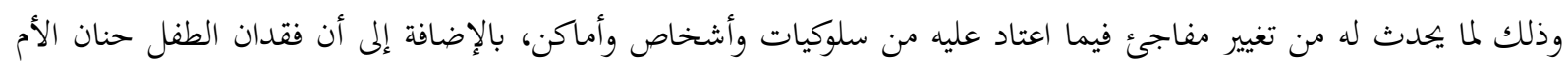
وعاطفتها وهو في عمر صغير سيكون منه في الغالب شخصية ضعيفة وغير مستقرة.

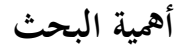

تتمثل أهمية البحث بضرورة مناقشة التعديل الأخير الذي طرحه البرلمان العراقي للمادة 57 من قانون الأحوال الشخصية

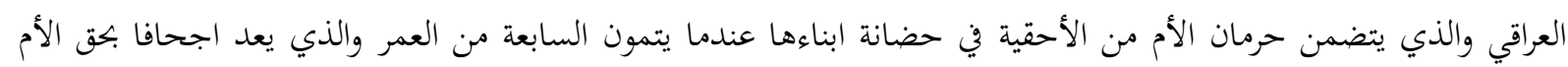

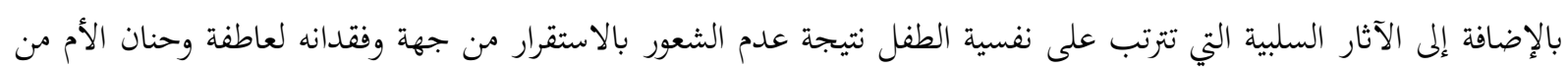

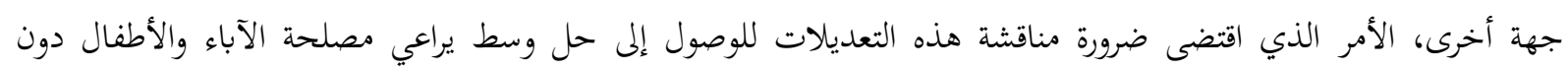
الإضرار بمصلحة الأمهات.

\section{هيكلية البحث}

سنقسم هذا البحث إلى مبحثين، نوضح في المبحث الأول ماهية الحضانة وأحكامها، والذي سنقسمه إلى مطلبين نوضح

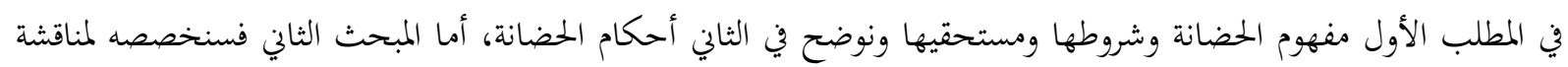
مقترح تعديل المادة 57 من قانون الأحوال الشخصية العراقي. 


\section{المبحث الأول}

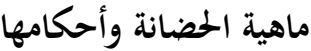

تعتبر الحضانة أثر من آثار الرابطة الزوجية وهي نوع من انواع الرعاية التي تقدم للطفل الصغير نتيجة عجزه عن القيام

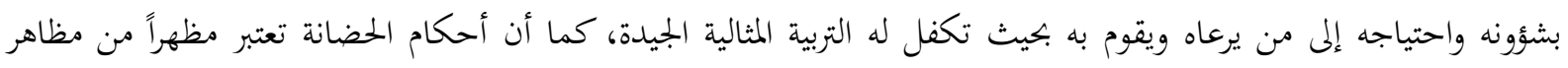
عناية الشريعة الإسلامية والقوانين الوضعية بالطفولة، وبغية توضيح المقصود بالحضانة وشروط استحقاقها ومستحقيها والإحاطة بهاه

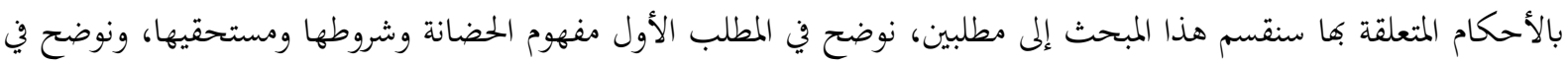
المطلب الثاني أحكامها.

$$
\text { المطلب الأول }
$$

\section{مفهوم الحضانة وشروطها ومستحقيها}

إن بيان مفهوم الحضانة يقتضي تعريفه لغةً واصطلاحاً، ومن ثم بيان أهم الشروط الواجب توافرها لاستحقاق الحضانة، ومن ثم بيان ترتيب مستحقي الحضانة، وعلى النحو الآتي: الفرع الأول: تعريف الحضانة

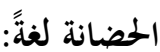

كلمة مأخوذة من الحضن وهي الضم إلى الجنب، يقال حضنت الصغير حضانته أي تحملت مؤنته وتربيته، والجمع احضان

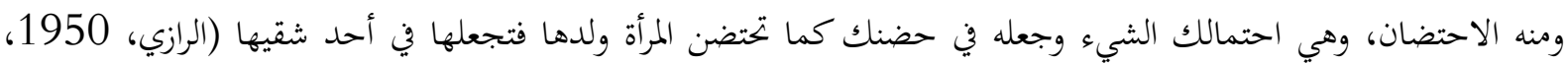
صفحة 142).

\section{الحضانة في الاصطلاح:}

عرف فقهاء الشريعة الإسلامية الحضانة بتعاريف متعددة حسب مذاهبهم، فعرفها الحنفية باهما "تربية الطفل ورعايته والقيام

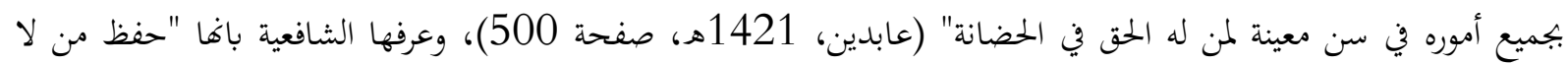

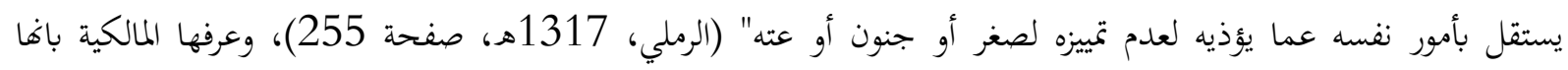

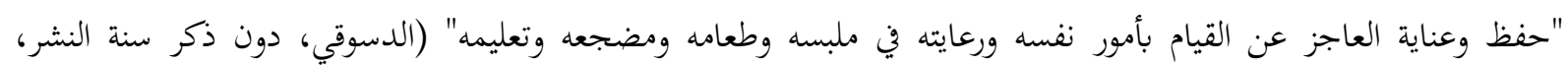

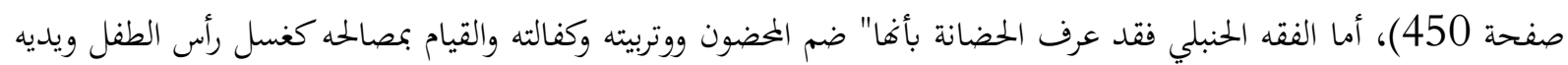
وثيابه والانفاق عليه وكل ما يتعلق بمصالحه" (البهوتي، دون ذكر سنة النشر، صفحة 495)، أما الفقهاء المعاصرين فقد عرفوا

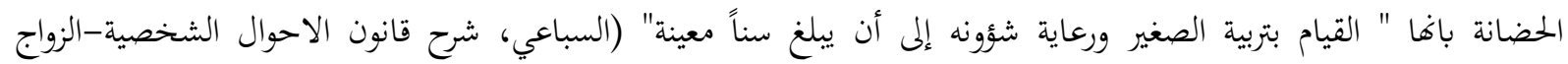

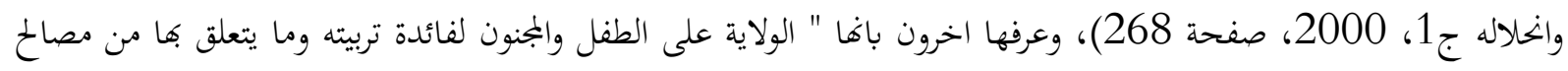

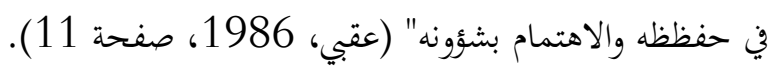
والملاحظ مما تقدم أن جميع التعاريف السابقة اختلفت في الفاظها إلا اغا تشاهت في معانيها، فجميعها تدور حول معنى واحد إلا وهو تربية المحضون ورعايته والقيام بشؤونه إلى أن يبلغ سناً معينة أما التشريع العراقي فلم يورد تعريفاً للحضانة في نصوص مواده القانونية مكتفياً بذكر أحكامه في قانون الأحوال الشخصية تاركاً المهمة للفقه على اعتبار أن وضع التعاريف هي مهمة فقهية. 


\section{الفرع الثاني: شروط استحقاق الحضانة}

لما كانت الغاية الأساسية من الحضانة هي تربية المخضون التربية المثالية الجيدة والعناية به وتنشأته النشأة الصحيحة، لذلك فقد احتاطت الشريعة الإسلامية وقانون الأحوال الشخصية العراقي في أمور الحضانة بأشتراطها شروطاً كثيرة يجب تونبه توافرها لاستحقاق الحضانة، فالقانون طابق الشريعة الإسلامية في بعض هذه الشروط وخالفها في البعض الآخر، وهي على النحو الآتي:

1

اتفق جميع فقهاء المذاهب الإسلامية على وجوب أن يكون الحاضن أو الحاضنة بالغا لان غير البالغ هو أحوج للحاضن

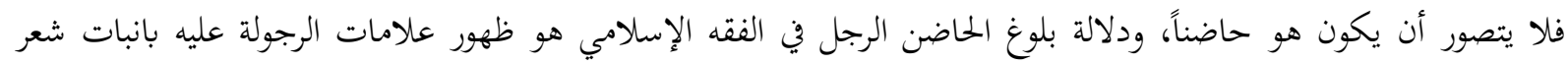

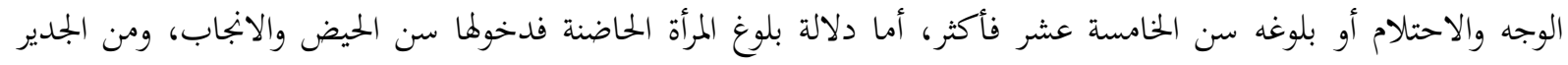

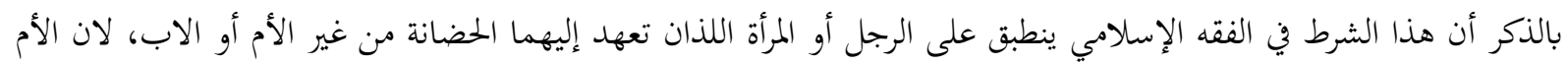

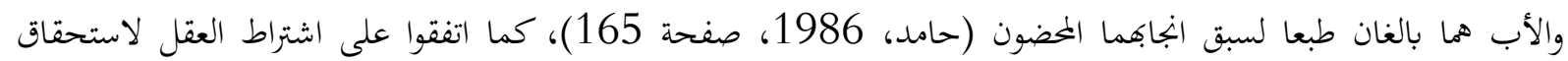

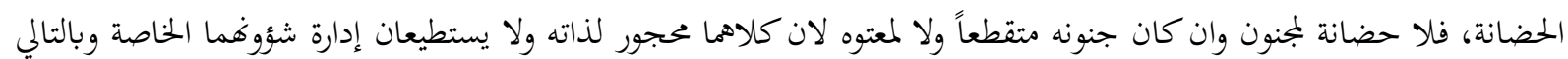
لا يصلحان لحضانة من هو بأمس الحاجة إلى الرعاية والاهتمام (نجيم، 1997، صفحة 179) (الشربيني، 2004، صفحة

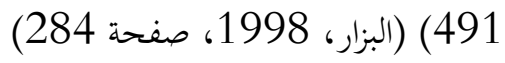

\section{3- 3- القدرة على الحضانة:}

لما كان المقصد الأساسي من الحضانة هو حفظ المخضون ورعايته والاهتمام به لذلك أتفق الفقهاء على اشتراط القدرة لإستحقاق الحضانة، أي لابد وأن يكون طالب الحضانة قادراً على رعاية المحضون وصيانته، فلا حضانة لكبير في السن ولا للعاجز ولا لمن لم الم

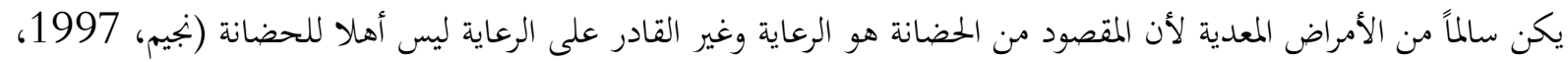

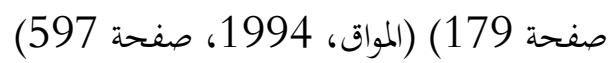

اختلف الفقهاء في تحديد معنى الأمانة، فذهب الحنفية إلى أن المقصود بالأمانة هو عدم الفسق أي أن لا يكون طالب

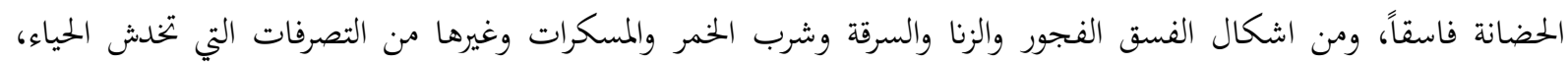

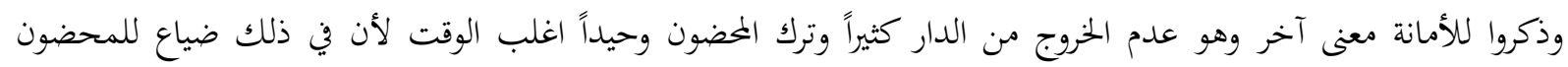

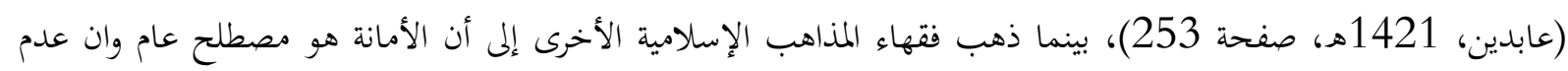

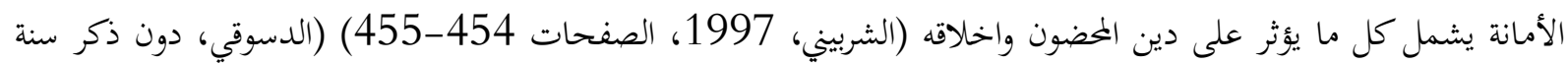
النشر، صفحة 528) (قدامة، 1997، صفحة 238).

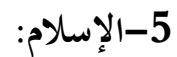

اختلف الفقهاء في هذا الشرط، فذهب الشافعية والحنابلة إلى اشتراط الإسلام لأستحقاق الحضانة أن كان المخضون

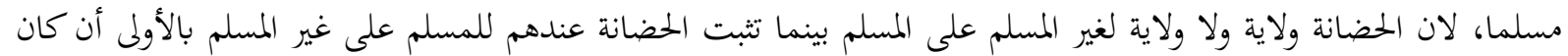
فيه مصلحة له (الشربيني، 1997، صفحة 455) (البهوتي، دون ذكر سنة النشر، صفحة 499)، بينما لم يشترط الحنفية والمالكية الإسلام لأستحقاق الحضانة ما لم يعقل المخضون الاديان أو يخاف عليه أن يألف غير الإسلام بأن تلقنه دينها أو تعلمه

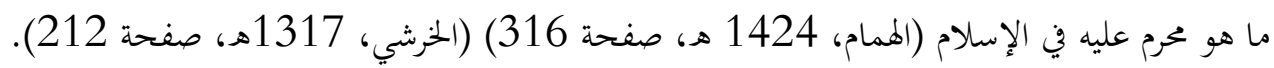




\section{6-عدم زواج الحاضنة بأجنبي:}

وهذا الشرط خاص بالنساء وسواء كانت الحاضنة أما أو غيرها، إذ اتفق فقهاء المذاهب الإسلامية الأربعة على اسقاط حق الحاضنة في الحضانة إذا تزوجت باجنبي عن المُضون، ذلك لان الغاية من الحضانة هي تحقيق مصلحة المخضون فإن تزوجت

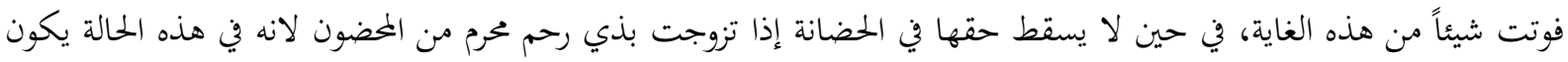

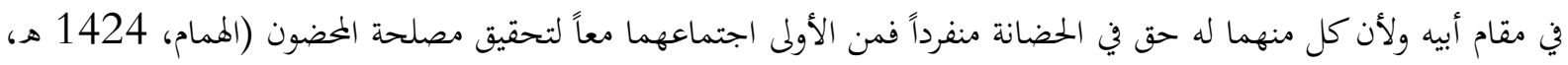
صفحة 316) (الشربيني، 1997، صفحة 456) (الدسوقي، دون ذكر سنة النشر، صفحة 529) (البهوتي، دون ذكر سنة

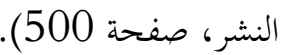

أما قانون الأحوال الشخصية العراقي فقد نص في المادة (57) الفقرة الثانية على " يشترط أن تكون الحاضنة بالغة عاقلة امينة قادرة على تربية المخضون وصيانته ولا تسقط حضانة الأم المطلقة بزواجها " والملاحظ أن شروط الحضانة المنصوص عليها في

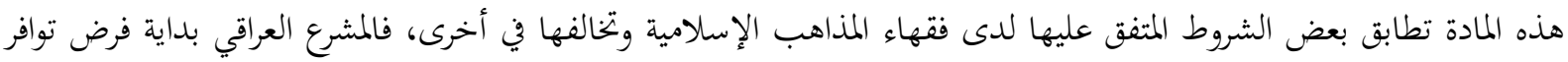
شروط الحضانة في الأم في حين لم يشترط في الأب أي شروط , فاشترط لكي تتولى الأم حضانة صغيرها البلوغ والعقل والقدرة

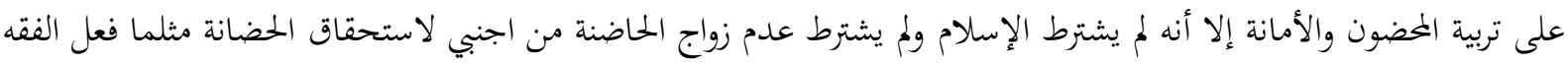

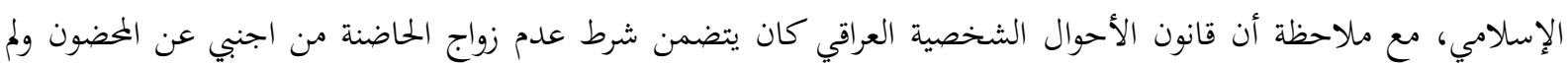

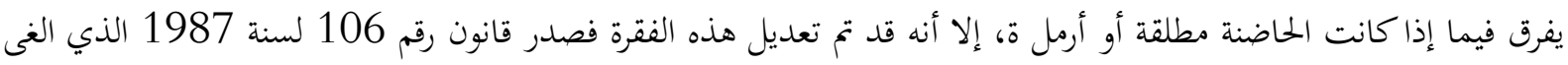

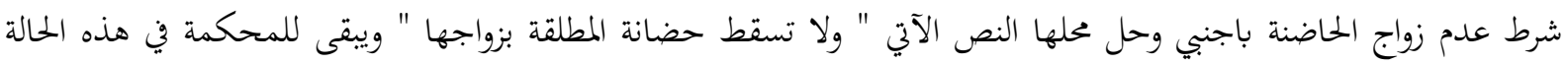

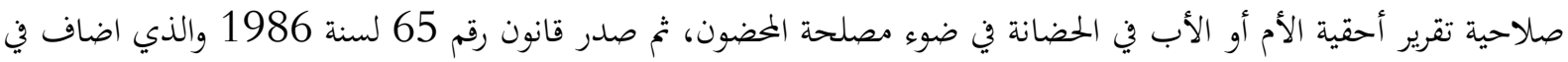

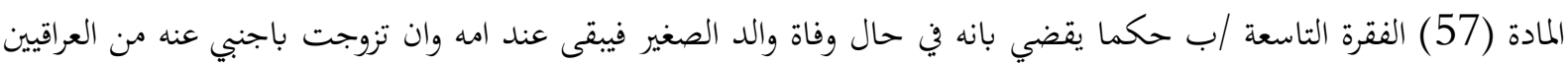
بشرط أن تكون الأم محتفظة ببقية شروط الحضانة وان تقتنع المحكمة بعدم تضرر الصغير من البقاء مع والدته وان يتعهد زوج الأم وأم

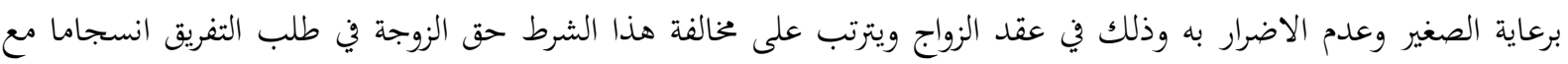

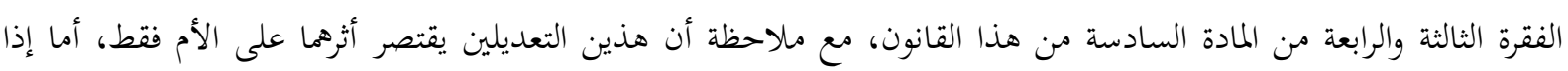
كانت الحاضنة غير الأم فلا تستفيد من هذه الأحكام

كما أنه وكما ذكرنا سابقا فإن المشرع العراقي في قانون الأحوال الشخصية قصر هذه الشروط على الحاضنة دون الحاضن

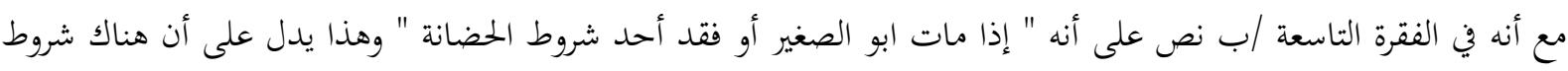
لابد من توافرها في الأب لاستحقاق الحضانة وهذه الشروط يوجب العقل أن تكون هي ذات الشروط المطلوب توافرها في

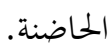

\section{الفرع الثالث: مستحقي الحضانة}

اتفق جميع فقهاء المذاهب الإسلامية على أن الأم هي احق الناس بحضانة الصغير إذا توفرت فيها شروط الحضانة كوغا

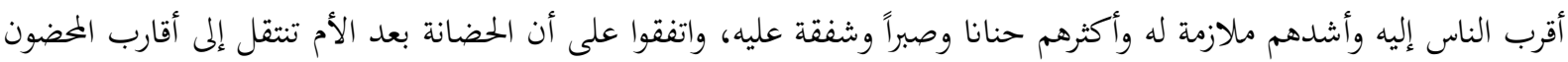

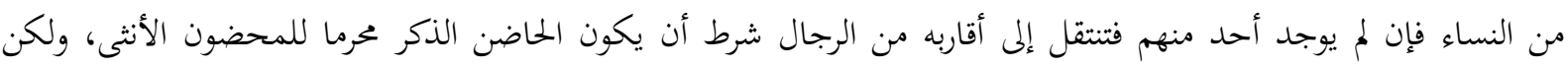
الخناف حدث بينهم في مراتب مستحقي الحضانة ولكل مذهب ترتيب تسلسلي مذكور في الكتب الفقهية ولا بجال لايراده هنا

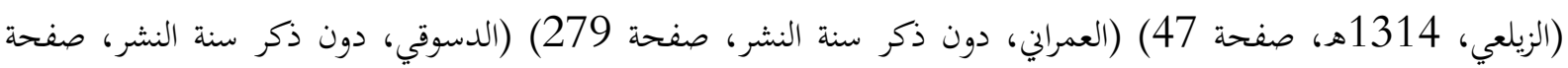

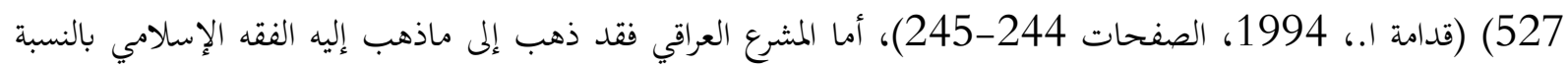

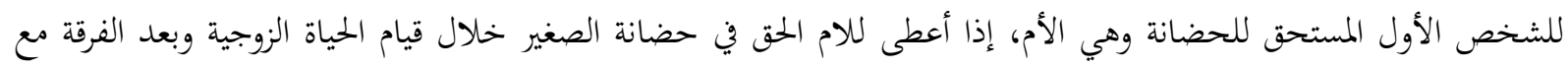


الاخذ بنظر الاعتبار مصلحة المضضون وذلك وفقا لما نصت عليه المادة (57) الفقرة الأولى والتي جاء فيها" الأم أحق بحضانة الولد

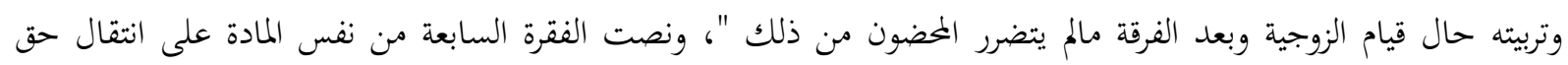

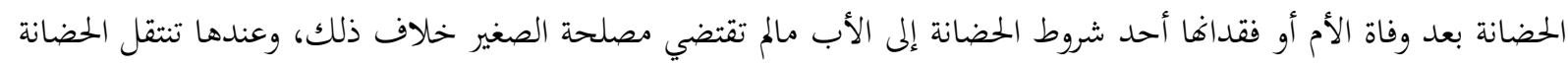
إلى شخص اخر يختاره القاضي مراعياً في ذلك كله مصلحة المحضون، ونصت الفقرة التاسعة على أنه في حال وفاة الأب أو فقدانه

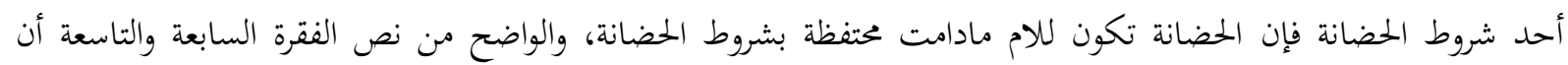

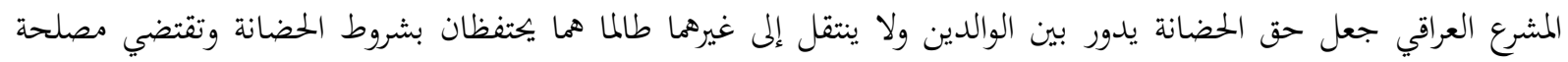

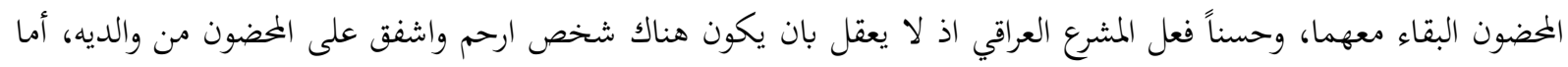

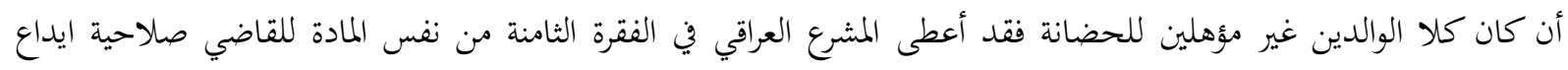

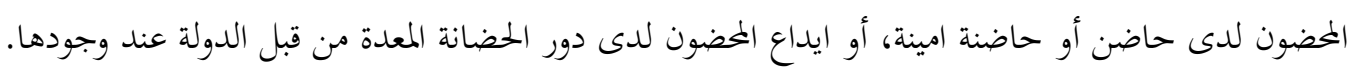
المطلب الثاني

أحكام الحضانة

بعد انحلال الرابطة الزوجية تنشأ عدة آثار تتعلق بحق الحضانة وهي تعتبر في نفس الوقت أحكاماً لها والتي نظمها الشرع بشكل مفصل بينما غفل القانون عن تنظيم بعضها، وهذه الأحكام هي مدة الحضانة ومشاهدة المُضون والسفر بالمضون، وهنو ما سنبحثه في هذا المطلب وعلى النحو الآتي:

الفرع الأول: مدة الحضانة

اتفق الفقهاء على أن مدة حضانة الصغير تقدر بقدر حاجة المحضون إليها، أي تبدأ منذ ولادته وتنتهي بانتهاء حاجة

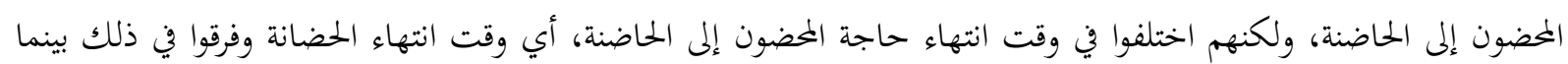
إذا كان المضضون ذكراً أو أنثى، فذهب الحنفية إلى أن حضانة الذكر تنتهي عند السبع سنوات والأنثى عند التسع سنوات (عابدين، 1421هـ، صفحة 255)، وذهب الشافعية إلى أن الحضانة تبقى للام إلى أن يبلغ الصبي والفتاة سن التمييز والادراك

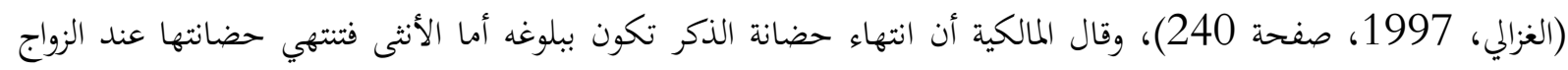

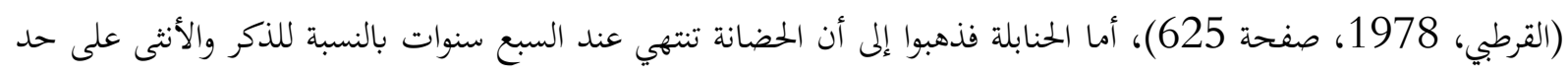

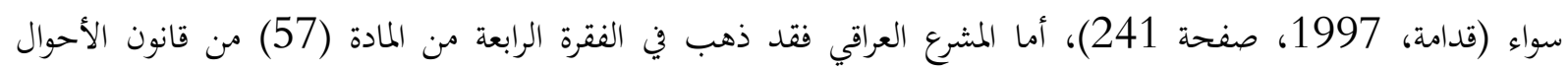
الشخصية العراقي إلى أن مدة حضانة الصغير تنتهي عند اتمام العاشرة من العمر، مع امكانية تمديدها إلى حين اكماله الخامسة

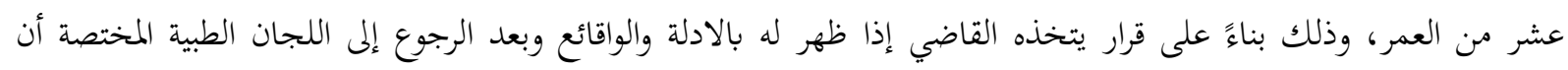

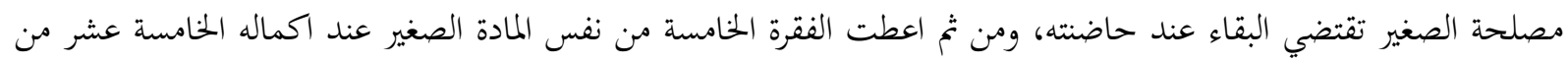

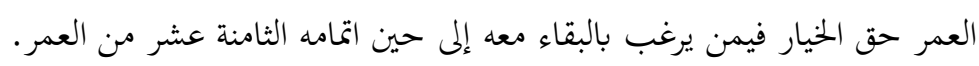

الفرع الثاني: مشاهدة المخضون

لما كانت الغاية الأساسية من الحضانة هي حفظ المخضون وتربيته ورعايته، لذلك وجب على الطرفين التعاون بينهما لتحقيق تلك الغاية، اذ أن مسؤولية المخضون تقع على عاتق كلا الطرفين في ظل قيام الحياة الزوجية وحتى بعد الانفصال، فالطفل

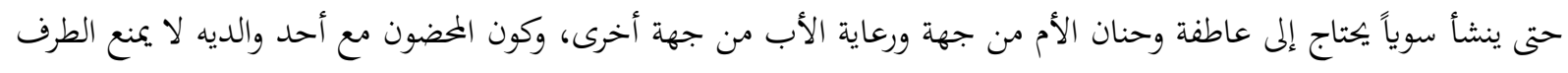

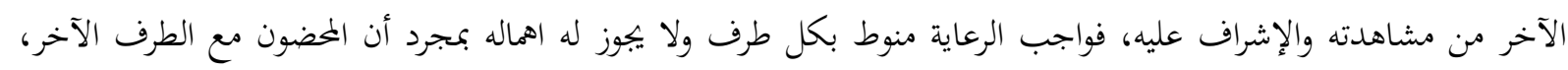

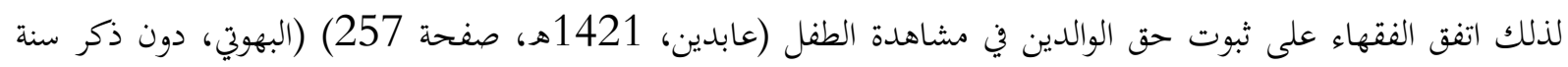

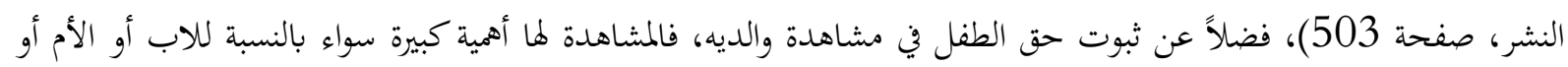


المخضون، فبالنسبة للاب والأم المشاهدة تحقق غايتان اولما اشباع عاطفة الابوة والأمومة، والأخرى لمتابعة شؤون الطفل وتربيته والاطمئنان عليه، أما بالنسبة للمحضون فمشاهدة والديه حق له كما اهما من باب صلة الارحام التي امرنا الله تعالى هما.

اما المشرع العراقي فلم ينظم أحكام المشاهدة بشكل واضح ودقيق، بل اقتصر فقط على اعطاء الأب حق النظر في شؤون

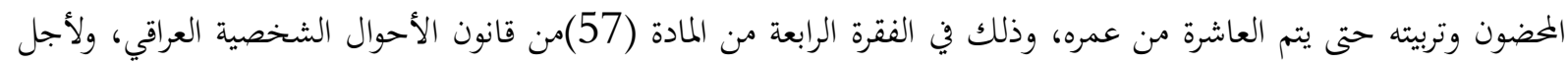

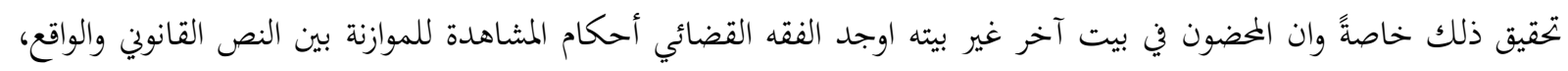

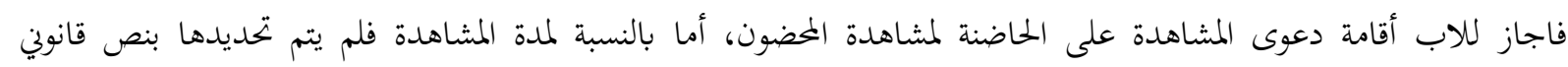

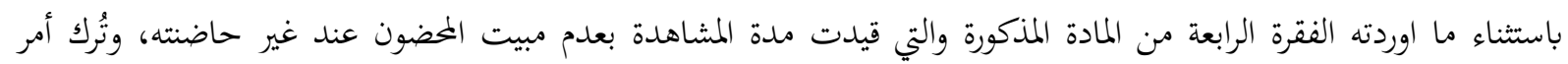

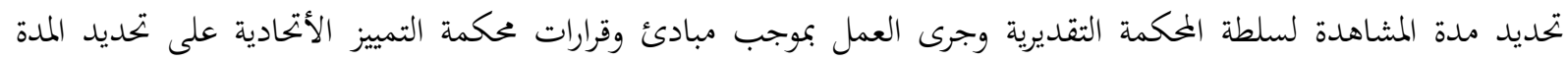

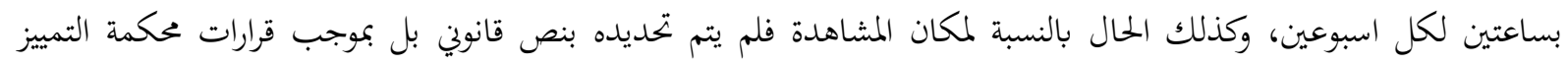

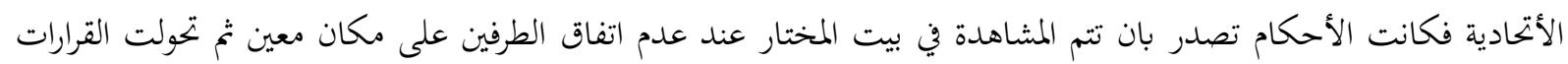

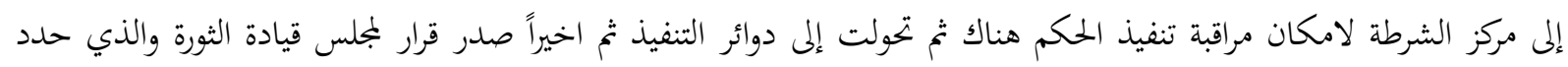

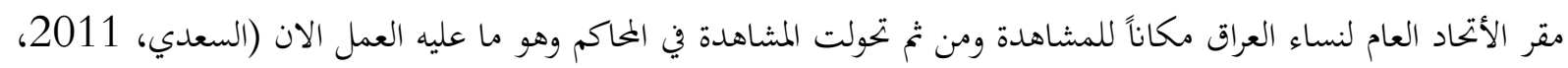

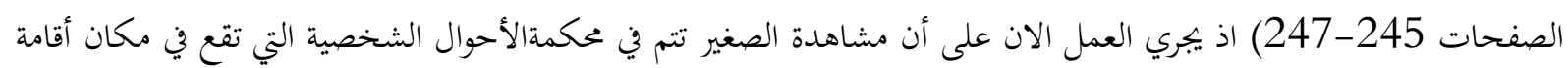
الصغير مساء كل يوم جمعة.

\section{الفرع الثالث: السفر بالخضون}

اختلف الفقهاء في حكم السفر بالمخضون وذلك بحسب الأساس الذي أقاموا عليه الحكم، فالحنفية قسموا السفر إلى قريب

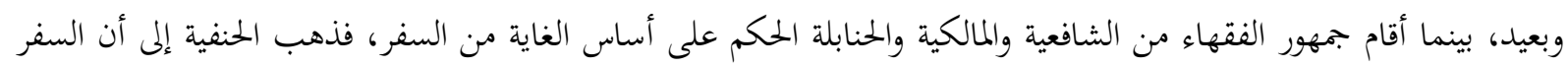

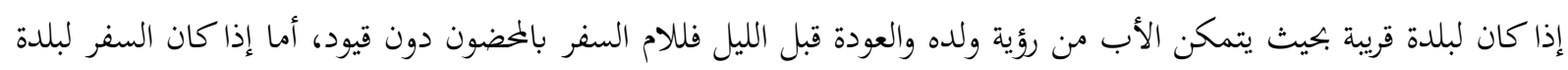

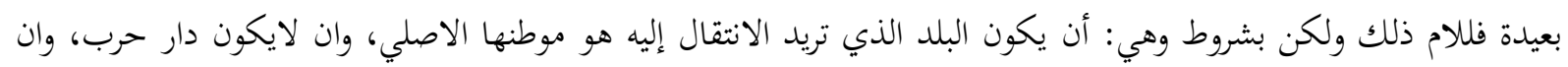

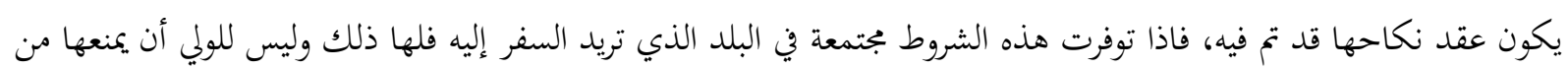

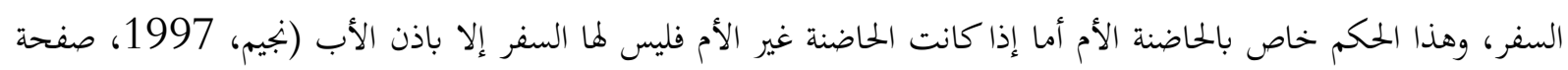

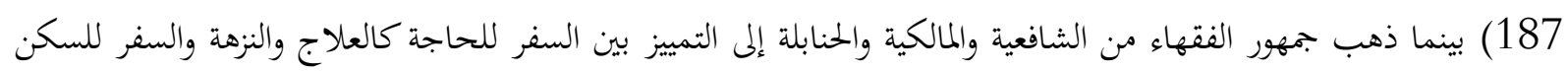

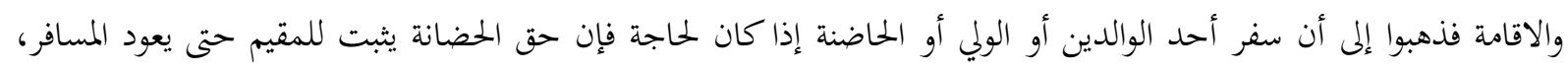

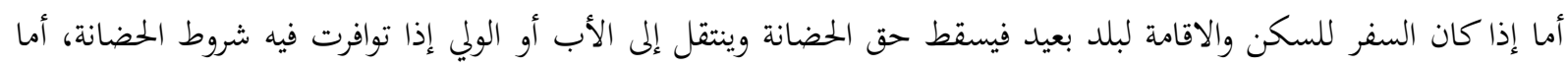

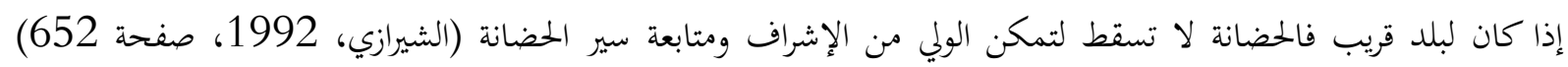
(الدسوقي، دون ذكر سنة النشر، صفحة 531) (قدامة، 1997، صفحة صنحة 217)|مان قانون الأحوال الشخصية العراقي فلم

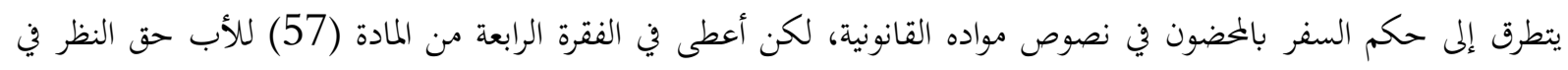

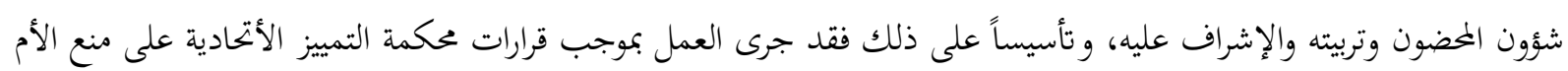

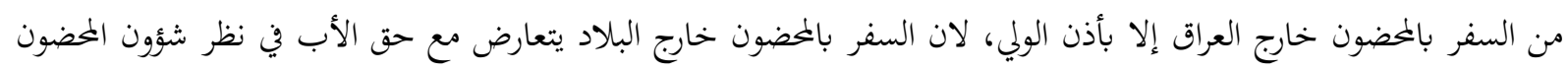




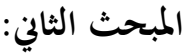

\section{مناقشة مقترح تعديل المادة 57 من قانون الأحوال الشخصية العراقي}

الحياة الزوجية رابطة مقدسة يتمخض عنها آثار مادية ومعنوية لا تقتصر على السلوك الاعتيادي لحياة الزوجين (الرجل، المرأة)

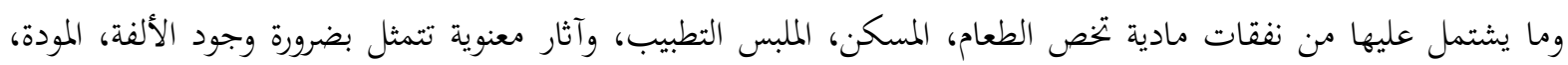

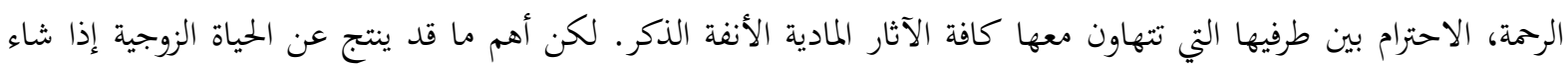

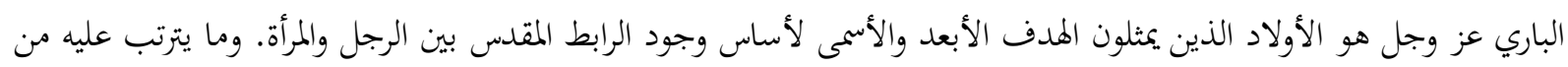
ضرورة رعاية مصالحهم.

فقد قسم الله سبحانه وتعالى واجبات الوالدين في حفظ الأولاد على مراحل حياتم فخص الأم بالحمل والولادة والرضاعة

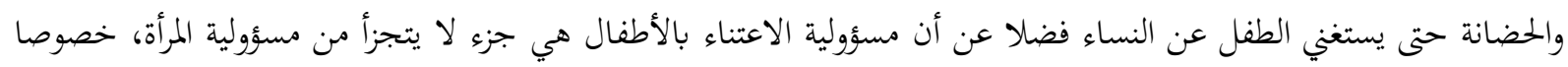

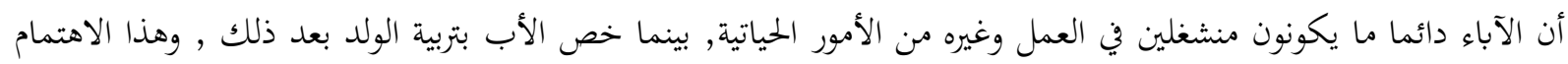

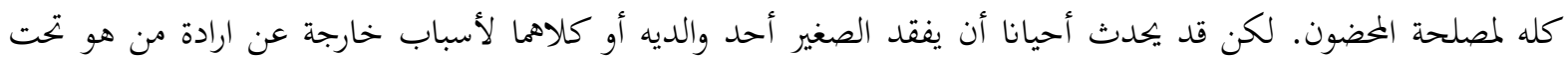

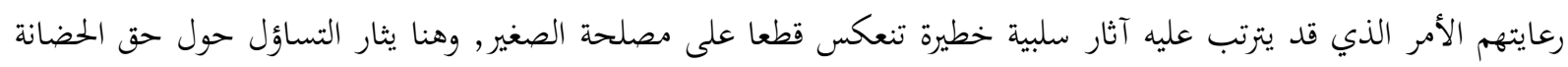

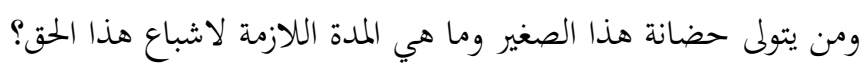
إن قانون الأحوال الشخصية العراقي رقم 188 لسنة 1959 قد نظم حق الحضانة بتسع فقرات تضمنتها المادة 57 منه

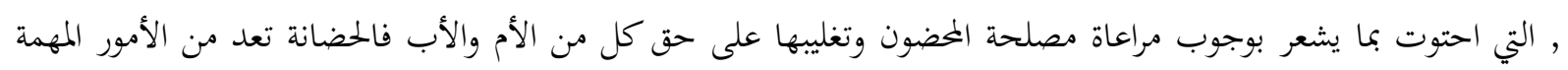

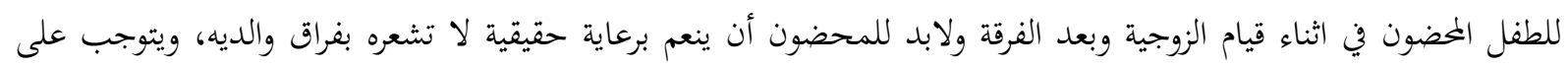

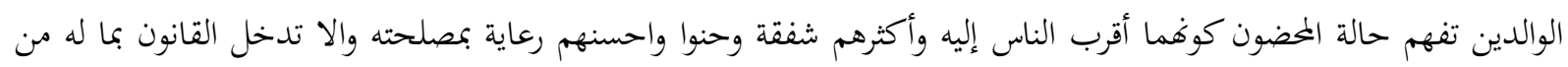

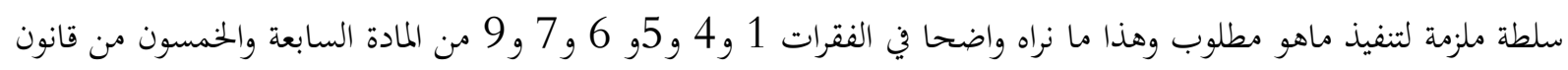
الأحوال الشخصية.

إلا أن البرلمان العراقي أجرى قراءة أولى في بداية شهر تموز الجاري لمشروع تعديل قانون الأحوال الشخصية رقم 188 لعام

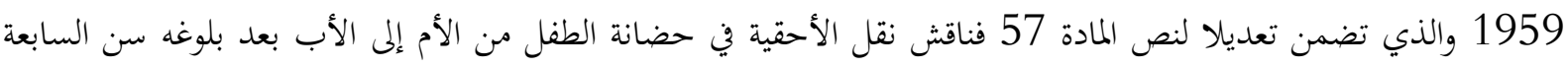

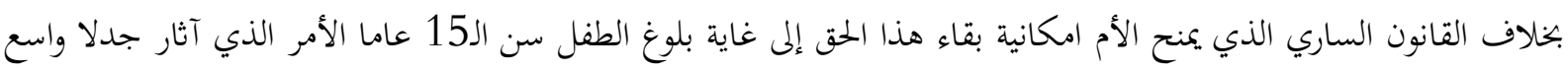

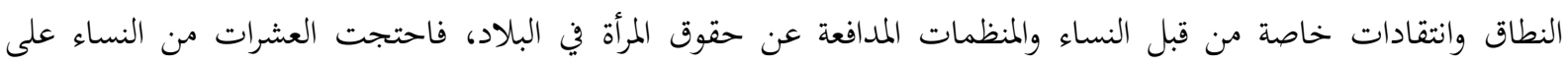
التعديلات المقترحة كوها تنص على أن تكون

الأم المطلقة أحق بحضانة الولد حتى يتم السابعة ويشترط عدم زواجها لأخذ الحضانة وبذلك، فإن الأصل يصبح حرمان

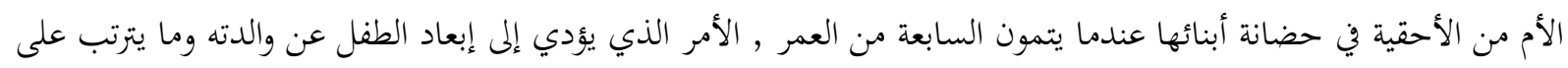
هذا من تبعات نفسية كبيرة خاصة وان عمر السابعة يعد من الاعمار الحرجة التي يجب أن يستمتع فيها الصغير بالاستقرار كوها

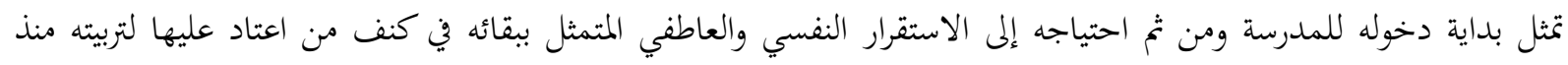

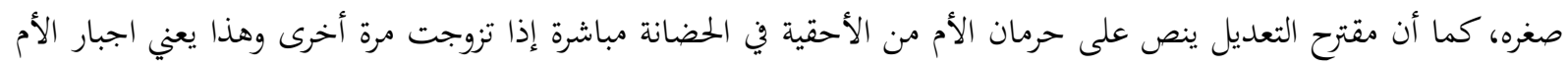

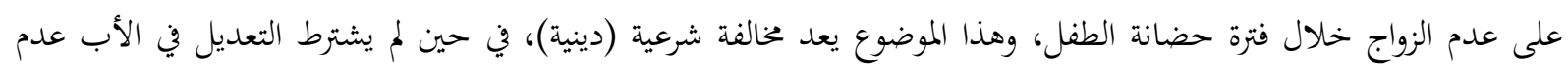

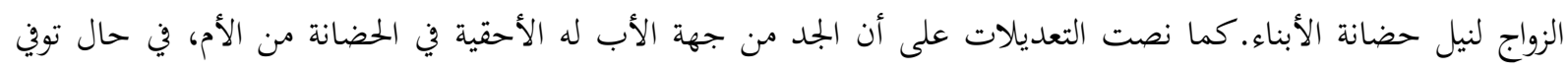
الأب أو انتفت لديه شروط الحضانة هذا من جهة، ومن جهة أخرى تدعم مطالب تعديل القانون آراء قانونية ودينية ترى في 
النص القانوين الحالي إجحافا في حق الآباء، وإضرارا بمصلحة الأطفال أيضا، مما يتطلب ضرورة البحث عن حل وسط يراعي مصلحة الآباء والأطفال دون الإضرار بمصلحة الأمهات.

وبغية تسليط الضوء على مقترح التعديل اعلاه لابد لنا من مناقشة الفقرات التي نص عليها التعديل والفقرات التي اغفل النص عليها وكالاتي:

1- أن مقترح التعديل بارجاعه سن الحضانة إلى سن التمييز الذي حدده المشرع العراقي بسبع سنوات كاملة بمقتضى نص الفقرة الثانية من المادة (97) من القانون المدني العراقي في الوقت الذي كان النص الموجود في قانون الأحوال الشخصية يجعل الثعل حضانة

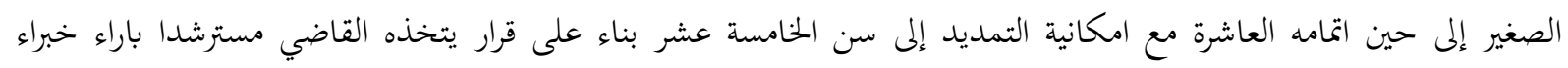

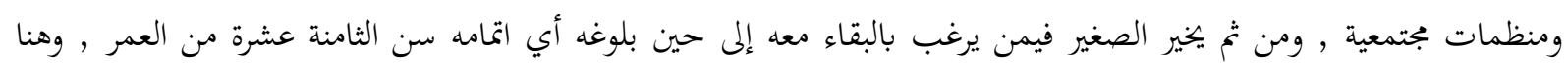

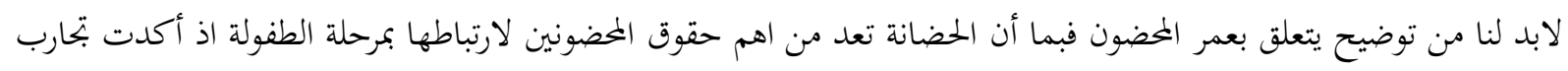

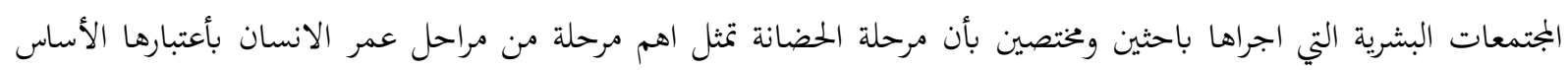

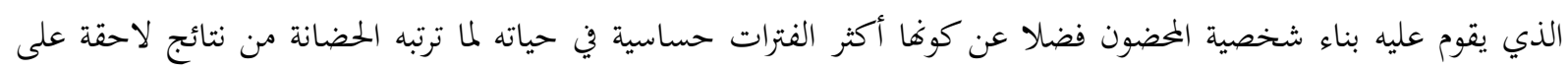

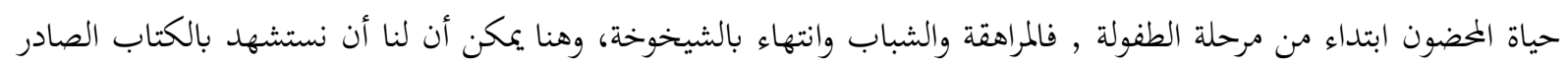

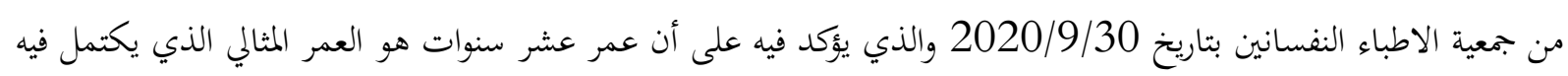

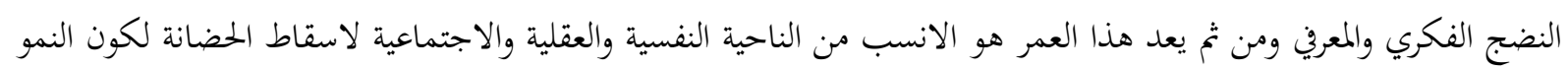
النفسي يفرق بين عمر 10 سنوات كمرحلتين منفصلتين من الناحية النفسية , ونظرا لان الاطراف المؤيدة لتعديل المادة (57)

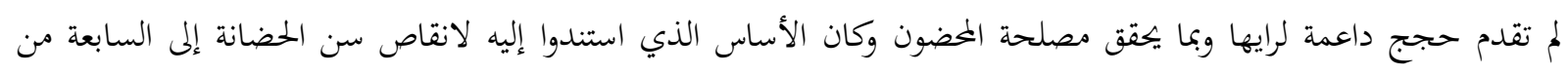

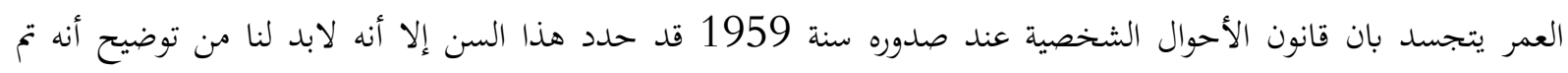

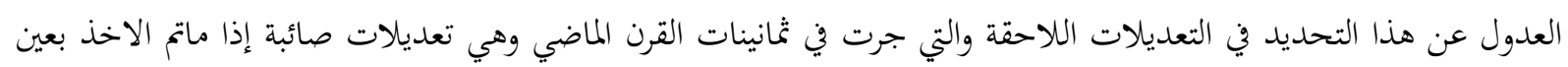
الاعتبار الاراء الطبية والنفسية والاجتماعية وهو ايضا ما يتم العمل به في الدول العربية ذات التراث الإسلامي والقانوين العريق. 2- أما فيما يتعلق بما نص عليه مشروع التعديل بنقل الحضانة من الأم إلى الأب بمجرد بلوغ الصغير سن السابعة فهو يتنافف

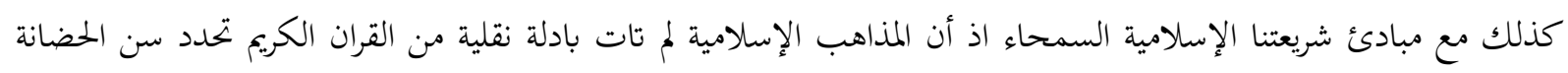

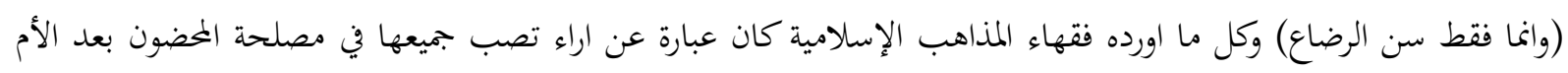

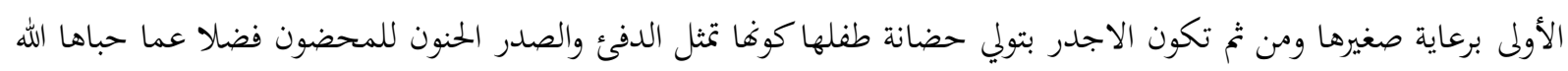

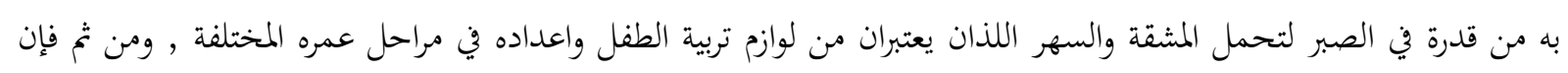

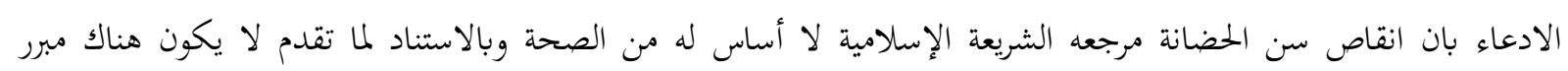
لانقاص سن الحضانة إلى السابعة.

3- وفيما يتعلق بسحب الحضانة من الأم بمجرد زواجها وحتى لو لم يبلغ الصغير السابعة من العمر فلابد من التنويه بداية إلى أن

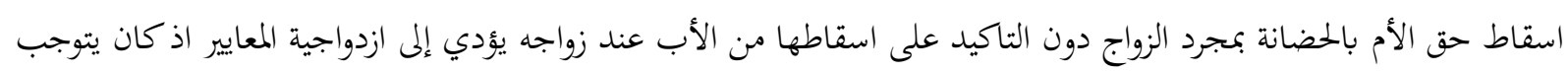

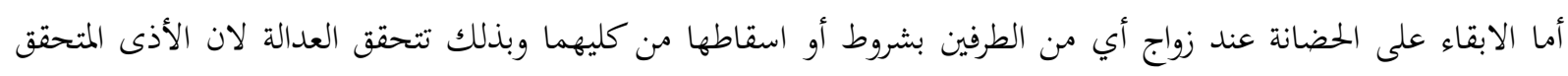

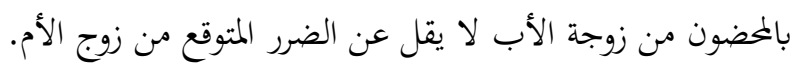

كما أن هذا الاسقاط يخالف توجهات الشريعة الإسلامية لانه سيجبر الأم على عدم الزواج خشية فقدان صغيرها

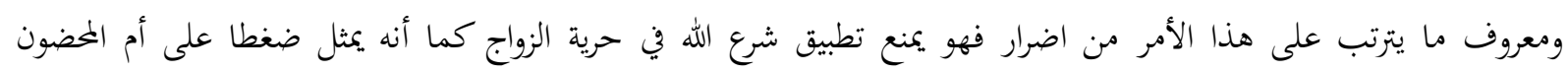
لاضطرارها إلى البقاء وحيدة دون زواج. 
4- أما فيما يتعلق بالفقرة الواردة بمقترح التعديل والتي تنص على انتقال الحضانة من الأب إلى الجد الصحيح (اب الأب وان علا)

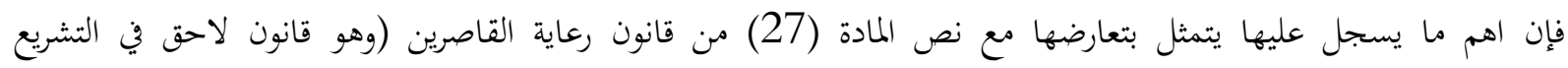

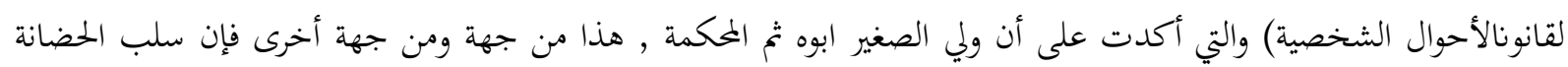

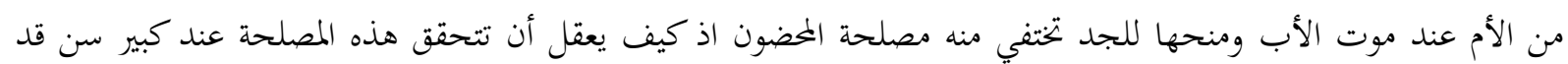
لايقوى على رعاية نفسه ناهيك عن مصلحة طفل.

كما أن هذه الفقرة تتعارض مع حقوق الارامل وخاصة زوجات الشهداء فاين المصلحة من سلب الحضانة منهن إذا بلغ المخضون السابعة وهو أصلا بدون أب سواء تزوجت هذه الارملة أم لا. 5- لابد من التاكيد على أن التعديل اغفل ما يضمن مصلحة المحضون اذ كان لابد أن يشتمل على حكم بمبيت المحضون مع والده لان نص الفقرة الرابعة من المادة 57 السابق يمنع ذلك، فكان يتوجب تنظيم هذان انلان الأمر خاصة وانه ينسجم وأحكام المادة 9 من اتفاقية حقوق الطفل الصادرة عن الجمعية العامة للأمم المتحدة في 20 تشرين الثانيمن 1989 والمصادق عليها من قبل العراق بموجب القانون رقم 3 لسنة1994 ، حيث ورد في نص الفقرة (1) من المادة أعلاه الآتي (تضمن الدول الأطراف عدم فصل

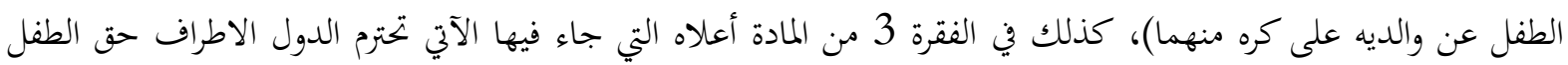

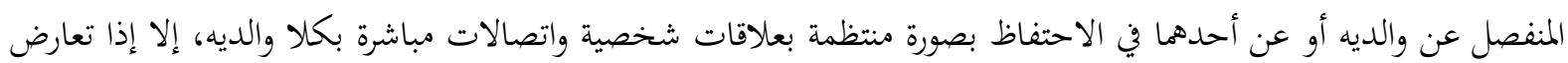
ذلك مع مصالح الطفل الفضلى.

6- إذا كان قانون الأحوال الشخصية النافذ قد رجح حق الحضانة للأم كجزء من واجب الرعاية والحماية والصيانة المقرر عليها

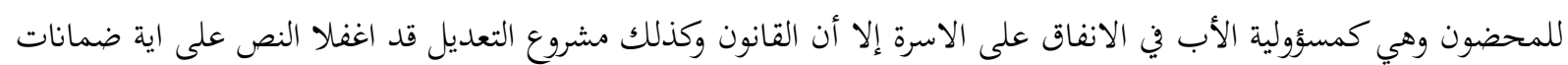

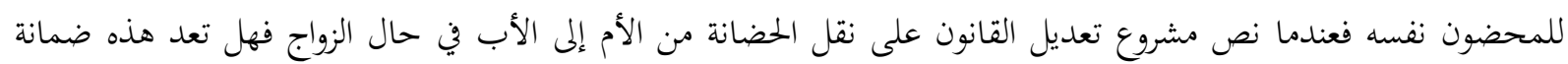

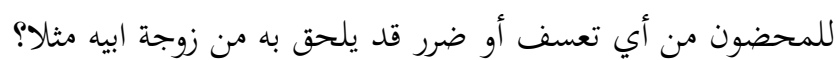
إن الإجابة على السؤال اعلاه تقتضي التاكيد على أنه لا يكفي وجود المخضون مع الأم أو الأب بدون ضمانات أساسية

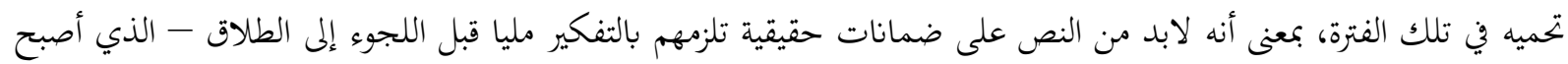

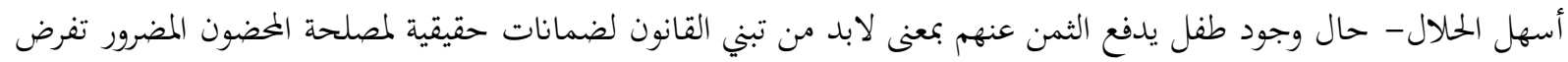

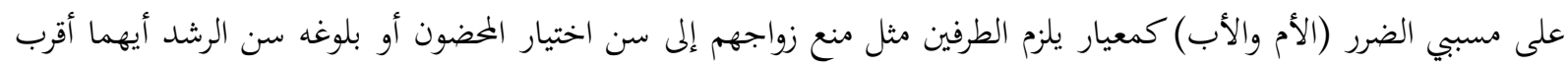

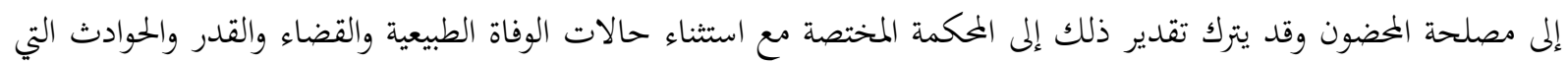
لا دخل لأرادة الشخص بها، أو النص على ضمانة مالية تستقطع من الأب مقدما لمصحلة المخضون وتودع لدى دائرة رعاية

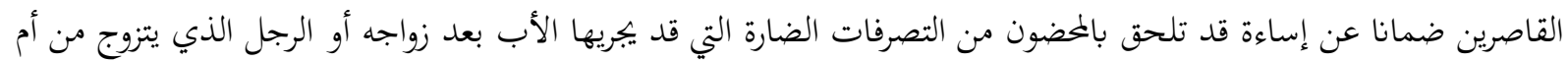

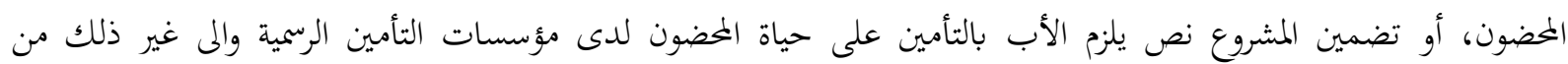

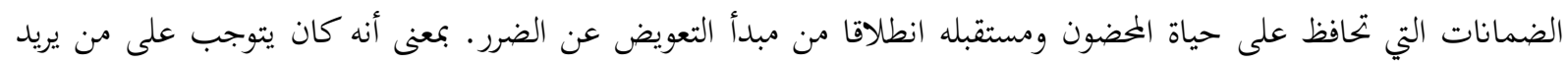

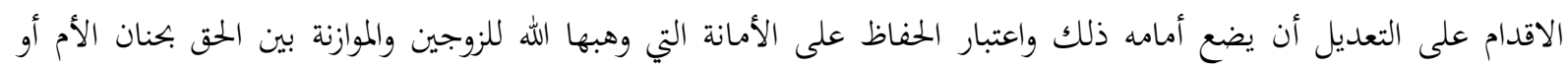

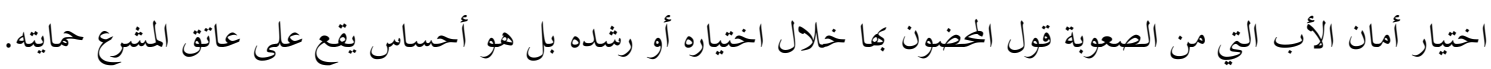
7- أن قانون الأحوال الشخصية العراقي قد ترك تحديد مكان مشاهدة المحضون لاتفاق الطرفين فإن لم يتفقا فقد كانت المشاهدة

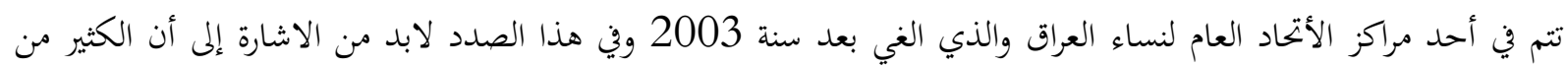

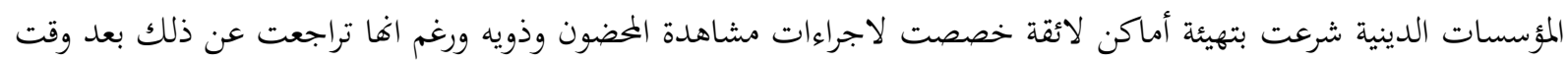
قصير بسبب ما تم رصده من خلافات وتصرفات تكون بالضد من مصلحة الصغير وطالبت الدولة بتحمل مسؤوليتها من خلال 
توفير أماكن تتوفر فيها ضمانات حقيقية تحقق المشاهدة بجو مريح لذلك كان الأولى بمشروع التعديل تنظيم مكان وزمان مشاهدة المخضون لاهمية هذا الأمر.

8- كما أنه في بعض الحالات - وهي من الأمور التي تم رصدها - قد لا يحضر الأب إلى موعد المشاهدة وما يترتب على ذلك فيك

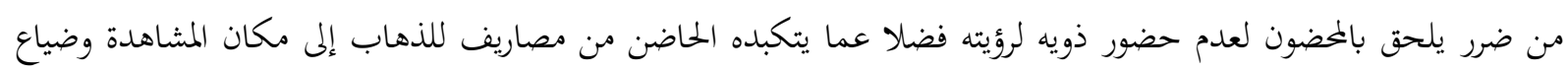

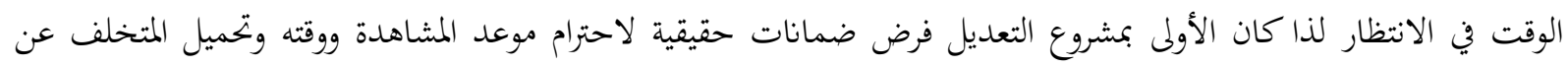
الحضور دون عذر مشروع غرامات فضلا عن عقوبات قد تصل إلى درجة حرمانه من المشاهدة لان عدم حضوره لمشاهدة صغيره

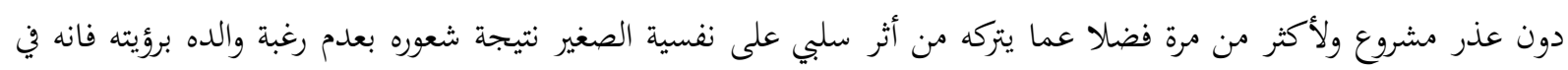
نفس الوقت دليل على عدم رغبة ذلك الأب بمتابعة شؤون صغيره.

9- أن موقف المشرع العراقي في قانون الأحوال الشخصية من مسألة الشروط المشتركة للحاضنين التي تتعلق بالحاضن لاستحقاقه

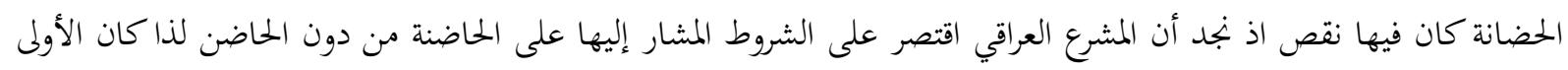

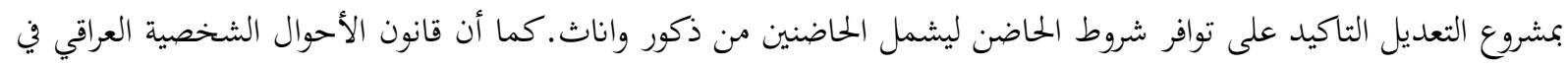

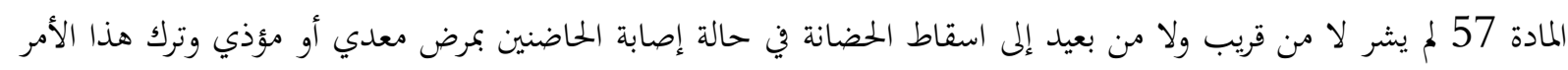
إلى مبادئ الشريعة الإسلامية الأكثر ملائمة لنصوص هذا القانون في حين كان الأولى بلى به النص على ذلى ذلك حفاظا على مصلحة المخضونن وهو أمر لم يتطرق إليه مشروع التعديل. 10- واخيرا فقد جاء قانون الأحوال الشخصية العراقي خاليا من أي نص تلميحا أو تعريفا لمسألة السفر بالمضون من قبل امه

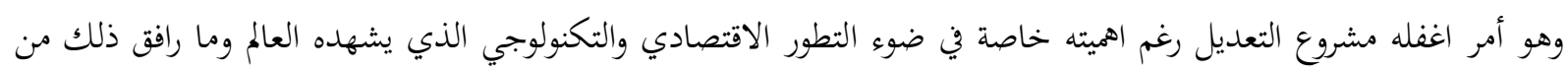

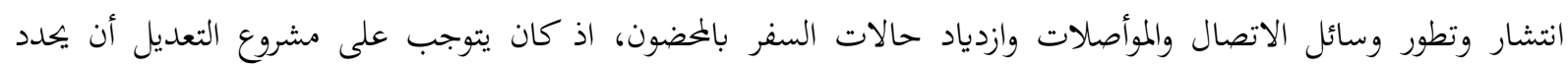

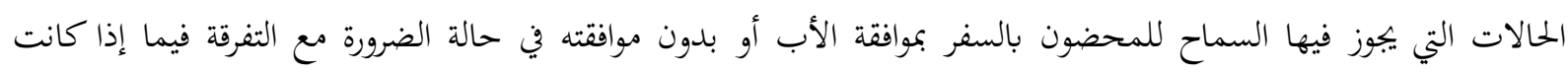
الحاضنة عراقية أم أجنبية، والتاكيد على حق الأب في حالة تخوفه من سفر المخضون في طلب كفيل.

الخايتمة

بعد الانتهاء من هذا البحث توصلنا إلى جملة من النتائج والتوصيات وعلى النحو الآتي: أولاً- النتائج

1-نظم المشرع العراقي موضوع الحضانة في المادة 57 من قانون الأحوال الشخصية العراقي رقم 188 لسنة 1959 إلا أنه لم

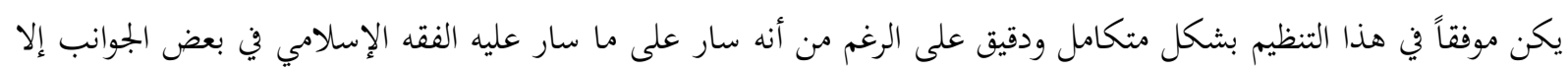
أنه لم يخلو من النقص التشريعي بالإضافة إلى عدم الدقة في تنظيم بعض الجوانب الأخرى. 2-نص المشرع العراقي على أربعة شروط يجب توافرها في الحاضنة لاستحقاق الحضانة وكان الاصح على المشرع العراقي ذكر مصطلح الحاضن ليشمل الذكر والأنثى. 3-نص المشرع العراقي على أن مدة حضانة الصغير تنتهي عند اتمام العاشرة من العمر، مع امكانية تمديدها إلى حين اكماله

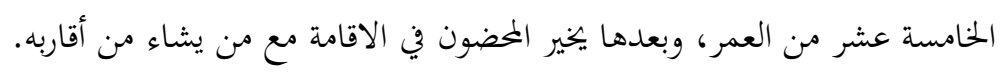

4-لم يتطرق المشرع العراقي إلى الأحكام الخاصة بمشاهدة المحضون من حيث مدة المشاهدة ومكاها وكذلك لم يتطرق المشرع

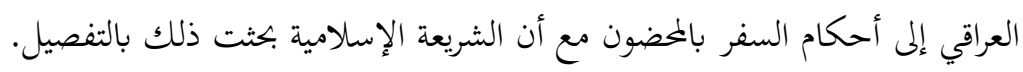


5-نظم المشرع العراقي الإشراف على الخضون ومدة الحضانة وتمديدها في فقرة واحد من المادة 57 بشكل متداخل وغير واضح،

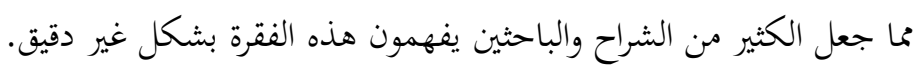

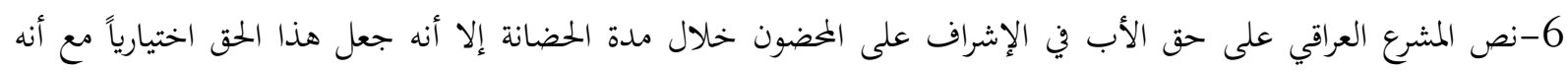

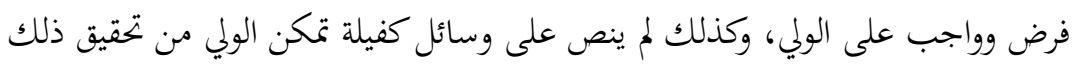

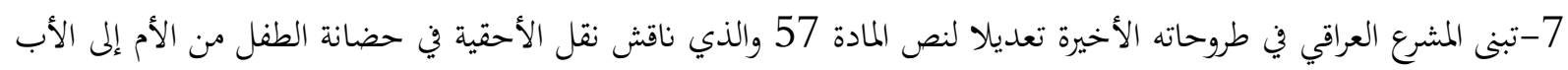

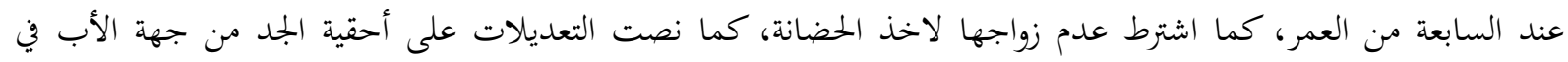

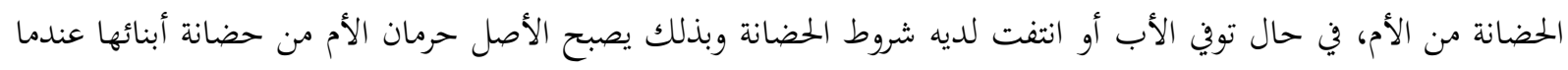

$$
\text { ثيتمون السابعة من العمر . ثلاًاً التوصيات }
$$

1- رفض مقترح التعديل المقدم إلى مجلس النواب (والمتعلق بانقاص سن الحضانة إلى سبع سنوات واسقاطها عن الأم في حالة

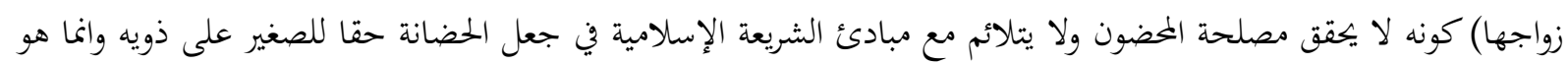

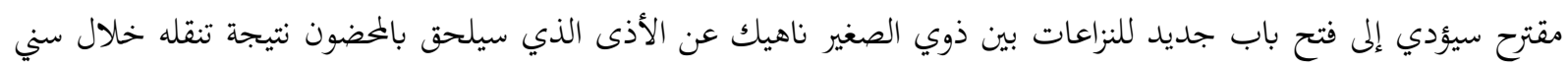

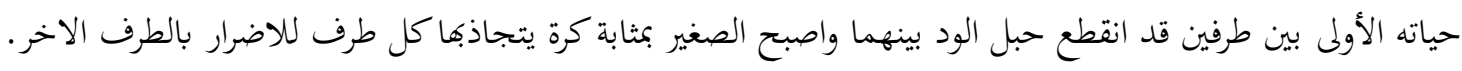

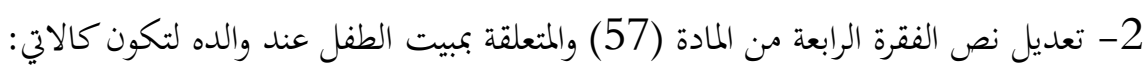
- للاب النظر في شؤون المخضون وتربيته وتعليمه حتى يتم العاشرة من عمره.

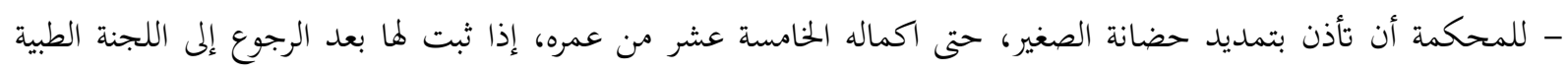
المختصة أن مصلحة الصغير تقضي ذلك.

- للمحكمة بناء على طلب من الأب أن تأذن بمبيت المضضون عنده لمدة تحددها إذا اقتضت مصلحة المخضون ذلك.

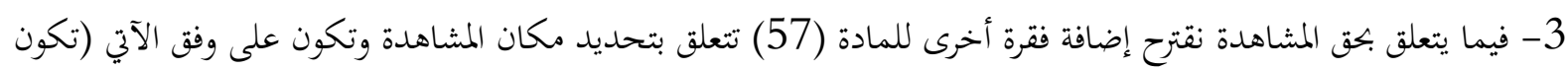

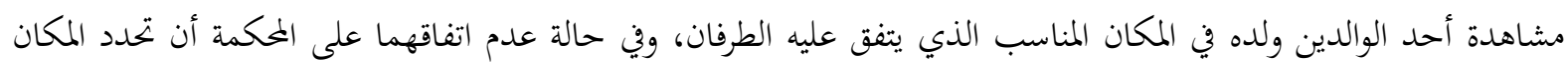
المناسب للمشاهدة في المكان الذي تقيم فيه الأم )

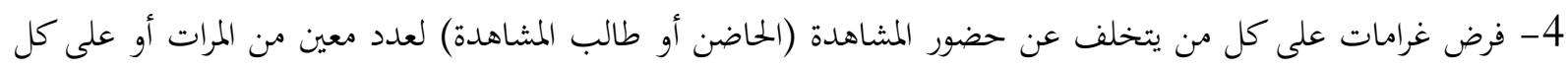

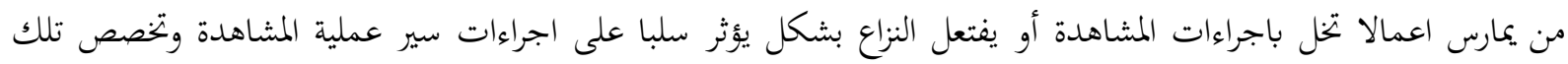
المبالغ في انشاء وتطوير أماكن خخصصة للمشاهدة تحت انظار السلطة وبحمايتها.

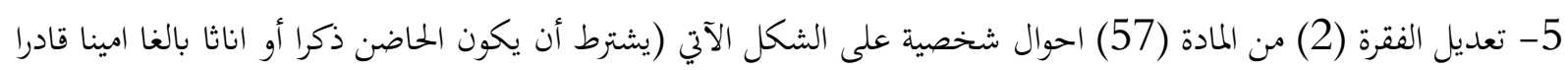

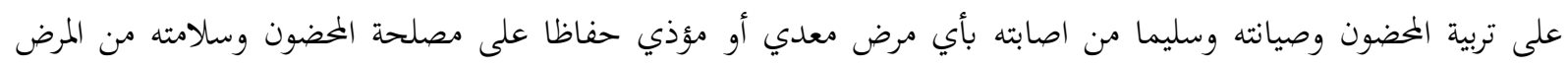

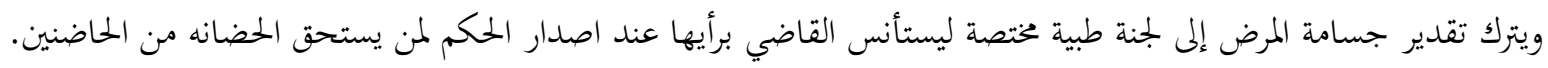

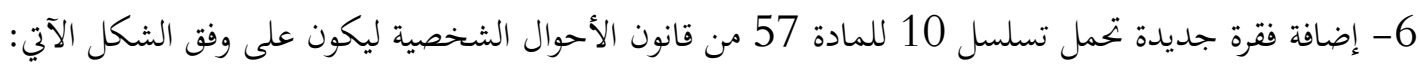

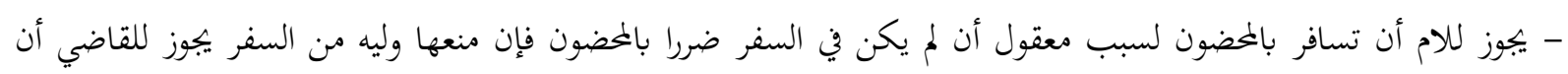

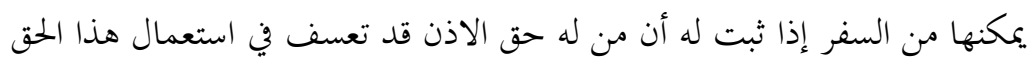

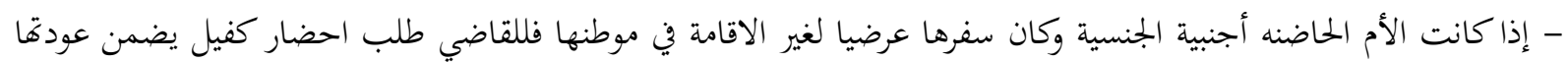

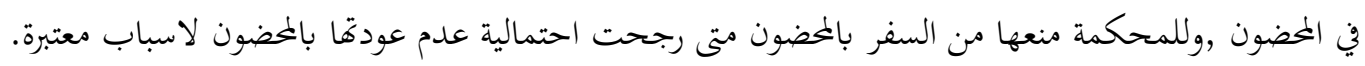




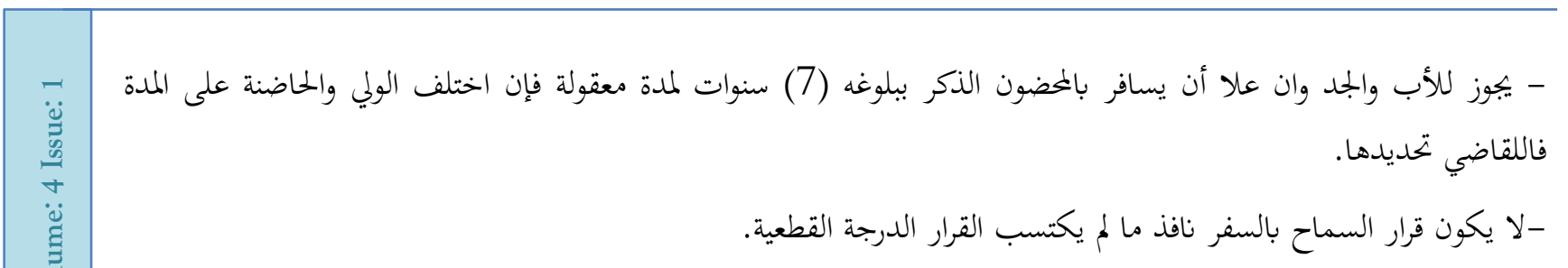




\section{المصادر}

ابراهيم بن علي بن يوسف الشيرازي. (1992). المهذب في فقه الأمام الشافعي. دمشق-بيروت: دار القلم-الدار الشامية.

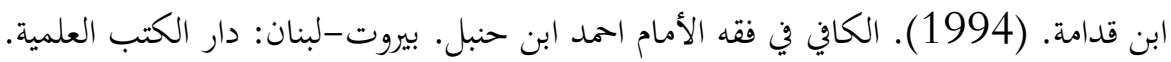

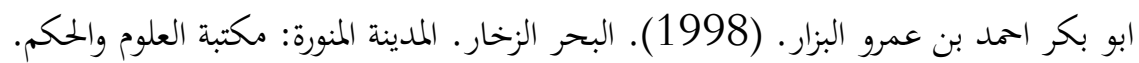
ابو بكر الرازي. (1950). غختار الصحاح. بولاق-مصر : المطبعة المبعة الأميرية. ابي عمر يوسف القرطبي. (1978). الكافي في فقه اهل المدينة. الرياض: مكتبة الرياض الحديثة. الدسوقي. (دون ذكر سنة النشر). حاشية الدسوقي على الشرح الكبير ج2. مصر : مطبعة عيسى البابي الحلبي.

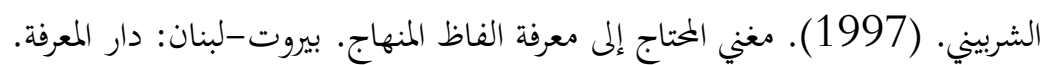

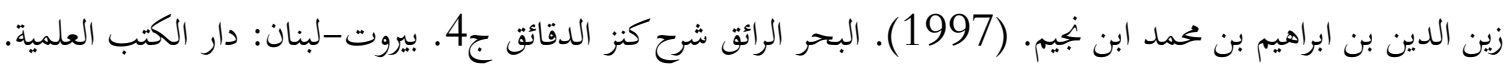

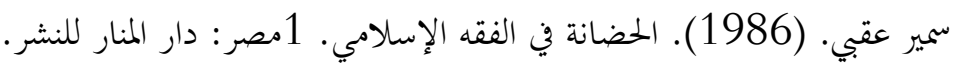

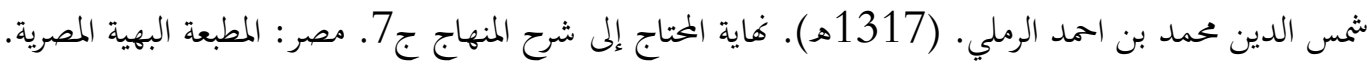
عبد الستار حامد. (1986). أحكام الاسرة في الفقه الإسلامي. بغداد: مطبعة الجامعة. عبدالله بن محمد ابن قدامة. (1997). المغني. الرياض: دار عالم الكتاب. لإناب. فخر الدين عثمان بن علي الزيلعي. (1314هـ). تبيين الحقائق شرح كنز الدقائق. بولاق: المطبعة الأميرية الكبرى.

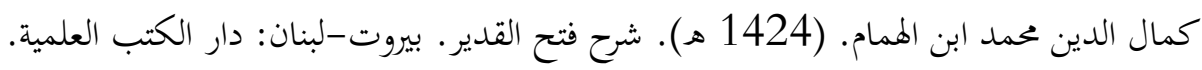

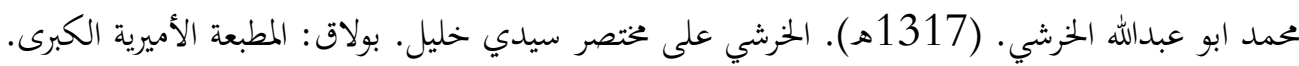

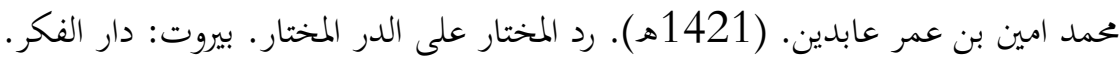

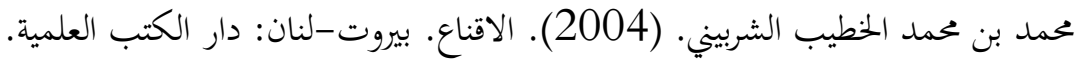

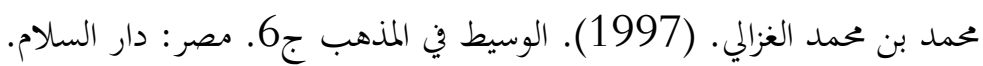

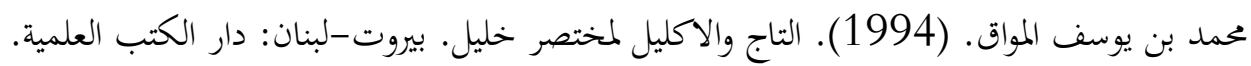
محمد حسن كشكول، عباس السعدي. (2011). شرح قانون الأحوال الشخصية. المكتبة القانونية: بغداد. لماد.

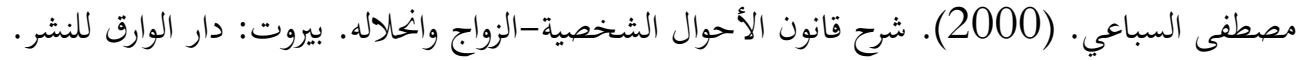

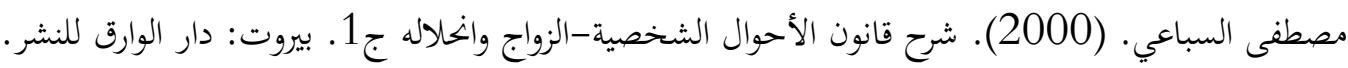

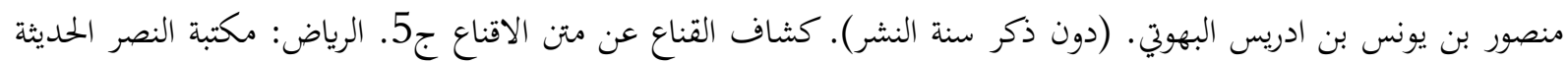
للنشر.

يهيى بن ابي الخير بن سالم العمراني. (دون ذكر سنة النشر). البيان في مذهب الأمام الشافعي. دون ذكر بلد النشر: دار المنهاج. 


\title{
THE POSITION OF THE OTTOMAN EMPIRE ON THE ISSUE OF THE MORISCOS AND ITS STRATEGY TOWARDS IT
}

\author{
Metin ŞERIFOĞLU ${ }^{1}$
}

\section{Istanbul / Türkiye \\ p. 488-502}

Received: 03/12/2021

Accepted: $17 / 12 / 2021$

Published: 01/01/2022

This article has been scanned I iThenticat No plagiarism detected

\begin{abstract}
:
This research deals with the issue of the Moriscan refugee crisis after the fall of Andalusia to the Spanish in 1492, and the brutal policies they carried out against the refugees. The research also deals with the policy of the Ottoman Empire towards this ordeal, which represented the largest global humanitarian crisis during the 16th and 17th centuries AD. The Ottoman Empire played a major role in the process of saving these Muslim and Jewish refugees, and their homeland in different parts of the Ottoman geography. The Ottoman Empire also succeeded in adopting an integrative policy for these refugees that took into account their social and sectarian specificities, as well as the societal privacy of the new settlement areas.

This policy has contributed to creating dynamism and vitality in these areas, and transforming Andalusian refugees into an active force on all cultural, social and economic levels. On the other hand, the Spanish and European refugee crisis revealed the mentality of the issue of religious freedom and the lack of recognition of other religious sects. At the same time, this crisis reflected the Ottoman mentality towards the issue of non-Muslim minorities and how the state interacted with them, and its ability to manage diversity within the Ottoman society.

In this context, we will try in this research to present a different analytical approach to the issue of Andalusian Muslim and Jewish refugees, as well as knowing the strategy of the Ottoman Empire towards it and the backgrounds that motivate it. This topic will be addressed through four axes as follows:

-First: Andalusia and its importance in attracting immigrants in the Middle Ages

-Second: The historical and political circumstances in which the Andalusian refugee crisis arose

-Third: The Andalusian refugee crisis and the position of the Ottoman Empire on it

-Fourth: The Ottoman Empire's strategy towards the refugee crisis -Fifth: The policy of the Ottomans towards the refugees from Andalusia.
\end{abstract}

Key words: Andalusia, Moriscos, Spaniards, Ottomans, Refugees, Jews.

http://dx.doi.org/10.47832/2717-8293.15.35

1 iD Dr. , Mardin Artuklu University, Türkiye, zoubeirk@ gmail.com 


\section{موقف الدولة العثمانية من أزمة المهاجرين الأندلسيين واستراتيجيتها تجاهها}

\section{متين شريف أوغلو 2}

الملخص: يتناول هذا البحث مسألة أزمة اللاجئين الموريسكين بعد سقوط الأندلس في يد الإسبان سنة 1492، وماقاموا به من سياسات وحشية ضد هؤلاء اللاجئين. كما يتطرق البحث إلى سياسة الدولة العثمانية بتحاه هذه المحنة التي مثلت أكبر الإسبان

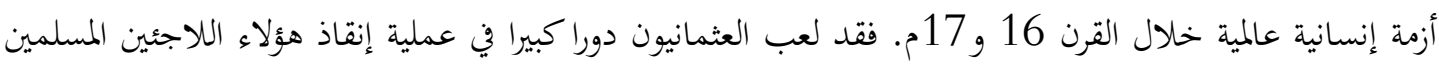
واليهود، ووطنتهم في أماكن متفرقة من الجغرافية العثمانية، كما نجحت الدولة العثمانية في انتهاج سياسة إدماجية لهؤلاء اللاجئين، راعت فيها الخصوصيات الاجتماعية والمذهبية لهم، وكذلك الخصوصية المجتمعية لمناطق التوطين الجلديدة. وقد ساهمت هذه السياسة في خلق ديناميكية وحيوية في هذه المناطق، وتحويل اللاجئين الأندلسيين إلى قوة فاعلة على ونى كافة المستويات الثقافية والاجتماعية والاقتصادية. من جهة أخرى كشفت أزمة اللاجئين الذهنية الإسبانية والأوروبية

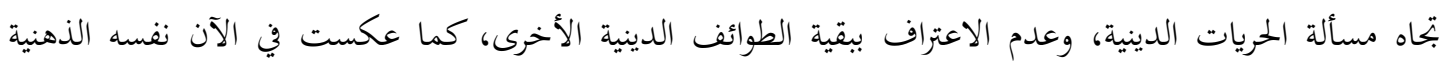
العثمانية بتحاه مسألة الأقليات غير الإسلامية، وكيف تفاعلت الدولة العثمانية معها، وقدرتها على إدارة التنوع داخل

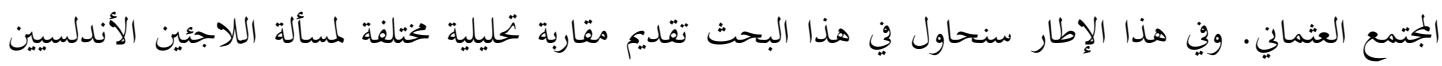
المسلمين واليهود، ووكذلك معرفة استرابتية الدولة العثمانية تجاهها، والخلفيات التي كانت تحركها. وسيتم تناول هذا الموضوع من خلال المحاور الخمسة التالية:

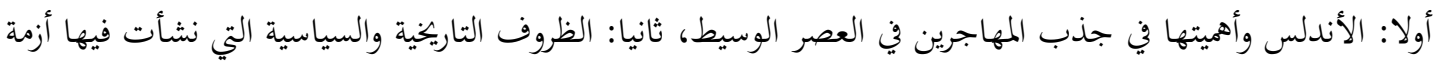
لاجئي الأندلس، ثالثا: أزمة اللاجئين الأندلسيين وموقف الدولة العثمانين فئنس منها، رابعا: استراتيجية الدولة العثمانية بتحاه

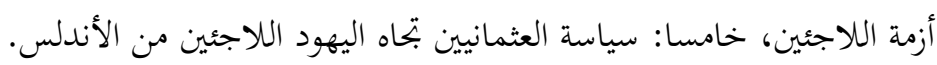
الكلمات المفتاحية: الأندلس، الموريسكيون، الإسبان، العثمانيون، اللاجئون، اليهود.

عندما نتأمل في التاريخ البشري نجد أن ظاهرة الهجرة واللجوء ظاهرة قديمة، وجدت منذ أن ظهر الإنسان على وجه هذه البسيطة. وقد عرفت مختلف مناطق العالم عدة موجات من الهجرة، ارتبطت أساسا بأسباب وعوامل مختلفة، منها ماهو إنساني، وماهو اقتصادي واجتماعي وثقافي وعسكري وغيرها. وقد كانت المنطقة العربية والإسلامية أحد أهم المناطق الرئيسية التي شهدت التهات

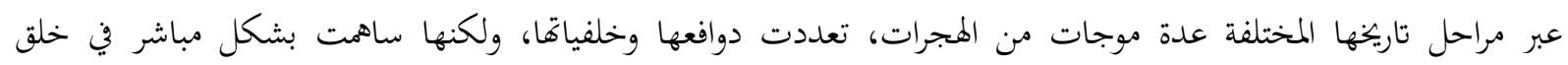

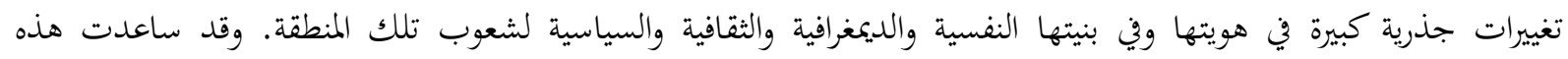
الهجرات على خلق حالة من التنوع الثقافي والعرقي والديني، ساهم في ظهور تبارب سياسية وثقافية وحضارية، تفاعلت فيها الثقافة

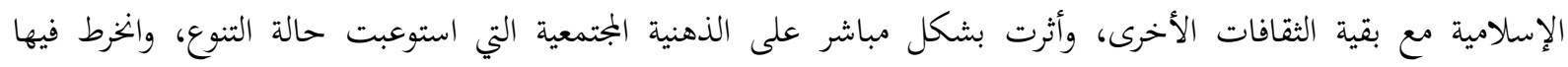
المهاجرون الجلدد بشكل تلقائي، وتحولوا إلى عنصر فاعل في تشكيل المنظومة الاجتماعية والسياسة والثقافية لتلك المناطق. وقد بلغ تأثير هذه الهجرات على منطقة العالم الإسلامي إلى درجة ظهور دول جديدة، أسس فيها اللاجئون القادمون من

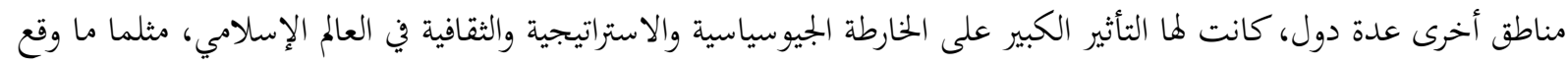


في منطقة الأناضول التي شهدت بداية من القرن العاشر ميلادي هجرات واسعة للقبائل التركمانية، قدموا من آسيا الوسطى، خصوصا بعد معركة ملاذكرد سنة 1071م. حيث نجحت الدولة السلجوقية بقيادة ألب أرسلان في تغيير المعادلة السياسية والاستراتجية والثقافية في منطقة الاناضول، ونجح في السيطرة عليها عبر استراتجية تشجيع القبائل التركمانية على الهجرة إلى منطقة الأناضول، وقدَّم لهم كل التسهيلات الضرورية لتحقيق عوامل الاستقرار فيها، والانخراط في نسيجها المجتمعي الذي تغير بفضل قوة تدفق اللاجئين التركمانية إلى مجتمعات تركية إسلامية.

وقد ساهت هذه الهجرات بشكل رئيسي في تدعيم أسس دولة سلاجقة الروم في منطقة الأناضول، وكذلك في ظهور أهم دولة في التاريخ السياسي الإسلامي بعد اهيار دولة السلاجقة، تمثلت في الدولة العثمانية التي كانت تنتمي إلى قبيلة قايي إحدى القبائل التركمانية القادمة إلى منطقة الأناضول في العهد السلجوقي، وقد تمكنت هذه القبيلة بقيادة عثمان غازي من تأسيس دولة

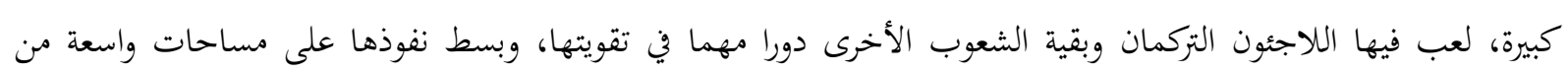
خريطة العالم الإسلامي وقسم واسع من القارة الأوروبية، كما أصبحت هذه الدولة لاعبا أساسيا في السياسة الدولية، خصوصا بعد فتح السلطان محمد الفاتح للقسطنطينية سنة 1453م، وتحويلها إلى عاصمة للإمبراطورية العثمانية التي بدأت تتوسع مساحتها الجغرافية، وانضوت تحت حكمها عدة شعوب وعرقيات ومذاهب أخرى، وأصبحت مركز جذب للهجرات الوافدة. غير أنه وفي الوقت الذي كانت فيه منطقة الشرق الإسلامي تشهد ظهور دولة إسلامية قوية، تؤمن بحالة التنوع الثقافي والديني والعرقي، وتشجع على الهجرات إليها لتسفيد من خبراتا المختلفة، كانت منطقة المغرب الإسلامي، وتحديدا في بلاد الأندلس تشهد في الآن نفسه حالة من الاهيار الشامل والسقوط في يد الإسبان الذين مارسوا تطهيرا عرقيا ودينيا بشعا جدا، لمج يشهد له العالم مثيلا. مما دفع بالمسلمين واليهود إلى الهروب من الأندلس وتركها، واللجوء إلى عدة أماكن مختلفة في أوروبا وفي شمال إفريقيا. وقد عكست هذه الممارسات التطهيرية حالة الذهنية الانتقامية المتطرفة التي لم تكن تؤمن بأي تنوع ثقافي أو ديني أو عرقي، بل إن هذه الذهنية الإسبانية لم تكن تعترف حتى ببقية المذاهب المسيحية الأخرى، وانتهجت بعد سقوط الأندلس سنة 1492م سياسة تصفية لكل الأديان الأخرى كالمسلمين واليهود والأورثودكس وغيرها. وفي ظل هذا المناخ التطهيري المرعب في إنبه الأندلس تعالت أصوات المسلمين اللاجئين الذين استنجدوا بالسلطان العثماني بداية القرن 16 من أجل إنقاذ حياقم، وإنقاذ معتقداتم وعائلاتم وأطفالهم ومتنلكاتم.

وأمام تفاقم أزمة اللاجئين في منطقة البحر الأبيض المتوسط، وتدفق أعداد كبيرة منهم على المناطق العثمانية، وازدياد سياسة الاضطهاد الاسباني للمسلمين واليهود تحركت الدولة العثمانية نخو إنقاذ هؤلاء اللاجئين، وانتهجت سياسة واسترابجية فعالة، ساهمت في إنقاذ الآلاف من اللاجئين، وتوطينهم في مناطق مختلفة من جغرافيتها. وقد وضعت الدولة العثمانية استراتيجية إدماجية لهؤلاء اللاجئين لكي ينخرطوا في مناطق التوطين الجديدة، والاستفادة من قدراهم وإمكانياهم وخبراتم. وقد اكتست هذه الاستراتيجية فعالية كبيرة، واستوعبت كل اللاجئين، بغض النظر عن انتماءاتم الدينية أو المذهبية، وساعدتم على الانخراط في بنية المجتمع العثماني المتنوع، حيث استفاد هؤلاء من مناخ الحريات الدينية ومن القوانين والتشريعات التي كانت سائدة في الجغرافية العثمانية.

-

تكمن أهمية هذا البحث في تسليط الضوء على محنة اللاجئين الأندلسين وموقف الدولة منها واستراتيجيتها في إنقاذ هؤلاء اللاجئين. فرغم أن العديد من الدراسات التاريخية قد تناولت مثل هذه المواضيع إلا أها لم تركز بشكل أوسع على الدور العثماين 
في التعاطي مع مسألة اللاجئين الأندلسيين المسلمين واليهود على حد سواء، ولم تتطرق إلى واستراتيجية توطينهم وإدماجهم في أماكن مختلفة من الجغرافية العثمانية.

\section{- أهدف البحث:}

يرمي هذا البحث إلى تحقيق عدة أهداف أساسية أهمها: - معرفة الظروف التاريخية والسياسية التي نشأت فيها أزمة اللاجئين الأندلسيين، وخلفياتما الدينية والاقتصادية والاجتماعية. - معرفة التداعيات التي خلفتها أزمة اللاجئين الأندلسيين وانعكاساتها على خريطة التوازنات الإقليمية والدولية

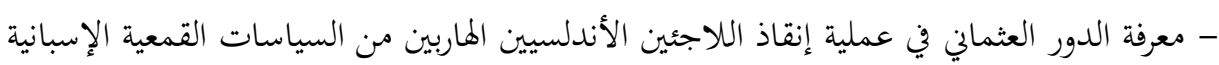

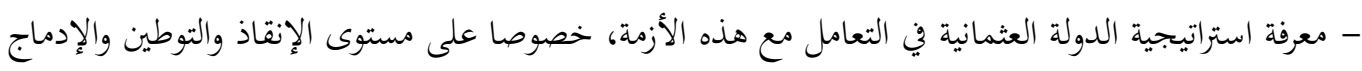
- معرفة موقف الدولة العثمانية واستراتيجيتها بتحاه اللاجئين اليهود الذين فروا من إسبانيا - معرفة وضعية الحريات الدينية في كل من الجغرافية العثمانية والدول الاوروبية خصوصا إسبانيا وفرنسا وإبجلترة

\section{- منهجية البحث:}

سيتم في هذا البحث تقديم قراءة تحليليلة تاريخية واستقرائية لمسألة اللاجئين الأندلسيين، وسيتم اتباع المنهجية التالية: - مقدمة - المحور الأول: الأندلس وأهميتها في جذب المهاجرين في العصر الوسيط

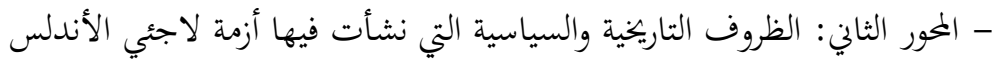
- المحور الثالث: أزمة اللاجئين الأندلسيين وموقف الدولة العثمانية منها لتهيه - المحور الرابع: استراتيجية الدولة العثمانية بحاه أزمة اللاجئين

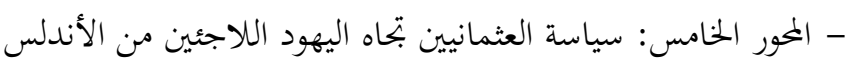
- الخاتمة -

\section{1- الأندلس وأهميتها في جذب المهاجرين خلال العصر الوسيط:}

لعله من المفيد حتى نفهم أزمة اللاجئين الأندلسيين بعد سقوط الأندلس أن نشير هنا إلى أن الأندلس كانت مركز جذب

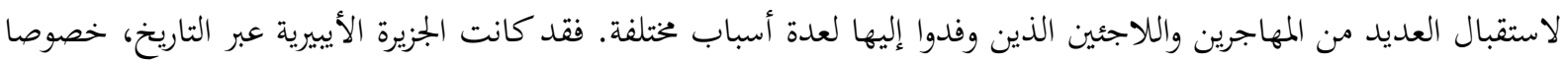
في فترة الحكم الإسلامي ملجأ آمنا للكثير من الشعوب اللاجئة، وذلك لطبيعة المناخ السياسي والاقتصادي والثقافي والحريات الدينية والفكرية التي توفرت في تلك المنطقة. ويمكن القول إن هناك أسباب مختلفة لتدفق اللاجئين على منطقة الأندلس خلال فئل فترة العصر الوسيط. ويأتي الدافع الديني في مقدمة هذه الأسباب، حيث اتسمت فترة الحكم الإسلامي في الأندلس بالحريات الدينية، الأمر الذي جعلها وجهة للعديد من الأقليات الدينية المضطهدة، خصوصا في أوروبا التي كانت تمارس سياسة الاضطهاد الديني، وكانت الكنيسة تمارس ضغطا كبيرا على مخالفيها من بقية الأقليات الدينية الأخرى، ومنها اليهود الذين تعرضوا إلى اضطهاد كبير،

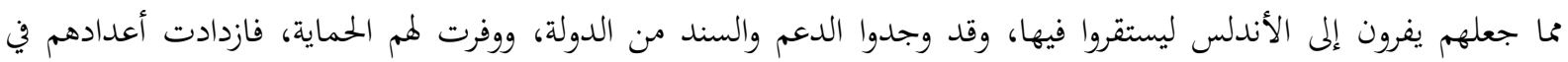

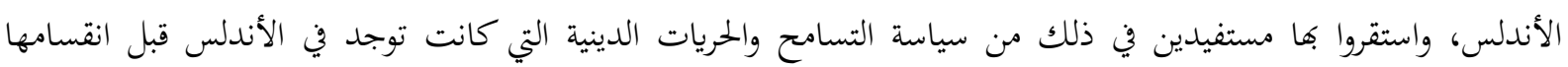
(حوراني، 2008، الصفحات 230-233). 
أما الدافع الثاني فهو دافع علمي، وذلك بسب ازدهار الحياة العلمية والفكرية التي شهدها الأندلس، ووجود العلماء

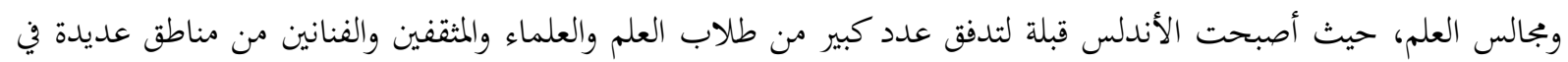

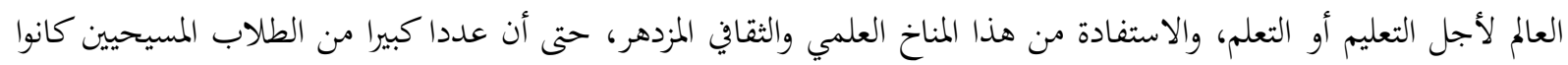

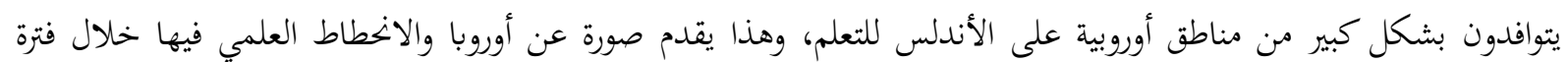

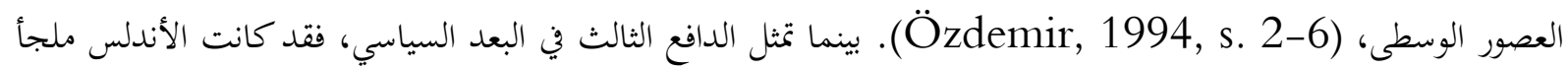
للكثير من المعارضين للدولة العباسية وللفاطميين ومن المعارضين للكنيسة. وقد استفاد كل هؤلاء من الحريات السياسية والدينية التي وجدت في فترة الحكم الإسلامي في الأندلس قبل فترة انقسامها، وقد تم استقبالهم من قبل الدولة، ووفرت لهم الحماية الكاملة من منطلق إنساني أخلاقي ديني، وكذلك من منطلق سياسي للاستفادة منهم في تعاملاقا مع تلك الدول التي فر منها هؤلاء جراء الاضطهاد السياسي الذي مورس عليهم، أو جراء التمرد والفتن التي عرفتها تلك المناطق (Lütfi, 2007, s. 30- (28). أما الدافع الرابع لتدفق الموجات على منطقة الجزيرة الآيبيرية فيتمثل في البعد الاقتصادي، حيث شهدت بلاد الأندلس في

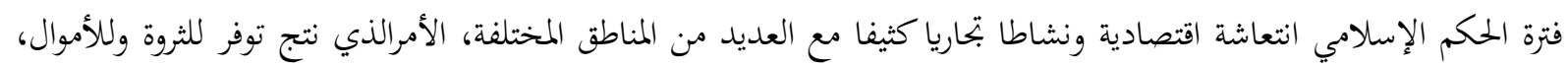

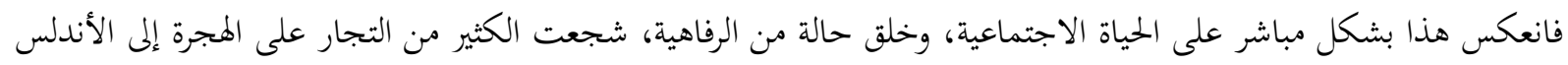

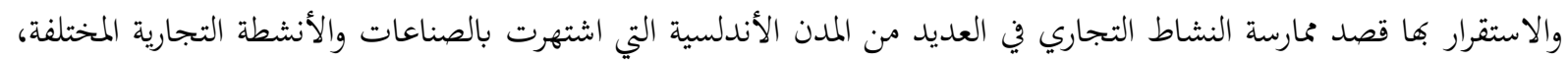

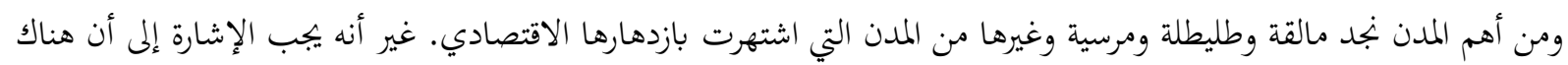

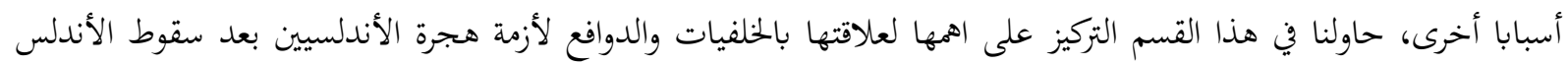

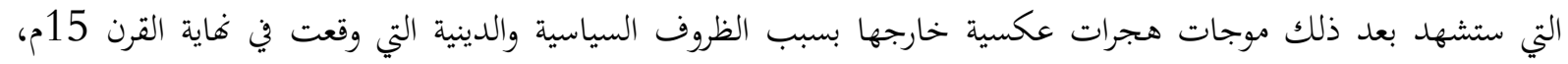

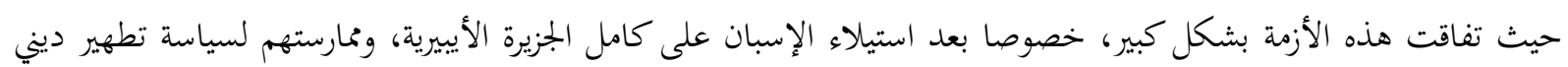
وحشية واسعة ضد المسلمين واليهود الذين كانوا يقطنون في الأندلس (4ka (Aka) 1997, s. 42).

\section{2- الظروف التاريخية والسياسية التي نشأت فيها أزمة مهاجري الأندلس:}

ظهرت أزمة اللاجئين في ظل ظروف تاريخية وسياسية صعبة شهدةا منطقة الأندلس نتيجة الانقسامات الطائفية وتراجع

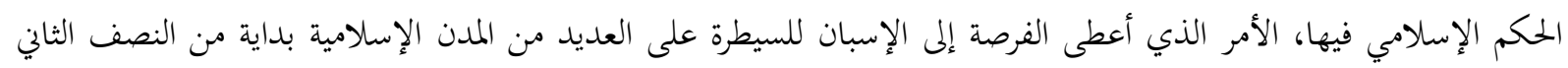
من القرن 15م. لذلك بدأ الخوف يدب في الكثير من سكان الأندلس، وشرع الكثير منهم يفكر في الهجرة ومغادرة الأندلس بحثنا عن أماكن أكثر أمانا واستقرارا. وقد أصبحت الأندلس محاصرة بعدة ممالك مسيحية، تترصد سقوطها للاستيلاء عليها، مثل مملكة البرتغال وقسطيلية والأراغون التي كانت تشن هجمات متكررة على المدن الإسلامية من أجل السيطرة عليها، وقد عانى السكان السان

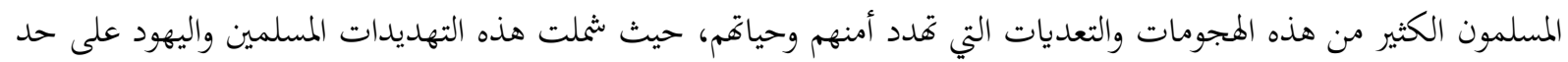
سواء، وبات واضحا أن الإسبان المسيحيين وبقية الممالك المسيحية الكاتوليكية متفقة فيما بينها على القيام بعمليات تطهير ديني وعرقي لكل المسلمين واليهود دون تمييز (Paşa, 2011, s. 23-24).

وقد آلت هذه الظروف السياسية الصعبة إلى سقوط مدينة غرناطة في يد الإسبان سنة 1492م، وبذلك ينتهي الوجود

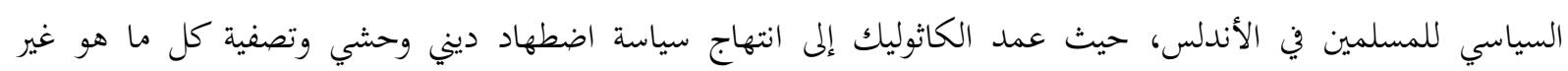
مسيحي، خصوصا من المسلمين واليهود، وتشكلت محاكم تفتيش لهذا الغرض، بتجبر المسلمين واليهود على ترك دياناتمب، وتجبرهم على اعتناق المسيحية والمذهب الكاثولوكي، كما تم سجن وقتل ونفي الكثير من رفضوا هذه الأوامر. وكانت الملكة وإليزابيت قد فئد أصدرت مع زوجها فرديناند مرسوما يمهل المسملين واليهود عشرة أشهر لترك منطقة الأندلس، ومن يخالف هذئ هذا القرار يعرض نفسيه 
إلى السجن أو القتل. وقد مثل هذا القرار إعلان الحرب من المسيحيين على كل ديانة أخرى تخالف المسيحية والمذهب الكاثوليكي، وقرارا بدأت بموجبه ممارسة عمليات تطهير ديني واسعة، استعملت فيها كل الوسائل الوحشية والبشعة والتنكيل

بالمسلمين واليهود الذين وجدوا أنفسهم مجبرين على ترك البلد خوفا على معتقداتم وأرواحهم (Güleryüz, 2015, s. 57). وفي ظل هذا المناخ السياسي الجديد الذي تيمن عليه ممارسات قمعية ووحشية بدأ الإسبان ومحاكم التفتيش في تطبيقها ضد المسلمين واليهود، فقد حدثت عدة ثورات وانتفاضات ضد السياسة الإسبانية، قابلتها السلطات الإسبانية بسياسة قمع وحشية، ومارست إبادات جماعية، وراح ضحيتها الآلاف من المسلمين المدافعين عن حرياتم الدينية، حيث عرفت هذه المرحلة موجات هجرة واسعة من المسلمين واليهود الفارين من القمع الإسباني، فقد لجأ هؤلاء إلى العديد من المناطق المختلفة، مثل شمئل منال

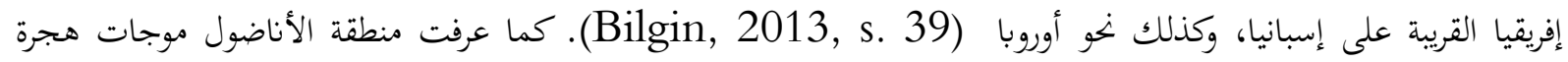
واسعة، وتدفق عدد كبير من اللاجئين الأندلسيين إلى مناطق الدولة العثمانية بحثا عن الأمان، الأمر الذي جعل السلطات

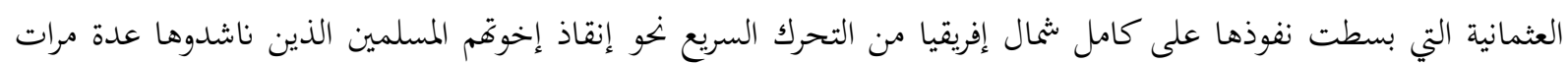

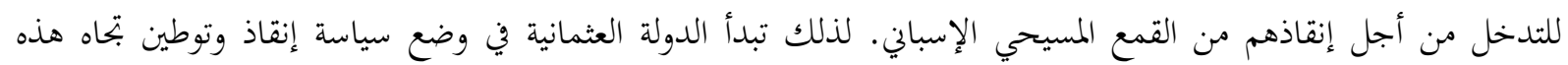
الموجات الكبيرة من اللاجئين المسلمين واليهود (Özdemir, 1994, s. 229). فكيف كانت سياسة الدولة العثمانية بتحاه أزمة اللازمة؟ وما هي الوسائل التي انتهجتها في التعامل معها؟ وماهي الحنفيات التي كانت تحرك الدولة العثمانية في استقبال مثل

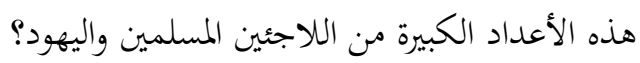

3- أزمة اللاجئين الأندلسيين وموقف الدولة العثمانية منها:

شكل المشروع الإسلامي العثماني في منطقة الشرق الإسلامي تمديدا كبيرا للدول المسيحية في أوروبا، خصوصا بعد فتح القسطنطينية، حيث انتهج العثمانيون بعد هذه المرحلة سياسة توسعية في ابتاه أوروبا، وبقدر ما كانت هذه الاستراتيجية مخيفة ومزعجة للغرب، فقد كانت في الوقت نفسه أملا وخلاصا جديدا بالنسبة إلى بقية شعوب الجغرافيا الإسلامية، خصوصا المسلمين في الأندلس، أملا وقوة دعم لهم على الأقل معنويا ضد التهديد المسيحي المحدق بكم في شثمال الجزيرة الأيبيرية، لذلك عمت الفيك الفرحة والسرور كل مناطق العالم الإسلامي عندما تواردت أخبار فتح القسطنطينية، وتويلها إلى عاصمة إسلامية، أصبحت قبلة جذئب

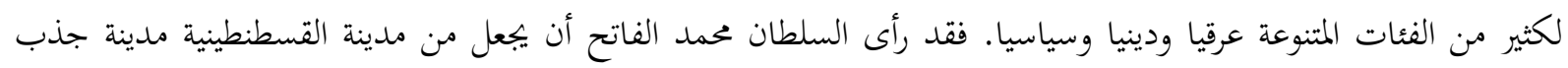

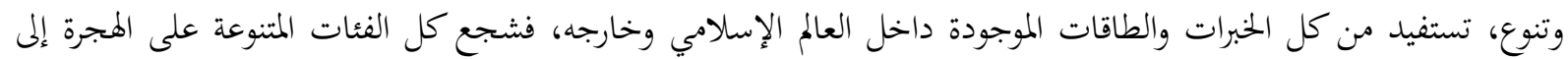
استانبول، وسهل لكثير من الأرمن واليهود وبقية الطوائف الأخرى عملية القدوم والدعم اللوجستي والمادي، ومنحهم حقوقهم الدينية وحرية معتقداتم وماية معابدهم وكنائسهم، بل إن السلطان محمد الفاتح أصدر نظام الملل لحماية حقوق الاقليات غير وني

المسلمة في الجغرافيا العثمانية، وكانت مؤسسة نظام تحت مراقبة السلطان نفسه (C.E.BOSWORTH, 1982, s. 37). خلال هذه المرحلة التاريخية بدأت العلاقات العثمانية الأندلسية تتوطد وتتعزز، خصوصا في عهد السلطان بايزيد الثاني الذي أرسل له آخر ملوك غرناطة عبد الله الصغير رسولا ليشرح له أوضاع المسلمين في الأندلس، ويعطيه فكرة شاملة حول بله

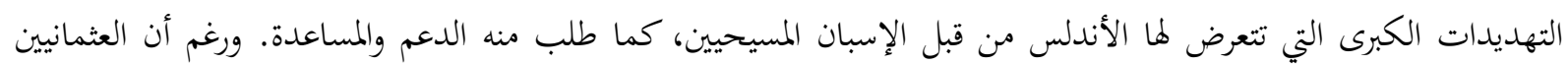

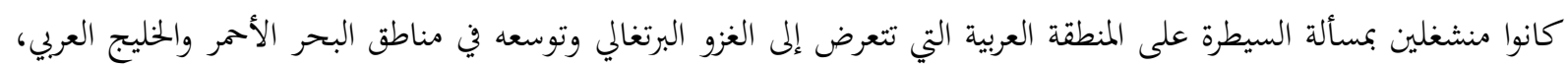

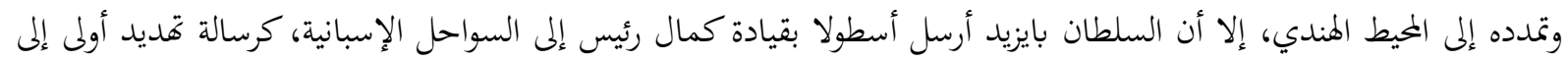
إسبانيا من أجل الضغط عليها للكف عن اضطهاد المسلمين في الأندلس من ناحية أولى، وكذلك من أجل نقل اللاجئين المسلمين واليهود الفارين إلى ثمال إفريقيا إلى العديد من المناطق المختلفة من ناحية ثانية (122-Sakaoğlu, 2002, s. 119). 
ويمكن القول إن العلاقات بين العثمانيين والأندلسيين بدأت تأخذ منعطفا أكبر مع صعود السلطان سليمان القانوني إلى

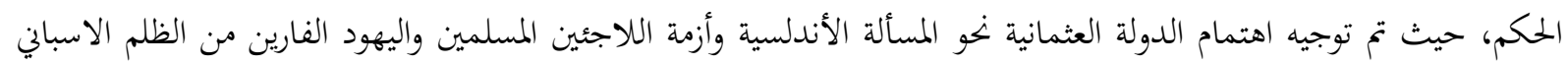

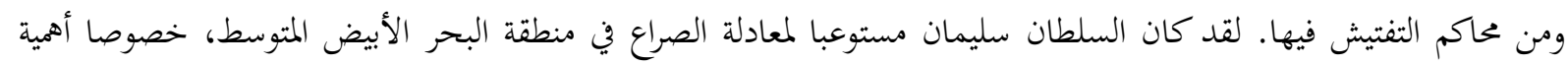

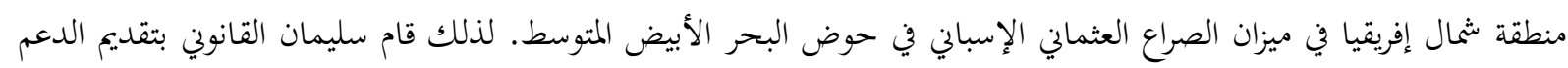

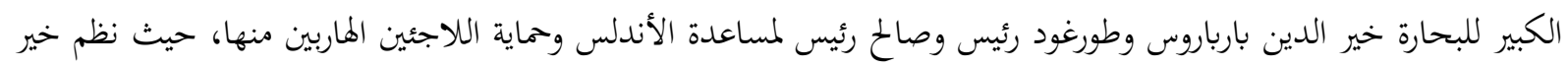

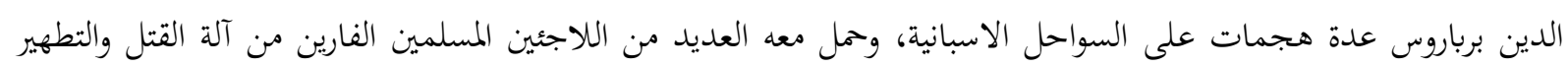
الديني الإسباني المسيحي (225-Özdemir, 1994, s. 224). وفي ظل هذه المتغيرات الجدية على مستوى الشرق الإسلامي، وبروز قوة العثمانيين، وكذلك في ظل اهيار الأندلس في يد

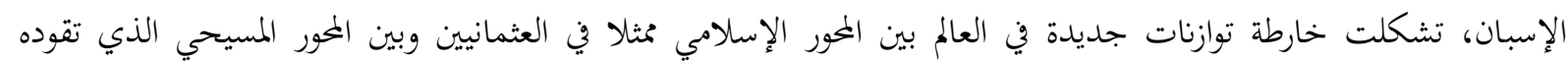

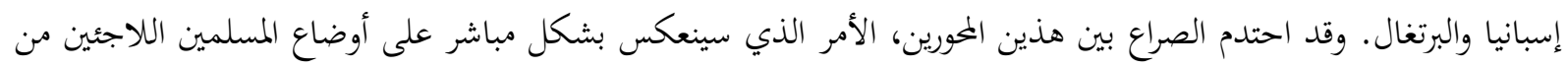

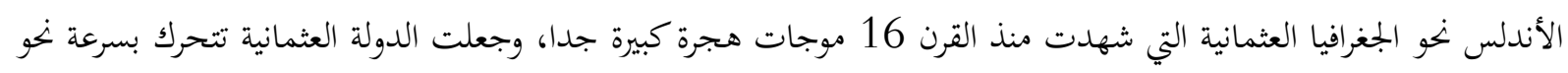

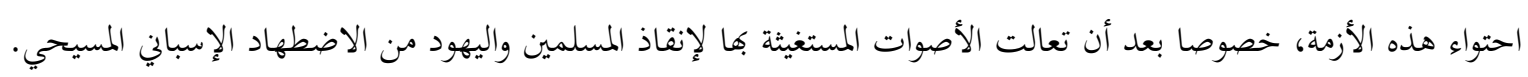
ورغم أن العثمانيين في البداية لم يستطيعوا أن يوجهوا جهودهم بشكل كلي نحو مساعدة مسلمي الأندلس، بسبب تعدد

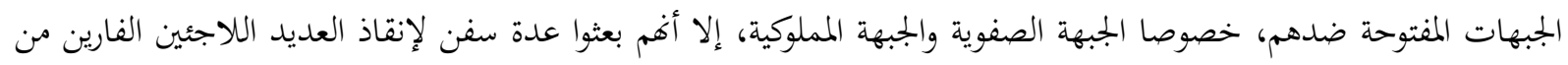
الأندلس. وأمام تصاعد حدة الصراع العثماني الإسباني في منطقة البحر الأبيض المتوسط وثمال إفريقيا زادت إسبانيا في ممارساهما

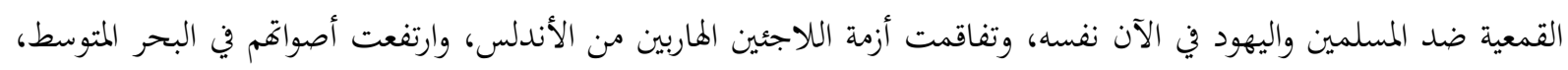

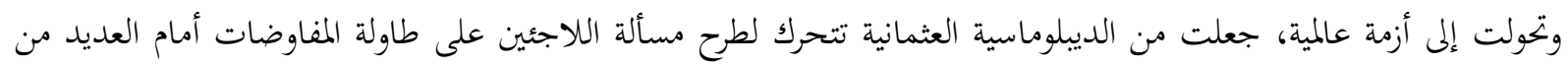

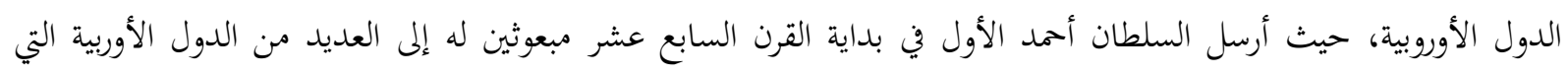
شهدت هي أيضا تدفقا للاجئين، وذلك بقصد التباحث وإيجاد حلول لاستقبال اللاجئين المسلمين واليهود الفارين من المحرقة

الإسبانية (229-Özdemir, 1994, s. 225).

\section{4- استراتيجية الدولة العثمانية تجاه أزمة اللاجئين:}

كان الهدف الأول للسياسة العثمانية في عهد السلطان سليمان القانوني هو السيطرة على منطقة البحر المتوسط ومنطقة شمال افريقيا، والوقوف ضد التمدد الإسباني الذي يحاول استطاع في القرن 15 السيطرة على مناطق استراتيجية فيها، وأصبح يمثل مديدا كبيرا للدولة العثمانية ووجودها في منطقة البحر المتوسط. لذلك حمل العثمانيون على عاتقهم أولوية تحرير الشمال الإفريقي، وقد نجحوا في ذلك في عهد سليمان القانوني، واكتمل في عهد السلطان سليم الثاني الذي أرسل فرمانا إلى علي قلج بلى باشا، ئأمره

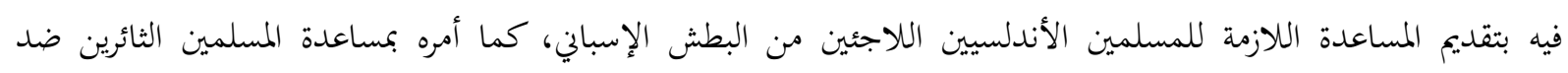
سلطات محاكم التفتيش الاسبانية (227-Özdemir, 1994, s. 223). لم تكن الاستراتيجية العثمانية تركز على إنقاذ المهاجرين الأندلسيين المسلمين فقط، بل كانت مهتمة أيضا بإنقاذ المهاجرين اليهود الذين كانوا يعيشون في الأندلس، وشملمتهم ممارسات الاضطهاد والقمع الصليبي الإسباني المتطرفة التي لا تعترف بأي دئي ديانة

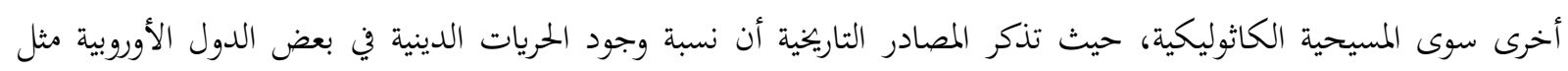

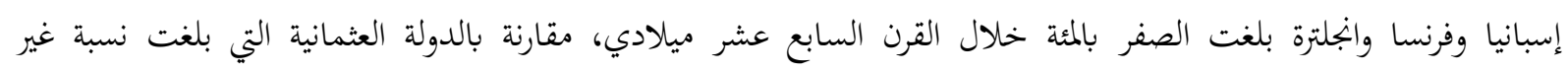

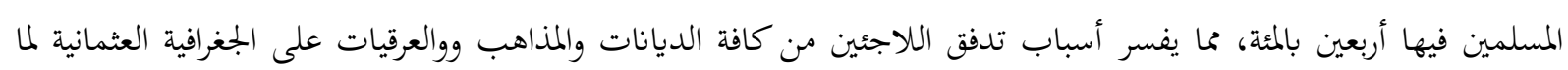


توفر فيها من مناخ واسع للحريات الدينية، بل إن نظام الملة الذي أصدره السلطان محمد الفاتح، وتم تطويره بشكل أوسع في عهد

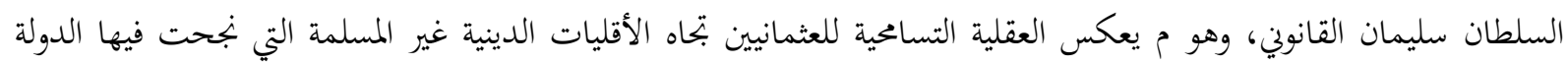

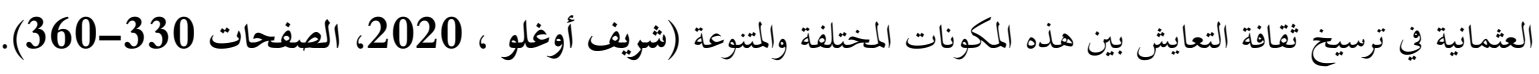
وقد ارتكزت الاستراتيجية العثمانية بتحاه مسألة المهاجرين الأندلسيين على ثلاثة مراحل أساسية، هي كالتالي:

أ- مرحلة إنقاذ المهاجرين:

كانت الدولة العثمانية تدرك حجم المخاطر التي يتعرض لها المسلمون واليهود على حد سواء في الأندلس، لذلك أرسلت

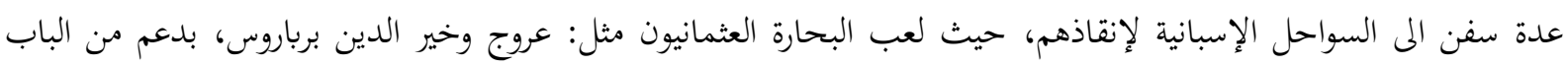

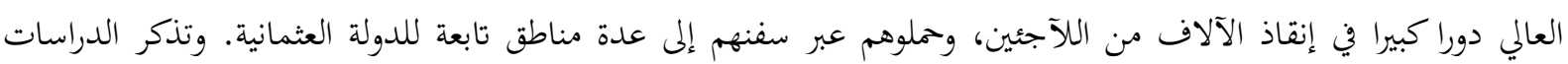

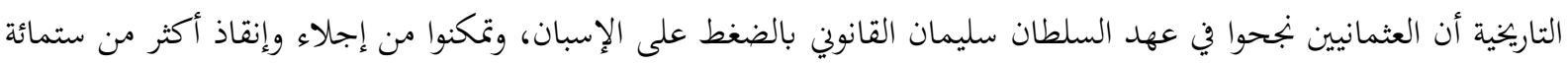
ألف لاجئ مسلم كانوا معرضين إلى الإبادة الجماعية من قبل الصليبين الإسبان، وكان السلطان العثماني قد هدد كل ألماني أوروبا بأنه إذا لم يتم توقيف قتل المسلمين في الأندلس فإنه سيقوم بقتل كل المسيحيين الموجودين في الشرق الإسلامي الخاضع للدولة العثمانية (الفيلالي، 2006، صفحة 247).

وفي الحقيقة يمكن القول إنه لولا هذا التهديد الجدي الذي وجهه السلطان سليمان القانوني إلى الإسبان وإلى كل الدول

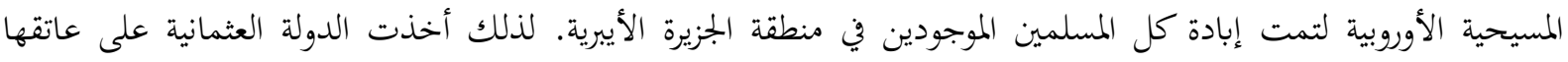

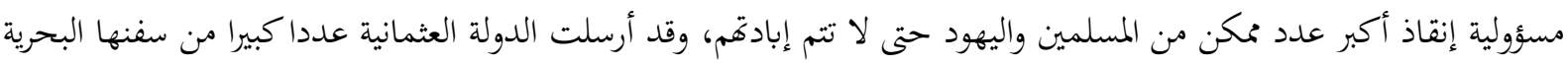

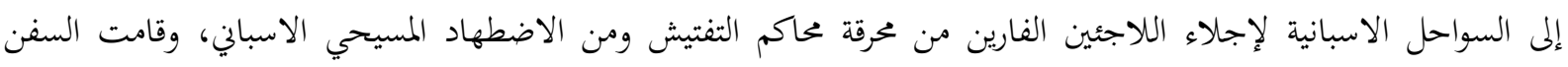

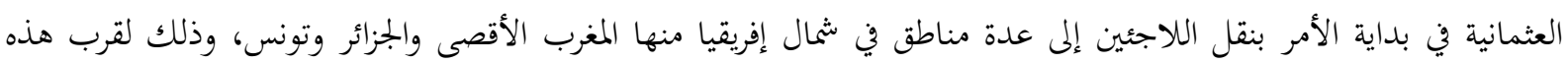

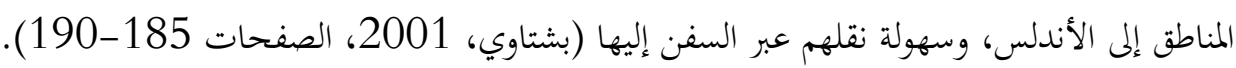

\section{ب- مرحلة توطين اللاجئين:}

أصبحت الدولة العثمانية بعد أن بسطت نفوذها على القسم الغربي من حوض البحر الأبيض المتوسط تمديدا جديا لأوربا

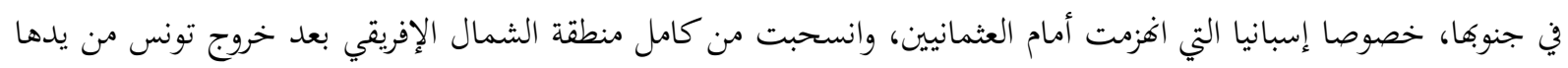

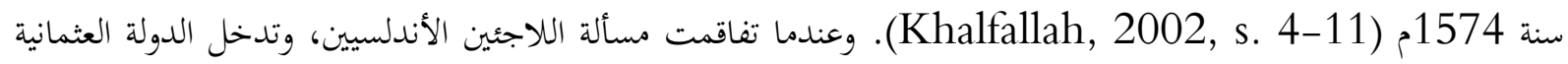
لإنقاذهم من الاضطهاد الإسباني، طرح السؤال الكبير على الدولة العثمانية وهو: ماهي الأماكن التي يمكن أن يتم فيها توطين

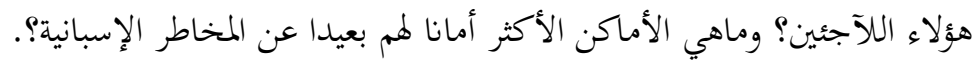

عملت الدولة العثمانية على وضع خطة محكمة لتوزيع هذه الأعداد الكبيرة للآجئين، وحددت الأماكن التي سيتم فيها هذا التوزيع، وكان من بين هذه الأماكن الجزائر وتونس وليبيا، وإزمير، والبلقان، والأناضول، وبعض المناطق الأوروبية. وقد تمكن

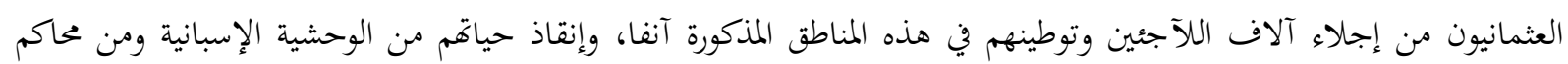

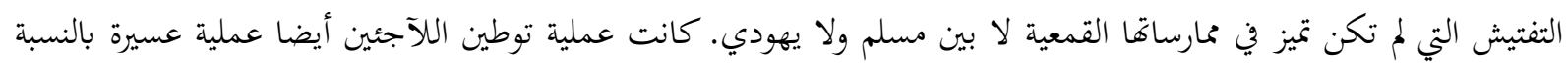

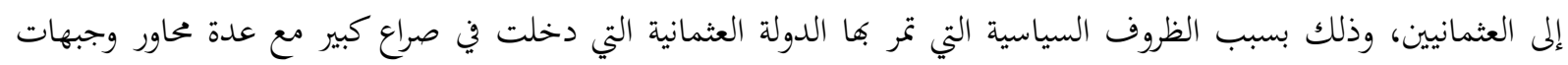

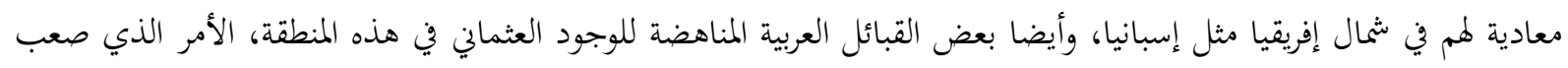

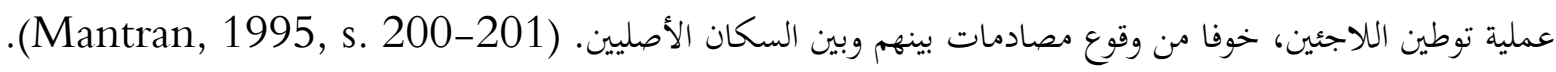
أما على مستوى جبهة المشرق العربي، فقد كان الصراع محتدم بين العثمانيين والبرتغاليين الذين نجحوا في الاستيلاء على

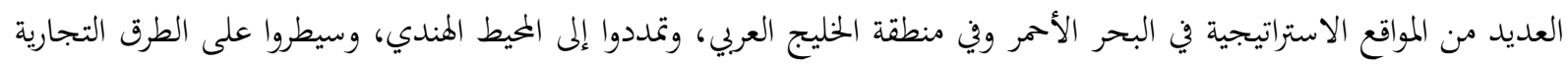


والممرات المائية الأهم مثل مضيق هرمز ومضيق باب المندب. أمام هذا الانشغال العثماني بهذه الجبهات العسكرية الصليبية التي

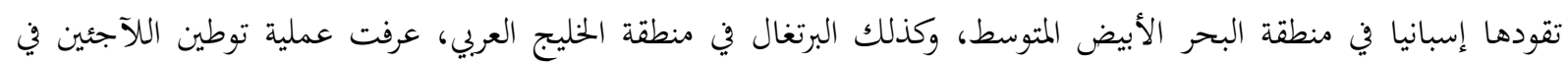

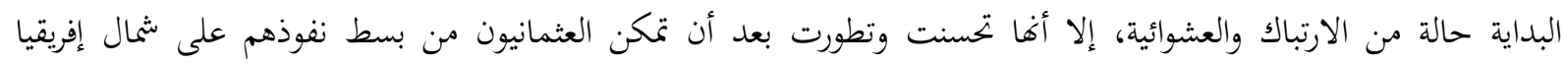

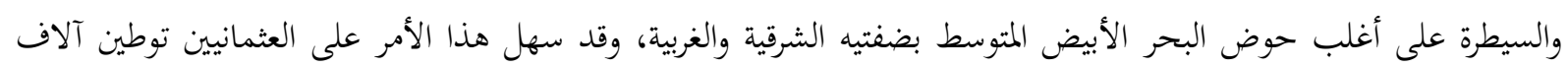

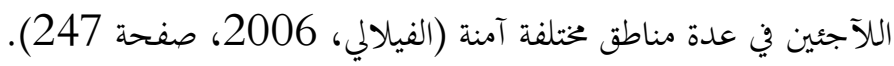

\section{- مواطن توطين المهاجرين الأندلسيين: - موإن}

تجحدر الإشارة هنا إلى أن عملية توطين اللآجئين تنقسم إلى ثلاثة أشكال، الأول يتمثل في عملية استيطان ذاتية قام بها

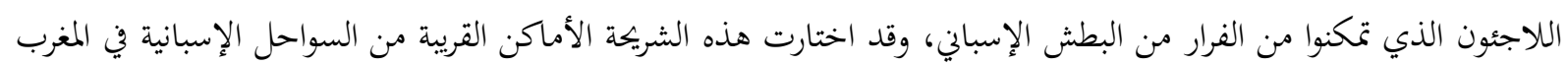

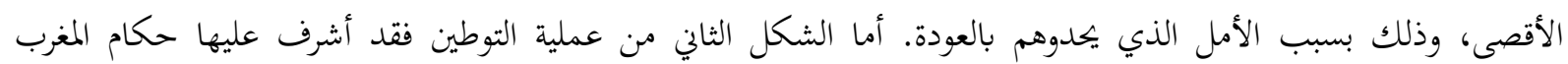

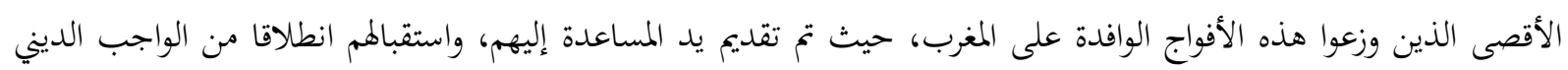

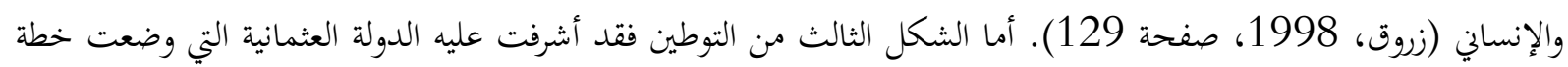

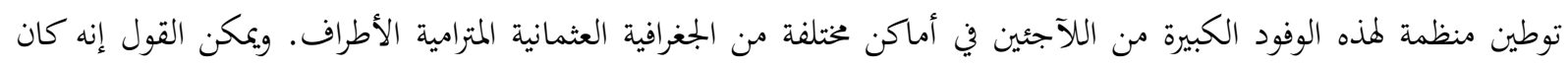

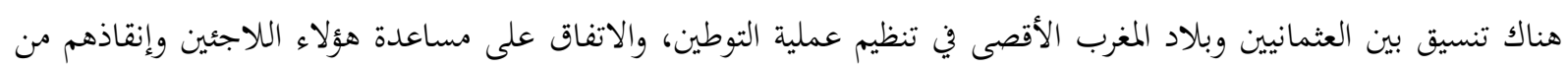

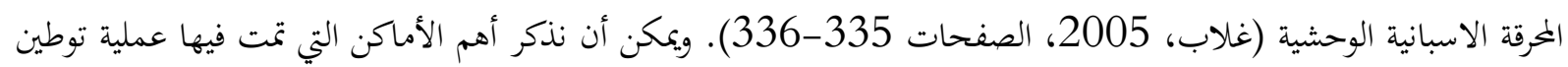
الاجئين الأندلسيين وهي كالتالي:

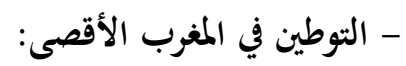

عرفت منطقة المغرب الأقصى تدفقا لعدد كبير من اللاجئين بعد سقوط غرناطة سنة 1492، وازدادت وتيرة موجات هذه

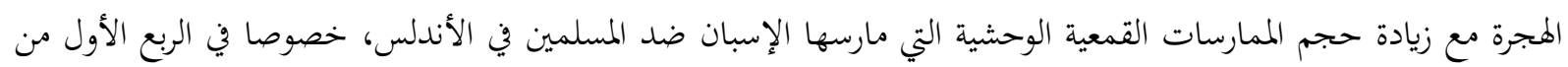

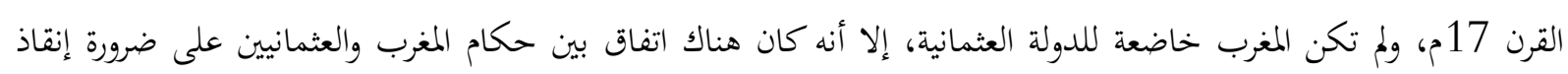

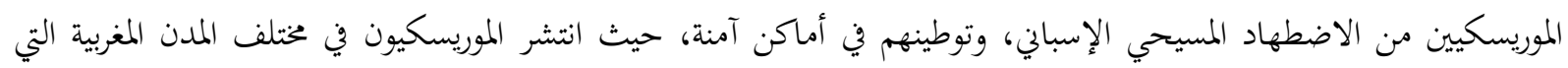

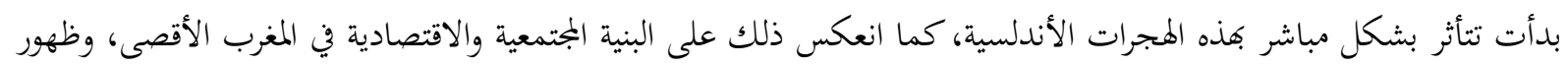

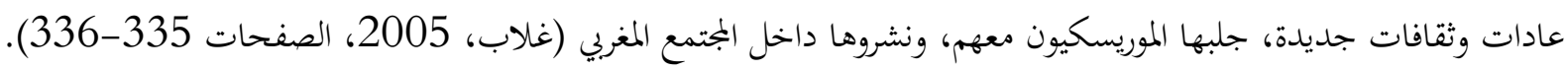

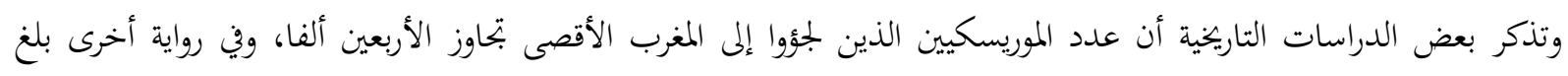

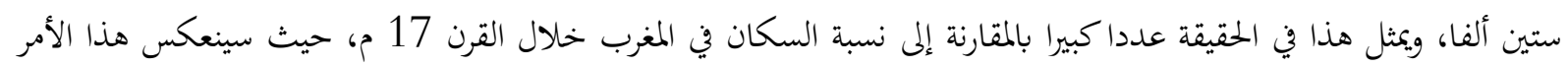

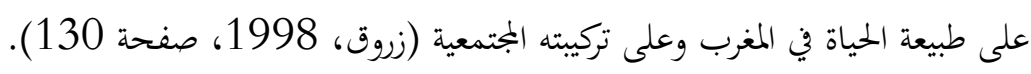

عندما حصلت محنة اللاجئين الأندلسيين وتفاقمت أكثر خلال القرن 16 م والقرن 17م، كانت الجزائر إيالة عثمانية، حيث تحرك العثمانيون منذ خير الدين برباروس بتوطين اللاجئين الأندلسيين في عدة مناطق جزائرية، وقدمت لهن لهم المساعدات

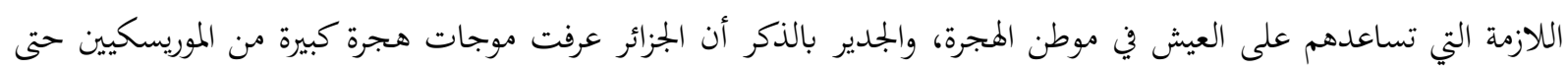

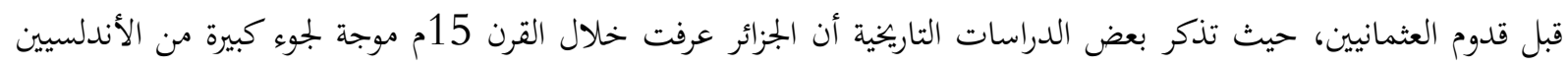

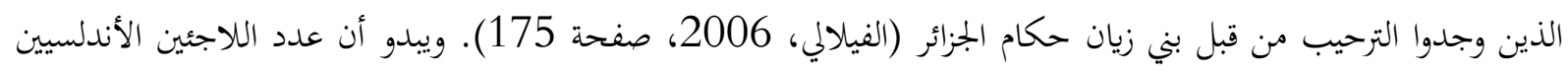

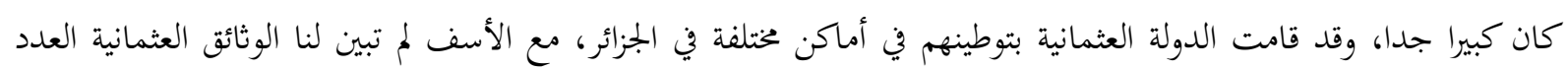

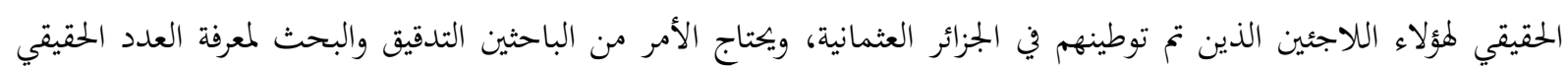


للاجئين الموريسكيين الذين وفدوا على الجزائر وعلى منطقة شمال إفريقيا مثلما يذكر ذلك المؤرخ المختص في الموريسكيين الدكتور

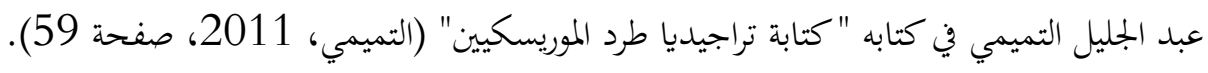
- التوطين في تونس: - n - n

منذ أن أصبحت إيالة عثمانية سنة 1574م تحولت تونس إلى قبلة للاجئين الأندلسيين الفارين من البطش الإسباني، وربما

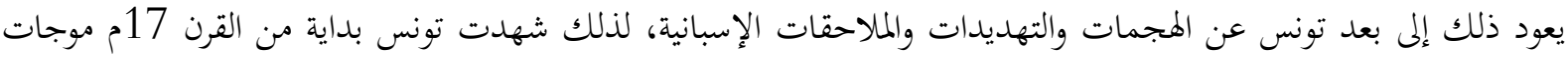

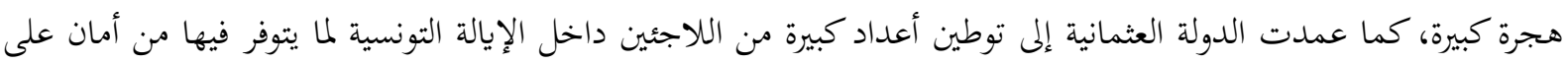

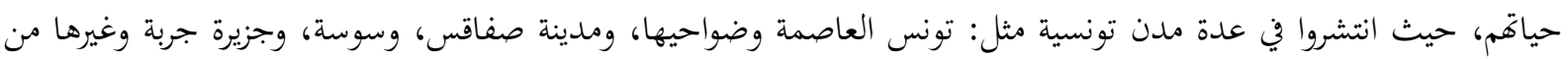

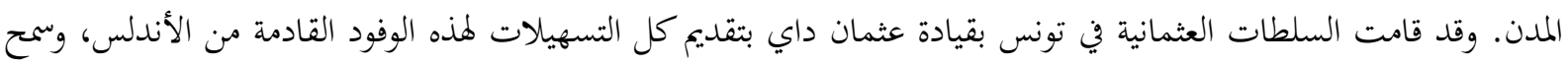
لهم ببناء البيوت والقرى والمدن مثل: تستور وقلعة الأندلس وغيرها، مما خلق هذا حركية كبيرة ودينامكية في الدورة الاقتصادية للإيالة التونسية (وآخرون، 1991، الصفحات 189-190). وبحدر الإشارة هنا إلى أن السياسة العثمانية في توطين اللاجئين الموريسكيين كانت تأخذ بعين الاعتبار مسألة أمن هؤلاء اللاجئين وتوطينهم في أماكن أكثر أمان، وبعيدة عن التهديدات الاسبانية التي تلاحقهم في كل مكان، وكانت تونس أحد أهم الإيالات التي وطن فيها العثمانيون أعدادا كبيرة من اللاجئين

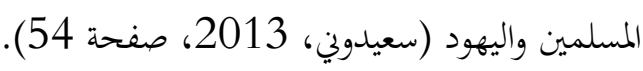

\section{- توطين في مختلف الجغرافيا العثمانية:}

قامت الدولة العثمانية أيضا بتوطين اللاجئين الأندلسيين من مسلمين ويهود في مناطق أخرى من الجغرافية العثمانية، مراعية في ذلك الحالة الدينية والمذهبية لمؤلاء اللاجئين، وقد تمت عملية توطين اليهود في سلانيك، وفي الشام وفي وإزمير واستانبول

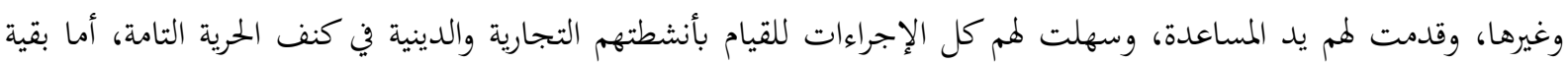
اللاجئين المسلمين فقد تم توطين قسم منهم في مناطق الاناضول والبلقان والشام وغيرها، ومنحتهم الأراضي للفلاحة، وسهلت لهم كل الاجراءات من أجل ممارسة أنشطتهم التجارية والعلمية والدينية بكل حرية (Lütfi, 2007, s. 30-38).

ج- مرحلة إدماج اللاجئين:

لم تكن عملية توزيع العثمانيين للاجئين الأندلسيين عشوائية، وإنما كانت عملية مدروسة تراعي الانتماء الديني والمذهبي وحتى المهني، وكذلك المستوى الاجتماعي. وكان الهدف من هذا هو خلق حالة من الاندماج داخل المناطق الجديدة التي سيتم

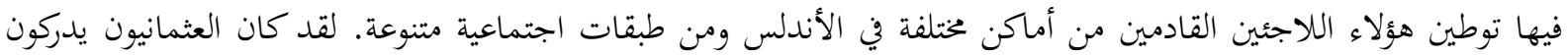
جيدا أهمية مسألة إدماج هؤلاء اللاجئين، لأفا عملية ستساهم بشكل كبير في خلق استقرار بجتمعي من ناحية، وكذلك بخلق حالة من الديناميكية والحيوية في تلك المناطق من ناحية أخرى (28) (Luitfi, 2007, s. 30). من جهة أخرى كان هناك عدد كبير من هؤلاء اللاجئين يتمتعون بمهارات، ويتقنون حرفا وعلوما سينقلوها إلى أماكن

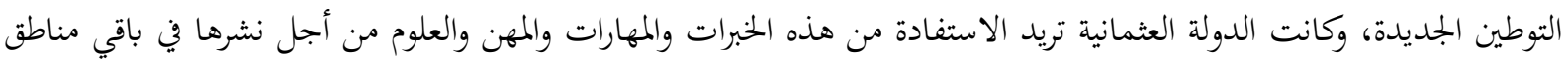

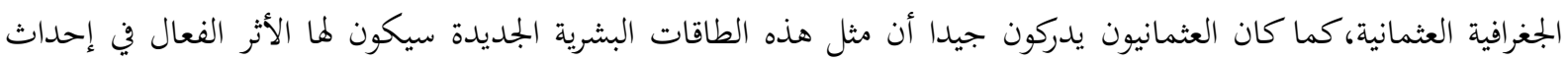

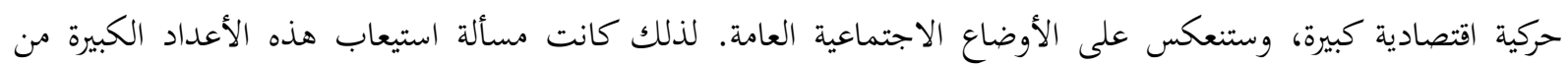

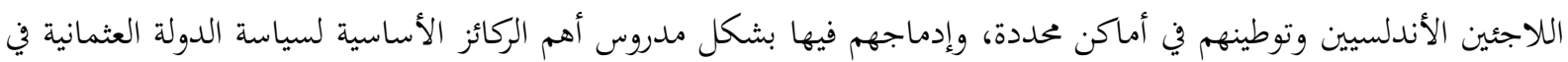

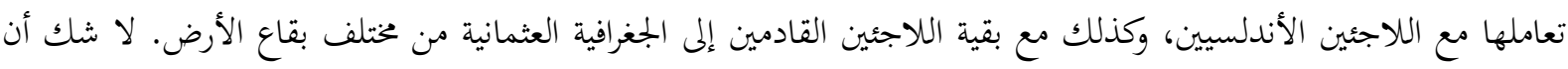

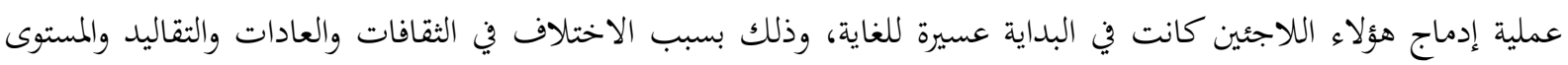


الاجتماعي العلمي والمهني، خصوصا أن أغلب اللاجئين القادمين يتكلمون اللغة الإسبانية، ولا يعرفون اللغة العربية أو التركية

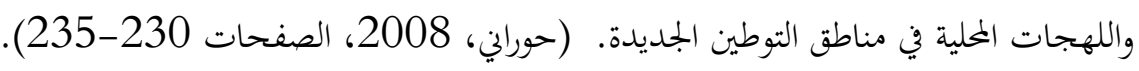

لقد عملت الدولة العثمانية على تذليل مثل هذه العقبات من خلال مساعدقم على التواصل مع المجتمعات الجديدة،

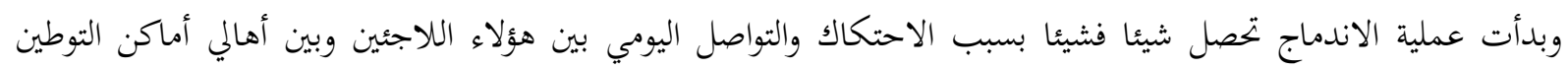

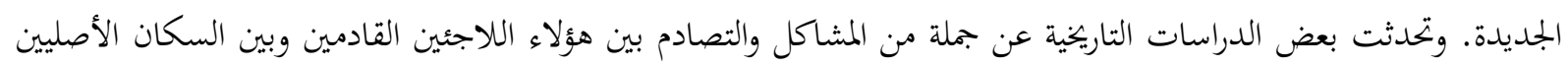

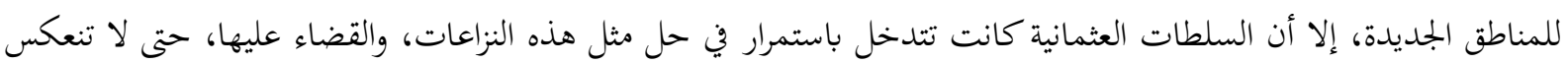

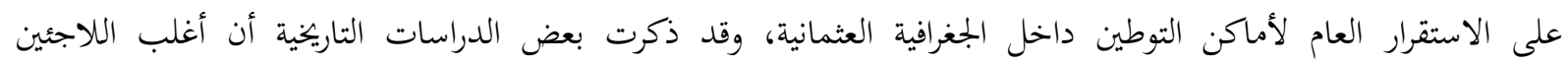

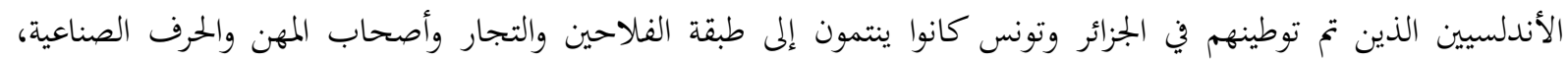
فانعكس ذلك على الأوضاع الاقتصادية في تلك المدن الشمال إفريقية، وتحركت فيها الدورة الاقتصادية مثل مدينة وهران بالجزائر

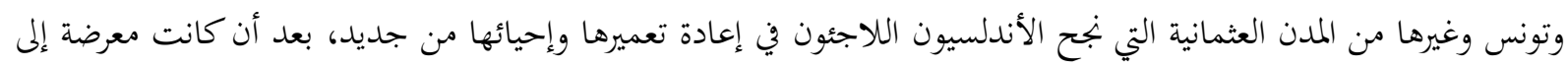
الخراب والاندثار، كما قاموا بزراعة الأرض وصناعة السفن وفتح مصانع للنسيج، خصوصا صناعة الحرير بسبب توفر التبات أشجار

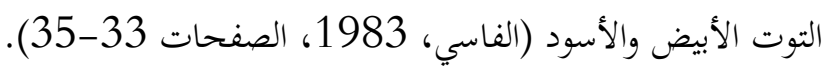

لقد امتزجت الثقافات والعادات والتقاليد التي أتى بها اللاجئون الأندلسيون مع الحالة الثقافية والمجتمعية داخل المناطق التي

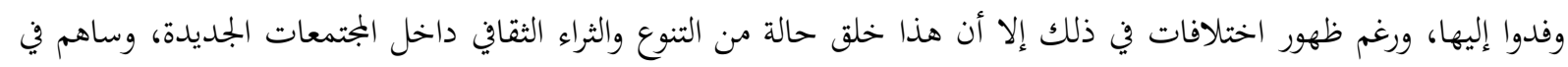

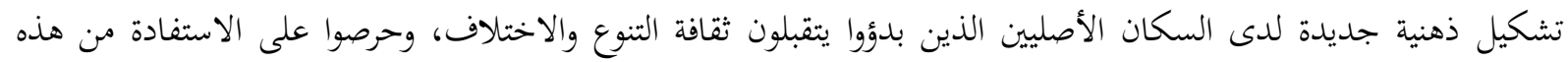

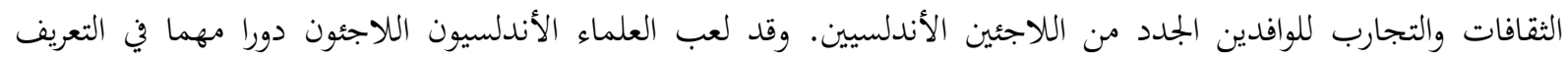
بالثقافات والعادات الأندلسية، مما سهل عملية الاندماج أكثر وبناء جسور تواصل مع الأهالي (Lütfi, 2007, s. 337-344). ويمكن القول إن اللاجئين الموريسكين نجحوا في عملية الاندماج، واستطاعوا أن يتحولوا إلى أحد المكونات الأساسية في

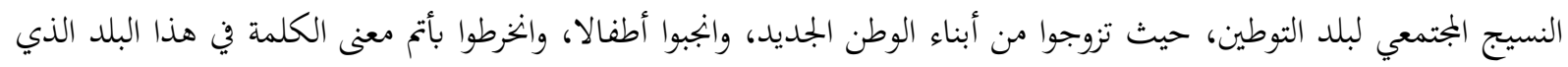

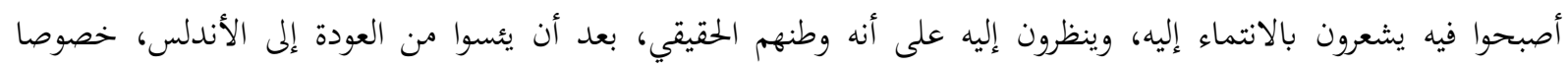

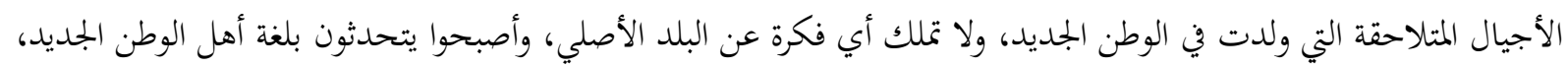

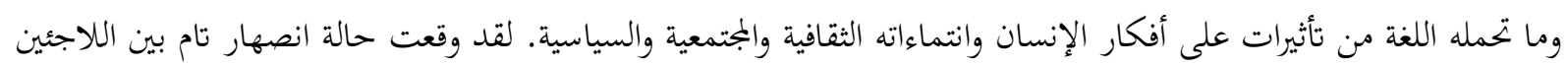

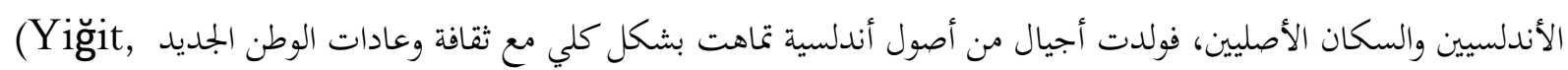

\section{5- 5 سياسة العثمانيين تجاه اليهود اللاجئين من الأندلس:}

تعاملت الدولة العثمانية منذ بداية محنة اللاجئين الأندلسيين الفارين من الوحشية الإسبانية من منطلق إنساني ومن منطلق

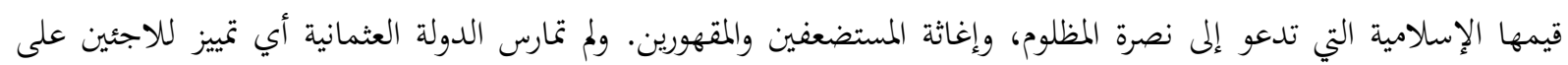

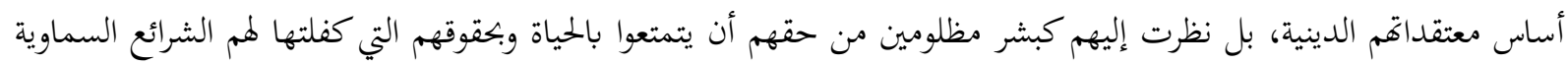

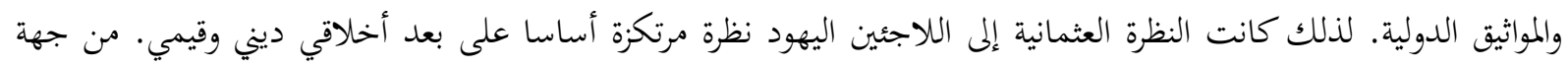

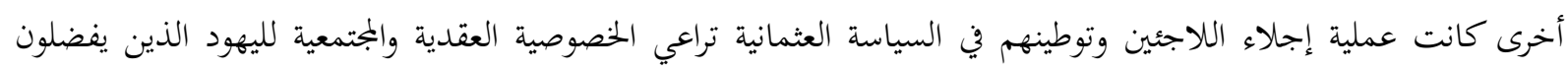
العيث مع بعضهم البعض في مجموعات متقاربة مع بعضهم وفي أماكن خاصة، تسمح لهم بممارسة معتقداتم الدينية وعاداتم

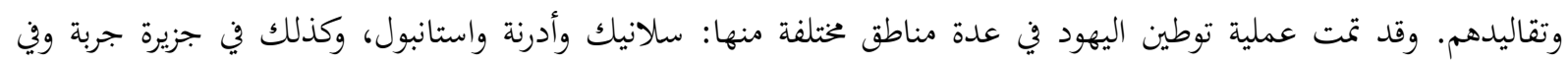


منطقة صفد وغيرها من المناطق التي يوجد فيها أقليات أخرى، ولم تجبر الدولة العثمانية اليهود على تغيير معتقداقم أو أسمائهم، بل

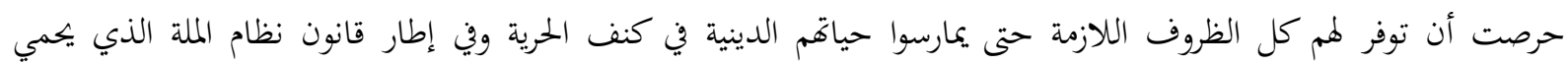
الطوائف الدينية غير المسلمة (Groepler, 1999, s. 134).

حرصت الدولة العثمانية أن تنقذ اللاجئين اليهود دون النظر إلى أوضاعهم الاجتماعية، فلم تفرق بين غني أو فقير، ولم

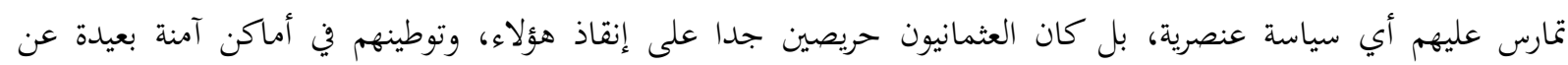
التهديدات الإسبانية، ووفرت لهم كل الظروف المناسبة لكي يتعايشوا كجماعات تتمتع بكل حقوقها، واشترطت عليهم الالتزام

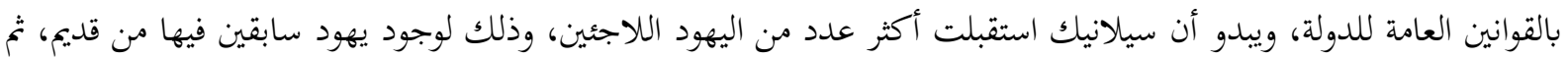
لكوها مدينة مناسبة جدا في خصوصيتها الاجتماعية لليهود (Lütfi, 2007, s. 352-355). وقد انتهجت الدولة العثمانية سياسة إدماج لليهود اللاجئين قائمة على أساس الخصوصية الدينية المناسبة لهم، وحاولت أن تقدم لهم يد المساعدة المادية

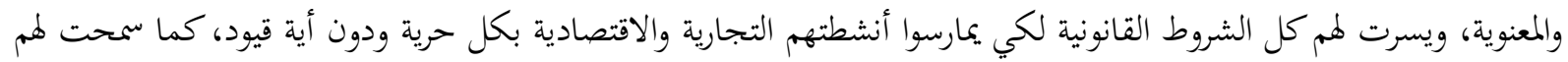

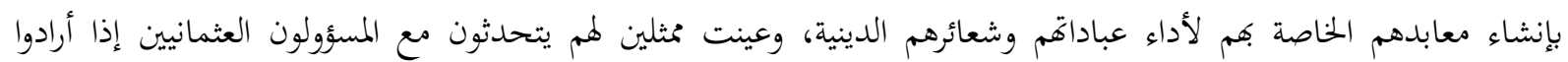

مساعدة من الدولة أو اللجوء لحل بعض المشاكل والصعوبات التي يعيشوها (41- Groepler, 1999, s. 38). لقد ساهمت هذه السياسة المتساعحة التي انتهتها الدولة العثمانية بحاه اللاجئين اليهود في انخراطهم في المجتمع العثماني، وأصبحوا فاعلين فيه ومستفيدين من القوانين التي سنتها الدولة العثمانية لحماية الطوائف الدينية غير المسلمة، كما استفاد اليهود

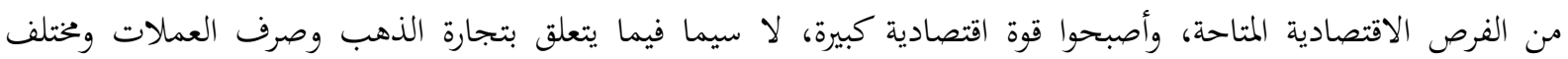
القطاعات التجارية المختلفة، خصوصا في استانبول وإزمير وعدة مدن عثمانية أخرى مثل: القاهرة والاسكندرية ودمشق وتونس تهره

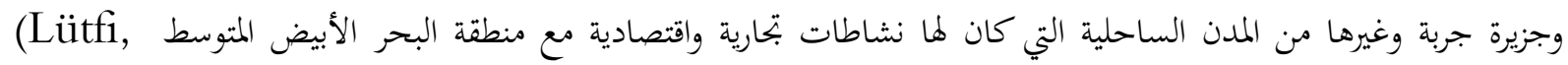
2007, s. 367-369)

إضافة إلى هذا كانت الدولة العثمانية ترغب في الاستفادة من اللاجئين اليهود ومدى قدرقم على خلق حيوية اقتصادية وبتارية، ستعود بالنفع على الدولة العثمانية وعلى المجتمع العثماني. غير أنه يجب الإشارة إلى أن اليهود سيتحولون فيما بعد إلى لئل

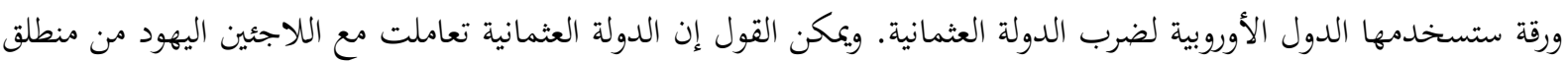
مرجعيتها الإسلامية التي تدافع عن المظلومين مهما كانت انتماءاقم العرقية أو الدينية والمذهبية، وكذلك من منطلق إنساني يحترم الإنسان ويدافع عن حقوقه وحريته الدينية والقانونية، كما كان رغبة العثمانيين في الآن نفسه هي الاستفادة اقتصاديا وبحاريا من هذه الطاقات البشرية التي كانت في الأندلس.

الخاتمة:

نخلص القول في بحثنا هذا إلى أن ظاهرة الهجرة واللجوء مثلت أحد أهم المشاكل التي عانت منها الشعوب والدول في نفس الوقت. ولعل الدولة العثمانية كانت أكثر الدول التي عرفت موجات هجرة كبيرة من عدة مناطق مختلفة، لأسباب مختلفة. وتعد موجات هجرة اللاجئين الأندلسيين الفارين من القمع الإسباني من القرن 15 إلى القرن 17 م أحد أهم الأزمات الإنسانية

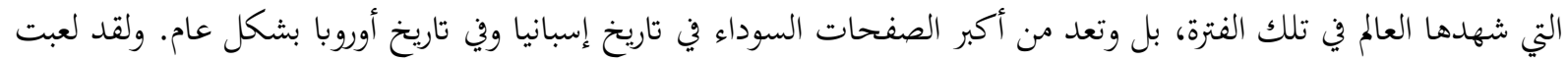

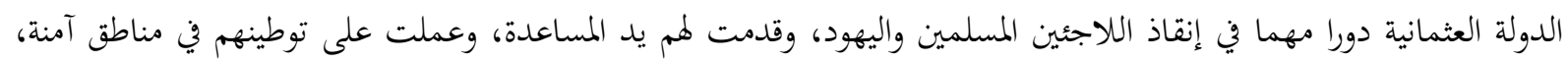

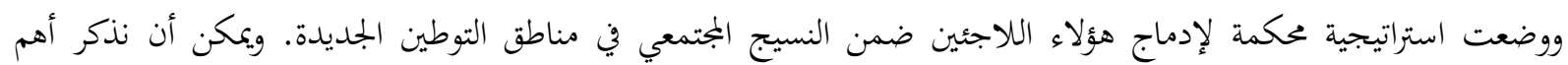
النتائج التي توصلنا إليها في بحثنا هذا وهي كالتالي: 
- أزمة اللاجئين الأندلسيين لم تكن أزمة عابرة نتيجة لظروف سياسية عابرة، وإنما كانت أزمة تعكس العقلية الاسبانية المتطرفة التي لا تؤمن بالتعايش ولا بحرية الآخرين، كما تكشف عن عمق الأزمة في كامل أوروبا التي بينت لنا فيها الإحصائيات عن تدهور كبير جدا لحالة الحريات الدينية في داخلها.

- لعبت الدولة العثمانية دورا بارزا في إنقاذ هؤلاء اللاجئين من محرقة الاضطهاد الديني الإسباني، وسخرت كل إمكانياتا من أجل نقلهم إلى أماكن أخرى، بعيدا عن التهديدات الاسبانية. - انتهجت الدولة العثمانية استراتيجية مدروسة، تقوم على ثلاثة مراحل: مرحلة إنقاذ اللاجئين الهاربين من الاضطهاد الإسباني،

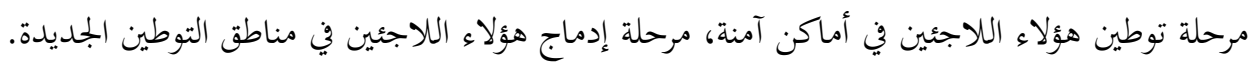
- لم تمارس الدولة العثمانية أثناء عملية إنقاذ اللاجئين الأندلسيين أي سياسة عنصرية أو دينية بين هؤلاء، بل استقبلت اليهود،

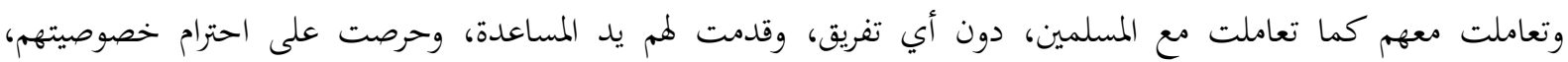
وتوطينهم في أماكن يستطيعون الاندماج فيها بسهولة. - مناخ الحريات الدينية والفكرية الذي كان سائدا في الدولة العثمانية جعلها ملاذا تلجأ إليها عدة عرقيات وأقليات من مختلف دول العالم، ومن مناطق أخرى تمر بأزمات مختلفة، كما تعاملت الدولة العثمانية مع ظاهرة الهجرات واللاجئين من منطلق مرجعيتها الإسلامية التي تؤمن بحرمة الإنسان، وتمنحه الأمان على حياته وعرضه ومتمتلكاته وحريته الدينية. - تشكف لنا أزمة اللاجئين الأندلسين حالة حقوق الإنسان والحريات الدينية في إسبانيا وأوروبا بشكل عام من القرن الخامس عشر الى حدود القرن السابع عشر ميلادي، كما تكشف لنا هذه الأزمة حالة الحريات الدينية وواقع الأقليات الدينية داخل الدولة

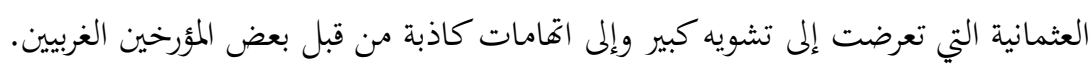
- سياسة التوطين التي انتهجتها الدولة العثمانية لهؤلاء اللاجئين كانت مدروسة، وتراعي الخصوصية الاجتماعية للاجئين، كما أن

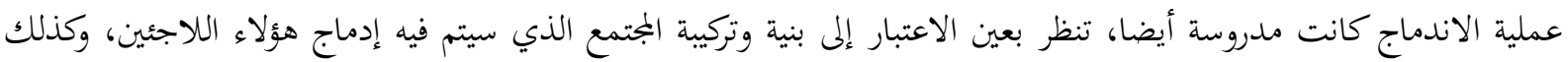
توفير الدولة العثمانية كل الشروط والظروف اللازمة لإنجاح عملية الاندماج بسهولة، وتحقيق استقرار حقيقي لهؤلاء اللاجئين. - دور اللاجئين الأندلسيين في التأثير على ثقافات وعادات مناطق التوطين الجديدة، ودورهم في خلق ديناميكية اقتصادية وعلمية واجتماعية داخل مجتمعات هذه المناطق، حيث نقلوا لمم علوما وبتحارب جديدة استفادوا منها كثيرا. 


$$
\begin{aligned}
& \text { ألبرت حوراني. (2008). تاريخ الشعوب العربية. دمشق: دار طلاس للدراسات والترجمة والنشر. }
\end{aligned}
$$

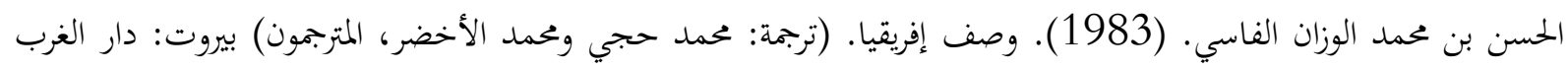

$$
\begin{aligned}
& \text { الإسلامي، طان. } \\
& \text { عادل سعيد بشتاوي. (2001). الأندلسيون المواركة. القاهرة: دار إهداءات. } \\
& \text { عبد الجليل التميمي. (2011). تراجيديا طرد الموريسكيين من الأندلس والمواقف الاسبانية والعربية منها (المجلد منشورات مركز }
\end{aligned}
$$

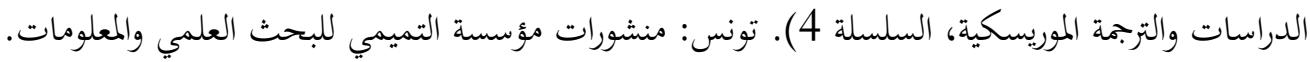

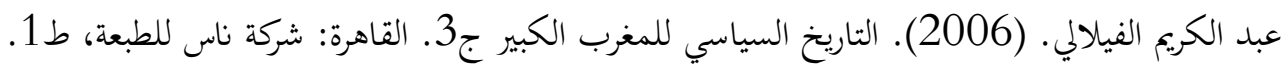

$$
\begin{aligned}
& \text { عبد الكريم غلاب. (2005). قراءة جديدة في تاريخ المغرب العربي عصر الإمبراطورية العهد التركي في تونس والجزائر. بيروت: } \\
& \text { دار الغرب الإسلامي طابد. } \\
& \text { متين شريف أوغلو. (2020). موقف الدولة العثمانية من مسألة التعايش وسياستها بتحاه الأقليات. تأليف التعايش وأشكاله من }
\end{aligned}
$$

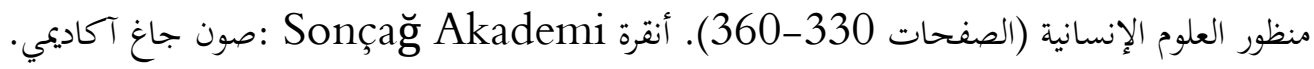

$$
\begin{aligned}
& \text { محمد المنوني وآخرون. (1991). التاريخ الأندلسي من خلال النصوص. الدار البيضاء: شركة النشر والتوزيع المدرسي، ط1 } 1 .
\end{aligned}
$$

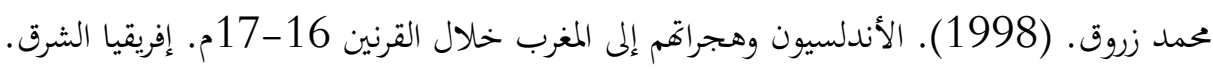

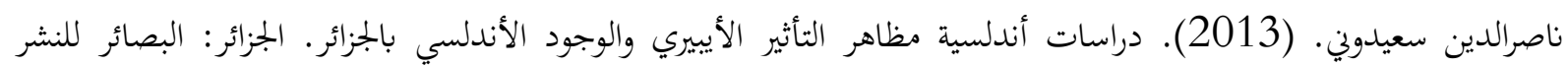

$$
\begin{aligned}
& \text { والتوزيع. }
\end{aligned}
$$

Aka, C. B. (1997). Modern Doğuşu İspanyol Altın Çă̆. Ankara: Dost Kitabevi.

Ataöv, T. (1987). Azınlıklar Üstüne Bazı Düşünceler. A.Ü. Siyasal Bilgiler Fakültesi Dergisi, c XLII(1-4).

Benjamin J.Kaplan, D. B. (2007). Religious Conflict and Practice of Toleration in Early Modern Europe. Cambridge: MA-Harvard Unniversity Press.

Bilgin, F. (2013). Endülüs'te Kalan Son Müslümanların (Moriskolar) İspanyadan Sürgünü(16091614). Din Bilimleri Akademik Araştırmaları Dergis(XIII(2).

C.E.BOSWORTH. (1982). The Concept Of Dhimma in Early İslam", Chiristians and Jews in

The Ottoman Empire". New York - London: Holmes \& Publişhers.

Groepler, E. (1999). İslam ve Osmanlı Dünyasında Yahudiler. (S. Kaya, Çev.) İstanbul: Belge Yayınları.

Güleryüz, N. A. (2015). Geçmişten Günümüze Anadolu’ya Yahudi Göçü. İstanbul: İstanbul Bilgi Üniversitesi Yayınları.

kapart, K. (1985). ottoman population 1830-1914. Madison university of Wisconsin.

Khalfallah, Z. (2002). Osmanlı İdaresinde Cerbe Adası XVI-XVII Yüzyıllar. İstanbul: Yüksek

Lisans Tezİ İstanbul Üniversitesii.

Lütfi, Ş. (2007). Mudejares \& Sefarades: Endülüs Müslüman ve Yahudilerin Osmanlıya Göçleri.

İstanbul: İz Yayıncilık.

Mantran, R. (1995). XVI-XVIII.Yüzyıllarda Osmanlı İmparatorluğu. Ankara: İmge Kitabevi.

Özdemir, M. (1994). Endülüs Müslümanları. Ankara: Türkiye Diyanet Vakfi Yayınlar. 
Paşa, Z. (2011). Ortaçağın Karanlık Çehresi: Engizisyon Mahkemeleri. İsanbul: İlk Taraf Yayınevi.

Sakaoğlu, N. (2002). Bu Mülkün Sultanları (36 Osmanlı Padişah). İstanbul: Oğlak Yayıncıllı.

Şener, A. (2010, Aralık ). Osmanlı Devletinde Dini Çeşitlilik: Farklı Neydi? Doğu Batı Dergisi(50).

Şerifoğlu, M. (2020). Osmanlı İmparatorluğunun Bir Arada Yaşama Konusundaki Tutumu ve Azınlıklara Yönelik Politikası. M. şerifoğlu içinde, Beşeri Bilimler Açısından Bir Arada Yaşama Kültürü ve Biçimleri (s. 329-360). Ankara: Son çağ Akademi.

Yiğit, İ. (2006). Murabitla. İstanbul: DİA Türkiye Diyanet Vakfi. 


\title{
SYCLE ONE SCHOOL PRINCIPLES'TEACHER JOB SATISFACTION IN NORTH AL BATINAH IN THE SULTANATE OF OMAN
}

\author{
Mohammed Saleh ALAJMI ${ }^{1}$ \\ Naima Salim Said AL RISI ${ }^{2}$
}

\section{Istanbul / Türkiye \\ p. 503-527}

\section{Received: 04/12/2021 \\ Accepted: $17 / 12 / 2021$ \\ Published: 01/01/2022}

This article has been scanned I iThenticat No plagiarism detected

\begin{abstract}
:
The study aimed to identify the leadership patterns practiced by the female principals of the first circle schools as seen by the teachers of the first field in the province of North Al Batina, and to identify the level of job satisfaction of the teachers of the first field, and to reveal the correlation between the leadership patterns of the female principals of the first circle and the job satisfaction of the teachers of the first field. The researcher used the descriptive correlation method, and designed two questionnaires: the questionnaire measuring the leadership patterns of the female school principals of the first episode in North Al-Batina, and the other the questionnaire of the measurement of job satisfaction in the teachers of the first field in The North Al-Batina, each questionnaire contained 30 paragraphs, and included three axes. The results of the study showed that the democratic leadership style came first, with a mathematical average of 4.45 , which is the most practiced pattern among the principals of the first circle schools in the province of North Al-Batina, followed by the autocratic leadership pattern, the leadership pattern, asindicated by the results of the study to the high level of job satisfaction in all axes with a mathematical average of 4.52 , and came first the center of job satisfaction related to satisfaction with the nature of work, with a mathematical average of 4.62 , followed by the axis of satisfaction of school mates, and came in third place the focus of satisfaction for the school principal, and also indicated the results of the study indicated the existence of a positive medium statistically function between the practice of the female principals of the first circle schools in the province of North Al-Batina of the democratic leadership style and the job satisfaction of the teachers of the first field, where the correlation reached the coefficient $r=0.61$. Based on the results of the current study, the researcher recommends: maintaining the level of active practice of the democratic leadership style of the female teachers of the first circle schools in North Al-Batina, because of its importance in achieving a good level of job satisfaction, and maintaining the level of high job satisfaction among the teachers of the first field in North Al-Batina, because of its role in achieving.
\end{abstract}

Key words: Principles, School, Job Satisfaction.

http://dx.doi.org/10.47832/2717-8293.15.36

1 iD Dr., Suhar University, Sultanate of Oman, majmi3@su.edu.om, https://orcid.org/0000-0002-6882-7608

2 (iD) Researcher, The Ministry of Education, Sultanate of Oman, Naema526@ moe.om, https://orcid.org/0000-0002-8174$\underline{3257}$

Copyright (C) Published by Rimak Journal, www.rimakjournal.com Rimar Academy, Fatih, Istanbul, 34093 Turkey 


\section{الأنماط القيادية لمديرات مدارس الحلقة الأولى بمحافظة شمال الباطنة في سلطنة عمان وعلاقتها بالرضا الوظيفي لمعلمات الجمال الأول}

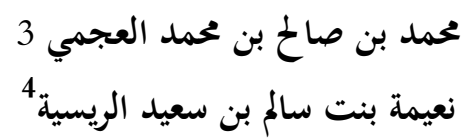

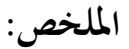
هدفت الدراسة إلى التعرف على الأنماط القيادية التي تمارسها مديرات مدارس الحلقة الأولى كما تراها معلمات المجال الأول في محافظة شمال الباطنة بسلطنة عمان، والتعرف على مستوى الرضا الوظيفي لمعلمات البمال الأول، والكشف عن العلاقة الارتباطية بين الأنماط القيادية لمديرات مدارس الحلقة الأولى والرضا الوظيفي لمعلمات المجال

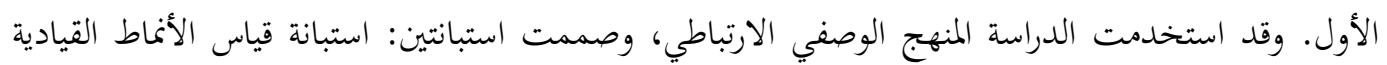

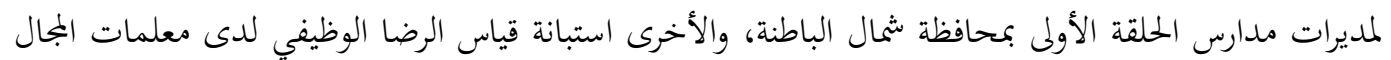

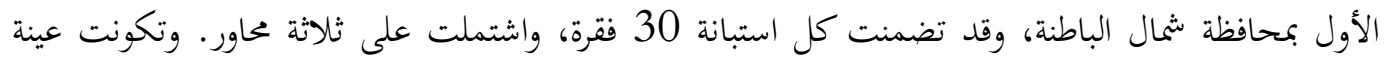

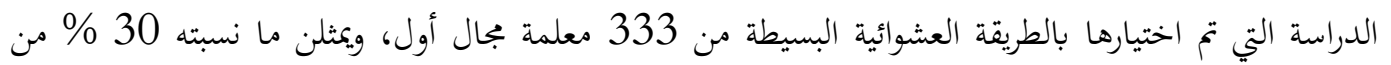

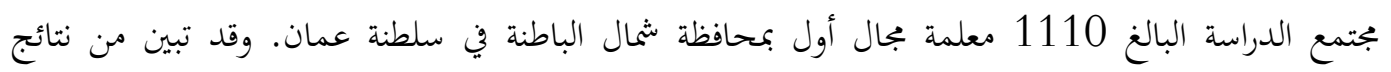
الدراسة أن النمط القيادي الديموقراطي جاء في المرتبة الأولى، بمتوسط حسابي مقداره فهو النمط الأكثر ممارسة لدى مديرات مدارس الحلقة الأولى في محافظة شمال الباطنة في سلطنة عمان، ثم تلاه النمط القيادي الأوتوقراطي بمتوسط حسابي مقداره 2.93، وبصفة ممارسة متوسطة، فالنمط القيادي الترسلي بمتوسط حسابي مقداره 2.64، وبصفة ممارسة متوسطة، كما أشارت نتائج الدراسة إلى ارتفاع مستوى الرضا الوظيفي في جميع المحاور بمتوسط حسابي مقداره 4.52، بصفة عالية جدا، وقد جاء في المرتبة الأولى محور الرضا

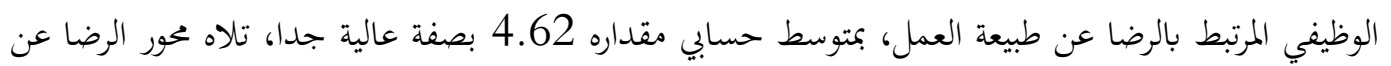
زميلات المدرسة بصفة عالية جدا، وجاء في المرتبة الثالثة محور الرضاعن مديرة المدرسة بمتوسط حسابي مقداره 4.37 بصفة عالية جدا. وأيضا أشارت نتائج الدراسة إلى وجود علاقة موجبة متوسطة دالة إحصائيا بين ممارسة مديرات مدارس الحلقة الأولى في محافظة شمال الباطنة للنمط القيادي الديموقراطي وبين الرضا الوظيفي لمعلمات

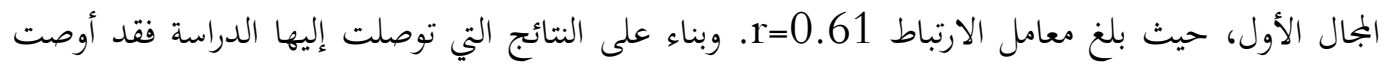
بالآتي: الحفاظ على مستوى ممارسة فاعلة للنمط القيادي الديمقراطي لدى مديرات مدارس الديأ الحلقة الأولى بمحافظة

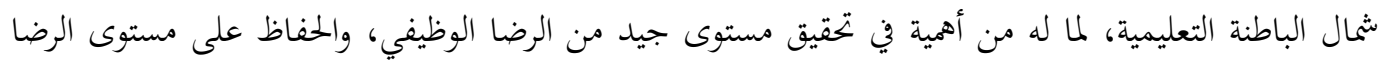

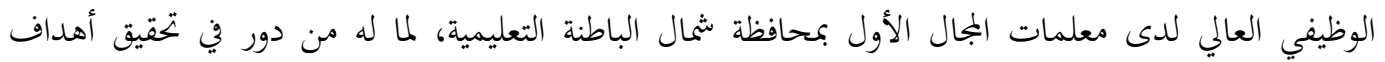
العملية التعليمية الكلمات المفتاحية: الأنماط القيادية، الرضا الوظيفي، التعليم. 
بدأ الاهتمام بالرضا الوظيفي مع بداية القرن العشرين، لأنه من العوامل الأساسية التي تساعد على تحقيق الازدهار في المجتمع المدرسي، فإذا توافرت الوسائل المادية والمعنوية اللازمة لإنجاز العمل، وتهيأت الظروف المناسبة في المدرسة كان المعلم أكثر لمان قدرة على الإنجاز والعطاء، لذلك فقد أصبح الرضا الوظيفي من أهم الموضوعات الإدارية التي تشغل خبراء الإدارة التربوية، كونه

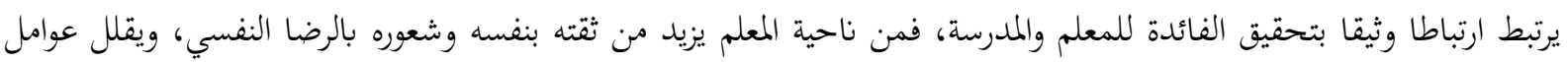

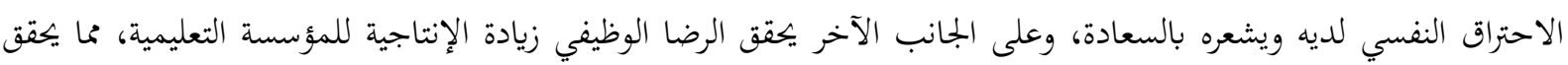

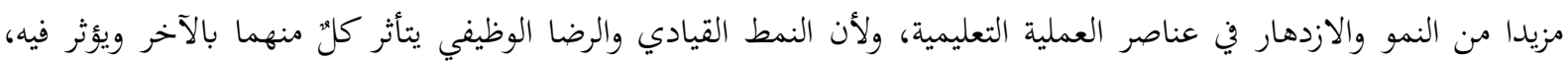
فالمناخ الذي يوفره النمط القيادي داخل بيئة العمل ينعكس على العاملين في المؤسسة ومدى تقبلهم لطبيعة العمل وزيادة الإنتاج،

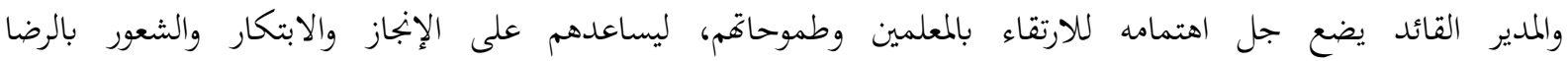

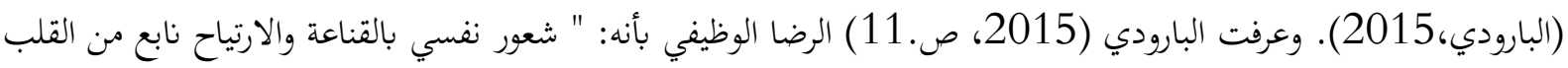

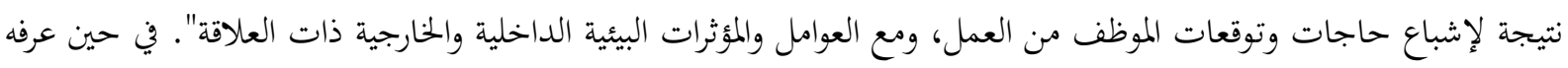

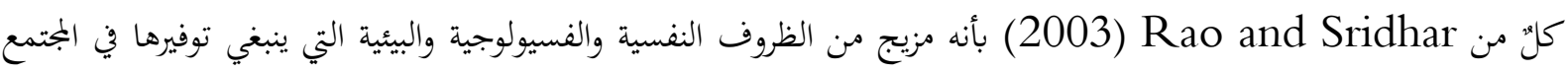
القيادي، والتي تجعل الشخص يقول أنا راض عن وظيفتي، فتجعله يقبل عليها برغبة. ويضيف Osbourne (2015) بأن

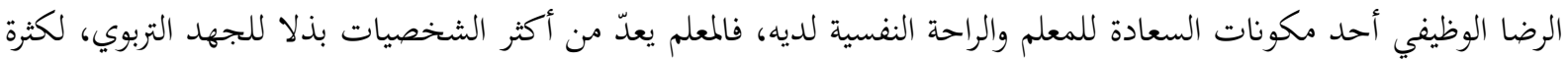

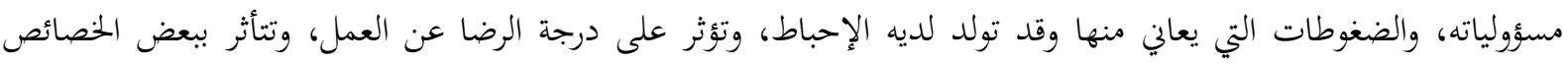

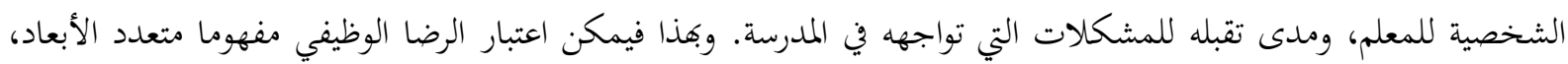

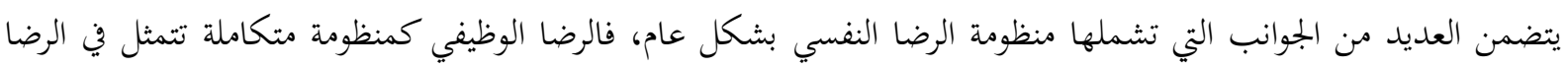

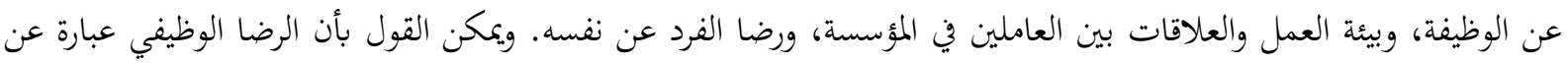
شعور بالراحة والسعادة في بيئة العمل، ويعبر عن رضا الفرد عن وظيفته ومديره وزملائه، ومتمثلا في الاحترام الذي يلقاه، وتقديره

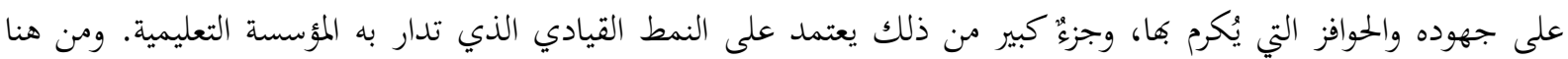

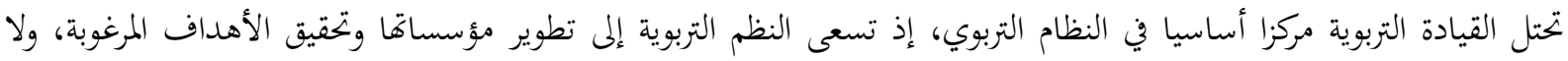

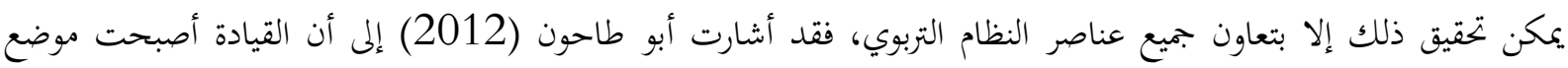

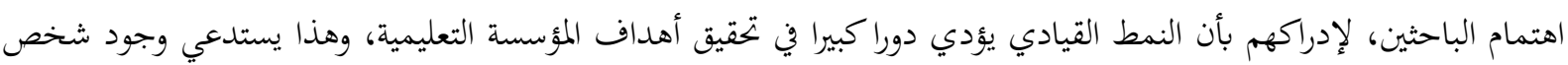
يتمتع بصفات القيادة الفاعلة، فالقيادة عملية يستطيع الفرد من خلالها التأثير على المجموعة لتحقيق الأهداف، والهي والقيام بالأعمال الموكلة إليهم بفاعلية. ويعتبر النمط القيادي الفاعل عنصرا مهما في تحقيق رسالة المؤسسة التعليمية ورؤيتها، لأن القائد ذو النمط

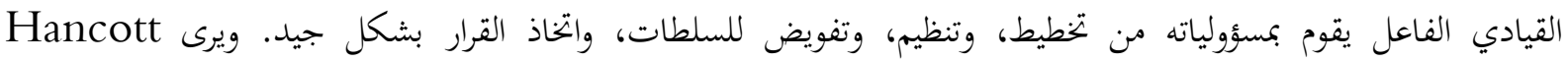

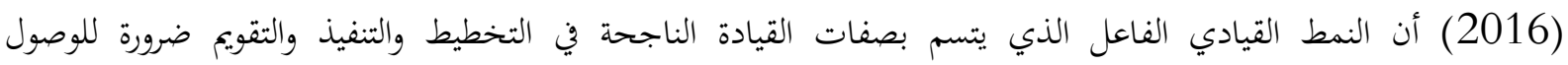

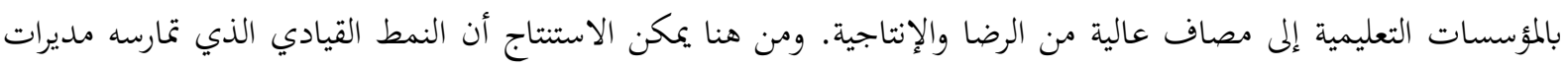

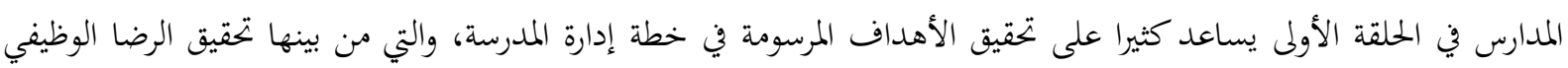
لجميع العاملين في المجتمع المدرسي، وبما يؤدي إلى تحقيق مخرجات تعليمية ذات مستويات جيدة في الأداء والتحصيل الدراسي.

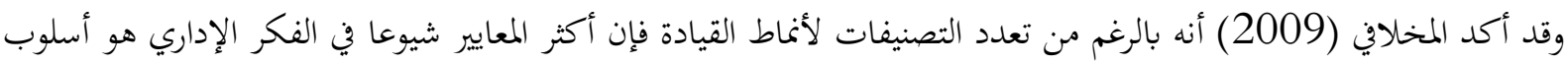

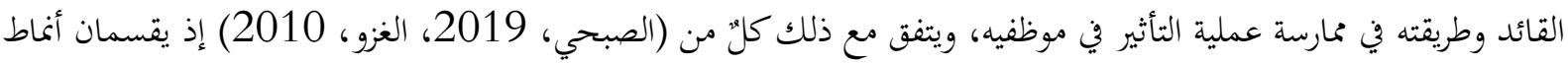

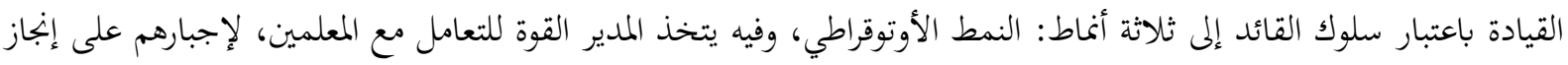

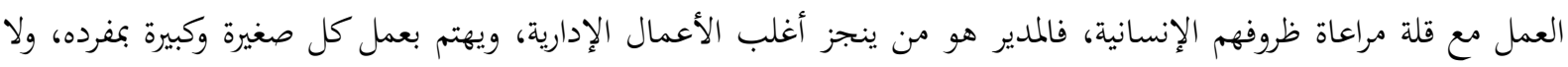


يلجأ للتفويض غالبا ولا يقبل بالآراء ولا يثق إلا بنفسه ولا يهتم بالعلاقات الإنسانية كثيرا، وينسب النجاح لنفسه غالبا، وهذه

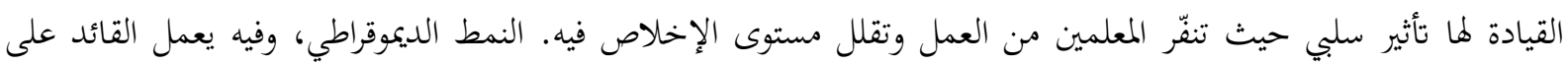

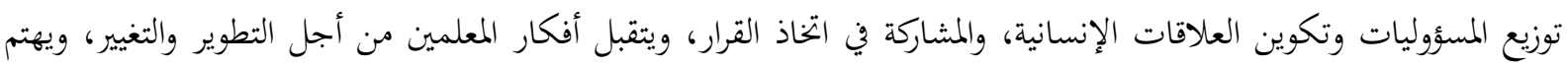

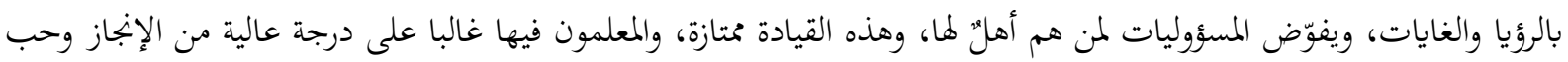

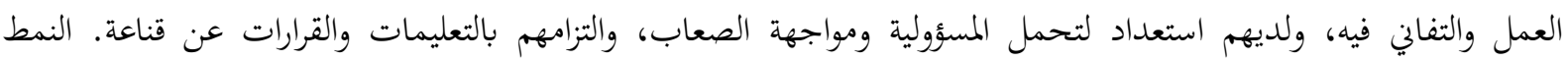

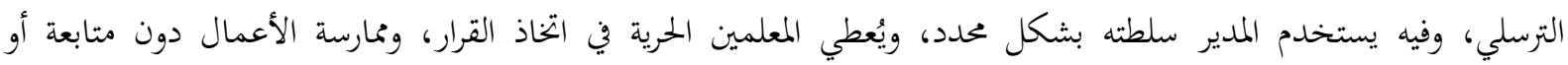

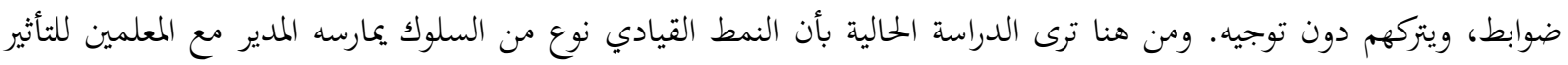

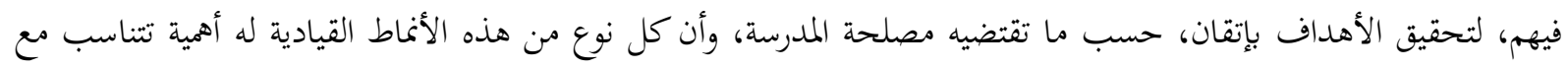

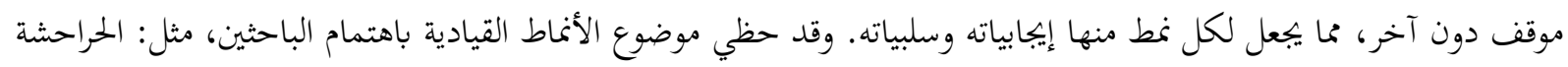
(2008) إذ أشار إلى أن هناك علاقة إيجابية بين النمط القيادي ومستوى الرضا الوظيفي للمعلمين. في حين أوصت دحلائه

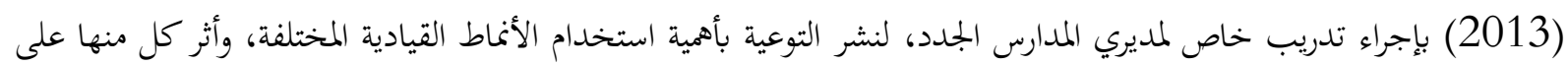

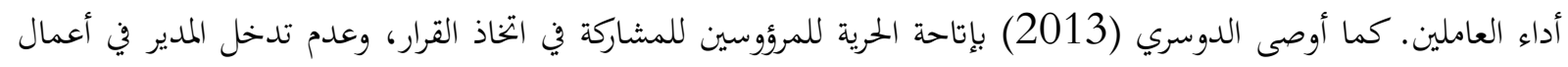

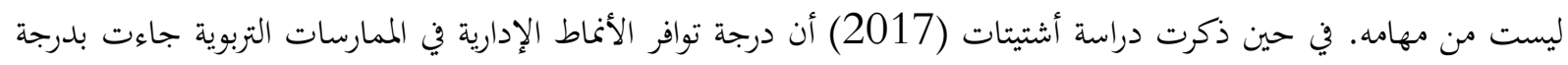

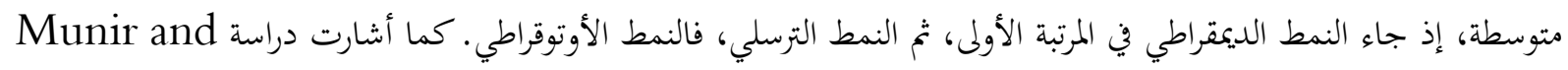
Iqbal الوظيفي للمعلمين، بينما يقلل النمط التسلطي من مستوى الرضا الوظيفي ومستوى الإنتاجية. في حين توصلت دراسة الصبحية (2019) إلى أن النمط القيادي السائد لدى مديري مدارس التعليم الأساسي هو النمط الديموقراطي، وفي المرتبة الثانية

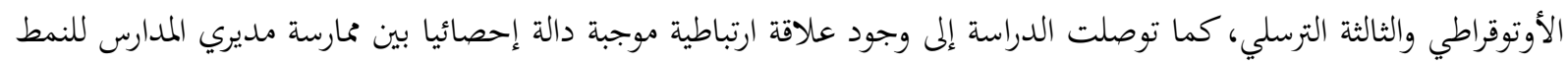

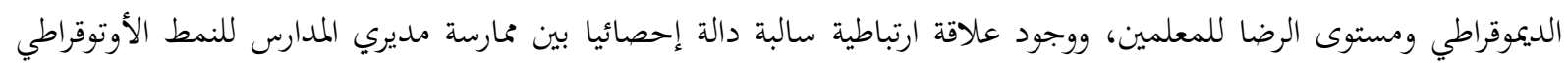

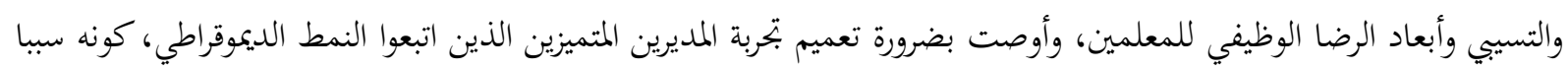
في تحقيق الرضا الوظيفي. وتتنوع أنماط السلوك القيادي من موقف لآخر ومن شخصية لأخرى، ومن أبرز الأنماط القيادية المنتشرة

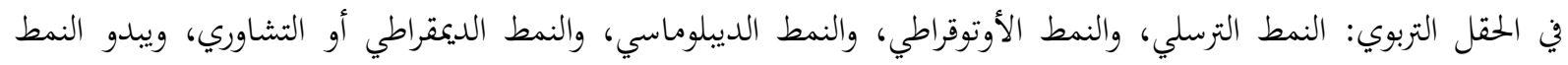

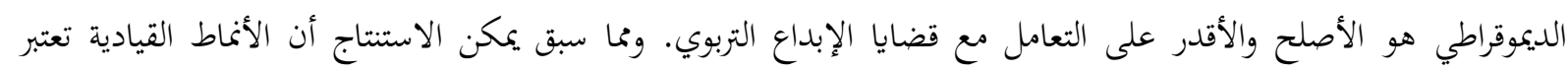

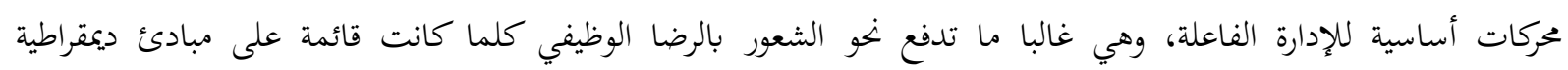

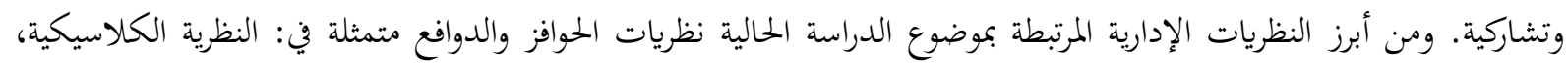
ونظرية YX، ونظرية العلاقات الإنسانية، ونظرية الحاجات الإنسانية. واعتمدت الدراسة الحالية على نظرية هيكلية الحاجات

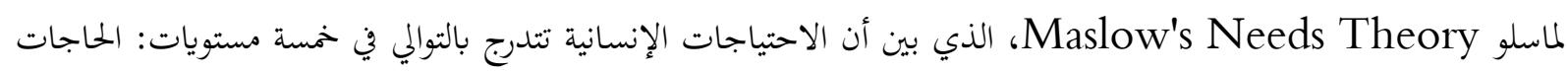

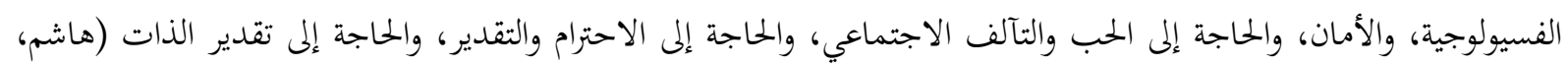

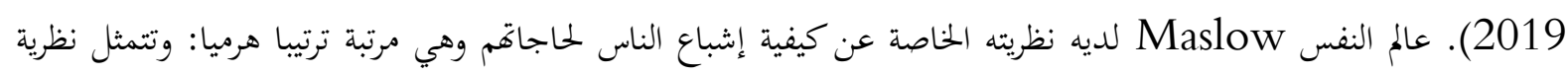

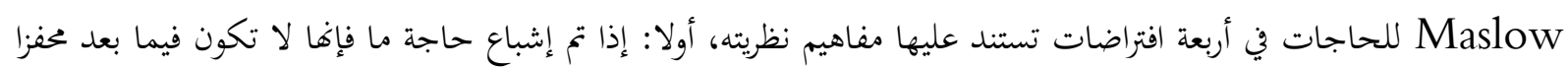

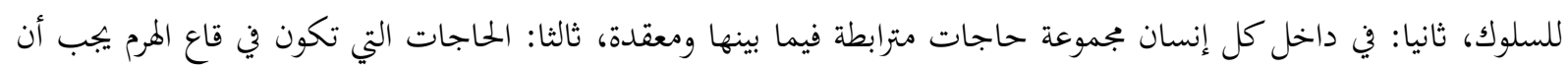

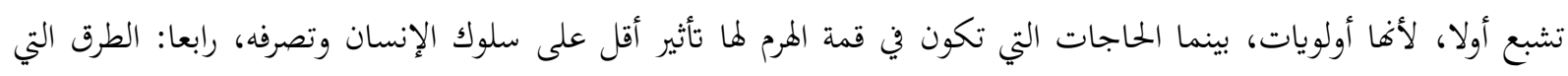

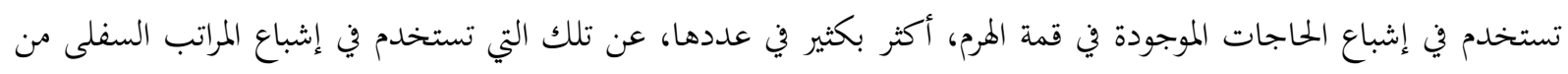
الهرم. حيث تكون حاجات الإنسان هذه متدرجة في خمس حاجات، بداية من الحاجات الفسيولوجية متمثلة في الحاجة إلى 
الأكل والشرب والهواء، تليها الحاجة إلى الأمان متمثلة في حاجة الإنسان للشعور بالأمان المادي والنفسي، تليها حاجة الإنسان

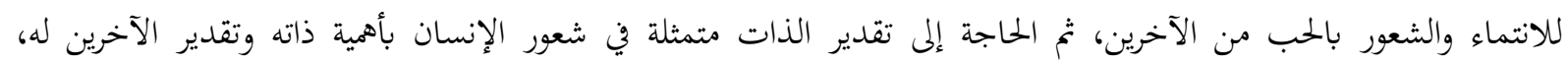

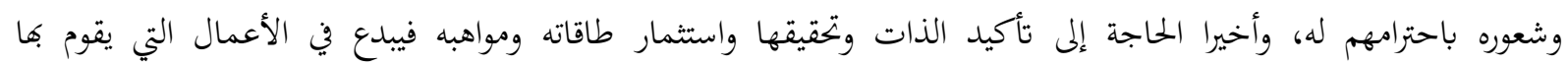

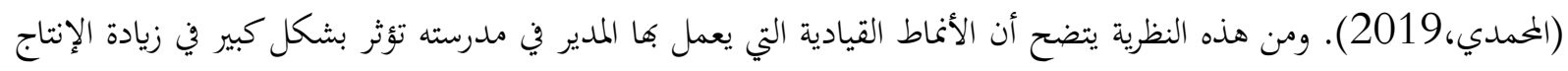
والإبداع وتحقيق الرضا الوظيفي في الجانب الإيجابي أو في الجانب السلبي. فاهتمام المدير بالمعلمين ومراعاة أحوالهم وظروفهم،

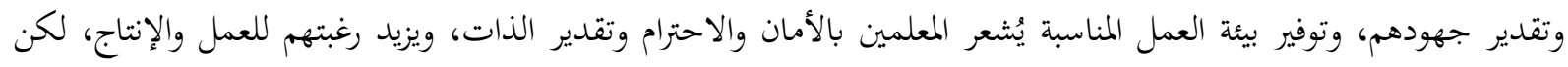

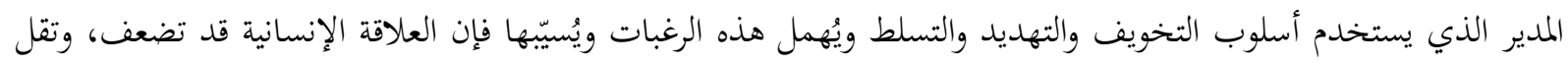

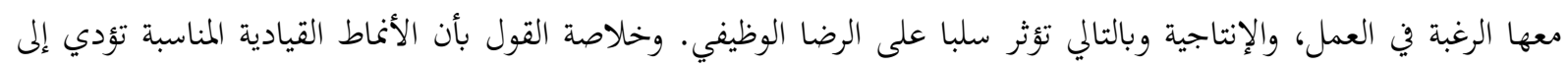
إشباع بعض الحاجات التي يسعى الفرد إلى تحقيقها، ليشعر بالرضا الوظيفي. ترعائ.

مشكلة الدراسة

يحتلّ تطوير أنماط القيادة في المؤسسات التربوية الصدارة في الأنظمة التعليمية، ويصعبُ التقدم في تلك الأنظمة إلا بأخذ

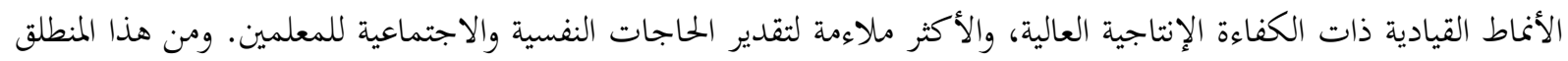

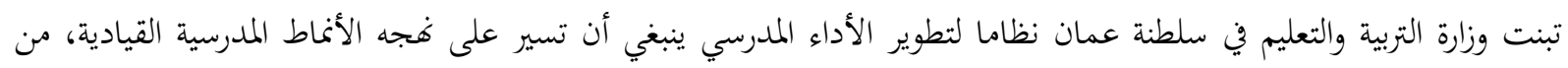

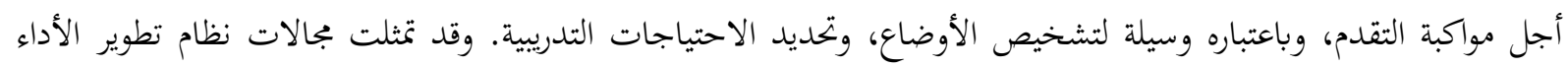

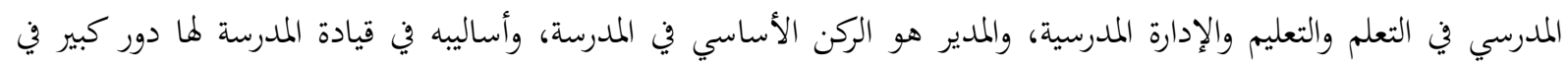
تحقيق الرضا الوظيفي للمعلمين من عدمه، لذلك ينبغي أن تتوافر فيه صفات القيادة الأكثر كفاءة (وزارة التربية والتعليم،

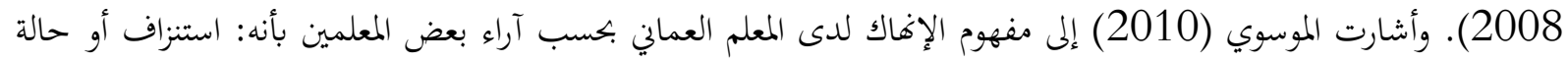

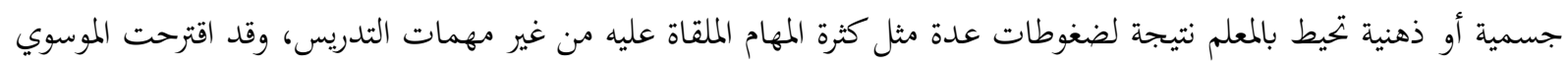

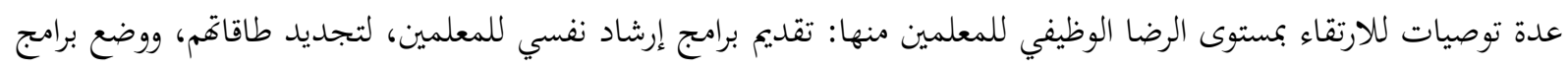

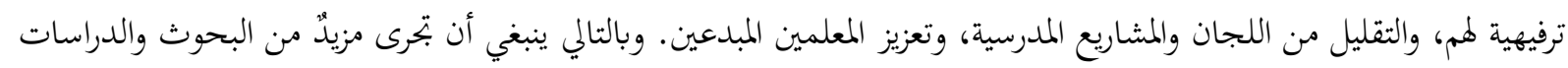

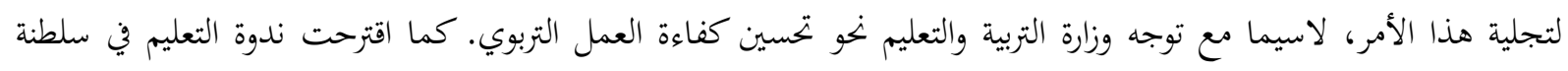

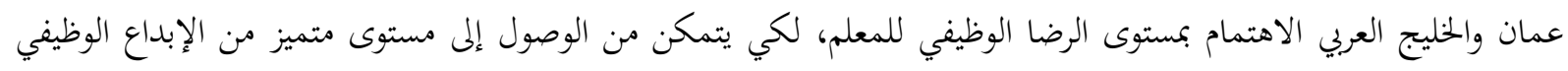

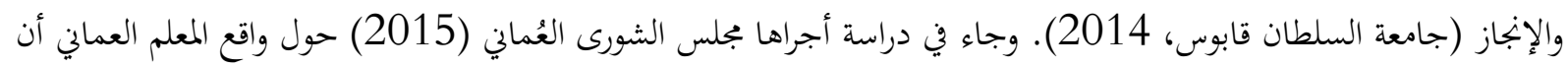

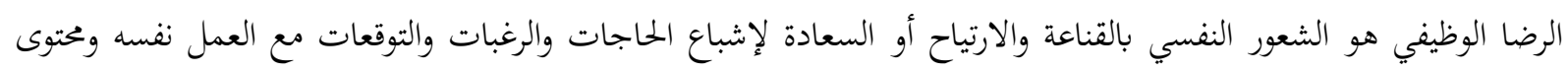

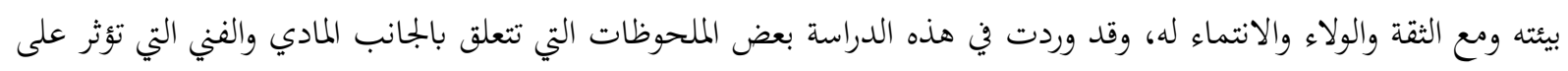

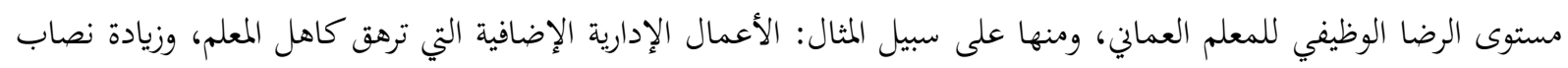

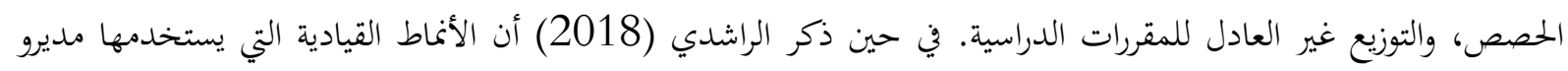

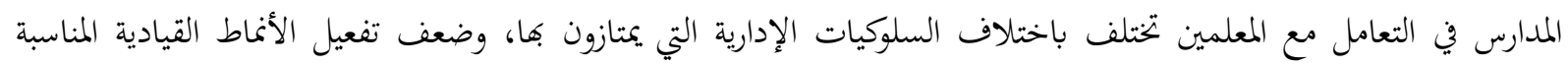
لظروف المعلمين قد يؤدي إلى قلة تققيق الأهداف المنشودة للعملية التعليمية، وكذلك توظيف القيادات الإدارية في الوظائف التي

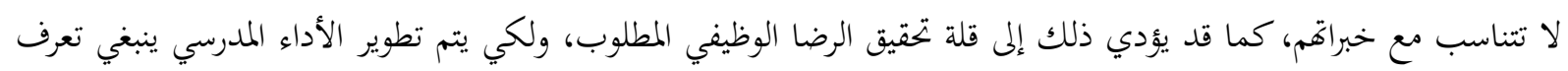

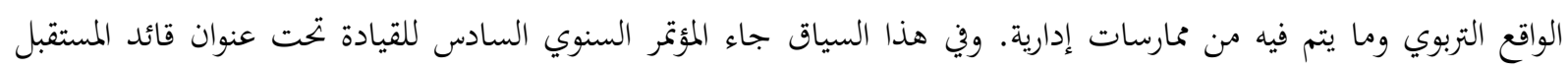
(2018) مستعرضا الصفات التي يجب أن تتوافر في قائد المستقبل، والمتمثلة في إثبات دوره القيادي أمام الآخرين، والرؤيا

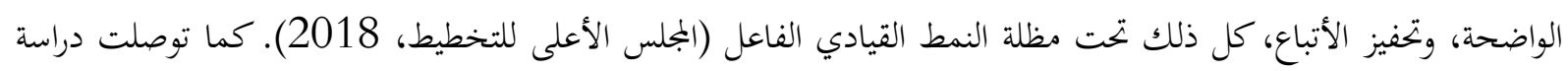


الشيزاوية (2008) إلى وجود علاقة إيجابية بين النمط القيادي الديمقراطي لمديري المدارس ومستويات الرضا الوظيفي السائدة

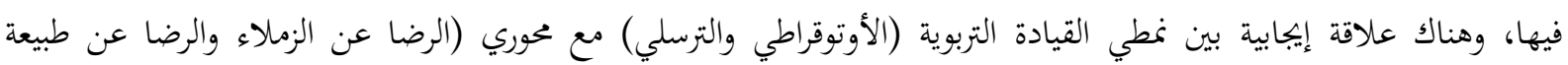

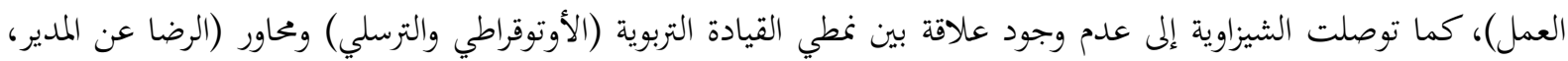

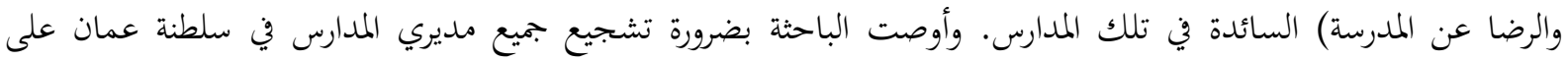
استخدام النمط القيادي الديمقراطي، لأنه يوفر التعاون والمناخ النفسي والاجتماعي للمعلمين، ثم يؤثر إيجابيا على الأداء والإنجاز

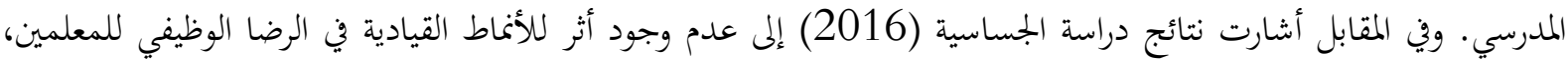
حيث أظهرت المتوسطات نتائج عالية لممارسة الأنماط القيادية مع مستويات متوسطة للرضا الوظيفي، وكان معامل الدلالة أقل من

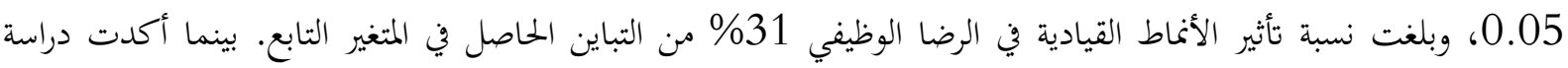

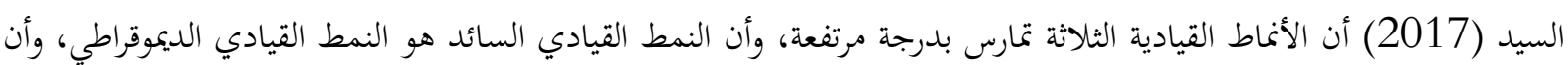
درجة الرضا الوظيفي المعلمين كانت مرتفعة، كما توصلت إلى عدم وجود فروق ذات دلالة إحصائية بين متوسطات درجات ممارسة مديري المدارس للنمط القيادي الأوتوقراطي والحر تعزى لمتغير الحبرة والمؤهل الدراسي. في حين توصلت دوريكي دراسة الراشدي (2018) إلى أن مديري مدارس التعليم الأساسي للصفين (11-12) بمحافظة شنمال الباطنة يستخدمون جميع الأنماط الإدارية

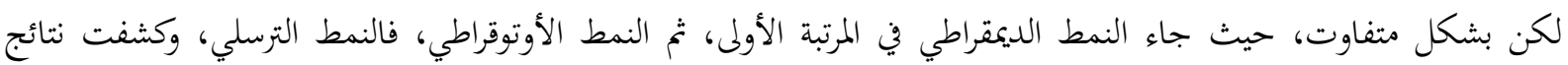

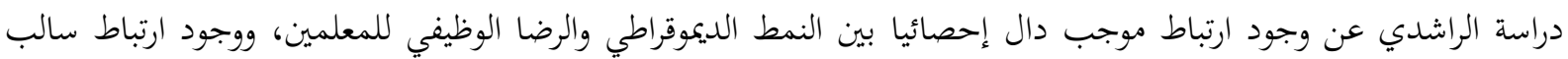
دال إحصائيا للنمطين الأوتوقراطي والترسلي وبين الرضا الوظيفي للمعلمين. وبناء على ما سبق فإن الأنماط المباط القيادية الإدارية تؤثر

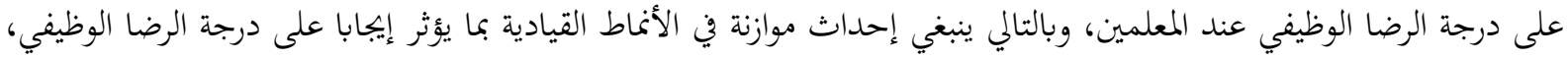
ويدفع هذا الاستنتاج إلى إجراء دراسات أخرى جديدة، لمعرفة درجة التأثير بين المتغيرين. وبالتالي فيمكن أن تتقرر مشكلة الدراسة في دراسة الأماط القيادية لمديرات مدارس الحلقة الأولى بمحافظة شمال الباطنة، وعلاقتها بالرضا الوظيفي لمعلمات المجال الأول.

أسئلة الدراسة 1. ما الأنماط القيادية التي تمارسها مديرات مدارس الحلقة الأولى كما تراها معلمات المجال الأول في محافظة شمال الباطنة التعليمية

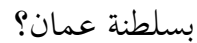

2. ما مستوى الرضا الوظيفي لمعلمات المجال الأول في مدارس الحلقة الأولى بمحافظة شمال الباطنة التعليمية من وجهة نظرهن؟

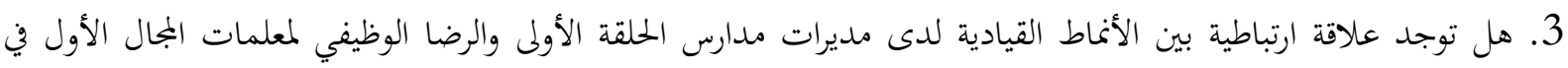

تبدو أهمية هذه الدراسة في كوها تتناول موضوعين مهمين في مجال الإدارة التربوية في سلطنة عمان وهما: الأنماط القيادية، والرضا الوظيفي باعتبارهما مرتبطان بفئة مهمة في المجتمع التربوي، ولمما دور بارز في تحقيق الإنجاز في المدرسة، والمساهمة في صندانع

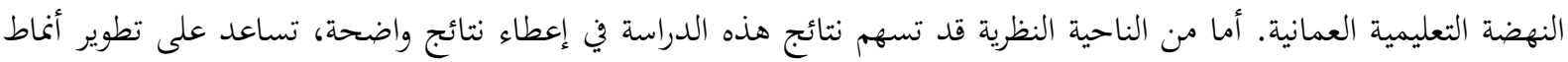
القيادة لدى الإدارة التربوية المدرسية من خلال تركيزها على النمط القيادي الأنسب لدى مديرات مدارس الحلقة الأولى في محافظة

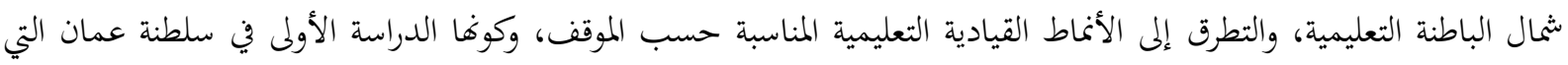
تسلط الضوء على الأنماط القيادية للإناث. أما من الناحية التطبيقية فإنه يتوقع من نتائج هذه الدراسة أن تقدم بيانات للمسؤولين

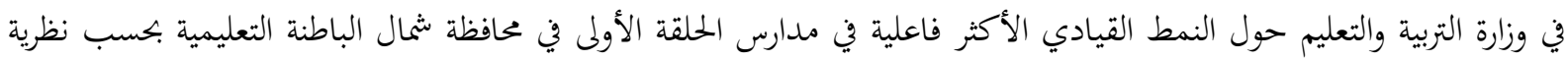


الحاجات Maslow، وبالتالي قد تساعد في وضع الخطط والبرامج التدريبية الأكثر ملاءمة للنهوض بمستوى هذه الممارسات الإدارية.

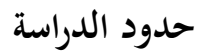

$$
\text { الحدود الزمنية: تم تطبيق هذه الدراسة في الفصل الدراسي الثاني من العام الدراسي 2019 2020. }
$$
الحمدود المكانية: تم تنفيذ الدراسة في مدارس محافظة شمال الباطنة في ولايات: صحار، وشناص، ولوى، وصحم، والخابورة، والسويق، وتم اختيار محافظة شمال الباطنة، كوها أكبر محافظة تعليمية، ويوجد بها طاقات بشرية متنوعة. الحدود البشرية: تم تنفيذ

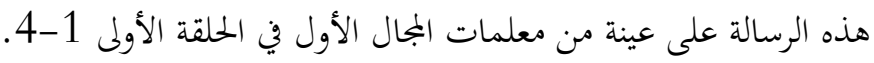
الحدود الموضوعية: الأنماط القيادية السائدة لدى مديرات مدارس التعليم الأساسي في مدارس الحلقة الأولى 1-4، وهي: النمط القيادي الديموقراطي، والنمط القيادي الأوتوقراطي، والنمط القيادي الترسلي، وعلاقتها بالرضا الوظيفي لمعلمات المجال الأول في محافظة شمال الباطنة.

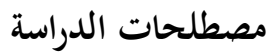
1. وسيتم تعريفه من خلال مناقشة مصطلحي النمط والقيادة كما يأتي: النمط كما عرفه مجمع اللغة العربية (2005،

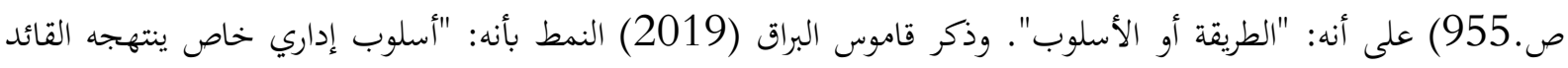

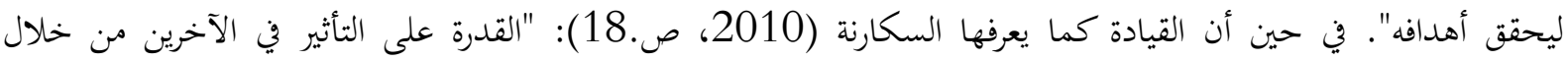

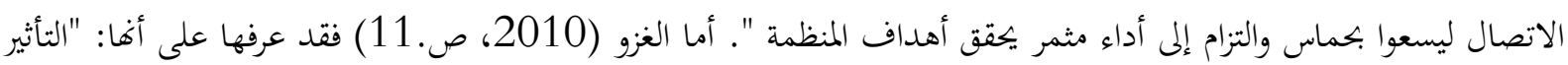
في شخص أو بجموعة أشخاص وتوجيهُم وإرشادهم من أجل كسب تعاوغم وحفزهم على العمل بأعلى درجة من الكفاءة في

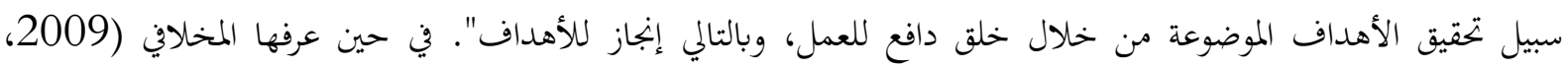

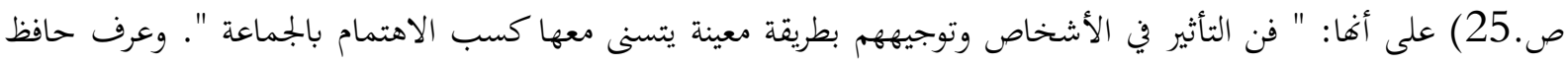

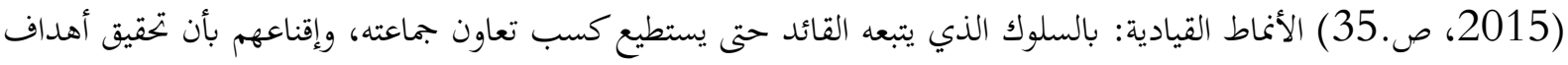
المنظمة تحقيق لأهدافهم". وفي سياق آخر أشار حافظ (2015، ص. (35) بأن الأنماط القيادية: "بجموعة من السمات السلوكية

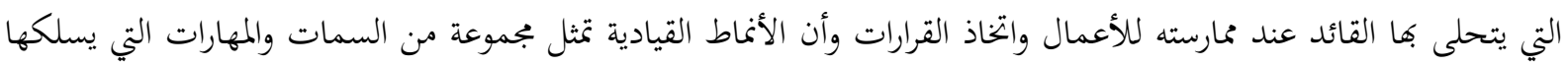

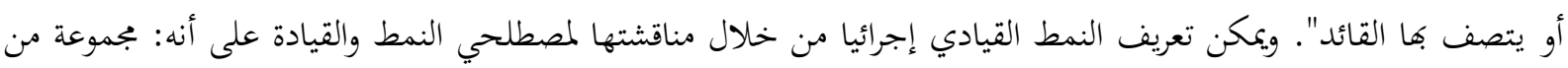

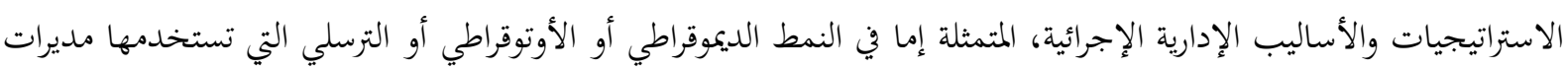

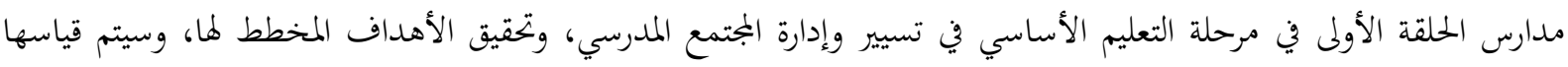
بواسطة الاستبانة المعدة لذلك الغرض.

2. 2 الرضا الوظيفي:

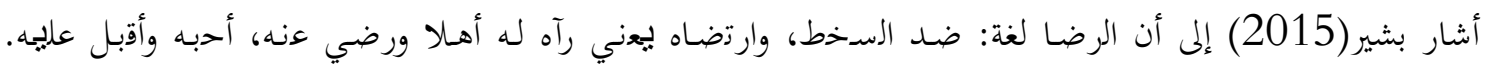

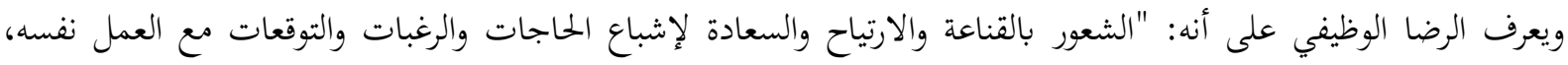

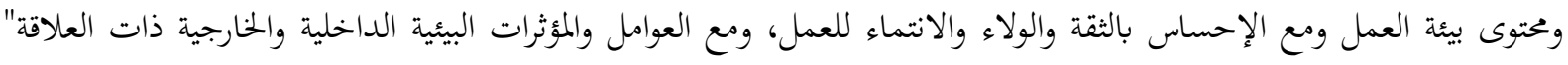
(أبو عساف والمرعي، 2019، ص.153). في حين يعرفه محمد (2018، ص.11) بأنه: "بجموعة العوامل ذات الصلة بالعمل 
الوظيفي، والتي تقاس أساسا بقبول الفرد ذلك العمل بارتياح ورضا نفس وفاعلية بالإنتاج نتيجة للشعور الوجداني الذي يمكن للفرد

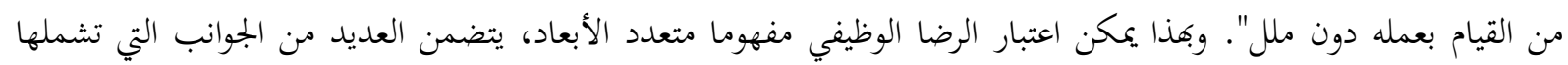

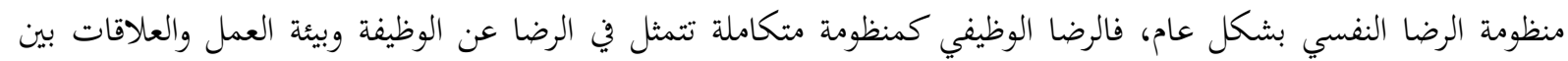

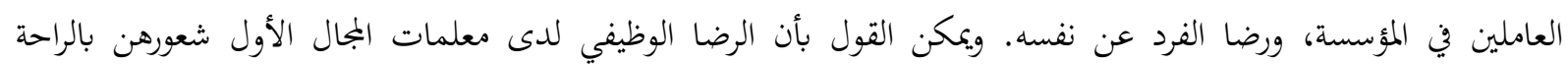

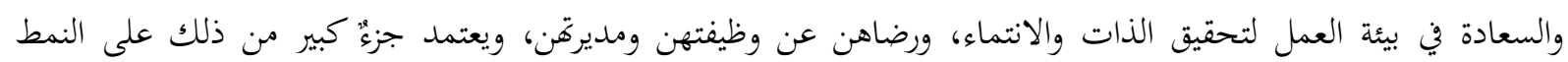

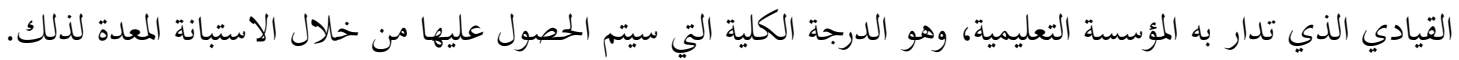

\section{منهجية الدراسة}

وظفت الدراسة الحالية المنهج الوصفي الارتباطي، للتعرف على آراء معلمات المجال الأول حول الأنماط القيادية لمديرات

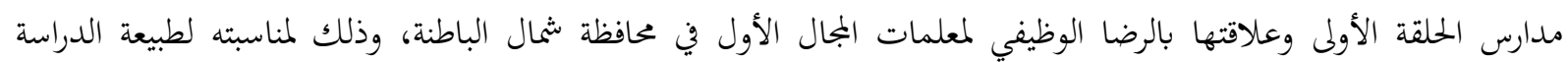
الحالية، وباعتباره يصف الظاهرة كما هي كمَّا وكيفا، فهو يهتم بدراسة العلاقات التي تربط بين أجزاء الظاهرة المدروسة بواسطة

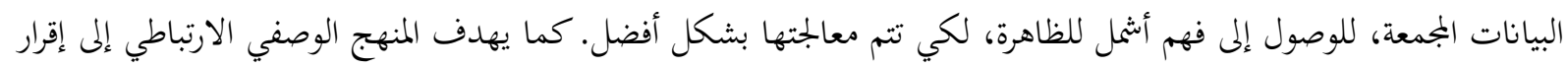

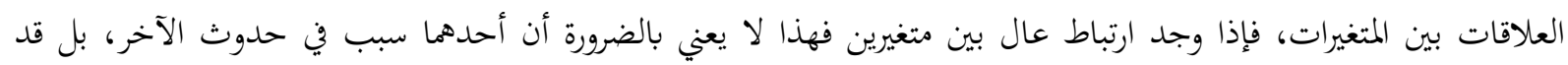

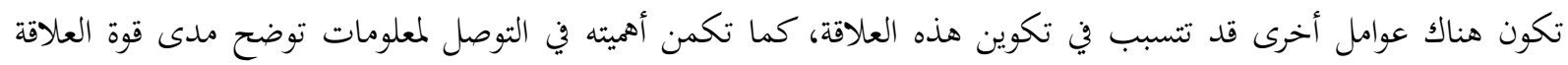

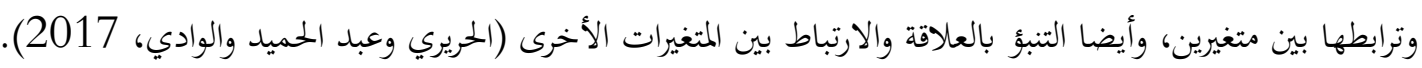

\section{مجتمع الدراسة وعينتها والأدوات}

يشمل بجتمع الدراسة جميع معلمات المجال الأول في مدارس الحلقة الأولى 1-4 من التعليم الأساسي في محافظة شمال الباطنة في ولايات: شناص، ولوى، وصحار، وصحم، والخابورة، والسويق، القائمات على رأس عملهن في العام الدراسي

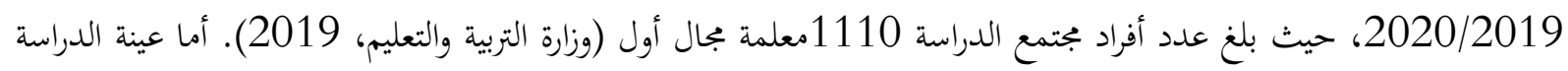

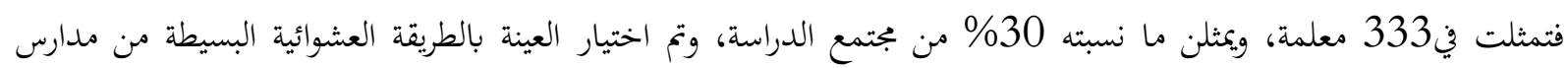
الحلقة الأولى في محافظة شمال الباطنة.

اشتملت الدراسة الحالية على أداتين، تمثل الهدف من الأداة الأولى (استبانة قياس الأنماط القيادية لمديرات مدارس الحلقة

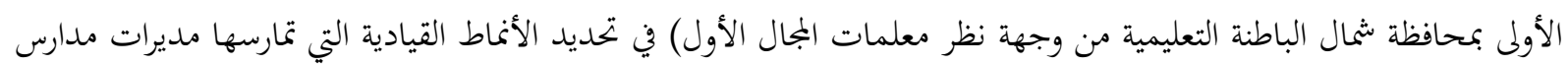

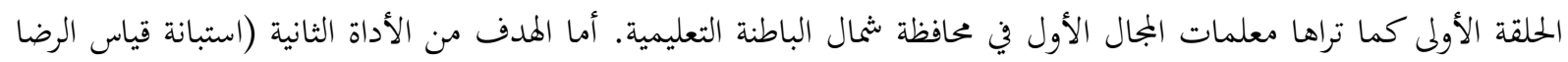

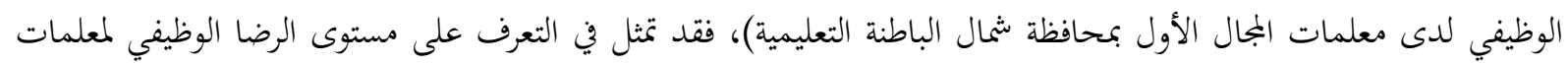

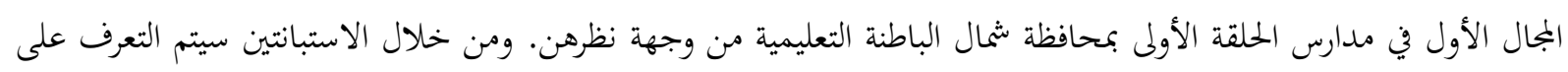

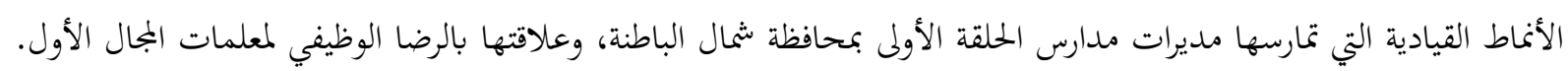

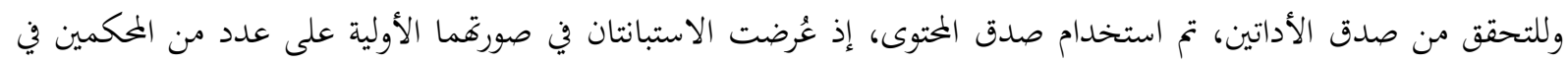

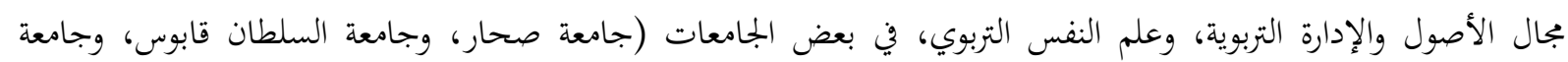
الشرقية)، وبعض المختصين في وزارة التربية والتعليم في تطوير الأداء المدرسي، لتحديد مدى تمثيل الفقرات للسمات المراد قياسها،

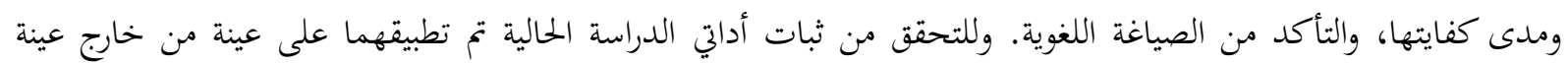

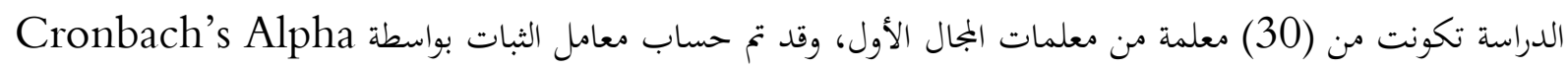


Coefficient، حيث بلغ معامل ثبات الاستبانة الأولى الخناصة بالأنماط القيادية 0.93، أما الاستبانة الثانية الخاصة بالرضا

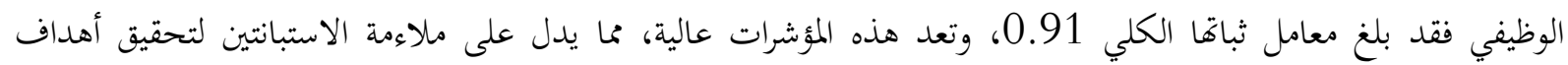
الدراسة الحالية، كما أشار ثابر إلى أن الثبات الكلي للمقياس يكون مناسبا عندما تلكون قيمته (Taber,2016). وبعد الحصول على الموافقة الرسمية من المكتب الفني للدراسات والتطوير في وزارة التربية والتعليم بتطبيق أداتي الدراسة، وبعد الحصول على الموافقة الرسمية من دائرة تنمية الموارد البشرية بالمديرية العامة للتربية والتعليم بمحافظة شمال الباطنة

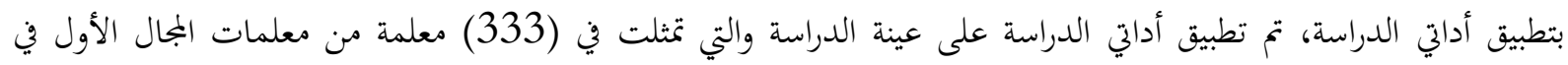
مدارس الحلقة الأولى 1-4 من التعليم الأساسي في محافظة شثمال الباطنة.

\section{الخطوات الإجرائية للدراسة}

الاطلاع على الأدب التربوي المرتبط بموضوع دراسة الأنماط القيادية وعلاقتها بالرضا الوظيفي (أبو عساف والمرعي،

2019، البارودي، 2015، محمد، 2018) والدراسات والبحوث المرتبطة بموضوع دراسة الأنماط القيادية وعلاقتها بالرضا

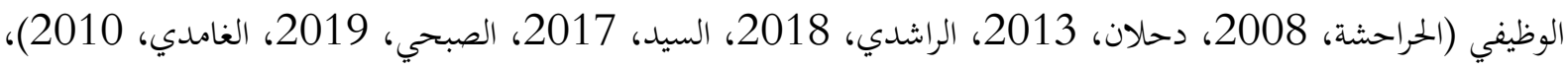

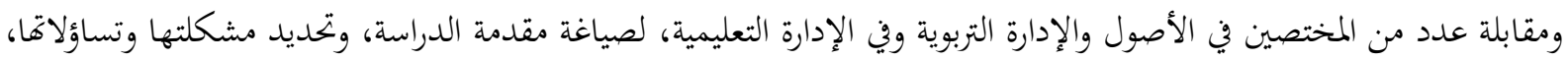

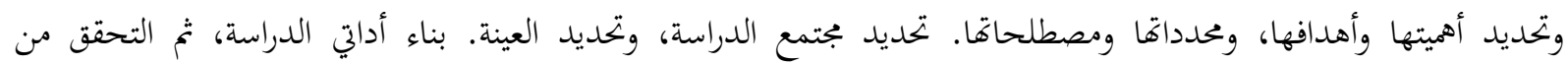
مؤشرات الصدق لمما، حيث تم اعتماد صدق المحتوى. التحقق من ثبات أدات واتي الدراسة باستخدام ألفا كرو نباخ "Cronbach's Alpha Coefficient" الاستبانتين على عينة الدراسة من معلمات المجال الأول. استقبال الردود على الاستبانات عبر الرابط الإلكتروني في برنامج google drive فاستخلاص النتائج والإجابات عن أسئلة الدراسة، وتحليلها ثم مناقشتها.

\section{الأساليب الإحصائية للدراسة}

تمت معالجة البيانات المستخلصة من الاستبانتين، باستخدام معالج البيانات إحصائيا في برنامج SPSS، لإجراء التحليل الإحصائي المطلوب للإجابة عن أسئلة الدراسة، وذلك وفق الآتي: في الإحصاء الوصفي للدراسة وظفت مقاييس النزعة المركزية:

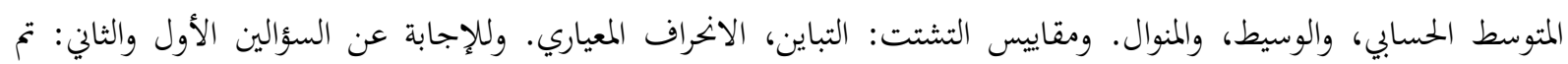

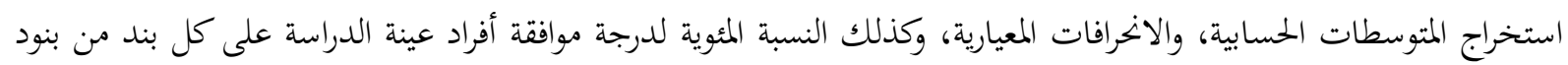

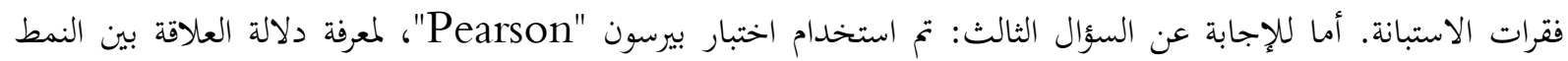
القيادي لمديرات مدارس الحلقة الأولى، والرضا الوظيفي لمعلمات المجال الأول. ولقياس ثبات أداتي الدراسة وظف برسوس معامل ثبات ألفا

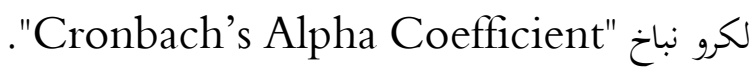

\section{نتائج الدراسة ومناقشتها}

1. ما الأنماط القيادية التي تمارسها مديرات مدارس الحلقة الأولى كما تراها معلمات المجال الأول في محافظة شمال الباطنة بسلطنة

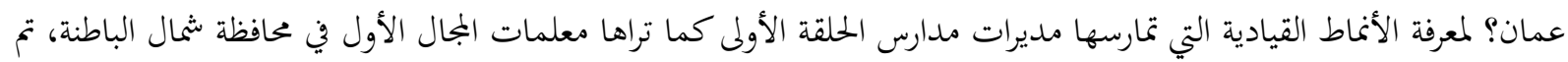
حساب المتوسطات الحسابية والاخرافات المعيارية لتقديرات أفراد العينة لمحاور أداة الدراسة، والجدول 1 التالي يوضح هذه النتائج. 
المتوسطات الحسابية والانحرافات المعيارية للأمناط القيادية التي تمارسها مديرات مدارس الحلقة الأولى كما تراها معلمات

البجال الأول في محافظة شمال الباطنة التعليمية

\begin{tabular}{|c|c|c|c|c|}
\hline درجة الممارسة & الرتبة & المعياري & المتوسط الحسابي & محاور أداة الدر اسة \\
\hline عالية جدا & 1 & 0.60 & 4.45 & النمط القيادي الديمقراطي \\
\hline متوسطة & 2 & 0.91 & 2.93 & النمط القيادي الأوتقر اطي \\
\hline متوسطة & 3 & 1.02 & 2.64 & النمط القبادي الترسلي \\
\hline
\end{tabular}

اتضح من الجدول 1 أن المتوسطات الحسابية للأنماط القيادية التي تمارسها مديرات مدارس الحلقة الأولى كما تراها معلمات المجال الأول في محافظة شثمال الباطنة بسلطنة عمان تراوحت بين 2.64- 4.45، إذ جاء في المرتبة الأولى النمط

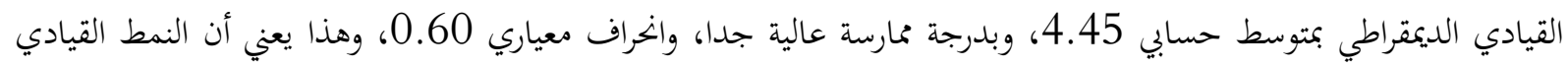

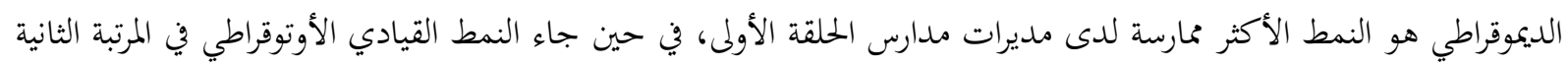

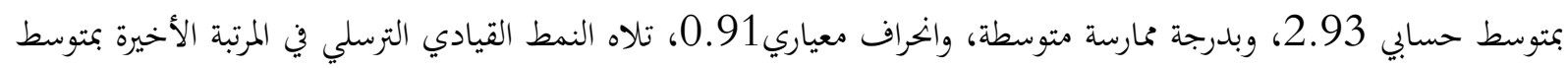
حسابي 64.64، وبدرجة ممارسة متوسطة، وانحراف معياري 1.02. ويمكن تفسير سبب حصول النمط القيادي الديموقراطي على متلى

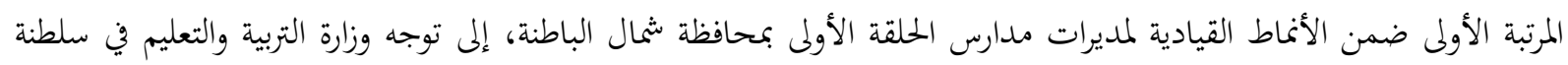

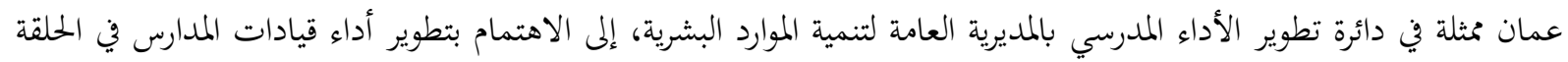

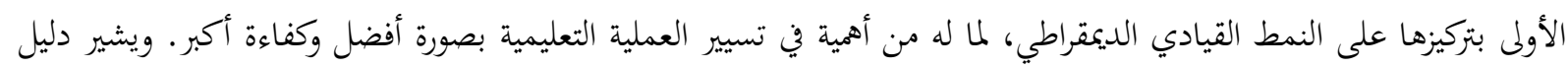
نظام تطوير الأداء المدرسي إلى أن على القيادات المدرسية التحلي بعلد من الميزيات القياديادية التي ينبغي أن تترسخ في في منارسات

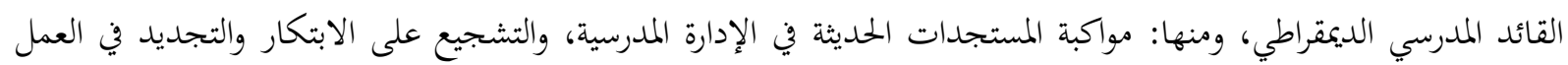

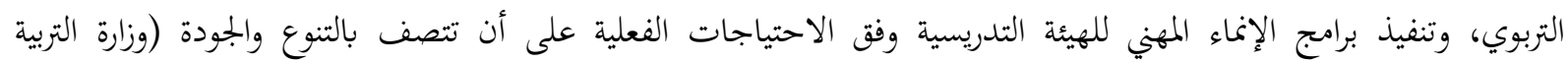
والتعليم.2008). ولذلك فإن تطوير أداء القيادات المدرسية، ورفع كفاءقا الإدارية عن طريق الجودة في خدمات التهات التدريب، والإنماء المهني قد انعكس إيجابا على الأداء الإداري لمديرات مدارس الحلقة الأولى بمحافظة شثمال الباطنة، كما تسعى وزارة التماء التربية والتعليم

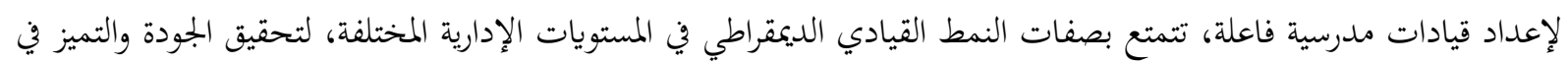
الأداء الوظيفي، وتمكينهم من القيام بوظائفهم بفاعلية وكفاءة، والتطبيق العملي للمهارات الإدارية، وتعريفهم بالمعارف والمافياهيم

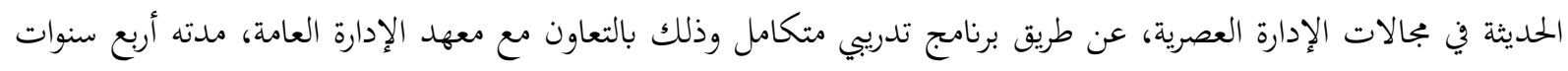
من (2017-2020) بواقع (100) ساعة، مقسمة إلى أربعة أسابيع على مدار العام (التربية والتعليم تواصل جهودها لردا الرامية

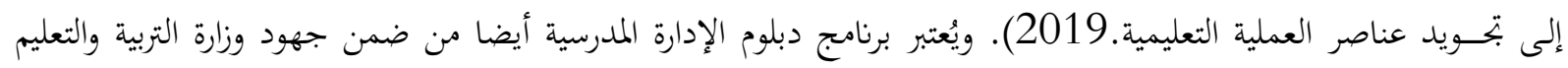

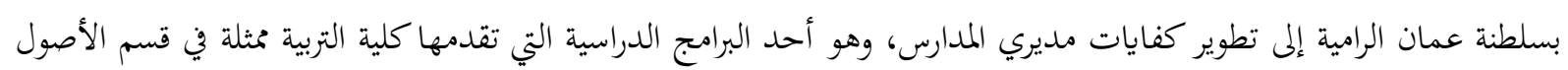

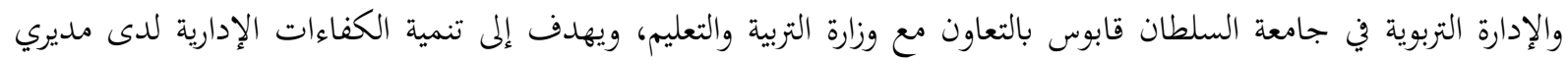


المدارس ومساعديهم، وغرس الاتحاهات الإيجابية المرتبطة بالممارسات القيادية الفاعلة في الججتمع التربوي (وزارة التربية والتعليم.2020). كما ترى الدراسة أن من أسباب حصول النمط القيادي الديموقراطي على المرتبة الأولى بين الأنماط القيادية

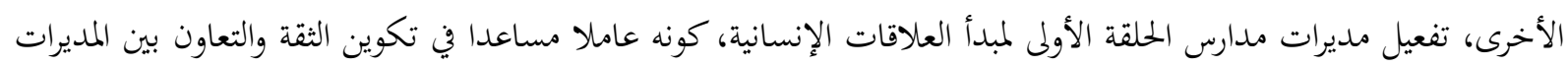
والمعلمات، وهذه واحدة من خصائص العمل الإداري في مدارس سلطنة عمان، تقتضي إشراك المعلمات في وضع خطط مدات مدات للمدرسة، والعمل كفريق واحد مع المديرات. في حين يُعزى حصول النمط القيادي الأوتوقراطي على المرتبة الثانية، بمتوسط حسابي المعاني

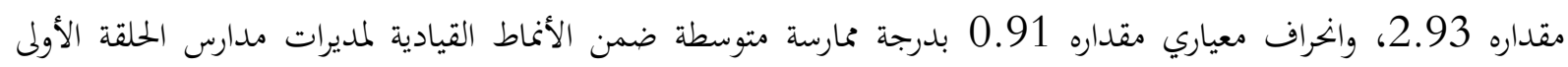

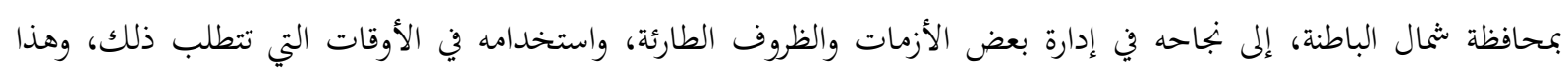

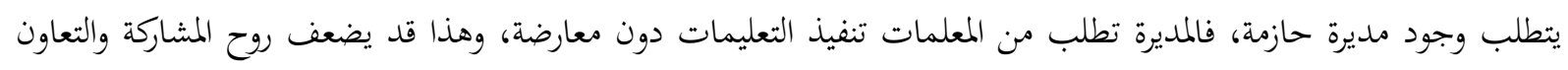

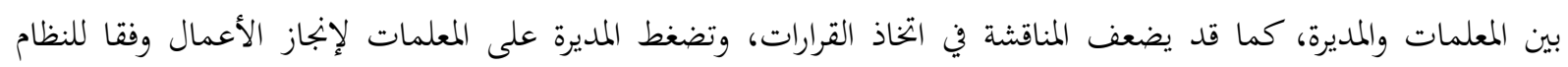

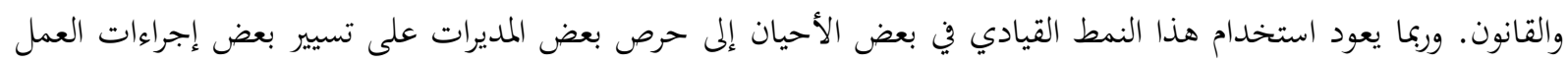

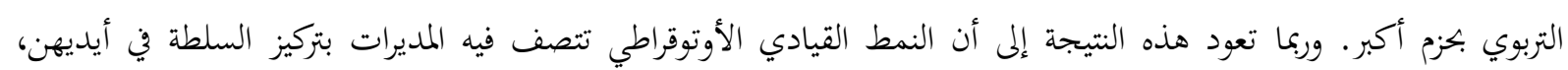

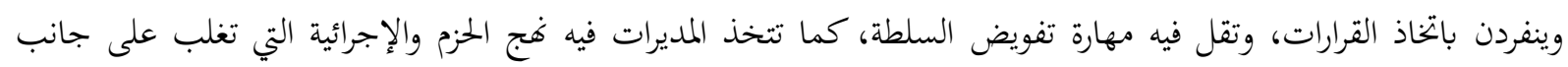

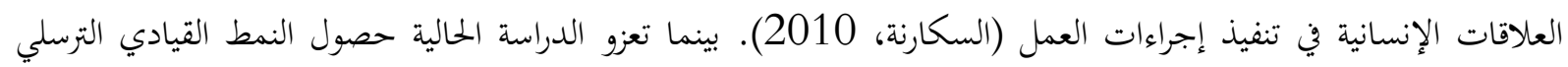

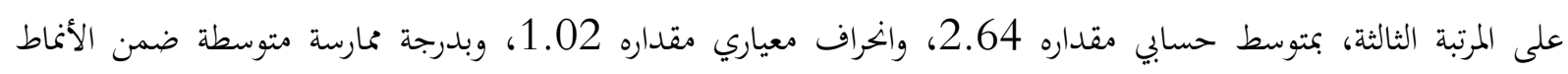

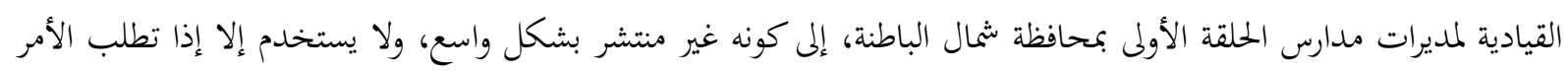

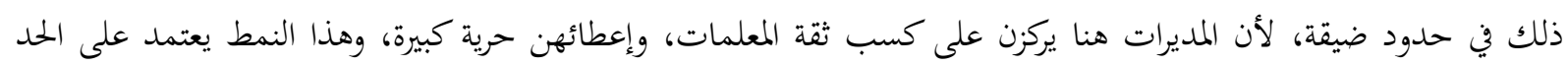

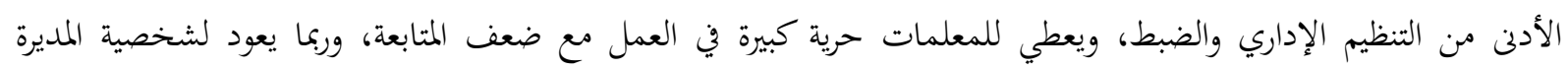
نفسها، فيغلب عليها أسلوب التساهل في جوانب العمل. وفي هذا الإطار تؤكد الدراسة الحالية حصول النمط القيادي الترسلي

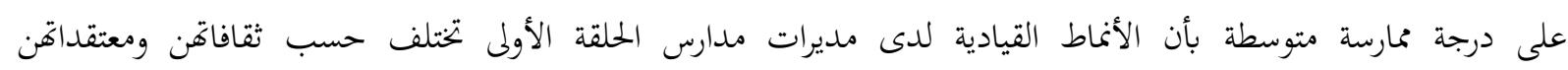

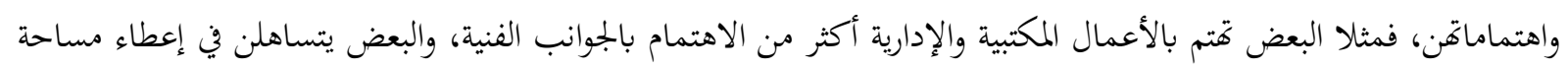

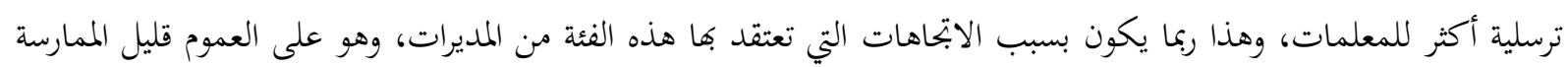

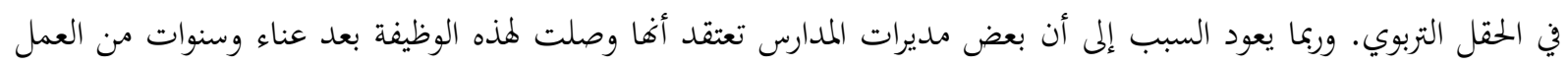

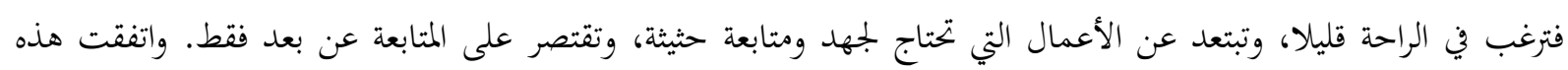

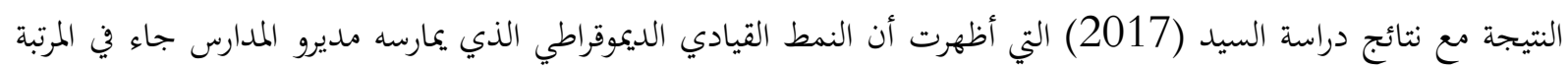

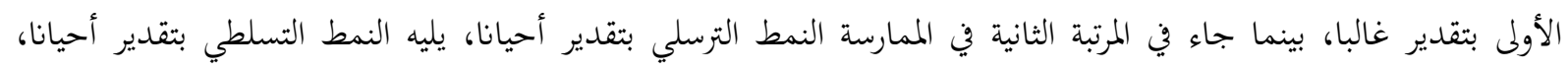

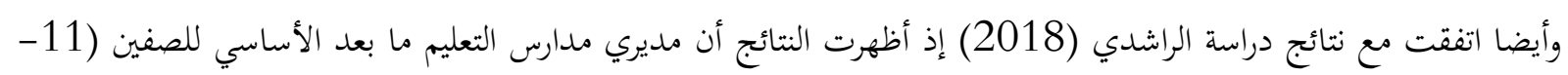

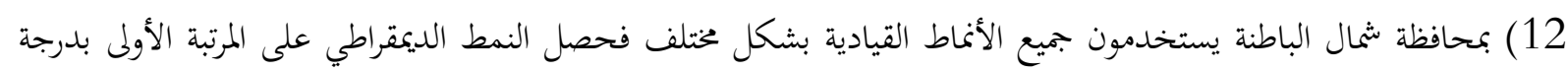

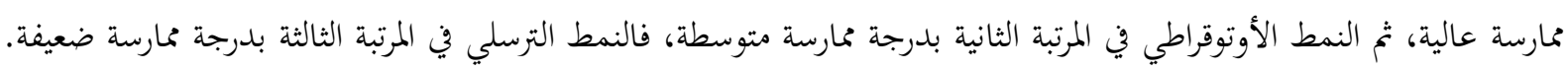

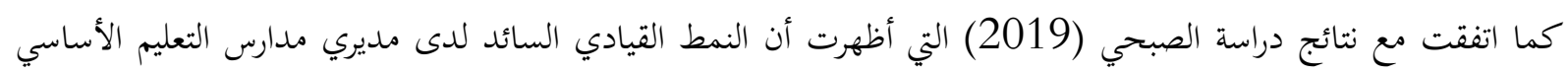

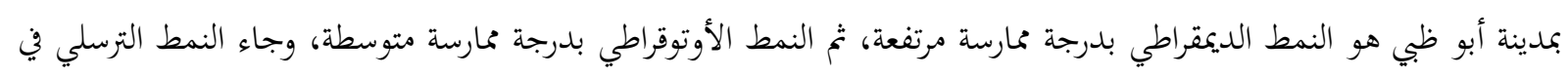

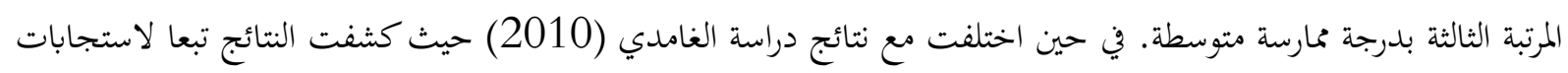
المعلمين لدرجة ممارسة مديري المدارس للأنماط القيادية في المدينة المنورة أن النمط القيادي الديمقراطي جاء داء في الرتبة الأولى بتقدير

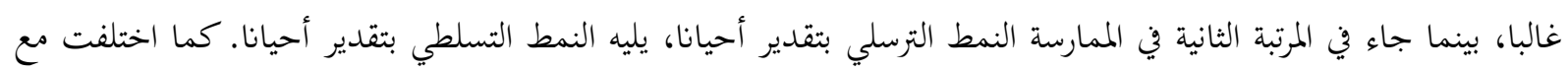
دراسة أشتيتات (2017) فجاء النمط الديمقراطي في المرتبة الأولى وبدرجة ممارسة مرتفعة، ثم النمط الترسلي في المرتبة الثانية 
بدرجة ممارسة متوسطة، وجاء في المرتبة الثالثة النمط الديكتاتوري بدرجة ممارسة متوسطة، وجاء في المرتبة الأخيرة النمط الأوتوقراطي بدرجة ممارسة متوسطة أيضا. وللوقوف على آراء عينة الدراسة حول درجة ممارسة كل نمط من هذه الأنماط تم حساب المتوسطات الحسابية والانحرافات المعيارية لجميع فقرات الاستبانة وفيما يلي عرض لهذه النتائج:

أ- النمط القيادي الديموقراطي

جدول 2 المتوسطات الحسابية والانحرافات المعيارية للنمط القيادي الديمقراطي

\begin{tabular}{|c|c|c|c|c|}
\hline المارجة & الانحر افياري & المتوسط الحسابي & الفقر ات & 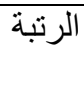 \\
\hline عالية جدا & 0.68 & 4.63 & للرعلمات مديرة المدرسة الجو انب الإنسانية & 1 \\
\hline عالية جدا & 0.72 & 4.62 & تحفز تحسين مستوى المدرسة الأداء لديهات على الاستمرار & 2 \\
\hline عالية جدا & 0.71 & 4.59 & المستجدات مديرة المدرسة اجتماعات، لمناقتة & 3 \\
\hline عالية جدا & 0.68 & 4.54 & تقيّم مديرة المدرسة أداء المعلمات بشكل دقيق. & 4 \\
\hline عالية جدا & 0.79 & 4.51 & تلدعم مديرة المدرسة المشاركة الإيجابية بين & 5 \\
\hline عالية جدا & 0.77 & 4.46 & لتهنبم مديرة المدرسة بتطوير بيئة محفزة & 6 \\
\hline عالية جدا & 0.84 & 4.39 & تلتيح مديرة المدرسة حرية التعبير عن الرأي & 7 \\
\hline عالية جدا & 0.85 & 4.32 & تلفعّوض مديرة المدرسة بعض الصدلاحيات & 8 \\
\hline عالية جدا & 0.88 & 4.28 & القرار ك مديرة المدرسة المعلمات في آلية صنع & 9 \\
\hline عالية & 0.98 & 4.17 & تنقبل مديرة المدرسة النقل بصورة موضوعية & 10 \\
\hline عالية جدا & 0.60 & 4.45 & النمط القيادي الديمقر اطي العام & \\
\hline
\end{tabular}

بيّن الجدول 2 أن المتوسطات الحسابية لفقرات النمط القيادي الديمقراطي تراوحت بين 4.17 - 4.63، وقد بلغ

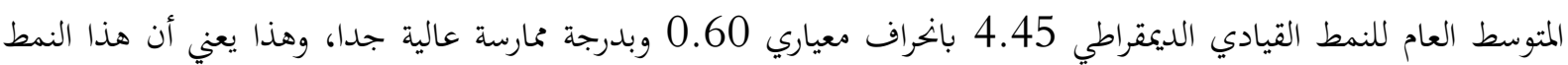
القيادي يسود بدرجة عالية جدا لدى مديرات مدارس الحلقة الأولى في محافظة شمال الباطنة من وجهة نظر معلمات المجال الأول. وقد حصلت الفقرة التي نصها: "تراعي مديرة المدرسة الجوانب الإنسانية للمعلمات" على الرتبة الأولى بمتوسط حسابي وانخراف معياري6806، وبدرجة ممارسة عالية جدا، في المقابل كانت الفقرة التي نصها: "تتقبل مديرة المدرسة النقد بصورة

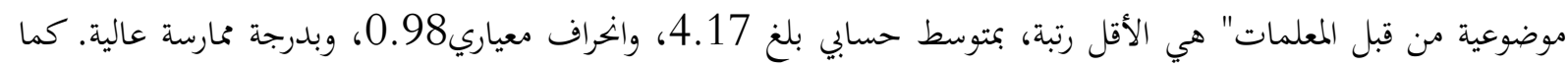

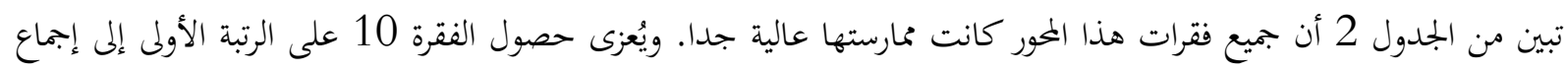

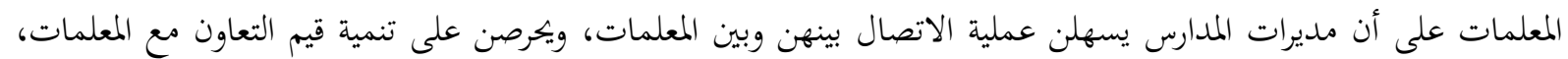
ويشجعن على المشاركة الفعالة، ويؤكدن على تقوية العلاقات الاجتماعية، ومراعاة الجوانب الإنسانية للمعلمات متمثلة في الاحترام والتقدير، ومراعاة الفروق الفردية بين المعلمات، فهذا كله يسهم في تقوية العلاقات الإنسانية بين مديرة المدرسة ومعلماتها، وهذا بدوره ينعكس إيجابيا على تحقيق الأهداف التربوية. وفي هذا الإطار يؤكد يامنة وخير الدين (2019) على ألى أن المديرة الديمقراطية

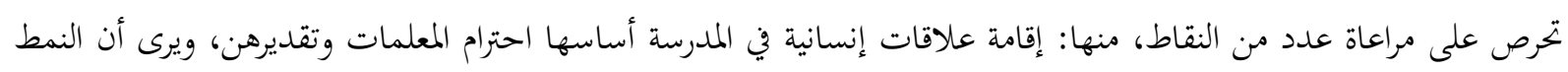


الديمقراطي له دور كبيرٌ في بناء العلاقات الإنسانية بين المديرة والمعلمات، مما ينجم عنه مجتمع مدرسي متماسك وقوي. ولعل

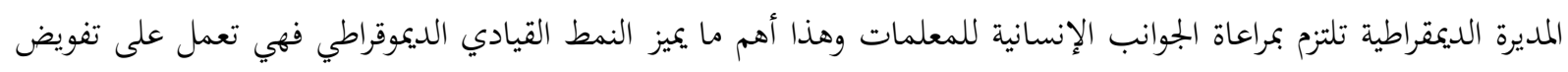
السلطات، ومشاركة المعلمات في اتخاذ القرار، والاهتمام بالعلاقات الإنسانية، ممثلة في المعاملة الحسنة، والثقة المتبادلة، والاهتمام

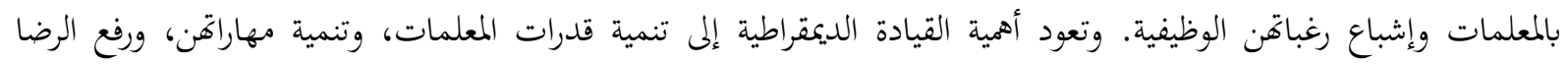

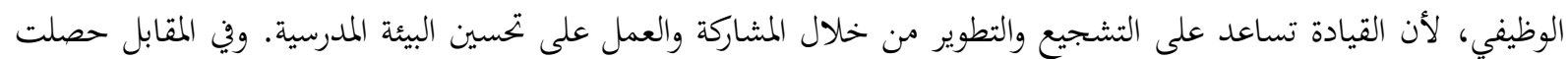

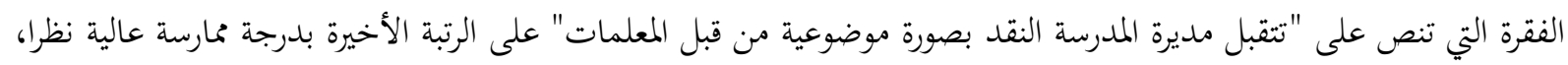

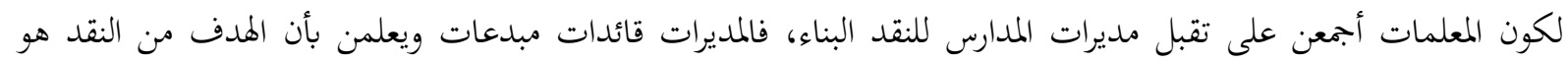

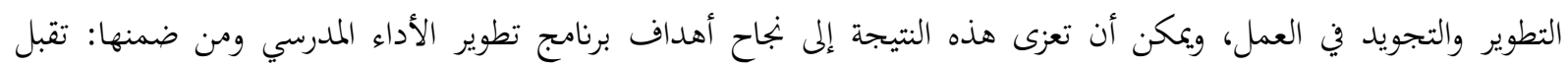

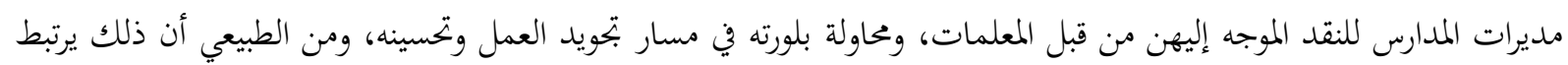

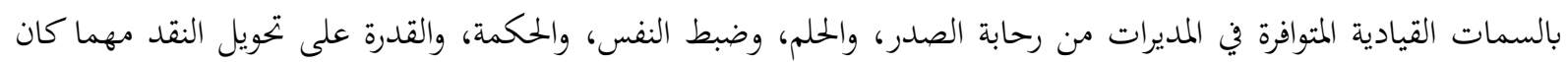
نوعه لصالح مسار العمل التربوي.

ب- النمط القيادي الأوتوقراطي

جدول 3 المتوسطات الحسابية والانحرافات المعيارية للنمط القيادي الأوتوقراطي

\begin{tabular}{|c|c|c|c|c|}
\hline 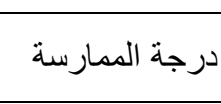 & 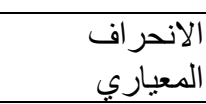 & ال الحتوسطي & 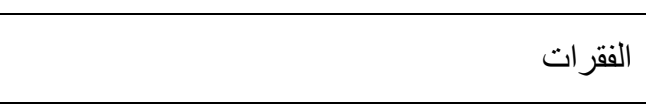 & 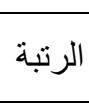 \\
\hline عالية & 0.98 & 4.11 & العمل. مديرة المدرسة المعلمات على تقصير هن في & 1 \\
\hline عالية & 1.14 & 3.98 & تحترصة العمل. مديرة المدرسة على الرقابة المبانرة في & 2 \\
\hline متوسطة & 1.36 & 3.17 & المطلقات دديرة المدرسة القو انين و التعليمات على & 3 \\
\hline منوسطة & 1.28 & 2.78 & تؤدي مديرة المدرسة كافة المهام دون تفويض. & 4 \\
\hline متوسطة & 1.30 & 2.72 & تصديمر مديرة المدرسة القرارات دون إشر اك & 5 \\
\hline متوسطة & 1.36 & 2.71 & التحتيلي مديرة اللطدرسة على المؤليات دون النظر إلى بقية المستية & 6 \\
\hline ضعيفة & 1.29 & 2.57 & تستخدم مديرة المدرسة أسلوب النقد عند مناقثة & 7 \\
\hline ضعيفة & 1.32 & 2.52 & التجل بين المعلمات. & 8 \\
\hline ضعيفة & 1.31 & 2.49 & توجه مديرة المدرسة المعلمات بطريقة تسلطية. & 9 \\
\hline ضعيفة & 1.24 & 2.27 & علتى الابنكار والإبداع. المدرة مهار ات المعلمات، وقدرنهن & 10 \\
\hline متوسطة & 0.91 & 2.93 & النمط القيادي الأوتوقر اطي العام & \\
\hline
\end{tabular}

أبان الجدول 3 أن المتوسطات الحسابية لفقرات النمط القيادي الأوتوقراطي تراوحت بين 2.27 - 4.11، 4.

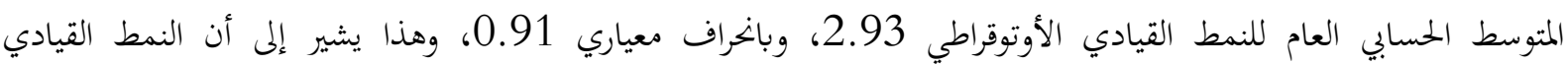

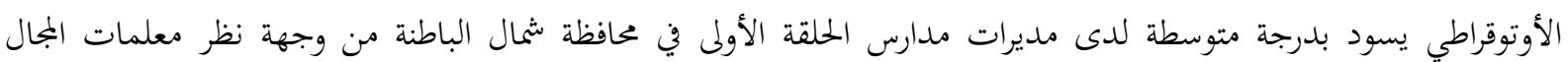

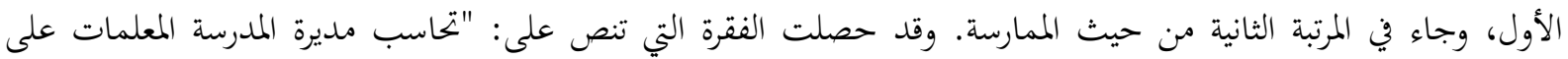

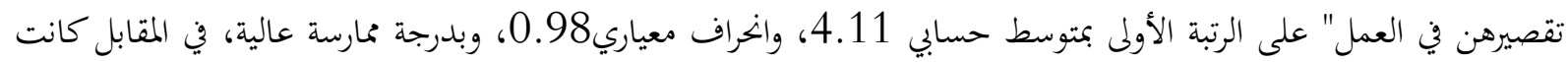

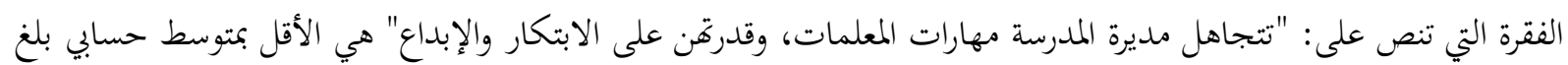

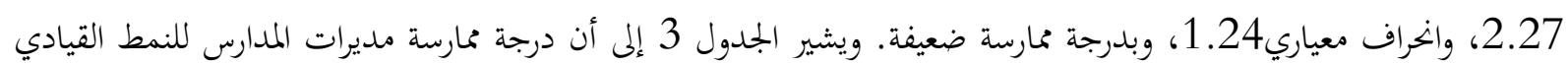


الأوتوقراطي تفاوتت بين الضعيف والمتوسط والعالي، ولعل ذلك يعود إلى حرص مديرة المدرسة على تعميم جميع التعليمات

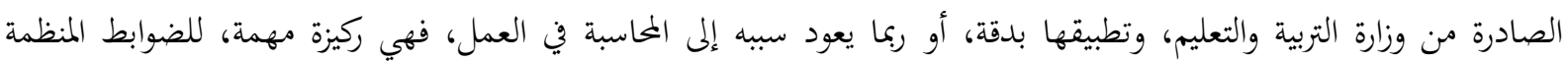

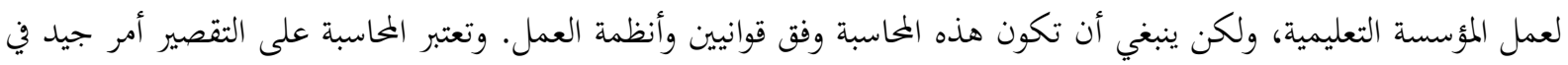

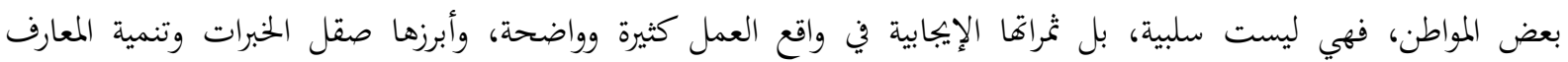

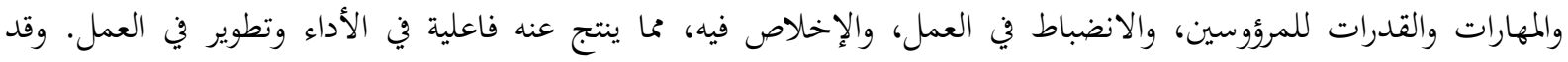

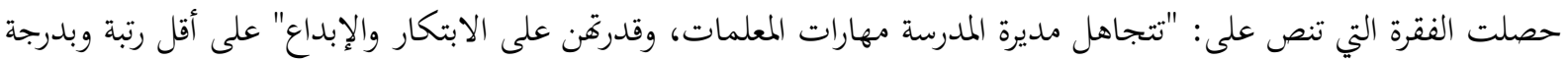
ممارسة ضعيفة، ولعل هذه النتيجة ترجع إلى شخصية المديرة الأوتوقراطية فهي تعتقد بأن تجاهل المعلمات هي أفضل طريقل تريقة

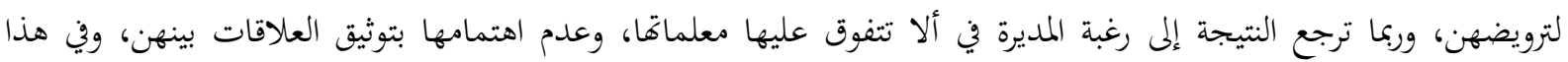

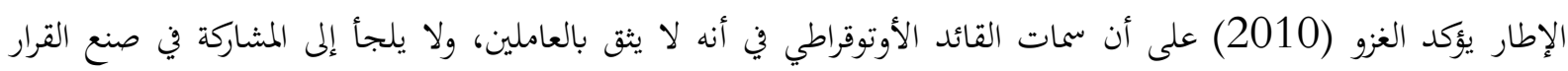

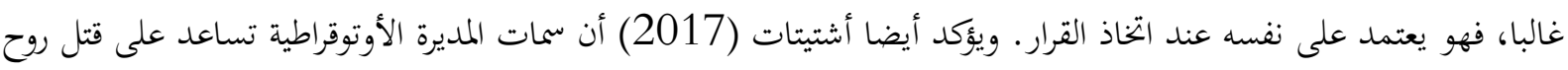
البحث والتفكير والتجديد والابتكار بين العاملين في المدرسة، وهذا يؤدي إلى ضحالة العلاقات الإنسانية في المدرسة، والتأخر في تحسين تأدية العمل، وبطيء النمو والتطوير الذاتي للمعلمات. ت- النمط القيادي الترسلي

جدول 4 المتوسطات الحسابية والانحرافات المعيارية للنمط القيادي الترسلي

\begin{tabular}{|c|c|c|c|c|}
\hline درجة الممارسة & الانحر اف المعياري & المتوسط الحسابي & الفقر ات & الرتبة \\
\hline عالية & 1.24 & 3.50 & تشعتى المعلمات مديرة المدرسة في حل & 1 \\
\hline متوسطة & 1.44 & 3.04 & الاجنى العلاقاتية على المدرسة حسابة & 2 \\
\hline متوسطة & 1.32 & 2.69 & تجقداعات مديرة المدرسة مخطط & 3 \\
\hline متوسطة & 1.40 & 2.65 & تعزيز المعلماته مديرة المدرسة & 4 \\
\hline ضعيفة & 1.32 & 2.54 & 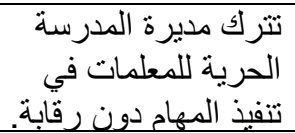 & 5 \\
\hline ضعيفة & 1.28 & 2.48 & 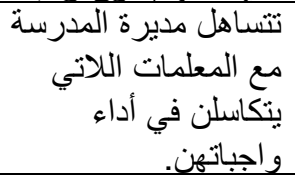 & 6 \\
\hline ضعيفة & 1.30 & 2.42 & تسند مديرة المدرسة & 7 \\
\hline ضعيفة & 1.22 & 2.42 & تقد المعلمات لأدائها. & 8 \\
\hline ضعيفة & 1.26 & 2.34 & فتي اتخاذ القرارات المدرسة & 9 \\
\hline ضعيفة & 1.25 & 2.31 & فتي قبول مديرة المدرسة & 10 \\
\hline
\end{tabular}




\begin{tabular}{|c|c|c|c|}
\hline متوسطة & 1.02 & 2.64 & النمط القيادي الترسلي \\
\hline
\end{tabular}

اتضح من الجدول 4 المتوسط الحسابي العام والانخراف المعياري العام لفقرات محور النمط القيادي الترسلي، إذ تراوحت

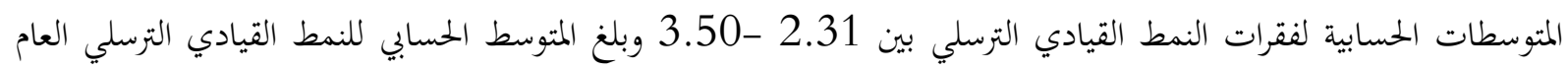
2.64 والاخراف المعياري 1.02، وهذا يدل على أن هذا النمط سائد بدرجة متوسطة ولكنه بدرجة أقل من المستويين

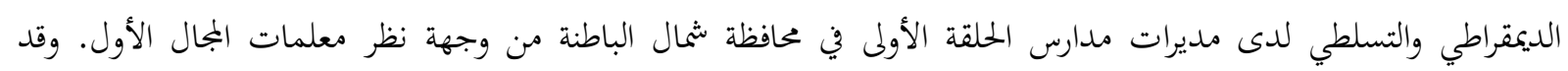
حصلت الفقرة التي تنص على: "تعتمد مديرة المدرسة على المعلمات في حل مشكلات الطلبة دون توجيه" على الرتبة الأولى، بمتوسط حسابي 3.50 وبانحراف معياري24.24، وبدرجة ممارسة عالية، وجاءت في الرتبة الأخيرة الفقرة التي تنص على: لتعلى "تتردد

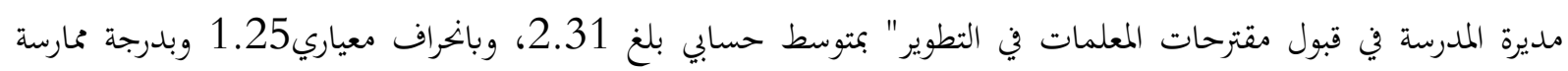
ضعيفة. كما يشير الجدول 4 إلى وجود 6 فقرات من أصل 10فقرات في هذا المحور حصلت على تقدير ضعيف، وربما يعود ذلك

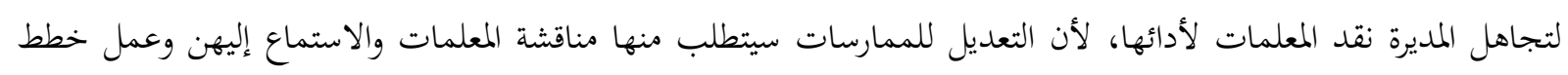

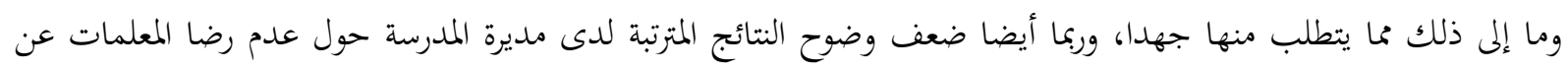

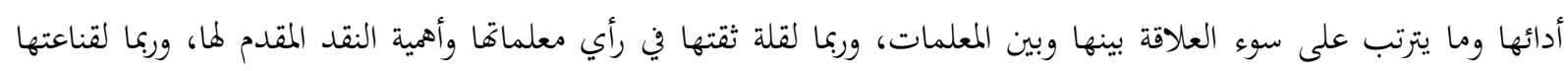

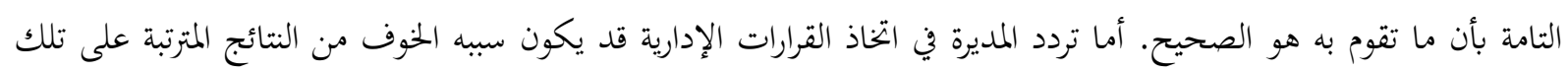

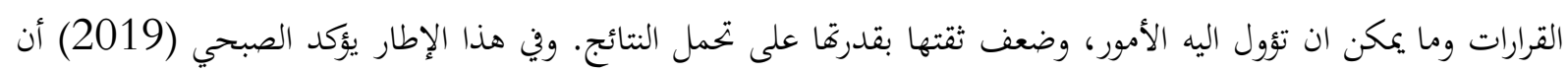

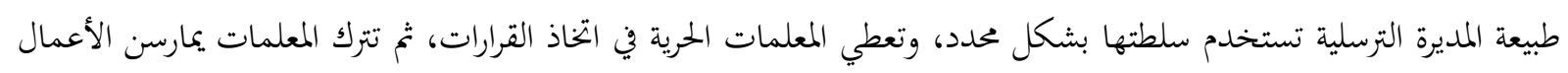

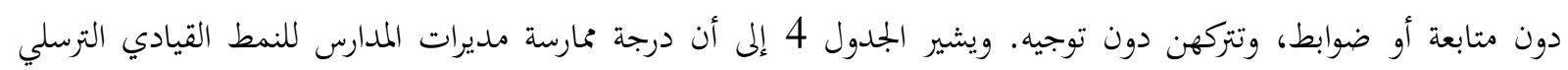

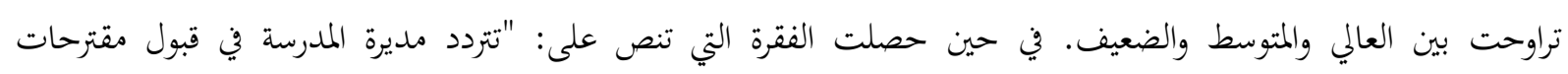

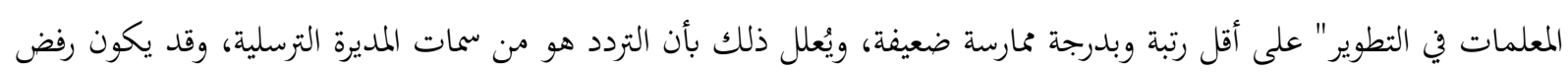

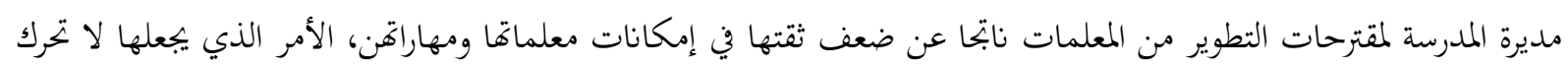

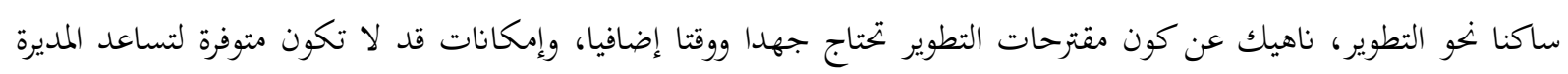

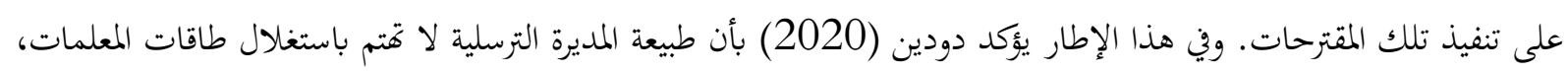
ولا تستفيد من إمكاناهن ولا تتدخل في طريقة العمل، ولا تلعب دورا في تحديد أهداف المجموعة، وهي قيادة تتخلى عن دورها الريادي، وتسير وفق الظروف.

2. ما مستوى الرضا الوظيفي لمعلمات المجال الأول في مدارس الحلقة الأولى بمحافظة شمال الباطنة التعليمية من وجهة نظرهن؟

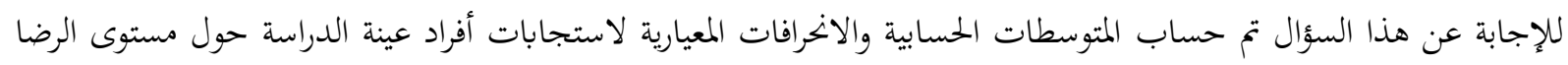
الوظيفي لمعلمات المجال الأول في مدارس الحلقة الأولى بمحافظة شمال الباطنة التعليمية لكل محور من محاور مقياس الرضا الونية الوظيفي.

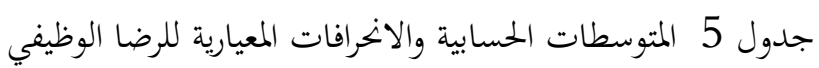

\begin{tabular}{|c|c|c|c|c|}
\hline درجة الرضا & الرنبة & الانحر اف المعياري & المنوسط الحسابي & المحاور \\
\hline عالية جدا & 1 & 0.42 & 4.62 & الرضا عن طبيعة العمل \\
\hline عالية جدا & 2 & 0.46 & 4.56 & الرضـا عن زميلات العمل \\
\hline عالية جدا & 3 & 0.71 & 4.37 & الرضـا عن مديرة المدرسة \\
\hline عالية جدا & & 0.43 & 4.52 & الرضا الوظيفي العام \\
\hline
\end{tabular}

اتضح من الجدول 5 أن المتوسطات الحسابية لمحاور الرضا الوظيفي لمعلمات المجال الأول في مدارس الحلقة الأولى بمحافظة

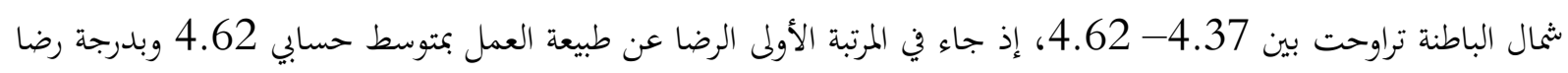


عالية جدا، وانحراف معياري 0.42. وجاء محور الرضا عن زميلات العمل في المرتبة الثانية بمتوسط حسابي 4.56 وبدرجة رضا

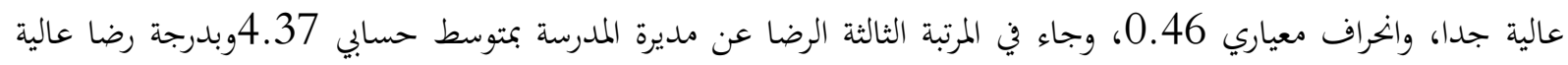
جدا، وانحراف معياري 0.71. وبلغ متوسط الرضا الوظيفي العام للمقياس

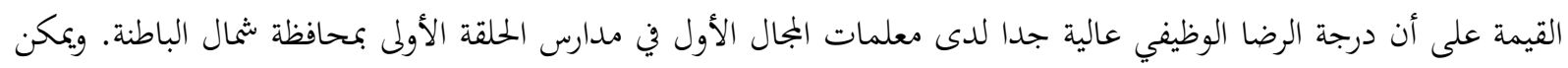
تبرير ارتفاع مستوى الرضا الوظيفي في جميع المحاور لمعلمات البمال الأول في مدارس الحلقة الأولى بمحافظة شمال الباطنة برؤية

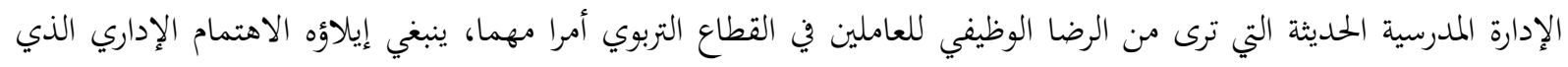

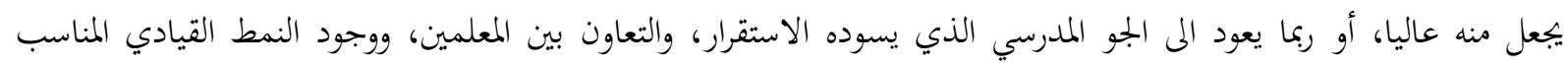

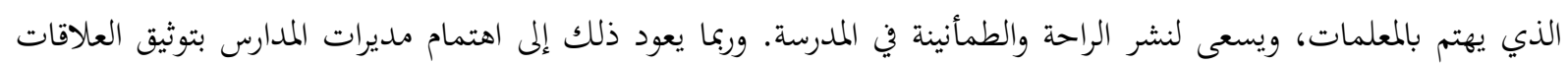

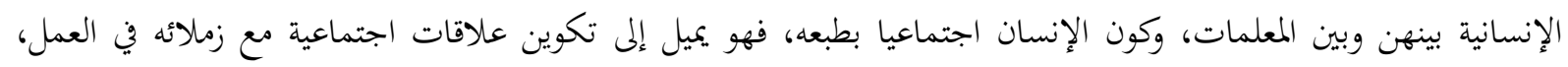

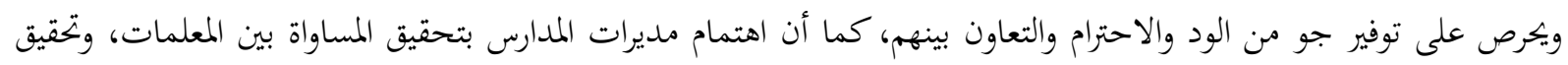

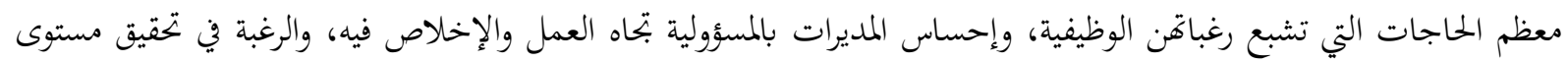

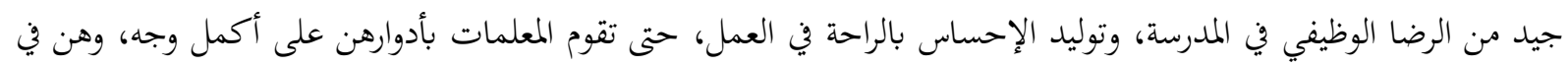

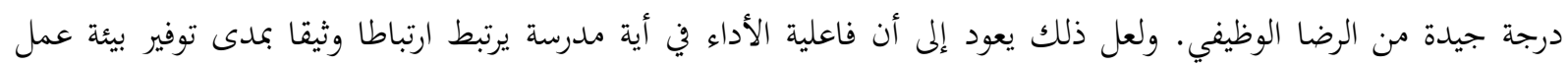

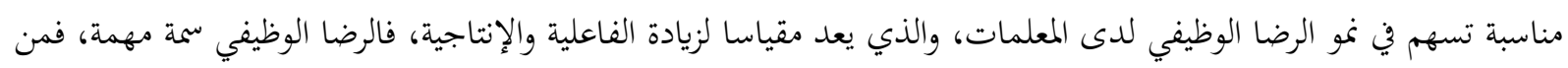

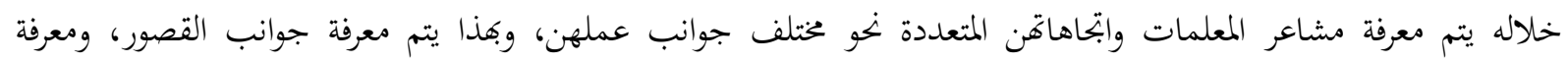

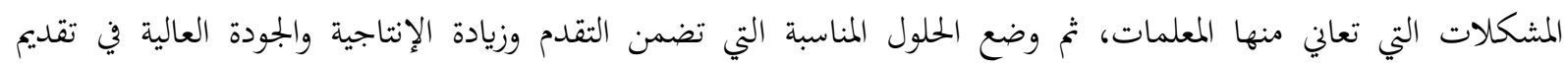

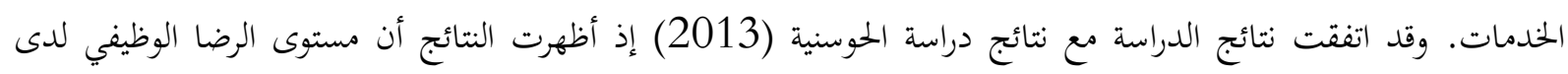

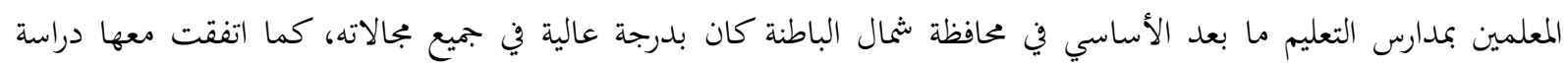
البدرية (2016) فأكدت النتائج وجود مستوى كبير من الرضا الوظيفي للمعلمين في مختلف مدارس محافظة الداخلية بسلطنة

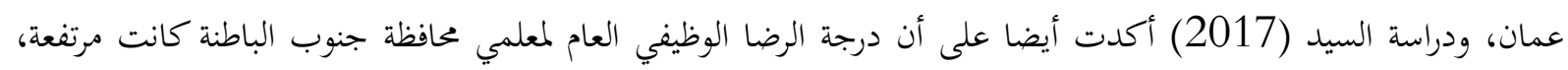

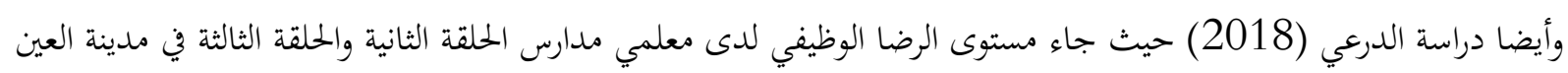

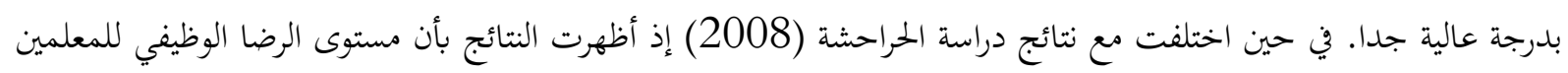
جاء بدرجة متوسطة، وأيضا دراسة الرواس (2013) أظهرت النتائج أن مستوى الرضا الوظيفي لدى المعلمين في مدارس التعليم ما بعد الأساسي كانت درجة رضا المعلمين فيها متوسطة. وللتعرف على مستوى استجابات أفراد عينة الدراسة وفقا لفقرات كل

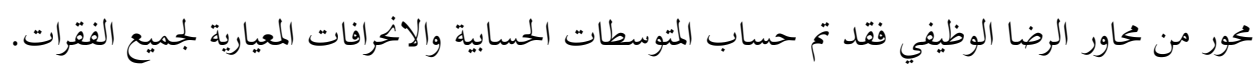

أ- الرضا عن طبيعة العمل

جدول 6 المتوسطات الحسابية والانحرافات المعيارية لفقرات الرضا عن طبيعة العمل

\begin{tabular}{|c|c|c|c|c|}
\hline 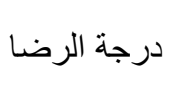 & الالنحري اف & الحسابي & الفقرات & 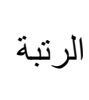 \\
\hline عالية جدا & 0.45 & 4.83 & أشتعر أنني أنجز عملا مهما في المجتمع الددرسي. & 1 \\
\hline عالية جدا & 0.47 & 4.79 & أنشعر بالرضا عندما أتغلب على التحديات في العمل. & 2 \\
\hline عالية جدا & 0.51 & 4.72 & أستخدم أفضل الطرق لإنجاز العمل. & 3 \\
\hline عالية جدا & 0.54 & 4.67 & أحرص على التنمية المهنية الذاتية في مجال عملي. & 4 \\
\hline
\end{tabular}




\begin{tabular}{|c|c|c|c|c|}
\hline 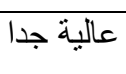 & 0.65 & 4.67 & أنشعر أن عملي يحقق لي ذاتي. & 5 \\
\hline 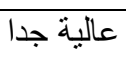 & 0.54 & 4.66 & أنفذ المهام المطلوبة مني في الوقت المحدد. & 6 \\
\hline عالية جدا & 0.65 & 4.62 & أشعر أن عملي يقدم لي مركز ا اجتماعيا جيدا. & 7 \\
\hline عالية جدا & 0.76 & 4.54 & يتفق عملي مع ميولي المهنية. & 8 \\
\hline عالية جدا & 0.90 & 4.41 & يوفر لي عملي فرصا للإبداع والابتكار. & 9 \\
\hline عالية جدا & 0.77 & 4.29 & أقضي كل وقتي في أداء عملي. & 10 \\
\hline عالية جدا & 0.42 & 4.62 & & \\
\hline
\end{tabular}

اتضح من الجدول 6 أن المتوسطات الحسابية لفقرات الرضا عن طبيعة العمل تراوحت بين 4.29 -4.83، جاءت

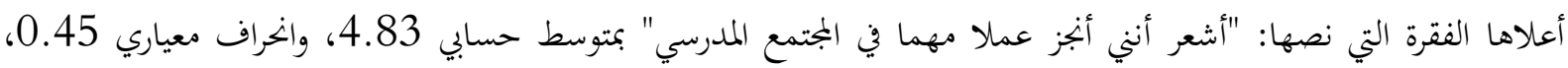
وبدرجة رضا عالية جدا، أما أقل الفقرات فقد كانت الفقرة فهي التي نصها: "أقضي كل وقتي في أداء عملي" بمتوسط حسابي بلغ 4.29، وانحراف معياري0.77، وبدرجة رضا عالية جدا. كما يتضح أن جميع فقرات هذا المحور جاءت درجة الرضا فيها بهايه عالية

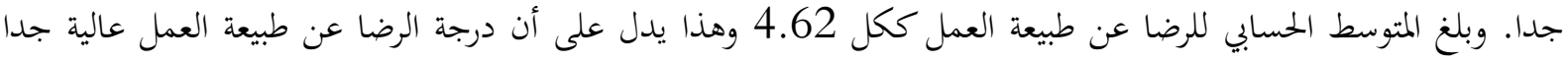
لدى معلمات المجال الأول في مدارس الحلقة الأولى بمحافظة شثمال الباطنة. وربما تعود هذه النتيجة إلى وضوح إجراءات العمل، ونسل ووضوح القوانين المنظمة له، ووجود المناخ الملائم للعمل، وتنظيم العملية التعليمية في سلطنة عمان، فهي تسير وفق خطة منظمة، لهنه

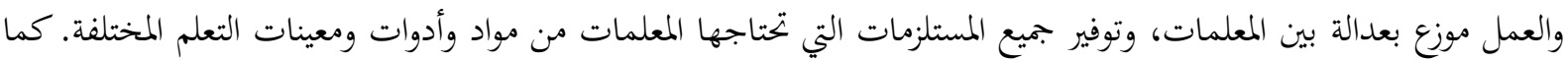

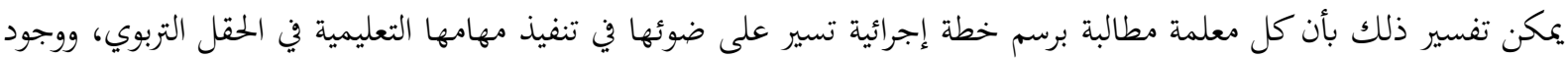
هذه الخطة قد يساعد على جعل الأمور أكثر وضوحا وإجرائية أمام هؤلاء المعلمات، وتؤدي مديرات لمهير المدارس دورا فاعلا في مراجعة هذه الخطط وفي متابعة تنفيذها، وتقديم التغذية الراجعة للمعلمات على إثر تحقق مؤشراتما. في حصلت الفقرة التي نصها:

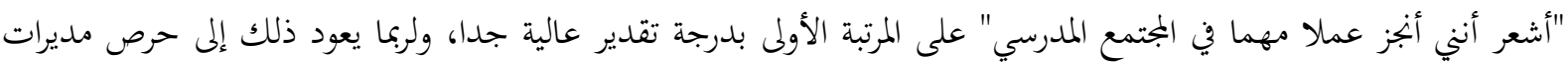

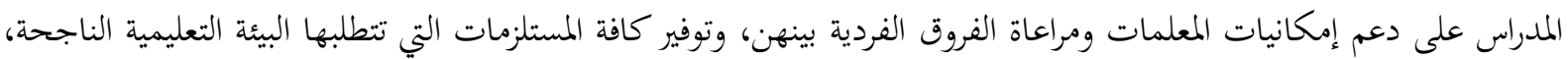
وتعزيز الجهود التي تبذل، وتقديم الحوافز المادية والمعنوية وشهادات التقدير للمعلمات المبدعات، لأنه يؤدي لزيادة الدافعية، وإنجاز العمل وتحقيق الرضا الوظيفي. في حين حصلت الفقرة التي نصها: "أقضي كل وقتي في أداء عملي" على أقل مرتبة ولكن بدرجة

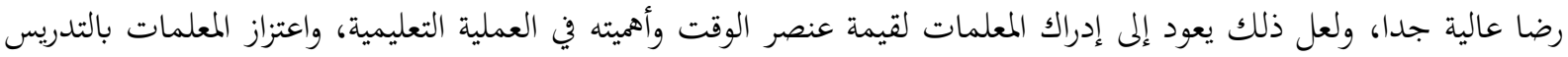

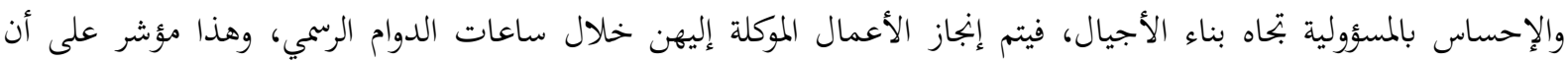
أغلب معلمات المجال الأول في محافظة شمال الباطنة يضعن جداول زيناء زمنية وظيفية تساعدهن على استغلال كل وقتهن فيما يتعلق

ب- الرضا عن مديرة المدرسة

جدول7 المتوسطات الحسابية والانخرافات المعيارية لفقرات الرضا عن مديرة المدرسة المدرسة

\begin{tabular}{|c|c|c|c|c|}
\hline درجة الرضا & المعياري & الحسابي & 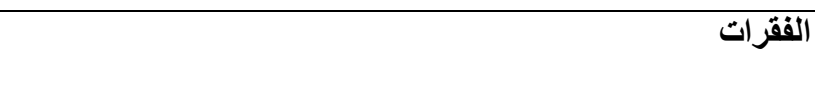 & الرتبة \\
\hline عالية جدا & 0.76 & 4.59 & تسعدني مشاركة مديرة المدرسة للمعلمات في المناسبات الاجتماعبة. & 1 \\
\hline
\end{tabular}




\begin{tabular}{|c|c|c|c|c|}
\hline عالية جدا & 0.80 & 4.49 & تمنحني مديرة المدرسة اختيار الأسلوب المناسب لأداء عملي. & 2 \\
\hline عالية جدا & 0.76 & 4.45 & تهتم مديرة المدرسة بالمبادر ات المقترحة في المدرسة. & 3 \\
\hline عالية جدا & 0.79 & 4.45 & تقدر مديرة المدرسة عملي وجهدي. & 4 \\
\hline عالية جدا & 0.81 & 4.39 & تتمي مديرة المدرسة مهار ات التفكير الإبداعي لدى المعلمات. & 5 \\
\hline عالية جدا & 0.85 & 4.39 & تطلعني مديرة المدرسة على كافة المستجدات التربوية. & 6 \\
\hline عالية جدا & 0.90 & 4.32 & تساعدني مديرة المدرسة على التتمية المهنية المسنترة. & 7 \\
\hline عالية جدا & 0.97 & 4.22 & تر اعي مديرة المدرسة العدالة في التعامل مع المعلمات. & 8 \\
\hline عالية جدا & 0.92 & 4.22 & تتقبل مديرة المدرسة النقد البناء الصادر مني. & 9 \\
\hline 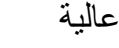 & 0.99 & 4.19 & تزودني مديرة المدرسة بالتجهيز ات الداعمة للتعلم. & 10 \\
\hline عالية جدا & 0.71 & 4.37 & الرضا العام عن مديرة المدرسة & \\
\hline
\end{tabular}

كشف الجدول 7 عن أن المتوسطات الحسابية لفقرات الرضاعن مديرة المدرسة تراوحت بين 4.19-4.59 جاءت

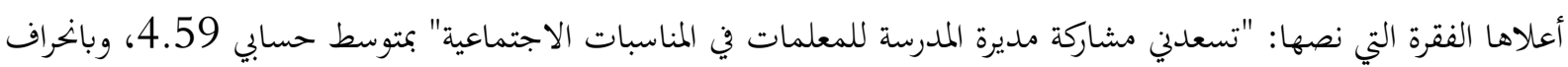

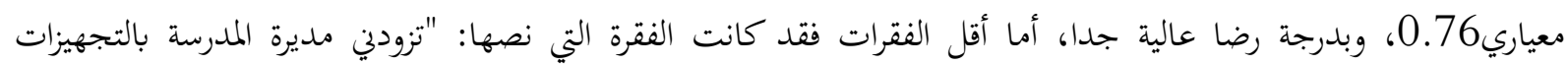

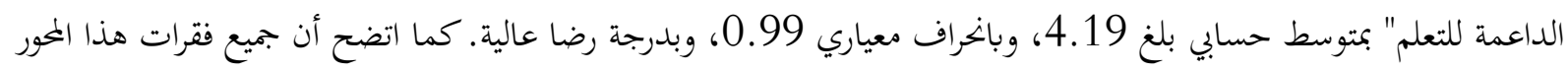

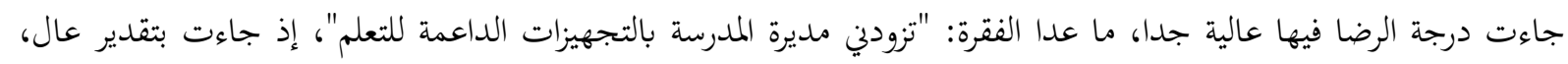

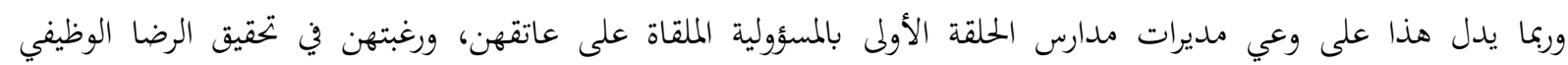

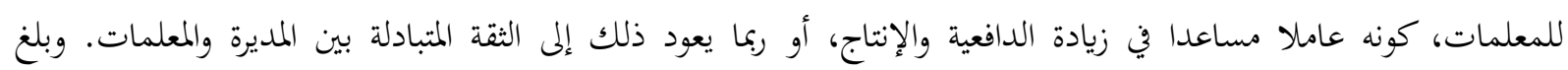
المتوسط الحسابي للرضا عن مديرة المدرسة ككل 4.37، وبهذا فإن درجة الرضا عن مديرة المدرسة عالية جدا لدى معلى معلمات المجال

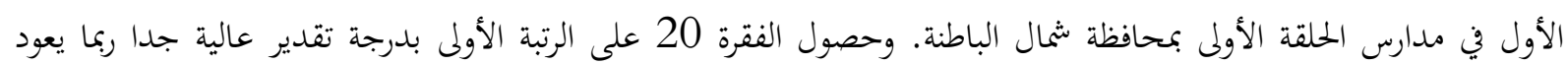

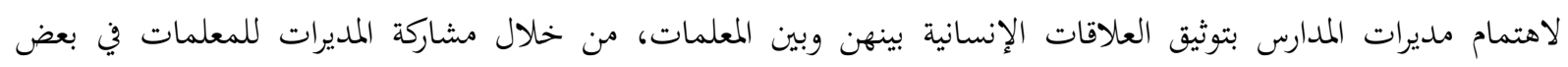

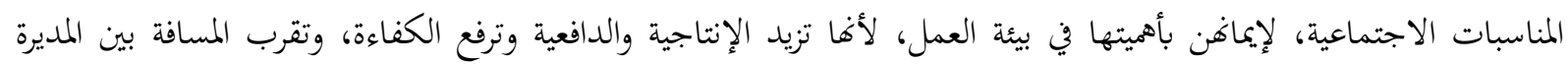

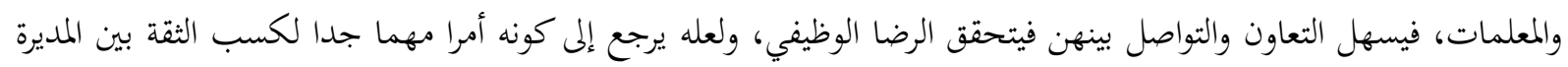

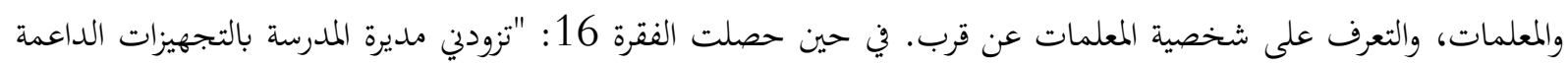

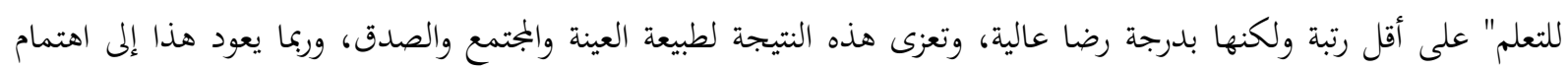

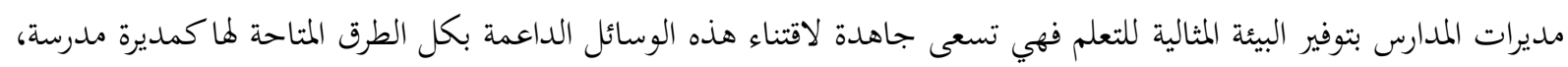

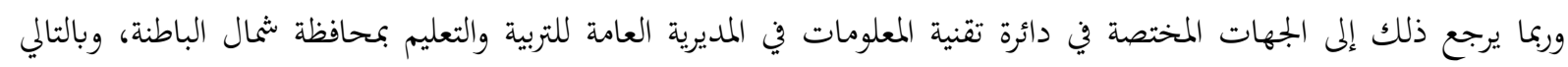
فالمديرات يتحركن في هذا الإطار، كما أن لديهن بعض الصلاحيات نحو مخاطبة بعض الشركات الشركات المتعاونة لخدمة المجتمع، لتوفير

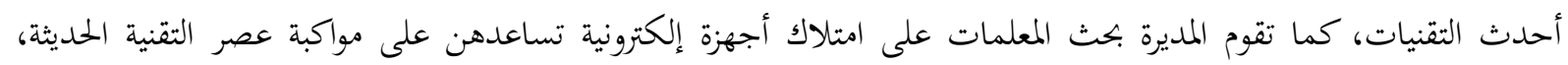

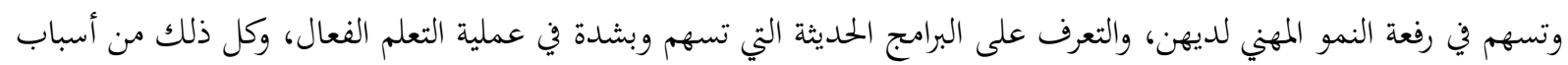
تكوين درجة عالية من مستوى الرضا الوظيفي للمعلمات نهو مديرة المدرسة. 
ث- الرضا عن زميلات العمل

جدول8 المتوسطات الحسابية والانحافات المعيارية لفقرات الرضا عن زميلات العمل

\begin{tabular}{|c|c|c|c|c|}
\hline 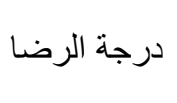 & 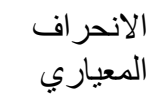 & 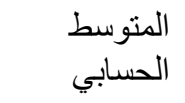 & الفقرات & 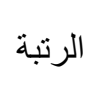 \\
\hline عالية جدا & 0.47 & 4.79 & أنشعر بالسعادة عندما أتعاون مع زميلاتي المعلمات. & 1 \\
\hline ع عالية جد & 0.43 & 4.78 & أنشئ علاقات طيية مع زميلاتي في المدرسة. & 2 \\
\hline عالية جدا & 0.58 & 4.66 & مدرستي. أنشارك زمبلاتي في حل المشكلات و التغلب على التحديات في & 3 \\
\hline عالية جدا & 0.63 & 4.65 & في بيئية العمل. لانطباع الإيجابي لزميلاني المعلمات عن التطوير و التغيير & 4 \\
\hline عالية جدا & 0.65 & 4.62 & تنظر زميلاتي المعلمات نظرة إيجابية لعملي في المدرسة. & 5 \\
\hline عالية جدا & 0.76 & 4.56 & توجهني زميلاتي المعلمات على الإخلاص في عملي. & 6 \\
\hline عالية جدا & 0.64 & 4.56 & تسود روح التتافس بيني وبين زميلاتي المعلمات. & 7 \\
\hline عالية جدا & 0.81 & 4.49 & تسود روح التعاون بين المعلمات في مدرستي. & 8 \\
\hline 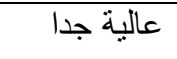 & 0.71 & 4.47 & تلقى أفكاري اهتماما من قبل زميلاتي. & 9 \\
\hline عالية & 0.97 & 4.07 & تشتجني زميلاتي المعلمات على إكمال دراستي العليا. & 10 \\
\hline عالية جدا & 0.46 & 4.56 & زميلات العمل ككل & الرضا \\
\hline
\end{tabular}

بيّن الجدول 8 أن المتوسطات الحسابية لفقرات الرضا عن زميلات العمل تراوحت بين 4.07-49.79 جاءت أعلاها

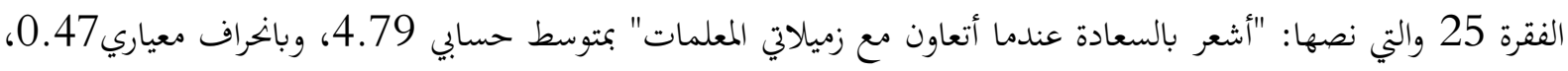
وبدرجة رضا عالية جدا، أما أقلها كانت الفقرة27 والتي نصها: "تشجعني زميلاتي المعلمات على إكمال دراستي العليا" بمتوسط

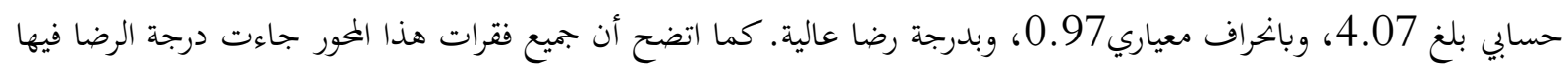

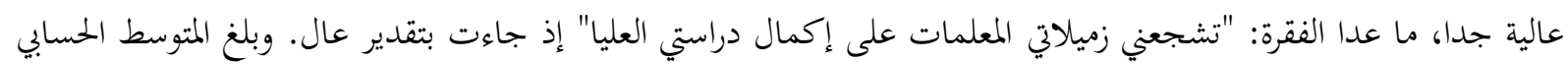

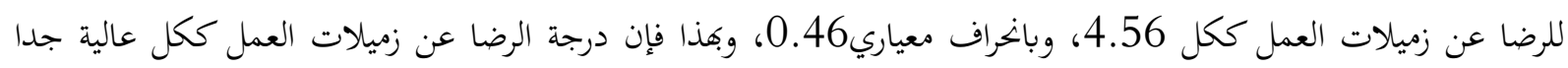

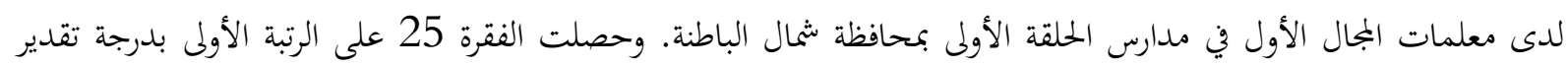

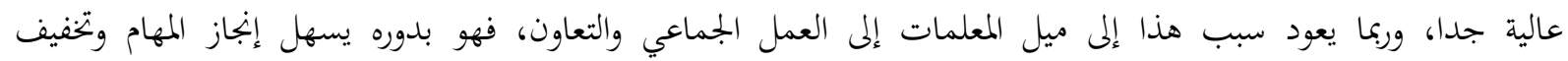

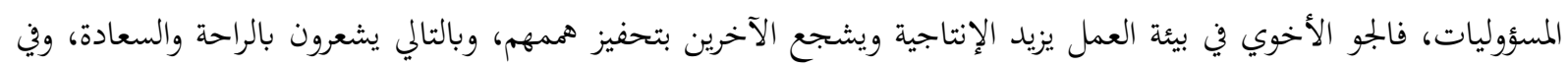

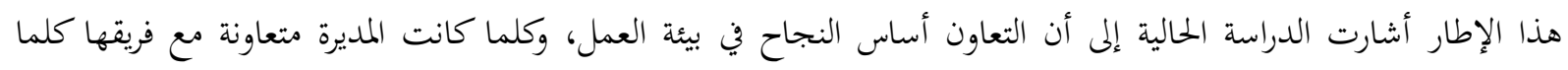
حققت النجاح والسعادة، وكذلك بالنسبة للمعلمات فالتعاون مع زميلات العمل يحافظ على الإنتاجية سواء من الناحية الاجتماعية أو النفسية أو الوظيفية، فالتعاون الإيجابي يضفي السعادة والمرح والسرور في نفوس المعلمات، وكل ذلك ينكات ينعكس إيجابا على مستوى الرضا الوظيفي لدى المعلمات. 
3. هل توجد علاقة ارتباطية بين الأنماط القيادية لدى مديرات مدارس الحلقة الأولى والرضا الوظيفي لمعلمات البمال الأول في

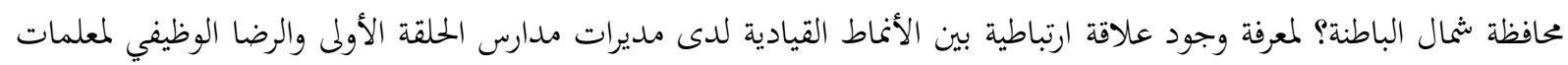

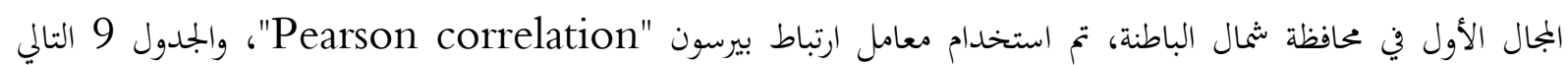
يوضح هذه النتائج. قيم معامل ارتباط بيرسون بين الأنماط القيادية والرضا الوظيفي

\begin{tabular}{|c|c|}
\hline الرضا الوظيفي & أنماط القيادة \\
\hline $0.61 *$ & النمط القيادي الديمقراطي \\
\hline$-0.14^{*}$ & النمط القيادي الأونوقراطي \\
\hline-0.10 & النمط القيادي الترسلي \\
\hline
\end{tabular}

(د 2 (ال إحصائيا عند مستوى (20.05)

اتضح من الجدول 9 وجود علاقة طردية متوسطة دالة إحصائيا بين النمط القيادي الديمقراطي والرضا الوظيفي، حيث بلغ

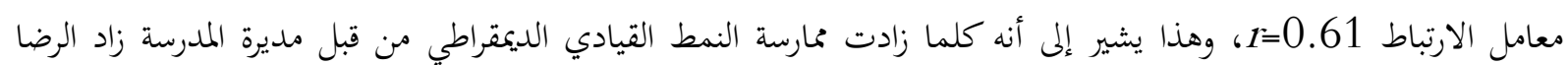
الوظيفي لدى المعلمات. كما أشارت النتائج أيضا إلى وجود علاقة سالبة ضعيفة بين النمط القيادي الأوتوقراطي والرضا الوظيل الوظيفي حيث بلغ معامل الارتباط

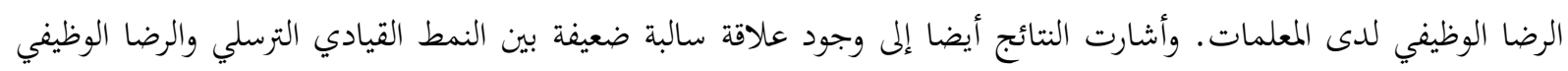
حيث بلغ معامل الارتباط (0.10-

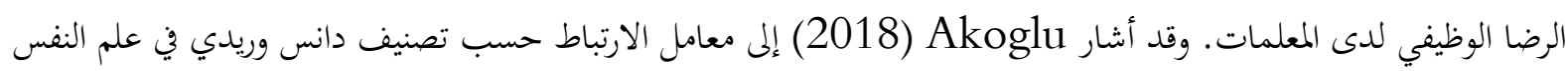
نتكون العلاقة متازة (1-1+)، ومن (0.7 Dancey and Reidy (Psychology)

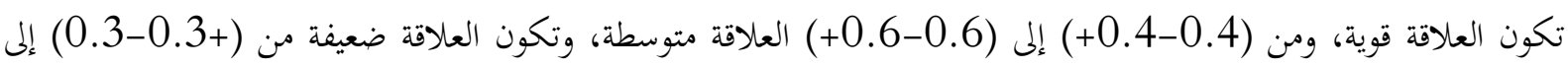

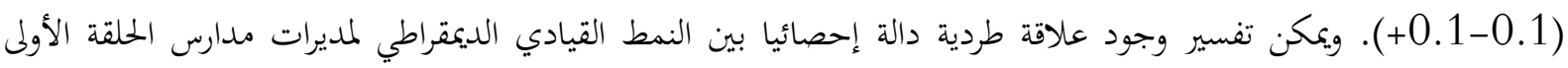

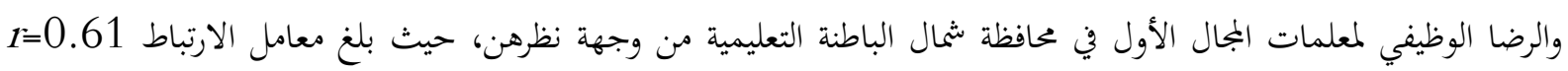

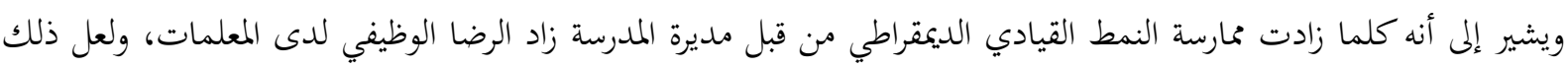

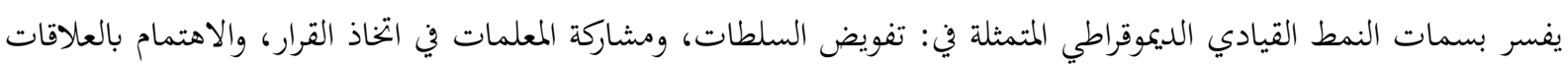

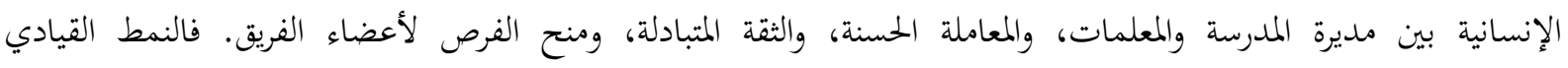

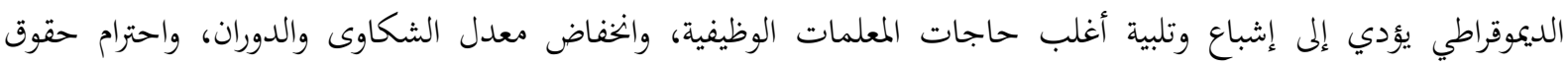

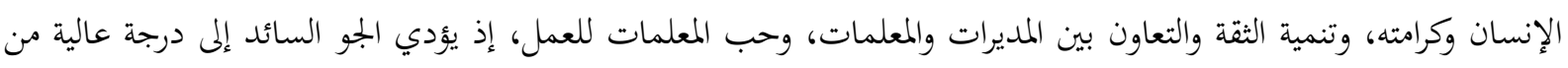

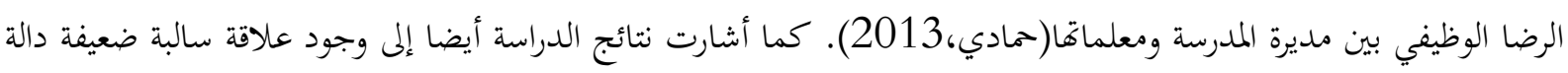

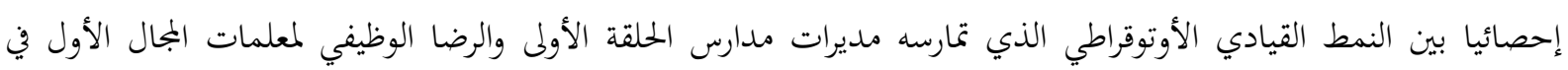

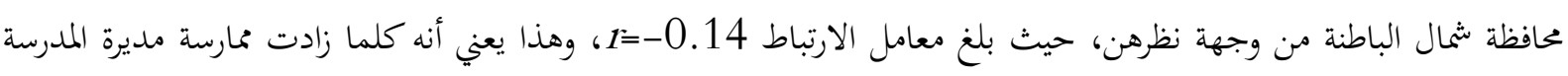

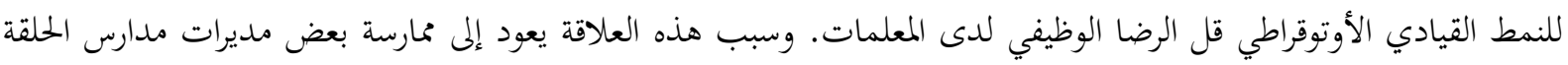

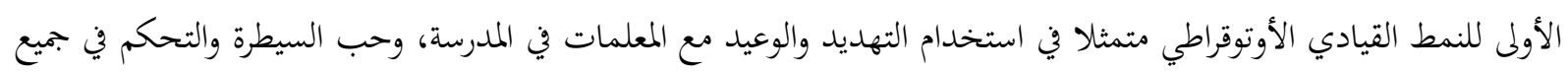
الأمور بالمدرسة، وضعف الاهتمام بتفويض بعض الصلاحيات للمعلمات بالمدرسة، وضعف العلاقات الإنسانية أحيانا، وربما قلة الاحترام المتبادل بين مديرة المدرسة والمعلمات، وكل ذلك ينعكس سلبا على سلوك المعلمات، ويكون شعورهن سلبيا بتحاه مديرة المدرسة، وينتج عنه ضعف مستوى الرضا الوظيفي، مما ينعكس سلبا على أداء المعلمات في مجال عملهن بالمدرسة. وأشارت نتائج 
الدراسة أيضا إلى وجود علاقة سالبة ضعيفة بين النمط القيادي الترسلي الذي تمارسه مديرات مدارس الحلقة الأولى والرضا الوظيفي لمعلمات المجال الأول في محافظة شمال الباطنة من وجهة نظرهن حيث بلغ معامل الارتباط

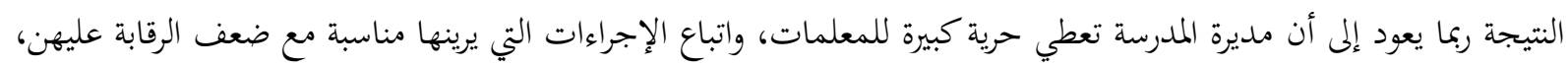

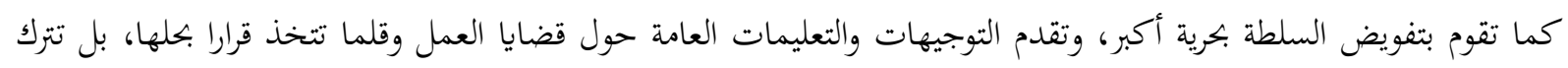

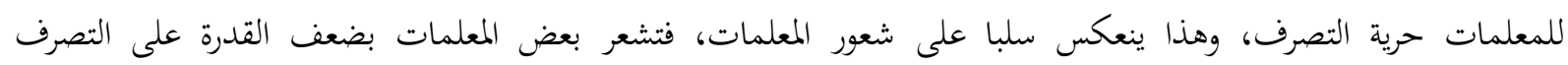

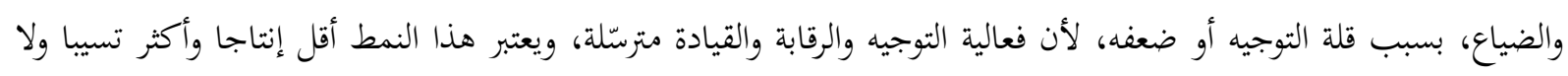

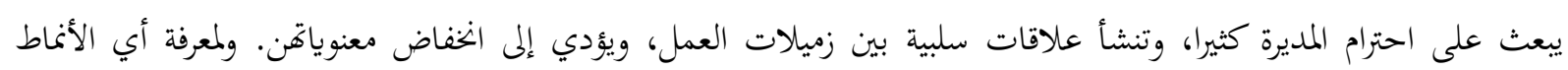

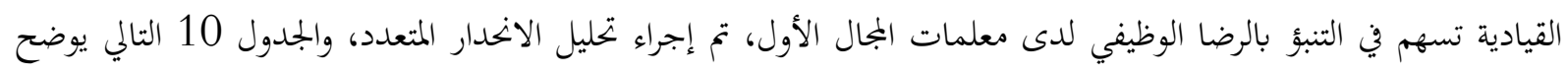
هذه النتائج.

جدول 10 ملخص نتائج تحليل تباين الانحدار الخطي المتعدد للتنبؤ بمستوى الرضا الوظيفي من خلال الأنماط القيادية

\begin{tabular}{|c|c|c|c|c|c|c|}
\hline قابثة & $\mathrm{R}^{2}$ & الاحتمالية & المحسوبة" & معامل الانحدار (Beta) & غير المعياري(B) معامل الآحدار & ألمدرسية القيادة \\
\hline \multirow[t]{3}{*}{2.44} & \multirow[t]{3}{*}{0.38} & 0.000 & 13.79 & 0.63 & 0.45 & الديموقر اطي \\
\hline & & 0.37 & 0.90 & 0.07 & 0.03 & الأوتوقر اطي \\
\hline & & 0.87 & -0.16 & -0.01 & 0.01 & الترسلي \\
\hline
\end{tabular}

اتضح من خلال الجدول 10 أنه يمكن التنبؤ بالرضا الوظيفي لدى معلمات المجال الأول بمحافظة شمال الباطنة من خلال

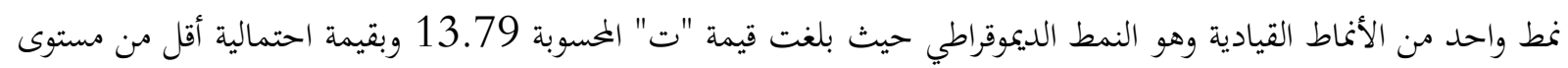

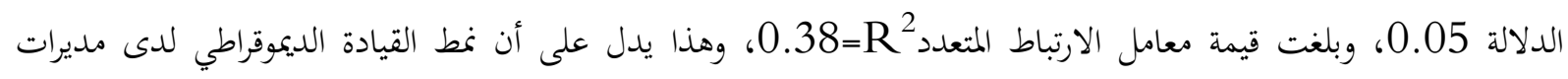
مدارس الحلقة الأولى يفسر ما نسبته 38\% من التغيرات الحادثة في الرضا الوظيفي لدى معلمات المجال الأول، أما النسبة المتبقية

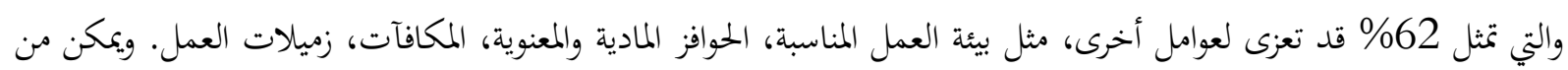

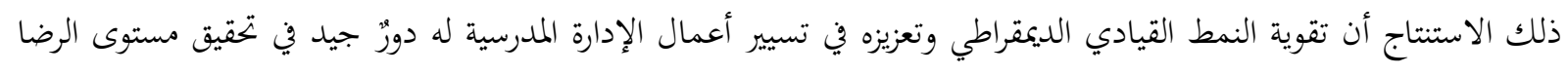

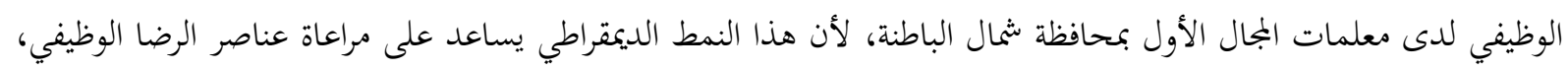

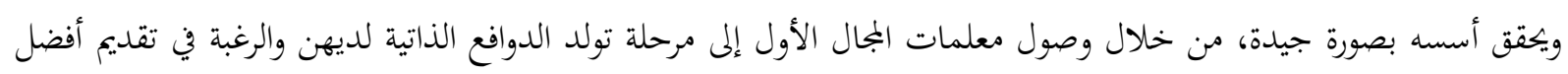

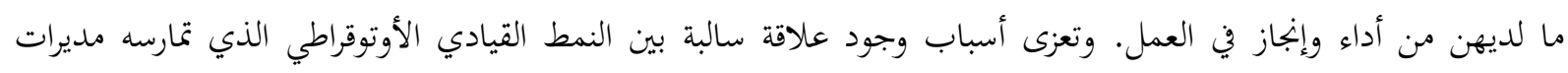

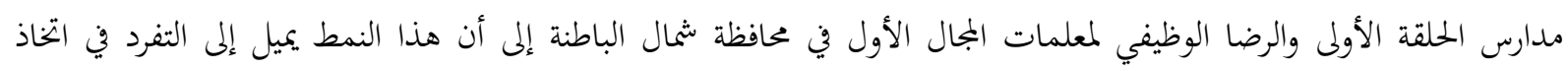

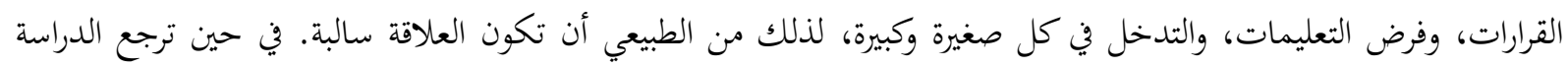

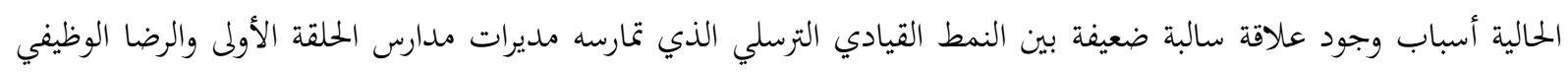

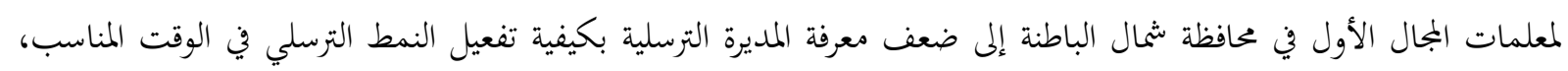

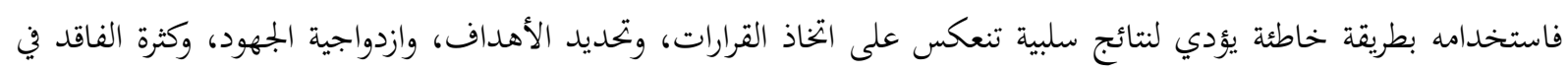

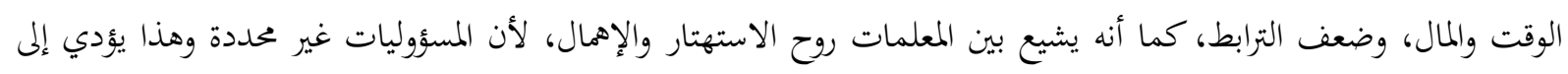

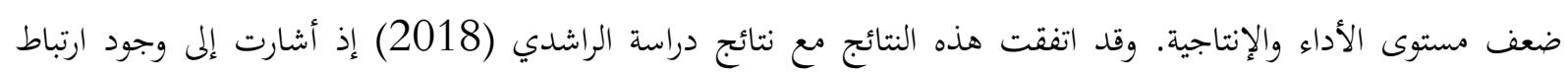

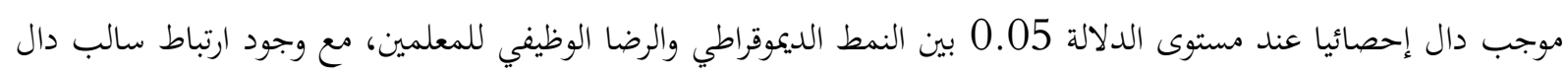
إحصائيا عند مستوى الدلالة 0.05 للنمط الأوتوقراطي، كما أظهرت نتائج دراسة الحراحشة (2008) بأن هناك علدين علاقة إيجابية 
بين النمط القيادي ومستوى الرضا الوظيفي للمعلمين. وأيضا اتفقت مع دراسة الصبحي (2019) بوجود علاقة ارتباطية موجبة دالة إحصائيا بين ممارسة مديري المدارس للنمط الديموقراطي ومستوى الرضا الوظيفي للمعلمين.

\section{التوصيات}

1. الحفاظ على مستوى ممارسة فاعلة للنمط القيادي الديمقراطي لدى مديرات مدارس الحلقة الأولى بمحافظة شمال الباطنة، لما له

$$
\text { من أهمية في تحقيق مستوى جيد من الرضا الوظيفي. }
$$

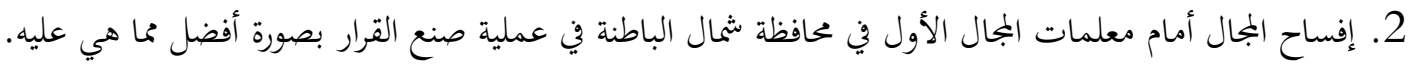

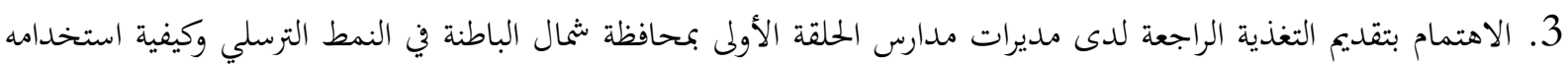

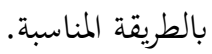

4. الحفاظ على مستوى الرضا الوظيفي العالي لدى معلمات المجال الأول بمحافظة شمال الباطنة، لما له من دور في تحقيق أهداف

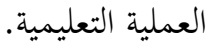

5. تعزيز مديرات مدارس الحلقة الأولى بمحافظة شمال الباطنة، لينعكس ذلك بدوره على المعلمات، وبالتالي تحقيق الرضا الوظيفي

6. زيادة الاهتمام بالجانب الإنساني بين معلمات المجال الأول في محافظة شمال الباطنة، ومديرات مدارس الحلقة الأولى.

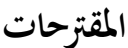

1. إجراء مزيد من البحوث لدراسة الرضا الوظيفي، لرفع مستواه عند معلمات المجال الأول.

2. إجراء دراسات مماثلة للدراسة الحالية، للتعرف على العوامل المؤثرة في الرضا الوظيفي لمعلمات المجال الأول.

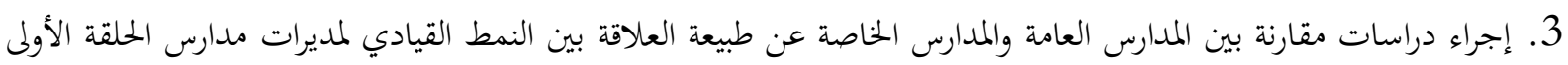

$$
\text { ومستوى الرضا الوظيفي لمعلمات المجال الأول. }
$$

4. عقد دورات تدريبية لمديرات مدارس الحلقة الأولى بمحافظة شمال الباطنة، لتدريبهن على كيفية استخدام النمط القيادي الفاعل

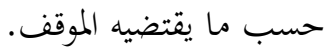

5. إجراء مزيد من البحوث لدراسة أثر النمط القيادي الترسلي والأوتوقراطي في تحقيق الرضا الوظيفي. 


\section{مراجع الدراسة ومصادرها}

أبو طاحون، أمل لطفي. (2012). القيادة التربوية الفاعلة. أمواج للطباعة والنشر والتوزيع. أبو عساف، مؤيد يوسف، والمرعي، هيثم عبد الله. (2019). التطبيقات العلمية في إدارة الموارد البشرية بالمؤسسات العامة والخاصة. دار أبجد للنشر والتوزيع.

أشتيتات، سامح محمد. (2017). النمط الإداري لمدراء المدارس وعلاقته بالأمن الوظيفي لدى المعلمين في محافظة إربد. مجلة

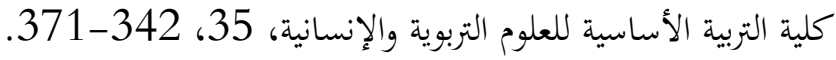

البارودي، منال أحمد. (2015). الرضا الوظيفي وفن التعامل مع الرؤساء والمرؤوسين. المجموعة العربية للتدريب والنشر. بشير، يوسف حسن. (2015). أثر الرضا الوظيفي على أداء العاملين في مؤسسات التعليم العالي [أطروحة دكتوراه غير الوراء منشورة]. جامعة السودان، السودان. التربية والتعليم تواصل جهودها الرامية إلى تجـويد عناصر العملية التعليمية. 29 نوفمبر.2019. جريدة عمان https://www.omandaily.om/?p=748340.

جامعة السلطان قابوس. (2014، مايو). ندوة التعليم في عمان والخليج العربي. مسترجع من https://www.squ.edu.om/osc-ar

الجساسية، بدرية مبارك. (2016). الأنماط القيادية لمديري مدارس التعليم ما بعد الأساسي في سلطنة عمان وفقا لنظرية المسار والهدف وأثرها في الرضا الوظيفي للمعلمين [رسالة ماجستير غير منشورة]. جامعة صحار . سلطنة عمان. حافظ، عبد الناصر. (2015). الأنماط القيادية الطريق لبناء الميزة التنافسية المستدامة. دار غيداء للنشر والتوزيع.

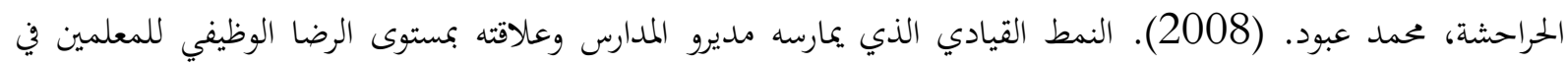
مديرية التربية والتعليم في محافظة الطفيلة. بجلة جامعة دمشق 24. الحريري، رافدة، وعبد الحميد، فاتن، والوادي، حسن. (2017). أساسيات ومهارات البحث التربوي والإجرائي. دار أبجد للنشر فئر

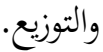

حمادي، عدي عطا. (2013). القيادة الإدارية الحديثة في إستراتيجية التنمية. دار البداية.

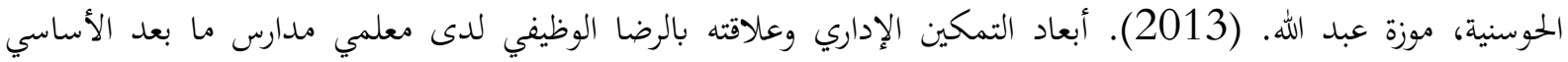
بمحافظة شمال الباطنة بسلطنة عمان [رسالة ماجستير غير منشورة] . جامعة نزوى، سلطنة عمان.

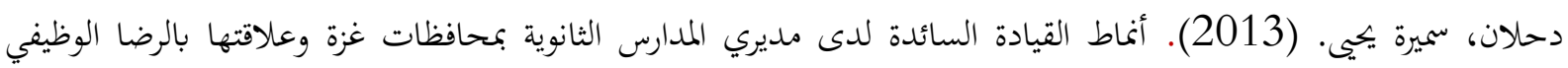
للمعلمين [رسالة ماجستير غير منشورة]. جامعة الأزهر، غزة. لماطئ. الدرعي، حميد راشد. (2018). أثر القيادة الديمقراطية على الرضا الوظيفي لدى مدارس مدينة العين بدولة الإمارات العربية المتحدة [رسالة ماجستير غير منشورة]. جامعة صحار، سلطنة عمان. دودين، أحمد يوسف. (2020). إدارة التغيير والتطوير التنظيمي. دار اليازور العلمية. الدوسري، حسن مرضي. (2013). الأنماط القيادية وعلاقتها بالرضا الوظيفي في كلية التقنية بالخرج من وجهة نظر المورئ الموظفين [رسالة ماجستير غير منشورة]. جامعة نايف العربية للعلوم الأمنية، المملكة العربية السعودية. 
الراشدي، سعيد راشد. (2018). الأنماط الإدارية السائدة لدى مدراء مدارس التعليم ما بعد الأساسي للصفين (11-12)

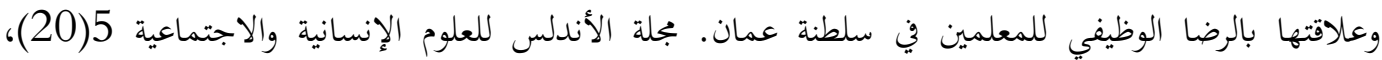

.228-181

الرواس، منى عبد السلام. (2013). الرضا الوظيفي لدى معلمي مدارس التعليم ما بعد الأساسي بولاية صلالة من وجهة نظرهم [رسالة ماجستير غير منشورة] كلية الآداب والعلوم التطبيقية، جامعة ظفار، سلطنة عمان.

السكارنة، بلال خلف. (2010). القيادة الإدارية الفعالة. دار المسيرة للنشر والتوزيع.

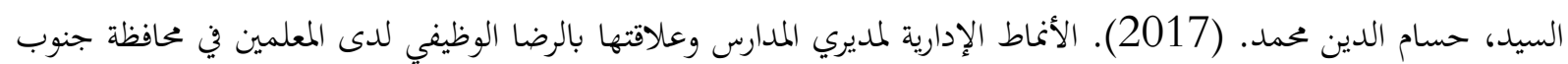

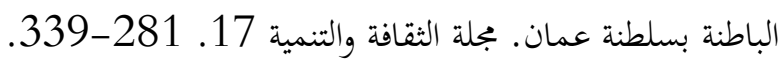

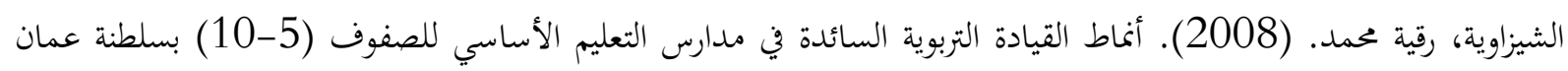

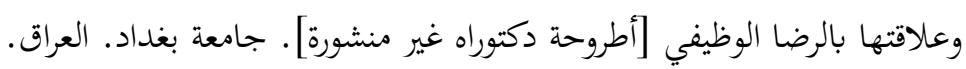

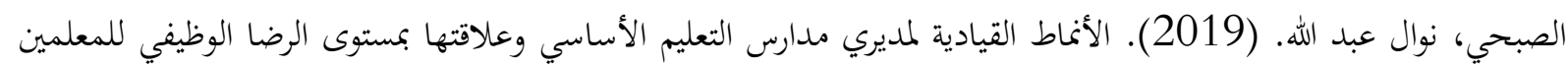
في مدينة أبو ظبي [رسالة ماجستير غير منشورة] . جامعة صحار، سلطنة عمان.

الغامدي، علي محمد. (2010). نمط القيادة التربوية لدى مديري المدارس في المدينة المنورة كما يتصوره المعلمون. مجلة العلوم

$$
\text { التربوية والنفسية. 11(4)، 107-135. }
$$

الغزو، فاتن عوض. (2010). القيادة والاشراف الإداري. دار أسامة للنشر والتوزيع.

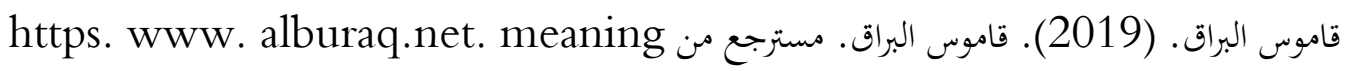

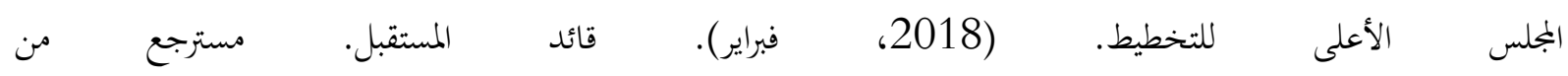
https://www.omandaily.om/?p=566706 مجلس الشورى. (2015). واقع المعلم في سلطنة عمان. مسقط. سلطنة عمان. المحمدي، سعد علي. (2019). إدارة الموارد البشرية، رؤية إستراتيجية ومنهجية متكاملة. دار اليازوري العلمية. محمد، مصطفى. (2018). الرضا الوظيفي وأثره في تطوير الأداء. دار ابن النفيس للنشر والتوزيع.

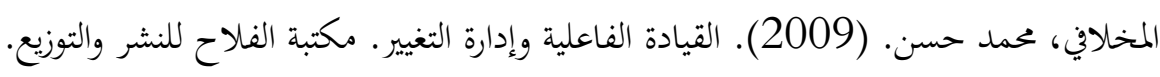
المكاوي، عاطف عبد الله. (2013). القيادة الإدارية. مؤسسة طيبة للنشر والتوزيع.

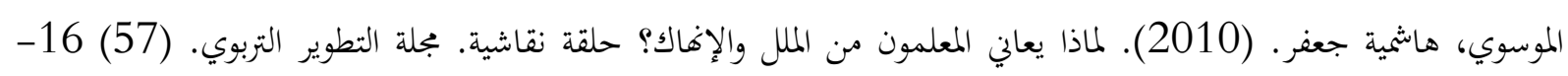
21 هاشم، عادل عبد الرزاق. (2019). القيادة وعلاقتها بالرضا الوظيفي. دار اليازوري العلمية للنشر والتوزيع. وزارة التربية والتعليم. (2008). دليل نظام تطوير الأداء المدرسي. مسقط. سلطنة عمان. وزارة التربية والتعليم. (2019). الكتاب السنوي للإحصاءات التعليمية (49). (49). سلطنة عمان.

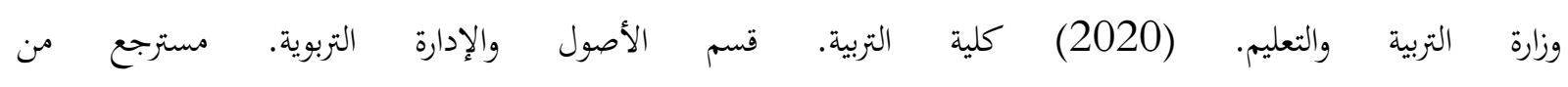
https://www.squ.edu.om/education-ar

يامنة، إسماعلي، وخير الدين، بن خرور. (2019). الأبعاد المحددة للعلاقات الإنسانية في الإدارة المدرسية. دار اليازوري العلمية. Akoglu. H. (2018). User's guide to correlation coefficients. Turkish Journal of Emergency Medicine. (18)91-93. 
Hancott, D. (2016). Leadership is what the importance of vision, integrity, and developing others? Lulu publishing services.

Munir, H. \& Iqbal, M. (2018). A study of relationship between leadership styles of principals and Job Satisfaction of Teachers in Colleges for woman. Bulletin of Education and Research. 40(2) 65-78.

Osbourne, R.(2015). Job Satisfaction. Nova Science Publishers.

Rao, B., \& Sridhar, D. (2003). Job Satisfaction of School Teachers. Discovery Publishing House.

Taber,K.(2016).The use of Cronbach,s alpha when developing and reporting research instruments in science education. Research in Science Education,48(6),1273-1296. 


\title{
THE INFLUENCE OF GREEK PHILOSOPHY ON ISLAMIC CULTURE AL-TAWHIDI IS A MODEL
}

\author{
Nada Mousa ABBAS ${ }^{1}$
}

\section{Istanbul / Türkiye \\ p. $528-542$}

\section{Received: 02/12/2021 \\ Accepted: $16 / 12 / 2021$ \\ Published: 01/01/2022}

This article has been scanned I iThenticat No plagiarism detected

\begin{abstract}
:
The East, with its ontological history, is full of religions, and the spirituality of the eastern mind is evident in its love for the literature of proverbs and wisdom that it was able to formulate, and its sanctification of the word is only due to its magical impact on himself; It is his consolation for his painful reality! It deals with its concepts and religious and worldly matters, and that he did not digest Greek philosophy until after the writers presented it with short sentences with wise meanings from the sayings of its philosophers! It is known that wisdom and proverbs are advice, guidance, advice and exhortation, expressing a subjective experience, length of contemplation and insight into life matters, and they often have moral dimensions and that they are suitable for all human societies in a time and place.

The concept of culture is so complex that it includes all human aspects. Speaking about the impact of Greek culture on Arab culture or even the presence of multiple connections, it stems from the phenomenon of influence and influence. Greek philosophy was mixed with Islamic thought and culture in the Abbasid era in general, and Arabic literature in general. In particular, it became one of the tools of expression, and the Greek philosophical culture penetrated into the Arab culture (its terms, concepts and sayings of its philosophers) until it spread in its three types: pure philosophical culture, literary philosophy, and philosophical literature. Islamic Society As the names of Greek philosophers gained popularity among members of society in all its classes!

The research focused on the issue of the impact of Muslim writers on the dissemination of Greek philosophical culture in the Abbasid era, taking from Abu Hayyan al-Tawhidi (d. 414 AH / $1023 \mathrm{AD}$ ) as a model; Although al-Tawhidi was not unique in mixing literature with philosophy; But it is a typical example of the writers of the Abbasid era who were influenced by Greek philosophy and whose literary culture was mixed with Greek philosophy. Greek philosophy has spread among members of the Islamic community by publishing the wisdom, proverbs and sayings of Greek philosophers and scientists.

The research was divided into three sections that dealt with the first topic: the relationship between literature and philosophy,
\end{abstract}

http://dx.doi.org/10.47832/2717-8293.15.37

1 iD Dr. , Diyala University, Iraq, nadaal.mosawi@yahoo.com 
while the second topic: the reasons for monotheistic influence on Greek philosophy, and the third topic: it follows the impact of Greek philosophy with the works of monotheism.

Key words: Culture, Philosophy, Literature.

\section{تأثير الفلسفة اليونانية في الثقافة الإسلامية}

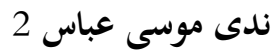

الملخص:

الشرق بتاريخه الأنطولوجي حافل بالأديان، وروحانية العقل الشرقي ظاهرة في حبه لأدب الأمثال والحكم التي جبل على صياغتها، وما تقديسه للكلمة إلا لوقعها السحري في نفسه، فهي عزاؤه عن أليم واقعه! يعابج بها مفاهيمه

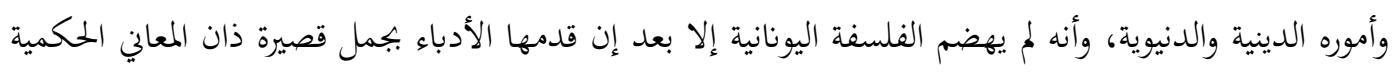
من أقوال فلاسفتها! والمعروف إن الحكم والأمثال هي نصح وإرشاد ونصح وموعظة، تعبر عن بتربة ذاتية وطول

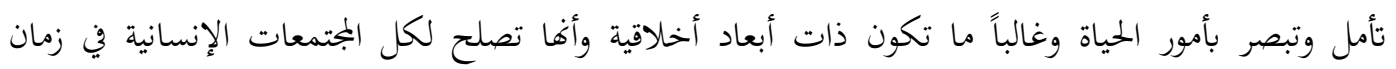

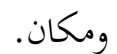
ركز البحث على مسألة أثر الأدباء المسلمين في نشر الثقافة الفلسفية اليونانية في العصر العباسي متخذاً من أبو

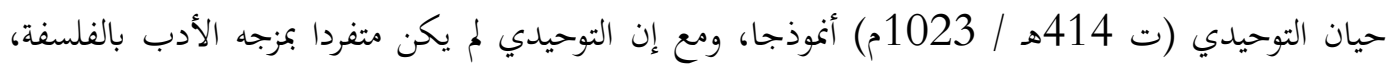

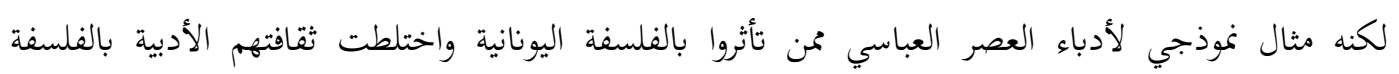

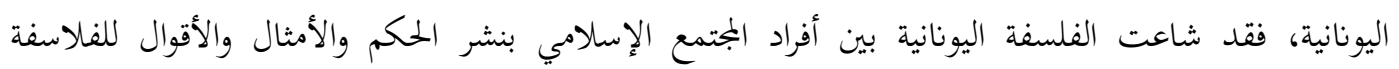
والعلماء اليونانيين. الكلمات المفتاحية: تاريخ، فلسفة، التوحيدي.

الشرق بتاريخه الأنطولوجي حافل بالأديان، وروحانية العقل الشرقي ظاهرة في حبه لأدب الأمثال والحكم التي جبل على

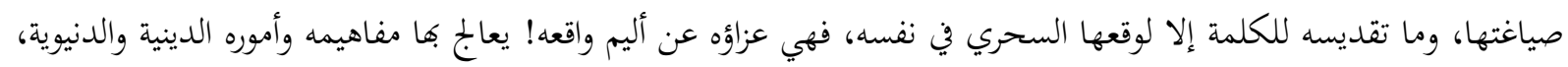

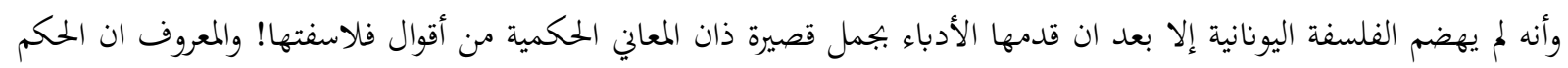

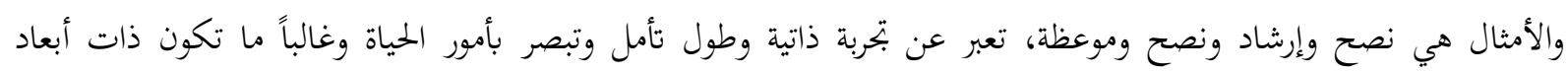

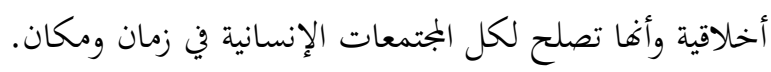

إن مفهوم الثقافة من التعقيد يصل لدرجة انه يشمل جميع النواحي الإنسانية، وفي الحديث عن أثر الثقافة اليونانية في

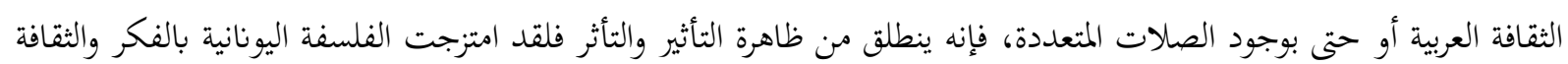

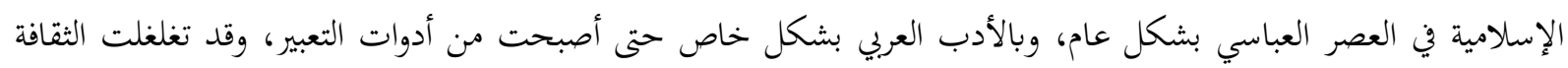

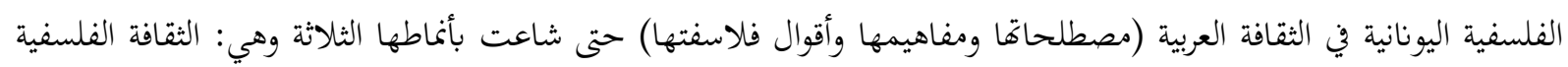


البحتة، الفلسفة الأدبية، والأدب الفلسفي ولذذا فقد ظهرت في نتاجاتما هوم ومشاكل فلسفية وإنسانية معبرة عن واقع البيئة في

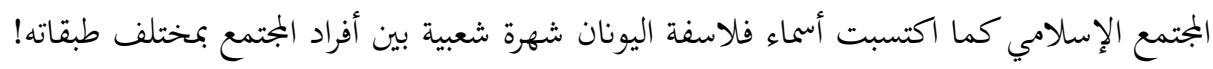
ركز البحث على مسألة أثر الأدباء المسلمين في نشر الثقافة الفلسفية اليونانية في العصر العباسي متخذاً من أبو حيان

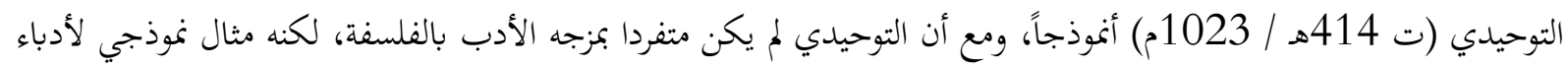

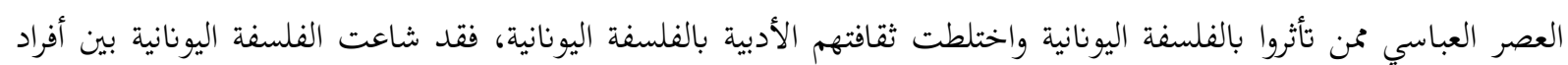
المجتمع الإسلامي بنشر الحكم والأمثال والأقوال للفلاسفة والعلماء اليونانيين. يبدو تأثر التوحيدي بالفلسفة اليونانية واضحاً بما أقتبسه من أقوال قصيرة حملت طابع الحكمة وبثها بين دفات كتبه لأشهر وأبرز وأهم الفلاسفة اليونانيين (الإغريق)، وكان قصده من تطعيم نتاجاته الأدبية وثقافته الإسلامية المحلية بثقافة الفلسفة اليونانية هو لتطويع المعنى وتعميقه للقارئ بشكل محسوس و تأكيده على المعلومة النافعة وتقريب فهم المعاني والقضايا والمسائل

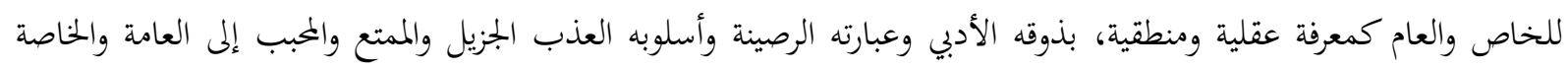
وبالسهل الممتنع.

لقد عكست مقتبسات التوحيدي للأقوال الفلسفية اليونانية، عقليته الفكرية الأرستقراطية المتفتحة للعلوم والمعارف والفلسفة وكل ما يخص طبقة العلماء والفلاسفة والمفكرين، ودرايته بثقافة عصره، فوبدا شغوفاً بالحكمة والمنطق والفكر والأقوال

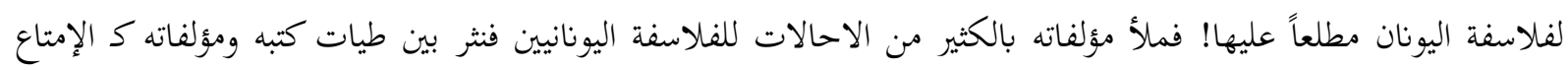
والمؤانسة والبصائر والذخائر والهوامل والشوامل والمقابسات والصداقة والصديق مقتبسات متنوعة من الترات التهات الأدبي العربي وأقوال

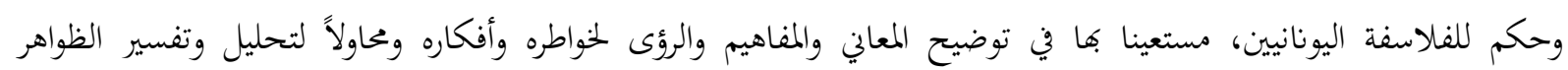
والحالات التي يشخصها في بجتمعه وبيئه.

تعتبر كتابات التوحيدي مؤلفات لا نظير لها من بين الكتب الباقية من التراث الإسلامي الوسيط كما أن أسلوبها البالغ

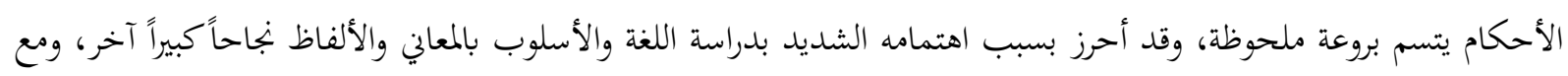

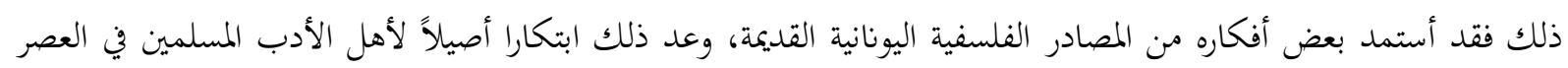
العباسي بالدرجة الأولى وبشكل ملحوظ. قسم البحث إلى ثلاثة مباحث تناول المبحث الاول: العلاقة بين الأدب والفلسفة، فيما بين المبحث الثاني: أسباب تأثر

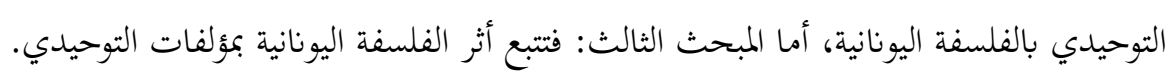

\section{أولاً: العلاقة بين الأدب والفلسفة:}

من الطبيعي أن نتساءل هنا هل تأدب الإنسان فبحث عن المعاني والأفكار لتنشأ منها الفلسفة؟! أم أنه تفكر وتفلسف

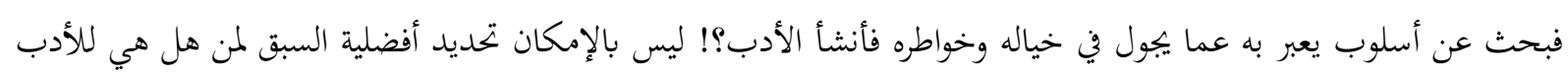

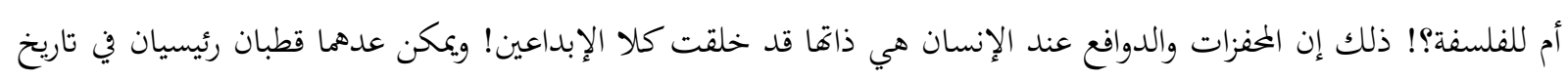

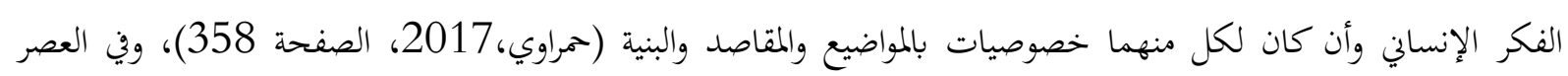
العباسي بدا لنا الأدب وقد حمل بين جنباته هوم وقضايا إنسانية برؤى ونظرات فلسفية! تعد اللغة القاسم المشترك الأول والأهم بين الأدب والفلسفة! أما القاسم المشترك الثاني بينهما فهو استخراج الأفكار

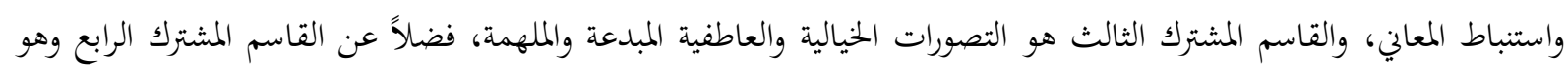

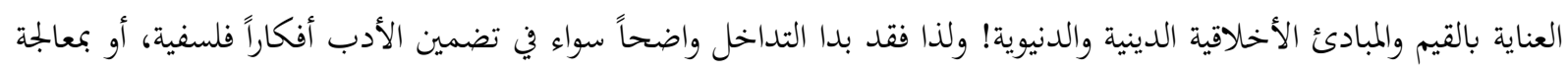


قضايا فلسفية بأسلوب أدبي جميل واضح وسلس وأيضا جميل ومبدع! يشد الإحساس إليه قبل الفهم، ومما هو مؤكد ان العديد من

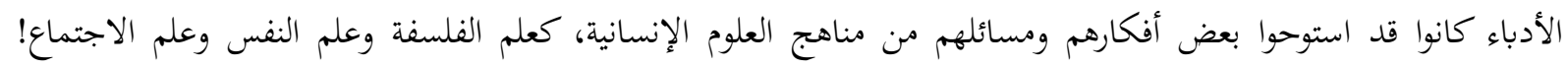

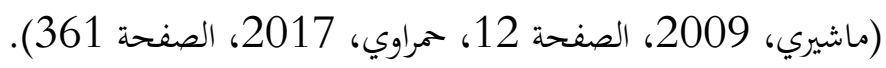

إن التمازج بين الأدب والفلسفة لا يعني ذوبان الحدود بينهما أو تلاشيها! فالاختلاف بينهما قائم ف العملية الأدبية تتميز

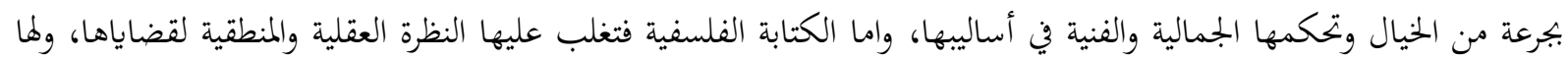

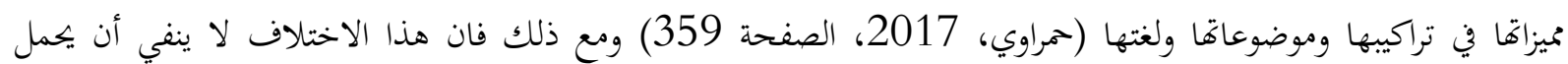

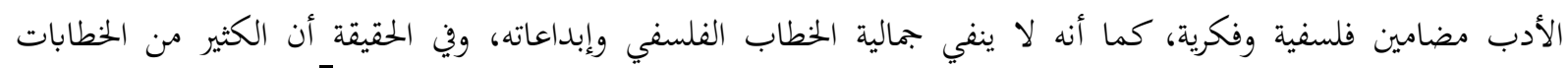
الفلسفية القديمة والحديثة عرفت تسلل جماليات التعبير الأدبي في ثناياها، بل كانت تعبّر عن أعمق القضايا الفلسفية في قالب أبلى أدبي (حمراوي، 2017، الصفحة 361).

لقد حمل العديد من الفلاسفة وعلى مر العصور هموم الإنسانية سواء كانت علمية أم أدبية! وعلى الرغم من لغتهم الصارمة

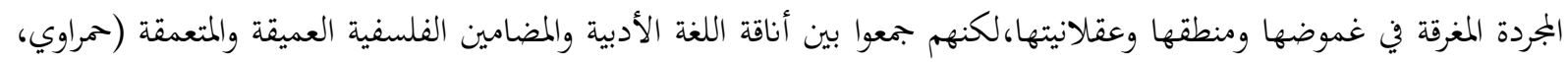

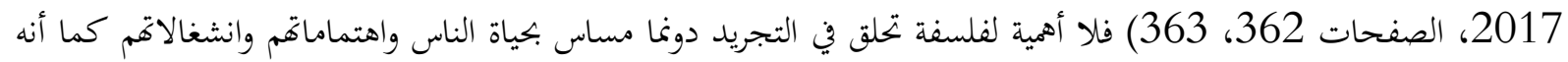
لا أهمية لأدب في أي جنس أدبي كان، إذا خلا من المعنى، إذ المعنى هو الذي يبث الحياة وأسباب بقائها واستدامتها في الأعمال

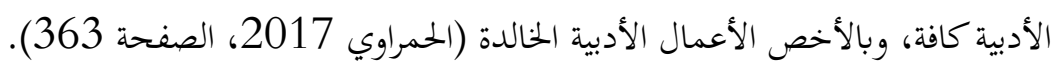

ولدينا على سبيل المثال جمهورية أفلاطون، فأننا نلاحظ إن أفلاطون قد أستوعب كل المموم والمشاكل والأفكار بفلسفته المتعمقة وصاغ حواراته بأسلوب أدبي، زاد في توهج ورُقي نتاجه الفكري، اذ حوى نسقه الفلسفي مجالات معان معرفية عدة من الحياة

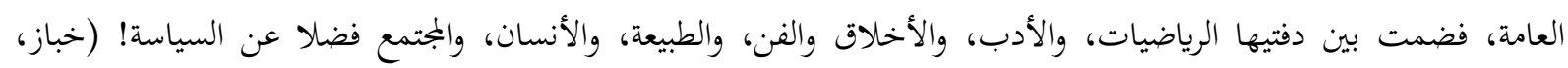
جمهورية أفلاطون، 1983).

والأمثلة التي تثبت أن كل أدب حقيقي هو في حاجة هذا القدر أو ذاك إلى الفلسفة (الزكوي، 2017)، مثل قصة الفيلسوف أبن طفيل المعنونة بـ حي بن يقظان وهي قصة فلسفية( الزكوي، 2017)، فكل الآداب العظيمة التي تمكنت من البقاء

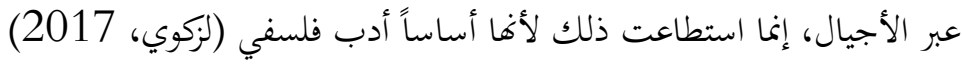

ويرى زكريا إبراهيم إن الباحثين قد أهتموا بطائفة الفلاسفة وطائفة الأدباء، ولكنهم لم يهتموا بطائفة الأدباء الفلاسفة أو

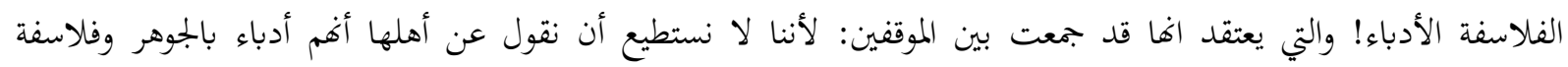

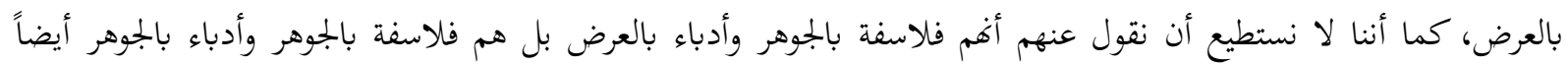
(إبراهيم، الصفحة 3). (3).

من المعروف ان الأقوال والأمثال التي تدخل في مجال الحكمة تعد إرهاصات للتفكير الفلسفي ونظراً لطبيعتها الإنسانية

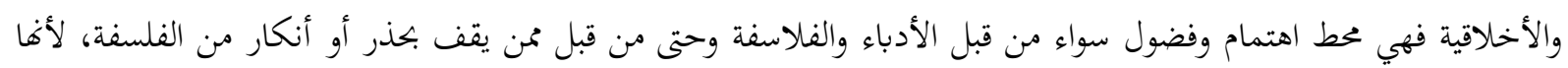

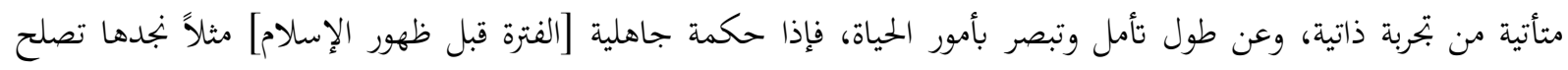

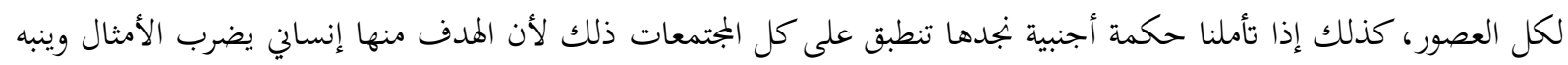

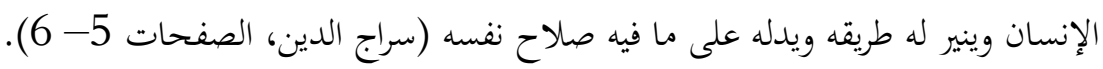
لم يكن ان التوحيدي متفرداً هذا الاتحاه، فقد سبقه عدد من أدباء القرنين الثالث والرابع الهجريين التاسع والعاشر

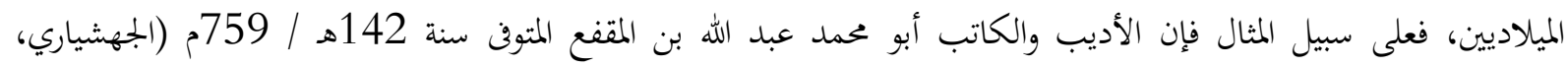

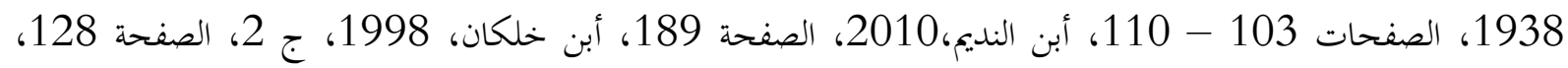


الشريف المرتضى، 1429هـ، ج 1، الصفحات 151 - 153) يعد من أول الأدباء الذين دبجوا الثقافة الفلسفية اليونانية

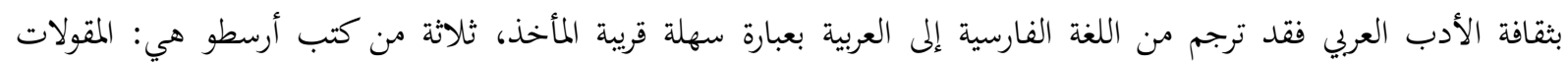

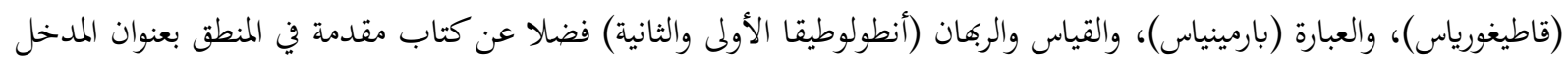

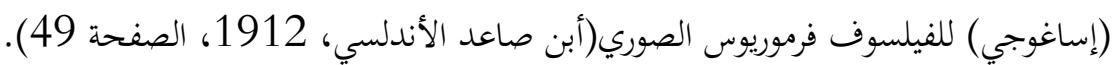

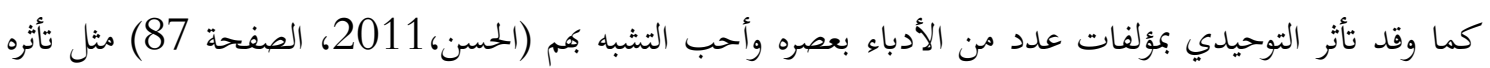
بالأديب الكبير الجاحظ المتوف سنة 255 هـ/ 868 م، الذي فاقت شهرته على كل أديب مفوه سبقه ولحقه في عصره والعصور

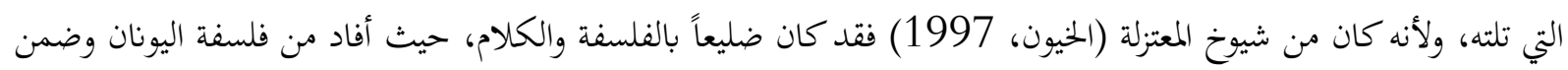
معارفه منها في شتى مسائله ورسائله المتنوعة التي حوتا مؤلفاته الأدبية والتاريخية والاجتماعية والأخلاقية والعقلية والعلمية (بلات، 1961، 1961، الدهماني، 2021).

وصاحب كتاب المعارف أبو حنيفة الدينوري المتوف سنة 276هـ / 889 م، والذي وصفه التوحيدي في كتابه المفقود

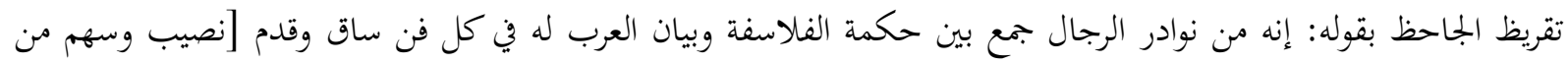

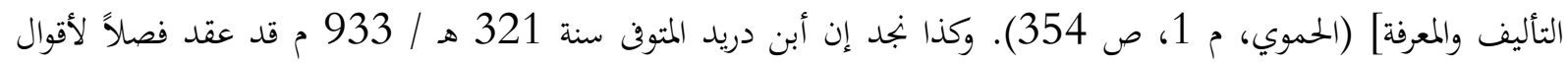

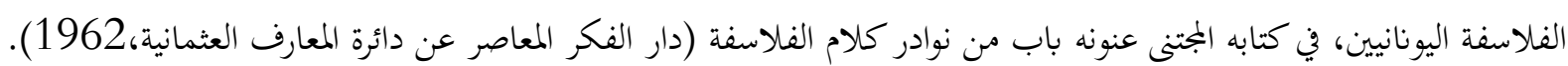
أما الفيلسوف والعالم والأديب والفقيه والجغرافي أبي زيد البلخي المتوفن سنة 322هـ / 934م، فقد لقبه الحموي بجاحظ

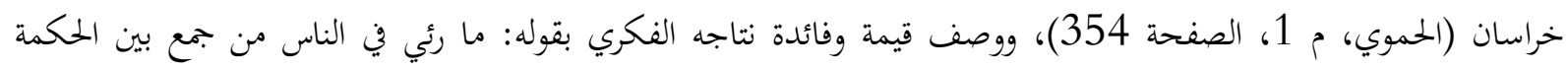

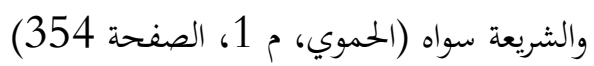
لقد ترك أبي زيد البلخي نتاجاً علميا وفلسفياً غزيراً، وصل إلى ما يربو السبعين (70) مؤلفاً بسائر علوم عصره

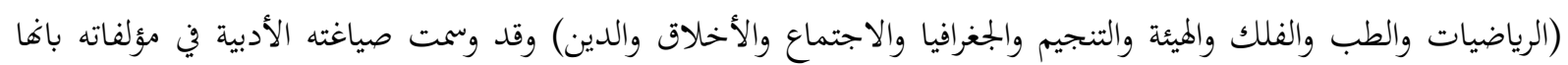

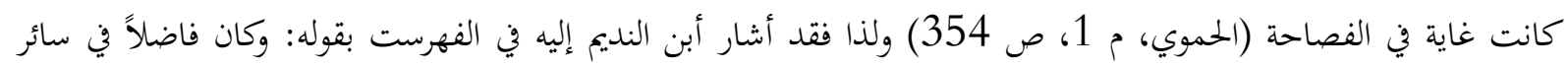

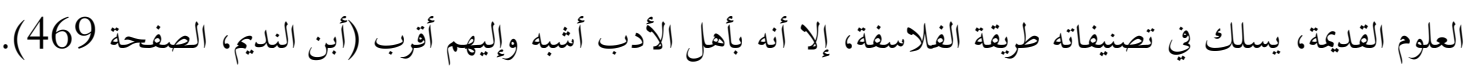
ويظهر تأثير الفلسفة اليونانية واضحا عند الكاتب الديواني قدامة بن جعفر المتوفى على الأرجح سنة 337 3ـ / ذكره أبن النديم قائلاً: كان قدامة أحد البلغاء الفصحاء والفلاسفة الفضلاء ممن يشار إليه في علم المنطق (أبن النديم، الصفحة

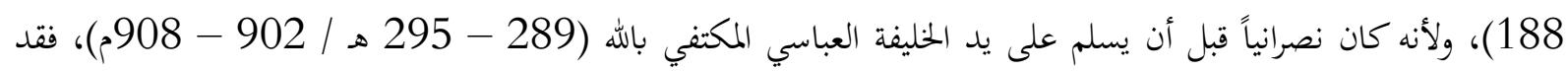

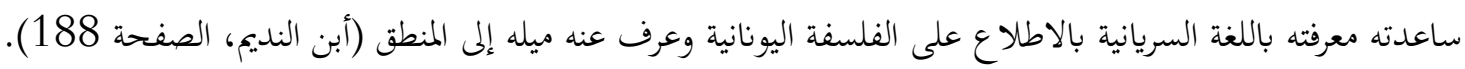
وبالمقابل فقد تأثر عدد من الأدباء بالتوحيدي فنقلوا عنه أقوال لفلاسفة أو علماء يونانيين، وأصبح نقل الأقوال عن

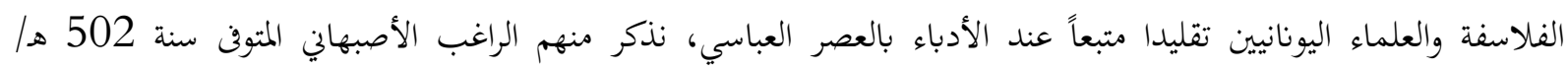

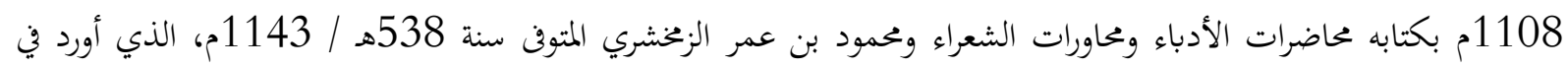

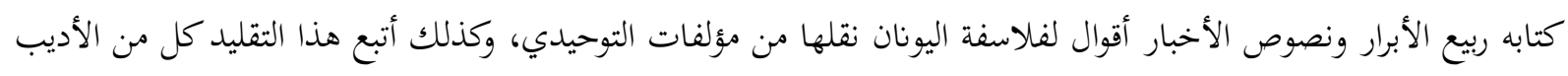

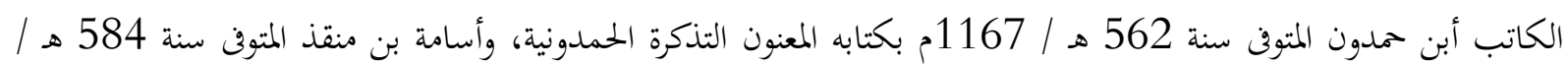

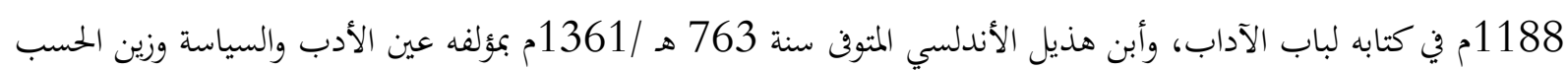


لقد ظهر انفتاح العقل العربي بشكل جلي على كل ألوان الثقافات العالمية، لعدم تعصبهم أو تزمتهم وفي التراث الثقافي

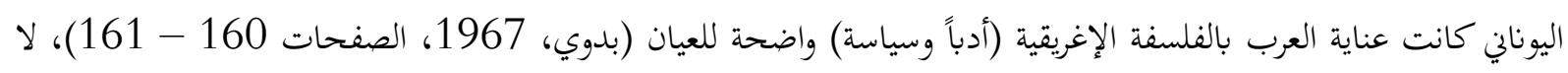

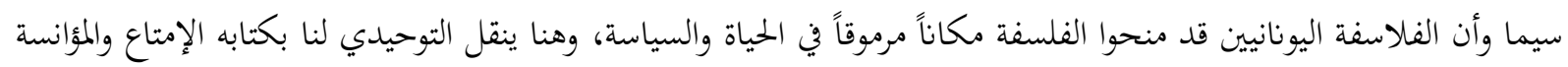
رأي عن الفيلسوف ديوجانيس في الفلسفة عندما سُئل: متى تطيب الدنيا؟! فكان رده: إذا تفلسف ملوكها وملك فيك فلاسفتها (التوحيدي، 2007، الصفحة 222).

من الواضح جدا ان التوحيدي لم يكن يتعامل مع الفلسفة اليونانية بأها ترفاً ثقافياً، بقدر ما هيه وسيلة وأداة تساهم في

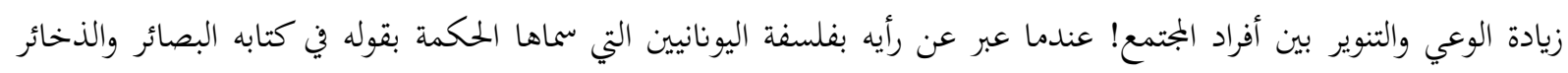

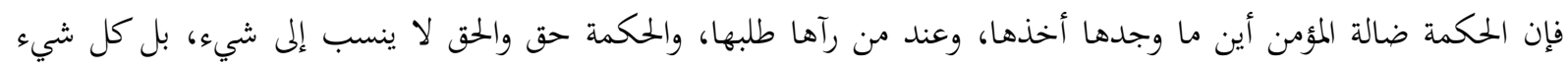

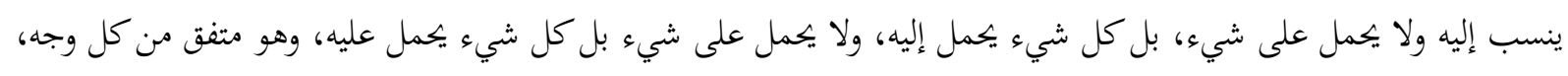

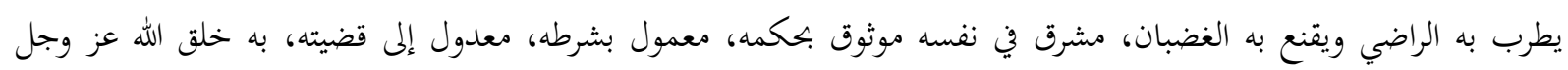

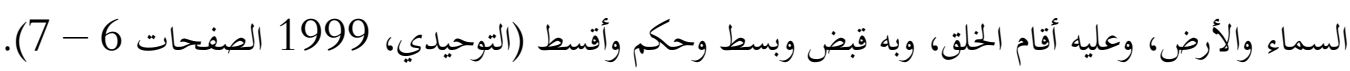
إن من أهم ما تميزت به الحضارة الإسلامية هو التسامح وذلك ما أشار إليه المستشرق آدم متز بقوله: لم يكن معروفاً في

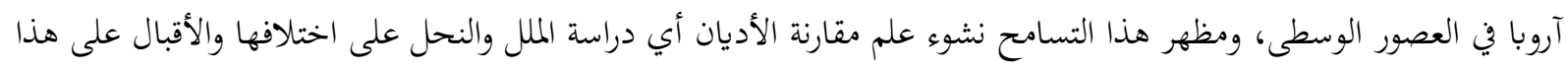

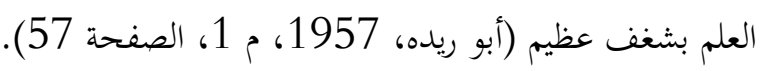
ولا ريب إن القيم الإنسانية النبيلة التي زهت بها أقوال فلاسفة اليونان كانت من أهم الأسباب التي جذبت التوحيدي

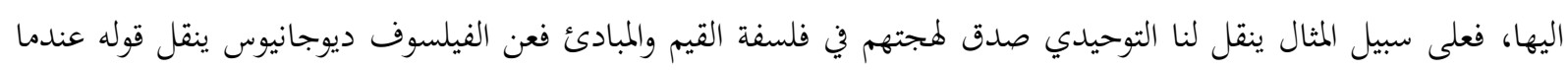

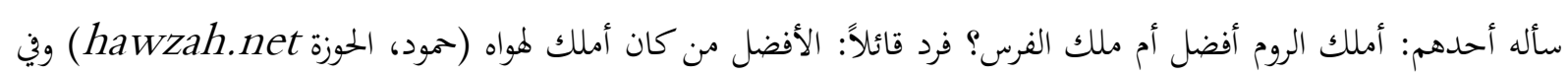

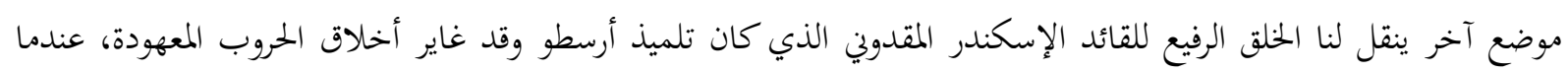

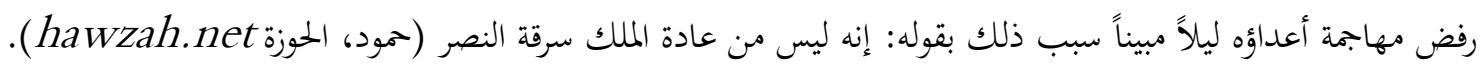
وكذلك هناك تأثير آخر على الثقافة العربية وهي في تأثير الحاكم على الرعية، نظراً لأن الناس على دين ملوكهم، والرواية

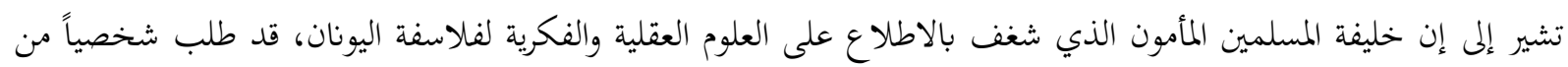

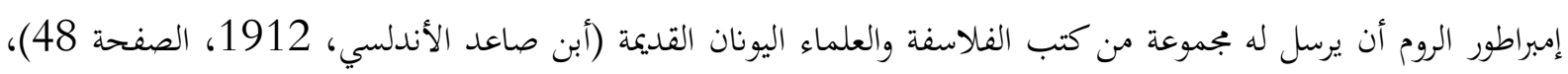
ولا شك ان اهتمام الخليفة هذا أثر على أذواق الرعية لأن الفضول دفعهم للاطلاع على التراث الفلسفي والعلمي والفكري لهؤلاء الفلاسفة والعلماء.

وصف ياقوت الحموي المتوف سنة 626هـ/ 1228م التوحيدي بمقولة أشتهر بها على مر الزمان! عندما قال عنه إنه فيلسوف الأدباء وأديب الفلاسفة (الحموي، مجلد 4، الصفحة 288) فقد كان التوحيدي موسوعي يعنى بالمعاني والأفكار والتساؤلات ذات المغزى الفلسفي أدت إلى نشوء علاقة وثيقة لديه بالفكر والقضايا الفلسفية اليونانية، فهو فيلسوف السؤي المال

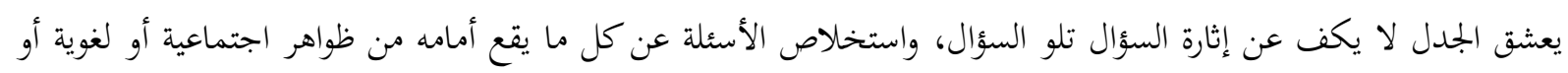

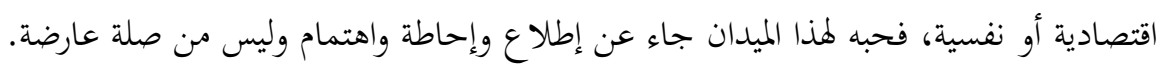

أبته التوحيدي نحو الثقافة الفلسفية اليونانية التي أعطته زاداً منوعاً أضافه إلى خزينه المعريف اذ طعم كتاباته الأدبية بأقوال

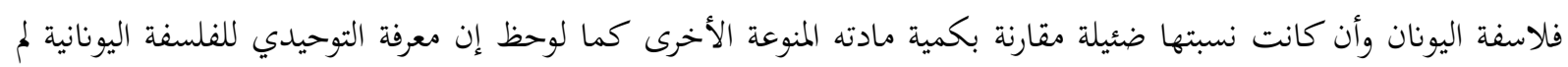

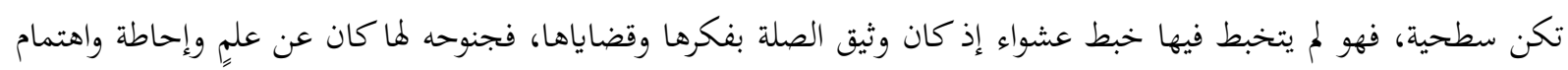


وحبه العقلاني للفلسفة كان وجودياً كأديب وإنسان، ويبدو أنه وجد فيها ملاذاً للتعبير عما يخالج فكره وما يعتمل في نفسه وما يعاني منه في حياته، مجارياً فيها روحية عصره.

كان التوحيدي أديباً يعبر بإحساسه عن المعاني، ثم يعود ليكسبها مسحة عقلية، ويمنحها نظرة فلسفية، وقد كان تأثره بالفلسفة اليونانية أمر ملحوظاً طغى على كل مؤلفاته، الأمر الذي يكشف النف تعاطيه للفلسفة اليونانية وموسوعية معارفه وشموليتها،

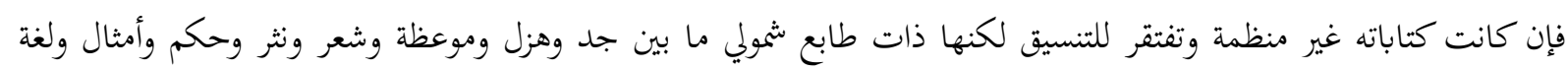

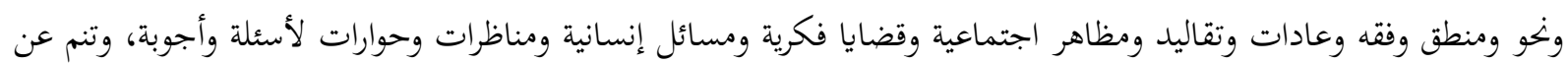

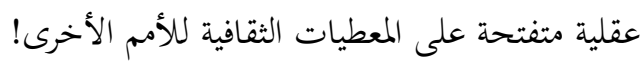
وعندما وضع التوحيدي يده على مواطن النفع في الفلسفة اليونانية، كان مثالا للأمانة في النقل هذا من جهة، ومن جهة

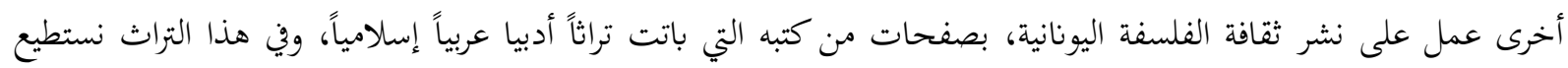

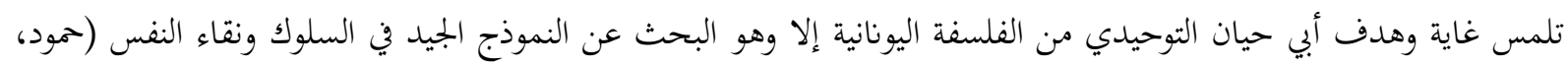

الحوزة hawzah.net)

عند تتبع ما أورده التوحيدي من أقوال الفلاسفة اليونانيين لاسيما في مؤلفاته الثلاثة الإمتاع والمؤانسة والبصائر والذخائر

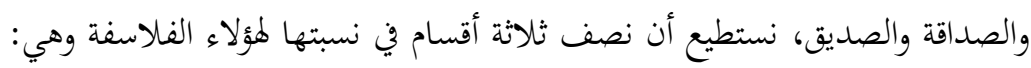
1- مشاهير فلاسفة اليونان وعلماؤها، الذين كانوا من أعلام الفلسفة اليونانية المعروفين عند الكتاب والعلماء والفلاسفة

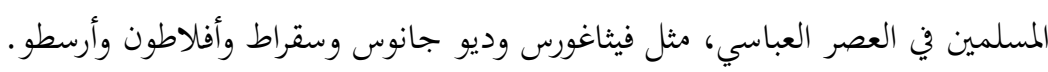

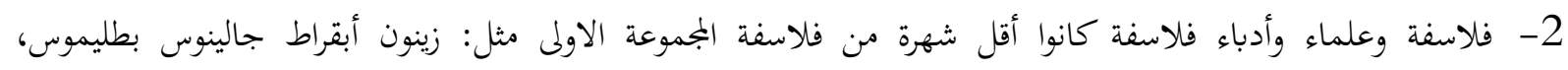

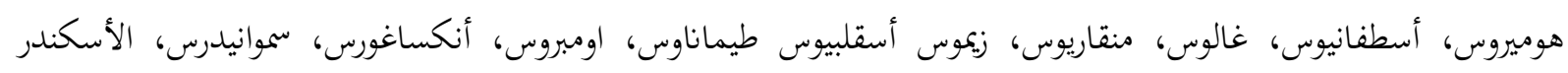
المقدوني.

3- فلاسفة لم يشر التوحيدي لأسمائهم وهم أكثر بالعدد من المجموعتين الأولى والثانية وأكتفى بنعتهم بالفلاسفة!

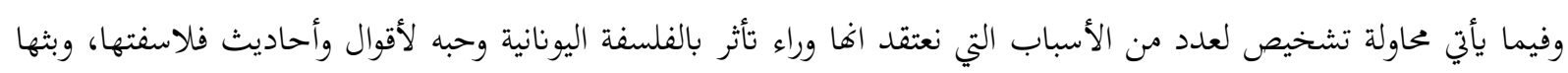

كل البشر يسعون وراء السعادة! والتوحيدي واحد منهم فقد عاث حياته برمتها يبحث عن السعادة التي حرم منها ولم

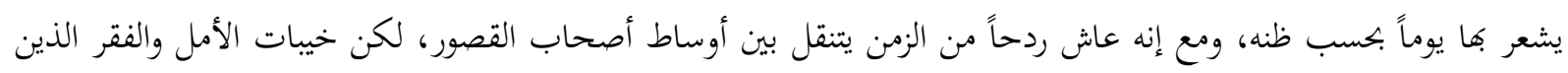

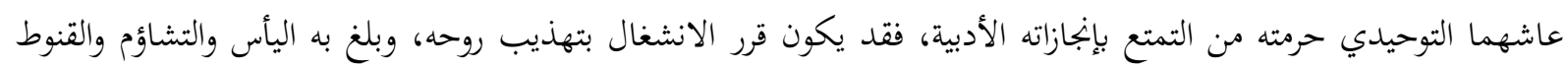

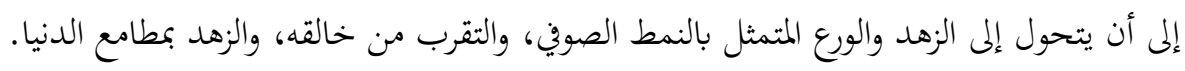

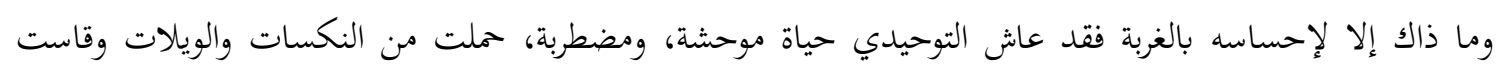

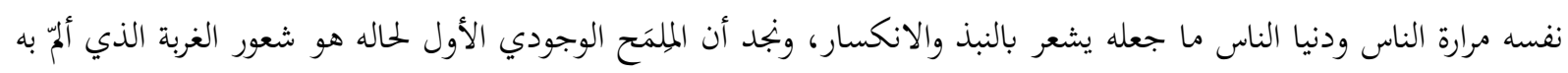

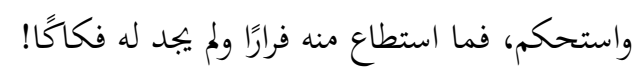

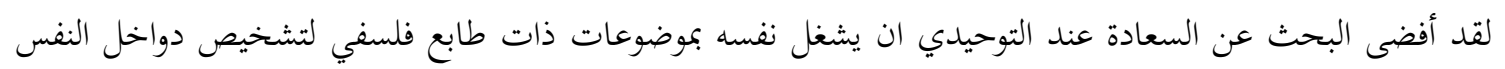

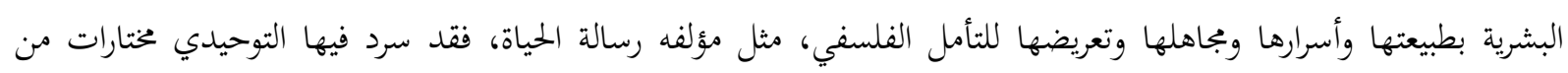

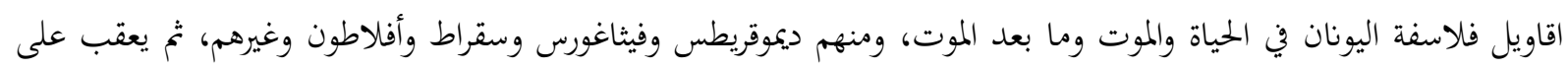


كلامهم بتعليقات مقتبسة من أبي سليمان المنطقي، وأبي زكريا الصيمري وعيسى بن زرعة وأبي الخير الخمار وغيرهم (ابراهيم، الصفحة 125).

قدم التوحيدي لنا في كتابه أخلاق الوزيرين الصاحب بن عباد وأبن العميد صورة مشرقة لفلاسفة اليونان وكيف كان

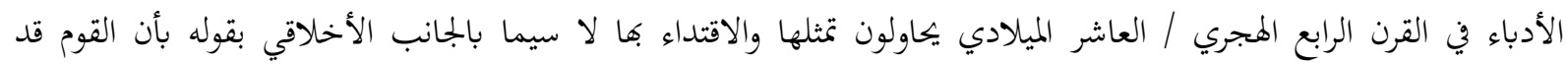

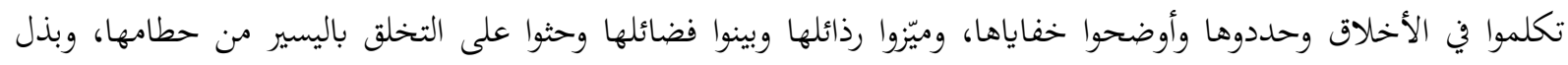

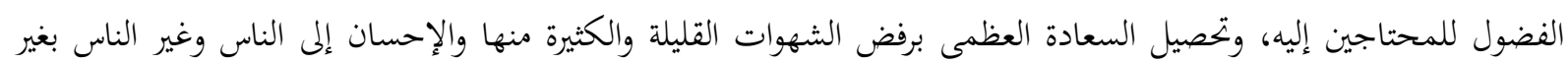

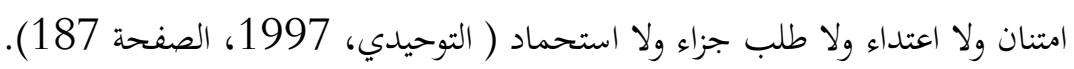

وما فتأ التوحيدي يذكر شدة تأكيد الفلاسفة اليونانيين على مسألة الأخلاق، ويدعو لمن أطلع على فلسفتهم وأحبها ان

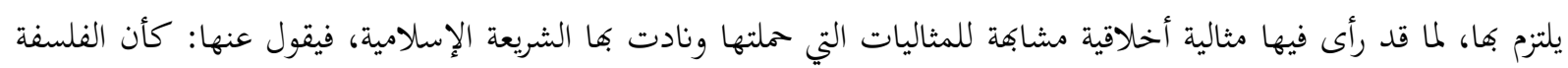

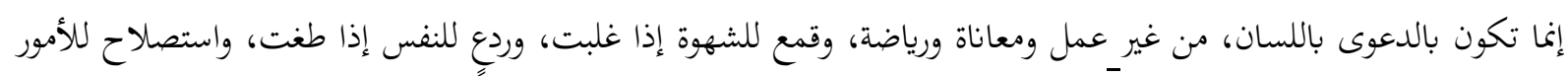

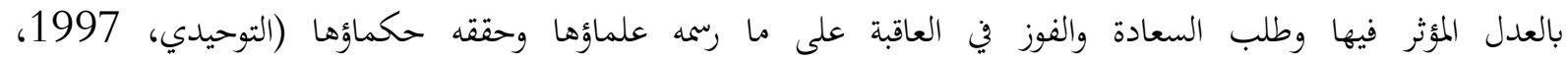

الصفحة237).

ولذا نجد التوحيدي على سبيل المثال ينتقد ويذم وزير ركن الدولة البويهي (320 - 366هـ / 932 - 976م) الكاتب أبن العميد المتوف على الأرجح سنة 366هـ / 987م، والذي لقب بالجاحظ الثاني فرغم توسع معرفة أبن العميد بالفلسفة

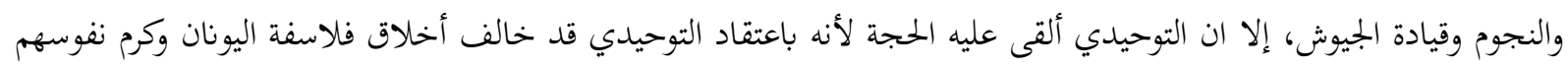

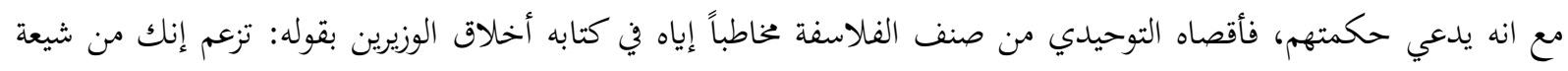

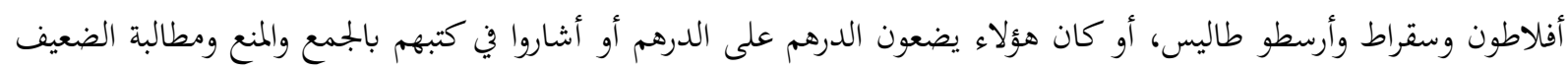

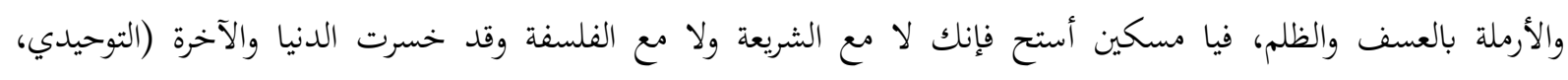
1997، الصفحة 166).

لقد أظهر التوحيدي إعجابه وشغفه بالفلسفة وأقوال ومسائل الفلاسفة والعلماء اليونانيين فكان يدافع عن فجهم الأخلاقي والعقلاني بالالتزام به، فعلى سبيل المثال قد ذم أبن زُرعة الذي كان هو الذانئ الآخر معجباً بالثقافة اليونانية، فذكر يوماً

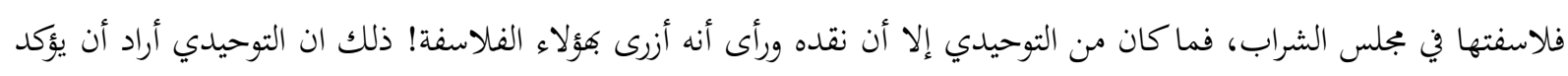

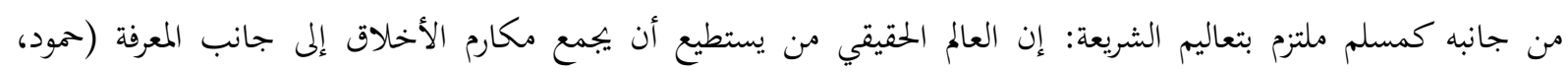
الحوزئ.nawzah. (haw

إذن لا نستبعد أن يكون التوحيدي قد وجد في الفلسفة اليونانية متنفساً نفسياً وأخلاقيا يخفف عنه ما كان يعانيه من

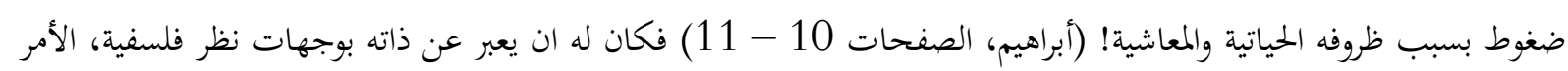

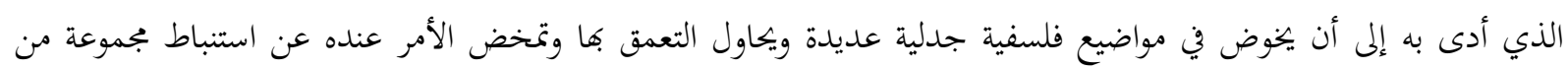

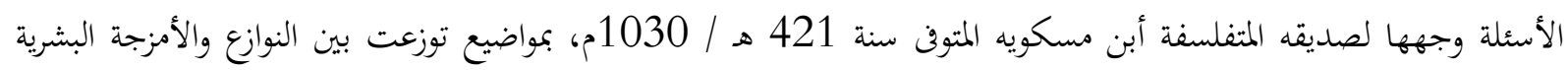

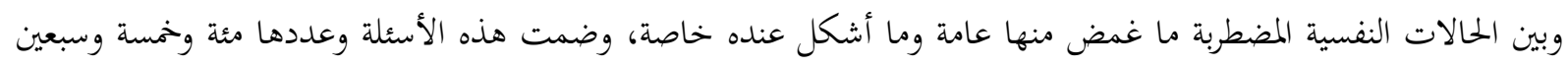

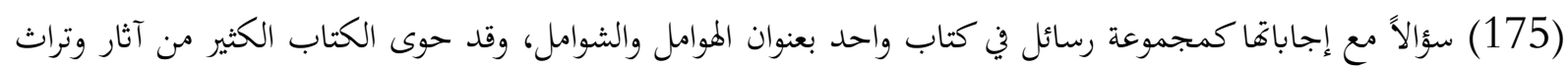

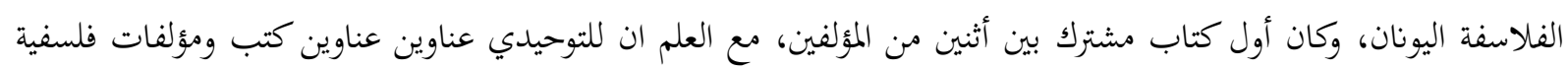
نذكر منها: المقابسات، كتاب الاقناع، الإشارات الإلهية المحاضرات والمناظرات الحج العقلي اذا ضاق الفضاء عن الحسن الفين الشرعي، 
رياض العارفين، رسالة في ضلالات الفقهاء في المناظرة رسالة في أخبار الصوفية، التذكرة التوحيدية، رسالة الحياة رسالة بيان ثمرات العلوم، رسالة الامامة أو رواية السقيفة.

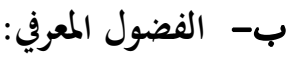

كانت الفلسفة اليونانية عند التوحيدي طريقاً للبحث عن الحقيقة الموضوعية في الحياة، فلا نستبعد نظراً لذهنيته المتفتحة

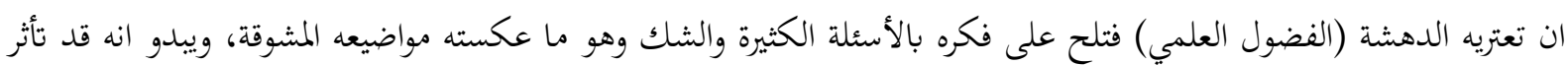

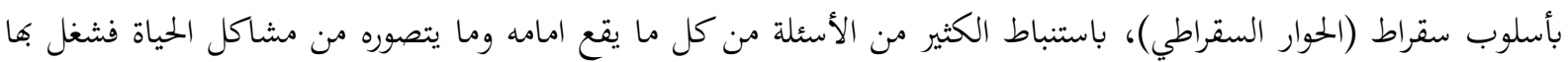

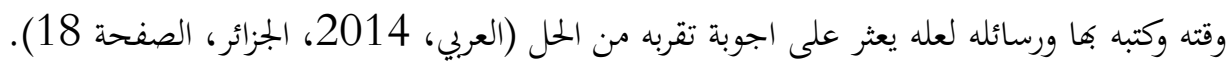

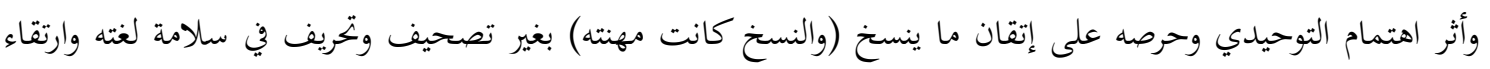

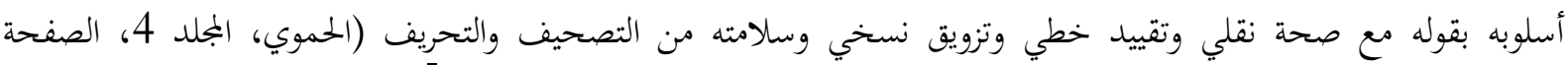

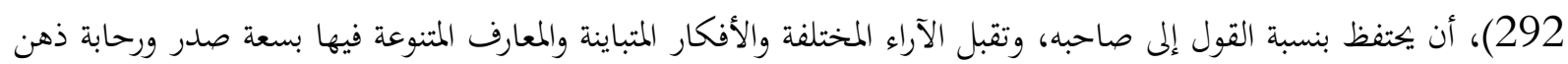

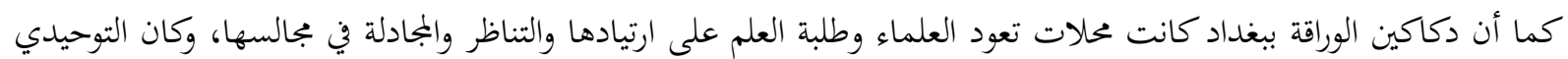
يشهد هذه المناظرات ويدونها.

ولهذا نلاحظ الموسوعية والتنوع والتلون بالمعارف لدى الأدباء فضلاً عن العلماء، فعلى سبيل المثال حوى كتاب التوحيدي البصائر والذخائر من المعارف الأدبية والنوادر والفكاهة والتاريخ والتصوف، فضلاً عن الكثير من الأحاديث العلمية والمسائل والأقوال من الفلسفة اليونانية جمعها التوحيدي وحشدها على مدى خمسة عشر (15) سنة مما سمع وقرأ. وقد عكس كل ذلك ذلك ولك بقوله يصف كتابه البصائر والذخائر قائلاً: حوى من الذهن لواقحه، ومن العقل قرائحه ومن الأخلاق محاسنها، ومن العلم

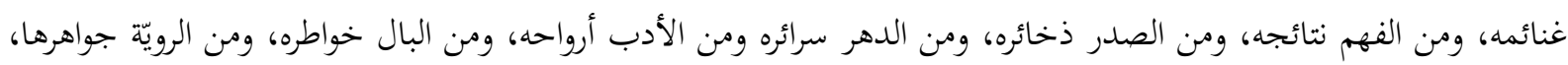

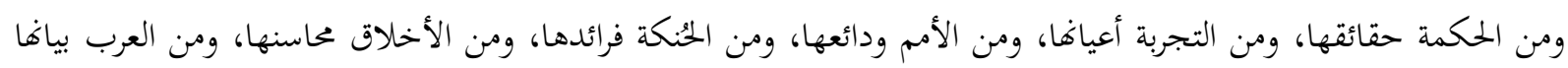

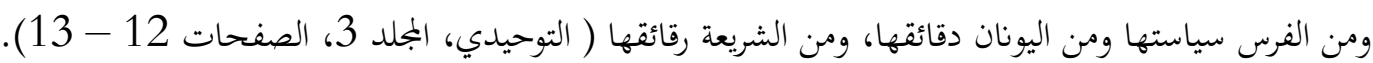
ولذلك فإن القيمة العلمية والمعرفية لمذا الكتاب البصائر والذخائر عديدة يحصيها التوحيدي بقوله: فهو أذن للكليل

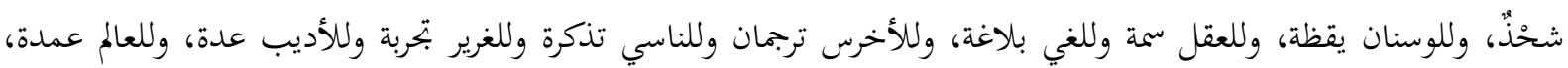
وللخامل نباهة وللناسك بصيرة وللعاقل نصيحة جمعتُ فيه كل غرة لائحة، وحجة واضحة، وبرهان مبين، وقول متين، ونادرة

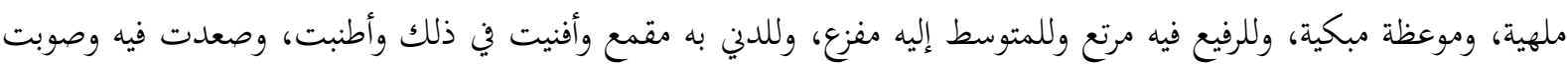

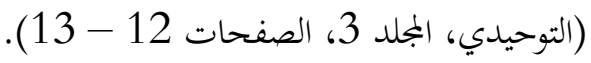

ورغم سوء الطالع وكثرة التشكي اللذين وسما حياة التوحيدي، إلا انه أتصف بالنباهة والتدقيق ورجاحة العقل التي كانت

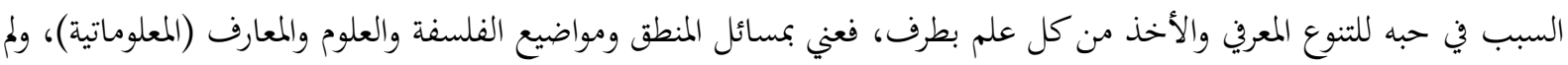

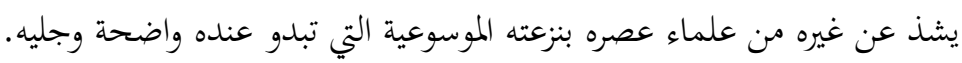

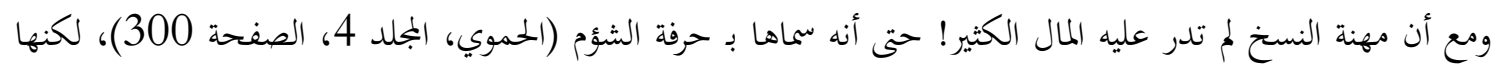
أفادته في التطبع بعدة أمور منها: 1 - مبعته على تقبل الآراء المختلفة والأفكار المتباينة. 2- أنعكس اهتمامه وحرصه على أتقان النسخ بغير تصحيف ولا تحريف، على خاصيته في الحفاظ على نسبة الأقوال لأصحابها والدقة في إيرادها. 3- ساعدته على التفرغ للفلسفة والتمعن في أقوال الفلاسفة اليونانيين، وبيان سلوكياتم ومدى التزامهم بثوابهم الأخلاقية. 
من الواضح ان الأديب العربي في العصر العباسي، قد ألغى كل الفوارق العرقية والدينية وأنفتح على ثقافات كل الشعوب،

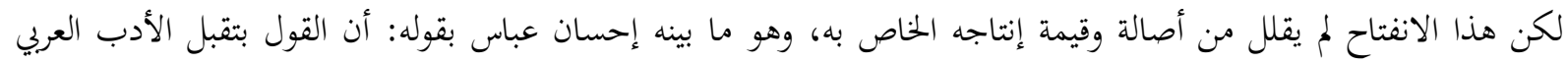

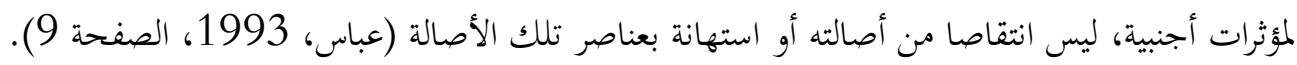
لقد سادت بيئة التوحيدي التيارات العقلية والفكرية والبحث والجدال، تلك الاجواء التي رافقت فلاسفة العصر العباسي،

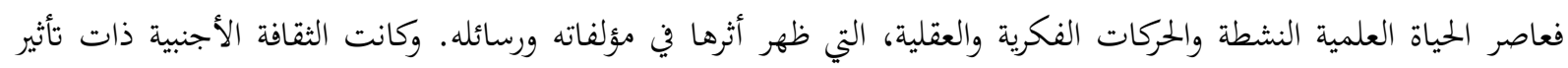

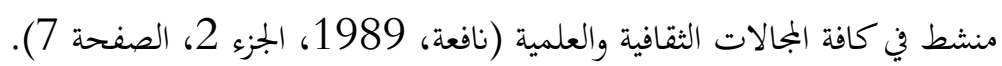

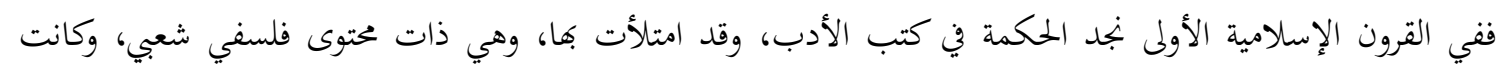

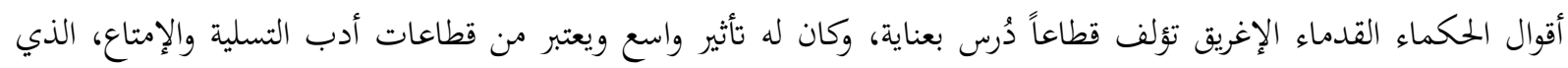

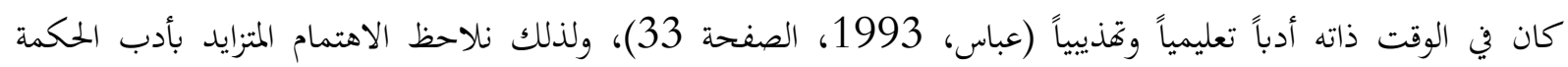
اليوناني، وكان قسم كبير من هذا الأدب قد ترجم في فترة مبكرة وكان أدباء هذا العصر يعيدوا إبرازه (عباس، 1993، 193، الصفحة

وكان لكبار علماء ومفكري وفلاسفة القرن الرابع الهجري / العاشر الميلادي، فضل في تلمذة التوحيدي بالفلسفة اليونانية

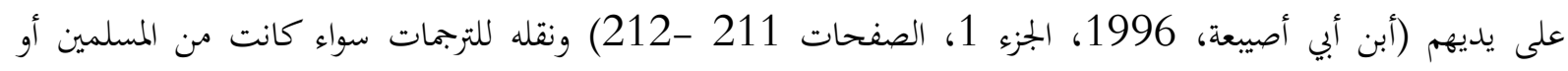

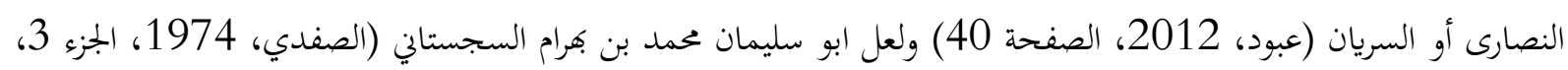

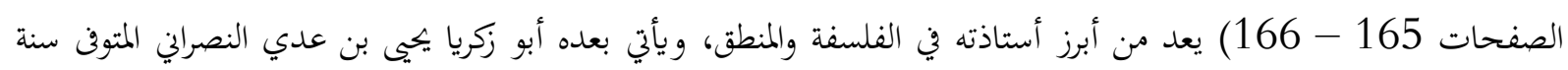

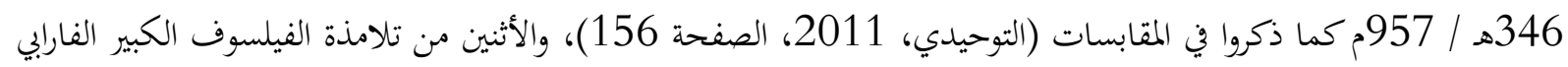

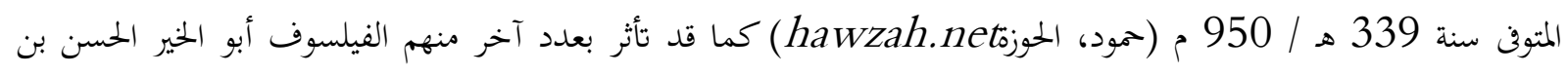

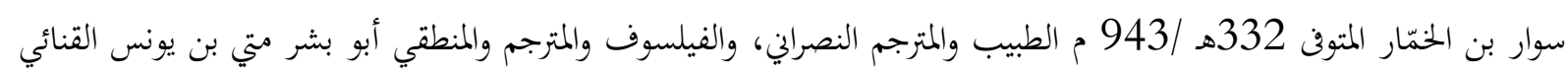

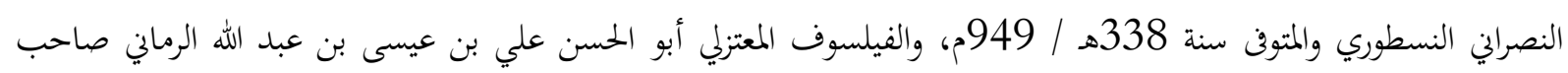

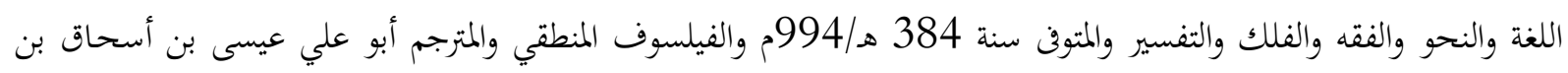

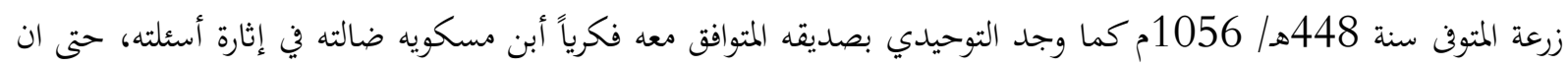

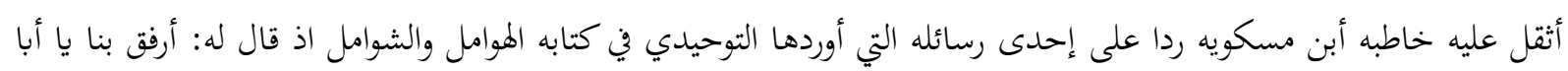

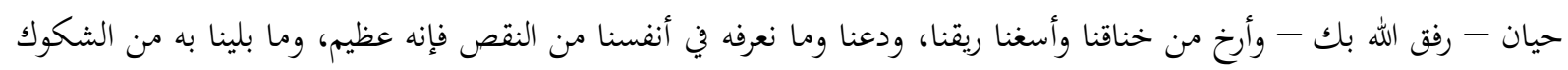

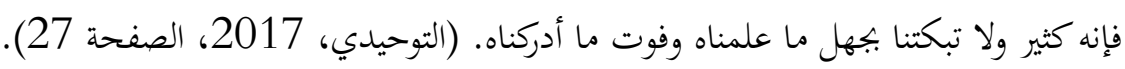

ثالثاً: الفلسفة اليونانية في مؤلفات التوحيدي

مما لا شك فيه إن الاتصال بين الثقافة العربية واليونانية كان قد بدأ بأولى حلقاته في العصر العباسي (أبو شهاب،

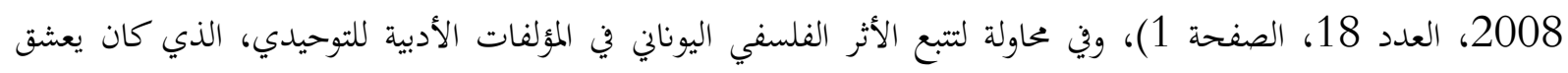

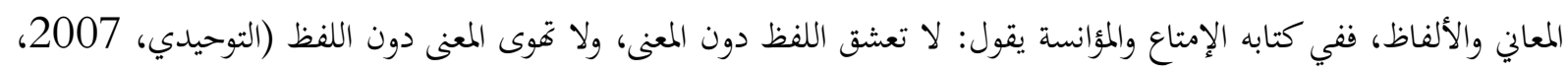

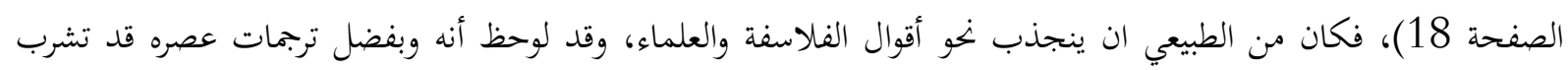
بالفلسفة اليونانية وحكمتها، لم يخفي انجذابه نخوها. 
كان إنشاء علاقات إنسانية متوازنة (حمود، الحوززhawzah.net) من أهم شواغل التوحيدي الفلسفية في كتبه ومؤلفاته

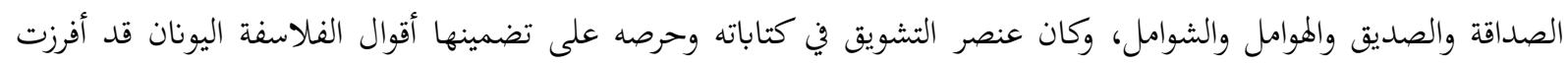
بسبب: ظهور شخصية المؤلف فيها بصورة واضحة بالإضافة إلى طبيعة المشاكل الخاصة التي تناولتها هذه الكتابات (نافعة،

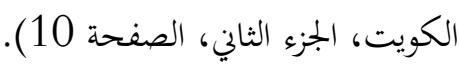

لقد وصف آدم مِتز التوحيدي بأنه أعظم كُتاب النثر العربي على الإطلاق! ومع ان كتاباته كانت غير منظمة ولا منسقة

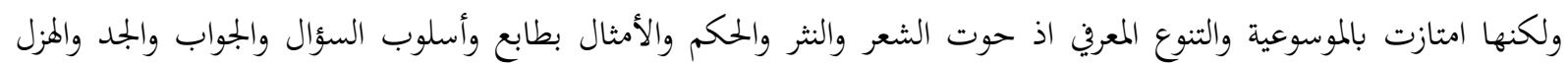
والنصيحة والموعظة، كما طغى حبه للفلسفة والتفلسف باستخدامه الألفاظ والتراكيب والاصطلاحات الفلسفية والمنطقية اليونانية

وأقوال لفلاسفة وعلماء وأدباء اليونان حتى أنه أود حكم لهوميروس ولمة (صاحب الإلياذة والأوديسة من القرن الثامن قبل الميلاد). فعلى سبيل المثال وردت في الليلة الثانية (2) والليلة السابعة عشر (17) من ليالي كتابه الإمتاع والمؤانسة الأربعون (40)

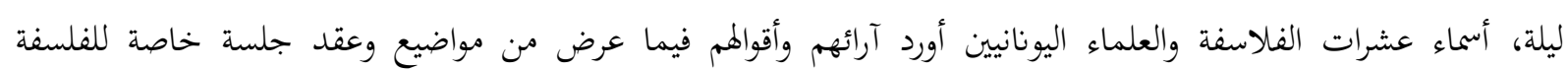

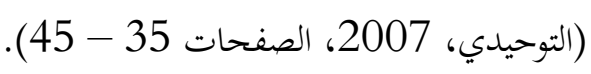

كما ذكر التوحيدي في كتابه الإمتاع والمؤانسة أخوان الصفا لأول مرة! ولم يكن قد ذكرهم أحد قبل التوحيدي ويبدو أنه

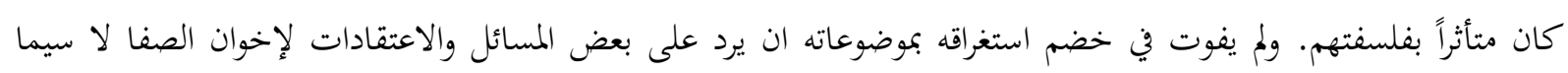

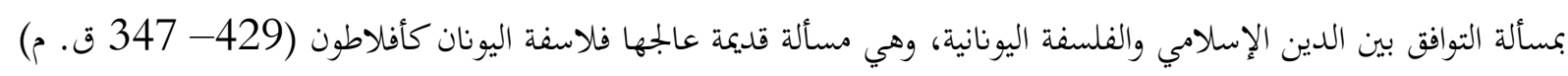

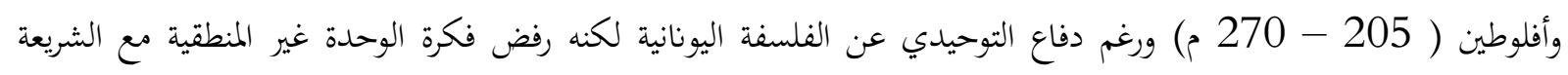

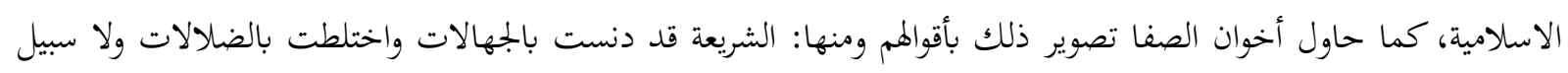

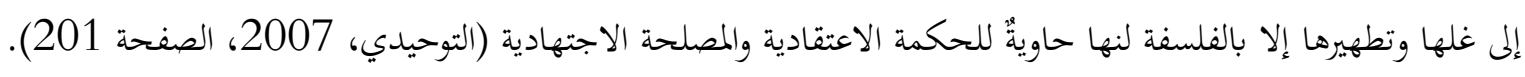
ويشير التوحيدي إلى أن أخوان الصفا قد ذهبوا بعيداً بقولم أنه متى انتظمت الفلسفة اليونانية والشريعة العربية فقد حصل

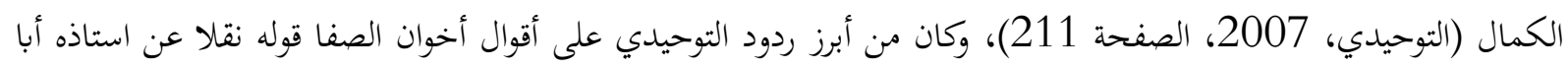

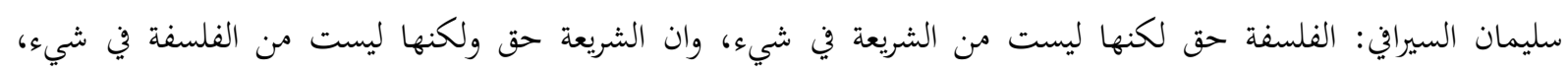
وصاحب الشريعة مبعوث، وصاحب الفلسفة مبعوث إليه وأحدهما خخصوص بالوحي، والآخر مخصوص ببحثيه، والأول مكفي

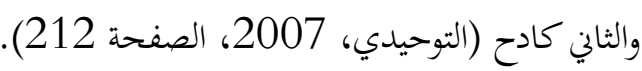

يمضي التوحيدي بمقالة طويلة برده على مسالة أخوان الصفا في التوفيق بين الدين والفلسفة فالتوحيدي ينفي أن يكون

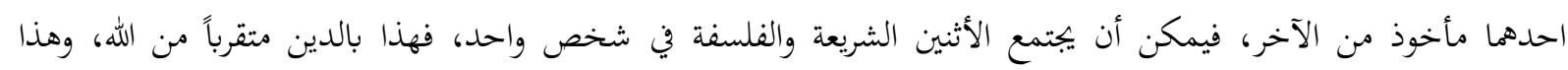

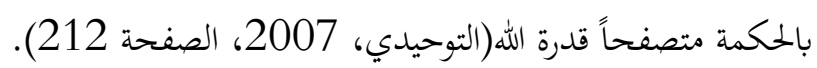

ويستند التوحيدي في ردوده على أخوان الصفا بآراء أستاذه أبي سليمان كقوله: من اراد أن يتفلسف فيجب عليه أن

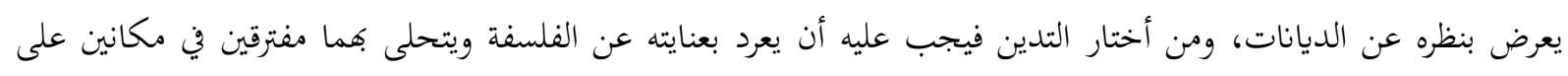

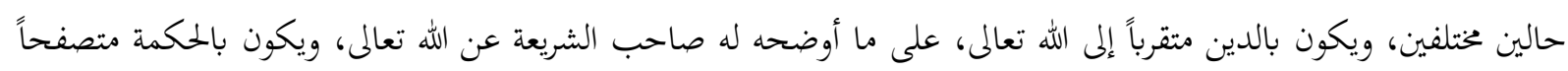

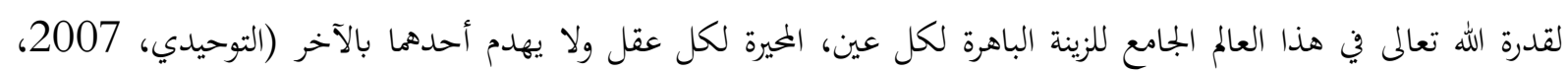
الصفحة 212).

لم يكن التوحيدي فيلسوفاً محضاً، ولم يكن صاحب نظرية في الفلسفة، لكنه عبر عن الأفكار الفلسفية المستسقاة من الكتب اليونانية المترجمة للغة العربية بقالب أدبي مبدع، فقد لخدص فيلم الأفكار الفلسفية هذه في كتابه المقابسات (التوحيدي،

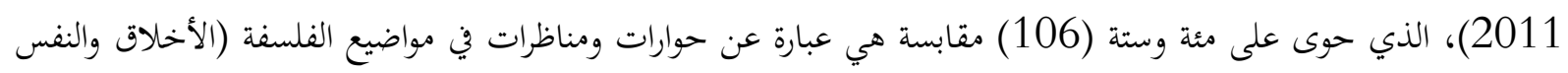


والطبيعة والإلميات) ناقشت بأسلوب أدبي قضايا فلسفية حتى إن البعض من الباحثين أعتبره كتابات أدبية بنكهة فلسفية ساهمت

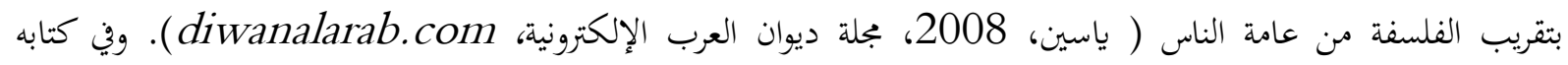
الإشارات الإلهية (التوحيدي، 1950) نجد التوحيدي يبث ابتهالاته بأسلوبه الفلسفي الفذ، مسجلاً في خضم ذلك العدئ العديد من الحوارات الفكرية والفلسفية.

رأى التوحيدي إن التباين أو الفرق بين الأدب العربي والفلسفة اليونانية لا يلغي إمكانية تعاوفما وإن النحو يزين المنطق

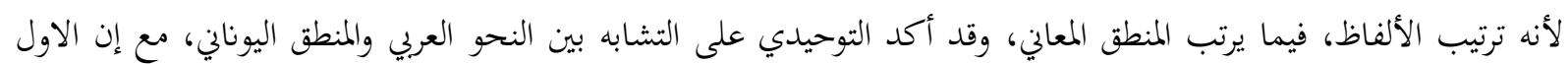

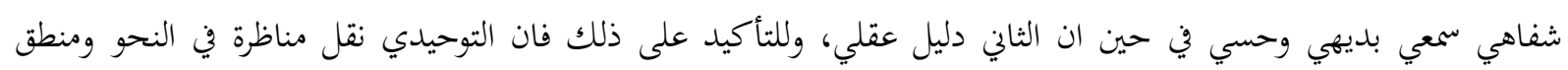

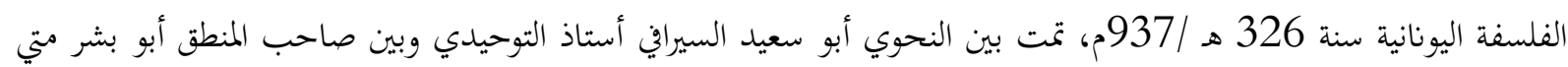

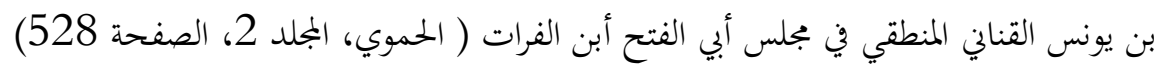
لقد بدت نزعة التوحيدي الفلسفية و تأثره بالفلسفة اليونانية وشغفه بها واضحة وبشكل جلي في كتابه الإمتاع والمؤانسة،

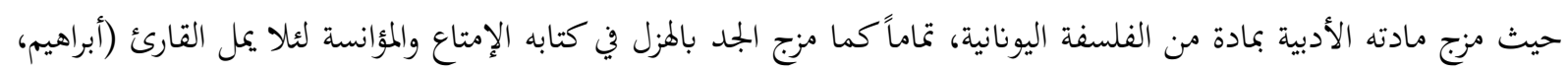

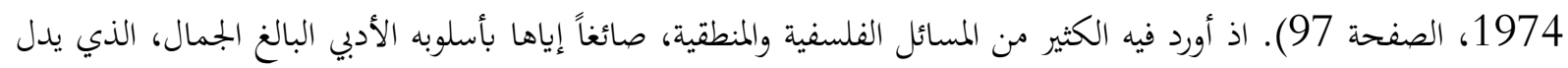

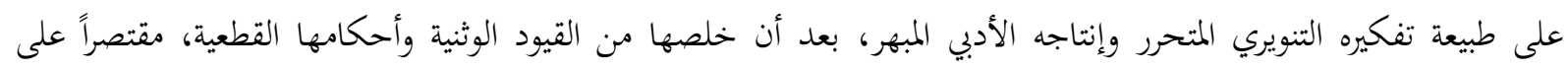
مناهجها الاستدلالية العقلية.

ولا ريب ان بداية تعرف التوحيدي على الفلسفة اليونانية في المرحلة الأولى تتبين من خلال عدم تحديد أصحاب بعض أقوال الفلاسفة اليونانيين واكتفائه بالقول: قال فيلسوف كما في كتابيه ال البصائر والذخائر والإمتاع والمؤانسة. أن العنصر التنويري في كتابات التوحيدي يظهر للعيان من جراء تعلقه بالفلسفة اليونانية وفهمه لوظيفة الفلسفة اليونانية

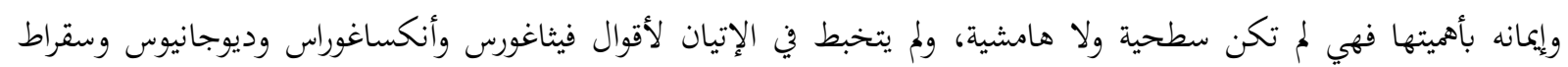
وافلاطون وارسطو.

ولذلك نجده لا يألو جهداً في الدفاع عنها والرد على من لم يفهم مقاصده منها وأول كلامه عنها، كما جاء في رسالته

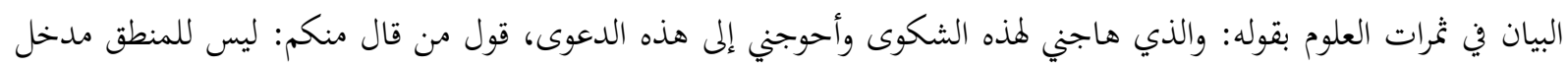

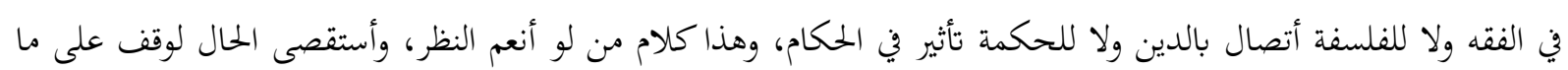

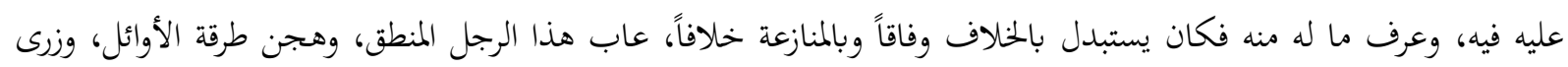

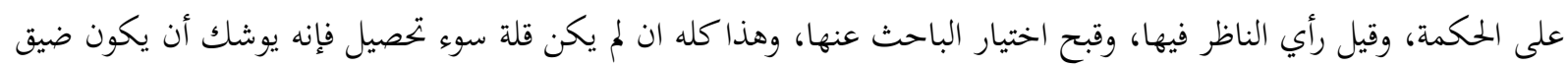

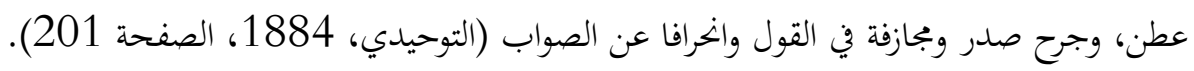
كما أورد التوحيدي في الإمتاع والمؤانسة مناظرة في سمة الفكر اليوناني وقيمته بخدمة الإنسانية ما بين كل من أبي بشر متي

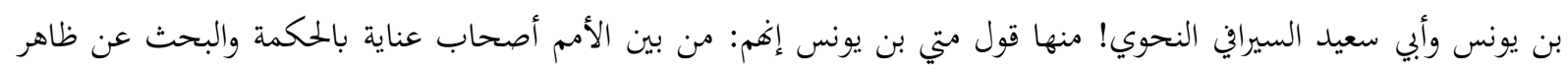

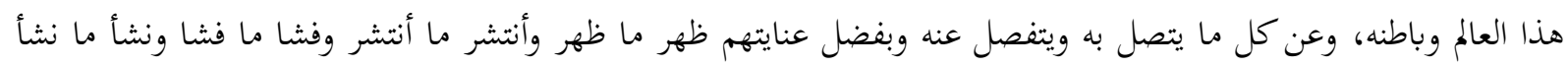

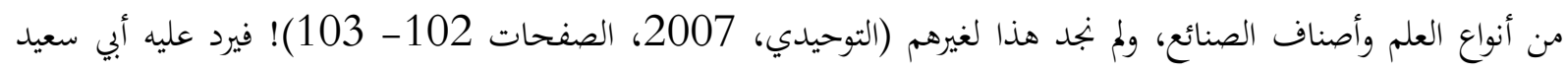

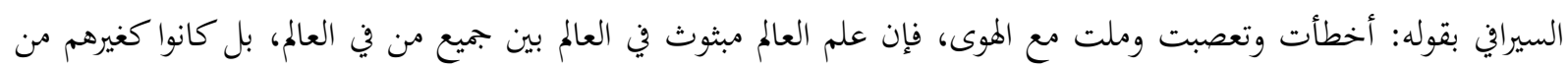
الأمم يصيبون في أشياء ويخطئون في أشياء، ويعلمون أشياء ويجهلون أشياء ويصدقون في أمور ويكذبون في أمور، ويحسنون في مني

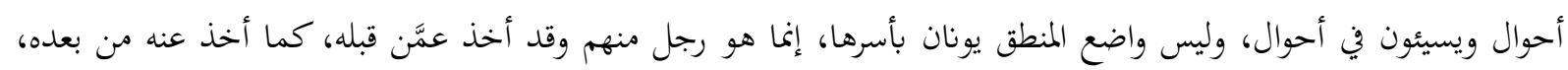

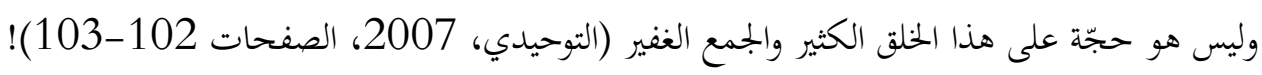


كانت الفلسفة والعلوم من بين أهم الروابط التي قاربت بين الثقافة الإسلامية التي باتت ثقافة عالمية في العصور الوسطى

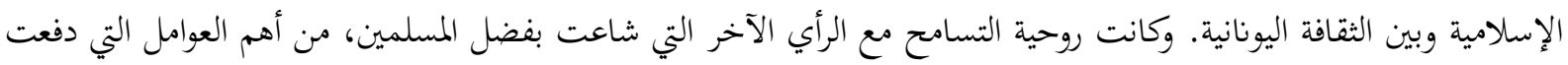

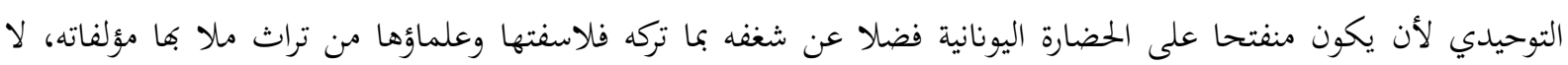

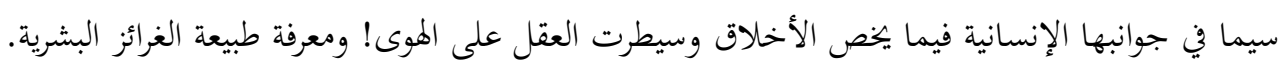

لقد أبدع التوحيدي في التعبير عن أفكار فلاسفة اليونان في القرن الرابع الهجري / العاشر الميلادي وصارت كتبه سجلات

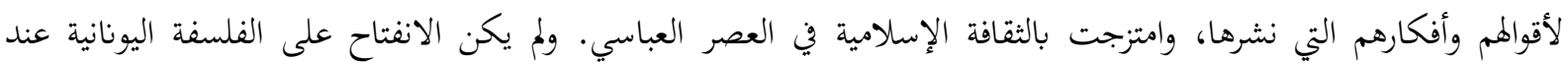
التوحيدي بالخاصية الذاتية، بقدر ما كانت روحية مشتركة بين عدد من أدباء عصره، وقد أبدى التهات التوحيدي أعجاباً شديداً

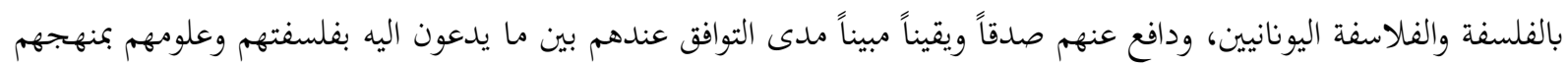
الأخلاقي والعقلاني، وبين ما كانوا ملتزمين به ويطبقونه بسلوكهم على أرض الواقع فعلاً وعملاًا! 
قائمة المصادر والمراجع:

أولا: المصادر

أبن أبي أصيبعة موفق الدين أبي العباس أممد بن القاسم بن خليفة بن يونس السعدي الخزرجي( ت668 هـ / 1270 م). (1996).

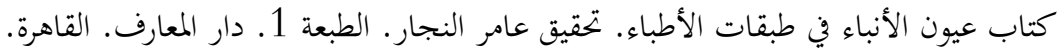

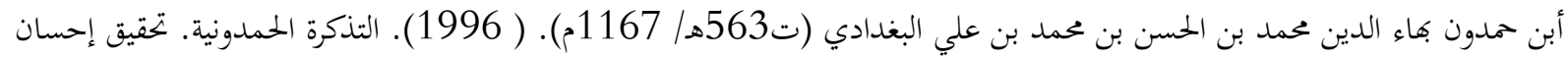

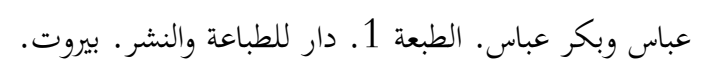

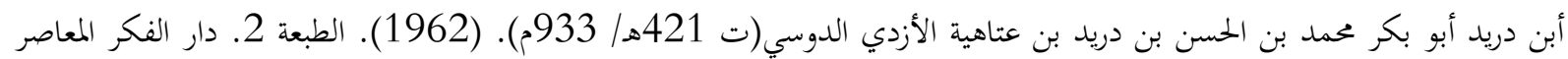

عن دائرة المعارف العثمانية.

أبن النديم أبي الفرج حممد بن إسحاق (ت 380 هـ/ 990م). (2010). الفهرست. تحقيق يوسف علي الطويل. الطبعة 3، دار الكتب

$$
\text { العلمية. بيروت. }
$$

أبن خلكان أبو العباس شمس الدين أممد بن محمد بن إبراهيم بن أبي بكر الشافعي (ت 681 هـ / 1282م). ( 1998). وفيات

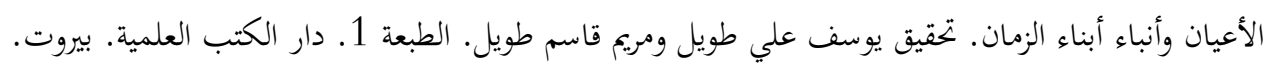

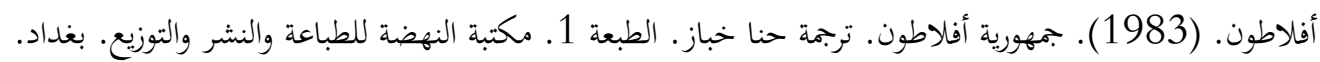

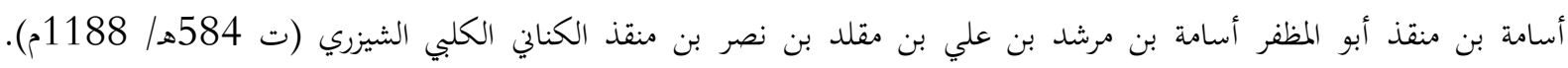
(1987) لباب الآداب. تحقيق أممد عممد شاكر . منشورات مكتبة السنة. الدار السلفية لنشر العلم. القاهرة.

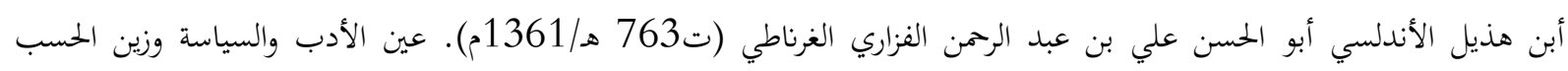

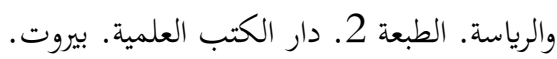

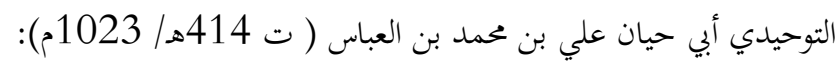

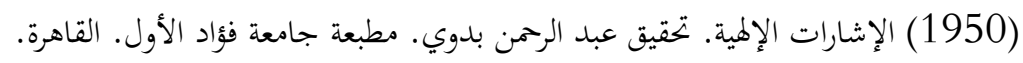

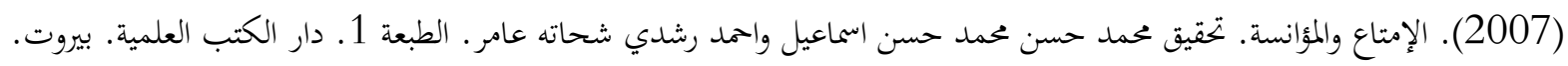

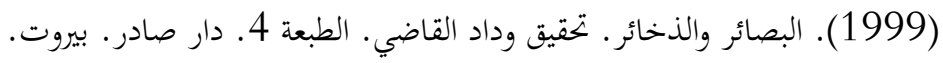

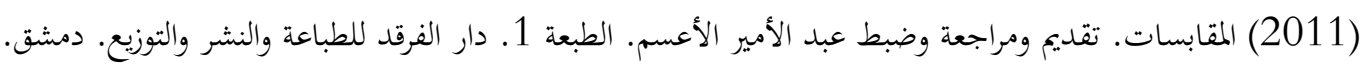

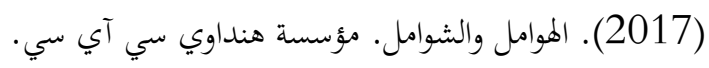

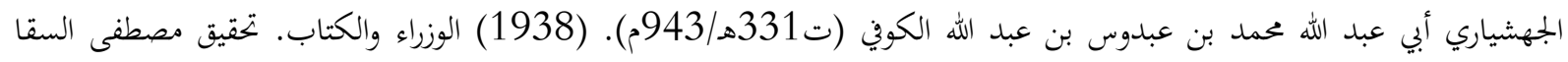
وإبراهيم الأبياري وعبد الحفيظ شبلبي. الطبعة 1. مطبعة البابي الحلبي وأولاده. القاهرة.

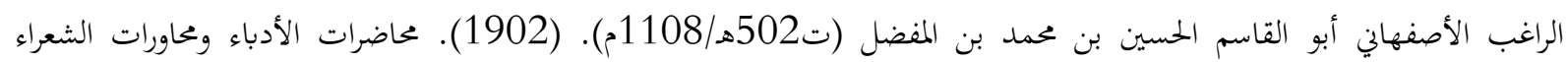

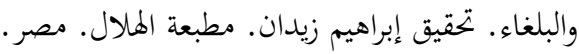

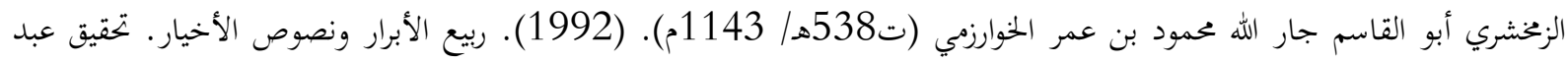

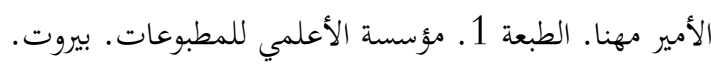

الصفدي صلاح الدين خليل بن أيبك (ت 764هـ 1363م). ( 1974). الوافي بالوفيات. تحقيق س. ديدرينغ،.فرانز شثاينر. فيسنبادن.

ياقوت الحموي أبو عبد الله ياقوت بن عبد الله الرومي (ت 626هـ/ 1228م). (1991). معجم الأدباء أو إرشاد الأريب إلى معرفة الأديب. الطبعة 1. دار الزهراء. دار الكتب العلمية بيروت.

ثانياً: المراجع

زكريا إبراهيم. أبو حيان التوحيدي. المؤسسة المصرية العامة. مطبعة مصر. القاهرة. معمود أبراهيم. (1974). كتاب أبو حيان التوحيدي في قضايا الإنسان. الطبعة 1، الدار المتحدة للنشر. بيروت. 
رامي أبو شهاب. (حزيران / 2008). الثقافة اليونانية وأثرها في الأدب العربي. مجلة الكلمة. العدد 18. عبد الرمن بدوي. (1967). دور العرب في تكوين الفكر الأوربي. الطبعة 2. القاهرة.

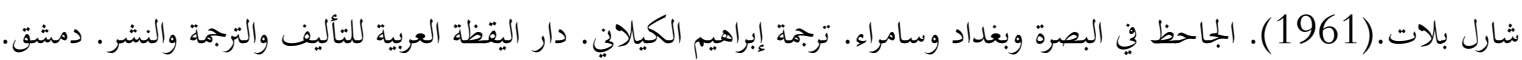

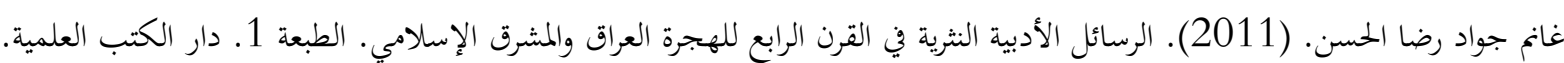

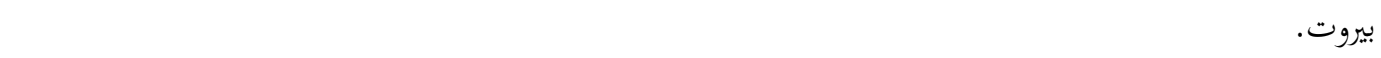

ماجدة حمود. صورة الآخر في التراث العربي صورة الآخر لدى أبي حيان التوحيدي. مجلة آفاق الحضارة الإسلامية. موقع الحوزة الإسلامي hawzah.net.

فدوى محمد سليمان الخوالدة. ثقافة الجاحظ الأدبية والنقدية واللغوية من كتاباته. رسالة ماجستير غير منشورة. جامعة آل البيت. كلية الآداب والعلوم الإنسانية. قسم اللغة العربية وآداهما. الأردن.

تركي بن الحسن الدهماني (2021). أخبار الجاحظ. الطبعة 1. أمواج للطباعة والنشر والتوزيع. عمان. الأنسان.

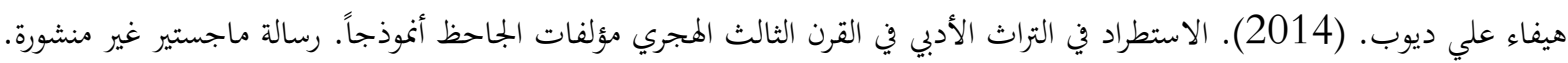
جامعة تشرين. كلية الآداب والعلوم الإنسانية. قسم اللغة العربية. اللاذقية.

عبد اللطيف الزكوي. (2017/1/22). الأدب الفلسفي. موقع جبهة النضال الشعبي الفلسطيني. أيمن فؤاد سيد.(1/ 7 / 1995). أبو حيان التوحيدي ومؤلفاته المخطوطة والمطبوعة. مجلة فصول. الهيئة المصرية العامة للكتابة. العدد 3.

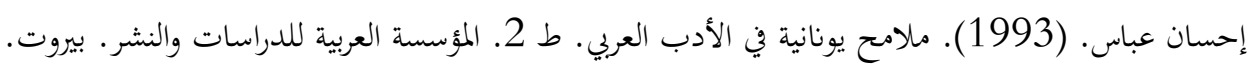
أحمد عبد المادي.(1997) . أبو حيان التوحيدي فيلسوف الأدباء وأديب الفلاسفة. دار الثقافة للنشر والتوزيع. القاهرة. مارون عبود.( 2012). أدب العرب. مؤسسة هنداوي للتعليم والثقافة. القاهرة. عبد القادر العربي. (2014). بلاغة الخطاب وإبلاغية التأويل في محاورات أبي حيان التوحيدي. حوليات الآداب واللغات جامعة المابلات المسيلة.

$$
\text { الجزائر. العدد } 344 .
$$

$$
\text { كامل محمد محمد عويظة. الجاحظ الأديب الفيلسوف. دار الكتب العلمية. بيروت. }
$$
بيار ماشيري. (2009). بم يفكر الأدب؟ تطبيقات في الفلسفة الأدبية. تربمة جوزيف شريم. ط 1 1. المنظمة العربية للترجمة. مركز دراسات

$$
\text { الوحدة الربية. بيروت. }
$$

آدم متز . (1957). الحضارة الإسلامية. ترجمة محمد عبد الهادي أبو ريدة. ط 3. مطبعة لجنة التأليف والترجمة والنشر. القاهرة.

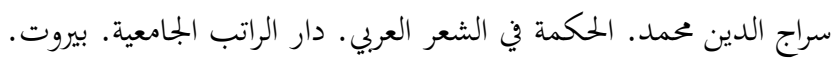

$$
\begin{aligned}
& \text { حسن نافعة وكليفورد بوزورث. (1989). تراث الإسلام، عالم المعرفة. الكويت. }
\end{aligned}
$$

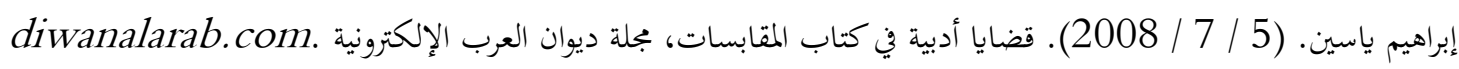




\title{
THE ROLE OF THE DIVAN CLERKS AND POLITICAL LETTERS IN THE DEVELOPMENT OF THE I. ABBASID PERIOD LITERATURE PROSE. AHMED BIN YOUSSEF'S ALHAMIS RESSALA AS AN EXAMPLE
}

\author{
Muhammet ABAZOĞLU ${ }^{1}$
}

\section{Istanbul / Türkiye \\ p. 543-556}

Received: $15 / 11 / 2021$

Accepted: 06/12/2021

Published: 01/01/2022

This article has been scanned I iThenticat No plagiarism detected

\begin{abstract}
:
Divan Scribe is a very old profession and it is said that it was one of the highest and most respected statures among worldly affairs, after the caliphate, when their positions in the state policy and judicial affairs are taken into account. Most of the time, the profession of the Divan Scribe was an important step to enter politics, as well as an important tool for reaching high positions such as Vizier. In general, Divan Scribes had a special role serving the Arab culture during the Abbasid period. Because the writing style of the Scribes had both lofty ideas and beautiful expression. As a matter of fact, as required by their statures, these people developed a dual-character expression that both emphasized the goals of the orders given from the administration and had the characteristics of Arabic rhetoric in the literal sense of the word. Their language was not a dry administrative language, on the contrary, it had brought together the requirements of the administrative language and the artistic beauties of the word. This study sheds light on the relations of the Divan Scribes with politics and the importance of this position during the Abbasid period. Again, in this study, the connection of the art of scribe with the vizier and the contributions of the scribes in service to the Arab-Islamic culture and especially in political thought are discussed despite the political crisis and troubles faced by the scribes.
\end{abstract}

Key words: Abbasid, Clerk, Divan, Ressala, Ahmed Bin Youssef.

http://dx.doi.org/10.47832/2717-8293.15.38

1 iD Dr. , Türkiye, m.abaz555@gmail.com, https://orcid.org/0000-0003-2153-3909 


\title{
BİRINNCİ ABBASİ DÖNEMİ EDEBİ NESR'İN GELIȘIMINNDE DİVAN KATİPLİĞİNINN VE SIYYASI RİSÂLELERİN ROLÜ: AHMED BİN YUSUF'UN HAMÎS RISÂAESİ ÖRNEĞİ
}

\begin{abstract}
ÖZET:
Divan kâtipliği gayet eski bir meslek olup kâtiplerin devlet politikasında ve yargı işlerinde edindikleri konumlar nazar-1 dikkate alındığında dünyalık issler arasında hilafet makamından sonra en yüksek ve saygın makamlardan biri olduğu söylenmiştir. Çoğu zaman kâtiplik mesleği siyasete girmek için önemli bir basamak olmasının yanında vezirlik gibi yüksek makamlara ulaşmak için de önemli bir araçtı. Genel olarak Abbasiler döneminde divan kâtiplerinin Arap kültürüne hizmette özel bir rolü vardı. Çünkü kâtiplerin yazım üslubu hem yüce fikirlere hem de güzel ifadelendirme özelliğine sahipti. Nitekim bu kişiler bulundukları makamın gerektirdiği üzere hem yönetim katından verilen emirlerin hedeflerini vurgulayan hem de kelimenin tam anlamiyla Arap retoriğinin özelliklerini taşıyan ve sanat yönü olan çift karaktere sahip bir ifade tarzı geliştirmişlerdi. Bu dil kuru yönetim dili olmayıp aksine yönetim dilinin gerekliliklerini ve sözün sanatsal güzelliklerini bir araya getirmiştir. Bu çalışma, Abbasiler döneminde kâtiplerin siyasetle olan ilisskilerini ve kâtiplik makamının önemini sunmaktadır. Yine bu çalışmada kâtiplik sanatının vezirlikle bağlantısı ve kâtiplerin karşılaştığ 1 siyasi kriz ve sıkıntılara rağmen Arap-İslam kültürüne hizmetteki katkıları ve özellikle de siyasi düşüncedeki katkıları ele alınmaktadır.
\end{abstract}

Anahtar Kelimeler: Abbasi, Kâtiplik, Divan, Risâle, Ahmed Bin Yusuf

\section{GİRIŞ̧}

İlk çağlardan günümüze kadar insanoğlu, etrafında ne olup bittiğine dair sürekli bir merak içerisinde olmuştur. İlk insanlar için iletişim ve haberleşme, hafıza ile sınırlıydı. Bilgiye sahip olmak ve onu korumak, haber vermek insan yaşamının vazgeçilmez gerçeğidir. İnsan hafızası tüm bilgiyi toplayacak ve koruyacak bir yapıda olmadığı için toplanan bilginin ve haberin kaydedilmesi zorunluluğu doğmuştur (Türk, 2019: 282). Abbasi dönemi boyunca süren yazışmalar aslında oldukça eski zamanlara dayanmakta olup milletler ve uygarlıklar kadar eskidir. Çünkü bu yazışmalar krallar ve diğer yöneticiler arasında bir tür iletişim ve karşı1ıklı anlaşma aracıydı. Ancak kaynaklarda geçtiği üzere başlangıçta şifahi olarak gerçekleşen iletişim; yazı araç ve gereçlerinin gelişme göstermesi, yazma ve okumayı öğrenenlerin çoğalmasıyla birlikte yazışma yoluyla nakle dönüşmüştür.

Konuşma becerisi diğer beceriler (okuma, dinleme, yazma) ile birlikte geliştirilmelidir. Konuşma, zamanla diğer beceriler (okuma, yazma, dinleme) ile gelişir (Türk, 2017: 787).

Daha sonraları da birbiri ardınca ortaya çıkan uluslar ve devletlerle birlikte yazışmalardaki yöntemler gelişme gösterirken divanlar da devlet idaresindeki önemli daireler arasından özel bir daire olarak ortaya çıkmıştır. Nitekim kâtipler ve yazışmalar için özel bir kurul ve meclis ihdas edilmiş olup saygınlık bakımından da krallar ve diğer yöneticiler ile birlikte anılır olmuşlardır. Böylece devletlerin iç ve dış ilişkilerini yürütmede kendi stratejilerini, isteklerini ve siyasetlerini dile getirebilecekleri bir iletişim sistemi kurmaları kaçınılmaz olmuştur (Beyyûd, Hüseyin, 1996, s. 13). İslam'ın yayılması ve İslam devletinin genişlemesiyle birlikte divanlar/kurullar çoğaldığı gibi yeni devletin işlerinin yürütülebilmesi için de gerekli olan uzmanlık ve görev alanlarındaki çeşitlilik artmıştır. Nihayetinde de divanlar ve bu divanlarda görev alan kişilere yetkiler verilmiş, bunlara özgü kanunlar çıkarılmış ve düzenlemeler yapılmıştır. Yapılan bu düzenlemelere Divaniye (Düzenlemeleri) terimini kullanabiliriz. İlim ehli yazı sanatkârlarında bulunması gereken özellikleri, ya da ifade araç ve gereçlerini açıklamışlardır. Abdulhamid el-Katib’in risalesi de kâtiplik kültürü alaninda derlenen ilk risaledir (el-Cehşeyârî, 1938, s. 74-79) (İbn Haldun, 2004, s. 1/431) (el-Kalkaşendî, Ty, s. 1/91).

Yazışma işi devlet sınırlarının genişlemesi, valiler ve memurların çoğalmasıyla ortaya çıkmıştır. O zamanlar devlet, çeşitli bölgelerdeki mevki ve makam sahibi valilere ve diğer memurlara devletin siyaseti ve yönetimiyle ilgili işlemleri iletme ihtiyacı duymuş ve mektuplar da bu işi için en uygun araç olmuştur. Sonuçta mektuplaşmaya/yazışmaya özgü bir divan kurulmuş, divan başkanına da makamı itibarıla günümüzdeki bakanlık 
makamına denk bir mevki tahsis edilmiştir. Bunlara ek olarak bu divanın memurları ve astları bulunmaktaydı ve her biri de divandaki konumunun kapsamına göre çalışmaktaydı (Ferrûh, Ömer, 1981, s. 1/374).

$\mathrm{Bu}$ makamın önemine uygun olarak orada çalışan kişinin de nitelikli ve bilgi birikimi açısından yüksek kapasitede olması gerekiyor. İbni Esir gramerci, hukukçu veya kelamcılardan farklı olarak kâtibin bütün ilimlerle alakadar olması gerektiğine dikkat çekmektedir. Buna göre kâtipler Arapçaya, dilbilimine, Arap atasözlerine, Arap tarihine ve yine devlet başkanlığında, emirlikte, hisbe ve benzeri teşekküllerde yer alabilmek için gerekli olan mülki idare bilgisine sahip olmalıdır. Ayrıca Kur'an ve hadis ezberine aşina olması gerektiğini belirttikten sonra sözü şöylece bağlamaktadır: "Toplu olarak söylemek gerekirse bu sanata teşebbüs eden kişi bütün sanat dallarını bilmeye ihtiyaç duyar. Öyle ki kadınların arasında ağıt yakan kadının, gelinin duvağını yapan kadın berberinin ve pazarda mal yığınının başında tellallık yapan adamın bile ne dediğini bilmelidir (İbnu'l-Esîr D. e.-F., Ty, s. 1/4-6).

Öyleyse kâtiplik makamına ulaşmak pek kolay olmayıp kişinin ansiklopedik bilgisi ve belge bilgisinin de olması, bilgilerinin çok yönlü olması ve hayli kültürlü olması gerekir. Bazen kâtip inceden inceye bir sınavdan geçirilir. Bu sınav üzerinden edebi ve fikri birikimi neyse ortaya çıkar. İşte bu noktada I. Abbasi döneminde kâtipte olması beklenilen geniş kültür, sağduyu, ince zevklilik, yumuşaklık, sabır, zekâ, işleri yürütme, hazır cevaplık, muhataplıkta zarafet, kalpleri ve kulakları cezp ederek devlet ricalinin gönlünü kazanan ve onların akıl düzeylerine baskın gelen konuşmadaki retorik ölçülerine dair birçok delil ve yazılı belge bulunmaktadır (Dayf, 1966, s. 485).

Buradaki büyük önem eski bilginler tarafından fark edilmiş ve bu makamı güzel bir şekilde nitelemişlerdir. Nitekim kâtiplik sanatı ile devlet işlerini kuvvetli bir bağ bulunmaktadır. Çünkü kâtiplerin divanında üye olarak bulunan ve yazışmalardaki kompozisyonu ayarlayan bir kişinin kralların yanındaki konumu her zaman yüksek ve itibarı da yüce olmuştur. Nitekim krallar bu kişilere sırlarını açmışlar, onlar da bu sırları saklamışlar ve erkânı arasında en yetkililerin bile bilmediklerine vakıf olmuşlardır. Buna göre sultanın yanında kâtipten daha seçkin birisi bulunmamaktadır. Zira kâtip, sultanın yanına ilk girip son çıkan kişi olup aynı zamanda sultanın kendisiyle fikir alış verişinde bulunduğu gibi sultanın sırdaşı da olmuştur (el-Kalkaşendî, Ty, s. 1/101).

İbni Abdi Rabbih de daha önceleri önemsiz olan ve kâtiplik sayesinde yükselen ve isimleri duyulan kişileri şöyle saymaktadır: "Çağımızda onlardan bazıları: Yakub b. Davud, Yahya b. Halid el-Bermeki, İbnu'l-Mukaffa', el-Fadl b. Sehl ve onun kardeşi Hasan, Ahmed b. Yusuf, Muhammed b. Abdulmelik ez-Zeyyat ve benzerleri" diyerek dile getirmiştir (İbnu Abdi Rabbih, 1983, s. 4/282).

\section{Abbasiler Dönemi Edebi Risale Çeşitleri}

Sanatsal özelliğe sahip risalelerde bütün çeşitleri bakımından gayet açık bir ilerleme gözlemlenmiştir. Bu alandaki düzyazı sanatı içerik ve üslupta aynı düzeyde gelişme göstermiş, içerik ve yönelimdeki çeşitlilikte örnek gösterilir olmuştur. Abbasi toplumunun gelişimi bu sanatın ortaya çıkmasına yardımcı olmuştur. Şüphesiz aynı toplum içerisinde çeşitli edebi, sosyal ve siyasi konulara katılan çok sayıda yazarın bulunması da bunun kanıtıdır. İbnu'l-Mukaffa', Sehl b. Harun, Abdulhamid el-Katib, Amr b. Mes'-ade ve benzerleri gibi yazarlar bu gelişime örnek olarak gösterilebilir. Böylece Abbasi dönemi risaleleri büyük ilerleme kaydederek Abbasi nesir sanatının en önemli eserleri arasında yer almıştır. Bu çalışmada da edebi risaleler ve dostluk (ihvâni) risalelerinin kısa bir tanitımindan sonra siyasi risaleler konusu ve özellikle de Me'mun'un veziri Ahmed b. Yusuf'un "Risaletü'l-Hamîs"i (Perşembe Yazıları) ele alınıp değerlendirilecektir.

Abbasi döneminde çok çeşitli gerekçelerle çeşitli risaleler yazılmış ve zamanla gelişme göstererek kadim Arap şiirinin dile getirdiği birçok konuya da girilmiştir. Bu da bu alandaki ifade yollarının çeşitliliğine işaret etmektedir. Bu alan ise şiirin ve risale yazma sanatının da ötesinde arı duru bir edebiyat alanını kapsamakta ve kendince önemli konuları dile getirmektedir. Bu gelişmenin sonucu olarak düzyazı sanatı ortaya çıkmıştır. Edebi risale yazarları da bu gelişime uygun olarak yenilemeye yönelmişler, daha önceki geleneksel risale formu dışına çıkarak yeni üsluplar geliştirmişlerdir. Dolayısıyla dostluk ve divan risaleleri de hem şekil hem de içerik bakımlarından geleneksel formunun dışına çıkarılmıştır. Bu risale türlerine bakıldığında; hem divan ve hem de dostluk risaleleri içerisinde edebi nitelik, 
düzyazı sanatkarlığı, yazı ve hitabet özelliklerini taşıdığından dolayı edebi risale grubuna girdikleri görülmektedir (Zeydân, Ty, s. 2/268).

\section{Dostluk Risaleleri:}

$\mathrm{Bu}$ risale türü kişilerin duygu ve düşüncelerini, arzularını ve korkularını arz eden risalelerdir. Bunlar övgü, sitem, özür, acındırma, kutlama, ağıt ve taziye içerikli olabilmektedir. Bu konular önceleri şiir yoluyla dile getirilirken Abbasi döneminde şiirsel bir nesir tarzıyla dile getirilir olmuştur. Bunun sebebi de düzyazıda seçkin bir yazar tabakasının ortaya çıkmasıdır. Bu yazar tabakası gayet güzel yazmakta ve geniş bir kültürden yararlanmakta idiler. Buradan itibaren geniş bir kitle tarafından temsil edilen medeni bir model haline gelmişlerdir. Böylece söz ya da konuşma, Arapların geçmişte sahip olduğu kabalık ve göçebelik görüntülerinin aksine olarak başkalarına hitap ederken sahibinin medeni imajını yansıtan daha dikkatli ve hassas bir düzeye ulaşmıștır (Dayf, 1966, s. 491).

\section{Siyasi Risaleler:}

Bunlar divan risaleleri olarak da bilinmektedir. Çünkü bu risaleler yöneticiler, valiler ve emirlerin divanlarından çıkmaktadır. Araplar bu risale türünü İslam'ın ilk döneminden beri bilmektedirler. Hatta Kalkaşendi, bu risale türünün ilk olarak Peygamber (sav) döneminde ortaya çıktığı görüşünü belirtirken şöyle demektedir: "Bil ki bu divan İslam döneminde tesis edilen ilk divandır. Nitekim Peygamber (sav) emirleriyle, ileri bölük komutanlarıyla karşılıklı olarak yazışmaktaydı. Yine yakın bölgedeki toprakların krallarıyla da yazışarak onları İslam'a davet etmekte ve elçileriyle bu krallara yazılı mesajlar göndermekteydi” (el-Kalkaşendî, Ty, s. 1/91). Aynı şekilde Peygamber (sav) Müslümanları okuma ve yazmayı öğrenmeye teşvik etmiş hatta yazıyı her bir fert için zorunlu görmüştür. $\mathrm{Bu}$ durumun en belirgin dinamiği ve bütün bölgelerde yaygınlık kazanmasının gerekçesi de bir devletin ilişkilerini, iç ve dış bağlantılarını anlatmasının ancak yazışmalar yoluyla mümkün olmasıydı. İsste böylece Peygamberin İslam devletini kurması, bir yazışma sisteminin de kurulmasinı gerekli kılmaktaydı (Nassâr, 2002, s. 38).

Divan risalelerinin içeriğine baktığımızda devletin idari, siyasi ve mali işlerini konu edinmesinin yanında anlaşmalara, geleneklere, hilafetin intikali, fetihler, biat etmeye çağrı, cihada teşvik gibi resmi ve idari yönü olan konuları da içerdiği görülür. Yazışma divanları zamanın ilerlemesi, İslam devletinin alanının genişlemesi ve siyasi olayların yeni boyutlar kazanmasıyla birlikte günümüzdeki resmi devlet dairelerindekine benzer resmi bir karakter kazanmıştır. Daha sonra da Emeviler döneminde Muaviye zamanında örgütlü görüntüsüyle ortaya çıkmıştır. Akabinde de bu risaleler Abbasilerin ilk dönemindeki büyük siyasi dönüşümün ve eş zamanlı siyasi olayların sonucunda benzersiz bir gelişme göstermiştir (Dayf, el-Fennu ve Mezâhibuhû fi'n-Nesrił-Arabî, Ty, s. 99).

\section{Devlet Yönetiminde Risalelerin Rolü ve Divan Risalelerinin Konuları}

Abbasiler dönemindeki siyasi çekişmeler boyutundan olaya baktığımızda risalelerin dahili ve harici olaylarda bariz bir rol oynadığını görürüz. Risalelerin gelişme göstermesinde siyasi gelişmelerin de etkisi olmaktaydi. Zira bu siyasi gelişmelerle birlikte devlet düzeni de gelişme göstermekte ve bu durum da risaleleri fikri-akli yönden ve diğer kültürlerle ilgili açılımlar bakımından şekillendirmekteydi. Yazılma amacı propaganda olan yüzlerce mektubun/risalenin eşlik ettiği bu olaylar arasından en öne çıkanı da Abbasi ayaklanmasıydı. Bundan sonra da Mansur'a amcası Abdullah b. Ali'nin ve Ebu Müslim elHorasani'nin başkaldırması, Muhammed en-Nefsu'z-Zekiyye ile kardeşi İbrahim'in darbe girişiminde bulunmaları ve veliahtlık konusundaki anlaşmazlık gelmektedir. Yine bu dönemde siyasi sahnede cereyan eden Emin ve Me'mun arasındaki büyük fitne, diğer ayaklanmalarla birlikte Babek ve Maziyyar ayaklanmaları da bu olaylar arasındadır (Dayf, 1966, s. 11); (et-Taberî, Ty, s. 1834); (Çelik, 2006, s. 95-106); (Bozan, 2014, s. 73-93).

Gerçekten de risaleler, kendi zamanındaki toplumun gerçeklerini yansıtmasının yanında yaşam şartlarıyla olan bağlantısı ve büyük bir tarihi değere sahip olması sebebiyle islam tarihi konuları arasında önemli bir yer tutmaktadır. Diğer taraftan bakıldığında birinci Abbasi döneminde divan risalelerinin altta verilen konular çerçevesinde ele alındığı görülür. 


\section{Abbasi Davas1 ya da Devrimi:}

Abbasi davası risalelerin sunduğu konular arasındadır. İbrahim el-İmam ve devrim propagandaciları arasında cereyan eden bu risaleler emirleri iletmek, taraftarları harekete geçirmek ve propaganda çalışmalarına dair açıklamalar yapmada önemli bir araçtı (etTaberî, Ty, s. 1444). İbrahim İmam'ın isteğiyle yazılan ve Ebu Müslim’in Horasandaki propagandayı yürüttüğünü kendi taraftarlarına haber veren şu risale de bunlardan biridir:

$$
\text { (إني قد أمرته بأمري، فاسمعو ا منه و اقبلو ا قوله، فإني قد أمرنه على خر اسان وما غلب عليه بعد ذلك) }
$$

"Ben işimin yürütülmesini ona buyurdum. Onu dinleyin ve sözünü yerine getirin. Ben Horasan'a onu memur kıldım. Bundan sonra kimse onun önüne geçemez" (Safvet, 1938, s. 2/476). Bu mektup Abbasi devriminin ilk aşamaları olduğu için ve o koşullara uygun olarak yazılmıştır. O dönemin tehlikeli olmasından dolayı mektupta da içerik bakımından gizlilik, dikkatli olma ve şüphe arz etmektedir ki, gözetilen amacı açıklaması ve yerine getirmesi o zaman bunu gerektiriyordu.

\section{Siyasi İç Çekişmeler:}

Siyasi risale konusunda elimize en çok ulaşan risaleler iç siyasi çekişmelerle ilgilidir. $\mathrm{Bu}$ çekişmeler en çok da Abbasilerle şu güçler arasındadır: Abbasi devriminin kendi önderleri ve propagandacıları, Ali evladından olanlar ve taraftarları, hariciler, ayaklanma ve fitne çıkarma taraftarları (Dayf, 1966, s. 26).

$\mathrm{Bu}$ konuda çok çeşitli risaleler vardır. Bunlardan Mansur ile Ebu Müslim el-Horasani arasında geçen Abdullah b. Ali konulu risalelerdir. Mansur, halifelik konusunda rakibi ve kendisinin amcası olan Abdullah b. Ali'nin üzerine yürümesi için Ebu Müslim El-Horasani'yi yönlendirdiğinde aralarında karşıllklı pek çok yazışma olmuştur. Mansur her ikisini de rakip ve güçlü figürler olarak gördüğü için hangisinin diğerini yeneceğini de umursamamaktadır. Ebu Müslim galip geldiğinde, Mansur onu öldürme emri vermişti. Bu yüzden onu bir komplonun içine çekmiş ve kısa süre sonra da onu öldürerek ondan kurtulmuştur. İşte bütün bu olanlar, aralarında gerçekleşen çeşitli yazışmaların akabinde olmuştur (Safvet, 1938, s. 3/26-30).

Yine risalelerin bu türünden olarak Mansur ile Abbasi tahtında hak iddia eden ve devlete başkaldıran Muhammed b. Abdullah (en-Nefsu'z-Zekiye) arasındaki yazışmalar da bulunmaktadır. Zira Muhammed b. Abdullah, Abbasilerin tahtı kendilerinden çaldığını ve aslında kendilerinin tahta daha layık olduğunu, kendileri olmasa devletin de olamayacağını, özellikle de bu anlamda Haşimoğullarının önde gelenlerinin kendileri olduğunu ileri sürmekteydi (et-Taberî, Ty, s. 1525). Nihayet Muhammed b. Abdullah başkaldırmış ve Mansur'un gazabına uğramamak için kaçarak gözden kaybolmaya ve güvenli bir sığınak aramaya koyulmuştu. Öte yandan da Mansur, onun nerede olduğunu araştırmakta ve aralarındaki yazışmalar aracılığıla ne yapacağını anlamaya çalışmaktaydı. Gerçekten de Mansur, istediği bilgiyi elde etmiş ve onun hali hazırda gerçekleştirmeyi planladığ başkaldırının zamanını öğrenmişti (Azimli, 2008, s. 55-74).

Mansur ve Muhammed b. Abdullah arasındaki yazışmaların, yazışma örneklerinin en güzellerinden olduğu söylenmektedir. Bu yazışmalar sadece retorik yönüyle değil aynı zamanda halifelikte hak iddia eden her iki kişinin de iddialarını ispat etmek için getirdikleri delilleri içermesi ve iddialarını delillendirme yöntemi bakımından da oldukça güzeldir. Mansur, başlattığı yazışmaları konuya delalet yönü kuvvetli olan Kur'an ayetleriyle desteklemiş ve akabinde de hem Muhammed'e hem de onun taraftarlarına güvence vermiş, kendisine bolca mal mülk vaat etmiş ve hapiste tutulan taraftarlarını salıvereceğini şu ifadelerle dile getirmiştir:

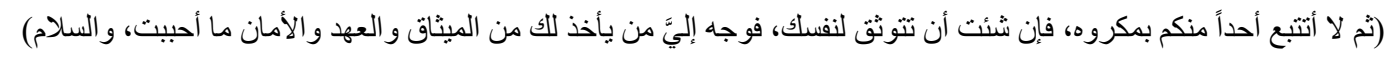

"Şu halde ben, rezil bir şekilde hiçbirinizin peşine düşmem. Kendinizi güvende hissetmek istiyorsanız sizin adınıza güvence alması için güvendiğiniz birisini bana yönlendiriniz. Selametle!" (el-Muberrid, 1997, s. 3/1488).

Muhammed de Mansur'un mektubuna Kasas suresinden bazı ayetlerle cevap vermiş, kendi dayanaklarını ve Abbasilerin hilafeti gasp yöntemini şu ifadelerle dile getirmiştir:

$$
\begin{aligned}
& \text { (و وأنا أعرض عليك من الأمان مثل الذي أعطينتي، وقد تعلم أن الحق حقنا، و إنكم إنما طلبتموه بنا، ونهضنتم فيه بشيعتنا، وأن أبانا علياً كان }
\end{aligned}
$$

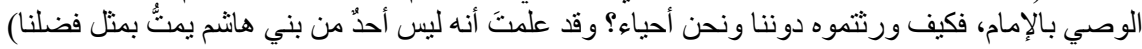

"Ben de sana, bana verdiğin gibi bir güvence sunuyorum. Hakkın bizim hakkımız olduğunu, aslında bizim sizden değil de sizin bizden bu konuda talebiniz olabileceğini ve de 
halifeliğe ancak bizim taraftarlarımızın yardımıyla geçebildiğinizi bilmektesiniz. Babamız Ali, imamın naibiydi. Pekala biz henüz hayattayken ancak biz olmaksızın ona nasıl mirasçı oldunuz? Haşimoğulları arasında sizinle akrabalığı bizimki gibi değerli olan hiç kimse yoktur..." (el-Muberrid, 1997, s. 3/1488).

Sonuçta bu yazılı münazaraların hiçbiri de yarar sağlamamıştır. Zira Mansur, kardeşinin oğlu ve veliahdı olan İsa b. Musa'yı en-Nefsu'z-Zekiyye'ye göndermiş, İsa da ona galip gelmiş ve onu öldürmüştür (İbnu'l-Esîr M. e.-Ş., 1987, s. 5/156).

\section{Diş Siyaset:}

Bir devletin diş politikasında olması gereken dış siyasete dair temel dinamikleri bu konu içerisinde görmek mümkündür. Söz konusu döneme ilişkin olarak Abbasi halifeleri ile Bizans kralları arasında yapılan bazı yazışmalarda da bunun en iyi örneğidir. Doğal olarak bu mektuplar iki devlet arasındaki ilişkileri düzenleyen yazışmaları içerdiği gibi taraflar arasında meydana gelen savaşları ve anlaşmaları içermektedir. Yine bunlara bağlı olarak İslam'a davetin iletimini yoksa da cizye ödenmesinin kabul edilmesi de bu alana dahildir (İbnu'l-Esîr M. e.-Ş., 1987, s. 5/327-333).

Bizans imparatoriçesi İrini ile Müslümanlar arasında yapılan anlaşmayı, imparatoriçeyi tahtından indirdikten sonra bozan imparator Nikeforos ve Harun Reşid arasındaki yazışmalar da bu türdendir (el-Cehşeyârî, 1938, s. 207). Harun Reşid, Nikeforos'un yazısına şöyle cevap vermektedir:

(بسم الله الرحمن الرحيم. من هارون أمير المؤمنين إلى نققور كلب الروم، قد قرأت كتابك يا ابن الكافرة، والجواب ما تراه دون أن تسمعه،

و والسلام)

“Rahman ve Rahim Allah'ın adıyla! Müminlerin emiri Harun'dan Bizans köpeği Nikeforos'a! Mektubunu okudum ey kâfirin oğlu! Cevabı ise duyduğun değil de görmüş olduğun gibidir! Selam!" (İbnu'l-Esîr M. e.-Ş., 1987, s. 5/333).

Mektuplardaki bu tarz, Me'mun'dan hediye talebinde bulunan Bizans kralı Theophilius ile Me'mun arasında yazılan mektuplarda da vardır. ${ }^{2}$ Mu'tasım'in Bizansla yaptığı yazışmalarında da aynı tarz görülmektedir. Bu mektuplar arasında, 223 h. yılında yapılan Mu'tasım'ın komuta ettiği ve Müslümanların kazandığı unutulmaz Amorion Savaşı sırasında yazılan mektuplar da vardır (et-Taberî, Ty, s. 1852). Bu yazışmada Mu'tasım tehdit ve cezalandırma üslubuna başvururken şu cevabın yazılmasını buyurmuştur:

$$
\text { (بسم الله الرحمن الرحيم، أما بعد، فقد قرأت كتابك، وفهمت خطابك، و الجو اب ما ترى لا ما تسمع، وسيعلم الكفار لمن عقبى الدار ). }
$$

"Rahman ve Rahim Allah'ın adıyla! Yazını okudum ve demek istediğini anladım! Cevabı ise duyduğun değil de görmüş olduğun gibidir! Kafirler cehennemi kimin boylayacağını görecekler!" (Safvet, 1938, s. 4/11).

Abbasi Devleti'nin hariciye yazışmalarında sert bir dilin, kuvvetli kararlılığın, düşmanı hakir görmenin ve durumlarını küçümsemenin, tehdit ve cezalandırma üslubunun ön plana çıktığını söylemek mümkündür.

\section{İdari Ve Siyasi Meseleler:}

$\mathrm{Bu}$ dönemde risalelerin ele aldığ konular pek çeşitli olmuştur. Valilerin görevlendirilmeleri, görevden alınmaları, eyalet haberleri, eyaletlerdeki durumlar, fetihler, biatlerin kabulü, güvence verilmesi, yönlendirmeler, haber iletimi için yazılan yazılar gibidir. Ayrıca devlet işlerinin yerine getirilmesi ve devlet yönetiminin düzene konulmasına ilişkin konuları da kapsar. Bütün bu işlerin her biriyle görevli kişiler olup tıpkı günümüzde olduğu gibi bağlı oldukları kurumlar/divanlar bulunmaktaydı (Dayf, 1966, s. 22).

$\mathrm{Bu}$ işlere dair bir olay olarak, Mansur'a ulaşan habere göre Hadramevt valisi çokça ava çıkmakta olunca valiye kendisini görevden aldığını haber veren şu iletiyi yazar:

$$
\begin{aligned}
& \text { ما كاك تكلتك أمك، وعدمتاك عشيرتك، ما هذه العُدة التي أعددتها للنكاية بالوحش؟ إنا إنما استكفيناك أمور المسلمين، ولم نستكفك أمور الوحش، }
\end{aligned}
$$

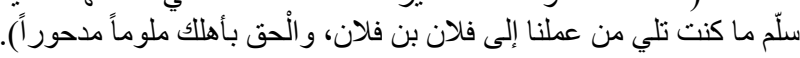

"Ölüm seni anandan ayırsın! Aşiretin seni yitirsin! Vahşi hayvanlara kıymak için yaptığın bu kadar hazırlık da neyin nesi? Biz, Müslümanların işiyle uğraşmanın sana yeterince meşguliyet çıkaracağını düşünürken vahşi hayvanları hesaba katmamıştık. Sana emanet ettiğimiz görevi falan oğlu filana teslim edesin! Sizin gibilere yerilmek ve kovulmak yaraşır!" (Safvet, 1938, s. 3/125).

\footnotetext{
${ }^{2}$ Safvet, Cemheretu Resâili'l-Arab, c. 3, s. 446.
} 
Mektuplardaki bu tarzı Abbasi halifelerinin bir kısmında da görmek mümkündür. Bunların bazılarında halifenin devlet idaresindeki katılı̆̆ını, yetki verilenlerden hesap sorulduğunu, halkın işlerinin ihmal edilmemesini, kararlı siyasete dönmek suretiyle idari yolsuzluğa karşı devlet ve yargı erkanının desteklendiğini görmekteyiz.

\section{Mektuplardaki Kurgu:}

Arap eleştirmenler ve belagatçılar yazışma sanatına çok önem vermişlerdir. Yazının hattına, yazıldığı kaleme, mürekkebe, yazının güzelliğine ve şekline ne kadar önem veriyorlarsa söylemin kolaylığı ve mananın uyumu arasındaki bağlantıya da o kadar önem vermişlerdir. Nitekim siyaset ve divan mecralarından çıkan risalelerde de en fazla özeni göstermişlerdir. "Çünkü bu mektuplar yüksek düzeyli muhataplıklarda, büyük işlerde, kamu politikasında, dünya ve dinin düzeninde etkili olan mektuplardır" (el-Kâtib, 2003, s. 342).

Mektupların kurgusuna baktığımızda üç ana biçiminin olduğunu görürüz. Bunlar: Giriş, ana konu ve sonuç bölümleridir.

\section{Giriş:}

İlk paragraf ya da başlangıç olarak da bilinir. Mesajın ne niyetle yazıldığını gösterir ve ana konusuyla bağlantılıdır (el-Kâtib, 2003, s. 38). Çünkü İbni Esir'in de dediği gibi "Konuşmanın kulağa ilk ulaşan kısmıdır. Eğer başlangıç, kendisinden sonra gelen anlama uygunsa artık onu dinlemek için yeterli sebepler vardır" (İbnu'l-Esîr D. e.-F., Ty, s. 2/224).

Giriş bölümünün bazı önemli öğeleri:

-Besmele: Allah'ın adını yüceltme ve bereketini ummak için mektuba besmele ile başlanır (el-Cehşeyârî, 1938, s. 6/222).

-Başl1k: Mektubun başında gönderen ve alıcının adı anılır. Burada asıl olan ise önce gönderenin sonra da alıcının adının yapmacıklık olmaksızın anılmasıdır (el-Kâtib, 2003, s. 330); (el-Kalkaşendî, Ty, s. 6/231). Ancak Abbasilerin ilk döneminde kâtipler, mektubu yazan iki taraftan hangisi daha üstün ise onu önce yazmaya önem vermisslerdir. Mektubu gönderen fazilet olarak daha sonra gelse bile bu böyledir. Mansur ile veliahdı olan kardeşinin oğlu İsa b. Musa arasındaki yazışmalarda da durum böyledir:

$$
\text { (بسم الله الرحمن الرحيم، لعبدالله أمير المؤمنين من عيسى بن موسى، سلام عليك با أمير المؤمنين ورحمة الله). }
$$

“Rahman ve Rahim Allah'in adiyla! Allah'ın kulu ve müminlerin emirine! İsa b. Musa'dan, ey müminlerin emiri! Allah'in selamı ve rahmeti üzerine olsun!" (Safvet, 1938, s. 3/92).

-Dua ve selam: Mektubun içeriğine işaret etmesi daha uygun görülür. İçeriğe temas ise başliktan sonra ve selamlamadan önce ara cümle olarak veya iki cümleden ibaret olarak gelir (el-Kâtib, 2003, s. 334). Selamlamaya gelince; söze onunla başlanır. Mektuplarda "esselamu aleyküm, selamun aleyküm, selamun aleyk" ifadeleriyle geçmektedir. Bazen seslenilen kişi selamdan sonra anılır. Bu da "Selam aleyk ey müminlerin emiri" örneğinde olduğu gibidir (Safvet, 1938, s. 3/92).

-Hamdele: Mektuplara Allah'a hamd ederek başlamak da güzel görülmüştür. Hamd ifadesi normalde "emmâ ba 'd" (imdi) ifadesinden önce gelmekle beraber bazen de hemen sonrasında gelebilmektedir (el-Kalkaşendî, Ty, s. 6/224). Emin'in öldürülmesinden sonra Tahir b. el-Hüseyin'in Me'mun'a yazdığ1 mektupta da bunu görmekteyiz:

(أما بعد، فالحمد لله المنعال ذي العزة والجلال والملك والسلطان، الذي إذا أراد أمراً فإنما يقول له كن فيكون، لا إله إلا هو الرحمن الرحيم).

"Emmâ ba'd! Hamd hükümranlık, mülk, celal ve izzet sahibi olan yüceler yücesi Allah'adır. O ki olmasını istediği şeye "ol" der ve olur! Rahman ve Rahim olandan başka tanr1 yoktur!" (Safvet, 1938, s. 3/308).

-Peygambere Salat: En tercih edilen uygulama, besmeleden sonra gelmesidir. Peygambere adıyla bereketli ve uğurlu olması ümit edildiğinden dolayı Peygambere salatın özel bir yeri vardır. Ancak şu da var ki Abbasilerin ilk döneminden önce nadiren de olsa divandan çıkan mektupların doğrudan Peygambere salat ile çıkarıldığı da olmaktaydı (elKâtib, 2003, s. 329). Kaynaklar, yazışmalarda Peygambere salatı uygulama geleneğine yerleştiren ilk kişinin Harun Reşid olduğu konusunda neredeyse fikir birliği içerisindedir (elCehşeyârî, 1938, s. 177); (es-Sûlî, 1922, s. 40). 
-Geçiştirme: Yani giriş kısmı atlanarak doğrudan konuya girilmesidir. Araplar bu davranışı kolaylaştırmak için hutbe ve yazışmalarda (أما بعد) "emmâ ba'd" ifadesini kullanmaktadırlar. Bunun anlamı "her neyse"dir ve kalıtsal bir ifade olarak giriş ile sözü edilen amaç arasındaki söylemi ayırma konumunda söylenmektedir. Elhamdu lillah ve duadan sonra geldiği gibi "falan oğlu filandan falan kimseye" ifadesinden sonra da gelebilmektedir (es-Sûlî, 1922, s. 337); (el-Kalkaşendî, Ty, s. 6/231).

Dile getirdiğimiz bu örnekler, giriş bölümünün kurgusunu bizlere sunmaktadır. Ancak kâtipler, giriş bölümündeki bu kurgunun tamamına veya bir kısmına riayet etmeyebilmektedirler. Bazen de öğeleri atlamakta ya da öğelerden birini öncelemekte veya sonraya bırakmaktadırlar. Yahut giriş bölümü olmaksızın doğrudan konuya girebilmekte ya da kâtipler mektuplara Kur'an ayetleriyle yahut da şiirden bir beyitle başlayabilmektedirler.

\section{Sunum veya Ana Konu:}

Burası kendisi dolayısıyla mektubun yazıldığı ya da kurgulandığı bölümdür. Eleştirmenler bu bölümde hem anlamsal çerçevenin çizilmesinin zorluğuna ve hem de içerikteki konuların sınırlandırılmasındaki zorluğa dikkat çekmektedirler. Zira İbni Halef elKatib'in de dediği gibi "anlamlar amaçlananın dışına doğru yaygınlaştırılabileceği gibi sonsuz olarak da uzayabilmektedir”. Bu bölümde risalenin amac1, konu bütünlügünden ortaya çıkan kasıt, mantıksal düzen, içeriği doğru kullanma sanatı, alıntı yapma ve kullanılan delillerle birlikte kâtibin delil getirme ve gerekçelendirme yeteneği, kültürel düzeyi ve sözün manaya uygunluk sunması ön plana çıkmaktadır. Buna göre her bir risalenin içeriği konu ve risalenin kimin tarafından gönderildiği bakımından diğer risalelere göre farkll11k arz etse de bir makamdan belli bir amaç için yazılan risalenin ihtişamlı olması, konusunun bölümlendirilmesi ve konu bütünlüğüne dikkat noktasında kâtipler oldukça hırslı davranmışlardır (el-Kâtib, 2003, s. 80).

Bir başka bakımdan da bu bölüm giriș ve sonuç bölümleri arasında yer aldığı için risalenin en önemli bölümüdür. Çünkü bu bölümde katip düşüncelerini serdetmeye ve açmaya koyulur. Bunun yanında söz içerisinde detaylandırma ve çeşitli sanatsal üslupları kullanmadaki becerisini ortaya koyar.

\section{Sonuç:}

Risaleleri sonlandırma ve sanatla süsleme noktasında katiplerin üslubu oldukça çeşitlidir. Çünkü risalenin bu bölümü kulaklarda en son kalan bölümü olduğu için risalenin diğer bölümlerinden farklı olarak zihinlerdeki kalıcılığı da daha farklı olabilmektedir. Kâtiplerin prensipleri arasında risalenin duaya eşlik eden bir selamla sonlandırılması bulunmaktadır. Bazen de sözü sonlandırma Kur'an ayetleriyle, hamdeleyle ve sonrasında da Peygambere salat ile veya risalenin konusuyla uyumlu çeşitli şiirlerden beyitlerle olabilmektedir (el-Kalkaşendî, Ty, s. 6/232 ve 267).

İşte risalelerin genel hatlarıla temel kurgusu bu şekildedir.

\section{Ahmed b. Yusuf ve el-Hamîs Risalesi}

Abbasiler dönemi, ulaştığı yüksek düzey bakımından düzyazı sanatının altın çağ1 kabul edilmektedir. Bu dönemin bayraktarlığını yapan kişileri ele alan çok çeşitli araştırma ve çalışmalar bulunmaktadır. Bu araştırma ve çalışmalarda ele alanın edebi düzyazı, bilimsel düzyazı, felsefi düzyazı ve tarihi düzyazı alanları olduğu göze çarpmaktadır. Zira İbnu'l-Mukaffa, Sehl b. Harun, el-Cahız ve daha birçok isim bu alanda oldukça başarılı görülen isimlerdir (Dayf, Ty, s. 121); (Aytaç, 1991, s. 1-14). Ufkun karanlık tarafında kalıp da görünmeyen düzyazı bayraktarları da ismi anılan kişilerden pek de geride kalmamaktadırlar. Bunlardan bir kısmı isim olarak her ne kadar değerli olsalar da şöhretleri gözlerden uzaktadır. Ahmed b. Yusuf da bunlardan biridir (el-Cehşeyârî, 1938, s. 304).

\section{Ahmed b. Yusuf:}

I Asıl ad1 Ahmed b. Yusuf b. el-Kasım el-'Ícli'dir. el-Katib lakabiyla bilinmektedir. Kûfeli olup Me'mun'un risale divanlarının başında bulunmaktaydı. Abbasiler dönemindeki kâtiplerin büyüklerinden olup 213/828 yılında Bağdat'ta vefat etmiştir (ez-Ziriklî, 1986, s. 1/272). İbnu'n-Nedim onun, çağının en belagatli kâtipleri arasında olduğunu şu ifadelerle dile getirmektedir: "Nitelikleri konusunda görüş birliği olan kitaplar: Erdeşîr'in Ahdi, Kelile 
ve Dimne, Umâre b. Hamza'nın er-Risaletu'1-Mâhâniyye'si, İbnu'l-Mukaffa'in er-Risaletu'1Yetime'si ve Ahmed b. Yusuf el-Katib'in Risâletu'l-Hamîs'i (İbnu'n-Nedîm, 2009, s. 2/391).

Kaynaklar onun yazarlığ meslek edinmiş bir aile içerisinde yetiştiğini; dedesinin ve babasının da çeşitli divanlarda kâtip olduğuna vurgu yapmaktadırlar (el-Hamevî, 1993, s. 2/560). Ahmed b. Yusuf da tabi ki yazmayı seveceği, yazının inceliklerine ve gerekliliklerine vakıf olacağ1 güzel bir ortamda yaşamıştır. Babasından ve dedesinden edebiyat, şiir ve yazarlık sanatına duyduğu sevgiyi miras olarak almıştır ( Kurd Ali, 2012, s. 212). Kraliyet işlerini ve protokolleri iyi kavramış, sonuçta zekâsı ve güçlü hafizasıyla mesleğiyle ilgili işlerde zirveye ulaşmıştır. Karakter ve fazilet bakımından şaha kalkmış olup kendisinin anılan her iki hasleti hakkında çeşitli hikâyeler anlatılır olmuştur. Adı edebiyat sahasında konuşmacı ve şair olarak geçmektedir. Sözündeki değer, dilindeki sadelik ve hat yazısındaki zarafetiyle nitelendirilmiştir (el-Bağdâdî, 2001, s. 6/463). Neşeyi ve eğlenceyi sevmesiyle tanınmış olup çeşitli meclisleri vardı (et-Tevhîdî, 2011, s. 3/333). Abdulhamid b. Yahya elKatib onu görmüş ve yazısını güzelleştirmesine yarayan yönlendirmelerde bulunmuştur (elBağdâdî, 2001, s. 6/463). Bütün bunlar, gerçekten yetenekli bir yazar olması için ona uzmanlık, deneyim araçları, kültür ve zevki sağlamış; nihayet uzmanlığındaki parlak şöhreti insanlar arasında yayılmış ve Me'mun'un veziri olmuştur (İbnu Abdi Rabbih, 1983, s. $5 / 376)$.

Emin ile Me'mun arasında çıkan fitne olayında Me'mun'a bir yazı yazınca yıldızı parlamış ve bu yazısında Me'mun'un halifelik meselesinde daha haklı olduğundan bahsetmiştir. Me'mun da onun yazısını çok beğenmiş, onu kendisine hem vezir hem de baş kâtip yapmıştır. Me'mun'a yazdığı yazı şöyledir:

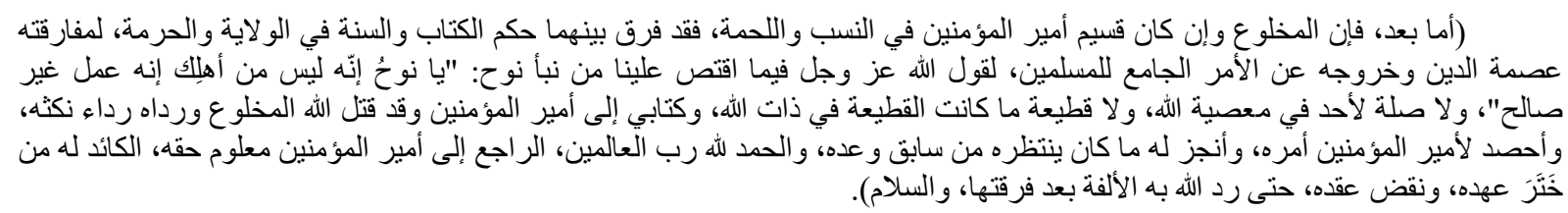

"İmdi, devrik kişi her ne kadar soy ve can bakımından müminlerin emirine hissedar olsa bile dini dokunulmazlıktan uzak olduğu ve Müslümanların genelinin hükmünün dişına çıktığı için kitap ile sünnet, yöneticilik ve dokunulmazlık bakımından artık ikisini birbirinden ayırmıştır. Nitekim Allah azze ve celle bizim için Nuh peygamberden örnekle haber vermektedir: 'Ey Nuh! O, artık senin ehlinden değildir! Onun kurtulmasını istemen de doğru değildir!' Allah'a isyanda olan kimse ile hiçbir bağ kalmamış ve esasen Allah katında kopmuş olan bağ koparan da yoktur. Allah devrik kişiyi hem bastırmış ve hem de ona anlaşmayı bozanın cübbesini giydirmiş; onun işini bitirmeyi müminlerin emirine nasip etmiş ve kendisine de daha önce sözünden dönenin beklediği akıbeti hazırlamıștır. Hamd, alemlerin Rabbi'nedir. Müminlerin emirine bağlı kalanın da hakkı bellidir. Ama ahdini bozanın başına gelen ne ise aldatan kişinin başına gelecek olan da odur. Ta ki Allah, ayrılığından sonra ayrıldığı kişiyle tekrar yakınlık kurmayı nasip edinceye kadar bu böyledir. Vesselam" (el-Cehşeyârî, 1938, s. 304).

Ahmed b. Yusuf bu mektupta, kardeşiyle çekişen Emin'in isyankârlığını ve Müslümanların oybirliğiyle aldığı kararın dışına çıktığını öne çıkarmakta. Emin'in kendi cezasını bizzat kendisinin kesmiş olduğu ve bir daha hem yönetim ve hem de merhamet ortamı asla kendisine dönmeyeceği için bu felaket bağlamında Emin'in isyankârllğı ile Nuh'un oğlunun isyankârlığı arasındaki ilişkiyi betimlemektedir. Zira Emin, kardeşi Me'mun'un veliaht olduğuna dair babasına verdiği sözü tutmayarak ailenin dışına çıkmış ve böylelikle de layık olduğu karş1lığ1 görmüştür.

\section{Risaletu'1-Hamîs:}

Risaletu'l-Hamîs'e baktığımızda kâtibin özenle ve özel çabasıyla yazması gerektiğini görürüz. Nitekim her Abbasi halifesi yönetime geçtiğinde yazıya geçirilmesi gerekli olan siyasi risalelerin en önemlilerinden birisi Risaletu'l-Hamîs'tir. Risalenin konusu ise Abbasi propagandasına katkıda bulunmak, mevcut halifenin desteklenmesi, hakkındaki öykülerin tek tek anlatılması, başarılarının tanıtılması ve halifenin kendi ailesi içerisinde halifeliği en fazla hak eden kişi olduğunun açıklanmasıdır. İlk olarak Risaletu'l-Hamîs yazan kişi, fasihliği ve kaliteli yazılarıyla meşhur es-Seffah ve Mansur'un kâtibi Umâre b. Hamza'dır (Dayf, 1966, s. 468); (İbnu'n-Nedîm, 2009, s. 2/366).

İşte bu Risaletu'l-Hamîs Abbasi halifelerinin başa gelmesi sırasında yazılmakta olup içerik olarak Abbasi Halifeliği için tanıtım broşürdür. Bu risale, Abbasoğullarının taraftarı 
olan Horasan halkından kimselere okunurdu. Bu risalenin ne sebeple Risaletu'l-Hamîs adıyla anıldığına ilişkin net bir açıklama bulunmamaktadır. Ancak ihtimaller arasında en güçlü olanı, bunun anılan ordunun niteliklerinden biri olması veya ordunun gücüne işaret ediyor olmasıdır ${ }^{3}$ (İbn Manzûr, Ty, s. 6/70).

İște Risaletu'l-Hamîs de bu noktada en önemli olabilecek bir risaledir. Zira bu risale türü yeni halife tahta geçtiğinde devlete başkaldırmaya ve isyana en yatkın olan Horasan halkına yazılmaktaydı. Çünkü Horasan halkı halifeliği ve sultayı ele geçirme niyetlerini açıkça dile getiriyordu. Hilafeti kimin hak ettiği konusundaki çekişmelerde kendilerine hak veriyorlardı. Abbasi devletinin kurulmasındaki en önemli payın kendilerinin olduğunu söylemek suretiyle Abbasi devletinin kurulmasında Ebu Müslim el-Horasani'nin katkısının olmasiyla kibirleniyorlard1.

Ahmed b. Yusuf bu risaleyi Me'mun'un halifeliğe geçmesi üzerine Horasan halkına yönelik olarak yazdığında şöyle demiştir (Safvet, 1938, s. 3/317-334):

(من عبد الله الإمام المأمون أمير المؤمنين إلى المبايعين على الحق و الناصرين للاين، من أهل خراسان وغير هم من أهل الاسلام: سلام

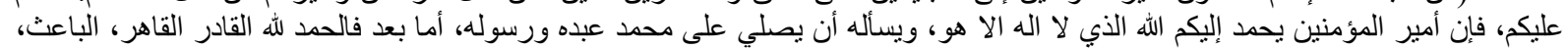

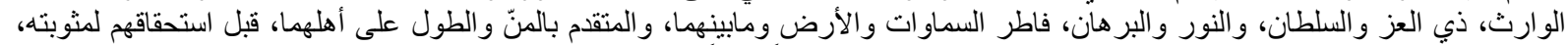

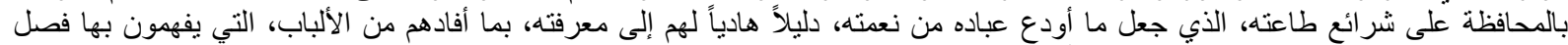

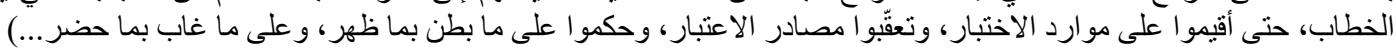

“Allah'in kulu ve müminlerin emiri İmam Me'mun'dan Horasan halkına ve dahi başka yerlerden ve İslam ehlinden olup hak üzere biat eden ve dinin yardımcıları olanlara hitaben! Selamun aleyküm! Müminlerin emiri sizden dolayı tek tanrı olan Allah'a hamd etmekte; O'ndan kulu ve elçisi olan Muhammed'e salat dilemektedir. İmdi! El-Kahir, el- Kadir, elBais, el-Varis, izzet ve hükümranlık sahibi, nur ve burhan sahibi, gökleri, yeri ve ikisinin arasındakileri ortaya çıkaran, itaat yollarını henüz muhafaza etmedikleri halde kullarına sevaplarını vermekten kaçınmayan ve bu haldeyken göklerin ve yerin ehlinin minnetlerini kendisine sunduğu Allah'a hamd olsun. O ki şu haldeyken gönüllerine fayda veren ve kendisinin tanınmasına yarayan bir kılavuz ve delil olması için kullarından nimetini esirgememiş ki böylelikle hele bir deneyimli kimselerin peşine düşsünler ve muteber kaynakları izlesinler! Bu deneyimli kimseler ve muteber kaynaklardır ki gizliye karşı açığa çıkanla ve dahi uzaktakine karşı da hazırda olanla hüküm vermişlerdir" (Safvet, 1938, s. 3/318).

Ahmed b. Yusuf, risalesine Allah'a hamd ile başlamış ve mükemmel bir özen göstermiştir. Sonra sözü Abbasilerin halifelikteki hakkına getirmiş, bunu da onların Allah elçisine olan yakınlıklarına bağlamıştır. Dolayısıyla Allah elçisine mirasçı olmaya daha müstahak olduklarını açıklarken şu sözleri söylemiştir:

$$
\text { بطاعته، فقال: (أطيعوا الله و أطيعوا الرسول الور أثة في محكم تنزيله قوله تعالى: (وأولوا الأرحام بعضهم أولى بعض في كتاب الله). ثم قرن طاعتهم }
$$

“Onları (Abbasoğullarını) mirasta haklı kılan husus Allah'ın indirdiği Kur'an'daki şu buyruğudur: 'Aralarında kan bağı bulunanlar Allah'ın kitabında (mirasçılık bakımından) birbirlerine diğer müminlerden ve muhacirlerden daha yakındırlar.'4 Sonra da Allah onlara itaati kendisine itaate yakın saymış (Safvet, 1938, s. 3/322) ve buyurmuştur ki: 'Allah'a itaat edin, Peygambere itaat edin, sizden olan ulu'l-emre itaat edin'."5

Böylece Ahmed b. Yusuf halifelikte Abbasilerin haklı olduklarına delil getirmektedir. Abbasilerin propagandasını yapmakta sonra da uzunca Me'mun'u överek kardeşi Emin'le aralarında geçeni şu sözlerle açıklamaktadır:

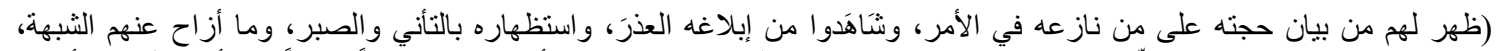

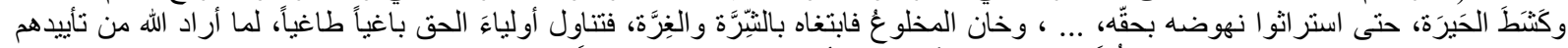

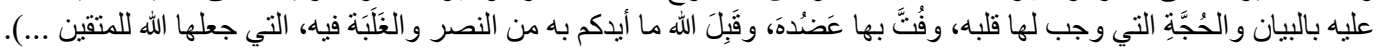

"Onlara, yönetime gelme hususunda çekiştikleri kişilere karşı delillerini getirme imkanı sunulmuş, iletimde bulunulduktan sonra ileri sürecekleri mazeretlerini belirtmeleri ve durumlarını açıklamaları için teenni ve sabır gösterilmiştir. Şüpheleri ve şaşkınlıkları giderilmeye çalışılmış ve iddia edilen hakları karşılıklı olarak elde etme çabası güdülmüştür... Ancak ne var ki devrik kişi ihanet etmiş, tahtı zorbalık ve ansızın elde

\footnotetext{
${ }^{3}$ el-Hamîs kelimesiyle kastedilen el-Ceyşu'l-Cerrâr adlı birliktir. Güçlü orduya işaret ederek beş bölükten oluştuğu için bu adla adlandırılmıştır. Bu bölükler: Öncü, merkez, sağ, sol ve artçı birliklerdir.

${ }^{4}$ Ku'an- Kerim, Ahzab Suresi, 33/6.

${ }^{5}$ Ku'an- Kerim, Nisa Suresi, 4/59.
} 
etmeye çalışmış, Hak sahiplerini de yoldan çıkmış azgınlar olarak değerlendirmiştir. Artık Allah, bunları gerekli açıklama ve delillerle ona karşı başarılı kılınca da tahttan indirilmesi gereği doğmuştur. Nihayet gücü kırılmış ve Allah sizin için peşinde olduğunuz kişinin zafer ve galibiyetini tıpkı takva sahiplerinin işini makbul saydığı gibi makbul saymıştır..." (Safvet, 1938, s. 3/324).

Tabii ki öte yandan da devlet taraftarlarının, öncelikle Abbasi devletinin kurulmasındaki katkılarını ikinci olarak da Me'mun'un zaferindeki katkılarını övmek gerekiyordu. Buna bağlı olarak Ahmed b. Yusuf risalede Horasan halkının faziletini övmekte, hasletlerini saymakta ve Abbasilerin zaferindeki katkılarını dile getirmektedir:

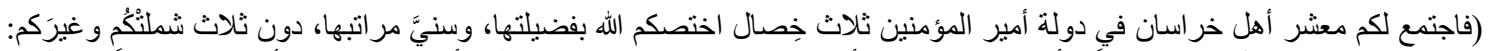

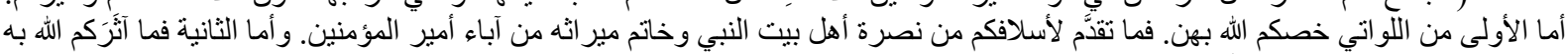

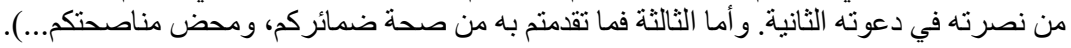

“Ey Horasan halkı! Müminleri emirinin devleti nezdinde Allah'ın size özgü kıldığı ve mertebesi yüce olan üç özelliğiniz bulunmaktadır. Bunlar size ve sizin gibilere özgü! Allah’ın size özgü kıldığı özelliklerin ilkine gelince sizden öncekilere, Peygamberin ehli beytine yardımcı olmak nasip olmadığı gibi müminlerin emirinin atalarından miras kalan mühre yardımcı olmak da nasip olmamıştır. İkincisi ise müminlerin emirinin ikinci çağrısında yardım etmek için Allah sizi seçmiştir. Üçüncüsü ise siz, yaptığınızı sadece vicdanlarınızın bütün temizliğiyle ve verilen öğüdü tutarak yaptınız!...” (Safvet, 1938, s. 3/324).

Ardından da Horasanlıların kendisine destek olması için sözlerini devam ettirmiş, verdiği öğütte düşmanlarla mücadele etmek ve de Me'mun'a teşekkür etmek için ne yapmaları gerektiğini açıklamıştır:

$$
\begin{aligned}
& \text { (و إلى الله يرغب أمير المؤمنين في إعانته على صالح نيته، وتبليغه منتهى سؤله، و غاية همه، في إعز از دينه، و إذلال من صداء صد عن سبيله، }
\end{aligned}
$$

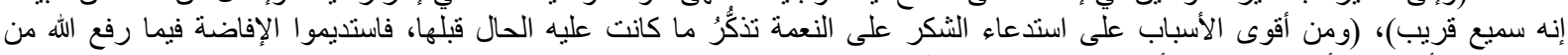

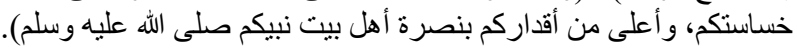

"Müminlerin emiri niyetini bütün temizliğiyle koruyabilmesi, isteğinin sonuna kadar yerine gelmesi, amacına erişmesi, dinini aziz kılması, O'nun yolundan alıkoyanları rezil etmesi hususunda Allah'in yardımını dilemektedir. O, en iyi şekilde kulunu duyan ve kuluna yakın olandır." "Teşekkür etmenin en güçlü sebeplerinden biri de daha önceleri vaziyeti ne olduğunu hatırlayıp ona göre nimete şükretmektir. Daha önce düştüğünüz alçaklığı artık Allah'in sizden kaldırması ve Peygamberinizin (sav) ehl-i beytine yardım ettiğiniz için değerinizi yüceltmesi nedeniyle Allah’a şükrünüzü artırınız!" (Safvet, 1938, s. 3/326).

Daha sonra da mektubuna Horasanlıları birlik ve beraberlik içinde olmaya çağırmak suretiyle devam etmiştir. Onları ayrılık ve bölünme tehlikesine karşı uyarmaktadır. Kendilerine o zamana kadar verilen ihsanlara devam edileceği sözü de vermiştir:

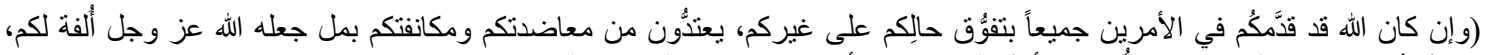

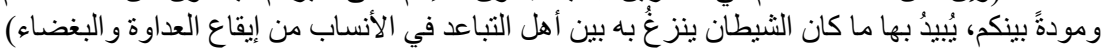

"Eğer Allah iki hususta hepten sizi öne çıkarsaydı başkaları nezdindeki statünüz yükselse bile Allah'ın size bahşettiği yakınlık ve aranızdaki sevgiye duydukları hasetten kalplerinin daralması sebebiyle yardımınızı ve desteğinizi kabul etmezlerdi. Halbuki Allah, şeytanın düşmanlık ve kin sokmak suretiyle zürriyetleri ayrı olan kavimler arasına yerleştirdiği ayrılığı sevgi vasıtasıyla ortadan kaldırmaktadır" (Safvet, 1938, s. 3/325).

Ahmed b. Yusuf Ma'mun'un diliyle onlara kıymetlerinden dolayı birtakım ibretli sözler ve öğütler yöneltmiş ve demiştir ki:

$$
\text { ( و اعلموا أن أمير المؤمنين متفقٌِّ من تثقيفكم وتقويمكم، على صالح الأدب، ومحمود السيرة، مالا يتفقد به من سواكم...). }
$$

"Ve biliniz ki müminlerin emiri gayet edepli bir şekilde sizin ne kadar aydınlandığını, ne kadar yeterli olduğunu, yaşantınızın ne kadar övgüye değer olduğunu, başkalarında görmediği şeyi sizden görmek ve anlamak istemektedir" (Safvet, 1938, s. 3/331).

Devamında müminlerin emirinin Horasanlıları başkalarına üstün tutmaya yönlendiren sebepleri açıklamaktadır:

$$
\text { إنكم أولى بحسن الطاعة وسر عة الإجابة، للطف محلّكم، وقرب مكانكم عند أمير المؤمنين). }
$$

"Sizler ki müminlerin emirine mevkiinizin yakınlığ1 ve konumunuzdaki zarafetinizle birlikte itaati güzelce sergilemede ve yardıma hızlıca yetissmede en önde gelmektesiniz" (Safvet, 1938, s. 3/331). 


\section{Risaletu'1-Hamis'teki Bazı Fikirsel Ve Betimsel Özellikler ve Ahmed B. Yusuf'un Üslubu:}

Risaletu'l-Hamîs, Cemheretu Risaletil-Arab adlı kitapta yaklaşık on beş sayfa tutmaktadır. Okunduğunda kelime seçkisindeki denge ve bazen de seci kullanımındaki genişlik fark edilmektedir. Şevki Dayf'ın de dediği gibi karşımıza şöyle bir görüntü çıkacaktır: "Anlamda açıklık, delil bolluğu, sözü çoğaltma, hitap yöntemiyle genişçe açıklama. Üslubu güzel; dili de arı duru, kolay ve anlaşılır bir dildir. Paragrafları gayet düzenli olup içerisinde müstehcen olmayan kafiyeler vardır" (Dayf, 1966, s. 469).

Ahmed b. Yusuf'un yazılarında en önde gelen özellikler arasında Kur'an ayetlerinden delil getirmek ve siyasi olayları delillendirmek için Kur'an'dan alıntı yapma olayıdır. Bir başka yönüyle de Ahmed b. Yusuf seci’i kullanmakta üstün bir üsluba sahiptir. Bunu da sadece sözün bazı yerlerde uzaması durumunda kullanmaktadır. Seci kullanması süsleme amacına dönük olup bu durum Risaletu'l-Hamîs'te gayet açıktır ( Kurd Ali, 2012, s. 213).

Risaletu'l-Hamîs'e kompozisyon üslubu yönünden baktığımızda Ahmed b. Yusuf'un kompozisyon düzeninde birçok üsluba dayandığını görürüz. Zira onun üslubunda kompozisyondaki söylemin ve anlamın gücü oldukça belirgindir. $\mathrm{O}$, bu risalesini Horasan halkına yazarak öğüt vermiş ve onları devlete tutunmaya teşvik etmiştir. Bu münasebetle de risalenin söyleminin içeriğine uygun olması gerektiği açıktır. Nitekim Ahmed b. Yusuf bu risalesinde emir ve nehyi kiplerini çokça kullanmış, bunun yanında uzun açıklamalar yapmıştır. Ayrıca sözde ayrıntıya ve uzatmaya meyilli davranmış ve birçok yerde de sözlerine Kur'an ayetlerinden deliller getirmiştir.

Eğer retoriğin temel kuralına gidersek karşımıza Arapların "sözün en hayırlısı az ve öz olanıdır" atasözü çıkmaktadır. Ancak bu temel kural bu risaleyle uyuşmamaktadır. Çünkü bu risale hem kendine özgü rengiyle ön plana çıkmakta hem de siyasi hassasiyet niteliğine sahiptir. Zira bu risale, devletin genel tebaaya yönelik hazırladığ 1 risalelerden farklı olarak özel bir kesime yöneliktir. Risale başka bir kesime değil de sadece Horasan halkına özgüdür. Dolayısıyla da diğer risalelerden farklı olarak siyasi propaganda karakteri ve diplomasi dili özelliği taşımaktadır. Böyle bir karakter taşıdığı için de kâtibin diğer risalelerdekinden daha farklı bir dikkat göstermesi, söylemde seçici olması ve cümlelerde de özenli davranması gerekmektedir. Bunun yanında yine kâtibin Kur'an'dan alıntı yaparken ayetlerin sözün sadediyle münasip olması için incelikli bir yaklaşım sergilemesi gerekir. Ayrıca bu risalede ön plana çıkan hassasiyete baktığımızda kâtibin sözü uzatmasının ve ayrıntılara girmesinin gayet doğal olduğunu görürüz. Zira kâtip, yazısında ve kompozisyon düzeninde hünerini sergileme hususunda oldukça hırslıdır. Bundan sonra da doğal olarak kompozisyon içerisindeki sözü uzatma ve ayrıntıya girme niteliği belirginleşmektedir.

Devlet bürokrasisi açısından olaya baktığımızda da görmekteyiz ki Ahmed b. Yusuf belli kural ve kanunlara göre ilerlemekte ve bunların dışına çıkmamaktadır. Nihayetinde kâtip, halife hazretlerinin yanında sadece bir memur olduğu için halifenin divanında olması münasebetiyle kanunlara uyması gerekecektir. $O$, yazısını halifenin dilinden yazmakta olduğu için divan protokolüne uyması bir zorunluluktur. $\mathrm{Bu}$ protokol, kâtibe, hem kanunlara uyması gerektiğini ve hem de bu kâtip Ahmed b. Yusuf'un bizzat kendisi olsa bile kanunları işletmesi gerektiğini hatırlatır ( Kurd Ali, 2012, s. 213). Çünkü burada siyasi birtakım işler söz konusu olup bu işler devlete özgü işlerdir. Bu siyaseti dillendirecek olan da siyasetin çerçevesini çizen kişidir. Buna göre Ahmed b. Yusuf'un divandaki bir kâtip gibi davranarak konuya bağlı kalması ve asla konu dışına çıkmaması gerekmektedir. Ancak bütün bunlarla birlikte bu risalenin kompozisyonuna, edebi yönüne, fikri ileri sürme üslubuna ve diğer sanat üsluplarının kullanılmasına özgünlüğünü kazandıran ise kâtibin kendisidir.

\section{SONUÇ:}

Son olarak; yazışmanın insanlık tarihi kadar eski olduğunu söyleyebiliriz. Arapların da yazı yazmaya ilgi duyması da çeşitli sebeplerden dolayı olmuştur. İslam'ın ilk ortaya çıkışı yazışmaları da beraberinde getirmiştir ve zamanın ilerlemesiyle bir sanata dönüşmüştür. Daha sonrasında bu sanat Emeviler döneminde gelişmiş ve şekillenmiştir. Risale kültürü, o zamanın yaşam şartlarını yansıtan siyasi bir karakter kazanmıştır. Abbasiler döneminde ise kalkınma ve gelişmenin zirvesine ulaşılmış ve sonuçta yazı yazma sanatı edebi ve sanatsal rengini kazanmaya başlamıştır. Bu dönemde kâtipler süslü sözler kullanmaya, ssekle ve diksiyona özen göstermişler bununla birlikte araç ve içeriği de ihmal etmemişler; bunlara uygun olarak içeriğe ve konulara zenginlik katmışlardır. 
Genel olarak Abbasiler dönemindeki kâtiplerin Arap kültürüne hizmet etmede çok önemli katkılarının olduğunu görmek mümkündür. Zira kâtiplerin yazı üslupları hem düşünme biçimindeki yüceliğe hem de ifadelendirmedeki güzelliğe dayandığ i için adına yönetim dili diyebileceğimiz çift yönlü bir dili kurgulayabilmişlerdir. Bu dil, hükümdarın emir ve amaçlarını yorumlayabilmeyi hedefleyen bir dildir. Ancak aynı zamanda kelimenin tam anlamiyla Arap belagatine dayanan bir sanat dilidir. Kâtiplerin siyasi risalelerinin, o dönem şartlarında devletin lisan-1 hali olduğu kadar Abbasi rejiminin meşruiyetinin savunulmasında da önemli bir rol oynadığını söylemeye bile gerek yoktur. Bu risaleler, modern çağda devletin üst makamlarının yayınladığı; propaganda ve bildiri amaçlı yayınlara büyük oranda benzemekte olup yayının bu türü, günümüzde resmi gazetenin bile yerini tutmaktadir.

Sözün özü, kâtiplerin siyasetle ilişkisi sıkı bir ilişkidir. Çünkü kâtipler hem devletin aldığ1 pozisyonun dili olan hem de devletin siyasetini ifadeye döken kimselerdi. Yüksek konumları itibarılya devletin siyasetinde inkâr edilemez bir etkileri olduğu gibi yönetim işlerini etkiledikleri de olmaktaydı. Hatta öyle ki içlerinden uyanık olan bazıları vezirlik makamına bile çıkmaktaydı. Onlar, siyasi düşünceleri sultanın ve devletin genel siyasetinin yörüngesinde dönen kimselerdi.

\section{Kaynakça}

Kurd Ali, M. (2012). Umerâu'l-Beyân. Kahire: Mektebetu's-Sekâfeti'd-Dîniyye.

Aytaç, B. (1991). Abbasi Devrinde Nesir ve al-Harîrî. Ankara Üniversitesi Dil Tarih ve Coğrafya Fakültesi Dergisi, 35(1), 1-14. 
Azimli, M. (2008). Abbasiler Dönemi Muhammed en-Nefsu'z-Zekiyye ve Kardeşi İbrahim'in İsyanı. Din Bilimleri Akademik Araştırma Dergisi, 8(3), 55-74.

Beyyûd, Hüseyin. (1996). er-Resâilu's-Siyâsiyye fi'l-Asri'l-Abbâsiyyi'l-Evvel. Dimaşk: Menşurât Vezâretu's-Sekâfe.

Bozan, O. (2014). Taberistan Emiri Mâzyâr b. Kârîn'in Abbasi İdaresine İsyanı. Şarkiyat İlmi Araştırmalar Dergisi, 6(11), 73-93.

Çelik, S. (2006). Abbasiler Döneminde Hurremiyye Mezhebi Ve Babek İsyanı. Balıkesir Üniversitesi Sosyal Bilimler Enstitüsü Dergis, 9(15), 95-106.

Dayf, Ş. (1966). Târîhu'l-e,Edebi'l-Arabî, el-Asru'l-Abbâsiyyi'l-Evvel. Kahire: Dârul-Maârif.

Dayf, Ş. (Ty). el-Fennu ve Mezâhibuhû fi'n-Nesri'l-Arabî. Kahire: Dâru'l-Meârif.

el-Bağdâdî, E.-H. (2001). Târîhu Medîneti's-Selâm (Târîhu Bağdâd). (B. A. Ma'rûf, Dü.) Beyrut: Dâru'l-Ğarbi'l-İslâmî.

el-Cehşeyârî, M. (1938). Kitâbu'l-Vüzerâi ve'l-Küttâb. (M. es-Sakka, Dü.) Kahire: Matbaatu Mustafa el-Bâbî el-Halebî.

el-Hamevî, Y. (1993). Mu'cemu'l-Udebâ İrşâdu'l-Erîb ilâ Ma'rifeti'l-Edîb. (İ. Abbâs, Dü.) Beyrut: Dâru'l-Ğarbi'l-İslâmî.

el-Kalkaşendî, A.-A. (Ty). Subhu'l-A'şâ. Kahire: Dâru'l-Kütübi'l-Mısriyye.

el-Kâtib, A. b. (2003). Mevâddu'l-Beyân. (H. S. ed-Dâmin, Dü.) Şam: Dâru'lBeşâir Mektebetu'l-Arab.

el-Muberrid, E.-A. M. (1997). el-Kâmil. (M. A. ed-Dâlî, Dü.) Beyrut: Muessesetu'r-Risâle.

es-Sûlî, E. (1922). Edebu'l-Küttâb. (M. B. el-Eserî, Dü.) Kahire: el-Matbaatu's-Selefiyye.

et-Taberî, E. C. (Ty). Târîhul-Umemi ve'l-Mulûk (Târîhu't-Taberî),. (E. S. el-Kermî, Dü.) Riyad: Beytu'l-Efkâri'd-Devliyye.

et-Tevhîdî, E. H. (2011). Kitâbu'l-İmtâ' ve'l-Mu'ânese. (H. H. et-Taîmî, Dü.) Beyrut: elMektebetu'l-Asriyye.

ez-Ziriklî, H. (1986). el-A'lâm. Beyrut: Dâru'l-İlm li'l-Melâyîn.

Ferrûh, Ömer. (1981). Târîhul-Edebi'l-Arabî. Beyrut: Dâru'l-İlm li'l-MelâyÎn.

İbn Haldun, V. (2004). el-Mukaddime. (t. A. ed-Derviş, Dü.) Dimaşk: Dâr Ya'rub.

İbn Manzûr, C.-İ. (Ty). Lisânu'l-Arab. Beyrut: Dâru Sâdir.

İbnu Abdi Rabbih, A. b. (1983). el-İkdu'l-Ferîd. (A. et-Terhînî, Dü.) Beyrut: Dâru'l-Kutubi'lİlmiyye.

İbnu'l-Esîr, D. e.-F. (1939). el-Meselu's-Sâir fî Edebi'l-Kâtibi ve'ş-Şâir. (M. M. Abdulhamid, Dü.) Kahire: Mektebetu'l-Arab.

İbnu'l-Esîr, D. e.-F. (Ty). el-Meselu's-Sâir fî Edebi'l-Kâtib ve'ş-Şâir. (A. e.-H. Tabbâne, Dü.) Dâr Nahdatu Misır.

İbnu'l-Esîr, M. e.-Ş. (1987). el-Kâmil fi't-Târîh. (M. Y. ed-Dekkâk, Dü.) Beyrut: Dâru'lKutubi'l-İlmiyye.

İbnu'n-Nedîm, M. (2009). Kitâbü'1-Fihrist. (E. F. Seyyid, Dü.) Londra: Müessesetü'1-Furkân.

Nassâr, H. (2002). Neş'etu'l-Kitâbeti'l-Fenniyyeti fi'l-Edebi'l-Arabî. Kahire: Mektebetu'sSekâfeti'd-Dîniyye.

Safvet, A. Z. (1938). Cemheretu Resâili'l-Arabi fî Usûri'l-Arabiyyeti'z-Zâhire. Beyrut: elMektebetu'l-İlmiyye.

Türk, O. (2017). Türkçe Öğretmenlerinin Konuşma İlgileri Ve Sınıf İçinde Kullandıkları Konuşma

Dili Üzerine Bir Araştırma. Turkish studies, 12(6), 783-798.

Türk, O. (2019). Osmanlı Döneminde Kıbrıs’ta Basının Yeri. Dicle Üniversitesi Sosyal Bilimler

Enstitüsü Dergisi (DÜSBED), 11 (22), 281-294.

Zeydân, Corci. (Ty). Târîhu Âdâbi'l-Luğati'l-Arabiyye. İskenderiye: Dâru'l-Hilâl. 


\title{
OTTOMAN NAVAL WARS (1454-1918): (HISTORICAL STUDY)
}

\author{
Sahira Hussein MAHMOUD ${ }^{1}$
}

\section{Istanbul / Türkiye \\ p. 557-576}

Received: $15 / 11 / 2021$

Accepted: 06/12/2021

Published: 01/01/2022

This article has been scanned I iThenticat No plagiarism detected

\begin{abstract}
:
Most researchers focus on the land wars of the conflicting countries in ancient, contemporary, or modern history, which gives naval battles and their effects a second role in the causes of victory or defeat. Ottoman naval power and its battles are no exception. Through my study of most of the Ottoman wars in the ancient Ottoman and modern Turkish sources, I found that the impact of naval warfare is no less important than land wars, although they were not the direct causes of victory or defeat. Therefore, my research came to show the naval battles of the Ottoman Empire and to shed light on their causes and consequences.
\end{abstract}

Key words: Ottoman Empire, Ottoman Wars, Ottoman Navals This Humble Research Includes An Introduction, Two Axes.

http://dx.doi.org/10.47832/2717-8293.15.39

Dr. , Basra University, Iraq, saheraedu@ yahoo.com 


\section{حروب البحرية العثمانية (1454- 1918)}

(دراسة تأريخية)

\section{ساهرة حسين محمود 2}

الملخص:

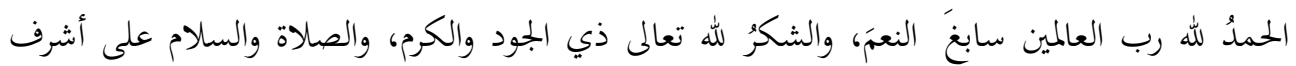

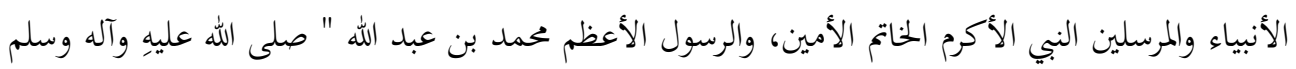

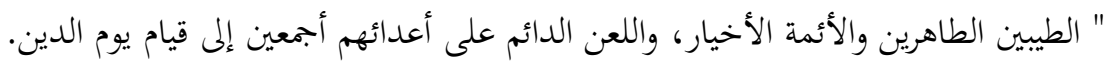
يركز أغلب الباحثين على الحروب البرية العائدة للدول المتنازعة في التأريخ القديم أو المعاصر أو الحديثين

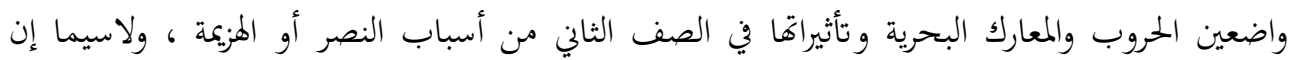

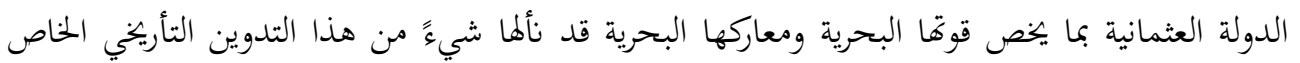
هذذا لموضوع، ومن خلال دراستي لاغلب الحروب العثمانية في المصادر العثمانية القديمة والمصادر التركية

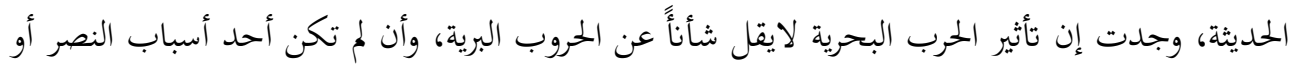
الهزيمة. فجاء بكثي هذا لأظهار المعارك البحرية للدولة العثمانية وتسليط الضوء على الأسباب و النتائج

الخناصة بما.

الكلمات المفتاحية: الدولة العثمانية، الحروب العثمانية، البحرية العثمانية .

كانت البحار مهمة للغاية في جميع جوانب تأريخ البشرية، تمامًاً كما هي اليوم، و لطالما أعتبرت الدول البرية أن الإبحار في

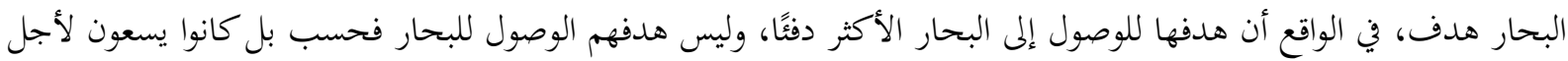

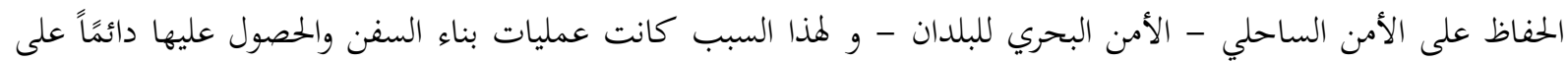

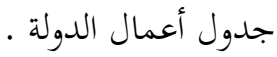

منذُ اللحظة التي بدأ فيها الأتراك الاستقرار في أراضي الأناضول المحاطة بالبحار من ثلاث جهات ، شعروا بالحاجة إلى التحول إلى البحر وبدأت عملية تطوير البحرية العثمانية في تأريخ الأنشطة البحرية التركية، عند إلقاء نظرة على المعالم الهامة سيساعدنا على فهم عمليات التنمية الطبيعية للبحر عبر التأريخ، وتفاعل التطورات الدورية مع الملاحة البحرية للأتراك، مما يوجه هذا التفاعل التنبؤات بالأنشطة والتفاعلات البحرية المستقبلية. و في هذه البحث الذي يهدف إلى إلى التحقيق في أوائل لقاءات الحربية للأتراك مع البحر في التأريخ، وتأثيره على الأنشطة البحرية الحربية إلى جانب عملية التطور التأريخي والسياسي ومراحل التنمية التي تتزامن مع عمر الدولة العثمانية.

أن المنظمات والسفن البحرية التابعة للعثمانيين، الذين كان لديهم تفوق خطير في البحار، تستحق أيضًا أهتمامًا خاصًا في

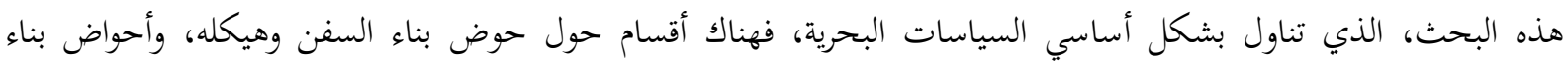
السفن في مناطق جغرافية أخرى من الإمبراطورية، والضباط العاملون في حوض بناء السفن والبحرية، والسفن المستخدمة في 
البحرية بالإضافة إلى ذلك، يجذب الأنتباه إلى قصص الحياة والأنشطة البحرية للبحارة الرواد، التي أدت إلى تغييرات وتحولات كبيرة في المجال البحري.

عندما أراد الأتراك أن يجعلون الأناضول وطنهم، شعروا بضرورة تنفيذ إستراتيجية جديدة، إذ أدركوا بما أن الأناضول محاطة

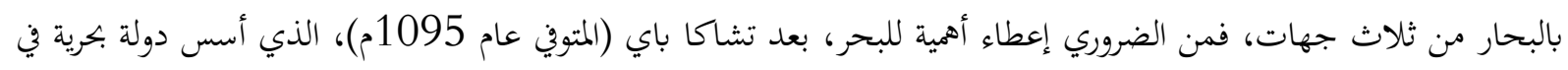
غرب الأناضول، فبدأ الأتراك في بناء أحواض بناء السفن ومقاعدها، وبناء القوات البحرية خلال حكم دولة تركيا الحديثة. 


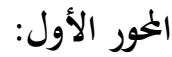

حروب البحرية العثمانية (1454 - 1700م) (170)

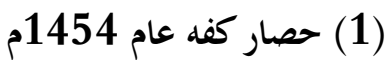

كان حصار (كفه Kefe) أحد العمليات العسكرية للإمبراطورية العثمانية وخانية القرم، اللتين تحالفتا في عام

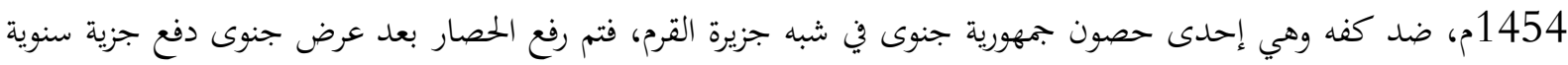

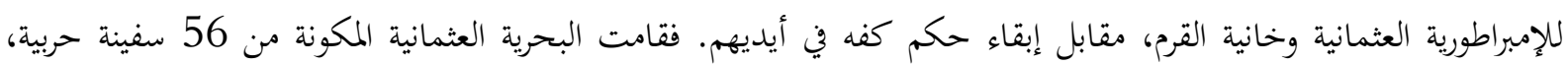

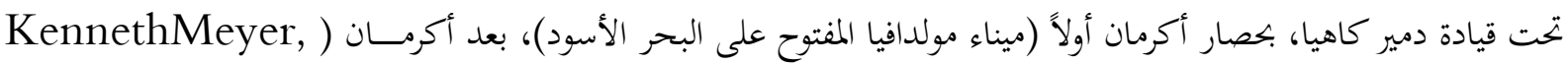

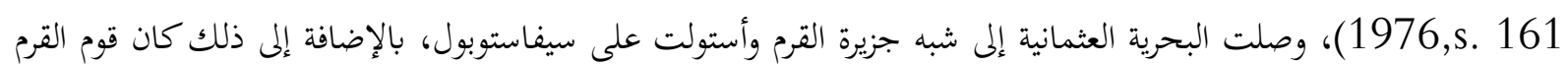

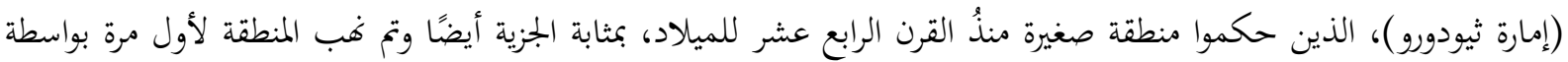
أسطول تركي أرسله السلطان مراد الثاني (1446- 1451م)، في عام 1446 م (İdris Bostan,2000,s.37).

\section{(2) (2) حصار أماسرا عام 1460م}

كان حصار أماسرا هو العملية البرية والبحرية التي أسفرت عن قيام الجيش العثماني بقيادة الفاتح سلطان محمد الثاني

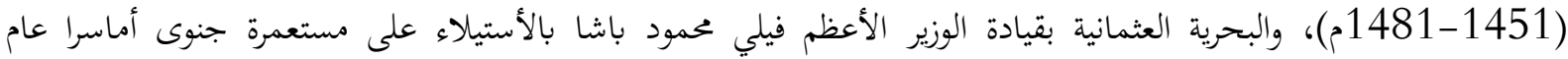

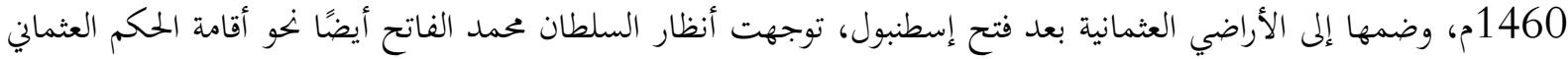

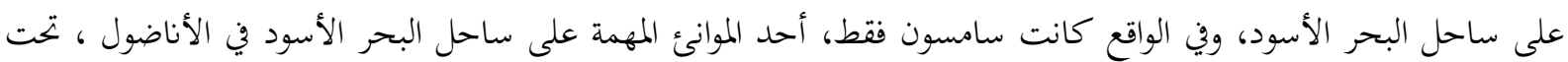

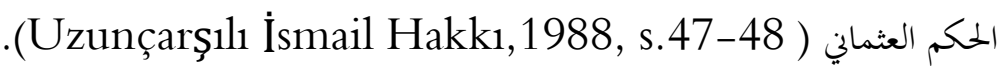

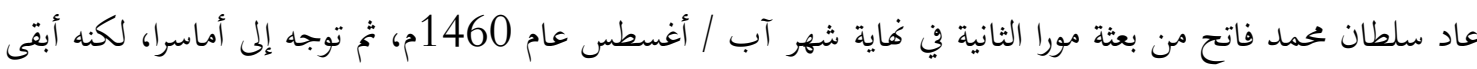

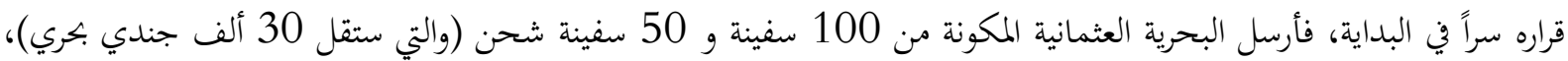

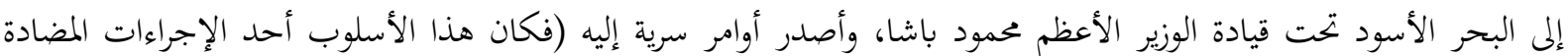

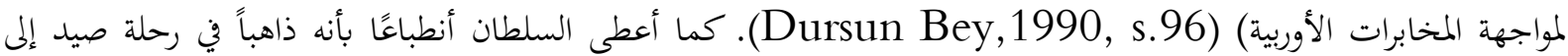

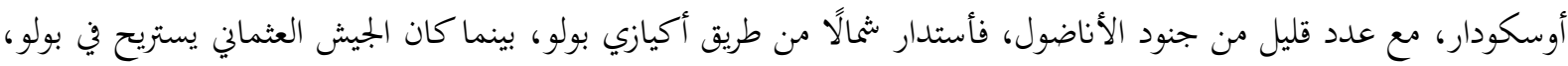

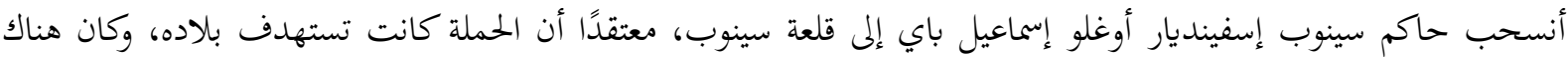

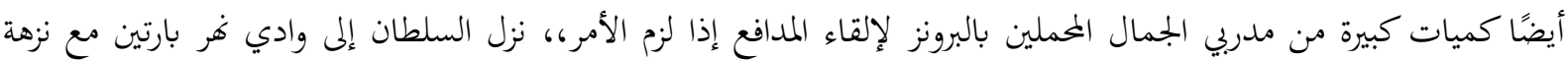

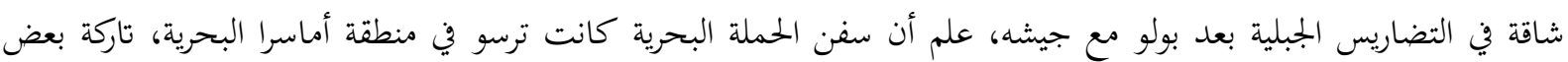

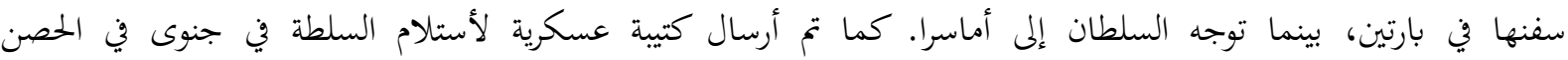

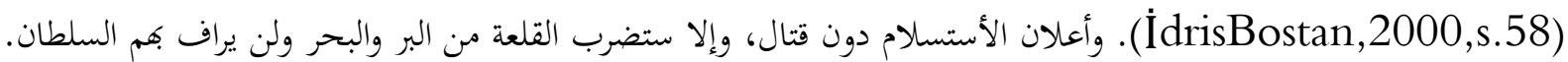

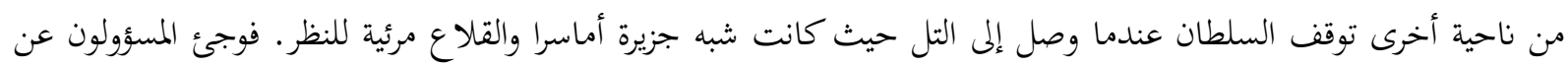

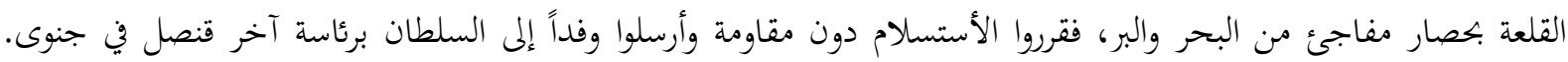

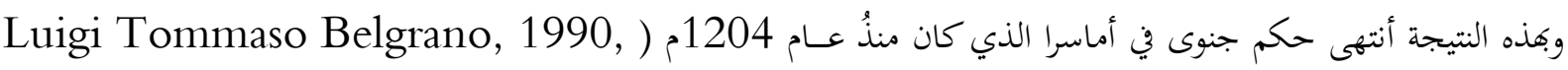
.(s.19, 20 


\section{(3) معركة الريس براق البحرية عام 1499م}

تُعرف أيضًا بإسم معركة بحر سابينزا أو معركة بحر زونشيو أو معركة بحر إنيباتي الأولى أو معركة جزيرة بوراك ريس البحرية.

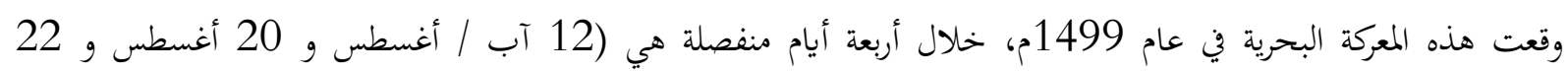

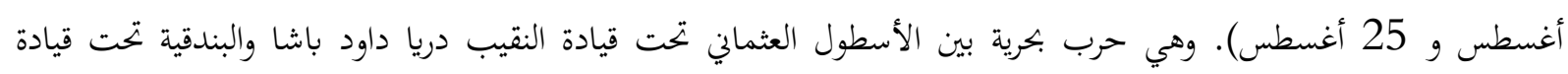
النقيب العام أنطونيو جريماني في عهد السلطان بايزيد الثاني (1481-1512م)، فقد كاندية الندانت معركة بحرية أنتهت بأنتصار تكتيكي

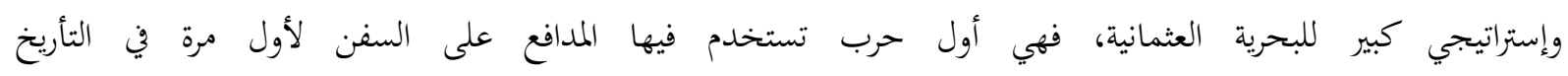
(GökhanAtmaca ve Doğan Tanriverdi ,2016 ,s.57.)

دخلت سفن الأسطولين في قتال متلاحم، وفقًاً لمصادر الفينيسية، فهاجمت سفنها السفن العثمانية ، بشجاعة كبيرة في

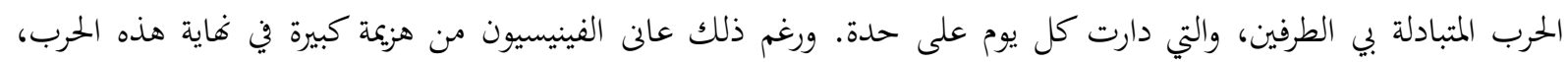

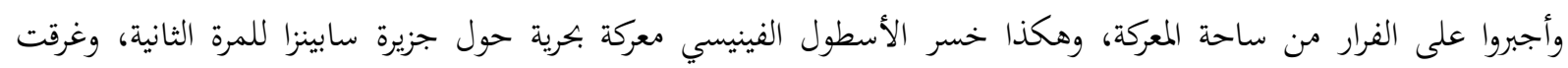

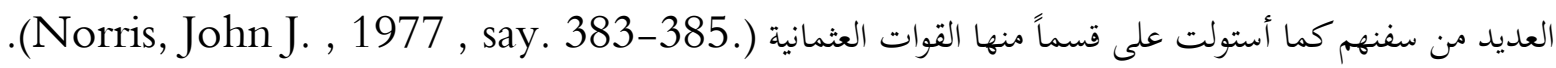

\section{(4) معرب ديو البحرية 3 شباط / فبراير عام 1509م}

كانت معركة ديو والمعروفة أيضًا بإسم معركة شاول الثانية، وهي معركة بحرية وقعت في 3 شباط / فبراير 1509م، قبالة

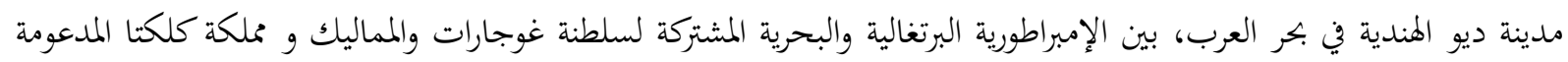

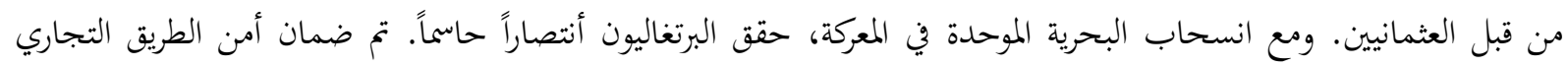

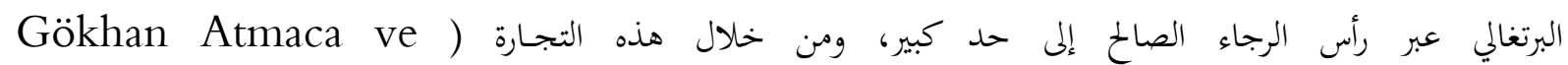
(DoğanTanriverdi ,2016,s72. فاصلة من الناحية الإستراتيجية إذ اهت سيطرة المسلمين على خطوط التجارة البحرية مع آسيا وبدء السيطرة الأوروبية على المسرح

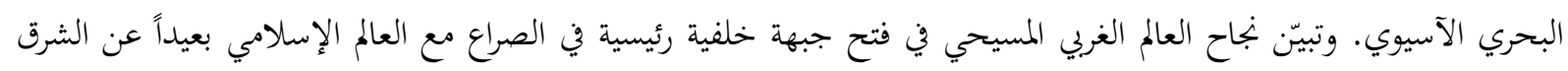

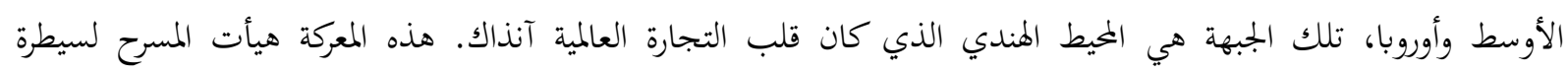

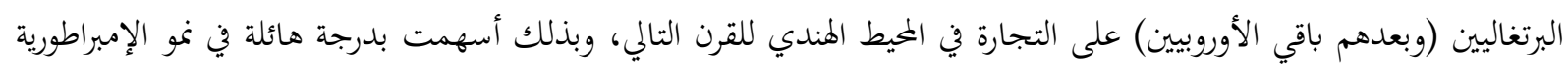
البرتغالية (ومن بعدها الإمبراطورية البريطانية) (233- Rogers, Clifford J. Readings 1995, pp. 299).

\section{(5) حصار جدّة 19 نيسان / أبريل عام 1517م}

تصدت جدة لحصار سفن البحرية البرتغالية - الهندية عليها في عام 1517م، من قبل البحرية والحامية المملوكية المدعومة

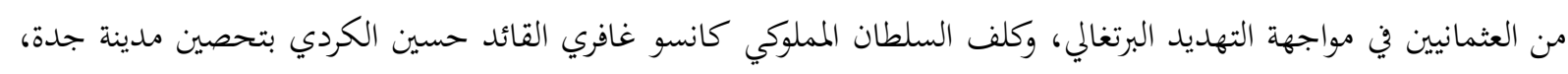

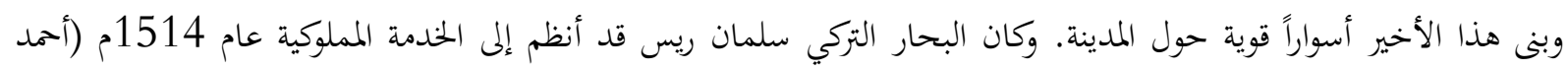

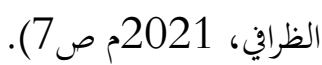

حاولت سفن البحرية البرتغالية الأستيلاء على مدينة عدن في عام 1513م، وأيضاً في عام 1517م، لكنها فشلت في

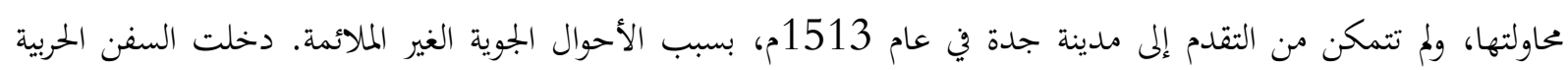

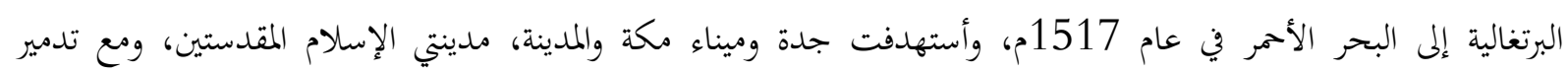

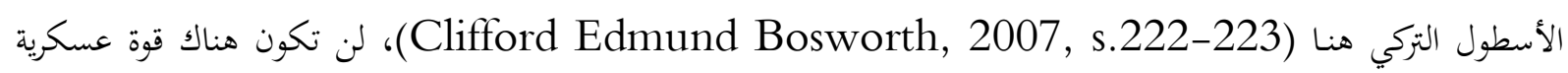
متبقية في البحر الأحمر يمكن أن تمنع السفن البرتغالية، التي شرعت في عملية أختراق لم تستطع أن تكون فعالة ضد نيران مدفعية

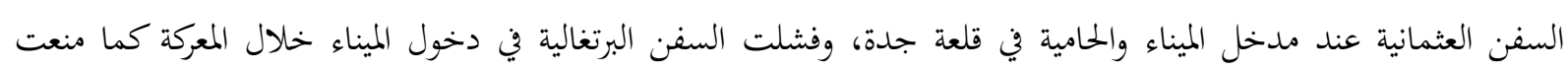


المدافع العثمانية من نوع باكالوشكا، التي يبلغ طولا 550 و 660 سم والقادرة على رمي قذائف المدفعية ما يقرب من 5 رئل كيلوغرامات السفن البرتغالية من الأقتراب أكثر من اللأزم من القلعـة (Ahmet Kavas, 2001, s 111)

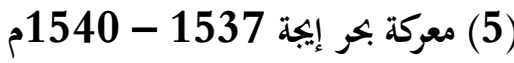

كان المدف الأول للبحرية العثمانية هو جزيرة سيها جنوب البيلوبونيز، وأستولت البحرية على قلعة باليو هورا وأستعبدت

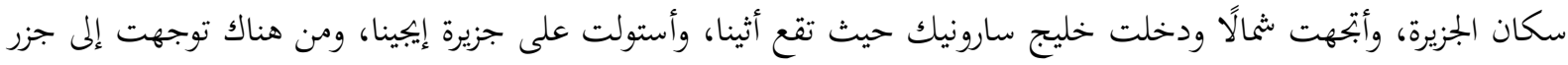

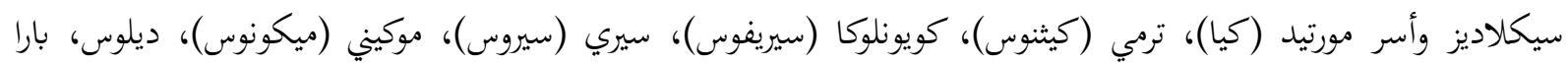

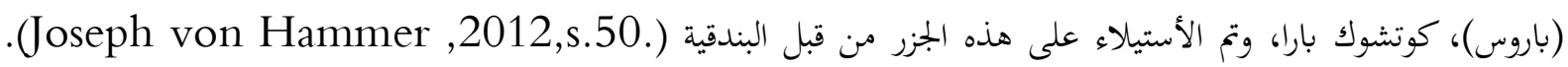

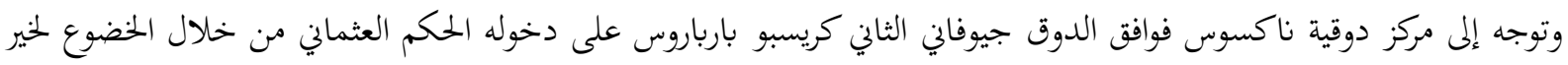

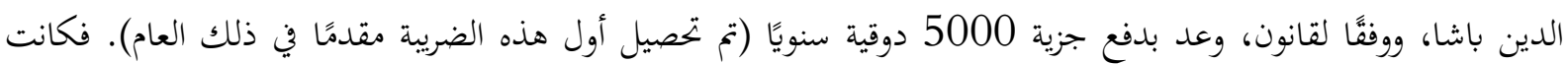

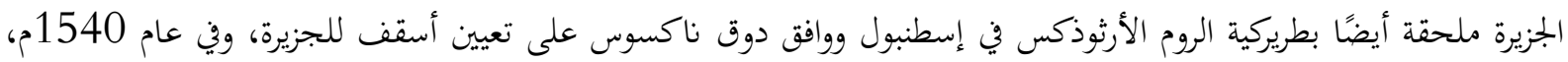

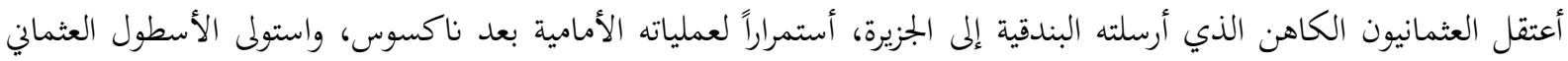

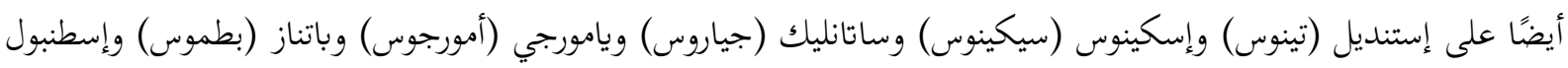

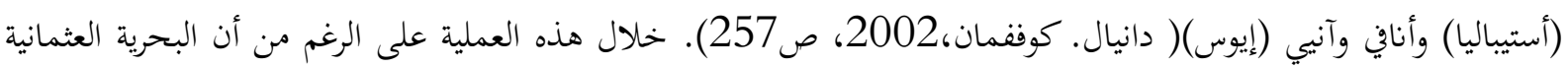

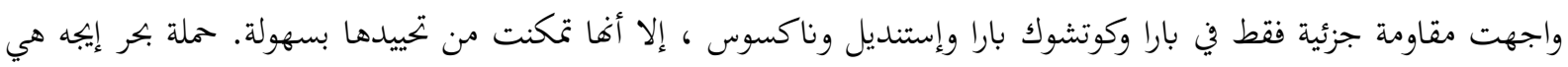

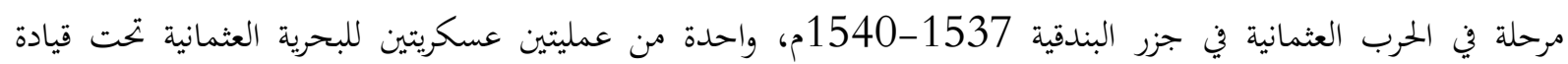

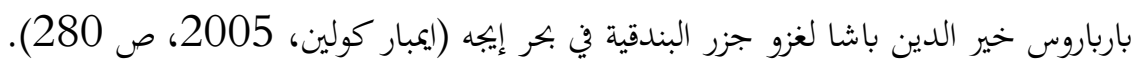

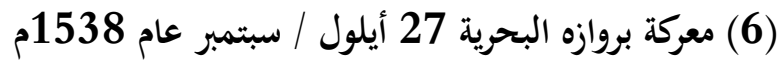

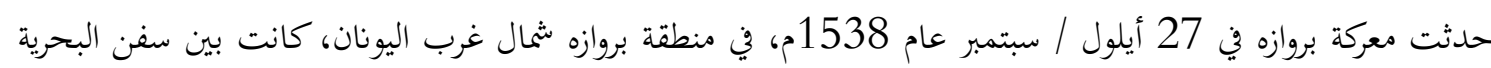

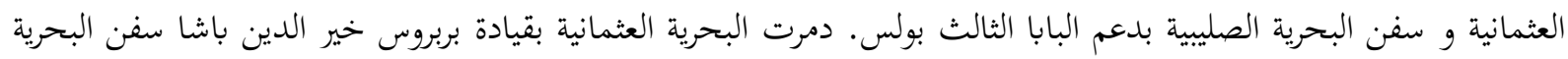

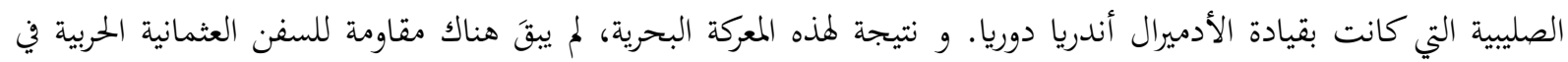

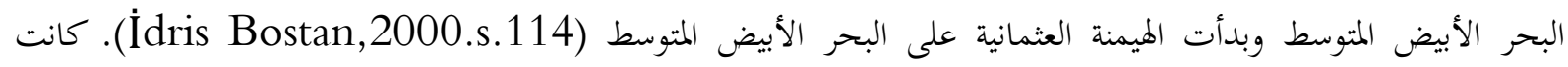

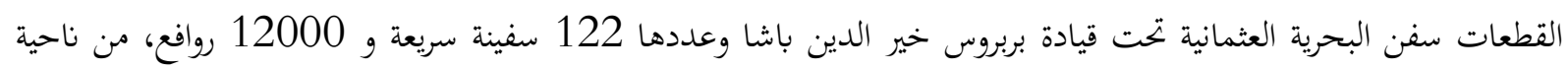

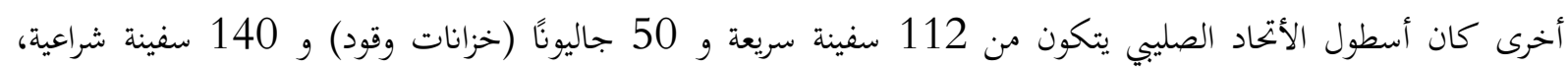

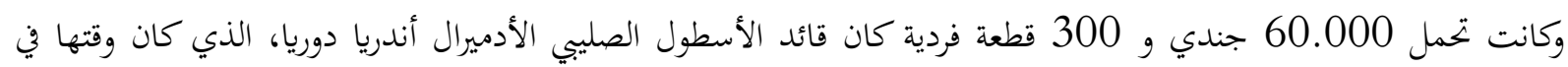

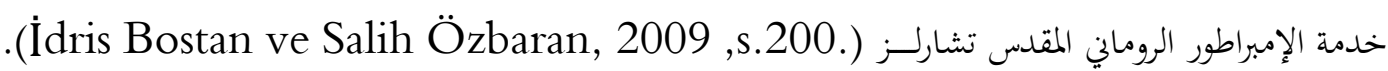

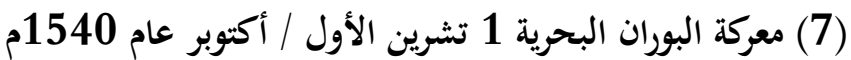

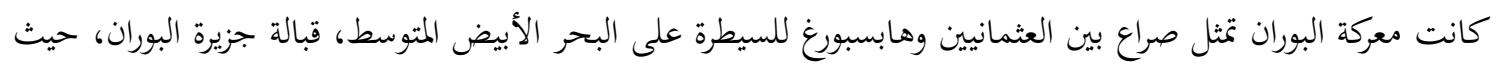

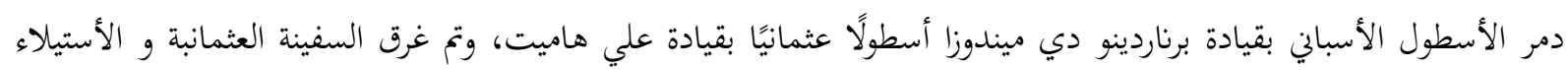

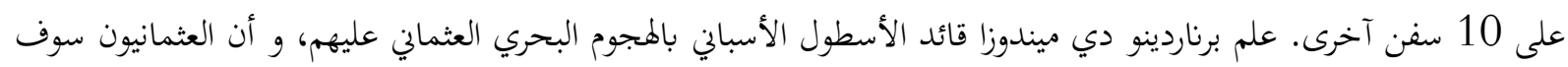

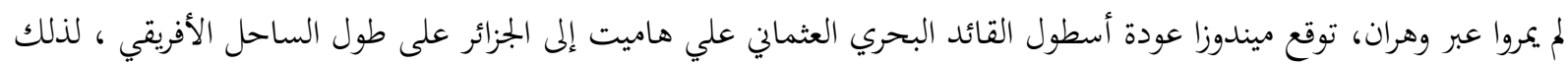

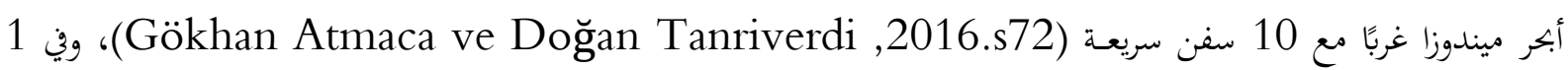

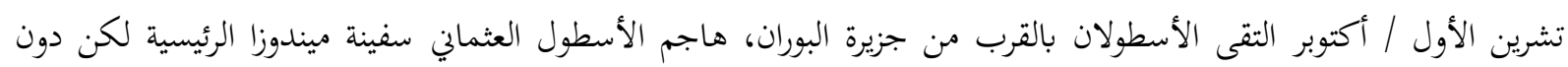

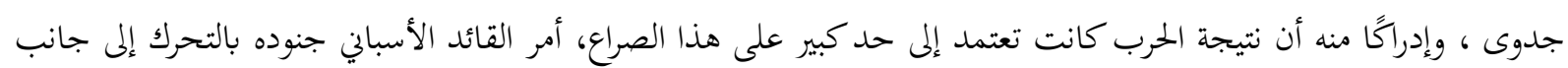


واحد، ورفع الجانب الآخر ليكون بمثابة مجموعة ضد نيران السفن العثمانية. ثم صعدت قوات ميندوزا إلى السفن العثمانية

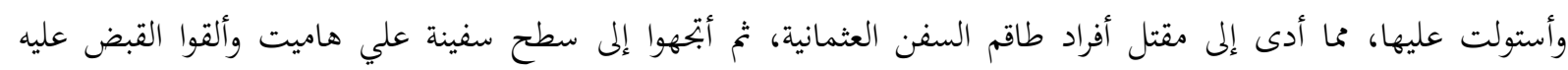
.(İdris Bostan, 2000.s 84)

وكانت من نتائج هذه المعركة الأستيلاء على عشرة من بين ستة عشر سفينة عثمانية، وغرق سفينة واحدة، كما تم قُتل

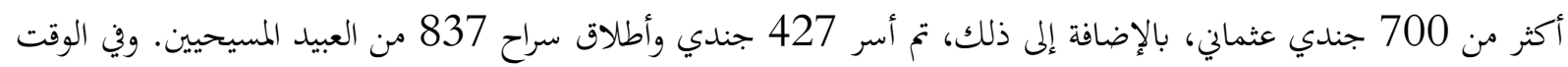

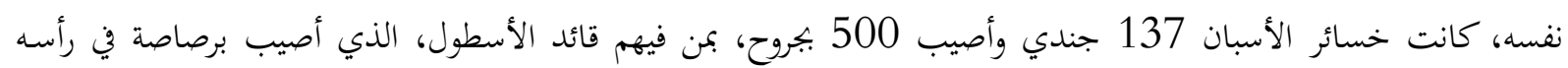
.(İdris Bostan ve Salih Özbaran, 2009.s.150)

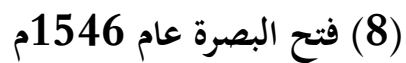

فتحت الإمبراطورية العثمانية البصرة في عام 1546م، منعاً من وقوعها في أيدي البرتغاليين. كلفت الدولة العثمانية والي

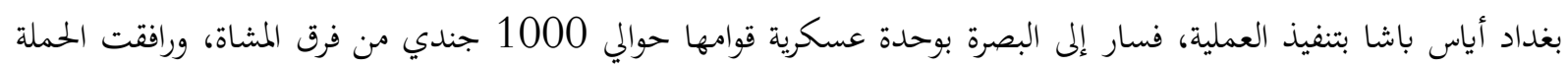
120 سفينة صغيرة تحمل مستلزمات الحصار و ذخيرة المدافع. (Abdurrahman Sağırl1, 2000, s. 44). على الرغم من أن أياس باشا بعث برسالة إلى الشيخ يميى على بوابات البصرة وطلب منه تسليم المدينة، فأرسل الشيخ

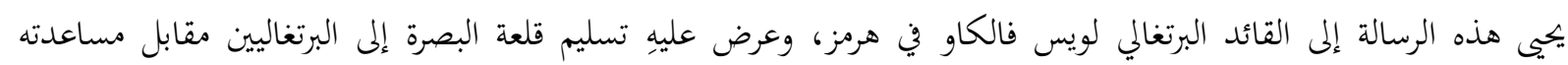
للتصدي للعثمانيين. وفي 30 تشرين الثاني / نوفمبر عام 1546م، أعرائ إعربت القيادة البرتغالية في هرمز عن وجهة نظرها للقائد العام

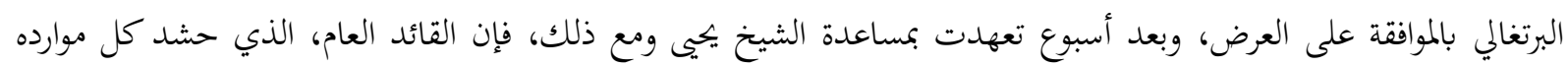

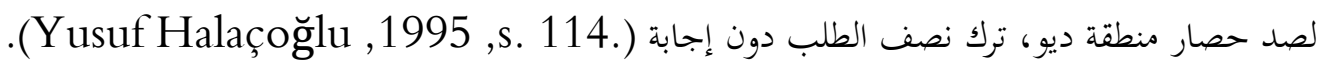
أسقطت الكتيبة العثمانية في وقت قصير قلعة زكية التي كانت تعتبر مفتاح البصرة، وكذلك منطقة الكرمة التي تقع على ضفاف غري دجلة و الفرات وشط العرب، إلا أها لم تستطع مقاومة القوة النارية الفعالة للجيش العثماني، وقد أكتمل إحتلال

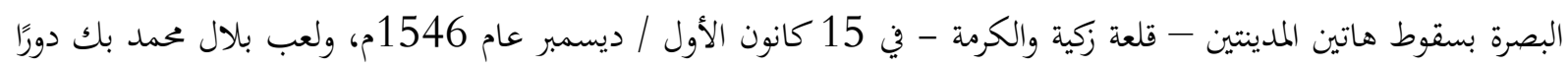

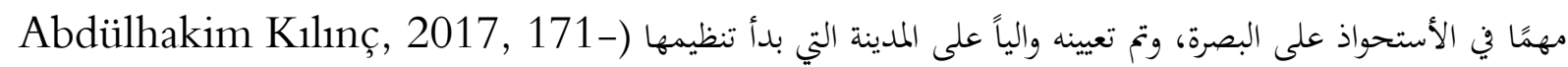

\section{(9) فتح عدن 26 شباط / فبراير عام 1548م}

أستعادة الإمبراطورية العثمانية مدينة عدن في 26 شباط / فبراير عام 1548م، التي سقطت في أيدي شيوخ عرب محليين

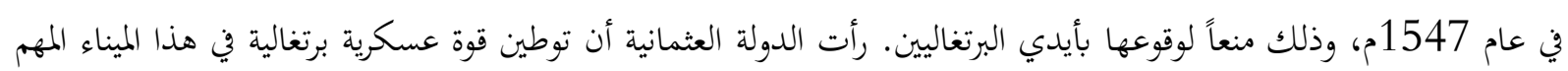

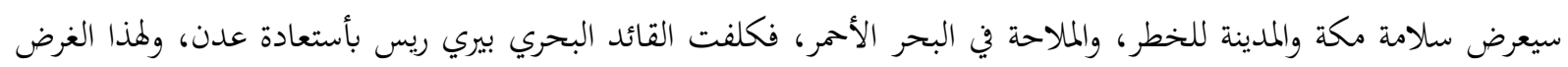

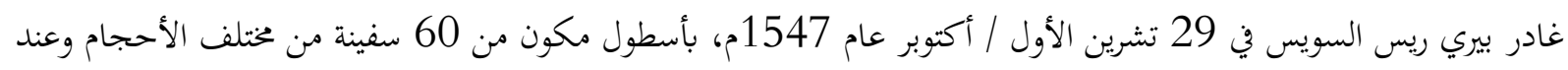

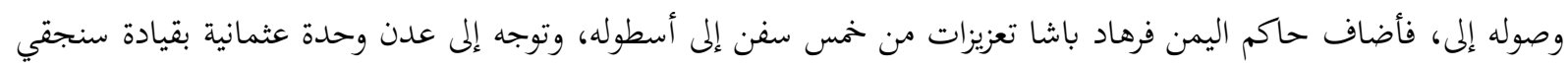
قاسم بك عدن فحاصرتما براً (Ertuğrul Önlap,2000,s.7).

وعند وصول الأسطول العثماني بالقرب من عدن في 15 تشرين الثاني / نوفمبر عام 1547م، هاجم علي بن سليمان

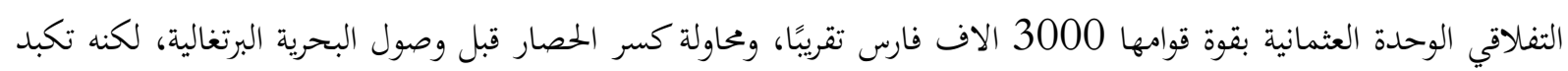

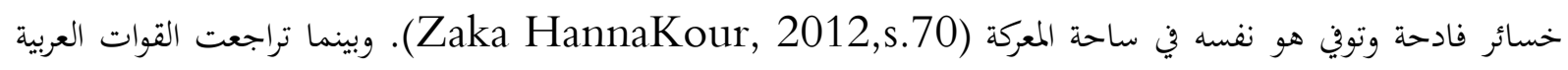

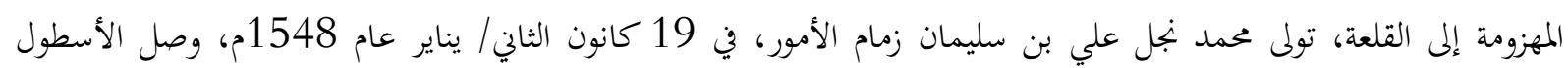

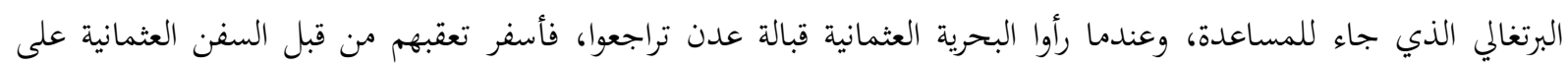


Aksaray, ) السيطرة عليها في ميناء زيلا الواقع قبالة السواحل الصومالية و الأستيلاء على 120 سفينة برتغالية و حرق بعضها (Y. Bülent, 2007,s.45.

عقب الأنتصار، حُصرت مدينة عدن من البحر أيضًا، ووضعت المدافع على الشاطئ وأضرمت النيران في الجدران، وفي

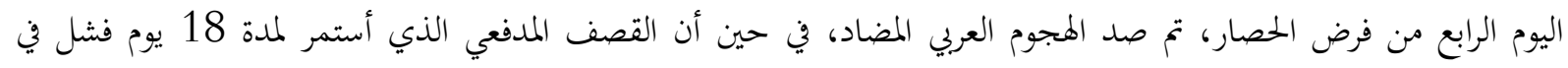

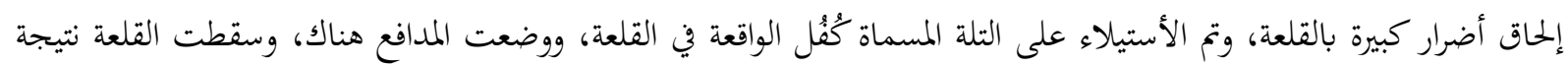

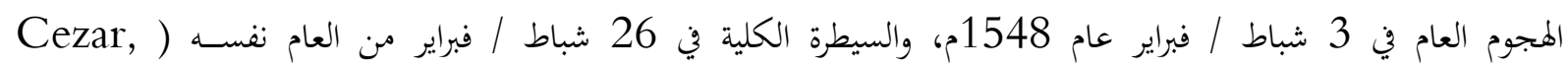
.(Mustafa, Mufassal, 1958,s.125.

\section{(10) معركة بونزا البحرية 5 آب / أغسطس عام 1552م}

معركة بونزا معركة بحرية وقعت قبالة جزيرة بونزا الإيطالية في العام 1552م، تقاتل فيها الأسطولين العثماني بقيادة درغوث

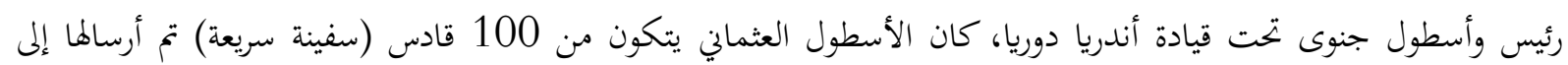

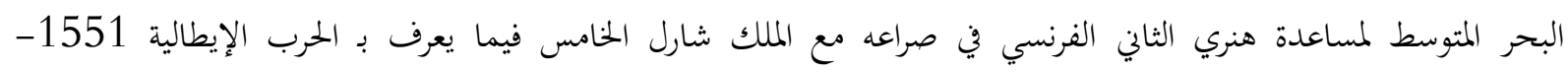

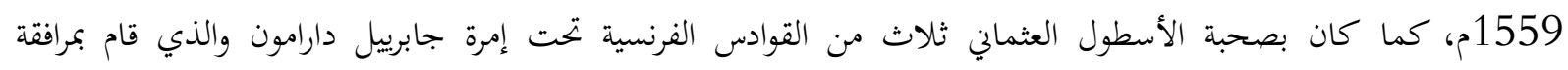

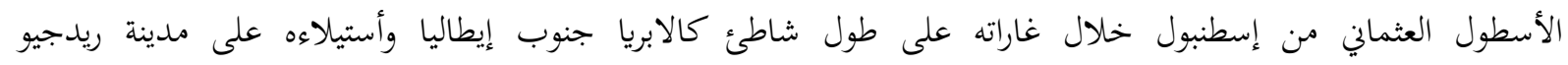

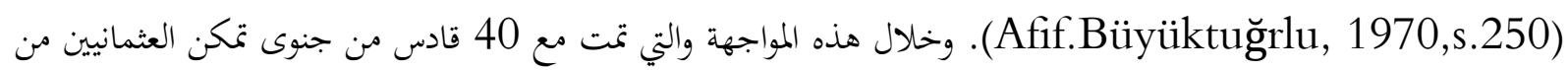

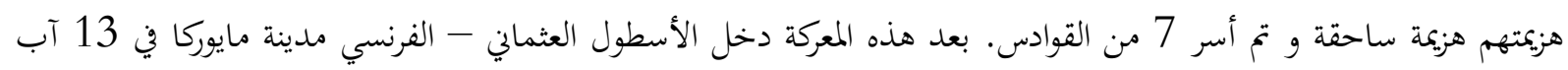

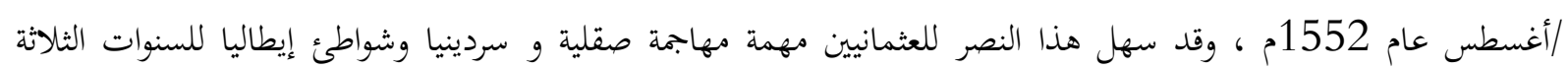
القادمة (Halil. İnalc1k , 2004,s.82).

(11) معركة هرمز البحرية 9-25 آب /أغسطس1554م

وقعت معركة هرمز في 9 آب / أغسطس عام 1554م، في مضيق هرمز بين البحرية الحربية العثمانية بقيادة سيدي علي

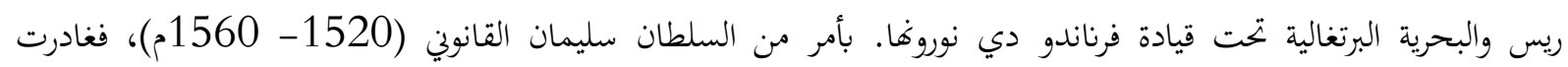

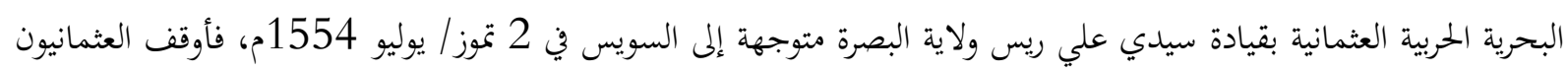

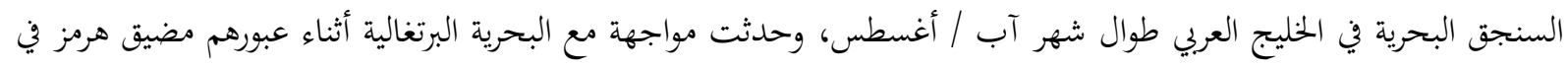

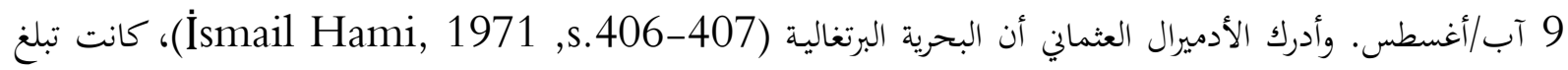

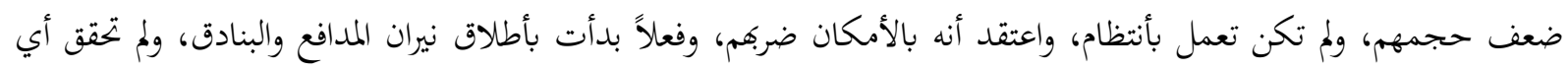
نتائج تذكر في المعركة، والتي أستمرت حتى الفجر، فقدت لندمن البحرية البرتغالية العديد من البحارة وأغرقت سفينة شراعية فوقها. عiئذ بدأت تتراجع بشكل غير متساوي بأبتحاه جزيرة هرمز (-) 
غادرت البحرية العثمانية، التي كانت في الحملة الهندية الرابعة في صيف عام 1554م، الخنليج العربي بعد معركة هرمز ووصلت إلى ميناء صحار في عمان، بعد مغادرة الميناء والأبحار إلى السويس ، وواجهت البحتية البحرية العثمانية البحرية الحربية البرتغالية التي حاصرت مسقط يوم السبت 25 آب /أغسطس عام 1554 م(Ahmet Güleryüz , 2004,s.250). اعتقدت البحرية البرتغالية بقيادة فرناندو دي نوروغا، والتي تتكون من 34 سفينة ولديها العديد من الجنود، وأفها ستعطل

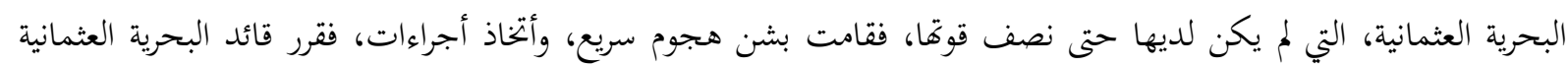

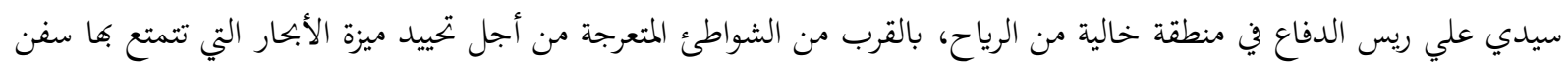

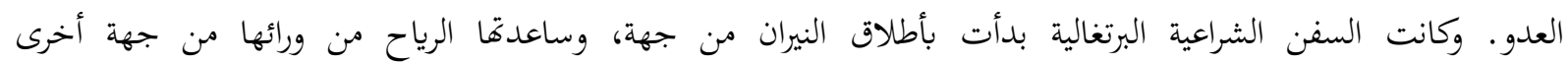

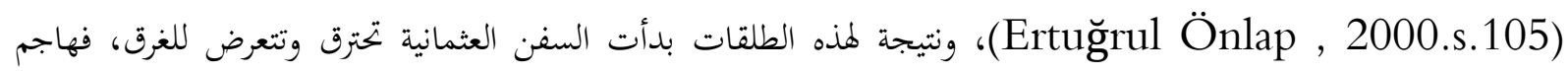
سيدي علي ريس 14 قودساً وركب سفنهم قبل أن تتمكن القوادس البرتغالية من اللحاق بها. وحدثت المواجهة بين الجانبين،

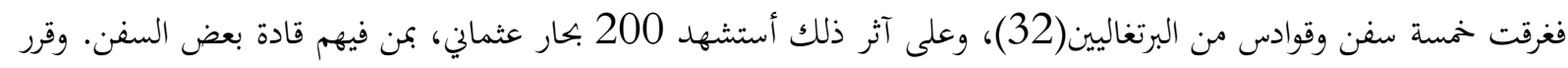

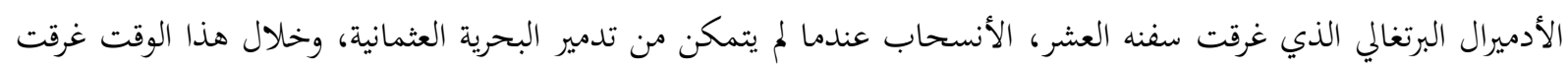

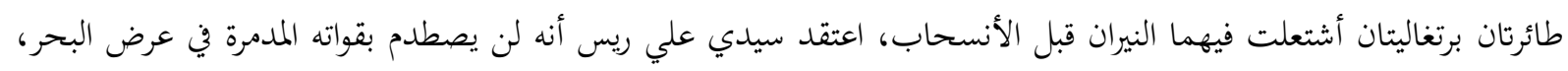

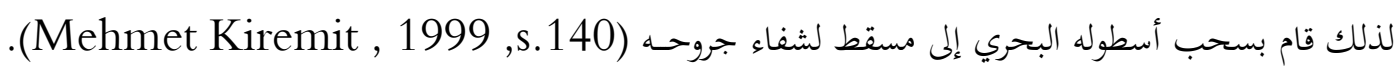

1560 13) معركة جربة البحرية

حدثت معركة جربة بين البحرية العثمانية بقيادة الأدميرال بيالي باشا والبحرية الصليبية بقيادة القوات الإسبانية في أيار /

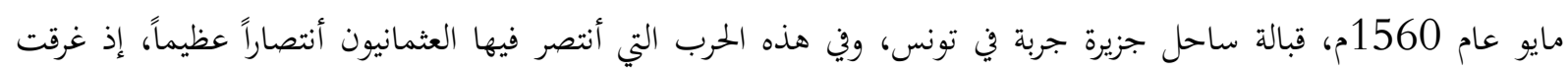

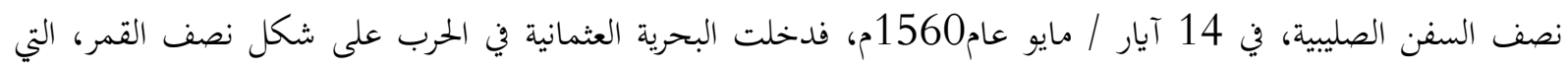

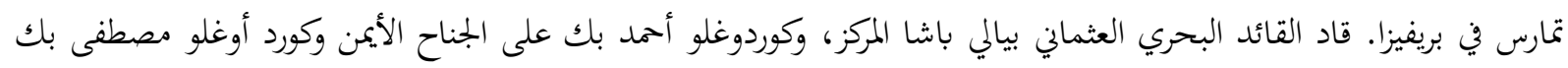

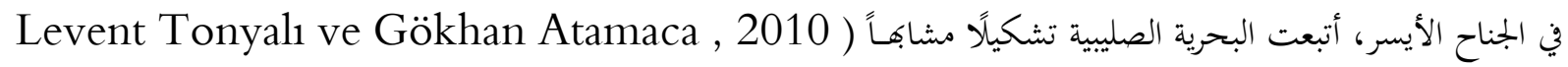

فبدأت هذه المعركة بالمدفعية، ولاحظ بيالي باشا علامات الذعر والهزيمة في الأسطول الصلبي نتيجة الضربات الدقيقة

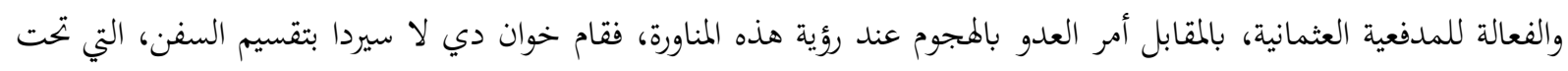

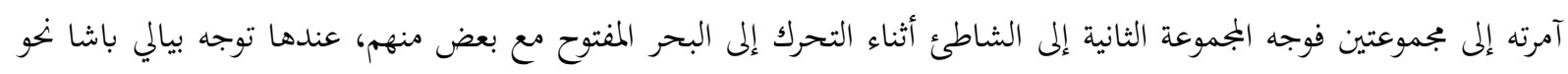

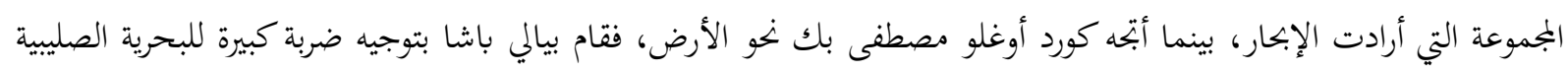

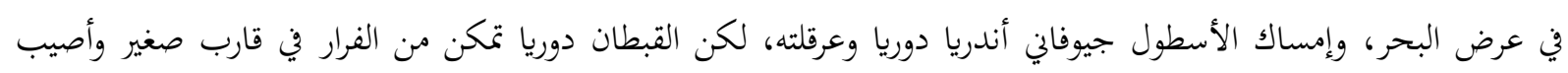

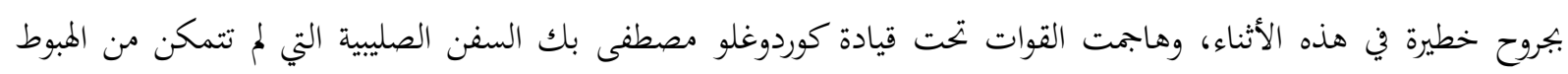

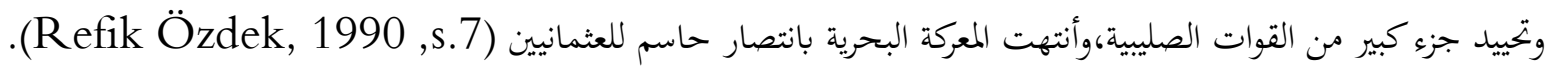

\section{14) حصار مالطا عام}

حصار مالطا أو حملة مالطا هي عملية حصار على جزيرة مالطا من قبل قوات الدولة العثمانية في عام 1565م، ودفاع

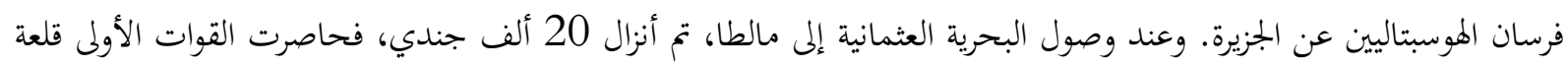

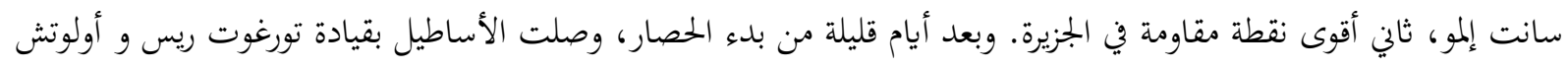

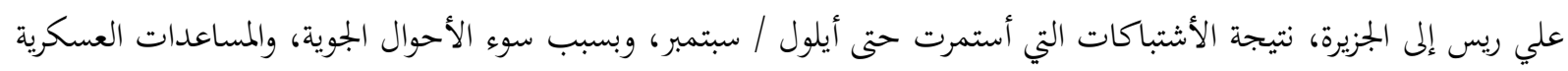


المتوقعة أيصالها للعدو من صقلية عبر شمال الجزيرة، قرر القائد العام كيزيلمدلي مصطفى باشا رفع الحصار والأنسحاب في 11 أيلول/ سبتمبر عام 1565م، ورفع الحصار بالكامل (Levent Tonyal1 ve Gökhan Atamaca,2010.s.70).

\section{(15) فتح قبرص 16 آيار / مايو عام 1570- 1 آب/ أغسطس 1571م}

الحرب العثمانية - الفينيسية أو حملة قبرص - هي الحرب الرابعة بين العثمانيين والبندقية. وقد كانت بين الدولة العثمانية

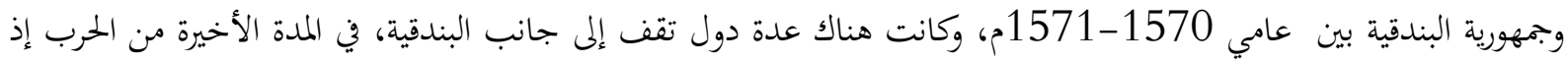

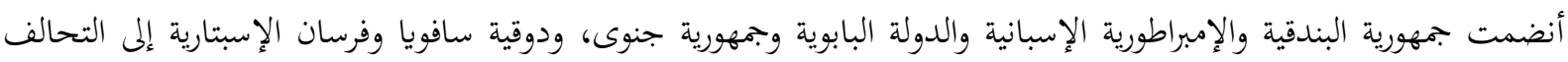
المقدس، الذي تم تشكيله بمبادرة من البابا بيوس الخامس(Refik Özdek , 2010,s.45). وكانت أهم عملية عسكرية لحكومة السلطان العثماني سليم الثاني (1566 -1574م)، أن التوتر الذي بدأ مع محاولة حصار مالطا في عهد السلطان سليمان الأول (1520-1566م)، وأستمر مع الرحلة الأستكشافية إلى قبرص الواقعة تحت سيطرة جمهورية البندقية. وبعد

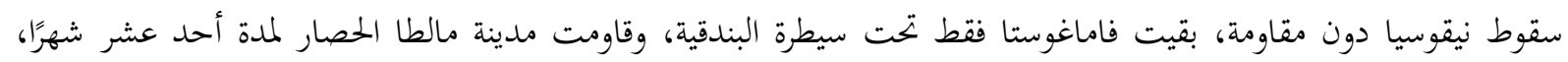

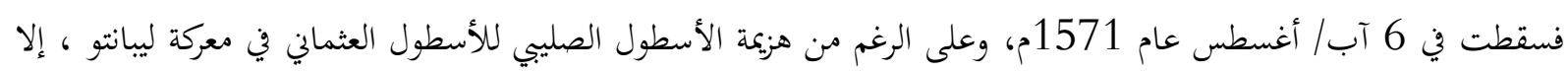

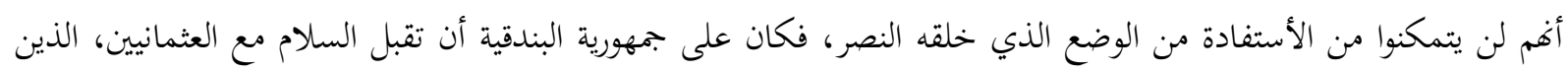
كانوا يقومون بناء أسطولم البحري بسرعة (Çevikel, Nuri , 2006, s. 102).

1571م (16) معركة ليبانتو البحرية عام

حدثت معركة ليبانتو البحرية بين الدولة العثمانية والأساطيل الصليبية على برزخ كورنث، بالقرب من ليبانتو، في 7 تشرين

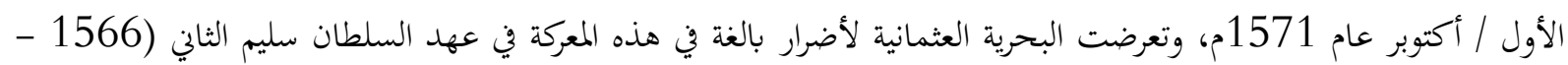

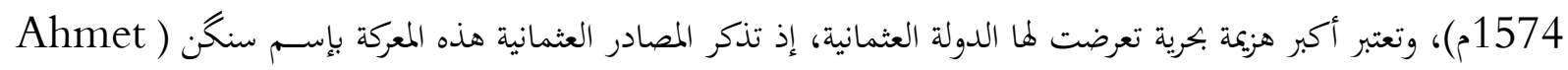

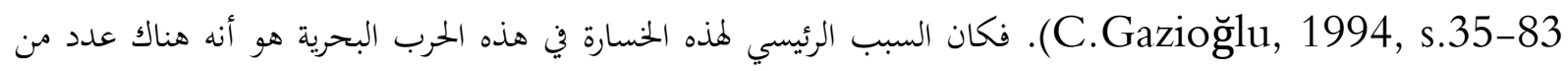

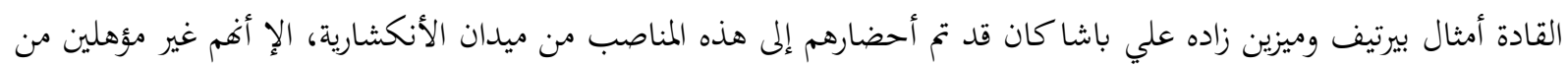

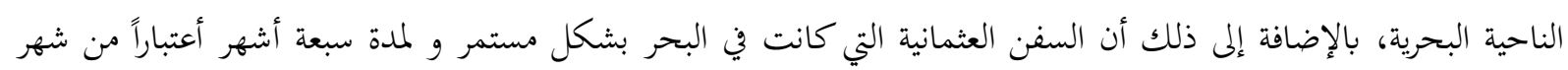

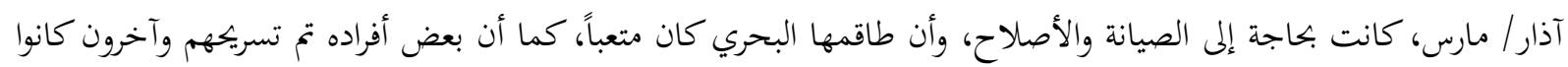
مجازين، فتم تعزيز الطاقم البحري من قبل الفرسان من غير البحارة (Günen Çoşkun , 1995 , s.562).

\section{(17) معركة وادي سيل البحرية عام 1578م}

معركة وادي سيل أو معركة وادي المعازين وهي معركة كانت بين قوات سلطان المغرب السعدي عبد الملك (1576 -

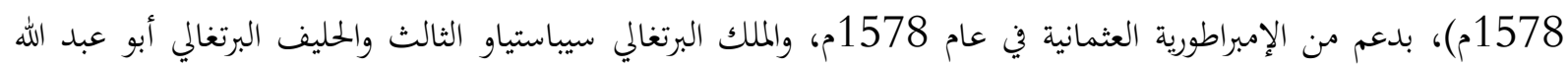

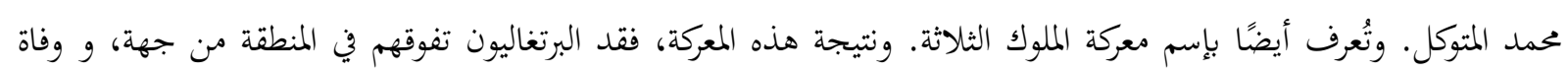

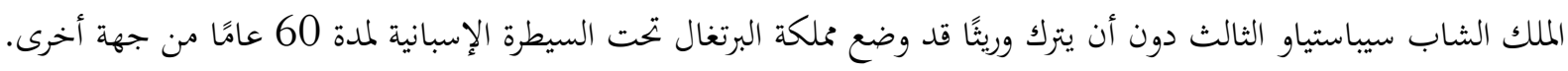

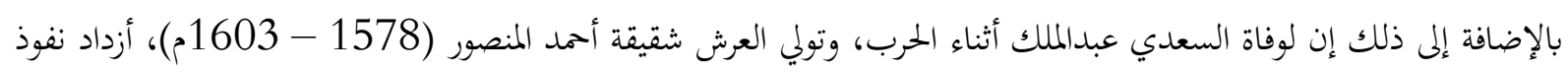
الإمبراطورية العثمانية على المغرب أكثـر (Nejat Tarakç1 , 2009,S.25).

(18) معركة مومباسا عام 1584 -1589م

وقعت معركة مومباسا في 5 آذار / مارس عام 1584م، في مدينة مومباسا، وهي مدينة ساحلية في دولة كينيا الحالية.

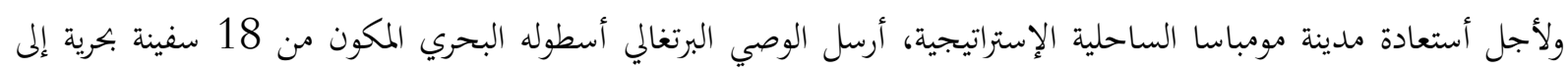

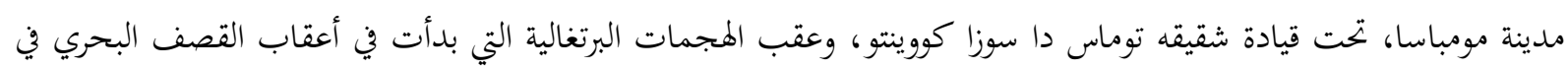


5 آذار / مارس عام 1589م، وتم خلال المواجهة بين الطرفين حرق السفن العثمانية، والأستيلاء على قلعة مومباسا، وُهزَم الأمير

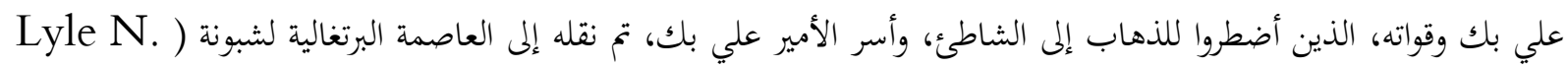
.(McAlister, 1984,p.p 125

\section{(19) معركة جهنم السوداء البحرية تموز/ يوليو عام 1609م}

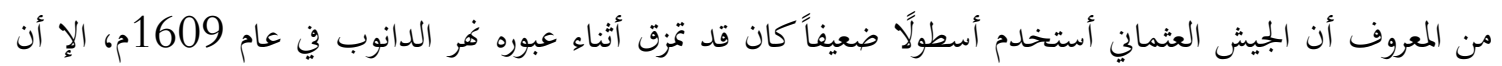

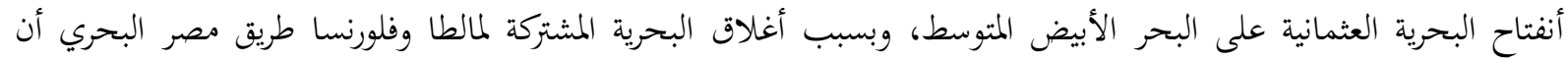

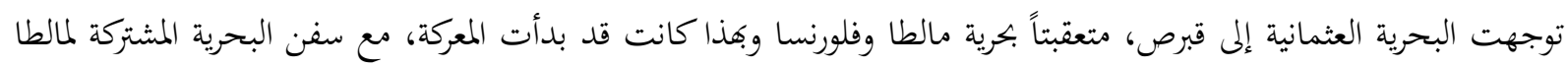

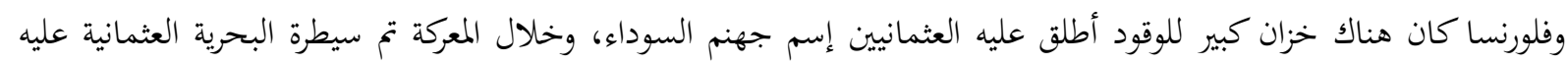

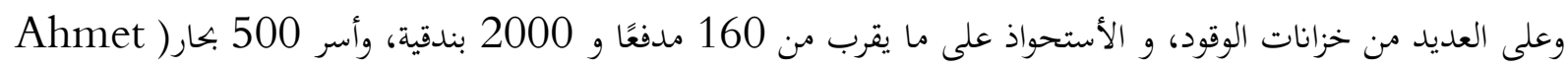

.(,Kavas , , 2005,s.170

\section{(20) معركة كيب جيلدونيا 14-16 تموز / يوليو عام 1616م}

كانت معركة كيب جيلدونيا قد وقعت بين الإمبراطورية الإسبانية والإمبراطورية العثمانية بين 14-16 تموز / يوليو عام

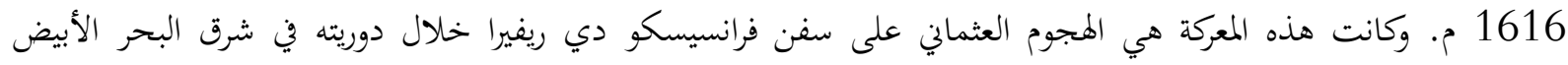

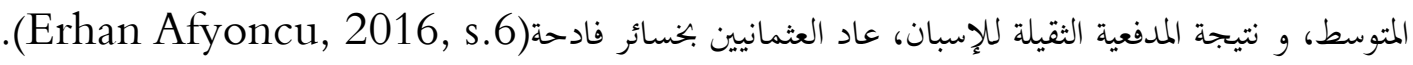

(21) معركة قارا هرمان البحرية عام 1625م

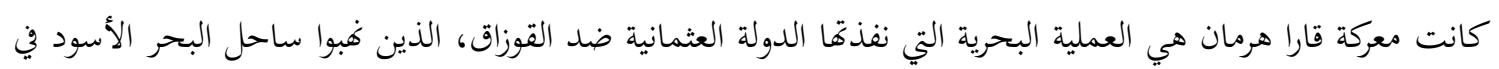

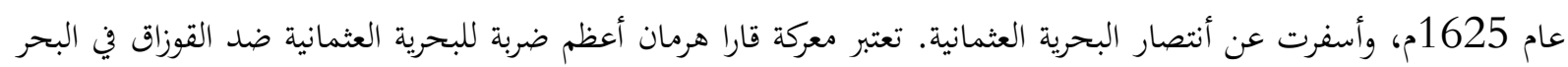

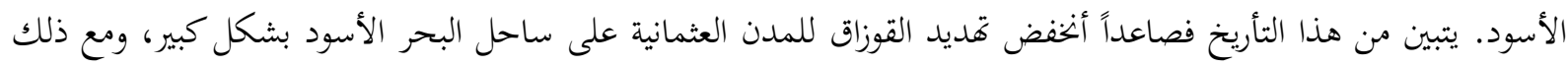

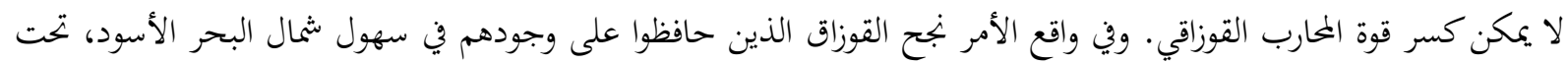

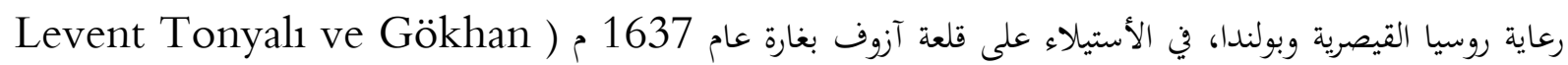
.(Atamaca, 2010, s.574

\section{(22) معارك جاناق قلعة البحرية عامي 1654 - 1669م}

كانت معركة الدردنيل البحرية الأولى التي خاضتها البحرية العثمانية تحت قيادة مراد باشا مع سفن جمهورية البندقية بقيادة إنيا

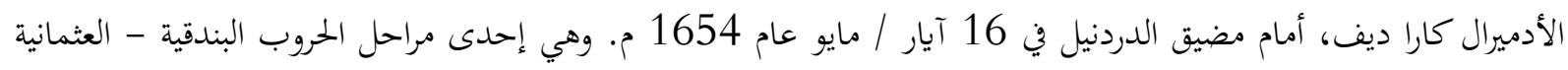

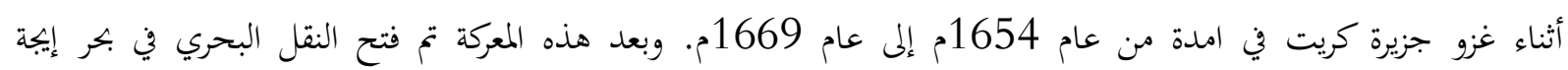

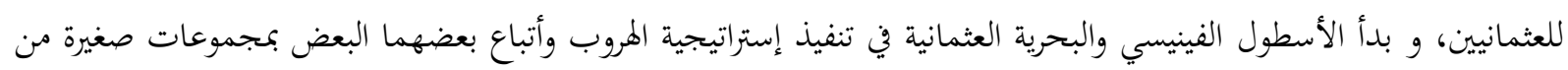

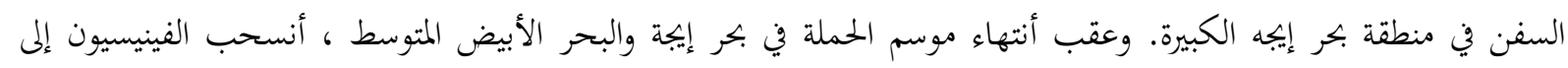

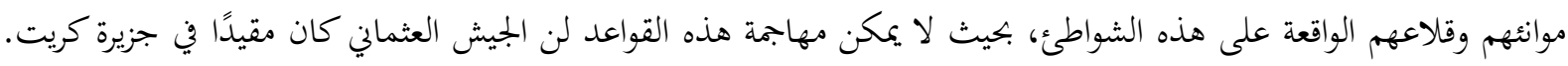

(Ahmet C.Gazioğlu, ,1994, s.245)

أما معركة الدردنيل البحرية الثانية بقيادة الأدميرال مصطفى باشا مع سفن البحرية لجمهورية البندقية أمام مضيق الدردنيل

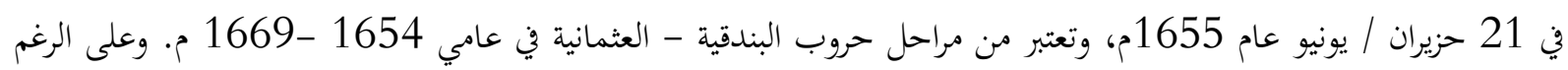

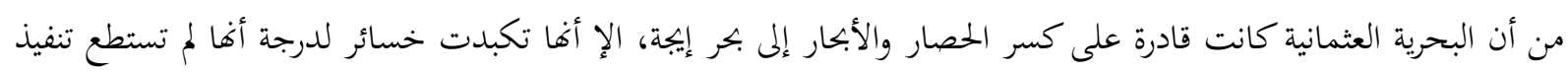


عملية حربية بحرية، على نطاق يمكن أن يغير الوضع في جزيرة كريت. الأ أن شجع هذا النجاح في الدردنيل البنادقة على أرسال أسطول أكبر إلى المنطقة بعد عام من هذه المعركة ( Levent Tonyalı ve Gökhan Atamaca, 2010,

معركة الدردنيل البحرية الثالثة، وهي المعركة البحرية للبحرية العثمانية بقيادة الأدميرال سري كنان باشا مع سفن البحرية

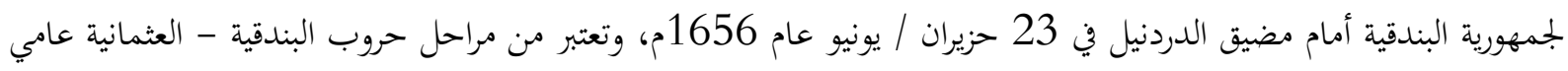

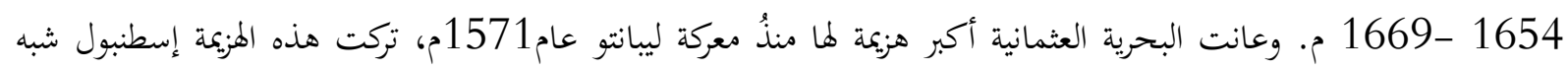
معزولة (Aktepe, M. Münir, 1994,s.375-376).

\section{7 (23) - (23) حصار ليمني عام}

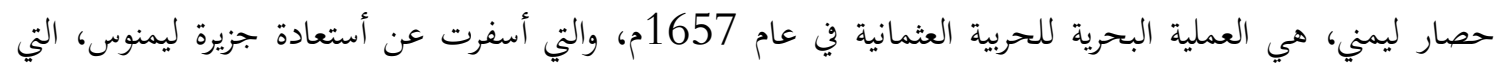

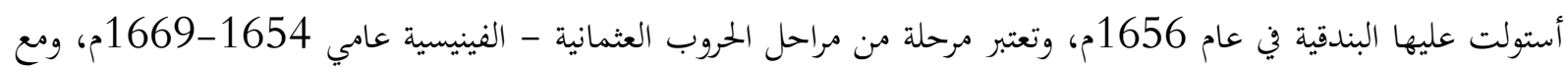

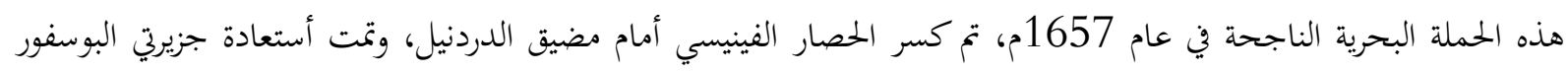

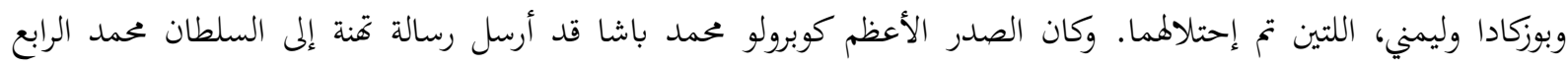

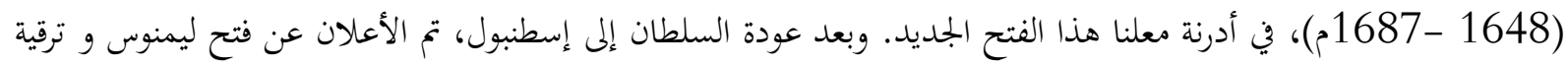

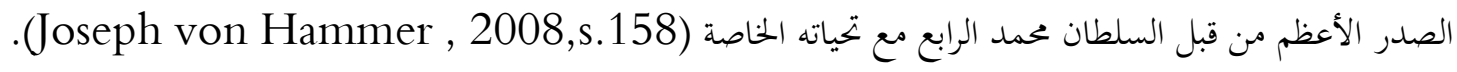

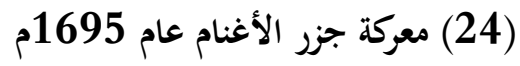

وقعت معركة جزر الأغنام للبحرية العثمانية بقيادة النقيب حسين باشا مع سفن البحرية لجمهورية البندقية بقيادة دريا

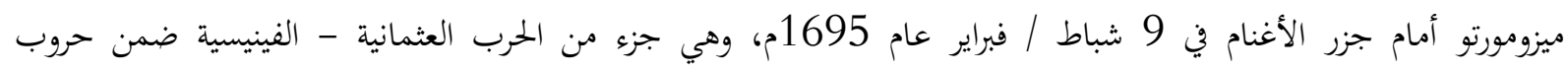

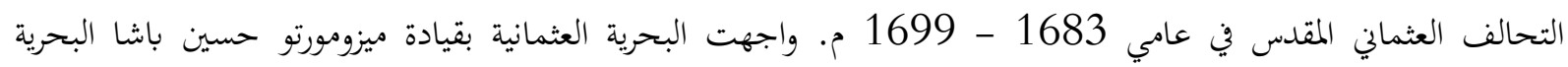

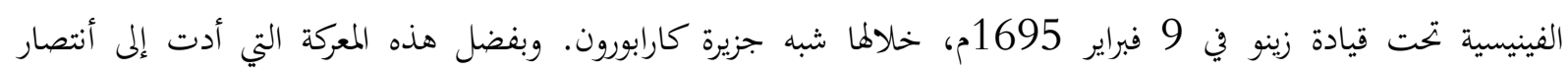

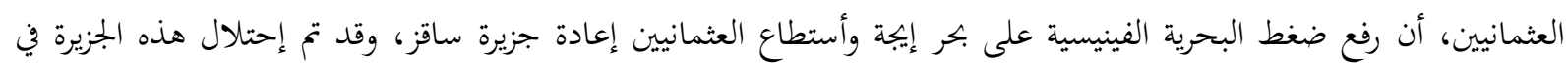

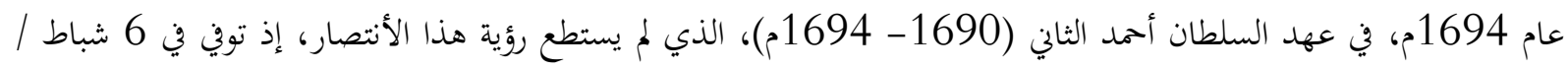
فبراير 1694م (Feridun Emecen , 2003, s. 191). 
الخور الثاني:

حروب البحرية العثمانية (1700-1918)

1) - (1) معركة إمروز البحرية الأولى عام 1717م

حدثت معركة إمروز بين البحرية العثمانية، التي كان لديها 44 سفينة حربية تحت قيادة كابتن دريا هوكا إبراهيم باشا،

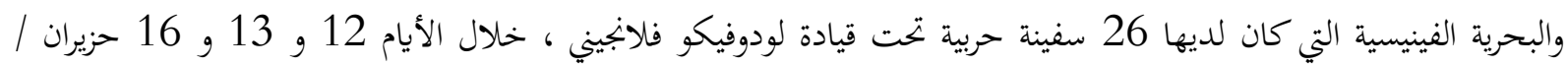

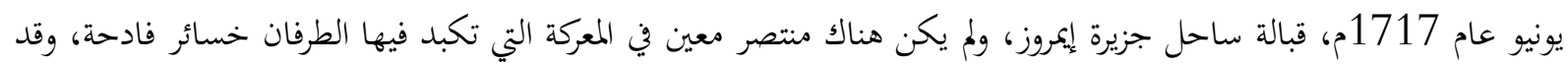

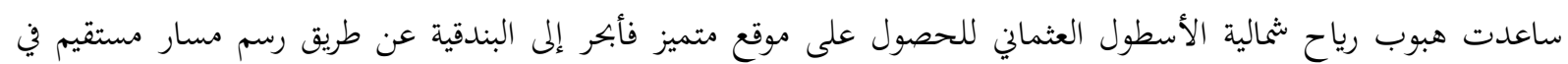
وقت مبكر حوالي الساعة الثالثة والنصف ليلاً، فهاجمت ثمانية سفن عثمانية السفن الفينيسية المسماة (كولومبا، تريونفو، سفينة

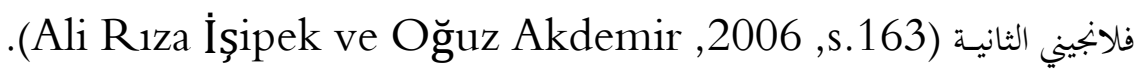
وفي يوم 13 حزيران / يونيو، التقى الاسطول الفينيسي مع الأسطول العثماني بالقرب من الطرف الغربي لجزيرة ليمنوس،

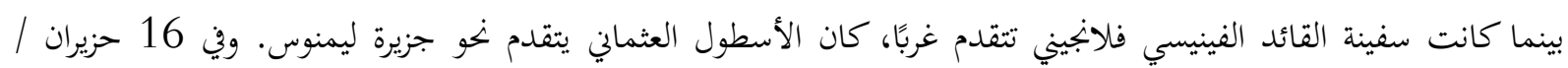

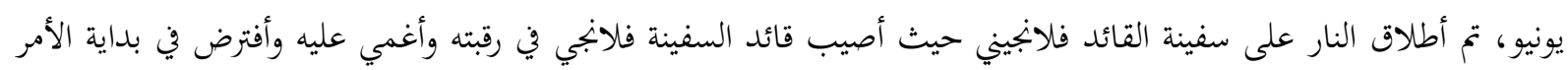
أنه قتل.

وفي تمام الساعة 15:30 أي بعد 5 ساعات من المعركة، أنسحب الأسطول العثماني بأتحاه جزيرة ليمني بستة سفن،

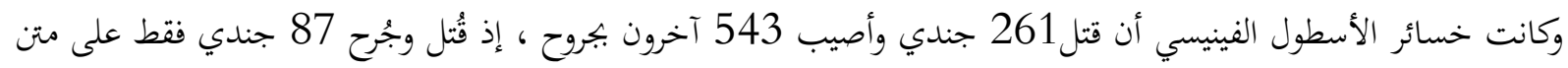

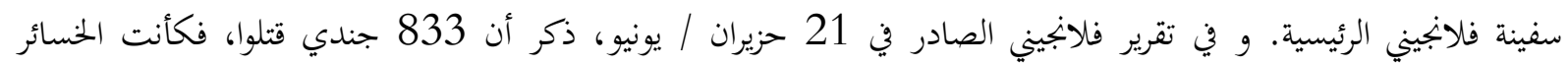

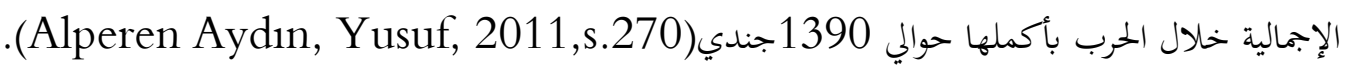

\section{(2) معركة لوري برنو عام 1737م.}

صباح يوم الجمعة المصادف 12 ربيع الثاني عام 1150 هـ، بينما كانت البحرية العثمانية في منطقة ديفيبوين، شوهد الأسطول الروسي المكون من 200 سفينة و خمسة قاذفات متجهه نخو بحر آزوف. عند ذلك تحركت البحرية العثمانية بأتحاه

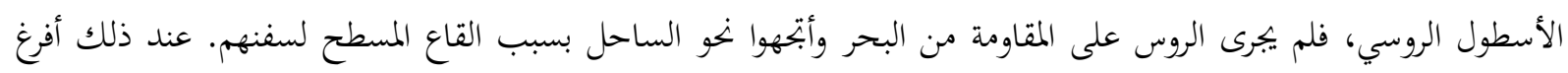

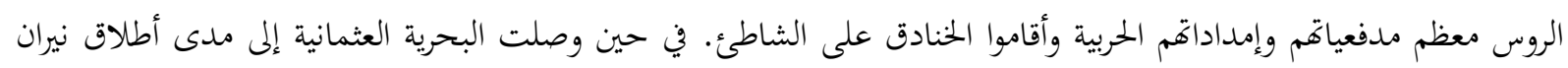

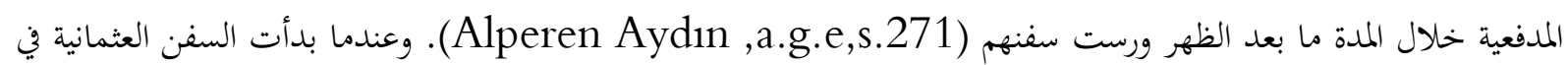
أطلاق نيران مدافعها، بدأ الروس في الرد على نيران سفنهم من الشاطئ. فكانت مدافع السفن العثمانية تضرب السفن الروسية

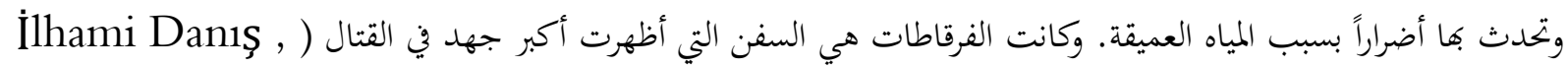
(2007, s. 72

\section{(3) معركة جشمة البحرية عام 1770م}

أندلعت معركة جشمة البحرية بين يومي 5-7 تموز / يوليو عام 1770م، بين البحرية الروسية والبحرية العثمانية مقابل

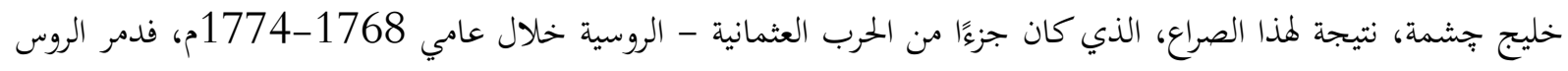

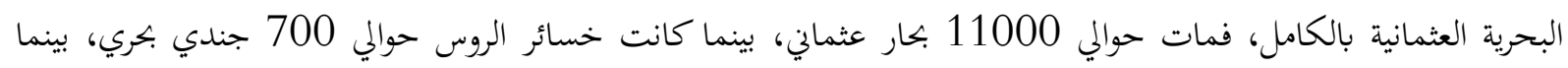
هرب الكابتن دريا ماندالزاده مع رئيسه النقيب حسام الدين باشا (Illhami Danış , 2007,s.72). 


\section{(4) - (4) - معركة كرج البحرية عام 1774م}

حدثت معركة مضيق كيرتش في جنوب كجز في شبه جزيرة القرم في يوم 20 حزيران / يونيو و يوم 9 متموز / يوليو عام

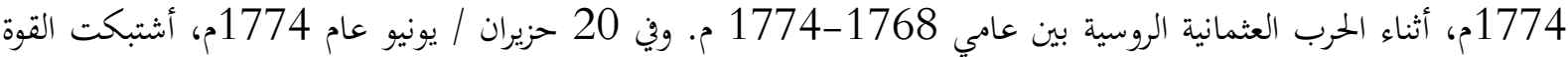

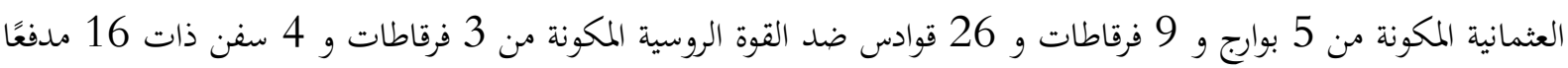

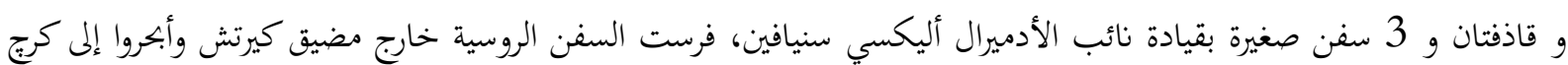

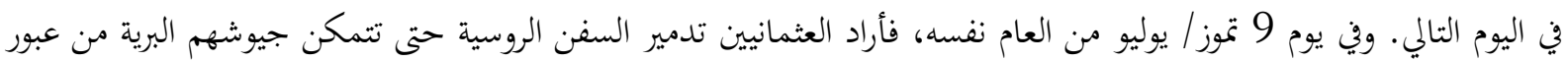

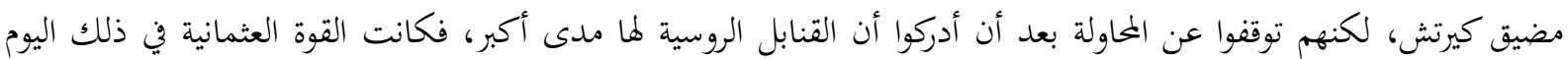

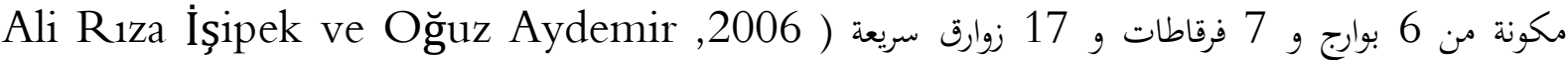

\section{(5) (5 ) حرب خليج ين قلعة 1787 - 1792م}

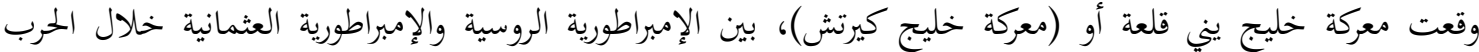

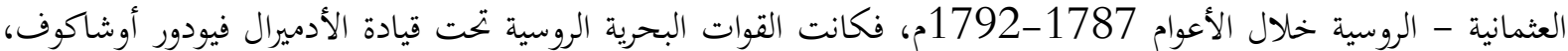

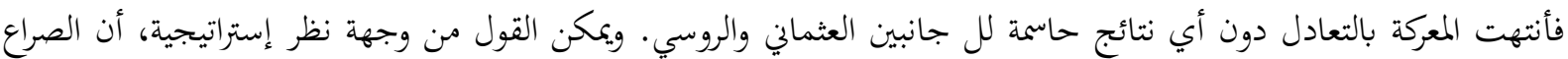

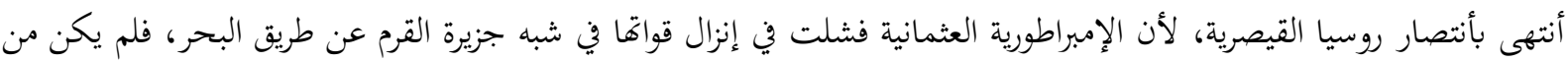
الممكن تدمير السفن الروسية نتيجة لذلك (R. C. Anderson , ,p.p 157).

\section{(6) - معركة ميناء طرابلس الأولى البحرية عام 1801 - 1805م}

سميت الحرب الطرابلسية نسبة إلى طرابلس (في لييا الحالية) أو الحرب البربرية الأمريكية الأولى (1801- 1805م)، و

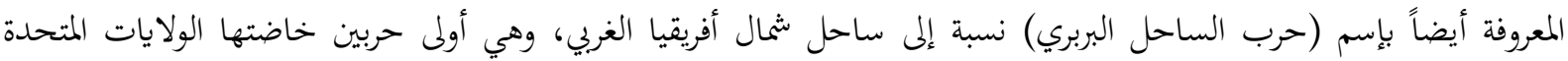

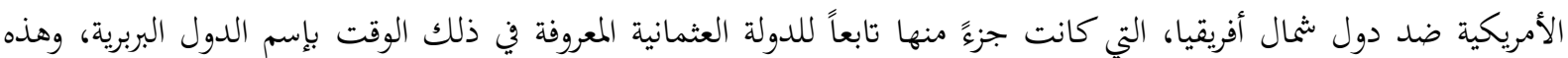

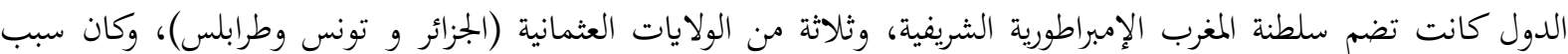

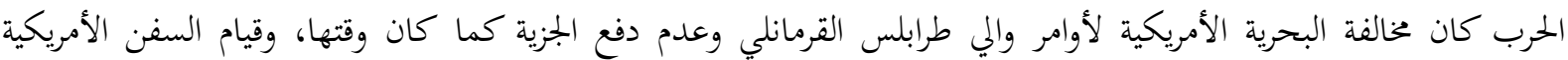

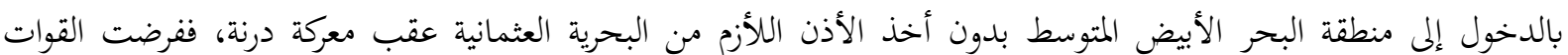

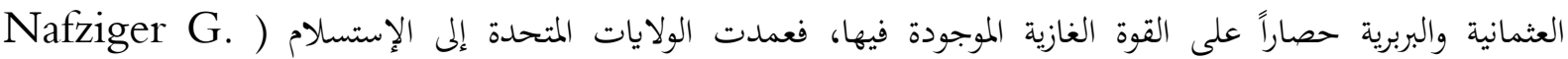

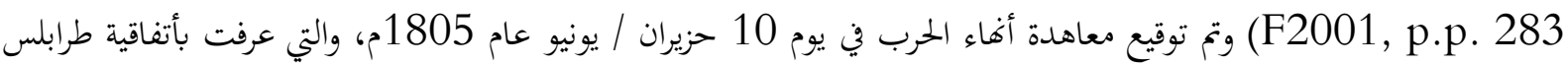
، وطلب باشا ليبيا يوسف باشا من الولايات المتحدة غرامات مالية تقدر بثلاثة ملايين دولار ذهباً، وضريبة سنوية قدرها

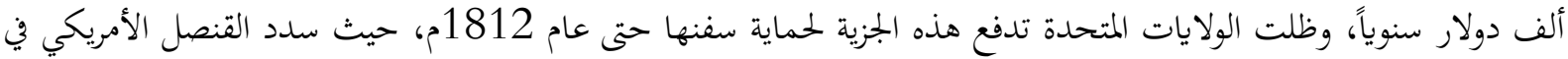
الدولة العثمانية 62 ألف دولار ذهباً، وكانت هذه هي المرة الأخيرة التي تسدد فيها الضريية السنوية والتي تسمى أحياناً (الحرب الحبائ

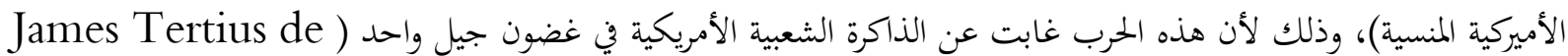
(Kay, 2004,p.p.253

\section{(7) الحرب البربرية الثانية عامي 1815 -1816م}

كانت الحرب البربرية الثانية حرباً بحرية بين الولايات المتحدة ودول شمال إفريقيا الأمازيغية التابعة للإمبراطورية العثمانية بين

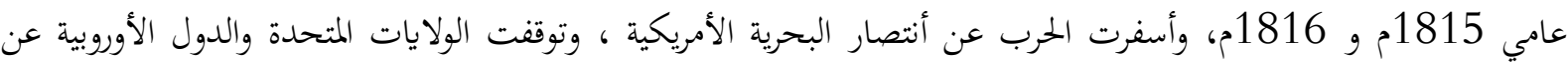

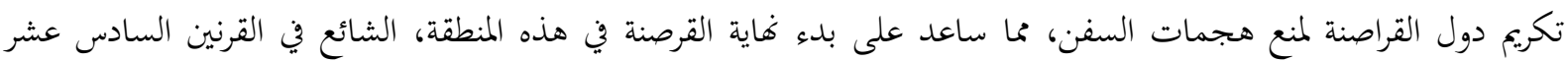


والثامن عشر للميلاد على مر السنين، فبدأت القوى الأوروبية في بناء سفن أكثر قوة فلم يستطع القراصنة البربريون مطابقتها في العدد أو التكنولوجيا (Wheelan, Joseph. 2003,p.p.232)

1827 (8) معركة ناوارين البحرية عام

وقعت معركة ناوارينو في يوم 20 تشرين الأول / أكتوبر عام 1827م، بين القوات البحرية العثمانية والمصرية ضد القوات البحرية البريطانية والفرنسية والروسية التي تعمل معاً، وتعرف هذه المعركة أيضاً بإسم (حادثة ناوارينو) أو (ناوارينو ريد) أو (كارثة

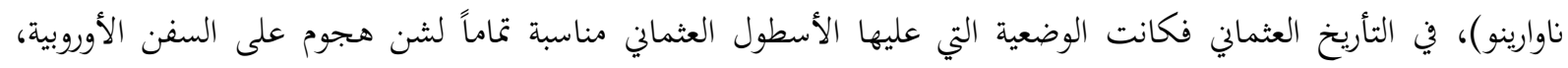

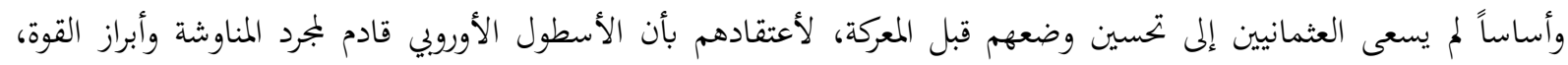

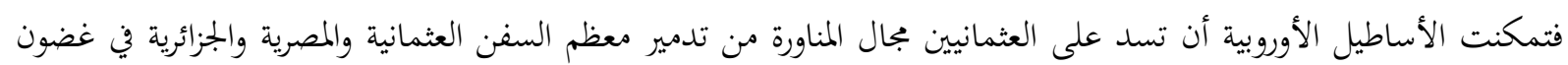
عدة ساعات ( Leiner, Frederic , 2007. s. 39-50)

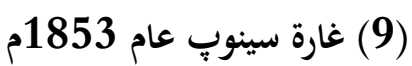

غارة سينوب (30 تشرين ثاني / نوفمبر عام1853م)، إحدى المعارك المهمة في حرب القرم، وفي هذه الغارة وجهت

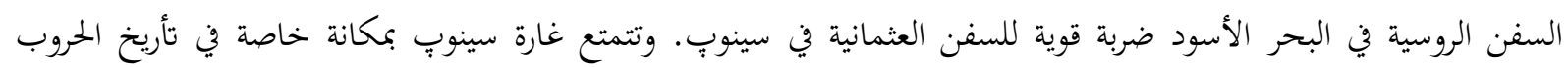

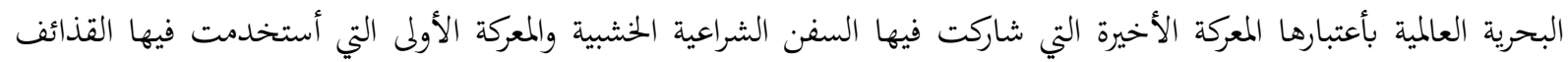

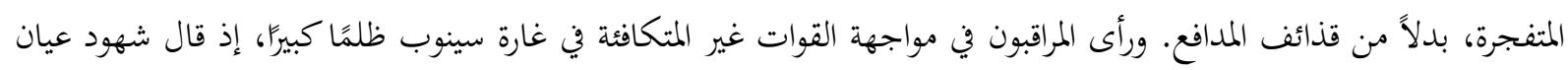

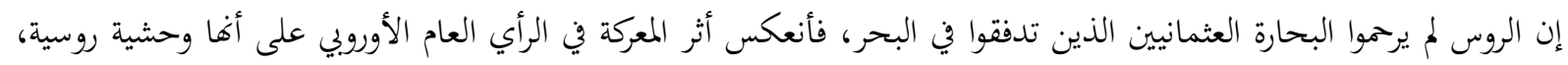

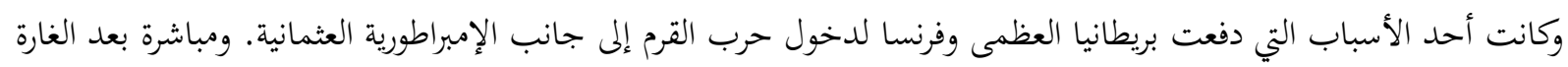

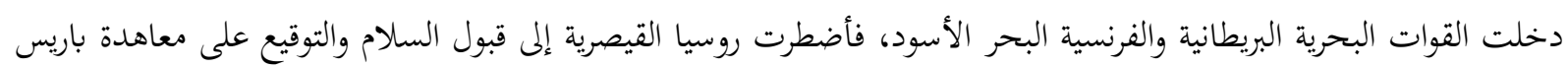
في 30 آذار / مارس عام1856م (W. James 1837, p.p. 89.).

\section{(10) حركة 93 الحربية عامي 1877-1878م}

وقعت حرب 93 أو الحرب العثمانية - الروسية عامي 1877-1878م في عهد السلطان العثماني عبد الحميد الثاني

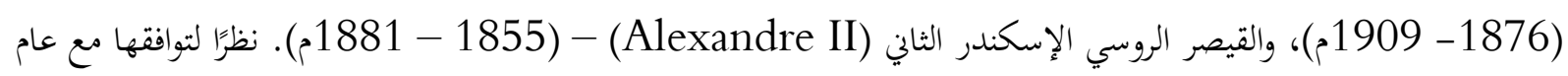

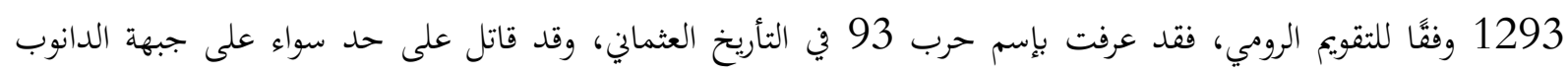

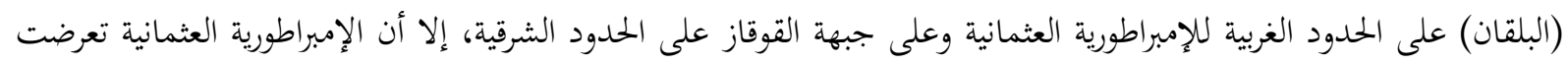

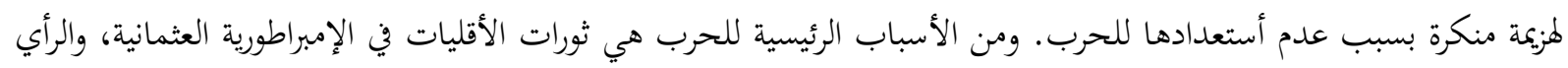

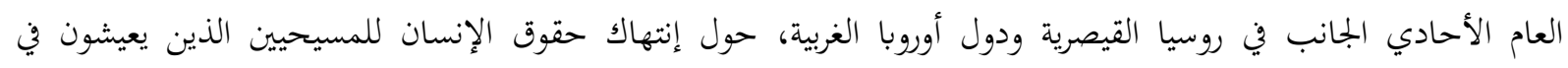

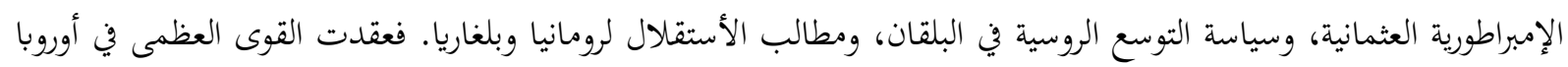

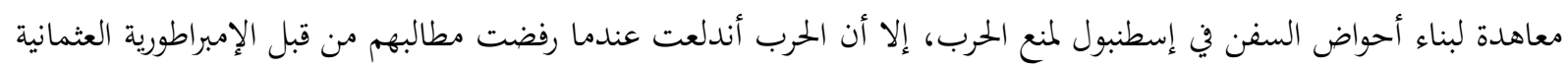

(Gulen, Nejat, 2001,s.225)

\section{(11) معركة إمروز البحرية الثانية عام1912م}

وقعت معركة إمروز أو معركة إيلي (سيدولاهير) خلال حرب البلقان الأولى في يوم 16 كانون الأول / ديسمبر عام

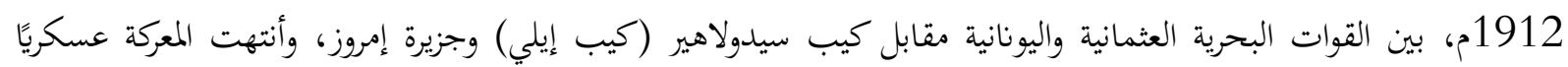

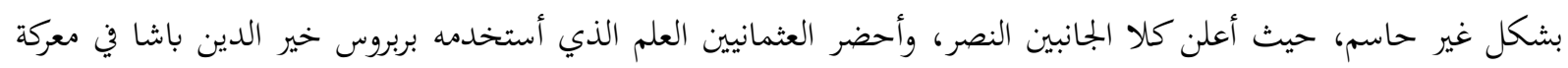
بريفيزا من المتحف البحري ورفعوه على سارية البارجة بربروس خير الدين (محمد فريد ، ص صلئ 587-647.)، بينما قدم اليونانيين 
عرضًا بحضور قائد البحرية في منطقة أفيروف و حافظ الإغريق على الوضع في شمال بحر إيجة لصالحهم، و لم تستطع البحرية

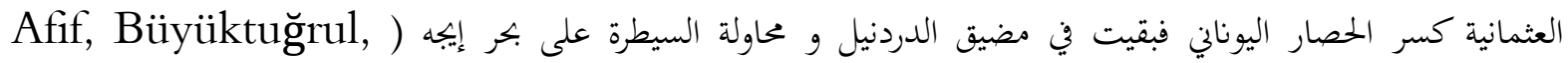
.(1974,s.175.

\section{(12) معركة موندروس البحرية عام 1913م}

وقعت معركة موندروس يوم 18 كانون الثاني / يناير عام1913م، بين الإمبراطورية العثمانية والقوات البحرية اليونانية،

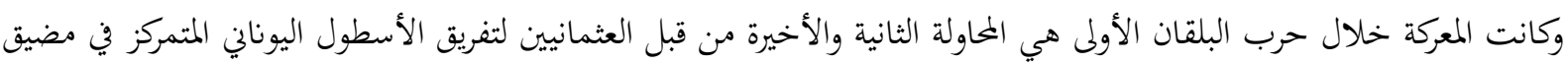

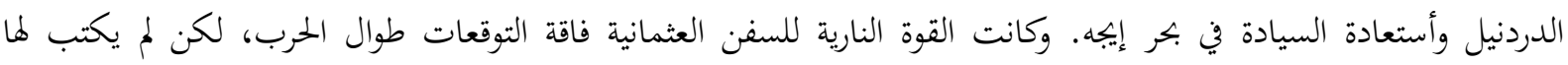
النجاح. ولم تتمكن سفينة أفيروف الروسية من تفادي نيران المدافع العثمانية، بينما تعرضت السفن العثمانية لاصابات باتهن بالغة نسبيًا،

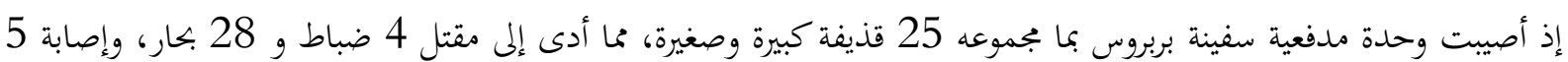

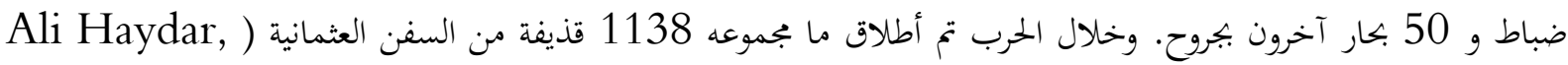

.(Emir, 1932,s.410.

\section{(13) حرب جاناق قلعة البحرية عام 1915م}

إن العمليات البحرية لحرب الدردنيل هي سلسلة من العمليات البحرية التي أجريت في مضيق الدردنيل في المدة من يوم 19 شباط / فبراير إلى يوم 18 آذار / مارس عام 1915م، بين أسطول الحلفاء الأوربيين والمدفعية البرية التابعة للإمبراطورية

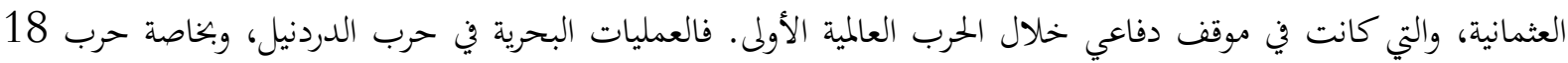

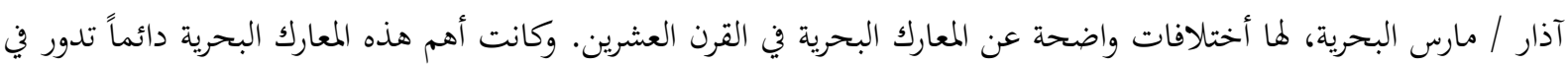
عرض البحر، ولم يتمكن أي مراقب من مراقبة ساحة المعركة بأكملها من موقعسه (

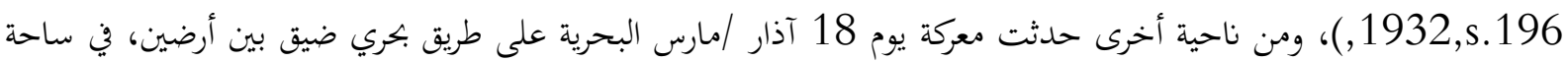

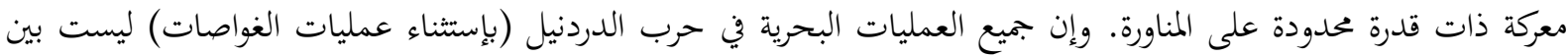

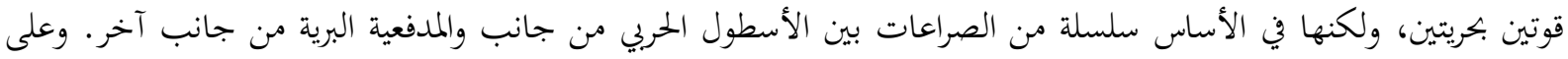

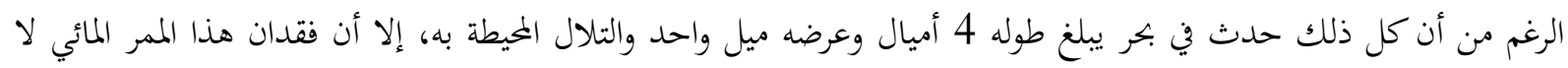
يعني خسارة معركة واحدة فحسب، بل خسارة الحرب بأكملها بالنسبة للإمبراطورية العثمانية ( بsarar Semiz

\section{(14) حرب إمروز البحرية الثالثة عام 1918م}

حدثت معركة إمروز في بحر إيجه في يوم 20 كانون الثاني / يناير عام 1918م، خلال الحرب العالمية الأولى. وحدث ذلك

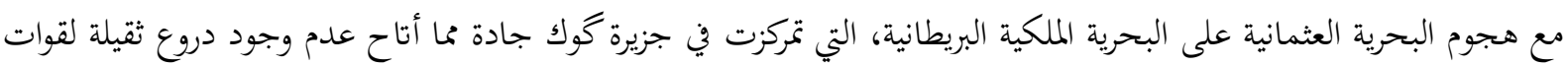
الحلفاء في هذه المنطقة، وهذا الأمر أعطى فرصة للطرادات القتالية العثمانية والتي كانت بإسم (يافوز و ميدلي الحفيف) لمهاجية

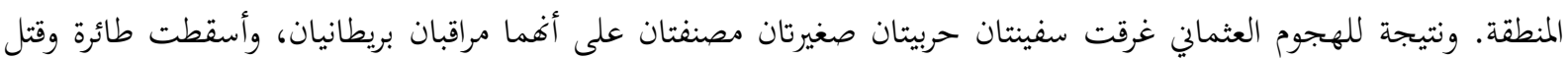
العديد من طاقمها(İbrahim Artuç , 2015,s.72) ، وكذلك ضربت السفن العثمانية التي لم تتعرض لأضرار كبيرة خلال المعركة، إلا أن الألغام البحرية التي زرعتها قوات الحلفاء لحماية الجزيرة من الهجمات العثمانية أثناء العودة. وقد تضرر الطراد

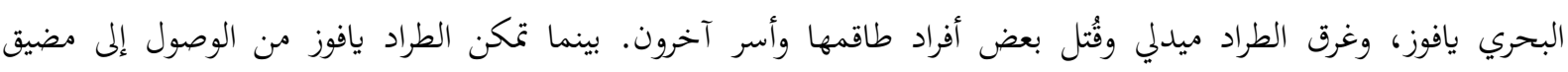

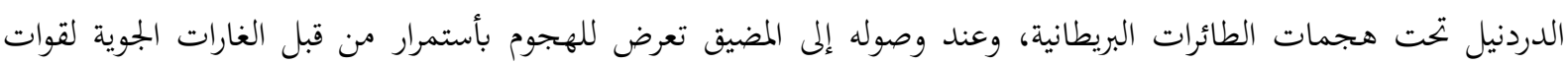


الحلفاء، حتى تم إنقاذه بعد ستة أيام. ونتيجة للضرر الذي لحق بأحدى السفينتين الحربيتين للإمبراطورية العثمانية وغرق الأخرى مماحدد بشدة التحركات المستقبلية للبحرية العثمانية (.Hüsamettin Sevengül, 1976,s.302.).

يلاحظ من خلال البحث فاعلية البحرية العثمانية، مع إن العثمانيين لم يتوقفوا أو يتأخروا في تحديث المنظومة الدفاعية

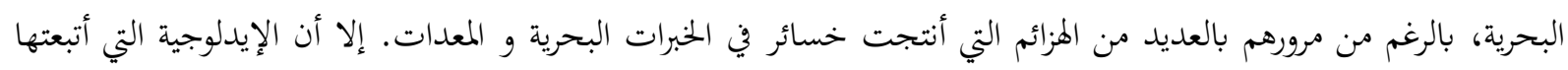

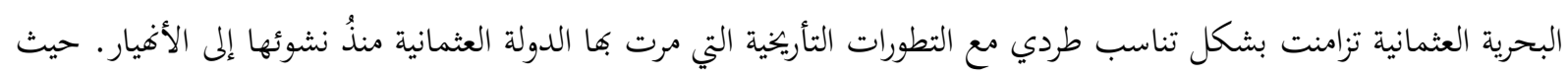

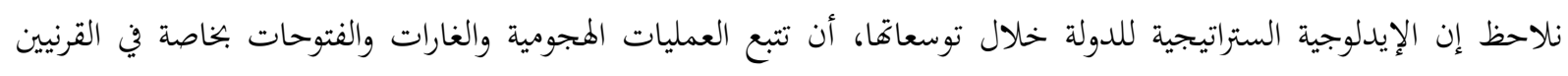
الخامس عشر والسادس عشر للميلاد، حيث تم فتح المناطق الواقعة على البحر مثل البصرة و مسقط و البندقية، غير إنه مع الركود

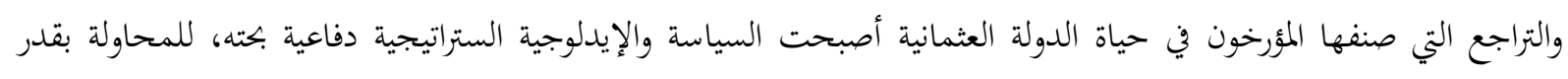

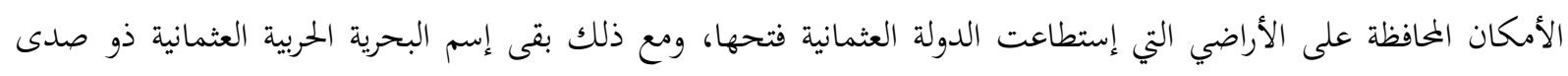

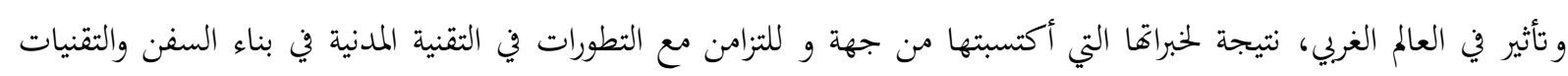
العسكرية البحرية التي حدثت من جهة أخرى أثر ظهور الثورة الصناعية في أوربا. 


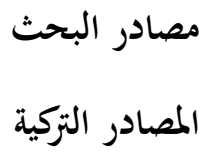

Abdurrahman Sağırlı, "Cezayir-i Irak-1 b veya Şatt-ül Arab'ın fethi , , İstanbul ,2000.

Abdülhakim Kılınç , Fuzulli’nin Kasidelerinde Basra Seferi , Türkiyat Mecmuası c.27/1 , Ankara, 2017.

Afif.Büyüktuğrlu,Osmanl Harp Tarihi, C.1, Deniz Basımevi, İstanbul.

Afif, Büyüktuğrul (1974). Osmanlı Deniz Harp Tarihi ,4. Cilt , Genelkurmay Başkanlığı Deniz Kuvvetleri Komutanlı̆̆

Ahmet C.Gazioğlu, Kıbrıs Türk Tarihi, Türk Dönemi 1570-1878, Lefkoşa; Kıbrıs Araştırma ve Yayın Merkezi, 1994, s.35-83.

Ahmet Güleryüz , Kadırgadan Kalyona Osmanlıda Yelken - Mikyas'ı Sefain , Denizler Kitabevi ,İstanbul , 2004.

Ahmet Kavas, Doğu Afrika Sahilinde Osmanlı Hakimiyeti:Kuzey Somali'de Zeyla İskelesinin Konumu, İslam Araştırmaları Dergisi (2001).

Aksaray, Y. Bülent, "Pîrî Reis'in Yaşamı, Yapıtları ve Bahriyesinden Seçmeler”, Pîrî Reis ,Araştırma Merkezi'nin yayını, Sayı: 7, İstanbul,2007.

Aktepe, M. Münir, İslam Ansiklopedisi ,Türkiye Diyanet Vakfi,Cilt:22, İstanbul 1994.

Ali Haydar, Emir, Balkan Harbinde Türk Filosu , Deniz Matabası , İstanbul ,1932,

Ali Rıza İşipek ve Oğuz Akdemir ,1770 Çeşme Deniz Savaşı,Denizler Kitabevi , İstanbul ,2006,s.163.

Ali Rıza İşipek ve Oğuz Aydemir , 1770Çeşme Deniz Savaşı,Denizler kitabevi , İstanbul ,2006.

Alperen Aydın, Yusuf, Sultanin Kalyonlari: Osmanlı donanmasinin yelkenli savas gemileri, 1701-1770, Küre Yayinlari, İstanbul ,2011,s.270.

Cezar, Mustafa, Mufassal Osmanlı Tarihi, Cilt II, Seher Matbaası, İstanbul,

Çevikel, Nuri Kıbrıs'ta Osmanlı Mirası (1570-1960), 47 Numara Yayıncılık, İstanbul 2006,

Dursun Bey, Tarih-i Ebû'l-feth,International Journal of Turkish Studies,1990.

Erhan Afyoncu, Osmanlı eşkıyayı inlerinde vurmuştu ,Sabah Gazetesi , Pazar, 20 Mart 2016.

Ertuğrul Önlap , Pîrî Reis'in Hürmüz Seferi ve İdamı Hakkındaki Türk ve Portekiz Tarihçilerinin Düşünceleri, Ankara Üniversitesi, Dil ve Tarih-Coğrafya Fakültesi , Ankara ,2000.

Feridun Emecen , ,"Limni", İslam Ansiklopedisi, Türkiye Diyanet Vakfi cilt: 27, İstanbul (2003). Gökhan Atmaca ve Doğan Tanriverdi, Türklerin Tarihinde 30 Büyük Deniz Savaşı, Denizler Kitabevi ,İstanbul ,2016.

Gulen, Nejat, Şanlı Bahriye: Türk Bahriyesinin İkiyüz Yıllık Tarihçesi 1773-1973, 2.baskı , Kastaş Yayınları , İstanbul, 2001.

Günen Çoşkun , Osmanlı Deniz Tarihinin Perveze - İnebahtı Döneminde Kaptanı Deryalık , Deniz Kuvvetleri Dergisi,Ankara, 1995 , s.562.

Halil. İnalcık ,Osmanlı İmpratorluğu Klasik çağı (1300-1600), YKY Yay, İstanbul 2004. 
Hüsamettin Sevengül, Birinci Dünya Harbinde Türk Harbi - Deniz Harekatı, 8. Genelkurmay Harp Tarihi Başkanlığı ,Ankara, 1976.

İbrahim Artuç, 1915 Çanakkale Savaşı, Kastaş Yayınları ,İstanbul ,2015.

İdris Bostan, Osmanlı Denizcilik Tarihi, İstanbulL Üniversitesi Açık ve Uzaktan Eğitimi Fakültesi Tarih Lisans Programı, İstanbul ,2000.

İdris Bostan ve Salih Özbaran, Başlangıçtan XV11 Yüzyılın Sonuna Kadar Denizcilik Tarihi , Deniz Yayınevi , İstanbul ,2009.

İlhami Danış , 1736-1739 Savaşlarında Kardeniz'de Osmanlı Donanması, Yayılmayan Yüksek Lisans Tezi, İstanbul Üniversitesi, 2007 ,s.72.

İsmail Hami, Danişmend, İzahlı Osmanlı tarihi kronolojisi , Türkiye Yayınevi , İstanbul ,1971. Joseph von Hammer, Hammer Büyük Osmanlı Tarihi , Üçdal Neşriyat, İstanbul , 2012.

Kavas, Ahmet, , İslam Ansiklopadisi , Türkiye Düyanet Vakfi ,Ankara ,2005,

Kenneth Meyer Setton , 1204-1571: The thirteenth and fourteenth centuries , American Philosophical Society, 1976

Levent Tonyalı ve Gökhan Atamaca, Türk Deniz Harp Tarihi Atlası, Deniz Kuvvettleri Komutanlı̆̆1 Yayınevi, İstanbul, 2010.

Luigi Tommaso Belgrano, Documenti Riguardanti La Colonia Genovese Di Pera ,. Behçet Gücer tercümesi, , Türk Tarih Kurumu Kütüphanesi , Ankara ,1990.

Mahmut Ak, Seydi Ali Reis, İslam Ansiklopedisi , Türkiye Düyanet Vakfi ,Ankara ,2019

Mehmet Kiremit, Mir'atü'l-Memalik (Seydi Ali Reis) ,TDK Yayınları ,Ankara, 1999.

Nejat Tarakçı, Deniz Gücünün Osmanlı Tarihi Üzerindeki Etkileri ,Deniz Basımevi Müdürlüğ̈̈ ,İstANBUL ,2009.

Refik Özdek, Türklerin Altın Kitabı, Tercüman Yayınevi , İstanbul ,2010.

Refik Özdek, Türkler'in Altın Kitabı Cilt-3: Tercüman Yayınevi. İstanbul,1990.

Uzunçarşılı, İsmail Hakkı, Büyük Osmanlı Tarihi, 7. Baskı, II. Cilt,TTK Yayınları ,Ankara, 1988.

Yaşar Semiz 18 Mart 1915 Çanakkale Deniz Savaş1: Sebepleri, Gelişimi ve Sonuçları , S.Ü.Türkiyat Araştırmaları Enstitüsünün Araştırma degisi, Sakarya ,2000.

Yusuf Halaçoğlu , İslam Ansiklopadisi , Türkiye Düyanet Vakfi , 5. Cilit.ankara,1995.

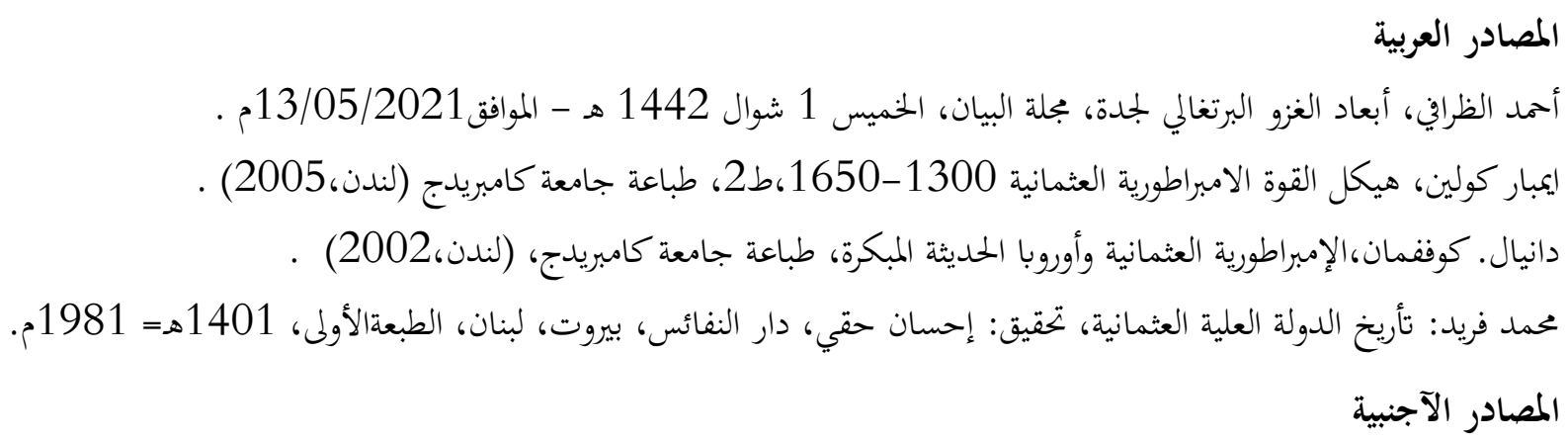

Clifford Edmund Bosworth, Historic Cities of the Islamic World, 2007

James Tertius de Kay, A Rage for Glory: The Life of Commodore Stephen Decatur, USN. Free Press, 2004. 
Leiner, Frederic C. (2007). The End of Barbary Terror, America's 1815 War against the Pirates of North Africa. Oxford University Press, 2007.

Lyle N. McAlister, Spain and Portugal in the New World, 1492-1700, Cilt 3 , Univ of Minnesota $\operatorname{Pr}(1984)$.

Nafziger G. F. Historical Dictionary of the Napoleonic Era. Scarecrow Press. 2001.

Norris, John J. , A History of Venice Penguin, Londra , 1977 ,

R. C. Anderson, Naval Wars in the Levant 1559-1853, Princeton University Press ,2010.

Rogers, Clifford J. Readings on the Military Transformation of Early Modern Europe, San Francisco: Westview Press, 1995.

W. James, Naval History of Great Britain, Cilt VI, (London, 1837).

Wheelan, Joseph. Jefferson's War: America's First War on Terror, 1801-1805. New York: Carroll \& Graf, 2003.

Zaka HannaKour, The History of Aden , Taylor \& Francis Compeny , Erişim,2012. 


\title{
A LITERARY READING IN THE LINGUISTIC EFFORTS OF IBN QUTAYBA IN HIS BOOK ADAB AL-KĀTIB “THE WRITER'S LITERATURE”
}

\author{
Saleh ABBOUD ${ }^{1}$
}

\section{Istanbul / Türkiye \\ p. 577-586}

Received: 25/11/2021

Accepted: $15 / 12 / 2021$

Published: 01/01/2022

This article has been scanned I iThenticat No plagiarism detected

\begin{abstract}
:
Ibn Qutayba (d. $276 \mathrm{AH}$ / $889 \mathrm{AD}$ ) was attentive in both the Arabic linguistics and its literature, whereas he hath assorted numerous workbooks which testify his care about, and those who came after, have been benefited from his critical material on the fields of language and literature, this incipit of the research is concerned with reading Ibn Qutayba's linguistic views through the subject of his book Adab al-Kātib "The Writer's Literature" particularly those related to orthography and solecism in the Arabs' language, and the importance of the research lies in shedding light on the Arab linguistic legacy in the third century $\mathrm{AH} \backslash$ ninth century AD, and displaying the impact of Ibn Qutayba in it, and the objective of the research is to analyze what was mentioned in two important linguistic topics from the book of Adab al-Kātib "The Writer's Literature" which are: the topic of rectification of the hand and the topic of rectification of the tongue, which they are both linguistic topics that show the prevailing linguistics status in the era of Ibn Qutayba, thence, they are also considered a door to understanding the linguistic opinions that the writer gleaned from his wells and sheikhs.

The research deals with linguistic problems related to the orthography and the Arab solecism and phonetics among the populace in the era of Ibn Qutayba, relying on a research framework that begins with a preamble considering both the writer and the book, and then deals with the linguistics status in the third century AH through what was mentioned in the book's sermon, then he presents some of what was mentioned in his book Adab al-Kātib "The Writer's Literature" in the two chapters; rectification of the hand and rectification of the tongue, then epitomized the disputations between Ibn Qutayba and the commentators of his book regarding the two mentioned sections, and the research is concluded with a brief epilogue that presents his most prominent conclusions.
\end{abstract}

Key words: The Writer's Literature, Ibn Qutayba, The Arabic Language In The Third Hijri Century, Solecism.

http://dx.doi.org/10.47832/2717-8293.15.40

1 (iD) Researcher, Marj Ibn ‘Amer College, Palestine, saleh3abboud@gmail.com, https://orcid.org/0000-0001-9027-4205 


\section{"قراءةٌ في الجهود اللّغويّة لابن قتيبة في مؤلّفه أدب الكاتب"}

\section{2 صالح عبّود}

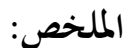

اهتمّ ابن قتيبة (ت. 276هـ/ 889م) بعلوم اللّغة العربيّة وأدمها، وصنّف في ذلك تصانيف تشهد على عنايته بها،

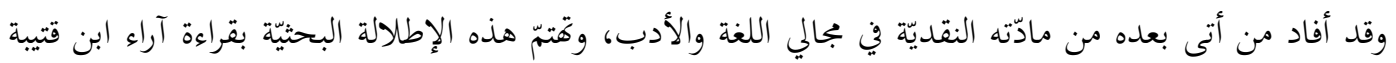

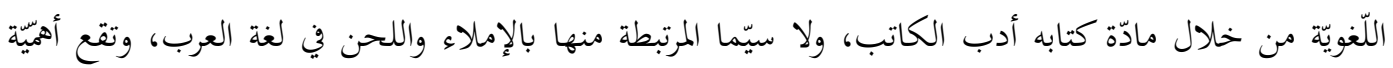
البحث في تسليطه الضوء على التراث اللّغويّ العربيّ في القرن الثالث الهجريّ/ التاسع الميلاديّ، وتبيان أثر ابن قتيبة فيه، وغاية البحث تحليل ما ورد في مبحثين لغويّين هاميّن من كتاب أدب الكاتب هما: مبحث تقويم اليد

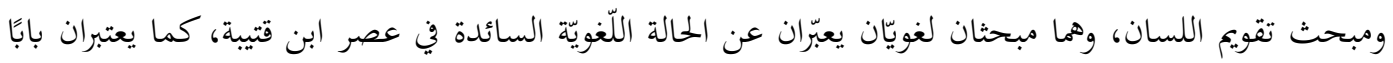
لفهم الآراء اللّغيّة التي استقاها الكاتب من مصادره وشيوخه.

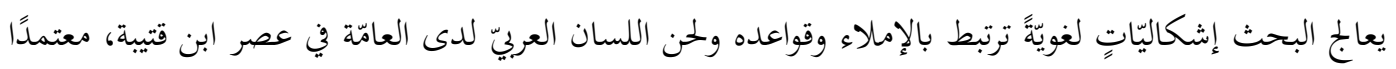

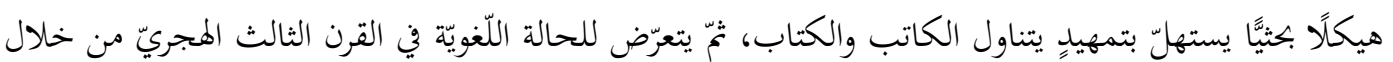

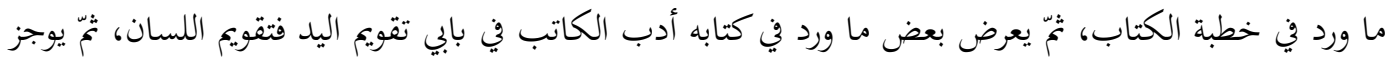

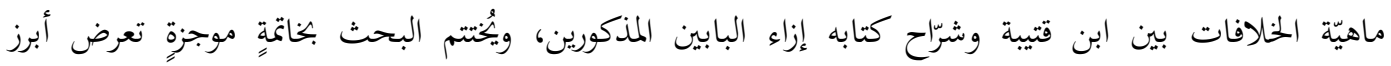

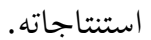
الكلمات المفتاحية: أدب الكاتب، ابن قتيبة، اللغة العربيّة في القرن الهجريّ الثالث، اللحن.

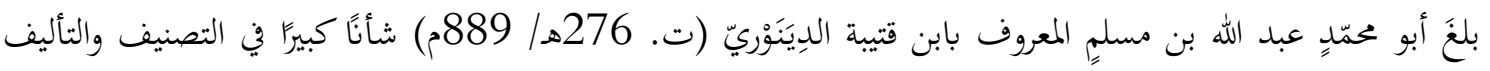

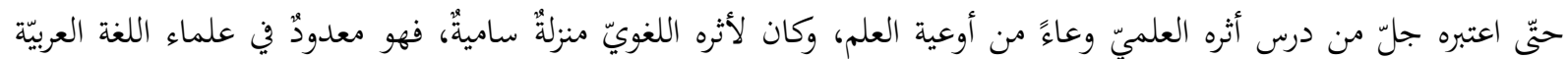
المقدَّمين (العليانيّ، 1991 194: 64).

من أبرز شيوخه في النحو واللّغة الإمامين سهل بن محمّد بن عثمان أبو حاتم السِجِسْتانيّ (ت. 250هـ/ 863ه)، وأبو الفضل العبّاس بن الفرج الرِياشيّ (ت. 257هـ/ 871م) وهما من المعدودين في علوم اللغة العبيّة ( ابن النديم، 2013 2013: 8687)، وكان من كبار النحاة وأهل اللغة في عصره، وجاء فيه أنّه "كان رأسًا في علم اللسان العربيّ، والأخبار وأيّام الناس" (الذهبيّ؛

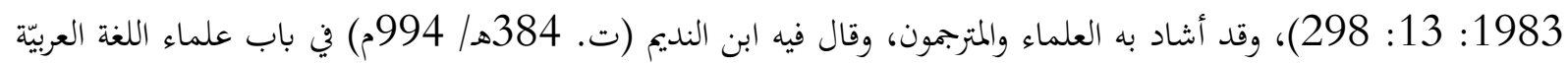

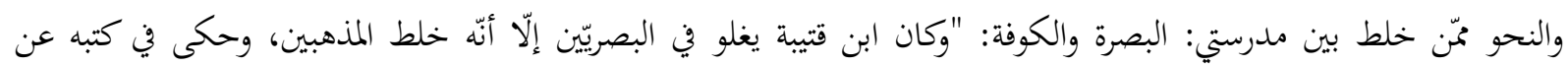

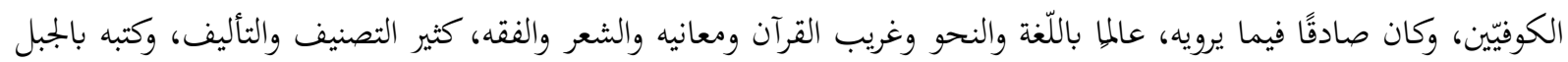

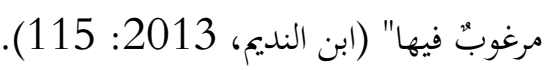


ترعرع ابن قتيبة في النصف الثاني من القرن الهجريّ الثالث، أي في فترةٍ عُرفت تاريختيّا بالعصر العبّاسيّ الثاني، وفيها عرفت

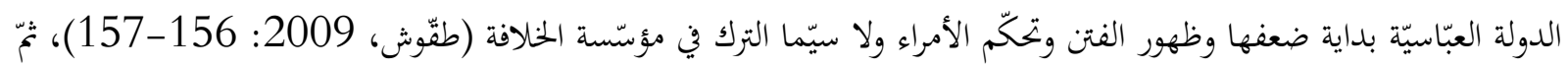

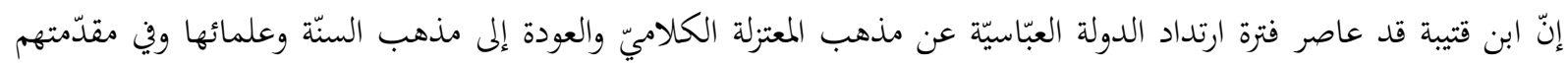

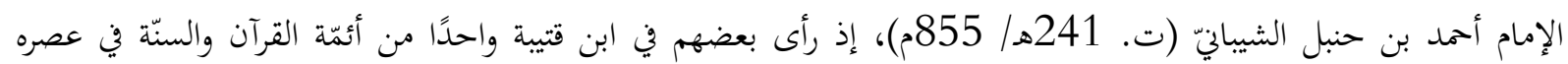

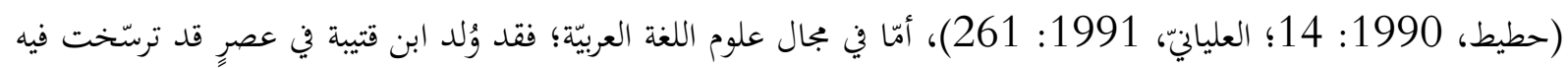

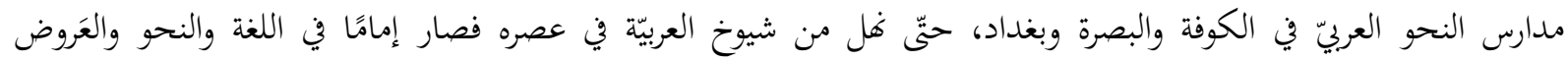
والقراءات (فضل الله، 2018: 58).

\section{كتاب أدب الكاتب}

كتابٌ إرشاديٌٌ توجيهيٌّ أدبيٌٌ لغويٌٌ يعرض فيه كاتبه أصول الكتابة وآدابها ومعارفها، وقد ألّفه ابن قتيبة خلال مقامه في

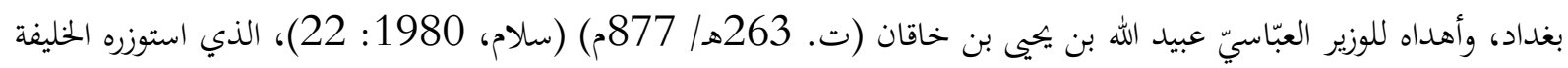
المتوكّل (ت. 247هـ/ S618) والمعتمد (ت. 279هـ/ 892م) (Sourdel, 1971: 3: 824). عدّه ابن خلدون في المقدّمة من الكتب الأربعة الأدبيّة اللغويّة التي تنتهي إليها أصول فنّ الأدب لدى شيوخ فنّ الأدب

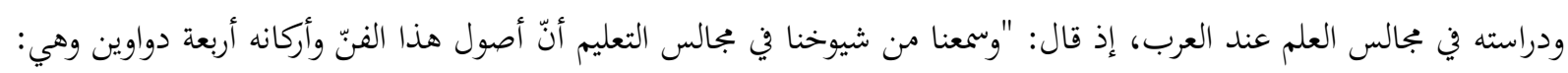

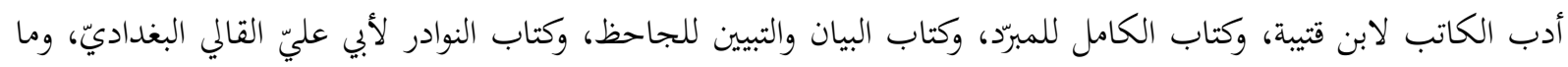

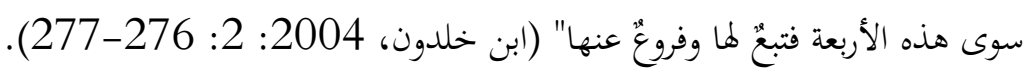
طُع كتاب أدب الكاتب عدّة طبعاتٍ تعتمد هذه الدراسة منها طبعة دار الكتب العلميّة في بيروت للعام 1988 بشرح

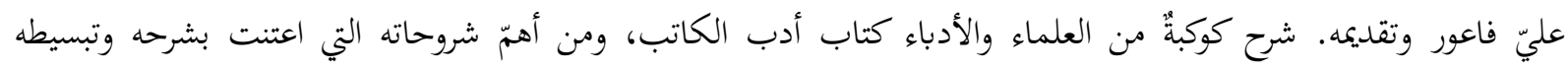
والوقوف عليه وعلى ما بحاوز فيه: الاقتضاب في شرح أدب الكتّاب لابن السِّيد البطليوسيّ الأندلسيّ (ت.

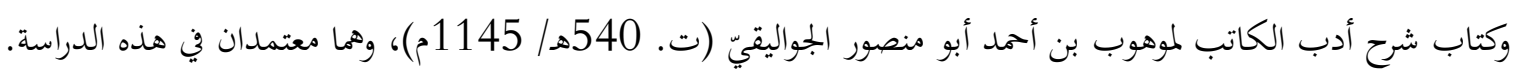

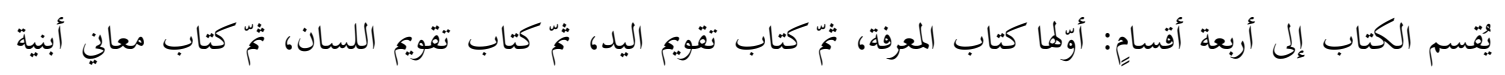

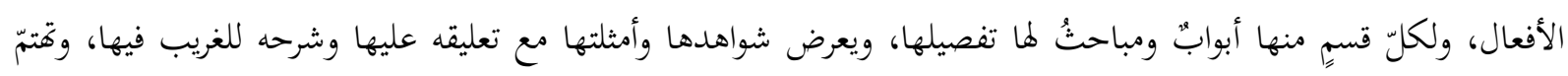

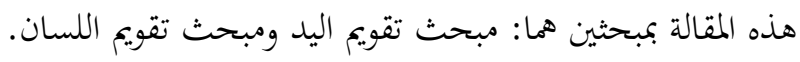

\section{الحالة اللّويّة الأدبيّة في عصر ابن قتيبة كما يصفها في أدب الكاتب}

يمكن الاعتماد عند وصف حالة اللغة العربيّة في عصر ابن قتيبة على ما أورده في مقدّمة كتابه أدب الكاتب، والتي اعتبرها

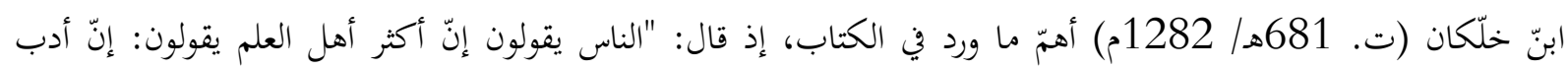

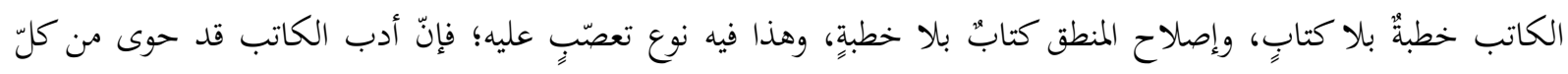

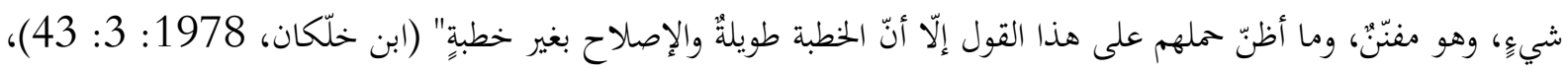

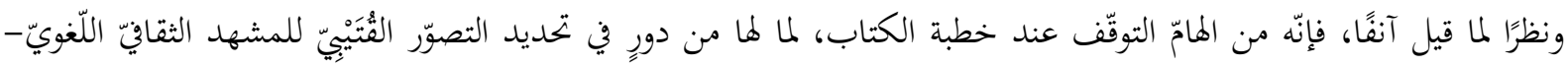

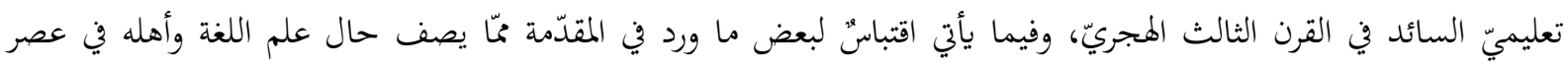

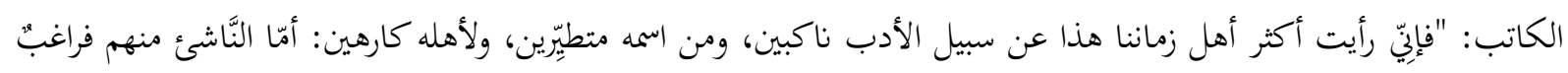

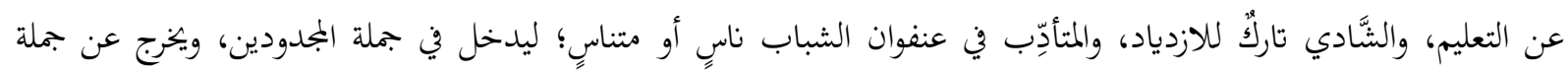


المحدودين، فالعلماء مغمورون، وبكرَّة الجهال مقموعون" (ابن قتيبة، 1988: 9)، تؤّدّد الفقرة شهادة ابن قتيبة في حال الأدب

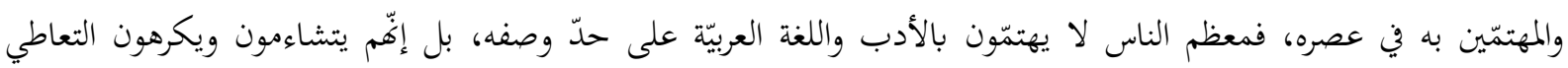

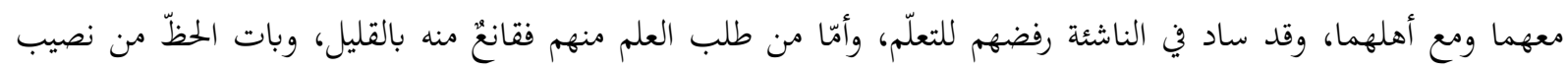

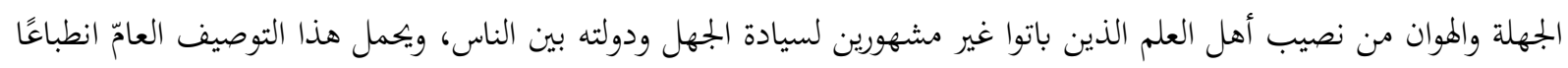

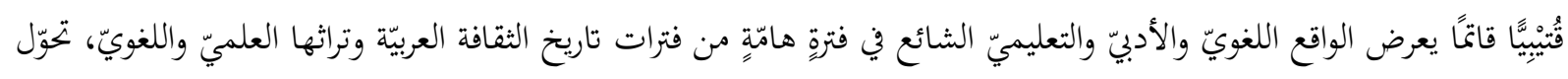

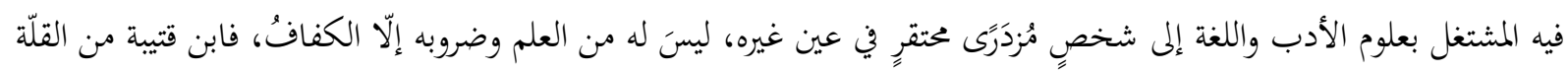

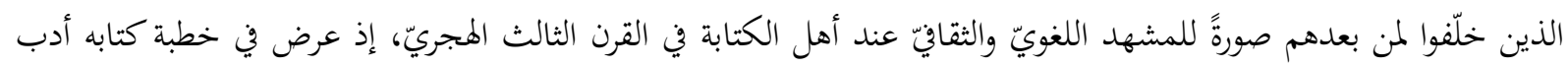

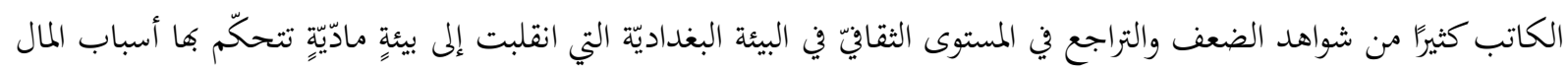

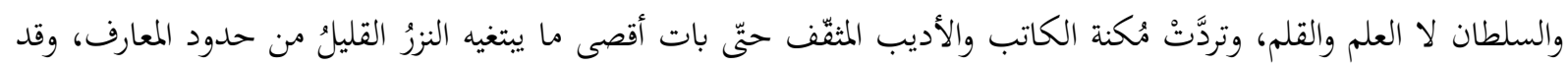

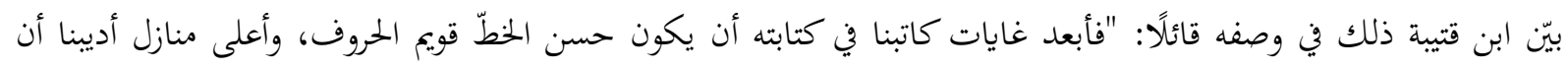

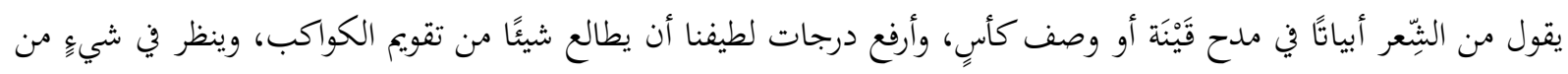

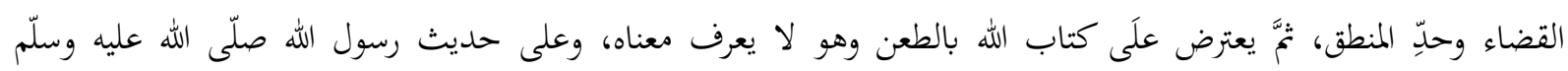

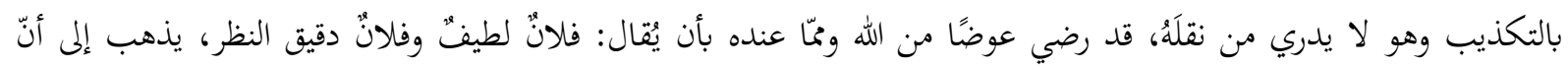

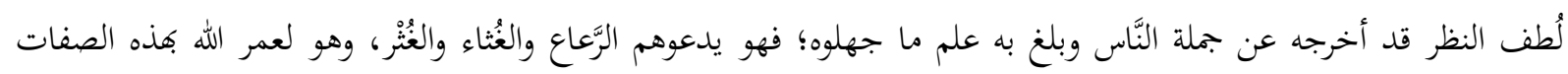

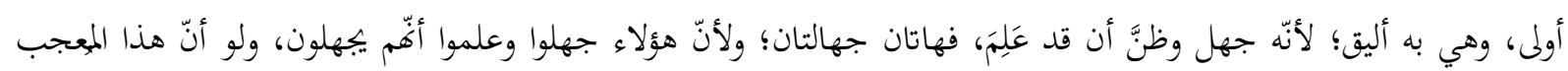

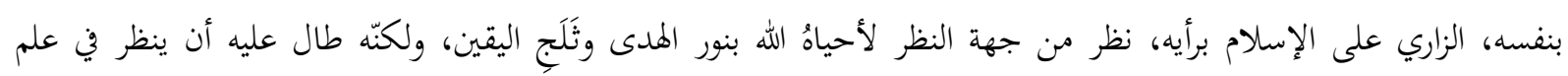

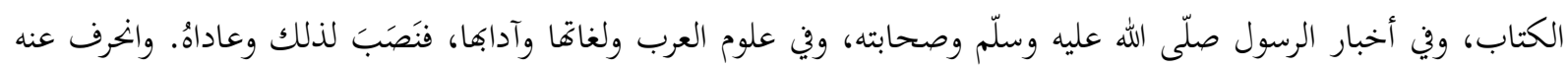

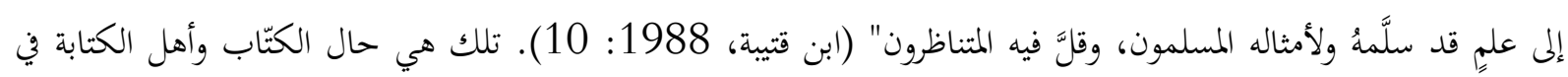

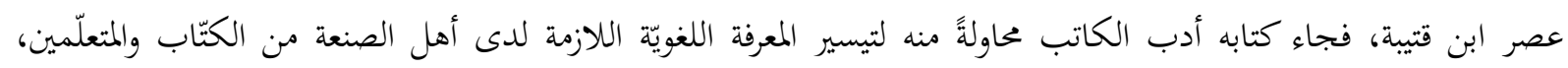

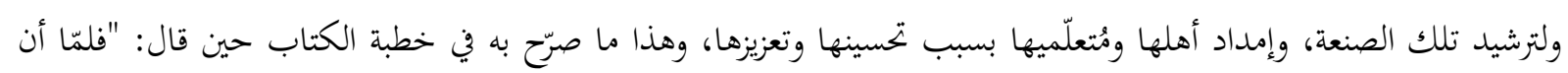

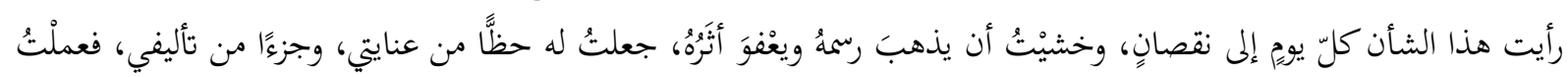

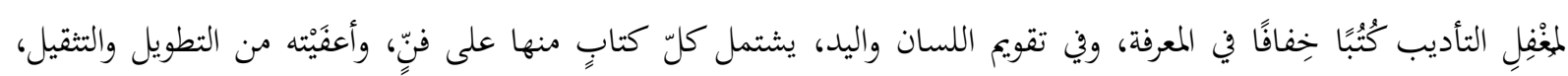

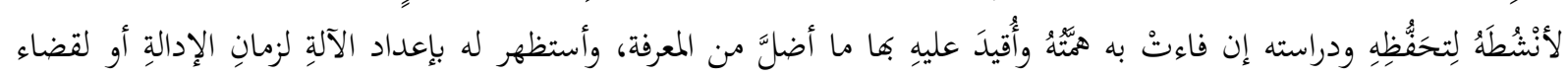

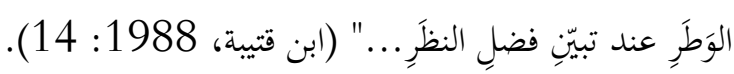

جاء باب المعرفة في كتاب أدب الكاتب محاولةً مبكّةًة لابن قتيبة لتصحيح ما وقع به الكتّاب والمتعلّمون والعامّة من أخطاءٍ

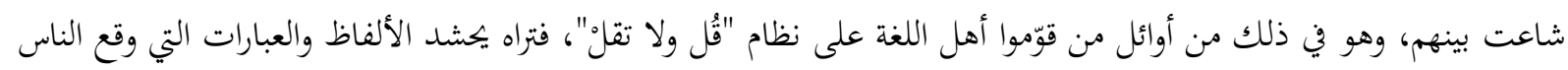

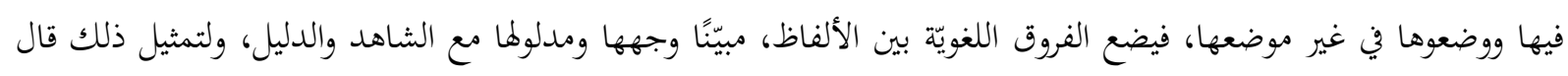

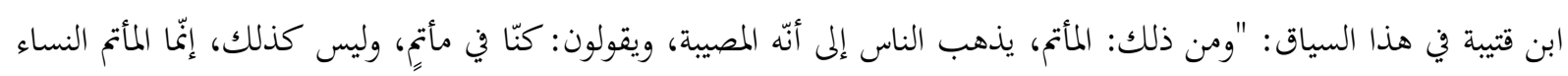

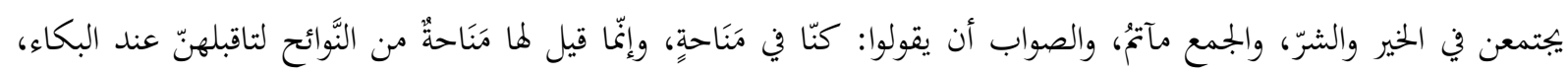

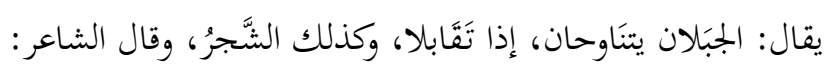

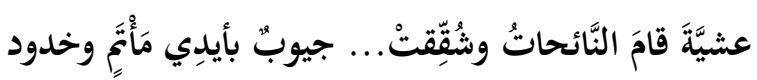
أي :بأيدي نساء، وقال آخر:

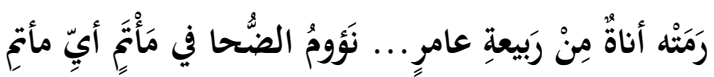

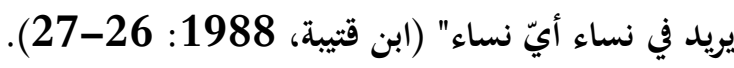


يتّضح من خلال قراءة المادّة اللغويّة في كتاب باب المعرفة أنّ ثمّة خلطًا كبيرًا عند الناس والكتّاب بين ألفاظٍ ومعانٍ تعكس تدنيًّا في تحديدها ومعرفة مدلولاتحا على النحو اللغويّ والمعجميّ السليم. يتطرّق ابن قتيبة في كتاب المعرفة إلى الكثير من القضايا اللّغيّة على غرار: القوالب المزدوجة المستخدمة في اللّغة العربيّة، باب ما يستعمل من الدعاء في الكلام، تأويل كلامٍ مستعملٍ عند العرب يشرح خلاله الكثير من العبارات الشائعة والتي يساء

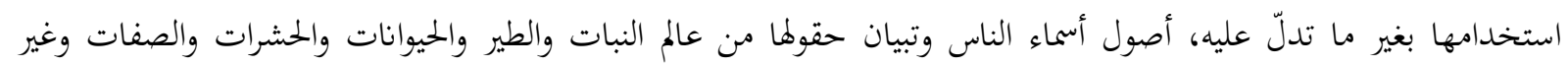

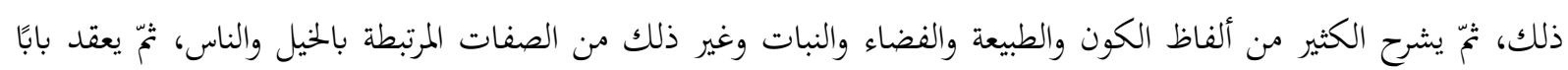

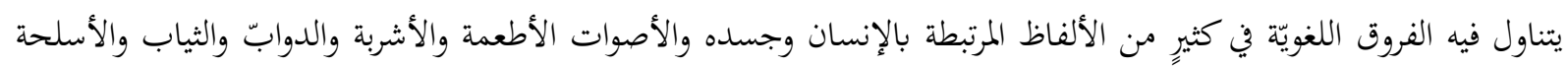

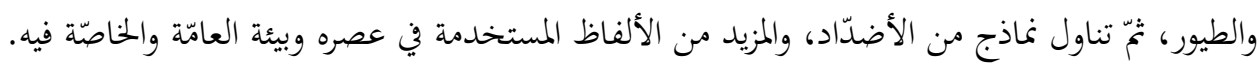

\section{مبحث كتاب تقويم اليد}

يصبو الكتاب إلى تيسير قواعد الكتابة والإملاء للمتعلّمين وأهل الكتابة؛ كي لا يقعوا في أخطاءٍ مردّها الجهل بأصول

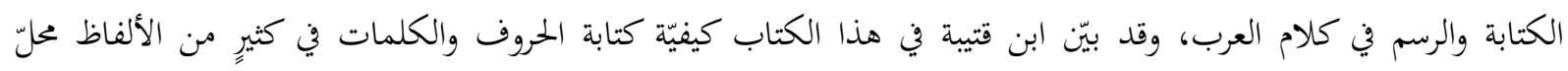

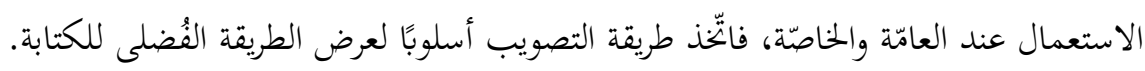

يتناول الكاتب في هذا الباب عدّة مسائل يهدف من خلالها إلى تقويم الكتابة وطرائقها، ومن أبرز مباحثه: حذف حروفٍ

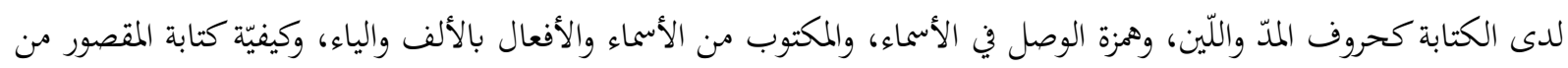

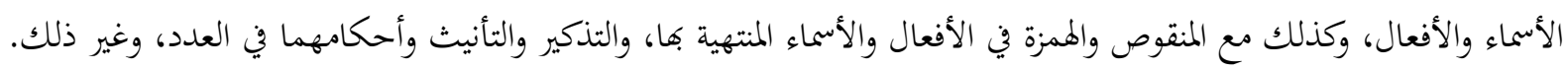
يستهلّ ابن قتيبة هذا الفصل من كتابه بعرضه قاعدةً لغويّة أصوليّةً يمهّد من خلالما لعرض التفاصيل والشواهد التي تتبع

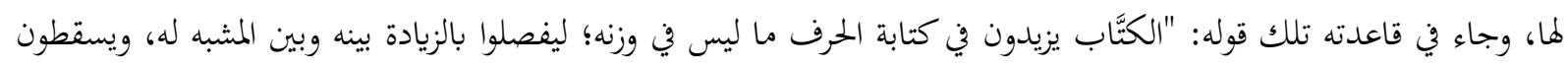

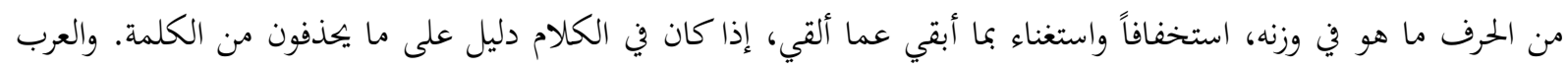

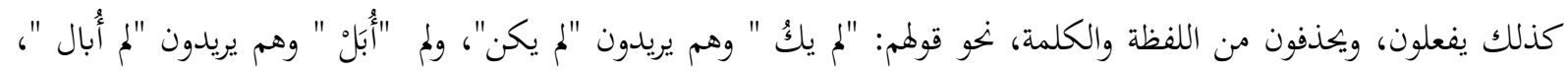

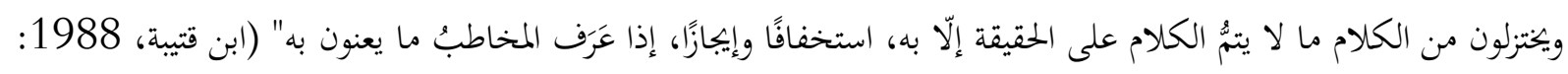

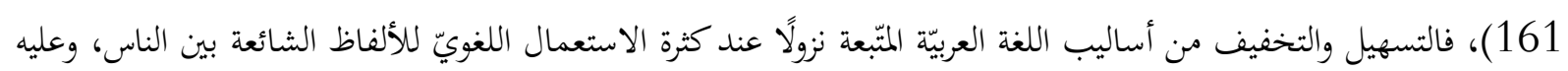
يعرض ابن قتيبة شواهده في الكتاب، ومن أمثلة ذلك تمثيلاً لا حصرًا: - كيفيّة كتابة "باسم الله": "تكتب "بسم الله " إذا افتتحت بها كتابًا أو ابتدأت بها كلامًا بغير ألفٍ؛ لأفّا كثرت في هذه

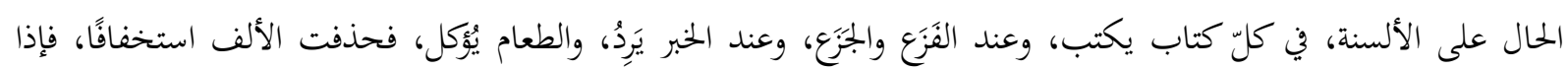

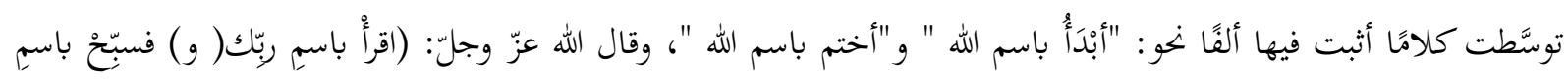

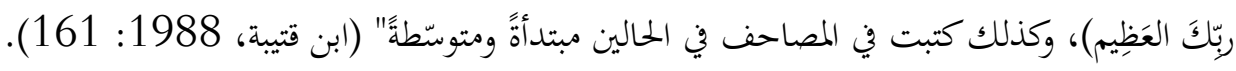

- كيفيّة كتابة الأفعال التي تبدأ بهمزة الوصل التي تليها في حروفها الياء والواو، فيعرض القاعدة من خلال الشاهد، وفي

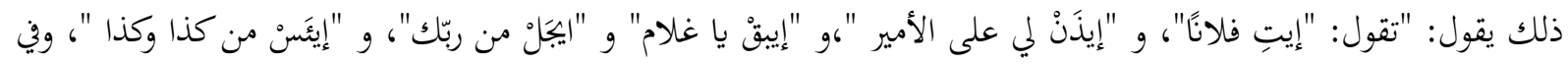

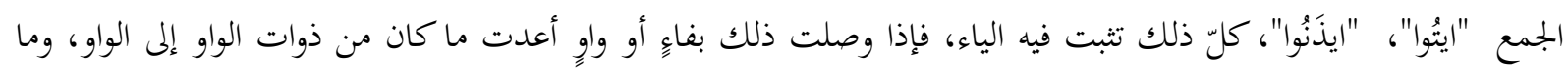

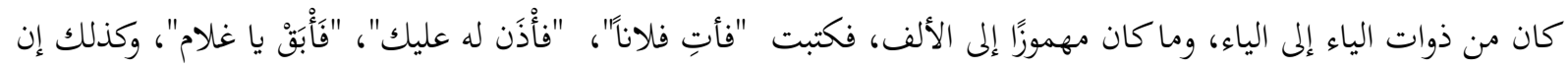

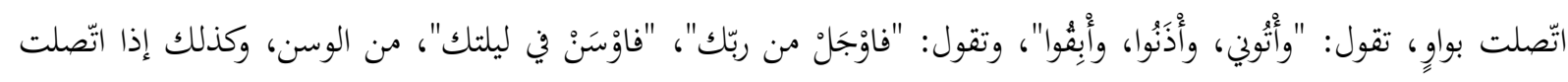

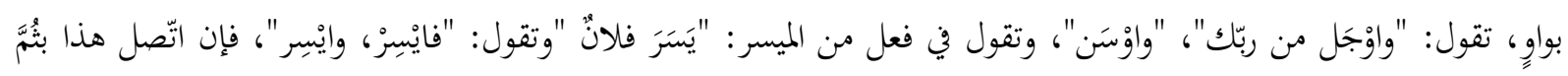




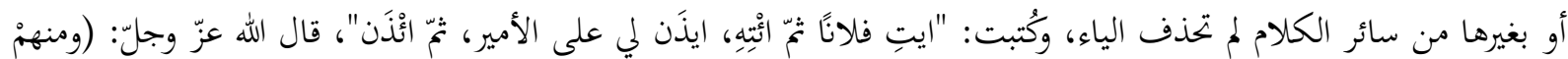

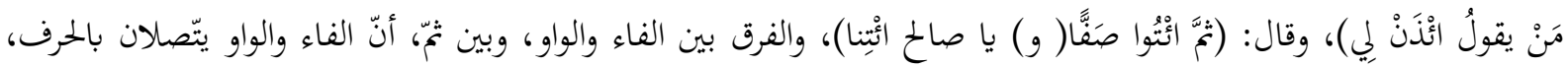

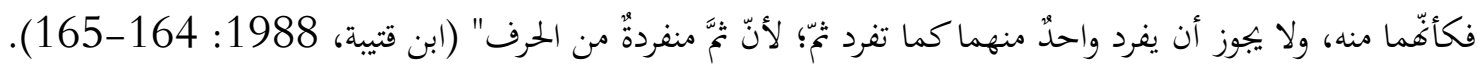
- كيفيّة كتابة الأسماء الأعجميّة وغير الأعجميّة التي فيها ألف: "تحذف الألف من الأسماء الأعجميّة نحو: إبراهيم،

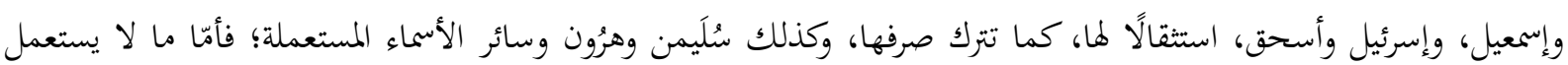

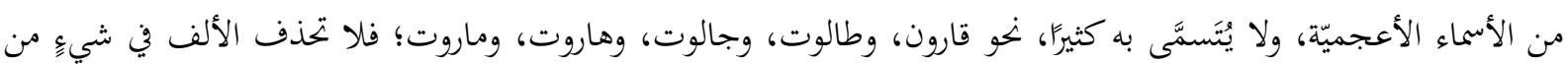

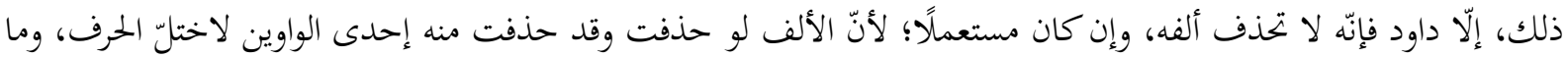

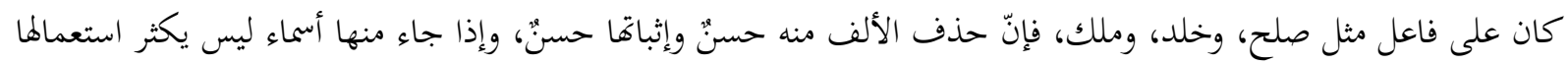

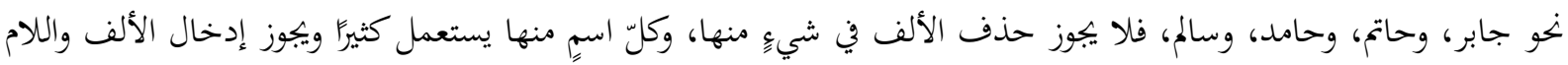

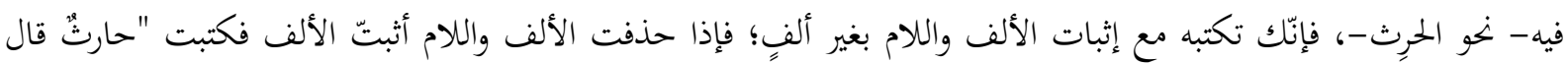

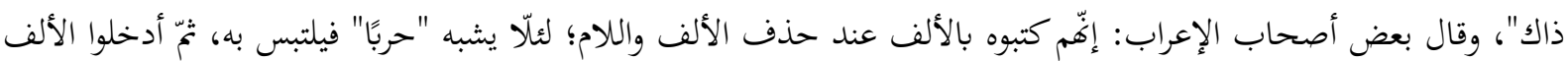

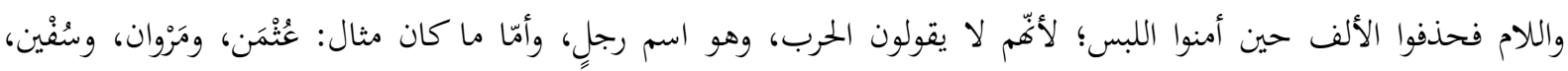

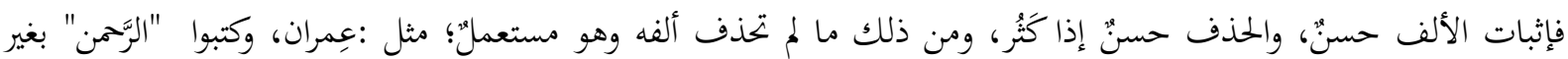
ألفٍ حين أثنتوا الألف واللام، وإذا حذفت الألف واللام فأحبُّ إليَّ أن يعيدوا الألف فيكتبوا لرَّمَّمَان الدنيا والآخرة"، وأمّا شيطان ودِهقان فإنبات الألف فيهما حسنُ، وكان القياس أن يكتبوهما إذا دخلت الألف واللام فيهما بغير ألفٍ، إلّا أنّ الكتَّاب

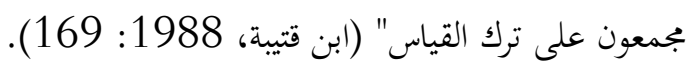
يعالج ابن قتيبة الكثير من القضايا الصرفيّة والإملائيّة المامّة والضروريّة للمشتغلين بالكتابة وشؤونها، وليس ببعيدٍ أنّه قد أورد

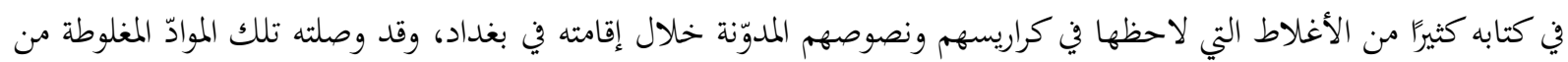
خلال تدريسه وعمله اليوميّ آنذاك.

\section{مبحث كتاب تقويم اللسان}

اهتمّ ابن قتيبة في هذا الباب بمعالجة اللُّحون اللّغيّة التي انتشرت في عصره بين المشتغلين بالكتابة، وقد انصرف في ذلك

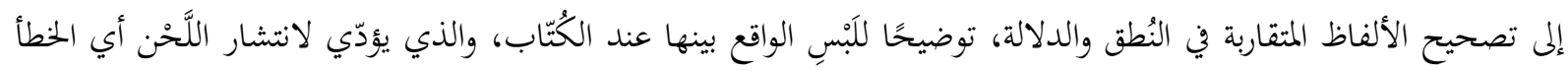

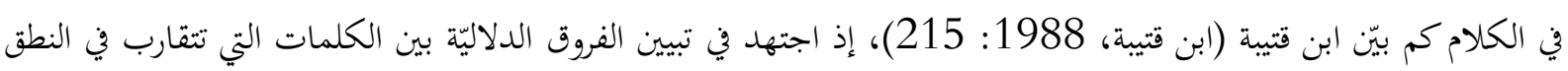

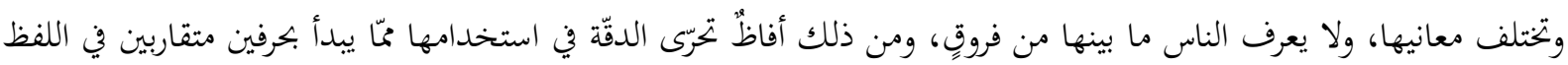

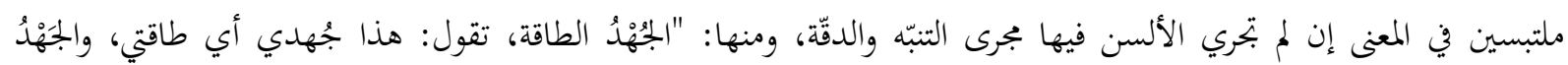

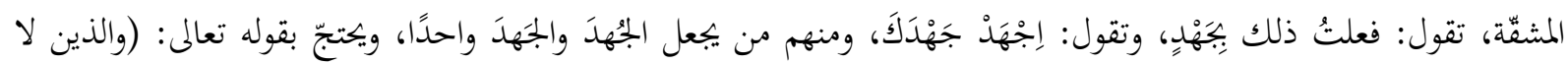

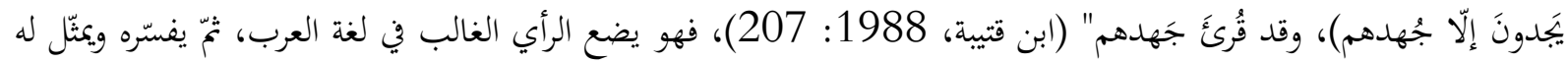

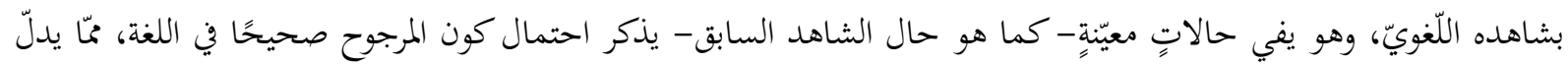

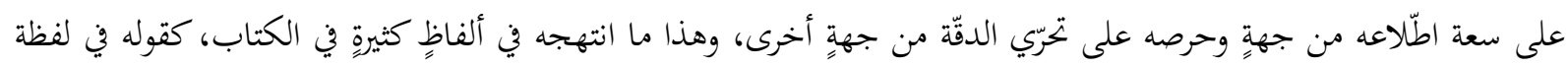

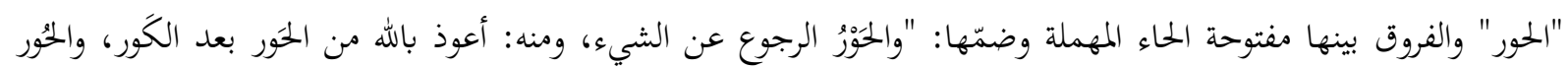
النقصان، قال الشاعر:

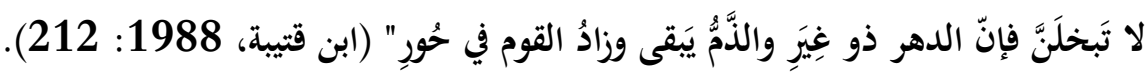


بوّب ابن قتيبة أصناف اللَّحن الواقع في الألفاظ الشائعة واستخداماتما عند الناس في أبوابٍ، وكان منهجه في ذلك توزيع

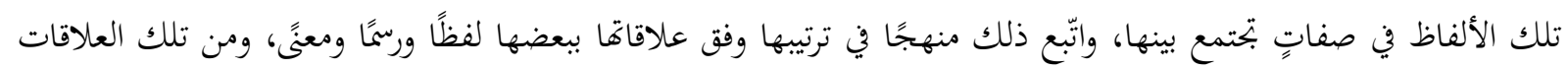

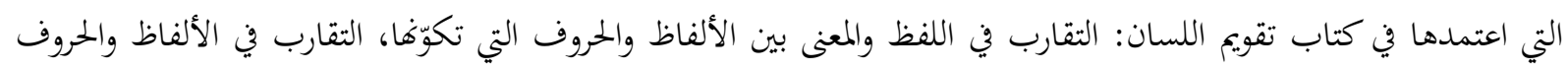

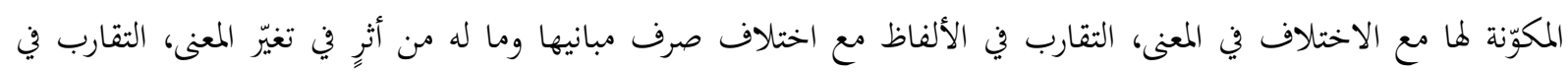

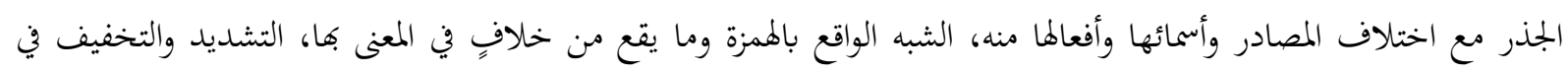

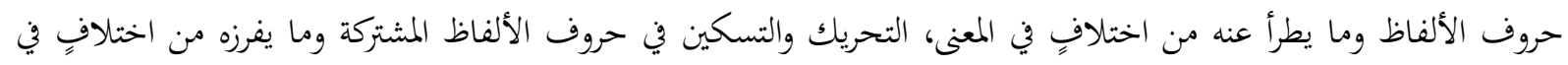
المعنى.

يعالجُ ابن قتيبة في كتاب تقويم اللسان ظواهر اللحن الشائعة من خلال ضبط بعض القواعد اللفظيّة والإملائيّة بغية

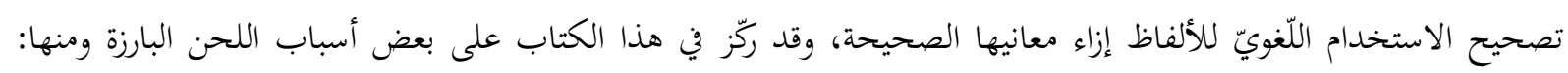
التصحيف، التحريك والتسكين، الهمز والتخفيف، التضعيف والتخفيف، وهي من عوامل دخول العامّة في كثيرٍ من الأخطاء واللحن واللبس الحاصل في اللغة العربيّة في عصره.

حاول ابن قتيبة تصحيح العديد من الأبنية اللغويّة التي أفسدها اللحن المتفشّي في عصره، وأسهم في ضبطها صرفيَّا

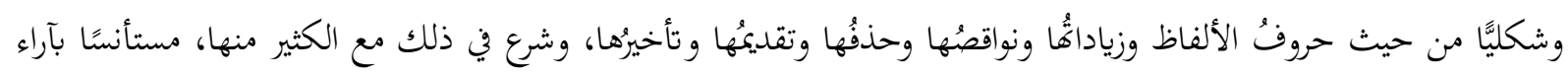

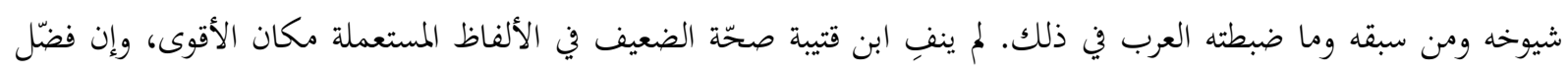

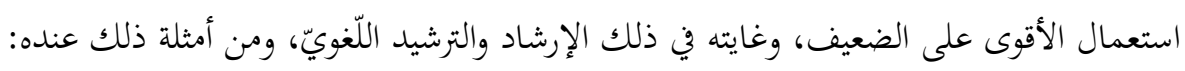

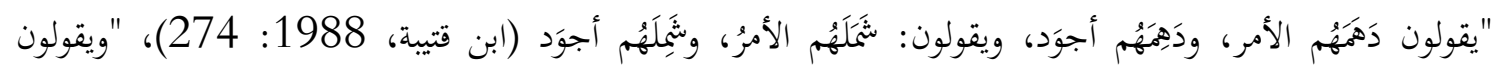

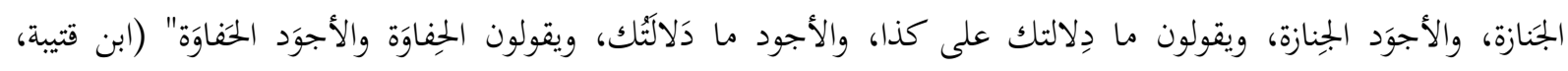

ما يقدّمه ابن قتيبة من موادّ لغويٍّ سريعةٍ مباشرة يعكس توجّهه الإرشاديّ المنهجيّ في الكتاب برمّته، فهو لا يعدو كونه

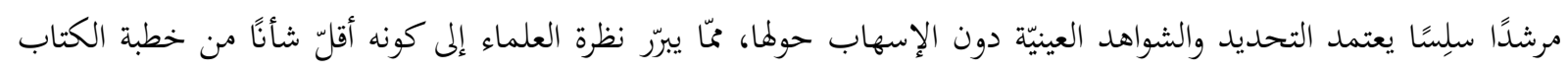
التي تتّجه نخوًا يعتمد العرض والتبرير والتوسعة في القضيّة. يدلّ منهج ابن قتيبة في كتابه ومحتواه اللّغويّ على بقاء النصص القرآيّ والشّعُعر العربيّ وحدةً لغويّةً محكمةً يحتكم إليها

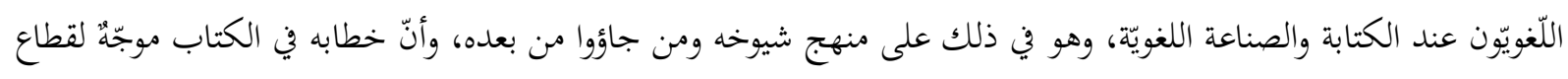

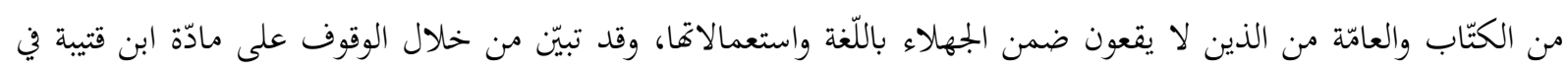

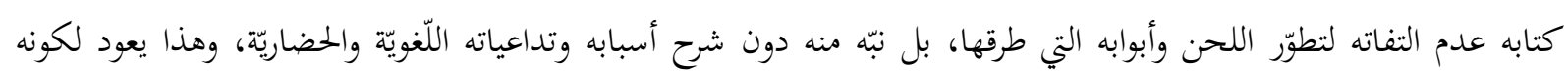

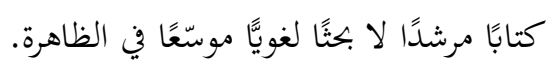

أضفت ثقافة ابن قتيبة اللّغيّة الواسعة في كتابه أدب الكاتب عمومًا وكتابي: تقويم اليد وتقويم اللسان فيه بنحوِ خاصِّ،

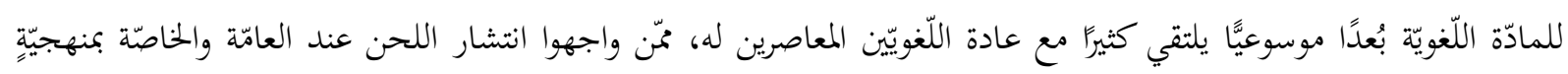

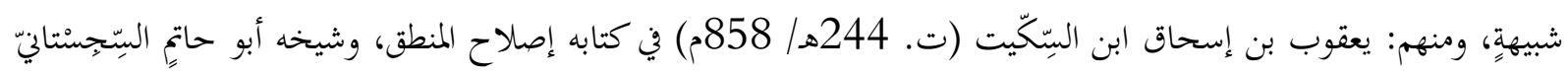

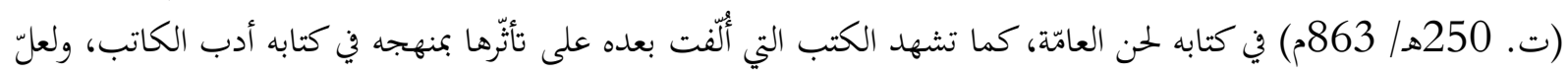

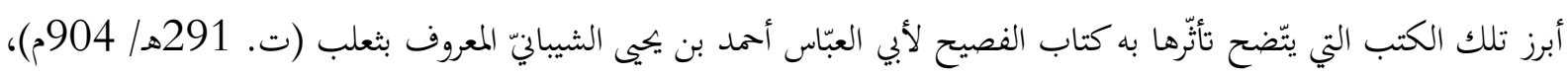

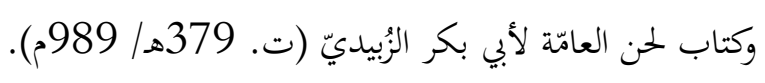


ليس من شاكِّ أنّ كتاب أدب الكاتب قد شكّل موجِهًا مفيدًا للكتّاب والعامّة من الذين غلوا منه وثقِّوا لسافم ولغتهم

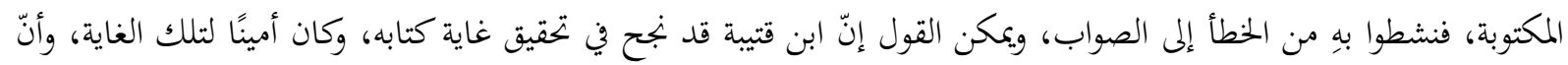

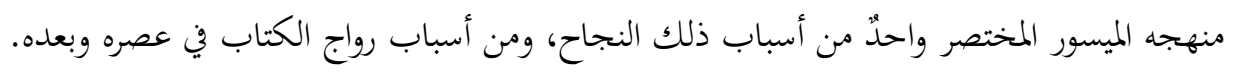
شرّاح أدب الكاتب

برز من شرّاح كتاب أدب الكاتب لابن قتيبة اثنان، أحدهما في المشرق، وهو أبو منصورٍ الجواليقيّ (ت. 540هـ/

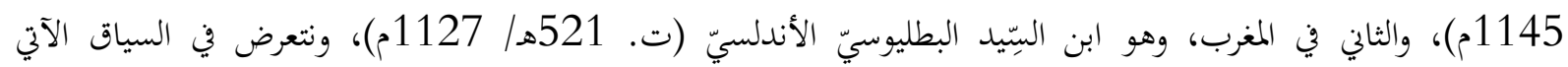

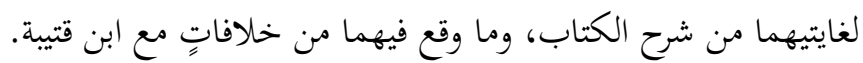

\section{كتاب شرح أدب الكاتب لموهوب بن أحمد أبي منصورٍ الجواليقيّ (ت. 540هـ 1145م)}

يحدّد أبو منصورٍ غايته من شرح أدب الكاتب لابن قتيبة في مقدّمة شرحه، ويذكر أنهّ يقصد من ذلك شرح خطبة

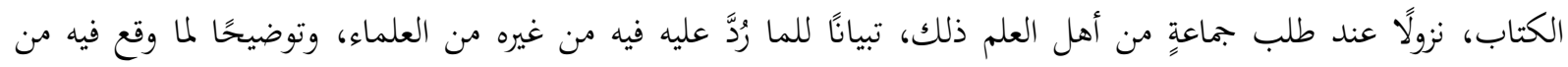

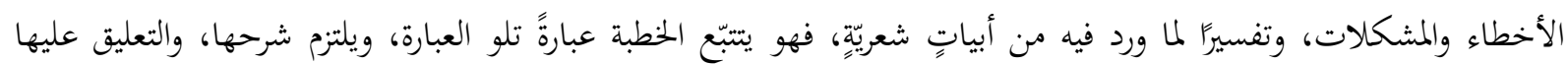

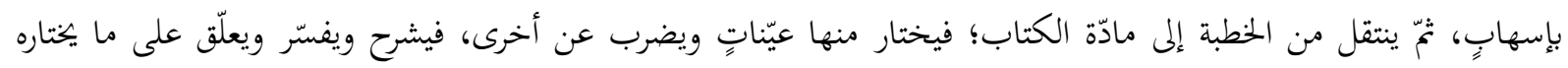

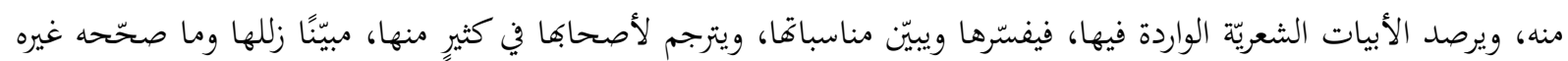
فيها (الجواليقيّ، 1995، 192: 1 1). وجّه الجواليقيّ نقده لكتاب أدب الكاتب من خلال اعتراضاته على بعض ما ورد فيه، ولا سيّما في المسائل المرتبطة

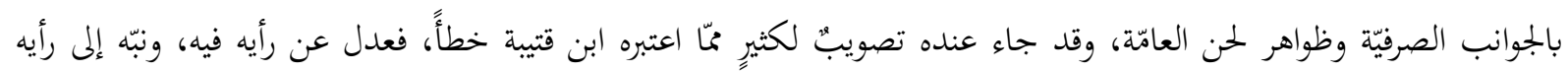

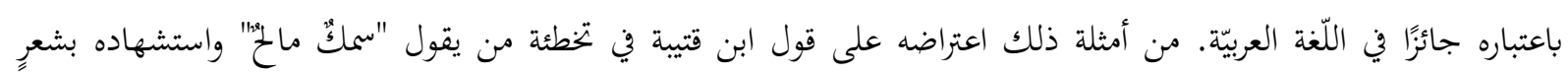

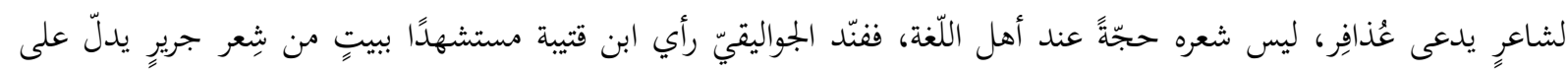

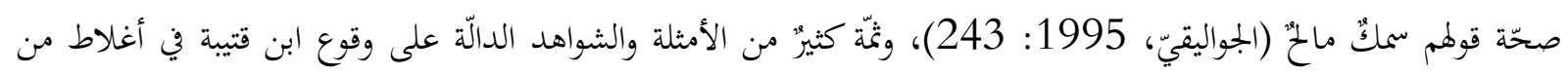
وجهة نظر من كانوا من بعده وشرحوا كتابه.

\section{كتاب الاقتضاب في شرح أدب الكتّاب لابن السِّيد البطليوسيّ الأندلسيّ (ت. 521هـ/ 1127م)} يذهب الشارح في هذا الكتاب إلى انتقاء مواضع معيّنة من مادّة كتاب أدب الكاتب لابن قتيبة، ويهتمّ فيما وقع فيه

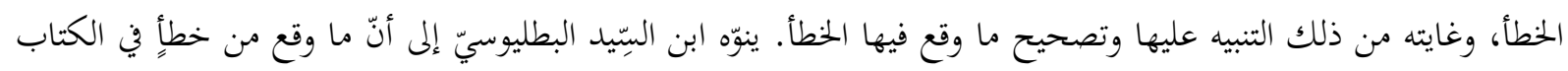

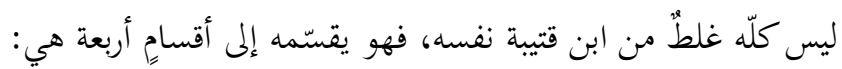
1. مواضع أخطأ فيها ابن قتيبة فينبّه عليها وعلى خطأه فيها.

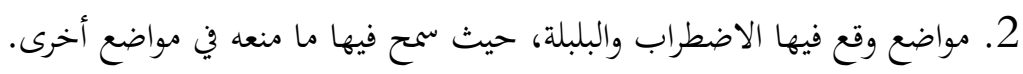

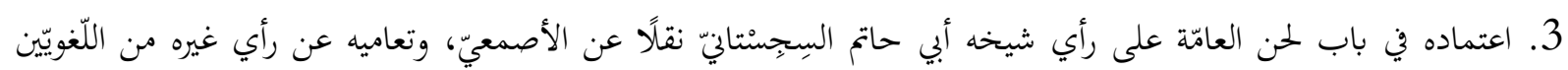
الكبار متّن لا يتّفقون معه؛ مّمّا يوهن قوله. 4. مواضع وقع فيها الغلط بسبب الناقلين لمادّة الكتاب لا لمؤلّفه.

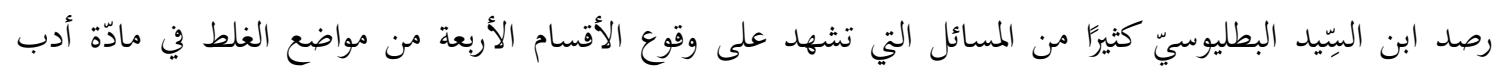

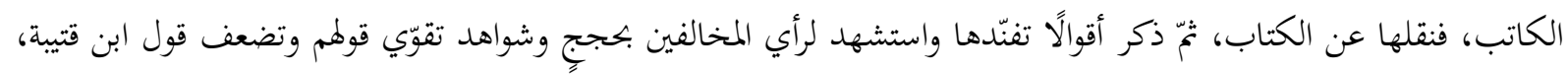

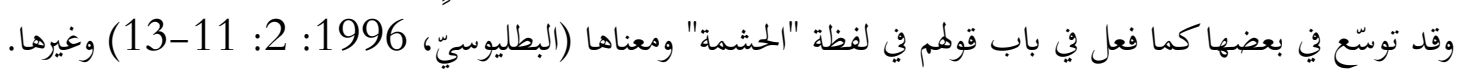


جاء منهج البطليوسيّ واضحًا في تعاطيه مع ما وقع في أدب الكاتب من أغلاطِ، إذ عرض قول ابن قتيبة مقتبسًا، ثمّ أنّا عرض آراء غيره مع ذكر أسمائهم، ثمّ استأنس بشاهدٍ أو أكثر يدعم رأيهم ويفنّد رأي ابن قتيبة في المسألة.

\section{استنتاجات الدراسة}

- ينضمّ ابن قتيبة إلى كوكبة اللغيّين العرب الذي حاولوا بجهودهم اللغويّة خلال القرن الثالث الهجريّ/ التاسع الميلاديّ أن ينهضوا باللغة العربيّة وعلومها من خلال تأليف الكتب الموجّهة الهادفة والتي تنفع الخاصّة والعامّة على حلدٍ سواء. - اجتهد ابن قتيبة في مواصلة مسار شيوخه وفيهم السِجِستنائّ والرياشيّ وغيرهما من علماء اللغة، فاهتمّ بالتنبيه على وجوه

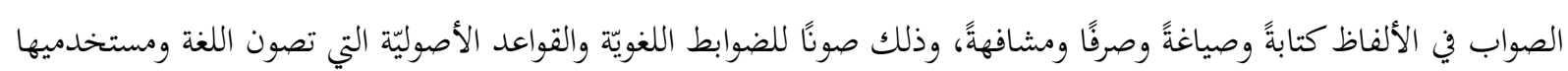

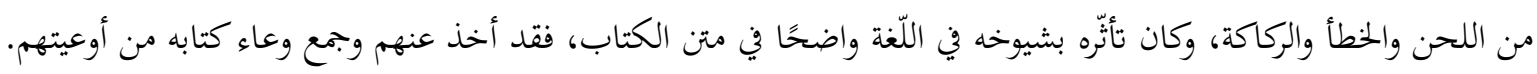
- اعتمد ابن قتيبة في كتابه أدب الكاتب على مقاييس لغويّة عمادها المشهور عند العرب ولغتهم، فاعتمده في تصويبه للأخطاء

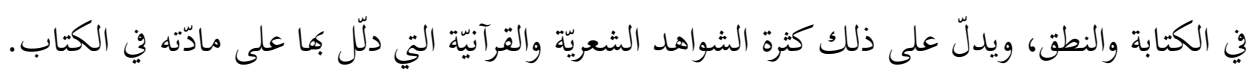
- يعتبر ابن قتيبة من المتشدّدين في وجوه قَبول الصواب ودفِع الخطأ، فهو من الذين يُقْبِلونَ على الأفصح المشهور، ويدَعونَ ما عَداهُ، بل يعتبرونَهُ لحنًا. - وجّه ابن قتيبة كتابه ومادّته فيه لشريحة الكتّاب الخاملين المتهاونين في اللغة وضوابطها، فجاء كتابه مرشلًا لهم ودليلًا عمليَّا يعينهم في صناعتهم. - يبدو من خلال مادّة كتاب أدب الكاتب لابن قتيبة أنّ المشهد الثقافيّ في عصره يعاني من ضعفٍ ووَهَنٍ أسبابه مرتبطةٌ بميل العامّة والخاصّة عن طلب العلم بطريقهِ وسبلهِ العلميّة السديدة. - تستنتج الدراسة أنّ ابن قتيبة قد يسّر في كتابه لجمهوره ما أمكنه من أسباب الشرح الموجز والمقارنات السهلة كي يجعلها مادّةً

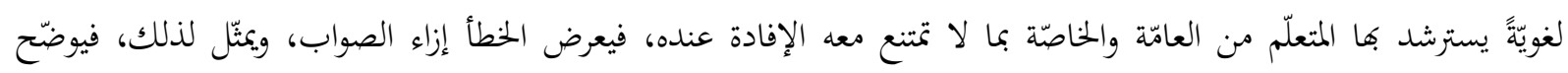
الشيء بضدّه إذا لزم الأمر.

- سعى شارحا كتاب أدب الكاتب: البطليوسيّ في الاقتضاب والجواليقي في شرح أدب الكاتب إلى تبيان وجوه ما جاء في

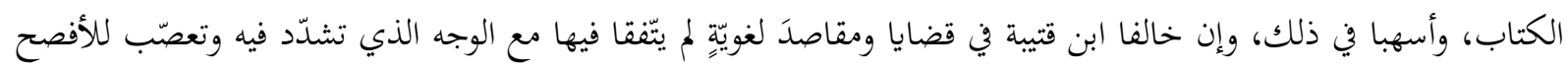

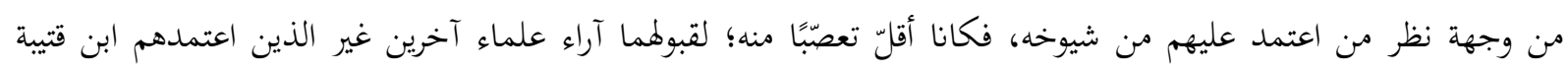
مرجعًا في آرائه، فعمدا إلى تبيان الصواب الذي ظنّه ابن قتيبة غلطًا؛ لاقتصاره على مذهب شيوخٍ وإضرابه عن رأي غيرهم. 
البَطليوسيّ، ابن السِّيد عبد الله بن محمّد. (1996). الاقتضاب في شرح أدب الكُتّاب. تحقيق: مصطفى السقّا وحامد عبد المجيد. القاهرة: مطبعة دار الكتب المصريّة.

الجواليقيّ، موهوب. (1995). شرح أدب الكاتب. تحقيق: طيبة حمد بودي. جامعة الكويت: قسم اللّغة العربيّة.

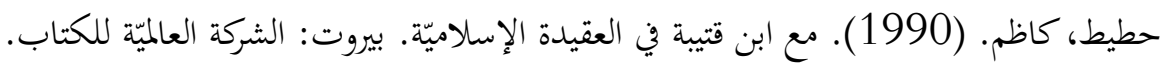
ابن خلدون، عبد الرحمن. (2004). مقدّمة ابن خلدون. تحقيق: عبد الله محمّد الدرويش. دمشق: دار البلخي. الذهبيّ، الإمام حممّد بن أحمد بن عثمان. (1983). سير أعلام النبلاء. تحقيق: علي أبو زيد. بيروت: مؤسّسة الرسالة. سلام، محمّد زغلول. (1980). نوابغ الفكر العربيّ: ابن قتيبة. القاهرة: دار المعارف.

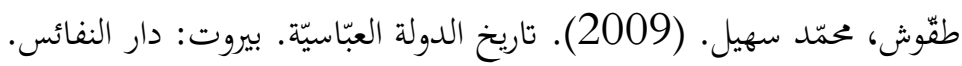
العليانيّ، عليّ بن نفيع. (1991). عقيدة الإمام ابن قتيبة. الطائف: مكتبة الصدّيق.

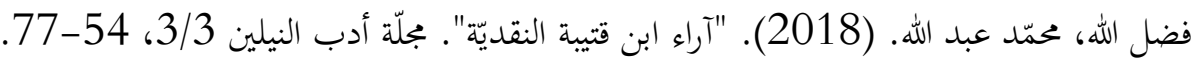

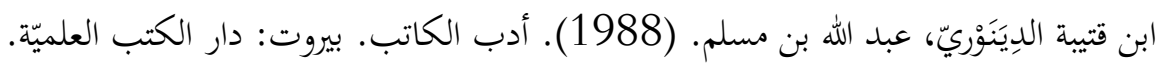

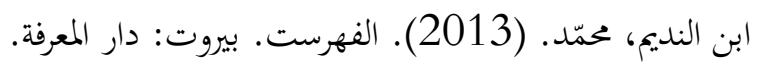

Sourdel, D. “Ibn Khākān”. Encyclopaedia of Islam. Second Edition, 1971, 3: 824. 


\section{THE DISTRIBUTIONALISED (AL) IN THE BOOK \\ (RAWDHAT AL-HADA'IQ IN EXPLAINING THE LAMA MESSAGE ) \\ BY ABDULRAZZAK IBN MUSTAFA AL-ANTAKI (ق 11 A.H.) \\ A STUDY AND AN INVESTIGATION}

Zena Kamil SHAKIR ${ }^{1}$

\section{Istanbul / Türkiye}

p. 587-604

Received: 29/11/2021

Accepted: 10/12/2021

Published: 01/01/2022

This article has been scanned I

iThenticat No plagiarism detected

http://dx.doi.org/10.47832/2717-8293.15.41

Dr. , Ministry of Education, Iraq, zeenakamil77@gmail.com 


\section{(الاستغراقية في (روضة الحدائق شرح الرسالة اللامية \\ لعبد الززاق بن مصطفى الأنطاكي ( ق11هـ) دراسة وتحقيق \\ زينا كامل شاكر}

الملتخص:

يتناول البحث تحقيقًا ودراسةً لموضوع (ال) الاستغراقية من المخطوط النحوي المعروف ب (روضة الحدائق في شرح

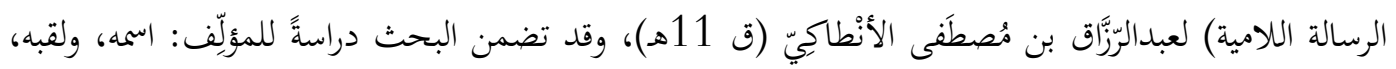
و صحة نسبة المخطوط له، وذكر أهم مؤلفاته، ثم أعقبته بذكر منهجي في التحقيق الذي تمثل بنسخ المخطوط

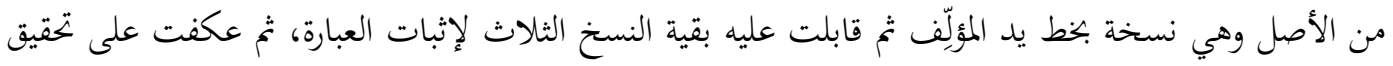
المخطوط متتبعةً المؤلِّف وشرحه، وقمت بتخريج الآيات القرآنية والأحاديث النبوية، والشواهد الشعرية، والأقوال

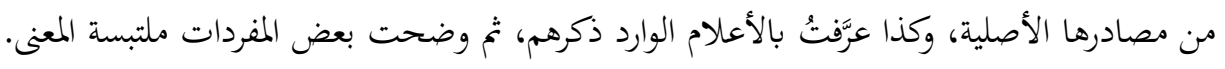
الكلمات المفتاحية: روضة حديقة، عبد الرزاق بن مصطفى الانطاكي، موضوع ال "سورة".

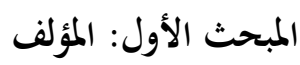

السمه ولقبه:

هو عبد الرزاق بن مصطفى الرومي الأنطاكي.

سبب تأليف الكتاب:

لم يذكر الأنطاكي عنوانًا لكتابه هذا في مقدمة كتابه غير أنَّهَ قد أومأ إليه بقوله: ((لما اختصرتُ اللامية مع ما فيه من

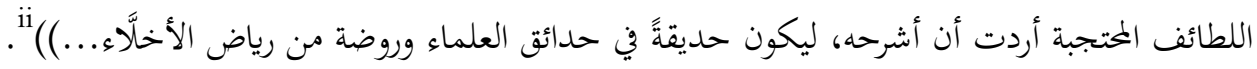

غير أنَّه قد ذكره صراحةً في الخاتمة بقوله: ((وقد وقع الفراغ من هذا التأليف الموسوم بـ(روضة الحدائق) يوم الثلث في شهر

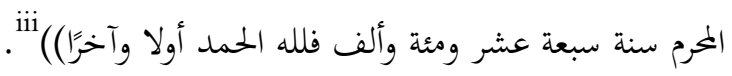

فإنَّهُ بعد تأليفه لرسالة في الألف واللام أراد شرحها وتوضيح مختصرها فعَمَد إلى جعل رسالته تلك متنًا شَرَهه في مؤلَّف

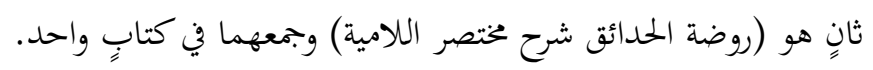

مؤلفاته العلمية

- ذريعة الطعام فيما جاء فيه من الأحاديث والأخبار. درسه وحققه: الشيخ أحمد فريد المزيدي، وطبعته دار الكتب العلمية عام

- خلاصة الذريعة في الطعام.

- مختصر اللامية وهي رسالة في لام التعريف. مخطوط محفوظ في مكتبة الملك عبدالعزيز العامة. ولم يزل مخطوطا. - روضة الحدائق شرح الرسالة اللامية في النحو: وهو ما نحن بصدد تحقيقه. 
- مفتاح الوصول شرح مرقاة الأصول، و ولم يزل مخطوطًا.

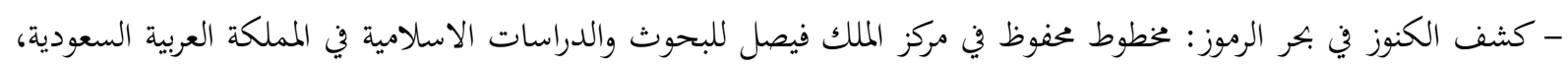
وكذا في اللجنة الملكية لشؤون القدس.

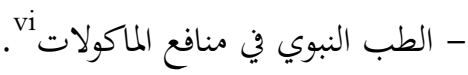
- ميزان التائين - في الموعظة. وفاته

لم تذكر المصادر التي ترجمت للأنطاكيّ سنة وفاةٍ محدةٍ له، فقد اكتفت بذكر القرن الذي تُوفي به وهو (ق11هـ).

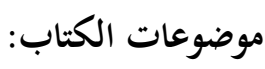

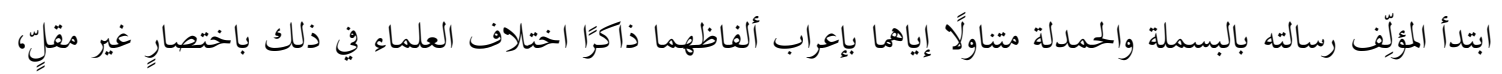

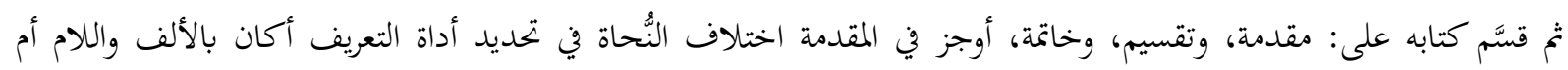

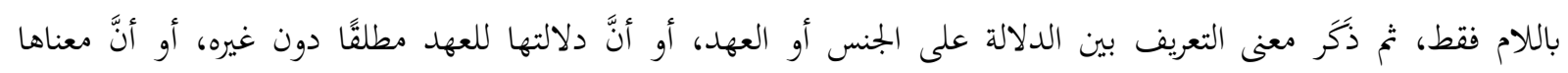

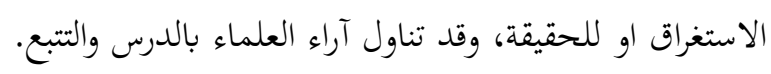
ثم بدأ بالتقسيم فقد قسَّم (ال) على قسمين: - (ال) التعريفية: ولها معنيان هما: (ال) العهدية الخارجية، والجنسية التي تكون لمعاٍٍ كالاستغراق وغيره. - (ال) الزائدة: وهي على نوعين: (ال) اللازمة، و(ال) العارضة.

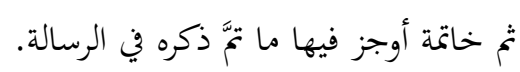

المبحث الثاني: الكتاب: تحقيق اسم الكتاب:

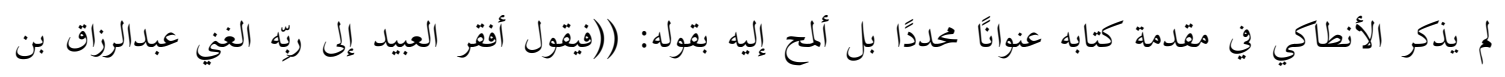

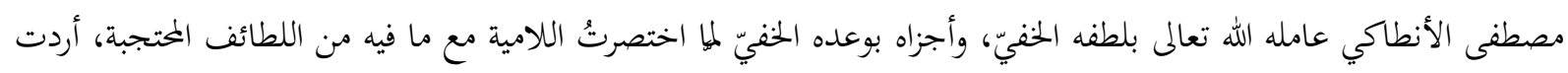

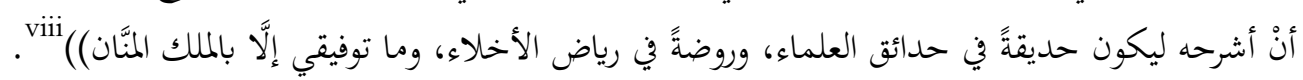

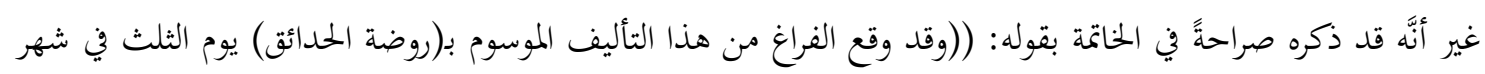

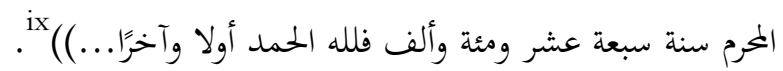

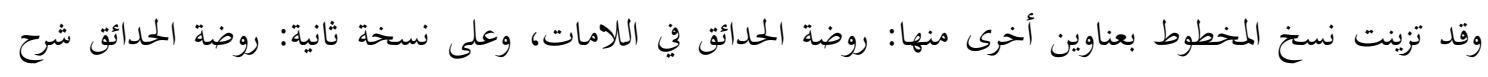

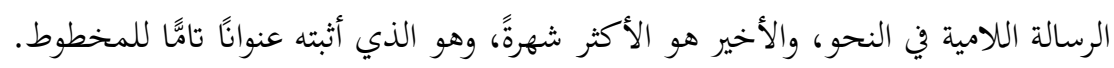

منهجي في التحقيق:

بعد نسخ المخطوط وإجراء المقابلة للنسخ الأربعة واثبات الاختلافات بينها من نقص، أو زيادة، أو تقديم وتأخير،وقدا

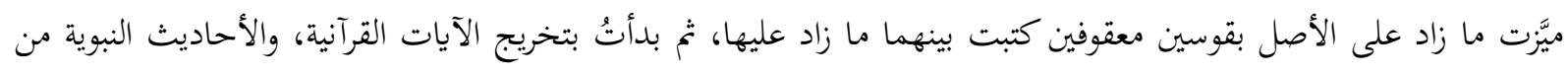

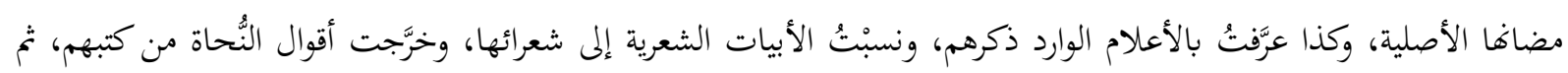
تناولت ما جاء في المخطوط بكنًا ودراسةً. 
- الأصل: وهي نسخة بخط يد المؤلِّف وقد كُتبت بخط مداد أسود للشرح أمَّا المتن فقد مازه عنه بخط أحمر، تقع في تسع عشرة

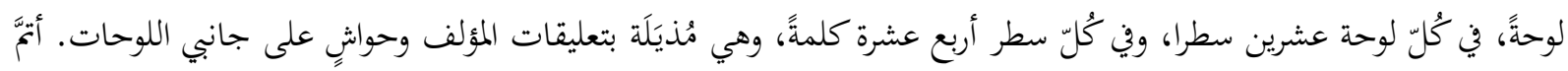
كتابتها يوم الثلاثاء من شهر المحرم سنة (1117هـ)، وقد حُفظت فئ في مكتبة السليمانية بقسم أنطاليا تاكي أوغلو، بالرقم العام (49) - النسخة الثانية: وهي نسخة تقع في أربع وعشرين لوحةً كُتبت بخط مداد أسود وتقع في سبع عشرة سطرًا في كلِّ سطر ما بين

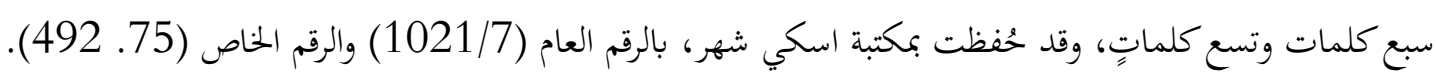

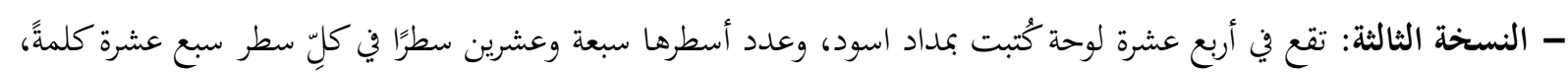

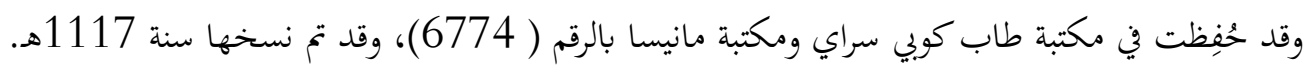

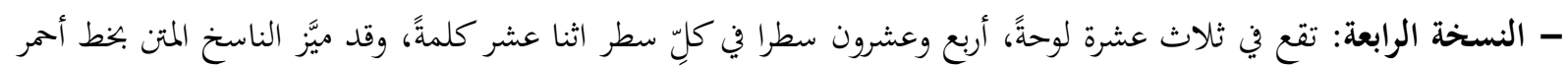

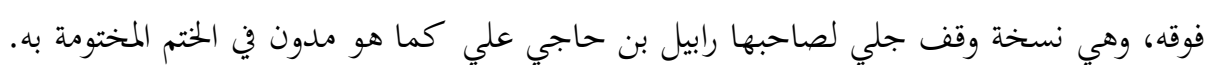

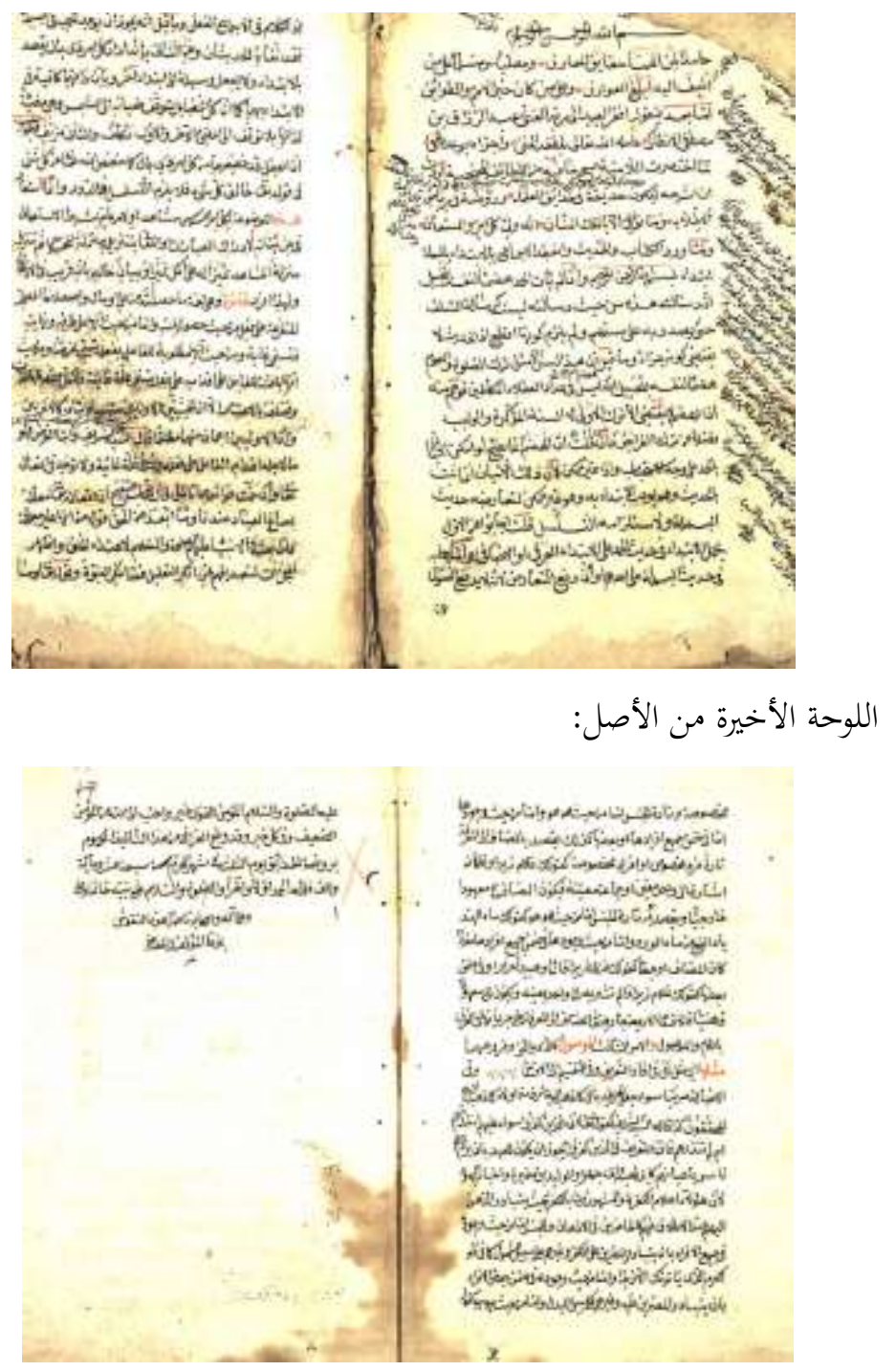


اللوحة الأولى من النسخة الثانية:

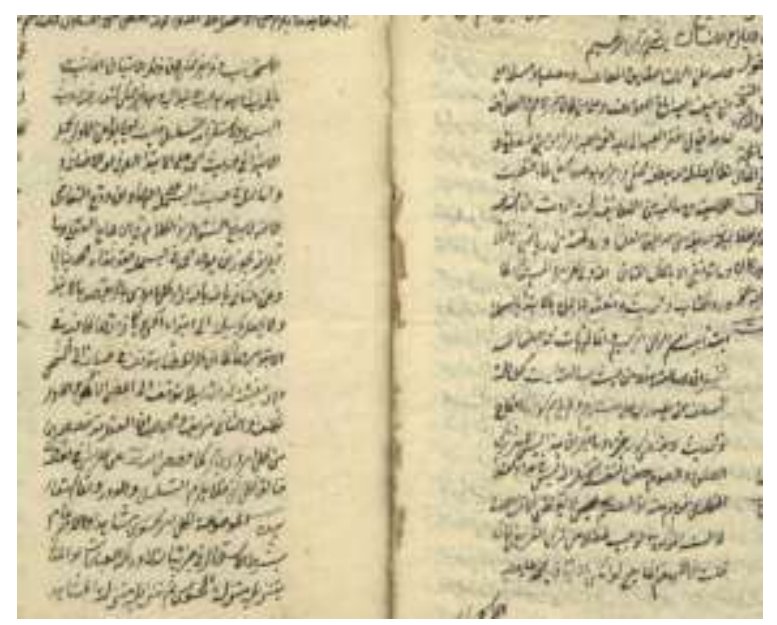

اللوحة الأخيرة من النسخة الثانية:

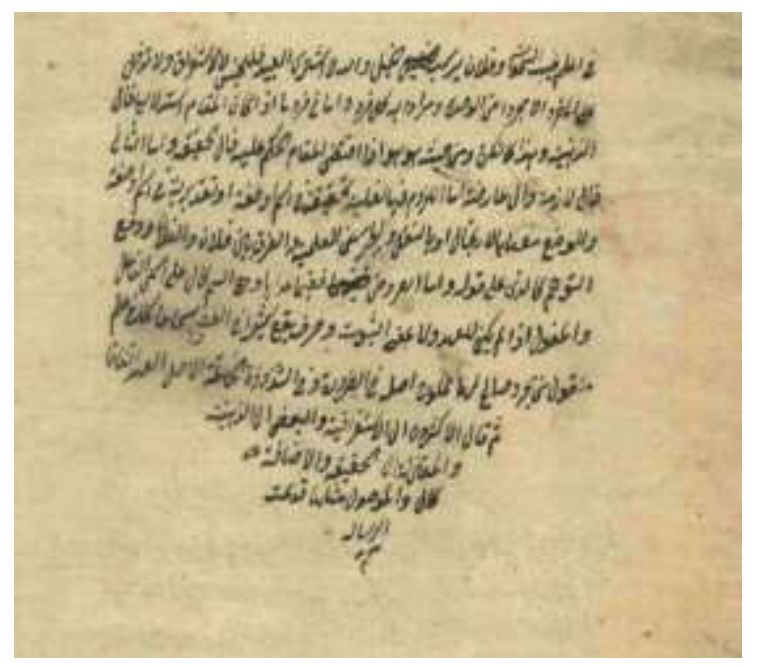

اللوحة الأولى من النسخة الثالثة:

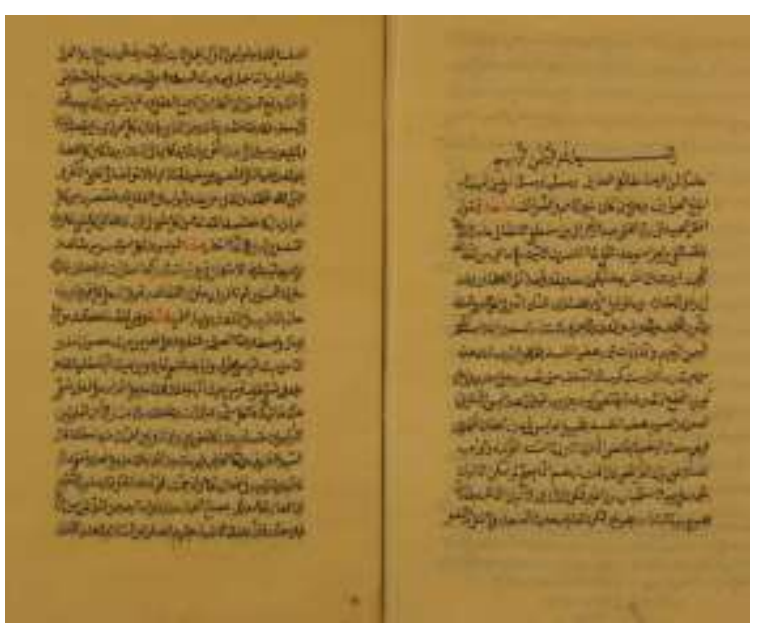




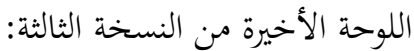

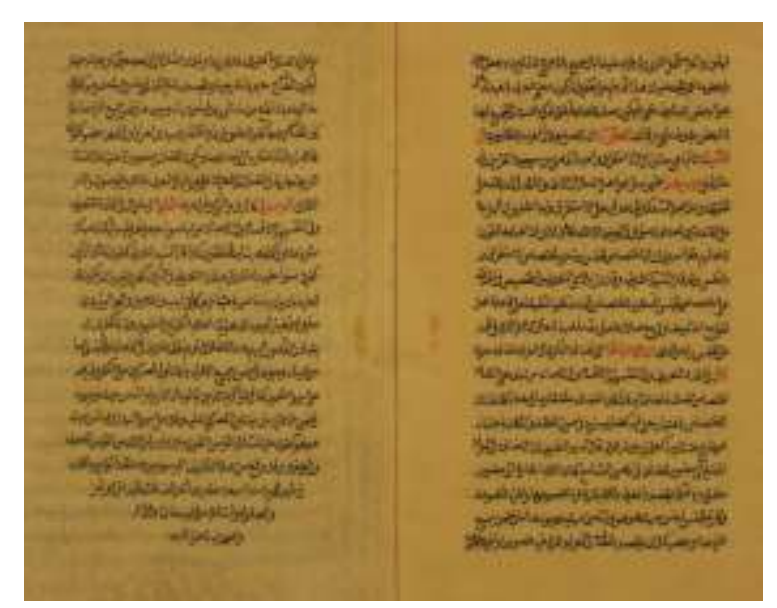

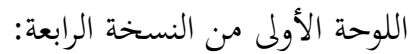

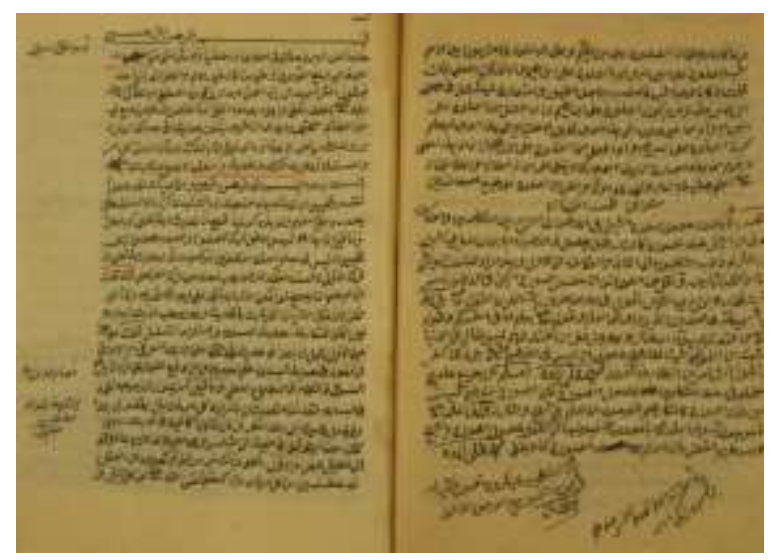

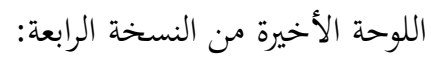

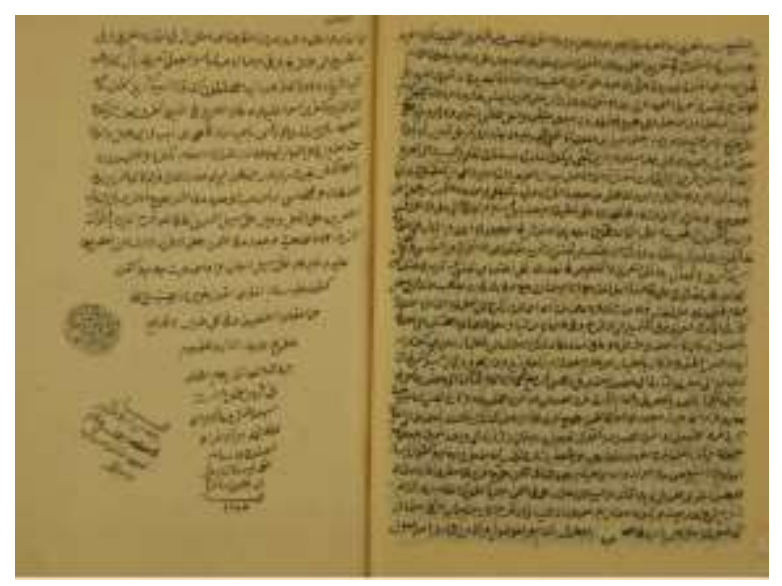

ثانيًا: التحقيق:

(ال الاستغراقية)

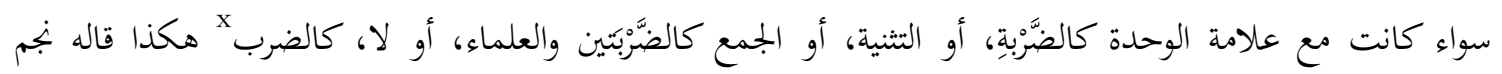

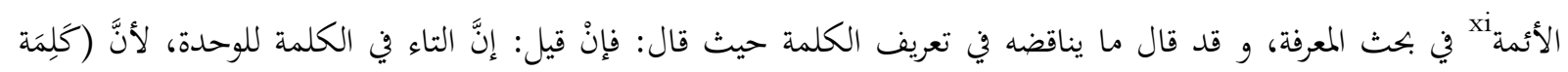

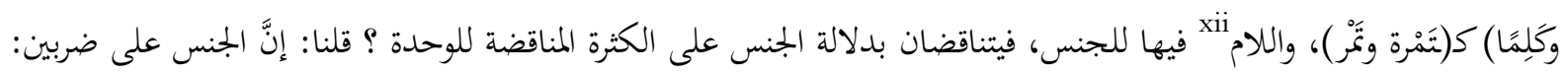




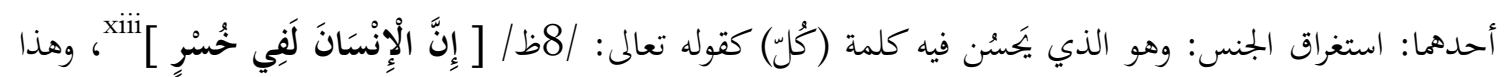

$$
\text { مفيدٌ للكثرة xiv فيُناقض الوحدة. }
$$

والثاني: ماهية الجنس: من غير دلالة xv اللفظ على القلة والكثرة بل xvi ذلك احتمالٌ عقليّ، وهذا يناقض الوحدة.xvii

$$
\text { والمراد هو الثاني xviii انتهى. }
$$

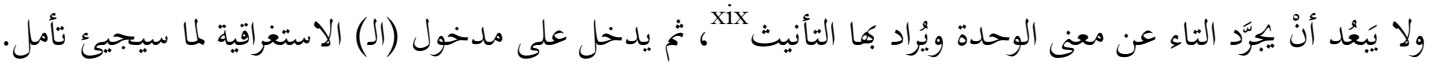
والمفرد المعرَّف بها يشمل كلَّ فردٍ فرد xx، والمثنى كُكَّ اثنين اثنين، والجمع كُلَّ جماعة جماعة فلا يُستنثى من الأول إلا الأول،

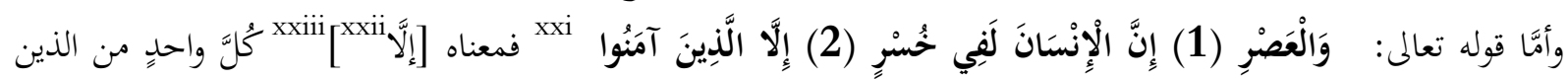

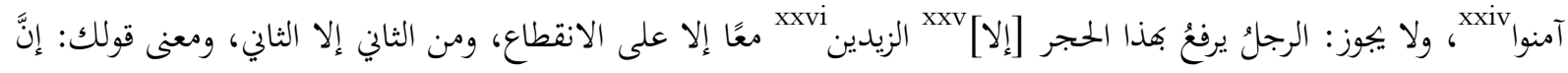

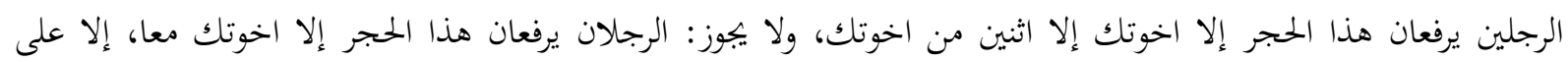

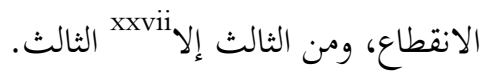

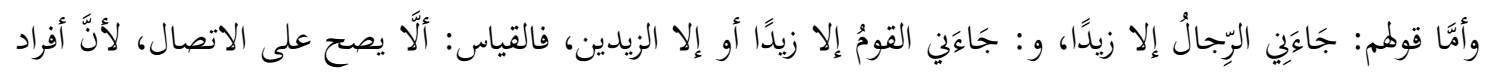

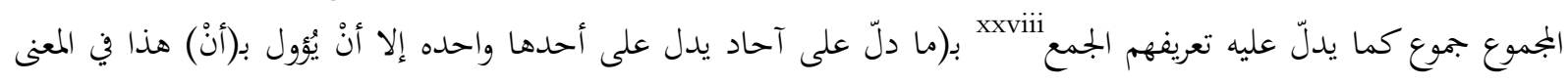

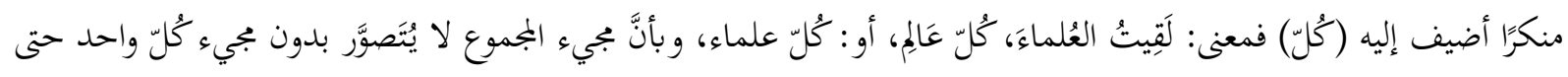

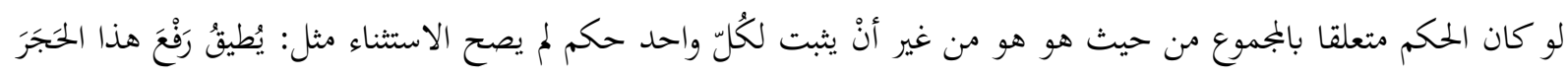

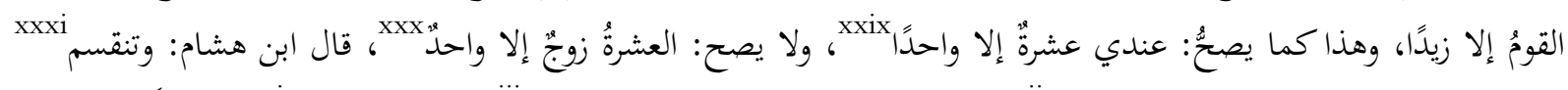

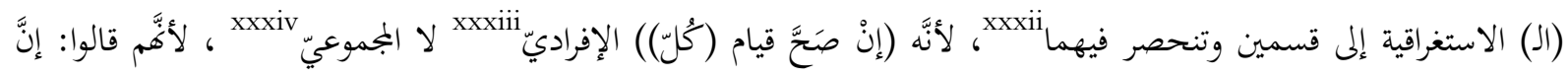

$$
\text { الاستغراقية مثل (كلّ) مضاف إلى نكرة }
$$

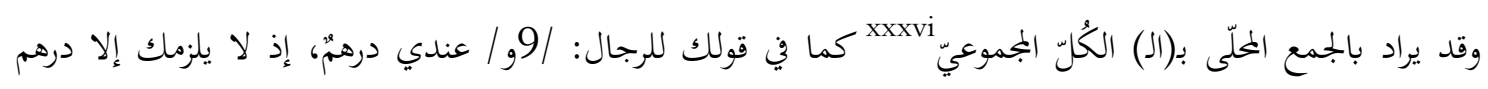

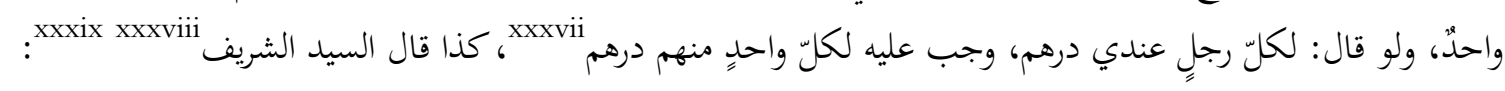
( مقامها حقيقة ف)يسمى ما يصح قيام (كُلّ) مقامها حقيقة (استغراق الأفراد) نهو: الرجلُ يرفعُ هذا الحجر إلا زيدًا، أو:

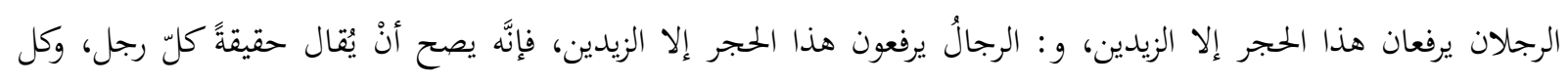

$$
\text { رجلين، وكل رجال. }
$$

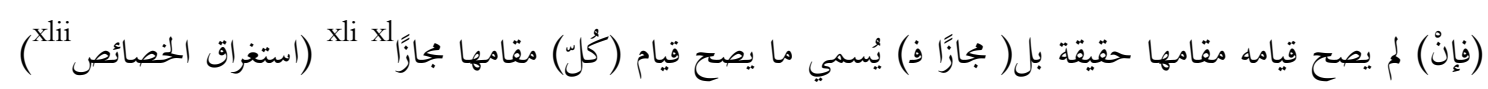

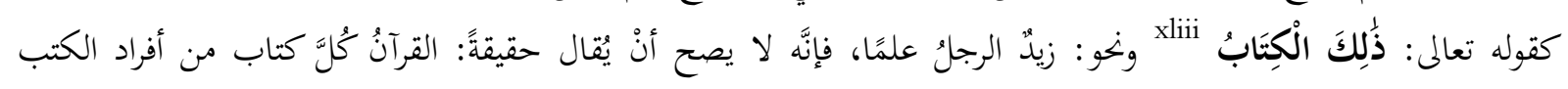

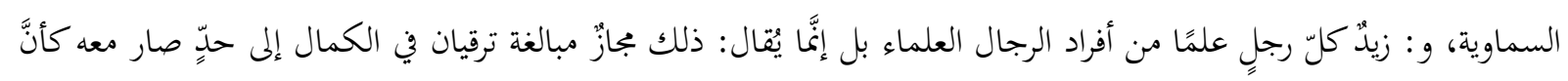

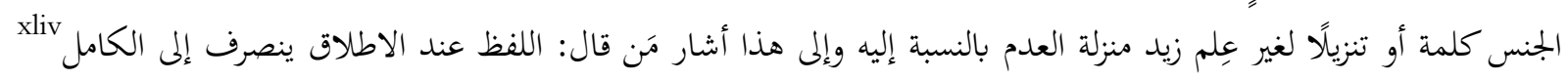

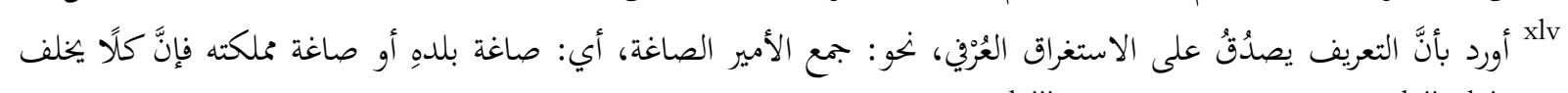

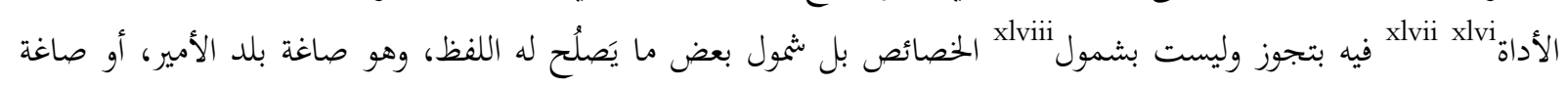

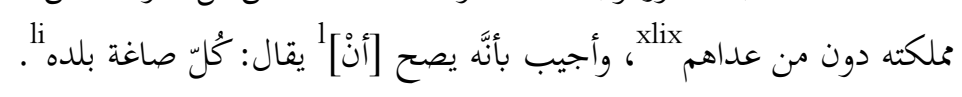

(ثخ) أراد أنْ يُقسِّم كلَّ من القسمين إلى قسمين فقال: ( إنْ كانت)، أي: فيما ذكرتُ من الأفراد وخصائص الأفراد

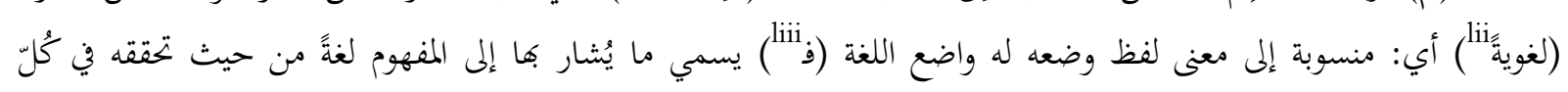

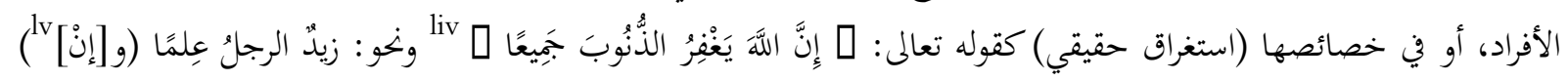


كانت (عرفية) أي: منسوبة إلى معنى لفظ وضعه ${ }^{\text {lvi }}$ /ظ/ له غير واضع اللغة سواء كان شارعًا، أو أهل اصطلاح، أو أهل

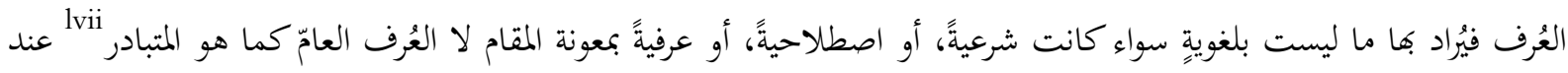

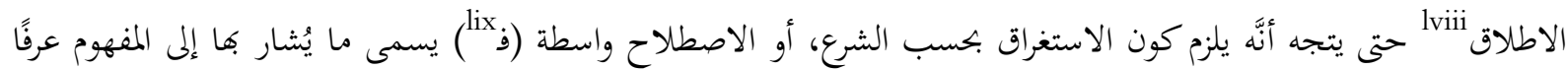

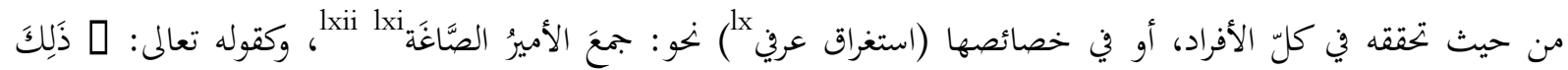
lxiii 1 الْكِتَابُ

قال بعض المحقين: إنَّ تخصيصهم ذلك التقسيم إلى حقيقي وعرفي تخصيص بلا خخصص lxiv ، لأنَّهّ يبري في العهد

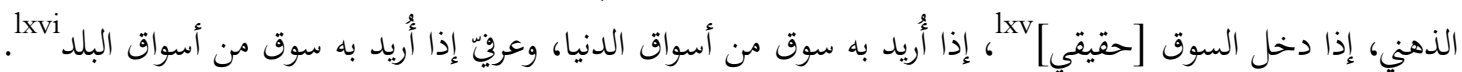

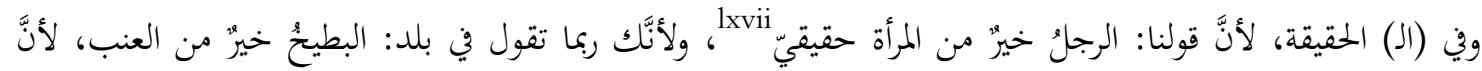

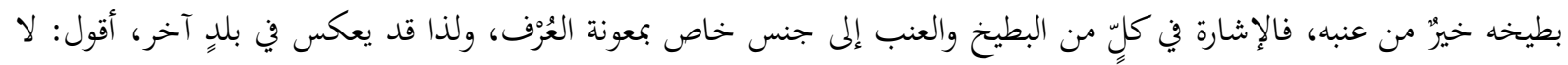

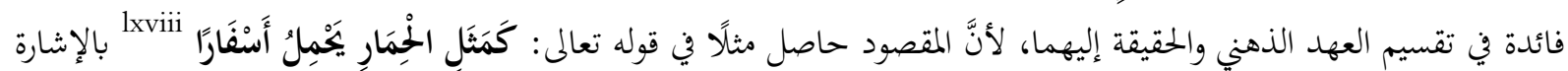

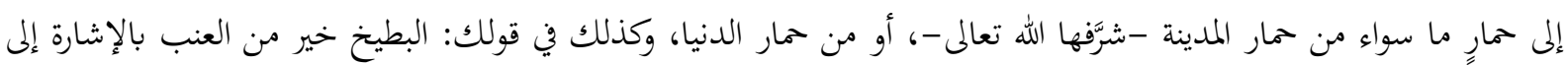

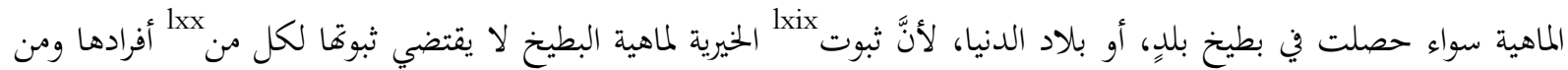

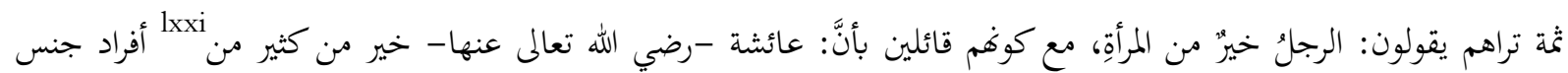
الرجل بخلاف تقسيم (ال) الاستغراقية فإنَّ الأحكام تارة تتعلق للأفراد اللغوية، وتارة للأفراد العاد العرفية. (و) قد تنازع الفُضَلاء في اشتمالية استغنxii استغراق المفرد من استغراق التثنية والجممع، قال السَّكَّاكيّ: (استغراق المفرد

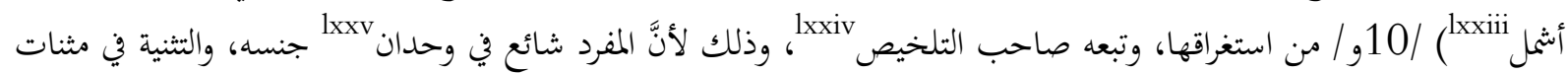

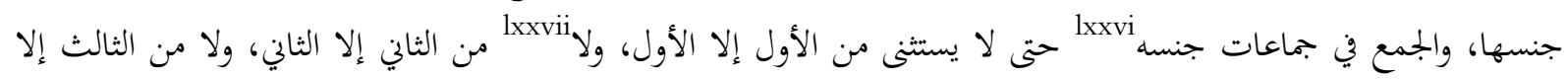

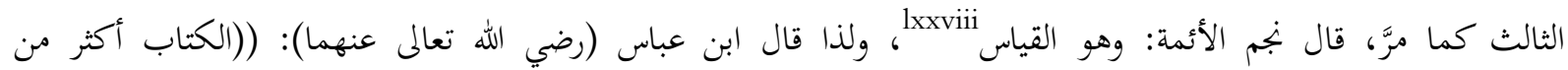

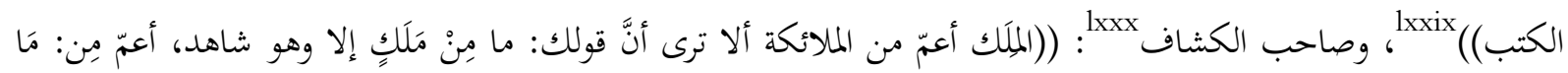
مِنْ مَالائكةة)

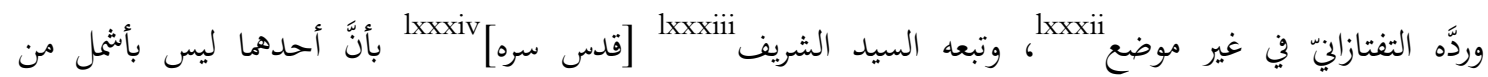

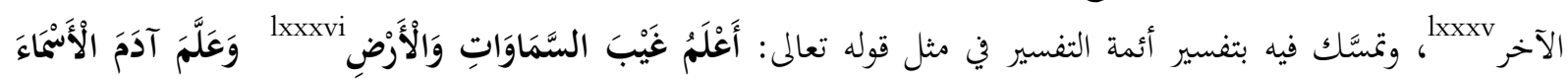

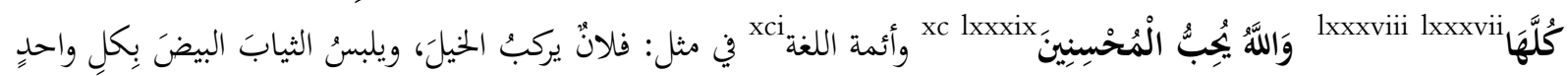

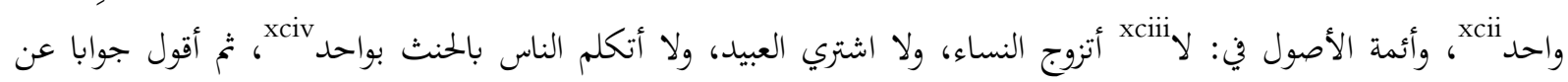

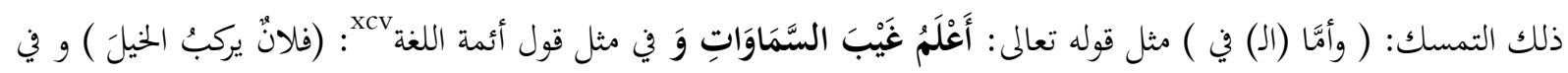

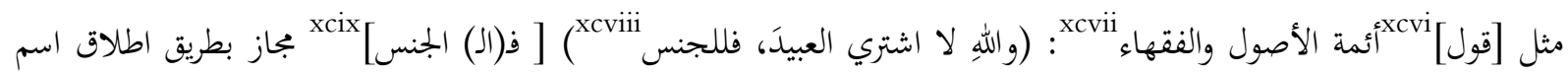

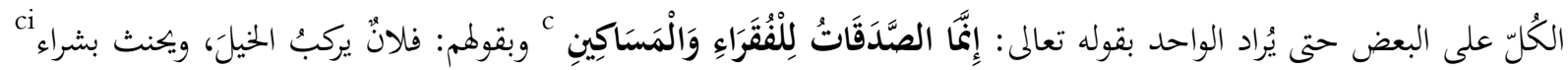
واحد ( لا الاستغراق). والكلام فيه قال فخر الاسلام cii وغيره cii : قال مشايخنا: الجمع المعرَّف إذا لم يكن هناك عهد، والاستغراق يجب حمله

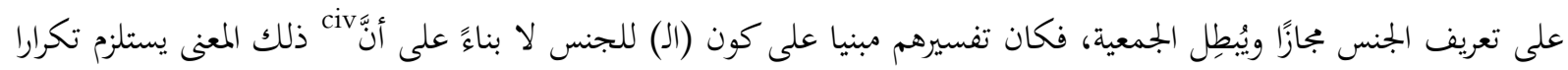

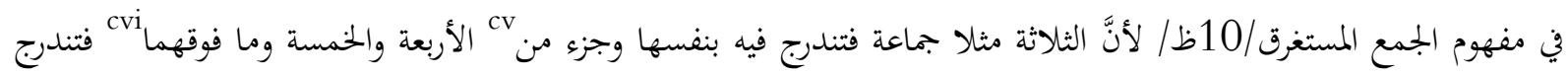

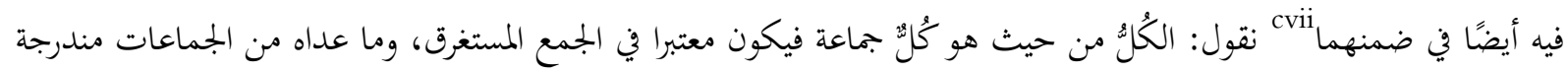

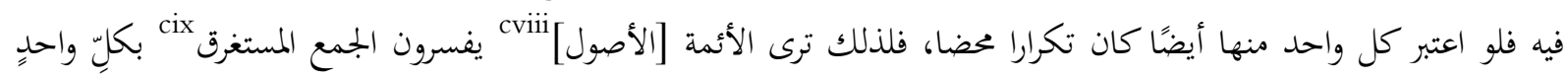


[واحد] فيكون كالمفرد في استغراقه كما قاله السيد الشريف cxic لأنه لو صحّ هذا البناء لزم ألا يُستعَمل في كلامهم جمعٌ من

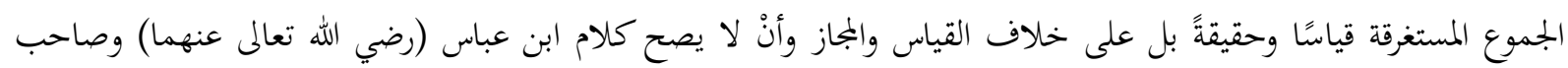

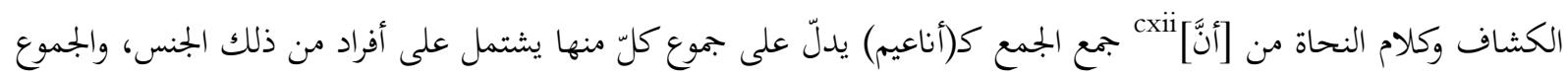

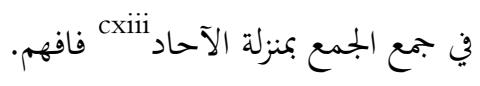

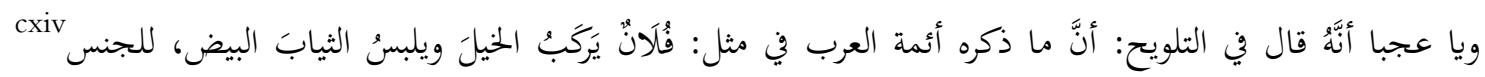

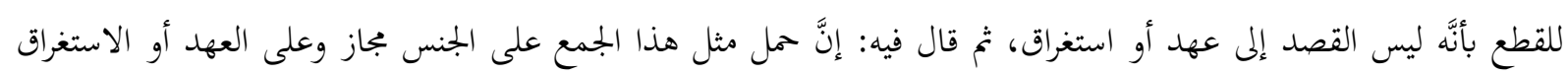
حقيقة وبما قلناه ظهر أنَّ ما قيل: المراد cxvi بالأشملية بالجملة cxvii لا دائمًا ليس شيء

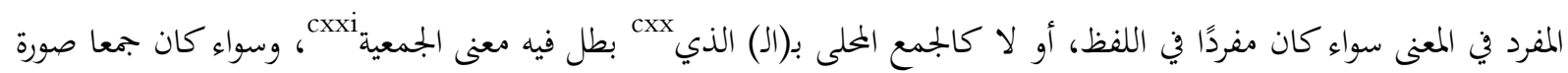

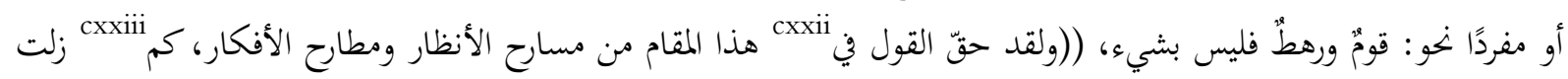

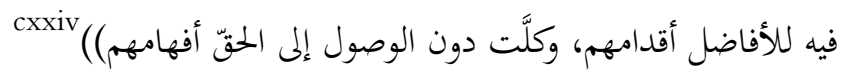

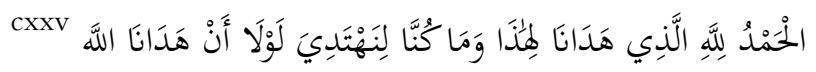

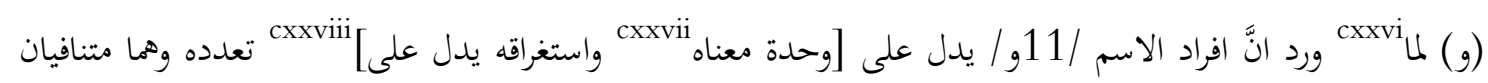
فلا يصح استغراق المفرد فضلاً عن كونه أشمل، أجاب:

أولا: بقوله: (لا تدخل)، أي: (ال) الاستغراقية (على) الاسم (المفرد) اكتفى به عن التثنية والجمع فلا يتجه أنَّ ذلك لا

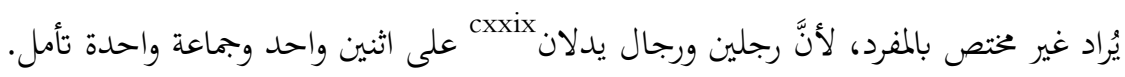
(إلا) حال كونه (بجردا عن

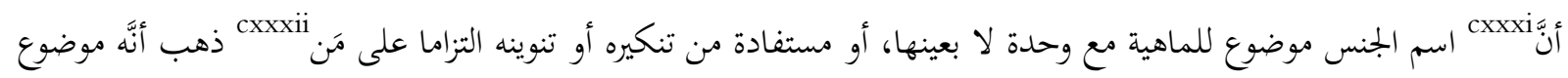
ها فقط. وقال السيد الشريف: ((إنَّ أسماء الأجناس cxxxii أكثر ما يُستعمَل في التراكيب لبيان النسب والأحكام، ولملما كان أكثر

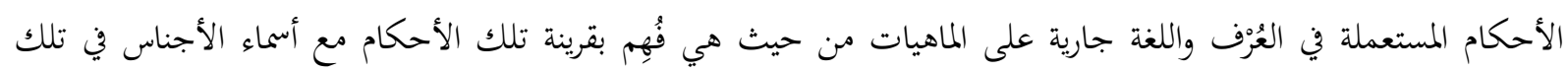

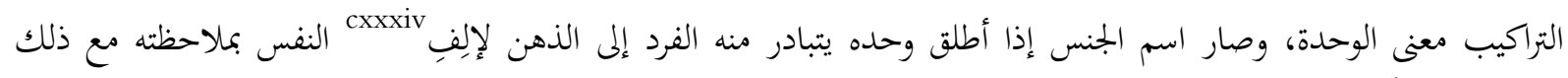

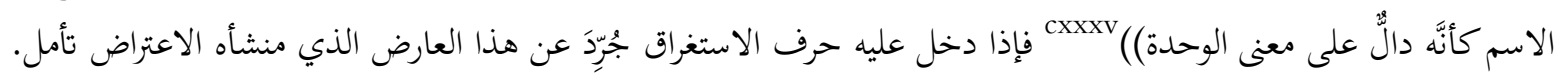
وأجاب ثانيا بقوله: (و) حال كونه (مرادا به)، أي: بالمفرد المستغرق معنى (كُلّ فرد) لا بجموع الأفراد وهو المنافي، إذ إذ إذاد

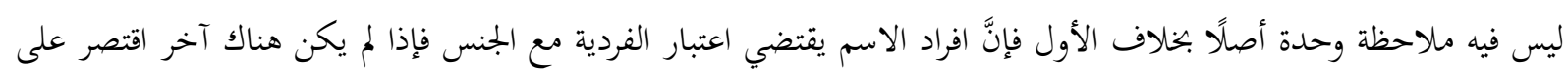

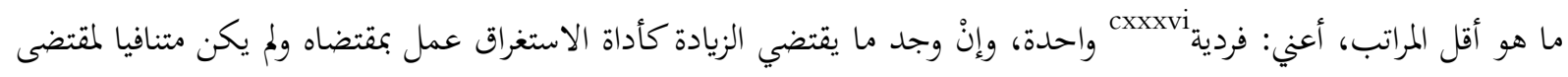

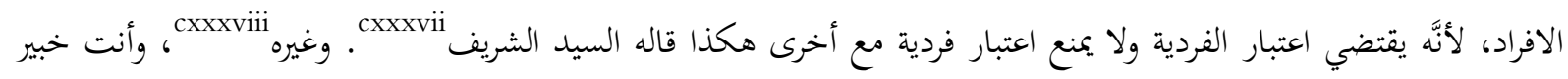

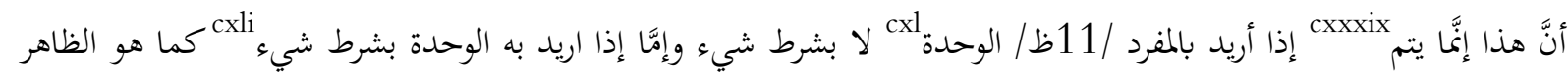

وإنَّا امتنع وصف هذا المفرد بنعت الجمع فلا يقال: الرجل الطوال، للمحافظة على التشاكل اللفظي هكذا قالوا،

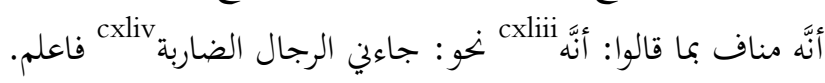




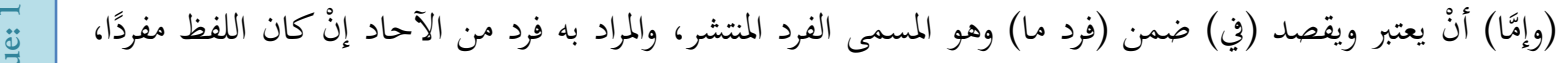

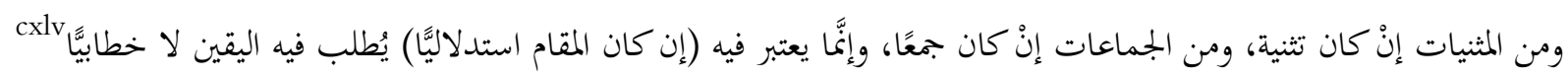

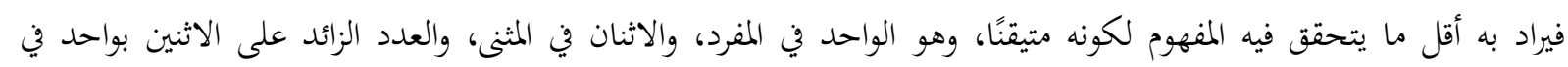

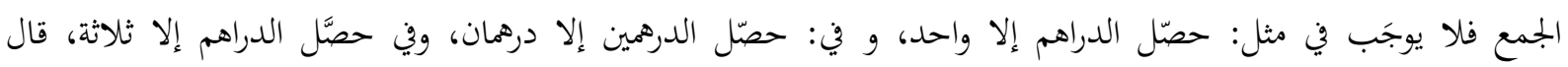

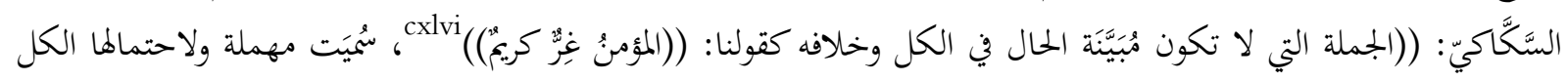

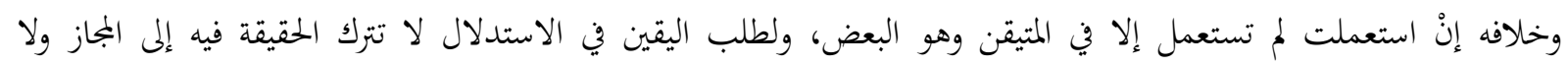
التصريح إلى الكتابة)( cxlvii تأمل. 
المصادر

الأدب المفرد بالتعليقات: محمد بن إسماعيل البخاري، أبو عبد الله (ت 256هـ) تحقيق: سمير بن أمين الزهيري، مكتبة المعارف

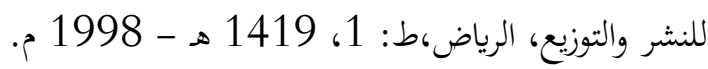

أنوار الننزيل وأسرار التأويل: ناصر الدين أبو سعيد عبد الله بن عمر بن محمد الشيرازي البيضاوي (ت: 685هـ)، تحقيق: محمد

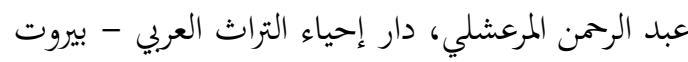

ط: 1: 1418 1418 هـ

الألغاز النحوية: عبدالرحمن بن ابي بكر السيوطي (ت 911هـ)، مكتبة الأزهرية للتراث، 1422هـ-02003

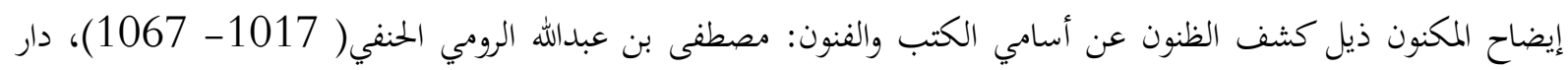

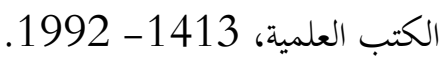

البحر المحيط: محمد بن يوسف الشهير بأبي حيان الأندلسي( 654هـ- 745هـ) تققيق: الشيخ عادل أحمد عبد الموجود، والشيخ علي محمد معوض، و د.زكريا عبد المجيد النوقي، و د.أحمد النجولي الجمل، دار الكتب العلمية، 1422هـ 2001

بغية الوعاة في طبقات اللغويين والنحاة: عبد الرممن بن أبي بكر، جلال الدين السيوطي (المتوف: 911هـ) تحقيق: محمد أبو الفضل إبراهيم المكتبة العصرية - لبنان / صيدا.

بيان المختصر شرح غختصر ابن الحاجب: محمود بن عبد الرحمن، شمس الدين الأصفهاني (ت: 749هـ)، تحقيق: محمد مظهر بقا، إنسا،

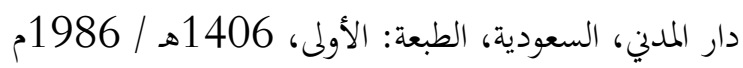

- تاريخ الإسلام ووفيات المشاهير والأعلام: شمس الدين أبو عبد الله محمد بن أحمد بن عثمان بن قَائمْاز الذهبي (المتوفى: 748هـ)،

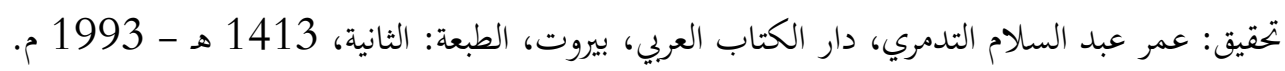
تسهيل الوصول إلى علم الاصول: محمد بن عبدالرممن المحلاوي ( ت 1341هـ) تحقيق: إلياس قبلان، دار الكتب العلمية، 2015

تشنيف المسامع بجمع الجوامع لتاج الدين السبكي: أبو عبد الله بدر الدين محمد بن عبد الله بن بهادر الزركشي الشافعي (ت:

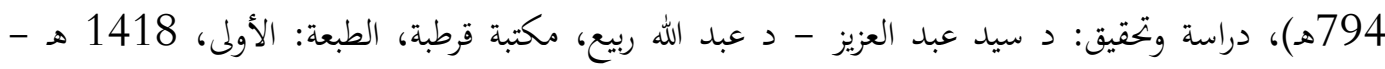
1998

الجامع في الحديث لابن وهب: أبو محمد عبد الله المصري القرشي (ت: 197هـ)، تحقيق: د مصطفى حسن، دار ابن الجوزي -

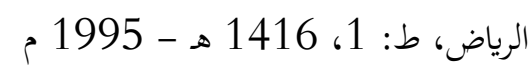

حاشية الدسوقي محمد بن أحمد بن عرفة الدسوقي المتوفى (1230هـ) على مختصر السعد: لسعدالدين بن مسعود التفتازاينّ المتوفى

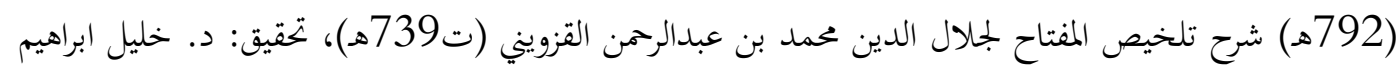

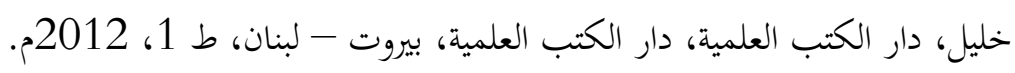

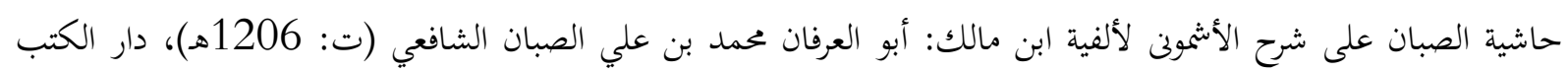

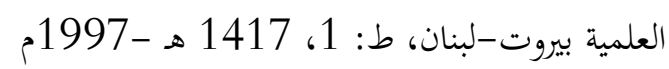

الحاشية على المطول شرح تلخيص مفتاح العلوم: الشريف الجرحاني تحقيق: رشيد أعرضي دار الكتب العلمية، الطبعة الأولى، $2007-1428$ 
الدر المصون في علوم الكتاب المكنون: السمين الحلبي (ت 756هـ)، تحقيق: الدكتور أحمد محمد الخراط، دار القلم، دمشق

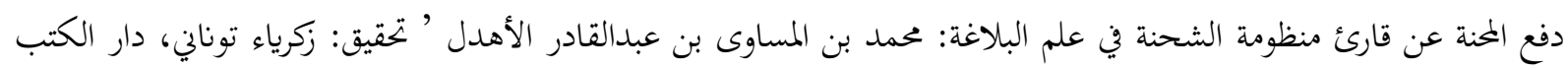

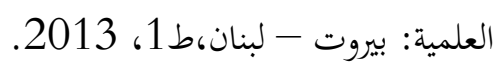

شرح الدرة الخفية في الألغاز العربية: لأبي عبدالله محمد بن أحمد شمس الدين ابن الركن الشافعي( ت803هـ)، تحقيق: أحمد

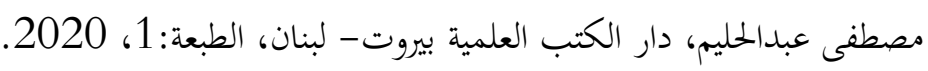

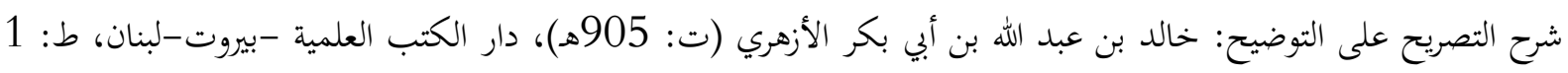

$$
\text { 2000- 1421 }
$$

شرح التلويح على التوضيح: سعد الدين مسعود بن عمر التفتازاين (المتوفى: 793هـ)، مكتبة صبيح بمصر.

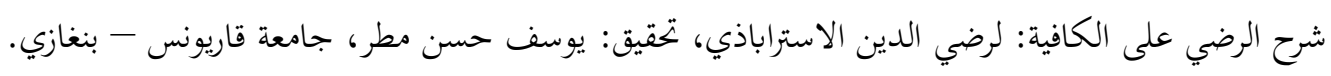

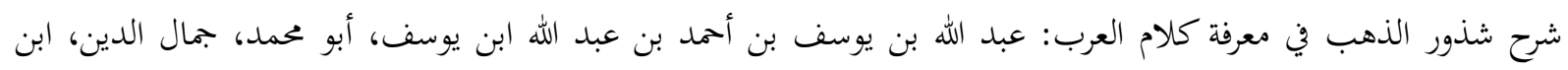
هشام (المتوف: 761هـ) تحقيق: عبد الغني الدقر، الشركة المتحدة للتوزيع - سوريا.

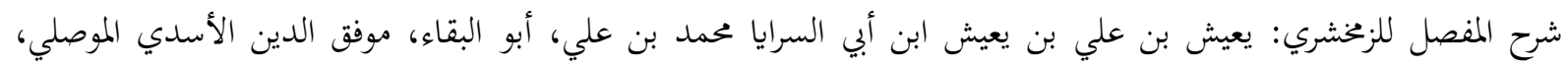

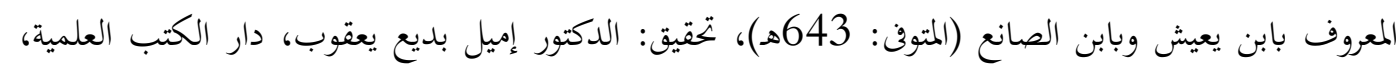

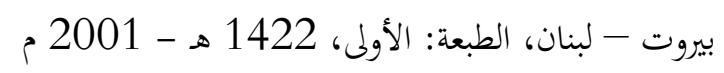

الشقائق النعمانية في علماء الدولة العثمانية: طاشكبري زادة (ت 968هـ)، دار الكتاب العربي،بيروت- لبنان، 1395هـ/ لوان 1975

عمدة القاري شرح البخاري: بدر الدين أبو محمد محمود بن أحمد العيني، تحقيق: عبد الله محمود محمد عمر، دار الكتب العلمية،

$$
2001-1421
$$

فصول البدائع في أصول الشرائع: محمد بن ممزة بن محمد، شثس الدين الفناري، تحقيق: محمد حسين محمد حسن إسماعيل، دار الكتب العلمية، الطبعة الاولى، 1427 - 2006

كشاف اصطلاحات الفنون والعلوم: محمد بن علي التهانوي (ت: بعد 1158هـ)، تحقيق: د. رفيق العجم، و د. علي دحروج، مكتبة لبنان ناشرون، ط: 1، 1996.

الكشاف عن حقائق التنزيل وعيون الأقاويل في وجوه التأويل: أبو القاسم محمود بن عمر الزخشري، تحقيق: عبدالرزاق المهدي،

$$
\text { دار إحياء التراث العربي - بيروت. }
$$

كشف الأسرار شرح أصول البزدوي: عبد العزيز بن أحمد، علاء الدين البخاري الحنفي (ت: 730هـ) تحقيق: عبد الله محمود

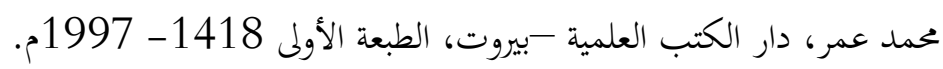

الكوثر الجاري إلى رياض أحاديث البخاري: أحمد بن إسماعيل بن عثمان الحنفي المتوفى 893 هـ، تحقيق: أحمد عزو عناية، دار

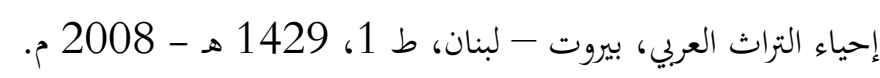

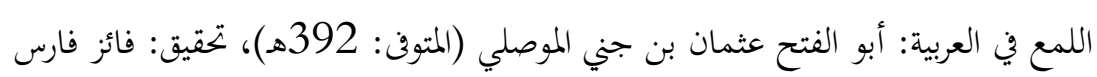
كار الكتب الثقافية - الكويت.

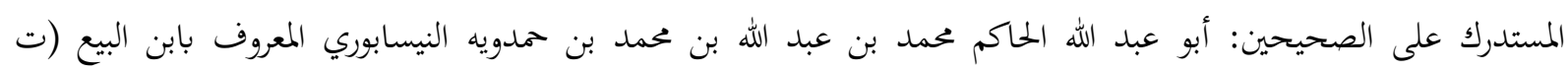

405هـ)تحقيق: مصطفى عبد القادر عطا، دار الكتب العلمية - بيروت، الطبعة: الأولى، 1411 - 1990

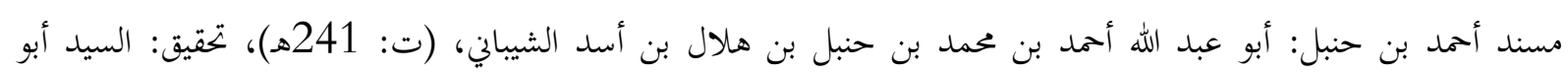

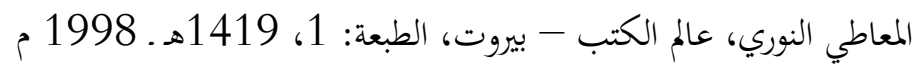


مصادر الدراسات الاسلامية القسم الثالث (الفقه الحنفي واصوله): أ.د. يوسف عبدالرممن المرعشلي، دار الكتب العلمية، الطبعة:14 1442هـ 144.

المطول شرح تلخيص مفتاح العلوم: سعدالدين التفتازاين (ت 792هـ)، تحقيق: د. عبدالحميد هنداوي، دار الكتب العلمية،

$$
\text { بيروت - لبنان، ط: 3: 3، 2013م: 2013. }
$$

معانى القرآن للأخفش: أبو الحسن الأخفش الأوسط (ت: 215هـ) تحقيق: الدكتورة هدى محمود قراعة، مكتبة الخانجي، القاهرة،

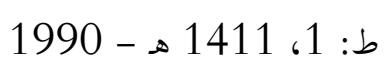

معاني القرآن الكريم: النحاس (ت 338 هـ)، تحقيق محمد علي الصابوني، جامعة أم القرى -مهة المكرمة، 1409هـ.

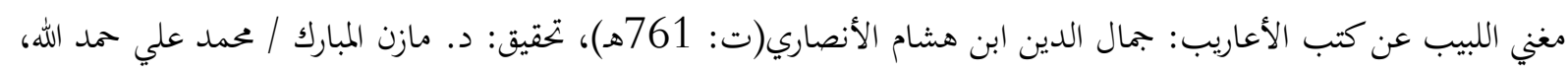
دار الفكر، 1985

مفاتيح الغيب - التفسير الكبير: أبو عبد الله محمد بن عمر بن الحسن الرازي الملقب بفخر الدين الرازي خطيب الري (المتوفى:

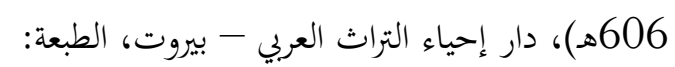

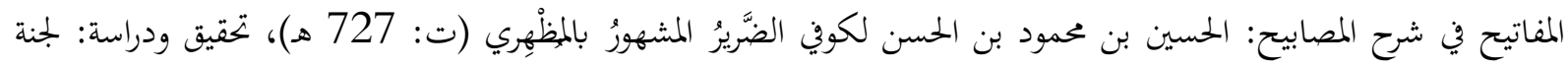

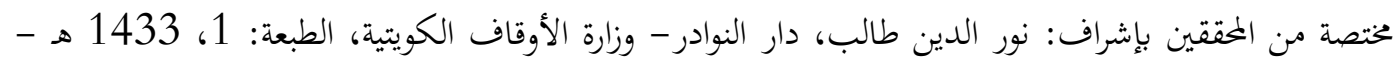

مفتاح العلوم: يوسف بن أبي بكر السكاكي (ت 626هـ)تقيق: نعيم زرزور، دار الكتب العلمية، بيروت - لبنان، ط2،

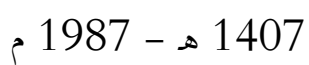

المفصل في صنعة الإعراب: أبو القاسم محمود بن عمرو، الزخشري (ت: 538هـ)، تحقيق: د. علي بو ملحم، مكتبة الهلال بيروت، ط:1:، 1993، 1993

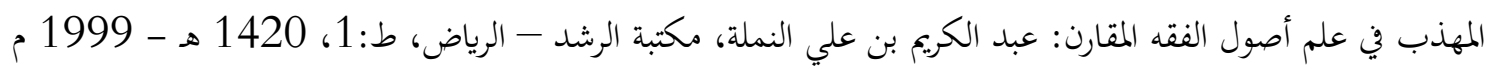
نفائس الأصول في شرح المصول: شهاب الدين أحمد بن إدريس القرافي (ت 684 6هـهـ

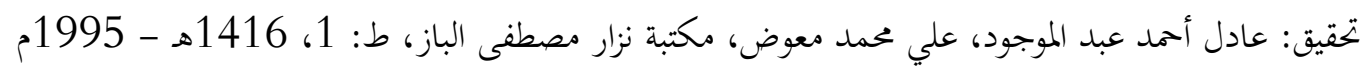

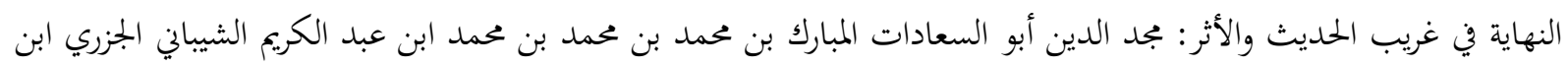

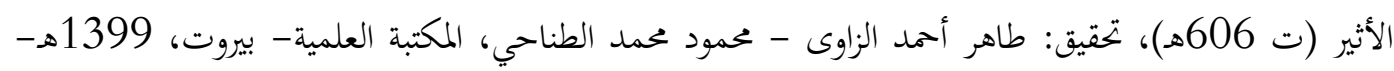

هدية العارفين أسماء المؤلفين وآثار المصنفين: إسماعيل بن محمد أمين الباباني البغدادي (ت 1399هـ)، دار إحياء التراث، بيروت-

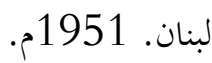

همع الموامع في شرح جمع الجوامع: عبد الرحمن بن أبي بكر، جلال الدين السيوطي (المتوفى: 911هـ) تحقيق: عبد الحميد هنداوي، المكتبة التوفيقية - مصر.

Makhțūțāt al-țibb wa-al-ṣaydalah fị al-maktabāt al-'āmmah bi-Ḥalab: Salman Qataya، University of Aleppo، 1976 


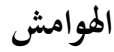

$$
\begin{aligned}
& \text { أنظر :هدية العارفين 568/1، وكشف الظنون 509/1.111. } \\
& \text { 1iii } \\
& \text { iii }
\end{aligned}
$$

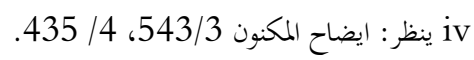

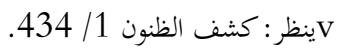

$$
\begin{aligned}
& \text { Makhṭ ūt āt al-ṭ ibb wa-al-Ṣaydalah:256 - ينظر : }
\end{aligned}
$$

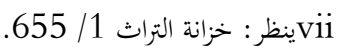

$$
\begin{aligned}
& \text { Viii } \\
& \text { ix } \\
& \text { ينظر : شرح الرَضي على الكافية 237/3x }
\end{aligned}
$$

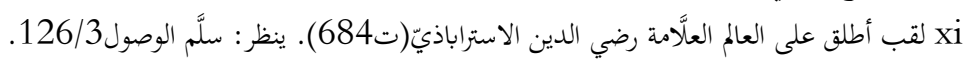

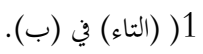

$$
\begin{aligned}
& \text { سورة العصر: Xiii }
\end{aligned}
$$

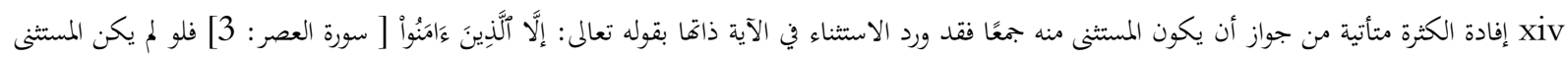

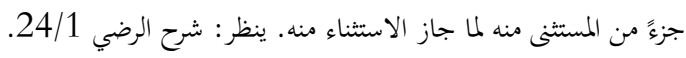
XV في الأصل: ولات. خطأ من الناسخ.وما أثبته من (ب).

$$
\text { Xu)xvi }
$$

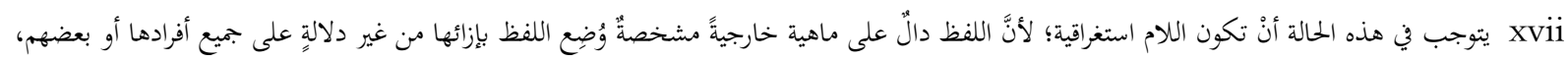
ولم يدل دليل على البعض فيتعين كوغا للاستغراق بمعنى (كلّ). ينظر: شرح الرضي 237/3.

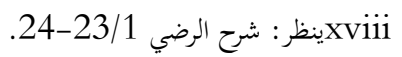

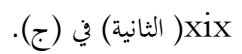

$$
\begin{aligned}
& \text { (فرد) نقص في (ب). }
\end{aligned}
$$

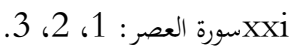

Xxii

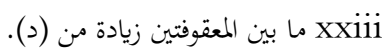

مxxiv

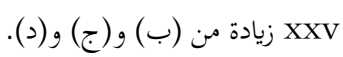

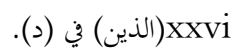

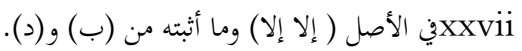

(الجمع) نقص في (د)xviii

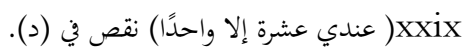

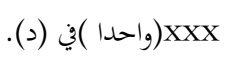

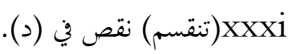

ينظر: شرح قطر الندى نxxii

Lxxxiiixxxiii

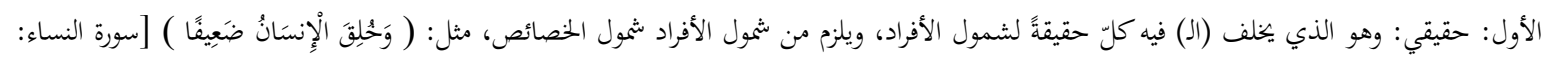
28] أي: كل واحد من جنس الانسان ضعيف؛ فيانَّه يصح هذا القول على جهة الحقيقة.

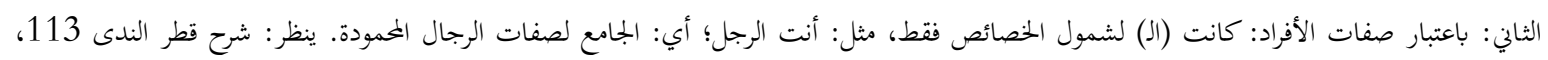
وتمهيد الفوائد بشرح تسهيل القواعد Xivxiv 
لأنَّ النكرة عامةٌ ومدلوها يقع على عامة أفراد الجنس، فهي تشابه الاستغراق في العموم. ينظر: حاشية بن حمدون على شرح المكودي لألفية ابن مالك

$.220 / 1$

Xeمxxvi

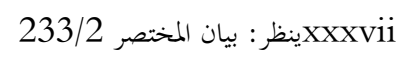

Xexxxiii

فيها Xxxix

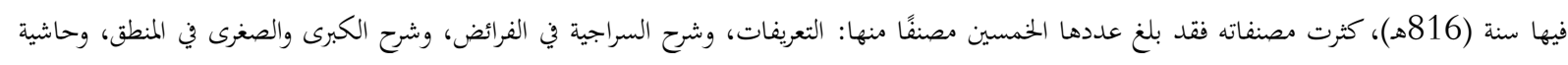

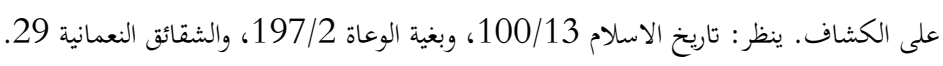

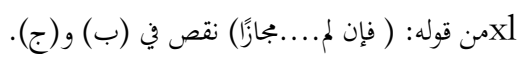

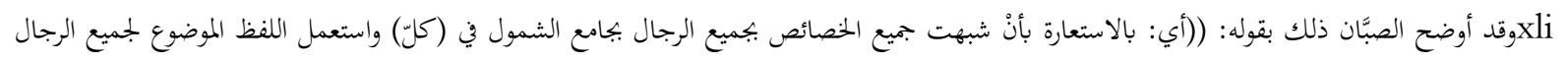

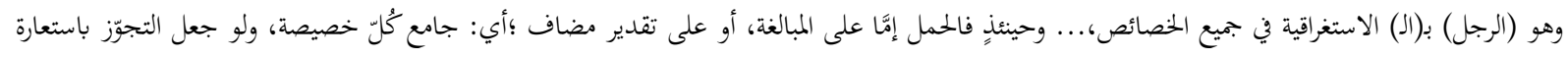

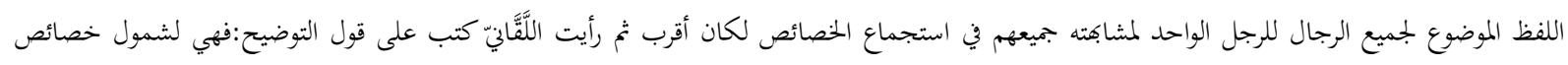

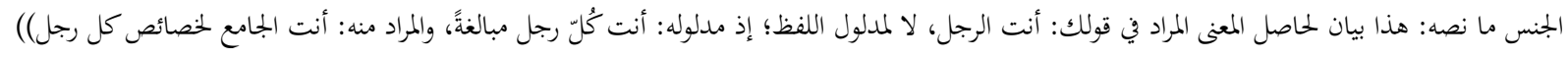

حاشية الصبان 262/1.

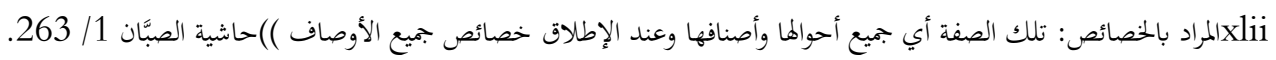
سورة البقرة: xliii 2. xxliv

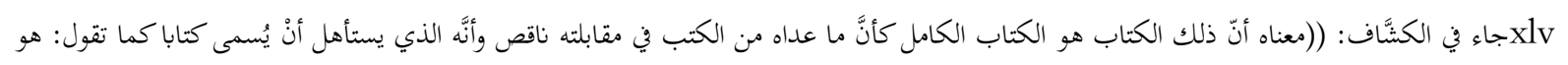

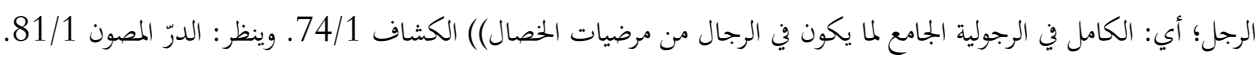
Xي (ب) (ب): إلا وإنَّ فيه.

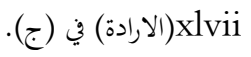
xhliii Xنين Xlix

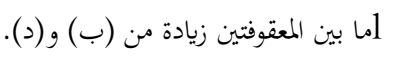

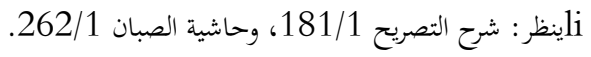
lii (ف) liii

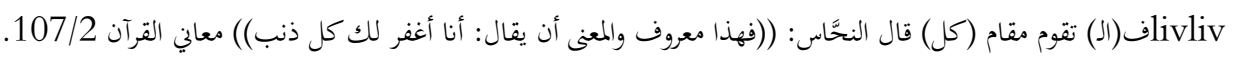

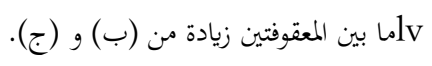
lvi

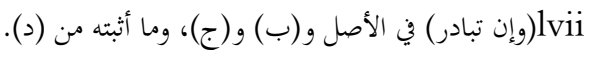
(ب)liii lix

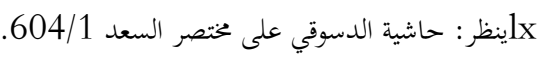

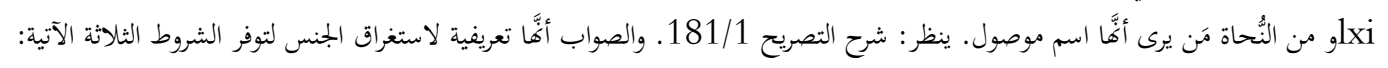

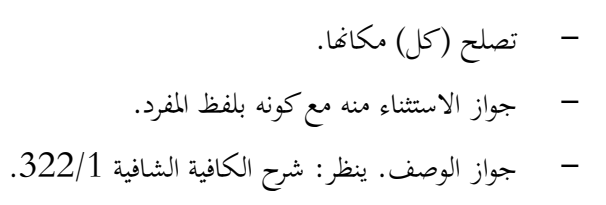

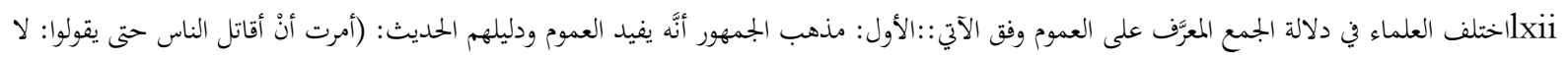

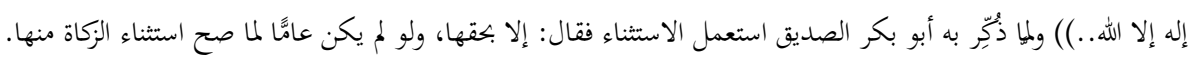

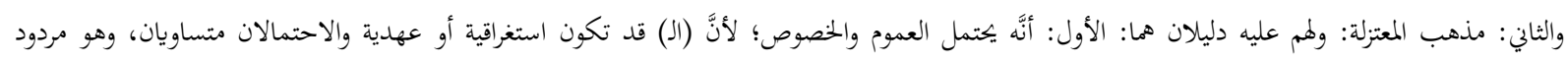

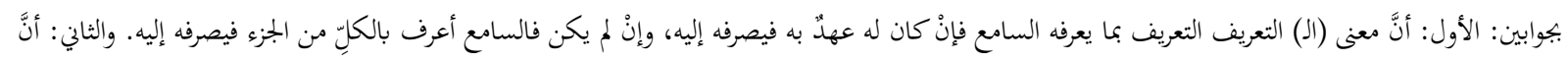




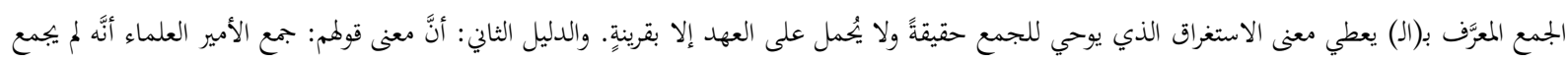

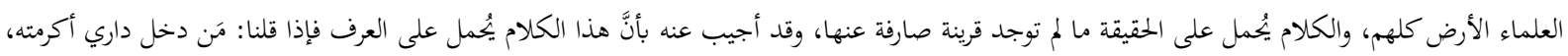
فالكلام عُرفًا لا يقتضي اكرام اللصوص. ينظر : المهذب في علم أصول الفقه المقارن 1497/4.

\section{إسورة البقرة: 2.

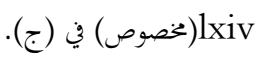

lxv

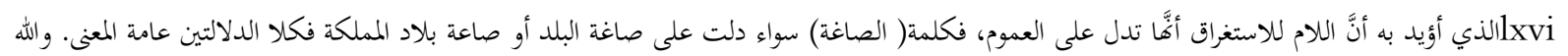
تعالى أعلم. إإذا أريد بها جنس الرجال وجنس الاناث، فكلمة(الرجل)معناها عامٌّ يراد به جميع الرجال، وكلمة (إمرأة) لفظ عامُّ يُراد به كل النساء. ينظر : شرح المفصل لابن

يعيش 349/3، و 133/5.

lxviii

lxix lxx

lxxi

lxxiilxxii

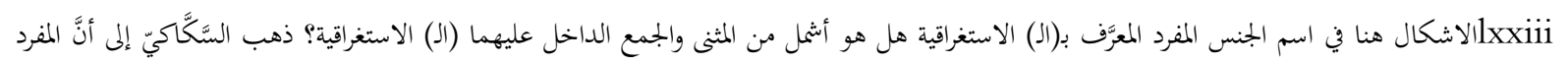

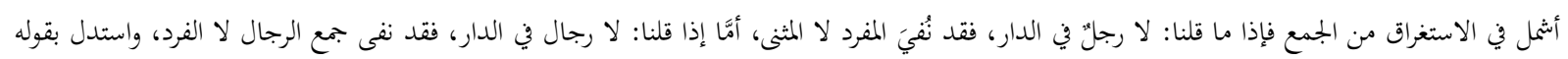

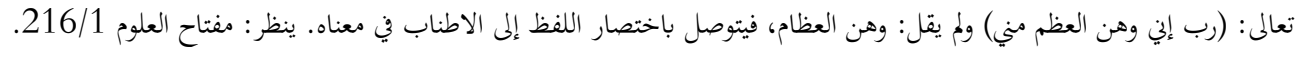
lxxiv lXxv lxxvi

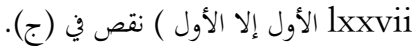

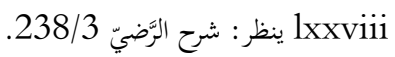

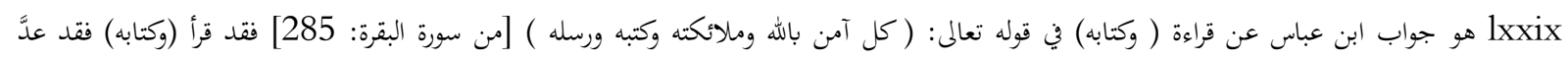

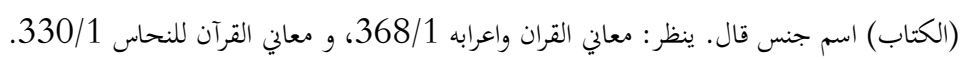

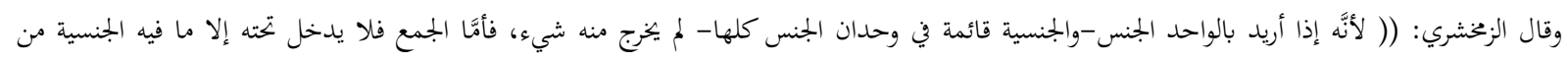
الجموع)) الكشاف (الكشف ) في (د) lixxx 605/4 الكشافllxxxi lxxxii

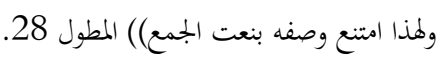

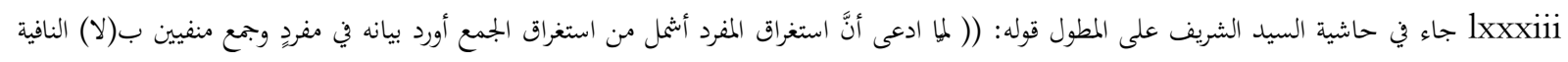

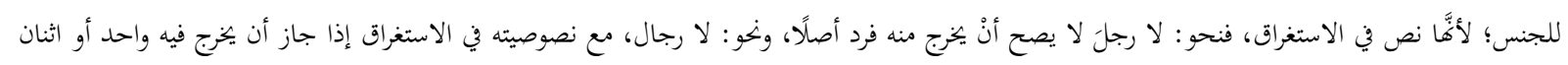

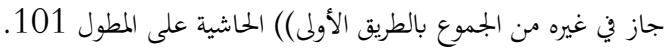

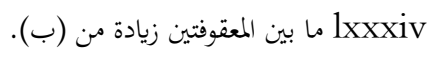
اوردَّه ايضًا السمين الحلبي بما يأتي:

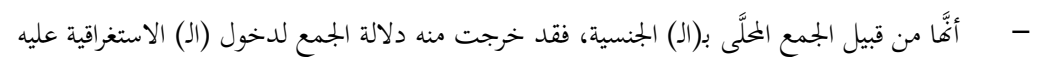

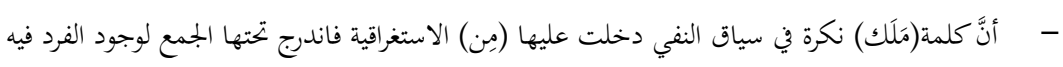

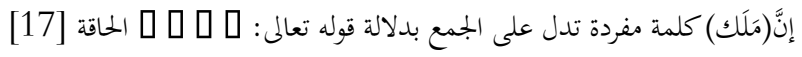

- ولو أريد به المفرد لما تحقق المعنى المراد وهو أنَّ الملائكة على أرجائها لا مَلك واحد ينتقل على أرجائها في أوقات. ينظر : الدرّ المصون 259/10. lxxxvi 
luxxvii

lilxxviii

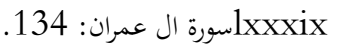

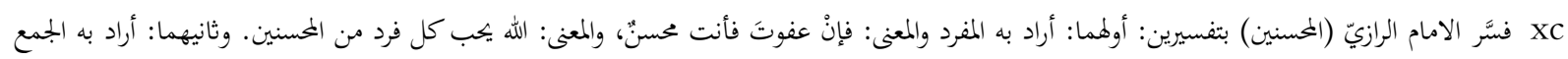

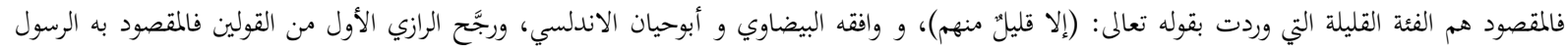

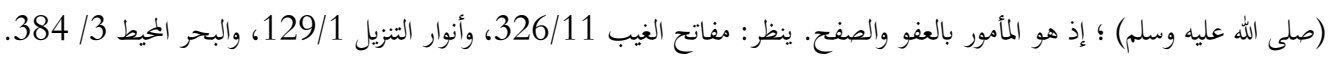

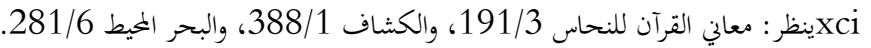
المكر xcii

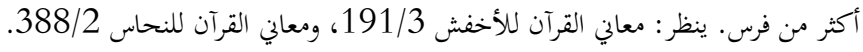
Xciii

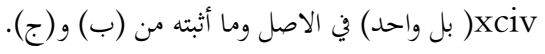

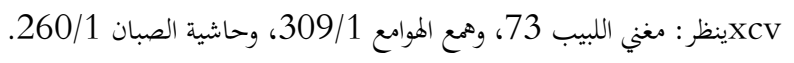
xا بين المعقوفتين زيادة من (ب)xcvi

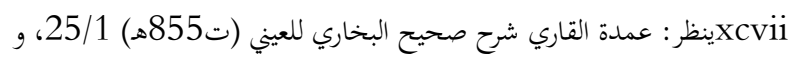

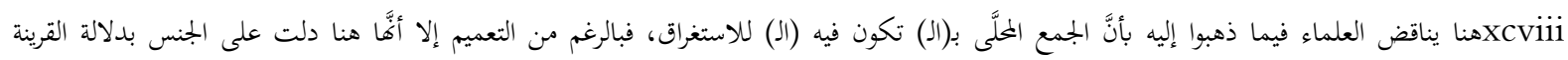

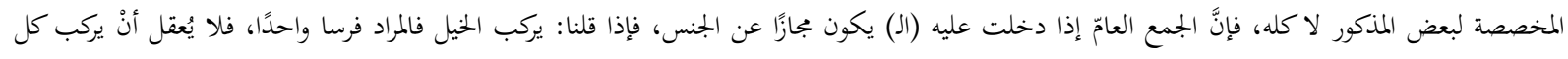

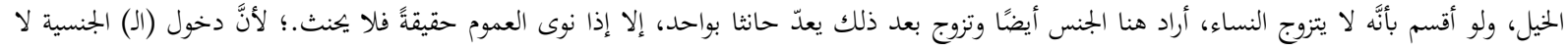

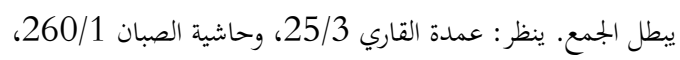

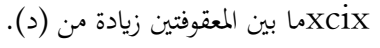

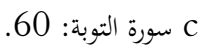
Ci (بشراء) نقص في (ج). Ci ci

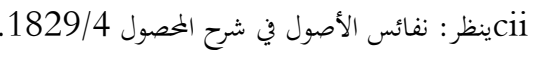

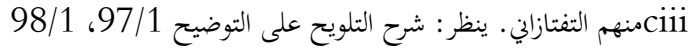

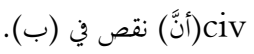

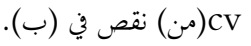

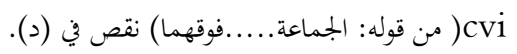

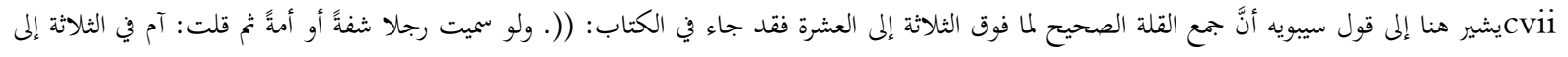

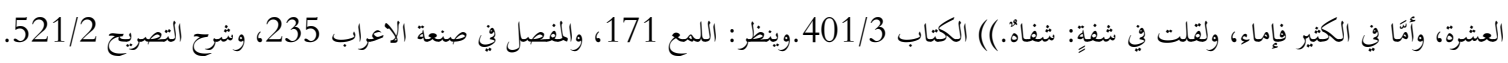

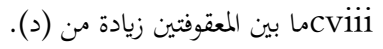

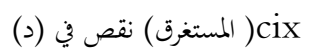

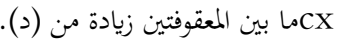

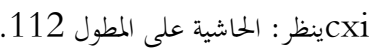
CCxii

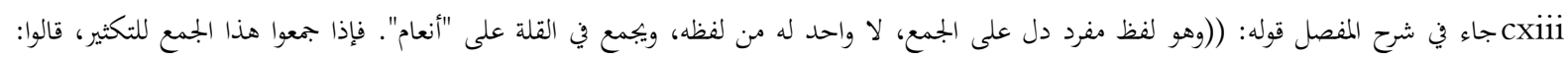

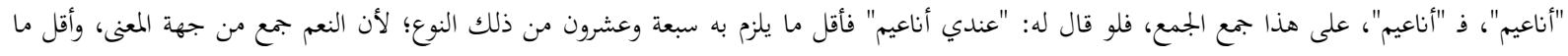

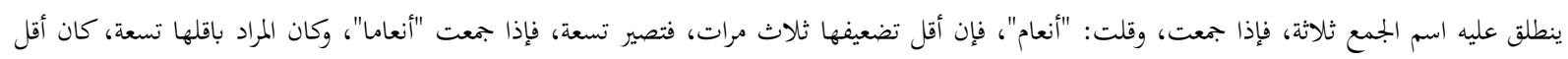

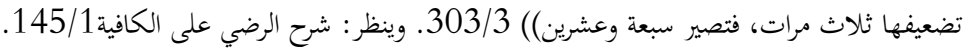
Cxiv

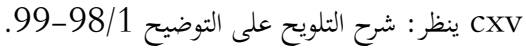
Cxvi

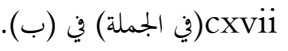

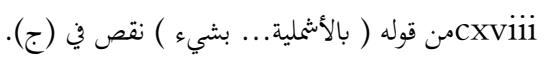
cxix 
cxx(الذي): نقص في (ب). cxxi Cxxii Cxxiii المطول شرح تلخيص المفتاح 232 cxxiv Cxxv Cxxvi CXXVii الذهنية لا تتناف مع التعدد الذي يقتضيه الاستغراق.

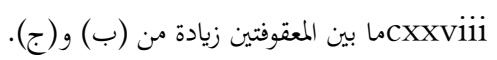
cxxix CXXX Cxxxi CXxxii

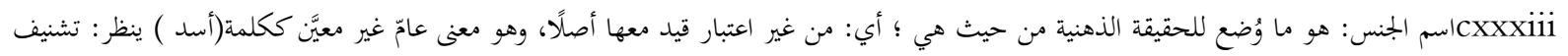
المسامع بجمع الجوامع 1 / 406. Cxxxiv كشاف اصطلاحات الفنون Cxxxv Cxxxvi ينظر : الحاشية على المطول Cxxxvii

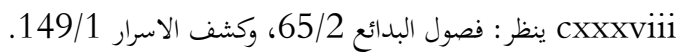
Cxxxix cxl Cxli cexlii

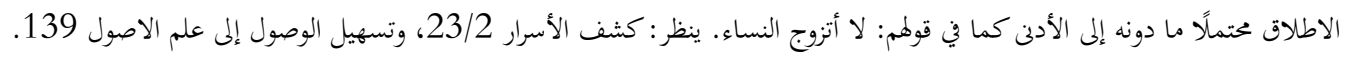
Cxliii

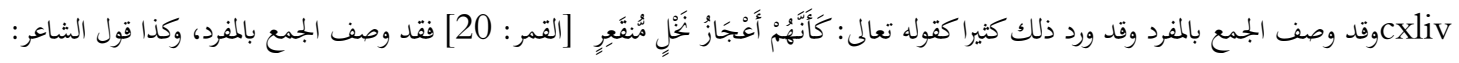

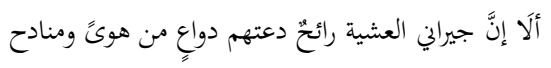

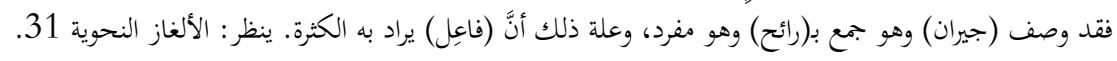

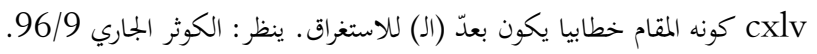

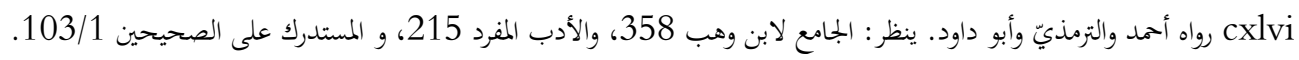

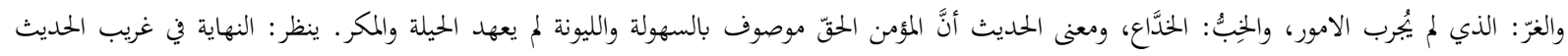
354/3، والمفاتيح في شرح المصابيح 253/5.

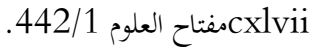




\title{
THE REALITY OF THE EVALUATION OF EDUCATIONAL PERFORMANCE IN THE LIGHT OF THE COMPETENCY-BASED APPROACH
}

\author{
Brahim TAMETELT ${ }^{1}$ \\ Asma Ben YAHIA ${ }^{2}$
}

\section{Istanbul / Türkiye \\ p. $605-616$}

Received: $21 / 11 / 2021$

Accepted: 09/12/2021

Published: 01/01/2022

This article has been scanned I iThenticat No plagiarism detected

\begin{abstract}
:
Scientific research endeavors to provide theoretical approaches to various fields and fields, It has been valued by field applications in experimental and descriptive studies on samples planned in several environments, In the pursuit of effective learning through an optimal investment of the learner's environment and its pillars, and by extending the activities of the school outside, from hypothetical problems to real problems of the reality of the learner life. The philosophy of the competency-based approach and its procedures were based on constructive steps to achieve the above, However, she stood on a deep challenge depicted in the assessment, When all the activities are based on the learner's use of his experiences to respond to all the situations he is confronted with, It is therefore a continuous process of evaluation.

practical difficulties, while promoting research with an office approach between the theoretical aspect stipulated in the process and the real environment in which it takes place.
\end{abstract}

Key words: Pedagogical Evaluation, Performance, Efficacity.

http://dx.doi.org/10.47832/2717-8293.15.42

Dr. , Ghardaia University, Algeria, tamehim@gmail.com, https://orcid.org/0000-0003-3485-8155

Researcher. , Ghardaia University, Algeria, soumadz82@ gmail.com, https://orcid.org/0000-0002-6445-1623 


\title{
واقع تقويم الأداء التربوي في ضوء المقاربة بالكفاءات
}

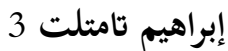 \\ 4 \\ أسماء بن يجيى
}

الملخص:

حرص البحث العلمي على تقديم تناولات نظرية لمختلف المجالات والميادين، ثمّنها بتطبيقات ميدانية في دراسات تجريبية ووصفية على عيّنات مقصودة في بيئات متعددة، سعيا نحو تعلم فعال من خلال استثمارٍ أمثل لبيئة المتعلم

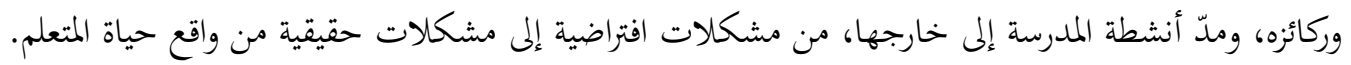

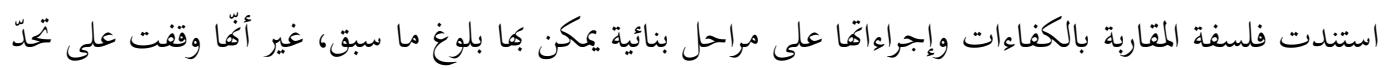

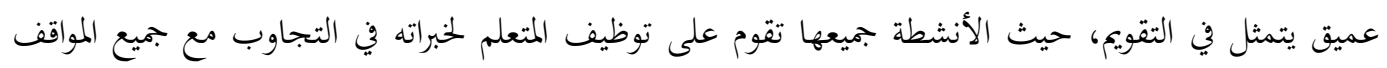
والوضعيات المجاجمة له، من ذلك فهي عملية تقويم مستمرة.

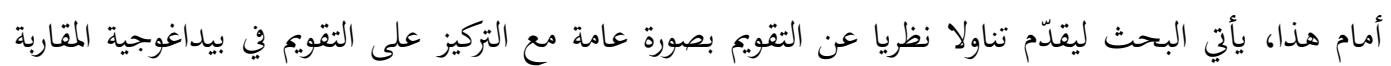

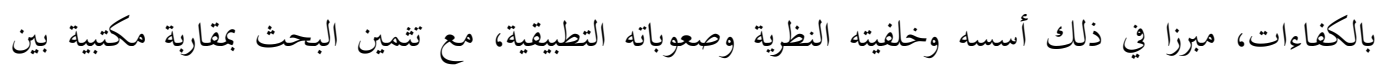
الجانب النظري الذي تنصّ عليه المقاربة والبيئة الفعلية التي تتمّ فيها. الكلمات المفتاحية: التقويم التربوي، الأداء، الكفاءة.

يعدّ التقويم التربوي ركيزة أساسية ضمن ركائز المنظومة التربوية، عليه تُرهن نجاح جميع عمليات التعلم الأخرى، باعتباره عاملا في تشخيص واقع المتعلم للشروع في تحديد مسارات التعلم من جهة وعاملا للوقوف على مستوى مكتسبات التعلم

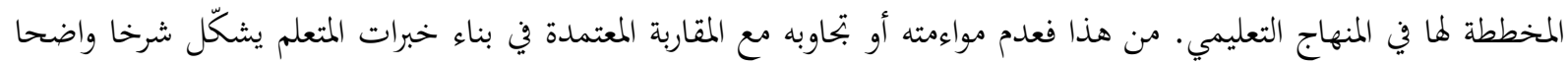

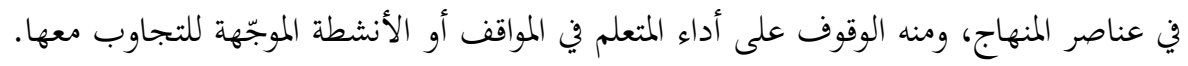

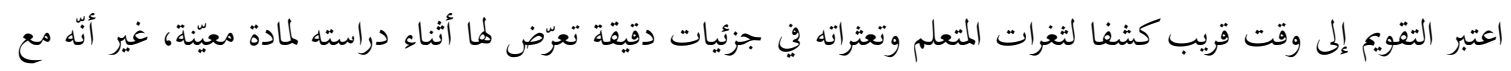

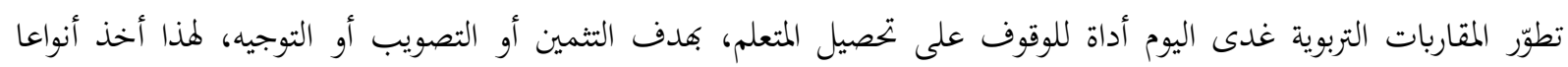
متعدّدة وأشكالا مختلفة، كل منها يستند على أهداف ومعايير محدّدة مسبقا تقف عليها الجهات الوصية، حيث تقوم بمتابعتها والحرص على إجراءاتها الشاملة والجزئية بصورة دقيقة ومستمرة.

فجتت المدرسة الجزائرية سياسات تربوية عدّة من الاستقلال إلى يومنا هذا، واجتهدت في مسايرة المقاربات الحديثة إلى آخرها اليوم والمتمثلة في المقاربة بالكفاءات التي تأخذ بفلسفة التعلم المتمركز على نشاطات المتعلم واستجاباته "مورية المتعلم

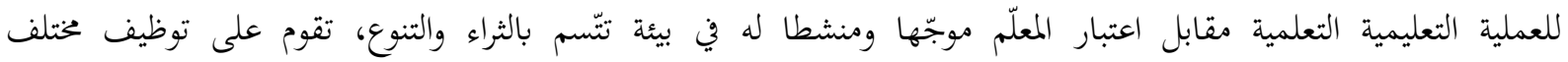

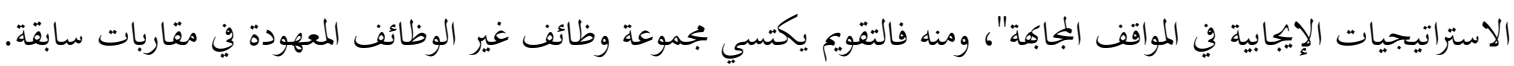


من هذا يعدّ التقويم في بيداغوجية الكفاءات أصعب مرحلة وأعقدها، حيث نالت الكثير من التساؤلات والاستفسارات

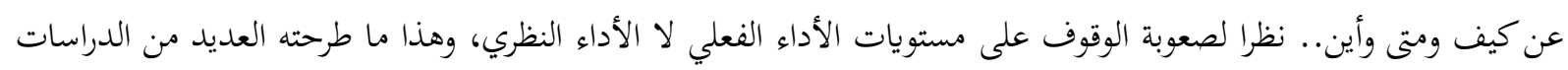

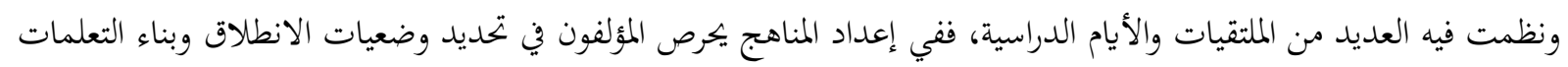

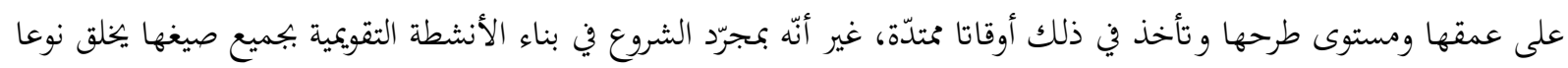

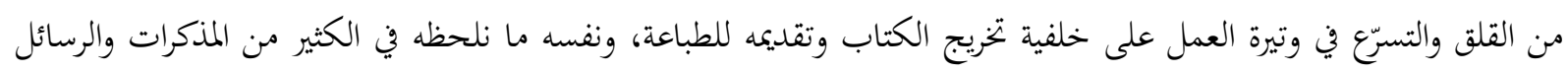

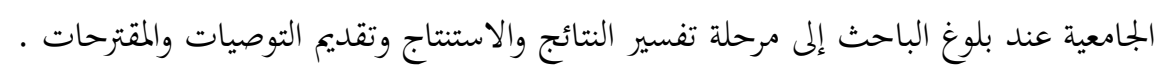
في ملاحظات ووقفات عابرة للباحثين في ميدان التربية والتعليم وقفا على العديد من المعيقات والصعوبات التي يشعر فيها

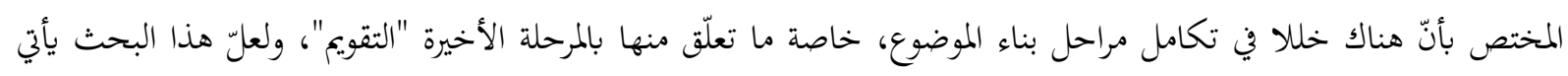

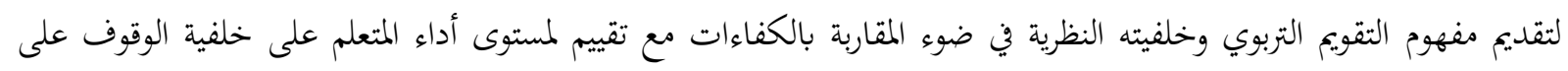
صعوبات المعلم في التقويم، منه يمكن تحديد ذلك في التساؤلات الآتية:

تساؤلات البحث:

1-ما الخلفية النظرية لبيداغوجية المقاربة بالكفاءات؟ وما مفهوم التقويم التربوي في ضوء نفس المقاربة؟

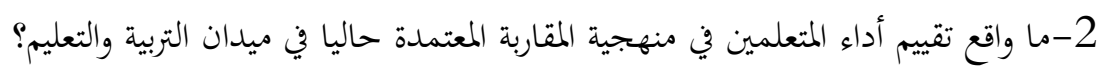

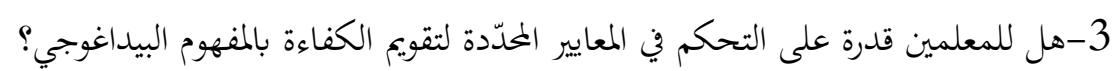

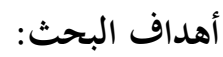

1 2 - تقديم قراءة تراكمية للخلفية النظرية التي قامت عليها المقاربة بالكفاءات.

3 - الوقوف إحصائيا على معيقات التقويم لدى المعلمين في المقاربة بالكفاءات.

4 -إبراز تحديات المقاربة بالكفاءات في ظل ظهور مشكلات تربوية لم تكن موجودة مسبقا.

أهمية البحث:

يأخذ البحث أهميّه في أنه يبحث في موضوع ذا علاقة بتكوين المتعلم، حيث تعدّ بيئة التعلّم شغل جميع السياسات

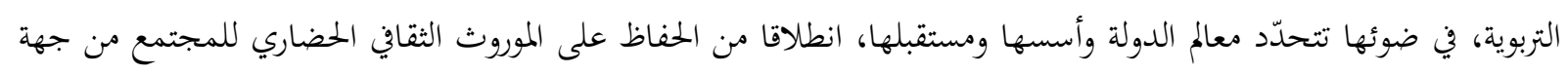

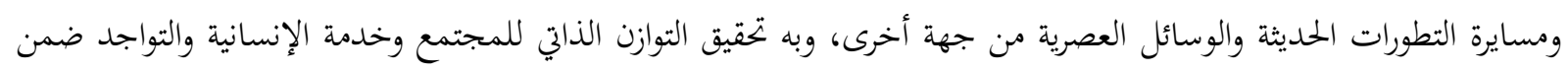

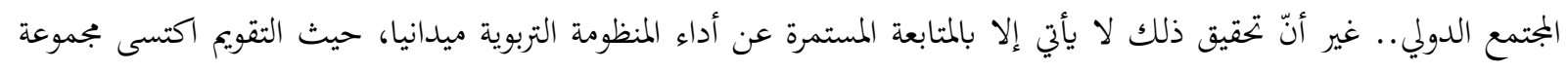

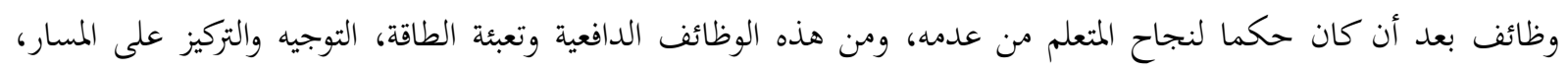
الإرشاد ومراجعة المسار.

وعليه فضعف التقويم في المقاربة المعتمدة يؤدي إلى ضبابية مسار العمل في تحقيق المقاصد والأهداف المنشودة، وانطلاقا

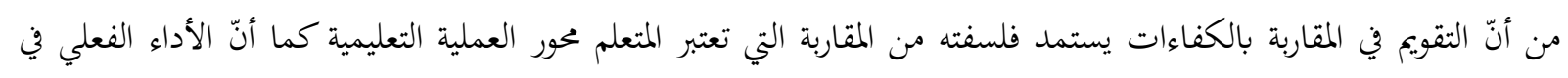

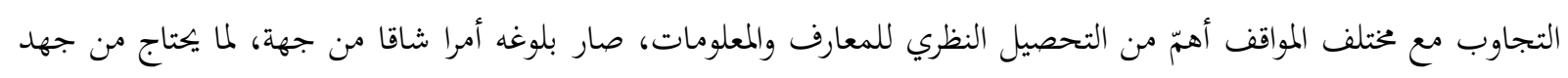

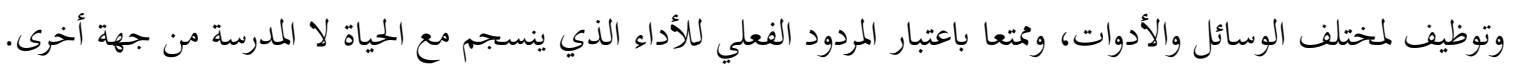


المعايير: "عبارة يستند إليها في الحكم على المهمة في ضوء ما تضمنته العبارة من وصف للسلوك، والممارسات التي تعبر عن قيم أو ابتحاهات أو أنماط تفكير، أو قدرة على حل المشكلات واتخاذ القرارات، باعتبارها خطوطا إرشادية تمثل المستوى النوعي أو الكمي

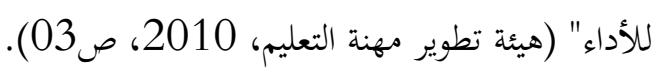

المستويات: تتشابه مع المعايير في أها أسس داخلية للحكم إلا أها تختلف في جانبين، أولمما أها تأخذ الصورة الكيفية وتحدد في

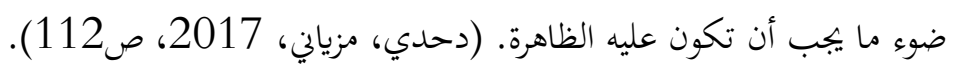
مستويات المعيار: "عبارات تصف السلوك والنشاطات القابلة للملاحظة والقياس، ويمكن تحقيقها والقيام بها، حيث يظهر من

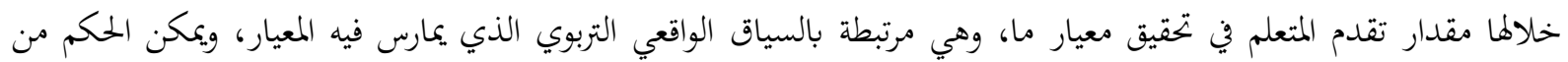

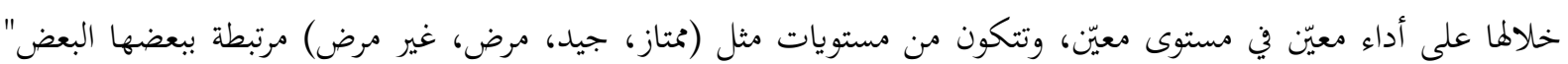

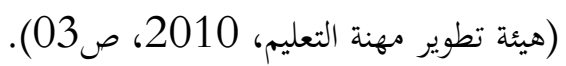

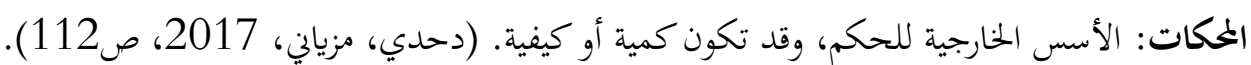
الأداء: ممارسات تطبيقية يقوم بها المتعلم لإنجاز مهام دراسية أو أعباء تنظيمية، أي درجة تحقيق المهام المكونة للوضعيات التعليمية

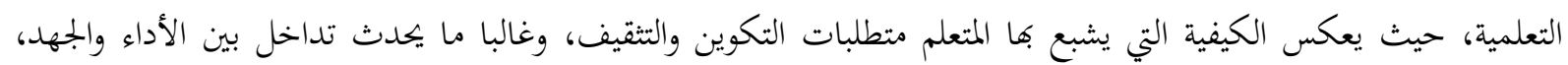

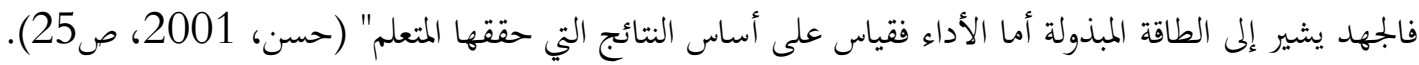
تقويم الأداء: عملية قياس مدى تقدم الفرد في إنجاز المهام الموكلة إليه، في ضوء المعايير والمتطلبات الخاصة بالمجال الذي يشتغل فيه. تقويم أداء المتعلم: عملية قياس مدى تقدم المتعلم في إنجاز وضعيات التعلم المدرسية والمواقف الحياتية الموكلة إليه حسب خصائصه

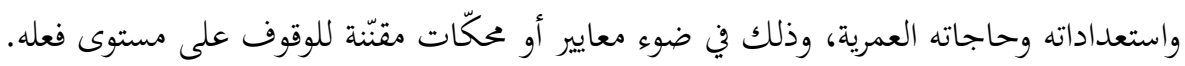
مفهوم التقويم التربوي: صنّف (دحدي، الوناس، 2017، ص117-118) مفهوم التقويم التربوي إلى ثلاثة أصناف، تتمثل في: الصنف الأول: الهدف من التقيم قياس مدى تحقيق الأهداف التربوية مسبقا، منه تعريف بنيامين بلوم "إصدار حكم لغرض ما على قيمة الأفكار والأعمال والحلول والطرق والمواد... يتضمن استخدام المحكات والمستويات والمعايير لتقدير مدى كفاية الأشياء

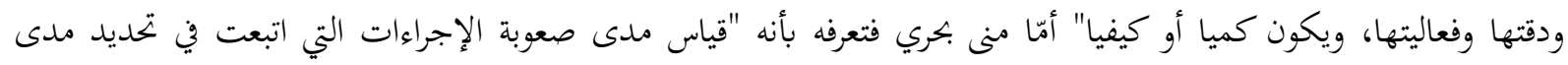

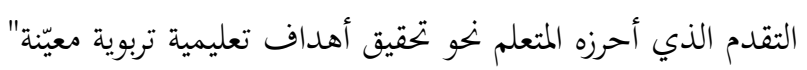

الصنف الثاني: يركز هذا الصنف على الوصف والمقارنة والتحليل والتوضيح كأهداف للتقويم، ومنه تعريف وورثان وسوندارز

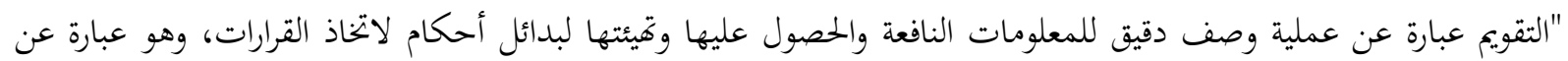

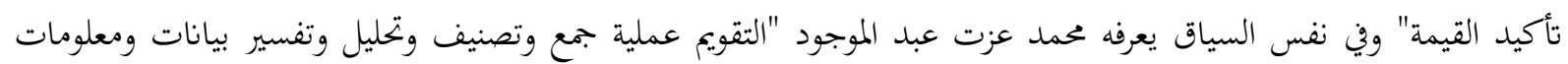
كميا أو كيفيا عن ظاهرة أو موقف أو سلوك بقصد استخدامها في إصدار الحكم أو القرار" الصنف الثالث: يتميز هذا الصنف بتقويم التخطيط لإصدار أحكام جديدة ومراجعة الأساليب الحالية (تغذية راجعة)، في هذا يعرّفه وايلز "التقويم عملية تصدر منها الأحكام تستخدم كأساس للتخطيط، إها عملية تشمل على تجديد الأهداف وتهاف وتوضيح

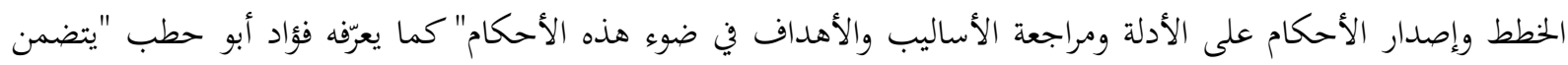
مفهوم التقويم عملية إصدار الحكم على قيمة الأشياء أو الأشخاص أو الموضوعات، وهو بهذا المعنى يتطلب استخدام المعايير أو لورداء 
المستويات أو المكات لتقدير هذه القيمة، كما يتضمن أيضا معنى التحسين أو التعديل او التطوير الذي يعتمد على هذه

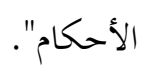

\section{مفهوم التقويم التربوي في المقاربة بالكفاءات:}

يعتبر التقويم التربوي في منهاج المقاربة بالكفاءات عنصرا أساسيا في العملية التعليمية التعلمية يواكبها في جميع مراحلها،

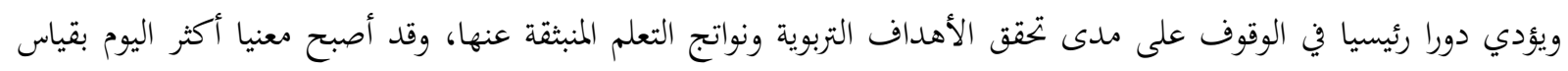

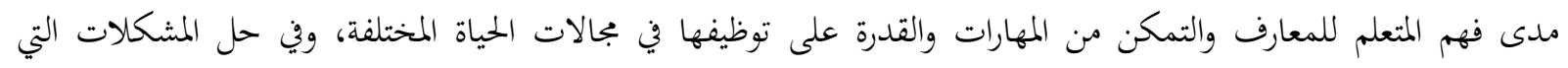
تواجهه، فهو عبارة عن مسعى يرمي إلى إصدار الحكم على مدى تحقيق التعلمات المقصودة ضمن النشاط اليومي للمتعلم بكفاءة ولفي واقتدار.

قدّمت (بوعيشة، بوعمارة، 2011، صادقار 739) مفهوما على أنه "تقويم شيء مركب، لهذا يجب أن يأخذ بعين الاعتبار

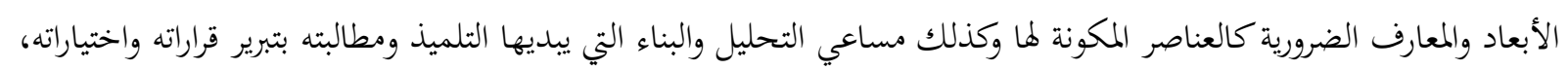

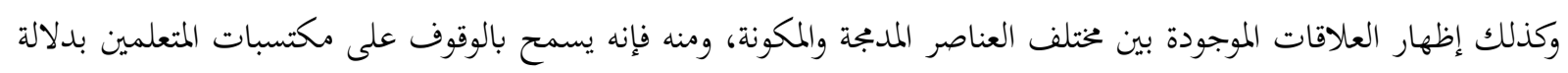

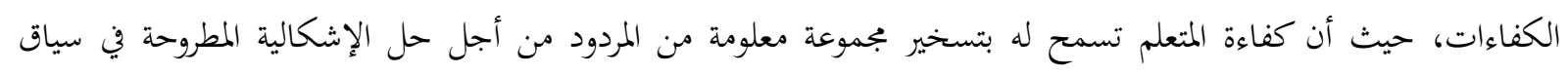
المعلوم".

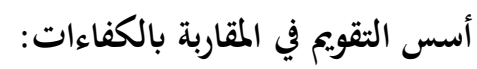

يراعى عند الشروع في تقويم مكتسبات المتعلمين من منطلق المقاربة بالكفاءات، الآتي: (بن سي مسعود، 2008، ص 139) 1- في البداية تحديد الكفاءة بدقة انطلاقا من الوضعية. 2-تبنى وضعية التقويم بشكل ييسر إدماج المعارف الفعلية والمعارف السلوكية والقدرات. 3-وضعية التقويم تكون جديدة على المتعلم. 4-تخضع وضعية التقويم إلى منتوج. 5-تخاطب الوضعية كل تلميذ على حدى. 6- التلميذ فاعل ومشارك.

7-توضع وضعية التقويم في سياق تواصلي وتكون منسجمة مع الكفاءة المستهدفة. 8-ضرورة مراعاة مستوى المتعلمين المستهدفين. 9-تكون وضعية التقويم ذات دلالة بالنسبة للمتعلم. 10-الحرص على الوضوح في تقديم وضعية التقويم وذلك من حيث المقروئية ودقة المعلومات.

الخلفية النظرية لبيداغوجيا المقاربة بالكفاءات: تستند المقاربة على مجموعة نظريات، نركز في هذا البحث على أهم النظريات، والتي تتمثل في:

أ. النظرية البنائية:

إن الأساس الذي نشأت منه المقاربة بالكفاءات هي المدرسة البنائية التي ظهرت كردة فعل عن المدرسة السلوكية التي تحصر التعلم في ( مثير واستجابة )، أما المنظور البنائي فينطلق من أن حصول التأثير يستلزم وجود قابلية في الجسم الذات النيات (المؤثر 
الذات - الاستجابة)، لقد أثرت البنائية على التصورات التعليمية حيث وجه الفعل التربوي نخو وضعيات تفاعلية تثير لدى المتعلم

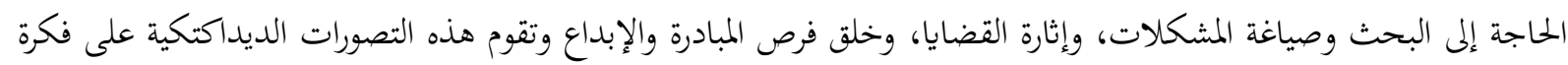

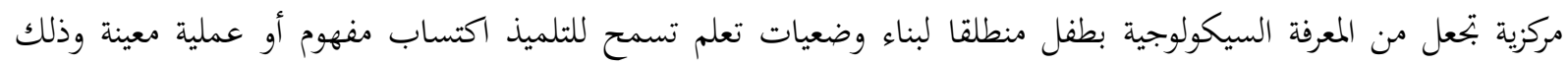

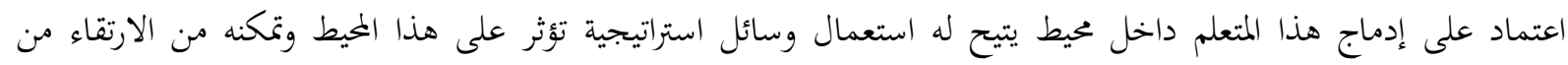

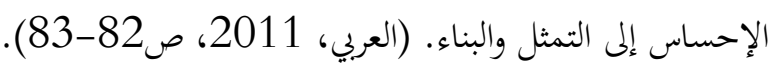

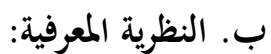

يرى المعرفيون أن السلوك وظيفة للفرد ويؤكدون على البيئة المعرفية لا تتألف فقط من معارف سابقة التعلم ولكنها تتضمن

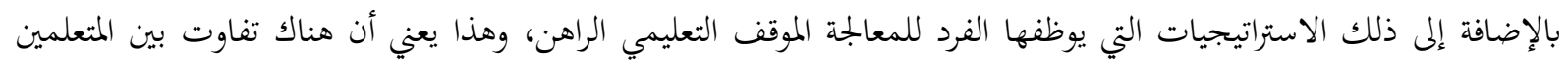
على الرغم من تشابه ظروفهم الخارجية، ذلك أن الاستراتيجيات التي يمتلكوها هي المسئولة عن معالجة الموقف التعليمي الراهن وهذا يعني أن هناك تفاوتا في بنايهم العقلية، وعلى هذا الأساس فان المعرفيون يركزون كثيرا في أي عملية تعليمية على الإمكانيات

الذاتية للمتعلم.

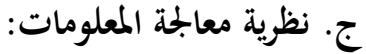

هناك عوامل عديدة أدت إلى ظهور هذه النظرية أهمها الأبحاث المتطورة التي حدثت في بجال الإعلام الآلي، وذلك نظرا للتشابه الكبير بين الحاسوب والذاكرة الإنسانية في معالجة المعلومات، فإذا كان الحاسوب يؤدي وظيفته من خلال ثلاث مراحل وهي: مرحلة إدخال المعلومات، مرحلة المعالجة وتنفيذ البرامج، مرحلة إخراج المعلومات .كذلك الأمر بالنسبة للإنسان فإنه يمر

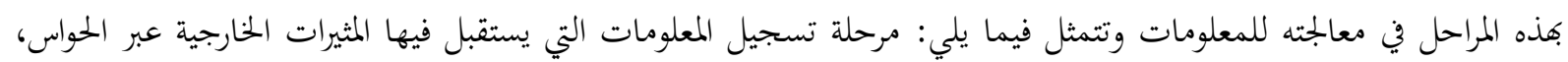

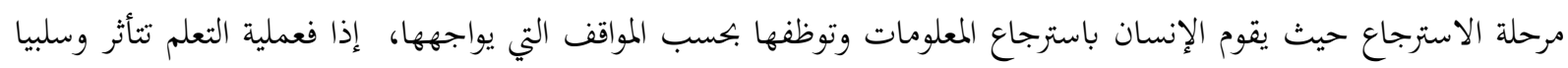

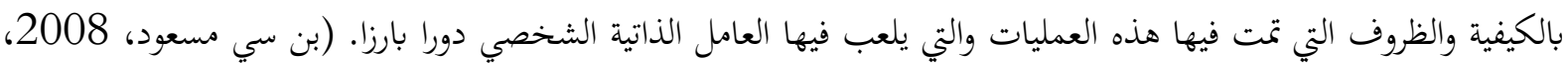
ص(87-86).

وسائل التقويم التربوي:

تتعدّد وسائل التقويم وتتنوع، غير أننا يمكن حصرها في: (رجب، 2001، صنوئم). *** التقويم القائم على الأداء: أي قيام المتعلم بتوضيح تعلمه من خلال توظيف مهاراته في مواقف حياتية حقيقية، او مواقف

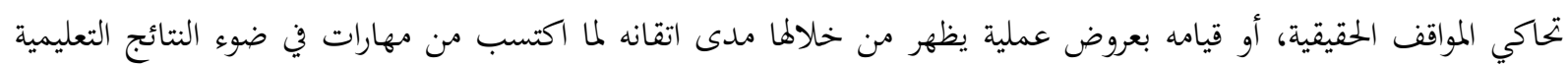
المراد إنجازها. *** ملف الإنجاز (البورتفوليو): تجميع هادف ومنظم لأعمال الطالب وإنجازاته عبر فترة زمنية محددة، ثمّ مراجعتها في ضوء محكات محددة للحكم على مدى تحقيق أدائه لمعايير الجودة المنشودة. 2**** التقويم الذاتي: تقويم المتعلم لنفسه. **قتويم الأقران: قيام كل متعلم بتقييم أعمال أقرانه. *** تقويم الأداء القائم على الملاحظة: عملية يتوجه فيها المعلم بحواسه المختلفة نحو المتعلم، بقصد مراقبته في موقف نشط، وذلك من أجل الحصول على معلومات تفيد في الحكم عليه، وفي تقويم مهاراته وقيمه وسلوكه وأخلاقياته وطريقة تفكيره. *** تقويم الأداء بالمقابلات: لقاء بين المعلم والمتعلم محدد مسبقا، يمنح المعلم فرصة الحصول على معلومات تتعلق بأفكار المتعلم وابتحاهاته نحو موضوع معيّن، وتتضمن سلسلة من الأسئلة المعدة مسبقا. 
*** تقويم الأداء بالاختبارات: الوسيلة التي تستخدم في قياس مدى ما يحققه الفرد ويكتسبه من معلومات وقدرات واتحاهات ومهارات في فاية الخبرة التعليمية. ** تقويم الأداء بخرائط المفاهيم: توجيه المعلم للمتعلم لتحديد المفاهيم المتضمنة في المحتوى عن طريق بناء خريطة مفاهيم، والربط بين هذه المفاهيم. *** دراسة الحالة: كثيرا ما يلاحظ المعلم أن بعضا من تلاميذه يعانون من حالة تأخر عن باقي زملائهم، لهذا يلجأ إلى دراسة

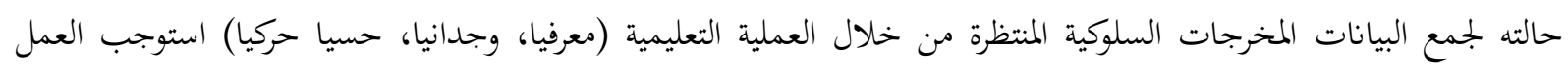

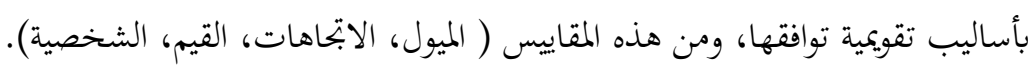
الأسس العامة التي يبنى اللازمة، والمتعلقة بحالثه الأسرية أو المستوى المادي والثقافي لأسرته، وهذا من أجل وضع خطة قصد معالجة

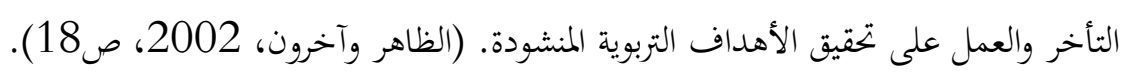
**** المقاييس: تنوع عليها التقويم: يبنى التقويم التربوي على مجموعة من الأسس سواء تعلق ببرنامج أو فرد أو مجموعة أفراد، حيث عدّدها (خوالدة، 2012، ص2012 *** الشمول: يجب أن يكون شاملا للموضوع أو المتعلم، بمعنى أن نُقوّم نمو الطالب في كافة الجوانب العقلية والجسمية والاجتماعية والثقافية. *** الاستمرارية: عملية مستمرة لا تتمّ دفعة واحدة كما هو الحال في بعض الامتحانات التي نحكم من خلالها على المتعلمين نجاحا او رسوبا، لذا ينبغي أن يسير التقويم جنبا مع التعليم من بدايته إلى فهايته. *** التعاون: يجب أن لا ينفرد بالتقيم شخص واحد فقط، فالتقويم عملية يشترك فيها الجميع بما فيها المسؤولين والمعلمين. ** مراعاة الفروق الفردية: يعدّ أساسا جوهريا يجب مراعاته، فليس معنى وجود متعلمين في حجرة دراسية واحدة أفم جميعا

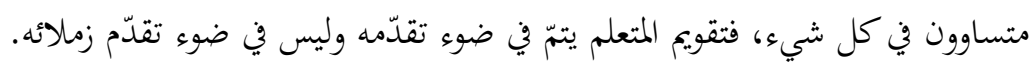
** أن يكون التقويم اقتصاديا: الحرص على الاقتصاد في الوقت والجهد والتكاليف بالنسبة للمعلم والمتعلم. مبادئ المقاربة بالكفاءات: جملها الباحثان (عواريب، الأعور، 2011، ص568) في: أ. الإممالية: بمعنى تحليل عناصر الكفاءة انطلاق من وضعية الشاملة (وضعية معقدة، نظرة عامة، مقاربة شاملة)، ويسمح هذا المبدأ بتحقيق قدرة المتعلم على بتميع مكونات الكفاءة التي تتمثل في السياق والمعرفة. ب. البناء: أي تفعيل المكتسبات القبلية وبناء مكتسبات جديدة وتنظيم المعارف. ج. التناوب: الشامل (الكفاءة)، الأجزاء (المكونات)، الشامل (الكفاءة)، يسمح هذا المبدأ من الانتقال من الكفاءة إلى مكوناها ثم العودة إليها. د. التطبيق: بمعنى التعلم بالتصرف، يسمح هذا المبدأ بممارسة الكفاءة بغرض التحكم فيها. هـ التكرار: أي وضع المعلم عدّة مرات أمام نفس المهام الإدماجية التي تكون في أو مع أو أمام نفس المحتويات، يسمح هذا المبدأ في التدرج بالتعلم. 
و. الإدماج: بمعنى ربط العنصر المدروسة ببعضها، لأنّ إنماء الكفاءة يكون بتوظيف مكونتها بشكل إدماجي إدماجي. ز. التمييز: الوقوف على مكونات الكفاءة من سياق ومعرفة. ح. الملائمة: تكرار وضعيات ذات معنى ومحفزة للمتعلم.

مبادئ التقويم التربوي وفق منهاج المقاربة بالكفاءات: عدّد (حثروبي، 2002، ص298) مبادئ التقويم التربوي في المقاربة

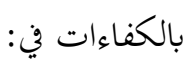

1 1-عدم فصل عملية التقويم عن عملية التعليم والتعلم، بل يجب أن تكون بعدا أساسيا فيها. 2-أن لا يتناول التقويم أساسا المعارف في شكلها الانعزالي، بل هو عملية تمدف إلى الحكم على مدى تحكم المتعلم في كفاءة ما،

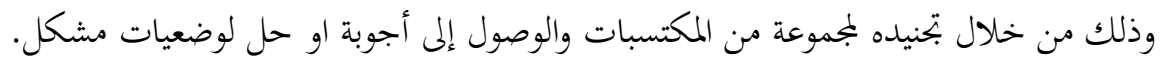

3-إدماج الممارسات التقويمية في المسار التعليمي كمؤشر لإظهار المستوى الذي بلغه المتعلمون، وبالتالي تعديل عملية التعلم. 4-الاعتماد في التقويم التحصيلي خاصة على الوضعيات الإدماجية القريية من الواقع، التي تجعل المتعلم في وعي من ذاته وتمكنه من توظيف مختلف موارده المهارية والمعرفية. 5-تنويع الوضعيات التقويمية التي تثير وتنمي لدى المتعلم مواقف واستراتيجيات مكيفة وفق ما يقتضيه حل المشكلات المطروحة. الفرق بين التقويم التقليدي والتقويم وفق المقاربة بالكفاءات:

\begin{tabular}{|c|c|}
\hline التقويم بمنظور المقاربة بالكفاءات & التقويم بالمنظور التقليدي \\
\hline 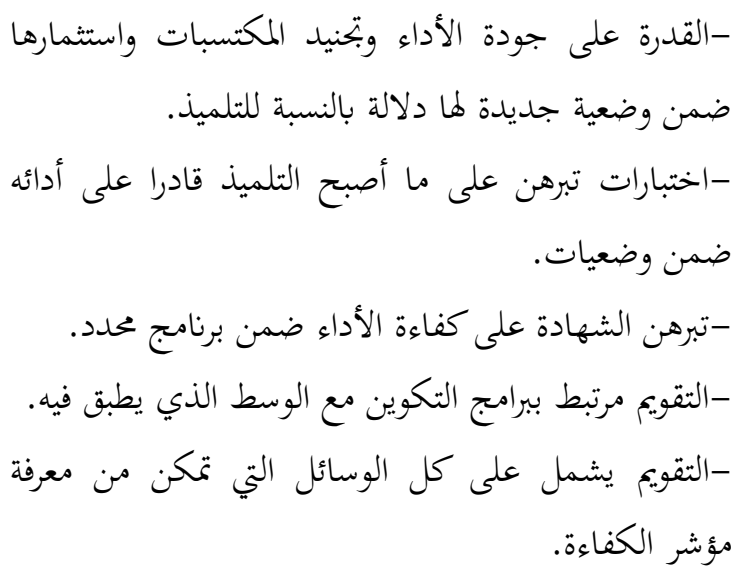 & 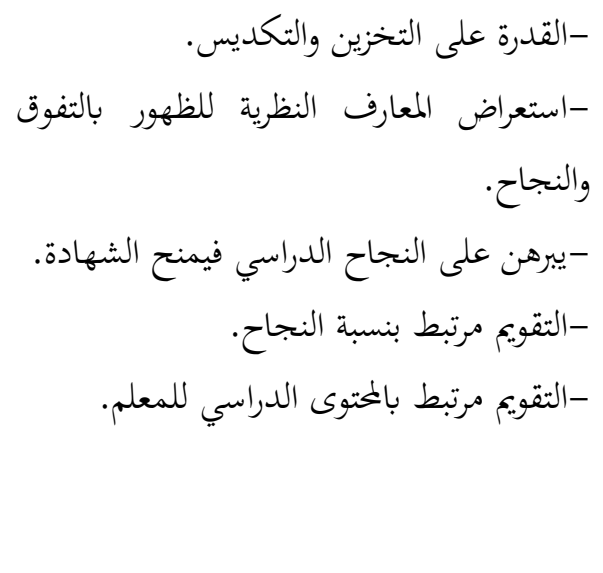 \\
\hline
\end{tabular}

وظائف الاختبار في التقويم بالكفاءات: يتحدّد الاختبار في التقويم بالكفاءات بثلاثة وظائف أساسية تتمثل في الوظيفة

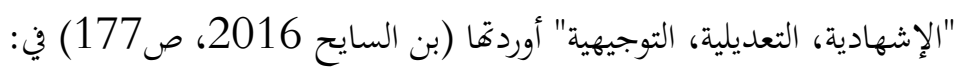

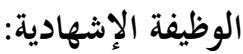

وهي تمدف إلى القيام بكشف شامل للمكتسبات الخاصة بالتعلمات التي من المفروض أها اكتملت، وتبعا لذلك سيسند عدد يتم بمقتضاه الحكم على نجاح التلميذ أو إخفاقه، كما يسمح بتحديد مدى تمّلك التلميذ للمكتسبات المقيّمة من خلاتلال الاختبارات الفصلية (ديسمبر، مارس، ماي)، ومن خلال هذه الاختبارات يتحدّد تملّك التلاميذ لتعلّمات كل فصل، إلاّ أن اختباري الفصلين الأولين يؤديان الوظيفة الثانية للاختبار. 


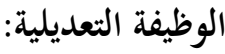

يؤدي الاختبار هذه الوظيفة طالما لم يبلغ التعلم غايته، ومثال ذلك الاختبارات الشهرية في المواد الأساسية (رياضيات، لغة عربية، لغة فرنسية)، حيث يتم اللجوء إلى هذه الاختبارات لتحديد مستوى التلاميذ والقيام بأنشطة علاجية قبل الاختبارات النهائية.

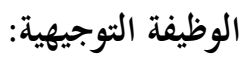

يؤدي الاختبار هذه الوظيفة عندما يتعلق بتقويم المكتسبات القبلية، (قبل بداية التعلّمات) حيث تمدف هذه الوظيفة إلى

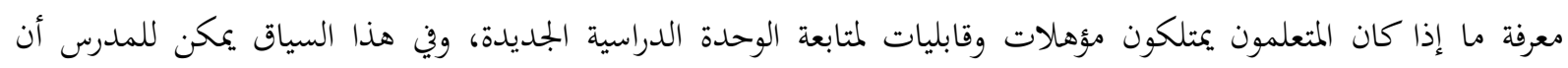
يستعمل اختبارات الاستعداد أو اختبارات تنبئية أو يعطي للمتعلمين تمارين آنية وعاجلة لمعرفة مدى تحكمهم في معارف معينة.

\section{معايير تقويم أداء المتعلم:}

يمكن أن نعتبرها (المعايير)"نظرة نقوم بتسليطها على موضوع أو نشاط خاضع للتقويم" حيث تتضمن أربعة معايير تتمثل في:

$$
\text { الوالاهلامة: الاهناءمة المنتوج للوضعية أي ما قدّمه المتعلم من جواب يعدّ مقبولا للوضعية. }
$$

الاكتمال: صفة الكمال في التناول والوقوف على جدوى اجتماعية للمنتوج مع الإبداع والشعور بالمتعة في الجواب.

صعوبات تقويم الكفاءات ومعيقاتا: ذكرت (بن السايح، 2016، ص207) نقلا عن (بن سي مسعود، 2008، ص140)

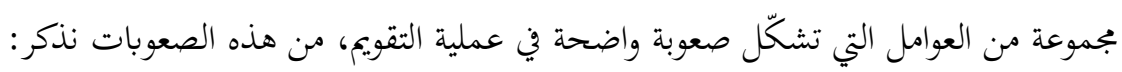
1-كثرة عدد التلاميذ في القسم لا يسمح بتوجيه التقويم نحو القياس وتقدير مدى تطور الكفاءات المستهدفة لدى التلميذ. 2-عدم تكوين المعلمين تكوين جيدا فيما يخص تقويم عمليات تعلم التلاميذ مع عدم إعطاء جانب التقويم الأهمية التي يستحقها.

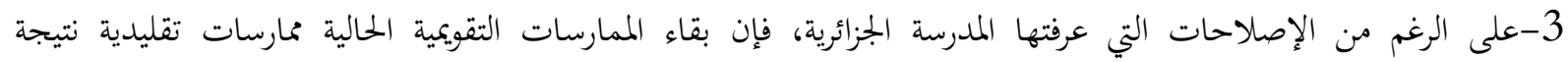
الصعوبات التي يواجهها التقويم بالمقاربة بالكفاءات. في دراسة استكشافية على عيّنة من المعلمين بمنطقة ورقلة للباحثتين (قاجة، بن سكيريفة، 2011) توصلتا إلى أن درجة

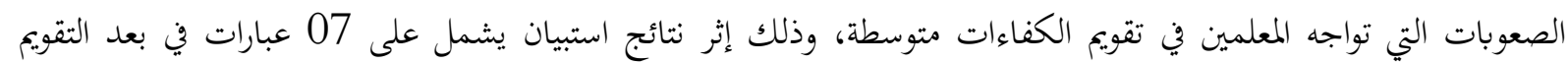

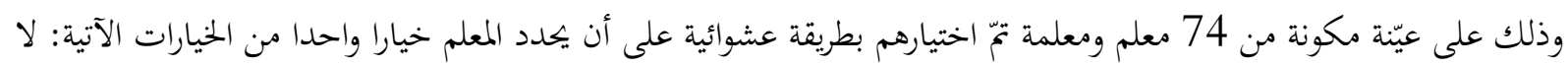
تنطبق (درجة واحدة) تنطبق أحيانا (2 درجتان) تنطبق تماما (3 درجات). علما أن الدراسة شملت ثلاثة أبعاد "التخطيط، مئية

\begin{tabular}{|c|c|c|}
\hline المتوسط الحسابي & 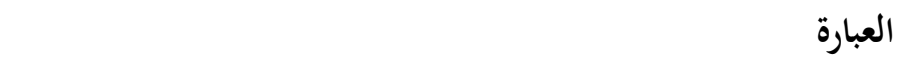 & 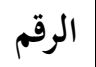 \\
\hline 02.2 & أجد صعوبة في جعل التلاميذ ينجزون كل الأنشطة (التمارين) المقترحة & 1 \\
\hline 01.94 & أجد صعوبة في تسجيل تقدم التلاميذ بصورة منتظمة & 02 \\
\hline
\end{tabular}

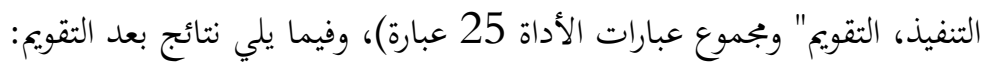

الجدول رقم 01 يوضح المتوسطات الحسابية للصعوبات التي تواجه المعلمين في التدريس في مرحلة التقويم 


\begin{tabular}{|r|r|r|}
\hline 02.09 & $\mathbf{0 3}$ \\
\hline 01.87 & $\mathbf{0}$ & $\mathbf{0 4}$ \\
\hline 02.08 & $\mathbf{1}$ & $\mathbf{0 5}$ \\
\hline 02 & $\mathbf{1}$ & $\mathbf{0 6}$ \\
\hline 01.83 & $\mathbf{0}$ & $\mathbf{0 7}$ \\
\hline
\end{tabular}

جدول رقم 02 يوضح المتوسطات الحسابية للصعوبات التي تواجه المعلمين في التدريس بالكفاءات

\begin{tabular}{|c|c|c|c|}
\hline درجة الصعوبة & المتوسط الحسابي & الصعوبات & الترتيب \\
\hline متوسطة & 01.8028 & مرحلة التخطيط & الثالث \\
\hline متوسطة & 01.8818 & مرحلة التنفيذ & الثاني \\
\hline متوسطة & 01.8857 & مرحلة التقويم & الأول \\
\hline
\end{tabular}

نقرأ في الجدول رقم 01 أنّ المتوسطات الحسابية كانت متوسطة قريبة إلى الارتفاع خاصة ما تعلق بالعبارات (01، 03، 05، 06) حيث نجد أن ضيق الوقت شكل صعوبة أولى في الترتيب تلته صعوبة تحديد الواجبات المنزلية، بعدها تصحيح أنشطة

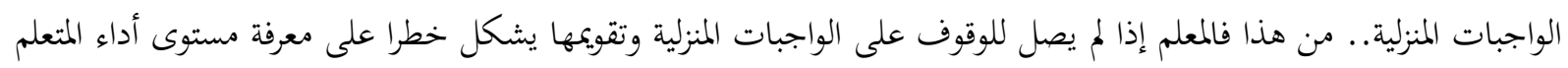

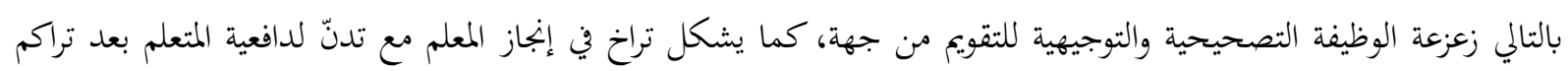

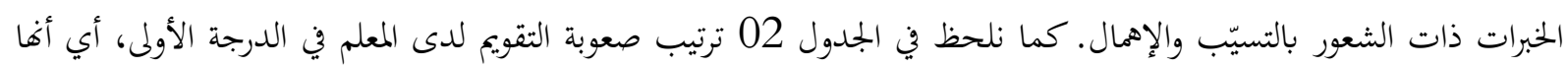
أكثر صعوبة من التخطيط والتنفيذ.

عَزَتِ الباحثتان النتائج إلى ضعف التكوين القاعدي للأساتذة مع الحاجة العميقة للمرافقة البيداغوجية، بدء بفلسفة المقاربة

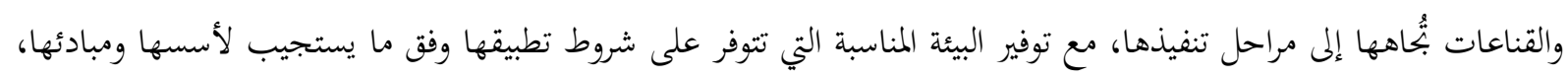

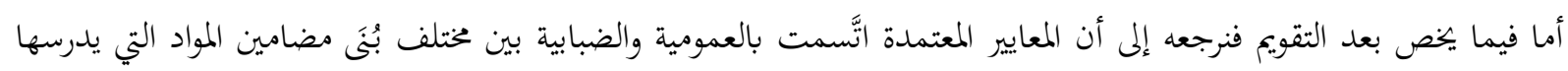

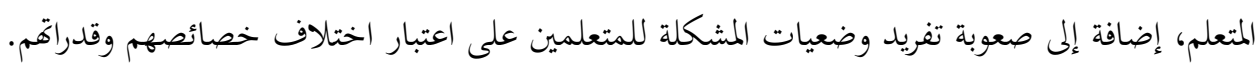

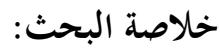

تبنّت المدرسة الجزائرية بعد سلسلة من المقاربات مقاربة الكفاءات، باعتبارها المقاربة التي تدعم المتعلم وتوجّهه في مختلف مواقف التعلّم، حيث هتم بتعليم المتعلم كيف يتعلم وكيف يستجيب مع مواقف حياتية تتشابه مع وضعيات التعلّم للأنشطة المدرسية.

تتطلب بيداغوجية المقاربة بالكفاءات ضوابط ومعايير تفرض توافرها في بيئة المتعلم، بدء بأركان العملية التعليمية إلى مراحل

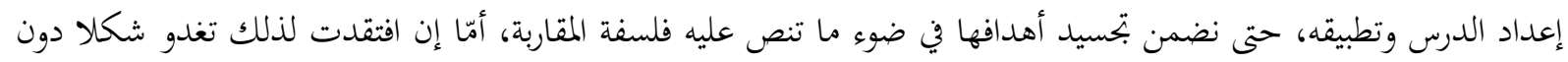
جوهرا، وهذا صلب ما تعانيه في التطبيق الميدان. يحرص التقويم في المقاربة بالكفاءات باعتباره ركنا أساسيا في تحسين العملية التعليمة باستمرار من خلال الرفع من المردودية

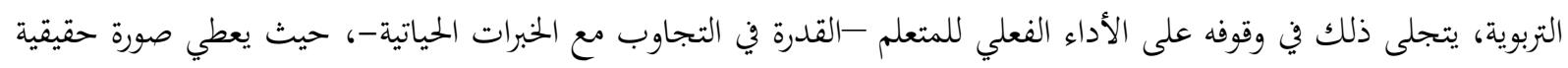
عن مدى تقدم كل متعلّم في تعلّمه. 


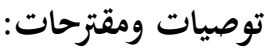

1-تخصيص ميدان التربية والتعليم بأقسام خاصة لمحاكاة التجارب والخبرات الجديدة بهدف نقدها وحوكمتها في ظل ظروف العوامل البيئية والاجتماعية والنفسية للمجتمع قبل الشروع في تعميمها.

2-التركيز على تحقيق الكفاءات المخطط لها في المناهج، على أن تكون السّندات والموارد المدرجة في بناء التعلمات وسائل لا

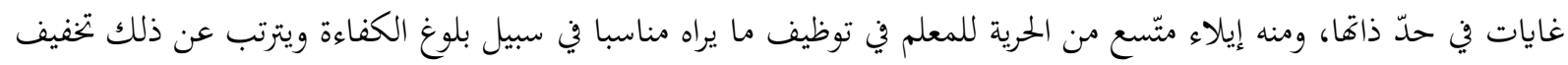
الأعباء الإدراية والتنظيمية.

3-الاهتمام بالتكوين النوعي لمنفذ المقاربة -المعلم-، بدءا بتثمين جهود التكوين والمرافقة المخصصة للأساتذة حاليا ودعمها ببرامج أخرى تخدم مختلف جوانب بيئة المتعلم ومنه مكتسباته المعرفية والمهارية والوجدانية. 4-استثمار بحوث مؤسسات البحث ودراساتا، سواء ما تعلق منها بالمشاريع المتخصصة أو مشاريع فرق المخابر للاستفادة منها

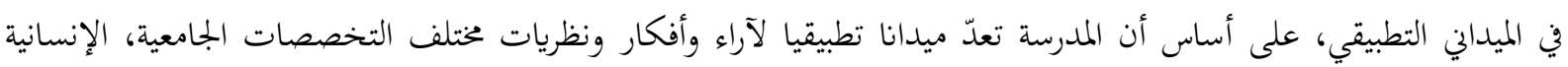
الاجتماعية الأدبية العلمية التقنية والاقتصادية.. 5-إيلاء التقويم التربوي بصفة عامة أهمّية قصوى باعتباره أساس محرّك المنظومة التربوية ونجاحها، ومنه تخصيص موضوع معايير تقويم أداء المتعلم ببحوث ميدانية متخصصة وفي مختلف مجالات المواد التي يدرسها المتعلّم. 
الأخضر عواريب، إسماعيل الأعور (2011)، التقويم في إطار المقاربة بالكفاءات، مجلة العلوم الإنسانية والاجتماعية، المجلد3،

$$
\text { العدد2. }
$$

إسماعيل دحدي، مزياني الوناس (2017)، التقويم التربوي، مفهومه واهميته، مجلة العلوم الإنسانية والاجتماعية، العدد 31، جامعة

$$
\text { قاصدي مرباح. }
$$

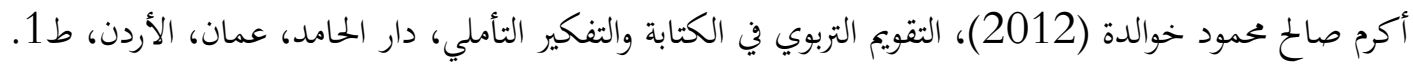
حبّار العالية (2017)، التقويم التربوي في ضوء منهاج المقاربة بالكفاءات، مجلة مقاربات، جامعة الجلفة، المجلد 02، العدد 28.

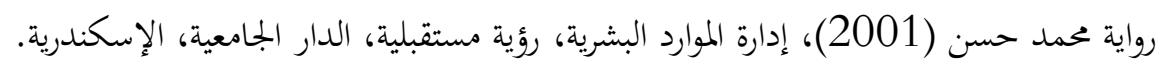
زكرياء محمد الظاهر، تمرجيان جاكلين، جودت عزت عبد الهادي(2002)، مبادئ القياس والتقويم في التربية، الدار العلمية الدولية

$$
\text { ودار الثقافة، ط1، عمان، الأردن. }
$$

كلثوم قاجة، مريم بن سكيريفة (2011)، الصعوبات التي تواجه المعلمين في التدريس بالكفايات، مجلة العلوم الإنسانية والاجتماعية بورقلة، عدد خاص: ملتقى التكوين بالكفايات في التربية: العدد4، جانفي، جامعة قاصدي مرباح

$$
\text { ورقلة، الجزائر. }
$$

لبنى بن سي مسعود (2008)، واقع التقويم في التعليم الابتدائي في ظل المقاربة بالكفاءات، رسالة ماجستير منشورة، كلية العلوم

$$
\text { الاجتماعية، جامعة قسنطينة. }
$$

محمد الصالح حثروبي (2002)، المدخل إلى التدريس بالكفاءات، دار الهدى، الجزائرة فئنة محمود العربي، دراسة كشفية لممارسة المعلمين المقاربة بالكفاءات، رسالة ماجستير منشورة، كلية العلوم الاجتماعية، جامعة وهران، 2011

مسعودة بن السايح (2016)، واقع التقويم في إطار المقاربة بالكفاءات، مجلة العلوم الاجتماعية والإنسانية، جامعة تبسة،

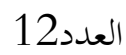

مصطفى رجب (2001)، القياس والتقويم التربوي، وزارة التربية السورية، مديرية الإعداد والتدريب، سوريا.

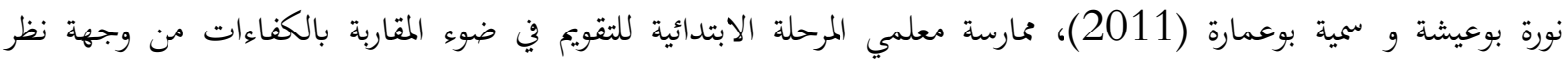
المفتشين التربويين، ملتقى التكوين بالكفايات في التربية، جامعة ورقلة، الجزائر.

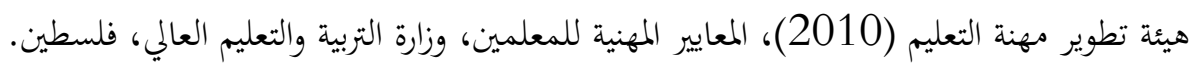

file:///C:/Users/USER/Downloads/37691311.pdf 


\title{
THE POSITION OF THE UNITED STATES OF AMERICA ON IRAQ'S ENTRY INTO THE LEAGUE OF NATIONS IN 1932
}

\author{
Ilham Mahmoud JADER ${ }^{1}$ \\ Rawaa Sabahh GANNAWI ${ }^{2}$
}

\section{Istanbul / Türkiye}

p. $616-634$

Received: $18 / 11 / 2021$

Accepted: 04/12/2021

Published: 01/01/2022

This article has been scanned I iThenticat No plagiarism detected

\begin{abstract}
:
The Iraqi government signed with Britain a treaty in $1930 \mathrm{AD}$, which approved a bilateral alliance between them that includes all political, economic and military issues, which will be recognized after Iraq's entry into the League of Nations. Iraq by entering the League and declaring his independence After the discussions, statements, and opinions that were presented at the meeting, the League's Mandates Committee announced on October 3, 1932, that Iraq had been accepted as a member of the League of Nations The independence of Iraq and its entry into the League of Nations is an important and pivotal issue, as Iraq became the first Arab country to get rid of the occupation, even though the independence was not complete because Britain sought to achieve this goal in exchange for a treaty that chained Iraq with many restrictions, including military and economic issues The United States of America has striven to develop its diplomatic relations with Iraq, given that Iraq was of strategic importance in the eyes of American policy planners. US to the level of an embassy in Baghdad The cultural relations between Iraq and the United States during the royal era developed significantly if compared to other fields, because it is considered the gateway to Iraq's entry to the League of Nations, and for this reason the Iraqi government set up in 1930 a committee of experts to improve education and recommended the necessity of adopting the American approach to education, and this The Americans wanted to exploit it after they had a share in Iraq's oil, and thus exploiting all means in order to secure their interests, especially the means of education, because it is an effective means in creating a trend of educated elites tending to the United States of America.
\end{abstract}

Key words: Political, Nations, Independence.

http: //dx.doi.org/10.47832/2717-8293.15.43

Dr. ,Kufa University,Iraq, ilhamm.kadhim@uokufa.edu.iq, ,https: //orcid.org/0000-0002-2704-4746

2 ID Reasearcher, Kufa University,Iraq, „rawaa.gannawi@uokufa.edu.iq,https//orcid.org/0000-0002-0940-4066 


\title{
دور الولايات المتحدة الأمريكية في دخول العراق عصبة الأمم عام 1932
}

\author{
3 إلهام محمود الجحادر \\ رواء صباح كناوي
}

وقعت الحكومة العراقية مع بريطانيا معاهدة عام 1930م والتي أقرت عقد تحالف ثنائي بينهما يشمل جميع المسائل السياسية والاقتصادية والعسكرية، يتم الاعتراف بها بعد دخول العراق عضوا في عصبة الأمم، ولتحقيق ذلك قدمت بريطانيا تقريرها بهذا

الخصوص إلى لجنة الانتدابات في العصبة لاتخاذ قرار الموافقة على طلب الحكومة العراقية بدخوله العصبة وإعلان استقلاله.

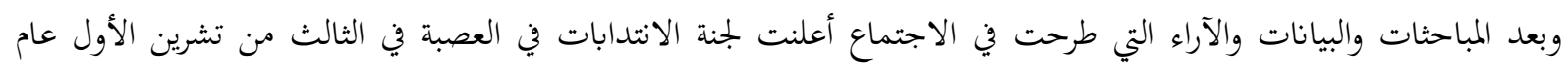
1932م قبول العراق عضوا في عصبة الأمم. إن استقلال العراق ودخوله عضوا في عصبة الأمم قضية مهمة ومحورية إذ أصبح العراق أول دولة عربية تتخلص من الاحتلال، رغم

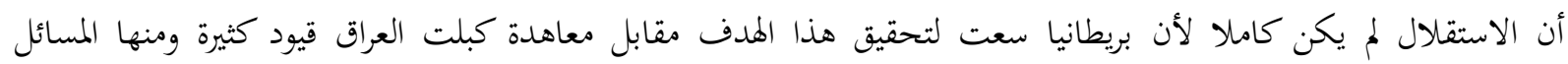
العسكرية والاقتصادية.

وسعت الولايات المتحدة الأمريكية حثيثاً من أجل تطوير علاقاتما الدبلوماسية مع العراق، لما كان للعراق من أهمية استراتيجية في

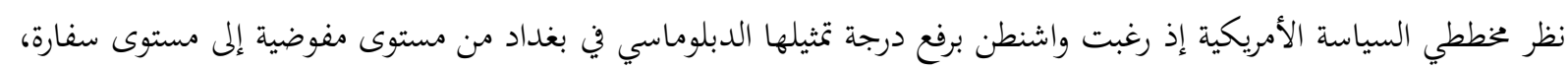

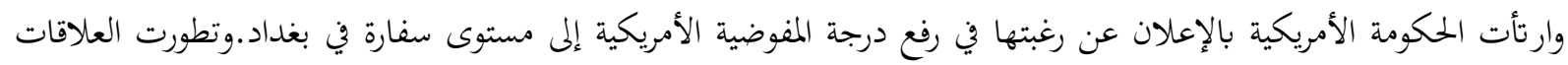

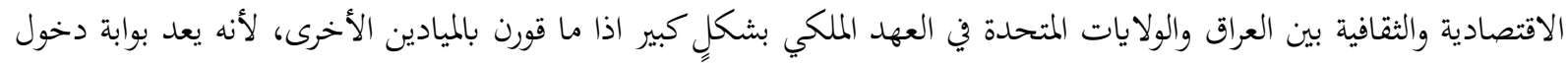

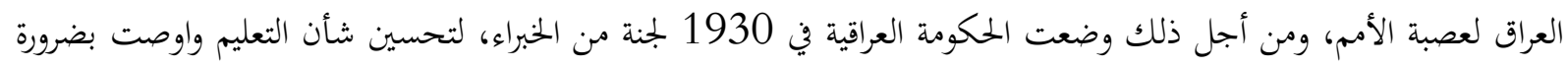

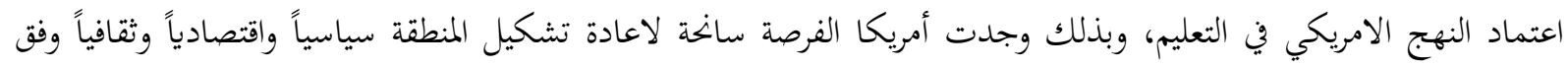

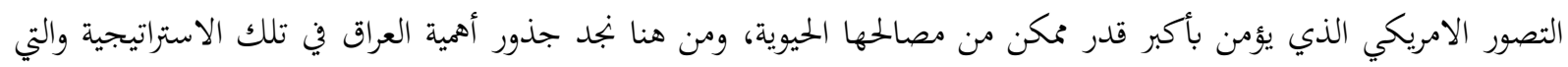
رسمت ملامح جديدة للعراق بما يتلائم وطموحاتما. الكلمات المفتاحية: الولايات المتحدة، عصبة الأمم، الدبلوماسية.

ازدادت أهمية العراق الاستراتيجية مع مطلع القرن العشرين، لاسيما مع تصاعد الصراعات السياسية والاقتصادية العالمية

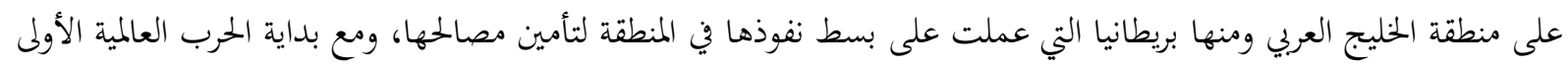

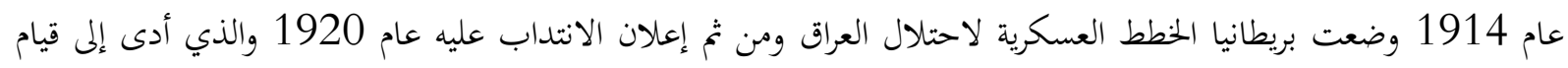

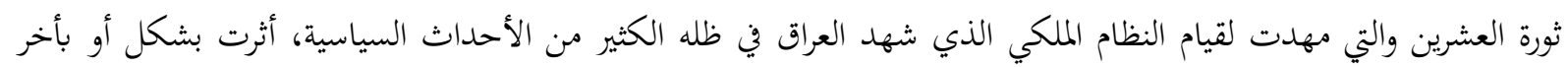

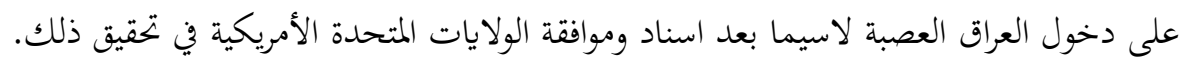

من هنا جاءت فكرة عنوان الدراسة، أما السبب في اختيار الموضوع الرغبة الشخصية لدراسة تاريخ العراق المعاصر وأهمية

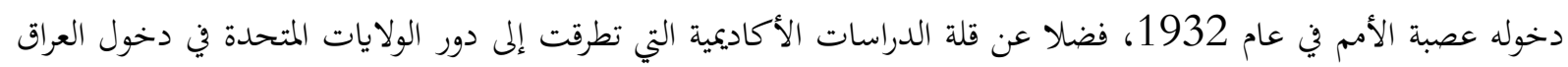


العصبة. ومن أهم أهداف الدراسة توضيح دور بريطانيا في ترشيح العراق عضوا في عصبة الأمم، وموقف الولايات المتحدة

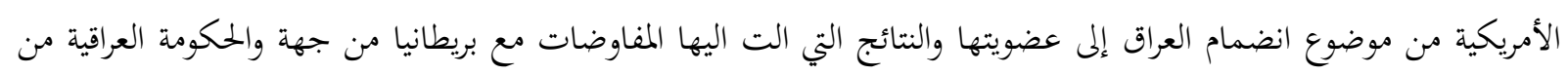
جهة أخرى. 


\section{المبحث الأول: ترشيح بريطانيا العراق كعضو في عصبة الأمم وإعلان استقلاله.}

تركزت مطالب الثعب العراقي منذ قيام الحكم الملكي على إهاء الانتداب ودخول العراق عصبة الأمم ونتيجة للتطورات

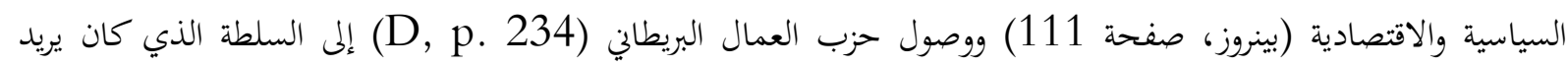

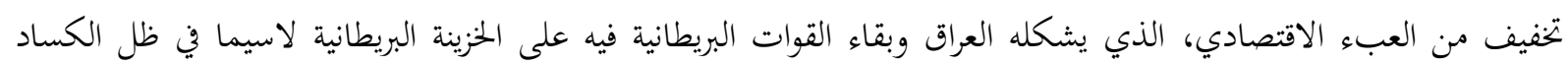
الكبير، الذي ضرب الاقتصاد العالمي حينها و تأثر بريطانيا به كثيراً.

طلبت الحكومة البريطانية من المندوب السامي البريطاني الجديد جلبرت كلايتون (السامرائي، 2015، صفحة 113) والذي وصل إلى العراق في 2 آذار 1929م و كاب مان متعاطفا مع المطالب العراقية، أن يعلم الملك فيصل (Clbert Clayton) الاول (اللطيف، 1911، الصفحات 10-15) والحكومة العراقية عن رغبة بريطانيا لإهاء الانتداب وترشيح العراق لعضوية

$$
\text { عصبة الأمم (العمر، 1977، صفحة 260). }
$$

جرت مفاوضات بين الطرفين لعقد معاهدة التحالف بدأت في 21أذار 1930م وقد ترأس الوفد البريطاني المندوب

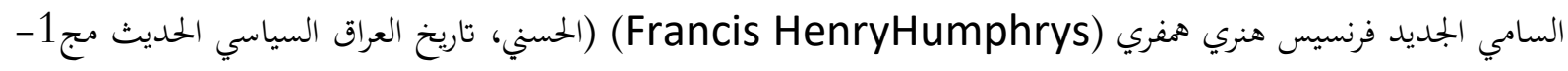

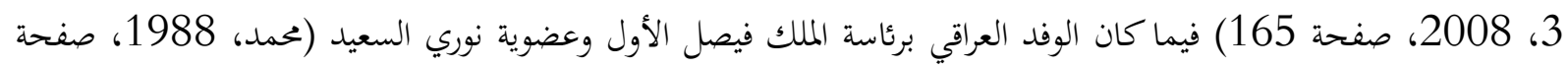

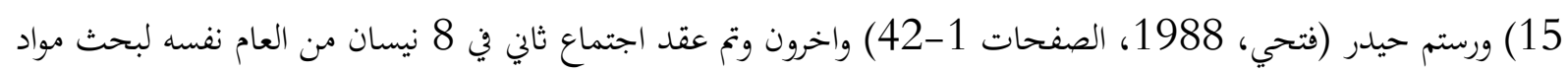

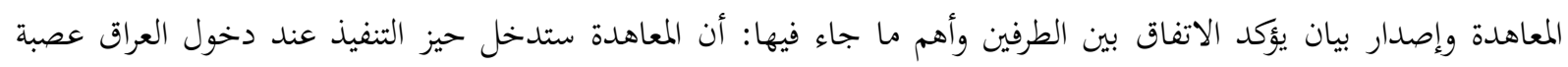
الأمم ويكون وضعه دولة حرة مستقلة، و ألحقت بالمعاهدة بنود منها أن تسري لمدة 25 عام (معهد القائد المؤسس للدراس المعاسات

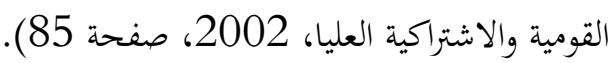

تعد معاهدة 1930من أهم المعاهدات التي عقدت بين العراق وبريطانيا، فعلى المستوى الداخلي فأها ألغت الانتداب

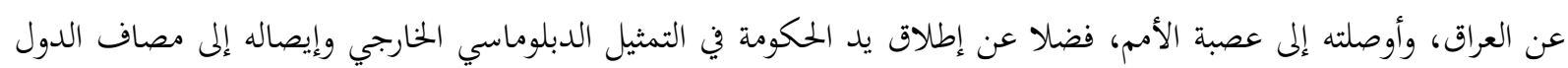

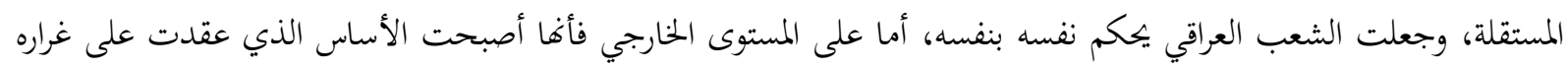

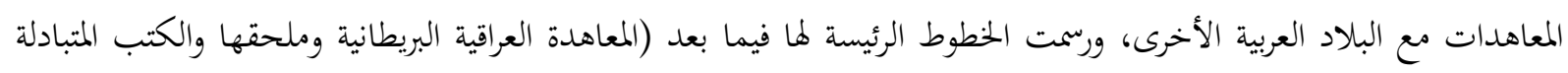

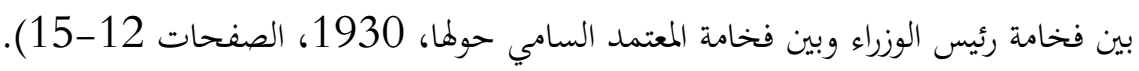
أشعرت الحكومة البريطانية عصبة الأمم في عام 1929، بعزمها على ترشيح العراق لعضوية عصبة الأمم إذا ما حل عام

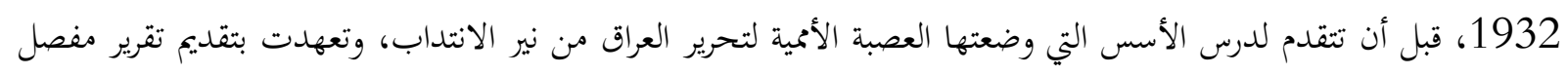

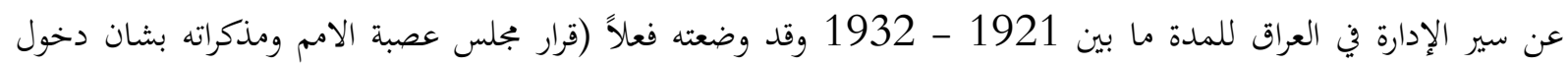
العراق عصبة الامم في اجتماعه المنعقد في 28 كانون الثاني 1932، 1932 1932، الصفحات لإندات 12-15) وقدم ممثل الحكومة البريطانية في العصبة اللورد سيسل (Cecil) (حمدان، 2013، صفحة 118) نسخة منه إلى

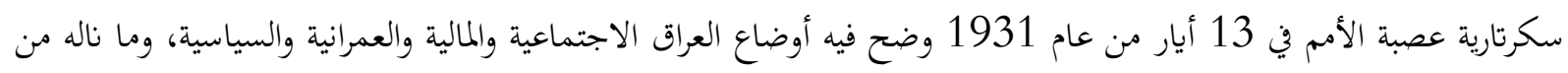

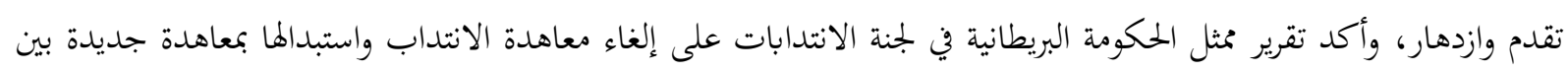
العراق وبريطانيا كبلدين مستقلين حليفين عبر تشكيل حلف وثيق ترسيخا للصداقة بينهما وإجراء تشاور صريح في كل قضائ قضاياه

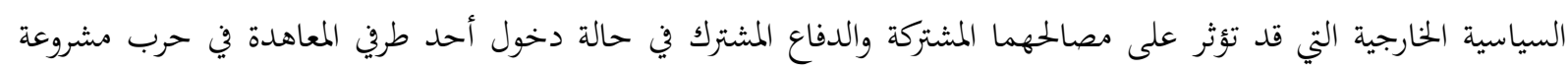
قانونياً أو التعرض إلى التهديد المباشر بها، إذ نصت على أنى أن يهب الطرف الآخر للدفاع عنهاع.

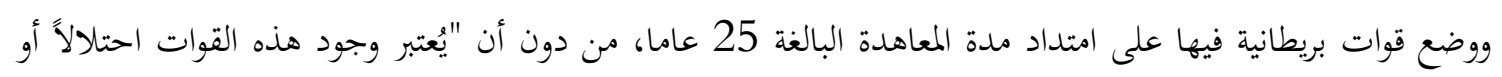

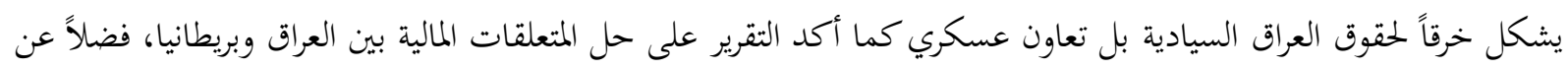


اتفاقية عدلية للتعاطي مع تحديات الثقة بالقضاء العراقي حينها (قرار مجلس عصبة الامم ومذكراته بشان دخول العراق عصبة الامم، الصفحات 15-16).

وتضمن التقرير أيضا على إلغاء كل الصلاحيات الانتدابية البريطانية في العراق، وحولتها للحكومة العراقية (أي السيادة

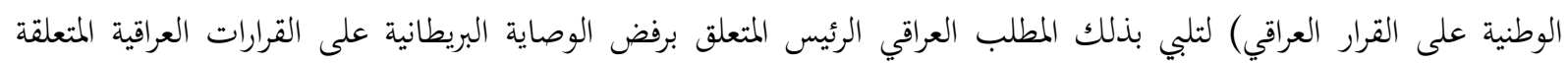

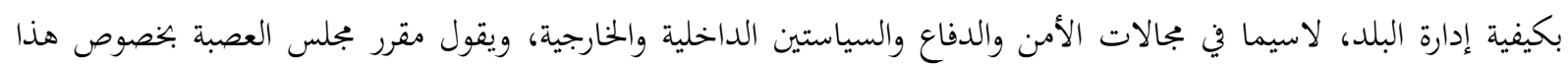

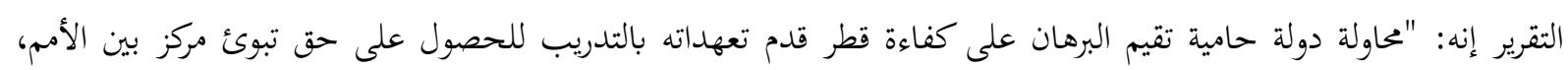

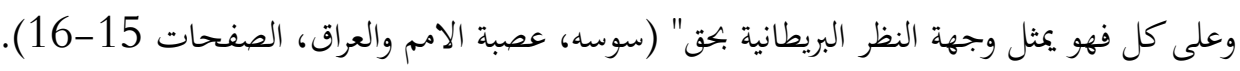

طلب المجلس في اليوم الرابع من شهر كانون الأول 1931م إلى اللجنة الدائمة للانتدابات أن تبدي رأيها في مقترح

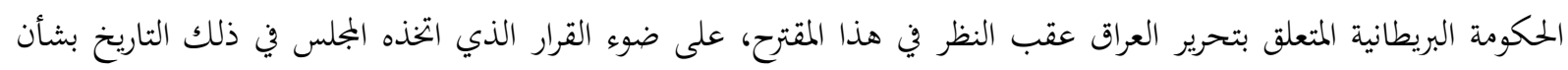

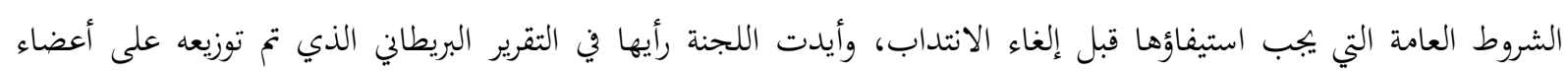

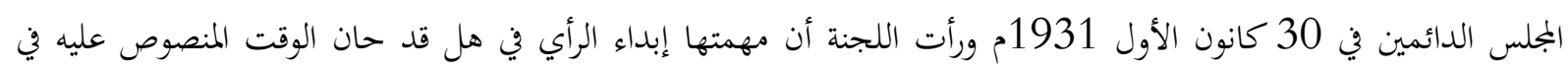

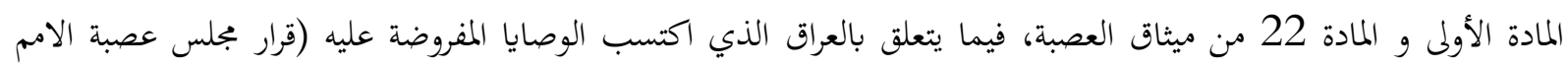

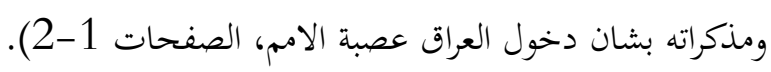
وبناء على طلب مجلس العصبة، رفع نائب رئيس لجنة الانتدابات السيد فان ريس (Van Race) (رباط، 2010، صفحة 15) تقريره ومن أهم ما جاء فيه: أنه يقتضي النظر في أمر انضمام العراق إلى عصبة الأمم إلى المادة الأولى والمادة الثانية

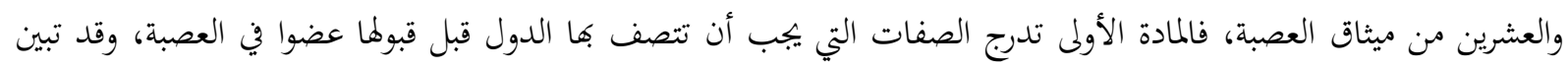

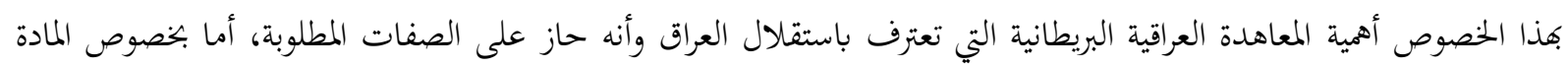

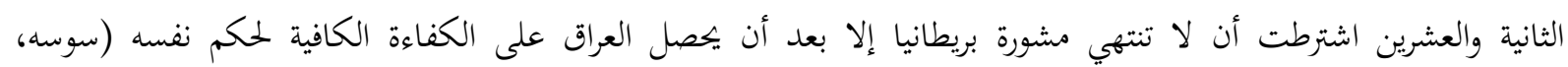

الصفحات 15-16).

وأشار نائب رئيس لجنة الانتدابات فان ريس أيضا في تقريره أن أمر دخول العراق عضوا في العصبة أدا أكدت الدولة

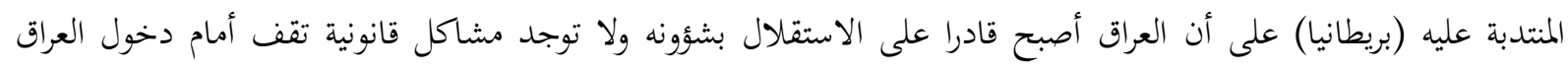

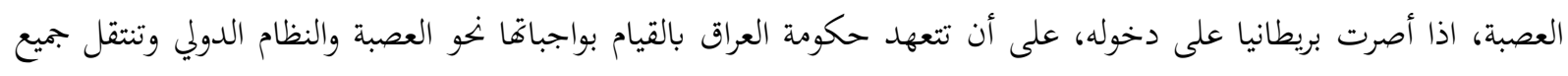

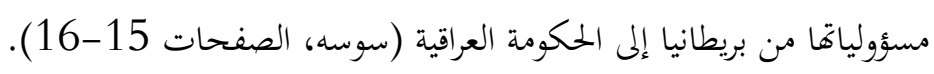
ولم تتمكن اللجنة في بادئ الأمر التوصل إلى نتيجة لأها لم تراقب أحوال العراق السياسية والداخلية عن قرب، وهذا هو

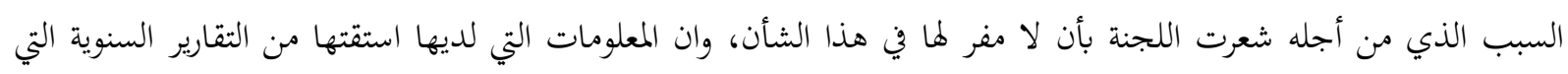

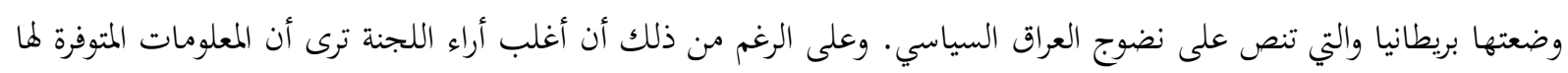

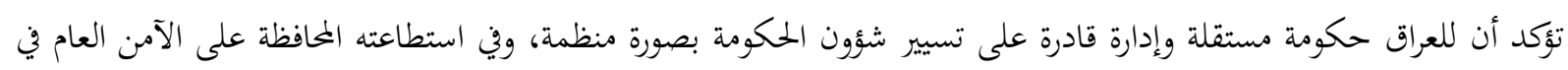
العراق وأثبتت أن لدى العراق مصادر مالية وافية لسد حاجات الحكومة، فضلا عن اعتماد قوانين ونظام قضائي فيها (طقوش،

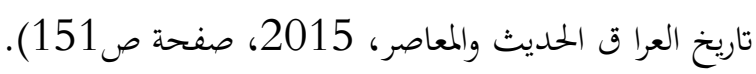

تولت لجنة الانتدابات الدائمة في عصبة الأمم فحص تقرير الحكومة البريطانية المنتدبة ممثلاً لاستجوابه، فأضاف هذا الممثل

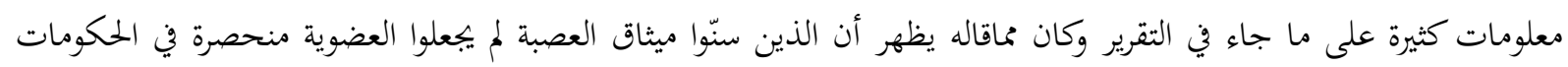

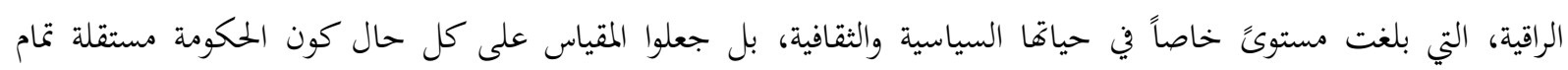
الاستقلال، وقادرة على أن تقف وحدها والدفاع عن نفسها. 


\section{قرار العصبة: - م}

استمر النقاش والسؤال والجواب طويلا ثم اتخذ مجلس العصبة هذا القرار لما كان المجلس مكلفا بالنظر في القضية الخاصة

المتعلقة بإلغاء الانتداب المفروض على العراق لذلك قرر المجلس الأمور التالية: (قرار مجلس عصبة الامم ومذكراته، صفحة 9).

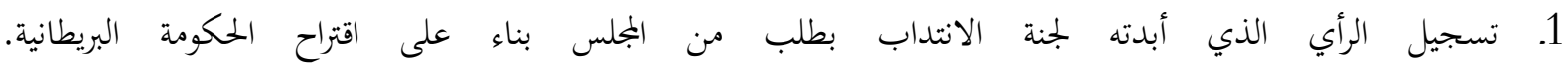
2. اعتماد المعلومات المتيسرة كافة للدلالة على أن العراق بوجه الإجمال قد استوفى الشروط الحقيقية المذكورة في ملحق القرار الذي الذي اتخذه المجلس في 4 أيلول عام 1931.

3. التصريح باستعداده مبدئيا للحكم بانقضاء عهد الانتداب في العراق، عندما تتعهد هذه الدولة أمام المجلس بعهود تنطبق على

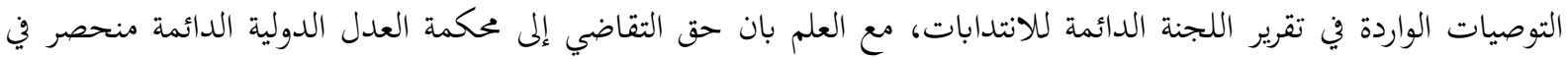
الأعضاء الذين لهم ممثلون في مجلس العصبة.

4. لذلك يطلب المجلس إلى مقريه لمسائل الأقليات والقانون الدولي والانتدابات وممثل بريطانيا العظمى في المجلس أن يهيئوا باستشارة ممثل الحكومة العراقية وعند الاقتضاء باستشارة مثثلي اللجنة الدائمة للانتدابات، لائحة تصريح تتناول شتى الضمانات الموصى بها في تقرير اللجنة الدائمة للانتدابات، وعرض تلك اللائحة على المجلس في دورته التالية. 5. أنه اذا حكم المجلس (بعد فحص العهود التي تقطعها الحكومة العراقية) بتقليص الانتداب عن العراق، ينفذ هذا الحكم ابتداء

$$
\text { من تاريخ انضمام العراق إلى عصبة الأمم. }
$$

هيأت اللجنة المختصة في عصبة الأمم مذكرتين مختصرتين بالشروط المطلوبة من العراق ضماناً لانخراطه في عضوية العصبة

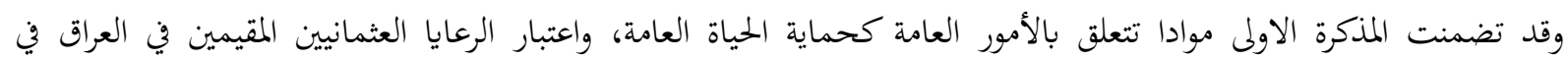
السادس من آب 1924 قد اكتسبوا الجنسية العراقية يتمتعون بحقوق متساوية مدنية كانت هذه الحقوق ام سياسية ام دينية، وكانت كل هذه الامور مدرجة في القانون الاساسي العراقي.

أما المذكرة الثانية فهي تقتصر على مصالح الاجانب وبعض الامتيازات الدولية كالسماح للبعثات الدينية، من جميع المذاهب، بحرية التبشير والتدريس والتطبيب وغير ذلك، وان يعتبر العراق مقيدا بالمعاهدات والاتفاقات التي كانت دولة الانتداب

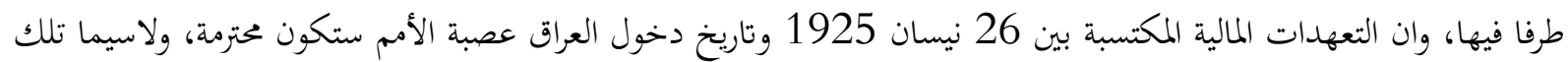

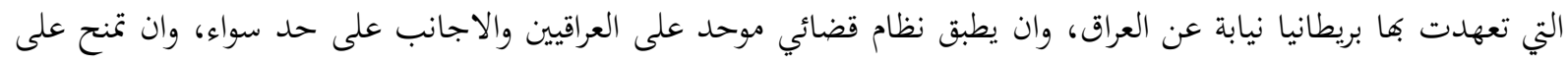

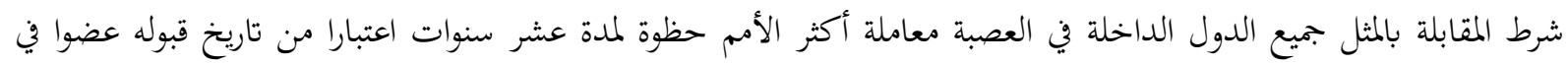

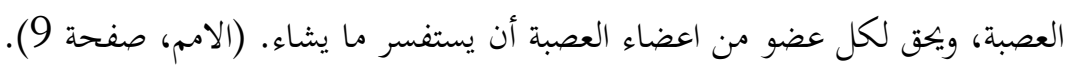




\section{المبحث الثاين: بدايات الوجود الامريكي في العراق}

من خلال استقراء التاريخ للعلاقات الأمريكية - العراقية وما أفرزته تفاعلاتما من احداث وسلوكيات، نجد أن الولايات

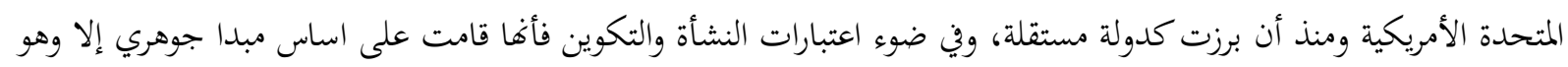

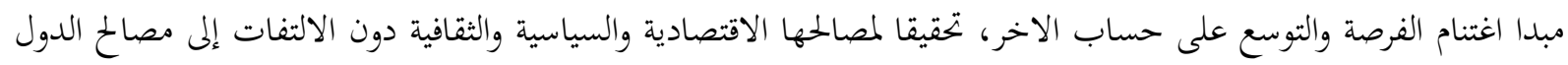

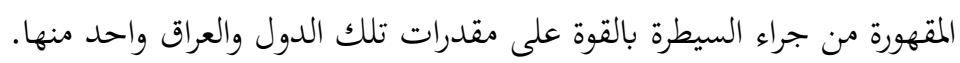
ولم يخف على الولايات المتحدة الأمريكية الاهمية الكبرى التي تشكلها بحيرة النفط التي يعوم عليها العراق ودول الخليج

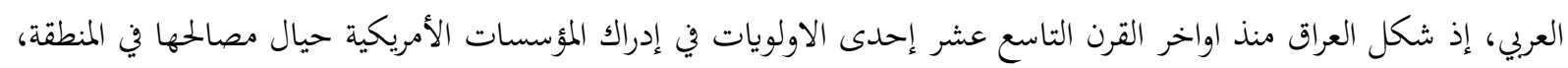

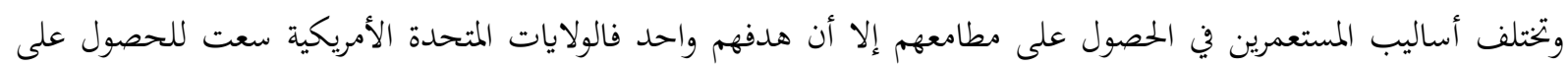

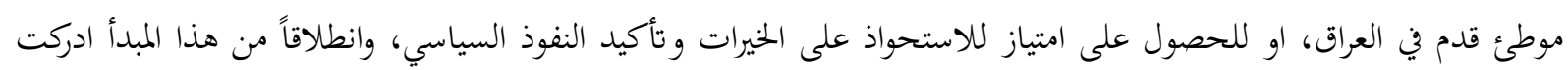

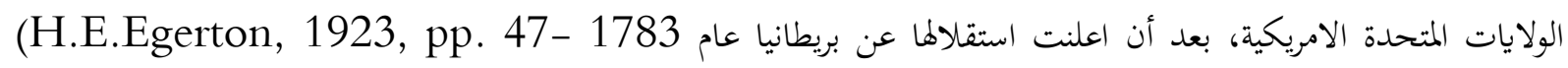

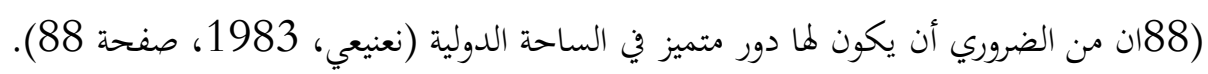
استخدمت حكومة الولايات المتحدة الأمريكية أساليب عدة لاستعمار الشعوب واستغلالما، فكانت أساليب هم

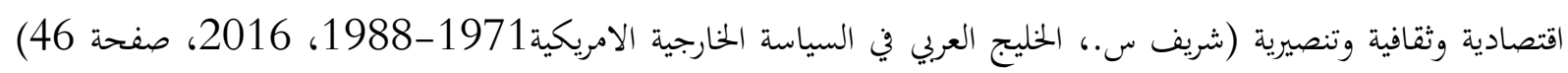

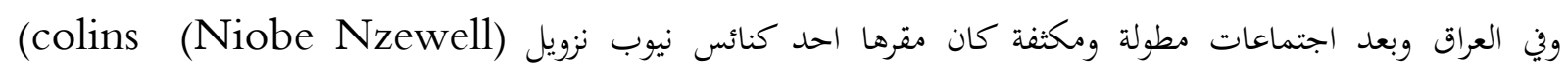
conices Encyclopedia, 1985, p. 473)

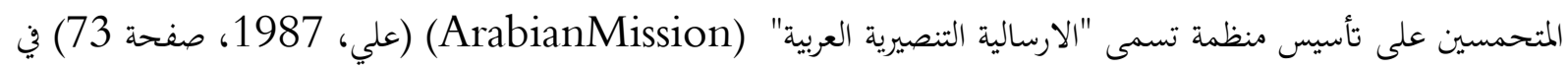

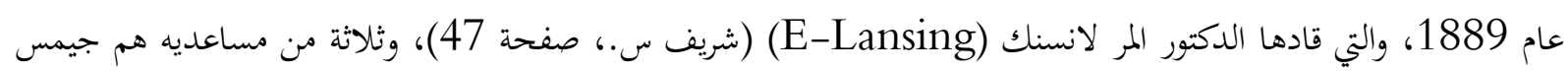

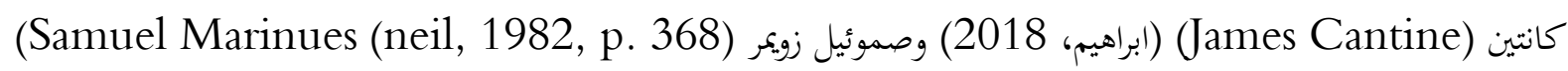

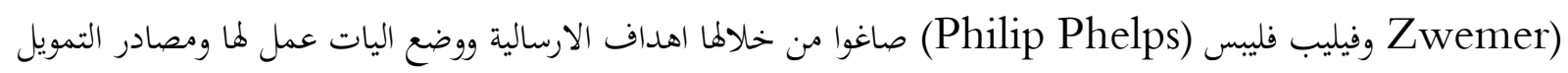

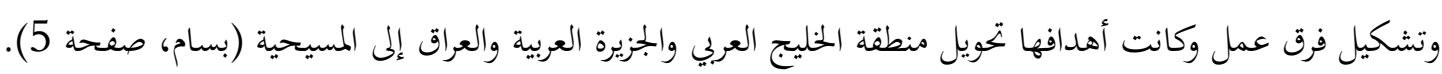
ابدت حكومة الولايات المتحدة الأمريكية اهتماماً ملحوظاً بالعراق منذ عام 1889، حين قررت تعيين أول قنصل لها في

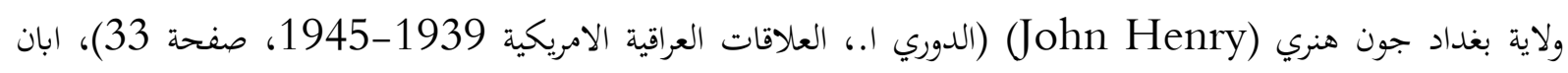

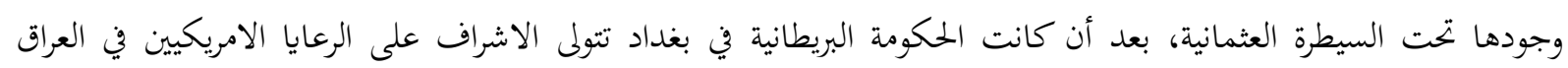

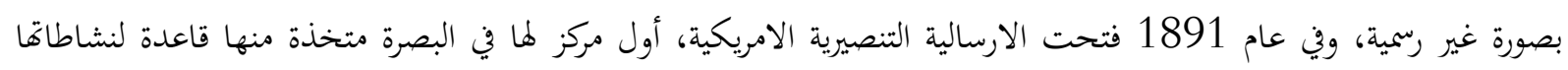
التنصيرية والثقافية في منطقة الخليج العربي، وفي اواخر عام 1895 وصل المنصرون إلى شمال العراق، متجهين نخو الميدانين الطبي

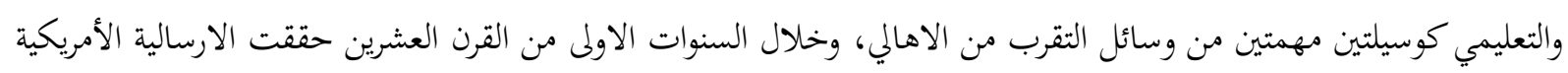

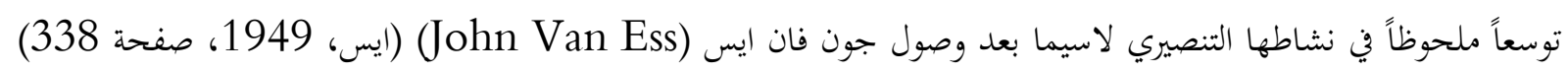

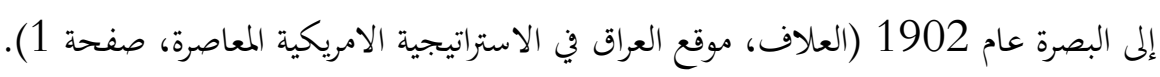

ساهم المنصرون الامريكيين وبشكل رئيسي في تغلغل نفوذ بلادهم في الدولة العثمانية والولايات التابعة ها، والى ذلك اشار

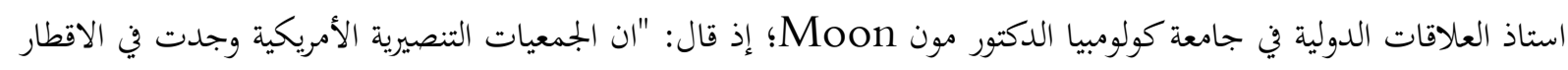
الخارجية من أجل بناء الامبراطورية " (Josef, 1961, p. 41).

ازداد الاهتمام الامريكي في العراق منذ اوائل القرن العشرين، إذ ارسلت الحكومة الامريكية، الادميرال الامريكي جستر

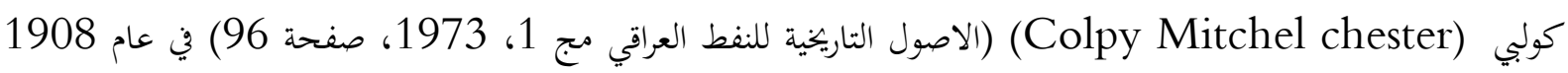


موفداً من قبل بجموعة من المستثمرين الامريكيين ليقود المفاوضات مع المسؤولين العثمانيين للحصول على الاسبقية في نفط الموصل

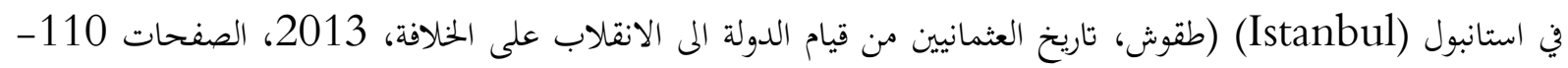

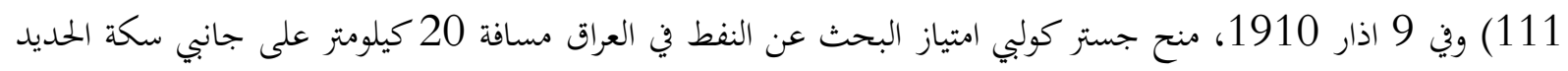

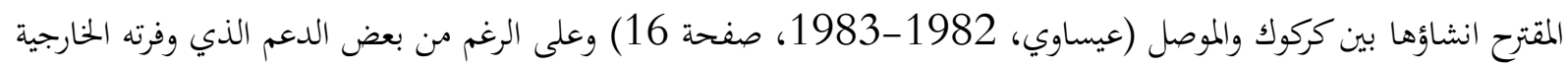

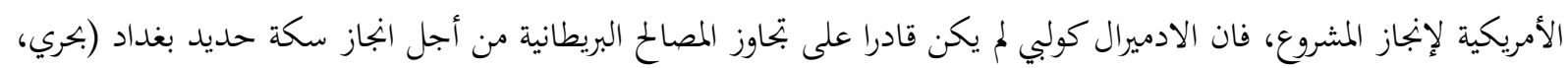
1967، الصفحات 69-72).

وبموجب اتفاقية سايكس بيكو (Sykes-Picot Agreement) (حسين، مشكلة الموصل دراسة في الدبلوماسية

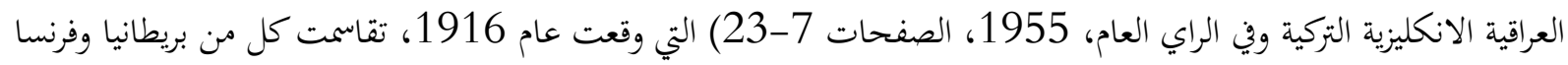
الأراضي العربية إذ حصلت الدولتان بموجب ذلك على حصة من نفط العراق، وقد اغضب ذلك الك الاتفاق الحكومة الإنبة الأمريكية لأنه

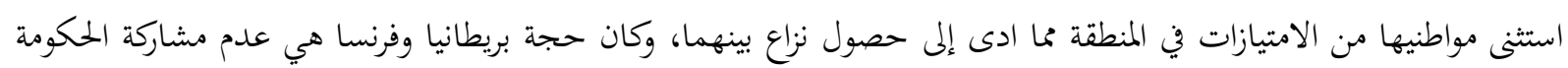

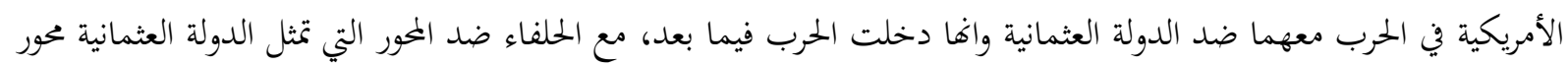
اساس فيها (الحمود، 1980، الصفحات 24-25)

امتعضت الولايات المتحدة الأمريكية من سياسة بريطانيا في العراق، هذا مع أن الرئيس الامريكي ودرو ولسن (1921-1913) (Woodrow Wilson) المتخلفة وفي 28 حزيران 1919 تشكلت عصبة الأمم بصورة رسمية واجتمع مجلس الحلفاء فوزعت المستعمرات الالمانية

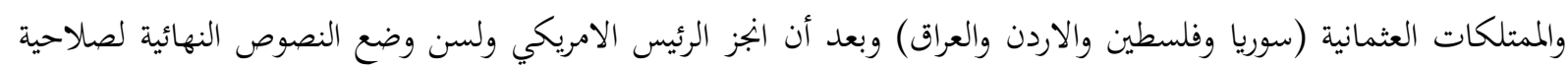

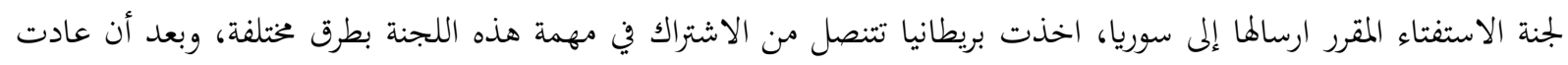

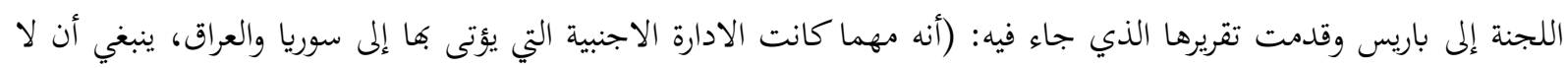

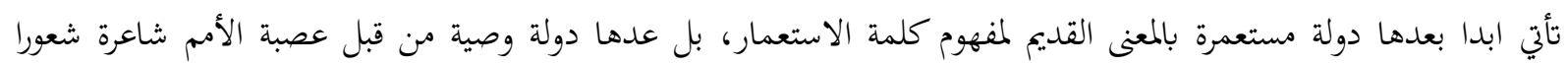

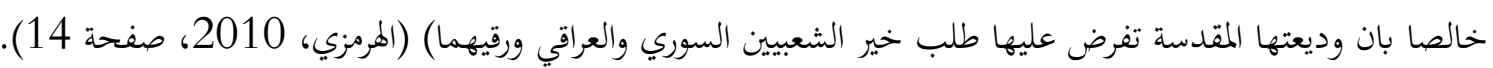
لذا طالبت الولايات المتحدة، من بريطانيا بضرورة اشراكها بنفط العراق والخليج العربي، لكن بريطانيا رفضت ذلك مما دفع الرئيس الامريكي ولسن (167-Academic American Encyclopedia, 1981, pp. 166) إلى ارسال

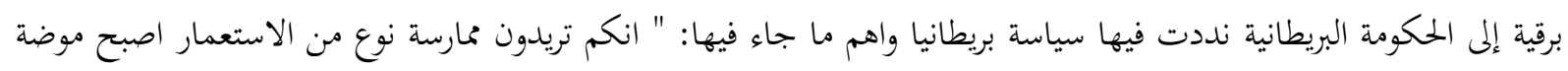

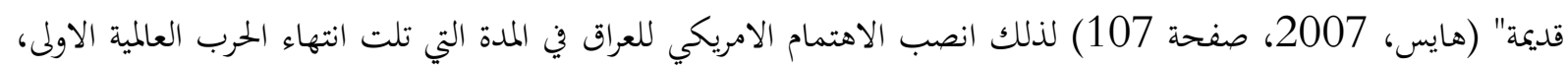

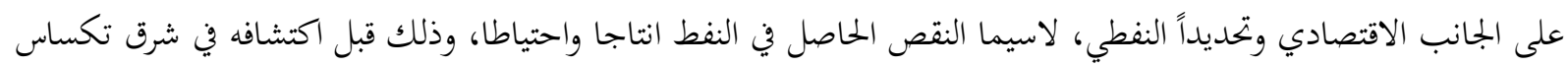

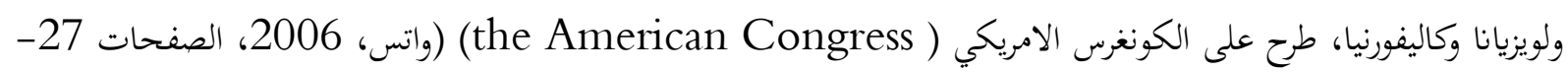
28) اقتراحاً لمعالجة ذلك النقص عبر تقييد تصدير النفط الخام والسيطرة على مصادر أخرى خارجية، ومساعدة الشركات الأمريكية في بلوغ هذا الهدف.

وعلى اثر ذلك تشكلت مجموعة شركات نفطية مكونة من (سكوني فاكوم Socony Facum، شركة تكساس

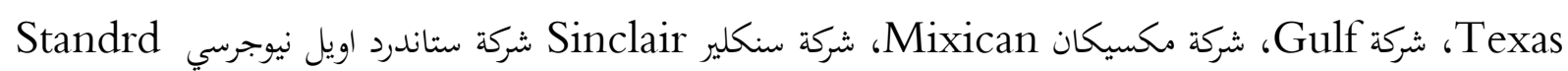
(Atlantic وإذ عقد اجتماع بين مدراء تلك الشركات انذاك مع المستشار التجاري في وزارة الخارجية الأمريكية للبحث في سبل تفعيل عمل هذه الشركات، على اساس مبدأ المشاركة الأمريكية في استثمار

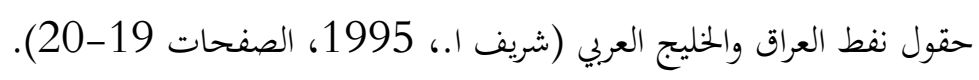


على أثر ذلك قامت شركة سكوني (socony) الأمريكية بإرسال بعثة من الجيولوجيين إلى العراق للبحث والتحري عن

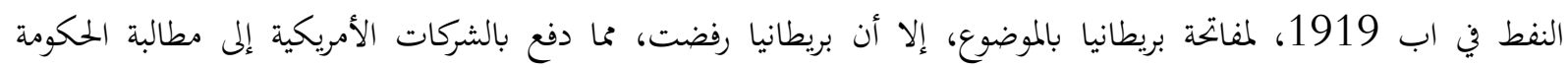

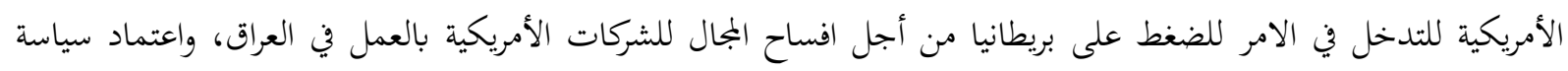

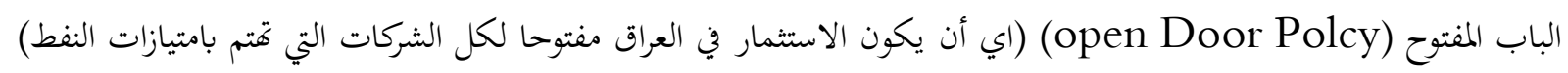

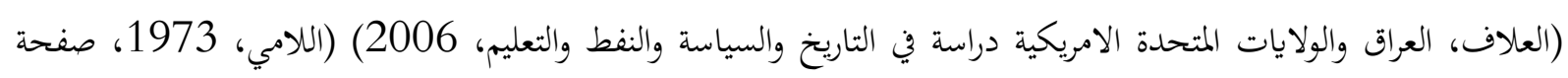
63) تمف من وجهة نظر الحكومة الأمريكية (الشرقاوي، صفحة 6) الحفاظ على حقوقها في الأراضي المسلوخة عن الدولة العثمانية والموضوعة تحت الانتداب.

وقد أصرت وزارة الخارجية الأمريكية على رفض العودة إلى أوضاع ما قبل الحرب (العكيدي ب.، صفحة 40) وذلك

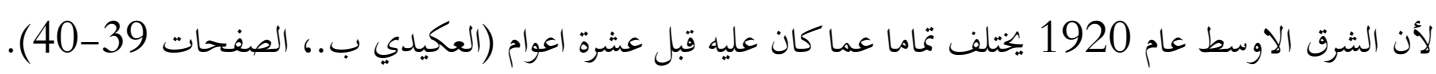
وبعد انعقاد مؤتمر لوزان (Lausanne conference) (عباس، 2014، صفحة 28) عام 1922، رأت بريطانيا أنه من الافضل لها اشراك الشركات الأمريكية لتحصل على تأييدها في مواجهة ادعاءات الدولة العثمانية في الموصل (حسين،

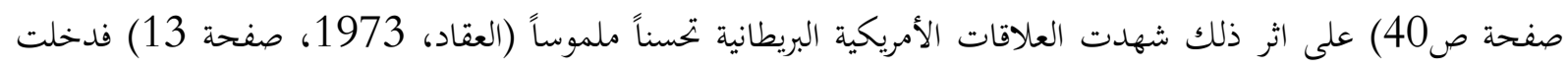

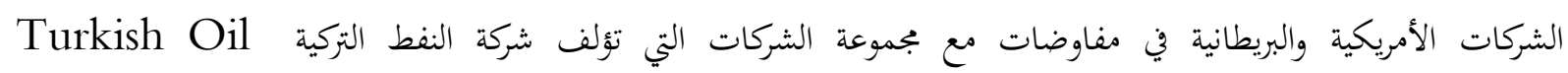
Company (خليل، 1979-1980، الصفحات 26-27) تمخضت المفاوضات عن عقد اتفاقية في 20 حزيران 1922، والخاصة بالمصالح الأمريكية البريطانية المتعلقة بموضوع نفط العراق وتتلخص بالاتي: لا يعترف بشركة النفط التركية إلا

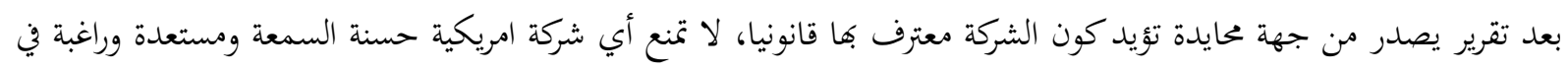

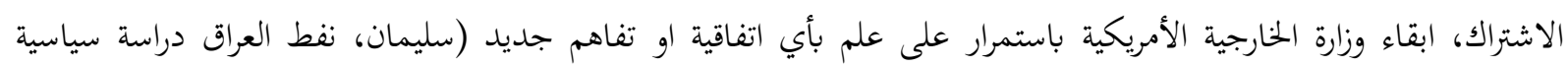

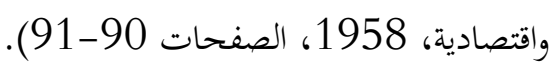

وبعد مفاوضات سرية دامت بين الحكومتين البريطانية والامريكية امتدت حتى عام 1926، انتهت بمنح الشركات

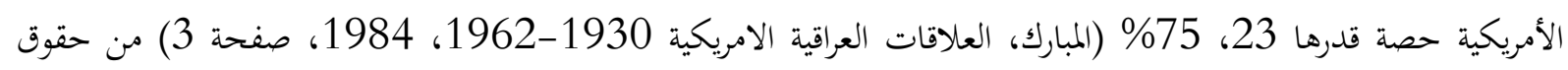

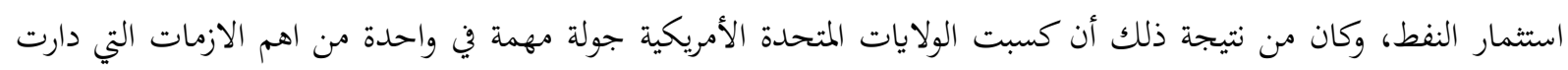

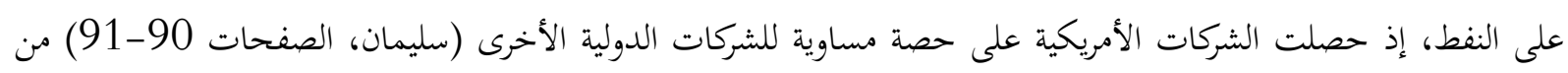

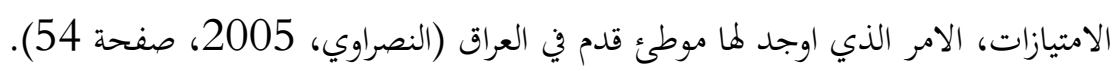

وعقب الاتفاقية التي وقعت بين شركة النفط التركية والحكومتين الأمريكية والبريطانية، وعلى اثر الاكتشافات النفطية

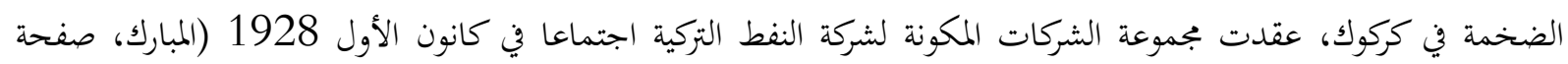

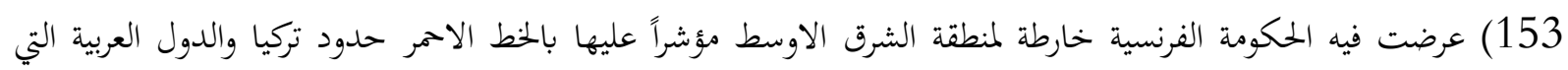

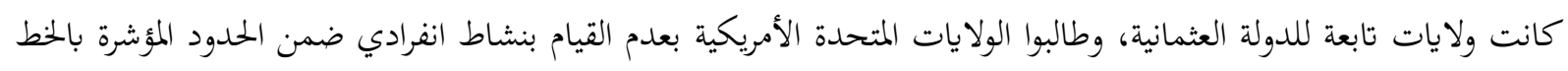
الاحمر (الغريري، 2013، الصفحات 23-24) إلا عن طريق شركة النفط التركية فوافقت الولايات المتحدة الأمريكية على كل

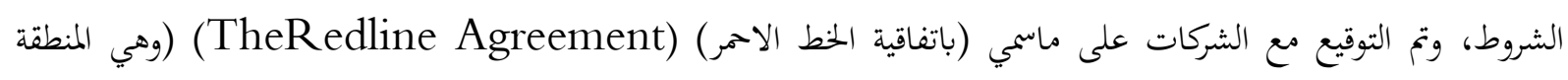

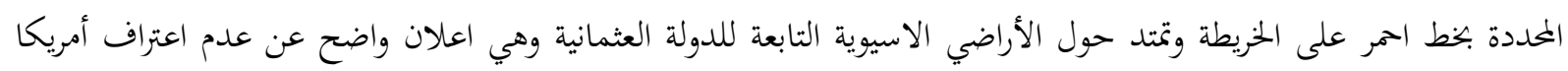
بالاتفاقية التي استبعدت الشركات النفطية الامريكية. وتم تاسيس كارتل يمارس نشاطه داخل المنطقة المحددة بخط احمر على الخارطة) (وهيم، 1982، الصفحات 106-

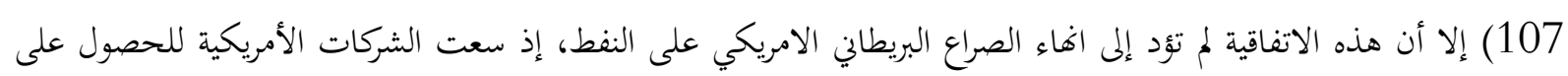


امتيازات نفطية منذ مطلع الثلاثينات من القرن العشرين، إذ ارادت أن تضع لها موطئ قدم في شركة نفط الموصل (سليمان،

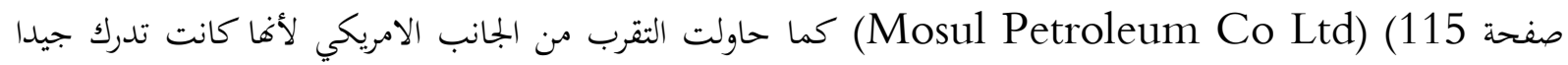
الامكانيات المالية الكبيرة التي تتمتع بها حكومة الولايات المتحدة (مراد، 1995، صفحة 82). من جانب اخر سعت الولايات المتحدة الأمريكية حثيثاً من أجل تطوير علاقاتها الدبلوماسية مع العراق، لما كان له من

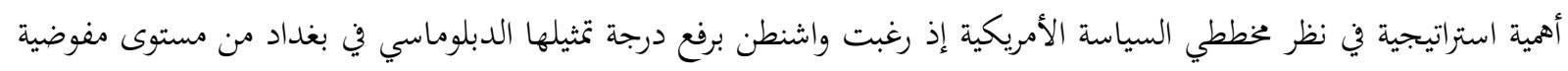

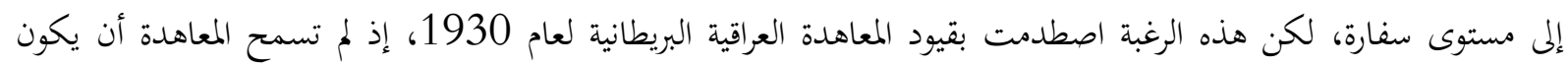

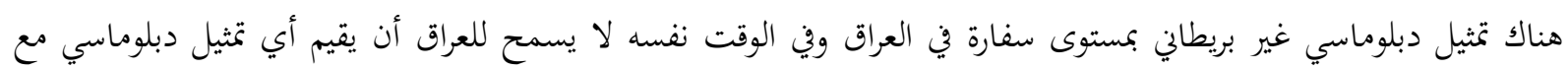
دولة أخرى، وان كانت بريطانيا على مستوى سفارة.

لذلك أبدت الولايات المتحدة استياءها الشديد لهذه الهيمنة البريطانية المفروضة على سياسة العراق الخارجية بموجب

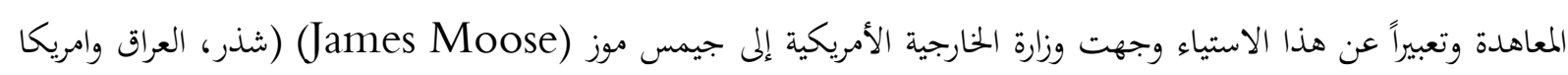
1945-1958، 1998، صفحة 102) انتقاد لما جاء في معاهدة 1930 من بنود تحول دون امكانية تطوير العلاقات

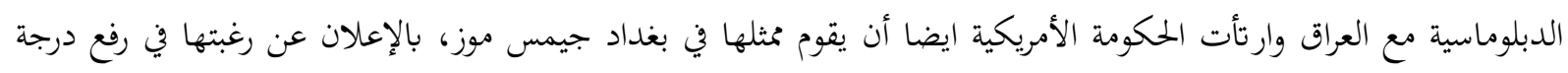

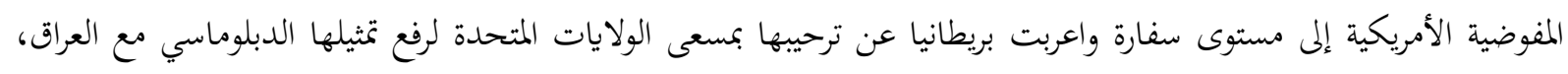

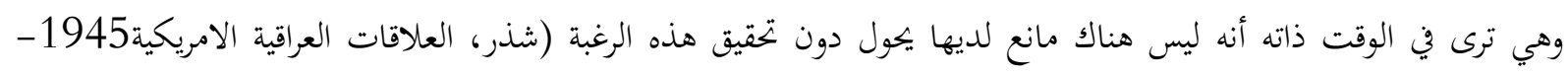

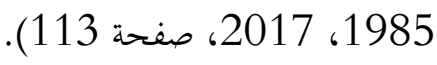

تطلب بجمل هذه التطورات في العلاقات القائمة بين العراق والولايات المتحدة الأمريكية تنظيم شؤوها في اطار معاهدات

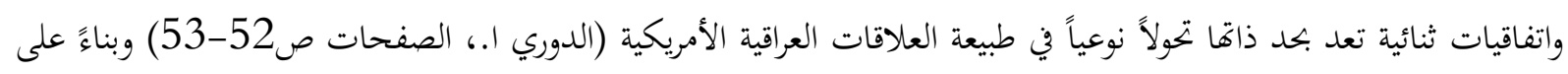
ذلك، جرت مفاوضات بين الحكومتين البريطانية والامريكية بخصوص اعداد لائحة تمهيدية لمعاهدة أرادت بريطانيا من خلالها، انتزاع اعتراف واشنطن بالانتداب البريطاني على العراق، فيما ارادت واشنطن وسيلة لاعتراف قطعي بحقوق الحكومة الأمريكية

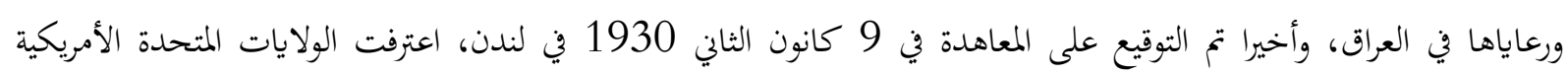

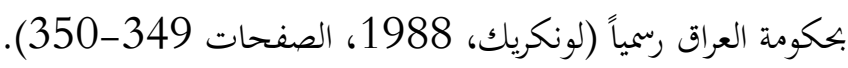

الامر الذي قيمه الملك فيصل بن الحسين في رده على المعتمد السامي البريطاني السير فرنسيس هنري همفريز Francis (Henry Humphries)

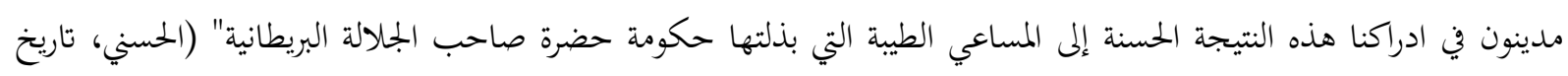

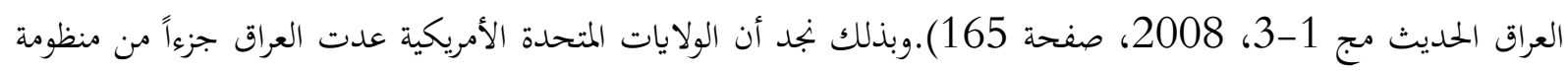

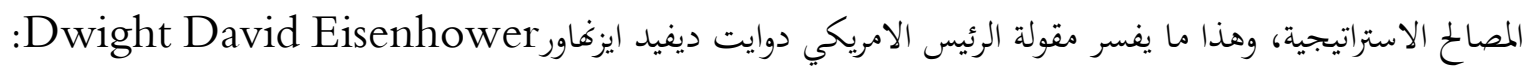

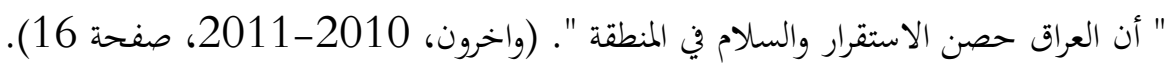




\section{المبحث الثالث: دور الولايات المتحدة الأمريكية في دخول العراق العصبة}

من الوسائل التي اعتمدقا الولايات لتأكيد تواجدها في العراق هو الجانب الثقافي لاسيما التعليمي منه، إذ طرأ على

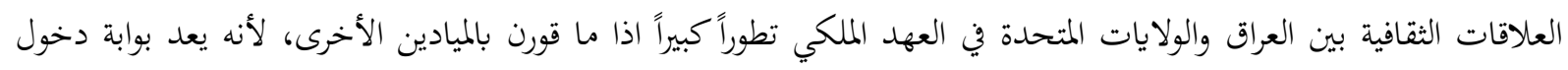

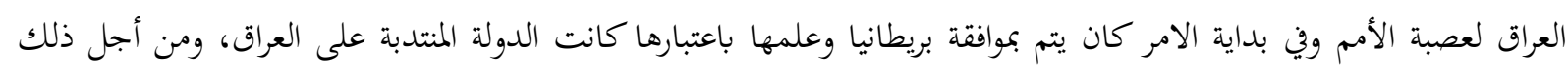

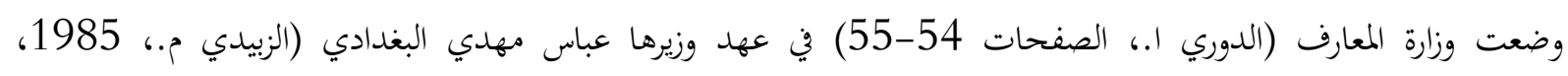

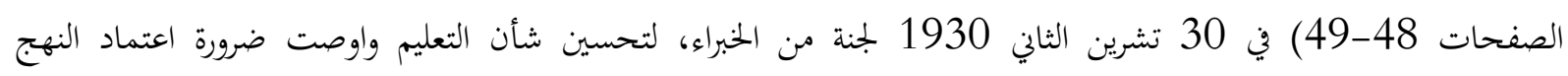

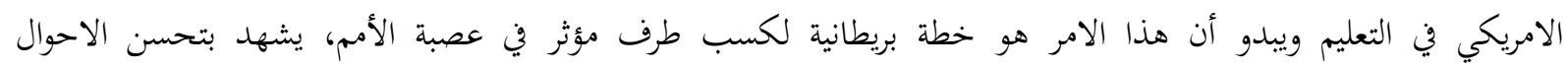

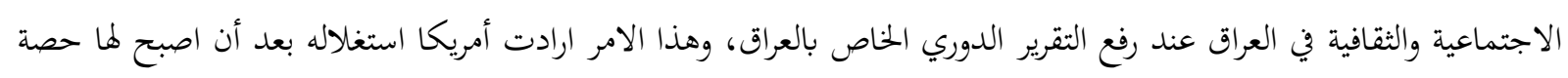

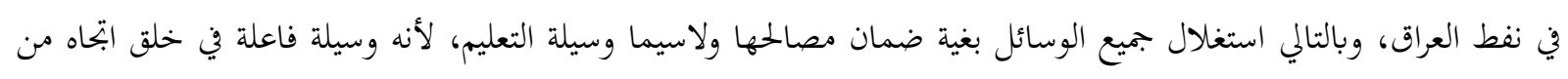

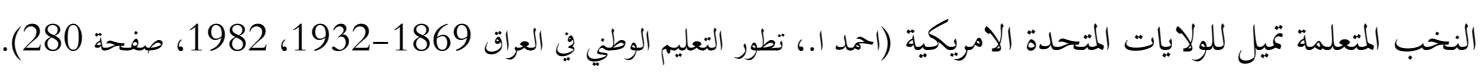
استغل السياسيون وفي مقدمتهم نوري السعيد التعليم في ادخال العراق كعضو في عصبة الأمم، لذلك استقر الامر على

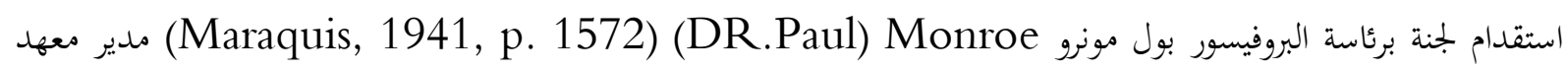

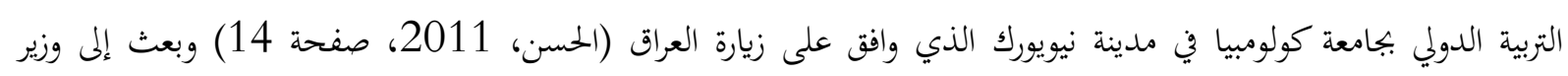
المعارف السابق الذكر، بكتاب يخبره بوصول اللجنة في اوائل شباط 1932 وكانت مؤلفة من: بول مونرو (P.Monrroe)

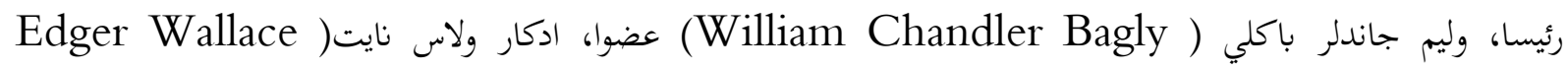
(Kinght ورافق اللجنة رسميا المفتش العام محمد فاضل الجمالي (احمد ا.، صفحة 313) الذي عاد إلى العراق مع اللجنة بعد حصوله على الدكتوراه في التربية من كلية المعلمين (Teachers College) في جامعة كولومبيا في السنة ذاتما. بدأت اللجنة عملها بان قدمت مقترحات عديدة لرفع مستوى التعليم وحل مشاكله ومن ذلك: تحسين أوضاع المعلمين، معالجة مشكلة الرسوب، ايجاد نوع من المدارس التي تسمى بمدارس التعليم بالعمل وذلك لمعالجة

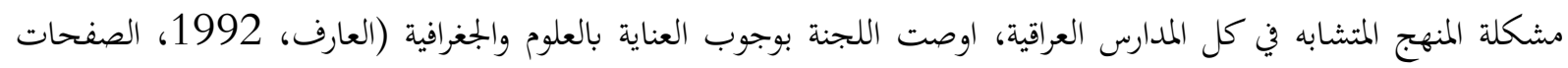

كان من اسباب استقدام لجنة مونرو هو رغبة الحكومة العراقية بتسجيل تطور كبير في ميدان التعليم (د.ك.و،الوحدة

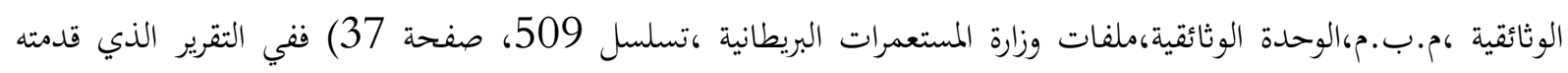

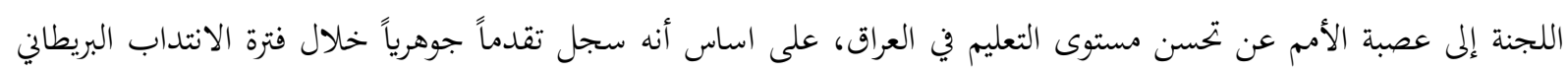
(احمد ا.، صفحة 333).

لقد تمثل الاتحاه الامريكي في التعليم، في قيام الحكومة العراقية بعقد مؤتمرها التربوي الأول في بغداد بين 9-15 نيسان 1932 برعاية الملك فيصل وقد حضر المؤتمر حوالي 70 بالمائة من العاملين في ميدان التربية والتعليم في العراق، افتتح المؤتمر في 9

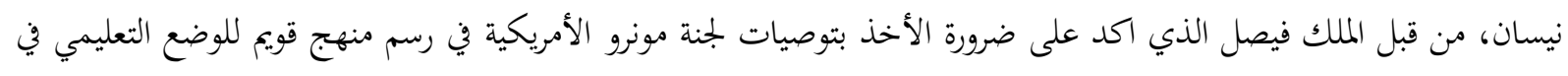

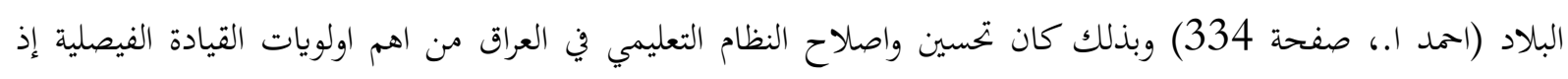
انصب التركيز على النهوض بالتعليم كعلاج لمختلف المشاكل الاجتماعية والاقتصادية في البلاد.

لقد كان من نتائج التوجه الامريكي افساح المجال للبعثات التنصيرية الأمريكية في انشاء عدد من المؤسسات التعليمية في

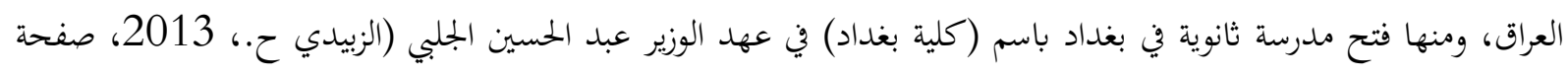


373) وترجع بدايات الدعوة لتأسيس هذه المدرسة إلى قيام الاب ادموند ولش (Admund Walsh) أحد اساتذة جامعة جورج تاون الأمريكية بزيارة العراق وذلك لغرض دراسة احوات التوعال التعليم في المدارس الكاثوليكية (تاريخ التعليم في العراق في عهد

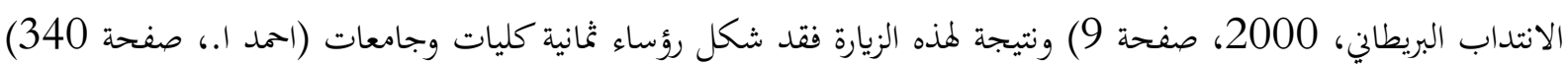

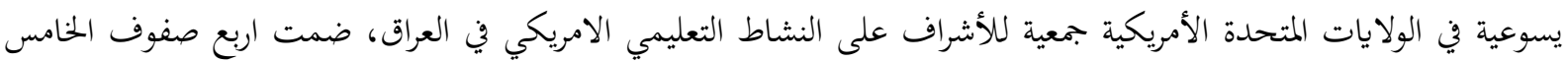

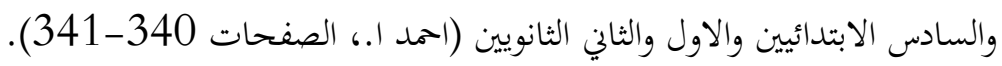

تتابع بعد ذلك وصول عدد من الخبراء الامريكيين التربويين إلى العراق منهم الخبير جورج كلوس (George Claus)

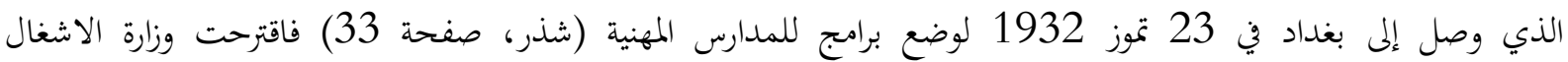
والمواصلات على مجلس الوزراء أن تستقدم خبيرا اجنبياً لادارة شؤون مدرسة الهندسة بهدف "اصلاحها وتطويرها لتكون معققة للرغائب والغايات المبتغاة منها (د.ك.و،الوحدة الوثائقية ، م.ب.م،مقررات مجلس الوزراء، مقررات شهر كانون اول 1924، صفحة 1). كما اقترحت وزارة المعارف في 7 ايلول 1932 على بجلس الوزراء تأليف لجنة لإصلاح المدارس الصناعية، على أن يرأس

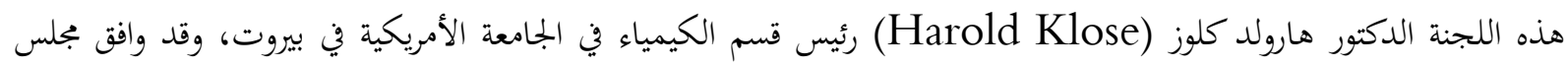

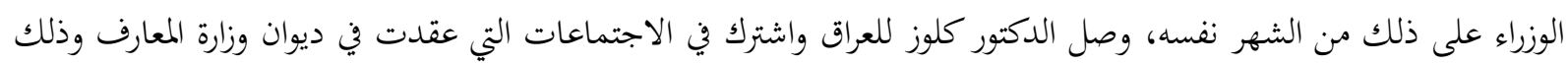

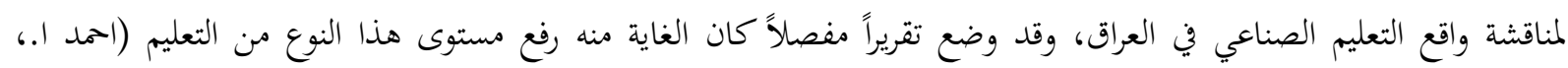
صفحة 342).

كما قدم الدكتور كالفن ستاوت (Clavins Staudt) طلباً لفتح مدرسة للبنين في بغداد وتمت الموافقة عليها، ومما

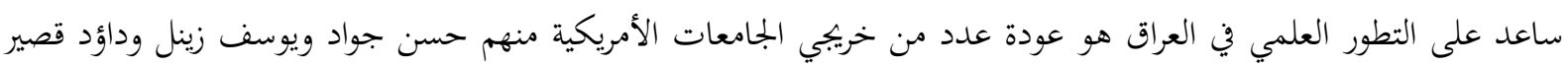

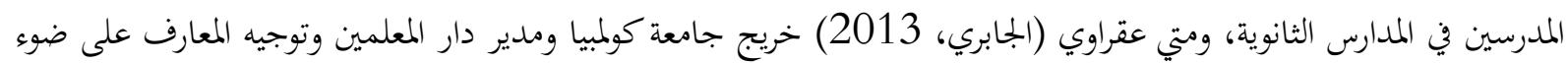

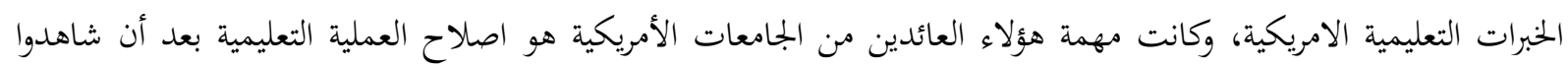

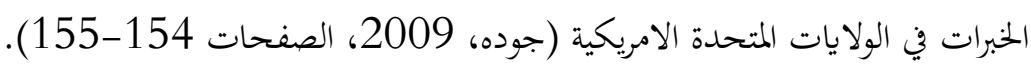
وكان للتقارير التي ارسلتها اللجان الأمريكية الخاصة بتطوير التعليم بالغ الاثر على موافقة مجلس العصبة على قبول العراق

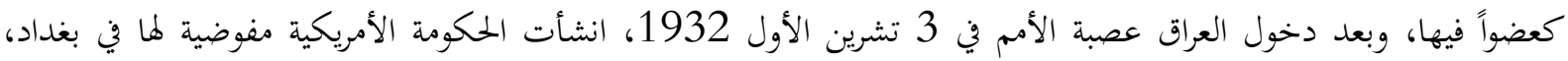

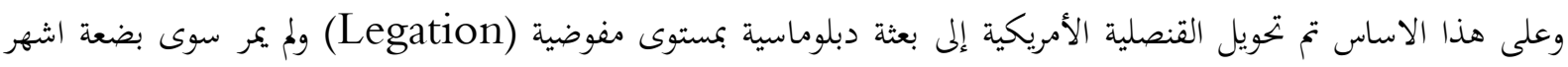

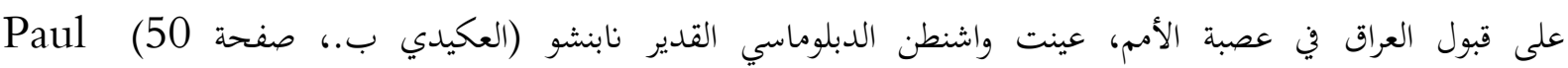
وزيراً مفوضاً لدى العراق، وكان ذلك بمثابة تحول نوعي في العلاقات العراقية الامريكية، لا سيما وان (Knabenshue)

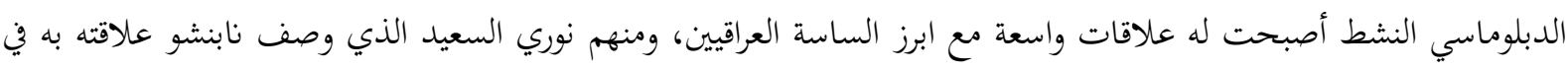

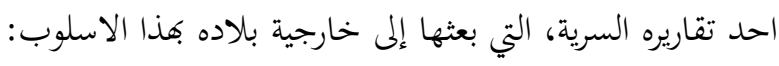
"انني ولحسن الحظ اتمتع بصداقة شخصية متينة مع نوري باشا، وعلى نطاق واسع من أي شخصية رسمية عراقية أخرى. اننا نتبادل الضيافة والزيارات على الدوام وهو يأتي إلى المفوضية للعب التنس، وفي الصيف الماضي علمته السباحة. انني اشعر بحرية

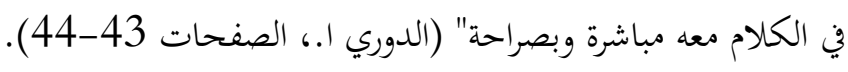
لقد شهدت الحقبة التاريخية التي اعقبت انضمام العراق إلى عصبة الأمم وما بعدها، تطورات سياسية واقتصادية واجتماعية تركت اثرها الواضح على مستوى التعليم فقد شهدت انعطافه جديدة في تاريخ التعليم ونقطة تحول ملموسة في مسيرته، فقد

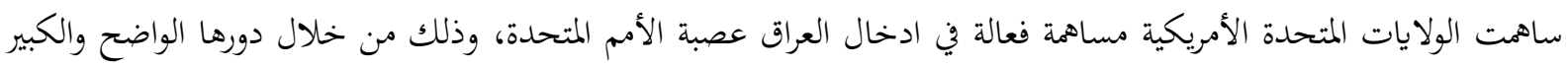


في النهوض بواقع العملية التربوية في العراق، وبذلك يكون للولايات المتحدة الأمريكية الدور الرائد والبارز في دخول العراق عصبة الأمم.

وبموجب الاحصاءات الرسمية العراقية بلغ عدد المدارس الأمريكية في العراق خلال العام الدراسي 1932-1933 ثماني

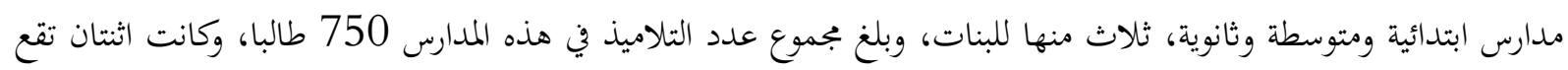

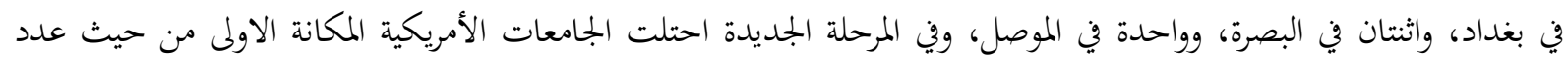

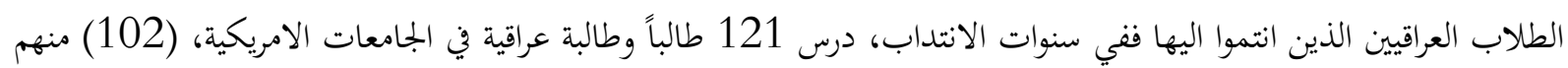

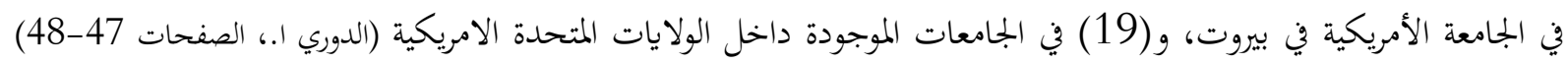

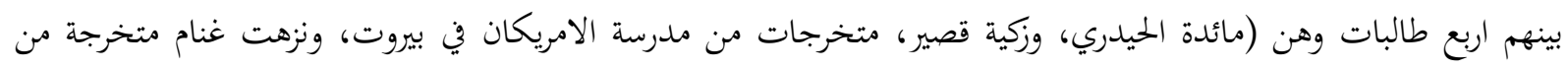

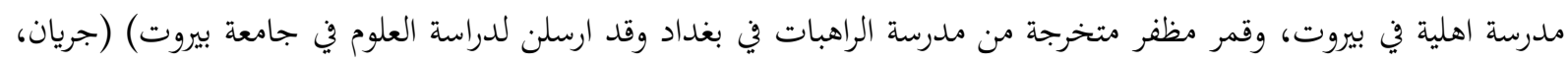
2005، صفحة 953)، ارتفع هذا العدد بعد دخول العراق عصبة الأمم المتحدة إلى (54) طالباً وطالبة، يدرسون في فئ الولايات المتحدة الامريكية.

ادناه جدول احصائي لطلبة البعثات العراقية إلى الولايات المتحدة الامريكية (زكي، 2013، صفحة 56)

\begin{tabular}{|c|c|}
\hline 5 & $1926-1925$ \\
\hline 4 & $1927-1926$ \\
\hline 3 & $1928-1927$ \\
\hline 3 & $1929-1928$ \\
\hline 1 & $1930-1929$ \\
\hline 4 & $1931-1930$ \\
\hline 5 & $1932-1931$ \\
\hline 19 & $1933-1932$ \\
\hline
\end{tabular}

وكان نتيجة الانفتاح على العالم الخارجي وارسال البعثات إلى الولايات المتحدة الأمريكية والاطلاع على مستوى التطور الذي شهده التعليم النسوي، فقد دعا الملك فيصل الاول، إلى تحرير المرأة وتعليمها وتثقيفها، مؤكدا على أن المرأة كلما ازدادت

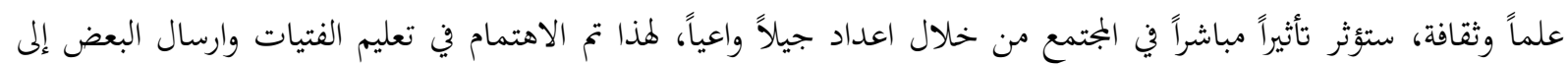

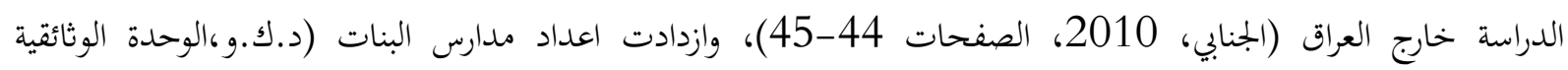

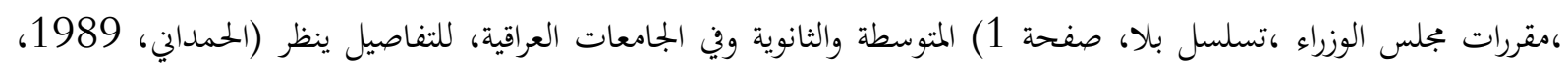
صفحة 80). وذلك بفضل السياسة التعليمية التي انتهجتها الحكومات العراقية وزيادة التخصيصات المالية في ميزانية الدولة لوزارة المعارف. 
يتبين لنا أن الولايات المتحدة الأمريكية سعت جاهدة ومنذ تغغغلها في العراق لجعله تابعاً لما، عن طريق السيطرة على

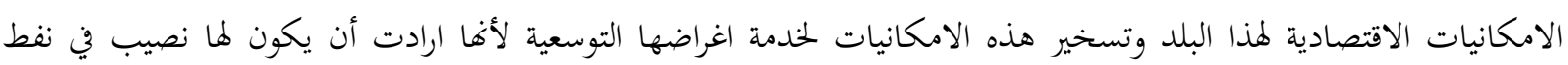
العراق، وقد اتضحت هذه المصالح في ميادين عدة سيما التعليم.

وهكذا استطاع الامريكيون انشاء مصالح اقتصادية وبحارية لمم في العراق خلال الفترة التي تلت الحرب العالمية الاولى، والتي كانت مليئة بالصراعات الدولية والتنافسات في منطقة الخليج العربي سيما العراق، وكيف استطاعت الولايات المتحدة الأمريكية

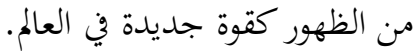


Academic American Encyclopedia. (1981). new jersy: Arete publishing company.

Albert Nelson Maraquis. (1941). whoss aho in America .chicago: the A.N.Marquis.

Bailey sydney D . Pprliamentary Macdonald J. Ramsay The Socialst Movement. colins conices Encyclopedia. (1985). london.

H.E.Egerton. (1923). The Causes and character of the American Revolution .london.

Jhon Josef. (1961). The Nestoriuns and the Muslims Neighbors princeten.

Stephen neil. (1982). AHistory of Christian Mission .London.

$$
\begin{aligned}
& \text { ابراهيم السامرائي. (2015). العراق البلد الذي نخره السياسيون 1914-2003. دار المعتز للنشر. } \\
& \text { ابراهيم خليل احمد. (بلا تاريخ). } \\
& \text { ابراهيم خليل احمد. (بلا تاريخ). } \\
& \text { ابراهيم خليل احمد. (بلا تاريخ). } \\
& \text { ابراهيم خليل احمد. (بلا تاريخ). } \\
& \text { ابراهيم خليل احمد. (بلا تاريخ). } \\
& \text { ابراهيم خليل احمد. (بلا تاريخ). }
\end{aligned}
$$

ابراهيم خليل احمد. (1982). تطور التعليم الوطني في العراق 1869-1932. البصرة: منشورات مركز دراسات الخليج العربي. ابراهيم خليل العلاف. (2006). العراق والولايات المتحدة الأمريكية دراسة في التاريخ والسياسة والنفط والتعليم. الموصل: مركز

$$
\text { الدراسات الاقليمية العدد السابع. }
$$

ابراهيم خليل العلاف. (بلا تاريخ). موقع العراق في الاستراتيجية الأمريكية المعاصرة. العراق: مركز الدراسات الاقليمية. ابراهيم شريف. (1995). الشرق الاوسط دراسة الاتحاهات وسياسة الاستعمار حتى قيام ثورة 14 تموز 1958 في العراقيه العراق.

$$
\text { بغداد: دار الجمهورية. }
$$

ابراهيم عكاشه علي. (1987). ملامح عن النشاط التنصيري في الوطن العربي. السعودية: جامعة الامام محمد بن سعود.

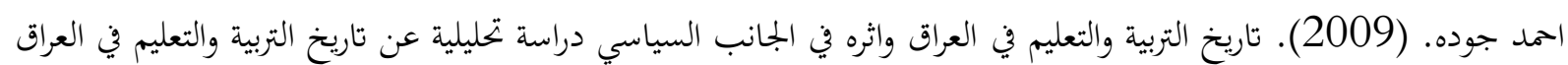

$$
\text { 1534-2009. بغداد: جعفر العصامي للطباعة الفنية الحديثة. }
$$$$
\text { احمد عطية الله. (1968). القاموس السياسي (المجلد ط3). القاهرة. }
$$

ادمون رباط. (2010). تطور سوريا السياسي في ظل الانتداب. (سليمان رياشي، المترجمون) بيروت: المركز العربي للابحاث

$$
\text { ودراسة السياسات. }
$$

اديث واي اف بينروز. (بلا تاريخ). العراق دراسة في علاقاته الخارجية وتطوراته الداخلية 1915-195. (عبد المجيد حسين

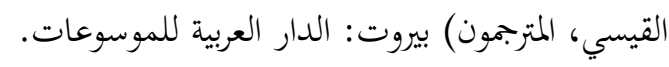

ارشد مزاحم مجبل الغريري. (2013). تطور العلاقات العراقية الامريكية. عمان: مركز الكتاب الاكاديمي.

اسامه الدوري. (بلا تاريخ).

اسامه عبد الرحمن الدوري. (بلا تاريخ).

اسامه عبد الرحمن نعمان الدوري. (بلا تاريخ).

اسامه عبد الرحمن نعمان الدوري. (بلا تاريخ).

اسامه عبد الرحمن نعمان الدوري. (بلا تاريخ). 
اسامه عبد الرمن نعمان الدوري. (بلا تاريخ).

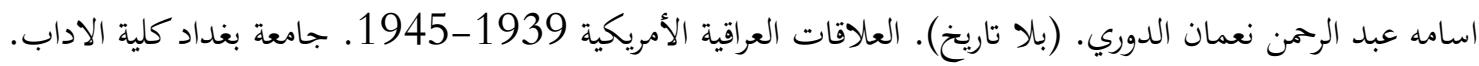
الاصول التاريخية للنفط العراقي مج 1. (1973). وزارة الاعلام مديرية الثقافة العامة.

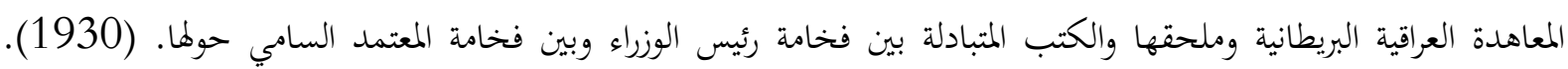

$$
\text { بغداد: مطبعة الحكومة. }
$$

اياد علي ياسين سرحان. (2001). بواكير النشاط الامريكي في العراق حتى عام 1921 رسالة ماجستير. جامعة الموصل كلية

$$
\text { التربية. }
$$

$$
\text { بشينة عباس الجنابي. (2010). الدور السياسي والاجتماعي لسيدات العهد الملكي في العراق. بغداد. }
$$

بشار فتحي جاسم العكيدي. (بلا تاريخ). صراع النفوذ البريطاني الامريكي 1939-1958 دراسة تاريخية سياسية رسالة

$$
\text { ماجستير. جامعة الموصل كلية التربية. }
$$

تاريخ التعليم في العراق في عهد الانتداب البريطاني. (2000). مجلة افاق عربية.

جاسم محمد هايس. (2007). العلاقات العراقية الأمريكية وتاثير النفط فيها. (جامعة البصرة كلية الدراسات التاريخية، المحرر) مجلة الخليج العربي المجلد الخامس والثلاثون.

جواد كاظم البكري واخرون. (2010-2011). العلاقات العراقية الأمريكية بحث منشور في كتاب التقرير الاستراتيجي العراقي.

$$
\begin{aligned}
& \text { بغداد: مركز حمورابي للبحوث والدراسات. } \\
& \text { جون فان ايس. (1949). اقدم اصدقاءي العرب. (جميل عمسو، المترجمون) بغداد. } \\
& \text { حسن لطيف الزبيدي. (2013). موسوعة السياسة العراقية. بيروت: العارف للمطبوعات. } \\
& \text { حسين طعمه شذر. (بلا تاريخ). }
\end{aligned}
$$

حسين طعمه شذر. (1998). العراق وامريكا 1945-1958. (2017) دار الملتقى.

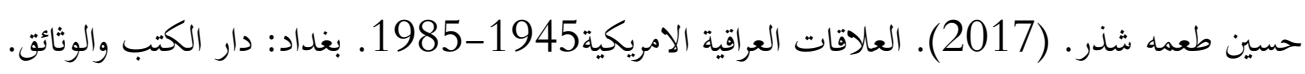

$$
\text { حكمت سامي سليمان. (بلا تاريخ). }
$$

حكمت سامي سليمان. (1958). نفط العراق دراسة سياسية واقتصادية. دمشق: دار اليقظة.

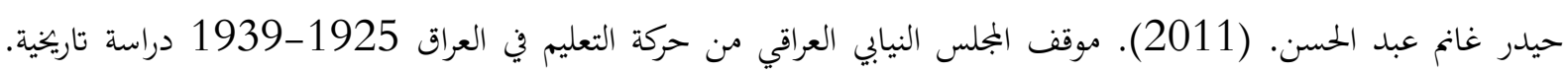

$$
\text { جامعة الكوفة كلية الاداب. }
$$

$$
\text { خالد بسام. (بلا تاريخ). ثرثرة فوق غر دجلة. عمانة. }
$$

خليل علي مراد. (1995). نشاة المصالح الأمريكية في نفط العراق. ندوة تاريخ الاطماع الأمريكية في العراق نظمتها جمعية

$$
\text { المؤرخين العراقية فرع نينوى. }
$$

د.ك.و، الوحدة الوثائقية، م.ب.م، مقررات مجلس الوزراء. (مقررات شهر كانون أول 1924). تسلسل بلا. كتاب وزارة الاشغال والمواصلات إلى سكرتارية مجلس الوزراء المرقم 7340 في 4 كانون أول 1924 المتضمن استقدام المستر الفرد 
د.ك.و، الوحدة الوثائقية، م.ب.م، الوحدة الوثائقية، ملفات وزارة المستعمرات البريطانية، تسلسل 509. (بلا تاريخ). كتاب

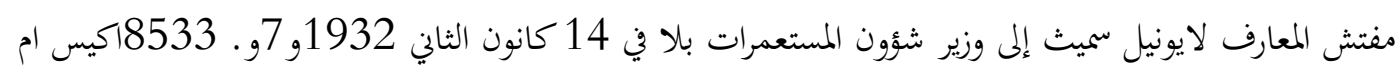

$$
\text { .69409/175/730 }
$$

د.ك.و، الوحدة الوثائقية، م.ب، م، مقررات مجلس الوزراء، تسلسل بلا. (بلا تاريخ). مقررات شهري حزيران وتموز سنة 1924،

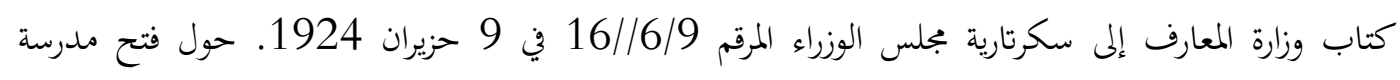

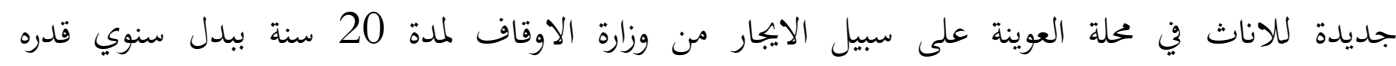

$$
\text { رونالد واتس. (2006). الانظمة الفيدرالية. كندا: منتدى الاتحادات الفدرالية. }
$$
زينب هاشم جريان. (العدد4, 2005). التعليم النسوي في العراق 1921-1958 دراسة تاريخية. مجلة كلية التربية للبنات المجلد 26

$$
\begin{aligned}
& \text { ستيفن همسلي لونكريك. (1988). العراق الحديث من سنة 1900-1950. بغداد: منشورات الفجر. } \\
& \text { سعاد رؤوف محمد. (1988). نوري السعيد ودوره في السياسة العراقية. بغداد: مكتبة اليقظة. } \\
& \text { سوسن جبار شريف. (بلا تاريخ). }
\end{aligned}
$$

سوسن جبار شريف. (2016). الخنليج العربي في السياسة الخارجية الامريكية شتريفية 1971-1988. سيف نصرت توفيق الهرمزي. (2010). الحرب الأمريكية على العراق الدوافع الاستراتيجية والابعاد الاقتصادية. بغداد: كلية

$$
\text { العلوم السياسية جامعة النهرين. }
$$

شارل عيساوي. (1982-1983). التطور التاريخي للعلاقات الاقتصادية الأمريكية العربية. (مركز البحوث والمعلومات، المحرر)

$$
\text { مجلة شؤون العرب الامريكية. }
$$

شعلة اسماعيل العارف. (1992). نظام التعليم في العراق. بغداد: دار الحكمة للطباعة والنشر.

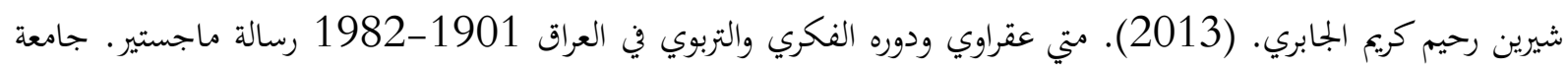
بغداد كلية الاداب.

صفاء عبد الوهاب المبارك. (بلا تاريخ). صفاء عبد الوهاب المبارك. (1984). العلاقات العراقية الأمريكية 1930-1962. (جامعة البصرة، المحرر) مجلة كلية التربية

$$
\text { للبنات العدد } 7 .
$$

صلاح العقاد. (1973). البترول اثره في السياسة الدولية والمجتمع. القاهرة.

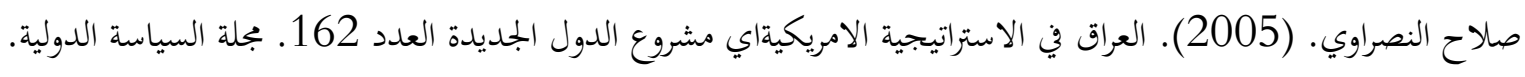

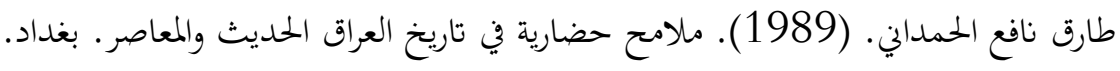

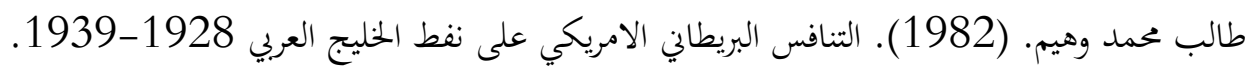

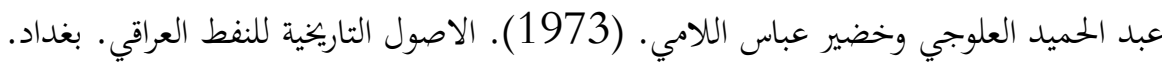

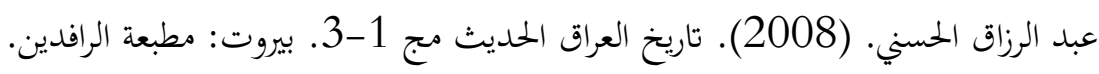

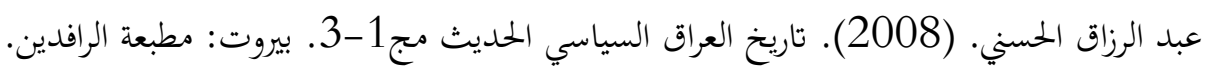

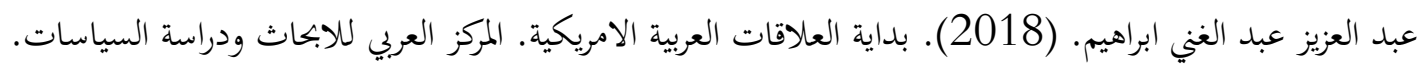

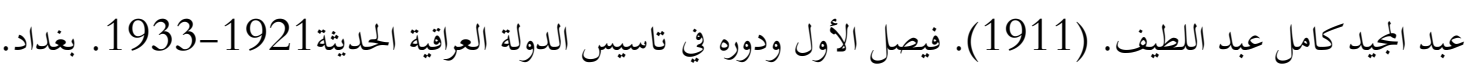

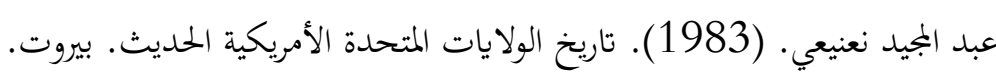


غازي دحام فهد الرسومي. (1986). التعليم في العراق 1932-1945 دراسة تاريخية. جامعة بغداد كلية الاداب.

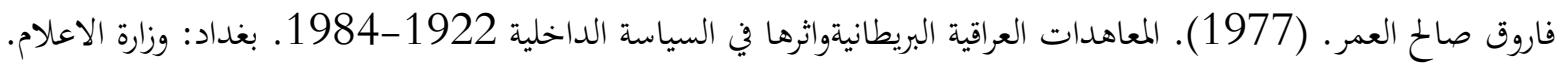
فاضل حسين. (بلا تاريخ). فاضل حسين. (1955). مشكلة الموصل دراسة في الدبلوماسية العراقية الانكليزية التركية وفي الراي العام. بغداد. فاضل عبد القادر احمد. (1989). صراع القوتين العظيمين في القسم الشرقي من البحر المتوسط بعد الحرب العالمية الثانية اطروحة دكتوراه. بغداد كلية الاداب.

فهد سعد الحمود. (1980). ثروات السعودية وسبيل الاستقلال الاقتصادي. بيروت: دار الفارابي. قرار مجلس عصبة الأمم. (بلا تاريخ). قرار مجلس عصبة الأمم ومذكراته. (بلا تاريخ). قرار مجلس عصبة الأمم ومذكراته بشان دخول العراق عصبة الأمم. (بلا تاريخ). قرار بجلس عصبة الأمم ومذكراته بشان دخول العراق عصبة الأمم. (بلا تاريخ). قرار مجلس عصبة الأمم ومذكراته بشان دخول العراق عصبة الأمم في اجتماعه المنعقد في 28 كانون الثاني 1932. 1932 (1932). بغداد: مطبعة الحكومة.

لؤي بحري. (1967). سكة حديد بغداد برلين بغداد حتى عام 1914. بغداد: شركة الطبع والنشر الاهلية.

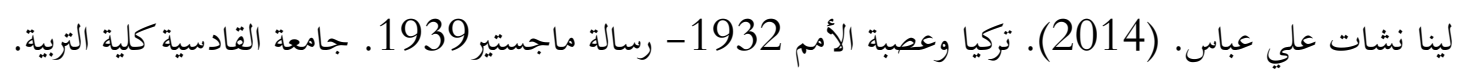

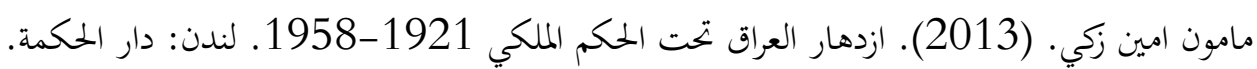
محمد حسين الزبيدي. (1985). العراقيون المنفيون إلى جزيرة هنجام. بغداد: دار الحرية.

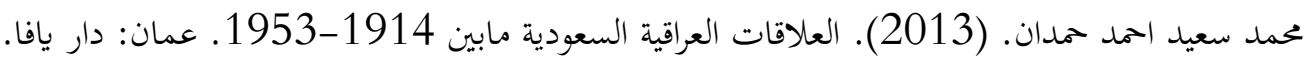
محمد سهيل طقوش. (2013). تاريخ العثمانيين من قيام الدولة إلى الانقلاب على الخنافة (المجلد ط3).

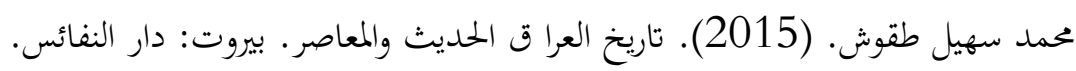
محمود الشرقاوي. (بلا تاريخ). أمريكا وبترول الشرق الاوسط. القاهرة.

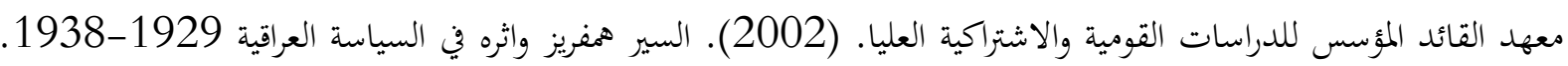

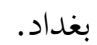
نجدة فتحي. (1988). مذكرات رستم حيدر. بيروت: الدار العربية للموسوعات. نسيم سوسه. (بلا تاريخ). نسيم سوسه. (بلا تاريخ).

نسيم سوسه. (بلا تاريخ). عصبة الأمم والعراق. بغداد: دار الطباعة الحديثة.

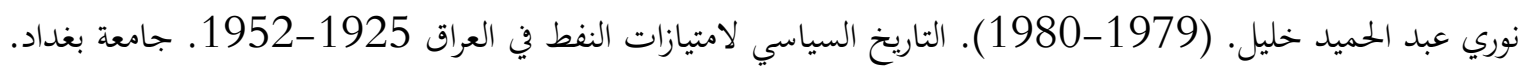




\title{
THE AESTHETIC DISCOURSE OF DECORATIVE ART (ISLAMIC CIVILIZATION AS A MODEL)
}

\author{
Jolan Hussien ALWAN ${ }^{1}$
}

\section{Istanbul / Türkiye \\ p. $635-655$}

Received: $26 / 11 / 2021$
Accepted: 07/12/2021
Published: 01/01/2022

This article has been scanned I iThenticat No plagiarism detected

\begin{abstract}
:
Islam is a major turning point in the life of the nation in particular and humanity in general, because the impact of the Arab-Islamic civilization on human life as a whole is still visible. Art was a manifestation of the Arab Islamic culture and that it represents a pattern of human civilization patterns. Arab Islamic art is one of the important tributaries that accompanied the life and development of the Arab Muslim man. Islamic religious buildings, such as statues, pictures, and other tools used by the Christian churches in their rituals, as these teachings prevented from imitating nature completely. The abstract of the reality of the Creator. This spiritual identity of art is the prominent feature that has marked the history of Islamic art, in all its diverse fields, from diagnosis to abstraction.

The Arab-Islamic personality crystallized under the Islamic religion, and art and its aesthetics became a source of interest for Muslim philosophers of beauty, including Al-Ghazali, Abuhyan AlTawhidi and Al-Farabi, because Islamic religious thought is far from everything that is analogous in Islamic art so as not to be an emulation of the Creator.

From here, the research problem started with the following question: What distinguished the decorative art from the rest of the Islamic arts through its vast civilization from the other arts? And to what extent does it include the aesthetic dimension within the opinions of Muslim philosophers who are interested in the aesthetics of art?

1-As for the importance of the research, it focused on: the possibility of considering it a source for those interested in studying decorative.

2-The possibility of seeing the aesthetics of decorative art and the artist's orientation to this type of art.
\end{abstract}

Key words: Decorative, Islamic Art, Culture.

http://dx.doi.org/10.47832/2717-8293.15.44

1 iD Dr. , University of Diyala, Iraq, jolanhussien33@gmail.com 


\section{الحطاب الجمالي للفن الزخرفي \\ (الحضارة الإسلامية أنموذجا) \\ جولان حسين علوان 2}

الملخص:

يعد الإسلام نقطة تحول كبيرة في حياة الأمة بصورة خاصة والإنسانية بصورة عامة، ذلك إن التأثير الذي أحدثته الحضارة العربية الإسلامية في الحياة البشرية قاطبة ما زلنا نلمسه ظاهراً. وقد كان الفن مظهراً من مظاهر الثقافة

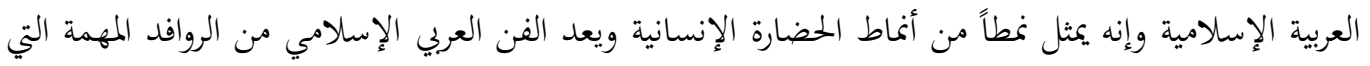

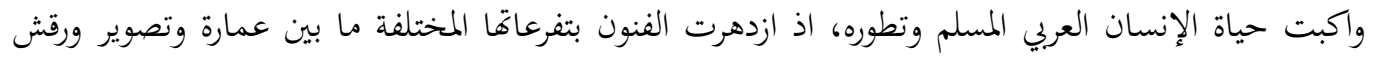
وخط وصناعات زخرفية وزجاجية ويدوية مختلفة، وقد خلت العمائر الدينية الإسلامية من التماثيل والصور وما إليها من الأدوات التي تستخدمها الكنائس المسيحية في طقوسها، كما حالت هذه التعاليم دون تقليد الطبيعة

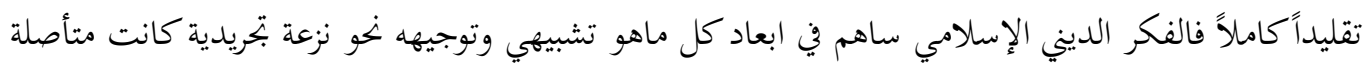

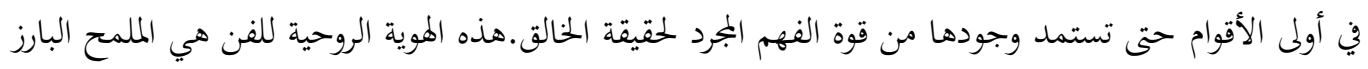

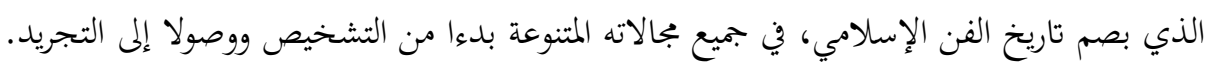
والشخصية العربية الإسلامية تبلورت في ظل الدين الإسلامي واصبح الفن وجمالياته مصدر اهتمام فلاسفة

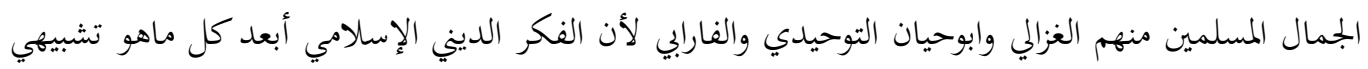
في الفن الإسلامي حتى لايكون مضاهاة للخالق.

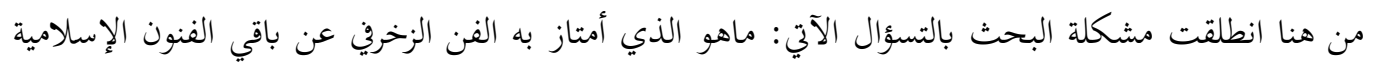

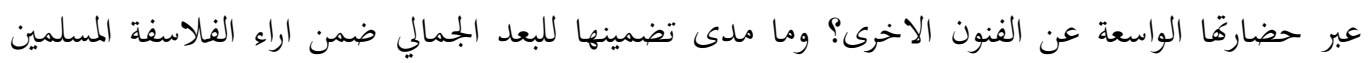

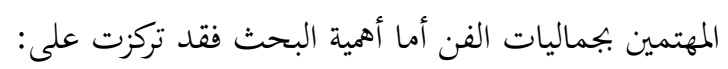
1 - 1 -إمكان اعتباره مصدر للمهتمين بدراسة الفن الإسلامي. 2-إمكانية الإطلاع على جمالية الفن الزخرفي وتوجه الفنان إلى هذا النوع من الفن. الكلمات المفتاحية: الفن الزخريف، الفنون، الحضارة الإسلامية. 


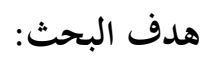

الكشف عن الخطاب الجمالي للفن الزخريف في الحضارة الإسلامية.

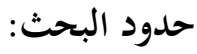

يتحدد البحث الحالي بدراسة الزخارف الفنية الإسلامية بجميع أنواعها.

وقد توصل البحث إلى اهم النتائج التالية:

1-الخطاب الجمالي يقوم على فلسفة الفنان المسلم من حيث الاعتقاد بلا هاية الوجود، فلمسلم يرى الله هو مركز الكون وكل شيء يبدء منه ليعود أليه . 2- 2 الابتعاد عن تمثيل الطبيعة وتقليدها. 3-الاهتمام بالزخارف المتوالدة والمتناظرة التي تتمركز حول عنصر لتدور وتعود إلى نفس التكوين.

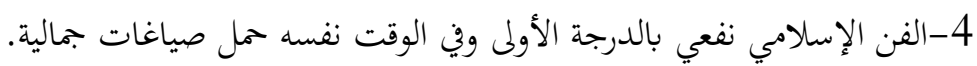

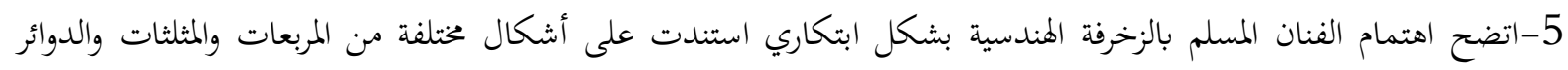
المتماسة والأشكال المتقاطعة بصيغة جمالية خالصة. 6-العناصر النباتية مصدرها فروع النبات واوراقه وازهاره ولكن بأسلوب محور .

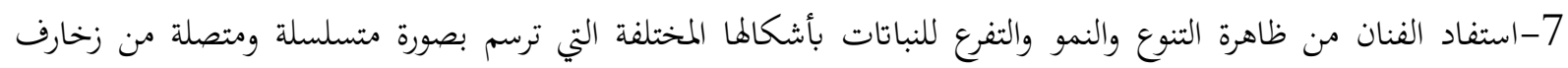

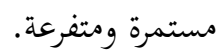
8 -استخدم الفنان المسلم الحطط العربي في الزخرفة والتزيين وفي بعض الاحيان أدخلوا عناصر نباتية في انتهاء الحرف.

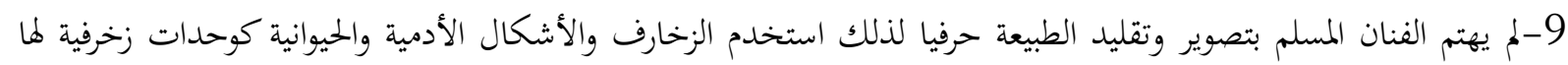
قيمتها الجمالية. 10-اشتهر الفن والتراث الإسلامي إضافة إلى الزخارف بفن الكتابة والتصوير وفن العمارة وفن الخزف وغيرها من الفنون التي جملت الطابع الجمالي. 


\section{الفصل الأول}

مشكلة البحث

ارتبط مفهوم الفن الإسلامي بما جاءت به التعاليم الدينية، فالفنان المسلم وظف نوع من الخطاب الشكلي للتعبير عن

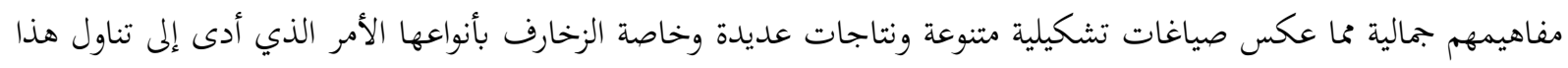

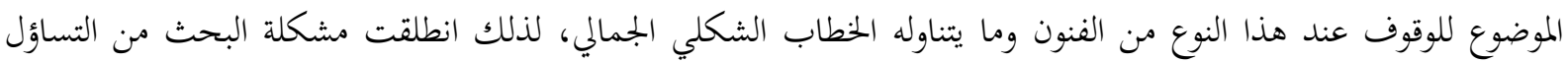

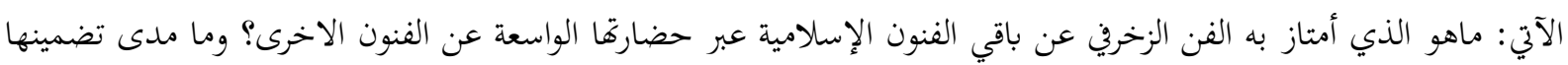
للبعد الجمالي ضمن اراء الفلاسفة المسلمين المهتمين بجماليات الفن.

أهمية البحث تتجلى أهمية البحث في: - - إمكان اعتباره مصدر للمهتمين بدراسة الفن الإسلامي.

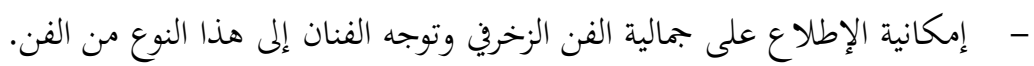

هدف البحث يهدف البحث الحالي إلى الكشف عن: الخطاب الجمالي للفن الزخرفي في الحضارة الإسلامية .

حدود البحث هناك الكثير من الفنون الإسلامية المختلفة والمتنوعة، لذلك تحدد البحث الحالي بدراسة الخطاب الجمالي للزخرفة بأنواعها

المختلفة.

تحديد مصطلحات

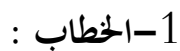

الخطاب عند (أرسطو) هو"الكلام المقنع. وهي نوع من القياس. والأدلة عنده قسمان، الأول خارج عن الفن

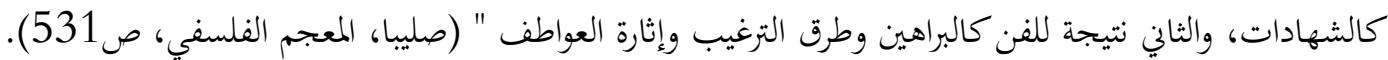
الخطاب عند (الفارابي) هو " كالجدل - تشتمل على البرهان المشوب. إلا أن الخطابة تعلم البرهان على الذي كذبه مساو لحقه،

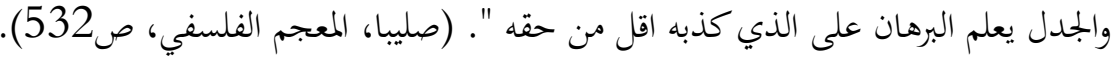
الخطاب عند (لالاند) "عملية فكرية بتري من خلال سلسلة عمليات أولية جزئية ومتتابعة. بنحو خاص، تعبير عن الفكر وتطوير

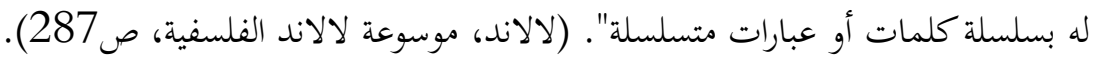
2 -الجمال:

جاء تعريف الجمال على أَنه"التناسب التام الممتع" (حسان، مقدمة في علم الجمال، ص16)، كما تم تعريفه على انه:

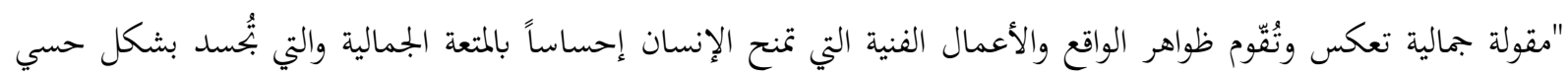


موضوعي حرية القوى الإبداعية والمعرفية وتمامها، وقدرات الإنسان في كل مجالات الحياة الاجتماعية، جوانب العمل والجوانب

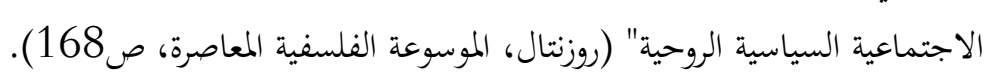
ويُعرف (كانت) الجمال على أنه " الإدراك الذي يصاحبه إثباع الحاجة الجمالية عن طريق الشعور بالمتعة، الخالية من أي

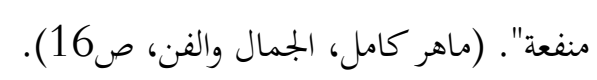
والجمال عند (سانتيانا) "يوجد في الإدراك ولا وجود له في غير ذلك. والجمال الذي لا يدرك هو لذة لا تُّس ومن تم فهو

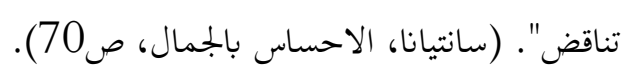
وقد جاء الجمال بتعريف (هربرت ريد) الذي يستند على أساس مادي حسي مفاده" إن الجمال وحدة للعلاقات الشكلية

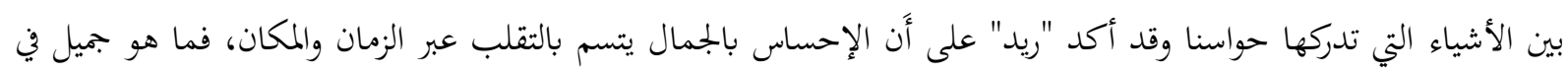

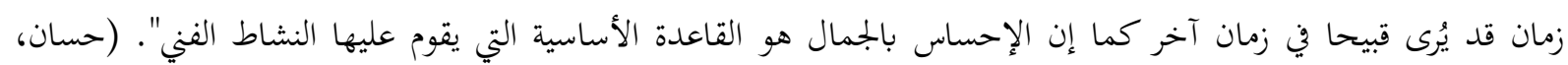

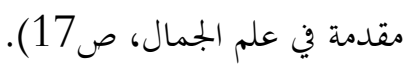




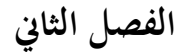

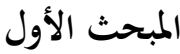

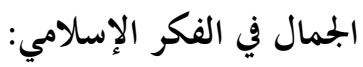

الفلسفة الجمالية الإسلامية انطلقت من روح الوحدانية وبلغت ارقى مراتبها وأكملها وقد تعددت الرؤى والأفكار الفلسفية، إذ نجد أن العرب المسلمين كانت لهم محاولات في تحديد مفهوم الجمال. ان الفلاسفة المسلمين تميزوا بنظرقم الفاحصة مرته

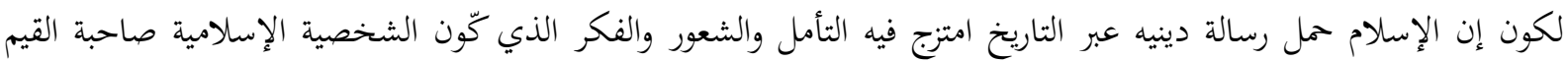

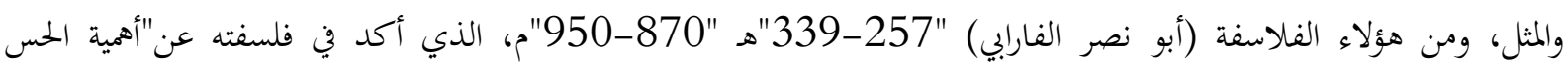
والمسوس فقد عد الفن صفة حسية أساسها التجريب، يتصف بالتصوف الرومانسي الرافض للماديات المبتذلة مصفيا للأرواح

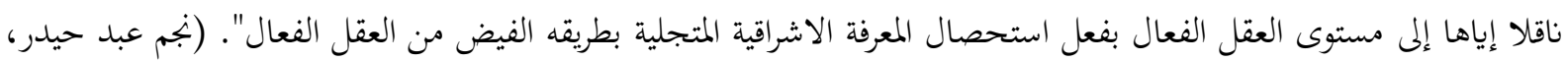

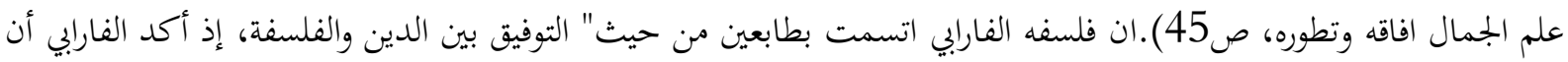

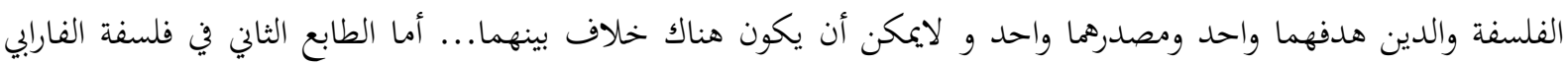
فهو التوفيق بين رأي أفلاطون وأرسطو ورفض أي اعتبار لخلافهما وهذا ماجاء في كتابه" الجمع بين رأي الحكمين" (نجم عبد واحد حيدر، علم الجمال افاقه وتطوره، صين راي الاطون ورسطو ورفض ال423).

فيعتقد الفارابي بان الخلاف بين أرسطو وأفلاطون كان خلافا بالظاهر وليس بالجوهر فمزج بنزعة رومانسية تحمل في طياتا

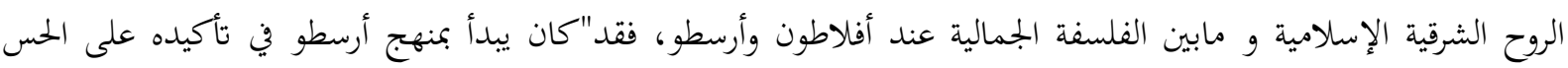

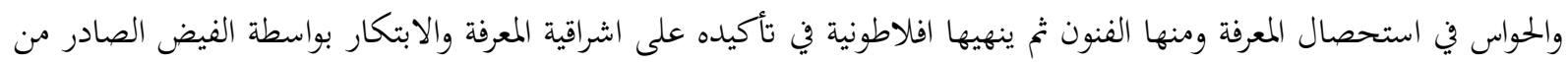
العقل الفعال واهب الصور الأبدية، فقد امتزج النظام الحسي ومعطياته وأهميته بالنظام المثالي الاشراقي الفيضي بواسطة التجرئه

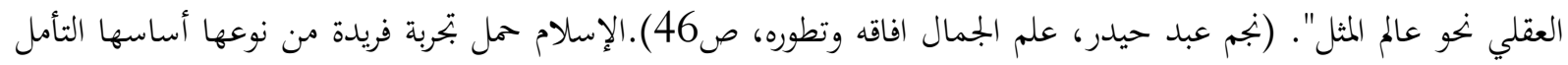

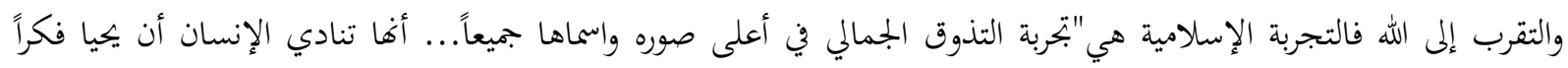

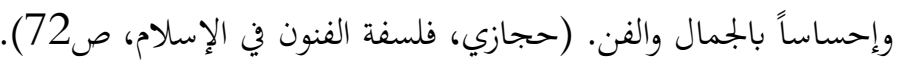

وهذا يؤكد الرؤية المثالية لابي نصر الفارابي على الرغم من تحديده درجات العقل وفعالياته وصولاً إلى اعلى المراتب وهي (الله

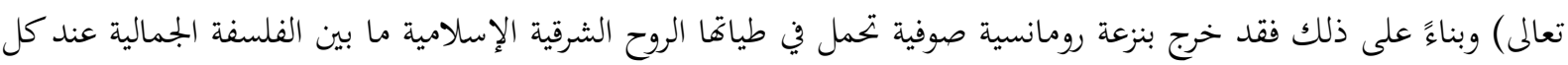

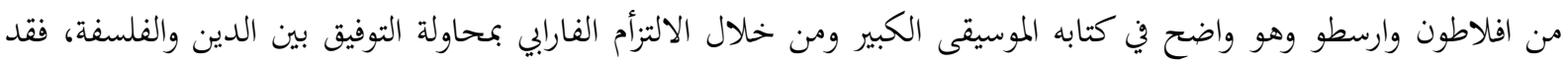

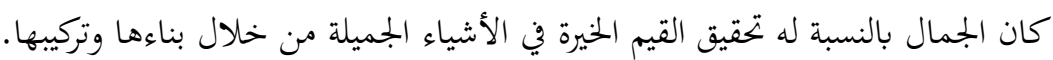
ومن خلال ما تقدم يتضح ان الفارابي قد حدد أو اشترط القيم الخيرة في معيار جماله وان صوفي النزعة، افلاطوني المثال وارسطو واقعي وهو ما عمل عليه، اذ حاول التوفيق بين الفلسفة الإسلامية والاغريقية لدى افلاطون وارسطو. أما الفيلسوف (ابن سينا) "370-428"هـ "980-1073" م.، فقد اتسمت فلسفته بأغا "عقلية في أصولها فهو كالفارابي يؤمن بالعقل الفعال مصدر للعلم والمعرفة، كما يؤمن به أيضا مصدراً للإلهام الروحي وتتسم فلسفته بأها صوفية في ألفاظها وتعابيرها وتوفيقية في غاياتا وأهدافها فلقد كان الطابع العام لفلسفة ابن سينا كما هو الحال عند الفهاب الفارابي التوفيق بين

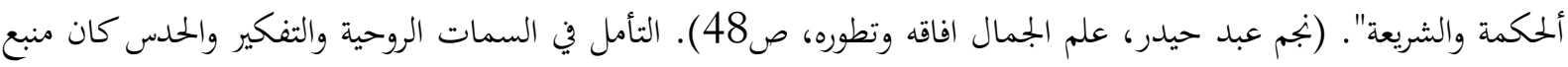

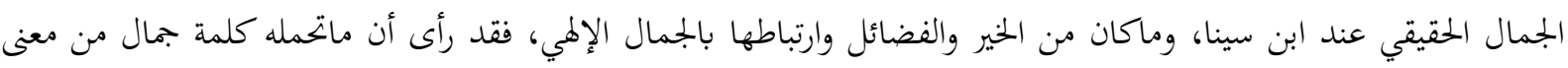

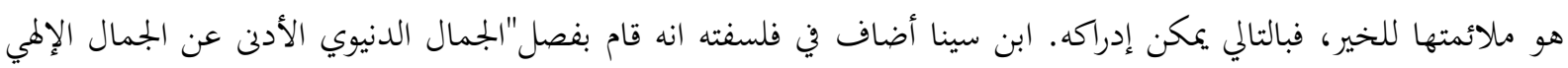

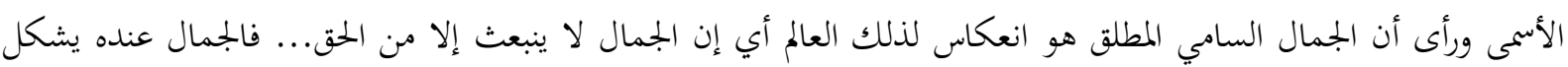


مفهوم متعدد الإطراف يدخل العقل في مجال فكري خالص فلا يوجد أي نوع جمال أو بهاء أكثر سمو من الجمال العقلي الخير

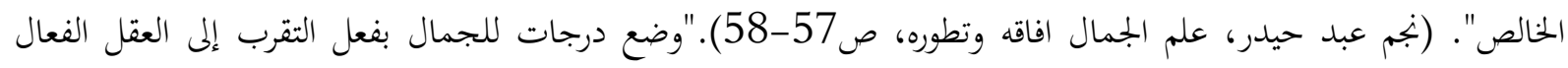
واهب الصور وواهب الكليات وبالنتيجة واهب الجمال، فالجمال الحقيقي هو الجمال الإلهي، الجمال المقترب من الجمال السماء

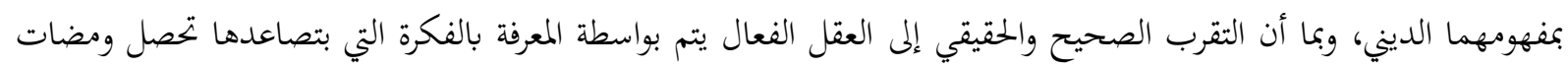

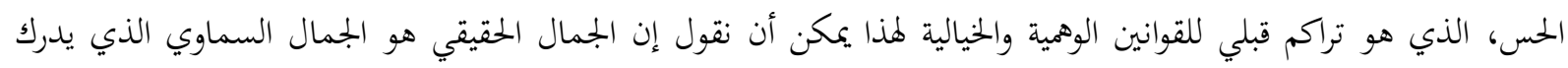

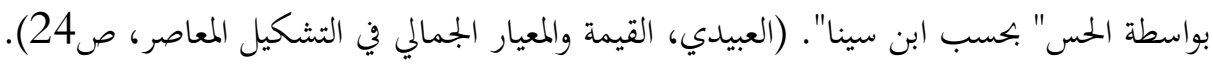

واشتملت المعرفة عند ابن سينا على ثلاثة مستويات:

$$
\begin{aligned}
& \text { 1- 1 "معرفه بالفطرة..." العقل الابتدائي العملي." } \\
& \text { 2- معرفه بالفكرة.... " العقل المستفاد." } \\
& \text { 3-معرفه الحدس..." العقل المبدع. المبتكر. العقل القدسي. الروح القدسية" بالفخرة. }
\end{aligned}
$$

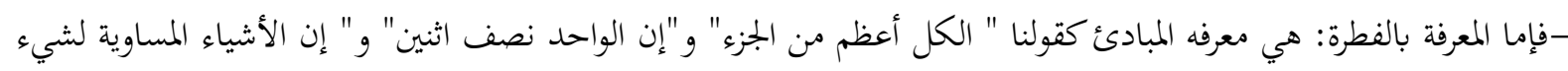

$$
\text { واحد متساوية." }
$$

- بما أن المعرفة بالفكرة مكتسبه وتكون بإدراك المجردات المعقدة والكليات العامة والانتعاش بها، والمرء يحتاج إلى مجهود أكبر من

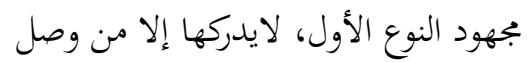

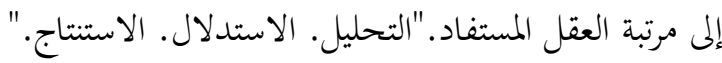

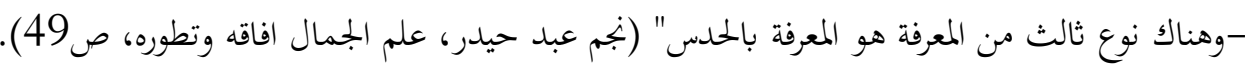

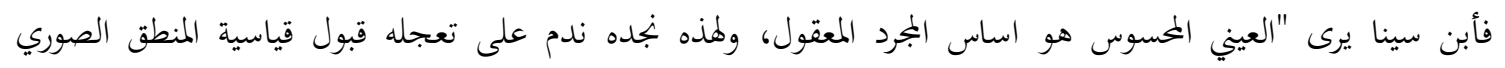

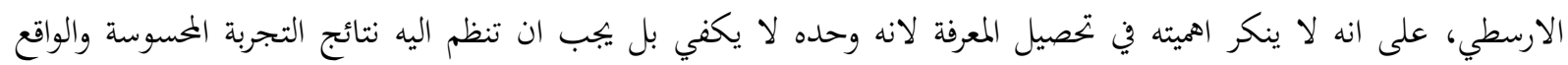

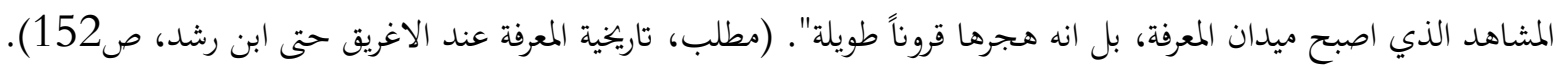
وعند انتقالنا إلى الموقف الجمالي عند (أبو حامد الغزالي)"1058-1111"نجده يقول "واعلم أَن كل جمال محبوب عند مدرك ذلك الجمال، والله تعالى جميل يحب الجمال وأَن كان الجمال بالحلال والعظمة وعلو الرتبة وحسن الصفات والأخلاق وأرادة

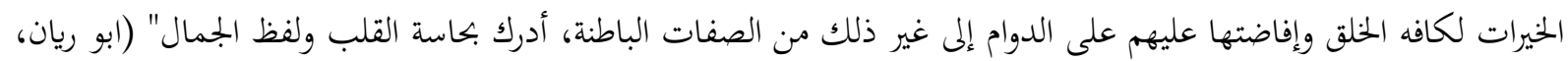

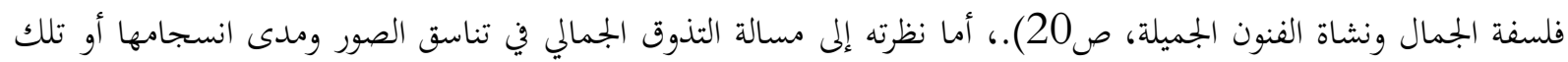
التي لها علاقة بالصفات ألباطنة وكيفية إدراكها، أو تلك التي تدرك بالعقل، نجده قد أشار إلى ثلاثة ظواهر مهمة وهي "حسية، وجدانية، عقلية"، موقف الغزالي الجمالي ارتبط أيضا بالجمالية الإلهية، إن كانت حسية وجدانية أو عقلية.

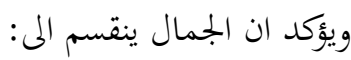

1 1 -"جمال الصورة الواضحة المدركة بعين الراس وهو جمال حسي.

2-جمال الصورة الباطنة المدركة بعين القلب ونور البصيرة وهو جمال وجداني" (الغزالي، احياء علوم الدين، ص306). إما الفيلسوف العربي (ابن رشد)"1126-1194" نجد أَنه قد عارض الغزالي"الذي دافع عن أسس "الاحتمالية المثالية"

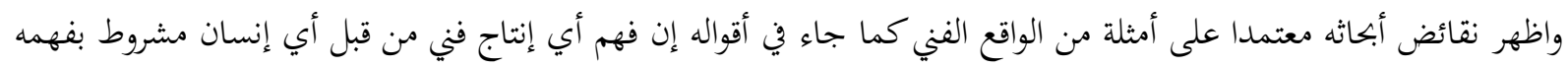

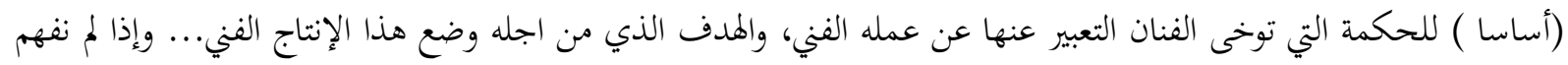

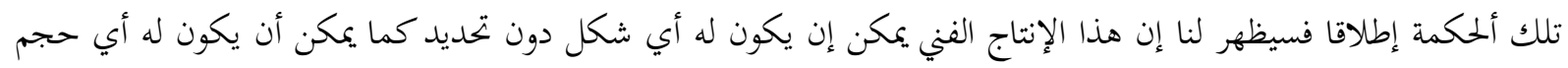

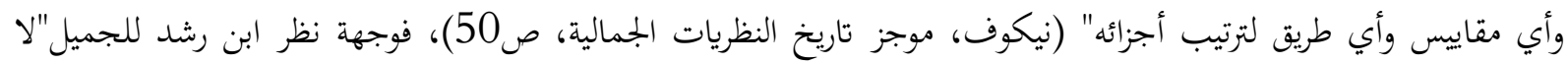


ينبغي أن تفهم كقيمة أو كطبيعة كونه كذلك وإنما يتعين أن يستدل عليه من تناول منهاجي تحليلي لواقع مدرك ينظر إليه على انه

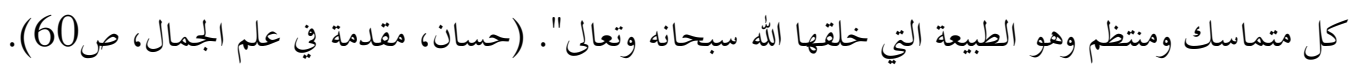

وهناك الفيلسوف العربي الإسلامي الأخر (ابو حيان التوحيدي) الذي يتساءل قائلاً: "ما سبب استحسان الصورة الحسنة؟

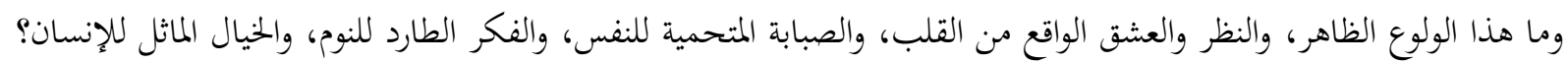

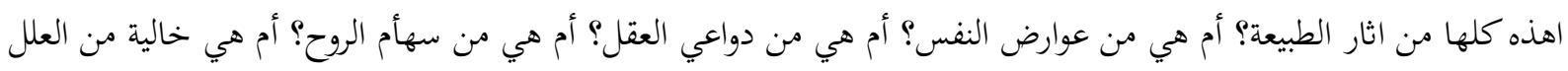

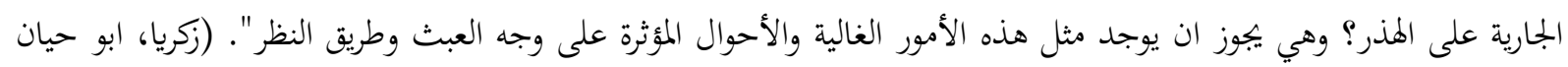
التوحيدي، ص273)

"لقد وضع التوحيدي شروطاً للتذوق الجمالي اولها اعتدال مزاج المتذوق والثاني هو تناسب اعضاء الشيء المتذوق في

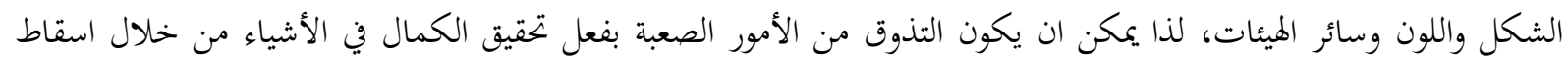

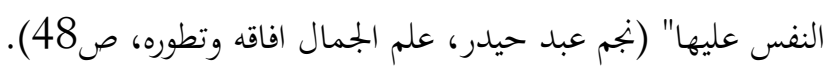

وفي هذا يذكرنا التوحيدي باشتراطات التناسب بين الاجزاء للعمل الفني لدى ارسطو وانسجأماته بين عناصره المتعددة

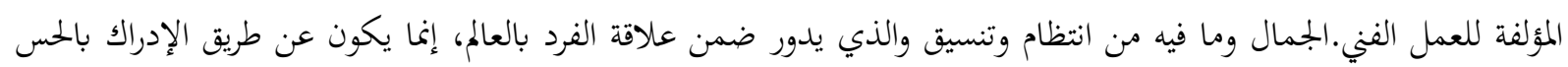

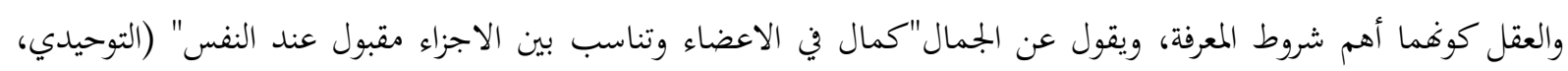

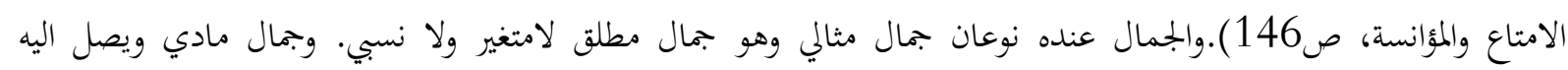
بالحواس وخاضع للتغيير، فالتوحيدي يربط الجميل بما هو نافع وخير. اما (ابن قيم الجوزية) فقد قسم الجمال المي: - الم 1 2-جمال باطن وهو يرى بان الجمال الباطن هو المحبوب لذاته وهو جمال العلم والعقل والجود والعفة والشجاعة وهو محل نظر الله

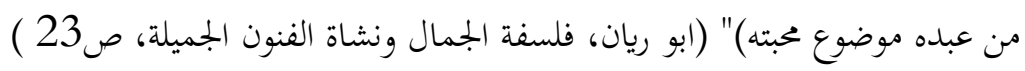
اما الفيلسوف ابن حزم الاندلسي فقد ذكر في كتابه (طوق الحمامة) عن الجمال"ان النفس الحسنة تولع بكل شيئ حسن،

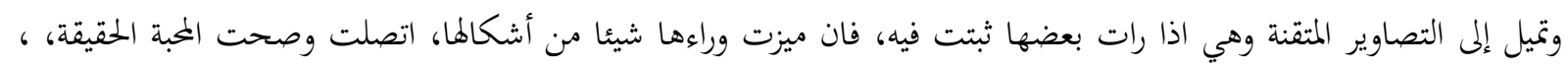

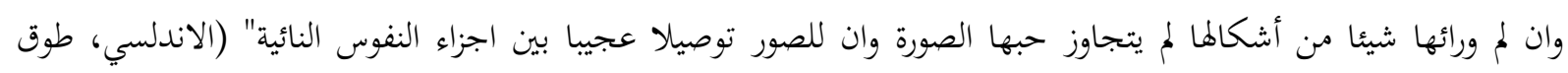
الحمامة، ص22).

وكان من أهم المفاهيم التي لعبت دورا ذات أهميه في نظريات الفلاسفة الجمالية هو" مفهوم التناسق " الهارمونيه" إن المفهوم

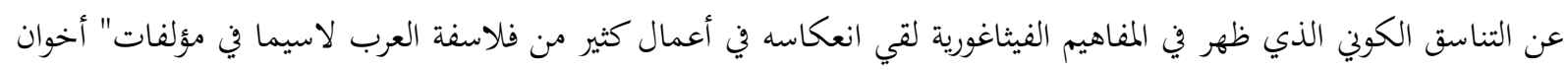

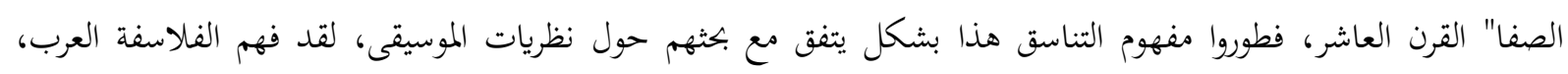

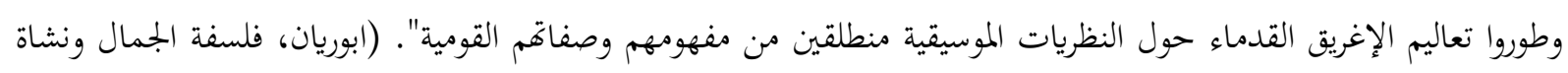

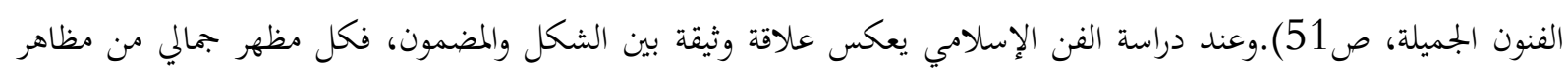
الفن الإسلامي يعكس مضمون فلسفي حامل لخطاب جمالي. 
للفن الإسلامي مكانة مهمة لكونه قد حمل خطاب لصور منتزعة من واقع الحياة الطبيعية أو انعكاسا لاشعوريا لوجدان وواقع الفنان ذاته، حيث كانت العلاقة بينه وبين الإسلام بوصفه فلسفة للحياة وعقيدة للإنسان المسلم ونظاما للمجتمع الجلديد

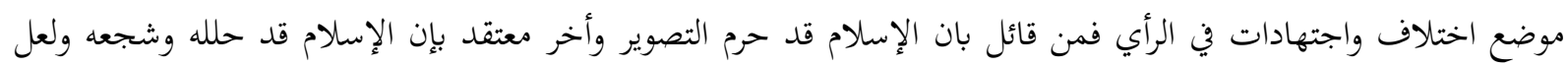

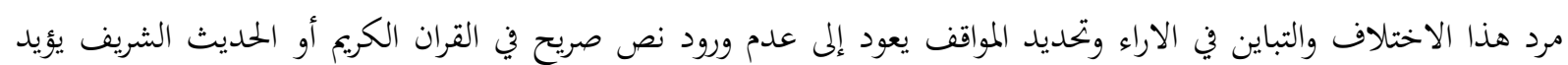
التحريم أو يؤكد التحليل.

أهم سمات الفن الإسلامي هي الفلسفة التي يقوم عليها من حيث الاعتقاد، فلمسلم يرى الله بقوته وعظمته ورحمته هو مركز

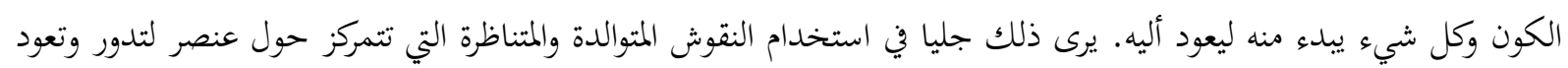

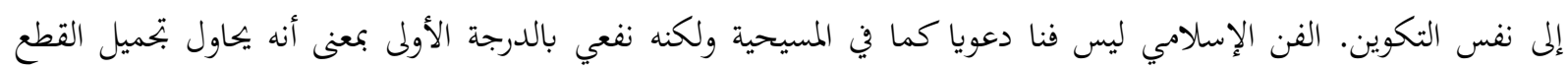

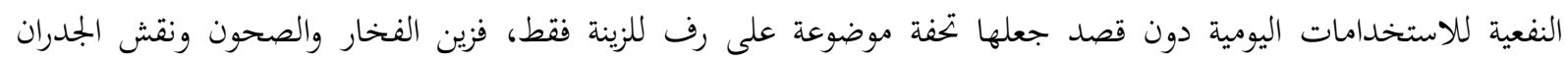

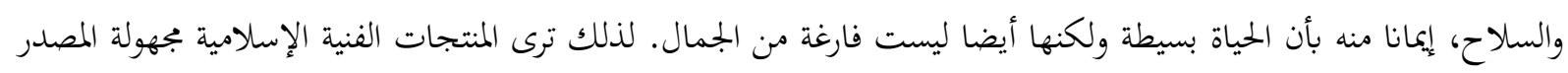
أو الصانع، لأن من يصنعها لم يقصد منها تقديم نفسه كفنان مستقل ولكنه كان يحرص على تقديم شيء جميل ينتفع به. لقد تطرق الفن الإسلامي إلى مجالات عدة، كالفخار والبناء (المساجد والقصور) والمعادن (السلاح والأواني والحلي)، و النسيج (السجاد والأقمشة).

كما عرف الفن الإسلامي التعامل مع بعض الخامات بابتكارية جميلة كالورق والجلود والخشب ووظفها بحرفية عالية. فتجد النجارة في الفن الإسلامي قد أسست لعلم جديد وإبداعي في استخدام الخشب وتطويعه بطرق غير مسبوقة كالارابيسك

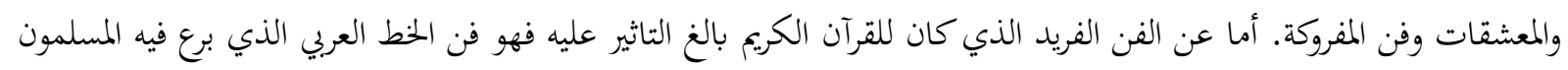

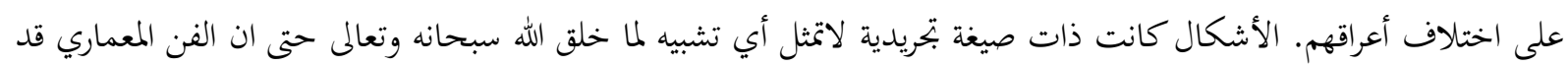

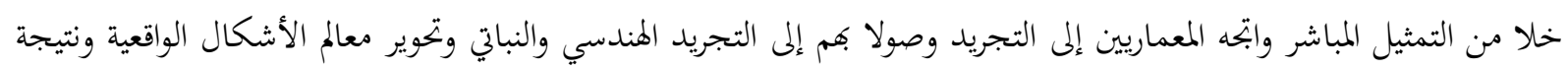

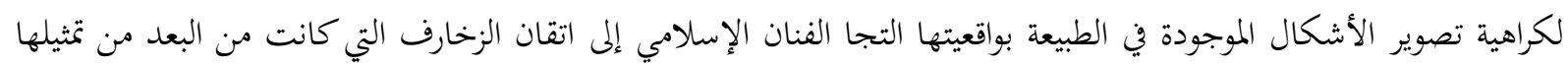
وبتحسيمها للطبيعة.انظر شكل 1، (2).

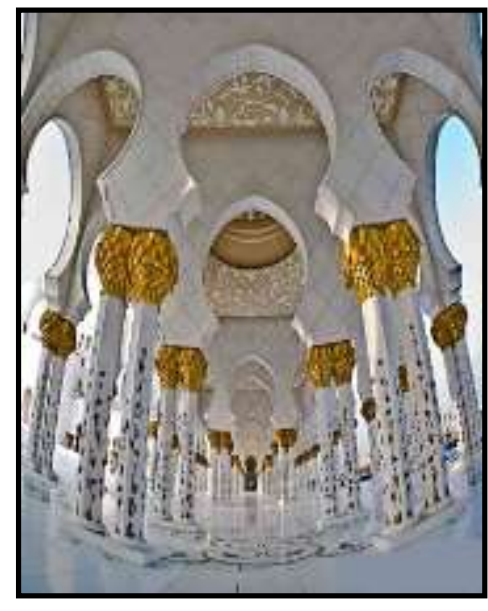

شكل (2) - )

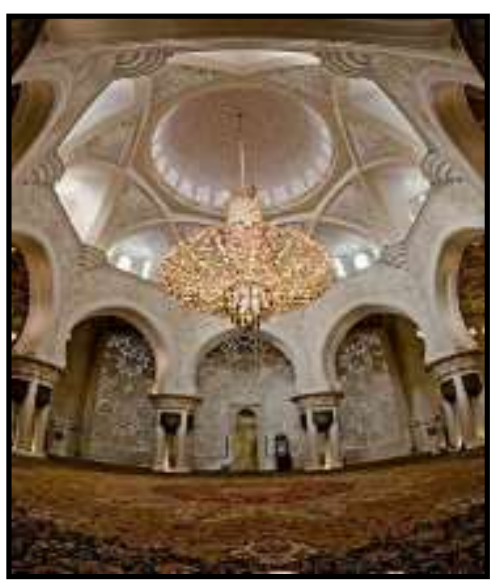

شكل (1) - ) 
يعد الإسلام نقطة تحول كبيرة في حياة الأمة بصورة خاصة والإنسانية بصورة عامة، ذلك ان التأثير الذي أحدثثه الحضارة العربية الإسلامية في الحياة البشرية قاطبة ما زلنا نلمسه ظاهراً."

ويعد الفن العربي الإسلامي من الروافد المهمة التي واكبت حياة الإنسان العربي المسلم وتطوره، اذ ازدهرت الفنون بتفرعاهما

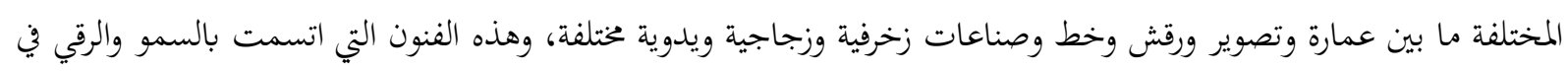

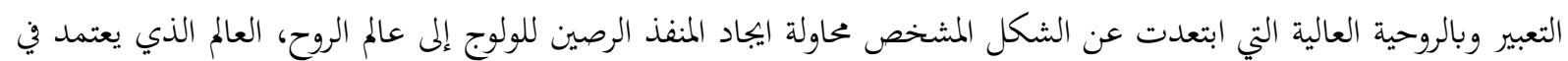

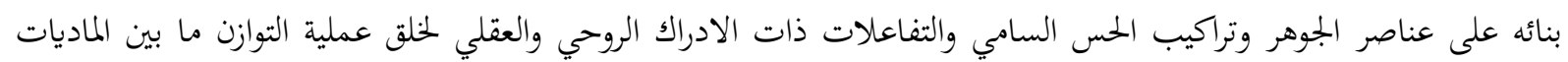

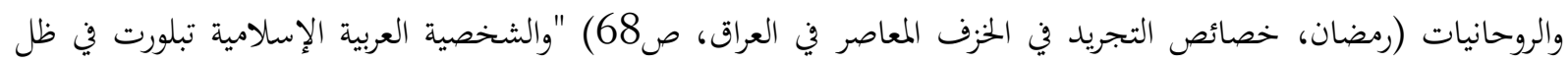
الدين الإسلامي واصبحت ذات كيان ووحدة متكاملة، وظهر ذلك جليا في الفنون التشكيلية والعمارة الإسلامية (الالوسي،

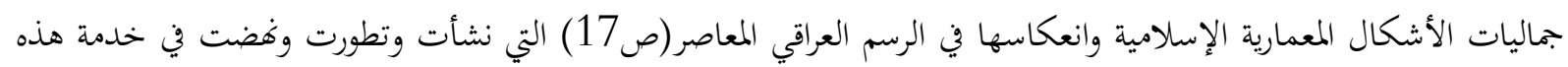

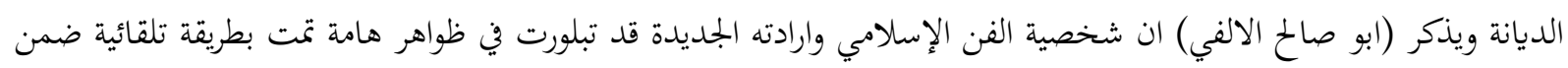
اطار الفلسفة الشرقية العامة واوجزها بما يأتي: 1 - كراهية تمثيل الكائنات الحية.

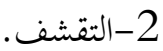

3-الاهتمام بزخرفة السطوح وشغل الفراغ." (الالفي، التذوق وتاريخ الفن، ص26-27). وبذلك لم يتجه الفنان المسلم إلى النحت في المدة الإسلامية وذلك طبقاً لتعاليم الإسلام فقد "خلت العمائر الدينية

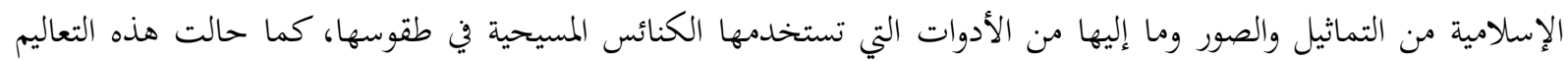

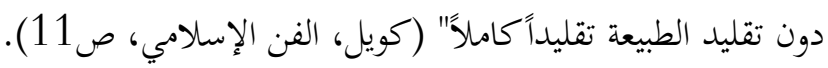
فالفكر الديني الإسلامي ساهم في ابعاد كل ماهو تشبيهي في الفن الإسلامي وتوجيهه نخو نزعة تجريدية كانت متأصلة في

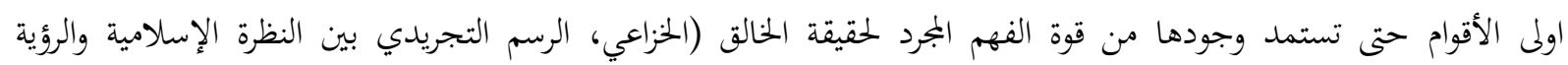

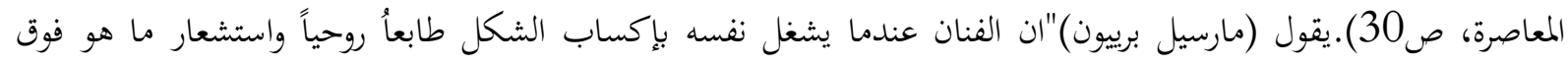

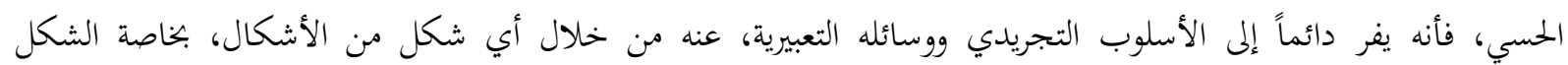

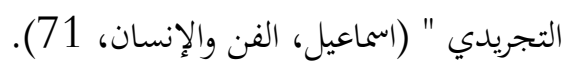
فنرى عدم رغبة الفنان المسلم وميله إلى النحت لأن الإسلام عندما جاء اعلن الحرب على الاصنام والوثنية وقد جاء ذلك

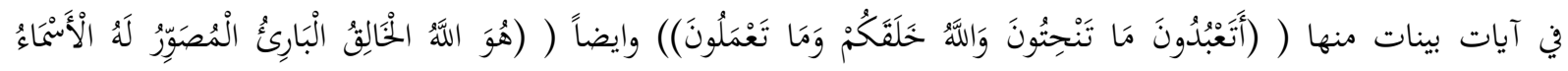

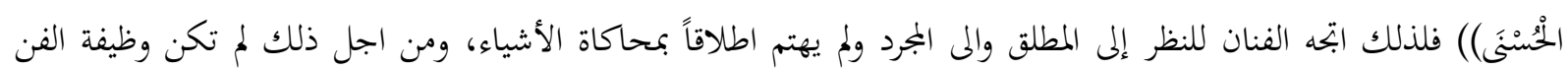

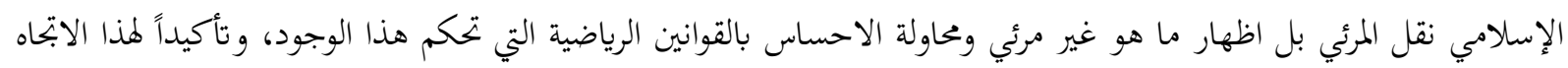

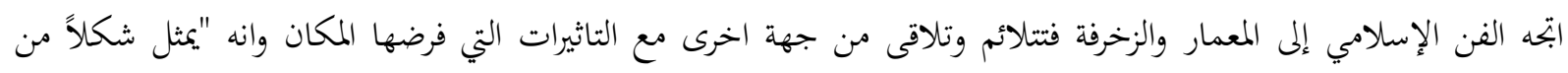

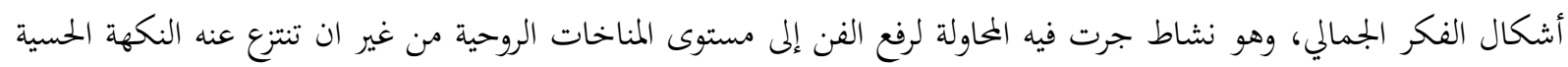

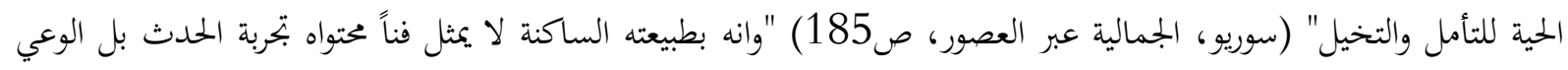

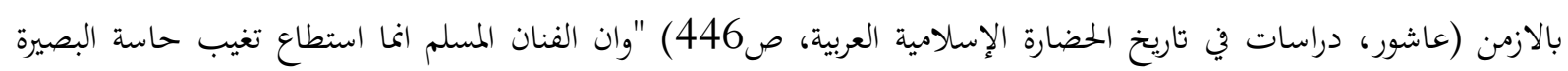

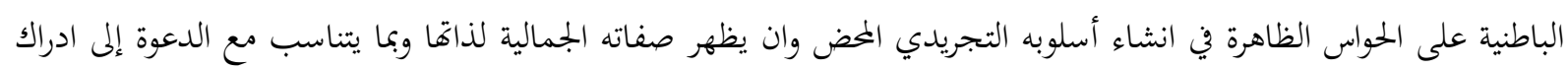

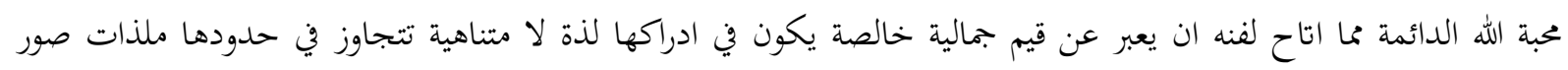

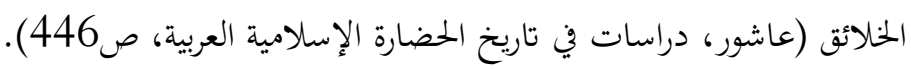


الفنان المسلم اوجد للطبيعة نظاما خاصاً بها وفرض عليها عالماً تشكيلياً نقلها من المدرك الحسي والظواهر الموضوعية إلى

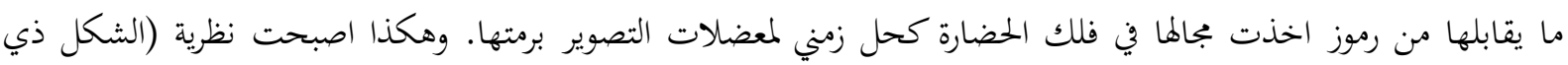

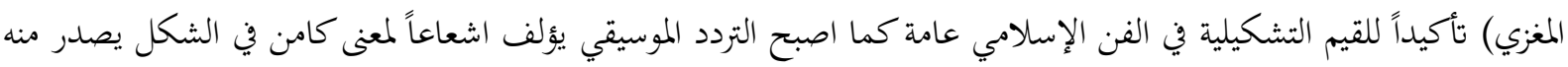
وينبيء عن صفاته الصورية. وكنتيجة لهذه الحالة، انتهى كل عصر إلى اختيار ما يناسبه من أشكال الفن، لأن تاثير التركمات التهات

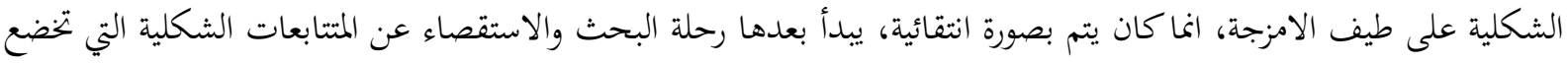

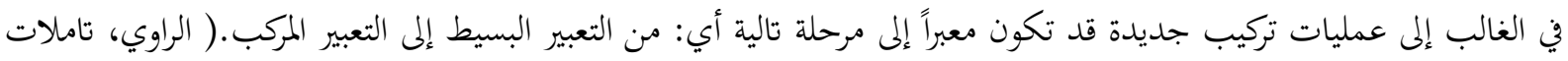
في الفن الإسلامي، ص6 ك-7)

إن الوسائل التصويرية التي هي بطبيعتها وجوهرها قد أعدت لوصف الأشياء وتقريبها إلى الحس اضحت وهي ذات قيمة مجردة فصلت عن موضوعها الذاتي ( ترمي إلى التعبير عن الافكار ) أو الترجمة عن المشاعر بشكل متسام يقرب من مهمة المطلق

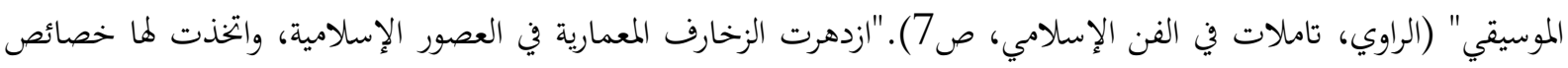

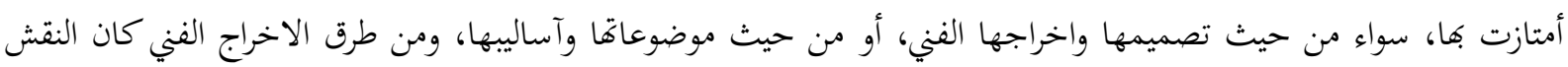

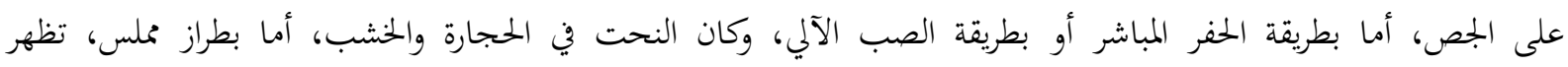

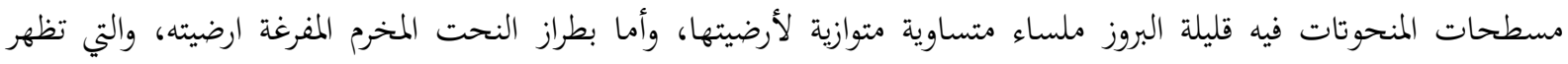
الزخارف عليها ناصعة واضحة المعالم، والارضية غائرة قاتمة، وانتشر استخدام الفسيفساء والقرميد والحجارة المختلفة الالوان".

$$
\text { (فكري، محيط الفنون، صنارف 188). }
$$

كان للفن الإسلامي هدفاً مختلفاً عن أهداف الفنون التي سبقته فقد البحه نحو التحوير والتجريد والتهذيب للطبيعة قد بحاوز

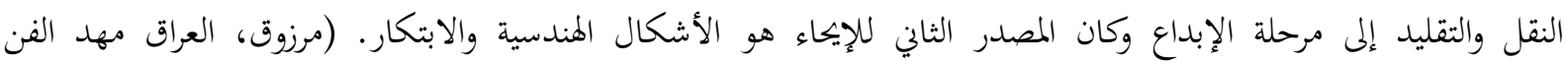

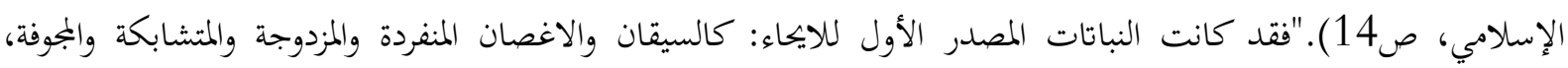

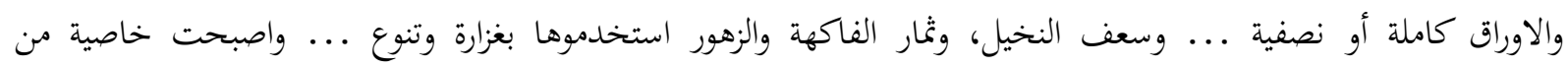

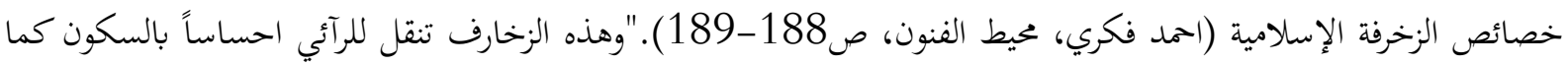

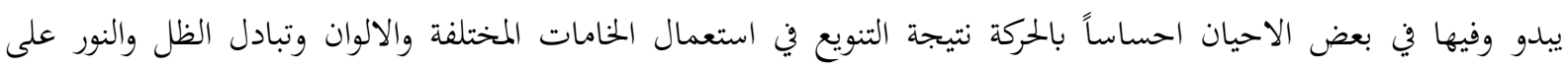

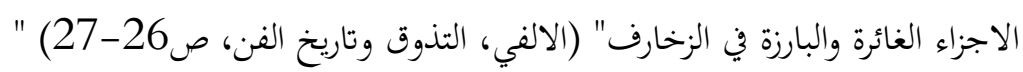

وكانت الكتابة العربية هي المصدر الثالث للايحاء الزخريف المعماري (شكل 37) واما من حيث الآساليب أو طرق التعبير

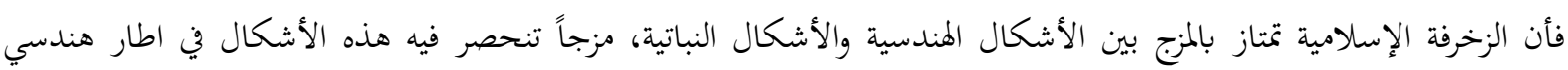

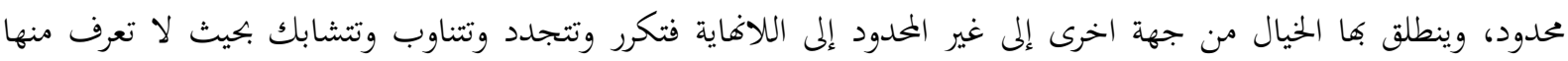

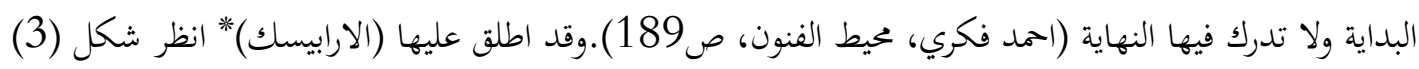

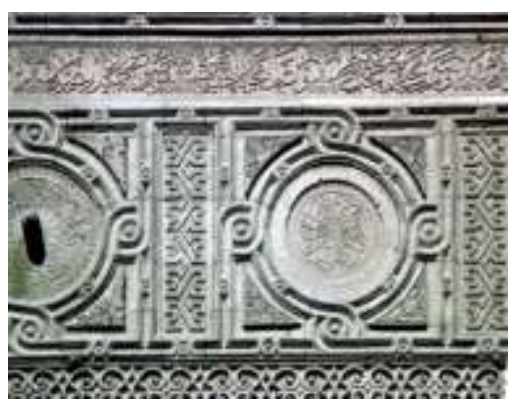

شكل (3) 
إن ابتحاه الفنان المسلم نحو الرقش والزخرفة محاولة نهو الاختزال واللاتشخيص فهو دائماً يبحث عن الروحي والقيم الظاهرة

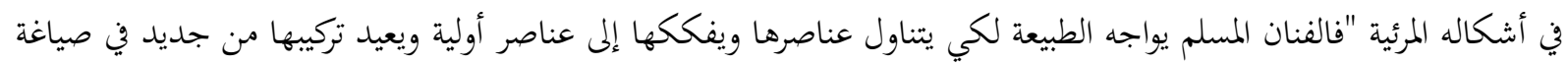

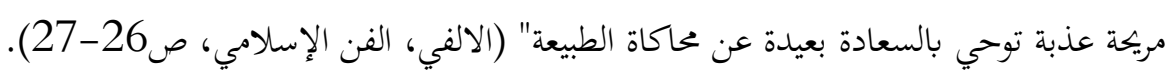

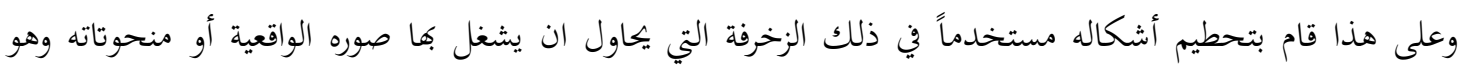

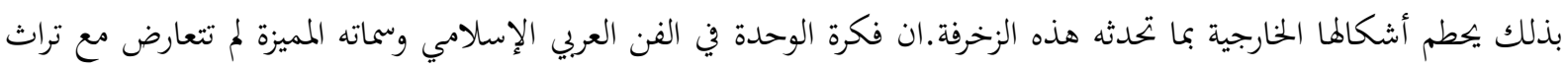

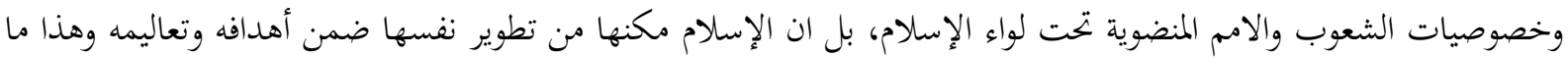

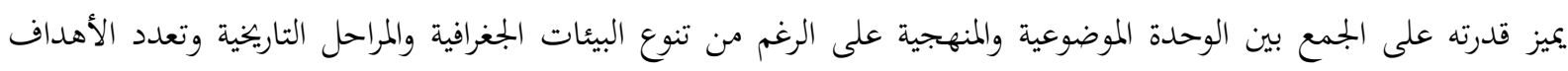

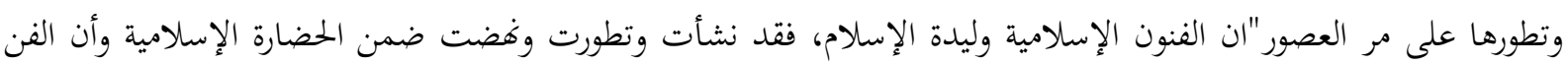

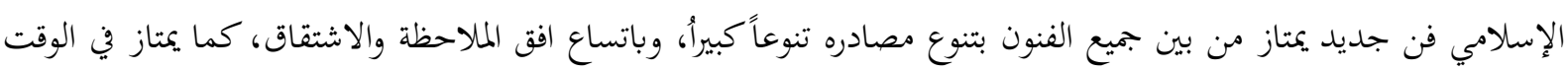

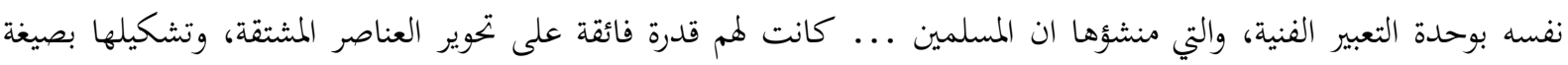

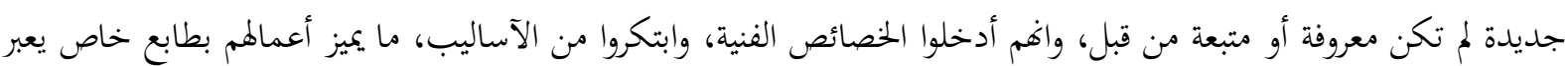

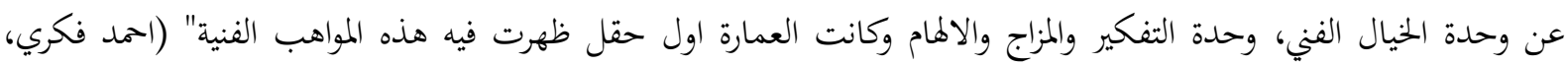

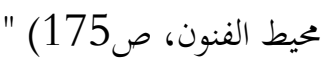
ولذلك انبثتت من الموروث الإسلامي الأشكال المعمارية التي يرجع نشوها إلى السيادة المطلقة للتعاليم القرآنية والشريعة

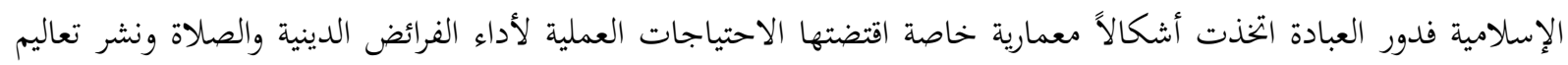

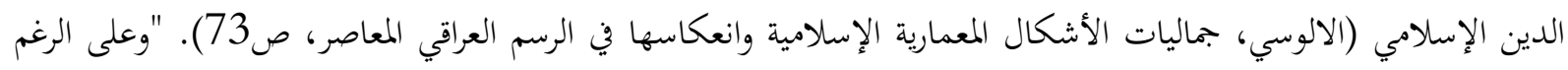

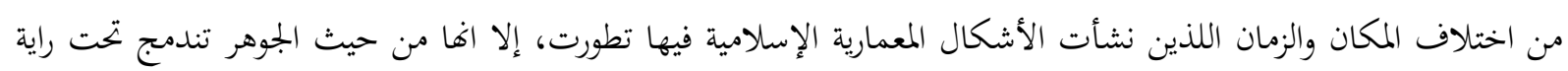

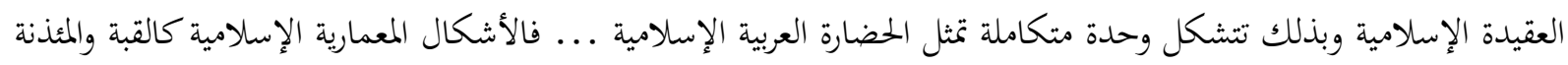
والعقد والحراب والزخرفة وغيرها ... هي اللبنات التي بنت عليها العمارة الإسلامية مجدها وعظمتها ل... وان الفن المعماري هو الإسية

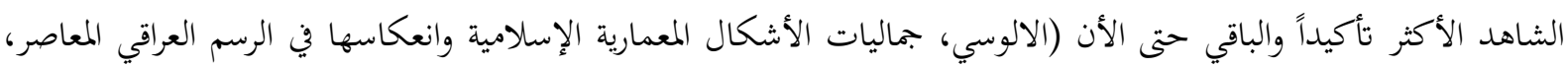

وبالنسبة لهذه التكوينات والأشكال المعمارية فقد شكلت كل واحدة منها عنصراً مهماً ذا قيمة فنية ووظيفة جمالية في آن

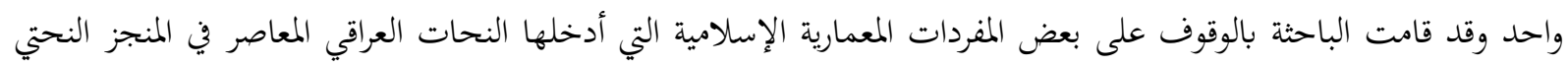

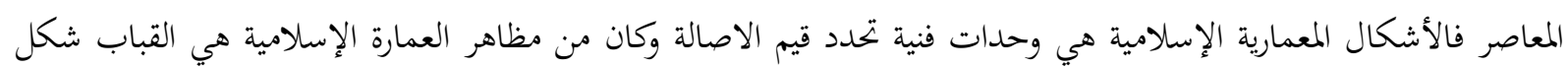

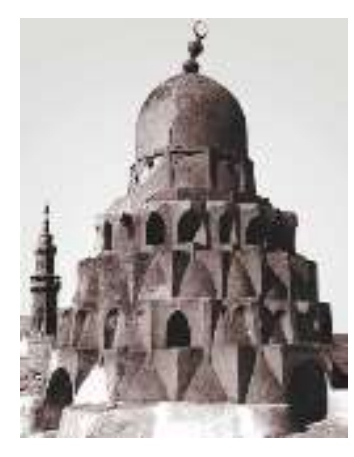

(4) شكل (4)

وقد استخدمت في العالم الإسلامي في الجوامع والاضرحة وهي "من الأشكال المعمارية التي عرفها الفن العربي الإسلامي

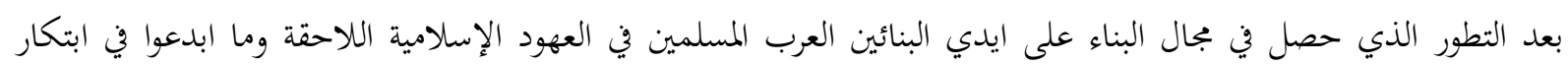


وإضافة وحدات زخرفية هندسية ونباتة وكتابية، مما اضفى عليها سمة جمالية خاصة وجعلها في مقدمة الأشكال المعمارية"

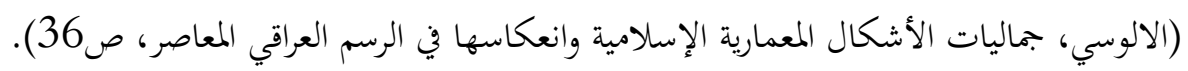

وقد كانت القباب تغطي بالواح من البلاط المزجج، واستخدمت المقرنصات في داخلها على عنق القبة من الخارج وتضيف

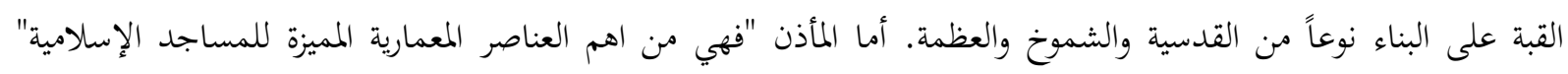

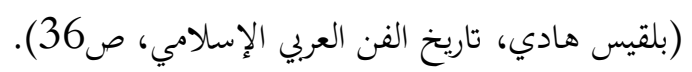

وقد تنوع أشكالها واحجامها من مكعبة واسطوانية وحلزونية وتعددت طوابقها وارتفعت اعناقها وامتشقت قوائمها.

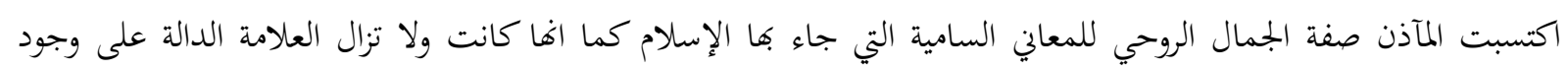

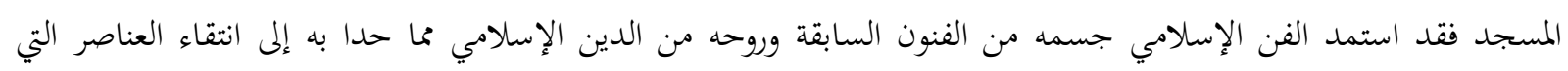

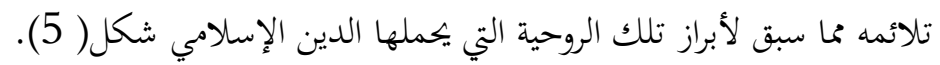

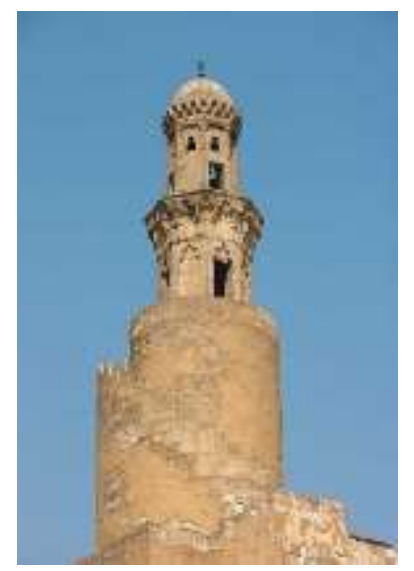

شكل (5)

لأن هناك نغمة اساسية وايقاعاً مشتركاً يتكرر بالحاح في جميع نواحي الوجود الطبيعي والحياة البشرية في الماضي والحاضر"

$$
\text { (الالفي، الفن الإسلامي، صوب). }
$$

وكان المحراب ايضاً ابتكاراً معمارياً وقد وضع في جدار القبلة لتعيين ابتاهها وفكرته كانت عند المسلمين منذ السنة الثانية

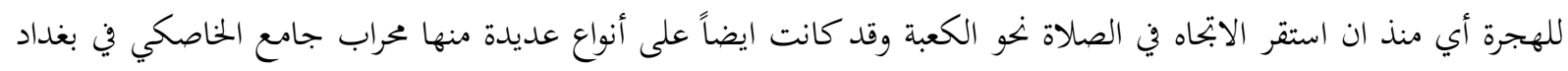
شكل (6)، وتطالعنا الأشكال المعمارية الاخرى وهي العقود والتي كان من ضمنها العقد المدبب شكاه الهل 7.

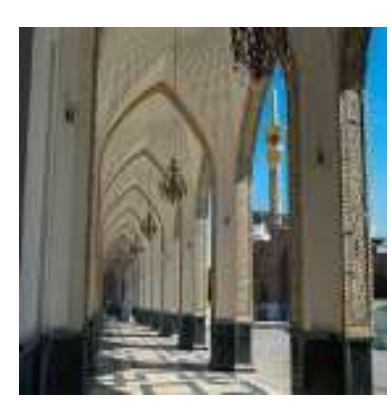

شكل (7)

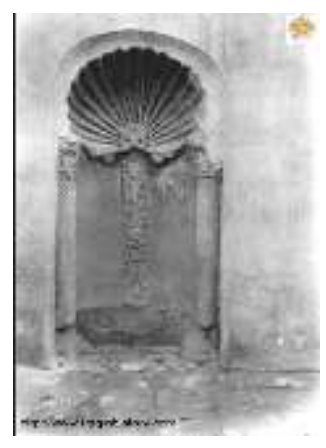

شكل (6) 


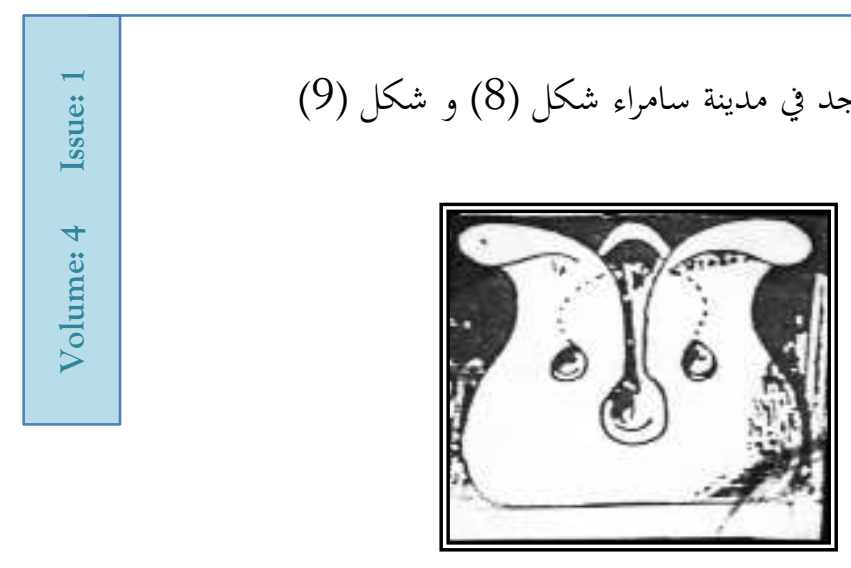

شكل(9)

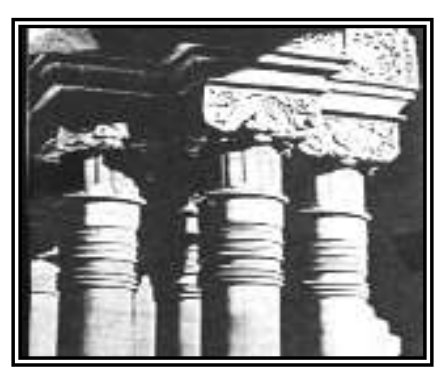

شكل (8)

وخلاصة ما تقدم هو انه نتيجة لأبتعاد الفنان المسلم عن المحاكاة الطبيعة فقد ابحه نخو الزخرفة بأشكالها النباتية والهندسية

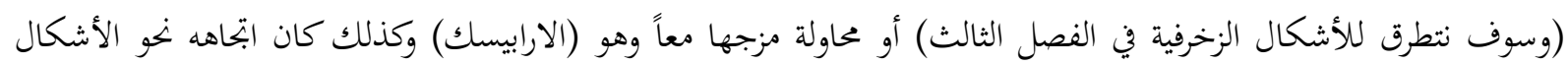

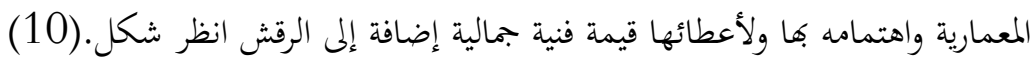

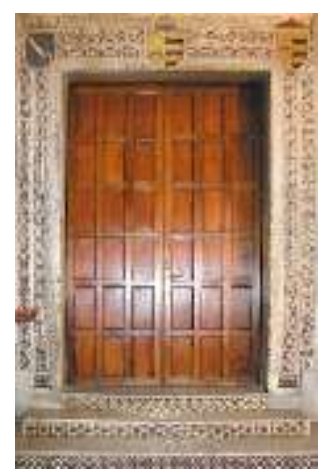

شكل (10) 

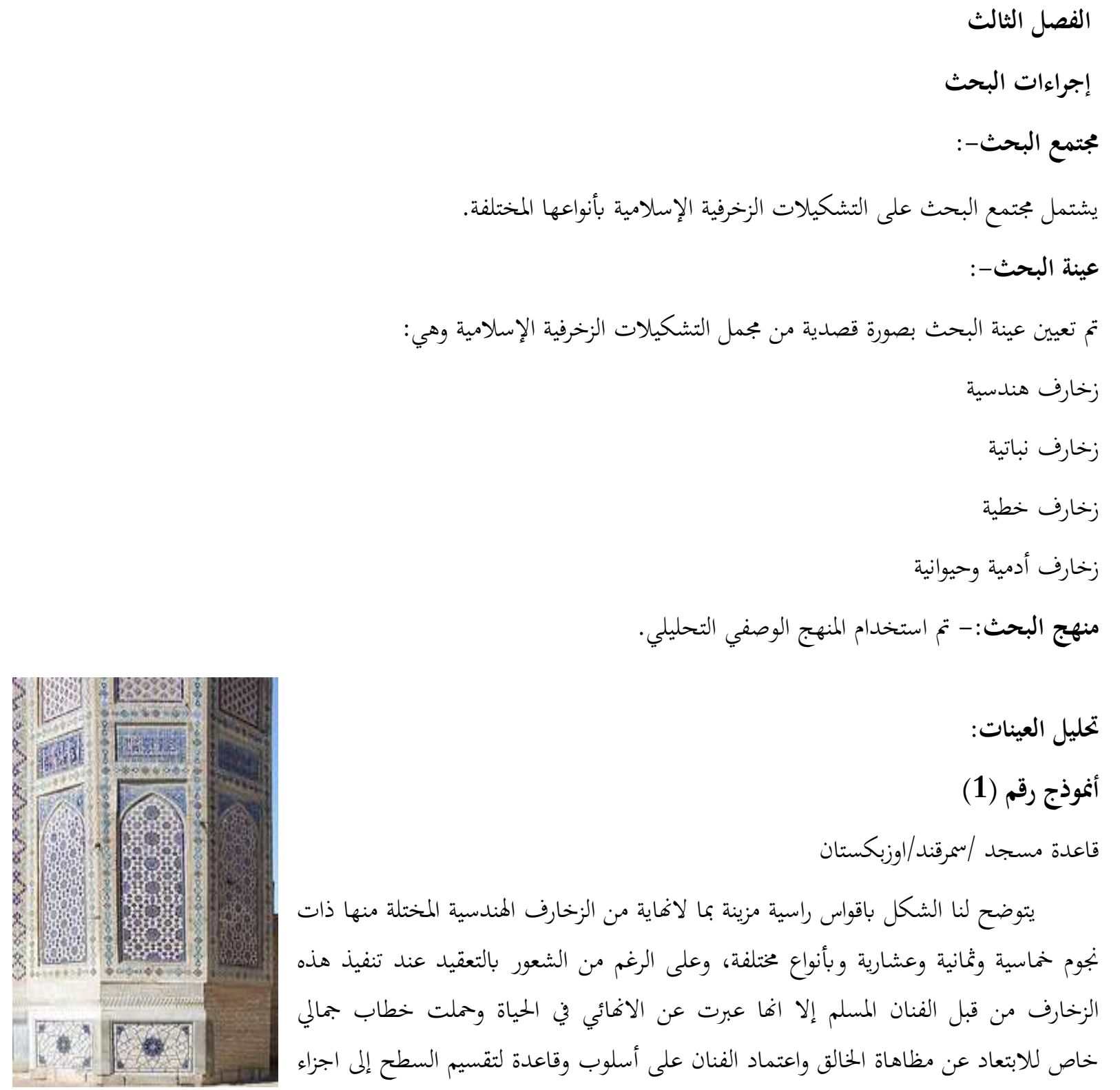

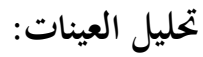

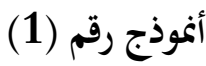

قاعدة مسجد /سمرقند/اوزبكستان

يتوضح لنا الشكل باقواس راسية مزينة بما لاهاية من الزخارف الهندسية المختلة منها ذات

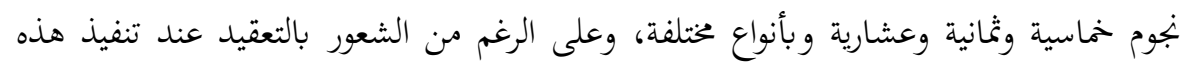

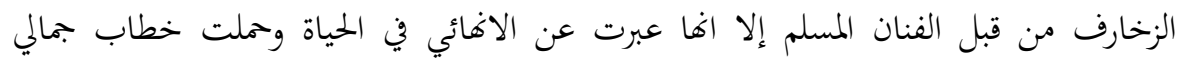
خاص للابتعاد عن مظاهاة الخالق واعتماد الفنان على أسلوب وقاعدة لتقسيم السطح إلى اجزاء متساوية لتنفيذ هذا النوع من الزخارف مما يعطي الانطباع لاهتمام الفنان المسلم بالشكل الهندسي نظريا وتطبيقيا فترتيب الأشكال الهندسية حملت نوع من الايقاع والتوازن والترتيب.

ان ابتحاه الفنان المسلم نحو الزخرفة هو محاولة نحو الاختزال واللاتشخيص فهو دائماً يبحث عن الروحي والقيم الظاهرة في

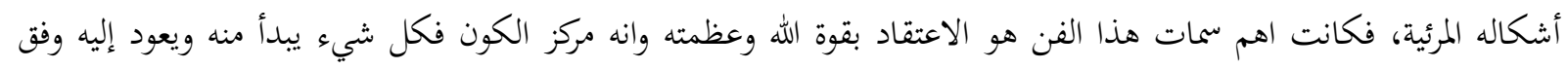

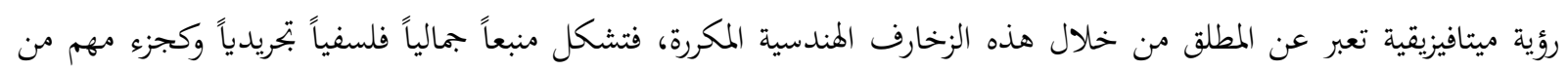

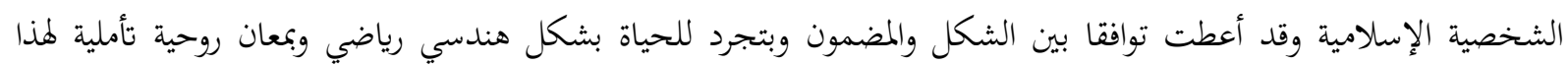

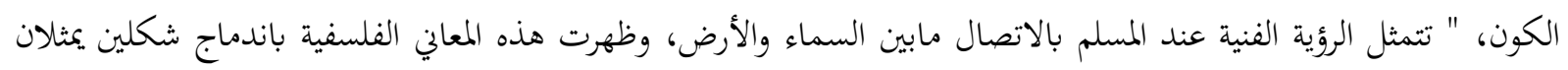

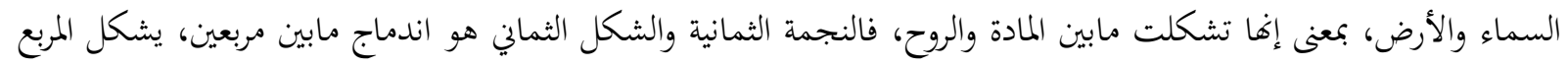

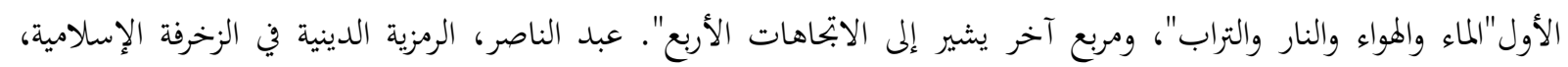

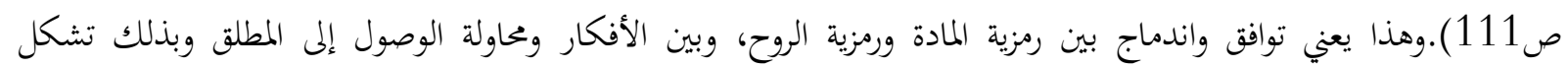
الوحدات الزخرفية حركة متتابعة فليس هناك بداية أو غهاية تمتعت بالديناميكية. 


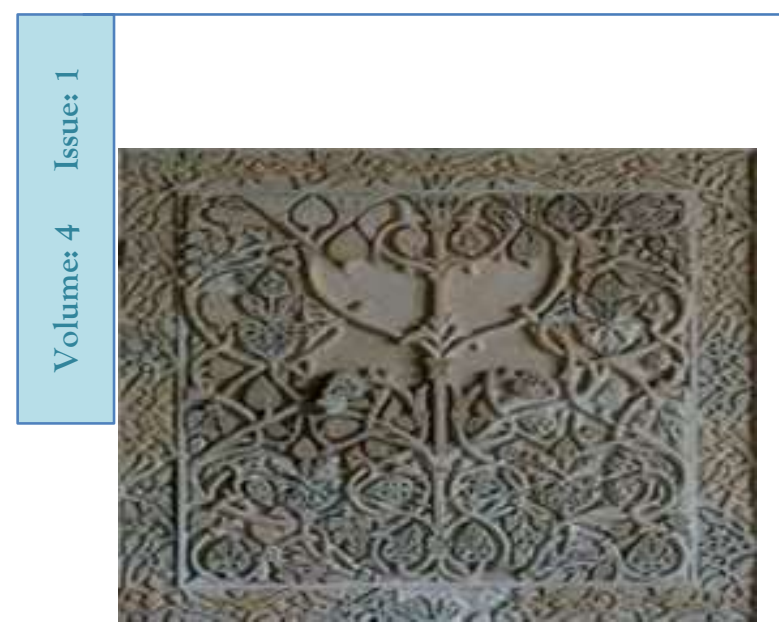

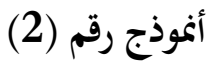

زخارف نباتية-سامراء

العنصر النباتي في الزخارف الإسلامية تأثر كثيرًا بانصراف المسلمين إلى

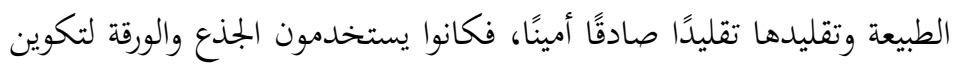
زخارف تمتاز بما فيها من تكرار وتقابل وتناظر، تدل على سيادة مبدأ التجريد والرمز في الفنون الإسلامية وأكثر الزخارف النباتية انتشارا في الفنون الإسلامية وناية

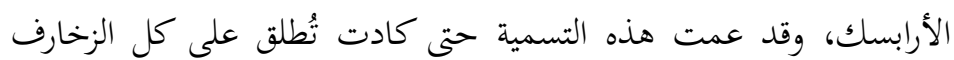

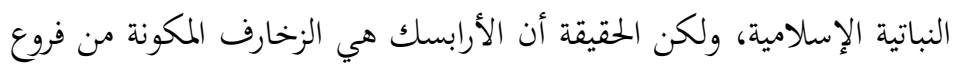

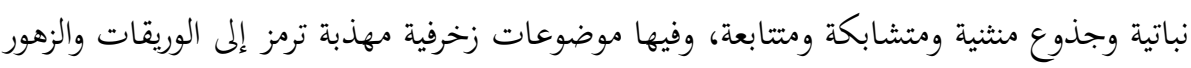
الحيز المجرد الفني الجمالي يتحول إلى بنية متجزئة ومشبعة بالضوء وتكوين مناخات ضوئية روحية تتنقل بين الساكن والمتحرك والفنان المسلم يحاول خلق مستويات على سطح الخامة وأي تغير في الضوء الساقط يعطي نوع من التغير في الوسيط الفني

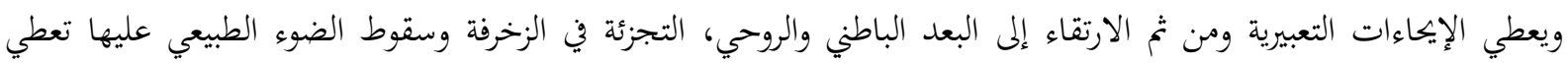

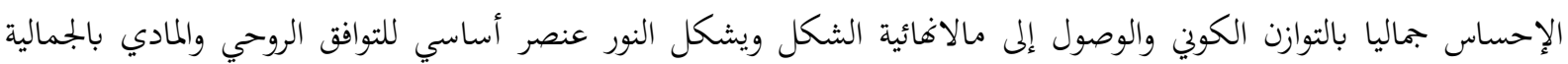

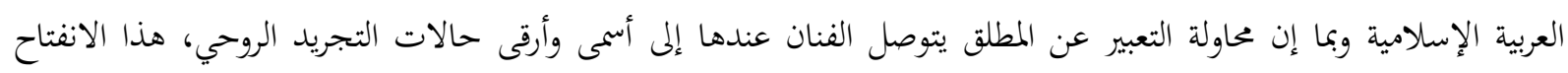

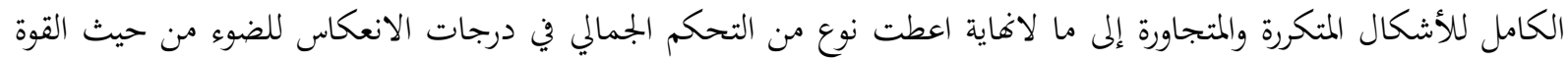

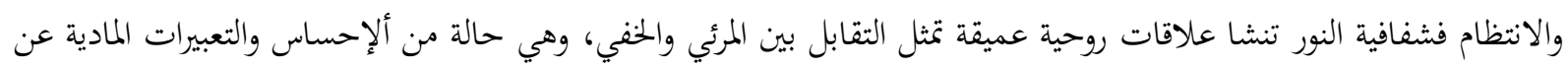

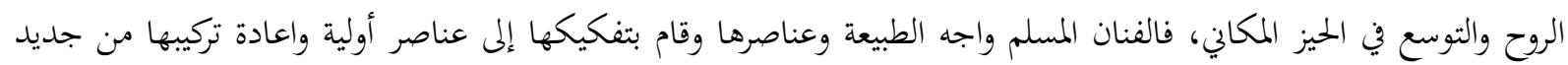

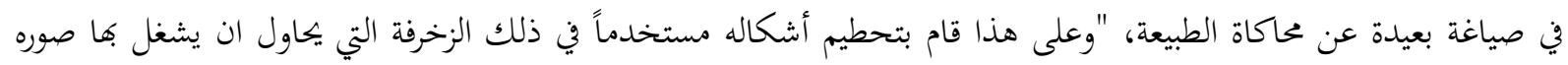

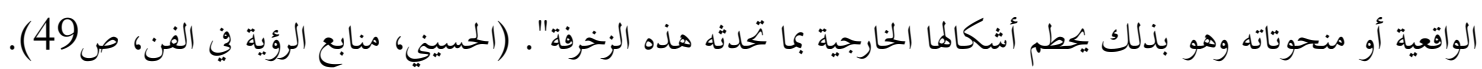

أنموذج رقم (3)

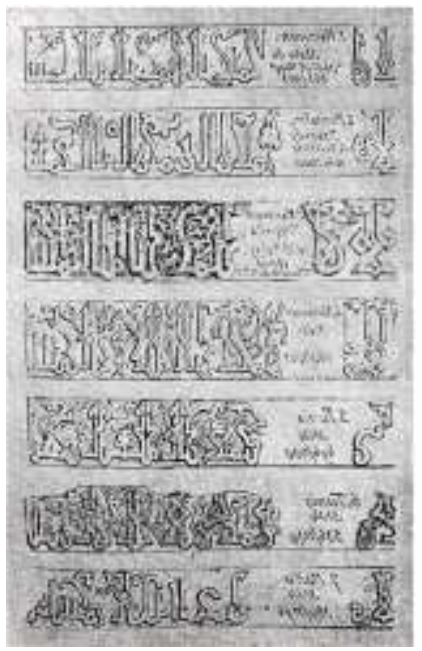

الخط الكوفي

يظهر لنا الشكل الزخري الكتابي حاملا خطاب فني جمالي منتظم، فالفنان المسلم

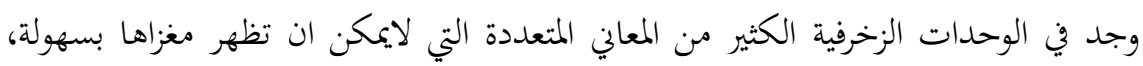

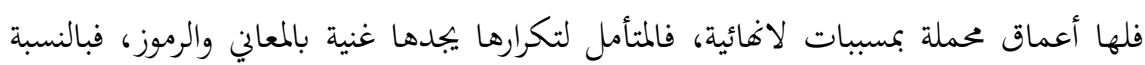

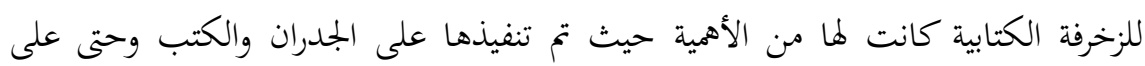
سطح الانيات الخزفية فالزخرفة الكتابية حملت مضمون واضح، والمضمون في منيك الزخرفة الإسلامية في الفن يرتكز إلى رموز تحتويه وتعبر عنه بشكل واضح للمتلقي.

ومن هذا المنطلق حمل الفنان المسلم الزخرفة الإسلامية رموزاً فنية تمتلك القدرة الذاتية

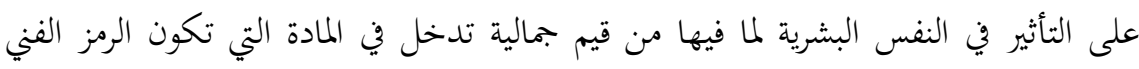
سواء على قطعه جلد أم على جدار، لهذا حاول المزخرف المسلم ان ينشئ من خلال أعماله الإبداعية صورة للعالم المطلق باستمرار وهي بهذا انعكاس للفكر الإسلامي، الزخرفة الكتابية الإسلامية تعد دعوة صريحة إلى التحرر من الماديات والتطلع إلى ما وراء

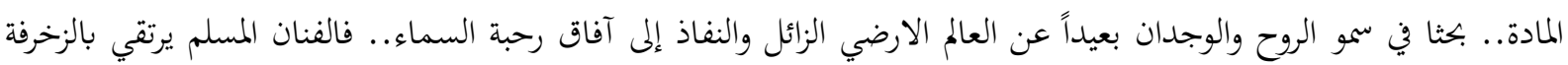


الإسلامية صعوداً إلى التشخيص والتجريد في ان واحد، فالتكرار هنا يحدد رياضياً في أوضاع وحجوم وهيئات متعاقبة في البعد الثالث في مستوى النظر وهو محدد بخط أفقي، فتستقر الحروف مع بعضها لتشكل نوع من التسلسل المتناسق حاملا نسقا زخرفيا متناغم مع السطح الذي تم تنفيذ هذا النوع من الزخرفة عليه.

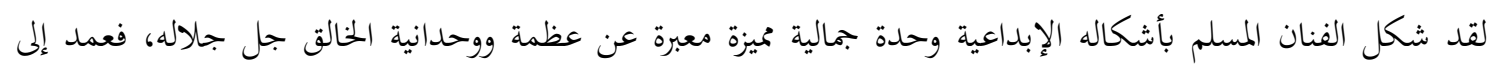
استخدام الزخرفة الكتابية بأسلوب فني جمالي وبصياغة ذات تناسق واضح فكان ذلك لكي يعبر عما في نفس الفنان المسلم من ونمان

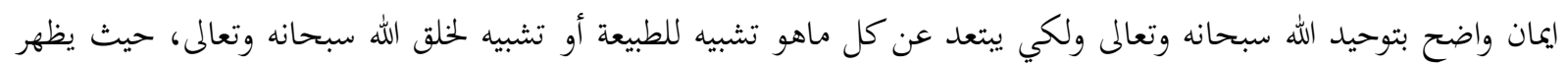

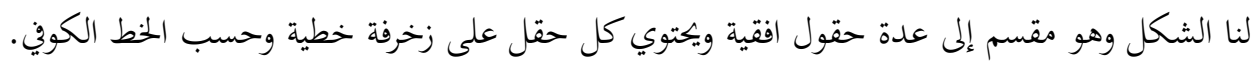

ابته الفنان المسلم بالحرف العربي من شكله البدائي إلى شكل فني زخرفي رائع ولم يعد له حد في التفنن والإبداع ولم يتخل

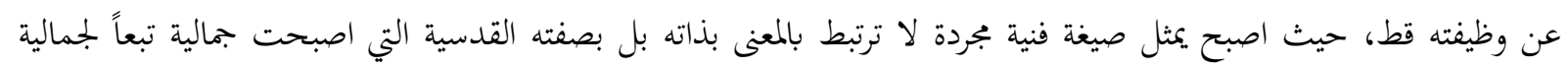

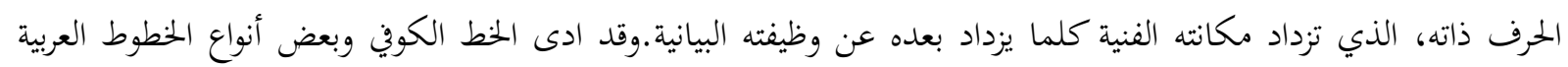

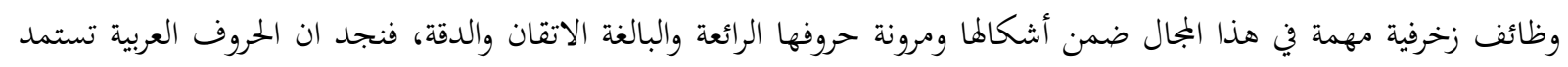

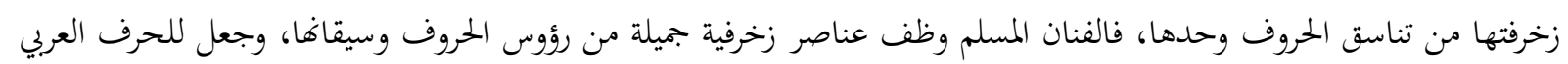

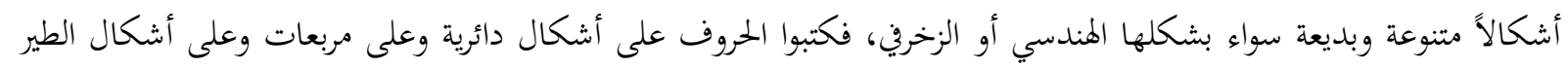

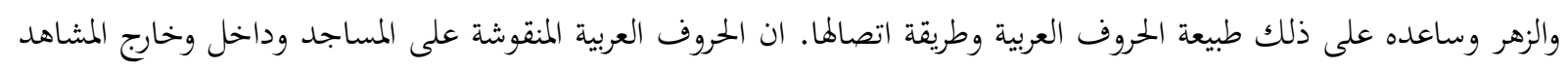

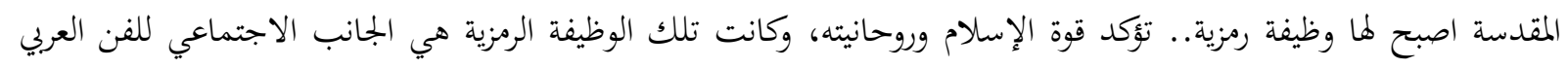

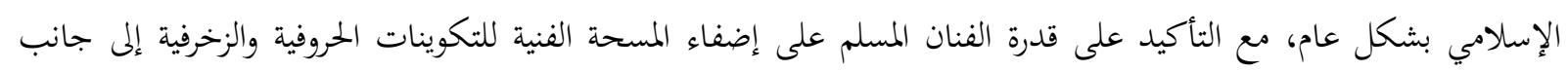
العطاء الروحي الذي يقدمه الإسلام.

\section{أنموذج رقم (4)}

\section{زخرفة أدمية وحيوانية}

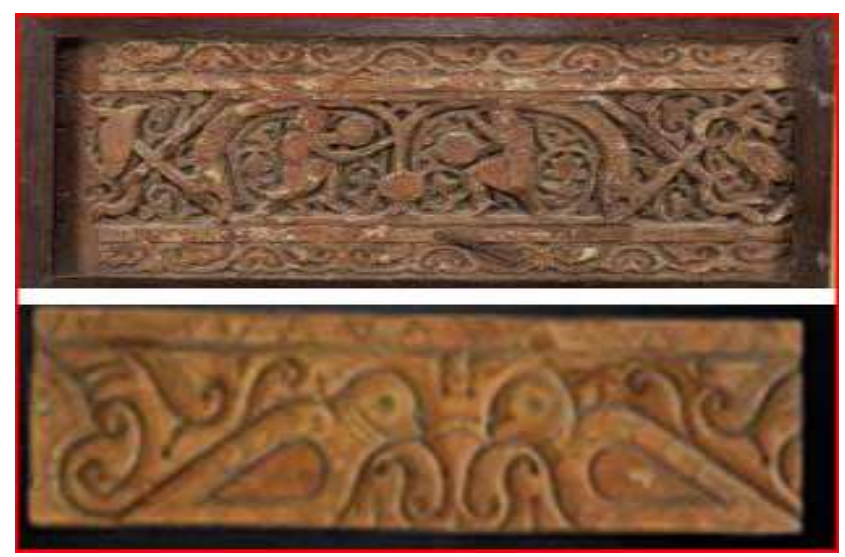

يظهر لنا الشكل الزخرفي الخشبي بأشكاله الأدمية في الجزء

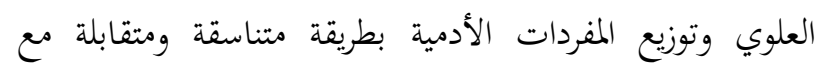
استخدام بعض الوحدات الزخرفية النبايتية وفي الحقل السفلي

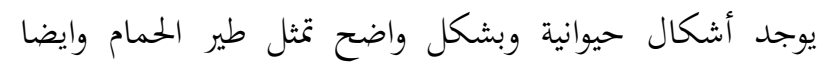
بوضعيه التقابل والتناظرمع وجود بعض الزخرفة عن طريق الخطوط وبنال

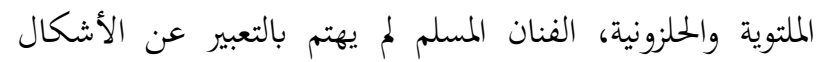

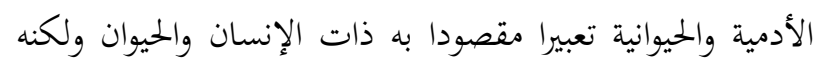
استخدم هذه العناصر كوحدات زخرفية بحتة لها قيمتها الفنية. وتبدو الأشكال قد بتاوزت المألوف لسعي الفنان إلى تحقيق وحدات زخرفية متنوعة. كانت الكائنات الحيّة وسيلةً تستخدم

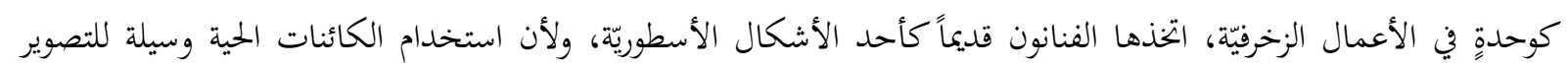

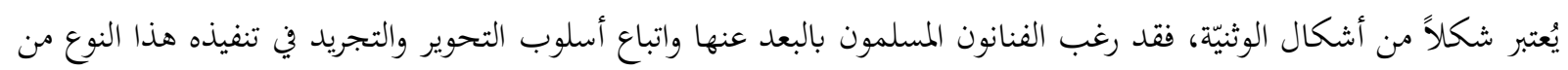
الزخرفة لأن تمثيل الشكل الحيواني والبشري بشكله الواقعي كان غير محبب عند الثند الإسلام. 
الفنان المسلم لم يكن يتجه كثيرا نحو الأشكال الأدمية والحيولنية لكن نجد في هذا الشكل الزخريف نوع من الجمالية الواضحة من خلال هذا التناظر اللامتناهي والمطلق، فالزخرفة بكل أنواعها تبتدا من نقطة ولاتنتهي محا يجعلها تتسم بالاستمرارية وهذا الشئ واضح للعيان عند المتلقي، ويظهر ايظا في هذا الشكل بساطة في تنفيذ الأشكال الأدمية حيث من الواضح لنا وجود اثنين من الرجال وهم بوضعية انحناء لواحدة من اقدامهم بينما تم الارتكاز على القدم الاخرى وكافم يقومون بتادية فعالية معينة من خلال هذا التقابل الواضح.ويبدو نفس الشيئ في تقبل الحمامات وكان هناك نوع من الخطاب فيما بينها صاغه هذا التقابل والتناظر والتماثل لتوصيل فكرة ذات رسالة جمالية لا متناهية وهو اتقان هذا النوع من الزخرفة بعيدة عن بتسيم الطبيعة الحية أو تصويرها محا حملت صياغة زخرفية أمتازت به الفنون الإسلامية، وبذلك لم تكن الكائنات الحية غاية وتعبيرا مقصود به ذات الإنسان والحيوان بل كانت وسيلة حتى يمكن استخدامها كوحدة زخرفية لما قيمة جمالية فنية فإضافة إلى الأشكال المختزلة الأدمية والحيوانية نفذ الفنان بعض الأشكال الاسطورية والمركبة لاها اتفقت في تركيبها في الابتعاد عن الحقيقة ومطابقة لصيغة التجريد التي اعتمدها الفنان ضمن المجال الزخرفي.

الفنان المسلم اتخذ من الجدران ايضا السطوح التي وذلك من مبدا كراهية الفراغ ولتغطية هذه السطوح والمساحات والاهتمام بمبدا التكرار ليحمل لنا الشكل خطاب جمالي نتيجة لصياغات جاءت متكررة ومتقابلة. 


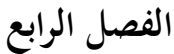

النتائج

1-الخطاب الجمالي يقوم على فلسفة الفنان المسلم من حيث الاعتقاد بلا غاية الوجود، فلمسلم يرى الله هو مركز الكون وكل شيء يبدء منه ليعود أليه . 2-الابتعاد عن تثثيل الطبيعة و تقليدها.

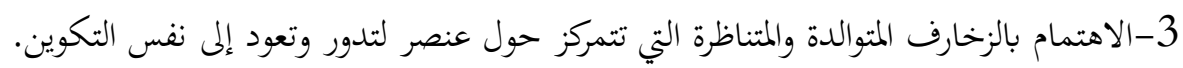

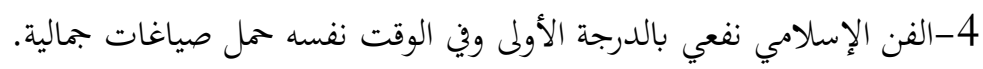

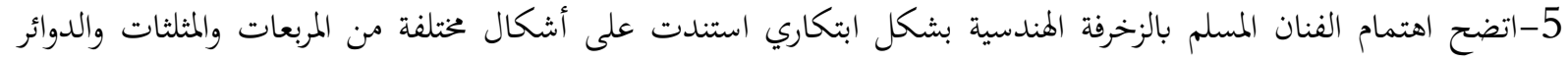
المتماسة والأشكال المتقاطعة بصيغة جمالية خالصة. 6-العناصر النباتية مصدرها فروع النبات واوراقه وازهاره ولكن بأسلوب معور.

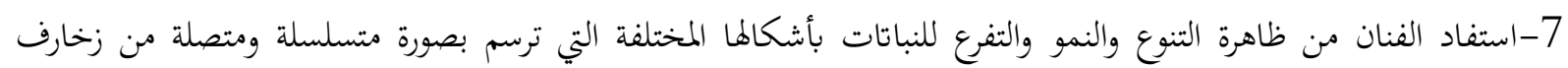
مستمرة ومتفرعة. 8- استخدم الفنان المسلم الخط العربي في الزخرفة والتزيين وفي بعض الاحيان أدخلوا عناصر نباتية في انتهاء الحرف.

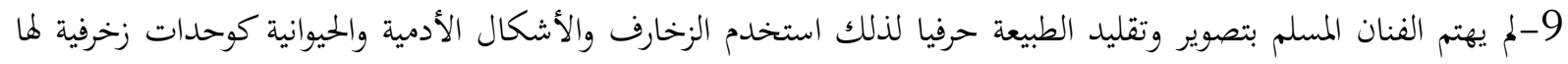
قيمتها الجمالية. 10-اشتهر الفن والتراث الإسلامي إضافة إلى الزخارف بفن الكتابة والتصوير وفن العمارة وفن الحزف وغيرها من الفنون التي جملت الطابع الجمالي. ضرورة الاهتمام باعادة تاهيل وترميم التراث الإسلامي للحفاظ عليه. - يجب توثيق الأشكال التراثية وخصوصا الزخارف وذلك نتيجة العثور على العدد القليل من المصورات الخاصة بالبحث. - استمرا ر الباحثين وطلبة العلم في دراسة الزخارف خصوصا وبأنواعها لما لها أهمية كبيرة لتعبيرها عن المطلق والماتلامتناهي. 


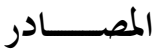

ابو ريان، محمد علي، فلسفه الجمال ونشأة الفنون الجميلة، دار الجامعات المصرية، ط5، الاسكندرية، 1977.

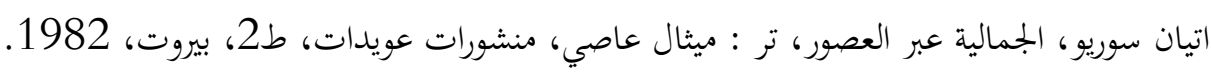

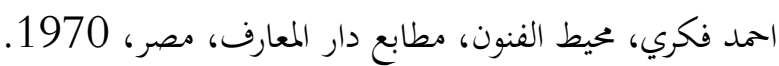

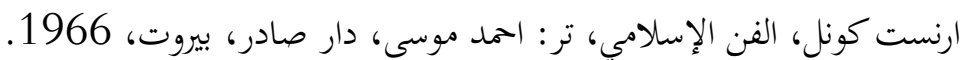

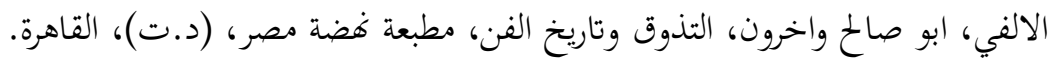
الاندلسي، ابو محمد علي بن احمد بن سعيد بن حزم، طوق الحمامة، بيروت، مؤسسة ناصر للطباعة، 1975.

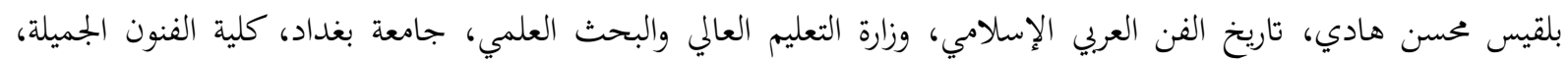
1990

التوحيدي، ابو حيان، الامتاع والمؤانسة، ج3، تحقيق:احمد امين واحمد الزين، القاهرة، مطبعة لجنة التاليف والترجمة والنشر، .1934

جميل صليبا: المعجم الفلسفي، ج1، منشورات ذوي القرب، إيران، ط1، 1385 هـ، . 1385

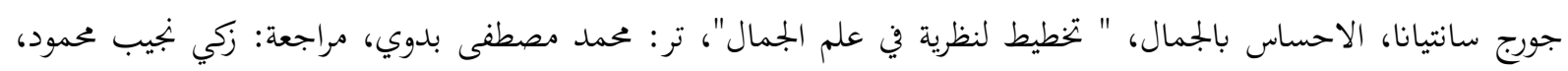

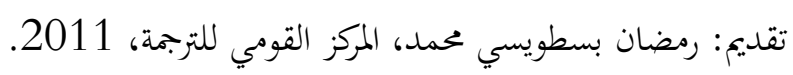

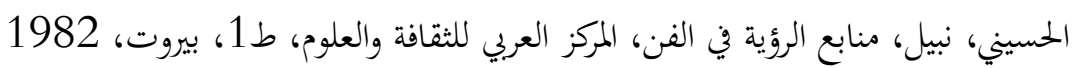
راجع المصدر، عبد السادة صاحب الخزاعي، الرسم التجريدي بين النظرة الإسلامية والرؤية المعاصرة، اطروحة دكتوراه (غير بروبات منشورة)، جامعة بغداد، كلية الفنون الجميلة، 1997.

الراوي، نوري، تأملات في الفن الإسلامي، بجلة الرواق، دائرة الفنون التشكيلية، وزارة الثقافة والاعلام، دار الحرية للطباعة.

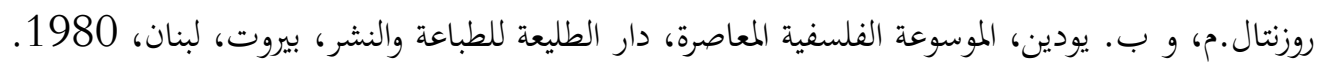

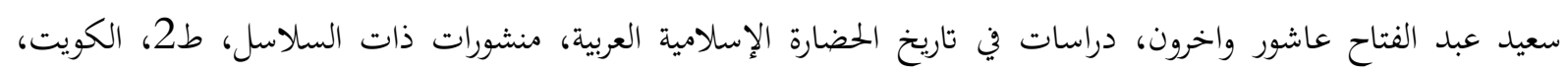
.1986

شوكت توفيق الالوسي، جماليات الأشكال المعمارية الإسلامية وانعكاسها في الرسم العراقي المعاصر، اطروحة دكتوراه (غير

$$
\text { منشورة)، جامعة بغداد، كلية الفنون الجميلة، } 2000 .
$$

العبيدي، جبار محمود، القيمه والمعيار الجمالي في التشكيل المعاصر، دار ضفاف للطباعة والنشروالتوزيع، ط1، العراق، 2013.

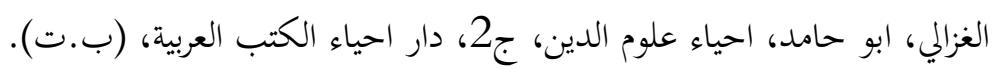

قتيبة صلاح عبد الله رمضان، خصائص التجريد في الخزف المعاصر في العراق، رسالة ماجستير (غير منشورة)، جامعة بغداد، كلية

$$
\text { الفنون الجميلة، } 2000 .
$$

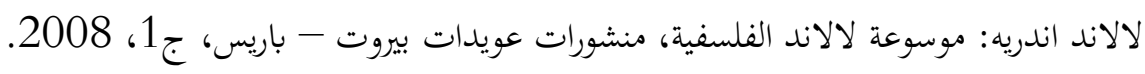

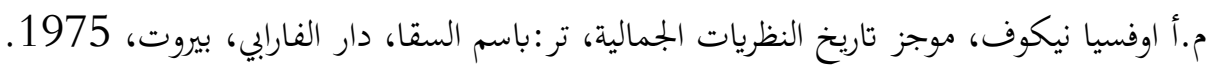

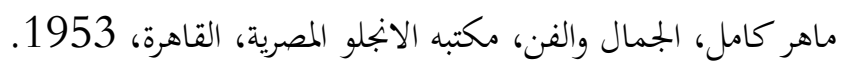

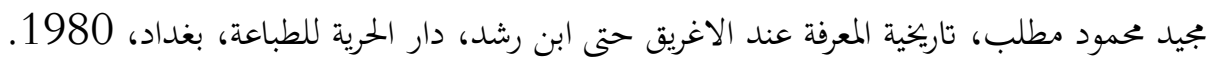

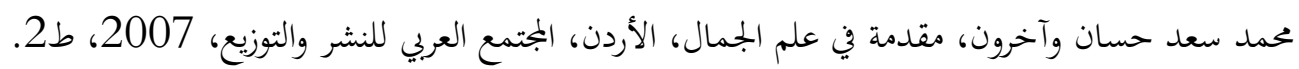

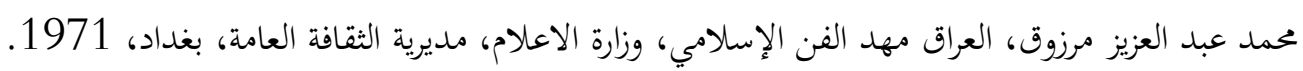

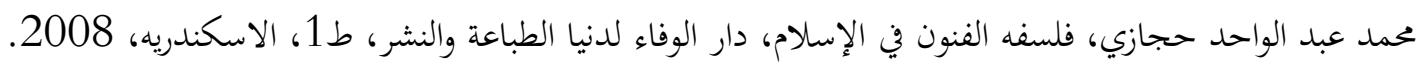


نجم عبد حيدر، علم الجمال آفاقه وتطوره، جامعة بغداد، كلية الفنون الجميلة، 2001.

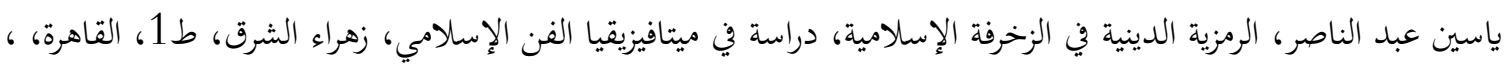
2006 


\title{
STRUCTURAL PATTERNS IN THE CONSTRUCTION OF THE QURANIC SCENE، A READING IN THE PURPOSES OF SHARIA
}

\author{
Basim Rashid ZOBAA ${ }^{1}$ \\ Osama Hamdan Abdullah RAHIM ${ }^{2}$
}

\section{Istanbul / Türkiye \\ p. $656-669$}

\begin{abstract}
Received: $24 / 11 / 2021$
Accepted: 09/12/2021

Published: 01/01/2022
\end{abstract}

This article has been scanned I iThenticat No plagiarism detected

\begin{abstract}
:
The Holy Qur'an is the Book of God Almighty، and He described it، Glory be to Him, with several descriptions, and He told about it that it is a book that needs contemplation that leads you to the goal of the intended verses, and you think about the verses، rather the wall، to come up with a conception of it. The event, rather, depicts it from its different angles, and that is the camera in the Holy Qur'an, as it paints for us a vivid scene that pulsates with life in which all the meanings of life are dialogues and embodiment of what is not in a body, a chemical substance or a physical space. The place is separate from the time, but the study of the scene is fragmented, with a metaphor here or a metaphor there, this kills the scene and takes it out of its beauty.

For this reason, the choice was made to study the scene in the Holy Qur'an، in order to clarify the beauty of the Holy Qur'an that is not limited to the verbal only, but comes out in the word to what is embodied، reasonable and metaphysical.

This research is based on an introduction in which I talked about the scene in language and terminology, then she added to talk about the role of some linguists in approximating the term scene. As for the requirements of the research, the first of them is devoted to the study of material examples, as the importance of the material aspect in nature in general is mentioned in it, and this is supported by texts from the Noble Qur'an.

As for the second، it was to study the moral examples، so I talked about the abstract morals, which are the perceptions of the mind, which do not possess tangible or tangible entities, and I included them with some examples of what was mentioned in the Holy Qur'an as well.

As for the third, it was to study the unseen examples, in which I dealt with talking about the unseen, which is everything that is absent from man, corroborating that with what was mentioned in the Holy Qur'an.

Finally, I say: This is a humble work in its chapter whose goal is to serve the word of God Almighty.
\end{abstract}

Key words: Construction, Research, Study.

http://dx.doi.org/10.47832/2717-8293.15.45

(iD) Prof. Dr., AL- Iraqia University, Iraq, b866198@gmail.com

2 (iD) Dr. , Sunni Endowment Diwan, Iraq

Copyright (C) Published by Rimak Journal, www.rimakjournal.com Rimar Academy, Fatih, Istanbul, 34093 Turkey 


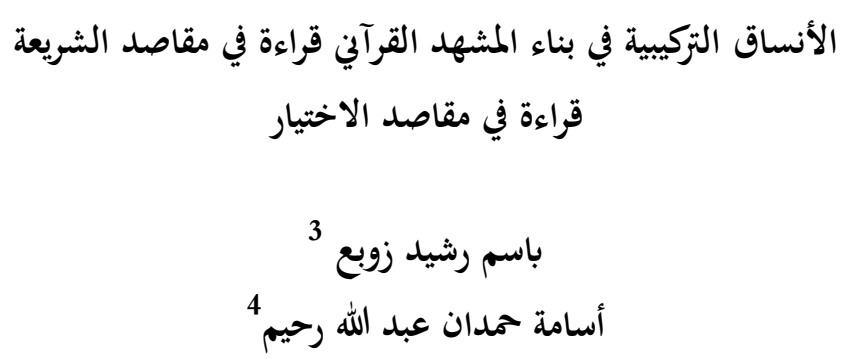

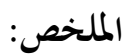

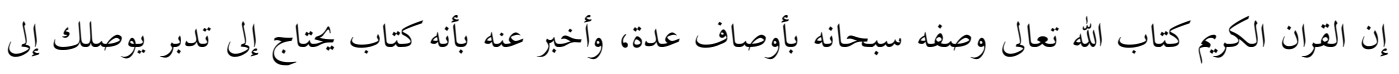

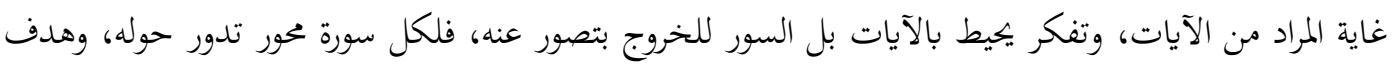

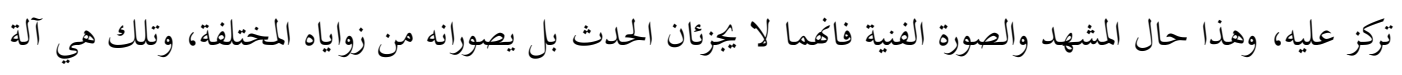

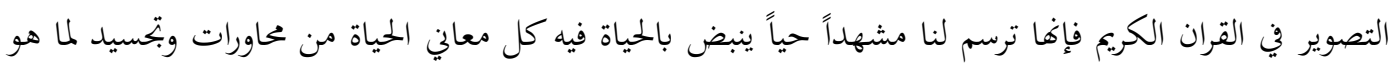

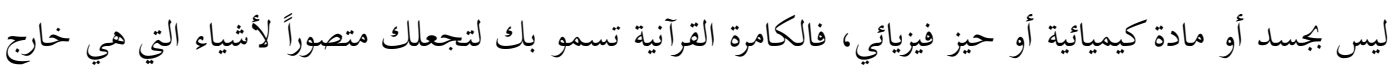

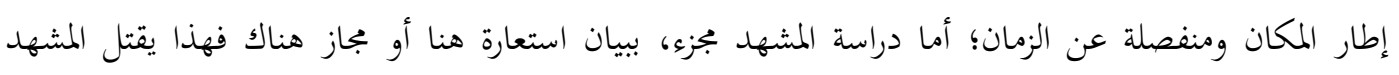

$$
\text { ويخرجه من جماليته. }
$$

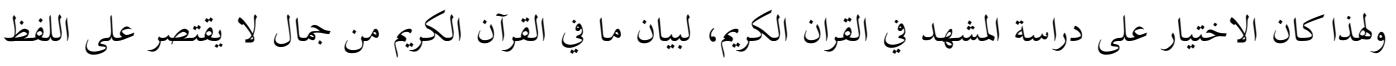

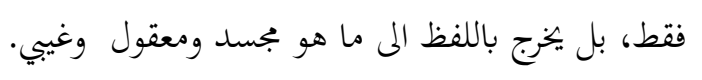

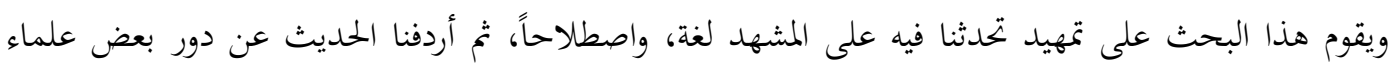

$$
\text { اللغة في تقريب مصطلح المشهد. }
$$

أما مطالب البحث، فقد أفردنا الأول منها لدراسة الأمثلة المادية، إذ ذكرنا فيه أهمية الجانب المادي في الطبيعة

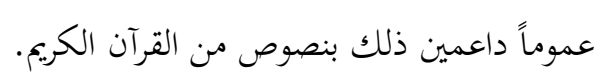

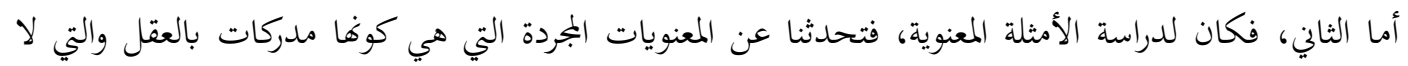

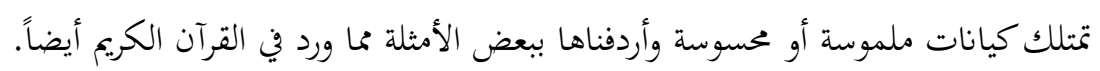

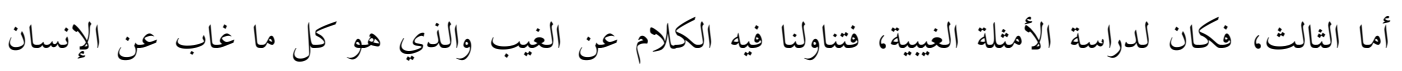
معضدين ذلك بما ورد منه في القرآن الكريم. وأخيرا نقول: هذا عمل متواضع في بابه غايته خدمة كلام الله تعالى، فإن كان قاصراً فمن نفسينا والشيطان، وإن كان تاماً فبتوفيق منه سبحانه. الكلمات المفتاحية: القران الكريم، الأنساق التركيبة. 
إن القران الكريم كتاب الله تعالى وصفه سبحانه بأوصاف عدة، وأخبر عنه بأنه كتاب يحتاج إلى تدبر يوصلك إلى غاية

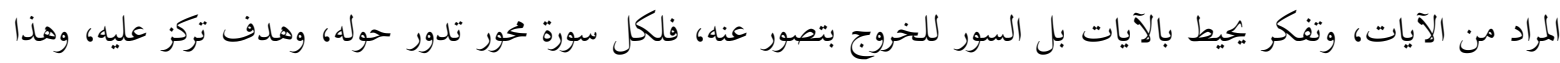

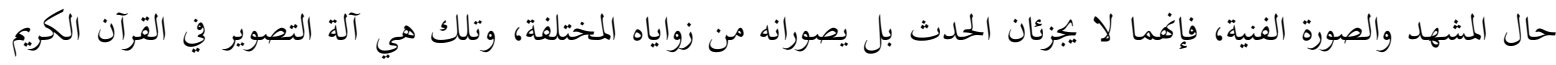

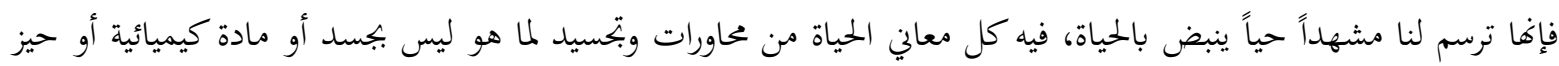

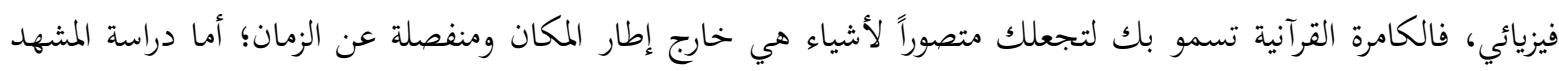

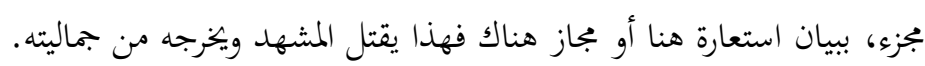

ولهذا كان الاختيار على دراسة المشهد في القرآن الكريم، لبيان ما في القرآن الكريم من جمال لا يقتصر على اللفظ فقط بل يخزج باللفظ إلى ما هو مجسد ومعقول وغيبي.

ويقوم هذا البحث على تمهيد تحدثت فيه على المشهد لغة، واصطلاحاً، ثم أردفت الحديث عن دور بعض علماء اللغة في تقريب مصطلح المشهد.

وقسمت البحث إلى ثلاثة مباحث تبعاً لمتطلباته، فقد أفردت الأول منها لدراسة الأمثلة المادية. أما الثاني، فكان لدراسة الأمثلة المعنوية. والثالث، فكان لدراسة الأمثلة الغيبية. وأخيراً أقول: هذا عمل متواضع في بابه غايته خدمة كلام الله تعالى، فإن كان قاصراً فمن نفسي والشيطان، وإن كان تاماً فبتوفيق منه سبحانه.

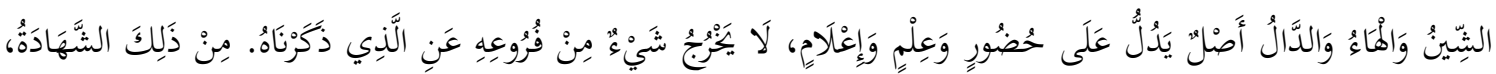

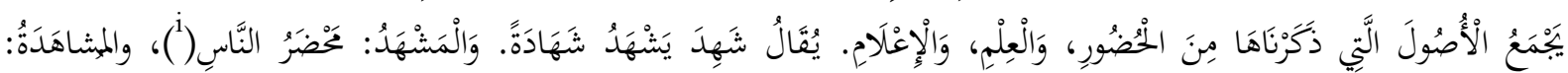

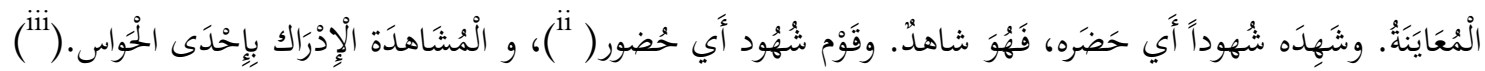

هو إخراج مدلول اللفظ من دائرة المعنى الذهني المجرد إلى الصورة المحسوسة المتخيلة، والحادث المحسوس، والمشهد المنظور، والنموذج الإنساني والطبيعة البشرية، ثم يرتقي بالمشهد الذي يصوره فيمنحه الحياة الشاخصة، أو الحركة المتجددة. فإذا المعنى الذهني هيئة أو حركة، وإذا الحالة النفسية لوحة أو مشهد، وإذا النموذج الإنساني شاخص حي، وإذا الطبيعة

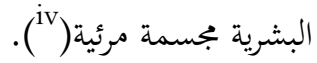

\section{دور علماء اللغة في تقريب مصطلح المشهد القرآني :}

لقد التفت علماء البلاغة واللغة القدماء إلى ظاهرة المشهد والصورة الفنية وإن لم يسموها باصطلاحنا المعاصر، وقد أشار في

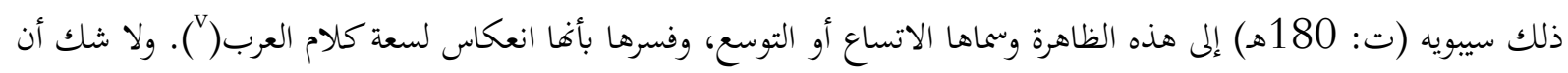

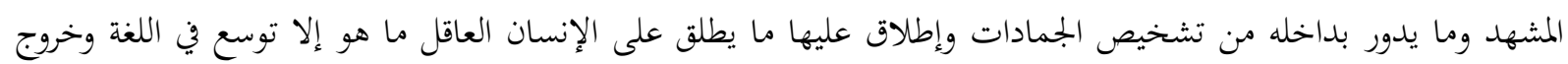

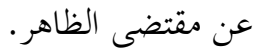


وأشار أبو عبيدة إلى هذه الظاهرة الأدبية وسماها: (بجاز ما جاء من لفظ خبر الحيوان والموات، على لفظ خبر

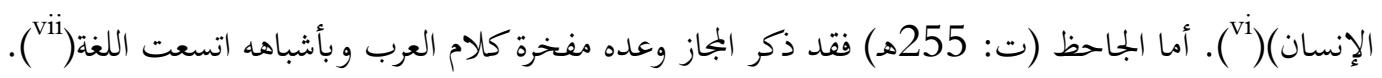
وتحدث ابن المعتز عن هذه الظاهرة بشيء من الوضوح عند حديثه عن شعر امرئ القيس:

\section{وليل كموج البحر أرخى سدوله عليَّ بأنواع المموم ليبتلي

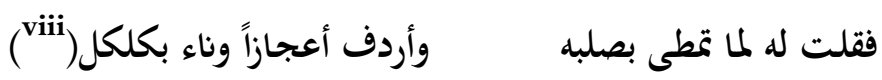

هذا كله من الاستعارات؛ لأن الليل لا صلب له ولا عجز( (ix)، وكان ابن المعتز يريد أن يقول إن امرأ القيس قد خلع على

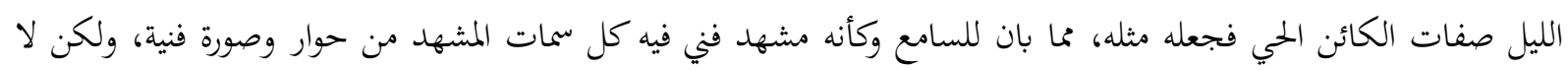

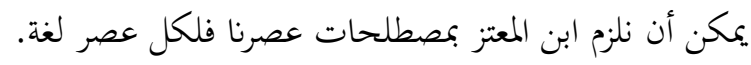

أما عبد القاهر الجرجاني (ت: 471هـ) فقد تناول موضوع الصورة الفنية، ويعد أدق من وقع على معنى المشهد وما يدور

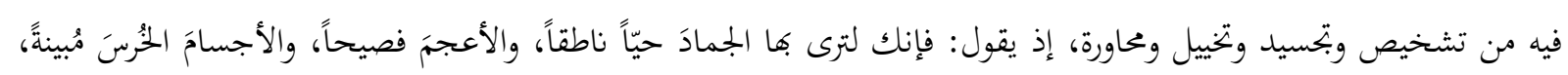

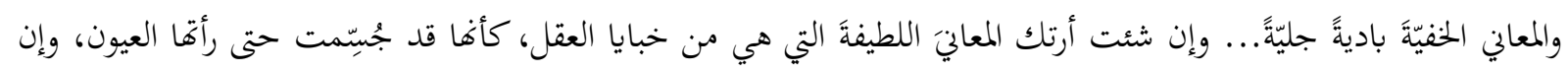

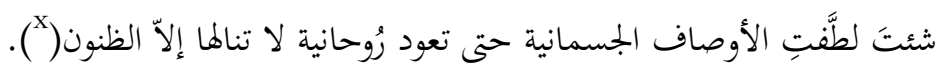
ويعلق الجرجاني على قول لبيد:

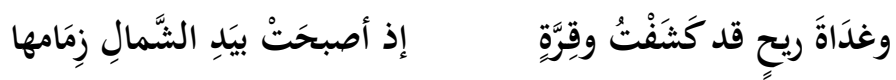

وذلك أنه جعل للشمال يداً، ومعلوم أنه ليس هناك مُشار إليه يمكن أن ثُجْرَى اليد عليه، كإجراء الأسد والسيف على لى

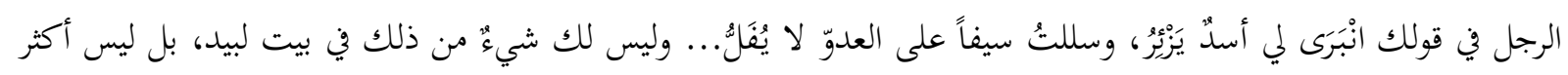

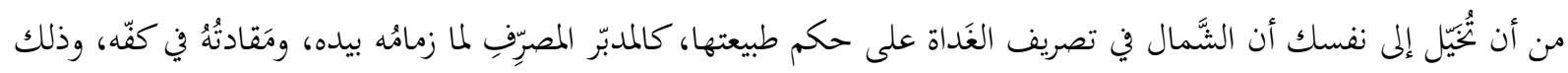

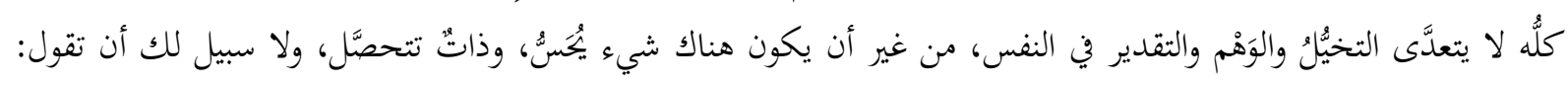

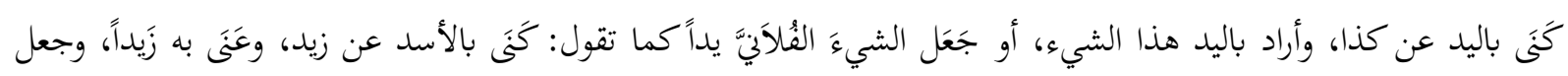

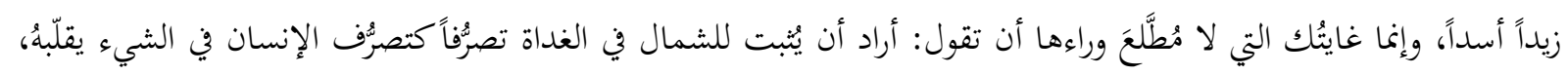

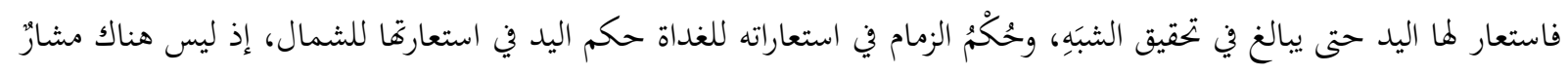

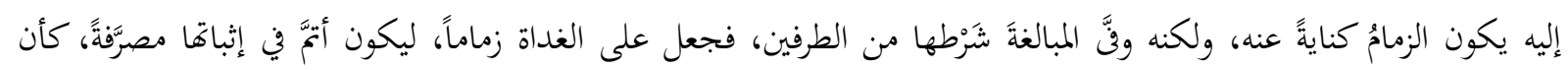

جعل للشمال يداً، ليكون أبلغ في تصييرها مُصرَّفِة(

وفي ضوء ما تقدم نستطيع أن نقول: إن علماءنا تنبهوا إلى هذه الخاصية الأسلوبية وأحسوا بوجودها وعرفوا مفهومها دون

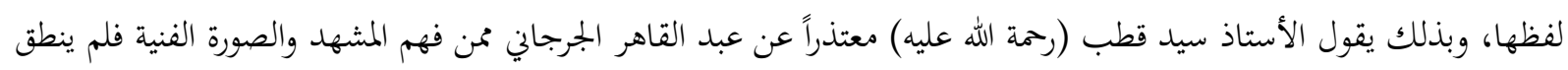

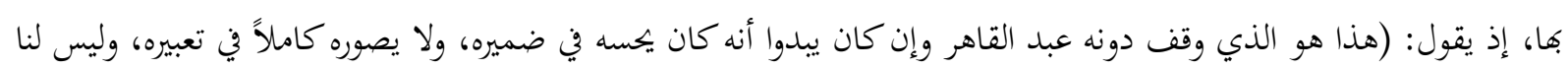

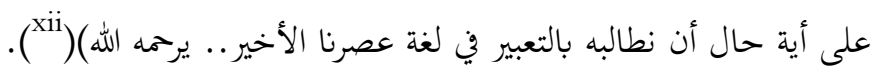




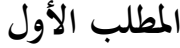 \\ النسق التركيب للمشاهد الملموسة}

يعد الجانب المادي من الطبيعة عموماً من أبرز مظاهرها المحسوسة التي تشكل حيزاً وجودياً ملموساً، فضلاً عن كون الطبيعة

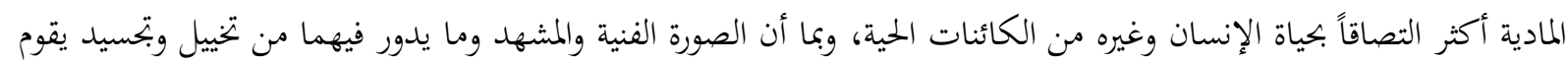

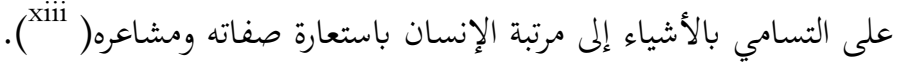

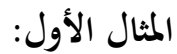

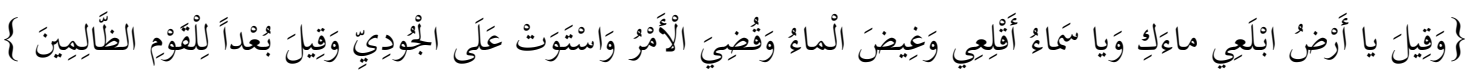

$$
\text { [44 سورة هود: آية }
$$

منح المشهد القرآي بما فيه من تشخيص وبحسيد الأرض والسماء بعداً إنسانياً، فقد خصهما الله تعالى بالخطاب، ووجه

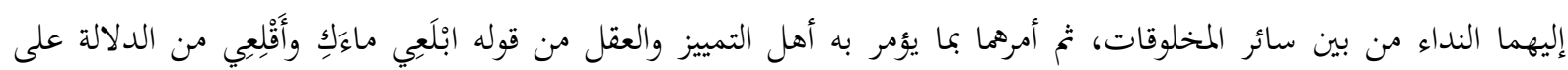

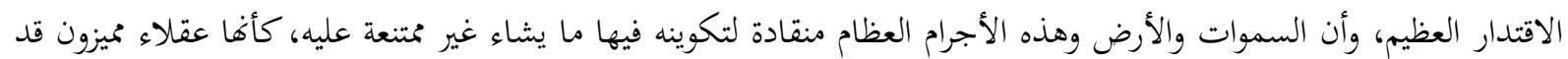

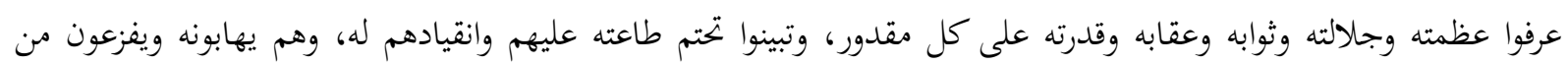

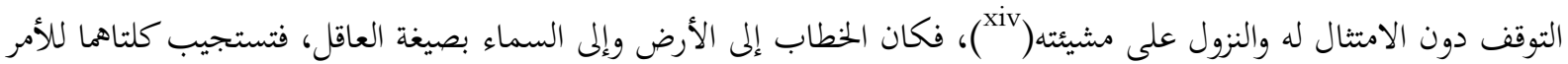

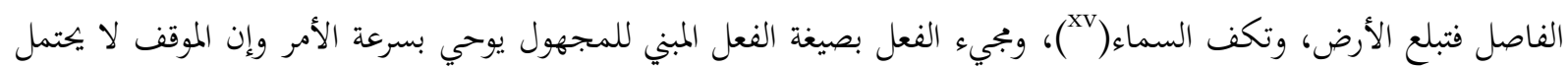

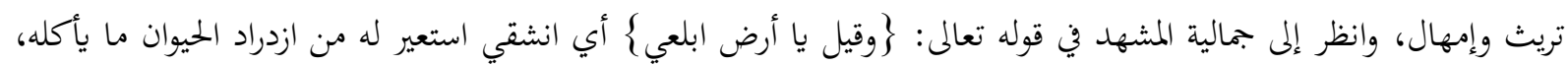

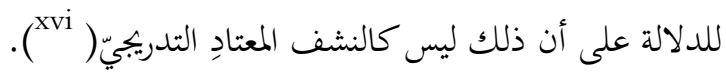

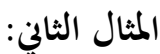

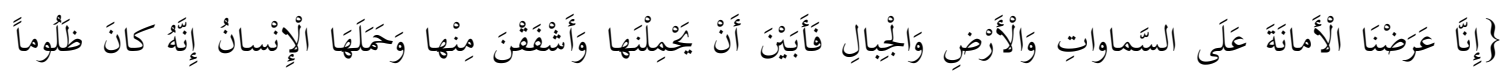
جَهُولاًا\{ [سورة الأحزاب: آية

إن بداية الآية أو مشهد العرض يوحي بتجسيم الأمانة حملاً ثقيلاً وعبئًا كبيراً يرزح تحت وطأته من يكلف بحمله ما استدعى بروز صفات إنسانية معنوية شعورية في هذه الجمادات التي انبرت تدفع عن نفسها هذا الحمل الثقيل.... أما في في قوله

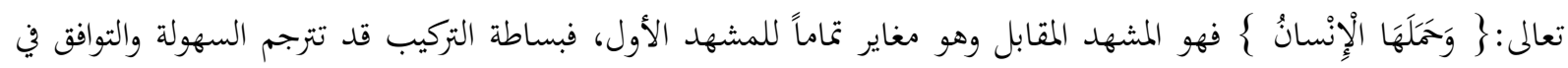
تقبل الأمر دون تفكير في العواقب $\}$ إِنَّهُ كانَ ظَلْوماً جَهُولًا

إن هذا المشهد، فيه إيقاع يكشف عن جسامة العبء الملقى على عاتق البشرية، وعلى عاتق الجماعة المسلمة بصفة خاصة

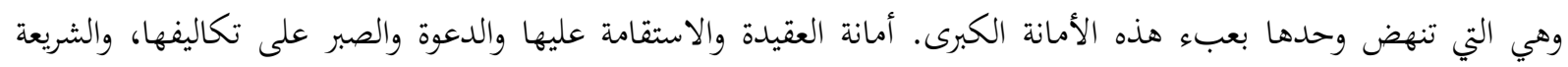

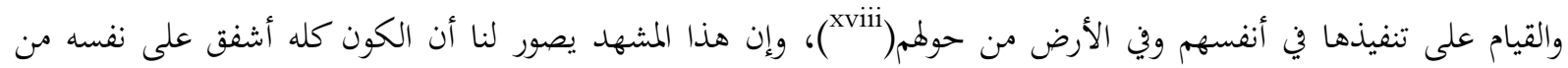

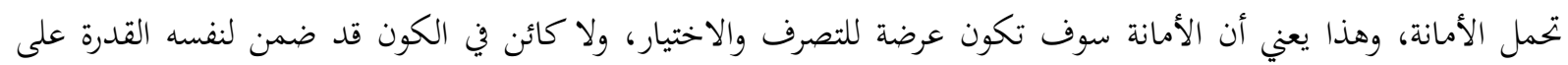

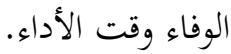

لقد أعلنت الكائنات قولها فأبين تحمُّل الأمانة وكأها قالت: إنّا يا ربنا نريد أن نكون مسخرين مقهورين لا اختيار لنا؛ ولذلك نجد الكون كله يؤدي مهمته كما أرادها الله تعالى، ما عدا الإنسان، أي أنه الذي قبل بما له من عقل وتفكير أن يتحمل أمانة الاختيار، وبلسان حاله أو بلسان مقاله قال: إنني قادر على تحمل الأمانة؛ لأني أستطيع الاختيار بين البدائل( 


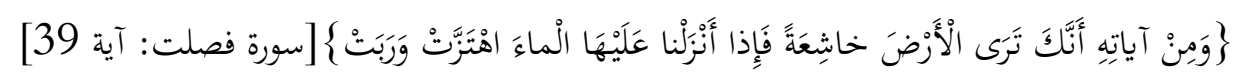

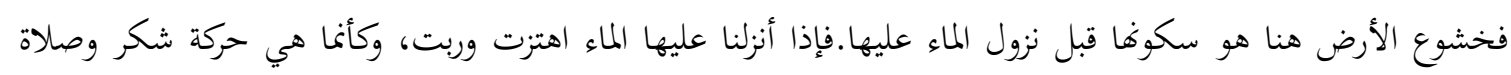

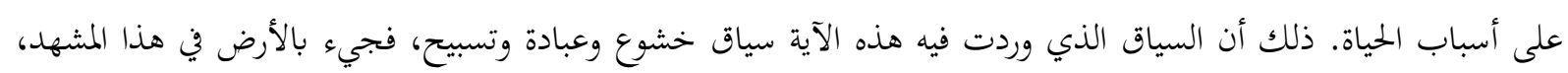

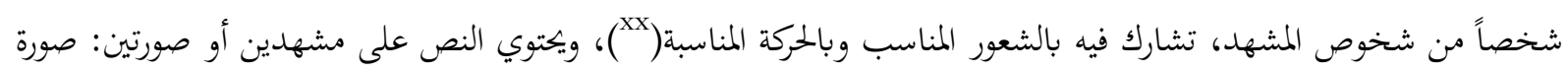

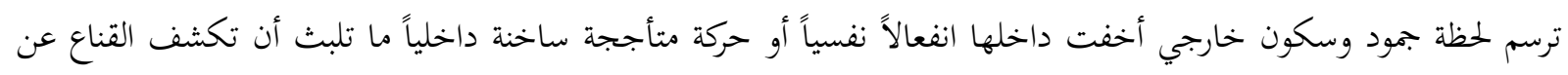

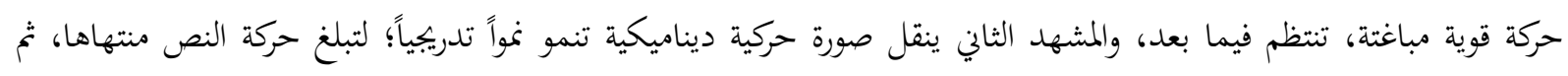

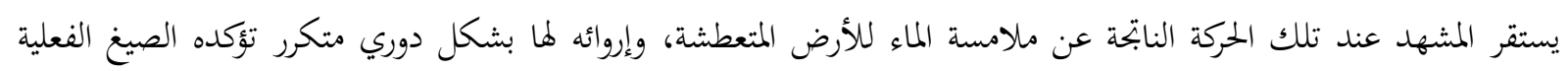

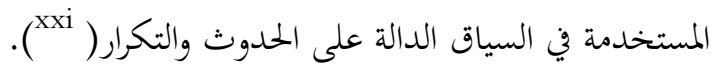


المعنويات المجردة هي المدركات بالعقل، التي لا تملك كياناً مادياً ملموساً أو محسوساً، لكنها تعد الوجه الآخر للوجود،

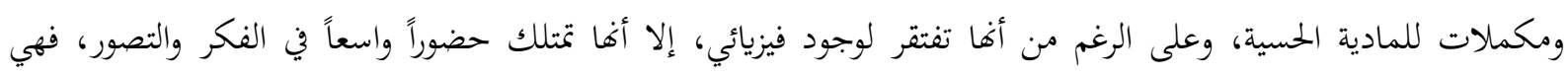

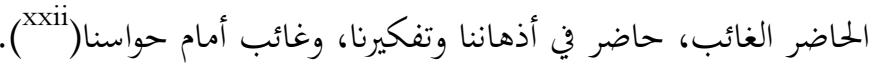

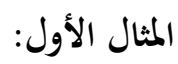

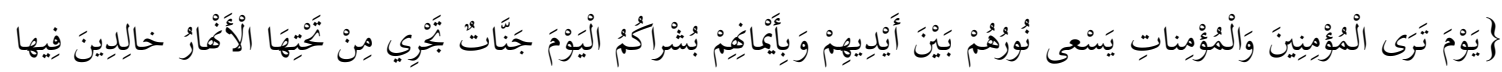

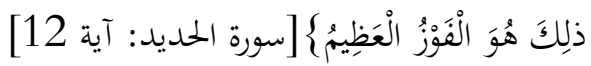

والمشهد هنا بإجماله وتفصيله جديد- بين المشاهد القرآنية- وهو من المشاهد التي يحييها الحوار بعد أن ترسم صورتا

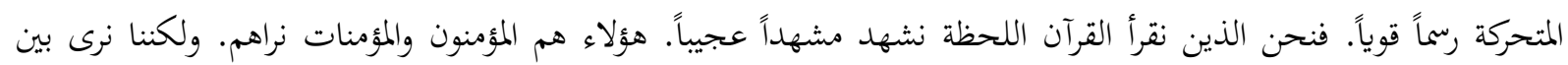

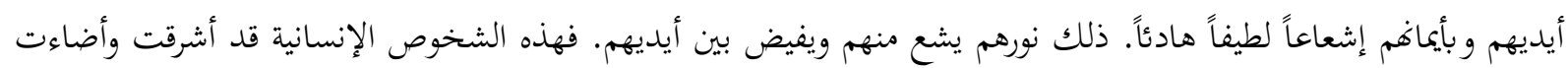
وأشعت نوراً يمتد منها فيرى أمامها ويرى عن يمينها.

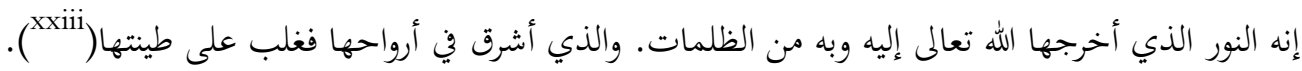
المثال الثاني:

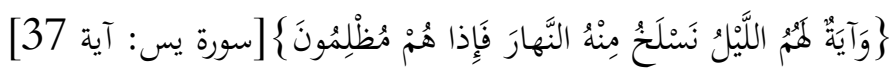
سلخ جلد الشاة: إذا كشطه عنها وأزاله...فاستعير لإزالة الضوء وكشفه عن مكان الليل وملقى ظله( (xxiv)، وأشار أبو هلال العسكري إلى معنى السلخ في هذه الآية، وهو أن الليل والنهار ليسا على الحقيقة شيئين يسلخ أحدهما من الآخر، إلا أفما

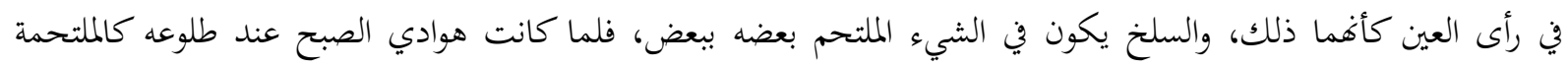

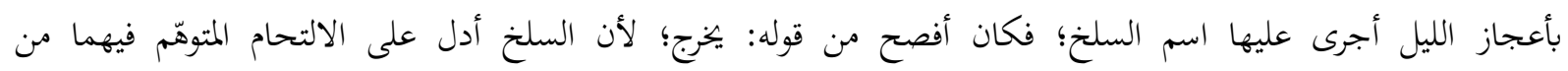

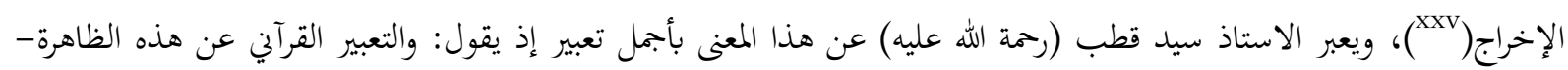

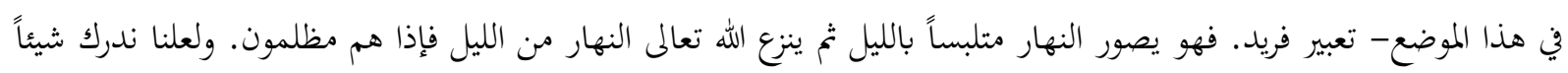
من سر هذا التعبير الفريد حين نتصور الأمر على حقيقته. فالأرض الكروية في دورتحا حول نفسها في مواجهة الشمس تمر كل نقطة منها بالشمس فإذا هذه النقطة فار حتى إذا

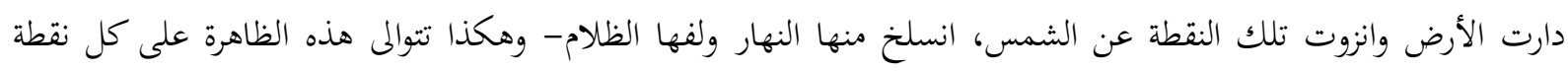
بانتظام وكأنما نور النهار ينزع أو يسلخ فيحل محله الظلام. فهو تعبير مصور للحقيقة الكونية أدق تصوير(

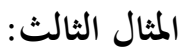

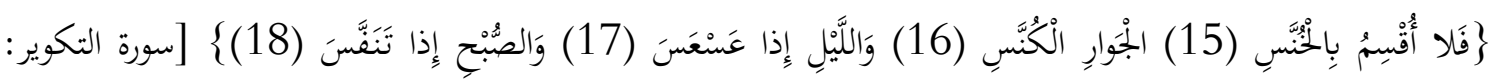

الآيات 15 الى 18

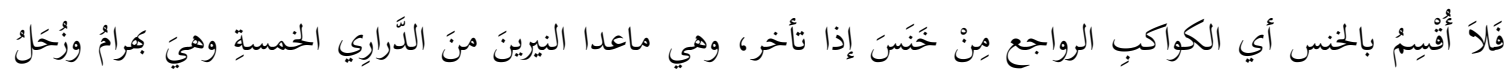

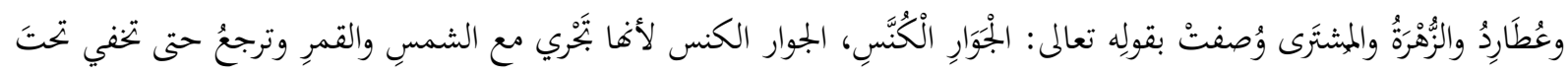

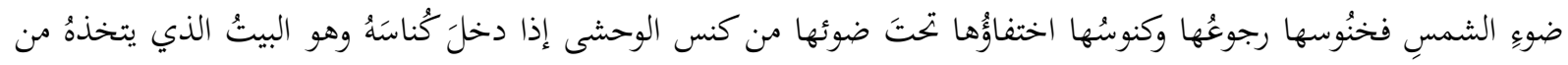




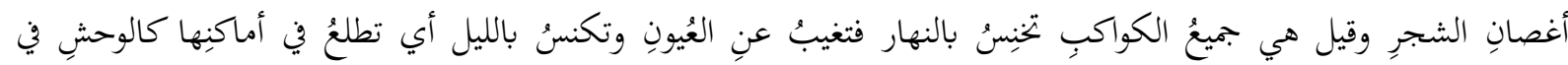

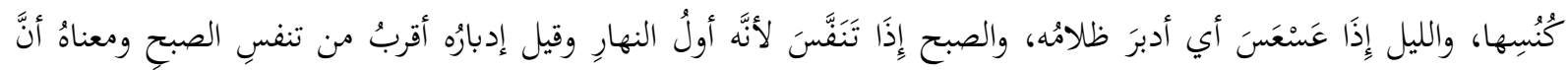

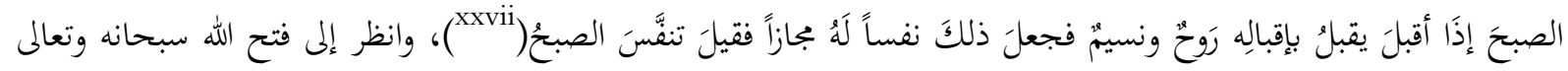

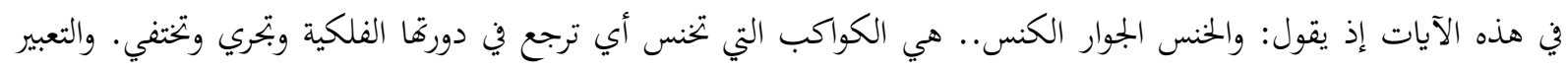

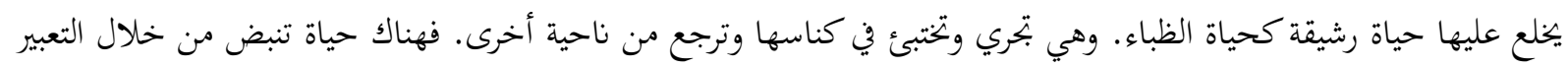

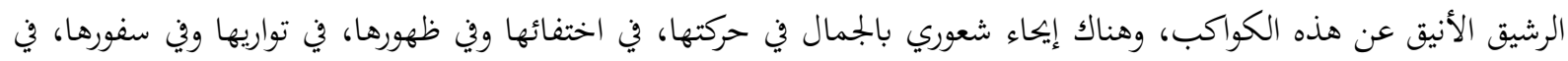

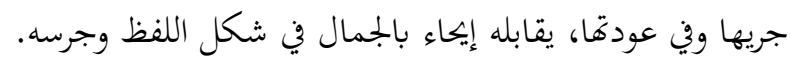

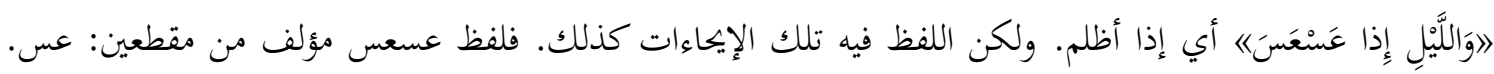

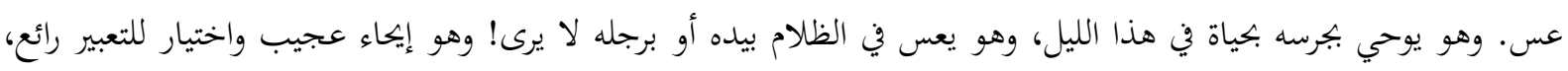

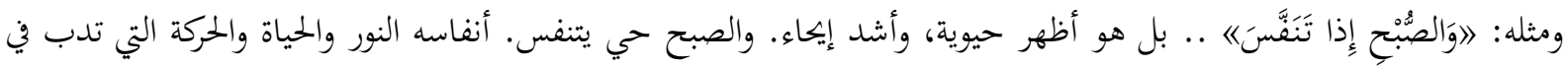

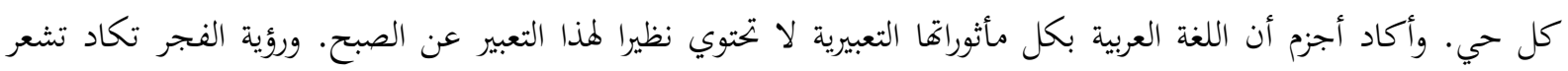
القلب المتفتح أنه بالفعل يتنفس! ثم يجيء هذا التعبير فيصور هذه الحقيقة التي يشعر بها القلب المتفتح.

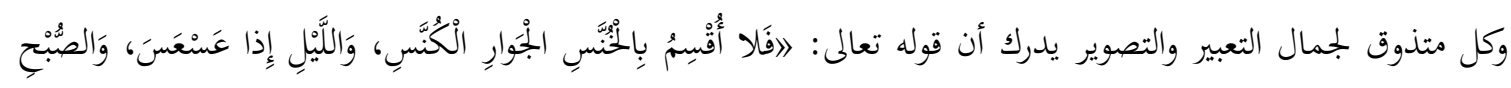

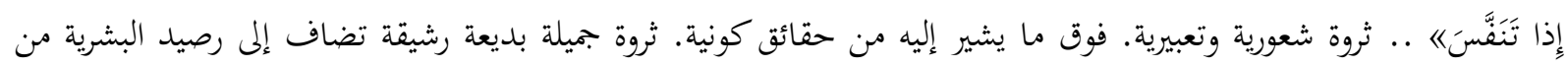
المشاعر، وهي تستقبل هذه الظواهر الكونية بالحس الشاعر. يلوح هذه المشاهد الكونية التي يخلع عليها الحياة ويصل روح الإنسان بأرواحها من خلال التعبير الحي الجميل عنها

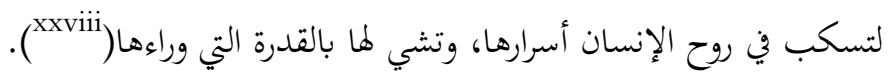

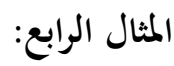

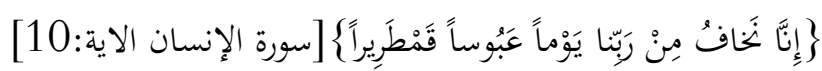

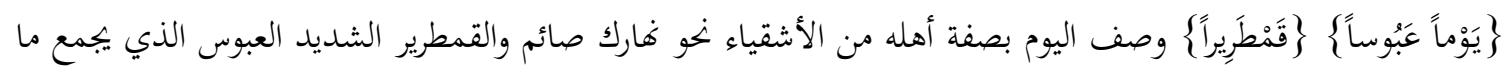

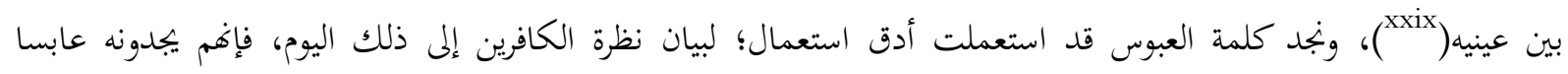

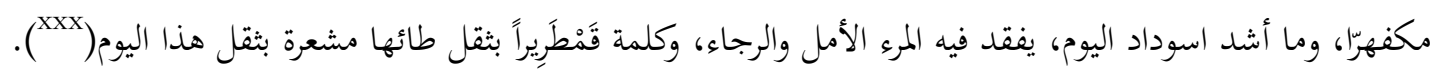
إن الخوف الشديد الذي يعتمل القلوب من هول ذلك اليوم، والإحساس الداخلي بخطورة الموقف في الزمن القادم جعل

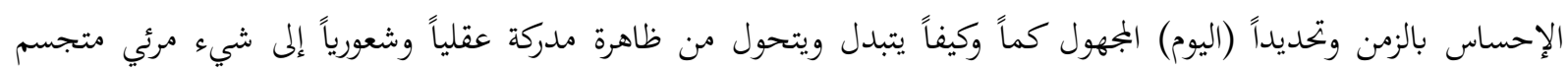

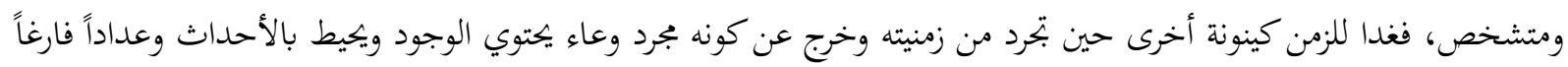

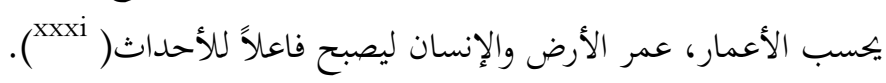




\section{النسق التركيبي لمشاهد المآلات الغيبية}

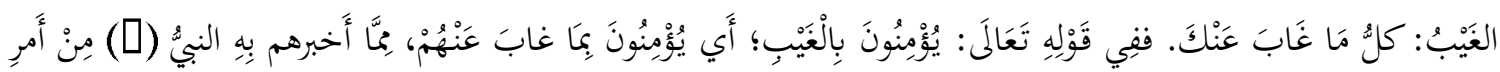

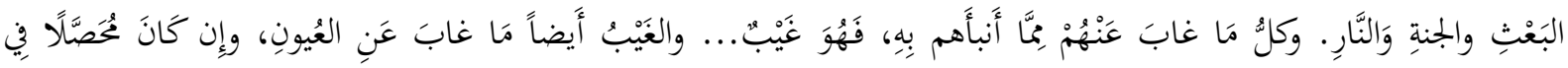

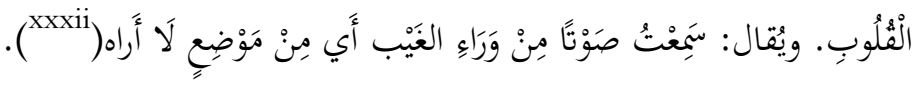

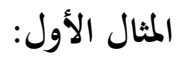

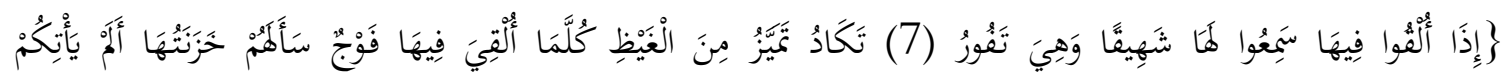

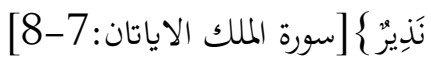

المنكر الفظيع بالشهيق وَهِيَ تَفُورُ تغلى بهم غليان المرجل بما فيه. وجعلت كالمغتاظة عليهم لشدة غلياها بهم، ويقولون: فلان يتميز غيظاً ويتقصف غضباً، وغضب فطارت منه شقة في الأرض وشقة في السماء: إذا وصفوه بالإفراط فيه(

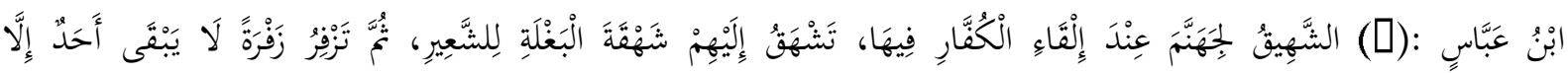

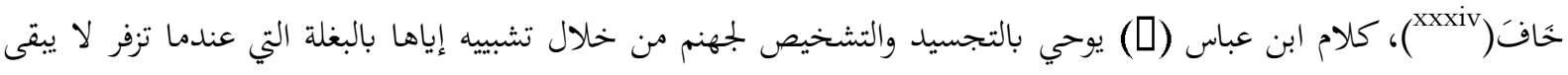

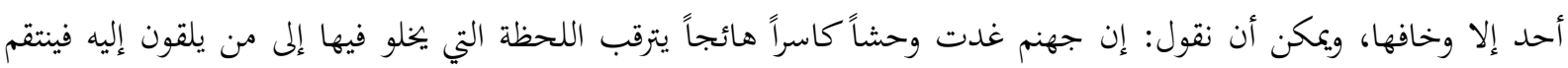

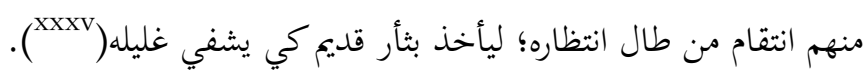
المثال الثاني:

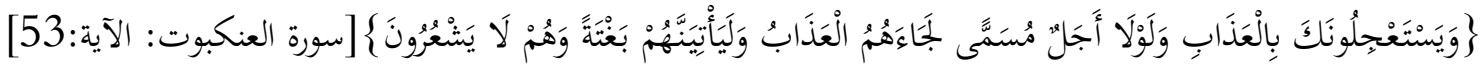
فالعذاب هو العقوبة والجزاء السيء الذي يلاقيه أهل النار، وهو معنوي في الأصل، غيبي مشخص مجسد وكأنه وحش يأتي

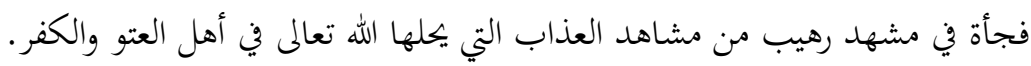

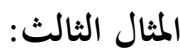

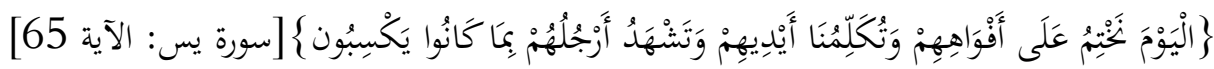

وهكذا يخذل بعضهم بعضاً، وتشهد عليهم جوارحهم، وتنفكك شخصيتهم مزقاً وآحاداً يكذب بعضها بعضاً. وتعود كل

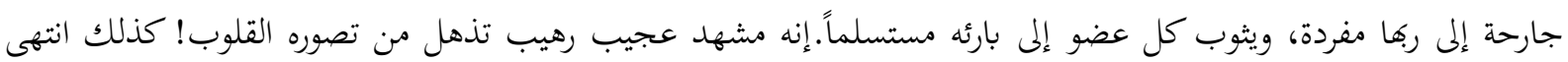

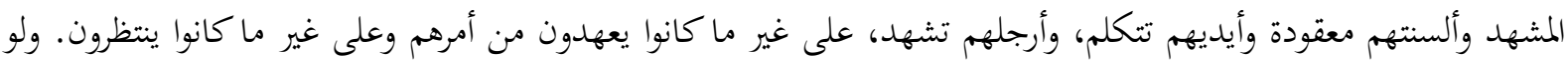
شاء الله لفعل بهم غير ذلك، ولأجرى عليهم من البلاء ما يريد( 


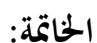

من خلال ما تقدم نستخلص الآتي:

1. يجب أن يدرس القرآن دراسة مورية شاملة لا متجزئة كل آية على حدة.

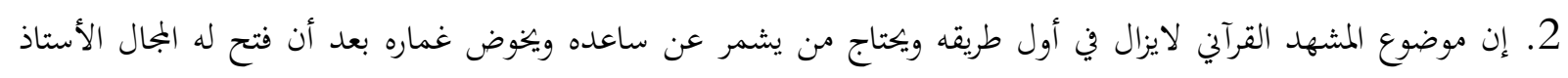

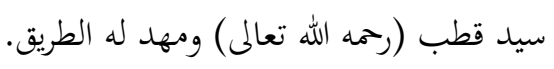


أسرار البلاغة، أبو بكر عبد القاهر بن عبد الرمن بن محمد الفارسي الأصل، الجرجاني الدار (ت: 471 هـ)،رأه وعلق عليه:

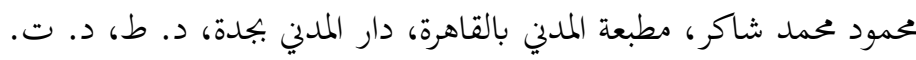

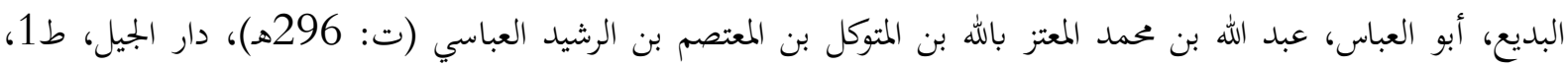

$$
\text { 1410هـ - 1990م. }
$$

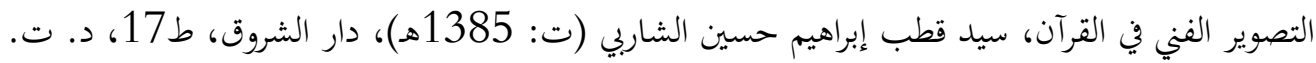

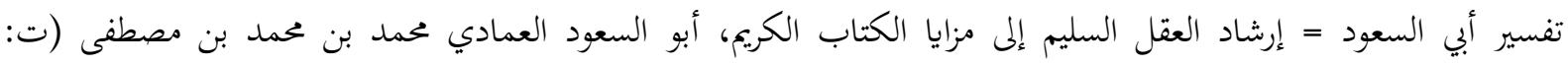

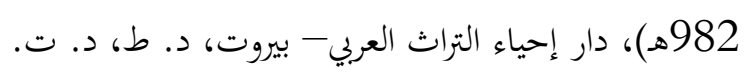

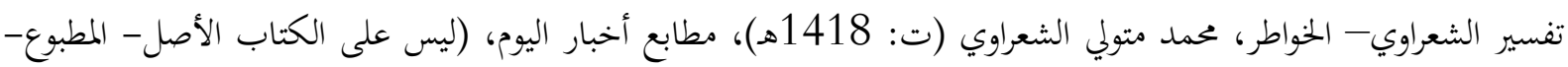

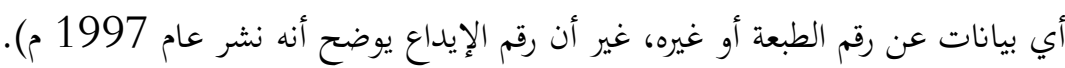

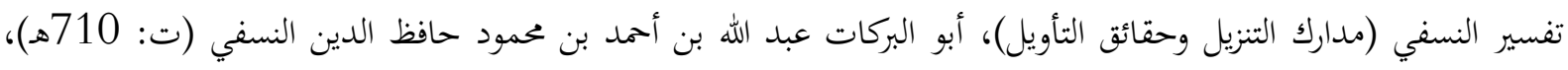

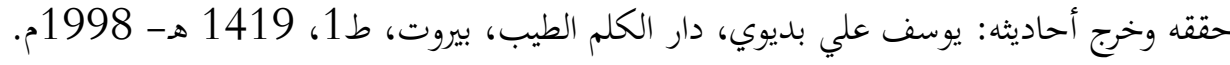

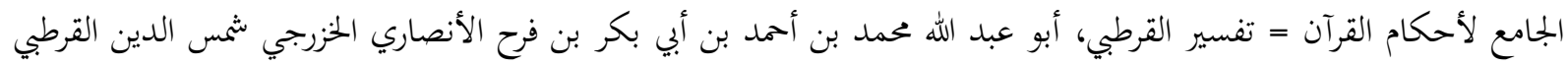

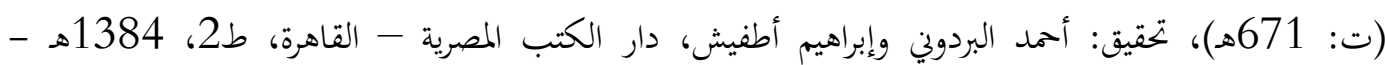

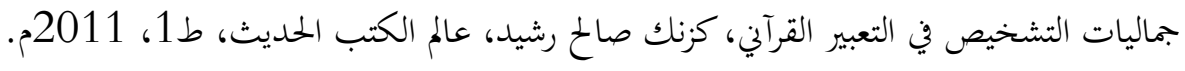

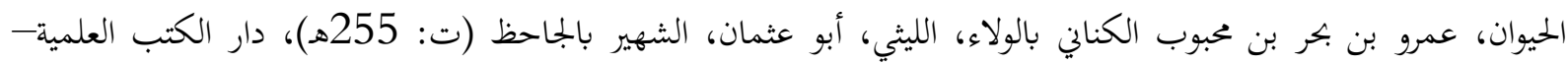

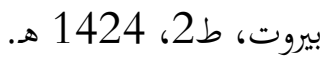

ديوان امرئ القيس، اعتنى به: عبد الرمن المصطاوي، دار المعرفة- بيروت، ط2، 1425، 1425هـ- 2004م.

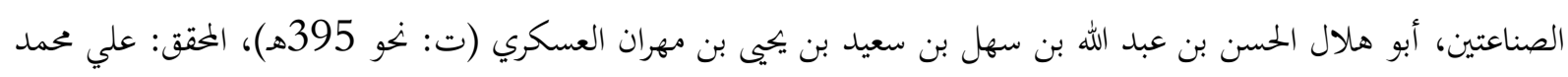

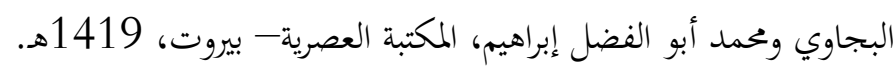

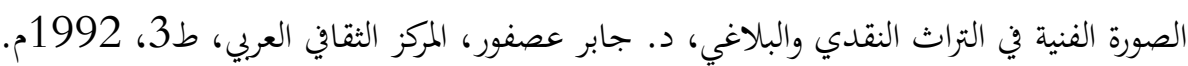

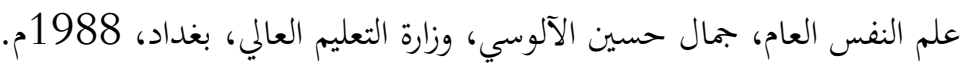

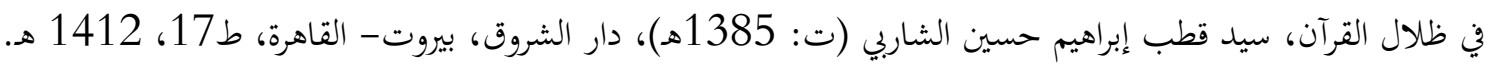

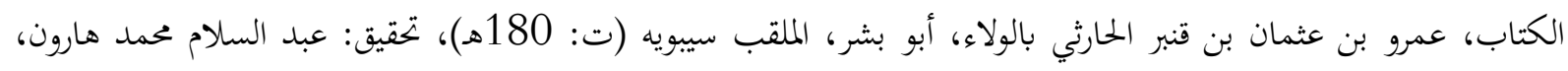

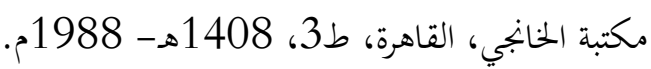

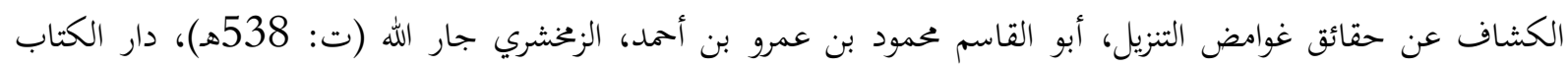

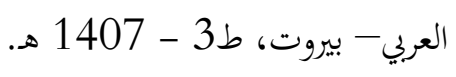

لسان العرب، عمد بن مكرم بن على، أبو الفضل، جمال الدين ابن منظور الأنصاري الرويفعى الإفريقى (ت: 714 هـأه)، دار

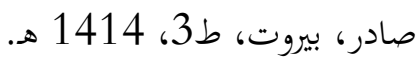

مجاز القرآن، أبو عبيدة معمر بن المثنى التيمى البصري (ت: 209 2013ه)، تحقيق: محمد فواد سزّين، مكتبة الخانجى- القاهرة، طبعة 1381

المعجم الوسيط، مجمع اللغة العربية بالقاهرة، (إبراهيم مصطفى / أحمد الزيات / حامد عبد القادر / عحمد النجار)، دار الدعوة

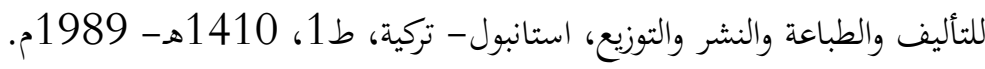


معجم مقاييس اللغة، أحمد بن فارس بن زكرياء القزويني الرازي، أبو الحسين (ت: 395هـ)، تحقيق: عبد السلام محمد هارون، دار

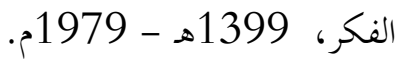

من بلاغة القرآن، أحمد أحمد عبد الله البيلي البدوي (ت: 1384هـ)، غضضة مصر- القاهرة، 2005م.

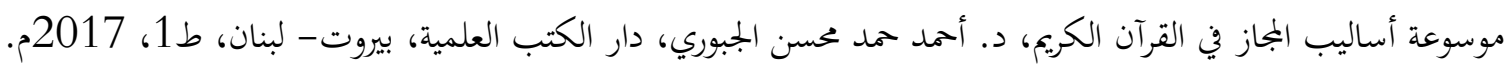


أمعجم مقاييس اللغة, أحمد بن فارس بن زكرياء القزويني الرازي، أبو الحسين (ت: 395ه)، تحقيق: عبد السلام محمد هارون, دار الفكر , 1399هـ - 1979م:

iii لسان العرب, محمد بن مكرم بن على، أبو الفضل، جمال الدين ابن منظور الأنصاري الرويفعى الإفريقى (ت: 711هـ), دار صادر، بيروت, ط3، 1414 هـ:

$.338 / 3$

iii المعجم الوسيط, مجمع اللغة العربية بالقاهرة (إبراهيم مصطفى / أحمد الزيات / حامد عبد القادر / محمد النجار), دار الدعوة للتأليف والطباعة والنشر والتوزيع, (14)

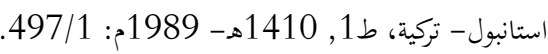
iv التصوير الفني في القرآن, سيد قطب إبراهيم حسين الشاري (ت:

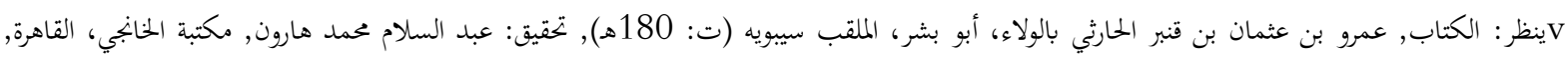
ط3، 1408 هـ 1408 هـ 1988م: 193

Vi vجاز القرآن, أبو عبيدة معمر بن المثنى التيمى البصري (ت: 209هـ), تحقيق: محمد فؤاد سزگين، مكتبة الخنانجى- القاهرة, طبعة 1381 هـ: 1 / 10.

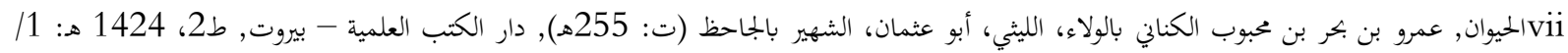

viii ديوان امرِئ القيس, اعتنى به: عبد الرحمن المصطاوي, دار المعرفة- بيروت, ط2، 1425هـ- 2004م: 15.

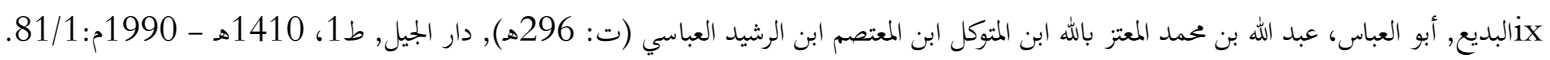

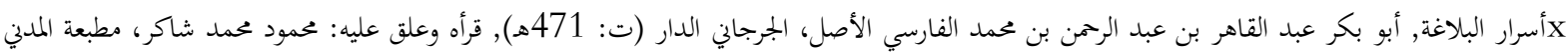

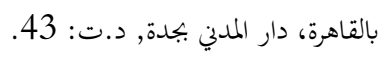
46-45:xi

Xنصوير الفني في القران: 33-Xii

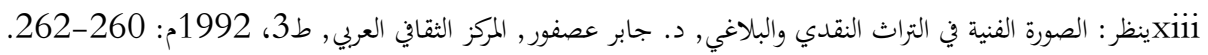

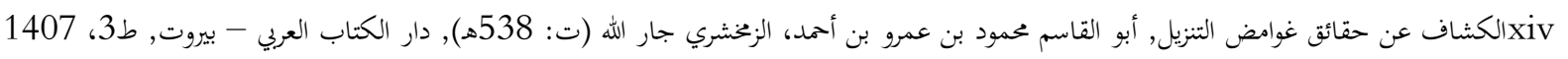
397/2 هـ

Xي ظلال القرآن, سيد قطب إبراهيم حسين الشاربي (ت: 1385هـ), دار الشروق، بيروت- القاهرة, ط17، 1412 هـ: 14 / 1879.

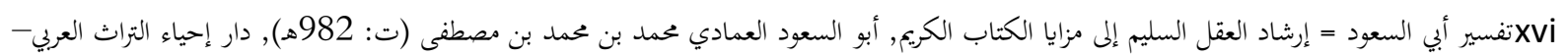

بيروت, د. ط, د. ت: 211/4

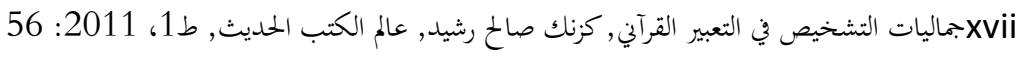

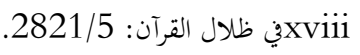

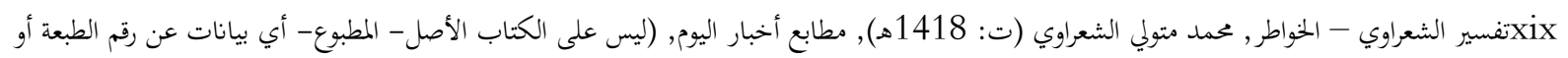

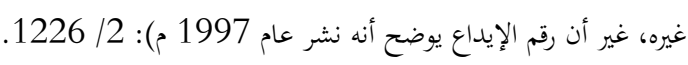
في ظلال القرآن:5xx جماليات التشخيص في التعبير القرآي: 76 فxxi علم النفس العام, جمال حسين الآلوسي, وزارة التعليم العالي, بغداد، فئسئ 1988xii في ظاعلال القران:xxiii الكشاف:16xiv XXV الصناعتين, أبو هلال الحسن بن عبد الله بن سهل بن سعيد بن يميى بن مهران العسكري (ت: نحو 395هـ), تحقيق: علي محمد البجاوي ومحمد أبو الفضل

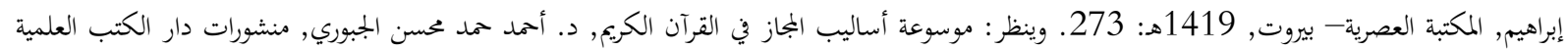
بيروت- لبنان, ط1، 2017م: 328.

xixxvi

تفسير أبي السعود:117xxvii Xi في ظلال القرآن: 38xviii تفسير النسفي (مدارك التنزيل وحقائق التأويل), أبو البركات عبد الله بن أحمد بن محمود حافظ الدين النسفي (ت: 710هix

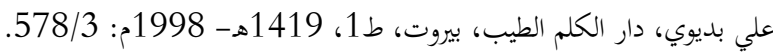

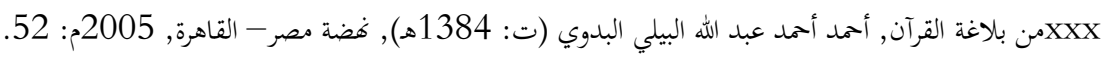


جمxxi لسان العرب, محمد بن مكرم بن على، أبو الفضل، جمال الدين ابن منظور الأنصاري الرويفعى الإفريقى (ت: 711 7هات), دار صادر، بيروت, ط3، 1414 هـ: مادة (ب) xiluxxiii

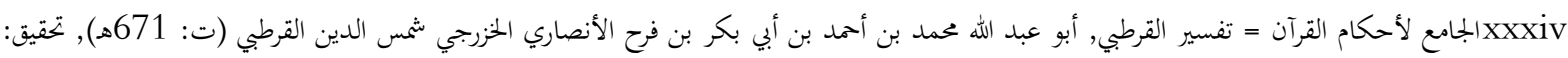

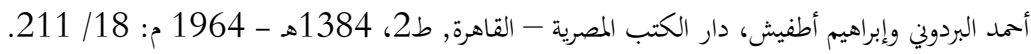
Xمxxv ماليات التشخيص في التعبير القرآني: 162. xفxxvi 


\title{
ELEGIES FOR THE PROPHET'S FAMILY BY \\ CONTEMPORARY LEBANESE CHRISTIAN POETS
}

\author{
Khalid Ahmad SINDAWI ${ }^{1}$
}

\section{Istanbul / Türkiye \\ p. $670-685$}

Received: $27 / 11 / 2021$

Accepted: $10 / 12 / 2021$

Published: 01/01/2022

This article has been scanned I iThenticat No plagiarism detected

\begin{abstract}
:
The study discusses elegiac poetry on the Prophet's family composed by Lebanese poets belonging to the Christian community there. We chose a selection of writings by four contemporary Christian poets: Joseph al-Hāshim, Paul Salāma, Raymond Qasīs and Joseph al-Harb. The study opens with a discussion of the meaning of elegies as a human, social and individual poetic object, that has been cultivated by poets since pre-Islamic times. Next, the study discusses the reason why the Prophet's family has been the subject of so many elegies, namely the important position this family occupied among poets. Subsequently we discuss why Christian poets in Lebanon have composed numerous elegies for members of the Prophet's family, especially 'Alī b. Abī TTâlib and his son al-Ḥusayn b. 'Alì, namely the fact that elegies constitute a unique human phenomenon that is in keeping with divine teachings, especially concerning the Prophet's family. The study uses both descriptive and analytic methods.
\end{abstract}

Key words: The Prophet's Family, Elegy, Al-Husayn B. 'alī, 'alì B. Abī Țâlib, Contemporary Arabic Poetry, Christian Poets, Lebanon, Christian Poetry, Shī'ī Poetry.

http://dx.doi.org/10.47832/2717-8293.15.46 


\section{رثاء أهل البيت لدى شعراء النّصارى اللّنبانيّين المعاصرين}

\section{خالد أحمد سِـنداوي 2}

الملخص: يهاف هذا البحث إلى الوقوف عند رثاء أهل البيت لدى شعراء لبنانيّين ينتمون للطّائفة المسيحيّة، وقد اختار

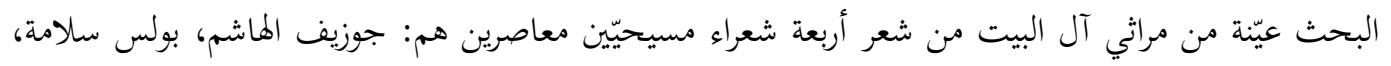

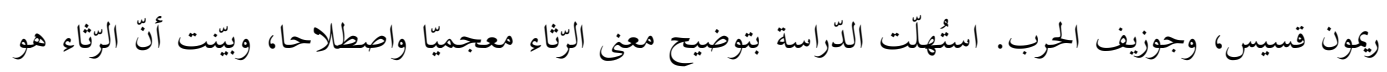

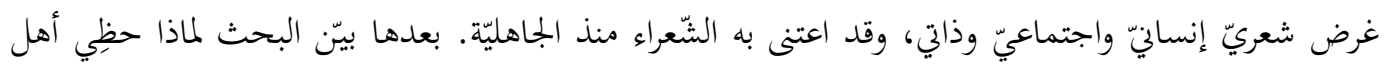

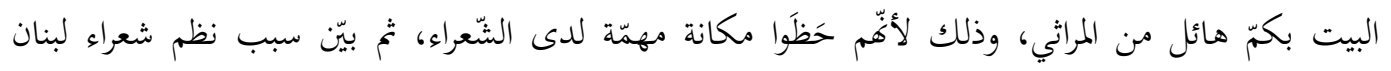
النّصارى مراثٍ عديدة في آل البيت خاصّة في علي بن أبي طالب وابنه الحسين بن علي، وذلئ وذلك لأنّ الرّثاء ظاهرة

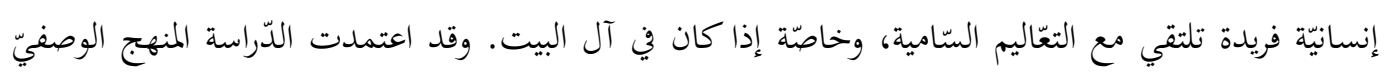

الكلمات المفتاحية: أهل البيت، الرّثاء، الحسن بن عليّ، عليّ بن أبي طالب، الشّعر العربيّ المعاصر، شعراء النّصارى، لبنان، الشّعر المسيحيّ، الشّعر الشّيّيّ.

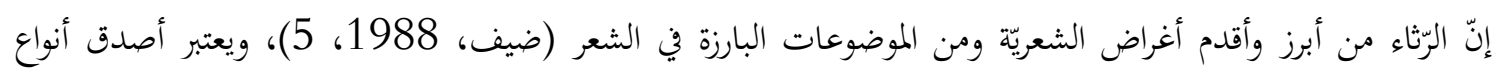

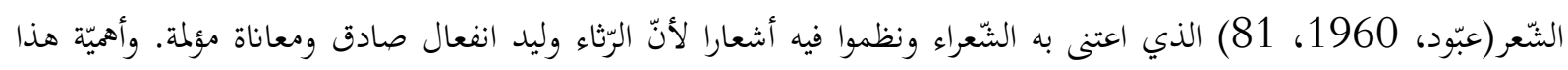

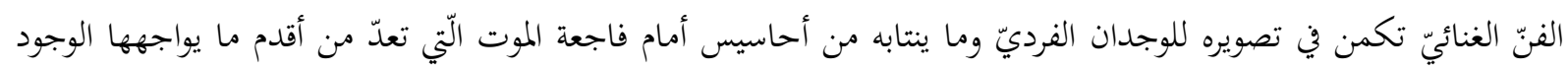

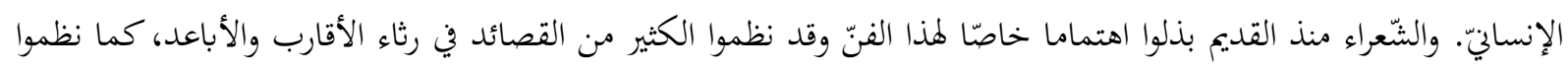

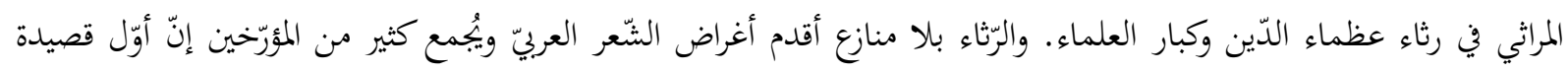

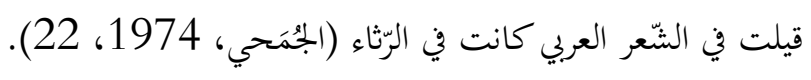

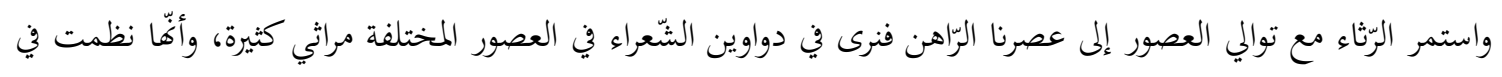

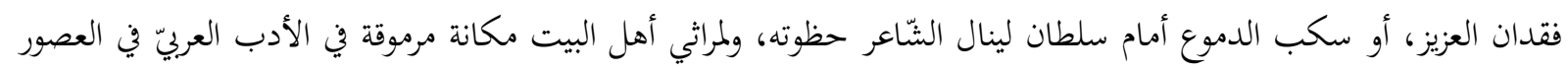

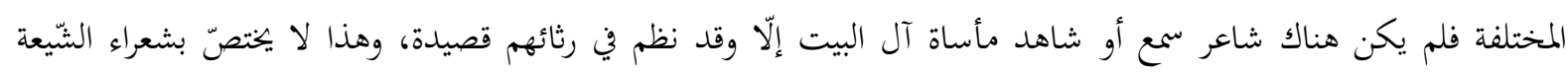

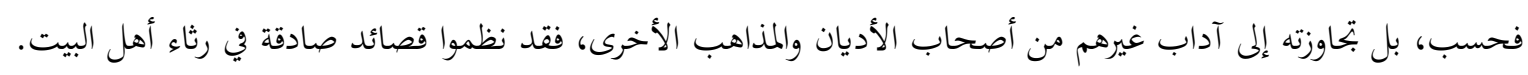

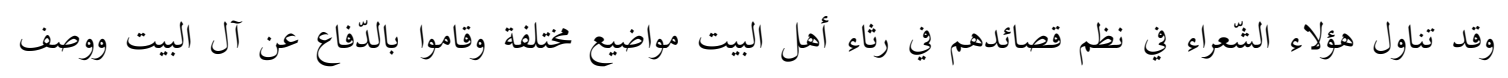
مصائبهم والمحن التي واجهها أهل البيت أثناء حياتم. لم يتّبع الشعراء في نظم مراثي أهل البيت طريقا واحدا ولكن من خلال دراسة هذه المراثي يمكن الإشارة إلى عدّة ميزات

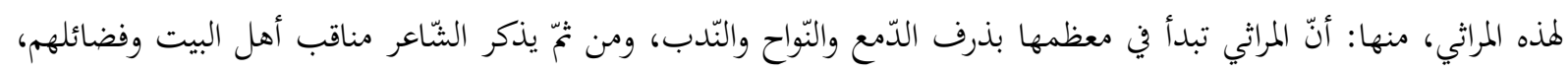


وذكر بعض أحاديث من الرّسول التي تدلّ على الخلافة لعليّ من بعد وفاته، ووصيّته في حبّ آل البيت وذمّ أعداء آل البيت،

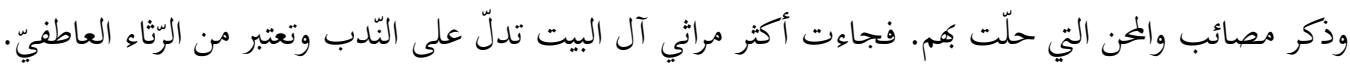

وقد تأثّر الشّعراء أشدّ التأثير بواقعة الطَّنَّ وأحداثها وما أصاب الحسين يوم عاشوراء عام 680م، فنرى المراثي التي

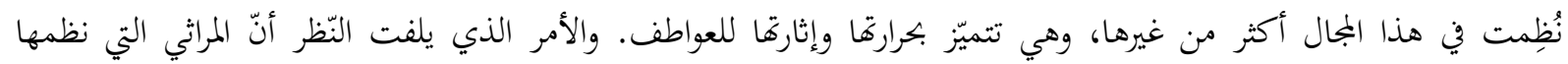

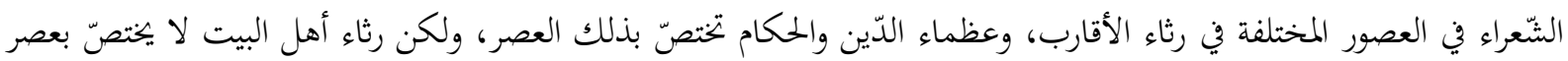
دون العصور، بل قد اهتمّ الشعراء في جميع العصور الأدبيّة برثاء آل البيت وقد صوّر الشعراء عظمة آل البيت ومكاءنتهم في

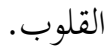
وما زال النظم في رثاء أهل البيت متدفّقا حتّى عصرنا الراهن، فهناك شعراء قد نظموا قصائد في رثاء أهل البيت منهم

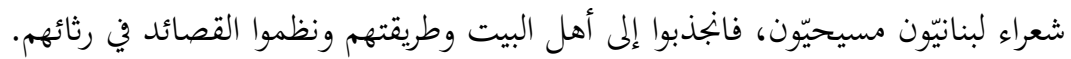
إنّ المدف المتوخّى من هذا المقال هو دراسة مراثي أهل البيت التي نظمها شعراء مسيحيّون من لبنان ونسعى في هذا المجال

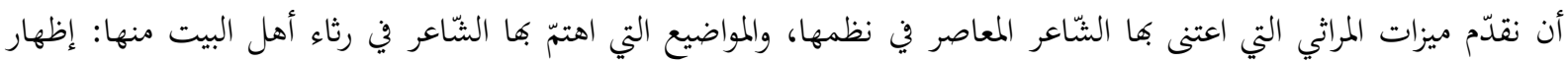
الحزن والألم من مقتل أهل البيت، ذكر فضائل أهل البيت وعظمتهم، وصف المصائب والمحَن الّتي واجهها أهل البيت ودور أهل

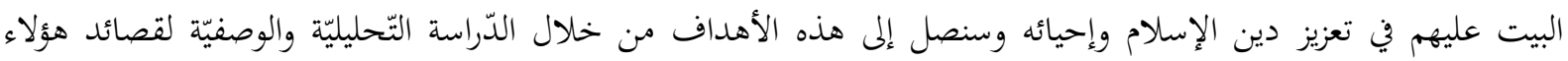

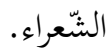

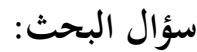
يسعى البحث للإججابة على هذه الأسئلة:

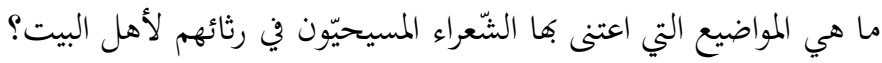

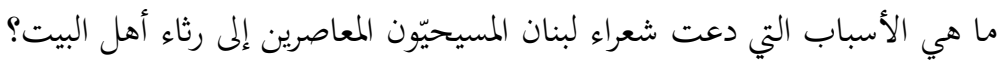
وما هي مميزات مراثي شعراء لبنان المسيحيّون المعاصرين في آل البيت؟

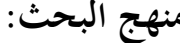

نظرا لطبيعة الدّراسة فقد اعتمد هذا البحث على المنهج الوصفيّ والمنهج التّحليليّ، أي وصف وتحليل مراثي آل البيت التّي اختيرت كعيّات للبحث، ومعالجتها وتحليلها ومقارنتها ببعضها لاستخلاص دلالاتحا والوصول إلى نتائج وتعميمات عن مراثي آل البيت لدى شعراء لبنان المسيحيّين.

الرّثاء في اللّفة والمصطلح

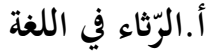

عندما نعود إلى مصادر التّراث في اللّغة العربيّة وهي غنيّة جدّا، نجد ثلاثة أصول لكلمة الرّثاء، حدّدها علماء اللّغة في معاجمهم وهذه الأصول هي:

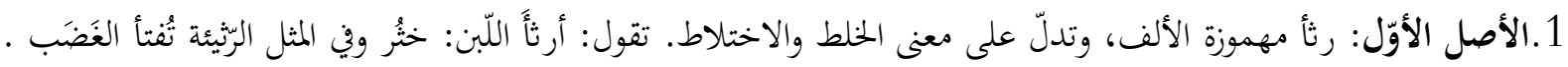

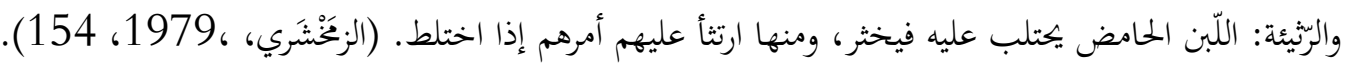


2.أمّا الأصل الثّاني فهو: رثى بالألف الليّنة ومضارعه يرثي و المرثيّة بالفتح وجَع في الرَكبتَين والمفاصل (الجوهري، 1990، 14:

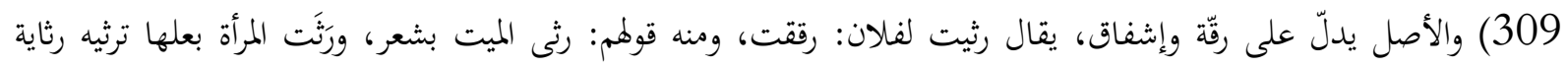

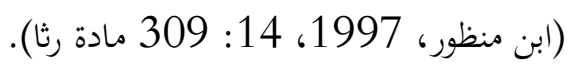

3.أمّا الأصل الثّالث فهو: رثّ بالتّضعيف، وهو أصل واحد يدلّ عل أخلاق وسقوط. يقال ثوب رثّ، ورجل رثّ الهيئة.( ابن

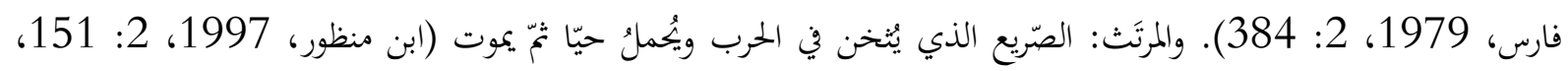
مادّة رثت) .

ب.الرّثاء اصطلاحا

كلمة الرّثاء اصطلاحا تعني: بكاء الميت وذكر مناقبه شعرا أو نثرا. و المرثيّة و الرّثاء: بكاء الميّت وتعداد محاسنه، فيقال:

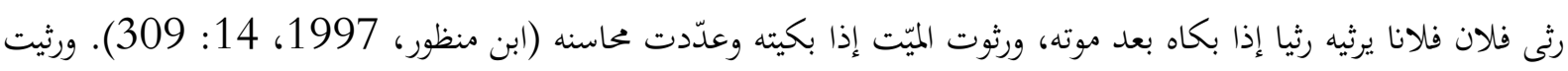

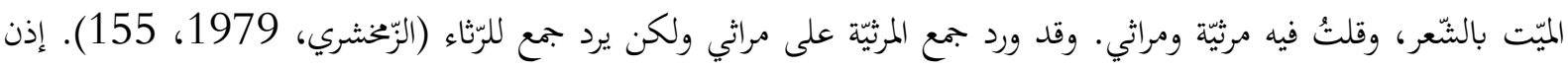

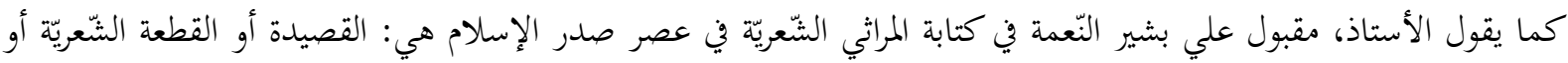

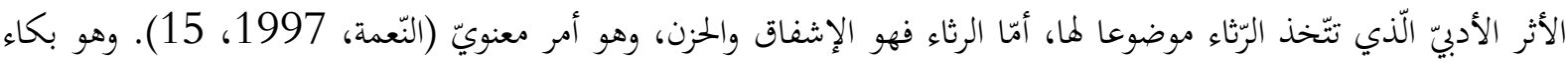

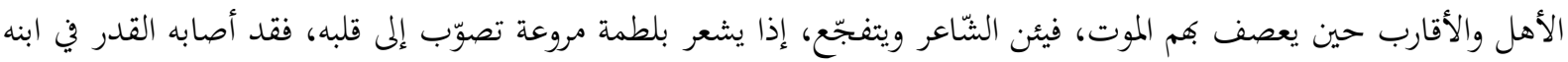

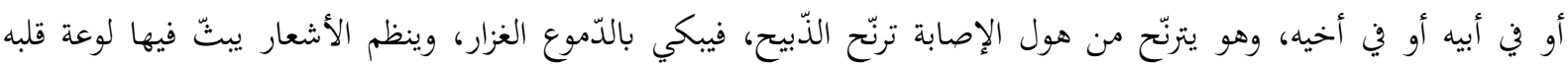

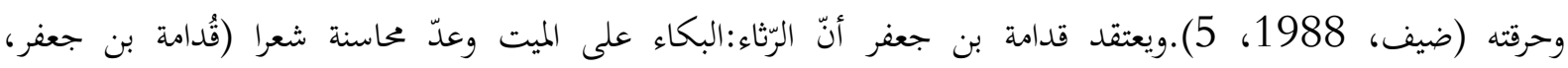

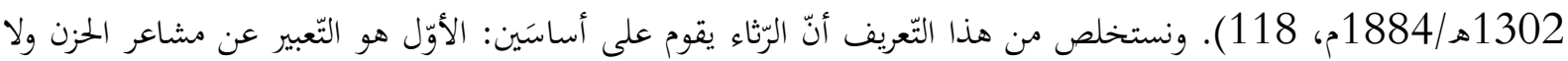
رثاء بدونه، والثاني ذكر محاسن المرثي له وأبجاده.

أمّا البكاء على الميّت والتّعبير عن مشاعر الحزن والأسى أمر ضروريّ إذ لا يستقيم الرّثاء بدونه، وهذه العاطفة هي التي

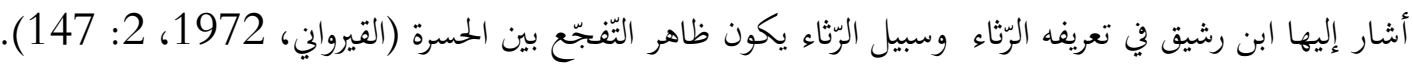
ولقد تداخل المعنى الاصطلاحيّ بالمعنى اللغويّ للرثاء فأصبح المعنى يمثّل مدلولا واحدا عند بعض النّاد. وقد أشارت

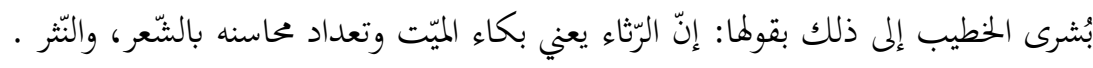
ولكل" أمّة مراثيها، والأمّة العربيّة من الأمم الّتي تحتفظ بتراث ضخم من المراثي، وهي تأخذ عندها ألوانا ثلاثة وهي،

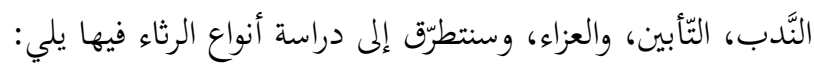
النّدب: هو بكاء الأهل والأقارب حين يعصف بهم الموت، فيئنّ الثّاعر ويتفجّع وينظم الأشعار ليبثّ فيها لوعة قلبه وحرقته. التّأبين: وليس التأبين نواحا ولا نشيجا على هذا النّحو، بل هو أدنى إلى الثنّاء منه إلى الحزن الخالص، إذ يخرّ نجم لامع من سماء

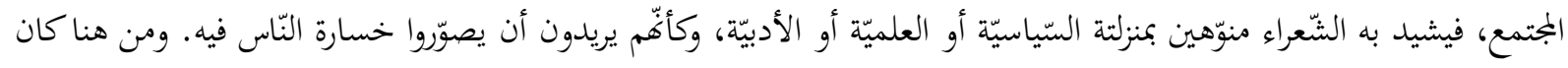

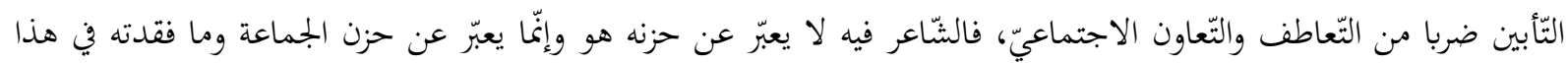

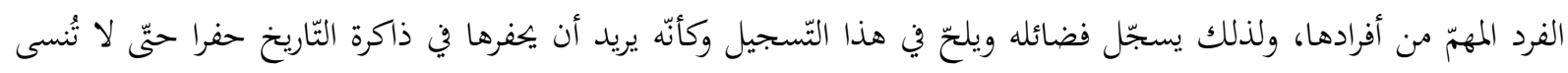

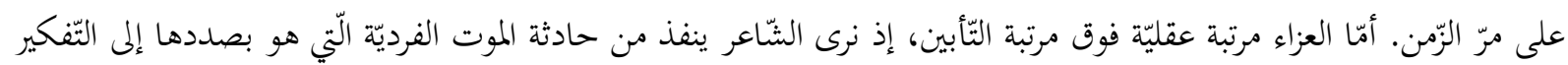

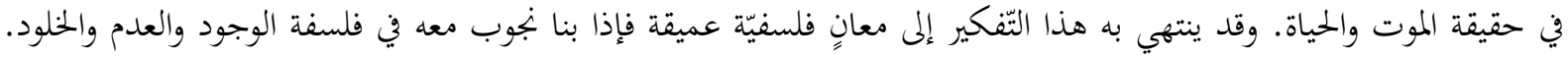

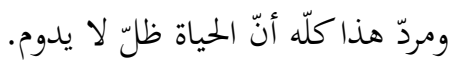


ونشاهد هذه الألوان الثّالثة من الرّثاء في جميع مراثي الشّعراء من عصر الجاهليّ إلى عصرنا الرّاهن سواء أكان رثاء خاصّا

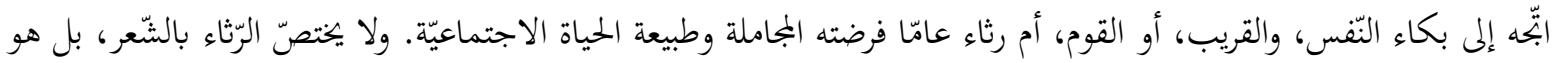
شائع في النّر والشّعر ولكن غلب هذاء الفنّ في الشّعر.

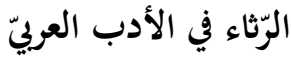

عَرف العرب شعر الرّثاء منذ العصر الجاهليّ لأنّ الرّجال والنّساء جميعا كانوا يندبون الموتى، كما كانوا يقفون على قبورهم

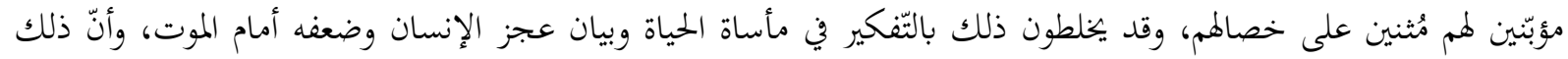
مصير محتوم. - مانم شعر الرّثاء فهو كان في أصله "تعويذات للميّت حتّى يطمئنّ في قبره". ولا بدّ أنّ هذه الصّورة الأوّليّة من الرّثاء خضعت

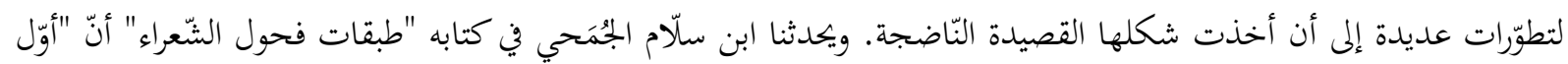

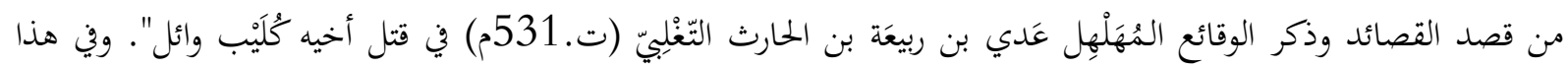
الخبر دلالات هامّة منها: 1. أنّ وقوع الموت كان من أقوى دوافع الشّعراء لنظم الأشعار في الرّثاء. 2. أنّ شعر الرّثاء وليد انفعال صادق ومعاناة مؤلمة. 3. أنّ الإنسان المخزون يحاول أن يخفّف من أحزانه بواسطة الشّعر. وتطوّرت قصائد الرّثاء في العصر الجاهليّ، إذ نرى قد استُخدم في نظمها وسائل فنيّة كثيرة، وقد نوّعوا هذا الفنّ تنويعا

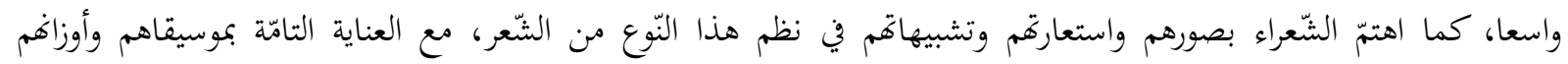

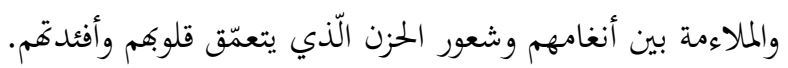
وكان يساهم في هذا الفنّ النّساء الرّجال والنّساء، بل ربّما كان للنّساء حظّ الأوفر من القيام عليه، إذكنّ هنّ اللائي يقمن

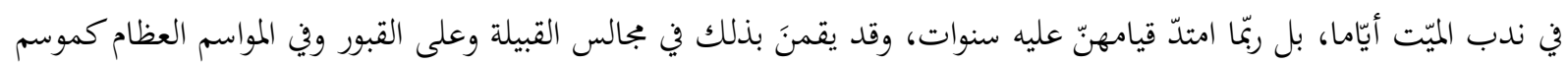
عُكاظ.

ومن الطبّعي أن يتفوّق النّاء على الرّجال في ندب الموتى والنّواح عليهم، لأنّ المرأة أدقّ حِسّا وأرقّ شعورا، وأيضا فإنّ

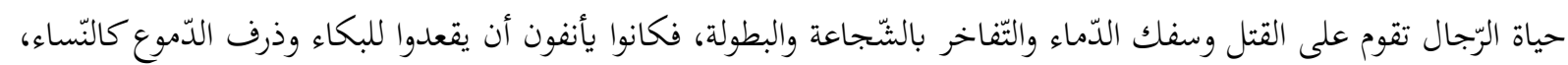
بل لقد ذهبوا يظهرون التّجلّد والصّبر على من يموت منهم.

وهذه الصّور الجاهليّة للرّثاء استمرت في الأدب العربيّ مع عصوره المختلفة، تارة تنمو وتارة تتطوّر، تحت أثير نمو العقل

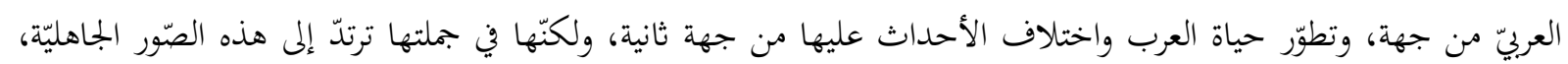
وتشتقّ منها كما يشتقّ الفرع من أصوله.

\section{رثاء أهل البيت لدى شعراء لبنان المسيحيّين}

إنّ دراسة شعر شعراء لبنان المعاصرين، تُبيّن لنا أدب هذا القطر العربيّ قد شاهد تطوّرا ملحوظا في العصور المختلفة، إنّ

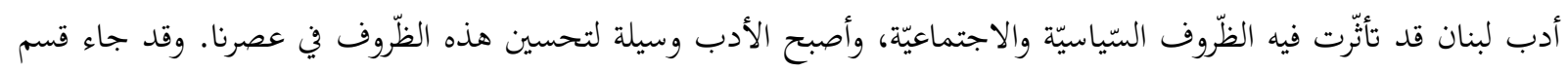

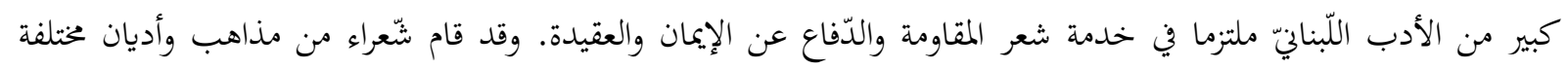


كالمسيحيّة وغيرها قاموا بالدّفاع عن وطنهم وعقيدقم وإيماغم، واتِّذوا عظماء الدّين أسوة لأنفسهم، فجاء شعرهم شعرا ملتزما،

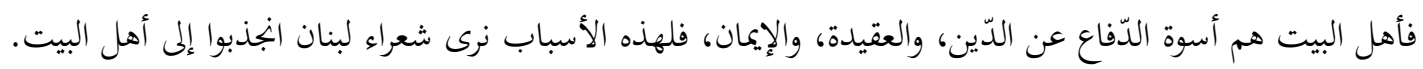
أمّا القصائد التّي نُظمت في رثاء الحسين بن علي، فهي أكثر ظهورا في شعر شعراء لبنان. فقد نظم شعراء لبنان المسيحيّون

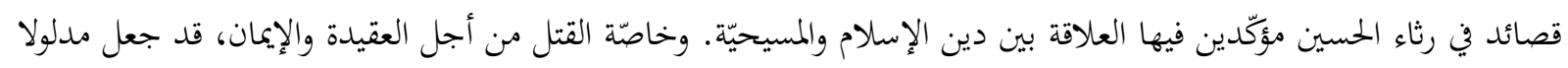

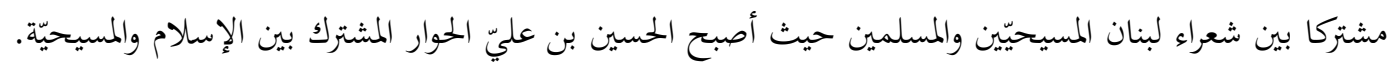
ولم يكتفِ شعراء لبنان المسيحيّون في رثاء الحسين بن عليّ ويوم عاشوراء بوصف الأحداث والمصائب الّتي شهدها آل

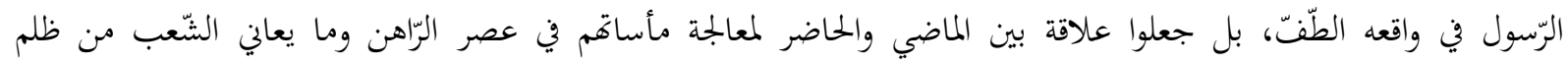

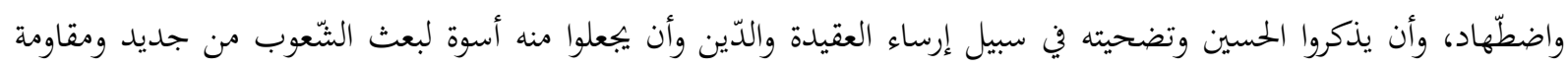
الظّلم والوقوف في وجه الطُّاة. فلهذا يصبح الحسين أسوة المقاومة والاستشهاد في شعر شعراء لبنان المعاصرين. وقداء وقد تطرّق

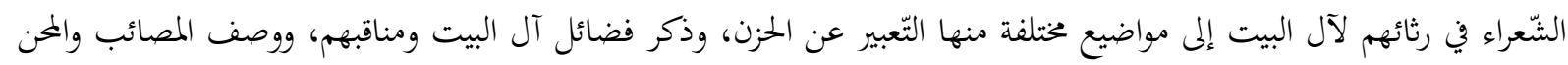

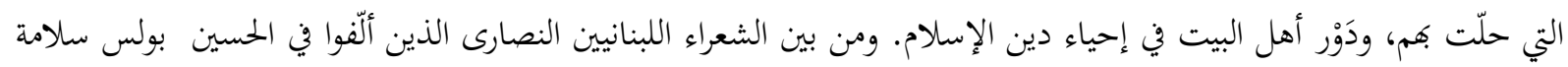

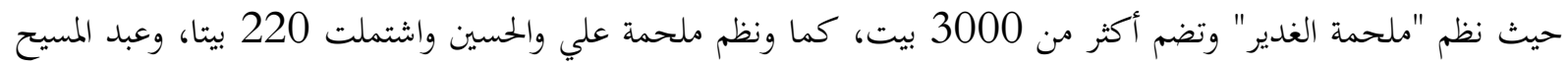

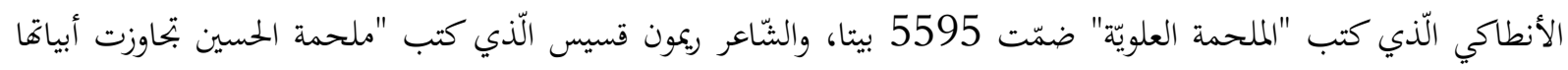

\section{التّعبير عن الحزن في رثاء أهل البيت}

تبدأ قصائد الرّثاء عادة بالبكاء ويصوّر الحزن والالم الذي حلّ به إثر فاجعة فقدان الأحبّة والأصدقاء والأقرباء و....

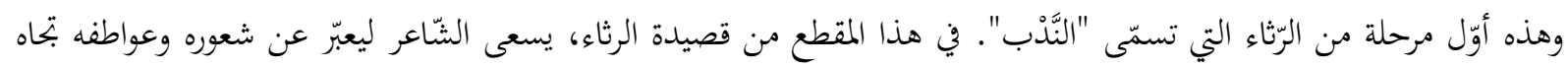

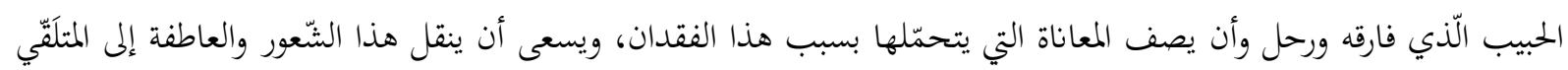

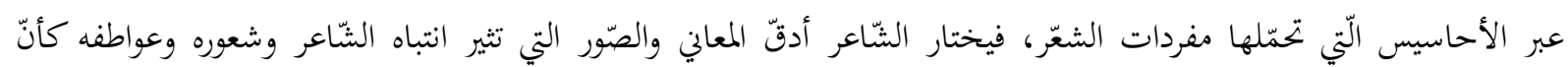
المتلقيّ هو الذي أُصيب بهذا الفقدان المفاجئ.

ولا تُستثنى المراثي التي نُظمت في رثاء أهل البيت إذ نرى هذه المراثي كغيرها تبدأ بالنّدب والتّعبير عن الحزن والأسى في

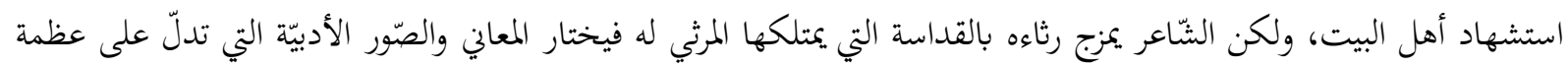

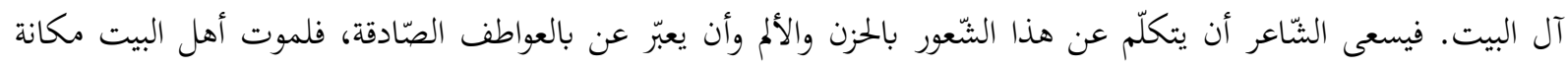

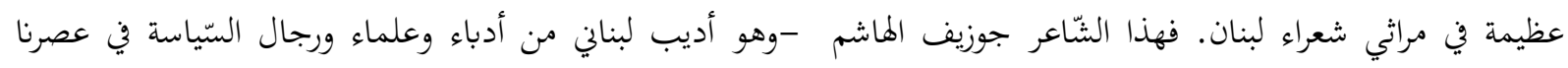

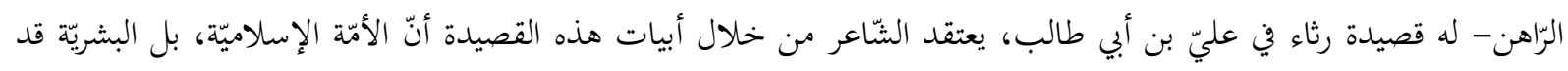

خسرت خسرانا عظيما بمقتل علي بن أبي طالب فيقول:

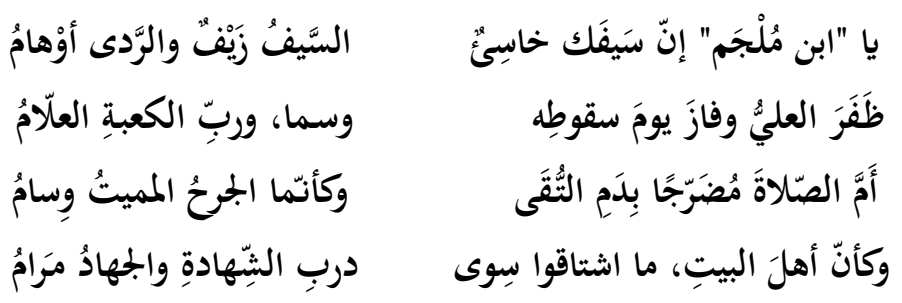

(الهاشم، 1999، 18) 
يشير الشّاعر في هذه الأبيات إلى تلك العبارة التي قالها علي في أثناء صلاة الصّبح عندما ضربه عبد الرحمن ابن مُلْجَم المُرادِيّ (ت. 661م) في رأسه، فقال: "فُزتُ وربّ الكعبةِ" وتشير هذه العبارة إلى غربة عليّ واشتياقه إلى الاستشهاد.

لم يكن مقتل الامام علي حادثة مفجعة فحَسب، بل هو رمز الصّمود وتضحية النّس من أجل العقيدة والإيمان وهو ركز

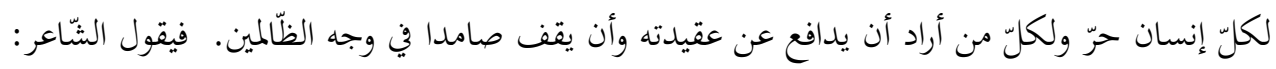

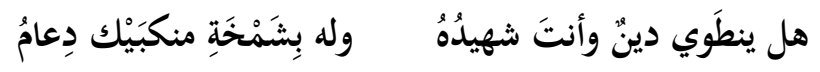

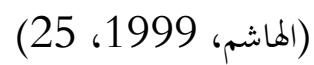

فيعتقد الثّاعر أنّ الدّين الذي قُتِل من أجله عليّ بن أبي طالب سيبقى على مدى الحياة ولن ينمحي من أذهان العالم،

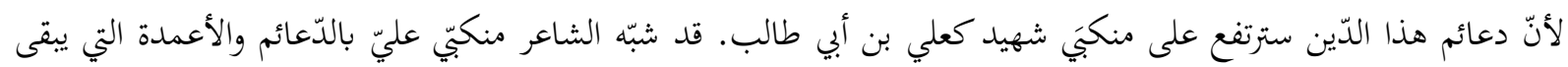
عليها الدّين مستحكِما وبهذا أشار الشّاعر إلى عظمة عليّ ودوره في تحكيم أساس الدّين. وللشّاعر بولس سلامة من شعراء لبنان قصيدة تحت عنوان "ملحمة عيد الغَدير" يتكلّم فيها بعاطفة صادقة عن مقتل

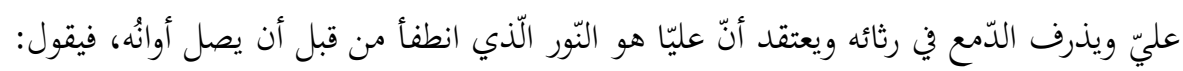
غابَ ضوءُ النّهارِ قبَل انقضائهِ هاتِ يا شعُر أدمُعا لرثائهِ فالأثيرُ الطّهورُ في أجوائسـِ واذكرِ النّسرَ عاليا لمُ يُدنَّس ويسدُّ الفضاءَ رحبِّ فضائهُ يكسف الثّمسَ بالجناح عريضًا من مناط العيّوقِ في إسرائهِ

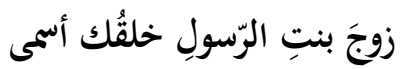
لا يمسٌُ الغبارُ كُنهَ صفاتِهِ شيمةُ النّورِ أن يظلَّ نقيّّا (سلامة، 1423هـ/2002م، 183- 187)

فالشّاعر في هذه الأبيات يتكلّم عن عظمة عليّ ويشبهه بالنَّسر في علو شأنه وشجاعته ويعتقد أنّ مكانته أعلى من

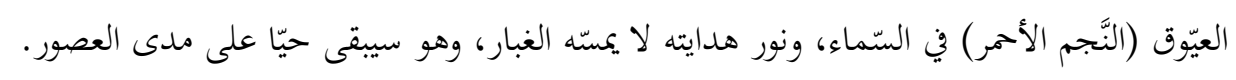
ويواصل الشّاعر ويقول:

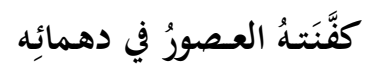
يـا عدوَ السَّماءِ في بغضائِه حين غابَ الإمامُ من فقهائهُ

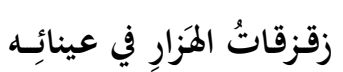

ليتَ يومًا قد جاءَ بابنِ مُراد ايه عبدَ الرّمَمِ نذلَ مُرادِ

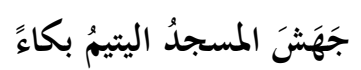

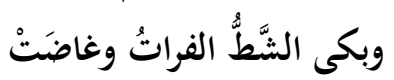

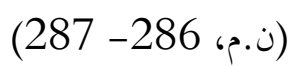

يعتقد الثّاعر أنّ عليّا بمقتله في محراب مسجد الظّهِهر بالكوفة الّذي هو موضع الإيمان وتمام الدّين. وقد جاء الثّاعر هذذه

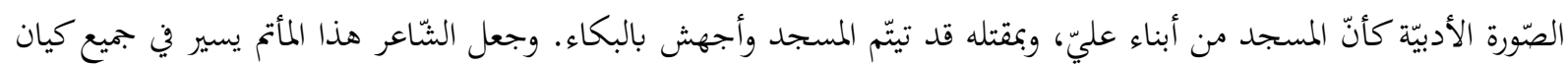
العالم حيث يبكي شطّ غر الفرات، عصافير الهزَار.

ويشير الشّاعر بولس سلامة في المقطع الأخير من قصيدته إلى واقعة الطَّنبّ، ويبيّن كيف تأثّرّ بأحداث كربلاء وأحبّ

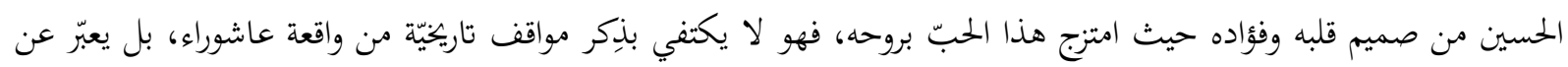

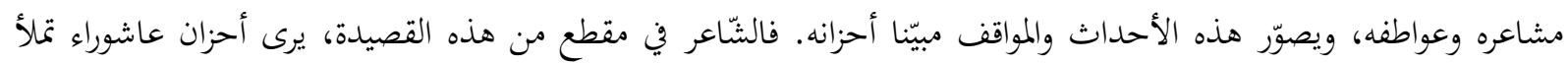

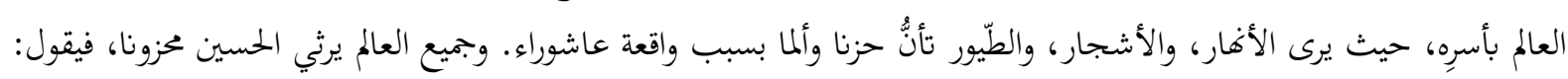




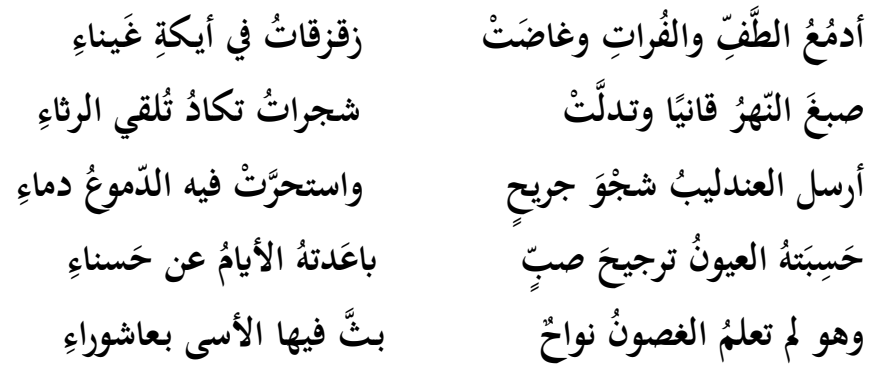

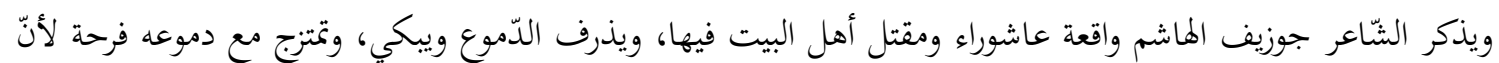

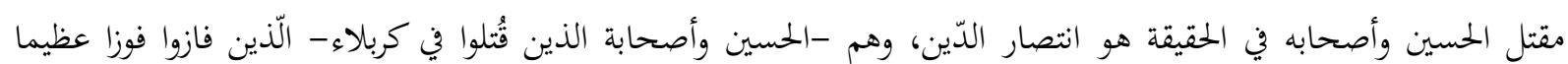
بمقتلهم، وقد خسر أعداء الإسلام وأنّ انتصارهم كان بالظّاهر، فيقول:

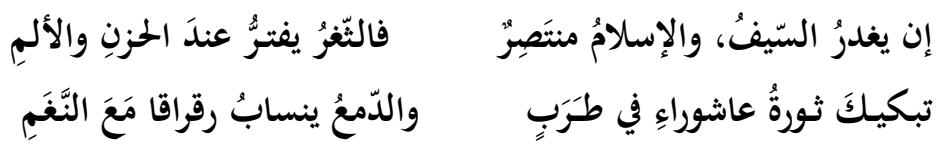

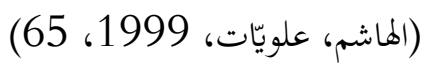

أمّا الثّاعر جوزيف حرب فقد تناول في قصيدة له موسومة بـ "بكائيّة رأس الحسين" رثاء الحسين بن عليّ وأصحابه،

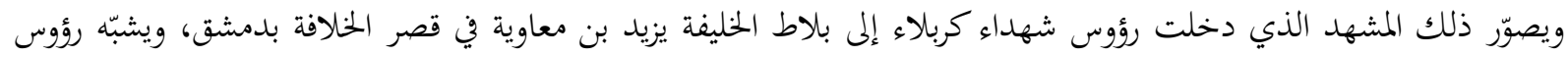

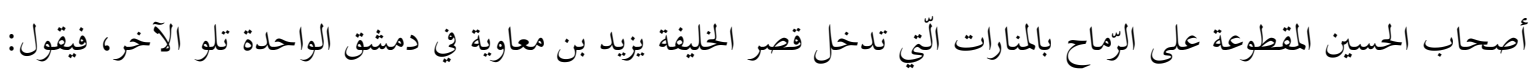

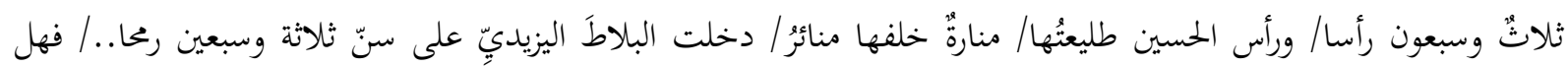

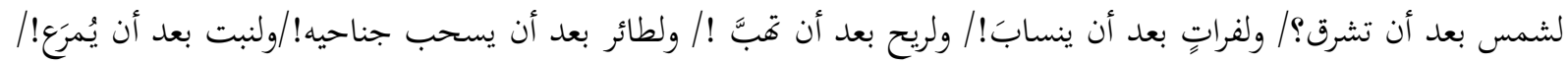

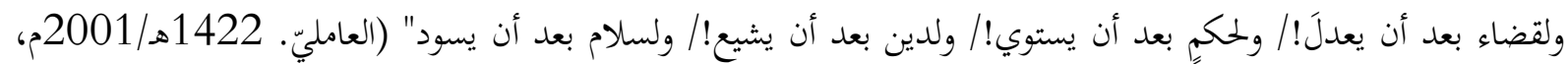
إنّ الثّاعر في هذا النّصّ الشّعريّ يرى أنّ الحزن يسري في جميع العالم بسبب مقتل الحسين، فالشّمس لا تشرق من بعده،

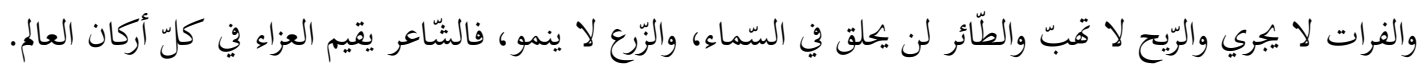

\section{ذِكر فضائل أهل البيت}

إنّ الشّاعر في رثائه يذكر محاسن الميّت، وفضائله وحَسبَبه ونَسَبَه وهذا ما يُسمّى التّأبين، وليس التَّبين نواحا ولا نشيجا،

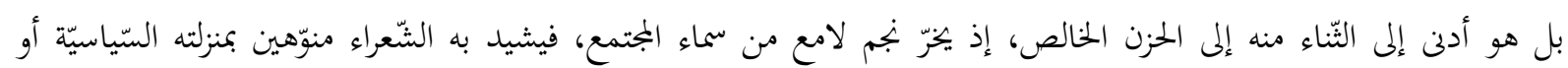

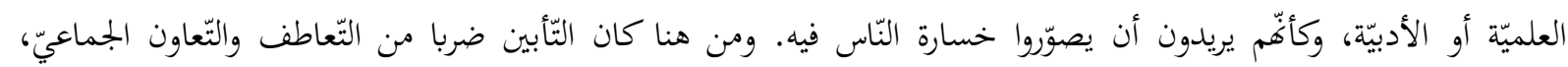

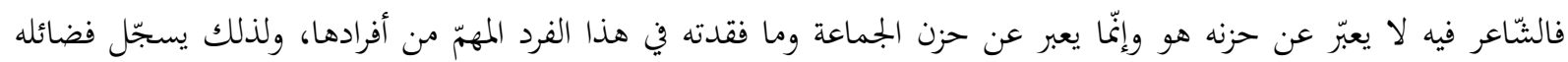
ويلحّ في هذا التّسجيل وكأنّه يريد أن يحفرها في ذاكرة التاريخ حفرا حتّى لا تنسى على عنى مرّ الزمان. إنّ شعراء لبنان المعاصرين أيضا في رثائهم لأهل البيت، ذكروا فضائلهم ومحاسنهم، وقد وصفوا هذه الفضائل في أشعارهم،

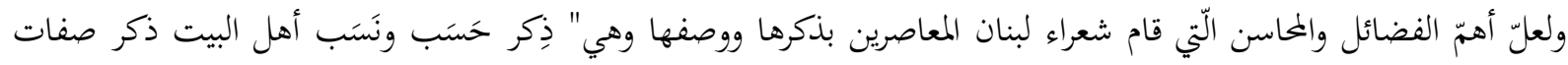

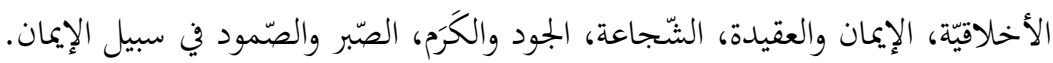
فالثّاعر بولس سلامة، يذكر عليّا في شعره بألقابٍ مختلفة منها: "سِدرة المنتهَى في الكمال الإنسائّ"، و"عليّ العصور" 
وهو يتكلّم عن عظمَة عليّ وفضائله ويعتقد أنّ الله خلق عليّا لمناصرة أفضل أنبيائه. وأنّ عليّا هو نور الهداية الذي يُهدى

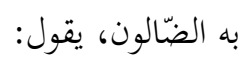

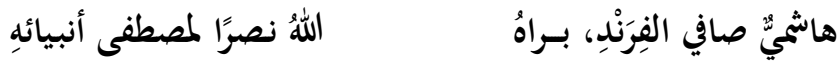

$$
\begin{aligned}
& \text { في خِضَّمّ من الضَّياءِ رحيبٍ }
\end{aligned}
$$

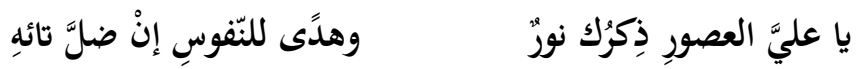

(عقل، 2009، 261)

والشّاعر المسيحيّ المعاصر جوزيف الهاشم الّذي يُعدُّ من أبرز شعراء النّصرانيّة في الأدب المعاصر، له ديوان شعر تحت

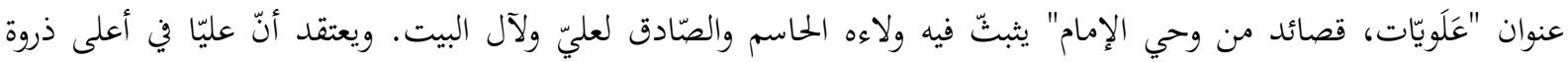

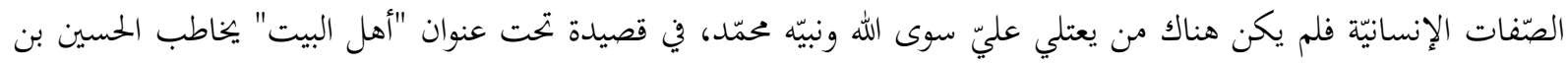
علي ويقول:

$$
\begin{aligned}
& \text { يا ابنَ العليّ، ومن يعلو العليّ سِوى اثنين، ربّك فوقَ الرّسلِ كِلّهم }
\end{aligned}
$$

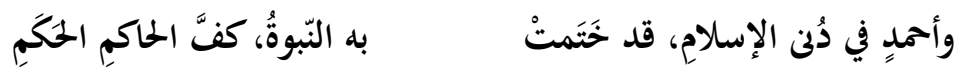

(الهاشم، 1999)

وفي موضع آخر يتكلّم الشّاعر عن نَسَب عليّ بن أبي طالب ويمدحه، ويذكر بعض صفاته كمولود في داخل الكعبة،

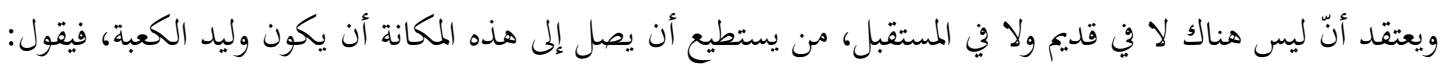

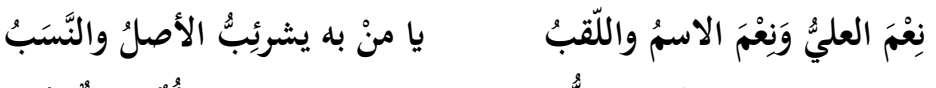

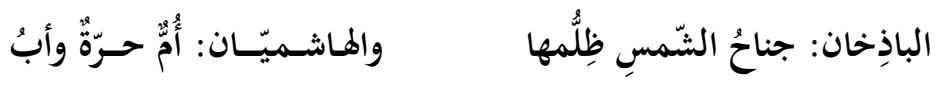

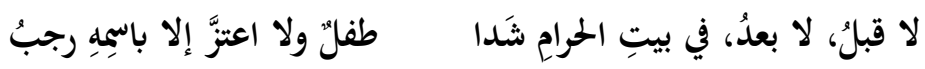

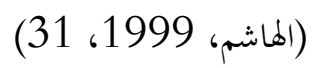

ويذكر الشّاعر أيضا صفة أخرى لعليّ، وهي أسبقيّة عليّ في الإيمان حيث سبق النّاس بالإيمان فكان أوّل من آمن بالله والرّسول في حين كان النّاس يعبدون الأوثان ويشركون بالله، فيقول:

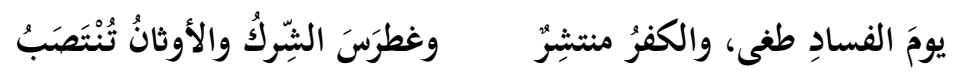

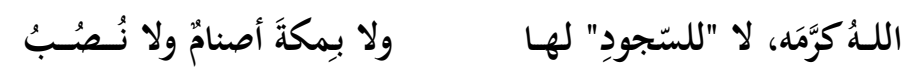

(الهاشم، 1999، 31). (الم،

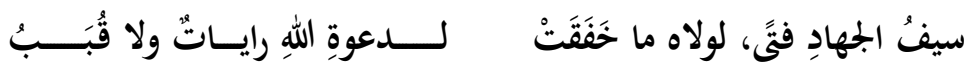

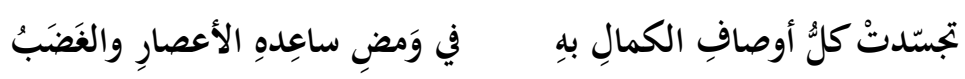

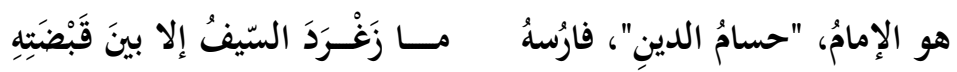

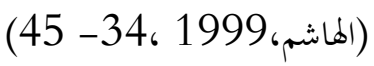

ومن الفضائل التّي يشير إليها الثّاعر حول عليّ، سِعة علمه، وفي هذا المجال يذكر عليّا بِلَقَبَيْن: "سيّد البيان" و "باب

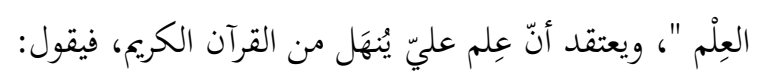

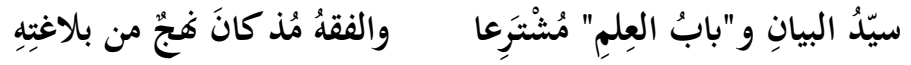

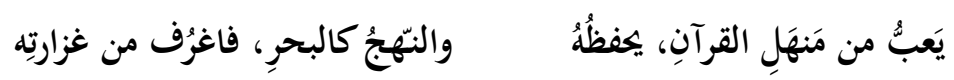




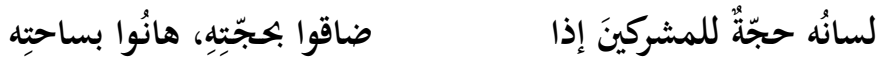

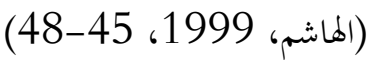

يصوّر الشّاعر في هذه الأبيات العلاقة الوثيقة فيما بين القرآن وكتاب "فج البلاغة" لعليّ، ويعتقد أنّ عليّا قد تلقّى معارف القرآن الكريم من صميم وجوده، واحتفظ بهذه المعارف في قلبه وعمل بها قولا وفعلا في حياته.

ومن الصَّفات الخلقيّة والفضائل التّي اعتنى بما الشّاعر المسيحيّ المعاصر في قصائده في رثاء علي بن أبي طالب وأمعن

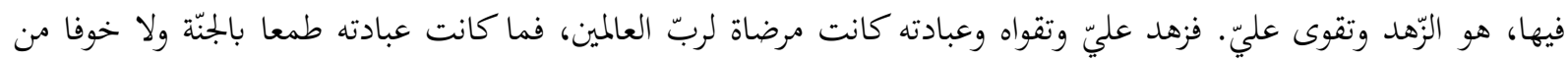

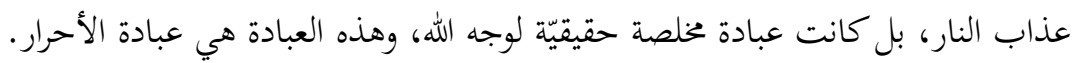

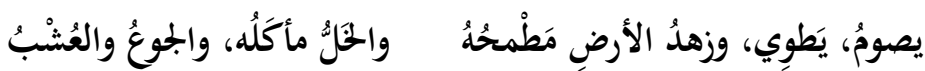

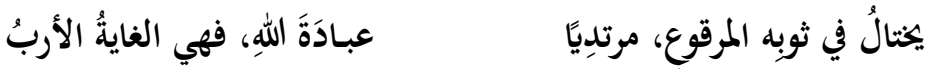

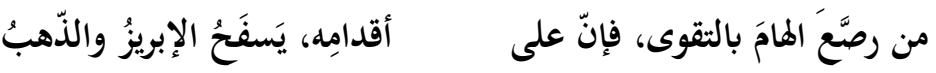

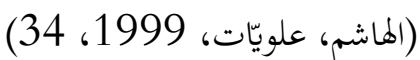

والشّاعر جوزيف الهاشم في قصيدة أخرى أنشدها في رثاء الحسين بن عليّ بهذا العنوان "مُشْعِل الثَّورَتَين"، يذكر فضائل

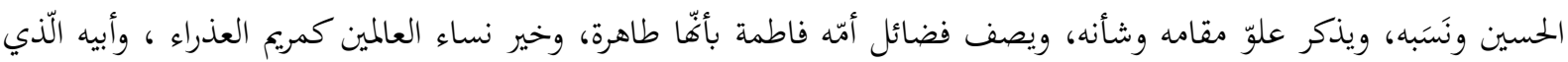

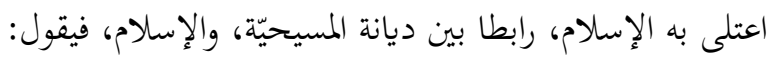

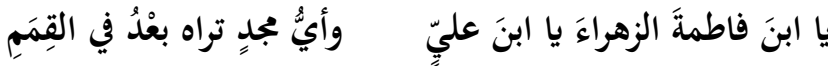

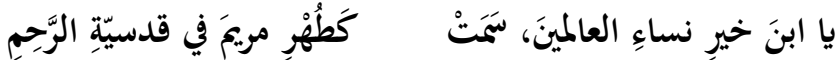

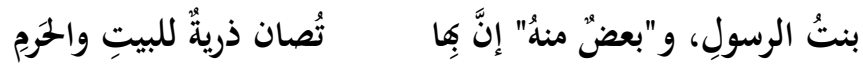

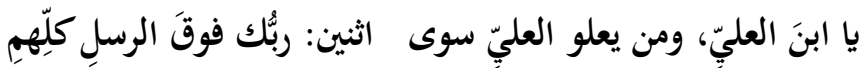

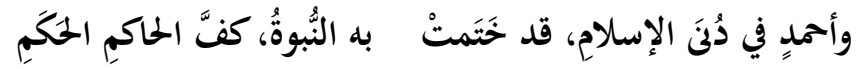

(الهاشم، 1999، 58)

وللشّاعر المسيحيّ المعاصر ريمون قَسّيس قصيدة طويلة في رثاء الحسين، بعنوان: "ملحمة الحسين" تقع في 114 بيتا، يوظّف الشّاعر في مطوّلته هذه أغراضا شعريّة مختلفة، كالمدح والصّور الأدبيّة المتنوّعة ويذكر مقاطع من ثورة الحسين، كما يذكر

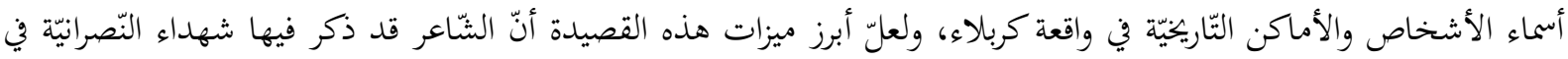

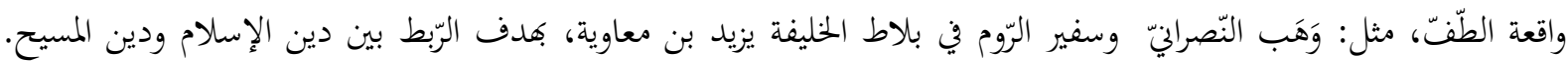

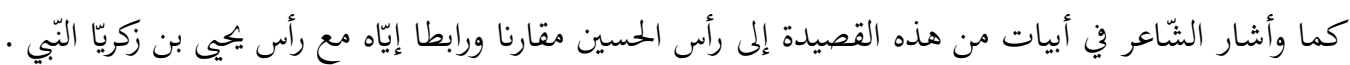
فيذكر الثّاعر في هذه القصيدة فضائل الحسين ويعتقد أنّه وجه رسوليّ، وهو سِبط النّبيّ الأعظم يحمل رسالته النّبويّة

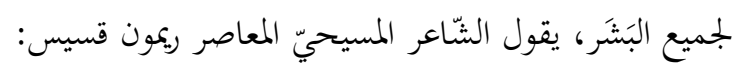

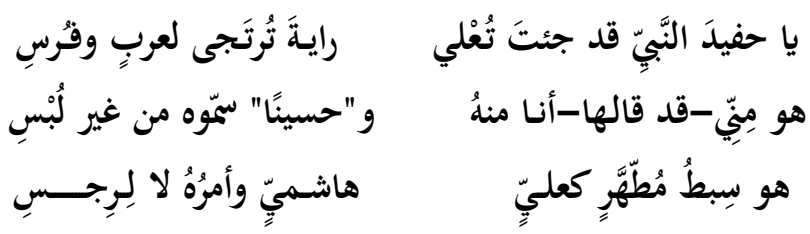

(قسّيس، 2011)

يشير الشّاعر في هذه الأبيات إلى الحديث النّبويّ القائل في حقّ الحسين: "حسين منّي وأنا من الحسين" الّّي يدلّ على

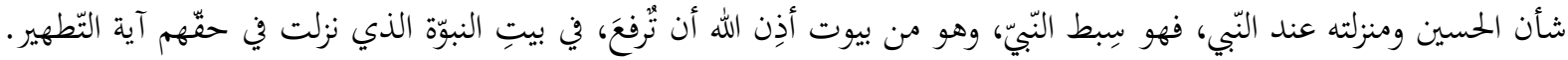


ويواصل الثّّاعر ريمون قسيس أشعاره بذكر فضائل الحسين في قصيدته "ملحمة الحسين"، فالحسين لا بديل له في

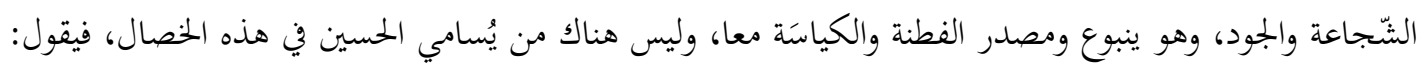

\section{جرأَة في شجاعةٍ جودُ كفِّ}

(قسيس، 2011، (29)

والحسين هو أبو الأئمّة الّذي يُهتدى به كما يُهتَدى بالفَرقَد بدون ذهاب ضوء، فيقول الشّاعر ريمون قسيس:

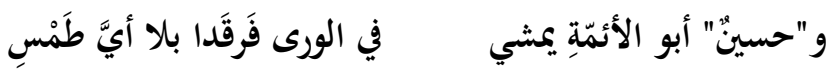

(ن) (ن) (ن)

قد شبّه الشّاعر في هذا البيت شأن الحسين بن عليّ في الهداية إلى نور النّجم الّنّي يضيء طريق الحقّ للبشريّة فيهتدي به البشر .

والشّاعر جوزيف الهاشم يصف الحسين بأنّه قد نَذَر نفسه الطّاهرة، وقد جاد بنفسه وهو غاية الجود ليكون شهيد الحقّ

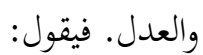

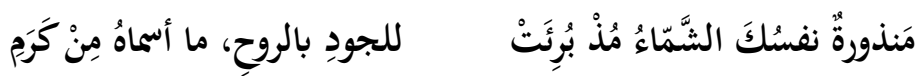

(الهاشم، 1999، (المر،

من القضايا التي اعتى هها الشّاعر أثناء رثائه لكبار الشّخصيّات، هو ذكر المصائب والمحن والآلام التي شهدها وواجهها

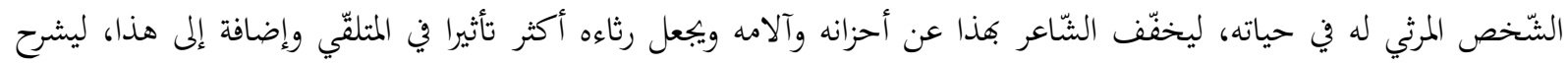
للمتلقّي مقاطع من واقع حياة المتوفّ في الماضي ليتعرّف عليه ويتأثّر من فقدانه.

فمن المصائب والمحن التي شهدها أهل البيت في حياتم وقد غيّرت هذه الحادثة مسار التّاريخ بأكمله هي قضيّة السَّقيفَة

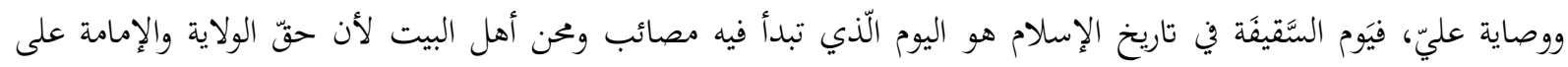
المسلمين قد اغتُصب من عليّ وأبنائه وقد كان أمرا إلهيّا.

وقد نزلت في هذا الشّأن آية تُعرف لدى الشّيعة بآية إكمال الدّين، قال الله تعالى: (اليوم أكملتُ لكم دينَكم وأتممتُ

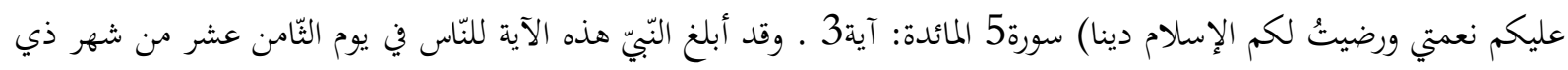

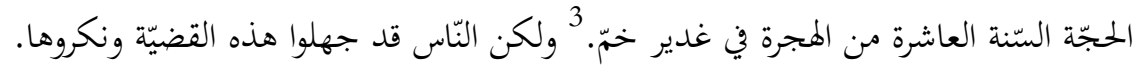

إنّ الثّاعر المسيحيّ اللّنبانيّ يرثي أهل البيت، ويشير إلى هذه القضيّة ويعتقد أنّه يوم السَّقيفَة هو اليوم الذي نُمكِّست فيه

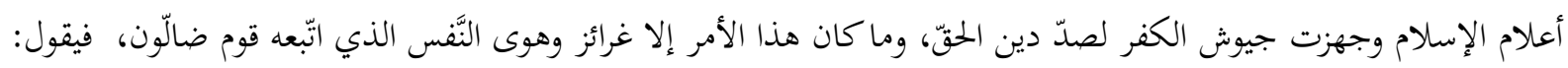

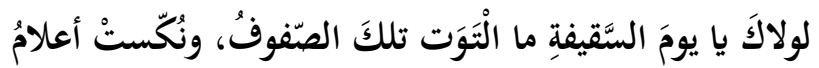

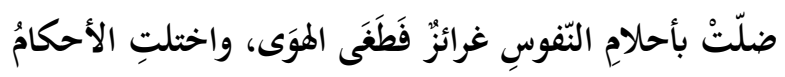

(الهاشم، 1999)

لا شكّ أنّ واقعة الطّّت هي من أفجع الأحداث في تاريخ الشّيعة، وقد وصفها الشّعراء في العصور المختلفة ورثى لمصائبها

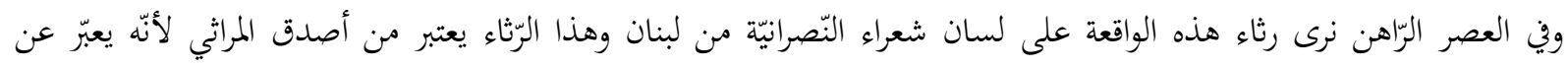
عاطفة صادقة رسمتها ريشة هؤلاء الشّعراء. 
فالثّاعر ريمون قسيّس يذكر زينب بنت عليّّ في مقاطع من قصيدته ملحمة الحسين بحماس ولففة، وبالاستعانة ببعض

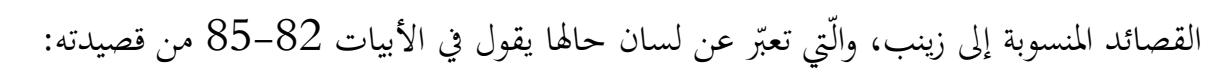

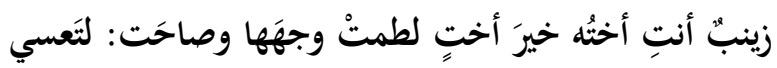

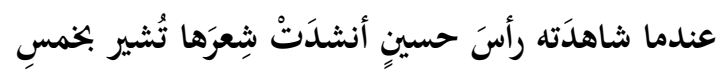

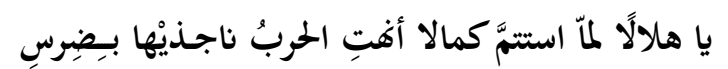

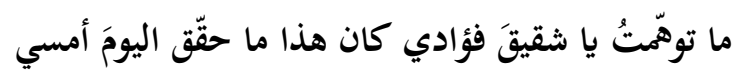

(قسيس، 2011، 37)

وأمّا الثّاعر اللبنانيّ المعاصر جوزيف الحرب، يرسم تلك المحن والمصائب التي حلّت بآل الرّسول، ويتفجّع لمشاهد منها.

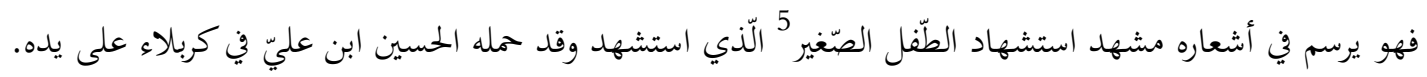
ويعتبر هذا المشهد من أفجع وأبشع مشاهد واقعة كربلاء والّذي لن ينمحي من ضمائر البشريّة، عندما طلب الحسين شربه

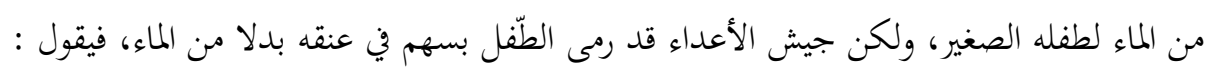

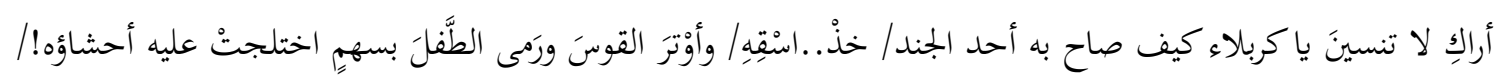

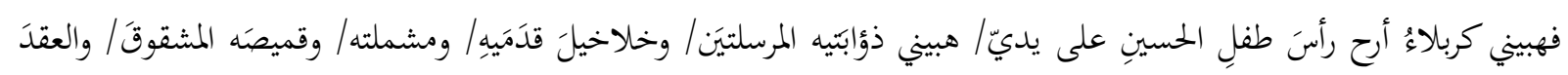

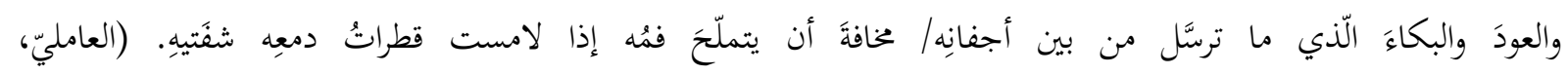

(42 2001/ 1422

\section{دور أهل البيت في إحياء دين الإسلام}

يعتقد الثّيعة أغّّم قدّموا حياقمم من أجل تثبيت الدّين والعقيدة، وقد جاهدوا في هذا السّبيل إلى درجة الاستشهاد

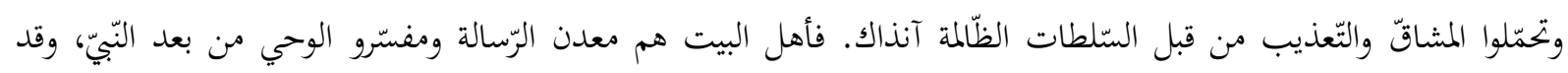

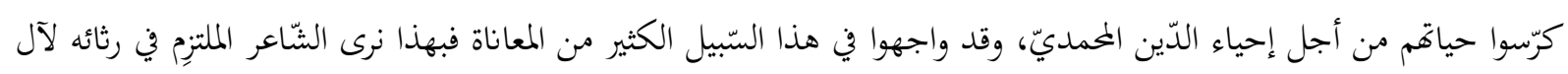
بيت الرّسول يشير إلى دورهم ومنهجهم وبجاهداقم في إحياء إحئ الدّين.

فنرى الشّاعر المسيحيّ المعاصر جوزيف الهاشم يتطرّق إلى دور أهل البيت في إحياء دين الإسلام، ويعتقد أنّه لولا علي لما

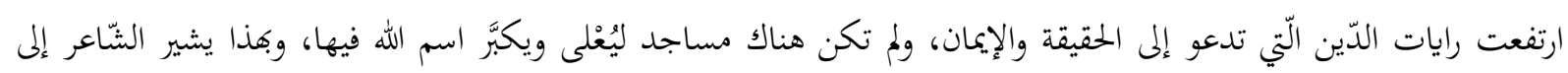

$$
\text { دور عليّ الحاسم في تعزيز الدّين، فيقول: }
$$

(الهاشم، 1999، (المب، (19)

وهذا ريمون قسّيس يقول: قد أراد الحسين من مقتله في معركة كربلاء الّذي كان قدرا مقدّرا من لدن الخالق، أن يترك

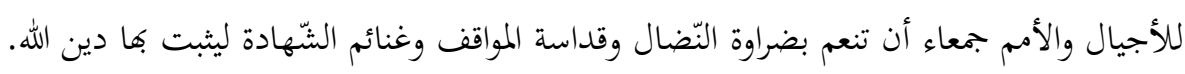

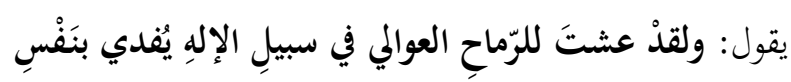

(قسيس، 2011، (ق24)

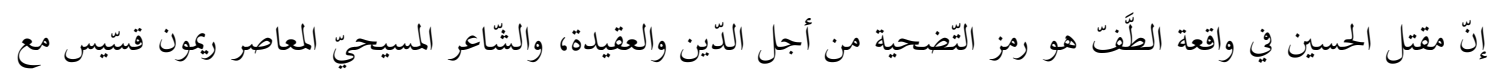
وصفه لمواقف واقعة عاشوراء ومقتل الحسين، يصوّر مدى دور الحسين في إحياء دين الله، فمقتله لم يكن إلا دعوة من الله وقد لبّاه

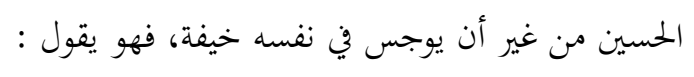




\section{(ن) (ن.)}

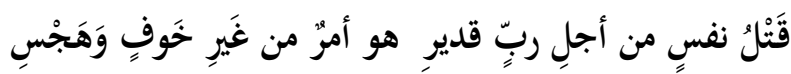

وفي هذا السّياق يصف جوزيف الهاشم مقتل الحسين بن علي في كربلاء بأنّه ثورة، وبرأيه أنّ هذه الثّورة قد حقّقها الحسين

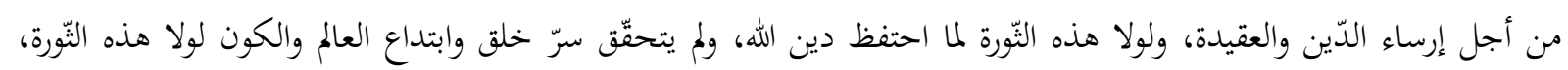

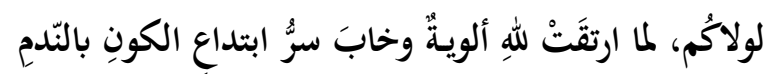

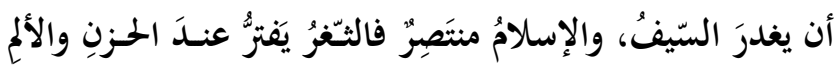

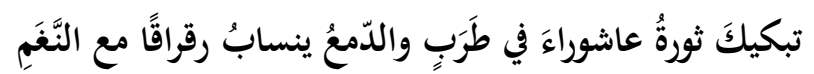

\section{(الهاشم، 1999، (الق)}

يشير الشّاعر في هذه الأبيات إلى انتصار الدّم على السّيوف، وهو انتصار حقيقيّ كما يعتقد أنّ شهداء كربلاء قد

$$
\text { انتصروا بدمائهم في غهاية المطاف على أعداء الإسلام. }
$$

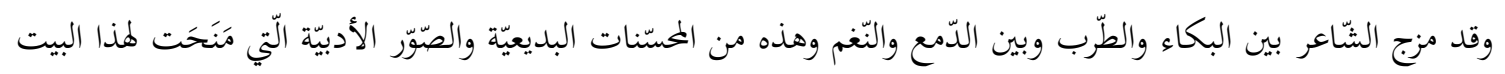

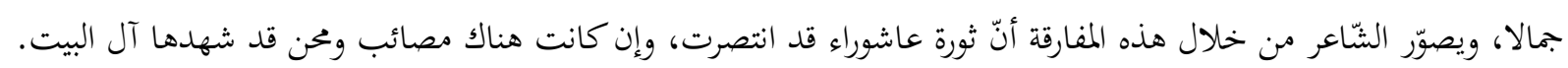

\section{النّيجة}

نستخلص من هذه الدّراسة الّتي تناولت رثاء أهل البيت في الشّعر شعراء لبنان النّصارى المعاصرين النّائج التّالية: - يرى شعراء النّصارى اللّنبانيّين أنّ أهل البيت هم أسوة الإيمان والعقيدة، وأنّ حبّهم هو حبّ الإيمان والكمال والحريّة والشّجاعة والعدالة والثّهادة والقيم الإنسانيّة السّامية، لذلك فليس عجيبا أن يشترك المسلمون وغير المسلمين في هذا الحبّ المعنويّ. - تأثر شعراء لبنان النّصارى المعاصرين من عظَمة أهل البيت، وقد نظموا الكثير من القصائد في رثائهم وقد تكلّموا فيها عن عظَمة أهل البيت. - اهتمّ الثّعراء في العصور المختلفة برثاء آل البيت، وفي العصر الرّاهن نرى أيضا قصائد كثيرة في رثاء أهل البيت عليهم، ونشاهد قصائد صادقة على لسان شعراء لبنان المسيّحين. - اهتمام شعراء لبنان المعاصرين بعقيدة صادقة في رثاء أهل البيت، وقد عبّوا في قصائدهم عن حزهم وآلامهم من مقتل أهل

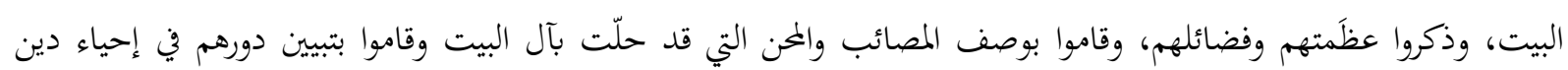
الإسلام. 


\section{قائمة المراجع والمصادر}

أخطب خوارزم، الموفّق بن أحمد المكّيّ. مقتل الحسين للخوارزمي. تحقيق: محمّد السّماويّ. قمّ: مطبعة أنوار الهدى،

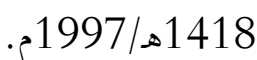

الأميني، محمّد هادي. عيد الغدير في عهد الفاطميّين. طهران: مؤسّسة الآفاق، 1417هـ/1997م. الأميني، عبد الحسين. الغدير في الكتاب والسّنة والأدب. قمّ: مؤسّسة دائرة الفقه الإسلامي، ابن فارس، أحمد. معجم مقاييس اللغة. تحقيق: عبد السلام هارون، بيروت: دار الفكر للطباعة والنشر، 1979.

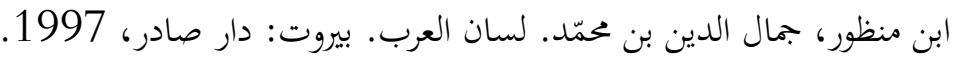
أصغر ياري، علي، رضائي، عليّ محمّد. الإنزياح والتكرار في ملحمة الحسين لريمون قسيس: دراسة أسلوبيّة ، دراسات استشراقيّة،

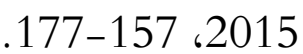

الجُمَحي، محمّد بن سلّام. طبقات فحول الشّعراء. شرح محمود شاكر، القاهرة: مطبعة المدنيّ، 1974. الجوهري، إسماعيل بن حمّاد. تاج اللّغة وصحاح العربيّة. تحقيق: أحمد عبد الغفور عطّار، بيروت: دار العلم للملايين، 1990. الخطيب، بشرى محمد علي. الرّثاء في الشّعر الجاهليّ وصدر الإسلام. بغداد: مديريّة مطبعة الإدارة المحليّة، 1977.

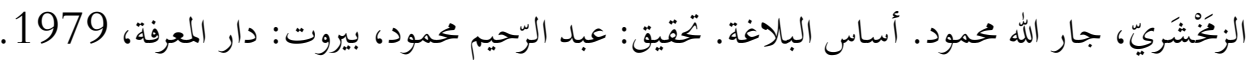

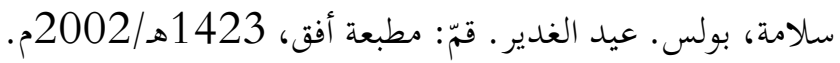

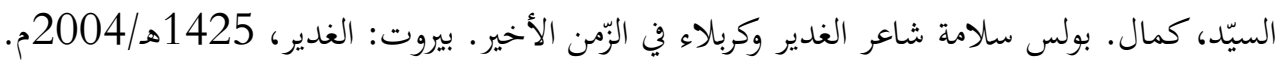

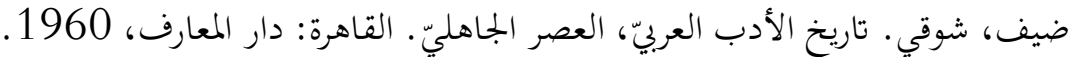
ضيف، شوقي. فنون الأدب العربيّ، الرّثاء.ط.4، القاهرة: دار المعارف، 1988.

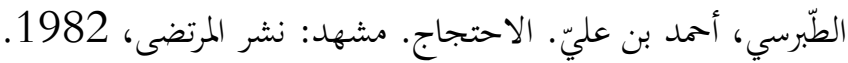
الطّوسي، أبو جعفر محمّد بن الحسن. الأمالي. تحقيق قسم الدّراسات الإسلاميّة مؤسّسة البعثة. قم: دار الثّافة للنّشر، 1414/1993

العامليّ. الانتصار مناظرات الثّيعة في شبكات الإنترنتّ المجلّد التّاسع دفاعا عن مراسم عاشوراء وقداسة كربلاء والتّربة الحسينيّة. بيروت: دار المسيرة، 1422هـ/ 2001م.

عبّود، مارون. أدب العرب. بيروت: دار الثّقافة، 1960.

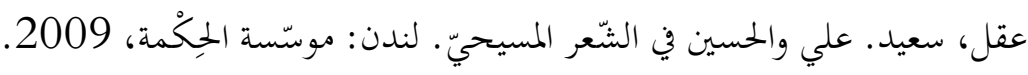

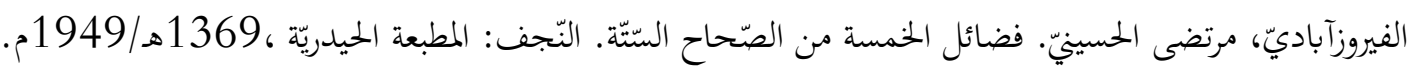

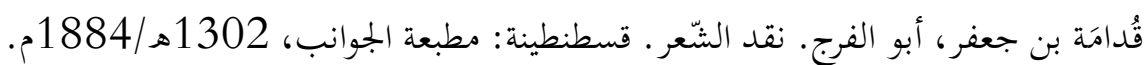

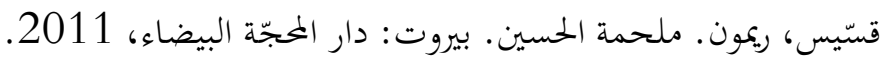

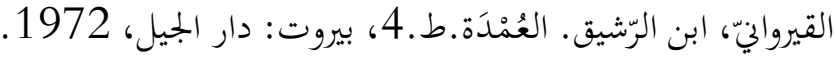
الكِرباسي، محمّد صادق. شريعة العيد. بيروت: بيت العلم للنّاهين، 2009.

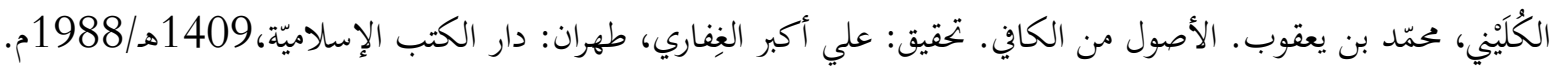

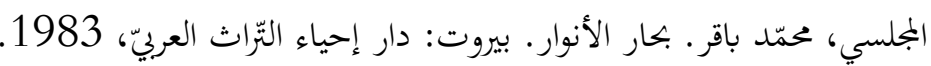
مُحََّدِثي، جواد. موسوعة عاشوراء. ترحمه من الفارسيّة إلى العربيّة خليل زامل العِصامي، بيروت: دار الرّسول الأكرم، ودار المحجّة

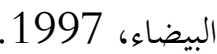

المرتضى، الشّريف عليّ بن الحسين. الشّافي في الإمامة. طهران: مؤسّسة الصّادق، 1987. 


$$
\begin{aligned}
& \text { النّعمة، مقبول علي بشير . المراثي الشّعريّة في صدر الإسلام. بيروت: دار صادر، } 1997 .
\end{aligned}
$$

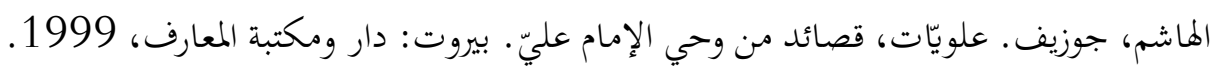

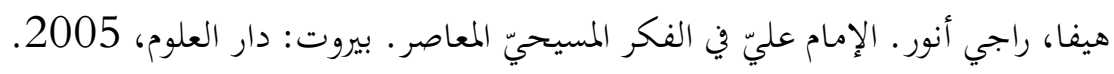

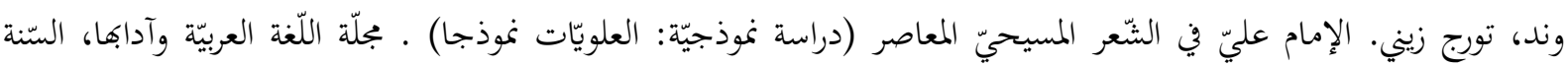

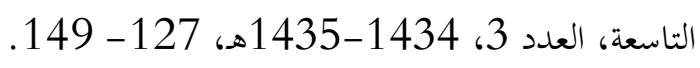

Bar-Asher, Meir. Scripture and Exegesis in early Imami Shiism .(Leiden: Brill, 1999).

Beinhauer-Köhler, Bärbel. Fatima bint Muhammad: Metamorphosen einer frühislamischen Frauengestalt, (Wiesbaden: Harrassowitz Velgar, 2002), 129-131.

Massignon, Louis. Der gnostische Kultus der Fatima im schiitischen Islam, in: Eranos Jahrbücher, (1938), S. 162.

McAuliff. Jane Dammen, Chosen of All Women: Mary and Fatimah in Qur'anic Exegesis Islamochristiana 7, (1981), 19-28.

Pinault, David. Zaynab bint 'Ali and the Place of the Women of the Households of the first Imams in Shi'ite Devotional Literature, in Women in the Medieval Islamic World, edited by Gavin Hambly, New York: St. Martin's Press, 1998, 69-98.

Sindawi, K., (2004). Al-Husain Ibn 'Ali and Yahya Ibn Zakariyya in the Shi'ite Sources: A Comparative Study. Islamic Culture.78(3), 37-54.

Veccia Vaglieri, L. Ghadir Khumm, Encyclopaedia of Islam, new edition, II, p. 993-994.

Sered, Susan. Rachel, Mary, and Fatima, Cultural Anthropology 6 (1991)، 131-146. 


\section{الهوامش}

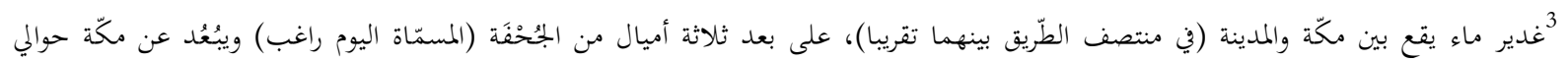

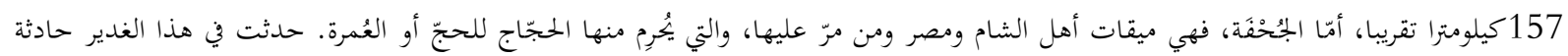

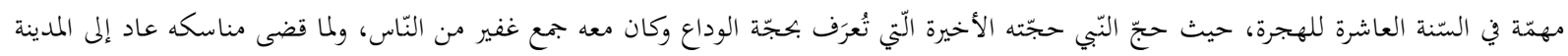

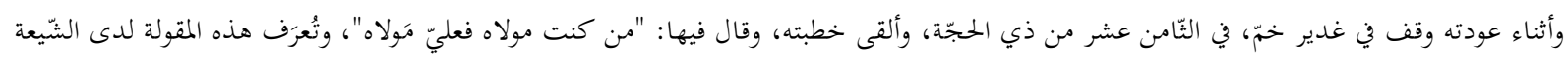

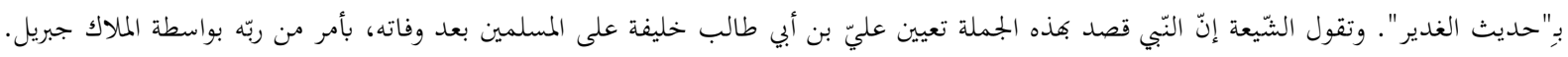

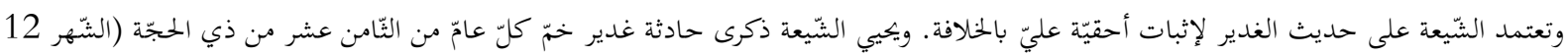

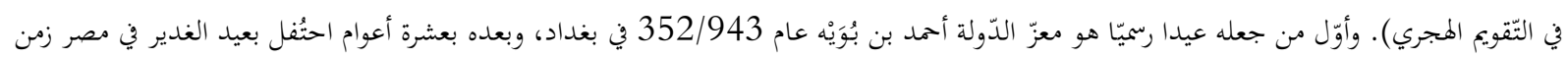

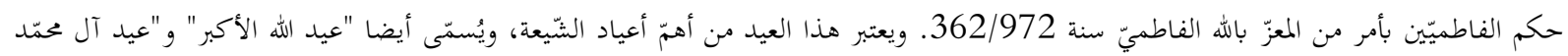

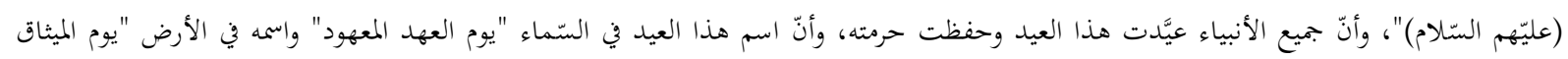

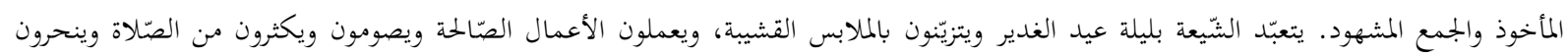

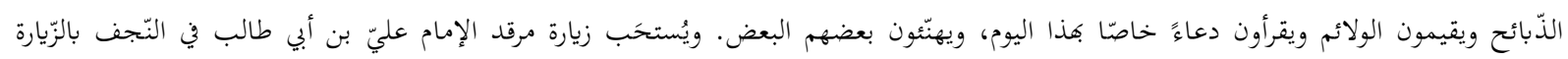

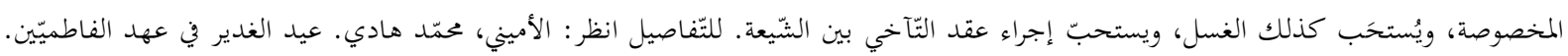

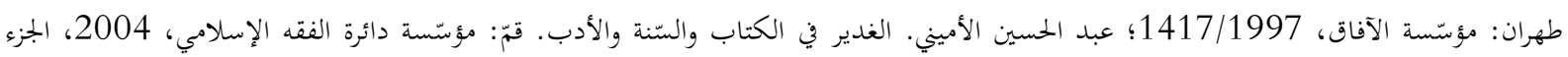

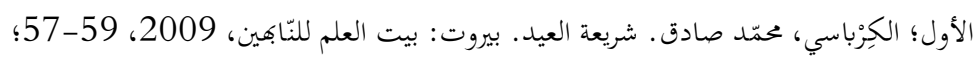
Veccia Vaglieri, L. "Ghadir Khumm", Encyclopaedia of Islam, NeW edition, II, P. 993-

994.

4هي زينب بنت علي بن أبي طالب، أمّها فاطمة الزّهراء.وبكسب بعض الروايات إنّ النّبيّ سمّاها زينب .شاركت أخاها الحسين في واقعة الطّّنّ، وكان لها

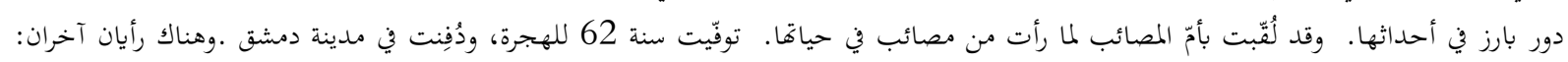

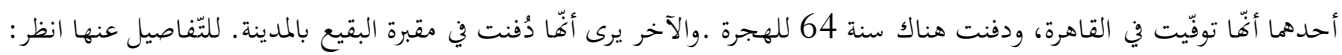

Pinault, David. "Zaynab Bint 'Ali And the Place of the Women of the Households OF the first Imams in Shi'Ite Devotional Literature," in WOMEN IN THE Medieval

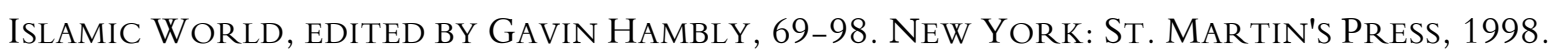

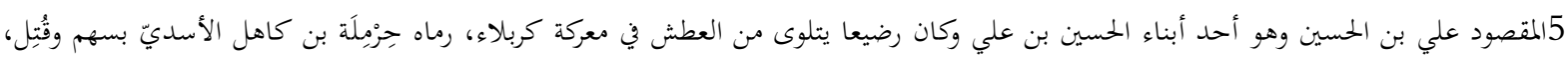

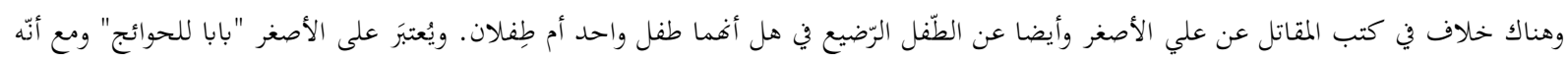

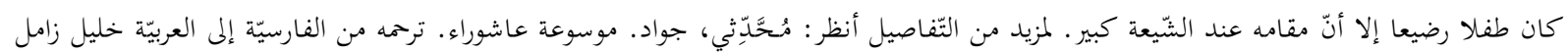

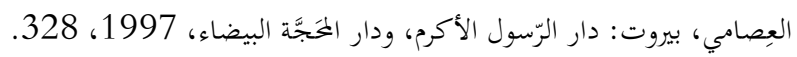




\title{
SPECIAL DATA ACCORDING TO THE BRAIN-BASED LEARNING STRATEGY IN LEARNING SOME BASIC VOLLEYBALL SKILLS FOR FEMALE STUDENTS
}

\author{
Magda Hamid KAMBASH ${ }^{1}$ \\ Nidal Fadel ABBAS ${ }^{2}$ \\ Esraa Fadel ABBAS ${ }^{3}$
}

\section{Istanbul / Türkiye \\ p. 686-701}

Received: $15 / 11 / 2021$

Accepted: 04/12/2021

Published: 01/01/2022

This article has been scanned I iThenticat No plagiarism detected

\section{Abstract:}

The use of modern teaching strategies aims to develop the practices of female learners inside and outside the classroom, which contributes to changing the role of the student from a negative role to a positive role in general. Therefore, learning strategies have become involved in the application of many educational and teaching programs and curricula, as they greatly help in conveying information to the learner. With less effort and time, except that the material to be learned is theoretical or practical. In light of what the current era is witnessing of a huge knowledge explosion and a wide technological revolution that covered various areas of life, it has become necessary for researchers to be interested in searching for ways to ensure the development of thinking among learners, which is one of the foundations of correct learning, some strategies, means and methods used in the learning process help. To bring the learner to a stage where he can access knowledge on their own by applying that knowledge and using it to overcome the problems they face in their daily lives. He has to use different and multiple methods and methods, and this requires him to be familiar with how learning takes place, and how the teaching methods and means used affect the speed of achieving the goal of the learning process and the success of applying the educational curriculum and achieving its goals.

One of the features of the modern era is technological progress in various fields and situations of life, as rapid change has become a feature of the era in which we live. There is no doubt that its use affects all aspects of life, including education and teaching, and with this clear progress in the level of mastery of learning skills in sports events around the world, it has become necessary to use learning strategies in programs and curricula for

http://dx.doi.org/10.47832/2717-8293.15.47

1 ID) Prof. Dr. , Diyala University, Iraq, magda.hamid@uodiyala.edu.iq, http://orcid.org/0000-0002-4565-8856

2 (iD) Researcher, Diyala General Directorate of Education, Iraq, nedhalfadel@ gmail.com, http://orcid.org/0000-0001-9388$\underline{8755}$

3 (iD) Researcher, Diyala General Directorate of Education, Iraq, esraafaduil76@ gmail.com, http://orcid.org/0000-0003$\underline{1160-0135}$ 
teaching and teaching physical education and learning basic skills for all games and events Sports, including volleyball.

The researchers found the lack of use of modern strategies in the educational process, and despite their active role in learning basic skills using modern methods, it requires the presence of exercises that contribute to learning basic skills in volleyball, whose weakness emerged from the research sample, which casts a clear shadow on the performance and levels of learners. The aim of the research is to prepare special exercises According to the brain-based learning strategy in learning some basic volleyball skills for students of the second average, and to identify the effect of special exercises according to the brain-based learning strategy in learning some basic volleyball skills for students of the second average, and to identify the preference of the experimental and control groups in learning some basic volleyball skills for female students. The second is average. The researchers used the experimental approach for the experimental and control groups, and the research sample was represented by (30) students, then the sample was divided into an experimental group of (15) female students and a control group of (15) female students.

Key words: Special Exercises, Brain-Based Learning Strategy, Basic Skills. 


\section{أثر تمرينات خاصة وفقا لاستراتيجية التعلم المستند للدماغ في تعلم بعض المهارات الأساسية بالكرة الطائرة للطالبات}

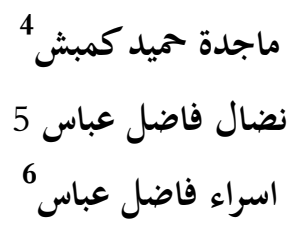

الملخص:

إن استخدام استراتيجيات التدريس الحديثة يهدف إلى تطوير ممارسات المتعلمات داخل الصف وخارجه مما يسهم في تغيير دور الطالبة من دور سلبي إلى دور إيجابي بشكل عام، لذلك أصبحت استراتيجيات التعلم تدخل في إنسات تطبيق الكثير من البرامج والمناهج التعليمية والتدريسية كوها تساعد بشكل كبير فئير في إيصال المعلومات إلى المتعلم بجهد ووقت أقل سوى كانت المادة المطلوب تعلمها مادة نظرية أو عملية. وفي ظل ما يشهره العصر الحالي من فئن تفجر معريف هائل وثورة تكنولوجية واسعة شملت بجالات الحياة المختلفة، بات من الضروري أن يهتم الباحثون في البحث عن السبل التي تكفل تنمية التفكير لدى المتعلمين والذي يعتبر إحدى أساسات التعلم الصحيح، تساعد بعض الاستراتيجيات والوسائل والطرق المستخدمة في عملية التعلم على إيصال المتعلم إلى مرحلة يستطيع فيها من

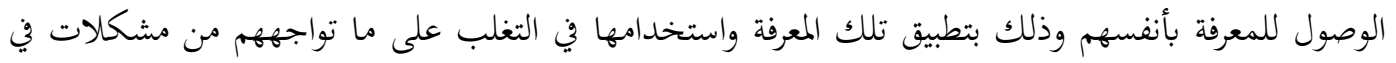

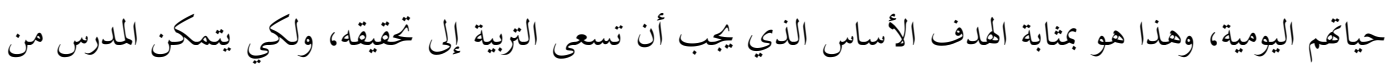

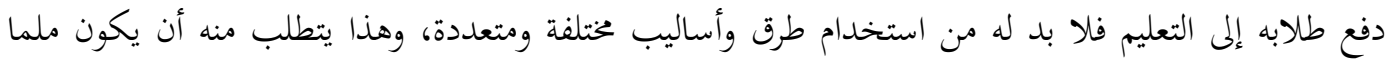
بكيفية حدوث التعلم، وكيف تؤثر الطرق والوسائل التدريسية المستخدمة فن سرعة تحقيق الهدف من عملية التعلم ونجاح تطبيق المنهج التعليمي وتحقيق أهدافه. الكلمات المفتاحية: تمرينات خاصة، استراتيجية التعلم المستند للدماغ، المهارات الأساسية.

إن من سمات العصر الحديث هو التقدم التكنولوجي في شتى بجالات ومواقف الحياة إذ أصبح التغير السريع هو سمة العصر الذي نعيش فيه، أن التطور التكنولوجي حقق طفرة كبير في علميات التعلم وما زال يخطو بخطوات ثابتة لتحقيق المزيد من التطور

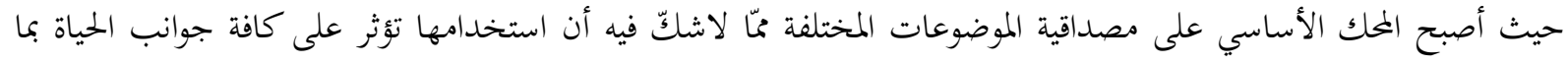
فيها التعليم والتدريس، ومع هذا التقدم الواضح في مستوى اتقان تعلم المهارات في الفعاليات الرياضية على مستوى العالم أصبح من الضروري استخدام استراتيجيات التعلم في برامج ومناهج تعليم وتدريس مادة التربية الرياضية وتعلم المهارات الأساسية لكافة الألعاب والفعاليات الرياضية ومنها لعبة الكرة الطائرة. 
تبين للباحثون قلة استخدام الاستراتيجيات الحميثة في العملية التعليمية ورغم دورها الفاعل في تعلم المهارات الأساسية

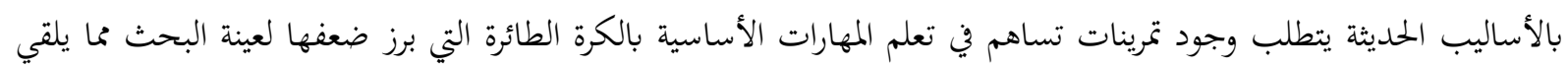
بظلالة بشكل واضح على اداء المتعلمين ومستوياقم.وهدف البحث إلى اعداد تمرينات خاصة وفقاً لاستراتيجية التعلم المستند

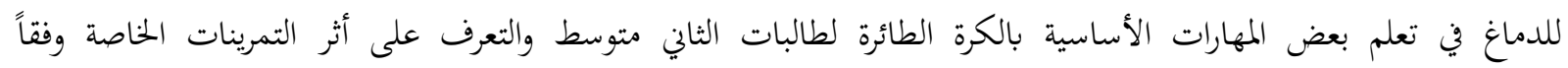

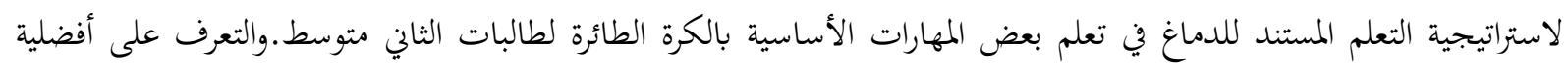
المجموعتين التجريبة والضابطة في تعلم بعض المهارات الأساسية بالكرة الطائرة لطالبات الثاني متوسط. واستخدم الباحثون المنهج

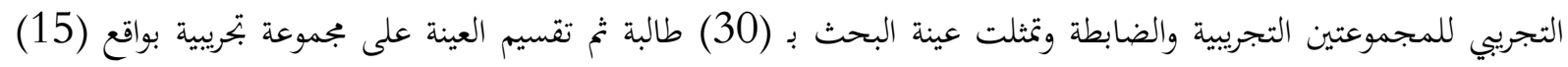
طالبة وبجموعة ضابطة بواقع (15) طالبة، وتمثل مجتمع البحث بطالبات الصف الثاني متوسط في القارعة للبنات في محافظة ديالى،

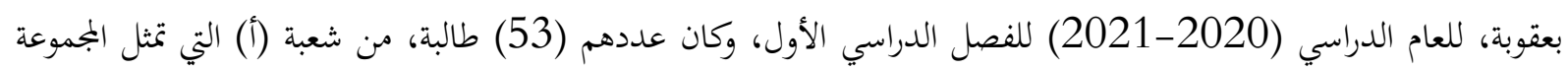

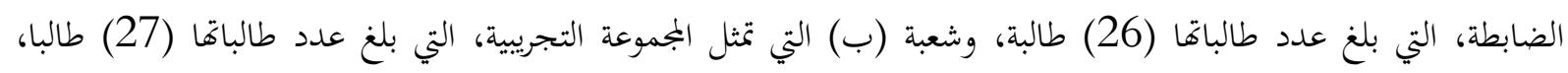
اختارت الباحثون عينة البحث بطريقة عشوائية عن طريق (القرعة)، فبلغ عدد افراد العينة (30) طالبة، موزعين بواقع (15) (15) طالبة البه

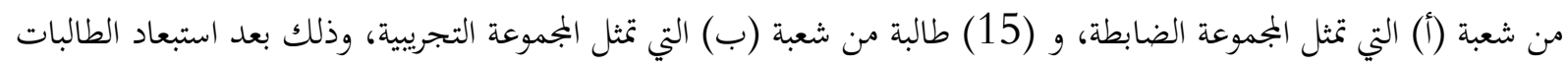

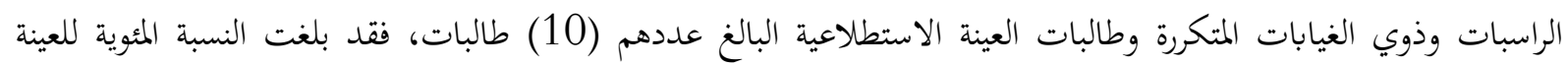

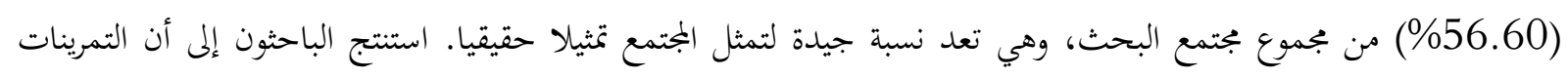

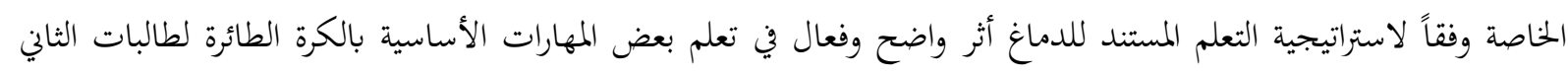

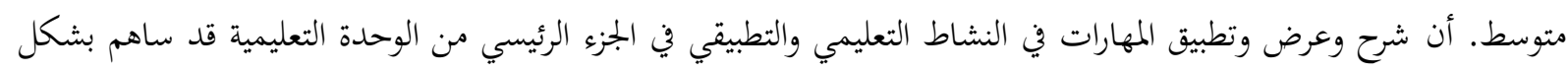

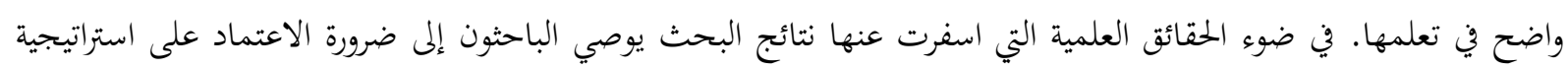

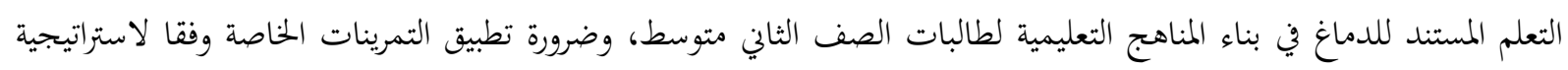

$$
\text { التعلم المستند للدماغ على عينات أخرى. }
$$

\section{1}

إن العملية التعليمية تركز على وسيلة مهمة، وهي نقل المعارف، والمعلومات من المدرس إلى الطالب، وبالطريقة المناسبة، وهذا يأتي عن طريق اختيار أفضل الطرائق، والنماذج، والاستراتيجيات التي تلائم المرحلة العمرية للمتعلّمين، ومنها استراتيجية التعلم

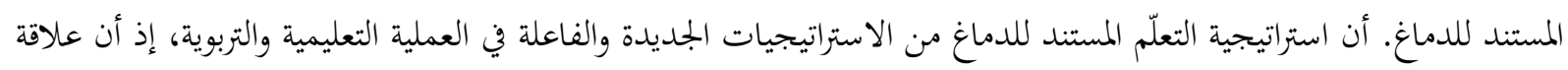

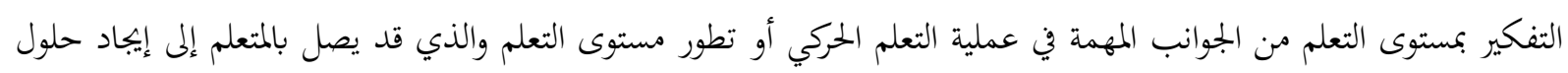

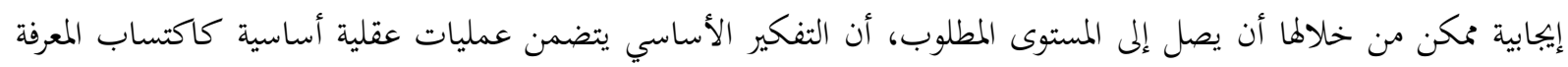

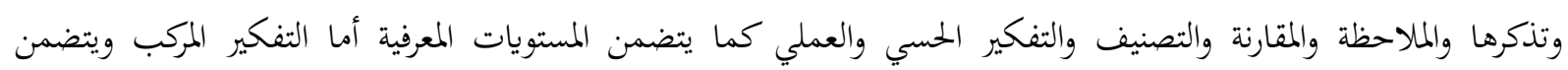

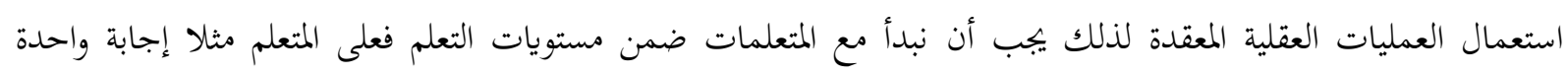

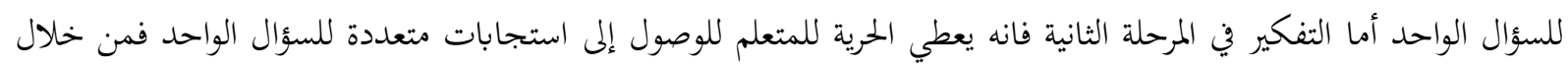

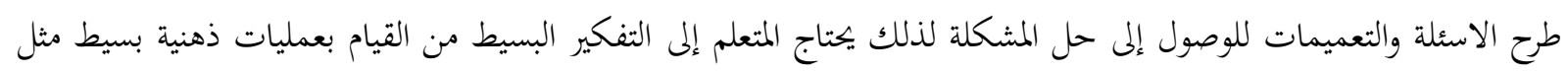
التذكر والاسترجاع والعودة إلى عملية الربط بين الجانب النظري والجانب التطبيقي لتعلم اي مهارة مثلا وهذا يتطلب التبات المرور

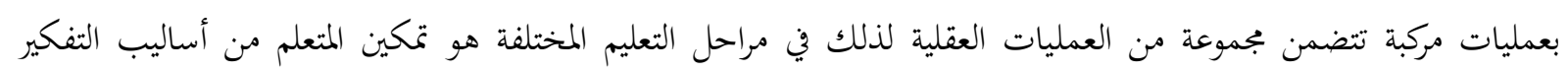

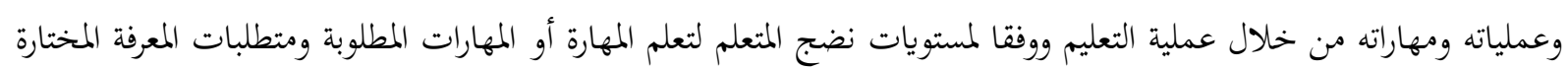
ووفقا لخصائص وبيئة التعلم التي يدور فيها التعليم وفي ضوء العلاقات التهات المتبادلة بين المعلم والمتعلم. 
إِنَّ لكُكّ لعبة من الألعاب الرياضية مهارات أساسية خاصة بها، فالكُة الطائرة إحدى الألعاب الرياضية التي انتشرت على

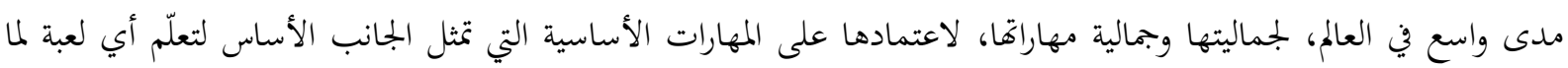

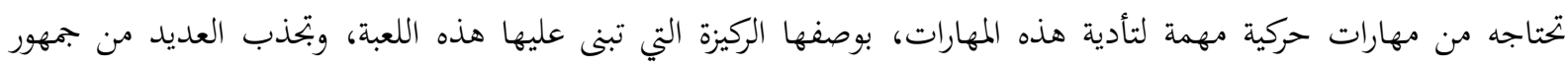

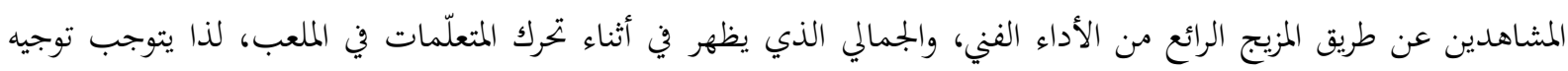

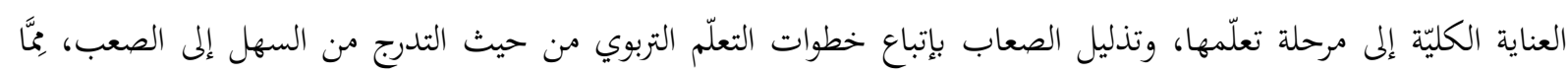
يجعلها أكثر أثارة، وتشويقًا وتنافسًا بالاعتماد على أسس علمية صحيحة تساعد على سرعة التعلّم، ومن هنا تبرز أهمية البحث في في إلى تَعَرُْف تأثير استراتيجية التعلم المسند إلى الدماغ، وذلك لتناغمها وفاعليتها للتطبيقات التي تعنى في مجال الفروق الفردية بين

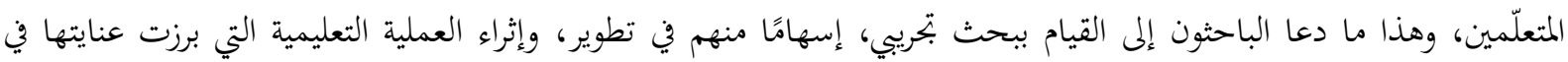

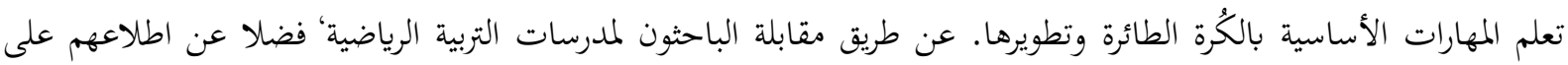
مجموعة من الدراسات والمصادر المتعلقة بالموضوع، تبين للباحثون قلة استخدام الاستراتيجيات الحديثة في العملية التعليمية ورغم دورها الفاعل في تعلم بعض المهارات الأساسية بالأساليب الحديثة مما يتطلب وجود تمرينات خاصة تساهم في تعلم المهارات

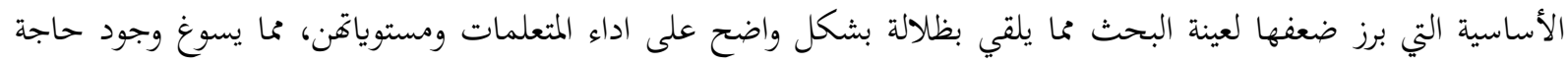

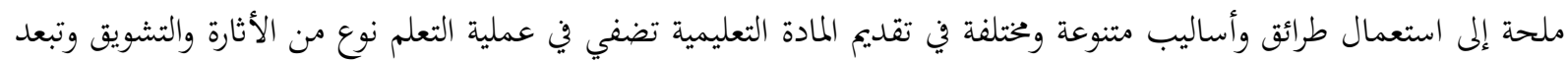
الملل عن الدرس وتسهم بشكل إيجابي في مشاركة الطالبات في عرض المهارة، ولذلك ارتى الباحثون القيام مهذه التجربة من خلال استخدام التمرينات الخاصة وفقا لاستراتيجية التعلم المستند للدماغ في تعلم بعض المهارات الأساسية بالكرة الطائرة للطالبات وهدف البحث إلى اعداد تمرينات خاصة وفقا لاستراتيجية التعلم المستند للدماغ في تعلم بعض المهارات الأساسية بالكرة الطائرة

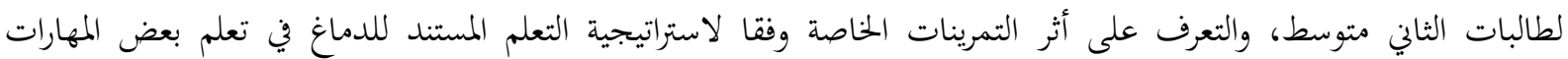
الأساسية بالكرة الطائرة لطالبات الثاني متوسط، والتعرف على أفضلية المجموعتين التجريبية والضابطة في تعلم بعض المهارات

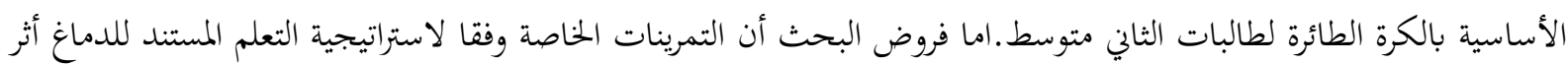
في تعلم بعض المهارات الأساسية بالكرة الطائرة لطالبات الثاني متوسط، وهنالك أفضلية للتمرينات الخاصة وفقا لاستراتيجية التعلم المستند للدماغ عن الأسلوب المتبع في تعلم بعض المهارات الأساسية بالكرة الطائرة لطالبات الثاني متوسط.

البجال البشري: طالبات الصف الثاني متوسط في متوسطة القارعة للبنات (للعام الدراسي 2020-2021)

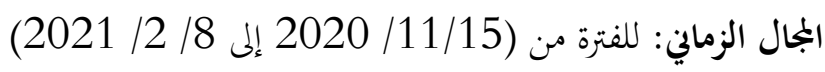
الجمال المكاني: ساحة متوسطة القارعة للبنات

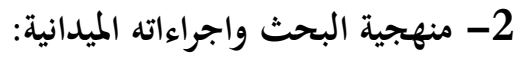

إن اختيار المنهج الملائم لمشكلة البحث وأهدافه من المتطلبات الضرورية في البحث العلمي، إذ استخدم الباحثون المنهج

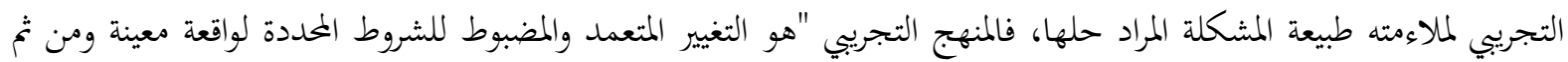

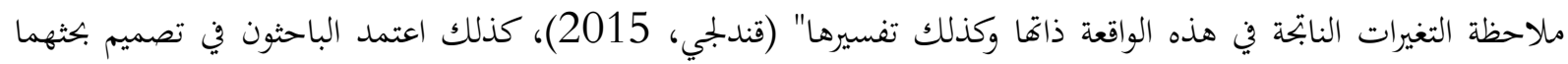
على أسلوب المجموعتين المتكافئتين (التجريبية والضابطة). 


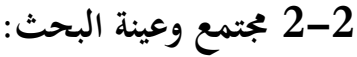

تم تحديد بجتمع البحث طالبات الصف الثاني المتوسط في متوسطة القارعة للبنات، للعام الدراسي (2020-2021) للفصل الدراسي الأول، وكان عددهم (53) طالبة، من شعبة (أ) التي تمثل المجموعة الضابطة، التي بلغ عدد الطالبات (26)

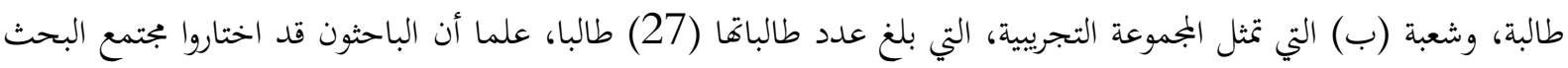

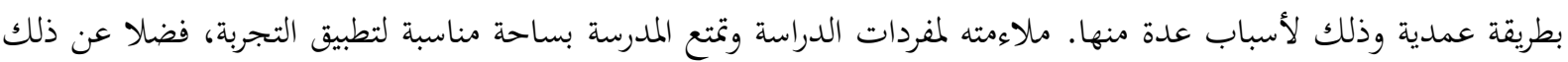

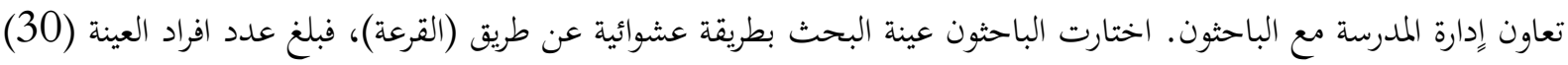
طالبة، موزعين بواقع (15) طالبة من شعبة (أ) التي تمثل المجموعة الضابطة، و (15) طالبة من شعبة (ب) التي تمثل المجموعة التجريبة، وذلك بعد استبعاد الطالبات الراسبات وذوي الغيابات المتكررة وطالبات العينة الاستطلاعية البالغ عددهم (10) طالبات.درس الباحثون طالبات المجموعة التجريبية على وفق استراتيجية التعلم المستند للدماغ، بينما درست المجموعة الضابطة

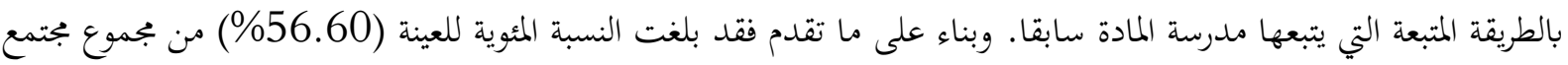
البحث، وهي تعد نسبة جيدة لتمثل المجتمع تمثيلا حقيقياً

الجدول (1) يبين بتحانس عينة البحث في متغيرات (العمر، والطول، والكتلة)

\begin{tabular}{|c|c|c|c|c|c|c|}
\hline معامل الالتو اء & الوسيط & الالانحرياري & الحسابي & وحدة القياس & المتغير ات & $ت$ \\
\hline 1.05 & 14.00 & 1.31 & 14.46 & سنة & العمر & 1 \\
\hline $0.50-$ & 158.00 & 2.47 & 158.41 & سم & الطول & 2 \\
\hline $0.68-$ & 46.00 & 3.48 & 46.56 & كغ & الكتلة & 3 \\
\hline
\end{tabular}

قيم معامل الالتواء محصورة ما بين 3د3، وهذا يدلّ على أن الدرجات موزعة توزيعًا اعتداليًا.

2-2 3 وسائل جمع المعلومات والادوات والأجهزة المستخدمة في البحث:

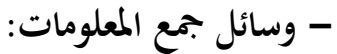
المصادر العربيّة والأجنبية، استبانة تحديد اهم الاختبارات المستخدمة بالبحث، فريق العمل المساعد' الملاحظة العلمية، المعالجات الاحصائية.

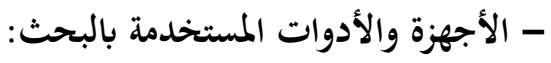
استخدم الباحثون الأدوات الآتية: ملعب كرة طائرة قانوين مع مستلزماته عدد (1)، كرات طائرة نوع (Mikasa) صينية الصنع، عدد (15) (15) كرة، ميزان

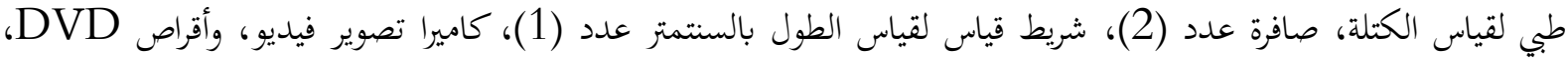
جهاز كومبيوتر نوع Lenovo عدد (1)، ساعة توقيت عدد (1).

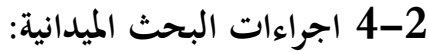

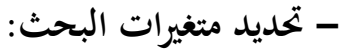

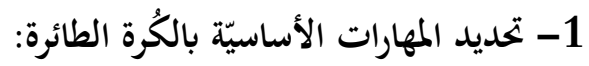
عن طريق المنهج المعتمد لوزارة التربية للمرحلة المتوسطة (الصف الأول متوسط) بالكُرة الطائرة (اخرون، 2012)، تم تحديد المهارات الأساسيّة (قيد البحث)، وهي: الإرسال المواجه من الأسفل، التمرير من الأعلى، التمرير من الأسفل) . 
قام الباحثون بإعداد استمارة لتحديد أهم الاختبارات التي تقيس الأداء المهارى للمهارات قيد البحث، وتم عرض تلك

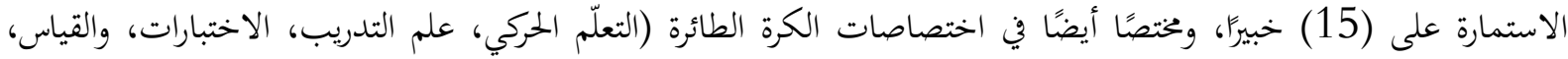

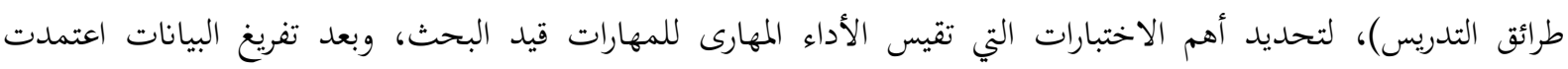

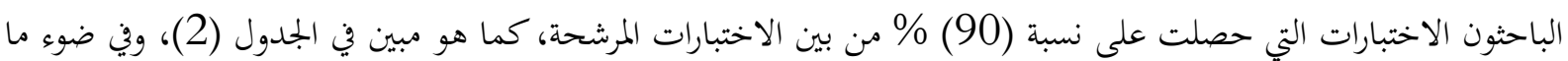
أفرزته استمارة الاستبانة، تم تحديد الاختبارات المهارية قيد البحث. الجلدول (2) يبيّن النسب المئوية للاختبارات المرشحة لقياس الأداء المهاري للمهارات قيد البحث

\begin{tabular}{|c|c|c|c|c|}
\hline المئو النسبة & الغرض من الاختبار & الاختبار ات المرشحة & 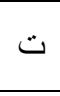 & 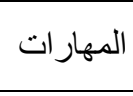 \\
\hline$\% 91$ & قالخبر اء. مستوى الأداء المهاري للإرسال عن طريق & إرسال إلى الجهة الأخرى من الملعب & 1 & \multirow{3}{*}{ الإلمو اجسه } \\
\hline$\% 65$ & قوقف مشابه للإِبار اة. لدى لاعب الكُرة الطائرة في & 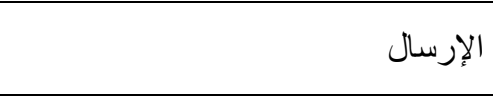 & 2 & \\
\hline$\% 68$ & 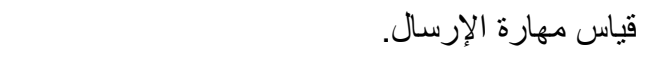 & 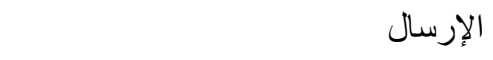 & 3 & \\
\hline$\% 86$ & قياس مستوى الأداء المهاري عن طريق الخبر اء. & المناولة فوق الر أس مستمرّة من الأعلى & 1 & \multirow{3}{*}{ الأنمرير } \\
\hline$\% 64$ & قن مهارة قدرة المختبر من أعلى برعة الأصابع. & اختبار تكرار التمرير على الحائط & 2 & \\
\hline$\% 66$ & قياس دقة التمرير من أعلى. & دقة التمرير على الحائط & 3 & \\
\hline$\% 88$ & قياس مستوى الأداء المهاري عن طريق الخبر اء. & التمرير من الأسفل & 1 & \multirow{3}{*}{ 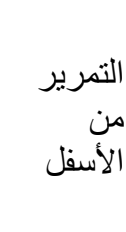 } \\
\hline$\% 60$ & تمكنه من مهارة التمرير من سن أسفل باليدين. ومقدار & اختبار التمرير من أسفل بالذراعين & 2 & \\
\hline$\% 69$ & قياس دقة التمرير من أسفل. & دقة التمرير على الحائط & 3 & \\
\hline
\end{tabular}

3- الاختبارات المهارية للمهارات الأساسيّة قيد البحث:

- الاختبار الأول : إرسال إلى الجهة الأخرى من الملعب (الشيخلي، 2016).

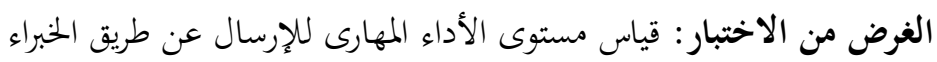

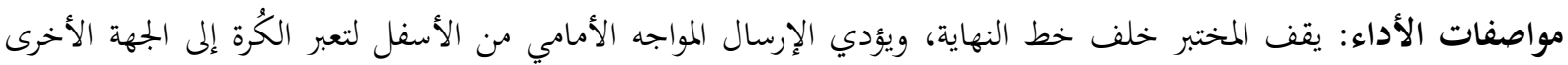
من الملعب، إذ يعطى لكُّل مختبر ثلاث محاولات. التسجيل: يتم تقييم أداء المختبر في المحاولات الثلاث عن طريق الخبراء، ويكون تقسيم الدرجة على النحو الاتي: (الجزء التحضيري: ودرجته (3)، الجزء الرئيس: ودرجته (5)، الجزء الختامي: ودرجته (2) )

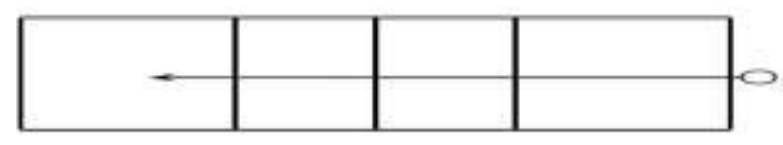

الشكل (1) اختبار الإرسال إلى الجهة الأخرى من الملعب

- الاختبار الثاني: المناولة فوق الرأس مستمرّة من الأعلى (الشيخلي، 2016) الغرض من الاختبار: قياس مستوى الأداء المهاري عن طريق الحبراء. مواصفات الأداء: يؤدي المختبر مناولة فوق الراس مرّة بعد مرّة (سيطرة على الكُرة)، ويعطى للكُّ مختبر ثلاث محاولات. 
التسجيل: يتم تقييم أداء المختبر في المحاولات الثلاث عن طريق الخبراء، ويكون تقسيم الدرجة كالآتي: (الجزء التحضيري: ودرجته

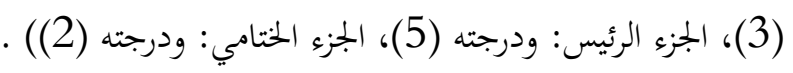

- الاختبار الثالث: التمرير من الأسفل: (الشيخلي، 2016) الغرض من الاختبار: قياس مستوى الأداء المهاري عن طريق

مواصفات الأداء: يؤدي المختبر مناولة من الأسفل مرّة بعد مرّة (سيطرة على الكُرة)، ويعطى لكُلّ مختبر ثلاث محاولات.

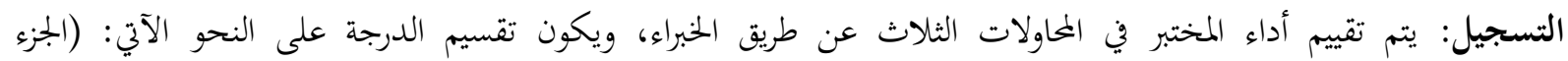
التحضيري: ودرجته (3)، الجزء الرئيس: ودرجته (5)، الجزء الختامي: ودرجته (2))

4- 4 التجربة الاستطلاعية:

التجربة الاستطلاعية هي: "تحربة صغيرة، أو عمل مصغر للدراسة العامة يقوم بها الباحث بغية الوقوف على السلبيات والإيجابيات التي ترافق إجراء التجربة الرئيسة للبحث" (صالح، 2004)، ومن أجل التأكد من سلامة الإجراءات، والطريقة التي لئي

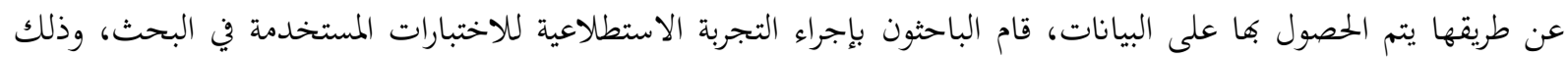

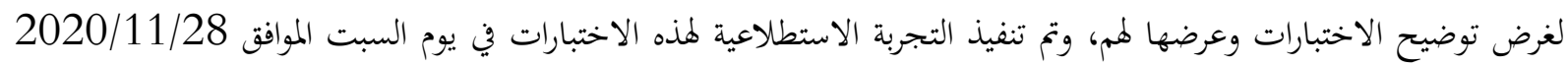
في تمام الساعة التاسعة صباحًا، والهدف منها: تَعَرُف الصعوبات والمعوقات التي قد توراجه الباحثون في أثناء تطبيق الاختبارات

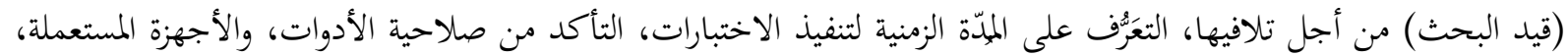

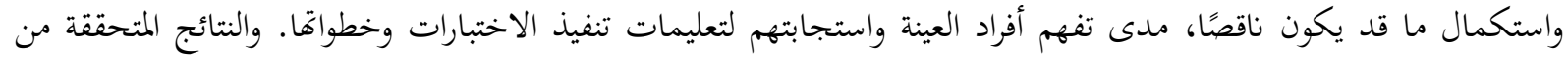
التجربة الاستطلاعية: (صلاحية الأدوات والأجهزة المستخدمة صلاحية الاختبارات المستخدمة جميعها من حيث تمتعها بالوقت المناسب للتنفيذ، وصلاحية المكان، وسهولة تطبيق عينة البحث للاختبارات، تفهم فريق العمل المساعد في طريقة تنفيذهم لاختبارات البحث).

\section{5- 5 الأسس العلمية للاختبارات المستخدمة في البحث:}

إنَّ من أهم خصائص الاختبار أو القياس الجيد هو توافر معاملات الصدق، والثبات، والموضوعية، فيتم ذلك عند

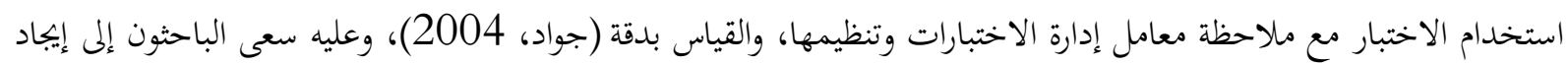
الأسس العلمية للاختبارات المختارة على النحو الآتي:

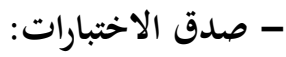

إِنَّ صدق الاختبارات هو: "أَنْ يقيس الاختبار ما وضع لقياسه، بمعنى أن الاختبار الصادق اختبار يقيس الوظيفة التي

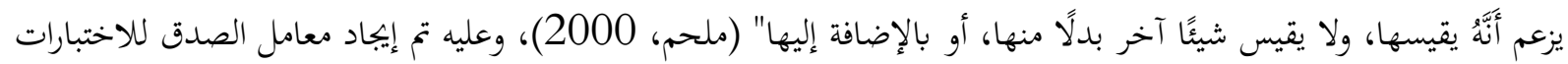

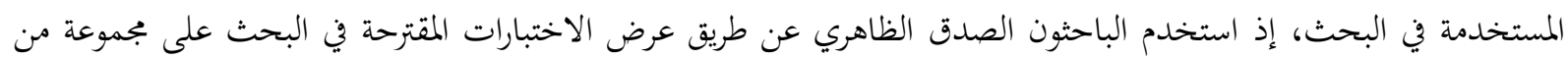

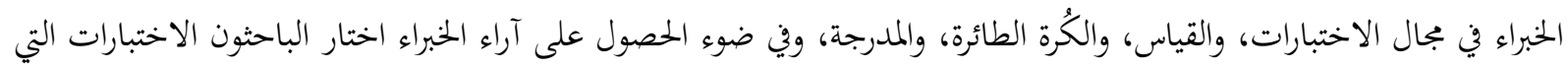

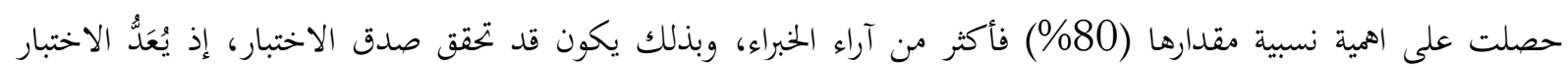

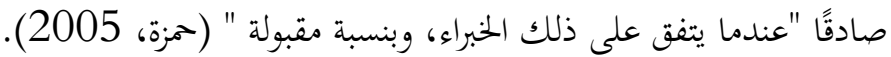

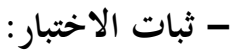

إِنَّ الاختبار الجيد هو الاختبار الذي يتصف بالثبات، فالاختبار الثابت هو: "الاختبار الذي يعطي نتائج متقاربة، أو

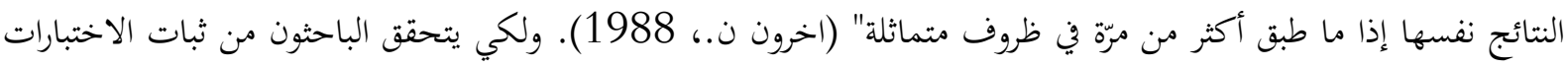


قاموا باستخدام طريقة الاختبار، وإعادة الاختبار على عينة مكونة من (10) طالبات من شعبتي (أ، ب)، وذلك في تمام الساعة

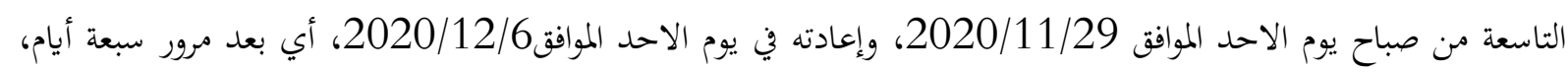
ويشير (ابراهيم، 2000) إلى أنَّهُ "لمعرفة ثبات الاختبار يعاد تطبيقه بعد مرور سبعة أيام على الاختبار الأول " (ابراهيم، 2000)، وبهدف معرفة الارتباط بين نتائج الاختبارين، قام الباحثون باستعمال قانون معامل الارتباط البسيط (بيرسون)، وتبيّن

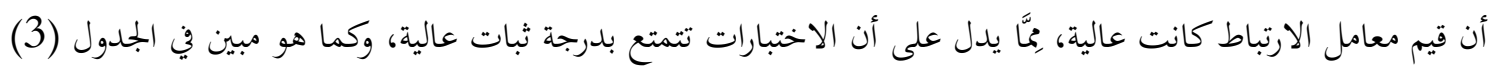

تعني موضوعية الاختبار: "الاتفاق في الآراء لأكثر من محكم لترتيب الأفراد وتقييمهم في أثناء الاختبار" (سلامة،

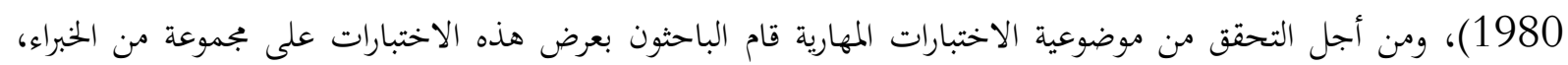

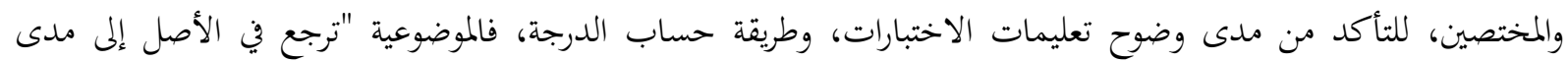

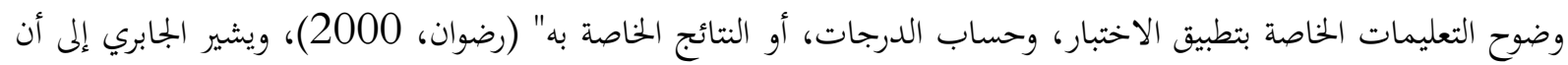

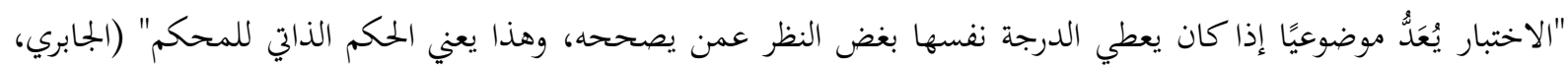

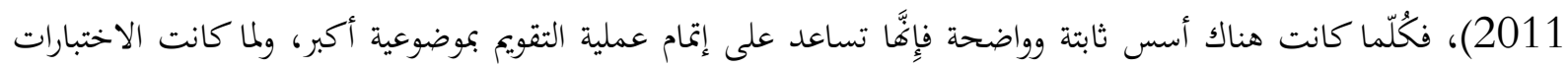

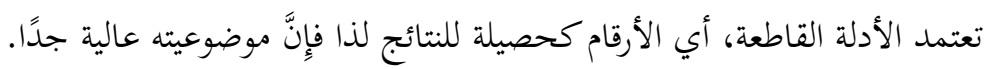
الجدول (3) يبيّن معاملات الثبات، والموضوعية للاختبارات قيد البحث

\begin{tabular}{|c|c|c|c|}
\hline الموضوعية & الثبات & 1 \\
\hline 0.89 & 0.86 & اختبار مهارة الإرسال المواجه من الأسفل. اختبار مهارة التمرير من الأعلى. & 2 \\
\hline 0.90 & 0.87 & اختبار التمرير من الأسفل. & 3 \\
\hline 0.90 & 0.88 & اختبار & \\
\hline
\end{tabular}

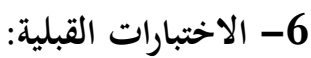

بعد تحديد الاختبارات المستعملة في البحث، وإيباد الأسس العلمية لها قام الباحثون بإعطاء وحدة تعريفية لأفراد العينة جميعها يوم الخميس الموافق 2020/12/10، لغرض تمكين الطالبات من معرفة شكل المهارة الأول ي، وكيفية تأديتها، بعدها

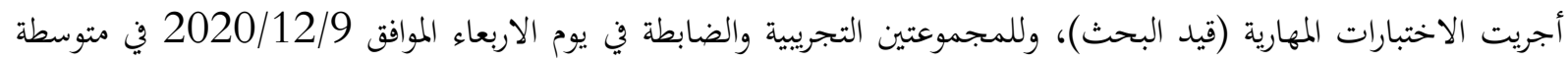

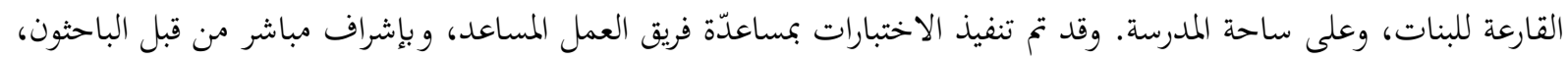

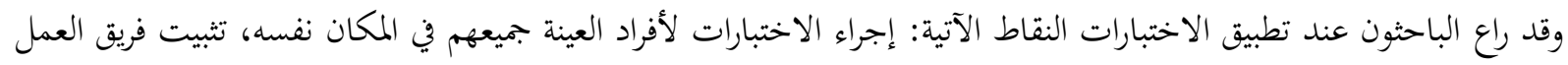

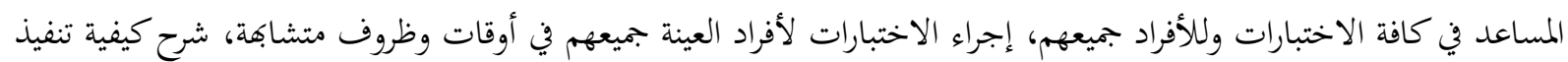

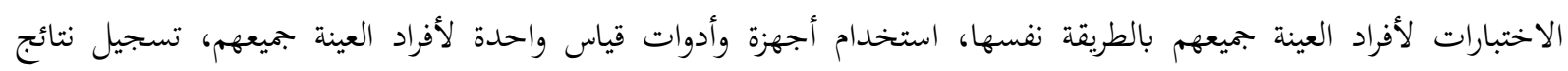

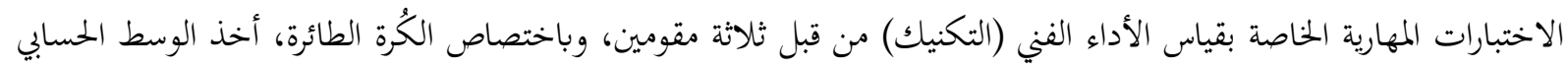
لدرجات ثلاثة مقومين لغرض تحديد الدرجة النهائية لكُلّ اختبار.

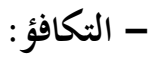

"لكي يستطيع الباحثون أن يرجع الفرق إلى العامل التجريبي يجب أن تكون المجموعات التجريبية متكافئة تمامًا في جميع ظروفها ما عدا المتغير التجريبي الذي يؤثر على المجموعة التجريبية" (بجيد، 1987)، ولغرض تحقيق ذلك قام الباحثون بإجراء 
عملية التكافؤ بين بجموعتي البحث في المتغيرات المستخدمة جميعها (قيد البحث)، وأظهرت النتائج عدم وجود فروق معنوية بين

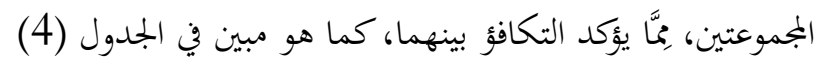
جدول (4) يبين التكافؤ بين مجموعتي البحث التجريبية والضابطة في اختبارات قيد البحث

\begin{tabular}{|c|c|c|c|c|c|c|c|c|c|}
\hline الدلالة & & قيمة t & \multicolumn{2}{|c|}{ المجمو عة الضابطة } & \multicolumn{2}{|c|}{ المجموعة التجرييية } & \multirow[b]{2}{*}{ القياس } & \multirow{2}{*}{ 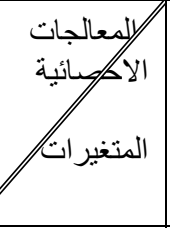 } & \\
\hline \multirow{4}{*}{ عند عندي } & مستو & المحسوبة & $\varepsilon$ & س & $\varepsilon$ & س & & & \\
\hline & $\begin{array}{r}0.8 \\
13\end{array}$ & 0.241 & 1.156 & 3.466 & 1.595 & 3.616 & درجة & الارسال الاسفل من & 1 \\
\hline & $\begin{array}{r}0.7 \\
83 \\
\end{array}$ & 0.279 & 0.794 & 2.416 & 1.300 & 2.281 & درجة & الاعلى من & 2 \\
\hline & $\begin{array}{r}0.9 \\
32\end{array}$ & 0.086 & 0.901 & 2.799 & 0.824 & 2.766 & درجة & الأسفليرمن & 3 \\
\hline
\end{tabular}

قيمة (t) الجدولية عند درجة حرية (18) وبمستوى دلالة (0.05) =0.10

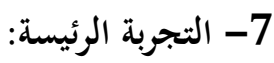

من أجل اتباع السياق العلمي السليم للتوصل إلى أدق النتائج لحل مشكلة البحث، ومن أجل تحقيق أهداف البحث

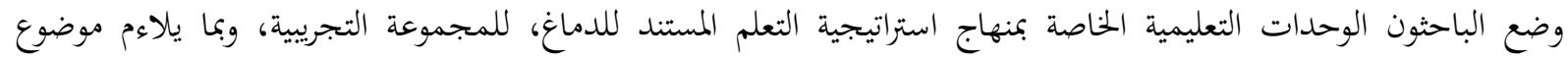
البحث وعينته، تضمنت (16) وحدة تعليمية، ولمدة (8) أسابيع، وبواقع وحدتين تعليميتين في الأسبوع ليومي السبت، والأحد،

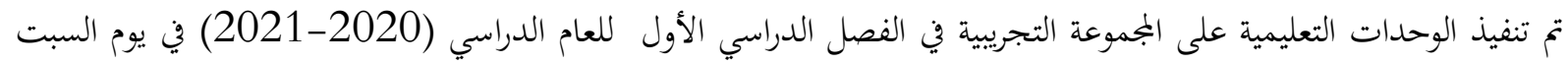
الموافق 2020/12/12، والانتهاء منها يوم السبت الموافق 2021/2/8 في ساحة متوسطة القارعة للبنات، تم استخدام (12)

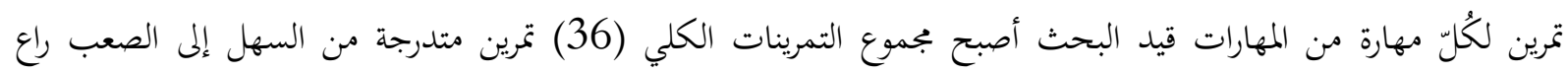

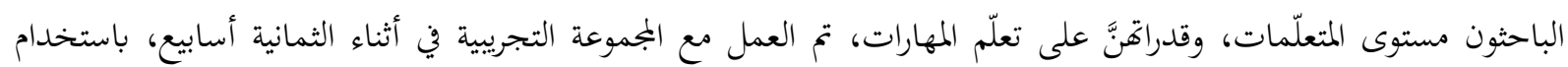

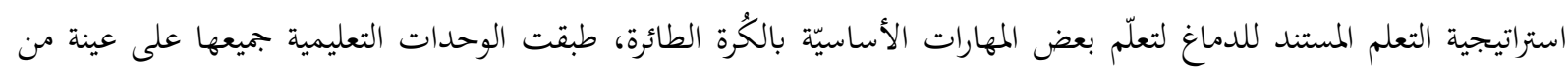
طالبات الصف الثاني متوسط/ متوسطة القارعة للبنات مراعية تسهيل عملية التعلّم إلى الطالبات باستخدام مبدأ التدرج في التعلّم من السهل إلى الصعب، ومن البسيط إلى المركب، إذ تم تطبيق التمرينات التي تتضمن التعلم المستند للدماغ بين الطالبات في فئنئ أثناء

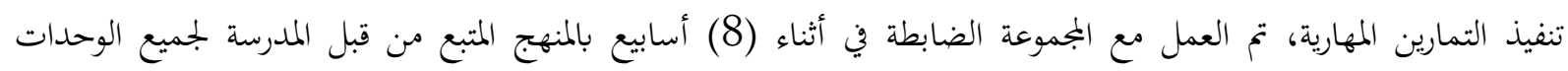

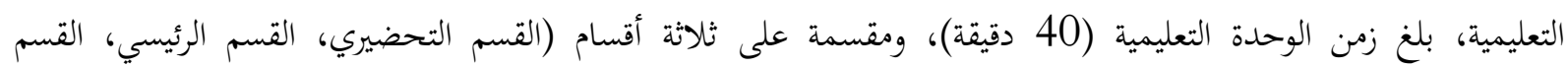

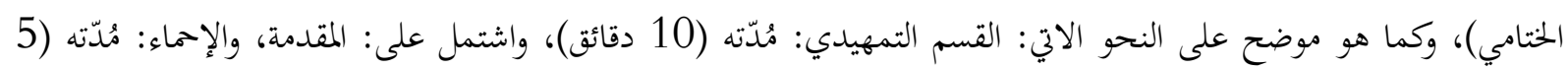

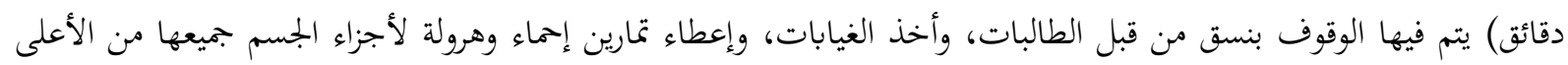

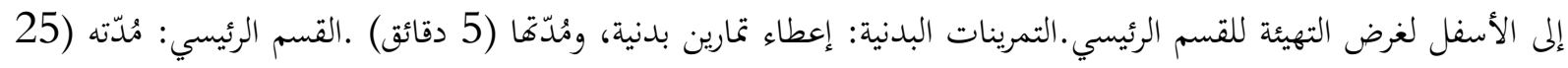

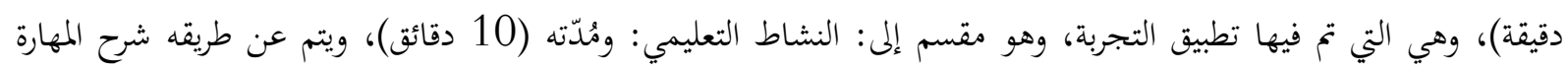

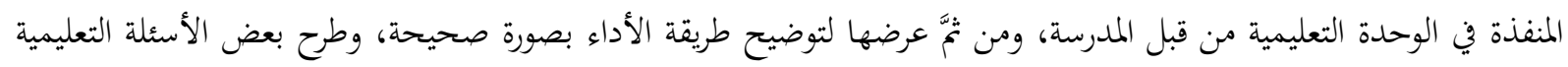

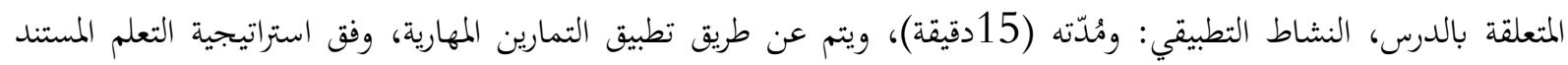
للدماغ، القسم الختامي: مُدّته (5 دقائق)، يتم في هذا القسم إعطاء لعبة صغيرة، لغرض تخفيف الجهاد للأعضاء، وبث الأثارة، 
والتشويق، والحماسة بين الطالبات، والوقوف بنسق، وإناء الوحدة التعليمية، والانصراف إلى الصف، وكما هو مبيّن في الجدول

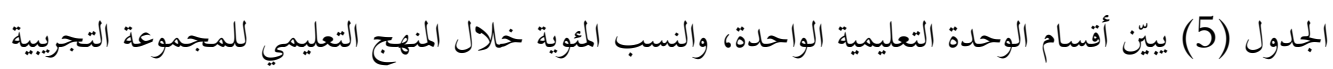

\begin{tabular}{|c|c|c|c|c|c|}
\hline \% النسبة المئوية & التطعيمي/ خلال المنهج & التعليمية/ دلال الوحدة & \multicolumn{2}{|c|}{ أقسام الوحدة التعليمية } & $ت$ \\
\hline$\% 40$ & (د160) & (د10) & الجانب التُعليمي (10د) & القسم & 1 \\
\hline$\% 60$ & 240 & $(د 15)$ & الجانب التطبيقي (15د) & $\begin{array}{r}\text { الرئيسي } \\
\text { (225) }\end{array}$ & \\
\hline$\% 100$ & 400 & $(-25)$ & & & 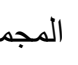 \\
\hline
\end{tabular}

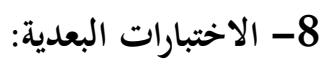

بعد الانتهاء من تنفيذ الوحدات التعليمية المعدّة على وفق استراتيجية التعلم المستند للدماغ، تم إجراء الاختبارات البعدية

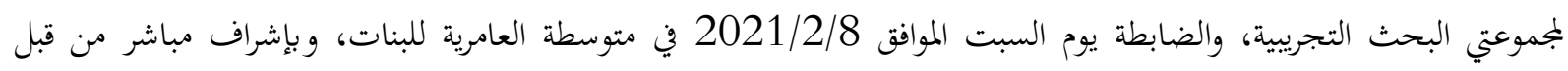

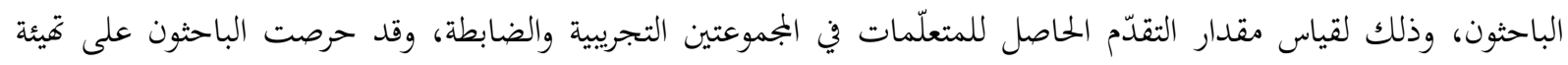

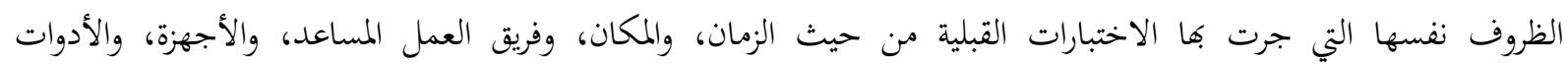
المستخدمة، وذلك لغرض الحصول على نتائج دقيقة.

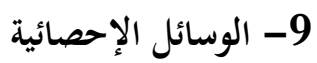

لغرض معالجة البيانات إحصائيًا استخدم الباحثون الحقيبة الإحصائية للعلوم الاجتماعية (SPSS)، وذلك لمعالجة البيانات الخناصة بالبحث.

3 - عرض النتائج وتحليلها ومناقشتها: 1- عرض وتحليل نتائج الاختبارات القبلية والبعدية للمجموعة التجريبة للمهارات الأساسية (قيد البحث) بالكرة الطائرة جدول (6) يبين قيمة T الخسوبة للمقارنة بين الاختبارات القبلية والبعدية للمجموعة التجريية للمهارات الأساسية (قيد البحث)

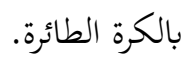

\begin{tabular}{|c|c|c|c|c|c|c|c|c|c|c|}
\hline \multirow{2}{*}{ الدلالة } & \multicolumn{2}{|r|}{ 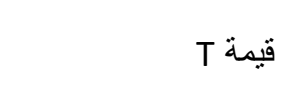 } & \multirow{2}{*}{ ف } & \multirow[b]{2}{*}{ نَ } & \multicolumn{2}{|c|}{ الاختبار البعدي } & \multicolumn{2}{|c|}{ الاختبار القبلي } & \multirow{2}{*}{ والقياسة } & \multirow{2}{*}{ 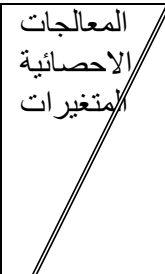 } \\
\hline & الخطبة & المحسوبة & & & $\varepsilon$ & سن & $\varepsilon$ & س س & & \\
\hline معنوي & 0.000 & 8.456 & 1.459 & 3.903 & 0.791 & 7.520 & 1.595 & 3.616 & درجة & الالمواجهال \\
\hline معنوي & 0.000 & 12.749 & 1.135 & 4.578 & 0.537 & 6.860 & 1.300 & 2.281 & درجة & من الإعلى \\
\hline معنوي & 0.000 & 10.460 & 1.089 & 3.603 & 0.598 & 6.370 & 0.824 & 2.766 & درجة & من الاسبفل \\
\hline
\end{tabular}

درجة الحرية (9) معنوي عند مستوى دلالة 20.05 
يتضح من الجدول (6) قيم الاوساط الحسابية والانخرافات المعيارية والوسط الحسابي للفروق وانحراف الفروق عن وسطها الحسابي وقيمة (T) المحسوبة ومستوى الدلالة في الاختبار القبلي والبعدي للمجموعة التجريبية للمهارات الأساسية بالكرة الطائرة (الارسال المواجه من الاسفل، التمرير من الاعلى، التمرير من الاسفل) . إذ تبين أن قيم الاوساط الحسابية لاختبار مهارة الارسال

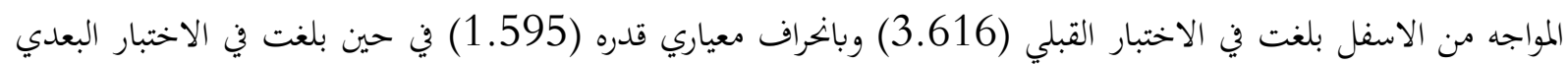

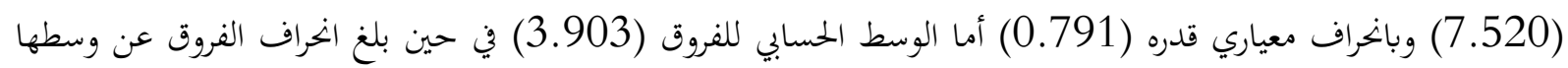

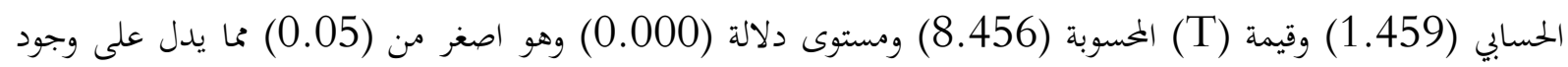
فروق معنوية في الاختبار القبلي والبعدي للمجموعة التجريبة. وتبين أن قيم الاوساط الحسابية لاختبار مهارة التمرير من الاعلى

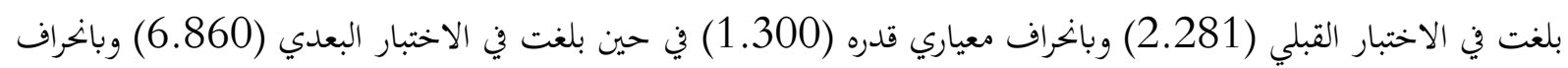

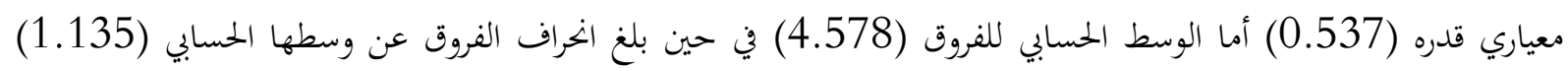

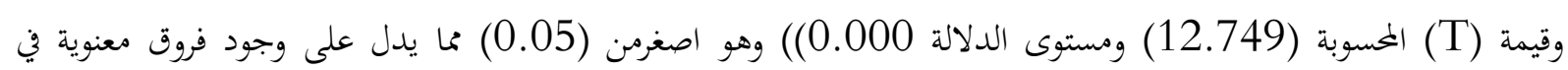

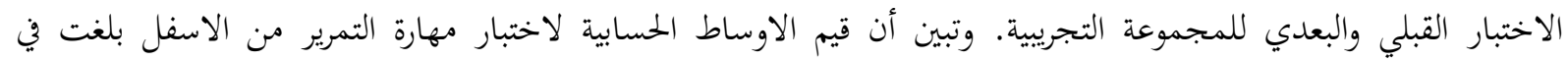

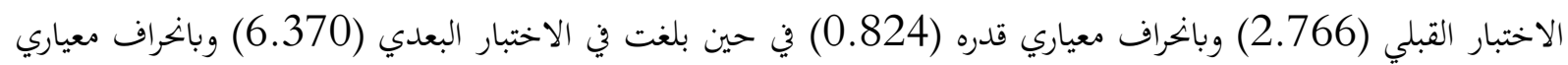

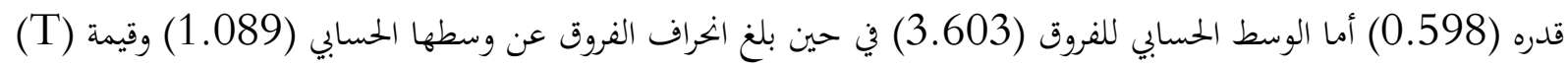
المحسوبة (10.460) ومستوى دلالة 0.000) وهو اصغرمن (0.05) مما يدل على وجود فروق معنوية في الاختبار القبلي

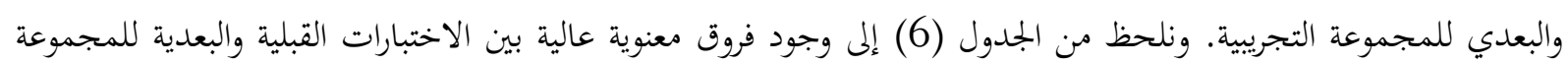

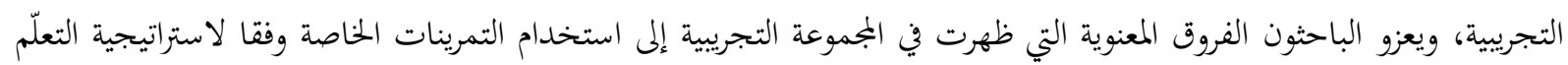

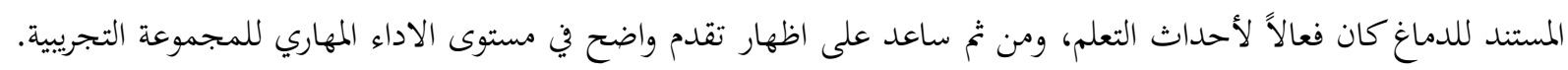

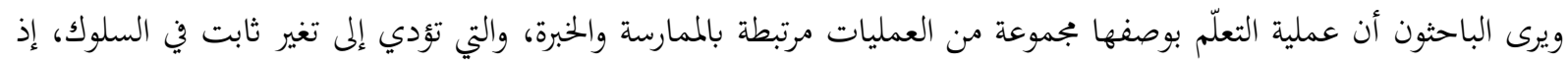

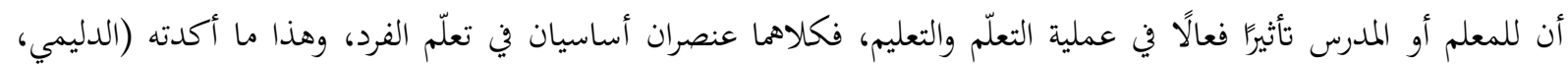

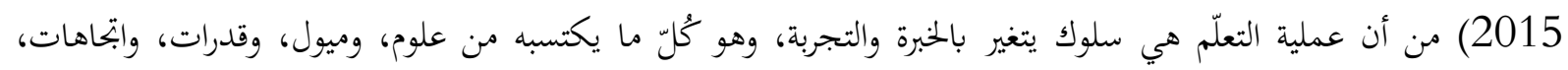

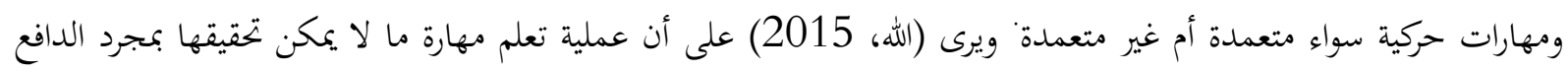

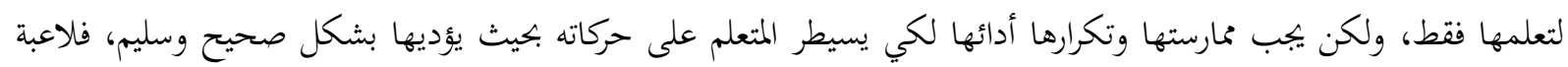
الكرة الطائرة لا تتعلم كيف تؤدي مهارة الارسال بمجرد أن تشاهد النموذج وانما تتعلم اللاعبة كل مهارات اللعبة بعد الشرح

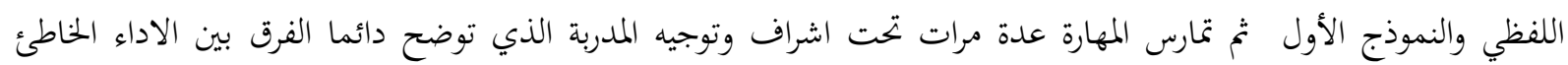

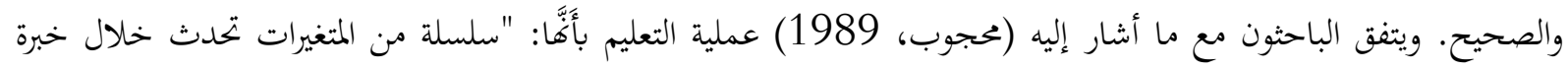

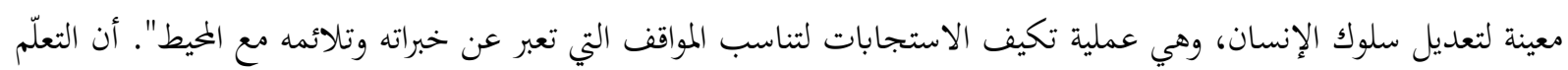
المستند للدماغ طريقة تعلّم وتعليم في أن واحدٍ يشترك فيها الطلبة بأنشطة متنوعة تسمح لهم بالإصغاء الإيجابي التي تبعل المتعلمين

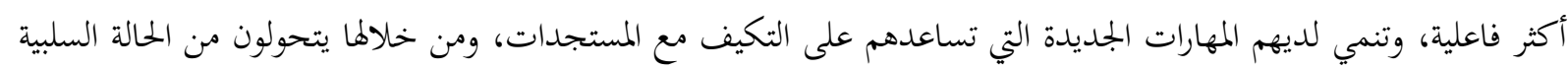

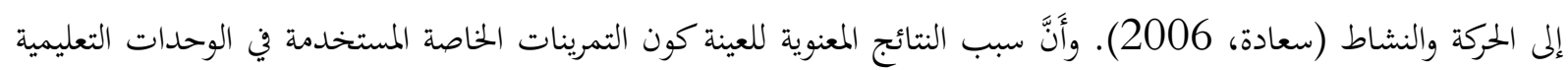

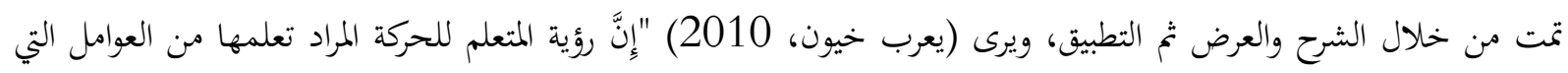

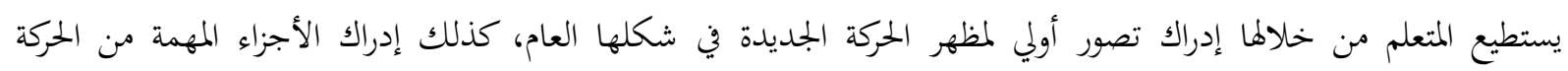

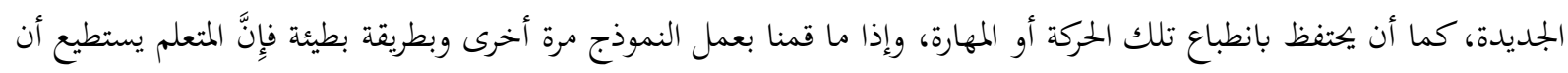

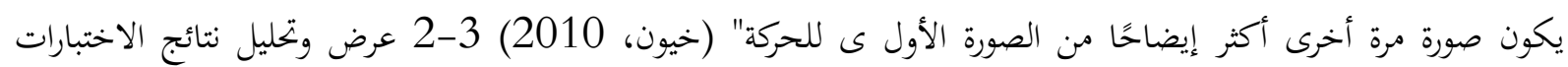
القبلية والبعدية للمجموعة الضابطة للمهارات الأساسية (قيد البحث) بالكرة الطائرة ومناقشتها البرها 


\begin{tabular}{|c|c|c|c|c|c|c|c|c|c|c|c|}
\hline \multirow{6}{*}{ 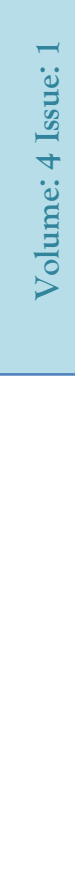 } & \multicolumn{11}{|c|}{ حدول (7) يبين قيمة T المحسوبة للمقارنة بين الاختبارات القبلية والبعدية للمجموعة الضابطة للمهارات الأساسية (قيد البحث) } \\
\hline & \multirow{2}{*}{ الدلالة } & \multicolumn{2}{|r|}{ قيمة T } & \multirow{2}{*}{$\underbrace{\varepsilon}$} & \multirow{2}{*}{ ن } & \multicolumn{2}{|c|}{ الاختبار البعدي } & \multicolumn{2}{|c|}{ الاختبار القبلي } & \multirow{2}{*}{ القباس } & \multirow{2}{*}{ |لالاحتصائية } \\
\hline & & 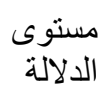 & المحسوبة & & & $\varepsilon$ & سَ & $\varepsilon$ & سَ & & \\
\hline & ي معنو & 0.007 & 3.512 & 1.264 & 1.403 & 0.689 & 4.870 & 1.156 & 3.466 & درجة & الارسال \\
\hline & مينو & 0.000 & 10.005 & 0.636 & 2.013 & 0.480 & 4.430 & 0.794 & 2.416 & درجة & التمرير من الاعلى \\
\hline & مي & 0.000 & 6.114 & 0.693 & 1.340 & 0.564 & 4.140 & 0.901 & 2.799 & درجة & التمفلير من \\
\hline
\end{tabular}

درجة الحرية (9) معنوي عند مستوى دلالة \05 0.05

يتضح من الجدول (7) قيم الاوساط الحسابية والانخرافات المعيارية والوسط الحسابي للفروق وانحراف الفروق عن وسطها الحسابي وقيمة (T) المحسوبة ومستوى الدلالة في الاختبار القبلي والبعدي للمجموعة الضابطة للمهارات الأساسية بالكرة الطائرة

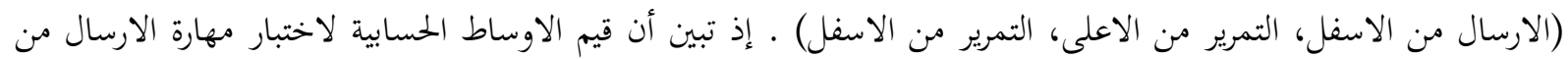
الاسفل بلغت في الاختبار القبلي (3.466) وبانحراف معياري قدره (156) (1.156) في حين بلغت في الاختبار البعدي (4.870) وبانحراف معياري قدره (0.689) أما الوسط الحسابي للفروق (1.403) في حين بلغ انحراف الفروق عن وسطها الحسابي

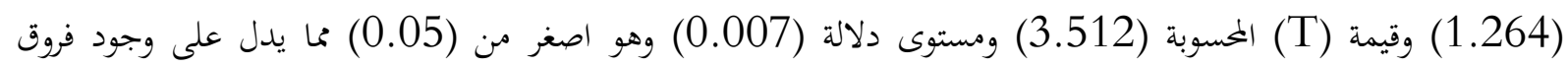

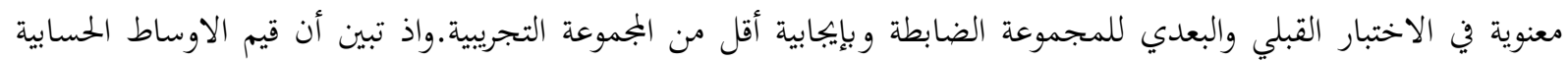

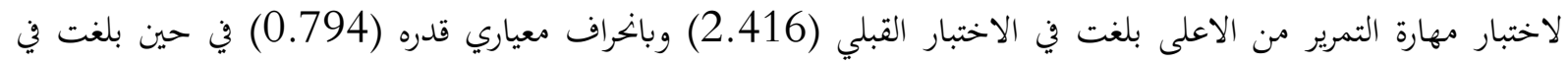

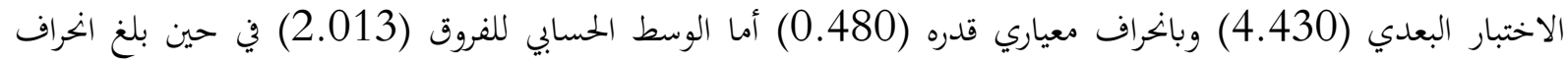
الفروق عن وسطها الحسابي (0.636) وقيمة (T) الخسوبة (10.005) ومستوى دلالة (0.000) وهو اصغر من (0.05)

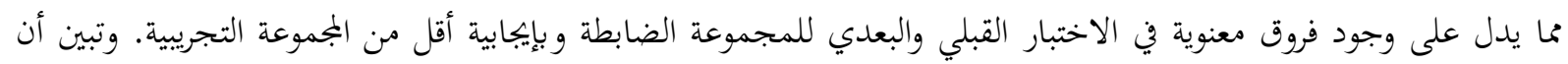

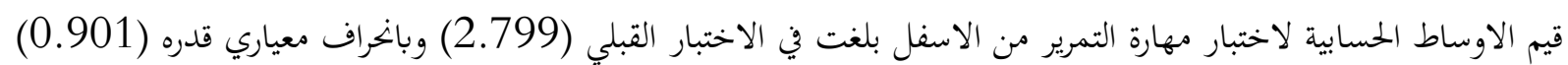

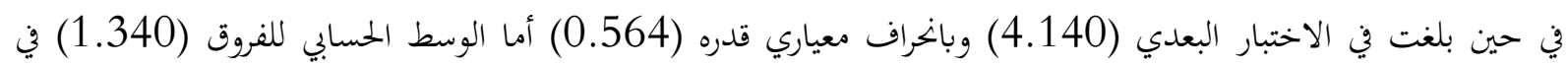

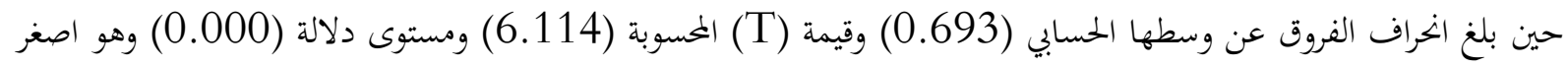
من (0.05) مما يدل على وجود فروق معنوية في الاختبار القبلي والبعدي للمجموعة الضابطة وبايجابية أقل من المجموعة

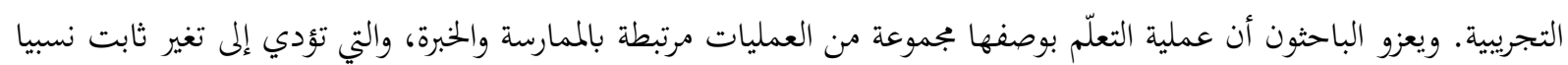

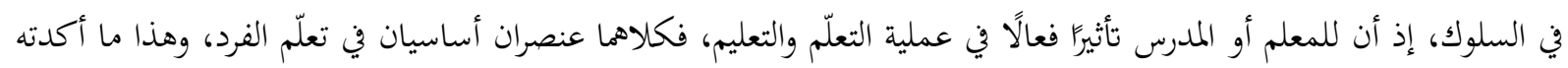

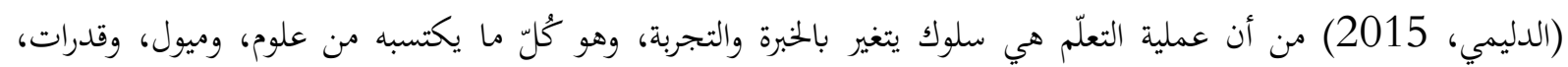

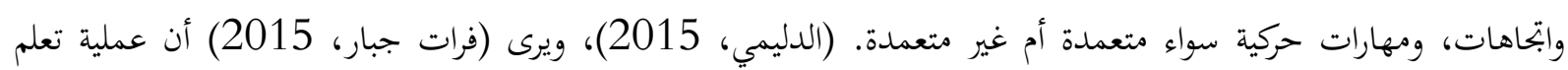

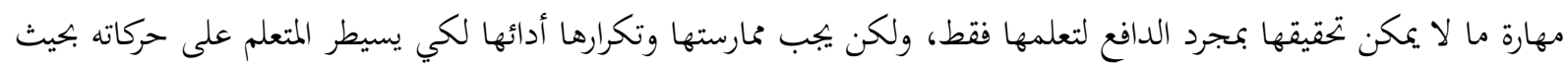
يؤديها بشكل صحيح وسليم (الله، 2015). وان اعتماد المجموعة الضابطة على أسلوب المدرس والى التكرارات المناسبة التي مئي 
رافقت الوحدات التعليمية بصورة مستمرة وكذلك التدرج في مستوى الصعوبات للمهارات والتي تضمن الأداء من الجميع إذ "إنّ الممارسة وبذل الجها بالتدريب والتكرارات المستمرة ضرورية في عملية التعلم والاكتساب كما أن التدريب عامل أساس في عملية

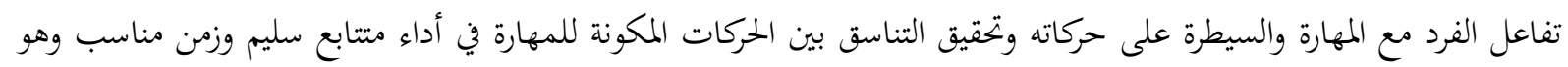
يزيد من تعلم وتطوير المهارة وإتقاها (صبحي، 2000).

2- عرض وتحليل نتائج الاختبارات البعدية للمجموعتين التجريبية والضابطة للمهارات الأساسية (قيد البحث) بالكرة الطائرة ومناقشتها جدول (8) يبين الاوساط الحسابية والانحرافات المعيارية وقيمة (T) المسوبة ومستوى الدلالة في الاختبارات البعدية للمجموعتين التجريية والضابطة للمهارات الأساسية (قيد البحث) بالكرة الطائرة.

\begin{tabular}{|c|c|c|c|c|c|c|c|c|c|}
\hline \multirow{3}{*}{ الدلالة } & \multicolumn{2}{|r|}{ قيمة t } & \multicolumn{2}{|c|}{ المجموعة الضابطة } & \multicolumn{2}{|c|}{ المجموعة التجريبية } & \multirow{3}{*}{ القياس } & \multicolumn{2}{|l|}{ /لالمعالجات الاحصائية } \\
\hline & الدلالة & المحسوبة & $\varepsilon$ & سَّ & $\varepsilon$ & سَّ & & & $ت$ \\
\hline & & & & & & & & المتغير ات & \\
\hline معنوي & 0.000 & 7.983 & 0.689 & 4.870 & 0.791 & 7.520 & درجة & الاسفل الارل المواجه من & 1 \\
\hline معنوي & 0.000 & 10.651 & 0.152 & 4.430 & 0.537 & 6.860 & درجة & التمرير من الاعلى & 2 \\
\hline معنوي & 0.000 & 8.576 & 0.564 & 4.140 & 0.598 & 6.370 & درجة & التمرير من الاسفل & 3 \\
\hline
\end{tabular}

درجة الحرية (18) معنوي عند مستوى دلالة 0.05

يتضح لنا من الجدول (8) قيم الاوساط الحسابية والانحرافات المعيارية وقيمة (T) المحسوبة ومستوى الدلالة في الاختبارات البعدية للمجموعتين التجريبة والضابطة للمهارات الأساسية بالكرة الطائرة (قيد البحث) ـ تبين أن قيمة الوسط الحسابي لمهارة

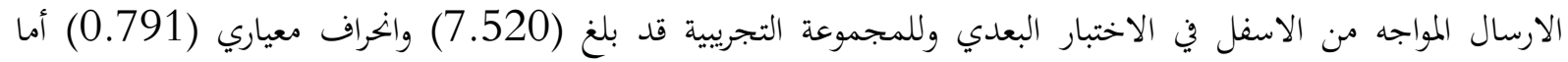

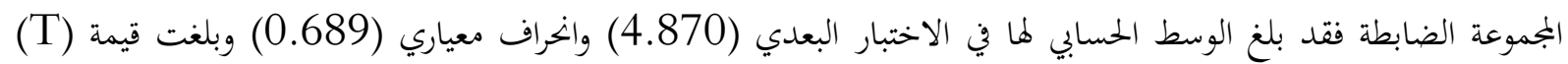
المحسوبة (7.983) ومستوى دلالة (0.000) وهو اصغر من (0.05) مما يدل على وجود فروق ذات دلالة احصائية في الاختبار البعدي للمجموعتين التجريبية والضابطة.اما قيمة الوسط الحسابي لمهارة التمرير من الاعلى في الاختبار البعدي

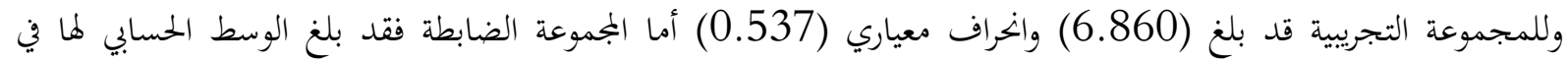
الاختبار البعدي (4.430) وانحراف معياري (0.152) وبلغت قيمة (T) المسوبة (10.651) ومستوى دلالة (0.000) وهو اصغر من (0.05) مما يدل على وجود فروق ذات دلالة احصائية في الاختبار البعدي للمجموعتين التجريبية والضابطة.

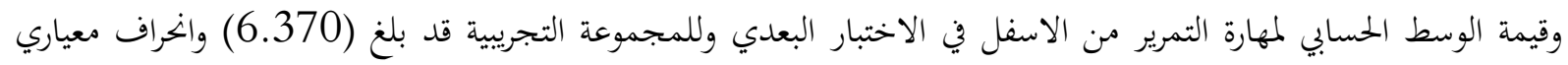

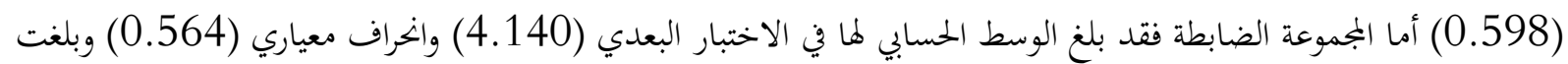

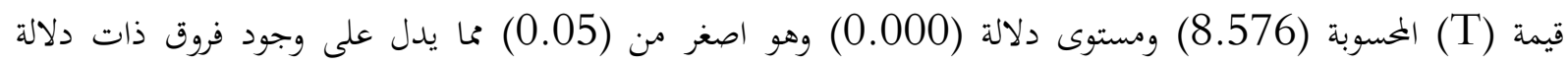

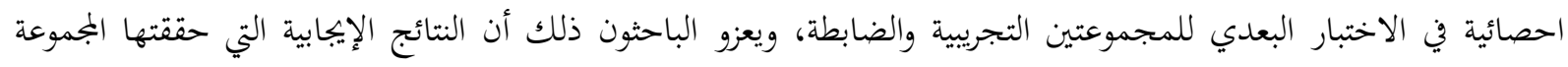

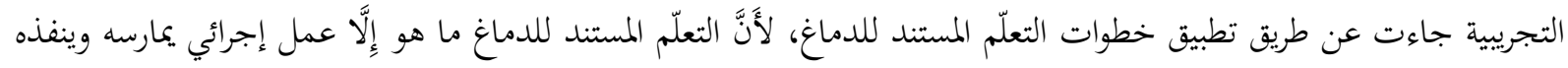
الطلبة داخل الصف الدراسي بمشاركة جميع المتعاملين، وييسر التعلّم بوساطة المعلم الميسر، ويختلف عن الإصغاء السلبي لما يقوله 
المتعلم، بحيث يشمل العمل والخبرات الإيجابية التي تساعدهم على فهم ما يسمعونه من معارف ومعلومات، وكتابة أهم الأفكار، وهذا ما تؤكده (البكري، 2016)من أنَّهَ يمكن تشبيه التعامل المستند للدماغ بالرياضة التي تكون للممارسة وليست للمشاهدة، ويرى الباحثون أَنَّهُ من خلال عرض النموذج تحقق لدى الطالبات عامل التشويق والأثارة، وميل الطالبات نخو الدّرس، وهذا أدى إلى الإسهام في التطوير الحاصل في المجموعة التجريبية، لأنَّهَّه من خلال عرض الأنموذج في الدّرس اقتربت المفاهيم المجردة إلى أذهان الطالبات، أن الهدف من هذه التمرينات الخاصة وفقا لاستراتيجية التعلم المستند للدماغ في تعلم بعض المهارات الأساسية وتحسينها بما يتلاءم مع قابليتهم وميولمم لغرض اكتساب التعلّم، والوصول إلى مستوى جيد لأداء المهارات الأساسيّة المراد تعلمها، فمن

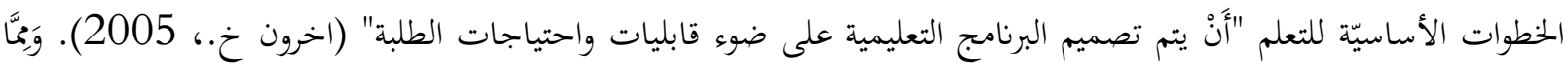
سبق نجد أهمية التمرينات الخاصة وفقا لاستراتيجية التعلم المستند للدماغ المستخدمة مع المجموعة التجريبية التي جاءت نتائجها مطابقة مع فرضيات البحث، إذ تطورت المجموعة التجريبية تطورًا معنويًا، وذلك من خلال نتائج الاختبارات، أما المجموعة الضابطة فقد تطورت هي أيضًا، ولكن ليس بالقدر الكافي، إذ تفوقت المجموعة التجريبية على المجموعة الضابطة في تعلم بعض المهارات الأساسية التي استخدمت استراتيجية التعلّم المستند للدماغ والتي تشير إلى الاداء الصحيح للمهارة بكافة تفصيلاكَا الدقيقة، وهذا ما سهّل أسلوب التعلمّ بنجاح الهدف وتحقيقه من الوصول بالعينة التجريبية تعلم بعض المهارات الأساسية بالكرة الطائرة للطالبات.

\section{خاتمة البحث:}

استناداً إلى ما أظهرته النتائج، وفي ضوء الاهداف والفرضيات توصل الباحثون إلى أن للتمرينات الخاصة وفقاً لاستراتيجية التعلم المستند للدماغ أثر واضح وفعال في تعلم بعض المهارات الأساسية لطالبات الصف الثاني متوسط بالكرة الطائرة. وان شرح وعرض وتطبيق المهارات في النشاط التعليمي والتطبيقي في الجزء الرئيسي من الوحدة التعليمية قد ساهم بشكل واضح في تعلمها. و ان زيادة خبرة الطالبات من خلال الممارسة والتكرار ساعدهن في تعلم المهارات الأساسية بالشكل الصحيح، وفي ضوء الحقائق العلمية التي اسفرت عنها نتائج البحث يوصي الباحثون ضرورة الاعتماد على استراتيجية التعلم المستند للدماغ في بناء المناهج التعليمية لطالبات الصف الثاني متوسط، ضرورة بناء مناهج تعليمية بالاعتماد على استراتيجية التعلم المستند للدماغ في تعلم بعض المهارات الدفاعية بالكرة الطائرة، وضرورة تطبيق التمرينات المهارية وفقا لاستراتيجية التعلم المستند للدماغ على عينات أخرى. 
المصادر:

ابراهيم احمد سلامة. (1980). الاختبارات و القياس ي التربية البدنية. القاهرة: مطبعة الجيزة.

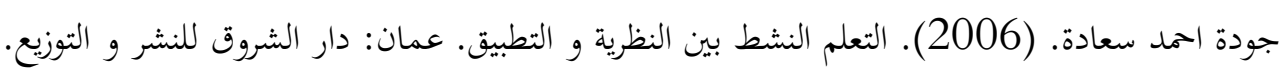
خليل ابراهيم و اخرون. (2005). أساسيات التدريس. عمان: دار المناهج.

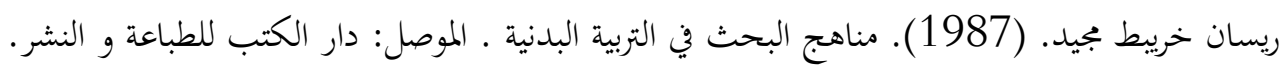
سامي ملحم. (2000). مناهج البحث في التربية وعلم النفس ـ عمان: دار الميسرة. سهام عبدالمنعم البكري. (2016). التعلم الحركي. عمان: دار الكتب و الوثائق. صباح حسين حمة. (2005). القياس و التقويم التربوي. صنعاء: مركز التربية للطباعة و النشر. عامر ابراهيم قندلجي. (2015). منهجية البحث العلمي. عمان: عامر ابراهيم -دار اليازوري العلمية . عبد الرزاق كاظم و اخرون. (2012). دليل مدرس التربية الرياضية للمرحلة المتوسطة. بغداد: مطبعة وزارة التربية. علي سلوم جواد. (2004). الاختبارات و القياس و الاحصاء في المجال الرياضي ـ القادسية: جامعة القادسية.

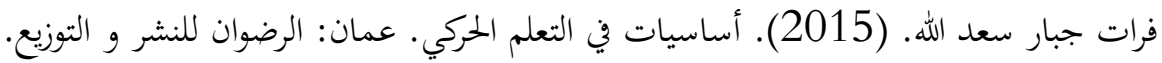

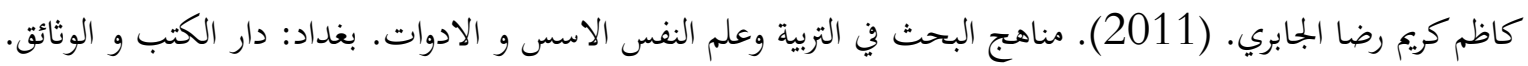

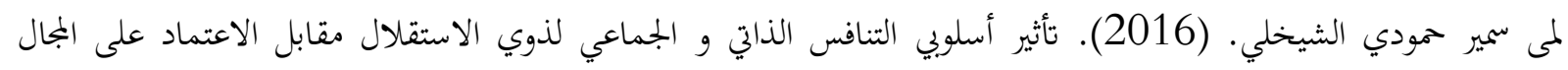

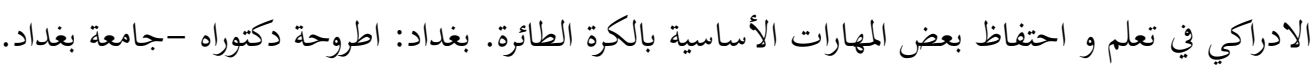

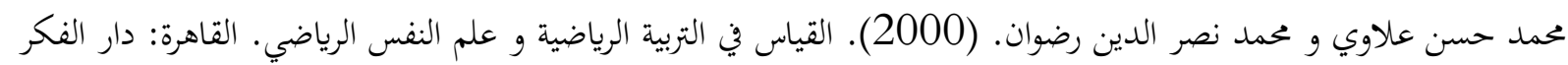

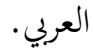

مروان عبدالمجيد ابراهيم. (2000). اسس البحث العلمي لاعداد الرسائل الجامعية ـ عمان: مؤسسة الوراق للنشر و التوزيع.

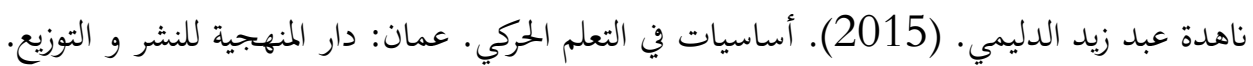

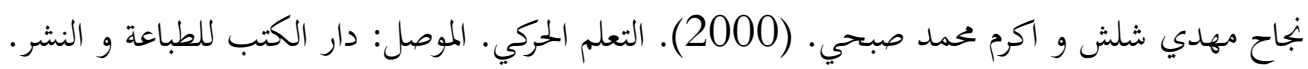

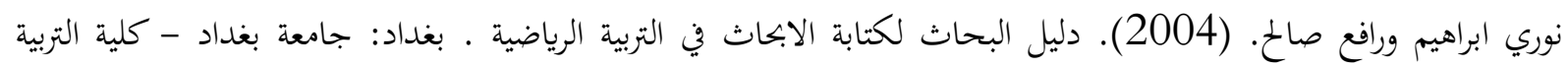
الرياضية

نوفل عبيدات و اخرون. (1988). البحث العلمي و مفهومة- ادواته -أساليبه. عمان: دار الفكر العربي.

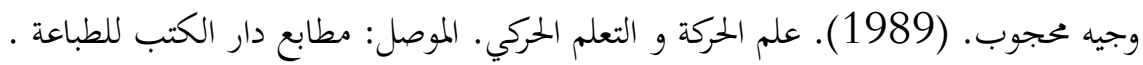
يعرب خيون. (2010). التعلم الحركي بين المبدأ و التطبيق. بغداد: دار الكتب و الوثيأق مطئق مطبعة الكلمة الطيبة. 


\section{SCIENTIFIC RESEARCH AND ITS ROLE IN DEVELOPING THE SKILLS OF \\ FACULTY MEMBERS IN THE LIGHT OF QUALITY STANDARDS AND PERFORMANCE EVALUATION AT THE UNIVERSITY OF TRIPOLI}

\section{Istanbul / Türkiye \\ p. $702-717$}

Received: $19 / 11 / 2021$

Accepted: 06/12/2021

Published: 01/01/2022

This article has been scanned I iThenticat No plagiarism detected

\author{
Abdegadir Emhammed Salih MANSOUR ${ }^{1}$
}

\begin{abstract}
:
Scientific research eventually considered as one of the most important functions and tasks undertaken by the university, and it is a balancing function to the function of education. Thus, universities have become concerned in the process of discovering, transferring and developing knowledge, and that their role is not limited to preparing specialized educates needed by the labor market. Scientific research also contributed to activating the role of The university in developing and serving communities, which imposed on the university to undertake a new mission that led to the necessity of linking the university with the community, and therefore the functions of the university steadily developed. Development, and therefore the university is entrusted with integrated tasks and functions that it performs through its specialized colleges and scientific centers.

University institutions have great significance in carrying out scientific research and development, transferring knowledge and technology to a variety of fields and activities of society, where scientific research contributes to adapting and keeping pace with global changes and challenges in the long and near term. We found that developed countries follow in this field many means, including provision of services Education, training for the community, and encouraging universities to carry out scientific research, and also development through their faculty promotion system. The topic of scientific research and its role in developing the skills of faculty members is among the topics that are of great significance at all local and international levels, where university education faces in This era of scientific and technological changes and developments, compulsory on universities to develop and modernize their educational system by paying attention to scientific research, so that they could have constructive possessions in improving the stage of students, in their scientific construction, and forming their characters.
\end{abstract}

Key words: Scientific Research, Quality Standards, Developing Skills.

http://dx.doi.org/10.47832/2717-8293.15.48

1 iD Dr. , Siirt-University,Libya, agsdadaa12345678@gmail.com, https://orcid.org/0000-0002-5621-3801 


\section{البحث العلمي ودوره في تطوير مهارات أعضاء هيئة التدريس في ضوء معايير \\ الجودة وتقييم الأداء بجامعة طرابلس \\ عبدالقادر الحممد صالح منصور 2}

الملخص:

يُعد البحث العلمي أحد أهم الوظائف والمهام التي تقوم بها الجامعة، وهي وظيفة مكملة لوظيفة التعليم، وبذلك

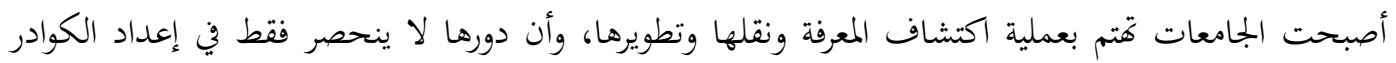

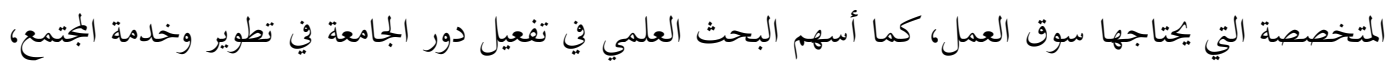
الأمر الذي فرض على الجامعة القيام بمهمة جديدة أدت إلى ضرورة ربط الجامعة بالمجتمع، وبالتالي أصبحت وظائف الجامعة تتطور بالتدريج، فبعد أن كانت وظيفتها تقتصر على التدريس ونقل المعرفة تطورت لتشمل

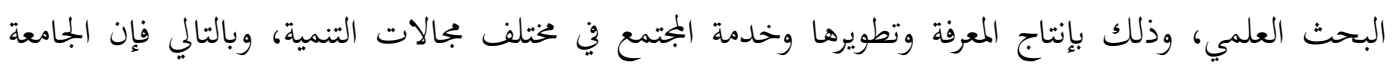

مناطة بمهام ووظائف متكاملة تقوم بما من خلال الكليات والمراكز العلمية المتخصصة بها.

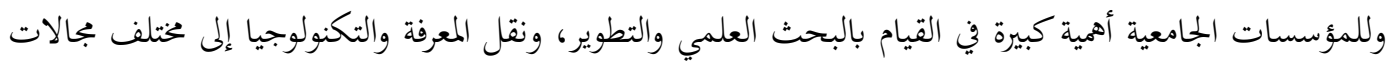
ونشاطات البجتمع، فالبحث العلمي يُسهم في ملاءمة ومواكبة التغيرات والتحديات العالمية على المدى البعيد والقريب، فنجد الدول المتقدمة تتبع في هذا المجال العديد من الوسائل من ضمنها تقديم الخدمات التعليمية والتدريبية للمجتمع، وتشجيع الجامعات على القيام بالبحث العلمي والتطوير من خلال نظام ترقية أعضاء هيئة

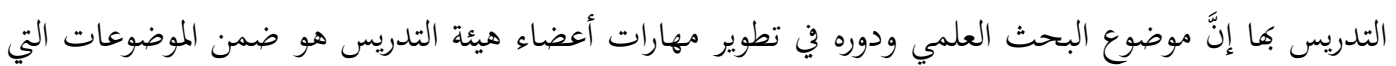

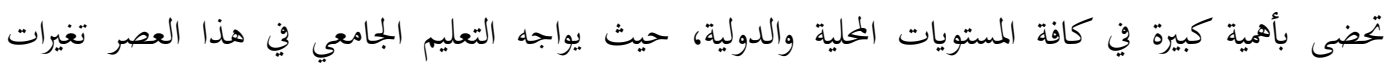
وتطورات علمية وتكنولوجية، فرضت على الجامعات تطوير وتحديث النظام التعليمي بها من خلال الاهتمام بالبحث العلمي، حتى تتمكن من أحداث تأثيرات إيهابية في تحسين مستوى الطلاب، ويف بنائهم العلمي، الكلمات المفتاحية: البحث العلمي، معايير الجودة، تطوير مهارات.

يُعد البحث العلمي من أهم الوظائف الأساسية التي تقوم بها الجامعة التي تؤدي دورا مهما في عملية التنمية من خلال

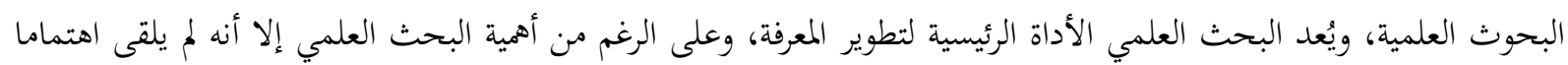
كبيرا وانتشارا واسعا بين الجامعات العربية، لذلك نجد أن كثيرا من البحوث والدراسات العلمية بتحى لأغراض الترقية العلمية لأعضاء هيئة التدريس بالجامعات في مختلف التخصصات والتي متتم بالناحية الفكرية أكثر من اهتمامها بالناحية التطبيقية، إضافة

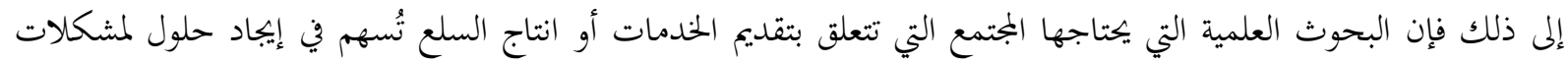

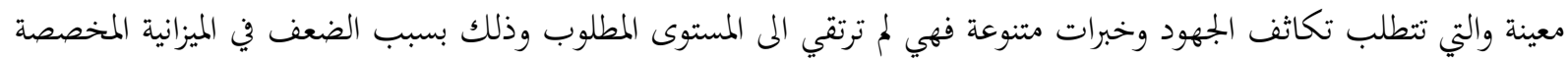

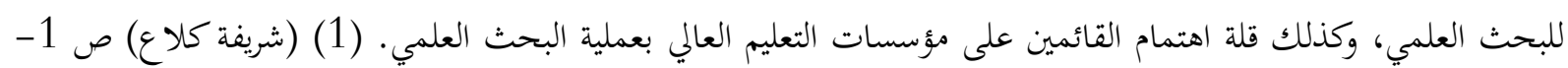


وللمؤسسات الجامعية أهمية كبيرة في القيام بالبحث العلمي والتطوير، ونقل المعرفة والتكنولوجيا إلى مختلف بجالات

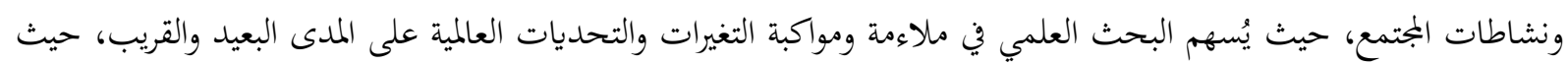

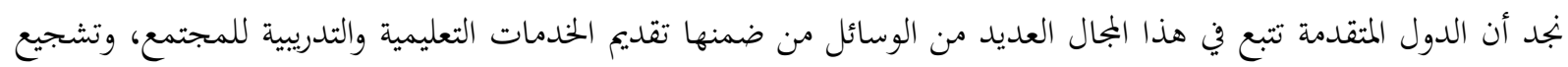

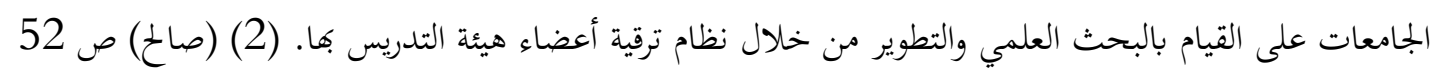
وُو عد عضو هيئة التدريس أحد أهم عناصر العملية التعليمية لما له من دور بارز ومهم في الارتقاء بالمستوى المعريف والعلمي

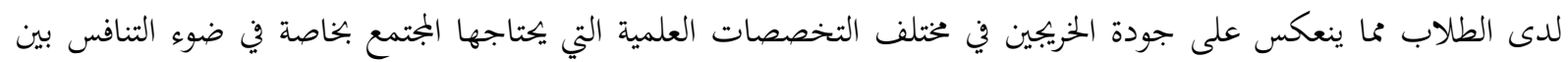
الجامعات في ظل التغيرات، والتطورات التكنولوجية، والمعرفية وثورة الاتصالات والمعلومات مما فرض على مؤسسات التعليم الجامعي

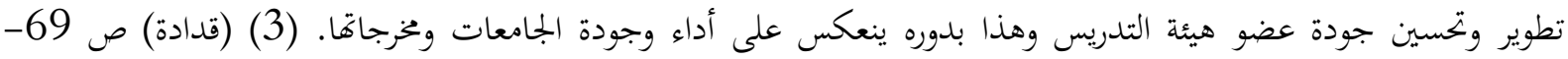

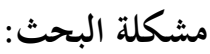

يُعد عضو هيئة التدريس أحد أهم العناصر المؤثرة في العملية التعليمية بالجامعة لما يمتلكه من مهارات وقدرات في مجال تخصصه بتعله في مواجهة العديد من المشكلات التي تعترضه أثناء تأديته لعمله كعضو هيئة تدريس جامعي، كما يمكن له بهذه الحصيلة المعرفية والمهارات والقدرات أن يخوض في مجال البحث والدراسة، والاسهام في حل الكثير من المشكلات التي تواجه

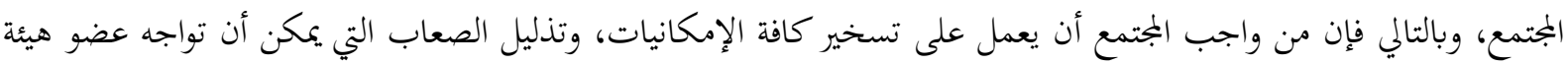
التدريس الجامعي في أداء عمله على أكمل وجه، وذلك للحاجة الماسة الى عضو هيئة تدريس تتوافر له كل الإمكانيات المهنية والتدريسية والعلمية والتي تؤثر بشكل إيجابي في المنتج التعليمي.

ويواجه التعليم الجامعي بليبيا العديد من المشكلات خصوصاً تلك التي تتعلق بأعضاء هيئة التدريس بالجامعات وتقف هذه المشكلات حائلاً دون تطوير مهاراتم وقدراقم، في ضوء معايير الجودة وتقييم الأداء. فقد أثبت بعض الدراسات ضعف تشجيع الجامعات الليبية لأعضاء هيئة التدريس على المشاركة في الندوات والمؤتمرات

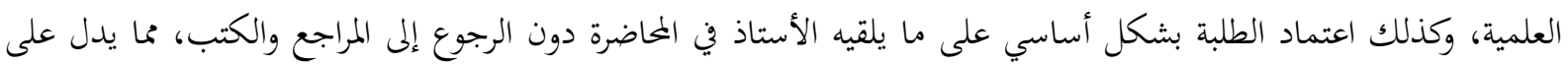
أهمية التطوير لقدرات عضو هيئة التدريس الجامعي.

كما اتضح ضعف متابعة عضو هيئة التدريس لما يستجد في ميدان تخصصه، وغياب التخطيط العلمي لإعداد الأستاذ الجامعي، وقلة مساهمه في القيام بالبحث العلمي، وضعف توافر فرص حقيقية لعضو هيئة التدريس للتدريب على استخدام التقنية

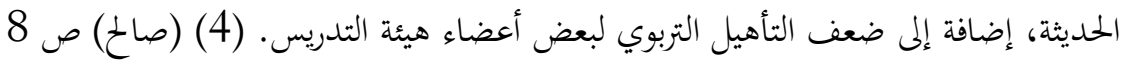
ومما سبق يتضح تأثير بعض المشكلات التي تواجه التعليم الجامعي الليبي على أداء وقدرات أعضاء هيئة التدريس بالجامعات الليبية مما يتطلب القيام بالبحوث والدراسات لتحسين وتطوير أداء عضو هيئة التدريس الجامعي مهنيا، وعلميّاً وأكاديميا من أجل قيامه بدوره الفعال في الجامعة، والرقي بمستوى طلابها، والمساهمة في تطوير وتنمية المجتمع. ويُعد تطوير قدرات أعضاء هيئة التدريس عملية ضرورية وملحة، وهذا لا يتحقق إلا بمواجهة تلك المشكلات والعوائق التي يواجها النظام التعليمي بالجامعات الليبية، ومن ثم تطوير قدرات ومهارات أعضاء هيئة التدريس، وتحسين أدائهم التعليمي والتدريسي من أجل الاسهام في تحسين مستوى الطلاب، الذى يؤدى إلى خخرجات ذات كفاءة عالية قادرة على الاسهام الفاعلة

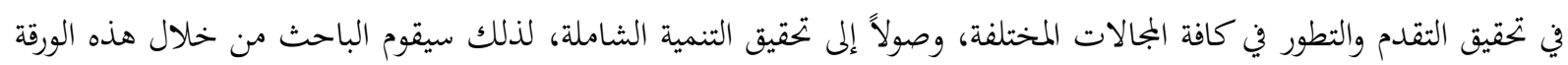


بالبحث والدراسة للدور الذي يمكن أن يقوم به البحث العلمي في تطوير قدرات ومهارات أعضاء هيئة التدريس بجامعة طرابلس

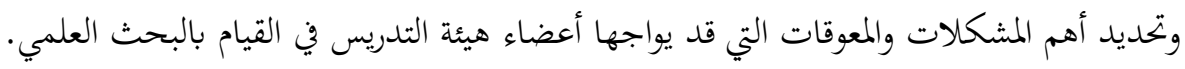

\section{مشكلة البحث}

- ما دور البحث العلمي في تطوير مهارات أعضاء هيئة التدريس في ضوء معايير الجودة بجامعة طرابلس؟ ويتفرع من هذا السؤال الأسئلة الآتية:

- ما أهم المشكلات والمعوقات التي يواجها أعضاء هيئة التدريس في القيام بالبحث العلمي بجامعة طرابلس؟

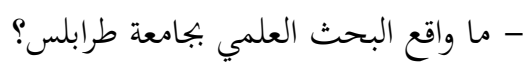
- ما أهم المهارات والقدرات التي يجب أن تتوفر في عضو هيئة التدريس بجامعة طرابلس؟

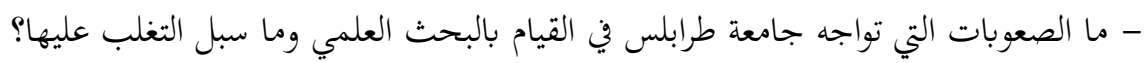

إنَّ موضوع البحث العلمي ودوره في تطوير مهارات أعضاء هيئة التدريس هو ضمن الموضوعات التي تحضى بأهمية كبيرة في كافة المستويات المحلية والدولية، حيث يواجه التعليم الجامعي في هذا العصر تغيرات وتطورات علمية وتكنولوجية، فرضت على على فئل

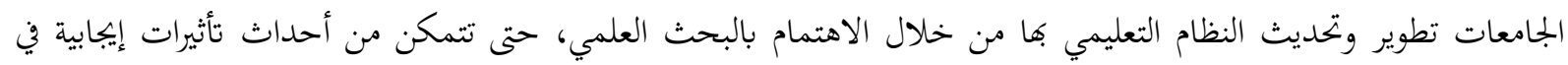
تحسين مستوى الطلاب، وفي بنائهم العلمي، وتكوين شخصيتهم. وتتحدد أهمية البحث في النقاط الآتية: - الاهتمام بالجامعات الليبية من خلال تطوير عمليات البحث العلمي باعتبارها المؤسسات التي تعمل على مد المجتمع بأهم الكفاءات والمخرجات التي يطلبها سوق العمل اللبيي. - - حاجة الجامعات الليبية الملحة إلى التطوير والتحديث في المنظومة التعليمية بخاصة فيما يتعلق بالبحث العلمي لمواجهة التغيرات والتطورات العلمية والتكنولوجية.

- تفيد هذه الدراسة في توجيه المهتمين بالتعليم الجامعي نحو الاهتمام بتطوير العملية التعليمية، والتعرف على الصعوبات التي تعوق الجامعات في القيام بالبحث العلمي وكيفية التغلب عليها.

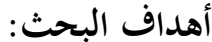

الكشف عن واقع البحث العلمي بجامعة طرابلس.

التعرف على الصعوبات التي تعيق أعضاء هيئة التدريس بجامعة طرابلس في القيام بالبحث العلمي. التعرف على الدور الذي يقوم به البحث العلمي في تطوير قدرات ومهارات أعضاء هيئة التدريس بجامعة طرابلس. تحديد أهم الصعوبات التي تواجه جامعة طرابلس في القيام بالبحث العلمي وكيفية التغلب عليها. تطوير قدرات ومهارات أعضاء هيئة التدريس بجامعة طرابلس. الكشف عن الحلول التي تسهم في تذليل صعوبات القيام بالبحث العلمي. 
حدود بشرية: وتشمل أعضاء هيئة التدريس الذين يباشرون عملهم الأكاديمي في جامعة طرابلس بصفة رسمية بمختلف الكليات.

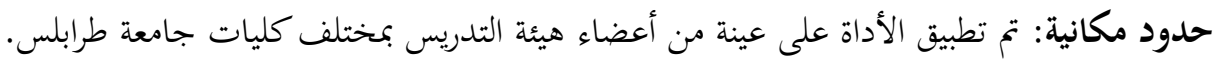

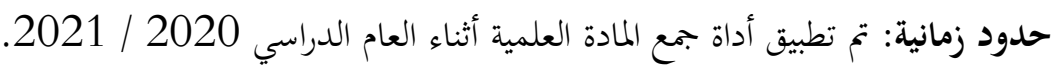

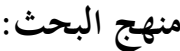

يستخدم الباحث المنهج الوصفي لجمع وتلخيص البيانات والمعلومات المتعلقة بالظاهرة موضوع البحث وإجراء التحليلات الاحصائية واستخلاص النتائج، ودراسة العلاقة بين المتغيرات إضافة إلى استخدام المنهج التحليلي من أجل التحليل والنقد

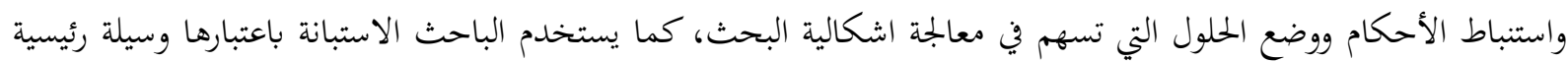
في عملية جمع البيانات والمعلومات اللازمة لاستكمال البحث.

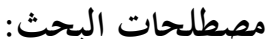

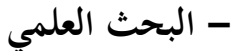

يعرف البحث العلمي على أنه " عملية فكرية منظمة يقوم بها الباحث من أجل تقصي الحقائق يشان مسالة أو مشكلة

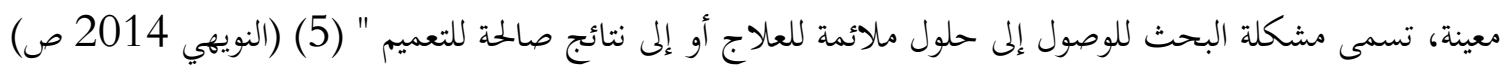

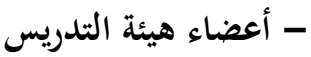
هم " كل من يحمل مؤهلا علمياً عالياً في أحد بجالات العلوم الأساسية التطبيقية، أو الإنسانية ويشغل درجة أستاذ، أو

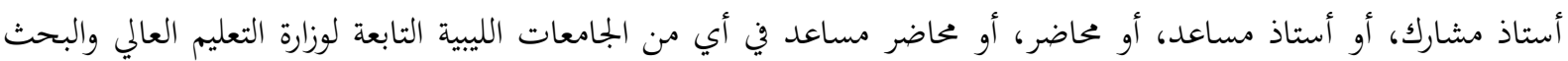

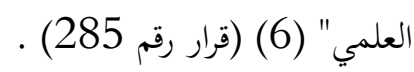

- الجودة -

هي " أسلوب لوصف جميع الأنظمة والمواد والمعايير المستخدمة من قبل الجامعات، ومعاهد التعليم للحفاظ على مستوى

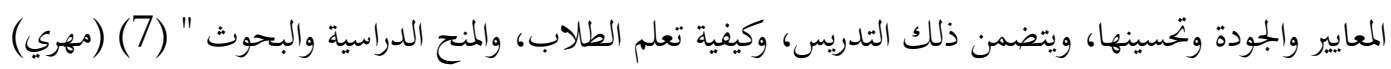

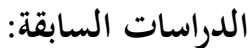

دراسة (الحويطي 2017) وكان من أهم اهداف هذه الدراسة التعرف على معوقات الانتاجية العلمية لعضو هيئة التدريس بجامعة تبوك من وجهة نظر أعضاء هيئة التدريس بها، وتم استخدام المنهج الوصفي المسحي، وكان من أبرز نتائج هذه الدراسة عدد من المعوقات أهمها (كثرة الأعباء الإدارية والتدريسية، وضعف مشاركة الباحثية ونين وقلة حضورهم للمؤتمرات الدولية والاقليمية، وكذلك ندرة وجود حاضنات بحثية داخل الجامعة، وغياب القطاع الخاص عن المشاركة وتمويل البحث العلمي، وأوصت هذه ونه

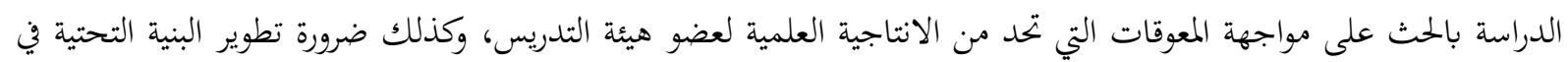
الجامعة للحد من المعوقات التي تواجه الباحثين في مجال البحث العلمي دراسة (العمايرة واخر 2008) هدفت هذه الدراسة إلى التعرف على معوقات البحث العلمي لدى أعضاء هيئة التدريس

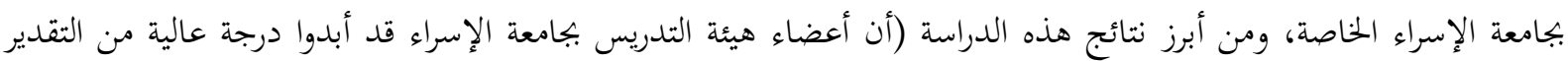


لوجود معوقات تواجهمم في البحث العلمي، ومن أهم هذه المعوقات (عدم وجود بجلة محكمة في الجامعة، وقلة التعاون مع

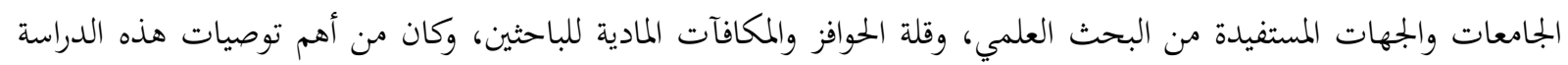
(ضرورة العمل على إيجاد مجلتين محكمتين تابعتين لجامعة الإسراء وأحداهما للعلوم الإنسانية والاجتماعية، والثانية للعلوم التطبيقية. دراسة (العبدلي 2017) هدفت هذه الدراسة إلى معرفة معوقات البحث العلمي لدى أعضاء هيئة التدريس في كلية التربية للبنات بالجامعة العراقية، ومن أهم نتائج هذه الدراسة (وجود معوقات تؤثر بشكل كبير على حركة البحث العلمي في كلية التربية

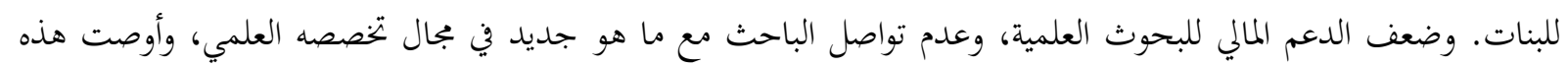

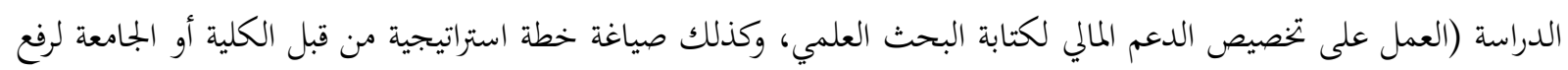
جودة البحث العلمي وفق المقاييس العالمية، أو العربية.

\section{التعليق على الدراسات السابقة:}

لقد أشارت الدراسات السابقة إلى وجود بعض المعوقات التي تواجه أعضاء هيئة التدريس بالجامعات، حيث اتضح من

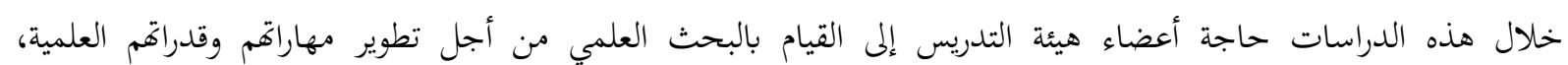

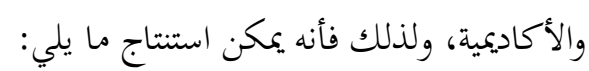
- من أهداف الدراسات السابقة هو التعرف على المعوقات التي تواجه أعضاء هيئة التدريس بالجامعات في القيام بالبحث العلمي، وهذا ما اتفق مع الدراسة الحالية - اتفاق الدراسات السابقة على وجود بعض المعوقات التي تواجه أعضاء هيئة التدريس في القيام بالبحث العلمي - اقترحت الدراسات السابقة بعض الحلول لمواجهة هذه المعوقات وهذا ما اختلف مولف مع الدراسة الحالية.

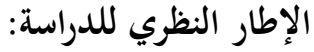

تبذل مؤسسات التعليم الجامعي كثير من الجهود والمحاولات لربط البحث العلمي باحتياجات المجتمع لما لها من دور في عملية صنع القرارات والتأثير في ابتاهات الطلاب والباحثين وتكوين شخصيتهم بتحاه البحث والاسهام في مواجهة المشكلات

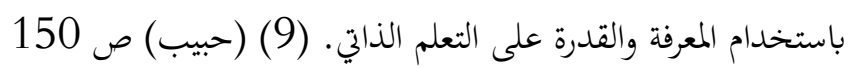

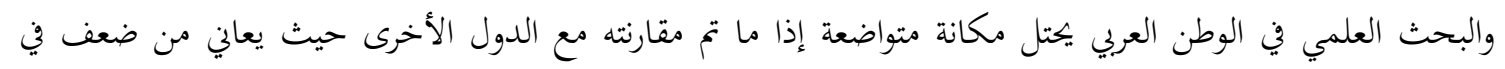

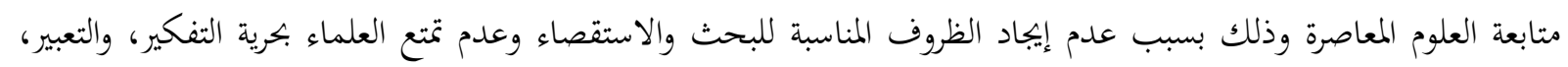
وتوفير الإمكانيات لهم. (10) (مريزيق) ص 136

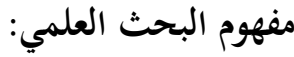

يُعد البحث العلمي أحد أهم الأسباب للتطور العلمي، والتنمية لما له من دور أساسي في التنمية الشاملة، ويساعد أيضا

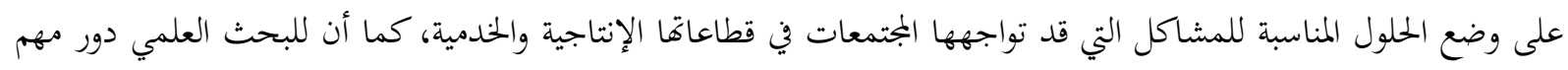

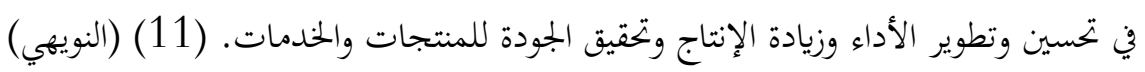
لذلك يمكن القول بأن البحث العلمي هو وسيلة الاستعلام والاستقصاء المنظم والدقيق لغرض اكتشاف معلومات أو

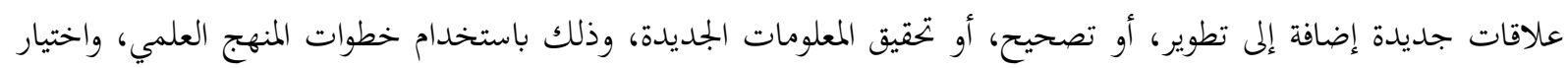

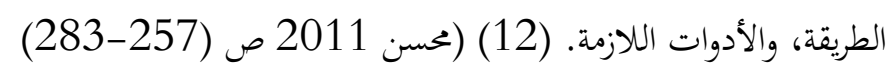




\section{أهمية البحث العلمي:}

يُعد البحث العلمي من أهم الركائز التي يقوم عليها التطور والازدهار، وتدفع عجلة التطور إلى الأمام في مختلف مجالات الحياة، ويساعد في التغلب على الصعوبات وحل المشكلات التي تواجهنا في خختلف المجالات، ويعد الوسيلة التي يحقق بها الانسان سعادته، ورفع المستوى الفكري والثقافي والاجتماعي للباحث، وإضافة جديدة للمعرفة والعلم ورفع كفاءة الفرد وتقليل التكلفة المتعلقة بإنجاز عمل معين، وزيادة الانتاجية، والحصول على الدرجات العلمية. (13) (علي 2019 ص 1-34) وتُعد الحاجة إلى البحث العلمي في وقتنا الحاضر أشد منها في أي وقت مضى، حيث أصبح العالم في سباق الوصول إلى أكبر قدر ممكن من المعرفة الدقيقة المثمرة التي تكفل الراحة والرفاهية للإنسان وتضمن له التفوق على غيره، وبما أن الجامعة مؤسسة انتاجية، تعمل على إثراء المعرفة، وتطوير الفنون الانتاجية، وإعداد الكفاءات البشرية، وصناعة الأجيال وتنشئتها علميا وفكريا

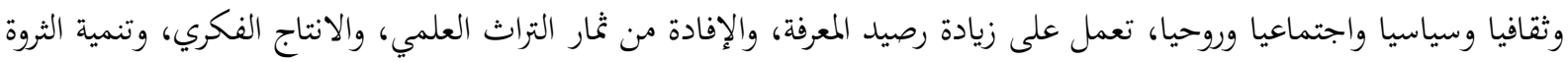

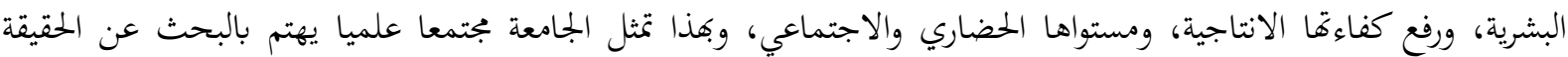
العلمية، فيحتل البحث العلمي موقعا هاما ضمن مسؤوليات عضو هيئة التدريس في الجامعات، الذي يتطلب منه أن يقوم بجهد علمي منظم يهدف إلى تنمية المعرفة الإنسانية في حقل اختصاصه إضافة إلى التدريس، وتولى الجامعة في الوقت الحاضر البحث العلمي عناية كبيرة تلتزم بتوفير الجوو الملائم والإمكانات اللازمة ليقوم أعضاء هيئة التدريس فيها بإجراء البحوث العلمية العية الأصيلة

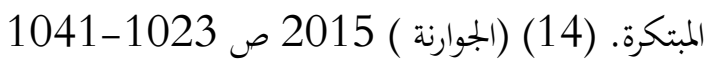

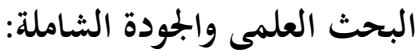

لقد كان للجامعات اهتماما كبيرا بإدارة وتطبيق معايير الجودة بهدف تطوير وتحسين مخرجات العملية التعليمية في كافة التخصصات العلمية، وتحسين مستوى الانتاجية العلمية وتطوير مستوى الأداء المؤسسي وتتمثل معايير جودة عضو هيئة التدريس

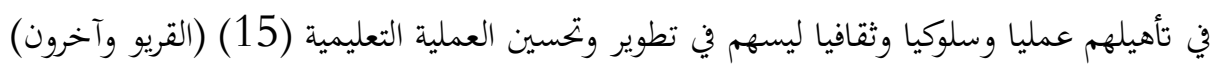
وتُعد الجودة معيار لاستمرار الجامعات وبقاؤها في أداء وظائفها وتحقيق أهدافها، وينبغي على الجامعات مواكبة التطورات

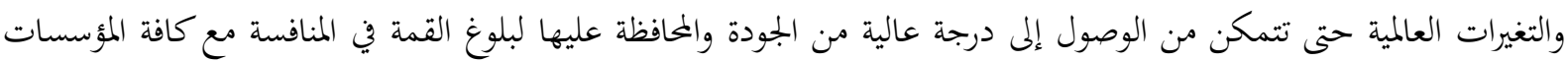

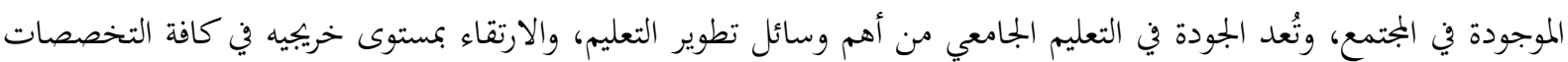
العلمية، حيث اصبحت الجامعة ملزمة باتباع معايير الجودة لضرورةا الملحة التي تمليها التغيرات، والتطورات العلمية المتسارعة التي

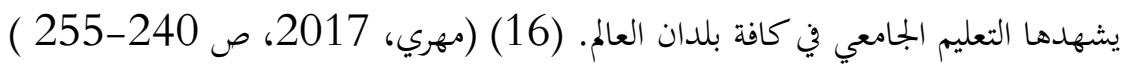

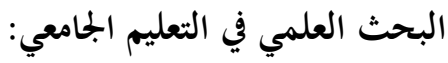

من مهام الجامعة الاهتمام بالبحث العلمي والعناية به باعتباره جزء لا يتجزأ من أنشطتها العلمية لذلك يجب أن تسعى

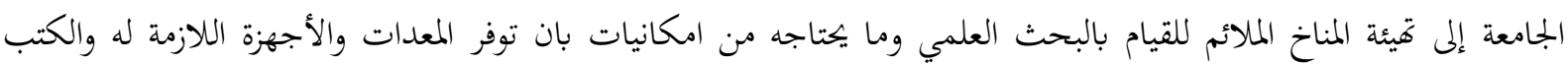
والمراجع بحيث تتيح الفرصة للأساتذة والطلاب استخدامها وبذلك يكون للجامعة دور كبير في عملية التنمية الذاتية لأعضاء هيئة التدريس والطلاب. (17) الخضير ص330

كما أن تطوير العملية التدريسية بالجامعة تعتمد بدرجة كبيرة على عمليات البحث العلمي لذلك فإن الأستاذ الذي يسهم في البحث العلمي بشكل مستمر يمتلك قدرات ومعارف تمكنه من أداء وظيفته التدريسية على أكمل وجه مما ينعكس إيجابيا على لى 
الطلاب وتحصيلهم العلمي إضافة إلى ذلك فإن البحث العلمي يكون له دور فعال في متابعة كل المستجدات العلمية مما يحقق له تطورا علميا في مجال تخصصه والأستاذ الجامعي لا يتوقف إعداده عند تخرجه من الجامعة وحصوله على الدكتوراه بل هو عملية

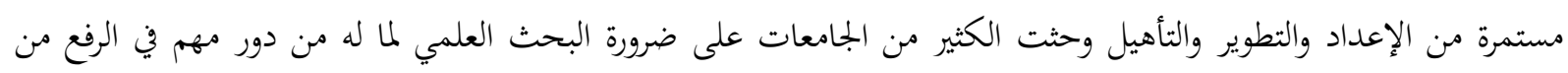

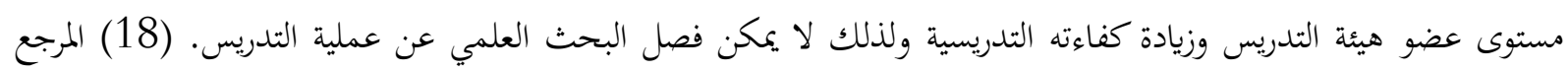
السابق ص330

ولم يعد دور عضو هيئه التدريس يقتصر على العملية التعليمية فقط بل تعدى الأمر إلى البحث والقيام بالدور التربوي

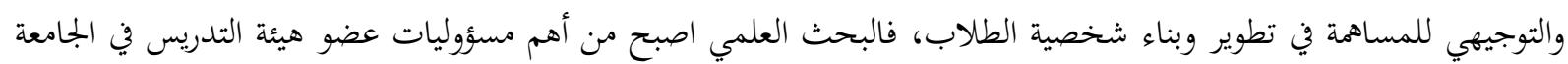
وذلك لما يقوم به من جهد علمي يؤدي إلى تنمية المعرفة وتطويرها في ججال اختصاصه. (19) (الحويطي)

\section{دور البحث العلمي في العملية التعليمية:}

لكي تتمكن الجامعات من تنويع التعليم وربطه بالخطط التنموية لابد من دعمها ماديا ومعنويا لتستطيع القيام بمهامها وتنفيذ أدوارها وتحقيق أهدافها وأداء وظائفها المتنوعة بشكل فاعل، وحتى تسهم في تحسين مهارات أعضاء هيئة التدريس بها

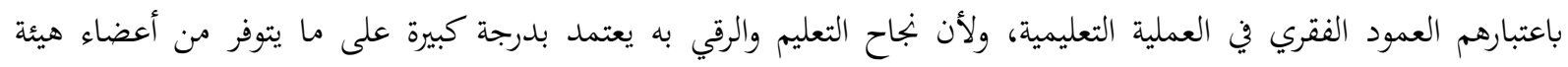

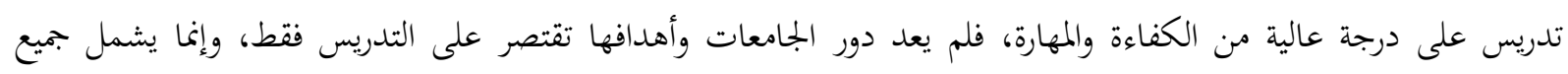
الجوانب الأكاديمية وفي مقدمتها البحث العلمي. (20) (العمايرة )

وتعتمد عملية انتاج المعرفة على البحث العلمي باعتباره عاملا أساسيا في توليد المعارف الجلديدة التي تُسهم في مواجهة

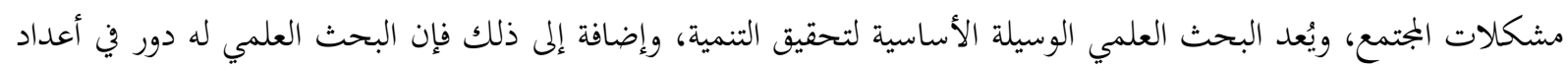

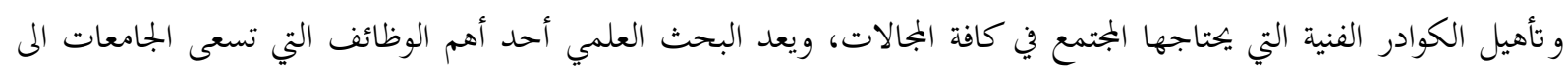
تحقيقها (21) (الحويطي)

ولكي تتمكن الجامعات من تنويع التعليم وربطه بالخطط التنموية لابد من دعمها ماديا ومعنويا من أجل أداء مهامها وتنفيذ أدوارها وتحقيق أهدافها والقيام بوظائفها المتنوعة بشكل فاعل، وحتى تُسهم في تحسين مهارات أعضاء هيئة التدريس بها

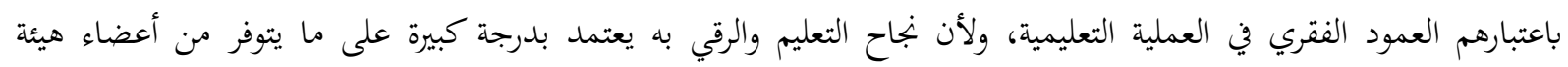

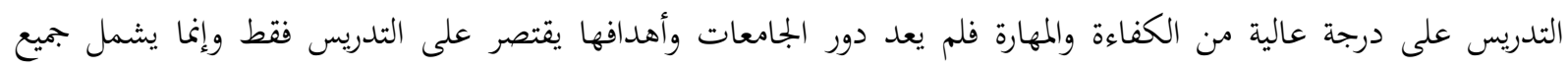

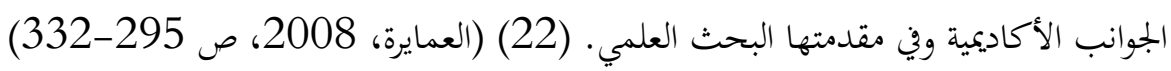

الإطار الميداين للدراسة: يتناول الباحث هنا أهم الخطوات التي تم اتباعها في إعداد الدراسة الميدانية، وذلك على النحو التالي:

لقد تم تطبيق أداة البحث على مختلف كليات جامعة طرابلس، ولاختيار هذه العينة تم تحديد المجتمع الأصلي وهو عبارة

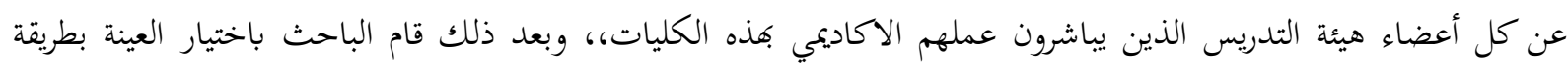
عشوائية بسيطة حيث بلغ حجمها (250) عضوا، وتم جمع (150) استبانة من مجموع الاستبانات الموزعة. 


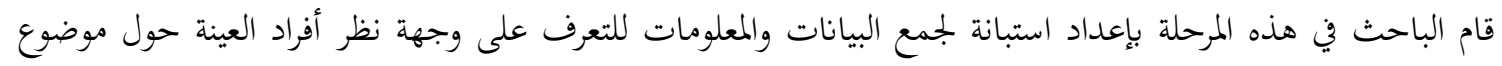
الدراسة، وقد مرت الاستبانة بالعديد من المراحل من أجل تصميمها وظهورها بشكلها النهائي وذلك على النه النحو التالي:

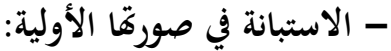

اعتمد الباحث في بناء محاور الاستبانة وإعدادها على الإطار النظري للبحث وبعض البحوث السابقة ذات الصلة المباشرة

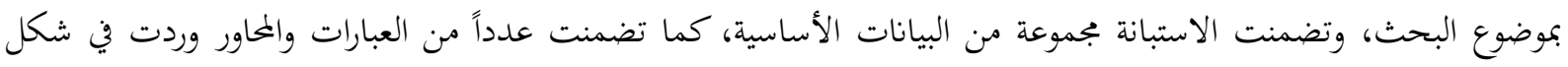
أسئلة مغلقة.

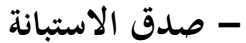

ويقصد به مدى قدرة الاستبانة على قياس الموضوع وصلاحيته لقياس الفرض الذي وضعت من أجله، لذلك قام الباحث بعرض الاستبانة على بجموعة من أعضاء هيئة التدريس المتخصصين في البحث العلمي والعلوم التربوية والنفسية لإبداء آرائهم

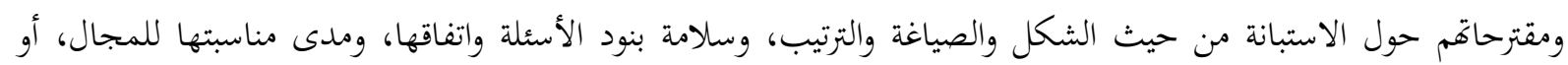

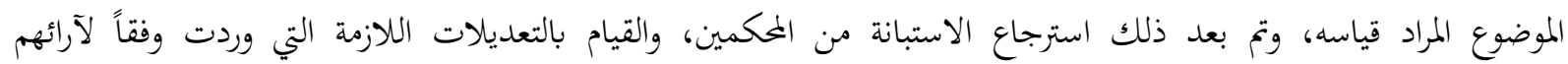
ومقترحاقم.

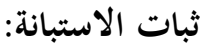

ويقصد به مدى الدقة والاتساق، أي أنه عند استخدام الاستبانة وإعادمّا مرة ثانية في نفس الظروف أو ظروف شبيهة

$$
\text { فإننا نخصل على نفس النتائج. }
$$

استخدم الباحث معادلة (ألفا كرونباخ)، وطريقة التجزئة النصفية على محاور الدراسة، وظهرت النتائج في الجدول التالي. جدول (1) نتائج اختبار ألفاكرونباخ والتجزئة النصفية لمحاور الدراسة

\begin{tabular}{|c|c|c|c|c|}
\hline \multicolumn{4}{|c|}{ المجموع } & \multirow[b]{2}{*}{ المحاور } \\
\hline معامل الثبات سبيرمان & معامل الإرتباط & ألفا كرونباخ & العبار ات & \\
\hline 0.818 & 0.692 & 0.884 & 20 & أهم الصعوبات التي تواجهاك في القيام \\
\hline 0.921 & 0.853 & 0.930 & 10 & اهم مهار ات عضو هيئة التنريس في العملية \\
\hline
\end{tabular}

يتضح من الجدول السابق رقم (1) أن معامل ثبات محاور الدراسة (معامل ألفاكرونباخ) قد تراوح بين (0.884، 0.930)

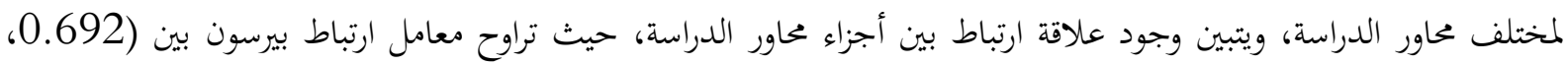

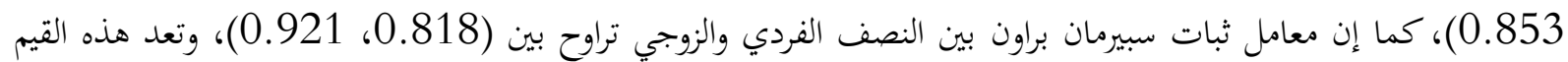
عالية ومناسبة للتحقق من ثبات المقياس.

- الاستبانة في صورتما النهائية استنادا إلى وجهة نظر المحكمين ووفقاً لآرائهم ومقترحاقم قام الباحث بعمل التعديلات اللازمة، ووضع الاستبانة في 


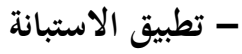

بعد الانتهاء من كل مراحل بناء الاستبانة قام الباحث بعملية التطبيق، وذلك من خلال توزيع الاستمارات على عينة

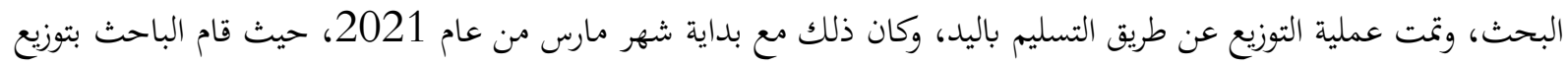

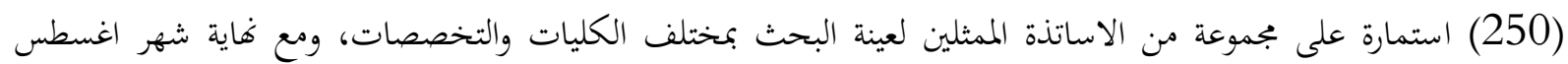

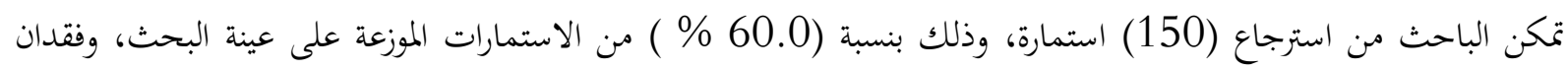
(100) استمارة بسبب إهمال بعض أفراد عينة البحث، وبذلك بلغ عدد الاستمارات الصالحة للتحليل الإحصائي (150) استمارة من أصل (250) استمارة.

\section{الأساليب الإحصائية المستخدمة في الدراسة}

لتحقيق أهداف الدراسة وتحليل البيانات التي تم جمعها من مفردات العينة التي تم اختيارها من مجتمع الدراسة، فقد تم

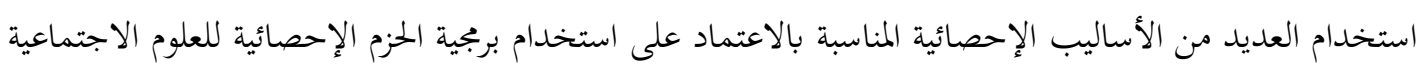
Social Sciences forStatistical Package" "والتي يرمز لها اختصارا بالرمز (SPSS) الإصدار 26، وفي ما يلي بجموعة الأساليب الإحصائية التي قام الباحث باستخدامها: - التوزيع النسبي، والوسط الحسابي، والانحراف المعياري. - اختبار t لعينة واحدة كأحد أساليب الإحصاء الاستدلالي، لإمكانية تعميم النتائج من العينة إلى المجتمع.

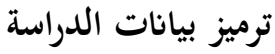

بعد بتميع استمارات الاستبيان استخدم الباحث الطريقة الرقمية في ترميز البيانات حيث تم ترميز الإجابات كما يلي: - المقياس الثلاثي: - n - ne

حيث أنه يقابل كل عبارة من عبارات محاور المتغيرات الأساسية للاستبانة قائمة تحمل الاختيارات التالية وفقاً لمقياس ليكارث الثلاثي: (متوفرة بشدة - متوفرة - غير متوفرة) وقد تم إعطاء كل من الاختيارات السابقة درجات لتتم معالجتها إحصائياً

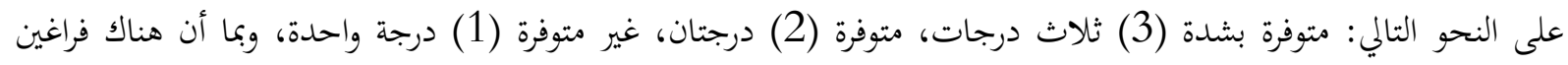
وثلاث اختيارات لذلك تم تحديد المدى لكل اختيار حيث أن المدى = يساوي 0.666، ومن ذلك فإن مدى كل اختيار يتم حسابه كما مبين بالجدول رقم (2) . جدول (2) يوضح مدى الاختيارات المستخدمة بالدراسة

\begin{tabular}{|c|c|}
\hline مدى الاختيار & الاختيار ات \\
\hline من 1 إلى أقل من 1.666 & غير متوفرة \\
\hline من 1.666 إلى أقل من 2.333 & 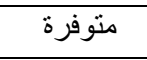 \\
\hline من 2.333 إلى 3 & متوفرة بشدة \\
\hline
\end{tabular}

- المقياس الثنائي: -

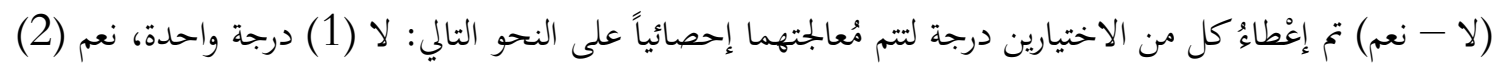

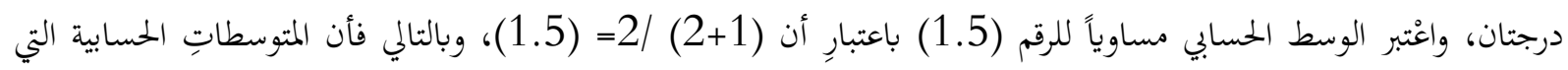


قيمتها أقلُ من (1.5) تُعبر عن درجة موافقة متدنية، والمتوسطاتِ الحسابية التي قيمثُها (1.5) تعبر عن درجة موافقة متوسطة،

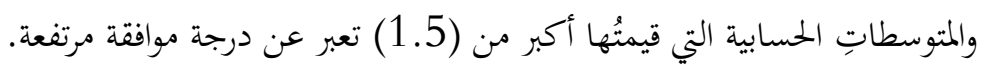

\section{خصائص عينة الدراسة}

جدول (3) خصائص عينة الدراسة

\begin{tabular}{|c|c|c|c|}
\hline النسبة المئوية & التكر ار & الفئة & الخصائص \\
\hline $65.3 \%$ & 98 & ذكور & \multirow{3}{*}{ الجنس } \\
\hline $34.7 \%$ & 52 & إناث & \\
\hline $100.0 \%$ & 150 & المجموع & \\
\hline $30.7 \%$ & 46 & الآداب & \multirow{12}{*}{ الكلية } \\
\hline $10.0 \%$ & 15 & الاقتصاد & \\
\hline $15.3 \%$ & 23 & تربية طر ابلس & \\
\hline $3.3 \%$ & 5 & حاسوب & \\
\hline $12.7 \%$ & 19 & طب & \\
\hline $5.3 \%$ & 8 & الزراعة & \\
\hline $3.3 \%$ & 5 & العلوم & \\
\hline $3.3 \%$ & 5 & القانون & \\
\hline $8.0 \%$ & 12 & صيدلة & \\
\hline $2.7 \%$ & 4 & هندسة & \\
\hline $5.3 \%$ & 8 & تقنية طبية & \\
\hline $100.0 \%$ & 150 & المجموع & \\
\hline $70.0 \%$ & 105 & دكتور اه & \multirow{3}{*}{ المؤهل العلمي } \\
\hline $30.0 \%$ & 45 & ماجستير & \\
\hline $100.0 \%$ & 150 & المجموع & \\
\hline
\end{tabular}

يتضح من الجدول رقم (3) الذي يوضح خصائص عينة الدراسة أها تتميز بالآتي:

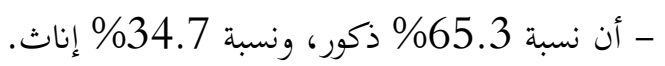

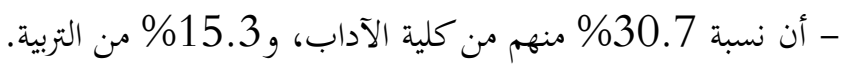

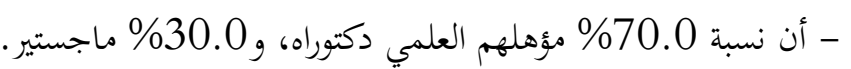

\section{نتائج الدراسة الميدانية وتفسيرها}

تم رصد نتائج الدراسة الميدانية وتفسيرها بحساب التكرارات والنسب المئوية لإجابات افراد العينة على فقرات اداة البحث، وذلك على النحو التالي: 
أولا: الصعوبات التي تواجه أعضاء هيئة التدريس في القيام بالبحث العلمي:

جدول (4) نتائج تحليل أهم الصعوبات التي تواجه عضو هيئة التدريس في القيام بالبحث العلمي

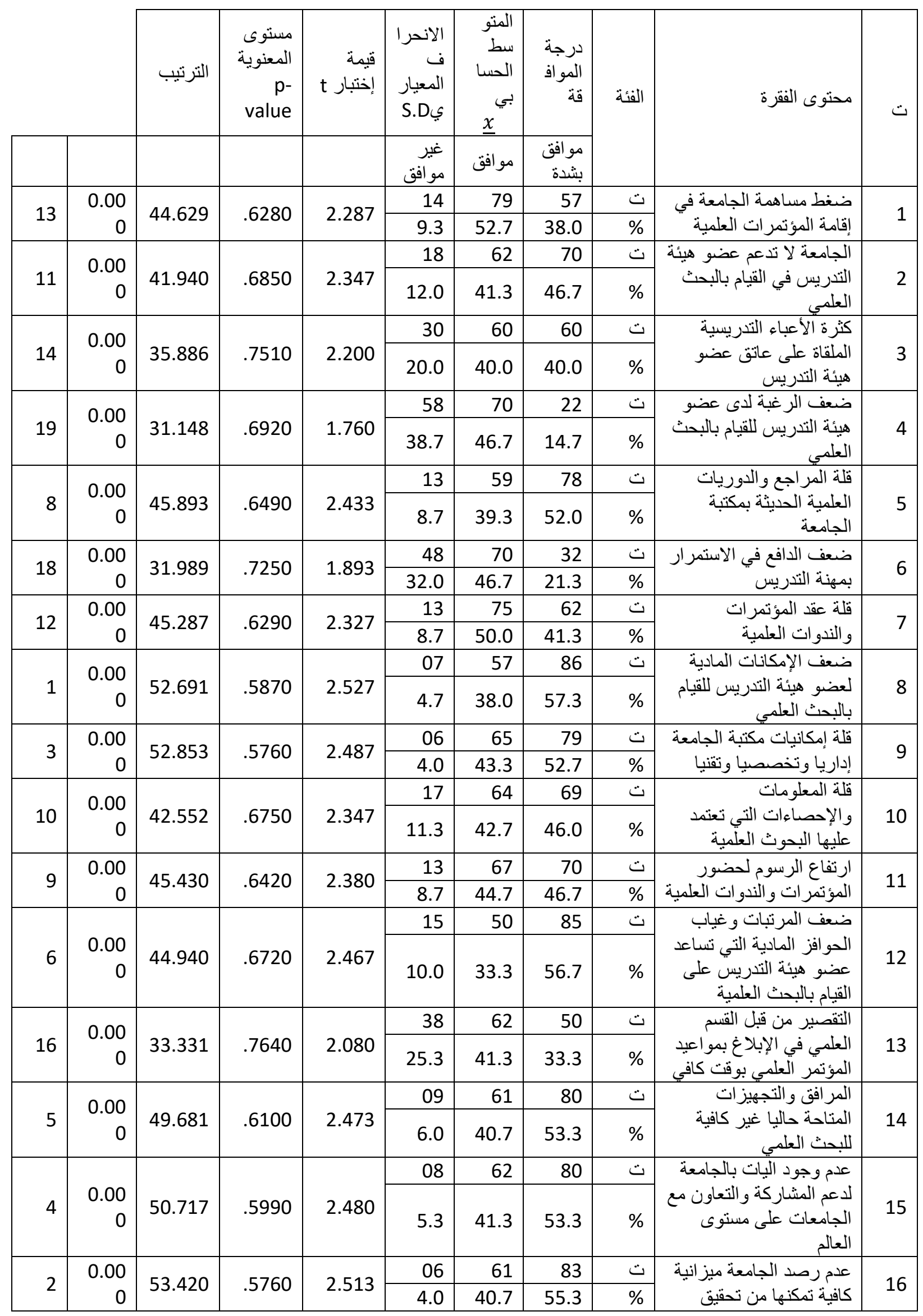




\begin{tabular}{|c|c|c|c|c|c|c|c|c|c|c|c|}
\hline \multirow{10}{*}{ 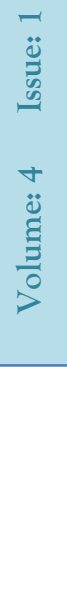 } & & & & & & & & & & خطتها البحتية & \\
\hline & \multirow[b]{2}{*}{7} & \multirow{2}{*}{$\begin{array}{r}0.00 \\
0\end{array}$} & \multirow[b]{2}{*}{49.473} & \multirow[b]{2}{*}{.6090 } & \multirow[b]{2}{*}{2.460} & 09 & 63 & 78 & ت & \multirow{2}{*}{ تسويق البحوثة لالى الجهات } & \multirow[b]{2}{*}{17} \\
\hline & & & & & & 6.0 & 42.0 & 52.0 & $\%$ & & \\
\hline & \multirow[b]{2}{*}{20} & \multirow{2}{*}{$\begin{array}{r}0.00 \\
0\end{array}$} & \multirow[b]{2}{*}{31.128} & \multirow[b]{2}{*}{6870} & \multirow[b]{2}{*}{1.747} & 59 & 70 & 21 & ت & \multirow{2}{*}{ التعمي لدى مهارات البحثي } & \multirow[b]{2}{*}{18} \\
\hline & & & & & & 39.3 & 46.7 & 14.0 & $\%$ & & \\
\hline & \multirow{2}{*}{17} & \multirow{2}{*}{$\begin{array}{r}0.00 \\
0\end{array}$} & \multirow{2}{*}{36.887} & \multirow{2}{*}{.6490} & \multirow{2}{*}{1.953} & 35 & 87 & 28 & $ت$ & \multirow{2}{*}{ تأخر المحكمين في تقييم } & \multirow{2}{*}{19} \\
\hline & & & & & & 23.3 & 58.0 & 18.7 & $\%$ & & \\
\hline & \multirow{2}{*}{15} & 0.00 & \multirow{2}{*}{36.385} & \multirow{2}{*}{.7000} & \multirow{2}{*}{2.080} & 31 & 76 & 43 & $ت$ & \multirow{2}{*}{ في القيام بالبحوث بين الأساتذة } & \multirow{2}{*}{20} \\
\hline & & 0 & & & & 20.7 & 50.7 & 28.7 & $\%$ & & \\
\hline & & $\begin{array}{r}0.00 \\
0\end{array}$ & 75.478 & $\begin{array}{r}.36704 \\
0\end{array}$ & $\begin{array}{r}2.2620 \\
0\end{array}$ & & & & & & الد - الد \\
\hline
\end{tabular}

من الجدول رقم (4) يتضح أن المتوسطات الحسابية حول (أهم الصعوبات التي تواجه أعضاء هيئة التدريس في القيام

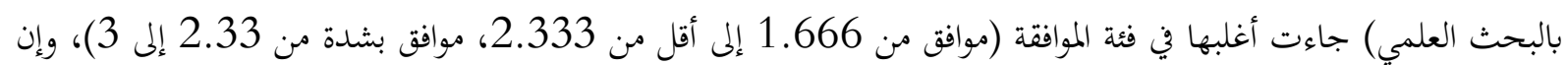

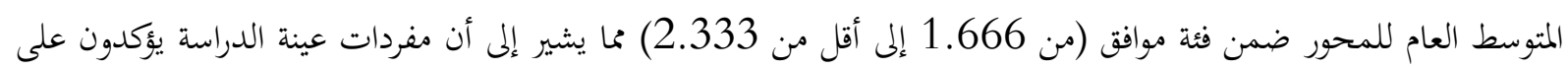

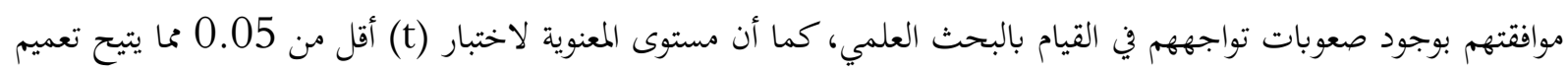
النتائج المتحصل عليها من العينة على مجتمع الدراسة.

ويتضح من خلال الجدول (4) إن من أهم الصعوبات التي تواجه أعضاء هيئة التدريس في قيامهم بالبحث العلمي هي

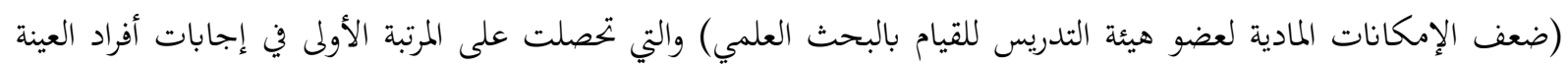

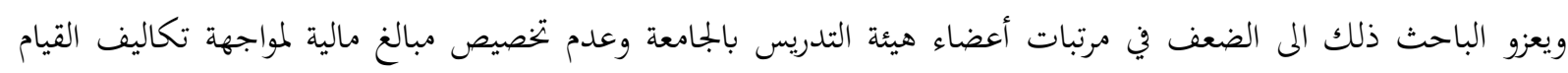

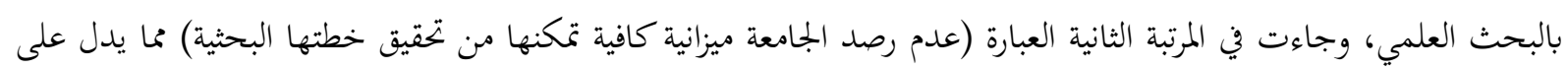

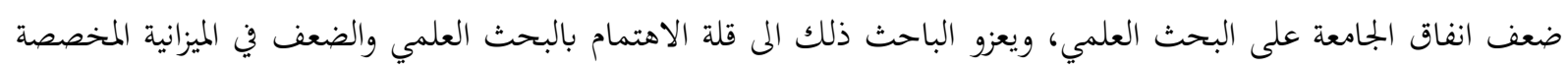

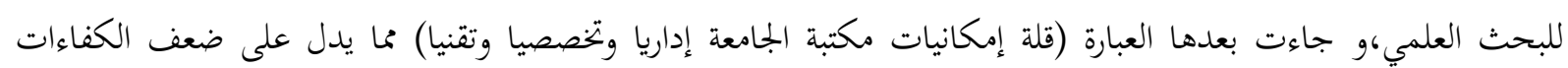

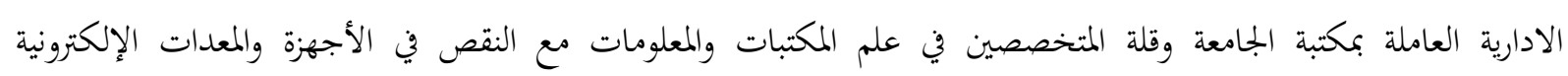

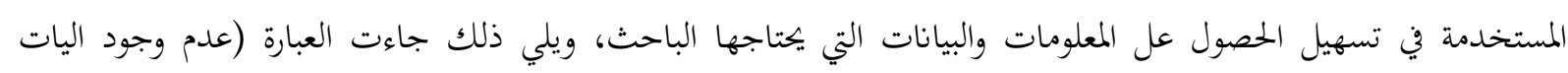

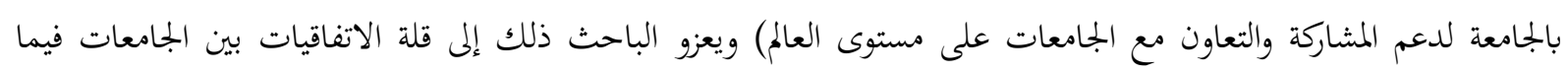

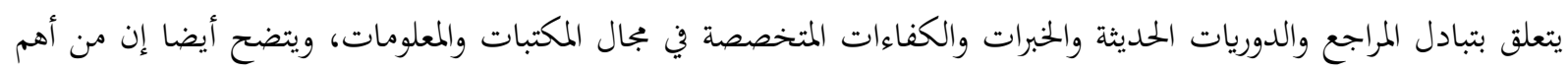

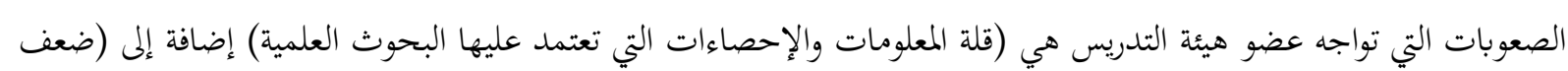
المرتبات وغياب الحوافز المادية التي تساعد عضو هيئة التدريس على القيام بالبحث العلمي.

ثانيا: المهارات التي لا يجيدها عضو هيئة التدريس في العملية التعليمية جدول (5) نتائج تحليل أهم المهارات التي لا يجيدها عضو هيئة التدريس في العملية التعليمية

\begin{tabular}{|c|c|c|c|c|c|c|c|c|c|}
\hline \multirow[b]{2}{*}{ الترتيب } & \multirow{2}{*}{$\begin{array}{c}\text { المعنوية } \\
\text { p- } \\
\text { value } \\
\text { value }\end{array}$} & \multirow[b]{2}{*}{$\begin{array}{c}\text { إختبار } \\
\text { قيمة }\end{array}$} & \multirow{2}{*}{$\begin{array}{c}\text { الانحرياري } \\
\text { S.D }\end{array}$} & \multirow{2}{*}{ 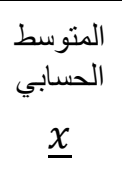 } & \multicolumn{2}{|c|}{ درجة الاستخدام } & \multirow[b]{2}{*}{ فئة } & \multirow[b]{2}{*}{ محتوى الفقرة } & \multirow[b]{2}{*}{ ت } \\
\hline & & & & & لا يستخذم & يستخدم & & & \\
\hline \multirow{2}{*}{2} & \multirow{2}{*}{0.000} & \multirow{2}{*}{$\begin{array}{c}34.54 \\
1\end{array}$} & \multirow{2}{*}{.4780} & \multirow{2}{*}{1.347} & 98 & 52 & $ت$ & \multirow{2}{*}{ مهار ات التعامل مع تكنولوجيا } & \multirow{2}{*}{1} \\
\hline & & & & & 65.3 & 34.7 & $\%$ & & \\
\hline 1 & 0.000 & 35.03 & .4940 & 1.413 & 88 & 62 & $ت$ & مهارات اللغة الإنجليزية & 2 \\
\hline
\end{tabular}




\begin{tabular}{|c|c|c|c|c|c|c|c|c|c|}
\hline & & 4 & & & 58.7 & 41.3 & $\%$ & & \\
\hline \multirow{2}{*}{4} & \multirow{2}{*}{0.000} & \multirow{2}{*}{$\begin{array}{c}34.67 \\
5\end{array}$} & \multirow{2}{*}{.4570} & \multirow{2}{*}{1.293} & 106 & 44 & $ت$ & \multirow{2}{*}{ مهار ات الاتصال الفعال } & \multirow{2}{*}{3} \\
\hline & & & & & 70.7 & 29.3 & $\%$ & & \\
\hline \multirow{2}{*}{7} & \multirow{2}{*}{0.000} & \multirow{2}{*}{$\begin{array}{c}35.17 \\
6\end{array}$} & \multirow{2}{*}{.4360} & \multirow{2}{*}{1.253} & 112 & 38 & ت & \multirow{2}{*}{ مهار ات العرض والتقييم } & \multirow{2}{*}{4} \\
\hline & & & & & 74.7 & 25.3 & $\%$ & & \\
\hline \multirow{2}{*}{8} & \multirow{2}{*}{0.000} & \multirow{2}{*}{$\begin{array}{c}36.15 \\
3\end{array}$} & \multirow{2}{*}{.4110} & \multirow{2}{*}{1.213} & 118 & 32 & $ت$ & \multirow{2}{*}{ مهارة تصميم المقرر الدراسي } & \multirow{2}{*}{5} \\
\hline & & & & & 78.7 & 21.3 & $\%$ & & \\
\hline \multirow{2}{*}{5} & \multirow{2}{*}{0.000} & \multirow{2}{*}{$\begin{array}{c}34.73 \\
2\end{array}$} & \multirow{2}{*}{.4540} & \multirow{2}{*}{1.287} & 107 & 43 & $ت$ & \multirow{2}{*}{ مهار ات استخدام الانترنيت } & \multirow{2}{*}{6} \\
\hline & & & & & 71.3 & 28.7 & $\%$ & & \\
\hline \multirow{2}{*}{3} & \multirow{2}{*}{0.000} & \multirow{2}{*}{$\begin{array}{c}34.62 \\
8\end{array}$} & \multirow{2}{*}{.4600} & \multirow{2}{*}{1.300} & 105 & 45 & ت & \multirow{2}{*}{ المهار ات الإدارية } & \multirow{2}{*}{7} \\
\hline & & & & & 70.0 & 30.0 & $\%$ & & \\
\hline & & 35.06 & 4400 & 1260 & 111 & 39 & $ت$ & الميار ات القبادية & 8 \\
\hline 6 & 0.000 & 4 & .4400 & 1.260 & 74.0 & 26.0 & $\%$ & المهارات الهيادية & 8 \\
\hline 6 & 0000 & 35.06 & 4400 & 1260 & 111 & 39 & $ت$ & معار ات البحث العلى & 9 \\
\hline 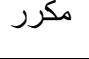 & 0.000 & 4 & 年 & 1.200 & 74.0 & 26.0 & $\%$ & . & \\
\hline 5 & $\cap \cap \cap \cap$ & 34.73 & 4540 & 1287 & 107 & 43 & $ت$ & مهار ات اتخاذ القرارات وحل & 1 \\
\hline مكرر & 0.000 & 2 & .4540 & 1.281 & 71.3 & 28.7 & $\%$ & & 0 \\
\hline & 0.000 & $\begin{array}{c}44.64 \\
5\end{array}$ & $\begin{array}{c}.35425 \\
0\end{array}$ & $\begin{array}{c}1.2913 \\
3\end{array}$ & بمية & & & هم مهار & \\
\hline
\end{tabular}

من الجدول رقم (5) يتضح أن المتوسطات الحسابية حول (اهم مهارات عضو هيئة التدريس في العملية التعليمية) جاءت كلها أقل من 1.5 (لا يستخدم)، وإن المتوسط العام للمحور كذلك أقل من 1.5 (لا يستخدم) منما يشير إلى أن مفردات عينة الدراسة يؤكدون على وجود ضعف في مهارات عضو هيئة التدريس في العملية التعليمية، وان منهم لا يجيد استخدام البعض من

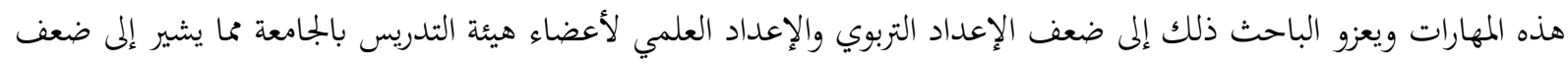
الاهتمام من قبل الدولة بأعضاء هيئة التدريس الذين يشكلون العمود الفقري للعملية التعليمية بالجامعة، كما أن مستوى المعنوية لاختبار (t) أقل من 0.05 مما يتيح تعميم النتائج المتحصل عليها من العينة على مجتمع الدراسة.

النتائج والتوصيات: أولاً النتائج:

حيث خلص البحث إلى بعض النتائج تمثلت في وجود العديد من الصعوبات التي تعيق أعضاء هيئة التدريس في القيام بالبحث العلمي ولعل من أهمها ما يلي: - ضعف الدعم المادي للبحوث العلمية وقلة الاهتمام بها - قصور الجامعة عن تقديم برامج كافية تساعد على القيام بالبحث العلمي - ضعف قدرات بعض أعضاء هيئة التدريس لاستعمالات الحاسب الآلي والانترنت باعتبارها وسائل ضرورية تساعد على القيام بالبحث العلمي. - ضعف قدرات بعض أعضاء هيئة التدريس في استخدام مهارات تصميم المقرر الدراسي ومهارات الاتصال الفعال ومهارات القيام بالبحث العلمي. 


$$
\text { - عدم اسهام الدولة في تشجيع الجامعة على النشر دوليا }
$$$$
\text { - عدم وجود تعاون مع الجامعات الدولية في بجال النشر والبحث العلمي }
$$

- الضعف في الإمكانات المادية لأعضاء هيئة التدريس للقيام بالبحث العلمي، وعدم رصد الجامعة ميزانية كافية تمكنها من تحقيق

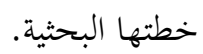

- ضعف الكفاءات الادارية العاملة بمكتبة الجامعة، ونقص المتخصصين في علم المكتبات والمعلومات مع النقص الشديد في الأجهزة والمعدات التقنية المستخدمة في الحصول على المعلومات والبيانات التي يحتاجها أعضاء هيئة التدريس.

- قلة الاتفاقيات بين الجامعات فيما يتعلق بتبادل المراجع، والدوريات الحديثة، والخبرات، والكفاءات المتخصصة في مجال المكتبات، والمعلومات.

- ضعف المرتبات وغياب الحوافز المادية التي تساعد عضو هيئة التدريس على القيام بالبحث العلمي. - قلة المعلومات والاحصائيات التي يعتمد عليها عضو هيئة التدريس في القيام بالبحث العلمي.

التوصيات:

- دعم مشاركات أعضاء هيئة التدريس العلمية إعلاميا، ومنح مكافآت تشجيعية للمتميزين. - اعتبار المشاركات البحثية عاملا أساسيا في تقييم عضو هيئة التدريس، وتحديد آثار قانونية تترتب على غيابها.

$$
\text { - دعم الجامعات في المجالات التي تخدم البحث العلمي. }
$$

- الاتحاه نخو تطوير قدرات أعضاء هيئة التدريس وتنمية مهارات البحث العلمي لديهم بما يتناسب مع المستجدات والتغيرات

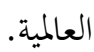

- البحث عن الحلول المناسبة لمواجهة المشكلات التي تعترض عملية القيام بالبحث العلمي. - نشر ثقافة التطوير والتعلم الذاتي مدى الحياة بما يسهم في اكتساب مهارات القيام بالبحث العلمي. - تطوير مهارات التفكير العلمي والإبداعي والابتكاري لدى الاستاذ الجامعي، واكسابه مزيدا من القدرات، والمهارات، والمعارف العلمية، والأكاديمية، والتدريسية، والبحثية.

- الرفع من مرتبات أعضاء هيئة التدريس بالجامعة وتخصيص مبالغ مالية لمواجهة تكاليف القيام بالبحث العلمي. - الرفع من القدرات والمهارات الإدارية والتقنية للعاملين بمكتبة الجامعة. - توفير الأجهزة والمعدات التقنية المستخدمة في الحصول على المعلومات والبيانات التي يحتاجها عضو هيئة التدريس للقيام بالبحث العلمي. - التعاون بين الجامعات فيما يتعلق بتبادل المراجع والدوريات الحديثة والخبرات والكفاءات المتخصصة في مجال المكتبات والمعلومات. 
آية عبدالله احمد النويهي، دور الجامعات في تقدم البحث العلمي وأثره على المجتمع، المركز الديمقراطي العربي، 2014.

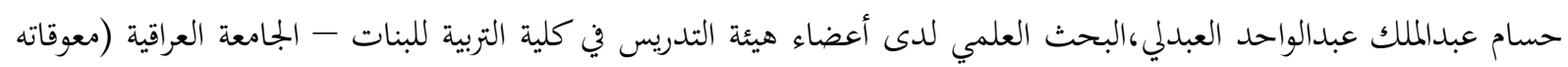

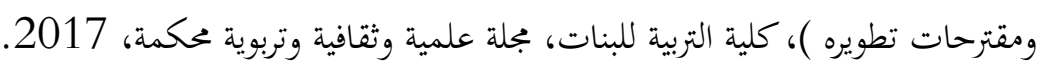

خضير بن مسعود الخضير،التعليم العالي في المملكة العربية السعودية بين الطموح والإنجاز،جامعة الملك فهد للبترول والمعادن، مكتبة العبيكان، 1419 هـ

شريفة كلاع، الجامعات العربية والبحث العلمي قراءة في واقع البحث العلمي ومعيقاته،المؤتمر الدولي التاسع - الجزائر 18-19 أغسطس 2015.

شناف خديجة عبدالحميد مهري، معايير ضمان جودة التعليم العالي - عرض لبعض النماذج العالمية، مجلة الدراسات والبحوث

$$
\text { الاجتماعية،العدد (24) ديسمبر } 2017 .
$$

عبدالقادر الحمد صالح، التنمية المهنية لأعضاء هيئة التدريس بالجامعات الليبية في ضوء الأدوار المتغيرة للجامعة، رسالة دكتوراه غير منشورة، كلية الدراسات العليا، جامعة القاهرة، 2011.

عماد ولد علي، العلاقة بين عوامل نجاح البحث العلمي وانتاجية البحث العلمي في الجامعات الفلسطينية، مجلة الجامعة العربية

$$
\text { الامريكية للبحوث، بجلد (5)، العدد، (1)، } 2019 .
$$

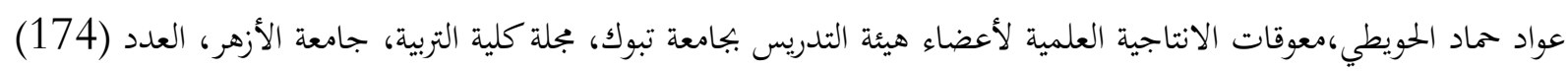

$$
\text { الجزء الثاني، يوليو، } 2017 .
$$

عيسى قدادة،و آخر، تقويم جودة أعضاء هيئة التدريس في مؤسسات التعليم العالي،المجلة العربية لضمان جودة التعليم العالي،

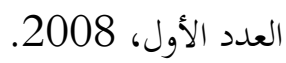

اللجنة الشعبية العامة سابقا، قرار رقم (285) لسنة 2006 بشأن لائحة أعضاء هيئة التدريس الوطنيين بالجامعات ومؤسسات

$$
\text { التعليم العالي }
$$

مجدي عبدالكريم حبيب،رؤية مستقبلية للتعليم الجامعي العربي (المتطلبات - الأدوار - التحديات - المعايير)، استراتيجيات التعليم

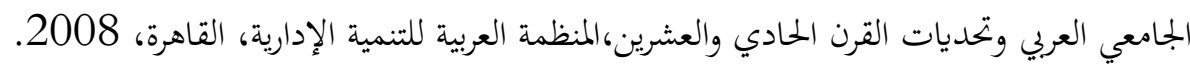

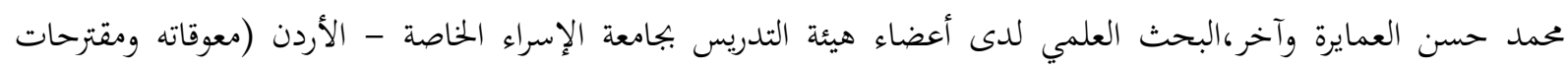

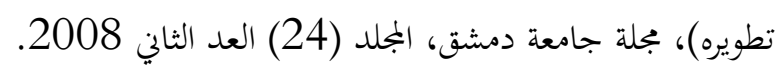

محمد عبدالسلام القريو وآخرون، دور إدارة الجودة الشاملة في تحسين أداء مؤسسات التعليم العالي اللبيي، المؤتمر العلمي الرابع

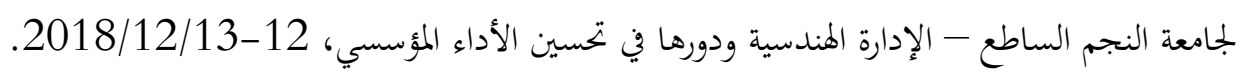

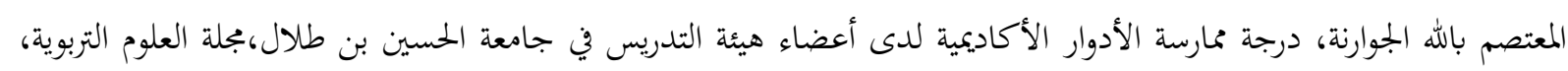

$$
\text { المجلد (42)، العدد (3)، } 2015 .
$$

منتهى عبد الزهرة محسن، الصعوبات التي تواجه البحث العلمي في جامعة بغداد من وجهة نظر التدريسيين، مجلة البحوث التربوية والنفسية، العدد الثاني والثلاثون، 2011.

هشام يعقوب مريزيق، وآخر، قضايا معاصرة في التعليم العالي، الطبعة الأولى، 2008. 


\title{
THE EFFECT OF COMBINING TEACHING GAMES ON ACADEMIC ACHIEVEMENT
}

\author{
Kamilia RADI ${ }^{1}$
}

\section{Istanbul / Türkiye}

p. $718-728$

Received: $22 / 11 / 2021$

Accepted: $10 / 12 / 2021$

Published: 01/01/2022

This article has been scanned I iThenticat No plagiarism detected

\section{Abstract:}

The study deals with the effect of combining games in teaching on the academic achievements in the subject of multiplication in mathematics. The teaching games discussed by the study are: "Social Interaction Assistance" and "Stay in a Movement Learning Activity" of a teaching game, aimed at improving any behavior that is aimed at the purpose of study.

The study involved 50 students from the same grade (third grade) who had once participated in control groups (regular learning) without any use of games) and once in an experimental group (using games in teaching) and then found that the group that experienced learning with the help of teaching games, reached higher and clearer achievements in the field of multiplication compared to the control group. And also, it emerged from the study that there is a significant positive correlation between the variables of teaching games and the improvement in academic achievement.

Key words: Combining Games in Teaching; Academic Achievements; The Subject of Multiplication in Mathematics; "Social Interaction Assistance"; "Stay In A Movement Learning Activity".

http://dx.doi.org/10.47832/2717-8293.15.49 


\section{Introduction}

The prevailing perception is that the game is intended for recreation, leisure and early childhood learning and the game does not find expression during primary school and almost disappears in high school. This perception is a result of concerns that the game is not suitable for learning complex content and may delay the learning power in adulthood, where there is an expectation of formal learning achievement-focused.

Over time, perceptions developed that saw the game in different aspects. For example, in the emotional realm - development of inter-personal communication and empathy that increases inner motivation and enjoyment that contribute to learning (Schiller, 2010) and activation of fine and gross motor skills important for the formation of cognitive connections (Karbach \& Schubert, 2013).

In the cognitive field, the game contributes to the acquisition of knowledge and the creation of new knowledge, to the development of the imagination, creativity and invention, exploration and criticism and acquiring learning habits (Levitt $\&$ Shonkoff, 2010).

This means that the game is an integral part of the learner's natural world and as the use of the game increases for learning purposes learning will be more meaningful and will be accompanied by higher successes and achievements (Morning, 2012).

This work will deal with learning math, in elementary school, through combined game lessons. It is known that many students experience significant difficulties in acquiring and understanding mathematical knowledge, over many years of study. Combining game in mathematics teaching allows for diversity in teaching methods, constitutes an unconventional practice may motivate students to learn mathematics, encourage creativity and make them fun (Reese, 2016).

The aim of the present study is to characterize the integrated learning lessons in heterogeneous primary classes. Therefore the study examines the characteristics of a learning environment that combines play in lessons with reference to motivation, enjoyment, concentrated learning, and a positive identity of the student about himself in heterogeneous classes, and hence the question of research which I discussed in this paper - is there a positive impact of teaching games on academic achievement?

\section{Literature Review}

\subsection{Teaching through games}

Meaningful learning is learning that occurs when it is active (Shute, Rieber \& Van Enk, 2011) because it activates all body systems, senses, cognition and thought, which expands the range of learning options (Boker, 2016).

Many studies dealing with teaching through different types of games point to many benefits: use of games increases learning and makes students take responsibility, encourages collaborations between them and improves the classroom atmosphere. Learning through play is suitable for different types of learners and provides a solution for active learners who have difficulty sitting for a long time. It enables peer non-threatening teaching, improves learning motivation and is a pleasure factor in the class (Boker, 2016). The game serves as a significant tool for strengthening the knowledge and understanding of the material studied (Ben Tzodek and Nachmias, 2011) is a natural way of learning and as such can be harnessed for teaching academic content (Arbel et al., 2011). 


\subsection{The contribution of the game to the development of the individual's personality}

When the individual takes part in an educational game, it allows him to express his personal, latent and visible abilities. The active participant in the educational game usually succeeds in giving expression to his special qualities. Boker (2016) claimed that the game is an integral part of the learner's natural world and as use increases

Boker argued that the game is an integral part of the learner's natural world and as the use in a game for learning purposes increases, learning will be more meaningful and will be accompanied by higher successes and achievements. In addition, the game provides thinking scaffolding for the material being studied (Broza, Ben-David, Kolikant, 2014) and to improve the advantages of the learning game there should be a discussion after the game about strategies in the game, ways of thinking for linking prior knowledge to the new knowledge and to reflect on the various game moves (Broza et al., 2014).

\subsubsection{The contribution of the game to the cognitive field}

In a study by Castellar et al. (2015) they examined whether traditional teaching methods versus teaching through play are different in terms of the impact on different cognitive processes. In their study they combined standard metrics of working memory, viso-motor Skills, accounting gains and self-reporting means of pleasure. It was found that the improvement in account performance as a result of game instruction and traditional instruction is not only different in terms of fun but also in terms of improvements in memory capacity in favor of game teaching.

\subsubsection{The contribution of the game to the social climate in the team}

Tami and Yehieli (2014) claim that there is interaction in the game, and cooperation required from the game, inviting development of moral thinking, out of free will (without the need for "preaching morality"). This means that when the game added value for teamwork exists, and personal responsibility for morality. In this way, it is a natural way to understand and acquire control of social skills (openness, listening, appreciation, conflict management, etc.). The game has long been a factor in the interaction between its participants. The individual goes through, in miniature process of acquiring social skills that will serve him in the future. The more he experiences as a child, the more he will acquire positions and tools that will be available to him and help him as an adult and an individual in the society. Today, more than in previous years, the individual is asked to discover skills of teamwork, work based on interaction, consideration, collaboration, organizational thinking, ability to locate problems and find a solution to them. In the learning game the conditions for success are usually learning, thinking, planning the next step, helping others and understanding

that "enemy" in the game is also "friend" in reality.

\subsection{The game in teaching}

Combining game in studies allows for diversity in teaching methods, constitutes an unconventional practice, may motivate students to learn math, and encourage creativity (when the students themselves build a game) and make them enjoy. It also allows the teacher to be aware of the students' difficulties in the mathematical subject that the game deals with (Reise, 2016). I plan to develop future research to test whether game serves as a factor that encourages learning and reduces anxiety and difficulty in studies.

\subsubsection{The game as one of the aids to overcome the difficulty in teaching mathematics}

According to one of the principles in the psychology of learning, pleasure and enthusiasm help the student to overcome difficulties in studying a particular material. Reese (2016) argues that combining mathematics teaching allows for diversity in methods 
teaching, which is an unconventional practice, may motivate students to learn math, encourage creativity (when students build a game themselves) and make them enjoyable. The game also allows the teacher to face student difficulties with the mathematical subject he deals with. In another study by Vrogte and colleagues (Vrugte, 2015), it was found that the game was able to target students, especially those with low prior knowledge. It is important to draw attention to the fact that children with low prior knowledge are those who have the potential to understand proportional thinking but have not yet encountered the right learning situation to adapt to their potential. Not only that, the study found that students should also have ongoing thinking throughout the game.

\subsection{The relationship between the combining games in teaching and the improvement in achievements}

During the study, the learning activity of social interaction was split into two: "movement interaction" and "verbal interaction" to sharpen the observation in the interaction processes. Both variables were found to be significantly positive correlated with improvement in achievement, but their correlations were relatively low. Keep in mind that the children in the experiment were elementary school students in third grade, and apart from a brief experience in the organizational processes before the beginning of the experiment, were inexperienced in interaction processes. Effective interaction for learning is not self-evident at this age. It is possible that the learning activity "social interaction" should be learned in early processes, so that it is possible to get the most out of it (Reiz, 2016).

Teaching games "Stay in a movement learning activity" include, in fact, a connection of all the behaviors that are done for the benefit of learning. The fact that this essay has received a particularly high correlation indicates that the various learning activities support each other in achieving the goal of improving achievement. Also, the different activities of learning related to game movement provides time for learning to understand the connection of the activities and the meaning of duration.

In a multivariate linear regression analysis, it was found that "stay in the game in teaching" is the most significant predictor of improvement in achievements. Game in such teaching has greater predictive ability than students' "score before" and "estimate". The students' "score before" represents the knowledge with which the learner came to the class. The fact that the learner stayed in the learning activity of game can overcome her basic data, and is significant for most learners, and especially for the weak.

This fact is even more important for the weak who study in heterogeneous classes, where the strong children can help them stay on task and thus promote them considerably. It was showed that when a learner stays in a learning game activity, he can overcome his low starting point, and perhaps even the teacher's prejudices. When taking into account the individual learning activities leaving the "stay in movement learning activity" out of regression, the "before score" and "after score" are revealed as variables that better predict the improvement in learner achievement than separate learning activities. Activities are still found to predict improvement: "Assistance with visual-movement illustration" and "socialmovement interaction". Of particular interest here are the findings concerning the movement interaction. Of the two types of interaction only "movement interaction" was found to be a significant predictor of improvement in achievement. To some extent this finding can be explained by the fact that the children were given during the learning tasks of "interaction movement", accompanied them and was secondary in importance. To understand this explanation one must pay attention to the manner of learning during (Reese, 2016). 


\subsection{Research questions}

In light of the above review, it was hypothesized: There will be a difference in the achievements of students who have studied with the frontal method and in the method of combining game in teaching. Thus it will be found that in the method of teaching combined with game, the achievements of the students be higher than their achievements in traditional frontal teaching.

\section{Methodology}

\subsection{Study population}

The study involved 50 third-graders who learned the subject of multiplication for the first time in the traditional frontal method. The second time they learned to play a game. After each time the students were tested accordingly.

\subsection{Research variables:}

Dependent variable: student achievements.

Independent variable: Combining game in teaching.

Background variables: sex, number of siblings.

\subsection{Instruments:}

A questionnaire consisting of two parts:

Part A - Background data questionnaire including: sex; age; number of siblings at home and student achievements in the first and second exams.

These variables were chosen because they are related to the level of student achievement.

Part B - Questionnaire for testing improvement in the learning process from the combining game. This section includes 8 items for examining combining game in teaching.

\subsection{Research design:}

Research design was divided into two parts: first, a descriptive statistics for information gathering on distribution averages and standard deviations to each of the variables and their factors. Second, for the purpose of testing the hypothesis, a T-test was calculated for dependent samples.

\section{Findings}

\subsection{Description of the study variables}

This study examined the effect of combining game on students' level of achievement, so that 50 students participated in this study. Table 1 shows the distribution of the students' demographic variables.

Table 1: Distribution of the Demographic Variables of the Sample $(n=50)$

\begin{tabular}{|c|c|c|c|}
\hline Variable & Component & Frequency & percentage \\
\hline & Male student & 26 & $52 \%$ \\
\hline Sex & & & $48 \%$ \\
\hline Age & Female student & 24 & $100 \%$ \\
\hline & 8 years & 50 & $12 \%$ \\
\hline Number of siblings in family & No siblings & 6 & $48 \%$ \\
\hline
\end{tabular}




\begin{tabular}{|l|l|l|l|}
\hline & $4-5$ siblings & 20 & $40 \%$ \\
\hline
\end{tabular}

Table 1 shows that 50 students from an elementary school participated in the sample. It appears that all participants are above the age of 8 years (third grade). 'The sample also shows that $52 \%$ of the participants are male students and $48 \%$ are female students. It also shows that $12 \%$ of the participants do not have siblings in the family and another $48 \%$ have 1-3 siblings and the rest $40 \%$ have $4-5$ brothers.

In this study the dependent variable was academic achievement (the two test averages) and the independent variable is learning combined with games.

Table 2: Distribution and scattering indices of learning efficiency and student achievement Frontal method $(\mathrm{n}=50)$

\begin{tabular}{|c|c|c|c|c|c|}
\hline Variable & Average & $\begin{array}{c}\text { Standard } \\
\text { deviation }\end{array}$ & $\begin{array}{c}\text { Minimum } \\
\text { value }\end{array}$ & $\begin{array}{c}\text { Maximum } \\
\text { value }\end{array}$ & scale \\
\hline $\begin{array}{c}\text { Satisfaction with } \\
\text { learning }\end{array}$ & 5.7 & 2.4 & 2 & 9 & $1-10$ \\
\hline $\begin{array}{c}\text { Academic } \\
\text { achievement } \\
\text { (exam average) }\end{array}$ & 72.6 & 11.2 & 40 & 95 & $0-100$ \\
\hline
\end{tabular}

Table 2 shows that the participating students were satisfied at an average level (moderate) $(\mathrm{m}=5.7)$ from the procedure of traditional frontal learning. The standard deviation was high (2.4) which indicates a distribution among the participants in everything related to the degree of students' agreement with the effectiveness of traditional frontal learning in multiplication lesson they learned. Some participants pointed out that indeed the learning efficiency of the frontal method is low (minimum value=2) and there were those who strongly agreed that frontal learning is very effective (maximum value $=9$ )

As for the academic achievements variable it was found that the average achievements of the participating students who studied in the frontal method was $m=82.6$, with a very high standard deviation was found (11.2) and with a lowest score of 40 and a highest score of 95 .

Table 3: Indices of distribution and scattering of learning efficiency and student achievement - combining game in learning $(n=50)$.

\begin{tabular}{|c|c|c|c|c|c|}
\hline Variable & Average & $\begin{array}{c}\text { Standard } \\
\text { deviation }\end{array}$ & $\begin{array}{c}\text { Minimum } \\
\text { value }\end{array}$ & $\begin{array}{c}\text { Maximum } \\
\text { value }\end{array}$ & scale \\
\hline $\begin{array}{c}\text { Satisfaction } \\
\text { with learning }\end{array}$ & 8.3 & 2.7 & 3 & 10 & $1-10$ \\
\hline $\begin{array}{c}\text { Academic } \\
\text { achievement } \\
\text { (exam average) }\end{array}$ & 84.6 & 10.5 & 45 & 100 & $0-100$ \\
\hline
\end{tabular}

Table 3 shows that the participating students were satisfied at an average level $(\mathrm{m}=$ 8.3) of the overall learning process combining game in learning. The standard deviation was high (2.7) which indicates a distribution among the participants in their degree of agreement on the effectiveness of learning combined with game in class. Some participants indicated that indeed the effectiveness of learning combining game is low (minimum value $=3$ ) and there are those who strongly agreed that learning combining game is very effective (Maximum value $=10$ ).

As for the academic achievements variable it was found that the average achievements value of the participating students who studied in the method combining game was $m=84.6$, 
with a very high standard deviation (10.5) and with the lowest score of 45 and the highest of 100.

\subsection{Inferential Statistics}

This study has one hypothesis and it found a difference in satisfaction from the learning process and the students' achievements who studied in the frontal method and in the method of combining game in teaching. Thus it was found that in the teaching method combined with game, satisfaction with the learning process and the students' achievements are higher than satisfaction with the learning process and their achievements in traditional frontal teaching. For the benefit of testing the hypothesis a T-test was calculated for dependent samples.

Table 4: T-test for dependent / paired samples for the satisfaction with the study process variable according to the study method $(n=50)$.

\begin{tabular}{|r|r|r|r|l|l|}
\hline Variable & $\begin{array}{l}\text { Method of } \\
\text { teaching }\end{array}$ & $\mathrm{N}$ & Average & $\begin{array}{l}\text { Standard } \\
\text { deviation }\end{array}$ & $\mathrm{t}$ \\
\hline $\begin{array}{r}\text { Satisfaction with } \\
\text { learning }\end{array}$ & $\begin{array}{r}\text { traditional } \\
\text { Combining } \\
\text { game }\end{array}$ & 50 & 5.7 & 2.4 & \\
\hline
\end{tabular}

Table 4 shows that there is a significant difference in student satisfaction in the two teaching methods $(\mathrm{p}<0.05 ; \mathrm{t}(98)=-1.09)$. In other words, students who studied in the traditional frontal method were found to be moderately satisfied $(\mathrm{sd}=2.4)(\mathrm{m}=5.7)$ which is lower than the average satisfaction of the students who studied in the combing game teaching method $(\mathrm{m}=8.3 ; \mathrm{sd}=2.7)$.

Table 5: T-test for dependent / paired samples for the academic achievements variable according to the study method $(n=50)$.

\begin{tabular}{|r|r|r|r|l|l|}
\hline Variable & $\begin{array}{l}\text { Method of } \\
\text { teaching }\end{array}$ & $\mathrm{N}$ & Average & $\begin{array}{l}\text { Standard } \\
\text { deviation }\end{array}$ & \\
\hline $\begin{array}{r}\text { Academic } \\
\text { achievement }\end{array}$ & traditional & 50 & 72.6 & $11.2^{*}-14.28$ \\
\cline { 2 - 5 } & $\begin{array}{r}\text { Combining } \\
\text { game }\end{array}$ & 50 & 84.6 & 10.5 & \\
\hline
\end{tabular}

$\mathrm{p}<0.05^{*} ; \mathrm{p}<; * * 0.01-\mathrm{p}<{ }^{* * *} 0.001-$

Table 5 shows that there is a significant difference in student achievement in the two teaching methods $(\mathrm{p}<0.05 ; \mathrm{t}(98)=-14.28)$. In other words, students who studied in the traditional frontal method were found to average their achievement $(\mathrm{m}=72.6$; $\mathrm{sd}=11.2)$ which is lower than the grade point average of those students who studied using the teaching integration method $(\mathrm{m}=84.6 ; \mathrm{sd}=10.6)$. In summary, it can be argued that the hypothesis has been fully confirmed.

In addition, variance in student achievements in the context of demographic variables was examined. T-test for non-samples depending on the context of the gender variable according to the teaching method was calculated and a one-way ANOVA to examine the differences in achievements in the variables age and number of siblings in the family in the two methods. Table 6 below shows the distribution for T-test calculations for independent samples.

Table 6: T-test for dependent / paired samples for the academic achievements variable and gender in the traditional study method $(n=50)$. 


\begin{tabular}{|c|c|c|c|c|c|}
\hline Variable & $\begin{array}{c}\text { Method of } \\
\text { teaching }\end{array}$ & $\mathrm{N}$ & Average & $\begin{array}{c}\text { Standard } \\
\text { deviation }\end{array}$ & $\mathrm{t}$ \\
\hline $\begin{array}{c}\text { Academic } \\
\text { achievement }\end{array}$ & Male students & 26 & 72.5 & 11.6 & \multirow{2}{*}{${ }^{*}-5.74$} \\
\cline { 2 - 6 } & Female students & 24 & 72.6 & 11.1 & \\
\hline
\end{tabular}

$\mathrm{p}<0.05^{*} ; \mathrm{p}<$;** $^{*} 0.01-\mathrm{p}<{ }^{* * *} 0.001-$

Looking at Table 6 shows that there are no significant differences between the achievements of the male and female students who studied in the traditional frontal method $(\mathrm{p}=\mathrm{ns} ; \mathrm{t}(50)=-5.74)$, meaning that there is no significant difference in achievements in the context of student gender in the traditional method.

Table 7: T-test for dependent / paired samples for the academic achievements variable and gender in the combining game study method $(n=50)$.

\begin{tabular}{|c|c|c|c|c|c|}
\hline Variable & $\begin{array}{c}\text { Method of } \\
\text { teaching }\end{array}$ & $\mathrm{N}$ & Average & $\begin{array}{c}\text { Standard } \\
\text { deviation }\end{array}$ & $\mathrm{t}$ \\
\hline $\begin{array}{c}\text { Academic } \\
\text { achievement }\end{array}$ & Male students & 26 & 84.3 & 10.64 & \multirow{2}{*}{$*-2.11$} \\
\cline { 2 - 5 } & Female students & 24 & 84.9 & 10.71 & \\
\hline
\end{tabular}

$\mathrm{p}<0.05^{*} ; \mathrm{p}<; * * 0.01-\mathrm{p}<{ }^{* * *} 0.001-$

Looking at Table 7 shows that there are no significant differences between the achievements of the students who studied using the combining game method $(p=n s . t(50)$ $=-2.11$ ), which means that there is no significant difference achievements in the context of student gender in the method of combining game method.

To examine the differences in achievement in the context of age and the number of siblings in the family variables, a one-way ANOVA was calculated.

Table 8 below shows the distribution of ANOVA ( $F$ test) to examine the differences in student achievements in the age context and a number of siblings in the family.

Table 8: One-way ANOVA to the number of siblings in the family variable for academic achievements in both methods $(n=50)$

\begin{tabular}{|c|c|c|c|c|c|}
\hline $\begin{array}{l}\text { Dependant } \\
\text { variable }\end{array}$ & $\begin{array}{l}\text { Number of } \\
\text { siblings }\end{array}$ & $\mathrm{N}$ & Average & $\begin{array}{l}\text { Standard } \\
\text { deviation }\end{array}$ & $\mathrm{F}$ \\
\hline \multicolumn{6}{|c|}{ traditional study method } \\
\hline & No siblings & 6 & 72.5 & 8.7 & \\
\hline \multirow[t]{2}{*}{$\begin{array}{c}\text { Academic } \\
\text { achievement }\end{array}$} & 1-3 siblings & 24 & 72.8 & 11.6 & 21.8 \\
\hline & $4-5$ siblings & 20 & 72.4 & 11.8 & \\
\hline \multicolumn{6}{|c|}{ Combining game method } \\
\hline & No siblings & 6 & 6 & 10.9 & \\
\hline \multirow[t]{2}{*}{$\begin{array}{c}\text { Academic } \\
\text { achievement }\end{array}$} & 1-3 siblings & 24 & 24 & 11.8 & 19.54 \\
\hline & 4-5 siblings & 20 & 20 & 11.4 & \\
\hline
\end{tabular}

Table 8 shows that no significant differences were found in the level of achievements in the context of the number of siblings in the family.

\section{Discussion}

The subject of this study is combining game in teaching and academic achievements. The study focused on examining the relationship between students' achievements for learning combined with game in arithmetic lessons (multiplication). In the study, 50 thirdgrade in elementary school students in the state Arab education participated. The research 
hypothesis was that a difference be found in satisfaction from the learning process and the achievements between students who learned in the frontal method and in the method of combining game in teaching, and that in a teaching method combining game satisfaction with the learning process and students' achievements be higher than in traditional frontal teaching.

For testing the hypothesis a T-test is calculated for dependent / coupled samples. The study findings confirmed the hypothesis and showed that satisfaction with the learning process and achievements of students who learned in the method of combining game were high than the degree of satisfaction and achievements of those students who studied in the traditional frontal method.

The research literature shows that combining with game learning in mathematics helps students in their studies and understanding the learnt material. For example, Reese (2016) argues that combining game in mathematics teaching allows for diversity in teaching methods, which is an unusual practice, that may motivate students to learn math, encourage creativity (when the students themselves build a game) and make them enjoy and also raise their academic achievements. Also game allows the teacher be aware of the students' difficulties in the mathematical subject in which he deals. In her research with third grade students she found that learning through combining game enhanced student achievements. In another study by Vrogte and colleagues (2015) they found that the game was able to target the students, and especially those with low prior knowledge. She found that learning combined with game motivates students to learn and enjoy school.

In my opinion, combining game into learning in classes is important and necessary in order to increase student interest. This is especially strongly expressed at younger ages in primary school so cognitive development improves more when combining learning with game.

In addition, a T-test was calculated for unmatched samples and a one-way ANOVA to examine differences in achievements by gender and the number of siblings in the family in both teaching methods. Findings of t-test and one-way ANOVA showed no significant differences in the level of achievements in the context of gender and the number of siblings in the family.

In conclusion, it was found that learning combined with game positively affects student achievements. These findings provide further evidence for the effects of combining game into learning on student achievements in that they show that environment variable positively affects achievements. In addition, cultivating an environment that encourages creativity as well as thinking strengthens the student's understanding and even increases the interest and thus her achievements increase accordingly.

\section{Summary and Conclusions}

This study examined the effect of combining game in learning on students' achievements in third grade arithmetic.

The findings of the study indicated a difference in the level of satisfaction with learning and achievements in favor of combined with game learning over traditional frontal learning. This study is another study in a large set of studies that examines the issue under investigation and its findings indicate the advantage of combining game into learning for the benefit of studying arithmetic over traditional learning (environment varibable) both at the level of students' satisfaction and at the level of achievements. In addition, no significant 
relationships were found between gender and number of siblings in the student's family on student achievements.

This research has one key conclusion which is that combining game in learning (environment variable) plays an important role in raising student satisfaction and achievements.

As to this research contributions, for example, raising awareness among teachers as well as parents about the benefits of combining game into learning. This situation requires the assimilation of the game as part of the learning process. In addition policy makers in the Ministry of Education have to prepare learning programs based on combining game as part of teaching and learning. I recommend future follow-up research that will include a larger sample of students and include different schools from different ethnic populations. 


\section{Bibliography}

Arbel A., Lachman D. and Epstein V. (2011). Educational Games - Template Kit. Internal Advertising, College Beit Berl Academy.

Hanan, Y. (2011). LAE - Learning in an Adventurous Environment. Eureka Science. Tel Aviv University.

Reese, R. (2016). Course of "Mathematical Games" Oranim College.

Tami, Y. and Yechiel, P. (2014). Game is a study material in disguise - a combination of play in learning. Academic Religious College of Education, Kiryat Shmuel Haifa.

Castellar, E. N., All, A., De Marez, L., \& Van Looy, J. (2015). Cognitive abilities, digital games and arithmetic performance enhancement: A study comparing the effects of a math game and paper exercises. Computers \& Education, 85, 123-133.

Karbach, J \& Schubert,T (2013). Training-induced cognitive and neural plasticity. Frontiers in Human Neuroscience, 7: 6-7.

Ramani, G. B., Siegler, R. S., \& Hitti, A. (2012). Taking it to the classroom: Number board games as a small group learning activity. Journal of Educational Psychology, 104(3), 661.

Schiller, P. (2010). Early brain development research review and update. Brain Development. Schiller, P. (2010). Early brain development research review and update. Brain Development. (pp. 26-30).

Shonkoff, J., and Levitt, P. (2010). Neuroscience and the Future of Early ChildhoodPolicy: Moving from Why to What and How. Neuron 67, 690-691.

Vrugte, J., Jong, T., Wouters, P., Vandercruysse, S., Elen, J., \& Oostendorp, H. (2015). When a game supports prevocational math education but integrated reflection does not. Journal of computer assisted learning, 31(5), 462-480

$\mathrm{Xu}$, A., \& Chen, G. (2016). A study on the effects of teachers' information literacy on information technology integrated instruction and teaching effectiveness. Eurasia Journal of Mathematics, Science \& Technology Education, 12(2), 335346.

Zinn, S., Stilwell, C., \& Hoskins, R. (2016). Information literacy education in the South African classroom: Reflections from teachers' journals in the Western Cape Province. Libri, 66(1), 3144-. 


\title{
THE DESIGN SYSTEM AND ITS FORMAL INFERENCE IN LOGO DESIGN
}

\author{
Fouad Ahmed Shallal AL-SAMARRAEE ${ }^{1}$
}

\section{Istanbul / Türkiye \\ p. 729-749}

Received: $26 / 11 / 2021$
Accepted: 11/12/2021
Published: 01/01/2022

This article has been scanned by iThenticat No plagiarism detected

\begin{abstract}
:
The communicative and cultural achievement is represented by an activity with adopted formulas confirmed by compliance and flexibility that enables it to keep pace with the creative path in the age of infomedia and contemporary digital publishing programs. The explanatory space, in its intellectual and technical forms, is based on logical foundations that work on creating latent patterns and patterns that enhance the purpose of its existence. And the system in art in general and design in particular represents a mechanism for arranging work vocabulary on the basis of principles that usually refer to a system that checks the state of damage between the design work vocabulary. The system stems from those defects embodied in expressive formats that are linked to concepts and ideas through the organization of different vocabulary within the workspace that have specific characteristics that reflect a particular idea and are linked to the specificity of the required utilitarian functional nature. The lesson of the system is not only to reach the relationships that exist between the vocabulary in their embodiment of the concrete form, but it lies on a much deeper level than that, which is the level of significance.

Where the formal characteristics of the product of organizational relations reflect patterns that often express their environment or are the result of those organizations with semantic reading, and the difference in the nature of the formulation of these organizations comes from the effect of the overlap of several different factors (cultural, social, religious, civilizational, functional).

The design thought derives its primary material through this overlap to start the system according to the rational methods in the drafting process. To evaluate things and this is the rule of logic.

From here the researcher sees that the principle of the system and its relation to the degree of formulation of the form, and the extent of variation of this formulation is due to the mental readiness in the process of organization and innovation, to be a specific formal inference related to its basic function and its structural composition in the designs of logos, so the idea of research and formulation of the research problem came according to the following question: Is there a role for the design system in formal inference in logo design? The importance of the research was formulated through:
\end{abstract}

http://dx.doi.org/10.47832/2717-8293.15.50

1 iD Dr. , Baghdad University, Iraq, foad.ahmed@ cofarts.uobaghdad.edu.iq 
-Informing those interested in the design issue, for the purposes of developing the mechanisms of their technical work.

-To benefit scientific and research institutions, as well as the press, publishing houses, and advertising agencies. The aim of the research lies in: Knowing the role of the design system in formal inference in the design of logos, and defining the limits of research, which lies in the objective limit: the design system and formal inference in the design of logos Spatial limit: some Examples of global logos that enhance the current research, And the time limit for the designed logos from (2019-2021), and definitions of the following terms were defined: design system and formal inference..

Key words: The Design System, Logo Design, Formal Inference. 
النظام التصميمي والاستدلاله الشكلي

في تصميم الشعارات

\section{فؤاد أحمد شلال السامرائي}

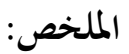

يتمثل المنجز التخاطبي التواصلي الثقافي بنشاط ذو صيغ متبعة تتوكده المطواعية والمرونة التي تمكنها من مسايرة الركب الإبداعي في عصر الانفوميديا وبرامج النشر الرقمي المعاصر، وهذا النشاط يحتكم لنظام وقواعد شكلية

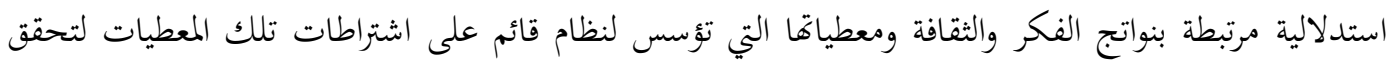
أعلى قدر من المساحة التوظيحية بشكليها الفكري والتقني على وفق أسس منطقية تعمل على أحداث انسات انساق

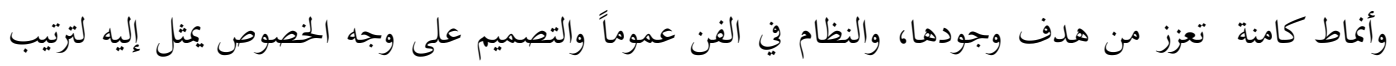
مفردات العمل على وفق أسس تشير في العادة إلى نظام محقق حالة التالف بين مفردات العمل التصميمي.

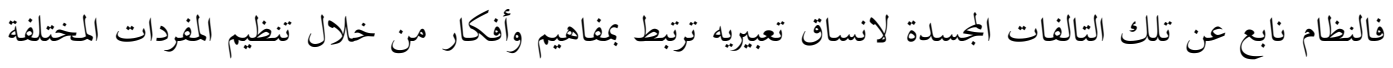

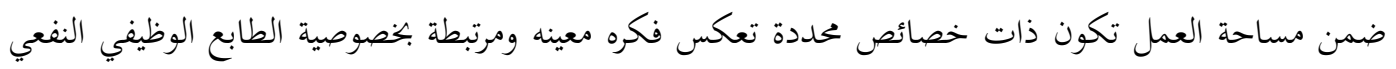

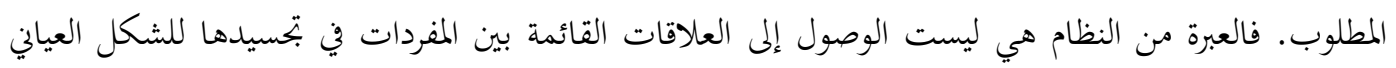

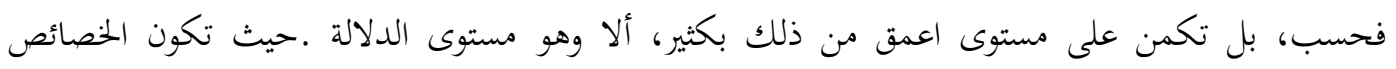

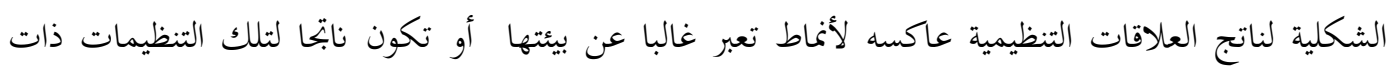
الاسقراء الدلالي، ويأتي الاختلاف في طابع الصياغة لهذه التنظيمات من اثر تداخل عدة عوامل مختلفة (ثقافية، اجتماعية، دينيه، حضارية، وظيفية). فالفكر التصميمي يستمد مادته الأولية من خلال هذا التداخل ليبتدئ به النظام على وفق الطرق العقلانية في

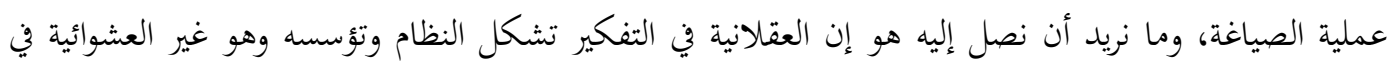

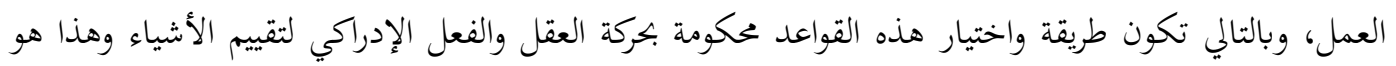
حكم المنطق. من هنا يرى الباحث ان مبدأ النظام وارتباطه بدرجة صياغة الشكل form ، ومدى تفاوت هذه الصياغة إنما

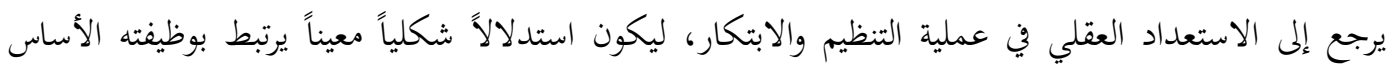
وتكوينه البنيوي في تصاميم الشعارات، فجاءت فكرة البحث وصياغة مشكلة البحث على وفق التساؤل التالي:

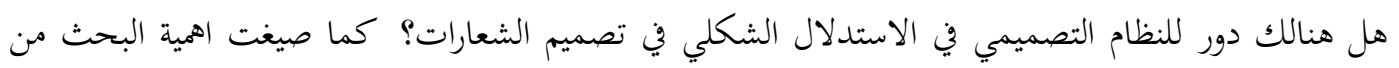

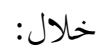

- إفادة المهتمين بالشأن التصميمي، لأغراض تتعلق بتطوير آليات عملهم الفني.

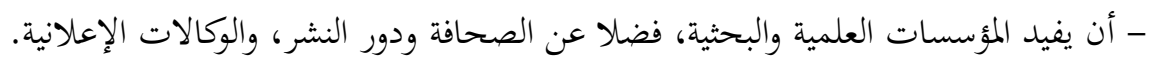
الكلمات المفتاحية: النظام التصميمي، تصميم الشعارات، الاستدلال الشكلي. 
تعرف دور للنظام التصميمي في الاستدلال الشكلي في تصميم الشعارات، وحددت حدود للبحث والتي تكمن الحد الموضوعي: النظام التصميمي والاستدلال الشكلي قي تصميم الشعارات الحد المكاني: بعض من نماذج الشعارات العالمية التي تعزز

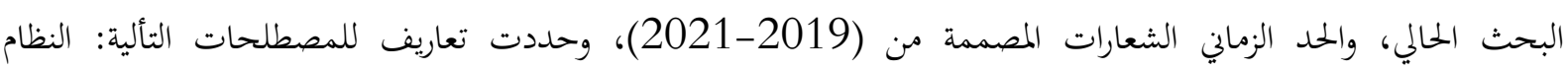
التصميمي والاستدلال الشكلي.

يؤلف النظام والتنظيم تكويناً محكم يميط بجميع المعطيات الداخلة ضمن العملية التصميمية من عناصر وأسس فضلاً عن

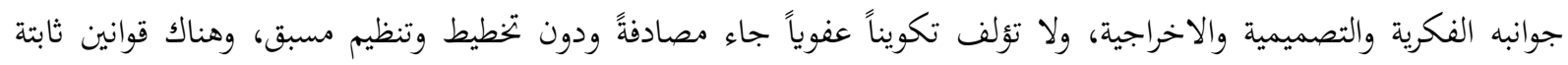

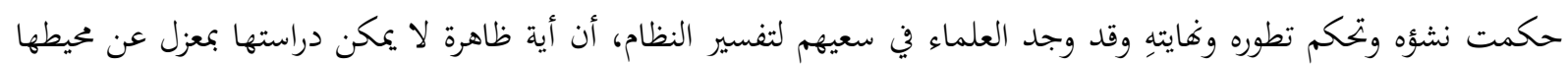
وعن الظواهر الأخرى التي تحيط بها، فهي جزء من كل لا يتجزأ من المحيط بكل مفرداته،ويرتبط هذا النظام بالطبيعة والكون،

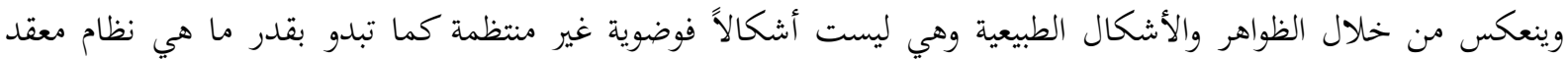
ودقيق، وهو ما يعبر عنه بالأشكال الهندسية المجردة كالخط، السطح، المربع، الدائرة، الأسطوانة، أي أن هذا النظام يرتبط بالطريقة العقلانية للتفكير، ومن هنا نجد أن الإنسان قد رصد طبيعة النظام في كثير من مجالات الحياة، وحاول أن يضمنها في مختلف نوابته إنها

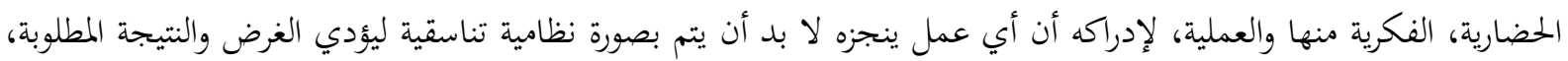
وقد انعكس هذا المفهوم في مجال الفكر والعلوم بشكل دقيق ومباشر وبقواعد منطقية وأسلوب منهجي. لإدري. أما في الفن فقد كان تجسيد النظام من خلال تنظيم مفردات مختلفة ضمن العمل الفني وفقا لخصائص محددة تعكس فكرة

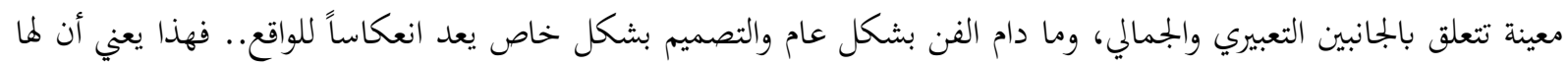

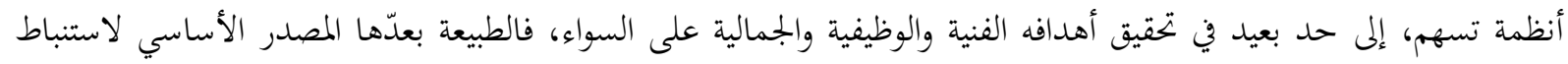

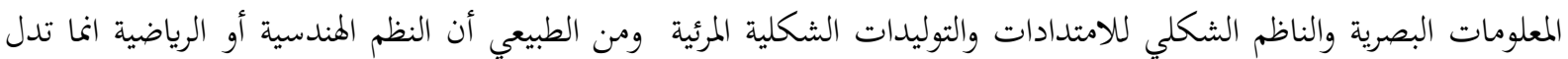
على التكوين الشكلي وما تتوالد عنه من دلالات تعبيرية تتناول المظهر الشكلي بكل تمثيلاته لاستباط المعلومات البصرية والتكوين لامتدادات وتوليدات شكلية دلالية، ومما تقدم وجد الباحث مسوغاً لصياغة مشكلة بحثه من خلال التساؤل التالي: ماهو دور النظام التصميمي في الاستدلال الشكلي في تصميم الشعارات.

- الأهمية النظرية: بناء إطار منهج معرفي يتناول فيه النظام التصميمي وكيفية بتحسيده للاستدلال الشكلي في تصميم الشعارات

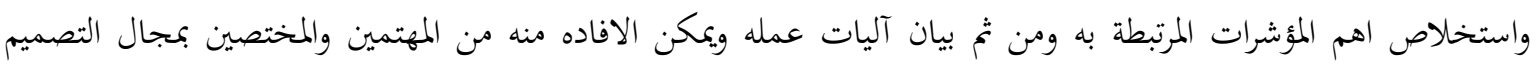
الكرافيكي نظرياً. - الأهمية التطبيقية: مساهمة وتنمية وتطويرالمهارات العملية للمشتغلين والمصممين بالجانب الكرافيكي وتسليط الضوء لهم على آليات تكون النظام التصميمي وكيفية تجسيد الدلالات الشكلية في تصميم الشعارات. 
حدود البحث:

الحدود الموضوعية: دراسة النظام التصميمي والاستدلال الشكلي في تصميم الشعارات.

الحدود المكانية: الشعارات المصممه (امريكا، اسبانيا، فرنسا،الامارات العربية المتحدة ) . .

الحدود الزمانية: 2019 - 2021

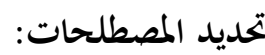

النظام فلسفياً: هو مفاهيم العقل الأساسية، ويشمل الترتيب الزماني، والترتيب المكاني، والترتيب العددي، والسلاسل والعلل

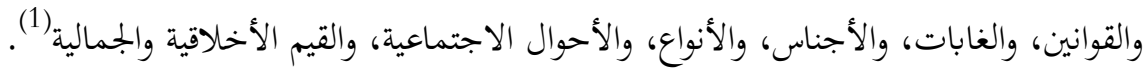
النظام لغوياً: نظمه ينظمه ونظمه ونظاما فأنتظم وأنظم، ونظمت اللؤلؤ أي جمعته في السلك والتنظم مثله، ومنه نظمت الشعر ونظمته، وأنظمت فيه الشيء من خيط وغيره وكل شعبه منه واصل ونظام كل امر ملاكه، والجمع أنظمه وناظم ونظم (2). النظام اصطلاحا: (n)

النظام: هو مجموعه من الأجزاء التي تعمل مع بعضها البعض في علاقة نظامية وفقا لغرض معين لكل من المبادئ والأفكار ينجز أو يرتب في بتحانس وتناغم المرتبة والمترابطة وظيفيا.

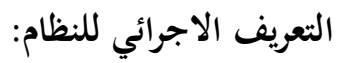

النظام: هو عملية ذات منهج متسلسل ومتناسق لتشكيل بجموعة عناصر داخل الفضاء التصميمي بطريقة تجسد الغرض

والوظيفة التصميمية في الشعار.

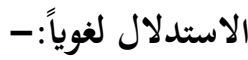

عرفه الجرجاني: الاستدلال: هو تقرير الدليل لإثبات المدلول. (3)

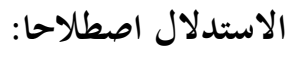

- - الدلالة (كدراسة أو علم المعنى).

- - استنتاج قضيّة مجهولة من قضيّة، أو من عدة قضايا معلومة. (5)

- فعل ذهني مؤلف من احكام متتابعة، اذا وضعت لزم عنها بذاتما حكم اخر لغيرها(6)

الاستدلال الشكلي اجرائياً: - الئ

هو فعل يقر دليلاً شكلياً كلمة لاحتواء الوسيط المستخدم وتوجيهه في وجهة معينة تفرض بالضرورة إمكانات تعبريية معينة بنظام ذو مواصفات، ويدل على تنظيم عناصر الوسيط المادي التي يتضمنها العمل وتحقيق الارتباط المتبادل بينها. 
يعتمد تحقيق النظام على مجموعة من العناصر المرتبطة ضمن شبكة من العلاقات التبادلية بين المكونات التي تحتكم له، ويعد النظام ألية تنظم تكوين الشكل وتنقله من واقع غير ملموس إلى واقع ملموس متضمن العناصر الموجودة والمحيطة للمنجز التصميمي ويعطيها قيمة بتسد ماجاءت به العناصر التصميمية من هدف وظيفي، ويمثل النظام في الفن والتصميم إليه لترتيب

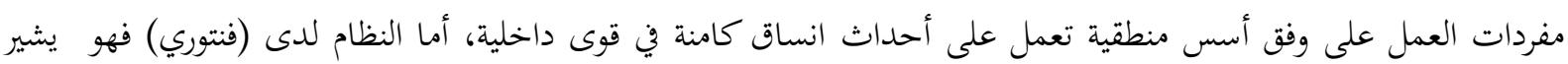

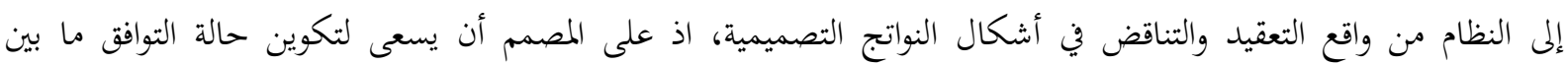
المتناقضات ويكيف عناصر تصميمية بنائية في تصميم المنجز، والنظام مبدأ أساس في التصميم وممثلاً للعملية الفاعلة التي تدور

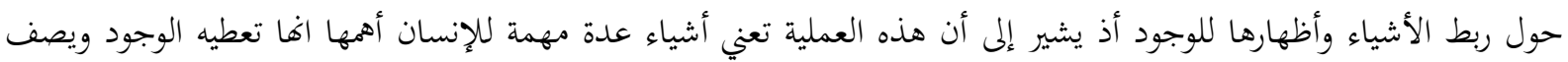

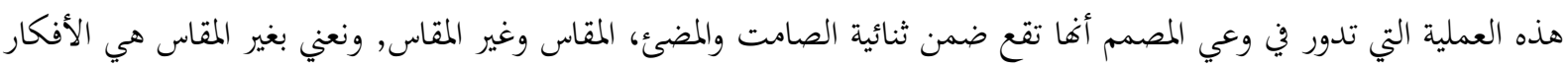

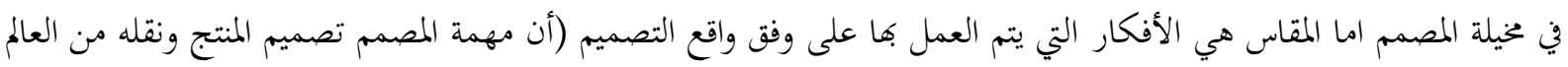
الصامت إلى العالم المضئ والنظام يقع خلف هذه الثميل الثنائية). إن أهمية النظام هذه تشمل مجالات عدة على اختلاف طبيعتها، أذ يشير (Arnhem) أنه أساسي ولا غنى عنه في

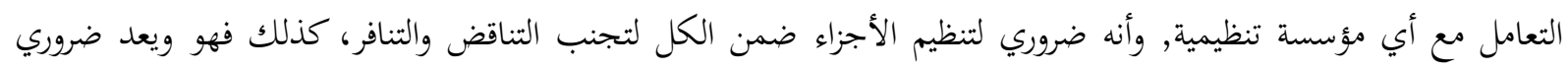

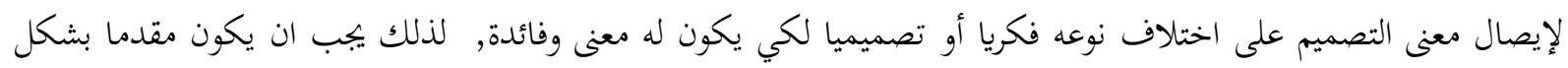
نظامي وبذلك يكون قد حقق التقبل لدى المتلقي. وبذلك فإن النظام كيان متكامل من المنجز التصميمي، ويتكون من ونس أجزاء

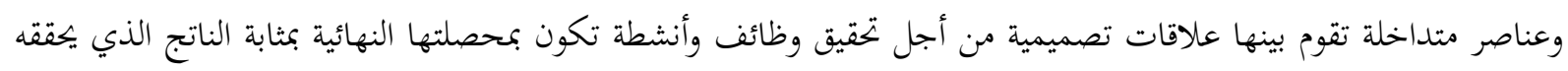
النظام كله. كما تشير هذه المفاهيم في مجملها إلى معنى النظام بأنه الأسلوب الذي ينتظم به عدد من العناصر والمفردات في علاقات تخدم بعضها البعض اذ ان الشكل يبدو في وحده كلية تمثل هذا النظام (7). ومما تقدم يرى الباحث أن احدى أهم مفاهيم النظام هو كونه يأتي كوسيلة لإنجاز التصميم بشكل منهجي ومنطقي وذو صيغة متسلسلة ومتتابعة في التصميم أحيانا، ويشمل طريقة وعملية مزج العناصر في تكوين موحد للحصول على لئى حالة التجانس،

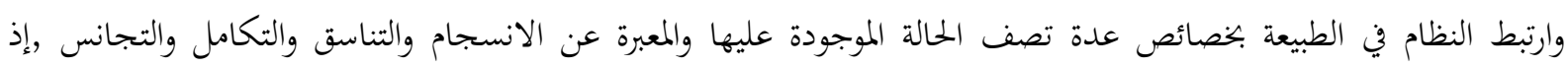

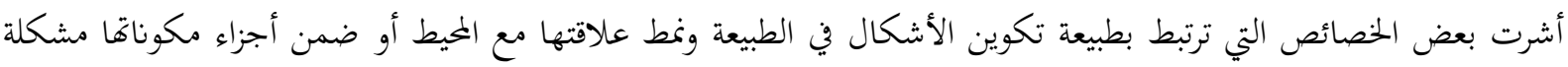

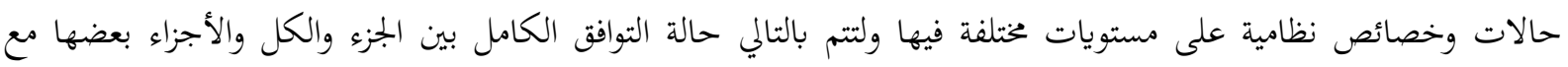
البعض الآخر، لقد تركزت هذه الخصائص في خاصيتين الاولى تشير إلى الوحدة التصميمية والثانية تؤدي اليها وهي خاصية التوازن التصميمي. إذ ان مفهوم الوحدة التصميمية ضمن الطبيعة وأجزاءها عدت من قبل بعض المصممين أساسا لفلسفتهم في العمل التصميمي وفي نظرقم إلى الحالات المختلفة في جوانب الحياة.

الدلالة مفهوماً: - 20 - n

علم الدلالة هو تفسير المعاني والرموز والإشارات، حيث يهتم بدراسة أنظمتها وآليات تكوينها، وقد تبلور هذا المفهوم بعد تيارات الحداثة التي ظهرت في ستينيات القرن العشرين "البنيوية وما بعدها" بوصفها ظاهرة لفهم العالم وتفسيره ودراسة الأنظمة

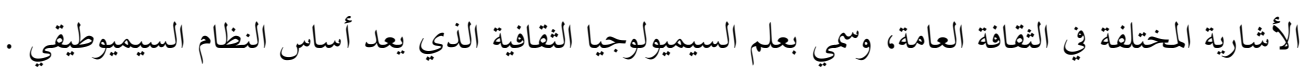


وكلمة الدلالة "السيميانتك" Semantique مشتقة من الأصل اليوناني "سيميو" أي علامة، ويرجع مصطلح

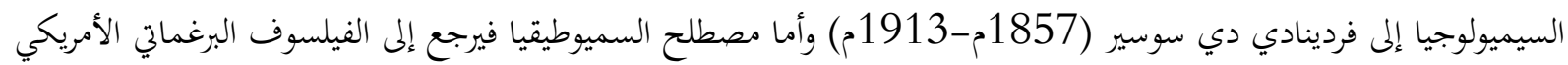

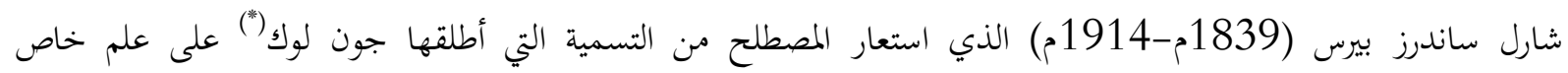

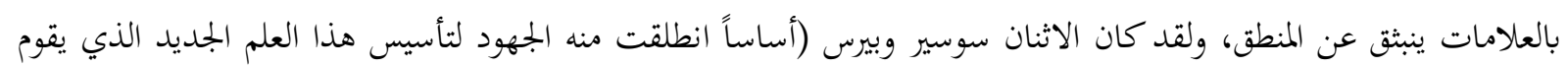
على دراسة أنظمة التواصل البشري)(8)، حيث ركز سويسر كما يقول جيرو على الوظيفة الاجتماعية للإشارة (العلامة) بينما ركز بيرس على الوظيفة المنطقية. والمظهرين على صلة حميمة، والكلمتان سيمولوجيا وسيميائيات تعطيان اليوم نظامًا واحدا. فالسيميولوجيا هي علم الأشارة الدالة مهما كان نوعها واصلها، وهذا يعني إن النظام الكوني بكل ما فيه من إشارات

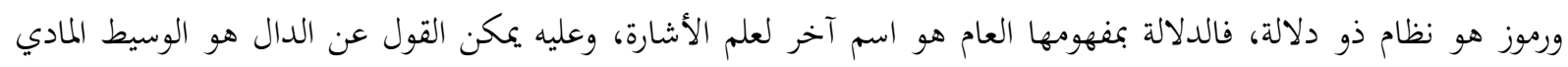
للمدلول. والربط بين الدال والمدلول يعد صفة تعاقدية مبدئية هذا العقد جماعي منقوش في زمن طويل. فاللغة نظام من العلامات،

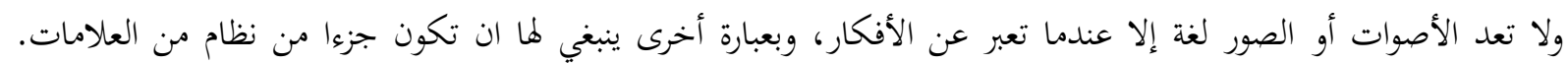

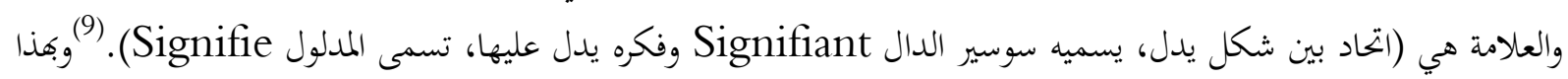

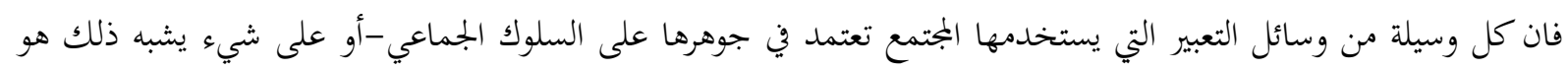

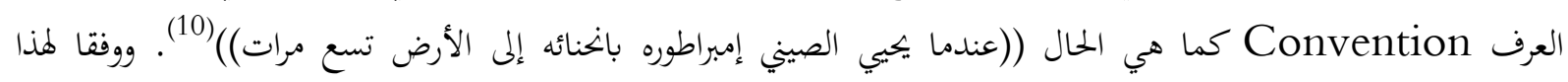

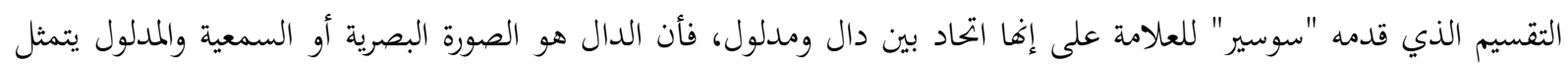

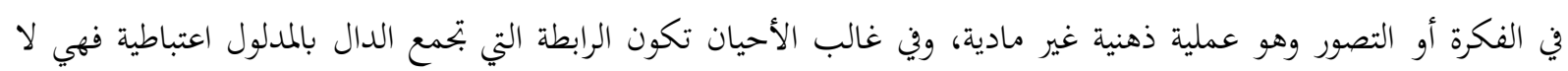

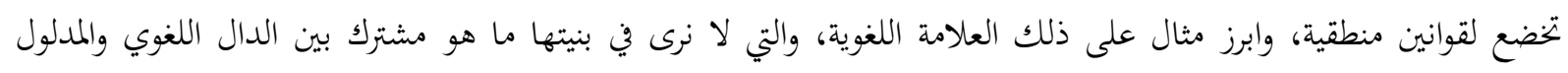

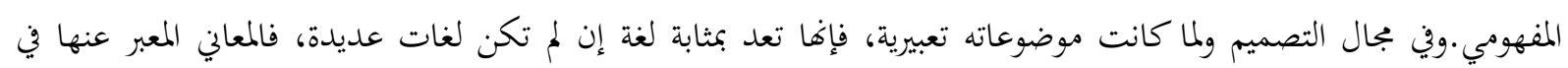
التصميم يمكن ترجتها إلى ألفاظ.

والعمل التصميمي يقوم على محاكاة الواقع ذو الوظيفة النفعية، وعليه فالمصمم ينتقي بعضاً من عناصر الواقع ويقدمها على ترئ

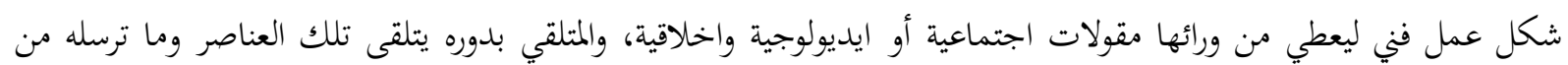
علامات، فيردها في ذهنه إلى مرجعها الحقيقي.ويمكن القول بان المرجع هو "تخيل المتخيل" المتماثلة طبعا من متلقي إلى آخر.

الدلالة الشكلية:

يذهب نقاد النزعة الشكلية إلى فهم طبيعة الفن المعاصر في وقت ما عند التفكير في موضوع الشكل نجده ينطوي على

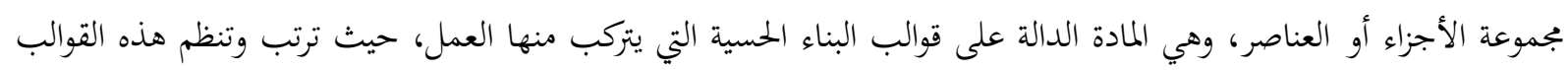

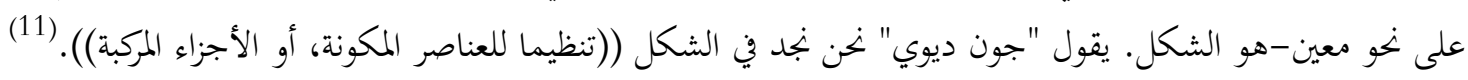
فالشكل هو جمع لعدة عناصر متحدة في كيان واحد له قيمة الإدراك العقلي. ويرى "هربرت ريد"، إن لفظة الشكل في

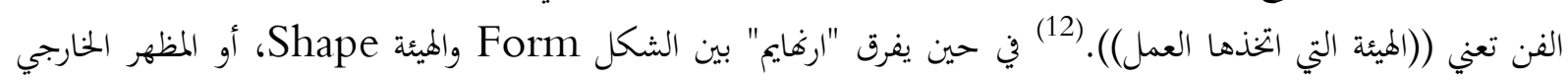

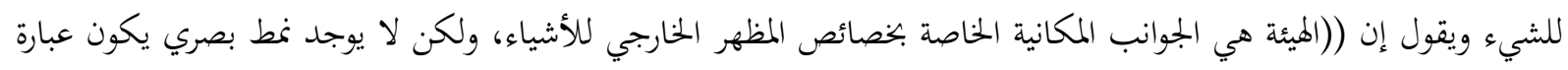

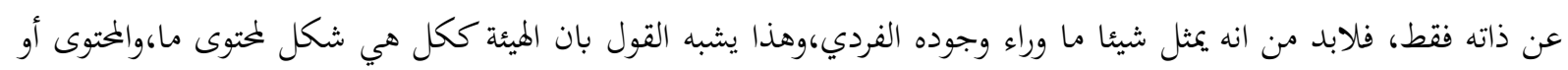

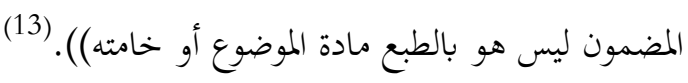
ويعد استخدام "ارغايم" لمفهوم "الشكل" استخدام يتضمن الميئة والمضمون. وعليه (فالشكل بالمعنى الإدراك ضروري

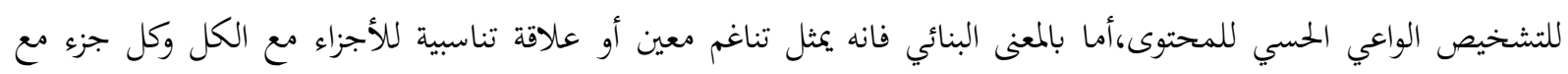


الآخر).(14) فالشكل يشير إلى طريقة خاصة في النظر إلى الأشياء والإحساس بها من خلال التركيب الخاص للعناصر،والتي تعد الجوهر الفعلي أو الموضوع الفني نفسه.

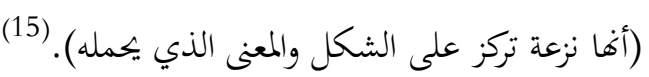

ولعل تركيز "لانجر" على الشكل وأهيته يرجع إلى إدراكها العميق للوظائف التي يقوم بها الشكل. وهذا السبب جعل من

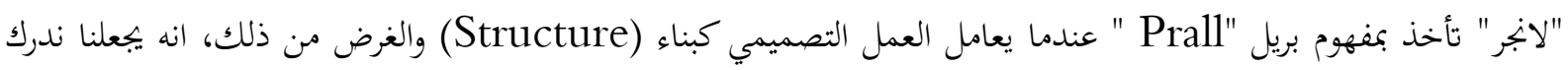

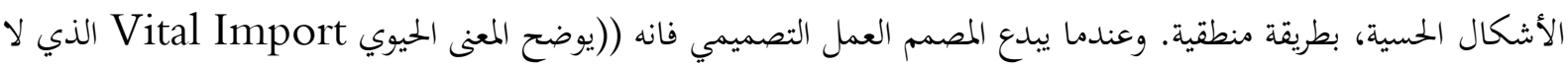

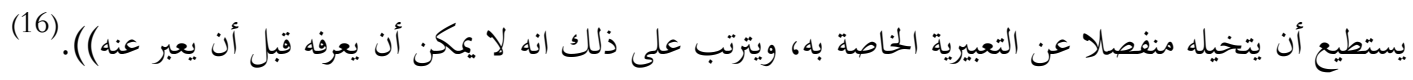

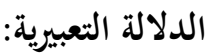

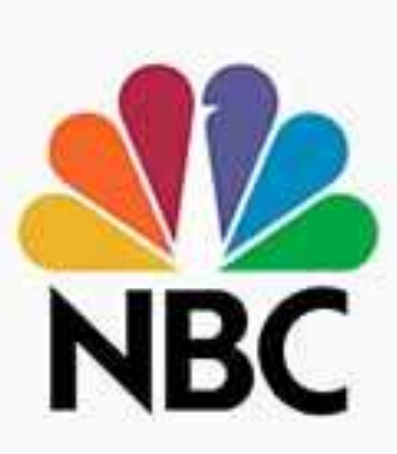

إن السيميائية تقوم على العلاقة بين العلامة والدال والمدلول، فالعلامة مكونة من دال

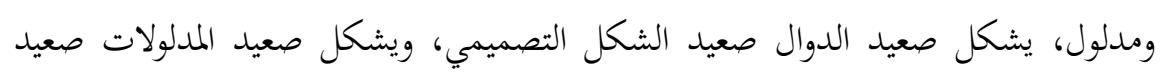
المحتوى، والعلاقة بين الدال والمدلول، علاقة وضعية اصطلاحية، وهي ضرورة لتحقيق التواصل الذي عبر عنه أحيانا بالبيان أحيانا بالإخبار.

وإذا أخذنا نظاما مثل التصميم، نجد انه يتكون من ثلاث عناصر أساسية: العنصر

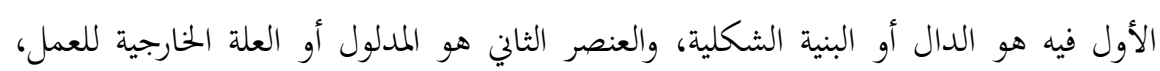

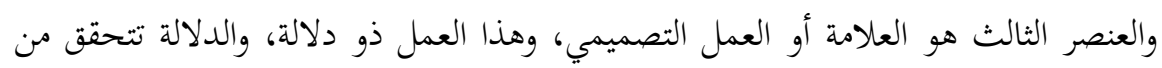
خلال قدرة الدال التعبيرية في توصيل الأفكار.

وعليه فالقدرة التعبيرية التي يتضمنها النص التصميمي يتطلب إدراك العالم الخارجي ((فالمعاني التي تعبر عنها النصوص

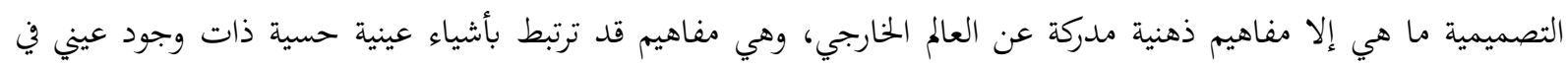

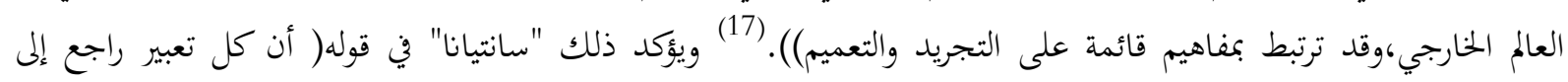

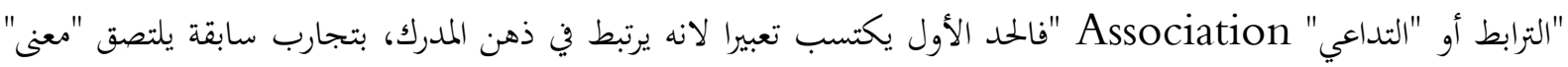

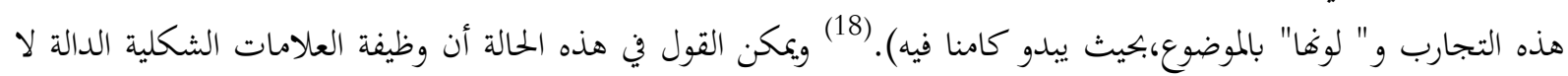

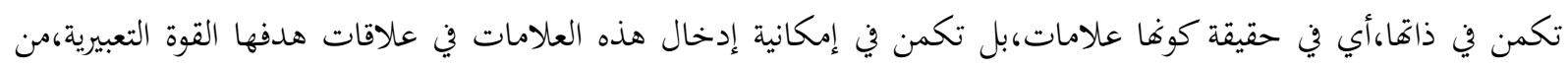

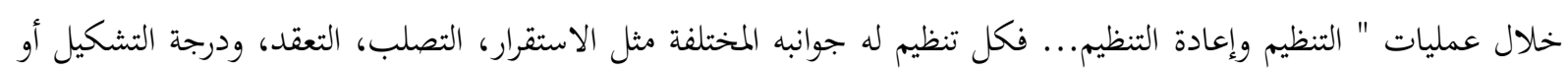
غيرها من الخصائص، وينتج التنظيم عن التفاعل، وإعادة التفاعل بين الكائن والبيئة" (19).

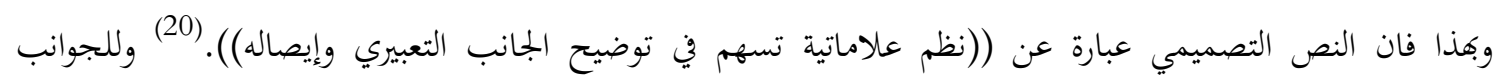
التعبيرية جذور متأصلة، في الأوجه المادية والشكلية والتصويرية للعمل. وهذه العوامل الأخيرة، عندما تحلل، تقدم شواهد تساعد على نسبة المضمون التعبيري إلى العمل، وعليه فان العمل التصميمي بوصفه علامة دالة يعتمد على منظومة ثلاثية من العلاقات بين الأطراف التألية: (مادة التعبير والمتمثلة بالألوان والمسافات، وأشكال التعبير وهي التكوينات التصويرية للأشياء، ومضمون التعبير وهو

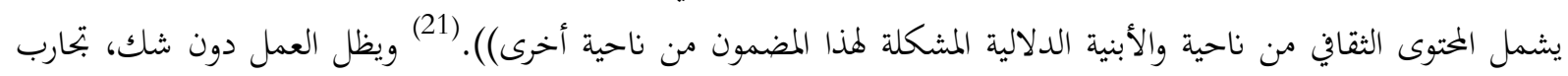

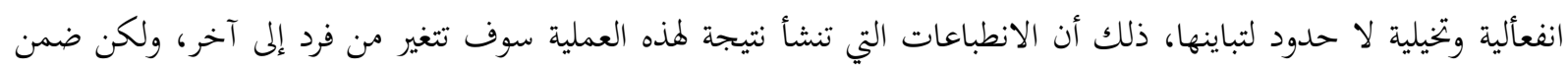

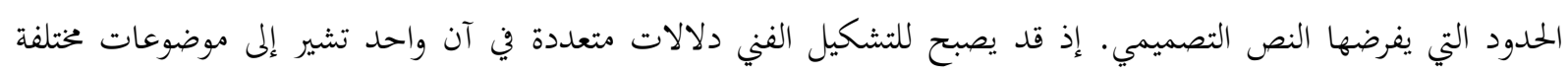


وبمعان متنوعة مما يسبب اضطرابا كبيرا للتنوعات الظاهرة في مضمونه المعبر عنه، إلا أها تبقى في سياقها العام مترابط تحمل أهمية

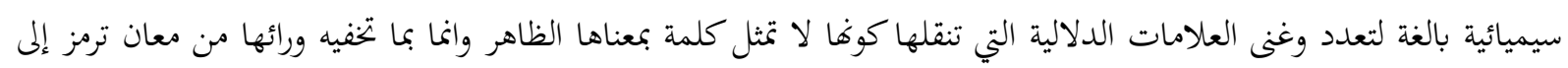

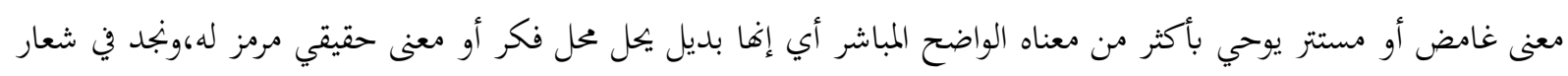

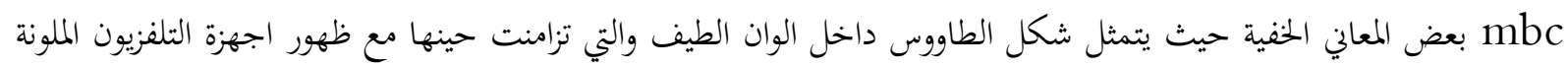

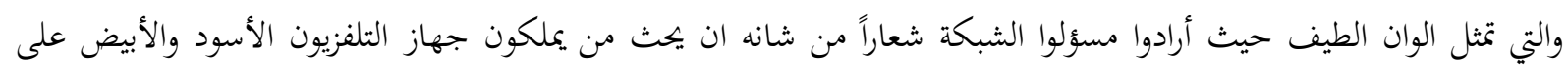

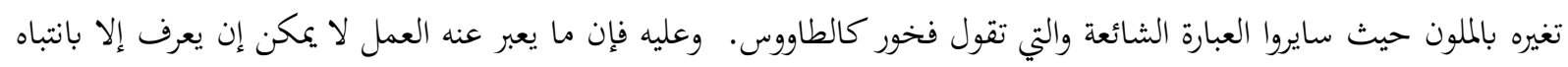

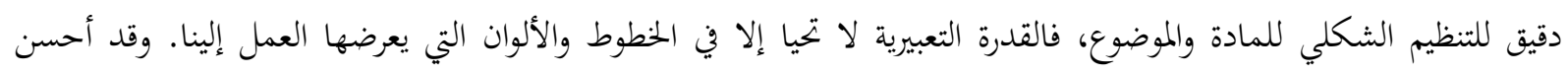

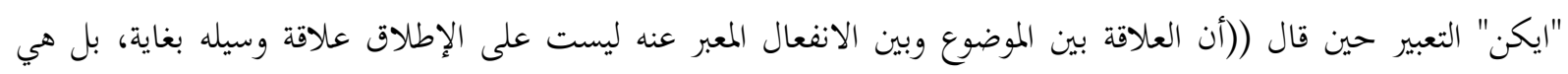

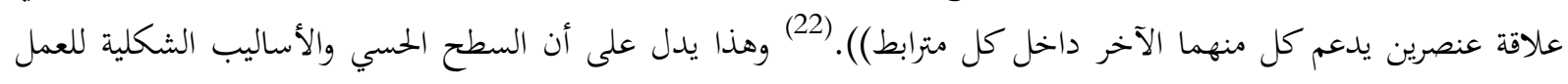

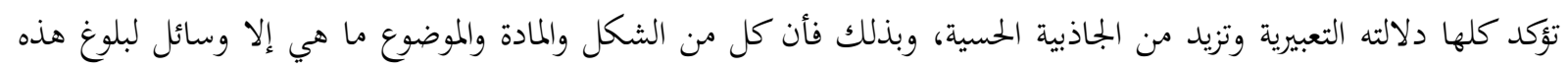

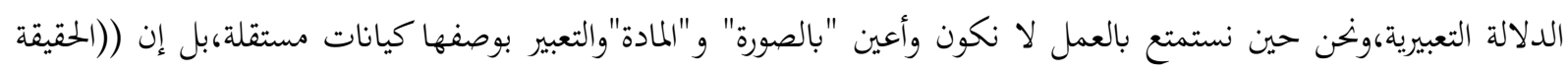

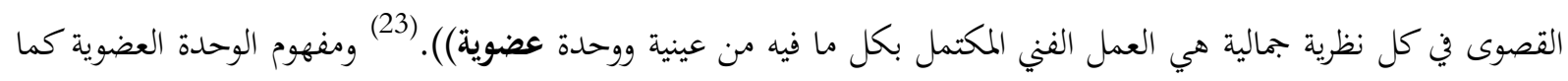
يستخلصها "عبد الرضا بهيه "من رأي "ستولينتز"(24) هو : 1. أن يكون كل عنصر في العمل الفني ضروريا لقيمته التعبيرية والجمالية. 2. أن يكون كل ما هو لازم لبناء القيمتين موجودا في العمل الفني. 3. إن تغيير أي جزء يؤدي،لا إلى حدوث فارق فحسب،بل إلى حدوث فارق مهم،خاصة إذا كان هذا الجزء

$$
\text { أساسيا وحيويا. }
$$

4. إن هذا الفارق المشار إليه إنما يكون في القيمة الجمالية للموضوع. ولا شك إن ما يهمنا في هذا السياق أن نؤكد على إن رؤية المصمم وأيديولوجيته ووجهة نظره واتحاهاته وقيمه وتصوراته

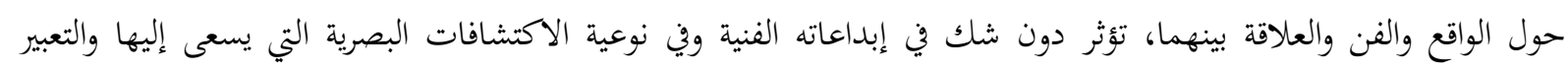
التشكيلي الذي يفضي إلى الدلالة الوظيفية للعمل أيضا.

\section{الدلالة الوظيفية: - 20 - n}

ترتبط الدلالة الوظفيية إلى حد ما بعملية الابتكار والتي تعني عمل الشيء الجديد، إرضاء لبعض الاحتياجات الإنسانية.

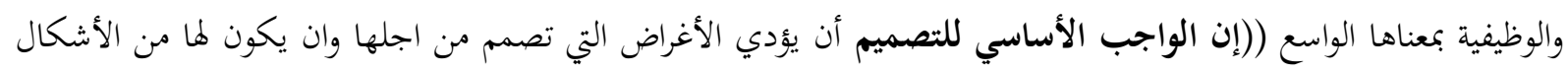

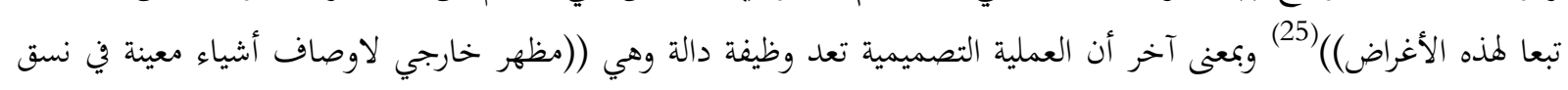
معين من العلاقات)(). (26)

وفي ضوء ذلك يمكن القول ان جوهر الوظيفة مرتبط بجوهر العملية التصميمية، أي جوهر الحاجة الإنسانية لهذا النشاط من جهة، ومشاعر وأحاسيس البشر من جهة أخرى. وعليه يمكن تحديد مسارين لمفهوم الوظيفة: الأول يتجسد من خلال البيئة الظاهرية للناتج التصميمي وهو مرتبط بالصياغة الفنية والجمالية، وهي وسيلة لتحقيق

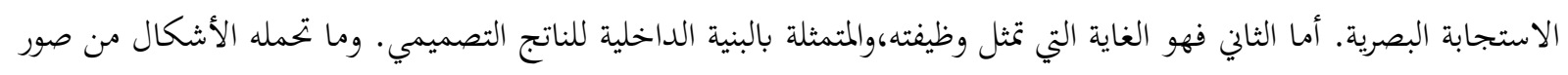
مرئية ذات معاني ودلالات رمزية معدة لغرض وظائفي، وهذان المساران لابد وان يتحدا لتحقيق الوظائفية بشكلها الصحيح

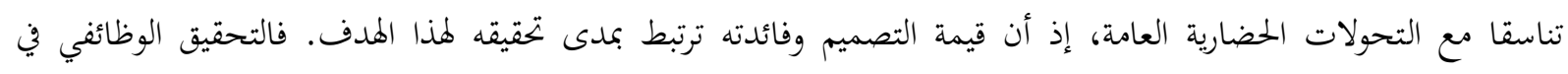


التصميم هو عملية ابتكاريه تعمل على استثارة بصر المشاهد وبصيرته.يقول "الكسندر اليوت" ((كل صورة عظيمة ترينا شيئا نبصره بالعين مع شيء ندركه بالبصيرة)).

فالجانب الأول يخضع لعملية الصياغة الفنية، وما يتضمنه من أسس وعناصر وعلاقات ترتقي بالتصميم،من خلال القيام

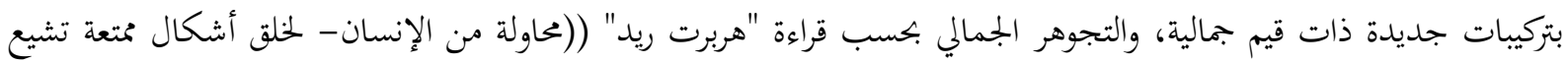

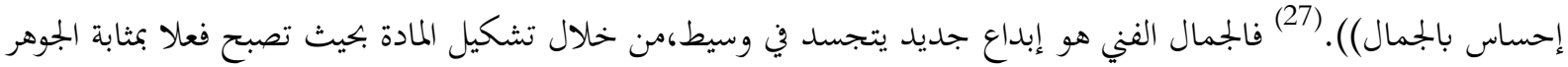
الحقيقي للعمل الفني (فكل عنصر في العمل يجب أن يؤلف مفردة ضرورية في المعنى التشبيهي، والوظيفي، والتعبيري، والجمالي الذي يهدف إله المصمم. انه الجمع الذي يوحد العناصر المنتقاة الذي يعطي العمل معناه0 ويكون باستطاعة المشاهد الذي

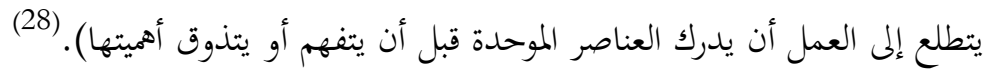
والجانب الثاني إنما يأتي من القدرة على إنتاج انساق تفسيرية جديدة، من خلال استخدام ((الوسائط التشكيلية كاللون

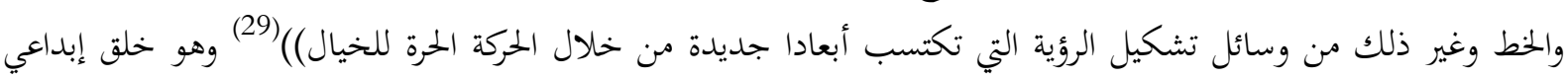

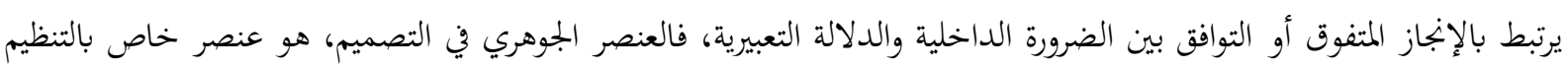

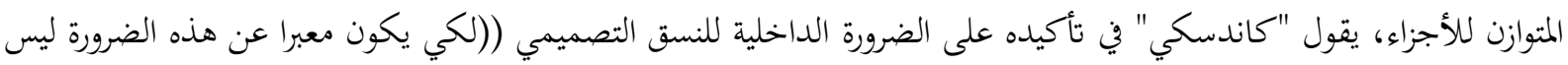

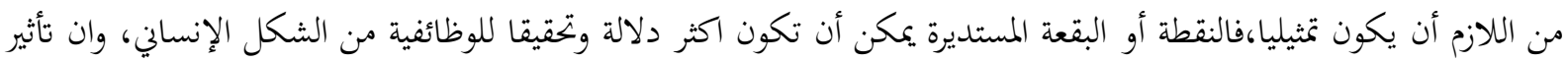

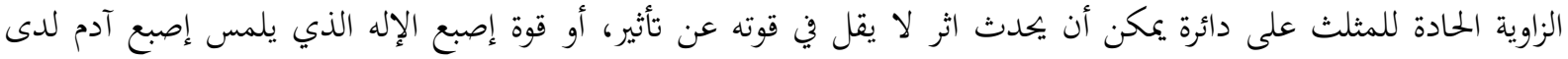

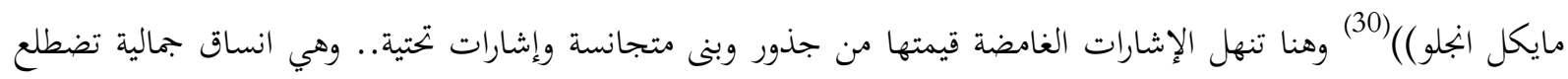

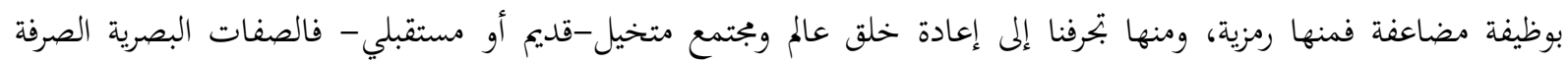
للنسق التصميمي، هي في الجوهر أقوى كل الوظائف فهي توصلنا إلى الشكل الأكثر عمقًا ومباشرة. وي ضوء ذلك فان مفهوم التصميم وبالأخص تصاميم الشعارات في الخطوط الجوية الاماراتية لم يعد محصورا بالتعريف، بل أصبح نشاطا ثقافيا بل وأصبح متحفا متجولا وهو يجمع بين الفن البصري وفن الطباعة والمكان الذي يربط بين الفن والمعرفة والعلم.

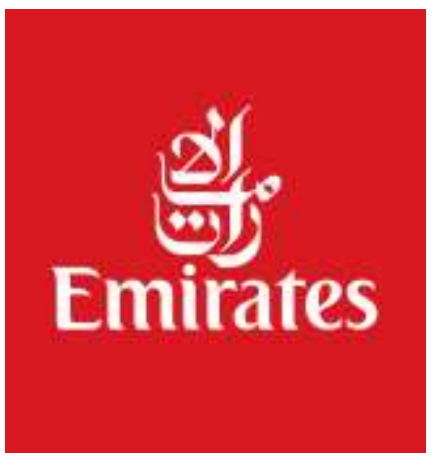

استأثر مصطلح الشكل إهتمام تحليلي متواصل في الدراسات الفنية والتصميمية ويورد الباحث جانباً من تلك التحليلات لغرض تحديد مفهومه وكما يأتي: ترى (سوزان لانجر) إن الفن هو " إبداع أشكال قابلة للإدراك الحسي بحيث تكون

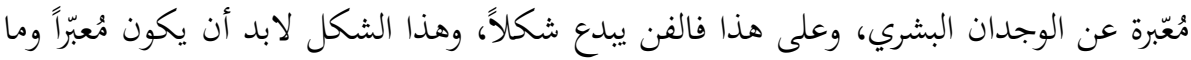

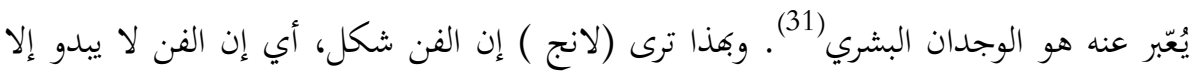
من خلال شكل ويصبح غرض الفن الأساسي هو إبداع الأشكال . وعَدَّ (سكوت) السبب الشكلي أساساً فاعلاً في العملية التصميمية إلى جانب الأسباب الثلاثة الأخرى وهي (الضرورة الإنسانية) والسبب المادي والسبب الفني التقني (32). ويعد (كاسيرير) الفن إلى جانب اللغة والأسطورة بأنه أشكال رمزية محددة للبناء الفكري ...... وإنه ليس بإمكاننا

إدراك الحقيقة إلا عبر خصوصية هذه الأشكال (33). 
ومما تقدم يُلاحظ إن الشكل رغم تعدد الإتحاهات النظرية التي حاولت إيجاد مفهوم مباشر ومحدد له، يبقى هو الصياغة

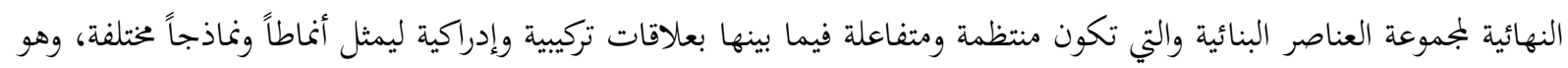

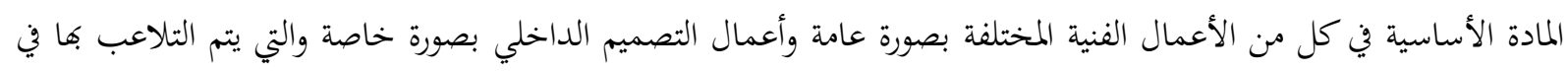
تلك الأعمال لأغراض متباينة بعض منها وظيفية والبعض الآخر منها جمالية وأخرى معنوية. ويُنظر إلى الشكل على أنه منظومة لما جانبين: 1. الجانب الظاهري ويشمل كل ما يتعلق بالوجود الفيزياوي (المادي) للشكل أي التأكيد على ماهيته والتعامل معه كظاهرة فيزياوية. 2. الجانب الفكري ويشمل كل ما يتعلق بالوجود الفكري (غير المادي) للشكل وما يحمله من القيم والأفكار والدلالات، أي التأكيد على ما يؤديه والتعامل معه كظاهرة حضارية(34). وبمعنى آخر إن دراسة مفهوم الشكل لا تقتصر فقط على الجانب المادي الذي هو محصلة الأجزاء والعناصر البنائية المترتبة على وفق علاقات منتظمة فيما بينها، ولكن تشمل الجانب الفكري للشخص الذي قام بهذا الترتيب حيث يتم إعتماد علاقات إتبات

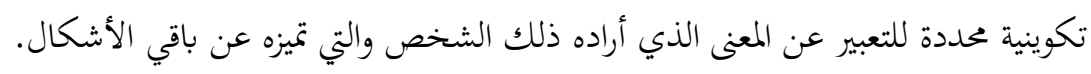

وظائف الشكل: إن للشكل طاقة تعبيرية كامنة، وتتمثل تلك الطاقة في قدرته على تحقيق وظائف جمالية تُساهم في بلورة وتشكيل هوية الفضاء الداخلي أو العمل الفني ومن تلك الوظائف: 1. الشكل يضبط إدراك المشاهد (المتلقي) ويرشده ويوجه إنتباهه في إبتحاه معين، بحيث يكون العمل واضحاً ومفهوماً وموحداً في نظره . ن. 2. الشكل يُرتبب عناصر العمل على نهو من شأنه تأكيد قيمتها الحسية والتعبيرية وزيادتما . 3. التنظيم الشكلي في حد ذاته له قيمة جمالية كاملة 35. فالشكل يوجه إدراك المشاهد ويجذب إنتباهه إليه كجزء من عملية التذوق الفني والجمالي للشكل، كما إن قيمة التذوق

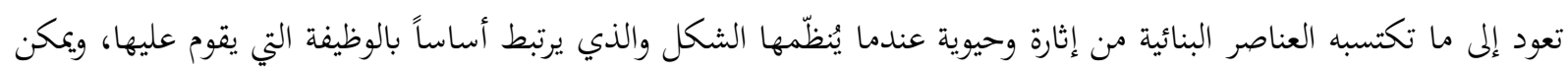

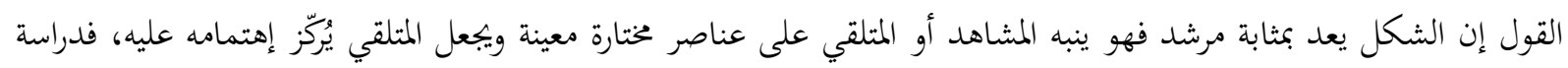

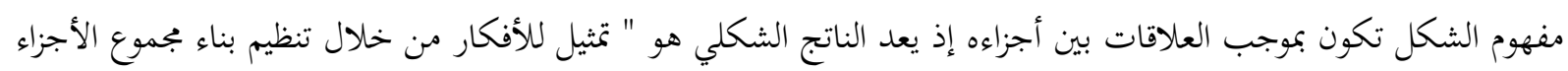
وعلاقات ربطها التبادلية لإدراك الشكل المرئي "

فالشكل في التصميم تتميز فيه النظم بوحدة متكاملة تعبر عن موضوع ماله تركيبته البنائية، وعناصره الأساسية التي لا

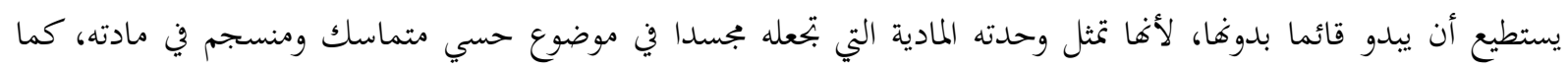
ينطوي على مدلوله الباطني، ويعبر من جهة أخرى عن حقيقة روحية يشعر بها المتلقي وفق قدراته، خارج واقعة الملموس. وبهذا فأن الشكل هو الصورة المادية المحسوسة واتتي تشير إلى صورة ذهنية تتجلى هذه الصورة من خلال مادة الشكل. وهنا يكمن حوار الرؤية بين كل من الشكل والمضمون. (الشكل هو العنصر الأساسي والاهم في الفن، بينما المختوى هو بمثابة العنصر الثانوي الناقص الذي ليست له القدرة على الإحاطة بكل جوانب الواقع)). (36) 
إن صياغة الشكل بصورته الدلالية تعد عملية فكرية وإبداعية في تكوين أشكال جديدة قابلة للإدراك الحسي، عن

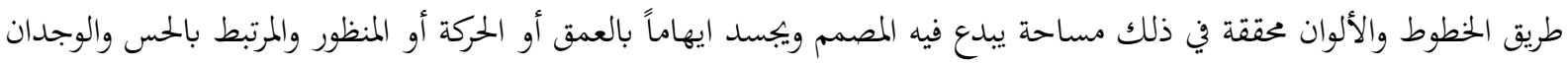

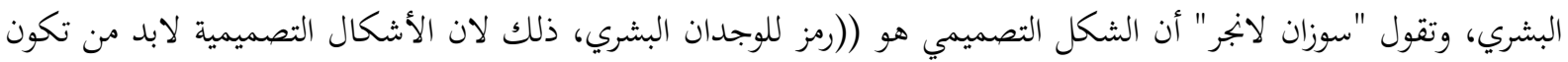

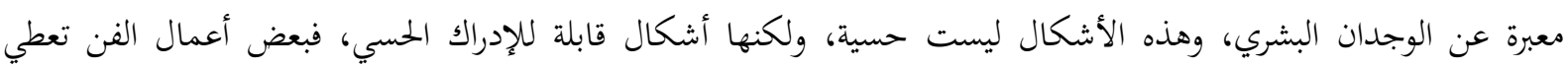
للخيال))(37). ومن هنا يصبح الشكل كرمز دالا على شيء ليس له وجه شبه، وهذا ما يتحقق في كثير من الأعمال التصميمية، كالعلامات التجارية والعلامات التي ترتقي إلى أن تكون شعارات معتمدة لشركات أو مؤسسات إعلامية لتهية أو غيرها،

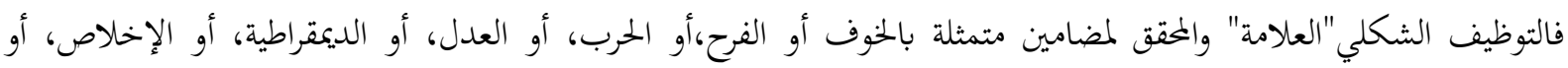

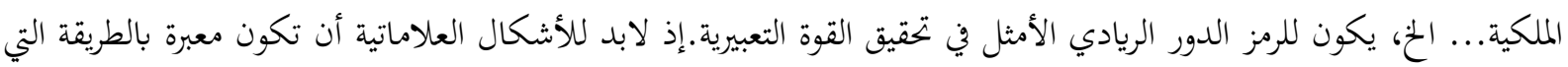

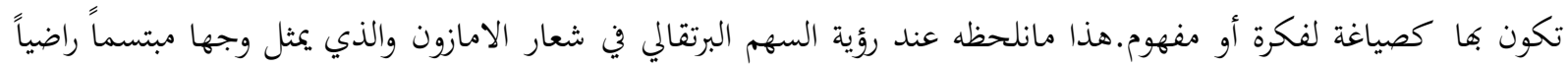

\section{amazon ذلك أن للشكل العلاماتي كيان خاص هذا ماسعت إليه الشركة

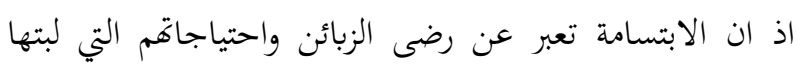

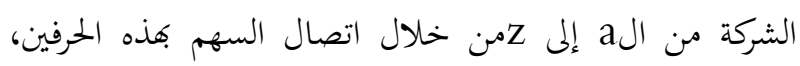

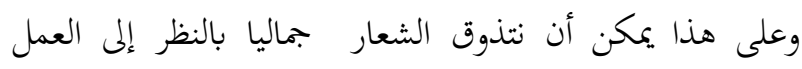 ذاته،والى جماله الباطني، ووحدته وفاعليته.}

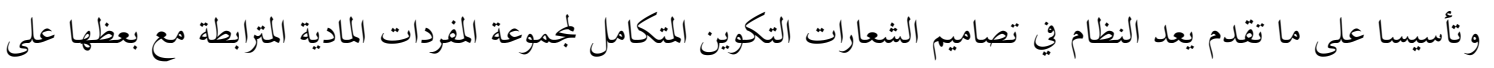
وفق قواعد معينة لتشكل مفهوما ذا خواص مميزه، فالتكوين بالنتيجة شكل form مستند إلى كل المفردات الداخلة في بناءه،

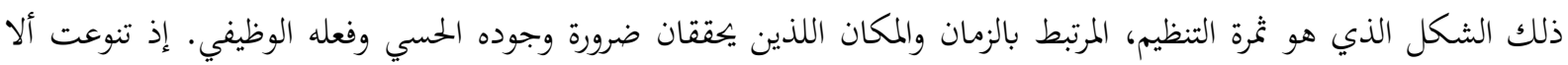

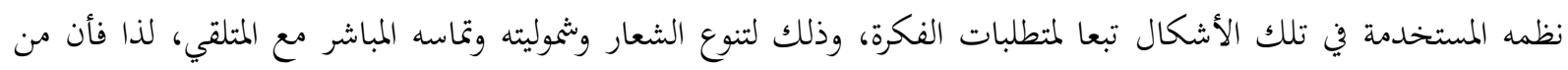

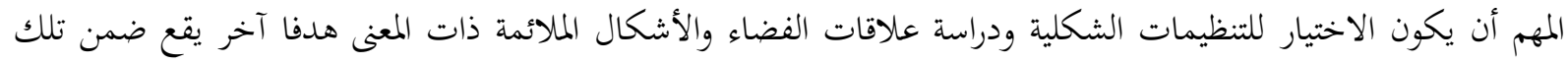
الأهداف وهو تصميم النظام ((العمل التصميمي هونتاج إنسان ينظم فيه المواد بحذق ومهارة لكي يوصل بتحبة إنسانية ما))( (38).

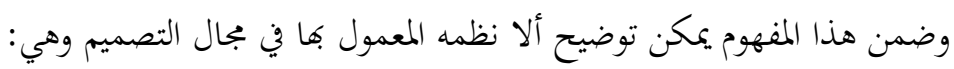

$$
\text { • }
$$

$$
\text { • • النظام الخطي. }
$$

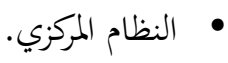

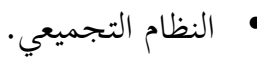

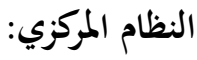

ويمثل هذا النوع من الأنظمة بالتنظيمات المتمركزة حول ذاها، والمتألفة من أشكال أخرى متمركزة حول الأشكال الأصلية السائدة، والتي تختلف عن بعضها البعض في الشكل والحجم، تبعا للمتطلبات الوظيفية، والمتطلبات التصميمية الأخرى. ويتسم

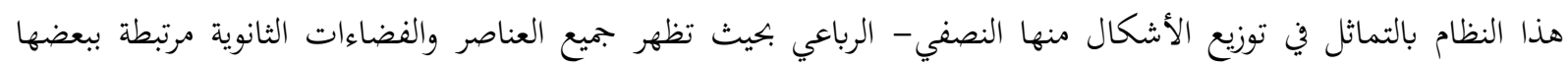

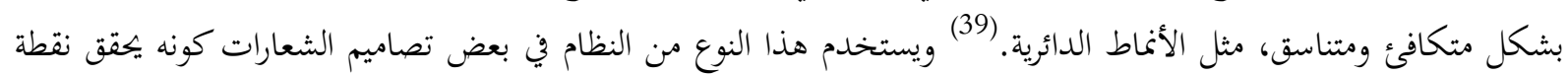
استقطاب المشاهد نخو الشكل. 


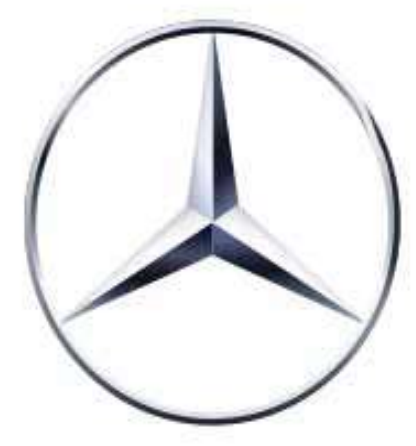

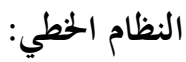

وتتوزع فيه العناصر التشكيلية على هيأة خط مستمر أو متقطع أو مستقيم أو مائل، منحن أو منكسر، وترتبط

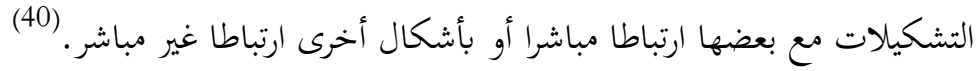

وهذا النوع من النظام يعطي إيهاء بالحركة والاتحاه والاستمرارية والاستطالة والنمو الناتج من تكرار وامتداد الأشكال

الخطية، محققة في ذلك (حركة في المجال المرئي). (41)

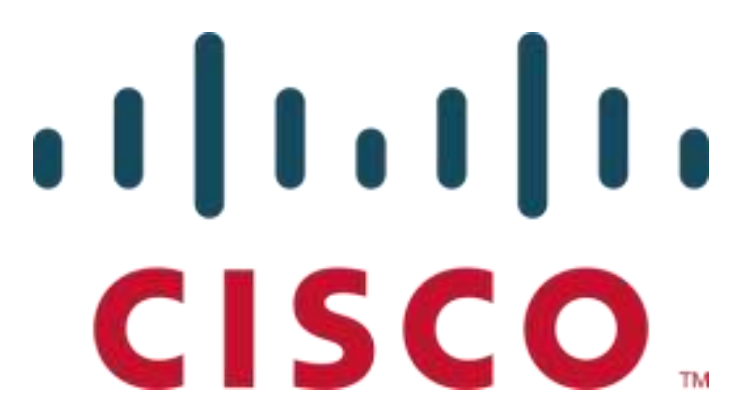

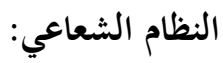

يتميز هذا النوع من النظام في العملية التصميمية بالإيحاء الحركي معتمدا الاتحاهات الخطية بطريقة إثعاعية، وهو يجمع بين

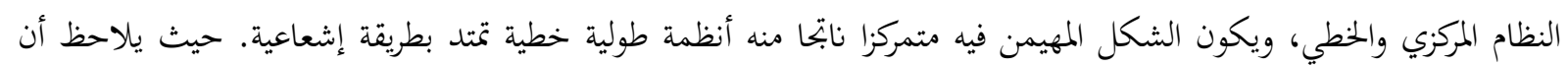

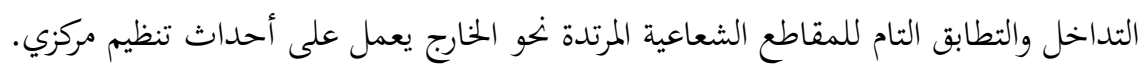

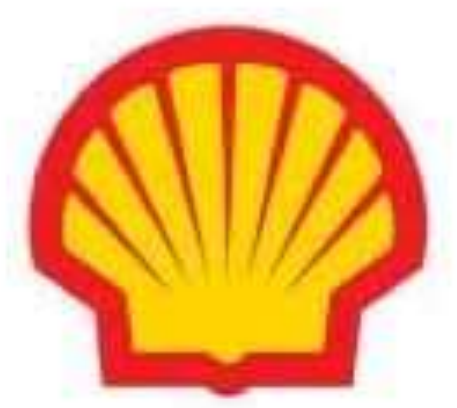




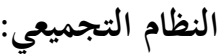

ويخضع هذا النظام إلى التجمع الشكلي المترابط والمتناسق أو المحوري، إلا أنه توزيع غير هندسي حيث يتم تجميع الأشكال

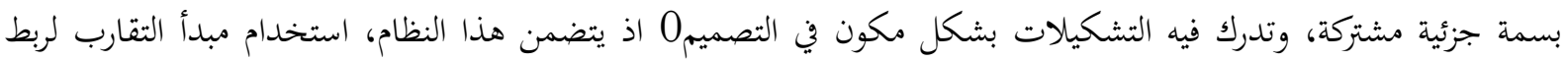
العناصر مع بعضها البعض ويتضمن أيضا مبدأ التكرار.

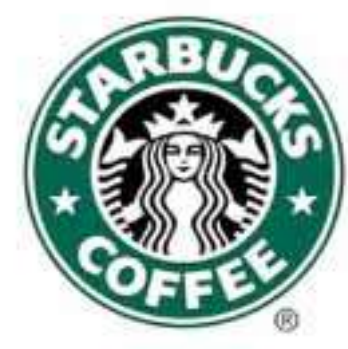

وهو نمط من الأنظمة المرنة التي تتقبل النمو والتغير دون التأثر بالطابع العام.

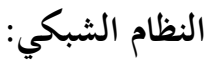

ويتمتع هذا النوع من النظام بالقدرة على توزيع الأشكال على وفق تنظيم خطي متقاطع اشبه بنظام الشبكة، ويحتوي على

مفردات داخل مجاله المرئي. (42)

وخاصية التقطيع للفضاءات داخل حدود الشبكة تعزز من مركزية هذا التنظيم وتحقق حركة مستمرة في المجال المرئي.

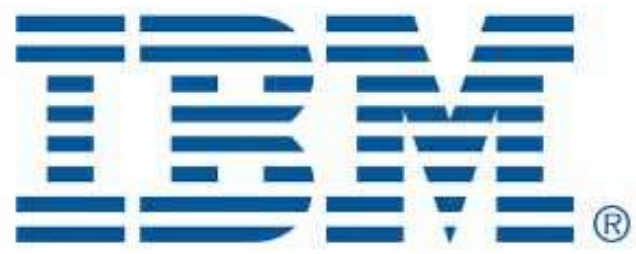

إن عملية تحقيق النظام في العملية التصميمية، سواء كان نظاما مركزيا، أو نظاماً خطياً أو غير ذلك من الأنظمة، إنما هي عملية تعمل على توحيد العناصر والتي يستخدمها المصمم في بناء متداخل ومتماسك والمجسد في الشعارات، وقد يساعد التهاء التكرار

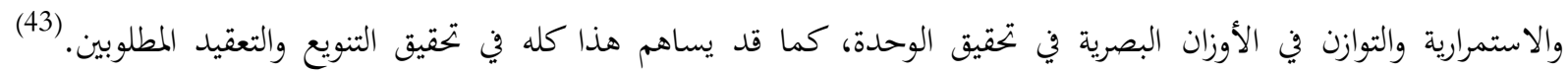

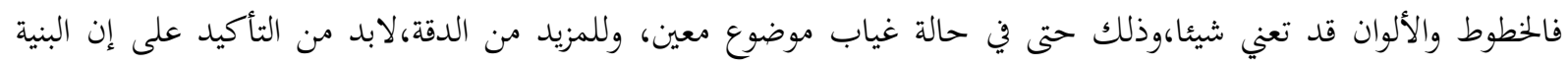

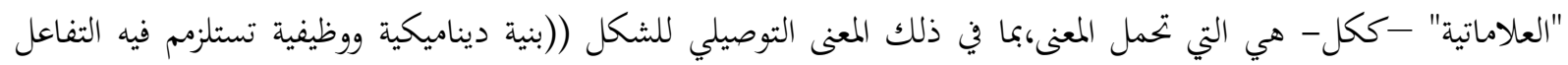

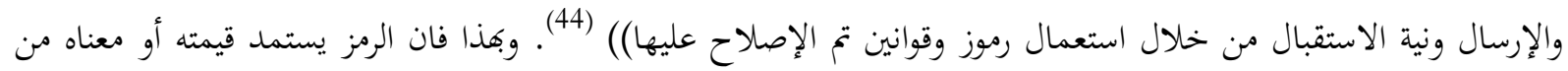

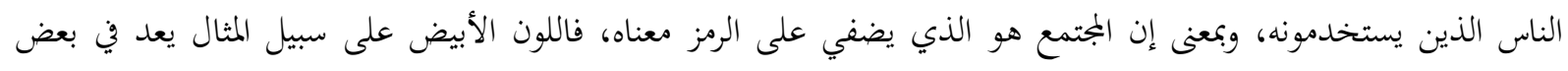

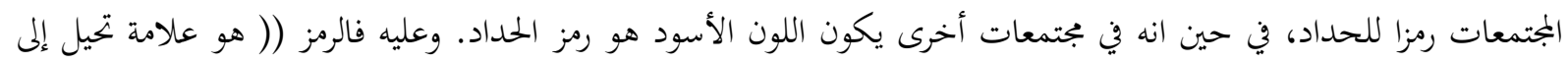

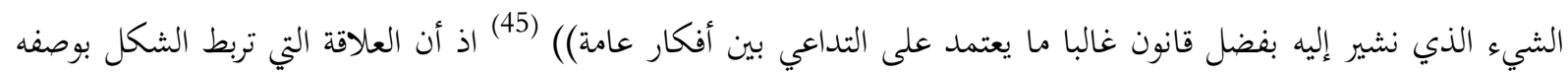

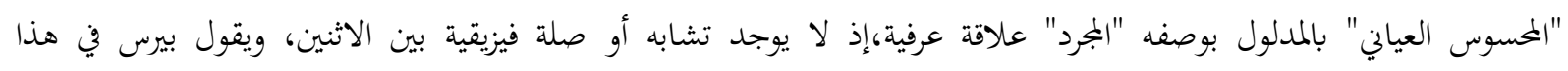

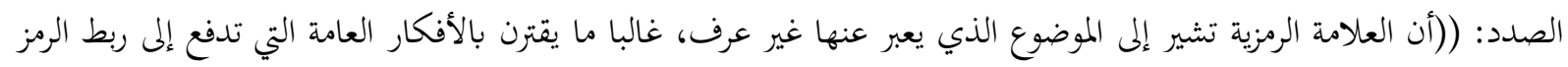

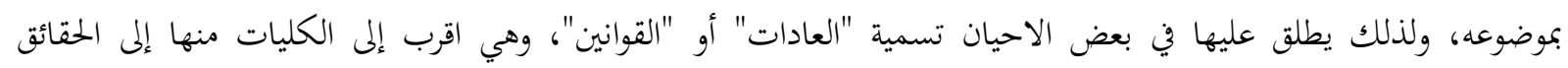


المتحققة،ويمكن القول إفها تجليات للرمز نفسه،مثل ارتباط الحمامة البيضاء بالسلام، والشمس بالحرية)) (46). ويعد من بين أنواع

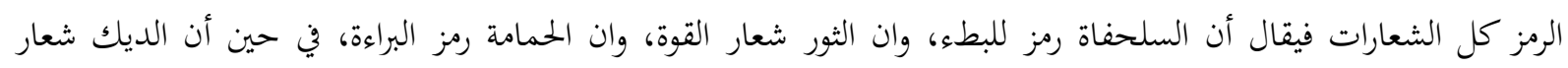
للحذر.

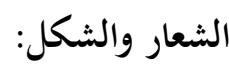

إن عملية الوعي للشكل وتوظيفه، ليضحى نظاماً دلالياً (إشاريا أو رمزيا) متفقا على بثه ومعانيه، ترتبط بمستوى الإدراك وصورته الزمكانية.

فالشكل Form هو الأساس والمنطلق، والوعي به هو بداية التشكيل وحركته. وفي الشعار نجد أن الشكل هو عملية بناء

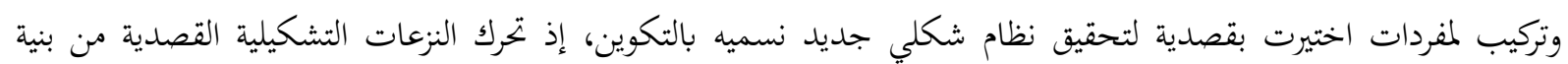

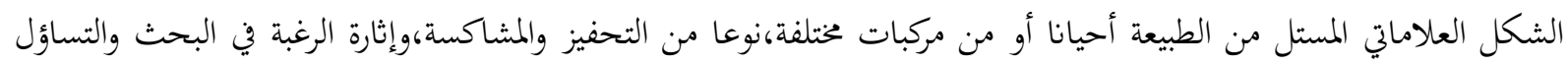
والكشف والانتقاء.فقدم التأويل في الشكل،وهي عملية تشكيل أنظمة جديدة يعتمدها المصمم في نسيج علاقاتها المختلفة. وعليه فان التكوينات الشكلية العلاماتية المتمثلة بّ"الشعارات" تقع ضمن ((العمليات التركيبية لأشكال جزئية منفردة أو

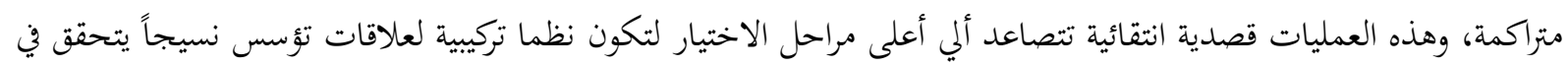

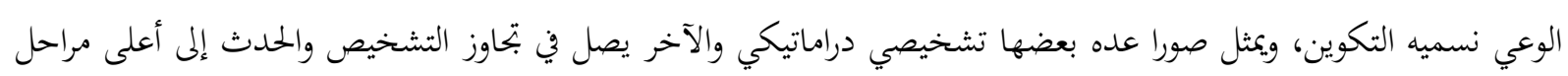

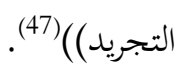

و تأسيسا على ذلك نجدان الشكل العلاماتي المتجسد في "الشعار"يعد شكلاً من أشكال التنظيم الواعي في تحقيق تأثيرات

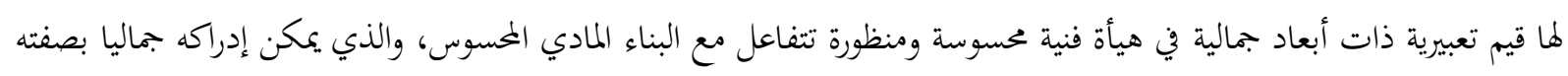
الشيء المنبثق من عملية التجسيد للوحدات البصرية الخاضعة للنظام القصدي. ولاجل هذا فان اقتراح الأنظمة التصميمية وتحقيق علاقاتما في الشكل العلاماتي"الشعار" يبقى يدور في الكيفية التي

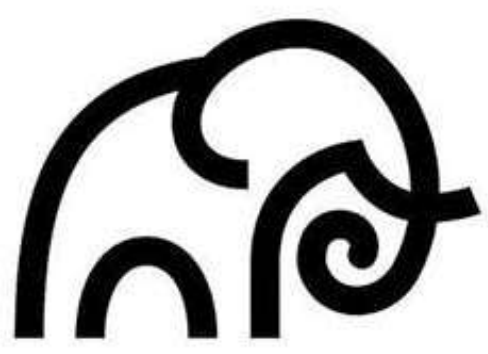

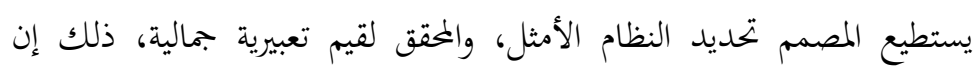

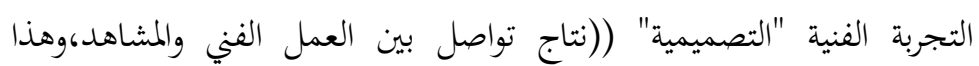

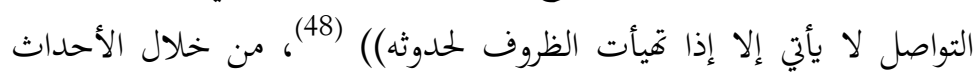
الحاصلة على سطح التصميم. وعليه فأن الاختيارات القصدية لتكوينات تنظيمية قد تتمثل بتكوينات انتشارية أو ايقاعية (محورية، مركزية، قطبية) هي اختيارات تحدد فاعلية التنظيم الشكلي في تصاميم الشعارات ودلالاتما. فالشعار بدلالته يعد عملية اتصال فعالة بينه وبين المتلقي من خلال التأثيرات الشكلية الحاصلة في بنية الشعار. (إذ يمكن أن

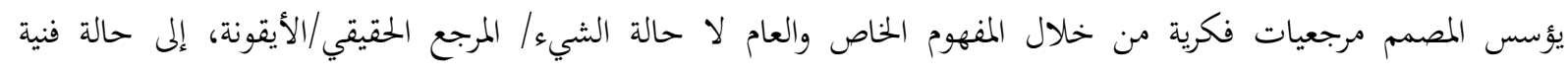

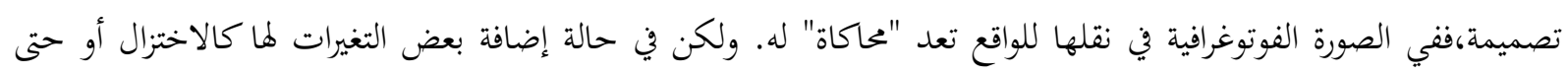
التشويش، أي خروجها عن المرجع تمهيدا لاحلال صورة فنية محل الصورة الشيئة، أي الذهاب إلى ما وراء البصر باتحاه الذهن.

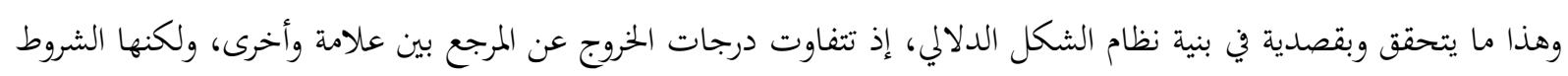
أو (الضرورة) بالمفهوم الفلسفي، ليكسب "الشعار" المشروعية التصميمية) (49). 
وهكذا ففي بنية نظام الشكل الدلالي في بعض شعارات الخطوط الجوية (لا تخضع العلاقات لتحديدات مرجعية بعينها بل تنفتح

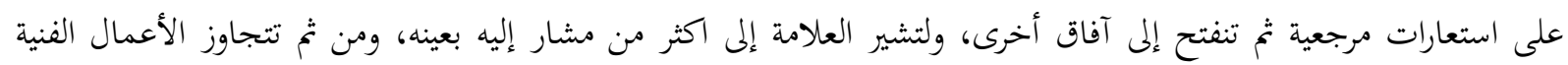

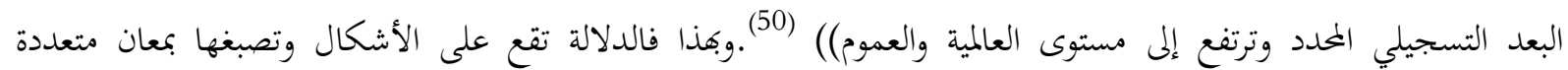

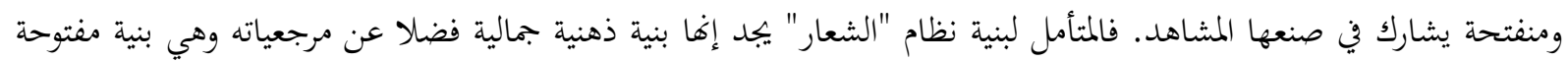
على التاويل.في إنتاج المعنى كما في شعار الطيران الكندي حيث حسئ جاءت الاستعارة الشكلية استعارة أيقونة، فيما جاءت الاستعارة الشكلية لشركة الطيران TAG مختزلة وهي مختصر لكلمة (تشالنجر) حيث جسدت الرمز الدلالي.

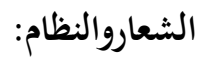

الشعار عبارة عن تكوين صغير الحجم يعبر عن معان ودلالات،يخضع إلى المعايير الفنية التصميميه والعلمية في فن الرسم

والخط والإخراج، ويحتاج إلى دقة في اختيار العناصر من حيث حروف الاسم ونوعها والخطوط والمساحات اللونية،فهو يعبر عن الفكرة ومضموها وهو يمثل العلامة التجارية للشركة، وتتصف بنية نظام الشعار بمواصفات بتعله سهل التذكر والتعلق بالذاكرة.

ومن هذه المواصفات هي: (51)

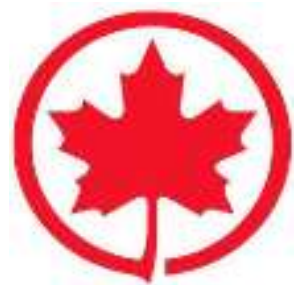

1. الملاءمة: حيث يتمتع الشعار بملاءمة محتواه من حيث المفردة الداخلة في تكوينه كان تكون حرفًا

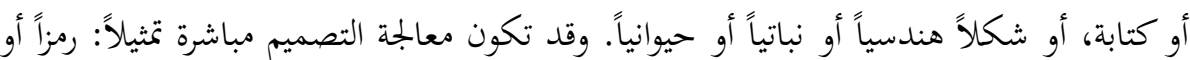

تجريداً بجتاً مع غرض شركة الخطوط الجوية والطبيعية العامة.

2. الإبداع: أن يكون الشعار من النوع الإبداعي واضح التميز والتفرد عن تلك المستخدمة في الشركات الأخرى التي بنفس الخط الإنتاجي في الأقل.

3. البساطة: آن يتميز الشعار بالبساطة، كي يعرف من لمحة واحدة مراعاة لزمن التلقي

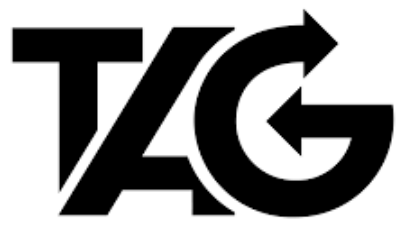

اللحظي.

4. المعاصرة: آي أن يعكس تصميم الشعار حسا معاصرا وله جاذبية تستجيب

لكقياسات الفنية المؤثرة اجتماعيا.

5. الجاذبية: أن يكون جاذب للمظهر، من حيث الاستجابة للاستعمال المرن قدر

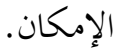

6. التذكر : أن يتضح الشعار بقوة الانطباع الدائم وان ينظر على نحو كاف لكي يتذكر.

7. النفعية: له إمكانية للاستعمال المرن وان يكون حيوياً وفعالاً.

8. المحلية: وفيها تتم معالجة البنية الشكلية"الشعار" بما يؤشر سمات محلية دون أن ينقطع كليا عن حس العالمية، أي أن يحقق

التوافق بين الملامح المحلية والتطلعات العالمية.

كما ويصنف الشعار على وفق طبيعته وعلى ضوء استخدامه كالآتي (52):-

أ. شعارات تأخذ هيأتها من الحرف، حيث تلجأ بعض المؤسسات أو الشركات إلى استخدام الحرف الأول من اسمها رمز يمثل 


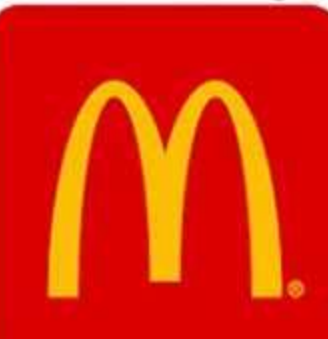

ب- شعارات تأخذ حروفها أو علاماتما الكتابية أي يعطي الاسم الكتابي للشركة.

\section{Callon}

ج. الشعارات التي تكون صورة مشتركة بين شكلين أو اكثر.

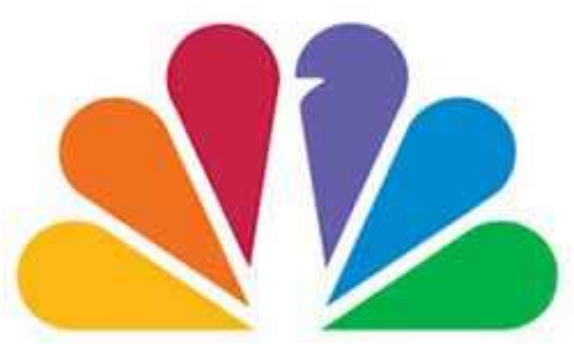

د. الشعارات التي تركب من الحروف والأشكال في آن واحد.

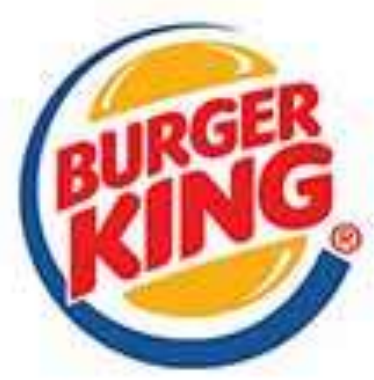

و تأسيسا على ما تقدم يمكن القول: إن كثيراً من المصممين يميلون إلى سمة التنوع الشكلي في تصاميم شعارات الخطوط الجوية العربية وغير العربية المتأتية من شرط (اللاتشابه) مع الشعارات الأخرى، فضلا عن من (اللاتطابق) تحقيقا لمبدأ التفرد للشعار. إلا أن سمة التعبير تعد الهدف الأول الذي يعنى المصمم بتحقيقه من خلال تظافر ثلاثة متغيرات فاعلة وأساسية-كما يحلدها " عبد الرضا بكية "وهي:- (53) 1. عناصر بناء شكل الشعار (متغيرات النظام الخاص). 
2. العوامل الساندة وهي: جملة المقاربات السيميائية وقوانين الجشطالت، التقنية التنفيذية فضلا عن طبيعة العلاقات بين العناصر

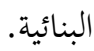

3. الأنساق البنيوية: وهي الاختيارات المرجحة للمصممم بشان مواصفات الطابع الشكلي من قبيل: النسق الهندسي،النسق ألا يقوني، النسق الحر وفي، والنسق المختلط.

\section{النتائج ومناقشتها:}

1. تحقق ادراك النظام التصميمي في جميع الشعارات، وذلك لوضوح الرسالة التصميمية التي أرسلها المصمم للمتلقي من خلال

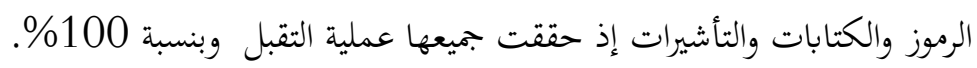

2. أظهر موضوع الشعار من حيث كونه لغة دلالية مرمزة أفكاراً مختلفة ترتبط بمحدد ثقافي تقترحه المؤسسة، أو الشركة. فالشعار

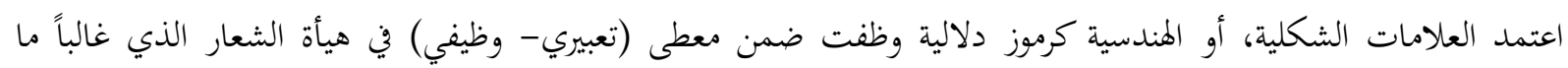

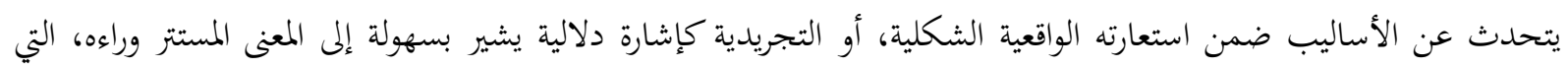
تكون خاضعة لمتطلبات الفكرة المرتبطة حتماً بالمحددات الوظيفية. 3. اعتمد التنظيم الشكلي على مجموعة من الأصول والمرجعيات ومدركات عقلية أسهمت استدراك الشكل في الشعات الشعارات, قد فـ

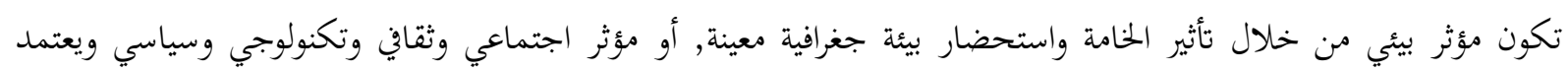
الرجوع إلى هذه المرجعيات إلى طبيعة وثقافة المصمم والبيئة المحيطة .

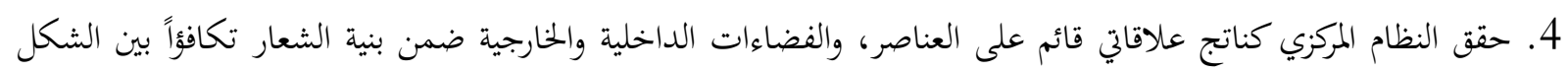

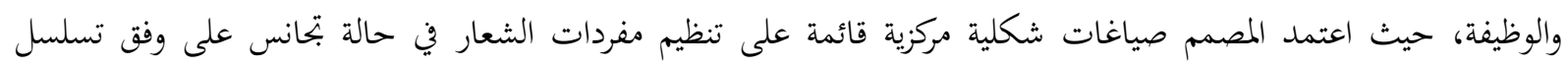
منطقي في ربط تلك المفردات مع بعضها البعض لتحقيق نقطة الاستقطاب البصري حول نقطة مركزية تعد الأساس في إيصال المعنى الشكلي، واستدلاله. 5. حقق النظام الخطي تأليفاً، واتساقًا بين العناصر، والأسس كافة الداخلة ضمن بنية تصميم الشعار كما هو في العينة (ibm)

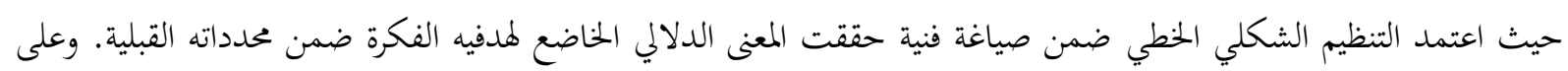

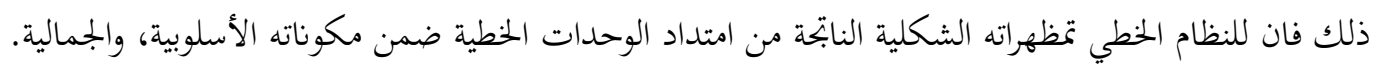

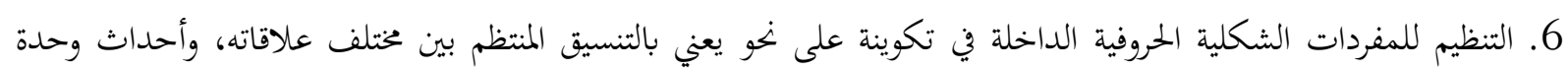

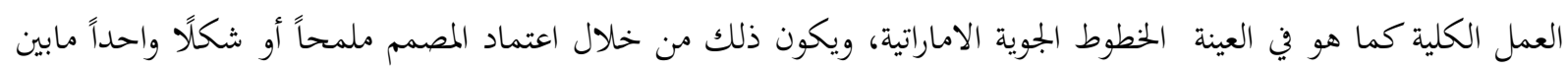
الحروف العربية واللاتينية. 7. حققت الشعارات قيمتها الفنية من خلال عمليات التنظيم، وظهر النظام التجميعي في ترابط بين الأشكال التي جاءت مستعارة من الواقع ضمن عملية بتميعية تدرك بشكل مكون تصميمي من النظام يعطي إيحاء بالحركة والاتجاه والاستمرارية

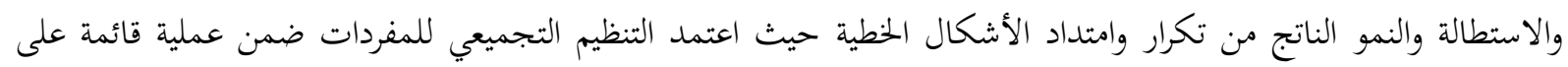
التقارب في ربط تلك المفردات مع بعضها البعض في أحداث التكامل ما بين الأشكال المختلفة لتجسد التكوين الشامل. 
1. يمكن المزج بين نظامين لتعريف الهوية هما نظام كلي يدلل على هوية وظيفية تقليدية ونظام كلي من خلال العناصر ضمن المشهد الاستدلالي الشكلي الذي يجسد طراز ين معين. 2. يتعزز الرمز في الشعار في احالة الصورة الذهنية إلى وجود عياني مسبق ذو طابع استدلالي تعبيري عن رموز تعزز وبحسد الهوية الوطنية. 3. العلامات الشكلية أو الهندسية كرموز دلالية جسدت المعنى الاستدلالي الشكلي التعبيري المرتبط بالوظيفة. 4. يتيح الاعتماد على أنظمة الألوان الحارة والتباين اللوني استدلالا بين المرئيات وإظهارها كمناطق إثارة وتحفيز بصري, وإدراك

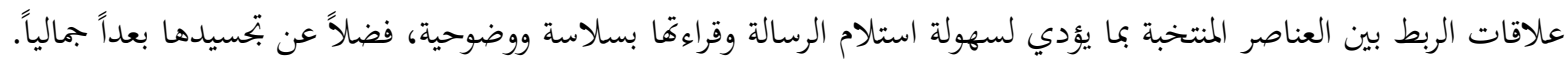
5. يمكن المزج بين نظامين للتجسيد وتعزيز الاستدلال الشكلي، كالنظام الشكلي المرتبط مع النظام الحروفي وهما نظامان يدلل

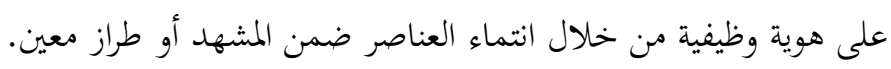

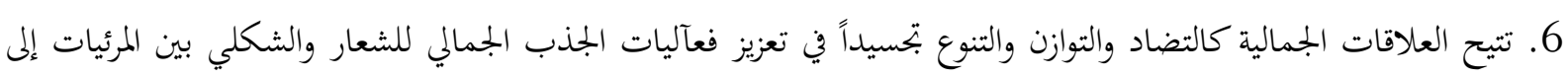

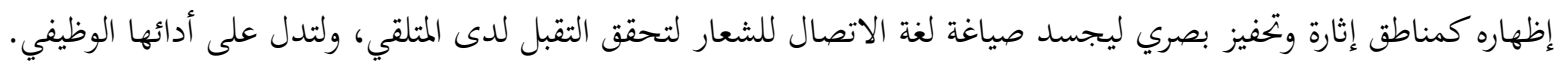

التوصيات: 1. تأكيد التمثيل الايجابي للسمات الممثلة لهوية المجتمع أو البيئة المخيطة من خلال عمليات التنظيم الشكلي ودلالاته ضمن تحقيق أساس الوحدة والتنوع للشعارات.

2. الاهتمام بعمليات توظيف الرموز والأشكال ذات الاستدلال الذي يعزز الهوية سواء كانت مفردة أو متعددة لما لما من اهمية في

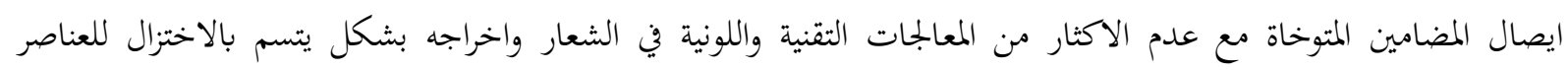

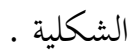

المقترحات:

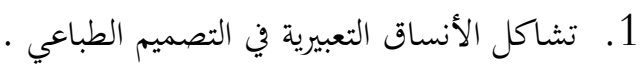
2. - 2. - التحول الدلالي في الشعارات التجارية . 
(1) جميل صلبا ، المعجم الفلسفي الجزء الاول، دار الكتاب اللبناني ،بيروت لبنان،1982م،ص 471.

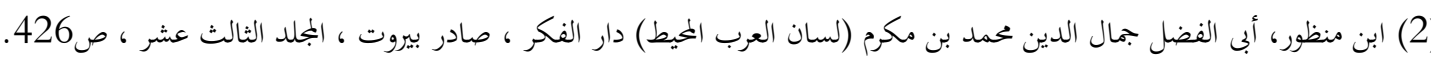

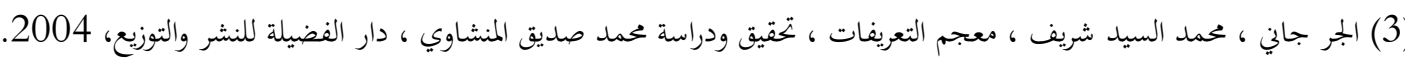

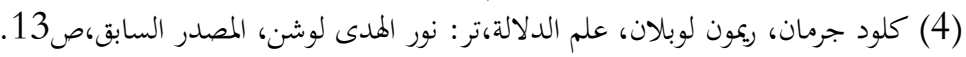

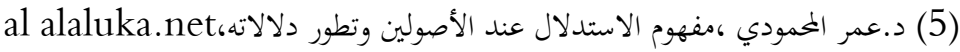

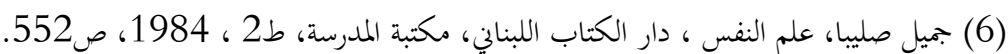

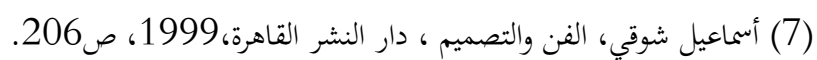

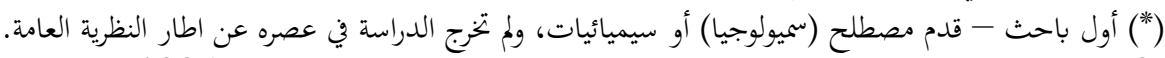

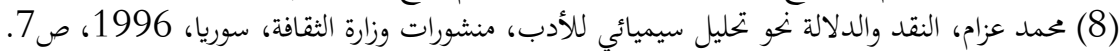

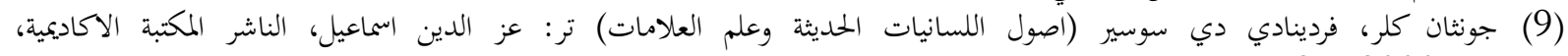

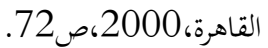

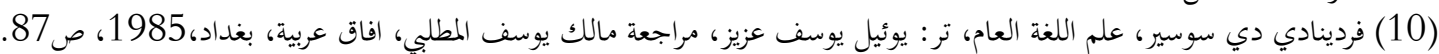

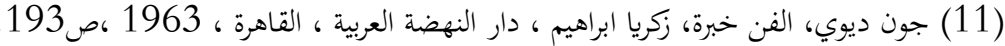

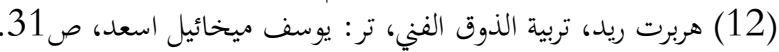

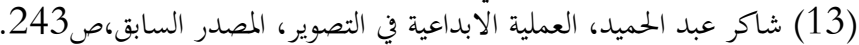

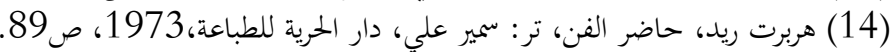

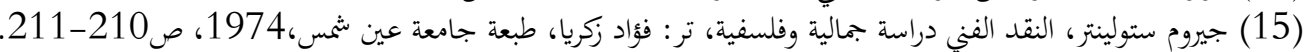

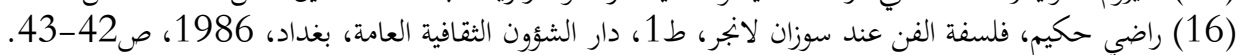

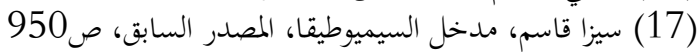

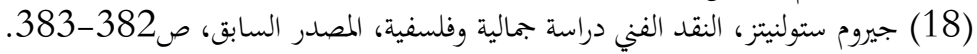

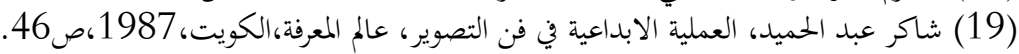

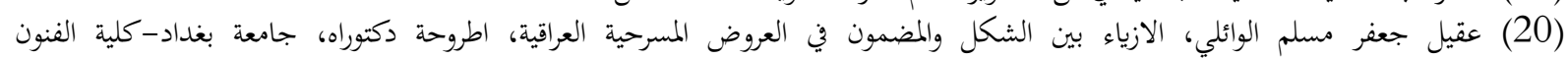

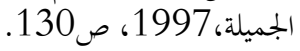

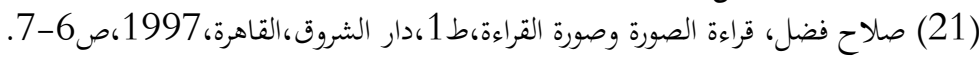

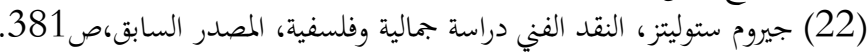

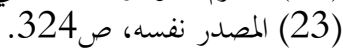
(24) عبد الرضا بهية داود، دور المعالجات الادراكية في اختزال البنية التصميمية للعلامة التجارية، بجلة الاكاديمي، كلية الفنون الجميلة- جامعة بغداد،

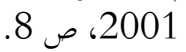

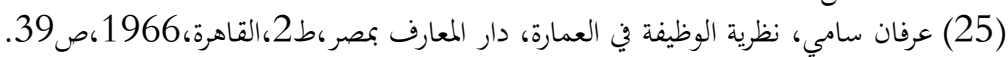

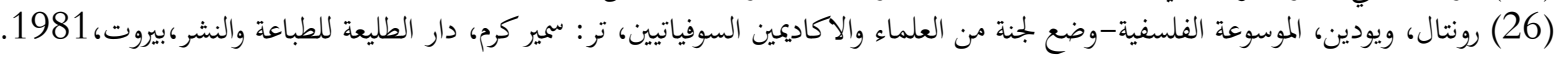

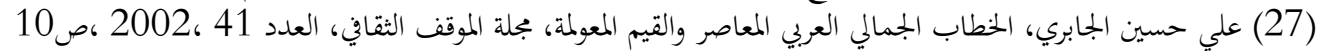

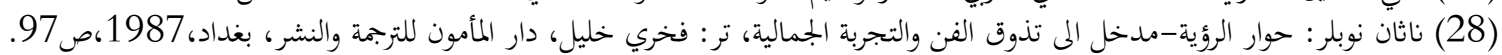

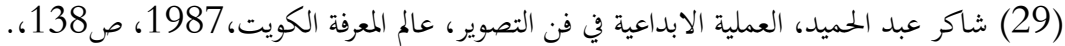

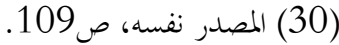

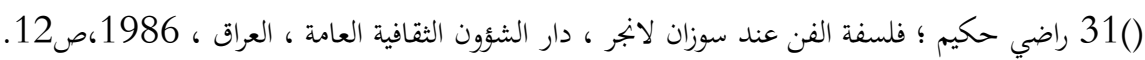

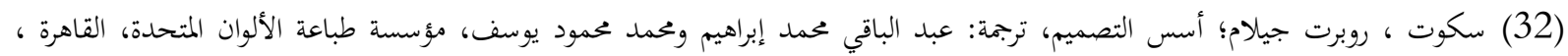

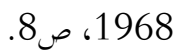

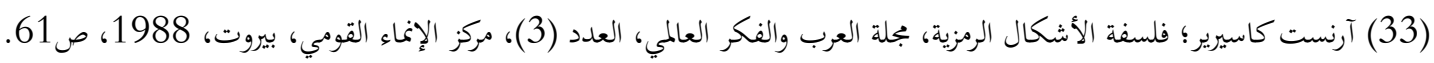

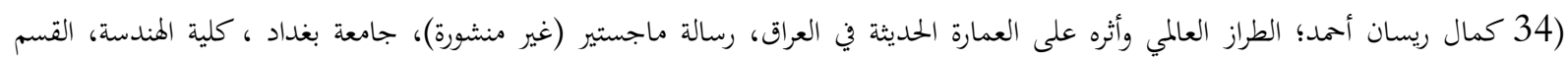

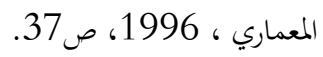

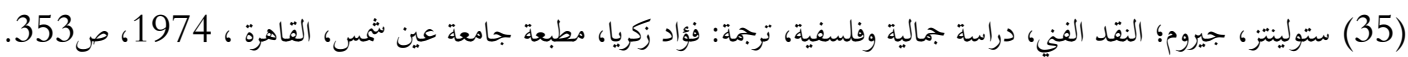

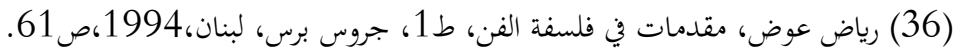

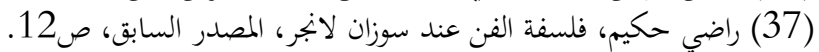

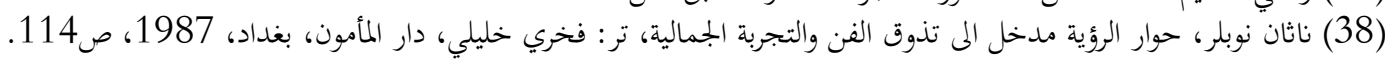

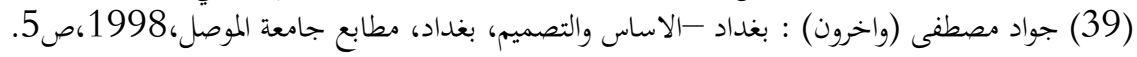




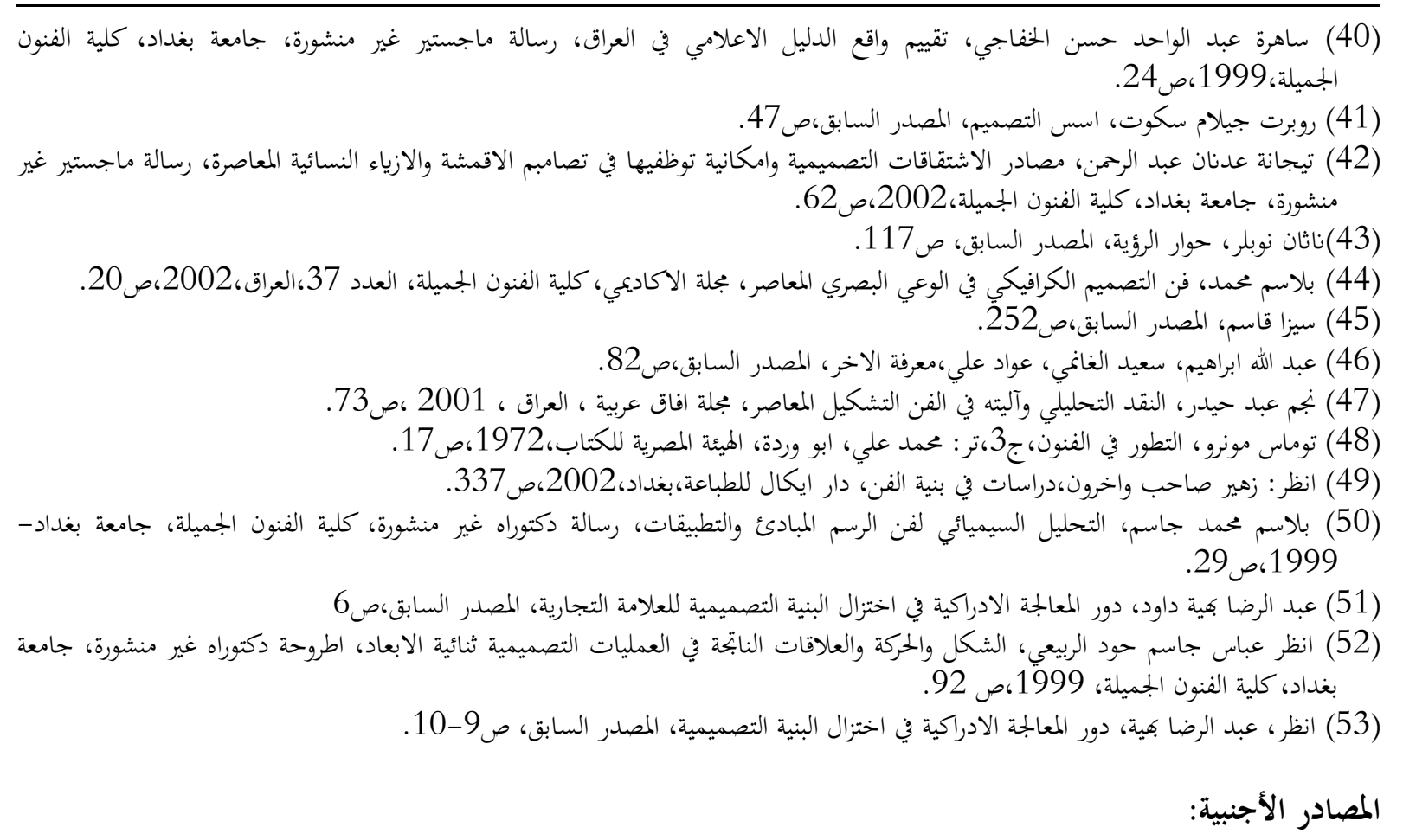

$\left({ }^{53}\right)$ Horrby, A,S.\&Paruwell,E,C,((Oxford:An English Readers Dictionary)),Oxford Un Iversity Prees, London ,18th Impression,1967,P444.

$\left({ }^{53}\right)$ Lobell, John, Between Silence and Light ,Spirit in the Architecture of Louis 1. Kahn Shambhala Boulder, 1979.p.p 56.

(2) Arnhiem, Rudolf, the dynamics of Architectural ,Univ of California Press, California, $1977, \mathrm{p} 135$.

${ }^{(53)}$ http://www. n:zwa.com /volume 34 /p122 128. htm1

$\left({ }^{53}\right)$ Arnheim, Rudolf , Art Visual Perception of the Creative eye , Berkeley University of Californi , 1974,p172.

${ }^{(53)}$ Ching ,Francis.D.K.:Interior Design,.New york..Van Nostrand Reinhold company, 1987.P.201

${ }^{(53)}$ Ching, Francis.D.K.:Interior Design,.New york..Van Nostrand Reinhold company, 1987. P.204

53 Ching, Francis.D.K.:Interior Design,.New york..Van Nostrand Reinhold company, 1987. P.204 



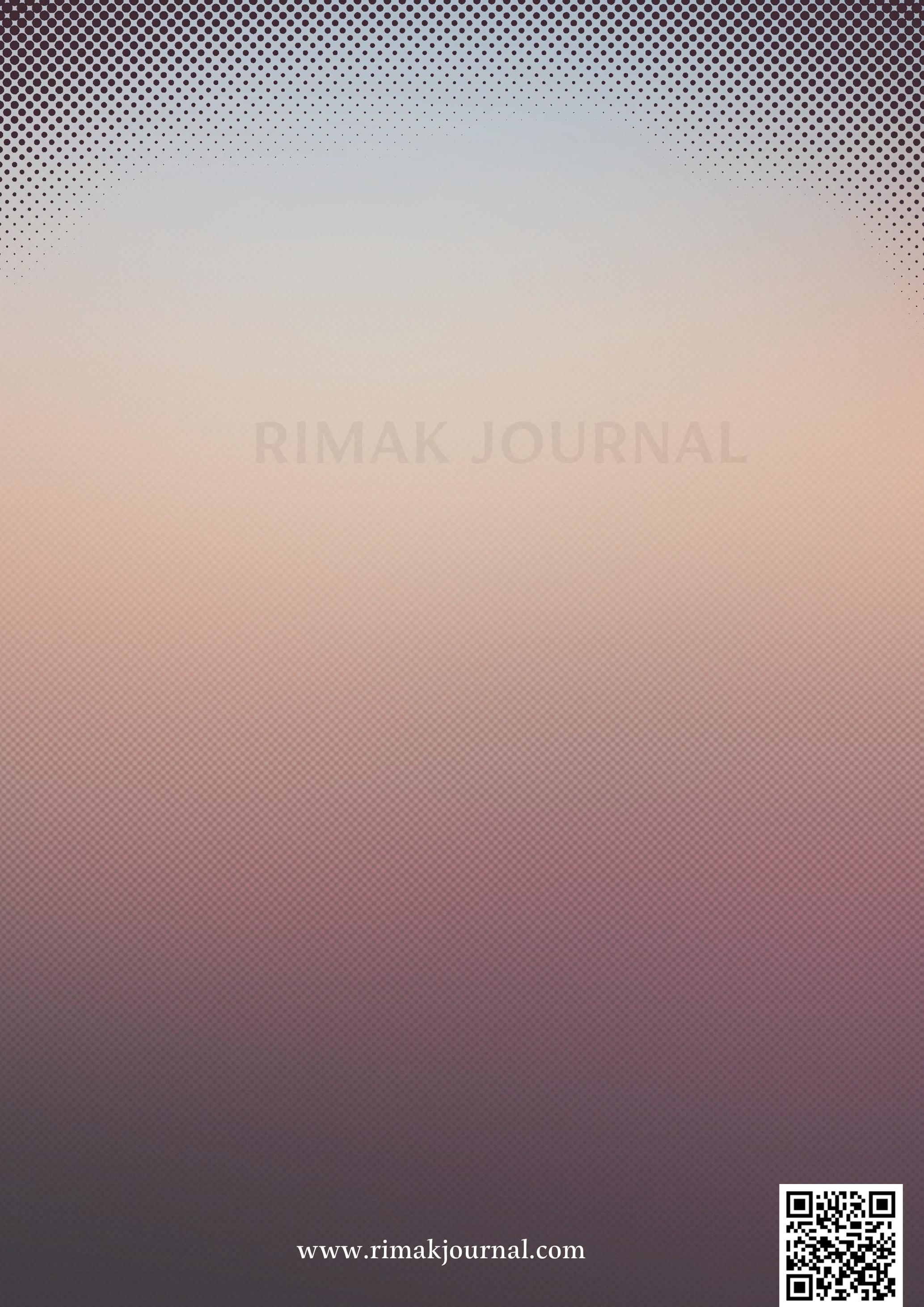

